LA CREACION

HISTORIA NATURAL

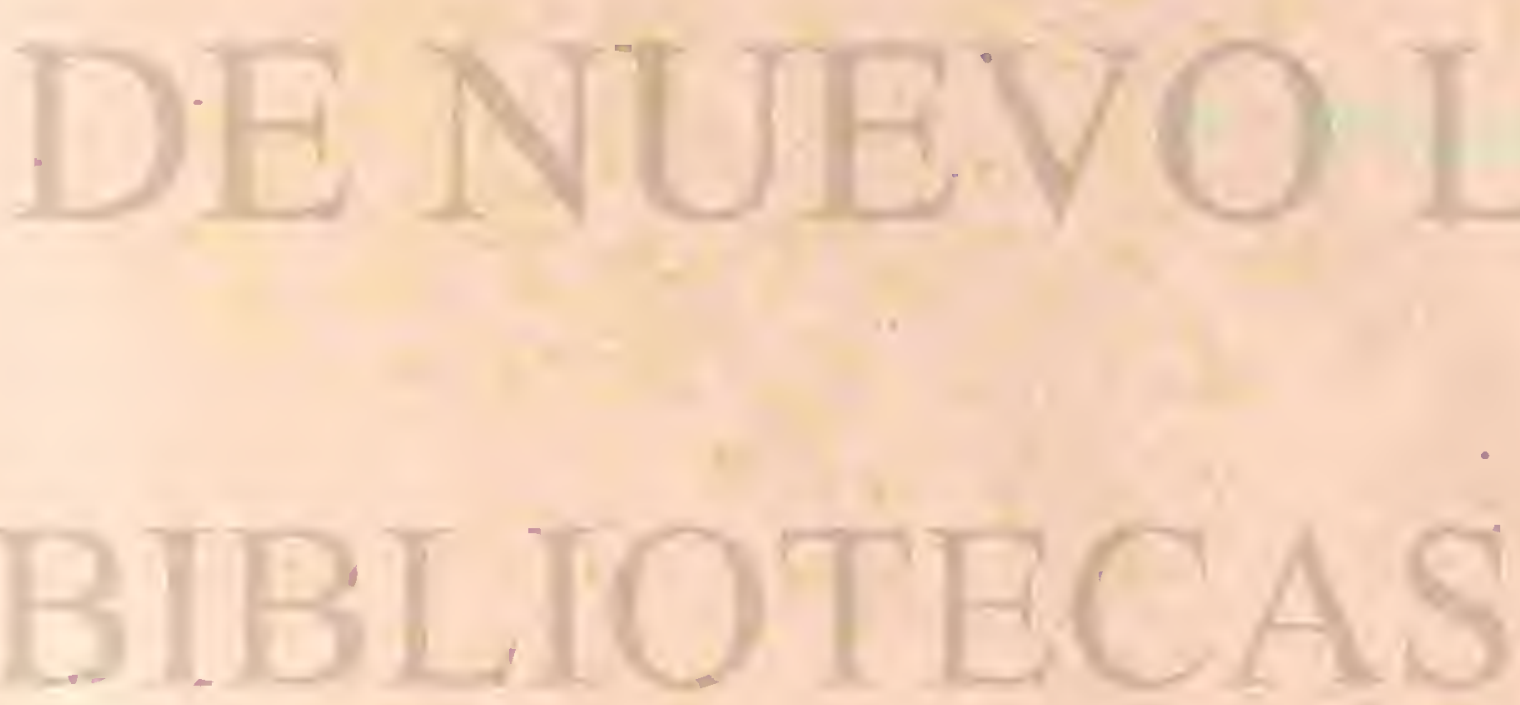




\section{LA CREACION}

\section{HISTORIA NATURAL}

OIVIBION DE LA OBRA:

\section{ZOOLOGÍA Ó REINO ANIMAL}

TRADUCLAS Y ARREGLADA DE IOA ĹLTISA EDICION ALEMANA DELA ORRA DEL CELEIBRE

DR. A. E. BREHM

ANTROPOLOGIA, BO'TANICA, MINERALOGIA, GEOLOGIA Y PALEONIOLOGIA

escritas por eruditos autores espaitoles

con presencia de los mas completos y recientes datos de estas diferentes ramas de la ciencia

\section{INSFCTOS}

POR EL DOCTOR E. L. TASCHENBERG

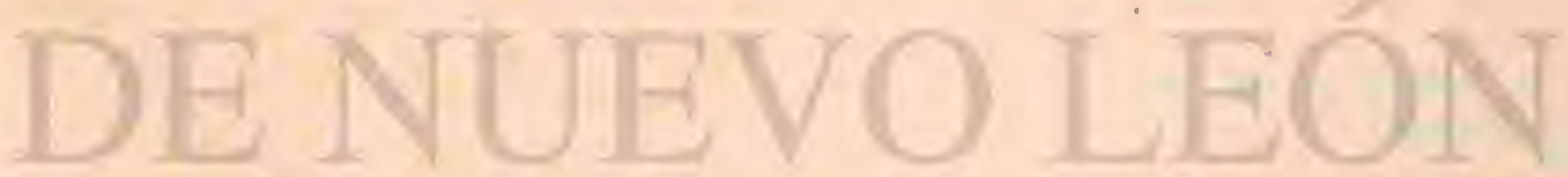

BARCELONA

MONTANER Y SIMON, EDITORES

CALLE DE ARAGON. NÚMS 309-318 


\section{INTRODUCCION}

\section{CONSIDERACIONES GENERALES SOBRE LOS ARTICULADOS Ó ARTROPÓDIDOS}

Las mariposas abigurradas, las hormigas laboriosas, las impertinentes moscas, las escolopendms, tan aficionadas a la oscuridad, las arañas tejedoras, y otmas muchas especies afines de los séres de que ahora vamos a ocuparnos, pertenecen a un grupo cuyas formas difieren esencialmente de las que hemos descrito hasta aqui. Mientras que los mamiferos, aves, anfibios y peces tienen una armazon interna, huesosa ó cartilaginosa, con una columna vertebral que sirviendo de tronco constituye el punto de apojo de todas las partes carnosas que crecen exteriormente, $y$ las ruales cubren las articulaciones de aqquella, en los séres de que vamos á tmar obsérvanse condiciones insersas. La piel forma ura coraya mas ó menos fuerte, que para facilitar los movimientos del individuo se divide en articulaciones unidas entre si por delgadns menbranas. Estas articulaciones se llaman en unos ciluesn, pecho y ahdomen; en otros, las dos primeras forman una sola pieza designada con el nombre de efalutorax; y en varias esprecies solo la cabera se destaca del resto de las articulaciones que representan el pecho y el abdómen. Tambien se da el caso de que aquellas estén soldadas por la parte del dorso, scparándose soln en la region infurior $\delta$ vice-versa; los bordes de cicrtas articulaciones 6 anillos, que tambicn se llaman seg. mentos, aunque muy raras veres representan anillos comple. tamente cerrados, se continunn en formas muy variadas de listas, apindices y prominencias, dispuestas en el interior del cuerpo para servir aqui de punto de apoyo a los músculos y otras partes blandas. Las articulaciones compractas constituyen, por decirlo asi, un esquelcto membranoso exterior; $a$ él pertenecen en la mayoria de casos unas apófisis articuladas i su vez que aparecen como apéncices independientes y sirven para varios fines: unos para el tacto; otros para comer; estos para la marcha, y aquellos para la reproduccion. Hay algunos cuyo objeto no se ha podido reconocer aun, si bien podria decirse que la major parte de esas apófisis sirven de piés. Atendida esta clase de estructura particular, todos los animales que la tienen se han reunido bajo el nombre de articulados (inseda); $y$ ofrecen un conjunto de formas muy distintats de las que hemos descrito hasta ahora. Debe advertirse, no obstante, que los gusanos, aunque no pertenecen por sus formas al grupo que nos ocupa, ni tienen extremidades articuladas, son tambien articulados. Tanto por esto como porque á principios de nuestro siglo se concretó la idea de la falabra insecto mucho mas que en los tiempos de Linneo, Cierstaecker dió en I $\$ 55$ a estos animales el nombre de artropó didos (artiropoda), calificativo adoptado hoy dia casi generalmente.
Los artropódidos dificren de los vertebrados no solo por sus formas exteriores, sino tambien por su estructura intcrna, segun resulta de un exímen superficial de la misma. En los rertebrados, la médula espinal, partiendo del cerebro, se corre por dentro de la columna vertebral á lo largo del dorso. como el tronco del sistema nervioso: en los artropródidos, en el sitio correspondiente del cuerpo hállase el llamado inso dorsal, tronco principal articulado para la circulacion de la sangre, qque difiere esencialmente de la que tienen los vertebrados; frente al vaso dorsal, á lo largo del abdómen se co:ren algumos nervios pitrendos que en ciertos momentos se dilatan en forma de nudo, constituyendo las llamadas cadenus de los ganglios, y en su conjunto midula abdominul, como eentro del sistema nervioso. Entre el vaso dorsal y la medula abdominal híllase el casal alimessticio, que tambicn cstablece una comunicacion entre la abertura de la boca, la parte anterior del orificio y la posterior del cuerpo, como en los verte. brados; y que se corre en linen recta ó con muchas circunvoluciones, difiriendo sin embargo esencialmente en sus partes aisladas del canal digestivo de los animales vertebrados. Para llegar a la abertura de la boca penetra con su parte anterior cutre los ligamentos que rcunen los dos primeros pares de ganglios de la médula abdominal, yo forma de este modo el anillo esofígion, comparado algunas veces con el cerebro de los vericbrados. Actemis de las formaciones glandulosas de distinta naturaleza y uso quue se hallan en una á otra relacion con los órganos alimenticios, las partes genitales lleman la cavidad abdominal, es decir sus segmentos posteriores. En rodos los artropódidos cxisten ambos sexos: la abertura de sus partes sexuales está delante del ano. I los órganos de los sentidos no alcanzan tanto desarrollo como en los vertebrados; comun a todos es la visia y el tacto; mientras que el olfato y el oido solo se han manifestado en unas pocas especies; estos órganos residen sobre todo en la cabeza, si no exclusivamente. Los artropódidos no respiran por medio de pulmones $\delta$ branquias, solo por la boca, hi por una abertura situada junto à la cabeza, sino que todo el cuerpo se emplea en esta funcion, pues le recorre una red de vasos muy ramificados, llamados triqueas (Trachae) que, comunicindose con el exterior por numerosos orificios que se designan con el nombre de estigmas (Stigmata), reciben el aire libre por rodas partes. Hay sin embargo artropódidos con branquias que bacen las veces de estigmas, como se observa sobre todo en los cangrejos, que cual verdaderos animales acuáticos se distinguen esencialmente de los artropódidos terrestres y aéreos. 
Entre las particularidades de los cangrejos, en cuyan descripcion no deho entrar ahora, pues trataré de cllos en otro lugar, se ha de hacer mencion de: la unateria de que se componen el esqueleto y la piel; en las sustancias principales de esta última figura la cal, mientras que la piel de los otros artropódidos, jroducida por unas cajnas muy particulares, es rica en 'carbono, insoluble en agrua, espliritu che vino, eter y ácidos no concentrados, asi como en compuestos concentra dos alcalinos; tampoco se funde en el fuego, como el enema, pero si arde. Se ha introdurido en la ciencia bajo el nombre de quifinn, y aunungeesta sustancia solo exteriormente se parece á la córnea, en nuestron descripcion designaremos à mo nudo ciertas partes con el nombre de cómeas, pero téngase entendido que lo hacemos obedeciendo á una costumbre de expresarse asi, no faicil de desechar, aun cuando hace mucho tiempo que la ciencia reconoció su incractitud.

listos pocos apuntes preliminares bastarin para camcterizar los artropódidos en general, haciendo resaltar las diferencias que existen entre ellos y los vertebrados. Fstas diferencias seran mas evidentes aun por todos estilos cuando estudiemos mas minuciosamente las definiciones de los grupos de artropódidos, que se reducen á cuatro: insectos, escolopendras, aranias y cangrcjos. Los tres primeros son los que vamos i describir desde luego.

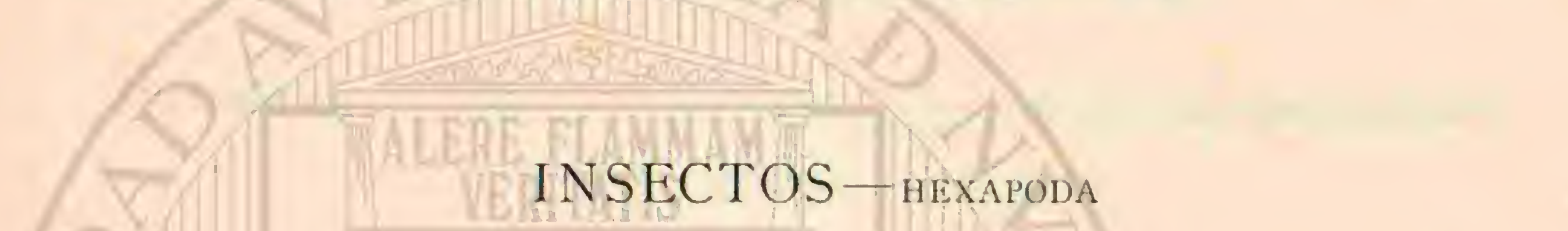

En el agua y en ricrn, en las plantas y en los árboles, arrastrindose por el suelo ó cruzando las regiones aćrens, en todis partes, en fin, donde es posible la vidh anima!, encuéntranse insectos: solo debe cxceptuarse de esta reglt la alta mar, puies las pocas especies que se han ubservido en la vegetacion submarina están demasiado aisladas. A medida que avanzamos hacia los polos escosean mas y mas las especies, aunque podrian encontrarse varios grupos de una misina; y por otra parte, tambien disminuye su nümero hasta la completa desaparicion cuanto mas penetramos en las monianas cubiertas de nieve, como por cjemplo en los Alpes de Suiza, á la altura de 2,812 metros sobre el nivel del mar. Su cirra aumenta, por el contrario, y mas variadas y maravillosas son sus formas y la belleza die sus colores, cuanto mas calido es el pais donde habitan

CARACTERES. - Los insectos se distinguen exteriormente por tener dividido su cuerpo articulado en tres partes principales; una de ellas, la cabeza, esta provista de dos ante. nas, y en el pecho hay seis piemas; In mayoria de las espe. cies tienen dos ó cuatro alas. En cuanto à su desarrollo, las mas se distinguen por un cambio de formas en las diferentes fases de la edad, ó en oiros términos, sufren una metamor. fósis 6 una trasformacion.

CABFzA. - Ia cabeza, que en el insecto completamente desurrollado consta al parecer de una sola pieza, unida. al tórax por una piel blanda, puede moverse independientemente en todos senticlos si está libre; pero sus movimientos son mas limitados cuando se inserta en la cavidad que se halla en la parte anterior del tórax, $\delta$ cuando este la cubre por arriba. Hemos dicho que la cabeza consta al parecer de una sola pieza, pero en su disposicion primitiva se compone de cinco anillos $\delta$ segmentos, segun llamaremos en adelante \& las articulaciones; en los dos primeros están los ojos y las antenas, y en cada uno de los siguientes hay un par de maxilas, órganos todos de la inayor importancia para el insecto, y que pam nosotros constituyen en su mayor parte caractéres distintivos demasiado esenciales para prescindir de ellos. Antes de estudiarlos mas minuciosamente debo añadir que la region situada entre los bordes superiores de los ojos se llama frenle; cl espacio que media entre los posteriores hasta la re. gion de la abertura de la boca, mejilla; la parte anterior desde la frente hácia ahajo, cara; y la anterior de esta por delante de la boca, escudo de lu soliear (Ciypous).
Ojos.- I os ojos de los insectos se insertan en ambos lados de la cabeza y son completamente inamovibles; mas a pesar cle esto es probable que el aninal abarque mayor horizonte que los vertebrados. Sin mover su cuerpo, el insecto mira a la vez hacin arriba y abajo, hàcia delantc y atrás, segun lo demucstra la mariposa, que no se deja sorprender sea cual fuere cl hado por donde el cazador se acerque. Til don de esta vista multiplicada explicase por la estructura del ojo del insecto, que se compone de un nímero sorprendente de ojillos, cuya superficie presenta como un exàgono regular, si se examina con un microscopio de poco aumento. Por lo regular su nómero varia de dos mil à scis mil; algnuas especjes tienen mas, y otras nuchos menos; en las hormigas solo se cuentan cincuenta; su conjunto forma els cada lado de la catbeza un solo ojo, al parecer, compuesto ó reticular, mas ó menos abovedado, a veces saliente en forma de hemisferio. Las borries de los ojitos ó facilas ofrecen en algunos inscetos la forma de prominencias regulares en la nentbrana córnea que cubre el todo; si estos bordes están provistos de pestainas, el ojo parece peludo. Debajo de cada faceta hay una especie de cono trasparente, rodcado en su parte inferior do una capa de color y de fibms nerviosas; todos los conos estain unidos por sus puntas y reunen sus fibras nerviosas en who solo que se dirige hácia el llamado cerebro: del diámetro y de la convexidad de la membrana córnea y de la distancia de esta hasta la retina, con su nervio óptico, depende el desarrollo de las facultades visuales de un insecto. Las copas de color que.à veces se hallan en el interior producen el magnifico brillo externo que se observa en muchus de estos ojos, pero que por lo regular desaparece con la mucrte del animal. Los ojos reticulares ocupan uma porcion mas ó menos grande de la superficie de la cabcza; á menudo están sesgados cn su parte interior en forma de riīon y divididos con mas ó menos exactitud, por una placa de la frente, en dos partes, la inferior y la superior. Muchos insectos tienen además de los ojos grandes, compucstos, otros pequenos sencillos, llamados cjuelos ó estemas (acelli, stemuta), y algunas especies solo cestán provistas de cstos últimos. En el primer caso estàn reunidos casi siempre, en numero de tres, en un arco plano 6 en un triaingulo: à veces hallanse por pares y con muy poca frecuencia aislados entre los bordes superiores de los ojos compuestos; exteriormente aseméjanse hasta cierto punto à una perla blanda partida por el platero y engarzada: en la estructura interna se ohserva casi lo mismo que hemos dicho sobre los conos que 
forman el ojo grande. Pocos insectos completamente desarrollados tienen solo ojos sencillos y es muy reducido el número de los ciegos. A esta categoria pertenecen algunos coleópteros que pasan su pobre vida en el interior de las cavernas ó cubicrtos por las rocas.

ANTENas. - Las antenas (ankenne) se consideran como ef par superior de los apéndices articulados, pues se insertan en los lacios ó en la parte anterior de la cabeza, mas arriba ú mas abajo, a menucio un el segmento de los ojos. Compo. nense de mityor ó inenor número de partes ó artejos, ofreciéndonos la primera prueba de la belleza de formas tan marcada en los insectos, y yue por todos estilos tendremos ocasion de admirar mas adclante. Sin ocuparnos con mas detencion de la variedad, debemos añadir que el artejo principal difiere de los otros por su grueso o longitud, y constituye bajo el nombre de trome el contraste con los que forman en su conjunto el lifligr ó maso. Ias partes de este pueden ser iguales en su formacion ó diferir, afectando la figum de peine, de absniro, de horon mas ó menns compacto, de porm, etc. En las antenas rectas puede decirse que todos los artejos tienen el mismo cje, mientras que en las angulosas, los correspondientes al latigo encrjan formando àngulo con el tronco, casi siempre prolongado, de lo cual resulta la semejanza con un látigo; $a$ esto se deben tambien las designaciones especiales que acabamos de indicar. Mientras que en algunos insectos las antenas son tan pequeñas, que una vista poco ejercitada no las distinguiria, en otros son varias veces mas largas que todo el cuerpo.

Los naturalistas no estan conformes aun sobre el objeto de las antenas, pero no cabe duda de que las mas desarrolladas sirven para uno de los sentidos, proporcionandu al insecto cierta percepcion del mundo exterior. En la mayoria de los casos sirven probablemente de órgano del tacto, como lo indica su nonibre aleman (fuchler); los continuos movinientos del tacto ó el vuclo de los insectos se hacen menos seguros cuando se lés cortan las antenas. En ciertas especies las antenas hacen las veces de órganos del oido y del olfato, sobre todo en las mejur totadas Errichson, que examinó con el microscopio un gran número de estas formaciones enigmáticas, encontró por lo regular en ciertos artejos, sobre todo en los terminales 6 en sus apéndices filiformes, unos orificios mas $\delta$ menos grandes, aislados ó reunidos en forma de taniz, $y$ detrás de cada uno una membrana estirada, rodenda de un corto filtro de espesos pelitos. Dicho naturalista cree haber reconocido en esta estructura el órgano que corresponde. a la nariz de los victebrados. lin efecto, dque observe una avispa cuando busca en la madera de un vicjo tronco la larva oculta à que şuisicra confiar sus huevos, podri deducir de su inteligente procecier, que esta avispa elfulea con las puntas de sus largas antenas todos los agujeros para encontrar lo que necesita. I.os machos de muchas mariposas buscan desde muj lejos sus hembras escondidas, alargando las antenas y arqueaindo. las mientras vuelan presurosos: y seguramente solo el sentido del olfato les permite hallar la liuclla buscada. Las abejas comunes y otros insectos parecen conversar por medio de sus antenas en un lenguaje incomprensible para nosotros: La observacion basta, empero, para révelamos, de qué puede servir la cerda corta y sencilla sobrepuesta en algunos artejos cirminales de otros insectos, como, por ejemplo, las cigarmas y libélulas. Iandois, al contmrio de Erichson, ve en la hoja fmal de las antenas del ciervo volador el órgano de! oida. Es condicion propia del organismo inferior que las funciones que en los animales superiores se desempeñan por dos úrginos distintos puedan prerenceer á uno solo. ó aun faltar conjpletamente, y por orra parte, no poclemos permitirnos expuiparar el organismo de nuestro olfato y oido con el de los insectos, cuya estructura difiere tan esencialmente. Por eso opino que seria muy natural que las antenas correspondieran en unas especies à las orejas, si tales órganos necesitan; en otras a la nariz de los animales superiores; y quizais en no pocas ni i las unas ni a la otra. Terminemos con esto las consideraciones sobre los órganos y sentidus de los insectos; pues lo que aun pudiern decirse de ellos no tiene nada de comun con la cabeza, siendo además de naturaleza tan especial, que me parece mejor tratar el asunte al hablar de las diversas especies.

Bocs. - Las partes de la boca ocupan la extrcmidad an. terior de la cabeza, y haremos ahora una breve descripcion de ellas. En medio de la gran variedad de formas distinguen. se como priucipales los órganos propios para mascar, y para clupar: los primeros son propios para triturar un alimento sólido; y los segundos sirven para recoger materias liquidas, lo cual no quiere decir que los çue mascan no puedan absorber tambien liquidos. Además del labio superior ó lalira (la(rrum) (o, figs, 1 y 9), articulado en forma de hojita en el borde anterior de la cabeza ó episfomo, aunque tambien puede estar soldado con él, las partes de la boca propias para triturar se componen de tres pares de piés articulados, trasformados en órganos de masticacion y llamados mandibulas, que se insertan en los tres viltimos segmentos de la cabeza. Mandibulas (mandibulce) (d, figs. 1, 2 y 5 ) se llama al primer par no articulado, que se inscrta en ia extrenidad de las mejillas libremente y cuyas dos mitades pueden moverse en pusicion horizontalmente opuesta, como los brazos de unas tenazas. Cada mitad de las mandibulas es comparable, segun su forma, con un azadon, una pala, un cincel, etc; sucle ser.córnea (de quifirsa), :uguda, puntiaguda if obtusa, denticulada sulo en sa parte anterior ó a lo largo de todo el lado interior. Por lo regular ascunejanse entre si, pero tambien puede su. ceder que la una sea mas grucsa quue la otra; mientras que en el ciervo volador macho sobresalen de la cabeza como unos cuérnos mucho mas largos que esta misına, amenazadores y peligrosos al parecer, pero inútiles para mascar, eri muchos de sus congéneres se ocultan debajo del labio superior ý rematan hacia adentro en forma de piel delgada, siendo impropios igualmente para la masticacion del alimento. En el mc. lolonta vulgar y en otras uspecies de su género que se nutren de hojas, las mandibulas estan ocultas tambien, pero tienen anchás superficies para triturar, semejames a los molares de los rumiantes. En muchos insectos, sobre todo en los tiplópteros y abejas, esos golosos que solo gustan de los dulces, las mandibulas estan por lo regular nuy desarrolladas, jero no sirven pam la masticacion del alimento: solı úrganos indis. pensables para construir los nidos, para el arreglo y trasjorte del materini y para recoger el alimento, aunque no tanto el propio como el dé la cria.

Se llaman maxilas ó mindibula inferior (nin.rilla) (r, figs 1, 5,6 y S), al segundo par articulado, comunmente mas blando gutue el primero, igual en algumas especies, for cjemplo, en las libélulas, y mas duro en otras, como en los geotropinos. Fncada una de las initades, siempre siméricas, a dercecha é izquierda de las maxilas, distinguense mas of menos bien las siguientes partes: una picen trasversal corta, llamada ruicio ( $f$, figs. 4,7 y $\$$ ), por medio de la cual la maxila se inserta en el lado de la garganta un poco mas abajo ye detrás de la mandibula superior: el quicio puede tener forma triangular ó prolongada, y es casi siempre córnco. I a pieza siguiente, el tronco ( 5 , figs. $2,4,6$ y 8), se articula en el (quicio formando un ángulo recto, y es por lo regular una hoja cormea, cuya longitud puede cxceder de una Y media à seis veces la del diametro trasversal; en las abejas parece un peine, poryue su borde interno esti cubierto de espesas rerdas. En el interior del tronco estan los firmolus, 
cuyas partes se distinguen tambicn bajo el nombre de órginos masticadores: cuando están provistas en la punta de dientes ó espinas, igualan en durcea á la mandíbula, pero de lo contrario son blandas y membranosas. Esta última parte prepara el aljmento antes de ser comido, y constituye por lo tanto el órgano principal de las maxilas; puede constar solo de un lóbulo ( h, figs 1 y 3), como sucede en muchos colé́pteros, en las abejas y otros, siendo muy larga $\delta$ en extremo corta; pero mas á menudo se compone de dos $\left(h / h^{2}\right)$, uno superior, situado mas haicia afuera, y otro inférior mas hácia dentro. Obsérvansc tambien las proporciones mas diversas respecto a su disposicion y forma y á la manera de insertarse en el tronco. Asi, por. ejemplo, el lóbulo inferior pende en ciertos colépipteros en toda su longitud, en el lacio interior del tronco (fig. .7) ó ambos están situados unó junto á otro en la junta, camo sucede en los tentredinos(fig. 4); obien se hallan sobrepuestos, insertindose sin embargo cada cual en el tronco, como por ejemplo los lóbulos mémbranosos del ciervo volador. En las langostas (fi. gura 8), cl supcrior se adapta a modo de casco sobre el inferion. Son por demás singulares las diversas proporciones observadas por éste concepto en tres grandes tamilias de coleópteros, que se han clasificado como carnivoros (cicindélidos, carabicidos y dicticinos). En estos el lóbulo cxterior sc trasforma en un cuerpo biarticulado filiforme $(h$, figs. 5 y 6$)$, de la misma naturaleral de un palpo de que a continuncion trataremos. Tambicn la cuibierta de los lóbulos cstí sujeta á muchas sminciones. En ciertas especies, un espeso conjunto de cerdas trasforma toda li parte interior en un cepillo, ó el borde en un peine, y los pelos pueden estar solo en la punta, ó faltar del todo; en ver de estos, bien sean blandos ó rigidos, algunas especies tienen dientes, prominencias movibles ó fijas formadas por escotaduras en el cuello. Los cicindélidos se caracterizan por un diente movible en forma de garm en la punta del lóbulo; las voraces langostas y las libélulas ( $r$, figura 6) tienen varios á lo largo de todo el lado interior. En la extremidad del tronco ó muy cerca de aquella insértanse hácia afuera unos úrganos del tacto, compuestos de uno a seis artejos, llamados palpos maxilares (falpus maxilaris) (i, figuras 2 y 8). I a longitud reciproca de los artejos, y sobre todo la forma de los mismos, ofrecen muchas diferencias.

El tercer par de piés articulados, en fin, forma la segunda mandibula inferior, que soldada, ó cuando mas escotada en la linea central, representa una pieza sencilla, llamada labio inferior (labism). La separacion de ambas mitades de otros artropodos demuestra que debemos considerar como segunda mandíbula este labio inferior, segun se observa por cjemplo, en los cangrejos; demuéstralo además la profunda escotadura dcl mismo en muchos coleópteros y en las langostas y tambien la presencia de dos palpos, llamados latiales (r, figs. I y j). compuestos de dos á cuntro artejos, casi siempre mas cortos que los palpos maxilares y que se insertan en el borde anterior ó mas cerca del labio inferior. En las abejins estos palyos se llaman uniformes cuando sus artejos igualmente formados se enfilan del modo ordinario con sus puntas ( $\epsilon$ fig. 3 ), y dáseles el nombre de biformes ( $c$, figs. I y 2 ), si los dos artejos de la base forman escamas largas y estrechas, mientras que los dos últimos se insertan lateralmente ó junto à la juunta del segundo en forma de dos lobulillos atrofindos. I a jarte posterior córnea del labio inferior, llamada bartia (mentum) ( $a$, figs. 2 y 5 ), se distingue de la lengriesa ( $\delta$, figs. 1 y 4 ), que es membranosa y esta mas ó menos desarrollada, hallandose delante ó sobre aquella. La barba ofrece varias formas; con frecuencia es mas anchaque larga; y prescindiendo de las diferencias de su parte anterior, tiene a menudo una figura casi cuadrangular en varios insectos, entrc ellos las abejas ó autofilas Ta longitud excede mucho de Ia anchura y entonces la barba rociea los lados de la lengüeta casi ell forma de tubo. Esta última esta, ya sobre la barba misma, sin sobresalir de ella, como en la mayor parte de los coleópteros, 6 bien se prolonga mas, cuando no se inserta del todo libre en el borde anterior de la nisma. En los casos en que no es necesaria para tomar el alimento, ó lo es muy poco, apenas se distingue; pero cuando su desurrollo es regular, su parte anterior se redondea, $\delta$ es mas $\delta$ menos escotada, ó bien está provista de tres lóbulos como en los tentredinos (fig. 4), 6 itvispas. A su major grado de perfeccion llega en las autófilas, aficionadas á la miel, pues á menudo la tienen mas larga que todo el cuerpo; su extremidad se halla provista de pelitos, à los cuales se adhicre la miel para poder introducirla en la abertura de la boca; compónese de tres lóbúlos, de los cuales los de los lados se distinguen bajo el nombre de lóbulos laterales de la lenguieta (b); los tres son casi iguales en las abejas falsas; y los de los lados rodean el central, que afecta la forma de faja en su base; de modo que todo el brgano de lamer ofrece casi el aspecto de una espiga de trign eu Anr ron sus fibras y su pólen.

Ia fuerza que estos pequeños séres desarrollan en los órganos masticadores es tan admirable como perniciosa parn el hombre. Recordemos las devastaciones ocasionadas por unos insectos de $0^{\circ}, 00_{4}$ de largo co las vigas de nuestras casas ó en los arboles, que en una extension de miles de hectáreas han perecido por sus dientes, y aun perecen ahora (I 875 ) en la Selva de Bohemia. Al que quiera formarse una idea de csa fuerza mandibular le bastará poner un dedo en la boca de un ciervo volador macho, y si desea ver correr la sangre, coló quelo entre las cortas tenazas de la hembra. Hasta un metal, como por ejenjplo el plomo, no puede resistir tales dientes. Conócense varios casos en que las vigas habitadas por larvas de este insecto se emplearon revestidas de plomo en fábricas de vitriolo, y al llegar la hora en que los insectos ciebian gorar de su existencin alada, à cuyo efecto les era preciso primeramente salir de su oscura carcel, despues de la madern, y por último de la capa de plomo, consiguiéronlo al fin con sus pequenos dientes. lin mi coleccion de insectos tengo uno de estos liéroes, que es el sericino comun (sirex jurencus), nacido bajo una plancha de plomo en Freiberpo.

los órganos chupadores de la boca ofrecen el aspecto de umas mandibulas, pero tan trasformadas que es improsible reconocerlas; mas á pesar de ello, y por grande que sea su variedad en cada uno de los órdenes, puede hallarse una analogia con los órgnnos masticadores de la boca. En las chinches, pulgones, cigarras y áfidos, es decir en todos afuellos insectos clasificados à causa de la forma análoga de la boca bajo el nombre de hemipteros, la trasformacion parece un pico (fig. 9). Fil tercer par de maxilas $v ́$ el labio inferior de los masticadores forma aqui un tubo de tres ó cuatro artejos, susceptible de acortarse por medio de una curvatura fija que se ve en la mayoria de las uspecies. Este tubo es el estuche ó la araik, yue contiene en su reducido hueco cuatro cerdas finas muy oprimidas entre si, correspondiendo cada dos a las mandibulas y a las maxilas. De este modo el insecto posec un aparato propio para chupar, pues introduciendo la punta de las cerdas en cuerpos animales ó vegetales, puede extrace el jugo alimenticio. Una hojita cómea. estrecha y triangular, que se inserta en el lado superior de la base de la vaina (1), corresponde al hbro; solo en algunas especies se han encontrado rudimentos de los palpos labiales. El pico 6 chupador, unas veces tan largo como la cabera y otras como el cuerpo, se apoya en la superficie inferior del tórax durante el reposo; mas cuando el insecto se sirve de él levantase en ángulo recto ú obtuso segun convenga, $y$ cuando es corto, grtieso y encorvado hacia abajo, algumas especies no pueden cambiar su direccion. 
Lis estructura del chupador ó de la trompa, segun se ha llamado este órgano en las moscas y en los mosquitos, no es muy complicada, a pesar de la gran variedad de sus formas. En su completo desarrollo se compone del labio inferior, que cierra la boca por debajo (a, fig. II) y que en la major parte de las especies se prolonga bricia adelante, siendo angular carnoso pira poder adajtarse mas ó nuenos al hucco de la buca. En la majoria de casos representa la parte mejor desar. rollada de todo el órgano. Cuando como por ejemplo en nuestra mosca comun, el labio inferior remata en uná superficie absorbente, es decir, en dos anéndices carnosos, situados uno junto $\mathfrak{d}$ utro, y que semcjantes à un martillito se insertan cumo en un mango, todo el órgano se llama trompa chupado. ra (fig. 31), y sus demás partes, excepto los palpos labinles, suelen atrofiarse mas ó menos. Frente al labio inferior estri el superior, casi siempje córned, y entre ambos se ven las utras picans, es decir los dos pares de masilas y la lengüeta (b) en forma de cerdas; los labios afectan a veces tambien la forma de cuchillos; pero raras veces alcanzan su complezo desarro110. Las cerdas de la boca pucden picar seusiblemente, segun nos lo prueban los mosquitos y los tábanos; a la vina puntiaguda le faltan entonces los apéndices chujuadores, y jor eso se ha distinguido esta forma de la primera bajo el nombre de trompra ficadorr. Los palpos labiales, compuesios de uno ai cuatro artejos, y que por su forma, color y demás condiciones sirven de excelentes caractéres distintivos, se inscrtan

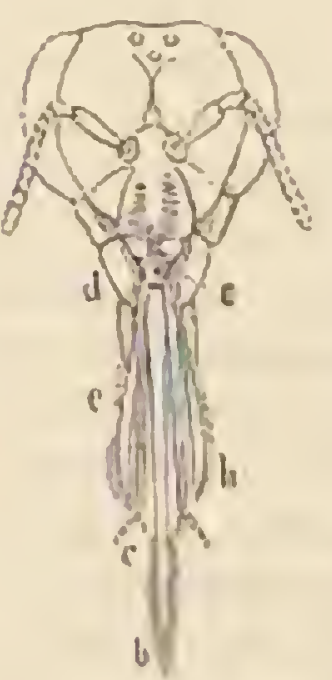

li

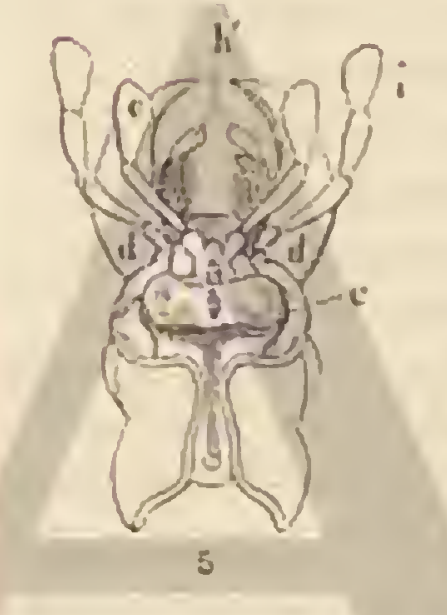

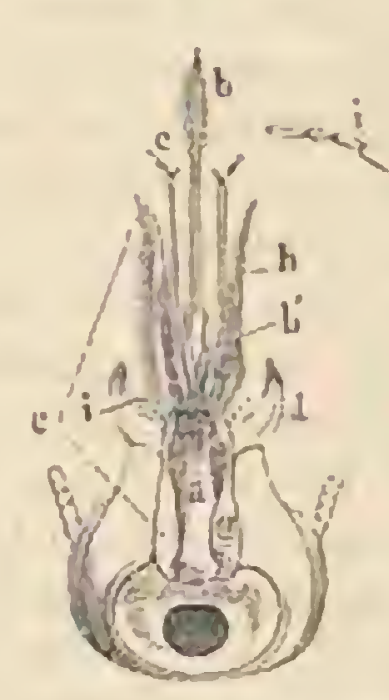

3

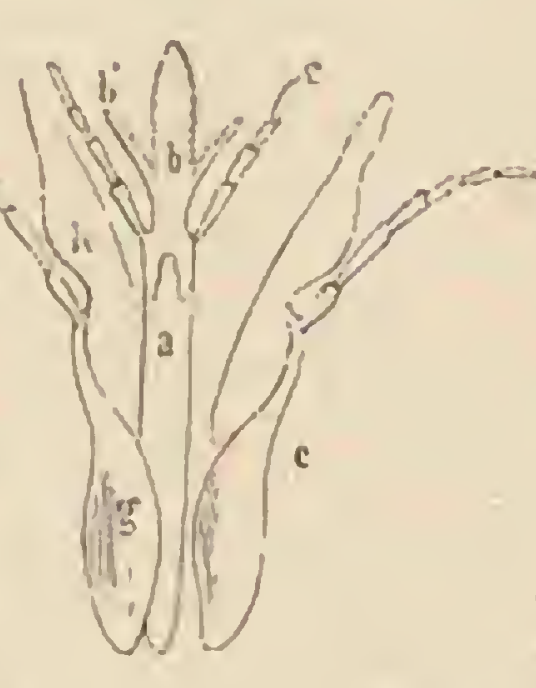

$\omega$

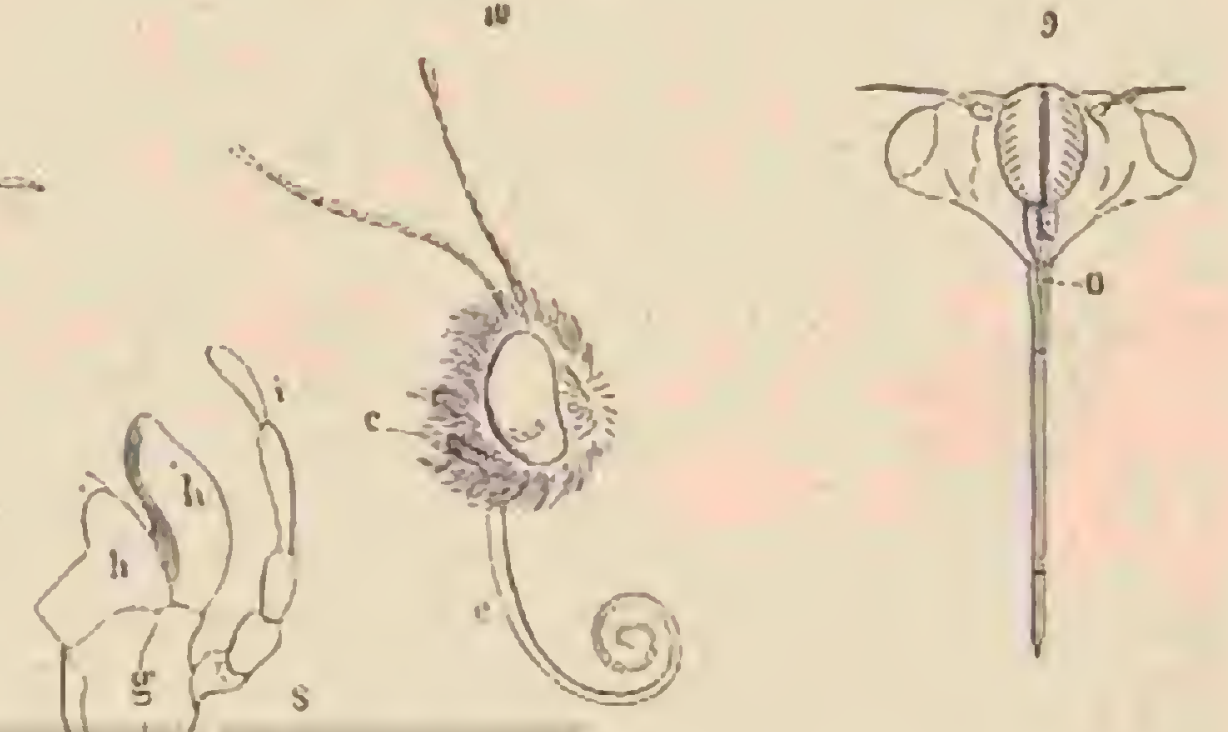

hácia arriba en la basc del latrio incerior, ja mas cerca de la abertura de la beca, 6 bien mas distante de ellil (e).

En las mariposas, en fin, cl labio superior $y$ las maxilas se atrotian del todo. Inmediatimentc debajo del escudo de la cabèa resalia una especie de cinta, mas corta ó mas larga, dura ó blanda, que en estado de reposo se enrosca como el muelle de un reloj; sirvele de apojo en su parte inforior el pequeño labio inferior en forma de lóbulo, y enciérranle en los lados los palpos del mismo, compuestos de tres artejos. Por consiguiente en este caso liw mandibula inferior solo está destimada à provecr á la mariposa de su alimento en forma de miel y gotas de rocio, y por lo tanto no parecen bien elegidos los nombres de lengut snroscalis of trompla chufindora con que se le designa. En cicrtos microlepidópteros se obser. ian variaciones poco imponantes de esta estructura, y sobre

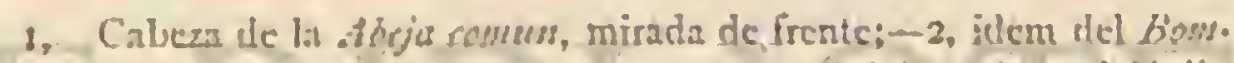

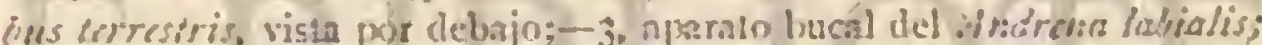

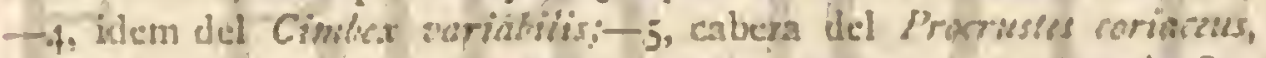

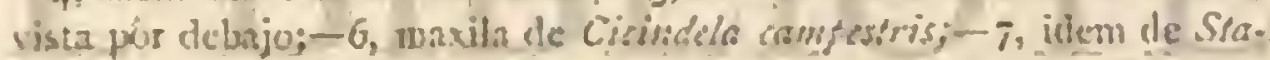

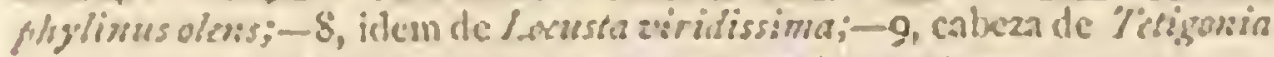

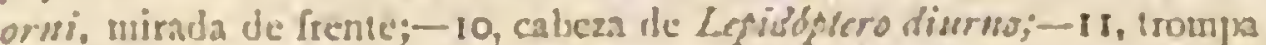
de Tachina srosses. - Tollas cet:is figuras cstán aumentalas considerablenente.

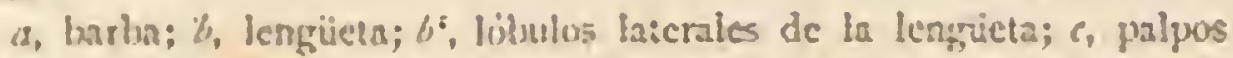

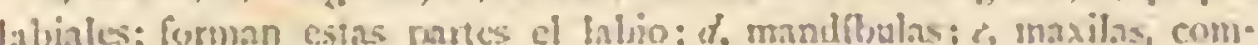

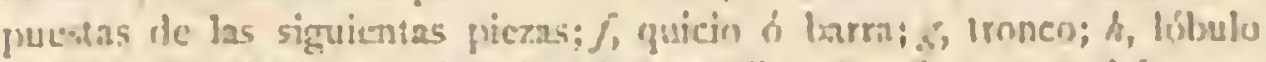

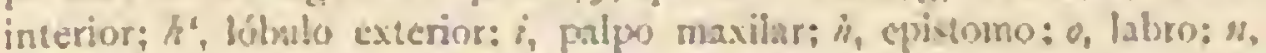
licnse meivil en la cxtremidad del fóbulo maxilas interios. todo cxistin en ellos tambien una cspecic de palpos maxilat res, llamadios palpos secundarios.

Tokax 6 coslilart. - El segundo grupo de los segmen. tos ó anillos del cuerpo forma el pecho, llamado tórax o cosclete, donde residen los úrganos del movimiento. Compónese de tres segmentos, llamados profirnax, con el par :unterior de patas; mesntórax; con el segundo y las alas anteriores en el caso de que existan los órganos del vuclo, y melufirux; con las patas y alas posteriores. Segun la conformacion. éstos tres segmentos estin desarrollados do distinto murlo, y el uno es casi sienupre mayor yue los otros. Ln muchos insectos el segmento anterior prepondera, en cuyo caso se inserta libre y es movible en el segundo, formando al parecer por si solo el tórax ó parte central del cuerpo cuando se ve el animal desde arriba (coleofntcros, chinches y lamgostas). A un protorax libre, cuya partc superior sucle liamarse escudo del cucllo, corresponden fuertes alas anteriores, denominadas clitros, y compensit con abundancia lo que ha perdido el animal en movilidad en los últimos. Como el centro del bordé posterior en el lomo resalta de sus partes inmeciatas como una conformacion especial, casi sicmpre triangular, que se distingue por un color y brillo particulares, esa jarte ha recibido el nombre de escudete (scutellusms), y a cel corresponde el escudele pusterior (postscustellums) cn el centro del borde anicrior de la parte posterior del lomo. Debcmos aniadir, sin embargo, que la suposicion geneml de que haya tres sugmentus en el tórax no es tan poco exacta romo de lo dicho parece re. 
sultar. Un antiguo estudio anatómico, olvidado hacia mucho tiempo, pero que se examinó de nuevo en nuestra época, ha demostrado que en muchos insectos (coleópteros, himenópteros y langostas) un llamado artcjo intermedio se inserta intimamente, como mitad superior de un cuarto segmento del tórax, en la parte posterior del lomo; mientras que en las moscas, hemipteros y libélulas forma un segmento cerrado tambien hícia abajo y perteneciente al ablómen; de modo que en estos últimos el tórax solo se compone de tres segmentos. En las mariposas tambien se considera como propio del tórax, si bien por la naturaleza de str conformacion parece pertenecer mas bien al abdómen.

Junto à las antenus y las mandibulas seis yiernas ó patas constituyen las extremidades de los insectos. Estas extreundades son las verdidems ibdominiles, segun se las designa, parn tódos los artrópuclos, a jesar de que en los instectos numca se insertan en el abdómen sino en el túrax. Cada pata de insecto se compone, à contar desde la base, de anca, trocinter (trockanter), femur, tibia y tarso. El anca (coxa) es el artejo siempre corto; que libre ó encerrado mas 6 inenos en el hueco de la articulación, media la comunicacion de todo el órgano de movimiento con el tronco. El trocanter reune, en forma de anillo sencillo y doble, proporcionalinente pequeño, el costado con el muslo imprimiendo la direccion y comunicando sin duda tambien la facultad de moverse a este úlcimo. Eil muslo (femur) forma por lo regular la paste mas robusta de toda la pata, sobre todo en la region posterior, en los insectos saltadores La pierna (rilia) suele tener la longitud del muslo correspondiente; aumenta en grueso poco a poco descle la articulacion, y està provista muy à menudo en cl lado interior de su extremidad de unas espinitas movibles, es décir de dos llamados espolones, ó solo de uno; mientras que el lado extcrior tiene con frecuencia en toda su extension dientes, espinas ó cerdas, fijas. El pié, en fin (tarsus), se compone de artejos cortos unidos entre si por medio de articulacione's, la última de las cuales termina en dos garris 6 garfos movibles ó a veces en una garra sola. lir ln mayor parte de las especies el múmero de cstos artejos es igual en tocias las patas, no excédiendo nunca de cinco; pero se dan algunos casos en que las patas posteriores tienen menos artejos que las anieriores. Ia uña rudimentaria y las llamadas brochas, unos lóbulos membranosos que hay entre las garras, comuni. can en muchos casos mayor seguridad i la marcha, y sobre todo la facultad de trepar por los objetos mas lisos, como por ejemplo los cristales de-las ventanas. Ln ningun insecto son iguales los tres pares de patas hasta el punto de que se pudiera confundirlos uno con otro; el anterior y el posterior están sujctos á diferentes variaciones, pues aquel esta destinado jara escarbar ó coger la presa, y estc para saltar ó nadar, segun to exija el género de vica del insecto.

Lis alas aunque son igualmente órganos de locomocion, no pueden clasificarse como las patas intre las apófisis 6 excrecencias del esqueleto membranoso, sino que deben consi. denrse, por extrano yue parezca, como órganos respiratorios trasformados, pues se ha reconocido, por lo menos en las mariposas, que los rudimentos de las alas se hallan ya en el segundo y tercer segmenios, debajo de la piel de la larva pequeña, y que además de la red de quitina, unos canales respiratorios cruzan la picl. Las cuatro alas, de igual conformacion, casi siempré de piel delgada, cruzadas de venas de quitina, ó bien las anteriores, se trasforman del todo en una masa de dicha sustancia, aciquiriendo una naturaleza compacta y que las impide ser órganos del vuelo: llamanse estas alas cubicrtas ó clitros (elytra), porque cubren y protegen las alas y partes posteriores del cuerpo. En las alas membranosas las venas ó nervios sirven de esqueleto y encierram á me- nudo entre si unos espacios eri la superficie del ala, llamados celdas. Los dipteros solo tienen alas anteriores; a muchos coleópteros les faltan las posteriores y no pocos insectos carecen de alas.

Amdómrix.-El abdómen, en fin, tercera jarte principal del cuerpo de los insectos, se compone de tres á nucic segmentos; aunque el número normal es de once, raras veces llegan ál, porque los dos últimos se reunen con la extremi. dad en el intestino grueso; si el número baja de nueve, los anillos que faltan, $\delta$ se han atrofiado ó están cubiertos por los immediatos; pueden haberse convertido en ubbos, aguijones, tenazas if otros apéndices, de los yue los impares suelen ser el caracter distintivo para el sexo femenino. Mejor que en ninguna otra parte del cuerpo juede reconocerse aqui cómo se compone cada segmento de una escama dorsal y otra abdominal, unidas entre si y con los segmentos contiguos por medio de membranas elisticas, de modo que el esqueleto meimbranoso del abdómen es susceptible de una gran extension, como se observa, jor ejemplo, cuando en las liembras se dilata el ovario. Ademas el dorso es de piel blanda en todós ayuellos insectos que tienen elitros. Prescindiendo de la forma determinada del abdómen, la manera de insertarse en el tórnx contribuye esencialmente à la forma del in. secto. Cunndo toda su cara anterior se adhiere intimamente allit posterior del tornx, como sucede, for ejemplo, en los coleópteros, se le llama soldado; este abdómen pareceria formar un todo con el tórax, si este no apareciera como tal, por la presencia de las piernas. En todas las especies en que no existen elitros, el abdómen se scpara marcadamente del tórax por medio de una estrechez llamacia pediculo ó pecciolo; cuando está reunido con él por una línea trasversal se le llama sentado (pimpla); en el ciso de que no se adelgace hacia adelante, como sucede en la abeja comun, se dice que estŕ suspendido en un punto, $\delta$ cuando en su base se estrecha en forma de mango mas $\delta$ menos largo, çuc esti provisto de tallo, segun se observa en los bombilidos. De este modo se ven insectos con una cintura tan delgada y graciosa que apenas se comprende como no se rompen, mientras que en otros falta del todo; entre estos dos extremus se observan to. das las formas de tránsito posibles, designadas de un modo poco concreto por palabras.

Eil esqueleto membranoso del cuerpo de losinsectos, con sus apéndices, de los cuales depende el nspecto exterior de cada individuo, ofrece una variedad extraordinaria, prescindiendo de la forma y de las proporciones de cada uma de las partes, del número de las mismas, sen 6 no completo, de la dureza y figura consiguiente de superficie, y hasta del color y de la cubierta. Pelos, escamas, aguijones y espunas, todo compuesto de quitina, cubren una ú otra parte; Ias tres primeras formaciones se extienden á menudo por todo el cuerpo de tal modo ryne la piel queda oculta debajo, en cuyo caso dichas formaciones producen tambien el cambio de colores. No solo las mariposas deben a las escamas de sus alas el magnifico brillo de sus tintes, sino que tambien los colcópteros y utros insectos, sobre todo los que pertenecen á la zona tropical, ostentan por medio de una capa de escamas ó de pelitos el mas puro color de oro y de plata, el de las esmeraldas y otras piedras preciosas. Ias cscamas no se hallan tan soldadas a la piel como las otras cubiertas, y por lo tanto es posiblé tque una parte de ellas se pierda con el tiempo, desfigurando al insecto de tal modo que apenas se le reconozca. Pero tambien la misma piel en que predominan los tintes oscuros presenta a veces los colores mas abigarrados, ya constantes $\delta$ inviariables, bien pasajeros, y mas pálidos despues de la mucrte, tan lue go como in sustanclit grasosa ú ucras cualidades yue desapat recen cuando sucumbe el individuo, influyen en la coloracion 
como sabe todo coleccionador de insectos. I.os aguijoncs y las espinas, los mas sólidos de esos adornos se hallan sobre todo en las piernas, y aisladamente como extremidades de una ú otra parte del cuerpo, contribuyendo muy poco it ia variacion de los tintes. los pelos 6 cerdas constituyen las cubiertas mas generales, y no faltan del todo en ningum insecto: las partes que no distingue la vista con el microscopio se llaman desnudas.

Músculos. - Los músculos, ó la carne de los insectos, carecen de color, $\delta$ tienden ligeramente al anarillento; compónense de hacecillos de fibras trastersales, y cuando solo sirven para la dislocacion de las partes del cuerpo cntre si, ó para la locomocion, forman un todo articulado que corresponde al espucleto exterior de la piel, con el que se sucldan ell su parte interior. 1.a reunion de los músculos en el tronco y un las extremidades se verifica segun la ley, al parecer de. ierminada, en virtud de la cual se efectún on un mismo músculo en dos articulos sncesivos y nunca saltando al siguiente. En los sitios en (jue se exige la fuerza motri\% mas fuerte, como, por cjemplo, en el tómx, para los órganos del vuelo y de la locomocion, hållase tambien el mayor número de músculos; en cl abdómen se inscrtan con preferencia en las pare. des del lomo y del vientre para la dislocacion de los segmentos.

SISTFMA NERVIOSO. - Respecto al sistema nervioso hemos hecho mencion ya en la prigiua primera del tronco principal, del cordon restral ó de la cadena de ganglios, cuya parte anterior, cl collar esofigrien, parece tener analogin con el cerebro de los animales vertebrados. Lebo ariadir que en los insectos los tres pares de ganglios del tórax son los mas desarrollados; por término medio hay, un ganglio por cada segmento del abdómen, y del superior del collar esofígico parten nervios, no solo hacia los ojos y antenas, sino tambien liácia las entranas; mientras que el ganglio un poco mas pe. queno inferior del collar esofígico emvia los suyos á las partes de la boca. Por lo demńs, los nervios situados entre los gan. glios se dirigen por torios los lados y en particular hacia los úrganos de la respiracion. Con frecuencia un segundo corcion sin ganglios acompania al cordon principal, situado inmediatannente debajo de él, y a veces hasta se ha creido distinguir cuatro cordones, pero cuanto mas se generaliza el estudio anatómico, tantas mas variaciones se observan en la estructura. En la distribucion igual de los nervios por todo el cuerpo debe buscarse indudablemente la causa, porque ningun insecto mucre al punto por la separacion de una ú otra parte principal del cuerpo, observindose que los grupos aislados de segmentos siguen dando señales de vida, por sus convulsiones, mucho ticmpo despues de la separacion. $\Lambda$ si,-por cjemplo, la mitad anterior de un grillo-talpa vulgar, partido casualmente por un azadon, no dejó de agitarse hasta des. pues de haber trascurrido ochenta y dos horas, y la mitad posterior se movió pror espacio de ciento ocho.

ORGANOS DF LA DIGESTIOx.-Estos órganos, muy sencillos, constan de un canal que se corre desde la abertura de la boca, trazando varias circunvoluciones hasta el ano, a causa de las cuales pucde llegar á ser dos 6 tres veces mas largo que el animal, y en ciertas especics alcanza mayor longitud aun. Di. videse este canal en cuntro partes: la anterior, llamada esófa. go, llegra hasta el centro del tórax y a veces al abdómen: es muy estrechn en las especies que solo se alimentan de liquidos, mas anchn en las masticadoras; en estas se observa tambien hảcia la catremidad una dilatacion en forma de bolș, ó en otros iérminos, un buchc. Ein la segunda parté la sustancia alimenticia sc irnsforma en el jugo necesario para la nutri. cion (chy/us); y en ciertos casos las parcdes interiores están furovistas de dientecitos ó glandulas que facilitan la digestion.
Aunque dicha parte del canal alimenticio desempeña asi las funciones del estómago en los animales superiores, no pucde sin cmbargo compararse con él, y con møon se niega la existencia de cstóningo en los insectos. En la extremidnd de la segunda parté del canal alimenticio hállanse en todos los insertos unos tubos sencillos, á veces ramificados y serponti. nos, llamados insos friliares, que vacian su contenido en el canal, desempeñando en la digestion las funciones de la hicl, hignda ğ riñones de los animales superiores, sin ser anślogos i ninguno de estos órganos. Ia tercera parte del canal alimenticio, Jastante corta, tiene un intestino ciego; sirve de conductor \& ln sustancia alimenticia (chrmus) y se designa por lo regular con el nombre de intestino delgado; mientras que el intestino grueso en union con el reccro, que forma la extremidad del canal, da paso à los excrementos del cucruo.

VAsOS DE la SANGRF. - Los vasos de la sangre, poco des. arrollados, se componen, segun Sicbold, de un viso dorsal contráctil que ocupa el lugar del cornzon, y de una gran artcria (aorta), yue conduce la sangre del corazon al cuerpo. El vaso dorsal, dividido en muchos compartimientos igunles, ocupa siempre la linea central del abdónien y' se inscrta en el dorso de los segmentos por medio de cierto número de músculos triangulares; sus paredes se componen de fibras longitudinales y trasversales y estån provistas además de una membrana delgada, que en los sitios estrechos forma una cs. pecie de válvulas, a lo cual se debe que el vaso dorsal se componga de tantos compartimicntos como estrecheces hay. Cacla uno de ellos tiene en ambos lados de su borde anterior una henaidura que puede cerrarse interiormente por un replicguc. La sangre que wuelre del cuerpo se reune en las re. giones mas próximas al corazon, penctrando por las hendidums laterales en los compartimientos que a interialos regu. lares se contraen de atrás hicia adelanze, impelienclo asi la sangre a la aorta con ayuda de las válvulas. Fista forma solo la continuacion del compartimiento anterior del corazon y se corre en forma de tubo estrecho y sencillo por delajo del tórax hácia el cerebro, donda remata en una sola abertura ó se divicle en cortas ramas. Ia longitud del vaso dorsal depende de la del abdómen, y por lo tanto, es variable; pero el mímero regular de los compartimientos del corazon parece ser de ocho. Cuando la sangre ha salido por delante cxtiéndese por el cuerpo en corrientes regulares, y libremente, dirigiéndose hảcia las antenas, alas, piernas otras extremidades; despues vuelve a todas jurtes como sangre venosa $y$ se reune al fin en dos brazos pirincijonles que la conducen hácia los repliegues laterales del vaso dorsal, por medio de ellos hácin este mismo. En su cirrulacion se mezcla con los nuevos-liquidos nutritivos que salen de las paredes del camal intestinal. I a sangre no tiene por lo regular color; en algunos insectos es amarillenta ó verciosa, y solo en muy procas especies roja En las orugas desnudas de mariposa los movimientos de la sangre en el vaso dorsal sc pueden reconocer muy bien sin microscopio.

ORGaNos [M: I.A RESTisacion-Con la sencille\% de los órganos que acabnmos de describir contrasta unn red de tubos llamados tráqueas (trachede) que se extiende por el cuempo atravesancio su interior cn todas airecciones; estas triquens, จุue en ciertas sitios se ensanchan en fornu de vejiga, tienen por objeto conducir el oxigeno del aire ó del agua a la sangre, y constituyen asi los órganos respiratorios. Hallanse dispuestos en dos cordones jrincipales, reunidos entre si por una especie de puente yo situados uno a cada lado del cuerjo, desde donde sus ramificaciones se exienden en figura de red por todos los lados. De los cordones principales parten unas ${ }_{n}$. mas cortas y gruesas que dirigiéndose hábia aftiera sirsen parn establecer por meclio de los estigmas (sfigminla) la 
comunicacion con el are amósferico. Los estigmas se hallan en los lados de la mayor parte de los segmentos; en el alydómen suclen estar en la membrana que une dos anillos próximos, situado unn de cllos en el lado izquierdo, y el otro, perteneciente al segundo cordon principal, en el derecho; de modo yue siempre se presentan pareados. El orificio de cada estigma, circuido de un anillo de quitina mas ó menos clevado sobre los bordes, puede abrirse y cerrarse á voluntad. I nss trácueas mismas parecen componerse de hilos espirales; pero minuciosas ohscrnciones permitienon reconocer que su piel intcrior produce este conjunto por efecto de ciertas dilaraciones en espiral de la masa de quitina. los ensanchamiencos en forma de vejiga, mas numerosos an las especies vola. doras, y que se asemejan a los huesos neumáticos de cicrias aves, no presentán tales dilataciones. Cuando el aire estra en cerrado en el cuerpo por efecto de ln contraccion de los cstigmas, los movimientos del cuerpo le liacen penetrar en al interior en todas direcciones: Ios estigmas se abren de nuevo, vuelven i cerrarse y continuan asi hasta que todas las traqueas estén llenas de aire. Los movimientos bien conocidós del melolonto vulgar antes de einprender el vuelo no tienen otro fin sino el de llenar el cuerpo de aire. Los inser. tos que viven en el agua suben de vez en cuando à la su. perficic para lievar i la profundidad una capa de aire por medio del filtro del abdómen, ó con la superficie del cuerpo apropiada al éfecto; otros tienen en ciertos sitios, sobre todo cuando se hallan en estado de larva, unos apéndices en forma de pluma, de hilo, ó de borla, llamados trígueos fromquiajes, que sirven para depósito del aire Estas träqueas sc hallan en los sitios en que los insectos aéreos tienen sus estigmas ó solo en la punta de la cola; en algunas especies se encuentrals en la region de la cabeza, ó bien se oprimen contra las paredes de los intestinos sin ser visibles exteriormente. Estos casos no cambian nada en la estructura de las triqueas; solo dan á conocer el diverso modo de llenarse estas: cuando se ciersan artificialmente los estigmas el insecto muere muy pronio asfixiado.

Voz. - Los mas de los insectos son mudos. Solo unos pocos producen sonidos que desde la antigüedad quisicron ya explicar los natumlistas, y que algunos poctas han celebrado en sus cantos. Homero compara los discursos de los héroes de su Jlicha con el canto de las cigarras, ye el del grillo pasa. ba entre los griegos por indispensable para los atractivos del verano.

Debe establecerse una distincion entre los sonidos que se producen por el frotamiento de ciertas partes del cuerpo, provistas de arrugas, listas y otras prominencias, y los emiti. dos por un verdadero órgano de la voz que se comunica con el de la respiracion como se observa en algunos animales superiores. In ciertos casos estos sonidos deben comprenderse como expresiones de la sensacion interna del animal: muchos colé́pteros dejan oir un ligero chirrido, sobre todo cuando sc les sujeta, $y$ este ruido se produce siempre por el frote de iarias partes de su duro cuerpo. Asi sucede en muchos capricornios, que frotan la parte anterior del borde posterior del tórax con el corro diente formado por el segmento medio de aquel y que encaja en ella; cn las necrófóros se cmite el sonido por el contacto de dos estrechas listas que hay en el centro del quinto segmento del abdómen con otra trasversal de la parte inferior de los clitros; en los peloteros prodúcese el soniclo por el irote del borde posterior de los costados, provisto de surcos irasversales, contra el dngulo agudo del tercer seymento del abdómen: en el criócero de las lilas por el roce del borde lateral listado de los elitros contra el punto correspondiente y granujiento que hay en el abdómen. A mas distancia se oyen los sonidos de las langostas; pero tambien estoś resultun solo del frotamiento de las piernas posteriores con las alas, $b$ de estas entre sí, sin que cxista ninguna relacion con los órganos respiratorios, como veremos mas tarde al describir dichos insectos. Las llamadas cigarras cantoras producen su ro\% que a menudo se asemejar is un tamborileo, valiéndose de un aparato bucal especial, que esti en comu. nicacion con algunos estigmas. En las abejas, bomtrix y sus congéneres, y cn las moscas zumbadoras influyen no solamente los movimientos rípidos de las alas y de sus múscu. los interiores, sino tambien unos apéndices en forma de hojas yue hay en el orificio de algunos estigmas, segun cxplicaremos mas detalladamente en su lugar.

ORGinos Grivirales. - Los órganos genitales se dividen en masculinos y feureninos en individuos separados: cuando se habla de hermafroditas entre los insectos entiéndese por esto unas monstruosidades que alguna vez se observan, y en las cuales, por cjemplo, la mitad izquierda corresponde á un scxó y la derccha al otro, hallándose en un solo cuerpo; tambien se comprenden los casos en pire existe una mezcla sexual de las martes del cuerpo de cualquiera otra manera. Si bien es dificil muchas veces pam la persona poco prictica reconocer ambos sexós en una nisma especie, á causa de su igualdad casi completa, no faitan por otm parte ejemplos de que ambos difieran de tal modo, que no dehe culjarse á ningun naturalista por haber descrito é introducido $\mathrm{cn}$ la ciencia el macho y in hembra bajo diversos nombres. Asi, por ejemplo, en rarios órdenes un sexo tiene alas, mientrás que otro carece de ellas, y el cuerpo del uno presenta formas y colorus esencinimente distintos de los del otro. Aun hay mas en cuantó á la variedad: en los grandes ditiscos se observan herubras con diferentes caractéres; en las unas se ven clitros lisos, iguales a los del macho: en las otras obsérranse liasta mas de la mitad unos surcos longitudinales. El gran lepidóptero americano, Papilio Memnon, cxiste igualmente en dos formas, escncialmente distintas en el sexo femenino, formas observadas en las mismas localidades y' que no tienen otras intermedias: unas hembras difieren de los machos por el color y el dibujo; las otras por tener una larga cxtremidad en forma de azadon en cada una de las alas posteriores:y un lepidóptero comun de la América del Norte (papilio turnus) tiene un color predominante amarillo $\mathrm{cn}$ ambos sexos, cerca de Nueva York y de la Nueva Inglaterra; mientras que en el star del Illinois la hembra es negra. I.a existencia de dos formas en una especic se ha designado con el nombre de dimorfismo, y hasta se ha presentado el trimorlismo en una tercera especic de lepidópteros (popilio ormenus). Darwin y sus partidarios hicieron uso últimamente del fenómeno cita. do en la doctrina del desarrollo de las especics; pero, segun dice Kicsenwelter con mucha razon, cn cicrto hasaje; ycomo no todo naturálista reune i la audacia parn combinar, que distingue à Darwin, el necesario saber positivo, ni el grado de prosa cientifica que preserva de los errores, y atendido que la estructura interior, el desarrollo y la vida de los insec. los no se conocen aun suficientcmente, ne limitaré ązuí á lo mas cierto é interesante de lo que yo puedo transcribir en el corto espacio pucsto a mi disposicion.

Ios órganos genitales de que nos proponemos hablar ocu. pan casi siempre los segmentos posteriores del abdómen y se componen en el macho de un par de glandulas para cl des. arrollo de los espermatozoos, es decir de los iestículos, de un camal que partiendo de estos se dirige hícia aruera, y en muchos insectos tambien de un órgano genital (penis) de inuy variadas formas. I ass partes sexwales femeninas constan de dos ovarios, de ordinario en forma de uva, y de un oviducto que los reune, el cual puede suírir en su parte anterior y en su orificio varios cambios, pero que sicmpre ofrece unas 
dilataciones en forma de cripsula ó bolș, destinada á recibir y conservar el sémen. Solo al pasar pror la bolsa se fecundan los huevos, cuando menos en el trascurso regular de la reproduccion.

Sin embargo, obsérvanse toda clase de irregularidades: hay hembras que no necesitan de la fecundacion para poner huevos susceptibles del desarrollo, ó para reproducirse, como sucede con ciertos cinipidos de los géneros synips ye neuroterus, - algunos cócidos (becausium hesferidum y otros), el género chermes de los afidios, cuyos machos ni siquicra se conocen, las hembras de los géneros de mariposas psjeise y solenobin, y todos los áfidos, que en verano dan a luz sus hijuelos vivos.

Siebold ha consigmado en la ciencia bajo el nombre de partenogénesis (reproduccion virginal) la facultad que tienen ciertas hembras de insectos de reproducirse sin fecundacion, hecho observado en la abeja comun y otras sociables, que si bien no carecen de machos, en ciertos casos las hembras desarrolladas y hasta las atrofiadas (trabajadoms) pueden poner huevos, de los cuales solo macen individuos del sexo masculino. Además de los casos citados en que la partenogénesis forma la regla, se ha visto aiguna ve\% un marias hembras de mariposa, en el esmerinto de los olmos (smerinthus popiali), en el arctia pardo (enprepion caja), en el gastropaca de los juinos (grastropacha pini), en el sericino de las moreras (bominy mori), y en la safurmin (polyphemus). Por el gran interés que ofrece este fenónieno apuntamos aqui los nombres cientificos de otros congéneres en que la partenogénesis se ha obsermado solo una vez. Sphinx ligustri, Smerinthus ocellontus, Eupropia sillica, Gastropactia quercifolia, potntoria. querius, Tiparis dispar, atiropoda, Orgyin pulibunda, Psyche apiformis. Mas tarde describiremos minuciosamente algun. de estas mariposas. Ia reproduccion regular ofrece otras excepciones adenás de la partenogénesis. Ya hemos hecho mencion de los áfidos viviparos; y aqui ariadiremos que en algunas hembras de coleópteros de lias familias de los esta filinos $y$ crisomelas tambien se ha obsernado esta vivipa ridad.

Scott cogió en Australia una polilla ì la que llamó Tinea sivipara, porquue al comprimirla casualmente entre las puntas de sus dedos salierón de su abdómen oruguitas; además es un hecho conocido há mucho que nuestro moscarcion comun produce larvas en ve? de huevos. Los hipoboscidos ponen una sola larva, semcjante a una crisálida; y los tincidos unas formaciones and́logas. Mas tarde hablaremos de un modo de reproduccion contrario is todas las leyes hasta ahora reconocidas.

Las opiniones de los antiguos sobre las condiciones se xuales de los insectos eran del todo diferentes de las nues. tras. Asi, por ejemplo, Claudio Eliano, que vivió en el. aino 220 desputues de 1. C., nos dice en su obra sobre los animales: «Los coleópteros son todos de género masculino; forman bolas de estiércol, las llevan á un sitio, las incuban veintiocho dias, y al cabo de este tiempo sale la progenie Los soldados egipcios llevan anillos en los que se ve grabado un coleóptero, con lo cual el legislador quiere indicar que todo el que lucha por la patria debe tener valor de hombre, porque el coleóptero no cienc natumleza femenina.

Volvamos a la descripcion del desarrolin regular. El huevo de los insectos se compone de una cáscara coriócen y coin. pacta, cuya pared interior contiene la finisima pelicula de la yema Esta membrana encierm un liquido claro en el que nadan unas bolitas y la ampolla del embrion formando la yema. Fil cuanto a la forma y dibujo y relieves, á menudo delicadisimos de la superficie, se nota una variedad que va en aumento á medida que progresa el desarrollo de los dife- rentes órganos hasta formarse el insecto perfecto. Vense hucvos esféricos, hemisféricos, cónicos ó cilindricos con los cxtremos redondeados: aplanados $\delta$ puntiagudos en ambos extremos, presentando diferencias tan grandes entre si como las que se observan entre las semillas de las plantas. La su. perficie es tan pronto lisa como angulosa, ó bien surcada en ambas direcciones; aqui se marca un punto en que al salir la larva se levanta una tapita; y alli este punto no se presenta porque la ciscara se rompe irregularmente. Otms diferencins dependen del lustre $\delta$ del color, quue cambia a medida que se desarrolla el gérmen en el interior. Segun el género de vida de los insectos varian los sitios donde las hembras depositan los huevos y su manem de hacerlo.

Aunque el cuidado de la cria, segun se llama el conjunto de todas las mediclas tomadas por la hembra para el bien de su progenie, se revela en los insectos de un modo muy diferente que en las aves, no es pror eso menos admirable. Mientras que el ave incuba por si misma los huevos y cria su progenie, el insecto confia el primero de estos deberes al calor del sol; $y$ en la mayor parte de los casos ni siquicra tiene la suerte de ver i sus hijuelos, ni menos aun la de poder demostrarles mas tarde su cariño. Todo su cuidado se limita por lo tanto á la colocacion de los huevos y corresponde cxclusivamente a la madre. Ia cualidad innata en cada especic, que se ha designado con la palabra instinto, la cual nada significa, permite il hembra hallar la planta de que el hijuelo se alimenta despues de salir del huevo; esta planta es jara muchos insectos, es decir para los llamados monófingos, muj determinada; los polifagos toman cualquiem, \& una que varia entre diferentes especies congenéricas. Algumas liembras depositan sus huevus siempre cerca de la raiz; otras en el tronco, y varias en los capullos, hojas ó frutos, adhiriéndolos exteriomente con una especie de liga que expelen en el acto de la puesta, o bien colocíndolos en el interior de la planta. Otras, que se alinentan solo de sustancias vegerales ó animales en putrefaccion, saben encontrarlas parn deposi. tar en cllas su cria. Muchos mosquuitos, moscas, libélulas y otros insectos, que cuando llegan a su completo desirrollo son verdaderos habitantes del aire, viven en su juventud en el agua, y por eso las hembras dejan caer sus huevos en el liquido, ó los depositan en plantas acuáticas. Los que pașaron la primera época de su vida en los intestinos de otros insectos, y hasta en los de animales de sangre caliente, saben encontrar despues à los individuos de su propia especie para reproducirse, aunque tengan que buscarlos en el interior de la madera ó en otros sitios tecónditos para picarles con su larga trompa. A pesar de que mas tarde el alinento y residencia de la hembra son esencialmente distintos que en el primer periodo de su vida, encuentra sin émbargo lo que ne. cesita jatra su jrogenie, cual si conservara un recuerdo de tiempos pasados. Perosi el hombre puede equivocarse, ¿por qué no seria esto posible en un sér tan inferior á él? Yo he encontrado ya muchas veces los huevos de la esfinge de los pinos, cuja oruga solo come las hojas de estos árboles, en troncos de encina que se hallaban cerca de aquellos; y segun se asegura, unas moscas exóticas que ponen los huevos sobre objetos en putrefaccion, se engaian algunas veces por el olor de cierta planta (Stapelia), y los depositan en ella. Mucho mas cuicado exige la cria de los insectos que construyen galerias ó sencillas cavidades en la arena, en paredes viejas de harro ó en nadera carcomicia, y que cogen toda clase de otros insectos para guardarlos como provisiones en sus viviendas. Algunas esplecies amontonan miel para el alimento de su cria, ó bien otros viveres, distinguiendose por este concepto en el mas alto grado las abejas, las hormigas y varios insectos que viven reunidos, formando verdaderas colonins 
ó Esstados, scgun veremos mas adelantc. Bajo la influencia del calor atmosférico efectúase en el huevo el desarrollo del cubrion; despues de formada la especie de membrana que le envuelie jrodúcese una fuerte contraccion de las coldas entre si, las cuales se reunen en major número en la extre. midad, donde mas tarde formarán la calveza. Con esto la membrana se ha comvertido en una sencilla faja en forma de lengua dividiéndose en dos cuerpos á manern de cordon, que se extienden longitudinalmente uno al lado de otro, separa. dos por una hendidura mas ó menos marcada, y son los componentes que determinan la estructura simétrica de los articulados, pues el desarrollo del huevo es esencialmente el mismo, no solo en los insectos sino en todas las démás cla. ses del grupa. Al propio tiempo sepárase hácia fuera la Jla. mada hoja cxterna, que viene d formar la picl del embrión. unientras que de las citadas prominencias ó cordones llamados hoja interior, fórmase todo el resto del cuerpo. Por la continua contráccion longitudinal se constituren entónces las jar. es articuladas del cuerpo, primero en pequeñas divisiones al redédor de algunos puntos centrales dispuestos uno tras otro, y gue son los rudimentos de los segmentos, despues mediante algunas divisiones mas grandes, y por fin las pro. minencias laierales en toda su extension, se acortan gradualmente, de modo que ya pueden distinguirse las tres pirtes delictierpo. El desirrollo, que no podemos seguir en todos Sils détalles, Ja demostrado que la cabera se compone, en el primer estado de su formacion, de varios anillos primitivos. ofreciéndonos además un indicio pan explicar el uso de las maxilas y de las patas anteriores, que no siempre desempe nan las mismas funciones, puesto que las primeras pueden ser a veces órganos de la boca, mientras que las segundas sirven parn la locomocion. El embrion cmpieza à desarrollarse en la parte que vendri a formar su vientre, y en el dorso se encierran por último las prominencias Jongitudinales que se ensanchian mas y mas en los lados. A cxpensas de la yema, que desajarece poco á poco, fórmanse las exiremidades on sitios dados, y en un tiemyo relativamente corto, el pequer̉o insecto se desarrolia de tal moxio que puede romper la cáscara del huevo y empezar a vivit independiente.

METAMORFósis. - Háse dado el nombre de lara a insecto.cuando sale del huevo, que por lo comun no tiene semejanza alguna, ocultando sus formas definitivas, con lo que ha de ser una ver.llegado a su perfecto desarrollo; repta como un gusano á la superficie ó pror debajo del suelo, y sa. tisface su voraz apetito con hojas, pequueños animales ó materias en descomposicion, mientras que en su estado perfecto suele generalmente tener una vida área y' alimentarse de los jugos azucarados de las flores y del rocio. Entre estos dos extrcmes se encucntra el perioäo de reposo de lin ninfa, como estado de transicion. Solo entonces; cuando se ha despojado de Tr máscara ó disfraz como larva y como ninfa, aparece el imago, la verdadera y completa imágen de lo que aquellas ocultaban, $\delta$ en otros términos, cl insecto sufre una complèta trasformacion ó melamorfosis. Sin embargo, no es igual en todos los insectos esta trasformacion. Hay algunos, si bien los menos, cuja larra se parece en lo principal a sus padres, faltandole tan solo las alas, algunos artejos de las antenas y de las patas ú otros detalles poco visibles; en estos la meta morfosis es farcial. Incuéntrase, por último, un corto número que no tienen alas ni aun en cl estado perfecto, y que por lo tanto no pasan por metamorfósis alguna; forman, en este concepto al menos, el tránsito á los demás articulados, que no necesitan de la trasformacion para alcanzar el estado adulto.

I a trasformacion de los insectos era yal conocida de los maturalistas de la mas remota antigiedad, y hasta se comparó entonces con la vida corporal y espiritual del hombre. Swammerdam, que habia penetrado mucho los secretos de la naturaleza y que sabia muy bien hasta dónde podia cxtender sus comparaciones, manifiesta su entusiasmo en un jasaje en que se trata de la metamorfósis, expresándose en los siguien. tes términos: «Lste procedimiento se efectúa en las mariposas de una manera tan maravillosa, y vemos realizarse á nuestra vista la resurreccion de tal modo, que debemos comprender. la Contemplamos a la oruga, que reptando por el sucln se alimenta de miseras sustancias, y despues de haber vivido asf muchas semanas $y$ hasta meses cnterns, pasa al estado de muerte aparente. Envuelta cn una especie de sudario, encerrada como en un féretro, y sejultada por lo regular en la iierra, espera que el calor de los rayos del sol la despierte. Entonces sale de su sepulcro, desembarizase de su cubierta, y revestida de un precioso adorno cmpieza a gozar de un estado sublime, dé la vida, estado en que todas sus facultades se desarrollan, alcanzando la perfeccion de su naturaleza; en que libre ya de la tierra, vaga por las regiones aéreas, alj. méntase del néctar de las flores, y comienza á experimentar la beraigna influencia del amor. Al ver todo esto, bien debemos explicarnos el triple estado por que el hombre pasa poco a paco, formándonos sobre todo una idea de aquel dia feliz. en que el grito del gran Sol de la justicia hara salir a los que descansan en sus'sepulctos, en que el mar devolvera sus muertos, en que la vida vencera ia la muerte, y en que los miles y miles de séres felices vivirán y amarin toda una eternidad:

La mariposa dorada en las cruces de nuestros difuntos es un simbolo que cada cual puede explicarse à su manera; segun las idens' de Swammerdam es el de la resurreccion ó de la inmortalidad del alma que se desprende del cuerpo mor. tal, lo propio que la mariposa, la cual abaridona'su cubierta de crisalicia al clevarse hicia la luz celeste.

El-desatrollo de los insectos, ya se verifique, como en la metamorfósis parcial, jrogresimmente, ya, como en la completa, por cambios en apariencia repentinos, es siempre gradual, fomentado en gran partc por las repetidas mudas de la juel, que sufre la larva. Estas mudas se verifican en épocas determinadas, que no son las mismas para todas las especies; repitense con mayor ó menor frecuencia, si bien en general no excediendo de seis veces, y tienen todo el carácter de una cnfermedad. Las larvas permanecen inmóviles mientras duran aquellas sin tomar alimento alguno, y se muestran entonces extraordinariamente sensibles a-toda influencia exterior, y muy en particular á la de la temperatura, hasta que la pjel antigua del cuerpo se rasga por la espalda, y se despojan de ella por medio de retorcimientos y sacudidas del cuerno, aparecicndo con su nuevo traje, il menudo mas vistoso y de distinto color que el antiguo. Fste cambio no es ian solo ex. terno; todos los órganos interiores participan de él, arrojando tambien la piel que los tapiza los varios componentes del canal digestivo y los innumerables tubos del sistema traqueal, y operándose además, gradualmente, modificaciones importantes: las larvas que viven en el agua pierden con la ultima muda las bmaquias, que no tiene ningun insecto perfecto, aun cuando continúc frecuentando este clemento despues de la metamorfósis. Comunmente no sufren la inuda las-larvas que por su género de vida no se hallan expuestas à la inmediata influencia de la temperatum, habitando el interior de cuerpos vegetales ó de otros animales, etc; pues, parece que fuera de las condiciones particulares de desarrollo impuestas a cada especie, el despojo de la piel solo se hace necesario cuando esta tiene que servir de escudo contra la influencia de la temperatura, y es por lo tanto demasiado sólida jarn 
poder dilatarse a medida que va aumentando el volúmen de la larva; en los casos que hemos indicndo, no ha menester el jóven insecto de tanto abrigo, y' consérmse la picl bastante blanda y clástica para no entorpecer cl crecimiento. I á época de este parn los insectos es la del estado de larva, lo que explica su extraordinaria voracidad durante este periodo. En el trascurso de 24 horas suele consumir una oruga de lepidóp. tero mas del doble de su propro peso de materia vegetal, aumentando aquel al cabo de 30 dins hasta 9,500 veces del que tenia la larva al salir del huevo. Considerando estas cifras, nos explicamos räcilmente las espantosas devastaciones que crusan en loda clase de plantas las larvas que viven en nues. tros jardines, en los huertos, y en los montes y prados.

lass larvas de los insectos de metamorfósis compleia tienen generalmente una forma prolongada, por lo regular anillada, pero no son por eso gusanos. A pesar de que muchas se putrecen à estos últimos, difieren sin cmbargo al cxaminarlas mas de cerca. Hay larvas con patas y otms sin ellas: las primeras presentan regulamente en los tres jrimeros segmentos del cuerpo que indican la cabeza, y que mas adclante forman el tórax, tres pares de patas articulados que remaian en una ó ell dos caras y que se han llamado patas del tónx; cuarido estas faltan, la larva debe considerarse como ápoda, aunque unas prominencias verrugosas ocupen el lugar de dichas extrenidades. Además de las patas del tórax, en algunos segmentos, ó en casi todos los del vientre, presentan patos abdominales yue nunca estản articuladas, pareciendo mas bien prominencias carnosas de la picl. Unos once ó doce segmentos forman además la cabeza y cuerpo de la larin. El múmero de 22 patas es el mayor que alcan\%a un in. secio. La cabeza córnea esta provista de órganos masticadores de la boca, aun en el caso de que la imagen sea un insecto chupador. I m mayor parte cie las larvas tienen en su interior dos glándulas tejedoras, en las que se desarrolla una sustancia viscosa que puede prolongarse como hilos y se en. durece en el aire; dos aberturas microscópicas en il labio iurerior dan salida a esta sustancia y con clla fabrica la larva sus tejidos. Fstos sirven sobre todo de alorigo en la juventud, y tambien mas tarde, ó en tiempo de necesidad cono medio de fuga; pero mas bien de abrigo en el tránsito del estado de larva al de crisilida. Muchas larvas fabrican su capullo, dentro del cual sufren la trasformacion en crisálida. Segun sabemos, cicrtas larvas producen la preciosa seda.

Ias larms sin patas se llaman gusunos, j' tienen una caLeza córnea, ó una extremidad anterior cuya forma no es determinada, pudiendo prolongarse en figura de punta ó contraerse mucho, sin que se reconorca ningun vestigio de rabeza con órganos masticadores de la boca. Se las ha llamado por esto larvins sin cobezn, y hahlaremos de ellas mas minuciosamente al tratar de los dipteros.

Toil circunstancia de que las insectos chupadores indican jor cn costado de larva sta alimento, demuestra la variedad del género de vida de las especies, y de ella pueden deducirse otras difierencias de las larvas respecto a las relaciones en que se hallan con el mundo exterior. I as mas viven libremenic en las plantas, y son a menudo muy abigarradas, $\delta$ bien habitan debajo de las piedras, de la hojamsca en descomposicion, ó en otros escondites que abandoman temporalmente, sobre todo de noche. Otras no salen nunca it la luz. pasando su vida en el suelo, en el interior de las plantas, en cuerpos de animales ó en el agua. Lass larras lucifugas se distinguen por sta color claro, y solo en los sitios cubiertos de quitina suelen presentar un tinte oscuro mas determinado; son mas pálidas despues de cada muda

De lo que llevamos dicho se desprende, que la larra no es mas que el insecto en su primera edad y periodo de desat. rollo, de modo que parece incapax, y asi lo es por regla general, de ejercer las funciones de la procreacion, que son distintivas de la madurez del cuerpo; sin embargo, descubri. mientos interesantisimos, hechos muy recientemente, han demostrado una véz mas, que la naturaleza no está sicmpre sujetia : las lejes que la perspicacia humana le ha fijado creyendo haber penetrado ya todos sus misterios, y que no iray regla por absoluta que parezca y por mas que como tal haya valido durante siglos, que i la prostre no venga a tener sus excepciones. Examinando N. Wagner en Casan, en agosto de I\$6r, unas larvas blanquecinas y bastantc desarrolladas, de cuntro á cinco y medio milimetros de longitud, que cogió debajo de la corteza de un olmo muerto y que resultaron ser de una especie de cecidómidos, encontró dentro del cuerpo de aquellas otras mas pequeñas en diferentes estados de crecimiento; la prinera idea que sugirió este hallazgn ả dicho naturalista fué la de que las últimas procedian de algun insecto parisito, viviendo à expensas de las otras y aguardande alli su matyor clesurrollu. Ial extraordinaria semejanza de las larvas pequeñas con las mayores $y$, aun mas, h circunstancia de que en aquellas tambien se formaron despues otras enternmente iguales, vinieron, empero, á demostrar que la conjetura anterior, que parecia la mas natural, era un error, y que unas y otras larwas pertenecian d la misma espe. cie. Fste descubrimiento de Wagner causó gran sensacion en el mundo científico, motivando el que varios entomólogos se ocuparan de caso tan extmordinario y procuraran averiguarlo por si mismos. Asi consiguió Fr. Meinert descubrir: en el mes de junio, debnjo de la corteza de un tronco de boj. gusanos viviparos de dijuteros, y criar alymnos de ellos̆ hasta su trasformarion en insecto jerfecto, al pue dis el nombre de Minstar metralons. Pagenstecher tuvo tambien ocasion de examinar en idénticas condiciones algunos gusinos que encontró entre antiguos ciesperdicios en descomposicion de una fíbrica de iuúcar; estos son distintos de los anteriores y pertenecen \& otra especie. Recientemente el propio Wagner ha podido asimismo obtener insectos perfectos de los suyos; yueda, pues, demostrndo por mas de una experiencia, que existen larvas viviparas de dipteros y que las que ellas dan á luz ya desarrolladas proceden, segun todas probabilidades, de huevos contenidos en su cuerjo.

Fuera de los casos aislados que acabamos de apuntar y que están en manifiesta contradiccion con todas las demás observaciones hechas hasta el dia, los insectos con nuctamorfósis completa pasan del estado de larva a un periodo de reposo à la jar que de irasformacion, que es el de ninfa; si bien aqueilos que solo la experimentan parcial llevan igualmente el mismo nombre en cierta Época de su desarro. Ilo, es porque asi se designa por analogia la larra que des. pues de su última nuda se presenta con los ridimentos de las alas. En la ninfor son yo visibles tndos tos apéndices del insectn perfecto; las antenas, las alas, todavia arrugadas, y las scis patas, encogidas $y$ a veces cubiertas en parte por aquellas, se distinguen perfectamente à través de la jiel fina I casi trasparente que envuclve todo ef cucrpo, aparecicndo este relativamentc mas comprinido y obtuso en su extremi. dad anterior. Llamanse minfos nprefadas las que se presentan en la forma que acabamos de describir, ye enaueltas o crisufliias las de los lepidópteros, revestidas de una membrana mas dura y articulada, que por medio de suturas, depresiones !: protuberancias marca asimismo la situacion de las frarses que hemos indicndo mas arriba, como tambien de la espiritrompa que le es jeculiar: su abdómen anillado suele ser $̊$ veces muy morible. En los gusanos de algunos dipteros se endurece a menucio la picl formando una túnica í manera de estuche en el que esta encerradal la ninfa fropiamente 
dicha, y por eso se les ha dado el nombre de ninfas crishlidas $\delta$ en esfuche. No debe confundirse esta tunica cubiesta con los iapullus, muy parecidos en h forma, pero que varian entre si en color, consistencia y desarrollo, y son hilados por algunas larvas, especialmente de lepidópteros, para servir de seyunda mortaja a las crisilidas.

lass crisâlidas libres nunca están expuestas inmediatamen te á la luz del sol por el cambio de temperatura, pues siempre se ocultan debajo del suelo entre las hojas y la corteza $\delta$ en el interior de otros cuerpros. Solo las ninfas cubiertas 6 encerradas en capullos se encuentran al aire libre, y en este caso el capullo sirve de abrigo al indefenso súr que espera el estado de perfeccion. Pareceria natural que la crisialida se encontram siempre alli donde vivia la larra, $y$ sin cabargo, esta suposicion no es exacta. No conozco ninguna larva que viviendo en el suelo abandone este para trasformarse en crisailida, pero en cambio sé de nuchas que habitan las hojas, frutos, tallos y hasta en otros animales y que buscan la tierra pam metamorfosearse en ninfa, of ruando menos especies que en estaco de larvas viven ocultas y pasan su tiempo de crisálida al aire libre. No puede indicarse en todos los casos la necesidad de este cambio de sitio, pues si quisiéramos sostener que las orugas que viven en el interior de las plantas deben salir de sus escondites antes de crisaliciarse, porque la mariposa careciendo de órganos masticadores no po. dria salir de las canas ó de la madera etc. este aserto pareceria justificado, pero no se fundaria cn la realidad. Precisa. mente las ninfas de estos insectos permanecen alli donde ha vivido la oruga porque esta turo el instinto natural de salir antes de su formacion hasta la epidermis de la planta y liasta fuera de la misma, cerrando el agrijero practicado con un tentue tejido, por el cual la futura mariposa penetra con la misma ficilidad que por la epjidermis vegetal. Además, nuchas crisulidas están provistas de espinas ú otros órganos joco visibles con los cuales se agarran à los objetos que los rodean para opioner á la imago alguna resistencia, facilitando asi mucho el penoso trabajo. Cuando ciertas larvas acuíticas abandonan el agua para crisalidarse, este acto sc relaciona in timamente con la trasformacion de los órganos respiratorios que entonces severifica Lasbrinquiastraqueales desaparecen del todo y solo quedan las internas. Hay; sin embargo, tambien casos en que es preciso confesar que no sabemos porqué en tal caso una cosa se hace de un modo mientras que en otro se cfectúa de distinta manera: la naturaleza lo ha establecido as! quizás con la sola intencion de darmos una idea de su infunita rariedad, de la iliunitada inventiva de que esta dotada.

Asi como la planta anua produce una sola ve\% en su vida tallos, hojas, fores y frutos, y con la madurer de estos ha cunyplido su mision, habicndo asegurado por medio de semilla fructifera la perpetuacion de su especie, del mismo modo ha llenado su destino el insecto cuando, despues de pasar por las varias fases de su desarrollo y trasformacion, alcampa la madurez. del cucrpo para poder aparearse, acto que verifica una sola ves. El macho muere pronto despues, y la hembra luego que ha puesto los huevos fecundados, to que en algunos casos, como por ejemplo en la éreina) de las abejas de una colmena, puede exigir un plazo de varios anoos, pero que por lo comun, se efectún inmediatamente, ó cuando se interpone la estacion rigurosa, en la próximn primavera.

Es, pues, por regla general, muy corta la vida del insecto, aunque no precisamente de duracion anual, como la de las plantas á que nos hemos referido mas arriba. Muchas especies adquieren su compleio desarrollo y se reproducen con tal rapider, que en el trascurso de doce meses se stice den varias generaciones; otras necesitan años, algunas lasta cinco, para producir una sola.

In la América del sur, el azabe solo al cabo de cien años produce de su capullo de hojas un tallo de enorme altum que en pocas semanas se desarrolla en un magnifico candelabroen forma de pirámide, ostentando miles de flores que en las puntas de las ramas brillan vivamente para morir despues: esta planta necesita, pues, cien años para alcanzar lo que las nuestras de verano realizan en menos de uno. En la America del norte existe, segun se asegura, un insecio que para su desarrollo exige mas tiempo que todos los demás. Una cigarra necesita, si hemos de dar fe al aserto de varios naturalistas, die\% y siete años para su desarrollo, por lo cual se le ha dado el nombre de iliada septemiecim: la hembra pone de diez di doce huevos en un profundo corte que con cierto órgano en forma de cuchillo practica en una rama, por ejemplo en el retoño anual de un manzano; al cabo de cincuenta y dos 6 sesenta dias salen las larvitas, déjanse caer desde arribat para penetrar en seguida en el suclo cerca de la raiz del arbol, y la rama herida muere entretanto. En el suelo viven diez y siete anos alimentíndose con el jugo de las ramas; y supónese un espacio tan largo porque las cigarras se presintanal cabo de tales periodos en enormes legiones. Despues salcn las crisílidas de sus escondites subterráneos, se agarran al primer objeto que encuentran en el suelo, y luego de abrirse su piel por la nuca linzase el insecto alndo por los aires paralgozar de una nueva existencia bajo la luz del sol. Si el insecto es un macho emite un chirrido como el de nuestros grillos; las hembras acuden y efectuase el apareamiento, Despues jonen sus huevos, y al cabo de unostrein. ta y scis dias todo ha concluido: los insectos vuclien a desaparecer:

Es preciso llamar la atencion de nuestros lectores en este lugar solire la manera de expresarnos, porque mas adelante usaremos de clla muchas veces. Decimos cria sencilla (gene. racion) de ún insecto cuando durante un año solo pasa uma vez por los diferentes grados de desartollo; y cria compuesla si sucedé en el mismo tiempo dos, tres ó mas veces, distin. guiendo, cuando se trata de dos, en cria de ierano y cria de inirierno: esta última exige siempre un tienupo mas largo, porque el insecto descansa en cualquier estado de su desarrollo dusante el invierno. 11 hablar asi no nos referimos al año económico, sino al espacio de dos meses, que para las diversas especies varia en su principio. La cria de verano del gran pierino, por ejemplo, empieza en abril ó mayo, cn cuyo tiempo deprosita los hueros; de estos macen las mariposas, poco mas $\delta$ menos en agosto, $y$ en este mes acaba la cria. Con los huevos de esas marizosas empieza la segunda, ó sea la de invierno, que antes de estc ticmpo produce la crisílida y concluye con el nacimiento de la marijosa en abril. Sin embargo, al hablar de la cria cuatrienal del mclolonta vulgar ó de la de diez y siete años de la cigarra nos regimos por el año económico.

Fin proporcion al enorme número de insectos, cuéntanse ınuy pocos en los que se haya observado la marcha del desarrollo: mas jor lo que hasta ahora sabemos se podran fijar las siguientes leyes: r." El estado de larna dura por lo general mas tiemiro que la vida del iusecto perfecto, a no ser que este deba invernar: otra cxcepcion de esta regla la consti. tuyen los insectos que viven reunidos en sociedades (abrjas, hormigas y térmites). 2." Jas larvas perforadoras ó subicrná neas necesitan mas tiempo para su desarrollo que las que viven libremente sobre las plantas, etc. ó en tierra. 3." las larvas åpodas, y sobre todo las que ademis carecen de cabe7.a, son las que menos tiempo exigen para su desarrollo. 4. Cuanto mas ticmpo necesita un insecto para desarrollarse 
tanto mas corta es la ciuracion de su vida en cstado perfecto. Asi como cstas, y quizás otras leyes que podrian fijarse no carecen de excepciones, del mismo modo podrain no ser siempre exacios los periodos fijados para la metamorfósis de cada especie. Fratiendorf, por ejemplo, cogió a fines de junio de i $s_{j} 6$ las orugas de un bombicido que vive reunido en los atredules $y$ se halla con mucha frecuencia en varias regiones de Alemania: estaban en dos nidos de la especic grastrupaclia lanestris. A mediados de agosto iodas las nrugns habian entrado en sus capullos; el is de setiembre se presentó la primera mariposa, y el 14 de octubre la segunda, observándose que las dos eran machos. Algunos individuos de ambos sexos nacieron en la primavera de 1837 (el tiempo justo); otros en otoño, varios en los años siguientes, y el último en 4 de majo de 1842 . El estado de crisálida habia dumdo pues en este último individuo cinco años y medio, mientras que en el primero solo necesitó el mismo número dè senınas. Observaciones semejantes, sunque no con tales diferen. cias de tiempo, se has liecho lambien en utras mariposas, excepto en las diumas y en los microlepidópteros. En un caso citado por $F$. Sinith, de doscientas cincuenta larvas de la especic osmia parietina, solo veinticinco se hicieron crisálidas en el verano de 1852 , aunque los huevos estaban ya puestos en 1849 , bastando por lo regular un ano para el desarrollo. No deben admirarnos tales ejemplos, sobre todo en las mariposas, porque los aficionados de las épocas mas remotas las obsernaron $y a$, dándonos i conocer la historia mas completa de su desarrollo.

La experiencia ha demostrado suficientcmente que el calor $y$ la humedad necesaria, $y$ para las larms que comen la atunciancia de alimento, apresuran el desarrolio, mientras yue la falta de esos elementos lo retarda: estas influencias contribuyen a dificultar aun mas los esfuerzos que se haren para encontrar leyes seguras. El aficionado experto que se ocupa en la cria de mariposas sabe que de la crisálida que en libertad no se convertiria hasta mayo en insecto perfecto, puede ohtener este por Navidad, con todo el brillo de sus colores, ncercándolo í la estufa caliente y humedeciéndolo á menudu. En cambio, si se tienen huevos de la especie Saturnia Pernyi es preciso dejarlos invernar para no exponcrse al peligro de obtener en primavera las orugas antesque su alimento, es decir, que las hojas de morern. En esos dos ejemplos no depende el resultado de la libre voluntad de la naturaleza, porque está sometido en parte ì la influencia del hombre, pero aun asi vemus confirmada la regla general El obserndor atento puede advertir cómo el desarrollo de un insecto puede retrasarse cuatro semanas, y aun mas cuando el tiem. po es desfavorable, sucediendo todo lo contrario si es bonancible, y no puede: monns de reconocer que el mismo insecto gue en verano ha suirido su metamorfósis, necesia para clla mucho menos tiempo que cuando aun debe pasar clinvierno. Mas evidentemente podemos convencernos de esta inAuencia de la temperatura en un insecto cuya áréa de disper. sion es muy extensa, que vive en regiones de grados de tem. peratura escncialmente distintos. El gran picrino, antes citado, es uno de estos insectos; en el centro y norte de Alemania vucla por primem rez, dado el caso mas favorable, en la se. gunda mitad de mayo, $y$ despues desde fin de junio hasta setiembre invernando en el estado de crisálicia. En Sicilia donde tambien se lialla esta especie plebeya entre las inariposas, ruelia desde noviembre hasta enero. En nuestros paises su oruga perce en invierno, mientras que la de otras especies solo invernan en estado de tal: en Sicilia pueden soportar el frio de un invierno templado. Ahora bien, podria creerse que en los paises cálidos, donde las intuencias de la temperatura son mas soportables que en las zonas templadas y frias, el desarrollo de los insectos se verifica de una manera uniforme, dependiendo solo de la naturaleza particular de las especies. Prescindiendo de la circunstancia de que como ya hemos dicho, el alimento influye mucho $y$ hasta es esencial para el desarrollo, y que por este concepto los parises del trúpico no son iguales durante todo el aro, rigen aquí tambien condiciones muy jarecidas a las nuestras. Moritz nos habla de un bombicido sociable de Caracas que en noviembre hila su capullo y no se trastorma en crisálida hasta principios de la estacion lluviosa, es decir en majo, para llegar a su completo desarrollo; dice tambien yue otro bombicido de color verdc aceituna, del género muy diseminado de los saturninos, nace de una manera muy irregular de las crisálidas. Al cabo de un mes de haberse formado la crisalida obturo un nuacho, en octubre, despues unn hembra, en diciembre, y por febrero les siguieron varios individuos de ambos sexos, quedando aun otras crisálidas viras cuando a fin del citado mes escribió a Europa si en estos y otros casos quisiéramos buscar la razon de ser de irregularidades tan extrañas, solo podriamos suponer que la naturaleza se ha propuesto asegurat de este modo la conservacion de la especie. Si por cualquier causa cl animal perece en su desarrollo regular, otros quedan que no han obedecido a la ley natural.

En los paises donde el invierno llem siempre consigo el hielo y la nieve, desaparece ajarentemente en esa estacion toda huella de insectos, pero \& la primavera siguiente reconócese que no han dejado de existir. Unos invernan en estado de huevo; otros como larvas, perteneciendo estos últimos naturalmente à las especies que necesitan dos ó mas años para su desarrollo: los hay que pasan la estacion fria en el ustado de cristlida, y no pocos como desarrollados. Fin raros casos un mismo insecto pasará por dos diferentes grados del desarrollo en la estacion citada. El que quiera formarse una idea del número de insectos que pasan como individuos sevuales el sueno invernal, debe buscar en otoño, cuando aun no está desnudo el bosque, debajo de la hojarasca amontonada en muchos años, ó en la maleza de las espesuras situadas en un sitio bien resguardado, ó ya debajo de las picdras'y sitios análogos no expuestos á la corriente del aire, y alli encontrara una variedad inmensa de coleópieros y moscas, avispas, $y$ aranas, chinclaes y otros parásitos, $y$ tambicn alguun que otm mariposa nocturna, que hara todos los esfuerzos posibles para sustraerse 3 la vista. Hay quizás muchos insectos conocidos que en rerano suelen vivir en otra parte, pero tambien no pocos que eligen tales escondites para su residencia constante, y que rara vez se dejan ver á la luz del dia Un par de alas de melolonta vulgar, una abeja medio seca y sin patas, y otros restos análogos podrian inducir a creer que se ha encontrado un gran cementerio de esos peyueños séres, y que en invierno ninguno escapara de la muerte: pero el obsernador que volviendo por segunda ver al mismo sitio antes de que el invierno haya terminadio, coja algunos puñados de hojarasca, los lleve a su casa en un saquito bien cerrado, y vacie alli el conienido despues de calentarlo algumas horas en la habitacion, no experimentara poco asombro cuando al remover las hojas secas vea que en ellas hay vida jy movimiento, y una infinidad de los mismos insectos que en el otono vió al are libre. Añadiré de paso que este procedimiento es un método bien conocido y excelente para el coleccionador que quiera enriquecerse con una infinidad de pequcios séres que en los paseos de verano no llaman su atencion, ó en los cuales no se fija porque precisamente se ocupa de otras especics.

Mucho tenởiamos que anadir a csta descripcion general de la clase, si quisiéramos extendernos en todo lo relativo at 
las costumbres y.gënero de vida de watos séres; pero son tan distintos entre si, que porco poctriarnos decir que fuera aplicable al conjunto; creemos, pues, mas oportuno reservar estos datos parn mas adchante.

Conócense unas mil quinientas especies de insectos fósiles que proceden de la formacion carbonifera, calcutándose el número de las que aún existen en un millon. Aunque se suponga que estos resultados de un clculo probable son exa. gerados, el ejército de los insectos es sin embargo enorme si se compara con el de los vertebradas. No cabe, pues, en to posible dar en esta obra una descripcion completa, ni siquie. ra que se aproxime poi tal concepto à la de los animales su. periores.

Al elegir las especies nos hemos fijado con preferencia en las que son propias de nuestros paises, haciendo mencion de las exóticas solo hasta donde las consideramos necesarias para completar una ojeada general, y como nuestra patria ofreceria por si sola un material demasiado considerable, se han escogido las especies que por una ú otril causa excitan el interés general. Ias presentamos para conservar el carácter del conjunto rotal en el órden por que suelen regirse los sistemáticos al tratar de los grupos uno por uno.
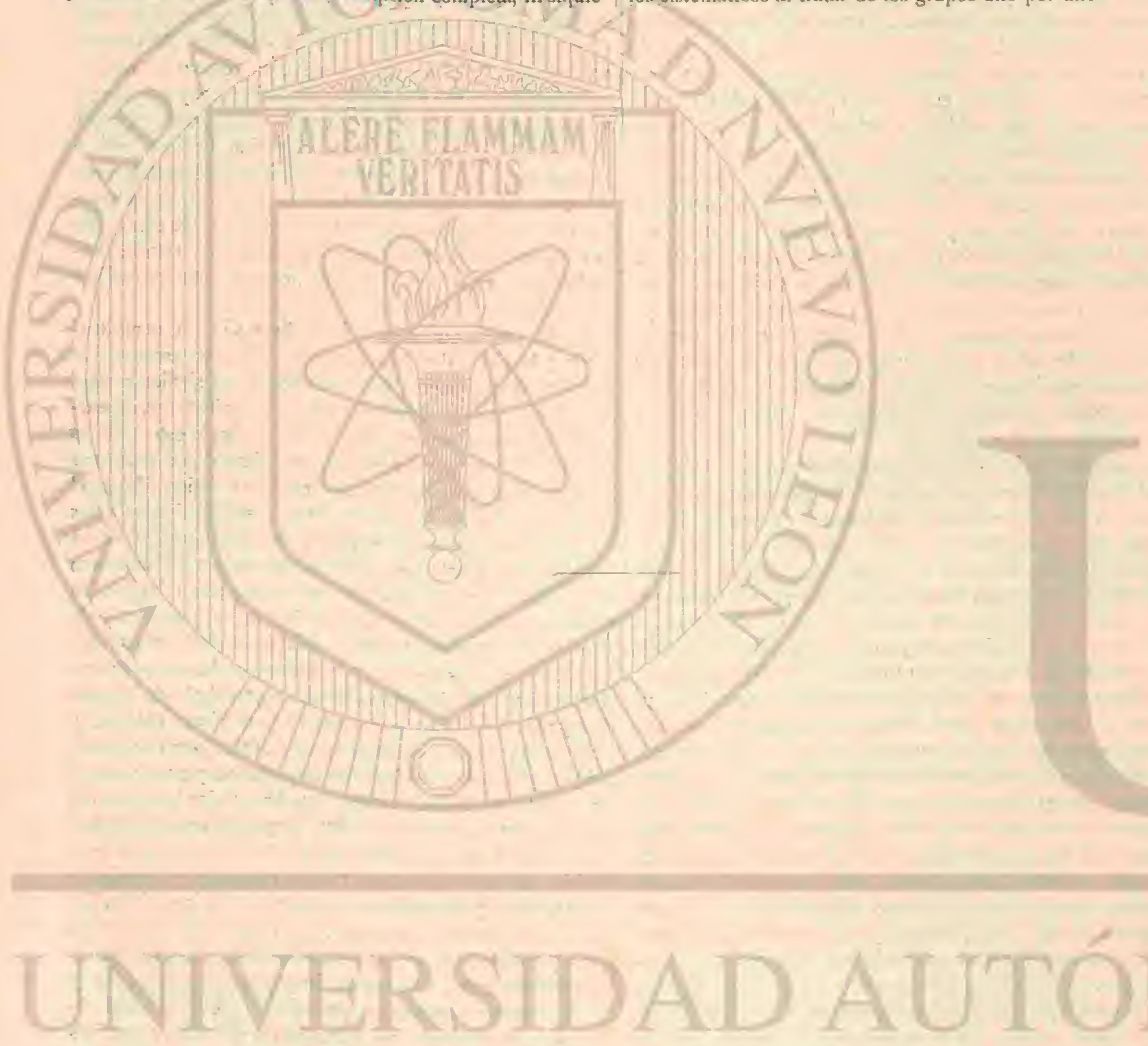

$$
\text { . }
$$
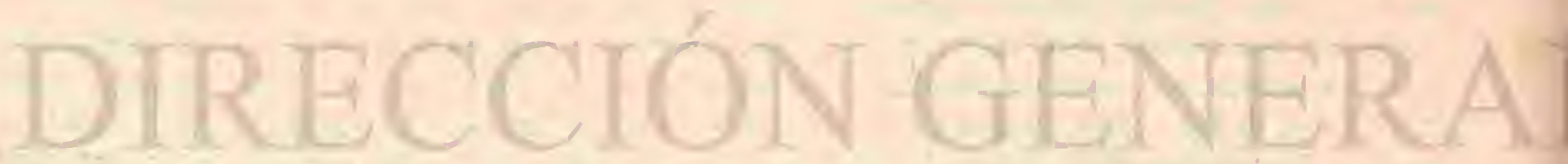


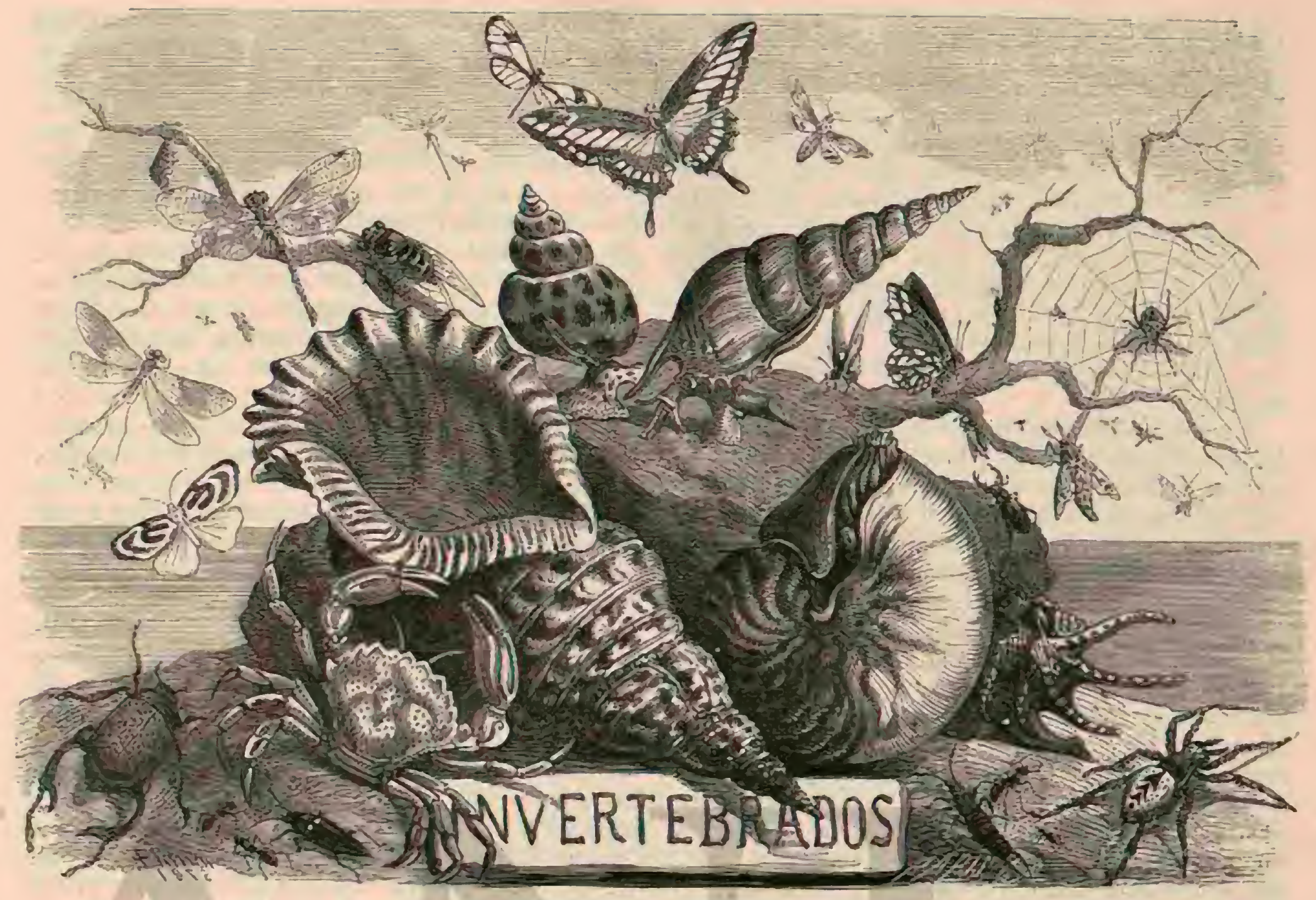

PRIMER ORDISN

\section{COLEÓPTEROS - COLEOPTERA Ó ELEUTHERATA}

CA RACTERES. - I os caracteresexteriores de loscoleóp | segmentos del tórax, influyendo por su forma esencialnzente ieros se reconocen desde luego en los órgamos masticadores, en el protórax libre, en cl abciómen, que está soldado, y en los elitros, que forman una sutura: la metamorfósis es completa.

In cabera queda muy raras veces libre por delante del es. cudo-collar, pues se recoge en cl mismo ì mas ó menos profundidad; la prolongncion de la region anterior en una espe. cie de trompa puede citarse como la forma mas particular, siendo muchas las variaciones. Respecto à los órganos mas ticadores, ya hemos dicho lo necesario en la introduccion, y aqui solo añadiré que los palpos maxilares de los colcópteros se componen de cuatro artejos y los labiales de tres, hallándose el labio inferior mucho mas desarrollado que l. lengua, que casi siempre es entera. Ios ojos son enteros ó «cotados, á veces tan profundamente que a cada lado se dividen en un grupo superior $y$ otro inferior de ojitos, mientras que los ocelos no existen, salvo muy pocas excepciones. En ningun otro órden se encuentra tal variedad de antemas como la que ofrecen los coleópteros; los mas las tienen con once artejos, aunque tambicn las hay hasta de treinta $y$ cuatro; mayores diferencias' se obscrian en la longitud; Ihs mas grandes recuerdan por su forma las cerdas, los hilos, las sierras, peines, abanicos, y otros objetos, no pudiendo hacerse á menuclo comparacion á causa de su irregularidad. Muchas de estas formas han adquirido gran importancia para la clasificacion de ciertas familias, segun veremos despues.

E) jorotórax libre, como se observa en todos los demás insectos que le poseen, adnquicre mayor desarrollo que los otros en la de todo el coléptero. Fil mesotórax esiá mucho menos desarrollado, pues no necesita ningun espacio interno mayor para la insercion de los músculos, porque la parte media de las patas tiene otro uso muy diferente y los clitros no son órganos del suelo; alli donde el cscudete está bien desarrollado se inserta en una escotadura de los elitros. T'ampoco el meta. tórax offece desarrollo, sobre todo un la parte superior; solo en los coleópteros cuyas patas posteriores deben hacer gran. des esfuerzos para nadar ó saltar, llega a la cari abcominal posteriormente y cubre en parte las primeras escamas abxio mimales.

Caracteristicos son los elitros, porque en la llamada sutura se tocan ó mas bien se encirjan en linea recta en el centro del cuerpo. En otros insectos cuyas alas anteriores forman elitros, el uno sobresale del otro, de modo que la sutura desaparece, segun se observa en los elitros de la especic melne y otrns exccpciones entré los colcóptcros. En la mayor parte de las especies los elitros no reposan sencillamente sobre el dorso sino que rodean con su borde exterior mas 6 menós intimamiente los lados del cuerpo. El punto donde se toca el horde exterior con el anterior forma los hombros, y cuanto menos marcadamente resaltan estos, tanto mas desaparece el contraste de los citados bordes y tanto mas se acorta el anterior. Solo en los elitros cortados se hacen notar tambien un horde posterior, sin el ángulo de la surum, y otro exterior. En la mnyor parte de casos, los clitros se adelgazan en sn extre. midad, tomando cada cual la forma de pumta, de mocio que 
llegan hasta la del abdómen 6 bien dejan libre una parte del dorso (fygidium) cubierta entonecs ambien de quitima. Fsta parte, llamada iambien rabadilla, quedia siempre visible en las especies en que los elitros estain cortados; pero tampoco faltan colcópteros en que los clitros son tan cortos que la mayor parte del abdómen queda libre y tiene tanto en el vientre como en el dorso una coraza de quitina. Ias alas posteriores suelen estar cruzadas por algunas renas fuertes y en la region central del borde anierior tienen una masscha de quitina llamnda señal. Estas alas posteriores, de membrana delgada, son las únicas que dan al insecto la facultad de volar, y. si faltan ó se atrotian, lo cual sucede a menudo, piérdese tambien aquella: - Ios elitros se sueldan entonces con frecuencia la sutura.

Segun la residencia y et género de vida de los coleópteros, las patas delgadas que atic todo sirven para la marcha y la carrem, trisformanse en matatorias, escarbadoras y saltadoras. Ias primems son aplanadas en 0 das sus partes, ensínchanse por una especie de pestatias cerdosis, solo se mueven en direccion horizontal, y se insertan casi exclusinamente en cl metatúrnx. Lass patas escarbadoras sé distinguen por tener los piés endẹbles, á veces atrofiados, tarsos anchos, denticulados en el borde exterior, y muslos cortos y gruesos, formacion que en su mayor desarrollo es propia de las patas anteriores. El movimiento de saltar solo se verifica con las patas posteriores, que entonces tienen muslos muy gruesos y tarsos rectos, relatimanente largos. Gmu importancia se atribuia antes al nümero de articulaciones del pie para la 'clasiticacion, dividiendo los coleópteros en fentímeros, es decir, que en todos los piśs tienen cinco articulaciones, y tetrimeros, $\delta$ que solo cuentan cuatro, aunque en apariencia una, muy pequeña, queda oculta bajo la siguiente. Los hetersmeros se distinguen por cinco articulaciones en las patas anteriores y cuatro en las posteriores, y trimeros se llaman los que cuando menos en las patas posteriores tienen tres.

la soldadura intima del abdómen con el tómx llega á ve. ces a tal punto que el primer segmento de aquel contriouye a formar el cóndilo para los costados posteriores; el número toral de los segnientos abdominales es por lo regular de siete, pero puede reducirse a cuatro. En la cara superior se distinguen ocho anillos de piel blanda hasta donde están cubiertos por los elitros; un estrechaniento en forma de espina ó de tubo, en la extrenidad del abdómen, sirve para depositar los huevos;y en esta parte no se ven apéndices movibles, circunstancin que ofrece un medio seguro para distinguir entre los coleopteros y los ortóptcros, cuyos elitros se tocan alguna vey en una sutura (furficula auriculariu).

La fórmula y la proporcion alternada de las tres partes principales del cucrpo son tan variables que la figura de los colépleteros no puede reducirse i un tipo fundamental conun, pues desle la forma lineal hasta la circular encuén. transe codos los trínsitos posibles, asi como desde la forma plana de disco hasta la casi esférica. En unas especies las tres partes principales del cuerpo se marcan muy bien en sus contornos; en lis otras se oprimen mucho en sus limites. Varios coléfpteros presentan protuberancias, cuernos y puntas, desatrolladas a menudo de tal manera que comunican å la parte respactiva, sca la cabeza ó el eścudo-collar, un as. pecto del todo diferente; mientras que otras especies tienen espigas, cerdas, plumones ó escrmas, que sobre un fondo liso $\delta$ aspero constituje armas amenazadoras, un adorno magnifico y un tegumento sencillo. Los colores son regularmente sucios y monótonos. particularmante en las especies de las regiones templadas y frias; pero, tambien los hay abigarrados y brillantes, noteniendo nada que envidiar por este concepto a los metales y piedras preciosas.
Mucho nos falta que saber todavia sobre las larvas de ilos coleópteros, jues aun suponiendo que a las seiscientas ochenta y una especies enumendas en 1953 por Chapuis y Candeae se hayan igregalo otras tantas, lo yue seguramente no pasa de ser una suposicion, la cifra de 1,300 especies no llega ni con mucho al total de coleópteros, que sin duda pueden calcularse en 80,000 . Por su aspecto exterior las larvas no clan ninguna idea de la variedad de ios coleópteros. Como ia major parte viven ocultas, les faltan los colores abigarrados, que dependen de la luz, y en rez de ellos predomina un blanco sucio y amarillento. Todas tienen la cabeza córnea, diez ú once segmentos y seis jiés córneos correspondientes a! tórax, $\delta$ bien uinguno; en el caso de que existan se componen de cinco articulaciones y rematan en una garra; algunas especies tienen dos y otras tres. I a cabeza, que i menudo puede recogerse un poco en el primer segmento del cuerpo. se incliua de modo que las partes bucales se acercan al pe. cho, ó bien se dirige hácia adelante, ofreciendo muchas diferencias. Los ojos sencillos ú ocelos, ó faltan del todo, como sueede i menudo, ó cuéntanse en número de uno a seis a cada lado de la cabeza. Las antenas en forma de hilo ó de cono son muy comunes entre los ojos y en la base de las maxilas; compónense regularmente de cuatro ó de menos artcjos. hallándose el tercero provisto a menudo de un apéndice lateral. Los órganos destinndos a recoger el alimento se hallan, en las especies que lo mascan, en la abertura y en los que lo chupan delante de aquella, cubriéndola. En los carnivoros falta casi siempre el labio superior, y la pro. longacion de la frente, ó un escudo separado de la cabeza cierra la abertura bucal desde arriba. Auncuc algunas partes del labio inférior pueden faltar, hállase este sin embargo con mas regularidad que las maxilas inferiores. Los doce segmentos del cuerpo son lisos, duros ó blandos, y con arrugas trasvursalés bastanie iguales entre sí, aumque puede suceder que las tres anteriores difieran porque lleguen á formar el tórax de un modo ú otro. Este último se cancteriza a veces por otra forma ó por tener apéndices que asi como $\mathrm{el} \mathrm{ano,} \mathrm{que}$ puede sobresalir en muchas especies, sirven para la locomocion. Fn los lados del primer anillo 6 muy cerca de él, y tambien en los de otros ocho, mas cortos desde el cuarto: hállanse en las larvas de coleópteros de doce segmentos los estigmas; en las de las especics acuáticas y de algunas otras (deonacin) que solo tienen once segmentos, cuéntanse solo ocho estigmas, porque el noveno se reune con la extremidad del cuerpo.

Ias crisálidas pertenecen à las llamadas mómias, y en cllaś se pueden reconocer todas las partes del futuro coleóptero, las patas, antenas y alas, cada una rodeada de una membran. fina, que se estrecha libremente contra el cuerpo. Muestranse en extremo vivaces cuando se les inquieta, permanecen tran. quilas en el lecho que la larva hizo, antes de trasiomarse, con la mayor sencillex; solo algunas veces descansan en un capullo, formado con varios materiales, 6 se cuelgan de una hoja, como muchas crisảlidas de mariposa.

Segun su tamano, el coleóplero necesita despues de nacer mas of menos tiempo para andurecerse, y para adjuirir todo su color, sobre todo el de los elitros, pero siempre exige un periodo mucho mas largo que la mayor parte de los otros insectos, circunstancia que se funda en tener los coleópteros una cubierta mas abundanie de quitina.

Aunque algunos de estos insectos vuelan ligernmente á la luz del sol, mientras que otros eligen para ello la noche presentandose solo entonces al carador en acecho, ó al sabio que en las noches de veraro se halla en su estudio con las ventamas abicrtas, y cuyr luz atrae a los insectos; los coleópteros alados dequenden, sin embargo, del suclo mas que 
In mayor parte de los otros insectos, asi como de la vegetacion ujue los cubre, pues aqui viven silenciosanente ocultos, pasando desapercibidos de la majoria de los hombres, que mas bien fijan su atencion en la abigarrada mariposa cuando se balancea en los aires, en la deseufrenada libélula, con sus brillanies alas, en la ruidosa langosta y en al abejorro 6 abeja que llena el aire con sus zumbidos.

Algunas veces ofrécese a los labitantes de un valle, cruzado por una corriente, la mejor ocasion, no solo para ver los colcopteros en enormes legiones, sino tambien para observar hasta yue punto depencien de lis localidades donde halsitan; csta ocasion es debida por lo regular á las inunda. ciones, je entoncess se contempla un cuadro en extremo interesante respecto al mundo de los insectos.

En el periodo del deshiclo, cuando los témpanos bajan por los rios, miles de insectos de que los coleópteros constitugen la mayoria, cstán sumidos en el letargo invernal, y solo algunos visitan las pendientes de las montanas banadas mas tiempo jor los rayos del sol, experimentando la benéfica infuencia del astro diurno. Fintonces se acercan con estrépito las heladas olas, arrollando todo cuanto se opone a su paso, todo cuanto sobrenada en la liquida superficie scgun las leyes fisicas, como pedacitos de madera, tallos de caña, restos de plantas yotros ufjjetos que nunca falian en las orillas de los rios y se depositan por fin cn ellas, senalando despues, cuando bajan las aguas, los puntos a que estas habian llegado. Estos depósitos dan a conocer todo cuanto habia en el suclo inundado, y su exámen es fácil 6 penoso segun el modo de hacerlo. Si se coge en seguicia una parte de los depósitos aun húmedos, para llevarlos a casa, : se colocan en vasijas, en habianciones caldeadas, se observara una animada vida de insectos tan luego como haya desaparecido la humedad, produciendo el calor sus efectos benignos. Si entonces se ponen algunos palitos en las vasijas pronto se llenarán de coleópicros de las especies mas diferentes, en mayor ó menor número de individuos; y en este caso solo debe esperarse el tiempo en que los rayos del sol despierten a los soñolientos, serando todo el depósito de modo que la humedad solo queda en las capas inferiores. En estas se presentan entonces todos los insectos encenllados en la arena y yue por de jronto se creen seguros en aquel escondict, hastiz puc proco á proco ste displer. san para ir en busca de su alimento y reproducirse. Además de los coleópteros y de sus frngmentos hállanse hemipteros, arañas, alguna oruga de mariposa y otros animales, segun la region donde se cogicron. Debo añaciir que estas inundaciones ofrecen al naturalista un merito seguro para conocer las especies de colcópteros que en esta region invernan en el estado perfecto.

Otro cuadiro se obsersa, mas animado sun y no monos curioso, cuando la inundacion es causada por una tempestad en verano. Los campjos cstán pobladas entonces de toda clase de anmales, y en particular las praderas yıe por lo regular se hallan mas próximas a los rios; en la inmediacion clel sitio donde la desenfrenada naturaleza abre sus esclusas celestes, una observacion como la indicadia no es posible, siendo preciso situarse alli donde las aguas avanzan mas lentamente y penetran cada vez mas en tierra firme. Al fijar nuestra atencion en este punto, observaremos una vida muy activa y al mismo tiempo del zodo silenciosa. Por un talio de yerba sube un elafro seguido de un rizotrogo y de un pesado grisoniele, todos huvencio del licjuido clesnento: unuy pronto trepan tanbien un carabo: nero ;ay! la delgada hoja se inclina bajo el peso. y el agua toca al coleóptero, yque sin percier por eso la serenidad cógese al tallo que debce salvarle y sube de nuevo. Sin embargo, todo es inútil, porque jesa demasiado, y cogido a su hoja desaparece bajo la liquida superticic. Entonces la suclta, poscido de espanto, rema cn aquel elemenio a que no esta desacostumbrarlo, sostiénese, avanza, y sim otro contraticmpo llega al fuerte tallo de una umbelifera. Aun tieno fuerza bastante para ircpar, y aunque encuentra á su paso un crisomélido pasa apresuradaniente sobre él: cste insecto, espantado à sll vez, déjose caer y se encuentra en la misma situacion de que ha salido su companero. Lil salvado, rendido de fatiga, y puesto sobre una hoja, limpiase con las patas.anieriores y parece haber escapado por lo pronto del peligro. Entonces ve à otros dos individuos nadando, cada cual á su manern, segun le obliga á ello la necesidad; 10 a poco aparece un tercero, cuyo cuerpo prolongado se distingue por un bonito color brillante de cobre: es un donacino, que cual si estuviese muerto tiende sus seis patas hácia abajo y las antenas hácia adelanic, dejandose llevar por cl agua, como si se resignara con su suerte. Iass antemas tocan en un objeto, inroluntariamente se entreabren, adhiriéndose con su cara interior; el insecto se aprovecha de esta circunstancia farorable; La vida vuelice á las patas, y entonces vemos cómo el intré pido madador trepa ligero por un tallo de yerba como si nada le hubiese sucedido.

Mas alli se ven, oprimiéndose sobre una hoja unos contra otros, varios coleópteros sojos, negros, verdes y azules, los cuales parecen deliberar sobre lo gue se debe hacer para escapar del peligro, pues tienen erguidas sus partes anteriores y las antenas se mueven de continuo. Mucho tiempo hace que dos ojos verdes se han fijado en ellos; y héte aqui uzue de pronto varios de aqquellos coleópteros pasan al estómago de una rana; los que escapan se mueven de todas las maneras posibles en el agua sin saber cómo salvarse.

Un pequeño sauce, que solo icue algunos retonos, sobresale mucho de las gramineas ý jerbas immediatas, y es un fuerte baluarte para sus habitantes primitivos y puerto seguro para muchos náuiragos, por lo cual estí poblado ahora de individuos de todas las iribus del jueblo de los insecios. Un clorófano verde, cuyo color resalta junto al borde amarillo de sus elitros, y al que sigue otro individuo de su especie, se ha fuesto en marcla parm subir un poco mas arriba, porque abnjo siente ya la humedad, y no tarda en réunirse con otros muchos. 'lodos aquellos insecios se entregaban alli í los placeres de la comida $y^{\prime}$ del amor antes de la inundacion, y lo mismo harain cuando haya desaparecido, pues viven en la nejor intcligencia con otros muchos, entre los cuales se cuenta un gran número de coleópteros verdes ó azules. Lin espectáculo parecido se 110 sofrece en una superficie libre del agua, desprovista de toda regetacion, y yue bordea las orillas álgo salientes de una pequeña ensenada. Aquif los apuros son nun mavores y no hay que pensar en refugiarse en tiern firme, ni aun por algunos momentos. El agua deposita hojas, fragmenlus de madera, cortezas y otros objetos, tal como tajones de corclio y restos regetales, etc, todo cubierto de nadadores involuntarios. Alli llega, posado en un frágil pedacito de caila, un pequeño habiante del estiércol (Afhodius), que sin duda ha hecho un buen viaje sobresu delicada embarcacion; y por otra parte acércase un miriajpodo buscando su salvacion. Los fragmentos de madera, atraidos por las ondas, se balancean en todas direcciones, chocan entre si, y cuando uno se desvia es reeny hazado al punio por otro objeto. En medio de todo esic cros sulo se ven animales terrestres incapaces de salit a la orilit ó de sostenerse tan solo un momento en la superficie del agua: $y$ basta formarnos una idea de la situa. cion de ayuellos poibres naufragos para comprender toda su angustia. Su resistencia vital es sin embargo major de lo que podria creerse, pues se oponen a las fuerzas del elemento que derriba las casas, y gracias a su tenacidad y valor lagran sal. varse. De pronto se ve llegar à la orilla un haz de cañas, que 
cncallan tan luego como el agua retrocede, lo c»al suele suce. der muy pronto, y entonces prodúcese de nuevo el caos en el ejército de insectos, que procuran aprovechar aquella ocasion para salvarse. Si despues se procura averiguar el número de insectos salvados, mucho nos admirara enconimr un gran grupo de individuos qque al medio dia ó por la noche vuelan por el aire pam buscar su alimento ó recrearse. To compren. demos porqué no hacen uso de su facultad de volar en ves. de abandonarse de ese modo á su suerte. Tambien en ouras ocasiones, por ejemplo cuindo han caido en las trampas puestas por los guarda-bosuues, no se salvan volando porque son prin-
cipalmente terrestres.

En otra época muy remota, cuando emn mas considerables las aguas que cubrian la tierm, produciéndose-revolu. ciones muy distintas de las que hoy pueden ocurir por una inundacion, murieron tambien, como hoj, muchos coleopte ros, descubiertos despues por el naturalista bajo la forma fósil. Conócense ahora unas mil especies que conenzando en la formacion carbonifera aumentán en número en la ter.
ciaria y en el ámbar.

CLASIFICACIUN.-Respecto a la clasificacion de los coleopterns, desde Linneo, muchos de los mas notables entomúlogos se han esforzado por hacer una lo mas natural posible; pues no puede negarse que ningun otro orden de insectos ha sidotan estudiado jor la ciencia comó el de los colcópteros Fabricius, Latreille, Westwood, Burmeister, Erichson, Le Contc y otros muchos se han ocupado de familias aisladas, enniqueciendo nuestros conocimientos para la clasificacion de los coleópteros; pero como no parece oportuno discutir aqui las razones en pro ó en contra de la conveniencia de uno ú otro método, ni podemos dar un sistenta completo, tomamos por guia el sistema de Iacordaire. Este nos ha dejado en su Generndes Colcopteres una obra inmortal que desde el año is 5 f ocupó toda la actividad de su autor, quiern desgraciadamente no pudo concluirla porqque la muerte le arrebató demasiado pronio de entre los vivos. Termina con los capricornios en el tomo noveno y no caracteriza ninguna especie, limitándose à las ramilias y los géneros.

\section{LOS GICINDELIDOS CICINDELIDAE}

CARACTERES, - las especies de esta familia se distinguen por tener un diente movible en la punta interior de un palpo de dos articulaciones formado por la maxila exterior de la mandibula inferios: cućntanse cuatrocientas distintas especies que, careciendo de este distintivo, pueden reconocerse por la conformacion caracteristica de su cuerpo.

\section{EL CICINDELA CAMPESTRE.-CICINDELA CAMPESTRIS}

CARACTERES. - Fil cicindela campestre es un coleóp tero verde de mediano tamaño $y$ de una agilidad extraordinaria, que en verano vaga por las regiones arenosas bien bañadas jor el sol. Sus caractéres, lo misino que los del género a que pertenece, son los sigtrientes. La parte posterior del cuerpo se compone en ul macho de sicte anillos y en la hembra de seis, hallándose soldados los tres primeros entre si, en ambos sexos; las patas, delgadas, estin provistas de cinco dedos; las posteriores son anchas, $y$ las anteriorts presentan otro distintivo sexual, pues en el macho se ensanchan mucho extremidad un surco aculaciones. El escudete tiene en cada rextremidad un surco trasversal $y$ dos longizudinales que los reunen; la calseza es rélativamente grande; la frenie apla- inada; la barba presenta una profunda escotadura, y la lengua está muy atrofiada. La maxila exterior de la mandibula inferior forma un párpado de dos articulaciones y la punta de la maxila interior tiene un diente movible (iig. 4).

USOS, COSTUMBRES Y REGIMEN.-El cicindela campestre no permite nunca al observador acercarse lo bastante para que pueda examinarle mas de cerca; siempre timido, vuela presuroso, dejando ver el brillo azul de su abdómen, pero vuelve á posarse á cierta distancia y da siempre media vuclta en direccion contraria a la que seguia. Si nos detenemos en el sitio en que se posó, con la esperanza de sorpren. derie, vemos elevarse de todos lados individuos de la misma especie, cuando abundan en el pais, pero antes de llegar al sitio en que con seguridad se cree poder atmpar uno, remóntanse por los aires y se alejan volando, hasta que sé cansan y continuan su fuga à la carrera. Vemos á menudo una infinidia de estos insectos al rededor de nosotros, $y$ a pesar de esto no cogemos ninguno en todo un dia de sol, como no nos valgamos de ardides particulares. En mis correrias logré con frecuencia coger uno de esos coleópteros, gracias à su cansancio, arrojándole de repente mi panuelo por encima; pero aun asi no se da yor vencido, pres si solo queda una pequeña abertura en el bordé de su improvisada prision, sale presuro so y escapa de nuevo. Si por el contrario se le sujeta bien, defiéndese valcrosamente; nucrde furioso con sus maxilas falciformes, ngita las piernas $y$ hace todos los esfuerzos posibles para recobrar la libertad. Las maxilas son muy puntiagudas, tienen tres dientes largos $y$ afilados, $y$ al cerrarse la una cubre la otra, comunicando al rostro una expresion sal. vaje. Los ojos son muy salientes; todas las prartes del cucrpo en extremo niovibles, $y$ sobre todo las antenas, que compues. tas de once/articulaciones y en forma de hilo, se insertan sobre la base de las maxilas.

El cuerpo es de color verde; la base de las antenas y las patas, muy peludas, tienen un lustre rojo cobrizo; cinco manchitas que adonsan el borde exterior de los clitros, otra mas grande que hay detrás del centro, en el disco, y el gran escudete, no aquillado, son de color blanco, el último cuando menos en la punta. En el tinte predominante, que í reces pasa al azul, y en los matices de los elitros, se obscrvan muchas rariaciones.

El cicindela campestre se oculta entre la yerba y el trigo cuando el cielo está nublado, pero no con mucha destreza. Siempre sale por la noche en busca de su alimento, que se compone de otros insectos: no recuerdo haber visto sunca uno de estos coleópteros comiendo, que es cuando mas llaman la atencion.

La larva, de extraño aspecto, tiene la region inferior del rostro dilatada, y dos espinas dirigidas hácia adelante en la parte supcrior del octaro segmento: a cada lado de la cabeza hay cuatro ojos; las anicnas tienen cuatro articulaciones $y$ los órgános masticadores se asemejan à los de los demás coleópteros. Las tres articulaciones anteriores del cuerpo jresentan en el dorso una hoja cómea, y en la parte del pecho hay un par de patas provistas de garras. La larva pernanece en un tubo vertical, del diåmetro de un carion de pluma y de unos (1)", 47 de profundidad, donde acecha los insectos, pequeños coleópteros, hormigas y otras larviss. Cuando ha cogido una se retira al fondo de su escondite, y alli muerde á su victima para chuparle el jugo. Ya se comprendera que no siempre se acerca el número necesario de víctimas para satisfacer el apetito de la larva, y asi es que esta ahandona de noche su retiro para cazar. No sé si se desarrolla del todo en el espacio de un año, pero lo dudo, porque en la primera mitad de agosto se ha observado la trasformacion en crisilida, y no debe suponerse que desde fines de mayo, cuando se presenta el co- 
leóptero, la larva pueda haberse desarrollado de tal modo. Antes de trasformarse ensancha el fondo de su zubo, cierm la entrada y' se metamorfosea en crisálida, la cual Ilama nuestra atencion por las prominencias en forma de espinas que presenta en ambos lados del dorso, muy desarrolladas sobre todo en la quinta articulacion del abdómen y que probablemente ayudan al coleóptero à salir de su cubierta. Por las observaciones hechas se ha reconocido quıe la ninia solo descans? quince dias en tal estado.

Muy pocos congéneres del cicindela campestre labitan en Alemania, mientras que se cuentan mas de cuatrocientas especies diseminadas en las regiones del globo y que habitan con preferencia los sitios secos y arenosos, tanto en el interior del pais como á orillas del mar, en las llanuras y en las montañas, buscando no oistante las zonas cilidas. Fuera de algunas especies de un color casi blanco de marfil, la mayor parte de las demás se distinguen por tener en los elitros matices de un fondo mas oscuro, por ejamplo de color de bronce, presentando además una mancha lunar en la cxtremidad del abdómen y una faja angulosa en el centro. 'Todas las especies miden por término medio una longitud de $\theta^{m}, 012$ i $11^{\circ}, 015 ; y$ en cuanto à su género de vida, es antilogo.

\section{EL COLIRIS DE CUELLO LARGO - COLIY - RIS LONGICOLLYS}

CARACTERES. - Esta especie puede servirnos para dar una idea de las formas inas prolongadas de esta familia: la tercera articulacion de las antenas, la mas larga de todas, es delgada y plana; el labio superior tan grande, que cubre las maxilas; la frente deprimida en forma de silla de montar; la cabeza se estrecha mucho deiris de los ojos, que son grandes. No es menester describir las formas de las otras partes y solo respecto al color dire que todo el colcóptern tiene un matiz negro azulado, excepro los muslos que son rojos.

DISTRIBUCION GEOGRAFICA. - Esta Especie y otras afines, todas ellas muy ágiles, habian exclusiramentc el sur de la peninsula indica $y$ las islas inmediatas.

\section{LOS TRICÓNDILOS-TRICONDYLA}

CARACTERES.-I,os insectos de este género ticnen las antenas filiformes $y$ bastante largas; los tarsos anteriores presentan los tres primeros artcjos dilatados en los machos; los palpos son pequeños; la cabeas bastante grande; el labio superior cubre enteramente las mandibulas; la escotadura de la barba carece de diente; cl coselete forma una especic de rodete por detrás y por delante; las paias son largas.

DISTRIBUCION GEOGRAFICÁ. - I.os insectos de este género son originarios de la Ocennia.

Conócense hoy dia mas de doce especies.

\section{EL TRICÓNDILO APTERO - TRICONDYLA APTERA}

CARACTERES.-Fl color de este insecto (fig. I) es negto, un poco azulado; los clitros estin cubiertos en sus dos tercios anteriores de rugosidades trasversales, y por la parte caterior son casi lisos; las ancas ofrecen un tinte pardusco.

DISTRIBUCION GEOGRÁfICA.-Esta especie es originaria dic Nueva Guinea.

USOS, COSTUMBRES Y RÉGIMEN.-El tricóndilo aptero anda con notable agilidad, y se le ve por lo regular en los troncos de los airboles; el trotamiento de su coselete produce un ruido poco perceptible.

\section{LOS MANTICORAS - MANTICORA}

CARACTERES.-En este género figumn las mayores especies de la familia: sus formas son robustas, $y$ al jrimer golye de vista ofrecen cierta semejanza con las grancies aranas del género mygale, con las cuales se han comparado a menudo. La cabeza de los manticoras es voluminosa y aplanada en la frente; los palpos grandes; las mandibulas iuertes, arqueadas y mas largas que la cabeza; tienen las antenas delgadas y filiformes, con el tercer artejo prolongado y anguloso; los oijos pequeños, redondendos y poco salientes; el coselete de la misma longitud que la caleza poco mas ó menos, y como dividido por un surco trasversnl: los elitros estain soldados ó presentan anteriormente una escotadura en semicirculo, son planos 6 un poco convexos, y carcnados lateralmente; las patas, bastante grandes, estan culbiernas de pelos rigidos y compactos; los tres primeros artejos de los carsos anteriores son sencillos en ambos sexos. Todos los manticaras son completamente negros.

DISTRIBUCION GEOGRÁFICA. - - l.05 insectos de este géncro son propios del Africa meridional.

\section{EL MANTICORA MAXILAR - MANTICORA MAXILLOSA}

CARACTERES.-El cuerpo del manticora maxilar (figu. ra 2), que es la especie típica, está todo cubierto de pelos escasos ! rigidos, mas numcrosos en las patas; los elitros ofrecen el aspecto de la piel, sobre todo en su parte posterior. Fl color del manticon maxilar es negro poco brillante. Su tamaño de una pulgada y sicte lineas de largo yor otras tantas de ancho.

DISTRIBUCYON GEOGRÁFICA.-Este insecto habita, como hemos dicho antes, en el Aírica meridional: se encuentra sobre todo en el Ciabo de Bucna Esperanza

USOS, COSTUMBRES Y REGIMEN.-LOS viajeros dicen que este insecto acostumbra d ocultarse debajo de las piedras; pero que a menudo se le ve correr por los parajes arenosos, distimguiéndose por la notable rapiácz de sus movimientos. listo es todo cuanto sabemos acerca de su géncro de vida.

Durante mucho tiempo no se conoció inas que esta especie; pero en estos últimos ticmpos se han descrito cuatro mas, si bicn son muy raras en nuestras colecciones.

\section{LOS OMOFRONES - OMOPHRON}

CARACTERES, - In cabeqa de estos inscetos es casi cuadrada; los ojos muy grandes y salicntes; cl labio supcrior del todo escotado 6 ligeramente; el coselete corto. pero mas ancho en la parte posterior; el cuerpo plano, casi orbicular; los elitros cortos y semi-ovales; las patas bastante largas; los tarsos anteriores se dilatan en los machos. I.os omofrones son siempre testáccos con fajas of manchas de un verde metálico en la parte superior.

DISTRIBUCION GEOGRAFICA.- Aunque las esplcies de cste género son poco numerosas, su área de disjlersion es muy extensa, puesto que estan diseminadas en furojar en el Cábo de Bucma Espemnza, en Madagascar, en Asia y en la América del norte.

USOS, COSTUMBRES X RÉGIMEN.-I.OS OMOírones viven en la arena fina que bordea las islas y los rios, de modo quue para cogerlos basta hacer un hoyo. De lo contrario, rara vez se les encuentra; pero cuando se les descubre es ficil apoderarse de muchos. 
Las larvas de estos insectos son por lo general muy ágiles, y cuando se les toca levantan in extremidad de su cuerpo. Habitan los mismos lugares que el insecto perfecto.

las especies de omofrones conocidas hasta hoy no pasan de veinte, cuya historia no ofrece de particular mas de lo clicho.

\section{LOS CARABICIDOS - CARABICID压}

CARACTERES. - I os caralúciclos ó coleópteros corredores, son por todos conceptos tan afines de los cicindélidos, sohre todo por la forma de los palpos de la naxila exterior de la mandibula inferior, que podrian reunirse con estos en una sola familia si no les fáltari el diente movible en la pun. ta de. la maxila interios. I a barba ticne una profunda ésco. tadura denticulada de varias maneras, las piernas no son sienzpre tan delgadas, y los piés del macho se ensanchin en tres ó cuatro articulaciones. En estos insecios vemos repetida támbien la forma general del cuerpo. Tas maxilas, sin embargo, no son tan largas como en los cicindélidos, y nunca están proristas de dientes puntiagudos á lo largo de toda la cara interior; los clitros llegan casi sicmpre a la extremidad del aludómen, pero tambièn se truncan, pudiendo ser lisos ó rayados. A menudo faltan las alas postériores ó se atrofian yor lo meños mucho, y aun en las especies en que existen sirven cuando mas de noche para el melo. El abdómen suele tener en ambos sexos seis segmentos, hallindose soldados los tres anteriores. Los colores abigarrados, propios de los cicindélidos, distinguen tumbien à varios crmbidos, mas por lo regular presentan un solo tinte negro, vercic, rojo, cobrizo o pardo bronceado, que comunica d la major parte de las especies de esta frmilin su aspecto en extremo monótono.

DISTRIBUCION GEOGRAFICA. - I AS $S, 500$ especies conocidins de carabicidos se dividen en 6 I 3 generos, une habitan toda la tierra, abundando en las regiones templadas y frias nus que los otros coleópteros: son caracteristicos para ciertas localidades; y asi, jor ejemplo, se encuentran algunas especies exclusiramente en la montaña y nuna en laillanura ó viccuersi.

USOS, COSTUMBRES Y REGIMEN. - LOS carabicidos evitan mas bien que buscan la lur celel sol, y por eso les gusta ocultarse débajo de lás piedms, en la madera podrida, etcétera; son coleónteros nocturnos que se alimentan de la carne de otros animales.

Desgraciadamente solo se conocen las larvas de pocas especies. Distinguense por su cuerpo prolongado, cubierto en el dorso mas ó menos de escudos de quitima que remain en dos apendices casi siempre duros y no articulados, llevan seis pies de dos caras en el tómx ý su raheza es proinngadia. Las maxilas sirven por lo regular solo para sujetar y herir la presa, pero no para mascar; con la abertura bucal chupan.

\section{LOS ELAFROS - ELAPHRUS}

CARACTERES.-Este género, compuesto de veintiseis especies, recuerda por muchos conceptos á los cicindélidos, sobre todo por los ojos muy salientes y por la forma de todo el cuerpo, que sin embargo es mas pequeño.

DISTRIBUCION GEOGRAFICA. - Los clafros habitán todos los paises fuera de los trópicos. Algunas especies se encuentran tambien en Alemania.

\section{EL ELAFRO DE RIBERA-ELAPHRUS RIPUARIUS}

CARACTERES. - Fl clicrpo de este pequeño coleóptero es de color verde metálico con espesos puntos y cada elitro está provisto de cuatro series de verngas deprimidas de co. lor violado. En la escotadura de la barba se ve un diente doble $y$ las cuatro primeras articulaciones de los piés anteriores del macho se ensanchan, aunque solo ligeramente. Este co. leóptero tiene ademais un aparato musical: la parte superior del penúltino segmento del abdómen está dividida en tres placas, de las que las dos laterales tienen un reborde algo aryueado y denticulado; con estos relsordes, el coleóptcro frota, al mover el abdómen, contra una vena prominenté huecil que tiene en su exterior profundos surcos en el lado exterior de los elitros: Landois hace una descripcion minu. ciosa de este apurato.

USOS, COSTUMBRES Y REGIMEN.-Tambien por su género de vida los elafros, y sobre todo el de ribera, jueden considerarse como tránsito entre los cicindélidos y carabicidos. El elafro de ribera busca la luz del sol, corriendo con una rapide\% extraordinaria, no en sitios secos, sino en las orillas cenagosas de las aguas, en el fondo de los charcos casi secns y en has praderas húmedas provistas de una escasa vegetacion de gramineas. No se sustrae a la persecucion volando, sino qute confia en la ligereza de sus patas y en su buena suerte jara llegar á un escondite seguro. Con una agilidad increible desaparece debajo de un pedazo de corteza 6 una caña, entre los juncos y yerbas de las praderas, y sabe aprovecharse muy bien de las hendiduras del suelo, que en los sitios conde habita se forman a los pocos dias por el calor de los rayos solares. En estos escondites permanecen tambien cuando hace mal tiempo, sin ser vistos de las aves insectivoras gue en los mismos puntos sorryrenden y devoran los animalitos que alli están tomando el sol.

\section{LOS CARABOS - CARABUS}

CARACTÉRES. - Ningun carabicido sera propio en tan silto grado para dar al naturalista una idea de toda la familia como el género de los carabos con sus afines, género que á toda la familia ha dado el nombre, ofreciendo en sus espyecies los individuos que con preferencia se recogen por los entomólogos y coleccionistas, à causa de su considerable tamaño, sus colores metálicos, y las formas del cuerpo, que corresponde al tipo de la fanilia. 'lambien Ilanın la atencion del profano, no solo en estado libre, sino tambien cuando se hallan cautivos. Las especies tienen por término medio la longitud de 1"",022 y raras veces miden menos de 6", or 5, que es el tamuio ordinario. La cabeza es prolongada, mucho mas estrecha que el escudete; el labio superior bipartido, la escotadura de la barba presenta un diente medio, y la extremi. dad de los palpos afecta la forma de hacha. El escudete, que en su parte anterior es siempre mas ancho que en la posterior, se separa marcadamente de los elitros:'estos son ovales y del mismo color que el escudete y la cabeza, aunque á veres presentan en sus bordes exteriores un tinte mas vivo, ofreciendo tambien la mayor variedad respecto a las proporciones de la superficie. Pocos parecen perfectamente lisos á la simple vista, pero aun estos no lo son en realidad, pues tienen rayas como trazadas con una aguja: en muchos se ven finas fajas longitudinales, $\delta$ bien presentan $i \dot{l}$ la simple vista una especie de arrugas; en las especies que tienen surcos finos se ven serries regulares de prominencias, de puntos cón. cavos, ú hoyitos con mas brillo. En los casos en que la superficie es áspera resaltan algunos rebordes longitudinales (3 en cada elitro), dejando profundos surcos en el centro, que a su rez pueden llevar diferentes adornos. Las alas se atrofian casi siempre excepto en algunas especies, de modo que todos los carabos solo son buenos para la marcha. Sus 
patas son fuertes y tienen la estructura indicada al hablar de In familia. En el macho solo se ensanchan las tres primeras articulaciones del pié, provistas de una planta velluda. En la mayor parte iambien la cuarta articulacion está un poco ensanchada, pero carece de la planta velluda, que cuando mas es atrofiada. El color siempre metálico es negro, verde dorado, azul 6 pardo bronceado: pero tanto el color conso ia naturalcan de los elitros ofrecen muchas diticultades parn la rasificacion de las especies.

DISTRIBUGION GEOGRAFICA, - Ins doscientas ochenta y cinco especies de carabos conociclas son propias de las regiones templadas del hemisferio septentrional y no traspasin en el antiguo mundo los paises del Mediterráneo, excepto algunas especies bastante grandes que viven en Siria, Palestina y el Cáucaso. En la Amćrica del norte estin diseminacias mas al sur, y hasta en Chile se encuentran diez especies.

USOS, COSTUMBRES Y REGIMEN.-Muchos carabos habitan exclusivamente en las montanas: las especies de los Pirineos son magnificas; en Alemania se hallan casi las mismas lass piedras de las pendientes y los malles, y los troncos cortados de los árboles en putrefaccion son sus principales escondites, en los que el coleccionador puede buscarlos con buen éxito, desde la última mitad de agosto, pues aqui, ó entre el musgo, nacen, se ocultan de dia y pasan todo el inviemo. Ias especies que viren en las llanuras en-

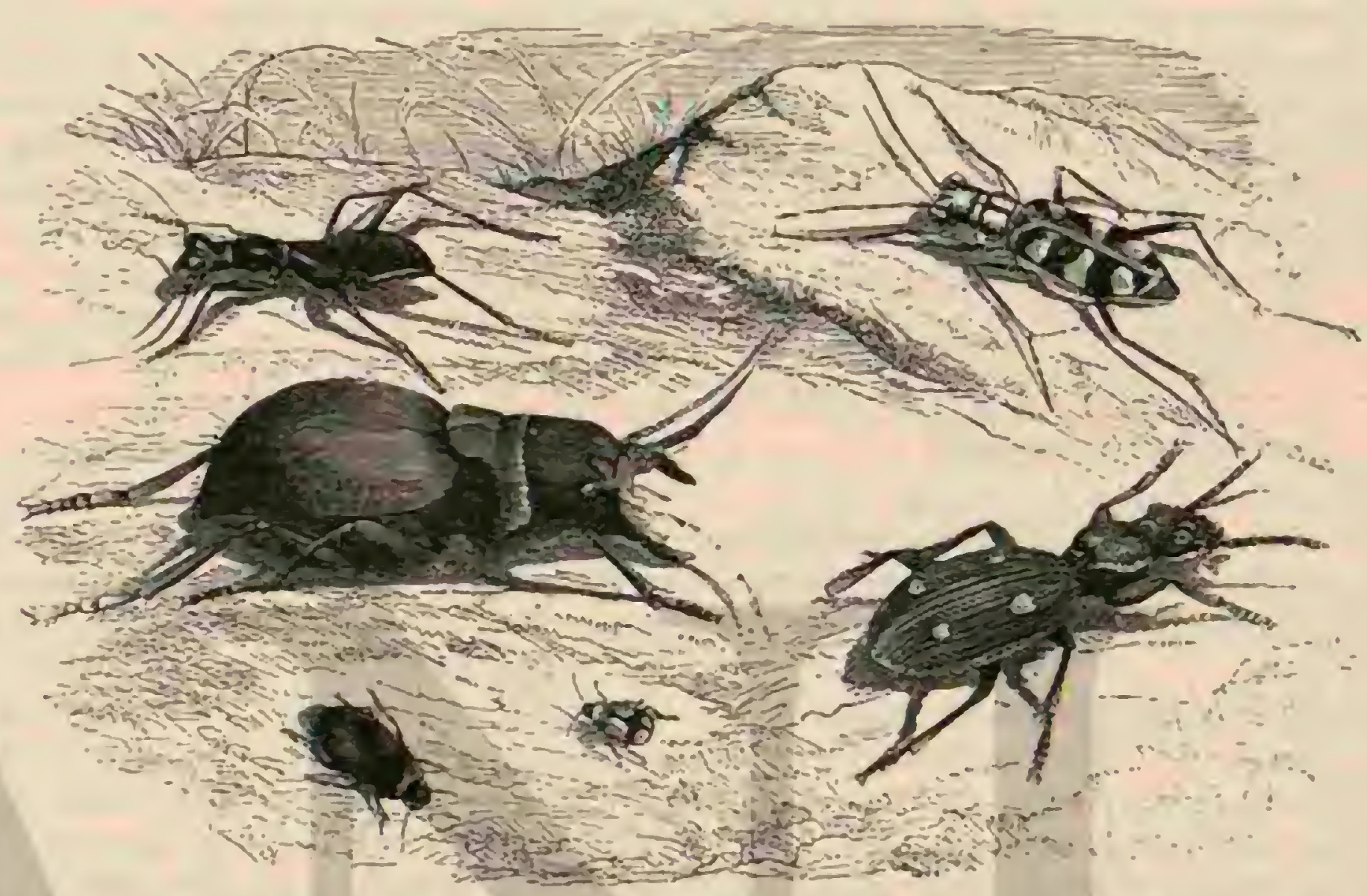

Fig. I.-R.1. TRICOSIDILD AITBRO

Hig, 2.-P.I. MANTICORA MAXILAR

Hig. 3.-EீL HARหATO ENEAS

Fig. 6. -EL 1.8:H1' H: CKLT. TERUESA

Fig. 4.-8.1. CICI:IDELA CASIPESTR:

Fig. 5.-F. ANTIA JE SEIS MANichAS

cuentran en el bosque los mismos refugios y en los jardines y campos algunas piedras, pedazos de tierra, milias de jerba, agujeros de ratones y utros sitios que les sustmen à la luz del sol, y donde otros habitantes, cono caracoles, lombrices y larvas de insectos, etc., les sirven de alimento. De noche salẹn en busca de su presn, pero vuciven a ocultarse tan luego como el astro del dia asoma por el horizonte.

Las pocas lartins conocidas se parecen no solo por el genero de vida sino tambien por su forma exterior. El cuerpo, prolongado y en parte cilincirico, tiene en todos los segmentos dell lomo escudos de quitinu de ua negro brillante, siendo mas claro en el vientre, porque junto sas membmas ligatorias, que son blancas, solo unas callosidades g rebordes indican los sitios duros. Ia cabeza, cuadrangular y prolongada, tiene las antenas de cuatro artejos, seis palpos, maxilas falciformes, y a cada lado un anillo de scis ocelos; la abertura de la boca es pequena $y^{\circ}$ solo sirve para chupar. Sobre el dorso de los dore segmentos del cuerpo se corre un lino surco central; el ultimo segmento remata haicia arriba en dos espinas de diferente, longitud y denticulacion segun la especie; y el ano puede sobresalir hacia abujo en forma de espiga. Ll primer anillo se distingue de todos los demás y los dos siguientes tambien del resto por su longitud. Las larvas viven en los mismos sitios y del mismo modo que los coleópteros, segun parece desde principios de la primavera hasta el otono, aunque podemos suponer que su desarrollo no se verifica regularmente, pues he hallado en la selva de Turingia á fines de agosto de $18_{74}$ algunas larras que parecian pertenecer al carabo dorado (ourabus auronitens), aunque esta especic se encuentra con hastante frecuencia desarrollada ya en dicho mes. Ia crisilida, ancha y blanc:a, havitn los mismos sitios donde la larva vivia y mecesita poen tiempo mara su desarrollo.

\section{EL CARABO DE LAS HUERTAS-CARABUS HORTENSIS}

CARACTÉRES. - lil carabo de las huertas. segun Jinneo ha llamado á esta especic, vive con mas frecuencia en los campos que en las huertas, y por lo tanto parece mas propia la denominacion de Fabricius, que le dió el rombre de carabo de piedras preciosas (cinrubus gematus), porque los bordes de los elitros, $y^{\circ}$ en cada uno de estos tres sicries de hoyitos planos, resaltan por su brillo cobrizo, asemejaindase il piedras precjosas solure un foncio de color negro mate.

DISTRIBUCION GEOGRÁFICA.-Habita por lo regular los bosques de la Alemanis orienial, llega por el sur lasta el Iirol y Suiza, for el este hasta Rusia, y por el norte hasta Suecia.

\section{EL CARABO DORADO-CARABUS AURATUS}

CARACTÉRES.-Este coleóptero pertence i las espe. cics muy surcacias, pues en cada elitro tiene tres rebordes y 
en medio varios surcos ligeramente rugosos. I a partc inferior del insecto es de un negro brillante; la superior de un verde metálico, y las patas y la base de las antenas negras.

DISTRIBUCION GEOGRÁFICA.-Fl carbo lorado se encuentra en cl oeste de Alemania, en verano con mucha frecuencia en los campos y jardines; falta desde la region de Wittemberg y no se le ve casi nunca en la Marca ni en Pomerania; pero reaparece en el territorio de Prusia; escasea en Inglaterra y Suecia, abundando co Prancia y Suiza.

USOS, COSTUMBRES Y REGIMEN. - Klingelhoeffer, de Darmstadi, ha hecho en esta especié uná observacion interesante que revela cierto grado de reftexion en ese colcóptero. Fn mi jardin, dice, a poen distancia del tanco en que estaba sentado, veiase un abejorro boca nuriba, haciendo va. nos esfuerzos para ponerse en pie Entre tanto salio del bosquecillo jróximo un carabo dorado, que precipitandose sobre el abejorro pelés con él lo menos cinco minutos sin poder dominarle, de lo cual pareció convencerse al fin, pues le abandonó para volier al bosquecillo. Al poco rato presentósc otra res, seguido de un compañero, en el canpo de batalla; y los dos coleópteros vencieron al abcjorro y se lo llevaron i su escondites

\section{EL CARABO DORADO DE LAS MONTANAS- CARABUS AURONITENS}

CARACTERES. - El carabo dorado de las montañas es muy afine de la especie anterior; el color del dorso es amarillo dorado con brillo mas vivo; la cintura y los rebordes de los elitros, negros.

DISTRIBUCION GEOGRÁFICA.- Este coleóptero no escasea en ninguna montana de Alemania ni tampoco en los Cárpatos, en los Alpes de Suizia y en la Francia orienial; mieniras que en la llanura solo se lé encuentra muy aislado.

USOS, COSTUMBRES Y REGIMEN.- Heer obtuvo en Suiza el 3 de junio de una larva ma cristlida, y de esta en is de jumio, el coleóptero que era blanco, si bien adyuirió al cabo de veinticuatro horas todo su color y direza. Ia larva tiene en la frenie una protuberancia juntiaguda; en el escudete otras dos obzusas y en su parte anicrior dos puntas espinosas de la longitud del último segmento. puntas que adquieren por dos espinas laterales tma forma triangular.

\section{LOS CALOSOMAS-CALOSOMA}

CARACTÉRES.-El género de los calosomas se distingue de los carabos por la seguncla articulacion de las antenas, en extremo cortas, por el escudete, dispuesto trasversalinente y muy redondendo en los lidos, por los clitros, anchos y de forma casi cuadrada, y por las alas, que suelen alcanzar bastante desarrollo.

DISTRIBƯCION GEOGRÁFICA.-Los calosonas, representados poco mas 6 menos por setenta $y$ nueve especies, están diseminados por toda la tierra.

USOS, COSTUMBRES Y REGIMEN,-Aurque tambicn viven en el suclo, habitan con preferencia los troncos de los arboles, por los cuajes suben y bajan en busca de las orugas y crisilidas de mariposas y de las larns de otros insectos, las cunales comen con gran voracidad.

\section{EL CALOSOMA ASESINO-CALOSOMA SYCO- PHANTA}

CARACTÉRES. - El calosoma asesino, llamado tambicn bandolero, etc., es de color axul metálico, con lustre verdoso $\delta$ rojizo dorado cn los clitros, que por lo regular son rayados $y$ tienen seis series de puntas: las partes de la boca y las ante. nas, excepto su punta mas prólida, asi como las robustas patas, presentan un color negro brillante de carbon; en estas ultimas obsérvase que las del macho se ensanchan en otra articulacion de los piés anteriores.

USOS, COSTUMBRES Y RÉGIMEN. - Este coleóp. tero se encuentra particularmente en los pinares y abunda sobre todo los años cn que hay muchas orugas, siendo por lo tanto su mision ayıdar a resiablecer el equilibrio perdido. Se ha observado cómo un mismo colcúptero subía docé ó quince veces por un árbol, precipitandose sobre una oruga, llevarla a tierra y repetir la misma operacion despues de haber muerto a la victima. En abierta lucha con esos insectos, y sin temor alguno, el calosoma asesino cac sobre su presa apenas la ve. la grande oruga de los pinos se resiste con tenacidad cuando se la ataca; pero el rapaz no la suelta y lín. zase con clla al suelo; llegado aqui continúa la lucha hasta que Ja oruga, debilitada y cansada, se resigna i su mala suerte. Fil vencedor, agarrándose con las patas nmeriores a la presa, y apoyadas las posteriores en el suclo, masca con sus fuertes maxilas reduciendo su victima á una papilla para devorarla. Si durante el festin se acera un intruso, se defiende con sus patas anteriores, y tambien con las masilas, hasta rechazar al adversario. Como ya hemos dicho, estas observacio. nes solo pueden hacerse cuando las orugas abundan en los bosques, pues si estas han desaparecido, el calosoma asesino escasea tanto, que pueden pasar anos antes de verse un solo individuo libre. Su desarrollo de la crisálida se verifica à fines de verano ó en otono; y el apareamiento despues del invier. no. Ia linrva ticne igual estructura que la de los carabos, pero como por lo. regular esta bien alimentada, su centro es mas grueso que las extremidades; tambien parece que los escudos de quitima no cubren del rodo el dorso, pues dejan ver las membranas ligatorias, mientras que en una larva flaca aque. llos se tocan marcadamente. Las espinas del último segnento abdominal son ganchudas y encorvadas hácia arriba, presentando en su base un diente. Asi como el coleóptero, la larvin trepa con la misma agilidad y con igual intencion, pero chupa su presa en vez de mascarla. A reces ocasiona destrozos en los nidos de las orugas de la especic Cueshocampra fimiora; y cuando varias larvas se encuentratn en uno mismo, la que primero se hartó corre peligro de ser victima de una de sus hermanas. Cerca ya la hora de trasformarse en crisalida, forma un lecho a poca profundidad debajo de ticrra donde solo permanece pocas semanas en estado de ninfa.

\section{EL CALOSOMA INQUISIDOR-CALOSOMA INQUISITOR}

CARACTERES. - El calosoma tiene de $0^{* 1}, 015$ a $0^{\circ}, 020$ de largo, y en sus elitros rnyados presenta seis series de puntos; el color de las partes superiores es un pardo bronceado con viso verdoso, raras veces azulado; el de las inferiores y de los bordes exteriores de los elitros verde metálico inuy vivo.

DISTRIBUCYON GEOGRÁFICA.- lil calosoma inquisidor solo se encuentra en los bosques frondosos del norte $y$ centro de Europa.

USOS, COSTUMBRES X REGIMEN. - No visita arboles viejos como el calosoma asesino: prefiere las encinas $y$ hayas de tronco delgado, que puedan sacudirse hasta con la mano. Yo le he hecho caer de las encimas jórenes en la primavera, sobre todo cuando estaban habitadas por numerosas orugas. Curioso espectåculo es ver cómo al sacudir el tronco caen varios calosomas incuuisidores sobre la hojarasca, en la cual se ocultan con la mayor rapidez posible, mientras 
que al mismo tiempo un sin numero de orugas quedan pendientes del ramaje por sus hilos, como ahorcadas. Cuando ha pasado el peligro vuelven à subir los trepadores, pero à menudo el rico botin que encuentran por el camino les compensa el susto sufrido.

\section{LOS BRAQUINOS - BRACHINUS}

Mientras que en todos los carabicidos hasta ahora descritos los tarsos anteriores no ofrecen nada de particular, en las especies siguientes presentan una escotadurn mas of menos marcada en su lado anterior, detris de la cual se hallia una de las dos espinas finales. El cjürcito de las especies provistas de este distintivo es muy superior en numero al de las anteriores, $y$ \& él pertenecen todos los cambicidos de iamaño regular, de color negro, verde ó pardo bronccado, que ammque son insectos nocturnos se encuentran tambien de dia en los caminos, por efecto de su abundancia, corriendo por to. das partes para encontrar un escondite conveniente, ó inmóviles como cadiveres aplastados por los piés del viajero. Solo nos ocuparemos de algunas especies, y entre cllas, en primera linea, la de los loraquiuos.

CARACTERES. - Estos insectos zienen la lengua grande, córnea en el centro y soldada del todo con los apéndices laterales; las maxilas bastinte salientes y fuetes, mas bien aplanadas y puntiagudas que corvas; la cabe\% oval algo estrecha por detris; las antenas fuertes y filiformes; un escudete-collar en forma de comzon; los elitros anchos y cortados en su partc posterior, cuyo ángulo exterior se redondea; cl cuerno recogido, pero aplanado, con ocho segmentos visibles en el abdómen en el macho y siete en la hembra: estos son los caractéres comunes da un gran número de carabícidos muy scincjantes, que tambien por su géncro de vida ofrecen muchos puntos de contacto. I as grandes especies, que alcanzan hasta una longitud de $0^{\circ \prime}, 0175$, tienen sobre el fordo negro casi siempre matices amarillos; las especies de Alemania estín provistas de alas desarrolladas que faltan en muchos braquinos de la Europa del sur j del Árica septentrional; son negras $\delta$ de un rojo de laćrillo, de un solo color en los clitros, casi siempre con brillo azulaclo y su tamano es mas reducido.

DISTRIBUCION GEOGRAFICA.- Estos interesantes colcúpteros se encuentran en todos los paises exccpto Australia; abundan mas en las regiones cilidas que en el norte, disminuyendo aqui de tal modo, que mientras en Francia viven aun once especies, solo se cuentan cuatro en Alemania, y muy raras reces una en Suecia. Además es muy dificil distinguirlos, debiéndose comar en consideracion el color y la diferencia de formas para clasificarlos.

USOS, COSTUMBRES Y REGIMEN. - I.os brquinos viven asociados entre las piedras ó en las raices de los arboles y tienen sobre todo la propiedad de exhalar con ruido un olor fétido por la extremidad del abdómen, jor lo cual los alemanes los han llamado bomburieres. Muy bien puecien ob. servarsc tales disparos si se echa uno de estos coleópteros en una botellita con espiritu de vino, pues al punto se oye un sonido bastante fuerte, varias veces repetido, hasta que el insecto ha gastado toda su pólvora yentrega las armas.

Otsérvansc notables variaciones en el tamano de muchas especiés, y como la historia del destrrollo no sé conoce aun, solo puede suponerse que la alimen:acion de la laria puede ser muy desigual sin perjudicar al desarrollo posterior. Ein fin, debo añadir que en el cuerpo ó en las extremidades de los braquinos se desarrollan á menudo setas: descle 1850 , año en que Rouget llamó la atencion sobre el hecho, esos insectos llegaron a ser un articulo muy apreciacio por los botinicos que estudian ese segctal.

\section{EL BRAQUINO ESTREPITOSO-BRACHINUS TREPITANS}

CARACTERES. - Esta especic, que mide hasta 0", $00 \$$, es una de las mas bonitas. Ia cabeza, las antenas, el escudete y las patas son de un rojo de ladrillo; los elitros, que carcen de puntos, de un arul oscuro, $y$ las demás partes in. feriores, negras. Si se examina el insecto mas de circa se verá que el tercero y cuarto artejos de las antenas son un yoco pardos y que todo el cuerpo, inclusos los clitros, estain cubiertos de pelos muy cortos.

DISTRIBUCION GEOGRÁFICA-Fsta especic estå diseminada en todo el centro de Europa; en los paisęs meridionales abunda mucho mas y alcanza mayor tamaño que en los septentrionales.

\section{LOS AGRAS - AGRA}

CARACTÉRES. - I OS agras son insectos de cabeza ovalar, muy estrechada por detrás y en forma de cuello; cl último artejo de los palpos labiales tiene forma de hoz; las antenas son filiformes; el coselete cilindrico y prolongado; los clitros largos y estrechos; los tres primeros artejos de los tarsos mas ó menos anchos y triangulares ó cordiformes; los ganchos tarsianos son dentados por debajo. Estos insectos tienen por lo general colores mas ó menos metalicos, y son bastante grandes

DISTRIBUGION GEOGRÁFICA. - 'Oodos los igras son propios de los paises de Amúrica.

\section{EL AGRA VARIOLADO-AGRA VARIOLOSA}

CARACTERES. - I a cabeza de este insecto es prolongada ó cuadrangular; la lengïeta membranosa y córnea en su centro; las mandibulas poco salicntes; las antenas medianas, y los elitros muy largos, asi como las patas. Fi color de este agra es pardo bronceado, y sus elitros presentan estrias punteardas. El tamaño es de seis lineas de largo.

DISTRIBUCION GEOGRÁICA.-Se encuentra muy a menudo este insecto en el Brasil.

USOS, COSTUMBRES Y REGIMEN. - El agra variolado, asi cono las demàs especies del género, acostumbra a vivir en los árboles, y clige con preferencia las hojas arrolladas por otros insectos, en las cuales se oculta, permaneciendo alli en una immovilidad completa, dirigicndo liacia adelante sus antenas y las dos patas anteriores, mientras que apoya las otras en el cuerpo en que se ha fijado. Su narcha parece torpey vaciante, á causa de la excesiva longitud de su cuerpo relativanente a las patas. Por lo general escasean mucho los agras, $y$ jamais se les encuentra reunidos en gmu número.

Las especies descritas hasta el dia ascienden i mas de 50: estos insectos son muy poco comunes en las colccciones y bastante buscados.

\section{LOS ODACANTOS - ODACANTHA}

CARACTERES. - I os odacanios se distinguen por su cabera oval, estrcelinda por detrás; el último artejo de los palpos termina casi en punta; las antenas son mucho mas cortas que el cuerpo y de artejos casi iguales; el cosclete ofrece la forma de bvalo prolongado, casi cilindrico; los elitros, largos y paralelos, se truncan en la extremidad; los tarsos son filiformes, con el penúlumo artejo ligeramente bilolardo.

DISTRIBUCION GEOGRÁFICA.-Los odacantos t'stán diseminados en Euroj̧a, Asia y la América meridional. 


\section{EL ODACANTO MELANURO-ODACANTHA} MELANURA

CARACTERES. - Este odacanto representa la especie tipica: su color es verde brillante; los elitros amarillos, con la extremidad azul negruzca; la hase de las anteriores, el pecho $y$ las patas del segundo de dichos tintes, y el abdómen aul.

Distribucion GEOGRÁfica. - Esta especie es originaria de Europa.

USOS, COSTUMBRES Y REGIMEN.-Bl odacanto melanuro, lo mismo nuue los demás del género, parece preferir los lugares húmedos: se le encuentra en los tallos, al pié de ciertas plantas y sobre todo en los juncos.

\section{LOS LEBIAS - LEBIA}

CARACTERES.- Los lebias son unos bonitos insectos que ostêntán por lo regular viros colores metálicas, en los que predomina el azul y el pardo. Su coselete es corto y trassersal, nias aricho que la cabeza, y prołongado posteriomentc $\mathrm{cr}$ su centro; los elitros son anchos y casi cuadrados; los artejos de los tarsos se inclinan á la forma triangular, y el penúltino es bitido; los ganchos tarsianos están dentados en su parte inferior.

DISTRIBUCION GEOGRAFICA.-Estos insectos es. tín distributidos en todo el globo, y sobre todo en las regiones intercropitales; pero en -ningura parte son tan numerosos como 5 at América

\section{EL LEBIA DE CRUZ PEQUEÑA-LEBIA CRUXMINOK}

CARACTERES. - Este insecto (fig. 6) se distingue esencialmente por tener en la parte posterior del coselete un dibujo en forma de cruz, á cuyo carácter debe el insecto su nombre especifico. Los machos se reconocen sobre todo por suśs grandes mandibulas, y por tener el tórax como dividido en dos partes. Este insecto es bastante pequeño: su colór es pardusco azulado.

DISTRIBUCION GEOGRÁFICA. - Fsté lebia abundà sobre todo en el sur de Africe, ó por lo menos alli es donde se le ha observado con mas frecuencia

\section{EL MORMOLICE FANTASMA - MORMOLYCE PHYLODES}

CARACTERES. - Esta especic, sin duda la mas cxtraña de todos los carabicidos, es propia de Java, donde sube a mucha altura en la montiña. las antenas y las patas son negras; el resto de un pardo de pez brillante, y los bordes, delgados y trasparentes, un puco mas claros. La barba, muy escotnda, está provista de un igudo diente, y los fuertes palpos rematan en articulaciones casi cilindricas, redondeadas en la extremidad. Ia larvn se parece por su forma prolongada a nucitros carabos, pero tiene la cabcza redonda, las partes del cuerpo redondeadas latemlmente y solo la primera de estas últimas cubierta del todo de una hoja de quitina, mientras que el resto del cuerpo solo riene dos mas jrequéras, de forma cuadrangular: dos hilos en forma de estilo hacen las veces de apéndices en el viltimo segmento. Esta lariat vive' en una especic de setas arboricolas llamadias por los japoneses gammur, y aliméntase sin duda de los otros insectos que tambien las habitan.

\section{LOS ANTIAS - ANTHIAS}

CARACTERES, - los insectos de cste género son gran- des carabicidos que se distinguen por tener la cabeza grande y suelta; labio superior redondeado; jalpos con el último artcjo casi cilindrico: lengiieta larga y compleramente córnea; antenas filiformes; mandibulas ocultas en gran parte por el labio; ojos salientes; coselete en forma de corazon; elitros ovales y convexos; patas fuertes, y antenas un poco dilatadas en los machos. Los antias son por lo general insectos negros, con manchas blancas formadas for uma especie de bozo: algunas especies son bastante grandes.

DisTRIBUCION GEOGRÁFICA. - El Africa es principalmente la patria de estos insectos: fuem de agquel continente no hay sino algunas especies disemimadas en Arabia, en Bengala y en el norte de Persia, cerca de las orillas del mar Caspio: se han encontrado bastantes ejemplares en el Cabo de Buena Esperanza.

\section{EL ANTIA DE SEIS MANCHAS-ANTHIA SEXGUTATA}

CARACTERES.-Este insecto (fig. 5), tipo del género, tiene la lengüeta muy larga; las mandibulas son variables segun los sexos. y siempre mas prolongadas en los machos; la cabeza está excavada entre los ojos; el cuello bien marcado por detrís, y el coselete muy cordiforme. Los elitros casi li. sos, fresentan cuatro manchas de un gris claro, formadas por un bozo corto y tupido, y' en el cosélete hay otms dos. Estc insecto mide unas diez y ocho lineas de largo por seis de an: cho: el color dominante es negro.

DistribúCION GEOGRÁFICA. - In el Cabo do Buena Esperanza es donde se ha observado mas á menudo este insecto.

USOS, COSTUMBRES Y REGIMEN,-EI anti: suele encontrarse en la arena, por lo regular no léjos de los estanques salados ó de los rios, cerca de los monumentos ruinosos, y debajo de las piedms; cunndo se le inquieta expele por el ano un licor ciustico. Fs sumamente voraz, segun lo indican ya todas las partes de su boca, conformadas para que el animal pueda triturar con facilidad una presa viva.

\section{LOS ESCARITES-SCARITES}

CARACTERES. - Los escarites constituyen un conjunto de formas del todo diferentes, que ofrecen toda clase de particularidades. La corta espiga formada yor una dilatacion del nesotórax hảcia adelante, para recibir el protórax, casi semilunar, indica una movilidad extraordinaria de este último; tos anchos tarsos anteriores, provistos de agudos dientes en su cara interior, revelan la facultad de escarbar, distinguiendose además en el lado inferior de la punta por tener una profunda curvatura y dos espinas que se insertan ligeramente. lin la cabern, que es grande y cuadmda, las tuaxilas son las parres de mas desarrollo; el labio superior esta dividido en tres lóbulos y las antenas son cortas; la líltima afecta la forma de cordon de perlas y tiene el arejo basilar muy largo.

DISTRIBUCION GEOGRÁFICA. - las cien especies, poco mas $\delta$ menos, conocidas hasta aqui, todas de un solo color negro, fl la nator parte de considerable tamaño, son propias de las regiones cálidas de todos los continentes.

USOS, COSTUMBRES Y REGIMEN. - Habitan en las orillas de los rios, en la costa del mar ó en otros sitios donde puedan practicar galerias, de las que no salen durante el dia: permanecen à la entrada acechando su presa, y despues de la puesta del sol salen cautelosamente, pero vuelven à su escondite apresuradamente cuando sospẹchan algun peligro, asemejándose en esto à nuestro grillo campestre. Ia oscuridad aunenta su valor y les permite continuar sin des- 
canso sus expediciones de meroleo. Iacordaire encontró en America algunas especies en los bosques debajo de las piedras ó cn arbolillos en putrefaccion, y cerca de Buenos Aires; una de ellas (Searites anthrainins): se ha!laba exclusivanento detxijo de cadiveres secos.

\section{EL ESCARITES GIGANTE - SCARITES PYRACMON}

CARACTERES. - Kste coleóptero se distingue por sus elitros brillantes de forma oval sin rayas ocultas, y por tener un corto diente en el borde latcral del escudete, cuyos ángulos anicriores sobresalen un proco, estando el borde anterior provisto de finas linens.

DISTRIBUGION GEOGRA FICA.- liste escarites habita las costas del Mediterraneo.

USOS, COSTUMBRES Y REGIMEN.-ES muy dificil cogerlo: un amigo que me trajo rarios individuos de España, me aseguró que no es posible conseguirlo hasta que se cierm. la entrada de su guaticia, antes de yue haya velelo á ella de sus expediciones nocturnas.

Heer conoció en Madera la larva de la especie seariles abireziatus y reficre que se distingue de las de otros carabicidos por su gran cabeza desprovista de ojos: las patas son bas. tante cortas, los costados relativanente largos, los trocanteres de los muslos y estos mismos son comprimidos y tienen en su cara interior una doble seric de espinas cortas: el estrecho segmento final del cuerpo presenta dos apéndices biarticulados. Los cambicidos escurbadores de Alemania son enanos en comparacion con los escarites, y pertenecen principal. mente al género dyschirius.

\section{LOS HARPALOS - HARPALUS}

CARACTERES.-I.os harpalos son por lo general de talla necliama ó pequevia, cuepro oblongo, cabezn redonderda. que se estrecha posteriormente, cosclete trapezoidal y elitros casi paralilos, siempre mas ó menos estrindos la mayor parte de las especies son negras, ó de un pardo negruzco luciente; algunas tienen un time verde cobrizo 6 bronceado y orras azul métálico: los machos son siempre mas brillantes que las hembms.

Las larvas tienen forma cilindrica, un poco aplanada; su cuerpo, compuesto de trece segmentos, sin comprender la cabeza, está cubierto de una piel escamosa, ligemmente viclluda; el úlimo segmento presenta algunas protuberancios en los lados, que terminan por dos apéndices carnosos; el ano esta provisto de un tubo saliente; la cabeza es volumi. nosa, con dos antenas cortas y filiformes, y las mandibulas: semejantes a las del insecto periecro.

DISTRIBUCION GEOGRÁFICA. - Ias especies de este género, indigenas unas y cxúticas otras, estan distribuidas en lodos los puntos del globo; pero se encuentran mas comunmente en buropa y Anćrica.

\section{EL HARPALO ENEAS-HARPAJUS ENEAS}

CARACTERES.- Esta. esprecie tiene el labio superior menos largo que ancho; las mandibulas arqueadas y poco agridas; la barba presenta un solo diente sencillo en médio de la escotadura; los cuatro primeros aricjos de los tarsos anieriores de los machos se dilatan mucho. Su tamaño es peçucno; su color pardo oscuro (fig. 3).

DISTRIBUCION GEOGRÁrICA.-Ia especie habit? en Europa yen el norte de Africa.

USOS Y COSTUMBRES. - Esic insecto, cuyas custum. Toso II bres se asemejan en un todo a las de los demis de la familia, parecen preferir los parajes áridos y arenosos, y se oculta debajo de las piedms, cuando no corre de un punto à otro con alguna presa; algunos trepan por los iallos de las gramineas: mas no debe creerse por esto yue sean herbivoros. Cuando se levantan las piedras se ven insectos de este género que penetran precipitadmnente en la tierra; las espinas de que estan provistas sus piernas les sirven sin duda para formar los albergues donde van à refugiarst.

\section{LOS ZABROS-ZABRUS}

CARACTERES.-Conocemos hasta ahora carabicidos voladores, trepadores yesarbadores, entre los carniroros, y

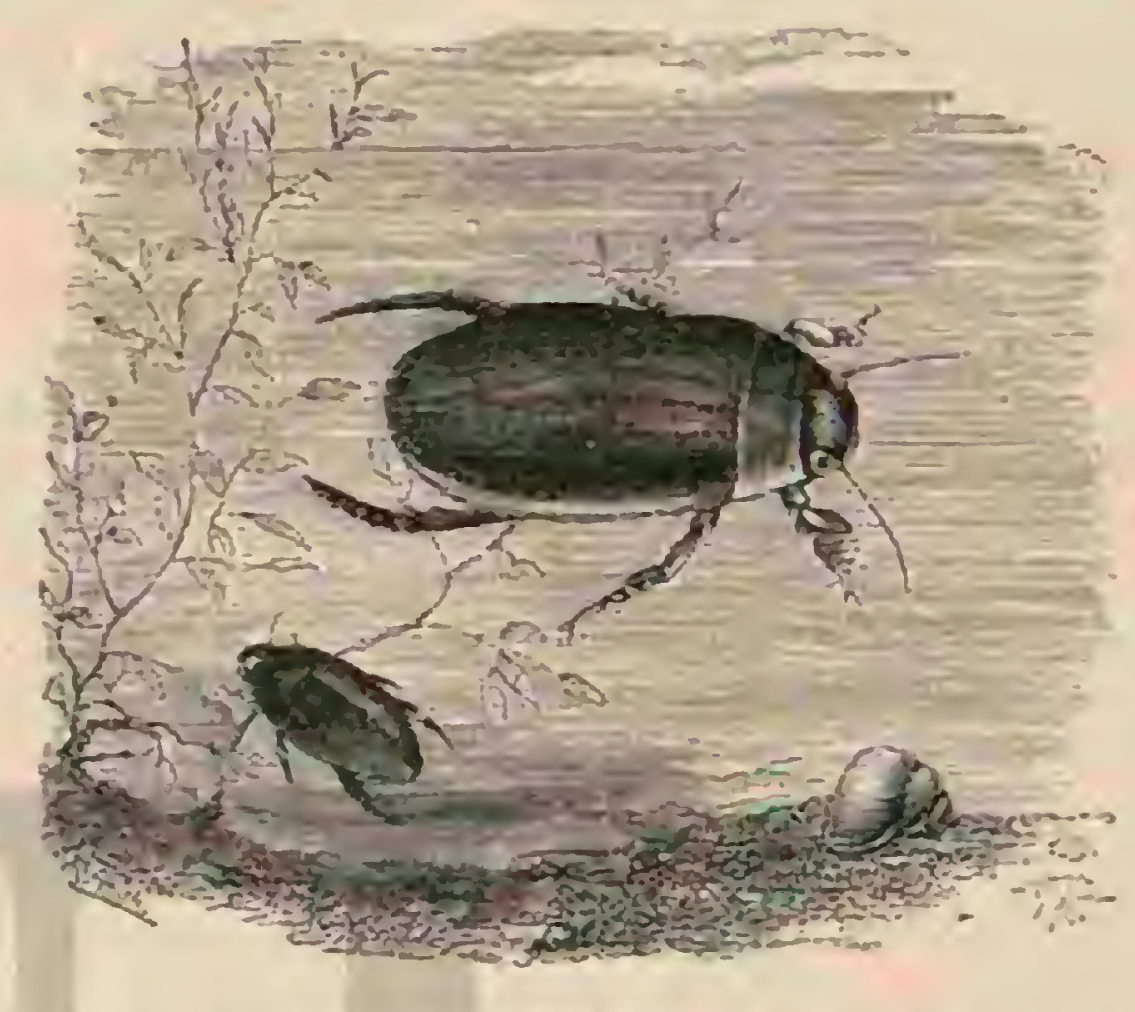

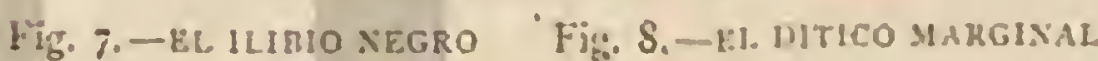

mmos a ocuparnos ahora de algunos plantivoros. Las especies grandes f pesadas del género de los zabros, se caracterizall por su labio superior, casi cuadrado, con una uscotadura en su parte anturior; por un diente centraj en la barlaa, y por las arriculaciones fimales de los palpos, casi cilindricas y por lo remular mas corias ugue la penuilina. El escuclece, abovedaclo, se oprime rontra los elitros, iambien abovedados y de igual anchura en su partc anterior, produciendo in forma recogich menos yraciosa del cuerpo; lis patas son gruesas, distinguiéndose por tener en los tarsos anicriores, además de las espinas regulares, otra mas pequena que se inserta en lia cara interior al lado de la esjuna inferior, en la junta del tarso. En el macho las eres primeras articulaciones de los piés anicriores estån mug dilatadas y tienen forma de corazon: los elitros son por fo regular mas brillantes que los de la hembra.

DISTRIBUCION GEOGRÁFICA.-1.ñs especies cono. cidas ell numero de susentay un, habian con preferencia los paises del Mediterráneo inclusas las islas Azores; solo algu. nas viven en la Europa centml y otra está diseminada desde Portugal hasta Prusia y desce lit isla de Chipre hasta Suecia.

\section{EL ZABRO DEL TRIGO-ZABRUS GIBBUS}

CARACTERES. - Esta especic ticne los mismos carac. têres del género! solo debo anadir que las partes smperiores son negras ó de un pardo negrusco en la cara inferior, y en las patas de un color mas claro, fondo de per: el escudete, ligeramente deprinido en su basc, tiene espesos puntos finos y es rectangular en sus ànghilos posteriores: los clitros son angulosos en los hombros y presentan un pequeño diente, profundamente marcado: las alas postcriores están del todo 
desarrolladas, carácter que no se observa en todas las esperies.

USOS, COSTUMBRES X REGIMEN.-El zabro del trigo ha adquirido cierta celebridad en algunas regiones por la abundancia con cuuc se presenta, pero esta celcbridad es por cierto bien triste. En isrz, en el distrito de Mansfeld (Sajonia), esta larva hubo de causar considembles daios en los campos de trign y mas tarde en los de cebada, presentindose tan inesperadamente y de un modo tan contrario a la naturaleza de los otros carabicidos, que los sabios comenzaron à dudar del hecho, enuncindo por Germar. Desde el año $18_{30}$ la desagradable presencia del a abro del trigo se ha repetido varias veces en los-puntos mas diferentes de Sajonia, a orillas del Rlim, en Honnover, en Bohemia y otras partes. Despues de haberse llamado tantas veces y tan generalmente la atencion sobre este adversario del trigo, nos hemos convencido del caracter cianino, no solamente de las larvas, sino tambien del coleópiero mismo, cuando ambos sé presentan en gran número.

El zabro de que hablamos habita los campos de zrigo durante el periodo en que este grano se halla en el primer estado de su desarrollo, y sale de la ninta en la estacion calurosa. Como la mayor parte de sus congéneres, sale muy poco de dia y descansa debajo de los retonos y otros cscondites por el estilo. Tan luego como el sol se po:xc. abandona sus escondrijos, trepa por un tallo de trigo hasta la espiga, $y$ si la encuentra bien llena, se agarra con las patas anteriores paria roer desde arriba los granos, sin cesat un momento en su ocupacion. Por lo regular se encuentran las espigas roidas de abrjo arriba, mas ó menos, y echadas a perder. Hreiter dice que en is6o un campo de trigo del condacio de Bentheim, que habia recorrido desde las ocho y media de la noche hasta las siete de la mañan, parecia alfon brado de negro, porepue ni una sola espiga estaba libre de aquellos insectos. En los mismos sitios se encuentran [am]bien los sexus y se a jarean. La hembra fecundada deposita al punto los huevos en gran número, sin duda à poca profundidad bajo la superficie del suelo junto a las jerbas que crecen en los compos y sus linderos, pues de las observaciones hechas en Moravia, Bohemia y Hungria, resulta que las yerbas comunes sirven de alimento a este insecto; en los citados paises siempre padecen mas los campos que antes eran praderas of los que lindan con ellas.

La larra, que no se hace esperar mucho, se alimenta de retonos ticrnos y capullos de las gramineas, habiéndose observado repetidas veces, y mas a menudo en la primavicr, cómo destruyen los campos de trigo. No es fácil confundirla con otra larva, porque ofrece los caractéres de todas las de los cambicidos. Ia cabcza, un poco cóncava en su parte posterior, es mas larga que ancha y menos estrecha que el collar esofígico; las maxilas rematan en una puinta afiliada y estan provistas en su centro de un diente obtuso: detris de aquellas hállanse las antenas, de cuatro artejos, contandose seis ocelos en dos series verticales a cada lado; los palpos maxilares tienen tambien cuatro artejos y los labiales dos. La parte superior de todos los segmentos del cuerpo está provista de hojas córneas, siendo las anteriores mas grandes y jardas; las siguicntes mas pequenias y de color rojo, pero todas rodeadas de un círculo Jongitudinal claro. Además de estas placas principales, los segmentos del abdó. mell, que carecen de paras, tienen una infinidad de manchitas córneas que en el vientre forman graciosos dibujos. La extremidad puntiaguda del cuerpo remata en dos cortas puntitas carnosas biariculadas, en las ejue, como cn todo el cuerpo, pero sobre todo en la cabern, se observan algunos pelitos verdosos y cortos. La larva desarrollada mide por térmaino medio $0^{n}, 018$. De dia permanece oculta, á la profundidad de unos I 50 milimetros en una galeria subterrànea, practicada por el mismo insecto, y solo sale de noche para comer. La manera de tomar su alimento y las costumbres de la larva ofrecen muchas particularidades; pero lo que ya hemos di. cho de otms de los carabicidos es aplicable es esta. No masca las hojitas del trigo para devorarlas sino para chuparlas; por eso forma en las plantas ticrnas unas ampollas qque al secarse cacn y cubren el suelo, semejantes à las que produce la lomloriz De cste modo se malogran antes del invierno los sembrados, y harto se conoce jor los daños que se observart, hasta yué punto llega la sociabilidad de las larvas, demostraindola además el hecho de que los huevos se depositan en pe. loton. Si se observa detenidamente, distinguese tambien el sitio ciunde ha comenzado la invasion. Como ya hemos dicho, esta larma permanece de dia en su retiro, el cual profun. diza, a medida que crece, casi verticalmente; y tan luego como sospecha un peligro imita al topo, dejändose cacr al fondo de su vivienda. Si entonces se quisiera sacarla con el a\%,alon se pociria tratajar mucho tiempo sin obtener el resultado ajetecido, porque una ve\% en la superficie, aunque cubicrta de una capa de tierra, se escaparia rapidamente sin ser vista. Para asegurarse de ella es preciso averigun antes dónde está la entrada de su galería y la direccion de la misma, lo cual es fácil gracias à las jelotillas secas que á minudo cubren el sitio; entonces se extrae rajpidamente con el azadon la ticr. ra á cierta distancia y encuéntrase casi siempre la larva, que no ha podido escapar de la profundidad de su guarida. Aun no se ha logrado averiguar mediante una cria artificial la duracion de la vida de la larva, pues las cautivas sc devoran eutre sf apenas el trigo no basta para su alimento. Ia circunstancia de que las larvas que viven al mismo ticmpo tienen diferente dimension, me indujo antes tambien a suponer para esta especie una cria de varios años, pero últimamente y' despues de otras observaciones, he cambiado de jarecer. Los coleópteros nacidos a mediados de junio invernan en diferentes estacios del desarrollo, trasfórmanse en crisáliclas à medindos de mayo siguiente y de estas salen cuatro semanas desprues los insectos perfectos; de modo que solo juede hablarse de una cria en un año. Es posible tambien que en estos carabicidos, asi como en otros muchos, el desarrollo no esté suieto à las leyes regulares, pues de este modo no podria explicarse de cónde salen á principios de la primavera los coleópteros que encontré muy aisladamente. I.a trasformacion en crisálida se verifica en el fondo de la galeria un poco ensinchada.

Alli donde los grandes campos de ung parecen alfombrados de negro, por las legiones de estos voraces coleópteros, o donde las larras viven tan agrupadas que á cada golpe de azadon salen de reinte á treinta individuos, como en 1869 sucedió en el distrito de Minden, el interés de los propietarios cxige sin duda adoptar medidas contra-tales desiructo. res. Al efecto quizass se pocirian sacar con la azada, pero no se lograria tan buen resultado como con el topo, cuya ausen. cia fué causa de que las larvas del zabro del trigo se presentasen alli en núnero verdaderamente considerable.

Es preciso recoger y matar los colcóptcros á un mismo tiempo en iodos los campos para que se haga imposible su cria. Julio Kuhn aconscja labrar en seguida los campos de trigo donde se hallen los coleópteros 6 se suponga que están deprositando los huevos. De este modo se destruye la cria y' sobre todo el alimento cuando esta medida se extiende á los campos vecinos. Además no debe procederse à sembraririgo en los campos infestados por el coleóntero. Con esias precau. ciones evitanse los futuros perjuicios que son de temer del zabro del trigo y de sus larvis: si estas últimas existen, es preciso cxterminarlas e impedir que se diseminen mas. Fisto 
se hace rodeando la superficie infestada de un ancho y profunco foso, cuyo fondo se cubre de cal. Cuando la invasion inspasa cierto línite se labran las partes infestadas a la profundidad de $0^{\text {" }}$, I 6 y se recogen las larvas por detris del arado: lo cual debe hacerse á cierta distancia de este, porque las larvas que están en los terruios intentan escajarse, pasando entonces à los surcos abiertos, donde se las puede coger. Este medio debe recomendarse tambien para exterminar otros insectos dahinos. T.os canupos que entonces no sirven ya en el mismo año para la siembra de trigo pueden utilizarse am paril la patata ú otms plantos senejantes.

Despues de haber descrito el género de vida de los carabicidos en general, $y$ las diferencias esenciales entre los géneros, no es preciso ocuparnos minuciostmente de esta familia. Eil que quiera encontrar numerosas especies congeneres del zabro del trigo debe buscarlas desde octubre hasta principios de ia primavera en sus curreles de invicrno: para esto no se necesita gran astucia ni experiencia practica. pues basta levautar una picorn grande en cualquier parte de los campos y examinar la superficic descubierta. Entonces se encuentra cierto número de insectos al parecer inertes $y$ sin movimicnto, si es invierno, pero cada vez mas vivaces á medicla que se acerca la primavera. Entre todos estos insectos, los carabicidos constituyen casi siempre la mayoria.

\section{LOS DITICIDOS-DYTI- CID死}

F.) que pascíndose por los tlorados campos de trigo ó por las verdes alfombras de las praderas, fija un pocosuatencion en las cosas de la Naturaleza, intcresindose tambièn tun las pequenas y de pocn importancia que it sus miradas se ofrecen, podrá ver algun caralbícido: pero no los coleopiteros que viven en el agua. I'ara observar á estos es preciso buscar los charcos y fosos de agna estancada y examinarlos minuciosamente. Alli se ren muchas cosas que maravillan, yo pocas pueden referirse de todos esos animalitos que temporalmente viven alli para comer y ser comidos, pues mas aun que los insectos del aire y de la superficic de la tierm, los coleopteros artuáticos se distinguen por su voracidad, puesto que, encerrados en un charco, no hay luga positble y ha de regir la ley del mas fuerte. Si por los rclatos que se refieren ál los coleóp. teros nadadores pudiesemos despertar un poco el interés de nuestros lectores, induciéndolos a ir à observarlos por simismos, labriamos logmdo el fin de nuestra obra; pues alli verian mas de lo que aqui podriamos decirles.

CARACTÉRES. - Jos diticidos de que aqui se trata son carabicidos trasformados que habitan en el agua; pero como la vida en este elemento ofrece menos variaciones, que en el aire, no encontramos hariedad que en las especies anteriores. Ins partes de la boca y las antenas de los diticidos no difieren de las del carabicido: la maxila exterior de la mandibula inferior afecta la forma caracteristica del palpo, pero el cuerpo se ensancha y’ aplana generalmente; la cabcza deja en descubierto una gran parte del collar esofígico, que à su vez. se une estrechanente con los clitros; el vientre jo el dorso se abovedan casi por igual tocándose en sus bordes, y el contorno afecta la forma de un óvalo regular. Del mismo modo se ensanchan las patas, principalmente las posteriores, que están cubiertas de espesos pèlos; sus costados son casi siemure grandes, llegando casi hasta el borde lateral del cuerpo, y estain soldadns del indo con el metatóras. A veres se atrofia la cuarta articulacion del pié de las patas anteriores, mientras que en el macho las tres primeras se ensanchan a veces de un modo particular. Los segmentos abdomimales existen en número de sicte, los tres primeros soldados; de modo yue los diticidos se asemejan yor este concepto à las dos familias anteriores Estos insectos no tienen solo la incultad de nadar, sino gue tambien vuelan. Si asi no fuera, como habitan las aguas estancadas, que i veces se agotan, estarian expuestos a una nucrte segura. De dia no abandonan su elemento; solo de noche emprenden el ruelo desde la planta acuática a que han subido, y esto explica que precisamente en las cisternas y ottos depósitos de agua se encuentren a menudo las especies mas grandes $\delta$ que se las vea a mucha distancia de su resiciencia acostumbracla, echados boca arriba sobre los vidrios de los invernaderos, que sin duda tomaron por una superficie liquida. Muchos individuos arostumbran a buscar sus cuarteles de invierno ciebajo del musgo de los bosques, conde a menudo los he visto aletargados junto a los carabícidos y otros coleópterus. Como no respiran por branjuias necesitan aspirar aire fuera del agua yo suben algunas veces á la suprerficie, colgandose sobre ella, por de. cirlo asi, de la extremidad de su abdómen; sirveles de boca el último par de tráqueas, para respirar, y con los pelos cer. dosos del vientre recogen una provision de aire para llevirsela a la profundidad. El calor del sol los atrae a la superficic, mientras que en los dias lluviosos se oculaan debajo de las plantas acuáticas; pues nunca buscan un charco. Los mas de estos colcópteros, gracias á sus anchos costados, pueden nadar segun todas las reglas del arte; algunas especies que los tienen mas estrechos lo hacen moviendo alteruativamente las patas anteriores. Respecto it la larva debemos confesar nuestra ignormucia. pues de las pocas que se han descrito solo podemos decir que estan provistas de scis patas délgadas y peludas de dos caras, que se componen de un segmento, y que en la parte stuperior están cubiertas de escudos de quitina; el último de estos afecta la forma de rubo y remata en dos ajéndices no articulados, pero provisios de una especic de plumas, cuyos apéndices se comunican con el último par de estigmas que ames se designaban como branquins tra(queales. Ia cabcua, plana y prolongada horizontalmente, sc distingue por las maxilas, sencillas y falciformes; las mandibulas quedan libres; los palpos ticuen una articulacion; la barba es corta y carnosa con palpos biarticulados y sin ningun vestigio de lengua; al labio superior no cxiste; las antenas constan de cuatro artejos. Las maxilas sirven i estas larvas, no solamente para sujetar y berir su presa, como lo hacen las de los carabicidos, sino tambien de abertura bocal, pues carecen de ella. Estas maxilas, huecas y abiertas en el lado de la extremidad por una hendidura, constituyen un órano chupador con el cual alsorben el alimento liquido. En vista de la-conformacion de los órganos bucales en esta familia $y$ las / dos anteriores, los sistemaiticos las reunieron antes en un grupo, dindole el nombre de carnivoros (Adephagi).

I.os diticidos, de los que hasta ahora se conocin unas sciscientas especies, están diseminados por todo el globo, pero con preferencia por las zonas tenupladas, y ianto se ase. mejan por sus formas y color, gue las de los paises calidos no se distinguen en mada de las nuestras. El color es negro pardó $\delta$ verde accituna, con ó sin matices de un imarillo sucio. En otolo se les encuentra en mayor numero, y segun parece todos son recien nacidos que pasan el invierno aletargados.

\section{EL DITICO ORILLADO-DITICUS MAR- GINALIS}

CARACTÉRES. - Bil clitico orillado (fig. 8) es uno die los coleúpteros mas grandes de toda la familia: acostumbra à col- 
garse por la extremidad de su abdómen sobre la superficie del agua, bajando despues con la rapidez del rayo al foncio de su elemento para pencerar en el cieno; otras véces se oculta en el caos de las plantas y vuelve á salir, persiguiendo á una pequeña larva ú otro habitante de la charca, hasta que sujeta triunfante la presa apetecida con sus agudas maxilas. La estructura del cuerpo y las patas posteriores; que reman al mismo tiempo, comunicanle la agilidad suficiente; las patas centrales $y$ las anteriores sirven para atrapar $y$ sujetar la presa, pero tienen diferente estructura en los dos sexos. Las cinco articulaciones del pié, algo comprimidas lateralmente en la hembra, tienen casi la misma longitud, excediendo cuando mas la articulacion de la garrailas tres primeras arti. culaciones de las patás del macho se ensanchan y, están provistas en la planta de una especié de cepillo de cerdas cortas. En las patas anteriores estas cerdas forman un disco circular que en la planta llevan el cepillo, estructura tan sencilia como maravillosa.

Cuando el animal oprime sus patas anteriores sobre un cuerpo, por ejemplo un cadiser nutante en el agua, ó la superficie lisa de su hembra, ete, la cará interior del disco se pone en contacto con la superficie; entonces un mísculo que pasa por en medio contrae la pared interior, tormándose asi un espacio vacio, y dentro de esta especie de ventosa, las patas se adhicren con un desarrollo de fuerza muscular diez veces mas grande. la supericie sjempre brillante, pero nunca húmedia, de todo el cuerpo, tiene en sus parses superiores un color verde aceituna excepto un borde alrededor del escudete y otro amarillo en los clitros. Estos Uttimos ofrecen en las de. más especies de diticos otro carácter distintivo para los sexos, carácter que en la especie que nos ocupa solo se observa en parte, porque los elitros de las otras cestán muy sur. Cudos en la mitad anterior de la hembm, mientras que precisamente en el ditico orillado se encuentran con frecuencia hiembras de elitros lisos, en todo iguales á los del macho. Hace murbo tiempo que se conoce esta difcrencia entre los clitros de ambos sexos y tambien se han hecho mu chos esfuerzos jara hallar una razon que explique la conveniencia de tal estructum Suponiase en primer lugar que la aspereza del dorso, producida por los surcos, facilitaba al macho el agarrarse á él para el apareaniento. Kirbyy Spence en su \& Introduccion a la entomologià, asi como Darwin en su «Origen del hombre y heleccion natural», parten de esta opinion, pero los primeros consideran la estructura de que hablamos como producto de la sabiduria divina, mientras que Darwin solo ve el resultado de un lento desarrollo por medio de la seleccion natural. Darwin dice además que si los surcos de los elitros ayudan al aparenniento, las hembras provistas de ellos tienen una preferencia sobre sus companeras de elitros lisos, en su luch por hexistencia; mientras que las úftimas, en cambio, tienen, segun la ley de la compensacion del desarrollo, en vez de los complicados elitros, una naturaicza mas fuerte y sobre todo patas nadado. ras mas robustas, fo cual les proporciona á su vez una ventaja. Ias formas intermedias menos favorecidas han debido desaparecer en el trascurso del tiempo. Joseph encontró últimanrente estas formas intermedias (Ditius Dimiatus), especie cuya hembra presenta indicios de surcos, como los dos que tiene el macho; son estrechos y poco profundósy solo el sexto y séptimo tienen mas anchura y profundidad. Cuando se encuentra una hembra de tal forma intermedia que aun no ha desaparecido, quizás tambien podri encon. trarse una sagunda y tercern que demostrarian que las citadas formas no se han extinguido aun. Por lo que hace á las patas nadadoras de las hembras lisas, este carácter es tan poco determinado, que los unos se han atenido à la opinion de Dar. win, mientras los otros han negado con mucha razon su cxistencia, combatiendo asi tambien la ley de compensacion del desarrollo.

Kiesenwetter da últimamente otra explicacion del dimorfismo de las hembras de diticidos, explicacion que corresponde a los principios de Darwin. Partiendo del principio de que, segun ya hemos visto antes, las alas son excrecencias de la piel apojadas en las venas ó nervios que en su origen han sido los troncos traqueales y que estos aunque no se distingan en la mayor parte de los clitros de los coleófiteros, pueden aun demostrarse, los elitros surcados contrastan con los lisos, como en la formacion primitiva En favor de esta opinion habla la circunstancia de que en la época terciazia se han encontrado diticidos con elitros surcados. Ahora bien, continúa Kiesenwetter, tenemos que buscar el tesarrollo, en extremo rico en formas, del tipo de los insectos, como de los animales articulados que respiran por medio de trágueas, no en el agua donde relativamente se encuentran pocos insectos, sino en la tierra; sobre todo los diticidas pueden considerarse como una forma originaria de los carabícidos, adaptada a la vida acuitica, ó para hablar mas exactamente segun los principios de Darwin, como una forma que poco i joco se ha adaptado is la vida acuática; no podemos proceder en sentido inverso designando los carabicidos coino diticidos trasformados en mpaces terrestres. Aquel sistema de surcos de los elitros cinga significacion aca. bamos de coplicar, es propia marcadamente del tipo de los carabos, y por lo tanto se le debe considerar como primitiva. mente tipico para los diticidos, suponiendo lógicamente rque los surcos al principio cxistentes, solo han desaparecido por la atraccion a la vida acuática, ya que exigen una superficic mas lisa del cuerpo, pero que ciertas hembras los han conservado en una forma mas ó menos amortiguada porque les eran útiles en el apareaniento, nientras que otras hembras los perdieron lo mismo que los machos A estas últimas hembras (sin lijarnos en la jureguma cuando menos problematica de si zicnen un desarrollo mas fuerte) les es de gran utilidad la stiperficie lisa para facilitar sus movimientos en cl agua, mientras que las primeras pueden aspirar a lener uma proge. nie mas numerosa: y cadia una de estas ventajias debe considerarse en la opinion de Darwin como suficiente para fjar en el trascurso de las generaciones la forma conveniente de la hembra, $\delta$ en los casos en que ambas circunstancias concur. ran en un mismo punto, para dividir los individuos femeninos en dos razas cue sejaradas existen una al lado de otra, mientras que las formas intermedias menos favorecidas desaparecen. Dejaremos al juicio del lector el aceptar una ú otra opinion ó rechazar las dos, no sin que reconozca en estas diferencias la expresión de la infinita riqueza en formas de la naturaleza orgánica.

Despues de esta divagacion que creimos necésaria para dar una idea de lo que pmede en este terreno desviarse la mente del naturalista del verdadero camino en la investigacion, volsamos a la caracterizacion del ditico orillado. La parte inferior de su cuerpo $y$ las antenas cerdosas de once artejós son amarillas, las patas un poco mas oscurns. Como los grandes caralicidos arrojan un liquido fétida de un color verde pardo para obligar á los que los cogen í soltarlos, el ditico orillado y las otras especies de tamano regular segregan del borde anterior y posterior de su escudete un liquido de color blanco de leche que tambien despide un olor desagradable.

Si queremos seguir la historia del desarrolin de este diticido, para tener una idea del de los otros, que en su gran conjunto no será muy diferente, solo necesitamos poner un número de estos coleópteros en un acuario que por encima. 
de la arena debe contener un poco de cieno, y en vez de las rocas en el centro algun puriado de césped. I a gran roraci. dad de los animales causa algunas dificultades en su alinentacion, pero $\{$ falta de otros insectos acuaticos pequeños y blandos, sirven tambien larvas de hormiga, huevos y renacuajos, peyueños peces, cararoles acuáticos, ratones mucrtos y' otros animales.

En primaven deposia la hembrn en el fondo de su prision un número considerable de huevos de color amarillo y de unos (1",00225 de largo. Estos necesitan doce clias para su desarrollo. Unos gusanitos muy perquenos pueblan entonces el agua, y su gran voracidad, que llega al extremo de no perdonarse el uno al otro, revela su crecinicnto rípido. Ya al calbo de cuatro ó cinco dias miden $f f^{\text {m, }}, 010 \mathrm{y}$ mudan por primera re\% de piel; pasado igual intervalo de tiempo han adquirido doble tamano y mudan por segunda vez: y al cabo de otros tantos dins, durante los cuales se siguen desarrollando con la misma rapider, verifican la tercem muda. Es cierto que muchas de estas larias caen victimas de rapaces mas fuertes, como por ejemplo, de las larvas de libélulas. En la edad mas adulta, cuando necesita mas alimento, su desarrollo continúa con menos rapide\% Con las tenazas abiertas perma. nece en acecho hasta que otra larva se acerca a clla, y esperando el momento favorable, se precipita sobre esta con movimientos serpentinos parn apresarla: despues desciende al suelo y agarrándose á una planta acuática chupa la sustancia de su víctima. El neimero de las larris habia disminuido mucho en el acuario, pues a pesar de que despues del nacimiento de las larvas saqué los insectos perfectos, que por lo demás morian en seguida, por haber ya cumplido su cometido; à pesar de que hice todos los esfuerzos posibles para dar a aquellas el alimento suficiente, no se perdonaron una à otra, sea que el contacto intimo en que vivian en el acuario excitase su inclinacion carnivora, ó porque no sitisfice bastante su continua vorncidad. Para no perderlas asi todas, cogi otras que, despues de examinarlas minuciosamente, reconoci como pertenecientes á la misma especic, poniéndolas despues en el depósito de las primeras. las mas pequeñas eran las mas expuestas, pues fueron cogidas en el mornento en que menos lo esperaban. Ins mas adultas comenzaron á perder parte de su voracidad: ocultábanse en la base pedregosa de los pedazos de césped y desaparecian por fin por debajo de este. Al cabo de quince cins levanté uno de aquellos pedazos que descansaban ligeramente sobre su base y encontré.con grande alegria algumas cavidades, cada una con una crisálida, en la que podia reconocerse la forma de las extremidades del futuro colcópiero. Despues de un descanso de tres semanas se rompe la piel por la nuca y el pequerio ca. leóptero salc. Las ninfas trasformadas en otoño pasan el in vierno en este estado. Trascurre bastante tiempo antes que el recien nacido se parezca en todo à sus padres. Primero sé desarrollan las alas y los clitros y despues las formas del cuerpo, que es sin embargo muy blando y de color blanco amarillento. Solo al cabo de ocho dias sale de su cuna, pues entonces es propio para la vida acuática, si bien se puede reconorer aun por el color patlido del vientre y por la cubicrta de quitina mas blanda. Continutia entonces la vida de asechanzas y ataçues mortales parn la larva Iil ditico orillado y las pocas especies de su género que sc encuértran en Alemania no convienen pasa los criaderos de peces, porque atacan la cria é impiden su desarrollo.

Mientras el género dyticus, escrito tambien dytiscus, tiene dos caras bastante iguales y movibles en las patas posteriores, en los diticidos de mediano tamaño, que pertenecen à los géneros acilius é hydutious, se encuentma dos garras prosteriores desiguales, siendo la superior fija: en la especie ghis- ter hoeselii solo hay una movible; en general la diferencia en la formacion de las garras y en el mayor desarrollo de las patas anteriores y inedias del macho constituyen los dos ca. ractéres distintivos mas esenciales entre los géneros.

\section{EL ACILIO SURCADO-AGILIUS SULCATUS}

CARACTERES. - El acilio surcado tiene afinidad con cl géncro de los diticos por la dilatacion en forma de disco de las patas anteriores del macho, pero se distingue por la estructura ya indicada de las garms en las patas posteriores y por la falta de una escotadura en el últino segmento abdominal. Las hembras tienen en los cuntro intervalos de los

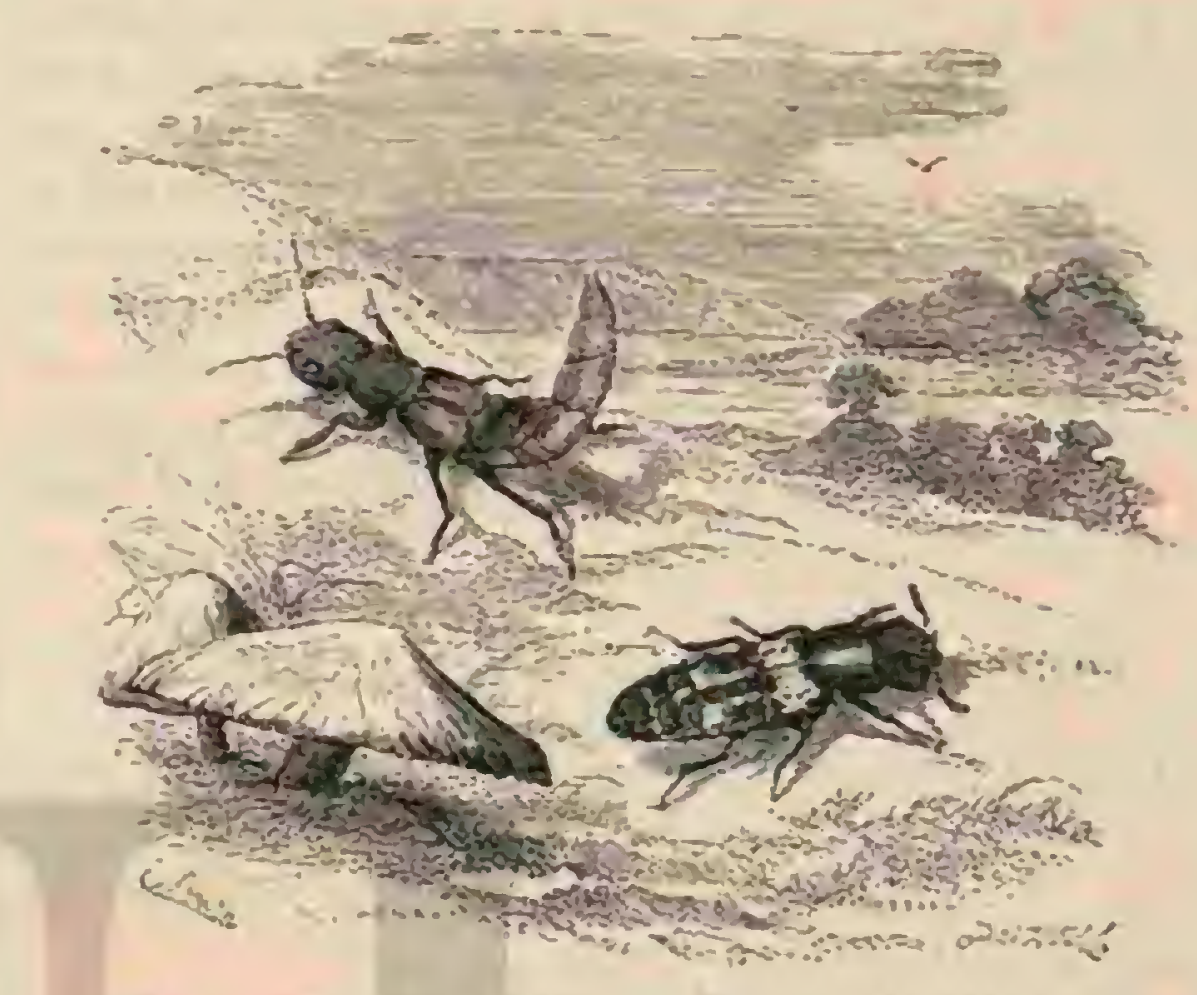

Fig. 9. - r.L ocipo comus:

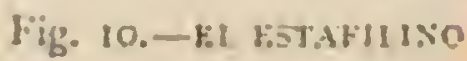

surcos longitudinales de los elitros, largos pelos y un monito de estos en las extremidades de la linea contral amarilla del escudete que esta provisto de un bordé claro. Ia carn superior del cuerpo es de un pardo negruaco, la infurior negra, cxcepto algunas manchas amarillentas en el vicntre. La larra se distingue de la especie anterior por los prolongados seg. mentos del tórax.

DISTRIBUCION GEOGRÁFICA.- El acilio surcado se encuentra en codas partes; junto con los otros diticidos, y no se distingue de la esuecie anteriormente descrita ni por su género de vida, ui por su desarrollo.

\section{LOS HIDROPOROS - HYDROPORUS}

CARACTERES. - Este género contiene lás especies mas pequenas entre los diticichos, pues llegan por término nedio apenas i $11^{\prime \prime}, 00.15$ de longitud: distinguense de tudos los otros géneros por tener solo cuntron articulaciones en los piés de los dos pares anteriores de las patas, y por las patas posteriores filiformes. Ins I 80 especies que se extienden por toda Europa, de la que una (migrolineatus) se encuentra al mismo tiempo en Europa y en la América del norte. dificilmente se distinguen una de otm. Muchas, sin embargo, se diferencian por sus bonitos matices claros, y sobre iolo una, el hidróporo elegante, que merece con roda propiedad este nombre. Sobre el fondo amarillo pálido de los elizros, cujo color es propio tambien de todo el cuerpo, hay bonitas lineas negras. Fiste colcóptero es una de las celebridades del lago salado de Mansfeld, o mas bien, de los charcos inmedintos; por lo demás solo vuelve à encontrarse en el sur de Europa (Írancia, Suiza, Kiew) y en los puntos del mar Adriático mas a propósito para coléópteros nadadores. 


\section{LOS CNEMIDOTOS-CNEMIDOTUS}

CARACTERES. - Para no olvidar las especies con los costados posteriores cstrechos y no prolongados, haré mencion aun del cnemiàotus cosus que en la estructura de su cuerpo difiere bastante de las especies anteriores. Su major anchura la alcanza este colé́ptero en los hombros; el escudete corto, prolongado en su parte posterior en forma de un dientecen. tral, se estrecha hácia adelante con un borde lateral en linca recta, y los ojos muy salientes producen o:ra vez un ensan. chamiento en la forma general. Iass antenas que solo tienen diez artejos se inscrtan en la frête; tel últimp artejo de los palpos maxilares cónicos es en extrémo largo comparado con el pentiltimo. Las patas son lodas delgadas, en especinl los piés que lo mismo que los tarsos solo llcran pelos en las patas anteriores. De los muslos posteriores solo se ve la extremidad por ocularlos una grande placa que sale de los costados posteriores y cubre casi todo el abdónien, icjando solo en medio una hendidira lateral. Los elitros muy abovedados, en cuya base no se olsserva ningun éscudito, están provistos de series de puntos grandes que poco à poco desaparecen hacia atrís; una mancha oscura comun i ambos y algunas manchas mas periucras en el dísco resalian sobre el fondo amarillo pàlicio.

\section{LOS HALIPLOS - HALIPLUS}

CARACTÉRES. - Este género, mas rico aun en espre. cies, yern menos bonito, se distingue diel anterior por la arti. culacion final de los palpos maxilares, corva y mucho mas pequeña que la penúltima.

USOS, COSTUMBRES Y REGIMEN. - T'odos estos animalitos viven ocuitos en el fondo de las aguas y solo lle. gan á la stuperficie gracias a la red dè maturalista uque busca material parn su coleccion de coleópteros.

\section{LOS ILIBIOS-ILYBIUS}

CARACTÉRES. - Este género tiene el penúltimo artejo de los palpos labiales tan largo como el último, y el cuerpo bastante convexo. La escotadura que tienen las liembras en el último anillo del abdómen es mas ó menos profunda en su extremidad, y presenta en la línen media una pequeña carena.

DISTRIBUCION GEOGRÁFICA. - Las pocas especies que comprende este género son propias de kuropa las unas, y de la América del norte las otras.

\section{EL ILIBIO NEGRO-ILYBIUS ATER}

CARACTERES. - El nombre especilico de este insectó (figura i) indica y'a cuál es su color dominante: entre los ojos se ven dos puntos y una linea vellosa longitudimal cerca del borde exterior, hácia los dos tercios del clitro, yotra mancha oblicua hácia el extremo; la base del borde lateral ciel coselete $y$ de los clitros es de color rojo ferruginoso oscuro; las antenas y los palpos amarillentos; las patas ferruginosas, como tambien una parte del abjómen; los elitros tienen una ligera escotadura hacia su extremidad.

DISTRIBUCION GEOGRAFICA.-Tambicn esta especie es propia de Europa.

\section{LOS GIRINOS-GYRINUS}

USOS, COSTUMBRES Y REGIMEN. - Mas aUn que los coleópteros nadadores que acabamos de describir mere. cen los girinos llamar la atencion de las personas que observan algunos minutos las aguas habitadas por las espe. cies arriba citadas; pues no es posible que estos pequenos coleópteros con su traje de accro azulado, relucicudo, por decirlo asi, al herirles los rajos del sol, puedan escaparse á su vista. Fácilmente podrian pensar que no hay' otro sér mas alegre y feliz 'Tan pronto se agrupa la pequeña sociedad en un punto, como cada uno se dirige por su lado; uno describe un círculo, otro le sigue y un tercero termina el círculo en direc. cion opuesta; un cuarto traza curvas ó espiriles, y de este modo sc accrcan ó se alejan bulliciosamente uno tras otro. En estos muvinientos ejecutados con extremada agilidad, como no podria initarlos el mejor patinador, el agua queda casi tranquila bajo cada incividuo aislado y solo alli donde varios se reunen se forman indicias de ondas. De pronto ane cerca de ellos una rama, y los pequeños nadadores se dispersan como el rayo, durando bastante tieupo su ausencia hasta que vuelven á reunirse para continuar el juego interrumpido. 'Tal es la vicia de los girinos cn los dias de sol ó cuando el aire es caluroso y pesado; pero en los dias crudos y desagradables no se ve ningun vestigio de estos coleópteros llama. dos por los alemanes tordellinos para designar probablemente el cterno torbellino en que pasan alegremente su vida: quedan ocultos entonces entre las hojas de las plantas de la orilla ó en el fondo de las aguas. Para observarlos en este caso no hay ulue acudir a su residencia natural; simo que es preciso cogerlos. Malinorski ha publicado en este concepto algunas obserwaciones interesantes de las que he sacado las siguientes noticins. Un gran numero de individuos de la especie gy rimus strigipensis sacado de una casa de banos en el 1) anubio, se coloćó en un globo de cristal lleno de agua. Al observar algunos dins despues que varios individuos flotalan muertos en la superficie, dancio lugar i la suposicion de que se mataban unos à otros por falta de alinento, se echó un pedacito de carne fresca al agua, y apenas hubo este llegado al fondo del vaso, cuando un sinnúmero de coleópteros intro. dujo sus cabezas en la carne; pero a pesar de eso y de que cl agua se mudaba con frecuencia, muricron todos al poco tiempo. Púsose luego en el mismo globo otro número de girinos dindoles en vez. de carne raices de caña y se hallaron mucho mejor; un solo colcóptero se encontró nuverto en la superficic, pero intacio ó respetado por sus compañeros. Cuando el girino se sumerge se provee de aire que en forma de una perla plateada lleva consigo en la extremidad del abdómen. Esta burbuja de aire se segrega sin duda de una capa de grasa del agua; pues se hincha, toma una forma puntiaguda y se fija de tal modo en la extremidad del abdómen, que Malinowski solo logró una vez quitarla con un palito. Pero al momento volvia i sustituirse por otra. Por debajo del agua el coleúptero se posa en una planta, agarrándose sobre todo con las patas medins; extiende repeidas veces las largas patas anteriores, como un hombrc que se prepara para nadar, $y$ coloca dichas extremidades sobre la cabera y parte anterior del dorso, como lo hacen otros insectos cuando se limpian. Además las patas posteriores siven para agarrarse cuando el coleóptero quiere cambiar de posicion. Cuando se posa en completo descanso, solo los palpos se meeven y no suele alarmarse por lo que pasa à su'alrededor. Tambien los girinos pueden volar, porque sin esta facultad perecerian en ciertas circunstancias: antes de elevarse, suben por una planta, mueven vivamente el abdómen levantando los elitros, hasta que por fin de un salto se clevan zumbando al airc.

\section{EL GIRINO ZAMBULLIDOR-GYRINUS MERGUS}

CARACTÉRES. - Examinemus ahora un de las especies mas comunes del género, para conocer las particularidades 
del mismo. Vemos el contomo oval como lo presentan las especies anteriores, pero el vientre es mas aplanado y abovedado hácia atrás, los clitros, cortados en su parte posterior, dejan descubierta la rabadilla. Ias patas anteriores, saliendo de costados libres y cónicos, son prolongadas en forma de brazos; las posteriores, cuyos costados están soldados con el tórax y en los que los tarsos y' los piés representan cada uno una hroja en forma de sombra, se han trasformado en verdaderas aletas. Iass antenas, aunque compnestas de once artejos, el último largo y los siete juntos, se presentan solo como muñones. En extremo particulares son los ojos, porque cada uno estí dividido por tuna ancha iaja trasversal en su parte inferior y superior, de modo que el coléoptero, al nadar, puede ver al mismo tiempo $\mathrm{cn} \mathrm{la} \mathrm{profundidad} \mathrm{y} \mathrm{en} \mathrm{el} \mathrm{aire,} \mathrm{pero} \mathrm{pro-}$ bablemente no en direccion recta. Ia barba es muy escotada y los lóbulos laterales muy redondeados; los palpos muy cortos, los labiales de eres artejos y los maxilares de cuatro. Ia mandibula inferior se distingue esencialmente de la de los carabicidos y de la de los diticidos, porque la maxila exterior toma la forma de un delgado aguijon. Las maxilas superiores, cortas y corvas, acaban en los dientes. El abdómen està compuesto en su cara inferior de solo seis segmentos, cuyos trés anteriores están soldados, el último com. primido y redondcado y en algunos casos cónico. Lil cuerpo tiene un fuerte brillo azul metálico, el borde de los elitros y del escudete, lo mismo yue las patas, son de un rojo de orin $y$ las delicadas fajas de puntos de aquelios cerer de la sutura aun mas finos que los otros.

DISTRIBUCION GEOGRAFXCÁ- lil género es rico en especies que en parte dificilnente pueden distinguirsey de las quue algunas se encuentran en Alemania y en la Anéríca del norte.

USOS, COSTUMBRES Y RÉGIMEN.-De una especie (grimus natator) se conoce ya la larva desde 17jo, larna qque entonces fué descrita por Modieer. Lis muy prolongada y eśtrecha la cabeza, casi cuadmngular y mas grande que cada uno de los tres segmentos siguientes, que juntos llevan seis patas de longitud regular, provistas de dos garras. A es. tos segmentos siguen ocho inas estrechos correspondientes al abdómen, de los qque los siete prineros tienen á cada lado un apéndice filiforme provisto de una cspocic de pestaña y de la longitud de una pata, $y$ las bmnnuias traqueales, de las que en el último segmento se observan dos. Con sus tenazas chupa su presa a modo de las larvas de los diticidos y cuando esta jróxima á crisalidarse, fabrica en una planta acuática, ó en otro sitio cerca del agua, un capullo puntiagudo en anbos extremos, de natumlezanpergaminada. Parece que la trasformacion en crisálida se verifica despues del invierno, pues en verano retozan los colcópteros pror cl agua: á principios de agosto-se depositan los huevos y la crisálida necesita por término medio un mes para si desarrollo. Es preciso hacer aun observaciones inas exactas sobre la historia del desarrollo de estos interesantes coleópteros.

In familia a que perrenecen los girinos (grrinida) se limita a ciento veinte y frico de especies, que se extienden por todos los continentes, teniendo representantes en las regiones cálidas, y llegan á una longitud de $0^{\circ}, 0175$ igualando en tamaio a nuestro diticidos de longitud regular.

\section{LOS HIDROFÍLIDOS HYDROPHILID死}

CARACTERES. - Una tercern serie de coleópteros designados sencillamente con el nombre de coicupperos ucuitscos, hidrofilidos y tambien con el de palpicornios habitan los mismos charcos en que viven los diticidos y los girinos. Son insectos que no se distinguen de los anteriores por los contornos del cuerpo, pero si por la formacion de las partes bucales y de las antenas; de modo que precisamente en un sistema que da gran importancia a estas partes, no es posjsible reunirlos con los anteriores. Los colépteros de este grupo no tienen la barba escotada, pero están provistos de una maxila exterior casi siempre ancha en forma de lóbulo cn la mandibula inferior, con palpos muy prolongados y filiformes que pueden llegar a la longitud de las antenas ob exceden aun de la misma, por lo cual pueden confundirse con aquellos, lo que indica tambien el nombre de palfiromios. Los cortos artejos de las antenas, el primero de los cua. les es prolongado, mientras que los otros forman una masa interrumpida, varian en su número entre seis y nueve, y tanbien hay diferencia en el número de segmentos abdominales (de 4 a 7 ) : cn la formacion de los artejos de los piés.

\section{EL HIDROFILO DE COLOR DE PEZ - HYDROFILUS PICEUS}

CARACTÉRES, - El hidrófilo de color de pe\% y sus congéneres que se extienden casi por toda la tierra, son los gigantes de la fanilia, y forman del cuerpo oml, mas 6 menos aquillado en la parte inferior y bastante abovedado cul la superior, una masa recogida y pesada, que en esta disposicion no vuelve á presentarse entre los colcóptcros. Las antenns, que tienen nueve artejos, empliczan con un artejo basilar corvo de color de orin y acaban con los cuatro viltimos, en una maza parda cuyo priner artejo es brillante; de los tres siguientes, se prolonga el primero y segundo hácia afuera en una rana, mientras que el último es oval. Como en los diticidos, se ensanchan los piés de las cuatro patas posteriores en forma de remo $y$ su cara interior está cubierta de fuertes pelos; el primer artejo es pequeño y se jresenta en la carn anterior con un sencillo apéndice; al paso que en el segundo es mas largo que en todos los otros: este es uno de los caractéres de todo el género. El macho se distingue fícilmente de la hembra por el íltimo artejo de las patis posteriores aplanadas en forma de hacha. Un segundo caricter del género, unuy bien marcado en esta especie, es que el mesotóraxy el metatórax forman una quilla comun aplanada en nuestra especie y provista en su parte anterior de un fuerte surco, cuya quilla se extiende en forma de una afilada purta de lanza sobre los costados posteriores. Además se elera acui el abdómen en una quilla central bastante fuerte. Los elitros provistos de surcos longitudinales, acaban en la sutura en un fino dientecito: en los-intervalos lleva cada segundo un punto.

USOS, COSTUMBRES Y RÉGIMEN. - Wiste colcóp. tero, brillnnte, de color negro de per. verdoso; vive en aguas estancadas y corrientes: yo le lie cogido en el tiemplo de las inundaciones de primavera en el Saale, particularmente en las praderas inundadas, encontrándole a veces cubierto de um capa de barro que no pude quitar clel todo. Muy interesantes son algunas proporciones en la organizacion interna del animal. Una vejiga traqueal muy grande $y$ en extremo delgada y en forma de globo, situada en el limite del tórax y del abdúmen, es propia, lo mismo que las múltiples dilataciones de las tráquens, para recibir en el cuerpo una considerable cantidad de aire, sirviendo al mismo tiempo de vejiga natatoria Tambien el intestino, ņue presenta un tubo lango y delgado, de igual conformacion en todas sus partes, difiere csencialmente del de los otros coleópteros acuáticos é indica un alimento vegetal que parece componerse de cierta alga, la cual trasforma muchos charcos en verdaderos pantanos; 
al menos he observado que gmn mimero de estos coleópteros, alimentados de esta planta, se conservaban mucho tiempo en cautividad y los excrementos en forma de morcilla de. positados en el fondo, dejaban reconocer marcadamente el resto de las ajgas.

En abril deprosita la hembra fecundizadia los huevos, procediendo de un modo digno de examinarse, porque dificilmente se encuentra en otro coleóptero yue no pertenece a sus congéneres mas próximos. Se coloca en la superficie diel agua, boca arriba, por debajo de la hoja flotante de una planta, que con las patas anteriores oprime contra el vientre. De cuatro tubós, de los que dos sobresalen del abdómen mas que los otros, si segregan hilos blanquizeos que, por movimientos iaterales de la punta del abdómen, se remen en un tejido que cubre todo ul vientre du anima. Hecho esto, se yudve lit lembra -coge el tejido sobre el tomo y fabrica entoncess otro igual que se reune por las lados con el primero. Por fin se encuentra con el abdómen en forma de saco abierto por delante. Llenandole desde el fondo de series de hueros, sale a medida que estos aumentan, hasta que por fin cl saquito queda lleno y la extremidad del abdómen ha salido. Entonces coge los bordes con las patas posteriores, tejiendo hilo por hilo hasta que lá abertura se hace mas es. trecha y presenta un borde abultado. Despues coloca hilos urasiersales y acaba de cerrar el saco conso con una tapa Sobre está tapa se coloca todavia una punta; los hilos corren dé ábajo hácia arriba y vice.versa, siendo los siguientes siem. pre mas largos hasta que la punta acatia en forma de un cuernecito corro. En cuatro ó cinco horns, despues de hiaber hechó yarios remiendos, quedia acabada la obra, que como uisa pequena lancha de forma especial, se balincea sobre la superficie del agua en medio de las hojas vegetales. Cunndo los movimientos de las olas la remueven, ruelve a levantarse en seguida con la punta hácia arriba obedeciendo ả la ley de gravedind, pries en el fondo se hallan los huevos, mientras que la part anterior esta llena de aire. Fsistos capullos avales ie huevos se desfiguran á reces por los restos de plantas quie se les agregan, de ral modo que no se les puede reconocer.

Desjuucs de diez y seis ó diez y ocho dias salen las lavitas pero quedan algun ticmpo en su cuna comun, segun se cree, hasta despues de la primera muda Còmo ni las caiscaras ni las peliculas de los huevos se encucutran en el capullo, que cntonces queda abierto por la tapa, es preciso que estas hayan servido de alimento a las larvas, lo misno que el teido que llemaba la parte inferior del nido. Respecto á la alimentacion de las larras, gue desgraciadamente no pude observar yo mismo, he oido mrias opiniones, quizas incxactas, circunstancin que prueba otra re\% mas que la vida de los insectos mas comunes y exiendidos, es la menos conocida. Unos creen que esta larva se alimenta en su juventud de sustancias vegetales, trasformandose tiespues de varias mudas en un carni. cero voraz; otros le atribuỵen únicamente este último carac. ter, diciendo que frecuentemente se alinienta de caracoles acuriticos, cuya concha rompen por encima del lomo, comiéndose al animal con toda comodidad. El alimento, ya se compuonga de carne $\delta$ de sustancias regerales, no se chupa por medio de las maxilas, sino por la pequena abertura del esófago, que se encuintra entre las maxilas y la frente (el la. bio superior falta). Cuando se coge la larva ó cuarido el pico de una are acuática la amenaza, sé finge muerta dejando colgar las extremidades de su cuerpo; si este ardid no produce el efecto deseado, segrega un lízuido negro y fétido por el ano, ensuciando el agua à su alrededor y escapando asi de la persecucion. La cabeza de la larva es aplanada, desprovista de occlos; las antenas de tres artejos se insertan en la frente, las fuertes maxilas llevan ell su centro un dicnte, la mandi- bula inferior libre sobresale mucho y lleva en su punta exterior un palpo de tres artejos y en la parte interior una pequena espiuna como indicio de la maxila. Ias cortas patas están provistas de una garra y el segmento ủtimo puntiagudo del tronco presenta en su parte inferior un par de apéndices filiformes. Ia piel áspera del cuerpo es de color negruzco, mas oscuro en el lomo. La larva desarrollada abandona el agua trasiormándose en crisilida en una cavidad luúmeda practicada cerca del agua. Bespues del rerano salu cl coleóptero que en su cuma espera hasta gaue se ha endurecido y. adyuirido su cuerpo todo su color, ! entonces ya entra en el igun.

\section{EL HIDROO NEGRÍSIMO-HYDROUS ATERRIMUS}

CARACTERES. - Iumamente con la especie que acabanos descritir, pero con mucha menos frecuencia, se encuentra el hidroo negrisimo; sus antenas son de color rojo de orin, los elitros no denticulados, el vientre solo aborcdado sin quilla; y la quilia del tórax desprovista de surco en su parte ancerior.

\section{EL HIDROO CARABÓIDEO-HYDROUS CARABOIDES}

CARACTERES. - Esta especic es nucho mas camun; mide 1$)^{\circ}$, o 175 y se distingue del genero halroflus por el labio stperior escotado, por la ẹuilla del tómx mucho mas estrecha e!r forma do reborde, cuja punta no sale de las caderas.

USOS, COSTUMBRES Y RÉGIMEN. - La hembra oculta stús huevos en un tejido semejante, pèro emplèa una hoja estrecha, que provec despues de una pequeña punta. La larva se distingue por bramniuias traqueales en los lacios de los segmentos y por dos ganchos cómeos en el último anillo.

Un crecido número de las 570 y pico de especies de esta lamilia viven en el agua, donde mas bièn se arrastran por el fondo cenagoso ó por las plantas acuaticas que na. dan; algunas especies de formas mas recogidas (entre otras las del género Snophidirm) abrandonan el agua, adḳuiriendo el carácter de los lamelicornios.

\section{LOS HIDROBIOS - HYDROBIUS}

CARACTÉRES.-El cuerpo es oblongo, algunas veces casi hemisférico; las mandibuias ciliadas en la parte membra nosa del lado interno; los palpos maxilares cortos, con el último artejo fusiforme, mas grande que el anterior; las antemas constan de nueve artejos; con los tres últimos ligeramente trasiersos ó globulosos, formando conso una maia prolungada: el trocanter de los muslos posteriores afecia la forma de virgula; los tarsos posteriores algo comprimicos, presentan largos pelos y están provistos de un diente rudimentario. I.a mayor parte de estos insectos tienen los elitros profunda. mente estriados: en los otros presentan series regulares de puntos oscuros. 1.os hidrobios son insectos de mediano tama. no. y algunos muy pequeños.

DISTRIBUCION GEOGRÁFICA.-- En Europa existen unas ocho eipecies: las otras estan diseminadas en la mayor parie de los puntos del globo.

\section{EL HIDROBIO OBLONGO-HYDROBIUS OBLONGUS}

CARACTERES. - Esta es la especie que principalnente representa el género: se caracteriza por su cabeza ancha y 
obtusa por delante; los ojos son grandes y poco salientes: cl escudo bastante voluminoso; los elitros ovales y convexos; las patas medianas, con los muslos comprimidos; el mesos. terno oirece una estrecha carena entre las ancas intermedias; el cuerpo es oral, mas ó menos corto. Esta especic es de reducido tamano.

DistribUCion GEOGRÁ FicA.- Ll hidrobio oblon. go se encuentra jarticularmente en Europa.

\section{LOS ESTAFILINIDOS- STAPHYLINIDE}

CARACTÉRES. - Las mas de las 4,000 especies hasta ahora conocidas de los estafilinidos, llamados nmbien brauguilitrus, y que están dišminadas por tada la superficie del globo, sce distingsen fácilmente de otros coleóptcros por sus alas cortas, ofreciendo por lo demas la mayor variedad en sus caractéres, género de vida y ciertas formas que son el distin. tivo de otras familias. Aunque los mas de ellos tienen piés de cinco artejos, no faltan especies de cuatro $y$ hasta de tres. Las antenas, casi siempre de once y á veces de diez artejos, son análogias en todas las especies por su forma prolongada, y regularmente filiformes; prero algunas se ensanchan en la punta, ó son angulosas, etc. Aunque la firum del cuerpo es en cicro modo lineal y generalnente muy prolongada, obsérvanse no obstante formas que tienen la parte anterior rectangular, y en que el abdómen se inscrta como en figura de una cola cilindrica; otras especies son de forma cónica; muchas recuercian a los carabicidos con su cuello largo; y al lado de las cilindricas las hay del todo aplanadas. Fil color opaco ó amarillo sucio, casi sin matices, es propio de la mayor parte de las especies de nuestros paises, cไy่o tamaño es tambien bastante reducido; muchas especies exóticas tienten, por el contrario un viro brillo metálico.

USOS, COSTUMBRES Y REGIMEN.-I.凡 mayor parte de los estafilínidos viven en tiern y suelen albergarse debajo de sustancias en putrefaccion, como por ejemplo en el estiércol, en cadáveres, en schas fibrosás, debrjo de la corteza de los arboles, de las piedras ye en sitios arenosos, reuniéndose nuchos individuos en un mismo sitio de modo que cuando ocurren inundaciones repentinas sufren la sucrte de los naiufragos, segun hemos descrito antes. Ciertas especies habitan exclusivamente en las colonias de hornigas (por ejemplo ha especic lomechusa): algunas evitan los sitios hú medos y ragan por las flores para libar su néctar. Cuancio luce el sol. los mas vivaces complacense en volar, como lo hacen tambien las especies grandes en las hermosas nuches de verano; su alimento se componc de sustancias en putrefaccion del reino animal y vegetal, asi como de animales viros. Algunos géneros y especies tienen un ojuclo ó dos cn la coronilla, cosa muy rara entre los coleojteros; jero mas lo es aun ln absernacion hecha últimamente por Schadie. de la cual resulta que algunas especies americanas de los géneros spiractha y rorotoca son viviparas.

I.as larvas de los estafilinidos se asemejan à sus coleópteros mas que otras, a causa de tener astos muy cortos los eliuros y prolongada la forma del cuerpo. Las pocas que si conocen tienen antenas de cuatro á cinco artejos, uno ó seis ojuelos'a cada lado, jatas cortas de rinco artejos, que rematan en una garm, y dos estilos articulados en una extrenidad del abdómen; el ano puede salir, ayudancio la locomocion. Las larvas de las especies mas grandes persiguen a otras, y pueden alimentarse con carne, cuando se las qujere criar. La trasformacion en crisálida se verifica en el sitio donde la lara habita, en alguna cavidad subterrabea, y al cabo de algunas semanas sale el coléoprero de la ninfa.
Despues de lo dicho, no es posible hacer una exacta descripcion de toda la familia, y por lo tanto limitamos nuestro estudia a algunas especies, notables por sus colores abigarrados $\delta$ por su tamano, las cuales á causa de su diseminacion pueden encontrarse en todis partes.

\section{EL ESTAFILINO DE RAYAS DORADAS- STAPHYLINUS CAESAREUS}

CARACTERES. - Esta especic, confundida à mi-nudo con el estafilino de alas rojas (staphylisus erglhopterus), es de color negro; la cabeza ! el escudete de un verde metili. co; las antenas y patas peludas, asi como los elitros de un pardo rojo; las series de manchas claras del abdomen y el borde claro del escudete estan formados por jelos sedosos y lisos de color amarillo domdo.

\section{EL ESTAFILINO DE ALAS ROJAS-STA- PHYLINUS ERYTHROPIEKUS}

CARACTERES. - Esta especie, mas endehle que la an. terior, se distingue de la misma por carecer del borde posterior amarillo dorado del escudete.

Los caractéres distintiros de todo el géncto, que aun cuenta varias especies bonitas y muy jeludas, son los siguientes: antenas rectas, que se insertan en el borde anterior de la frente; maxilas fuertes, falciformes y salientes: la mandíbula interior bipartida, con palpos filiformes: la lengua nembranosa y escotada, provista de apéndices laterales coriáceos, estrechos y' un poco mas largos; la cabeza cuadrada, con los ángulos redondeados, tan ancha ó un poco mas que cl escu. dete, que es redondendo en su parte posterior, y cortado en linea recta en la amterior; comunicase con él por una estrechez en forma de espigin; los elitros son redondeados en la punta o cortados oblicuamente hácia adentro; los costados se ensanchan y las patas anteriores se desvian de las del centro.

USOS, COSTUMBRES Y RÉGIMEN - El estafilino de alas rojas se encucum por lo regular en los bosques. donde raga for la hojarasca, aunque segun mis obsernacio. nes vive tambien 2 la manera de los caratricidos trepadores, pues en los sitios donde aluunda le he hecho caer il menudo de los troncos dejgndos de encina. No le he visto comer aqui, pero creo qque busca su alimento y gue no se nutre tan solo de sustancias en putrefaccion, como han pretendido varios autores. En pro de mi ascrto tenemos el hecho de que Bouché crió varias larvas con carne fresca. Nuestra especie, lo mismo que sus congéneres, se encuentra al reces en tiempo caluroso en los caminos, donde se la ve elevar al aire su ahdómen, muy movitle. Este modo de ahuecarsc, mus semejan. te al de un pavo real, parece indicar cierto carictur muy excitable, o cuando menos un sentimiento de satisfaccion del individuo, segun lo demuestran las evoluciones agiles y atre. vidis del-cuerpo.

\section{EL ESTAFILINO DE PELOS CORTOS- STAPHYLINUS PUBESCENS}

CARACTERES. - Lista especic se distingue por su color pardo de orin, mas oscuro en los escudetes que en los elitros, mas claro en el escucio cie la cabeza y siempre bri. llante, á causa de los pelos sedosos que cubren todo el cuerpo, produciendo los colores mas abigarrados en el vicntre y metatorax, que son de un gris platcado: en el dorso se ven manchitas negras aterciopreladas. 


\section{EL OCIPO COMUN Ó FÉTIDO-OGYPUS OLENS}

CARACTERES.-El ocipo fétido, una de las especies mas grandes de la familia, es de color negto, excepto la punta de las antenas, que tienen un tinte pardo de orin; esti cubierto de pelos sedosos, dilerenciandose de otra especie mas endeble del mismo género, que carece de alas. Los costados centrales, muy próximos entre si, son la ḱnica diferencia entre este género yol anterior (fig: - g).

USOS, COSTUMBRES Y RÉGIMEN,-El ocipo fétido vive con proferencia y masladimente en los bosqutes.

\section{EL FILONTO DE COLOR DE BRONCE PHYLONTUS ANEUS}

CARACTÉRES. - El filonto de color de bronce pertenece a un género compuesto de cien especies europers, muy difiril de distinguir, género que tiene todos los earacteres esenciales comunes à los anteriores, reconociéndose solo por una leugua entern, redondiada úniramente en su parte anterjar.

USOS, COSTUMBRES Y REGIMEN.-Los filontos, que no escasean en uinguma parre; viven en los sitios laúme. dos, y al parecer no les agrada inucho el estícrcol, a juagar por su nombre cientifico.

\section{EL OXIPORO ROJO-OXXPORUS RUFUS}

CARACTÉRES.- İsta esjecie es sin dida una de las mas notaliles de la familia lil colorpredominante, negro brillante, del coleóptero, se sustimye for un rojo vivo en el escudete, en el ángulo de los elitros. formados por los hombros, jien cl abdómen, excepto la extremidad; las patas, menos la base que es negra, lienen tambien aquel color; hat antenas afectau In forma de maza; las partes de la boca, excepto las maxilas, son rojas listas últimas son Inrgńs, falciformes y se cruzan al cermrse; el artejo final de los pal. pos labiales constituye el caracter tésencial del género, que le distingue de los tres anteriores.

USOS, COSTUMBRES Y REGIMEN. - La Especic habita en las setas carnosas y fibrosas y no cs rara.

\section{EL PEDERO DE RIBERA-PEDERUS} HIPARIUS

Caracteres. - Mientras que en todos los estafilinidos hasta aliora descritos y otrus muchos no citidos, se re detris de los costacios anteriores el estigma del protórax, en Ia especie que nos ocupa queda cubierto por al borde de quitina encorvado del escudete. El pedero de ribera tiene la cabeza roja; la extremidad de las antenas, los dos segmentos posteriores del tórax y la punta de la cola son negras; y los elitros azules, con grandes puntos.

El labio superior es entero: el úttimo artejo de los palpos maxilares es muy pequeno: el cuarto ąrtejo del jué lipartido; los costados posteriores cónicos; un escudete casí es: férico; fo las antenas se insettan en el borde lateral de la frente. Thales son los caractéres del género, de cujas treinta especies se encuentran unas once en Europa.

USOS, COSTUMBRES Y REGIMEN.-El pedero de ribera habita con preferencia las orillas de las aguas corrientes y estancadas, sube tambien d los arbustos y se en. cucintra casi sicmure reunido cn peyuenas socicdacies.

\section{LOS EPSELÁFIDOS PSELAPHIDE}

CARACTERES. - I.os epseláfidos, unos colcópteros pequenisimos y que ofrecen muchos aspectos interesantes, viven ocultos debajo del musgo, la hojarasen húmeda, la coricza de irboles, las piedras y en medio de las hormigas. Forman una familia independiente, muy atine de la de los estafilinidos, poryuc tambien en ella los elitros son demasiado cortos para cubrir al abdómen en toda su extension, à pesar de lo cual no es posible confundir ambos grupos. Lil cuerpo de los epselafidos ofrece por lo regular inas anchura hacia la punta del abóómen, careciendo de la facultad de levantarle ómoverle, mientras que precisamente por este con. cepto los estafilinidos poseen ciertahabilidad; los cinco anillos de que esta compuesto aparecen estrechamente soldados. En cambio, las especics que pertenecen al grupo que nos ocupa mueven continuamente las antenas en forma de maza, con el tillo at modo de cordon de perlas y los palpos naxilares compuestos de uno a cuatro artejos, los que en la mayor partc de las especies cuelgan a mucha distancia de la Loca? Los paipos labiales, al contrario, son muy cortos; de los dos lóbulos membranosos de la mandibula inferior, el exterior es mucho mas grande que el interior. En los piés cuéntinse, a lo mas, tres artejos, el último de los cuales lleva una ó alos garras.

USOS, COSTUMBRES Y RLEGIMEN.-LAS Especies, cuya existencia no dejende de las hormigas, vuelan de nohe: las inundaciones veraniegas arrojan fuera de sus viviendas a centenares de individuos y mezchados con ellos lanzan tambien a otros/companeros de infortunio, yendo unos y utros a caer en la orilla arenosa, en donde el coleccionista puede hacer abuindante cosecha cuando las circunstancias le favorceen; por otra parte estos animalitos se dejan coger con fucilidad.

Ias laryas no se conocen aun, mientms que se cuentan coleópleros de este grupo originarios de todos los continentes, excepto del 1 sin, donde, sin duda, los coleccionistas no han herho aun caso de ellos; pues en todos los paises menos en Europa, se buscan siempre en primera linea las forinas de major tamaño, olviciando colcúpteros tan perjuenos como los pertenecientes á la familia de que venimos ocupandonos, que por término uncedio solo alcanzan una longitud de $6^{\prime \prime}, 00225$.

\section{EL CLAYÍGERO AMARILLO-CLAYYGER TESTAGEUS}

CARACTERES. El clavigero amarillo pertenece à las pocas especies, cuyo género de vida ofrece el mayor intcrés. Los contornos del cuerpo vuelven á encontrarse tambien en las restantes especies de la familia Los distintivos mas ca. racteristicos del clavigero son: la falta de los ojos, los ängulos posteriores de los elitros soldados y replegados, unos mechones de pelos encima de cllos y un hojo profundo en la parte superior de la base del abdómien. En los pies, provistos de una garra, los dos primeros artejos son tan cortos que por mucho tiempo no sc los pudo cencontrar: el audómen es la parte inas brillante del cucrpo, porque solo en su punta está cubierto de pelos, como el resto del cuerpo; su forma es casi esférica; en los lados tienen un fino reborde y solo en el vientre se advierten los cinco segmentos que le componen. E] macho se distingue de la hembra por un diente mas pequeño en la cara interior de los muslos y por los tarsos de lass patas medias. 
USOS, COSTUMBRES Y REGIMEN.-EI clarigero anarillo vive dehajo de las piedras y en los nidos de las hormigas amarillas, las que le cogen como ia sus propias ctisálidas para llevarle al interior de su nido, cuando se levantan las piedms. produciendo esto una perturbacion en el órden doméstico de dichos animales. Este rasgo indica relaciones intimas entre los dos insectos, rejaciones que han sich confirmadas tambien, en otro concepro, for observaciones minuciosas. Tinles observaciones las detwemos al señor P. W. I. Mueller, antes pastor protestante de Wiasserleben, cerca de IV crnigerode. El citado observador, en extremo maravillado por el fenóneno mencionado, se llevó à su casa coleópteros, hormigas, la cria de estas en varios estados de desarrollo y ticrra del uido, con tallos de musgo: ya al dia siguiente los cautivos habian arreglado su habitacion, y Mueller hizo con el auxilio de un microscopio, un eximen tan ninucioso de ellos, que cunnto se refiere a continuacion se funda en detalles y observaciones sobmdo repetidas para que puedan considerarse infundadas. I as siguientes palabras son de Mueller:

Uas hormigas se entregaban â sus ocupaciones acostum. bradas; algunas arreglaban y lamian la cria, otras reparaban el nido, llevando de un lado á otro la tierra, algunas descansaban, permaneciendo horns conteres en un mismo sitio, y muchas, en fin, limpiaban su cuerpo. Cada hormiga hacia por si misma este uiltimo trabajo, por lo que concierne i aquellas partes del cuerpo en izue podia efectuarlo, mientras que otras la ayudaban en las partes à que no podia llegar con su boca y patas. En tanto los clavigeros corrian fitmiliamente $y$ sin cuidado entre las hormigas, ó permanecian quietos en las galerias, extendidas en su mayoria por las pa. redes de cristal que les servian de prision, denostrando ell todo su comportamiento la misma conformidad à su condicion actual gue a la vida en libertad.

- Despues de haber seguido todos los movimientos de mis cautivos por algun tiempo con la mayor atencion, vi de repente, con gran asombro, que cadia ver que uma hormiga encontraba a un clavigero, le tocaba cariñosamente con las antenas y le acarieiaba; y mientras ą̧ucl le correspondia con sus antenas, lamin con visible avidez el lomo del hijo adoptivo. El sitio en que lo efectuaba cada rez, era el mechon de pelos, en el ángulo posterior de los elitros. La hormiga abria desmesuradamente sus grandes maxilas, chupando varias veces por medio de las restantes partes de la boca el mechon de pelo y lamiendo despues toda la superficie anterior del dorso, sobre todo el hoyo: este procedimiento se repesia cada ocho 6 dicz minutos, ya por una ya por otra hormiga, cuando el coleóptero encontraba varios de sus huéspedes, nunque en el último caso las honnigas solo se detenian poco mito en examinurle.

Así como en las ramas de los àrboles los pulgones ofrecen ì otras hormigas su miel, dando lugar á que estas les busquen con decidida aficion y los traten muy amistosamente, los clavigeros ofrecen á estas especies, que no suloen a los irboles, una golosina en la humedad que segregan los mechones de pelos de que están provistos: pero las hormigas tambien se muestran reconocidns. Veamos cómo continúa el citado obsermador:

"Para no dejar morir de hambre á mis cautivos y para poderles observar el mas largo tiempo posible, me ví obligado à ofrecerles cualquier alimento conveniente. Con esta inten cion humedeci las paredes del cristal cerca del suelo y de al. gunos tallos de musgo, por medio de un pincel, con agua pura y con agua mezclada con miel, poniendo además algunos giedacitos de azúcar y de cerezas maduras en otros sitios, para que cada cual pudiera elegir lo que mas le conviniera. Una hormiga despues de otra, segun en su carrera llegaban a un sitio humedecido, se paraba y lamia ávidamente, y de este modo pronto se reunian varios individuos. Algunos clavigeros llegnban tambien á los mismos puntos, pero pasahan, sin hacer caso de ellos. Entonces varias hormigns satisfechas se poniar en camino, se paraban al encontrar una ú otra com. pañera que aun no labia hallado el alimento, para darla tambien de comer, siguiendo despues la marcha con objeto de hareer lo propio con la cria que se hallaba en la parte inferior del cristal. Pensé entonces procurar otro alimento á los cla. vigeros porque no tocaban al existcnte, cuando vi cómo uno de los coleupteros encontraba una hormiga satisfecha, $y$ ambos se paraban: aumenté mi atencion, y entonces se ofreció a mi vista un especticulo tan extrano como incsperado; pues vi marcadamenre como el clavigero se alimentaba de la boca de la hormiga Apenas pude convencerme de la reali. dad del hecho, estando aun en duda si lo que habia visto era exacto, cuando inmediatamente despues la misma observacion se confirmó en tres, cuatro y mas puntos. Algunas hormigns alimentaban à los coleópteros junto à la pared de la botellita, de modo qune por medio de un microscopio de mayor potencin, pude observar marcadamente lo ocurrido. Cada vez que una hormiga encontraba a un colecóptero hambriento, este dirigia la cabera y las antenas hicia arriba, es decir, at la boca de aquella, y ambos se paraban; despues de tocarse con las antenas, el colébtero abriala boca, $y$ l la hormign, haciendo otro tanto, le daba el alimento que acababa de comier; ambos limpiaban despues las partes internas de la boca y continuaban su camino. Tal alinentacion dura por lo regular de ocho á áoce segundos, despuses de cuyo intervalo de tiempo la hormiga solia lamer los mechones de pelo del $\mathrm{co}$. leófytero: de esta manera todos los clavigeros se alimentaban varias veces al dia, con gran regulasiơad, y nunca vi à un colleóptero que hubiern comido directamente del alimento que se hallaba en la botellita, miel, axúcar y fruta : cuando mas lamian los vapores acuosos que en la pared interior del cristal se habian fijado.

\$Por grande que sea el carino y el cuidado de las hormigas para su cria, no puede exceder á la termura con que tratan à los clavigeros. Conmuere, en efecto, el ver cómo los acari. cian con las antenas, aun cuando no exista alimento en los mechones: cómo les alimentan siempre con igual termura y voluntad, atan antes de atender a su cria; cómo les dejan cruzar con gran paciencia por encima de ellas; y hasta cómo se entregan a todo genero de juegos, cogiéndoles con las temazas nor el lomo y llevindoles á cierta distancia, desde don. de vuelven a depositarlos en el prinitivo lugar. Por otra parte, la familiaridad de los coleopteros para con las hormigas no es menos admirable. No se cree tener à la vista dos diferentes géneros de insectos, sino mas bien á los individuos de misma familia; en rigor podemos decir que vemos en los claví geros hijos que sin cuidado viven en la habitacion de los padres quuienes les alimentan y cuidan, y á los que piden la comida siempre que la necesidad lo exige; demostrindoles en cambio su gratitud en todas ocasiones: asi por ejemplo of que un clavigero limpiaba i una hormiga que se lialtaba descansando: cepillstrala con su boca el lomo y el abdómen, ocupando casi un cuarto de horn en cste trabajo.

Interesante es tambien la observacion electunda con una segunda especie del mismo género de coleópteros, que vive junta con otra especie de hormigas exactamente del mismo modo: se la trata de igual manera por las hormigas amarillas que al clavigero amarillo, aunque las dos especies de hormigas se hagan la guerra. Al recoger a mbas especies, se jusicron, por un descuido, algunes colcópteros !' seis à ochn hormigns de la otra especic en la misma prision que has hormigns amarillas, las que se precipitaron en seguida sobre las intrusas, 
matåndolas poco á poco; pero perdonando a sus colcópteros, a los que alimentaban del mismo modo que á los suyos. Esta observacion se confirmó mas tarde cambiando, con toda in tencion, las dos especies de coleópteros (Claitger forcolatus y longicormis) de una a otra botellita, donde se les mezclaba con las hormigas cxtranas.

Los clavigeros dependen exclusivamente de ciertas especies de hormigas, que les quieren, protegen y alimentan como á sus hijos adoptivos, ya por instinto innato, ya porque la presencia de aquellas les ofrece a clllos mismos ur placer. Los coleópteros que, por falta de ojos yo de alas, no podrian atender á su vida, no pueden vivir ell parte alguna, simo en los nidos de hornigas, donde se propagan y mueren sin haberlos abandonado jamis. ¿Quién creeria liallar tal miestra de amis. tad y carino oculto debajo de his piedras?

Del grabado que el relerido observador publia, represen. tando la piel de crisjlida del clavigero amarillo, resula que la larva de este coleóptero debe tener seis patas.

\section{LOS SÍLFIDOS - SILPHIDE}

CARACtéres. - De la tamilia de los sillidos, tan dife. rentes en la estructura de su cuerpo, solu podemos decir, en genenl, que las antenas, compuestas regularmente de once artejos, se ensanchan poco it poco en direccion a la punta, ó que en esta llevan una cabeza marcadamente separada ambos lóbulos de la mandibula inferior se distinguen marcadamente y son cómeos ó membranosos; la lengua es bipartida y los elitros llegan casi sicmapre hâsta la punta del abdómen. Los silfidos se distinguen de todos los demás colebjteros de cinco dedos y con anteans en forma de inaza, por los rostados cónicos que salen libremente en las cuatro patas anteriores, y por los seis segmentos movibles del abdómen.

USOS, COSTUMBRES Y REGIMEN.-Todas las especies se presentan en los cadáveres animales, sea para alimentarse de cllos, $\delta$ bien para depositar en ellos sus huevos; poserendo la cualidad poco agradable de segregar un jugo fétido del ano ó de ja boca, óbien de ambos al propiotienpo, si se les toca. A falta de cadireres buscan tambien las sustancias vegetaics en descomposicion, ó ntacan á insectos vivos, no perdonando tampoco a sus iguales. Sus movinientos son ágiles y su olfato en extremo desarrollado: pues desde mucha distancia llegan a los sitios donde un ave, un concjo, un topo, etc, muertos, empiezan el proceso de la descompo-
sicion.

Conócense actualmente cuatrocientas sesenta esplecies di. seminadas por toda la superficie del globo, siendo, empero, mas numerosas, a lo que parcece, en las zomas templadas.

Hay conformidad en el género de vida que observan las larvis entre si y con los coleónteros; Inero no en sus formas exteriores, circunstancia que nos obliga i ocuparnos de ellas al tratir de los diferentes géneros.

\section{EL NECRÓFORO COMUN-NECROPHORUS VESPILLO}

CARACTERES. - El necróforo comun se distingue con sus cuarenta y jico de congéneres, de los que la nayor parte viven en Europay en el norte de América, por los caractéres siguientes: Los cuatro últimos de los dicz artejos de las antenas forman un boton esférico; la cabeza grande, estrechacla en su parte posterior en forma de cuello, està cubierta en parte por el collar esofágico, casi redondo y provisto de un ancho borcie; los elitros truncados dejan libres los tres úl timos segmentos del abdómen; las patas fuertes se distinguen por los tarsos muy ensanchados en la punta, y en los maches por el ensanchamiento de los cuatro primeros artejos en las patas anteriores y medias 1) los palpos, que terminan en forma cilindrica, los maxilares son mucho mas largos que los
labiales. El necróforo comun se camcteriza por los tarsos posteriodorados, por la punta amarilla de las antenas, dos fajas de color de naranja en los clitros, y por el color negro en él predominante. Debo añadir que puede producir una especie de chimico nl rozar la parte superior del quinto segmento del abdómen, con sus dos rebordes, contra los bordes posterio. res de los clitros (fig. I1).

USOS, COSTUMBRES Y REGIMEN.-EI nectóforo se presenta en los puntos donde existe un cadiver, aunque por lo demas es dificil verle, porque su género de vida es con proferencia nocturno. Se anuncia con el zumbido de un abcjon, dando i los elitros una posicion caracteristica, pues se levantan al aire de derecha á izquicrda y al volver hácio afuera la cara interna, se tocan con los borles exteriores y cubren el lomo en forma de tejado. En los citados puntos se reunen dos, ires y lasta seis individuos, que por lo pronto cxiaminan el cadiver próxino a ser enterrado, y despues el suclo, muchas reces no muy propio para servir de cementerio: cuando los coleópteros lo encuentran todo en úrden, se colocan a ina distáncia conveniente, con objeto de no estorbarse uno i otro; por debajo del cadácer, escarban la tierra con las patas hácia atris, de modo que forman una especie de terraplen al rededor dél raton muerto, $v$. g., que poco á poco baja por su propio peso: cuando el tmbajo se paraliza en a]gun punto, ó cuanclo una parte queda mas alta que otra, uno ú otro de los trabajadores aparece en la superficie, examina cón/aire expurto por todos sus lados la parte resisien. te, y al cabo de breve rato se observin yue esta tambien baja poco á poco, pues entonces todas las fuerzas se remuen ell este punto. Apenas puede creerse en cuan poco tiempo es. tos animales hacen desaparecer de la superficic el cuerpo entero del raton; de modo que solo un pe(puenoo monton de tierra indica el sitio donde aquel se hallaba, cuyo monton es, por último, allamado tumbien. En terreno ligero bajan los cadáveres lassta uma profundidad de $0^{\circ}, 30$. Gleditstch, hombre de mucho mérito en punto a botánica y cconomia, ha observado en su tiempo y con frecuencia estos entierros, praciicados por los coleópteros, y nos refiere que cuatro de estos insectos enterraron en cincuenta dias dos topos, cuntro ranas, tres ares pequeñas, dos langostas, los intestinos de un pe\% y dos pedazos de higado de bucy. ¿Para qué tal actividad y tal prisa? A los séres irraciomales se lo dice el llamado instinto, aquel impulso naturāl que nos hace ver milagros al examinarlos en sus diferentes manifestacione's. El siguiente hecho prueba, sin enibargo, que a menudo no debe contarse con tal instinto y que no puede hablarse asi tratándose de estos y de otros insectos pequeños: ciertos necróforos a los que se habia abandonado un cadaver colgado de un hilo fijado en un baston, dieron en ticrra con este, cuaudo se convencieron de que segun el procedimiento acostumbrado nada lograrian con el cadáver. No ignoran estos animales que varios de sus iguales; silfidos de varios géneros, y solure todo moscardoncs, podrian tomarles la delantera, y por eso, y para asegurar á. su cria el alimento necesario hacen esfuerzos sobrenaturales; pues no enticrnn el cadiver para conservar una golosina, como un perro harto oculta un hueso, sino para depositar en él sus huevos. Se les encuentra reunidos con numerosos compañeros, manilestando unos y otros gran avidez glotoneria; con los estafilinidos ya citados, con los silfidos de que á con. inuacion nos ocuparemos, con los dermestidos, histéridos, 
y entre un caos de repugnantes larvas de mosca, por debajo de grandes cadaveres no enterrados y de los que, por tin, solo quedan los huesos.

En la descripcion anterior hemos supuesto que las condiciones del terreno cran propias para el entierro; pero no su. cede siempre asi. Un suclo pedregoso y duro, ó cubierto de una capa de gramineas, puedo hacer ineficaces los trabajos mas repetidos de los pequeños mineros. Estos lo compren. den pronto y eligèn los cadáveres situndos en él, para su propia alimentacion y no pam su cria; tambien en tales ca. sos han dado otms pruebas de sus facultades inielectuales; pues se ha observado cómo, reuniendo todos sus esfuerzos cn una misma direccion, han trisladado un cadiver pequeño a cierta distancia, hasta conducirlo a un terreno vecino a propósito para sus fines.

Cunndo por último, venciendo obstáculos mas 6 menos grancies, pero siempre merced al empleo de todas sus fuerzas, han logrado el entierro, se verifica el aparenmiento, y la hembra viclve a desaparecer bajo tierra, donde en determinadas circunstancias permanece invisible de cinco il seis dias. Al aparecer mas tarde, apenas se la reconoce, porque todo su cuerpo essa cubicrto de unos pequeños acarinos de ocho patas y de color amarillo rojizo (Ganimasus coleopierorum:. Ha cumplicio su destino y sobre ella se ha fijado aliora orro sér que á su manera goza de las dulicias de una corta cxis. tencia. Si empero queremos examinar cómo este movible coleúptero, con sus fajas de coior naranja y con su dorndo collar, se ha desarrollado, es preciso ocuparnos en un tmbajo desagradable y volver a exiraer el raton penosamente enterrado, colocindole, con la ticra necesaria, en un vaso de cristal, de mancra que en parte roque la parèd de éste, con objeto de poderle observar; fues en menos de quince disis las larvas salen de los huevos. La observacion de estos gusanos tiene poco de éstético para permitir aqu una descripcion mas detallada. En muy poco tiempo, y despues de mudar varias veces de picl han llegado a su completo desatrollo. Su color predominanic es un blanco sucio: las seis patas flébiles provistas de una garra, la cabeza con antenas de cuntro artejos y las maxilas poco desarrolladas, son de un pardo amarillento, lo mismo que las placis dorsales que tienen forma de corona y que apoyindose en los bordes anteriores de los seginentos, sirven, con sus puntas, para la locomocion. Fin la cabeza existe un labio superior; los seis ocelos se dividen en dos grupos, porque los dos imferiores estin situados \& mucha distancia de los otros. Parn convertirse en crisilida la larva entra a mayor profundidad on la ticra y se trasiorma en una ninfa blanca al principio y que pasado algun tiempo se vuclve mas y mas oscura, a medicia que se acerca su trasformacion en insecto perfecto. Aunque el desarrollo se verifica con bastante rapidez parn permitir dos crias al año, es de suponer que no da lugar sino dá una sola.

Del mismo modo se forma da vida en las otras especies. que en su majoria llevan tambien fajas rojas. In especic nerropltaros humiator, que mide $4^{\text {"m, }}, 026 \mathrm{y}$ tiene el hoton de las antenas amarillo, y el necróforo aleman ( $N$. girmamus), Ia mayor que existe en Europa, son negris del todo y'llevan, solo excepcionalmente, una maricha rojä en la punta de los clitros.

\section{LOS SILFOS - SILPHA}

CARACTERES. - El género de los silfos propiamente dichos que dinn el nombre à toda la familia, se distingue por un cuerpo aplanado, de contornos ovales, porque el borde posterior y el collar esóägico, mas ó menos semicircular, enz cubrên un tanto la cabeza vertical y puntiaguda; los elitros cubren tambien casi por completo la punta del abdómen y hasta sobresalen de ella, sobre todo cu las hembrats; ambos tienen sus extremidades redoadeadas en forma de semicirculo. I.as antenas de once artujos se ensanchan poco á po. co hácia la punta hasta iormar una maza de tres a cinco artejos. Un gancho córneo aparece en la cara interior de la mandibula inferior y sus palpos son, lo mismo que en los necrúforos, mas largos que los palpos labiales.

Ins sesenta ! siete esprecies conocidas son, con muy pocas

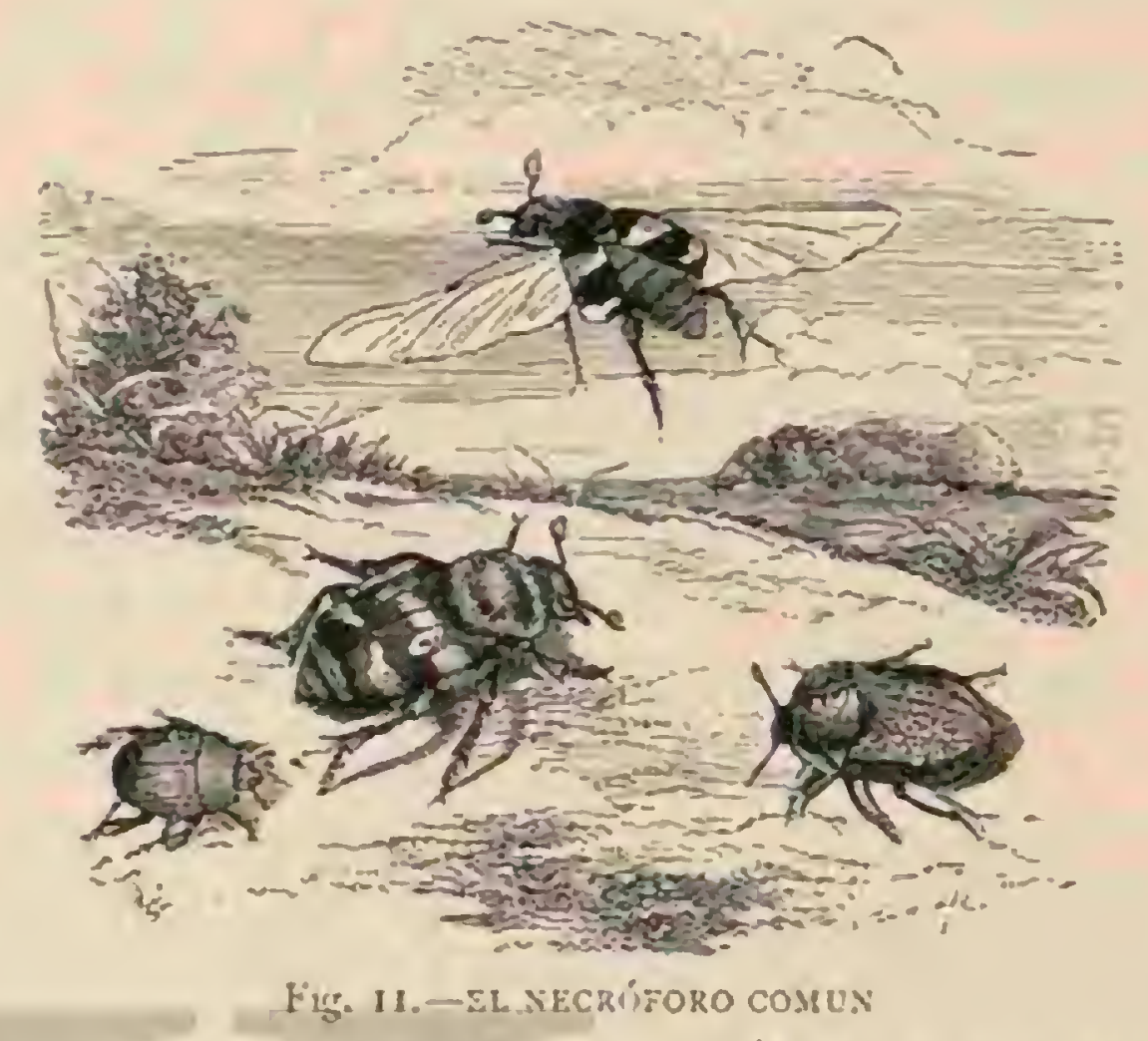

l̈̈g. 12.-KR. HISTES CAUAVERLIO

Jig. 13.-RL SII FO NiRKO

excepciones, wasi del todo negrns y dependen aparentemente por su alimentacion, del suelo; habitan adem is de la Australia todos los continentes.

\section{EL SILFO NEGRO-SILPHA ATRATA}

CARACTERES.-Fsia especie es una de las mas dise minadas é interesantes, porque su larva pone con frecuencia á contribucion los campos de zamahorias. Fil insecto perfecto se encuentra todo el verano en los campos, y por delxijo do las piedms y pedazos de tierra; por lo regular debajo del cadáver de un animal. Sus contornos son elipticos, su parte superior ligeramente convexa y el todo de un negro brillante: la cabeza en direccion vertical hacia abajo, como todos sus congéneres, está cubierta en su parte superior del escudo collar, proristo de puntos gruesos, el cual forma semicirculos con reborde, excepto en la parte posterior en la que excede un poco de la base de los elitros, sobresaliendo de ellos otro poco en anchura. Ios elitros tstan tn el bordc exterior muy encorvados hacia arriba, redondeados en la parte posterior; de modo que en la sutura apenas se prescnian escotados. Por encima de la superficie de cada uno de ellos corrén tres quillas longitudinales, obtusas, con intervalos iguales cutre sí de la sutura que tambien se cleva en forma de reborde. 1,os intervalos están provistos de puntos gruesos y rugosos: las patas se distinguen por tener en los tarsos cerdas y cinco artejos en los piés: las anteriores del macho por las plantas vellosas. Fijándose en estos caractéres, diticil será confundir esta especie con otras dos muy parecidas (silpha laigata, reticulatr).

La larva, negra en la jarte superior y clura en el vientre, se compone de doce segmentos que desde la cabeza hácia el centro aumentan en anchurn, estrechándose despues inucho poco á poco: la considerable anchura del centro aumenta en los bordes laterales dilatados en forma de lóbulos en los escudos. El último segmento tiene en la punta dos apéndices 
carnosos. En el ano se forma una apófisis por fuera que facilita la locomocion. In la cabera, que está oculta, hay antenas bastante largas de tres artejos; detrás de su base cuatro ocelos y mas abajo otros dos.

Is larva, asi como las de oiras especies, permanece oculta debajo de los animales muertos y crece rápidamente mudando varias veces de piel; encuéntrase à inenudo en tal mumero, que le faltaria el alimento ordinario, si no se hiciese plantirora, y comiera entonces los primeros retonos de las zamahorias, causando sensibles estragos en las regiones en donde el cultivo de estas plantis octupa grandesterrcuos destinados ála fnbricacion de azucar. Gracias i. su gran voracidad la larma crece rapidamente; en cada una de lis cuatro mudas sale blan. ca, pero adquiere una hora mas tnrde el color negrodellomo: es muy vita y se oculta cu el monento en que se la persigue; cuando es asiulta penetra i bastante profundidad en la ticra erasformándose en una crisálida blanca, encorvada en forma de 2 y que por su gran escrido collar y sti calera ocuita por debajo del mismo ano revela su naturaleza de silfo. Al cabo rie unos diez dias sale cl coleóputero: cste, que puedetener doscrins nl año, inverna cn estado perfecto. I a inundacion de abril de 1865 echó a nuestra orilla gran número de individuos de la especie que nos ocupn y del silfo oscuro. A prinripios de la primarera se varificú el apareamiento y despues Ia puesta de los huevos debajo de la hojarasca en descomposicion ó de la capa superior de la tierra, en cuya ocasion el abdómen puede prolongarse mucho semejando un iubo. lista operacion requicre mucho ticmpo, por lo cual las larvas salen en tiempos diferentes, circunstancia que es causa de que en verano las larvas y los coleópteros pueden encontrarse al mismo ticmpo.

\section{EL SILFO TORÁCICO-SILPHA THORACICA}

CARACTERES. - Il silfo torácico es una de has dós especies alemanas que no tienen el color negro de las otrás, presentando del escudio collar un viro color rojo.

\section{EL SILFO DE CUATRO PUNTOS - SILPHA QUADRIPUNCTATA}

CARACTÉRES.- Liste silfo es el segundo de color diferente, que además se distingue por su gênero de vida; en el cuerpo predomina el color negro, sobre todo en el disco del escudo collar, en el escudete j en cuntro manchitas redondas de los elitros, mientras que el resto de las partes staperiores licne un color amarillo verdoso.

USOS, COSTUMBRES Y REGIMEN. - AUnque no conor.co el desarrollo de esta especie, supongo que tambien se verifica en el suelo; pero al coleóptero perficto no le gus. ta vivir en los campos y' en los caninos, ni debajó de anima. les en descomposicion; prefiere al parecer las alturas, y agridale la carne fresca en rez de la podrida. Por eso sube a los arbustos, y sobre todo á las cncinas y hayas jóvenes donde busca orugas vivis para su alimento. Yo he visto al este inserto comerins, y todos los anos le he hechn caer en bastante número de dichos árboles, mientras que el pequeño calosoma inquisidor solo algunas veces. se encueutra en su com pania. Fin cl modo de conducirse ambos coleópteros al caer nótase una gran diferencia. El carabicido emprende con la mayor rapidez la fuga, mientras nue el silfido permanece inmóvil con Ins patas recogidas, cunl si estuviera muerto; pero como pronto se mueve y escapa, es probable que su primera posicion sea solo una consecuencia del susto y de la brusca caida.

\section{LOS HISTERIDOS - HISTERID FE}

CARACTERES.-En los sitios fivoritos de los necrófo- ros y silfidos suelen cncontrarse tambien representantes de la familia de los histéridos. Son coleópteros recogidos, aplanados y á veces del todo planos, rodeacios de una coraza muy brillante y dura. La cabeza, pequeina y estreclia, se inserta á mucha profundidad en el escudo collar y puede re. cogerse en una especie de pro hasta desaparecer del todo: el escudo collar, yue tiene rebordes en los lados, ensinchase poco i poco hicia atrás, oprimiéndose por la parte posterior contra la base de los clitros que mas 6 menos truncados cu. bren siempre la rabadilla en forma de punta redondeada, provista de una hoja de quitina triangular; cstin cruzados por finos surcos longitudinales, muy útiles para distinguir las especies. Ias cortas antenas, de once artijos, toman descle la base otra direccion, ofreciendo por lo tanto un aingulo que remata en un boton anillado, formado por los tres viltimos artejos. Jas imaxilas sobresalen; los lóbulos exteriores de la mandibula inferior son mas largos que los interiores, y unos y otros membranosos y jeludos; la lengua, que es corta, se oculta casi sicmpre detris de la barba, y los palpos son casi siempre filiformes. En el vientre se distinguen cinco ani- llos, de los cuales el primero alcanza una gran longitud. I.ns patas, que sou aplanndas, pueden recogerse en unos hojos de la cara inferior del cuerpo, de tal modo que un ojo inexperto no reconoce al pronto su presencia; las anteriores tienen tarsos escarbadores; las posteriores, nuy distantes unas de otras, tienen piés filiformes de cinco artejos, raras reces de cuatro, que ençajan en un surco mas ó menos marcado de los tarsos.

USOS, COSTUMBRES Y REGIMEN.- La marcha de los histéridos es lenta à causa de su estructura reconó çese cue hay presion general de todo el conjunto, yo son por esto como las tortugas entrc los reptiles. Mucho influye en ello la costumbre particular de pararse en medio de los cnminós y recoger las paras y la cabcra para fungirse muertos ajenas sospechan un peligro. En las calurosas noches de ve. rano, ratas veces ponen en movimiento sus alas para franquear distancias mayores de un modo mas cómodo, y particularmente para huscar alimento; este no se limita á sustancias ardimales en descompasicion; tambien buscan las vegetales en tal estado, y por eso se les encuentra en gran número en el estiércol yen las setas carnosas. Aigunas especies se hallan detris de la corteza de los airboles, y otras en los hormigue. ros. lin cuanto à los colores, predominan el negro con brillo metálico, el azul ó violeta, yademás cl rojo. Conócense unas I, I50 especies que estån discminadas por todo el globo.

Tas jarvas, de forma jrolongada, tienen doce segmentos, córncos solo en la cabeza y en el protórax, y semejantes á los de los estafilinos por los apéndices articnlados en la extremidad ypor el ano que puede salirse para ayudar á la locomo cion. I as patas, cortas y delgadas, se insertan cerca del borde exterior y rematan en una garra casi cerdosa. I a cabeza, en la ņue haltan el labio superior y los oidos, esta provista de antenas de tres artejos, el primero de ellos largo y el último corto, encorvado hácia adentro. Las fuertes maxilas denticuladas en el rentro se arquean en forma de hor y las mandibulas están provistas de palpos de tres artejos: los labiales tienen dos y se-insertan en troncos soldados enire si, córneos en la base y camosos en la punta; el labio inferior corece de lengua. Ia abortura bucal es en citremo pequena, por lo cual el insecto debe clupar el alimento que segun parece se compone de cadáreres de animales y de sustancias regetales en descomposicion.

\section{EL HISTERIDO DÉL ESTIÉRCOL - HISTER FIMETARIUS}

CARACTERES. - Estin especic pertenece ot los tipos de la familia que pueden recoger la cabeza con una protuberancia 
redoncieada del protórax; debnjo de un reborde de la punta se insertan las antenas, que son angulosas y rematan en una maza oval de tres artejos, la cual puede ocultarse en un hojo en el borde anterior del protórax. Las maxilas, denticuladas en el centro, se dirigen oblicuamente hacia abajo; la rabadilla sé inclina hacia atràs, y' los tarsos posteriores están provistos en su cara posterior dc dos series de espinas. Todos estos caractires son comunes a las especies del género histel, muy diseminado por todo el globo (fig. 12).

La citada especie se reconoce además por twer una pequeỉa apófisis redondeada en el borde posterior del protórax y que encaja en una escotadura del mesotórax; solo presenta una faja lateral en el esrudo collar, y marcados pumtos en los bordes de los elitros, que en su parte superior lleran tres fajas entems hácia afuera y otra central que remata junto á la sutura, presentundo todas una mancha roja.

USOS, COSTUMBRES Y REGIMEN. - El histérido del estiércol vire con preferencia en terreno seco y arenoso, en el estiércol, y se preseuta a reces tambien en los senderos del campo, pero es tan jesado para andar que á menudo le aplastan, pornue no puede evitar las pisadas del viajcro y del transeunte.

\section{EL HETERIO CUADRADO - HETCEIUS QUADRATUS}

CARACTERES. - El heterio cuadrado, gracioso coleópturo que mide solo. $0^{\circ}, 00225$ de largo, es de color amarillo de orin brillantc; estí cubicrto de algunos pelos rigidos; tiene Ins lacios del escudo collar gruesos, y los elitros adormados de finas fajas. Todo el géncro à que pertenece se distinguc del anterior por el tallo corto de las antenas, por tener una maza cilindrica al parecer, no articulada, y por ser los tnrsos mu! anchos, con un surco hácia afuera, conde encajan los piés.

USOS, COSTUMBRES Y REGIMEN. - li heterio cuadma vive entre las hormigas, particularmente en las colonias de la especic roja (formica rufur), pero en condicionés mas independientes guc los clavigeros: pues se le ha encontrado tambien sin hormigas debajo de las piedras. 1.os coleccionadores que se ocupan de los llamados mirmecófilos, es decir de los culeópteros que solo se encuentran en los hormigueros, echan toda la colonia de hormigas en un harnero de alambre, por cuyos agujeros no pueden pasar, y llevan el producto obtenido en unas bolsitas á su casa, para cxaminar alli el resultado de su operacion. Siempre eligen los meses de abril y marzo y la citada especic de hormigas parn su penosa tarea, poruque en esa estacion las hormigas son mas pe. re\%osas y menos mordedoras.

\section{LOS SAPRINOS - SAPRINUS}

CARACTERES. - Los saprinos constituyen al lado de los histéridos el género mas sico en especies de toda la farnilia y tienen la misma distribucion geográfica. En cuanto á los colores del cucrpo son anîlogos pero mas brillanies, con matices azules, veróes y violados. Por lo que hace al género de vida es el mismo, poco mas ó menos.

l.os saprinos se distinguen por la falta de peto, pero pueden recoger a pesar de ello da cibeza. Joda la cara superior del cucrpo está cubierta de puntos mas ó menos espesos, cxcepto en una mancha comun is la base de ambos elitros.

\section{LOS NITIDULARIOS - NITIDULARIÆ}

CARAGTERES. - En gran número estin diseminados por tocia la América y Europa y aisladamente en el Africa y Australia, contándose umas 800 especies que se han agrupado en la familia de los nitidularios. En ellas se reproduce en miniatura la forma fundamemtal de los histéridos, pero no tienen ni la dureza ni la monotonía de los tegumentos y colores del cuerpo. Los elitros son casi siempre cortados: las patas breves: los costados anteriores y jostcriores trastersales: los piés tienen cinco articulaciones y solo cuatro en el último par, ensanchandose casi siempre las primeras tres; las antenas, no angulosas, presentan en su extremiciad un boton de tres á cuntro artejos. La mandibula inierior no tiene en la mayor parte de las especies sino un lóbulo.

USOS, COSTUMBRES Y REGIMEN.- Iistos colcónteros se encuentran en muy diferentes condiciones: fornzando a reces bandadas, se les re en toda clase de flores, debajo de la cortera de los arbustos, en las secreciones de algunos de nuestros árboles (encinas, abedules y hayas), en lis setas, eu los restos de animales, y hasta recuerdo que en mi juventud vi salir de un molino una especic (nitidssle rjpustulata), cuyos numerosos individuos estaban en la torta servida en la mesa, lo cual hizo perder las ganas de comerla.

\section{EL MELIGETES DE LA COLZA-MELTGE- THES AENEUS}

CARACTERES. - El meligetes de la colza llama con frecuencia la atencion por su considerable abundancia en las flores de la colza y otras cruciferas, jo mas tarde un las fores de arbustos mu diversos; cl individuo aislado pasa fáciluncute desapercibido, pues solo tiene $\|^{* 13}, 00225$; es de color verde metálico y afecta la forma de un cuadro con ángulos obtusos; liene el protúras estrecho en su cara inferior y adclgazado hacia atris. Los tarsos anteriores son angostos y denticulados en al borde anterior: en otros son un poco mas anchos y istản provistos de cortas y finas cerditas desde su punta hasta el centro dis borde exterior.

USOS, COSTUMBRES Y REGIMEN. - Despues del letargo invermal abandona su escondite, busca las citadas plantas y se alimenta de sus capullos y-flores; vucla at la lur. del sol y' se aparea. 'l'res ó cuatro dias despues la hembra introduce la extremidad prolungada de su abdómen en los capullos, dejando en su fondo un huevo blanco de forma oval. En el térnino de ocho ó quince dias, segun el tiempo, desarróllase la larva, alimentandose de las flores y’ mas tarde de los frutos, por lo cual ocasioma muchos danos. Con intervalos de ocho á dice dias sufre tres mudas, trasfórmase à la última en crisilida y vive por térnino medio un mes.

El adulto mide cuanto inas (1)",co 45 de largo, afecta la for. ma cilindrica, es de color amarillento y asemcjase a la larva del pulgon.

I a cabera es de un pardo negruzco, contandose doce segmentos, con seis patas cortas en los anteriores y una verriga en el último. En el dorso de cadn segmento, cxcepto el primero ३ue está cubierto, se ven tres manchitas cómens de las que las centrales mas pequeñas faltan en los segunentos anteriores, siendo los laterales de forma omal prolongada é iguales yor su tamaño entre si. In cabeza, estrecha, sosticne i cada lado seis ocelos, antenas de cuatro artcjos y un labio superior córneo. I.ns fuertes maxilas estån escotadas en la superficie masticadora y rematan en un diente puntiagudo. Se necesita mucha atencion para descubrir estas larvas cutre las flores de las cruciferas, y por lo tanto se comprenderi que han de causar muchos dainos en los frutos.

Para crisalidarse la larva se deja cace, penetra á poca pro. fundidad en el suelo y fabrica um ligero tejido en el que mas tarde puede cncontrusse la crisilida movible, que presenta 
dos puntitas camosas en su parte posterior. Al cabo de diez, á doce dins, á principios de junios salc el coleopntero. El 3 de junio llevé larvas adultas a mi casa, obteniendo el 20 del mismo mes insectos desarrollados; estos viven en las flores, asi como los indiviauos invernados, pero no se propagan en el aủo corriente, sino en el que sigue.

\section{LOS DERMESTIDOS - DERMESTID屟}

El coleccionador sistemático de coleópteros se pierde en las especies anteriores en un laberinto de géncros y fanilias que le ocupa mucho tiempoy le gasta la vista cunndo quicre distinguirlas con seguridad, pues hay numerosos séres diminutos que en parte son nuy dificiles de encontras. Segun mi plan debo describir ahora unas especies que en nuestro pais representan cierto papel y que pueden recomendarse it la persecucion mas cricarnizada Estas esjecies y muchas afr. nes, cuyo múmero no llega á 200 , se han agrupado en la familia de los dermestidos, que toma sis nombre de las mayores:

CARACTERES. - Un cuerpo no separado en sus tres divisiones principales y por lo tanto soldado, pero lo demis muy diferente, una cabeza inclinada y recugible, escotada en su parte inferior para recibir las antenas en forma de maza, insertas en la frente, y que lleva casi siempre un ocelo en la coronilla; los costados anteriores estin nuy próximos; los posteriores son cilindricos, casi siemure ensanchados en su pirte inferior $y$ posterior, y con un surco en que encajan los muslos, que à su vez tienen otro para los tarsos; los piés cuentan cinco articulaciones y el abdúmen se compone de otros tantos segmentos. 'Iales son los-caractérés comunes a todás las especies de la familia.

USOS, COSTUMBRES Y REGIMEN. - EstoS insectos, cuyo género de vida es muy análogo, tienen tambien la costumbre de fingirse muertos en caso de peligro. Esencialmente perezosos y vagabundos, no se cuidan nuica de la eleccion de companeros hi de residencia, siéndoles del todo igual vivir al laco de una mariposa aérea en las perfumadas flores, ó en medio de los ténebrosos y sucios coleópteros, en los restos de un cádáver fético; lo mismo les da estacionarse en los adornos de piel de un vestido que en los cojines de nuestros sofis, ó en el vientre de un magnífico coleóptero disecado, orgullo de algun coleccionador; todo esto parece indiferente a muchas especies, pero tienen sus parajes favo. ritos, segun se ha ubservado. Como el alimento de los co. leópteros, y sobre todo de sus larvas (pues aquellos son mas contentadizos), se compone principalmente de las partes secas de sustancias animales de toda clase, se encuentran tam bien en todas partes al aire libre, en nuestras habitnciones, en los buques, en las pieles y en las colecciones roologicas, etc.; vinjan al rededor del mundo y llegan à ser en parte cosmopolitas, en la verdadera acepcion de la palabra. Viven ocultancnie, $y$ en sus escondites se propagan sin estorbo, de tal manera, que en cicrtas circunstancias pueden causar considerables perjuiciós en nuestra propiedad, sobre todo en las pieles, cojines, colchis y alfombras de toda clase, y particularmente en las colecciones zoológicas.

Esto parece aplicarse ante todo á las voraces larvas, las cuales se caracterizan por un tegumento de espesos pelos rigidos que en la parte posterior forma por lo regular espesos mechones, $\delta$ que tambien puede extenderse en forma de es. trellas; las antenas son cortas y de cuatro artejos; por lo regular cxisten scis ocelos a cada lado, $y$ las patas son cor. tas, provistas de una garra. En la metamorfósis, la piel se abre á lo largo del dorso y la ninfa se sirve de ella como de un abrigo.

\section{EL DERMESTES DEL TOCINO-DERMESTES LARDARIUS}

Caracteres. - El dermestes del tocino se reconoce fäcilmente entre sus congéneres, yor término medio mide $0^{\prime}, 0076$ : tiene cl color negro pardusco ron una faja pardo clam que cruza la base de los elitros y que está cubierta de algunos puntos negros.

El género dermestes se distingue por los carnctéres siguientes: la barba es mas larga que ancha, redondeada ó ligeramente escotada; la lengua, membranosa, tiene en su parte anterior espesos pelos; las maxilas, coriaceas, son tambien mug peludas en la mandibula inferior; la interior remata en un diente, mientras que la exterior, mucho mas graude, está cortada oblicuamente en su parte anterior. Los palpos mavilares terminan en un artejo cilindrico y cortado en su parte anterior, y los labiales en otrn nal y obtuso. El collar esofágico, convexo y estrechado hácia adelante, tiene en su borde inferior dos escotaduras, en cada cara inferior de los lidos un hoyo para recibir el gran boton de las antenas. Los elitros se extienden en igual anchura hicia atrás, doncie se redondean cubriendo completamente la extremidad del abdómen y formando la figura casi cilindrica de todo el cuerpo cubierto de espesos pelos lisos. En este género los sexos se distinguen facilmente porgue el macho tiene en el tercero 6 cuhrto segmento del abdómen ó en el último, un hovo redondo 5 brillaute.

La larva, adelgazada en su parte posterior, es casi tan larga como el coleóptero; tienc el vientre blanco y el dorso pardo, cubierto de pelos bastar:te largos, dirigidos hacia atris, los de mas longitud forman en la extremidad inferior una especie de pincel; en la base de este elévanse, en la parte superiór del vítimo segmento, dos ganchos córneos encorvados hácia atràs. Ias seis patas y el ano, que puede desviarse, facilitan su movimiento rápido y ágil. Ia lasia se encuentra désde mayo lasta setiembre, durante cuyo tiempo muda cuatro veces, descubriendo su presencia por las pieles abandonadas en los sitios donde el viento no puede llevárselas, como por ejemplo en las colecciones de insectos. Por fin la larva se muestra mas perezosa, acórtase y deja de ser tan peluda, in. dicios todos de que se halla a punto de metamorfosearse. Al efecto se oculta lo mejor posible; pero la crisálida queda con la parte posterior de su cuerpo en la última piel de larra. Es blanca por delante; tiene rayas pardas en las partes posteriores, $y$ muéstrase muy irascible cuando se la inquicta. El coleóptero suele nacer en sctiembre, rompe la piel y permanece mucho tiempo en la cuhiern, que es entonces doble. En los parajes cálidos sale antes, $y$ en los mas frios se retarda. Llegada la primavern siguiente efectlase el aparcamiento $y$ las puestas de los huevos.

El dermestes del tocino y su larra se encuentran no solo en la despensa siro en todas partes donde hallan restos de animales, en las casas, al aire libre, debajo de los cadáveres, entre las piedras y en las colecciones zoológicas. Me acuerdo de una ocasion en que se demostró cuànias deben ser las precauciones para conseguir que estos irsectos causen el meruor daño posible en su obra de destruccion. Úna cajita llena de coleópteros del Brasil y bien cerrada habia estado mucho tiempo sin llamar la atericion, y' cuyo contenido se habia considerado ya sin valor. Al poner en órden la coleccion se en. contró esta cajita, la cual encerraba centenares de cicrtos coleópteros que en aquel pais debian ser abundantes y que habian venido como regalo de un comerciante del Brasil. Al 
examinar el contenido para elegir los poros individuos intac. tos, y cuando se llegaba al fondo, parecio que los cadiveres encerrados hacia años, recobmban la vida, pues se no: cho moviniento. ¿Qué espectáculo! Fin medio del prolvo y de los pedacitos de coleópteros, agitábase una infinidad de larvas del dermestes, enojadas al parecer porque se las inquietaba. Yor fortuna la estufa estaba encendida y todos aquuellos huéspedes fueron entregados al punto í las llimas, para que no se escapara ninguno y pudiera probar la fuerat de sus dientes en otros sitios donde hubiern sido mas sensible.

Los otros dermestes de color gris de raton 6 negro en la cara superior $y$ con pelos lisos en la inferior, se encuemiran principalmente al aire libre, debajo de los cadiveres ó entro efectos mal empanquetados que han hecho un largo viajê.

Un fenómeno particular, que se funda en la estructura de los dermestes, llama la atencion del coleccionador acostumbrado á perforar el elitro derecho de los coleópteros, muertos de un alfilerazo para colocarlos despues en la coleccion. Esta preparacion ofrece, segun la dureza de los elitros, mas ó me- nos dificultades, y casi nunca se logra en los dermestes, no por la gran dureaa de los elitros, sino por su mayor resistencia en proporcion á las membranas ligatorias blandas y endebles de todas las partes mas sólidas, que se sepamn regularmente cunndo se cjerce presion sobre el elitro con la puntis de la "gruja. Lista facultad excepcional de ensancharse la membrana ligatoria se reconoce tambic:s al introducir un dermestes en espiritu de vino, pues aqui el cuerpo se llena de ial modo, que entre las partes principales del cuerpo aparece una picl blanca semcjante a un corto intestino. Hay varios coleópteros (silfos y algunas especies del género aphodius), en los que puede observarse un fenómeno igual. Solo cuando (l coleóptero está bien resecado, sus escudos de quitina se hacen bas. tante compactos para que los elitros se puedan perforar.

\section{LOS ATAGENOS - ATTAGENUS}

CARACTERFS. - Un ocelo en la coronilla distingue el géncro de los atagenos del anterior; la boca es libre, úmcjor

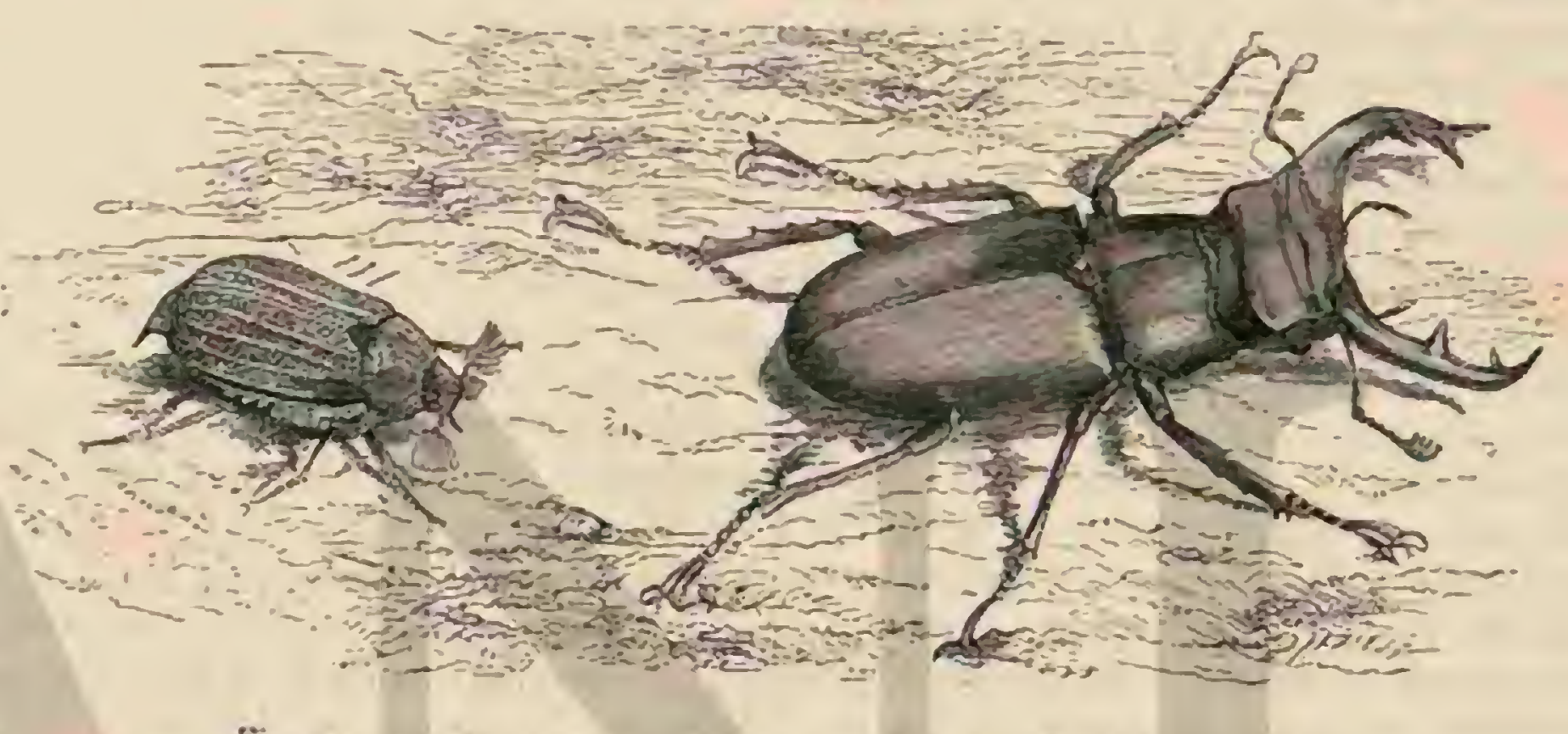

Fig. 14. - EL MEB.OLONTA CONUS:

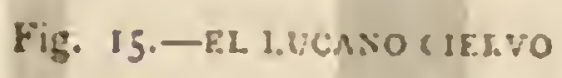

dicho, no está cubierta por el protórax; y las patas centrales sc hallan nuy próximas. Por estos caractéres le distinguer de lus otros géneros jrovistos de un solo occlo.

\section{EL ATAGENO DE LAS PIELES-ATTAGENUS PELLIO}

CARACTERES. - El ntageno de las nieles tiene la forma. del cutrpo del demestes con ha diferencia de que el dorso es menos conrexo y el tamaño mucho mas reducido, pues mide por término medio $11^{\prime \prime}$, co4. 'Tiene el color gris negruzco, y'en el centro de cada elitro jresenta un punto de pelos de culur blanco plateado.

USOS, COSTUMBRES Y REGIMEN. - II atageno de las preles vive al aire libre, y durante el vernno habita en ciertas flores y plantas, donde con su buen compaĩero, el antreno de los museos yotros muchos insectos esti en la mejor inteligencin; de tal modo se cubre de pólen, que no se le puede reconocer; es un insecto del todo inofensivo. Con mas seguridad se fe encuentra en nuestras habitacionis, cuando en la primavera, despues de salir de sus escondites, vuela por los vidrios de las ventamas, creyendóque puede pasar por ellos para llegar al aire libre; eneonces se le ve siempre caer bocia arribs y esforzarse por recobnar el cquilibrio perdido. Al efecto se sirve de los elitros, abricindolos cual si quisien volar. Sin caridad se le debe coger en tal posicion y aplastarle entre los decios, que apenas se humedecen, para que muera sin descendientes, pues aumųue tenga en si poca importancia, sus larvas son muy peligrosas, justificando su exterminio yo al Tомо VI del colcóptero. Cicrto dia, al componer un sofí que durante 17 anos habia prestado buenos servicios, el tapicero se asombró al ver las muchns polillas, que no eran oirn cosa sino las pieles de has larvas del atageno, que en grandes montones se habian albergado cr los brazos del mueble, dando a conocer Las inmensas legiones de coleópteros alli nacidos. El material, que contenia muclias cerdias, se hubo de calentar en un horno para natar la cria. En una tortuga terrestre disccada, de la coleccion zoobgrica de Halle, en cuyo cluro cuerpo nada habia comestible, habitaba hacia muchos años una familia de estos destructores que solo se descubricron pror una especic dic harina que de vez. en cunndo rodeaba el cuerpo del rejptil acorazado; y en este caso tambien fué preciso exjoner la tor. unga algunas horas al calor del horno para natar los parisitos. Hace poco tiempo me enviaron una caja de rape y una boxuilla, ambos objetos de cucrno, y annupe muy bien cerndos, contenian cicto múmcro de larvas vivas, pertenecicntes à la especic que nos ocupar

La larva itene gran semejanza con la del derniestes, pero es mas prequena en tstąo adulto y carcce de ganchos cór. neos en la extremidad mas estrecha del cuerpo. la cabera, muy grande, esti cubierta de pelos, y en el ciorso los hay mas cortos dirigidos hicia arris de un color pardo amarillo; en la extremidad se ve un ligero mechon de pelo mas largo. Esta larna ticue la costumbrc de recoger la parte anterior del cuerpo hácia abajo, fo se trasforma en crisilida exactamente lo mismo que las de la especic anierior, y ill mismo tiempo, es decir a lines de agosto.

Cuando puede clecrir su alimento preficre siempre el pela- 
je y la lana de las pieles, entre las cuales penetra en las casas, donde los muebles tapizados y las alfombras le ofrecen escondites tanto mas seguros cuanto menos se limpiar. Majo, junio y julio son los meses en que la larva es mas activa y por eso es preciso limpiar y sacudir repetidas veces las pieles que entonces no se tisan.

\section{EL ANTRENO DE LOS MUSEOS-ANTHRE- NUS MUSEORUM}

CARACTERES. - W tercer coleofptero en esta trinidad de destructores es el antreno de los muscos, insecto pequeno y redondo, quie tiene la cara inferior cubierta de pelos grises, y la superior de color pardo oscuro, can tres fajas po. co marcadas, formadas por pelitos de un gris amarillo. Las antenas tienen ocho artejos ensanchándose los dos últimos en forma de boton. Ia caheza puede ocultarse del todo en el protórax, que à su vez, se recoge en parte en el mesotórax trasversal y hendido; el labio superior queda libre.

En esta especie se ve tambien un ocelo en medio de la coronilla. Este insecto, de 10,00225 de largo, se encuentra igualmente, como ya hemos dicho, en las flores y en nuestras hábitaciones, visitando en particular toda coleccion de insec. tos que no esté bien resguardada.

USOS, COSTUMBRES Y REGIMEN. - El coleóptero se podria tolerar, pero su larm, aggo aplanada, provista de pelos pardos, jo de un largo mechon en forma de cola, es un recino nuy peligroso. A causa del diminuto tamano que ticne al nacer, es tan dificil cescubrirla como fácil para el insecto penetrar por las rendijas mas estrechas Auncule se guarden mucho las cajas en las colecciones, la larva sabe introducirse, siquiera sea en forma de huero, con el cadáver de algun insecto sospechoso, y los cestrozos çue una soli larva puede ocasionar nadie los comprenderi mejor que guicu los ha visto por sus propios ojos. Regularmente vive en el interior del animal, pero tambien se pasea por la superficic, de modo que todas las partes quedan corroddas. En el primer caso un montoncito de polvo pardo bajo el insecio habitado, $y$ en el segundo la caicla de las patis, antenas af otras partes, descubren la presencia del enemigo, oute muchas veces armanca toda la presa del alfiler. Sacudiendo con fuerza la caja se le hace salir fácilmente y si se expone toda la coleccion a un grado conveniente de calor que no perjudique a los insectos, mueren las larvis. Tambien penetra en la piel de los mamíferos disecados para comer el pelaje, y lo mismo bace en las ares con los tallos de las plumas, devora la piel alrededor de las fosas nasales y en las patas, procediendo de igual manera que la larva de la especie anterior. Al coger una por mitad del cuerpo con unas pinzas ofrece un aspecto particular y sorprendente: el mechon de la cola sc dilata en extremo y en cada lado de su boca fórmanse tres abanicos de pelo en extremo delicados y trasparentes Ia larra se encuentra casi todo el año; por lo regular trasfórmase en crisálida en mayo ó á principios de junio despues de varias mudins. Los intervalos entre dos mudas son muy desiguales, pues se han observado diferencias de + in 36 semanas. Las muchas pieles que à reces se encuentran al lado de un solo coleóptero en una caja de insectos bién cerrada parecen indicar mayor número de mudas del que por lo regular se supone; pero habrin de hacerse aun minuciosas observaciones sobre este punto. El coleóptero tiene las mismas costumbres que sus congeneres y permanece semanas enteras en las pieles que le abrigan.

\section{EL BITURO TOMENTOSO-BXTURUS TOMENTOSUS}

CARACTERES. - Al fin de la familia hago mencion tambien de un coleóptero cubierto de pelos lisos, de color gris amarillo, que por la forma de su cuerpo y los demás ca. ractéres es análogo al géneru dermestes, pero tiene en la segunda y tercera articulacion de los piés apéndices lobulosos, y en la base de las garras un diente: por el tamano se asemeja al atageno de las pieles.

USOS, COSTUMBRES Y REGIMEN - No visita nues. tras casas, sino que vaga por las flores, sin llamar la atencion de los que no son entomólogos; estos víltimos le dan el nombre de by'urus somentosus. La larva, por el contrario, parecida á las otras de la familia y desprovista de pelos visibles, habita los frutos del frambueso, haciendo repugnante à las personas delicadas esta fruta en los años favorables para dicho insecto. Fijjase con preterencia en los frutos del frambueso silvestre, pero los abandona si se humedecen con agua un joco antes de comerlos.

\section{LOS BIRROS-BYRRHUS}

Dela numerosa serie de familias y̨ue los naturalistas sistemáticos agrupan antes de ocuparse de las especies mas cono. cidas, solo laremos mencion en pocas palabras del género de los birros, porque son una reproduccion de los histéridos. Se alimentan de distinto modo, pero observan en lo demás tas mismis costumbres, $y$ son tambien maestros en la astucia de fingirse muertos. Cuando estos colcópteros, ovales, muy convexos y pequeñisimos, recogen lats extremidades, es dificil reconocer su presencia.

CARACTERES. - Las patas, aplanalias, se oprimen estrechamente contra el cuerpo; los tarsos encajan con su borde interior en un surco de los muslos, y las patas tienen cinco articulaciones entre los tarsos y el tronco: en este conjunto se cree ver algunas suturas, pero no patas. I a cabeza encaja cin toda su exténsion en el escudo collar, de modo que solo la frente y la cara quedan visibles por debajo, pero mada por arriba Las antenas, que afectan la forma de maza, pueden ocultarse bajo los bordes laterales del escudo collar. Las dos maxilas de la mandibula superior estín desprovistas de dientes. En el vientre se distinguen cinco segmentos, hallándose los primeros soldados.

USOS, COSTUMBRES Y REGIMEN, - LOS birrOS, 11 mados tambien coleópteros pildoras, cubiertos de un pelo aterciopelado pardo, se alimentan solo de sustancias vegetales, sobre todo de musgo y de hojarasca, pues se les encuentra á menudo en gran número en las pendientes de las montañas caldeadas por el sol, y tambien á mucha elevacion donde la temjeratura suele ser muy baja; en el verano reptan lentamente por el suelo, mas por lo visto prefieren esperar la noche para volar; en las demás horas no abandonan nunca el suelo: ciertas especies no faltan nunca entre los coleópteros que las inundaciones de la primavera llevan a la orilla.

Las larvas hasta ahora conoridas de los birros son cilindricas, y estån cubiertas en su parte superior de duras placas, mas perfectas en los tres segmentos anteriores, de los que el primero es tan largo como los dos siguientes; las placas de los otros son un poco mas blandas y de forma semicircular. Además del primer anillo, el penúltimo y el último son los mas largos, provisto este de un apéndice que, como una garra, sirve para la locomocion. La cabeza, dispuesta verticalmente, tiene en cada lado un hoyo redondo, dos ocelos, antenas de dos artejos y maxilas casi triangulares; los palpos del labio inferior, que carece de lengua, se componen solo de dos artejos. Las larvas se encuentran en el suelo, debrjo del césped, donde se trasforman en crisálidas, y despues en co. leópteros, antes del invierno.

Las ciento treinta y dos especies de que se compone toda 
la inmilia, estan diseminadas solo en luuropa y el norte de América, siendo mas numerosas en la montana quue en la llanura.

\section{EL LUCANO CIERVO-IUCANUS CERVUS}

Fl lucaro ciervo fue conocido ya de los antiguos, pues l'linio dice en un pasaje $(H, 2 S, 34)$ de su Historia natural: rIos escarabajos (siarabei, coleónteros) tienen sobre sus débiles alas una cubierta dura, pero carecen de aguijon. Iin cambio existe una grande especie que lleva cuernos, en cuyns puntas hay horquillas de dos brazos que pueden cermrse a voluntad. Se les cuclga al cuello de los niños como remedio. Nigidio la llama lucanus.). Moufet, que en su Jnsectorum siric Winimsorum Animatium theatrum reunió cuidadosamente todo cuanto hasta su tiempo cra conocido sobre los insertos, dando un gran número de grabados en su mayor parte ficles, dibujat tambicn el macho del lucano cierso, pero cree deber considerarle como hembra, porque Aristóteles prezende que en los insectos los machos son siempre mas pequeños que las hembras. Moufet considern pues los machos pequeños como hembras. Todos los niños que solo conocen algunos coleópteros y que viven en una region polslada de encinas donde habita el lucano ciervo, sauen ahora yue los individuos con astas son los machos y los con maxilas las hembras. Jas ultimas observaciones hechas en otms especies de lucanos hau demostrado que segun sea la alimentacion de las larvas escasa ó abundante, los coleónteros nacen pequeños ó grandes y que sobre todo en los inachos liss maxilas en forma de astas dan un aspecio muy diferente, por su poco desarrollo, a los coleópteros jequeños, comparados con los bien desarrollados. Se han distinguido por lo tanto de las diferentes especies formas intermedias y pecjuenas sim darles nombres particulares lo mismo que antes: en la especie comun se distingue una variedad, el lueansus capreolus ó hircus.

CARACTERES. - Ėl género lucrnus se caracteriza por la forma prolongada del cuerpo, por un gran diente situado delante del centro y una punta bipartida de las maxilas del macho, que salo de la cabera; esta última es mas ancha que cl escudo collar; el tallo de las antenas es delgado; en la borla de las antenas se ven de cuntro a seis dientes fijos; el labio superior se arquea hacia alıajo; la lengua estí muy escotada en la parte interior de la barba, y la maxila interior carece de dientes en la mandibula inferior.

La especie de que nos ocupamos tiene un color nagro mate y los elitros y las astas soll de un castano brillante: es uno de los coleópteros mas grandes y gruesos de Furopa (fig. 15). Desde el labio superior hasta la punta redondeada de los elitros puedo medir $0^{\circ}, 052$ de longitud que por las astas auméntise en linea recia en $6^{\prime \prime}, 022$ mas. Una hembra de $U^{m}, 0,3$ tiene ya buen imaño.

USOS, cosTUMBRES Y REGIMEN.-En junio se encuentm este coleóptero en los bosques de encinas, donde por la noche los machos vuelan con fuerte zumbido alrededor de las cojas de los arboles, mientras que las hembras estin mas ocultas. De dia pelean a veces debajo de la hojarasca, descubriendo por el ruido su presencia, 0 bien permanecen en los troncos para chupar el jugo. C!op reproduce en la Garfinlaulie un relato interesante sobre el proceder de estos insectos, rclato que al mismo tiempo da una prucba die que en ciertas ocnsiones se reunen en gran numero. A la sombra de una añosa encina de cierto jardin, en Sondershausen, habiase sentado el autor una calurnsa tarde del mes de junio de $1 \$ 6_{3}$, cuando de pronto llamó su atencion un rumor extrano; á poco cayó del àrbol un objeto negru\%co, que resultó ser un lucano cicrro; y despues de buscarle largo rato, el observador le viós subiendo por la ispera cortez.a. Como el ruido no cesabs. el naturalista fijó sus miradas en la copa del àbol y á una altura de mas de cuatro netros vió en el tronco uni masa de color pardo. Al cabo de media hora habian caido poco à poco once lucanos ciervos de ambos scxos, y como el ruido continuó, el observador buscó una escala para examinar el cxtrano fenómeno: entonces sc presentó á su vista un cwadro interesante.

En una superficic de unos $11^{-\infty}, 8$ a cuadrados la añosa corteza estaba cubierta de jugo, y parn recrearse con esta golo. sima se habia reunido una sociedad mixta compuesta de los mas diferentes insectos. Grandes hormigas subian y bajaban, gran número de moscas se agolpaban unas contra otras, mientras el abejon rodeaba, zumbando, el tronco. Los hués. pedes que mas llamaban la atencion, tanto por su número como por sus cualidades, eran sin duda los lucanos cierros, que se contaron en número de veinticuatro, sin incluir los que ya se haljian cogido antes. Representaban sin duda el patjel mas importante en este convite y parccian, à pesar del regalo de la comida, hallarse algo sobrexcitados; pues ni los abejones se atrevian a acercarse á los pesados animales como si temieran los ejectos de sus poderosas tenazas, guardando al contrario una distancia respetable. Mas encarnizadas eram, si cabe, las luchas de los lucanos entre si, pues dos terceras partes for lo menos disputaban. Como tambicn las hembras intervenian en esta lucha y se habian agarrado con sus tenazas cortas y fucrtes, no prodia atribuirse la causa i los celos, sino a la codiria del alimento. Muy interesantes eran las lu. chas de los maclios; con sus maxilas sobrepuestas a las del adversario, sobresaliendo del cescudo collar de este, comba. tian con encarnizamiento, liasta que uno de los contendientes, perdiendo la fucrza, daba con su cuerpo en el suelo. En mas de una ocasion un individuo hibil logró coger al adversario por el cuerpo y clevando la cabeza, dejóle patalear en el aire. precipitándole por fill. El ruido nute se dejaba oir era producico por el cerrar de las maxilas; sin embargo, la lucha parecia mas furiosa de lo que era en realidad, pues no se observabin heridas, sino ligeros mordiscos cn una maxila Al acercarse el observador hicieron caso omiso de él: los combatientes proseguian su contienda, y los vencedores lamian ávidamente el jugo. Solo cuando el aliento del observactor llegala a cllos demostraban inquietud; en cambio cl inas leve ruido, como el crujido de una rama, producia en seguida cfecso en toda In reunion; se erguian todos ripidamente y parecian uscuchar algun rato. Otro tanto sucedia cuando uno de los caidos se acercaba subiendo desde el fondo; tambien en este caso se endercyaban los machos, saliendo al encuentro del adversario, á un palmo de distancia, con las maxilas preparadas para el combate. Por la noche se alejó poco á poco la mayor parte de los coleópteros, y a las ocho, cuando el ob. servindor abandonó el jardin, solo se oian algunos sonidos desde la altum del airbol.

De una naturateza mucho mas séria que las luchas que acalanmos de describir, son las que sostienen los machos por una hembra, segun to demuestran las profundas scinales y hasta perforaciones de los elitros de la cabeza ó de las astas de algunos machos Haaber observó en los alrededores de l’nga lifuria con que los machos persiguen á una hembra: su. jetando a una de estas últimas, cogiú desde las once hasta las doce y media setenta y cinco machos, rodos de forma pequeña. Los vuclos nocturnos son idénticos á los preparativos parn la boda. $\Lambda$ fines del citado mes, ó en los primeros dias del siguiente, el corto periodo del celo ha pasado; el apareamiento se ha verificado de noche, las hembras han depositado sus hueros en la madera putrefacta de las encinas 
viejas, y los restos endurecidos de los cadáveres masculinos, privalos desus intestinos por las hormigas ó aves, evièencian que allí han vivido lucanos cicrvos. J'bede llegar a sticeder, go mismo to he observado varias veces, que los machos hormigas presa, vivos aun, de las penosa the, privados del abdómen blando, se arrastren ram hoine solire sus largas patas por algun rato, formando hembrom para akgunas hormigas. l.os cadáveres de las

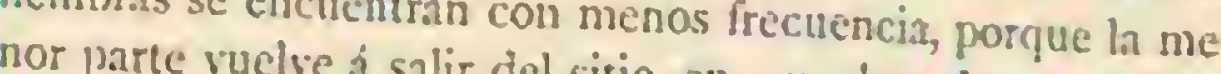
huevos y porque a dir del sitio en yue han depositado los te del de los machos.

Ins larvas salc crecen mux lentone unos huevos de 1,"00225 de largo facta de las encinaso alimentandose de la madera putre longit longitud de 6 ; 105 con et grueso de un dedo. Por sir aspecto exterior se patecen a las larias de sus congéneres de la mis ma familia: lleva la laria en la cabeza cómea, sntenas de cuatro artejos, cuyoultimo es muy corto: una superficie nos cadora en las maxilas, dos maxilas en la mandibula inferior. que se adelgazan en punta, y están provistiss de una especie de pestanas en la cara interior. Los tres primeros segmentos del cuerpo, que por lo regular se separan un poco en la cara superior, tienen seis patas bien desirrolladas, pmristas de una garra, y su color, camo el de là cabeza, es claro: solo las partes córnens de la boca son negras. No cabe duda que los antiguos tambien conocieran estas larvins, pues Plinio refie re lo siguiente: 1 .os grandes gusanos que se encuentran en las encinas huecas y se llaman cossis, se considemn como go losina $y$ hasta se engordan con harina. Deben haberse usado como alimento, pues Jerónimo dice. Án el Ponto y en Frigia unos gusanos blancos, provistos de una cabeza negruzca y que se reproducen en la madera putrefacta, son objeto de un comercio importante y pasan portun alimento muy sa.
broso.

I a larra adulta fabrica un capullo sólido del tamaño de un puno, con los pedazos putrefactos de madera, y se interna en el tronco al nutucha profundidad del suelo, donde forma su habitacion cuyo interior alisa cuidadosanente. Tres mescs poco mas ó menos pasa hasta gue se ha trasformado en crisálida y de esta nace un colcóptero.

Este permanece por lo pronto en su cuna y sale del. todo endurecido y" con todo su color al ųunto ó sexto ano, â fines de junio, para gozar apenas cuatro semanas de su existencia aéréa. El mismo tiempo, poco mas ó menos, se le puede con servar en cautividad, alinentándole con agua arucarada ó

I as noticias de Chop hacen suponer que en $\mathrm{IS}_{3}$ habia grandes masas de lucanos ciervos en los alrededores de Sondershausen. Bueltner hace mencion de una bandada de estos coleofptr.ros que alıggindose en el Báltico, fué arrojacia por las olas á la costa cerca de libau. Curnelius da cuenta de la particular frecuencia con que los lucanos ciervos vola. ron en 1867 en un espacio limitado cerca de Elberfeld y. suponé que cada cinco años inclien à presentarse en jual número; de modo que el tiempo de desarrollo fijado por Roesel debe rebajarse de cinco a seis años. Haber cree poder afirmar esta suposicion; en primer lugar porque en I 862 Y despues en is6j observó en los alrededores de Praga a los lucanos ciervos en tal manera que llamabar ha atencion general. Tanto aqui como cerca de Elberfeld prosperan en los troncos vicjos de encinas cortadas, que parecen fovorecer en extremos su propagacion. No careceria de interés el que en oiras regiones se hicieran tambien observaciones respecto a Ii) tuch que vuclan estos colcópteros.

[i] lucano ciervo se encuentra diseminado por todo centro y norte de Europa hasta las comarcas limitrofes del Asia y solo falta en las regiones que carecen de encinas.

El género luenmus de linneo, dividido filtimanente en otros géneros numerosos, se encuentra diseminado en toda la superficie del globo: los inas de estos animales se encuentran en el sud de América (34) y los menos en Europa; todos tie. nen el caricier de nuestro lucano cierro, porejue las maxilas del macho estan desarrolladas en formade astas y son mucho mas grandes que las de la hembra. Al rededor del géncro de los lucanos se agrupan aun varios otros que cuentan escascis representantes en Europa, a los que no puede aplicarse este caracter, aunque la formacion de las antenas y de la barba estén conformes: circunstancia que ha dado lugar a que se les agregan a la tribu de los lucanidos (lucasuda). Su barba no esta nuuca escotada en la parte anterior, y lleva cn su superficic interior, raras veces en la punta, la lengua membranosa ó coriácea muy dilatable con la quue estos coleópteros haien el jugo como alimento exclusivo.

\section{LOS PASÁLIDOS-PASSA- LID压}

CARACTERES. - En una segunda tribu, la de los pasilidos, habarha tienc una escotadura en su parte anterior, y en ella una lengua córnea que termina en tres dientes.

Los piślicios, reunidos con preferencia en el género passalus, ofrecen poco mas 6 menos la forma del cuerjo que en la prígina to se nos ha presentado en los cscarites. El escudo collar, provisto de un tallo, es en ellos tmsversal y rectangu. Lar, un poco, mas estrecho en su parte antcrior; cl cuerpo en In mijor parte de las especies es mas aplanado; de modo quue los elitros on especial, provistos de profundos surcos, presentan en su disco un plano perfecto. En la cabcza, mas estrecha que el collnt, se notan coicovas, prominencias y un borde anterior anguloso, a menudo poco simétrico; la borla de las an. tenas es tan larga, que el tallo está cubierto de espesas cerdas, y termina en los tres ó seis últimos artejos, segun las espuecies, en dientes de peine. In mandibula superior, que casi siempre alcanka la longitud de la cabeza, se cancteriza pror un diente movible inserto en el centro.

'Todas las especies, cuyo número asciende á ciento setenta y rinco, $y$ de las que casi seis séptimas partes pertenecen i la América ý ni una sola à Europa, son muy brillantes y tic. nen un color negro ó pardo,claro.

USOS, COSTUMBRES Y REGIMEN.-Ias larias viPen, como las de los lucánidos, en la madera de los árboles en purrefnccion; son lisas, desprovistas de repliegues tmasversales, tienen antenas de dos artejos, y el tercer par de patas muy poco desarrollado.

Ias dos tribus de los lucinidos y pasailidos forman la fa. milia de los pectinicornios (pectivicornio), separada de la que a continuacion se describe y que ofrece los siguientes caractéres comunes: las antenas angulosas de die\% artejos se ensanchan de los ires a los siete últimos en figura de dientes y forman en su inmovilidad una especie de puine. De las dos maxilas de la mandibula inferior, la interior tiene por re. gla general forma de gancho, mientras que la exterior solo la posee excepcionalmente. Fi abdómen prolongado, compuesto de cinco segmentos cisi iguiales, está cubierto del todo por los elitros. Ios costados de todas sus patas están disjuuestos trasiersalmente, $¥$ cuando mas, en algunas especies, los de las patas medias adquieren una forma algo mas esférica; los piés y las garras son siempre sencillos; un a!éndice en medio de las últimas, provisto de dos cerdas, forma la llamada gnrra rudimentaria. Fil viltimo catílogo de coleópteros de Harold y 
Gemminger continúa quinientas reintinueve esperics como representantes de toda la familia.

\section{LOS LAMELICORNIOS LAMELLICORNIA}

CARACTERES. - Los lamelicornios, llamados tambien esianbeidos, constituyen la famiia inmediatamente afine, de la quue se conocen mas de scis mil quinientas especies diseminadas por todo el globo, contando los menos de sus répresentantes en Australia y los mas en el Africa: en Luropha existen trescientas ochenta y cinco especies. Además de esta riqueza a la que, segun puede concelbirse, hay que añadir una gran variedad en el aspecio exterior, la familia se distingue por su tamano y por la belleza de las formas, lo misino que por el brillo de los colores, pues conticne los gigantes entu los coleópicros. No se encuentra tampoco en ninguna familia una diferencia tan gmadé entre los dos sexos de una mis ma especie. Ios machos difieren no solamente por prominencins en la cabez, en el escudo collar, ó bien en ambos a un mismo tiempo, sino tambien en algunos casos por su color y sus contornos tan esencialmente del otro scio, que podriamos vacilar en reconocerlos como pertenecientes a una misua especie; lo mas rnto de todo es que estas diferencias se notan marcadamente en las especies mas grandes, disminuyendo y desapareciendo casi del todo, cuanto mas pequeñas son. Esta ley se manifiesta y rige no solamente para las distintas especics, sino tambien para los diferentes individuos de una: misma especie Como en los lucnnos, asi tambien en este

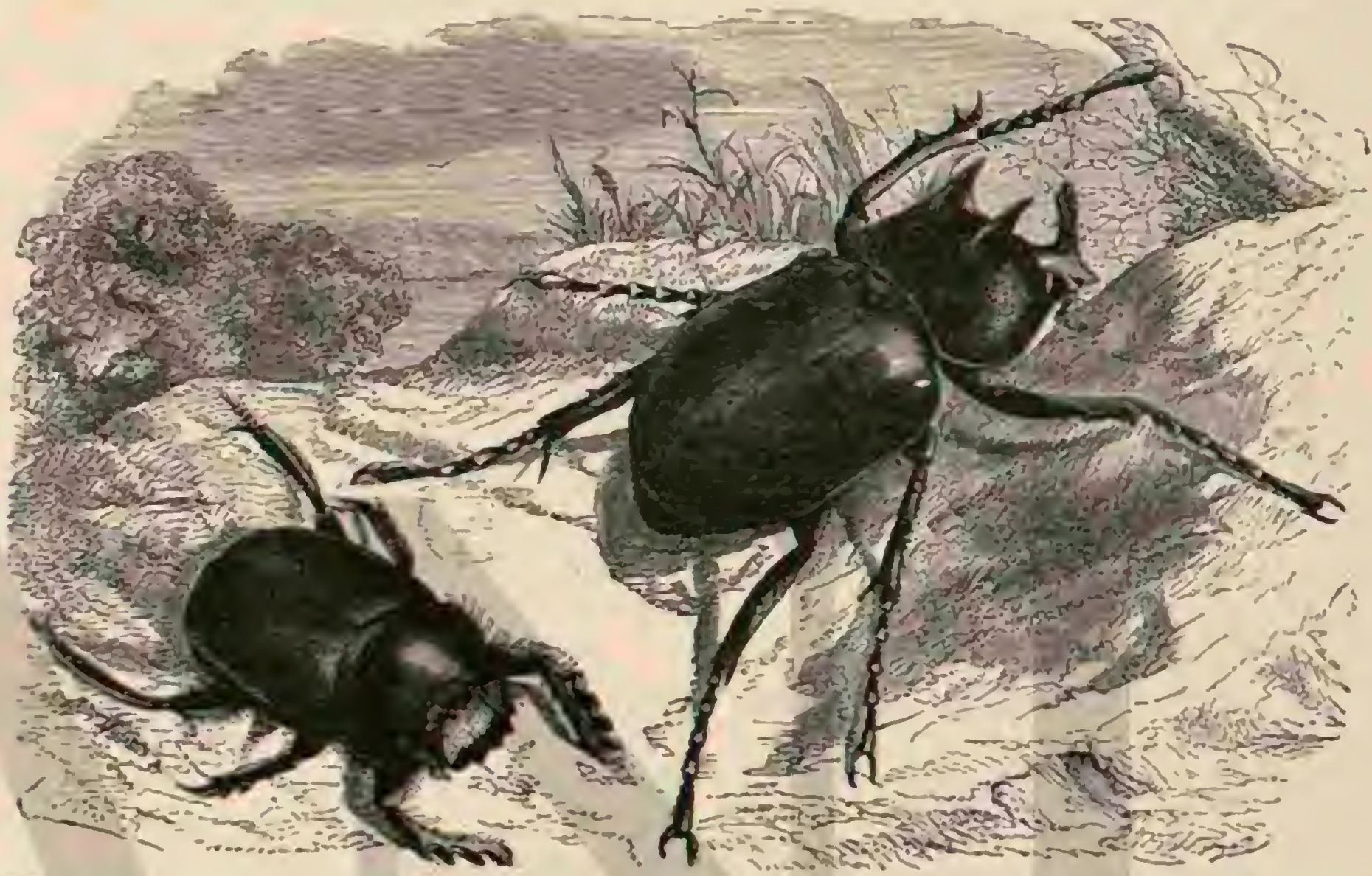

Fig. 16. - 21, A1rico s.16ratro

Fig. 17.-E1. CALCOSOMA ATLAS

grupo, sobre todo en los lamelicornios gigantescos, se observan formas mas pequeiras y menos desarrolladas, producidis por la atrofia de las larvas: si cstas pertenecen al sexo masculino son mas parecidas i- has hembras, disminuverdo el tanaño en las espigas de los relyordes, cuernos, horquillas, ó én los adornos de las partes anteriores del cueruo, cualesquiera que sean, los que a veces tambien solo aparecen indicados.

A pesar de todas estas diferencias, estos miles de coleópteros guardan conformidiad en la estructura de 5 us antenas, de mediuna longitud. En cada uno de los tres a siete últimos artejos muy cortos se halla inserta una hojita muy delgada, con frecuencin mas larga en el macho que en la hembra, a guisa de apéndice dirigido al exterior:y cada una, en el estado de descanso, oprime estrechamente á su vecina. De este modo se forma la llamada unaza de hojas. Tan luego como d coleóptero se prepara para volar $\delta$ cobra mayor agilidad, aquellas hojitas se abren como un ahanico, cuya circunsancia constituye la diferencia esencial entre los lamelicornios y pectinicornios. Los ojos estann situados en los lados de la ca. beza y mas ó menos separados joor el borde de las mejillas; las patas, sobre todo las anteriores, sc demuestran aptas para escarbar, pues tienen los iarsos anchos y denticulados hácia afuern; los muslos son gruesos y fuertes, los costados cilindricos, los piés se componen siempure de cinco articulaciones: pero difieren mucho en la formacion de las garras. A consecuencia de esta estructura tienen todos una marcha torpe: muchos son hábiles escarbadores, y la mayor parte a pesar de su pesado cuerpo, vincla con vapicle\%, y siu que pueda vencerles la: fatiga.

I.as larvas, blandas, conas y casi sicmpre rugosas, son gordas y tienen seis patas, antenas bastante largas de cuatro artejos; carecen de ojos, y ofrecen en su abdómen uma punia ensanchada en forma de bolsa, con la abertum del ano trastersol. Todas se parecen à las del abejorro, y a causa de la forma curva de sa cuerpo no pueden audar, á pesar de sus seis patas, sino que amanzan escarbando con el suclo ó en la madera jutrefacta, manifestindose irritadas en cxtremo cuando se las sara de esta residencia. Tanto ellas como los colcóp. teros sc alimentan exciusivamente de materias vegctales, y ciertas especies pueden causar considerable daño en las plantas de cultivo, nicntms que otras solo atican las plantas muertas, apresurando por medio del mantillo su descomposicion. Como en todas partes encontmmos excepciones de la regla, aqui tambien aparecen coleópteros y larvas ngue sce alimentar de cadaveres.

No fỉaindomos en los numerosos géneros y subgéneros, los lamelicomios pueden clasificarse en dos grujos: los lamell:-

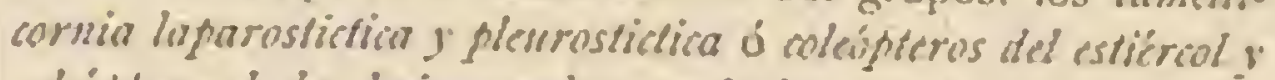
coleipteros de las hojors: ambos se designan asi por su género de vida. En el priner grupo la lengun puede distinguirse siempre de la barba, y los estigmas del abiómen solo se encuentran en la membrana ligatoria de los anillos medios del lomo y del vientre; las dos maxilas de la mancibula infe 
rior de las larvas son libres. En el segundo grupo la lengur es a menudo cúrnea, pero tambien coriacea ú membranosa; parte de los estigmas se halla en aquella membrana ligatoria (los cuntro anteriores prolongados), parte en los mismos anillos del vientre (los tres posteriores mas reclondeados), y en las larvas ambas maxilas de la mandibula inferior estrín soldadas. In podemos fijarnos mas minuciosamente en los demás distintivos de ambos grupos, que exigirian una descripcion rimug circunstancinda.

\section{LOS COPROFAGOS-COPROPHAGA}

CARACTERES. - LOS Copró́ngos tienen el labio superior, In mandibula superior y la lengua membranosos, el primero oculto, la úfím librci tos pojpos labiales insertos en el borde dé lá hartor la maza de ins antenas compuesta de tres aricjos, cl apendice de la pieza lateral del mesotörn culbiertó.

USOS, COSTUMBRES Y REGIMEN.-Compónense en su maynr parté de insectos pequenos ó de tamafio media no, los cuales, lo mismo que sus larias, viven preferentemen. te ch ul estiércol de los mamiferos solidungulados, y perciben con su olfato desarrollado á mucha discancia los excrementos recicntcmente depositados, à los que acuden en seguida poblando en trevisimo tiempo tales sitios Los agujeros gran. des $\delta$ peyuerios situados debajo de estos indican que el suelo esta minado por sus galerias y que los nicios para la cria se han construido en él. La de ciertas especies se desarrolla en el mismo suelo proveyéndose del alimento en la superfi cie; mientras que otras especies empjezan su vida en los mismos mantones de estićrcol.

\section{EL ATEUCO SAGRADO-ATEUCHUS SACER}

Ii ateuco sagrado es un coleóptero en extremo interesurte, tanto en el concepto biológico, como en el arqueológica, cujo coleúptero habita los paises del Mediterránco y há represciniado un papel en el culto que profesában a los animales los antiguos egipcios. Estos encontraban en el género de vida y en la forma del coleóptero la imágen del mundo, del sol y del gucrero váliente, de modo que le representaban en sus monumenos y le colocaban csculpido en piedra de colosal tamano (los liamados esiaratios) en sus templos. Fliano ( $\left.10, r_{j}\right)$ dice: 4 Los colcopteros (canthares segun los llama) son todos de séxo masculino: forman bolas de estiercol, las hacen rodar y despues de incubarlas véintiocho dias salen los hijuelos. Plinio $(11,2 S, 34)$ refiere de ellos: \&Hacen enormes pelotas de estiércol, las que empuịan haicia atrás con sus patas ! depositan en ellas pequenos gusanos (se entiende, los huevos), los que deben próducir nuevos culeúpteros de su especie; tambien abrigan las bolas protegiéndolas del frio. En otro pasaje dice el mismo auror que además de los varios remedios que prescribe la medicina clinica, se cmplea tambien el coleoptero que hace pildoras contra las cuartanas. Pales fucron las ideas pucriles que los antiguos tenian de la historia del desarrollo de un coprófago.

CARAGTERES. - Despues de mencionat esas fibulas vamos a presentar a nuestros lectores este animal maravilloso en su forma natural y en su género de vida bien obsermado, haciendo notar por el primer concepto que la cabeza semicircular tiene el borde anterior provisto de seis marcados dientes; los ojos de cada lado divididos completamente en una mitad superior y otrn inferior; las antenas de nucre artejos; los clitros no escotados lateralmente, truncados en su parte inferior y dejando descubierta la rabadilla; los tarsos de las patas anteriores denticulados en forma de dedos carecien- do de pies; los otros tarsos muy delgados que llevan en su extremidad una espina y el abdómen compuesto de seis seg. mentos. Todos los caracteres anteriores dan a conocer el género á que pertencec la especie que nos ocupa. Fsta misma se distingue además por dos pequeñas prominencias en la frente, por los tarsos anteriores escotados en la base, por la hoja lisa de la mbadilla, por los ligeros surcos longitudinales de los elitros, por las franjas negras en la cabeza, en el escudo collar y en las patas, por las fmnjas de un pardo rojo en los tarsos posteriores de la hembra y por el color negro poco brillante del cuerpo aplanado.

USOS, COSTUMBRES Y REGIMEN. - Fil ateuco sagrado lo mismo que todos los coprófigos, de los que mrios poco diferentes habitan la misma patria, mientras otros se encuentran en el Asia central, preparan unas bolas en forina de jelotas para su cria. Del mismo modo que en los necrótoros ambos sexos cuidan de preparnr la habitacion de sus hijuelos, asi tambien ocurre en el caso presente. Primero quita uno de los dos esposos por medio del escudo de la cabeza la parte del estiércol destinada para la pelota, la consolida con ayuda de las patas, y despues que la hembra ha depositado en clla un huevo, hncen rodar aquella, arrastrindola, uno de los coleópteros con las patas anteriores, mientras que el otro la empuja con la cabeza. De este modo, la pieza, al principio blanda y angulosa, se trasforma poco i poco en una bola sólida y lisa de casi cinco centimetros de diametro. Ias especies mas pequeras lacen tambien las pelotas mas pequenas. Despues abren los coleópteros una profunda galeria en ticra en la que entierran la bola. Cada hueroi cxige el mismo trabajo, en el upu se emplea el corto rato de vidá de que estos animales puscien gozar. Exhaustos de cansancio quédan los colébpteros por fin en ha escena donde se desarrollo su actividad y en la que mueren.

En la bola sepultada se despierta una nueva vida. Del huevo nace la larva y esta encuentra la provision suficiente de alimento para desarrollarse liasta alcanzar su completo tamaño. Tiene la forma de uma larva de abejorro, pero es mas semicilindrica, provista en la parte supperior de manchas (de un gris pizarra y casi desnuda en su cuerpo; de los cinco artejos de las antenas, del segundo al cuarto forman una especie de maza: aquel es tan largo como los dos siguientes, cl quinto es el mas largo y delgado. El escudo collar es cua. drangular; el labio superior se compone de tres lóbulos; rada maxila es obtusa y estå provista de tres dientes planos por dclante de la punta cuyo color es negro: la mandibula tiene dos lóbulos, cubiertos de pelos espinosos y provistos en la punta de un gancho córneo; sus palpos constan de cuatro artejos, los labiales son cortos y solo tienen dos.

Esta larva necesita varios meses jara șu desarrollo. En la primavera siguiente el coleóptero sale de su cuma y las parejas jóvenes fabrican bolas del mismo modo y con el mismo objeto que sus padres, pudiendo cjecutar tambien trabajos de otra clase. Muy curioso es el relato de un pintor aleman que observó en Italia un coleóptero a cuya especic no se atribuia tanta sagacidad. El insecto se ocupaba en hacer rodar una bola por un ierreno poco llano, cuando de pronto aque11 a cayó en un hoyo; como todos los esfuerzos del coleóptero fueran intitiles parn sacarla fuéra, dirigióse a un monton de estiércol vecino y volvió à poco acompañado de tres de sus semejantes, que reuniendo sus esfuerzos lograron sacar la bola del hojo. Obtenicio este resultado favorable los ires ayudantes volvieron, con la marcha lenta que les es propia, \& su habitual vivienda ¿Debera rerse en este hecho, asi como aal vez en la fabricacion de las bolas, esa necesidad natural llamada instinto, $\delta$ demuestra este modo de obrar por el contrario una actividad hija de cierta premeditacion? 
Recordenos los necróforos que hicieron caer el palo de que estaba colgado el topo; tengamos presente aguel carabicido que tambien llamó en su auxilio un compañero para dominar i un abejorro, y veremos que la observacion hecha en los copnóf́agos no es aislada ni única en su género.

Livingstone da cuenta de una especie del pais de los ku. ruman, llamada en el lengnaje popular skamianger-lece (probablemente tambien un ateuco), que contribuye à la limpieza de los pueblos, trasformando al punto el estiércol recien depositado en bolas que à menudo alcanzan el tamaño de las de billar. En el relato dice que es iprobablemente un ateuco, pues hay aun varios otros géneros que demuestran igual cuidado para su progenie y hacen pelotas para abrigo y alimento de la larm, como por ejemplo el sisifo de Schaeffer (sisjphus Schaefferi), con sus patas largas, que con frecuencia busca el suelo calcáreo. Yo tengo una de estas pelotas que un amigo me ha traido de Espana; la he resecado poco à poco en la era y es tan compacta que fué preciso aserrarla para poder examinar su interior sin romperia. El diimetro es de $0^{2}, 034$; una capa de $0^{\prime \prime}, 0055$ es completamente sólida y forma una costra esférica. El interior, en cambio, deja reconocer muy bien la composicion ligera y fibrosa del estiércol y se halla separado de la cáscarn sólida, cuya forna es am. bien ligeramente esférica. Pura no destruirla por completo no quise hacer uso de todos unis recursos; de otro modo no se puede examinar por completo el interior. En su esfera, muy reducida y fibrosa, se encuentra nrobablemente el huevo seco ó la larva muerta en su juventud que para su completo desarrollo, sin cluda, habria requerido toda la bola interior, mientras que la capa esférica habria servido de capullo para la crisálida.

\section{LOS ONTÓFAGOS - ONTHOPHAGUS}

CARACTERES. - Otrns especies, como los copris, del todo negros y mas prolongados, pero en cxtremo converos; las del género phanceus con su magnifico color en parte azul ó verde metálico, domdo ó rojo; y los ontófagos, cuyos centenares de especies habitan en todo el globo, viven sienzpre reunidos en gran número en el estiércol, debajo del cual abren agujeros para depositar sus huevos. En muchas especies el macho se distingue por tener un cuerno ó dos dispuestos como los del toro en la cabeza y í veces tambien en el escudo collar. Se cuenta que una especie de copris (midas), propia de las Indias orientales, salió de un duro predizo de tierra, que al principio se tomó por una abala de canon, despues de haber estado en ella trece meses; otro abandonó semejante prision a los diez y suis meses.

\section{LOS AFODIOS-APHODIUS}

CARACTERES. - Los afodios, que se asemejan a todas las especies anteriores por la estructura de la boca y de las antenas, difieren no obstante por tener el abdómen compuesto de cinco anillos, los tarsos posteriores provistos de dos espinas en el extremo y los elitros redondeados en su parte posterior, no dejando en descubierto la parte posterior del cuerpo. los varios centenares de sus especies están diseminados por toda la tierra, en mas número en las zonas templadas : frias de Furopa, donde se cuentan ciento quince Son los insectos que en las hermosas noches de verano, $\delta$ de dia, á lit luz del sol, se agitan en los aircs $\delta$ revolotean como las abejas domésticas alrededor de un monton de estiércol, que parece haberse convertido en una absigarrada mole de estos pequerios séres. No escarban en el suelo, ni hacen pelosillas para sus descendientes; limitanse simplemente á poner sus huevos en el estiércol, y de vez en cuando abandonan la asquerosa basura ó el hediondo hango por el aire puro o jara tomar el sol, entregándose á sus juegos. Los mas tienen el eucrjo casi cilíndrico, de escaso tamaño y color negro 6 pardo sucio; su cabeza semicircular presenta un ligero escote en su parte media y ticne dos ojos no divididos: el escudo del cuello esti orillado por una membrma delgada en el borde anterior, distinguiéndose claramente en la parte posterior: los costados de las patas medias son semejantes; las posteriores cubren en su ensanchamiento, por regla general, el nacimiento del abdómen.

\section{EL AFODIO ESCARBADOR - APHODIUS FOSOR}

CARACTERES. - Este colé́ptero, de color negro lus. troso, a menudo rojo pardo en los elitros, es nuestra mayor especie: distinguese por tener êl escudo de la cabeza ensanchacio junto a los ojos, formando un pequeto ángulo redondeado; el escudo cervicil carece de pelos; los clitros, ligeramente rayados, no tienen diente en la parte posterior; el escudete es grande; ln primera articulacion de los tarsos posteriores es mas corta que las cuntro siguientes juntas. En el escudo de la cabeza se halla el caraicter distintivo del sexo: la hembra tiene tres tubérculos que apenas se indican, mientras que en el macho son mas pronunciados, presentando el central una estructura córnea. La larva tiene la cabeza parda con una breve depresion longiudinal y algunos pelos largos; el escudo de la cabeza esta bien marcado; cl labio superior se redonden; los tarsos presentan cinco artejos siendo el central el mas largo; las mandibulas, muy prolongadas, son negras, ysu mitad izquierda mas grande que la derecha; los palpos maxilares tienen tres artejos y los labiales dos. Ii cuerpo se comprone, segun costumbre, de doce anillos, con algunos repliegues trassersales. Esta larva se encucutra ya crecida en la primavera, enternada debajo del estiércol de vaca del ano anterior, y se convierte muy pronto en escambajo.

\section{LOS GEOTRUPOS - GEOTRUPES}

CARACTERES. - Los mayores escarabajos peloteros de Alemania son conocidos con cl nombre de geotrupos (jreolrupes), llamados antes, con otros muchos, Searaberus. A menudo los vemos arrastrarse pesadamente por los caminos. el campo ó el bosnque, con los tarsos tendidos. En las noches de verane jasan zambando con fuera junto á nosotros. No tienen la mandibula superior $y$ las naxilas membranosas como las especies anteriores, sino córnens y descubiertas; el apéndice lateral del mesutúrax queda libre; en los tarsos se cuentan once artejos, y los ojos están completanente divididos. Ademis se lés reconoce por el escudo de la cabeza, que es romboideo, voluminoso en la parte anterior, y separado de la cara en la posterior; el escudo del cuello es trasversal, con los bordes posteriores rectos; tiene un escudete en forma de corazon y seis anillos abdominales libres; el cuerpo es corto, de forma ovalada obtusa ó bastante abovedada. Ias patas se caracterizan por una manchia de pelo en los inuslos delanteros; el borde externo de los respectivos tarsos afecta la forma de sicrra. Los largos costados de las patas posteriores pre. sentan rebordes y surcos, y cuando se rozan con el borde del tercer anillo abdominal producen un ligero rumor.

DISTRIBUCION GEOGRAFICA.- Los geotrupos negros ó que tienern un brillo metálico viren solo en lix zona templada de Europa y de la América del norte, en el Himalaza, en Asia, Chile, la América dul sur y la costa septentrional de Africa. 
USOS, COSTUMBRES Y REGIMEN.- L.OS geotrupos, que viven principalmente en el cstiescol de caballo, son insectos pesados y torpes, mas propios para escarbar que para volar, y su existencia no riene unda de envidiable, pues en la primavera, cuandos ven la luz por primera vez en su vida, despues cie abandonar su profundo hoyo, deben ocuparse desde luego en la reprociuccion. Cada especie busca los excrementos de los solijedos que han pasado por el camino; $y$ cuando la estacion está adelantada, agrádanles tambien los hongos favoritos de muchos insectos y de las limazas. En el rnonton de estiércol ó un el hongo sacia su apetito y practica un agujern casi vertical de unos $0^{\circ}, 30$ de profundidad, en cuyo fondo deposita una porcion de alimento que llega à cubrir la entrada: la hembra yone alli un solo huero, $y$ debe abrir tantos agujeros como liueros quiera depositar, viéndose obligada a menudo a buscar varios móniones de estiércol, porque este escarabajo no es el único que las necesita; con el se asocian otros de sú especie $y$ de su familia asicomo vatios de que ya nos hemos ocupado y muchos que no citaré. Se ha de tener en cuenta, sin embargo, que no todos los terrenos donde se encuentra esta fuente de vida se prestan para practicar un hoyo, y por lo tanto ofrece su dificulad hatlar un sitio conveniente. Cuando vemos al geotrupo emprender de dia riajes de exploracion y le oimos por la noche pasar zumbando junto a nosotros, es que busca un sitio a propósito para abrir un agljero. Su predileccion por la noche se denuestra en el hecho de ser mas activo durante esta; mućvese entonces mas vivamente y ocúpase en la reproduccion. Los lugares donde habitan y su costumbre de escarbar ha tierra ponen at los gectrupos en contacto con los nismos insectos que liemos conocido al ocuparnos de los nectóforos. Aguno de estos parásitos corre rípidamente por el pecho y el abdómen del cscarabajo y su número aumenta tanto mas, cuanto mas extenuadas están las fuerzals de acjucl, curnto mas se acerca el termino de su vida. Fin utoño se encuentran algunos que apoyados en el dorso de los seis tarsos, y del todo rigidos, parecen cadaveres disecados de los que lriyen hasta los pai. rasitos que acobanios de mencionar. Estos insectos han șthcumbido de muerte naturil, mientras que otros de sus semejantes han sido victimas de algun pico cruzado, gue tos clavaria en una espina, como láce csta ave con muchos abejorros.

Con el tiempo desaparece la vivienda pamitiv del geotrupo, y solo un agujero redondo rodendo de tierra atestigua su reproduccion. En el trinscurso del verano y del otono se desarrolla en el fondo de aquel agujero la larva, la que se convierte en crisálida y esta en escarabajo que en la primavera siguiente celebm su resurrccion del modo que hemos des-
crito.

\section{EL GEOTRUPO PRIMAVERAL - GEOTRUPES VERNALIS}

CARACTERES. - Es la mas pecjueria de las especies alemanas, mide de $0^{n}$, or 3 a $0^{\circ}$, or 5 de longitud, tiene un hermoso azul de acero y el dorso liso casi pulimentado.

\section{EL ESCARABAJO ESTERCOLERO VULGAR - GEOTRUPES ESTERCORARIUS}

CARACTERES. - Tiene los clitras profundamente acanalados, $y$ el clorso de color negro con brillo azul ó verde, $y$ el abdómen de un azul violeta, midiendo por lo menos $0^{\circ}, 015$ y á veces mas. A mi entender, solo conocemos bien la harva de esta especic, caracterizada por sus tarsos con cuatro artejos, asi como por sus mandibulas muy denticuladas.

\section{EL GEOTRUPO TRICORNIO-GEOTRUPES TYPHCEUS}

CARACTEREs. - Fis nuestra especie mas hermosit, pues el escudo del cuello del macho estí adornado por tres cuernos dirigidos hácia delante; los elitros son algo mas lisos que los de las demás especies, y de un negro puro muy lus. troso, como el resto del cucrpo. La circunstancia de que esta especic tenga las mandibulas marcadamente tridenticuladas en la punta, el lólulo interno de la mandibula inferior mas desarrollado y la barbilla menos escotada, ha inducido à nucstros sistematicos á separar esta especie de todas las detris bajo un nombre genérico especial (Ceralophyus). Encuéntmse principalmente en los áridos prados donde pacen las ovejas, cuyos excrementos, y tal vez tambien los del cierro y del gamo, constitujen el régimen alimenticio de este escarabajo jo de su larva.

\section{EL LETRO DE CABEZA GRANDE-LETHRUS CEPHALOTUS}

CARACTERES. - El letro de cabeza grande (Lethrus ceplialotirs) se ascmeja por su estructura á las especies anteriores, pero difiere de todos los congéneres de su familia por la conformacion de sus antenas, pues los dos últimos artejos se insertan en el antepenúltimo que és truncado, como el interior de una cebolia en sus cubiertas. A causa de este carácter las antenas no rematan en forma de abanico, parecien. do compuestas de nieve artejos. Además las maxilas son denticuladis en el borde interno y inuy grandes, distinguién. dose sobre todo las del macho, que son ya de si fuertes y estin provistas de un grueso diente dirigido lácia abajo. Este insecto, de color negro mate: tiene los elitros muy cortos, de mollo que juntos forman casi una semiesfera.

DISTRIBUCION GEOGRAFICA. - Este insecto habjta er los terrenos arenosos del sudeste de Europa, donde se le ve en los excrementos secos y alrededor de las raíces de los vegetales resistentes. Vive en parejas en agujeros del suelo. y desde hiace mucho tiempo llamó la atencion de los viticultores húngaros por los perjuicios que causa.

USOS, COSTUMBRES Y REGIMEN. - Cuando ^ principios de la primavera los rayos del sol han calentado el suelo y los botones de las vides empiezan á retonar, vénsé en al suelo numerosos agujeros, idénticos à los que abren nues. tros gentrupos indigenas en las dehesas y en los sitios despo. bindos del bosque. Fistos escarabajos salen de sus agujeros principalmente por la maniana y por la tarde desde las tres en adelante, pero se refugian inmediatamente en sus escondites apenas usen algun ruido, procodiendo en esto como los grillos campestres. Si no sc les inquieta, Irejan rajpidamente por las rides, cortan botones ó pámpanos y los arrastma i sus agujeros, nndando siempre hácia atrás. Esta ocupacion continún durante tocio el rernno, y sugun dice Erichson, cortan hasta la yerba y las hojas de diente de leon. Ningun autor habla del régimen de estos coleópteros, limitándose à decir que cortan los racimos, pero es rerosimil que las hojas y demís sustancias vegetales marchitadas err sus viviendas sirven de alimento á estos escarabajos, principalmente á sú cria, pues cuando han recogido suficientes provisiones en un agujero, ta hembra pone un solo huevo en el mismo, abriendo despues otros y recogiendo nuevas provisiones para los demás huevos. No dudamos que, prescindiendo de la variacion del alimento para su prole y del desarrollo de la misma, se repetirá en esta especie lo que sucede con nuestros geotrupos. Cunndo llueve, el letro de cabeza grande no se deja ver, y segun se ha dicho, hasta puede desaparecer sin dejar vestigio alguno si la 
lluvia dura largo tiemro. Tampoco se te re ya durante la recoleccions porque despues de criar los hijuelos. ha cumplicio su ticonpo y la pregenic no se presenia a continuar el trabajo de sus padres hasta mas tarde. Lis dificil escarbar la tierra en busca de estos escarabajos sin dañar las raices de las vides, y por lo mismo no se ha hecho nunça, debiéndose à ello que no se haya estudindo suficientemente la larva y el desarrollo dc este enemigo de las viñas.

\section{LOS LAMELICORNIOS PLEU- ROSTICTICOS}

CARACTERES.- I a segunda division de los lamelicor nios (Lamellicomin pliuresticfica), asillamada por I acordaire à causa de la diferente posicion de los tres conductos aéreos del atiómen. comprénde primero i los melolóntidos (melslonthiaic) provistos de garms iguales á lis ugue caracterizan al abcjorro. Las larvas se alimentan, por lo que hasta ahora se sabe, de las raices de plantas viris, en tanto que los escarabajos deroran las hojas, pudicndo algunos de ellos ser nuy nocivos à la economía humana donde se presentan en gran multitud. Este género muy rico en especies, es de los mas dificiles de describir, puesto que esos escarabajos, en geneml de color pardo, pardo gris ó nevgro, se asemejan muchisimo en el conjumto, siendo preciso cxaminar atentamente los camactéres distintivos para reconocer las diferencias; que se hallan principaimente en las partes bucales, en la forma de los costakios, en la estructura del último anillo del abdómen, en el escudo, eil los dientes cxternos de los arsos, en los caraciéres sexuales, en la estructura de las garras, yue son

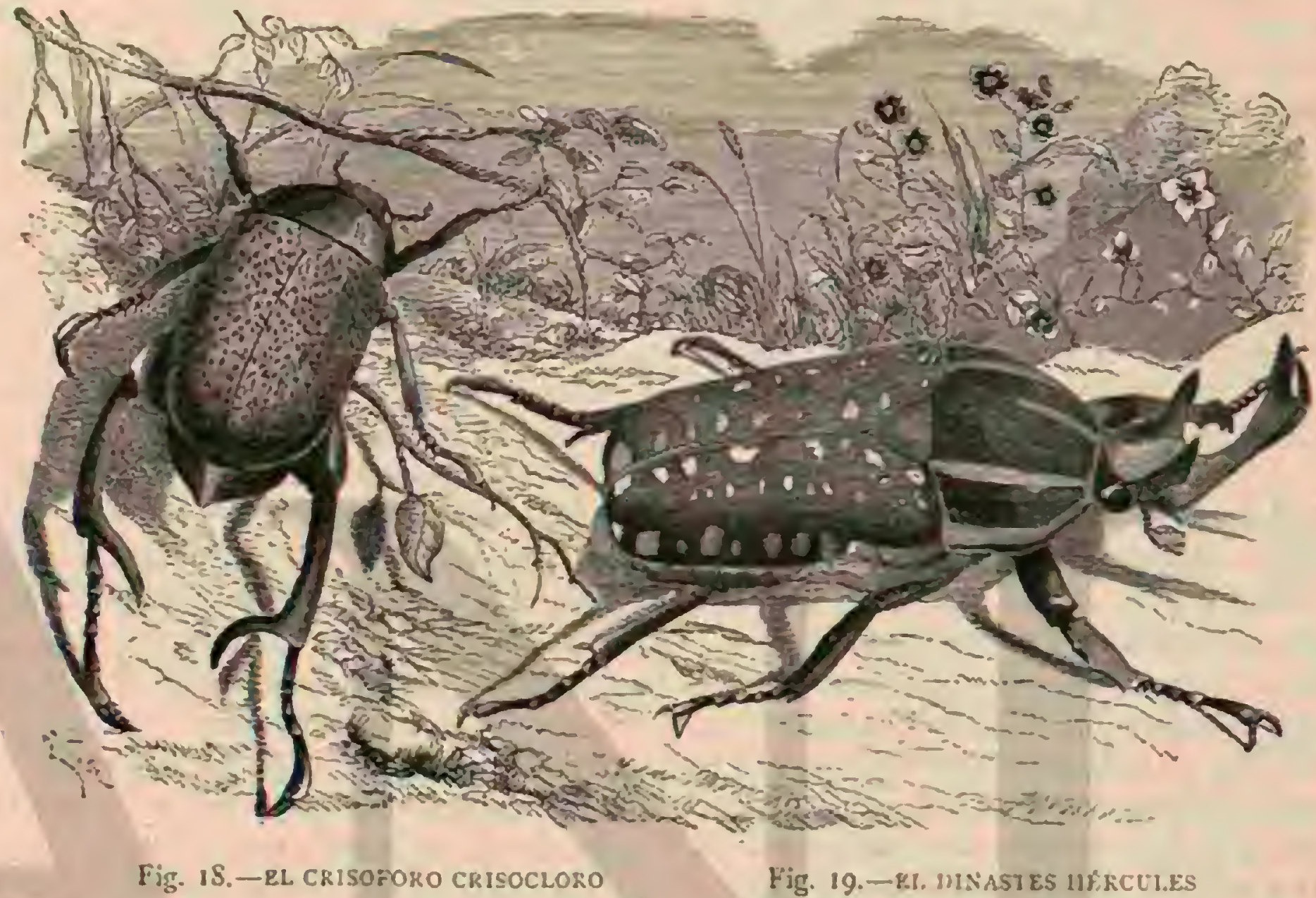

siempre iguales entre si, y en otras varias partes. Por lo nismo no se puede ser prolijo ni anticipar um descripcion general, debiendo limiarnos á observar que los uses últimos conducios aéreos son mas redondos, diferenciandose de los anteriores solo por hallarse en el borde superior de los respectivos anillos abdominales, sin correrse mucho hácia abajo.

DISTRIBUCION GEOGRÁFICA. - I .a mayor parte de los melolóntidos habitan en Europa, aluundando mas en Asia, América del nortey Australia. In cada uno de estos paises se cuentan de $103^{\text {a }} 121$ especies y en la América del sur $264:$

\section{EL MELOLONTA O ABEJORRO VULGAR- MELOLONTHA VULGARIS}

CARACTERES. - Consiciesamos al melolonta ó abejorto vulgar (Melolorthn s'ulgaris) como representante de todo el género. Este abejorro se diferencia ce sus congéneres por la maza de las antenas, que en el macio tienen 7 artejos y en la hembra 6, y por las garras denticuladas en su nacimiento, garras que son comunes a ambos sexos. In especie se reconoce por unas manchas triangulares blancas en los costades del abdómen, por el ino termiuado por un largo gancho y por las antenas, los tarsos y los elitros de color rojo, predominando en las demis partes el color negro. asi como por el color blanco mas ó menos subido de todo el cuerpo, cuỵo color se fresenta gnstado en los indivicuos viejos. Ita varic- dad que presenta el escudo del cuello de color rojo, no stiele ser rara: en cambio hay algunos tipos, en su mayoría meridionales, que se párecen mucho a la especie vulgar y a los melolontas hipocastaneos (Mclolon/hn hippocasioni). Este difiere del abejorro vulgar por su tamaño algo menor, por el gancho anal mas corto, bruscamente estrechado, qque en ocasiones ructre a ensancharse, y por el color rojizo del escudo die la cabeza y del cuello, yue solo en casos excejcionales, se presentan de color negro.

USOS Y COSTUMBRES. - Estc escarabajo ajarece por regla general en mayo. Cuando la primavera es muy tenplana salen ya i fior de tierra en el mes de abril; en el caso contrario no lo verifican hasta el mes de junio, y en los lla. mados años de emigracion se les puede encontrar desde mayo hasta mediados de julio. En el ano bisiesto de $\mathrm{I}_{4} 4$, que fue abundante en abejorros en gran parte de Alemanin, no se prescntaron estos á causa del mal tiempo hasta el Ijó 14 de mayo, pero en tan inmensas multitudes, que el suelo estaba á trechos macrialmente agujereado como una cribu. Hicieron estragos hasta nediados de junio, y despojaron por completo de sus hojas, cntrc otros årtoles, à las majestuosas cncinas: desde aquella época empezaron à disminuir lentamente. El dia $\$$ de julio y el dia 28 del mismo mes cncontré una pareja en intima union. Es cosa excepcional encontrar alguno de estos abcjorros en uro ú otro de los meses comprendicios entre setiumbre y marzo, antes de emprender su ruelo regular. No obstante, de vez en cuando se presentar 
excepciones, siendo originadas por el trabajo del arado. Su presencia es hija por regla general de determinadas circunstancias puramente locales, apareciendo, dadas tales circunstancias, á intervalos regulares y en grandes masas. En la mayor parte de las comarcas alemanas se ha reperido este fenómeno, funesto para agricultores y selvicultores cada cuatro anus. En Franconia se presentaron en enormes cantidades durante los anos $1805,1809,1857,1 \$ 6 \mathrm{r}, 1865,1869,1873$; en los airededores de Munster en $1858,1862,1866,1870$, $1874, y$ en Berlin en 1828,$1832 ; 1836,1860,1864,1868$, 1872 . De igual modo la observacion efectuada en gran parte de la Sajonia, autoriza a suponer que ics anos bisiestos son los en que mas abundan los abejorros. No sucede lo mismo en Suiza. Alli, como en las provincias rhinianas y en Francia, aquellas masas de insectos' se presentan cada tres años; se han distinguido agumos por la numerosa emignación de los misínos, como ocurrio en Basilea ( $1830,1833,18{ }_{3} 6$, 1839); en Francia donde llegó hasta el Jura $y$ las provincias rhinjanas, en Berna, al este del Jura, en la Suiza occidental y septentrional, los años $1831,1834,1837,1840$; en Uri, años $1 \$_{32}, 1835,1 \$_{3} 8,1841$, etc., al sur $y$ al este del lago de los Cuatro Cantones. En las provincias del Rhin se pre. scintaron en gran multitud en $1 \delta_{3} 6,1839$ y 1842 , aparecien. do á arillas del lleser en 1838 , is $4 \times$ y 18.44 . Esta diferencia en las épocas de su desartollo depende, sin ciuda, de circunstimcias locales, la primera de las cuales es quiza al mayor o inenor grado de calor que afrece la temperatura media del año.

Una ve\% salidos i flor de tiern y cuando no les deticne el mal tiempo, los abejorros revolocean durante las templadas noches en busca de alimento y con objeto de aparearse, siendo a veces apetecida presa de los murciélagos y de'algunas aves rapaces nocturnas: muéstranse asimismo muy activos en los dias de un calor bochornoso. Fácil es que el lecior los haya visto armstrandose en grupos de cuatro y mas por las encinas y los frutales casi despojados de hojas, disputancose el reducida alimento, ó bien rinendo los machos por las hembras. En otras ocasiones puede haberlos observado en las espigas del trigo, en los tallos del lino y de otros vegeta. les bajos, jo lo que es peor aun, quizas haya percibido el pes. tifero hedor de sús excrementos, al pasar por el bosque despojado de hojas durante las años en que aquellos abundaron.

Estos animales solo buscan el descanso durante las altas horas de la noche ó á las primeras de la mañana: en los dias rigurosos estän débilimente suspendidos por los tarsos de arboles y arbustos, sobre todo de los ciruclos de nuestros jardines, de las encinns, de los hipocastanos; de los plátanos, de los chopos" y de la mayor parte de los arboles frondosos, pudiendu consegutir con faciliciud su caida y adquisicion tan solo con golpear los troncos, pero sin sacudirlos.

La hembra fecundada necesita algunos dias para poner sus huevos. Intérnase en la tierra, prefiriendo el terreno pojo al sólido, calcíreo ó arenoso $y^{\circ} a$ unos $11^{\circ}, 05060^{\circ}$, o 7 debrjo de la superficie, y pone en junto hasta 30 huevos de forma oblon. ga, blancos y algo comprimidos. Terminado este trabajo, $\delta$ no vuelve à presentarse, ó bien sale de nuevo \& la sujierficic de la tierra; sigue empero, ra extenuada por las fatigas, igual suerte que el macho, y como al perece. Al cabo de cuatro ó scis semanas aparecen las larvas, las que hasta últimos de se. tiembre comen las fibras finas de las raices inmedintas, ó se aprovechan de la tierra mezclada con las mismas raices carco. midas, internándose mas en el suclo, para aletargarse durante el invierno. En la primavera siguiente aparecen, como todos los animalo aletargados, en ha superficie, en la que se alimentan de nuero. Poco tiempo despues vuelven al interior de su morada para mudar la primera piel. Al reaparecer en la superficie, empiezan su trabajo acostumbrado con major afan, para reparar a fuerza de alimenio las fuerzas que perdieron. Intonces cuentan ya cerca de un ano de edad. A fuerza de comer estos animales se hacen mas visibles y se diseminan mas: es de notar que ente el dia mas largo del ano y el equi. noccio de oroño causan los mayores perjuicios. luego decre. cen y se aletargan por segunda vez y mas tarde se repite lo sucedido en el ano anterior. Por fin, pasados tres años desde la puesta de los huevos, y encontrarse ya maduros para crisalidarse, ruelven á entermase å mayor profundidad, pudiendo admitirse como cierto que iodas las larvas de un mismo año estan trasformadas ya en crisilidas por el mes de agosto ó primeros de setiembre, y los escarabajos desarrollados por completo en el otoño: estos, si no se les inquieta, permanecen tranquilos en su.cuna. Scgun la profundidad a que esta se encuentra y segun la solidez del suelo que cubre al escarabajo, necesita mas ó menos tiempro para llegar à la superficic, paralo cual elige las boras de la noche. El extraño movimien. to (el abcjorro cuenta) quc agita todo su cucrpo, y sus elitros entreabiertos antes de remontarse por el aire, tiene su razon de sér. Litena por este medio los conciuctos aéreos y asi ad. quiere su pesado cuerpo la aptitud necesaria para el iuelo. Los conductos á́reos, que arrancan lateralmente de los dos principales y se dirigen hacia las partes interiores del cuerpo, conilenen, segun las investigaciones de Landois, 550 vesiculas, que ent parte son mas grandes en el macho que en la hembra. Dichos conductos se cierran sicmpre al efectuar los movimientos respiratorios, a consecuencia de lo cual todos los demás, asi como las vesiculas, se lleman de aire, produ. ciendo el éfecto que acabamos de indicar. Me parece bastante dudoso que este modo de cerrar los conductos ejerza grande infuencia en el fuerte zumbido que, segun la opinion del citado naturalista, produce cuando ruela.

Ia larva es temible enemigo para nuestros cultivos, por lo que no omitiremos su descripcion externa. De sus tarsos con cuatro artejos no arranca mas que una sola garra, que, como su desnuda cabeza, es de color amarillo rojizo, en tanto que el cuerpo formado de pliegues trasversales, presenta un color blanco sucio, que hácia el borde posterior raya en azul. La cabeza carece de ojos; las antenas tienen cuatro artejos, de los que el penuiltimo se inclina en forma de diente sobre el úlkmo; la boca es ancha, negra, sin diente, las maxilas robustas y las mandibulas soldadas, asi como los palpos maxilares provistos de tres artejos. Tales son los caractéres distintivos de esta larva, cuyo labio superior semicircular y duro y el inferior carnoso y provisto de palpos de dos artejos, cierran lateralmente la abertura bucal.

USOS Y COSTUMBRES. - Asi como el escarabajo se encuentra bien a la luz del sol, la larva no puede sufrirla, y muere muy pronto si se expone por breve tiempo a ella No obstantc, no es conveniente, al coger las larvas, arrojarlas en monton para hacerlas morir bajo los myos del sol, porque la capa inferior, no herida por ellos, tiene aun fucral bastante para ponerse en salvo hundiéndose en el suelo. La recoleccion de estas larvas, siguiendo a poca distancia el amdo, es uno de los medios para precaverse de los daños que aquellas acarrean; otro todavia mas radical, por sus efectos, es recoger y matar cada ano sodos los abrjorros dondé quiera que se encuentren. Lo que puede hacerse por este concepto to ha demostrado entre otras la comision regional de la Sociedad central de agricultura de la provincia de Sajonia en el año 1868 , en cuyo año hubo emigncion de cscarabajos. Se gun demuestran los estados formados acera del particular, se mataron 30,000 quintales. Si nos atenemos únicamente desta cifra (los abejorros recogidos extraoficialmente la aumenta- 
rian mas), la cantidad de peso corresponde poco mas 6 menos i mil quinientos millones de abejorros, puesto que stegun repetidos ensayos $5.3^{\circ}$ pesan por térnino medio una libm. Ios trabajos y sacrificios que requiere tal campaña de destruccion. estin, empero, compensados; pues en el siguiente año (18;2) se presentaron los escarabajos como en muchos otros, pero no en tal número como en los años bisiestos. Eil mismo fenómeno se repitió en $18 ; 6$, en cuyo año la temperatura riguros? y constante que se notó en la primavera, hubo de ser muy desfavorable para los cscarabajos. Fstos, cuando se recogen en tan extraordinario número, se utilizan como abono matándolos con agua hirviendo ó con rapor, echándolos luego en los montones de abono, mezclados con cal y cubriéndulos de tierra. Tambien se obtiene de ellos por medio de la destilacion un buen aceitc para el alumbracio, y lo que es mas raro, una sopa cordial, recomendable á los convalecientes, para lo cual no se necesita esperar a los años en que abunde.

\section{EL MELOLONTA CURTIDOR-MELOLONTHA FULLO}

CARACTERES. - El melolonta curtidor (Melolonthn fullo) es el mas hermoso de todos los melolómidos europens. Se le reconoce facimente por los elitros de un pardo rojo mezclado de blanco: aunque carece del gancho anal y en la hembra la maza de las antenas solo tiene cinco artejos y el diente de las garras situado en medio y no en la raiy. lo agregaremos al melolonta vulgar, consignando empero que Harris ha introducido para él, y cierto número de especies exóticas, el nombre genérico de Polyphylla. Fste melolonta se encuentm con abundancia en Europa; prefiere las llanuras arenosas y pobladas de pinos á cualquier otro terreno y devor tanto anquellos como los árboles frondosos que regetan entre los mismos.

No se ha observido, empero, que se presenten inultitud de ellos á intervalos regulares, pues solo aparecen en igual número todos los años en la primera mitad del mes de julio. Mientras el melolonta vulgar prefiere, si los puecie elegir, los arboles a las mirtas, el melolonta curtidor mora preferentemente entre los matorrales y sobre todo en los pinos bajos. Si se sacuden estos, anuncia su presencia con un fuerte grito. Rozando el agudo ángulo de la penúltima articulacion abåominal con un reborde de las aias que se halla en la articulacion de la misma, produce un chirricio muy fuerte.

La larva se asemeja mucho i la cel abejorro, pero es mucho mayor, diferenciandose por sus mandibuhs relativamente mas fuertes, las antenas mas gruesas y mas cortas, asi como por la carencia de garra en los tarsos posteriores. Aliméntase tambien de raices, siendo en ocrsiones perjudicial porque devora las de la yerba en los médanos: estas yerbas sirien para sujetar la arena movediza y se plantan con este objeto en los arenales. Impide además la vegetacion de los pinos 6 de los árboles frondosos, royendo asimismo las raices, ó el tronco subterrineo de las plantas. No se sabe hasta ahoin la duracion de su vida, pero parece qque es de varios años.

\section{EL RIZOTROGO SOLSTICIAL-RHIZO- TROGUS SOLSTICIALTS}

CARACTERES. - El rizotrogo solsticial sirve de tipo á una multitud de animales de este género que se le asemejon mucho y habitan mas al Mediodia. Su tamano llega it la mitad poco mas 6 menos del que tiene el abejorro vulgar: su color es pardo amarillento en el dorso; ln nuca, el disco del escudo del cuello y todo el abdómen, mas oscuro; la region aniero-dorsal, el coselete y el pecho revestidos de un pelo largo y áspero, algo mas escaso en cl abdómen. I a diferencia que media entre el géncro jrecedente y los rizotrogos, consiste en que la maza du las antenas de estos es trifolinda y los palpos labiales arrancan de la superficic externa del labio inferior, terminando en punta ovalada: carecen, como en el melolonta curtidor, de gancho anal.

USOS Y COSTUMBRES. - El rizotrogo difiere del abejorro por varios conceptos. Segun lo indica su nombre, empieza i volar mas tarde, hácia el dia de San Juan, y solo durante unos quince dias, presentandose entonces de ve\% en cuando en gran número. De dia no se le puede ver, porque descansa en los matorrales, segun mis observaciones en los tiernos irutales que franquean los anchos senderos del campo. Asi que el sol desaparece del horizonte, saltan estos escarabajos sobre los campos de trigo, los árboles cercanos y' los matorrales, indiferentes ya para el inofensivo transeunte al que son tan molestos, pues a manera de impertinentes moscas se posan siempre en el mismo punto de la cara, revoloteando sin cesar al rededor del viandante. Si este trata de ahuyentarlos con la mano, no necesita ser muy prictico para cogerlos en gran númcro. Examinados atentamente, resultan ser casi todos machos. Las hembras permanecen sobre las plantas cerca del suelo, y los machos parecen revolotear sin cesur a causa del apareamiento. Al mismo tiempo se procuran el necesario pasto, considerando como mas conveniente el que les ofrecen los bosques frondosos y las conifurns; los retoños que despuntan por San Juan son objeto de sus atalques, sobre todo si les ha precedido una invasion de abejorros vulgares. las hembras fecundadas ponen sus huevos junios a las raices de varins plantas, devorando las larvas preferenteniente las de las yerbas y tambien las de los cereales. Las larvas son muy semejantes á las del melolonta vulgar; pern, cuando adultas, se diferencian de aquellas, por tener la cabcza mas gruesa y una estructum mas comprinida en su conjunto. En mi concepto, su desarrollo se verifiea en el trascurso de un año; por otra parte se afirma que este puede durar dos años, porque al cabo de este tiempo los rizotrogos se pre. sentan en mayor multitud. Yo no he observado nunca mayor cantidad de estos escarabajos cada dos años, no obstante no he dedicado a este asunto suriciente atencion para poder desmentir terminantemente la afirmacion citada.

Ia duracion de la vida de esta especic y de algunas mas pequeñas, clasificadas en parte en otros géneros, parece ser muy corta: de modo que algunas de ellas pueden llamarse raras of muy raras, porque pasan a veces años enteros sin que aparezca ningun ejempllar; en tanto que se hubieran po. dido recoger á centenares si à su aparicion ó proco despues, se hubiesen visitado los sitios donde criaron. La limitacion de la mayona à un pequeño territorio, contribus a la citada circunstancia en todas aqueltns especies que, como la presénte, no vagan en gran multitud.

\section{LOS RUTÉLIDOS-RUTELIDE}

CARACTERES. - Todos los lamelicornios que tienen los tres últimos conductos aéreos del abdómen, no en la mem. brana conjuntiva, entre los anillos dorsales y abdominales, cuyas gartas no son iguales en tamaño, ni en la misma pata, constituren otro género de los melolóntidos llamado rutiliio. Su lengua córnea estả adherida á la barba: las mandibulas, que son tambien cúrneas, llevan par regla geneml en la paric intima una corta Y̧ estrecha membrana vellosa. De los nueve $\delta$ dic\% aricjos de sus antenas, la maza consta siem. pre de los tres últimos. El apéndice triangular de tamahio proporcionado de la pieza lateral en el metatómx está siempre marcado. Del total de las especies (600), el menor 
número corresponde a Europa y á la Nueva Holanda: el major al Asia (200) y la América del sur ( 1 \$3); la América del norte y cl Africa alcanzan poco mas ó menos la misma cifra.

\section{LOS ANISOPLIOS-ANISOPLIE}

CARACTERES. - l.os anisoplios son coleópteros de $0^{n}, 000$ a $0^{n}, 015$ de longitud. Se encuentran en varias plantas, pero sobre todo en las yerbas, y tambien solbre los tallos de trigo, en Europa y Asia: en Africa se presentan pocos; en la India oriental estin representados por la especie congénere Dimurhina; en Anérica faltan por completo. El gracioso anisoplia ind trigo (aniseplia frulicola) es de un verde bronsendo, blanco por debrijo; el escudo del cuello revestido ce una pelusa amarilienta, los clitros de un rojo de orin en el macho, y del misno rolor, pero mas auvarillo, en la hembra, teniendo en esta, alrededor del escucio, una mancha cuadrangular de color verde, como el fondo. El esrirdo de la cabeza se adelgaza hácia adelante en todas lás especies de este género, encorvaindose hácia arriba en el borde; pero cubriendo por completo el labio superior. I a superficie externa de la mandibntà inferior está provistá de seis dientes largos y agudos. El Mréndice de la pieza literal del mesotórax, que carece de prominenciśs, esta cubierto; la garra externa de los tarsos delanteros es siempre la mas grande y está hendida en su parte anterior. Ia citada especie se encuentra en las espigas de centeno, sobre todo en las que se producen en terreno arenoso, en la éproca de la florescencia $\delta$ inmédiatamente despues, para devorarla ó para comer los gér. menes del grano, causando grandes estragos si se presentan en gran muleitud. Dicha especie no visita de ordinario sino las espigas de los citados campos, donde los sexos se juntan. Tanto los individuos de esta especie, como los quue le son congéneres, cuando estin posados, inclinan sus pesndos tarsos traseros oblicuamente hácia arriba, empleảndolos tambien cuando se arrastran. Bouche tiene por inofensiva a la larva, muy parecida a la del mulolonta vulgar, á la qué encontró siempre en elabono semi-descompuesto, criandola tambièn en el mismo; sin embargo roe las raices del trigo. Nada se acerca de la duracion desu vida: no obstante considero que el desarrollo del insecto se prolonga solo un ano. En el mediodía de Europa, por ejemplo, en Hungria se presentin otras varias especies, en parte mas robustas y al parecer con mas frecuencia y en gran multitud; de modo que los estragos que causan en las espigas pueden ser mucho mas sensibles que los que acarrean nuestros anisoplios.

\section{EL FILOPERTO HORTÍCOLA-PHYLLOPER-} THA HORTYCOLA

CARACTÉRES.-Un coleóptero muy comun pertene. ciente á este género, y que visita todos los años los rosales de muestros jardines para destruir sus botones mas bonitos, si no se toman medidas preventivas, es el llamado filoperto horti.

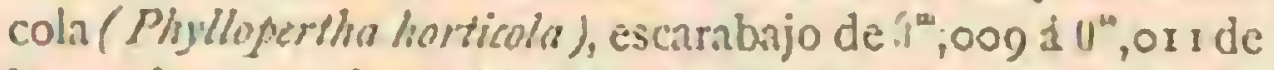
largo, de un verde azul brillante, muy velloso, de igual forma que el precedentc, puro menos itplanadó. En sus elitros parrdo oscuros ó negros alternan listas longitudinales irregulares con series de puntos tambien irregulares. El escudo de la cabeza está partido y rodeado de una delicada lista marginal, recta en la parte anterior. El escudo del cuello llega hasta los elitros y se estrecha hácin delante. Los tarsos anteriores se camcterizan por estar bidenticulados por fuera, y tener dobles puntas en las garras; la superficie externa de la mandibula inferior está provista de seis dientes, uno arriba, luego dos y tres abajo. Este escarnbajo al parecer albunda mucho y no falta por completo uingun ano; sin embargo, se presenta á veces en gran multitud, segun mis propias observaciones, aunque no a intervalos irregulares; de manera que no solo deshoja los arbustos de adorno y los frutales enanos, sino que puebia tambien toda clase de matorrales, principalmente durante el mes de junio. Su aspecto es perezoso como el de todos sus congéneres, sin embargo vuela à la luz del sol y tiene con regularidad una vida muy breve, si bien ln época. de su desarrollo dura semanas enteras, pues se le puede en. contrar mas 6 menos aishado hasta el otoño. Altum le obser. vó á millones á últimos de agosto y à jrimeros de setiembre en la isla de Borkum, sobre las cruciforas unarinas, las zanzas Y los sauces enanos. En los puntos donde su misma multitud ic hace molesto, se le puede recoger por la mañana y en los dias rigurosos, con un paraguas abierto, sacudiendo los àrboles.

USOS Y COSTUMBRES - I a larva vive junto á las raices de varios arbustos, no respetando ni las flores de las macetas, tales como la sanifraga, el trolluis, etc Parece que cl desarrollo de este insecto dura tambien un año solo.

\section{LOS DINÁSTIDOS - DYNASTIDEE}

Caracteres.-Los dinástidos (Dyrastida) se dife. rencian del género anterior por sus garras iguales, y del que sigue, llamado de los melitófilos, por tener los costados anteriores trassersales y hundidos. El escudo de la cabeza está soldado a la cara j deja descubierto el borde externo de las mandibulas. Estas son córneas, por regla general denticuladas por dentro, y pobladas de ordinario de pestañas a cortos trechos. El lóbulo externo de la mandibula inferior está soldado con el interior, $y$ la lengun, que es cómea, con in barba. Sus antenas, compuestas casi siempre de diez artejos, terminan en un boton trifoliado, igual en ambos sexos. El apéndice de la pieza lateral del metatórax está siempre marcado, siendo medianamente grande y triangular; los tres últimos conductos aéreos del abdómen se dirigen hácia el exterior. Este y los dos últimos anillos del mesotórax estan circuidos lateralmente por los elitros, que son por regla general lisos y de un color pardo ó negro. Segun lo indica su nombre, pertenecen à este género no solo los lamelicornios mas grandes y corpulentos, síno los gigantes entre los coleópteros en genernl. Y aq̨ui aparecen las contradicciones mas grandes entre ambos sexos de una nisma especie. Ios machos cstán armados por regla general en la region anterodorsal ó en esta y en la cabeza, de cuernos y puntas de las formas mas extravagantes, excrecencias de cuyo uso no sabemos darmos cuenta en la mayoria de los casos, adornos quizàs del macho, que serian intiiles para la hembra y hasta molestos durante la cria. Por lo mismo tienen estas a veces el escudo del cuello granujiento, escudo que va aumentando de anchura hácia la parte posterior y facilita la introduccion de estos animales en la madera ó en los troncos huecos para poner sus huevos. Los mas permianecen ocultos durante el din en la madera carcomida, en los agujeros de los árboles, debajo de la hojarasca y en otros escondrijos; por la noche son mas vivaces y despues de largos preparativos $y$ de repetidos movimientos del abdómen, emprenden ún pesado vuc. lo produciendo un zumbido que se oye à gran distancia, le. vantando un poco los clitros sin desplegarlos.

Las dos larvas hasta hoy conocidas viven en la madera carcomida, jo se asemejan mucho álas de los melolóntidos jor sus pliegues trasversales $y$ por la dilatacion del extremo del cuerpo en forma de saco; la cabeza parece pecjueña en pro. porcion al cuerpo, comprimido y gordo. Sus maxilas se carac- 
terizan por los dientes en ln punta y por los surcos trasversales de la parte externa, hallindose revestido el cuerpo de un pelaje aterciopelado mas ó menos espeso y cubierto de algunas cerdas por él disenimadas. Antes de la metamorfósis, a la que preceden varios anos de vida, constnyen las larms una sólida vivienda, en la quıe permanece el coleóptero hasta que ha ndquirido consistencia y puede salir a la superficie sin contusiones of fracturas. Sin embargo, los cuernos mutilados y todas las demás deformidades yue se observan con frecuencia en $\dot{l}$, parecen indicar que has sido demasiado impacientes y no han esperado una solidincacion perfecta.

DISTRIBUCION GEOGRÁFICA.-IAS quinientas especies que poco mas ú menos constitujén el género de los coloópteros gigantes, se encuentran exclusivamente en las \%o. nas tórridas, correspondiendo mucho mas de la mitad it la América, en tanto que algunas especies aisladas y menos gigantescas se presentan diseminadas por todo el globo.

\section{EL DINASTA HÉRCULES-DYNASTES HERCULES}

CARACTERES.--El dinasta hércules macho (dyuastes Hercules) ha adquirido cierta celebridad por su tamano y por su forma. Su longitud es de $0^{\prime}, \mathrm{r}_{5}$, cuya mitad mas pequeisa corresponde a un cuerno que, arrancando de la region antero-dorsal, se dirige en linea recı hácia adelante, encorvandose luego hácin abajo. Este cuerno, provisto en su parte inferior de una cresta de pelos amarillos, cubre, visto desde la parte superior, otro cuerno que arranca de la cabeza y mide dos tercios de la longitud del primero: el superior tiene dos dientes laterales en su parte inedia y el interior wrios en la parte interna; su color, como el de rodo el cuerpo, es negro lustroso, y solo los elitros, de un verde claro aceitunado, conservan a trechos aquel tono. Los tubérculos, detris de los costadós anteriores y el nacimiento del ano, tienen pelos largos y amarillos. No asi la hembra, que no presenta ningun vestigio de armaduri en la parte anterior, y' si solo un pelaje pardo mate; tienc arrugas toscis en la parte superior del cucrpo, cuyo color no es de un negro puro; las puntas de los clitros lisas,y mide 1$)^{\prime \prime}$, og 1 de largo. Este magnifico coleóp. ¿cro parece (que no figura entre las curiosidades de la América tropical, segun lo demuestran las colecciones curopeas.

Moufet indica otra especic congénere, llamada megaloso. ma elefante (megralosomia elephas), y dice con toda ingenuidad: ¿Segun la lejo de los coleópteros blandos (Canthoriurums), no tiene hembra, $y$ ha de engendmerse la progenie por si misma. Juan Canternrius, hijo, lo describió en el siguicrte distico, al enviar la imágen de este escarabajo á Pennius:

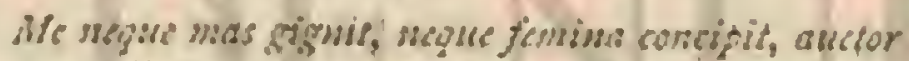
Jpse minis solus, seminturmque misi

iAsi se escribia cnionces la historia!

\section{LOS CALCOSOMAS - CHALCOSOMA}

CARACTÉRES-1.os insectos de este género se distinguen por sus mandibulas dilatadas cxteriormente, enteras y obtusas en su extremidad; la frente de los machos uresenta uis cuerno inuy fucrte y arqueado, y el protórax esta provisio de otros dos muy grandes, laterales y sencillos, que se dirigen hácia adelante; los elitros son muy lisos; las patas lar. gas; las piernas del mismo par son tridentadas en ambos sexus, y las cuatro posteriores estan provistas en su borde externo de cuatro dienes dispuestos por pares.

Este gencro no estả representado mas g̨ue por una grande y magnifica especie, la mas antiguamente conocida entre los dinastidos, y la cual inscribimos a continuacion.

\section{EL CALCOSOMA ATLAS-CHALGOSOMA ATLAS}

CARACTERES. - No es necesario consignar aqui los atributos genernles de la especie, puesto que ella es la tinica que representa el género (fig. 17). Solo resta anadir, respecto al color, que los dos sexos varian del verde bronceado oscuro al negro mas is menos incenso, siendo este tinte el mas oscuro en la hembra. Los tegunentos of́recen algunas veces en su parte superior un aspecto sedoso, pero este caracter se observa en pocos individuos. Eil macho de esta especie tiene un lsermoso color vercie aceituma, brillante inctilico; pero ha hembra es de un tinte mas pàlido; el tórax y la base de sus elitros son ásperos, y el verde tira al negruzco. Mide este insecto unas treinta $y$ seis lincas de largo total, con corta difurencis

DISTRIBUCION GEOGRAFICA.- Lil calcosoma Atlas es propio de las Filipinas y de una parte de la India; pero probablemente se encontrari tambien en otros puntos.

\section{EL ORICTES RINOCERONTE-ORICTES NASICORNIUS}

CARACTERES. - Tiene esta especie un cucrno medianamente grande en la cabeza y tres tubérculos iguales sobre la protuberancia del escudo del cuello, en su parte media anterior; los elitros del macho están crizados por series de puntos y el pardo negro de su cuerpo tiende en el abdómen al rojo. Jas maxilas y los lóbulos de la mandibula inferior están desarmados, estos poblados de pestanas en su parte externa; cl labio inferior prolongado y puntiagudo; los tarsos posteriores provistos exteriormente de dos ranums oblicuas y revestidas de cerdas; los delanteros sencillos en am. bos sexos. La hembra carece de cuerno, no presentaudo sino un tubérculo obtuso, en el sitio donde el macho tiene aquel signo caracteristico. Su longitud mide de li",026 \& $1^{m,}, 037$. Este magnifico escarabajo vive con preferencia en el norte de Europa: se le ve en el zumaque con que se rodean los cua. dros de mantillo de los jardines, y tambien en los caminos principales, segun se observia en Brema y Hamburgo. Iin los puntos donde se instaló una vez, suele vérsele con frecuencia. Durante los meses de junio j julio, seguidamente despues de su aparicion, efectúase el apareamiento; despues de lo cual el macho muere, en tanto que la hembra se interna en cl zumaque para poner sola sus huevos. Estos nparecen a últimos de agosto, e:i tanto que las larvas requieren algunos años antés de haber absorbido el suficiente alimento, pues su comi. da es allgo escasa. Comparados a los del ciervo volador, sus conductos aéreos son mas grandes y su cabeza marcadamente punieada. Para crisalidarse se internan á mayor profundidad en la tierra, construyen una vivienda ovalada, en la que se encuentra al cabo de un mes, poco mas ó menos, lá crisílida, y dos nueses despues ol escarabajo: este permanece en la misma hasta que todas sus partes están completamente endurecidas.

\section{LOS MELITÓFILOS - MELITOPHILA}

CARACTERES.-Fil último género, el mas rico en especies despues de los melolóntidos y copróáagos, consia de los melitósilos (melitophisla), que de todas aquellas. son los que tienen la forma mas perfecta y la coloracion mas hermosa. Son coleópteros engendrados en su mayoria bajo el influ- 
jo del sol en las horas en que irradia con mayor intensidad; insectos que no esperan la oscuridad de la noche por miedo in la lur, sino que por el contrario salen de sus escondrijos para divagar á faror de esta por las flores, las yerbas y otros arbustos aromáticos y para comer en compania de las fugaces mariposas, de las moscas vivarachas y de las asiduas abejas, devorando el pólen con los cálices y las hojas de las flores, $\delta$ lamiendo la goma que brota del tronco de los áboles. Son en su mayoria (sin qque por eso dejemos de reconocer que existen excepciones) los insectos mas nobles y escogidos de esta familia, ya que siben apreciar los delicados gores que ofrecen las hojas verdes, los hongos putrefactos, $y$ las sustaxcias que han pasado ya por el cucrpo de mamiferos que se alimenten de vegetales. Su cuerpo comprimido y de un tamano proporcionado estí medianamente'aplanado yosrece en su contorno la forma de un escudo. Los elitros dejaren descubierto el ano y se hallan siutudos sobre la region postero. dorsal, sin que por eso circuyan sus costados, manteniéndose en la misma posicion, aunque algo mas flojos, durante el vuelo. Los costados delanteros arrancan en forma cilindrico-cónica, en tanto que los posteriores se ensänchan por encima del primer anillo abdominal. Ia cara está soldada por el escudo de la cabeza, el cual cubre el labio superior y las maxilas, estándolo su lengua córnea i la barba. Lis man. díbula superior consta de una parte exterma cónnea y una interna membranosa; la mandibula inferior de una maxila externa movible; cada antena de diez artejos, y la maza de las antenas de tres de estos últimos. Segun la hoja lateral del metatónx se distingue o no desde la parte superior por el escote de los elitros detrás de la region escanular, à causa de la falta de aquel escotc. El género se puede subdividir en dos secciones: la de los cetónidos (Celonidke), que es la mas rica, y la de los triquidos (Trichiida), la mas pobre en especies.

Las larvas difieren notablemente de las demás de la mis. ma agrupacion porqृue su último segnento no está dividido en dos por un surco trasversal; siendo su diferencia menos no. table por lo que respecta á su cabeza, pequera en comparacion con su cuerpo comprimido: por los surcos trasversales mas débiles on los anillos y por su pelaje aterciopelado mass abundante. Se parecén á las larras de los dinastidos por sus maxilas denticuladas en la punta y surcadas trastersalmente en el exterior, $y$ viven exclusivamente de madera carcomida.

DISTRIBUCION GEOGRÁFICA.—Mas de una terce. ra parte de los animales pertenecientes á este género se encuentra en Africa, y la vigésimaqquinta parte en Europa: no por eso dejan de encontrarse en las diversas regiones del globo, pero los tipos mas perfectos son propios de la zoma túrrida.

\section{EL GIGANTE GOLIAT-GOLIATHUS GIGANTEUS}

CarACteres. - El gigante Goliat (Goliathus gigur. beus) de la Alta Guinea tiene una estructura perfecta Eil escudo casi circular del cuello, mas ancho en su parte media, presenta tres escalonamientos en el borde posterior, siendo mas corto en el lado anterior del escudo triangular situido mucho mas atràs que los hombros: la sutura de los elitros es notablemente mas corta que el borde externo. Su cabeza ofrece un declive oblicuo y cuenta, además de los ojos, con dos lóbulos obtusos y levantados y con una horquilla córnea, ancha, corta y roma en la punta. Su barba convexa, mas corta que ancha, la robusta y bidenticulada maxila externa de la mandibula inferior y los tarsos delanteros desarmados, caracterizan, prescindiendo de otros detalles, al gigante Goliat. Este es de un negro aterciopelado: la cabeza, el escudo del cuello á excepcion de seis rayas longitudinales, el escudete, una gran mancha triangular en la sutura y el borde externo de los elitros, de un blanco yesoso. Su longitud alcanza $10 ", 098$. L ..a hembra es algo mas pequeña, mas briIlante, sin adornos en la cabeza; pero con tres dientes en el borde externo de los tarsos delanteros. Este coleóptero es conocido en Europa desde 1770 , y tan buscado por los coleccionistas que se han pagado 30 talers por una pareja: a contar de aquella fecha se han descubierto cinco especies mas del mismo género, las cuales solo existen en el Africa.

\section{EL DICRANORINO DE SMITH - DICRANO- RHINA SMITHI}

CARACTERES. - Este goliátido, que vive en Puerto Natal, es un bonito coleóptero de color verde bronceado; los muslos, los tarsos, el escudete, el borde posterior de la region anicro-dorsal son rojos; liente una mancha pálida en el disco, y otras dos negras en sus rojos elitros; ta parte inferior del abdómen es roja y el pecho pardo. En la hembra, que es algo mas ancha, falta la armadura de la cabeza; el escudo dél cuello parece menos áspero: los tarsos son mas cortos; los anteriores mas anchos en la punta y provistos exteriormente de tres agudos dientes; estos faltan en cambio en la parte interna, donde el macho los presenta mas pequeños. I A anchura, poca extension, aplanamiento y redondez de !a anófisis del mesotórax; la maxila córnea externa de la mandibula inierior, que se prolonga y encorva un poco: $y$ la maxila interna, que en el macho no tiene armadura, rematanco en la hembra en un diente, son los caractéres que diferencian al genero en cuestion de sus afunes.

\section{LOS CRISÓFOROS-CHRYSOPHORA}

CARACTERES.-Fstos insectos tienen diez artejos en las antenas: el primero grueso, cónico y velludo por detrás y el segundo globuloso: los dos tarsos posteriores son muy prolongados; la cabeza bastante grande; las mandibulas descubiertas; el labio superior escotado; el coselete trassersal; el escudo semicircular; las dos piernas posteriores muy largas, arqueadas, y provistas de una gran espina que se encorva en la extremidad.

Estos insectos tienen algunas reces colores brillantes, $y$ stelen ser de bastante tamaño.

DISTRIBUCION GEOGRAFICA. - Los crisoforos habitan ch ambos continentes.

\section{EL CRISÓFORO CRISOCLORO - GHRYSO- PHORA CHRYSOCLORA}

CARACTERES.-Esta especie (fig. 18), que puede considerarse como tipo del género, es un insecto de gran tamanoo, que no mide menos de catorce líneas de longitud por ocho de anchura: es de un hermoso color verde cobrizo muy brillante, $y$ dorado en la parte inferior dal cuerpo, en las nalgas y la placa amal; los elitros estan cubièrtos de puntos hundidos, semejantes a las depresiones de la cabeźa, y ofrecen además unas manchas purpúreas.

DISTRIBUCION GEOGRAFICA. - La especie habita principalmente en la India.

\section{EL CETONIO DORADO-CETONIA AURATA}

CARACTERES. - En el cetonio dorado tenemos el ripo 
de todo el género. Fácil es que el lector conozca este coleóptero, de color verde domdo, con algunas rayas tmsversales formadas por escamas blancas en la mitad posterior de los elitros, coleóptero que en los dias de sol visita zumbando los arbustos y las matas de los jardines, bosques y praderas, buscancio en unos las rosas y los ruibarbos, y en otros el blanco espino, la pelota de nieve, etc.; pues siendo blandas las maxilas de su mandibula inferior, solo pucde roer las tierıas hojas de las flores 0 lamer las gomas. Pósase subre las llanas umbelas, y cuando le hicre el rayo del sol semeja una piedra preciosa centellante: mas bello aspecto ofrece el ver a menudo á cuatro de ellos sobre una misma for. Cuando se cansa de ellas vuelve a alejarse repentinamente, zumbando $y$ desplegnindo sus largas alas por debajo de los dorados elitros; cuanto llevamos dicho solo tiene lugar empero cuando le banian los ardientes rayos del sol. Si este no brilla permanece horas enteras en un mismo punto, como aletargado, arrastrándose liácia el interior si la temperatura dcja de ser benigna. Si se le coge segréga un jugo blanco, sucio y oleoso, de olor repugnante, tal ver con la intencion de recobrar su libertad. En las encinas viejas ú otros àrboles cuyas grietas destilan jugo, el cual es para muchos insectos como fuente inagotable de vida, se encuentra con frecuencia al cetonio dorado en apiñados grupos, reluciendo à lo léjos con dorado brillo, al herirles la luz solar. No olvidaré nunca el momento en que, situado debajo de la copa de uma añosa encina en el desierto de Dessau, sitio de recreo favorito y productivo para los entomólogos coleccionistas de los alredeciores, acechaba, entre una apiniada multitud de la especie comun, semejante a las perlas, a la especie mucho mas rara, casi doble mas grande y de color de oro puro, llamada Cetonia speciosissima. El sitio no era accesible; pero en casıbio cra el aspecto del insecto sobrado seductor para que dejase de intentarlo todo con objeto de apoderarme de él. Mi baston me sirvió de lanza arrojadiza, $y$ despues de algunas malogradas tentativas, ture la dicha de derribar al cetonio especiosísimo, junto con algunos cetonios vulgares, en tanto que una parte de los deurás continuó royendo y la otra echó á volar. Los cetonios no son en realidad nocivos; pero si comparecen en grandes multitudes en un jardin destinado al cultivo de los cappullos de rosas, perjudican notablemente in cosecha, $y$ echan a perder la rosa en flor.

La citada especie se diferencia de algunas oiras muy atines, por una linea en relieve situada sobre los elitros, a cada lado de la sutura, de modo que esta parece un surco; y por una apófisis en forma de boton en la placa del mesotórax; la parte inferior es de un rojo cobrizo, la parte superior de color verde con reflejo dorado o cobrizo, muy raras veces azuh, y menos aun negro; el escudo de la cabeza termina en línea recta por delante, tiene un borde de relieve y esta salpicado de puntos espesos, lo mismo que el escudo del cuello, pero solo en los lados. La especie llamada por Aristótéles Melolontha aurata no era quizá la que acabanas de describir, sino otrn muy.afine que se presenta en el Mediodia de Europa, y que junto con el abejorro, servia de juguete para los niños griegos, ó si se quiere de medio para ejercitarse en atormen. tar a los animales.

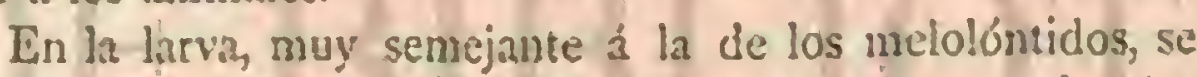
distinguen el escudo y la cabeza con el labio superior; las maxilas desiguales; los palpos maxilares con cuatro y los labiales con dos artejos; las antenas que arrancan de una prominencia, con cuatro. Sus cortos tarsos rematan en un boton, sin garras, y el borde lateral de su abdómen llano forma un ángulo obtuso con el dorso. Vive en la madera carcomida y ha sido encontrada con frecuencia en el fondo de las viviendas de la hormiga roia (Furmica rufa), donde se alimenta de pedazos de leño carcomido que las hormigas han aglomerado. El cetonio marmóreo (Citonin marmurata) de color pardo oscuro, con varias rayas y puntos blancos sobre su lustroso dorso, es algo mas grande y mas raro que la especie precedente. Lo cncontré casi siempre en los sauces viejos, lamicndo el jugo que despedia el tronco; y me inclino a afirmar, con Bouché, que su larva se alimenta principalmente de dicho jugo.

\section{LOS TRIQUIOS-TRICHIUS}

CARACTERES. - Prescindiendo de que los elitros no están escotados en la parte posterior de los hombros, las especies que se agrupan alrededor de los triquios difieren tambier por su aspecto general. El escudo del cuello es mas circular ó en forma de disco, nunca escotado delante del escudeté, á menudo levantado á manera de reborde en el borde posterior. En cambio los elitros parecen mas anchos, pero como carecen del escote lateral, es preciso que al volar los levanter.

Las larvas se asemejan mucho à las de los mclolóntidos, diferenciåndose de estas principalmente por su abertura anal trilobada: Ia mitad superior de la hendidura trasversal forma punta en el medio; la inferior tiene una pequena hendidura en el sitio correspondiente.

\section{EL OSMODERMO ERMITAÑO-OSMODERMA EREMITA}

CARACTERES. - El asmodermo ermitnño (Osmoderma eremila) merece ser mencionado en frimcra linea, como el coleóptero mas grande que esta division cuenta en Furopa, coleóptero que representa en cicrto modo à los gigantes, si tenemos en cuenta su aspecto general $y^{\prime}$ la circunstancia de que las hojas laterales de las caderas son aun visibles desde la parte superior. Este insecto de un pardo negro brillante, con reflejos violáceos, mide de $1^{m}, 026$ a $6^{m}, 033$ de longitud y vive en los árboles carcomidos; ticne el corso surcado lon. gitudinalmente; la region escapular delantera, pequeña; los elitros grandes, mucho mas anchos y arrugados; el escudo de la cabeza cóncavo, con los bordes en relieve, y el macho está provisto de un tubérculo encima de cada ojo, careciendo estos de aupuella concavidad del ribcte un la hembra. Ia superficie externa de la mandibula inferior es corta y triangular, aguda y cơrnen, y la interna termina en un diente muy encorvado y agudo. Este escarabajo huele á cuero y jresenta, como todos sus congéneres, un aspecto perezoso. Nunca se le encuentra sobre las flores, sino, segun ya hemos dicho, en los árboles carconidos. Como en ciertas localidades los sauces son con preferencin los arboles mas carcomidos, constituyen estos su morada jurincipal; los robles, las hayas, los abedules, los tilos y los frutales le albergan tambien, con tal que le brinden con un leño enfermizo, del qque la comprinicia larsa se alimenta q̨uizás varios años.

\section{EL TRIQUIO LISTADO-TRICHIUS} FASCIATUS

CARACTERES. - El triquio listado produce una impre. sion mas grata que el ermitano. Las foliculas de los costados no son visibles desde la parte superior; los tarsos son mas esbeltos, bidenticulados los delanieros en su parte externa en ambos servos. Ia superficie externa de la mandibula inferior es corniforme y triangular, y la interna sencilla; el escudo de la cabeza, mas largo que ancho, esta escotado por delanie, y cubierto, asi como la cabeza y el escudo del cuello, de un 
pelaje muy àspero y amarillo; en el abdómen se observa quic los lados posteriores se tocan, siendo el ano de color mas claro: liss dos fajas de los clitros, que se unen en la sutura, son amarillas. Esta especic es propia de las montañas de la Ale. mania central y meridional, encontrándose desde el mes de junio hasta agosto en las flores de las praderas y en las zarzas floridas: es a veces muy frecuente en el monte Harz. A seme. janza del cetonio durado penetra en la fior y roc en su seno casi sin moverse. Su larva vive en los árboles frondosos y carcomidos, como codis tas demás; sin embargo, que jo sepa, tenemos tan escasas nuticias acerca de la durncion de su vida, como de la de las demás especies congéneres. J'a se compren. dera que la observación de todas las especies que viven de este modo presenta las mayores dificultades.

\section{EL EUQUIRO LONGIMANO-EUCHIRUS LONGIMANUS}

CARACTÉRES. - Merece ser mencionado aqui, aUnque brevemente, otro lamelicomio muy interesante, melitófiloque vive en Amboina: el cuquiro longimano (Evelisus longimamus ). Recuerda por su forma à lós dinistas, acercándose à los melolóntidos por la estructura de su labio superior y por tener las garras de los arsos denticuláas; sin embargo, debe clasificirse entre los triquidos por ln conformacion de la cabeza y de la parte superior del cuerpo. Tos tarsos del macho son tan prolongados, que śu cuerpo, midiendo li, 065 , abarca, a' contar desde la punta, un espacio de 0", i 3. Este colcóptero es de un pardo castaño, negruzco en las patas delanteras y en todos los tarsos, de color rojo en la maza de las antenas y revestido de un pelaje pardo amarillo en la parte inferior.

\section{LOS BUPRÉSTIDOS - BUPRESTID压}

CARACTERES:- Los bupréstidos (Bupresfiffe), que constitu; en otra familia, viven, tanto en estado de larras come en estado perfecto, del misno modo que los cetonios:ariuellas en los troncos, estos sobre las fores y los arbustos, diferencindose, sin embargo, notablemente délos citados lanelicurnios por su aspecto exterior. En primer lugar, el cuerpo es por regla general prolongado y puntingudo hácin atrás, mas 6 menos comprimido, raras veces cilindrico y cubierto de una fuerte capa de quitina. Su pequena cabeza, hundida hasta los ojos en el anillo abdominal delantero, lleva por debijo las reducidas partes bucales, entre las que se distinguen los dos lóbulos de la mandibula inferior por su estructura membra. nosa, por estar desarmados y revesticlos de pestañas; en la parte superior se encuentran las antenas, cortas, con once artejos, de los cuales el tercero, cuarto y séptimo șon denticulablos como una sierra. El escudo del cuello se adhiere i los elitros, que vienen poco mas ó menos la misma ancliura: aniadase a estos caractéres el brillo metálico de la mayoria de estos tipos y su aspecto rigido, y podrá formarse de ellos perfecta idea. Sus cortos tarsos se prestan poco para la loconizocion; dos de los anteriores y los centrales tienen los costados esféricosy están en extremo abiertos hacin atris, siendo los poste riores foliculares: todos tiener los anillos de los muslos muy marcados. I.05 tarsos cuentan cinco articulaciones, yotras tantas el alxdómen, donde las dos primeras están soldadas entre si. Fil protórax termina en una apoffisis llana que se exticnde hasta el mesotórax, á reces hasta el metatómx. Cuando los bupréstidos abandonan su cuna, atravesando agujeros en forma de lanceta, les gusta solazarse posaclos en los troncos de los árboles, con preferencia sobre los que carecen de ra- maje, y en las arboledas bajas. Cuando ålguien se aproxima a cllos, déjanse caer como muertos ó clévanse presurosos por los aires si al sol resplandece en el sereno firmamento, pues son verdaderos hijos de la luz Sus alas se replegan sencilla. mente; de modo que pueden desplegarse y recogerse con ra. pider debajo de los clitros, que tienen la misma longitud.

Las larvin, conocidas solo en algumas especies, viven detràs de la corteza de los airboles sanos ó enfermizos, y se reconocen a primera vista por su parte delantern yute es grande y en forma de disco, formada por las tres primeras articulaciones, $a$ las que se adhieren las nueve del abdómen, en su mayoria cilindricas, como el mango en forma de pala de panadero. Su cabeza, horizontal, es retrictil y córncin solo en los bórdes bucnles. A excepcion del anillo del cuello, las restantes partes del cuerpo son carnosas y blandas, sin envoltura córnea. El ano, que consituye por decirlo asi la décimatercia árticulacion, sobresale algo como órgano de movimiento, abriendose en una ancha hendidura Inngitudinal: á veees se presentán dos apénelices en forma de tenazas. I.os conductos iéreos, en runjunto nueve pares, son semilunares; cl delantero en la region dorsal bastante grande. I a cabe\%a carece de ojos, y los robustos anillos torácicos de tarsos.

Fsta fanilia se distingue especialmente de las demás por los caractéres ya citados y por otros anatónicos que podemos cimitir, justificando su nombre en la mayoria de las especies. Se conocen unas dos mil setecientas de estas, diseminadas por toclo el globo, predominando, sin embargo, en la rona tórrida. Ians especies que alli viven son tambien muy superiós, por el brillo de su cuerpo y' la viveza y el fuego de sus cólores, a nuestras especies indigenas Eistas, por regla gene. ral, son pequeñas, poco vistosas y desprovistas de condiciones para que se distinga a su fanilia; no se jresentan nunca en multitudes, y la falta completa de nombres para clasificarlas demucsira cuán poco populares son liasta ahora.

Segun la distribucion de los poros microscópicos de las antenas, visibles en la mayoria de los casos debajo del pelaje, la familia se divide en tres géneros: los juiodidas no presen. tan poro alguno, los caloforidos los tienen en escaso mimero en ambos lados de los artejos, y los buprestidos propiamente dichos los reunen en un hoyito de eacha artejo, cuyo hoyito debe buscarse en diferentes puntos, segun las uspecies.

\section{LOS JULODIDOS - JULODIDAE}

CARACTÉRES.-El primer género, el de los julodiclos, pertenecientes solo à las ronas cálidas, cuenta cil su forma fundamental, es decir, en su género julodis, muy numerosas especies, que se distinguen por el volumen del cuerpo, casi circular en el corte trasversal. Ios elitros relucen con un brillo miciálico y están cubiertos de una especic de escarcha en toda su superficie. ó solo en unas depresiones en forma de manchas. 1.as especies se distinguen además por tener unos mechones de pelo dispuestos en series y por otros muchos carnctéres. I.os mas viren reunidos en familia.

\section{EL JULODIS FASCICULADO - JULODIS FAI- CICULARIS}

CARACTERES. - Iil julodis fasciculnr tiene $11^{m}, 026$ de longitud por $11^{m}$, or l de anchura en el centro y $10^{m,}, 0875$ de grueso en el mismo punto: es propjio del Africa meridional.

En su cara superior, muy rugosa, de color verde metálico, tienc cinco mechones de pelos en cada uno de los elitros, un poco ondulados desde el centro del borde lateral, : otros once iguales en el escudo collar, situados todos in unas de. 
presiones, de modo que casi podria compararse este insecto a un crizo.

\section{LOS CALCOFÓRIDOS - CHALCO- PHORIDE}

CARACTERES. - I os calcofóridos sun las especies mas grandes de toda la familia, y en ellas se reconocen los puros de las antenas, cuando no estan cubiertos de pelos largos y espesos.

Los diferentes subgéneros se distinguen por la longitud proporcional de las dos primeras articulaciones de los piés en las patas posteriores; por la presencia marcada del escudeic, por el macimiento de los dientes en las antenas, y por algunos otros caractéres. Varios subgéneros cxisten en Europa.
EL CALCÓFORO MARIANO-CHALCOPHORA MARIANA

CARACTERES. - El calcóforo mariano, ó gran: buprís. tido de los finos lisos, de color pardo metálico, con polvillo blaucri, tiene cinco prominencias longiudinales lisas en cada uno de los elitros, de cuyos surcos el del centro esti interrumpiclo por dos hojos cuadrados. Este inserto, una de las especies europens de mayor tamano, se distingue por su cuerpo prolongado, eliptico y ligeramente convexo, siendo su longitud de $\left(1^{m}, 026\right.$ i $0^{\circ}, 0,30$. El escudete cxiste, pero es muy pequeño y cundrangular. Ia cabeza es cóncava y las antenas, cuyos artejos son mas largos que anchos, cstin provistas desdc el cuarto de dienies obtusos en forma de sierra.

USOS, COSTUMBRES Y REGIMEN. - Este insecto

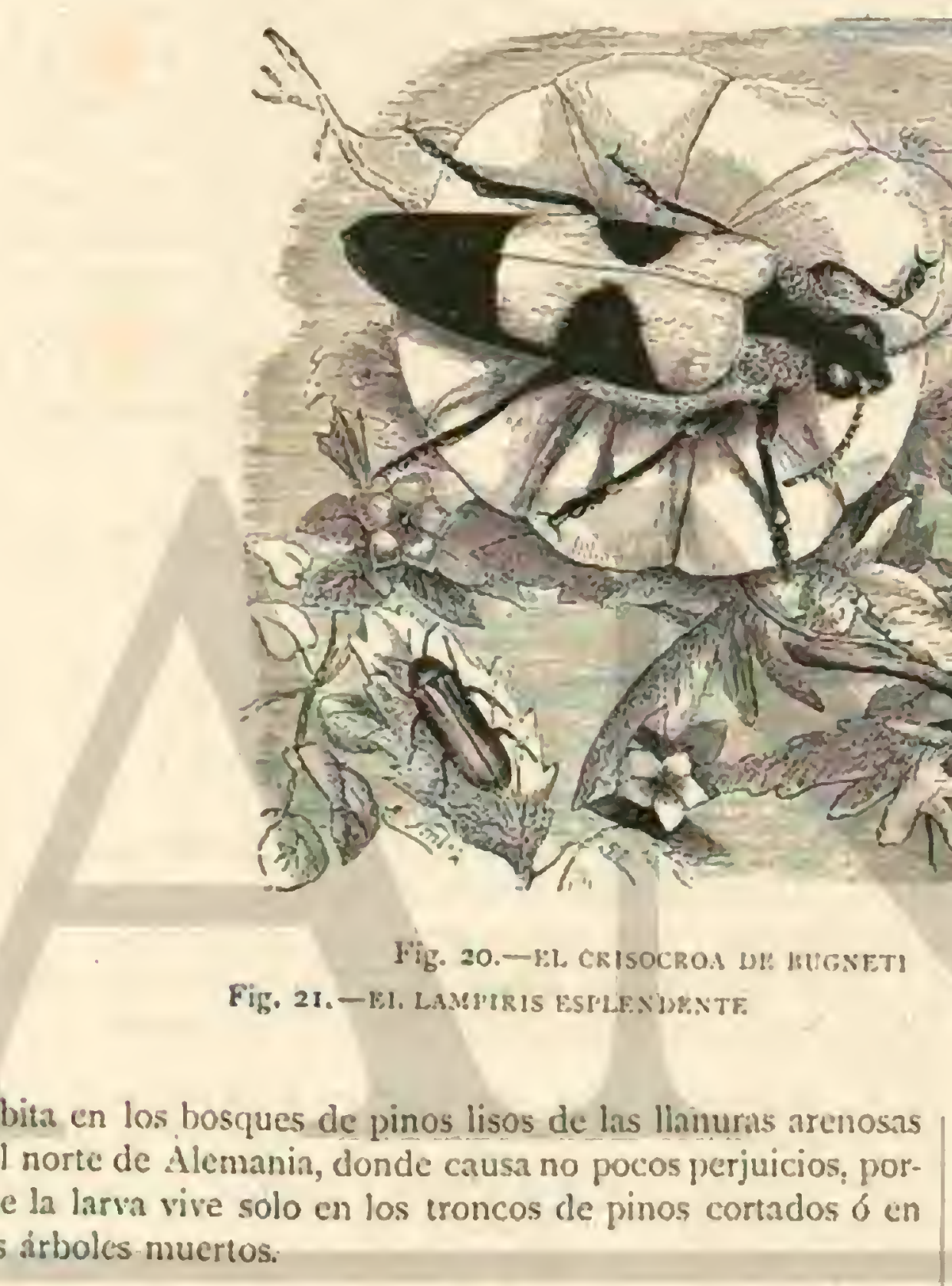

\section{LOS BUPRÉSTIDOS PROPIA- MENTE DICHOS-BUPRESTES}

CARACTERES. - En los buprésticlos propiamente di. chos, cuyos poros se limitan en las antenas a unos hoyitos de los artejos, se ręiten las mismas formas que en el género anterior. Al subgénero poxcilonota (lamspra) pertenece en realidad la especie mas bonita de Alemania que es la siguiente:

\section{EL PECILONOTO DE LOS TILOS - POEGILO- NOTA RUTILANS}

CARACTERES. - Esta especie es de color verde esmeralda, con los bordes exteriores de un roio cobrizo. Los elitros estan cubiertos de linens y manchitas irasversaies negras; el dorso del abdómen es de un bonito azul metálico; de ma. nera que el coleóptero ofrece magnificos colores. Cuanco vucla alcanza una longitud de $\|^{\prime \prime}$, or 1 i $11^{m}$, or 3 .

Tomn $\mathrm{rI}$
USOS, COSTUMBRES Y REGIMEN. - SegUn MiS observaciones, este insecto vive exclusivamente en los tilos, alli donde este árbol favorito adorna los jardines públicos en gran número. Cuando yo era colegial habia notado ya esta circunstancia, y mas tardc, cuando llegadas las vacacioncs emprendi un vinje á la ciudad de Altemburgo para visitar á un anigo que me ensenó su coleccion zoológica, tuve oca. sion de ver varios bonitos ejemplares y de observar que en los tílos de los alrededores de Altemburgo alsundaban estos coléjpteros. De vuelta a mi ciudad matal prosegui mis pesquisas, haciendo varias excursiones at un pueblecito inmedia10 , al que se va por una larga alameda bordeada de tílos. Muy pronto se ofrecieron á mi vista varios agujeros trasversales en forma de lanceta, en bastante número en los troncos anosos !' enfermizos. Yo ignoraba entonces que estos agujeros cran precisamente los del colcóptero buscado, y sin ducla to hubiera ignorado aun mucho tiempo à no ser porgue en uno de ellos vi aparecer de imuroviso la frente dorada de uno de esos insectos. Sin detenerme un instante comencé a examinar el tronco, y no tardé en hallar varios individuos, todos muertos.

A lo que me pareció no habian tenido bastante fuerza para salir del agujero a causa de su major anchura en el centro del ruerpo. Haciendo uso del cuchillo, vime pronto en posesion de varios pecilonotos bien conserndos; y al con- 
tinuar mi pesquisa encontré tambien algunos individuos vivos, asi en los troncos como en el césped seco del suelo. No les vi volar, pero esto me importaba poco entonces, y hasta me convenia, pues solo anhelaba la posesion del bonito coleóptero.

Segun puedo recordar, esto aconteció por la manana, cuando los rayos del sol no habian calentado aun lo bas. tante la coraza metálica; pero llegada la hora en que son mas agiles, hora en que otros muchos insectos duermen la siesta, apenas seria posible, a no tener red y gran habilidad, coger ni uno solo de estos ligeros coleópteros, segùn mas tarde he podido reconocer muchas veces con-algunas especies pequeñas de bupréstidos

\section{LOS AGRILINOS - AGRILIN AE}

CARACTERES. - Ias esjecies del subgénero agrilus difierén esencialmente de sus congéneres por la figum de su cuerpo, pues los lados paralelos afectan una forma bastante cilindrica y el dorso es aplanado.

Los palpos maxilares ierminan en un artejo oml, las anienas se hallan insertas a mucha distancia de los ojos, en grandes cavidades de la frente y son denticuladis desde el cuarto artejo. Eil escudo collar es mas ancho que largo, dos reces escotado en el borde posterior; el escudete, triangular: los clitros mas anchos por detrás del centro, pero relativnmente d su longitud vienen á quedar muy estrechos, terminandó en una punta ancha y redondeada. En las patns se observa que el artejo de la base es muy laggo y comprimido en los pies, y las garras hendidas. Las especies, muy dificiles de distinguir, estan diseminadas por todo el globo. Muchas veces se presentan en tal número que causan cstragos en los bosiques.

\section{EL AGRILO DE DOS MANCHAS-AGRILUS BIGUTTATUS}

CARA CTÉRES. - Una de las especies mas gralides es el agrilo de dós manchas, bastante comun en lis encinas de Alemania: alcanza una longitud de $0^{\circ}, 0085: 0^{\circ}, 011$. El macho es de color retúc arulado y la hembra dè un pardo rerdoso; en el tercio posterior de cada elitro, se re cerca de la sutura, una mancha de pelos blancos, los cuales, junto con unas manchitas iguales en los lados de los segmentos abdominales, le dan i conocer con facilidad.

La larvir de esta especie, como la de los otros agrilos, acaba en forma de tenaza: en la corteza de las encinas abre unas galerias irregularmente onduladas.

De igual mancra viven otras especies, las que se encuentran formando grandes sociedades en determinados sitios, sobre todo en la parte mas caldeada de los troncos pequenos ó de las ramas debajo de la corteza: estas especies han cau. sado estragos alguna que otra ver, particulamente en las hayas y encinss.

\section{LOS TRAQUISINOS-TRACHYSINA}

CARACTERES. - Encuentrase con bastante frecuencia en Alemania, en las hojas di los sauces, un insecto peçueño, aplanado, casi triangular, muy brillante y de color pardo, con algunas fajas blancas en zig-zag, formadas por pelos. Este animalito recuerda por su aspecto los antrenos antes citados, pero es un bupréstido muy afine del género que acabanos de describir; es, en una palabra, el traquis pequeño (trachys misuta).

El Africa, Madagascar y las Indias orientales poseen aun algunas especies, aunque las mas de ellas son propias de Europa. Lo mas particular en ellas, y en los otros subgéneros afines (Bracin's y Aphanisticus), es el género de vida de las larvas que no vegetan en la madera simo en las hojas. Con respecto al desarrollo del traquis pequeño se sabe que la hembra deposita en majo sus huevos en la cara inferior de las hojas de la campanilla agreste (Condoluulus arrensis). La larvia se alimenta de la parte carnosa de las hojas, des. pues de penetrar por la epidermis. Sin practicar galerias, vacia en cuatro ó cinco semanas la mitad de la hoja mudando en este tiempo tres veces: despues de una existencia de quin. ce dias en estado de larva trasfórmase cn insecto perfecto.

\section{LOS CRISOCROAS-CHRYSOCROA}

CARACTERES.-Los crisocroas son insectos de forma prolongada por lo general, bastanie convexos, con las antemas poco robustas y medianamente dentadas. La cabeza es mas o menos cóncava, y al mismo tiempo muy surcadn; el Ióbulo del protórax ancho y redondeado en la majoria de casos. Casi todos los insectos de este género tienen gran talla. y. un color rerde dorado brillante, con fajas ó manchas de un rojo de fucgo, que en algunos individuos se cambian en un amarillo testáceo ó en azul.

DISTRIBUCION GEOGRÁFICA.-I.os crisocroas habitan en las Indias orientales y en Africa, pero se encuentran mas enjecies en este ultimo pais.

\section{EL CRISOCROA DE BUGNETI-CHRYSOCROA BUGNETII}

CARACTERES. - Esta especie (fig. 20) constiture el mas hermoso tijo de la familia, así por su tamano como por sus colores: tiene los lados del tórax cubiertos de puntitos muy redondosy deprimidos, semejantes ia los de un dedal; el color de la cabeza y del centro del tórax consiste en un azulado cobrizo; los elitros son blanquizcos, con una mancha de azul púrpura á cada lado, y otra en la extremidad.

DISTRIBUCION GEOGRAFICA. - En la India es donde se ha observado con mas frecuencia este insecto.

\section{LOS ELATÉRIDOS- ELATERID压}

CARACTERRES. - Los elatéricios, aunn̨ue por su aspecto general y su iorma prolongada y estrecha se asemejan á los bupréstidos, difieren de ellos tan esencialmente por otros conceptos, que es imposible reunirlos en un grupo.

Ia cabeza, en extremo inserta en el escudo collar, se inclima hícia abajo, sin tomar en la mayor parte de los casos una direccion vertical, y está casi siempre oculta en su parte inferior por una especic de peto fornado por una prolongacion del protórax. Las antenas, compuestas de once á doce artejos, se insertan cerca del borde interior de los ojos y son denticuladas, provistas con frecuencia en el macho de una especie de peine, $y$ à menudo tambien filiformes. Fl labio superior es muy marcado; cada lóbulo de la mandibula inferior afecta la forma de hoja, y está provisto de una especie de pestaña; la lengua carece de apéndices latemles; los hojos en quue encajan los costados casi esféricos de las patas anteriores están abiertos jor detris; los costados de las posteriores se ensanchan en forma de hoja y tienen surcos en su cara posterior; pero en todas las especies faltan los trocinteres de los muslos, que en los bupréstidos ofrecen bastante desarro1lo. Los tarsos tienen cortos espolones en su extremidad, y 
cinco artejos, hallandose provistos á menudo en su parte inferior de apéndices lobulares; el abdúmen se compone de cinco scgnentos.

Una particulariclad distingue de tocios los demás coleópte. ros á la mayor parte de las especies de esta familia Como á causa de sus cortas patas se esforzarian inútilmente en volver a ponerse en pie, despues de haber caido de espalda, la naturaleza les ha concedido la facultad de elevar su cuepo en el aire y revolverse en él, para lo cual necesitan gran movilidad entre el protórax y la parte posterior del cuerpo, asi corio una apófisis en la parte posterior y una escotadura para esta en el borde interior del mesotórax. Cuando el coleóptero quic. re aprovecharse de esta ventaja, levanta el centro del dorso haciendo fuerza con el escudo collar, apoja las puntas de los elitros sobre un objeto sólido, y la apófisis del protórax contra el borde anterior del mesotórax. De este modo imprine movimiento por medio de los fuertes músculos del pecho, at la apófisis del protórax, que al encajar en la escotadura del mesotóras (lo cual se verificá con un ruido muy extraño), eleva todo el cuerpo en el aire, en el que se revuelve cayendo despues de pié. Si por la falta de un buen punto de apoyo no consigue su intento la primera vez, el coleóptero continúa abalanzándose hasta que ha logrado su objeio.

USOS, COSTUMBRES Y REGIMEN.-ES muY fácil obligar al coleóptero a demostrnr su habilidad, colocándole boca arriba sobre la palma de la mano: mientras se le mantiene entre los dedos, se sienten y se ven los movimientos del escudo collar, y tambien se oye el ruido que produce. Pare. ce por consiguiente que ejecuta los imorimientos descritos cuando trata de librarse de una situacion penosa. En efecto, el citado movimiento y unas paritas cortas son los únicos medios de salvacion para este insecto, pucs tan pronto comn tocan sus piés el suelo alćjase apresuradamente y jrocura ocultarşe del mejor modo posible. En la fuga no hace uso de sus alas, que emplea solo para posarse a la hora del medio dia sobre las flores, ó para buscar durante la noche a la hembra.

Respecto al género de vidn, las diversas especies tienen distintas costumbres. Unas vagan por el suelo, visitan las ffores para libar su miel, y se vuelven tanto mas viraces cuanto mas ardiente es el sol; otras eligen los arbustos y sus verdes hojas para moradi, encontrindose por lo tanto mas en cl bosque que en el campo y en las praderns. Cuando àlguien se acerca déjanse caer al suelo con las paias recogidas, y entonces se hace dificil encontrar estos insectos, por mucho quê se busque. Hay tambien algunas especies que durante el dia se ocultan debajo de la corteza de los árboles $\delta$ entre las partes pregajosas de los capullos de las coniferas. Todas se presentan en Alemania con la primavera y desaparecen pocoś poco en otolio: ya para morir, ya para invernar antes de propagarse. Hasta ahora se conoce muy poco la historia desu desarrollo, de la qué resulta que estos insectos pasan varios años de su vida en el estado de larvas.

Las larvas conocidas son verniformes, cilindricas o ligeramente deprimidas; tienen rodeado todo su cuerpo de una coraza de quitina sólida y brillante, y ustán provistas de seis patas. A primeta vista ofrecen gran semejanza con el conocidu gusano de harina, es decir, con la larva de la especie tenebrio moli. for; pero el que ve las dos una junto á otra reconoce al junto una diferencia en la forma y posicion de la cabeza. Las larvas de los elatéridos tienen la cabeza aplanada, cóncara en la coronilla, prolongada en línea recta hricia adelanic: en su cara exterior se distinguc por tres fajas cuadrangulares $y$ prolongadas que se tocan en una profunda escotadum del cråneo; las dos exteriores, que se ensanchan hdcia ndelante, representan el tronco de las mandibulas, $y$ la del centro la barba. De la forma del último segmento abdominal parecen depender principalmente las diferencius en las especies.

Estas larvas corren rapidamente y viven en la tierra 6 en la madera putrefacta, alimentándose de sustancias vegetales, por ejemplo, de setas y pulpas jugosas; de modo que al gunas causan bastantes perjuicios en las plantas. Tanzpoco deşrecian el alinzento animal; en tiempo de escaser. se comen unas a otras, y tambien penetran en larvas de insectos. En el último punto de residencin la larva se trnsforma en una crisálida delgada, muy viva\%, que sin duda descansa poco tiempo en una caridad del suelo ó de la madera que la roden

En las colecciones se encuentran unns 3,000 especies, de las que muchas ni tienen siquicra nombre. Estan diseminadas por todas las partes del globo, siendo mucho mas numerosas en las regiones calidas y tambien mas grandes $y$ hermosas que en las templadas, aunque en general tienen mediano tamaño y un color monótono; de modo que entre las especies exóticas y las nuestras desaparece el contraste obsermdo pur este cunceytu en los buprestidos.

I atreille reunió los elatéridos con los bupréstidos y otm familia mas pequeña, los eucnemidos, en el grupo de los es. ternoxios (stemoxia). Tinneo clasificó todas las especies de la familia de que se trata bajo el nombre genérico de Elarer que hoy dia se ha conservado para un reducido número de especies Seria demasiado fatigoso citar aqui tan solo un represemtante de cada uno de los géneros que los sistemáticos indican en el trabajo clásico de Candeze; y de nada serviria caracterizarlos ni atenernos siquicra al órden cientifico. Bastara indicar algunos rasgos esenciales como caractéres distintivos de diferentes grupos; y despues nos ocuparemos de algunas especies mas interesantes. Las exóticas tienen una serie de particularidades que en las de nuestros paises solo se encuentran muy aisladamente ó faltan del todo. Asi, por ejemplo, en cadn lado hay una larga hendidura en la cara inforior del escudete, para recibir las antenas en estado de reposo: esta hendidura forma al mismo tiempo el limite lateral del protórax y el lado de la parte anterior del dorso doblada hácia abajo, carícter que se observa rara vez en nuestras especies: una de las mas comunes, sin embargo, se distingue por este caricter: es el lacon murino, elatérido plano y ancho que segun se dice destruye los tallos de las flores en los rosales y perjudica, cuando es larra, las raices tiernas de los arbolitos en los plantios. In citada hendidura no debe confundirse con otra que parn el mismo fin se halla en algunas especies cerca del borde labial del escudo-collar. La posicion de la cabeza, la circunstancia de que la frente se una desde luego con la parte anterior de la cara, ó esté dividida por un reborde trasversal; la forma de los artejos de las antenas, asi como la Inngind del tercero de estos: Ia forma del escudete; la falta ó presencia de lóbulos nembranosos en ciertas articulaciones de los piés; la forma de los anchos costacios prosteriores, y otros caractéres, deben tomarse muy en cuenta en los elatéridos, cuyo protórax se ensancha en forma de estuche y cuyo metatórax es redóndeado 6 se trunca hácia adclante; mientras que en el último género (Compylida) aquel peto falta y el metatórax remata hacia adelante en punta.

\section{EL ATOO ASPERO-ATHOUS HIRTUS}

CARACTERES - El atoo áspero pertenece a un subgénero representado sobre todo en las regiones frias y templadas del hemisferio septentrional, y es una de las especies mas co. munes que i menudo se encuentran en las flores de las praderas y de los linderos de los campos duranie el vernno. Alli chupa el néctar, y por ia tarde recorre diversos sitios ilumi- 
nados por el sol. Es un coleóptero del todo inofensivo, de unos li",003 de largo por 11",004 de ancho. Su frente está limitada por un reborde surcado en la parte anterior; cada uno de los artejos centrales de las antenas es tan largo como ancho y el segundo mas corto que el tercero; el escudo collar es mas largo que ancho y un poco recogido junto á los ángu. los posteriores, que son agudos y un poco salientes, hallan. dose cubiertos de finos puntos iguales; los elitros, poco anchos, $y$ con ligeros surcos y puntitos, se redondean por detris en una línea conum. I a parte anterior del pecho se ensancha un poco hacia adelante y carece de surcos para las antenas. Los lados de las patas posteriores sc ensanchan un poco hácia adentro; los pies y sus garras son sencillos y la primera articulacion tiene tanta longitud como las dos siguientes juntas. El brillo del cuerpo, de color negro, se oscurecc un poco por los pelos grises, aunque se hallan con bastante frecuencia individuos de elitros pardos.

USOS, COSTUMBRES Y RÉGIMEN. - La larra del atoo óspero nn puede considerarse como inolensiva, porque ocasiona grandes estragos en nuestras plântas cultivadas cunndo se presentan muchas. Tienen la estructura vermiforme de todas las larvas de elatéridos conocidos; la cabeza es carác. tetística por los tres cuadriláteros de la cara inferior; las seis cortas patas torácicas y el solo tegumcnto de quitina, de color amarillo rojizo. El primero de los dos segmentos det cuerpo es doble que los otros, los cuales son iguales entre sf; sobre todos corré un surco longitudinal en el centro del dorso. El últinio segniento, que apenas se estrecha, tiene una escotadura en los lados y se aplana en su parte anterior, presentando varias arrugas; el borde posterior se recorta en semicirculo de modo que al cada lado de la escotadura una apófisis cónica de tres dientes forma en cierto modo dos apéndices Dos dientes de cada uno de estos apendices cuadrangulares estàn dispuestos uno junto a otro, mientras que el tercero, situado sobre el anterior, se dirige hácia arriba. Estos tres dientes, así como las yrominencins obtusas de los lados y las protuberancias del segmento, suclen tener un color pardo. El vientre; de forma aplanada, está un joco mas hundido que los bordes do los escudos dorsales, en curos tepliegues scocultan los estigmas; en el último anillo jresenta un pequeño reborde asquendo que reune los Jaterales; dentro de él y en el anterior del último segmento se abre el ano, que puedé salir en forma de espiga, sirviendo de auxilio en la locomocion.

La larva, fácil de reconocer por el último segmento que acabamos de describir, habita, segun ha observado Candeze, debajo de la corteza de árboles muertos; yo la he visto en el suclo, $y$ tambien en varias plantas, sobre todo en las zanahorias. Asi como la larm del abejorro, devora la punta de la pequena planta, que muy pronto cnfcrma, no pudiendo ya cntonces desarrollarse. En cuanto á la duracion de la vida de esta larva, nada puedo asegurar de positivo, pero sin duda suhsiste maios años, segun suponen todos los demás autores.

\section{EL CUCUYO-PYROPHORUS NOCTILUCUS}

CARACTÉRES, - La América central y meridional, tan ricas en insectos, producer en sus regiones cailidas unas cien especies de elatéridos que ademais de los carnctéres de la familia tienen la maravillosa fncultad de lucir de noche, como las luciérnagas. Son las moscas de fuego, insectos gran. des 6 de tamaño regular, casi todos de color pardo ascuro y cubiertos de un espeso pelo gris amarillo. Perteneren al sub. género pyrophorus, y fảcilmente se reconocen por una mancha de color amarillo de cern, inmediata á cadia angulo posterior del escudo collar: de estas manchas parte la luz mágica que despiden esos insectos. La frente, truncada ó reclondeada, presenta un grueso reborde en su parte anterior, pero carece del trasversal; los ojos son muy grandes; las antenas están aserradas de dientes desde la cuarta articulacion ó carecen de ellos. El escudo collar trasiersal es casi siempre abovedado en forma de cojin, y prolongado en los bordes posteriores en una punta espinosa mas ó menos fuerte. Ias patas, comprimidas y filiformes, están cubiertas de pelo en su cara inferior (fig. 22).

OBSERVACIONES GENERALES. - No debemos ad. mirarnos de que unos insectos dotados porla maturaleza de cua. lidades tan notables como las que ofrece la mosca de fucgo hayan llamado la atencion de los hombres que no conside. ran las cosas bajo el punto de vista de nuestros naturalistas modernos. En la obra de Moufet $\left(16_{34}\right)$, vemos ya un grabado bastante bueno y una descripcion de una especie grande, en la cual se llama al coleóptero cicindela, en griego $C_{\ell-}$ phalolampis, porque su luz no parte de la cola sino de su cabeza, refiriéndose del modo siguiente lo que sobre él se ha leido en la descripcion de los viajes de Oviedo: "El cucuyo, cuatro veces mas grande que nuestra especie voladora (en un pasaje anterior hablaba del lampyris tambien como de un cicindela), pertenece al género de los escarabeos (scarabeoromi). Sus ojos brillan como una linterna, con cuya luz el espacio se ilunina de tal modo que cualquiera puede leer, escribir ú ocuparse en otro trabrjo en su habitacion. Varios individuos juntos dan una luz mucho mas clara, de modo que muchns personas podrian viajar en la noche mas oscura con esta luz, que ni el viento, ni la niebla ó la lluvia pueden apagar. Los habitantes primitivos del pais no se servian de oira luz ni en las casas, ni al aire libre. Los españoles, no obstante, prefieren la luz de antorchas ó de lámparas porque el brillo del insecto luminoso desaparece poco ia poco con la edad; pero cuando de noche tienen que salir al aire libre 6 han de luchar contra un enemigo que acaba de abordar, solo buscan el camino con ayuda de este coleóptero y cargando un soldado cuatro cucuyos engaisan al enemigo de muchas maneras. Pues cuando el noble Tomás Candisius y el caballero Roberto Dudley, hijo del célebre Roberto conde de L.cicester, pisaron por primera vez la costa de las Indias occiclentales y en la noche de su llegada vieron acercarse de pronto por un bosque inmediato una infunidad de luces, como de antorchas encendidas, volvieron presurosos í sus buques creyendo que los españoles estaban en acecho con cañones y mechas encendidas. Alli se hallan varios insectos de este género, pero como el cucuyo es el mas notable de todos, Oviedo pasa en silencio las otras especies. Los indios suelen untarse la cara y el pecho con un ungüento preparado con esos insectos, à fin de parecer hombres de fuego. No se comprende cómo esto puede scr posiblc, pucs con la vida del coleóptero desaparece tambien su luz radiante, ó por lo menos no puede durar mucho tiempo.

Como entre los indios tienen un uso tan general, pues no podrian dormir sin ellos á causa de los mosquitos nocturnos (los cuales caza el cucuyo con la misna aficion que las golondrinas las moscas), ni tampoco trabajar de noche sin estas luces naturafes, han inventado varios medios para cogerlos, los cuales daré a conocer al lector segun los informes de Pe. dro Mártir, 6 de testigos oculares. I.os indios, que están colldenados a la ociosidad durante la noche por falta de luz, salen con antorchas encendidas, y gritando en alta yoz cuccu$y \dot{x}$, cuccuye, agitan aquellas por el aire de modo que los co. leúpteros acuden atraidos por la luz ó caen al suelo. Algunos indios cogen los insectos con ramas y pañuclos, y otros los retienen con redes hasta que se dejan coger con las manos.

x Hay alli tambien otros animalitos voladores que lucen de noche, pero son mas grandes que los de nuestros paises y su 
luz mucho mas clara; brillan de tal mocio, que cuando los naturales emprenden un viaje llevan estos cicindelas viros sujetos en la ropa por la cabcza y las patas; de modo que se les divisa a bastante distancia, atemorizando i los que no conocen la naturaleza del hecho. Ias mujeres no se sirven de ninguna otm luz en sus trabajos domésticos nocturnos.

Excepto el aserto errónco de que los coleópteros cogen moscas, los relatos se han confirmado en lo esencial, y tam. bien puede suponerse que el nombre cucuyo, usado en la Habana, y probabiensente tambien en ol continente, se emplen para designar el pirb́foro noctiluco de los autores modernos. Segun Alejandro de Humboldt y Bonpland, la larva vise en las raices de la caña de azúcar, donde causa á veces considerables estragos: mas parece que, asi como las especies do nuestros paises, no se limita à una sola clase de plantas, pues el coleóptero se ha importado aisladamente con varias maderns a Europa. En 1 766 se vió volar uno en el armbal de San Antonio de Paris, infundiendo terror por las calles; y en el sexto decenio de nuestro siglo, Snellen Van Vollenhoven vió uno en Leiden, que fué cogido en el palo campeche; su luz, verdosa era tan radiante que sin dificultad podia leerse con ella un libro de impresion regular. La misma, ó quizas tambien otras de las especies grandes que en Puerto-Rico llaman cucubano, vuelan desde marzo á mayo a menudo por las calles de los pueblos, encontrandose en los almacenes de madera, de modo que es de suponer que tambien su larva vive en anuella. Los indios cogen estas moscas de fuego ngitando un pedazo de carbon encendido atado en una cuerda, por cuyo medio se atrae á los coleópteros que venden en Veracru\%. Estos insectos se guardan en cajitas de alambre fino hechas a propósito, y se los alimenta con pedacitos de caina de azúcar, bañandolos dos veces al rlia para que por la noche iluminen mejor. Es posible que se les pueda conservar vivos algun tiempo, pues últimamente se han llevado algunos a Inglaterra. La brillante luz de las moscas de fuego se emplea en las diversas regiones de distinto modo. Asi, por ejemplo, se colocan algunos'de esos insectos en calabaz.as vacias con pequeños agujeros, formando de este modo una especie de linternas naturales. Muy ingenioso es el uso que las señoras hacen de ellas para aumentar sus atmctivos. Por Ia noche ponen los colcópteros en un saquito de tul fino, el cual colocan en ciertas partes del vestico en forma de lazos ó rosetas, adorno que se reaima mas cuando con flores artificiales hechas de pluma de colibri y con algunos brillamtes, se ponen como diadema en el cabello. Segun la opinion de Spix, el brillo proviene de una masa encernda en una vejiga cubierta de numerosas tráqueas, cuya masa es, segun dicen, grasosa y granujienta como fósforo derretido.

\section{EL AGRIOTE DE LOS SEMBRADOS} -AGRIOTES SEGETIS

CARACTÉRES-Fil agriote de los sembrados, elatérido en extremo comun de aspecto sencillo, ha flamado la atencion general mas que. otros de sus congéneres á causa de su larva, adquiriendo una triste celebridad. El. cuerpo es menos aplanado que el de la especie que acabamos de describir; la frente no esta scparada de la cara por ningan surco trasversal, sino que se encoria en el centro hácia abajo, formando un borde sobre la boca; las antenas mas filiformes, se componen, además del primer artejo cilindrico, de otros diez de tamaño bastante igual y de forma córnea, pre seritando solo la última la forma de lanceta. El escudo collar, muy convexo en su parte anterior y redondeado en los àn. gulos, es tau largo como ancho y remata en aquellos en fucrtes puntas: las suturas del protórax son dobles y cónca- vas cn su parte anterior, pero sin formar surco para las antenas. En cada clitro se cuentan ocho series de puntos ne. gros dejando intervalos iguales en su centro, de los cuales el segundo y cuarto, contados desde la sutura, son menos oscuros que los otros. Fon los pies, sencillos y comprimidos, el primer artejo es prolongado. Toda la cara superior del colcóptero y las patas son de un gris amarillento i causa de los pelos; en la carn inferior, en cambio, el color negto del fondo predomina mas. Ia longitud del insecto pasa de $(1), \infty$ oog.

USOS, COSTUMBRES Y REGIMEN.-I a circunstancia de que las inundaciones de la primavera sacan a este coleóptero de sus escondites invernales, arrojändole à la entrada aun antes de que despierte de su letargo, demuestra que el agriote de los sembrados inverna antes de propagarse. Vaga por los campos, praderas y caminos, y se aparen. Ia hembra deposita sus huevos cerca de las plantas en el suelo, y la larva se alimenta do sustancias vegetales, crece muy lentamente, y segun parece, vive cuatro anos en el mismo estado que antes de trasformarse en crisilida. Su forma es la de otras larvas de elatéridos: el último segniento re. mata en una puntita obtusa, y tienen en su boca, a cada lado, dos depresiones negras de forma oval; en la parte inferior, delante de su reborde arqueado hallase la abertura redonda del ano, cl cual sirve para la locomocion ciactamente del mis mo modo que hemos indicado al hablar de otra especie. I.os segmentos del cuerpo, muy sólidos, son amarillos, cilindricos y un poco deprimidos, distimguiéndose apenas uno de otro: el primero y duodécimso son un poco mas largos que los demás. In cabeza se adelgaza hicia adelante y es mas oscura al rededor de la boca; las antenas tienen trece artejos; los ojos son visibles, las maxilas tienen dos dientes, las mandibulas son muy prolongadas, con palpos de cuatro artejos y lóbülos en forma de palpos de tres artejos. En la barba, muy rectangular, se inserta un labio inferior triangular en su parte anierior, con palpos de dos artejos y sin vestigios de lengua; desde arriba la frente cierra la abertura bucal por falta de labio superior.

lil 12 de sctiembre recogi doce individuos de estas larvas, que estaban entre las raices de unas coles en un campo húmedo, y las puse en un tiesto, en el que se sembrinon simientes de navina, a fin de que con las raices de estas plantas tuvieran alimento. Cuando las plamtitas alcanzaron I 2 pulgadas de altura comenzaron á marchitarse. En este estado permaneció la maceta que a veces se humedecia un poco en la ventana de la habitacion, bien calcenda. En febrero sembré algunos guisantes que llegaron á tener un pié de largo, pero de pronto tambien comenzaron à marchitarsc. El 6 de julio examiné la tierra, cruzada por numerosas raices fibrosas, y halle tres coleópteros recien nacidos de la especie que nos ocupa, así como las pieles de crisílida, pero ningun vestigio de las otras nueve larvas.

La crisilida, de color blanco, tiene los ojos negros, y sobre ellos una puntita parda, y acaba en dos colitas cortas; descansa sin capullo solo algumas semanas debrjo de tierra

El que se inierese en estas cosas y en los coleópieros, podrí ver como desde la primavera hasta el otoño vagan estos por ciertos sitios buscando su alimento en las fiores de las praderas, pero no debe creerse que los que se han visto en la primavera sean los mismos del otono, pues aquellos han mucrto despues de propagarse, aunque sin duda existen algunos aun cuando nacen los coleópteros jóvenes que hicia el otono aumenian en número, ocultaindose en sus cuarteles de invierno cuando el tiempo les obliga á cllo. La larva está mas diseminada que la del attoo áspero y ha llamado en varias ocasiones la atencion por los estmgos que causa en las plan. 
tas, sin demostrar predileccion por una ni otra clase. Ataca todo cuanto tiene á su alcance, las plantitas de la cebada que acaban de salir; los sembrados de invierno, en octubrey noviembre, aunçue no tanto como los de verano; las plantas jórenes de los guisantes, y tambien las zanahorias que à veces se encuentran marchitas en grupos enteros. Se ha observado que causan mas perjuicio en la tierra ligera que en la pesada, y que ocasionan las devastariones mas considerables en campos recien cultivados. No le basta esto: en las huertas y jardines la larra anuncia su desagradable presencia destruyendo las coles, las lechugas, los claveles, los linos y otras plantas útiles y de adorno, obligando al hombre i perseguirla å muerte.

1)esgraciadamente lós medios aue se han propuesto contra estos enemigos de las plantas han resultaclo insuficientes. Los jardineros ingleses recomiendan los ccbos; en los puntos infestados se colocan durante los meses de verano tronchios de lechuga: las larras, muy audas de este alimento, se presentan de noche en gran número en los cebos y deben recogerse todas las manamas. Para los camplos se propone otro medio que, segun se dice, dí buenos resultados despues cie emplenrlo dos $\delta$ tres años seguidos. Este medio consiste en cortar pedacitos de lino del tamaño de una avellana, que se merclan despues con una regular cantidad de tierrn, introdu. ciénáolos en el suelo á una profundidad de unos $4^{\circ}$, 10. "1'o. das las ares insectivoras, y tambien varios pequenos mamiforos, persiguen a estas larvas y saben muy bien darles caza alli donde se hallan. Curioso es el hecho de que hasta un pecjueno icneumónido sepa encontrar las larvas subtertáneas jara dépositar en ellas sus huevos. Kollar los ha criado dán. doles el nombre de lirneon dispar.

\section{LOS DACILIDOS-DACIL- LIDE}

De la reducida familia de los dacilidos harémencion, noa causa de la mayoria de sus representantes, que sonpenuenos, orales y aplanados, $y$ ofreccn poco interís gencral, sino por la larvi de una especie, que for su forma y genero de vida puede confundirse con un enenigo más peligroso de nuestros cultivos.

\section{EL DACILO CERVINO-DACILLIUS CERVINUS}

CARACTERES. - El dacilo cervino, de color negro de pez, esia cubierto de jelos muy espesos, finos y grises; de manera que solo las caras de los piés y el ano, y a veces los elitros, conservan el color del fondo; las antenas son filiformes, y las patas de color gris pardo. Ia cabeza es mucho mas estrecha que el escudo collar: este último, tan largo como ancho, se estrecha en su parte anterior, reuniéndose estrechamente en la posterior con los clitros, que son casi cilindricos. los costados son trasversales y sobresalen en forma de cono: los piés tienen cinco articulaciones, de las que las cuatro primeras se ensanchan en forma de lóbulos. Este carácter, las maxilas falciformes y fuertes, los lúbulos compucstos de dos membranas y hendicos en la mandibula inferior, y la lengua. compuesta de cuatro partes, constituyen los mogos distintiros de la familia

USOS, COSTUMBRES Y REGIMEN. - Fl dacilo cervino se encuentra con bastante frecuencia en diferentes plan. tas. Fin muestra region no le he visto nunca, pero vive en las montañas de Alemania y Austria, en la Lusacia baja, en la provincia de Brandeburgo, y segun parece en las llamuras de la Alemania septentrional.
A principios de abril de $1 \$_{74}$ me enviaron un gran núme. ro de larmas virns que en la lusacia baja se habian encontrado en inmensas legiones en las raices de las yerbas de una prade. ra, de modo que asi se descubrió un enemigo hasta entonces desconocido de los agricultores. Yo supuse que la larva se hallaba en su juventud y pertenecia á una especic de lanielicornio afine al rizotrogo solsticial, porque muchas larvas de este grupo toman su alimento en las gramineas de las praderas. I a larva de que hablamos se parece por la forma del cuerpo à la del abejorro, distinguiéndose sin embargo por su cabeza grande $y$ la extremidad mas 6 menos delgada del abdómen, qué es truncado y está cubierto en algunas partes de quitina. La cabera tiene poco mas ó menos la forma de la de la larva del abejorro, carece de ojos y está provista de antenas de cuatro artejos. Las maxilas ofreceil una conformacion esencialmente distinta: son un poco encorvadas; tienen en la extremidad un diente sencillo y en el centro otro bipartido. La mandibula inferior lleva palpos de tres artejos y dos maxilas cómeas longitudinales, que rematan en una punta ganchuda bi-partida. Las patas, provistas de una garm, se acercan mas a la linea central del pecho que en las larvas del abejorro. Al enviarme los individuos me dijeron que las cornejas ya no comian estos insectos, y que tres semanas antes solo se habian encontrado larras grandes, que por término medio,tenian (1", or 7 y se sacaban en parte de una profundi. dad de 11,235 . Colocando las larvas en una gran vinsija de cristal llena de tierra, en la que sembré gramineas, obiure desde el 5 de mayo algunos dacilos cervinos con los clitros mas 6 menos atrofiados. En proporcion al número de larvas hubicrn debido obtener muchos mas coleópteros, pero como cricontré pocos restos de aquellas, supongo que estos se devoraron entre si. Los huevos se depositaron sin duda a principios de la primavera anterior.

\section{LOS MALACODERMOS - MALACODERMA}

CARACTERES. - Bajo el nombre de małacodermos ó colebpteros blandos la siguiente familia comprende una infinidad de especies que se asemejan casi exclusivamente por tener los tegumentos blandos de su cuerpo mas coriáceos y por los elitros, que se doblan fácilmente, sobre todo en los individuos muertos. Distínguense además 'por los siguientes caractéres comunes: los costados de las patas medias y anteriores son cilindricos, los de las posteriores trasiversales, los tarsos casi siempre desprovistos de espinns en su extremidad y piés de cinco articulaciones ó de solo cuatro en las patas anteriores. En muchos machos el abdómen tiene de seis á siete segmentos libres, $y$ las antenas son de muy variada forma, que regularmente se componen de once artejos, aunque tambien las hay de dié y de doce La lengua, córnea y membranosa, ca. rece de lóbulos laterales; las dos maxilas de la mandibula inferior, cuyo interior a veces se atrofia, afectan la forma de hoja y están provistas de una especie de pestañas; los palpos labiales están compuestos de tres artejos, y las maxilas de cuatro; las maxilas superiores son cortas. Fn la mayor parte de las especies se notan marcadamente las diferencias sexuales en los dos últimos segmentos del abdómen y en-las nntenas, en los clitros, alas ó piés anteriores.

USOS, COSTUMBRES Y REGIMEN.-Ia mayor parte de las especies de insectos pertenecientes á este grupo se encuentran en las flores y los arbustos; pero por lo regular no para buscar la miel, sino para perseguir su presa. Como los colé́pteros perfectos, ofrecen muchas diferencias dentro de los limites indicados y uada puede decirse, en general, acer- 
ca de las larias, á no ser que tienen seis patas yparecen alimentarse de carne. Volveremos a oruparnos de ellas al hablas de los diferentes géneros.

Tambien tenemos nosotros, como los habitantes de las Indias occidentales, moscas de fuego, que sin cmbargo son de naturaleza esencialmentc diferente de las que scencuentran en ayquellas. Moufet trata en el capitulo décimoquinto de su obra, del cicindelo, y demuestra por los numerosos nombres con que se le ha designado, que, descie remotisimos riempos el hombre del pueblo conoció la facultad radiante de estos insectos nocturnos y que muchós naturalistas han observado su género de vida. Entre los griegos y romanos se les designó con numerosos nombres, que indican la facultad radianic y en parte tambien el punto en que se produce, tales como Inmpuris, pygolanpis, kysolampis, pyrolampis, bostrykos, fyrgolampis, etco, entre los primeros, y entre los segundos cicirdela, nocticula, nisedula, Iucio, Iwewla, Iuciola, Iucernuta, zsuns, etcétera. Los pueblos latinos han consernado uno is otro de estos nombres, ó los han trasformado cada uno ds su manera. Los italianos llaman a este coleóptero iuciola, iucio, farfalla, bistola, fucgola, laceriola, Iniserda; los españoles luciérnaga; los polacos sknotnike, chreazezik, sivienng; los húngaros eleltaiudocklo, bogaratska, vilantso; los franceses Ver luissant, mouche dairc; los ingleses gloworme, shine-atorme, glassaworme y los alemanes les designan con los nombres zindusele, liegethmugh, sindauurmile hablando del macho; pues en muchas especies de Alemania el macho alado ecicindela no brilla, poscyendo esta condicion solo la hembra, llamada gusario de la yerba, gugle, colóptem de fucjo. En la region de Francfort sobre el Mein, el insecto se llama mosca de San Juan. Despues de esta cnumeracion de nombres, el autor inglés ariade: I Ios machos ó los cicindelas alados no lucen tampoco nqui como en las provincias Yisscongadas de Espanaa; solo las hembras, que son gusanos, producen la luz: mientras que las de Italia y de los alrededores de Heidelberg carecen de la facultad de brillar, poseséndola en cambio los machos. A los filósofos dejo la averiguacion de la causa. Despues el autor describe minuciosamente el macho alado, diciendo que en la extremidad del abdómen tiene dos manchas en forma de luna, que son las que producen de noche una claridad semejante a la del azufre encenclido, por lo cual parecen ascuas fotantes en el aire. Al describir la hembra no alada dice que es un insecto de forma de oruga que se arras. tra lentamente, alimentandose de sus propios excrementos; y que de la extremidad blanquizca del abdómen (los tres últimos anillos), emite un brillo maravilloso que en cierto modo simila unas estrellas y que parece compctir en claridad con la de una linterna ó la de la luna. Además, segun las observaciones de dos hombres célebres, se asegura que el apareamiento dura desde la noche hasta el medio dia siguiente, que el macho muere en seguida $y$ la hemira veinte horas despues de haber depositado muchos huevos. El autor no comprende las noticias de Aristúteles sobre el desarrollo, $y^{\circ}$ concluye su docto tratado con una poesia de Antonio Thy lesius, en la que se celebra al cicindela volador.

En aunellos tiempos pues ya se sabia que la hembra carece de alas y que existian varias especies. En Alemania exis tén dos de las que una ú otra predomina segun la region

\section{EL LAMPIRIS COMUN-LAMPYRIS SPLEN- DIDULA}

CARACTERES.-El mas pequerio y mas generalizado de estos insectos es if lampiris comun. El macho, de color pardo, se reconoce ficilmente por las dos manchas vidriosas del escudo collar, que tambien pueden soldarse i un borde anterior trasparente; la hembra, de color blanco amarillento, se distingue por dos lobulitos situndos detrás del escudo collar que son por lo menos un indicio de los elitros: aciemás se caracterizan ambos sexos por sus maxilas delgadas falriformes. Ina larva, que es vermiforme, tiene seis patas muyabierias y la cabeza muy pequeña, invisible en el estado de reposo. Todos los anillos del cuerpo tichen poco mas ó menos la misma longitud, el último afecta la forma de un: cminto compuresto de dos circulos de radios cartilaginosos reunidos entre si por una piel geiatinosa. Estos dos circulos radiados pueden extenderse y recogerse constituyendo un instrumento de limpięa necesario para el género de vida de este animal; la larm se alimenta de caracoles y' esta siempre muy sucia, a causa de la sustancia mucosa segregada por anuellos y de las particulas de tierra adheridas. Si se toca con un pincel el cuerpo de esta larva, este expele la porqueria, lo cual puede haber dado lugar á la creencia de que la hembra confundida con la larra, se alimenta de sus propios excrementos.

\section{EL LAMPIRIS NOCTILUCO-LAMPXRIS NOCTILUCA}

CARACTERES. - El lampiris noctiluco, ó luciérnaga, tiene las maxilas salientes, carece de manchas vidriosas c'll el escudo collar y presenta en cambio dos relucicntes y mas pequerias en la extremidad del abdómen, y de consiguiente no puede brillar tanto: su longitud es de $0^{2}, 011$. La hembra, que mide de $10^{m}, 015$ i $0^{n}, 0175$ carece de los munones de los elitros; de modo que tiene la forma de una laria, distinguiéndose de esta, sin cmbargo, por el escudo collar mas grande y desarrollado, por la cabeza monos oculta y' por su mayor facultad luciente.

DISTRIBUCION GEOGRÁFICA.- Ėsta esprecie parece que se encuentra con mas frecuencia en Francia y en el Sud de Alemania, que en el centro de este últimó pais.

USOS, COSTUMBRES Y REGIMEN.-I.OS Sitios himedos, cubicurtos de maleza, a orillas del agua, alimentan numerosos carncoles terrestres y son por lo tanto la verdadera residencia de los lampiris.

En las calurosis noches de verano tienen lugar en estos sitios unos espectículos que dejan muy atras las concepciones fantasticas del pais de las hadas y clfos, espectáculos que hacen carrtar à un poeta- sentimental como Klopstock en su Fiesta de la primavera: \&e Pero tú luciérnaga de la primavera sque a mi lado retozas, vives alegte en tu restido verde dorado, quizas ajena a la inmortalidad. Centenares de chispitas de fuego se agitan brillantes for tl ambiente embalsamado y cuando ante la vista deslumbrada una se extingue, vuelve a presentarsi otra que gira silenciosa pero vertiginosamente.

Aqui y aculls, en el hímedo suclo respiandece una migica huz. fosforescente, iluminando los tallos y las hojas de las grn. mineas, el musgo y las piedrecitas, luy que se extingue luego desrancciéndose en una niebla nebulosa, mas tenuc cadasez, Irasta que cede por fin ì la tenebrosit noche: esta luz esti fija en un mismo punto y a pesar de su maravilloso brillo no puede calentar. Las estrellas errantes son los machos: Jas estrellas fijas mas radiantes en la yerbas, las hembras: y unas y otras forman en cosijunto una verdadera danza de antorchas, la danza del himeneo. Al asomar la aurom por el horizonte la fostorescencia ha desaynrecido; y la chisplita dive hoy lucia, manana se extingue para siempre, cuando para ella himenco ha encendido la antorcha nupcial: mientras no to ha efeco mado vaga todas las noches por los contomos, continuando su vida ermnte.

De dia queda oculto este animal en la jerba, de la que 
tambien se alimenta, cuando la suerte te ha concedido vida mas larga. En los años en que escascan las luciérnagas, aquella magica danza de antorchas picrde mucho de su brillo por el reducido número de los concurrentes, y además porque cuando se efectua el apareamiento del lampiris noctiluco, los machos producen una lu\% mas débil que la especie co. nun, a la que tambien se refiere lo dicho en mi descripcion anterior: los efectos del apareamiento son sin embargo siem. pre los mismos. Los huevos redondos, de color amarillo, depositados en el suelo, se desarrollan pronto en larvas que en estado adulto solo puede distinguir el inteligente que seja buscarlas; pues aunque tambien despiden cierta luz no se descubren fácilmente por ser estr débil y reflejarsé en el suelo. Al cabo de algunas samanas se trasforman en crisulida de forma diferente, y de ella sale un macho ó una hembra Ia crisi lida masculina presenta las alas futuras como lobulicos y tieue perfectamente la forma de una vinfa de coleúptero, mientras que la crisilida femenina forma el tránsito entre la larva y la hembra. larga seria la tarea de indicar minuciosamente la diferéncia de los tres grados de desarrollo, y por eso solo designamos á la ninfa de la hembra como una larva un poco encorvada é inmóvil.

Los órgnnos mdiantes se componen de numerosas cerdas, cncerradis en cápsulas de paredes delgadas y de forma poligonal, cuyas cardas son en parte tmasparentes y en parte están provistas de una masa carnosa, y además dé una espesa red de deliandas tamificaciones de las tráquias.

Kobbliker cree que las cerdas trasparentes son el elemento luminico, y que la lus depende de la voluntad del animal y de los nervios correspondienies; Matteuci, en cambio, es de opinion que la masa radiante arde i expensas del oxigeno que se introduce por las traqueas. I.o cierto es que la tuerza luminosa, mediana solo en el estado de descanso, sé aumenta considerablemente, a causa de la excitacion exterior, volviendo a disminuir, sin embargo, cuando esta excitacion es cxcesira.

Otras clases de lampiridos, que se extienden por todos los paises del globo, viven en mayor numero en la Amé. rica meridional. Estos lampiridos ofrecen las formas mas di. ferentes, aunque en su mayor parte aladas en ambos sexos, y la conformidad que guardan entre sí y con las de nuestros paises estriba en que la cabera esta oculta, casi siempre, por debajo del escudo collar, ensanchado y redondeado en su parte anterior; los palpos son fuertes; las antenas se insertan en la-frente; los costados de las patas comprimidas se tocan, y en el abdómen algunos anillos con manchas claras indican el sitio de donde parte la luz. Segun parece, en las diversas especies las hembras aladas no difieren de los machos esencialuente por su género de vida.

Osten Sacken, al hablar de la especie mas comun de los alrededores de Washington, la lighming bug (shosinus pyrnlis), dice poco mas ó menos lo siguiente: El macho y la hembra se parecen en un todo, con la sola diferencia de que el primero tiene las antenas mas largas y la facultad de brillar mas desarrollada; pues en él lucen dos segmentos enteros del abdómen, mientras que la hembrn solo tiene una mancha semi-redonda luciunte en el'segmento antepenúltimo y dos pequeños juntos en el penúltimo. La luz produce verdaderos rajos, y si se sujeta al cóleúptèro con las manos, deslumbra su brillo. Al ciscontrarse en uma pradera humeda se goza de un espectáculo parecido al arriba descrito. Despues de la puesta del sol elévanse miles de coleópteros en linea vertical por el aire, vuclan a cierta distancia, bajan à poco para remontarse de nuevo; y como no brillan sino al subir, solo se les ve al clevarse: los machos llevan el cuerpo vertical cuando vielan, de modo que el abdómen jende como una lin- terna. De tiempo en tiempo el uno ó el atro sostiene el vuelo probablemente para buscar a la hembra en la yerba. Las hembras permanecen tranquilas, colocando el abdónen hacia arriba para hacer radiar la luz y llamar la atencion de los machos. En un principio puede observarse con claridad el vuelo de los coleópteros en su conjunto y aislados. Entonces se ve cómo, despues de columpiarse algun tienıpo en cl aire, el macho baja, asi que la luz del dia ma extinguiéndose, a fin de posarse a cicta distancia de la hembra, con la que por fin se reune para aparearse; los machos que entonces se observan aun en el aire, son los que no han encontrado una companiera.

\section{LOS TELEFORINOS - TELEPHO- RIN Æ}

Muchos de mis lectores tendrain tal vez noticias por los periódicos de unos agusanos de nieve que, segun se dice, caen, con la primere lluvia de invierno, sobre la niere. Ya en I672 50 ubservú y apuntú cuidadosamente este fenómeno el zo de noviembre en Hungria; un milagro igual se verifico, segun refiere Degeer, en enero de 1749 en varios puntos de Suecia. El citado autor menciona la circunstancia de que y: antes se encontraron tales gusanos en medio del hielo y de la nieve de un lago; de modo ąue tal vez el viento los habia traido. A fines de un invierno unuy riguroso (I I de febre. ro de 1799), aquel fenómeno causó en las regiones del Rhin tal isombro, que las respectivas declanciones de los que en aquel dia ascuruman haber visto la lluvia de los insectos al aire libre, se consignaron en el tribumal del canton de Stromberg. Como era de suponer, las jersonas supersticiosas, acosumbradas a ver siempre la ira de Dios en tales fenómenos de la naturaleza, creveron entonces reconocer tambien los mas infalibles indicios de peste y carestia: y todos los horrores de una nueva guerra.

En febrero de i 8 i l los mismos gusanos se observaron en Sajonia, y el 30 de enero de 1856 en Suiza En este pais, sobre todo en Mollis (canton de Glaris), cubrian los insectos de un tamaño de $0^{m}, 013\left\{6^{m}, 033\right.$ una superficie de nieve de 25 a 30,000 brazas cuadradas; de tal modo que en cada braza se contaban de cinco a seis individuos y de doce á quince cerca de los bosques. Se llegaron á encontrar algunos en los techos del puéblo. En todos los casos citados el fenó. meno tenia su explicacion racional. Todos los datos convicnen en que aquellos gusanos, que a continuacion describiremos, y de los que por ahora solo diré que pasan el invierno dcbajo de las piedras, en la hojarasca $\delta$ en las raices de los arboles, se habian visto obligados por causas muy distintas a salir de sus escondites. En un punto era debido a la cicesiva humedad, á consecuencia de continuas lluvias: $\delta$ bien al grado de calor; en otros it que los lenadores habian revuelto el suelo al cortar los árboles de un bosyue; pero en todos los casos se obstrvó que una violenta tempestad ó un huracan trajo consigo dichos insectos, jumtanente con otros que observan igual género de vida, y como iban à parar á los campos cubiertos de nieve, se los podia observar con facilidad. I. mismo puede suceder con frecuencia cuando falta la blan. ca capa de nicve: entonces no se ven los irsectos, que, sin embargo, pucden cubrir el suelo en el mismo crecidisimo número. En otras ocasiones, aun cuando no falta la capa de nieve, los insectos no se presentan, porque el ano anterior su número era tan pequeno, que los pocos individuos llevados por la tempestad, no llamaban la atencion. Asi queda explicado todo el milagro que se nos presenta ya como cosa muy natural.

Debemos preguntamos ahora: ¿cuåles son los gusanos de 
que se refieren cosas tan interesantes? No es preciso ir a buscarlos a Hungría, Suecia ó Suiza, ni tan siquiera esperar una de las llamadas lluvias de insectos. Dirigiéndonos al lindero de un bosque ó de un campo, o a otro sitio parecido, y levantando una piedra un poco grande, encontraremos en invierno en un hoyo redondo, cubierto de un poco de tierra, en posicion semi-lunar, un animalillo negro aterciopelado, $y$ si aguardamos un tiemplo mas benigno, le encontramos ocupado, fuera de su nido, en devorar á uno is otro de sus ptqueños companeros. Tambien se nos presenta a reces en los caminos para chupar algun pequeño colé́ptero muerto de una pisada. Por doquiera que le encontremos, siempre lo reconoceremos en seguida pot el oscuro fieltro aterciopelado de que toda su cara superior esti cubierta, de tal modo que solo la parte anterior de la cabeza queda libre. Esta es aplanada, córnea, provista de dos ojos, de un par de antenas cortas de tres artejos, carece del escudo y de labio superior; las maxilas son cortas y sólidas, con un fuerte diente en el centro; los palpos maxilares se insertan en una esrotadura semicircular; el labio inferior, bastante grande, tiene dos palpos de dos aricjos. Las cortas patas de que esti dotado en los tres primeros segmentos del cuerpo, nos demuestran, además de los caractérès ya citados, que tenemos à la vista, no un gusano, sino una larva de coleóptero.

A fines de marzo ó à principios de abril del ya citado año, cuando las larvas cran muy frecuentes, podia observarse cóno una ú otra cogia una lombri\% ó uma larva de mosq̨uito, agarrándose de tal modo å su presa, que se dejaba levantar con ella: la chupan primero y a veces la comen tambien del todo. Èn tiempos en que aun no conocin a estas larvas, al buscar órugas en primavera habia puesto algunas de estas juntas con aquellas y entonces pude convencermt con toda seguridad de que apenas podria traer una oruga sana y salva à mi casa; la mayor parte estaban mordidas por las larvas del coleóptero y hasta muertas; de modo que estos animales demuestran ser muy útiles a los horticultoris y agricultores. En abril 6 mayo las larvas se vuelven mas pesadas en sus movimientos, y poco a poco mas cortas; al cabo de cinco ó seis dias mudan la piel y se trasforman en una crisálida de color rojo pálido, un poco encorvada hácia adelante y yrovista de ojos negros.

Cuando la primasera despliega toda su riqueza, cuando el espino negro ha dispersado ya en todas direcciones la nieve de sus delicadas fores, abandonando el premio de la belleza a su hermana, el espino blanco, cuando las golondrinas han vuelio à encontrar sus nidos del año anterior $y$ los han pre. parado para sus hijuelos, cuando miles de insectos hace muchos dias que abandonaron sus escondites de invierno ó la frágil cubierta de crisilida; entonces se presenta un coleóp. tero delgado, negro, no muy bonito, parm posarse sobre las Dores que en gran varicdad se le ofrecen, sobre todo las de los numerosos arbustos; este roleóptero vuela calentado por el sol de una à otra rama ó se agarra, como el abejorro en ticmpo húmedo y desagradable, al ramajé, lleno; de mal humot.

CARACTERES, - El teleforo oscuro (Telephorus Fisscus), pues de este colcóplero se trata, esta cutierto de finos pelos grises: la base de las antenas, de once artejos, es de color rojo amarillo y se haila inserta é la frente; del mismo color es la parte anterior de la cabeza, que se inclinat y queda oculta en parte bajo el escudo collar; este último es redondardo, y en el abdomen se cuentan siete segmentos. I as patas, relativamente delgadas, tienen todas piés de cinco artejos, de los que el penúltimo està hendido en dos lóbulos. Ia garra exterior de las patas posteriores ticne en la base un pergueno diente yue falta en las demás. En el conjunto de estos caracteres se funda la diferencia entre esta especic y varios centenarts de otras muy parecidas (llamadas antes ianthares) que estan diseminadas por todo el globo, y que son propias de las regiones trias y sobre todo cle las montaIas: i estas pertenecen las larvas que han dado lugar a las *lluvias de insectos. Todas guardan conformidad en la lengua, gruesa y provista de pelos, en la maxila exterior redondeada de la mandibula inferior, en la maxila interior estrecha y puntiaguda y por fin en la forma del cuerpo.

USOS, COSTUMBRES Y REGIMEN. - Para encontrar su elemento buscan los colcópteros con preferencia las plantas en flor, donde dan caza á otros insectos que se presentan para sacar la miel. Sin embargo, parece que no son exclusivamente carnivoros, sino yue tambien chupan jugos vegetales, y la especie citada lo mismo que oira muy afinc (Telephorus obscurus), suelen comer los retonos del fresno, por manem que las puntas de estos se secan. Es errónco que una especie aniarilla de barro, de las que existen varias en Alemania, produzca los granos negros del trigo, curruyéndulos mientras están blandos.

El género de que acabamos de hablar y otros propios con preferencia de la América, se distinguen por los siguientes caractéres comunes: la cabeza libre; el escudo no separado; el labio superior poco marcado; las patas no comprimidas: cl trocinter del muslo, situado en la cara interior de este últi. mo: la cuarta articulacion de los piés bipartida y el abdómen compuesto de siete segmentos. I'odos los citados géneros se han reunido en el grupo de los icleforidos.

\section{LOS MELÍRIDOS-MELIRIDE}

CARACTERES. - En este gnupo, cuy̆as especies se encuentran exclusivamente en las flores y pque se distinguen por cl modo diferente con que aparecen insertas las antenas y por el escudo de la cabeza marcadamente separado. la que mayor interés ofrece es el gran malagsio (malachisus seucus). Solo mide 11,0065 , pero es la especie mas grande de las numurosas que componen su género, propio de Europa y de las regiones limitrofes del Asia y del Africa. El cuerpo, que tiene igual forma que el del teléforo, es de un color verde urillante; la parte anterjor de la cabeza de un amarillo dorado: los angulos anterioras del escudo collar y los clitros de un rojo escarlata, excepto una gran mancha verde en la sutura. En el macho el segundo y tercer artejo de las antenas, que son filiformes, remata hácia abajo en un gancho; las antenas están insertas á mucha profundidad en la frente, de la cual sepirase marcadimente el escudo cuadrangular de la cabeza. Fiste melirido tienc, como todas las demás especies, la facultad de hacer salir de los lados del cuerpo unas j)rotubemucias rojas cuando se le toca ó irrita.

USOS, COSTUMBRES Y REGIMEN.-Este coleóptero, comun en codas partes durante la primavera, tiene cierto valor para la agricultura, porque persigue las larvas del meligetes de la nabina.

Ias larviss de todo el género tienen mas de un - ocelo en cada lado, estan provistas de seis patas y terminan en dos puntitas carrosas. Viven por lo regular ocultas detris de la corteza de los airboles, en techos viejos de paja, erci, mas bien yue libremente en la superficie de las plantas.

\section{LOS CLÉRIDOS-CLERIDE}

CARACTERES. - Fil clerido formicario (elerus formionrivs), representa la familia de los cléridos que se compone de mas de seiscientas especies, en su mayoria cxúricas. El citado coleóptero se presenta con frecuencia en los boscques 
de conifirns, pero sobré todo en los troncos cortados. En cllos corre, como una hormiga, persiguiendo a su presa que preferentemenie se compone de escolitidos. Cuando han cazado uno le sujetan con las patas anieriores y devóranle. El escu. do collar y la base de los elitros, hasta la anterior de las dos fajas tmaversales, lo propio que la cam interior del cuerpo (que por lo demás es negro), son de color rojo. I as cien especies próximamente de estos coleópteros, abigarradas todas cllas, se encuentran diseminadas por todo el globo, y tienen como caractéres comunes: una lengua bipartida, un grande artejo en la extremidad de los palpos labiales, la barba cuadrangular, el labio superior y los ojos escotados, del sexto al octavo artejo de las antenas mas cortos que los anteriores, y los tres últinos reunidos en forma de una maza, poco fuerte y denticulada. la parte superior del escudo coIlar que tiene forma de corazon, estrechandose ell la base, se suelda a los costados y es mas angosta que los elitros paralelos. Ins patas anieriores tienen los lados inedianamente salientes yo dorma cilindrica; los costadus de las centrales son casi esféricos; los de las posteriores quedan cubiertos por los muslos; la primera articulacion del pié, muy corta, esta cubierta por la segundas de modo que solo parecen existir cuntro.

Fn la lárva, de color sonrosado, el escudo collar está completo en el dorso; los dos segmentos siguientes, cubiertos de quitina, ajparecen solo en forma de nianchas. La cabeza tiene à cadá lado cinco ocelos en dos scries: debajo de una prominencia mas arrịba de la base de las maxilas, hállanse las antenas, de dos artejos; el escudo de la cabeza es angosto y apergaminado, un labio superior prolongado, con una escotadura en su parte anterior: los palpos maxilares cortos y compuestos de tres artejos, los labiales de dos, que se insertan en troncus córneos soldados en la bast. Esta larva réune mejores condiciones para los bosques que el insecto perfecto. pties persigue detrits de la corteza de los arboles las larnas de los diferentes parisitos.

\section{LOS TRICODES-TRICHODES}

CARACTERES. - Mas fuerte es la estructura de los tricoles, coleópteros por lo regular muy peludos, de color azul oscuro ó verde brillante, con clitros rojos y fajas azules, ó elitros azules y fajas rojas. El labio superior es casi cua. drangular, la mandibula superior provista en la punta de tres dientes, la inferior compuesta de -dos lóbulas framjeados y largos palpos filiformes, el artejo en la cxtremidad de los palpos habiales, que aun son mas largos, es triangular, lo mismo que la maya aplanada de las anienas, compuesta de los tres últimos artejos; la escotadura de los ojos es igualmente triangular. El escudo collar, cilindrico, se estrecha hacia atrás; los elitros ticnen igual forma que los de los cléridos. 'Tambien aqui la primera articulacion de los piés es mas curta que las otras, mientras que la segunda de las patas posteriores afecta la forma de un largo cilindro.

USOS, COSTUMBRES Y REGIMEN. - las veinticinco especies conocidas son propias casi exclusirumente del hemisferio septentrional; preséntanse en las flores, para perseguir á otros insectos.

\section{EL TRICODES APIARIO-TRICHODES APIARIUS}

CARACTERES.-El tricodes apiario mide $0^{\text {" }}, 012 \mathrm{de}$ largo y es de un color negro axulado brillante, provisto de es pesos puntos y de jelos ásperos; los elitros, cujos juntos son mas grucsos, se, cusanchan ligeramente hacia atras y son de un color rojo vivo, excepto la punta y dos fajas trasiersales.

USOS, COSTUMBRES Y REGIMEN. - Se le encucntra desde mayo á julio en los sitios indicados, en Alemania.

La larva se parece mucho à la del clérido, si bién es un poco mas recogida y mas gruesa en su parte posterior. Permanece desde julio hasta abril del año siguiente en las galerias de los siricinos (sirex), á los que persigue, en los nidos de varias abejas silvestres (osmia, megachile), y tambien en los de la abeja doméstica, donde come las larvas crisálidas de las abejas medio muertas. Se encuentra particularmente en el suelo de colmenas sucias, ocultándose entre las rendijas; pero cuando ha entrado en un panal, practica galerias en su interior y come las crias sanas: solo cuando estas no existen, se aleja y pasa el invierno en la madera. En abril empieza otra vez á comer, hasta mayo, y entonces penetra en el suclo, trasformándose á los tres ó cuatro dias en crisálida. Al cabo de cuatro ó cinco semanas nace el coleóptero. Muchas larvas parucen crisalidarse ya al primer año, invernando en este estado; tstas producen ya en majo siguiente los coleopteros.

\section{EL TINO LADRON-PTINUS FUR}

CARACTERES. - El tino ladron es uno de los desagradables companieros de lá casa, segun ya hemos tenido ocasion de ver, al tratar de los derméstidos y otros de estos parásitos. Como estos, vive oculto en los rincones y sale casi solo de noche, subiendo por las paredes en busca de su presa. Su larva, de color blanco gris, que solo mide $0^{m}, 0045$, tiene la cabezal parda sin ojos; las antenas muy cortas; maxilas fuertes: seis patas y un cuerpo peludo, que puede encorvarse. No parece agradarle el cainpo raso; fija su residencia con especialidad én los herbarios y colecciones de insectos, donde crusi grandes estragos, en los depósitos y almacenes de vivere, y en una palabra, en todas partes donde se conservan comestibles que no se hayan tocado en mucho tiempo. En todos estos sitios esta larva encuentra su alimento necesario. En agosto rodea su títimo lecho de una especie de capullo, se trasforma en crisilida, $y$, al cabo de quiuce dias, en un coleóptéro pequeño que alcanza apenas $0^{\mathrm{m}}, 0035$ de largo, cuyo aspecto varia segur el sexo. Ia hembra tiene los elitros ovales, con manchas blancas en la parte anterior ! posterior: el macho los tiene casi cilindricos y sin manchas, con fajas ondeadas, un escudo collar casi esférico, pero en su parte postcrior estrechado, con cuatro prominencias formadis de mechones de pelo en su disco, muslos en forma de maza y provistos de un tallo: el color pardo de orin del cuerpo es propio de ambus sexns y sirre para distinguir $\dot{z}$ esta especie de las otras.

El género ftimus se reconoce por su cabezal recogida; antenas filiformes con los artejos cilindricos á contar desde el cuarto; ojos redondos ý salientes; artejo largo y cónico en la extremidand de los jalpos; el escudo-collar estrechado en su parte postcrior, cuyo dorso se suelda con los hipocondrios, y costados cilindricos poco salientes en las patas anteriores, algo ensanchados hicia adentro en las posteriores.

\section{EL TINO AMARILLO DE LATON-PTINUS HOLOLEUCUS}

CARACTERES. - Alguna que otra vez se presentan en las riviendas humanas otras especies del mismo género, como por ejemplo, el tino amarillento de laton, especie importada en Alemania por el comercio, y que ha llamado bastante la atencion. Este coleóptero con el escudo-collar esferico, y los 
elitros anchos, de forma nval, se distingue por los pelos sedo. sos y espesos de color amarillo de laton que cubren su cueppo. cuyo color predominante es negro. 1 causa de su estructura recogida y de la escotadura del labio superior, asi como por tener un diente en el centro de la barba, que es puntiaguda, esta especie la sido elegida como tipo pam formar un género indep̧endiente (riptus). Hace muchos años que este animal llegú de Inglaterra y vino á figumr en las colecciones de los alemanes. Ultimamente se ha encontrado vivo en algunas casas de Hamburgo, Zwickau y Rosswein; yo le recibi a funcs de abril de I\$ $\$ 3$ tambien vivo, con la noticia de que, á pesar de su extremada propagacion en los almacenes de Quedlinburgo, comenzaban â disnimuir en número; por fin le observé en mi propia casa, donde probablemente se le importó en objetos de cristal. Eil coléptero es originario, sin duda, del lejano Oriente, pues Falderman fué el primero que le nombró y describió en su fauna trascaucisica. No se ha propagrado hasta ahora en Alemania al aire libre; por lo menos no se sabe de cierto.

\section{LOS ANOBIOS-ANOBIUM}

CARACTERES. - Los anobios viven en estado de larv' en la madern muerta, con preferencia en las coniferas ú olmos, en los tilos, abedules, alisos y otros trboles que se distinguen por su blandura; de modo que pueden causar considembles perjuicios en los parijes donde no se les molesta, como por cjemplo, en las iglesias, en los castillos deshabitados, en las imágenes, esculturas preciosas, etc. Con el cuerpo encorvado y recogido, como la especie anterior, y provistos de seis pequenas patas, abren galerias en la madera, por su interior. seduciéndola poco i poco a polvo y fragmentos. Despues, en mayo, 6 mas tarde, segun la especie, cuando llegan ds ser adultos, abren una cavidad mas espaciosa para trasformarse en ella en crisálida; de esta nace al cabo de algunas semauas el coleóptero que continúa la obra de la lania y sale por un agujero circular al aire libre. Varios de estos agujeros, que mas tarde sirven a las larras posteriores para extrace el polvo, descubren con el tiempo lit presencia del "gusano en cualquier mueble de madera, en vigas ó en las puertas y ventanas de edificios; pero entonces poco puede hacerse ja para la conservacion del objeto atacado.

En junio comienza por lo regular el periodo del celo, y cntonces se les encuentra ocupados en el aparcamicnto; en este acto el macho mas pequeño se coloci sobre la hembra mas grande. Con el microscopio puede disinguirse la parte anterior del dorso, arqueado, que afectala forma de capucha, provistat de un ayudu borde lateml, yo por lo tanto no soldada a los hipocondrios: la cabeza, pequeñ ¿ inclinada, guueda en su mayor parte oculta en dicha capucha; la antena, tan larga 6 mas que los antejos anteriores, tiene una ligera maza; el cuerpo es cilindrico. El artejo extremo de los palpos labiales se ensancha y está truncado; la punta de las maxilas tiene dos dientes; la mandibula inferior se compone de dos maxlas peludas y de paltros filiformes de cuatroartejos, truncados oblicuamente en su parte anterior. En los dos pares anteriores de patas los costados son poco salientes y cilindricos; los de las patas posteriores apenas se ensanchan hacia adentro: todas tienen cuatro articulaciones en los piés y pueden oprrimirse como las antenas contra el cuerpo pues tambien estos coleópteros se fingen muertos, permitiendo que se haga con ellos cuanto se quiern, por lo cual se ha dacio a una especic el nombre de aterco. Conócense unas 60 especies la mitad de ellas propias de Europa.
EL ANOBIO ABIGARRADO-ANOBIUM TESSELLATUM

CARACTERES. - El anobio abigarrado, la especie mas grande de todas, se distingue de las otras por el cscudo collar, no cóncavo en su parte inferior, yor unos puntos finos que se extienden por iodo el cuerpo, inclusos los elitros: ademas le distinguen los artejos de los piés, que son tringulares; en la parte superior del cuerpo, de color pardo, iiene pelos de un gris amarillo.

\section{EL.ANOBIO TERCO-ANOBIUM PERTINAX}

CARACTERES. - Esta especic es negra $\delta$ de un pardo de pez y mucho mas pequena; el borde lateral y los ángulos del escudo collar son redondeados, asi como una depuresion romboidea de la base del último on ambos lados del nismo hay una manchita de pelos amarillos, y asi como en las especies siguientes, profundos surcos puntendos en los clitros.

\section{EL ANOBIO RAYADO-ANOBIUM STRIATUM}

CARACTERES, - El anohio rayado, casi la mitad mas pequeño que la esprecie anterior, ticne un color pardo de pez. mas claro 6 mas oscuro, cubierto de pelos linos y cortos: los clitros, redondeados, no se eruncan en su prare pasterior.

\section{EL ANOBIO DEL PAN-ANOBIUM PANICEUM}

CARACTERES.-- Esta especie, \& menudo muy numerosa, es una mitad mas grande que la anterior; ticne el escudo collar convexo, muy poco estrechado en su parte anterior y unos pelos funos bastante espresos en todo cl cuerpo, que es cilindrico y de color pardo rojizo. Esta especic no vive solamente, como lo indica su nombre, en el pan seco y duro; tambien se la encuentra en sustancias vegetales harinosas y en semillas. juniamente con el tino ladron, causando ambos graves perjuicios, cada cual ó su manera. Fin tales objetos la hembra deposita sus numerosos huevos, y las larms penetran en el interior, reduciendo aquellos con ajudir de los coleópteros, a peda\%os y a polvo cuando no se les interrumpe en su obra.

USOS, COSTUMBRES X REGIMEN. - Todos esios coleopleros producen en cierto tienupo un rumor semejante al çue resulta del tictac de un reloj de bolsillo. Cuando se oye de noche en el silencio de una enfermeria, sitio el mas propio para tales olsservaciones, segun la antigua supersticion, los golpecitos anuncian las uiltimas horas de la vida del enfermo, ereencia que lia dado lugar á que se llimara el citado rumor «el reloj de la muerte." Cuando se busco uma cxplicacion razonable de este fenómeno, creyóse haberia en contrado en el hecho de que esas larvas y sus coleóptcios producen al corroer en la madera, unos sonidos que, si bien muy acompasados, no tienen, sin embargo, ninguna semejanza con el tictac de un reloj. I os coleópteros jrorlucén este mido del modo siguiente. Con las jatas anterioris y las antenas recogidas apojan el cuerpo principalmcute sobre las extremicades del centro. y adelantan la frente y el escudo collar, que chocan con la madera Becker de Hilchenbach da cuenta de sus observaciones subre este particular del modo siguiente: "I De las muchas veces-qque oi los golpecitos, solo recuerdo una en yue el colcóptero los-producia fuera de su galeria de madéra Fl 1." de mijode 1863 , hallandome en mi habitarion. donde hatria algunas tablas viejas, los oi por prinsera vez, y cierta noche al volver cuidadosamente ln madera, encontré dos colcópteros recien na. 
cidos de la especie anobium tessellatum; coloquélos debajo de una campana de vidrio sobre una mesa, y al cabo de una hora los encontré, con gran asombro, estrechamente unidos. Pasado algun tiempo, separáronse i la distancia de tres pulgaclas uno de otro; entonces la hembra empezó d dar golpecitos, llamando al macho; este tendio las antenas como para escuchar y respondió i la segunda llamada de la hembra con la misma seital. Los golpecitos y los apareamientos duraron con intervalos mas ó menos grandes hasta la tarde siguiente; entonces ambos coleópteros permanecieron quietos y separados. 11 otro dia el macho demostró por todos sus movimientos gran debilidad; no podia andar bien $y$ murió à la mañana siguiente. *

Un año mas tarde el obsernador pudo confirmar de nuevo sus experiencias, y babla de otra pareja que el ro de abri del tercer añó sacó de la madera, colocando cada uno de los individúos en cajitas de fósforos bien cerradas. «II S de abril, dice, oi los golpecitos de uno por la tarde, á los que el oiro cóntestó poco despues. El macho habia muerto por la noche; pero raliendome de una aguja de hacer media intenté imitar los golpecitos, a los cuales me respondió la hembira del mismo modo, y en los dias siguientes i todas horis, con tal iuerza que fácilmente descubrí la causa: dominábanla seguramente sus deseos amorosos. El 2 de mayo me contestó por luitima vez y vivio aun hasta el 15 del mismo mes sin haber tomado durante seis semanas alimento alguno, al menos que yo sepr.

Tambien yo ture ocasion de observar la misma especie, aunque menos completamente que Becker, al producir sus gólpecitos. $\mid$ E 15 y 16 de abril de $18 \% 2$, estando por la tarcie cn mi casa, situnda en una calle de mucho trinsito, oi unos golpes bastante fuertes: el primer dia cesaron pronto, por lo cual no busqué, pero al dia siguiente, como resonamn mas largo tiempjo, busqué al autor y encontré por fin en medio de la ventana, detrás del papel pintado, un anobio abigarrado que al tocar el pajuel, rigido y seco, habia producido un rumor mas fuerte que de costumbre. Ios golpes que desde junio hasta agosto se oyen en los dias y noches calurosas, los produce el anobio terco, que se desarrolla mas tarde. E ereloj de la muerter de los ignorantes se ha trasformado, segun las observaciones de Becker. en un reloj de la vida. Para producir mas animacion los anobios se reunch llamándose unos a otros con los golpecitos, de la misma manera que lo hacen los lampiridos con su luz fosforescente.

Todos estos coleópteros se hallan tambien al aire libre, donde en uinguna jarte falta la madera vieja, pero tambien otros muchos muy parecidos, aunque mas pequeños, pues solo alcanzan $0^{\circ}, 00337$ de longitud y que pertenecen al género cis, habitan a menudo a centenares las setas fibrosas de los árboles, donde practican galerias del mismo modo que las de la madera. Lacordaire los agrupa con otros varios géneros en una familia independiente, pero nosotros hemos preferido reunirlos con las anteriores en la familia de los jilófagos (xilophagi ó ptiriores) que se distinguen por los siguientes caractéres comunes: la barba es córnea; la lengua membranosa ó coriácen: tienen dos maxilas en forma de hojas, con pestañas; las antenas cuentan por lo regular once artejos, que se inscrtan por delante de los ojos; los costados de las cuatro patas posteriores son cilindricos ó esféricos; los jiés tienen cuatro articulaciones, rara vez siete, y el cuerpo es cilindrico.

\section{LOS TENEBRIONIDOS -TENEBRIONID压}

CARACTERES. - Con la familia de los tencbriónidos of melasomatos empicza la serie de los heferímeros. Por variado que sea el aspecto de los numerosos géneros en que sc han distribuido mas de 4,500 de sus especies, ofrecen sin embargo tanta analogia con otros insectos en cuanto al color negro y la forma de los piés, qque constituyen un todo bien circunscrito. La barba, que se inserta en una escotadura de la gar. ganta, cubre á menudo la lengua con sus apéndices laterales; las maxilas, cortas y tuertes, presentan en su base una especie de molar; de los dos lóbulos de la mandibula inferior, el interior y mas pequeño esti provisto à menudo de ganchos cúrneos. Los ojos son mas anchos que largos, casi siempre planos y escotados en su parte anterior; las antenas tienen once artejos, mras veces diez, y se hallan insertas lateralmente debajo de los ojos, en el borde salicute de las mejillas; estin marcadamente separadas, lo cual les comunica cierta forma de cordon. Las ancas estan siempre distantes una de otra; las posteriores son mas anchas que largas y las caras de los piés sencillas. En el abdómen se distinguen siempre cinco anillos. Como en estos insectos negros, que casi siempre carecen de alis, los élitros estín soldados con frecuencin hasta en la sutura, carecen de la facultad de volar, por lo cual huyen de la luz. del dia, albergándose debajo de las piedras, detrís de los sacos y en las rincanes sucios de las casas, por lo cual adquieren un olor repugnante: son hijos de las tinieblas y por demás desagradables. Al lado del gran ejército de especies de color oscuro, que viven con preferencia en el Africa y los paises del Mediternineo, y que solo tienen algunos representantes en otros puntos, hay tambien otras de brillo metálico, provistas de alas mas movilles, que vagan por los troncos de los àrboles ó se elevan a mas altura, demostrando asi mas afinidad con otras familias de heterómeros.

En las pocas larvas conocidas los tencebriónidos ofrecen gran semejanza: el cuerpo es prolongado, vermiforme y un poco deprimida; remata en una punta 6 en dos apéndices, y está cubierto de una corraz dura; cuértanse seis patas de cinco articulaciones, antenas de cuatro, solo hay una maxila en la mandibula inferior, y suelen carecer de ojos; cuando los tienen varian de dos a cinco en cada lado de la cabeza.

Pasando en silencio una serie de formas recogidas ó prolongadas propias solo del sur de Furopa, haremos mencion de una especie que en los rincones oscuros de las casas pasa su triste vida.

\section{EL BLAPS ENLUTADO - BLAPS MORTISAGA}

CARACTÉRES, - Esta especic es menos conocida del pueblo que de los naturalistas con el nombre de colcupteso comun eslutado ó coleoplero de la muerte. Tambien Moufet hace mencion de él al hablar de los escarabajos, diciendo que tal vez habria quedado desconocido si Plinio no lo hubiera designado con el nombre de Blatta fretida, como coleóptero de rabadilla puntiaguda, porque sin esta cualidad se le hubiera podido confundir fícilmente con otros coleópteros, sobre todo con los ateucos. A pesar de que su cuerpo tiene tal configuracion que podria jurarse que esta provisto de alas, ni siquiera el macho es alado en estos insectos, como dijo Plinio. Moufut anade: Vive en las bodegas y en los esterco. leros; sale de noche con paso lento y se retira apenas ve una luz lí oye la vor humana; es en vérdad un insecto sumamente lucifugo que parece conocer el mismo su mal olor y sus fechorias; agrídale comer porquerias; penetra por las grietas de las paredes, y repugna por su mal olor, no solo a los que están mas cerca de él sino á toda una vecindad. Vive solitario y mra ver. se encuentran dos juntos. No sabemos si es producto de la basura ó del apareamiento de macho y hem. bra. Esta uiltima duda esta resuelta hace tiempo, y varios 
compatriotas de Moufet han dado mas tarde dibujos de la larva del coleóptero, que se parece inucho al gusano de la harina. Moufet exagera las cualidades desagradables y el temor del animal a la lua, porque no cxhala un olor mas rejugnante que otros individuos de la iamilia y otros centenares de coleópteros que obserran el mismo género de vida.

Todos los blaps tienen los elitros soldados; el labio supe rior visible; cl último artejo de los palpos maxilares en :orma de hacha; la lengua oculta debajo de la barba; en los costados de las patas centrales y posteriores hay un peçueño apéndice; dos espinas en la extremidad de los tarsos anteriores piés muy joco comprimidos, siempre mas cortos que sus tarsos. En la especie que nos ocupi, la punia prolongada de los elitros tiene igual longitud en ambos sexos. El macho se distingue de la hembra por tener un mechon de pelos amarillos en el borde posterior del primer anillo abdominal.

\section{LOS PIMELIOS - PIMELIA}

CARACTERES.- De los pimelios cuéntanse cuarenta especies en la Europa meridional, y mas aun en el norte de Asia y en el Asia Menor. Todas sus partes son recogidas y robustas; cl último artejo de los palpos esta muy truncado; el labio superior escotado y saliente; cl tercer artejo de las an. tenas, gue son cortas, se prolonga mucho; los tarsos anterio. res se ensanchan en triangulo y los otros son comprimidos y cuadrangulares.

\section{EL PIMELIO DISTINTO - PIMELIA DIS- TINCTA}

CARACTERES.-Esta especie, propia de España, se distingue por el escudo collar, brillante, liso, y con puntos prominentes en los lados; los elitros, de un color opaco, están cubiertos de puntos rugosos, q̨ie ademas de la sutura tienen cuatro surcos longitudinales dispuestos en intervalos iguales. Solo por la naturaleza de la superficie y en aigunos casios en la forma del cuerpo, distinguense unas de otras las especies semejantès.

USOS, COSTUMBRES Y REGIMEN. - LoS pimclios se encuentran particularmente en las costas maritimas, donde se ocultan debajo de las piedras, en. las conchas mcias y en medio de las plantas marinas arrojadas a la playa. Nunca les faltan sustancias de toda clase en descomposicion. Como nadie se toma gran interés por ellos, no se ha observado hasta ahora la historia de su desarrollo, al menos qque yo sepa.

\section{EL TENEBRIO MOLINERO-TENEBRIO MOLITOR}

Haré mencion de otra especie y la única quizás que podemos hallar en nuestras habitaciones sin que nos parezca desagradable: refiérome al tenebrio molinero. Este nombre cientifico ha sido aplicado a toda la familia, no porque la representa mejor sino porque es el mas conocido. Sus nom. bres alenanes de colespiem de la tarrina y molisero indican su residencia y' su cuna, por lo cual no debe asombrarnos encontrar en el pan uno de sus pardos elitros, ó los restos de su cuerpo, 6 quizis tambien su larra, cuando el panadero no ha tenido la precaucion y el aseo necesarios.

La larva ó el gusano de la harina, segun se le llama gene. ralmente, no vive tan solo en el fondo de las cajas de harina y salvado, ni tampoco so limita a los molinos, panaderías, etcétera, pues tambien se halla en parajes muy diferentes donde se alimenta de sustancias diversas. Una rez encontre un gran número, de distinto tamaño, en una caja llena de tlerra destinada á la cria de orugas de mitriposa, en la que las larvas se alimentaban de las crisalidas y de algunos cadiveres de mariposa. Otros se han encontrado en el estiércol de los palomares y todos los aficionados á jajaros insectivoros crian los gusanos de harina para dirselos a sus favoritos alados. Al eferto se echa cierto número de larvas en una olla vieja muy ancha, con un poco de silvado, pan duro y trappos, cubriéndola para que los coleópteros nacidos no puedan escapar. Muy fecunda es la cria si de vez en cuando se les da el cadiver de un pequeño mamifero $\delta$ ave. Los coleópteros y las larvas dejan un esquelcto an limpio que puede servir para colocarlo en una coleccion de objetos naturales. Antes de que los gusanos de harina lleguen á ser adultos murlan cuatro veces de piel, la cual podria tomarse por algun animal muerto, pues á causa de su dureza conscrva la forma del cuerpo. Son de color amarillo brillante y de una longitud de $1, ", 026$; tienen la cabeza pequeña, oval y sin ojos; la abertura de la boca se inclima hicia abajo, las antenas son cortas, de cuatro artejos; cuentanse seis patas con otros tantos artcjos; y en el úlimo segmento del cuerpo hay dos puntitas córneas negras dirigidas hácia arrilua. Al hablar de las larnas de los dermestes hemos indicado ya la forma análoga de los gusanos de harima; estos liftimos pucden deslizarse muy bien a causa de su lisura y vigor muscular si no se les sujeta con fuerza.

Paco mas ó menos en julio se trasforma la larva en el mismo paraje donde liabita; es muj delicada, de color blanco; tiene moradas las extremidades y dos puntitas cómeas de color pardo en la cola. Cada segmento del audómen se ensancha en uma prominencis cuadrangular con un borde denticulado. Al cabo de algunas semanas aparece el coleóptero, al principio amarillo, y despues de un pardo oscuro, mas claro en el vientre y con viso rojizo. Este insecto es bastante plano: excepto su estrecha cabera, y rasi de igual anchura en toda la extension de su cuerpo; aunque presenta un todo compacto, las tres partes principales de su cuerpo están solo ligeramente unidas à causa de las delicadas membranas ligatorias. La cabeza plana y redondeada en su parte extcrior, se dirige hacin adelante y. lleva en sus bordes laterales las antenas, de once artejos en forma de cordon, un poco mas gruesas hicia la punta; los ojos están éscotados por las mejillas: la maxila interior de la mandibula inferior tiene un diente córneo; los palpos maxilares rematan en forma de hachay los labiales en un artejo oval truncado.

Este coleóptero, que mide mas de $11^{*}, 0 r_{5}$, es muy vivar de noche y vuela mucho, víndosele por la mañana en sitios donde aun no se le habia hallado, lo cual explica que sus larvas se encuentren por todas partes. Su desarrollo cxige por término medio un año.

Pasando por alto una serie de heterómeros, nos fijaremos ahom en una reducida familia cuyas especies, si bien no excitan un interés general, ni por su abundancia, ni por sus relaciones con el hombre, ofrecen no obstante un desarrollo tan particular y diferente del de los colcónteros hasta ahom descritos, que parece necesaria una corta descripcion.

\section{LOS RIPIFÓRIDOS RHIPIPHORIDE}

CARACTERES. - Vamos a oruparnos de la familia de los ripiforidos, que solo cuenta unas pocas especies. Los rijpifóridos son unos colebpteros muy pequcrios, cuya cabern se relaciona con el escudo collar, estrechandose mucho; ul macho tienc anienas en forma de plumero $\delta$ de peine $y$ la hem- 
bra en figura de sierra; ta mandibula superior carece de borde nembranoso en su interior; el último artejo de los palpos maxilares no tiene forma de hacha, como en otros congéneres muy afines. I.os elitros apenas son mas anchos que la base del escudo collar; todas las ancas se insertan a poca distancia y saten en forma de espigas de unos hoyos en que encrjan.

\section{EL METECO PARADÓJICO-METCECUS PARADOXUS}

CARACTERES. - El meteco paradójico, una de las es. pecies mas grandes de la familia, mide de 17,0076 á $11^{\circ}, 0$ ro, y es negro, de un rojo amarillo en los lados obtusos del escu. do collar, lo misma que en el vientre, que afecta li forma de. quilla : tiene del tocio amarillos los elitros 6 parte de ellos: los artejós de sus antenas llevan cada uno, desde el cuarto, dos largos ajxéndices en forma de banderas; mientras que las de las hembras solo están provistas de un diente. El escudo collar de lineas rectas en los lados, y mas largo que ancho, sobresale en los ángulos posteriores en forma de diente, presentando en el centro del borde posterior tres puntas, y en el centro de su disco un hoyo longitudinal. Cada elitro llega á la extremidad del abdómen; pero se adelgaza de tal modo en forma de cuña, que las puntas se desvian mucho, estructura taras veces observada en los coleópteros. En las patas, largas y delgadas, los piés posteriores son mins largos que sus tarsos y muslos.

Este coleóptero nace on los nidos de la avispa comun y en condiciones tales que por mucho ticmpo han sido objeto de discusion. Andrew Murray pretendis en r 869 que la larra, lo mismo que la de la avispa, habita una celda; y que, como esta, es alimentada por las trabajadoras de la colonia de las arispas. A esta opinion se manifestó contrario, en el mismo periódico (Ann. and Mag. Nat. Hist. Ser. iv) y en el mismo año, Smith, apoyzindose en las observaciones de Stone. Segun las mismas; la larma del meteco paradójico se manifiesta como verdadero parisito. Iha hembra deposita su huevo en una celda de avispa, y zan luego como la larva legitima que habita en ella ha llegado a su completo desarrollo y ha ccrrado la celda para esperar su metainoriósis, la larva del meteco, nacida, en tanto, del huevo, se introduce en su companera, deroraindola en el terrmino de cuarenta y ocho horas excepcion hecha de la piel y las maxilas. Al ano siguiente continuó la discusion entablada. Murmy presentó nuevas opiniones, fundadas en observaciones insostenibles ó incompletas, mientras que Clanpmann aģoýo å su adversario, publi. cando las noticias mas completas que hasta entonces habian aparecido con respecto al género de vida del meteco. Segun ellas, probablemente la hembra del meteco paradójico no defosita sus huevos en los nidos de avispas, sino fuera de los mismos.

La larva nacida del hucvo mide $\bigcap^{\mp}, 005$, y lleva, en una cabeza de oruga, antenas de tres artejos: muy distantes una de otra, y ocelos: en los tres segmentos anteriores del cuerpo un par de patas articuladas, cuyas tres articulaciones del pié se ensanchan en forma de hoja y' están provistas en la extremidad de dos ó tres garras y de un disco, a manera de troinpa de mosca. Cada segmento del cherpo lleva una cerdá la teral encorvada hảcia atris, $y$ el último un disco doble de forma parecida al de los pies Probablemente esta larva penetra en la celda de una laria de arispa, introduciéndose en ella entre el segundo y tercer segmento del lomo, antes de que aquella haya cubierto la celda. Mas tarde se distingue a la larva al través del tercero y cuarto anillo de la larva de avispa. El parisito chupa entonces al animal en el que habita del mismo modo que otros parisitos, sin herir sus órganos escnciales. Su cuerpo se hincha, y ensancha las membranas ligatorias entre los anillos de quitina del cuerpo. Despues, la larva parásita rompe la piel de la avispa de que hasta entonces se alimentó, mudando al propio tiempo la suya, para tomar la forma de gusano. Entonces se agarra al cuarto anillo de la larm de avispa que exteriormente chupa aun colocándose en el costado abdominal, un poco conveso, de la misna. Esta forma de larva fue encontraday descrita por Murray.

Cunndo la larva del meteco alcanza la longitud de $\theta^{m}, 006$, vuelve á mudar; su piel se abre en el dorso, y una ver varia, queda pendiente entre la lana y el insecto que habita, al qque absorbe á fuerza de chuparlo, trasformándose despues en crisálida. El coleóptero se presenta dos dias mas tarde cul las celdas vecinas y se rerifica la trasformacion completa en unos doce á quince dias. El coleóptero se encuentra á fines de agosto ó i principios de setiembre aisladamente en las fiores; ini hijo cogió en 1864 una hembra en el polvo de un camino del bosque. Segun estas obserraciones, y teniendo en cuenta que las avispas construyen al año siguiente nuevos nidos, la opinion de Murray, de que las hembras no abandonan las celdas, pierde su fundamento.

Solo por mara casualidad se coge este coleóptero, relativamente raro, al aire libre; por lo que se han buscado medios para apoderarse de un modo seguro de él. Borck ha indicado últimamente un procedimiento que en los anos en que abundan las avispas produce el efecto desendo. Cuando las avispas, por la noche, han vuelto is su nido, se cierra la abertura del mismo con un tajon de lana, mojado de un aceite mineral, lo mas fétido posible (petróleo, bencina, ó aceite de trementina), empujáncole todo to posible hácia el interior por medio de otro tapon seco, y cubriéndolo todo ligeramente de terra $A$ la manna siguiente se cogen los habitantes del nido que han llegado mas tarde y que no pudieron entrar en él para prevenirse contra sus jicadas. Despues se abre cautelosamente la puerta del nido, cerrada la noche anterior, ó se pracrica al lado de la misma un segundo agujero, para convencerse de los efectos del petróleo. Si no sale ninguna avispa viva, se saca el nido con un azadon, alejando antes la tierra à una distancia de ()$^{10}, 40$ de circunferencia. Es muy conveniente ponerse unos gruesos guantes para prevenir los ataques de las avispas que quizas quedaron vivas. Dešpues se examinan los panales uno por uno y se encuentran los metecos si los hay.

\section{LAS CANTÁRIDAS - CAN- THARIDE}

La familia que inmediatamente sigue à la anterior, tiene el nombre de vejigatorios (iesicanta) ó cantiridos, porque algunas especies producen una materia particular, la cantaridina, que causa vejigas tan luego como se aplica a la piel: se emplea por lo mismo en ciertos casos por la medicina como remedio de uso externo, tal como los revulsivos, y en otras circunstancins tambien interiormente. L.os antiguos ya conocian esta cualidad; pero es difícil sacar nada en claro de los nombres dados à los respectivos animales y de sus descripcioncs. Moufet en su tratado sobre los buprestes y los cantáridos, contribuye mas bien a perturbar que a explicar el asunto; porque al lado de la cantárida verdadera ó mosca esfañola, da el grabado de algunos carabos y de otros coleópteros acerca de los que nada ha podido saberse.

CARACTERES. - Además de la citada propiedad fisiológica, que segun ya hemos dicho no es propia de todas las especies de la familia, todas estas tienen los siguientes ca- 
matéres comunes: la cabeza, notable por una coronilla muy convesa, esta dispuesta verticalmente, se estrecha en su parte posterior en forma de cuello y queda visible en toda su extension; en la frente, 6 por delante de los ojos, tiene las antenas, de nueve á once artejos filiformes, que se ensanchan hácia la punta ó pueden ser de conformacion irregular. EJ escudo collar es mas estrecho en el borde anterior que !a cabeza; en el borde postcrior mucho mas estrecho que los clitros elásticos. Todas las ancas sobresalen en forma de espigas ý se hallan muy próximas uma i otra. Los cuatro piés anteriores tienen cinco artejos; los posteriores solo cuatro con garras hendidas en mitades desiguales.

DISTRIBUCION GEOGRÁFICA.-- La major parte de las ochocientas especies pertenecen preferentemente i las regiones cálidas.

\section{LOS MELOINOS-MELOE}

CARACTERES.-I.OS meloinos forman el priner género de la familia, muy rico en especies, y viven, excepto algunas, las americanas, solo en el antiguo mundo. Los telitros son de una conformacion especial, pues no se tocan en una sutura recta, como en casi todos los demís coleópteros, siro que el uno se sobrepone al otro en su base, segun se nota en los gimnonotos; cuando cubren el abdómen de una hembra se abren muy pronto y presentan un par de yequeños lóbulos. En el macho, a menudo mucho mas pequeno, cujo abdómen no hinchado de huevos guarda proporcion con todas las demis partes, los clitros no se abren, sino yue cubren del todo el abdómen: ambos sexos carecen de alas. El nombre latino de froscarabseus aplicado por Moufet á este género, le justifica el citado autor fundindose en que estos animales, al contrario de los escarabeos, tienen un sexo femenino.

USOS, COSTUMBRES Y REGIMEN. - IOS meloinos se presentar en époci temprana del año, jues hc encontrado la especie comun el is de marzo: vagan por la jerba, entre sus tallos y en los caminos; en mayor numero en el mes de mayo, disminuyendo despues poco á poco; de modu çué à funes de junio han desaparecido del todo. Su alimento se compone de plantas bajas, sobre todo de yerbas blandas, de violetas y otras, las que comen por la mañana y porla noche con gran roracidad. En esta ocasion abrazan la planta con sus largas patas y acercan a su boca con las patas anteriores la parte que quieren comer: pairanse a veces mientras lo efectuan y demucstran por todos conceptos el mayor bienestar.

Cunndo el sol es demasiado fuerte, buscan la sombra, avanzando con bastante rapide\%, a pesar de su pesada estructum. Si se les toca recogen las paias y las antenas y dejan salir de todos los irocanteres la canturidina, especie de liquido aceitoso y amarillo. Las palabras de Nicandro: e cl ganado se hincha cuando ha comido el animal llamado por los pastores buprestisi, se refieren probablemente al coleóptero que nos ocupa. En la medicina veterinaria los meloinos se emplean en varias ocasiones, sobre todo en ciertas enfermedades de los caballos; aunque en tiempos anteriores representaban, un papel mucho mas importante, pues sc refiere que los ditmarsos los secaban, los reducian á polvo y los bebian con la cerreza. Esta bebida, Hamada astieanta. rimus 0 kaddentrank (kadde significa meloinos) servia de remedio para toda clase de debilidad.

Cuando despues de presentarse los coleópteros, los sexos se han encontrado, se verifica el apareamiento. El macho muere en seguida extenuado, pero la hembra, solo despues de dar a luz la cria; a este efecto abre con las patas antcriores un agujero en ccrreno no demasindo blando, sirviéndose de las restantes para extraer la ticrn. Al trabajar se revuelve varias veces, de morto que el agujero adquiera una forma bastanie circular. Cundo este ha alcanzado una profundidad de 6"026, sale del hoyo ! pone cl abdómen hinchacio de hueros sobre el fondo del mismo, agarrándose con las patas an. teriores al borde. Haciendo varios esfuerzos deposita un monton de huevos cilindricos de color amarillo de jema, y antes de acabar este trabajo, con pequeños intervalos que sirsen jara recobrar nuevas fuetzas, empieza a colocar tierra en el hoyo. El abdómen medio cubierto apurece por fin al exterior, y el animal acaba de cerrar el agujero. Despues se aleja à su manera, rapjidamente, para rehacer sus tuerzas con una buena comida. La madre aun no esta pronta a morir; su jrovision de hueros no se ha agotado, por lo cual repite el mis. mo trabajo descrito, en dos ó tres diferentes sitios, confiando asi \& la tiern un enorme numero de gérmenes. Deposita hasta mil hueros, a no ser que un tiempo continuanente desfavomble la retriga ocasionandole una muerte lenta.

Al cabo de veintiochn s cuarenta y dos dias, nacen las larvas, y buscan en seguida las flores mas próximas, las anémonas blancas y amarillas, varias clases de raninculos, crucifuras, etc.: pues saben muy bien que en ellas se presentarin tambien las abejas en busca de la miel. Fintonces se las puede ver reunidas en espesos enjambres negros. En un caso de cria artificial, la maceta que servia á este efecto en la ventana de una habitacion, cstaba ligeramente cubierta de un pedazo de vidrio. Pronto las pequeñas larvas corrian á centenares por el alfeizar de la ventana, y agrujaindose en mon. tones grandes y perquenos, permancecian bastante quictas. No [asó nutho rato sir que las moscas comenzaran á moverse penosamente ó quedaran inmóviles, bocn arriba: al examinarlas de cerca se hallaron del todo cubiertas de larviss de meloinos. Esta circunstancia demuestra su inclinacion à irepar por otros insectos, aun a trueyue de engañarse en muchas ocasiones. Estos perjuenos séres no buscan el alimento, co. mo otras larias que salen del huevo; únicamente se esfuerzan en cncaramarse al lomo de una abcja. Volvamos a las Rores para encontrarla sobre el cuerpo de aquella. La larva de meloino se parece mucho en su forma a la de la cantárida: es muj prolongada y cubierta de quitina. En su cabeza triangular se halla à cada lado un ojo yo una antena de tres artejos que acaba en una larga cerda: las seis patas abiertas en exireno acaban cada una en tres garras, y el abdómen en cuatro cerdas. El animalito se pasea por en medio de los pe. los de la abeja, y por lo regular no le hace daño alguno, sino yue la considera solo como un medio de alcanzar su prosperidad. La abeja i su vez. construye su celda, la llena de miel y deposita encima de ella su huevo: cste es el momento apetecido por la larva de neloino, que bajando de su bienhechora, se coloca sobre el huevo. listar cicra la celda $y$ desde acjuel momento empicza la vida verdadera de la larvita. Come el husevo, su primer alimento, y despues de mudar la jicl, acdquic. re un aspecto esencialmente diferente, pues se tmsforma en larra de piel blanda, que puede ya aprovecharse de la miel, In que absorbe poco á poco hasta llegar á su completo desarrollo. Este sér parecido á la larva del abejorro tiene doce anillos en el mesotórax, y está provisto de estignas en los ocho primeros segmentos del abdómen. En su cabcza cómea faltan los ojos; cl habio superior afecta la forma de trapecio; las maxilas cortas y fuertes son poco corvas, y provistas en su cam interior de un diente; las antenas, los palpos maxilares y los labiales se componen de tres arrejos; los piés son cortos y estin provistos de una garm.

P'uede darse el caso de que la larma de nieloino, llamada tambien piojo de abrjor, suba a una abrja macho ó à una mosca preluda; y tal error puede causar su pérdida P'ero como 
en estos insectos el desarrollo depende de mayor número de condiciones que en otros, la maturaleza ha tomado sus precauciones para la conservacion de la especie, que estriba en la gran fecundidad de los ovarios de la hembra. Ademas ha dotado a las larvas de instinto, dandolas vida en tales condiciones, que encuentran las abejas necesarias para su prosperidad, y particularmente entre las especies de los géneros antophorn, macrocera, afis y otros.

Podria creerse que cuando la larva ha comido toda la micl y alcanzado su tamaño completo cutra en el curso regular del desarrollo, es decir, que se trasformarí en crisálida; pero no sucede asi. I evántase al contrario su piel sin romperse, y dentro de la misma se presenta una especie de ninfa córnea, muy parecida en sus contornos a la larva anterior: esta ninfa, llamada pseudo cristidida, ya no toma alimento. Su vientre es aplanado; ell lomo inuy convexo; Ia cabeza, una especic de careta, en que algunas promincrecins inmóviles indican cierta conformidad con las partes futuras que deben componerla ; en vez delás patas se observan hinchazones verrugosas. Gerstaccker pretende que esta pseudo crisálida no se forma en la especie mejoc erjthrocnemus. Dentro de esta ninfa, cuya piel córnea a su vez se levanta, formase de nucvo una larva vermiforme, de piel blanda, que en poco tiempo se desarrolia convirtiéndose en verdadera crisailich. Este es el curso de la metanorfósis, que en algunas especies se ha observado conupletamente; ell otras con interrupciones. A Newporty Fabre debemos en primera linea las interesantes observaciones verificadas en la especie indoc cicatricosiss.

\section{EL MELOE ABIGARRADO-MELOE VARIEGATUS}

CARACTERES. - El meloe abigarrado se encuentra diseminado por toda la Europn, el Asia norte occidental y en el Caucaso, y parece abundar mucho en Alemania. Es de un color verde o azulado metálico, con viso mas ó menos purpúreo, cubierto de puntos gruesos y de arrugas; el escucio collar, trasversal, se estrecha hácia atrás, y los bordes se levantan muy poco. I.a longitud es $11^{\mathrm{m}}, 0$, 1 a 0,026 , segun que la primera larva encontró menor 6 mavor provision de miel en la celda (fig. 24). La larvá tiene $0^{\circ}, 002$ of $0^{\circ}, 003$ de lar. go; es de color negro brillante y de la estructura indicada mas arriba. I.as demás formas del desarrolio de esta especie se desconocen.

USOS, COSTUMBRES Y REGIMEN,-La primera forma de larva. en extremo frecuente muchos años, se encuentra tambien en la abeja donuéstica, pero en condiciones muy particulares; pues no se contenta con pasear por entre les pelos, sino que se introduce entre los segmentos del abdómen y en otras articulaciones, causando la muerte de las abejas. Pero tambien la larva, obligada à abandonar el cadaver, perece despues de vagar algun tiempo por el suclo de la colmena. En abril ó mayo la larva (ignoro si de esta ó de otra especie) se ha encontrado tambien con abejas desparramadas por encina de la miel, en los panales, doncie ja esraba moribunda, pues no chupa la miel antes de comer y' de haberse inudado el huevo. Fil meloe abigarrado no causa, por lo tanto, dano en las colnenas de la abeja doméstica á pesar de su vida de parasito, pues solo su primera larva es la que perjudica at las abxjas hembras, de tas cuales se vale para introducirse en las colmenas, y tambien hace daño á las trabajadoras y a los machos recien uncidos.

\section{EL MELOE PROSCARABEO-MELOE PROS- CARABEUS}

CARACTERES. - El meloe proscarabeo ó conun seen. cuentra con mas frecuencia que la especie anterior en las mismas regiones. Es de color negro azulado con viso violeta y está provisto en la cabeza y en el escudo collar de puntos deprimidos. Esste último es casi cuadrado, un poco estrecha. do hácia atrás y redondeado en los ángulos; los elitros provistos de arrugas trasversales; en el macho el sesto y septimo artejos de las anteuns se ensanchan en forma de disco; el tamano es tan variable como en la especie anterior y los elitros sobresalen del abdómen. las primera larva es un poco mas pequeĩa que las del meloe abigarrado $\left(11^{\prime \prime}, 0025\right)$; ticne la $\mathrm{ch}$ beza menos triangular, redondeada en su parte anterior, y de ii) color amarillo mas ó menos oscuro. T'ampoco se ha ob. sermdo su desarrollo. Este animal se encuentra tambien, alguna que otra ve\%, en las abejas domésticas, sobre todo entre os pelos del tórax; pero nunca penetra en el cuerpo, y no causa por lo tanto daño alguno: puede llegar á veces de este modo à st desarrollo. Assmuss encuntró solo una vèz en una colmena de la provincia de Moscou dos larvas de la segunda forma, de $0^{\circ}, 013$ de largo, las que clasificó como pertenccientes a nuestra especie, porque a fines de majo habia ob. servado la primera forma de la misma en sus abejas. Desgraciadamente las larvas no pudieron criarse, a pesar del mas cxquisito cuidado, y murieron á los pocos dias.

\section{EL CEROCOMA DE SCHEFFER-CEROCOMA SCHEFFERI}

CARACTERES. - El cerocoma de Scheffer es un bonito coleóptero que mide $0^{\circ}$, or y y que a mediados de verano se encuentra en las flores, sobre todo en la yerba de San Juan y en el Chrysanthemum leucanthemusm, en Alemania y mas hácia el este hasta el sur de Siberia. Recuerda por su exterior al ya mencionado género de colé́pteros blandos, telephorus, pero tiene los elitros de color verde de esmeralda con pelos de un amarillo claro, reuniendo los caractéres de la familia de que nos venimos ocupando. Sus antenas, sin embargo, son de una formacion muy diferente. Se componen de solo nueve artejos, que terminan ensanchándose en forma cle yala y que en los machos son denticulados: su color es rojo lo mismo que el de las patas y se hallan insertas detras de la abertura bucal. Las maxilas sobresalen larga y estrechamente, como un pico, 5 la exterior de que está dotada la mandibula inferior se prolonga mucho. El macho se distingue tambien de la henbra en el último artejo de los palpos maxilares hin. chado á manera de vejiga y en las patas anteriores ensanchadas y peludas. El doctor Jacobo Cristiano Scheffer, hom. bre notable como conocedor de insectos, siendn predicador protestante de Ratisbona publicó en 1 ; 64 sus 7 rostados de los inseclos en los que dedica lí este coleopterito un tratado particular con el cpigraie: $\varangle \mathrm{El}$ coleóptero de corona y maza, de cascara blandax y al que acompaña una prigina con 2: figuras al cromo que reproducen al colcóptero en diferentes posiciones, asi como las exrremidades del mismo con el cuidado y la exactitud propios del autor. Este, refiriéndose al nombre del coleóptero, dice rue, cuando en 176 s auunció su obra, podia suponer que iba dit tratar de una especic bastante desconocida ó que cuando menos no habial sido descrita. En realidad, el autor de la Histuria parisiense de inseclos le habia tomado la delantera, dando al insecto el nombre genérico de cerocoma, pero no por eso guiso jrivar al puiblico de su tra. tado; porque aquella historia solo contenia una breve descripcion y un solo grabado sin colores. Mas tarde continúa: $\{\mathrm{E}$ célebre naturalista sueco, caballero linneo, ha dado à conocer en su última edicion del Edificio de la naturalesa (1758) las conocidas moseas espanolas (cantairidas), del género de las luciérnagas, incluyéndolas en el género meloe. Como 
la especie de coleópteros de que hablamos en estas lineas tiene à simple vista la mayor semejanza con las cantáridas, tambien ha tenido que clasificarla en el útimo género. Probablemente he siclo yo el primero en dar á conocer al señor Linneo estos coleopteros; jues me acuerdo muy bien, que hace ya muchos anos le envié un dibujo al cromo de esta especie: tal circunstancia le ha obligado, sin duda, segun su costumbre, a darle mi nombre como distintivo: melore Sillefferion

Mas adelante continua el autor: ¿o le llamo coleópiero de corona, porque las antenas de los machos se parecen ia una corona; pero tambien se le puede llamar coleópiero de ma\%a, porquc las antenas de las hembras no se parecen en mada a las de los machos, pues afectan la forma de maza. De paso añadire que llliger ha propuesto mas tarde el nom. bre de colesptero de andesias confusas. Despues de haber descrito el coleóptero muy ininuciosamente en todas sus partes cateriores, Scheffer se exilende en gran numero de detalles acerca del ticmpo en que se presenta y su género de vida, obscrvaciones que están del todo conformes con mis experiencias. Tambien yo he encontrado á este coleóptero solamente en las flores blancas del camjo $y$ cubierto á reces del todo por cl pólen amarillo. Por lo regular solo existe aislada. mente, y en muchos anos es tn extremo frecuente. Como rodos los coleúpteros blandos, y como la cantárida, los meloes (sobre todo las hembras) recogen tambien las pa. tas, encorran la cabeza y el escudo-collar hácia abajo y se fingen muertos, cunndo se les molesta. Ln época de exiccsivo calor, se vuelien muy movibles, y vuelan tan ripidamente, en especial los machos, que es difícil cogerlos con las ma. nos. En las flores se verificar tambien el apareamiento, que dura poco tiempo y no ofrece particularidad alguna. Ni Schef. fer, ni los observadores posterioress saben dar razon de la historia del desarrollo; tampoco cxiste la cantaridina en el cucr. po del cerocoma de Scheffer, al menos yue yo sepa.

\section{LOS MILABRIDOS-MYLABRIS}

Otro género muy rico en especies, en comparacion del anterior, y que se enrucentra en las mismas regiones, sobre todo en los jaises del Africa y del Asia, es el conocido con el nombre de Mylabris. Estas especies son muy dificilus de dis. tinguir, á causa de la monotonia qque ofrece su estructura y el colur del cuerpo. Los ciitros que a manera de tejado cubren las alas y el cuerpo, ensanchindose poco à poco hácia atras, llevan en su fondo negro fajas claras, casi siemure rojas, o tambicri manchas, ó por el contrario, sobre un fondo claro, ajarecen dibujos negros. Sug largas patas se caracterizan fror los musilos y tarsos lineales, estando los viltimos jurovistos en su extremidad de largos espolones; los piés son un poco comprinicos y cada garma lleva mitades iguales y sencillas. 1) las $200 \%$ pico de especies existentes se encuentra tambien una en Alemania. Yo encontré el milaliris fruesslini en los acianos en flor, cerca de Boren; pero nada si decir con respecto al género de vida y al desarrollo de todo el género. Es posithle que Hipserates se hubiera servido ya de una ú otra especic para vejigatorios; porque parece que mrias especics abundar bastante en Grecia.

\section{LA CANTÁRIDA VEJIGATORIA-LYTTA VEXICATORIA}

CARACTERES. - I A cantårida vejigatoria, llamada mesen esfraniolu, se encuentra muchos años en jurio en alyunas regiones, en número sorprendente, $y$ descubre entonces su fresencia à gran distancia, por el olor penetrante que despiTosso VII de. El gripo formado por estos animales devora todas las hojas de los arbustos de fresnos, siringas, de sauces y otras plantas; y solo cuando ya no encuentra nada que comer prosigue su camino. Los elitros, de un bonito color verde, cubicrtos de espesas arrugas y provisto cada uno de dos finos surcos longitudinales, en el macho de un verde de esmeralda y. mas prolongados, en la heinbra mas anchos y de un verde dorado mas claro, caracterizan á estos animales, si no bastara por si solo el olor. Lats antenas filiformes tienen en atyuellos la mitad de la longitud del cuerpo, mientrasque en estas son la mitad mas cortas. Este coleopptcro, que mide $0^{\circ}, 017$ i $0^{\prime \prime}, 195$, se distingue además por la cabeza en forma de cora. zon y por el escudo-collar trasiersal, obtusamente penta. gonal.

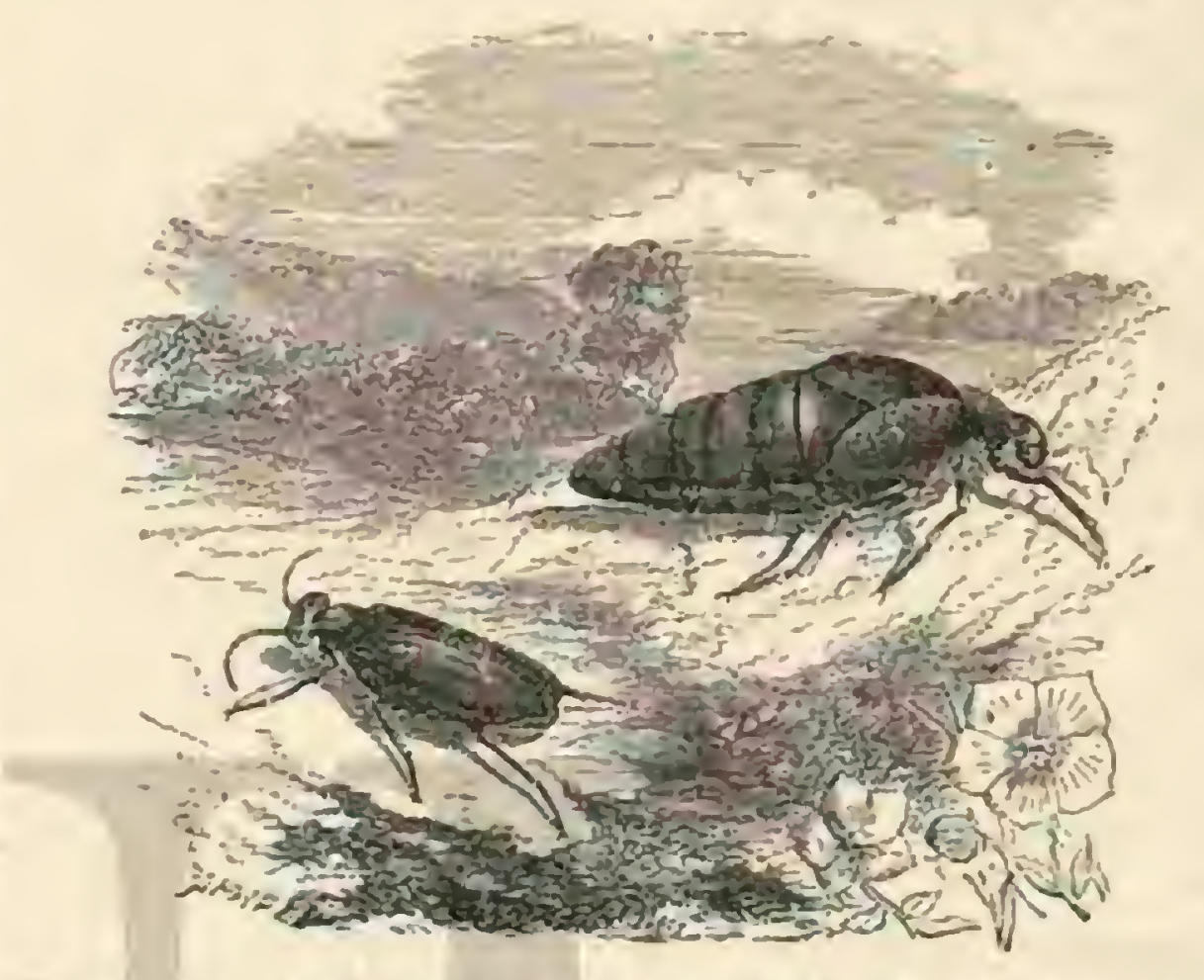

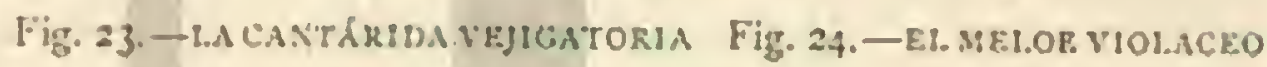

Fin sus pastos se presentan gran número de parejas unidas con las cabezas opuestas. La hembra dejosita sus numerosos huevos en la tierra: de estos salen, segun se ha observado, unas larvas con la extremidad posterior hácia adelamte, larvas crỵ forma es la ya michas veces mencionada y acerca de cuyo desarrollo ulterior nada se sabe. A cairsa de su semejanza con las larvas conocidas, y por la conformidad de los coleópieros ya formados, se ha supuesto qque llegan á su desarrollo en los nidos de las abejas subterráneas, entre los que viven como parásitos, lo mismo que las lamas de los géneros meloe, sonifis, sitaris y de dos géneros mas de la familia. la circunstancia, sin embargo, de que las cantiridas se presentan temporalmente en enormes masats, habla en contra de tal su. posicion; porgue no puede ponerse de acuerdo segun algunos obsernadores con tal género de parisitus. Pero si consideramos el enorme número de ciertas abejas subternineas, ejuc salen en primavem de sus agujeros, y el aumente del de otros pirásitos cuando sus huispedes son extraordinariamente numerosos, podemos convenir en qute lo mismo puede suceder con la cantirida vejigatoria.

Este insecto se encuentra en Suecia, Rusia. Alemania, y sobre tudo en el sur de Europ̧a. Una nota de mis dia. rios entomológicos dice: Naumburgo sobre al Sale 16 de junio de 1850 . Un número crecidisimo de lyta iexiontorio en Ligustruns arugare y thalictium, despues de liaher despojado por complcio de sus hojas á los fresnos vecinos. Algunos años despues las encontré casi en igual número en la extremidad oriental de la provincia de Sajonia: pero en los 20 años de mi residencia entre estos dos puntos, en Halle, solo las vi pocos años (1873) muy aisladamente. En Espaxa se encuentran segun pirtece con freruencia, al menos asi lo indica su nombre aleman. Liste mismo nombre se habia usado ya en 
tiempos de Moufet, pero no en Alemania; pues este autor dice que el coleoptero se llama entre los belgas spainsche aljeghe, entre los ingleses Camharis ó spanisl: fijc, mientras que los alemanes le llaman coleóptero verde ó dorado. Cuando los coleópteros existen en tal número yue valga la prena de recogerlos, a las primerns horas de la mañana ó en dias nublados se les sacude de los arbustos, haciéndolos caer sobre unos paños; despues se les mata, secándolos por medio del calor artificial, siendo preferible colocarlos en un horno, y encerrando despues muy bien semejante mercancia, que ha perdido mucho de su peso. Reducidos a polvo y mezclados con una sustancia pegriosa constiuyen el conocido vejigatorio; $y$ : cuando se les dustila en alcohol, producen ta tintura de cantaridas. In fanosa mpun. Tufrim, no era scgun Ozanari otra cosa que un extracto de cantíridas con espiritu de vino diluido en igua la casitaritinu fura consiste en hojitas brillantes que fácilmente se disuelven en éter: en aceites grasos. Hl precio de los coléṕpteros secos varia segun las condiciónes; un farmacéutico amigo mio que habia hecho en su jardin rosecha de cantáridas vejigatorias, recibió al venderlas en Berlin un taler ( 15 reales) por libr.

Se conocen mas de cincuenta especies de cantáridas de las que la nanjor parte viven en Africa y en Ámérica. Las propias de este último continente tienen el color juredominante negrob griș, a causa de sus espesos pelos, 6 tambien llevan rayas de ámbos colores. Estas especies se han separado ultimamente del género bifta, constituyendo otro indejuendiente bajo el nombre de epicoufa, porquic sus antenas cerdosits son mas cortas, no tan Inrgas como la mitad del cuerpo, el escudo collar mas prolongado y mas largo que ancho, y los clitros mas estrechos en la base, en cuyar region cl cuierno, en general, parcuce mas comprimido lateralmente. Varias especies de la Améric:a del norte, como la epicauta sivierere y aritusa, se encuentran a vecus en immenso número en la yerba de las patatas y deseruyen, cuando no se las estorba, las hojas de toda la cosecha, lo nismo que el coleóptero del Colorado tan afamado actualmente.

\section{EL SITARIS DE LOS MUROS-SITARIS MURALIS}

CARACTERES. - Iil sitaris dé los muros, llanado antes megadalis humeralis, es un interesante y frequeño coleojptero, propio de la Europa meridional. El punio extremo septentrional de suárea de dispersion es, segun hasta ahora se ha observido, el sus de lirol; últimamente se han encontrado varios individuos en una Mas en Francfort sobre el Mein. Re: cuerda por su cxterior, y mas aun por la historia de su desarrollo, el metecus paradaxus. El coleóptero se conoce ficilmente por los elitros separados desde la hase, ascoiados en el borde exterior, muy estrechados hícia atris, y provistos en su extremidad de una punta obtusa, y i la que solo cubren, si bien muy poco, las alas completamente desarrollacias; las antenas son filiformes; las maxilas encorradas en forma rectangular, desde el centro; las garras sencillas, es decir, desprovistas de dientes y las caderas posteriores muy separadas de las del centro. El cuerpo es negro y los hombros rojos.

Fabre encontró agujeros subterrineos habitados por la antophora pilipes, abcja que construye habitaciones aisladas, recoge miel y se presenta en los primeros tiempos de la primavera; su àren de dispersion es muy vasta, encontrindose tambien en nuestro pais con bastante frecuencia. A fines de agosto salieron de los agujeros algunos sitaris de los muros, al principio machos, yque, con grande impaciencia esperaban i las hembras, abriendo el capullo de las unismas para apresurar su nacimiento. "I’an luego como estas últinas se presen- taron se verificó en la entrada de las habitaciones de las abejas el apareamiento y la puesta de los numerosos huevecitos ovales en la parte posterior de las galerias subterranens que conducian á los nidos; $a$ fines de setiembre salieron las larvas de un milimetro de longitud y' yue se distinguian por sus lar. gas antenas y largas patas provistas de pelos tambien muj largos, por dos cerdas caudales encorvadas en la extremidad del cuepro, la cual cra de forma adeigazada y de punta obtusa, y por dos ojos en cada lado de la cabeza. Tocios estos caractéres y los tegumentos duros del cuerpo recuerdan la primitiva forma de larva de los tipos descritos de esta familia. Cuando en la primavera se despierta una nueva vida. los habitantes legítimos de las celdas, las pequeñas antoforas, abandonan su cuna, y entonces ya las larvas de sitaris están prontas para agarmare a las abejas y para hacerse llevar por ellas. Como los machos de las abcjas aparecen siempre varios dias antes que la hembra, las larvas se agarran en su mayor parte a las abejas machos. Estos no las ayudarian mucho en su desarrollo ulterior, para el cue solo pue. den servir las hembras. Bien spa que por medio de las flores ó durante el apareamiento de las abejas pasen a las hemibras, ó bien porque muchos permaneciendo en los machos mueren, consta sin embargo que se encuentran, segun lo exige su destino, en las antoforas hembras. Estas, siguiendo el ejentplo de sus madres, construyen nidos, recogen niel en sus celdas, cólocan un hucvo en cada una de ellas y las cierran. La larva de sitaris se fija en el huevo y se deja encerrar. El 2 a de mayo, labre observó celdas llenas y en algunas de ellas una larra sobre el huevo. Tan luego como la celda esti cerrada. Ia larva abre el huevo, come su contenido, despues del Jargo ayuno por que ha pasado, y permanece sobre la cás. carn del huevo, para comer desde alli las provisiones destinados a la larsa de abeja. En su forma primitiva dificilmente podria ocurrir esto, porque el duro tegumento del cuerpo es demasiado poco flexible y no permitiria sil crecimiento. Ina trasformacion se verifica sin duda inmediatamente despues que la larva ha conido el huevo y antes de que se alimente de la miel, de la cual depende el desarrollo completo. Despues de haberla comido, lia segunda forma de larva desarrollada tiene el aspecto mas parecido a un gusano: un cuerpo grueso y blando, provisto de una cabera pequeña y sin ojos, en la que se pueden distinguir los rudimentos de las antenis y' las maxi. las; los tres segmentos anteriores llevan seis patitas muy cortas. Esta segunda forma de larra se acorta poco a poco, se endurece y adquiere la forma de huevo y condiciones para invernar, cuyo estado se ha designado como de jseudo-ninfa. De esta se forma en la primavera siguiente una tercera larva muy parecida à la segunda, y de esta última, por fin, la verdadera crisálida de la que nace el coleóptero a fines de agosto, el segundo nño despucs de puesto el huevo.

Lil historia del desarrollo, segun hemos podido apreciarla en sus principales rasgos en las dos últimas familias, sorprende por la variedad que ofrece comparativamente a las dos formas de iránsitos de la larva y de la crisálida en los demas coleópteros. Hay aqui una circunstancia que no debemos perder de vista y upue constituye la vida del parásito, la que mas tarde conoceremos en otro órden en formas desarrolladas, jero tan oculta y' misteriosa, que solo.aquel que se halla habituado a manejar el microscopio puede darse cuenta del secreto, si bien en condiciones favorables. Solo se han hecho muy pócos experimentos: y. de estos ha resultado, sin embargo, igual variedad en la forma de larra. Yara los in. sectos alemaneś no se necesitan aquellos aparatos, y la instruccion cientifica podrá procurarnos medios para formar una idea de aquellos interesantes descubrimientos, que facilitand una ocasion oportuna y la perseverancia del observador. 
Supnniendo que en uno ú otso de mis lectores puedan existir estas condiciones the hecho mencion de tales circunstancias, dando asi la ocasion para que se estudien, rectifiquen ó completen.

\section{LOS TETRAMEROS- TETRAMERA}

Haciendo caso omiso de algunos diminutos coleópteros, muy prolongados y congenéricos de los anteriores, coleópteros que viven en flores y se reunen en la familia de los edemeridos, llegamos a los que solo tienen cuatro artejos en todas sus jatas, por lo que reciben el nombre cle tetrameros. Los naturalistas modernos quieren que se les llame rolebpiero cryplo pentamera, porque realmente en muchos el jxenúltimo artejo, aunque oculto, puede mostrarse, y por lo tanto en realidad existen cinco artejos.

\section{LOS CURCULIONINOS -CURCULIONINA}

CARACTERES. - Los curculioninos ó coleópteros de trompa son los que ocuparán preferentemente nuestra atencion. Segun su nombre indica, se prolongn ell ellos la calbeza en forma de trompa, y lleva en la punta de esta prolongacion los órganos mascadores, que existen en todas sus partes, excepto el labio superior, distinguiéndose por los palpos muy cortos provistos de tres artejos en el labio inferior y de cuatro en las masilas. Las mandibulas tienen regularmente un solo lóruslo y estan cubiertas del todo ó en su mayor parte por la barba en los que, segun Incordaire, pertenecen a la primera agrujacion formada por este naturalista y que a su vez se divide en scis géneros; ú bien están del todo descubiertas en los pertenecientes á la segunda agrupacion que comprende los otros sctenta y seis gencros. De las maxilas solo puede decirse que son cortas, pues su forma varia mucho. Las antenas de ocho à doce artejos salen de un hojo ó surco de la trompa, y son por lo regular angulosas, afectando la forma de miza. El dorso y los lados del escudo collar estan soldados; los costadus anteriores se tocan $\delta$ aparecen separados como los demás, moviéndase en hoyos cerrados. Las patas, cuya tercera articulacion sucle componerse de dos lóbulos, tienen por lo regular una planta esponjosa y cuntro artejos marcados; á menudo existe tambien el q̧uinto oculto. El abdúmen rodeado por los elitros se compone de cinco, raras veces de seis segmentos, de los que el tercero y cuarto son regularmente mas cortos que los restantes. La trompar, como carácter esencial de esta familia, es en extremo variable, sobre todo por lo que atane a su longitud. En los nuchos casos en que es gruesa como la cabeza, apenas se la podria designar como tal á causa de su corteza, lo que nos haria dudar si tenemos a la vista un curculionino, si en él no se reunieran todos los carncté res propios de esta farnilia. Fin las formas del otro extrenso la trompa filiorme es tan larga, 6 mas que el cuerpo. I $a$ trompa primera, corta 6 mas 6 menos prolongada y delgnda, camtia de tat modo el aspécto de los coleópteros, que hasta ahora se distinguian dos grupos principales, los de trompa corta y trompa larga. Para distinguir los 350 géneros que aproximadamentc existen, es preciso fijarse bien en la estructura del órgano en cuestion: pero no solamente ella, sino tambien las antenas, las patas y toda la forma del animal, estin sujetas, dentro de los limites indicados, a todas las formaciones posibles; asi, por ejemplo, se encuentra, por el úlimo concepto, la forma esférica al lado de la lineal.
USOS, COSTUMBRES Y REGIMEN。-Todos los CUTculioninos, que con pocas excepciones son de mediano tamaño, se mantienen de plantas, y como à menudo ciertas especies de aquellas dependen de especies deterninadas de estas, el área de dispersion de los primeros esta en intima relacion con el mundo vegetal. No hay parte alguna de una planta, desde el extremo de la raiz hasta la parte ya madura, que esté libre de los atnq̨ues de sus larvas.

Estas tienen la cabeza redonda, dirigida hácia abajo, y el cuerpo ligeramente encorvado, rugoso, desprovisto de pa. tas, mas 6 menos peludo y que se estrecha un poco hácia su parte posterior. Las partes de la boca se componen del escudo cuadrangular de la cabeza; de maxilas cortas y fuertes; de una barba gruesa y carnosa, en cuya extremidad an. terior aparecen los palpos biarticulados que parten de una raiz comun, y además la maxila interior de la mandibula inferior pestaneada y soldada estrechamente con la lengua. las antenas tienen la forma de verrugas: los ojos no existen,,$\dot{c}$, lo sumo, solo en reducido múmero.

Ia familia de los curculioninos es superior a todas las de. más por la riqueza de sus especies, cuyo último indice cuenta 10,1 4. Respecto á su distribucion geográfica son superiores a todas las restantes especies á medida que se encuentran mas próximas al Ecuador. Preficren la América al mundo antiguo: y sobre todo el sud del citado continente es abundantísimo en insectos de esta clase, contando especies, cuyo brillo y composicion de colores es imposible describir. Las incicaciones dadas bastan para demostrar cuantos deben ser los vacios que han de resultar de nuestras descripciones anteriores.

\section{EL SITONES LISTADO-SITONES LINEATUS}

CARACTERES. - Puedc scrvimos esta especie para formarnos una idea de las de trompa corta, por lo regular muy poco bonitas. Sus ispesas escamas le prestan un color gris 6 gris rerdoso; la cahezo, tres fajas longitudinales, el escudo collar, y altcrnativamente, los intervalos planos entre las series de puntos de los elitros, tienen las escamas mas rlaras y de un color amarillento. La cabeza se distingue ademís por su profunclo surco longitudinal, y' el escudo collar, ligeramente hinchado en sus lados, es mas ancho que largo. Otras varias especies, en parte dificiles de distinguir, por lo cual se las confunde con la citadia, cruzan en gran múmero por el suclo y entre las plantas bajas, despues de despertar del letargo invernal. Parece que, como alimento, prefieren las papilionácens á las demás plantas; al menos puede suponerse asi, observando los campos poblados de guisantes, habichuelas, etc. lin las plantas júvenes de las citadas especies se ven à menudo los lóbulos de has simientes, en las plantas mas viejas Jas hojas tiernas de los tallos escotadas en toda su circunferencin, irregularidad producida por los dientes de los sitones hambrientos y que sin duda perjudican el desarrollo de las plantas cuando se han cebado demasiado en ellas. A pesar de la frecuencia con que se les encuentra, no se conoce aun el desarrollo de estos diminutos coleópteros.

Ias ochenta y dos especies conocicias del género viven en los paises del Mediterrineo, en el sesto de Furopa y alguna en el norte de América, existiendo conformidad en los caractéres siguientes. Prolóngase por delante de los ojos, muy salientes, la cabeza que se adelgaza muy poco, y forma por lo tanto una trompa c:orta y angulosa, en cuya superñcie se distingue un surco longitudinal. lans antenas, insertas en las extremidades de la boca, son regulares y bastante delgadas: su tailo llega hasta el centro de los hojos, en cuyo burde in- 
ferior termina el surco destinado á cllas. Los clitros se en. cucntran juntos, son mas ó menos cilindricos, siempre mas anchos que el escudo collar, obuusos en los ángulos y' en la punta : cubren la extremidad del cuerpo y has alas. Las patas están ocultas, tienen mediana longitud y carecen de ganchos córneos en las extremidades de los tarsos.

Para aquellos de mis lectores yue tengan ocasion de ver una coleccion numerosa de curculioninos, débo manifestar que los géncros de trompa corta, cyphus, shałounus y compsus, propios solo de la América del sud, contienen esjecies que se notaran por la delicadeza de los colores y el billo de las escamas dorsdas.

\section{EL OTIORINCO NEGRO-OTIORHYNCHUS NIGER}

CARACTERES. - Ell otiorinco negro, ó el grande có léptero negro con trompa, segun lo llaman generalmente los guardabósques, es un coleóptero de un negro brillante, gue tiene las patas de un amarillo rojo, excepto las rodillas y los artejos de los piés que son negros, y sus elitros lievan series de hojitos, en cada uno de los cuales sé encuentra un pelito gris. Este coleóptero puede darnos idea de ?a forma recogida de un género, especialmente europeo, pero que tambien se encuentra en los paises del Mediterráneo no pertenecientes a Europa y en el Asia. Ningun otro género propia de nucstros paises cuenta tal número de especies (4+4). Estos coleópteros, cuyas especies mas grandes son con preferencia propias de los bosques situados en monte, se distinguen por su cabera ligeramente inclinada, no recogici en el escurio collar hasta el borde posterior de los ojos y que se prolonga hácia adelante en una corta trompa. Fsta trompa, escotada en el borde anterior, se ensancha lateralmente por encima de la base muy pronunciada de las antenas en forma de lóbulos, justificando de este modo su nombre cientifico. El hoyo para las antenas está dirigido hicia el borde superior de los ojos y es demasiado corto para poder recibir el tallo de alguelias que cuenta por lo menos doble longitud. El látigo se com pone de diez artejos, de los gue los dos primerós son inucho mas largos que anchos, mientras que los tres útimos, nuy unidos, forman cl boton de las antenis, adelgazado en forma de huevo. El escudo collar esta cortado en linea recta én ambas extremidades y ticne los lados mas ó menos ensanchados; cl escudete esti poco marcado. Ios elitros son duros y mas anchos que el escudo collar, pero poco salientes en los hombros cuyja forma es redondeada, mas estrechos y con la punta algo prolongada en los machos, los cuales son mas delgados que las hembras. Inas ancas anteriores se hallan muy aproximndas al centro de su anillo; los tarsos llevan todos en su extremidad un gancho cncorvido hácia adentro: las patas tienen cuatro articulaciones y estan frovistas de gar. ras sencillas. Estos coleópteros carecen de alas. Los distintiros característicos comunes al género presentan casi siemure el color opaco, negro ó pardo, a causa de las escanias grises que cubren el cuerpo, si bien ciertas especies se distinguen por las escamas doradas of plateadas de alyunos puntos. A pesar de pertenecer á la region templada septentrional del globo, son muy inferiores por este concepto à sus proximos congéneres de las islas Filipinas y de la Nuéva Guinea Alif se encuentran tambicn especies negras de irompa gruesa (Pachyrhinchus), cuyo escudo collar y elitros son, por térmi. no medio, mas aluultados aun, pero provistos de ajas 6 manchas compuestas de escamas de color azul celeste, doradas ó plateadas, ofreciendo maravilloso aspecto.

La especic de que tratamos se encuentra casi rodo el año en los bosques de coniferas de las montanas, aunque tampoco falta del todo en la llanura. I a carencia de alas hace que dependa del sitio de sumacimiento, enconträndose siempre alli donde una lez se ha fijado. Desde agosto youn mas tarde, se encuentra el coleóptero en su patria, siempre debajo del musgo, de la hojarasca y de las piedras, casi rigido y suma. mente perezoso. Ia circunstancia de encontrarse a su alrededor y con abundancia los restos de sus hermanos, puede hacernos dudar de si la piedra es um monumento mortuorio ó si le sirve solo de abrigo durante el sueno invernal. Ambas suposiciones pueden aunarse. Los coleópteros viejos nque han alcanzado el fin natural de su vida buscan un lugar retirado para morir: el coleóptero jóven nacido durante el verano en cl seno de la tierra, busca un refugio para pasar en él la estacion rigurosa, despues de haber disfrutado durante algun tiempo de la vida al aire libre. Sea como fuere, durante la Pascua de Pertecóstes los coleópteros se encuentran en mayor numero en los bosques de pinos donde corroen los arbolitos jovenes a ras del suelo, sobre todo cuando cubiertos por la yerba no experimentan estorbo en su trabajo. Con el tiempo suben por el tronco atacando tambien a los retoños. Por medio de los ganchos de que esta provista la catremidad de sus tarsos pueden agarrarse á él de tal modo, que el viento mas violento no puede arrojarlos con facilidad, siendo no menos dificil despremderles del dedo a que se agarran en el acto de cogerles. Durante el ticmpo ya citado se verifica el apareamiento; la hembra fecundada penetra en la ticray de. positi sus numerosos huevos; las larvas que de ellos nacen corroen las raices de las roniferas, a manera de la larva del abejorro, y se encuentran casi siempre reunidas en pequeinas sociedades. La larva es muy parecida a la del hylobius abietis, pero soure unas series trasversales de prominencias espinosas esta provista de mechones de pela. Como en verano se cncuentran todos los grados de desarrollo, la metamorfósis debe ser muy desigual, aunque se verifique en el trascurso de un ano desde la puesta del huevo hasta que aparece el coleóptero. Esta irregularidad permite que se explique la aparicion de nuevos colépteros en los meses de julio à se. ticmbre; y por lo tanto su presencia durante todo cl ano. Las plantas atacadas se vuelven amarillas durante el primer año; en el segundo rojas y entonces inueren; por cuyo motivo es preciso impledir la propagacion del coleóptero, recogiéndolo y matíndolo.

Dada la gran multitud de los otiorincos plantivoros y que por otra parte no dependen exclusivamente de una planta determinada, viéndose obligados á permanecer-en el sitio donde nacieron, a no ser que el agua les conduzca á otros lugares, no debemos admirarnos de que una ú otra, especie perjudique nuestros cultivos. Asi sucede, por ejemplo, con el otiorlajnchus sulcatus, especie mas pequeña, con manchitas de jelos de un gris amarillo que cubren irregularmente el cuerpo negro. Este coleóptero vire en los retoios de las cepas, mientras que su larva corroe las raices de las primulas, fresas, etc. El otiorhnehus migrita, parecido al anterior, pero mas gris aun, y el otiorhyehus picipes han perjudicado alguna que oira vez. los retonos de las cejas, micntras que el oliorhyuchus ligustici ataca a los melocotoneros. Estas y otras especies dañinas deben recogerse cuidadosamente, tan luego como se presentan, antes de que las hembras hayan deposita. do sus huevos: de este modo sera iácil destruirlos pronto.

\section{LOS FILOBIOS - PHYLLOBIUS}

Con el nombre de coleópteros de trompa verde, Ratzeburg ha reunido un numero de especies de trompa corta pertenecientes á distintos géneros, porque el cuerpo de los mas está cubierto de abundantes escamas de color verde do- 
rado, rojo cobrizo o azul metalico, y porque cn su mayoria visitan diferentes arbustos frondosos para romer las retonos. E. citado coleccionista clasifica con el nombre mencionado al género Phyllolius, en el que, desde el surco de las antenas elévase la trompa casi en linea recta hácia la initad anterior de los ojos, mientras que los elitros de forma oval prolongada en los hombros, cubren las alas. Pertenecen tambien a este grupo algunos géneros alados, sobre todo los Wetallites, cuya trompa es cuadrangular, plana en su parte superior, $y$ los artcjos de la base del látigo de las antenas coniformes: tienen ademas el polydrosus con in trompa redondeada y los artejos de la base del látigo prolongados. Ia historia del desarrollo de estos coleópteros vulgares es hasta ahora poco conocida: se parecen, sin embargo, mas yue la mayor parte de los de nuestro pais, it las brillantes formas de las regiones ca. lurosis.

\section{LOS BRAQUICEROS-BRACHYCEROS}

CARACTERES. - In Airica $y$ en las costas europens del Mediterráneo se encuentran numerosas especies del género de los braquicuros, coleópteros de forma encogida, cu. yas partes aisladas presentan colores opacos y que demuestran á primera vista la condicion de arrastrarse perezosa y torpemente por el suclo y por debajo de las plantas. Al examinarlos detenidamente, se observa que los clitros ovales 6 rectangulares, lisos $\delta$ provistos de rasgos prominentes, están soldados. Ia cabeza, dispuesta casi verticalmente, presenta uma trompa muy gruesa, separada de ella casi siempre por un frofundo surco trasversal ensanchado hácia adelante, y provista de un surco arqueado para las antenas, queson gruesas y cortas. Los ojor estàn rodeados, mas ó menos por completo, especialmente hicia la parte superior, de una prominencia que aumenta la aspereza de la superficie, la que se nota mas aun en el escudo collar trasversal, porque en él, los surcos, protuberancias, espinns laterales, ctc, producen gandes irregularidades. Con frecuencia se ensancha anuella en forma de glóbulo cerca de los ojos, de modo que estos quedan cubiertos en parte como por una anteojera. El escudete falta. Los elitros cambian mucho en su forma; se dirigen formando ligeros arcos hácia las partes laterales del cuerpo ó se doblan por debajo de los bordes en ängulo recto; se redondean en los hombros hàcia atrás, $\delta$ presentan casi un rectángulo ó bien un cuadrado. Las patas son pesadas, comotodas las demás partes del cucrpo; los muslos se ensanchan poco ia poco, y los situados en medio se tocan con las ancas; los tarsos son rectos, provistos de un àngulo exterior é interior; los piés estrechos casi cilindricos; lis tres primeras ariculaciones prolongadas en la extremidad en forma puntiaguda. El tegumento quitinoso del cuerpo grueso suele ser en gencral duro en los curculioninos, aunque en el caso presente excede notablemente de lo regular.

\section{LOS LIXOS-LIXUS}

-A la segunda agrupacion de Lacoráare, es decir, 2 los curculioninos con maxilas libres no cubiertas, pertenecen todas las especies que nos quedan por describir, y en primer lugar los lixos. Estos coleópteros, muy prolongados y de forma cilindrica, ofrecen la particularidad de segregar un polvo amarillo, con el que cubren su cuerpo, polvo gue renuevan hasta cierto punto cuando se ha gastado por efecto del roce. Se encuentran diseminados por todos los continentes en larvas de las especies de nuestro pais, y viven en los tallos de diferentes arbustos, en los que abren galerias.
EL LIXO PARAPLÉCTICO-LIXUS PARAPIECTICUS

CARACTERES. - F.1 lixo parapléctico es un coleóntero de prarticular estructura, de color pardo gris cuando se ha des. pojado de la capaz amarilla; el escudo collar está provisto de funas arrugas puntendas, y en la region ocular del borde anterior se halla cubiurto de largas pestañas. Háscle dado su calificativo fundindose en la errónea opinion de yue los caballos se paralizan cuando comen la larm. Estn vive en los gruesos tallos huecos del fhellandrium aguaticum, llamado últimamente renante aquation, junto con las del belodes sheIlnndrii, sjum latifolium, y otras plantas acuáticas. Si cuandn aparece la flor fijamos nuestra atencion en las reducidas espesums de anuellas primeras plantas situadas a orillas de un pantano, podremos descubrir algunos agujeros del tamano de un grueso perdigon. En tal caso el coleópiero ha salido y:a; pero al mismo tiempo se encuentran en los tallos ilesos las crisilidas, coleópteros recien nacidos, del todo blandos y blancos, tambien del todo desarrollados y prontos a salir. En cada celda vive un lixo, mientras que los ntros cohabitantes se encuentran regularmente reunidos en major número.

El coleóptero pasa el invicmo en seguro escondite, cerca de los sitios en que en ln primasera nacen los retonos de la planta que les sirve de alimento. Yo le he cogido muy desarrollado y cubierto de una espesa capa de polvo en 30 de setiembre de $18 ; 2$, en un charco cosi seco, rodendo de plieIlosdriun y en parti entre hojas estrechamente unidas. 1)n. rante la primavera siguiente se verifica tambien, segun otros observadores, el apareamiento. Cuando las sitios en nque residè son inundados por las aguns de jrimavera, se da á conocer como experto naveganc, ó mejor dicho, nadador. Entonces baja tambien por la planta a la profundidad del agua, donde Ia hembra deposita sus huevos aisladamente en los tallos. Iisto lo hace duranie el tiempoen que la menor parte de las plantas que le sirven de alimento ha salido de la superficie del agua, I. para que no tenga que esperar a çue aquellas aparezcan, Ia naturaleza le ha organizado conveuientemente is fin de que pucda verificar la puesta por debajo del agua.

I as puntitas ahoruguilladas en las extremidades de los clitros son propias tan solo de alguna que otra éspecie; pero to. das ofrecen analogia por la trompa cilindrica de mediana longitud, en la que el surco de las antenas se dirjge hácia la garganta. Los ojos, ovales, se hallan dispuestos libremente delante del escudo collar. en cuyo horde stuperior se observan dos ligeras escotaúur. El escudicte faita; los muslos anteriores se insertan en ancas cortas en forma de espigna, y con los mrsos acabados en un corto gancho el animal se agarna vigorosamente à su base. Sućltala, sin embargo, en seguida, y se deja caer con las patas recogidos si receln un peligro, por cjenplo un sacudimiento de la planta en que habita. etcétern; por eso es tan fácil cogerle con la red, cayendo con ella sobre las partes superiores del fhellandrium.

\section{LOS HILOBIOS - HYLOBIUS}

El género pissodes, representante del gnipo anterior en las regiones templadas y frias del hemisferio septentrional, es en extremo congenérico del grupo heilisus, propio de la Ame rica del sur.

CARACTERES. - I as especies pardas, provistas de pelos cerdosos de un color claro, viven como los hilobios, en extremo semejanies à ellas, a costa de las coniferas, en las que chupan la savia de los retonos en el tiempo de la subida de la misma. La savia sale por numerosos ayujerus. In corteza se hincha y salta y la rama muere. I os phantios quedan muy 


\section{I.OS TETRAMFROS}

perjudicados por estos colépteros, de los que dos especies solure todo son un extremo odiadas de los guarda-hosques. lil hilobio de los abetos (iglolius abiefis) opta preferentemente por los pinos, y es, de las dos especies mencionadas, la mas grande. Por lo que respecta a los colores que adornan su rucrpo, solo diré que sobre un fondo castaño mas ó menos claro, aparecen manchas cnfiladas a manera de fajn, formadas por cerdas de un amarillo de orin. Tres caractéres esemciales distinguen á esta especie de la siguiente: las antenas, insertas en la trompa, que es mas gruesa cerca de la boca; cl cscudete plano, triangular; y una cscoiadura bastante profunda en el borde anterior, es decir, en la parte anterior del pecho. Una callosidad obiusa delante del extremo de cada elitro y la punta cspinosa en que los tarsos àcaban hácia dentro, son caractéres comunes con el pisoto punteado, del que se distinguc, lo mismo que de otros congéneres, por el dientu visible źn cada uno de sus gruesos musjos. Con aỹida de la espina de şue sus tarsos estan provistos, estos peréosos coleópteros pueden ámirarse de tal modo que es dificilly hasta doloroso desprenderlos de un dedo. Fi apareamiento del coleóptero se verifica durante los meses de mayo y junio, aunque en el mismo setiembre se encuentran parcjas úniths, por lo que se echa de verptue la hembra no ha con¿inuado el irabajo de la cria Nuestro coleóptero vuela ia la luz del sol, dirigiendose con preferencia, para reproducirse, á los sirios mas distantes, tan luego como conprende que el liggar en que nació no le es conveniente. Ilegadoá su nueva residencia, se le ve jascar con marchn perezosa á posarse en tiernos arbolillos y en mmas, de las quic coine.

Segun ya hemos dicho, es odiado por los guarda-bosques, 6. caisa del perjuicio que ocasiona en los plantios; porque no atacal los troncos viejos cuya corteza es gruesay durn, sino que corroe solo la corteza tierna en determinados puntos. El tronco I mma heridas despiden el jugo, lo que les da un aspecto desagradable, rolviéndose despues los conos ama. rillos y murićndo jor último la planta. Durante el aparen. miento, el nuacho mas pequeño cubre a la hembra; aubos permanecen bastante tiempo en esta posicion, permitiendo se les observe en los troncos. montones de macicros, tabias, et cétern. Consumado el matrimonio, su apetito disminuye; los machos mueren y las hembras tantien, despues de haber depositado sus huevos.

Estos son de color blanco sucio y trasparentes; se depositan en las hendiduras de troncos cortados, debajo de la parte gruesa y saliente de las raices, sobre todo en sus extremos cortados, y por lo tanto pululan en los bosques de aznachos $y$ de pinos de tala.

los bosques de mayor extension son, con preferencia á los pequuios $y$-estrechos, verdaderos sitios de cria para estos roleópteros.

Las larvas salen dos 6 tres semanas mas tarde de los hueros, penetrando en galerias mas $\delta$ menos onduladas, las que se ensainchan, á medida que estos animales se desarrollan y llegan hasta la médula, $\delta$ si la cortera es muy delgada. mas hácia el interior, internándose en las raices hasta una profun. didad de 0 , 6.4 por debajo de la superficie del suelo. La crisálida aparece en la extremidad mas ancha de la galenia. Por lo que resprecta $i$ la duracion del desarrollo, este no es tan regular que pueda apreciarse con toda seguridad; pues en invierno se encuentran larvas, crisilidas y colebpteros. Estos últimos viven debajo del musgo, de la hojarasea, en agujeros de otros insectos ó ambier en el suclo. Hay quien supone á la cria un año de existencin, otros ojjinan que debe contar dos: pueden tencer razon unos y otros; porque el punto de cria, la mayor ó menor tempreratum, el tiempo mas ó menos favomble, segun los años, la puesta nas ó menos temprana de los huevos, son circunstancias que pueden influir esencial.
mente en el desarollo.

Segun hemos visto, en este caso; no es la larra, sino el coleóptero el que causa los perjuicios, inmediatamente por la muerte de las plantas jóvenes, o mediakamente porque los agujeros atraen al pequeño pisodo punteado, ó al escolitido de la corteza, continuando ambos la obra destructorn, bien que cada uno a su manera. Ya hemos mencionado los puntos en que con preferencia se fija el coleúptero. Tambien corroc los capullos que a la sazon no pueden desarrollarse, los retoños tiernos de mayo que con facilidad se rompen á impulso del viento, atacando además los capullos de los pequeños
alisos, abedules y fresnos. Toros perjuicios se precar

Estos perjuicios se precaven con mas seguridad si se espetrascurran dos ó tres años, es decir, cuando se pueblan de nuevo los claros producidos por la corta de los árboles; porque cutonces la cria existente en los troncos y raices de los arboles talados se ha extinguido y el coleóptero se ha visto obligedo a buscar otros sitios, a causa de faltarle el alimento. Ial nicdida de precaucion se ha empleado con el mejor éxito, sobre todo en el Harz: dejaremos de consignar otra, por no ser este libro una obm de setvicultura. Solo debo mencionar el mas importante medio de destruccion del colcóprero ya existente. Se coloca una corteza en el suelo, especie de urampa jor debajo de la cual se reunen los coleópteros, los que se recogen a primera hora de la mañama, ó por la tarde. Para este objeto, la cortera del azcachon es mejor que la del pino: porque se conserva mas tiempo fresca. I as fajas de corteza se doblan hácia adentro, colocandose con la cara interior apoyada en el suelo, y sujetúndolas con una piedra para ásegurar sú posicion. En el reino de Sajonia, se recogicron de éste modo en i 855 en todos los bosques del Estado 6.703,747 coleópteros mediante un gasto de 1,973 thalers, 20 y medio groschen, y eń el año anterior 7.043 .376 coleópteros por 2,001 ihalers, $6 \mathrm{y}$ \% / groschen, desde 1." de mayo hasta 15 de julio, durante cuyo tiempo, en 30 de mayo, se cogieron en mayor número estos insectos.

El hilobio de los pinos (hylobius pinastri) es la mitad mas pequeno, y lleva en rez. de las fajas, manchas formadas por los pelos de un color amarillo pálido. Se encuentra con preferencia, segun observaciones del jefe de guarda-bosques, Kellster, en la selva de 'luringia y es an perjudicial como la especie anterior, distinguiéndose, sin embargo, por la mayor agilidad en el vuclo y por fijar su residencia en árboles mas alros.

\section{LOS EUFOLOS - EUPHOLUS}

CARACTÉRES. - Los insectos de este género tienen las antenas algo mas cortas, mas robustas y cilindricas que los paquuirincos á los cuales se parecen; cl protórax no es tan deprimido, y los elitros, mas paralelos, se estrechan brusca. mente por detrás. I os cufolos son tambien mas homogéneos por su color, que consiste siempre en fajas negras y tmsversales en los elitros, sobre un bonito fondo verde mas ó menos metálico, tinte que se extiende à todos los órganos sin ex. ceprion.

DISTRIBUCION GEOGRÁFICA. - Las especies de este géncro parecen ser propias de la Nueva Guinea y de tas Molucas.

\section{EL EUFOLO DE LINNEO-EUPHOLUS LINEII}

CARACTERES. - Los atributos esenciales de esta especie (fig. 26) son los indicidos en el genero. 
DISTRIBUCION GEOGRÁFICA. - Se enclientra sobre todo en Cayena y en las Molucas.

\section{LOS PISODOS-PISSODES}

El perzueño pisodo punteado se distingue esencialmente del hilobio de los abetos por las antenas inscrtas en el centro de la trompa mas delgada, por su escudete reciondo y prominente y por la parte anterior del tórax no escotado. Tiene un color pardo mas ó menos amarillento ó rojo. Los mecho. ues de cerdas de uque esta provisto, son claros, casi blancos; $y$ de ellos algunos se hallan sobre el escudo collar que afecta la forma de quilla, se agrupan en los clitros, formando manchas mas grandes delante del centro ó bien fajas deirás del mismo. No todos los individuos tienen el mismo matiz claro que además varia por el roce de las cerdas. Con fre. cuencia la desaparicion de los dibujos formados por los puelos y las escamas puede dar un aspecto esencialmente diferente a un pisodo viejo, del que presentan los individuos jóvenes. El pisodo punteado (pissodes nofalus) se distingue entre los demás pertenecientes à este género, por el puntuado desigual de sus elitros; pues los puntos son mucho mas grandes en el centro de aquellos y afectan una forma casi cuadrangular, nientras que los de los contornos son mas juequeños y redondos.

Lo mismo que el hilobio de los abetos, se presenta cista pequeña especie en mayo, pero en mayor número y en una extension mas vasta (pue aquel. Al principio solo se ocupa en comer, atacando la corteza de los azcachones, raras veces de los alerces y pinos; perfora la superficie de estos con la trompas, pero extrae poco alimento. de mudo que produce en aquella muchas heridas. Estas parecen' gruesis picaduras de aguja y dan á la superficie un aspecto sarnoso. Por lo regular el pisodo se fija en plantas de cuatro á ocho ab̂os: pero nó desprecia por eso a falta de aquellas, las mas viejas y hasta las de treinta anos. Cuando los dias son calurosos, la vivacidad del coleóptero aumenta y el apareamiento se verifica del mismo modo y en los mismos sitios indicados en la especie anterior: si bien ambas se distinguen mucho en la puesta de los huevos. I.a hembra de la especie que nos ocupa busca no solamente los troncos enfermizos de quince it treinta años y aun de mayor edad, sino tansbien los sanos, y solo cxcepcionalmente las raices cortadas ó los montones de maderos. Las galerias de las larvas comienzan casi siempre por el punto de interseccion de la rama superior con el tronco ó bien un poco mas arriba, ý se dirigen ondulada y regu. larmente hácia la parte inferior de aquel, ensanchindose poco a poco por debajo de la corteza. El espacio no queda hueco, sino lleno de desperdicios pardos y blancos, precidos à la morcilla. En la extrumidad de las galerias, in laria construye un hoyo oral que pénetra profundamente en la maderay hasta toca la médula en los tronquitos jóvenes formando los desperdicios tiernos un lecho, donde se irasforma en crisilidin en cuyo estado reposa pocas semamas. El colcóptero sale casi siempre por un agujero del tamaño del que produce un perdigon del número seis $\delta$ sicte. Todavia en el otono, pero mas tarde, vuclve á ocultarse entre las hendiduras de la corteza, en el musgoy la hojarasca, para pasar alli el inviemo. Como el desarrolio es tan desigual invernan tambien larnats y crisalidas. En piñas del ano anterior, de los arboles muy poco desarrollados, se han visto aun larras aisladas y hasta reunidas de tres en tres.

Como al coleóptero le gusta limitar toda su actividad a un mismo arbol, cn el que come y deposita su cria, pronto llega à ser pernicioso, en particular para las planias jóvenes, y cuando otras especies de insectos le ayudan cn su obra destructora. Por esto es preciso vigilarle bien y retinu al punto las plantas que preficre.

'Toda una serie de otras especies del misnıo género lłaman La atencion del guarda bosque, pero no nos queda espacio para hacer mencion de ellas minuciosamente.

\section{LOS APIONES-APION}

CARACTERES. - Ios apiones son peyueños coleópteros representados por unas cuatrocientas especies disemin:das por todo el globo. Algunos pucden vicrse durante tocio el año, pues cuando han despertado de su sueño invernal visitan los arbustos ian luego como estos comienzan à revestirse de su verde follaje; otros se pasean por las plantas bajas, qุue sirven de alimento, no solo a los coleópteros sino tambien á sus lamis; y en in, hillanse en todas partes, aunque al pronto no se les ve a causa de su pengucñez. El cucrpo, que afecta la forma de pera, es mas grueso en su parte posterior, prolongándose en la anterior por una delgada trom. pa cilindrica, que suele ser mas larga yo endeble en la hembra que en el macho, y à veces mas gruesi en su mitad posterior nue en la anterior. El escudo collar, siempre mas largo (que ancho, es del todo silindrico of un poco cónico; los muslos afectan por lo regular la forma de maza; los tarsos son rectos y los piés delgados. El segundo segmento abdominal, separado del primero solo por una sutura muy fina, es mas largo que los dos siguientes. El cherpo carece de dibujos, pero tiene á menucio un brillo metálico, negro, azul ó verde; y tambicn hay esprecies de un rojo de minio; los elitros suelen tener profuncos surcos. Por su amalogia y jutyuchez la clasificaciun de muchas especies ofrece grandes dificultades.

\section{EL APION DEL SOL-APION APRICANS}

CARACTERES.-Esta especie, llamada tambien mascyranita aniga del sol, tiene una tromja de igual grueso ch todas sus partes y algo corra; lats antenas se hallan en el centro; el escudo collar se estrecha hácia adelaniz: los elitros. de forma oval esferica, presentan rayas puntendas, con los espacios libres ligeramente convexos.

Este pequerio colcóptero siene un color negro brillante, con la base de las antenas de un rojo amarillo, como el de las patas anteriores y los muslos de las otras, mientras quic todos los artejos sor negros, lo mismo que los jiés.

Despues de invernar los coleópteros se aparęn, y hecho esto la hembra deposita varios huevos en las flores del trébol. lelegado el tiempo de la prinera cusecha, las larvas son adultas y conviértense en erisalidas entre las flores.

No se a punta fjo si en el mismo ano se verifica una stgunda cria. Jil apion assimiley el asion trifolis observan el mismo género de vida, y de utras nuchas especies se sabe que viven igualmente en las simientes, sobre todo de las papilio. náceas, donde jasan al estado de crisilidas; para esto practican a veces galerias en los tallos. I a lara del afion cracie devora las simientes de una especie de arbeja (aricia ernecos). el apion ulicis (ó tambien ilicis) busca las del whex europeus: el apion sayi, propio de la Anverica del nortis, prefiere los granos de la baptisia tinctoria; el afions fiarifes vive on las flores del trébol blanco de Holanda; y el afion: ulicienla produce agallas en el wher momis, en los çue la lavia inserma y se trasforma en crisilida. El apion: rodiolus abre galerias en los tallos de las malvas ó del fanacetum aulgar, en los que tambien se convicre en erisalida las numetosis especies que viven en los arbustos se desartollan sin duda en ellas de un modo desconocido aun. I as larnss observindas se parecen unas à otras de tal manco que dificilmente se distinguen con el microscopio. 
A los apiones siguen algunos otros géneros que se caracterizan por tener las antenas rectas, distinguiéndose sobre todo por la solicitud de las hembras con sus crias, tanto mas curiosa cuanto que es un fenómeno raro entre los coleóp. têros.

A fin de proporcionar a su progenie las condiciones necesarias para la vida, las hembras buscan las partes de las plantas yue mas lés convienen, y que suelen ser las que están marchitas, lo cual demuestra que la larva necesita un alimento seco que solo contenga la humedad del aire. Algunos casos concretos y las costumbres de ciertas especies parecen confirmar el hecho.

\section{EL APODERO DE LOS AVELLANOS-APODE- RUS CORYII}

CARACTERES. - El apociero de los avellanos us un coleóptero de color negro brillante, sojo en la parte anterior del dorso; los elitros presentan ravas de juntos y varias arrugas en los intervalos: su longitud varia de $\left(1^{m}, 0065\right.$ il $0^{\circ}, 000$.

Este insecio tiene una trompa corla y gruesa, que como un nudito se inserta en la parte anterior de la cabeza, preseniando en su cara superior las antenas, yue son rectas y en forma de maza; la cabeza se estrechn en figura de cuello por detris de los ojos, que son sailentes; el escudete, grande y trasversal, es recto en su linea anterior: los elitros sobresalen del escudo collar y se ensanchan en su parte posterior dejoindo descubierta la rabadilla; los costados, en forma de esjuga, se tocan; los muslos, en figum de maza, carecen de protuberincias; los tarsos, que son rectos, rematan en el macho en un gancho y en la hembra en dos; el último artejo de los pies lieve garras unidas en la base l.os dos primeros segmenros abdominales están soldados.

DISTRIBUCION GEOGRAFICA.- Este coleópiero es comun en toda ja Alemania y en Suecia.

USOS, COSTUMBRES Y REGIMEN.-Este insecto sucle encontrarse por lo regular a mediados de mayo (en e! ano $1 \$ 22$ le halle ya el 27 de abril) en los avellanos, arbustos bajos, alisos y hayas; pero no causa en ellos jerjuicios de ninguna importarcia, por lo que toci al alimento; la hembra en cambio, deposita sus capullos, que tienen la forma de un pequeno rollo, en las hojas mas grandes, á veces en númcro de dos ó tres, con lo cual las inutiliza como órgano de alimentacion de la planta. En el bosque inmediato à nuestra ciudad, donde no existen las hayas, esta especie y el atelabo curculionoideo, de los que mas tarde haremos mencion, se limitan casi exclusivamente a las hojas de encina. Para trasformarlas en capullos, la hembra practica un corte un una mitad i cierta distancia del talio, corte yue alcanza un joco la segunda mitad de la superficie; despues vuelve el pedaro asi cortado, una ver. marchito, de modo que el nervio cênutral quede en el eje longitudinal, micntras que la punta de la hoja y el pedazo cor. tado se doblan y ciersan el rollo por arriba y abajo. Entre los repliegues de aquel, y casi siempre cerca de la punta, hállase el huevecito, de color amarillo de ámbar, y a veces dos $y$ hasta tres reunidos, que sin duda son depositados mientras la hembra construye el capullo: y no despues. Es natuml que la hembra fabrique mayor número de capulios yoponga de consiguiente sus huevos en el espacio de varias semanns. Cuando la temperatura es calurosa desde la seyunda mitad de mayo yu junio, y si hay calma, el trabajo avinza con rapider y los capullos aumentau visiblemente. La larsa se alimenta en el interior del capullo, humedecido cuando mas por la lluvia ó el rocio y le llena posco à poco de excrementos filiformes ondulados, de color negro. En la mayor parte de casos el rollo cue, probablemente en lat hojn mal alimentada, antes de que la larra llegue á ser adulta. Yo encontré larvas vivas aun en capullos, los cuales recogi en la segunda mitad de setiembre de 187 ; púselos sobre arena ligeramente humedecida y no los abri hista el 25 de abril de 1872 , de lo cual deduzco que en ellos se convierten en crisílidas. A pesar de las numerosas hojas que en invierno quedan aun en los arbustos, provistos de muchisimos capullos, no pude encontrar uno solo con larms, ni en los arbuston de encina, ni en el suelo. Ratzebury dice que el coleóptero de una cria de verano esta desarrollado ya en agosto, se propraga á 54 vez, y que luego las larvas de esta cria invernan; pero esto no pasa de ser una excepcion. Nunca he visto capullos con agujeros de salida, fijos en los arbustos, pero si muchisimos no consumidos en su interior, y cuyos huevos, por lo tanto, no habian podido desarrollarse. Quizas el alimento de las larvas despues del invierno difiere esencialmente del que encuentran en rimno en los capullos secos.

In larva es de color amarillo de yema, y tiene el cuerpo tan arqueado que parece doblado en su mitad; las prominencias de los tres primeros segmentos del cuerpo sobresalen laicia abajo, y los del cuarto á sexto se clevan mas en el dorso que en las otras partes del cuerpo, hallándose provistas de pelítós cerdosos. La cabeza de color gris pardo, mas oscuro en los órganos masticadores, adelgráase un poco y se prolon. ga. A causa de ser el cuerpo muy arquendo no parece à primera vista que estos insectos tengan la longitud de $U^{\text {m }}$,orr.

\section{EL APODERO DE CUELLO LARGO - APODE- RUS LONGICOLLIS}

L1 apodero de cuello largo, especie de Java, se parece mucho â la nuestrá, y no seria mas grande si el cuello no se prolongase de tal manera, sobre todo en el macho, que Fabricius tomó este insecto por una esprecic independiente, dán. dole el nombre cientifico de apoderus cygmus (apodero cisne). En efecto, se asemeja al cisne por lo cuue hace a la forma de su cuello. Este insecto es tan extrano que no puedo menos de hacer mencion de él.

\section{EL ATELABO CURCULIONOIDEO-ATTE- LABUS CURCULIONOIDES}

CARACTÉRES. - Estr especie se asenieja al apodero de los avellanos por la estructura y el género de vida, pero difiere por su forma recogida ! por tener la superficie del cuerpo casi hemiś́érica. Su trompa es gruesa y cilindrica, casi tan larga como la cabeza, que en su parte posterior no se estrecha à manera de cuello; cerca de su base, mas hácia la region superior, y en un profundo hoyo, hállanse las antenas, que son rectas y rematan en un boton compuesto de tres artejos. El escudo collar, casi esférico, parece pulimentado: el escu. dete es casi cundrado: los clitros, de esta última forma, en su contorno son muy comveros, mas anchos que el escudo collar, y cada cual redondeado de manera que la rabadilla queda visible; en la superficie son ligeramente rayondos, ticneti varias arrugas, $y$ en los intervalos puntos muy finos. Ios muslos son gruesos; los tarsos tienen dos ganchos en la extremidad, y los anteriores son denticulados en su cara interior. Este coleóptero es de color negro brillante en Jos elitros, y en el escudo collar de un rojo brillante, como suele serlo casi siempre tambien la base de las antenas.

USOS, COSTUMBRES Y REGIMEN.-Desde Mayo hasta julio se encuentra este insecto en los arbustos, donde la hembra construye un capullo yara cada huevo, 10 mismo que el apodero de los avellanos. Yo he cogido capullos de uno y otro insecto, creyendo que pertenceian à uno solo de 
manera nue únicamente por la diferencin de las larvas reconoci yuce cran de dos especies. Ja larva del atelabo tiene en todos sus segmentos iguales arrugas trastersales, y son poco peludas; la cabeza se inserta i poca profundidad en el primer segmento grande, que es liso: en el dorso cuacirangular; el cuerpro no tiene el color amarillo de yema, sino de un blanco sucio. Fi] 30 de junio encontré coleópteros que construian sus capullos y me llevé á casa algunos de estos; en cada uno de ellos habia un huevo esférico de color amarillo verdoso. Los capullos, recogidos en la segunda mitad de sectiembre, tenian todos el 6 de noviembre un agujero, por el que la larva habia salido para penetrar en la arena y sufrir su inetamorfósis; los capullos que no tenian el orificio pertenecian á la especie anterior. De estas obserwaciones resulta como diferencia entre las dos especies congenéricas que las larvas del atclabo se convierten en crisálidas en tierra.

\section{LOS RINQUITOS-RHYNCHITES}

CARACTERES, - Las tres citadas especies no son las únicas cuyas larras tienen la curiosa costumbre de cons. truir viviendas. Se conoce además cicrto número de otras, llamadas rinquitos (arrollodores de hojors), aunque no todos sus congéneres saben hacerlo. Son insectos diseminados por toda la superficic del globo, excepto Australia; pero abundan sobre todo en las regiones del hemisferio septentrional del antiguo continente. Todos estos coleópteros carecen de dibujos y tienen por término medio el tamaño de los anteriores, aunçue tambien se encuentran mas pequeños; la mayor parte de ellos se distinguen por su color azul con brillo metálico, verde, rojo cobrizo y pardo bronceado. La cabeza es cuneiforme y no se estrecha en forma de cuello; los ojos se hallan en la parte anterior de la base de la trompa: esta última, mas ó menos prolongada, filiforme; ó recorgida, se arquen casi siempre un proco y tiene, poco mas ó menos en su centro las antenils, que son rectas y se ensanchan poro á poco, formando una maza foliacea de tres artejos. El coselete se estrecha en ș jarte anierior y en la posterior: el escudetc esti dispuesto trasversalmente: los elitros, siempre mas an. chos que el coselete, ya cortos, ya largos, y medianamente convexos, se redondean en su parte posterior de modo que el trocánter queda casi siempre visible. I.os costados de las patats anteriores forman espiga y se tocan, pero no los esfé ricos de las otras patas.

USOS, COSTUMBRES Y REGIMEN. - A estos coleópteros les agrada volar cuando brilla el sol; déjanse caer como muertos cuando ven que se acerca un hombre y sacude el arbusto doncle se hallan 6 turba de cualquier modo su tranquilidad. Se les puede coger por lo tanto, aunque no sin gran precaucion, poniendo una mano ó cualquier objeto debnjo de ellos, mientras que la otra los sujeta.

\section{EL RINQUITO DE LOS ABEDULES -RHYNCHITES BETULETI}

CARACTERES. - El rinquito de los abedules tiene un color azul, á veces verce dorado, brillante y sin prelos; la tromma no alcanza la longitud de la cabeza y del coselete juntos; la cabeza es ligeramente cóncava entre los ojos; el coselete tan largo como ancho en el centro, con numerosos puntos, como los de los elitros; no es rugoso, pero si deprimido ligeramente en su parte anterior, presentando vestigios de un surco longitudinal, provisto en el macho de una es. pina que se dirige hacia adclante.

USOS, COSTUMBRES Y REGIMEN.-Liste colcóptero arrolla las hojas de los mas diversos arboles y arbustos, reuniendo à menudo varias hojas en su cajullo. Se presenta en mayo y junio en el bosque donde visita las hayas, los tilos, varias especies de sauces y abedules; en el Canada visita los perales; membrilleros y cepas. Ia causa de ser tan variada su residencia se explica, segun parece, por el hecho de alimentarse de las partes blandas de los arrboles, cligiendo las hojas tiemas para la conseruccion de los capullos. A reces ocasiona grandes destrozos en los pernles, y sobre todo en las cepas, picando los retoños, que despues se marchitan: cuando no encuentra ya hojas tiernas arranca con la trompa estrechas fajitas de la epidermis de la cara superior de las hojas, dejando solo intacta la inferior. I.os capullos tienen figura de cigarros; la hembra los construye en las diferentes plantas de un modo muy diverso: en las hayas, perales y sauces necesita varias hojas, à causa de su pequeñez, mientras que en los membrilleros y en las cepas le basta una; picando los retonos, ó bien los tallos de las hojas, interrumpe la circulacion de la savia; las hojas comienzan a marchitarse y se atrollan. No puedo menos de reproducir aqui la inieresante observacion de Nordlinger. "Fl 12 de jumio de 1856 a las nueve y media de la mañana, dice, cuanclo hacia sol, pero soplando el viento, observamos un rinquito de los abedules en el retono de un álamo del Canadi, árbol que este insecro preficre para construir sus capullos, porque las hojas son mas espesas y crecen quizas menos ripidamente durante el trabajo. Era hembra, pues carecia de las dos espinas en el tórax, que además del tamano mas pequeno, son el distintivo del macho. El coléptero corria ansioso por varias hojas de la copa, que pendian un poco marchitas, j en las cuales veinse un agujero, que el rinquito habria practicado en el retono por la manana ó el dia anterior para interrumpir la circulacion de la savia. Sin duda con la misma intencion, y para que fuese mas flexible el retono, habia hecho varias incisic. nes trasversales en toda su longitud.

\$ El retono destinado parn la construccion de un capullo se componia de una hoja bastante fresca y rigicla aun, de otra menos desarrollada, del tamaño de las del chopo, y bastante marchita, y por úlumo, de una tercera mas pequeña aun, semejante por su dimension a las de la siringa de Persia: estaban cubiertas, lo mismo que los capullos de hojas, del jugo vegetal, y por lo tanto eran poco propias para arrollarsc: en algunos sirios de las hojas veianse particulas de excremento negras. Ia hoja mas marchita y fiexible, y menos desarrollada, habia llamado la atencion del coleóptero, y en ella quiso comenzar sin duda el capullo, pues se agarraba con las patas, oprimiendola fuertemenie para hacerla mas flexible, mas á pesar de toclos sus esfuerzos no pudo dar principio à su trabajo. Por esto examiusó todas las hojas de la cona para comencerse de que tampoco servian, y luego volvió à la primcra, hacicndo nuevos esfuerzos para arrollarla, aunçue sin conseguirlo. 'Temimos que perderia ta paciencia, pero no fué asi: el coleóptero se dirigir á la hoja desarrollada y comió de ella un poco para recobmr iuerzas, volviendo muy pronto á renovar sus tentativas, aunque otm vez fue.en vano. Impaciente ya, abandonó la hoja para pasar a otra inmediata, jero no dió como antes la vuelta jor los tallos, sino que se tendió horizontalmente, apoyaindose solo en las patas posteriores para coger la hoja. Hegado ś. ella detúrose de repente, atemorizado quizás por nuestra jurescucia, levantó sus antenas ripidamente y volvió pronto a su paseo. Varias veces le vimos picar con su trompa los tallos de lns hojas, sin duda para marchitarlas antes: luego volvió otra vez à la primera hojo, pero aun no pudo hacer nada, y entonces dirigióse á la hoja sana para comer. Al efecto, arrancó la epidermis y la parte carnosa de la mra superior, no como de costumbre por fajitas, sino pror jequeños puntos bastante re- 
dondeados. Entonces se acercó un pesado coleóptero volando, $y$ sin duda hubiera puesto en fuga al que observibamos, si no hubiéramos parado el golpe. Nuestro protegido permaneció inmóvil en el primer momento, pero despues, mas tranquilo, continuó comiendo y descansó cinco minutos. Cuando hubo examinado todas las hojas picadas volvió á la primera, en la que tantas veces habia probado inútilmente sus fuerzas, y oprimió con la trompa el repliegue que se formaba en ambas extremidades. Iuego se agarró ả él con todas las patas, oprimióle fuertemente con la trompa, repitió esta maniobra varias veces, y en pocos minutos tuvo arrollada la mitad de la hoja, a pesar del estorbo que le oponia el viento y el balanceo particular de las hojas. En seguida continuó en la otra mitad su trabajo, pero viendo sin duda que del modo empezado no podia acabar, ralióse de otro medio, que consistió en pegar el borde de la hoja con un liquido segregado de la parte posterior de su cuerpo. Ern curioso ver cómo el colećptero podia coger la hoja hasta por la superficie lisa, valiéndose de los ganchitos de sus garras y atrayéndola por medio de sus fuertes patas.

\$ El primer capullo quedó hecho, pero aun presentaba prominencias, las cuales hizo desaparecer el insecto oprimiendo la trompa y por medio de la sustancia pegajosa ya citada. Debajo del punto de que pendia el capullo, en el tallo de la hoja, el coleóptero practicó un profundo agujero en aquel, de tal modo que desapareció toda su trompa. Terminada la operacion, el coleóptero se volvió, puso la parte posterior del abdómen en el orificio, elevó el tórax, y mas aun la cabeza, y depositó el huevo. Hecho este trabajo, en el que empleó unos ocho segundos, volvióse rápidamente á fin de arreglar con la trompa la posicion del huevo en el agujero, y despues ocupóse en agrandar el capullo, alrededor del cual debia arrollar primero una hoja, operacion que exigia, no solo una fuerza particular, sino tambien inteligencia. Despues de varios preparativos, este trabajo avanzó tambien rápidamente. Es muy divertido ver cómo por fin la segunda parte de la hoja se arrolla del todo, quedando pegada con la punta del abdómen. Cuidadosamente y por los nisinos medios se cierran las extremidades del rollo, semejante a los que se hacen con la moneda: en esta operacion las patas y la trompa representań los dédos, la sustancia pegajosa el lacre, y la extremidad del abdómen el sello. El capullo, compuesto de dos hojas, quedó muy pronto acabado.

„El coleóptero se esforzó despues en traer la tercera hoja, la cual envolvió en espiral alrededor del rollo, en cuyo trabajo empleó unos seis minutos. Apoyándose luego en las patas posteriores cogió la quinta hoja pequeña, atrảjola hàcia si y la pegó; pero como estaba marchita, y cubierta de esa humedad propia de las hojas mas tiernas de los álamos, no se adheria bien. El colcóptcro cogió entonces la penúlti$\mathrm{ma}$ hojita, estiróla vigorosamente y la dobló, mas viendo que tampoco servia, fué á comer un poco, descansó algunos minutos y comenzó a preparar la hoja grande $y$ fresca de que hasta entonces solo se habia servido para comer. Con la tromja cortó la mayor parte del tallo á cierta distancia del retoño, en cuyo trabajo empleb nucve minutos, y despues mordió varias-veces ligeramente dicho tallo, ya colgante. Era de. supponer que el coleóptero dejaria pendiente la hoja hasta que se marchitase, para desarrollarla con mas facilidad; y en efecto, volvio al capullo y depositó como antes un huevo, pero empleando esta vez muy poco tiempo. Una nueva tentativa para arrollar las hojitas finales no produjo todo el resultado npetecido, porque la última opronia resistencia, lo cual indujo al insecto á comenzar el trabajo en la hoja fresca y rigida en que antes habia comido. Sin embargo, como la parte colgante del tallo exa demasiado larga y la hoja queda. ria à demasinda profundidad en el capullo, atrájola con fuer2a hácin este, arrollándola de modo que el nervio principal de la hoja se corriera trasversalmente alrededor del capullo. Conseguido esto dejó que se desarrollase otra vez la hoja, pero solo para enroscarla de nuevo del mismo modo, opera. cion que hubo de repetir warias veces porçue aquella estaba demasiado rigida y resistente. Por fin, reconociendo $\mathrm{la} \mathrm{im:}$ posibilidad de dominarla, abandonóla y volvió á enroscar la hojita anterior, que entre tanto se habia desarroliado. Lina nueva tentativa para hacer lo mismo con la hoja grande fra. casó cuando el trabajo estaba ya casi concluido. Esto suce. dia à las doce y media de la manana, hora en que dejamos al coleóptero, ocupado siempre en su trabajo.

* De vuelta al sitio á la una y diez minutos, la hoja grande estaba muy bien arrollada. El coleóptero se paseaba por los contornos, réstregando a intervalos las patas contra el cuerpo y fija la mirada en una hoja próxima, cuyo tallo intentó atraer hácia si, soltandola varias veces para adherir mejor el borce de la hoja últimamente arrollada. Esta vez vimos !a sustancia glutinosa adherirse en forma de hilo, sin duda porque el calor era sofocante. De repente el coleóptero se di. rigió á otra rama, alejándose mucho, pero al cabo de un minuto volvió so posarse sobre una hoja cerca del capullo. Volaba al rededor del sitio, alejabase de nuevo, se apro. ximaba otra vez al capullo, $y$ al fin desapareció para no volver:s

Parn dar una idea de la habilidad, fuerza y perseverancia con qque trabajan estos coleópteros, Nordlinger dice que mientras hacia su observacion soplaba un aire bastante fuerte que dificultaba mucho el arrollar las hojas del àlamo del Canadi, muy movibles ya de por si, $y$ de las que otro coleóp. tero hubiern caido mas de cien veces. Es posible que se hayan visto dos coleópteros retorando cerca de un capullo, pues son muy rivaces cuando el tienipo es caluroso; pero me parece muy aventurado deducir de esta circunstancia que tambien el macho ajuda á la hembra en el trabajo.

La descripcion anterior habla en contra de este aserto, como tambien las experiencias hechas en otros coleópteros, de los que un gran número, sobre todo himenóp:eros, construyen viviendas para su cria, sin que se conozca un solo ejemplo de que los perezosos machos se hayan ocupado en esta tarea: solo las hembras excitan por este concepto nuestro interćs en tan alto grado, ofreciendo pruebas conmovedoras de solicitud maternal y generosa abnegacion, que pueden servir de ejemplo á muchas madres desnaturalizadas.

Para completar la historia del desarrollo de esta especie añadiremos que los capullos examinados el 24 de julio estaban llenos en su mayor parte de hilitos negros de excrementos, pero no contenian ya ningura larva, pues habian peneirado á tres ó cuatro centímetros de profundidad en el suelo para trasformarse en crisalidas muy corvas de color blanco sucio: con gruesas cerdas y ojos pardos. El 8 de agosto se encontraron las crisálidas, pero ninguna larva, y el $83 \mathrm{na}$. cieron los primeros coleópteros.

El estado de larva dum dos semanas, y todo el desarrollo sesenta dias. En cada capullo se encuentran de cuatro á seis huevos, pero jamís una abertura por là que puedan llegar al capullo ya hecho, pues ya sábemos que la hembra los introduce durante la construccion del capullo del modo indicado. A veces se encuentran capullos comenzados que por cualquiera causa no se concluyeron, sin contar que cuando el tiempo es húmedo algunos se deshacen. Por lo regular se resecan los mas y quedan pendientes en la planta, aunque la larva esté desarrollada, $;$ entonces le es forzoso dejarse caer al suelo. Tambien se da el caso de que el siento derribe el capullo. 
I.os coleopteros que vemos en otoño, algunas veces apareandose, son de los huevos primemmente puestos ó de otros posteriores, desarrollados antes por el tiempo favornble, fenómeno que tambien se observa en otrós curculioninos. Antes del invierno vuetien a ocultarse sin continuar su reproduccion, pues dos generaciones en un mismo año, como algunos han supuesto, serian contra la regla

\section{EL RINQUITO DE LOS ÁLAMOS-RHYNCHI- TES POPULI}

CARACTERES,-Esta especic es muy parecicia ă la anterior pero un poco mas pequeña; tiene mas fina la extremidad de los elitros y dos colores en cl cuerpo: la parte superior es de un cobrizo verdoso 6 dondo, y la inferior de la trompa y las patas de un azul metálico. Arrolla las hojas de las diferentes especies de álamos empleando solo una para el capu110. La siguiente obsernacion denuestra cuanta es la irregularidad del desarrollo. De un número de capullos recogidos el 17 de julio y colocados sobre arena húmeda nacieron algunos coleópteros en la primera initad de sericmbre, en una habitacion bien caldeada; mientras que el is de diciembre se encontraron aun ocho larvas, al parecer adultas, pero solo una en cada capullo.

\section{EL RINQUITO DE LOS ABEDULES-RHYN- CHITES BETULAE}

CARACTÉRES.-Esta especie, mas pequeña aun, mide apenas $0^{*}, 0045$; es del todo negra yo provista de pocos pelos; trabaja en las hojas de los abedules, alisos y hayas, contentåndose siempre con um hoja y aun a reces con las dos terceras partes anteriores de una grande del aliso. Su manera de proceder en el trabajo difiere esencialmente de la que hemos descrito: comenzando poco mas ó menos en la mitad mas pequeña superior del nervio central, el coleóptero traza una línea arquueada que sube hácia el tallo de la hoja, corrne la superficie jor un lado, como por ejemplo, el derecho, jo deja ilesos los nervios laterales que encuentra, haciendo des. pues lo mismo en el lado izquicrdo; y terninada esta opera. cion, corta en la primera mitad los nervios laterales, aislando asi aquella de su capullo. En el ángulo exterior separa un poco la epidermis de la hoja, introduce en la bolsa asi formada un huevo, y arrolla despues la hoja de modo que el ángulo que contiene el huevo quede en el centro del capu. Ilo; este se sujeta fícilmente, gracias 2 la la superficie glutinosa de la hoja de aliso, ayudando el coleóptero en algunos puntos por medio de sus maxilas. Fl lado izquierdo se arrolla despues sobre la primera nitad hasta que el pequeño cartu. cho queda pendiente del nervio central de la hoja. La larua sale muy pronto $y$ abre galerias en todos sentidos. 10 cual apresura la muerte y el resecamiento completo de la hoja. Cuando el viento la hace cacr a ticrra, la larva puede aprovecharse del incidente, pero sin duda no espera esta casualidad, sino que sale del capullo cuando esta desarroliada, cae al suclo sin hacerse daño y comviértese en crisálida en el seno de la tierra.

\section{EL RINQUITO CÓNICO - RHYNCHITES CONICUS}

CARACTÉRES. - Zil rinquito cónico tiene un color azul intenso, que en algunas partes presenta un brillo verdoso; las patas y la trompa son negras y todo el cucrjo está cubierto de pelos algo oscuros. La trompa es mas corta que la cabeza y el escudo collar; este úlimo presenta en la superficie pun. tos gruesos y aislados y se ensancha poco hícia atris. Los clitros csiśn profundamenie surcados, tienen puntos en los intervalos y son mas anchos en la parte posterior. I a longitud del insecto hasta la base de la trompa es de $0^{\circ}, 003$.

USOS, COSTUMBRES Y REGIMEN. - Asi como las otras especies, cuando el rinquito cónico sale de la tierm, en majo y junio, visita los mas diversos árboles frondosos, como por ejemplo los fresnos, alisos y cerezos silvestres, perjudicando particularmente nuestros frutales, los perales, ciruelos, manzanos y albaricoqueros. Menos daño causan por corroer los capullos tiernos, sobre todo en los plantios, que por la solicitud de la hembra con su progenie, pues pica los tiernos retonos para poner un huevo ó mas en la médula, que á causa de esto comienza a secarse, por servir de alimento a la futura larva. Cuando la hembra ha encontrado una rama que cree conveniente corroe la parte del rallo que le parece ba de romperse, dirigese despues mas hácia la punta, abre um agujero hasta la médula, deposita un huevo encima y le in. troduce con la trompa hasta el fondo del orificin hariendo todo esto en el espacio de una hora. Ia solícita madre vuelve despues al primer sitio para corroer el retoño de tal ma. nera que se rompa al menor soplo de aire y caiga en segui. da: à menudo interrumpe su trabajo para dirigirse hácia la punta y ver si todo está en orden, necesitando para todo esto una hora ú hora y media. Un tallo corto contiene un huevo; otro mas largo dos ó tres, depositado cada cual en su agujero. Ia laria sale, por término medio, al cabo de ocho dias, se alimenta de la médula jo conviértese en crisalida en el suclo.

Alli donde cierto número de hembras irabajan del modo indicado en los atrboles frutales, ocasionan bastanics perjuicios, que solo pueden evitarse recogiendo cuidadosamenec los retonos picados de los árboles 6 del suclo y quemandolos tan luego como se vean, para exterminar la cria que en ellos se encierra.

\section{EL RINQUITO DE LOS MANZANOS - RHYN- CHITES AILIARIAE}

CARACTERES.-De un modo muy semejante vire la larva del rinquito de los manzanos, pequeño coleóptero coniundido á menudo con la especie anterior, de la cual difiere por los pelos grises de los lados del cuerpo; tiene además el coselete mas cilindrico, y los elitros apenas ensanchados en su parte posterior, con los intervalos en forma de reborde, sin que se reconozcan puntos con un microscopio de aumento.

USOS, COSTUMBRES Y REGIMEN.-IA hembra pica las hojas de los manzanos en la cara inferior; desde el callo pasa al nervio central, y a causa de esto la superficie de la hoja se inclina hacia abajo, secindose pronto por falta del alimento, asi como tambien el tallo, órgano importante parn la nutricion del tronco. Encontre casi siempre dos larvas, y á veces solo una, pero tambien hasta cuatro en el tallo de la hoja 6 en la base del nervio central, tan oprimidas que se necesitaba gran precaucion para sacarlas entems con un alíler. El insecto pasa.al estado de crisilida en tierr.

\section{EL RINQUITO BRONCEADO - RHYNCHITES CUPREUS}

CARACTÉRES. - Otras especies viven como larms en las frutas verdes y para darlas à conocer ciaré conı ejemplo el rinquito bronceado. Tiene las mismas dimensiones del rinquito de los álamos y color bronceado un poco mas claro en el dorso, con algunos pelas grises; la trompa es ? delgadn, : 
los elitros presentan rayas bastante marcadas con puntos en los intervalos.

USOS, COSTUMBRES Y REGIMEN.-Se alimenta como larra, de las ciruelas, cerezas, frutos del fresno $y$ del mango (pirus torminalis), cuando son verdes. 1legadas las ciruelas al tamano de una almendra, la hembra corta en el espacio de una hora la mitad del tallo, busca en la fruta un sitio conveniente para poner, abre un agujero poco profundo, le ensancha lesionando lo menos posilble la epidermis, pone el huevo, arréglalo con la tronupa y oprime despues la epidermis sobre la incision. Despues vuelve al allo y corroe la otra milad de modo que el mas ligero vienio 6 el propio peso de la fruta le hace caer. Fin todo este trabajo cumplea unas tres horas. In larva nace al cabo de quince dias, se alinenta de la fruta verde y desarróllase en cinco ó seis semanas trisfonmandose despues en la tierna en crisálida los pocos coleópteros que vemos en otono son los pre coces que vuclven á ocultarse para pasar el inviemo; los mas no salen del suclo hasta la primavera siguiente.

\section{EL BALANINO DE LOS AVELLANOS-BALA- NINUS NUCUM}

CARACTERES. - El balanino de los avellanos y sus congéneres son las especies de nuestro pais que ticnen la trompa mas larga. Todo el mundo conoce la larra en las avellanas, y tambien el orificio por donde sale para trasformarse en el suclo; todo el mundo sabe igualmente que en las avellanas con agujeros no se encuentra ya ningun insecto, y si solo las señales de su presencia y actividad. In hembra fecundada deposita un huevo á mediados de julio ó antes, en el interior de la avellana á medio madurar, haciéndolo en el tiempo que basta para cicatrizar la herida; de modo que es preciso examinar la fruta muy bien para poder reconocer has hucllas de la Jesion. Descle mayo el coleóptero vaga por los avellanos y encinas, pero no es nacido de las larvas del ano anterior, porque estas no se trasforman hasta junio del ano siguiente en ninfa, de la cual sale el colebpteró en agosto, presentandose ya en el mismo año, ú ocultándose hasta la primavera próxima. Tienc una trompa muy larga cerdosa, ensanchada en la base y rayada, de color pardo rojo, ligera mente encorvada en el macho y muy arnueada en la hem. bra; junto à su centro se hallan tas antenas, que son finas y angulosas y encajan por su tallo en un hoyo; prolongandose hasta los ojos, remiatan en un boton formado por los últimos artejos, que apenas son mas largos que anchos. Fil coleóptero, de forma oralada y color negro, está cubierto en todas partes de pelos grises amarillos, mas claros en el escudete; este último es prominente y se redondea en la superficie de los elitros que afectan la forma de corazon. Los muslos se ensanchan hácia adelante, presentando en la cara inferior un diente triangular; los tarsos rematan en un gancho; la tercera articulacion del pié es bilobada y la base de las garras denticulada (fig. 27).

En Alemania se encuentran aun dos especies muy seme. jantes, el balanino de las bellotas (balaninus glandium ó tenosus), cuyo coselete baja en los lados desde el centro verticalmente hácia la base de los elitros, formando con ella un angulo casi recto:y el balanino turbado (bolaninus turbiatus), cuya trompa se encorva muclio, sobre todo en la hembra, y en el que los lados del coselete forman con la base de los elitros un angulo obtuso como en el balanino de los avellanos. Ambas especies viven como larvas en las bellotas, causando en ellas los mismos daños que su congénere en las avellanas.

DISTRIBUCION GEOGRÁFICA.-Estos insectos, cu. yas esprecies son muy dificiles de distinguir a causa de la monotonia de sus formas, están diseninados en casi toda la superficie del globo, abundando particularmente en Europa. Tambien tienen la costumbre de dejarse caer con las patas recogidas contra el cuerpo, apenas sospechan un peligro.

\section{LOS ANTONOMOS - ANTHONOMUS}

CARACTÉRES.-Los antonomos podrian considerarse por su aspecto exterior como apiones mas grandes y pesados; pero difieren de ellos por tener las antenas angulosas, por las fajas ó manchas de pelos claros en el fondo pardo de los elitros y por otros diversos caractéres. In trompa, por cjenuplo, es delgada y recta; los ojos pequeños y redondos; las antenas endebles, con el lítigo de siete artejos, de los que el primero se prolonga, mientras que los ultimos forman un huso anillado; e] escudete es bastante grande. I.os costados anteriores en forma de espiga, se tocan; todos los muslos se ensanchan; los tarsos son corvos y los segmentos abdominales quedan libres.

DISTRIBUCION GEOGRÁFICA.- Este género estả discminado igualmente por todo el globo, y es menos numeroso en América que en otras partes.

USOS, COSTUMBRES Y REGIMEN. - Las mayores especies curopleas de estos coleópteros, no muy grandes, perjudican por muchos conceptos à los árboles frutales en cuyos capullos de hojas y hores la hembra deposita un huevo ó varios. La larva que de ellos nace los devora, impidiendo su desarro 110, Ins partes exteriores de la for toman un color pardo; si un manzano ó un peral tienen muchos de estos capullos, ofrecen un aspécto sungular, como el de airboles quemados; $y$ hé aqui por qué el insecto es designado en muchas regiones con el nombre de quimador, nombre que no puede aplicarse à una especie determinada porque varias viven del mismo modo. Por lo regular, sin embaryo: se designa con este nombre el antonomo de los manzanos (anthonomus pomorum), que se distingue por tener una faja oblicua, gris y poco marcada en cada uno de los elitros, cuyo color es pardo de pez. Esta iaja, compuesta de pelos grises, es recta en una especie muy afine, el antonomo de los perales (anthonomus prot), no llega completamente á los bordes de cada elitro. I as dos especies, que por el carácter cirado se reconocen á primera vista, viven en los manzanos y perales. Salen muy pronto de sus cuarteles de invierno, y aunyue vuclan rápidamente, cuando luce el sol, trepan casi sienupre por los troncos de los àr. boles, bajando de ellos del mismo modo. En otoño se ocultan debajo de la corteza, en agujeros abiertos al pié del ronco 6 cerca, a pora profundidad. Otros observadores, y tambien yo, hemos dudado de la exactitud de esta costumbre del coleóptero, hasta que me remitieron individuos cogidos en la primavera y en otono en los anillos de alquitran que servian de trampa para coger orugas. Ia hembra fecundada practica agujeros en los capullos, ya pam vivir en ellos, ó bien parn depositar un huevo en cada orificio. Ios efectos producidos por esto pueden ser muy diferentes en las flores de ambos árboles frutales, porque, segun se sabe, los capullos contienen varias flores en el principal. Cuando este último se halla todavia cerrado, varios capullos pequenos pueden sufrir los ataques del insecto, y llegada la hora de la flores. cencia los que contienen un huero se atrofian; mientras que la flor ilesa se desarrolla. Cunndo los capullos aislados alcanzan mas desarrollo es posible poner huevos en todos;al resecarse parecen quemados, pero en su interior la larn se desarrolla rapidamente, trasformándose en ellos en una crisálida delgada y muy vivaz. Yo he criado la segunda especie de capullos de peral, que estaban quenados en su primera cubier- 
ta, y de los cuales no Aoreció ninguno. El desarrollo de los insectos se verificó ripidaunente, pues los capullos principales, recogidos como secos a mediados de abril, ofrecieron ya el 30 del mismo mes gran número de larvas de color terroso. No sé si los individuos jóvenes que se presentan en mayo perinanecen ociosus hasta despues de haber pasado el invierno ó si son coleópteros de una segunda cria que en la primavera inmediata se cuidan de la reproduccion, pero nadie supone dos crias, al menos yue yo sepa. Los árboles frutales cuyas flores tardan en abrirse son por lo tanto las que mas sufren los ataques de estos colcópteros, aumentandose los perjuicios en los años en que por el tienıpo 6 por la mala situacion de los árboles el desarrollo de los capullos se retarda, pues segun resulia del género de vida citado de esos insectos, las larvas solo pueden desarrollarse en capullos. Cuando estos se abren antes de que la larva se haya hecho adulta, la existencia de esta llega i ser muy dudosa.

Una tercera especic no menos interesante es el antonomo de las almendras (anthonomiss druparum) un poco mas ro. busto que las anteriores, cubierto de espesos pelos de un gris amarillo, y con el cuerpo pardo rojo. Este coleóptero, que segun se dice corroe mucho las flores del melocoton, se encuentra particularmente en el prumus padus, en cuyo hueso vive la larva aisladamente. Creo, sin embargo, que observa una vida bastante vagabunda, pues yo recibi una vez cerezas agrias y secas en cuyos huesos encontré larvas, crisálidas y coleópteros, naturalmente todos mucrtos por el calor del homo. Uno de los coleópteros habia abicro el agujero, dejando solo una delgada capa; otro llegaba ya a la carne, sorprendiéndole la muerte cuando le faitaba solo la última operacion para recobrar su libertad. Es de suponer que la larva vive tambien en los huesos de las endrinas. Esta especic y otras muchas afines se fingen muertas cuando se las toca $y$ déjanse caer à tièrra con la trompa y las patas recogidas.

\section{LOS ORQUESTOS-ORCHESTES}

Mis lectores conocen los pequeños pulgones ovales que saltan alegremente al acercarseles álguien; ! alguno halurá tenido quizas ocasion de oirlos saltar, pues cuando en otoño nos pascamos sobre la hojarasca del lindero de un bosque, oimos como el grupo de estos insectos saliadores, reunidos para invernar, vuelven a caer sobre las hojas secas, despues de remontarse con cierto ruido. Seria, sin embargo, un error considerar á todos estos pequeños coleópteros como pulgones, pues hay entre cllos tambien algunos curculioninos. De aquellos se hablara mas tarde, y de estos solo diré que pertenecen al género orciestes, muchas de cuyas especies habitan en la Europa, y tambien en el nucvo continente.

\section{ELORQUESTODELAHAYA-ORCHESTESFAGI}

CARACTÉRES. - lil orquesto de la haya es la especie que \& pesar de su pequeñe , llama mas la atencion del obsermdor. Este diminuiocoleóptero, que siu trompa mide $0^{\prime \prime}, 0025$, es negro con pelos grises; las antenas de un pardo amarillo claro; la trompa, redonda y ligeramente corva, es mas larga que la cabeza y el coselete juntos, y las antenas están secas rerca de los ojos. La cabera y el coselete son pequeños en proporcion a los largos elitros, de forma oval, y en cuya base el pequeno escudete parece un hoyito; el abdómen presenta ambien en la superficie rayas y puntos. los costados anteriores están muy próximos; todos los muslos, cortos y gruesos, tienen debajo de su extremidad un dientecito; los posteriores y sus tarsos, son propios para saltar, y se ensanchan en su base en forma de diente.
USOS, COSTUMBRES Y REGIMEN. - A principios de mayo este coleóptero visita las hayas para buscar su alimento y reproducirse. Al efecto practica pequuerios agujeros en los capullos; y una vez satisfecha su primera necesidad, la hembra deposita un huevo muy cerca del nervio central y de la base de la hoja, debajo de la epidermis. Casi siempre elige para ello hojas enterns, poniendo en cada una solo un huevo de color blanco amarillento. La larva nace a los ocho dias y abre entonces entre la epidermis y la cara inferior de la hoja una galeria que dirigiéndose hácia el exterior se ensancha poco á poco y regularmente desemboca cerca de la punta de la hoja Llegada aqui, la larva, provista de un costlete oscuro bipartido y de una espiguita cónica en el último segmento, ensancha la galeria y se convierte en crisálida en un tejido trasparente. De esta nace el coleóptero, por lo regular desde mediados de junio, pero tambien antès, porque la larva apxenas necesita tres scmanas para su desarrollo, y la crisálida solo una. Este insecto salta alegremente por las hojas, las corroc como sus padres y se oculta cuando lo exige la crudeza de la estacion. J)igamos ahora cóno revela su presencia.

Ia galeria, es decir, el borde y la punta de la hoja corroidos, toinan un color pardo tan luego como el insecto ha comido la parte carnosa, y durante el verano, dicha galeria se extiende de tal modo que la hoja atacada presenta una especie de dibujo ondulado $y$ bordes fibrosos, quedando herida hasta el nervio central. Cuando miles y miles de hojas de una ailosa haya ofrecen estc aspecro, el arbol parece alrumado de arriba abajo, ó bien creeriase que las hojas verdes de la primavera han sufrido una helada 6 un pedrisco. Aunque un árbol añoso pucde resistir una y aun dos veces estos ataques, las hayas suelen perecer cuando durante varios anos se repite en ellos la misma jlaga.

\section{LOS CIONOS-CIONUS}

CARACTERES. - IAs larvas de los cionos vienen costumbres muy distintas de las que hemos descrito, pues viven libremente en las flores y simientes jóvenes de ciertas plantas, y caréciendo de patas para la locomocion, avanzan solo por medio de los repliegues trasversales del cuerpo y de una secrecion pegajosa y sucia. Iistos pequeños colcópteros son casi esféricos, pero prusentan bonitos matices, formados por una especie de mosaico de manchitas regulares de pelos claros, con el fondo de otro color. J.os mas de ellos tienen en la base, ó en el centro de los elitros, una mancha redonda de color negro aterciopelado en la sutura. La trompa, de forma cilindrica, se oprime contra el pecho, que no presenta ningun surco marcado; los ojos estrin muy próximos en la frente; el látigo de las antenas, que son angulosas, se compone solo de cinco artejos, de modo que es igual en longitud al tallo; el escudete es oval, $y$ las puntas de los elitros redondendas. Fil primer segmento del abdómen está soldado con el segundo, y ambos son largos, pero los dos siguienies muy cortos. Fil macho se distingue de la hembra por la última articulacion del pié, que es mas larga, y por tener sus caras desiguales, siendo la interior mas larga que la exterior. Esta diferencia sexual se nota mas marcadamente en las patas anteriores.

\section{EL CIONO ESCROFULARIO-CIONUS ESCRO- FULARIE}

CARACTÉRES, USOS Y COSTUMBRES. - Esta es. pecie vive en numerosos grupos, en la escrofularia notbosi, que florece desde el mes de majo al de agosto. El ip de julio encontré algunas larvis de un verde pardo yue estaban á punto de trasformarse en ninfa; hallábanse con otras en- 
cerradas en un capullo. Al rabo de unas tres semanas, nacieron los primeros coleópteros. En una épora anterior, cuando aun no conocia estos graciosos insertos, ni menos su manera de proceder, solo habia obsermdo que de las pequeñas vejigas se desarrollaban diminutas avispas (Crysocharis onnspicua), pertenecientes a la hamilia de los teromalinos. El coleóptero, de color negro, esta cubicrto de espesas escamas; los lados rel tórax y el protórax son de un blanco de nieve; los elitros de un gris de pizarra oscuro; los intervalos prominen. tes que alterman entre las fajas de un negro aterciopelado, con dados blaucos; la sutura presênta una gran mancha negra en la parte anterior y otra en la posterior, del mismo tamano. Oirns varias especies viven de igual manera en el icherascum.

\section{EL CRIPTORINCO DE LOS ALISOS - CRYP-} TORHYNCHUS LAPATHI

CARACTERES. - El crintorinco de los alisos es el único tipo europleo de un género americano muy rico en especies (200), algunas de las cuales, distribuidas en otros tres géneros son representantes de uno de los grupos mas consideratiles (cripporinquidos) de toda In familia en Europa. I a trompa de este coléptero encaja en un profundo surco del pecho que termina entre los costados centrales, separando natunlmente los antériores. Fil latigo de las antenas se comyoné de sicte artejos; el cuerpo, protegido por un espeso tegumento de escanas, es de color negro, pardo y blanco, el tercio posterior de los clitros presenta este último tinte; la superficie del cuerpo es muy áspera. In longitud de este bonito insecto varia de $0^{\circ}, 0075$ a $0^{\prime \prime}, 009$.

USOS, COSTUMBRES Y REGIMEN. - Esta especic sc posa en los arbustos de sauce y en los alisos negros of blancos, sin causar daño en las hojas. En mayo se le encuentra en mayor número, y por lo regular aparendo. Despues comienza á escasear, y al fin desaparece en julio ó en Ins pri. meros dins dé agosto no reaparece hasta despues del otono, y entonces solo y aisladamente. El 28 de agosto de 1872 vi de paso una docena de parejitas unidas, y aun el 3 de octubre algunos colcúpteros aislados. Como á fines de julio se encuentran larvas maduras y crisálidas, los coleobteros que mas tarde se presentan deben ser del mismo ano, de los que aun se reproducen $\delta$ han vuelto á ocultarse a fin de aparearse pasado el imvierno. Ia hembra fecundada deposita sus huevos en la madern de las citadas plantas, y la larva practica al principio agujeros debajo de l. corteza, subiendo despues por una galeria recta. Es posible que esta manera de proceder indique una cria de dos años, pues en otms larras que abren galerias se ha observado que al primer año corroian la superficie, pasando en el segundo al interior de la madera. La larva adulta vuelve á la extremidad de la galeria y se trasforma en crisálida. En las orillas del Saale, cerca de Halle, la larra vive en los troncos añosos de sauces, que a causa de esto mueren antes de tienmo. Mas dañinas son sin embargo estas larvas en los plantios de alisos y en los bosques, donde corroen la madera tierna y vieja hasta que nuere. Tambien se encuentran en los plantios de abedules, en los que causan grandes destrozos. Alli donde llegan a perjudicar tanto no queda otro remedio sino cortar las partes infestadas por la cria y quemarlas.

\section{LOS CEUTORINCOS-CEUTHORHYN-} CHUS

CARACTERES. - Si hacemos aun mencion de otros criptorincos, es decir, de los ceutorincos, no es por tel aspec- to exterior de sus numerosas especies, que, excepto unas pocas, propias del norte de América, viven con preferencia en las regiones frias y templadas de Europa, Asin y norte de Africa, figurando entre las mas pequetias y menos bonitas, sino porque cierto número de ellas llama nuestra atencion de un modo muy desagradable en nuestros campos y huertas. Algunas se distinguen por tener sobre su fondo oscuro manchitas claras, generalmente algo confusas y dificiles de distinguir en varias especies a causa del tinte oscuro de los tegumentos. La trompa, que es filiforme, puede oprimirse entre los costados anteriores, de forma cónica, aunque no ten. gan un surco marcado, como en el género anterior. I.os surcos para las antenas se inclinan hácia abajo; estas últimas son corvas y delgadas, prolongándose bastante los siete artejos del látigo. El corto coselete se redondea en los lados, estréchase mas ó menos liácia adelante y se ensancha luego en forma de lóbulo en el borde anterior, de modo que muchas veces, cuando la trompa descansa, los ojos, redondos y planos, quedan cubiertos en parte 6 del todo. Los clitros, cortos, mucho mas anchos en la base que el coselete, y obtusos en los hombros, se redondean en su extremidad posterior, dejando descubierta la rabadilla Los tarsos del macho carecen siempre de espina en la extremidad; los de las patas centrales y posteriores de la hembra presentan casi siempre una especie de espolon; las garras no están soldadas i la base.

\section{EL CEUTORINCO DE CUELLO SURCADO- CEUTHORHYNCHUS SULCICOLLIS}

CARACTERES.-El ceutorinco de cuello surcado tiene un color negro intenso, poco brillante; en la parte inferior, particularmente en los hombros, vénse espesas escamas grises qué escasean mas en la parte superior; carecen de todo dibujo mas claro, como el que suele formarse en otms especies por la aglomeracion de las escamas. El coselete, muy punteado: tiene en su parte anterjor un ligero reborde, à cada lado una prominencia peq̨ueña y en el centro un profundo surco; los elitros, marcadamente rayados y planos en los intervalos, son muy rugosos, y presentan junto á la extremidad unas prominencias escamosas; los muslos son denticulados en su parte anterior. La longitud del insecto suele ser por término medio de $0 ", 003$ escasos por $10 ", 002$ de ancho en los hombros.

USOS, COSTUMBRES Y REGIMEN.-Como el desarrollo es muy desigual, el coleóptern se encuentra desde principios de la primavera hasta cl verano en las cruciferas, tanto silvestres como cultivadas, aunque en estas últimas $1 / a$. ma naturalmente mas la atencion por el darnn que causa la hembra fecundada deposita sus huevos a poca altura sobre el suelo, en los tiernos tallos del lino, ó bien a poca profun. didad debajo de la superficie en la raiz de la misma planta, asi como en las coles de nuestras huertas; pero tambien en una especic de mala yerba muy comun en nuestros campos. La parte en que el huevo se ha depositado, debajo de la epi. dermis, dilatase poco á poco formando una especie de agalin. Las plantas jórenes podrian confundirse con los rabani. llos cuando la agalla, mas ó menos esférica, reposa en el suelo. Si se reunen muchos de estos coleópteros, las agallas de una planta aumentan bastante, constituyendo en su conjunto formaciones irregulares y tuberculosas, en cuyo interior podrian encontmase en medio de los excrementos hasta reinticinco larvas. Ina larvia, blanca y arqueada, como otras de los curculioninos, ticne marcados repliegues trasversales, careciendo de todo otro distintivo. En verano llega á la edad adulta, poco mas ó menos à los dos meses de la puesta del huevo. Sale 
por un agujero redondo de la agalla, construye á poca pro. fundidad, debajo de tierra, un capullo oral, y solo descansa algunas semanas como crisálida. Ias larvas nacidas de huevos puestos mas tarde invernan en sus agallas, segun puede observarse en los sembrados del lino ó en los ironcos gruesos de varias especies de coles. I.as agallas producidas por la puesta retrasada de los huevos en los tallos ya fuertes de las coles, no se circunscriben tanto á la base, pues elévanse a menudo à mucha altura. Es por lo tanto uma imprrudencia dejar en el campo los troncos de col con tales agallas sin agujeros durante el invierno; no queda otro remedio sino quemarlos para exterminar la cria. I.os coleópieros se alinientan de las hojas y flores de las plantas sin causar grandes perjuicios; los primeros que se presentan proceden por lo regular de la crisálida ó se habian ocultado en el otoño anterior; la cria nacida de ellos tiene aun tiempo de producir otra, por lo menos hasta el estado de larva, antes del invicrno. En otras regiones encuéntranse mas especies, cuyas larras corroen el interior de las coles sin producir agallas.

\section{EL CEUTORINCO ASIMILE-CEUTHORHYN- CHUS ASSIMILIS}

CARACTERES. - Esta especic, muy semejante i la anterior, es un poco mas delgaday de color gris en la parte dorsal, a causa de las escamas blancas, mas numerosas; los puntos del coselete son menos profundos; las prominencias laterales mas puntiagudas y las extremidades denticuladas. Tambien ataca varias especies de nabos y coles, aunque yo solo la encontré en la colsa y en la nabina, observando sus larmas aisladamente en las vainillas, donde se alimentan de las simientes verdes y blandas aun. Ia vainilla atacada se abre por esto prematuramente, dejando caer la larva, que se trasforma en crisálida debajo de tierra.

\section{EL CEUTORINCO DE MANCHAS BLANCAS -CEUTHORHYNCHUS MACUIA-ALBA}

CARACTERES, - El ceutorinco de manchas blancis se caracteriza en particular por tener espesas escamas blancas en la cara inferior y en los bordes de los elitros; al rededor del escudete y en la línea central del coselete hay una man. cha; las antenas, los tarsos y los pies tienen un color rojo de orin.

USOS, COSTUMBRES Y REGIMEN. - Ista especie vive en estado de larva en las semillas verdes de la ador. midera, y se crisalida fácilmente en su capullo debajo de tierra.

\section{LOS BARIDIOS-BARIDIUS}

CARACTERES, - Los baridios están representados por numerosas especies diseminadas en toda la superficie del globo.

Se les reconoce por sus perfiles ovales y prolongados, por la superficie muy dura de su cuerpo, cuyos colores, verdes ó azules, tienen á menudo brillo metálico, y por la costumbre de fingirse muertos cuando se les persigue. In cabtza afecta la forma estérica; los ojos, inuy pequeños, están situados en la base de la trompa; esta última, cilindrica, gruesa y algo corva, esta cortada en su cxtremidad en sentido oblicuo, como el diente incisivo de un raton; las antenas son angulosas y su tallo encaja en dos profundos surcos cuando el insecto reposa. El latigo se compone de ocho artejos: el primero es grueso y largo; el último grande, en forma de boton, y en medio de ellos se ensanchan los otros gradualmente. El co- selete, rectangular en sus perfiles, se recoge un poco en cl borde anterior, presentando dos escotaduras en el posterior; cl protórax es plano y no tiene ningun surco en medio de los costados anteriores, muy separados y de forma esférica. El escudete es pequeño, pero bien marcado y redondo; los elitros, rayados, apenas tienen entre los dos la mitad de la anchura de todo el coleófztero, medido desde el borde anterior del coselete, de modo que dejan libre la pequeña rabadilla; los tarsos rematan en un ganchito.

Tales son los caractéres de las especies curopeas, que miden por término medio $L^{\varpi, 0045}$. Como su número total asciende a 300 y su aspecto no es igual en todas nuestras esperies, no dan ninguna idea de las formas mas bellas y do los colores abigarrados de las especies de la América tropical, que debe considerarse con1o su verdadera patria. El baridio de la colza (baridius chloris) tiene un color verde brillante, a veces con viso azulado; el coselcte presenta escasos puntos; en el centro es casi liso, y los intervalos que median entre aquellos bastante grandes; los clitros son sencillamente rayados, y vistos con un microscopio de mucho aumento distinguense en las intervalos series de puntos. En los lados de la trompa y del tórax, los muslos y el vientre, desprovistos de escamas blancas, presentan en su parte anterior puntos gruesos, mientms que en los lados del protórax son nas bien rugosos.

La larm, de color blanco, abre galerias en la parte inferior de los tallos de la colza y de la nabina, $y$ sin duda tambien en otras cruciferas, bajando hasta la punta de las raices donde se trasforma en crisalida. El coleóptero nace ya en junio, y ocúltase en ciertas circunstancias, pero cuando encuentra en los sembrados favoritos una ocasion conveniente para de positar sus huevos, lo hace antes de que comience el invierno, segun lo ha demostrado la desigualdad de las larvas encontradas en la primavera. Otrus no se aparean hasta la viltima estacion, y su progenie se presenta cuando está muy $\mathrm{cn}$. trado el verano.

El baridio de color de pez (bnridius firinus) vive diel mismo modo en otras copecies de coles y deposita sus hueros en la primavera, despues de salir de sus escondites de invierno, con frecuencia en los troncos de la col blanca donde nació el otoño anterior.

El mismo género de vida observa el baridio de tronipa roja (baridius cupriroslris), que se distingue por su color verde claro metálico. La larva vive en los troncos de la col blanca y de la col nabo, donde produce agallas, siendo peligrosa para las plantas pequeñas. Atendido que dos especies de este género 0 del anterior viven à veces juntas en una planta pequeña, acompanindoles ciertos pulgones, comprendemos que todos juntos pueder perjudicar bastante al agricultor y al horticulior, nunque cada especie de por si sea po. co nociva.

\section{LOS CALANDRIDOS - CALANDRIDF}

No puedo menos de hacer mencion de un género casi.exclusivamente propio de las regiones tropicales y que en el sur de Furopa solo esta representado por algunas especies pequenas. En este génèro figuran, sin cmbargo, los gigantes de la familia, caracterizados por formas muy graciosas, y tambien uno de los tipos mas diminutos que se halla en nuestros graneros.

Sin entrar en detalles sobre los distintivos del género, citaré como esprecie tipica el riznchophorus Shuch, haciendo notar que las antenas se distinguen esencialmente de las hasta ahora descritas por la forma del último artejo, que en otras especies congenúricas ofrece tambien un aspecto casi 
siempre muy extrano: las antenas no se insertan mas alla del primer tercio de la longitud de la trompa. La rabadilla no se toca munca con los elitros aplanados; la trompa tiene en la superficic como un aspero cepillo de pelos, y el color de to. do el insecto es pardo negruzco, cubierto con frecuencia de una especie de escarcha; en ciertas partes, sobre todo en la superficic del coselete, distinguese un viso rojo viro La es. pecic que nos ocupa tiene el cuerpo bastante ancho, pero hay otras mucho mas estrechas que, relativamente poco aplanadas, afectan cierta forma de huso. Enalgunas se ensancha la trompa en su extremidad, formando un ángulo ó un diente; y en varias (macrocileirus longipes), las patas anteriores se prolongan mucho, caracter que tambien se observa en oiros grupos no mencionados. In la coraza, muy dura, predomina el color pardo negruzco $\delta$ rojizo, pero tambien otros como el rojo, el amarillo y el gris, nniformes 6 con manchas Los machos se distinguen esencialmente por la forma de la trom. pa, de las patas, de las antenas, ctc.

Las pocas larmas que se conocen viven con preferencia en el interior de las plantas monocotiledóneas (palmas, cicádcas, bananin, caña de azúcar), donde a menudo causan considerables daños, porque muchas veces se presentan en gran número.

1.acordaire quiere que el nombre de calasidra, que anies se daba a todo el grupo, se apligue solo a las esjrecies mas pequeñas de todo el género. Dos de ellas se lian exportado por el comercio, propagándose no solo en toda Europa sino tambien en otros continentes: la cilondm granaria, llamada tambien sitophilus granarius, habita en los almacenes y graneros, porque se alimenta de la harina de trigo, y sus harvas del único grano en que la madre ha depositado el huevo. Acqui sigue la larva comiendo y alcanza su completo desarrollo cuando del grano solo existe la cascara, en la que se trasforma en crisallida. Al cabo de cinco ó seis semanas despues de la puesta del huevo se presenta à principios de julio la prinera cria de los coleópteros invernados. Quince dias mas tarde los individuos jóvenes comienzan a propagarse, y antes del invierno se desarrollan por segunda vez, retirándose luego á las hendiduras de las tablas, de las vigas, y a otros rincones del granero. Hace mucho tiempo se sibe que la limpieza y una buena ventilacion son los mejores prescrvatiros contra este enemigo, empleando ûltimamente con al mejor éxito un procedimiento ingenioso para hacer desaparecer la calandra: por medio de una ventilacion efectuada con tubos colocndos á intervalos de tres metros en los montones de trigo y merced á los cuales se pueden airear aisladamente, prodúcese dentro de aquellos la misma temperatura que en el exterior y los coleopteritos aficionados al calor que para su desarrollo necesitan, abandonan el trigo. Este procedimiento permite además hacer lus montones de trigo mas altos de lo que por lo regular seria posible sin perjudicar los cercales. La calandra granaria es de un color cujo matiz varia desde el pardo rojo al pardo negruzco, un poco mas claro en las antenas y patas, y mide, exceptuando la trompa, $\|^{m}, 00375$ por $0 \%, 0015$ de ancho en los hombros. La trompa, delgada y ligeramente encorvada, tiene poco mas 6 menos, la longitud del escudo collar: lleva en su base, delante de los ojos, las antenas de forma angulosa provistás de la borla que está compuesta de seis artejos de forma oval prolongada; el coselete aplanado en su parte anterior, y no estrechado, esti cubierto de espesos y prolongados puntos longitudinales que solo dejan libre una brillante linea longitudinal en el centro. Los elitros, de la anchura del coselete $y$ paralelos en los la. dos, se redondean comunmente en la parte anierior de la rodilla y estin cruzados por pequeñas fajas punteadas, cuyos intervalos son lisos. Los tarsos están provistos de un gancho córneo en la punta; los anteriores denticulados en el borde interior.

Asi como este coleóptero vive de trigo, centeno y mair, la calavirn eryza se alinsenta de los granos de arroz, $\mathrm{Cu}$ yos alnacenes forman su residencia; porque tampoco este puede propagarse en nuestras regiones al aire libre. Se distin. gue de la especie anterior por una manchita en cada hombro, otra detrás del centro de cada elitro y el borde lateral de color rojo, sobre un fondo negro mate; por un coselete cubier. to de espesos puntos dispuestos circularmente en una marcada linea central, y por los elitros cubiertos de espesas myas punteadas, cuyos intervalos muy estrechos están provistos alternativamente de celditas amarillas.

\section{LOS BOSTRIQUIDOS- BOSTRYCHIDE}

CARACTERES, USOS Y COSTUMBRES. - LoS paqueños curculioninos, casi siempre estrechos y lisus, que se distinguen esencialmente de los anteriores por la rabadiIla cubierta, y que, reunidos en el género de los cosónidos, cuentan tambien numerosos aunque diminutos representantes en Europa y especialmente en Alemania, nos conducen como por la mano á la familia de los bostriquidos. En su aspecto exterior se ascmejan enire si por la pequeñez del cuerpo cilíndrico; por una cabeza gruesa con maxilas salien. tes: por las partes bucales no visibles; por las antenas angu. losas provistas de una gruesa borla y por los ojos muy prolon. gados, distinguiéndose de los demás por la poca longitud de la cabeza, de los palpos, antenas y patas, en los que unos dorsos aplanados que acaban en un gancho cuentan con piess de cuatro artcjos. De los cinco anillos abdominales. los dos frimeros se sueldan à menudo entre si. No es dificil distinguir uno de otro los dos sexos de una especie. I as larvas tienen la mayor semejanza con las de los curculioninos; pero se presentan menos encogidas y del todo cilindricas. I a sociabilidad de estos animales, lo mismo que la de los insectos perfectos, y el modo cómo forman galerias en la corteza de los árboles ó por debajo de la misma, indican su afinidad natural. Existe al comenzar la galeria un espacio algo mas ancho, en el que muchas especies verifican el apareamiento; las hembras continuan despues trabajando y construyen la llamada egaleria maternal, en cuyos lados depositan los huevos en pequeñas cavidades, situadas á iguales intervalos. Las larvitas que han salido de los hucvos abren a -su vez á derecha é ir.puierda de la galeria principal cuando esta corre vertical ú oblicuamente, ó bien en su parte superior $\delta$ inferior, cuando avanza en direccion casi horizontal, las galerias Jaterales mas 6 menos onduladas, que se ensanchan à medida que la larra crece, terminando en una cavidad mas ancha en la que prepara cómodo lecho para la crisilida. De este modo se construyen graciosas formaciones ramificadas a manera de árbol, y cuya disposicion fundamental depende de la determinada especie de coleóptero, si bien sufren ciertos cambios, segun el espacio ó segun cxista un segundo sistema de galerias. Considerando la fecundidad dé estos pecueños animales, muchos de los cuales crian dos reces al ano, no debe admiramos que á veces centenares y miles de hectareas de hermosos bosques se hallen infestados por ellos, como se vió hace muy poco tiempo en la sulva de Bohemia. l.as coniferas sirven de alimento á la gran mayoria de las especies europeas y sufren relativamente mas que los árboles de follaje, en que viven otras especies. Sin embargo, no todos los verdaderos bostri. quidos viven del modo indicado. Asi lo prueban, entre otros, el Bostrvehus lispiuus, que se encuentra en las ramas de en. 
redaderas del clematis ritalba; el hostrychus dactyliperda, que penetm a centenares hasta $\mathrm{cl}$ hueso del dátil, inutilizando la fruta con sus excrementos, y que se desarrolla además en la fruta de la areia katechu. Lin la primesa especic Rach ha observado la costumbre de dar golpecitos propia de los anobios; de inanern que podemos suponer sea esta la manera de llamarse empleada por varias especies de la familia.

\section{EL BLASTOFAGO DE LOS PINOS-BLASTO- PHAGUS PINIPERDA}

CARACTERES. - El blastofago de los pinos puede servimos como representante del género, que se caracteriza por una cabeza dispuesta verticalmente y visible desde la parte superior, por sus ojos, de facetas finas y granosas, la borla de las antenas oval y anillada, relacionada por medio de sus artejos con el tallo, un protórax soldado en su parte dorsal y abdouninal, $y^{\prime}$ la tercera articulacion del pié bilobada; la especie se distingue además por un color negro de pez, que solo en las an. tenas y jatas se trasforma en un rojo de orin; los individuos no desarrollados (hylesinus lestaceus de Fabricius) son tambicn dẹ un amarillo de orim ó pardos.

USOS, COSTUMBRES Y REGIMEN. - Este coleóptero se presenta en buen tiempo, en el mes de marzo; pero el aparamiento no sucle verificarse hasta abril y tiene lugar en el agujero de salida, en el que el macho es siempre visible. Las crias son depositadas con preferencia en troncos recien talados ó en las raices de los mismos; las galerias llegan hasta la cara inferior de la corteza y prosiguen á lo largo de la misma; las laterales se aproximan mucho unas a otras Y alcanzan la longitud de ocho centimetros. Para trasformarse en crisálida, la larwa adulta abre en la corteza un lecho.

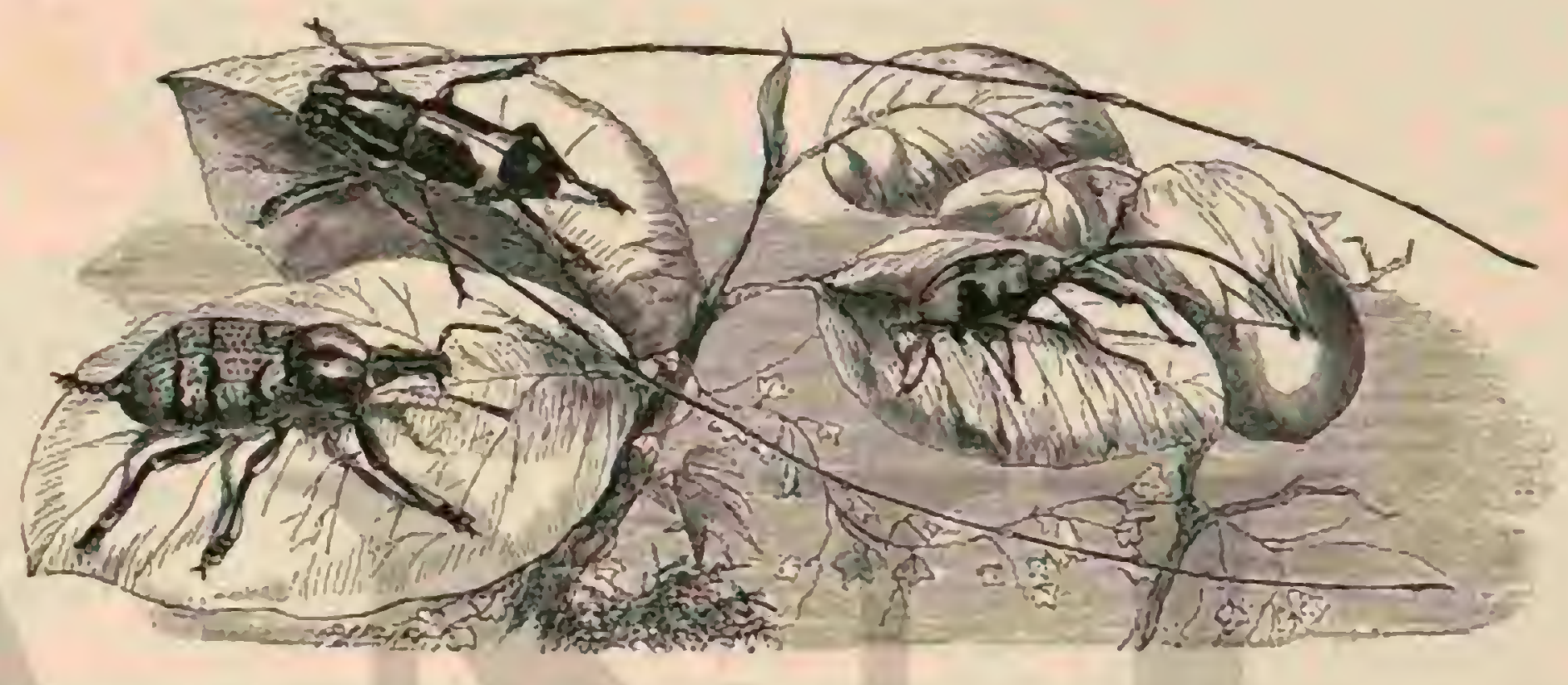

Fig. 25. EL JFEOCFRO HRILLANTH:

Fïg. 26. -EL EUPOLO Uะ LIS.SE

Fig. 27. - EL. BALANINO DI: L.OS AVEJ.LANOOS

En 1836 , año que en un principio favoreció el desarrollo de las larvas, retariàndole sin embargo déspues à causa de la crudeza del tiempo, Ratzeburg observó el 22 de abril la lleganda de los coleópteras, el 27 las galerins de cinco centinetros de largo contenian de $3^{\circ}$ á $40^{\circ}$ huevos; el 2 de mayo vivian las primeras larvas y el 18 habian llegado á la mitad de su tamano; cuatro semanas despues, el i 8 de junio, sc encontraron las primeras ninfas; el 2 de julio colcópteros del todo formados, blancos y planos, y el 15 del mismo mes los primeros agujeros de salida. En tiempo desfavorable la cria no se desarrolla hasta agosto. Entonces dan principio $a \dot{a}$ las devastaciones: los coleópicros penetran horizontalnente hasta la méduh de los retoños jóvenes y aun de los viejos pro. vistos de piñas, y se dirigen de la misma manera hàcia arriba. Al rededor del agujero de entrada se forma ma protuberancia por efecto del jugo que el tronco despide; los retoños se rompen fảcimente cuando son delgados y penuucros ó bien quedan solo los retonos de la copa, sustituyendo à los capullos devorados otros algo mas espesos. Como es consiguiente, el árbol cambia su desarrollo natural y se nos ofrece como criado artificialmente, motivo por el cual al causante de este fenómeno se le ha llamado jardinero del bosque.» Para pa. sar la estacion de invierno, vuelie regularmente a salir, bien por el agujero de cntrada, bien por otro abierto mas arriba de aquel. Busca con preferencia arbóles altos y se oculta en los troncos, próximo à la raiz, no solamente por detrás de las escamas de la corteza, sino tambien en agujeros practicados al efecto, que à menudo llegan hasta el dermis. El blastofago de los pinos se encuentra en la Alemania del sur donde quiera existen estos airboles, extendiéndose en direccion norte hasta Suecin y Rusia.

\section{EL BLASTOFAGO MENOR - BLASTOPHAGUS MINOR}

CARACTERES. - Iil blastofago menor, muy parecido $a$ la especie anterior, no siempre se distingue por su tamano mas reducido, sino por la circunstancia de que la serie de pelos en el segundo intervalo, entre las series punteadas de los elitros, llega hasta el borde posterior de los mismos, mientras que en el blastofago de los pinos dan principio esos puntos donde comienzan à inclinarsc los citados bordes.

Usos Y COSTUMBRES. - Su género de vida es el mismo, pero suárea de dispersion es menos extensa que la del anterior. Para reproducirse ataca solo la corteza lisa, es decir, los pinos jóvenes ó la region superior de los árboles viejos.

Ocupariamos demasiado espacio si q̨uisiéramos tratar de otras especies muy peligrosas para los jinos.

\section{LOS BOSTRICOS-BOSTRICHUS}

CARACTERES. - Los verdaderos bostriquidos, los bostricos $\delta$ tomicos, tienen una cabeza esférica y cinco artcjos, entre el tallo de las antenas y la borla redonda, compuesta de cuarro artejos, de los que el primero, desnudo, roden los restantes, peludos desde su parte superior. El escudo collar se prolonga en su parte anterior en forma de gorra, sobre la cabeza, y estí yrovisto en su mitad anterior de espesas y finas prominencias. Los elitros suelen ser truncados ó cón. cavos en la punta, mas ó menos denticulados en el borde lateral de esta escutadura. Los tarsos aplanados se caracterizan por el reborde interior denticulado. 


\section{EL BOSTRICO TIPÓGRAFO - BOSTRYCHUS TYPOGRAPHUS}

CARACTERES. - Una de las especies mas dañinas para los pinos y al mismo tiempo una de las de mayor tamano $\left(11^{n}, 0055\right)$ es el bostrico tipógrafo, llamado tambien hios trico comisn ó de ocho dientes, pues lleva en cada lado de la profunda cavidad de la punta de sus elitros, rayados por series de gruesos puntos, cuatro dientes de los que el tercero es el mas fuerte: su color es pardo rojoú negro de pez, con largos jelos amarillos.

USOS, COSTUMBRES X RÉGIMEN. - Pasados los primeros dias calurosos de primavera se ve cruzar el aire, con vuelo perezoso, á algunos tipógrafos que no producen ruido de ningun genero. No se encuentran distantes de sus cuarteles de invierno, en los que vuelven a ocultarse cuando la temperatura baja. Hácin mediados de mayo suelen despertar de su sueno invermal, comenzando a reproducirse. Cuando gustan de los sitios en que han nacido ellos ó sus antecetores lo efectian asi; en el caso contrario se elevan a gran altura en el aire para buscar í lo que parece sitios convenientes; y sin exageracion, despues de un ano favorable á su cesarrollo, ha podido comparárseles in bandadiss de abejorros ó á perqueñas nubes.

Estos animales suelen manifestarse exigentes respecto a su residencia; pues gustan dela madera vieja con preferencia d la tierna, la cortada por cl hacha 6 f por el viento, mas que Ia de los árboles que se mantienen en pié; eligen con preferencia ciertos puntos y el pino liso (pinus abies) a otras conúferns. Cuando han encontrado el lugar de su preferencia, abren verticalnente un agujero en la curteza, en cuya cara interior practican otra cavidad major, en la cual se verifica el aparenmiento, dando principio desde ella à ln conśtruccion en sentido vertical de la galeria, donde depositin los huevos, segun arriba hemos descrito. Las larvas nacidas abren sus galerias laterales à derecha é izquierda. Poco despues de la puesta, las hembras mueren en la misma galería ó salen, si bien penosanente. La cria del todo desarrolla. da permanece cierto tiempo en el sitio en que nació, abriendo galeriás irregularés llenas de desperdicios y que difieren mucho de la construccion yrimitiva A medida que la estacion adelanta permanece en ella para invernar, pero cuando el tiempo bonancible la atrae al cxtcrior, vaga al aire libre, ocultándose despues en otros sitios. Los colé́pteros mas precoces abandonan juntos su residencia durante el dia despues de una ligera lluvia; vuelan, hacen una segunda puesta, la que en las circunstancias mas favorables alcanza todavia su completo desarrollo, invernando empero en la ma. yoría de casos en estado de lavia ó de crisilida, sin estar expuesta á ningun peligro cuando la corteza está bien adherida y no penetra la humedad. Los que mas resisten son los insectos perfectos, pues se ha observado que à su tiempo salicron de la madera de una balsa que habia estado helada durante tres semanas. Las larvas y las crisálidas perecen fäcilmente si se las expone a los rayos del sol, arrancando la corteza. - En varins especies de este género, ambos sexos se diferencian notablemente por su aspecto: I hembra carece de escotadura en el extremo de los elitros, $\dot{o}$ estos son muy cortos y casi esféricos en el macho (. Bestrychus dispar): contándóse además otras diferencias. Mas importantes son aun las que se refieren al régimen alimenticio, pero no prodemos conceder mas espacio á estos escarbudores, y solo diremos quee además de las galerias verticales y horizontales que practican las hembras, encuéntranse tambien otras estrelladas.

Los ecuplogrerstrios (Eccuphoyraster) se distinguen fácilmente de todos los demás por su perfil; los dos segneentos abdomi. nales están soldados, y el abdómen se eleva bruscamente, como se ve en el cuppogastrio destructor. El ecoptogastrio escolito ( $E$. scolytus) vive tambien en los olmos, como los bostriquidos en las coniferas; $y$ en general este género representa al anterior en los árboles frondosos.

\section{LOS BRÉNTIDOS-BREN- THIDE}

CARACTERES.- Los individuos de esta familia, los bréntidos (Brenthida), presentan un aspecto muy singular. Porla estructura de su trompa han sido clasificados recientemente como familia independiente, tuniénduse además en cuenta otras particularidades mas importantes todavia. En ninguna otra familia de coleópteros se. prolongan tanto las partes del tronco: la cabeza, horizontal, se adelgaza gradualmente terminando en tromps; en los ensanchamientos laterales, donde se insertan las antenas, no hay angulo alguno, ni surco trasversal, ni puntos, por los cuales se pueda decir dóndè comicnza una partc y termina otra.

Más allá de la insercion de las antenas, el cuerpo suele ser completamente cilindrico cuando los órganos bucales en los machios de muchas especies no presentan un boton muy ancho y comprimido. El labio superior falta; la barba es grande; el cnelio, la lengua y las mandibulas inferiores son sus palpos. I fa longitud de la trompa varia mucho segun las diversas especies y sexos, siendo de ordinario la del macho mucho nias larga que la de la hembra. Las antenas, de once ärtejos, rara vez de nueve (Ulocéridos), son mas gruesis a veces hácia adelante y están dispuestas como las perlas enfi. ladas en un cordon; el primero debe poseer una ductilidad especial y hallarse en la trompa, pues vemos con no poca - sorjresa que todas las antenas se mueven al sacudir de algun modo los bréntidos disecados de una coleccion. Ein el segménto abdominal anterior, que es siempre mas largo que ancho, y de ordinario no mas estrecho que los elitros, los costacios estín soldados por completo con el dorso. Los elitros, largos: estrechos y paralelos, presentan en algunos machos apéndices caudales. El metotórax se prolonga y mas aun cada uno de los dos primeros segmentos abdominales que están unidos entre sí.

L.os tarsos son esbeltos, en proporcion con su cuerpo prolongado, y no muy largos; los costados de los anteriores esPéricos y casi hundidos en un hoyo cerrndo por detràs. Es notable ademås el tamaño desigual que se observa á menudo entre los individuos de la misma especie. Tos bréntidos, en número de 600 especies, habitan, á excepcion de una (Amerphoceplinlus coronutus), que es juropia del mediodia de Europa, en las demás parte's del mundo, no predominando en America como se creia antes, cuando muchas especies asiáticas eran aun desconocidas. Viven en sociedadés debajo de la cortezn de los àrboles, y se asemejan á los jitófngos en el sentido mas lato de la palabra. El Brenshus Auchorago, comun en el Brasil, dará una idea de los coleópteros que acabamos de describir. La trompa del macho de esta especic alcanza una longitud mas considerable que en ninguna otra del género. Su color predominante es un pardo rojo oscuro, presentando en los elitros dos tayas longitudinales de un ro jo de sangre. Muchos individuos de la familin tienen tambien dibujos y manchis.

\section{LOS ANTRIBINOS- ANTHRIBINIS}

CARACTERES. - laz familia de los nntibrinos est? répresentada por especies en que la cabezal se prolonga en una 
trompa algo ancha, no larga, nunca cilindrica ni separada por una linea trasversal. las mandibula inferior es bilobadit; los lóbulos, estreclios, lincales y redondendos en la punta, estain cubiertos de una pelusa fina; los palpos maxilares, niliformes y puntiagudos, tienen curtro artejos y los labiales solo tres; la mandibula superior soluresale mas ó meros, es ancha y denticulada en la ral\%, y se adelgaza hácia la punta. El labio superior se redondea en la parte anterior y esti cubierto de pelusa. Las antenas tienen once artejos, formando el último una cuña articulada que à menudo desaparece á causa de su prolongacion; estan insertas en la trompa en una cavidad lateral, y en algunos machos alcanzan uma considerable longitud, por lo cual, y quizis tambien por la forma de su cuerpo, jresentan á menudo cierta analogia con las de los capricornios de que nos ocuparemos mas adelanic. Lin surco trasversal del protórax constituye un caracter especifico importante para estos insectos. Las ancas de las cuatro patas delanteras son casi esféricas y ustin stparadas: las del último par mucho mas anchas que largas; los tarsos, olutusos en la punta, no tienen espolones ni ganchos, y el tercero de sus cuatro artejos suele hallarse tan oculto en el segundo, yue se podria dudar de su presencia; las garras llevan un diente cada una en la parte inferior. Fil abdómen se compone de cinco segmentos bastante iguales, siendo ol dittimo siempre visible en el dorso. El color oscuro del cucrpo parece mas claro ó manchado il causa de los pelos.

DISTRIBUCION GEOGRÁFYCA.- In familia, com. puesta de mas de 800 especies, de las que dos tercems partes no están todavia descritas, está diseminada por toda la tierra, predominando en los puntos del Asia labitados por los malayos; Europa no tiene sino siete géneros con Ig es. pecies.

USOS, COSTUMBRES Y REGIMEN. - I.OS antrihinos se encuentran en los troncos de los árboles enfermizos ó en los hongos; raras vices en las hojas ó las flores. I.os mas vuelan con pesader, pero algunos son muy vivaces, yo los hay que pueden halsta saltusr. La mayoria de las larvas viren en las plantas, las cuales perforan.

\section{EL ANTRIBO ALBINO- $\wedge$ NTHRIBUS ALBINUS}

CARACTERES. - Esta es una de las especies mas caracterizadis. Sobre un fondo pardo presental dibujos de un blanco de nieve, siendo del nismo color-tambien la cabeza y el abdómen. Ėn la miz de su tromp̧a, ancha y vertical, se hallan en direccion oblicua los ojos, en forma de rinones; delante de estos eléranse las antenas, filiformes y que en la hembra no alcanzan sino la mitad de la longitud del cuerpo, engrosindose en cambio hicia adelante. La esperie se caracteriza además por la distancia q̨ue media entre las ancas delanteras. A veces lo encontré en los troncos carcomidos de la haya, pero siempre como una curiosidad.

\section{LOS BRAQUITARSOS -BRACHYTARSUS}

Interesantes son las pequeiras y poco vistosas especies do este género que viven en Europa yo en Ansérica. Los colcóp. teros se encuentmn sobre las fiores; las larvas dehnjo de las conchas hemisféricas que los cocos (Cocus) dejan sobre su prole para protegerla, crevéndose ademảs que se alimentan de los huevos de los mismos. A lo menos se ha obsermio este fenómeno en el braquitarso cscabroso (B. subrosis) y en el braquitarso mriado ( $B$. inrius). Ambos son pequeños insectos de forma oval obeusa con la trompa anehi, angulosa en los lados y corta, con un estrecho surco lateml dirigido hacia abrjo, yo antenas de escasa longitud, ligeramente euneiformes. Sus grandes ojos tocan el borde anterior del escudo del cuello, que es cuadrangular, con dos escotaduras en la base: cuyos ángulos posteriores agudos se apoyan en los clitros: entre estos el escudo aparece por delante en forma de punto.

\section{LOS JENOCEROS-XENOCERUS}

CARACTERES. - Esste géncro corresponde al grupo que los autores llaman de los jenocéridos: los insecios que le re. presentan tienen la cabeza tan ancha como larga, con la trom. pa mas corta y tnsversal; antenas excesiramente prolongadas, que miden en algunos individuos hasta cinco veces la longitud del cuerpo; protórax medianamente convexo; escuço mariable; elitros largos, planos en el disco, y paralelos en sus tres cuartos anteriores; patas bastante largas y robustas; mesosterno prolongado, y cuscrpo jubescente.

I as antenas de las hembras vienen à tener una mitad del largo del cuerpo, y son mas robustas que las de los machos.

Los insectos de este género, uno de los mas ricos de la familia, ofrecen mucha mriedad en cuanto al tamaio. Respecto al color, suele consistir en fajas ó manchas blancas sobre un fondo tan pronto negro como de un amarillo ver. doso pålido.

DISTRIBUCION GEOGRÁFICA.-Los jenoceros son propios del continente Indio, de sus archipiélagos y de los puntos próximos at la Polinesia.

\section{EL JENOCERO BRILLANTE-XENOCERUS LUCTUOSUS}

CARACTERES. - Esta notable especic (fig. 25), el mas hermoso tipo del género, se distingue sobre todo por la desmesurada largura de las antenas, asi como tambien por la beIleza de sus colores. El macho es de un hermoso color negro, con estrechas fajas blancas en la cabeza y tórax, ofrceciendo los clitros el mismo adorno. Ia hembra es tambien blanca y negra, pero predonina el primero de dichos tintes, redu. ciéndose el segundo a unas motas en los lados de la cabeza y del tómx; en el centro de los elitros tiene dos manchas ne gras:

DISTRIBUCION GEOGRÁFICA. - Este precioso in. secto es originario de Amboina.

USOS Y COSTUMBRES. - Son las mismas que hemos indicado en la descripcion de la fanuilia.

\section{LOS CAPRICORNIOS CAPRICORNIA}

CARACTERES.-Ia familia de que vamos i ocuparnos comprende de tres mil a cuatro mil especies de los coleópteros mas magnificos, igualmente hermosos por sus formas, quie revelan fuerza $y$ confianza en si mismos, por la distribucion de colores vivos, y por los adomos de las antenas ciue se mucren en todas direcciones y caracierizan à la familia. Aunque io son rapaces, pues viven de sustancias vegetales en los dos estados en que necesitan comer, quisiera poder compa. milos con las a iguilas, entre las aves, a lo menos cicrtos géneros, por su estructura esbelta: aunque muy robusta, sus ame. nazadoras mandibulas y su cabeza prolongada Su nombre de capricornios (Capricorsio ó Lungricurnsa) concuerda joco con los caractéres que acabamos de describir, pero es apropiado si se consideran las antenas y el aspecto de su cabeza en perspectiva. Si se les quiere comparns con otra familia de su 
órden, esta debaria ser la de los crisomelinos, à los que se asemejan for su hermosura, rigucza y variedad de formas, por la exuberante abundancia con que se uresentan en los trópicos, asi como por las marcadas diferencias sexunles: pero aqui los machos se distinguen por sus maxilas mucho mas robustns, antenas mas largas, de diferente estructura y dienticuladas á manera de sierra 6 de peine. En los tarsos se notan grandes variaciones, á veces preselutan otra forma, $y$ tambien cambia la coloracion del cuerpo. La hembra se diferencia del macho principalmente por tener el abilómen mas agudo $y$ protráctil. Los capricornios se caracterizan por sus antenns cerdosas $b$ filiformes, á menudo mas largas que el cuerpo y compucstas de once artejos. siendo el segundo muy corto. I.as maxilas rematan de ordinario en un diente aguda; los palpos en un artejo cu forma dé hacia ó fusiforme; sus prolongados elitros ocultar todo el abdómen compuesta de cinco segmentos movibles; pero hay tambicn especies due lo dejan descubierto en toda su longitud. Las puntas de todos los tarsos tienen espolones y las ancas de los anteriores no se tocan.

USOS Y COSTUMBRES. - Débenos considerar à los capricornios en general como insectos vivaces, que vuelan i la luz del sol y en dias calurosos, de una jarte á otra, exami. nando las fiores y las partes carcomidas de los troncos de los árboles, y sobre todo los montones de leña hacinados en los bosyues: mientras que otros esperan la noche parn emprender sus excursiones y aparearse. Muchos producen un zumbido si se ios sujeta entre los dedos $y$ se les frota el borde de ha parte anterior del corso alli donde la extrenidad de la region media de la espalda se inserta con la anterior.

I as larsas de los capricornios se asemejan à las de los bu. préstidos, pero se diferencian por sus palpos labiales muy marcados, sus conductos aéreos elipticos ó circulares y la abertura anal en forna de Y. I a cabeza, plana y horizontal, puede recogerse en parte en el primer segmento; su escudo es muy marcacio y coriaiceo; el labio superior córneo los ojos, ó no existen, ó hay uno á cada lado, y á reces tres, dirí ciles de reconocer; las antenas tienen tres artejos y son tan pequeñas y ocultas en un pliegue de la piel, que pasan facilmente desapercibidas. Las partes bucales mas desarrolladas son las maxilas cortas y córneas; la inferior es ancha y lleva un palpo corto con tres attejos y una robusta mandibula dirigida hácia adentro y cubierta de cerdas. El labio inferior se compone de una barba carnosa; los palpos, grandes, y en su mayor parte soldados, tienen dos artejos; la lengua es carnosa y está rerestida de pelos en su parte anterior. Los tarsos faltan por completo ó son muy cortos y con una sola uñ. El segmento torácico anterior se caracteriza por su considerable tamaño y anchura; en cada lado de los demás hay una cubierta córnea, de superficje áspera que los separa en su insercion.

Ias larvas viven principalmente en la madera carcomida y necesitan sin duda en la mayoria de casos mas de un año para desarrollarse. Algunas especies pequen̉as sin embargo, visitan tambien los tallos y sobre todo las raices de las yerbas, pudiendo en ciertos casos ser muy perjudiciales para. la agricultura.

La lista mas reciente de estos insectos contiene siete mil quinientas sesenta y ocho especies, cifra que dificilmente corresponderá á las especies vivas, porque las regiones cálidas exploradas hasta ahora, albergan sin duda una multitud de tipos pequeños é invisibles que no se han estudiado todavia, y los bosques del interior de Africa nos proporcionarån con seguridad mas de una magnifica especie cuando aquellas inhospitalarias comarcas sean accesibles á los pue. blos civilizados. Jacordaire clasifica los tres grandes grupos en que se divide la totalidad, en varias sub-familias, que à su vez se subdividen de muchas maneras.

\section{LOS PRIÓNIDOS-PRIONIDE}

CARACTERES. - En esta primern sub-familia figuran los tipos mas toscos, pero al mismo tiempo mas gigantescos: el dorso del coselete está separado en los lados por un ángu. lo; la lengua es córnea y gruesa, las ancas anteriores trasver. sales: los palpos no fusiformes $\delta$ puntiagudos; las antenas se insertan en la raiz de las maxilas; los tarsos anteriores pre. sentan un surco trasversal en la cara interna. Estos insectos no tienen la propiedad de producir ruido por el roce de las partes antes citadas. El numero de priónidos es inferior al de las otras dos sub-familias y muy característico para Europa, no presentándose al parecer sino,cos especies en nuestros bosques de Alemania.

\section{EL PRIONO CURTIDOR-PRIONUS CORIA- RIUS}

CARACTERES. - Esta especie tiene las antenas en forma de sierra, y en rigor podirian llamarse escamosas, puesto que cada escama se inserta en la precedente que tiene forma de embudo; en el macho, que es mas pequeño que la hem. bra, hay doce de estas escamas, pero á pesar de esto no miden en su conjunto ni la mitad de la longitud del cuerpo. La cabeza es pequeña y oblicua, el coselete ligeramente arqueado, con tres dientes a cada lado; el central, mas grande, se dirige hácia arriba.

El color de este coleóptero es negro; el pecho está cubier. to de una espesa pelusin de color gris.

USOS, COSTUMBRES Y REGIMEN.-De estos séres enojosos solo podemos decir que a mediados de julio y en agosto se encuentran en la parte inferior del tronco de los árboles viejos, $\mathrm{en}$ las encinas y en las hayas. $\mathrm{A}$ la hora del crépisculo, vuelan pesadamente zumbando de un lado a otro, cuando los machos buscan á las hembras. Despues del apareamiento estas últimas ponen sus huevos en la madera carcomida; la larva se alimenta durante varios años de las sustanciss en putrefaccion, y su estado de crisálida durn poco tiempo.

\section{EL ERGATES CARPINTERO-ERGATES FABER}

CARACTERES. - Esta especie es mas esbelta y prolongada que la anterior, $y$ tiene las antenas cerdosas; en el macho son tan largas como todo el cuerpo y en la hembra una mitad menos; el agudo borde lateral del escudo del cuello es denticulado; el ángulo de la sutura de los elitros sobresale en forma de pequeño diente. Este coleóptero es pardo ó de un color rojizo.

USOS, COSTUMBRES Y REGIMEN. - Vive en th carcoma de las coniferas, pero en ciertos puntos perjudica tambien los pinos. Lucas crió las larvas poniéndolas en cajones de serrin húmedo.

\section{LOS CERAMBÍCIDOS - CERAMBY-}

\section{CID.E}

CARACTERES. - las especies de la segunda subramiJia, ceramlícidos, cuya denominacion se hace extensiva por algunos naturalistas à toda la familia de los coleópteros de cuernos largos, tienen la cabeza oblicua, nunca vertical. Aqui encontramos los tipos mas nobles, las antenas mas her- 
mosas y el mas magnifico brilio metslico; pero una variedad extruordinaria por el aspecto externo en lis 9,000 especies que se cuentan. En el escudo del cuello; el dorso y' los cosrados estan unidos: las ancas delanteras tienen una forma variada, esférica ó cónica en las especies indigenas. Ia lengua cs membranosa; el último artejo de los palpos no es fusiformic $\delta$ puntiagudo; la cara interna de los tarsos anteriores carece de surco trasversal I as antenas se insertan, en las mas de las especies, en una escotadura de los ojos.

\section{EL ESPONDILIS BUPRESTIDO-SPONDYIS BUPRESTOIDES}

CARACTERES. - Este coleóntero, ruya longitud varia de $0^{m}, 014$ : $l_{1}^{\prime \prime}, 020$, es negro, con un ligero brillo; al cuer. po es cilindrico; las maxilas, robustas yo oblicuas, pueden morier de una manera muy sensible; si se le toma en la mano, sus antenas son conas y parecen un collar de perlas; el escudo del cuello se arquea á manera de cojinete; los clitros, no muy anchos, presentan dos listas longitudinales obtusas y punteadas. Los tarsos son cortos, las ancas anteriores afectan la forma de cilindro trasversal; todas las patas ticnen cinco artejos, pues el boton de la garm se inserta con el último. Los tarsos y el abdómen están revestidos de una pelusa corta de color pardo de crin.

USOS, COSTUMBRES Y REGIMEN.-Fiste colcóptero singular se desarrolla y vive en los bosques de coníferas y es muy vivaz. En verano, despues de haber salido de la crisálida, ruela en los hermosos dias a fior de tierra; corre torpemente sobre la arema, y si alguna ve\% se cae trepa por las paredes, $\delta$ por lo menos asi to ha observade Kriechbaum.

In larva, de un color rojizo violeta irasparente, tiene seis tarsos cortos y abunda mucho en los troncos de los pinos, donde el pico negro la persigue con afan; tambien visita oiros irboles.

Este coleóptero es bastante comun en Alemania.

\section{LOS CERAMBICINOS - CERAMBYCIN XE}

CARACTERES. - Si el nombre génerico de cerambix. no dehe desaparecer por completo del sistema, lo conservarain las magnificas especies de color oscuro, diseminadas por to da la tierra y que encontramos clasificadas hoy dia bajo la denominacion de hamatiqueros (Hamntiguerus). "Tienen-la cabeza muy prolongada; los ojos cóncavos; las amtenas de once artejos, que se ensanchan desde el tercero hasta e] quinto formando cuña, y rematan con uno muy delgado, aparchteruente partido: y su longitud excede considerablemente de la del cuerpo. El coselete presenta surcos trasversales y arrugas, formándose en el centro una jibosidad; los elitros, que en su parte anterior presentan un escudete triangular obtuso, son casi dos veces tan anchos como el borde posterior del coselete y exceden en longitud dos veces it su anchura.

\section{EL CERAMBIX HÉROE-CERAMBIX HEROS}

CAR ACTERES. - Fl cerambix heroe, cuyos principales caracteres son los ya indicados, es aque! magnífico coleópte. ro de color negro brillante que vemos en las encinas con el ciervo rolador. Sus elitros de color pardo, mas claro 6 rojizo hácia atras, presenian una sutura apenas perecpible yo se arrugan sobre todo en su parte anterior; en la inferior y en los tarsos brilla su pelusa scdosa de un blanco platcado.
Su larva, que en su forma perfecta tienc varios escudos cartilaginosos en el dorso, vire de tres a cuntro años en el interior de las encinas vicjas. Sus galerins, muy anchas y planas, son al principio tortuosas y entrecruzadas; se corren debajo de la corteza, estín llènas de carcoma y al fin condu. cen al interior del tronco, ailquiriendo à veces una conside. rable anchura. Es evidente que muchas larvas pueden echar a perder con el riempo muchos troncos por medio de sus taladros; y si un árbol algo enfermizo tiene para ellas un atractivo especial, no hay duda que los efectos producidos por estas larvas enormes son incalculables.

USOS, COSTUMBRES Y REGIMEN.- El colé́ptero que sale de la larva en el mes de julio no se deja ver de dia, ó asoma todo lo mas las antenas por el agujero, retirin. dose apresuradamente si no nos acercamos con mucha cau. tel. Despues de la puesta del sol sale de su escondite y vuela á poca altura, buseando a la hembra. Ei aparamicn. to se verifica de noche y dura poso tiempo.

\section{EL CERAMBIX LABRADOR-CERAM- BIX CERDO}

CARACTÉRES. - Esta especie, mas pequena que la anterior, solo mide de $0^{\circ}, 02$ a $0^{\circ}, 03$ de largo y es tambien de color negro, brillando con pelusa sedosa de un blanco plateado, pero no se adelgaza en la extremidad de los elitros.

USOS, COSTUMBRES X REGIMEN. - Fiste coleóp. tero solo habita al parecer en comarcas determinadas. Por su proceder difiere notablemente de su congénere, puesto que vuela á la luz del dia, visitando los arbustos fioridos co mo el espino blanco y otros para libar en ellos el dulce néc. tar. Su larva se caracieriza por una serie de surcos longitudinales que comprenden la mitad posterior de la placa que tiene en la region antero-dorsal. Vive debajo de la corteza y en la madera de los árboles carconidos y en las encinas, manzanos, cerezos y otros. Nordlinger las encontró en 18.43 bastante grandes en un manzano, pero no obtuvo el coleóp. icro hasta $1 S_{47}$, suponiendo que la sequedad de la madera habrá sido la causa de su lento desarrollo.

\section{EL AROMIA ALMIZCLADO - AROMIA MOS- CHATA}

CARACTERES. - Esta especie tiene las antenas y los tarsos de un azul de acero: la parte superior, que es muy rugos. de un verde metálico ó broncendo; el escudo del cuello, de forma exagonal y cubierto de tubérculos, es brillante, y en los clitros casi matc; los tarsos posteriores se prolongan; las patas son comprimidas y ligeramente arquendas. Fl género de los aromias se diferencia del anterior por no tener el escưdo del cuello rugoso, siendo los artejos inferiores de las antenas poco abultados; su escudete triangular, la homogeneidiad del color de sus elitros y sus palpos labiales, mas largos en proporcion à los maxilares, le distinguen del género siguicnte.

USOS, COSTUMBRES Y RÉGIMEN. - LA especic, que por su olor de almircle se ha llamado almizclada, vive en los sauces tanto la larva como el coleóptero.

Fin ver del dibujo del dorso, la larsa tiene surcos de contornos cuadrangulares que en el abdómen son tambien visibles, aunque siguen oira direccion, estando limitados en los tres prineros segmentos abdominales por tarsos en extremo pequeños, que pasan facilmente desapercibidos. Taladra so. bre todo los sauces y las raices nudosas de los juncos, practicando galerias muy irregulares, y contribure en compania de otros coleópteros à destruir muchos árboles. 
Cuando al principio del verano el coleóptero sale de la larva, raga por el lugar donde ha nacido hasta que ambos sexos se encuentran. Si hace mal tiempo reposa en el follaje of en la carcoma con las antenas replegadas sobre el dorso; pero en los dias de sol vaga con viveza por los troncos y las ra. mas agitando mucho las antenas: tambien vuela cuando se trata de buscar hembra.

\section{LOS LEPTURINOS-LEPTURINI}

CARACTERES. -Constituyen un género bien marncterizado de esta subfamilia y se reconocen fácilmente por su cabeza adelgazada detrás de los ojos y que se prolonga hácia adelante en forma de hocico; tos ojos son casi esféricos, y entre ellós se ven á mas ó ménos distancia tas cortas antenas; las ancas anteriores están muy próximas.

USOS, COSTUMBRES Y REGIMEN, - LAS mas de las especies vuelan con viveza á la luz del sol, visitando no solo las matas sino tambien las jerbas Boridas, asi del bosque como de las pradernas y de los campos, aunque se hallen nuy léjos.

Ins especies han sido distribuidas en muchos géneros, pero se confunden entre si por sus carnctéres de tal modo, que es dificil distinguirlas. La forma y estructura de la superficie del escudo del cuello, los elitros, las proporciones de estos con aquel, ln finura is aspereza de los ojos, son los distintivos mas importantes de los géneros. Las larvas se alimentan de carcoma.

\section{EL ESTRANGALIO ARMADO - STRANGALIA ARMATA}

CARACTERES. - Este es el tipo general del género, El cuerjo es negro, á excepcion de los tres primeros segmentos abdoninales, que son amarillos con puntos negros; las antenas, los tarsos y los elitros son de un amarillo de cern; las primeras vesde el tercer artejo: los tarsos tienen anillos negros; las patas presentan puntos de este color; los elitros, escotados hácia dentro en fornia de arco, tienen en la punta cuatro líneas negras angulosis que no siempre son muy marcadas, puesto que las dos primeras se convierten á menudo en una mancha.

El macho se diferencia de la hembra, que es mas grande, por tener dos dientes en el borde interno de los tarsos posteriores. I a larva, que vive en los troncos de los abedules, tiene los ojos poco marcados, pero los tarsos visibles, la cabeza muy grande, las antenas de tres artejos y el escudo de la cabeza y el labio superior, bien visibles. El coleóptero aparece tres ó cuatro semanas despues de haberse convertido en crisitlida. No se le debe confundir con el estrangalio de cuatro fajas ( Strangalia quadrifasciati), cuyos elitros tienen poco mas ó menos el mismo dibujo, pues los tarsos y el abdómen son negros y las antenas no tienen el color amarillo; sin contar que las formas son mas robustas. Ia majoria de las de màs pequeñas especies congéneres tienen los elitros de un pardo anarillo, azules, negros ó pardo-negros, pero de ordinario de color mate.

\section{LOS TOXOTOS - TOXOTUS}

CARACTERES.-El género de los toxotos comprende las especies que tienen el escudo del cuello cilindrico, muy encogido por delante y detris y jrovisto de un tubérculo en el centro, fornado por un surco longitudinal. Sus antenas filiformes son casi siempre tan largas como el cucrpo, su tercer artejo mucho mas largo gue el cuarto y los clitros algo adelgazados hácia atrás, à lo menos en el macho. Ina especie mas comun en Alemanin es el toxoto variable (Toxofus meridiunus), que tiene el quinto artejo de las antenas por lo menos dos veces mas largo que el cuarto, y el tercero mas que el quinto. En los lados del escudo del cuello, que se en. sancha algo hácia atrás, hay un tubérculo obtuso; los clitros, muy adelgazados hricia atrás en el macho y poco en la hembra, rematan en una punta ligeramente arqueada. El tórax está revestido de pelos espesos de un gris plateado. El coleóptero es, $\delta$ sodo negro, $\delta$ de un amarillo rojizo en la rair de los artejos de las antenas, en los tarsos y en el borde dorsal de los elitros; la mitad anterior del cuerpo sucle tener este tinte; la parte superior de la sutura y la punta son de color negruzco, predominando en todo el insecto un pardo amari11 o rojizo. Su tamano varia entre $0^{m}, 013$ y $0^{\circ}, 022$.

USOS, COSTUMBRES Y REGIMEN.-A primeros de junio se ven los machos por las matas y las Bores, sienpre dispuestos a dejarse caer si se alarga la mano para cogerlos; las hembras suelen vivir mas aisladas y son mas perezo. sas. En algunas plantas del ioparganio florida, que en dicha estacion son en la pradera las mas propias para atraer toda clase de insecios, los machos se hallan en gran número; mientras las hembras están aisladas en los tallos de yerba, debajo de dichas plantas, pareciendo no participar de la vicha tan activn que reina à su alrededor.

\section{LOS RÁGIOS - RHAGIUM}

CARACTÉRES. - los rigios tienen la cabeza grande, casi cundrada; has antenas cortas y en forma de cordon, muy aproximadas en la frente; los ojos son anchos, en forma de rinones; el escudo del cuello pequeno, encogido por delante y détrás y espinoso en el centro; el coselete es angosto, trian. gular $y$ agudo; los elitros deprimidos, los tarsos largos, pero toscos; las ancas delanteras cortas, gruesas y separadas.

\section{EL RÁGIO INDAGADOR - RHAGIUM INDA- GATOR}

CARACTERES. - Es la mas comun de nuestras especies alemanas. Los elitros son de un pardo amarillo pailido, revestidos de una espesa pelusa, con tres líneas longitudinales prominentes en cada uno $y$ dos fajas trasversales desnudas y de color negruzco.

USOS, COSTUMBRES Y REGIMEN. - En los bOSques de coniferas sé encontrará raras veces un tronco seco que no esté poblado debajo de su corteza de una infinidad de larvas de esta especie, descubriéndose además sus galeríns irregulares. La hembra que quiere poner sus huevos, no busca nunca un tronco sano, sino los que están ya taladrados por-otros insectos, de manera que pueda arrancar la corteza sin dificultad. De la misma manera, $y$ solo en las coniferas vive la rara especic rigio de dos fajas (Rhagium bifasciatum), mientras que otras dos habitan en estado de larvas los árboles carcomidos, por lo que no tienen importancia en la selvicultura.

\section{EL NECIDALO MAYOR-NECYDALIS MAJOR}

CARACTERES. - El necidalo mayor puso hace tiempo en apuro al ya citado Schoffer, segun resulta de una carta que dirigió i Reaumur. Este coleóptero, salido quizas del tronco de un ciruelo, cucontrólo en el taller de su cuñado, çue era tornero, y quien le presentó á Schoffer para oir sto parecer acerca de un insecto tan extraño. El naturalista lo comparó con el gran urocero, mas al examinarlo detenida- 
mente parecióle que debia ser un lepturino. Envió la descripcion y un dibujo a Reaumur, diciéndole al final de la carta: eSi tiene V. para estos insectos (iba tambicn una especie mas pequeña del género que se llama hoy dia Molordriss) nombres mas propios y mejores, los llamaré en lo sucesivo como V. lo determine. (Ratisbona it de marzo de 1753.) I.o particular de la especie consiste en la cortedad de los clitros, que no cubren ni su estrecho y largo abdómen, ni las alas prosteriores, compuestas de una membrana délgada. Todo el coleóntero es negro, está revestido de una pelusa de color de oro; las antenas, los tarsos, los elitros y la base del abdomen son de un pardo anırillo rojizo; la extremidad de los muslos posteriores mas oscuros; las antenas del nacho ama. rillas, solo cn la raiz.

USOS, COSTUMBRES Y REGIMEN. - Este curioso capricomio se halla en las matas y en los troncos de los árboles carcomidos; yo lo encontré en las encinas y en los cerrezos, en cuyo interior habia vivido la larra con seguridad, segun lo demostraban los agujeros de ha madera: no es comun, pero si el mas hermoso de los representantes indige. nas de este género, que viven principalmente en la América del sur.

\section{EL HILOTRUPO DOMÉSTICO-HYLOTRUPES BลิIULUS}

CARACTÉRES.-MUchos capuricomios viven en estado de larvas en el maderamen de nuestras casas, doncie encon. iramos por lo mismo tambien de vez en cuando los coleópteros perfectos, sobre todo en los edificios antiguos, sin que nos expligjuemos de dónde proceden semejantes fenómenos. Fisto sucede mas i menudo con una especie que por lo mis. mo se ha llamado hilotrupo domistico (Hylotrupes bigjulus), coleńpicro que tiene el cuerpo estrecho y comprimido, carac. terizándose por sus antenas cortas y filiformes; el escudo del cuello afecta la forma de disco: y el oricucto de la henibra se prolonga en figura de cono. Su cuerpo es negro ó pardo, revestido de pelos blancos, sobre todo en el escudo del cue llo donde hay algunas asperezas que presentan un aspecto mas oscuro, of́reciendo á veces un dibujo idéntico al de la carn. Su tamaño varia notablemente entre (1",0065 y $\|^{m}, 0195$.

USOS, COSTUMBRES Y REGIMEN.-Cuando este coleóptero abandona su escondrijo sáliendo cubierto de ses. rin; parece extrañatse de lo que obserna it su airededor; pues procura inmediatamente escapar con toda la velocidad que le permiten sus cortos tarsos, pero sin saber adonde, y manifiesta uma gran satisfaccion si puede encontrar una ventana abierta. La hembra intraduce su oviducto en las rendijas de los maderos de cualquiera especie, y cuando vemos los mar cos de las ventanas, los postes de los setós y otros, lienos de grancles agujeros, puede asegurarse gue el hiloirupo domes tico es el autor de aquella obra destructora. Su laria habitaba hace tiempo las paredes $y$ el delgado fondo de un cajon para guardar insectos, el que, fuera de uso, habia estado antes varios años en el suclo, siendo de este modo entregado s su primitivo destino. El rumor producido por la larva que tal. draba y el serrin que arrojaba descubrieron su presencia; los agujeros que se veian por fuern condujeron por fin i su retiro, y se vió que habia respeiado las paredes externas aun trabajando en la tabla delgada.

\section{EL CALIDIO VARIABLE-CALLIDIUM VARIABILE}

CARACTERES. - Es otra de lis especies que viven en la madera vicja y por lo mismo la cncontramos en las casas $\delta$ en sus inmediaciones Tiene los tarsos mas largos y movi- bles que la especie anterior, pcro se asemeja por sus caractéres mas importantes. Sus antenas, insertas en los bordes de las grandes caridades orbitarias, son tan largas como el cuerpo y su tercer artejo casi tres veces mas prolongado que el segundo; el escudo del cuello es casi circular, pero algo mas ancho que largo, presentando en la superficie cuatro tubir. culos poco marcados: los elitros, cilindricos y no nas anchos que la parte media del escudo del cuello, estan deprimidos en el dorso y se reciondean en su parte posterior. El mesotórax es triangular y obiuso entre las ancas centmales, pero nunca con bordes arqueados; los muslos tienen varios surcos. Este brillante coleóplero es, ó iodo negro, con puntos muy finos de un azul de acero en los elitros, ó tiene las antenas, el escudo del cucllo, y en mayor ó menor extension tambien los tarsos, de un color rojizo, ó rojo amarillo, con los elitros de un pardo amarillo y negros en la punta. Su longitud varia de $11^{\circ}, 010$ a $11^{\circ}, 01 \hat{\jmath}$. Como en la esplecie antcrior, la larva practica tambien galerias irregulares, llenaindolas de serrin.

\section{EL CALIDIO AZUL-CALLIDIUM VIOLACEUM}

CARACTÉRES.-Orm especic análoga es mas baja que la anterior y mas torpe; mide 1,"016 de largo; tiene las antenas mas cortas y filiformes ! las mismas dimensiones proporcionales que aquella entre el segundo y iercer artejo. Fl escudo del cuello se redondea simétricamente en los lados y ticne menos anchura que los elitros; estos y los muslos son menos gruesos. Todo el coleóptero tiene la parte superior mas clara, con el abdómen de un azul oscuro y muy punteado, predominancio en las antenas y en los tarsos el color negro. Esta especie, así como el hilotrupo doméstico, importados en la América del norte, se han aclimatado alli.

\section{LOS CLITOS-GLYTUS}

CARACTERES.-El género de los clitos tiene sus representantes diseminados por toda la tierra. Los machos se caracterizan por sus tarsos largos y anicnas cortas; corren con rapidez y están siempre dispuestos à volar cuancio brilla el sol, agradándoles posarse sobre los arbustos floridos. I,os clitos se distinguen primcipalmente por sus dibujos abigarmdos, predominando el color amarillo. Sus antenas, sedosas ú filiformes, siempre mas cortas que el cucrpo, solo miden á veces la mitad de la longitud del mismo, elevandose entre la esco. tadura $y$ una lista frontal que se corre perpendicularmente hácia abajo; la cabeza, muy redondeada, no esti bastanie hundida en el escudo del cuello para que los bordes anteriorés se ioquen con los posteriores de los ojos; dicho escudo es de forma esférica ú ovalada; los clitios varian por su forma, siendo unas veces cilindricos ó adelgnzádos hiscia atris, y otras deprimidos; los tarsos se ensanchan at menudo en forma de cuña hícia la exiremidad; los posteriores se prolon. gan. Una de las especiés alemanas mas conocidas es el clito comun (Clytus ariefis), caracterizada por su escudo esférico, tarsos gradualmente ensanchados hácin adclante y redondendos en la punta, y clitros cilindricos. Este coleóntero, que tiene de 6,010 a $($ "', or 5 de largo, es negro, $y$ has antenas y los tarsos cie color rojo; está revestido de espresos pelos de un amarillo dorado. En el pechn se vei algunas manchas, y en los clitros cuatro fajas: la primera de estas se jierde detrás del escudo, dividiéndose en dos inanchas irasversales; la tercera sigue la nisma direccion, pero es completa y se halla detrás de la parte media; la cuarta forma el borde posterior del escudo dorsal y por último la seguncla representa en cada elitro una linea oblicua que se dirige hácia afuera. simétrica en sis curso. 
A esta especie se asemejan por su coloracion y dibujo otras dos; una de ellas, el clito ramni (Clytus rhammi), algo mas pecueño, tiene detras de la espaldilla una mancha que no puede considerarse como resto de una faja trasversal recta, porque sus puntas anteriores se dirigen oblicuamente hácia afuera, $y$ sus segmentos abdominales se adelgazan en el centro $\delta$ desaparecen alli por completo. la otra, el clito campes. tre (Cly hrs aricola), tiene el cscudo del cuello escotado en los ángulos posteriores; los clitros recortados oblicuamente hácia adentro en el extremo, y el segundo segmento inclinado hảcia afuera casi en ángulo recio desde la sutura. La larva del clito comun vive entre la corteza de varios árboles frondosos como las encinas y hayas caidas. Nordlinger observó el desarrollo dul coleóptero en mayo, en un tronco de rosal seco. Es un insecto que no encomtramos en las casas ni eni los cmimpos despejados, sino en los bosinues y jardines, sobre todo en las inmediaciones de los àrboles frondosos.

\section{LOS LÁMIDOS - LAMIIDE}

CARACTÉRES. - los lámidos, que constituyen la terceri sub-familia, tienen palpos que; al contrario cie todos los precedentes, rematan en punta aguda y no roma ó en forma de hacha Sus tarsos anteriores presentan ademas un surco oblicuó en la parte interna; los centrales tienen otros ićenticos por fucra; la cabeza es yertical y la frente forma un ánguló recto, si no agudo. En una palabra, los individuos de este grupo tienen a pesar de la gran riqueza de formas bastantes particularidades para que se reconorca inmediatamente que pertenecin à este grupo. La cifra total de sus especies excedo ii la de las dos precedentes sub-familias juntas.

\section{LOS DORCADIONES-DORCADION}

CARACTERES. - Prescindiendo de un género de tránsito, en yue la cabeza no tiene todavia la posicion renuerida, sino scmejante a la de los cerambicidos, y el escido del cue llo con una lista en calda lado, prescindiendo de este género, que vive en las islas del archipiélngo Indio y enta Polinesia, deben agruparse inmediatimente despues los dorcadionts. Sirva este como tipo dél gészero de igunal nombre (Dorcadion) que habita en el mediodia de Eusopa y el Asia occidental hasta Siberia, representando en esta familia á los pimelios entre lus tenebriónidos, y los braquiceros y otros coleópteros terrestres entrelos curculiones. Todos los dorcadiones tienen una estructura comprimida; susantenas soncerdosas y gruesas, pero nunca tan largas como el cuerpo, disminuyendo sus artejosgradualmente en longitud hácia la punta. El escudo del cuello, mas ancho que largo, tiene en cada lado un tuberculillo agudo enelcentro. I.os elitros ąpenas son en su base mas anchos que el escudo del cuello, alcanzando su mayor extension en el centro; se redondenn en la pumta, y tienen una longitud como dos veces su anchura total ó mas todavia. I.os tarsos son cortos y' gruesos; los centrales tuberculosos cerea de la extremidad externa. El cuerpo, sin alas, suele estar revestido de una pelusa que produce sobre todo en los costados, cubiertos por los elitros, graciosos dibujos, rayas, cruces y manchas que por su delicadeza se desgastan fácilmente, dificuitando mucho la distincion de las especies, en párticulat porque el di. bijo de ambos sexos de una misma varia mucho.

USOS, COSTUMBRES Y RÉGIMEN.-Los dorcadiones aparecen de ordinario en la primavera y se arrastran por los caminos y los muros, ocultándose debajo de las piedras cuando hace mal tiempo; parece que en estado de lar. vas se alimentan de las raices de las plantas mas diversas, y

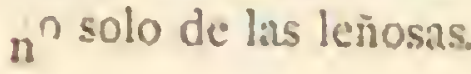

\section{EL DORCADION CRUZADO-DORCADION CRUX}

CARACTERES. - Una de las especies mas pequeñas y graciosas es el doradion cruzado (dorcadion erux ), que vive en Esmirna y sus inmedinciones. Su cuerpo de un negro aterciopclado, está abundantemente revestido de una pelusa blanca y blanda como la seda, que cubre un profundo surco lon. gitudinal de la cabeza; el escudo del cuello y los tarsos no dejan descubierto sino el ángulo lateral obtuso de los elitros y una ancha faja junto a la sutura, que ternina formando uma mancha casi semicircular en el centro.

La especie que mas se interna hácia el norte es el dorcadion negro (Dorcadion atrum), que en ciertos años abunda en Turingia y en el Harz faltando en el mediodia Este in. secto, que mide mas de $0^{\circ}, 016$ de largo, es completamente negro, tiene un surco obtuso en medio del escudo del cuello, confusamente puntendo, y otro tambien en la parte posterior de los elitros entre la sutura y el punto donde el borde externo se encorva hảcia abajo, esto es, en el ángulo lateral. El dorcadion gris (dorcadion fuliginator), que vive tambien en el sur; sucle presentarse con el precedente, diferenciandose del nuismo sobre todo por su pelusa de un blanco sucio en los elitros y por los escasos pelos de color homogéneo que cubren todas las demás partes de su cuerpo, que es negro, particularmente en los tarsos. Hoy dia se le considera como tipo primitivo y la especie negra como una variedad.

\section{EL LAMIA TEJEDOR-LAMIA TEXTOR}

CARACTERES. - El lamia tejedor tiene el aspecto de un capricornio y se caracteriza por su pelusa muy fina y ama. rillenta, entre ja que resultan tubérculos negruzcos cono puntos lustrosos; tiene un color pardo sucio y mide $1, ", 0026$ a $10,003^{2}$ de largo. Sus nudosas antenas que miden dos terćios de la longitud del cuerpo, reposan con su artejo inferior, grueso, largo y con verrugas, en una gran jibosidad. Su escudo oblicuo y cilindrico, tan ancho como la cabeza, tiene en cada lado una gran prominencia espinosa. Los elitros, mucho mas anchos, se aplanan algo desde su parte media hảcia atrás: los gruesos tarsos se caracterizan por una protuberan. cia en la parte externa.

USOS, cOSTUMBRES Y RÉGIMEN. - Este lamia, único resto del género de igual nombre, que tan rico era en especies, se encuentra en los sauces, donde se arrastra perezosamente por las ramas ó se para mas a menudo todavia con cierta indiferencia, pues parece ser un insecto mas bien nocturno que diurno. La larva vive tambien en las ramas de sauce, siguiendo el tubo medular, y practica en el extremo de su gálería un espacio mas ancho para su crisálida, envuelta e. el serrin. la larva carece de tarsos y remata en su parte pasterior en una jibosidad verrugosa que constituje el ano. El primer segmento es el mas grande y de forma ovalada; siguenle dos muy cortos, y los otros siete tienen en su dorso surcos profundos, y en el abdómen una ancha depresion trasversal ancha y recogida.

\section{EL ACANTOGINO EBANISTA - ACANTHOCL- NUS EDILIS}

CARACTERES. - Esta especie es uno de los fenómenos de nuestros capricornios indigcras. El macho se caracteriza por sus antenas cerdosas que miden cinco veces la longitud del cuerpo, estando anilladas de negro, á excepcion de la punta. Por su tamaño y coloracion se asemeja al calidio azul, sobre todo por lo que toca a sus elitros deprimidos y forman- 
do ángulo recto con los hombros; son dos veces mas largos que la anchum total de los dos, adelgnzándose hácia atrás mas en la hembra que en el macho; estin revestidos, como el resto del cuerpo, de una espesa pelusa -gris. La superficie de aquel se camcteriza por estar cubierta de prominencias y vestigios de surcos longitudinales punteados, de color oscuro, con dos íajas trasversales mas ó menos marcadas y desnudas. Para completar los caractéres del género aniadiremos que los artejos de las antenas tienen la misma longitud ó van aumentando desde el terccro en adelante; el escudo del cuello es oblicuo, rematando en los lados en una prominencia espinosa con una faja trasversal de cuatro puntos amarillos en la mitad anterior; la punta del ano de la hembra termina en un largo oviducto; el túltimo segmento abdominal del m.. cho es escotado; y por último, el hoyo en que se insertan las ancas centrales del macho se cierra hácia afuera.

USOS, COSTUMBRES Y REGIMEN. - El acantocino clanista se halla al principio de la primavera en los troncos de pinos caidos $\delta$ en sus cepas, y vaga por las arboledas. Su larva vive entre la corteza de los pinos. Cuando brilla el sol este coleóptero vuela, por lo que se le encuentra tambien en los árboles altos y en los montones de leña. Algunas semanas despues termina su reproduccion, la hembra introdu. ce su oviducto entre las escamas de la cortera, y al coleópte. ro desapharece, á no ser que algunos rexagados, que pasaron el invierno en estado de crisilida, se presenten aun mas tar.

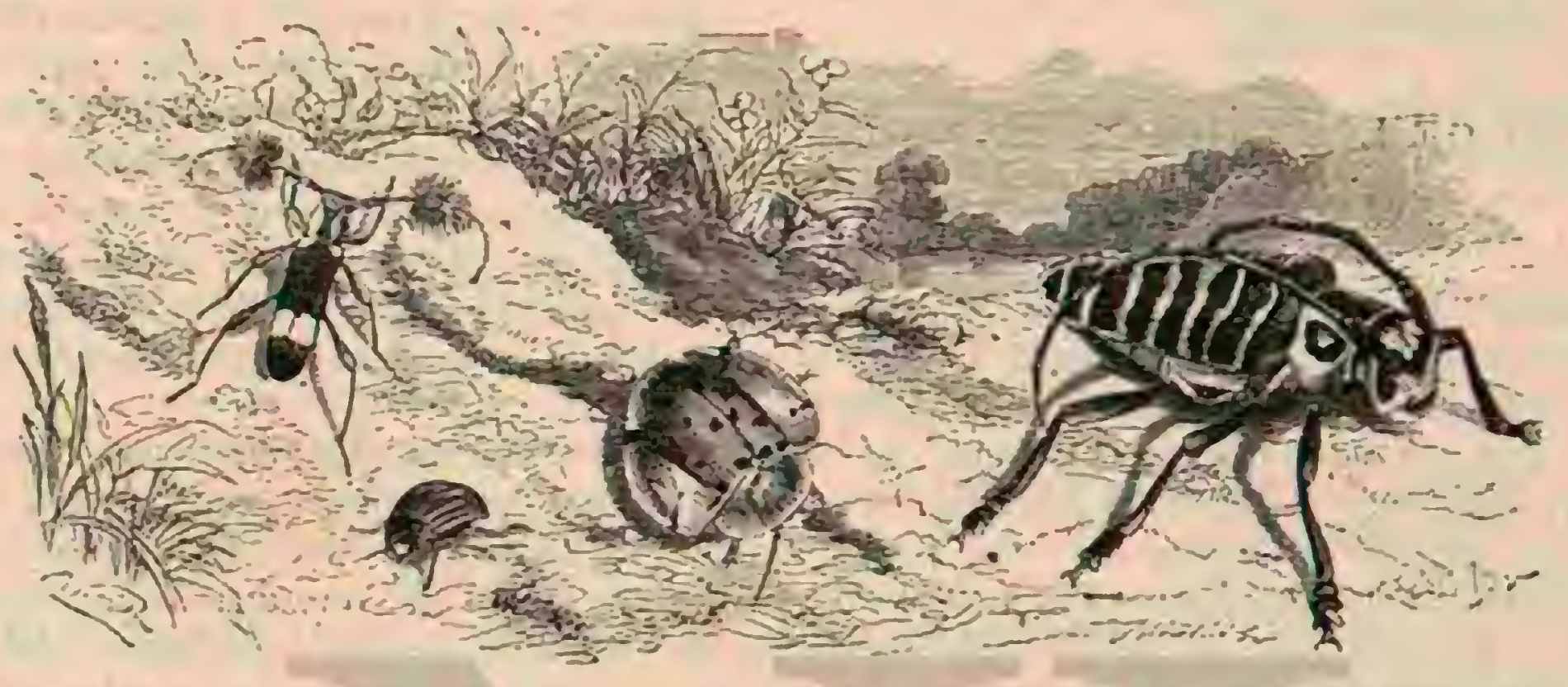

Fi: 28. - EL COSMISOMA DE CAYE.SA

Fig. jO. EL CRISOMELA I)E LOS CERIRLKS
Fig. 29.-1:1. I'Lt:CTROUEKO LSTALO

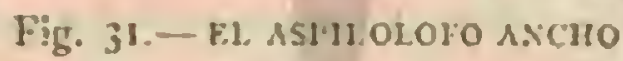

de. La larva llega cón las maderas de construccion á nuestras casas; de modo que este insecto de largas antenas se halla tambien en aqquellas.

DISTRIBUGION GEOGRÁFICA.-Con la esjecic de que hablamos, cuyo nombre ha variado ya mucho (Ceramby: (edilis Astyromus) hállanse algumas otras, menos comunes, en Europa y en la América del norte, puesto que el género no se disemina fuera de los citados paises.

\section{LOS COSMISOMAS-COSMISOMA}

CARACTERES. - El atributo esencial de los insectos de este género, consiste en tener el quinto artejo de las antenas provisto, en su mitad terminal, de un mechon globuloso de largos pelos finos y levamidos, que a veces se prolongan, siendo mas cortos en una parte del sexto.

I.os colores de los cosmisomas varian bastante, y nada po. demos decir en general.

DISTRIBUCION GEOGRAFICA.-Ia América del sur es la patria de estos insectos.

\section{EL COSMISOMA DE CAYENA-COSMISOMA CAYENENSIS}

CARACTÉRES. - Esta especie (fig. 28), tipo del género, se reconoce desde luego por el carácter antes indicado: los hacecillos de pelos, que comunican álinsecto un aspecto singular, son de color negro con las puntas blancas; la base de los elitros tiene un tinte amarillo anaranjado, $y$ en todo el cuerpo predomina el color negro intenso, con mezcla de un blanco plateado.

DISTRIBUCION GEOGRÁFICA. - Esta esprecice e's originaria de Cayena.

\section{LOS SAPERDOS - SAPERDA}

CARACTERES, - I as saperdos y' sus congéneres mas afines constituyen otro genero de los genuinos límidos, que en su conjunto se asemejan mucho á los otros por tener el hoyo en que se insertan las ancas centrales abierto hácia afue. $\mathrm{ra}$, careciendo de surco trasiersal en la parte externa de los tarsos centrales; tambien tienen un ancho apéndice triangular en el mesotórax y la cabeza no esti bastante separada de los costados anteriores para poderla recoger entre ellos. Lus demás caractéres del géncro son: el escudo del cuello cilindrico, trasversal y sin protuberancias of espinas; los elitros forman ángulo recto en los hombros, y son mucho mas anchos y casi cilindricos; los tarsos no esbeltos, jero tarnjoco muy cortos.

\section{EL SAPERDO GRANDE-SAPERDA CARCHARIA}

CARACTERES.-Esta especic es de color amarillo gris; la hembra de ocre, cubierta de pelos sedosos, que solo faltan en las puntas de los artejos yo en las protuberancias granujientas de los elitros.

USOS, COSTUMBRES Y REGIMEN. - Este coleóp. tero se encuentra en junio y julio en los troncos y en las ra. mas de varias clases de chopos y sauces. Parece perczoso, y no se despeja quizis hasta la noche, para atender à la repro. duccion. Ia hembra fecunciada pone sus huevos á mucha profundidad, entre las rendijas de la corteza al pié de los troncos. Iass larvas que salen de los mismos practican en los primeros años sus galerias debajo de la corteza y pasado el invierno penetran en la madiera y elévanse por ella en linea recta. Las largas astillas yue arrancan son arrojadas por un 
agujcro, con lo cual descubren fácilmente su presencia. Ia larva del longicurnio de los sauces produce exteriormente un fenómeno idéntico, pero arroja montones mas grandes y vive de ordinario en troncos mas viejos. Pasado el segundo invierno, la larva, que carece de tarsos, alcanza la edad adulta, convirtiéndose en crisálida; entonces se esconde entre el serrin de las galerias tapadas y al cabo de pocas semanas sale el coleóptero. Donde se presenta en gran número perjudica mucho los plantios de chopos que flanquean los caminos ó las hwertas, etc, pues pueden ser derribados fácimente por el viento. Los troncus viejos y habitados solo por algunas larvas resisten á su talídro, pero como el colépptero suele utilizar sicmpre los mismos sitios para anidar, aquellos se echan tambien á perder con el tiempo, sobre todo si las larras au. mentan à causa de esta costumbre.

\section{EL SAPERDO DE LOS CHOPOS-SAPERDA POPULNEA}

CARACTERES.-Es mucho mas pequeno, de 1", oro at $0^{n}, 013$, de color gris verdoso ó gris amarillento, a causa de los pelos de que está revestido: tiene tres lineas longitudinales amarillas en el escudo del cuello, y en cada uno de los elitrós una serie longitudinal de manchitas amarillas; las antenas presentan tambien anillos oscuros.

DISTHIBUCION GEOGRAFICA. - Los saperdos de los chopos se extienden por toda la Europa y la América del norte comprendiendo una seric de tipos magnificos, mudhos de los cuales viven en estndo de larvas tambien en otros regetales. A cllos se agrega $\mathrm{el}$ último género de Iacordaire llamado de los fitécidos (Phylecide), que no se diferencian en rida por su aspecto, á no ser por la estructura de las garras.

Mientras que zodos los coleópteros hasta ahora descritos, y. otros que jertenecen tambien i los lámidos, tienen las garras simples, formndo en la raiz un ángulo recto con el artejo, de modo que ambos representan en su parte interna un semicirculo, que se adhiere al artejo de la garra como aे suे mango, los fitécidos tienén/estas partes en la posicion ptinitiva; pero cada garra lleva/en su raiz un apéndice, por to que parece lobulada ó hendida, segun que aquel sea ancho y truncado ó puntiagudo.

USOS, COSTUMBRES Y REGIMEN. - En mayo y junio se le ve sobre las hojas del chopo temblon, siendo sin ducla mas vivaz que su congénere; vuela cuando brilla el so! y déjase caer si al tratar de cogerle no se consigue. Pertene. ce á los capricornios diurnos, por lo cual se encuentran tambien las parejas aisladas. Hil macho se echa sobre la hembra que es algo mas grande, y ambos descansan en las hojas ó los tallos de las plantas de que se alimentan, pudiéndose ase. gurar que las destruyen. En el árbol que les sirve de albergue se ven aqui y allá unas protuberancias nudosas con un agujero negro en la madera. El coleóptero sale de aquel y la larva devora dentro del nudo convirtiéndose luego en crisá. lida. El sitio en que la larma se introduce á mediados de junio presenta excrecencias circulares. En el primerverano permanece entre la corteza, pero pasado el invierno se introduce en el tubo medular y se dirige hácia árriba; de modo que el interior de un tronco jơven ó de una rama está agujereado por galerias longitudinales negras, de cuyas resultas la mina muere, porque de ordinario se instalan en la misma muchas larvas. Dada la importancia secundaria de los chopos en la selviculura, la accion de este insecto es menos sensible que la de los anieriores; pero, por lo que toca a las arboledas de chopos temblones, perjudicanlas bastante.

\section{EL OBEREA DE LOS AVELLANOS-OBEREA LINEARIS}

CARACTERES. - En vez de todos los capricornios que pertenecen á este lugar, mencionaremos solo el oberea de los avellanos, coleóptero muy prolongado, casi completamen. te cilindrico, puesto que los elitros sobresalen apenas del escudo del cuello; todo el cuerpo es negro y está revestido de una ligera pelusa, de color amarillo en los tarsos, en los palpos y en una mancha que hay debajo de la region esca. pular. Sus antenas filiformes no alcanzan la longitud del cuerjo, y sus clitros, reticulados, se recortan oblicuamente hácia adentro en la punta. Su longitud es de $0^{\circ}, 0139$, el ancho de la region escapular $0^{\prime \prime}, 0025$.

USOS, COSTUMBRES Y REGIMEN. - Esta bonita especie vive en majo $y$ junio en las matas de avellanos, rerolotendo à la luz del sol al rededor de los mismos, y en. tonces se encuentran los sexos. Ia hembra pone un huevo á unos 15 centimetros debajo de la punta de un retoño tierno. La larva que sale del mismo ahonda inmedintamente la blanda madera y se alimenta de la mécula perforando de arriba abajo. Las hojas marchitas precozmente descubren su presencia.

Pasado el invierno se introduce mas adentro hasta la capa de tres años, para convertirse en crisálida, despues de tras. currido el segundo invierno. Es de color amarillo de cera, carece de tarsos, está revestida de una ligera pelisa y presenta en el dorso del primer segmento abdominal que es el mas ancho, un escudo de quitina cuadrangular y grandes verrugas detris del mismo. El coleóptero practica un agujero de salida despues que la larva ha resecado toda la parte del retono que está sobre el agujero. En el jardin botánico de Halle vive esta larva de igual modo en las matas de la estrya onulgaris.

\section{LOS PLECTRODEROS- PLEC- TRODERA}

CARACTERES. - El macho de esta especie tiene la cabéza bastante cóncasa entre sus tubérculos anteniferos; los lóbulos interiores de los ojos son grandes; el protórax nuas ancho (que largo; los elitros converos; las patas medianas y robustas; el cuerpo prolongado, macizo y en parte pubescente.

La hembra tiene los tarsos anteriores sencillos y el último segmento abdominal mas largo.

\section{EL PLECTRODERO LISTADO-PLECTRO- DERA FASCIATUS}

CARACTERES. - Esta especie (fig. 29), rinica que representa el género, es un hermoso insecto de color negro asaz brillante, con mezcla de un blanco sedoso; en los clitros forma este tinte numerosas fajas trassersales, mas $\delta$ me. nos internumpidas en su centro; la puntuacion de estos órga. nos es muy fina, tanto que no se distingue bien sino con la ayuda del anteojo. El plectrodero listado es un insecto bas. tanie grande.

DISTRIBUCION GEOGRÁFICA. - Este bonito insec. to abunda en las partes mas meridionales de los Estados. Unidos.

\section{LOS BRÚQUIDOS-BRU - CHIDE}

CARACTÉRES.- Los brúquidos son pequeños coleóp- 
teros de forma ovalada, menos arqueados arriba que abajo $y$ semciantes por su género de vida y yor la forma de sus lar. vas a los curculiónidos, con los cuales se les agrupaba antes, pero tienen demasiadas particularidades para no separarlos. Su cabeza dirigicla hácia abajo se estrecha un poco dcirás de los grandes ojos, que tienen la forma de rinones, y se prolonga en su parte anterior en figura de lrocico, como en muchas de las especies anteriores, y no en una tromja verda. dera las anteras son fuertes, á menudo denciculadas $\delta$ en forma de peine y no angulosas, constando de once artejos que se insertan libremente, es decir, sin hoyo, delante de los ojos.

Ias ancas anteriores no son análogas en todos los géneros: en el género bruchus afectan la forma de cuna, se aproximan en su parte posterior y reposan sobre el pecho; las de las patas medias son casi esféricas, $y$ las posteriores, muy trastersales, se acercan mucho entre sí los inuslos son comprimidos y anchos: los tarsos rematan en un gancho y las garras de los piés, que tienen cuatro dedos, llevan apéndices. De los cinco segmentos abdominales el primero, que por lo regular se prolonga en punta, es mas largo que los otros; de la rabadilla se ve una gran parte.

Sin tomar en consideracion la estructura de las partes bucales $y$ de las antenas, ni tampoco la circunstancia de que el tercer artejo del pié esta marcado, diré que las especies afines de esta familin ofrecen gran analogia con los antribinos y entre si.

DISTRIBUCION GEOGRÁFICA. - Mas de 400 espe. cies están diseminadas en todns los continentes, la mayor parte en imérica y Furopa. Como las larvas hasta ahora conocidas se alimentan de simientes, en particular de las papilioniceas, se les ha llamado tambien colejgteros de las simiente's.

\section{EL BRUCO DE LOS GUISANTES-BRUCHUS PISI}

CARACTERES. - El bruco de los guisantes es negto, cubierto de espesos pelos lisos de un gris amarillento 6 blan. co; el coselete tiene en el centro de cada lado un dientecito orulto debajo de los pelos; en los elitros se re una faja trasversal, compuesta de manchitas blancas, cerca de la extremidad posterior, en la cual se redondea cada uno de por si: Ia rabadilla presenta dos manchas negras ovales desprovistas de pelos. Los cuatro primeros ariejos de las antenas, en forma de maza, son de un rojo amarillo; los muslos anteriores del todo negros; los tarsos y los artejos de los piés anteriores, In catremidad de los centrales y tambien los artejos de los piés correspondientes, son de un rojo amarillo; los muslos posteriores están provistos en su cara inferior, cerca de la punta, de un solo diente.

DISTRIBUCION GEOGRÁFICA. - Este coleóptero, que parece ser perjudicial para los guisantes, abunda mas el la America del norte y en la Alemania meridional que en otras partes.

USOS, COSTUMBRES $\mathbf{Y}$ REGIMEN.-En la primavera, lo mas tarde a principios de mayo, este insecto sale por un agujero circular de los guisantes y permanecc como muerto en medio de ellos ó en el suelo, cuando la temperaurra es fresca; pero corre ó vuela contra las ventanas si hace sol. Tan luego como los guisantes entran en su primera fior, los coleópteros acuden y se aparean, y la hembra adhicre algunos huevos i la ciscam muy rierna; estos son cilindricos, cuatro veces mas largos que anchos en ambas extremidades, redondeados y de amarillo de limon. Cuando termina la reproduccion, que naturalmente ocupa siempre algun ticmpo, sobra todo cuando se interrumpe por varios dias de lluvia, Ia hembra ha llenado su cometido y muere. las larvitas penetran en la cáscara y buscan los guisantes, de cuyo desarrollo depende que una larva necesite dos ó se contente con uno. Si este es bastante grieso para que la larva no interrumpa su desarrollo, ambos prosperan al mismo tiempo y um guisante basta al pequeno insecto para desarrollarse; si, por el contrario, el guisante es demasiado endeble cuando la larva se apodera de él, esta última necesita un segundo grano en el que penetra bastante a tiempo para que la herida cau. sada pueda cicatrizarse aun del todo por encima de aquella. Con los guisantes mas duros se recoge un gran número de estos insectos, aun en el estado de larvas, pern puede suponerse que en cada guisante habitado el coleóptern se ha desarrollado antes de principiar el invierno; á mi, por lo menos, no me parece exacta la suposicion de que durante ese perio. do la larva coma aun. Al abrir unos guisantes que a mediados de febrero de 1875 se me enviaron de Olmutr, hallé algunas larvas resecadas, y muy pocos coleópteros muertos antes de su desarrollo; de los mas salió en scguida un bruco de los guisantes, que volando rápidamente por la habitacion dirigióse hácia la ventama cuando hacia sol, y manifestaba grande alegrin por haberse librado de su prision.

\section{EL BRUCO DE PATAS ROJAS-BRUCHUS RUFIMANUS}

CARACTERES. - Esta especic se parece mucho à la anterior y solo se distingue por su coselete relatiramente mas largo, con los dienteciros laterales menos marcados: tiene los elitros mas cortos, difiriendo aigo sus matices. los muslos anieriores son de un rojo amarillo, y los posteriores ticnen dientes menos marcados. La larva vive en las liabichuclas, y sin duda no ataca los guisantes, aunque asi como la especie anterior, abre un agujern vertical de orificio circular, de nodo que por fuera no se ve ninguma lesion en la simiente $a$ no ser que á causa del desarrollo el agujero circular se mappa. rente por la epidermis.

\section{EL BRUCO DE LOS GRANOS-BRUCHUS GRANARIUS}

CARACTERES. - Este coleóptero es al parecer la espe cie mas comun en Alemania, y, segun se ha observado, la menos exigente respecto d su alimento. Puede proceder de orolus twierosus y de especies de lashyrus; yo le oltuve, como otms, de la ivicia sepium, y tambien se le cncuentra en la ircin faro. En las arvejas, que son mucho mas pequenas, no queda de las simientes nada mas que la cascara, lo cual hace presumir que al insecto no le agrada permanccer durante el invierno en su cuna. Teniendo en cuenta que se desarrolla mas pronto en las arvejas silvestres, que se encuentran antes, podemos cxplicarnos con facilidad que a mediados de setiembre se vea ya el pequeño colerfptero al aire libre, paseindose por los contornos, segun he observado en los individuos que yo crié La larva que carece de ojos, de patas y' de antenas, no se distingue, i la simple vista, de las especies antcriores; pero el cuerpo es mas pequeno, mas corto y de color diferente, siempre de un negro bastante brillante: los cuairo artejos de la base de las antenas y las patas anteriores son de rojo amarillo; los piés y los muslos negros. I.os muslos yosteriores tienen una profunda escotadura junto á la extremicind, y el angulo que hay delante de esta se trasforma en un pe. queño diente, de distinta forma en los scxos. El disco del coselete presenta dos puntitos blancos y una manchita mas grande delante del escudete; este es igualmente blanco, yo una 
manchita que se ve detrás, en la sutura, de color amarillento. Los dibujos blancos de los elitros se componen de manchns irregulares dispuestas mas 3 menos en forma de faja; en la rabadilla hay otras dos del mismo color, sin pelos grises.

El bruco de las lentejas (bruciuus lentis) ataca estas leguminosas; varias especies tropicales se alimentan de las simientes de otras plantas, de las mimosas, acacias, palmeras, etc.

\section{LOS CRISOMELINOS- CHRYSOMELIN死}

CARACTERES. - Tos crisomelinos, representados por unas diez mil especies de coleópteros, no nuy bien conocidas aun, de mediano tamano 6 nuy peçuentas, constituyen la útima familia de los tetrameros Algumas esjecies en que el coselete se estrecha mas que los elitros apenas se dis. tinguen exteriormente de cicrtos longicornios, con los cuales se agrupaban aun en los tiempos de Tínneo. Tlos mas se caracterizan, sin embargo, por las formas recogidas que les son esencialmente propias, sin que se pueda indicar ningun distintivo importante. la caheza se inserta mas ó menos profundamente en el coselete, ocultándose á veces debajo del nismo; las antenas, filiformes ó cerdosas, presentan por ex. cepcion una maza, por lo regular de mediana longitud, y once artejos, carácter que puede servir para la clasificacion de los géneros segun el sitio en que aquellas se inserter. Los ojos ocupan los lados de la cabeza; las maxilas rematan casi siempre en una punta hendida; los jalpos son cortos; los artejos de los piés casi siempre sedosos en la planta; las garrns á menudo denticuladas ó hendidas; la articulacion en que se insertan cncaja en una profunda escotadura de la anterior, como en los longicornios, el abdómen se compone de cinco ser. mentos libres.

USOS, COSTUMBRES Y REGIMEN.-Estos coleópteros, que en su mayor parte tienen colores abigarrados, con frecuencia de un magnifico brillo metálico, devoran las par. tes tiernas de has plantas, con preferencia hojas, $y$ se presentan bastante \& menudo con especies aisladas, en tal nimero que causan considerables perjuicios en las plantas cultivadas: sus larvas observan el miśmo régimen alimenticio; muchàs viven al aire libre y se distinguen entonces por sus colores mas oscuros á menudo abigarrados; otras abren galerias en las partes blandas, pero nunca en la madera, como lo hacen las mas de las larvas de los longicornios, de las cuales dificren esencialmente, no solo por su aspecto exterior sino tambien por tener las patas bien desarrolladas.

Por lo demás, ni de estos ni de aquellos insectos puede hacerse una descripcion general. Chapuis y Candeze los dis. tribuyen en los cinco grupos siguientes: $1 .{ }^{\circ} \mathrm{J}$ arvas prolongadas de color blanco y de forma casi cilindrica que viven en el interior de las plantas acuáticas y para crisalidarse fabrican un capullo, fijo debajo del agua en la raiz de la planta en que habitan (donacia, hamonia). 2. I arvas que se cubren con sus excrementos: son de color pardo y de forma prolongada, y para crisalidarse penetran en la tierra (crioccris, lema); es. tas no están provistas de órganos particulares para llevar los excrementos, mientras que otras anchas y de forma oval los recogen en un apéndice ahorquillado del último artejo y se convierten en crisalida en las hojas (cossida). 3. Tarvas de forma cilindrica adclyazada en ambos extremos: se trasforman en ninfas en el interior de la planta ó en el suelo (altica) y otras viven en él dentro de las hojas, pero tienen verrugns laterales (hispa). 4." I arvas cortas, gruesas y coloradas, que se distinguen casi siempre por tener unos apéndices verrugo. sos en la parte posterior, y verrugas en los lados del cuerpo, asi como por la facultad de segregar un jugo glutinoso: viven libremente en las hojas; para crisalidarse cuélganse por la ex. tremidad del cuerpo ó penetran en el suclo (cummlpos, criso. melas y galerucos). 5. I.arvas claras, prolongadas, bastante cilindricas, pero rerrugosas, que en su parte posterior se encorvan en forma de gancho: habitan en un capullo fabricado con sus excrementos ý fijo en las plantas, ó bien habitan en el interior de los hormigueros, trasformándose en ninfa en el mismo sitio y dentro de su capullo (clitridus y criptuefá. lidos).

Como solo podemos ocuparnos de pocas especies de las numerosas familias, no descenderemos á una clasificacion mas detallada, limitándonos a citar algunas de las mas in. portantes en el mismo orden en que suelen colocarlas los roólogos.

\section{LAS DONACIAS - DONACIA}

I.as houitas donacias se encuentran en numerosas especies en Europa y en el norte de América y se hallan si fines de mayo $\sigma$ á prinsipios de junio, â menuclo en grandes agrujacioncs, en cains, juncos y otms plantas acuáticas, cuando nó en las hojas fotantes, en cuyas partes tiernas han vivido co mo larvas. El coleccionador las conoce por el ácido que se halla en su cherpo, pues ningun otro coleóptero deja en el alfiler que le perfora tanto verdin trasformandole en poco tiempo en tal; el verdin abre los elitros y el abdómen y des. truye los individuos.

Por esto se los deja resecar semanas enteras humedecién. dolos despues un poco para que estén dexibles, perforándo. los luego con el alfiler, que debe ser platendo, aunque tam. poco es scguro evitar su oxidacion evitando la destruccion; lo mas conveniente es pegarlos sobre una fajita de papel al ha. do del alfiler, lo que por lo regular no suele hacerse con co. leópteros de su tamaño. Ia semejanza que puede existir $\mathrm{en}$. tre las donacias y los longicornios nos ha sido demostrada por la descriprion que ha hecho Degeer de una especie que se encuentra en las hojas de la rosa lacustre, la donacia gras. sipes ó leptura nquatica.

I a clonacia de patas de maza (donacia clavipes, ó tambien menyanthidis) puede servirnos para dar una idea de estos bonitos insectos. Pertenecen á la forma mas prolongada y á los pocos en que el macho no difiere de la hembra por tener uno 6 dos dientes en la cara posterior de los muslos posteriores, sino solo por su menor tamaño. la superficie es de color verde dorndo: la parte inferior del cuerpo está cubierta de espesos pelos plateados; las antenas, insertas en medio de la frente, son filiformes y de la longitud del cuerpo; las patas rematan en garras sencillas de color rojizo. El coselete, cundrangular y provisto en ambos lados de su parte anterior de una prominencia, se encorva ligeramente en el centro y esth cruzado por finas arrugas trasversales y un surco longitudinal. Jos elitros presentan rayas, puntos $y$ arrugas en extremo finos, redondeandose en su extremidad posterior, donde tam. bien se adelgazan un poco, siendo un doble mas largos que anchos; los muslos posteriores llegan à la extremidad de los elitros; los costados anteriores son cilindricos y se tocan. Notable es en todas las donaciás el primer segmento aldo. minal, porque tiene mayor longitud que todos los siguientes. juntos.

Solo he visto á este coleóptero, cuya hembra mide mas de $0^{\circ}, 018$, en el mes de mayo y á principios de junio: en 866 le vi con mucha frecuencia apareado en la caña comun de nuestras orillas del Siale, en punto muy distante del sitio donde se encuentra la alisma plannago designacla por Heeger como planta alimenticia, de modo que debo suponer que 
la larva tambien vive en otras plantas. Tampoco he observado al coleoptero en octubre 6 noviembre; aunque se le debe ver entonces, pues dicho observador pretende que regularmente sale del agua en octubre, apareándose algunos dias despues cuando hay calma. Los colcópteros que se presentan á fines del mencionado mes ó hasta en noviembre, no se aparean hasta la próxima jurimavera, despues de haber pasado el invierno debajo de sustancias vegetales en descomposicion en el agun.

La hembra fecundada en la primavera vuelve al cabo de seis ú ocho dias a sumergirse en el agua, y deposita de dia los huevos aisladamente en las raices gruesas de las plantas alimenticias; para poner todos los huevos, en numero de cuarema à cincuenta, necesita de I 4 á 18 dias; en el espacio de 10 à 20 nace la larva, que se alimenta al principio de las licrnas raices fibrosas, mas tarde de las gruesas y despues de la tercern muda de las mayores. La muda se verifica di in. tersalos desiguales, necesitaindose para el completo desarrollo de cinco á seis semanas. Fn el estado adulto tiene una longifud de $0^{\prime \prime}, 01$ i a $6^{m}$, or 3 por $10^{n}, 00337$ de grueso. Es casi cilindrica, un poco convexia en el vientre, y de color gris verdoso pálido. La cabcza es muy pequeña, redonda y retráctil; tiene seis patas, y en el penúltimo segmento (undécimo) dos es. pinas pardas, cóneas, encorvadas hacia afuera y próximas una a otra en su base, de modo que en estado de reposo se oprimen hácia adelante contra el vientre, sirviendo de ajuda en la locomocion. La cabeza, q̧ue es cómea, apenas tiene la cuarta parte de la anchura del mesotórax; las antenas cuentan tres artejos; los palpos labiales, muy pequeños, solo dos; la mandibula inferior tiene la maxila interior coriàcea y de forma oval; la exterior ofrece la misma estructura, pero es mas corta; sus palpos se componen tambien solo de dos artejos; los ojos faltan. El labio superior es trasversalmente cuadrangular y' cada mitad de las maxilas se adelyaza, lia. llándose provista en la superície interior de dos dientes obtusos.

La laria construye en la raiz de la planta alimenticia un capullo oval aperganminado, de un negro violeta en la parte exterior y blanco en la interior, en el que la ninfa del todo separada del agua, descansa de reinte a veinticinco dias. Se gun ya homos dicho, el colcóptero nace antes del invierno: despues de levantar una pequeña tapa, mantiónese cogido algun ticmpo a la plane alincuticia, hasta que el agua lo cleva á la superficie; una ve\% aqui. sube á ln primera planta que encuentra y emprende el vuelo como todas las donacias, pues algunas se encuentran ì larga distancia del sitio donde nacieron y en plamtas que seguramente no les sirvieron de cuna.

Eun las regiones calidas del Asia y del Africa, estos insectos adquieren proporciones gigantescas, a veces de 6", 082 a $1,0,035$ de longitud, y representan a uuestras donacias. Son las especies del genero sagra, magnificas y fáciles de conocer por los inuslos posteriores del macho, que son muy gruesos en la cara inferior, hallindose provistos de numerosos dientes, $y$ por los tarsos posteriores encorvados. Este génera suele figurar à la cabera de la familia.

\section{LOS CRIOCEROS-CRIOCERIS}

CARACTERES. - Fil yue al contemplar las magnificas arucenas (Jilisum candidum) de nuestros jardines ha visto corroidas las hojas, examinindolas para descubrir al malle chor, habrá obseriado unos cuerpos húmedos de color negro brillante que perczosamente se mueven en el tallo $\delta$ con la inayor actividad pican las hojas. Lo único que de cllos se vie son los excrementos, con los cuales se cubren, dejando solo el vientre libre. Al examinarlos mas de cerca, reconoce que son unas larvitas gruesas, adelgazadas hácia delanec y con seis patas; en verano se aliusentan de aquellas hojas, pene. tmando despues en el suelo para crisalidarse. En la primavera siguiente, se presentan los conocidos coleónseros de los lisios (crioceris meridigera), de color negro brillante, con el coselete y los clitros rojos, y que desde luego se aparean, montados unos sobre otros. Por su forma se parecen a las donacias, pero son mas recogidos; las antenns, en forma de cordon, llegan solo a la mitad de la longitud del cuerpo, y además las patas son unas gruesas. Como en el género anterior, el coseletc casi cilindrico y muy éstrechado hácia atris, no llega cor inucho á la anchura de los clitros, que son reciangulares en los hombros; la cabeza, triangular, se estrecha hácia atrís en forma de cuello y es mas ancha en el punto en que se insertan los ojos salientes, algo escotados hacia dentro. los palpos maxilares, que rematan en cun̉a; ๖ las garras de los piés, del todo separadas, distinguen el género de otros muy parecidos por su exterior (lema, eesuguphora). El crioceris de los lirios, que mide $0^{\circ}, 0066$ de largo, puede producir un chirrido fuerte, en proporcion à su tamaño, recogiendo yo alargando el último segnento abdominal, provisto en su dorso de un reborde cortado en el centro y surcado, el cual se roz.s con numerosas escamitas de quitina, en las puntas de los elitros; en este contasto, la parte cortada del reborde toca la sutora de aquellos, junto a la cual se hallan dichas escamiias. Poniendo junto á la oreja un coleóptero cncerrado en el hueco de la mano, percibese el sonido muy marcadamentc; sirve á los sexos para llamarse en el periodo del celo. El crioceris de! esparrago (riveceris asfaragi), mas pequeño y aplamado yue el de los lirios, es de un verde azulado brillante: tiene el coselete, casi cilindrico, y el borde de los elitros de un tinte rojo, con manchitas confusas de color blanconmarillento, reunidos entre si $\delta$ con el borde. I.a especic, asi como su larva, que es de un color verde aceitunado, con escasos pelos, bordeada en los lados de replicgues y provista de șcis patas, vive en las hojas del esprirrago crecido, de las cuales tambien se alimenta. Para trasfonmarse en criślida, la larva penetra en el suelo, donde la ninfa y muchos coleópteros y. desarrollados pasan el inviemo. Eil reborde con que produce el chirrido no está cortado, y roza con la última extremidad de los clitros.

El crioceris de doce puntos guarda un têrmino medio por su tamaño y forma entre las dos especies anteriores. Ial cabeza, el coselete, los elitros, el abdómen, el centro de los tarsos y los muslos, excepto su punta negra, son de color rojo, y negras las partes restantes, la cara superior del cuerpo, el escudete y seis puntos de cada elitro. Tambien este pequerio coleóptero se presconta en el espárrago crecido para comer las hojas. I ai larvi, de seis patas, de color gris de plo. mo y desnuda, con el coselete bipartido, vive aisladamente en las bayas de la planta. Parn metamorioscarse penetra taubien en el suclo. El órgano con que el colcóptero produce el chirrido se asemeja al de la especie anterior, solo que el reborde es mas ancho en la basc del dorso del últino segmento del cuerpo.

\section{LOS CLITROS-CLYTHRA}

CARACTERES.- Con el género de los clitros que tillimamente se ha dividido en cuarenta sub-géneros, y cuyas doscientas cincuenta especies habitan casi exclusivamente el antiguo mundo, pasamos á otro grupo de formas mas cerradas y cilindricas, cuyo coselete es igual en anclums en su horde posterior á la base de los clitros paralelos. Lais's especies de este genero tienen la cabeza situnda oblicuamerte, inserta 
hasta los ojos en el coselete; las antenas, cortas, son casi siempre denticuladas, se fijan debajo de aquellos y estín muy distantes una de otra, por ser muy ancha la frente. l.as maxilas rematan en tres dientes, y la lengua, que es córnea, esta truncada en su parte anterior. En muchas especies las patas anteriores, sobre todo del macho, se prolongan extraordinariamente, pero tienen, así como las otras, las garras muy hen. didas. El primer anillo del abáómen recoge en los lados el apéndice correspondiente á los costados del metatórax, y el último es igual 6 superior en longitud à aqquel.

\section{EL CLITRO DE CUATRO PUNTOS-CLYTHRA QUADRIPUNCTATA}

CARACTERES. - Esta especie, dé color brillante, está cubierta de pelos finos grises en su carn inferior; tiene dos manchís negras en cada uno de los elitros, de un tinte rojo amarillo brillante; otra mancha mas pequeña en la depresion de los hombros, y una grande detrás de la parte que en formia de faja se sobrepone a los elitros; las patas anteriores no son mas largas que las demás. El macho se distingue por tenet un hojo en forma de cuna en el último segmento del abdómen, mientras que la hembra solo presenta un surco longitudinal.

USOS, COSTUMBRES Y RÉGIMEN,-El colé́ptero es muy comun durante el verano en la yerba y en los arbustos, sobre todo en los sauces. Se desarrolla en el término de un año de una larva que vive en un capullo negro fabricado con sus excrementos, y el cual cierra el insecto por la parte superior para invernar y cuando quiere trasformarse en crisálida. De la extremidad inferior mas gruesa sale al cabo de pocas sernanas el coleóntero, levantando la tapa inferior del capullo, para lo cual necesita poca fuerza, gracias á la ligera construccion del mismo. Se ha visto at menudo la larva en montones de hormigas (formica rufa).

\section{LOS ASPIDOLOFOS-ASPIDOLOPHA}

CARACTERES. - Los aspidolofos se caracterizan por tener el cuerpo medianamente prolongado 6 muy corto, y mas ó menos ensanchádo por detrás jel protórax es lobado en su base; el escudo grancle, con frecuencia carenado en la línea media; les elitros encogidos por detrás y no muy convexos: las patas poco robustas: las piernas bastante delgadas.

DISTRIBUCION GEOGRÁFICA. - Las especies de este género habitan sobre todo en el continente indio; $\mathrm{cn}$ Java y Sumatra existe una y en Borneo otra.

\section{EL ASPIDOLOFO ANCHO- ASPIDOLOPHUS A MPLISSIMA}

CARACTÉRES. - Este insecto (fig. 3 I) debe su nombre especifico å la notable anchura de su cuerpo, que oculta del todo sus uniembros; el protórax es corto; el escudo pequeño; las patas poco robustas y las piernas raquiticas. Este insecto tiene un color pardusco verdoso algunas veces, y mas generalmente pardo del todo, ofreciendo en algunos individuos una mezcla negruzca.

DISTRIBUCION GEOGRAFICA. - El aspidolofo ancho se encuentra muy á menudo en las islas Filipinas.

\section{LOS CRIPTOCÉFALOS-CRYPTOCE- PHALUS}

CARACTERES.-I os criptocéralos ó coleópteros de ca- beza oculta, porq̨ue esta encaja de tal modo en el coselete que solo se ven la frente y la cara, representan un tipo mas pequeño qque el del género anterior, péro tienen largas antenas, las de mayor longitud que pueden lallarse entre los crisome. linos.

USOS, COSTUMBRES Y REGIMEN. - I AS nume. rosas especies viven en arbustos y flores, y alli donde exis. ten se las encuentra siempre reunidas, aunque no sociable. mente. Nuestra especie mas comun y grande, criptocephalus sericeus, de color verde domdo, $\delta$ azul intenso, habita en el fondo de las flores. Así como los coleópteros anteriores, cuando álguien se acerca déjanse caer con las patas recogidas y las antenas apretadas contra ta cabeza, fingiéndose nuertos durante largo rato. Este es el único medio defensivo con que cuentan muchos colérpteros para librarse de los ataques de sus enemigos. En las larvas se repiten las mismas circunstan. cias del género anterior respecto á la metamorfósis.

\section{LOS LINAS-LINA}

CARACTERES. - I os crisomelinos propiamente dichos tienen las antenas filiformes, un poco mas gruesas en su extremidad junto à los ojos; el coselete no se redonden en su borde anterior, sino que es truncado y mas ancho que largo; el cuerpo, de contormo oval, es convexo en su parte superior y blando por debajo. I as larvas viven libremente en las hojas. Ins especies del género lina, al quue ahora nos referimos, presentan en los thrsos posteriores un surco profundo que casi llega hasta la punta; el coselete es en su base menos ancho que los elitros, que tienen en los hombros varias prominencias; las antenas son cortas y en forma de maza.

\section{EL LINO DEL ALAMO-LINA POPULI}

CARACTÉRES.-El lino del álamoes negro, con brillo verde 6.azulado; el coselete se redondea ligeramente en los lados y presenta un reborde; los clitros, que son rojos y pierden mucho su color en los individuos muertos, tienen la pun. ta negra.

\section{EL LINO DEL CHOPO-IINA TREMULA}

CARACTÉR ES. - En esta cspecié, un poco mas peqqueña y que presenta los mismos colores, el coselete, recto en los lados, se estrecha insensiblemente haicia delante, $y$ junto al borde tiene un surco formado por gruesos puntos que le comunican un aspecto muy voluninoso; los elitros carecen de la puntita negra.

USOS, COSTUMBRES Y REGIMEN.-Ambas especies se encuentran en los arbustos, en los sauces y álamos, y sobre todo en los chopos pequeños. Preséntanse despues de su sueno invernal, tan luego como las hojas empiezan à brotar; entonces se efectua el apareamiento y la hembra deposita sus huevos rojizos uno junto à otro, casi siempre en la cara inferior de las hojas, poniendo unos diez en cada una. Al cabo de ocho ó doce dias, segun que la tenperatura sea ca. lurosa ó fria, las larvas salen de los huevos, reconociéndose su presencia desde mayo, sobre todo porque perfuran las hojas. Despues de varias mudas alcanzian su mayor tamaño. Su color es un blanco sucio con viso negruzco; el dorso de los dos segmentos posteriores del tórax ofrece un color blanco mas puro; en la cabeza, el coselete y las patas hay varias series de puntos; las verrugas son muy peludas en los lados del cuerpo, que tienen un color negro mas intenso y brillante. Ia cabeza esta provista en cada lado de seis ojos. La larva de la especie mas grande tiene un asjecto semejante, pero es un 
poco mas ancha en el abdómen. Cuando se tocan estos insectos sègregan una gotita de un liquido lechoso fétido, que vuelve a introducirse en el cuerpo cuando no se pone en contacto con otro objeto. La larva adulta se fija con la extrenidad de sı cuerpo en una hoja; despójase de la última piel y se trasforma en una crisalida de color blanco sucio con manchas negras en el dorso: la mayor parte de su abdómen queda circuido por la piel abandonada. Al cabo de seis á diez. dias nace el coleóptero, que al principio muy blando y' de color mate, solo se perfeccioma cuando todas las partes estain bien resecadas. No perfon las hojas, sino que se las come, dejando tan solo los nervios mas gruesos. Fil hecho de encontrarse la larva desde mayo hasta agosto, de existir al mismo tiempo en verano las larvas, las crisailidas y los coleópteros, y por último la circunstancia de ser muy sipido el desarrollo de cada uno de esos estados, cuando el tiempo no es muy desfarorable (observironse en 13 de setiembre los coleopteros de huevos puestos en 2 de agosto), parecen indicar que se verifican dos crias al año.

\section{LOS CRISOMELAS - CHRYSOMELA}

CARACTERES.-El género chrysomela carece del surco en los tarsos posteriores, y cuando el coselete está indicado llega en su borde posterior casi a la anchura de los elitros; el seguncio artejo del pié es mas estrecho que el primero y el tercero. las especies mas vigorosas, que carecen de alas, se han separado en los sub-géneros timarcha y chrysomela.

DISTRIBUCION GEOGRÁFICA - De esic último grupó se conocen unas 150 especies, propias en su mayoria de Europa; las mas bonitas, de magnificos y vivos colores meta. licos, habiian con preferencia cn las montahas.

USOS, COSTUMBRES Y REGIMEN.-Los mas do estos insectos viven en plantas determinadas que sirven de alimento a sus larvas. Estas últimas son cilindricas $y$ casi arquicadas, y no tienen verrugas peludas en los costados.

I a.ehrysumela ivolacea, de un bonito azul metilico, vive en varias especies de yerba buena; las chrysomela cerealis (fig. 30), rayadas de rojo ó dorado y azul oscuro, solo se hallan debajo de las piedras en las pendientes aridas, de cuya escasa vegetacion graminea se alimenta sin duda la larva; la chrysomele fassuosa, de un vivo brillo amarillento, con los elitros rayados de azul, se alimenta del galeopsis iersicolor; la clonsomela graminis, bastante rugosa, de un solo color verde de esmeralda y de mayor tamaño, se nutre en los helechos, y regularmente se la suele encontrar en mayor numcro en las plantas alimenticias. En una ú otra especie se han hecho obserraciones muy curiosas respecto \& su género de vida. En el sur de Francia, en Mirsella, Portugal, etc, encuéntrase la chrysomelir diluta, como insecto nocturno, pues desde setiembre hasta funes de noviembre busca de noche las hojas del plantago cormopus cono alimento, y se oculta de dia debajo de las piedras. Es probable que tambien el género de vida del chrysomela cerealis sea nocturno.

Los huevos se depositan en octubre en la citada planta; a principios de diciembre salen las primeras larvas, mudan dos veces y se trasforman en crisalida a fines de fubrero. Al cabó de tres semanas, es decir, á funes de marzo, nacen los coleópteros, penetran a mucha profundidad en el suelo, y pasan los meses calurosos en una especie de letargo del que solo despiertan cuando las noches comienzan á ser mas frescas. Segun las observaciones de Perroud, las dos magníficas es. pecies shrysomeda superba y chrysumela speciosa, producen larvis que no nacen del huevo en el vientre de la madre, segun las observaciones del citado autor.
EL LEPTINOTARSO DE DIEZ LÍNEAS-LEPTINOTARSA DECEMLINEATA

CARACTER ES.- El leprinotarso de diez lineas, llamado tambien coleóptero del Colorado y de las patatas, ha adquirido hace unos quince anos en la América del norte una triste celebridad, infundiendo tambien temor en Europa, pues por su causa la Dieta alemana, en primer lugar, y despues el gobierno francés, han prohibido la importacion de patatas de la Amúrica del norte en los puertos de ambas naciones. El coleóptero pertenece a lis especies mas afines de las que habitan nuestros pises, y observa el género de vida del lima del álamo, con la sola diferencia de que se propaga nucho mas, penetrando en el suelo para trasformarse en crisalidia. El color predominante del cuerjo es un amarillo sucio, con manchas negras en la cabeza, en el coselete y en toda la cara inferior; las puntas de las antenas, de los muslos y los piés son negros. Cada elitro tiene cinco myas longitudinales de dicho color, que excepto la última no son visibles. Desde la parte superior, están orilladas cada una de dos series irregulares de puntos, los cuales desaparecen en los intervalos amarillos, sobre todo en la mitad exterior de los elitros. I.a raya negra de la sutura se reune hacia atras con esta misma, siguiéndola $\delta$ desapareciendo antes de llegar is la extremidad; la segunda y tercera únense igualmente una con otra, avanzando juntas à cierta distancia, mientras que cada una de las dos siguientes desaparece aislada poco antes de tocar la punta de los elizros.

Ia larva, carnosa y gruesa, y en un todo scmejante por la cstructura a los crisomelas de nuestros paises, tiene un color amarillo sucio muy brillante; pero la cabeza, el borde poste. rior del cosclete y las patas, son de un negro de pez, corriéndose por los lados dos series de manchas redondas y negras, mucho mas pequeñas en el segmento, cuando no faltan del todo 6 en parte. Los muñones de las antenas tienen tres ar. tejos; los gruesos palpros maxilares cuatro, y los labiales ires; los ojuclos existen en mumero de cuntro en anda lado, y las cortas maxilas están provistis de cinco dientes.

USOS, COSTUMBRES Y REGIMEN.- El leptinotarso inverna en el stelo à mas de $0^{\circ}, 06 \hat{j}$ de profundidad segun se asegura, pues se encuentra muy abundante en tol mes de abril al labrar los campos. Apenas reverdecen los camplos de patatas, esos insectos acuden para alimentarse de las hojas, en cuya cara inferior fijan sus huevos prolongados, de color amarillo de yensa, en grupos de ireinta y cinco á cuarenta. Me parece exagerado lo que se ha dicho de que un.a hembra puede poner lasta mil doscientos; y aun el número de setecientos, indicado por varios observadores, es en mi concepto bastante crecido. Al salir de los huevos, las larvas continuan las devastaciones de sus padres, que poco a poco mueren. Su crecimiento es rápido; para unsiormarse en crisílida penetran en el suelo, del que salen al poco rato como coleópteros, cuya cria, segun se dice, produce una segunda y tercera. Aun suponiendo solo dos, la propangacion seria enorme, y no podria extmnarmos eucontmr en verano todos los grados del desarrollo al mismo tiempo, tanto mas cuanto que en los casos de gran fecundidad la puesta de los huevos no se veritica a la vez y las larvas por lo tanto han de tener una edad diferente. Segun el informe que tengo a la vista, hasta el 10 de junio se encuentran los coleópteros, hasta el 20 de junio los huevos, $y$ hasta el ro de julio las larvas: esta indicacion permite muy bien suponer la posibilidad de una cria anterior y de otra desptres. Fil coleóptero y su larrá se alimentan al principio de solanácens silvestres (yerba de cabra, beleño, estramonio, yerba mora, ctc.) en las montañas pedregosas. Por el cultivo de la patata, que mas y' mas se ex- 
tendia hacia el ocste, dichas solaukeas llegaron it ponerse en contacio con los insectos, de modo que gracias à esta planta sc propagaron con increible rapidez. hácin el este y nordeste. En 1859 estos insecios se hallaban aun á cien leguas mas al oeste de Omaha, en Nehraski; en 1865 cruzaron el Mississipi, invadiendo el Illinois; en 1870 se fijaron en Indiana, Ohio, Pensilvania, Massachuselts y el Estado de Nueva York; : un 187 r las bandadas de estos insectos cubrian el rio Detroit, en Michigan, franqueando dlago Erie en hojas, ramas y pedazos de madera, comenzando sus devastaciones entre los rios de Santa Clarn y el Niagara Como este enemigo de la patata destruye las partes verdes de las plantas, no pueden formarse los tubérculos en sus raires, ó cuando menos son mu incompletos; de modo que la cosecha escasea mas ó menos.

Iin las tentativas que hasta ahom se han hecho inútilmente para librarse de estos insectos, se ha citscubierto que tienen propiedades/venenosas; de modo que se debe aconsejar el uso de guantes viejos para recogerlos. Asi como muchas dé las ésjecies propias de nuestros paises, segregan una sustancja glutinosa, no solo el colcúpiero, sino tambien su lana, y esta sustancia produce hirchazones en las manos. Se ha reconocido que humedeciendo las plantas con agua mezclada - con óxido de cabre, 6 acido arsuruosolverde de Schweinfurt) se matan los insectos sin causar daho 1 los regeta'es. El coleoptero del Colondo tiene muchos/enemigos: una especic de fahirin deposita sus huevos en las larvas; los de ciertas cochinitas (marranitos de San Anton) devoran los del leptinotarso de diez lineas; y las correderas, chinches, batra. cios y comejas toman parte en la disminucion de tan peligro. so insecto. A causa de haberse encontrado algunos coleópteros en el buche de una codorniz, enviaronse patos y gallinas paralluchar contra el enemigo, $y$ estas aves cumplieron su mision; pero respecto à las gallinas las noticias no están conformes, pues se dice que en algunas partes murieron por ha. ber comido estos coleópteros.

Como en virtud del gémero de vida del coleóptero del Colorado este no hace caso de las patatas sino solo de las yerbas: como á falta de alimento tambien invaden sus especies otras plantas no pertenecientes a la fanilia de las solanàcens (inalas yerbas y especies dé coles); y como por orm parte los grupos de cstos insectos observados solo se afanan en buscar su alimento predilecto, y ningun grupo de crisomelas consta de un crecido número de individuos, debemos considerar por todas estas circunstancias como puranente excepcional la invision de los campos por este coleóptero, que si acaso se encuentra en ellos en cierta caniidad es á causa de los individuos que pasan el inviemo en el suelo. La suposicion de que este coleóptivo se haya impartado à los paisus de ultramar en las patatas es poco probable, porqué en este caso dichos tubérculos teridrian que estar mezclados con micha tierra y porque en las regiones infestadas por el coleóptero dificilmente existen tantas patatas que sc puedan exportar ó emplear tan solo como alimento de la tripulacion de los buques. Creemos por lo tanto que el temor à la importacion de este insecto es infundado.

Atendido que tambien los hombies de la ciencia se han ocupado de este asunto, y como a causa de la analogia de dos especies ha ocurrido ya confusion de nombres, diremos que la esprecie de que hablamos se ha descrito ya antes por Say y Suffrian, de Nebraska y de Texas, bajo el nombre específico arriba citado, pero tambien con otro mas genérico (Dorgphora), debiendo añadir que una segunda especie de Georgia y del Illinois ba sido descrita por Germar con el nombre ihrysomela (segun la mas reciente clasificacion, leplinotarsin) juncta. Esta última se distingue de la anterior por los siguicntes caractérés: las cinco fajas longitudinales negras de cada clitro, excepto la del borde, están orilladas de una seric regular de puntos; la raya de la cintura se corre de adelante atrás paralelamente con aquella sin tocarla; la segunda faja es la mas corta; la tercera y cuarta, reunidas en su extremidad, se aproximan a veces de tal modo, que solo queda una muy estrecha fajita amarilla cutre ellas, cuando no se confunden completamente. Las patas son de un solo color amarillo sucio, à no ser que hayia alguna que otra mancha negra en los musios.

\section{LOS DORIFOROS-DORYPHORA}

CARACTÉRES. - En la América del sur nuestros criso. melas estan representados por una especies mas grandes de los mismos bonitos colores y muy numerosas, pertenecientes al genero doriforn (portadores de lanza), que se distinguees. pecialmente por la larga espina dirigida hacia adelante en la que se reunen el nesotórax y el metatórax; las antenas se ensanchan y : tulanan un poco en la punta y su gran cabeza está encerracla por el cosclete, prolongado en los ángulos.

\section{LOS CALIGRAFOS-CALLIGRAPHA}

CARACTÉRES.-Muy afine à nuestro género lina, cs cl americano de los caligrafos, que en su cara superior de co. lor claro, lleva toda clase de caractéres misteriosos de un co. lor oscuro.

\section{LOS PAROPSIS-PAROPSIS}

CARACTÉRES. - I Los crisomelas de la Nueva Holanda pueden reunirse igualmente con los nuestros. Estos animales tienen casi todos una superficie àspera, y por lo tanto, un aspecto mate. Su color general es un pardo sucio. Son coleópteros muy convexos, cortos, ovales y forman el género paropsis (notodea).

\section{LOS GALERUCOS - GALERUCA}

CARACTERES.-Los demás congéneres se distinguẹn menos por el aspecto, que por el modo con que aparecen insertas en ellos las antenas. Estas se hallan en medio de la frente, próximas una á otra En los galerucos, el tercer artejo es mas largo que el cuarta. De este grupo se han separado las ademonias, formas mas robustas, cuyos elitros, mas largos que anchos, se ensanchan en su parte anterior hacia atràs.

La ademona anaceti es un coleóptero de un color nègro brillante, provisto de puntos gruesos y profundos en la cara superior, de $0^{\circ}, 00877$ de largo y $0^{\star}, 0065$ de ancho. Se encuentra en verano en tocias partes, en las praderas y en los caminos cubiertos de gramineas. I.as hembras fecundadas llaman sobre todo la atencion porque su abdómen se hincha de tal modo, que únicamente à costa de gran trabajo puede àrmistrarle, no siéndole posible ocultarle debajo de los elitros: estos son bastante planos, redondeados cada uno de por sf en su parte posterior. El coselete es casi doble mas ancho. que largo, adelgazado desde la mitad hácia su parte anterior, y provisto de un reborde en la orilla lateral angulosa; de manera parecida se estrecha la cabeza, que desde su parte posterior presenta una forma trasversalmente rectangular, hácia adelante y hácin abajo. Las ancas anteriores en forma de espigas casi llegan a tocarse. Las garras de los piés hendidas y los cinco segmentos del abdömen son iguales en longitud. El que trate de fijar su atencion en el mocio de ser 
de estos insectos, observari, en los mismos lugares en que viven, pero solo en las hojas de yerba de San Juan y en tienpos en que solo esta se halla provista de hojas, una larva de un color negro mate, provista de espinas de erizo. Si esta existe en gran número, la ademonia sigue en las mismas masas; pues a esta especic pertencee la larva citada, que para crisalidarse penetra en el suclo. En un caso que tuve ocasion de apjeciar, este coleóptero y su larva destruyeron las plantas jórenes de la remolacha.

Otros crisomelinos llaman asimismo la atencion por el gran numero con que se prescntan y por los estragos que causan, tanto cllos, como sus larvas, pues unos y otras perfo. ran-las hojas de los arbustos de tal modo que apenas se encontrará una hoja ilesa. Recucrdo al galeruca ibibrri de color jardo gris y' de pequeño tamaño que, junto con su larva, de color amarillo verdoso, con abundantes verrugas negras, perfora dos veces al año las hojas de su planta alimen. ticia; al galeruco de los olmos (galeruca .xanthomelarna) que del mismo modo trabija en los olmos, y a otras especies del mismo género y del mismo aspecto en los arbustos de sauce La agelostica de los alisos (agclosticn almi), coleóptero de un azul violeta, produce en los alisos los mismos efectos, lo que no es b́bice para que en oiros arbustos produzca diferentes estragos. Divagariamos demasiado si quisiéramos fijar en to dos ellos nuestra atencion.

\section{LOS ALTÍCIDOS-ALTICID在}

Muy conocidos son los pequenos crisomelinos que presentándose regularmente en grandes masas, tienen la propiedad de saltar, por lo que se les ha llanando pulgas de tierra ó pulgones. Su número es nuy considerabley no faltan en parte alguna de la superficie del globo.

Ia Anérica del sur ticne especies que alcanzan hasta $f^{m}, 00 \gamma_{7 j}$, mientras que en nuestros paises figuran entre los pequeños. Invernan en su mayoria en istado perfecto; pero como larsa, empiczan tambien desde el principio de la primavera á producir estragos en los campos y en los jardines, siendo sobre todo perjudiciales cuando atacan a las plantas jórenes (colza, aleli, diferentes especies de coles, etc.). Su antiguo nombre cientifico de allien ó hallien se ha conservado actualmente, bien que para pocas especics, sustituyéndose por varios otros, segun su cuerpo tenga la forma oval o hemisiérica (spharoderma y musophila). Los piés posterio res se insertan en la punta de los tarsos, ó en medio de un surco longitudinal, por delante de los mismos (psy/lodes); los tarsos acaban en una espina sencilla, ó en una ahorquillada (dibolia), presentando otrns diferencias, fundadas principalmente en la formacion de las patas.

En Alemania viven mas de cien especies, de las que muclas, solo habitan una planta; pero se encuentran tambien en mayoria en otras partes. No son exigentes respecto de su alimento y extienden sus visitas á plantas congenéricas.

\section{EL PSILIODES DE CABEZA DORADA- PSYLLIODES CHRYSOCEPHALA}

Caracteres.-El psiliodes de cabeza dorada, llamado tambien pulgon de la colza, no vive solamente en la plan. ta que le motivó su nombre aleman y en la que su larva puede causar considembles estragros, sino tambien en varias otras. Observé su género de vidá en los sembrados invernales de colza, y le describiré en poras palabras. Al comenzar la primavera, cuando las plantas invermadas comienzan á dar nuevas seriales devida, se observan algunas, y i veces muchas de ellas, cuyo tallo aun corto, lo propio que sus hojas, es pardo en vez de verde, ó bien, donde et tallo principal falta del todo y esta sustituido por escasos rétonos latemles, el con. junto de las hojas se presenta asimismo de un color pardo. Al examinar mas minuciosamente estas plantas sé cncuentran, ya cu el tallo, ya en el interior, unas larvas de $11^{\circ}, 002 \$ 0^{\circ}, 006 y$ aun mas. Muclas semanas despues, cuando la flor jrincipal lia desaparecido y las raicillas se han formado, prometiendo rica cosecha, aun se encuentra la misma larva, pero de ma. yor tamano y a mas altura; aparece con mas seguridad en los tallos doblados, aumentando tanto en núnero, que los cam. pos ofrecen triste aspecto, cual si hombres ó ganado hubieran cruzado atropelladamente por cllos. Las larras han comido poco à poco la médula de los tallos, dejindolos indefensos al empuje del viento. En ciertos puntos, sobre todo por debajo de las ramas, se observan tambien agujeros, de los que lan salido larvas maduras para trasformarse en crisalida.

In larva de que hablannos es de un blanco sucio, ligeramen. te deprimido y tiene seis patas; la cabeza córnea; el escuclo en la nuca tambien córnco, y el último segmento, oblicuamente deprimide y redondendo en el borde posterior, pro. visto en la parte anterior de este de dos espinitas, son de color pardusco; y del mismo color, pero mas claras, son tam. bien las manchitas córneas que corren formando series por los otros segmentos. En la cabciza se distinguen marcada. mente las antenas cortas, en forma de cono, un ojo por de. trás de cada una y tres dientes en la punta de las fuertes maxilas. In larva adulta tiene por termino medio una longitud de 0 ",007; abandona el tallo y se metamorfosea en la tierm, sin cncerrarse en el capullo. A mediados de mayo, poco mas ó menos, se presenta el coleoptero, que segun ya hemos dicho, se encuentra no solamente en las coles y en las plantas de vaina, sino en las mas diversas. Sus patas posteriores se insertan por delante de la punta de los tarsos; en el cuerpo. de un color negro azulado ó negro verdoso brillante, la mitad anterior de la cabeza, mas veces toda la superficie de la misma, la base de las antenas y las patas, excepto los muslos posteriores, son de un rojo amarillo; los muslos de las patas anteriores y medias son yor lo regular poco mas oscuras que los tarsos respectivos. La frente es lisa, sin depresiones; el cosclete provisto de puntos muy finos y yoco profundos, los elitros cubiertos de rayas muy marcadas. Cuando el scmbrado invernal de la colza y uabina se manifiesta en la superficie de la tierra, los coleópteros se presentan para comer para depositar en las hojas aisladamente los huevos, continuando este trabajo semanas enteras: pues las larvas que, despues de invernar, se encuentran de tamaños, diferentes, demuestran los grandes intervalos entre sus crias y nacimiento. Al cabo de unos quince dias nace la larva, penetra en el nervio central, y desde aqui se interna aun mas en la pequeha planta lel colcóptero, despues de cumplir su comctido, muere antes que llegue el invierno: nunca encontre un individuo de esta especie en los escondites comunes en que estos pequeños insectos pasan el invierno.

\section{LA ALTICA OLERACEA-ALTICA OLERACEA}

CARACTERES. - Estr especie vive de distinto modo. Despues de invernar se aparea al llegar la primavera, y las hembras depositan sus huevos en las plantas inas diferenies, en cuya superficie viven despues las larnas. I as encontré, por ejemplo, en gran número en el epilotium argustifolium. Liste es de color pardo gris y cubierto de cerdas de erizo. En la cabeza, negra y brillante, se reconocen las antenas conicas y por detris de cada una un ojo sencillo. Las partes de la boca son anilogas á las de la especie anterior. En todos los anillos se hallan dos series de verrugas prominentes, de las que cada 
una esta provista de un pelo cerdoso. De este modo, el dorso, visto de lado, se presenta denticulado regularmente, ofreciendo cada segmento dos puntas. El último se distingue de los otros, en su cormacion, por su pequenes, por tener una sola seric de verrugas y por el ensanchamiento lobuloso de su pié en dos apéndices que sirven para la locomocion, como en las orugas de mariposa. Ia lana adulta tiene unos $0^{\mathrm{m}}, 006$ de largo. El 21 de julio recogi varias en tal estado, obteniendo el to de agosto los primeros colépteros; la metamorfósis se verifica en el suelo, en un capullo plano. Un espacio de seis semanas basta paria que el huevo se desarrolle y apa. rezca el coleobtero, si no lo impiden el frio y una humedad demasiado excesiva; pero aun asti es yrobable que se desarrollan dos crias al año. El coleóptero es de forma oval prolongada, de uná longitud de mas de $U^{\pi}, 004$ de un color verde accitunado oscuro, mas ó menos azulado, con los artejos de las patas y las antenas negrucos; la cara superior está provista de puntos muy finos y espesos; el escudo collar, ligerumente deprimido en la parte anterior de su borde pósterior, y en este mismo junto mas ancho, aunque no tanto como los elitros, provistos de puntos irregulares mas marcados, redondendos en su parte posterior.

\section{LA ALTICA DE LAS ENCINAS-ALTYCA CRUCAE}

CARACTERES. - La historia de la altica de las encinas es muy parecida a la del coleóptero interior, por lo que se le ha confundido is menudo con él. Se distingue principalmente por el coselete, provisto de rebordes ten los lados; por la es. tructurn del cucrpo, un poco mas vigoroso, y por ser otra su planta alimenticia; pues el colcóptero y su larva viven todo u año en encinas, devorando poco a poco de tal modo las bojas que solo quedan los nervios; de stierte que los arbustos de encina presentan en verano un aspecto por demas triste, cuando, como sucedio duranic varios años en un fresal próximo á esta ciudad, los pequenos saltadores se encuentrai en grandes masas.

Al despertar a la vida del sueño invernal, el colébtero abandona su húmedo lecho de imvierno y trepa desde el suelo con tardio paso á causa de la escasa fuerza de sus músculos saltadores, por los arbustos y arbolitos de cncina, corrojéndolos superficialmente y como retozando entre los capullos apenas nacidos. Solo cuando son ya visibles las ho. jas verdes, se posan en ellas de un modo permanente para alimentarse, el maclio montado en la hembra.

Pocas semanas despues, los coleópteros disminuyen consi. derablemente, pero en combio aumentan los agujeros en el tierno follaje; pues en vez de aquellos, muertos yn, las larvas que les reenplazan necesitan un alimento mas abundante. Iistas se hallan jgualmente provistas de espinas de crizo, pero menos angulosas en el dorso y menos incisas en los lados que las anteriores; porqque a(gui, las verrugas de color negro brillante que cubren el cuerpo, son menos numerosas y un poco mas pequeñas. Tambien las larvas del pulgon dé la encina aparecen menos negras que las anteriores; en junio $y^{\circ}$ julio se las cncuentra en gran número en una sola hoja, pero desprues descienden al suclo para trasformarse en crisálida durante el mes de agosto.

Mientras los coleópteros habitaban los arbustos de encina y los arbolitos de una misma especie en el fresal arriba citado, no era posible, á causa de la naturaleza del suelo, el buscar sus crisálidas, pero á medida que iban diseminandose $y$ ganando terreno en otras direcciones, habitaron tambien los árboles del lindero, y podian verse las ninfas amarillas reunidas en uúmero de tres y de cuatro en las hendiduras vertica. les de los troncos. Desde entonces los colcópteros disminu. yen sensiblemente, á pesar de que nada se haya intentado contra ellos. Los pulgones que en setiembre salen de la cri. súlida, vingas, mientras lo permite el tiempo, por el follaje destruido ya por sus larvas: aumentan aun con su irabajo los agujeros de las hojas y permanecen, cada vez. mas pere. zosos, reunidos en compactos grupos de diez y de doce inclividuos, hasta que por fin desaparecen en el suelo. Tal es el modo con que por lo regular se verifica una cria, aunque no trato de negar que en circunstancias favorables pueden tener lugar dos.

\section{LA FILOTRETA DE LOS SOTOS - PHILLC- TRETA NEMORUM}

CARACTERES. - Ia filotreta de los sotos, cuya larma vive en el interior de las hojas de las coniferas, la filotreta arquenda (phillotreta fexzosa) y algunas otras especies de rayas amarillas, pertenceen a nuestras especies mas comunes y abigarndas quc, sin embargo, son muy inferiures en tamaño y en la variedad de los colorés, a las numerosas de la América tropical. A pesar de su pequeñez perjudican a me. nudo seusiblemente à los agricultores, escapando á toda persecucion a causa de su movilidad, cuando el calor y una humedad moderada favorecen su desarrollo.

\section{LOS CÁSIDOS-CASSIDA}

CARACTERES. - Antes de dar por terminada la serie de los crisomelinos haremos mencion de los cásidos, coleóp. teros muy especiales por muchos conceptos. Estos insectos de forma oval, se reconocen fácilmente por cl coselete redondendo en su parte anterior, el cual cubre completamente la cabeza, y reuniéndose estrechamente con los elitros, forma, junto con estos, una especie de escudo que sobresale del cuerpo en toda su circunferencia, cubriéndole del todo deste su parte superior. Fil color del coleóptero vivo suele ser verde de yerba amarillento ó gris rojizo, formando a veces unas fajas doradas ó plateadas sobre el dorso que se extinguen una vez muertos. I.os cinco últimos artejos de las antenas se ensanchan en forma de maza.

DistRIBUCION GEOGRAFICA. - Numerosas espe. cies se encuentran en Europa y pocas en el Africa.

USOS, COSTUMBRES Y REGIMEN. - las larvas de este colcóntero de forma aplanada, provistas de espinis en los lados y de una horquilla caudal, viven libremente en las hojas de las jerbas, en las que tambien se trasforman en crisilidas. Todos estos coleópteros inverman en estado perfecto propagándose en la primarera y produciendo quizás dos crias al año.

\section{EL CÁSIDO NEBULOSO-GASSIDA NEBULOSA}

CARACTERES. - El cásido nebuloso pertenece à las espécies mas comunes y se conoce por los siguientes caractéres: los aingulos posteriores del coselete son anchos y redondeados; los elitros presentan fajas regulares de puntas aquilladas en los intervalos y inuy salientes en los hombros: la parte superior de los individuos adultos es de un pardo de orin, con brillo rojizo de cobre y manchas negras y regulares en los elitros. Los individuos jóvenes tienen un color verde pálido y manchas brillantes blancas en la base del coselete: cuando no luce mucho el sol necesitan de tres a cuatro semanas para adquirir su color definitivo. Ia cabeza y las patas son de un amarillo de orin, y estas últimas son invisibles desde arriba; los muslos y las antenas, que tienen la forma 
de maza, son negros, excepto en su base, que tiene un tinte amarillo de orin; cl tórax y el abdómen son negros, pero este último presenta un ancho borde amarillo de orin. Nuestra especic se distingue de las otras tres, muy parecidas, por su forma, por la superficie de los elitros (cassida berolinensis nhsoleta, ferruginea), por el diferente color, y \& primera vista por las manchas negras de aquellos. Ia larva, aplamada como el coleópiero, tiene una forma oval muy prolongada, se adelgaza hácia atrás y remata en dos cerdas caudales que por lo regular se apoyan en el dorso.

La cabeza, pequeña y visible solo por arriba cuando el animal repta, tiene once segmentos, contándose en los tres anteriores scis patas cortas y ganchudas; el ano, que sobresale en forma de cono, forma el duodécimo segmento. El protómx tiene cuatro espinas y unas ramitas laterales muy finas, de las cunles las dos anteriores cstán muy. próximas y dirigidas hácia adelante. Los dos segmentos siguientes del tórax tienen dos espinas iguales, rectas, y todos los demás una, que se inclina lícia atrás. Fin el primer seginents del alulómen y en el cuarto vénse unos tubos. en cuya punta se abren los estigmas. Cada segnento del abdómen desde el cuarto, está como dividido por un surco trasversal. I as cerdas cau. dales ya citadas sirven para llevar los excrementos que poco á poco se acumulan en pequeños copos encima del dorso sin tocarle. Ia larva es de un verde amarillento; la cabeza mas oscura; las espinas laterales muy claras y hasta blancas, y los tubos traqueales del mismo color; por el dorso se corren dos fajas longitudinales paralelas blancas, un poco adelgazadas por delante y deiras, y que no llegan a las extremidades del cuerpo. la crisilida se encuentra con la extremidad del abdómen en la piel de larva muclada, y por lo tanto su parte posterior tambien estí provista de espinas laterales: se fija por la cabeza en una hoja.

USOS, COSTUMBRES Y REGIMEN. - En la primem mitad de junio se puede encontrar este insecto en sus tres es. taclos, asi en los campos cono en los montones de escombros, segun se obseria en el chenopodiun altum y en el alviflex mirens; tambien visitan á veces las plantas jóvenes de là remolacha, destruyéndolas para devorar las hojas.

Is hembra deposita sus numerosos huevos en la cara inferior de las hojas. I.as larvas habitan en ellas por mayo y abren agujeros para comer mas tarde desde el borde. Mudando varias veces de piel crecen con mucha rapidez si el calor las farorece, pero lentamente si el tiemplo es vario y lluvioso. Despues se fijan donde filtimamente se alimentaban, con el abdómen en la hoja, parn trasformarse en crisilida, de la cual se prodice \& los ocho dias el coleóptero, muy aficionado à volar por el aire cuando hace sol. Los cásidos buscan como los otros crisonedinos, plantas alimenticins deterninadas, prefiriendo, segun parece, las quenopodiaceas.

El Asia, y sobre todo Américo, poseen otras especies de colores màs bonitos y de un brillo magnifico; cutre ellas, las que tienen los elitros vidriosos y manchas de lustre metílico, pertenecen al género coptocycla y habitan en nuestros prises, mientras que las mas grandes no tienen representantes en Europa. Hace ahora 25 años que Boheman describio unas 1.300 esplecies. Para dar una idea de las de la America del sur hago mencion de la mesomphalio conspersa de Germars (sfigmatica Dej.), coleóptero muj particular, cuyos elitros se clevan en la parte anterior formando una joroba puntiaguda: la cara supcrior es de un negro verdose mate, con brillo metálico en las depresiones redondas, que son de un negro aterciopelado: tambien se ven seis manchas mas grancies con pelos scdosos de un pardo amarillo. Una especie aniloga de color verde dorado (desmonofa íariolosa) se monta en oroy se emplea como alfiler de corbata.

\section{LOS COCINÉLIDOS} COC-

\section{CINELLID死}

CARACTERES. - Los cocinćlidos, llamados tambien coleópteros esféricos, coleopteros de Santa Maria, yo en İs. paña marranitos de Sin Anton, constituyen la tíltimi familia de coleópteros, cancterizada por el menor númcro de arte. jos del pić; en las patas posteriores solo existen tres, por lo cual se ha llamado tambien á estos insectos trimeros (trime. ra), por los que solo se fijan en la estructura del pié.

En la estacion en que toda la naturaleza se dispone á en. tregarse al sueno invermal, cuando las hojas de los árboles y arbustos adquieren un color amarillento antes de cacr, y los pequeños séres se apresuran á conquistar un buen lecho pa. ra dormir, dificilmente se veri una hoja seca algo enroscada en cuya cavidad no se hallen cuando menos tres, cuntro 6 cinco coleopteritos con puntos negros en el dorso, mezrlados á veces con manchitas claras, los cuales esperan que la hoja caiga y que la hojarasca los cubra en el suclo. Oprimiéndose unos contra otros, algunos se albergan en las copas de los pinos jóvenes, mientras otros se ocultan detrás de la cor. teza de alguma añosa encina, ó bien se reunen debajo de una mata de yerba en la pendiente de un foso orientado al sur, como lo hace en particular la pequeña micraspis dusdecimpunetaro, de color de madera, cuyos elitros, de sutura negra, están cubiertos de numerosas manchitas del mismo color; los pequerios insectos están colocados de modo que parecen un montoncito de semillas de pimiento: $y$ entonces se les encuentra siempre en gran número en los escondites donde han de pasar el invierno; ambien se introducen en nuestras habilaciones, pero llegado el verano salen al aire libre. Siempre son mas numerosos alli donde los pulgones de las hojas, esos diminutos insectos verdes, pardos ú negros, acuden para chupar el jugo de las planias, porque sirven de alimento a casi todos estos coleópteros y mas aun a sus vii. rias larvas. Sus nombres populares, tales como coleóptero del sol, mquita de nuestrn Señora, ternerita del sol, orejita de Dios, gusanito de Maria, lady-birds, zaches a Dien y otros, de. muestran cuán conocidas son las especies quue atendido su ré. gimen alimenticio, se deben cuidar cuanto sea posible. Como el cuerpo en parte oval ó hemistérico de los marranitos de San Anton puede dar lugar á que se los confuncla con otros coleópteros, debemos cxaminar tambien los demás carnctéres de roda la familia. I a cabeza, muy corta, sobresale poco del cosclete y su escudo no se destaca bien de la frente; las antenas, que.son cortas y aiectan un poco la forma de maza, se insertan por delante de los ojos y debajo del borde lateral de la cabeza, hallándose casi siempre ocultas, prorque pueden replegarse por detris del borde lateml del coselete, que no es marcado. I.os palpos maxilares rematan en forma de hacha, por lo cual Mulsant designó á la familia con el nombre de securifialpos. Los apéndices de las ancas del mesotórax son triangulares; los costados anteriores son trasversales y cilin. dricos; los muslos de las patas medias posteriores pueden recogerse en unos hoyos, y los arsos doblarse; las gamas del pié son casi siemure denticuladas $\delta$ hendidas en la punta. El abdúmen presenta cinco segmentos libres; el anterior se prolonga entre los costados posteriores, crisanchándose ó estrechíndose hácia el metatórax; en los lados presenta un re borde muy fino. Todos estos caractéres son buenos distintivos para los numerosos géneros en que se dividió el género primitivo cocsmella.

las larvas, de forma prolongada, ýa menudo con numerosas verrugas, se ascmejan il las de los crisomelinos por su aspecto cxterior, por las antems de tres artejos, por tenertres 
ó cuatro ojos en cada lado y por las patas, quue á causa de ser los muslos y tarsos muy largos, se desvian mucho del cuerpo. Sus movimientos, mas ágiles, dependen de su género de vida diferente; y el color, mas abigarrado, basta para reconocerlos fácilmente, sin que sea menester obscrvarlos antes con el anteojo de aumento. Los cocinelas, representados por unas mil especies, están diseminados por toda la tierra, y son muy útiles; pues segun ya hemos dicho, devoran los pulgones: solo las especies mas peludas de dos géneros (epi. lachna y lasia) han sido reconocidas últimamente como plan. tivorne, juntamente con sus larvas. Debo añadir que al tocarlos con los dedos encogen las antenas y las patas y segregan una sustancia amarilla fétida, que sin duda será pan estos insectos, asi como para otros muchos, el único medio defensivo que la naturaleza les concedio para preservar su corta vida.

\section{LOS COCINELAS-COCGINELLA}

CARACTERES. - Las especies del género cocsivella tie. nen el cuerpo hemisférico ó scmi-oval y desnudo; en las antenas se cuentan once artejos; el cscudete es muy marcado; cl segundo artejo del pié afecta la forma de corazon y el tercero queda oculto; las garras están hendidas en el centro ó tienen en su base un diente triangular.

\section{LA COCINELA DE SIETE PUNTOS- COCCINELLA SEPTEMPUNCTATA.}

CARACTÉRES. - Esta especie es una de las mas grandes y comunes de nuestros paises. Solbre el fondo negro del cuerpo se destacan dos manchas de color blanco amarillo, como el de los ángulos del coselete; los elitros, de un rojo de minio blanquizco en su parte anterior, presentan siete nianchas redondas negras.

USOS, COSTUMBRES Y RÉGIMEN.-A principios de la primavera, cuando comienza la resurrecciongeneral, esta especie abandona su lecho de invierno, aparéase $y$ á fines de mayo se pueden ver laryas casi adultas, cuyo número aumenta en junio y julio. Las larvitas, de! todo negras en su primera juventud, viven al principio juntas y retozan cerca de las pieles resecadas de los huevos, sin separarse despues tampoco mucho. Ia cuidadosa madre deposita los huevos alli donde los hijuelos encuentran bastante alimento entre las colonias de pulgones; gracias á esto crecen rápidamente, mudan varias reces, y adquieren poco á poco su color gris de pizarra azulado. Los lados del primero, cuarto y séptimo segmentos, asi como una seric longitudinal de puntos dorsales, tienen un colorido rojo. Para convertirse en crisálida, la larma se fija con la punta de la cola, encógese hácia adelante, recoge la cabeza, pierde los pelos y al fin se abre la piel por el dorso. Cuando sale la ninfa, que es de color rojo ónégro, colócase sobre lia piel de larva como en un cojin. Si se la toca levanta la parte anterior del cuerpo y déjala caer despues, à menudo tan acompasadamente como el inartillo de un reloj. Al cabo de unos ocho dias nace el coleóptero. Como en julio se en. cuentran los hucros, que tienen un color amarillo sucio, en número de diez. á doce, fijos en la carn inierior de las hojas en medio de los coleópteros de larvas, es probable que haya por lo regular dos crias, no siendo imposible una tercera en circunstancias favorables. Muchos cocinelas ofrecen gran variacion en el color del dórso, sobre todo cuando el negro alterna con otro tinte mas claro.

\section{La COCinela de pústulas-COCGINEL- LA IMPUSTULATA}

CARACTERES. - Esta especic tiene un color amarillo sucio con manchas negras, pero estas pueden extendersc de tal modo que el primer color aparezca como una mancha sobre fondo negro, ó hasta desaparece del todo.

\section{EL COCINELA DISPAR-COCCINELLA DISPAR}

CARAGTÉRES. - Esta especie es mas variable que to. das las otras sin que las diferencias dependan del sexo, como erróneamente se ha supuesto. En unos individuos los clitros son rojos, con una mancha negra central, y el cosclete negro, orillado de amarillo; tienen los elitros negros, con una mancha roja en forma de gancho en los hombros, y una segunda, redonda, cerca del centro de la sutura, contándose muchas, en fin, que ofrecen otras variedacies. Antes de haberse reco. nocido estas como tales se formaron muchas mas especies de las que se distinguen en la actualidad.

\section{LOS QUILOCOROS-CHILOCORUS}

CARACTÉRES. - Las especies de este género tienen un color negro brillante, por lo regular con manchas rojas; el cuerpo es redondo y muy convexo; las antenns, cortas, con nueve artejos, rematan en forma de huso; el escudo de la cabeza es muy escotado; los tarsos se ensanchan en la base; las garras presentan en la base dientes anchos.

USOS, COSTUMBRES Y REGIMEN. - Estos insec. tos viven principalmente en los árboles, donde vagan por los troncos, en los cuales se hallan tambien las ninfas, que solo se ven un poco porque en su mayor parte quedan ocultas en la última piel de larva.

\section{EL QUILOCORO DE DOS PÚSTULAS-CHI- LOCORUS BIPUSTULATUS}

Caracteres. - Esta especie, que mide $0^{\circ}, 00337$ de largo, es en su mayor parte de color negro brillante; la cabeza, los lados del abdúmen, las rodillas y una estrectha faja compuesta al parecer de manchas que se corren por el centro de los elitros, son de un rojo de sangre.

A causa de su considerable pequeñer, de su color oscuro $y$ de su résidencia en las copas de los árboles ó en otros sitios inaccesibles, ocúltanse á nuestras miradas centenares de especies afines de la misma fanilia; de modo que es como si no existieran para los que no son naturnlistas.

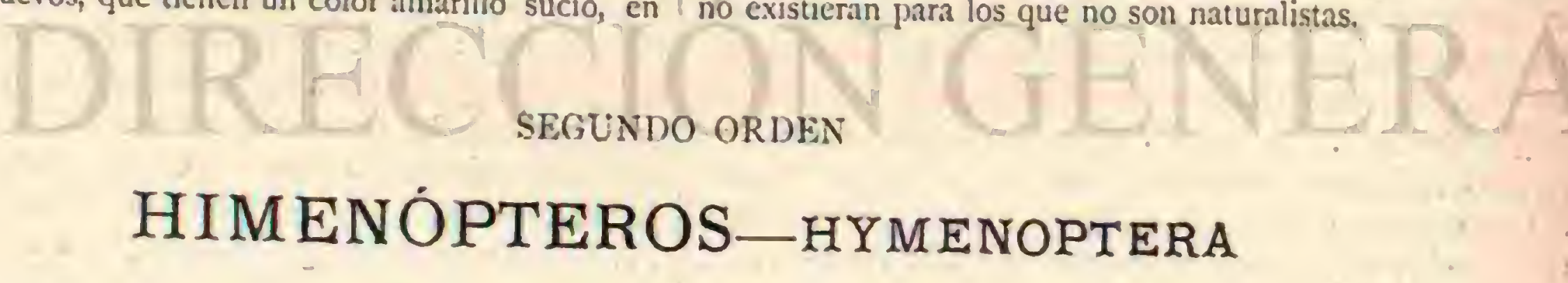

Tan análogas por la estructura general de su cuerpo como diferentes por su género de vida, las inuy numerosas especies de himenópteros, entre las que las abejans, hormigas, avis- pas y abejorros son insectos generalmente conocidos, constituyen el mas considerable de todos los órdenes. Les concederiamos el primer lugar si no fuem porque alterariamos asi 
el método observado hasta ahora. Por la variedad de sus condiciones vitales, cuyo carácter especial ofrece al observador de la naturaleza viva inagotable asunto para entregarse à un detenido estudio y á profundas reflexiones, y por la inteligencià que demuestran en sus construcciones artificiales, debemos conceder decididamente à los hinenópteros el primer rango.

CARACTERES. - Los himenópteros tienen todos su es. queleto membranoso y duro; el tóras completamente soldado en sus tres segmentos; los órganos masticadores bien desar. rollados, asi como la lengua; y cuatro alas iguales, cruzadas por algunos nervios y al parecer desnudas, siendo las anteriotes mas largas y anchas que las posteriores. Estos insectos se forman por una metamorfósis completa. Muchos carecen del todo de alas, pero las de otros ofrecen canctéres tan determinados que puecien servir de distintiro.

USOS, COSTUMBRES Y REGIMEN. - En estado perfecto, los himenópteros se alimentan casi sin excepcion de sustancias dulces, las cuales lamen, debiéndose a ello que ofrezcan siempre un gran desarrollo, aunque jamás à expensas de parte alguna de los órgnnos bucales. Pociemos pasar aqqui en silencio su estructura porque ya la hemos explicado, y porque en la distincion de las especies solo representa un papel secundario. Solo diremos que saben extract las sustancias dulces de las flores y de los pulgones: sabido es que estos ticrnos insectos que solo viven del jugo de las plantas, y que regularmente se hallan reunidos en grandes grupos, segregan por unos tubitos laterales de la extremidad de su cherpo, $y$ principalmente con sus excrementos, una sustancia dulce, á veces en tal cantidad que cubre verdaderamente las hojas de una especie de lacre. Este jugo es muy buscado por otros insectos, en particular por las moscas, á las cuales sire casi de alimento exclusivo. El naturalista sabe por experiencia que en ninguna parte puede recoger un botin tan abundante como alli donde unas manchas brillantes, a menudo negruzcas, en las hojas de los nrbustos, revelun á cierta distancia la presencia de numerosas colonias de pulgones. En la primaviera del sicmpre notable año de 1866 , crucé por una espesura de sauces donde las abejas comunes volaban en tal número que podia crecrse que muy cerca habia una colmena. Al pronto pensé en las flores de los arbustos, que como se sabe son las fuentes mas tempranas y abundantes en miel para esos insectos, pero al examinar los arbustos de cerca vi que las flores eran muy escasas y que las abejas, en vez de acudir á ellas, volaban, por el contrario, de abajo arriba al rededor de los tronguitos de sauce, desprovistos de follaje, pero cubiertos de miles y miles de pulyones; hasta mi ropa estaba cubierta de ellos, pues à causa de la espesura no se podia dar un paso sin tocarlos. Ahom bien, si las nobles abejas no desprecian el producto de los pulgones, ¿cómo ha de suponerse que no le búscarian los otros himenópteros que recogen miel? Aun de aquellos que no lo hacen puedo asegurar que son aficionados à la sustancia dulce de los pulgones, fundándome en la experiencia de muchos años.

Tan igual es el régimén alinenticio de los himenópteros períctos como diferente el de sus larvas. Las de ciertas es. pecies tienen numerosias patas (hasta 22), y por lo regülar colores abigarrados. Suelen estar siempre en las hojas de que se alimentan. De ellas provienen los tentredinos, cuyos congéneres, los uroceros, viven como larvas en forma de gusano de la madera. Unos y otros revelan por la estructura de su cuerpo, y por cierta independencia en su género de vida, un grado de desarrollo superior al de todas las demais larvas de los himenópteros que por carecer de piés prodrian llamarse con razon gusanos. Las larvas tienen la cabeza córnea, con doce seymentos; entre ella y el primero de estos se inserta el deci- motercero que sirve de cuello, en el que la cabeza se oculta en jarte cuandio la larva descansa; se distinguen tambien maxilas córneas, muñones de palpos y aherturas textiles, pero no se ven ojos y solo hay senales muy cscasas de antenas. Algunas de estas larvas viven en plantas, pero no las perforan del modo regular, sino en unas excrecencias particulares forniadas, por la picadura de la hembra al poner los huevos, y que generalmente se conocen con el nombre de agallas, por la cual los insectos que de ellas salen lleran el nombre de avispas de agallas. Ins otras habitan aisladas ó reunidas en nidos hechos expresamente, á los cuales llevan su alimento.

Los antofilos 6 avispas de las flores, recogen la miel y el pólen: las avispas rapaces se alimentan de otros insectos, y en fin, un gran número de otras larvas viven como parásitas en los cuerpos de otros insectos, como los icneumones y leucopridos, que representan un papel muy principal en la economia de la naturaleza: son como unos vigilantes para la conservacion del equilibrio, puesto que cada uno recibe el sér por la muerte de otro insecto, sobre todo plantivoro, po. niendo asi un limite à su propagacion; si esta le traspasa alguna vez por la arcion reunida de varias circunstancias favorables, preséntanse al junto los icneumones, encuentran el animal que habitan en mayor número, pueden propagarse por lo tanto mas y reducen muy pronto a los otros á su limite regular. Comunmente lns grandes avispas parásitas viven aisladns en su anfitrion; las pequeñas por familias de centenares de individuos, y podra formarse una idea de la pequeñe\% de muchos con decir que los pulgones son visitados por parasitos y que unos huevos de insectos mas pequenos aun que aquellos dan vida á otros parísitos.

Las hembras de la mayor parte de las especies taladran larras para depositar en ellas un huevo ó marios, y los individuos que de estos huevos nacen viren ocultamente en el interior del animal que habitan, contandose muchas que se fijan tambien exteriormentc. I.os géneros Ptevamalus, bracon; spathius, tryphom, shigadewon, onyphes, fimpln y otros que mas tarde conoceremos, contienen especies que segun parece eligen larvas de tentredinios y múscidos, y las orugas de algunos bombícidos y lepidópteros y larvas de coleópteros que habitan debajo de la corteza de los àrboles ó en la madera, viviendo luego en ellos exteriormente. Tambien por otro conlcepto las relaciones del anfitrion con su inquilino forzoso, ad. q̨uieren una forma diferente segun la especie. En los unos, y sobre todo puede decirse esto de los parásitos socinbles, las larvas maduras salen de la oruga para trasformarse en crisílida en la piel de la misma, pues nada mas queda ya de ella; en otros casos la oruga construje su capullo y mas tarde espera á que en este se halle la crisálida. Pero jcuántas veces se engano el coleccionador de mariposas que csperaba obtener un hermoso ejemplar de estos hijos del aire! En vez de la crisilida legitima encuentra un capullo prolongado y negro, $y$ sabe por experiencia que esta hecho por una larva madura y que es sólido como el pergamino. En un tercer caso la oruga que no teje tiene aun hastante fuerza para trasformarse en crisk. lida, al parecer sana. Pero iah! con el tiempo csta pierde su movilidad y no tiene ya el peso que le pertenece, indicio seguro de que ha sufrido otra vez un engaño. Un dia se la encuentra con la cabeza perforada, viéndose cómo se pasea alegremente en el interior una magnifica avispa $\delta$ çuiras un gracioso icneumon por la prision. El que se ocupa en el esudio muy interesante de los cinipidos recogiendo con aficion sus productos, procedimiento de todo punto necesario para conocer y distinguir los animalitos, sabe que á menurlo no se ve ningun individuo, pero si las formas mas extranas de toda clase de icneunónidos, dos ó ires especies de una aga- 
a, y en ciertos casos, cuando ha recogido muchos de estos, tambien al habitante legitimo. Estas y otras experiencias adquieren los que observan la actividad de la naturaleza en circunstancias que facilitan el estudio, debiendo obtenerse muchas al aire libre. Alli se ve, por ejemplo, cómo un icneumon se coge á una crisálida de mariposa, aun del todo blanda, que acaba de colgarse en un tronco de árbol; se pasea con visible satisfaccion sobre la ninfa resistente, palpa con sus movibles antenas, introduce su taladro en la piel blanda, penetrando mas y mas, y los huevos quedan depositados: esto no se puede ver, pero muly bien suponer, pues á su ticmpo no sale ninguna mariposa de la crisálida sino cierto número de icneumones exactamente parecidos al que lizo la puesta. En algunos casos, que deben considerarse como excepcion de la regla, se ha visto que algunas larvas de parásitos, $\delta$ es. tos mismos, satieron de coleópteros del todo desarrollados. En tal caso es posible que el icreumon haya depositado sus huevos en el insecto perfecto, ó que el anfitrion se desarro. Jlase antes que el parásito vencienda su influencia danina, de modo que ambos llegaron paralelanente á su perfeccion.

No basta que un insecto viva en otro à sus expensas; las infoluntarias relaciones entre anfitrion é inquilino se extienden aun mas allá, porque este tíltino ha de servir á su vez de albergue á otro sér, ò en otros términos, hay parásitos en los parásitos, circunstancia que no contribuje a explicar las muy interesantes condiciones vitales de estos diminutos séres.

Fxtraño y misterioso seguira siendo el género de vida de los icneumónidos, y ese instinto que guia à la hembra para poner sus huevos. ¿Cúmo sábe, cuando se retarda, que en el interior de un insecto se ha depositado ya un huevo, y que por consiguiente una segunda larva no podria alimentarse en cl? Para nosotros solo en pocos casos hay una señal exterior para reconocer que una larva cstá taladrada. Algunas manchitas ó una decoloracion en las orugas de mariposa revelan el gérmen de la muerte; pero estos indicios no se deben siempre al icneumon, sino á moscas parásitas de las que algunas faunilias contribuyen esencialmente a esta obra de exterminio. Tales y otras pre guntas se dirigira el observador, que solo puede contestarlas por suposiciones.

Despues de haber estudiado la significacion de los nombres de tentredinos, uroceros, cinipidos, icneumónidos, avispas rapaces y antofilos, deberemos dirigir una ojeada sobre la estructura de estos séres para poder distinguirlos con seguridad de los demás insectos y entre sí. Ia cabeza está situada libremente delante del tórax, cual si estuviera unida con él por medio de una espiga, y vista por arriba parece casi siempre mas ancha que larga; muy pocas especies la tienen estérica, hemisférica ó en forma de dado. En la co. ronilla hay casi siempre tres ojuelos que brillan como perlitas. montadas en una diadema. Las antenas tienen casi siempre los artejos iguales y pueden ser filiformes ó cerdosas, rectas ó angulosas: raras veces se ensanchan en la punta en forma de maza. Su longitud no es nunca muy grande ni tampoco son muy cortas en proporcion de su cuerpo. Como se insertan en la parte anterior de la frente, por lo regular una junto a otra, dirigense sicmpre hảcia adelante y nunca hảcia atrís.

El tórax, de contorno generalmente oval, puede ser tam. bien cilindrico, y por lo regular se encorva poco hácia arriba, reconociéndose los seginentos por las suturas. El protórax, al contrario del de los coleópteros, es la parte menos desarrollada; se ve tan poco en el dorso que se le ha dado el nombre de ecollarin, y en el pecho solo ofrece a las primems patas el espacio necesario para insertarse. El mesotórax forma la mayor parte dorsal y al mismo tiempo la jorola, hallảndose dividido muy á menudo en tres partes por dos impresiones longitudinales inuy próximas en su parte posterior, los llama. dos libulos, de los cuales el del centro remata en el escudete. El metatórax, liso en la superficie, dividido en varias placas por los rebordes, ofrece importantes caractéres distintivos para muchos himenópteros. Solo de paso haré mencion del hecho de haberse reconocido por las mas recientes observa. ciones que todos los himenópteros, excepto los tentredinos y uroceros, tienen un cuarto segmento de! tórax, que del misno modo está reunido con el tercero por una sutura fija, como este, en el mesotórax. Debo añadir que este des. cubrimiento tendra mayor imprortancia para la clasificacion ma. tural que el que se funda en la existencia de uno ó dos trocinteres.

La manera de unirse el abdómen con el tórax no influye en ninguna especie de insectos tan esencialmente como en los de que tratamos, por lo que hace a su aspecto exterior, porque en ellos se encuentran todas las formas tal como las hemos descrito en las primerns juiginas. El abdómen se compone de seis a mucre segmentos, cuyo número en ciertos casos puede disminuir hasta tres. Nada mas curioso que el notable órgano con que la hembra deposita sus huevos, llamado el faladro: por regla general se comprone de un aguijon cómen que tiene tres $\hat{b}$ cuatro partes, y está cerrado lateralmente por dos vainas como en forma de estuche. El aguijon se divide en una mitad supcrior, á menudo acanalada, el oviducto y en una inferior mas pequeña; las llamadas espinas se unen estrechamente y encajan en la primera mitad. El oviducto puede dividirse tambien por completo ó en parte en dos pie. zas reunidas por una membrana, y que por lo tanto son susceptibles de ensancharse. Por esta estructura se hace posible una dislocacion de las espinas contra el oviducto, hícia arriba 6 hácia abajo, cuando se trata de perforar cuerpos sólidos. Estas espinas representan la lezna, el cuchillo, el taladro, la sierra, en una palabra el instrumento cortante con ayuda del cual los irssecios pueden penetrar en el cuerpo que se halla entre ellos y el punto que debe ocupar el huevo. En muchos icneumónidos, en ciertas avispas y en los antofilos, al aguijon está oculto en el abdómen; es corto y mas puntiagudo q̨ue la mas fina aguja, y propio tambien para punzar sensiblemen. te los declos a quient trate de privar de su libertad á estos diminutos sćres. Hay sin embargo notable diferencia en las pi. caduras; la de un icneumónido solo ocasiona el diolor que produciria una aguja y no dum mucho; pero si una avispa ó un antofilo introduce su aguijon en la carne, experiméntase un escozor muy vivo, seguido al punto de una inflamacion mas ó menos marcadr, porque el insecto no solo pica, sino que introduce veneno en la herida. Este liquido (ścido fórmi. co) se recoge en una rejiga en la base del aguijon; al picar el insecto, ejércese presion sohre aquiclla, y entonnes segrega una gotita que sale por el mismo conducto que da paso al huevo. Este aguijon venenoso es indispensable para ciertas especies de avispas que con él paralizan â los insectos que segun ya hemos indicado necesitan para su progenie: los antofilos se sirven solo de él como arma defensiva. Como el órgano de que hablamos y que está destinado para la puesta de los huevos no es en los otros himenópteros aguijon renenoso, como el de los citados, ni se le asemeja por su forma exterior, sino que con frecuencia sobresale del abdómen en figura de cerda caudal corta ó larga, se le ha llamndo taladro, tubo de puesta (terelira), para distinguirlo del aguijon (aculcus), dando á las especies provistas de él, el nombre de hymenoptera llrebratia. En las hembras de los tentredinos es visible en el vientre, aunque no aumenta la longitud del insecto; tiene la forma de una hoja de cuchillo, pero à causa de sus espinas denticuladas completamente ofrece el aspecto de una sierra. En los uroceros sobresale en forma de barm de la extremidad 
del abdómen, y puede compararse mejor con una escofina; en muchos icneumónidos afecta la figura de cerda larga ó corta, que forma con el abdómen un ángulo agudo y puede moverse hicia adelante, siendo de tanta mas longitud cuanto mayor es la profundidad a que la hembra debe buscar la larin de los insectos á que se propone contiar una cria. Sobre estos taladros se ven despues de la muerte del animal tres cerdas caudales filiformes, la ceutral mas rigida, $y$ las laterales irregularmente arqueadas y rétorcidas, porque constituyen la vaina, mas blanda, que despues de resecarse no ha podido conservar su rigidez. En los icneumónidos pequeños y en muchos cinipidos, el taladro alcanza una longitud desproporcionada, aunq̨ue no sale del cuerpo en el estado de descanso; y conviéneles asi, no precisamente porquue esos insectos deban introducir su órgano á mucha profundidad para poner loshuevos, sino porque necesitan aumentar con su fuerza elástica la muy escasa de los músculos de estos pequeños séres. A este efectosc oprime en forna de faja contra las paredes internas de la cavidad abdominal, y el mecanismo está dispuesto de tal modo, que el taladro se mueve alternativamente como el muelle de un reloj. Hasta hay casos en que el abdúmen cuyo volúmen no basta para esto se ensancha de un modo muy particular, ya en el lado del vientre, donde forma como una protuberancia cónica que llega al mesotórax, ó ya en la cara dorsal, en la que se produce como un cuerno redondo que se cxtiende hasta la cabeza (Platygaster Boscii), ofrecien. do asi el espacio necesario para que funcione el maravilloso mecanismo. O. J. Wolff ha exaninado precisamente este órgano en numerosas hembras de himenópteros y me ha asegurado que ofrece diferencias muy notables y útiles pata la ocasion; pero desgraciadamente no ha jublicado aun estos preciosos datos recogidos en sus ratus de ocio.

En cuanto á las patas, cuyo par anterior se desvia mucho die las dos posteriores, que en cambio están muy juntas, solo diré que en los tentredinos, uroceros, icneunónidos y cinipidos tienen trocánteres de dos artejos, de los que el de la hase es el mas largo; en ciertas avispas y en los antofilos los tro. cánteres solo tienen un artejo. Ln una familia (froctotrupios) que reuniremos con los icneumónidos, cuéntanse especies que tienen trocinteres de uno y de dos artejos, demostrando por esto y por su género de vida parasito, ó idéntico al de algunas avispas, que en todas partes hay grupos de trinsito que con mucha frecuencia oponen obsticulos al naturalista sistemático que solo se ocupa de la clasificacion. El pié se compone en la major parte de casos de cinco artejos.

Jas alas, órganos esenciales para el movimiento de estos séres aéreos sicmpre inquietos, se componen todas de uni piel delgada, a primera vista casi siempre desnuda, pero en la cual se reconoce con el microscopio una cubierta de pelos cortos, de un color semejante al del agua un poco turbia, ó de aspecto ahumado; con frecuencia este color tira al amari110 , siendo los bordes exteriores negruzcos. Tambien presentan i menudo unas fajas turbias que cruzan la superficie. Me. nos en los himenópteros de nuestros paises que en las numerosas especies exóticas, mucho mas grandes, toda tl ala ó parte de ella tiene un color negro, azul, violeta pardo, rojo ó amarillo, contribuyendo mucho a la belleza del insecto. A proporcion de las alas de algunas especies (neurópteros), la piel esta cruzada por muy pocas venas $\delta$ nervios, que entre si 6 con el borde del ala forman las celdas. En el estado de reposo, las alas suelen apoyarse horizontalmente sobre el dor. so cubriendo el abdómen; en las avispas propiamente dichas se repliegan longitudinalmente, penden mas en los lados del cuerpo y no cubren el abdómen. Cada ala anterior se reunc con su prosterior durante el vuelo, prendiéndose esta con unos ganchitos inuy finos en el borde posterior de aquella. En el punto en que se inserta el ala anterior hay una jlacyuita córncal movible, llamada la escamita de las alns, que di veces se dis. tingue por un color particular, llamando nuestra atencion mas bien por esta circunstancia que por su extraña forma. In el borde anterior de la major parte de las alas, detris del centro, hay una manchita de quitina, que por ser cómea como las venas se distingue facilmente de la tenue membrana de las alas por su color diferente: esta manchita se llama la señal de las alas. En las esprecies en que $n 0$ existe, las venas esca. sean mucho ó faltan del todo. Debcmos fijar nuestra atencion en los nervios y en las celdillas, porquue constituyen caracté. res distintivos, sin los cuales no seria posible reconocer los géneros. J os diversos autores opinan sobre este punto de dis. tinto modo, sin estar tampoco de acuerdo en cuanto d los nombres de las partes aisladas. Sin entrar en detalles, procu. raremos tratar este asunto lo mas sencillamente posible de. mostrando yque no es tan dificil como parece a primern vista.

Para el ala anterior lo arriba dicho es valido en toda su extension. 1)os fuertes nirvios (la vena radial y la cubital, costa y subcosia), muy juróximas entre si, jen muchos tentre. dinos reunidas en una fajita córnea, forman el borde anterior de las alas, su mas firme apoyo: la señal solo es un ensanchamiento del primero 6 una corta expansion de los dos: Las dos células de mayor longitud, que afectan mas 6 menos la forma de uña, y que desde la mitad de la base del ala des. embocan hácia el hombro, son las células humerales, media é inferior; la superior solo adquuiere importancia cuando la costa y la subcosta dejan una fajita membranosa en medio de ellas. Desde la señal del borde hácia la extremidad de las alas hay una célula, y en muchos tentredinos clos que se oprimen contra el borde anterior y se llaman cilslas radiu!es. A reces el nervio que las encierm sale un poco de la pumta y forma un apéndice. Debajo de la célula radial, el cribito y las venas cubitales trasversales forman una seric de células en uúmero de una á cuatro, que se llaman cubitales y se cuentan desde la seiral de las alas hasta el borde. Al observar mas minuciosamente las alas se comprende que cuatro células cubitales solo son posibles cuando el cúbito se prolonga hasta el borde del ala, como sucede regularmente con los icneumónidos y los tentredinos, pero nunca en los anto. filos. Iil ala de los verdaderos icneumones, en la que cuando mas solo hay tres de estas células, 6 dos si se atrofia la segunda, merece particular atencion como cariciter distintivo, por lo cual se le ha dado el nombre particular de espejo. Otra paricularidad en la formacion de las alas de que hablamos consiste en la soldadum de la primern cúlula cubiral con la central superior, obsernindose a menudo un pequeño resto del nervio divisorio, $\delta$ ramo nerviosos. I as células cenirales ó discoidales se hallan, como lo indica su nombre, en el centro de la superficie del ala (disius) y están formadas por los dos nervios branquiales: tambien estos tienen $54 \mathrm{im}$. portancia en la clasificacion, sobre todo por la célula cubital, en la quue desembocan. En ciertos icneumones, en los bracónidos, la falta completa de las venas branquiales es un caraic. ter distintivo de la fanilia La vena longitudinal que sigue al cúbito se ha llamado icna paralela ó discuidal, y la célula que encierm à menudo en el ángulo interior del ala cilula aficial. Tendremos que ocuparnos aun del espacio que midé desde aqui hasta el borde exterior, espacio importante para las alas de los tentredinos, aunque cxclusivamente de cllos, que contiene la llamada célula de forma de lanceta, la cual ofrece importantes caractéres distintivos. Unas veces remata sencillamente como estrecha faja, que hàcia adelante y atris se ensancha un poco, en los hombros, ó bien se divide por una vena trasversal oblicua en dos células. Segun otra ley de formacion, estréchase en el centro continuando à mas ó 
menos distancia como riervio sencillo, y entonces se la llama estrechada; en la celda de forma de lanceta pedunculada, por último, aquel nervio sencillo se extiende hasta los hombros sin separarse otra vez para tomar la forma de célula.

En el ala posterior, mas pequeña, los nervios pueden clasificarse mas fảcil ó dificilmente, del mismo modo que en el ala anterior, y tambien aqui sc hallan caractéres para distinguir las especies. Las alas faltan del todo en algunos icneu. mónidos del género pezomachus, en nuchos congéneres de los icrieumónidos, en los cinipidos, en las hormigas inabajadoras y. en las hembras de las nuitias.

Muchos himenópteros producen un zumbięo, segun 10 judemos oir en los abejorros, abejas, avisuns $y$ avispones. Sabemos como se emite, gracias it las tiltimas e incansables observaciones de Landois. Segun este, una serie de tonos, como ya se sabia, deben su origen at los movimientos de las alas, tanto en las inoscas como en otros insectos; por tal concepto los himenópteros y los dipteros ofrecen la mayor varie. dad en tonos bajos y altos. La membrana tenue produce, por la extmordinaria rapide\% de esos insectos, un zumbido carac: terístico. I andois establece las siguientes leves. Ios sonidos de las alas son constantes en el mismo inaividuo; cuando ambos setios de una misma especie se diferencian por su tamaño, tambien difieren mucho por el sonido de sus alas: los insectos mas pequeños emiten a menudo con el ruelo uno mucho mas bajo que el de los grandes. Naturalmente no hablamos del ligero rumor que algunos icneumónidos dejan á veces oir, asi como las mariposas diumas, cuando vuelan rcunidos en gran número, yo sobre todo tambien las langostas con sus clitros mas fuertes. Úna segunda seric de sonidos producen los himenópteros (y difteros) con los estigmas del tórax, \& del abdómen; y estos sonidos son voluntarios, porque expulsan por aquellas aberturas el aire. Estos aparatos rocales pueden compararse con los silbatos de lengüueta, pues cn los insectos vibran unas membramas situadas en la extremidad de las aberturas traqueales. Ios silbatos son las tra queas, en cuya extremiciad no dividida se inserta el aparato vocal, como la laringe en la faringe de los mamíreros. Precisamente antes de penetrar en el aparato li triquea se estrecha y contiene en los himenópietos a menudo órganos que permiten expulsar, segun la necesidad, mas ó menos aire, exactamente como se haria con un fuelle. El aparato vocal se compone principalmente de hojitns de quitina, que estan pendientes en forma de cortina, ó tienen la forma de tubitos; al salir al aire vibran y producen un sonido. Landois demostró que el aire expulsado y no el que entra es el que emite los tonos, y hasta expresó por notas los zumbidos de varias moscas y antofilos. No todos los estigmas están provistos del apurato vocal, sino principalmente los del tómx; en los antofilos y en cicrtas avispas los del abdomen, y cu muy poras especies unios y otros a la viz. Por interesante que estc asunto sea, no podemós ocuparnos mas detenidamente de él, pues nos falta el espacio, pero debemos recomendar las «Voces de los animales del autor citado.' (Freisburgo, en el I'reisgau, I 874 .)

Los himenópteros fósiles se encuentran rams veces en el terreno jurásico, y aun los individuos son dudosos; pero hállanse con gran frecuencia, sobre todo las hormigas, en los errenos terciarios y' en el ambar:

Respecto $a$ la clasificacion de. Ia familia, abrigamos algunas dudas, pues los pocos autores que han tratado del gran conjunto de los himenópteros estin inuy: poco conformes en sll modo di ver: y como no se han ocupado con suficiente detencion en el estudio de estos insectos tan interesantes, no podemos decir cual es la clasificacion que ha merecido cl aplauso general.
I no siendo posible determinar nada respecto al punto de vista bajo el cual considera este úrden la ciencia sistemática mas moderna, deberemos tomar en cuenta en el primer lugar, siguiendo el ejemplo de Lepelletier, el género de vida de estos insectos, exponiéndonos al peligro de no llegar al mismo resultado que el naturalista que solo observa y distingue el insecto desarrollado al hacer su clasificacion.

\section{LOS ANTOFILOS-ANTHOPHILA}

CARACTERES.-Los antofilos, ó abejas, que como primera familia colocamos al frente del órden, se han citado ya varias. veces, pero no de modo que podamos conocer una sola de ellas. Fi trocanter sencillo les es propio, lo mismo que a varias especies de avispas, de las que difieren en la mayoria de los casos por tener el cuerpo recogido y muy peludo, y por la estructura particular de las patas posteriores. Ningun antofilo tiene el abdómen pedunculado como mtichas avispas; en las especies mas grandes se inserta por el contrario en la cara infcrior del ancho borde anterior, por medio de un anillo circular que casi tiene la forma de punto en la extrenidad inferior del metatórax y en las especies pequeñas se estrecha en ambos lados, adquiere contornos elipticos yo pertenece á los abdómenes anscendentes, negun se les llama.

Los espesos pelos que cubren el cuerpo de la mayor parte de las abejas, comunicindolas por lo regular sus colores abignrrados, constituyen un caracter que las distingue de varias especies de avispas. Cierto que tambien las hay casi des nudas: mas á pesar de esto, una vista algo experta pronto las reconoceri como antofilos.

1.as abejas recogren, segun sabemos, para su cria miel ! pólen; la primera se conserva en el interior de su cuerpo; el segundo en el primer artejo de los tarsos posteriores. Ias patas posteriores son en los antofilos cl distintivo del sero femenino, con pocas excepciones. Los tarsos, con el primer artejo del pié, que casi tiene la misma longitud, y en las abejas se llama metatarso, son en extremo anchos; el tiltimo tiene además en la cara anterior de su base un apéndice en forma de palo, llamado orejula. El tarso puede estar un poco deprimido en su cara exterior, es brillante y hállase cubierto en los bordes de largos pelos, su estructura es la mas propia para recoger y llevar el pólen, como en un cestito; por eso se ha llamado tambien con frecuencia este órgano cestito. Su brillo notable es debido, segun ha obsermado O. J. Wolff, as las gländulas sudorificas, que situadas debajo de la piel quitinọa se abren hácia afuem. penetraudo el pólen con su se: crecion, sustancia aceitosa diseminada tambien por otras partes del cuerpo, y reuniéndole en forma de bola. Bastante a menudo se encuentra, cono complemento del curioso úrga. no, una especie de cepillo para reunir el pólen, es decir; unas cerdas cortas y rigidas que en la extremidad del tarso se in. sertan como las de ciertas clases de cepillos. 'lambien el tarso sirve, aunque no con tanta eficacia, para recoger el pólen que se adhierce á los largos pelos. Las abejus cuyas patas posteriores tienen semejante estructura, se llaman por este carácter coleccionadoras de farsos. En otros antofilos las citadas partes no se desarrollan con tal perfeccion para dicho objeto: la cara exicrior del társo no forma cestito, y solo esta cubiertia de escasos pelos; pero en cambio, los muslos, las ancas y hasta el lado del abdómen están provistos de jelos mas largos en jarte rizados: estos coleccionadores de musios no son por eso menos jropios para recoger cl alimento indispensable para las abejas. Como,en todas partes, la naturaleza ha demostrado su sábia prevision en estos insectos, creando r:t. rias especies de abejas cuyo órgano coleccionador estí situa- 
do en la region del vientre: varios pelos cortos y cordosos dirigidos hicia atrits, y que cubren la cam inferior del abdómen, ticnen por objeto en las colecionadorns de sientre cepillar y sujetar el pólen. los antofilos que carecen casi del todo de pelos, tanto en los tarsos, muslos y vientre, como en el resto del cuerpo, dejan la recoleccion para los que son propios para ella, y depositan sus huevos furtivmente en los nidos de estos. I a vida parásita, tan general en todo el mundo, hàllase aqui en esa forma uspecial, jo está del lodo justificada por la estructura del individuo, debiéndose à ello que ciertas especies se desigmen con el nombre de abija fortsiln. l.os órganos tan curiosos de que acabamos de ocuparnos !’ ylue sirven para cuidar la cria, son propios de las hembras y de los individuos femeninos, que sin ser nunca madres, deben desenprenar sus funciones, Las llamadas trabajodorns, que en algunos antofitus sociables constituyen una tercera y muy poderosa casta, están provistas tambien de un aguijón para su défensa. I os machos, que no récogen, no necesitan los órganos para ello, y por consiguiente no tienen tantos órganos distintivos, siendo en su consecuencia dificil para el natura. lista reconocerlos como pertenecientes a cierta hembra, no solo en los antofilos, sino tambien en otros muchos himenóp. ieros.

No debcmos extranar timpoco que los dos sexos de una misma especie se hayan designado con diferentes nombres, ni que en los abejorros y otros géneros ricos en especies muy parecidas, reine un caos babilónico por tal concejuto, debido á las diferentes opjiniones de los matumlistas.

Ya hemos indicado al principio cuán desarrollada esta en los antofilos la lengua çue en parte se halla circuida por el

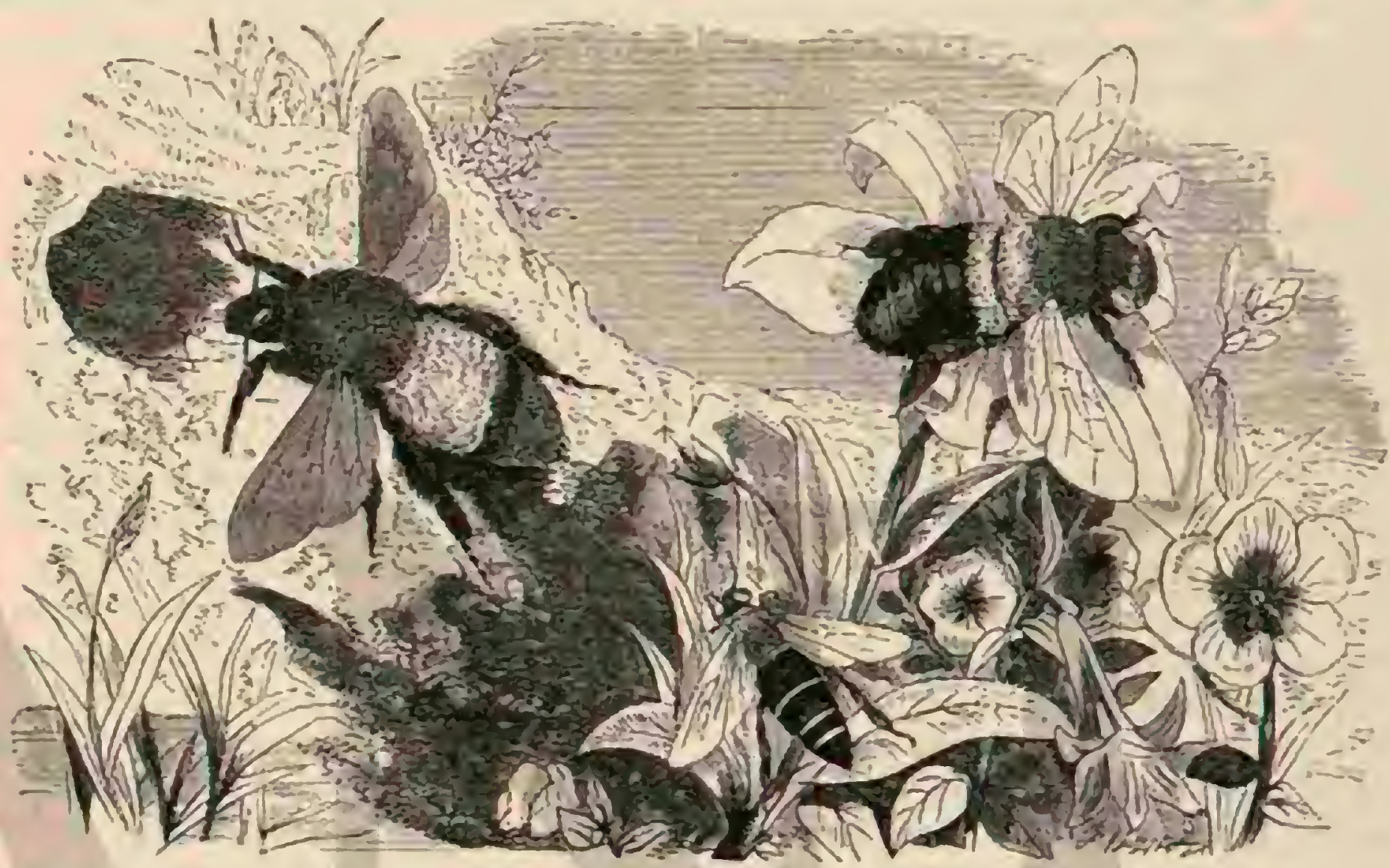

Fig. 32.-1:i. aHrjorro ORIENTAL

Fig. 33. - A MBEJA DE TRAJAS

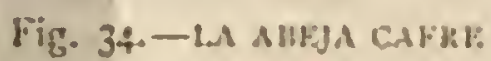

estuche, y en el estado de reposo se oprinze hicia atris en la garganta. 'Tal estructura es propia de las verdaderas abejas (apidac): en las abejas falsas (andraridac) la lengua es mas corta que la barba y no puede recogerse durante el reposo.

Estas diferencias han inducido a varios maturalistas a hacer otra clasificacion quizas mas cientifica, i dividir lus antofilos en dos familias. Las antenas de todos son nngulosas, aunque en muchos casos apenas visibles a causa del corto tallo, yen las especies que nos ocupan se componen de doce artejus en los machos y trece un las liembras; el látigo es filiforme, cnsanctiado ó aplanado á veces hácia la punta, pero siempre obtuso; sus artejos, que se distinguen bien, no se estrechan mucho en las extremidades ui se dilatan en las pumtas, $y$ it veces se insertan en la cara inferior, siendo un proco nudosos. Encontramos por lo tanto en una familia tan rica en especies una mra analogia en la estructura de una parte del cuerpo que en los denás insectos ofrece la mayor varicdad de formas. I os ojucles existen siempre, pero son dificiles de distinguir à reces a causa de los espesos pelos de la co. ronilla. I as alas anteriores tienen sicmpre una célula radial $\sin 6$ con apéndice $y$ dos $\delta$ tres cubitales; la parte posterior de la superficie del ala es relativamente ancha sin vena alguna, pues con pocas cxcepriones, detris de los tíltimos nervios transrersales cesan las dos venas longitudinales, la cuhiral y la paralela. En muchas especies, sobre todo en las grandes, esti espacio se reconoce por unos espesos punios of delicadas fajas longitudimales, y' toda cl ala se distingue ademís con frecuencia por su color mas oscuro. En los individuos yue solo tienen dos células cubirales, las dos venas braquiales desembocan en la última, la primera à veces exactamente en el limite anterior: en las esplecies en que existen trés de estas células, la segunda y tercera recogen cada cual uno de ayuellos nervios con pocas excrpciontes; como por cjemplo las abejas de la miel. El abdónen se compone de seis segmentos, tanto en la hembra fecunda como en la atrofiada, y en el macho de siete. Alli dondic hay hores que contengan néctai, las abejas acuden siempre para saquearlas, à fin de utilizar ese producto en provecho de su progenie; mas parece que los paises tropicales, con su abundancia de flores no son proporcionalmente tan ricos en abejas como nuestras regiones templadas.

\section{LA ABEJA DOMÉSTICA-APIS MELLIFICA}

CARACTÉRES. - I al abeja doméstica se distingue de las especies europens por carecer de toda esplina en los an. chos tarsos anteriores. I as alas ticnen una célula radial redondeada en su parte anterior y cuatro veces mas larga que an. cha: tres células cubitales y otras tantas discoidens cerradas; aquellas se asemejan entre si bastante por el tamaño y la superficic, pero la última es romboidal y se aproxima à la base del ala por la rextremidad anterior mucho mas que en la postcrior, hallåndose dispuesta por lo tanto muy oblicua- 
mente. El cucrpo es negro de un brillo sedoso, si los pelos rojizos que tiran á gris y se extienden hasta los ojos, desgastándose no olstante con el ticmpo, no cubren la base dindole este últimn tinte. Los bordes posteriores de los segmentos del abdómen y las patas tienen un color pardo, y hasta rojo amarillo, cuando menos en la hembra, ctya maturaleza noble se aprecia por el brillo dorado de las patas. Las garras de los piés están bipartidas en la punta; los palpos maxilares tiencu un artejo, $y$ los labiales cuatro.

La diferencia entre los machos, hembras y trabajadoras resulta de los siguientes caractéres: lia hembra carece de los pelos para recoger pólen, y el macho del dientecito en la base del metatarso. I a trabajadora, llamada sencillamente abejo: ese sér femenino que por tener atrofialos los órganos genitales no puede contribuir a la propagacion de su especie, debiendo encargarse en cambio de cuidar la cria, tiene en la lengua mas larga, en las maxilas, igualmente mas prolongadis, y un el costito de las patas posteriores, los órganos para ejecutar sus penosos trabajos, asi como en el interior de su cuerpo un pequeño laboratorio quimico, donde se preparan, segun la necesidad, la miel, la cera y el alimento para la cria.

USOS, COSTUMBRES Y REGIMEN. - Ias abejas constituyen un Estado bien adnuinistrado, en el que las trabajadoras representan al pueblo; una hembra fecunda, elegida por este, es la reina querida y mimada por todas, $y$ los machós los nobles ociosos, indisperssables, si, pero solo tolerados cuando se les necesita. Esta institucion es un vardadeto modelo, poryuc cada parte, en su cargo, cumple estrictamente con su deber, y' porque nadie quiere ser mas ni menos de aquello que le permiten sus facultades.

El hombre ha reconocido siempre la actividad de la abeja, dignándose aceptarla como simbolo de tan alta virtud, peró tambien has sabido apreciar los productos de su tralonjo, á lo cual se debe que no enconiremos ya aquellos estados de abejas en la naturaleza libre (solo por excepcion los que han vuclto al estado salvaje) ni podamos decir tampoco cuándo y dónde se han encontrado por primera vez. El órgulloso «scrior de la creacions indica á los insectos su sitio en la colmena, construida de distinto modo en las diversas epocas; y serialales el paraje en que han de fundar sus estados; pero auñ̨ue los ayuda por muchos cónceptos, no ha podido cambiar en miles de aros el caracter inuato de esos vitiles insectos. Las opiniones a menudo contrarias que encontramos en los roluminosos escritos sobre las abejas no tienen su razon en las costumbres cambiadas de la abeja sino en el grado del conociniento de estas costumbres. Hasta hoy dia no nos ha sido posible decir que todo está explicado en este maravillo. so organismo, que ya esta comprendido todo por el hombre dedicado á la cria de abejas, no solo en cuanto al aprovechamiento de la cera y la miel, sino tambien por lo que hace al estudio general referente à la activiciad de la naturaleza y al gínero de vida de esos graciosos insectos. Intentaremos ahora trazar un cuadro lo mas fiel posible de esn vida tan arreglada, y sin embargo tan borrascosa, descripcion que no destinamos a los que se dedican $i$ la cria de abejas, sino al amigo cstudioso de la natura!eza.

Supongamos que es dia de San Juan yo que un enjambre retrasnda (lo que esto significa y:a lo diremos en la descripcion oiguiente) acaba de establecerse en una colnena con la cono cida puertecilla en la base de una de sus paredes y la tablita por delante de la misma cono es de costumbre. Apenas colocada la colmena, preséntase alguna que otra abeja en la tablita de la entrada, empinase todo lo mas posible, entreabre las antenas, cleva el abdómen y mueve las alas de un modo particular, comosi temblara. Este singular proceder es ta expresion de su alegria y de su bicnestar, y el dueño de la colmena sabe con seguridad que al recoger el enjambre se halla en el la reina, cosa gue podria muy bien no suceder si la maniobra es torpe, $\delta$ cuando el sitio donde el enjambre se ha reunido no es í propósito. En el caso de haber sucedido esto, ú si por una ú otra causa la colmena no gusta à las abejas, estas no permanecen ni un momento en ella; todas salen precipitadamente y vagan ansiosas por los alrededores hasta encontrar á la que desean confiar la direccion de su futuro estado, y si no la hallan, $\delta$ si la colmena ofrecida no reune las condiciones apretecibles, vuelven a su antigua vivienda. En la colmena que tomamos por modelo todo esti en órden.y por lo tanto se da principjo al trabajo, ó sea a laconstruccion de las celdas, que comienza en el techo de la colmena. Los que se ocupan de la cria de abejas suelen prestar ayuda, colocando algunos panales vacios en la nueva habitacion; pero no trataremos ahora de esto. I.os insectos llevan el material de construccion consigo; y sabiendo muy bien que los trabajos de la casa no les dejan tiempo por lo tanto para recoger alimento, han tomado triple racion, $i$ fil de no padecer hambre y poder preparar la cera indispensable.

Esta sale en forma de unas hojitas de entre los anillos abdominales cuando se necesita, constituyendo una especic de cadena sencilla ó doble, por el enlace de aquellas. En aquel estrecho récinto reina una confusion extraña, pues cada cual se afana en su taren; el trabajo del obrero y del maestro se desem. peña por un solo individuo; una abeja coge las hojitas de cera del abciómen de la otra, las masca y mezcla con su saliva, y todas las que han preparado de este modo el material se di. rigen al sitio de la construccion para colocarle. Por lo pronto se forma un reborde recto, aunque no del todo reyular; a este se adhieren a derecha é izquierda celdas que se tocan por los lados y el fondo en posicion horizontal, hasta que se forman los panales abiertos à derecha é izquierda, los cuales penden verticalmente hácia abajo. Cada lado de estos representa una graciosisima red de nallas cxagonales, de una regularidad que solo podriamos alcanzar con el compás y la regla las celdillas son, como ya sabemos, exagonales, deprimidas en el fondo en forma de puchero, y en su extremidad abierta por delante cortadas en linea recta; miden 1, ,007 de largo por $0^{-}, 005$ de ancho y cada una tiene exactamente la dimension de la otra. De estos pannles se encuentran con el tiempo en la misma direccion ramos como permite el espacio de la colmena, quedando entre dos siempre el espacio de la altura de una celda. I.os arquitectos dejan tambien en ciertos puntos unos agujeros con pasadizos. Los panales se desarrollan de un modo bastante igual y ninguno se agranda tanto como lo permite el espacio antes de que el otro alcance su dimension. Pero no nos adelantemos demasiado en la des. cripcion. Al cabo de algunas horas se puede ver ya en nues. tra colmena una punta triangular de $U^{*}, 0105$ cuadrados que cuélga hácia abajo.

Todo principio es dificil : esta es una verdad que tambien se confirma en cadia nuevo estado de abejas. Su rusiduncia no es la misma en que los habitantes nacieron, y por eso es indispensable el mas minucioso conocimiento de los contornos para cada individuo antes de emprender sus excursiones. Ia abeja, como se sabe, es ial esclava de sus costumbres, yue varias veces, al volver de sus correrias, se posa exactamente en el mismo sitio donde estaba la entrada de su colmenil, cuando esta se ha desviado solo algunas pulgadas por cualquiem causa. Para reconocer la localidad, $y$ a fin de retener bien en su memoria los contornos del pequeño espacio que les sirve de entrada y salida, las abejas salen mirando a dercha \& irquierda lentamente la tablita; cléranse ejecutando cortas evoluciones; vuelven a posarse; se rimontan de nucro para trazar arcos mas grandes que se ensanchan en circulos, 
y durante su vuelo tienen siempre la vista fija en la entrada. Despues de esto quedan convencidas de que ya no olvidarín cl agujero de la entrada: y entonces, remontándose con ripido vuclo, aléjanse a mucha distancia que en caso de necesidad puede llegar a dos looras de camino. La abeja busca las fores y sustancias resinosas; alli donde hay fảbricas de azú. car en los alrededores saben encontrarlas pronto, y agrádale mucho saquearlas, aunque casi siempre en perjuicio suyo, pues miles de ellas encuentran alli su muerte, porque saben entrar y no pueden volver a salir. En vano vuclan contra las rentanas haciendo esfucrzos para salir; al fin caen exhaustas al suclo y perecen. Recogen muchas cosas, miel, agua, pólen y resina: lamen la primera con la lengua, introdícenla en la boca, §arrójanla de nuevo en furma de verdadera miel. 'Joman el agua del misno modon, sirviéndoles para su propio alimento en la construccion de los panales y para preparar la nutricion de las larras, pero nunca hacen provision de ella en la colmena, sino que cada vez van á buscarla segun la necesitan. Con las partes peludas del cuerpo, la cabeza y el tórax, la abeja recoge involuntariamente el pólen de las flores al penetrar en ellas, y sabe cepillarlo nuy bien con las patas pam tijarlo en las posteriores. Con las afiladas maxilas abre el pistilo de la nor, si está cerrado todavia, coge su contenido con las patas anteriores, traslidale á las centrales y despues a las posteriores, que con el cestito y el metatarso constituyen el verdadero órgano de la recoleccion. El pólen se adhiere fícilmente por medio de la sustancia aceitosa de que hemos hablado, acumulandose a veces en forma de gruesos punios. De los capullos de los ålamos, alisos yotros ârboles, asi como de las coniferas que siempre segregan resina, esos insectos toman las sustancias que necesitan con los dientes, deposi. tándolas en el órgano recolector. Que las abejas, tanto las domésticas como las salvajes, son por su trabajo las únicas internediarias para la fecundacion de ciertas plantas, es un hecho reconocido que solo de paso recordanos.

Cunndo la abeja ha recogido su carya, guinda por ef instinto de localidad, maravillosamente desartollado, dirigese por el camino mas corto á la colmena, y una vez aqui, suele posarse en la tablilla para descansar un poco, entrando despues apresuradamente por la puertecita. Segun la naturaleza del botin que trae, varia la manera de descargarse de él; si es uniel alimenta á alguna compañera, ó la deposita en la celda de provisiones. Algumas reldillas contienen-iniel para el uso diario; otras, con ureferencia las series sujueriores de los panales, sirven de despensa para lo futuro, y se cierran con una tapa de rera apenas estan llenas. Para desprenderse del pólen que llevan en las patas posteriores agitan estas, depositåndole en una de las celdillas destinadas para las provisiones quésirven de alimento á las abcjas, ó bien desprenden con las maxilas parte del uisino y lo devoran, si no se presenta una companera con la misma intencion y recoge la carga. las sustancias resinosas, el propolea (propolis), segun se le llama, sirven parn cerrar las rendijas, por donde la humedad $y$ el frio pudieran penetrar, asi como para achicar la entrada, 6 eı un caso excepcional para envolver objetos extranos que no se sacan á causa de su tamanio, pero que pudicran infestar la colmena por su jutrefaccion. Dicese que se han encontraclo un raton 6 una limaza envucltos de este modo en una ú otra colmena.

Ia construccion de las celdillas, como primer trabajo, y la recoleccion como segundo, se continuinn mientras existe el enjambre, y se ejecutan por cada abeja del mejor modo posible; pero aun falta el alma de todo, el cuidado pam la progenie en el que se fijan las miras de todos los insectostan luego como han llegado a su conpleto desarrollo.

los machos que no se cuidan ni de la construccion ni de
Ia recoleccion, y comen solamente lo que otros buscan penosamente, no tienen mas trabajo que salir al medio dia pam ejercitar un poco su vuclo vacilante, con las patas colgadas y zumbando ruidosamente. Esto lo sabe muy bien la jóven rei. na, aunque en su cstado no hubiera ninguno de estos zanga. nos. Pasados los primeros dias de su entrada en la colmena, la reina experimenta el deseo de cmprender una excursion y pronto encuentra un macho; el apareamiento se efectúa y termina con la muerte del elegido. Despues de una corta ausencia la reina vuelve fecundada para toda su vida que puede durar cuatro y hasta cinco años. Scgun los experimentos he. chos, puede poner anualmente de $\$ 0,000$ is 50,000 huevos, pero sienapre menos en los últimos años; en interés del enjambre no se les suele dejar en actividad mas que cuatro. Si dentro de los ocho primeros dias no se ha efectuado la fecundacion, la reina sera infecunda.

Cuarenta $y$ seis horas despues de su vuclta comienza a 10 ner: por lo regular deja intacto al principio el panal anterior y la pared del siguicute: las series superiores de todos están provistas de tapas y contienen miel, hallándosc debajo de ellas las celdillas destinadas para la cria. En su trabajo, que casi sicmpre continúa sin ninguna larga interrupcion para descansar, la reina esta acompañada de varias trabajadoras que la ofrecen alimento, la acarician con las antenas y lámeula con la lengua, dispensandole todas las atenciones que una abeja tiene para su reina En cada celdilla en que se propone depositar un huevo introduce primero la cabeza, cual si quisicra convencerse de que todo está en órden; despues vuelve á salir, coloca su abdómen en la celda, y cuando sale se ve en el fondo, junto á la pared inferior, el huevo de. positado verticalmente. Fs de un blanco de lache trasparente, de mas de 1$)^{\circ}, 002$ de longitud, ligeramente encorvado, y en su.extremidad inferior apenas mas estrecho que en la superior. La prinera puesta es para el pueblo la seinal de redoblar su actividad, porque aumentan sus quehaceres Ias celdas de la cria se llenan al punto por detris del huevo de un montoncito de una mata gelatinosa blanca, preparada con miel, alimento de las abejas y agua en el laboratorio de las trabajadoras. Al cuarto dia sale la larva en forma de gusa. nito anillado, toma el alimento que se le da y continúa recibiéndole desde afucra $\operatorname{Sin}$ moverse ni expeler sus excrementos, crece y engorda tan rópidamente, que al sesto ó séptimo dia llena toda la celdilla. L.as cuidiadosas trabnjadoms ensanchan entonces ron sus dientes los bordes de aqueIla, encorvándolos hácia adentro y completan lo que falta con una tapa de cera plana para cerrar la celda del todo. Pero aun no basta esto: las celdillas de la cria tapacias no se abandonan nunca; siempre estin rodeadas de espesos grupos de abejas, que en cierto modo las ancubany. En el interior, la larva fibrica un tejido sedoso que la rodea, muda de piel y se trasforma en crisálida. El dia vigésimoprimero despues de puesto el huevo, la tapa se levanta desde adentro y' la jóren ciudadana se deja ver; despues se presenta alguna trabaja. dora para preparar la celda, alisando su abertura, etco, i fin de que se pueda depositar otro huevo. Ias prieles mudadas se retimn en parte, pero no todas, pues por medio de cllas las celdillas se estrechan con el tiempro; las abejas que uacen en las muy antiguas son mas pequeñas, segun lo ha demostrado lo experiencil.

Ia recien nacida es saludada amistosamenic por sus com. pariens, que la lamen y alimentan; mas apenas adquiere fuerzas suficientes, lo cual sucede al calo de pocas horas, méz. clase entre las trabajadoras y se dedica á los quehaceres domésticos: en los primeros quincè dias la jóven abcja se ocupa probablemente en alimentarse, incubar y proveer de tapas a las larvas; toma pare en la limpieza de la colmena y 
saca los pedazos que caen de las celdillas, pero al cabo de este tiempo cada una siente cl deseo de la libertad. Despues de ejercitar como ya hemos indicado su instinto de localiciad, emprende el ruelo y trae provisiones con la misma destreza que sus compañeras mas ancianas.

A esto se reduce la verdad de lo que han dicho los autores antiguos, quienes pretendian que habia dos especies de tratiajadoras: las jóvenes se encargan del servicio doméstico; las viejas van al campo, al bosque y á las praderas para recoger provisiones. De esta manera proceden durante todo el verano y solo en los dias lluviosos y frios se quedan en la colmena. Cuanto mas abunda la miel y mas favorable es el año, tanto may̧or es la aficion con que el pueblo trabaja; vive en armo. Jia con su reina; haligala y la ofrere abundante alimento; mientras que ella, en cambio, pone numerosos hueros. El pueblo aumenta de dia en dia, y con él has benélicas fuerzas imbajadoras.

Casi podria suponerse que esta actividad, tan penosa por unibas partes, poniendo mas en relieve la pereza de los machos, despierta poco á poco el rencor contra ellos; pero no hal de creerse asi: el convencimiento de que ya no son necesarios es lo que induce a darles muerte. Ias abejas se precipitan sobre los machos; persiguenlos por la colmena; los reunen todos en un rincon y alli los encicran para nue mueran de hamibre, ó bien los muerden, sacándolos por las alas de la colmena, ó les dan miente á fuerza de clavarlos el aguijon. Es un hecho curioso que el uso de este órgano en tales casos no sea pernicioso para el individuo yue le emplea. Sabemos que la abeja que nos pica en la carne deja su aguijon del todo ó en parte en la herida, ả causa de los ganchitos que tiene, $y$ muere. ¿Por que no sucumbe cuando le introduce entre los segmentos del abdómen del macho? Porque la masa quitinosa no cierra la herida como la carne elástica: el orificio queda abierto, y los ganchos pueden salir ílesos. Ia colmena donde a principios de agosto no se matan los machos queda sin reina, como lo saben muy bien los criadores de abejas.

Una verisacados los cadáreres de la colmena vuctre á reinar el órden, y el trabajo y la actividad pacifica siguen su curso. El mejor tiempo, no obstante, ha pasado, ya, por lo menos en las regiones donde faltan. los brezos, y es preciso recurrir a las provisiones recogidas en dias mas favorables, sin contar que se despicrta la inclinacion al robo, pues antes 6 despues de la estacion favorable la cosecha éscasea; muchas abejas manifiestan una gran disposicion al merodeo, y procuran penetrar en las colmenas ajenas, ả pesar de los centinelas, para saquear los panales llenos, cual si fueran fores. Cuando una ó dos logran penetrar traen à la segunda vez varias com. paneras, $y$ la partida de ladronas se organiza muy pronto. La visita y entrada en las fábricas de axucar no es en rigor otra cosa sino una exjedicion gencral para entregarse a la ratjiña.

Tambien las celdas de cria cmpiezan à disminuir aunque en tiempo favorable nacen trabajadoras hasta octubre. No se crea que el pueblo es ahora mucho mas numeroso que el dia de San Juan, cuando se estableció la colmena; muy por el contrario, puede haber disminuido si al tiempo no fué favorable. Ia falta de los machos no se toma en consideracion, pero si el gran número de trabajadoras que perecen poco á joco por accidentes ó sucumben de muerte natural. Ia vida de una abeja, en la época principal de la cosecha, dura solo seis semanas. Durante mucho tiempo las opiniones han sido contrarias en este punto, pues por la larga vida de In reina hacianse suposiciones falsas respecto a la de las tra. bajadoras, hasta que la introduccion de las abejas italianas en Alemania hizo desaparecer toda duda. A principios del periodo de la cosecha, durante el cual la abeja desarrolla su mayor actividad y se gasta mas, dióse a un cnjambre aleman una reina italiana fecuudada, y al cabo de seis semanas desapareció acjual, excepto algunas pocas abejas, sustituyéndole un puéblo de abcjas italianas que por la base roja de su ab. dómen se distinguen fácilmente de nuestra variedal sepien. trional. Durante el invierno se encontró en la colmena el panal anterior relleno de micl y cubierto de tapas; el siguiente la contenia en la carn anterior, y todos los oiros mas o menos en su parte superior; mas hácia abajo se hallaban las celdillas para las provisiones llenas de alimento y tapadas, y además las celdas de cria desocupadas. Bastante a menudo las celdas contienen en su mitad inferior alimento de abeja y en la superior miel, como observa el dueño con gran disgusto cuando quiere recoger su cosecha. En las celdas de cria las abejas se oprimen todo lo posible para jasar el invierno. Así como los animales de sangre caliente procuran obtener calórico reuniéndose en apretado grupo, del mismo modo algunos insectos elevan la temperatura reuniendo. se en gran número, y por esto la abeja no se queda rigida como los insectos que imvernan al aire libre, necesitando jor consiguiente el alimento de que sc ha provisto durante tl verano.

El inviemo debe ser muy riguroso y el frio muy duradero para que en una colmena la temperatura baje mucho tiempo de S'Reamur, temperatura que es empero necesaria y se conserya continuamente tomando alimento y por diversas cvolucioncis; en los dias frios todo el enjambre produce un zumbido causado por sus bruscos movimientos.

Como la comida aumenta cl calor del cuerpo, y por lo tanto támbien la temperatura de toda la colmena, las abejos necesitan en los inviernos frios mas alimento que en los templados. Si el aire exterior tiene la citada temperatura, unuchis abejas se atreven \& emprender una excursion, $y$ hasta en dias de invierno, si brilla el sol aunque haga mas frio, algunas salen con vuelo rípido de la colmena par beber agua ó desembarazarse de sus excrementos. Sumamente aseada, la abeja no deposita nunca sus excrementos en la colmena, sino al aire libre. Si a causa del frio los debe retener demasiado tiempo, ó si come miel perdida que no estaba tapada, enferma pronto, ensucia su vivienda y toda la colmena suele perecer en hreve. Cuando el invierno no es muy riguroso no cesa tampoco el trabajo, aunnue solo se reduzca a trasladar las provisiones de las celdas posteriores á las anteriores, ya racias. Por lo demás, la reina comienza ya a mediados de febrero la puesta en su lecho de invierno.

En abril ó marzo los benéficos rayos del sol llaman poco á poco á todas lasabejas que se hallan en su cuartel de invierno: zumbando y revoloteando dan \& conocer su bienestar al salir de su estrecha prision, para disfrutar de la libertad con que les brinda el sol de primaver. Su primera diligencia es depositar los excrementos; y si entonces sucede calsualrnente que uma mujer dejó ropa blanra colgada en los alrededores jaira secar, seguro es que la encontrará pintada con gran disgusto suyo, cubierta de puntos pardos, pues á las abejas, lo mismo que à otros insectos, agrádales mucho pararse en objetos blancos. Despues da principio la limpieza de su ha. bitacion cual si se estuviera en la vispera de una gran fiesta. Los cadáveres de las hermanas muertas, de los que siempre quedan algunos, se sacan fuera, $y$ remćdianse los desperfectos de los panales que exijan reparacion. El trabajo mas jenoso consiste sin embargo en recoger y trasportar los centemares de capas de cera, que han caido al suelo al abrir las celdas de miel. Ias expediciones empiezan á medida yuue lo permite el tiempo, cuando las Rores de los avellanos, de los ccrezos, de las margaritas, de las campanillas de nieve, en fiu, todas las graciosas hijas de Flora, ofrecen su corola a dulces. besos; pero no dura mucho esta actividad inusitada. Si el en- 
jambre no estaba demasiado débil à la entrada del invierno, y si no ha padecido mucho a causa del frio, el numero de individuos aumenta con exceso, el espacio es mur reducido, y se deben tomar medidas para reunir otro enjambre.

Cuando una vey se forma una nueva serie de celclas iguales a las otras por su forma y disposicion, 'pero mas grandes por su espacio interior, la reina deposita en él un huevo del modo descrito. I..3s irabajidoras proveen las celdas de ali. mento, y cuidan de la larva jóven hasta el octaro dia de su desarrollo, tapan la celdilla y la cubren, indo de la manera ya descrita El dia vigésimocuarto despues de la prtesta del huevo se abre la tapa, pero esta ve\% sale un macho mas gras. de cue la trabajadora, por lo cual csta le prepara una ceida mayor. Ia reina recunoce al examinarla, y sobre todo al in. troducir el abdómen en el espacio mas ancho, que alli debe depositar un huevo de macho, el cual se distingue de los puestos hasta entonces por no estar fecundado. En el arificio del oviducto interior se encuentran a los lados, en todas las hembras de insectos, segun hemos dicho yia, las bolsasesprer. maticas que en el apareamiento con el macho se llenan del licor prolifico: cada huevo ha de pasar por estas bolsas y se fecundiz.a. I a reina puede fecundarlo ó noà su antojo, yesto viltimo es lo que hace con todos los que sedepositanen las espaciosas celdas de machos, hecho maravilloso del que Dzier\%on liablú primero, y que fué demostrado cientificamente por Siebold.

En la colmena todo se complica cada vez mas: cunndo el número de los machos aumenta fórmase por lo regular en los bordes de los pamales una tercera especie de celdas, cuya cifra puede acrecentarse bastante; estas celdas estan dispucstas verticalmente, y son mas grandes y fuertes que las de los machos. I.a reina deposita en cada cual un huevo, no sin alguna resistencia, en opinion de algunos, pero fácilmente segun otros. I a celdilla encierra el mejor alimento, y al cabo de seis dias tiene ya una tapa abovedada, con la cual se cierra, ofreciendo entonces cierta analogía con el capullo de crisálida de ciertas mariposas: esta celda se uincuba» con mas aficion que las otras. Ias citadas diferencias, la nueva disposicion y forma de la celda, el mejor alimento y una temperatura subida producen tambien una diferencia en el desarrollo de la laria, gue al cabo de dier y suis dias es una hembra fecunda. Si la dejaran salir de su celda y la reina existiese aun se trabaria una lucha a vida $\delta$ muerte, porque dos hembras fecundas una al lado de otm no pueden existir. Esto lo saben muyg bien fos protectores de la jóven princesa y" por lo mismo no la dejan salir aun, ó por lo menos podemos hacer esta suposicion aunque 110 sea cxacta en todos sus casos.

Ia cautiva no pucde reprimir su enojo, y produce un sonido semejante al de una corneta, sicndo posible que tam. bicn sc oiga en la celdilla real. Tan pronto como la primitiva reina oyc aquel leve rumor comprende que ha nacido una rival y no puede ocultar su inq̨uietud; las trabajadoras sospechan tambien que se prepara un grave sucesoy forman en cierto modo dos bandos, compuesto el uno de las vicjas y el otro de las jóvenes. La inquietud sa creciendo de punto, porque predomina el espiritu turbulento de los muchos miles de individuos encerrados en la colmena, pues presintiendo que ha de suceder algo, muy pócos han salido, y reina por to tanto en el estrecho recinto un calor insoportable. Algunas abejas estál posadas en grandes enjambres y dejas oir fuertes żแmbidos á la entrada; las pocas que estan fuera vuelven cargadas no penetran como solian en el interior para desembarazarse de su carga, sino que se reunen con sus compañeras en la pueriecilla. En el interior continúa sienupre la agitacion: resuenan sin cesar los zumbidos de aquella multiund de insectos que llenan la colmena, y diriase quue al órden ha sucedido la anarquia. De pronto se precipita apresuradamente como un torballino en direccion a la salida, un enjanbre de 1,000 \& r, joo trabajadoras (viejas), entrc las cuales va lia reina; todas salen presurosas y forman como una nube que oscurece ol sol; al balancearse en los aires dujan oir un sonjido alegre y particular que se oye á mucha distancia: es el canto del crjambre. Unos diez minutos dum este espectáculo cediendo su puesto despues á otro: en la rama de un airhol vicino $\delta$ en un pedaro de cortema, que el dueño de las colne. nas ha colocado á este cefecto en una pértiga, ó ya en otra parte, fórmase pror in pronto un espeso inonton de abcjias, del tamaño de una mano, al que se agregan orns y otras, hasta que por fin todas se han reunido, constituyendo una masa negra en tigura de racimo, en cuyo centro estí la reina. Este es el enjambre principal que como todos los otros, los denjambres posteriores solo salen en dias hermosos, por lo regular al medio dia y no se alcjan a mucha distancia, porque la reina llena de hucros es demasiado pesada. Eil dueño de la colmena, adiernido ya por toda clase de indicios, tiene a mano una nueva colmena, en la que enciem cuidadosa. mente el enjambre, colosindolo en el sitio destinado para el. Fsta es la primera colonia, cuyo desarrollo se efectúa exactamente del modo ya indicado, con la diferencia de que la reina no ha de salir primero para fecundarse.

A los criadores de abejas les complace mucho qque los en. jambres saligan pronto, pues entoncés la colonia puede reforzarse mejor y recoger abundantes provisiones de iuvierno, no necesirándose entonces el alimento artificial, siempre caro. De aqui el antiguo proverbio: \&un enjaubre en mayo vale una carga de hero; un enjambre en junio, una galliua gordn; pero un enjambre en julio no vale ni el tallo de una pluma Volvamos a nuestra colmena, de la cual acaba de salir un enjambre con la reina vieja. Úua reima jóren sale de su celda y es recibida por el partido que antes se habia formado en su favor, con los debidos honores. Como urimogénita seria sin duda la duciá, porejue la madre la abandonado el cam. po, pero hay otras rivales con la misma preiension, y no se sabe cuál será el resultado. A los tres, siete ó nueve dias puèden salir enjambres posteriores, de los que el último es el mas débil ó bien el primer enjambre q̨ueda pror único dueño, pern sea cual fuere el caso, siempre hay eadiveres porque dos rejnas al mismo tienuo en una colmena no son posibles; todas excepto una, son muertas por las tmbajadoras si no se forma oiro enjambre; en casos muy raros se decide la cuestion por un desafio entre las dos pretendientes. Huber nos cita uno: Ambas reinas habian salido casi al mismo tiempo de sus celdas, y apenas se vieron precipitironse furiosamente una sobre otra, encontrándose de modo que una sujetaba con las maxilas las antenas de su adversaria, oprimiendo cabcza conera cábezá, pecho contra pecho y abdónen cuntra abdómen, de manera yute no necesitaban hacer otra cosa sino encorvar la extremidad de este último para matarie las dos: pero no sucedió asi; ninguna tenia ventaja sobre la otm, se soltaron y: cada cual retrocedió. Al cabo de pocos minutos se repitió el ataque del mismo modo y con el mismo resultado, hasta qute por cierta evolucion lat una cogió el ala de la otra, subió so. bre clla é infirióle una herida mortal. A lin de averiguar si las reinas ya fecundadas eran jgualmente furiosas, el obstrvador puso wna en una colmena donde se hallaba otra de igual condicion. En seguida se formó un circulo de abejas atrededor de la inirusa, mas no para ofrecerla sus homenajes sino para impedir que se escapara. Mientras tanto se reunió otro grupo alrededor de la reina legitima, y teniendo en cuenta las demostraciones de respeto y carino que suelen dispensar à su soberana legitima, y a causa de la desconfianza que al principio inspira una reina desconocida, aunque hayan 
perdido in suya, podia suponerse que no las dejarian empeñar un duelo, sino que se reunirian para defender al jefe de su estado; pero no sucedió asi: los ejúrcitos no debian combatir por sus soberanas; queriase que estas diriniesen la contienda de por sí. 'Tan luego como la reina legítima se preparó al ataque, avanzando hácia la parte del paunal donde estaba su enemiga, las abejas se retiraron dejando libre el espacio entre ambas; la reina se precipitó furiosamente sobre la intrusa, la cogió por la raiz de un aln, oprimióla contra el panal de modo que no pudiera moverse, y la mató con su aguijon. Las observaciones de fluber son demasiado concienzudas para que se pueda desconfiar de su relato; puede haber visto to que dice, pero es un caso aislado y no una regla generál. Io que sí sucede es que algunas trabajadoras suelen cercara una segunda reina cuando entra en una colmena, y entonces la matan sin mas cumplimientos.

Un enjambre posterior suele alejarse í mas distancia atendich la mayor ligereza y agilidad de la liembra no fecundada, siendo entonces necesario que cl amo vigile mas cuidadosaménte, pues de lo contrario, el enjambre emprenderia mas tarde el vuelo desde el sitio donde sé reunió para instalarse en un árbol frueco, en la liendidura de un muro ó en otro sitio conveniente. De antemano salen algunas abejas exploradoras, como aposentadoms, para buscar un cuartel convenien. te. Enll libertad, csic enjambre perece pronto, ya en otoño S en invierno, aunque no faltan pruebas de que, en condiciones favorables, se ha coniserndo muchos anos en estado salvinje.

Fin muy mos casos sale, además de los citados enjambres, uno de trabajadoras, cuando otro posterior, habiendo salido muy pronto, aumenta tan rápidamente, que durante el verano puede producir otro cnjambre.

Ya hemos visto cual es el curso regular de la vida de un estado de abejas; pero hay tambien algunas irregularidndes, sobrado curiosas para que las pasemos en silencio.

Supongamos que ta colmena por cualquier casualidad pierde su reina, y que por falta de la progenie real, no tenga espermazas de obencr otra. Entonces pueden suceder dos cosas: $\delta$ cuando ocurre la desgrncin, hay celdas de cria no tapadas, con huevos $\alpha$ latras, $\alpha$ bien están todas cubiertas. En el primer caso, se trassoma en celdilla real a toda prisa una celda que contengá un huevo o ma larva muj jóven; quitanse las paredes, $y$ las celdas inferiores para ganar espacio, y arréglase al punto la forma redonda y la disposicion vertical. La larva toma el alimento real, y los esfuerzos no quedan sin resultado, pues en el tiempo oportuno sale una hembra fecunda de la celda tmsformada. En otro caso, es decir, cuando todas las celdas estaban ya tapadas, la cosa es mas intresesante aun. Una trabajadora fuerte y lo mas grande posible ocupa el trono; la eximen del trabajo, la cuidan y alimentan bien, y tribútanla los mismos homenajes que a una soberana de estirpe real. Pronto empieza la puesta de los huevos, y estos se desarrollan por el descanso y el cuidado porque la elegida denuestra que es propia para sus funciones. Pero ayy! solo existen huevos de macho, porque les falta la fecundacion; las larvas gue de ellos nacen, no tienen sitio en las peçueñas celdas, y estas han de cerrarse con una tapa muy convexa. 1.0 mismo sucede en otra colmena, cuya reina no ha llegado á fecundarse; pero ni esta, ni la trabajadora dejan por eso de ser atendidas, porque si falasen el pueblo no podria cumplir con sus obligaciones.

Fil fenómeno por el cual una trabajadom infecunda, ó una hembra no fecundada, pueden poner huevos, de los que nacen sin embargo abejas, hecho observado en otros insectos, sobre todo en algunas mariposas, y que en los otros himenópteros sociables, como las avispas y hormigas, se repite mas á menudo que en la abeja doméstica, fué designado por Siebold con el nombre de partenogimesis (reproduccion virginal). Aristóteles conocia muy bien este fenómeno en la abeja do. méstica, pues dice lo siguiente: 1 los machos se forman tanbien en una colmena sin reina. I a cria de trabajadoras no se produce siempre. Las abejas pueden tener machos sin apareaniento.

Cuando se da un golpe en una colmena que tiene su reina, byese un rumor queal momento cesa, mientras que en aquella que ha perdido su soberana resuena un zumbido muy duradero: esta colmena perece pronto si el dueno no presta su auxilio, proporcionándola una nueva reina.

Mucho podria decirse aun acerca de estos interesantes insectos, particularmente de ciertos rasgos de su vida, que revelan un sencillo "instinto, si no cierta inteligencia, porque estan fuera del limite de las costumbres y de las preocupaciones innatas; pero no debemos darles demasiada preferencia entre tantos otros congéneres, cuyas condiciones vitales apenas nos ofrecen menos particulariciades notables. Solo añadiré que respecto al color del cuerpo, se pueden distin. guir seis variedades: la ya descrita, de un solo color oscuro, es la abeja septentrional, diseminada no solo por todo el norte de Europa, donde hasta hace pocos años era la única, sino que tambien por el sur de Francia, España, Portugal, algunas regiones de Italia, Dalmacia, Grecia, Crimea, islas del Asia Menor y sus regiones costeras, Argelia, Guinea, el Cabo y una gran parte de la América templada. Ia abeja italiana (apis ligustica), tiene la base del abdómen de un pardo rojo y las patas de un rojo viro. Se encuentra en las regiones septentrionales de Italia, en el Tirol, Suiza italiana, y se importó con un gran número de colmenas en Alemania. Una variedad que de la anterior se distingue por el escudete amarillo hállase en el sur de Francia, en Dalmacia, Croacia, Sicilia, Crimea, en las islas y el continente del Asia Menor y en el Cáucaso.

La abeja egipcia (apis fasciafa) (fig. $3 \hat{3}$ ) tiene el escudete rojo con pelos blancos, habita en Egipto y está diseminada en Sicilia y la Arabia, hasta el Himalaya y la China Las socie. dades de aclimatacion la han importado últimamente tambien en Alemania. La abeja egipcia se confunde insensiblemente con la especie africana (fig. 34), que á excepcion de Argelia y del Egipro habita en toda el Africa; y por último, la-abeja muy negra de Madagascar vire solo en esta isla y en Mauricio. Fn Cachemira, donde todos los agricultores tienen colmenas dispuestas de cierto modo en las paredes de la casa, la abeja es mas pequena que la nuestra y probablemente otra especic, la cual vuelve á encontrarse en una parte del Pendjab.

Ilambien se halla en las montañas meridionales otra abeja mas grande que la nuestra, que forma numerosos enjamtres, pero su micl tiene propiedades venerrosas.

\section{LAS MELIPONAS-MELIPONA}

En los paises ecuatoriales, sobre todo en el Brasil, en las islas de la Sonda y en la Nueva Holanda, viven numerosas especies de abcjas salvajes que en el primer pais se conocen bajo el nombre genérico de abellas, y sin necesitar la inter. vencion del hombre te proporcionan ricas provisiones de miel cuando sabe encontrar sus nidos.

Muy extraño es el medio de que se valen para esto los indigenas de la Nueva Holanda: cogen una abeja, adhieren á su cuerpo una plumita blanca, vuelven a soltarla y la persiguen en su vuelo aunque sea al través de las mas enmaranadas espesuras. A pesar de que muchas veces tropiezan con una presa de tal género, segun se dice, raras veces 
pierden de vista la abeja señalada, encontrando entonces el nido como prenio de su trabajo.

Las méliponas, como acquellas abejass se llaman en el len. guaje cientifico, tienen de comun con nuestra abeja doniés. tica la falta de la espina en los tarsos posteriores, pero se distinguen en todos los otros camctéres esencialmente, y son tambien mucho mas pequeñas. Sobre todo carecen de aguijon; si una de estas abejas quiere defenderse se sirve de sus luertes maxilas. El ala anterior tiene una célula radial, no del todo cerrada en su parte anterior, y carece en rigor de la célula cubital, porque los nervios trasveriales faltan del todo ó son poco marcados; dos células discoideas son cerradas. En algunas especies las alas de la reina parecen atrofiadas. Fi metatarso carece de gancho y es mas corto que el tarso; en varias especies el aboiómen es convexo por arriba, apenas aquillado en el vientre (melipona; en o:ras, corto, triangular y aquillado por debajo (trigona); y hay un grupo, en fin, en que se prolonga y es casi cuadrangular (telraguma). Ia cera preparada en el interior no salc de entre las escamas abdominales, como en nuestra abcja doméstica, sino de entre las escamas dorsales. Los machos se parecen mucho a las trabajacioras por su color y forma, pero no tienen órgano recolector; las garras son hendidas. Ins hembras fecundadas, que solo se conocen en algunas pocas espucies, distinguense por su mayor tamaño, color pardo, etc.

Además de algunos informes nuy incompletos sobre las abejas sin aguijon de la América del sur, poseenos deste hace poco tres relatos minuciosos debidos a Bates, Drory y H. Mueller sobre esns especies. Sin tomar en consideracion el numero extraordinario de las que se citan, hemos entresa. cado de estas noticias lo que nos parció conveniente para el fin de nuestra obra.

Las mcliponas construyen sus nicios con preferencia en troncos huecos, pero tambien en las grietas de las orillas cscarpadas, y en nidos de térmites, cerrando las hendiduras y otras aberturas excepto un agujero de entrada, sobre cl cual á menudo se encuentra una especie de tubo ó de entbudo. Pari csta y pam otris partes interiores del nido no emplenn In cera, simo sustancias vegetales, resinosas y otras, como las usa tambien nuestra abeja doméstica, pero prefieren el harro. Listos materiales de construccion se recogen con los mismos órganos con que toman el pólen, es decir, con las patas posic. riores. A menudose ve un grupo de trabajadoras que con una agilidad increible se afanan en una superficie de barro para armncar con las maxilas la capa superior. Los montoncitos pequeños que asi forman se reunen por medio de las patas anteriores $y$ se fijan con las centrales en las posteriores; cuando la carga es bastante ligera para que la abeja pueda llevarla aléjase con ella. Ia aficion a buscar los objetos útiles es tan mareada en estos inscctos que puede degenerar facilmente en tendencia al saqueo, como en nuestra abejia doméstica. Drory tuso ocasion de obsernar esto, porque hace muchos anos que posee ineliponas, las cuales le envian anualmente del Brasil. Una vez nuandó barnizar el interior de su casa de abejas, dejando abiertas las ventanas para que se secara mas pronto. Ia melipona scutellaris se aprovechó do estas circunstancins, ocupandose duranie acho dias en rascar en muchos sitios el barnir, para llevársele con sus patas posteriores. Otra especie (trigona flaceola) invadió con miles de sus compañérus varios panales de la abeja domésti$\mathrm{cr}$, cargó la cera en sus patas posteriores y robó la micl, sin que ninguna de las abejas saqueadas se atreviera a defender su propiedad. Mucho divicrte, segun se dice, su aficion y șu modo de proceder en la construccion de sus viviendas, pues entonces ambien se roban unas á otms. Cuando una teme que la quiten su cargn, vuélvese rápidamente, haciendo frente. al ladron y produce un zumbido ronco, agitando con fuers. las alas.

Por lo que tocn a la fabricacion de la cera en el intcrior del nido, difiere esencialmente de la de la abeja doméstica, ofreciendo las celdas jarn la cria y las de las provisiones un marcado contraste. los panales pueden compararse en su construccion con el nido invertido de nuestra abeja comun, pues unos pamales sencillos, compuestos de celdas abiertas por arriba, se sobreponen en forma de pisos, uniéndose entra si por medio de columnitas. Mas bien por su estrecho contacto que por su construccion primitiva, las celdas afectan la forma de exigonos, pues las de los bordes tienen una figura cilindrica mas ó menos regular. Las de los machos no difieren de las que pertenecen a las trabajadoras; solo las celdas de las hembras fecundas sobresalen por arriba y abajo í cau. sa de su longitud. Las provisiones de miel y de alimento de abejas (pólen con miel) se recogen en celdas particulares que por término medio tienen la forma de un huevo de pajaro y se aplanan solo en los puntos de contacto; se componen de paredes gruesas de cera, que se enlazan con las del nido jor fajas sólidas del mismo matcrial, variando su tamano seyun In especie. Estas dos partes principales de un nido de meliponas, no presentan, aunp̧ue sean de una misma especie, la igualdad de las construcciones de la abcja doméstica y mas aun varian en el plano mismo de la construccion en varias especies. Drory, fundandose en las observaciones hechas hasta ahora, distingue en sus once especies tres diferentes planos de construccion: I. Los panales de la cria y las reldas de miel estin rodeados juntos de uma capa de cer: escamosa ó membranosa, de modo que desde fuera no se ve nada mas que una gran bolsa de color pardo oscuro (otra semejanza con los nidos citados de nuestra avispa comun). 2. Solo las cetdas de cria estain rodendas de este manto, mientras que las de la miel se encuentran libremente en el espacio del nido, como por cjemplo en la melignen soutellaris, llamada por los indigenas abelka urussu. 3." La trigena cilipis no construye ni manto ni pisos de pamales de cria, sino que deposita sus hucros en celdas aisladas y redondas, reunidas entre si como las uvas de un racimo, rodeando esic cxtrano laberinto las celdas de la miel. Debemos contentarnos con estas indicaciones; quien desee adquirir mas detalles deberi cxaminar los dos vílimos informes arriba citados aunųuc tampoco en iellos encontrará detalles en extremo minuciosos.

Otm diferencia de la reproduccion de las meliponas y de nuestra abeja doméstica y una analogia completa de aquellas con otras abcjas solitarins, consiste, segun mis tarde veremas en la circunstancia de que cada colda se llema por las trabajadoras de alimento de abejas antes de que la hembra deposite un huevo en ellas. Encorsando los bordes salientes hicia ndentro, la celda se cierra despues por las trahajarinras. lina vez nacida la abeja jóven, lo cual se efectúa del mismo modo que en la especie doméstica, las paredes de las celdas que acaban de vaciarse se deseruyen para echarlas al monton de excrementos de los quie el nido, poco aseado, siempre conticue varios, ó hien se emplean para otros trabajos. Dichos montones se componen, ademas de la cern y de los excrementos de las abejas, de los cadiveres de los individuos muertos en el nido: cuando aumentan demasiado de volumen se sacan fuera poco à poco. 'Tambien las culdas de jrovisio. ues se destruyen por lo regular cuando se han vaciado $y^{\circ}$ construifense otras nuevas. Muller cree que esto lo hacen porque la cera fäcilmente se pierde cuando se mezcla con otra sustancia. Ën los informes arriba citados solo se habla de una reina para cada Estado, encargada exclusivamente de la puesta de los hueros, mientras que todos los demis yue. haceres se desempenan por las trabajadorts. 
Dichos relatos no indican nada sobre el proceder de los machos ni de sus excursiones pam el apareamiento. De una noticia de Saint-Hilaire resula como probable que este últi. uno no se verifique; el citado autor habla de cierta domesticacion de algunas usprecies, ņue segun las últimas experiencias han aumentado mucho, y con este motivo cita tambien un medio del que se valen los irdigenas para aumentar los nidos de meliponas: cuando estas salen para hacer sus provisiones sacan algunos panales con lasias y hueros, y colocanlos en una nueva colmena, perfumada de antemano cuidadostmente con incienso. Una parte de las abejas toma posesion de la nueva vivienda, y esta se llena tronto de nuiel y de cera.

Ademas de las diferencias ya cindas en la construccion del nido, obsérvase la major rariedad respecto al tamaino del cuerpo, las fornias, las costumbres, cte.j entre las nume. rosisimas especies. - Mrientrasriguelas unas guardan silencio y se retiran timidamente tan luego como se da ungolpe con tra el irbol ó el cajon que habitan, otras se inuestran muy yalerosas, colocando centinelas en la entrada de su nido: estas ultimas, ya grandes.o pecueras son poco tolerantes cuandó una abeja, una avispa $\delta$ un individno extraño de su pro. pia especie llega para examinar la entrada de st vivienda, $\delta$ cuando un hombre se acerca ras de lo que desean. Ias especies pequenas se precipilan al punto en mayoria solbre el supucsto agresor, y una vez cogido. ambas partes están perdidas, pues los defensores no suchan nunea la presa y mueren á menudo con el enemigu. Cuando un pequeno insecto, y hasta una abeja doméstica seacerca to una especie grande de melipionas, una sola centinela se opone al enemigo, cógele por el vientre ó por el dorso, se agarra con sus patas, 6 in. troduce furiosamente sus afiladas temazas en el cuello entre el tórax y el abdómén. En sano la abeja domésica, aunque mas grande, intenta hacer uso de su nguijon; su cabeza y el abdónaen caen pronto, y la meliprona se aleja como rencedora, sucumbiendo solo raras veces. En una reunion de criadores de abejas de Alemania y Austria yue desde el 16 al 18 de setiembre de 1874 se verificó en Halles, Drory presentó una raja con meliforias squtellaris: como el tiempo en magnifico y caluroso, las meliponas abandonaron su prision y volaron entre numerosos cujambres de la aboja doméstica, matando varias reces algunas abejas al vuelo. Las especies salvajes se precipitan al punto sobre el hombre que se acerca à su nido ó que les roba la miel; se le agarmn al rostro, al cabello $y$ à las orejas; producen un aumbido que irrita los nervios y despiden a reces un olor muy agucio que lias:a causa vértigos y vómitos. La picadura, apenas visible, produce algunas horas despues un escozor que nada calma, y al dia siguiente se ve en el sitio una vejiga de agua del tamano de un guisante, rodeala de un borde nuy encarnado; esta vojiga desaparece pronto, pern el color rojizo de la picl se conserva olgunas scmanas. Fstos dos últimos ciectos son causados particularmente por la prequeña trigrona fina'cola. No por el humo, sino por una permanencia de varias horas en una bodega fresca, se consigue domesticar al fin a las meli-

No solo constituyen estas esfecies por su género de vida un transito entre los himenópieros sociales y los solitarios, sino que ofrecen además muchas particularidades no mencionadas aqui, resultando de una continuada observacion que existen muchos juntos de contacto entre los dos citados grupos de himenópteros. Las observaciones deben hacerse, no obstante, à la otra parte del Oceano, pues segun la expe. riencia obtenida hasta ahora, la Europa serviri dificilnente de patria a las meliponas, que necesitan una temperatura mas constante y subida que la que ofrece nuestro conti-
nente.

\section{LOS ABEJORROS-BOMBUS}

Los ahejorros, torpes y ruidosos, los «tipros gruñones\%, se. gun los llama landois, esos insectos que anidan en cavidades subterráneas, no son nada en rigor si se comparan con las abejas en sus grandes ciudades, si se comparan con las avispas y avispones en sus castillos de papel y de carton; y a pesar de eso stu sencilla vida caumestre, las pecpuenas sociedades que forman y las chozas subterráneas ocultas en cuyos recintos habitan pacificamente, ofrecen bastante poe. sia para ocuparse de estos insectos mas minuciosamente. Su estado, ó quizás mejor dicho, su familia, es, segun se dice, mas compacta aun que en las abejas, porque se han visto juntas hembras grancies y pequenas, siendo debido el poco desarrollo, en mi opinion, à la escasez del alimenta.

Todos cieben su sér à una madre que ha logrado pasar el invierno sin perder la vida, nque oculta en su seno maternal los embriones de su futura progenie, y que espera la resurreccion gencral del año próximo para saludar la primavera. En las fores del sauce y en las otras jrimeras fores dal año nuevo, se presentan con otras companeras hambricntas, entomando un alegre concierto que se reduce à sordos zumbidos, pero los cuales no puede imitar ningun insecto de la especie. Hosados perezosamente en las flores, dice un au. tor, sicmpre estain zumbindo; y parece que no se ocupan de otra cosia

Sin embargo, no dejan de afanarse como las abejas, pues el misno trabajo sirve de recreo á los abejorros. Un antiguo nido abandonado, un monton de tierra no ocupado aun por las hormigas, la galeria tortuosa del topo ó un agujero de ratón bastan á estos insectos para construir al punto las viviendas que necesitan. Segun la especie prefiérese uno ú otro sitio; pero todas unieren tener una entrada oculta y cómoda. Fon este nido depositan la miel mezclada con aburdancia de pólen, en inontoncitos y sin arte alguno, en lo cual se recono. ce desde luego una diferencia esencial entre los abejorros $y$ las abejas. Aquellos nada saben de arquitectura, ni construyen celdas para su cria, ni despensas para la micl; en aquel montoncito la cuidndosa madre deposita algunos huevos: cuyo numero aumenta a medida que el monton crece, siendo de suponer que el trabajo se apresura ó se retarda segun que el tiempo sea mas $\delta$ menos farorable. Tan luego como las larvas han salido de los huevos, penetran en la masa alimenticia y abren algunos espacios; las paredes se adelgazan mas y mas pror su actividad, pero nucvas masas de pólen sustituyen desde fuera lo que en el interior se consume. Las larvas, muy parecidas d la de abeja, crecen ripidaucnte y tc. jen al rededor sujo un capullo vidrioso y cerrndo. Todos estos capullos, puestos sin órden uno al Jado del otro, ó rellnidus entre si mas estrechamente, segun el mayor ó menor número de las larras de igual edad, se consideraron durante mucho tiempo como las celdas de los abcjorros; cuando están vacios y abiertos por arriba por sus habitantes, se llenan a veces tambien de alimento para que este no falte en los dias malos. De los capullos de crisilida, al principio nacen trabajadoras que siempre se conocen por su mayor pequeñez. Ayudan enionces a su madre, traen alimento, reunen los capullos uno con otro, cubren algunos puntos del hido con una capa resinosa, presentando en esta circunstancia una particularidad el abejorro del musgo. En una palabra: su actividad no acaba nunca. Desde muy temprano por la mañana hasta por la noche, estos insectos zumban sin cesar: en dias lluviosos, cuando todos los demás insectos se ocultan ó se entregan al sueño, el abejorro zumba de for en flor, y poco le importa pasar la noche en una corola, esperando que jase la tempestad $\delta$ el aguacero. Wahlberg los vió trabajar en el w:- 
tremo Norte, en la Iaponia y Finnmark durante las noches claras de verano; y hé aqui por qué el calificativo de epere. zosos que les atribuye la poesia solo puede referirse s. los movimientos mas pesados y rorpes de los abejorros en coin. paracion con los de las abcjas mas vivaces.

Mas tarde, al cabo de un ano, preséntanse hembras mas pequenas que solo depositan huevos de machos; despues aparecen estos, y por último, hácia el otono, hembras grandes, destinadas á invernar. Si fuera posible observar tan cuidadosamentc los nidos de abejorros como las colmenas de abejas, quizas se confinnaria lo que dice Goedart, à saber, que cada nido tiene una especie de corneta que por la manana sube al techo, mueve sirs alas y jroduce ciento ruido durantc un cuarto de hora, para llamara los habitantes al trabajo. En general conoceriamos mas particularidades de la vida de estos himenúpteros que aun no se han estudiado bien. La miel, por ejemplo, que se la encontrado en los ca- pullos vacios, parece destinada para criar la madre real de la larsa, pues debe suponerse que necesina mojor alimento que los demis individuos de la familia.

Entre las hembras grandes $y$ la madre primitiva ocurren al principio, segun parece, algunas disputas, pero terminan sin rejertas. No se sabe si la hembra primitiva vive siempre cuando se presentan las gmandes; yo creeria lo contmario. En una familia de cien individuos sucle haber unos reinticinco machos, quince hembras y el resto son irabajadoras. 1)esde mediados de setiembre hasta la primera quincena de octubre se aparean las hembras grandes; en cualquicr sitio algo elevado esperan, cuando brilla el sol, a qque se acerque un macho, el cual cac rendido en ticra despues del apareamien. to y muere. Tambien los demás individuos de la comunidad sueumben poco a proco, y solo las hembras grandes conservan la vida durante el invierno. Huber refiepe una bonita hisioria en la cual se da a conocer la buena indole de los

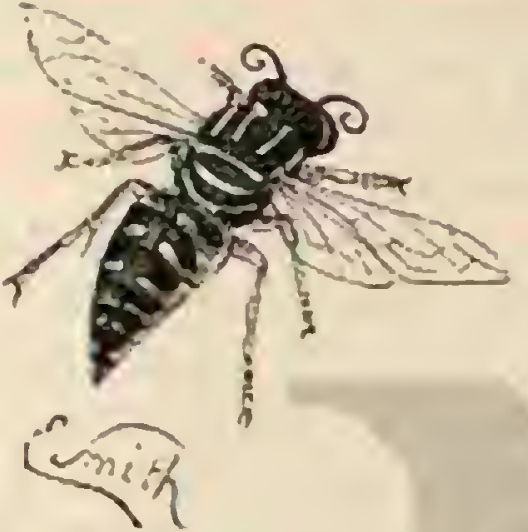

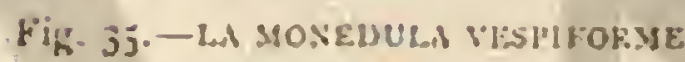

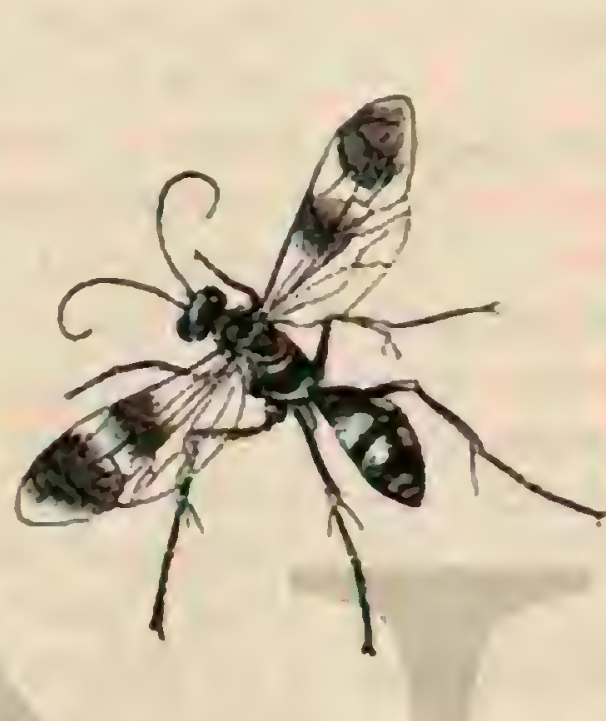

Fig: $36 .-E L$ TOMBJLIO NOBLE:

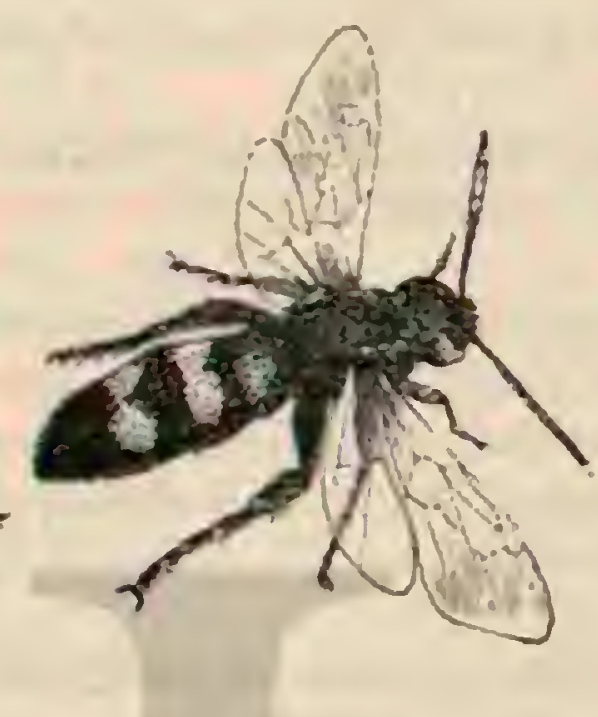

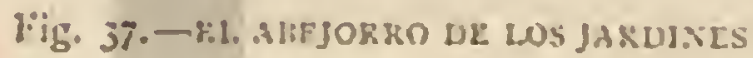

abejorros y su proceder con sus enemigos. En una caja babia colocado, debajo de una colmena de abejas, un nido de abejorros. En tiempo de escasez, algunas de aquellas robaron las pocas provisiones del nido de los segundos, ýa pesar de ello, estos úlimos siguieron trabajando sin descansar. Otro dia, cuando las abejas regresaban à su vivienda, siguiéronles y no se alejaron hasta que les sacaron el poco alimento que llevaban. Llamaron à los abejorros, presentáronles su trompa, los rodearon, y lograron por fin que repartieran con ellas el contenido de su vejiga de micl. Los abejorros volvieron a salir y a la vucita se presentaron tambien las mendigas. Mas de tres semanas habia durado esto, cuando tambien las avis. pas se presentaron con la misma intencion que las abejas, pero entonces los abejorros, cansados de tanta impertineszia, no volvieron ya à su nido.

A pesar de su vicia oculta, haj bastantes intrusos que pinetran en los nidos de dichos insectos, sin hacer mencion de las aves que se apoderan de ellos para comerlos en seguida ó para clavarlos en espinas. El gran raton campesino, la comadreja y la garduna son los que destruyen major número de nidos, en los que habitan además muchos parasitos que se alimentan de las provisiones ó de las larms, como por ejemplo algunas moscas (áolucelln, myopa y conops), las cuales conoceremos mas tarde; las hormigas arncnoides (matilla): las larvas del colcóptero del aceite y otras. L os abcjorros mismos están habitados por una mita que ya hemos conocido a hablar de los necróforos y jeloteros.

Tolos mis lectores creen quizas conocer bastante los abcjorros para no confundirlos con otros congéneres: el cuerpo pesado, y los espelos pelos, regularmente negros, cortados a veces por una faja roja $\delta$ blanca, son en su opinion caracté. res del todo infalibles. ¡Pero puco a poco! Hablaremos mas tarde de algunos abejorros, que si bien tienen el mismo aspec- to, viven de un modo muy diferente; y tambien hay abejas que el profano en la ciencia confundiria sin duda con dichos insectos. Es preciso, por lo tanto, fijar la atencion en los si. guientes caractéres: los abejorros tienen formas esencialmente análogas a las de los appidos, con la única diferencia de que los anchos tarsos posteriores estan provistos de dos espinas en su extremidid y de que los metatarsos tienen en vez del dientecito un gancho bien formado. El órgano recolector de las pratas pusteriores solo es propio de las hembras y trabajadoras; la lengun es larga, y si se estira aleanza, cuando menos, la longitud del cuerpo; los dos primeros artejos de los pal. pos labiales la encierran como en un tubo, pero atendido que los dos siguientes se dirigen en forma de cortos npéndices, los pralpos labiales deben designarse como tales de doble forma; los palpos maxilares, en cambio, son pequeños y de un solo artejo. En la coronilla se ven los ojuclos eñ una linea recta. El ala antenior tiene el unisino múmero de celdillas yue en la abejia doméstica, pero la celda radial es mas corta y en su parie anterior mas angosta: la tercera celdilla cubital se estrecha mas hacia el borde anterior del ala que hácia aden. tro y remata posteriormente en forma de arco. Eil macho, mas pequeño y' delgado, se reconoce como tal por su cabeza, mas pequenia, y sus antenas largis, que a causa del corto tallo apciras parecen angulares, y por el abdúmen, mas cstrecho. las patas pusteriores carecen del órgano recolector y de los ganchos de los nietatarsos, presentando en la cara posterior largos pétos. Tas mas pequenas de todo el grupo son las hembras que tienen atrofiados sus organos sexuales; en cuan. to i lo demias, por su estructura y color son enteramente analogas a las hembras fecundas, grandes ó periueñas. El macho ell cambio difiere bastante de la hembra respecto del color, lo cual ha producido gran coniusion en los nombres. Ia vida de estas especies obscrvada cn un mismo nido debió dar á 
conocer por fin lo cierto, pudiéndose entonces corregir las faltas cometidas.

\section{EL ABEJORRO TERRESTRE-BOMBUS TER- RESTRIS}

CARACTÉRES. - Los pelos negros del cuerpo de esta especie, mas comun, se merclan en los tres últimos segmen. tos del abdómen con otros blancos; en el segundo y en el collarin los hay amarillos en forma de fajas. Las tre's formas tienen exactamente el mismo color, solo que en el macho se hallan á veces enere los pelos de la cabeza algunos blancos y la parte amarilla del abdónen no se limita marcadamente al segmento. El tamaino, no obstante, difiere mucho; la hembra, bastante ancha, tiene li", 026 y mas de largo; of macho

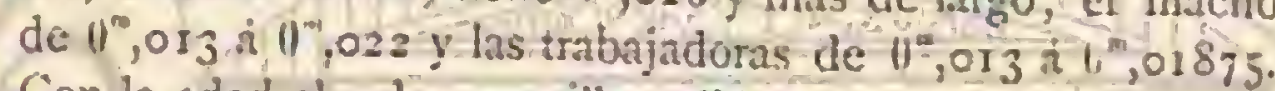
Con la edad el color amarillo palidece mucho.

DISTRIBUCION GEOGRÁFICA. - Ia especic está diseminada por toda la Euroja y el norte del Africa.

\section{EL ABEJORRO DE LOS JARDINES-BOMBUS HORTORUM}

CARACTERES. - En el abejorro de los jardines (fig. 37), que tiene el mismo tamano y timbien in extrenidad del abdómen blanca, el collarin, y casi siempre el escudete y el primer segmento del abdómen son amarillos, pero la parte posterior de aquel negm.

\section{EL ABEJORRO DE LAS PIEDRAS-BOMBUS LAPIDARIUS}

CARACTERES. - Esta especie, del mismo tamaño que las anteriores, tiene un bonito color negro, con los tres últimos segmentos del abdómen de un rojo pardusco. En los machos, la cabeza, la parte anterior del dorso y el pecho, y á menudo tambien el escudete, son amarillos; los pelos de los tarsos posteriores rojizos.

\section{EL ABEJORRO ORIENTAL-BOMBUS ORIENTALIS}

CARACTERES. - El abejorro oriental (fig. 33 ) tiene el coselete amarillo por encima y los lados con una faja entre las partes inferiores de las alas; los dos primeros segmentos del abdómen son amarillos: el tercero negro; los dos últimos y el ano rojos. Lais alas, asaz trasparentes, son un poco ahumadas hácia la extremidad. La hembra mide diez linens de largo.

El macho ofrece varios pclos amarillos en la parte inferior de la cara y en la superior de la crbeza; el sexto segmento del abdómen es rojo. Solo mide unas seis lincas.

DISTRIBUCION GEOGRÁFICA. - la especie ha sido observada sobre todo en los Pirineos, particularmente en la parte oriental.

\section{EL ABEJORRO DE LOS MUSGOS-BOMBUS MUSCORUM}

CARACTERES. - El abejorro de los musgos es del todo amarillo; el tórax y la base del abdómen tienen un tinte rojizo, y en usta última se mezclan tambien algunos pelos pardos y negros: el resto del abdómen es de un amarillo mas claro. Con la edad palidecen los colores, todo el insecto adquicre un rolor blanquizco. La longitud varia de $0^{\prime \prime}$, or 8 i5 á $0^{\prime \prime}, 022$.

USOS, COSTUMBRES Y REGIMEN.-Este abejorro debe su nombre à la costumbre de cubrir el nido con una ligera capa de musgo y de hojarasca. Con alguna precaucion se puede coger y entonces se ve que toda la construccion se asemeja á un nido de pájaro, en el que los capullos de las crisálidas se hallan en forma de huevos, sin órden alguno, pero pegados uno al otro. Mientras el observador aun esta léjos del nido, los animales vuclven á recoger el musgo y cada individuo trabaja entonces sin distincion de sexos. Para llevar el material duro le armstran; tres ó cuatro individuos se colocan uno detrás ciel otro, el mas distante coge un pedacito con las maxilas, to extiende con las patas anteriores lo empuja por debajo del cuerpo para que el segundo par de patas lo coja y entregue al tercer individuo, que lo acerca todo lo posible al nido. Otros dos ó tres abejorros trabajan del mismo modo en el montoncito de material hasta que este llega al nido. Aqui hay otros individuos que ya esperan para partir con sus dientes y patas anteriores el material y oprimirlo contm el nido. De este modo se forma poro á poco una bóveda de $0^{\mathrm{n}}, 026$ á $0^{\text {"t, }}, 052$ de espesor. Esta manera de construir un nido solo es pusible alli donde el material se halla en las inmediaciones. Las partes interiores se cubren con una nasa resinosa del grueso de una hoja de papel. La entrada del nido, prolongada á menudo en forma de galería, sucle estar guardada por un centinela, que debe rechazar a las hormigas $y$ otros insectos.

Además de un numero muy crecido de especies que habi. tan la Europar, en ambas mitades del continente americano, un Asia y Africa, viven otras especies que por la forma del cuerpo y los colores se distinguen poco de las nuestms, nunque siempre se reconocen sin dificultad como afines.

Intre las abejas sociables hasta ahora descritas figuran las que recogen con los instrumentos antes citados. Estas abejas viven solo apareadas y carecen de las hembras no desarrolla. das como trabajadoras, porque las fuerzas de cada hembra bastan para el cuidado de la cria.

\section{LOS. PODILEGIDOS - PODILEGID}

CARACTERES. - Los podilegidos se asemejan por la forma de sus patas posteriores à los abcjorros, $y$ las hembras estản provistas de órgano recolector; en muchas especies de nuestros paises falta este y el tarso posterior esta cubierto de largos pelos como el metatarso. Estos últimos se han trasformado en el cepillo mas arriba mencionado. Las maxilas son rectas, provistas en la superficie de impresiones irregulares en forma de puntos y en la cara posterior de un solo diente. La lengua, casi cilindrica, apenas sobresale de la cabeza en estado de reposo; estirada es mas larga que todo el cuerpo y tiene In forma de la de las abejas; los palpos labiales ticnen dos formas.

USOS, COSTUMBRES Y REGIMEN.-Ios podilegidos construyen, como otras abejas solitarias no parisitas, celdas de diferentes materias, pero no de cera; las llenan de alimento suficiente de una mezcla de micl y de pólen, las depositan encima y ciersan la celda. Cuando su larwa ha pasndo por ta metamorfósis, sale unos once meses despues de la puesta del huevo la abeja perfecta, pero no encuentra un cuidado tan carinoso como las abejas domésticas y los abcjorros. Los machos que nacen primero, se encuentran en las fores, donde buscan su alimento y alguna hembra. 'Tambien esta abandona el sitio donde nació, y muy pronto se desorienta. El carino mutuo no es cosa desconocida en las diversas especies, pero el macho muere despues de aparearse. La hembra fecundada necesita aun bastante tiempo para cuidarse de la progenie. Si la cosecha de la miel es abundan- 
te, el rerano hermoso y el trabajo adelanta, la hembra puede preparar una numerosa descendencia; pero cuando la ternpe- ratura es fria y la obliga á permanecer en el nido. impidien. do la construccion, esta adelanta lentamente y el tiempo no se puede aprovechar, la hembra ha puesto solo un reducido número de huevos cuando la muerte la sorprende.

Algun parisito se aprovecha de la ausencia de la madre y deposita su huevo en la celdilla, y de el sale la larva antés que la legitima, sobre todo cuando se alimenta de miel, y a reces acaba por perseguir a la abeja. Muchos himenópteros de la misma familia son verdaderos tmidores, figurando en. tre ellos algunas avispas doradas, un icneumon, moscas de los géneros bombylius y anthrax y varios coleópteros de los géneros trichodes y silnis.

\section{LOS ANTOFOROS - ANTOPHORA}

CARACTERES, - Los antoforos se extienden en muchas especies por toda Europa y' el Africa septentrional, pero no faltan tampoco del todo en la América meridional y en el Asia En el ala interior se encuentra el mismo número de celdas que en el género precedente; una celda radial redondeada en su parte anterior provista de un pequeño apén. dice, cuya celda no se cxtiende mucho mas hácia atras que las úlimas cubitales. Las garras de los piés son bipartidas; las espinas de los tarsos, en las patas posteriores, existen en número de dos; las antenas, angulosas ẻ iguales en ambos sexos, son de mediana longitud, y los ocelos están dispuestos en triảngulos. Estos himenópteros recuerdan à los abejorros no solo por la estructura de su cuerpo sinn tambien por sus espesos jelos: pero una ojeada sobre las patas posteriores, particularmente en la hembra, basta para distinguir un género de otro. Ia diferencia del sexo consiste en la falta de la brocha en el macho, que en cambio tiene a veces en los piés de las patas medias varios pelos, y la region inferior de la cara de color de marfil, mientras que en la hembra es negra como la mitad superior. El artejo muj peçueño y puntiagudo en la extremidad esta rodendo en la hembra de espesas juntas, de modo que dicha parte aparece mas 6 inenos escotada. las diferencias de los sexos de ambos géneros son tan im. portantes, que no basta la simple vista sino la observacion en individuos libres, para reconocer $y$ distinguir los caractéres sexuales en una misma especie.

USOS, COSTUMBRES Y REGYMEN.-Los antoforos construyen sus nidos en ticrn, en los agujeros de las paredes, en-los huecos de àrboles y en los muros de barro: estos nidos tienen la forma de tubo y están divididos en celdillas por delgadas paredes. Los antoforos se presentan á primeros de año y vuelan con gran rapidez produciendo una especie de silbido y posándose de Hor en fior. En abril ó mayo, durante las horas mas calurosas del dia, puede verse á los machos volar uno detrús de otro en línea recta por delante de un muro 6 de una pendiente arenosa en que hay muchos nidos de donde las hembras acaban de salir. Cuando una de estas tiene deseos de aparearse jreséntase en la entrada, un macho se precipita sobre ella, la coge y ambos desaparecen por los aires. Es probable que la hembra fecundada vuelva á buscar el sitio en que nació para criar: pues en las paredes viejas de barro sc observan muchos años seguidos los agujeros de las mismas especies, si no se lia molestado it esos insectos, ó si los parásitos, que tambien conocen sus nidos, no les obligan à huir al fin.

EL ANTOFORO DE PELOS BASTOSANTHOPHORA HIRSUTA

CARACTERES. - Fsta especie está cubierta en todas partes de espesos pelos, de color rojo ó pardo amarillento en el tórax yen la base del abdómen, amarilios en las patas posteriores y en las otras partes negros. En el macho, el tegumento quitinoso del tallo, de las antenas, del escudo de ln cabeza, del labio superior, de las mejillas y de la base de las mandibulas es de color amarillo: las patas medias se distinguen por una dilatacion en forma de hoja, cubierta de espesos pelos negros en el primero y quinto artejos de los piés.

\section{EL ANTOFORO TRUNCADO-ANTHOPHORA RETUSA}

CARACTERES. - Ia hembra de este antoforo tiene el tamaño y la forma de la especic anterior, pero estí cubierta completamente de pelos negros; solamente los de los tarsos de las patas posteriores son de un rojo de orin. El macho, un tanto mas pequeño y raquitico, llamado por I.epelletier arifliopiora pilipes, tiene pelos rojizos en la cabeza, en el tórax y' en la base del aboómen, pero mas hácia atris son nscr. ros y negros. El primeroy úlimo artejos del pie de las patas medias se ensanchan por una estrella negra de pelos, como en la especie anterior, yolo faltan en todo el pié los largos pelos en la cara posterior.

USOS, COSTUMBRES Y REGIMEN. - EI macho vucla un poco mas tarde que la hembra, y" esta se utiliza en las Siete montañas y en el Valle de Paris de las hendiduras de las rocas, que comunican a esos parajes un aspecto tan particular, para depositar en cllas su cria.

\section{EL ANTOFORO DE LAS PAREDES - ANTHO- PHORA PARIETINA}

CARACTERES. - Esta especie se distingue joor una particularidad en la conseruccion de su nido: habita en los agujeros de las paredes viejas de barro, y cubre la entrada de un tubo sobrepuesto, un poco encorvado lácia abajo, cuyo material recoge entre los restos contenidos en el interior de la pared. La hembra de csta especic es un poco mas pequeña que la de las amteriores y está cubierta de pelos negros, excepto la extremidad del abdómen que es de un rojo de orin. El macho se distingue apenas por el color de la especie pre. ceciente: tiene un viso gris en los pelos: que parecen blanqueados por el sol: las patas medias no presentan distintivo alguno.

\section{LOS MACROCEROS-MACROCERA}

CARACTERES. - Otro grupo de podilegidos se distin. gue jor tener los machôs antenas muy largas, que a causa de Las dilataciones ligeramente nudosas en la cara anterior de los artejos podrian compararse con los cuernos de un capricornio: por esto se llamaron macroceros 6 abejas de cuernos largos; pero como en Alemania no existe ninguna especie, pues solo algunas habitan la Europa meridional y los paises cálidos, describiré una especie alemana nque se les asemeja en un todo por su aspecto exterior, aunque a causa del me. nor número de celdillas cubitales no pudo reunirse con este género.

\section{EL EUCERO DE ANTENAS LARGAS- EUCERA LONGICORNIS}

CARACTÉRES. - El eucero de antenas largas se ve ya descle fines de mayo, jero a mediados de junio pierde inucho de su aspecto porque los pelos palidecen ó se gastan por el rose. Lìn su primera jussentud el macho tiene cubierta la ca. 
beza y el tórax de espesos pelos de un bonito rojo, así como los dos prineros segmentos del abdónen, que es muy convexo; tambien tiene algunos negros mas hácia atrás; ’ enton. ces parece mas desnudo. I as largas antenas y e! amarillo del escudo de la caheza y del labio superior, le sirven sin embar. go de adorno constante. Su liembra, un poco mas grande, difiere esencialmente por su aspecto exterior; las antenas son regulares y angulosas; el abdómen, menos convexo, se estre. cha hácia adelanie y adquiere unos contornos elipticos, por lo cual se la podria confundir con una andrena, particularmente porque los bordes posteriores de los segmentos presentan fajas blancas, cortadas en los tres anteriores en el centro, dibujo que con frecuencia remos en dicha especic. Solo el cepillo de los tarsos posteriores distingue a la hembra del eucero, pues ninguna andrena tiene este órgano característico. I as citadas rajas están formadas por petitos cortos grises y lisos, pasajeros como todas las cosas bonitas. Por esto puede succdet que en verano enconeremos desnuda la hemora que antes tenia dichas partes cubiertas de pelos de un rojo pardo, que tambien palidecen cono en cl macho. Tiene un aspecto tanto mas misero cuanto mas concienzudamente cuinple con sus deberes de inadre.

Un tubo subterrineo sencillo sirve para deposint la cria; esta dividido por paredes trasversales en celdas, cuyo número aumenta de atrás adelante tan luego como los últimos se han llenado de miel y la hembra deposita un huero.

El caraicter distintivo de este género consiste en tener solo dos celdas cubitales, de las que la segunda recoge cerca de sus limites las dos venas braquiales. Por lo demás es anålogo al género mncrocera. Los ojuelos estan dispuestos en linea recta y las grandes garras son hendidas.

Anérica es muy rica en especies análogas á la nuestra por las diferencias sexuales $y^{\circ}$ el color del cuerpo.

\section{LOS IILOCOPOS - XYLOCOPA}

CARACTARES. - Iin los jilocopos encontranos los ti pos mas grandes de toda la familia. Por su torma son abejorros con un abdómen aplanado, casi siempre en su dorso, pero tienen mayor tamaio, yal examinarles mas minuciosamente vemos que difieren mucho por caractéres esenciales. Ias alas anteriores, casi siempre de color óscuro, con brillo violíceo $\delta$ bronceado, tienen una celda radial puntiaguda en ambos lados, en la parte posterior un poco encorvada hácia adentro, y que forma pico con un apéndice mas ó menos marcado. De las tres celdas cubitales, la del centro esti del todo cerrada; la primera, es de un tamano bastante igual y casi triangular; la tercera tan larga como las dos primeras juntas; en el centro ó por detrás de ella desemboca la segunda vena, y exactamente en su principio la priutera; los tarsos posteriores, no inuy anchos, y sus metatarsos, cubiertos de espesos pelos, tienen dos espinas sencillas en su extremidad; en los meta. tarsos se insertan los artejos del pié en su cajıa exterior. Las garras son de dos dientes; los ojuelos estin dispuestos en triángulo. Jos palpos de la mandibula inferior, que es córnea, se componen de seis artejos que poco á poco disminuyen en magnitud; la forma de las partes bucales es análoga a la de las abejas fnisas y por lo tanto la afinidad de los uroceros con los himenópteros anteriores solo depende del génerú de vida semejante y no de la estructura del cuerpo. Además del menor tamano, los pelos son mas cscasos en las patas posteriores. Muchos machos difieren de las hembras por ser los pelos del todo diferentes ó por tener los ariejos ensanchados en las patas posteriores (como en el gran xileropa latipes de las Indias Orientales, Jasa, etc.,) por estar los ojos mas proximos entre si haicia la coronilla. En la especie ayloropa caffra, por ejemplo, el macho tiene el dorso de un verde accituna amarillento, mientras que la hembra es negra, con fajas tras. versales amarillentas en la parte posterior del dorso, en el es. cudete y en el primer segmento del abdómen.

USOS, COSTUMBRES Y REGIMEN.-Los jilocopnos construyen sus series de celdillas en la madera y viven con preferencia en las partes cálidas de Africa, América y Asia. Varias especies muy afines entre si, y muchas veces confun. didas hasta ahora, habitan en la Europa meridional, encontraindose una en varias regiones de Alemania (Nassau Bam. berg). Esta especie es la siguiente:

\section{EL IILOCOPO VIOLÁCEO-XYLOCOPA VIOLACEA}

CARACTERES. - Esta especie, de tamaño variable, tiene el color del todo negro: el iercio artejo de las antenas se adelgaza en la base, y es tan largo como los tres siguientes jun. ios. En el macho, cuyo abdómen es mas corto y oval, las an. ienas afectan la forma de $\mathrm{S}$ y los tres artejus jenúltimos son de color rojo amarillo; las ancas posteriores tienen una espina dirigida hácia abajo; el borde interior de los tarsos se arquea regularmente en forma de $S$, prolongaindose en una apófisis de color pardo rojo, ensanchada en forma de lanceta y esco. tadá; el citado borde esta provisto de prestañas iguales.

USOS, COSTUMBRES Y REGIMEN.-Segun Schenck, este insecto vucla al principio de la primavera, por lo me. mos las hembras invernadas; desde julio hasta el utono se presentan en las fores de las papilionáceas las abejas jo. venes. Gerstaccker cogió ambos sexos en dos diferentes años cerca de Bozen, a mediados de agosto; Kriechbaum los obtuvo cerca de Trieste y de Iiume en los primeros meses de la jrimavera. De aqui deduce el prinsero que no es contrario a las observaciones de Réaumur si se suponen dos crias al año, hecho que en las abejas septentrionales no se ha observado aun; pero no debe asombramos en vista de las condiciones mas benignas de aquellos paises: Es cxtraño que en 1956 se cogiese en Inglaterra un solo jilocopo: Newmann cree que quizás la considerable importacion de naranjas con motivo de la exposicion industrial seria la causa de este suceso.

Produciendo un sonoro zumbido la hemlsra vucla por las paredes de tablas y por las vigas y palos, para que la toquen los rayos del sol, pero pronto se aleja. Estos movimientos tie. nen por objeto, segun parece, sobre todo despues de elegir un sitio a propósito, depositar la progenie a que consagran su corta vida. La madera vicja, una viga ó un tronco de àrbol, descortezado en algumos sitios, son los sitios mas convenientes para el trabajo de la hembra. Con mucho afan la abeja practica un agujero de la circunferencin de su cuerpo, penetra algunos milimetros en el interior $y$ se dirige luego hácia abajo. Para esto necesita un .punzon y unas tenazas, pero de tales le sirven las maxilas; las astillas son extraidas muy promso, aumenta la profundidad, $y$ al fin se forma un tubo igual que puede tener una longitud de $11^{n}, 3$ I y se encorva en su extremidad un poco hácia afuera. Ial cuidadosa madre solo descansa cuando es preciso visitar un poco las fores, en las cuales recobra nuevas fuerzas por la recoleccion del néctar. In la parte inferior del niclo se coloca la miel mexciada con pólen en una cantidad detcrminada; sobre esto se deposita un huevo, y la última parte del tubo se tapa con unos anillos concéntricos formados por virutas. In primera celdilla está cerrada y su tapa constituje el fondo para la segunda superior; esta recibe igual cantidad de alimento y otro huero;y de este modo se continua sin la menor interrupcion hasta que todo el espacio queda lleno por una columa de celdas si un tiempo desfavorable no lo impide. Ia madre 
cuidadosa ha hectio todo lo posible y gastado todas sus fuerzas en la obra. Supongamos que su acrividad comienza a principios de la primavera: si todas las circunstancias han sido favorables queda asegurada la descendencia, y los hijuclos de la prinzera cria siempre serán mas numerosos que los de la segunda.

Al cabo de pocos dias nace la larva que en nada difiere de las ya descritas en la ojeada general sobre esta familia. l'ermanece encorvada ó inmóvil, y al cabo de unas tres se. manas vénse en la cavidad de la celda unos granitos negros, yue son sus excrementos. Entonces fabrica su capullo y' trasfórmase en crisilida. Como la larva inferior es la mas vieja, naturalmente debe ser la priniera en desarrollarse; despues la segunda y por último la superior. En la segunda cria la larva inferior espera hasta que sus hermanas estén fiera para abrirle el camino de su prision: en la primera cria que concluye en agosto no sucede así. A la larva inferior se le indicó el camino mas corto por el cual puede salir de su cárcel; se coloca de cabeza, $y$ solo necesita moverse para empujar su cuerpo hacia adelante; entonces vera que el espacio es blando. De este modo llega á la extremidad de la cura, llena de ligeras virutas: comprendiendo por instinto el uso de sus temazas, las emplea por primera vez y pertora la delgada capa. Asi lo supone, por In menos, Lepelletier: Reaumur, en cambio, dice que la abeja madre abre el agujero en la extremidad del tubo y a veces un tercero en el centro. Ia segunda laria que sale sigue á la primera hasta que por fin toda la fanilia se aleja y el niclo queda vacio. En las regiones en que los jilocopos'se han fijado una vez, se aprovechan sin duda por muchos años los antiguos puntos de cria, y parn producir una progenie mas abundante disponen de mas ticmpo que cunndo tierien que construir de nuevo sus nidos del mo do descrito.

\section{LOS MERILEGIDOS - MERILEGID E}

CARACTÉRES. - Jos merilegidos se distinguen esencialmente de las especies del género anterior por acercarse sus órganos de recoleccion mas al cuerpo, pasando à los lados del mismo cerca de las patas posteriores y à sus ancas y muslos, aunque tambien á los tarsos y metatarsos queda agarrnda gran cantidad de pólen. Todas las especies tienen los palpos labiales de una sola forma, de modo que segun el sis. tema de I.atreille, pertenecen à las falsas abejas.

\section{EL DASÍPODO DE PIÉS ERIZADOS-DA- SYPODA HIRTIPES}

CARACTERES. - No podemos pasar en silencio å causa de la belleza de su hembra, á este diasipodo, propio de la mayor parte de Europa, aunque 110 haya que decir nada de importancia sobre su género de vida. Como sus nune. rosos congéneres la hembra deposita su progenie en un sencillo agujero subterraneo. Por lo que toca a la estructura del cuerpo, la celda radial en forma de lanceta se oprime con su punta en el nervio radial $y$ de las dos celdas cubitales cerradas, la segunda, mas corta, recibe los nervios braquiales cer. ca de sus extremidades. El segundo artejo de la brocha de las anterias se adelgaza en forma de tallo; los palpos labiales se componen de cuatro artejos, y la lengua, aunque no sea tan corta como en las andremas, no puede llamarse tampoco larga Lo que da à la abeja su bonito aspecto son los largos pelos de un rojo de \%orro que estàn dispuestos alrededor de los tarsos posteriores y de sus métatarsos, además las fajas de pelos blancos en el segundo hasta el cuarto artcjo del abdó. men cubierto de cortos pelos negros; el abdómen es ajulanado, eliprico y se ensancha en la punta por medio de unas franjas negras mas largas. El tórax y' la base del abdómen estin cubiertos de espesos pelos de un rojo de zorro salpicados de gris; la cabeza es negra y hácia atris con preferencia gris; su longitud es de $0^{n}$, or 1 a $0^{n}, 013$, de modo que ocupa uno de los primeros lugares entre sus congeneres.

El macho, mucho menos bonito, es mas pequeño; tieuse el abdómen fusiforme, y mucho mas convexo; en las antenas, mas largas, el segundo artejo de la brocha no forma tallo; los pelos, de un gris amarillento, son mas escasos y claros en los bordes posteriores de los segmentos del abdúmen. Siempre he visto el dasipodo solo desde mediados de julio hasta fines de agosto.

\section{LAS ANDRENAS-ANDRENA}

Las andrenas constituren, jurtamente con el género siguiente, cuando menos en las regiones centroles y septentrionales de Alemania, la tercera parte de todas las abejas silvestres que visitan las florcs, conunicando por su incansable actividad y sus agradables zumbidos un atractivo particu. lar al paisaje. lias andrenas son las que a principios de la primavera vagan en compañia de la abeja doméstica, mas innupuila y prudente, entre las nlores de los sauces y de otras plantas, vacilando mucho tiempo antes de posarse para celebrar con un festin la fiesta de la resurreccion de todos los séres animados; ellas son las que in las pendientes expuestas al sol suben de agujero en agujero, recorriendo tales sitios en grandes grupos á fin de preparar nidos para su progenic. Por lo regular constrúfenlos en suelo arenoso, practicando en direccion oblicua un tubo de 13 a jocentinsetros de jrofundidad, en cuyo extremo abren cavidades redondeadas 6 cortas ramificaciones del tubo jrincipal, donde las celdas se llenan de pólen en asombrosa abundancia. Despues de haber depositado en cada celda un huero, la abeja las cierra con arena, y tambien la entrada al nido.

CARACTERES. - I as andrenas tienen la lengua corta, en forma de lanceta, y chr estacio de reposo no se dobla hácia atrás sino que se recoge en la parte superior de la barba, de modo que Westwood ha formado con este grupo el género de las abejas de lengua puntiaguda. Ios palpos labiales son uniformes y se componen de cuatro artejos; los de la mancibula inferior de seis. La celda radial de las alas anteriores se estrecha muy poco en su mitad posterior $y$ no toca con su punta redonderada el nervio radial; de las tres celdas cubitales cermdas, la primera llega casi a la longitud de las otras dos juntas; la segunda es la mas pequeña, bastante cuadrada, y recoge casi en su centro el jrimer nervio bra. quial, estréchase cousiderablemente hácia arriba y abarca la segunda de las citadas renas muy hácia atrás. Toda la cam exterior de las patas posteriores hasta la mitad del metatarso está cubierta en la hembra de éspesos pelos destinados á recoger el pólen, y tambien se observan otros en los lados del tórax; cn la cara interior del metatarso los hay inas cortos y espesos, formando estos el cepillo; de modo que las hembras vienen todas estas partes cubicrtas de una espesa capa de pó. len. Ias garras de los piés están provistas por detrás de su centro de un dientecito lateral y llevan en medio un marcado lóbulo membranoso. El abdómen se estrecha en su base, esóval, de forma de lanceta, ó se redondea como un huevo. En él se reconoce fácilmente la diferencia de ambos sexos: en la hembra es mas aplanado, provisto en la extremidad, es decir, en el quinto stgmento, de un borde de pelos, que cubre mas 6 menos el pequeño segmento. El ma. cho, no an grande, aunque mas prolongado, tiene el abdómen mas convexo en su dorso y no toma nunca la forma 
lincal: por las antenas apenas se distingue de la hembm: son isperas, mas largas, presentando un espeso mechon de pelos de color claro en la cara y el labio superior, $\delta$ á veces en toda'su extension, pero nunca exclusivamente en el borde anterior: como no han de recoger pólen, los jelos de las patas posteriores del macho son mas escasos que en la hembra.

Las andrenas abundan en parásitos; entre los cuales los pequeños nómadas (nomada), además de un sér extmño que mas tarde conoceremos con el nombre de Stylops, y liasta ciertas larvas de coleópteros (Melox) representan un papel muy importante.

Segun el color y: los tegumentos del cuerpo, las numerosas especies (Smith cnumera en su registro de las abcjas inglesas 6S) pueden dividirse en varios grupos: especies que tienen la piel del abdómen negm y roja; otras en que es de un solo color negro, á veces de un viso azulálo pero sin fajas; $y$ abejas, en fin, euyo abdómen, menos negro, esta provisto de rajas claras debidas á unos pelos espesos mas ó menos lisos. Esté último grupo comprende la mayor parte de las especies que ofrecen gran semejanza entre si.

\section{LA ANDRENA DE SCHRANK - ANDRENA SCHRANKELLA}

CARActeres. - Esta especie tiene el segundo seg. mento del abdómen de color rojo, y poco mas ó menos del mismo tinte el princro y el tercéro; tódo lo demás es negro, presentando en la cabeza y el tórax unos pelos bastante espesos de color gris amarilio. La hembra tiene en los bordes posteriores, desde el segundo hasta el cuarto segmento abdominal, unas iajas estrechas de pelos blancos; el cepillo de los tarsos se compone de pelos amarillentos y en la extremidad del abdómen hay una franja cic color parcio. El macho, cubierto en todas sus partes de pelos mas iguales grises, tiene la cara amarillenta, con dos puntitos negros en el centro y con su borde anterior provisto de espesos pelos blancos.

USOS, COSTUMBRES Y RÉGIMEN.-Esta especic ruela desde junio por las fores, los arbustos y la yerba. Es bien conocida en los alrededores de Basilea, pero no abunda en ninguna parte.

\section{LA ANDRENA CENICIENTA-ANDRENA CINERARIA}

CARACTÉRES, - Ia andrena cenicienta es negra, cubicrta en la mitad anterior del cuerpo de pelos blancos, mas 6 menos espesos; escasean en la cara de la hembra, pero en el tórax son mas abundantes; en el macho forman mechones; el abdómen, de un negro arulado, es ciesnudo en la hembra, mientras que en el macho ticne en la base algunos pelos; el cepillo de los tarsos y la franja en la extremidad son negros en la hembm, y las alas muy oscuras en la nitad exterior.

USOS, COSTUMBRES Y REGIMEN. - Esta grande especie se presenta muy temprano cuando el tiempo es favo. rable; se la ve a fines de abril y parece preferir sobre todo el néctar de las flores del sauce - pues en allas la encontré siempre: Imhoff la cogió cerca de Basilea, y le enviaron ejemplares tambien de Ginebra. Asimismo se encuentra en I.ivonia é Inglaterra; de modo đjue su àrea de dispersión es muy extensa.

\section{LA ANDRENA OVINA-ANDRENA OVINA}

CARACTERES. - La hembra de esta especie, muy parecida à la anterior, tiene el dorso cubierto de pelos sin in- terrupcion en el centro; el abdómen de ambos sexos es mu. cho mas ancho y ovalado.

\section{LA ANDRENA DE MUSLO PARDO-ANDRENA FULVICRUS}

CARACTERES. - I a andrema de muslo pardo es negra, con la cabear y el tórax cubiertos de pelos de color pardo amarillo; al abdómen de la hembra, prolongado y liso, pre. senta cuatro fajas de un pardo amarillo que muy pronto se vuclven blanquizcas, $y$ ademas una franja parda cn la extremidad. I os pelos destinados á la recoleccion del pólen y el cepillo de los tarsos sori del mismo color. El macho tiene pelos tambien en el primer segmento abdominal, y en la cara otros negros muy abundantes, adornando el abdómen cinco fajas tmasversales claras. En el dorso, bastante desnudo á causa del roce, de una hembra de mi coleccion, vi dos larvas amarillas del gusano de mayo.

USOS, COSTUMBRES Y REGIMEN.-Tambien esta especie se deja ver muy pronto, por ln regular en el mes de abrili se alimenta de las flores del sauce, segun ha observado Schenk, y principalmente de la colza y del dicnte de leon. Los machos acostumbran a volar rasando el suelo cuando van en busca de las hembras. Esta especie se halla en los mismos parajes que la anterior.

\section{LOS HILEOS - HYLEUS}

CARACTERES - Los hileos ó halictos (halictus), menos abundanies en especies que el género anterior, se asemejan a el por su género de vida, y al tercer grupo de las andrenas por su aspecto exterior. La hembra se distingue solo por tener una mancha desnuda y brillante en forma de cuna, en el centro de la framja de la extremidad: el abdómen del maoho se estrechia en forma de lima, ensanchándose á veces por detrás de su centro; la brocha de las antenas es muy prolongada y a menudo tambien el borde anterior del labio supe. rior. I.as patas tienen en muchas especies un color blanco mas ó menos extenso, carácter por el cual es mas tảcil distinguir los machos de las hembras; pero en la mayor parte de casos todas las de los himenópteros ofrecen un carácter genérico bien marcado. Exxcepto algunas especies mas grandes, muchas solo alcanzan al tamaño medio de las andrenas; pero en cambio hay una infinidad muy pequeñas.

USOS, COSTUMBRES Y REGIMEN.-Los hileosse presentan por lo regular un poco mas iarde que las andrenas, y sus hembms pertenecen por lo tanto i las abejas que en medio del verano visitan las flores de los, fresales y otras. Muchas reces se desfiguran tanto por el roce de los pulos que ya no puede rcconocerse su especie.

Construyen sus nidos, en forma de tubos, con preferencia en el suelo endurecido, y por eso vagan por los caminos muy pedregosos, donde se ven á menudo ciertos agujeritos, yjunto á cada cual un montoncito de tierra. Si el obscrvador fija'su atencion un buen rato, veri como de alguno de esos agujeros sale una abejita, mientras que por otra parte llega una segunda que desaparece en su guarida, cuya entrada es ân estrecha que podria creerse que el insecto al jasar por ella dejarí todo el pólen. Algun muro vertical de barro, situado hacia el oriente ó al mediodia $y$ lindante con un desfiladero ó un foso; y hasta la estrecha prominencia del borde de un campo, son los sitios que buscan estos insectos, y donde se ven todo el dia, cuando el tiempo es hermoso, centenares de hembras del hileo, que entran y salen de continuo sin equivocar nunca su vivienda, aunque hay centenares de agujeros todos iguales Los hileos son los que, juritamente con los grandes abejorros 
y otras abejas activas, duermen en las flores de los cardos y en otras, esperando en ellas tranquilamente cuando cae un aguacero que no les permite llegar á su vivienda.

Por su exterior se les pucde clasificar en especies negras con fajas de pelos blancos en el borde posterior y en la base de alguno ó de todos los segmentos abdominales: en especies sin tajas; $y$ en otras verdes, cuando menos en el tórax. A veces se hallan tan cortadas las tajas en el centro del dorso, que solo quedan lineas laterales.

\section{EL HILEO GRANDE - HYLAES GRANDIS}

CARACTERES. - El hileo grande, nuestra especie de mayor tamaño, seri muy propio para demostrar las diferencias de ambos seros de los de las andrenas.

USOS, COSTUMBRES Y REGIMEN. - Vuela en julio y agosto visitando con preferencia las flores del cardo. Construye sus nidos siempre en los declives expuestos al sol; reuniendose para cllo con numerosos individuos de su ce. pecie.

\section{EL COLETES RUDO-COLLETES HIRTA}

CARACTERES, USOS Y COSTUMBRES.-El coletes rudo, muy afine de los dos géneros anteriores, fabrica su nido en una cavidad subterrinea, en direccion horizontal. Las celdas se componen de una piel fuerte, semejante a la de una vejiga de cerdo y hállanse una detrás de otra. Figurémonos una serie de dedales de igual diámetro, de los que cada uno encaje por su fondo en la abertura del anterior, y tendremos una idea de la disposicion de estas celdillas, que ademís estån sujetas por un anillo de la misma materia en el punto donde la una se adapta a la otra. El diametro trasversal de una celda es de unos $11^{\circ}, 00718$ y la longitud varia dè $10^{\circ}, 015$ a $0 \%, 0175$. No necesito decir que la primera debe estar llena de alimento (miel y pólen) y que contiene un huevo antes que la abeja dé principio á la construccion de la segunda. las crisálidas, y aun quizás las abejas aduitas, permanecen durante el invierno en sus celdillas, y salen por mayo, cuando el tiempo es favomble. I.as celdas que tuve ocasion de observar estaban abiertas en un lado con toda regularidad, per lo cual supongo que cada abeja abandona su prision independiéntemente de la otra.

Lista cespecic aicne el tamano y la forma de una trabajadora de la abeja doméstica; y está cubierta completamente de pelos de un gris pardo; que en el abdomen escasean lo bastante para que se trasparente el color negro del cuerpo; mien. tras que en la hembra la parte superiur de la cabeza y la cara inferior de todo el cuerpo son mas negras, ya por la presencia de pelos de este color, 6 bien por la éscasez de los claros. Iil macho, un poco mas pequeño, tiene un viso blanquizco y un mechon de pelos del mismo color en la cara y en el dorso; los bordes posteriores de los segmentos abdo:ninales son tam. bien un poco mas claros en los individuos jovenes. Los pelos de las patas posteriores'son escasos en la hembra. Ios coletes se distinguen de las andrenas por tener la lengua ensanchada en su parte anterior, con una ligern escotadura, y por ser las otros partes bucales mas cortis.

\section{EL CALICODOMO DE LOS MUROS-CHALI- CODOMA MURARIA}

CARACTÉRES. - El calicodomo de los muros ofrece todo el asprecto de un abejorro. I a hembra es del todo negra, inclusas las alas, que hacia la punta clarean un foco: cl macho es de un rojo pardusco; la lengua muy larga; los palpos maxilares tienen dos artejos: las maxilas, enanchadas en su parte anterior, están provistas de cuatro dientes y presentan cuatro surcos. Eil vientre y tambien el dorso están cubiertos de espesos pelos, mas cerdosos en la hembra y dirigidos hacia atrás jara recoger el pólen destinado a la preparacion del alimento. En una palabra, esta esjecic recoge su alimento con el abdómen.

USOS, COSTUMBRES Y RËGIMEN. - Cuando cn mayo han salido ya las abejas de sus nidos y se han apareado, las hembras comienzan a fabricar su uido, para lo cual cligen alguna piedra como lo hace la golondrina. El material de construccion se compone de granitos de arena, que por medio de la saliva se adhieren de tal modo, que se necesita fucrza y un instrumento puntiagudo para abrir una celdilla. En una ligera depresion, que la abeja encuentra sicmpre sin necesidad de buscar mucho tiempo, construye en breve rato una celda vertical, en forma de un dedalito, mas estrecha hácia arriba.

I a celda es lisa en su interior s áspera por fuera, de modo que se pueden distinguir los' granitos de arena. Tan luego como queda concluida, el insecto la llena de miel, deposita en ella un huevo $y$ in cierra lo mas pronto posible.con el mismo material empleado en sus partes infariores, ofrecien. do entónces el aspecto ciel capullo cerrado de muchas crisálicias de mariposa. I a celdilla se debe cerrar con toda la iapiciez posible, porque hay muchos enemigos que jueden saquearla. Junto à la primera se fabrica una segunda que cn elángulo formado por la pared con la pendiente de la primera tiene su tabique posterior. 1) este modo se reunen poco á poro celdas, dispuestas una sobre otm sin órden determinado, ó bien puestas una contra otra paralela ú obli. cuamente. Su numero depende del tiempo y de los obstículos ujue puede encontrar la hembra para la construccion. No ticne una verdadera vivienda, pues el sitio libre donde fabrica sus celdas no le ofrece abrigo por ningun concepto. No recuerdo nunca laaber encontrado mas de diey caldats juntas, y si siemure menos. El insecto las alisa toscamente en la superficie ondulada, de modo (jue el nido se asemeja al fin á un pedazo de excremento reseco.

Una hembra sola fabrica el grupo de celdas descrito, cuya ejecucion concluye á principios de julio, cuando desıparece la arquitecta. En otro sitio cercano trabajan por lo regular otras hembras: jues los nicios se encuentran reunidos en ma. yor numero. Estas abejas no son sin cmbargo mada sociables, sino que al contrario luchan entre si, como lo ha observado Réaumur. «Mientras la una tmbaja, dicc el citado naturalista, á menudo llegr otra que se empeña en apropiarse la celdilla, y con bastante frecuencia se defiende media hora contra la propietaria al volver esta. los dos insectos se precipizan al vuelo uno contra otro, astojanse al suclo y lichon a la manem de los gladiadores. A veces la una se remonta verticalmente por el aire y déjase caer de repente sobre la otra, que cutonces inienta evitar al ataquc y parece rolar hácia atris. Por fin se cansa una y se aleja; si es la propictaria vuclve pronto y renuévase la pelea; no se ha observado si intentan picarse en esta ocasion. Cuando una abeja muere ciurante el trabajo, otra toma posesion del nido en construccion; si este es vicjo queda vacio, porque la propictaria le abandona, pero entonces llega otm, saca los tejidos y los excrenentos, llema la celda de alimento y la cierra. En tal ocasion surgen á veces contiendas. Este es en extrncto el selato de Reaumur.

I a lara, cuyo aspecto no ofrece ninguna particularidad, es pronto adulta, rodéase de una membrana vidriosa, se trns. forma en crisálida y esta en abeja, pero en diferente tiempo. En el calurosa varano de 1859 encontre ya el 15 de agosto abejas desarrolladas, y el to de abril del ano anterior vi tc. 
davia las larvas. Consta sin embargo que aquellas no nacen por via natuml antes que estas, es decir a principios de junio. Los agujeros redondos de la cara superior del nido son los sitios por donde han salido las abejas.

El calicodomo de los muros tiene muchos enemigos de las mas diferentes especies de insectos, figurando entre ellos, segun Franenfeld, el Mcle erythrocnemys, un coleơptero y una especie de mosca (argromocla subnotata); yo obtuve de un capullo de crisálida diez y seis hembras y dos machos de una pequeña avispa llamada por Foerster Monodontomerus Chalicodome, un teromalino de unos $0^{m}, 005$ de largo, de color verde oscuro metálico, con el tallo de las antenas de un rojo de orin, patas del nuismo color descle los tarsos y las alitas sin nervios, un poco sucias al rededor del borde. El taladro de la hembra tiene la mitad de la longitud del cuerjo. No pudo haber penctrado, en mi opinion, por la cribierta pedregosa hasta la larva; los huevos fueron šin duda depositados antes de cerrarse la celdilla y se desarrollarian mucho antes que los de la abeja para que las pequeñas larvas encontrasen su alimento en la otra, mas ó menos adulia.

\section{LOS ANTIDOS-ANTHIDIUM}

CARACTERES.- Las especies que recogen su alimento con los pelos del abdómen son bastante numerosas, ja dilas pertenecen los antidos, llamados tambien abejas de bola ob de lana, debiendo este último nombre á la costumbre de tapizus su nido con sustancias vegetales lanosas. Su abdómen es casi esferico, desnudo y manchado de amarillo, 6 bien orillado del mismo color, lo que raras veces se observa en las abejas.

\section{LAS OSMIAS-OSMIA}

CA RACTERES. - I as osmiás ó abcjas de los muros tic. nen un abdómen de igual anchum y muy comvexo en el dorso; los palpos, tanto labiales, como maxilares, constan de cuatro artejos: la celdilla radial de las alas anteriores no toca con su punta la vena radial: el segundo nervio braçuial termina a bastante distancia de la extremidad de la segunda y al mismo tiempo de la viltima celda cubital.

USOS, COSTUMBRES Y REGIMEN. - Los antidos fabrican sus nidos en los agujeros de los muros ó utilizan el nido abandonado de otras abejas: iambien parece convenirles las vigas $y$ troncos de árboles, etc. Sus celdillas afectan la forma de dedal y algunas se hallan en conchas de carncol vacias, como sucede con la osmia bicolor.

\section{LA OSMIA ROJA-OSMIA RUFA}

Caracteres. - Ia osmia ruj: es un bonito insecto perteneciente al género anterios, especie que por su tamaño y aspecto exterior recuerda á primera vista la andrena amari. lla. Su abdómen tiene un color rojo pardusco dorado y esta cubierto de pelos mas escasos en el dorso, de modo que la piel del cuerjo deja ver un brillo metálico. El tórax y la cabeza, asi como las patas, estin revestidos de pelos negros; en la hembra sobresalen de la boca, en los lados de la cabeza, dos cuernos gruesos ce irregulares.

USOS, COSTUMBRES Y REGIMEN. Esta especie aparece muy pronto en la primavera, y agrádale anidar en cavidades en forma de tubo, que con barro dividen en cel. das. Schenti encontró entre el marco de una ventana y un ıablado, en el gimnasio de Weilburgo, un gran número de estas celdas (de 12 a 20 ) una junto d otra, todas cllas cons. truidas de barro. Fin las mas viejas se encontraron larras adultas y muy poco ó nimgun alimento; en las siguientes, las
Jarvas eran mas pequeñas, y las provisiones de alimento seco, ricas en pólen; despues seguian algunas celdas con huevos, y en la última vióse la abeja, que fabricando aun, no se ale. jó, poniéndose á la defensin como lo hacen los abejorros, con las patas estiradas. Los agujeros hechos para la salida de] agua de lluvia permitian á la abeja la entrada en aquel sitio.

\section{LOS MEGAQUILOS - MEGACHILE}

CARACTERES. - Este género es muy afine del que acábamos de describir. El ablómen de la hembra se aplana mucho en el dorso, y toca con el aguijon regularmente hácia arriba; el segundo nervio braquial tcrmina mas cerca de la extremidad, en la segunda celda cubital; los palpos maxilares se componen solo de dos artejos. En el macho, los tiltimos artejos de las antenas son aplanados y los dos viltimos segméntos del abdómen se encorvan hácia abajo. La diferente denticulacion de ciertas partes es el carácter que mejor sirve para distinguir las especies, muy semejantes cntre sí. En un grupo los machos tienen las patas anteriores ensanchadas y difieren entre si por varios dibujos característicos en la cam interior de los muslos; en otro, se caracterizan por los dientes. En la escotadura de la extremidad del alxiómen, los últimos artejos y las antenas, asi como la distribucion de los pelos, ofrecen buenos caractéres para la clasificacion.

USOS, COSTUMBRES Y REGIMEN.-Estas abejas fabrican sús nidos en agujeros de árboles, herdiduras de mu. ros ó cavidades subierráneas, donde forman celdas enfiladas en figura de dedal, hechas habilmente con hojas de ciertas plantas.

Se han elicontrado en su uido como material de construccion fragmentos de hojas del álamo blanco, de la haya blanca, del sauce, de la for de la adormidera silvestre y sobre todo del rosal.

\section{EL MEGAQUILO CENTUNCULAR-MEGA- CHILE CENTUNCULARIS}

CARACTERES.-Esta especie, muj comun, tiene el tó. rax de un pardo amarillo mezclado de negruzco; con la edad se vuelien tambien los pelos grises, sobre todo en el inacho. Eil abdónen, casi desnudo, esti provisto solo en su parte an. terior de pelos grises y de fajas, con frecuencia cortadas en los bordes prosteriores desde el segundo hasta el quinto seg. mento. Espesos pelos de un pardo rojo cubren el vientre y el último segmento del macho, que no se reconoce por una escotadura, sino solo por dientecitos poco marcados.

DISTRIBUCION GEOGRAFICA.-Segun Smith, est? especie se encuentra, no solamente en Europa, sino tambien en el Canadá y en los prises situados alrededor de la bahia ie Hudson.

USOS, COSTUMBRES Y REGIMEN, - A fuES de mayo of principios de junio se presentan las abcjas, y segun costumbre, los dos sexos se encuentran muy pronto, y despues del apareamiento empiczan los trabajos de la hembra. No puedo determinat si esta especie labrica sus celdas exclusivamente en la madera vieja $\delta$ en tierra; pero si diré que las tales celdas se han encontrado en aúbas partes, no sicn. do posible que hayan pertenecido á dos especies difurentes. La cavidad, 6 mejor dicho, el tubo era en el primer caso la galeria de una oruga del longicornio de los sauces, preparada al efecto; $y$ en el segundo caso un agujero de raton algo ruinoso que halvia servido a la abeja de cuna. En una pala. bra, es probable que en todas partes se sirva el insecto de un nido abandonado por otro animal. Lo mas importante del 
trabajo, consiste en la construccion de las ceidas: la alueja llega presurosa, pósase al punto sobre una hoja de rosal, y corta 1811 pedaro del iamaño necesario; con el último mordisco la encorva en forma de cucurucho entre las patas y se aleja por el aire. Cuando la hoja ha servido para el fin descado, el insecto vuelic pronto para buscar otros pedizos; suéltalos al llegar al nido, y una vez encormados los oprime contra la pared gracias a su elasticidad. I a pared queda tapizada por fin con ires ó cuatro grandes pedazos de hojas, a los que sigue una segunda capa de otros, mas estrechos en una extremidad que en la otra; la parie del borde denticu. lado de la hoja se coloca hácia fuera, y la cortada hácia dentro. En este estuche la abeja construice un iercero con pedazos iguales entre si, cuya superficie cubre los surcos de los anteriores, hasta que por fin el jequeño dedal yucela acabido. Despres de llenarle de nicl y deposiar en él un huevo, la hembra le ciersa con un pedacio de hoja perfectamente circular, sobre el cual se coloea el fondo retondeado del estuclic siguiente: y de cste modo continún el trabajo, hasta çue por fin se forma toda uma serie de capullos sohrepuestos. Ia larva desartollad:a teje su capullo y exteriormente quueda todo en órden hasta la proxiuna primaivera. tal como lo dejó la cuidadosa madre. lin este tiempo se repite lo mismo que ya hemos indicado al bablar del jilocopo, con la sola diferencia de que la salida està por arrils2.

Aunquec la abeja, sobre todo el macho, se encuentra bastante á menudo en las fores, es sin embargo, una casualidad feliz hallar su nido, yorque nos falta la destreza de los salva-

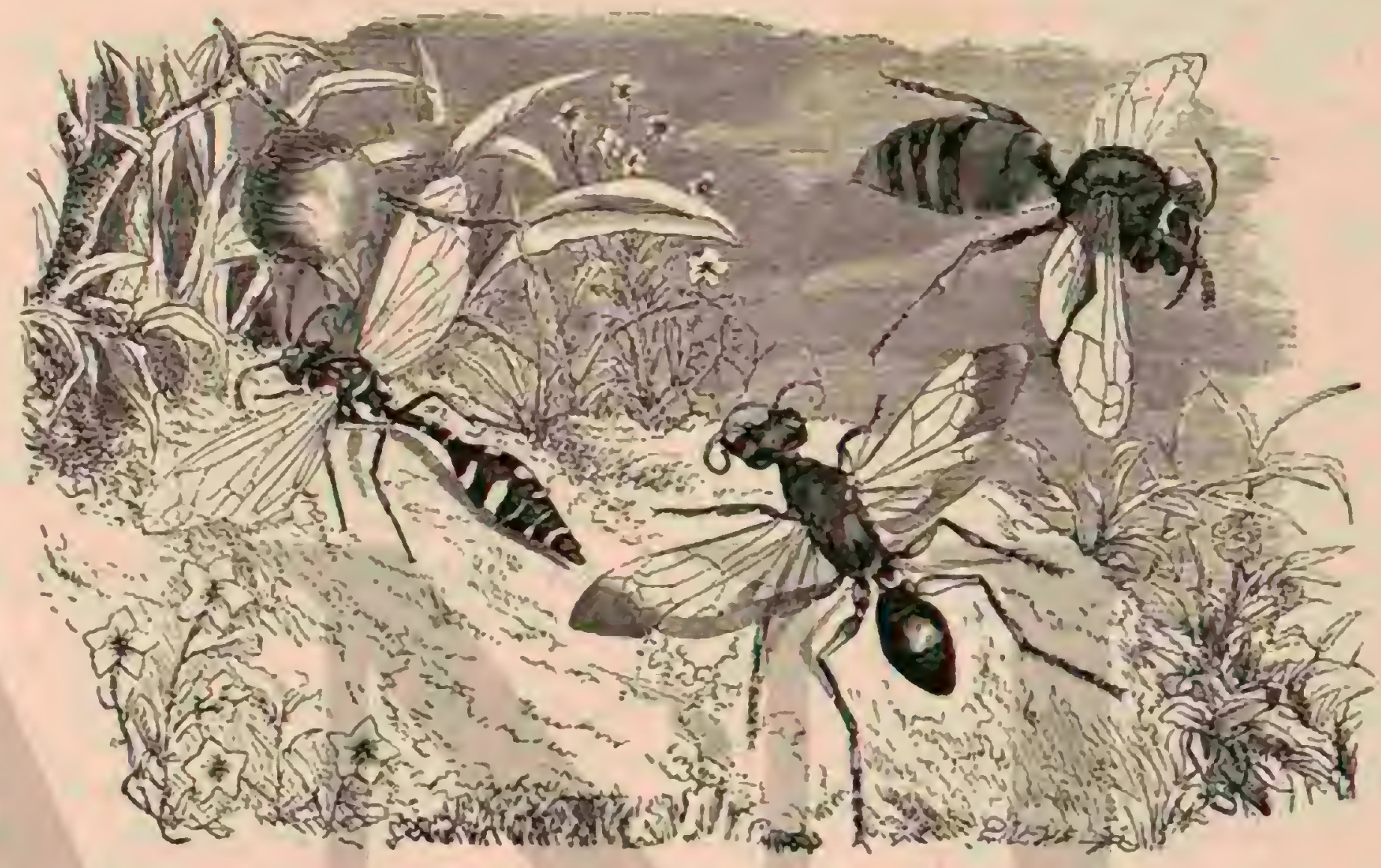

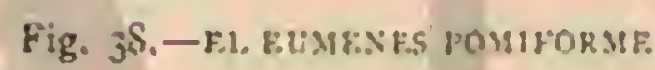

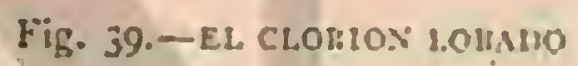

Fig. 40.- F.L AVISTOO

jes de la Nueva Holanda, quienes persiguen à la hembra, reconocida por la hoja, descubriendo al fin su vivienda. Del mismo modo lo hacen con las melipomas.

\section{LAS ABEJAS PARÁSITAS}

El gran numero de especies en parte bastante bonitas, cuyas hembras -110 tienen ni en las patas, ni en el vientre. Ios pelos destinados para la recoleccion, $y$ d las cuales no se ve por lo tanto nunca entrar en sus agujeros subierráncos cargadas de pólen, se consideran como abejas paraisitas. Segun sus obsertaciones, Snith no tas reconoce como tales; jero lepelletier las clasifica con ese caricter. $y$ por lo tanto será preciso hacer aun observaciones imparciales para saber á qué atenernos en todas las especies.

I as abejas parisitas depositan sus huevos en la celda acabada de otra especié, y yuizás destrozan tambien al huevo legitimo, como lo hace a veces el cuclillo. la larva que nace del huevo ilegitimo se alimenta de las provisiones ajenas y en ver de la progenie para la que se han construido las celdi. llas, aparece otro insecto, extraño para la propiciaria del nido, aunque de una especic afine.

Los parisitos se asemejan à menudo à las especies en cuya vivienda se hospedan, y gracias a esto consiguen introducirse en cl nido extraizo. Respecto a la formacion de su boca, las abejas parasitas pertenecen à las dos familias naturales, á los andrenidos y a los ápidos: y ateniéndonos a esto describiremos unas pocas esfrecies, las de lengua larga.

\section{LOS APATOS - APATHUS}

CARACTERES. - A los abejortos siguen, por lo que hace à la cstructura general del cuerpro, los ajatos ó abejorros parásitos. De las seis especies propias de Alemania, el apato de las rocas, el campesino, el de verano y el silvestre (afitthus rupestis, campestris, astionlis y saltusum). son los mas diseminados. Sus hembras difieren de los verdaderos abejorros por los siguientes caractéres: el labio superior presenta en su parte inferior un ángulo obtuso, mientras que en aquellos termin en linea recta; los ojuelos están dispuestos en una linea ligeramente arqueada; los tarsos posteriores carecen de órgano recolector, pero tienen en su cara exterior una superficie prominente y peluda; los metatarsos carecen de orejitas. La parte superior del abdómen, excepto el último segincinto, es casi desnuda y brillante; el áltimo segmento se encurva y presenta en su cara inferior una prominencia angulosa que á cada lado forma una espina. Si por lo ianio. is f́ácil distinguir, mediante un exámen minucioso, la hembra del apato de la del abcjorro, los machos ofrecen mucha mas dificultady se confunden fäcilmente, aunque se tenga el mayor cuidado. Lal cabeza de los apratos es mas corta, casi tan larga como ancha en su parte anterior, y casi siempre mas peluda que en la posterior. Como las hembrs depositan sus huevos en los nidos de los abejorros sociables, es decir, de las esprecies a que se asemcjan, no necesitan ayudantes; preséntansce en la primavera, y sus machos llegan mucho mas tarde. Se ha creido por eso yuc no recogen provisiones, y que 
cuentan con las de las especies a que molestan con su parasitismo. Dudo de la exactitud de este aserto. ¿No podria hacerse la siguiente consideracion? Una abeja doméstica trae miel y pólen para preparar alimento y lo confecciona en su vivienda; otra puede hacer lo mismo en la for y llenar su celda, sin necesitar los organos exteriores de que dispone la otra. I a naturaleza es tan sariable en sus creaciones, que muy bien podria suceder así.

\section{LOS NÓMADAS-NOMADA}

CARACTERES. - A has abejas parásitas mas comunes y ricas en especies pertenecen los nómadis ó abejnc-avispas, las mas abigarndas de toda la familia. su cuerpo que por lo regular tiene de $\|^{*}, 0835$ a $0^{m}, 013$ de largo, es calsi desnudo; el abdómen cliptico, con manclias ó fajas amarilias, blancas y rojas sobre un forido negro brillante ó rojo. El escudete dorsal tienc dos vernigas; los tarsos posteriores son un poco aplanados y cubiertos solo de escrisos pelitos cortos, sobre rodo en su cara inferior. Las alas anteriores, á menudo opacas; tienen una celdilla mdial, medianamente adelgazada en ambos lados $y$ tres cubitales, ofreciendo la primera poco mas 6 menos el tamano de las otras dos juntas. La boca se caracteriza por una lengua larga, paipos labiales de doble forma y palpos maxilares de seis artejos. El macho un poco mas pequeño, se distingue por tener el abdómen mas estrecho y puntiagudo, por carecer de una franja cue la hembra tiene en el penúltimo segmento, y casi siempre los pelos mas espesos en la mitad anterior del cuerpo, y otros phateados en la cara.

USOS, COSTUMBRES Y REGIMEN.-ILS nómadas viven como parisitos, particularmente en las andrenas y longicornios, y vuelan por lo tanto en gran número alli doncic estos tienen sus agujeros subterráneos. Entonces se ve cómo las hembras rasan la ticrra con vuelo no muy rapido para buscar los nidos de nquellos insectos en los termplenes, linderos de los bosquites, etc. Los unos se presentán muy al principio de su estacion; otros mas tarde y algunos en otoño. Segun opinion de, Schenk, los hay que se presentan dos veces al año. Los primeros que llegan reúnense con sus anfitriones y otros insectos en las fiores de las sauces, del grosellero espinoso, y mas tarde en las yerbas en flor. Cuando descansan de noche, ó hace mal tiempo, obsérvase en estas especies una costumbre muy particular: se agarran con las maxilas a una hojita ó ramita, recogen todas las patas, inclinan las antenas hicia atrís y quedan así pendientes, en posicion vertical. Sus numerosas especies, í menudo variables en tamano y color; se distinguen a veces dificilmente y muchas de las propias de nuestros paises se encuentran tambien en la Imérica del norte, mientras que en las regiones cálidas están representadas p por otras formas.

\section{EL NÓMADA DE ROBERJEOT - NOMADA ROBERJEOTIANA}

CARACTERES. - Esta especie, de mediano tamaño, es al mismo tiempo la mas abigarrada y no se presenta hasta últimos del verano ó en otoño. El abdúmen, ancho y corto en ambos sexos, es rojo en el primer segmento, y en los siguientes negro por lo regular, donde adquiere á veces poco a poco un tinte rojizo; en el macho se ven unas manchas triangulares blancas en los lados; en la hembra solo dos y una cuadrangular en la punta. El tórax de un negro mate tiene en el macho un color amarillo, lo mismo que la carn y la parte inferior de la brocha de las antenas; y el tallo de estns, el escudete y las patas, son mas ó menos rojos; las últi- mas presentan manchas negras en los muslos. En las hembras los dibujos claros son mas escasos y solo adquicren un tinte rojo.

\section{LAS MELECTAS-MELECTA}

CARACTERES. - Las melectas tienen una estructura mas fuerte y la cabeza y el tórax cubiertos de pelos, pero este se reconoce fícilmente en las manchitas de pelos blancos sobre el abdómen, que es negro y ancho y se adelgaza hảcia atrás bruscamente. La celda radial es regularmente ovalada; las celdas cubitales y la forma de la boca se asemejan a las del género anterior. En cl escudete, muy convexo, hay dos dienies laterales, ocultos por los pelos. La hembra pica con un aguijon muy largo y fuerte hácia arriba, mientras que el macho prefiere morder. Viven como parásitos en las especies de anthophorn, y segun cree Lepelletier, tambien en las gran. des especies de megachile.

\section{LA MELECTA PUNTUADA-MELECTA PUNCTATA}

CARACTERES. - Esta especie tiene la mitad anterior del cuerpo cubieria de pelos de color blanco sucio (gris amarillo).

USOS, COSTUMBRES Y REGIMEN. - Vive como parásita con preferencia en la anthophora refusa.

\section{LA MELECTA LUCTUOSA-MELECTA LUCTUOSA}

CARACTERES. - Fsta especie tiene las mismas partes cubiertas de pelos blancos.

USOS, COSTUMBRES X RÉGIMEN، - Vive como parásita sobre todo en la anthophera astizalis, y anda por el suelo para buscar los nidos; tambien halla su alimento en la yerba de aspid y en otras flores.

\section{LOS CELIOXIS - CELIOXYS}

CARACTERES.-LOS celioxis, que despues de los nómadas constituyen el género de parisitos mas rico en especies parn nuestras regiones, se asemejan en un todo por su exterior a las especies que recogen su alimento con los pelos del abdómen, pero el de la hembra es mas puntiagudo, mientras que en el macho es obtuso y tiene varios dientes encor. vados hácia arriba Las especies son diniciles de distinguir, pues todas parecen negras, y estan cruzadas de fajas blancas poco marcadas: caractetrizanse además por el escudete prominente, provisto a cada lado de una espina; por tener solo dos celdas cubitales, por el labio superior, casi cuadrangular, y por su olor desagradable.

USOS, COSTUMBRES Y REGIMEN. - Viven como parásitos en los mismos géncros que las especies anteriores y ađemás en el saropoda.

Hace algunos años que en la primera mitad de junio visité una casa de campo. La fachada anterior del cuificio se componia de una pared de barro bastante larga, sin blan quear, orientada al sur y que al parecer servia de vivienda a muchas abcjas y avispas; nunca habia visto tantas reunidas. la pared estaba perforada de tal modo que parecia un harnero. En las abejas predominaban trés géneros, anthophora, melecta y culioxys; volaban y zumbaban sin cesar y em divertido ver su agilidad; solo sentia que no hubiera un buen sitio para la observacion cerca de la casa. Los parisitos vagaban de un punto á otro, esperando solo el momento favo 
rable en que un antoforo saliem de su nido. Apenas se alejaba alguno, presentailuase un intruso para examinar minuciosamente el agujero. Cuando por descuido se dejaba coger por la propictaria que volvia demasindo pronto, tratuíbase una lucha mas peligrosa en apariencia de lo que era en efecto; pues la habitante legitima, terminada la lucha, continuaba su ocupacion acostumbrada, y la otra parecia olvidar a poro rato la leccion, pues proseguia tambien sus pesquisas, si no en el mismo nido, en otro. De un modo semejante proceden las pequeñas avispitas llamadas doradas, que pronto conoceremos.

Dejando ahor los antofilos, fijare mi atencion en las avis pas rapaces, que menos por su género de vida que por su aspecto exterior son demasiado diferentes parn poder reu. nirlas en una sola familia

\section{LOS DIPLÓPTEROS - DIPLOPTERA}

CARACTERES. - Yos diplópteros, llamalos tambicn sencillamente avispas (éespnria), se distinguen de todos los otros himenópteros porque en estado de descanso las alas anteriores recogen en un repliegue longitudinal parte de las posteriores y colocindose á los lados del abdómen no cubren este. Il cuerpo, casi ó del todo desnudo, no tiene por la re. gular la piel negra como en los antofilos, sino que unas man. chas y fajas amarillas ó blancas producen en la cabeza y en el abdómen matices abigarrados. Encontramos colores pare. cidos tambien en varias familias siguicutes, pero en cambio es otra la forma de las antenas y de las alas, de modo que con un poco de precaucion no es posible confundirlas. Las avispas tienen como las abejas antenas angulosas, en el ma. cho menos marcadas a causa del poco desarrollo del tallo; el aguijon defensiro solo es propio del sexo femenino y de la tercera casta de las hembras no desarrolladias, cuando cxisten. Aunque las avispas mismas solo buscan sustancias dulces, que lamen con la leugua, la mayor parte de las esprecies crian sus larras con otros insectos, queles ofrecen mascandolos antes.

DISTRIBUCION GEOGRAFICA.- El mayor número de especies de la familia habita en las regiones calidas, mientras que en Europa se encuentran relativamente muy pocas; cunnto mas se aleja un pais del ecundior tanto mas escasean en él las avispas.

\section{LOS MASARIS - MASSARIDA}

CARACTERES. - Por SU eŝtructura y en parte tambien por su género de vida, los dijlópteros ofrecen "muchas diferencias que son caltsa de que se les divida en tres géneros. En los unos, las alas anteriores tienen solo dos celdas cubitales cerradas; el escudo de la cabeza recoge por una escotadura en su parte anterior el labio superior, y la lengua remata en dos finos hilitos. El escudete se sobrepone a la parte siguiente, al llamado escudete posterior. Jas antenas se complonen solo de ocho artejos que hricia adelante se ensanchan en forma de maza. Los citados caractéres son los de los masaris $\delta$ avispas masaridas, que comprenden unas treinta especies propins de los paises cillidos, de las que dos, el celonites arjo formis y el ceramius Fonscolombi, pertenecen a la Europa meridional.

USOS, COSTUMBRES Y REGIMEN.-Ël género de rida de la mayor parte de estas especies no se conoce aum lo bastante, pero atendido que algunas se han reconocido como paraisitas, se cree poder considerar las de todo el género como tales.

\section{LOS EUMÉNIDOS-EUMENIDE}

CARACTERES. - T os euménidos construyen el segundo género. Tichen en el ala anterior tres coldas culsitales cerra. das (hasta podria decirse cuatro, porque el cúbito liega rasi siempre al extremo del ala); la lengua larga, dividida en bres partes; los jalpos filiformes, de seis artejos en las maxilas y de cuatro en el labio inferior; el escudo de la cabeza afecta la forma de corazon ó es oval, sin rematar nuncá en un dien. te: los ojos llegan hasta la base de las maxilas y tienen una profunda escotadura en el borde anterior, cerca de la coroni11. Ins antenas, angulosas, se ensanchan ligeramente hicin adclante, componiéndose de dos ó tres artejos. Las maxilas, mas largas que anchas, strelen dirigirse en forma de pico hácia abajo; las garras de los piés llevan en la cara interior un diente, raras veces varios, y los tarsos medios un solo es. jolon.

USOS, COSTUMBRES Y REGIMEN.- $\mathbf{Y}$ sí como las especies anteriores, estas viven tambien aisladamente con preferencia en paredes de barro y pencientes arenos:ss, pero algunas visitan los tallos secos de las plantas, en las que ronstruyen series de celdas de tierra (odyerus mbicola). Nuestras especies, cuando menos, no viven nunca en tierra sencilla $\delta$ en la arena ligera y provecn a su cria una ve\% para siempre de la provision necesaria de larvas recogidas.

\section{LOS VÉSPIDOS - VESPIDE}

CARACTERES. - I.os véspidos viven por lo regular sociablemente; tienen hembras infecundas jor trabajadoras, $y$ construyen nidos muy artificiales, donde alimentan su cria del nismo modo q̨ue las abejas domésticas y los abejorros. Por su exterior se parecen en un todo al género precedente, pero tienen las garras de los piés sencillas: en los tarsos medios hay dos espolones: la lengua es corta, compuesta de cuatro lóbulos: las maxilas son mas cortas y á su base no llegan por lo regular los ojos: el escudo de la cabera es cuadrangular. los dos últimos géneros, segun linneco, se desig. nan con el nombre genérico de iespa.

\section{LOS ODINEROS - ODYNERUS}

CARACTÉRES.- Estce es un grupo muy rico en especics, disenimadas por toda la tierra, y en el se ve una de las formas primitivas del abdómen. Esta parte, que is pendiente. comienza con un segmento y̨e alecta mas ó menos la forma de campana, siendo nuas angosto que el segundo, de modo que el abdómen parece un poco estrechado en el sitio donde aumbos se reunen: en el vicntre hay un profundo hoyo; el es cudo de la cabera es escotado y se prolonga en cada lado por un dientecito. Casi lodas las especies son de color negro, con fajas de un amarillo viro en el abdómen y manclitas amarillas en la cabeza ó en el tórax. El macho, un poco mas pequeño y delgado, tiene la extremidiad del ahdómen un poco mas ancha, con dos apénäices en los órganos genitales, que despues de la muerte sobresalen á menudo como das pequeñas espinas de la punta abdominal:además se caracteriza en muchas especies por las anteuns, en forma de espiral hácia afuera. Ultimamente se han formado con este grupo varios géneros, tomando en consideracion pequeñas diferencias de estructura general, que consisten, por ejemplo, en ser la parte posterior del cuerpo redondeada ó angulosa, ó estar dividida por un reborde trasiersal en una parte anterior verticalmente deprinida, y en otra posterior horizontal, ctc; todos estos gi: neros sun análogos sin embargo por muchos conceptos. 


\section{EL ODINERO DE LAS PAREDES - ODYNE- RUS PARIETUM}

CARAGTÉRES. - Esta especic varia mucho por sus ma-

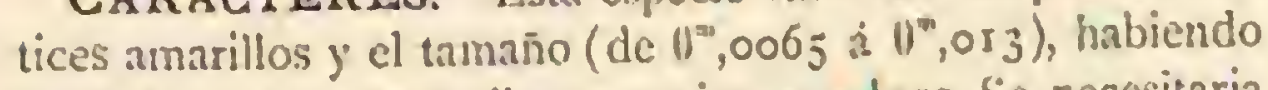
recibido de los entomólogos varios nombres. Se necesitaria uma descripcion muy minuciosa parn distinguirla de muchas especies parecidas. La parte posterior del dorso tiene un surco central y se deprime verticalmente hácia el primer segmento del abdómen; este segmento, deprimido tambien ver. ticalmente en su parte anterior, usta orilladó en la posterior de una faja amarilla muy ensanchada hácia adelante en los lados; otra de igual anchura se corre entre los otros segmentos, $y$ tambien en cl vientre se ven borles amarillos, mas anchos en el centro, indicádos solo hácia la extrumidad por manchas centrales. Las patas son regularmentc amarillas en la mitad posterior de los muslos, en el túrax y el collarin; dehinjo de la base de las alas tiay una manclia redonda, otras dos iguales en el escudete, y una línea por detrís de cstc; parte de las escamitas de las alas son tambien amarillas, lo mismo que el borde del escudo de la cabeza, una manchita en cada maxila, otra en medio de las antenas, la cara inferior del tallo de las mismas y a reces una manchita por detrás de cada borde exterior y superior de los ojos. En los inatices amarillos de la cabeza y del tórax se fundan principalmente las variedades que se observan. En el macho los dos uiltimos artejos de las antenns se encorran er forma de gancho hàcia atrás; el escudo de la cábeza es del todo amarillo, pero falta la mancha debajo de las alas.

USOS, COSTUMBRES Y REGIMEN.-El odinero de lis paredes se presenta en los últimos dias de mayo y la hembra puede verse en los meses siguientes ocupada en los deberes para con su progenie. Fabrica su nido en una pared ruinosa de barro 6 en la pared de un foso, practicando poco ¿ paró con sus maxilas un agujero de 10 centímetros de profundidad y de una circunferencia poco mas grande que la de su cuerpo; cl barro que extrae lo inoja con saliva y sin duda con el agua gue bebe al efecto, formando despues delante de Ia entrada un tubo que se prolonga à medida que el agujero se hace mas profundo. Isste tubo sale al principio en linea recta desde la pared, perose encorra poco á poco liácia abajo, reconociéndose los ladrillitos de barro que con ayuda de la boca, de las patas y dé las antenas ha fijado la avispa a su alrededor. No todo el barro extraido de la pared se emplea sin embargo de este modo, pues á menudo se observa que la avispa lo deja caer al suelo. Se han buscado varias razones para explicar qué podria inducir al insecto à formar este tubo, y se ha creido que estí destinado á la defensa contra los ataques de un enemigo, y á evitar el calor del sol, ctc. Sin poder probar mi parecer por una observacion directa, creo que la avispa quiere tener á mano el material de construccion aun cuando ha de cerrar el hido. Cuando la habikacion está hecha, la cuidadosa madre trac larwas de coleópteros y de pequeñas mariposas destinadas para el alimento de su cria. Llegada al nido, coge la presa por la cabeza, la lleva al fondo y la oprime contra la pared; la larva no ha muerto, solo está paralizada por una picndura, y toma una posicion circular correspondiente a la forma de su cuerpo en el estrecho tubo. Una segunda, tercera hasta octava larm, ó mas, se colocan una al lado de otra y llenan el espacio del nido; cuando la provision es suficiente, la hembra deposita un huevo $y$ cierra la abertura con barro.

Para depositar un segundo huevo hay ņue construir otro nido, pero de una observacion de Reaumur resulta que el trabajo adelanta rápidamente cuando el tiempo es favorable, pues cl citndo obscrvador vió como en una hora una avispa penetró en la pared con todo su cucrpo. Sin cmbargo, tamthien utilizan nidos vicjos, y se cree que aprovechan asimismo los de los antoforos. Al cabo de pocos dias sabe la larva alimentarse con las provisiones que encuentra, $y$ à las tres semanas llega d la edad adulta. Despues construye un capullo bastante sólido, de color pardo sucio, pegado al suelo del rido y espera en él la primavera. Pocas semanas antes de que se presente la avispa se trasforma en crisálida y roupe fácilmente la tapa de su celda para salir á la luz del dia Wesmael refiere una bonita historia que demuestra cierta inteligencia en el insecto. Una avispa encontró una hoja arro. llada por una oruga de mariposa, reconoció las dos extremidades abiertas con sus anienas, corrió despucs al centro y ojrimiỏ el rollo con sus dientes hasta que la oruga, molesta. da, salió por la abertura de su retiro, siendo cogida entonces por la rapaz, que se la llevó presurosa.

\section{EL ODINERO ANTÍLOPE-ODYNERUS ANTILOPE}

CARACTERES. - Una especie muy parecida á la anterior es el odinero antilope, cuya hembra, que mide mas de 04,015 , se reconoce por el borde arqueado superior de color amarillo del escudo de la cabeza y por in escotadura mas ancha que distingue la faja amarilla del primer segmento del abcóómen.

\section{EL ODINERO DE PATAS ESPINOSAS-ODY - NERUS SPINIPES}

CARACTERES. - Esta especie no tiene sutura trassersal en el primer segnuento del abdómen, como las dos anteriores; carecé de la escotadura è la faja annarilla del mismo yitiene las fajas de los otros segmentos mas estrechas. los muslos de las patas medias del macho presentan en su cara inferior profundas escotaduras y las antenas forman circunvoluriones en la punta como una espiral.

Saussure describe 207 especies de este género, propias de todas las regiones del globo.

\section{LOS EUMENES-EUMENES}

CARACTERES. - Una segunda serie de formas de los cu. ménidos ofrece el grupo eumenes tan diseminado como tf anterior, pero mas escaso en especies; es el que dió á todo el género su nombre, y últimamente se ha dividido tambien en otros varios. Los eumenes tienen cl abdómen pedunculado; el primer segmento, muy dihatado en su parte posterior, se estrecha hácia adelante en forma de tallo, y el abdómen fusi forme desde el segmento segundo, se inscrta en él. Esta es tructura les comunica la verdadera forma de avispa. El tónar corto y casi esférico ya de por si, parece mas corto aun en comparacion con su abdómen tan prolongado. En el macho, que en la extremidad del abdómen presenta el caricter șa dicho, el último artejo de las antenas forma un delgado gancho muy puntiagudo; el penuiltimo es muy corto y mucho mas grueso y el anterior se cusancha mas aun.

\section{EL EUMENES POMIFORME-EUMENES POMIFORMIS}

Caractéres. - Ia única especie que en Europa se extiende mas hácia el norte y tampoco escasea en Alemanin es el eumenes pomiforme, cuyo macho tiene tambien el nomt bre de eumenes catarta. Fil escudo de la cabeza tiene uris marcada escotadura hácia adelante; el tírax se deprime rer 
ticalmente por atmis; el primer segmento abdominal tiene la mitad posterior un poco mas grande, en forma de copa; el segundo se le parece en longitud, pero su circunferencia es cuatro veces mayor. El cuerpo mide de $11^{\infty}, 013 \$ 10^{10}, 015 \mathrm{dc}$ largo y es negro, con manchas amarillas mas abundantes que en otras especies, y mas variables aun (fig. $3^{8} 8$ ).

USOS, COSTUMBRES Y REGIMEN, - Lepelletier encontró en un arbusto sólidas celdas de barro, proco mas ó menos del tamano y forma de una avellana; contenian unas larvas verdes parecidas a las del odinero de las paredes, $y$ supone que pertenecian al cumenes pomiforme, porque en otra ocasion observó, en un dia húmedo y fresco de verano, con iguales condiciones, una celda comenzada, en la que se hallaba una hembra de la citada avispa, la cual se defendió al acercarse el observador. Fn otras celdas concluidas vió las larvas verdes. Además se pretende de esta especic que tiene dos crias al año, presentandose la progenie de las hembras invernaclas en junio, y que aqquella se propaga otra ve\% hasta el mes de agosto, despues de un periodo de 23 dias. In chrorsis igmita pertenece a los parasitos del eumenes pomi. forme.

\section{LOS VÉSPIDOS-VESPIDE}

Ia mayoria de los véspidos socinbles nos asombra por la construccion de sus castillos y palacios: nunca hubiéramos esperado de unos séres tan belicosos y salvinjes, como lo son todas las avispas, el maravilloso instinto para construir las obras de la paz. Tambien aqui encontramos panales como los de las abejas, pero no dobles sino sencillos, con las aber. turas de la celda dirigidas hácia abajo y no hechas de cera. Tambien aquí hallamos hembras no desarrolladas, que los construyen lo misuno que las trabajadoras. El material sê compone principalmente de partes vegetales, que mascadas y amasadas con abundante saliva quuitinasa, se trasforman en aquellas obras de arte, ya solidas, ya elásticins. Los nidos, hechos como de japel, se componen de largas celdas de corteभa, semejantes al carton de fibras vegetales, ó de una mízcla de estas con pedacitos de corter. El producto mas desme. nuzble de nuestros avispones es el parénquima de la corteza, que aparece siempre en fajas y que proviene de diversos árboles. En algunos casos, pero rarn ver, las avispas exóticas construyen sus nidos tambien con tierra fangosa ó estiércol de animales plantivoros.

Mucho mas variado que el material es el plano de cons. truccion y el modo de fijar los nidos. L.os unos estan dis. puestos en forma de tablas en la cara inferior de una hoja o de un tronco de árbol; los otros recogen con su extremidad inferior una rama y quedan pendiences en forma de un cilindro, de una bola ó de una semi-esfera, 0 bien se ocultan en. tre las ramas de hojas con que se han construido en parte jo en algunos casos toda la construccion se apoya sobre un tronquito o varios. El nido mas sencillo se compone de una 6 diversas series de celdas exagonales, dispuestas en forma de rosetas circularmente, con las desembocaduras inclinadas hácia abajo. Si los panales estuviernn dirigidos hàcia arriba se recogeria en ellos la hunedad de la lluvia, y además no se recibiria el calor necesario para el desarrollo de las larvas.

Con esta sencilla construccion no secontentan, sin cmbargo, la mayor parte de las avispas, sobre, todo las que viven ent grandes sociedades. Protegen, por ló regular, sus panales con una cubierta construida de dos modos esencialmente diferentes. Con los panales fabrican nidos en forma de tapa $\checkmark$ de columnas. Consideremos, jor ejenuplo, el gracioso nido de la polybia seduln, especic propia de la América del sur, de 0 ",0060 de largo. In avispita se da á conocer por abun- dantes manchas de un blanco pailido sobre un fondo negro mate, $y$ fija su nido por medio de un tallito en la carn inferior de una hoja. Hecho el primer panal, construye por debajo de él, a media distancia de una celda, una tapa, que se fija mediante la prolongacion de las paredes laterales del panal. I a cntrada queda reducida a un agujero laterai. Cuando la pequeña sociedad aumenta en número, la habitacion llega i ser sobrado estrecha. Entonces se fija en la taja del primer panal, un segundo provisto tambien de una tapa y de una entrad. Segun la necesidad, el numero de pisos adheridos puede ir en aumento y el nido viene a formar por fin en su conjunto un cilindro cada ver mas prolongado. Ln otra especie puede adquirir la forma de cono y en una iercera hin. charse en el centro.

De un modo algo diferente edifica la polybia rejecta. Ro. dea una rama con el primer pasial y deja en el centro de la tapa la entrada. Cuando el tamano del nido aumenta, constriyge un segundo panal, y en cste queda abierta lat currespondiente entrada. De este modo se continúa la ohra hasta ilc. gar a cuatro y mas pisos. Del mismo modo construye il chatergus chartarius, avispa de mediano tamaño y de color negro, cuyo abdómen pendiente presenta unas fajas amarillas.

El totun morio negro, muy frecuente en Cayena, cuyo ahdómen ancho $5 e$ adclgaza en su parte anterior, como en los eumenes, en forma de tallo y cuyas alas son muy parduscas, cuclga sus nidos, de una longitud de varios piés, en las ramas, en las cuales se fijan del mismo modo que los de la poljyia re. jeilas. Estos nidos se distinguen por el sistema de construccion de los de la especie citada, por tener las eniradas, no en el centro de la tapa, sino en la pared. Presentan un color par. dusco, son muy duros, gruesos y en extremo hímedos. Este nido se construje á principios de la época de lluvias y va aumentando durante la misma en tamano; à consccuencia de la humedad se cubre de nusgos y de otras plantitas criptógamas y queda durante mucho tiempo pendiente de los árboles, aunque sus habitantes hayan nuerto i principios del invierno, es decir, de la estacion seca. El Museo de Paris conservin, segun Saussure, un nido cilindrico comprimido de la polynio lifincen del Brasil, el cual por su tamaño demuestra el enorme número en que estas avispas pueden vivir juntas. El citado nido está roto en su parte inferior, J por lo tanto es incompleto: a pesar de esto mide por una anchura de $1, ", 314$ $\left\{0^{\circ}, 628,1^{\circ}, 25 j\right.$ hasta $1^{*}, 57$ de longitud, estando formado de 26 pamales ó pisos. Este nido se ensancha insensiblemente lrácia abajo tiene una cubierta delgada rugosa, un color pardo rojo, el aspecto de la madera, es bastante obluso y la cutrada se halla en el centro de las tapas. La poljliva iajenensis cuns. truje igualmente nidos de panales en forma de tapa, con un birro meaclado de hierro ó cuarzo de un color gris amarilin, fijandolos en delgadas ramas que se dirigen oblicuamente haicia tierra. El notable peso del material empleado pone limite pronto al tamaño: los nidos de $10^{\circ}, 366$ de longitud por $0^{\circ}, 105$ de ancho pertenecen \& los mas grandes que hasta ahora se han encontrado. Fin todos estos nidos de panales en forma de tapa, la cubierta está intinamente relacionada con las celdillas, faltando los espacios 6 lusecos que suele halser entre ellos. Ninguna avispa europea construye tales nidos: pero si numerosas especies de la América del sur.

Ias avispas del antiguo mundo $y$ muchas americanas que protegen sus nidos de panales en forma de columna con una cubierta, siguen otro sistema. Rodean á cierta distancia los panales, que por medio de columnitas estàn adheridos unos i otros y van formando i manera de pisos, de una especie de manto. Las entradas interiores huelgan, porque los janales son accesibles por todos lados. En estos uidos predomina 
la forma oval ó esférica, pero en su construccion interior pueden existir dos diferencias esenciales. El chatergrus apicalis de la América del sur, avispita del todo negra, fija varios panales provistos de tallos, uno debajo del otro, en una rama, y los rodea de una cubicrta parecida a papel de color ceniciento. Diferente aspecto presentan los nidos de otras especies, que siguen el mismo sistema de construccion. Mientras que las columnitas que aqui llevan los panales se fijan cada una de por si en un objeto cualquiera, recorren en la mayoría de los casos los panales entre sí, como por ejemplo en los de la folylia ampullaria. Hay conformidiad de construccion entre el nido de esta y los de nuestras arispas, de los que unos se encuentran en lís ramas de arbustos y árboles, otros en agu. jeros sutterraineos, algunos en troncos de ârboles huecos, en los aleros de tejados ó en sitios parecidos, guarecidos de la Iluvia Segun el sitio cambia la arispa el plano de construc. cion. As por ejemplo, tos nidos de avispones, adheridos a un tronco de ärbol hueco, no necesitan de la tapa, pero esta nunca falta cuando el nido pende libremente.

1)ifriendo de las formas principales que acabamos de describir, construyen las numerosas y pequenas especies del género necsarinia, propio de las regiones cálidas de la América. Ia capa parecida á papel es generalmente esférica y se compone de una sola hoja, no de capas ni de pedacitos en forma de hoja, como la mayor parté de las otras, y creemos no encierra pisos en el interior; las celdás forman, por el contrario, esferas concéntricas encajadas una en otra con mayor regularidad y su materia es muy frágil. Los panales se unen con la cubierta por medio de fajas, y entre si, por otras de papel con circunvoluciones $y$ en figura espiral. En estos puritos de reunion quedan las aberturas; de manera que las fajas presentan, en cierto modo, escaleras que conducen á los panales y sirviendo además como fondo de las celdas llenan à la vez tres objetos. El interior está cruzado de humerosas ramas que aumentan ta solidez de esta ligen construccion. Tales nidos llegan a contar à reces $0^{m}, 628$ de diametro y tienen numerosisimas celdas. Las indicaciones que acabanos de hacer pueden ser suficientes para dar idea de su gran variedad que unida à una construccion graciosa, llega i causarnos asombro. Todos estos nidos sirven solo para un verano. En primavera los principia una hembra fecundada, oculta durante el inyierno; y con el tiempo van adçuiriendo mayor tamaño mediante el esfuerzo de las trabajadoras, siguiéndose exactamente el plano indicado por la madre y constructora prinitiva; cuando se acerca la estacion cruda quedan abandonados como los de los abejorros.

El génèro polyobia, varias veces mencionado, está representado por numerosas especies en la América del sur, y es propio, en general, solo de los paises ecuatoriales; su aspecto cxterior nos recuerda à los eumenes. En este género el abdómen se fija tambien en el tórax por medio de un tallo muy hinchado en su parte posterior. Pero al recordar las diferencias genéricas ya citadas, segun las que, los tarsos medios siempre llevan en su extremiclad dos espinas, los piés están provistos de garras sencillas $y$ los ojos no llegan hasta la base de las maxilas, no podemos menos de dudar si tenemos à nuestra vista una avispa sociable, 6 una solitaria. Además, los polibios no llegan al tamaño de muchas especies de eu. menes; tienen desde el segundo segmento un abdúmen mas oval ó casi esférico, mientras que en aquellos es regularmen. te fusiforme y se adelgaza mucho haicia atris.

Un segundo género diseminado por todo el globo es el de los polistes. Sus especies tienen los contornos del abdómen en forma de lanceta; el primer segnento se estrecha poco a poco hácia adelante, pero no se prolonga en figura de tallo; y como la parte posterior del dorso se deprime oblicuamente, aparece entre ella y el abdómen un notable intervalo. El escudo de la cabeza se prolonga angulosamente en su parte anterior, es truncado, casi en linea recta en su borde superior, y una antena se halla á bastante distancia de la otra. Las maxilas, casi iguales en longitud y anchura, es. tán provistas en la superficie mascadora de cuatro dienteci. tos, cuyos tres posteriores iguales guardan los mismos intervalos, mientms que el diente de la punta, colocado muy pro. ximo al inmediato, se distingue de ins demás por su poca
longitud y por su forma obtusa. Las antenns de los machos longitud y por su forma obtusa. Las antenas de los machos encorvan hácia fuera sus puntas en forma de gancho. Los nidos son de los mas sencillos, y se componen de un panal, raras veces de dos, descuhiertos. El polistes francés (polistes gallica) se extiende en gran número, no solamente en Frnncia, sino tambien en Alemania; en este pais, segun parece, en no son del todo amarillas, sino cuando mas tienen su cam inferior de un color rojo amarillento. Todo el cuerpo estí provisto de abundantes manchas amarillas, sobre un fondo negro. Ios bordes posterinres de los segmentos abdominales están todos provistos á su alrededor de bordes amarillos que
en la parte anterior del dorso se presentan cual si estuvieran corroidos y en el vientre carecen de la escotadura central.

Al comenzar la primavera se presenta la hembra fecundada y construye en la rama de un arbusto, ó debajo de la prominencia de una pared, en una reducida columnita, algunas pocas celdas que con el tiempo forman una especie de rosetas sin cubrir.

Ell verano debe ser nuy farorabie à la pequeña sociedad; pues aumenta de tal modo que necesita ya un pequeño panal, el cual se fija en el primero mediante una columnita central. Lepelletier observó à menudo tales nidos cerca de Paris, y calcula los habitantes de este Estado, en la estacion avanzada, en 60 y hasta 120 individuos, de los que unos 20 a 30 son hembras. En algunas celdas encontró tambien provisiones de miel, destinadas, en mi opinion, à la cria de larvas femeninas.

El 16 de agosto de 187.3 encontré en Imunden el nido de dicha variedad con sus habitantes, y numerosas celdas provistas de tapas debajo de una ventana lienando una pequeña cavidad del suelo. Las avispas, que estaban tranquilamente sobre el nido, se empinaron todo lo posible, cuando me acerqué a ellas, moviendo sus alas; mas permitieron que introdujera el nido en una caja, ha cual cerré sin que ninguna se alejase. Esta circunstancia y la posicion del nido (la ventana pertenecia á la fachada anterior de la fonda reunida i una cerveceria y un camino muy frecuentado pasaba por de. lante de la misma) demuestran la escasa timidez y el carácter poco salvaje de estas avispas. Despues de haberlas aturdido, haciéndolas salir del nido, te envolvi en un papel colociln. dolo con algunos objetos de viaje en una caja de carton, porque mi estancia tocaba á su término en aquel punto. Mas tarde, sentado en un coche del ferro-carril, vi como por el saco de viaje se paseaban algunos polistes. Ias crisálidas del nico habian nacido poco a poco $y$ las avispas se habian alejado, dejando ligeras huellas de su aficion constructora; pues varias celdas en medio del panal uresentaban bordes blancos, en los que e] papelen que el nido estabri ensuelto habia
servido de material.

Mucho mas interesantes son las observaciones que Siebolả ha hecho en la misma variedad. Colgó en pequenas tablillas los nidos, abundantes en los alrededores de Munich, y los colocó en la fachada meridional ú oriental de paredes de tablas ó de edificios inmediatos, para poderlos examinar en todo tiempo. Despues de haber observado que las colonias júvenes, próximo el verano, contenian al lado de la madre 
primitiva tan solo trabajadoms, pero ningun macho, cogió en algunos nidos la mudre, saco de las celdas lodos los hueros y las larvas mas jóvenes, de modo que solo quedaron à las trabajadoras las mas aduitas. Despues de estas, se encontraron en las celdas vaciadas huevos que segun la opinion de Siebold solo podian haber sido deposiandos por las trabajadoras primitisas, porque estas nunca sufren que otra avispa entre en el nido. De estos huevos se formaron los machos, y teniendo en cuenta esta circunstancia, el obsersador demues. ira que en el folistes gallica los machos se forman por medio de la partenogénesis de huevos no fecundados, como hace tiempo se sabia con respecto a la abeja doméstica.

\section{LAS AVISPAS-VESPA}

CARACTERES. - El género avispa comprende especies propias de nuestros paises, de formas y colores tan amalogos, que à menudo es dificil distinguirlas con seguridad una de otra, sobre todo porque en muchas los machos difieren en este último concepto de sus hembras; y aumenta esta difi cultad para la clasificacion de las especies. La mayor parte de las de nuestros paises son negma y amarillas y muy aná. logas tocante a la distribucion de estos colores. Por lo regular los bordes posteriores de los segmentos abdominales están orillados de amarillo; en las hembras atrofiadas, estas fajas son un poco mas débiles y adquieren la forma de puntas. I a del abdómen es, en la avispa fusiforme, truncada verticalmente, reuniéndose con la parte posterior del tórax igualmente deprimido; por lo cual el intervalo entre ambos es estrecho y profundo. El escudo de la cabeza esta ligera. mente escotado en su parte superior y en la inferior adoptando la forma de arco y se acerca mucho a la base de las antenats. Las maxilas son en su parte anterior nucho mas anchas que en la posterior, truncadas oblicuamente, y están provistas de dientes en la mitad inferior de su superficie mascadora que aumentan en tamaio desde la parte anterior a la posterior. I as antenis del macho, mucho inas largas en la brocha, no encorvan su punta hácia afuera.

DISTRIBUCION GEOGRÁFICA. - Pocas especies de avispas habitan la Europa, siendo numerosas en las regiones templadas y frias de la America; se encuentran en China, Jara y en las Indias orientales; no conozco empero ninguna especie del Africa, ni de la Niueva Holanda. Los panales de sus nidos estín rodeados de una envoltura compuesta de hojas.

\section{EL AVISPON-VESPA CRABRO}

CARACTERES. - El avispon se distingue de las demás eșpecies por su extraordinario tamano y por el color rojo predominante en la mitad anterior de su cuerpo (fig. . o).

USOS, COSTUMBRES Y REGIMEN. - La hembm invernada comienza à primcipios de mayo la construccion del nido en una viga, en una colmena vicja, en un tronco añoso de árbol y en otros sitios solitarios El cimiento de su nido es un pedazo de la superficie esférica que mas ade. lante constituira la cubierta, y en cuya carn interior se inserta en una fuerte columnita el primer panal, provisto de unas celdas exagonalés abiertas Iácia abajo. II material se compone de la corteza verde de diferentes àrboles, sobre todo de saúcos jóvenes, que à veces quedan pelados y á los que perjudica.

Lo mezcla con saliva y prepara una masa que lleva al nido, entre las maxilas y el protórax. Entonces el avispon sujeta el material de construccion entre las patas anteriores, lo coge con las tenazas, lo oprime contra el sitio en que ha de construir y lo revuelve continuamente, mordiendo consecutivamente pedacitos que coloca, fija y alis?. I'odo esto lo efectua con tal rapidez, que podria creerse deshila el hilo de un ovillo. All mismo tiempo, con el numero de las celdas crece la envoltura que las rodar por medio de una apófisis que se prolonga en forma de espiral y que por fin forma una ciscara desmenuzable, cruzada de espacios planos parecidos \& vejigas. Cuando se ha terminado un pequeno nimero de celdas, comicnza la puesta de los huevos.

La cuidadosa madre pone primero la cabeza en la celda; toca el interior con sus antenas, se revuetve, penetra en clla por medio del abdómen, y' cuando pasados ocho of diez minutos, vuelve is salir, pucde verse en el fondo de la celda el huevo. Cinco dias mas tarde nace la larva, que encuentra ya una provision de alimento. Recibi un pedazo, mur curioso por cierto, de un nido de avispon con larras resecadas en celdas abiertas y cerradas, y en estas últimas tambien hijue. los desarrollados. En el fondo de las primeras habia una masa negra, sin duda el alimento secado, que se compone de cuerpos mascados de coleópteros, abejas, etc. Tambien so mezcla en ella miel, cuando el avispon puede procurirsela.

lil avispon se precipita cono la avispa sobre la presa escogida, la echa al suelo, le quita las patas y las alas y' se posa despues con ella en la rama de un àrbol vecino, eligiendo entonces la parte que quiere aprovechar, la que lleva despues is su nido. Ilegado á él, se posa sobre el panal, toma ol alimento entre las patas anteriores y lo distribuye en pedaciros entre las larvas mas grandes, colocándoselos en la boca. Estc modo de alimentar à las larvis adulias fué observado por el pirroco protestante P. W. F. Mueller, quien rio formarse entre sus colmenas uno de estos nidos: mientras las larras eran pequeias no pudo observar cómo se alimentaban; el mismo les ofrecia en un palito miel espesa que comian ron igual. voracidad que d slimento ofrecicio por la madre. Cuando la larm, al noreno dia de su nacimiento, es ya adul. ta, no solamente llena toda ia celda sino que sobresale de ella, por lo cual, la tapa con que cierra su clausura tiene una forma del todo hemisférica. En mi pedazo de nido he observado marcadamente que esta capa se compone de un tejido y no de la masa de la celda. Solo cuando la celda estra cermada, la larva puede atreverse a desamollar su cucrpo en el fondo sin temor y ocuparse en fabricar su tejido vidrioso.

Hecho esto, muda la piel, trasiórmase en crisálida, y al cabo de otros quince dins sale la jóven trabajadorn de avis. pon, que por lo tanto, necesita, entre todo, cuatro semanas pari desarrollanse. Tan luego como se-acostumbra á su nucvia posicion, limpiase las antenas $y$ las paias, vuelve i su cuna, déjala bien ascada y preparalo todo para dar cabida un segundo huevo, dando asi ejemplo del órden y limpicza instintivos, no aprendidos. Cuando ya encuentra al nacer otras hermanas, toma de la primera que llega un pedacio de alimento, lo distribuye entre las larvas, y despues de haberse dedicado de este modo dos dias à los quehaceres domésticos, sale con las hermanas a carar 6 buscar maicrial de construc. cion, sin descuidar por eso su propio alimento. Pronto el primer panal no basta; entonces se construye una columita y se da principio al segundo, dejando el intervalo que pueda ocupar una celda; el número de colmenas aumenta segun se necesitan; no se colocan en sitios determinados, pero su cifra es tanto mas considerable cuanto mas seahonda el fondo del panal: segun el ticmpo, el nido progresa rapida ó lentamente. Uno que yo poseo, no acabado y roto en la parte inferior de su cubierta, se compone de cinco paunles y liene $0^{*}, 31$ de altura por $U^{*}, 4 j$ de diametro en la cubieria del quinto panal, construccion que sin duda se debió is un año muy favorable para los avispones. Un nido acabado que pen- 
de libremente afecta poco mas ó menos la forma esferica; en la parte inferior tiene una abertura para entrar y salir y en este sitio se ponen siempre centinelas que al acercarse un intruso se retiran para avisar a los habitantes, los cuales salen con furia para precipitarse sobre el agresor, haciendo uso de sus armas envenenadas.

1)esde la sigunda mitad de setiembre, pero sobre todo à principios de octubre, nace la segunda cria de machos y hembras. No se sabe aun si respecto á los huevos rigen las mismas condiciones, ni tampoco se conocen las circunstancins que influyen en el desarrollo de una hembra fecunda. No he podido descubrir en ningun nido de avispon celdillas reales que hubieran tenido otra direccion, pero si he visto algunas en las filas gue se distinguen por su mayor longitud y circunferencia Cuando se ncerca la estacion fria, despues de haberse encontrado las parejas, las trabajadoras, hasta entonces an cuidadosas, anięuilan por si mismas la cria, aun existente, segun dicé Reaumur, pues conviértense en furias salvajes y la maltratan. Si este proceder fuera regla entre los avispones y avispas, lo que, sin embargo, no quisiera asegurar, demostraria otro marcado contraste cntre los véspidos carnivoros y salvajes y las especies de carácter pacifico, como los abejorros y abejas de la miel. Ixcejto las hembras fecundadas, que se ocultan durante el invierno en sus escondites ncostumbrados, las trabajadoras $y$ los =machos mueren poco à poco.

De las interesantes noticias del párroco ya citndo resulta que tambien se domestican si se lis trata con precaucion $y$ de un modo conveniente. Dice que podia llevar de una par. te atra la colmena donde estaba el nido; que le cxamina. ba a su antojo; y que no tenia dificultad en mostrarla à sus amigos para que observasen la vida familiar de estos animales, todo esto sin que los salmajes $y$ feroces insectos le molestarán nunca. I a colmena del párroco acabó no obstan. te de una manera triste: la madre que siempre iba y venia, no volvió cierto dia: la aficion de las trabajadoras se amortiguó y joco à poco abandionaron el rido.

Todas las demás especies del género iespa que en verano y otoño ragan por nuestros campos, y' que en la cosecha de Ias huertas de ártroles frutales $y$ en las viñaș, toman mas parte de lo que conviene al propictario, pasan por avispas a los ojos de la persona inexperta, sin distincion alguna. El natu. ralista, sin emlargo, conoce varias especies, cuyos nombres son mucho mas numerosos de los que realmente se conocen, demostrando que las opiniones están divididas y que no faltan errores. Como se necesitarian descripciones-demasiado detalladas para clasificar con seguridad todas las especies tan semejantes, nos limitaremos à dar aqui por lo pronto algunas uoticias sobre las diferencias en el género de vida.

\section{LA AVISPA ROJA-VESPA RUFA}

CARACTERES, USOS Y COSTUMBRES.-CON relativa facilidad la avispa roja se distingue de las otras por la base roja del abdómen. Tambien habita en la América del norte y construye nidos subterraineos, pero solo se la encuentra en pequenas agrupaciones, de modo que, cuando menos para nuestras regiones, debe considerarse como rara.

\section{LA AVISPA COMUN-VESPA VULGARIS}

CARACTERES. - Esta especie, que tambien construye nidos subterraneos $y$ abunda en el norte de Africa y de América, asi como en todos los puntos de Europa, suele te. ner en el escudo amarillo de la cabeza una linea longitudimal negra cnsanchada hácia abajo.

\section{LA AVISPA ALEMANA-VESPA GERMANICA}

CARACTERES.- Iil escudo de la cabeza en las hembras y trabajadoras suele tener tres puntos negros. El nombre de esta especie no está bien aplicado, pues no solo traspasa en Europa muchas reces las fronteras politicas de Alemania, sino que tambien se encuentra en Siria, en el notte de la India, en Argelia y’ en América.

Las tres últimas especies de que hemos hecho mencion, tienen la forma de la cabeza análoga, porque el borde infe. rior de los ojos casi toca la base de las maxilas.

\section{LA AVISPA MEDIA-VESPA MEDIA}

CARACTÉRES. - I a avispa media, tan comun entre nosotros como las dos especies anteriores, tiene el color amarillo del abdómen mas sucio, de un tinte pardusco mas mezclado que el de todas las otras especies.

\section{LA A VISPA SILVESTRE-VESPA SYLVESTRIS}

CARACTERES, - IA avispa silvestre, $y$ algunas otras uspecies mas raras y poco determinadas, se caracterizan por tener en medio de las partes ya citadas de la cabeza un marcado intervalo.

USOS Y COSTUMBRES. - Esta avispa fabrica sus nidos en el follaje de los árboles y arbustos, ó cuando menos en cualquiera eminencia del suelo. Se componen de una masa analoga al papel que las avispas confeccionan con las raspa. duras de la superficie de la madera, descompuesta y meacla. da con su saliva. FI fabricante de pajel de Ulm que entre sus productos jresentó en la Exposicion Universal de Viena de $1 \delta_{73}$ un nido de avispa, quiso sin duda indicar que hace mucho tiempo los fabricantes no habrian ofrecido al mundo un papel an malo como el de hoy dia, si antes hubieran imi. tado a las avispas. Ios nidos se fabrican exactamente segun el mismo plano que los del avispon, y los que están colgados libremente aventajan i los subterráneos y á los que se fracen en árboles huecos, porque pueden desarrollar su forma natural, que es la de un huevo 6 de un limon provisto en la extremidad de la cubierta de un agujero de entrada y en el interior de varios pisos de pamales, cuyo centro tiene natural. mente major circunferencia que la de ambas extremidades.

La avispa silvestre vive en sociedades muy poco numerosas, por lo cual construye solo nidos pequeños. Encontré uno sin concluir, cuya dueña primitiva debia haber perecido De co. lor gris blanquizco, y del tamaño de una nuez grande, pendia de una ramita de sauce, formando un ángulo de unos 4.5 grados. En su base estaba circuida de una capan exterior: sin duda la cubicra segunda, aun no acabada, que rodea todos los nidos completos de esta especic. La extrenjidad de la tapa interior estaba abierta en un agujero redondo de unos $0^{*}$, o 1 I de diimetro y permitia examinar el fondo. En la lase de la cavidad labia una roseta formada de doce celdillas exagonales estrechadas hicia atrais, siendo la central mas larga y completa que las laterales. El manio del nido de la avispa media y de otras especies se compone de pedacitos en forma de concha que se sobrep̧onen como tejas y solo están unidos en la base y en los lados, mientras que en la superficic separanse y forman espacios huecos en forma de vejigas. 'lengo algunos nidos de la citada especie de poco mas ó menos un palmo de largo por mas de tres cuartos de palmo de ancho.

Todo el mundo conoce la impertinencia $y$ la indole salvaje de las avispas, aungue como me sucedió i mi, no haya sido atacado por todo un enjambre al pasar inadvertidamen- 
te por un sendero donde estaba su nido. Hace pocos años que un perro de pastor y su ganado se hallaron en un caso semejante. En una pradera pacian vacas; el sitio estaba cu bierto de numerosas toperas, y en una de ellas fué a sentarse el perro, buen vigilante del rebano. De repente lanya un cerrible aullido, y desesperadamente arrójase al agua que corria por un lado de la pradera. El pastor no sabiendo lo que habit sucedido acude en auxilio de su fiel ayudante, llamale y le encuentra lleno de avispas, ocupado aun en sacudirse los insectos un poco refrescados por el agua, sin advertir que tambien él se hallaba solbre un volcan. Las irritadas avispas suben por sus piernas, por dentro de los pantalones, $y$ tambien se ve obligado á buscar refugio en el agua jara suavizar el dolor de las picaduras. Iil número de enemigos es cada vez major: aquellas toperas estaban habitadas por numerosas bandadas de avispas que hasta entonces no se habian visto; las vacas acababan de pisar algunos nidos, y los furiosos insectos las atacaron tambien. Todas mugen terriblemente $y$ se precipitan en el agua; la lucha es general y cuesta grain trabajo restablecer poco a poco el órden. Ias tentativas para destruir aquellos nidos y hacer accesible el paso para el ganado no tuvieron resultado, porquue las avispas, demasiado numerosas aquel año, habianse enseñoreado de aquella localidad. Cuando una avisja, con su amenazador zumbido, que podria tmducirse por tsu, $/ s u$, fsu, entra por la rentana, infunde temor. Busca una mosca, una araña, un pedacito de carme ó cualquier cosa dulce y no hace caso de las persecuciones á que esta cxpuesta. Con el mismo zumbido se aleja cuando no encuentra lo que busca; visita las carnicerias, los cestos de frutas y las confiterias, donde encuentra abundancia de alimento cuan(jo una vez. cambia su vida campestre por la de la ciudad. "Lista ha olfateado el cognac", dijo un viajero it su compañero en el lago de \%urich, cuando acababa de tomar un trago de su botella y apenas podia defenderse de una impertinente arispa. Sin embargo, kquién no perdonaria deste insecto su carácter salvaje y sus bruscos movimientos si reflexiona que en el corto termino de apenas seis meses debe construir un castillo de gran extension, fundar un estado y criar sus habitantes para asegurar á su progenie la reproduccion en el año siguiente? Para estas cosas el tiempo es oro, y se necesitan actividad y energia; pero estas parecen, al que suele olrar antes de meditar, salvajismo y precipitacion.

La progenie se cria del mismo modo que la de los avispo. nes, y apenas la jóven ciudadana ha entrado en la comuni dad, dedicase a los trabajos ele sus hermanas mas viejas. Edificar, cazar, asesimar, alimentar à sus larvas y reponer sus propias fuerzas, son quehaceres que ocupan toda la vida del insecto. En otono se presentan tambien machos y liembras para propagar la especie. Despues del apareamicnto y cuan do se siente poco a yoco un cansancio general, la autigua energía renace de pronto con un acto de crueldad contra los propios parientes. Las larras y crisalidas que aun se hallan en el nido sacanse y se exterminan; una excitacion general siembra el desórden; y excepto las hembras fecundadas, que buscan escondites seguros, todos los demás individuos mue ren uno tras de utro. Cuando comienzan las naches frias, la indomable fucrza de estos insectos, que no conocen resistencin, se agota del codo; y entonces quedan solitarios los sitios que habitaban, mudos testigos de su actividad pacifica.

I os antiguos conocian el caracter salvaje de los avispones y avispas: la expresion que se lee en Plauto de crntroncs ir rifare tenia sin duda el mismo significado que el proverbio usado hoy dia en Alemania de vexcirar un nido de avispas. Respecto al género de vida encontramos aun muchas cosas oscuras. I as noticias mas exactas y concretas son las de Aristóeles, que dice lo siguiente:

"Hay dos especies de avispas (spher.): la una comprende las mas raras y salvajes; estas viven en la montaña, no construyiu sus nidos en tierra, sino en las encinas: son mas gran. des y jrolongadas, de color mas oscuro, y mas valerosas que las otras; todas están provistas de un aguijon. Este es tambien relativamente mas largo y su picadura mas venenosa. Viven asimismo en invierno en las encinas huecas, de las cunles salen hasta en dicha estacion cuando se dan golpes en el árbol. Hay entre ellas, lo mismo que en las mas domesticadas, avispas madres y trabajadoras.

En las avispas donesticadas bay tambien dos clases; las reinas (hegenton), que se llaman avispas madres (metra) y las trabajadoras (ergates). I as primeras son mucho mas grandes y mansas; las últimas no llegan à un año de edad y' mue. ren todas tan luego como comienza el invierno, lo cual puede deducirse de la circunstancia de que cuando se siente el frio se atontan y no se las ve ya durante el solsticio. Ias reinas, en cambio, invernan en tierra, y se las ve á inenudo al labrar los terrenos, pero nunca se hallan trabajadoras. I a propaga. cion se verifica del modo siguiente: tan luego como la avispa madre, al acercarse el verano, ha elegido un sitio conveniente, fórmase al punto un nido de avispas (sphecon), que al principio es pequeño y tiene unas cuatro celdas. En estas se forman trabajadoras que se desarrollan pronto y construyen panales mas grandes, en los que vuelven i criarse hijuclos, aumentándose el múmero de aquellos hasta cl otoño, y en tonces es cuando los nidos son mas grandes pero entonces la avispa madre no produce ya trabajadoras y si solo hembras. Estas crian en la parte superior del nido, como larvas mas grandes, en cuatro ó mas celdas unidas, casi del mismo modo que los reyes en las colmenas de abejas. Tan luego como hay trabajadoras en el nido, las madres no trabajan ni van á cazar, encargándose aquellas de traer el alimento. No se ha observado aun si las avispas madres del año anterior son mucrtas por las jóvenes cuando han nacido otras, 6 si las dejau vivir mas tiempo. I madre tiene el cuerpo ancho, es pesada y mas gruesa y grande que la trabajadora; ruela pesadamente, y por lo tanto no puede franquear una gran dis. tancia; permanece siempre en el nido, en cuyo interior sigue construyendo. Esta madre se encuentra en la mayor parte de los nidos de arispa, pero los autores no están con. formes aun en si tienen aguijones o no. Parece, sin em. bargo, yue los poscen, como el rey de las abejas, pero no lo hacen salir y no pican. Fintre las trabajadoras hay algunas sin aguijon, como en los machos de abejas, pero otras le tienen. Las que earecen de él son mas perueñas y cobardes, pero las otras mayores y valerosas. Muchos llaman a estos últimos insectos machos y los primeros hembras. Muchas avispas que en rigor tienen un aguijon parecen perderlo en invierno, segun se dice, pero nadic ha podido confirmar el hecho como testigo ocular. I as avispas se producen sobre todo en los años secos y en las regiones pedregosas. Construyen sus panales con una mezcla de toda clase de cosas y tierra.

En otro pasaje dice que fabrican los panales econ un material semejante a lacorteza y a la tela de araías y que Ecada uno sale de un sitio como de una raiz. Recogen su alimento de algunas fores y irutos, mas por lo regular en sustancias animales. In cria de avispas no parece formarse por nacimiento, porque es desde luego muy considerable.s En otro lugar Aristóieles habla de huevos, lárvas y crisálidas, de. las cuales se forman las avispas perfectas. «Si se coge una avispa jor las patis, dejåndola zumbar con las alas, acuden las ņue no tienen aguijon, pero no las otras, circunstancia por la cual muchos autores deducen que aquellas son ma- 
chos y estas hembras. En invierno se cogen a veces en cavidades avispas con aguijon y otras sin él. Muchas avispas hacen pequenos nidos con pocas celdas y otros grandes con muchas. Las madres se hallan en gran número durante el periodo del solsticio en los álamos donde recogen sustancias glutinosas y resinosas. Una vez se presentó un gran enjambre de madres despues de haberse visto el año anterior muchas avispas y de llover copiosamente. Las avispas cazan en pendientes escarpadas y hendiduras del suclo y todas parecen estar provistas de aguijones.

\section{EL BELONOGASTRO-BELONOGASTER}

CARACTERES. - Al fin de toda la familia haré mencion tambien del belonogastro de Puerto Natal. I a cabera, el tórax, y el tercero y cuarto segmenios del abdómen que es muy pedunculado, son negros; la cara, la boca, las antenas, las patas, las escamitas de los bordes de las alas, una parte de los nervios de las mismas j el resto del abdómen de co. lor rojo. A causa de los pelos cortos, lisos y mas claros que cubren todo el cuerpo, los colores parecen turbios. Las alas son de un amarillo sucio en la punta; en el borde de la segunda celda cubital, muy estrechada contri la radial, se recogen los dos nervios braquiales. Como varias especies del génem no se han descrito aun, ni tengo a mi disposicion ninguna de estas avispas, dejo de clasificar la especie que nos ocupa.

USOS, COSTUMBRES Y REGIMEN.-El belonogas: tro, muy comun en Puerto Natal, es rimy aficionado a visitar las viviendas humanas; $y$ los indigenas le temen mucho a causa de la dolorosa picadura que infiere cerca de los ojos del hombre. A fines del otoño de aquella region: que es el mes de mayo de nuestros paises, cuando se hace mas seco el frio. la avispa se introduce aisladamente en las labitaciones para invernar. 1)espues de buscarse un sitio conveniente consti. luye un tallo córnco e insértale horizontalmente en cualquier sitio, por cjemplo, en el marco de una puerta, inclinảndole ligeramente hácia abajo. Este tallo llega á tener en su catremidad una pequeña roseta de celdas blancas parecidas al papel y muy fragiles. En este nido pasa el invierno, pero sale al aire libre cuando los dias son hermosos. En la primavem auméniase esta pequeña serie de celdas, convexas desde afuera y cóncavas en su exterior, encorvadas primero hícia abajo y reducidas despues à la figura de un lazo en el punto de su salida para reunirse aqui por medio de un segundo tallo con el primero. Poseo tres nidos de una construccion algo mas sencilla y veo que todos tienen el fondo cóncavo, dirigido hácia arriba; las celdas exteriores no sirven para la cria, pero si las centrales; cada una de estas fnarece un cucurucho de papel prolongado, un poco obtuso en su parte anterior, y cuando está cerrada su tapa forma casi un hemisferio. Estas celdas están dispuestas en series, no del todo regulares, una junto à otra, y son mucho mas anchas en su parte superior que en la inferior.

Debo estas y otras noticias, asi como los nidos, al misionero Gueinzius, en Puerto Natal, que hasta su muerte y df pesar de su quebrantada salud ha demostrado gran interés cn tales observaciones. Una vez habia pernitido á una avis. pa colgar su nido dentro del marco de la puérta de su habitacion, de modo que al pasar, el insecto estaba solo á pocas julgadas de distancia de su coronilla. Aunque la puerta se cerrabia menudo con violencia, poniendo en movimiento todo el nido, dumnte los varios meses qque duró la construccion y la cria, solo una rez. una avispa jóven le picó en la coronilla, dejindole por el pronto privado del uso de sus sentidos. Ningun cafre quiso acercarse a la puerta y me- nos aun pasar por ella. I as avispas vigilan cuidadosamente el nido, se enderezan tocias al acercarse un objeto cxtraño, dirigen la cabeza hacia el lado de donde viene y producen un zumbido: entonces conviene alejarse; tocar el nido seria la señal de ataque para las avispas. Por muchos conceptos recuerdan estas noticias al polistes francés.

Cuando varias celdas estuvieron provistas de tapas, sin que ninguna avispa hubiese nacido aun, Gueinzius trajo una muy jóven, de la misina especie pero de otro nido, para ver qué haria la madre. El espectáculo fué verdaderamente conmovedor: apenas vió a la recien llegada dió muestras de la mayor alegria; cogióla entre las patas anteriores, como abrazándola y lamióla con el mayor afan, cual una cabra á su hijuelo, para quitarla el polvo. Despues se le trajeron hijos adoptivos; todos fucron recibidos con el mayor cariño y ale. gria, y la madre los limpió del mismo modo. Aunque toda. via muy débiles y vacilantes en sus movimientos, aquellas avispas jóvenes empezaron en seguida a trabajar, invitando 4 las larras encerradas en las celdas à salir, para lo cual mordian y sacudian la tapa, ofreciéndolas una gota de liquidu claro que salia de su boca, liquido con que se habian alimentado al nacer. Si no encontraban ninguna larva para dársela, la recogian con una pata anterior y la echaban en el borde del nido. Eista gota aparecia en todas las avispas jóvenes poco despues de su nacimiento.

\section{LOS FOR MICIDOS- FORMICID死}

CARACTERES - I . f familia de los formicidos pertenece igualmente à los himenópteros sociables, cuyas agrupaciones se componen algunas veces de tres, castas, de los machos $y$ hembras alados y de las trabajadoras sin alas, 6 hembras atrofiadas. Estas últimas se hallan muy rara vez en las esprecies europers, y con mas frecuencia en las exóticas bajo dos ó tres formas; la mas notable tiene una cabean muy grande y se ha distinguido tambien con el nombre de soldado de for. mas regulares. El estado de los formicidos dura como el de la abeja domestica varios años.

La cabeza de la hormiga es relativamente grande, à veces mucho en las trabajadoras, y pequeña en los nachos; en ella destacan mas las fuertes maxilas que raras veces son cilíndricas, sino por lo regular aplanadas con la superficic masticadom, que es afilada ó denticulada. Ocultas debajo de esas maxilas se hallan las-inferiores, con un solo lóbuloy con palpos cilindricos de uno a seis artejos; los palpos labiales cuentan de dosá cuatro, tambien cilindricos, y la lengua $n o$ alcanza tanto desarrollo como en los otros himenópteros. Muy importantes para la clasificacion son los llamados rebordes frontales, las prominencias en forma de reborde, libres hácia afuera y soldadas haicia adentro con la superficie de la cabeza que comienza por encima de las antenas, y que hácia atris $y$ arriba son paralelas, divergentes y rectas 6 arquendas en forma de Z. Las antenas son angulosas, aunque esta forma es a reces en el macho poco marcada, a causa de ser el tallo corto: la brocha, compuesta de nueve i doce artejos, t's filiforme $\delta$ sc ensancha hácia la punia mas ó menos en forma de mara. Los tres ojuelos de la coronilla faltin a menudo en las trabajadoras.

El tórax no ofrece en las hormigas aladas particularidades especiales, pero es muy estrecho, sobresuliendo hacia arriba en ángulo obtuso, en las especies que nunca tienen alas; esta es la parte que à todo el cuerpo imprime el carácter de formicido y que enseña à distinguir una trabajadora de los otros individuos aunque estos hayan perdido las alas. Es- 
tas tíltimas se insertan bastante ligeramente y caen tan luego como se ha verificado el apareamiento. Sus nervios son es casos: una celda radial no siempre cerrada en su parte anterior, una cubital cerrada, raras veces dos, una a dos discoideas y las dos humemles constituyen todo el conjunto. I.as patas son delgadas; las ancas y los inuslos se unen solo por un sencillo trocinter, como en todas las avispas rapaces y los antofilos. El espolon del tarso opuesto al primer antejo algo cóncavo de las patas anieriores, está provisto en su cara interior de pestanias cerdosas, y forma un printer artejo del pié pestañeado tambien en cl mismo punto: es el órgano con que la hormiga se limpia, cepillando sobre todo las antenas, los palpos y las otras partes bucales.

Iil abdúmen se compone de seis segmentos; en el macho de siete, y es siempre pedunculado, de modo que al describir su estructura, el tallo suele considerarse como una forma particular ceneral que al abdómen comunica una gran movilidad. El tallo se compone de uno 6 de dos segmentos y forma en el primer caso un nudo entre el metatórax y el ahdómen $\dot{o}$ un dado redondeado en los ángulos (typhlopone), pero regularmente hay en su cara superior un reborde trasversal cuadrangular, redondeado, mas ó menos elevado en su parte suplerior y dirigido hácia atrís (tafinoma). En un tallo de dos segmentos, el segundo representa un nudo esférico ó que se ensancha hícia los lados, siendo el primero peclunculado. El abdómen, con una sola excepcion (crematograster), estå soldado en su borde inferior con el tallo; ticne una forma esférica, oval, eliptica, prolongada ó de comzon, que scestrecha solo raras veces entre dos segmentos. En el macho la última escama abdominal (vallvula anal, vàlvula ventml) presenta diferencias particulares, como entre los órganos genitales, si son pequeños, ó los deja descubiertos en parte cuando, como sucede a menudo, son muy grandes. 1.os machos se distinguen facilmente de sus hembras por estas partes, por tener la cabeza pequeña, las patas mas largas y delgadas, las maxilas mas estrechas, y mayor número, tanto de segmentos del abdómen como de artejos de la brocha de las antenas; no pierden tampoco despues del apareamiento las alas, como las hembras. Estas últimas, asi como las trabajadorns, insectos mordedores, expelen un fuerte ácido, el cual se inocula en la herida que la punta del abdómen infiere, encorvada á este efecto hácia adelante; otros tienen un aguijon con cl que se defienden. Dicho aicido, llamado efórmicos, produce es. cozor y una ligera inflamacion al penetrar en la herida.

Las larvas, vermiformes y ápodas, tienen doce segmentos, no sicmpre marcados; la cabeza es córnea, encorvada hảcia alxajo, y el color blanquizco. En la cabeza se distinguen munones de maxilas y maxilas inferiores carnosas, reunidas en una picza y escotadas en su parte anterior; á cada lado ticnen dos cortos pelos cerdosos; el labio inferior es cáunoso y retráctil; no hay ningun ojo. Con pocas excepciones, el cuerpo se adelgaza hácia adelante, ensanchíndose hácia atras, donde se redonden, presentando un orificio en forma de hendidura Estas larvas, del todo dependientes, no pueden moverse del sitio y deben alimentarse. Son iguales durante su primera juventud en todas las castas y solo mas tarde se distinguen por cambios de forma poco importanie, pero mas. por las dimensiones. Fs posible que la diferencia entre el macho $y$ la hembra se oculte en el huevo, pero la que hay entre la hembra y las trabajadoras en sus diversas formas se desarrolla probablemente solo en el estado de larva. No sa. bemos, sin embargo, con qué condiciones, pues no puede suponerse que sea por el diferente alimento como en la abeja doméstica, porque este siempre se compone de gotas de liquido vomitadas por las trabajadoras. Ia larva adulta de algunas especies fabrica un tèjido prolongado de color blan- co sucio ó pardusco en el que se trasforma en crisilida Es. tas crisilidas curueltas constituyen, bajo el nombre falso de shuevos de hormiga), un alinento favorito para ciertas aves de jaula Otms especies no tejen munca, y algunas guarcian un término medio, porque se encuentran crisálidas desnudas y emvueltas jumtas en el nido. En tal caso queda demostrada en la larsa la facultad de tejer y puede suponerse que las que no tejen no podrán desarrollar en sus glandulas el suficiente material textil, ả citusa de la alimentacion ó de oiras condi. ciones. Ias hormigas provistas de un tallo abdominal de dos segmentos no tejen regularmente en estado de larva.

USOS, COSTUMBRES Y RÉGIMEN. - Asi como to. nos los himenópteros, las hormigas se alimentan tambien exclusivamente de liquidos dulces que hallan en los objetos mas diferentes, en los frutos, jugos vegetales de toda clase, carne y cadiveres de animales, pero sobre todo en los pulgones, cuyos excrementos buscan con afan. Por eso las hormigas se presentan siempre en gran número alli donde abundan esos inscctos, buscíndolos en lias plantas, à las cuales solo pueden perjudicar cuando con sus construcciones subtermineas impiden el desarrollo de las raices. 'Tambien se ali. mentan solo con gotas claras como el agua que hacen salir de la boca á las larvas, los machos y hembras de su nido, ú otro trabajador de su tribu que lo necesite. No hacen provisiones por lo tanto como la abeja doméstica y estros antofilos sociables. Ademis del alimento indicado necesitan un poro de humedad parn prosperar, y a ella se atienen en la elec. cion de sitio.

I.a mayor parte de los nidos de hormiga se hallan en tier. ra. Forel ha publicado últimamente en las Nuevas memorias de la Sociedad Cieneral Suiza para todas las Cicncias maturales (Zurich, 1\$77) sus apreciables obserraciones so. bre las hormigas de aquel pais, dedicando tambien a la descripcion del nido una parte considerable de su relato. Dis. tingue: 1." nidos subterraincos sencillamente socavidos, o provistos cuando menos en parte de paredes y un monton de tierra, ó bien situados debajo de una piedra; 2." nidos de madera practicados en la misma en galerias semejantes, en parte regulares, del mismo modo que aquellos en la tierra búmeda. Ios anillos amuales se conservan casi siempre como paréles y el curso de las fibras de la madera deternina el de las galerias y espacios huccos. Fn la construccion de estos nidos se observan á inenudo formaciones en extremo singulares. Algunas pequenas especies cuyas sociedades son me. nos numurosas y pertenecen al género leftothorax, minan en la corteza de arboles vicjos galcrias poco profundas, que se comunican entre si. Como las hormigas que anidan en la madera no perjudican nunca los arboles sanos, y apresuran en los enfermos la descomposicion por el canblio de sustancias, sobre todo en los troncos de airboles vicjos, criaderos de muchos insectos dañinos, el guardabosyue ve en esos insectos sus aliados y los protege. $3^{\circ}$ Nidos crnvucltos (nids en corlon): los construye en Suiza solo el lucius fuliginesus, especie cuyas glándulas cstán muy desarrolladas, formando una especie de mortero con que el insecto fabrica, con preferencia en hadera, los espacios interiores, con paredes de fibritas leuosas. A esta clase de nidos pertenecen probahlemente los que construyen los llamados comehers de PuertoRico, ú hornigas aque alimentan su cria en cuadras, de las cuales hablaremos despues. Las primeras construyen por lo regular en unedio del mmaje, nidos gigantescos como colme. nas, cubriéndo! todo, ramas, ironcos, hojas y piedras, en los caminos que conducen a ellos, con una capa que les preserva de la luz y del agua, sicndo su anchura interior det diametro de un canon de pluma. Ios cornehens penetran tambien en las casas, perforan los muebles de inadern, y en su 
marcha hacen muchos rodeos cuando se les oponen obstacu. los impenetrables. 4. Como cuarta forna, Forel indica los nidos de construccion compuesta, a los que pertenecen los de nuestras hormigas rojas silvestres, formados con sustancias regetales, sobre todo pedacitos de madera; tambien pertene. cen à ellos las construcciones en los troncos viejos de airboles en los que la madera descompuesta sirve lo mismo que la tierra en los nidos subterráneos. $50^{\circ}$ Como nidos variables se designan los que no pueden clasificarse en niiguno de los grupos anteriores, por ejemplo los que se encuentran en las hendiduras de los muros, grietas de rocis, viviendas humanas, etc.

Estas indicaciones bastan para reconocer la gran variedad en la construccion de los nidos, gue para una especie determinada de hormigas no es sin cinbargo caracteristica, pues apenas hay otros insectos que sepan acomodarse tan bien á las discrsas condiciones. Aunque ciertas esjuecies ejecutan sus construcciones casi exclusivanente debajo de piedras, en la tierra, otms (canponotus) prefieren la maclera. La mayor parte de las especies propyias de nuestros paiscs se amoldana las condiciones que hallan, hasta el punto de ocupar nidos abandonados por otras.

Cuanto mas reducida es la tribu, tanto mas sencillo es el nido; cuanto mas grande, tantas mas galerias y espacios huecos se extienden horizontalimente, sobrepuestas en pisos, formando un laberinto de caminos separados, sostenidos por paredes y columnas de la tierra cxtraida Ciertos caminos tan á purar al exterior, a menudo mas léjos que los otros, pues ponen en comunicacion el nido con los parajes donde buscan su alimento las hormigas. Bastante á menudo se en cuentran grandes superficies del suclo cubicrtas de numerosos nidos de una misma especie, los cuales se comunican todos entre sí; mientras que debajo de una piedra viven dos ó tres especies de hormigas, en tain próxima vecindad que las galerlas de unas cruzan los nidlos de las otras, sin que las paredes divisorias dejen de separar perfectamente un nido del otro.

Ia construccion y conservacion de los nidos, en cuyos trabajos las maxilas y las patas anteriores represcntan el papel principal, j tambien los quehaceres domésticos, están a cargo de las trabajadoras. Segun veremos ahora, estos quehàceres no son del todo ficiles, por lo que hace al cuidado de la cria. En las hormigas, cuyas trabajadoras se presentan en diferentes formas, parece haber hasta cierto punto una division determinada, ó por lo menos se ha reconocido que los individuos de cabeza grande, los que llaman soldados, aunque en las expediciones no son los defensores, sino mas bien los guias, mascan con sus maxilas mas grandes la carne y la otra presa, proporcionando a sus compañeros mas delicados el medio de poder llevar jedacitos correspondientes à su fuerza. Además, podémos observar bastante á menudo que alli donde a cada uma de las trabajadoras no le basta su vigor, una segunda y una tercera le ayudan, logrando no pocas veces con sus fuerzas reu. nidas cosas que parecen imposibles. Solo en la union tiene la hormiga su fuerza, y solo demuestra todo su valor y carácter pendenciero cuando puede contar con la ayuda de sus iguales; aislada y léjos del hormiguero, cvita todo encuentro con un enemigo.

El cuidado mara la cria, se extiende en las hormigas a los huevos, larvas y crisálidas. Los primeros, recien puestos, son prolongados, blancos 6 de un amarillo claro; pero antes de salir la laria se dilatan, arquuéanse un poco en una extremi. dad y se ruelven vidriosos. Despues que la hembra los ha depositado, reunidos en montoncito, en una celda, las trabajadoras van à recogerlos y los lamen, impregnaindolos, al pa. recer de una humedad alimenticia; luege los llevan a un piso superior del nido cuando el tiempo es caluroso, y ruel. ven á bajarlos, si la temperatura comienza à ser fria y des. agradable. Lo mismo se hnce con las larvas, que además se alimentan con las gotas expelidas; lamenlas y las limpian si estån manchadas de barro. Tambien las crisálidas se llevan, segun la temperatura, a diferentes sitios, como puede verse, cuando al levantar una piedra debajo de la cual están, du. rante las horas de sol, en la superficie ciel nido, las cuidado. sas guardianas acuden presurosas, cogen una y desaparecen rápidamente en el interior de las galerias a fin de preservarlas de todo peligro. Para llemrlas se sirven de las maxilas, y cuando se pierde alguna, las antenas sirven para volver á encontrarla. Aun cuando la jóven hormiga esté saliendo de la cubierta de crisálida, sus hermanas la ayudan, mientras que todos los demás insectos recien nacidos deben desprenderse ellos solos del capullo. Por lo tanto, el cuidado para la cria llega en las hormigas al major grado de perfeccion, entre to. dos los himenópteros sociables. Si refexionamos ahora que las trabajadoras, desprovistas de alas, deben buscar el alimen. to prifujio y el destimado para la cria, asi como tambien el de los numerosos machos y hembras en ciertas temporadas, pues ninguno se cuida de nutrirse, y que además la construccion, el ensanchaniento y conservacion del nido están a su cargo, facil es comprender que solo por su mucha diligencia pueden cumplir con tan penosas tareas y que por fin todas sucumbirian por el cxceso de trabajo, si la naturaleza previsora no hubiera tenido presente que los nidos podian llemarse dema. siado.

En el trascurso ulterior de una descripcion general de la vida de las hormigas, solo podemos fijarnos en algunos fenómenos especialmente particulares, porque segun la especie y las condiciones puede ser muy variada y en su nıyor parte aun 110 muy conocida. En primer lugar, la duracion de la vidx y el tiempo en que los diferentes grupos se prescntan en el nido difieren segun las especies, la estacion y años. $\mathrm{Al}$. gunas depositan todos los huevos en otono, y las hembras fecundadas no se encuentran por lo regular en la primavera en el nido (soienopsis fugrox); en la major parte de las otras, desde la primavera hasta el otono se hallan huevos en el hormiguero, necesitandose probablemente el tiempo mas cor. to ( 5 dias), para pasar al siguiente grado del desarrollo. En la especie arriba citada, las larvas viven desde el otono hasta julio del año siguiente, mientras que, por ejemplo, en el género tofinoma, las larvas que al principio de abril han salido de los hueros, pueden trasformarse en crisalidas a principios de mayo. La duracion de la vida de una hormiga perfecta is dificil de fijar: cuando mas podria decirse por comparaciones, que la de los machos, destinados uinicamente á la propagacion en ciertos periodos, es la mas corta, y la de las hembras fecundadas mas larga que la de las irabajadoras. Se supone que las madres pueden vivir un poco mas de un aio, pues se las encuentra a menudo en mayor número en su hormiguero, no conociendo los celos de las reinas de abejas; las hembras aladas no suelen hallarse sino en determinados periodos, aunque tambien por este concepto se obserran excepciones. Asi, por ejemplo; los hormigueros de la especic formica pratensis tienen durante todo el ano maclios y hem. bras con trabajadoras; los de la lepthotorax en una estacion solo machos, y en otra solo hembris.

L.os machos del género ariergales carecen de alas, y en otras especies son demasiado grandes en comparacion a la hembra para que esta los pueda llevar al ruelo; en ambos casos el apareamiento no se verifica por lo tanto en el aire. Sin embargo, en los hormigueros donde en tiempos determinados, sobre todo en agosto, se presentan maclios y hembras alados, obsérvase que permanecen algun tiempo en el inte- 
rior y que las últimas toman parte tamtien en los trabajos domésticos, ayudando a trasladar las larnas y crisilidas. Por lo pronto, los machos que han macido para la vida aérea, viendo que los espacios subterrineos son demasiado estrechos, sc pasean en la superficie caterior del monton, trepan por las yerbas y otras plantas de los alrededores y manifiestan gran inquietud. Fn medio de ellos se presentan las trabajadoras, los cogen con sus tenazas y procuran hacerlos volver al nido. Esta cscitacion dum algunos dias, pero des. pues ofrécese a la vista del obscrvador un espectáculo sorprendente, un casamiento de hormigas Nada de humano padria dar una idea de la agitacion turbulenta, de la que no se sabe si significa amor $\delta$ furia. En medio de irritadas pare. jas de novios que segun parece han perdido casi el conoci. miento, vagan individuos sin alas, que atacan en particular a los que mas han promovido el embrollo, y muérdentos con tal fuerza, que casi podria crecrse que intentan matarlos. Sin embargo, no es tal su intencion; solo quicren reducirlos á la obediencia Estos individuos vigilan por lo tanto á los amantes y ejercen una screra policia en estos preludios de la boda, que es una verdadera fiesta popular. Entonces el salvajismo degenera en demencia; en revuelta confusion los machos corren seruidos de las hembras, y subiendo y bajondo llegan á considerables alturas: los primeros se precipitan sobre una hembra de las pequeitas, a veces varios al mismo tiempo, y se a parean con ella. Un objeto elevado les sirve en cierto modo como señal en esta maniobra: la copa de un árbol, la punta de una torre, la cima de una montaita, y hasta un hombre aislado en una llanura, como pudo observarlo Huber, i qutien debemos tantas noticias sobre las costum. bres de las homigas, y-al que una bandada siguió una vez lentamente por encima de su cabeza. En i 869 reconoci yo mismo, al subir en compania de unas señoras la oscum escalera de la atalaya de Kynast, hasta qué punto pueden molestar esos insectos. Unos viajeros que bajaban nos aconsejaron no subir mas, a causa de haber alli una bandada de hormigas; pero no quisimos perder aquella ocasion de contemplatar la magnifica vista que desde alli se ofrece al observador, y aranzamos ralerosamente. Los miles de hormigas que se fijaron en nosotros, sobre todo en una señora cuyo vestido era blanco, nos causaron mucha molestia, pues apenas llegaban a tocar la piel desnuda, mordian la carne, demostrando por todos conceptos una excitacion extraodinaria. Tales pruebas se pueden hacer cuando llega la estacion de visitar todas las atalayas, que no faltan en ninguna montaña de la Alemania central.

En las hermosas tardes de agosto, sobre todo despues de algunos dias de lluvia, las legiones de hormigns de las especies lasius, flauus niger, alienus, fuliginosus, my rmia, solenopsis fugax, topinoma caspirum y utras, latn ntemorizado a veces a los hombres, sobre todo cuando las diversas tribus de una gran extension se reunen y forman una verdadera nube, rodeando las cimas de las torres. El 4 de agosto de 1856 se produjo cerca de San Saforino, en Suiza, una verdadera lluvia de millares de hormigas aladas negras. El 10 de agosto, desde las 5 y 20 minutos hasta las 6 de la tarde se obserró entre Wattwyl $y$ Iicchtenstein, a lo largo del "Thur, una nube de hormigas aladas, de color pardo negruzco, que à la altura de 300 piés se dirigia del sudeste al noroeste. Ëntre ambos puntos se disolvió, distribuyéndose en los árboles, en las casas y en las yerbas. Eun setiembre de i $S_{1} 4$ un cirujano inglés refrió á bordo de un buque que una columna de $S$. a 10 piés de ancho por seis puigadas de altura, compuesta de grandes hormigns, habia cubierto el agua en un espacio de cinco a seis leguns inglesas. Tambien las antiguas crónicas hablan de tales cosas. $1: 1=$ de agosto de $186 \%$, i las tres de la tarde, se observó tal multitud de hormigas por cncima de la torre de la iglesia de Santa Isabel, de Breslau, que el pucblo creyó seria el humo de un incendio. l'oco despues repitióse el mismo fenómeno alrededor de las otras torres; mas apenas habia durado una hora cuando cajeron al suelo, de modo que se las hubiera podido recoger á montones. El ig de julio de 1679 , a las dos de la tarde, pasó una nube de grandes hormigas sobre Pressburgo, cayendo al cabo de un cuarto de hora en tal nimero que en el mercado no se podia dar un paso sin aplastar algunas docenas; habian per. dido las alas y corrian lentamente por el suelo, pero desapa. recieron al cabo de dos horas. Basta de ejemplos, y pregun. témonos mas bien: ¿qué pasa durante el período del celo en el nido, y que se hacen las bandadas que se elevan por el aire?

L.os esfuerzos de las trabajadoras para cstablecer el órden entre sus companeras aladas solo bastan para retener algun macho y hembra que se aparean en las proximidades del hormiguero. Una ó algunas de estas hembras son conducidas al nido, donde las despojan de sus alas, dispensindolas todas las atenciones que las abcjas prodigan a su reina. Esta madre primitiva pone huevos, cuidandose asi de la conservacion del nido. I.os que se han clevado por los aires caen à ticrra, segun ya hemos visto, a mucha distancia del lugar donce macieron; muchos miles son presa de otros animales, ólos machos mucren de muerte natural al cabo de algunos dias; mientras que las hembras que se han conservado forman nuevos hormigueros, diferentes segun la esprecic, sin que se sepa hasta ahora de qué modo lo hacen. I a hembra fecundada se despoja de las alas con ayuda de las patas, penetra en el suclo en sitióconreniente je desita los huevos. l'odria. mos suponer que asi como la madre de avispa y de abcjorro, se cuida de que estos hueros se trasformen en trabajadoras que se encarguen de la corsstruccion del nido mientras que ella se cuida solo de la pucsta de los huevos; pero nunca se ha encontrado una hembra de hormiga aislada con crisilidas, ni. siquiera con larvas adultas, sino solo con huevos 6 con gusanitos muy pequcios; tampoco sc han obtenido jamás en la cautividad hormigas trabajadoras por medio de una hembra fecundada. En vista de esto se ha creido que las trabajadoras de una misma especie cogen una hembra fecundada, caida en tierra, y fundan con clla una colonia nueva. Ias pruebas hechas en averiguacion de la verdad no dieron tampoco, sin embaruro, resuitado alguno. Siendo asi, el problema sobre la formacion de ruevos hormigueros esta por resolver aun, pero es de supponer qque su establecimiento ista sometido igualmente a la mayor variedad, lo nismo que el género de vida de estos pequeños séres tan interesantés.

Vamos á dar aqui algunos detalles mas sobre este último punto, pero advirtiendo que el siguiente relato solo debe con. siderarse como un bosquejo. Del mismn morio que otros ani. males, tambien las hormigas tienen sus parísitos, que entablan con ellas las mas variadas relaciones, por cierto muy distintas de las que se observan entre otros himenúpteros y sus jarásitos.

Varias especies de hormigas habitan on lan mismo hormiguero, formando lo que se llama colonias mixtas. Aqui se pueden dar dos casos muy distintos: ora vive una especie bajo sus tres formas en el nido de la otra romo huéspeda, o bien se encuentran solo trabajadoms de otra especie, que Ins habitantes del hormiguero han robado en el estado de larva $\delta$ crisálida de otro nido, por lo cual se las ha llamado lormigas rapaces. A las que son huéspedas, ò sea al primero de los dos citados grupros, en la formica rufa y rongrerens, pertenece decididamente la pequeña stemamma Wesfaroodi, de color amarillo rojo brillante, yue nunca se ha encontrado indepen. 
diente, y de la cual debe suponerse que su existencia depende de las otras. Una segunda especie, asemorhoptrum lipputum, se ha considerado tambien como huéspeda de la Insirrs fuliginosus bruncus y formion sanguinen: Hagens la encontró sin embargo asimismo en tribus independientes. A las hormigns rapaces pertenece la formicu sangurnea, de la cual hablaremos mas tarde, y que sin cmbargo trabaja lo mismo que sus esclaras segun se ha llamado a los trabjjadoras robadas, por lo cual no hay ninguna razon aparente que explique su bandolerismo. No sucede asi con la hormiga amazona (foljergus rufesecus), especie de cólor rojo pardusco, propia de la Europa meridional, aumque se ha observado igualmente cerca de Kleve, Mombchn, Maguncia y Soden. Koba las larvas de la formica fusso yel cunimularis, mostrándose en extremo atrevida y mordedora, pero cumo na le agrada el trabajo, moriria de hambre si sus eschanas no la alimentaran. En otras especies consideradas como rapaces (stronglogualhus testaicus y mýrica alrota) las condiciones son otras y no se conocen auir bastante. La hormiga mazona y la primera de las dos últimas especies tienen, al contrario de todos los demàs formicidos de nuestros países, maxilas cilindricas no denticula? das, y carecen por lo tanto de la estructura que trasforma las maxilas de las otras especies en órganos del trabajo.

Los amiges de las hormigas (mirmeciofilos) son otros habi. tantes de los hormigueros y pertenecen i los mas diversos órdenes de insectos. Varios naturalistas lian estudiado este asunto con preferencia, formando largos indices de esos insertos, esforzandose en averiguar el proceder que observan entre sí. Pueden dividirse en tres grupos: 1. Mirmecófilos gue solo como larvas y crisalidas viven eutre las hormigas; àdinitiéndoseles como compañeros inofensivos. Asi, por ejemplo, se alimenta li larva del coleóptero cetonin aurata, de las pedacitos de madem podriday de las partes inferiores del nido de la hormigr silvestre. 2. " Mirmecófilos que se encuentmn en los hormigueros en estado perfecto, pero no ex. clusivámente aqui. A estos pertenecen varios histéridos y los pulgones, qque no voluntariamente, sino obligados por las hormigas, han de vivir entre ellas como tracas de leche Ya hemos dido á conocer antes la gran preférencia que todos los himenúpteros manifiestian por los pulgones, y la aficion de las hormigas a buscarlos pam comer sus excrementos dulces. Los tocan con sus antenas, los lamen, y logmn obtener tambien por toda clase cie caricias el jugo de los tubos de micl ú gordeñarlos, segun sencillamente se ha llamado este procedimiento. Pam mayor comodidad, se llevan á los indefensos y débiles insecios a sus nidos, demostrando menos un cariono maternal que un marcado egoismo.

En las especies que anidan en troncos de árboles, como lasius fulginosus y bruneus, vive a menudo un julgon llamado lachmus longirostris, que con su pico, tresveces mas largo que el cuerpo, chupa en la madera tierna del árbol; en los hormigueros subterrineos diversas especies de pulgones obtic. nen su álimento de las raices de las yerbas y otras plantas. Las hormigas rodean à menudo a un grupo de pulgones con una casita de tierra ó de otros materiales de construccion. Lle. van tambien sus larvas a este nido, y por medio de una galeria ponén en comulicacion á los pulgones con el hormi. guero. De tales hormigas dice Osten-Sacken, que đalimentan su cria en cuadrast, y habla de una pequeña especié rojiza del género formica, cuyo abdúmen es pardo, que cerca de 11 ashington habia rodeado una colonia negra de laclinus con una casita en una rama. El estuche, que tenia la forma de un tubo, componiase de una masa sedosa de color pardo gris, que resultó ser una porcion de pelitos reunidos, probablemente fibras lenosas, pues tenian olor resinoso: media unos $0^{m}, 36$ de largo por $10^{\mathrm{m}}, \mathrm{I}_{2}$ de ancho. Fill otra ocasion, el mismo uatumlista encontró en Virginia, en un tallo de asclepias cubierto de una esjesa capa ile pulgones, un capullo fraigil y esférico de unos $0^{\circ}, 0219$ de diametro, producto de una hormiga negra. En los paises calidos donde faltan los pulgones sustitúyenlos sus congéneres, las pęqueñas cigarms. 3. Mirmecófilos que en todos sus grados de desarrollo viven exclusivamente en los hormigueros de especies determinadas, sin las cuales no podrian existir. A estos pertenecen varios colépteros y sobre todo numerosos estafilinos.

En Alemania se conocen mas de 300 especies de insectos de todos los órdenes, quue pertenecen á uno ú otro de estos tres grupos; la mayor parte son coleópteros, y entre estos solo hay 159 estafilinos. I os mas de ellos viven con haspecie lasius fuligirosus (1 50 especies) y con la formica rufa (100 especies), pero de muy pocas se conocen hasta ahora las relaciones intimas que mantienen con sus anfitriones.

La gran actividad de las hormigas les lia valido con preferencia á otros miles de insectos, el interés mas vivo por parte de las personas qque se ocupan de tales cosas, segun nos demuestran las observaciones, en prurte muy exactas, de los naturalistas griegos y romanos de la mas remota antigüedad. Is vidi de has hormigas, segun Plutarco, es en cierto modo el espejo de todas las virtudes: de la amistad, de la sociabili dad, del valor, de la perseverancia, de la continencia, de la prudencia y de la justicia. Cleantes pretende que estos animales no tienen uso de razon, pero dice haber visto lo siguiente: unas hornigas se habian acercado á un monton de otms extranas llevando una compañera muerta; del monton sálieron al encuentro del cortejo fúnebre varios individuos, que despues volvieron, repitiendo lo mismo dos ó tres veces. Por fin las hormigas del monton sacaron un gusano y entre. gáronle a las portadoras del cadáver para rescatarle; estas aceptaron el gusano y dejaron su carga.

Arato dice que cuando amenaza lluvia las hornigas sacan sus huevos al aire; pero otros aseguran que no son hievos, sino granos que exponen al aire para evitar la descomposicion. Tambien saben prevenirla de otro modo muy ingenioso: como no pueden siempre preservar completamente los granos de la humedad, la consecuencia natural es que se ablanden y empiezan á echar brotes, lo cual evitan las hormigas sacando de cada uno el gérmen. Aristóteles dedica en varios pasajes \& las hormigas algunas lineas. "Las avispas, dice, las hormigas, las abejas y las grullas viven en socieda. des circunscritas; las grullas y las abejas tienen un jefe, pero las hormigas no. Estas son en parte aladas, en parte no ala. das, y olfatean la miel a mucha distancia. Si se cubre su vivienda con azufre se marchan. Las hornigas dan a luz larvas que al principio son pequeñas y redondeadas prolongaindose luego y adquiriendo patas con el desarrollo. La jropagncion se verifica sobre todo en la primavera. Tas hormigas estín en continua actividad; corren siempre por el mismo camino; sacan u ocultan el alimento, y hasta trabajan de noche cuando hay luna llena. No cazan de por si, pero recogen lo que encuentran.

Plinio $(11,30,36)$ repite en lo esencial las opiniones anteriores, y continún despues: ¿Cuántos son sus esfucrzos en su trabajo, y cuanta su perseverancia y actividad! Sin saber nada ni unas ni otras traen mercancias de diferentes regiones $y$ tienen sus mercados, en los que se pasa revista general. Fntonces se reunen todas y las que se encuentran se preguntan y conversan largamente. Se ven piedras en que han abierto poco i poco camino, circunstancia por la cual se reconoce cuảnto puede la asiduidad aun de los séres mas débiles. Las hormigas son, ademis del hombre, los tinicos animales que dan sepultura á sus muertos. En Sicilia solo hay individuos sin alas. 2 
Tambien Eliano habla en algunos pasajes de la recoleccion de granos y de su procediniento para impedir que broten.

Excepto lo de dar sepultura \& sus muertos, cuyo error es debido probablemente a la circunstancia de que toda hormiga coja, ó que necesite auxilio, es conducida por sus hermanas al nido, donde la cuidan, el carácier de las hormigas se ha reconocido ya desde la antigüedad, apreciandose exactanen. te sobre todo su gmn actividad y prudencia, $y$ la facultad de comunicarse noticias. Por este concepto se han emitido en tiempos posteriores toda clase de opiniones, denostrándose por varios ejemplos qque usan un lenguaje por senas, supouiendo bastante generalmente que las antenas son el órgano mas importante para recibir las impresiones exteriores. Ian. dois cree haber probado últimamente yue las hormigas ticnen ademis un verdadero lenguaje vocal, que sin embargo, no es casi nunca perceptible para el oido humano.

Despues de asegurar que en las hormigas-aranas (mutilla) se habia encontrado en algunos segnientos abdominales el órgano con que estos insectos pueden producir sonidos muy perceptibles para el oido humano, el citado maturalista exa. minó varios géneros de hormigas y encontró en el ponern rebordes de roce inuy desarrollados en el segundo y tercer segurentos abdominales, cujo sonido tambien era perceptible para el hombre; menos perfectos los halló igualmente en otros géneros, de modo que el citado autor cree justificada la presuncion de que antes hemos hablado.

No podemos ocuparnos mas de este muy interesante asun10, pero tampoco hemos podido pasarle del todo en silencio.

Las hormigas fósiles se encuentran en gran número en las capas del periodo terciario; las hojas de pizarra de Oeningen, en el distrito del lago de Baden, estin á menudo cubiertas de impresiones de hormigas de las especies nıs diversas; y tambien el aimbar contiene numerosas hormigas, nas por lo regular solo aladas.

El cjército de las especies aun existentes se ha dividido en cinco géneros: los formicidos (formsicide) ú hormigas glandulosas, cuyo abdómen, no estrechado en los segnientos, se fija en un tallo escamoso de un segmento; los odontomaquidos (odonlomachida) is hormigas de tenazas: tienen la misma forma del abdómen y un aguijon defensivo, y las hembras maxilas cujos puntos de insercion se tocan alternativamente. En los ponéridos (ponerida) ú hormigas de nguijon, se observa una estrechez entre el primer segmento y el segundo del ab. dómen; el aguijon venenoso y el tallo de un segmento son caractéres comunes con el género anterior y el siguiente. Los dorilidos (dorylida) ù hormigas ciegas: las hemuras y las trabajadoras carecen de ojos. I.os mirmicidos (myrmicide) í hormigas nudosas se caracterizan por el tallo abdominal de dos segmentos y por tener aguijon.

\section{LOS CAMPANOTOS - CAMPANOTUS}

Este género es uno de los mas ricos en especies de los formicidos; se caracteriza por los rebordes frontales encorvados en forma de $S$, por lns antenas, que se insertan a mucha distancia del escudo de la cabe\%, y por la falia de ojuelos en las trabajadoras.

\section{EL CAMPANOTO HERCÚLEO-CAMPANO- TUS HERCULEANUS}

CARACTERES.-Esta especie se distingue por las puntas amarillas de sus grandes alas que sobresalen mucho del abdómen. Cuando se la examina minuciosamente, todo el cuerpo parece de un tinte gris, á causa de los pelos de este color. Los machos que carecen de vello en el tórax y las tra- briadoras tienen de $0^{\circ}, 00 \$ 15$ a $11^{\circ}, 011$ de largo. Bajo el mismo numbre que la especie tiene en Alemania y que es al de hormiga de caballo se conoce una segunda especie (cam)forotus ligniperdus) que se distingue por unat mancha de un rojo oscuro en el tórax.

DISTRIBUCION GEOGRÁFICA.-Estas dos especies están discminadas en Europa hasta el este de Siberia, y en el norte de Anérica, ciesde la llanura hasta los Alpes mas elevados.

Otras numerosas especies del mismo género se encucutran en todos los continentes sin excepcion.

USOS Y COSTUMBRES. - La hormiga mas grande de Alemania, el campanoto hercúleo, busca con preierencia las regiones montañosas cubiertas de bosques y construye su nicjo en la parte prosterior de árboles viejos. Cuando en verano se le observa antes del periodo del celo nos asombramos de las colosales hembras de hasta $0^{m}, 0175$ de largo que tiñen la base de aquellos troncos de negro.

\section{LAS HORMIGAS PROPIAMENTE DICHAS-FORMXCA}

CA R ACTERES.-Este géncro tiene los siguientes: doce artejos de las antenas en la hembra, trece en el macho; anuellas insertas inmediatamente por detras del escudo de la ca. beza que no se continúa entre sus tallos: la frente tiene una placa bien limitada, y rebordes frontales poco divergentes hicia arriba. Ias trabajadoras tienen ojuelos como los sexos alados y los machos valvulas en forma de navaja en sus grandes órganos genitales.

\section{LA HORMIGA ROJA-FORMICA RUFA}

CARACTERES. - Esta especic tiene un escudo en la cabeza no escotado; la placa frontal presenta finas arrugas; los ojos carecen de pelos; cn el tallo hay una escama afilada y en forma de corazon invertido; el tórax es de color rojo pardo, provisto de cerdas y con manchas negruzcas, mientras que en el macho es de un pardo negruzco con viso gris, í causa de los pelos; el macho es mas grande que la hem. bra (10,01 1$)$; esta mide solo $\left(1^{m}, 009 S_{7}\right.$ ! las trabajadoras hasta $0^{\prime \prime}, 0045 \mathrm{a}(1 \%, 0065$.

DISTRIBUCION GEOGRÁICA.- La hormiga roja habita en toda la Europa, en el Asia, hasta las Indias orientales, y en la Anrérica del morte.

USOS, COSTUMBRES Y REGIMEN. - De todas las especies propias de nuestros paises, la hormiga roja constru. ye los nidos mas yrandes, formando en los bosyuts de coniferas montones de $0^{\prime \prime}, 94$ i $x^{\prime \prime}, 25$ de aitura de partículas de hojas, pedacitos de corteza, de tierra ó de madern, con una persererancia y actividad admirables. Los nidos ocupan debajo de la superficie del suclo mucha major extension aun. Al descubrir uno de estos nidos salen miles de trabajadoras. Si el viajero cansado quicre restaurar sus fuerzas, nada mejor puede hacer que dar con la palma de la mano rápidamenie algunos golpes sobre tal monton y olerlo despues; pero es necesario apelar en esta ocasion à toda la rapider. prosible para que ninguno de los furiosos insectos se agarre á la mano ó suba por el cuerpo, pues de lo contrario se vengaria con mordiscos muj desagradables. Una vez hice el experimento en un nido situado en el lindero de un bosque a cierta altum, exactamente bajo la luz del sol, que iba a ponerse. I)es. pues que las serioras que me acompanaban y yo hubimos aspirado el olor aromatico del hormiguero, y cuando yat nus ibamos, volvimos hacia los insectos visiados, $y$ entonces 
contemplamos un especticulo único en su género: centenares du chorros plateados iluminados por los rayos del sol clevábanse por todos los lados hasta una altura de 6 z centimetros, perfumando el aire y resolviéndose en diáfana nicbla al caer. Un segundo despues todo desap̧arecio, y solo cierto rumor nos indicaba á mucha distancia aun la cxcitacion de los insectos, tan bruscamente perturbados en su retiro. Sabia que de la extremidad del abdómen segregan el aicido fórmico comunicando su olor al órgano घ̧ue se pone en contacto con cllus, pero no laabia creido que pudieran lanzarlo en chorros con tal fuera ni á tantil altura.

Iil interior de estos nidos contiene un laberinto de galerias de prequeñas cavidades en las que trabajan y retozan los ha. bitantes y de las que en tódas las direcciones parten caminos grandes y pequerios ia mucha distancia del monton, verdaderamente pulinentado por el continuo trinsporte de restos regetales.

\section{LA HORMIGA SANGUINEA-FORMICA SAN- GUINEA}

CARACTERES. - Esta especic se parece mucho i la anterior y se ha confundido a menudo con ella, pero se dis. tingue por el escudo de la cabeza escotado y en el sexo mas. culino por el borde masticador de las maxilas, provisto de cuatro a cinco dientes, mientras que la especic anterior carece de ellos (fig. 46).

USOS, COSTUMBRES Y REGIMEN. - Se distingue aderiás esencialmente por su género de vida Sus montones son de menor tamano y alberyan a varios coleónteros (por lo regulir la lomechusa strumosa y In dinarda dentata), así como indiriduos de las especies formika jusca, cunicularia, y mas raras reces tambien la de lasius aliemus, a los que roban las imbajndoras del nido en estado de larva. Fn verdaderas expediciones gucreras se dirigen al nido de una de las citadas especies, penetran con impetu, matan todo cuanto se les resiste ! se llevan las larvas y criślidas de las trabajadoras. Tales batallas se han observado por varios naturalistas. Las hormigas nacidas de aquellas crisálidas reconocen al fin que han entrado en un servicio extraño, y trabajan para la hor miga sanguínea, mas parece que con preferencia se ocupan de los quehaceres domésticos. Si se destruje parte del nido se presentan para remediar el desperfecto, mientras que los scnores solo corren de un punto at otro y raras veces se presentan con aguellas fuera del nido. En una enigracion de la hormigas anguinea observada por Danwin, los señores llevaban a los esclavos entre las maxilas; mientras que Hagens obserró igual emigracion en agosto, en la que ora los señores llevaban á los esclaros, ora estos a los señores a la otra colonia; pues sucede à veces que las hormigas abandonan voluntariamente su nido y forman una nueva colonia cuando alguna circunstancia les ha hecho desagradable su residencia (humedad, repetidas molestias por parte del hombre ó de otras hormigas, cuando se ha puesto estiércol por encina 6 al lado del nido, etc.).

\section{LOS LASIOS - LASIUS}

CAR ACTERES. - Mientras yuc las especies del género formier andan en el suclo, los lasios ó formicidos de joroba, eligen los sitios mas diversos para sus construcciones.

El género puede reconocerse por los siguientes caractéres de las trabajadoras y hembras: el escudo de la cabeza, no escotado en su borde anterior, y en forma de trapecio, es conveso, muy redondeado en los ingulos josteriores, donde empiezan los rebordes frontales, bastante cortos, y se insertan las antenas, de doce artejos. Su brocha tienc la forma de maza; cada artejo es un poco mas grande que el anterior, y el último mas largo que el primero. 1.os ojuelos son muy poco marcados; el tórax se estrecha mucho por delante del meta. tórax encorvado y desprovisto de dientes; el anillo abdominal está cubierto por una escama cuadrangular vertical, $\delta$ casi vertical, en la que no descansa el abdómen: en el ala de la hembra liay una celda radial y una ó ninguna de las discojdeas. Las anchas maxilas del macho tienen el borde mastica. dor afilado, provisto solo en la punta de un diente, ó bien del todo denticulado; los artejos de la brocha, casi iguales entre si, son filiformes, el jurimero mas grueso; las antenas se componen de trece artejos. Las partes genitales, muy pequenas, se cubrén desde la cara dorsal en forma de techo; su vàlvula exterior forma una placa que se estrecha mas y mas, y en la extremidad se redondea en semicirculo; la valiula anal no presenta escotadura.

\section{EL LASIO NEGRO BRILLANTE-LASIUS FULIGINOSUS}

CARACTERES. - Fsta especie se distingue por su colo? negro brillante $y$ es la mas grande de todas, pues mide has ta $0_{1}^{\text {m }}, 011$.

DISTRIBUGION GEOGRÁFICA. - Está diseminada por toda Europa, excepto las perinsulas pirendica y del Bal. kan.

USOS Y COSTUMRRES.-Construye laberintos en los troncos vicjos de árboles, 6 bien por medio de una especie de argamasa cuando la madera se ha trasformado ya en tierm.

\section{EL LASIO NEGRO-LASIUS NIGER}

USOS Y COSTUMBRES. - Fsta hormiga propia de to. da la Europa y del norte de Africa y que tambien se encuentra en la isla de Madera, construye su nido, lo mismo que la especie lasins alienus, propia solo del sur de Europa, en la tierra y los árboles entre el musgo ó en otras partes, segun mas le conviene.

\section{EL LASIO ORILLADO-LASIUS EMARGI- NATUS}

USOS Y COSTUMBRES. - E! lasio orillado clige con preferencia las grietas de las paredes de los jardines para construir en ellas sus nidos.

\section{EL LASIO AMARILLO-LASIUS FLAVUS}

USOS Y COSTUMBRES. - Las hormigas amarillas, hamosas por sus dolorosos mordiscos y que tambien pertenecen à este género, comprenden varias especies, de las que el lasio amarillo es la mas propagada. Construyen sus nidos debajo de tierra, ó de las piedras.

\section{LOS PONÉRIDOS-PONERIDE}

CARACTERES. - Los ponéridos ú hormigas de aguijon tienen este nombre porque las trabajadoras y hembras estan provistas de dicho órgano.

USOS Y COSTUMBRES. - Sus sociedades se componen casi siempre de pocos individuos que por lo regular se conoren exclusivamente en el estado de trabajadores y es. casean bastante en Europa. 
LA PONERA ARMADA-PONERA CLAVATA

CARACTERES. - I a hembra madre no ticne en el coselete mas que un tubérculo corto y obiuso, y carece de pun. tas: el nudo del primer segmento del abdómen está armado de una fuerte esplina; las nervaduras de las alas son pardas; las formas del cuerpo y los colores se asemejan en un todo a las de la obrera, pero su tamaño es algo mayor.

La obrera tiencel cueppo de un negro pardo, con algunos pelos grises rojizos, particularmente en el abdómen; las antenas, un poco mas largas que el coselete, son bastante gruesas, filiformes, pardas en su extremidad, y se inscrtan por delante de los ojos, cerca de las mandíbulas. la cabera es grande y cuadrada; los ojos salientes; las mandibulas grandes, de un tinte negro pardo, anchas, triangulares, punteadas, vellosas, algo corras en la punta y dentadas en el lado interno for pequenas estrins. El cosclete, casi cilindrico y comprimido lateraimente, se redondea por encima, y el dorso se encorva insemsiblemente en su parte posterior. En cada parte humeral hay un grueso tubérculo cónico; el primer segmento del abdómen, en forma de nudo, afecta la de cuadro si se mira lateralmente. Los demas segmentos no ofrecen nada de par. ticular. Inas patas, bastante largas y del color del cuerpo, son rellosas, y están provistas cada cual de una especie de espolon amarillento. Ia hembra fecunda mide unas 10 lineas de largo (fig. 41).

DISTRIBUCION GEOGRAFICA. - La especie es originaria de la América meridional.

\section{LOS ODONTOMACOS - ODONTO- MACHUS}

CARACTERES. - Eil gínero odontomaco, formado pror Intrcille, y clasificado hasta ahora cntre los ponéridos, se

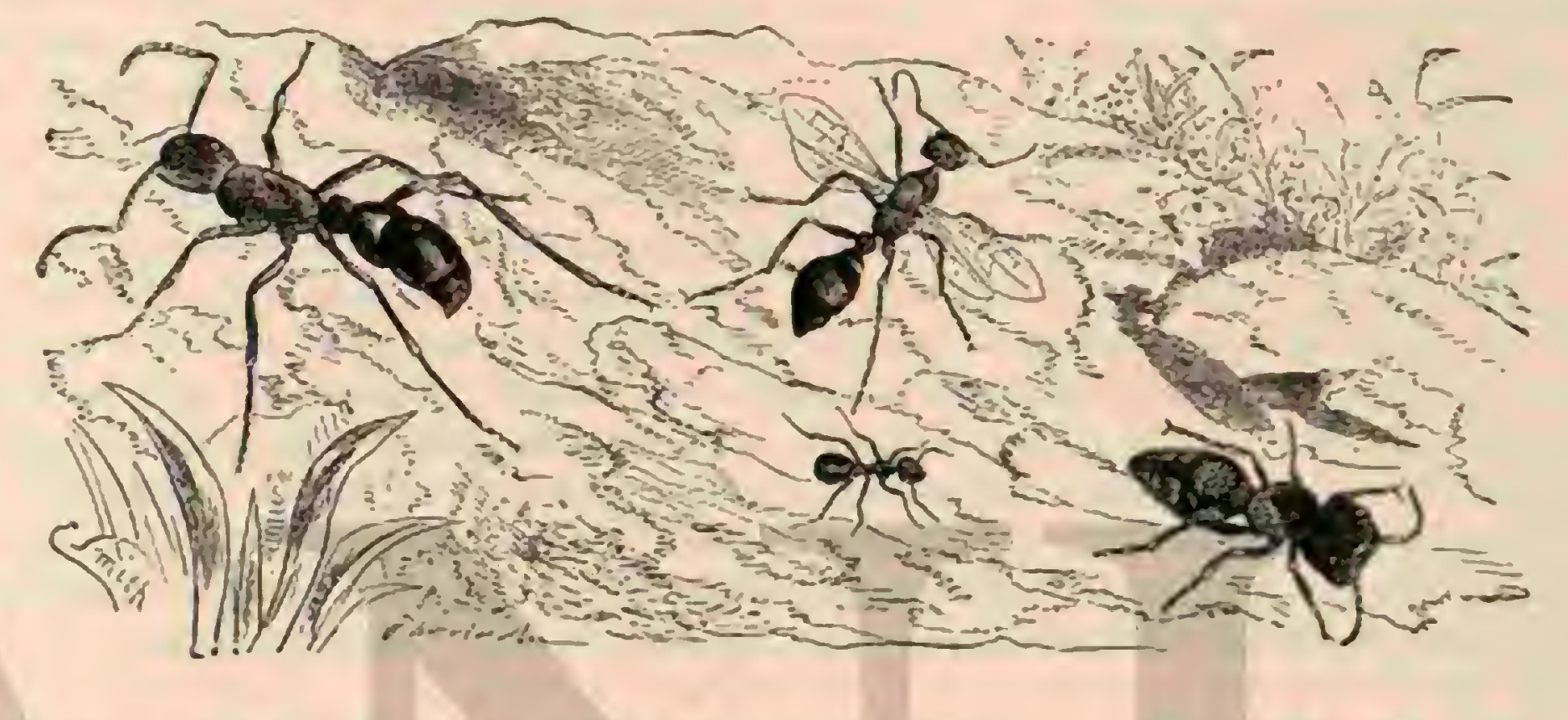

Fig. 41.-LA IONE.SA ARMAUA

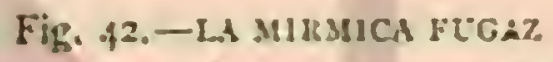

Fig. 43. - FL คว7'A CAยEz:DO

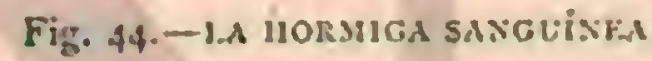

agrupó con algunos otros en una fanilia independiente: comprendićndole entre los formicidos y los ponéridos. Estos insectos, delgados y estrechos, se distunguen por la espina larga y dirigida haicia atrás, que presentan en el nudo de su segmento abdominal; tienen dos celdas cubitales y tres discoideas en las alas; pero lo mas extrano en las hembras y traba. jadoras es la forma é insercion de las maxilas, que excesivn. mente largas, encajan con su base nuy próxima, en la extremidad de la cabeza que es muy prolongada, como los brazos de unos alicates delante del punto de su union.

DISTRIBUCION GEOGRÁFICA.-Solo el Asia y la América del sur poseen tan interesantes insectos.

\section{LOS DORÍLIDOS-DORYLIDE}

CARACTERES Y DISTRIBUCION GEOGRÁFIGA. - Un cuarto género igualnentc exótico, clasificado por otros autores como familia independiente, despues de las hormigas, debe figurar aqui, segun cierro informe sobre las condi. ciones vitales de una especic. I.os dorilidos (dorylus, lalidus, anomma yotros), que se conocen aun muy poco en las tres formas de sus especics, pertenecen solo a las regiones cálidas, preferentemente i las Indias orientales, a la Senegambia y al Brasil.

\section{EL ANOMA CAPATAZ-ANOMMA ARCEUS}

USOS Y COSTUMBRES.-Esta especic, habitante dei Africa occidental, ha adquirido cierta celcbridad por su ge. nero particular de vida. Ia tribu, que se compone de hormi-

Teso vi gas pequenas y grandes, liasta $0^{\circ}, 01 \mathrm{I}$ de largo, no tiene residencia fija, sino una vida ragabunda, porque los rayos ardientes del sol pueden ser perniciosos para estas hormigas: por eso se ocultan de dia entre la jerba y la espesura, y solo salen de noche para buscar su presa. A veces, sin enbargo, se ven obligadas á presentarse al descubierto, y entonces construyen al punto, en la calle que deben atravesar, una galeria aboredada, empleando una especic de argamasa de tierra y salivi. Lin sus expediciones de merodco atacan al los animales grandes, agarrándose en primer lugar í los ojos, con lo cual matan hasta los pitónidos; segun se dice chupan la sangre de la victima, desmenuzan la carne y la llevan á sus escondites. Tambien se dejan rer a veces en las viviendas humanas, donde una fuga general de los ratones, ratas, escarabajos y lagartos que en cllas habitan, anuncia su llegada, amonestando á las personas a dejar á toda prisa sus lechos y salir al aire libre. Cunndo en la estacion lluviosa so inundan sus escondites, reúnense formando una masa redonda, colocan la cria con los individuos mas débiles en medio y flotan sobre las aguas hasta que estas las conducen a cualquier punto de la ticrra firme. Al cruzar los riachuclos y otras corrientes angostas forman un puente animado, fijändose uno en utro, como pronto observarcmos tambien en una especié americana.

\section{LOS MIRMÍCIDOS-MIRMICIDE}

CARACTERES. - I LOS mirmicidos ofrecen la mayor riquear en formas y obligan å la ciencia sistemática á distri. buirlos entre mos cuarenta y dos géneros, cuyo número, 
segun es de supioner, se aumentarí aun. 1.os caractéres comunes a todos son los siguientes: el segmento abdominal tiene dos anillos y el aguijon existe en las hembras y trabajadoras.

1) los principales géneros, tales como Myrmica, Eiciton, Atta, Aphcenogastaer, Monomorium, Typhlattoy otros, los tres primeros son conocidos hace tiempo, mientras que los otros deben su existencia a dos notables naturalistas de la época moderna, G. Mayr de Viena y Snith de Lóndres, pertencciendo todos a este grupo, conpuesto de numerosas especies. Solo haremos mencion de algunas jropias de nues. tros paises a fin de ganar espacio para ciertas duscripciones interesantes sobre la maravillosa vitalidrid de rarias especies exóticas.

\section{EL TETRAMORIO DEL CESPED-TETRAMO- RIUM CIESPITUM}

CARACTÉRES. - Esta especie se carncteriza por tener el escudo de la cabeza encorvado hicia arriba en los ladós de su parte posterior, que rodea el: hojo de las antenas por debajo; los palpos maxilares tienen cuatro artejos y los labiales tres; los tres últimos del broche son cuando menos tan largos ó mas que los otros; el tórax no es estrechado y tiene en su parte posterior dos dientes. Los machos se distinguen por una impresion en forma de horquilla que se ve en el dorso del tórax. La celda radial no está dividida; las anté. nas, de diez artejos, tienen el tallo mas corto que el segundo artejo del broche; el borde masticidor de las maxilas es denticulado. El tetramorio del césped varia en su color, desde el pardo amarillo hasta el negto pardusco; las maxilas, el broche, las articulaciones de las patas y de las antenas son mas clariss; la cabeza, el tórax y el tallo presentan rayas lon. gitudinales rugosas; el tónx y el escudetéson lisos. $\mathrm{BI}$ macho, de color pardo negruzco, tiene las maxilas, las antenas y las patas amarillentas; presentando solo en la cabera y en la parte posterior del dorso surcos longitudinales. Las trabajadorns alcanzan un tamano de $0 \%, 0023$ a $0 \%, 0035$. In hembra mide lo menos de $0^{\circ}, 006$ \& $0^{n}, 008$ y el macho hasta $6 ", 00 \%$

USOS X COSTUMBRES. - Estr espjecie es muy comun en todns partes en los bosques, jardines y praderas, debajo de las predrns, en los troncos de árboles cortados y en el ces. ped. Las galerias subterraneas se extienden a mucha distan. cia: el tetramorio lesanta la tierray perjudica por esto las raices de las plantas tiernas de los jardines. Como las crisálidas no se encierran en un capullo y además las de las hem. bras parecen giganiescas en comparacion de las pequeñas trabajadoras, ofrecen un aspecto muy particular y supone gran esfuerzo en estas, pues trasladan diariamente varias veces la cria de un sitio a otro. El periodo del celo comienya para estas hormigas en agosto y dum hasta setiembre; en. tonces se ve á las aladas posarse ó correr en todas partes por las yerbas. Las trabajadoms se encuentran como esclavos tambien en los nidos de strongtogrnathus testacens.

\section{LA MIRMICA ROJA-MYRMICA LEVINODIS}

CARACTÉRES.-Fn esta especie no se notam tales diferencias por lo que hace al tamano, pues las trabajadoras miden $0^{\circ}, 005$ y las hembras hasta $10^{\infty}, 007$. El color es pardo rojo, mas oscuro en el centro del primer segmento abdominal; yen cuanto a los caractéres genéricos, son los siguientes: los palp̧os inaxilares tienen seis artejos; los labiales cuatro; en las antenas, los tres últimos son mas cortos que los anteriores juntos; las espinas de la parte posterior del dorso y de los muslos afectan la forma de maza; los espolones de los tarsos son denticuiados. El nudo del alsdómen es en esta especie brillante en su párte superior y liso: el tallo de las antenas se arquea en la base, $y$ la superficic masticadora de las maxilas está provista de sicte á ocho dienites.

Esta especie vive como la antcrior y tiene la misma area de dispersion.

\section{LA MIRMICA AGRICULTORA-MYRMICA MOLIFICANS}

La mirmica agricultom ha sido objeto de un relato que Darwin presentó á la Limnean Society en Lóndres, fundaindose en las observaciones hechas por Linsecom en Texas. In este relato dice: "La especie que llamo agricultora es una gran hormiga de color pardo, sumamente notable, pues se ha observado que procediendo como un ngricultor adopta las disposiciones convenientes para las diversas estaciones; en una palabra, revela una habilidad, inteligencia y perseverancia incansable, para hacer frente á las necesidades $y$ apuros que pueden ocurrirle en la vida. Cuando ha elegido sitio para establecerse, practica en ticrra un agujero, alrededor del cual forma un reborde cuga altura varia de tres a seis pulga. das, con un terraplen bajo y circular que desde el centro hasta la línea exterior, que por lo regular se halla a tres ó cuatro piés de distancia de la entrada, forma un suave declive Cuando el jrais es llano eleva el terraplen en figura de un cono, bastante puntiagudo, hasta la altura de $15 \delta 20$ pulgadas ó mas, practicando la entrada cerca de la cima, aunque en la estacion en que construye el nido el terreno está del todo seco. En todo caso la hormiga limpia el suelo alrededor del terraplen, desvia todos los obstáculos y alisa la superficie hasta una distancia de eres a cuatro piés por delante de la puerta de su vivienda, comunicando al sitio el aspecto. de un bonito empedrado, como lo es hasta ciesto pusito. Dentro de esta especie de patio no se ve jamás ninguna hoja verde, como no sea una sola especie de gramínens graniferas. Despues que el insecto ha plantado aquellas en una circunferencia de dos á tres piés desde el centro del terraplen, cúidalas continuamente, mordiendo todas las demas gramineas y yerbas que nacen en medio ó alrededor del campo; la graminea cultivada crece en abundancia y da ricos productos y pequeñas simientes blancas tan duras como la piedrn, que vistas con el microscopio se parecen mucho al arroz. Cuando han madurado, se recogen cuidadosamente por las trabajadoras, que con las espigas las llevan al granero, donde se extracn de estas para formar un monton.

Los desperdicios se arrojan fuera de los limites del patio. Cuando el tiempo ha sido lluvioso sacan los granos al aire libre tan pronto como brilla con fuerza el sol para evitar que broten, volviéndolos despues al granero, excepto los que ya. no soin buenus.

*En una huerta de melocotoneros, continúa el autor, cerca de mi casa, hay un cerrillo de considerable elevacion con una extensa base pedregosa. En la arena que cubre algunas partes de esta eminencia se ven bonitos patios de las horinigas agricultoras, que sin duda cuentan bastante tiempo. Mis observaciones sobre su género de vida se limitan á los últimos doce años, durante cuyo periodo una sólida cerca ha impediclo al ganado entrar en los cannos de las hormigas. Los que se hallan fuern de aquella, asi como los de la huerta, es: tản sembrados del \&arroz de hormiga; puede verse cómo brota hícia el 1." de noviembre. En los títimos años, no obstante, desde que la agricultura y el ganado han ido en aumento y este último come las gramíneas mucho mas cerca del suclo, impidiendo asi que el sembrado lleğge á madurarse, observo que hace mucho tiempo que las hormigas agricultoras construyen sus patios á lo largo de los cami- 
nos, en medio de los campos, de los senderos de los jardines; y en una pilabra, en juntos donde pueden cultivar sin ser molestadas por el ganado. No debe dudarse que la especie particular de graminea ya citada se planta con toda intencion: procediendo lo mismo que los agricultores, esos insectos arrancan del suelo cuidadosamente todas las demas yerbas en el tiempro del desarrollo; cuando el grano esta ma. duro, cuidanse de cortar los tallos secos, traslidanlos i su vivienda, y el patio queda abandonado hasta el otoño siguien. te, procediéndose asi uno y otro año, en todas las circunstancias en que las colonias de hormigas cstán al abrigo de los animales herbivoros.?

\section{LA MIRMICA FUGAZ-MYRMICA FUGAX}

CARACTERES. - Ia mirmica fugnz es de un color the gro pardo pubescente; las antenas y las mandibulas de un leonado amarillento claro; el coselete negro, casi liso; el metatórax presenta una truncadura y solo tiene dos dientes endebles; el nudo anterior del primer segmento abdominal está un poco escotado en su centro; las patas son amarillas; las alas blancas. La hembra fecunda mide un poco menos de dos lineas de largo.

Lil color del cuerpo de la obrera es de color leonado amarillento, pubescente y casi liso; los ojos negros; el abdómen luciente. Solo mide una linea de largo.

El macho, mas estrecho que la hembra, es de un color negro brillante y jubescente; las antenas de un pardo claro, con los dos artejos de la bise mas gruesos, la extremidad posterior del metatórnx es obtusa, sin tubérculos aparéntes; las patas de un pardo amarillento; los muslos mas oscuros; las alas blancas (fig. 42).

DISTRIBUCION GEOGRAFICA. - Se encuentra en Ins mismos paises que la especie anterior.

USOS, COSTUMBRES Y REGIMEN. - Esta especic liace su nido en tierra yo se aparea en setiembre.

\section{LOS ECITONES-ECITON}

CARACTÉRES, - I.ns ecitones habitan el Brasil desde donde algumos pasan á Mexico, pero hasta ahora casi solo se conocen en su clase obrern. Se distinguen de los otros mirmicidos por los palpos maxilares de dos artejos y los labiales de tres, y por tener un hoyo para las antenas, que cuentan doce artejos; este hoyo se toca por dentro con los rehordes frontales; los ojos, muy pequeios y sencillos, pueden faltar del todo; las garms del pić son casi siempre bidenticuladas.

USOS, COSTUMBRES Y REGIMEN.-Bates da en su «Naturalista santes sobre la vida de estos insectos, lamados por los ind: genas tourn; estos detalles nos servirán de guin en la siguiente descripcion. Los ecitones salen todos en bandadas, $\mathrm{cm}$ prendiendo expediciones de merodeo; ncompinales una inosea (stylogoster), que poco mas ó menos á un pié de altura. vuela sobre el ejército de hormigas, bajando bruscamenic, segun parece, para depositar un huevo en las larras robadas por los ecitones. Casi cada especie tiene su particularidad en el modo de formar sus ejércitos y tampoco los individuos que los componen son iguales. Se distinguen muy bien entre ellos las trabajadoms de cabeza pequéina, que sin cmhargo solo en algunas especies (eiston hamatum, erralicum, :astator) demuestran, por la figura de las maxilas, que no tienen ambos la facultad de hacer el mismo trabajo; en la mayor parte de los demis individuos se reconocen tránsitos en el tamano del cuerpa; jero Bates no pudo observar ninguna diferer:cia en los trabajos de las especies de cabeza grande $y$ pequeña. El ciilnn rafax; el gigante del género, porque en usie se encuentmn trabajadoras de hnsta 0",013, cruza el bos. que formando reducidas columnas y parece saquear principalmente los nidos de una especie de formica, ó por lo menos se hallan a menudo cuerpos mutilados de la misma en sus caminos.

En una segunda especie, citon leginnis, que es mucho mas pequeira, difiriendo poco por esto yo por el calor de la mirmica roja (myrmica rubrie) propia de Europa, las dos formas no se reparten los quehaceres, ó cuando menos, proceden en sus expediciones de la misma manera. Esta especic fut observada por Bates en los campos arenosos de Samarem, tanto mejor cuanto que ninguna espesura fe impedia ver. Los ejércitos se componen de muchos millares de individuos, que avanzan en anchas colummas; cuundo se les estorba, atacan el objcto que se les opone, con la misma furia que las otras especies. En una ocasion penetraron en la pendiente die una colina, en la tierra poco complacta, à una profundidad de 0",262 para coger individuos de otra especic, los cuales sa:caron del hormiguero, reuniendo sus fiterzas, para destrozar. los desputs. El observador deseabia recoger algunas de las hormigas atacadas, pero en su furor los agresores se las qui. taban de cntre las manos, de modo que á Bates le costó mu. cho trabajo obtener algunos individuos ilesos. Al practicar las minas que las rapaces debian abrir para llegar á su presa, las trabajadoras pequeñas parecian distribudias en diferentes divisiones, escarbando las unas mientras que las otras sacaban las particulas de tierna. Cuando hubieron penetrado it mas profundidad, y como las dificultades del trabajo iban siendo mayores, procedieron como los albañiles: los que esperaban en el borde exterior de la mina tomaban la carga de los compañeros que venian desde abajo y la trasportaban hácia afuera, relewándose de ves en cuando en el trabajo: los mineros quedahan iuera y los otros tajaban para sacar la tierra al borde; pero tan luego como se divisó la primera presi todos se precipitaron sobre clla llevándose tantos individuos como permitian las tuerzas para bajar por la pendiente. Al cabo de dos horas los hormigueros estaban bastante vacios, y formando compañias los vencedores se dirigieron al pié de la colina, dondescremicron cri una columna que se extendia en el espacio de sesenta á setenta pasus.

El cjército de hormigas subió por usa colina pedregosa, y muchos individuos que no llevaban nada nyudaron á sus companeros, comparticndo la carga: poco a poco desapare. cieron todos los insectos en la profundidad del nido.

Otras dos especies muy comunes (eciton lonmeturny drefa. nophorum) se parecen tanto que se necesita un exaimen minucioso para poderlas distinguir: pero nunca se mexclan, sino que, siemure sepamdas, sus numcrosos cjércitos cruzan á millares las selvas virycoses del Amazonas. El tamaño de las hormigas que forman esas legiones varia mucho, pudiéndose ver cnanos que apenas miden la quinta parte de tua pulgada junto á indiviciuos de calxeza gmude con maxilas de nedia pulgada de longitud. Antes de que el viajero encuentre senejonte ejercito de insectos adviértenselo ciertas avecillas, entre ellas el mirlo hommigucro, que con innuietud revolotea en medio del follaje. Si a pesar de esta advertencia el viajero avanza algunos pasos mas, se ve de repente atacado por las pequeñas rapaces que én grupos conyactos, con una rapidez increible, suben por sus picrnas, se agarran con las maxilas à la piel, encorvan la punta abdominal hácia adelante y pican con coda su fuerza.

Entonces no queda otro remedio sino traslitdarse a toda prisa a la otra extremidad de la colmmna ' Las hormigas"se agarran de tal modo que, al retirarlas, la cabeen queda er la herida. No cra sin embargo la intención de las loormigns ata- 
car al desgraciado viajero que solo casualmente se encontró con ellas: los que deben temerlos sobre todo son los insectos $\sin$ alas, otras hormigas, las larvas y orugas. l.os ecitones no suben á mucha altura por los árboles y molestan por lo tanto poco los nidos de pájaros. Bates cree poder afirmar que su ataque se efectua del modo siguiente: la columna principal, con cuatro $\delta$ seis individuos de frente, uno junto a otro, avanza en una direccion determinada, limpiando el suelo de toda sustancia animal viva $\delta$ muerta, mientras se destacan pequenas columnas de los lados para recoger provisiones destinadas al grueso del cjército, reuniéndose luegro otra vez con él. Cuando cerca de la línea en marcha se descubre un sitio favonble, como por ejemplo un monton de madem podrida en la que viven nuchas larras de insecios, las hormigas toman este punto con su numeroso ejército; con furioso afan examinan todas las hendiduras y destrozan cuartas larvas sacan áluz Es curioso ver cóno saquean los nidos de avispas que se encuentran à veces en los arbustos bajos. Corroen las tapas de pajel de las celdás para llegar í las larvas, crisálidas 8 avispas ya desarrolladas y destruyen todo sin perdonar á los propietarios y vigilantes del nido. Ios cjércitos no recorren munca largas distancias por un camino frecuentado, aunque Bates los ha seguido i menudo a media legua de distancia sin encontrar nunca un nido. Cierto dia obscrvó una expedicion que pasaba por un estrecho sendero y que tenia una longitud de 60 a jo pasos, mas no pudo ver vangundia ni retaguardia. Todas las hormigas se movian en la misma direccion, excepto algunas que iban en los fiancos del ejército, y que retrocedian à corta distancia reunienciose luego otra vez con la corriente; este movimiento retrógrado se efectuaba por derecha é izquierda y parecia ser una me dida de precaucion para contener el ejército, pues los fianquendores se detenian á menudo un momento, locándo a uno h'otro de sus compañeros de la columna con las ante. nas para comunicarle alguna noticia. Cuando Bates inter. rumpia la marcha, dabase parte del incidente a todas las filas y el ejército comenzaba a retroceder. 'Todas las trabajadoras pequeñas llevaban algunas larvas blancas entre-sus inaxilas, que al principio Bates tomó por su cria, pero luego pudo reconocer que cran robadas. En aquella extraña expedicion era curioso en particular el aspecto de las trabajadoras de cabeza grande, de las cuales se contaba unia por cada docena de pequenas, y de las que ninguma llevaba carga, sin hacer mas que correr fuera de la linea á intervalos bastante irregulares. Esto era mas fácil de obsernar por la circunstancia de que las grandes cabezas sobresalian de las de sus companeras. Bates no vió que como soldados defendieran á las demás, bien es verdad que la estructura de sus maxilas no lespermite agarrarse á un enemigo. Tambien observó cómo retozaban cuando hacia sol, lamiéndose y limpiảndose unas a otras y descansando de este modo del trabajo.

Bar tuvo ocasion de ver en la Guayana, cerca del rio Sinnamary, como dos expediciones de hormigas se cruzaban, componiéndose la una de las llamadas hormigas de Padicur (segun dice el naturalista, eciton canadense), la otra de la hormiga de risitas. Aquellas iban de viaje; estas se ocupaban en sus quehaceres domísticos. Los ecitones habian encontrado un canal formado por un pedazo de madera; las hormigas de visita pasaban por debajo del camino y todo se hacia con el mejor órden. aNos sentamos, dice, para observar el proceder de las dos especies, tan distintas que nos produjeron el efecto de dos razas de hombres del todo diferentes. I as hormigas de visita llevaban pedazos de hojas mas grandes que ellas, y aunque troperaban con muchos obstáculos y caian á menudo, volvian siempreả levantarse, continuando su canino sin soltar la carga. Nada mas adnimble que el afan y el celo con que estas hormigas cumplian su cometido. Ia otra especie se dis. tinguia por su vivacidad, destreza y prudencia que reconocimos en los movimientos de las antenas: mumerosas hormigas agarradas unas á otms llemaban las cavidades demasiado profundas y allanaban el camino. De pronto nos ocurrió una feliz idea, cual fué la de retirar el pedazo de madera por donde pasaban los ecitones. ;Gran perturbacion! Los individuos de las grandes maxilas, que parecian infundir cierto respeto, se vuelven de un borde á otro, van y vienen, las otras se detienen delante del obstáculo que les oponen las hormigas de visita. A la distancia de algunos centimetros se ve un pedazo de madera del grueso de un cañon de pluma, y muy pronto le utilizan como puente; es demasiado estrecho, pero no se tarda en allanar la dificultad. Una, dos, veinte, cincuenta hormigas se agarran ả cada lado en dos filas; el puente se ha ensanchado, y la colımma pasa, lo cual dura bastante tiemp̨o, tanto que las intrépidas pontoneras parecian cansadas. Tambien derribamos este nuevo puente para ver hasta dónde llegaba el valor y la inteligencia de una especie y la perseverancia de la otra. i Nuevo trastorno: Desgraciadamente no hay otro pedazo de inadera cerca para sustituir el juente; la per. turbacion va en aumento; un grupo de ecitones se detiene delante del que forman las hormigas de la otra especic, sobre el cual deben pasar, con riesgo de verse separados de los suyos. Rápidamente toman su resolucion: treinta ó mas liacen una invasion; el desórden llega à su colmo; las otras hormigas, mas grandes y fuertes, gracias a sus poderosas cargas con. timaban su camino, pero las mas pequeñas se dejan caer al suelo, oponiendo no obstante un obstáculo. De repente, como a una señal dada, precipitase una multitud de ccitones en un espacio de $1^{\circ}, 20$ a $0^{\circ}, 30$ y' se fijan en tierra con sus largas patas; otros suben por encima, forman un segundo piso $y$ despues un tercero, y al mismo tiempo forman de este modo dos muros à la distancia de $l^{\star \prime}, 05$ a $U^{*}, 06$ uno de otro. Li co. lumna pasa en triunfo, mientras que las hormigas de visita se dispersan en todas direcciones sin poder reunirse otra vez. leniamos a nuestra vista un espectáculo sublime para un observador, y nuestra alegria era superior á todo cuanto puede imaginarse. Sin que lo notáramos habian pasado las horas y con asombro observamos que el sol iba a ponerse y que amenazaba un aguacero, el cual cayó á los pocos minutos ahuyentando à los observadores $y$ à las hormigas. Frra de noche cuando llegamos al vapor.

\section{EL ECODOMA CEFALOTES - CECODOMA CEPHALOTES}

USOS, COSTUMBRES Y REGIMEN.-FI ecodoma cefalotes, llamado tambien hormiga de visita ó mandioc, se conoce en toda la América del sur bajo el nombre de Sauba y se le teme mucho, pues por lo regular arranca las hojas de los mas preciosos árboles, é imposibilita casi del todo la agticultura en las regiones donde forma inmensas agrupaciones. Los indios consideran el abdómen de las hembras, lleno de. huevos, como la mayor golosina; se lo cortan con los dien. tes y lo comen con sal. Cuando la cosecha es abundante las asan, y segun se dice, gustan entonces tambien $\dot{a}$ los euro. peos.

Las costumbres de estas hormigas son análogas, por muchos conceptos, a las de las especies europeas ya descritas; constituyen montones, no muy altos, pero si extensos, en sus plantaciones $y$ bosques. Bates indica 40 pasos de circunfereucia por $62^{\text {' }} \mathrm{S}$ centimetros de altura; otros viajeros hablan de 180 y de $25 \%$. Estos montones forman solo la capa exterior de una red de galerias que se extienden ad mucha profundidad en una gran circunferencia, presentando numerosas 
aberturas hacia afuera, por lo regular cerradas. De los muchos medios emplleados jara expulsar el sauba de los jardines botánicos de Para, uno de ellos fué encender hogueras delante de las entradas principales de las colonias, introduciendo despues rap̧ores sulfúricos por medio de fuclles. Bates vió salir los vapores de un gran número de aberturas, una de las cuales se hallaba a setenta jasos de distancia del punto de intraduccion. I.os montones se componen de una tierra lige. ra sacada de la profundidad, y que por esto ofrece un color algo diferente del de los contornos. Por lo demus, las colonias se conducen en el periodo del celo, es decir, a principios de la estacion lluviosa, ó sea en enero y febrero, exactamente del mismo modo que nuestras especies. Fl cuidacio de la cria está á cargo de las trabajadoras, cuyo tamano varia des. de $0^{\prime \prime}, 0045$ a $10^{n}, 015$, y presentan diversos caractéres: las verdaderas trabajadoras son las mas pequeñas y tienen la cabeza diminuta; entre las de cabeza grande las hay que la tienen brillante y desnuda; en las trabajadoms subterninens es peluda en su parte anterior y en la coronilla esta provista de ojuelos que filtan en las otras. Bates no se expresa con mucha claridad sobre su estructura y continúa despues: $\$$ Al excavar el lado de un pequeno monton de hormigas recien formado vemos una ancha mina cilindrica de una profundidad de $0^{*}, 628$ de la superficie; $y$ al sondear con un palo que penetra a $10^{\mathrm{m}}, 125$ sin tocar el fondo, algunas de estas poderosas hormigas comienzan á subir lentamente por los lados de la mina. No eran muy pendencicras como temia, y nunca las vi en otras circunstancias que las indicadas, por lo cual no puedo adivinar en qué consiste su ocupacion especial.

Las trabajadoras pequeñas y grandes con las cabezas lisas y brillantes, los soldados, segun se les llana por lo regular, aunque no se encargan de la defensa de los débiles, salen fuera del nido y pueden ser muy perjudiciales por todos conceptos para los habitantes de aquellas regiones. Ya hemos hablado sobre el particular, y ahora diremos que causan mucho daño en los naranjos. Llegan en grandes legiones; las pequenas suben a un arbol, cada una se posa sobre una hoja y corta con sus maxilas denticuladas un pedazo del tamaño de una pieza de cinco céntimos; despues coge el pedazo con las ienazas, lo arranca con fuerza y abandona el árbol. A menudo el fragmento de la hoja cae, y entonces otra hormiga se encarga de llevarle. Avanzan sujetando el pedazo verticalmente hacia arriba con su borde inferior entre las tenazas, y entonces ofrecen un aspecto muy particular que las ha valido tambien el nombre de hormigas de parasol. El ca mino por donde pasan continuamente adquiere pronto el aspecto de una cartetera en la hojarnsca. Raras veces eligen los animales las hojas de árboles incultos propios del pais. Los pedazos de hoja los emplean para construir la bóveda de las gnlerias de sus viviendas, que tienen un diametro de $0^{\circ}$, ro 05 a $60^{\circ}, 1_{3}$, y con preferencia la de las entradas.

Una mala cualidad de estas hormigas es su costumbre de visitar de noche las casas para buscar las sustancias dulces. La opinion de que purgan las viviendas humanas de insectos molestos se funda probablemente en un error. No cabe duda que pueden ser en rigor hormigas rapaces y comerse los insectos, pero la utilidad que con esto ofrecen es muy inferior a los perjuicios que causan. Son animales nocturnos, y por lo tanto mas activos de noche que de dia, y además, en ciertas ocasiones se creen mas scyuros en las viviendas humanas. Bates, que al principio no quiso dar crédito al ascrto de los habitantes de aquellas regiones cuando le aseguraron que estas hornigas penetraban de noche en las casas para robar la harina con que se hace el pan de las clases inferiores del Brasil, pudo convencerse mas tarde de la verncidad del hecho. Una noche le despierta su criado diciéndole que las ratas corroen los cestos de harina y al examinarlos encontró una columna de estas hormigas. Los cestos con la harina se hallaban en una alta mesa y estaban cubiertos completamente de aquellos insectos; al corroer las hojas secris que cubrian los cestos habian producido el ruido y las que se marchaban llevaban cada una un grano a menudo mas grande y pesado que el insecto. La tentativa de matar los intrusos con cuatro zuecos no daba uingun resultado, pues los grupos que continuamente llegaban sustituian en seguida a los aniquilados. Ias noches siguientes se encendió pólvora en su camino, lo cual las csjantó al parecer, pues por fin no volvieron a presentarse $y^{2}$. Bates dice que no puede expli. carse para qué emplean los granos de mandioca que contienen muchas fibras pero nada de goma y no pueden servir como alinento.

Los ecodomas soll rojos; las trabajadoras tienen la cabeza en forma de corazon y en cada lado de su borde posterior una espina, viéndose un reborde frontal encima de las antemas; estas últimas se componen de once artejos; las maxilas son denticuladas; Ios palpos maxilares tienen cuatro artejos y los labiales dos. En el protórax hay dos espinas laternles dirigidas hảcia atrảs, lo mismo que en el metatórax. El tallo, compuesto de dos nudos, es aquillado. En las hembras muy grandes, la cabeza es menos escotada en la coronilla y está provista de espinas mas cortas por encima de las mejillas; los rebordes frontales, las antenas !' sus hojos, tienen la misma estruçura que en las trabajadoras; en cl metatóma hay espinas mas cortas. Los machos, en fin, tienen antenas de tres artejos, la cabeza mucho mas pequeña y además están provistos como el otro sevo de un diente sobre las an. cas anteriores. Las alas de las hormigas sexuales tienen una celda mdial cerrada, otra cubital y una discoiden, siendo amarillentas en la region del borde anterior.

Otms especies del géncro riondomn, que se lia separado del género affa, se distinguen por tener mas espinas en la cabeza, en el tórax y en el tallo. Yo стео, sin embargo, poder suponer que el subdia de los brasilcnos comprende varias especies en parte muy conocidas de los entomólogos europeos: Las hormigas, de las que hasta ahorn se han descrito unas mil doscientas cincuenta especies, las cuales aumentan todos los anos desde que los naturalistas citados y algunos otros se ocupan con preferencia de ellas, representan decididamente un importante papel en la eronomia de la natura. leza. Fn los paises ecuatoriales, donde la putreiaccion y la descomposicion se operan con mas rapide\% que en las regiones templadas, las hormigas son las que principalmente apresuran aquellas, impidiendo que se desarrollen gases daninos para el cuerpo animal; exterminan otros muchos insectos, manteniendo el ecjuilibrio natural, a su-ve\% sirven de alimento is muchas aves, à los hormigueros y otros animales para que no puedan extender sus devastaciones mas alla de ciertos limites. De las noticias expuestas, resulta evidentemente que esos insectos son muy daninos para el hombre; entre todos los naturalistas que han viajado por aquellas re giones apenas habra uno que no haya debido rquejarse de las hormigas y que no hubiera de valerse de todos los medios posibles para proteger su alimento $\delta$ sus colecciones contra los agudos dientes de esos insectos que, aunque pequeños son poderosos por su perswerancia y enorme número.

\section{LOS HETEROGINOS- HETEROGYNA}

Bajo el nombre de heteroginos, que forman nuestra cuarta familia, Iatreille habia reunido las mutilas y las lrormigas, 
considerando la falta de las alas en las hembras como caracter esencial. Ias últimas fueron separadas, sustituyéndose por Klug con las avispas falsas (thrmus) cuyas liembras carecen igualmente de alas; pero los machos debian resolver igualmente la cuestion; las avispas de punal (scolia) debian reunirse como tercer grupo con los otros, porque las condicinnes de parentesco entre sus machos y los de los tinos tambien se habrian de tomar en consideracion. A la prequeira fanilia, compuesta asi de 1,200 a 1,300 especies, se dejó el nombre dado por latreille, pero en general solo podria decirse de ella que el protórax llega con su borde posterior hasta la base de las alas: que las hembras pueden defenderse. $y$ que no se encuentran trabajadoras de órganos sexuales atrofiada.s.

\section{LA MUTILA EUROPEA-MUTILLA EUROP EA}

CÁRACTÉRES, - I a hembra sin alas de esta especie, llamada tambien hormiga amna, tiene la cabeza plana, nuy ispera, con -unos puntos irregulares y sin ocelos; el tórax es igualmente åspero, de contornos cuadrangulares y de color rojo: el abdómen negro, con pelos lisos de este color y fajas dé un amarillo de orin pálicá en algunos bordes posteriores de los segmentos. Estas fajas solo son enteras en el primer segmento; en los otros estan cortadas. Las patas, cortas y negras, son asperas, mas bien por los pelos cerdosos que por las espinas. En el vientre, en fin, se ve en medio de los dos segmentos primeros un profundo surio trassersal. El macho se distingue por tener ocelos y alas y por el tórax, en el cual se reconocen muy bien los tres segmentos á pesnr de la espesura de los pelos. El mesotórax y el escadetéson de color pardo rojo; las tres fajas claras del abdómen tienen un brillo plateado; las del centro son mas estrechas y no son cortadas. Tambien se.mezclan entre los pelos del aldómen y de las patas muchos blancos. Por el roce del tercero y cuarto segmento abdominal, ambos sevos pueden producir un chirrido quizis para llamarse mutuansente, porque su géncro de vida es distinto. Fin la superficie del cuarto segmento se eleva una placa triangular con finos surcos, cubierta por el tercer seg. mento que en su parte inferior tiene un pequeño reborde afilado y saliente que recóge los segnentos abdominales, los cuales encajan unos en ótros, como los tubos de un anteojo de larga rista.

USOS, COSTUMBRES Y REGIMEN.- Las hembras acostumbran d ragar en rerano, sicmpre aisladamente, por caminos y pendientes arenosas, activas como una hormiga, mientras que los machos, mas escasos, visitan las flores y los arbustos habitados por pulgones. Unas y otros nacen en nidos de abejorros, pues la larva vive en ellos como parásita $y$ devora las larvas adultas de sus anfitriones. Clurist, el primer observador que en un nido de abejorros encontro el habitante legitimo y en una celda vecina una larva de mutila, supone que una vida familiar reune a los dos insectos; pero no sucede asi: la hembra de mutila ciebe depositar su luevo por medio de su largo aguijon en una larva de abejorro mientras esta vive y se alimenta libremente en su celda abierta; y aunque lleva el gérmen de la muerte en su interior fabrica un capuIlo. Aqui se hacen secretamente cosas que no se pueden observar, pero llegado el tiempo no sale un abejorro sino una mutila. Drewsen, que habia llevado a su casa un nido del bominus serimsliraniss con mas de 100 capullos cermdos, crió del mismo 76 mutilas, entre ellas o 4 , machos y solo 2 de abejorro. Ademis aparecieron otros varios parisitos en forma de moscas, dos machos del ivlusellar fiumata, una hembra de iobucelia bombylans, cuyas larvas salieron del capullo yo se convirtieron en crisididas fuera: y en fin, dos especies de anthomya. Si todo nido de abejorro fuera tan visitado por insectos extranos, muy pronto su género desapareceria de la tierra. Las mutilas criadas se aparearon, todos los machos muricron y las hembras penetraron en la tiern para invernar. Encontré una el 5 de mayo debajo de una piedra. Llega. da la primavera siguiente su primera ocupacion es buscar ni. dos de abejorros para depositar en ellos sus huevos.

De la abundancia de nutilas en la América del sur, don. de escasean los abejorros, resulta que no todas las mutilas habitan parisitas en esos insectos. En anuel pais hay numerosas especies que prertenecen á los mas abigarrados de todos los himenópteros, pues además de los machos de pelos ó injas en el borde posterior, de un magnifico brillo dorado ó platendo, el abdómen esta provisto à menudo de puntos claros. Las muchas especies ạue por su abdómen casi esférico, tórax arqueado, cabeza baja y largas patas recuerdan cicras araỉas, justifican el nombre aleman de todo el género mejor que las especies pertenecientes al sur de Europa.

\section{LA ESCOLIA HEMORROIDAL-SCOLIA HAE- MORRHOIDALIS}

CARACTERES.-Esta especie, í la que la scolia ery. flirocepiala pertenece como hembra, puede servirnos de tipo de su género. Vive en Hungria, Turquain, (irecia y el sur de Kusia, y su nombre genérico (scolia, avispa de puñal) indica que la hembra tiene un buen aguijon. El color negro del cuerpo está cortado por dos manchas laterales amarillas en el segundo segmento abdominal y otras dos anilogas en el tercero; la hembra tiene además en el protórax y en la cara superior del quinto seginento unos pelos de color rojo de orin; los del macho cubren todo el tórax hasta el escudeté, y la cara superior del abdómen desde el cuarto segmento, aunque aqui son menos espesos. Además, las manchas de la piel se reunen à veces, formando fajas. Las otras partes del cuerpo están cubiertas de espesos pelos de color negro. Como caractéres genéricos se consideran: el profundo surco entre los primeros segmentos abdominales; las patas cortas, al mismo tiempo peludas y espinosas, hallándose las cuatro posteriores muy distantes por sus ancas; $y$ las antenas largas y fuertes del macho, cortas y angulosas en la hembra Las alas propias de ambos sexos varian mucho en la dispo. sicion de sus nervios. En la especie que nos ocupa y en otras muchas se cuentan tres celdas cubitales y dos radiales; en algunas se observa la proporcion inversa. Iguales variaciones ofrecen los caractéres sexuales; hay machos que por el color se parecen mucho id las hembras, mientras que en otras especies difieren notablemente. Respecto al tamaño, algunas escolias son superiores á todos los demás himenópteros. Li hembra de la scolia cafitata propia de Java, llamada por Fr. bricius scilin procer, mide $0^{\circ}, 059$ de longitud por $0^{\circ}, \mathrm{O}_{3} 3$ de ancho en el abdómen.

USOS, COSTUMBRES Y REGIMEN. - Io poco qQU se sabe sobre el género de vida de estas especies indica. su parasitismo: segun Comebert, dos viven en las larvas de unos grandes coleópteros que en Madagascar practican á centenares sus galerías en las palmeras, causando considerables es. tragos. De la escolia de las huertas (scolia hortorum) se conoce tambien el género de vida parásito; Bumeister vió una especie brasilena llamada por él scolia campestris que salia en gran número de los nidos del ecodoma.

\section{LAS TIFIAS-TIPHIA}

CARACTERES. - Mientras en la scolia y algunos géneros afines (mesia y myine) la lengua es prolongada, desaja- 
rece casi del todo en las tifias y el primer segmento abdominal se destaca tambien en el dorso por una estrechez del scgundo. Ias pequeñas especies, de las que tres se encuentran en Alemania, son de color negro brillante, y los sexos difieren poco por la forma del cucrpo.

USOS, COSTUMBRES Y REGIMEN. - Ia ierm de que i menudo estin cubiertas las tifias denuestra que penetran en el suclo; tambien les gusta chupar las flores, en las que muchas pasan con frecuencia la noche. Cuando descallsan ó quieren precaverse del peligro enroscan su cuerpo.

\section{EL ATTA CABEZUDO-ATTA CEPHALOTES}

CARA GTERES. - El attit caberudo es de un color paréo castaño muy oscuro, sedoso y rojizo en la cabeza y el coselete, yue así como las patas, estan erizados de asperidades. Ias mandibulas son muy fuertes; el escudo prominente; los dos nudos del primer segmento del abdómen cortos, pero anchos, en forma de plano inclinado; las alas sobresalen nuucho del abdómen, y ticuén un rolor oscuro; las nervaduras son de un pardo intenso. Mide 10 lineas de largo (fig. 43).

Ia obrera tiene à menudo la cabeza sumamente grande, brillante, cordiforne, con la parte posterior dividida por un surco en dos porciones redondeadas, cada una de las cuales presenta en su extremidad una pequeña punta; las antenas son largas: las mandibulas ivertes, planas, anchas, en forma de hoz y ganchudas en la punta; los ojos pequenos y negros; la parte superior del cosclete alta, ancha, con cliatro protu. beraucias puntiagudas ó espinas cortas, dispuestas trasversal. mente dos a dos; eucima de las ancas de las dos patas posteriores hay otra pequeña. I a parte posterior del coselete está separada de la primera por una dêresion, y sus ángulos presentan tambien una fuerte espina cónica. El primer segmento del abdómen, muy áspero, está provisto á cada lado dé un pequeño tubérculo; los otros forman una inasa oval, pexucria y casi redonda. Ias patas son largas. Fiste insecto mide siete lineas de largo.

El macho es algo mas pequeño que la hembra, sobre todo en cuanto a las proporciones de la cabe\%a, de las mandibulas y del abdómen. Tiene el cuerpo negruzco y las antenas rojizas; el coselete no presenta espinas marcadas en sus ángulos posteriores.

DISTRIBUCION GEOGRÁFICA.,- 1.a especie habita en Cayena y en el Brasil.

USOS Y COSTUMBRES. - Este heteroginido es el que despoja en poco tiempo á los árboles, y particularmente los naranjos, de su follaje, segun dicen los viajecros. Tambien se introduce en las casas, como ya hemos dicho en la historia de la familia.

\section{LOS POMPILIDOS POMPILIDE}

Como arispas asesinas se agrupaba un gran numero de himenópteros muy diferentes, que para sus larvas hacen provisiones de otros-insectos en agujeros subternincos, en las hendiduras de las muros ó en la madera vieja, hasta que Viesmael observó una diferencia esencial en la proporcion del protórax y del mesotórax, por lo cual propuso una scparacion en dos familias. La que nos ocupa se designa con al nombre de pompilidos. El exámen de los caractéres esencia. les basta para reconocer desde lucgo de cuall de ellas se tmata.

CARACTÉRES. - l.05 pompilicios tienen el trocainter sencillo, comun con todas las familias hasta ahora observadas y con las dos siguientes, pues pertenecen a las avispas rapaces. El borde posterior del protomx toca la base de las alas; el primer segmenio abdominal no se destaca del segundo, sino yue todos forman un abdómen pendientic estrecindo de adclante atrás. Se distinguen muy fácilmente de un pequeno géncro de la familia anterior por las palas largas ! por las antenas delgadas y rectas. Inas patas posteriores so. bresalen mucho de la extremidad abdominal y estån provistas en el borde exterior de los tarsos, sobre rodo las de la hembra, de abundantes espinas ó dientes. Las antenas se componen de doce artejos y en el macho de trece, separndos casi siemure marcadamente unos de ntros I a cabeza es redondenda, lisa y brillante como el tórax, y los pelos escasos; d negro y rojo son los colores predominantes, pero k menudo se ven matices amarillos y blancos. L.os maclios, siempre mas pequeños, difieren de las henibras por la estructura del cuerpo, un poco mas delgado, y' por tener menos espinas en los tarsos posteriores.

Para poder distinguir los pocos géneros en que se ha dividido la familia, $y$ las especies que comprenden, debenos fijarnos sobre todo eri la disposicion de los nervios del ala anterior, en la forma de la extremidad abdominal y en la estructura de las patas anteriores. En las últimas se observan en muchas hembras, además de las cerdas irregulares, unas espiuas largas, dispuestas de modo que comunican al piéla forma de un peine.

\section{LOS POMPILOS - POMPILUS}

CARACTÉRES. - I OS pompilos, que a toda la familia han dado el nombre, constitujen el tipo prinitivo de la mis. ma. I as dos celdas humerales tienen igual longitud en los lados en que se tocan: hay tres cubitales del todo cermdasy dos discoideas; no se ve ningun surco tmsversal en el segundo sigmento del abdómen de la tiemum, y los tarsos poste. riores de esta se redondean, caracter distintivo del género.

USOS, COSTUMBRES Y REGIMEN.- LAS numerosas especies se distinguen for una maravillosin rapider y agilidad en sus movinientos, sobre todo los del abdómen; anidan en las rendijas de los muros, en los agujeros de vigas viejas, en troncos de ärboles muertos ó én tierra: y aliméntanse de arañas, orugas, hormigas, moscas y otros varios insectos. Si se licieran las ofservaciones minuciosas de que aun carece. mos, tal vee resultaria que cada especic tiene por este con. cepto costumbres del todo determinadas. Cunndo van de caza y eucuentran algun nido de araia, acírcanse, hảcenla salir fuem, se precipitan sobre ella y' la aturden con su pica. dura sin cnredarse munca en la tela. Las especies que se alimentan de arañas no las sacan siempre de los nidos, sino que cogen tambien las que encuentran en el camino. Asi, fror cjcmplo, el pompilus formosus enganin à un migńlido commu en Texas (Mygale Helevii), le jaraliza y llévale á su nido, aunque el peso de su cuerpo es cuandó menos tres veces mayor que el suyo. Gueinzius the envió entre otros objetos la hembra de un bonito pompilo al que he dado el nombre de pompilo de Ninal (pompilus Natulensis) porque no se parecia a ringuna de las especies hasta entonces descritas. Fis de color negro aterciopelado, con la base de las antenas amarilla; las jatas, desde la mitad anterior de los nuslos hicia abajo, y ia extremidad del abdómen son de un rojo sucio, y las alas de un amarillo dorado, con la base y la punta mas oscum. fil interés que ofrece este pompilo, mas grande que todos los propios de nuestros paises, no seria tan general si no tuviésemos algunas noticias sobre su género de vida. Vuela sin temor algumo en las casas autiguas, saliendo y entrando en ellas; agridale pascarse por los vidrios de las ventanas por arriba y por abajo, consistiendo su diversion farorita en cazar entre 
las vigas y en los rincones cubiertos de telaranas; entonces se re siempre obligado a limpiarse con las patas las antenas, cubiertas de polvo. La cuidadosa hembra oculta en los sitios arenosos, en los rincones de la casa ó debajo del balcon las arañas cogidas y paralizadas, en las cuales deposita un huevo. De todas las arañas persigue con preferencia una gran espe. cic de color pardo amarillo, con las patas anilladas que vive en los techos viejos de paja, y sucle bajar de vez en cunndo durante la noche lentamente por las paredes. Una vez obser vó el citado naturalista como una hembra muy grande de esta araila penetró apresuradamente por la puerta abierta en su habitacion, ocultandose luego detrás de una cajita en el corredor. De la prisa del insecto, por lo regular an cachazudo, coligió que le habrian perseguido en el techo y que buscaba un refugio. No se habia engañado, pues á poco apareció un pompilo en la juerta, que dirigiéndosé derecha é izquierda, examinábalo todo como un perro perdiguero; cuando hubo llegrao al ángulo de aquella cajita, la auraña, presintiendo el peligro, salió por el lado opuesto y dirigióse otra ver hacia la puerta. En el mismo instante fué alcanzada y' se trabó una liuclia á vida y nuerte. Era un espectáculo que «daba frio ver camo la araña, echada boca arriba, procuraba rechazur con sus largas patas al encmigo, sabiendo muy bien que una sola picadura le seria mortal. De repente volvió á levantarse y quiso avanzar, prero muy prono viósc obligada á tomar otra vez la posicion anterior. Sus esfuerzos eran demasiado peno. sos para que pudiera resistir los ataques de la avispa mucho tiempo, y al fin se mantuvo innóvil con las patas recogidas, como muerta. En el mismo instante la vericedora la cogio con sus maxilas por el cefalotórax, aplicándole desde abajo repetidas picaduras en el abdómen. Fuem de un ligero tenblor de los palpos, la araña no se movin mientras recibia los golpes mortales. Ia avispa, zunibando con fuera, daba rucltas al rededor del cadáver: luego bailó su danza guerrera, tocando á la victima de vez en cuando en las patas ó en los falpos para convencerse de su muerte; y tranquilizada al fin, limpióse todo el cucrpo, cogió la araña por el cefalotórax y alcjóse andando hácia atrás para ir á enterrar su presa.

Aristóteles conocia y las cacerias de los pompilos contra las arnnas; pues dice $(\mathrm{IX}, 2,1)$ : 1 Las avispas liamadas icncumones (nombre que hoy dia se ha dado a unos hinenópteros muy diferentes), y que son mas pequeños que los otros, matan las aranas; llevan los cadáveres álos muros rumosos ú otros cuerpos perforados y cubren el agujero con barro; pero de aqui se producen las avispas investigadoms. Menos conocido seri lo que Fermando Karsch ha observado cerca de Munster. Este cogió el 2 de julio de 1870 una hembra adulta de la tarisstula ingurilina que llarmo su atencion por su abdómen, poco dilatado, por la falta del ovario y por una prominencia de un blanco rojizo en el lado derecho del dorso del abdómen, lo cual le hizo creer que habia herido al insecto al cogerlo. Reducida i la cautividad para observar la puesta de los huevos, el 16 de julio se ofreció á la araña una mosca, y al poner en su prision um poco de agua, cxaminóse mas minuciosamente la jrominencia roja; viuse que era mu. cho mas grande, y entonces se pudo reconocer con el anteojo de aumento la larva chupadora de un parásito. Eximño era que la araña no solamente no se quitase rquel apéndice con su pata posterior derecha, sino que evitarn cuidadosamente tocarlé. Là araña fué trasladada á una caja de cristal espaciosa, cuyo fondo estaballeno de tierra ligera; penetró muy pronto en esta y cerró la entrada del agujero de modo que ya no fué posible observar.

El 4 de agosto se levantó la capa de la entrada, descubriéndose un capullo de crisálida y unos hilos de color gris amarillo, pero ya no se vió huella alguna de la araña. El 17 de agosto, un pompilo de la especie llamada pompilus tranga. lis paseábase alegremente por la vasija. En el capullo, exa. minado despues, se encontraron aun algunos restos de patas, los pedazos do piel dura del celalotórax y las inaxilas de la aran้ล.

\section{EL POMPILO COMUN-POMPILUS VIATICUS}

CARACTÉRES.-Los individuos jóvenes tienen la punta de las alas casi negra, el abdómen rojo en la base, con el borde posterior de cada segmento negro; las fajas anteriores se prolongan hácia adelante, rematando en punta. El metatórax tiene algunos pelos largos y rizados, y el borde posterior del protórax presenta una escotadura angulosa. En la hembra los piés anteriores afectan la forma de peine. Ia última escama dorsal del abdómen esta provista de cerdas en los lados. En el macho se ensanchan las garms de las patas anteriores un poco hacia adentro.

USOS Y COSTUMBRES. - El prompilo comun visita á principios de la primavera los sauces en flor $y$ se muestm activo todo el verano. Habita en la arena donde la hembra penetra con gran agilidad y rapidez, escarbando con sus pa. tas anteriores, como un perro ó un conejo, hasta que llega á una profundidad de $6^{\prime \prime}, 08$ ó mas. Dhalbom cree poder afirmar que varios tubos conducen al nido, porque el pompilo se escapa por uno, cuando se le persigue por el otro No tengo datos para corroborar este aserto que necesita confirmacion.

\section{EL POMPILO NOBLE-POMPILUS NOBILIS}

CARACTERES. - Distinguese particulamente el pompilo noble (fig. 36, paig. ro7) por presentar su cuerpo vinias placas 6 capas de un vello alisado, muy corto, y de color de plata brillante, que no se nota en las antenas ni en las patas: las alas son trasparentes, negras en su extremidad; las sujkeriores ofrecen dos fajas trasversales y las inferiores una sola de color negro. El protórax es muy corto, y escotado posteriormentc; el metatórax bastante largo, combado, y con un surco dorsal muy distinto. Hil tamano de la hembra difiere poco del de la especie anterior.

DISTRIBUCION GEOGRAFICA.-Este insccto es comun en el Brasil y en Cayena.

\section{LOS PEPSIS - PEPSIS}

CARACTERES. - Se camcterizan estos insectos por tener los palpos maxilares un poco mas largos que los labiales con sus artejos casi de igual longitud; las antenas de los machos, casi rectas, se componen de artejos companctos, que van aumentando de grueso hasta el segundo tercio de su largo; disminuyendo despues para terminar en punta; el coselete es menos largo á proporcion que en otros géncros; el protórax afecta la forma de un cuadro trasversal, y no es mas largo que el mesotúrax.

DISTRIBUCION GEOGRÁFICA. - Las éspecies del género parecen en su mayor parte exóticas: se encuentran sobre todo en Africa y América.

\section{LOS PRIOCNEMES-PRIOCNEMES}

CARACTERES.-Este género se distingue del anterior por la celda humeral inferior, que sobresale de la extremidad de la superior, por un surco trasversal en el scgundo segmen. to abdominal de la hembm, yor tener los tarsos posteriores denticulados. No es menos dificil distinguir las especies, a menudo muy semejantes, como sucede en el género antcrior. 


\section{LAS AGENIAS - AGENIA}

S.ARACTERES.-MUy parecido al genero anterior es el de las agenias, solo que el abdómen tiene un tallo apenas visible y los tarsos posteriores no son denticulados.

USOS Y COSTUMBRES.-I - Is hembras fabrican en la arena, en paredes de barro, debajo de la corteza de los árboles, etc, cierto número de celdillas en forma de toneles, com. puestas sencillamente de pedacitos de arcilla. He visto varias veces las de la agrina punclum debajo de los frngmentos de corteza de los troncos de árboles muertos. Cada una está provista de una amina de mediana longitud para la larva, pero desplojada de las patas. Gueinzius, al hablar de una especie, la regria domestien, que mide $11^{\prime,}, 019$ de largo, dice lo siguiente: "De todos los himenópteros que conozco, este es el mas familiar, pues manifiesta cierta inclinacion al hombre; en diversos puntos donde anos enteros vivi cerca de los bosques, todos los veranos tenia algunos individuos en mi habitacion. Cuando estaba en la puerta de mi casa y el sol tocaba en ella, la avispa se posaba con las juaras entreabiertas y paseábase tranquilamente por los vidrios de la ventana ó volaba inquieta hasta que la dejaba en libertad. Si tenia en la mano un libro $y$ el sol le tocaba, presentábase al punto una avispa. Parecia agradarle que soplara, pues no se alejaba por esto, ó cuando menos volvia al momento, trepaba por el brazo y se posaba en mi barba $\delta$ en la boca, sin picarme nunca De este moda la agenia me molestaba i inenudo, i causa de su demasiada impertinencia. For la noche penetra. ba en la habitacion por un agujero que habia en el marco de Ia ventana, para buscar sus escondites. Esta especie construye celdas de tierra debajo 6 dentro de los cajones, 6 tambien en los nidos de pájaros; estas celdas tienen la forma de bolsa, son poco limpias y regulares, y carecen de capa cxterior.

En los paises cálicios viven de un modo análogo unas es. pecies muy grandes que miden hasta (,", og 2; se han clasificado en una serie de otros géneros; pero no podemos ocuparnos aqui de ellas.

\section{LOS ESFÉGIDOS-SPHE- GID死}

CARACTERES. - Bajo el nombre de esfégidos, aüispas csearbadoras $\delta$ asesinas (sphegide crabronea), reunimos en una familia todas las avispas rapaces, en las que el borde posterior del protóna queda como suspendido antes de llegar á la base de las alas, esirechándose con bastante frecuencia un poco hácia el mesotónx. Ias especies pertenecientes á este grupo no ofrecen ni por sus formas ni jor sus colores la misma analogin que los tipos de las especies de la fannilia anterior; el abdómen, pedunculado, con un rallo it menudo mus largo, pero tambicn pendiente, les comunica el aspecto mas variado. Muchos son de un solo color negro, negro y rojo, $y^{\prime}$ mas en general amarilio, pero la major parte tienen el fondo negro con matices le un amarillo muy vivo; en muy pocos individuos es blancu, y aun en la misma especie puede cam. biar det modo mas jiverso. De este modo, la forma de los colores y los movimientos contribuyen a que estos insecios sean uno de los fenómenos mas agradables y graciosos.

DISTRIBUCION GEOGRÁFICA.-Esản diseminados por toda la superticie del globo y se conoccu actualmente inas de 1,200 especies.

Fl antiguo género splicx, que con preferencia labita los paises cólidos, comprende los gigantes de la familia; pero hace tiempo que ha degenerado: coll su abundancia de formas, ya no tra posible agrupar bajo un nombre todo lo que en tiempos anteriores Limneo pudo reunir, atendido el corto numero de especies. Teniendo en cuenta las formas del abdómen pedunculado, la mariedad de la celdilla radial y de las tres cubitales cerradas, la disposicion de los nervios braquiales y otros muchos caractéres, á menudo sobrado rebusca. dos, creóse una multitud de géneros, de los que solo muy pocos y los mas reduciúos son propios de Europa.

\section{LOS ESFEX-SPHEX}

CARACTERES. - T.OS esicx, ó matadures de orugus, comprenden las especies con el tallo abdominal sencillamente liso, cuya segunda y tercera celda cubital del ala anterior

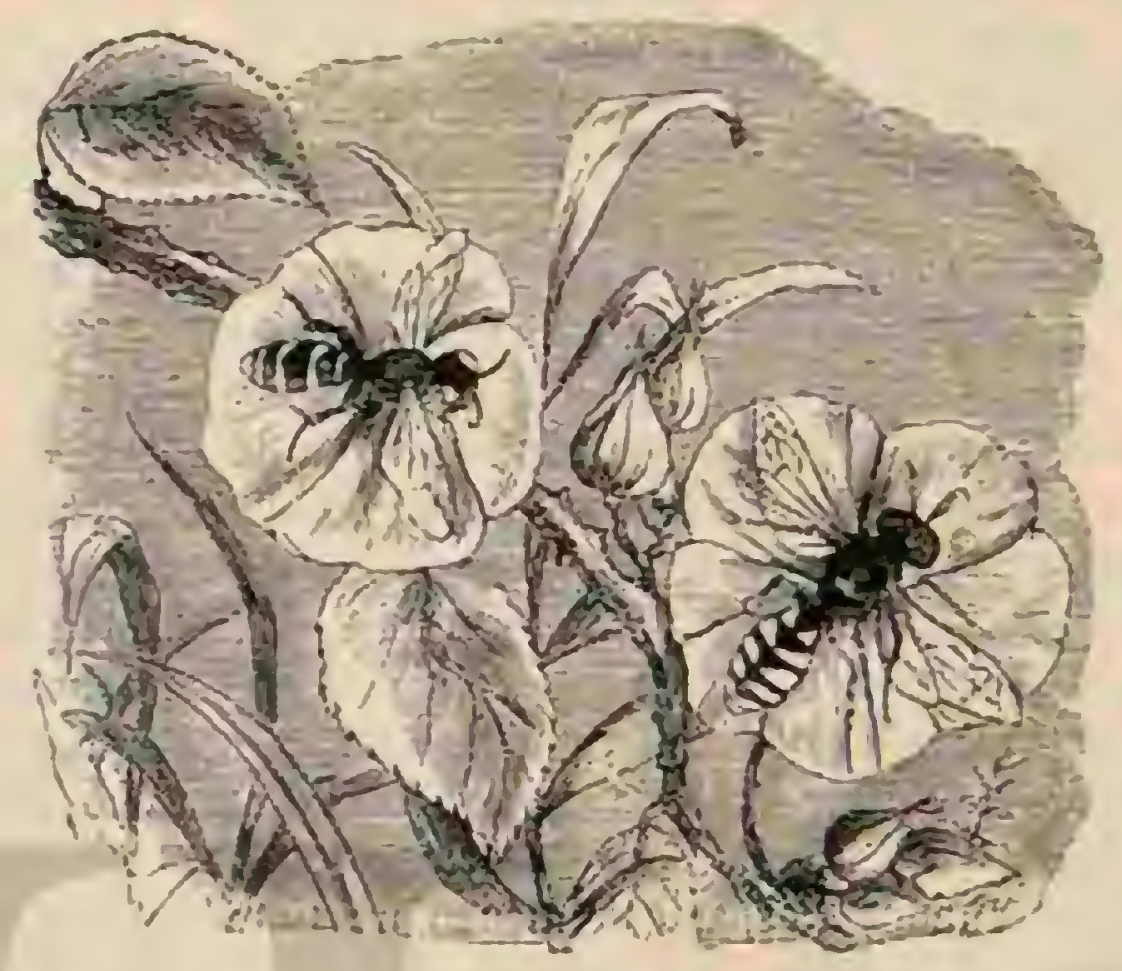

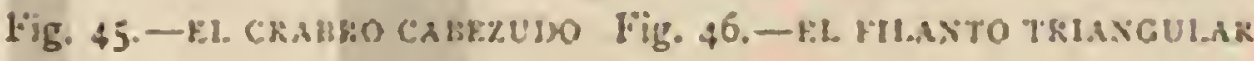

recoge cada una un nervio braquial; los tarsos posterio. res estin provistos de espinas y las garras son bidentadas en in base.

USOS, COSTUMBRES X REGIMEN.-Una especic (spher ma.tilosa) prarece ser la que en Luropa está diseminada mas hicia el noric. De otras dos especies unas meridionales, del esfex de alas amarillas (sphex flaripersis) y del esfex de segmento blanco (sphex abisecta) debemos interesantes olsservaciones af Faber.

la primem tiene la singular costumbre de llevar cuatro grillos á su nido; la scugunda da caza á las langostas del género adifoda. Cada cual se precipita sobre su victima y procura herirla en el pecho; entonces se iraban violentas luchas, pues un animal de muslos tan robustos como los del grillo no se rinde sin defensa, sino que resiste mientras puede. No siempre quecia vencido; pero cuando el esfex logra tenerle debajo, sujeta con las patas anteriores los cansados muslos de su adversario, oprimele con las otras la cabeza y le aplica dos 6 tres ficadas venenosas. la primera va dirigida al cuello, y la segunda al sitio donde se reunen el protó. rax y el mesotórax. En este caso el grillo está perdido; no puede vivir ni muere, pero queda paralizado. El esfex le armastra penosamente hasta su guarida subterránea y déjale en la entrada para reconocer antes si todo está en órden. Faber cogió à una misma avispa cuarenta vecus su presa, cuando estaba ausente, para poncrla a cierta distancia del nido, pero otrís tantas el insecto volvió à buscarla, examinando, sin em. bargo, cada vez de nuevo su vivienda antes de introducir en ella la victima. Fil esfex de alas amarillas deposita el huevo entre el primero y seguncio par de patas en el tóma del gri. 110. Aqui sale la larva y absorbe en seis ó siete dias com. pletamente la sustancia, dejando casi ilesa la cubierta ųuitinosa. Cuando ha llegado á una longitud de $10^{\circ}, 01 j$, sale 
por la misma abertura y come uno desinues de otro los tres grillos que llevó la hembra. I a larva adulta mide entonces de $0^{*}, 026$ i $0^{\circ}, 0305$; se cncierra en un capullo i las cuarenta y ocho horas, permanece inmóvil desde setiembre i julio del año siguicnte, y solo entonces se trasforma en crisálida, de la cual sale al poco rato el esfex.

\section{LOS CLORIONES - CHLORION}

CARACTERES.-Los palpos maxilares y labiales de estos insectos son casi de igual longitud; los primeros constan de seis artejos y los segundos de cuntro; las maxilas y el labio son cortos; las mandibulas, poco ciliadas por dentro, tienen un diente medio asaz fuerte y compuesto de varias puntas; las antenizs se insertan debajo del centro de la cabeza, cerca de la boca; la radial no tiene npéndice; las cubitales no ofrecen ninguna particularidad digna de mencion.

\section{EL CLORION AZULADO-CHLORION AZUREUM}

CARACTERES.-Este bonitó insecto siene ln cabeza de un hermoso verde dondo con visos azules que se reconocen muy bien; la parte anterior y la posterior de los ojos están guarnecidas de un vello plateado. entre el cual apuntan pelos neyros; las antenas son de este color: el coselete del mismo tinte que la cabeza y velloso: el metatćrax presenta estrias trastersales; cl abdómen es de un verde dorado, lo mismo que las patas y los tarsos, cuyos pelos y espinas son negros; las alas, aunque trasparentes, tienen un tinte rojizo, con la extremidad ahumada; la escama es de un verde dorado. Ia hembri mide unas is lineas de largo.

El macho difiere solo por tencr el último segnento del ab. dómen como los precederates.

DISTRIBUCION GEOGRÁFICA.-Esta bonita cspe. cie es originaria de la China.

\section{EL GLORION LOBADO-CILORION LOBATUM}

CARACTERES, - Lá coloracion de este insecto (fig. 39 página r15) difiere tan poco de la del anterior, que hasta cierto punto podrian confundirse, predominando siempre el tinte verde dorado. Las alas son rojizas aunque trasparentes, con el borde posterior ahumado; las nervaduras carecen de punto marginal $y$-son ferruginosas.

Il macho tiene la parte anterior de la cabeza como guarnecida de un vello ferruginoso, $y$ el sexto segmento del ab. dómen se parcce á los demás.

DISTRIBUCION GEOGRAFICA.- Africa parece serla patria de este insecto, ó por lo menos es donde mas abunda.

\section{LOS PELOPEOS-PELOPOEUS}

CARACTERES.-Los pelopeos ó matadores de arañas, tienen exactamente las mismas formas de las especies del género esfex, de las cuales solo difieren en que los dos nervios braquiales terminan en la segunda celda cubital, y en tener los tarsos posteriores desprovistos de espina.

\section{EL PELOPEO DESTILATORIO-PELOPOEUS DESTILLATORIUS}

CARACTÉRES. - Il pelopeo destilatorio, habitante de los paises del Mediterrineo, aunque segun dicen se ha cogido tambien en Hannover, tiene un color negro brillante; el largo tallo abdominal, las escamitas de las alas, la parte posterior del escudete, el tallo de las antemas y las patas, desde los muslos hasta abajo, son de color amarillo, cxcepto las puntas negras de los muslos y de los tarsos de las patas posteriores. Ebersmann excontró en una elevada roca del Ural un nido pegado a la piedra, en forma de riñon bastante irregular: su interior contenia unas catorce celdas longitudinales, cada una con diez individuos del tomisus citricus, es. pecie de arañas que muy raras veces se encuentran.

\section{EL PELOPEO ESPIRIFEX-PELOPOEUS SPIRIFEX}

CARACTERES. - De otra esprecie muy jarecida, jo que quizås solo es una variedad, el pelopeo espirifex, poseo va. rios individuos de la Furopa meridional y de Prerto Natal, asi como tambien algunos nidos de este ultimo pais; el insecto difiere solo del anterior por tener las antenas y el tómx del todo negros. El nido se parece mucho al de nuestra abeja de las paredes, y' sus celdas cstán sicmpre tambien yruvistas de araias.

Una tercera especie mug afine, tambien de Puerto Natal, construye sus celdas con excrementos recicites de vaca y las cuelga aisladins ó cie dos en dos en los tallos de juncos.

\section{EL PELOPEO AZUL-PELOPOEUS CHALIBEUS}

Fste compatriota de las especies anteriores construye el nido én los tallos huecos del hambú ó en los techos de las casas, y para hacer las paredes divisorias emplea los excrimentos de aves, que raspa de las hojas y mezcla despues con su saliva.

\section{EL PELOPEO SILBADOR-PELOPOEUS PHISTULARIUS}

CARACTÉRES.-Reconúcese esta especie por el tallo abdomimal, que es negro, por tener seis manchas anmarillas en el dorso, y las alas ligeranente turbias.

DISTRIBUCION GEOGRÁFICA. - Este pelopreo es propio de la América del sur.

USOS, COSTUMBRES Y REGIMEN. - Construye celdas aisladas de barro, de la longitud de $0^{\infty}, 052$ y en forma de un huevo. Zumbando alegremente, como si celebrase algun triunfo, la hembra lleva el material de construccion, le coloca convenientemente, alisale con las maxilas y el labio inferior, lo amasa, siempre zumbando alegremente, y despues de examinar toda la pared con las patas, desaparece, pero pronto vuclve, y ya no descansa basta que la celdilla queda acabada; entonces la llena de pequeñas amñas del género castra y la cierra. En una de sus expediciones por las orillas del Amaronas, Bates se detuvo una ver con su canoa ocho dias en el mismo paraje donde una de estas avispas habia enupezado a fabricar nido: y apenas cerrada la celda, la enbarcacion volvió á ponerse en movimiento. A pesar de que hasta entonces la avispa se habia mostrado familiar y confia. da, no volvió ya, aunque la canoa avanzó muy lentamente por cerca de la orilla.

\section{LA SAMÓFILA ÁSPERA-PSAMMOPHILA HIRSUTA}

Para la Alemania y el norte de la Europa, dos especies, la samófila áspera y la amófila comun representan los esfex mayores, de los qque principalmente difieren por no tener las garras de los piés denticuladas. 
CARACTÉRES. - La samúfila áspera mide $\theta^{\text {th }}$, or 95 de largo: el tallo abdominal es tres reces mas corto que el del pelopeo dentilatorio y tiene el color negro, excepto la base abdominal que es de un pardo rojo; las patas y la mitad anterior del cuerpo están cubiertas de pelos negros, sobre todo ch el metatórax, que tiene arrugas muy marcadas.

USOS, COSTUMBRES Y RÉGIMEN.- T'odo el verano estas avispas vagan por parajes arenosos, y cuando les aguijonea el hambre buscan las fores $y$ los arbustos poblados de pulgones. Cuando pelean, la una se pone sobre la otra y la muerde en la nuca; a veces llega tambien una tercera ó cuarta, y citonces se forma un grupo que se revuelan en el suclo, deshaciéndose al fin. No se sabe si el deseo de retozar ó el celo dan lugar à estas luchas.

\section{LA A MÓFILA ARENOSA-AMMOPHILA SABULOSA}

CARACTERES. - Esta especie no se distingue por su género de vida de la anterior. El primer artejo de la maza de las antenas es delgado y cilindrico, el segundo casi de igual longitud, se ensancha un poco hácia atrás, y asi sucesivamente hasta el quinto, desde donde la maza se estrecha bruscamente hácia la punta. El tallo abdominal se compone de dos seg. mentos, mientras que en los otros camctéres se repiten las mismas particularidades que on la especie anterior. Excepto la maza, que es de un rojo pálido, predomina tambien aqui el color negro, pero en los lados del tórax el corto pelo forma unas manchas plateadas que desaparecen con el roce. Bi macho se distingue fácilmente de la hembra por es escudo de la cabeza, estrecho y cubierto de pelos plateados, mientras que en aquella es mas ancho $y$ desnudo.

USOS, COSTUMBRES Y REGIMEN.-Pista especic se encuentra durante todo el vesano, segun parece, siempre alegre, ocupada ya en examinar el terreno ó en extraer su alimento de las flores de la morera ó de otras que contienen néctar. El observador puede recrearse horas entcras con es. tos atrevidos insectos, sobre todo cuando se hallan en gran número unos al lado de otros, demostrando toda su actividad. Eligen la pendiente de un foso y otros sitios análogos, pero sicmpre despejados, para construir su nido. Como un perro que abre un hoyo en el suelo, la hembra de la amúfila escarba con las patis anteriores y echa la arena hácia atrás, zumbando ruidosamente. Al oir este rumor especial, el observador puede estar seguro de que encontrana la avispa en ta! ocupacion. Cuando la arena se amontona demasiado por delante del agujero se posa por encina y dispersa todo el monton. Las piedrecitas no suelen faltar en estos terrenos.y si la arena es húmeda el insecto se ingenia para extraerlas con las patas anteriores. $\mathrm{L}_{\mathrm{a}}$ uvisipa sale del ngujero hàcia atrás, echa à volar y deja caer su carga. En el mismo instan. te ha desaparecico nuevamente en el suelo, y se ta ve repetir tres ó cuatro veces la misma maniobra. Despues se detiene delante de la abertura, se limpia y examina con orgullo la construccion. A los pocos momentos ruelve á desaparecer en el interior: cuanto mas penetra, tanto mas tarda, y cada vey sale con la carga, aunque lo hace en un tiempo schativamente corto. Por último emprende el vuelo, sin duda con la intencion de descansar del penoso tmbajo y lames un poco de niel, pues no es carnivora. No menos divertida que la cons. truccion del nido es su caceria de orugas de mariposa para la futura cria, pues solo estas, aunque de diversas especies, son las que le convienen. El sitio donde cierto dia ture ocasion de observar un gran número de nidos no cra muy favo. rable para el trasporte de la yresa, pues aquellos se encontrabar en la pendiente de un foso a lo largo del lindero de un bosque; en un camplo qque habia en al lado opuesto del foso estaban las orugas de ciertas mariposas. Cuando la avispa encuentra una de ellas no vacila un instante; con dos picadas en el quinto ó sexto segmento abdominal la paraliza al punto para que no entre en descomposicion. Conseguido esto, el insecto debe pasar por un largo camino en medio de yerbas, hasta la orilla del toso; luego ha de cruzar este y subir por la orilla opuesto. Este no es jequeño trabajo para un solo insecto con una carga a menudo diez veces mas pesada que su propio cuerpa. En las hormigas sociables se ayudan los companeros cuando hay necesidad, pero la amórila debe hacerlo con su propin fuerza y agilicad y por su ingenio, si asi se me permite decirlo. Coge la presa con las temazas arrastrándola como puede; llegada al trorde del foso, déjase caer con la oruga, soltándola en medio del camino y llega ilesa al fondo. Pronto ruelve a encontrar la oruga, la coge de nuevo y sigue arrastrándola; desjues trata de subirla por el lado opuesto, y para desarrollar toda su fuerza la avispa tiene que avanzar hácin atris. A veces se escapa la carga y todo el trabajo ha sido inuítil, pero el insecto no pierde el ánimo, y por fin logra el resultado apetecido. In oruga se halla delante de la aberiura y el insecto se detiene, no para descansar, sino por desconfianza ó precaucion; luego entra solo primero en su vivienda para reconocer si todo está en órden. Durante este paseo ha recobrado ya fuerras para dar cima por lin á su pesada obra. Avanzando hácia atris arrastra a la oruga al fondo del agujero, lo que por regular hace sin accidente, pero a veces queda cagida en alguna parte y entonces es preciso en. sanchar mas la entrada Semejante perseverancia, que con frecuencia observamos, tanto en esta especic, como en las hormigas y en otros insectos de este género, es verdadern. mente admirable y digna de imitacion.

Por fin ta amófila $y$ la oruga han desaparecido y pasa mucho tiempo anies de que aquella ruelvo á presentarse, pues tiene que poner por remate en la oruga un solo huevo prolongado. Entonces sale, pero aun no la concluido su tarea, pucs debe ocultar la entrada del nido con algunos pedacitos de tierra ó de madera, a fin de horrar todo vestigio de su existencia y para que otros parásitos no puedan aprovecharse de la ocasion y depositar tambien sus huevos. Para cada uno de estos la amúfila debe répetir los mismos trabajos, mas a pesar de esta vida tan penosa siempre esta contenta, hasta que muere á fines del veriuno. En las cntranas de la tierra se tras. forma pronto en larva, que penetra en la oruga y chupa toda la sustancia; segun que la oruga es grande ó pequenha, la avispa que resulta es de diferente tamano, el cual puede variar

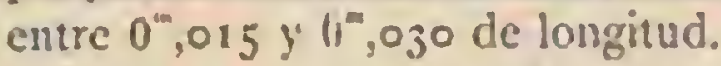

la larma que para su desarrollo desde la salida del huevo necesita cuatro semanas, fabrica un tejido blanco y delgado, y por dentro de este otro mas espeso y sólido que la encierra estrechamente y tiene un color pardo. En este capullo se trasforma pronto en crisálida, de la que no tarda en salir la avispa despues de abrir una tapita. Es posible que liaya dos crias al año, sobre todo cuando el tiempo favorece el desarrollo. La uilima inverna como larva ó crisalida.

En la Europa meridional viven algunas otras amófilas muy parecidas; las especies de las regiones cálidias se distinguen de las nuestras en ventaja suya por el color predominante del cuerpo, que es rojo, ó por numerosas escamitas plateadas.

\section{LOS MELINOS - MELLINUS}

CARACTERES - los melinos ó airisfas lisas forman otro géneto de un aspecto esencialmente distinto en sus pocas especies. Se caracterizar por tener el abdómen eliptico marcadamente pedunculacio, por la celda radial sin apéndice 
y par tres celdas cubitales cermdas, la primera de las cuales recoge el primer nervio braquial y la tercera el segundo. El tallo de las antenas es corto, pero grueso; la brocha filiforme; y el tallo del abdómen ensanchado en forma de maza. El macho, que es mas pequeñoy delgado, tiene segmentos abdominales; la hembra uno menos y el títimo mas largo en el dorso.

EL MELINO DE LOS CAMPOS - MELLINUS ARVENSIS

CARACTÉRES.-FI melino de los campos es una especie comun é impertinente que á menudo se encuentra en los bosques de conileras y répta con bruscos movimientos por el ierreno arenoso. Se ruelvey revuelve en todos sentidos, vuela zumbando en un corto trecho, vuelve a - posarse pana comer otra vez, y asi continúa largo rato. Mucho le agrada ponerse en la ropa del viajero, revolviéndose con el mismo atrevimiento qui en tierra, pero no elige este punto con mala intencion, sino impulsada al parecer por cierta curiosidad. En las espesuras pobladas de pulgones, en los pinos cubiercos de especies de quermes presentause con centenares de sus iguales y toda clase de coleópteros para libar las sustancias dulces; raras veces se le encuentra en las flores. Su cuerpo, de color negro brillante, tiene tres anchas fajas amarillas en el dorso del abdómen y entre-las dos últimas dos manchas laternles de dicho color, que es tambicn el de las patas. Amarillos son además el escudete, el collarin, las escamitas de las alas, una manchita que hay ciebajo de estas, la parte anterior del tallo de las antenas y uma mancha cuadrangular abierta por arrita en la ancha cara. Asi como en muchos esfégidos, falta tambien en este la constancia de los dibujos amarillos. In longitud del cuerpo varia de $11^{\prime \prime}, 00 \$_{35}$ á $1,0.013$.

La avispa practica tubos ranificados en la arena y recoge solo moscas, sobre todo, muscidos (muscarndis y otros); dis. tinguiéndose, sin embargo, de casi todos los otros samofilidos por depositar ya en la primera mosca el huevo alinentando la larva aun mientras comen. Hasta el iño siguiente no termina el deśarrollo de esta.

\section{EL MELINO ARENOSO-MELLINUS SABULOSUS}

Una segunda especie mas pequeña, se encuentra siempre en compania de la anterior. La hembra construye sus nidos aisladamente; estos se reconocen por pequeilos montoncitos informes en la superficie; la avispa recoge tambien exclusivamente moscas de los géneros sarcophagra, caroria, anthombya, Iucilia, orfonzura y seppluus. I)eposita la presa delante del nido antes de colocarla en el mismo, y entra en él andando hácia atrís.

\section{LOS BEMBEX-BEMBEX}

CARACTERES.-Se distinguen ficimente por la forma de la boca de todos los demás esfégidos. Fil labio inferior pende como un largo pico, y se oprime cuando el insecto reposa, cubricndo la larga lengua contra la garganta. Por su exterior estos himenópteros se parecen en extremo a un avis. pon ú otra grande atispa, y son por lo regular amarillos. De las tres celdas cubitales, que son cerradas, la del centro recoge los dos nervios braquiales, en extremo largos. Ias antemas son angulosas y su brocha casi filiforme, encorvada en la punta ligeramente hácia afuera. El macho tiene los últimos artejos de la brocha obtusos y denticulados y además se distingue del otro seio por tener algunas gibosidades en el centro del vientre.

\section{EL BEMBEX COMUN - BEMBEX ROS CRATA}

CARACTERES. - Esta especie es el esfégiclo mas gmnde de Alemania; su tamaño varia de $C^{\star}, 015$ a $0^{\circ}, 0175$ de laryo por 0,0065 de ancho. El color negro del fondo presenta numerosos matices de un amarillo pálido, mu variados en el tórax, en forma de fajas centrales en los segmentos del abdómen. La primera de estas fajas estí cortada en el centro, y cada una de las otras es ondulada. la cara y las patas son tambien por lo regular amarillas.

DISTRIBUCION GEOGRÁFICA.-Esta bonita avispa se encuentra en toda la Europa, pero en las regiones centra. les y septentrionales se la re mas aislada y no todos los años en el mismo sitio.

USOS, COSTUMBRES Y REGIMEN. - $\perp$ fines de julio de I $_{5}$ j encontré en un sitio descubierto muy seco, en medio de un pinar en nuestra region, una intinidad de nidos cuya presencia me reveló el fuerte zumbido de las avispas que los rodeaban. Desde entonces he visitado todos los años el mismo punto, pero nunca he vuelto á ver ni aqui ni en mis otras expediciones una hembra. Estos insectos se distinguen mas que todos sus congéneres por su indole salvaje, a juzgar por sus fuertes zumbidos y su brusco vuelo. Los nidos se forman del modo indicado y penetran en direccion oblicua bajo tierra. Los naturalistas no están conformes sobre el modo de construccion de estas especies ni sobre su género de vida. Segun llestwoode, varias hembras depositan sus huevos juntos en el alimento recogido. Dahlbom cree çue los largos tubos se ramifican y tienen varias entradas y salidas. Lefielletier dice que para cada huevo se reunen diez ó doce moscas, que los tubos oblicuos se cierran con arena y que cada hembra deposita unos diez huevos. Bates, por fin, ob. servó que el bembex ciliata, propio de la América del sur: tenia en cada nido solo un huevo y por lo tanto tendrian que cristir tantos nidos cuantos luevos deposita una hembra. Todas las noticias están conformes en que solo cogen y reunen grandes moscas, como alimento de las larvas. La primera de dichas opiniones seria contraria a las experiencias he. chas en todos los demás esfégidos; las otras me parecen mas lógicas, pero no me atrevo á decidir cuall es la mas cxacta, porque no he hecho obsermciones propias.

\section{LAS MONÉDULAS-MONEDULA}

CARACTERES. - Los bembex viven con preferencia en las regiones callidas y varian aqui en parte por la estructura del cuerpo, de modo que I atreille se vió obligado à formar un género especial bajo el nombre de monedula. Mientras que en los bembex los palpos maxilares se componen de cuatro artejos y los habiales de dos, se aumenta aqui el número a seis y cuatro respectivamente $y$-además se estrechan las dos últimas celdas cubitales marcadamente hàcia adelante. Además de algunas diferencias menos importantes, las dos citadas, que son las principales, han bastado para la separacion.

\section{LA MONÉDULA VESPIFORME-MONEDULA SIGNATA}

CARACTERES, - Bates dice al hablar de esta especic (fig. 35): «Este insectoes un verdadero beneficio en lastegiones del Amazonas para el viajero atormentado por la sanguinaria mutuca de los indigenas, ó el hadans lepidofus de los maturalistas. Por primera vez observé que la citada avispa persigue a esta mosca, al abordar un dia á un banco de arena en la inmediacion de un bosque para preparar la comida. El insec. 
to tiene cl tamaño de un arispon, pero se parece mucho á una avispa. No me admiré poco cuando de la bandida que volaba por encima de nosotros destacóse un individuo y se dirigió en linea recta à mi cara; habia visto en mi cuello una mufuea, sobre la cual se precipitó, cogióla conlascuatro patas anteriores ý se la llevó, opriniéndola cariñosamente contra el pecho.

\section{EL FILANTO TRIANGULAR-PHILANTHUS TRIANGULUM}

CARACTERES. - El tamaño de estos insectos (fig. \$6), que tienen la cabeza muy ancha, varia de $11^{m}, 009$ a $11^{\circ}, 016, y$ los dibujos amnrillos cambian de tal modo, que à veces en el abdómen ese color se cxtiende mas que el nejro del fondo, quedando solamente algunos triangu!os negros en la base de los segmentos. Por lo regular, los bordes posteriores de los segmentos abdominales son negros, con fajas amarillas muy ensanchadas en los lados; el tórax, cl collarin, las escamitas de las alas, el escuclete y dos manchas que hay delante del mismo ofrecen igual color. I.os dibujos de la cabeza son blancos; en su parte iuferior, hasta el centro de las antenas, hay una nancha triangular, que se extiende á los bordes interiores de los ojos hasta una profunda escotadura. Las cortas antenas se caracterizan por una brocha ensanchada en el centro, y por estar mas separadas una de otra; las alas anteriores tienen tres celdas cubitales cerradas y otmas tantas discoideas; de las primerns, la segunda, que es pentagonal, recoge en un centro el primer nervio braquial, y la tercera, muy estrechada hácia adelante, recibe en su principio el segundo de estos nervios.

USOS Y COSTUMBRES. - Fil filanto triangular, llamado tambien lobo de las abejas abigarrade, es un companero muy perjudicial, por su continua persecucion contra la abeja do. méstica, a la cual parece preferir, auncue tambien ataca à las samófilas, de las cuales recoge de cuatro a seis para cada huevo: á esto debe su nombre de bobo de las abejas. Atrevido y.aigil, precipitase como un gavilan desde arriba sobre su presa, arrójala al suelo y la paraliza antes de que pueda pensar en la defensa, lleviudola despues i su nido. Este se halla tambien debajo de tierra, en la inmediacion de los nidos de otras avispas rapaces y de abejas melíticas. Jas pendientes arenosas banadas completamente por la luz del sol ofrecen al observador la mejor ocasion para estudiar los costumbres de todas estas especies. Schenck encontró los agujeros en medio de los adoquines del cmpedrado nuevo de Wiesbaden; - y yo cogi uno de estos rapaces con su presa en loe paseos situados alrededor de Meran. El filanto practica sus galerias, de $\|^{\circ}, 3^{1}$ h, del mismo modo que los otros congéneres de la familia; enșincha la extremidind pusterior cn forma de nido y cierra la entrada despues de haber depositado en las abejas reunidas el huevo. Para cada uno necesita un nuevo nido. En el mes de junio salen los filantos pequeños; y las hemims fecunda. das proceden exactamente lo mismo riue sus madres en el verano anterior.

\section{LOS CERCERIS-CERCERIS}

CARACTERES. - A las especies mas afines de los filan. tos pertenecen los cerceris, que en gran número están diseminados por toda la tierra. En ellos, el primer segmento abdominal se destaca en forma de nudo y los siguiontes sc estrechan de un modo nuy marcado en los artejos, de manera que por la forna del abdómen se reconoce en seguida el género. Ia segunda celdilla cubital es triangular y ticne tallo: la radial se rédondea en su cetremidad. Fintre las antenas apenas angulosas, sc corre un reloorde longitudiual hicia la cara, que en el macho, siempre mas pequeno, se distingue por muchos matices amarillos sobre fondo negro, y por pestañas doradas en los angulos del escudo de la cabcza. Ia hembra carece de este adorno, pero en algunas especies tiene varias plaquitas y unas apófisis en forma de nari\% en la cara. li último segmento dorsal, la llamada válvula anal su. perior, suele ser en el macho cuadrangular; en la hembra se estrecha por delante y por detrís en forma de arco, de modo que ofrece un contorno oval $\delta$ eliptico. I a major parte de los cerceris son de color negro, con fajas del mismo color ó ama. rillas en el-abúómen; en las regiones cilidas, empero, se encuentran ambien especies del todo rojas 6 de un rojo amarillo, con ligeros makices oscuros.

USOS, COSTUMBRES Y REGIMEN. - Estas avispas se encuentran en las fíores; y sus tubos encorvados penetran hasta una profundidad de $11^{4}, 162 \mathrm{cn}$ el suelo. Varias especies cazan diferentes insectos para alimentar a sus larvas; las que son propias de nuestros paises persiguen con preforencin a las sambfilas y otros himcinopteros. Fabre reco. gíb en el nido del cerceris icspoides de Rossi (majur Spin), el cleomus ophtisalmicus, coleóptero muy dificil de encontrar á causa de su escasez. Solo dos picaduras de la avisja entre el primero y segundo segmento del tómx son muy bastantes parn inutilizar al coleóptero en seguida. Dufort vió otrn espluccie en Francia que llevaba à su nido hermosos y raros bu. préstidos, por lo cual la llamú iereeris inspresticidio, ó matador de bupréstidos. Cunndo se arrebataban los coleópteros del niclo de la cuidadosa lembra, esta volvia pronto con nueva presa. La caz.a menor de los entomólogos tiene tambien sus atractivos y mucha mas variedad que la "caza major "a los animales superiores. I.epelletier observó cómo muchas veces cuando la avispa tmia la presa, una taquina se acercaba para depositar en ella su huevo; una tarde encontró tambien la crisálida de la mosca en el nido. Fil aficio de estos insectos, como el de miles de otros, ; de animales superiores. no es otra cosa sino el asesimato, el latrocinio ye el engano, que pa. recen ser indispensables para la conservacion de esta especic, y en parte para bien del hombre.

\section{LOS TRIPOXILONES-TRYPOXYLON}

CARACTERES, USOS Y COSTUMBRES. - Numerosas especies de estégidos, mas pequenas, pero igualménte solicitas y cuidadosas de su progenic, puchan los arbustos en que abundan los pulgones, construyendo sus nidos en terreno arenoso, en muros y maderos viejos, cuando no depositan sus huevos en nidos ajenos. A causa de la diferencia en l.25 renas de las alas se dividieron en varios géneros.

CARACTERES. - Por la disposicion de ias dos celdas cubitales, de las que la segunulı cstá cerrada, pero por un nervio tar pálida que no es fácil reconocerla, el géncro de los tripoxilones constituye el tránsito a todos los en quet solo se encuentra una de estas celdas. Ias especies de este géneta se distinguen ficilmente por tener los ojos muj escotados en el borde exterior, por su abdómen prolongado en forma de ma. za, obruso en el macho y jumtiagudo en la hembra.

\section{EL TRIPOXILON COMUN-TRYPOXYLON FIGULUS}

CARACTERES. - El iripoxilon comun es un inserto del todo negro y delgado, cuyo tamaño varia de $0^{n}, 00 \div 5$ 3 1), OII.

USOS, COSTUMBRES Y REGTMEN.-Duranie iodo el verano este insecto se distingue por su actividad en las 
vigas viejas y en los troncos de árboles desprovistos de corteza. Introduciéndose muchas veces en los agujeros de otros insectos, las hembras recogen pulgones y pequeñas arañas para su cria; forman en sus tubos paredes divisorias y cierran por fin la entrada. La larva se desarrolla ripidamente y fabrica un capullo, pero no se tmasforma en crisálicla hasta la primavera siguiente.

\section{EL TRIPOXILON DE TARSOS BLANCOS- TRYPOXYLON ALBITARSE}

\section{CARACTERES. - Esta especie tiene 0" ,019 de largo.}

DISTRIBUCION GEOGRAFICA.-Es propia de li América del sur.

USOS, COSTUMBRES Y REGIMEN.-Siempre rUMbando ruidosamenie, este insecto falrim nidos tubiformes de casi $11^{\prime \prime}, 078$ de largo, en los rincones ó en las vigas de las viviendas humanas; persigue a las amins de continuo.

\section{EL TRIPOXILON FUGAZ-IRYPOXXION FUGAX}

Esta especic es propia del Brasil, se aprovecha de los nidos abandonados de un poliśes y cierm sus celdas con arci-

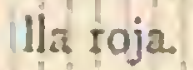

Otra especie propia de la América del norte, construje sus nidos poco mas ó menos como el pelopeo, ó bien sc apro. vecha de los nidos abandonados del mismo.

\section{EL TRIPOXILON DE FRENTE DORADA- TRYPOXYLON AURIFRONS}

USOS, COSTUMBRES Y REGMMEN.-1 as celdins del tripoxilon de frente dorada, propio de la region del Ama\%on:1s, tiénén un aspecto en cixiremo gracioso: en forma de botella de barro, de cuello muy corto, hállanse fijas en diferen. tes objetos, y casi sienupre llenas de orugas.

\section{LOS CRABRONES-CRABRO}

CARACTERES. - Uno de los génerus mas ricos en es. pecies es el de los crabrones, caracterizado por una celda cubital en las alas anteriorés, separada de la discoidea y situada mas hácia atrás. La célda radial se continua en la corta apófisis que poco mas ó menos es paralela con el borde del 2la La cabeza roma desde arriba casi la forma cuadrada y en su escudo tiene pelos plateados ó dorados. El abdómen, de color negro brillante, presenta matices amarillos. Solo las especies mas pequeñas son del todo negras y dific: tes de distinguir, como por ejemplo el crossocerus sculalus, crabro don gatulus, pero hay algunas excepciones. Los machos, mas delgados y pequeños que sus hembras, tienen una vallvula anal en forma de media luna; las antenas $y$ las patas son de forma irregular; estas viltimas, sencillas en las hembras, cstán provistas á menudo en los tarsos anteriores de espinas; $y$ la válvula anal superior es casi triangular. Los machos tienen ademas cl borde de la brocha aplanado, y d veces algunos artejos cóncaros, que parecen como curroidos. Fn otras especies el tarso anterior se ensancha en forma de concha, segun puede observarse en el crabro aquillado (crabro striatus). A causa de los puntitos claros trasparentes, este ensanchamiento se ha comparado con un harnero. Iin varias especies se olservan otras diferencias.

USOS, COSTUMBRES Y REGIMEN. - Estas avispas parecen ser las viraces de la familia; lo mismo anidan en la madera vicja que en el suelo, utilizindose a menudo de los agujeros y galerias abandonadas de los jilofagos, en las cuales practican celdas con el serrin que recogen de la madera. Las pequenas especies negras recogen con sus maxilas y patas anteriores pulgones y pequeñas moscas; las especies mas grandes parecen preferir tambien las moscas. Cierto dia cogi la hembra de un crabro (cinrinpus) fatellatus, que se habia apoderado de una hemathopota plurialis.

\section{EL CRABRO CABEZUDO-CRABRO GEPHALOTUS}

CARACTERES. - Distinguese la especie (fig. 45) en primer lugar por su cabeza bastante grande, guarnecida en su parte anterior de un vello dorado; en todas las demás pantes del cuerpo predomina el color negro, pero en el abdómen se ve una faja amarilla irregular que ocupa el borde posterior; las ancas son amarillas en su extremidad, sicndo tambien este el color de las piernas y de los tarsos; las alas trasparen. tes, las nervaduras de un pardo ferruginoso.

El macho ofrece algunas ligeras diferencias: el primer artcjo de las antenas tiene en su parte anterior una linea negra; las fajas amarillas de los cuatro primeros segmentos del ab. dómen son incompletas; el ano tiene una mancha de aquel tiutte á cada lado. I a hembra mide y lineas y el macho cinco.

DISTRIBUCION GEOGRÁFICA. - Ls muy comun en el mediodia de Francia; tambien se encuentra en las In. dias y otros varios paises.

\section{EL OXIBELO COMUN-OXIBELUS UNYGLUMIS}

CARACTERES. - Debo hacer mencion de otra especie, perteneciénte a un género que sin dificultad se reconoce por la espina casi siempre acanalada en que remata el escudete, y por las escamitas membranosas en ambos lados del mismo. El ala anterior se caracteriza por tener un apéndice en la celda radial, y solo hay una cubital, separada de la discoi. dea superior por un nervio muy pilido. El abdónten, fusiforme y pendiente en el metatórax; remata en el macho en una vilvula anal cundrangular y plana; Ia de la hembra sé estrecha poco å poco, presentando manchas laterales ó fajas, amarillas $\delta$ blancas. I as cortas antenas soll angulosas; un reborde en forma de nariz se corre en el macho longitu. dinalmente sobte el escudo de la cabeza, escotado en suparte superior y cubierto de pelos plateados, mientras que el de la hembra es obtuso en su parte anterior y solo protuberante en el centro. Los citados caractéres son genéricos; la especie que nos ocupa, que mide de $10^{m}, 00,+10^{\prime \prime}, 0075$, es negra tambien en las maxilas $y$ en la valvula anal superior; tiene en el abdómen unas manchas laterales variables, de un b!anco de marnil, en el macho desde el primero hasta el cuano segmento, y en la hembra desde el segundo hasta el quinto. Los tarsos y los piés son rojos, los primeros anillados de pardo en la base. Ias escamitas del escudo, por lo regular blancas en la hemlıra, no se reunen en su base; la espina, de mediana longitud, tiene la extremidad obtusa. Yor lo regular el macho es de un color algo mas opaco, pero mas brillante que el del otro sexo.

USOS, COSTUMBRES Y REGIMEN. - I h hembra fecundada practica galerias de 5 à 9 milimetros de largo en terreno arenoso, una para cada larva, comenzando en mayo y continuando hasta fin del verano. Cuando un nido está terminado ciem la salida cuidadosamente y la avispa se aleja para buscar alimento para su futura progenie. Segun las interesantes noticias de Siebold sobre este punto, encuéntranse en el nido varias especies de moscas, pero en particu. lar de la llamada de los antomios. In hembra se precipita 
sobre la victima, arrójala en ticrra, y una vez boca arriba, la pica en el cuello y llérala con el aguijon al nido. A menudo sucede que cuando entra en el nido para examinarlo antes, otro insecto le roba la presa desapareciendo con ella antes que la propictaria legitima lo advierta, en cuyo caso debe comenzar su cacería de nuevo.

Una pequeña mosca, la millogramma ionica, tiene la mala costumbre de depositar su huevo en el nido del oxibclo para que su larva pueda alimentarse de la de este. Hé aqui porqué la citada mosca vaga jror los sitios donde anida cl oxibelo. I'an luego como esta llegá con la jresa, remóntase la miltograma y vuela por encima de aquella como la rapaz que ha clegido su victima; la avispa conoce muy bien i su enemigo é intenta enganarle, lo que sin cmbargo no es ficil, porque la mosca no la pierde de vista. I a avispa con su carga se cansa por lo regular antes que la mosca, libre en sus movimientos, y que con igual pertinacia y energia persigue su objeto, solo por amor a su progenic. Entonces el oxibelo abre su nido para introducir la presa: tan luego como entra en él, la millograma le sigué, pero vuelve a silir jurunto, perseguido de cerca por su adversaria. De jaso diré que varias especies de millogramma hacen lo mismo con otros esfégidos. Segun la observacion de Siebold, la samófila ástuera es perseguida por la milfogramma sunstata.

\section{LOS CRISIDOS-CHRYSIDÆ}

CARÁCTERES.-En los crisidos ó avispas doradas se nos presenta otra familia bien caracterizada de himenópteros de regular tamaño ó pequeños, que en nuestras regiones templadas tienen los mismos brillantes colores, ó hasta mas abigarrados aun que en los paises cálidos, donde segun parece no existc mayor nimero de especies aunque hay al. gunas mas grandes.

El cuerpo, cubierto por lo regular de puntos muy finos en el abdómen, es tan ancho ó mas que la superlicie de la calxya y que el tórax, el cual presenta igualmente muchos puntos mas ó menus gruesos; tienen brillo metálico y color amarillento dorado, rojo de fuego, violíceo, azul intenso ó verde; raras reces se ve uno solo de estos colores, sino mas bien una mezcla de ellos. Algunas especies son negras; los colores blan. cos ó claros no metálicos faltan del todo. Fl abdómen, corto, y en este caso semicircular, prolongado, cilindrico, redondea do en su parte posterior, se compone de tres $\delta$ cuatre seg mentos, convexos por lo regular en el vientre, cuyo carácter permite á estas avispas enroscarse en caso de ataque de un cnemigo, como lo hacen al erizo y otros animales, pues aquella cavidad sirve para recoger la cabeza y el tórax. Junio a la extremidad abdominal de muchos crisidos se corre un jrofundo surco, i menudo puntcado, i lo largo del borde, por manera que el segmento parece bipartido. Ia naturaleza de la superficie de este último, péro en particular de su borde posterior, que puede ser entero, escotado ó denticulado de diferentes modos, ofrece importantes distintivos para las es. pecies. Por debajo de este borde posterior la hembra puede alargar su taladro en forma de anteojo de larga vista, con cuya punta córnea le es fácil picar en circunstancias favorables; se recoge cuando el insecto reposa, pero suele sobresalir un poco en el individuo nuerto. Fil tórax, bastante cuadrangular en sus contornos, es saliente en los ángulos posteriores, que presentan mas 6 menos la forma de dientes. En la cabcza se ren ojos ovales no escotados; hay tres ojuelos en li coronilla, y las antenas angulosas, se componen de trece artejos, hallandose situadas una cerca de otra y de la boca: las antenas se mueven por lo regular y encorvan su extremi dad en forma de espiral; las anteriores de los crisidos tienen menos nervios que las de los esfegidos. En estas especies solo hay una celda radial abierta por detrás; una cubital, solo indicada, dos discoideas y dos humerales; estas últimas no faltan casi en ningun himenóntero. En las patas, ni largas ni cortas, las pequeỉas garras ofrecen, por la falta ó presencia de dientecitos, importantes carnctéres distintivos.

USOS, COSTUMBRES Y REGIMEN. - Durnte el verano, y particularmente en julio y agosto, los crisidos visitan las flores, construcciones de madera y los muros, y las astutas hembras dęrositan sus hwevos en los nidos de otros himenóp. teros, sobre todo de los escarbadores. I.os géneros osmiz entre las abejas, adynerus y eumenes, entre los icneumónidos, fhilauthus, cerceris, trypexylun, craluro, bembex entre los esfégidos, y' oiros muchos que no hemos descrito aun, no estàn ni un momento libres de sus ataques. No se sabe aun si las larvas de todos los crisidos comen el alimento reunido por aquellos ó si atacan à las larvas de los anfitriones; mas por lo regular se ha obserndo lo primero. In metamorfósis se verifica dentro de un año, solo una vez.

\section{EL PARNOPO DE COLOR DE CARNE-PAR- NOPES CARNEX}

CARACTERES. - Entre las especies mas mas se dis. tingue el parnopo de color de carne por su larga lengua, que se adhiere a la garganta cuando el insecto reposa; sil base queda encerrada por la mandibula superior, y ofrece gran semejanza con el órgano anailogo de las aisejas. 1.05 palpos solo tienen dos artejos. In cabeza, el tórax, el primcr segmento abdominal y las patas, hasta los trocinteres, son de un verde metálico oscuro, con gruesos puntos, sisi como el escudetc posterior, çut es muy saliente. Los dos $\delta$ tres segmentos siguientes (el macho tiene uno mas) son de color rojo vivo de carne; los bordes posteriores de todos y las patas, desde los trocinteres, de un tinte mas bajo. Fil animal tienc $0^{m}$, ors of mas de longitud.

USOS, COSTUMBRES Y REGIMEN. - Vire cUMO 1). rísito en el hembex comun, y se encuentra por lo tanto solo en los sitios donde esta especic abunda.

Con algunas votras especies anílogas en la formacion de la boca, representa un género indeprendiente.

\section{LOS ESTILBOS - STILBUM}

CARACTERES, - Tiste género comprende las especiés mayores y mas grandes de foda la familia, asemejandose por el cuerpo prolongado al anterior; asi como al siguiente por tener ia lengua de mediana longitud, por scr igual In forma de las partes bucales y por las scneillas garras de los piés. Los estilbos se caracterizan en particular por el escudete posterior, cubicrto en su parte anterior por el escudetc visible en forma de una espina acinalida.

\section{EL ESTILBO ESPLÉNDIDO-STILBUM SPLFNDIDUM}

CARACTERES. - El estilbo espléndido se carncteriza por tener el borde posterior del abdómen provisto de cuntro dientes, redondcado en la extremidad del escudete posterior; convero, de color azul metalico ó verde dorado, ó bien muy brillante con ambos colores al mismo tiempo.

Este crisido tiene una longitud de $0^{m}, 015$, a la cual, sin embargo, no llegan siernpre: esta especic y otra afine son los mayores crisidos de liuropa.

DISTRIBUCION GEOGRÁFICA. - Se encuentra en los paises del Mediterríneo y mas hácia el este en Asia.

No sé mada pasitivo sobre su género de vida. 


\section{LOS CRISIS-CHRYSIS}

CARACTERES. - El género chrysis es el mas rico en especies y se distingue de los otros por tener el escudete posterior libre. 'leniendo en cuenta la forma del último seg. mento abdominal, Dahibum ha formado oclo grupos, en los cuales se toma en consideracion si el borde posterior es enteroy liso, un poco ondulado, con una ligera incision en forma de diente en el centro, ó si tiene dos dientes laterales, tres, cuatro, cinco ó seis; cuatro ó scis se encuentran con mas frecuencia

DISTRIBUCION GEOGRÁFICA. - Los especies que tienen el thimo segmento entero y liso habitan con preferen. cia en los paises del Mediterráneo y solo una en la América; algunas estan diseminadas hácia la Alcmania y hasta Suecia, como ha Chrysis austriacs, Bivelor, imbierillo y otras.

De las pocas especies provistas de borde ondulado podria decirse poco mas ó menos lo mismo, solo que una de ellas (chrysis clcyans), se encuentra hasta en Alemania, y utra (uniculor), naras reces mas al norte en suecia.

\section{EL CRISIS AZUL-GHRYSIS CYANEA}

Caracteres. - El crisis azul es la única especie que está diseminada por toda Furopa y que tiene el borde abdo. minal cividido en tres dientes. Es por lo regular del todo azul, con algunas fajas negras en el aludómen, y con parte de las patas verde. Pertenece à las especies mas pequeñas, pues sólo mide $6 ", 0515$.

USOS, COSTUMBRES Y REGIMEN. - Deposita suS huevos con preferencia en los himenópteros que construyen su nido en los troncos de la morera, como por ejemplo el trypoxylon figulus, crabro lafidarius, la pequeña abeja cliclostoma florisomine y otras.

\section{EL CRISIS FÚLGIDO-CHRYSIS FULGIDA}

CARACTÉRES. - Esta especie es una de las pocas extendidas por toda la Europa rue tiene el borde posterior provisto de cuntro dientes; se reconoce sobre todo por el color igual de la cabeza, del tórax y del primer segmento abdominal. Las citadís partes presentan un vivo brillo azul violeta, ó azul verdoso; los dos últimos segmentos son de un rojo dorado, pero el macho tiene en el segundo una mancha arqueada del color de la parte anterior del cuerpo.

\section{EL CRISIS COMUN-CHRYSIS IGNITA}

CARACTÉRES. - El crisis comun, la especie mas diseminada y comun de todas, pertenece tambien al misino grupo. Este crisido varía tanto por su tamaño $\left(17^{\circ}, 00515\right.$ ál",ori $)$, como respecto a su color; tiene la cabeza y el tórax azules ó verdes, ó mezclados de ambos colores; el abdómen presenta un brillo dorndo, á veces con viso verde metálico, $\delta$ de un rojo intenso; tumbien sucle tener bordes negros en las articulaciones de los segmenios, $y$ en el vientre manchas negras; el abdómen está cubierto de puntos bastante gruesos, presentando en el dorso una quilla longitudinal muy marcada, sobre todo en el segmento central.

USOS, COSTUMBRES Y REGIMEN.-ES POCO eXigente respecto al himenóptero en que debe depositar sus huevos, pues lo hace en un gran número de sus congéneres, como por ejemplo el philanitus triangulum, el sericris ornata, el odynerus farietum, el antilope spinipes, y el eumenes fomiormis. Agrá danle sobre todo muchas avispas que no hemos descrito. El que quiera observar algun tiempo el crisis comun, pronto reconocerí que es astuto y celoso. Durante toda su vida revela estas cualidades, nada agradables.

Los crisidos que tienen seis dientes en la extremidad pos. terior del abdómen, pertenecen segun parece á los paises cá lidos, sobre todo al Africa y à la América del sur, y algunos tambien å los paises del Mediterraineo; el chrysis Zetierstedts parece ser la única especie que se halla hasta la Suecia. Has ta ahora hemos hablado de las formas prolongadas. Los crisidos de cuerpo corto, cuyo aludómen apenas es mas larro que ancho, y cuy'as garras del pié son denticuladas de un modo diferente, no se ven por lo general á causa de su reducido tamaino y tambien porque escasea el número de espe. cies, mucho mas que las del género chrysis. En ellos la celda cubital y discoidea desaparece casi; pero por mas que estos caractéres y su aspecto exterior los separan de los otros, tam. poco pueden encontrarse distintivos comunes i los géneros principales, muy diferentes por la forma de su boca, comose observa en las especies clampus y hedychrims. El primero se parece al chrysis por la lengua, corta y cuneiforme, y al se. gundo al-stillum por tenerla prolongada y escotada en la punta: las diferencias fundadas en las garras y en la estruc. tura del último segmento y que han inducido à proponer otras divisiones, no dan ninguna seguridad cuando se trata de clasificar una especie dificil.

\section{LOS HEDICROS-HEDYCHRUM}

CARACTÉRES. - rste género se distingue, en cuanto se refiere a nuestras especies, por el borde posterior del abdúmen, que no es ni tan siquiera surcado, y por tener un diente delante del centro de las garras del pié.

\section{EL EDICRO LUCIENTE-HEDYCHRUM LUCIDULUM}

CARACTERES. - Esta especie, una de las mas comunes y bonitas, cuyo macho ha sido descrito por Fabricius, como el chrysis regia, tiene el abdómen ancho, un poco prolongado; cl dorso rojo dorado y el vientre negro El tórax es en el macho verde ó verde azulado, mientras que en la hembra el protórax y el mesotórax suelen ser de un rojo purpúreo. Ias alas son mas turbias desde el centro. La longitud del insecto varia de $0^{\circ}, 0045$ a $0^{n}, 00875$.

USOS Y COSTUMBRES. - Esta especie se ha encontrado como parásita en el osmia nigriventris, en varias abejas y en la chalycodoma muraria.

\section{EL EDICRO SONROSADO-HEDYCHRUM ROSEUM}

Caracteres.- Esta especie, llamada por Panzer tambien chrysis rufa, se caracteriza fácilmente por su abdómen de color sonrosado, provisto de espesos puntos; la cabeza y el tórax son de un verde azulado, azul ó violcta, con numerosos puntos dispuestos casi en forma de red; los ángulos posteriores del tórax sobresalen en forma de espinas. La lon. gitud de esta especie es cuando mas de 0",0045.

DISTRIBUCION GEOGRÁFICA, - Esta graciosa avispa vive principalmente en las regiones secas y se la observa hrácia el norte solo hasta los $60^{\circ}$ de latitud.

\section{LOS ELAMPIDOS-ELAMPIDE}

CARACTERES - Los pequenios elampidos, género cuỵas especies son muy dificiles de distinguir, tienen unas garras que afectan mas ó menos la forma de peine; el último seg- 
mento del abdómen, de borde entero, es un poco cortado en el centro; y en algunas especies ligeramente adelga\%ado.

UsoS Y COSTUMBRES. - Segun parece; viven como parásitos, con preferencia en los jilbfagos. El omalus auratus se encontró en una agalla en medio de pulgones, que sin du. da fueron recogidos alli por un pequeño esfégido despues cie que el cinipido hubo abandonado su agujero; tambien se cria la misma especie en el nido del cemonus smicolor, que es un pequeño esfégido. El clampus aneus y tridentulus depositan sus huevos en los agujeros del esfegido psen carliginosus. De los pafses cálidos solo se conocen dos especies de la Anverica del sur y dos de Africa pertenecientes á este grupo; la mayoria, unas veinte especies, se han observado en los paises del Mediterránco y algunas tambien mas al norte de Europa.

\section{LOS CINIPIDOS-CYNI- PID压}

Jas bonitas eminencins esféricas de matices rojos que a veces penden de la cara interior de una hoja de encina son conocidas de rodo el mundo bajo el nombre de agallas y tambien se sabe de otra especie mas fibrosa que llega desde el Oriente, y sin la cual no se puede hacer buena timta. Fstas y otms inuclias excrecencias en las plantas sellaman genemlmente agallas, queriéndose indicar que son protuberancias enfermizas del tejido celular, formadas bajo una intuencia animal y destinadas a ofrecer alimento $y$ vivienda $i$ la cria del producior. E!l múmero de los insectos que producen agallas es bastante crecido, figurando critre ellos las moscas, coleópteros, pulgones, tentredrinos y cinipjidos. Como ninguna parte de la planta desde la rair lassta las ramas, desde la hoja hasta la flor, estin al abrigo de la produccion de agallas, no plede admirarnos encontrar una extraordinaria variedad de estas formaciones. Este interesante asunto, aun 110 agotado, ha Ilanado últimamente la atencion de algunos natumlistas, pero no podemos ocuparnos de ell mas que hasta donde se refiere á los himenópteros, y sobre todo á los cinipidos ó avispas de agallas, familia independiente del citado órden de insectos y quc produce las agallas mas perfectas.

Cuando uno de estos pequueños séres, de los que examinaremos algunos í continuacion, jica en un punto determinado que le indica su instinto, en una planta preferida, en la que con su taladro introduce un hueso en la herida, debe producir forzosamente de un modo milagroso, una excrecencia en forma de esfera, de espiga, de cono ó de bola peluda ó sabe Dios en qué otra figura: esta excrecencia continúa creciendo mientms el insecto lo necesira. Solo despues, cuando el habitante ya no crece mas, la agalla tambien ha madu. rado. Se ven por lo tanto muy bien aqui la causa y su efec10, pero no se comprende bien el modo de ser. Ia frsiología vegetal deberá resolver mas tarde este probleua, juntamente con el de la fisiologia de los animales: nosotros solo tomaremos en consideracion las condiciones bajo las cuales se puede formar una agalia. Por lo pronto es indispensable la vitalidad de la respectiva parte de planta, y la posibilidad de seguir desarrollándose en la plantr madre, pues toda agalla perece tan luego como se coita la parte del vegetal en que se halla, aunņue se la conserve fresca poniéndola en agua I a segunda condicion es la herida de la parte de planta sana por el cinipido al poner sus huevos por medio de un taladro oculto en el abdómen, pero que puede jrolongarse muchoy penetrar mas a fondo cuando el insecto quiere introducir en la herida el huevo. La planta ha recogido con cste un euerpo extrano, y entonces comienza, como en todo otro organismo, da reaccion contra este cuerpo, tanto mis cuanto que 1 so se mantiene estacionario sino que continúa su desarrollo. Por lo pronto se trata de la causa del desarrollo anó malo, $y$ de si este ha de efectuarsce en forma de una bola, de una lenteja, de una bellota, etc. El jugo de formacion de la encina en general, y de una especie de estos arboles en particular, el sitio en que se presentan los efectos, y que puedo Ser la carne, un nervio de hoja, la corteza 6 la madera tierna, influye segun parece esencialmente, pero de una manera exclusiva, pues la misma forma, por ejemplo, la esférica, puede desarrollarse en los mas diferentes sitios, y tambien las mas diversas formas pueden encontrarse en uma misma hoja de encina. Es preciso por lo tanto que haya otra influencia que la del jugo de formacion y la sola irritacion: el jugo propio de todo cinipido, que sale al mismo tiempo con al huero, el ieneno cinffido, segun podemos llamarle respecto a las plantas, debe producir estas notables diferencias. Otra condicion para la prosperidad de la agalla se encuentra en fin en el desarrollo y er la actividad de la larva de avispa en el interior, pues la agalla deja de crecur si el insecto muere. Los cinipidos tienen numerosísimos parísitos que en muchos ca. sos hacen las veces de la larva de cinipido para el desarrollo cie la agalla, mientras que en otros no influyen; pues se encuentran agallas atrofiadas cn que falta todo insecto, sin duda porque la perecido demasiado pronto para que se efectúe el desarrollo.

De ese modo tan milagroso la agalla se trasforma en pars. sito de la planta, no al servicio de esta, sino del insecto que se halla en su interior. El cinjpido adquiere por lo tanto un dominio sobre el regetal como ningun otro insecto, y como nunca lo podrá alcanzar el hombre con sus experimentos de inoculacion.

Las agallas producidis por los cinipidos estan del todo cerradas, y no se abren por sí mismas, como otras, sino que la avispa perfecta la perioma al salir de ella. Una oruga que practica minas en la parte carnosa de las hojas. una larna de coleóptero que homda iablas viejas, ticnen vierta libertad; aunque estan estrechadas por las sustancias alimenticias que las encierran, pueden abrir sus galerias donde lus parece, y ensanchar de este modo á su antojo la vivienda; pero no sucede asi con la larva del cinijido. Esta se halla en un cen. tro mas sólido, jedregoso, en la llamada cimara de lisrin, lo mismo que la simiente de la cereza ó de la cirnela en su hueso; estr somerida d una estrecha clrusura, y el insecio desarrollado ha de salir it imvés de esta capa y de la exterior. ya sea carnosa ó fibrosa. La agalla comun coniiene en su centro una sola camara de larva, y por ln tanto pertenece a las que se designan con este calificativo, yara diferenciarla de las que tienen dos, tres ó mas.

Segum la naturaleza de las agallas, es. decir, segun sean tibrosas, carnosas, harinosas, ctc, segun el sitio en rue se fijan, ya en una hoja, en una raix, en un capullo ó una fruta, segun su forma y disposicion en el caso de que haya vintas juntas. designanse con un gran número de calificativos, que en su mayoria no necesitan explicacion. Por lo regular cada agalla tienc sul sitio fijo on una planta detcrminada y se presenta siempre en la misma forma. Sin embargo, no hay nin. guna veglo sin excepcion. Las agallas del sparliegaster baccarum se encuentmn en las hojas, pero tambien en las Bores de las encinas; el cinipido de los rosales hicre por lo regular las ramas, pero puede atacar tambien la raiz i otra parte del rosal. Un curioso cinipido sin alas, la bioriisa oplera, vive por lo regular ell las agallas de las rajces de la encina, pero tambien se ha encontrado en la rair de los pinos. Es posihle que por unit observacion miuxciusa aumentc aun el número de las especies que cambian de residencia. Iass agallas de uแa misma especie difieren no solo por su tamaño sino tam. 
bien en el color y la forma. Osten.Sacken pretende haber criado últimamente en la América del norte dos diferentes formas de agalla, los dos sexos de una misma especic. Las moscas de agallas viven en las plantas mas diversas, las avispas de agallas con muy pocas excepciones en las especies de encina. En este árbol solo sc encuentran, segun dice Mayr en su obra (al as agallas de encina de la Europa central des. critas con texto y grabadosk, Viena $\left(S_{j} /{ }_{1}\right)$ dos agallas de rair, ocho de corteza, treinta y nueve de capullos, treinta y cuatro de hojas, nueve de pistilos y cuntro de frutas. Para Francia y la Euroja meridional estas condiciones varian, y tambien las encinas de la América del norte producen otras clases de agallas. Osten-Sácken cuenta veintiocho en las en. cinas de este pais, sobre iojo alrededor de Washington. Además se encuéntran agallas en plátanos, rosales silvestres y zarzales. Entre las yerbas presentan sus formaciones caubien algunas liguliforas (Hievacium: cenfauren, scursoneri), la sdormidera silvestre $y$ varias plantas de sinientes bilobas. Segun las insuficientes observaciones hechas hasta açui en los paises $n o$ europjeos donde se conocen esas formaciones, no fal. tan en ninguna parte las agallas, pero si laynultitud de cinipidós que alimentan nuestras regiones. Frauenfeld encontró desde Alejandria hasta la extremidad de la peninsula del Sinai numerosas agallas en el tamarisco, pero pretende que ninguna de cllas puede pertenecet á un cinipido. Schrader, al hablar de los insectos de la Australia que producen aga. llas, solo cita algunos cinipidos, refiriéndise principalmente at las moscas y pulgones.

El estudio de estos insectos puede aclejantar solo por la cria de los mismos, que sin embargo exige paciencia, principalmente por dos razones. Cuando se cugen las agallas demasiado verdes se resecan, y con ellas las larvas, y el ponerlas en agua no sirve casi de nada. Si en cambio se cogen en el punto favorable de la madurez, tumpoco se juede estar seguro de hallar los productores, pues á menudo están sustituidos por sus parásitos. Se necesita por lo tanto tambien una gran inteligencit yo poca precaucion para enriquecer con nuevas verdades los estudios cientificos.

CARACTERES. - I os cinipicios se distinguen te todos los himenópteros hástá ahora descritos jor los trocinteres de dos artejos, y adcmás se reconocen ficilmente por la con. formacion particular de las alas anteriores. Estas carecen en primer lugar de la seinal y de toda celda discoidea; solo tienen una radial cerrada y dos cubitales tambien cerradas ademais de las dos humerales. Se distinguen dos-especies principales; en la una in primera celda cubital es muy estrecha y larga, la segunda forma un triángulo que casi desaparece, y la tercera no está cerrada, al causa de estar el cúbito cortado; en la otra, la primera celda cubital es mas grande y regularmente cuadrangular, formandose por la union de la primera y segunda, mientras que la tercera estí cerrada por el borde y el cubito que llega hasta aquel: en ambas especies intercálise la ancha celda madial casi en rectångulo. Las alas posteriores tienen cuando mas un solo nervio y carecen por lo tanto de celdillas: hay especies cuyas hembias ticnen alas atrofiadas $\delta$ carecen de ellas, asemejandose pror esto a varios pequeños icneunónidos, con los cur. les, sin embargo, no se les pucde confundir á causa de su abdómen redondeado, comprimido lateralmente, y de otrós caractéres.

Todos los cinipidos son diminutos insectos, no muy bonitos, que miden poco mas ó menos \& a 5 milimetros de largo; pocos llegan at ser mas grandes, muchisinios no alcanzan siquiera la longitud de $0^{\circ}, 00225$ : son negros, ó de este color con mexcla de rojo claro, hasta pardo, ú del todo pardo claros y carecen de dibujos blancos ó amarillentos. 1.as an- tenas, no angulosas sino rectas, son filiformes 6 se ensanchan poco a poco y ligeramente hácia adelante; se componen de doce í quince artejos, por lo regular bien separados, sicndo el primcro mas grueso, el segundo muy corto y el tercero por lo regular muy prolongado; el macho suele tener uno ó dos mas que la hembra, y á menudo tambien un tercer artejo arqueado ó escotado, que se prolonga mas. la cabeza, pequeña y casi circular, se inserta muy hácia abajo en el tórax que es muy convexo; en la coronilla hay tres ojuelos; las partes bucales están medianamente desarrolladas; el labio superior es muy pequeño; las maxilas cortas casi siempre bidentadas; las interiores se ensanchan y son franjeadas en la extremidad; el labio inferior carece de escotadum; la lengun es muy corta y los palpos apenas salientes; los maxilares tienen cuatro ó cinco artejos $y^{\circ}$ los labiales dos 6 tres. El corto abdómen, comprimido lateralmente, i veces de tal modo que el vicn. tre $\delta$ tambien el dorso presentan una quilla, se inserta en el metatórax, o en otros casos se comunica con él por medio de un corto tallo ó de un anillo, qque como en las hormigas se toma por segmento de trinsito y no se cuenta con el ab. dómen. Los segmentos dorsales son muy raras veces iguales en longitud, y cl últino segmento ventral sobresale de la escama dorsal, cuando menos en la hembra, en forma de una escrumita, iy ambas se desvian con frecuencia mucho en la punta. El taladro de la hembra es una cerda fina, á veces muy larga: afecta la forma de espiral en el abdómen, y en el estado de reproso no suele scr visible. Ia extremidad abdo. minal es en el macho siempre nas obtusa, y este difiere además de la hembra por su nenor tamoño y por la forma diferente de las anienas. En una serie de especies no se ha en contrindo hasta ahora el macho, y debe suponerse por lo anto que se propagan sin prévia fecundacion.

USOS, coSTUMBRES Y REGIMEN.-Asi como n.o todas las agallas provienen de cinipidos, tampoco todas las avispas pertenccientes por su aspecto extcrior á la familia se desarrollan en agallas; ro son verdaderos cinipidos, pero muchas de ellas depositan sus huevos en agallas ticrnas en las que la larva nacida se alimenta de la sustancin vegetal. Estas avispas se han llamado inguilinos ó cinipidos falsos, de curas esprecies dos pueden vivir en una misma agalla. Seggun las viltimas y minuciosas observaciones de Mayr (\&L.os in. quilinos de las agallas de encina de la Europa centraly) sobre este asunto, pueden distinguirse en las relaciones del inq̨uilino con el anfitrion cuatro diferentes casos: 1." vive en el compartimiento de larvas del verdadero cinipido, upue perecen en su primera juventud, dividiéndose aquel por tenues meinbranas en tantos espacios como larvas hay; $2^{\circ}$ el compartimiento de la verdadera laria de cinipido y una parte del tejido celular que lo rodea pueden quedar destruidos, susti. tuyéndoles un espacio hueco dividido igualmente en camaras por las larvas del incuilino: 3 . la cavidad natural de ciertas agallas puede estar lıbitada por larvas de inquilino, y tambien ensanchada, sin que se perjudicue por eso la productora legitima; 4." los espacios de los inquilinos están distribuidos en el parénquima al rededor del compartimiento de larvas y se desarrollan uno junto a otro. Con seguridad se han reconocido hasta ahorn como inquilinos los tres géneros Syorgus, Saphobutus y Cicotres.

Una terdera seric de cinjpidos vive en estado dé larvia del mismo modo que el icreumónido en otros insectos de los que se alinenta; estos son los numcrosos cinipidos parisitus.

Las larvas que viven en agallas, ya seau sus productoras ó solo inquilinos, son gusanos gruesos, desnudos, un poco encorvados, con la cabeza córnca, provista de fuertes maxilas superiores, pero sin ojos. Los verdaderos parásitos phasan quizas en su desarrollo por cambios semcjantes a los que 
Rat\%eburg la observado en algunos icneumb́nidos. El desarrollo ocupa mas o menos ticmpo, y todas las especies son iguales en cuanto a lo de convertirse en crisailidas en su agaIla; no fatbrican por lo regular ningun tejido ; descansan poco ticmpo en el estado de ninfa. Algunas invernan como larva, y otras como avispa en la agalla cerrada. Un agujero redondo en esta indica sicmpre que el habitante ha salido de su prision, $y$ a menudo se reconoce por el tamano del orificio si em un cinjpido ó un parisito.

\section{LOS CINIIPES - CYNIPS}

CARACTERES. - Ios cinipes ó cinipidos de encina, aunque carecen de machos, son el tipo primitivo de los mas grandes entre los verdaderos cinipidos y se reconocen fácil. mente como género por varios caractéres distintivos: el dorso del tórax está cubicrto de espesos pelos; el escudete es grande, casi hemisférico; el abclómen, redondo y comprimido, tiene el primer segmento mas largo que cada uno de los otros: las antenas se ensanchan ligeramente en la punta; la celda radial de las alas anteriores es prolongada; la segunda cubital, muy pequeña y triangular, está situada en la base de aquella. Los palpos mavilares se componen de cinco artejos, y los labiales de dos. Litimamente, siguiendo el ejemplo de Foerster, se han separado de los cinipes dos géneros, dejando á las especies con pelo sedoso, liso en la punta del abdómen, su nombre antiguo, llamando á las que carecen de estos pelos afhilothrix, $y$ a las que los tienen erizados en las patas y antenas dophlantn. En la nomenclatura de las pocas especies descritas no hemos tenido en cuenta esta division.

\section{EL CINIPES COMUN-CYNIPS SCUTELLARIS}

CARACTERES:-Este diminuto insceto es el fabricante de las agallas esféricas carnosas (segun se ha areriguado viltimamente yo el grnips folis, como lasta ahora se creia) que se hallan en la cara inferior de las hojas de encima (quercies sessilifolia y pedunculnta), de modo que nada se ve mirando por arriba. El insecto tiene el cuerpo de color negro brillante; el escudete, las patas y la cabeza de un pardo rojo; las antenas y las patas estan cubiertas de pelos erizados; una pequeña escama rentral tiene pestanas cerdosas.

USOS Y COSTUMBRES. - En un tiempo en qque los capullos de todos los árboles ducrmen aun (la encina, como yin se sabe, es de nuestros árboles salvajes el que mas tarde brota), la avispita vaga perezosamente por los capullos pican. do uno ú otro para depositar con cada picadura un huevo. Acabado su trabajo, nueren, y por lo tanto es preciso buscarle antes de que los arboles se cubran de verde. Las hojas pica. das presentan en verano, y sobre todo en otoño, aquellas agallas un poco arqueadas, con los lados rojos; se habian formado en el centro con la larva y se maduran con ella. En otono se pueden encontrar, al alsrir la agalla, las avispas ya desarrolladas, que sin embargo no salen por lo regular hasta el ano siguiente. I as agallas resecadas que aun cstán pendientes en la planta hállanse habitadas por parásitos, à los q̨ue perteniece entre otros un teromalino verde dorado (tornmins regius) (que con su largo taladro pica la agalla medio desarro. lladaj entonces el abdómen se dilata y la títima cscama ventral se abre mucho. La especie da albergue á tres inquilinos: Symergus pallienrnis, Tsehicki y Supholyzus connalus.

I.a agalla crmiss folii se encuentra à principios de julio exclusivamente en la cara inferior de la hoja del gicreus fusles. cens; es mas lisa, y cuando alcanza todo su desarrollo solo tiene ef tamnno de un guisante. El grnips longgientris produce las agallas en las hojas de quercus feduneulata del mismo iamaño y forma, pero rayadas de rojo y amarillo. Las ngallas que á menudo se encuentmn en gran número en los nervios laterales de las hojas de nuestras dos especies de encinas y que tienen el tamario de un grano de clñamo, encerrando con su dum ciscara una cavidad, deben su origen al guips agama.

\section{EL CINIPE DE LAS PIÑAS DE ENCINA- CYNIPS GEMMAE}

CARACTERES. - Unas agallas que tienén el compartimiento de larvas oval en el centro y están cubiertas de una excrecencia particilar de la que pueden sejararse en el cstado de madurez, se hallan a menudo reunidas en mayor número en las puntas ó en los àngulos de las hojas de los tiernos retoños de las tres especies de encina hasta alıora citadas, y pertenecen al clmips gemme; tienen el aspecto de una pina; el animal está cubierto de pelos lisos, seciosos en las antenas y patas; su color es negro, $y$ la base de ayuellas y los muslos de estas son de un pardo rojo.

USOS, COSTUMBRES Y REGIMEN.-Necesita mucho ticmpo para su desarrollo. Fin las agallas que en otoño de 3865 recogi en el suclo, encontré à mediados de ortubre de 1867 aun larvas viras que nunca lian llegado a desarrollarse. En experimentos anteriores de cria obtuve de las agnllas solo un bonito parásito, el ormuyrus tulinlosus, notable por el magnitico brillo metálico y por los bonitos dibujos de la superficie del cuerpo.

\section{EL CÍNIPE LEÑOSO-SYNIPS LIGNICOLA}

CARACTÉRES. - Essta especie, de color pardo amarillo, tiene cubierta la extremidad del abdónen de jelos lisos.

USOS Y COSTUMBRES. - Construye igualmente aga llas en los cajullos, del tamaño y forma de la especie co mun, que sin embargo adquieren cl aspecto leñoso. Hace varios años que abundaban mucho en Halle, donde crié una infinidad de moscas, pero desde entonces no las he visto mas. Se parecen inucho al oruips finstoria, gue produce las agallas de Levante.

\section{EL CÍNIPE PSEN-CXNIPS PSENS}

Sabido es ya que los antiguos aprovechaban este cinipido para la produccion de higos mas suculentos y sabrosos; hoy dia se liene en Girccia el mayor cuidado en la caprificacion de los higos en árboles inoculados por esos insectos. Viven en la higuera silvestre y se han desarollado del todo a fines de junio; cuando la fruta no está maclura todavia, continuarian en ella si no se les impidiese. Para ello se cogen los higos, reuniendolos de dos cu dos con un largo junco; despues se echan sobre las ramas de las higuems cultivadas distribuyéndolos, lo mas igualmente posible, entre el fruto de las mis. mas; el resecamiento de los higos silvestres obliga á los insectos à salir, y entonces forman una segunda cria (anormal) para la que eligen los higos buenos como albergue. Antes de que esta cria se desartolle recúgense los higos, y los insectos perecen despues de haber aumentado la abundancia de jugo en la fruta. Uitimamente este insecto ha recibido el nombre de blastophaga psenes, clasificindose en el géncro de teromalinos, lo cual no puede justificarse por la actividad que acabamos de indicar.

\section{LOS ANDRICOS-ANDRICUS}

CARACTÉRES. - Fn este géncro se hallan ambos sexos, distinguiéndose por cllo del anterior, nsi como por tener el 
dorso del túrax desnudo, corinceo y lleno de armugas: el escudete menos convexo, presenta dos hoyos en su base, y el abdómen, recogido, no se comprime tanto. En el macho, el tercer artejo de las antenas es arqqueado y tiene una escotadum. I as esprecies llegan raras veces á la longitud de $11^{n}, 00225$; forman agallas on los capullos $y$ hojas, y sobre todo en las flores, aunque menos notables y regulares que las del género anterior.

\section{EL TERAS TERMINAL-TERAS TERMINALIS}

CARACTÉrEs. - I as alas de esta avispa tienen la misma estructum que las de los cinipes, y trumbien las antenas, pero el escudete es deprimido y aplanado; los palpos maxilases se componen de cuatroartejos y los thibiales de dos. El insecto es de un verde amarillo en sts mitad anterior, de, un pardo rojo en la base del abdómen, detrás de un pardo negruzco; la estrechn escana ventral de la hembra presenta un largo mechon de pelos.

USOS, COSTUMBRES Y REGIMEN.-Produce laS agallas esponjosas en los lados de las ramas de encina; estas agallas son a principios de la primavera blancas, con los lados rojos: pero mas tarde adquieren un color desagnadable y están perioradas. Encuéntranse cn esta especie hembms con alns y sin ellas y además mechos alidos. Por lo regular viven ambos sexos separndos en las agallas. De estas se han criado nẻemảs de varias especies de synergus, cuarenta parásitos, sobre todo teromalinos. Tambien un coléptero (balanillus i:llosus) deposita sus huevos en la agalla para que la larvia se alimente de la carne de la nismia.

\section{LA BIORIZA SIN ALAS-BIORHIZA APTERA}

CARACTERES. - Esta especie rara se parece mucho á has hembirns no aladas de la especie anterior, $y$ solo se encuentran las que no alcanzan la longitud de $0^{2}, 0045$. Su color es pardo nmarillo rojizo, un poco mas oscuro en In brochà de las antenas, y tienen una especie de faja negruzca nirededor del abdómen, que es inty comprimido. El peqqueño escudete sobresale ajenz.ss y el tórax es menos ancho que la cabeza y el abdómen.

USOS Y COSTUMBRES. - Ia avispa se presenta muy pronto en primavera, despues de soportar el invierno, pues en 22 de noriembre de $18 ; 0$ la he recogido en gran número en varias encinas. Viven en las raices de las encinas ricjas, á menudo i varios piés de profundidad debajo de lierra, donde las agallas de varios espacios se encuentmn en major $\delta$ menor número, tan oprimidas entre si que no deben confundirse con las agrallas del gmits radicis parccirias tuna patata.

\section{EL DIASTROFO DE LOS ZARZALES - DIAS- TROPHUS RUBI}

CARACTERES. - Esta especie se parece por los nervios de las alas á los cinipes $y$ tambien por el primer segmento abdominal, mas largo que los otros. Las antenas, filiformes, se componen de trece at catorce artejos, y en el macho de cluince. Todo el cuerpo es de un negro brillante; las patas de un pardo rojo, mas ó menos claras.

USOS Y COSTUMBRES. - Fste cinipido produce en los tallos de los zarzales agallas de un aspecto a menudo extraño, de las que en abril del año siguiente salen las avispas cadn cual por un agujero.

\section{EL DIASTROFO DEL GLECHOMA-DIASTRO- PHUS GLECHOM E}

CARACTERES.-Fsta especie está provista de pelos en el protórax y de resrugas en el mesotónax, lo mismo que en el escudetc; su color es el mismo que el de la especie anterior, pero menos brillante.

USOS Y COSTUMBRES. - Producen en la glechoma hederncea agallas carnosas esféricas de un compartimicuto y de bonito color rojo.

\section{EL RODITO DE LOS ROSALES - RHODITES ROSAE}

CARACTERES.--El rodito de los rosales $y$ sus pocos congéneres reunen respecto a la estructura de las alas anteriores las dos formas ga citadas, porque tienen una ancha celda radial triangular, y al mismo ticmpo una segunda cubital tambien triangular, situada debajo de la base de aquella. La cabeza es mas ancha que el tórax y menos deprimida que cn los cínipes. Todo el abdómen, excepto su extremidad, y las patas son de un pardo rojo y lo demás negro, como en el macho la major parte del abdómen. La última escama ventral de la hembra se abre con un largo pico puntiagudo. I.os machos viven muy aishados.

USOS Y COSTUMBRES. - Ia citada especic produce en los rosales silvestres, $y$ tambien a veces en las centifolias de los jardines, unas agallas velludas, llamadas rejes de rosa, mansanas de sucrio 6 bedejuar. En tiempos antiguos se atribujan á estas agallas propliedades medicinales; para obtener su efecto debian colocarse en posicion natural debajo de las almohadas de los ninos de sueño agitado, ó bien se tomaban en forma de polvo para combatir las lombrices, la diartea, etc.

In agalla es madura en otono, pero solo en la primavera salen los habitantes, no solamente las avispas, sino á menudo tambien inquilinos, como por cjemplo el aulax de hranet, Y especies del género synergrus, pero sobre todo icneumónidos de las frmilias de los feromalinos ibraconides.

\section{EL RODITO DE LOS JAZMINES-RHODITES EGLANTERIFE}

CARACTÉREs.-Esta especie, muy semcjante à la anterior, tiene las alas mas claras, y en ver del triảngulo de la segunda celda cubital solo presenta un puntito de color rojo mas claro.

USOS Y COSTUMRRES. - I'roduce unas agallas duras y esféricas del tamaño de un guisante, ó mas pequeñas; há. llanse en la cara inierior de las hojas, pero tambien en otros sitios: tampoco carecen de parásitos.

Algunas otras especies viven bajo las mismas condiciones en los rosales, y es por lo tanto muy ä̉il confundirlas.

No nos es posible describir mas agallas ni productores, pero si creemos deber recomendar, à los que descen conocer las que se encuentran en las encinas, la obrita ya indicadia.

\section{LOS INQUILINOS Ó CINIPIDOS FALSOS}

De este grupo solo haremos mencion de los géneros synergus y oulax, cuyas venas de las alas corresponden a la segunda forma, en la que hay dos celdas cubitales, la primera y la tercera, entre las cuales se intercala la ancha celda mdial triangular. El abclómen, ligeramente comprimido, se enlaza con el tórax por un corto tallito dilatado que se distingue por varios surcos longitudinales, mientras que en las especies de aulax es liso. Los palpos labiales tienen dos artejos, con un grande apóndice en la extremidad, que falta en los aulax. En estos últinos los artejos de la brocla no difie- 
ren en longirud y las antenas, filiformes, se componen de tre. ce á catorce artejos en la hembra y de quince a diez y scis cin el macho. Lina especic de los sinergos (symergus fncialis) vive como inquilino en el egnifs salitaria, rining glutinosa, allopenstata, teras terminalis, spathegaster incenrum, tricolor y otros, apareciendo en el mismo año en que se ha formado la agalla. Es de color negro brillante, con las antenas, las patas y la cabeza, excepto la frente y la coronilla, de color amarillo; mide de $0^{*}, 0013$ i $0^{\infty}, 0026$ de largo.

No todas las especies de aulax son inquilinos; tambica hay entre ellos cinipidos verdaderos que nunca producen agallas en la encina, pero si en algunas yerbas (aulax lieracss, sabaudi, potertilla ); una especie, el abla. rhocndis, vive en las caipsulas de la adormidera.

\section{LAS ALOTRIAS-ALLOTRIA}

Mientras que las especies hasta ahora descritas y otras muchas habitan las agallas producidas por ellats uismas, 6 como inquilinos se alimentan por lo nemos en sus protuberancias, las que nos resta citar son rimifidos farisitos, es decir, que se parecen por la estructura de su cuerpo lo bastante á los cinipidos para poder agruparse con ellos, pero no ticnen mada que ver con las agallas, sino que se desamollan del mismo modo que los icneumónidos en los cuerpos de otros insectos, como por ejemplo, las cuarenta pequenas especies del géncro que nos ocupa en los pulgones.

CARACTERES. - Respecto d la forma se asemejan al grupo anterior: el cuerpo es corto y casi redouda; el abdómen es apenas pedunculado; la forma de las alas corresponde ála segunda clase; la superficic pulinentada del pequerio cuerpo, sin embargo, $y$ las delgadas antenas, por lo regular tan largas como aquel, les distinguen fácilmente. En muchas especies la celda radial no se cierra del todo hácia atris, y en algunas otras, solo se ven muñones de las alas; de modo que seguramente el género se habria subdividido en varios si la historia del desarrollo no fuera tan analoga en todos.

\section{LOS FIGITIDOS_FIGITIDE}

CARACTERES. - I.os figitidos constituyen otro grupo que se caracteriza por el cuerpo mas prolongado, puntiagudo en la hembra, y por el taladro saliente. La celda radial de las alas anteriores es corta y triangular, tanto como ancha; la es. cama dorsal del segundo segmento abdominal no llega ni à la mitad de la longitud de todo el abdómen; el maclio tiene las antenas de catorce artejos, la hembra de trece.

\section{LOS FIGITES_FIGITES}

CARACTERES- Este gencro, mas rico en especies, el fsilograster de Hartig, se caracteriza por el tallo abdominal corto anular dividido por una escotadum lorizontal en la parte principal sujerior y otra inferior obtusamente denticulada; la superficie de aquella lleva surcos longitudinales. Los dos prineros segmentos del ahdómen oval solo ligeramente comprimido, se parecen hastanicen longitud en el dorso, pero cl primero se estrecha poco á poco en los costados sin tener la base cubierta de jolos como en otros géneros. I.as antenas son filiformes en el macho, ligeramente hinchadas en su jar. te anterior en la hembra: los ojos están provistos de muy escasos pelos.

\section{EL FIGITES ESCUTELARIO-FIGITES SCU- TELLARIS}

CARACTÉRES,-Esta especic es de un negto brillante, solo roja en las patas anteriores desde los irocinteres hácia abajo: la cabcza, los lados del tórax y el escuciete son rugosos, el borde anterior del segundo segmento abdominal pro. visto de surcos: cl escudete se distingue por dos hoyitos profundos casi cuadrados

DISTRIBUCION GEOGRÁFICA.-Esta especie parece extenderse sobre casi toda la Europa.

USOS, COSTUM BRES Y REGIMEN.-Vive como pa. rásita en el género de moscas sarcoplingas; todas las otras especies del género que hasta ahora se han observado se alimentan de larvas de mosca.

\section{LA IBALIA DE FORMA DE CU. CHILLO-IBALXA CULTELLATOR}

CARACTÉRES. - Esta avispa difiêre demasiado ciel género anterior para poder clasificarse con él, si no constituje por su estructura muy particular una forma que poco se aco. moda a toda la familia. lil abdómen inserto es tan comprimido lateralmenie que casi ofrece el aspecto de una hoja de cuchillo fija en el tórax cilíndrico y prolongado como en su mango: sus segmentos son de igual longitud entre si $\delta$ cn la hembra es el quinto mas pecjueño. Ei tóra muy rugoso en su dorso llew un escudete ligeranente escotado y dos surcos longitudinales en el dorso del mesotónax. El protórax arquęa. do en su borde posterior se prolonga hicia adelante en un corto cuello en el que se inserta la nncha cabera tambien muj rugosa Las antenas de la hembra se compronen de trece artejos y las del macho de quince. I as alas de aspecto turbio liener nervios fuertes de color negro y pertenceen á la pri. mera forma; pero a causa del grosor de los nevios la celda cubital del centro desaparece casi del todo. I as patas son muy fuertes, sobre todo las posteriores cuy'a primern articulacion del pié tiene mas de dos terceras partes de la longitud del tarso. I a longitud de la avispa es de mas de $\theta^{*}$, or 1 : su color es negro con las patas anteriores desde los tarsos y con el abdúmen pulido de un rojo pardo.

USOS, COSTUMBRES Y REGIMEN. - Vive parisita en las larvas del jilúfago comun, que mas adélante conoceremos. En un año que habia procreado mucho el citado jiló. fago en el bosque recino de nuestra ciudad, el tronco de un pino estaba literalmente cubierto de estos cinipidos parisj. tos, sobre todo de machos. Desde entonces no lo he visto ya en aquel bosque sino aishadamente en las flores silvestres durante el verano en la Suizid y últimannente una vez en la pared exterior, otra vez en la ventann de una casa recien construida, de modo que el parisito lo mismo que su anfitrion se importa en los edificios por medio de la madera de construccion.

\section{LOS PROCTOTRUPIDOS -PROCTOTRUPID死}

CARACTERES, - Bajo este nombre (codrirns, oxiuros, de los autores antiguos) los naturalistas modemos reunen un númcro bastante considerable de jequeños parssitus, que como grupos de trínsito apenas pueden caracterizarse en su generalidad, y que constituyen nuestm novena familia. In forma de los nervios de las alas, semejante ia reces a la de los cinipidos, no permite, sin embargo, que se reusan ambos grupos, porque en el caso nque nos ocupa no falta la scñal como alli; rambien el aspecto general del cuerpo se opone à esta agrupacion; y por otra parte obsérvanse carnctéres que se inclinan á la familia siguiente, como las antenas angulosas 
y la falta de celdas y venns en las alas, excepto la cubital en las anteriores; tambien serian un obstáculo para semejante reunion algunas diferencias, asi como la circunstancia de que en las hembras el taladro sobresale de la extremidad del abdómen. Los proctotrúpidos son gencralmente avispitas negras que sin ser delgadas ni graciosas tienen la estructura del cuerpo prolongada, y que sin poderse llamar perezosas de. muestran cierta lentitud y pesadez. Del nismo modo que el abcjorro pesado, pero siempre activo, forma contraste con otras especies de abejas mas rápidas en sus movimientos, asi los proctotrípidos le ofrecen con los calcidios. No fijan su atencion en el enemigo á mucha distancia, ni umpoco tratan de escaparse emprendiendo la fuga Viven con preferencia en sitios húmedos debajo de la hojarasca en la parte inferior de gruesas cercas, mientras que los calcidios, siempre en movimiento, y curas hembras buscan de continuo el objeto á que confiar sus huevos, prefieren el sol, eligen la sombra en nedio de la abundancia del verde follaje, y solo reposan en centros de putrefaccion cundo se ven obligados a buscar un lecho seguro contra las infiuencias perniciosas del invierno, a fin de preservar la delicada estructura de su cuerpo. Podriamos presentar una serie de las especies mas graciosas, pero no açabariamos nunca. Prefiero por lo tanto dar noticjas sobre el proceder de uno de estos diminutos insectos, describiendo al mismo tiempo una forma que recuerda singularnente la familia que sigue, sirviéndola de trànsito.

La primera de estas especies es el recas iccivesculus de Ratzeburs, is phalacsarum de Hacrtig; la otra, muy anäloga, pero difcrente por la extremidad del abdómen, es el telias Vercornis, ambas, y dos mas que Ratzeburg quiere separar de estrs, son de un color negro brillante, con las ancis y los muslos de un pardo negruzco. Las diferencins, apenas visibles para cl naturalista, läo pueden tomarse aqui en consideracion; pero on cambio daremos algunas noticias sobre el género de vida de estas avispitas. Las hembras depositan sus huevos en los de mariposas, la primera en los del feleas tenetronis y la segunda en los de otra especie análoga de que mas tarde trataremos. En estos pequeños huevos se desarrallan á vecés dos, tres, y hasta trece de csas avispitas, que para su desarrollo necesitán de cuatro à scis semanas. Bouché crió en agosto, en el espacio de quince dias, varios de estos insectos, de modo que prueden suponerse varias crias al ano con tal que existan bastantes huevos de mariposa como alimento. Ratzeburg observó el teleas terelirans al depositar los huevos. Apoyado en las patas posteriores, moviendo las anteriores y las antenas lentamente, alarga y recoge el taladro con uma lenta pulsacion sin ciue se abra el abdómen, mientras que la parte anterior del cuerpo avanzando y tetrocediendo ajuda a cjecutar el movimiento. Ias alas se despliegan a ve. ces, pero vuelsen en seguida á reposar suavemente sobre el cuerpo: esto dura poco mas ó menos un cuarto de hora, $y$ micntras tanto se pasean otros de sus compañeros por encima de los circulos de huevos, tocíndoles sin cesar del modo acostumbrado con las graciosas antenas.

\section{LOS CALCIDIOS-CHAL- CIDIE}

CARACTERES. - La muy numerosa familia de los cal. cidios ó teronalinos, segun antes se llamaban, con sus especies, en la mayor parte pequeñisimas, se aisla como grupo de los otros himenópteros mucho mas que los froctosripidos. I.as antenas, siempre angulosas, las anchas alas sin nervios, el brillo metalico del cuerpo, recogido ó prolongado y gracioso, y cl talidro, que en la hembra sobresale del vientre por delante de la punta del abdómen, son caractéres especiales rue distinguen los calcidios de sus congéneres mas afines.

Los ojos reticulares y relativamente grandes, de forma oval prolongada, no son nunca escotados; los ojuclos existen en la coronilla; las alas no tienen células, las anteriores ca. recen de la sciral; $j^{\circ}$ en cuanto a las venas, solo la cubital ofrece un marcado desarrollo, ofreciendo buenos caracićres distintiros; sale de la base del ala, se corre à cierta distancia cerca del borde anterior, reuniéndose luego con este mismo, y despues sepirase en forma de rama hacia la superficie, re. matando en un boton mas 6 menos desarrollado. Las antenas, marcadamente angulosis y en figura de látigo, ofrecen gran abundancia de formas $y^{\circ}$ hasta difieren à veces en los dos sexos de una misma especie; á menudo se intercalan entre el tallo y cl látigo algunos artejos muy cortos, diferentes de los otros, los llamados anillos Los piés tienen por lo resular cinco artejos, presentando á veces tambien tres 6 cuatro. Todos estos caractéres influyen en la rlasificacion de los géneros y especies, sin contar la forma del tórax, sobre todo en el mesotórax, que puede tener una superficie ordinaria 6 dos surcos longitudinales, dividiéndose en tres lóbulos. Tales son, a grandes rasgos, los caractéres de ese ejército de pequenisimos insectos, de los que describiremos algunas for. inas en gencral, pues de lo contrario deberiamos hacer una descriprion demasiado minuciosa.

En oiro lugar deciamos que la hembra del forjumus regius depositaba un huevo en la larra de una agalla, para que el gusano nacido pudiera alimentarse de los jugos del cinipida Durante el acto permanece tranguilamente con la extrenidad abdominal abierta y con la primera escama dorsal levantadá. De un pequeño orificio que en rigor deberia abrir In habitante legitima, sale por fin nuestra avispita domda, ostentando un brillo azul en el dorso y las patitas de un rojo amarillo.

\section{LOS TEROMALOS-PTEROMALUS}

CARACTERES.- MUY parecido por su aspecto genern! a los teleas antes citados, el género de los teromalos, sumamente rico en especies, se distingue de ellos esencialmente portener la superficie del abdomen deprimida en forma de hojo. Ias antenas, de tres artejos, se insertan en medio de la carn apenas punteada, presentando en la base del látigo ligeramente ensanchado, dos anillos muy pequenos. Fl abcó. men puede considerarse cuando mas, como pendiente, pues no se distingue ningun tallo marcado, y en la hembra no so. bresale el ialadro. Por lo demás, ni las patas ni las alas ofreren un cirácter particular, excepio la rama bastante larga del nervio cubital, en cuyo boton se divisa por lo menos un dientecito. El abdómen de todaslas especies presenta un brillo metálico verde, i veces con viso azul. De los cinco artejos casi siemipre claros del pié, solo el de la garra es negro. Lass especies se distinguen por manchas en las alas, por el tómx mas ó menos punteado $y$ por el color de las antenas $y$ las paias.

USOS, COSTUMBRES Y REGIMEN.-1.OS teromalinos visen en coleópteros jilifagos. algunos en pulgones : larvas de mosca, y el pheramalus (Diplolepis) fuparum en las crisálidas de varias mariposas diurnas. En los sitios en que se encuentran estas crisilidas, los teromalinos vagan silencio. samente, mas apenas la oruga ha cambiado por última rez su piel y queda pendiente como crisálida, paséase tambien sobre ella alguna ú otra hembra de teromalino deposita en su interior una infinidad de huevecitos, á pesar de que la victima se mueve y opone resistencia con sus segmentos ab- 
dominales, único medio defensivo de que dispone. Con el tiempo la crisálicla pierde toda su movilidad y su color, ofreciendo, despues que todas las avispitis han salido, cada cual à su tiempo, el aspecto de harnero. En verano se verifica el desarrollo de esta especie á las cuntro semanas. En las crisalidas que invernan, las avispitas se reunen a veces hasta en número de cincuenta en una sola ninfa. I as formas recogidas que vemos en el follaje de las encinas brillando con los mas magnificos colores azules y verdes metilicos viven en diéerentes agallas.

\section{EL CALCIS CLAVIPEDO-CHALCIS CLAVIPES}

CARACTERES. - Fista especie se encucntra á menudo en gran número en las hojas de encina y se mueve mas bien a saltos que volando; busca decididamente con preferencia la sustancia dulce de los excrementos de los pulgones, y mas se ocupar en esto que en los deberes de la reproduccion.

\section{EL ESMICRA CLAVIPEDO-SMICRA CLA- VIPES}

CARACTERES - Fste calcidio es el mas gmadic de nucstros paises, puedc alcanzar la longitud de (t),006 6 mas.

Este prequeno insecto, de estructura graciosa, tiene has protas mas ó menos rojas, y el cuérpo de un negro brillante; las alas se distinguen de las de otras especies de la familia por la mayor abundancia de nervios.

USOS Y COSTUM BRES. - Desclemayohista agosio vive en los cañaremles; en el agua bordenda por estos habita lat larva, de forma prolongada y semejante a una sanguijuela, de la especie conocida con cl nombre de mosca de arnus, larva que para convertirse en crisálida sale del líquido elemento en busca de la tierra húnzeda. En este viaje que se verifica con bastante lentitud, la hembra del esmicra encuentra probable. mente ocasion de cumplir con sus deberes maternales. No he podido observark, pero obtuve la avispa de una de las citadas crisilidas.

\section{LOS EVANIADOS- EVANIAD压}

CARACTERES. - I.os limites que encierran esta familia son muy poco maturales, pues en clla se han reunido todos los jencumónidos en que el abdómen no se inserta del modo regular en el borde inferior del metntórna, sino en el centro ó por encina del mismo, agregandose algunas otms especies que no pudieron clasificarse de otro modo.

\section{LOS EVANIOS-EVANIA}

los evanios, que como el género mas rico en especies ha daclo el nombre á la familia, se encuentman en todos lus contincutes y viven como parisitos de los blatus, segun se ha demostrado cuando mencs en algunas especies.

CARACTERES. - Las especies que cuentan las avispas mas pequeijas ofrecen un aspecto jarticular, porque el abdó men, falsiforme y muy comprimido, inserto at mucha alturn en el tórax, es casi rectangular y muy inferior en tamaño is este, sobre todo cunndo los delgados muslos posteriores te cubren lateralmente. La ancha cabera tiene en medio de los ojos las gruesas antenas, de tanta longitud como la del cuerpo; en las alas anteriores hay una gran celda radial, una cubital y otra discoiden, pero tambien se hallan especies que casi carecen de nervios, teniendo solo dos braquiales, especies que se han separado con el nombre particular de brachy jass. fer de los evanios, clasificando entre idlas tambien al perque. no bractuggaster mimuta, olyjptia minuta.

Esta especie mide 1",00337 a 10",0045; es negra, con puntos ásperos en la cabeza y en el tórax; y es, segun parece, de todas las especies conocidas la mals diseminada hácia el norte. En el espacio de casi veinte años, solo pude cogerla una ver en los alrededores de Halle, á orillas de un foso.

\section{EL FENO ASECTADOR-FCENUS ASSEC- TATOR}

CARACTERES. - Esta especie qué vive como paraisit en los himenópteros que habitan en las muros, es un insecto del todo comprimido lateralmente, de color neyro con man. chas rojas en el aldúmen, y rojo en los trocinteres de los tarsos posteriores; el taladro tiene poco mas o menos una cuarta parte de la longitud del abdómen.

USOS, COSTUMBRES Y REGIMEN. - Vuela en ve. rano por las paredes ruinosas de barro, pero de una manera tan particular, que no es posible pase desapercibida à la vista de un observador algo atento. Levintando el abdómen y entreabriendo los tarsos posteriores, ejecutal ligeros movinientos, arqueaindose siempre a lo largo del muro; apenas se camsi, anda algunos pasos, y diespues ruela de nuevo en la misma posicion.

Yo he cogido esta avispita con unucha frecuencia, mliéndome de unat ventosa, pero siempre me admiró su vuclo ligeto y gracioso, qque durante mucho tiempes se continuaba cn un reducido esjancio, sin que ninguna parte clel cuerpo chocara contra las paredes de la prision.

\section{EL FENO DE FLECHA-FEENUS JACULATOR}

CARACTERES. - Esta especie, mas rara, pero un poco mas grande, se distingue de la anterior por los tarsos y piés blancos en la base, cundo menos los de has paras posteriores, por el abdómen, rojo en el centro, y jor el taladro, mucho mas largo.

Algunas formas extrañas, con las partes muy prolongacios, lrabitan los paises cáliclos.

\section{LOS BRACONIDOS - BRACONID}

CARACTERES. - I.os bracónicios, nuestra funilia duodécima, constiluyen el trinsito entre los calcidios y los verdaderus icneumónidos, por ló que cocià la estrictura del cuerpo, inientms que por su género de vida se asemejan à aquucllos. Son por término medio avispas mas pequeñas de $11^{2}, 00225$ à $11^{\prime \prime}, 0065$ de largo; muy pocas llegran a $11^{*}, 013$ de longitud. Se reconocun inas facilmente por los nersios de las alas, pues el ala anterior solo tiene una vena braquial. Además el segun. do segmento abdominal se une con el tercero ess el durso y no deja ninguna sutura, os es inmóvil en la impresion trasversill correspondiente. Este carácter facilita el reconocimiento de las jocas especies sir alas que tambien aqui se encuentran. aunque son mucho mas comunes en los teromalinos. Solamente los afidios prescntan una excepcion del citado ca. ricter y una forma mas sencilla de las alas.

Excepto algunos raros casos, las anteras rectas de los bra. cónidos son filiformes ó cerdosas y se componen cie mayor número de artejos de los que suele haber; las patiss tienen dos trocínteres del muslo, y los piés cinco artejos.

Pam reconweer los géntros y especies es preciso fijarse en 
si el mesotỏrax tiene ó no los surcos longitudinales indicados ya al hablar de los calcidios, y observar la estructura del ine. tatórax que à veces se halla dividido en placas por medio de rebordes, pero dispuestas de otro modo que en los verdaderos icneumónidos. En cuanto al abdómen, es sobre todo im. portante el primer segmento, segun se estrecha en toda su longitud 6 solo en la mitad de la base en forma de un tallo. Los calificativos de abdómers pedunculado, casi pedunculado, inserto: etc, tienen aqui tanta importancia como en las familias siguientes. En cambio los nervios de las alas anteriores, à causa de su mriedad, son mejores distintivos que en otras esplecies.

Antes de todo debemos fijarnos sin embargo en las partes bucales, por cuyas diferencias la famitia se hà chividido en tres géneros. En el printero (Clidostomo) el escudo de da cibeza se redondea en el borde anterior, es puntiagudo of solo muy ligeramente escotado; las maxilas encajan de tal manera que la abertura bucal queda cubierta del todo ó solo aparece como una estrecha hendidura.

En cl segundo género, los cirlostomos, el escudo de la cabeza es muy escotado en el horde anterior, y el labio superior esta dispuesto de tal manera que forma, por decirlo asi, el paladar de la cavidad bucal; al mismo tiempo las maxilas son bastante cortas para que al cerrarse solo se toquen con las puntas. A causa de csta formacion particular la boca cerrada parece solo una abertura redonda.

Ini el tercer caso, por uiltino, el mis anormal, las maxilas son, no solamente muy cortas, de modo que no se pueden tocar una con otra, sino gue están situndas tambien de tal modo que la parte cóncava mira hácia afuera: estos bracónidos con las maxilas tan mal dispuestas se llaman exodontos

\section{LOS AFIDIOS-AFIDIAE}

CARACTER ES. - Estos insectos, que cuando mas llegan a. $\left(0^{\mathrm{m}}, 002,37\right.$ de largo, se caracterizan por tener las antenas arqueadas hácia abajo; el abdómen, en forma de lanceta, es. marcadamente pedunculado sin otro apréndice; el ségundo tercer segniento no se unen; $y$ la celda discoideá superior está soldada con la primera cubitnt.

USOS, COSTUMBRES Y RÉGIMEN.-Todós los affdios viven en los pulgones, asi coine los cinipidos parasitos arriba citados del género allutria, y se pueden obtener de consiguiente mejor por medio de la cria. El pulgon picado entreabre las patas, dilata el abdónzen y muere en medio de sus compañeros sanos cuando el parásito que le habita ha llegado átrasformarse en larva adulta. Si se ve un agujerito en el cuerpo, solo del tamano de una jicadura de aguja, ya se sabe que el afidio ha salido. Al presentarse una de estas avispitas causa verdidero terror entre los pulgones tan tranquilos é inofensivos; conocen' mul bien su enemiga y saben que no hay resistencia posible, pero tampoco ignoran que por medio del pico y de las garras de las dos patas anteriores pueden mantenerse firmes en su puesto; por eso sucitan las otras cuatro, lerantan el abdómen 6 le bajan cuando están en la carn inferior de una hoja, agitan las primeras extremidades y muévense para rechazar al chemigo 6 evitar cuando menos su picadura. Sin embargo, la arispa no hace caso de la resistencia, toma hasicion conveniente, entreabre las patiss y en un instante el movible abdómen se adelanta prara picar ála victima. Del mismo modo procede repetidas veces.

\section{LOS MICROGASTROS-MICRO- GASTER}

CARACTERES. - Sin duda el género mas comun de toda la familia y el mas rico en especies muy dificiles de dis. tinguir, y que no ofrecen tampoco nada de interesante en su forma, es el de los micrograstros. Se reconoce por el abdómen pequeño inserto, y apenas pedunculado; las antenas cuentan hasta 18 artejos; la vena radial está casi borrada desde la senal de las alas; y el mesotérax no tiene tampoco los surcos laterales bien marcados. Muy caracteristica es para el género la formacion de las células cubitales, de las que se cuentan dos ó tres. Ia primera, regularmente sexagonal 6 heptagonal, está situada cerca de la señal, bastante grande; la segunda es cerrada y triangular, $\delta$ fornia solo, como en la mayor parte de casos, un ángulo puntiagudo, faltando el nervio para cerrarla haicia afucra. Esta célula cerrada no se in. serta siempre como su estribo en un tallo que forma casi un rectángulo con la vena radial y baja á mas ó menos distancia. En la extremidad de este tallo se ve 6 un ángulo puntiagudo ó el principio del nervio radial. El abdómen es siempre mas corto que la parte anterior del cuerpo, por lo regular comprimidn en el vientre hácia la extremidad, que en la hembra se abre a menudo mucho cuando hace uso del taladro; los cjos, reticulares, están por lo regular cubiertos de pelos, y los ojuelos son visitiles en la coronilla. Los machos tienen un abdómen mas perueño y menos comprimido; las antenas son un poco mas largas, y en muchas especies presentan manchas ó fajas oscurás en las patas, por las que se distiuguen de las hembras.

USOS, COSTUMBRES Y REGIMEN.-Estas esprecies, excepto dos que se han criado $\mathrm{cn}$ huevos de arana y de pulgones, viven en las orugas de mariposa, en las peludas mas que en las desnudas; pero están habitadas ì su ver, en el estado de lárva, pór pequeños teromalinos. Llegado el tienpo de la madurez, las larvas de microgastro salen de la oruga, pero se encierran prontamente en un capullo, segun po. demos observar en el microgaster glomeratus, al que las orugas proveen de un blando lecho compuesto de sus amarillentas crisálidas, y en el microgaster nimorum, uno de los numerosos parásitos de la oruga del gastropacho de los pinos. Los capullos de la crisálida son de un blanco de nieve. Las larvas empiezan á tejer cuando salen de la piel de oruga tan luego como estan libres y acaban la construccion de su casita en menos de 2.4 horas. En diez 6 doce dias sale la avispita, naturalmente en tiempo en que no faltan orugas, que segun se sabe invernan en estado medio adulto, faltando desde junio a mediados de agosto, en cuya estacion pueden ser tambien demasiado pequenas para que la hembra del microgastro se pueda aprovechar de ellas para sus fines. Ia célula cubital del centro no está cerrada hảcia afuera y la madial aparece solo indicada. La avispita es de color negro. brillante; los bordes josteriores de los dos jrimeros segmentos abdominales son claros: las escamitas de las alas amarillas, y las patas de un amarillo rojizo, excepto las posteriores, yue son negras, y las extremidades de los muslos $y$ tarsos, asi como los piés que parecen ahumados.

\section{EL MACROCENTRO MARGINADOR.-MA- CROCENTRUS MARGINATOR}

CARACTERES.- Esta esjecie, una de las doce de! género, se parece por su aspecto exterior mucho á cicrtos icneumónidos verdaderos, pero prertenece á este grupo por la forma de los nervios del ala.

la célula radial està del todo desarrollada y es relativamente grande; ademas se cuentan tres celdas cubitales cerradias, y de la humeral posterior solo sale un nervio longitudinal, y no dos, como en el género carinus. La coronilla es estrecha sin borde afilado, el dorso juresenta tres protube- 
rancias; el abdómen tiene muy prolongados los segmentos anteriores y con surcos longitudinales; es un poco compri. inido en la extremidad y esti jrovisto en la hembra de un taladro que cuando menos alcanas la longitud de todo el cuerpo. 'l'ales son los caractéres genéricos.

La especie que nos ocupa es de un negro brillante, pero los largos palpos y las delgadas patas tienen un tinte aunarillo rojizo; solo los tarsos posteriores son negruzcos desde los trocinteres, y los piés blanquizcos; tambien los nervios de las alas y has escamitas son de un rojo amarillo. Ia hembra, que sin taladro inide cuando menos ocho milimetros, indica por la longitud de aquel brgano que no deposita sus huevos superficialmente.

USOS, COSTUMBRES Y RÉGIMEN. - I avispita vive como parásita en ciertas orugas que practican sus gale. rias en los abedules. Cuando la parisita ha devorado la sus. tancia del insecto en que habita teje un capullo largo y cilíndrico a su alrededor, yen vez de la graciosa mariposa para la que se habia abierto la salida preséntase a su ticmpo la delgada avispa.

\section{LOS BRACONES-BRACON}

CARACTERES. - Este primer género de los ciclostomos de que hablamos se compone de muchisimas especies, pues solo in Alemania se conocen unas 200 , pero las mas llegan de los paises tropicales para nuestras colecciones, quizás por. que predominan alli, $\delta$ porque se las preñere á causa de su graciosa forma, llamando mas la atencion que otras especies menos bonitas la cabeza esférica, redondeada cu su parte

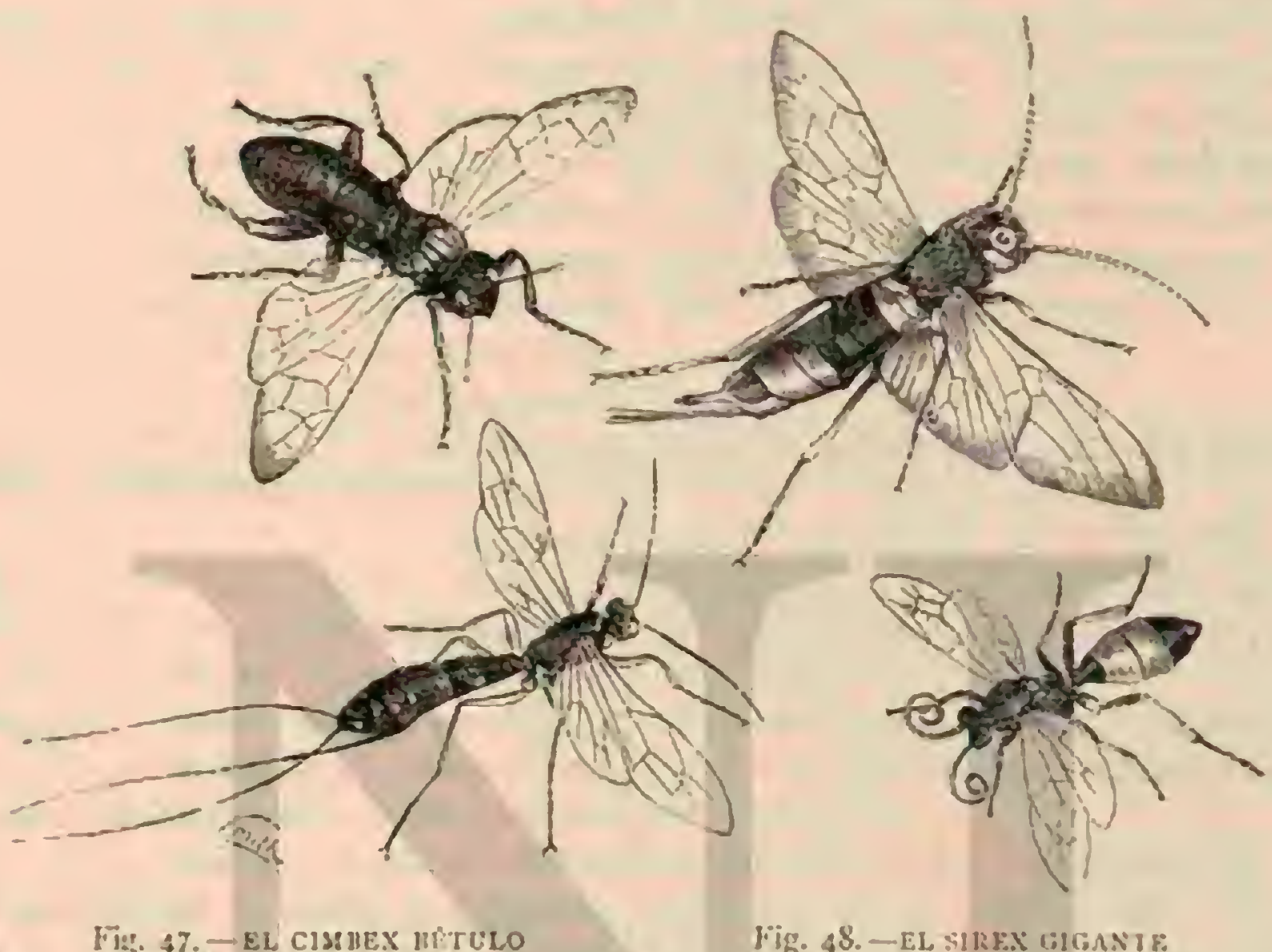

Fig: 47. $\rightarrow$ EL CISIIEX MTCLO

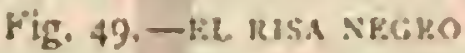

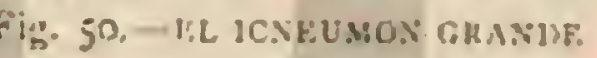

postcrior $y \sin$ reborde afilado, la longitud jgual de ambas células humerales en el ala anterior, el abdómen eliptico ó en forma de lanceta, inserio $\delta$ apenas pedunculado, con el primer segmento mas corto que los cuatro siguicntes juntos, el tercer artejo de las antenas mas largo que el segundo, y la forma de la boca, son caractéres genéricos propios de las especies de nuestros paises. En cunnto á su tamaño miden trece milimetros de largo, pero has exóticas son mucho mas grandes.

El tónx, nas delgado, y un poco'estrechado hácia adelante y atrăs, es siempre liso y desnudo, excepto el metatórar; las antenas son siempre muy largas, y el taladro de la hembra sobresale mas ó menos. Respecto a los colores, predominan el rojizo ó amarillento, mientras que las especies del todo claras ó completamente negras son rams. Muy comunes son las alas de color turbio y hasta negras, que en las especies exúticas tienen manchas ó fajas de un amarillo vivo.

USOS, COSTUMBRES Y REGIMEN. - J LOS bracones viven con jreferencia, segun parece, como parisitos en las larvas de los coleópteros que habitan en la madera muerta, y por eso se les suele encontrar en aquella cuando no buscin la miel de las flores.

\section{EL BRACON PALPEBRADOR.-BRACON PALPEPRATOR}

Caracteres. - Esta cspecie fué una de las que RatToso $\mathrm{VI}$ zeburg crió en ambos sexos en gran número de leños de pino llenos del fissodes nofratus, coleoptero que en este írbol causa grandes perjuicios.

El clorso del mesotórax es del todo liso y brillante; iodo el insecto es negro; las patas, excepto las posteriores y de las ancas centrales, la parte inferior del cuello, la cara y la frente, hasta las antenas, y en el macho tambien la base de estas son de color rojo, asi como el abdómen, excepto una mancha negra del primer segrmento.

\section{LOS ROGAS-ROGAS}

CARACTERES.- Este género, igualmente rico en especies, se asemeja mucho por sus formas al antcrior; peru se distingue facilmente de él si se hace un eximen minucioso. I a cabeza, ancha y tmsversal, esta provista en su parte pos. terior de un afilado reloorde; el segundo segmento abdominal esiá separado del tercero por un profundo surco tras. versal; el taladro queda oculto ó es muy poco visible. Ias alas anteriores tienen siempre tres células culbitales.

USOS, COSTUMBRES Y REGIMEN. - Iodas las eSpecies hasta ahora criadas se encontraron en orugas de mariposa disı̧uestas de un modo muy particular. El icneumónido se encierra en el interior de aquellas en un capullo y las petrifica en cierto modo, atrofiandolas y convirtiéndolns en una especie de momins, que aun se identifican como orugas. si bien no es posible reconocer su espuecic; en tal estado se 
hallan bastante a menudo en las ramas y en los tallos de plantas. El que vea una puede estar seguro desde luego, que un rogas la ha reducido á tal situacion.

\section{EL ESPATIO CLAVADO-SPATHIUS CIAVATUS}

Esta especie, tipo del género de los ciclostomos, es una fiel compañem y cohabitante de nuestras casas; con ella no faltan ciertos colé́ptcros.

CARACTERES. - El espatio difiere de los bracones por cl largo tallo abdominal y por el bordc afilado en los lados de la parte posterior de la cabeza; las alas anteriores tienen tres células cutitales del misno tamaño y una radial continuada hasta la extremidad; ef priner segmento del abdómen forma en toda su extension el tallo y es de color mate, por cfecto de unos finos surcos longitudinales; el segundo es punteado; los siguientes brillantes, $y$ todos se reunen en forma de maza. Debajo de la extremidad abdominal sobresale un taladro de la longitud de las antenns. Fil insecto tiene un color rojo pardusco, pero los artejos de las patas son mucho mas claros; el tamaño varia de $0^{\circ}, 004^{\circ}$ a $0^{\circ}, 008 ; 5$; el macho siempre mas pequerio, liene tambien las antenas mas del. gadas.

\section{LASS ALIIAS - ALYSIA}

CARAciteres. - Este géncio de los exodontos es el que está mas diseminado, caracterizindose por la forma de la boca, $y$ indicada, $y$ por un ancho abdómen inserio.

\section{LA ALISIA MANDUCADORA-ALYSIA MANDUCATOR}

CARACTERES. - La alisia manducadora tiene las ma. xilas anchas, provistas en la punta de tres dientes; cunndo están abiertas ofrecen el aspecto de dos alas laterales mas bien que de partes de la boca; la cabeza es gruesa y muy peluda; las antenas, en forma de cordon de perlas en la hem. bra, son filiformes y mas largas en el macho. El metatórax presenta toscas arrugas y es de color mate lo mismo que los lados del tórax, cuya lóngituơ iguala il la del abdómen, oval y bastante aplanado. El primer segmento del mismo es de color mate, á causa de unos surcos longitudinales, y debajo de la extremidad sobresale en la hembra el taladro. Cuén. tanse tres células cubitales; y una grande señal negra distingue las alas anteriores. 'Todo el insecto es negro y brillante; las patas están cubiertas de cortos pelos y tienen un color pardo rojo; sus tarsos son mis oscuros.

USOS, COSTUM BRES Y REGIMEN. - I a especic vive como parísita, lo mismo que todos los demás tipos de los exodontos, en larvas de mosca, como la Authomyin dentipes, Cyrtoneura stahulans y otras, y no chi las larvas de peloteros, segun se ha creido, porque estas y las de mosca tienen à menudo la misma residencia.

\section{LOS ICNEU MÓNIDOS - ICHNEUMONIDE}

CARACTÉRES. - Esta familia se distingue fácilmente de los parásitos que acabamos de describir por la forma de las alas, pero ofrece las mismas dificultades cuando se trata de reconocer las numerosas especics. I as alas anteriores de todas tienen los nervios tan análogos que solo en muy pocas pueden survir para reconocer el excesivo número de géne- ros. La forma tipica nos ofrece desde luego en la existencia de dos nervios braquiales la diferencia entre esta familin y los bracónidos, que por otro concepto pueden confundisse en parte fácilmente con aquella. Aclemás, la celda discoidea anterior se suelda siempre con la primera cubital, y una pe. quueỉa rama nerviosa indica á menudo el principio de las vemas separatorias. Eil ala anterior de un icneumónido verdadero tiene por lo tanto una señal, una celda radial, tres 6 dos cubitales y dos discoidens.

Otro carrícter propio de todos los icneumónicios son las antenas, rectas, con muchos artejos, de igual grueso en toda su extension, excepto en los artejos de la base, siempre mas fuertes, 6 adelgazados hácia la punta; otras afectan la forma de maza, pero escasean mucho; con mas frecuencia vemos en ciertas hembras antenas dilatadias 6 ensanchadas junto á la punta. Los tres ojuelos, la boca cerrada en su parte ante. rior por el escudo de la cabeza, los palpos maxilares de cinco artejos y los piés tambien de cinco, el abdómen inserto ó provisto de un delgado tallo, son canctéres de los icneumóni dos, aunque se observan igualmente en otros muchos himenóptcros, y de este modo solo quedan los nervios de las alas como distintivos esenciales. Cuando estos faltan, lo que tambien sucede en ciertas especies pequeñas, puede haber duda en ciertos casos sobre la calificacion del respectivo insecto.

Ningun icneumónido produce un zumbido cuando estå posado 6 vuela, pues se aproxima siempre sin ruido á su virtima: solo las especies mas grandes se ojen a veces por su alcteo.

Para la descripcion general solo nos qqueda el exámen de las partes del cuerpo que nos permitirá distinguir los cente narés de géneros y los muchos miles de especies.

En las antenas de todas rige la misma ley de formarion: at un grueso artejo de la base, que á veces puede ser camcterístico, y á un segundo muy peŗueño, que por lo regular sobresale muy poco del primero, siguen los otros, que corres. ponderian al látigo de las antenas angulosas y que cuando menos descle la mitad de su longitud total hasta la punta de las antenas se acortän siempre; si hasta la punta tienen el mismo grueso, forman antenas filiformes, pero cuando se adclgazan, son cerdosas. En la forma de los artejos hay además dos diferencias: ora son tocios, y este es el caso regular, completamente cilindricos, y entonces dificiles de distinguir, ora cada uno se dilata un poco hácia arriba, formando una especie de nudos circulares en la hembra, mientras quue en el macho se observan mas en la cara inferior y recuerdan una sierra con clientes obtusos. Por poco importante que pa. rezca este carácter, es muy decisivo, sin embargo, para el efecto gencral que las antenas producen of la vista del obsesvador. En las hembras que tienen los artejos de sus antenas cortos y nudosos, estas se chroscan despues de la muerte mas ó menos. El escudo de la cabera, los dientes de las maxilas y la forma de aquella, regularmente mas ancha que larga, y por lo tanto trasversal, influyen muchas veces $\mathrm{cm}$ la clasificacion. En el tórax, el metatórax merece sobre todo un exámen minucioso; ver si sus estigmatos, situndos delante ó hácia arriba, son ovales ó circulares: si está dividido marcadamente en una parte horizontal y otra deprimida, $\delta$ si entre ambas hay un trinsito suresivo, pero sobre todo si Ia division es por placas; por rebordes $y$ de qué modo. En la division mas completa que es posible jueden distinguirse dicz y seis placas, las cuales han recibido todas sus nombres: en la cara anterior hay cinco; una en el centro, la mas característica, y a cada lado dos; despues siguen simétricamente en cada lado la en que se halla el estigmato, despues otra mas grande hácia abajo, jo una muy pequena en el án. gulo extremo. En la parte deprimida, la mayor placa estáen 
el centro, y do cada lado dos mas, que todas sie exticnden como anchos radios al rededor del centro del borde posterior en que se inserta el abdónen.

Lste tiltimo se halla sometio $i$ las mayores variaciones: y respecto al modo de fijarse ofrécense los contrastes ya citados de abdómen inserto yedunculado en todos sus trinsitos. En el primer segmento se debe ver si solo la parte anterior forma el tallo os si todo aquel se adelgaza poco à poco hacia adelante Otro carácter de gran importancia ademís es la posicion de los estigmatos en este primer segmento, que á reces se halla debajo de unos nudos salientes en los lados, en cuyo caso reconócense con faeilidad, pero de lo contrario estan mas ocultos. En muy ratos casos se hallan precisamente en el centro del segmento; con mas frecuencia los remos delante $\mathcal{S}$ detrás, mas cerca del borde posterior del mismo.

La maturaleza de la superficie del abdómen, la presencia ó carencia de quillas y surcos, la manem de encajar la parte pusterior del tallo y la anterior del mismo en los lados, y otras muchas circunstancias exigen a menudo un minucioso exímen. Este no se limita sin embargo al primer simmento, sino i todos los. siguientes; aqui se presentan desde luego otros contrastes que serian caracteristicos si la naturaleza se rigiera siempre por cllos: el abdómen puede ser mas ó menos aplanado desde arriba abajo (deprimicio), presentando un contorno ural, ú bien comprimido lateralmente, ofreciendo en su desarrollo mas completo una quilla obtusa en el dorso, yen el vientre una mas afiladia; y entonces se ensancha de adelante atris yo por su perfil recuerda una ho\%. Entre ambas formas hay muchos transitos que i veces conducen a dudar sobre cuál de las dos formas fundninentales deben adoptarse. Muy caracteristico es para muchas hembras el abdómen por el taladro, saliente, à veces muy largo, y de cuya estructura ya hemos hablado. Su relatim longitud $y$ la circunstancia de si sale de la punta ó de una hendidura del vientre son de gran importancia para la clasificacion. I as dos válvulas siempre peludas que forman su estuche se insertan naturalmente sienpre en la extremidad del abdómen, mas por eso no es preciso que de esta misma salga el taladro, sino que á menudo una buena parte de su base este cubierta por el abdómen mismo. En otros casos aquella cola exterior falta del todo, porque el corto lalidiro que aqui se parece precisnmente al orificio de lias abcjas, tiene sitio bastante en el vientre mismo. los caractéres del abdómen y de las antenas son marcados sobre todo cn las hembras, que por lo tanto se distinguen-mucho inas fácilmente que los machos, los' cuales ticmen una estructura mas uniforme. Tomando en consideracion que tambien por su color difieren esencialmente de sus hembras, y que solo muly rims veces se encuentran los individluos en el apareamiento, el cual efectuan los mas dunnte la noche $\delta$ en sitios ocultos, se comprenderin fäcil. mente la gran inseguridad expresada en las diversas opiniones de los naturalistas, los muchos nombres de un mismo insecto, $y$ las dudosas reuniones de hembra y macho verificadas en individuos muerzos en las colecciones. Al mismo tiempo aconsejamos al amigo de la naturaleza que ayude por "una observacion atenta \& cultivar un campo muy extenso aun, campo que solo puede dar buenos frutos labrindole con fucrias reunidas.

USOS, COSTUMBRES Y REGIMEN. - I'á hĕmos he. cho mencion en otro lugar de la variedad en el género de vida de parásito: en cuanto al desarrollo de una ú otra especic, hablaremos de ello en la descripxion de lasavispras falsiformes. Se supone que el parssito se alimenta en su anfitrion de la sustancia grasosa, masa amarilla que por lo regular rodea el intestino y contiene la sustancia alimenticia por la que el in secio adquicre su completo desarrollo, y quizàs principalmen te su desarrollo sexual. Todas las partes mias dobles de que depende la vida de la larva quedan ilesas mientras el para. sito no ha llegado aun a su madurez.

Para dominar por lo menos un poco el poderoso ejército de los icneumónidos se les ha dividido en cinco generos bien determinados en sus fornas principales, que sin embargo se reunen por irinsitos que al naturalista siempre ofrecen dificultades. En primer lugar considero a los icneumónidos como el conjunto de las formas mas nobles de la fanilia.

\section{LOS ICNEUMONES-ICHNEUMONES}

CAIRACTERES. - El abiómen deprimido, en forma de lanceta, es pedunculado, de modo que la parte posterior del primer ségmento se halla ia mas altura que la base del tallo; los estigmatos de aquel estan jor detras de su centro y' no mas próximos uno á otro que á la extremidad del segmento. El taladro se oculta casi siempre del todo en el vientre. Ias célula discoidea es jentagonal y forma hácia el borde anterior un ångulo; lis antenas tienten los artejos un poco dilatados; en el macho son siempre cćrdosos; los de la hembra son de la misma forma ó filiformes, y en los individuos muertos mas ó menos surcados en su parte anterior. Lass placas de la par. te posterior del dorso existen aqui en mayor numero, y sus ustigmatos an solo en las pequeñas especies circulares.

Entre los icncumones se encuentran las avispas mas abigarradas de todo el grupo, hembras en cuyo cuerpo se reunen el rojo negro y blanco $\delta$ amarillo, colores juros que en general solo vernos cn la familin; tambien observamos ayui las mayores diferencias sexwales. Ias larvin que hasta ahora se conocen distinguense por cierto aspecto marchito, fo parece que no tejen porque las grandes crisálidas de mariposa les sirven de capullo.

USOS Y COST UMBRES. - Estas avispas se crian, segun mis observaciones, solo de las citadas crisálidas, cuya parte superior de la cabeza abren para salir. la hembra deposita por lo tanto solo un huevo en la oruga.

\section{LOS CRIPTIDOS-CRYPTIDES}

CARACTERES.- 1.os criptidostienen la forma del ab. dómer pedunculada; las antenas ligernmente nudosas y en parte tambien la rélula discoidea, que es pentagonal y se inclina al cuadrado; aqui es menos completa la division de las placas del nactatórax, pero se distinguen por tener un taladro saliente en el estado de reposo, que sale de una hendidura ventral; los estigmatos del primer segmento ahxiomimal estan uas próximos uno a otro que a la extremidad del mismo. Los artejos de las antenas, por lo regular inucho mas delgados, se ensanchan à menudo por delante de la punta.

Las especies de este género difieren ya demasiado para poder caracterizarse con pocas palabras completamente: Cravenhorst ha reunido los únicos icneumónidos sin alus en las hembras en el grupo de los pezomacos (pesomachus).

\section{LOS PIMPLARIOS - PIMPLARI压}

CARACTÉRES. - Fste tercer genero se caracteriza ge. neralniente por un abdónsen inserto y deprimicio, en cuyo primer segmento no arqueado los estigmiaios se hallan en el centro ó por delante del mismo: en el último de la hembra el taladro sobresale à menudo a muchn longitud. I a ccelda discoidea es regularmente triangular, pero falta à veces del todo; la division del metatorax en placas es muy poco marcala; sus estigmatos son con mas frecuencia circulares y muy 
pequeños, pero no longitudinales; los artejos de las antenas generalmente cilinàricos, y divididos paco marcadamente uno de otro.

\section{LOS OFIÓNIDOS-OPHIONIDE}

CARACTERES. - Los ofiónidos ó avispas falsiformes tienen tambien el abdómen comprimido lateralmente, provisto por lo regular de un tallo recto y del cual el taladro apenas sobresale. Los artejos de las antenas son cilindricos en la hellavigia slegans, avispita muy graciosa de color pardo y amarillo, siendo tanto mas gruesos cuanto mas so/ncercan à la punta. La celda discoidea es triangular ó falta.

\section{LOS TRIFÓNIDOS-TRYPHONIDES}

CARACTÉRES. - De los trifónidos puede decirse en rigor tan solo que son las especies que déspues de formados los géneros anieriores pertenecen it toda la familia. En muchos, el abdómen, ya inserto, ya pedunculado, es caracteristico por su, redonder, y un poco mas grueso die adelante atris, dejando ver apenas el taladro; cuando no sucede asi, el aspecto exterior recuercia uno de los otros géneros, pero la forma de las antenas ó de las alas, o de alguna otra parte, no permite la reunion con ellos.

USOS Y COSTUMBRES. - Habitan con preferencin en las cañas y otras plantas congenéricas.

\section{EL EXENTERO ORILLADO-EXENTERUS MARGINATORIUS}

CARACTERES. - Este trifónido, de (i)",on de largo, se reconoce por los bordes posteriores amarillos de los segmen. tos abdominales, por variables matices amarillos en la cabeza y. el túrax sohre un fondo nugro y áspero débido a varias ar. rugas, y por la falta completa de una espina en la extremidad de los tarsos posteriores, cuja punta es negra. El escuclo de la cabezal sepárase de la cam por una depresion que se arquea; las alas anteriores tienen una celda discoidea triangular $y^{\circ}$ el abdómen se inserta con el segmento de su basc upenas estrechado, provisto en el corșo de dos quillas en el metatórax, deprimido casi verticalmente y con una division de varias placas.

USOS Y COSTUMBRES. - Esta avispa vuela con preferencia en los pinares, porque en sus árboles deposita sus luevos en el Jophyrus pini. Con la facultad propia de todos los icneumónidos para olfatear su presa y con su continua unvilidad, la larva verde casi adulta del lofiro no puede ocultarse mucho tiempo à la hembra del exentero, que le deposita exteriormente un huevo por medio de un ganchito y á pesar de la resistencia. Entonces se fabrica un capullo para invernar. Del huevo del parasito nace la larva, que chupa la sustancia de su anfitrion dejando por fin solo la picl resecada en un rincon del capullo, mientras que cl intruso fabrica otro parn si, que solo ciene la mitad del tamaño de aquel. En vez del lofiro sale al año siguiente el trifónido a través de las dos cubicrtas, por un agrijerito irregularmente redondo, junto à la parte superior.

\section{LOS BASOS-BASSUS}

CARACTÉREs.- Otro género, del qque varias especies ahigarradas se encuentran con frecuencia, es el de los basos, fácil de reconocer por el segmento de la base, casi cuadrado, con que el abdómen, muy deprimido, corto y oval, se inserta en el tórax. En algunas especies falta la celda discoidea; en otras existe en forma triangular; el primer nervio braquial se arquea en ángulo.

\section{EL BASO DE SEÑAL BLANCA-BASSUS ALBOSIGNATUS}

CARACTÉRES. - Esta avispita mide de $0^{m}, 00517$ a $10^{\prime \prime}, 00857$ de largo: tiene el cuerpo negro, con abundantes manchas blancas en el escudo de la cabcza, en los bordes interiores de los ojos, en las escamitas de las alas y debajo de las mismas, en el escudete y escudete posterior, en los bordes posteriores de varios segmentos abdominales, $y$ por fin en un anillo en los tarsos prosteriores, que son negros: las patas son de un rojo vivo. El ala anterior carece de la celda cliscoiden,

USOS, COSTUMBRES Y REGIMEN.-Deposita suS huevos en las larvas de los sirfos (syrphus) que tienen la forma de una pequeña sanguijuela. A pesar de esto la larva sigue comiendo y creciendo y se encierra por fin en un capullo fijado en una hoja ó en otra parte de planta. No se desarro. lla inmediatamente en este capullo ninguna crisalida de mosca sino una de icneumónido, de la que sale despues la arispita.

Otras especies se han encontrado de igual género de vida, una de ellas como parisita en las larvas de coccinella, que se' gun se sabe se alimenta de pulgones.

\section{EL BANCO FALCADOR-BANCHUS FAL- CATOR}

CARACTERES. - Esta especie, cuya hembra labricius tomó jior otra, llamándola Banchus zernator, es un ofiónico, pero no vercadero, porque el abdómen, inserto solo en su segunda mitad, adquiere el carácter del género comprimiéndose mucho Jateralmente; se reconoce además por el escildete prolongado en una espina mas ó menos puntinguda, por los estigmatos lineales del borde posterior del dorso, por la célula discoidea, casi romboidal, $y$ por las garras de los piés en forma de peine. Ambos sexos se distinguen no solamente por el color del cuerpo sino tambien por la forma del abdo. men, y esto explica fácilmente las faltas comctidas por varios naturalistas. Fin el macho, el abdómen es falsiforme visto de perfil, se ensancha de adelante atris, tiene la extremidad oblicuamente cortada y deja ver un par de glóbulos pertene. cientes á las partes genitales. En el abdómen, de color negro brillante, vénse en las citadas especies cuatro manchas amarillas en forma de silla de montar. Del mismo color son las delgadas patas, excepto las ancas y las puntas de los tarsos posteriores, el escudete, las escamitas de las alas, un triảngulo que hay delante de ellas, dos manchas longitudinales mins hácia abajo, y en fin, casi toda la parte, anterior de la cabeza con la cara inferior de las antenas, que son filiformes. La hembra tiene el abdómen puntiagudo; es por lo regular negro, y solo la mitad anterior del abdómen, las patas, excepto todas las ancas, y la punta del tarso de las posteriores son de un color rojo amarillento. Ias alas de ambos sexos son de este ûtimo color.

USOS, COSTUMBRES Y REGIMEN. - LOS bancos viven como parásitos en las origas de mariposa, sobre todo en las de las nocturnas; estas no llegan á convertirse en crisálidas, y en vez. de la ninfa aparece un capullo negro de gran solide\%, compuesto de seis á siete membranas sobrepuestas, à través de las cuales el insecto debe salir Iıácia afuera. Estos cajullos parecen caracteristicos para los ofiónidos, pues yo he criado de los mismos las mas diferentes especies, como por ejemplo varios del subgénero cxctastes. 


\section{LOS EXETASTES-EXETASTES}

CARACTERES، - Tambien en cSte grupo e! abdómen es inserto $y$ puntiagudo en el macho, mientras que en la hembra se ensancha un poco hácia atras y deja salir algo cl taladro. Ias garras son sencillas, los estigmatos del metatórax ovales ó circulares; la celda discoidea, relativamente mas pequeña, se continuia bastante à menudo en un pequeño tallo.

\section{LOS ANOMALONES-ANOMALON}

CARACTERES, - 1.a mayor parti de los ofónidos se camcteriza por un abdómen jedunculado que poco á pocose ensancha hácia atrás.

\section{EL ANOMALON CIRCUNFLEJO-ANOMALON CIRCUMFLEXUM}

CARACTERES. - I Aa cabera, el tórax, la punta del abdómen, las ancas $y$ en las patas posteriores la punta de los tarsos y muslos, son de color neegro, y todo el resio rojo amari. Ilo; los piés mas claros y las antenas de un pardo rojo. Caractéres gencéricos son: el escudo de la cabeza, truncado en su parte anterior, dos dientes desiguales en la extremidad de las maxilns, estigmatos ovales del metatórax y las garras scncillis.

USOS, COSTUMBKES Y REGIMEN - Esta especic y sus numerosos congéneres muy parecidos vaclan con la mayor gracia en medio del iollaje de los arboles y arbustos, particularmente en los bosques. Alli se les re alargar i cada momento sus largas patas posteriores, levantar las antenats y arquear el abdúmen ligeramente hacia abajo; de vez en cuando se posani en una hoja para recoger la niel que ha dejado un pulgon ó parn lamer una gota de lluvia volvicndo despues a elevarse, pero siempre con cicrta tranquila digni. dad. I a hembra deposita un huevo en la oruga de un gastro. jaco de los pinos y la larva p̧ue nace de este huevo vive libremente en la oruga; mide $11^{\prime \prime}, 00225$ de largo, no es mu. cho mas gruesa que una crin de caballo, tiene la cabeza córnea, de color jardo, y una cola larga. Despues se ensancha acortandose su longitud, porque la cola desaparece poco at poco. El cordon principal de los órganos respiratorios con los principios de su ramificacion demuestra entonces el pro. greso en el desarrollo. En el tercer grado de este las triqueas están del todo ramificadas, pero aun faltan los estigmatos; Katreburg cree que la cola falsiforme los sustituye. Ademais de las maxilas, ya existentes, se han desarrollado maxilas inferiores y el labio, palpos y antenas articuladis quc comple. tan las partes del insecto. Ratreburg encontró esta forma de larva cncerrada en una piel cuya presencia no ha podido explicarse En el cuarto grado, por último, la larva adquuicre el asjecto por que se reconocen otros parásitos. I a cabeza es entonces relativamente pequerha, propia mas bien para chupar, y la cola ha desaparecido. El animal parcce ocuparse enionces menos en su alinentacion que en buscar un sitio en el anfitrion, el cual mucre-lentamentc. Mientras que el parásito sufre las trasformaciones ritadas, la oruga crece, muda de piel, inverma, vuclve à mudar, fabrica un capullo que irasiorma en crisálida, en la que tambien la larva del pa: rásito adquiere csta forma, desarrollándose hasta mayo ó junio: entonces es cuando sale nuestra avispa.

Es posible que las larras de otros himenópteros que de este nrodo viven como parisitos pasen por trasformaciones análogas, ó cuando nenos, algunas observaciones de Katzeburg inducen á suponerlo asi.
Numerosas especies afines, parecen pertenecer à primera vista à una misma, à causa del ispucto evterior y del color igual del cuerpo, pues en todas partes encuntramos ofiónidos de color amarillo de barro paseándose con lns alas levantadas 6 que vuelan lemtamente, produciendo en su vuclo a veces un rumbido con las alas. Estos insectos tienen exactamente la misma forma de los anomalones, pero de un cxámen mas minucioso resulta que no solamenie son de distinta especie sino que tambien pertenecen al varios géneros.

\section{LOS OFIONES-OPHION}

CARACTÉRES.-Este grupo se distingue ficilmente de todos los ciemais ofiónidos por los nervios de las alas. Jas dos venas braquiales desembocan en la primera celda cubi. tal, porque la discoidea central no existe. Conoceremos mas tarde ejemplos en que es incompleta por la nusencia del ner. vio exterior, pero no hay otra especie en yue se observe la falta completa de esta celda. Las garras tienen la forma de peine, y el metatórax es liso, mientras que en los anomalones y otros jresenta arrugas. Las especies se distinguen por diferencias de poca importancia en los colores, que varian desde un pardo gris a un rojo amarillo sucio y por la presencin 6 ausencia de manchitas en las alas anteriores.

DISTR1BUCION GEOGRÁFICA.-Este grupo, que ha dado nombre à todo el género, está diseminndo en numero. s.s especies de igual aspecto por todos los continentes.

\section{LOS PANISCOS-PANISCUS}

CARACTER ES. - liste subgénero tiene los nervios de las alas como los de los anonsalones, pero difiere de ellos princijalmente, así como de otros subgéneros afines, por tener las garras del pié en forma de peine y los estigmatos del primer segurento abdominal delante del centro.

Es posible que algun naturalista clasifique en este grupo un trifonido (mesaleftrs testuicus), hijánduse solo en el color igual de su cuerjo.

REPRODUCCION-Si no hago mencion de todos estos ofiónidos, no es parn cvitar que se confundan entre si: es porque desco iocar un punto muy interesante de su historia de] desarrollo observado ya por Degeer yo otros. Refiérome à los huevos pedunculados que amtes cite. y que se han observado en los ofiónidos y irifónidos. Estos huevos están yen. dientes à reecs de la extremidad abdominal de la hembra, aisladanente ó en grupros compuactos; $\}$ solo me puedo explicar este fenómeno suponiendo que la hembra necesitaba depositar sus huevos, pero no encontró el objeto a que confiar. los. A menudo encontré tales huevos pedunculados en número de uno á ires en diferentes sitios, pero particularmenti cerca de la cabeza de alguma oruga desnuda de mariposa. Son de color negro brillante, bastante parecidos a las simicntes de muchas plantas, y se fijan por un ganchito en la pied de la oruga. Segun las experiencias hechas por mi, obsérnanse en el desarrollo de los hucvos dos casos esencialmente distintos. Hace algunos años quese encontre la bonita oruga del Hybucampa Milhauseri, bumbicido muy apreciado de los coleccionadores por ser muy raro: desyraciadamentc estaba picada, pues en el lado izruierdo de los segmentos anieriores habia dos huevos del aspecto descrito. Con la esperanza de llegar aun a tiempo para remediar el mal los aplasté con una pinceta, pero solo encontré las caiscaras vacias; de mocio que su contenido debia haber penetrado por lo tanto ya en el cuerpo de la oruga. A pesar de eso cuiclé la oruga dánciole un pedazo de corteza de encina para facilitarle su trasforma. cion en erisilida, que se verificaba de un modo del todo re- 
gular. Entonces formú un lecho poco profundo, de forma cliptica, encerróse en él y se cubrió lo mismo que lo hubiera hecho en libertad. Fsto sucedia á fines de verano, y en mayo del año siguiente debia presentarse la mariposa, en el caso de existir aun la posibilidad de hacerlo. Antes de llegar el tiempo, ni curiosidad me indujo à abrir el tejido, y debajo de él encontré, en vez de la crisálida de mariposa, una ninfa negra, prolongada en forma de tonel, que hacia tiempo conocia como perteneciente á un icneumónido. Algunas semanas despues nació de ella un ofiónido, el pariscrus testacers que ya dos reces antes habia criado del mismo tejido de mariposa. No puedo decir qué se habia hecho del sègundo huevo.

Un sergundo caso que quiero referir para dar a conocer otra csinecic de parasitismo, es el siguiente. A riltimos de verano recogi cierto número de orugas desnudas de una noctinia, no muy rara, de la rescria typiera. Eran aun bastante jóvenes y se alimentaban con el polygonum ariculare, yerba camun en todos los caminos. Pronto observé que algunas orugas se atrasaban en su desarrollo, micntras que las otras crecian rápidamente, y al examinarlas mas de cerca, vi que estaban juicadas y que tenian cercr de la cabeza uno ó dos de los huevos arriba descritos. Si bien habian mudado de piel; como sus companeras, no habian podido aislarse de los peligrosos apéndices. Al punto coloqué dos de estas orugas entermas, con alimento suficiente, en una cajita de carton, y observélas varias veces al dia. Cada una tenia un huevo al lado de la nuca; muy pronto se abrió esta por una hendidura longitudinal, y vióse entonces la parte anterior de una larsa En una de las orugas aquella creció, al parecer lentamente, trasformándose despues la piel en una pequeña crisalida; y de la oruga se desarrollo támbien una ninfa, pero atrofiada en ta cabeza. Desgraciadamente murió la pequeña crisalida del icneumónido. De la abservacion solo resultó que el huevo estaba picaco por otra avispa parisita, haciéndose menos danino para la oruga, cuyo desarrollo regular impedia sin embargo. Muy distintas fueron las condiciones en la segunda oruga enferna. La larva chupaba continuamente en su anfitrion, segun podia verse por los movimien. tos de las partes del cuerpo, visibles al través de la piel tras. parente, y por su rijpido desarrollo. Al cabo de ocho clias era completamente adulta y habia sacado toda la sustancia de la oruga. Entoncés comenzó á tejer, pero no llegó à construir un capullo cerrado, si bien se trasformó en crisailida descansando libremente sobre su tejido. Cuando el insecto se hubo desarrollado lo suficiente para demostrar por su color amarillo de barro y por la forma del cuerpo que pertenecja al grupo de que tratamos, murió, quizís por haberle fal. tado la humednd necesaria. Si nos fuese dado suponer que una misma especie puede vivir como parásito en un caso exteriormente $y$ en otro interiormente, considerarin el animal atrofiado como el panisco ya citado. En todo caso, las observaciones nos permiten echar una ojeada sobre el género de vida muy interesante de estos tan variados parásitos.

\section{LOS ICNEUMONES - ICHNEUMON}

CARACTERES. - Gravenhorst describió en I 829 en su Jchnermonologia earopea doscientas cuarenta y siete especiés propias de Europa y con preferencia de Alemania, y entre las que babia un número bastante crecido de un solo sexo. Wesmacl se ocupó desde $18_{44}$ en diferentes trabajos de la Academia de Bruselas, entre ellos la reunion de dos sexos en una especie, ateniéndose sobre todo á las especies del pais. El número de los géneros ý subgéneros aumentaba bastante y no menos el de las especies, á causa de nuevas averiguaciones.
En este grupo encontramos las formas mas grandes y los colores mas viros entre todos los icneumónidos: especies de un negro intenso, claro, y sobre todo azuladas, con matices de un blanco de marfil. Estos matices se hallan sobre todo en los bordes de los ojos, en la cara en general, en el colla. rin, el escudete, las escanitas de las alas, en las patas en forma de anillos, raras veces como bordes de los seginentos abdominales, $y$ con frecuencia en la extrenidad del ano. El amarillo, que tambien se encuentra, suele verse mas i menudo como faja en los segmentos, ó se extiende sobre algunos de los anteriores. En nuchas especies el abdómen tiene dos colores, rojo y negro, $\delta$ cuando el rojo es un poco mas claro se agregan algunos bordes blancos en los segmentos posteriores. Estos pocos matices producen la mayor variedad y regularmente los machos son menos abigarrados que las hembras, circunstancia que aumenta mucho la dificultad para la reunion de ambos sexos en una misna especie. Ias hembras sc reconocen facilmente como tales por las antenas filiformes ó cerdosas, un poco nudosas en los indivirluos muertos, siempre mas $\delta$ menos enroscadas $y$ solo en raros casos visibles en el estuche del taladro.

USOS Y COSTUMBRES. - Excepto algunos icneumones que invernan debajo del musgo ó en troncos de árboles pútridos, pocos se ren antes de junio. Con las alas apoyadas en el dorso vagan por el follaje de las espesuras aisladas 6 tanto mas numerosos cuando los julgones han dejado para cllos la sustancia dulce, ó cuando existen orugas á las cuales puedan conliar sus huevos. Se oye un sordo rumor cuando numerosas uspecies en compañia de otros himenópteros de Ia misma familia y sobre todo ligeras moscas, se reunen como golosos 6 manaces; $y$ es divertido observarlos a todos, los unos por su actividad, los otros por sus movimientos pesados, muchos por su atrevimiento y no pocos por su timide\% Esta es una vida singular, dificil de describir, y que debe ser vista cuando se trata de apreciarla segun merece. Ture ocasion de observarla una vez, contemplando con detencion estos pequeños séres. Era un verano seco, y todos los animales y las plantas apetecian una lluvia fertilizadora; una tempestad la trajo, y despues de ella conservironse algunos puntos hímedos y charcos entre la yerba y los zarzales de un ancho camino que en ciertos puntos cruzaba un bosque frondoso abundante en coniferas. Por este camino pasé $\frac{1}{\mathrm{a}}$ la caida de la tarde, á fin de observar un agradable espectaculo, el cual me dió à conocer una vez mas cuán indispensable es el agua tambien para estos séres, que jor lo regular nada tienen que ver con ella Miles de insectos sedientos se ha. bian reunido alli; icneumónidos grandes y pequeños, con cola y sin ella; ofiónidos y bonitas especien rel género de que. tratamos, moscas y mariposas. Todo revolotenba ó reptaba en un abigarmado caos; la fresca jerba, pero sobre todo los húmedos bordes de los charcos, ejercian un atractivo irresis. tible en todos aquellos insectos, pareciendo comunicarles un carácter pacífico, aunque son tan belicosos y en parte enemigos unos de otros. Desgraciadamente los icneumones y la tmayor parte de sus congéneres de la familia, solo se aparean de noche $\delta$ en sitios ocultos, de modo que nunca se les ha observado en este acto: al momento en que depositan sus huevos en una oruga solo se ha sorprendido raras vecus. cuando ciertas orugas existen en número exésivo.

\section{EL ICNEUMON PISORIO-IGHNEUMON PISORIUS}

CARACTERES. - El tallo abdominal de estn especie es menos ancho que alto la extremidad del abdúmen, compuesto de sicte segmentos, es puntiaguda en la hembra; la ciltima 
escama ventml se halla a cierra disiancia de la base del tala. dro; los estigmatos del metatórax son prolongados; el coselete y el escudo de la cabcza no ofrecen carácter particular. Estos son los distintivos que en union con los ja citados camctéres genéricos, sobre todo de los nervios de las alas, constituyen los del subgénero ichnemmon, segun le compren. de Vesmacl. En la especie que nos ocupa el tallo posterior presenta diversas rayas: las impresiones en la base del segundo segmento son profundas, y cuando menos tan anchas como su intervalo, cubierto de rayas; la placa supérior del centro del metatúrax as casi cuadmada, 6 cuando mas un poco redondeada en su parte anterior; las antenas de la hembra $y$ las de todos los machos se adelgazan hícia adelante en punta. El escuciete y una línea en la base de cada ala son amarillos; el abdómen de un rojo de orin pálido mate, à causa de los puntos, excepto el segmento del tallo, que es pardo. El macho ticne toda la cara y las patas amarillas; la hembra solamente los bordes de la frente $y$ de la coronilla: las jatas son negras; alrededor de las antenas hay un anillo blanco.

USOS, COSTUMBRES Y REGIMEN.-Esta especic vaga ciesde junio por los bosques merclados de coniferns. Es un insecto atrevido $y$ alegre, que vucla ligeramente, luciendo sus alas de color amarillo de vino. I a hembra deposita un huevo en las grandes orugas de esfingidos, sobre todo del gastropaco de los pinos, basiante comun en los sitios habitados por esta avispa. El parásito molesta muy poco á la oruga jicada, puresto que se desarrolla por medio de una meta. morfósis regular, cuando menos en crisilida segun parece. Solo en esta despliega el intruso toda su actividad: poco á poco la crisálida se vuclve rigida, y cuando se la abre á tiempo encuéntrase una larva marchita de color blanco amarillento, de $11^{\prime \prime}, 0,5$ de longitud. Is cada lado tiene por encima de los bordes muy protubernntes de los segmentos nueve esligmatos, los tres últimos menos desarrollados al parecer. Al cabo de quince dias despues de trasformarse ell crisilida se presenta la avispa.

\section{EL ICNEUMON FUSORIO-ICHNEUMON FUSORIUS}

CARACTERES. - Esta especic se asemeja mucho á la anterior por su género de vida, por su tamaño y el color general, solo que en ella el escudete y los bordes de los ojos se dirigen a la coronilla; a reces hay uno ó dos puntos en la base de las alas, de color blanco: los tarsos y metatarsos son rojos.

\section{EL ICNEUMON GRANDE-ICHNEUMON MAGNUS}

CARACTÉRES- Este insecto tienc el metatónx sobrepuesto de unas lineas elcvadas, dos de las cualcs forman á cada lado por su encuentro una promincncia angulosa en forma de espina. En esta especie predomina el color negro que en el abdómen tira un poco al azulado; en las antenas se ve un anillo blanco; las alas sor ahumadas, ligeramente violácens, con las nervinciones negms 6 de un negro azulado. Fiste insecto mide i) ${ }^{m}$, or S de largura total (fig: 50).

DISTRIBUCION GEOGRAFICA.-LOS individuos de esta espercie abundan princijalmente en la America septentrional.

\section{LOS AMBLITELES-AMBLYTELES}

CARACTERES.-No es dificil distinguir las hembras de este géncro de los icneumones por la extremidad del abdómen, que es mas obtusa, ! por la última cscama ventral, que casi llega á clla y se halla mucho mas cerca de la hase del taladro que en el gúncro anterior; muchas se distinguen por un brillo particular de la superficie del cuerpo y jor colores vivos; sus delgadas antenas son tambien menos anilladas que en los icneumones. Se conocen unas cuarenta especies, que casi todas por su tamaño y color pertenecen à los icneumones mas bonitos y miden por lo regular (1\%,0175, pero pueden alcanzar tambien mayor tamaño. Las numerosas especies peçuenas del género tienen casi sicmpre los colores mas monótonos, siendo el aludómen cie color negro ó rojo, y presentando el escudo de la cabem ó las ancas posteriores distintivos particulares y el metatórax estigmatos de forma circular. Wesmac! le ha distribuido en un gran número de otras subgéneros, de los cuales, sin embargo, no podemos ocuparnos.

\section{LOS FIGADEUONES-PHY- GADEUON}

CARACTERES. - El trinsiro mas natural de los icneumones à los cripidos es el géncro de los ligadeuones, compuesto en su mayor parte de avispas pequeñas y de formas recogidas. Las antenas de la hembra se componen de artejos muy cortos y nudosos, siendo el lercero mas largo; alcanza doble longitud, se cnrosea bastante y remata en punta obtusa. A veces se alargan mas y se ensanchan por delante de la puntn; si falta este carácter, la civision detallada del notatómx en placas ofrece bucnos caractéres distintivos. El taladro sobresale muy poco de la extremidad del abciómen, que es oval y pedunculado y sale de una hendidum en el vientre. En los machos se ensancha la parte posterior del sallo visiblemente, en comparacion con la parte principal del mismo. A jesin de esia igualdad de formas con los icneumones, $y$ de la analogia en la naturaleza de los nervios del ala, la distinta disposicion de los estigmatos y las antenas lisas, proco sepraradas en los artejos, tambien en el macho, constituyen una linea divisoria que no puecie desconocerse.

\section{EL FIGADEUON COMUN-PHYGADEUON PTERONORUM}

CARACTERES.- Fista especie periencec a las mas grandes y comunes, y mide de $0^{\circ}, 0065$ a $0^{\circ}, 00875$ de largo.

USOS Y COSTUMBRES.- Iis el parisito comun de las crisálidas del lofiro de los pinos. Ratzeburg habia recogido en otono un gran número de ninfas de la citada avisyn y colocólas en uma habitacion caldéada. El 24 de abril del ano siguiente aparecieron dos individuos de un juequeño criptido, del hemileles ariafor. Jos dos tejidos de que habian salido se somcticron á un examen minucioso, hallindose en ellos pri. mero el habitante legitimo, despues el lofiro, cuyas alas no estaban bien desplegadas; y por fin el figadeuon, dispuesto a volar. ¿Cómo se explicaria este caso cxtraordinario? l'ro bablemente la larva de lofiro, cuando el figadeuon la habia picado, tenia en su desarrollo una ventaja tan considerable que ya no podia impedirse su metamoriósis y perfeccionamiento. La larra del figadeuon tenia la misma ventaja cuando el hemiscles le confió su hucro, y los tres se desarrollaron del mismo modo que el primero; a los dos restantes les inliaba la fuerza para salir del tejido.

\section{LOS CRIPTOS - CRYPTUS}

CARACTÉRES.-Este généro se distingue de los icnen- 
mones por el taladro saliente de la hembra, por una celda discoidea, generalmenie cuadrangular, y por la division de los espacios del metatóras en placas, debida solo á dos rebor. des trasucrsales.

DISTRIBUCION GEOGRÁFIGA. - Se extienden por todo el globo.

\section{ELCRIPTO DE TARSOS BLANCOS-CRYPTUS TARSOLEUCUS}

Caractéres.-Esta especie es delgada y tiene, como otras muchas, algunos artejos blancos en los piés pasteriores.

USOS Y CostumBREs:- Los criptos viven como parásitos por lo regular en varios individuos juntos; en los lofiros y bombicidos.

\section{EL MESOSTENO GLADIADOR-MESOSTE-} NUS GLADIATOR

CARACTERES.-Esta avispan negra cuyo metntórax ca. rece de espinas y es muy áspero a causa de sus puntos, tiene los estigmatos ovales y se distingue de los criptos por la celda discoidea, muy pequeña y cuadrangular. Otro caràcter distintivo ofrece la punta del taladro, encorvada hàcia abajo. Ios muslos y los tarsos anteriores $y$ sus piés son rojos, $y$ a veces tambien la mitad de la base de los tarsos posteriores del macho; el segundo, tercero y cuarto artejo de los piés posteriores $y$ algunos de las antenas de la hembra son blancos.

USOS Y COSTUMBRES. - lista graciosa avispa vuela en junio; se la ve principalmente en los inuros ruinosus, 10 cual induce a suponer que vire como parásita en las avispas y abejas que habitan tales sitios.

\section{EL HEMITELO ARADOR-HEMITELES AREATOR}

CARACTERES. - Este diminuto insecto, que tiene de $0^{*}, 003.37$ a $11^{m}, 00517$ de largo, se distingue de sus numerosos y perqueños congéneres por la celda discoider pentagonal, cermda hácin afuera. Fil primer segmenio abdominal se ensancha poco á poco hasta las protuberancins nudosas y desde aqui otra vez hasta la extremidad del tallo posterior; estå cubierto de espesos puntos, lo mismo que los siguientes. La graciosa avispa se distingue además por las antenas filiformes, per tres fajas tmsversales oscuras en las alas de la hembra y dos en las del macho, por varias manchas negras sobre un fondo rojo en la cabeza, en el tórax y en el segundo segmento abdominal, $y$ por tener las patas rojas con las puntas de los tarsos blancas en las posteriores.

USOS X COSTUMBRES. - Ya hemos hecho mencion de la especie como parísita de otro parisito. Se cria de los insectos mas diferentes, de la oruga, del platypterix falcula, de orıgas de tincino, de las larvas de varios coleópteros, y por lo tanto se puede encontrar desde junio à noviembre en las ventanas en que se hallan esas larvas.

\section{LOS RISAS - RHYSSAS}

CARACTEREs.-Asi como los criptidos son avispas de cola con el abdómen pedunculado, los pimpliarios son tales con el abdómen inserto. El taladro de la hembra, que figura como cola, sobresale en ciertos géneros de una hendidura ventral, y en otros de la extremidad del abdómen, llegando alli a veces á la triple longitud de todo el cuerpo. Por este concepto, el géncro de los risas, caracterizado por el dorso del tórax cubierto de arrugas trasicrsales, es superior à todos los demás, y mayor que los otros tipos de la familia.

Sin fijarnos en algunas especies americanas, cuyas hembras tienen un taladro del grueso de una crin de caballo, de $10_{4}^{4}$ centimetros de longitud, se encuentran en nuestros bosçues de conferas algunas especies negmas con abundantes dibujos blancos y las patas de un rojo amarillo, poco inferiores en tamano is sus congéneres norte-americanos.

\section{EL RISA PERSUASORIO-RHYSSA PERSUA- SORIA}

CARAGTERES. - Esta especic, que es una de las mas grandes, tiene los camctéres del género.

USOS Y COSTUMBRES. - Vive como parásita en las larvas de los siricinos que construyen sus galerins muy en el interior de las coniferas; las hembras introducen el taladro hasta la base, es decir, a una profundidad de 6 cent. para de. positar en la madem sana su huevó en la larva que all se encuentra. Hace algunos años, en ocasion de dirigirme à la capilla de Tell, y como quisiera franquear un número de tron. cos de pino sin corteza que habian caido de la montaña, numerosas avispas de la citada especie llamaron mi atencion. Una de ellas habia penetrado con toda la longitud de su taladro; yo la cogi, sin hacer muchn fuerza, á lin de extraer cl taladro sin lesionar el resto del cuerpo; pero no lo consegui, pues los últimos segnentos del abdómen se arrancaron antes de que cl taladro hubiera salido del todo de su longitud; entonces observé que los movimientos musculares de los segmentos arrancados duraban bastante tiempo.

Nos encontramos aqui con un fenómeno, of mas bien, un enigma. Aquella cerda clástica se introduce í 6 cent. y mas de profundidad en el tronco de la madera blanda; por la misma pasa un huevo, y todo esto se repite sarias veces por parté de una misma avispa ;Cuảl no será la fuerza muscular de que disponen estos pequeños séres! Decididamente el taladro se acomoda y adajta moviéndose á derecha é izquierda en los intervalos de las fibras y los vasos de la madern, porque solo penetra muy lentamente. Fs posible que el huevo haya avanzado en el órgano casi liasia in punta antes que comience su marcha, $\delta$ cuando menos es inexplicable cómo las partes flexibles del taladro pueden ser activas aun con ta. les condiciones. ¿Cómo puede saber la hemibra de avispa que en cierto sitio del árbol hay una larva propia para depositar en ella su huevo? ¿Qué instinto la advierte que en aquella larva no haya ya depositado otro huevo de una de sus compañeras? No podemos suponer que trabaje para hacer una prueba, sino jara lograr su fin cumpliendo con sus deberes de madre. Parn todás estas pregurtas no tengo sino una contestacion: tocamos, como en tamtas otras cosas, con un secreto de la naturaleza, que quizis algun dia, 6 tal vez nuncir se descubriri. El espiritu humano ha logrado mucho y logrará mas aun, pero hasta un limite que no puede marcarse. Es mas reducido para el uno y mas extenso para el otro, pero solo el atrevido y el impertinente cree poder pasar mas allä, pues «no hay limites eternos parn él, pero si eternamente un límice.

\section{EL RISA NEGRO-RHYSSA ATRATA}

CARACTERES. - Este 3 un insecto negro (fig. 49), a excepcion de las antenas, de las patas y de la cabeza, que son amarillas; en esta última parte se cruza una fạja del mismo tinte, y á veces hay dos lineas en el escudo, $y$ un punto á cada lado de la parte posterior del protórax, unas y otros de color amarillo; las alas son ahumadas; el estigma rojizo 
en su primera mitad. Fi metatórax presenta puntos mus finos: tiene la parte posterior lisa, y en su base un surco longitudinal bastante profundo. Este insecto mide (1) o.jo de largototal.

DISTRIBUCION GEOGHÁFICA.-Fsta sipecie habita en la América septentrianal.

\section{LOS EFIALTOS-EPHIALTES}

CARACTÉRES.- Este género, muy rico en especies, tiene el dorso del mesotúna liso, unientras que por los prolongados segmentos del abdúmen, mas ö menos ásperos, por Ia relativa longitud del taladro yor el color de las putas, tiene gran semejanza con el género anterior.

\section{EL EFIALTO EMPERADOR-EPHYATES IMPERATOR}

CARACTERES. - Esta especie se distinguc dc otras muy análogas por el color, por las placas romboideas redondendas que se forman en medio de los segmentos centrales del abdómen, por los escudos de los lados, por los piés posteriores, mas largos en comparacion con sus tarsos, y en fin, for los cortos pelos del estuche del tialadro. En el cuerpo, que es negro, solo las escamitas de las alas tienen el color pardo rojo de las patas y de estas á su vez solo los piés y tarsos de las posteriores son negros. La punta de las alas, que son amarillentas, es de un pardo oscuro, y la celda discoidea triangu. lar. Todas las especies de efialtos varian mucho por la lon. gitud del cuerpo, segun el tamaño de la larva que habitaban. He tenido una hembra de i's cent. de longitud, cuyo taladro tenia casi la misma largura; ofrecia csta dimension en su estuche, pero como sale de una hendidura ventral y su basese inserta por lo tanto mas hácia delante, el taladro debe tener bastante inas longitud. El macho, siempre mas pequeño, se distingue por tener mas delgado el abdómen.

USOS Y COSTUMBK Lis. - En verano lus efialios vagan por los bosques con preferencia en los troncos de ásboles perforados por Jarvas, pues solo aqui encuentran lo que necesitan para su progenic. I a hembra examina todos los agujeros con tal atencion que pierde su timidez de modo que el observador fuede acercarse sin ahuyentarla. Cuando, por fin, ha enconirado el sitio conveniente, levanta el abdómen de modo qque el animal esté de cabeza, introduce la punta del talidro, alargrindola cuidadosamente liasta la larva, y entonces inclina el abdómen poco á poco por su punta, mientras que el esiuche está dirigido sienıpre verticalmente hácia la avispa. En tal posicion permanece la avispa lasta que el huero está juesto, y queda mientras tanto como entorpecida, porque ella mis. ma se fija. Al ano siguicnte la larva adnlta construye un ca. pullo negro y cilindrico: la avispa le rompe y por el agujero de la galeria sale cl animal que liabitaba.

He criado los machos de muchas pequenas especies de las orugas de sesia splogiformis, de la de un tincido (scardia proly pori), de l.2s protuberancins numerosas que produce la larva del saperiln populnea y además de una piñ. Toxlos viven como parísitos en las larias ocultas en la madera, segun yia lo indica el largo taladro de la hembra, pero, segun parece, al poner los.huevos siguen la cireccion de los agujeros, porque no les seri posible penetrar por el centro de los vasos de la madera muy solida de encina, como las hembras del risa en las maderas blandas. Por lo demas no difieren de estas en el génço de rida.

\section{EL PIMPILO INVESTIGADOR-PIMPLA INS- TIGATOR}

CARACTERES. - Uno da los icneumónidos mas comunes, y cuando para el desarrollo tiene alimento abundante, una de las esprecies mas gandes del géncro, propira de muestros paises, es el pimpilo investigador, insecto negro: con los tarsos lo piés de un rojo amarillo vivo en las cuatro patas anteriores, mientras que en las posteriores solo los tarsos tienen ese color. El macho se distingue por las escamitas claras de las alas y por los palpos; la hembra tiene el abdómen menos ancho, y su estuche del taladro apenas tiene la mitad de la longitud del órgano, presentando un color oscuro. Pam distinguir las numerosas especies, i menudo muy parecidas, es preciso fijar la atencion en la circunstancia de que los estigmatos del metatórax ancho y aspero son prolongados: la frente presen. ta una superficie aspera, por efecto de sus rayas trasversales; en las antenas los artejos se dilatan un poco en la punta; las garras no iienen en su base ningun apéndice lobular; el nervio arasversal interior del ala posterior forma un ángulo mu. cho mas alla de sis centro, destacindose asi un nervio longi. tudinal.

USOS, COSTUMBRES Y RÉGIMEN. - I 2 circunS. tancia de que el pimpilo investigador sea tan comun, ofreciendo notables diferencios en el tamaño, que varia de $0^{\circ}$, or I a $0^{\prime}, 019$, reconoce por causa la particularidad de que la hembra deprosita sus huevos en un gran número dc orugas de mariposas muy diferentes, que particularmente pertenecen is los bombicidos. 'lodas estas orugas, que perjudican nuestros jardines, y muchos de los destructores mas difamados de los bosques, como por cjemplo las orugas de la ocneria monja, del gastropaco de los pinos $y$ del cnetocampo procesionario le gustan y jor eso vemos a este vagabundo en codas partes Casi sicinpre se le ve pasear con las alas un poco lerantadas, por los troncos de árboles. en las cercas, en las paredes de barro, y en una palabra, en todas partes, buscando sicmpre alguna presa. Deposita su huevo en el interior de unal oruga antes de que esta eche de ver el jeligro; al momento desaparece la malhechora, y continúa su obra maligna sin que nada la detenga. "ampoco los huevos de ararins estiu al abrigo de los ataques de estas avispas.

I a diferencia esencial de los dos géneros fimpilo y ephisalte se funda en la estructura mas recogida del cuerpo de las es. pecies del primero; los segmentos abdominales son siempre mas anchos que largos, cuando menos en la hembra, y al. canzan ia longitud del abdómen.

Los pimpilos, asi como las especies del género anterior, estan diseminados por toda la vierra.

\section{LAS GLIPTAS - GLYPTA}

CARACTÉRES. - Iil abdómen es àspero como en los dos géneros anteriores, pero no à causa de los nudos, sino por dos impresiones longitudimales en el serundo a cuarro segmento.

\section{LA GLIPTA RESINOSA-GLYPTA RESINAN F:}

LAFACTERES. - I A35 secreciones resinos2s en las puntas de las ramas de los pinos jóvenes no tienen nada de pur. ticular: se las ha llamado agallas resinosas, pero sin razon, jues no se encuentra en ellas ninguma protuberancia del tijido celular vegetal, simo el ufecto de la actividad de una oruga que trabaja en la madera tierma; de esta sale el jugo resinoso y se endurece en el airc. Esta secrecion, que llega al tamaho de una nuez, se forma por varias orugas de gmcio. sas mariposas. Al recoger aquella en la yrimavera para criar el forfrix resinara, pues así se llama la especie de que aqui so trata, el natumlista se ve muy at menudo enganado. En vea. de la mariposa, preséntase la glipta resinosa, pimpilo que apenas mide $0^{\omega}, 00875$ de largo. 
En este insecto las garras del pié son sencillas; el metatórax hundido; las alas anteriores carecen de celda discoiden; el escudo de la cabeza y las patas, excepto los tarsos y los piés, son de color negro, con la base de las posteriores roja; el macho tiene los tarsos posteriores de este color y el escudo de la cabeza negro. El taladro que en todas las gliptas sale de la punta del abdómen, alcanza casi la longitud de todo el cuerpo.

USOS Y COSTUMBRES. - Fin verano esta avispita trepa por los conos de los pinos, donde no faltan los pulgones. Cuando la hembra encuentra una secrecion resinosa reciente la exaunina con roda detencion $y$ sabe encontrar muy bien la oruga oculta en ella. Esta vire dumnte todo el invierno con el gérnien de la muerte en su interior, y sulo en la primavera, cuando es adulta y se prepara para convertirse en crisálida, descubbrese el hecho. Ln vez de la crissilida negra de mariposa, se ve un tejido claro, y de este sale pronto la glipta descrita.

Hemos hablado bastante del parasitismo que en ningun ónder de insectos se desartolla tanto como en los liimenóp teros, para que se forme idea de los misterios de la vida tan interesante de estos animales. Siplo deseamos ahora que esta ojeada sea un aliciente para hacer averiguaciones mas detenidas y profundas à fin de enriqunecer mas y mas nuestros conocimientos imperfectos. Pasamos ahora á la última familia, no parasita, y que tanto por este concepto como por atros sepárase marcadamente de los otros grupos del órden.

\section{LOS HIMENÓPTEROS FITÓFAGOS}

CARACTŔRES. - La familia de los himenópteros fitó. fagos ó fitosfécidos (pizyrospheces) comprende especies que se caracterizan por tener el abdómen soldado y por el mayor nimero de celdas de las alas anteriores, entre las cuales hay una en figura de lanceta. I ans larvas se distinguen por su mayor independencia, pues en su mayoria viven libremente en las plantas, asi como en el interior de las mismas, alimén. tanse solo de sustancias yegetales. A las-larvas se reficre por lo tanto tambien el nombre de la familia; pues ya hemos dicho antes que todos los himenópteros lamen con preferencin en su estado perfecto las sustancias dulces: ninguno come hojas ó madera.

la cabeza se halla regularmente muy inmediata à la parte anterior del tórax, y está provista de ojuclos, de palpos maxilares de seis ó siete artejos y de labiales de cuatro. Las antenas no angulosas, son filiformes ó cerdosas, como se observa generalmente en todo el órden, pero hállase toda clase de formas secundarias, sobre todo como adorno en los ma. chos; se componen de nueve á once ó de tres artejos, que tienen cièta importancia en la clasificacion; cunndo hay mas no see suelen contar.

Eil tórax ocupa por término medio la tercern parte de toda la longitud del cuerpo, excepto la cabeza, y como en todos los himenúpteros está mas desarrollado en su segmento cen. tral, pero en el metatórax mucho menos que en todas las otras familias, porque no existe la parte deprimida y porque el abdúmen soldado ocupa toda la cara josterior. El dorso, muy corto, presenta d cada lado una manchita membranosa, por lo regular de color mas claro, que se llaman granitos dorsales.

El abdómen es un poco deprimido en el macho y en la mayoria de las hembras cilindrico, viéndose en su cara inferior los estuches del taladro si este no sobresale de la punta en forma de cola. Esta no aparece nunca como aguijon, sino que afecta la forma de cuchillo, de siern, de mano, lima, ctc

Las venas de las alas, solure todo en las anteriores, son dignas de atencion porgue sirven en primer lugar para distinguir los numerosos géneros. En las patas, estas avispuns tienen los dos trocánteres de los muslos comunes con todos los himenópteros sin aguijon. Las dos espinas de la extremidad de los tarsos anteriores, í veres solo una, no presentan la forma regular de tales, sino que son a veces aplanadas, mas membranosas; las plantas de los piés de muchas especies presentan dilataciones que llaman fatilas, $y$ las gamas tienen dos dientes.

Clasificacion, - Las avispas de que acabamos de hacer en general una breve descripcion, se dividian y dividen aun muchas veces en dos familias: la primera es la de los siricidos, que tienen taladro saliente, y cuyens larvas son ajyo. das, o cstán provistas de seis patas, y que abren galerias en la madera; la segunda es la de los tentredinos, que tienen el taladro oculto, y cujas larvas, provistas de varias patas, se alimentan exteriormente en las plantas. Entre los últimos figuran, sin embargo, avispas tan marcadamente distintas po: su aspecto exterior, la forma de las harvas y el género de vi. da, que tambien deberian formar una familia indenendiente. Parere por in tanto lo mas oportuno considerar a todas como una familin subdividida en tres géneros, scyun lo hacemos a continuacion.

USOS, COSTUMBRES Y REGIMEN, - De los hi。 menópteros hasta ahom observados solo las larvas de los ver. daderos cinfpidos dependen del alinento vegetal que ellos mismos buscan, pero son sére's del todo dependientes, porque viven en agallas y no pueden moverse del sitio. lin la familia que nos ocupa se encuentran igualmente larvas q̧ue, privadas de la luz, tienen cierto color de hueso, como todas lis de esta especie, pero que gozan de mas libertad, pues pueden dar á sus galerias la direccion que se les antoja. Fstas pertenecen á los siricidos, $y$ tieneu scis platas bien marcadas ó atrofiadas.

I as mas de las larvas viven libremente en las hojas, se parecen por sus colores abigarrados à las orugas de maripo. sa, con las que el hombre inexperto las confunde bastante á menudo, y alcanzan por lo tanto mas independencia que ninguna otra larva de himenóptero.

Estas orugas falsas, segun se las ha llamado, viven socirblemente y permanecen en estado de reposo enroscadas como un caracol, colocindose en la cara superior ó inferior de su planta alimenticia. Cuando comen avanzan por el borde de la hoja, rodeándole de un modo muy particular si se re. unen varios individuos. En tal caso mushos tienen la coss. tumbre de levantar la parte posterior del cuerpo, moviéndola acompasadamente hácia arriba y abajo apenas ven un compancro que lo hace. Fs muy divertido observar estos detalles, pero tambien se ve que no lo hacen para recrearse, sino jara rechazar un peligro supuesto. Basta acercarse a ceta pequeira sociedad para que al instante divisen al intruso y en seguida comiencen todas à moverse del modo indicado. dejándose caer tambien al suelo cuando se las molesta demasindo.

Fixcepto el cuarto, y á menudo tambien cl penúltino seg. mento del cuerpo, cada uno está provisto de un par de patitas cortas, de las que los tres pares anteriores, córneos en los segmentos del tórax, son articulados y tienen una garra, mientras que los otros parecen espigas carnosas ó vernugas movibles.

Por sus movimientos particulares, y por tener de veinte á veintidos patas, las orugas falsas se distinguen de las las. vas de mariposa, que cuando mas cuentan diez y seis. Su pict 
parece á primera vista desnuda, pero un exámen minucioso permite reconocer algunos escasos pelos, $y$ a menudo unas singulares puntitas espinosas, bastante espesas en muchos casos. Los colores son vivos, pero no varindos, y por lo regular se ven manchas oscuras sobre un fondo mas claro. Las orugas falsas estan provistas de ojuclos y de pequeñas anteuas; mudan varias veces la piel, y al mismo tiempo muchas cambian, no solo el color sino tambien la forma de un modo bastante esencial.

Una tercera especic, que pertenece á los tentredinos tejedores, difiere bastante por su forma y género de vida de las orugas falsas, de las cuales hablaremos despues al describir este género.

Cuando han llegado á ser adultas la mayor parte de las orugas falsas abandonan su planta alimenticia y fabrican debajo de tierra, de la liojarasca ó del musgo, asi como en los tallos de diversas plantas, un capullo pergamineo, 3 mas fino, donde pitsan el invierno y solo poco ticmpo antes del naci. miento de la avispa se trasfornan en crisílida.

Muchas llegan á sener dos crias a! año, mientras que otras necesitan uno para su metamorfósis, si no mas tienupo. Por este concepto hay. sin cmbargo tambien excepciones particuLares: asi, por ejemplo, las larvas de un hilotomo brasileño (diclocerus Ellissi) convićrtense en crisálidas sociablemente. El nido tiene la forma de un huevo prolongado de 10,5 cent. i 13 ce largo, y penden verticalmente de una rama. Cada larva tiene su celdi propia que en varias capas se sobrepone de modo que su cje trasversal coincide con el eje longitudinal de la mana y sus dos extremidades quedan libres. Todas estín encerridas por uma capa comun, sedosa en su interior. Orra excepcion se observa en la frevga Irivisii, especic de la Nueva Holanda. En abril deprositn la hembra sus huevos, de color amarillu pálido, en dos series, en el nervio central de Ia hoja de una especie de eucalipto. A los pocos dias se pre. sentan las larvitas, de color verdeoscuro, 5 comen de noche; la hembra permanece sobre los huevos y la cria, siendo ast que por lo regular la madre no existc cuando la progenie nace.

Se conocen hiasta ahora cuando menos 1,000 diferentes tipos de la samilia.

\section{EL SIREX COMUN-SIREX IUVENCUS}

CARACTERES. - Un carácter genérico muy esplecial del grupo á que pertenece esta especic es el que el protorax se divide en dos medios segmentos, los cuales pueder encajar uno en otro y de los que el uno forma el dorso y el otro el pecho del primer segmento tomícico. Ademas hay en el nietatónx dos hendiduras en format de estigmatos, y la boca rarece de palpos maxilares.

Ei abdómen remata en una esjuna anal, ya indicada en la larva, y cuntra la cual se oprime en su cara inferior cl cstuche del taladro.

I a cirada esprecic es de color azul metálico; las patas, desde los muslos, muy cortos, son de un rojo amarillo, $y$ las alas son de este último time. En estas hay dos celcins radiales, cuatro cubitales f tres discoidens. El aspecto del macho es esencialnunie discinto: Im ancho espacio al rededor dil ab. dúmen es de color pardo amarillo, y los tarsos y piés de las patas anteriores tiénen el mismo color oscuro que el cuerpo, Fil tamaño de una hembra es por término medio de (1",016 y el del macho de $0^{\circ}, 0{ }_{3}$, pero tambien tengo un individuo que alcanza casi $0^{\infty}, 022$ y una hembra de solo $0^{n}, 011$. I iferencias tan notables apenas se explican, porque la alimentacion se verifica en un mismo sitio.

Ia larvin tiene la cabeza córnea, muñones de las antenas y mavilas bien desarrolladas pero no simétricas: los ojos no existen.

USOS, COSTUMBRES Y REGIMEN.-El ; de octubre de 1857 observé esta especie en un tronco de pino a pocos piés de altura sobre el suclo; tenia el taladro negro, y el resto que sale del centro del abdómen introducido en la mis. dera descorteyada. Como las obras de historia natural indican los meses de junio y julio, ó cuando mas agosto, como periodo de la reproduccion de los siricidos, me sorprendió el fenómeno, acerquéme cuidadosamente, § pronto reconoci que icnia a la vista un cadaier bien conservado. Faltábanne los instrumentos indispensables para ver si la madre habia depositado el huevo, y no ture bastante fuerza para extmes el taladro.

La misna experiencia se ha hecho por otros naturalistas, que al cxaminar la madern no encontraron ningun huevo. Es de suponer, por lo tanto, que la hembra, cansada ya de los trabajos anteriores de la puesta, murió al cumplir sus deberes. Algunos años despues $v i$, el 7 de noviembre, una perjucin hembra muy vivaz aun, que se paseaba por un tronco de irbol cortado, y al ano siguiente, in mediados de setiembre, se presentaron las arispas en los alrededores de Halle en mayor número que nunca. El 20 del citado mes encontré en el tronco de un prino, de unos 25 años de edad, nacla menos que seis hembras, de las que cuatro tenian introducicla la mitad de su taladro en la madera. Sacarlas sin romperlas era dificil, y no pucie conseguirlo sin bastante trabajo, cogiendo el taladro mismo. Si se quisicra coger la avispa para sacar el raladro, el aludómen se romperia, segun de cllo me he convencido varias veces.

Tste esprecie y la siguiente se presentan nuchos aios en gran número, pero de las noticias que sobre este particular tenemos no resulta ninguna regularidad en ia repeticion del hecho. Fil desarrollo es igual en ambas especies y hablaremos de él despues de describir la segundia.

\section{EL SIREX GIGANTE-SIREX GIGE}

CARACTERES. - il sirex gigante 6 de los pinos tiene el atidómen amarillo, con la punta negra en el macho ó con un espacio negro detris de la base, en la hembra; la cabeza y el tórax son de un negro mate; aquella tienc las mejillas muy salientes y las anienas amarillas, 10 mismo que todas las patas (fig. 48. )

Se encuentro en las regiones donde hay pinos (pinus sicen) poique la larva habita con preierencia esta conifera.

USOS, cOSTUMBRES Y HEGIMEN. - Ambas especies se presentan mas pronto ó mas tarde, pero no es fácil verlas antes de fines de junio; y viver poco tiempo. Lixcepto los años en que abundan mucho, apenas se las ve, pues quedan bistante ocultas en los respectivos troncos ó en sus copas. Al rolar producen un fuerte zumbido que se aserneja no pocu al de un avispon. Depositan sus huevos hasta una profundiaad de is milimetros en la madera sima. Ia larva nace pronto, penctra mas adentro y practica galerias iortuosas, zanto mas anchas cuanto mas crece el animal, que al fin pue(ien tener un diámetro de $10,00.5$ : están llenas entonces de virutas y de exerementos. La larva necesita para ser adulta cuan. do menos un año, pero cambien pucden pasar varios, segun podemos deducir de algunas observaciones. La larva adulta ensancha la extremidad de su galeria como lecho para su crisálida y, segun cree Ratzeburg, practica despues desde alli un canal hasta debajo de la superficie del tronco pan facilitar á la avispa su salida. Esta opinion se funda en liecho probado respecto a las orugas de mariposias. que serian incapaces de librarse de su prision; puro csias avispas saben corroer muy 
bien, segun se ha demostrado por numerosos casos, y por lo tanto no asegurare que la larva le facilite tanto la salida de su carcel. Muchas larvas, sobre tocio del sirex gigante, llegan con la madera de pino á nuestras habitaciones, donde las personas que nunca han visto estas avispas en libertad, se asombran mucio al encontrar de repente un vecino tan extrano. Segun reñere Bechstein, en julio de 1 j98 se presentaron en la imprenta de Schnepfenthal diez dias seguidos, todas las mananas, numerosos individuos de la especie ama. rilla, que salieron del entarimado recien construido, volando por las ventanas. En ha casa de un comerciante de Schleusingen se presentaror en el mismo mes de 1843 las mismas avispas en gran numero, suliendo de las vigas por debajo del tablado colocado en el año anterior; habian tenido que per. forar por lo tanto tambien las tablas. En Jaurten, por fin, pa. a cirar otro de estos casos, que al nusmo tiempo explica mas Ia durncion del disarrollo de los siricidos, salieron en agosto de 1856 , del misno sitio que en Schlensingen, de 60 à so individuos del sinx comun; la casa contaba dos años y me. dio, $y$ las vigas habian sido expuestas algun tiempo antes al aire libre. Es posible que durante este tiempo se depositaran los huevos; de modo que pasaron unos 3 ahos hasta que las avisyas salieron. 'lambien en las minas se han importado las larvas, que como duendes de la montaña apagaron las luces de los mineros. Se sabe que perforaron hasta las hojas de plomo, además de la madera, para recobrar su libertad, pues Kollar rofiere, que en la nueva Casa de monedia de Viena la especie amarila penetró no solaménte por unas vigas de madera muy gruesas. sino zambien por lns planchas de plomo de i'6o pulgadas de espesor de una caja destinada para la conservicion de soluciones metalicas. Farias reces se habia observado ya en Xessdorf, y últimamente en Freiberg, que estos insectos habien perforado las cajas de plomo en las fa. bricas de ácido sulturico; en el segundo de dichos puntos to habia liecho el sirex comun. De estos ejemplos resulta cuár desagradables pueden llegar a ser en ciertas circunstancias esos animales qué en el árbol mismo no perjudican en modo alguno.

Además de algunas especies mas raras, propia de Europa, la América del nore alimenta otras-en parte inuy análogas.

\section{LOS XIFIDRIOS - XIPHYDRIUS}

CARACTERES.- En este segundo género de siricidos la cabeza, esférica en extremo movible, inserta en una prolongacion en forma de cuello del protóras, ticne antenas mucho mas cortas, y en la boca palpos labinles de tres a cuatro irte. jos como en el género anterior, pero tambien palpos maxilnres de cinco; la estructura del tórax es análoğa a la del género anterior.

USOS Y COSTUMBRES. - I ins especies de este grupo solo se encuentran en arboles frondosos (abedules, encinas, ảlamos $y$ otros).

\section{EL CEFO PIGMEO-CEPHUS PYGM AEUS}

CARACTERES.- LSte pequeño insecto de 3 lineas de largo, se reconoce acilmente por su cuerpo de color negro brillante, con muchas manchas amarillas; el abiómen com. primido permite ver en la hembra un corto estuche de taladro; las antenas que afectan la forma de una ligera maza, se insertan en una cabeza casi esférica. El ala anterior tiene dos celdas sadiales y cuatro cubitales; los tarsos anteriores una espina algo ganchuda en su extremidad.

USOS, COSTUMBRES Y REGIMEN.-El cefo pigmeo no se uculta à la vista de los que buscan tales animalu. chos, pues visita desde mayo las ranúnculas amarillas, la yerba de San Juan y otras fores, á lo largo de los linderos de los campos. En medio de los ardientes rayos del sol se les re volar libremente de fior en flor para libar el néctar ó examinar las plantas; cuando el ciclo está nublado mantiénense tranquilos y son perezosos. He encontrado a veces cinco ó seis individuos en un punto, de lo cual podria deducirse su grin inclinacion al apareamiento.

Por demás inofensivas parecen estas avispitas, pero sus larvas pueden llegar á ser muy rocivas para los campos de trigo y centeno, en cuyas cercanias se ve tambien à la avispa con mas seguridad. Despues del apareamiento la hembra se posa en los tallos, taladra uno de los nudos superiores y de posita un solo huevo en cada tallo. El orario contiene de doce í quince huevos, de los que cada cual exige el mismo trabajo. Al cabo de unos diez dias sale la larra y penetra en seguida en el interior del tubo. Aqui se alimenta de los fragmentos corroidos de las paredes interiores, perfora los nudos y se pasea arriba y abajo estrechada en su prision. Tienen cieru forma de $S$ cuarido se las saca del iubo, su cuerpo nudoso se adelgaza gradualmente, y entonces distinguense en el pecho unas prominencias verrugosas, pero no verdaderas patas, como por cjemulo las de ciertos coleópteros. En la cabeza, que es córnca, se reconocen unas cortas antenas, dos ojos y sólidas partes bucales. Cuancio se acerca el tiempo de la sic. ga, la oruga llega à su codad adulta, se retira a la cxtrcmidad inferior del tallo, y teje un capullo sedoso, en el cual permanece durante el invierno, aun despues de cstar los tallos cortados, y solo quince dias antes del periodo del celo se trasforma cla crisálida. Los tallos habitados por la oruga no ofrecen nada de particular, pero si las espigas, que pronto comicnzan a perder su color. Aun cuando las espigas sanas comiencen á madurar 110 distinguiéndose ya por su aspecto de las enfurmas, estas se pueden reconocer por cl tacto; al coger entre los dedos una espiga que no tiene granos en su parte inferior, se puede estar completamente seguro de descubrir al mathechor si se abre el tallo. Al mismo tiempo y en los mismos sitios se encuentra un ofiónido, el fachymernus ialcitrator, que mas tarde busca los mismos tallos para depositar su huevo en la larn del cefo.

Hay algunas especies muy semejantes en cuyo género de vida se ha fijado hasta ahora muy poco la-atencion; solo de una (cephus compressus) se sabe que como larva se alimenta de la médula de los retoños anuales de los perales.

\section{LAS LIDAS-LYDA}

CARACTERES. - I as lioias constituyen con sus numerosas especies, dificiles de distinguir, y poco conocidas por su género de vida, un segundo gruiro marcadamente separado de los otros. Yor sus largas antenas cerdosns, su cabeza inserta en un cuello y muy movible, y los nervios de las alas, son afines de los siricidos; la cabeza aplanada, dispuesta casi horizontalmente, el tórax y el abdómen igualnienie aplanados, y el último provisto de rebordes en los lados, son caractéres distintivos para estos insectos, mientras que por el taladro no saliente, y por ser la larva fitófaga, se ascmejan d los tentre. diniclos verdaderos. Por el último concepto, sin embango, no se parecen del todo, pues las larvas lienen menos patas y viven en un capullo tejido ó compuesto de hojas, como cjer. tos tineidos entre las mariposas.

\section{LA LIDA CAMPESTRE, - LYDA CAMPESTRIS}

Esta especie, no muy rara, nos servira para estudiar todas estas condiciones. 
CARACTERES.- In larva, de color verde sucio, solo tiene scis patas toracicas: las antenas largas, con siete artejos; en el ano hay un ganchito córneo, y à cada lado un apéndice de tres artejos.

El cuerpo de la avispa desarrollada es de un negro arulado, excepto la mitad mas grande del abdómen que es de un amarillo rojizo; la boca, las antenas, una mancha en los ojos, el escudete, los trocanteres, los tarsos, los piés y las alas son amarillos. Estas últimas tienen el punto aanl. Ja celda radial estri dividida en tres partes por un nervio longirudinal ahorquillado en la punta, mientras que en otras especies solo se observan dos, por faltar la horquilla. En las alas anteriores se distinguen dos celdas radiales y cuatro cubitales: la tiltima no se cierra del todo.

USOS, COSTUMBRES Y REGIMEN-La larva vive por julio en los pinos de ires as cuatro años, en los que se fija en un tejido tubiforme tabricado con sus excrementos y no trasparente; por lo regular solo saca la parte anterior del cuerpo de su capullo para comer algun cono que se lalle inmediato a su vivienda, y el cual devora desde la punta hasta la base en una hora poco mas ó menos. Cuando han desapare. cido todos los conos que estaban cerca de su nido, este se prolonga y la larva puede muy bien devorar de este modo tados los retoños de mayo de los arbolitos jơrenes. A fines de agosto ha llegado a la edad adulta, y si el verano es caluroso, antes: baja por un hilo y penetra i una profundidad de hasta $11^{m}, 013$ en la ticrm ligera; aqui prepara un tejido, $y$ con su cuerpo arquendo pasa alli el otoño y el invierno. A mediados de abril del ano siguiente se puede encontrar en cicrtas circunstancias una crisilida, pero tambien es posible quc is fines de majo la larria no se haya metamorfoseado aun, lo que alguna rez sucede tambien durante todo un ano. Al cabo de quince dias sale de la crisálida la arispa, que se mantiene bastante oculta. entre los conos. Cuando liace sol se eleva tínidamente al aire y descúbrese por un ligero zumbido de sus alas cuando una persona pasa cerca.

La hembm fecundada deposita sus huevos, cuando mas tres, en un arbolito en diterentes retorios, adhiriendolos á estos sencillamente.

\section{LA LIDA ESTRELLADA-LYDA STELLATA}

USOS X COSTUMBRES.-Esta segunda especie, nurcho mas dañina, vive tambien en los jinos: su tejido se conserva bastante trasparente.

\section{LA LIDA DE CABEZA ROJA-LYDA FEYTHRO- CEPHALA}

CARACTERES.- ISta especiese reconoce facilmente por el cuerpo, de color azul metrilico, jo por tener la cabera rojin. UsOS Y COSTUMBRES. - Su larva vive igualmente en los pinos.

\section{LA LIDA HIPOTROFICA-LYDA HYPOTRO- PHICA}

USDS Y COSTUMBRES. - Fsta especie vire sociablemente, y sucle elegir los pinos de cuince st veinte anos.

\section{LA LIDA DE LOS PERALES-LYDA PYRI}

In lida de los perales habira en estos árboles y los arbustos del espino blanco.

\section{LA LIDA DE LOS ROSALES-LYDA INANITA}

USOS X COSTUMBRES. - I a larva solitaria de esta lida construye un largo capullo con pedacitos de hojas de rosa en cujo interior se encierra.

Muchas particularidades de una ú otra especic jodrian citarse aun si el espacio lo permitier.

Todas las larvas se distinguen solo por el color y los matices, 10 mismo que por el género de vida indicado. En el sur de Europa existen, segun pareci: mas especies abignmadias que en otras regiones septentrionales, ó cuando menos he recibido algunas formas muy graciosas, que en su mayor parte tho tienen aun nombre.

\section{LOS TENTREDINIDOS-TENTHRE. DINIDE}

CARACTERES.-Foste género, mas rico en especies, esta diseminado en todas partes: de sus larnas y de su géne. ro de vida puede repetirse lo que hemos dicho arriba. I.2s avispas mismas, que en su conjunto ofrecen fomas muy jrolongadas y recogidas, tienen en gentral antenas de nueve artejos, ! algunas de tres, que en el macho presentan as menudo otra conformacion distinta de las de la hembra; por ellas y por los nervios de las alas se distinguen principalmente las numerosas tribus. El abdómen de los marhos es deprimidos: remata en un arco trasversali el de la hembra termina en punta obtusa, que en estado de reposo oculta el taladro.

Usos Y COSTUMBRES.-Muchas especies tienen dos y mas crias al ano, pero es preciso proceder con precaucion al juzgar estas condiciones à menudo mas ó menos variables por efecto de un desarrollo irregular.

\section{EL LOFIRO DE LOS PINOS-LOPHYAUS PINI}

CARACTERES. -Muy carncteristica es esta (ejpecic y su género, for las antenas de die\% y siete a veintidos artejos en las diferentes formas. Una celda radial, tres cubitales y dos espinas en la extrenuidad de los tassos anteriores son distintivos para el género, mientras que nuestra especie difiere de las muchas que hay anailogas por el gran tamaño de la lrembra, por las antenas, mas gruesas en el centrn, por la cabeza yol tónx, provisto de espesos puntos, por los nervios de las venas, que faltan en algunas partes, y por las dos espinas que hay en la cxtremidad de los tarsos de las patas posteriores. Lá cabeza, el dorso del tórax y el centro del abuómen son completamente negros, to mismo que una mancha central en el pecho, mientras que el resto presenta un armarillo de orin sucio. El macho se reconoce por su color negro, excepio las patas que son de un amarillo de orin turbio desde los trocin. teres, por el punto espeso de las alas, muy oscuro, y por tener otros iguales a los de la hembra.

USOS, COSTUMBRES Y REGIMEN. - Segun hace suponer su nombre, soló vive en los pinares, donde la larva causa á menudo considerables perjuicios. Se la visto como cubrian de tal modo lus árboles que los troncos parecian ama. rillos, $y$ se han hallado aglomernciones de estas orugas del tamaño de la cabeza de un lombre, pendientes de las ramas. Despues de haber devorado todos los conos verdes se diri. gieson a otro punto, algo distante del teatro de sus fechorias, y habiendo encontrado un riachuelo, miles y miles se reunieron en la orilla del mismo, pero como no cambiaran de direccion cayeron al agua. Todos los dias llegaban desde el interior dej bosque saqueado para encontrar alli una mucrte segura; de modo que durante este tiempo, el riachuelo no parecia llevar agua viva, sino una verdadera corriente forma. da por esos insectos moribundos. Tales fenómenos sun bas. tante comunes, nas á pesar de esto los estmgos siguen sier. do bastante considerables, aunque no tan cxorbitantes como en el caso iélerido. 
Por lo regular la oruga falsa se deja ver desde mayo, aun. que en un número muy reducido. Tiene veintidos patas, un color verde que segun la edad tim al amarillo pardo y unos matices particularmente arqueados, de color gris, como ahumado ó negro por encima de las patas anteriores. Al cabo de tres semanas, ó poco mas, llega á la edad adulta, despues de mudar cinco veces la piel, y á fines de julio sale la avispa a la luz del dia.

Inmediatamente despues de presentarse se aparea, y la hembra fecundada deposita sus huevos unos al lado de otros á lo largo del nervio central de los conos, hendidos préviamente. Acabada la puesta se cierra la hendidura por medio de una sustancia mucosa mezclada con serrim, depositindose asi de dos á veinte huevos en un cono, cuyo reborde se cierra por otros tantos nuditos de dicha sistancia. Una hembra puede depositar de ochenta a ciento veinte huevos, y lo hace siempre en conos inmediatos. Con cortos intervalos continúa el trabajo de dia y noche, $y$ solo una pronta muerte es el premio de sus esfuerzos y afanes.

Segun la temperatura, bastan de catorce á veinticuatro dins jara que nazea la larva; la duracion total de la vida del insecto es de unos tres meses. Cuanda el período del celo, bajo condiciones regulares, se presénta por primera vez en abril, por julio se producira la segunda cria, siempre mas numerosa que la anterior, y los estragos de las orugas de la primera se observan por lo tanto en mayo y junio, ași como los de la segunda en agosto y setiembre. Estas orugns tejen sus capullos debajo del musgo, pasan aquí el invierno, y al ano siguiente comienza la reproduccion. Sin embargo, no sugede sicmpre esto con la misma regularidad, sino que se han obsermdo excepciones bastante considerables de esta regla. foxtraña es la circunstancia de que las larvas de la misma és. pecie de avispas solo puedan permanecer procos dias en su tejiclo, mientras que en otros casos, jor cierto raros, están varios años.

Por lo general la oruga falsa es bastante sensible a las in. fluencias exteriores; no faltan ejemplos de que despues de una noche fresca, de una tempestad, de lluvias copiosas, etc., se hayan encontrado familins cnteras muertas, en las mas diferentes posiciones $y$ ofreciendo los mas diversos colores, ya en los conos $\delta$ debajo de los árbóles.

Tambien sufren los ataques de muchos parásitos, pues han producido hasta cuarenta especies distintas. En invierno los ratones recogen los capullos y comen la sustancia.

\section{LOS NEMATOS -NEMATUS}

CARACTERES. - Este género, cuyas especies ofrecen diferencias nuy insignificanteśá causa de la grande analogia de los colores, indeterminados á menudo, tiene una extensa área de dispersion. Se caracteriza por las antenas cerdosas de nueve artejos, que en comparacion con el pequeño cuerpo parecen á menudo bastante largas; cuéntase una celda radial y cuatro cubitales existentes en principio, que no están del todo desarrolladas, por la falta del nervio trasversal en medio de las dos primeras; la segunda de estas recoge ambos nervios braquiales.

Las larvas tienen veinte patas y se distinguen por el centro del cuerpo, de color verde azulado; las dos extremidades son amarillas con varios puntos, y la cabeza negra en una especie qque desde julio á octubre se presenta en varios sauces.

\section{EL NEMATO DE LOS SAUCES-NEMATUS SALICIS}

CARACTÉRES - Esta avispa es amarilla con manchas negras en la coronilla, en el fondo espeso de las alas, en las antenas y en el mesotórax; mide casi $0^{n}$, oro de largo.

\section{EL NEMATO ROJO AMARILLO - NEMATUS VENTRICOSUS}

CARACTÉRES. - Este tentredino, que cuando mas mide $\left(0^{\circ}, 0065\right.$ de largo, es, como su nombre lo indica, de un color amarillo rojizo; la cabeza, excepto la boca, y la cara inferior de las antenas, con tres manchas en el dorso del tórax y en la base del abdómen del macho, son de color negro, que predomina mas 6 menos tambien en el pecho; la punta de los tarsos y los piés de las patas posteriores son pardos.

La larva es de un verde sucio, amarilla en las lados del primer segmento y de los tres últimos; está cubierta de verrugas negras y de cortos pelos y provista de una cabeza negra.

USOS, COSTUMBRES Y REGIMEN.-Esta larm Se presenta dos veces al año; por primera vez en mayo y despues en julio y agosto. De algunas de e'stas orugas falsas recogidas en 22 de mayo, obtuve ya el 3 de junio dos hembras. La circunstancia de que estas últimas pueden depositar hasta ciento seinte huevos explica fácilmente la considerable pronagacion de esos insectos. Las protuberancias en forma de habichucelas de las hojas de sauce, diferentes en su estructura y extension, no son otra cosa sino productos de unas oruguitas falsas de color verde, de las cuales se desarrollan varias especies del género de que hablamos.

\section{LOS DOLEROS-DOLERUS}

CARACTERES. - Las especies de este género tienen dos celdas radiales y tres cubitales; las antenas filiformes y pesadas, compuestas de nueve artejos. 1.as dos venas bra. quiales desembocan en la celda media cubital. Las especies son por lo regular negras, á veces con manchas rojas.

USOS Y COSTUMBRES. - Se encuentran en la primavera en los tallos de yerba y flores de sauce, desde las cuales se dejan cner al suclo cuando ven que se les quiere cogrer.

\section{LOS SELANDRIAS-SELANDRIA}

CARACTERES. - Todo un cjército de especies de cuerpo corto y forma oval, à las cuales pertenece la mas pequeña de toda la familia, han constituido un grupo que se distingue por los siguientes carnctéres comunes: dos celdas radiales y cuatro cubitales, de las que la segunda y tercera recogen los nervios braquiales; las antenas casi siempre filiformes, de nueve artejos, que solo llegan á la longitud de la cabeza con el tórax: este grupo es el de los sclandrias.

Segun la naturaleza de la celda en forma de lanceta, el número de las celdas cerradas en el ala posterior y las proporciones de los artejos de las antenas, las numerosas especies se han distribuido en una serie de subgéneros.

USOS Y COSTUMBRES. - Se encuentran desde la primavera hasta el verano, casi siempre en los arbustos, donde permanecen cunndo los dias son frios, casi inmóviles, aun. que siempre dispuestos a fingirse muertos cuando alguien se les acerca; si brilla el sol son muy viraces $y$ cruzan alegre. mente su elemento.

\section{EL SELANDRIA ADUMBRADO-SELANDRIA $\triangle D U M B R A T A$}

Nos limitaremos á la descripcion de dos especies, ocupándonos en jrimer lugar del selandria adumbrado: pero ob. servaremos ante todo que no se llamia selandria alliops, co. 
mo se lee en muchos lihros, y que bajo este nombre se conyprende un tentredino negro muy afine, que en su estado de larva vive en las hojas de rosa.

El selandria adumbrado es de un negro brillante, y solo en los tarsos antcriores de un pardo pailido. Las alas ante. riores tienen un nervio trasversal en la celda de forma de lanceta, $\mathrm{j}^{\mathrm{e}}$ en las alas posteriores hay dos discoideas. Mi. de $0^{m}, 0055$ de largo por $0^{\circ}, 011$ de punta á punta de ala.

USOS, COSTUMBRES Y REGIMEN. - A principios de junio, pero tambien mas tarde, las avispitas salen de sus capullos sólidos, entretejidos con grani:os de arena, y que durante el invicrno han reposado debajo de tierra. Suhen despues al árbol $\delta$ al arhusto bajo $\mathrm{cl}$ cual han invernado, $y$ parecen préferir siempre los cerezos, perales, etc Por lo regular en julio, y tambien dumnte agosto, hallanse cn esos árboles y otros frutales larvias negras, de un color de tinta, aisladas ó reunidas en la cara posterior de las hojas, de las cuales devoran la epidermis y la parte carnosa, pero sin tocar nunca la carn inferior. Fsta adquiere muy pronto un co. lor pardo, que por fin se comunica a toda la copa del árbol habitado. Despues de mudar cuatro veces la picl, la larvin, que tiene veinte piés, es ya adulta y penetra en el suclo para crisalidarse. A causa de li irregularidad en el nacimiento de la avispa, se la puedeobservar casi tres meses sin duberse su. poner por esto dos crias.

En Alemania, Francia y Suecia, esta especic molestn á veces mucho por sus larras. En nuestras regiones se ha pro. pagado mucho en los últimos años, y à fines de vernno todos los cerezos plantados á las mảrgenes de los caminos estản llenos de sus larvas.

\section{EL SELANDRIA DE CUERNOS AMARILLOS -SELANDRTA FUIVICORNIS}

CARACTERES. - Este tentredino tiene la ceida de forma de lanceta cstrechada un cl centro: y es de color negro, con pelos amarillos, y cortos en la caberat y ell el tómx; las an. tenas son cortas, de color pardo amarillo mas ó menos rojiro, asi como las patas, excepto la hase de los inuslos de las posteriores que es negra. Esta avispa es solo un poco mas pequena que la anterior.

USOS, COSTUMBRES Y REGIMEN.-Se presentan en la estacion en que forecen los ciruelos: $\mathrm{en}$ estos árboles litan la micl y se aparean. I a hembra deposita sus huevos aisladamente en una parte del cáliz, $y$ al cabo de cinco ó seis semunas la larva cae con la fruta verde al suelo: sale por un gran agujaro lateral para pasar la noche en tierra é inverna en un capullo sólido.

la larva es de color amarillo rojo, con la cabeza amarilla; tiene veinte patas, se adelgaza hacia atris, y' despide un fuerte olor de chinche, descubriendo su presencia por una gota resinosa ó una particula de cxeremento en la cincla. Alli donde estas avispitas son mas comunes, se deben sacudir los árboles de vez. en ruando para recoger las frutas caidas y exeerminar de este modo las larvas.

Varias oruguitas falsas de color verde viven del modo mas diverso cu las hojas de los rosales ó en los retorios tiernos de los mismos, y se desarrollan en parte iambien como avispitas pertenecientes á este grupo; pero deberiamos extendemos demasiado si quisiermos hacer mencion de todas ellas.

\section{LA ATALIA DE LA COLZA-ATHALIA SPINARUM}

Fiste insecto es a menudo por su larva, sobre todo la de la segunda cria, una verdadera plaga para el agricultor, pues devora del todo las hojas tiernas de la colza en setiembre.
CARACTERES. - La avispa es de color amarillo de jema, con brillo negro en la cabeza, en las antenas, en el dorso del tórax, escepto el collarin, en el cscudete y ademis en el borde anterior de las alas anteriores; tiene las patas anillat. das de negroy de amarillo, y antenas en forma de mazn, compuesta de once artejos.

USOS, COSTUMBRES Y REGIMEN.-Se presenta en majo y apenas se la ve, porque siempre vucla aisladamente. Con frecuencia se oyen quejas respecto it la lasvia, que algunas veces, como por ejemplo en junio de 1860 , causó grnndes estrigos en los alrededores de Halle. A fines de julio y en agosto, la avispa se aparen por segunda rez, y a menudo se la ve en los troncos, por su gran abundancia en los dias de sol. Depositan sus huevos en los bordes superio. res de las hojas de la col. En setiembre y octubre, las larvis de color verde gris, rayadas de negro, llaman la atencion por los estragos que causan. Tienen veintidos patas y son à me mudo del todo neyras por la reunion de las manchas y rayas del dorso, de modo que en Inglaterra se les ha llamado migrgeer (négros) para distinguirlas de la oruga verde de una mariposa, que poco mas ó menos al mismo tiempo causa estragos en las campos. En octubre las lirras son adultas, peneiran en el suelo y fabrican un cajullo merclado con particulas de ierra, donde pasan el invierno.

Algunos otros tentredinos se parecen mucho por su color y tamano á la especie descrita, pero no pueden confundirse con ella cuando se examinan minuciosamente los nervios de las alas y la forma de las anténas; solo una especici, la atha. lin rosce, se asemeja a ella tambien por estos conreptos, pero distinguese por su menor tamano y por tener del todo negro el diorso del tómx.

\section{LOS TENTREDOS-TENTHREDO}

CARACTERES.-I.os tentredinos mas grandes pertenecen al antiguo género tenthredo que aun hoj dia compren. de muy numerosas especies, no siempre faciles de distinguir, especies en que los machos suelen diferir jor su color de las hembms, particularmente porque estas ultimas tienen a menudo el abdúmen negro, mientras que en el macho es negro y rojo. Las antenas, que son cerdosas, tienen nucre artejos, por lo regular mas largos que el abdómen, dos celdas radiales y cuatro cuhitales en las alas anteriores. Fil géncro se ha dividido en ma seric de subyéneros, segun la naturaleza de la celda en forma de lanceta.

USOS, COSTUMBRES Y REGIMEN.-LOS tiniredos son insectos tan graciosos como audaces, los únicos entre los tentredinos que i veces hacen uso de sus fuertes maxilas parm comer. La carne no es su alinento regular, jero no la des. precian, segun he podido observar varias veces.

Haré Ia descripcion de algunas espuecies fáciles de recono. cer, en las que la celda en forma de lanceta está dividida por su nervio trasversal, y que tienen dos celdas discoideas en las alas posteriores (temthredo propiamente dicho).

\section{EL TENTREDO ESCALAR - TENTHREDO SCALARIS}

CARACTERES.- Estc teniredo, de color verde claro, riene en el dorso del tórax y del abdúmen manchas mas ó menos extensas, reunidas en el último regularmente en forma de una raya central.

USOS Y COST UMBRES. - F.s bastante comun en nuestros paises, y vive en los arbustos enfermiros.

EL TENTREDO VERDE-TENTHREDO VIRIDI

CARACTERES. - Esta especie, confundida a menudo 
con In anicrior antes de que Klug purgara su tratado sobre estas avispas de muchos errores, suele ser de color negro, con ligeros matices de un verule claro.

\section{EL TENTREDO DE CUERNOS A MARILLOS- TENTHREDO FLAVICORNIS}

CARACTERES. - lass antenas, las patias y el abdómen son de color amarillo, con la punta negra en el último. Perrenece a las especies mas graciosas, y mide $0^{\mathrm{m}}, 013$ de largo.

\section{LOS MACROFIOS - MACROPHYA}

CARACTERES.- Fiste género se distingue por las ancas posteriores, tan prolongadas que casi lleygan hasta el borde posterior del tercer segmento abdominal, y con la extrenidad de sus muslos â la del abidómen.

\section{LOS ALANTOS - ALLANTUS}

CARACTERES.-Fil género de los alantos se distingue de los tentredos por tener las antenas mas cortas, poco mas largas que el tórax, insertas en un' grueso artejo basal.

\section{EL ALANTO ESCROFULARIO-ALLANTUS SCROFULART AE}

CARACTERES. - bilalanto escrotulario ticne las antenas del todo amarillas, el abdómen negro, con seis fajas amarillas estrechas; los dos escuderes de aguel color; en la cabeza hay algunas manchas del mismo tinte, asi como en el tórax; las patas son tambier amarillas, excepto las anias y muslos, que en tres lados son negros. Ia superficie de la larva tiene un aspecto gris blanco aterciopelado: el dorso es de un gris de perha à veces con una especie de polvillo verduso y blanco de leche. Cinco series longitudinales de puntas negros se corren pur el dorso. Despues de la última muda la larva adquiere un color rojo amarillo, mas oscuro en el dorso, con unos puntos negros.

USOS, coSTUMBRES Y REGIMEN, - I l lann, de $0^{*}, 006$ de largo, visita en agosto y sctiemtre las hojas de la escrofularia nudosa, en las que labra agujeros. Inverna como to:las las orugas falsas en un capullo eliptico debajo de ticrra

\section{EL HILOTOMA DE LOS ROSALES-HYLOTO- MA ROSAE}

CARACTERES.- Este gracioso insecto podria confundirse por su tamaño y color con la atalia de la colza, pero se distingue de ella esencialmente por algunos caracteres. Las alas solo tienen una celda radial provista tanto en las alas anieriores como en las posteriores de un apéndice; la celda de forma de lanceta se estrecha en el ceniro; las antenas se componen solo de ires artejos, afectando el tercero la forma de maza en la hembra, mientras que en el macho esta cubierto en la cara infurior de espuesos pelos cerdosius. Entre los caractéres genéricos cuéntanse tambien las garras, que son sencillas en todos los piés, y una espina lateral cn los tarsos posteriores.

DISTRIBUCION GEOGRÁFICA.-La especie esti diseminada descle la Suecin por toda la Europa hasta Italia y no escasea en ninguma parte, sino que todos los aficionados á las rosas conocen y odian su larva: esta tiene solo dicz y ocho patas y una longitud de 15 a $19^{6} 5$ milim. Es de color verde pardusco con manchas amarillas en el dorso, que á menudo st. reunen. Ën cadí segmento, exceptuando los tres últimos, hay seis pares de verriggas de color negro brillante y de diferente tamairo, provistas cada cual de una cer. dita. Inmediatamente despues de cada muda las verrugas anarecen como grandes vejigas grises, con muchos puntitos negros, y solo poco á poco adquieren su color y forma regulares.

Esta oruga falsa se encuentra desde julio a sctiembre en los rosales silvestres y culcisados. Para imsformarse fabrica un tejido doble, cuya capa exterior ofrece el aspecto de una red de mallas. De las larvas adultas en julio, sale in avispa en agosto; las que se desarrollan mas tarde invernan y no salen hasta el ano siguiente; de modo que se cuentan por lo tanto dos crias la hembra practica en los retoños tiernos dos scries paralelas de incisiones, destinada cada cual para un huevo. A causa de esta herida la rama se encorva en el sitio dañado y adquicre un color negro.

\section{EL HILOTOMA DEL ESPINO AGRIO- HYLOTOMA BERBERIDIS}

CARACTERES. - Esta cspecie y otras muchas son de uil color negro azulado, con las alas coloradas; la larva es abigarrada y se encuentra á veces en gran número en el espino agrio (verteris). El Brasil, la Chima y el Japon tienen sus especies particulares.

\section{LOS ESQUIZOCEROS-SCHIZOCERA}

CARACTERES. - En este género, muy afine, la celda radial carece de apéndice; el tarso posterior de la espina lateral y el tercer artejo de las antenas del macho es hendido en forma de homuilla.

\section{EL CIMBEX DE LOS ABEDULES-CIMBEX BETULA}

CARACTERES. - Esta avispa pertenece al último grupo, cuyas especies se distinguen fácilmente por la forma de maza de las antenas $y$ por las pesadas formas del cuerpo. los cim. bex, que por su estructura representan i los abejorros entre los tentredinos, tienen dos celdas ridiales, tres cufitales y una en forma de lanceta, dividida por un nervio trastersal recto. Las especies en que esta tilima se estrecha en el centro se han separado con el nombre genérico de albias. I.a cabeza, el tórax y las patas son en la especie nue nos ucupa negras, $\delta$ estain cubiertas de pelos amarillos, que sin embargo no cubren el color negro brillante de la superficic El abdómen es mas ó menos pardo rojo, y en la hembra mas claro; las antenas y el cuerpo son de un pardo amarillo ó de un amarillo puro. Las alas, claras como el agua 6 amarillentas, presentan manchas pardas al lado del punzo espeso, y turbias en el borde posterior; el macho, mas oscuro, tiene las ancas posteriores prolangadas y los muslos correspondientes muy gruesos.

Ial laven adulta tiche un color verde vivo y varias verrugas irregulares blancas, sobre todo en los lados; en el dorso hay una linea longitudinal negra cortada por delante y orilla. da de amarillo, y de este mismo color es tambien la cabeza. El numero de patas asciende á veintidos. En su juventud presenta un solo color, por efecto de una especie de escarcha blanca que la cubre.

USOS, COSTUMBRES Y REGIMEN. - Se alimenta aisladamente en los abedules y tiene la costumbre, propia de sus semcjantes, de expeler for los lados del cuerpo una 
Sustancia verdosa cuando se le toca, jero no con tanta abundancia como en otras especies. Cuando descansa de dia suele permanecer enroscada en la carn inferior de las hojas y para comer se agarma al trorde de las mismas. Ilegada i la cdad adulia, fijase en la rama de un capullo de color pardo y apergaminado en el que desde sctiembre a octubre descansa hasta majo del año siguicnte, trasiomándose en crisalida solo algunas semanas antes del periodo del celo. Ia avispa abre una tapiza y sale, aunque sea en el bolsillo de un chaleco, como cierta vez sucedió du un anigo mio que habia co.

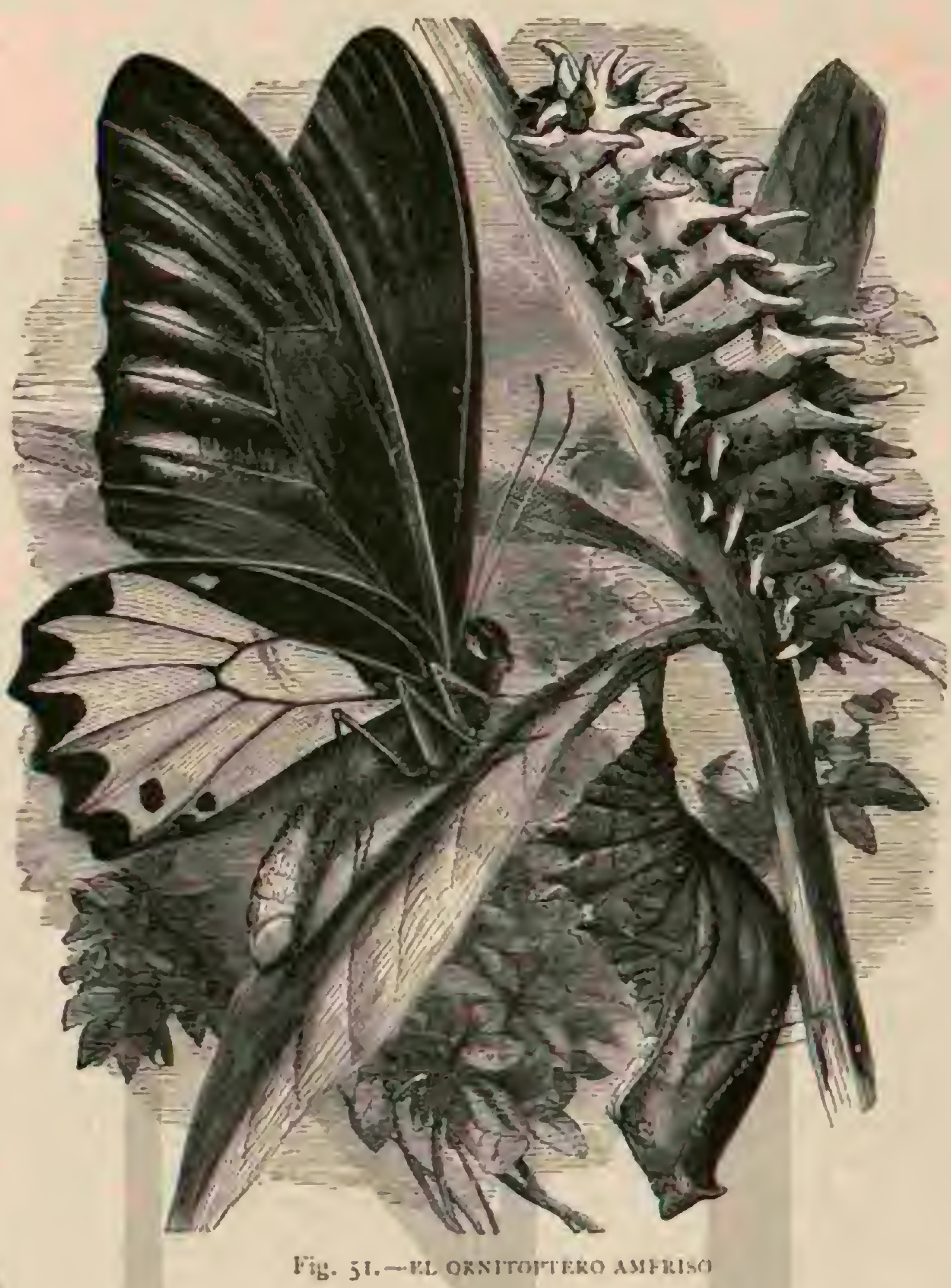

gido para mi un capullo y se le olvidó darmelo. Parece que la salicia no le cuesta mucho trabajo, pues sus maxilas son ran fuertes que pueden hacer sangre en los dedos de un nino.

Otras especies parccidas viven en los sauces, alisos y hayas. Por lo gue toca i los nombres, debo advertir que el cicntifico es nuevo, pues Klug habia reunido en su monografia de este grupo (1829), bajo el nombre de cimbicx iarialilis un gran numero de formas diferentes transitorias glie los autores precedentes habian designado, tales como cimliex. femorata, imbex sylarmus y otros. Sin cmbargo, cumo desde entonces la crin de las orugas ha demostrado que esto no se puede permitir, Zaddach ha liecho uso del nombre que acabamos de indicar.

Con esto nos despedimos de los himenópteros, no sin experimentar un sentimicito de admiracion y gratitud hacia ellos, pues hemos conocido muchos que no menos que la abeja merecen servir de modelos y simbolos de una incansable actividad, asi como de cmblema del órden mas riguro. 50. Abandoníndolos passamos al grupo que en brusco con. inste con ellos son simbolos de la ligereza j del desórden.

TERCER ORDEN

CARACTERES. - Teniendo en cuenta la impresion geneml que el aspecto cxterior de un insecto produce en el olservador, debemos clasificar despues de los himenópteros i las mariposas, esos insectos abigurndos favoritos de nuestros jóvenes maturalistas.

Tомо VI
I.os tres segmentos del tómx de estas esprecies se hallan completamente soldados; la cabeza se inserta libremente en la parte anterior de aquel, con sus anicnas rectas, siempje marcadamente visibles; al cuierpo, en general prolongado, est protegido sicmpre por una coraza quitinosa; y por tilti. 
mo, cuatro alas comunican á estos séres la facultad de aban. donar el suclo húmedo y sucio para elevarse por el ambiente perfumado, su centro habitual. 'lodo esto, pero además la aficion a la miel y a las perlas liquidas del rocio como alimento de su corta vida, y los tres grados del desarrollo, marcadimente distintos, son las condiciones que estas mariposas tienen en comun con los himenópteros. Tambien difieren de todos los demás insectos por la forma de las partes bucales y por la estructura de las alas, gracias a lo cual no es posible confundirlas con un sipo análogo de otro órden, ni siquuera cuando en casos aislados están privadas de la vida aćrea por el deterioro de las alas.

las partes bucales son chupadoras. Segun ya hemos dicho antes, la mandibula inferior, cóncava en la cara interior en cada mitad en forma de medio tubo, forma un aparato chupador ya mas largo ú corto enroscable, la liamada iengejor en. roscable, calificativo que da ciencia no puede sin cmbargo aprobar. El labio superior y las maxilas superiores consisten en tres plaquitas córneas fijas, tan pequeñas y tan ocultas bajo los tegumentos de la cara que el profano en las ciencias naturales las buscaria en vano; una puntita triangular con palpos de tres artejos en cada lado se puede reconocer sin embargo fácilmente como labio interior, debajo del apasato chupador. I.os palpos oirecen imfortantes caractéres distintiros, sobre todo en los microlepidópteros; los maxilares, en fin, existen en la major parte de especies, pero se atrofian en cortos apéndices de dos artejos, y solo en los tineinos al. canzan un desarrollo extraordinario respecto á la longitud y al número de artejos.

Las cuatro alas, de las cuales las anteriores casi sicmpre son mucho mas grandes que las posteriorcs, estan cruzadas de un modo bastante regular por varios nervios, generaimente longitudinales. Como los naturalistas modernos atribuyen gran importancia \& la direccion de los mismos, no podemos pasar del todo en silencio las proporciones mas esenciales y los nombres con que regularmente se distinguen. Del centro de la base parte la celda discoidea, que poco mas $\delta$ menos en el centro de là surperficic del ala está cernda par una vena trastersal corta que sucle arquearse ó que les angulosa, mientras que en raros casos tambienlqueda abierta. Fil nervio de la celda que la limita hácin el borde anteriot del ala se llama nervio central anterior; el corresposidiente del lado opuesto es el nervio central posterior. fistos dos nombres resultan de la disposicion en que se ponen las alas regularmente cuando se coloca la mariposa en una coleccion; segun como se dirijan hácia el cuerpo deberản llamarse respectim. mente nerio centml exterior $\delta$ interior. De ambos nervios centrales y del trasiersal parte cierto número de otros longitudinales que rematan en el borde y en el nervio exterior del alar Fstos nervios se cucentan en aquel desde el ángulo interior comenxindose por dos, sin tener en cuenta si salen separaramionte de los dos nervios centrales y del trasversal ó si dos $\delta$ mas se reunen en direccion á la base y parten de aquellas en un tallo comun. Además de los dichos hallanse en el borde interior de uno a tres nervios que salen de la base del ala y reinatan en el borde interior. Fistos se llaman nervios dorsales y llevan todos el numero I; alli donde cxisten varios se les distingue desde la base hácia la orilla ó el angulo anterior por $\mathrm{I} a, \mathrm{I} \cdot \mathrm{b}, \mathrm{l} \mathrm{c}$. En el borde exterior nace el nervio del borde anterior ó nervio costal immediatamente en la base del ala, y' al contar se le designa siempre con el número mas alto. En el ala posterior se reunc en nuchas mariposas nocturnas con el nervio central anterior, cerca de la ba. sce, á corta distancia ó hasta anquelin misma, y en este último caso parecen salir de la celda discoidea. La division no es sin embargo tan sencilla como podrin creerse, porque en el ala anterior del nervio central anterior se destacan una tras otra tres ramas, constitujendo de este modo toda clase de diferencias, yue pueden hacerse caracteristicas para muchas mariposas. En el ala posterior solo se desvian dos ramas que rematan en el borde y presentan mayor uniformidad.

las celdas formadas yor dos nervios seguidos y el pedaci. to del borde del ala en medio de ellos se designan igualmen. te con números, de modo que la celda lleva cada ver la cifra del nervio á que sigue desde el centro haicia afuera. Así, por ejemplo, una celda discoidea abierta se trasforma en la celda muy larga 4 porque se halla entre los nervios 4 y 5 .

En otros casos la citada celda csta dividida por uno 6 tam. bien por dos nervios longitudinales supernumerarios; i ve ces se ahorquilla uno de ellos en direccion del borde $y$ forma en la extremidad de la celda discoidea misma una pequena celcla triangular que llaman intercalada. "Iambien en su ángulo anterior puede formarse por la direccion particu. lar de los nervios una célula pendiente y por fin puede haber en el ala anterior, delante de la base, una gran célula secundaria.

Este es, a grandes rasgos, el esqueleto mas oculto de las alas; pero la mayor importancia para la vista y para la natu. raleza de la mariposa reside en los tegumentos. Cuando se dice que las alas de mariposa están cubiertas de un polvillo que se puede quitar, esta manera de expresarse es cuando menos muy inexacta, pues todo el mundo sabe que eso que llaman polro no es una reunion de cucrpecitos sin forma, dispuestos de cualquier mancra y muy finos, que comunican á las alas su belleza, sino unas escamitas muj delicadas de una forma regular del todo determinada. Estas se fjan ligeramente con tallitos largos 6 cortos en la membmna del ala en series ordenadas, se cubren como las tejas de un tejado y tienen en una misma ala, segun el sitio que ocupan y segun la especie de mariposa, diferente tamaño, forma, color y superficie. En el centro de la del ala suele reinar la mayor uniformidad, si exceptuamos el color, en el horde in. terior y en el exterior: las escamas se trasforman en forma. ciones pelosas ó en verdaderos pelns, lo cual sucede á menudo tambien en la cam inferior; las que rodean el borde se llaman franjas. Hay mariposas brasilenas cuyas alas no llevan ninguna escama, y tambien en Europa existe un género de bonitas mariposas en las que una gran parte del ala se conserva trasparente, mientras que las escamas de otra parte adquieren las formas mas diferentes. La disposicion de las series ofrece al lado de la diferencia del tamano, forma y co. lor de las escamas, una variedad extraordinaria, comunican. do al inimikable cuadro los majores atractivos. Ia simpre. sion al naturaly por el sistema cmpleado hasta ahom en algunas imprentas de Viena lia producido los mejores trabajos en grande escala, habiéndose aplicado hace tiempo de un inodo muy sencillo pero esencialnente distinto para liacer reproducciones de mariposas en el papel. Esie procediniento, del cual hablaremos ahora, ha demostrado que en muchisimos casos, sobre todo con las mariposas diumas, que son las mas propias para ello, el revés de las escamitas de las alas es igual à su cara superior. Esto sucede, por ejemplo, con los individuos cuyas alas adquieren diferentes colores segun les hiere da luz. Naturalmente soln pueden reproducirse las alas sobre el papjel; el cuerpo, con las paias y antenas, han de completarse con el nincel. El que quicra obtener de este modo cromos de mariposa debe proceder como sigue: Una solucion no demasiado liquida de goma arábiga muy jura, merclada con una jenuena dósis de goma tragacanta que retaja el brillo de la otra, hace las reces de liga. Extiendesc sobre el papel una ligera capa de esta solucion en la forma que poco mas ó menos ocupan las cuatro alas de 
la mariposa, pero es preciso tener preparadas las ąlas que han de imprimirse porque la sustancia se puede secar rípjo damente. Una mariposa recien cogida es mas propia para la mpresion; si es antigua debe ablandarse primero sobre arena húmeda, porque sus escanas estín mas adheridas quie en la otra. Con suma jrecaucion se comunicara despues a las alas, naturalmente sin moverlas horizontalmente, la posicion que sobre la goma deben ocupar; se deja el espacio necesario pari el tómx y el abdómen, nque deben pintarse; se coloca un pedazo de papel liso sobre las alas y se pasa la uña cuidadosamente por encima para que no puedan dislocarse, cuidando de hacerlo en todis las partes. Hecho todo esto, debe resultar, una vez levantadas las alas, la imágen de las mismas sobre el papel, sin uque haya quedado ninguma escama en la carn interior de aguellas. I as manchitas de goma que sobresalen de los bordes, y que quizas ofendan à la sista, pueden quitarse sin difisultad con agua y un pincel. Este procedimiento puede cambiarse un poco doblando el papel cuando se quicre tener la cara anterior y posterior al mismo tiempo, pero siempre se obtendra, con la atencion necesaria $y$ alguna práctica, el resultido apetecidio.

l.as alas posteriores estản provistas con bastante frecuencia de una delgada espinita ó de un copete de cerdas que encajan sobre las alas anteriores.

Para facilitar la descripcion de los dibujos, sobre todo en el ala anterior que tambien aqui represênta el papel mas importante, dividimos la superficie en tres partes principales, la de In base, la del centro y la del borde. En un gran número de mariposas esta division está marcada por dos fajas tmasversales sencillas ó compuestas, la primera de las cunles separa la parte de la boca de la del centro, y la segunda, esta parte de la del borde. 'lambien se distingue asi en los casos en que por la falta de aquellas fajas no hay limites visibles. la forma, los dibujos $y$ la disposicion de los nervios de las alas son caracteristicos para las especies, tanto como su posicion en estado de descanso. Aúemás de las partes bucales yo de las alas como distintivos característicos del órden, las otras yartes del cuerpo merecen tambien alguna atencion. En la cabeza, cubierta de pelos, ó tambien de escamas, los gran. des ojos reticulares, salientes y de forma hemisférica ocupan Ta mayor parte de la suncricie. Los ojuelos que solo existen en número de dos, se ocultast en la coronilla ó faltan del todo. lass antemas, de cuatro artejos, son en la majar parte de casos cerdosas ó filiformes, y para las mariposas diurnas, en las cuales se dilatan en forma de boton en la punta, conslituyen un caricter diistintivo, aunque tambien difieren muchas veces de esta forma. Los machos están provistos de series sencillas ó dobles de dientecitos en las antenas, y se distinguen ademís de las hembras por tener los colores inas vivos, asi como yor la forma mas delgada y sintétrica del abdómen.

Il tórax, rubierto en general de pelos verdaderos, puede tener pelos escamosos qque no permiten distinguir los tres segmentos, mas a pesar de esto, el corio protórax se indica como un collarin por dos escamins mas grandes, sus estrechos lados rematan haicia afuera y por abajo en punta, tocándose a derecha é izquierda con una escama grande $y$ triangular que cubre la base desizucia de las alas. Bastante á menudo se destaca ln cubierta del centro del dorso $y^{*}$ del collarin de la nuanera mas graciosa, formando una especie de inoño. En el abdómen, soldado cuando menos, nunca pedunculado, se cuentan de sicte ả nueve segmentos. Su forma mas pesada, que se dilata por los ovarios, permite reconocer en muchos casos á la hembra, en la que ademais se ve un largo taladro que puede extenderse cuando los huevos no se depositan tan superficialmente como sucede por to regular. De los tegumentos del abdónen prodensos decir lo mismo que dijinos del tórax; en el dorso de los segmentus anteriores del abdómen se observan igualmente moños y la extremidad remata algunas veces, sobre todo en cl macho, en graciosos coperes que ciertas especies pueden desplegar á su antojo en forma de alanico.

Aunque las patas, par sus espesos y largos pelos ocupan mayor circunferencia, debemos decir sin embargo yue son delicadas, finas y ligeramente insertas, pues la mariposa puede perder fácilmente una de ellas. Los tarsos estan provistos por lo regular de largas espinas, no solamente en lit extremidad sisso tambien en los lados; los piés, que rematan en pequeñas garras, se componen de cinco ariejos.

De este modo los tegumentos, generalunente escamosos, que cubren muy bien el cuerpo, las alas y las patas de las marjposas, contrastan con la completa desnudez $\&$ el pelo escaso de los himenópteros, exceptuando quizás algunas antófilas y heteroginas. Tambien contrasta su vida perezosa con Ia actividad, á menudo artística, de los himenópteros.

Las larvas ú orugas de las mariposas se conocen ahora de un modo mas completo que las de cualquier otro órden de insectos, porque en nada tanto como en esto se han ocupado los profanos en la materia. 'Tenemos razon para admirar las unas por su belleza y para temer las otras fyor su voracidad. Estas orugas tienen la cabeza córnea; doce segmentos carno. sos en el cuerpo, de los que los tres anteriores presentan un par de piés articulados que rematan en una punta. En la extremidad ciel cuerpo hay, con pocas excepciones, dos piés carnosos no articulados, que sobresalen hicia atrás y ajudan á la locomocion. Eintre estos últimos y aquellos se cuentan además de dos à acho piés cortos, en forma de discos, dispues. tos de manera que entre ellos y los torícicos por un lado, y. los posteriores por otro, quedian otros tantos segmentos li. bres. Una oruga puede tener de consiguiente cuando mas diez. y seis piés; pero tambien solo diez, y en casos muy raros hasta ocho; si hay mas se caracterizan conso orugas falsas de un tentredino. En la America del sur, sin embargo, cxisten, segun se dice, orugas y mariposas con veiute patas.

Alli donde solo hay un par 6 dos de pies ventrales, la locomocion es muy particular; la oruga se estira en coda su longitud, y cuando se ha fijado con la parte anterior, avanza la posterior del cucrpo, encorvando el centro en forma de lazo; coloca las patas anteriores del vientre detrís de las pos. teriores del tórax, suelta las últimas, estira la parte anterior del cuerpo y adelanta de este modo rápidamente. Estas orugas jertenecen a las llamadas geometricas. los nueve estigmas en los lados del cuerpo se reconocen fácilmente en las orugas no demasiado prequenas; solo falian en el segundo, tercero y último de los segmentos.

En las unas la piel te desnuda ó casi desnuda, pues solo se ven pelos aislados; en otras un espeso vello cubre el fondo, vello que además del color puede producir la impresion mas diferente en la vista ciel espectador, segun al espesor y la longitud de los pelos. Bastante il menudo están dispuestos en copetes que en uno if otro segmento sobresalen mucho de los otros. Además de los pelos tambien hay verrugas, espigas carnosas, sencillas ó espinosas, desnudas ó preludas, y tambien aprendices de otra clase, que podemos considerar como adornos de la superricie en general, ó como distintivos para ciertos segmentos. Ia cabeza, compuesta esencialmente de dos conchas córncas laterales, tiene las partes bucales inasticadoms del todo desarrolladas, y una abertura microseópica en el lado inferior, de la cual sale la sustancia textil desarrollada an las dos glàndulas en forma de hilos, pues casi todas las orugas pueden tejer. En el ángulo anterior de cada concha se halla un grupo de cinco á seis njuelos, y por delinte de estos, 
en cada lado una antena compuesta de pocos artejos cn forma de espigas.

USOS, COSTUMBRES Y REGIMEN.-Tambien respecto al género de vida se observan mayores diferencias de las que podrian figurarse. Las unas se hallan siempre aislat damente, porque los huevos se han depositado de este modo; las otras viven mas ó menos tiempo sociablementé con ó sin el tejido comun que habitan. Ia mayor parte permanceen sobre las hojas de las mas diferentes plantas; pocas criptóga. mas habrá en que no se encuentre cuando menos uma especie de oruga; solamente la encina tienc en nuestros paises 121 es. pecies. Cuando la oruga come sucle ponerse, por lo menos con la parte anterior del cuerpo, sobre el borde de la hoja, porque estas orugas de maripusa, tan luego como han pasado los primeros dias de su juventud, devoran las hojas solo desde el borde y no abren agujeros, como otrns muchas orugas falsas y larvas de coleoptero. De este modo es siempre fácil reconocer por el modo de estar comidas las hojas la especie que

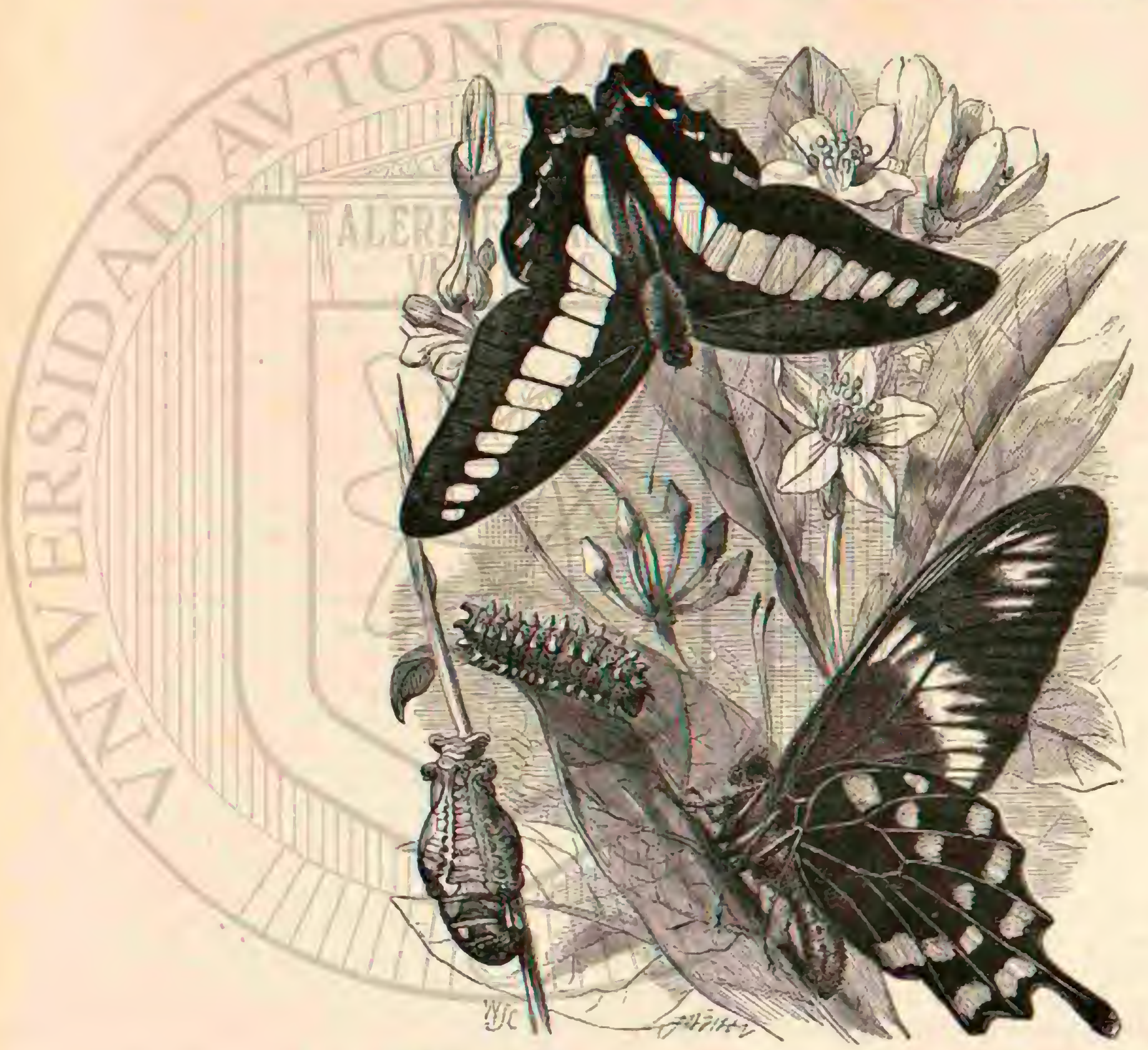

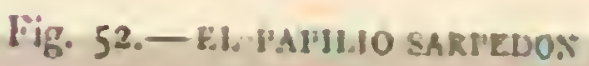

Fig. 53.-EI. PAPH1.10 IIECTOR

las mordió. Las diferencias en las costumbres se refieren por lo tanto al descanso. Unas orugas refosan er cualiquiera parte de las hojas, sea en la superior $\delta$ en la inferiori otrns abanconan la hoja y pasan á los tallos vecinos, y en los árboles at tronco, à las hendiduras de la corteza ó bien al suelo, donde se introducen à poca profundidad de la superficie, como lo hacen muchas orugas de mariposas nocturnas que comen solo en la oscuridad, en las yerbas y otras plantas bajas. Algumas se cubren con una parte del borde de la hoja ó la trasforman toda en un tubo, en el cual avanzan y retroceden con igual destreza para protegerse contra los ataques ene. migos; otras fijan dos hojas por la superficie colocindose en medio, ó fabrican una bolsa con los restos de la planta ali. menticia, en la que viven como cl caracol en su concha. Hay tambien numerosas orugas que permanecen siempre ocultas a la vista, porque viven en la madera ó en los tallos de las yerhas y temen la luz del dia. Esas orugas tienen siempre un color pálido ó blanco sucio, y cada una mina à su modo, $x \mathrm{c}$ conociéndose por esto su presencia.
Muchas orugas se consideran por el hombre del pueblo romo venenosas y se temen por lo mismo à menudo, mas que por los perjuicios que causan en las plantas de cultivo. Ninguma tiene órganos venenosos, pero en muchas los pelos ó las espigas carnosas, provistas de abundantes ramitas latemles movilies y huecas, contienen àcido fórmico muy con. centrado, y producen escozor fror lo tanto cuando se rompen las puntas. De este modo tienen, cuando menos algunas larvas, un medio defensivo, mientras que ni uma sola mariposa podria nunca đefenderse, viéndose obligada en caso de peli. gro á emprender la fuga, ó dejarse caer al suclo para fingirse muerta y engañar asś á su perseguidor.

Mudando varias veces la piel, con lo cual se efectuan mas a menudo cambios de color que de formas, las orugas se desarrollan en mas $\delta$ menos tiempo que con frecuencia se prolonga todo un invierno, $y$ una vez. maduras, trasfórman. se en crisálida. Esta última es mas abrigada que la de ningun otro insecto, pues los segmentos no solo quedan enrueltos en las delicadas membramas, que tambien vemos en 
otras partes, sino que se hallan rodeados de una capa quitinosi articulada comun i todos, pos lo cual la crisálida puede llamarse encubierta. Respirnn por los nueve estigmas que les quedan en cada lado, y de los cuales los posteriores se cierran con el tiempo; en el dorso se distinguen por lo regular nuere segmentos, es decir, tres menos de los que tenia la oruga, porg̨ue los anteriores se han soldado para constituir el futuro tórax. En los lados del vicntre se distinguen las alas, antenas, ojos y trompa, y mas ó menos marcadamente tambien las jatas. Por lo que hace al color y la forma, el primero cambia i veces con la edad; los segmentos y la figura de la extremidad asi como tambien la manera de fijarse estos insectos, ofrecen un gran número de diferencias, de las que en parte podria deducirse el género à que pertencece la futum mariposa. Asi, por ejemplo, las criślidas angu. losas de la mayor parte de las mariposas diurnas se fijan con la punta de la cola cn cualq̨uier objeto, rodean tambien con un segundo hilo su cuerpo, y quedan pendientes en sentido vertical ú horizontal. Ias crisalidas de la mayor parte de los bombicidos se encuentran en un capullo particular que fijan entre las hojas ó en las ramas; viras descansan con o sin tal capullo en el suelo. Cuancio por fin ha llegado el tiempro del desarrollo se abre la sutura que se corre por detrás de los estuches de las antenas y con ella el lado de la cara de la crisálida hasta los estuches de las alas; la superficie del tórax se hiende desde arriua longitudinalmente y la mariposa sale temprano por la mailana, cuando le agma el din "el sol, of por la tarde si despliega su actividad de noche: si solo se ha tijado permanece del todo inmóvil y descansa de los esfuer. zos que la hecho. las alas están en el dorso como un par

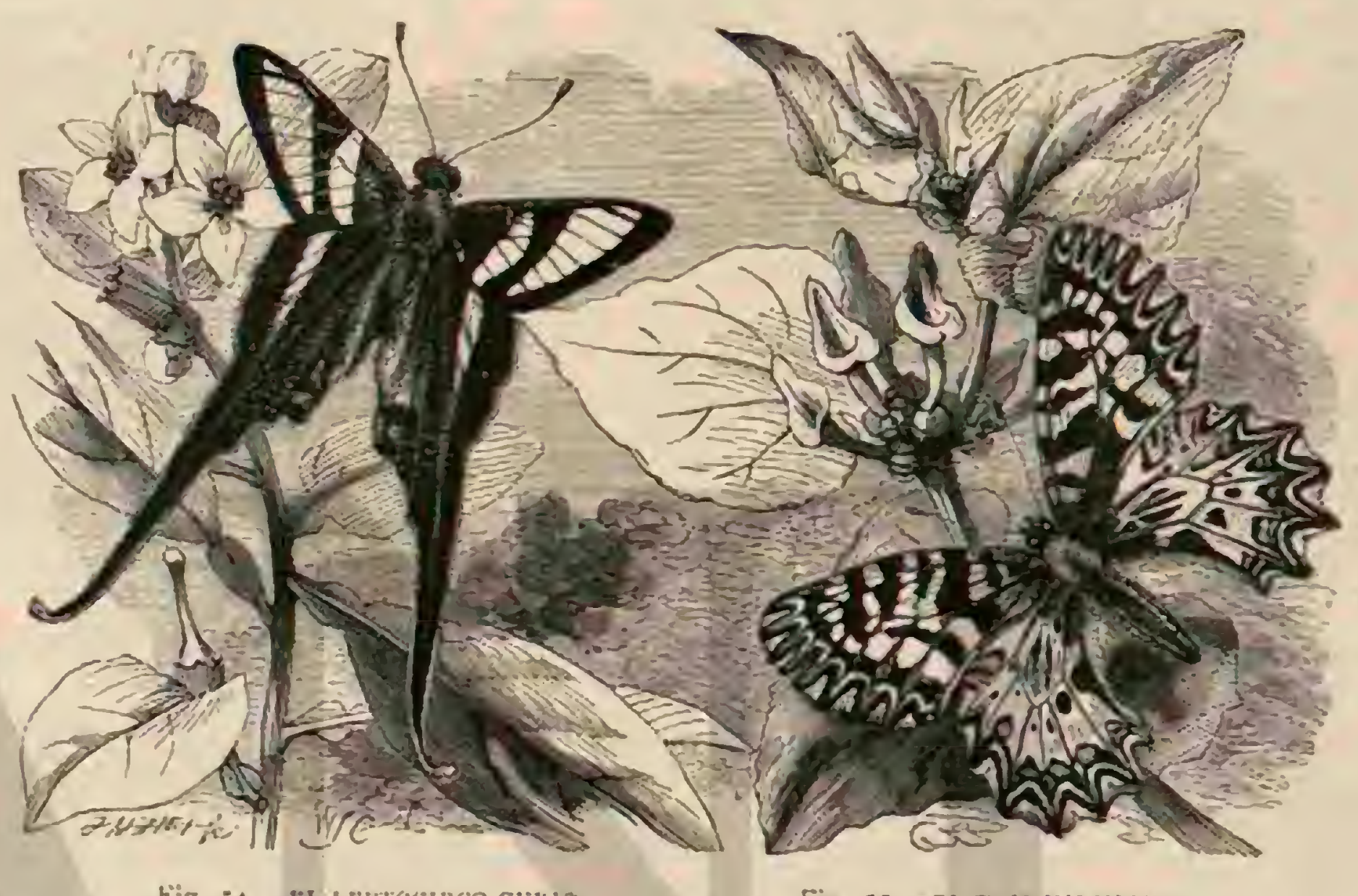

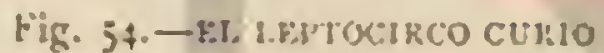

Fif. 55.-EL ThIS MII'SIMIIA

de delicados lobulios cncorvados; se juede ver cómo crecen en el espacio de media hora en las mariposas de tamano re. gular y un poco mas tiempo en las esprecies niayores. l.os dibujos existian yit marcadamente al salir la crisilida, en la que las escamas abigarradas se desarrollan muy pronto. Ias alas permanecen un corto tiempo en la misma posicion, y despues quedan colocadas de la manera propia cie la especie, reconociéndose por esto que y'a está complcto el desarrollo. Sin embargo, aun son tiernas y delgadas y solo se resecan y cndurecen con el aire. $A$ las pocas horas pueden ya funcio. nar activamente, en las pequeñas mariposas antes que en las grandes. Cuancio la mayor parte de especies, sun de las mas grandes, no llegan al cato de algunas horas a su desarrollo matural, ya no le adkivieren nunca y quedan atrofiadas.

Sapayer calcula el numero de todas las especies de mariposas en 300,000 , representadas algunas casi en todo el globo, y ufuc dependen esercialmente del reino vegetal de que

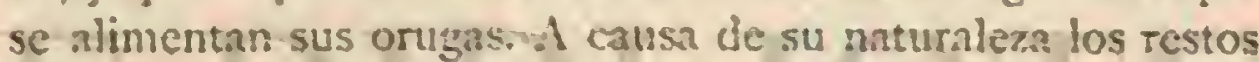
fósiles no han podido conservarse tan fícilmente comolos de otros insectus y se encuentran por lo tanto tambien mas rams veces; pero tenemos en el terreno terciario varios esfingidos bien conservados, y encersadas en el ámbar formas mas pequeñas y delicadas.

Durantc largo tiempo los naturalistas se contentaban con la division de Linneo, en mariposas diurnas, crepusculares y nocturnas, de las que solo los dos prinseros grupos forman familias naturalmente limitadas, mientros que el último se compone de las formas mas diferentes. Los esfuerzos para clasificar tambien las numerosas cspecice exćticas conocidas en el trascurso del tiempo, y para utilizar las minuciosas investigaciones sobre las cspecies de nuestros paises, hace tuempo conocidas, dieron por resultado poco í poco una serie de familias mas ó menos natural, de las que describiremos las de mayor importancia à continuacion.

\section{LAS MARIPOSAS DIUR. NAS-DIURNA}

CARACTER ES. - El primer lugar le ocupan las marjposas diurnas (diurnn, rhogalocern), el género popilio de linneo.

Un cuerpo delgado y' mquitico con débiles tegumentos, alas grandes y anchas, levantadas en estado de reposo de modo que las superficies superiores se tocan, y las antenas delgadas, mas gruesas en la punta 6 inmedianamente, por delante de la misma, constituyen en su reunion los caracte. res distintivos por que se reconocen los numerosos tipas de esta familia. Sulo en los bormbfcidos se repiten las propor. ciones de tamaño entre las alas y el cuenpo, pero las antenas obedecen á otra ley de formacion.

las marịosas diumas no tienen nunca ojuelos, carecen de cerdas prensiles en las alas postériores, tienen par lo re. gular solo dos espolones en la extremidad de los tarsos prosteriores y vuelan exclusivamente de dia. Sin embargo, no 
todas las mariposas atctivas de dia pertenecen ì esta familia. Se presentan con la misma perseverancia que distingue a los holgazanes, y sus orugas se pueden considerar como los mas insaciables destructores de las plantas. Las larvas son, sin embargo, demasiado diferentes por su estructura interna para que podamos decir de ellas en general otm cosa sino que tienen 16 patas y no les cubren espesos y largos pelos. I'odas las orugas de espima de nuestros paises pertenecen i este grupo.

Las larvas de las mariposas diurnas son de color claro, distinguiéndose por toda clase de ángulos en el dorso y por puntas en la extremidad de la coronilla; de modo que bastante á meuudo presentan por la parte anterior de su dorso la figura de una cara cxtrana. La oruga fija por medio de un ganchito la extremidad de su abdómen en - ma especie de cojin, el cual teje en una tabla, rama, tronco de ârbol, etc. se encoryá en forma de arco, despójase de la piel y se presenta chtonces como crisilida con la cabeza dirigida hícia abajó, ó bien se apoya antes en una faja que tiene al rededor del cuerpo y descansa vertical ú horizontalmente con la cara ventral sobre su lecho; en casos mas raros se encuen. tra la crisílida tambien debajo de las piedras, pero nunca se encierra en un capullo ni en un tejido ligero. Excepto al. gunas orugas que en su juventud construyen un nido que les sirve de abrigo, sobre todo para el invierno, estas larvas tienen pocas ocasiones de tejer; por lo cual los órganos que sirven à este efecto no están muy desarrollados.

Respecto al estado de desarrollo en que invernan las mariposas diurnas, resulta, segun Werneburg, que de cien especics alemanas, solo nueve invernan como huevo; poco nias ó menos el mismo número como mariposas, cincuenta y nueve cumo orugas y veintiocho como crisálidas.

Cuál es la influencia de la luz 5 del calor precisanente sobre esta familia resulta del area de dispersion y del brillo de los colores que pertenece an solo a las especies que ha. bitan las regiones expuestas a los rayos casi sicmpre verticales del sol, donde en ciertos lugares se encuentrin en agrupaciones tan considerables, que muy bien compensan la falta de ffores en la selva virgen. En latitudes septentriouales para las que el if forma el extremo limite de la existencia de las mariposas y en las montañas mas altas, cuyo limite varia para esos insectos, segun los grados de hatitud, entre $2 S \mathrm{I} 2$ y $40 \mathrm{So}$ metros, nunca suelen alcanzar dichos li. mites las mariposas diumas. Mientras que en Alemania ni siquiera se encuentran doscientas de estas estuecies, y en Europa cuatrocientas, inclusos los paises fronterizos del Asia, que por este concepto apenas pueden separarse, cerca de Pará, en el Brasil, se conocen sciscientas. Este solo cjemplo bastarí para que se reconozca la ureponderante abundancia de esos insectos en las regiones tropicales. Suponiendo cinco mil especics de mariposas diurmas no exageramos; muy léjos de ello, es posible que no lleguemos aun al número verdadero. Esta abundancia hace dificil la eleccion de las pocas especies de que podemos tratar aqui.

\section{EL ANFRISO-ORNITHOPTERA AMPHRISUS}

Se conocen unas veinte especies propias de las Molucas, Filipinas, Nueva Guinea y otras islas de aquellas aguas, que à causa de su gran tamaño Linneo designó con mucha ra7.on con el nombre de caballeros: decididamente son los gigantes de todas las mariposas diurnas.

CARACTERES. - En la cara interior de la celda dis. coidea de las alas anteriores, que son angulosas y muy grandes, y en la base de las alas postcriores solo hay un nervio dorsal. Ias antenas se cusanchan poco a poco hácia la punta y se cncorvan ligeramente por atris, adornando la cabeza, no muy grande, como de un par de varitas de ballena.

Ia especie que nos ocupa, propia de Jara, presenta en la cara superior de sus alas casi el mismo dibujo que en la ilferior; solo que alli la superficie de color pardo negruzco aterciopelado de las alas anteriores, carece de lis rayas blancas al lado de los nervios; las alas posteriores son de un amarillo dorado, orladas de un borde negro. La cabeza y el tơrax, muy desarrollado, son negros, el collarin del último de un rojo carmesi muy vivo en la nuca el abdómen de un pardo oscuro en su cara superior, y amarillo en la inferior.

la oruga, provista de uma serie de gruesas espigas carmosas, puede presentar en la nuca dos cuernos ahorquillados, que exhalan un olor desagradable y sirven al insecto como medio äefensivo. En la crisálida, los estuches de las alas son muy grandes y la forma denticulada en el dorso del abolómen y en la cabez. Su modo de fijarse tiene algo de singular, porque todos sus congéneres mas afmes se fijan verticalmente.

\section{EL PRIAMO - ORNITHOPTERA PRIAMUS}

CARACTERES. - Esta especie es mas conocida que la anterior y ofrece un aspecto muy diferente en los dos stxos. El macho tiene las alas anteriores de un negro aterciopelado, con los bordes de un verde esmeralda y las alas posteriores orilladas de verde y negro, con cuatro puntos negros y algunos de un amarillo dorado sobre el fondo rerde. Ia liembra, en cambio, tiene las alas de un pardo pailido con manchas blancas, yi nide de $0^{m}$, 0157 a $11 \%$, or $\$_{3}$. El aldómen tiene en ambós sexos un color amarillo domdo.

\section{EL PAPILIO MACAON - PAPILIO MACHAON}

CARACTERES. - En las alas anteriores de este wimbllere, muy conocido, se notan marcadamente las escamitas de man. chas y nervios negros sobre un fondo amarillo de la parte de la base y de la faja negra por delante de las manchas amarillas del borde; en las alas posteriores, que se prolongan en forma de cola, la faja correspondiente tiene manchas ansles oculares y se continúa en forma de ojo de color rojizo, con borde azul algo marcado. I a cam inferior tiene casi los mis. mos dibujos, solo que los colores son mas mates, predominando el amarillo.

DISTRIBUCION GEOGRÁFICA. - Sc extimde no solamentc por toda la Europa sino que se encuentra tairntien en el Himalaya y en el Japon.

USOS, cOSTUMBRES Y REGIMEN. - En jolio y agosto se ve a esta bonita mariposa volar lentamen:e soho los canmpos de trébol, ó libando la miel de las flores le lis praderas, de los jardines y bospues, mientras extiendes $=$ dits hori\%ontalmente 6 las cleva y cierra en parte. Si quuiere [ecdic tambien volar rapidamente y seria capa. de franqueas beras distancias en poquisimo tiempo. Fil naturalista sabe que en dicha estacion tiene á su vista la segunda cria, que es ì eas numerosa; por mayo se ve esta especie en el estado dianjalida. La hembra fecundada busca en las praderas, es las jerdines $\delta$ en los claros del bosnue diferentes umbelifert. suts codo el hinojo, anis, conino y zahanoria; deposita un toeno en cada planta y muere.

la oruga jóven es negra, con manchas blancas en è duss. y estå provista de espinas rojas, pero pronto adquier es color verde, con anillos de un negro aterciopelado, sin $=-a n$ distintivo particular en la carn superior, porcue las apinas desajarecen al fin. Cuando se la roca presenta en la wuaju espigas carnosis en forma de horquilla, sin duda parrizin:dar al impertinente, ó muere con violencia su rucme la 
crisalida, de color amarillo verdoso, ron rayas amarilias, aquillada en el dorso y tambien un poco áspera, tiene dos puntas obtusas en la cábeza. Se fija por un hilo con posicion hori\%ontal ó vertical, en cualqquiera ramita, y asi pasa el invierno, mientras que la de la primera cria se trasforma a las pocas semanas en mariposa.

\section{EL PAPILIO DE VELA-PAPILIO PADALIRIUS}

CARACTÉRES. - Sus alas de un amarilla de paja están rayadas de negro; las anteriores tienen un borde de este mismin color, asi como igualmente dos fajas enteras y tres cortadas en forma de cuna; todas tienen la extremidad que parte del borde anterior. Ias alas postcriores, provistas de larga cola, son denticuladas en el borde $y$ de color negro, con medias linas azules, presentando en el interior dos fajas anchas, con las que se toca otra roja y ademís dos muy estrechas en el centro.

Ia oruga, de color verde amarillo, vive en el espino negro: tienr: varios puntos rojos y unas lineas dorsales de color blanco amarillento, asi como otras oblicuas del mismo color en los Iados; carece de la horquilla en la nuca. La crisálida es par. da en su parte anterior y amarilla en la posterior, con anillos y puntos pardos; yor lo demás no sé distingue en cuanto á su forma ni el modo de fijarse: como sucede en las anteriores.

DISTRIBUCION GEOGRAFICA.-Fista especie, menos diseminada que la anicrior, y mas circunscrita a las regiones formadas por colinas, es propia de nuestros países, pero no se ha visto aun ni en la l'omerania ni en el Schleswig.

En los otros continentes, sobre todo en la América del sur, existen aun mas de 300 especies de estos caballeros, que se distinguen en parte por tener fajas 6 manchas negras sobre un fondo amarillo, poco mas 6 menos como las especies nuestras; otras presentan un magnifico color negro aterciopelado con series de nunchas amarillas ó fajas de color carmesi vivo 6 blancas. Muchos tienen una sola en forma de pala cn cl ala posterior: otros presentan puntas cortas y puntiagudas ó dientes obusos, ó bien les falıan estos distintivos del todo, pues de ellos no depende en modo alguno el caricter genérico. Precisamente en este órden se observan las mayores diferencias en los colores y matices y en la forma de las alas en ambos sexos de una misma especie, pero todas se ascmejan en los siguientes carnctéres: de la celda central de las anchas alas anteriores triangulares parten cuatro nervios longitudinales hacia adentro; las patas anteriores tieneu tanto desarrollo como las otras y todas rematan en una garra sencilla: y la maza de las anienas es larga y encorvada hicia arriba, con el último artejo de los palpos muy corto.

Las orugas sc rodean, antes de convertirse en crisálidas con una especic de liwo, para que la cabeza de la ninfán no quede pendiente hácia abajo. Todos estos caractéres son propios del género papilo. Solo por distintivos de poca importancia difieren de él muchos géneros cxóticos.

\section{EL PAPILIO SARPEDON-PAPILIOSARPEDON}

CARACTERES.- En esta mariposa (fig. 52) la parte supserior de las alas es negra, con una faja trasicrsal de un verde azul hastanie ancha, iglue se estrecha en sus exiremida. des, terminándose por manchas redondeadas; las inferiores tiench el borde posterior dentado obtusamente y precedido de una serie de cuatro ó cinco manchitas de un tinte verde. En la parte inferior es el color mas pailido: la faja de las segundias alas presenta en un fondo muy negro scis manchas de un rojo carmin, una de cllas trasversal, y las ofms cinco dispuestas paralelamente: el cuerpo es negro por encima y ceniciento por abajo.
DISTRIBUCION GEOGRAFICA.-Esta especic habita en China, en las Molucns, en la Nueva Guinea y en Java. Los individuns de este uiltimn punto son siempre mas peyuenos cuue los de las Molucas.

\section{EL PAPILIO HECTOR-PAPILIO HECTOR}

CARACTERES.-Las alas de esta mariposa (fig. 53) tienen un tinte azul aterciopelado; el horde josterior de las superiores presenta un feston blanco; en el centro ostenta una faja trasversal del nismo tinte compuesta de manchas bifidas; cerca de la punta hay otra semejante, pero mucho mas corta: las alas inferiores tienen dientes obtusos y una cola negra de mediana anchura, con filete blanco. Ei cuerpo es de color escarlata; en las escotaduras hay dos series de manchas de un rojo de sangre muy vivo; el tórax; el centro del pecho y la base del abdómen son negros en la parte su. perior. Conócense no obstante algunas variedades. Esta mariposa mide unas a pulgadas de punta do punta de ala.

DISTRIBUCION GEOGRÁFICA.- Esta mariposa sc encuentra en la costa de Coromandel, en Ceilan, Pegú y otros prises de Bengala

USOS Y cosTUMBRES.-Asegúrase que la crisailida frecuenta con preferencia las aristoloquias.

\section{EL LEPTOCIRCO CURIO - LEPTOCIRCUS CURIUS}

CARACTERES. - Fin esta especic las alas posteriores se prolongan de ial modo en forma de cola que apenas pucde haber orra mariposa en que se olsserve lo mismo. Ia maripo. sa pequeña, comparada con los otros caballeros, tiene las alas pardas, con una faja verdosa en el centro, muy descolorida en la hembra, asi como otra mas ancha y vidriosa que hay junto al borde del ala anterior. In posterior presenta ademas una estrechn orla de color blanco (fig. 5\%).

DISTRIBUCION GEOGHÁFICA. - Este lepidójueto es propio de Siam y de Java.

\section{EL TAIS HIPSIPILA - THAIS HYPSIPYLE}

CARACTERES.--1.a parte supyerior de las alas de estc lepidóptero (fig. 55) es de color amarillo de ocre, con una faja marginal negruzca, dividida en toda su longitud por una línea amarilla en forma de feston; las superiores ienen i lo largo del lado cinco fajas negras trasversales; las inferiores ofrecen en la base y en el centro del borde abdominal un tinte negro; en la celdilla discoidea hay una mancha negra oval, precediona por fuera de una lines arquenda de manchitas negras. Fn la parte inferior de las primeras alas predomi. na un tinte amarillo muy pálido; la primern, la tercera y la quinta fajas costales son rojas; debajo de las segundas reina un tinte blanco mate; las nerviaciones son de un leonado rojo ó anarnnjacio y en algunos individuos se ven átomos arules. El cuerpo es negruzco; el abdómen tiene à cada lado dos series de puntos amarillentos: los de la linea inferior presentan un filete blanco por detras; tambien se ve una raya ventral leonada, aunque poco aparente; las patas son pardas, guarnecidas de pelos rojos; las anienas pardas iambien, con la maza negruzca Fista mariposa nide unas 2 pulgadas de punta d punta de als.

In oruga es de un color amarillo limon, con nueve series de espinas cortas y' carnosas, de un leonado rojo, terminadas por pelos negros.

DISTRIBUCION GEOGRAFICA. - La especie habita en Austria, Hungria, la Rusia meridional, Grecia C Italia. 
USOS Y COSTUMBRES. - L A oruga vive durante el mes de agosto en las aristologuias: la crisślida, que es de un color gris terroso, pasa el invierno. El individuo perfucto sale a luz en la primavera.

\section{LOS PIERIDOS - PIERIDE}

CARAGTERES. - 1.os pieridos 6 mariposas hlanguiscas son genemalmente mas pequerias; en ellas solo parten los nervios longitudinales del borde interior de la celda discoidea del ala anterior, y dos dorsiles de la base del ala posterior, que siempre carece de cola. La celda discoidea de ambos se cierra en su parte posterior por unos nervios hi mas fuertes

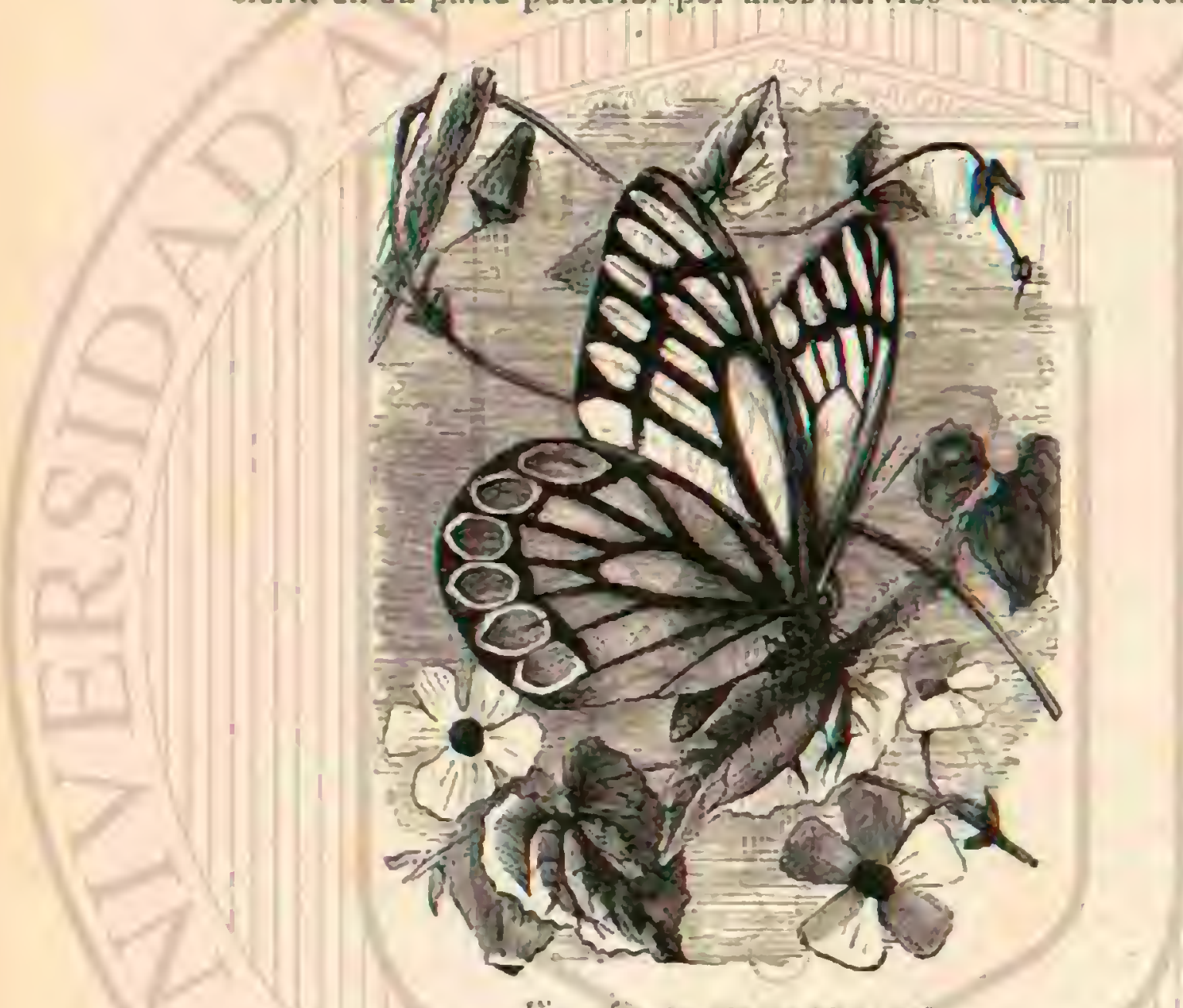

ni mas endebles que los otros. Las garras de has seis patas, de igual longitud entre si, resultan dobles por efecto de las rudimentarias.

Las crisalidas se fijan igualmente con un lazo.

\section{LOS PIERIS - PIERIS}

CARACTÉRES. - Esta forma primitiva de un grupo, se distingue por tener una corta maza cunciforme en las antenas, los palpos mas largos que la cabeza, siendo el ultimo artejo por lo regular ian prolongado como el penúltimo, y en fin, por las alas anteriores tambien angulosas y redondendas, mientras las posteriores son ovales.

DISTRIBUGION GEOGRÁFICA. - Las numerosas 25 pecies se hallan diseminádas por todos los paises del globo y perjudican en parte mucho a los agricultores y jardineros, por la voracidad de sus orugas.

\section{EL PIERIS DE LAS COLES-PIERIS BRASSICAE}

CARACTERES. - Esta especie se distingue por la punta negra de las alas anteriores y por tener una mancha del mismo color en el borde anterior de las posteriores; en las primerns la hembra tiene adenís dos manchas regras redondas, sobrepuestas detrás del centro de la superficie, y una negra confusa desde la segunda de anguellas hasta el borde interior; las alas posteriores, amarillas en la cara inferior, tie. nen escamitas de color negro y están distribuidas de un modo igual. La liembra mide 0 ",065 de punta a punta de ala.
USOS, COSTUMBRES Y RÉGIMEN.-Esta sencilla aave de verano, segun se la llama en Alemania, vaga desde julio por los campos, práderas y jardines; en estos viltimos siempre revolotea alrededor de las plantas de col cuando intenta depositar sus huevos; pero si solo busca el néctar le convienen todas las flores. Semejante a un pedacito de papel blanco, impelido por el viento, vuela sobre todo en agosto, hasta en medio de las calles y plazas de las ciudades con tal que no falten en las cercanias ventanas con tiestos de fores ó jardines que le proporcionen su alimento, asi como ocs. sion para depositar su cria. A veces se la ve mucho tiempo delante de una ventana cerrada, detrás de la cual abigarradas flores despiertan su deseo de libar el néctar. Dejemos ahora algun tiempo el jardin $y$ la huerta llena de coles, para obser. yar la alegre actividad de estos insectos, sin hacer aprecio alguno de los perjuicios quue nos causan sus orugas. Alli hay una hemlura que por sus colores desgastados demuestrn que hace tiempo ha revoloteado ya en medio de las grandes hojas. Examineinos una de estas: mas de cien huevecitos ama. rillos se hallan en la superficie oprimidos unos contra otros como una verde masa; en otras hojas se encuentran en la cara superior, tambien en menor númcro, pero siempre varios reunidos. Si observamos un huevo aislado, veremos que este puede pertenecer à la especie llamada pieris de la colza, que tambien se encuentra aqui y difiere solo de la otrn por poner los huevos aislados. En otra hoja, cerca del nervio central, se ve un gran número de orugas negras con manchas amarillas, cugo tanano demuestra su edad juvenil, mientrns que los agujeros de ha superficie de la hoja prueban que ya han satisfechó su apecito. Las orugas mas desarrolladas devoran toda la came de las hojas, dejando tan solo los nervios. Así puede suceder que en los arios en que abundan cstas mariposas encontremos los hueros, las orugas de todos tamaños, las mariposas y tambien las crisálidas juntas, caso muy raro por lo demás entre los insectos. I as crisálidas no se encuentran sin embargo en una de las plantas, pues para metamorfosearse sube la oruga á un árbol $6 \mathbf{a}$ una pared, donde mas tarde se encuentran crisálidas y orugas acupadas en trasformarse, con la cara ventral dirigida hácia la base, la cabeza hácia ar. riba, en un sitio bien resguardado, doncic toman ura posicion horizontal. Muchns orugas se encuentran tambien en calpullos amarillos (no huevos segun cree el incxperto) y no se trasiorman nunca en crisálidas, porq̨ue un pequeño icneumó. nido las pica, $y$ sus larvas tejen el lecho de muerte de la oruga: las criślidas sanas invernan y de ellas nacen en abril $\delta$ mayo del ano siguiente las mariposas, que entonces vuelan aisladamente y no llaman tanto la atencion como la segunda cria, cuy:a actividad acabamos de describir. En un verano ca. luroso, seguiclo de un agradable otono, puede haber tres crias, aunque dos constituyen la regla, pues las orugas crecen rápidamente y pasan muy bien por sus cuatro mudas si no hay mucha humedad.

El agricultor tiene una idea de la multitud en que existen à veces estas mariposas y puede calcular mejor su número por el daño que le causan las orugas. Esta idea, sin embargo, no es aun bastante exacta, segun se ve por algunas noti. cias contenidas en las obras entomologicas. Dohrn nos liabla de un incidente ocurrido en el ferro-carril, el cual presencio en $\$_{54}$ entre Brum y Praga El tren acabala de pasar por un pequeño túnel cuando de repjente su marcha disminuyo en rapidez de una manera extraña, sin que se viern ninguna estacion; poco despues el tren se paró del todo. Natumlmente todo el mundo miró por las ventanas; algunos viajeros ta. jaron, y entre ellos tambien el naturalista para preguntar a
los enjpleados, que examinaban con atencion las ruedas de la maiguma. Entonces ví, continúa cl autor, la causa tan 
inesperada como increible de la paralizacion de un tren en plena marcha. Lo que un elefante, un buíalo, no lograrian, excepto quizas el caso en que su cadảitr destrozado hiciera descarrilar el tren, esto lo habia hecho la oruga de nuestra mariposa. En el lado izquierdo de los rajls habia algunos campos, y por los esqueletos de las plantas de col reconociase de un modo bastante marcado la actividad de dichas orugas. Como a cierta distancia; a la derecha de los rails, se extendian algumos campos de coles cuyas plantas conserva. ban aun todas sus hojas, las orugas habian resuclto sin duda poco antes, en un conciliabulo, en virtud del ntincipio usi besc ibi patria, abandonar el campanento de la i\%ulerda de los rails y trasladarse al de la derecha. A consecuencia de esto los mils estaban cubiertos a mas de 200 piés de largo de una espesa capa de orugas cuando el tren llegó con toda su rapidez. En natural que en el primer espacio que ocupaban los desgraciados viajeros quedaran aplastados por las torpes ruedas de la mápuina en un segundo, pero la masa de

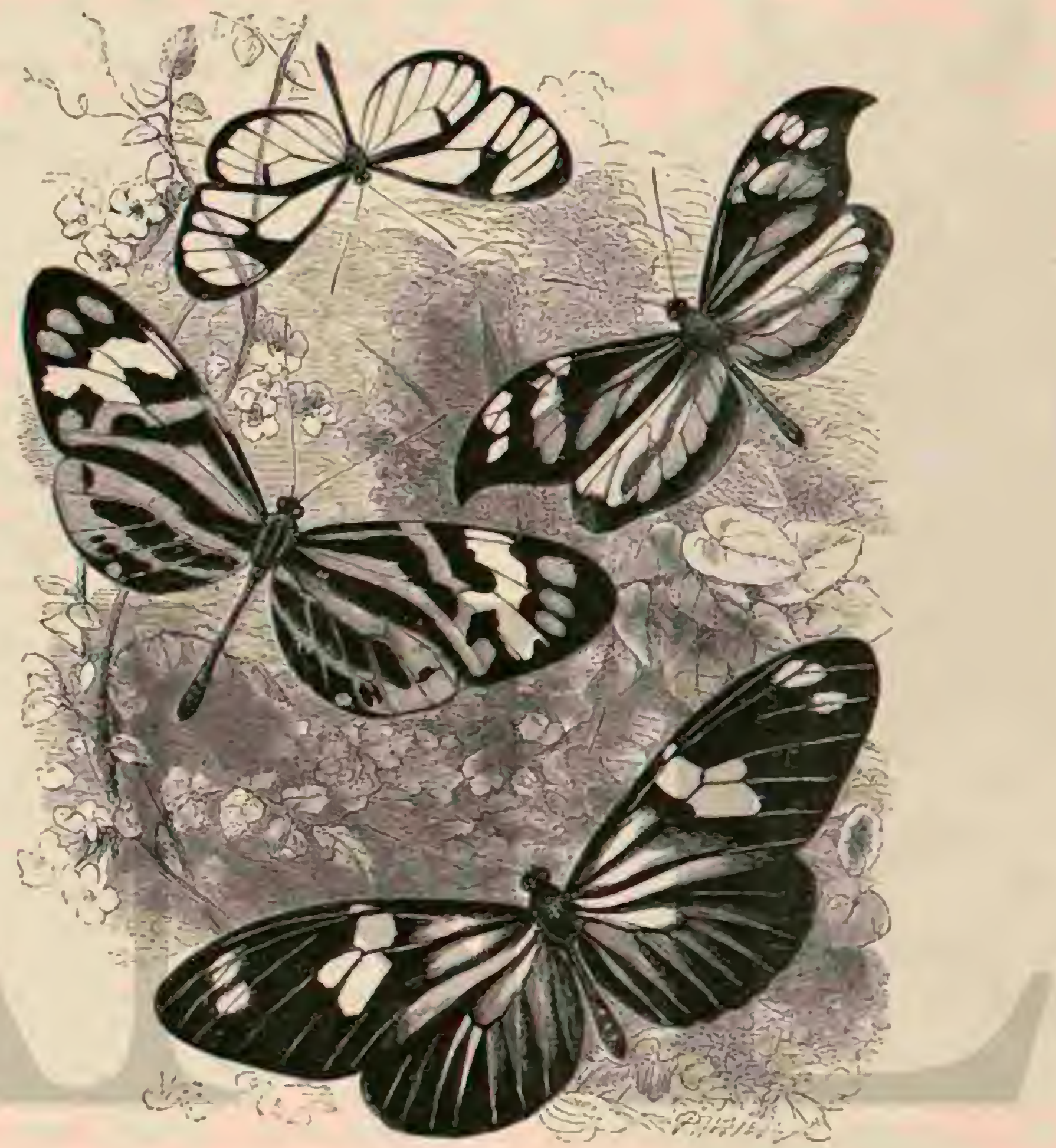

Fig. 58.-1:2.1TOMIA TKASBAKE.NIK

Fig. 57.-E1. MF.CANito MarRSEO

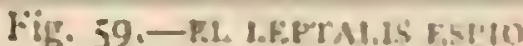

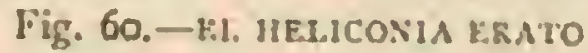

Ios miles de pequeños cuernos grasosos se adhirio de tal modo à las ruedas, yue un momento despues con dificaltad icnian bastante roce pan avanzar, y como a cada paso las rucdas se llenabiun de mas grasa, negaronse al fin i funcionar antes de llegar al fin de la columna de larvas. Pasaron mas de diez. minutos antes de quue con escobas se limpiaran los rails por delante de la locomotora, y con trapas de lana las ruedas de ésta y de los coches, lo bastante para que el tren pudiera poncrse otm vez en marcha . A fines del vera. no de r\$.4 se observó cerca de Dover uma innsensa bandada de pieridos que segun se decia habian venido de Alemania. Igual cjército probablemente de las mismas especies vió el pastor protestante Kopp el 26 de julio de 177 i las tres de la tarde cerca de Culmbach. Las mariposas volaron en tal nimero que se las veia por doq̨uiera que se dirigia la vista. Pa. saron algunas horas anies de que esta bandada se irasladase desde el Nordeste al Sudoeste: la temperatura era calurosa y reinaba calma T'ales bandadas se han observado igualmente en otras partes, $y$ hasta en el verano de $1 \$-6$, sin que se sepa cuatl es la causa jue las produce.

\section{EL PIERIS DE LA COLZA - PIERIS RAP}

CARACTERES - Ia hemos dicho que el pieris de la colza es un fiel companero de la especic anterior. Mide por término medio (1),0 5 de punta \& punta de ala y se parece mucho por su color á su congénere anterior, solo que el negro de la punta de las alas anteriores es mas mate y me. nos extenso; la manclia negra borrada en el borde intcrior falta por lo regular un la hembra: pero el macho tiene una del mismo color en la cara superior de las ains citadas. La crisilida ofrece la forma de la de la especie anterior; de rolor verde ó gris verdoso con puntos negros y tres lineas longitudinales anuarillas mas ó menos marcadas. la oruga 
se distingue esencialmente por su color verde sucio, un poco aterciopelado á causa de los espesos pelos, y presenta en el dorso ye con los lados unas lincas amarillas á reces un poco interrumpidas jas laterales corren á lo largo de los estigmas orillacios de negro.

USOS, COSTUMBRES Y RÉGIMEN. - Come las mis. mas plantas que la anterior, pero tambien ataca la reseda odorifica. Aunque para metamorfosearse lo mismo que el pie. ris de la col busca utros sitios, se la puede encontrar á me.

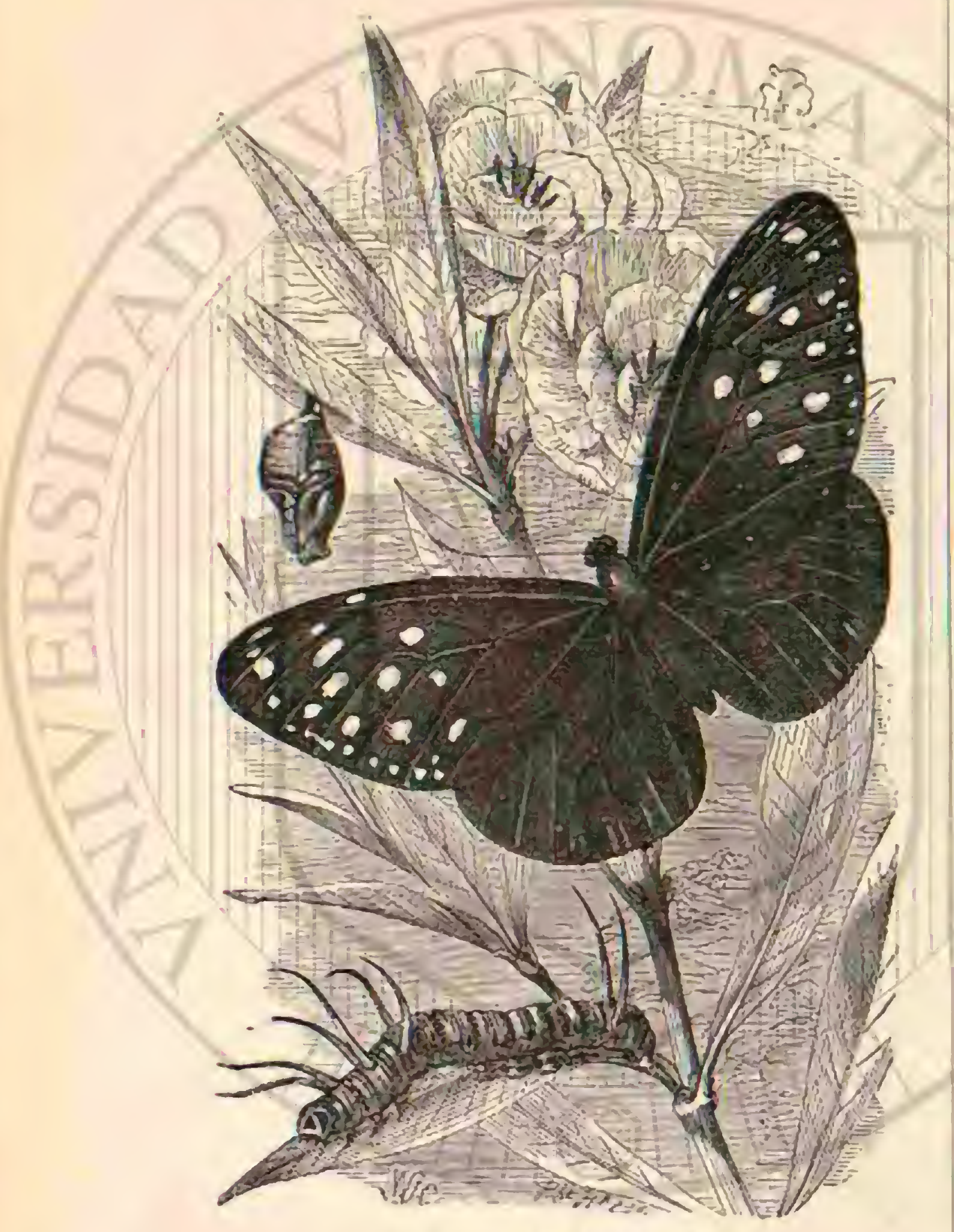

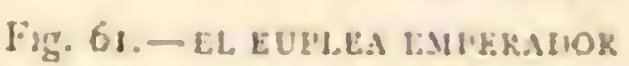

nudo tambien en el nervio de - las hojas alimenticias. El 29 de octubre vi en una pared un indivicluo que acababa de ceñirse su faja alrededor del cuerjo. De algunas orugas recogiclas a principios de setiembre, á punto ja de crisalidarse, las primuras dieron al a 7 del citado mes las mariposas; de modo que tambien aqui, en circunstnncias favorables, las crisalidas destinados a invernar pueden perienecer a una tercera cria

\section{EL PIERIS DE LA NABINA-PIERIS NAPI}

CARACTERES. - Fiste pierido, menos comun, se pare ce por el tamano al anterior y se reconoce fácilmente por las extremidades de los nervios, -que son negnizcas en - la cara. superior de las alas anteriores, y por los nervios del mismo tinte en la carn inferior amarillenta de las alas posteriores. Su oruga puede confundirse con la de la mariposa anterior; pero titne un color verde un poco mas oscuro, mas charo en los lados, y con algunos puntitos negros y verruguitas blancas.

La crisilida es mas negra, con fondo amarillento: compa. rada con la anterior, tiene la misma estructura.
USOS Y COSTUMBRES. - Fste pierido preficre las plantas espesas y deposita tambien sus huevos aisladamente.

\section{EL PIERIS DE LOS ÁRBOLES-PIERIS CRATAGI}

CARACTERES. - Esta especie se caracteriza por sus nervios negros y por la aglomeracion de escamitas del mismo color can las extremidades de las alas. Debe añadirse que el nervio al parecer mas grueso en el limite medio de la celda discoidea, en las alas anteriores, resulta ser asi por las escamitas mas espesas.

USOS, COSTUMBRES Y REGIMEN.-El género de vida de este picrido es del todo diferente del de los anterio. res. 1.a mariposa se presenta en julio y la hembra dejosita en seguida stis huevecitos amarillos, de forma de botella, en grandes y pequenos montoncitos, en las hojas de los ciruelos y perales, en el espino negro y mas raras veces quizás en cl espino blanco, al que la mariposa debe su nombre cientifirn. En vioño salen las oruguitas y comen aun, pero reunen en seguida algunas hojas en su rama, fijandolas por medio de hilos, para qure queden agarradas al caer las hojas. En este tejido sedoso pasan el invierno. Cuando los árboles han perdico sus hojas, estos pequeños nidos de oruga se ven fácilmente. En la primavera siguiente, tan luego como los capullos cmpiezan a brotar, las oruguitas comienzan á comer y cuando se han hecho mas grandes se dispersan. La onga adulea es gruesa y brillante, bastante peluda, $y$ tiene en el dorso rayas longitudinales negras $y$ rojas que alternan; el vientre es de un gris ceniciento. A fines de junio se crisalida casi siempre cerca de su última residencia que sin embargo ambien abandona para subir at otros objetos; es de un color pardusco ó verde amarillonio con fajas negras. Al cabo de doce á catorce dias sale la mariposa, que como la mayor parse de las hojas poco despues de su nacimiento, segrega cierto jugo de su ano. Este jugo es de un color rojo de sangre, y' como en ciertas épocas se encontró en gran cantidad, dió origen á la fábula de la «lluvia de sangre» q̧ue segun se decia era presngio de toda clase de desgracias. Decidiciamente esta mariposa se ha hecho con el tiempo mas rara que antes. Por Pentecóstes de iS $\$ 9$ el camino real de Erfurt a Gotha ofrecio, segun refiere heferstein, in aspecto extraño. Todos los árboles frutales que se hallan en anbos lados del mismo estaban blancos, cual si se encontrasen en el apogeo de su florescencin; pero aquello no era orm cosa sino una inmensa masa de pieris de los árboles. Desde entonces csta especie no se ha visto nunca otra ver en tanto número. Cosa semejante puedo referir del tiempio de mi juventud. En el jardin de mis abuelos encontré entonces estas mariposas en una multitud que infundin temor. Interesante era sobre ado ver ciertas plantas en que para pasar la noche se posaban en tal número que las cubrian del todo. Tambien rodeaban de dia los pequeños charcos, aficion propia segun parece de los pieridos y de la que tambien hablan los viajeros en paises lejanos al describir este grupo de mariposas. Desde entonces han pasado cuarenta y tantos años, $y$ apenas he rucho a ver un pieris de los árboles al aire libre. Y esto no solamente puede decirse de la provincia de Sajonin, sino tambien de otras regiones. Un iraficante de mariposas de Hungría me refirió hace algunos años que tenia $\mathrm{el}$ encargo de enviar cien pieris de los árboles á América, y uque habia reunido a las mujeres de su casa para que le ayudasen en su caceria de esta cspecie, pero que no creia que pudiesen recoger tal número. Me parece probado en esta mariqosa que por la persecucion general y enérgica, que aqui puede hacerse por miedio de la destruccion de los nidos de la oruga, de 
un insecto enojoso, puede llegar it ser este con el licumpo un objeto rato pam el coleccionador. El traficante no creia poder reunir cien individuos, y en ałuel tiempo maté muchas no. ches $S o 0$ sin observar disminucion alguna

Del nombre aleman del género, que puede aplicarse a muchas especies del pais y extranjeras, no debe deducirse, sin embargo, gue todas son blancas. Las regiones lejanas tienen pieridos ó mariposas blancas en las que solo se ve un poco de este color en las alas posteriores, y no hay que buscar muy lcjos para enconirar formas en que el blanco esti sustituido por el annaillo ó color naranja

\section{EL PIERIS EPICARIS-PIERIS EPICHARIS}

CARACTEREs.- Este lepidóptero (fig. 56) tiene las alas blancas con un filete negro bastante ancho, dividida en las superiores por una seric de minchas ovales grandes del color del fondo, y en las injeriores pror una linea de otras parecidas. Ia parte inferior de la hembra es de un blanco ama. rillento, y las nerviaciones de las cuatro alas negras y muy dilatadas; las primeras tieicen su parte inferior semejante a la superior, excepto tres manchas marginales que son amarillentas en el macho y de un bonito amarillo en la hombra. Lista especic mide unas 3 pulgadas de punta i punta de ala

DisTRIBUCiON GEUGKAFICA. - Lista esprecic se encuentra en Cachemira; es bastante comun en Bengala, y debe remontar mucho hicia el norte, pues ha sido observada en lazbore.

\section{EL ANTOCARIS AURORA-ANTOCHARIS CARDAMINIS}

CARACTERES. - En esta preciosisima especic, el macho presenta junto a la punta negra de sus alas anteriores un color roja de naranja vivo, mientras que la cara inferior cie las posteriores cicme en ambos sexos los dibujos mas graciosos, en forma de arbolitos de un verde de musgo.

l al oruga, delgada, de colos verde claro, tiene en el dono unas fajas de color verde blancquizco y puntitos negros en los lados. Vive en diferentes crucifems de las praderas y se tras. forma cu una crisálida muy particular: esta se adelgaza hácia adelante yo por detras casi por igual, y se parece i una lanzadera de eejedor un poco encorvada.

USOS, COST UMBRES Y REGIMEN.-1)e la crisálida que inverna nace en abril ó mayo cl bonito pierido que solo vuela en una cria en los mismos sitios que el pierido de la nabina.

\section{LA RODOCERA DEL CRUCERO - RHODOCE- ARA RHAMNT}

CARACTERES. - la rodocera del crucero, nuestra co. nocida mariposa de color de limon, pertenere tambien a este género, atmulue dificre por el cortc de sus alas y por el gé. nero de vida. L Lis mazas de sus antenas se ensanchan poco i poco, $y$ el tiltimo artejo de las palpos es muy pequeño y redondeado.

USOS, COSTUMBRES Y REGIMEN. - I A licmbro fecundada, que tiene un color amarillo prílido, inverna en tal estardo. En la primavera se la puede ver en medió de las abrejas y abejorros en las flores de los sauces. Desde allf busca un crucero (rhammus) que este brotando. para depositar en él sus huevos. las orugas que de ellos nacen se alimentan de las hojas y son verdes, provistas en los lados de: una mancha blanca que hácia arriba pasa pocóá poco al co!or predominante. Se trasforman en crisalidas angulosas de color verde con fajas de un amarillo claro en los lados y manchas pardas de orin con los estuches de las alas, yue son salientes en angulo obtuso. La mariposa vucla en julio y agosto; el macho se distingue de la hembr, mas pritida, por el color amarillo de limon.

\section{LA RODOCERA CLEOPATRA - RHODOCERA CLEOPATRA}

CARACTERES. - la rodocera Clenparm, que algunos naturalistas lian considemdo como viricedad de nuestra espeecic, es propia de la liuropa meridional.

Otros pieridos se distingıen por una mancha plateada en

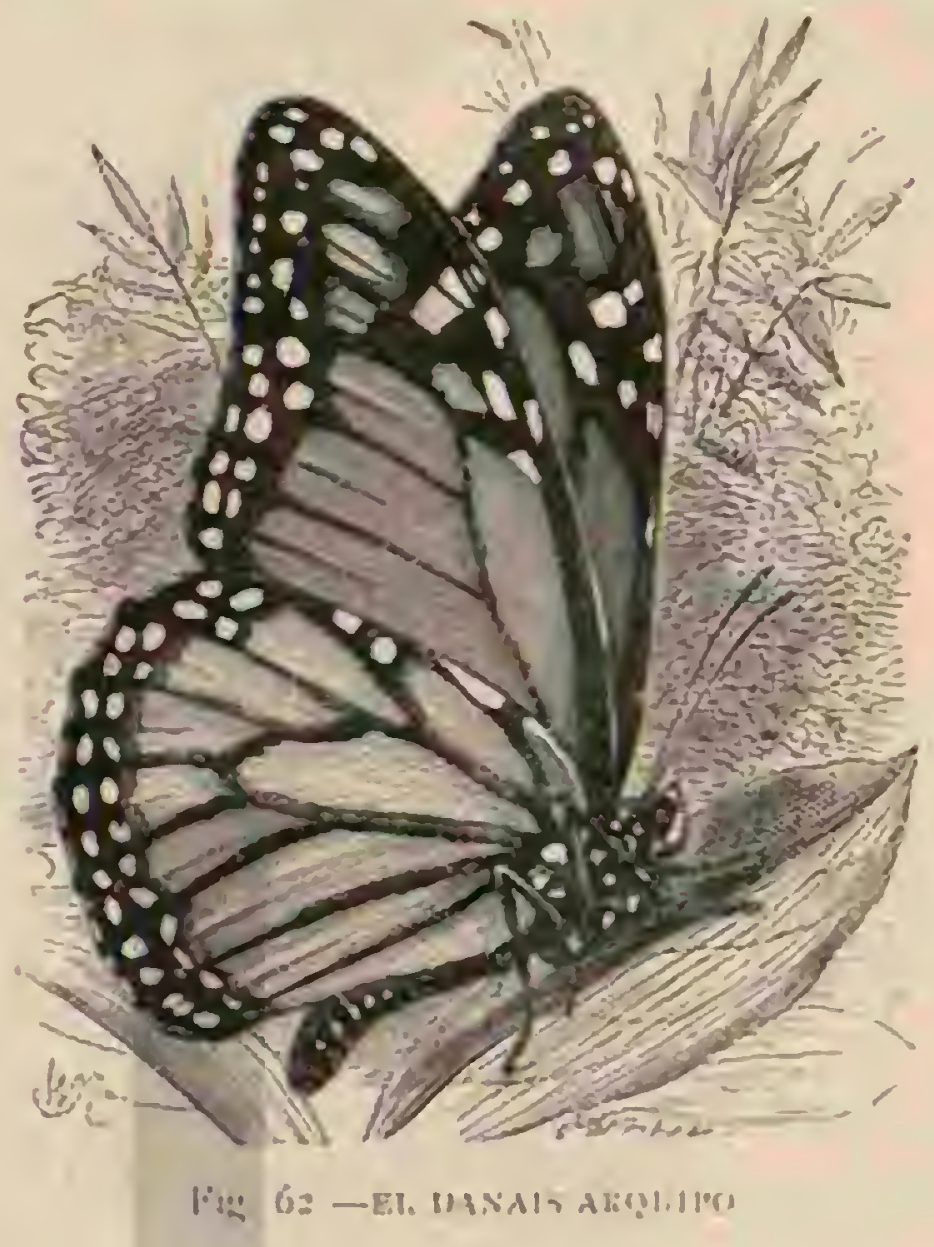

In carn inferior de las alis posteriures, chyomancha recuerda la forma de un \&. como por éjemplo el colias loyble. de un amarillo pálido, con la citada suancha dorada i cl mins colrsn, de un amarillo de naranji con bordes negros, youros.

\section{LOS LEPTALIS-LEPTALIS}

CARACTERES. - Los individum perfectos de esta es. pecie se caracecrizan por su calvesa pequenil, ligerancinte escomosit; los palpos son mas contos quic açuella prarte; vello. sos, próximos entre si, y' con artejos poco marcados; el uliimo es un proco saliente y puntingudo; las antenas, largas y raquiticas, ternihnan en maza fusiforme y prolongada: el abdómen. largo yo delgado, sobresale mucho, comumnente, de las alas inferiores, solire rado en las hembras. I as alas son muy lurgas y estrerhas, con celdilli discoidea cerrada; las inferiores abarcan apenas la parte inferior del cuerpo, $y$ son mas anchas en los machos que en lis hembras; las patas largas y endebles; cl primer par se atrolia un poco en lus anachos.

Las diferencias sentrales consisten menos en el dibujo qque en la forma de las alas: los machos tienen las inferiores algon nuas anchas, y su borde anterior de un pảilido luciente.

DisTHBUR:1ON GEOGHÁFーCA-Los leptalis se encuentran descé las Amillas hasta el Brasil meridional: jero las especies no son muy numerosas.

\section{EL LEPTALIS ESPIO-LEPTALIS SPIO}

CARACTÉRES. - In esprerie de esic momire (fig. 59) es muy bonita: sus alas supuriores son ublongrs clipticas, de 
un color pardo negruzco, con tres fajas de un leonado rojo, una de ellas longitudinal y algo arquenda, y las otras dos oblicuas, dispuestas paralelamente. Las alas inferiores son negruzcas; debajo de las primeras el tinte es mas pálido en la parte inferior, viéndose varins manchas verdosas à lo largo del borde costal.

DISTRIBUCION GEOGRÁEICA.-Esta esprecie habita en las Antillas; es muy conocida en Guadalupe.

\section{EL EUPLEA EMPERADOR-EUPLEA IMPERATOR}

CARACTERES. - A primera vista no.llaman la atchcion los colores de esta manifica mariyosa ( (ing. 61), cuyas alas son por to regular de un bonito tinte pardo; pero este se

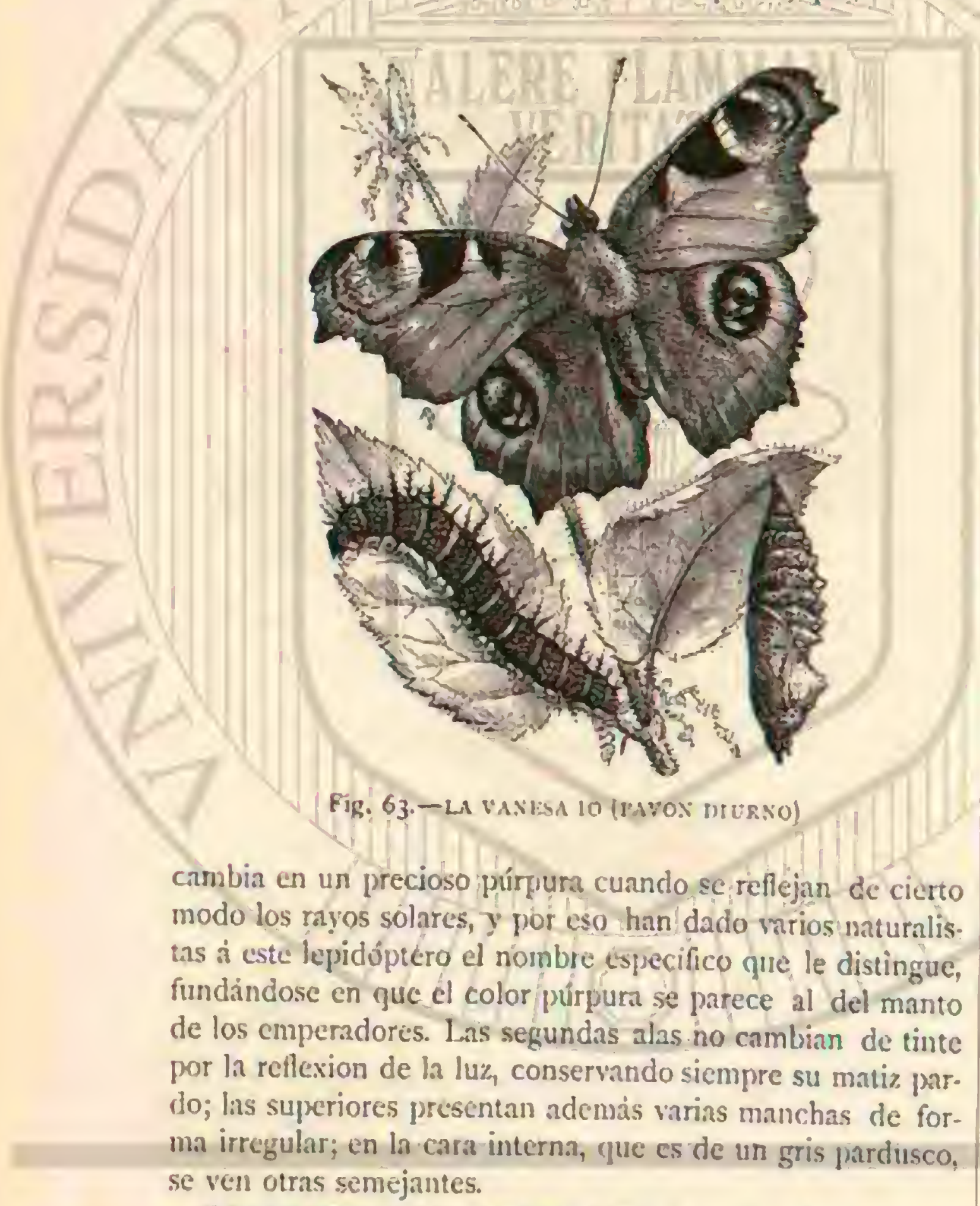

DISTRIBUCION GEOGRAFICA. - Esta bonita espe. cie ha sido observada principaimente en Australia.

\section{LOS DANAIS - DANAIS}

CARACTERES. - Las mariposas que figuran en este género ticnen las antenas tan largas como la mitad del cuerpo, $y$ ierminan gmdualmente en maza; en has patas del primer par son del mismo largo los fémures y las tibias; los tarsos cortos; los del macho pareren dividirse en dos artejos; los de las hembris se componen de cuatro, todos ellos provistos de espinas en los lados.

Las orugas, de forna cilindrica, se estrechan hricia la ca. beza, presentando en el tercero y último segmentos, y a ve. ces en el sexto, amos tentáculos largos, carnosos y no retráctiles.

I ase crisilidas son ovoideas y' tienen el abelómen muy corto.

DISTRIBUCION GEOGRAFICA. - Ios danais estin diseminados en el antigurs y el nuero continente: una especie. el darais chrysippus, está diseminada desde Nảpoles hasta el cabo de Buena Esperanza; y por el este se la encuentra has. ta la China.

\section{EL DANAIS ARQUIPO-DANAIS ARCHIPPUS}

CARACTERES. - En esta mariposa (fig. 62) predomina un precioso color castaño, rayado de negro; los bordes de las alas están adornados de manchas blancas é irregulares dis. juestas en series dobles; la base ofrece matices semejantes, pero mas pálidos; la cabeza, el tórax y el abdómen son de un negro aterciopelado, con manchitas de un blanco de nieve. Esta mariposa mide proco mas de \& pulgadas de puntra á punta dè ala.

DISTRIBUCION GEOGRÁFICA.-El danais arquipo se encuentra en toda la América, desde el Canadá hasta el Brasil.

\section{LOS HELICONIAS-HELICONIA}

CARACTÉRES. - I Los heliconias tienen cabeza ancha; ojos ovales, muy prominentes; maxilas bastante desarrolladas; palpos Inbiales escamosos, provistos de jelos prolongados; las antenas son largas y terminan en maza; el borde anterior de las alns superiores es redondendo; las inferiores son mas 6 menos ovales; el abdómen se prolonga en maza, sobresalien. do mucho de las alas en la mayoria de los casos.

Las orugas y las crisílidas no son bien conocidas.

DISTRIBUGION GEOGRAFICA.-1 Los heliconias, que constiturer exclusivamente un género americano, son bastante numerosos y se extienden un poco mas alla de los trópicos; parecen mas comunes cerca del ecuador, $y$ habitan de ordimario regiones bastante altas.

Una de lás especies mas notables de este género es el heliconia Erato, representado en la fig. 60.

\section{LOS NINFÁLIDOS-NYMPHALIDE}

CARACTERES. - lan mas bonitas y grandes de nuestras mariposas diurnas, que no pertenecen a las ya citadas, tienen de comun con otras especies extranjems, mucho mas numerosas, las patas anteriores atrofiadas, maxilas grandes oblicuamente extendidas, alas de igual desarrollo, en las qque las posteriores, el nervio seis y siete salen separadamente de la celda discoidea.

USOS, COSTUMBRES Y REGIMEN .-Sus crisilidas suelen estar pendientes con la cabeza hácia abajo, y' se dis. tinguen mas å menudo for magnificas manchas doradasy platerdas.

\section{LOS ARGINIS - ARGYNNIS}

CARAGTERES. - Ios arginis ó mariposas de nácar, de. hen su nombre à la cara inferior de las alas posteriores, y son conocidos de codo el mundo En el sitio indicado de las citadas alas se encuentran varias series de manchas $\delta$ fajas de brillo platcacio ó nacatado, mientras que unos dibujos negros parecidos á las casillas del tablero de hjedrcz cubren el fondo rojo de naranja de la cara superior y entre ellos algunos pa. recicios a cifras mal escritas detrás del borde anterior de las alas anteriores.

USOS, COSTUMBRES Y REGIMEN.-Son habitantes del hosque y sus contornos. Algunas especies, à veces mezcladas, visitan los fresnles en flor y el céspect en medio de los claros de bosque. Cuando el sol es caluroso vuelan al rededor de las flores produciendo cuando hay muchos un li- 
gero rumor con las alas. En los miles de florecitas una mariposi releva is la otra para libar la miel; juguetenndo yo retozando se persiguen unas a otras al ruelo, desajareciendo de nuestra vista a mucha distancia. Ahora vuelve una, luego la otra en diferentes direcciones; ahuyenta a una mosca $\delta$ d otra compañera de la flor en que se posa ó despliega en las hojas de un arbusto de encina recino toda la superficie de sus alas exponiéndola al sol que la refleja con tintes dorados. Fin este caos no hay descarso, prorque esas mariposasas, ostentando sus galas a la luz del sol, laallan en esto su recreo favorito, y sin embargo, iqué contraste existe entre esta actividad y la de la trabajadora abeja, de la pendenciera avispa y de otros himenópteros que están mas ó menos representados en tales sitios! De pronto se oculta el astro del dia pror detris de una espesa nube y entonces todo enmudece entre estos graciosos hijos del aire. Detengámonos un poco para estudiar una ii otra forma.

\section{EL ARGINIS DE RAYA PLATEADA - ARGYN- NIS PAPHIA}

CARACTERES. - Nuestro arginis thas graride es el ar-

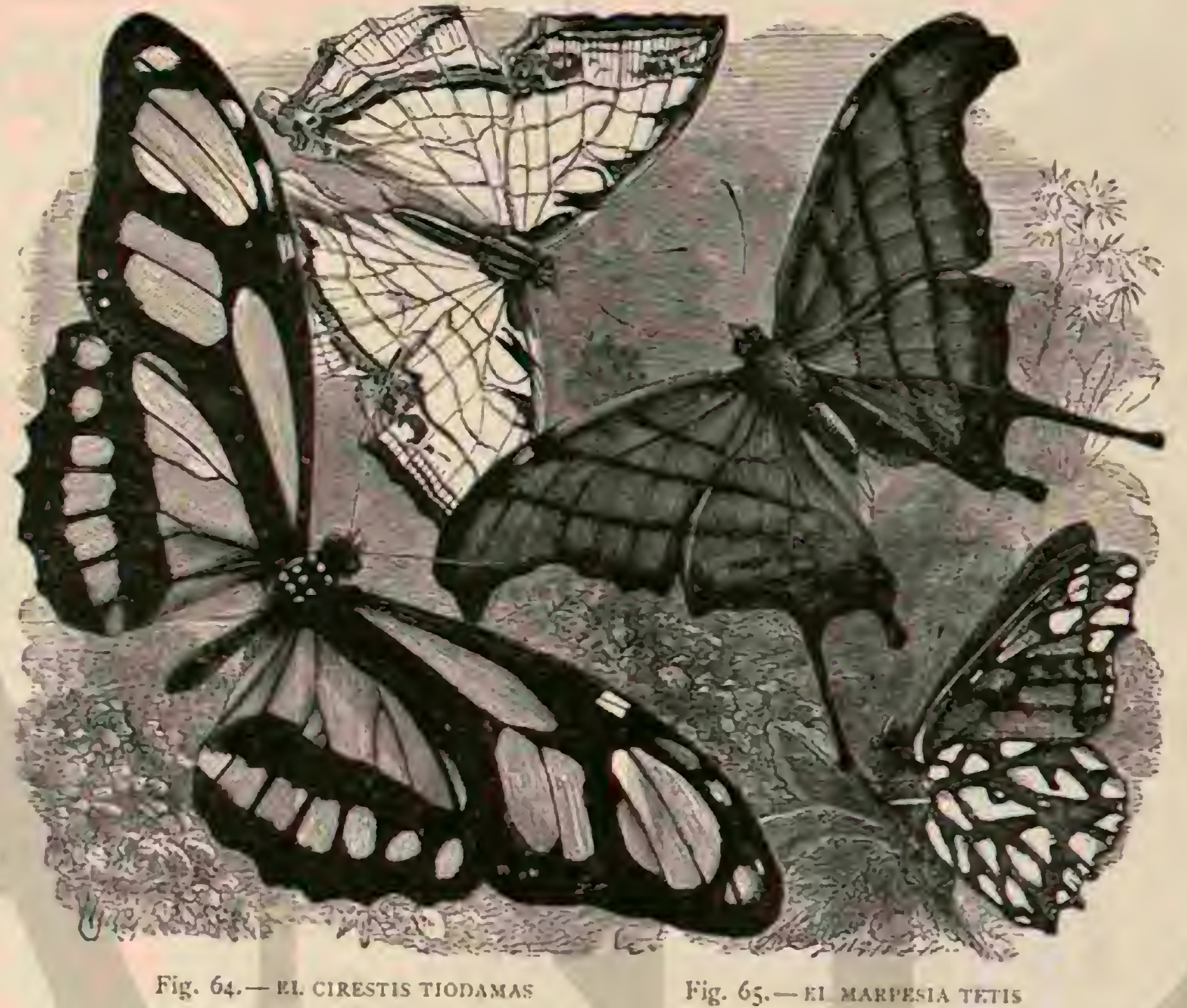

Fig. 66. - Fi CLEOSIA DIDO

ginis de raya platenda, que mide cuando menos $\theta^{\infty}, 06$ de punia á punta de ala. Ias alas de un rojo de naranja presentan en la parte dol borde tres series de manchas negras; las anteriores en la parte de la base, cerca del borde anterior tienen un dibujo en el que $\mathrm{d}$ la derecha sc puede leer'mas ơ menos.marcadamente el núniero 1556.

Fn el ala izquicrda se siguen estas cifras natumlmente en sentido inverso. Lin el macho se dilatan adcmás los nervios, provistos de escamas negras, en forma de callosichdes En la cara inferior verde de las alas posteriores brillan cuatro fnjas de un color violeta o de naicar, dos en forma de cuna. cortadas en la parte de la base y dos cnterns cerca del borde. lat oruga, de color amarillo, esta provista de espinas pardias y sobre su dorso se corre una linea longitudinal dividicha, de color amarillo orillado de pardo.

USOS Y COSTUMBRES. - Viven en las violetas y frnmbuesos de los hosinues, $y$ sobrc todo en la llanura. Invernan en un estado bistante jóven.

\section{EL ARGINIS AGLAYA - ARGYNNIS AGIAJA}

CARACTERES. - Esta especie se canctcriza solre todo por la punta amarilla verdosa en la cara inferior de las alas anteriores, en la que brillan seis puntos plateados; unas manchas parceidas estin dispuestas on cuatro series tras. rersales en las alas posteriores. I a oruga esti provista de espinas negras ramificadas; sobre un fondo negruzco se distingue una faja dorsal amarilia y unas manchas laterales de un rojo de ladrillo.

USOS Y COSTUMBRES. - Vive en las violetas sin olor, lo mismo que la especit precedentt:

Europa tiene ademis de estas dos especies otras 25. de las que is se encucnuran en Alemania y llesan nombres como nichi, dafne, latumia, etc.; en otros paises, pero solo.en el hemisferio sejuentrional, se encuentran especies distintas, pues las especies americanas del mismo color y con las manchas de nácar mucho mas espesas en la cara inferior de todas las alas, sc distinguen por la forma esencialmente variada de estas y constituyen el gíncro agraulis.

\section{LOS MELITEOS-MELIT EA}

CARACTERES.- LoS melitcos son igualmente muy numerosos y. se parecen mucho i las esjecies anteriores por el color y por los dibujos en la cara superior de lasalas; la cam inferior en cambio carcece de las manchas flatendas; estas 
son de color mate lo mismo que en las variedades de mu. chas especies de arginis. La celda discoidca de las alas posteriores queda abierta $y$ las largas maxilas estan provistas de pelos erguidos, mientras que en los arginis aquella está cerrada y estas provistas de escamas lisas.

Las orugas tienen en re\% de las espinas mechones de pelos, y se alimentan, como las anteriores, de jerbas. Las crisálidas pequeñas son amarillas, con dibujos blancos y negros sin brillo metálico.

DISTRIBUCION GEOGRAFICA.-La mayor parte de las diez y seis cspecies, poco mas ó menos, propias de Europa, se encuentran tambien en Alemania.

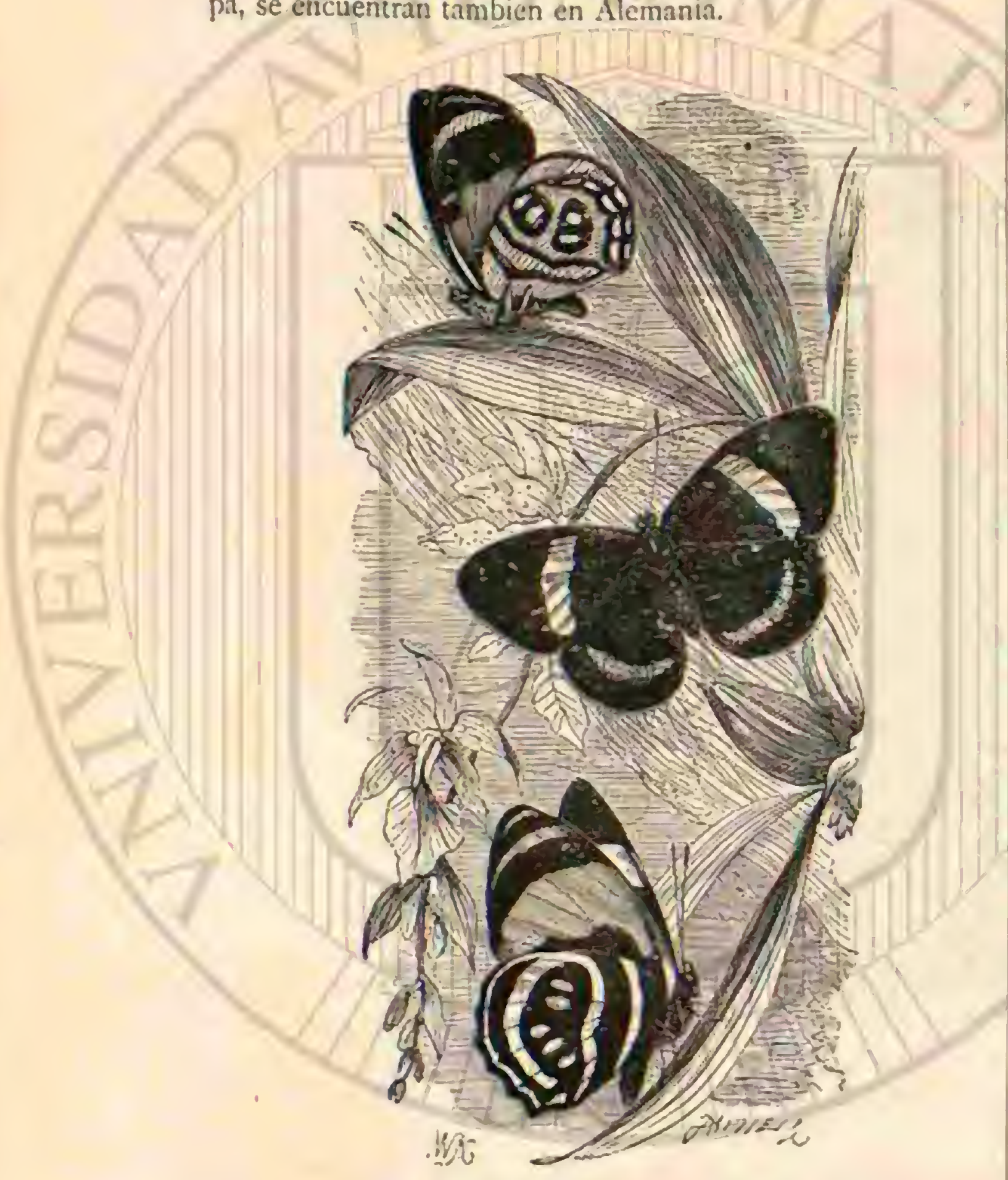

Fig. GS. - RL CATAgRasia l'MLOMA

Fig. 69. - EL CAIAGKAMA CEMBNE:

Fig. 70.-8.L CATHCFAMA LICA

USOS Y COSTUMBRES. - Viven en Jas praderas silvestres y en los.claros de los bosques donde se presentan los satiridos de las praderas, de los cuales hablaremos despues.

\section{LAS VANESAS-VANESSA}

CARACTERES. - Lats vanesas pertenecen à las mariposas mas grandes y graciosas respecto à la forma de las alas y i los colores abigarrados, à menuclo muy bonitos, de la cara superior de las alas; la cara inferior es por lo regular de color opaco, con dibujos semejantes a los del mírmol; los ojos están cubiertos de espesos pèlos, $y$ las mazas de las antenas provistas de botones.

DISTRIBUGION GEOGRÁFICA.-Son unas mariposas muy diseminadas, en parte cosmopolitas, $y$ se encuentran tambien en Alemania.

USOS Y CostumbREs. - Estos lepidópteros vuclan en todas partes, sin preferir los bosques ó sus contornos. Las orugas de todos tienen una piel provista de espinas del todo inofensivas, $y$ viven en las yerbas ó en los árboles y arbustos. Ias crisálidas, angulosas, se distinguen sobre todo por su bo. nito brillo metálico, que en una misma especie puede encon. trarse à faltar, porjue es debido á la humedad que hay debajo de una delicada membrana vidriosa, y que sin perjuicio para la crisálida puede resecarse tambien.

\section{LA VANESA IO-VANESSA IO}

CARACTERES. - El color de esta especie es pardo rojo vivo aterciopelado; cerca de los ángulos anteriores de has cuntro alas hay magnificas manchas oculares sobre fondo pardo negruzco, negro y azul en las alas posteriores, y ademis otras amarillas en las anteriores. Un punto claro en el borde anterior, bastante negro, es del mismo color amarillo de madera, como el exterior de la mancha ocular (fig. $66_{j}$ ).

Usos Y COSTUMBREs. - La oruga, de un negro brillante, tienc finos puntos blancos. Vive sociablemente en la ortiga grande $y$ en el lúpulo. Nace de las hembras invernadas, $y^{\circ}$ si las circunstancias son favorables, llega tambien una segunda cria a su desarrollo. Tambien la crisílida es angulosa y su parte central del dorso puede compararse con la ca. ricitum de una cara.

\section{LA VANESA ATALANTA - VANESSA ATA - IANTA}

CARACTERES. - Ia vanesa atalanta, llamada tambien el almirante, es del mismo tamano $\delta$ un poco mayor que ta especie anterior. Tiene un color negro aterciopelado en la cara superior ciel ala, blanco en las franjas, $y$ con una faja de color rojo cinabrio que desde el borde anterior de la extremidad de la parte dorsal se corre hasta cerca del ángulo interior; tambien hay dos fajas mas grandes, asi como algunas mancinas blancas pequenas. El borde posterior de las alas pos. teriores es igualmente de un rojo de cinabrio con cuatro puntos negros. En la cara inferior se repiten en las alas anteriores los dibujos de la cara superior, pero mas pílidos; has alas posteriores presentan viros matices jaspeados y tonos amarillos en los que cerca de la base se lee la cifra Si IS en caractéres negros.

USOS Y COSTUMBRES. - l a oruga, provista de espinas, y con colores abigarndos, vive aisladamente encermods entre las hojas de la ortiga. Tambien debe su sér á las hem. bras invernadas.

DISTRIBUCION GEOGRÅFICA. - El alınirante pertenece á las mariposas cosmopolitas, porq̨ue esta diseminado por toda la Europa y cl nortc de América; tambicn se le re en el Himalaya, en las islas de la Sonda, en la Nueva Zélan. da y en las Indias Orientales.

\section{LA VANESA DE LOS CARDOS -VANESSA CARDUI}

SARACTERES. - Se parece mucho al almirante fror sus dibujos; tiene el color rojo, negro y blanco con una distribacion casi igual de los dos primeros colores.

DISTRIBUCION GEOGRAFICA.-COn corta diferen. cia viene á ser poco mas 6 menos la misma que la de ta especie anterior.

USOS Y COSTUMBRES.- La oruga vive como la del almirante en los cardos, y tambien en las alcachofas cultiva. das. En junio se presentan las primeras mariposas, que ả veces llegan á tener una segunda cria. Las hembras fecundadas invernan. A veces se ven las vanesas de los cardos formando numerosisimas agrupaciones, cual si estuvieran dominadas 
por un irresistible deseo de viajar. Prevost observó en ag de octubre de 1822 , en Francia, una bandada que media al me. nos de 10 il 15 piés de amclio, y de inmensa longitud. que se dirigin desde el sur hácia el norte. Ghiliani vió en el sur de Europa el 26 de abril de $1 \$_{51}$ otra bandada de estas ma riposas recien macidas.

\section{LA VANESA ANTIOPE-VANESSA ANTIOPA}

CARACTERES. - Mide $0^{\circ}, 066$ de punta à punta de ala y es una de las majores mariposas de nuestros paises; se reconoce ya å mucha distancia por un ancho borde de colar amarillo claro en las alas, que son de color pardo negro aterciopelado y tienen por delante de anuel una serie de manchas arules.

DISTRIBUCION GEOGRÁFICA.- Habita principal mente en los hosques clonde su oruga se alimenta de las hojas de los abedules, y csla diseminada por toda la Europa y el norte de America.

USOS, COSTUMBRES Y RÉGIMEN.-Desde julio se presenta asimismo cerca de los pueblos y ciudades donde hay sauces y álamos, pues tambien de estos se álimenta la oruga, que vive sociablemente en los citados airboles. I.a hembra invernada deposita sus huevos á hastante altura, formando montoncitos en los capullos de las hojas. Los sitios en que estas filtan permiten al observador atento reconocer la presencia de las orugas. Cuindo estas son adultas ticnen un color negro azulado oscuro con manchas de un rojo de ladrillo á lo largo del dorso y cortas espinas por todo el cuer. po. Entonces bajan de su altura, se disjersan, y cuẻlganse por la extremidad del abdónen en una mama, en el tronco $\delta$ en otro objeto, encorvandose hácia el lado del vientre; luego elevan los cinco segmentos anteriores mas y mas hácia arriba de modo que la cabeza sigue la misma direccion. En tal estado se trasforma en crisálida, que despues de salir de la piel de oruga encorva la cxtremidad de su abdómen en forma de $S$ hasta que se ha despojado del todo de la piel. Lintonces descansan las crisílidas de los trabajos y cuidados de su estado de oruga; pero todo en ellas ha cambiado. 1.os piés ya no son lo que eran, pues ¿qué haria la futum mariposa, destimada a cruzar los aires, con las muchas patas pesadias de la orugat? Ial cabeza ha perdido las poderosas maxilas, porqque el futuro sér alado solo consu larga lengua se alimenta de sustancias dulces. I a parte principal 6 interior de la oruga, el aparato digestivo arrollado, ha desa parecido casi del todo; en cambio se han desarrollado los órganos scxuales, y el ovario de la hembra ocupa casi todala cavidad abdominal. '1'odo esto ya existe y' existia en la oruga en principio, pues en algunas se han observado ocho dins antes de su metamorfosis los gúrnienes de los huevos. Al abrir una crisalida recien trasformada se ve en su cáscara solo una sustancia nucosa sin forma, en la que en mas ó menos tiempo se consolidan las articulaciones de la futura mariposa. Fl desarrollo es igual. mente progresivo y representa aqui la crisilida tambien exteriormente todas las partes indicadas del insecto futuro. Pocas scmanas bastan para que el colur consolide el liquido y haga nacer la marijosa.

\section{LA VANESA. DE MUCHOS COLORES-VA- NESSA POLYCHLOROS}

CARACTERES. - Algunas vanesas de un pardo de naranja tienen las alas orilladas en parte de manchas azules re dondas sobre un fondo negro. la vanesa de muchos colores presenta dos manchas negras grandes en el borde anterior de las alas anteriores, y cinco mas pequentas redondeadas en la superficie de las mismas; otra mas grande en el borde anterior de las alas posteriores y además una faja negra delante del borde de todas has alas.

USOS, COSTUMBRES Y REGIMEN. - Su orign, pardo negruzca, provista de espuinas amarillas, y sobre cuyo Corso se corren tres fajas del mismo color, vive sociablementc en los cerezos, jerales y algunos otros átboles, comiendo el iollaje de las puntas de las ramas. Solo se encuentra una vez al año y nace de la hembra invernada. Se la ve con mas

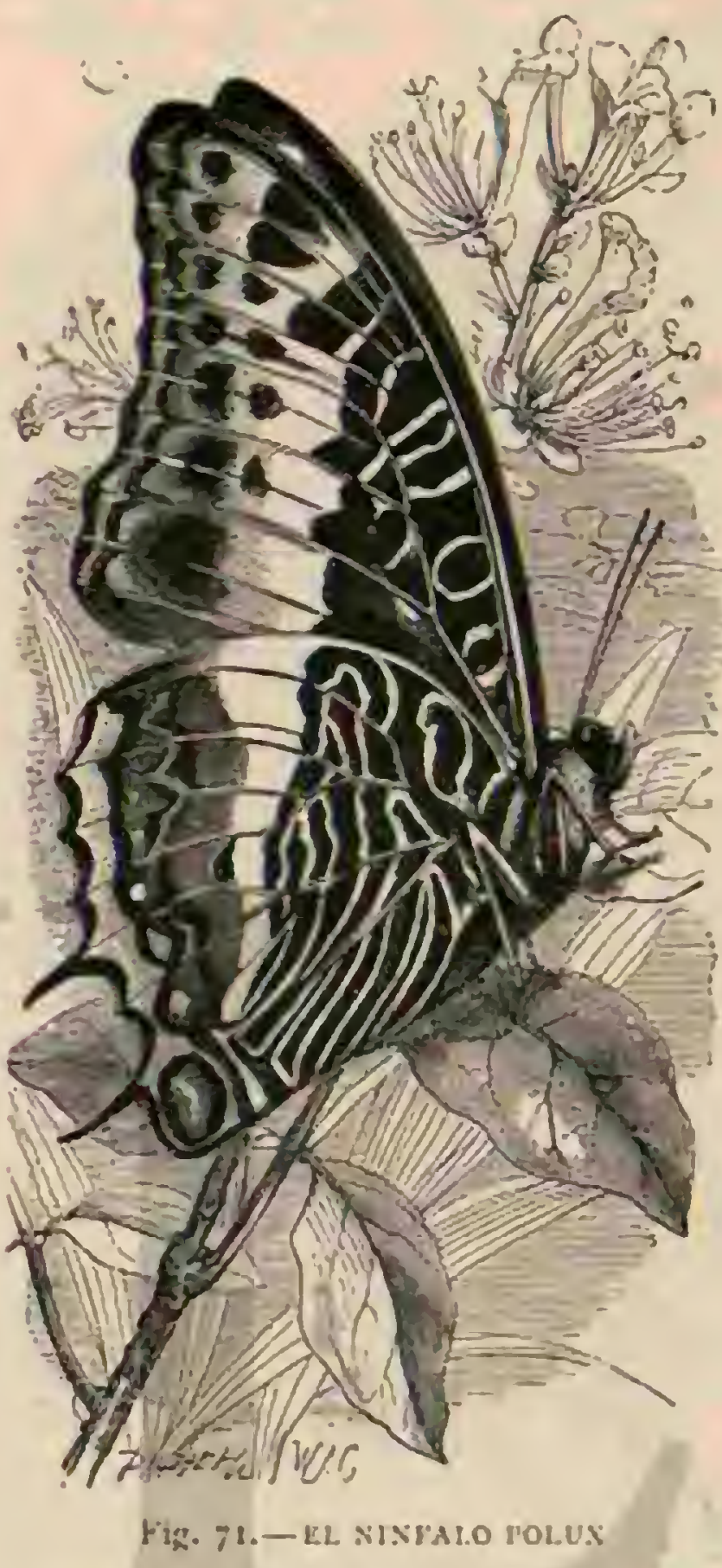

frecuencia en los arboles que bordean los caminos, y le gusta mucho á la bonita mariposa volar por los linderos de los bosques exponiendo sus alns al sol, ó ya en el st:elo, ó à mu. cha altura en las hojas.

\section{LA VANESA DE LAS ORTIGAS-VANESA URTICAE}

CARACTERES. - Esta especie es de un pardo algo mas claro que tim al rojosmarillo, con la base de has nlas negras, sobre todo la de las posicriores; en las anieriores hay tres manchas mas pequeñas en el disco, tres grandes cuadrangulares en el trorde posterior, del mismo color, ý entre la última de estas y la faja negra del borde una blanquizca.

USOS, COSTUMBRES Y REGIMEN.-Ia mariposa vuela en todas partes casi todo el ano é inverna en su estado de desarrolio lo mismo yue el rodocero del crucero. Ia oruga negra, provista de esjuinas, vive sociablemente en la ortiga de la que a menudo deja solo los troncos. Se la recanoce por las fajas longitucinales amarillas y de un amarillo verde en los lados 'Tambien esta mariprosa emprende ì veces viajes reunida en masas innumerables. Godet observó en el lago de Neufchatel en julio de $8 \$ 2 \delta$ una bandada de poco menos de media legua de longitud. 
EL LIMENITES DE LOS ÁLAMOS-LIMENITIS POPULI

CARACTÉres.-Esta especie figura, despues de las caballeros, como una de las mayores marijosas diurnas de Europa, pues hay individuos que miden $11^{\prime \prime}, 07$ y mas de punta á punta de ala. La hembra tiene la superficie de las alas un poco arqueada en el borde, que es de color pardo intenso, con una faja de manchas blancas que se corren trasversalmente por las alas posteriores; en las anteriores se observan otras blancas aisladas, formando las centrales

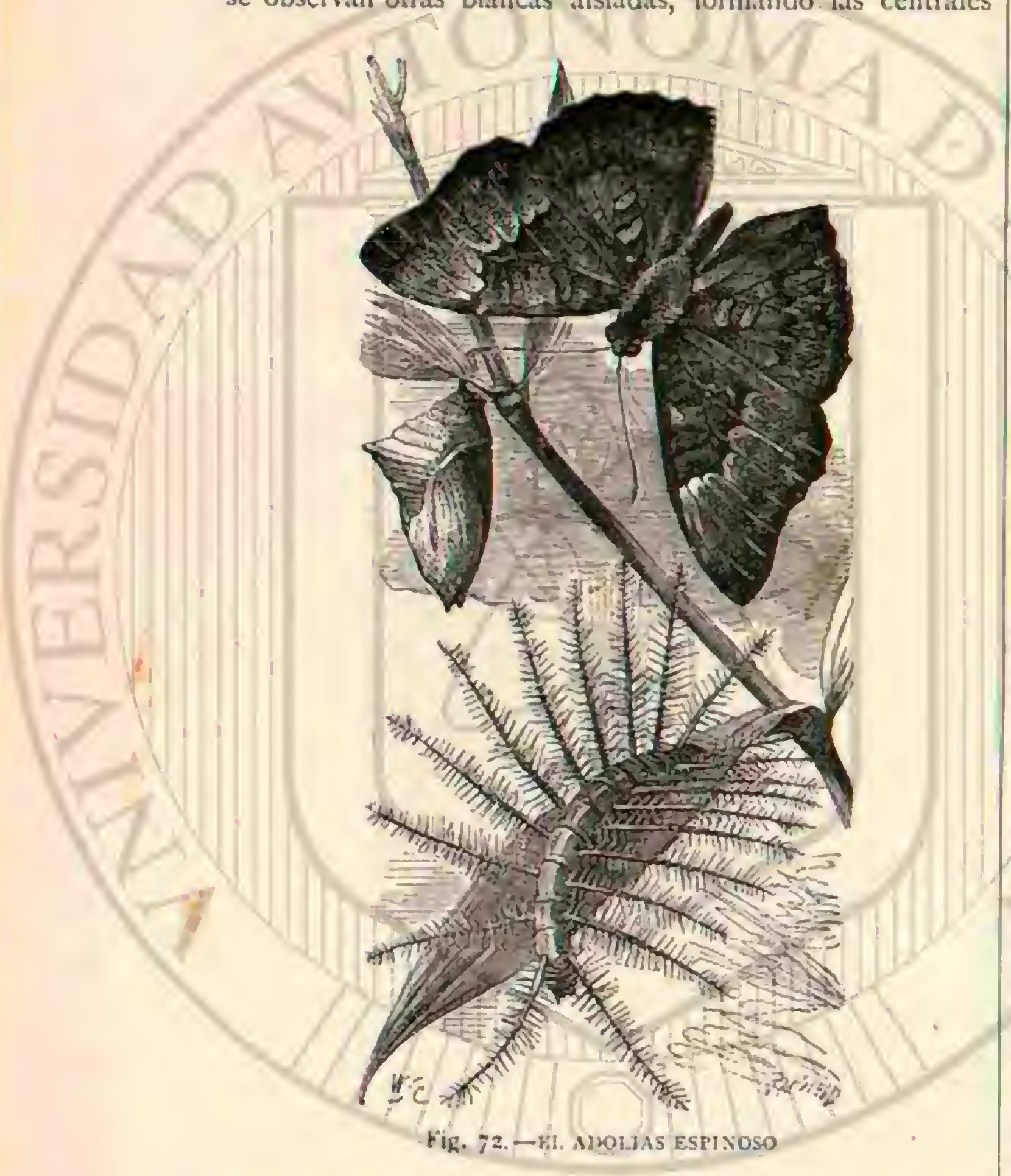

igualmente una faja trasversal oblicua. Estos dibujos blancos solo están indicados en el macho. Además se distinguen en ambos sexos cerca del borde unas manchas negras prolongadas, orilladas por dentro de unas manchas semilunares de un rojo amarilio claro, y que regularmente son mas marcadas en las alas anteriores que en las posteriores. En contraste con este color blanco y opaco sorprende el color vivo y abigarrado de la cara inferior. Los dibujos blancos se pre. sentan mas marcadamente tambien en el macho; el fondo es de un rojo amarillo interrumpido por series de manchas negras, indicadas tambien en la superficie Solo el borde interior de las alas anteriores y el posterior, orillado de negro en ambas alas, son de un gris de plomo; en las alas anteriorés tiene el angulo un viso negro. Su origga es de un amarillo verdoso, con el cuarto, sexto, octavo y noveno segmentos de un pardo roiizo, con fajas de inanchas pardas y négruzcas, y otras muy grandes en los lados del quinto y séptimo segmentos; en el dorso hay dos series de gruesas espinas carnosas con pelitos cubiertos de botones, mas largos en la muca que en las otms partes del cuerpo.

USOS, COSTUMBIZES Y REGIMEN. - Habita en los bosques, excepto, segun parece, los del oeste de Alemania; domina las regiones superiores del aire y no se digna nocz. clarse con los pequeños insectos en las flores; se la ve parti cularmente en los charcos de los senderos de los bosques, donde aynga su sed, y es tan timida que se la coge con facilidad. Ví hace tiempo a mediados de junio, pues solo en este tiempo vuela la mariposa algunas semanas, una de las hembras mas raras y buscadas por los coleccionadores; volab. a mucha altura, y pasando por encima de un claro de bos. que, fué á posarse junto á un riachuelo, cual si hubiera olfa. reado el agua á mucha distancin. En este vuclo habia algo muy diferente de lo que por lo regular se observa en las ma riposas y que traducido en palabras jarecia decir: \& No tengo nada qué perder; si no vengo hoy volveré mañana, $y$ sino otro dia; el sitio, poco importa; lo que quiero es solo distracrme. Aquella hembra sabia adónde queria ir, pero la realizacion de su deseo la perdió; pues cayó en poder del cazador, y cubierta con la red vióse privada de la libertad y de la vida.

La oruga de la primera cria vive en mayo $y$ junio $y$ la de la segunda en julio y agosto, en los altos álamos; parn convertirse en crisálicla se cuelga de las hojas. I a crisálida, amarillenta y con manchas negras, tiene la cabeza y el dorso del tórax cubiertos de protuberancias, una de ellas en forma de orejita. la crisálida de la primera cria se convierte ya al cabo de ocho ó nueve dias en mariposa. El género Limenite; contione aun varias especies mas pequeñas, semejantes por los dibujos, aunque no por la mezcla de los colores, y que conservan el carácter general del grupo, asi por la forma de las alas, como por la disprosicion de las espinas de las orugas, que todas viven en los árboles.

\section{LAS APATURAS - APATURA}

CARACTERES. - Las apaturas tienen la misma forma de las alas y casi los mismos dibujos del limenites de los âla. mos, y tambien la celda discoiden abierta en todas sus alas, pero la maza de las antenas es aplanada; los palpos, pun. tingudos y mas largos cue la cabeza, se tocan, $y$ la cara supe rior de las alas se distingue en el macho por su brillo vivo en magnificos matices azules ó violicceos: además cada ala ticne una mancha en forma de ojo.

Las orugas, verdes y sin espinas, se adelgazan hácia atrás, ofreciendo los contornos generales de una limaza, $y$ se diistinguen por dos puntos particulares en la cabeza, dirigidos hácia arriba.

USOS Y COSTUMBRES. - Viven en los sauces y en los ה́limos.

\section{LA APATURA IRIS-APATURA IRIS}

USOS Y COSTUMBRES. - Esta especie j la afafura Ilia, propias de Alemania, están bastante diseminadas, aunque dependen de ciertos sitios, presentándose en los bosques con mucha frecuencia.

Se distinguen por un vuelo sostenido y por la actividad incansable con que pasan al lado de los anchos senderos quue cruzan los hosques ó corren por sus linderos.

\section{LOS CETOSIAS-CETHOSIA}

CARACTERES, - Los cetosias tienen ln cabezn estrecha Y peluda; ojos ovales y salientes; maxilas un poco mas largas que el tórax; palpos labiales divergentes; antenas casi tan prolongadas como el cuerpo, y que terminan gradualmente en una maza rałjuitica: tórax oval, poco robusto; protórax pequeño; alas superiores triangulares, con el borde anterios ligeramente reciondeado, y el externo dentado; las inferiores 
son sultriangulares: el borde interno forma una canal bien marcada para recibir el abdúmen, y con una escotadura en una parte de su extension.

Lis orugas y las crisálidas son desconocidas.

DISTRIBUCION GEOGRÁFICA.-Ias pocas especies que se conocen de este género estan diseminadas en el Asia meridiomal, cu las islas asiáticas y en Australia.

\section{EL CETOSLA DIDO-CETHOSIA DIDU}

CARACTERES. - El color del fondo de las alas de esta mariposa (fig. 66) consiste en un pardo negruzco; los tintes mas claros son de un honito verde con un ligero matik aperlado, la cara interna es de un color de chocolate; asi las alas superiores como las inferiores estan adornadas de manchas de color de plata, y fajas del mismo tinte.

L.a oruga de esta mariposa es verde, con lineas rojas $y$ blancas a cada lado del cuerpo, que esti revestido de varias serres de espiuas cortas yo dos apéndices en la cola.

DISTRIBUGION GEOGRÁFICA. - lista especie se encuentra en el Brasil, en la Gunyana y en la provincia de Venczucla.

\section{LOS AGRAULIS-AGRAULIS}

CARACTERES. - I.Os agraulis tienen la cabera escamosa, medianamemte ancha, algo peluda en la frente y en el vértice; ojos ovales; maxilas casi tan largas como el cuerpo; palpos labiales escanosos, terminados por una maza obtusa, corta y jiriforme; cl tómx es prolongado, oval, y está cubierto de pelos en los lados; las alas superiores, largas y subtriangulares, se encorsinn un poco en el borde'anterior; las iuferiores tienen el anterior redondeado, y el externo forma un diente en la terminacion de la primera nerviacion mediana.

Ins orugas son cilindricas y estin provistas de largas espinas ciliad.as; las crisílidas angulosas.

DISTRIBUCION GEOGRAFICA. L LSE género, poco numeroso cn especies, tiene sus representantes en las dos Américas.

\section{EL AGRAULIS MONETA-AGRAULIS MONETA}

CARACTERES. - I n especic de este nombre (fig. 67), una de las mas conoridas, puede considcrarse coma ipo del géncro. Las alas son de un precioso tinte castaño en la cara externa; en la interna hay varias grandes manchas que tienen la brillantez de la plata, y pareccn literalmente bruñidas; el color del fondo de las alas interiores es ambien pardo, mas púlido, tambien con manchas plateadas.

DISTRIBUCION GEOGRÁFICA. En México, en la provincia de Fenezuela y en la de Nueva-Granada es donde se cncuentra mas a menudo esta bonita marinosa.

\section{LOS MECANITOS-MECHANITIS}

CARACTERES. - La cabera de los mecanitos es de regular iamaño y cscamosa: los ojos prominemes; los palpos labiales raquiricos y escamosos: el tórax oval y pequeño; las alas superiores subtriangulares y muy prolongadas, sobre todo en el macho; las ineriores son subovales jo largas tambien; las patas del primer par del inacho muy pequenas; las de la hembra tienen los fémures un poco inas largos que las tihias, y casi cilindricos.

Tampoco se conocen bien las orugas y las crisilidas de este génetro.

DISTRIBUCION GEOGRÁFICA.-Los mecanitos se Томо VI encueutran deste la parte meridional de México hasta el sur del Brasil.

\section{EL MECANITO-MARSEO-MECHANITIS MARS AEUS}

CARACTÉRES. - El bonito lepidópricro designado con este nombre (fig. 57), tiene el fonan de las alas de un precioso color negro, variado con muchas rayas y manchas ana.

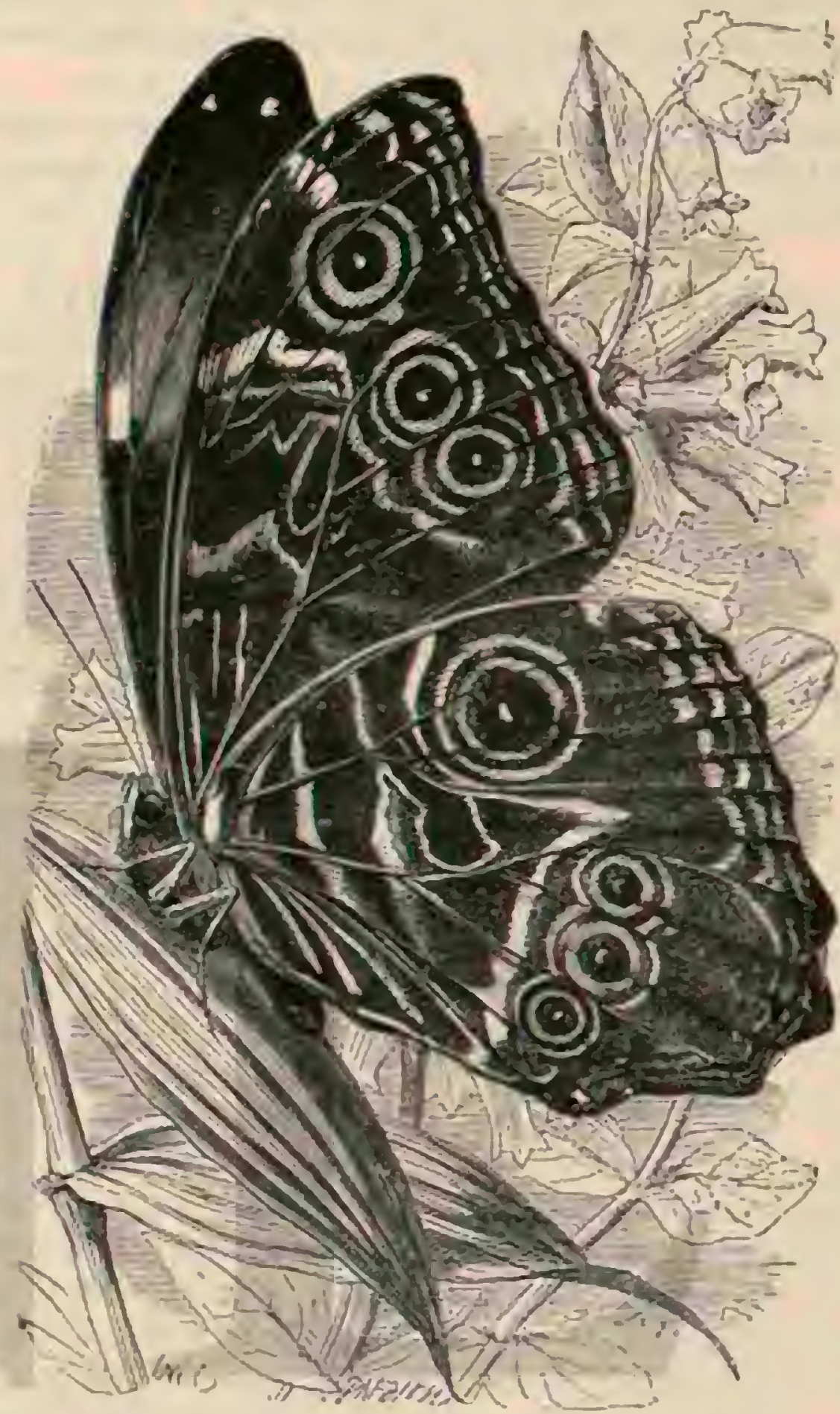

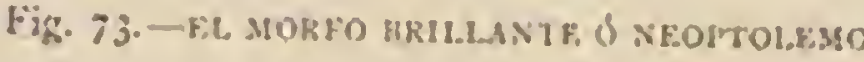

ranjadas, sobre todo a través de la extremidad de las supe. riores. Mide unas 3 pulgadas de punta a punta de ala.

DISTRIBUCION GFOGRAFICA. IA especic es ori. giriaria de la América tropical.

\section{LOS ITOMIAS-ITHOMIA}

CARACTERES. - Los itomins tienen la cabern bastante ancha: ojos redondos y maxilas mquúticas, paco mas $\delta$ menos del mismo largo que el tórax; palpos labiales que no sobresalen de la frente; antemas casi han largas como cl cuerpo, que aumentan de grueso gradualmente hasta su extremidad; tórax pequento, ovil, casi redondo, con el protórax mas dis. tinto que en el género anterior; alas superiores subtriangu. lares, prolongadas y redondendas en la punta. Ias patas del primer par del macho son muy cortas, con lizs tibias y los tarsos representados tan solo por una prominencia cwoiden, sin indicio de articulacion; las de la hembrn, algo raquiticas, se prolongan bastante; los tarsos son mas largos quue las tibias: cl abdómen prolongado.

DISTRIBUCION GEOGRÁFICA.-I as numernens t5- 
pecies de este género abundan particularmente en la parte intertropical de América. Algunas se encuentran en Venezuela, en la (iungana y en ol Brasilo

\section{EL ITOMIA TRASPARENTE-ITOMYA PHONO}

CARACTERES. - Las alas de este curioso insecto (figu$m$ 58) son casi del todo trasparentes, quedando reducidas las partes de color a una estrecha faja que se corre por el bor. de, con algunas manchas y myas, cuyo color consiste en un pardo negruzco, excepto en la parte inferior, donde el fesinn de las alas posteriores ofrece una ligera mezcha de ama. rillo.

DISTRIBUCION GEOGRÁFICA.-WI itomia trasparente habita en la Jamaica, en el Brasil, y en otras regiones c.cronnas.

\section{LOS MARPESIAS - MARPESIA}

CAHACTERES. L Los lepidópzeros de éste género son notables principalmente por el cajrichoso contorno de lás alas, y la cola protongada que las sirve de adorno.

\section{EL MARPESIA TETIS-MARPESIA TETIS}

CARACTERES. - Esta singular mariposa (fig. 65) tiene la parte superior del cuerpo de color castaio rojizo uniforme, con varias lineas estrechas y trasversales, que se corren en toda la extension de las alas, pasando desde el borde del par superior à la extremidád de la inferior; del márgen de cada una de las alas inferiores parten dos projecciones 6 es. pecies de colas, una corta y oira muy larga, estrechas y ligeramente ensanchadas en sus extremidades.

DISTRIBUCION GEOGRÁFICA.- Esta curiosa especie se encuentra en ol Brasil y en la Guayana.

\section{LOS CIRESTIS-CYRESTIS}

CARACTERES.-1 - Los cirestis son lepidópteros de cuerpo pequeno y delgacto: alas grandes, de una textura delicada; cabera pequeina, mónos ancha que el tótax, provista de un hacecillo de pelos en su parte autcrior; los ojos son muy prominentes; antenns raquiticas, terminadas gradualmente por una maza prolongada; palpos labiales largos y escamosos, que no sobresalen de la frente; tónax escamoso tambien, muy peludo; alas superiores gramdes, con el borde anterior un poco redondeado; el ángulo apicial es bastante agudo; las alas inferiores son bastante prolongadas, exagonales, con su borde costal casi recto hasta el centro, y escotado despues hasta el aingulo externo. Las patas del primer par del macho son muy largas y peludas; las de la hembra mas largas, con los tarsos poco desarrollados y compuestos de cinco artejos.

Las orugas y las crisalididas son desconocidats.

DISTRIBUCION GEOGRÁFICA.-De las especies que representan este género las mas habitan en la India y en su archipiélago; una tiene por patria la isla de Madagascar; y otra se encuentra en Sierm Leona. En la Nueva Cuinea, $y$ particularmente en la tierra de los Papúes, han sido observidas tambien algunas muy bonitas?

\section{EL CIRESTIS TIODAMAS-CYRESTIS THYODAMAS}

CARACTEHES. - El color de este lepidóptero (fig. 64) es muy especial: el fondo consiste en un blanco agrisado, $y$ en zoda la superficie se cruzan líncas y rasgos de un tinte castaño, que difieren bastante por su anchura, pues unas son sumamente finas $y$ las otras gruesas; en el borde de las alas se ven algunas lineas dobles del mismo color; la cam interna de aquellas es mucho mas pálida y el dibujo mas menudo.

DISTRIBUCION GEOGRÁFICA.- Esta especie es la que se encuentra en la India, particularmente en Nepaul en Silhet.

\section{LOS CATAGRAMAS - CATAGRAMMA}

CARACTERES. - Distinguense los catagramas por su cabeza muy ancha y peluda; ojos salientes, grandes, ovalares y' lisos; maxilas del largo del tórax; palpos labiales escaumosos, que sobresalen de la frente; antenas robustas, como el tórax, que es oval y peludo; alas superiores triangulares, con el borde anterior redondeado; las inferiores obovales, con el borde externo redondeado y algo sinuoso. Las patas del pri. mer par del macho son escamosas, con los fémures delgados, casi cilindricos y algo corvos; las titins son anchas y conıurmidins; las patas análogas de la hembra se distinguen for lo cortas, robustas y escamosas.

i.25 onignas no son conocidas.

DISTRIBUCION GEOGRÁFICA. - Las especies de este género, bastante numerosas, tienen una extensa árca de dispersion. Algunas se hallan en las regiones inferiores de la América tropical, pero el mayor número habita en las regiones montañosas.

\section{EL CATAGRAMA PALOMA-CATAGRAMMA PERISTERA}

CARACTERES. - En algunas partes se ha dado á este lepidóptero el nombre que lleva (fig. 68), á causa de la semejanza que ofrecen los visos cambiantes de las alas con los matices opalinos que se observan en el cuello de ciertas palomas. El color dominante de la cara superior del cuerpo is negro, con dos grandes manchas escarlata en el centro de cada ala, que se cambian en violáceas cuando la luz se refleja oblicuamente; la cara interna de las alas superiores ticne un tinte semejante, aunque mas pálido; en el horde lleva una ligera linea azulada; las alas inferiores son amarillentas, con dos manchas negras en el centro, cada una de. las cuales presenta unos puntos azulados.

DISTRIBUCION GEOGRÁFICA. - Este lepidóptero habita en las regiones montañosas de América.

\section{EL CATAGRAMA CLIMENE-CATAGRAMMA CLIMENUS}

CARACTERES.-Esta esjecie (fig. 69) tiene las alas negras, con un viso azul violáceo en los machos; las primeras presentan además una linea del mismo tinte en su base, y una faja oblicua en su parte media, de color verde amarillento muy brillante; las segundas ofrecen otra del mismo matiz en su borde. Fsta especie tiene de $22 \dot{2} 24$ lineas de largo.

DISTRIBUCION GEOGRAFICA. $\Rightarrow$ Fsta maripost habita en las regiones cilidas del nuevo continente, y sobre todo en el Brasil.

\section{EL CATAGRAMA LICA-CATAGRAMMA LYCA}

CARACTERES. - Esta mariposa tiene la cara superio: de todas las alas negra, con grandes manchas de un amarillo anaranjado, sobre el primer par, y en el segundo con otra üs un precioso azul; la parte inferior de las alas es tambien ne- 
gra, y hacla el borde de las primeras hay una linea anaran. jada, seguida de otra azul; los dibujos que ofrece el segundo par son de un tinte amarillento de ocre, con manchas azu. ladas: la estrecha linea que circuye el márgen es azul (iig. jo).

DISTRIBUCION GEOGRAFICA.-lil catagrama lica habila asimismo en las regiones mas cailidas del nuevo continentc. Ia especie abunda sobre todo en Mexico, en cl Bra. sil y en Bolivia

\section{LOS NINFALOS-NYMPHALIUS}

CARACTERES. - Fl cucrpo de las especies de este género es muy robusto; las alas inferiores cstan provistas comunmente de una $\delta$ dos colas; la cabeza es medianamente voluminosa; los ojos muy prominentes; los palpos labiales grandes y peludos; las antenas cortas, robustas, rectas y terminadas gradualmente en una maza prolongada y fusiforme, que se adelgała en su extremidad. El tómx, oblongo y muy robusto, parece aterciopclado; las alas superiores son subtriangulares: las inferiores grandes y un poco ovales. I ats patas del primer par del macho son pequenas, escamosas y peludias, con las tibias y los tarios un poco mas largos que los fémures; las patas del primero de la hembra son escamo. sas y tienen los tarsos comprimidos.

I as orugas afectan la forma de limaza, llevando en la cabeza cuatro cuernos; cl uiltino anillo es aplanado y termina en forma de cola de pescado.

DISTRIBUCION GEOGRAFICA.-1,us ninfalos, que habian en el antiguo continente y en Australia, abundan sobre todo en el Africa tropical. En Europa se conoce por lo menos una especie, designada por los autores con el nombre de simphalius josius.

\section{EL NINFALO POLUX-NIMPHALIUS POLLUX}

CARACTERES. - I a mariposa designada con este nombre (fig. 71) llama desde luego la atencion por las erormes dimensiones del tórax: la parte superior de las alas ofrece un magnifico color negro pardusco intenso, mas pailido en el cuerpo; el dibujo de las alas superiores es anarillento, me. nos subido en las inieriores : el ligero filete de estas tiene un tinte axul; las manchas que adornan los bordes son negras, con lineas blancas, entre las cuales corre una faja del mismo color, completando el dibujo varios rasgos de distinta forma, de un tinte castaño. Lits piernas son negras y blancas, lo mismo que la base de las alas.

DISTRIBUCION GEOGRÅFICA.- Este magnificole pidóptero es originario de Guinca?

\section{LOS ADOLIAS-ADOLIAS}

CARACTERES. - Distinguense los ndolins por su cuerpo mas ó menos rolusto; antenas largas y estrechns; alas grandes; cabeza ancha; ojos prominentus; antenas muy largas, filiformes en la base, $y$ que se cnsanchan poco ì poco para formar bruscamente una maza larga y cilindrica: los palpos habiales sun pequenos y aprenas sobresalen de la frente, sien do los del macho mayores que los de la hembra; las maxilas. en forma de espiral, son robustas y comprimidas hacia su ex tremidad, y ciliadas hácia los lados. El tórax mas 6 menos robusto y peludo: las alas fuertes por lo regular; las superio res algo triangulares, y las inferiores redondendas. Las patas no ofrecen ninguna particularidad de estructum; el abdómen es de un largo regular.

I as orugas, lineales y prolongadas, estin provistas a cada lado de apéndices braquiformes; tienen patas cortas y peque. nas, del todo ocultas por los apéndices laterales.

Las crisálidas, cortas fo angulosas, se atenúan en ambas extremidades, y sus ángulos presentan espinas en extremo delgadas.

DISTRIBUCION GEOGRÁFXCA. - I.Os adolins, tambien muy numerosos, tienen por patria la India, su archipiclago y la China.

\section{ELADOLIAS ESPINOSO-ADOLIASACONTHEA}

CARACTERES. - I.OS de esta especic (roy. 72) no ofrecen mada de notable, como no sea los apyéndices en extremo largos que presenta la oruga. Los colores son uniformes y oscuros, $y$ no tienen tampoco nada de particular. la crisili. da presenta una forma singular que se asemeja hasta cierto punto a la de un casco antiguo.

DISTRIBUCION GEOGRÁ FICA. - Tista esprecie sect1cuentra en la India, y es bastante comun en Java.

\section{LOS MÓRFIDOS-MORPHIDFE}

CARACTERES. - I os giganiescos mórfidos de la amé rica de! sur son mariposns de un color brillante, que á mucha altura retozan en los claros y en los anchos caminos de los hosques del Brasil, ofreciendo al espectador un cuadro sorprendente. Al contrario de los grandes caballeros de que an. tes hablamos, que vuelan por las calles de las ciudades, cruzan los jardines y hasta penetran en las habitaciones, nuestros *héroes troyanos, bu Mesclaus de color a\%ul magnifico, un Telemaco, เม Vector, que tienc una faja trasversal azul de color mas mate, un Morfo Lenertes del todo blanco, con un graciosísimo mosaico en la cara superior de las alas posteriores, y otros muchos, no se rebajan tanto, sino que solu descienden a la tierra despues de una lluvia tenupestuosa a fin de apragat su sed. 'Todos cllos miden con las alas exten. didas de $\left(0^{m}, 130\right.$ a $1^{m}$, iso y mas aun, de modo que so les ve à bastante distnncia. los machos de todos los morfos tienen las patas anteriores muy jequeins, en forma de pincel; en ambos sexos las antenas son delgudas, con maza pequetia; los palpos comprimidos, muy separados, que rematan en un artejo pequeno en forma de cono: los ojos desnudos, y las alas anteriores por lo regular un poco escotadis en el borde anterior.

\section{EL NEOPTOLEMO-MORPHO NEOPTOLEMUS}

CARActéres. - Este mórfido tienc: en là cara superior un color azul de ciclo de brillo metálico que presenta los colores del arco iris como un ópalo, pero en matices mu. cho mas intensos. Ia cara inferior, de color pardo, tiene numerosos dibujos (fig. ij).

Semejantes a esta especie hay otras muchas que eshin diseminadas en las regiones ecuatoriales.

\section{LOS SATIRIDOS-SATYRIDA:}

CARACTERES, - l os satiridos constiruyen un género rico on isperies, el cual se distilgute mas bicil pur el color los dibujos que por la forma de las alas y otros caractéres. Ia cara superior de aquellas, de un pardo claro il oscuro, puede tener un solo color, pero suele disinguirse por unos punti. tos redondos ó manchas oculares que en mayor ú menor numero se hallan cerca del borde. la cam inferior de las alas. generolmente igual en su partc anterior y superior, yresent. varios dibujos de color pardo, y las manchas oculares son mas 
marcadas y completas; estas manchas, por lo comun negras, tienen el centro blanco ó à veces tambien de un brillo metalico. Además de estos dibujos en las alas, todos los satiridos presentan en comun los caractéres siguientes: los nervios seis y siete parten separadamente de las celdas discoideas de las alas anteriores; el cuerpo es peludn; las garras de los piés hundidas os escotadas; los palpos, separados y de mediana longitud, se dirigen hácin arriba y están cubiertos de espesos pelos erizados. I a mayor paric de las especies solo alcanzan un mediano tamaño.

DISTRIBUCION GEOGRAFICA.-Muchas especies se encuentran exclusivamente en el extremo norte ye dis tingucn por el color mas claro del fondo y por los tegunen. tos cscamosos, mus dejgados yi trasparcntes; otras son pro. pias de los Alpes yide varias altas montunas que alimentan numerosis espccies. I estás betterieceńn las mas oscuras, que
Se distinguen por tener en la cara inforior de las alas dibujos
muy finos.

USOS, COSTUMBRES X REGIMEN - Vuelan solbre todo en las praderas. Las orugas, que tienen la extremidad adelgazada en dos puntitas, y que son lisas ó rugosas, cybiertas á menudo de pelos aterciopelados y provistas de rayas longitudinales ya claras ú oscuras, se hallin casi exclus: vamente en las gramineas; comen de noche y se ocultan de dia en la base de su planta alimenticia, en el suelo, 6 en 1 superficie del mismo. Las crisáliclas, de color pardusco, se redondean mas que las otras mariposas diurnas, y hailhanse á poca profundidad debajo de tierra 6 de las piedras, aurque tambien hay algunas que se cuelgan.

Clasificacion. - Las numerosas especies se han dividido en una serie de géncros segun la naturaleza de algunos nervios longitudinales, las proporciones de los tarsos

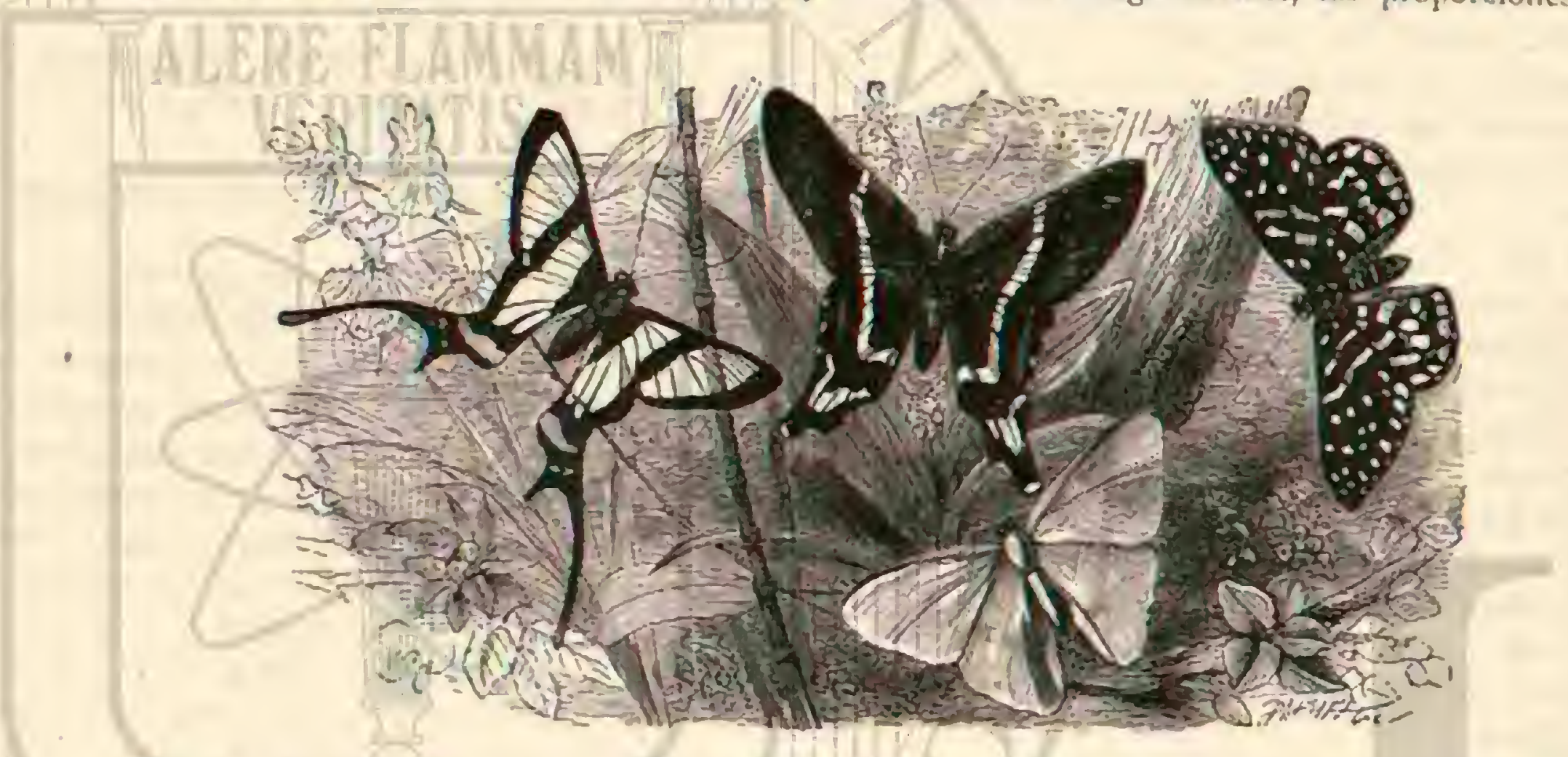

Fig. 74.-EL zEosia, tor. I.A. I:S

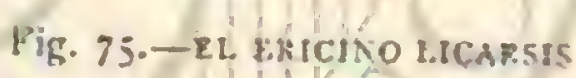

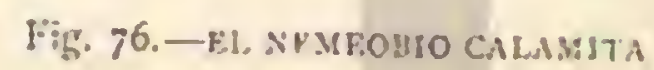

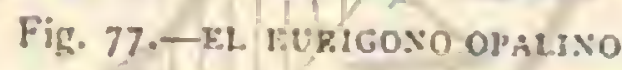

medios y los phés, las antenas provistas de hotion ó de maza, y la forma de las alas posteriores. De estos generos. los llanna-

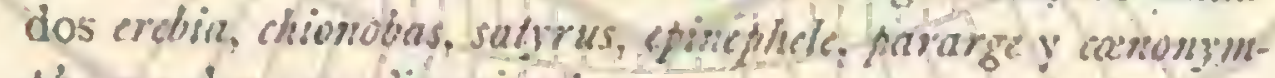
pha son los imas diseminados.

\section{LA SEMELE-SATYRUS SEMELE}

CARACTERES. - la cara superior de las alas es de color pardo con viso gris: las anteriores tienen en la parte del borde dos manchas oculares blancas, y una con el ala posterior cerca del ángulo anterior; cl fondo es de un rojo amarillo claro, mas marcado en la hembra que.en el macho, que es de menor tamaino y tiene tintes mas oscuros. Fu la cara inferior de las alas anterjures los dibujos son bastante igunJes á los de la cura superior; en las alas pesteriores lá superficie es gris, con dibujos scmejantes á los del mármol, pardos y negros; el ojuelo solo es visible en la hembra, mientras que en cl macho desaparece, pero este tiene en cambio una faja oscura hácia la base con los bordes angulosos. E1 nervio costal y ul central se dilatan cerca de la base en forma de callosidad; las antenas ticnen botones; los palpos, mas ó menos separados, están provistos de pelos cerdosos; su último artejo, mas delgado; se balla cubierto de escamitas lisas. I. a hemirn mide por término medio $0^{m}, 058$ de punta à punta de ala.

La oruga lisa de color gris, con el vientre verdoso, tiene cinco fajas longitudinales negras, pudiendo ser la central mas oscura; en cada estigma hay un punto neyro y seis fajas del mismo color en la cabeza.
USOS Y COSTUMBRES. - I a semele es una mariposa tan timida como ágil, que en todas partes sé ve durante julio y agosto, particularmente en las alturas cubiertas de espesa vegetacion y en los linderos de los bosques de coniferns. Se posa en un tronco de árbol con las alas plegadas y visita las flores del lindero del bosque donde encuentra gran número de sus semejantes y otras especies.

De pronto se eleva, vuelve á posarse con las alas plegadis, remóntase de nuevo y repite la misma maniobra toda el dia, micntras que el sol no haya desaparecido del horizonte y mientras el cielo no esté encapotado. Nunnar se la ve exponer Ja cara superior de sus alas al sol, sino jue siempre las tiene plegadas, y por eso es dificil ver la superficie de las misnas en el insecto libre à causa de su rápido vuelo.

la oruga se alinsenta de yerba é inverna siendo aun bas. tante jóven. La crisílida descansa á poca profundidad en el suelo, ó debajo de una piedrn.

\section{LA BRISEIS-BRISEIS}

CARACTÉRES. - Del mismo modo se desarrolla la briseis, que se distingue por una faja amarilla y blanca de ins alas anteriores y por otra de manchas del mismo color.

\section{LA ALCIONE-\$ATYRUS ALCYONE}

CARACTÉRES. - Fsta especie es un poco mas grande y oscura y tiene la faja blanca amarilla de las alas posteriors mucho mas marcadia. 
USOS Y COSTUMBRES. - l.ns dos especies, tan aigiles como timidas, no extienden nunca las alas cuando están posadas, sino que siempre las recogen. Se las encuentra en las alturas pedregosas baniadas por el sol, donde rasan el suclo volando rípidamente; se posan en una y otra piedra, y siempre cstán dispuestas a remontarse de nuevo parn posarse ian pronto en un árbol como en otrn. Hista esprecie, mas escasin que las otras, se ve con mas frecuencia ell el norte, en el este y sur de Alemania.

\section{EL EPINEFELE HXPERANTO-EPINEPHELE HYPERANTHUS}

CARACTERES. - Eil epinefele hiperanto es un verdadero habitante de las praderas, de un aspecto por demńs senciHo. Sus alas, de un pardo oscuro, tienen franjas y dos manchas oculares negms con el centro blanco yo borde amarillo. La cara inferior es de un gris amarillo y presenta cr las alas infuriores una tercera mancha ocular pequeña debajo de las

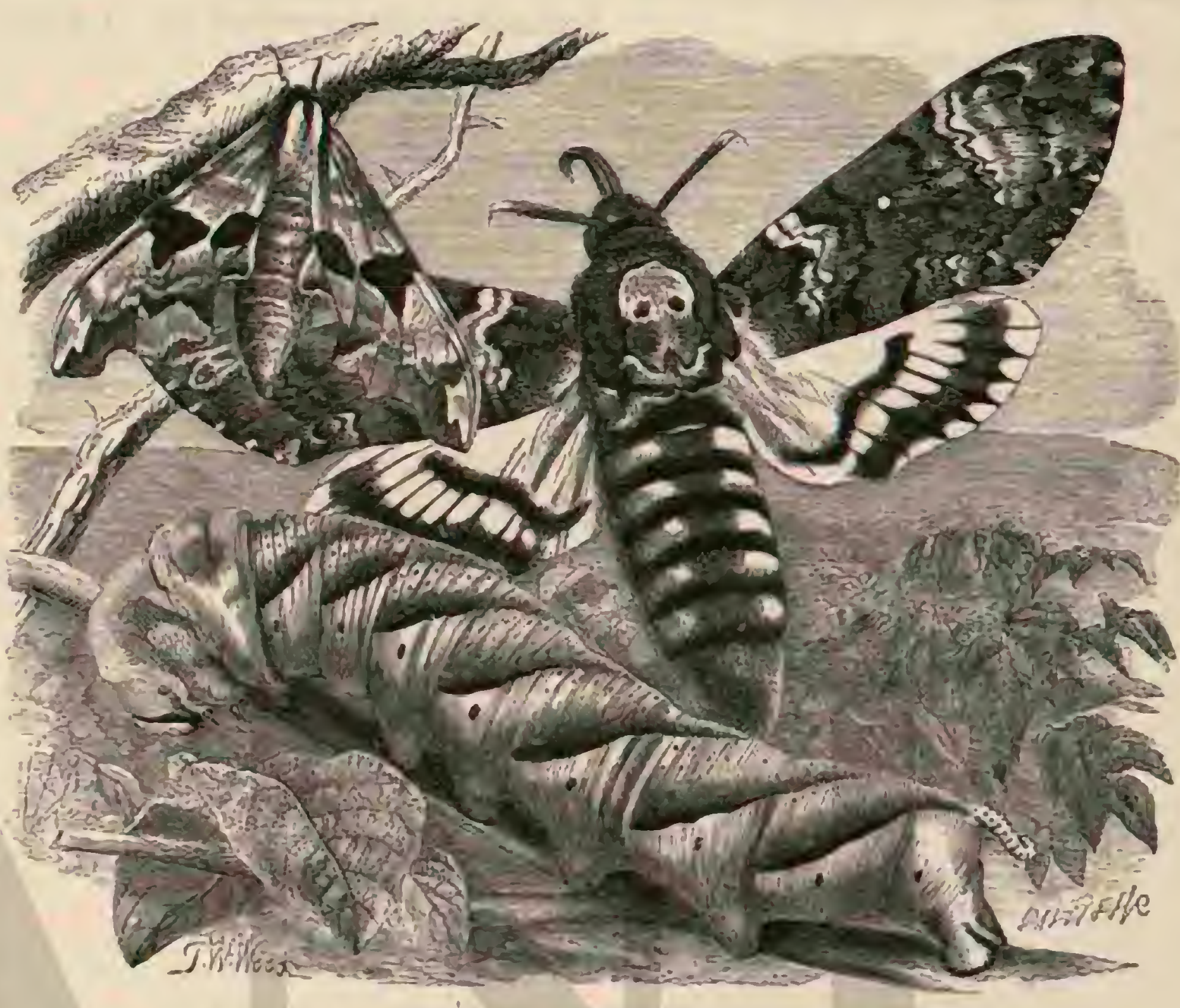

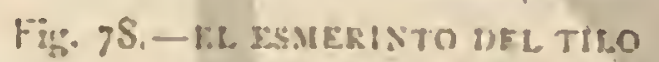

dos superiores, y ademas en el centro del borde anterior otras dos en forma de $\$$ en las alas posteriores. Fil nervio costal y el central sc ensanchan en forma de callusidades en la base y el borde interior de las alas posteriores, encorvindose ligeramente hácia el ángulo interior. las antenas se ensanchan poco a poco en forma de una larga maza deigada:-los paipos rematan en un anejo largo y delgado, y los larsos medios son algo mas coros (que el pié. Las hembras, mas grandes, mi. den $11^{\prime \prime}, 041$ de punta á punta de ala.

USOS, CUSTUMBRES Y REGIMEN. - Desde me. diados de junio hasta agosto, esta mariposa raga por todas parties, se coge a los tallos de las fores con las alas entreabicrtas, recorre in verde alfombra de las praderas, de los fo. sos poblados de yerba y de las pendientes de las colinas. Su vuclo es racilante y poco sostenido. Cuando llega la noche entrégase al sucno como todas las mariposas diurnas, con las alas plegadas. Su oruga se alimenta con preferencia del milicina effussum, pero tambien de otras especies de grami. ness, como por ejemplo de la for amisu. Está cubierta de pelos de un tinte gris rojizo, y sobre los pies, de color gris, tiene una faja blanca y otra parda i lo largo del dorso, aunque solo bien marcadas desde el quimto segnento. Despues de invernar se trosforma, à principios de junio, en una crisilida corta en forma de cono, redondeada en su parte anterior, cuya superficic pardo clara está cruzada de fajas oscurns.

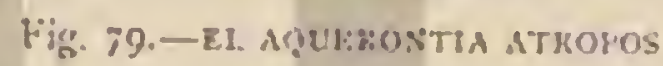

\section{EL EPINEFELE JANIRA-EPINEPHELE IANIRA}

CARACTERES. - Lil macho y la hembra se distinguen en esta especic mas que en otras muchas. El primero tiene la cara superior de las alas anteriores de un pardo oscuro, cubierio de pelos bastante largos en la base y en la parte central con una mancha ocular en ha punta, mancha quuc tiene un centro blanco en la cara inferior, cuyo matiz. es amari110 rojo con un borde pardusco. Ias alas posteriores, que carecen de mancha ocular, son de colur pardo gris en el nacimicnto de una faja clara que se corre hácia el borde.

la hembra es de un color mucho mas claro, y iene la faja de las alas postcriores mas marcada, con una mancha roja alrededor de la mancha ocular que esta provista de un cen. tro blanco en la cara superior de las alas anteriores. In forma de los nervios de las anienas, de los palpos y de las alas posteriores es la misma qué en la especie anterior.

I a oruga, verde ó de un verde amarillento, liene una faja longitudimal blanca delantc de las patas, y unos pelitos cortos en todo el cuerpo. Se alimenta de diferentes gramineas, sobre rodo de la fora prasensis y vive como la oruga de la especie anterior. La crisálida tienc en la cabeza dos ligeros puntos, distinguiéndose por varias fajas longitudinales de color violíceo pardusco y dos series de puntos pardos en el dorso solbre un fondo verdoso. 


\section{LOS PARARGES-PARARGE}

CARACTERES. - Este gTupo se distingue de los epine feles por tener los ojos peludos, pero tienen con ellos de comun el nervio costal y el central interior que se ensanchan en forma de callosidades; además en todas las especies afines las anteuas son negras con anillos blancos y rematan en un botoncito largo de forma oval; los palpos son unas largos que la cabeza; el último segmento está cubierto de pelos lí. sos. Los tarsos medios son mas cortos que los piés.

\section{LA MEGUERA-PARARGE MEGARA}

CARAGTERES. - Ials manchas oculates tienen un centro blanco de cujo color son tambien las franjans entre los nervios. El dorso de las alas posteriores tiene un tinte pardo ainarillo còn viso gris blançuizco.

USOS, COSTUMBRES Y REGIMEN. - A esta marijosa le agrada posarse con las alas entreabiertas en his paredes de barro, $\delta$ en el suelo, sin que llamen por lo tanto su atencion las praderas ni el follaje de los bosques, ni las pintadas flores. Los individuos procedentes de sarias crias vuelan descle la primavera hasta muy entrado el otoño,y hasta invernan algunas veces, mientras que la oruga lo hace casi siempre. Esta última vive en toda clase de yerbas; csta cubierta de pélos aterciopelados y es de color vurde pálido; por encima de sus estigmas se corre una faja blanca que poco a poco desaparece; otras cinco, de un verde oscuro, con borde pálido, se prolongan á lo large del dorso. La crisálida, de color verde negruzio, tiene dos series de botoncitos claros en el dorso.

\section{LA TECLA DE LAS ENCINAS-THECIA QUERCUS}

CARACTÉRES.-Fsta mariposa llama menos la atencion al aire libre que la mayor parte de stus congéneres, pues solo se la ve aisladamente $y$ abandona muy pocas reces las regiones superiores del aire en los bosques, 6 cuanco menos las espesuras. Con las alas plegadas se pasea por una hoja de encina expuesta i la luz del sôl y jarece buscar la soledad; con un ruelo corto desaparece de esta lioja y repite en otra sus paseos. Solo cuando la hembra espera la visita de un macho despliega sus alas, de las cuales las anteriores afectan la forma de cuña, mientras que las posteriores se redon. dean; tienen una superficie unicolora pardo negruzca con un viso violảceo cuando están expuestas à una luz favorable. En el macho brillan dos manchas en forma de cuña, del mas magnifico azul ccleste, en la base de las alas anteriores; están muy próximas entre si, y la interior es mas grande que la exterior. La cara inferior de las alas es de un gris plateado y tiene en la parte del borde una faja blanca mas oscura hảcia adentro $y$ algunas manchitas rojizas por detris. Lns antenas presentau uraciosos anillos blancos, ensanchanse poco á poco en forma de cuña y llegan con su punta hasta la mitad del borde anterior de las alas. Los ojos, rodendos de delicadas escamitas blancas, son peludos; las alas ante. riores, en ambos sexos, un poco mas endebles que las otras, miden de $11^{\circ}, 0325$ a $10^{\circ}, 035$ de punta á purta.

DISTRIBUCION GEOGRAFICA. - Esta bonita mariposa se encuentra en todos los puntos de Europa donde hay encinas.

USOS, COSTUMBRES X REGIMEN, - La hembra, nacida de la crisálida invernada, deposita despues sus hueros aisladamente en las hojas de las encinas. Las oruguitas, que se alimentan en dichos árboles, no solo llegan durante el verano á su tamano completo, sino que penctran tambicn debajo 'del musgó para convertirse en crisálidas. Son convexas por arriba, aplanadas en la parte inferior y de forma recogida. Su color predominante es pardo, amarillento en la parte posterior, con pelos muy finos, je en el dorso unas series de triangulitos amarillos prominentes, divididos por una linea longitudinal negra.

La crisailida de color claro con manchas pardas podria llamarse oval si no se estrechara un poco por delante del centro. Se la encuentra rigida é inerte, y nunca se mueve con viveza, con la parte posterior de su abdómen, cuando se ia toca, como suelen hacerlo las crisilidas de las mariposas diurnas.

Otris muchas especies (spini, fruni, rubi, ilicis, etc.) son propias de Alemania, y análogas á las ya descritas respecto a la forma de las alas, antenas, patas y ojos. Viven del inismo mado en otros árboles, como la tecla comun en las encinas. Ia superficie de sus alas es de un pardo oscuro, ó de un verde oscuro (thedar ruhi), con manchas rojas ó rojo amariUlentas 0 bien sin ellas. La cara inferior presenta siempre co lores mas vivos, pero carece de las oculares.

\section{EL POLIOMATO DE VERGA DORADA- POLYOMMATUS VIRGAURERE}

CA HACTÉRES. - Este lepidúptero tiene la misma forma y tamaño que la esjecie anterior. El macho es el mas notable entre las mariposas de nuestros paises, no por su caracter, sino por su color, pues la faz. superior de su cara brilla como una moneda recien acuinada, pero tiene los bordes negros, mientras que la hembra parece sembrada de manchas negras, cunndo menos en las alas posteriores; en las anteriores se hallan dispuestas en dos series tmasversales en la parte dei borde, y oiras dos ocupan la parte central. La cara inferior es bastante igual en ambos sexos; sobre un fondo rojo amarillento sin brillo se ven diseminados varios puntitos negros en el ala interior, $y$ debajo otros tres dispuestos en linen recta dentro de la celda cliscoidea, que es un carácter genćrico. El ala posterior tiene los puntos negros mas escasos, pero hácin el borde hay dos blancos que en la hembra se ensanchan formando una faja completa. Su borde es un poco anguloso, sobre todo en la parte posterior, que no es denticulada, como en la especie anterior, por lo cual estas mariposas, de las cuales la mas comun es el poliomato manchado (polyommatus phlicus) se distinguen del género anterior.

DISTRIBUCION GEOGRÁFICA.-El poliomato de veria dorada se encuentra en Alemania, excepto en el nuroeste del pais.

USOS, COSTUMBRES Y REGIMEN. - Vuela en jU. lio y agosto por las flores, en los bosques y sus contornas; ; cuando está posada muestra la cara superior de sus alas. La ongga, de color verde con fajas amarillas, vive en el selidugo airgauren. La crisálicla tiene las formas recogidas y la innovilidad de la especie anterior; es de color amarillo pardusco con los estuches de las alas mas oscuros.

\section{LOS LICENOS - LYCANA}

CARACTERES. - Los licenos ó mariposas azules deben su nombre a la cara superior de las alas del macho, que ts de un benito color azul; en las de la hembra predonina el pardo oscuro y el azul se ve solo en la base como viso. La cara inferior presenta mas ó menos jumtos negros ó manchas oculares, que hảcin el borde forman series y á menudo tienen un vivo brillo en el centro: que es platendo. Uno de estos puntos. Hamados tambien ojus aigros, se cincuentra sicmpre en 
el nervio trasversal de las alas anteriores, como cassicter genérico. Los ojos, reticulares, pueden ser desnudos ó peludos Algunas esprecies que vuelan apenas entmdo el añ por las espesuras, tienen una pequeña puntita en las alas superiores, que falta en la mayor parte de las otras formas.

DISTRIBUCION GEOGRÁFICA.-Se conocen virios centenares de especies en todos los continentes.

USOS, COSTUMBRES Y REGIMEN.- Fstas pequenิas mariposas reıozan por todas partes en rerano, en las fiores de las praderas y de los campos, de los bosques y de los fre sales sceos, pero no parecen emprender vinjes a gran distancia

\section{EL LICENO ICARO-IYCAENA ICARUS}

CA RACTERES.- Fösta especie, el licero alexis de Fabricius, tiene aun otros nuchos nombres, comn la mayor parte de sus congéneres, circunstancia que patentiza cuan dificiles en la unifornidad de muchas, para los autores, distinguir in lat deseripejon una especie clasificada por oiro naturalista.

La carn superior de las alas es de un bonito azul brillante y esta orillada de un fino borde negro por delante de las franjas blancas. Ia carn inferior ess de un gris pardusco, con la base de un verde azulado, cubierta de numerosas manchas oculares y de manchitas de un rojo amarillo en las alas posteriores.

USOS, COSTUMBRES Y REGIMEN - I a mariposa vuela casi todo el año y es comun en todas partes. No tiene siempre los mismos dibujos. La oruga es de un color verde pálido, con fajas oscuras, orilladas de blanco, y con dos series de lineas oblicuas oscuras. Se encuentra en mayo y despues en julin en el onomis spincesa, pues se alimenta sobre todo de las fiores de esta planta.

\section{EL LICENO ADONIS-IICAENA ADONIS}

CARACTERES. - El liceno adonis es decididamente el mas bonito de los licenos de Alemania, jues ningun otro ostent:s tan vivo brillo en cl azul cie sus alas; en los años en que abunda vénse tambien hembras cuyas alas, en la mayor parte pardas, brillan por un viso a\%ul.

USOS, COSTUMBRES Y REGIM EN.-Este lepidóp tero tiene dos crins: la orngg vive un el trébol con otras papilionáceas, mas parece que solo se encuentm en ciertas regiones: falta en las llanuras de! norte, al paso que abunda cerca de Halle y mas arriba cn el valle del Sale.

\section{LOS ERICINOS - ERYCINE}

CARACTÉRES.-Distinguence has especies de este género por su cabeza de regular tamaño; ojos salientes y bastante grandes; palyos largos, separados, dirigidos hatcia delante y escnmosos; el segundo sobressle inucho de la frente; el uiltimo es mas delgado y mas corto; las antenas terminan en fornia de maza fusiforme. Las patas del primer par del macho son incompletas y muy vellosas; las de la hembra completas; el cucrpo de las alas, que ieminan por una larga cola, es bastante robusto. I as orugas y las crisilidas no se conocen.

DISTRIBUCION GEOGRÁFICA. - Ias pocasiesfrecies comprendidas en este genero habian en América.

\section{EL ERICINO LIGARSIS-ERYCINA LICARSIS}

CARACTERES. - Fl ericino licarsis ( riposa muy honita: In cara superior de las alas es de un color negro intenso, sobre el cual se extienden dos fajas de un es. carlata brillante; la cara interna es mas preciosa todavin, pa- reciendo á primera vista de un sencillo tinte pardo oscuro con una mancha en el borde interios de las alas inferiores; conviértese este mati\% en un brillante azul, con visos verdosos, cuando la lu\% se refieja latemlmente. El conjunto que ofrece asi la coloracion de csta mariposa es verdaderamente admimble.

DISTRIBUCION GEOGRÁFICA.- Esta especic tiene por patria la Guayna y cl Brasil.

\section{LOS EURIGONOS - EURYGONA}

CARACTERTE. - l.os atributos esenciales de estos lepidópteros consisten en lener las antenas muy cortas, formando en su extremidad una diminuta maza; los palpos son tambien muy pequerios y menos largos que la cabeza.

DISTRIBUCION GEOGRÁFICA. - En América es donde se encuentran principalmente las especies del género.

\section{EL EURIGONO OPALINU-EURYGONA OPALINA}

CARACTERES. - El curigono opalino (fig. 77) Ilama tambien la atencion por sus magnificos colores: si la lu\% no se refleja de una manera favorable, esta mariposin parece ser solo de un sencillo color de namuja; pero cuando se reflejan de cierto modo los rayos del sol por la parte superior del in. secto, diriase que las alas son de oro, y admira ef brillo que despiden; al girar el insecto, durantc su ripiclo vuclo, ofrecen sus alas todos los colores del arco iris. Representamos en el grabado cste insecto en su tamano natural.

DISTRIBUCION GEOGRÁEICA.-Fsta esprecic lıalita en Cayena.

\section{LAS ZEONIAS - ZEONIS}

CARACTERES. - la cabera de estos insectos es voluminosa; los ojos salientes; los palpos villudos y escamosos, con artejos poco distintos; las antenas son largas y no tcrmi. nan en maza. Las patas del primer par del macho abortadas y muy vellosas; las de la hembra completas y un poco mas delgadas que las de los otros pares El cuerpo es robusto, lo mismo que las alas: cstas últimas icrminan en una rola mas ó menos larga, que nace comunmente de un aprindice anal muy pronunciado.

Las orugas y las crisalidas no son conocidas.

DISTRIBUCION GEOGRAFICA.- I as pocas especics que representan a este género tienen por patria la A mérica meridional y sepientriomal.

\section{LA ZEONIA DE BATES-ZEONIA BATESII}

CARACTERES. - I a bonita esprecic (fig. 74) designada con este nombre en obsequio ä M. Bates, que fué quien ia descubrió, tiene las partes blancas de sus alas membranosas $y$ trasparentes, y el resto de un color muy oscuro, casi negro; la base de las inferiories es de un azul intenso: por el centro de las otras corre una faja de un precioso tinfe escarlata: la cola que parte de las inferiores es casi recta.

DISTRIBUCION GEOGRÁFICA. - I A especie habita en la América meridional.

USOS Y COSTUMBRES. - La zconia de Bates vive on los bosques, donde se la encuentra algunas veces reunida con un gran número de sus semejantes. Vérase lo que dice el sabio natumlista al hablar de su descubrimiento: "Paseándome una tarde de julio por un bosque situado en las inmediaciones de Ega, llamóme la atencion un grupo de estos lep:- 
dópteros, tanto mas cuanto que habiendo pasado varias veces por el mismo sitio en diversas estaciones no los habin observido nunca. Internaindome mas por la selva, quedé a poco sumamente admirado at ver que en una extension que no tendria menos de treinta à cuarenta varas en cuadro, estaban los árboles literalmente cubiertos de estos lepidópteros, hasta el punto de no laber apenas hoja alguna donde no se posara un individuo. Pude adquuirir fácilmente cerca de ciento; pero no tuve el gusto de encontrar ninguna larva, á pesar del cuidado con que practiqué mis observaciones. A los cuatro dias pasé por el mismo sitio, y apenas ví ya una docena de estas mariposas.

\section{LOS NEMEOBLOS NEMEOBIUS}

CARACTERES. - Las antenas de estas mariposas son tan largas como el cuerpo, no comprendida la cabexa, rectas y terminadas por un diminuto boton aplanado; los palpos cortos y recios; los flos frimeros poco vellosos, f el tercero casi desnudu; los ojos son oblongos; la extremidad de los tarsos muy pequena; el tórnx algo robusto; el abdómen hastante largo.

Las orugas, de forma oval, estín erizadas de pelos finos: tienen la cabeza muy pequeña y globulosa, y las patas cortas

Las crisálidas son redondeadas, y con el cuerpo cubierto de muchos pelos finos.

DISTRIBUCION GEOGRÁ FICA.-Parece que csta especie habita en las regiones del Amazonas.

\section{EL NEMEOBIO CALAMITA-NEMEOBIUS CA- LAMITA}

CARACTÉRES. - La cara superior de las alas de este

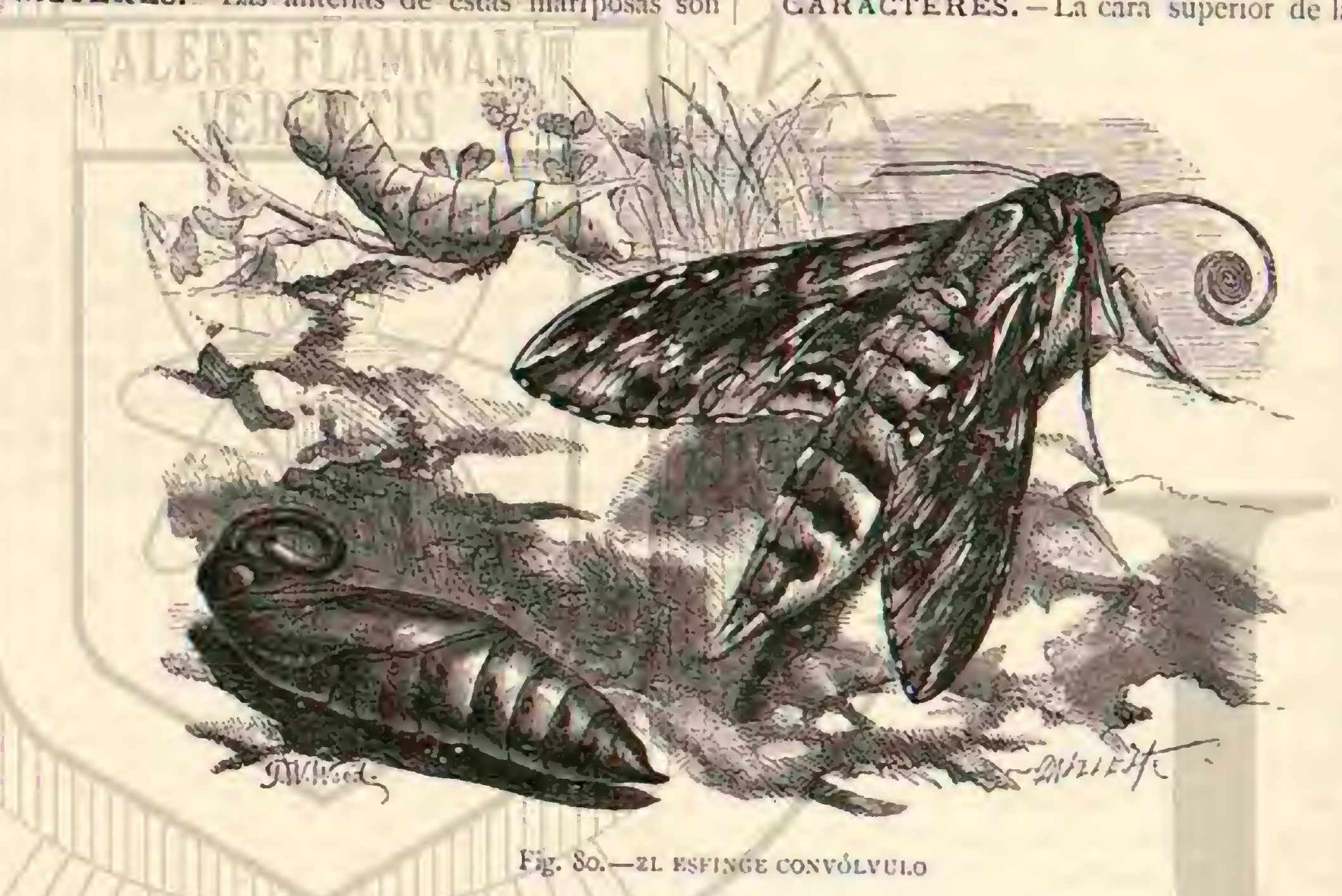

insecto es completamente negra, cubierta de numerosos lu. nares azules y bláncos; en la inferjor predomina un tinte pardo, con numerosas manchas blancas y negras, que forman en cierto modo como una línea junto a los bordes de las alas (fig. 76).

DISTRIBUCION GEOGRÁFICA.-Esta especie vive en la América meridional: se encuentra principalmente en los paises del Amazonas.

\section{LOS HESPÉRIDOS-HESPERIDAE}

CARACT ERES. - Los hespéridos se distinguen fácilmen te de todas las demás mariposas diurnas por su cabera volu. minosa y por tener dos pares de espolones que en las otras especies se observan en los tarsos posteriores. Las especies europeas llegan poco mas ó menos ì la mitad del tamano de los licenos, pero tienen formas mas recogidas y colores mas monútonos. Las cortas alas presentan nervios fuertes y las posteriores una celda discoidea abierta. En la cabeza, que es voluminosa, hay grandes ojos desnudos, $y$ un mechon de pelos rizados en la base de las antenas, muy separadas una de otra y que por lo regular se encurvan en la maza de la pun. ta; en ambos sexos las patas anteriores no están menos desarrolladas que las otras. Estos son poco mas $\delta$ menos los caractéres del género Hesperia, muy rico en especies.

DISTRIBUCION GEOGRAFICA. - Hay centenares de especies de las que la mayor parte habitan en la Ancérica del sur, distinguićndose muchas por la forma mas robusta, por los colores mas viros, por las manchas oculares claras y por las colas de has alas posteriores largas, notindose otras parti. cularidades.

USOS, COSTUMBRES Y RÉGIMEN.-IATs orugas viven entre hojas arrolladas. Con un vuclo bastante ripidoy recto, se presenta la mariposa cn una for para lithr ó en el suelo; abre las alas posteriores y levanta las anteriores. Tan pronto como llega ruelve à desajarecer. Todos sus movimientos indican cierta elasticidad en el cuerpo, energía y audacin

\section{EL HESPERIO COMA - HESPERIA COMMA}

Caracteres. - El macho y la hembra tienen la parte superior de un pardo amarillo $y$ la inferior de un pardo ver. doso, no presentando el mismo aspecto interiormente. El primero ticne un borde pardo oscuro, cinco manchas mas claras y una callosidad central oblicua de color negro, diridida longitudinalmente por unas lineas platendas en las alas anteriores, y otro borde oscuro, con manchas claras, en las alas posteriores. En la hembra se corre una serie de manchas. por ambas alas, manchas que en el ala posterior ofrecen un color blanco amarillento; $y$ en ver de la callosidad negra hay en la cara posterior numerosas escamas verdes. La oruga es verde con puntos negros en los lados, y vive cu las arvejas. 
Ahora daremos a conocer las cifras de las cenpecies de mariposas europens y alemanas por los diferentes géneros. De los 14 papiliónidos europeos se encuentran 6 en Alemania; de los 3 r pieridos 16 ; de los 59 ninfálidos 46 ; de los 57 licenidos 49; y de los 29 hespéridos IS. Además existe el crisịpo (danais chrysipus) aisladamente en Sicilia como tinico danaido en Europa; y en el Nemeolio Lucina, el rico género brasileño de los cricínidos, tiene su único representante en Europa y Alemania

\section{LOS ESFINGIDOS- SPHINGID压}

CARACTERES. - Por su aspecto exterior jo por su gúne. ro de vida los esfingidos, como segunda familia de mariposas, ofrecen un verdadero contraste con las especies diurnas. Se distinguen a primera vista de aquecllas por su cuerpm grueso y' voluminoso, cubierto de espesos pelos 6 escamas, pror las alas provistas en su cara inferior de fuertes nervios revestidos á menudo de pelos; las anteriores son por lo regu. lar estrechas y prolongadas; las posteriores redondendas y pequenas. El abdómen, fusiforme, se une estrechamente con cl tórnx. I.os palpos son cortos y anchos; la cabeza, relativamente pequuena, de extremidad obtusa en su parte anterior, carece de ojnelos y tiene antenas cortas y gruesas, tringulares, con su base por lo regular un poco mas delgada que de ordinario, rematando en punta encorvada hácia atris in forma de gancho. I lengua alcanza su mas completo desarrollo y es a veces doble mas larga que el cuerpo. Los tegumentos

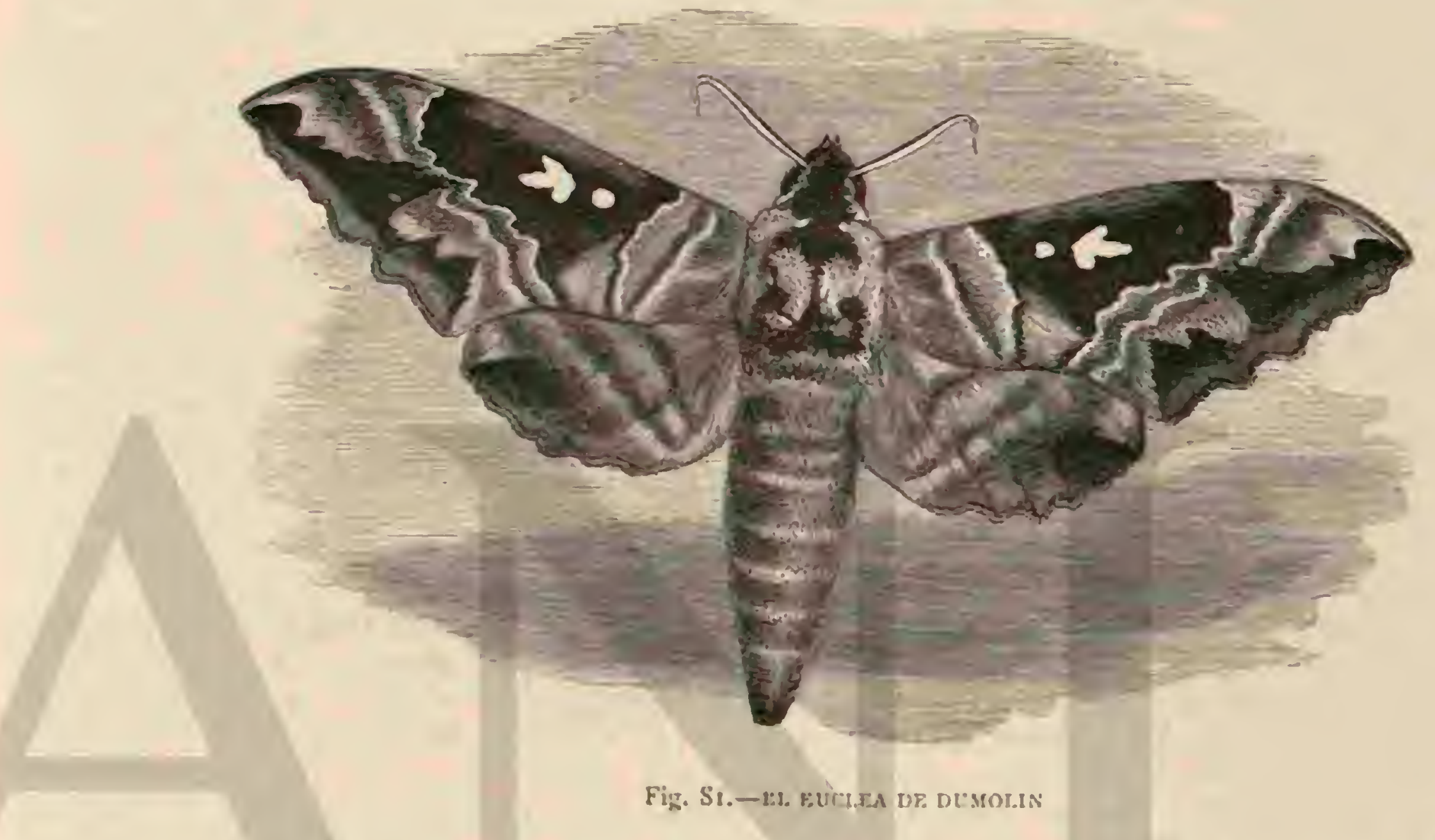

del túrax y del abdómen son lisos en nuestms especies y solo en algunas cxóticas foman en aquel un moño muy pequeño.

Las alas anteriores se distinguen por un nervio domal ahoryuillado cerca de la base; las alas posteriores, provistas de cortas franjas, tienen nervios dorsales y una rama oblicua que reune el nervio costal yo el anterior de los centrales. I as patas anteriorés no están nunca menos desarrolladas que las otras y los tarsos de las posteriores se hallan provistos de dos pares de espolones Asi como en muchas mariposas diurnas, tampoco en los esfingidos se notan mucho las diferencias sexuales exteriormente.

USOS, COSTUMBRES Y REGIMEN. De dia permanecen estas mariposas, por to regular, tranquilas en los sitios oculios, apoyando las nlas un poro aliertas y horizontalmente sobre el cuerpo; oprimen las antenas, inclinadas hícia atris, contra la base de las alas, de modo que no se sen, y duermen, ó cuando menos se dejan coger, sin hacer ientativa alguna para escaprarse; pero tan luego como llèga el creIrúsculo vespertino, los ojuelos comienzan á lucir. Dejan sus escondites para buscarse entre si y visitar las flores, y por lo regular se las oye antes de verlas, pues cruzan los aires con un fuerte zumbido. Tan perczosas son de dia como salvajes y revoltosas al oscurecer: con la rapider. del.rayo vuelan de fior en flor y se alejan cuando ja no encuentran nectar para libar $\&$ cuando se las molesta. Su rípido vuelo dura sin inter rupcion hasta muy entrada la noche, hasta que los sexos se han encontrado ó los músculos necesitan descanso despues de una actividad de horas enteras. Lsta extmordinaria facilidad para volar depeende de las alas estrechas y largas y de una red muy desarrollada de iríqueas en el pesado cuerpo; á ella debe atribuirse que algunos esfingidos curopeos, como el sphini nerii, eterio y lineala, en los veranos calurosos, ajudados quizis por los vientos del sur, lleguen hasta las costas septentrionales de Alemania para depositar alli su cria. El género de los esinerintos; de que mas tarde hablaremos, carece de esta facultad de volar, a causa de las diferentes formas de sus alas, pero se asemeja a los otros por su desarrollo y por la estructura de las orugas. Estas son todas desnudas, prolongadas, por lo regular un poco adelgazadas por delante y provistas de 16 pies; en el dorso del penúltimo segmento presentan un cuerno mas largo ó corto; tienen à menuto colores muy vivos; y asi como las mariposas de que antes heinos hablado, son perezosas y permanecen agarradas a su planta alimenticia durante el dia. De noche se despier. ta toda su voracidad, pero no viven nunen sociablemente. A su tiempo penetran en el suelo y se trasforman en crisa. lida fusiforme, de color oscuro ó tambien claro; y mueven vivamente el abdómen cuando se las molesta. Cacha una necesita un invierno parn su desarrollo, mientras que oiras solo dejan la mariposa al cabo de varios años.

Ia tamilia comprende en numeros redondos, 400 espe- 
cies, de las que la mayor parte pertenecen à la América del sur y las menos à la Nueva Holanda; en Europa se encuentran con seguridad solo 35 , de las cuales las alemanas todas invernan en estado de crisálida.

\section{LA AQUERONTIA ATROPOS-AGHERONTIA ATROPOS}

CARACTERES. - La aquerontia atropos, llamada iam. bien colacera, es por su tamano, despues de la agueronfia medor, de México $\left(11^{\mathrm{m}}, 01925\right.$ de diametro), la mas gran. de de sodins las mariposas, y se ha hecho célebre en cierto modo por dos conceptos. El tórax, cubierto de espesos pelos pardos con viso gris, presenta en su derso un dibujo amarillo de ocre muy semejante a una calavers debijo de la cual se cruzan dos huesos; y ademas, cuando se irrita esta mariposa produce una especie de silbido ó chimido. Desde las observaciones de Reaunur suponiase genenalmente que este sonido se emitia por el roce de ciertos órganos de la parte anterior del cuerpo, es decir, de la trompa con la base de los palpas, provista en su parte inferior de unos ligeros bordes: pero los estudios anatómicos de R. Wagner dieron por resultado que una vejiga absorbente, muy grande, dilatada por el aire, y que se halla muy cerca del estómago, describrese en Ia extremidad del esófago, llena toda la parte anterior del abdómen y sale en seguida desde atris cuando esta se ature: el esófago sicmpre se encontró lleno de aire. Wagner cree probable, y hasta seguro, que el sonico se produce por la entrada y salida del aire en dicha vejiga por el estrecho esó. fago, principalmente por la trompa; y que cuanto mas corta es esta, anto mas débil es el sonida Sin cmbargo, parece posible que parte del aire pase por una hendidura que en el centro de la cara anterior puede queciar abierta por las mitades de la trompa no del todó oprimicas. Tambien Landois cree poder confirmar la opinion de Nigner por sus tilimas observaciones, pero supone que la aşucrontia atropos hace salir el aire de la vejiga absorbente per aquella hendidura de la trompa. Obsérvase que tambien azunas otras mariposas emiten sonidos. Darwin ha oido a la reronin feronia, jroducir un rumor semejante al que emition una rueda dentada al rozar con un ganchito, sobre todo cuando dos de estas mariposas brasilenas se perseguian, y sujpone que probablemente se produce tambien el sonido durante el apareamien. to. Doubleay ha descubierto una bolia membranosa en la base de las alas anteriores, que probablemente contribuye à la prodiccion de aquel sonido, asi cumo tambien un hoyo que hay en las alas posteriores del macho de la thecophorn (noctua) fobea, segun la observacion is Berthold.

I.a aquerontia atropos tiene una longitud de unos $0^{-2}, 055$ por $0^{\circ}, 114$ de ancho de punta a puria de ala. las antenas, cortas y de igual grueso en toda su exzension, rematan en un pincel de pelos y el abdómen en una punta redondeada. Las alas anteriores son de un pardo oscurs, casi negras, con dibujos de un amarillo de ocre, divididas jor dos fajas trasversales amarillentas en las tres partes onocidas; la del centro prescnta un puntito claro. Ias alas pesteriores, de un amarillo de ocre, presentan dos fajas trasvesales negras, siendo la exterior mas ancha y denticulada en los nervios. Por el abdómen, igualnente amarillo y orillado de negro. se corre una. faja longitudinal de color gris azulado ifig. i9).

Ia lengua, fija y muy corta, mucho mas qaue la de otro estingido, no permie à la mariposa somar su alimento del morlo indicado.

USOS, COSTUMBRES Y REGIZEN. - Se la encucntra en Alemania, solo en otoño, posads en alguna pared, con las alas plegadas sobre el cuerpo, ó bien busca la luz, presen- tandose a reces en las habitaciones, en cuyo caso infunde muchas reces temor y asombro.

La oruga, muy grande, se encuentra regularmente en julio $y$ agosto en la yerba de las patatas, y del lycium barlanom: pero tambien se ha visto, segun se dice, en el jazmin (jami"um offurisale) y en la zanahoria Mide $0^{\circ}, 1_{3}$ de largo tiene en el penúltimo segmento un cuerno encorvado en for ma de S, adelgazado en la base, que pende como una colita Se pueden distinguir por el color diferentes variedades, mas por lo regular es de un amarillo verdoso con espesos puntitos de un brillo azul, excepto en los tres primeros segmentos y en el último; desde el cuarto presenta unos dibujos angulosos de un bonito azul, abiertos hacia ildelante, orillados de negro en su borde inferior.

Algunas veces se hallan muy numcrosas orugas, mientras que por lo regular se encuentran aisladas 6 no se ren. En ${ }_{17} S_{3}$ un coleccionador recogió cerca de Weinar 38 in. dividuos. Antes de crisalidarse penetran en el suelo, vuclven a salir i reces al cabo de cinco ó seis horas, ó solo alargan la cabeza para trasladarse de una hoja a otra que se halle a su alcance. La agitacion de muchas de cstas orugas en ese periodo se reconoce a primera vista, y puede aumentar por diversas causas. Así, por ejemplo, un amigo me refirió que la óruga del splinin conzolimli, que para crisaliciarse habia pene. trado en el suelo, rolvió siempre à salir paseándose por su prision an luego como cerca de ella se tocaba el piano.

La crisálida, de color pardo negruzco brillante, tiene su parte anterior por detris de la cabeza ligeramente deprimida. Sc encuentra en nuestras regiones aisladamente, en al. guna curidad subterrànea, cuando se recoge la cosecha de las patatas; de esta crisálida sale muy pronto ó nunca in mariposa, porque exige mas que las otras que no se la moleste en su desarrollo.

DISTRIBUCION GEOGRÁFICA. - IA aqueronia atropos se encuentra en México, en toda el Africa y en Java; en Europa se halla mas bien en las regiones meridionales que en las septentrionales. Las que en el centro y norte de Alemania nacen durante el otoño, no se propagan, y en la primavera no se ha encontrado aun ninguna, al menos que yo sepa. Por esto las orugas que en nuestros paises se en. cuentran deben proceder de hembras extraviadas:y en pro de esta opinion habla tambien su presencia pasajera limitada á ciertos sitios.

\section{EL ESFINGE DE LOS SAUCES-SPHXNX LIGUSTRI}

CARACTÉRES. - Esta especie es uno de los esfingidos mas grandes de nuestros paises. Sus alas anteriores, quue de punta is punta miden $0^{*}, 108$, son de un pardo rojizo, mez. clado de gris en el borde anterior y con uma faja oblicua desde el borde posterior hácia la punta, sobre fondo negruzco; en algunos sitios presentan entre los nervios lineas ne. gras; las alas posteriores son de color de rosa, cruzadas por tres fajas trasversales negras. El abdómen, puntiagudo, cruzado en el centro por fajitas negrns, es gris, con los lados sonrosados y íajas negras.

DISTRIBUCION GEOGRAFICA.-Vueh en marzo y junio produciendo un fuerte zumbido: se la ve en toda la Alemania.

USOS, COSTUMBRES Y RÉGIMEN. - Se presenir en las primeras horas de la noche en las fores para libar el néctir de las mismas con su trompa inuy larga Como mariposa nocturna solo se la cncuentra casualmente dormida en algun tronco de árbol. Algunos meses mas tarde se ve tacilmente la oruga adulita en las plantas de claveles (syringra) en 
los jardines y parques, en los sauces, etc. Fis de un verde vi. ro y brillante, con numerosos nervios trasversales y un cuerno negro en el dorso del penúltimo segmento, que presenta i cada lado sicte lineas oblicuas de color lila en su parte anterior, blancas en la posterior; en la pequeña cabeza, muj recogica, hay ambien una linen de color lila. A fines de agosto o principios de setientore penetra en el suclo y se tmsforma en criślida dentro de una cavidad alisada; entonces adquicre un color pardo negruzco, y el estuche de la trompa sobresale como apéndice en forma de nariz, bastante oprimido.

\section{EL ESFINGE DE LOS PINOS-SPHINX PINASTRI}

CARACTÉRES. - Esta mariposa es la menos bonita de todos los esfingidos, pues apenas se distingue su color del ironco del pino en que este posada; y no fatta nunca en ninguna parte donde se encuentra este árbol. I.a cara superior de sus delgadas antenas es manchada; las franjas son blancas: las alas anteriores tienen algunas myas longitudinales negras; el abdómen es como el de la especie anterior, con Ia única diferencia de que las fajas laterales clams tienen un color gris blancoy no sonrosado. La trompa alcanza una longitud de $11 " 04$.

USOS, COSTUMBRES Y REGIMEN. - Cuando h mariposa ha pasado su corta vida y la hembra depositado sus huevos de color verde pálido en los conos de un pino, trascurren unos diez à quince dias hasta quue nacen las oruguitas; estas mudan por término medio cada diez dias, devoran casi siempre su piel, como lo hacen tambien otras muchas, y adquieren con el tiempo sus fajas longitudinales aljigarmadas, de color amarillo verde ó lila. In oruga adulta uresenta, despues de la cuarta muda, unas arrugas trasversa. les en parte negras, y' tiene los colores arriba indicados, que forman mas ó menos fajas de manchas. Al tocarla, se resiste con viulencia, arroja un jugo estomacal pardo é intenta morder. Poco mas $\delta$ menos $\mathrm{cn}$ la priners mitad de sciembre penctra en el suelo para crisalidarse é invernar despues en tal estato. I a crisilida se caracteriza por el estuche de li trompa que sobresale en forma de nariz. Ya hemos dichn antes que en la primavera siguiente no nace siempre la mariposa, apareciendo en su lugar grandes icneumónidos (ichneumon fisurius é ichneumon fusorius). A veces se presentan las orugas en numero perjudicial para los árboles, como lo demuestra, por ejemplo, el hecho de que en $183 i$ y 18.38 , en la huerta de Annaburg, la administracion de bosques concedió un prenio de 20 céntimos por cada cuartan de estas orugas, gastándose considerables cantidades al efecto.

\section{EL ESFINGE DEL EUFORBIO-SPHINX EUPHORBIAE}

CARACTERES. - ¿ Ouién no habri visto la bonita oruga del estunge del euforbio, que en vemno se encuentra exclusivamente en la cuphortio genrisio, y de la cual sale el es. fingido mas comun de todos? Las alás anteriorcs son de un amarillo cie cucro, á menudo con un viso sonrosado: en la basce y detris del centro se ven nianchas de un verde aceituna, y una faja en forma de cuma del misno color por delante del borde rojo; las alas postcriores, de un tinte sonrosado, unas ó menos claro, presentan una faja negra en la base y junto al horde son blancas en el angulo interior, lo mismo que los lados del tórax y del abdómen.

Colores semcjantes se obserinn igualmente en otros mu. chos esfingidos del pais y del cxtranjero.

\section{EL ESFINGE DEL LAUREL ROSA - SPHINX NERII}

CARACTERES. - Esta especic es respecto da la riqueza de sus colores y su agilidad en el vuelo el primero entre todos los estingiclos de Europa. F.l color predominante es un verde muy vivo, con fajas y manchas blanquizcas sonrosadas y vio. láceas en las alas anteriores y dibujos abigarrados en la base de las alas posteriores, asi como en el cuerpo.

DISTRIBUCION GEOGRÁFICA. - Pertence en Europa solo a las especies de paso; el norte de América y el Asia Menor deben considerarse como su patria.

USOS, COSTUMBRES Y RÉGIMEN. - Cuando la primavera es temprana, segun dice Keferatenit, este csfingido se presenta en Francia, donde a los noventa dias se desarrollan de los huevos puestos mariposas nuevas, que se dirigen mas hacia el norte $y$ depositan los suyos alli donde encuentran el laurel rosa en gran número de jardines. Desde el año i 830 à 18.40 la mariposa se ha cogido varias reces ú obtrivose de orugas durante veranos calurosos en Suiza, en los alrededores de Barmen, Elberfeld, Passau, Halle, Pirna, Berlin, Finncfort sobre el Oder, Stettin, Brunswict y hasta en Rign jo oiros puntos. Ya cn julio se encontró jror lo regular la oruga cerca de Brunswick, mientras que comunmente no se la ve hasta el mes de agosto. La aclulta varia por su tamaño de $11^{\circ}, 092$ a $0^{\circ}, 110$, ofreciendo como la larva de la aquerontia, dos diferencias de colores: un matiz verde en el fondo y fajas parduscas poco marcadas, of un fondo amarillo de ocre; al color del cuerpo corresponde tambien el de la ca. beza. En la mitad anterior del tercer anillo se halla en cada lacio un espacio formado por dos manchas en figura de rino. nes, de color negro azulado, que por un círculo pardo pasan al centro blanco; la una es mas grande y posterior, y la otm anterior y mas pequenia, cuya superficie en el estado de des. canso de la oruga quecia en parte cubierta por el segundo segmento y solo es visible del todo cunndo la origa se estirn al andar. Poco mas ó menos en el centro del lado del cuerpo se corre desde el cuarto hasta el décimo segniento una linea blanca, que pasa hasta por debajo de la base del cuerno amarillo, acompañada en ambos lados de numerosos puntitos blancos, azules $\delta$ de color de liia. Unas veinticuatro horas antes de penetrar en iicra cambia esencialmente las colores. Debajo del suelo construye una especie de capullo de musgo y otros objetos y se trasforma al cabo de seis dias, ú menos, en una crisálida delgada, al principio de un amarillo pardusco, y luego mas oscura con numerosos puntitos negros, menos brillante en el lado áspero del dorso que en la parte lisa del vientre. Al rabo de cuatro ó seis semanas sale cl bonito esfingido, cuyas alas alcanzan al cabo de media hora todo su tamaño, adquiriendo i las tres ó cuntro horas su posicion horizontal definitiva.

\section{EL ESFINGE CONVÓLVULO-SPHINX CONVOLVULI}

CARACTÉRES. - Este es otro de los lepidópteros mas ronocidos entre los que se dedican al estudio de la entomologia (fig. So). Iars alas superiores de los machos son de un gris ceniciento, listadas de negruzco en la parte media; en las hembras son de un gris ceniciento. tambien con pequeñas lineas negruzcas, y á veces una blanquizea en el tercio ter. minal. las alas inieriores son grises, con tres fajas negras: la primera, situada hácia la base, es acodada; la segunda estí dividida por uns linea gris, y la tercera es paralela al borde margina. El coselcte tienc el color de las primeras alas. Fil abdómen está alternativamedre anillado de negro y rojo: el 
dorso, de un tinte gris, of́rece en el centro una pequeña linea divisoria y negru\%ca; el primer anillo negro está un poco orillado de amarillento, y cubierto de pelos de un gris azulado; el primero rojo ofrece un filete blanco. La base de las alas es de un gris ceniciento, con una doble raya trasversal negruzca.

La oruga varia por el color desde el verde al pardo; la varicdad mas comun en nuestros paises es de un hermoso verde con dos series de puntos negros en ol dorso y siete fajas blancas oblicuas: encuéntrase à veces otra de un verde oscuro con dos rayas dorsales negras y siete fajas oblicuas del mismo rolor.

La crisalida es de un pardo castano, y tiene cl estuche de la trompa muy desjrendico, en forma de asa.

DISTRIBUCION GEOGRAFICA. Wl esfinge convól. vulo no habita solo en Europa; es tambien muy comun en toda el Africa, asi como en las Indias orientales, donde se te ve durante todo el año. Asimismo habita en Taiti $y$ en la Nueva Zelanda.

USOS Y COSTUMBRES. - Segun todos los obsernadores, la oruga de este esfinge vive en la mayor parte de las convolvuláceas: Mr. Horsfiełd la vió en Java en el phassolus maximus, especie de habichuela. El individuo perfecto se ve en nuestros pasises, en los años calurosos, descle fines de julio hista últimos de seciembre; en Tairi parece que frecuenta las patatas.

Como el aquerontia atropos, el esfinge convólvulo no es en rigor una especic curopren; llega con los vientos del sur y nos da una ó dos generaciones. Las crisálidas atrasadas que se conservan durante el invierno, no salen jamás á luz en el

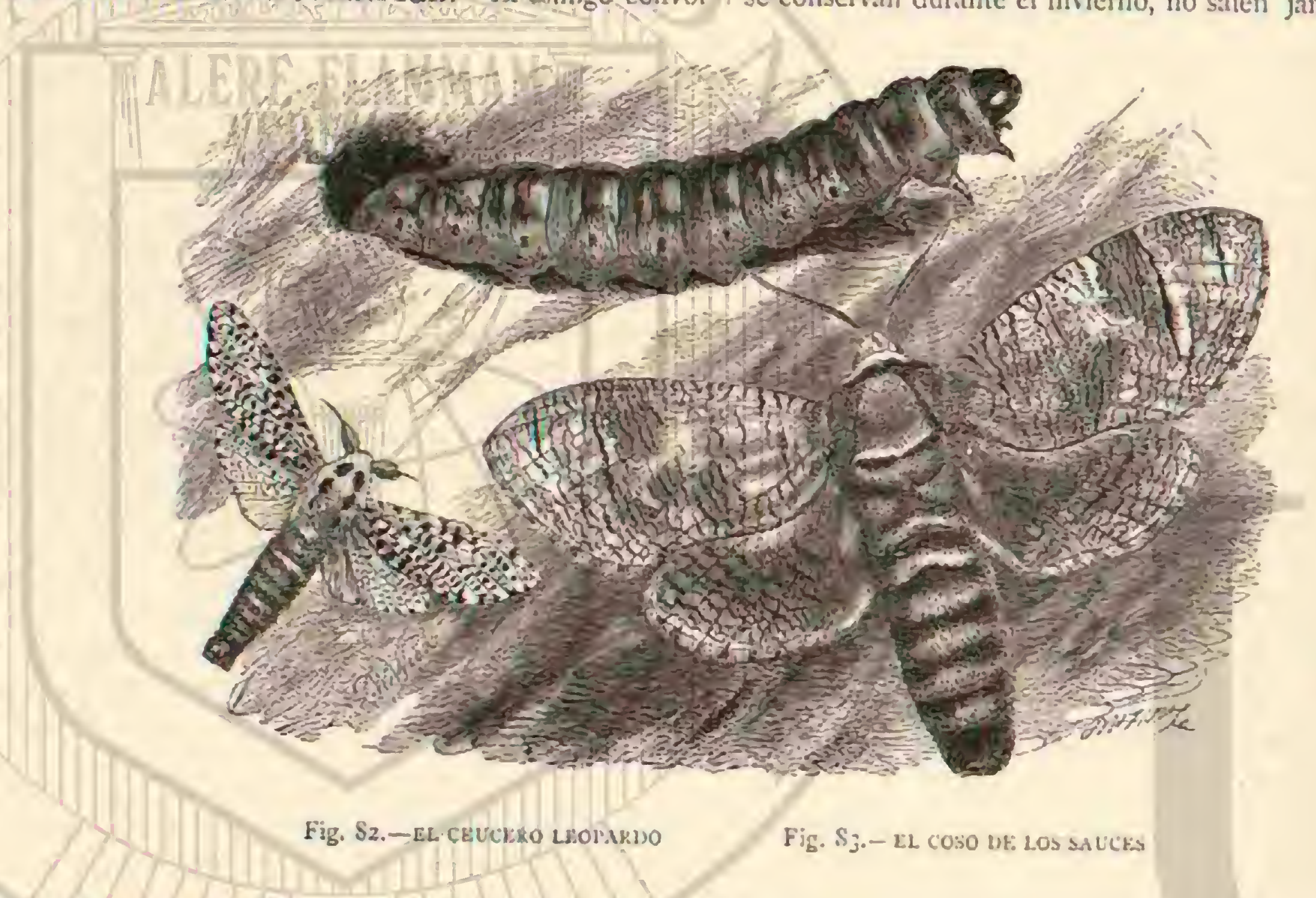

norte y en el centro de Europa, aumque parce, sin conbargo, que en España y en Italia, y hasta eri el mediodia de lirancia, no perecen todas las crisálidas, viendosclas à veces salir à luz en mayo $y$ junio.

\section{LOS ESMERINTOS-SMERINTHUS}

tin majo y junio se ve bastante a menudo en los troncos de álamos de los caminos reales ó de los estanques de los pueblos una mariposa de color gris rojizo que á cierta distancia podria confundirse con una hoja seci.

Las alas, denticuladas, están dispuestas sobre el dorso de tal manera que el borde exterior de las alas anteriores sobresale del anterior de las otras. Esta marijosa se coge solo con las primeras patas, $y$ a veces see encuentran dos individuos juntos pendientes con las cabezas opuestas, en cuýn prisicion permanecen horas enteras. Es una particularidad de estas mariposas, que á causa de sus alas diferentés se han Jlamado tambien esfingides dentivulados; al contrario de los esfingidos verdaderos, se aparean durante el dia: y cuando los dos sexos nacen en cautividad cohabitan desde luego. Otra particulari. đad consiste en que á causa de su lengua blanda y endeble no producen sonido alguno al volar; vagan durante la noche cruzando con ligereza los aires sin buscar las flores, ó por lo menos no se las encuentra en los sitios en que tantos otros

esfingidos buscan néctar zumbancio. A pesar de esto los csjirgidos denliculados pertenecen al grupo de los esfingidos por la forma general de su grupo, por la direccion de los nervios de las alas, por la forma de las antenas, por la oruga cornuda y por su manera de crisalidarse.

\section{EL ESMERINTO DE LOS ÁLAMOS-SMERIN- THUS POPULX}

CARACTÉRES. - Fl esmerinto de los álamos tiene las alas bastante anchas, con puntas obtusas. Iin las anteriores dos fajas estrechas un poco onduladas, de color pardo rojo, dividen las tres partes, en cuyo centro se distimgue una mant. chita redonda blanca y otra de color pardo rojo: las alas pos. teriores escotadas en el angulo anterior, son de un pardo rojo en su borde interior, $y$ tienen dos fajas. las antenas del macho, cuyo cuerpo es mas delgado, se distinguen por una seric doble de dientecitos. A úlkimos de verano se ve alguna que otra oruga de cabeza puntiaguda, de color verde anarillo, íspera por unos puntos prominentes, cuyos lados presentan lineas oblicuns blanq̨uizcas y cuyo último segmento tiene un cuerno de punta negra; frecuenta los caminos, cubriéndose de polvo de tal manem que no se le puede reconocer. Baja de un árbol para buscar en la tierra una cavidad donde convertirse en crisílicha, y aliméntase de las hojas de los snuces. 
EL ESMERINTO DE MANCHA OCULARSMERINTHUS OCEILATUS

CARACTERES. - Se distingue de todos los esfingidos de nuestros paises por la mancha ocular azul cu las alas posteriores, que son de rojo carmesi, el cual palidece fácilmente.

USOS, COSTUMBRES Y REGIMEN.-IA orUga habita los sauces, de cuyas hojas se alimenta.

\section{EL ESMERINTO DE LOS TILOS-SMERIN- THUS TILYFE}

CARACTÉRES.-Esta especie (fig. 78), que tiene las alas antcriores escotadas y' es de color amarillo de ocre con fajas oscuras variables, es el esmerinto propio de Alemania; tod̉as las especies del género propias de nuestros paises, tienen una forma distinta en las alas.

\section{LOS EUCLEAS - EUCLEA}

CARACTERES. - I á especie unica en que esta basado este nuero género figura en una tamina de las foumblias ratuvales de Latreille como un esmerinto; pero estudiada despues cuidadosamente, se ha reconocido, por la singular conformacion de sus palpos, que debia constituir un género independiente.

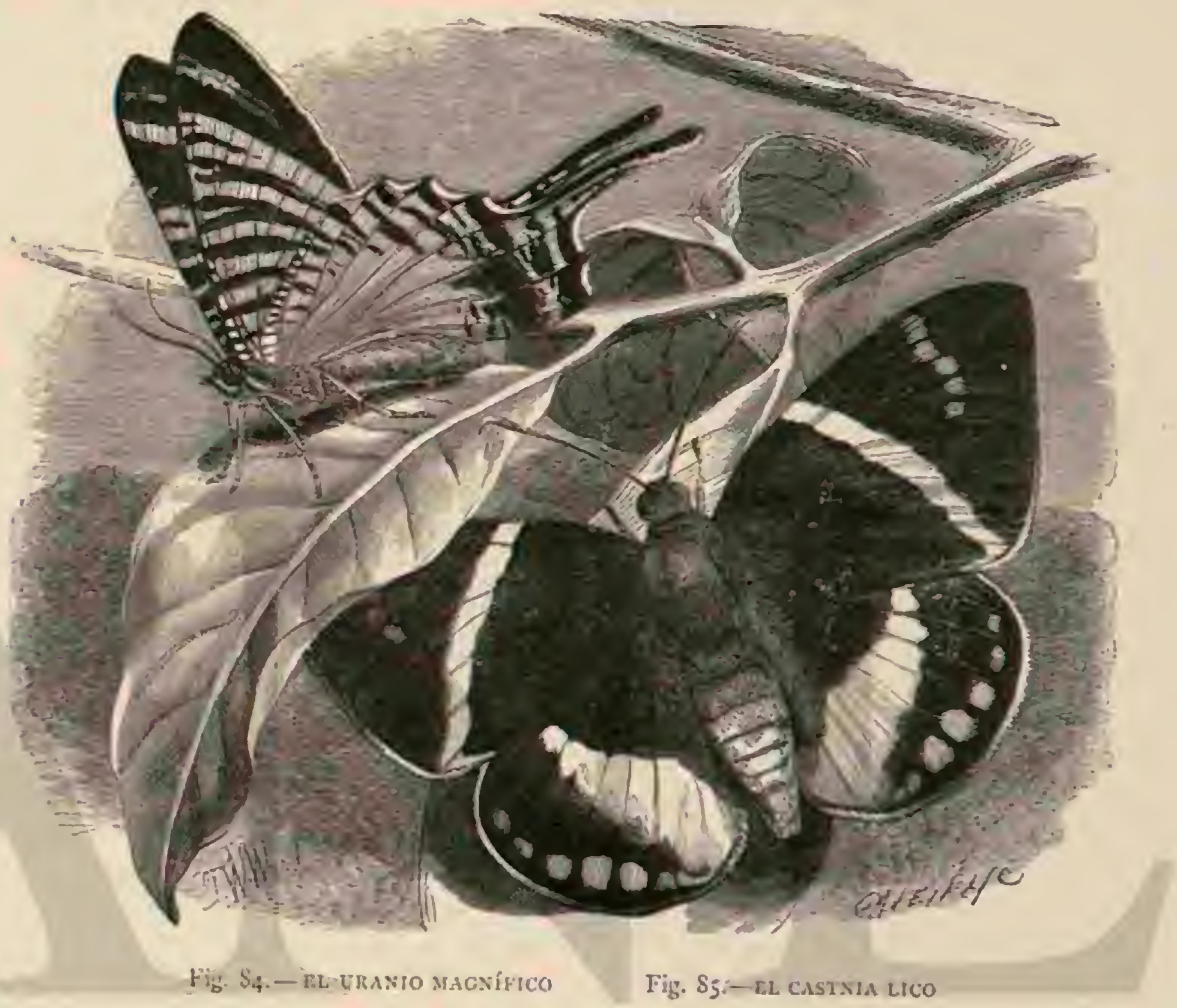

El individuo perfecto tiene la frente cubicrta de polos muy compantos: palyos horizontales, no-ascendentes, de mediana extension, relludos y escamosos, con el íltimo artejo terminado por una jequeña punta desnuda, bien marcada; la trompa us corta; las antenas bastaute largas, un poco deigadas y rematantio en garcho; los ojos grandes; d cuerpo bastante robusto, con ul abdómen cilindroidéo obtuso; las alas dentadas y muy anchas.

Segun Mr. Dumolin, que ha estudiado dos individuos vivos, la oruga es verde y' rugosa, con fajas laterales oblicuas.

\section{EL EUCLEA DE DUMOLIN - EUCLEA} DUMOLINII

CARACTERES. Este Magnifico csingido (fig. SI), perfectamente representado en el dibujo quc se acompana, tiene las alas stuperiores regularmente dentadas, y de un color gris brillante; en el centro de ellas se ve una gran mancha triangular de un pardo brillante que termina antes de llegar al borde interno; esia mancha aparece dentada por ambos lados, y junto â ella se ve un gran punto en forma redondeada. Entre la base y la mancha parda existen dos myas blan quizcas. Las alas inferiores son de un ga is pardusco; el coselete es del color de las superiores, con uma gran mancha media parda y una faja tmstersal del mismo tinte tn su punto de union con el abdómen; este es de un gris oscuro; lits antenas blancas; la parte inferior de las cuatro alis de un gris blanquiaco, con una mancha parda lasiante grande en el borde costal. Este hermoso insecto mide unos $11^{m}, 11$ de punta a punta de ala.

Mr. Dumolin, que encontró la oruga de esia especie en la adaptsomia digritalo, dice que es de color verde, muy rugasa. con siete fajas oblicuas de un blanco amarillento, la rabeza forma un tritingulo orillado de este úlimo tinte: y cn el unde. cino anilio jresenta un cuerno arijueado.

DISTRIBUCION GEOGRÁFICA. - L OS individuos ob. sernados fueron cogidos en Natal.

\section{LOS MACROGLOSOS -MACROGLOSSA}

CARACTÉRES.-Se distinguen por tener el alsdómen ancho, provisto en los lados y er la punta de miechones de pelo; por las antenas en forma de maza nas largas que la 
mitad del borde anterior de las alas, y por la lengua larga y córner.

USOS Y COSTUMBRES. - La mayor parte de cstos esfingidos, que son los mas pequenos, vuelan de dia cuando hace sol del mismo modo que los otros a la hora del crepúsculo.

\section{EL MACROGLOSO DEL DON DIEGO DE NOCHE-MACROGLOSSA (ENOTHERAE}

CARACTÉRFS. - Este macrogloso es el mas gracioso de los de nuestros paises, y se distingue par el borde escotado de las alas anteriores; estas soll verdes en el borde, con la faja central mas oscura; las alas posteriores, marillas, tienen una taja neysa e» la orilla. Yo no conozco ninguna maripo. sa que por su tamaño sen inferior is su oruga Verde en su frimera juventud, a adquiere éstił uas tarde un color pardo gris. con espesos puntos de un pardo negruzeo en el dorso, manchas oblicuas negras y lineas longiiudinales del mismo color en los lados. Fin medio de las manchas laterales se ven los estigmas amarillos, $y$ en lugar del cuerno que existe en sus congéneres, una mancha oculat amarilla con borde ne. gro y superficic pulimentada.

USOS, COSTUMBRES Y REGIMEN.-IA Oruga se alimenta en julio y agosto del don Diego de noche (uruthera), etc., y se encientra en los sitios donde habita en mafor numero gue otras, segun me han demostrado mis observaciones en los alrededores de Hallc. Suárea de dispersion no es general y parece limitarse en Nlemania, sobre todo, a las colinas y a los promoniorios de las montanas. I oruga adulta tiene en cautividad la mala costumbre de correr sin descanso, de tal manera que nuere pronto, y asi cs que los mas de los coleccionadores no han logrado criar la mariposa. Despues de muchos experimentos frustrados, uno de mis amigos logró su fin del todo, colocando cada oruga inquieta sobre un tiesto lleno de tierra y cubierto con un pedazo de vidrio para impedir la fuga y aumentar los efectos dé los rayos del sol, que bañaban el tiesto. Todas las urtugas tratadas de este modo penetraron en seguida en tierra, trasformándose en crisálida capa\% de desatrollarse en mariposa. Esto lo refiero como ejemplo para todos los que quieran criar el macrogloso del don Diego de noche.

\section{EL MACROGLOSO DE COLA DE PALOMA- MACROGLOSSA STELLATARUM}

CARACTt́RES. - Excepto las alas posteriores de un amarillo de urin, algo mas oscuro en el borde, este esfingido es de un pardo gris con algunas fajas oscuras en las alas anteriores y en el abdómen, en cuyos lados tambien se observan manchas blanquizcas.

USOS, COSTUMBRES Y REGIMEN.-Este macrogloso vaga en todas partes desde mayo hasta octubre, por las mas diferentes flores y su ruclo rápido contrasta de un modo singular con el de otras mariposats.

Ia oruga, cornuda, es de un verde claro oscuro, á veces de un pardo rojo, con ocho series de manchas perladas blanquizcas y prominentes y cuatro lineas longitudinales blancas, de las que dos se reunen por delante del cuerno verde azulado en el dorso y las otras por detris del mismo. La cristlida, áspera y de un pardo gris, tiene una faja dorsal oscura; la extremidad de la cabeza se adelgaza obtusamente, siendo por lo tanto mas raquitica por delante que por detrás; la de in segunda cria inverma.

\section{EL MACROGLOSO FUSIFORME-MACRO- GLOSSA FUSIFORMIS}

CARACTERES. - Esta especic y el macrogloso hombiliforme se parecen superficialmente a los abejorros y constituyen por sus alas, en ciertos sitios trasparentes, el trinsito it los sesias.

USOS, COSTUMBRES Y REGIMEN.-Deben su origen estas mariposas a orıgas cornudas, que viven libremente en las escabiosas.

\section{LOS XILOTROFOS - XYLO- TROPHA}

CARACTERES. De la familia de los xilotrofos solo se han de apuntar dos carnctéres comunes: las antenas son puntiagudas en su ratremidad, y hay dos pares de espolones en la cara anterior de los tarsos posteriores; por lo demás dificren nucholentre si: Se observa en cllos la ancha forma de las alas, que recuerda las mariposas diurnas y la estrecha de los esfingidos, asi como la figura central que en union con el abdómen, muy grieso, caracteriza a los bombicidos. De. bemos tratar por lo tanto aqui de un grupo de trínsito cu yos tipos no podrian reunirse sino fundandose en la marcha de su desarrollo! Las ortgas de todos son cilindricas ó de. primidas, escasamente peludas ó provistas de 16 patas.

USOS, COSTUMBRES Y REGIMEN. - Viven en sujuventud débrajo de la corteza de las plantas fibrosas, en cuya madera abren galetins. Fivitan siempre la luz del sol fuerte $y^{\prime}$ la inayor parte tienen un color de hueso claro, propio tambien de las otrás larvas de insecto que viven de este modo. Todos los xilotrotos necesitan para su desarrollo mucho tiem. po y pasan cuando menos un invierno, cuando no dos. Muchos fabricall un capullo cerndo mientras que otros se trasforman en crisilidas libremente en alguna cavidad ensanchada en forma de galería: pero en todos la oruga prepara la salicia para la mariposa. Dumnte su vida ha practicado un agujero que le sirve para sacar'los excrementos, y que mas tarde serviri a la mariposa para salir al aire libre. Los excrementos quedan en parte en el agujero y lo cierran, descubriendo la presencia de la oruga, la cual, llegada la hora de convertirse en crisálida, se dirige inmediatamente por detrís de dicha salida cerrada. la crisálida está provista en la cabera de una punta afilada $\delta$ de varias cerdas en sus segmentos que le sirven para avanzar facilitando asi la salida a la mariposa. Por lo tanto esta no se ha perjudicado en nada en comparacion a sus hermanas, cujas crisálidas se hallan al airc libre, pues solo ha de hacer algunos movimientos como el gusano para romper la cubierta de crisilida por la nuca. Esta particularidad en el desarrollo y la falta de ciertos caracteres propios de otras especies, cuyas larnas viven tambien en la madera, justifican la reunion de los yéneros siguientes en una familia.

\section{LOS SESIAS - SESIA}

CARACTÉRES, - Los sesias se asemejan ì los esfingidos. cuando menos por al aspecto de su cuerpo $y$ la forma de las antenas, asi como por el órgano pronsil p̧ue se halla ch las alas posteriores; se distinguen de los citados lepidópteros por el género de vida descrito, por la presencia de dos ojuelos en la coronilla, por las alıs posteriores del todo claras como el cristall, y por las anteriores cubiertas en parte de escamas.

DISTRIBUCION GEOGRÁFICA.-De estas grariosisimas mariposas se conocen unas sesenta especies en Europa, 
entre ellas veintisiete propias de Alemania, y además muchas de América. Probablemente no faltan en los otros conttinentes, pero es dificil encontrarlas.

USOS, COSTUMBRES Y REGIMEN.-Segun mis experiencias, las mariposas nacen de las nueve á las doce de la mañana, permanecen algun tiempo en el tronco del árbol parn secarse del todo y vuelan luego vivamente por el follaje a fin de aparearse. Su viuelo es en extremo ligero y rípido, pareciendo que dan saltitos en el aire. la duracion vital es probablencute corta. Quien sabe qué tiempo cxige el desarrollo y conoce la planta alimenticia de las especies; puede coger en ciertos - casos muchos individuos, mientras que el coleccionador ignorante de estos detalles, podria buscar muchos años sin encontrar ni casualmente un individuo. Las especies cuyas orugas pueden cogerse sin cortar los árboles se crian tambien sin dificultad. Para esto se colocá cada una en un tronco de morera hueco; el insecto penetra mas en el interior, cierra la abertura con un tejido y prosp̧ern muy bicn. Excepto algunas pocas cspecies, como la sesia ennpiformis Esp., sesia tenthrediniformis Ochsenh., de color amarillo, cuja oruga vive en la raiz del cuforbio, mientras que la mariposa vuela al rededor de esta planta alimenticia, se ve con frecuencia nuestra especie mas grande que es la siguiente.

\section{EL TROQUILO APIFORME-TROCHILIUM APIFORMIS}

CARACTERES. - lil cuerpo es amarillo dorado sobre fondo pardo ó pardo negruzco, de cuyo color son tambien las antenas; los nervios, las franjas de todas las alas y el borde anterior de las anteriores, asi como las patas, son de un amarillo de orin o color de bronce.

USOS, COSTUMBRES Y REGIMEN.-La oruga vive en la parte inferior del tronco de los ảlamos jóvenes, con preferencia á flor de la raiz, pero tambien à mas profundidad, $y$ no faltan cjemplos de haber tronchado el huracan estos tronquitos, ofreciendo la oruga exactamente los mismos ejemplos que la larva de la del coleóptero saperda carcharias de que antes hemos hablado. La trasformacion de la oruga exige un ano. A principios de julio depositan los huevos entre la corteza, y en marzo siguiente se encuentra ha oruga bastante adult.. Cuando vive en la raiz la trasformacion en crisalida puede verificarse en tierm, cerca de la superficie.

Advertimos de paso que el amtiguo géncro sesia se ha dividido últimamente en varios, y que las mariposas que conservan ese mombre son mucho mas delgadas en el abdómen que la descrita, rematando dicha parte en un gracioso moño de pelos que puede abrirse en forma de abanico, como sé observa siempre en el apareamiento.

Cierno dia, por la mainana ( 11 de junio), fui á cazar la bonita sesia myopiformsis, de color pardo azulado brillante, cuyo abdómen ciclgado tiene un anillo rojo, y cuya oruga vive debajo de la corteza de los manzanos; fijé mi atencion primero en las jerbas del foso que se corria a lo largo del camino real, y casualmente vi la mariposa que buscaba, asi como una avispa muy grande que estaba á su lado. Cuando me acerqué parn apoderarme de la sesia alejóse el himenóptero y grande fue mi asombro al ver que habia cogido un inacho cuyo abdómen tenia los dos últimos segmentos del de una hembra: toda la otra carne de este desgraciado lepidóptero habia sido presa de la avispa.

\section{EL COSO DE LOS SAUCES-COSSUS LIGNI- PERDA}

CARACTERES.-Sus alas anteriores y el tórax presen- tan finos dibujos como los del mirmol en todos los matices de pardo gris y uegro; la coronilla y el collarin se distinguen por un color gris amarillo; las alas pusteriores son de un par. do gris, un poco mas oscuras por delante del borde. El abdómen gris con anillos blanquizcos, remata en la liembra en un taladro que puede prolongarse para depositar los huevos a mucha profundidad en las hendiduras de la corteza.

In salta de ojuelos, una celda intercalada en la discoidea, dos nervios dorsales libres de las alas anteriores, tres de las posteriores que tambien tienen cerdas prensiles, $y$ dos pares de espolones en los tarsos posteriores, constituyen los caractéres principales del género que aun cuenta algunas especies mas raras, asi como tambien hay varios generos afines (iig. 83.)

USOS, COSTUMBRES Y REGIMEN. - Ia larva vive con preferencia en el sauce, pero tambien en irboles frutales, ảamos, alisos, encinas y tilos, a los que el viento impele casualmente a la hembra, bastante perezosa. Viven por lo regular aisladamente $\delta$ en reducido número, aunque tambien se encuentran en agrupaciones considcrables. En cl parque de Goettingen se cortaron en diciembre de $18_{3} 6$ tres sauces llorones, y al partirlos se encontraron centenares de orugas.

Debajo de la corteza de un tronco cortado de encina encontré una vez en marzo nueve orugas de color sonrosado de la misma especie, de unos $0^{\circ}$, or 3 de largo, procedentes de huevos puestos en julio del año anterior: aun no habian penetrado en la madera la oruga crece muy lentamentey antes de que llegue a su longitud completa de $0^{n}, 09$ por casi $1 \|^{n}, 02$ de anchurn, han de trascurrir curndo menos dos años. Corno ataca la madera sana lo mismo que la podrida, la na. turaleza la ha dotado de maxilas muy fuertes y numerosos músculos (la célebre Anatomia de la oruga del coso de los saucess, publicada por Pedro 1,yonnet, describe 4,04 I musculos) y en ella se dice que el insecto expele una sustancia caiustica que arroja tambien al rostro del que le inquieta. El color sonrosado de la oruga jóven se cambia con la edad en un color de carne sucio en los lados, en el vientre y en las incisiones de los artejos, mientras que el dorso, la nuca y la cabeza son negros. Para crisalidarse acércase al agujero de salida y fabrica un capullo. I a crisilida, parda, con la cabeza puntiaguda, en forma de pico, mide unos $0^{\circ}, 04$ de largo por casi $11^{\circ 0}, 013$ de ancho, y es muy áspera, á causa de las cerdas que cubren los agudos bordes de los segmentos. Cuasto mas se aproxima-la hora de la libertad tanto mas sc inquicta; sale del capullo, se dirige hácia la entrada, y al poco rato se abre la piel de crisålida por la nuca. Lal mariposa sale con patas, cabeza y antenas, y valiéndose de aquellas se agarra para quedar libre del todo. Las alas crecen en poco tiempo, pero necesitan mas la influencia del aire y del calor para adquirir la solidez necesaria. Solo con la noche parece recobrar la vida; revolotea alrededor del sitio donde nació, y 'disfruta muy poco de su corta existencia. De dia permancee inmóvil en la corteza del árbol, de la que apenas se distiugue por su color.

\section{LOS QUELONARIOS CHELONYARI}

CARACTERES. - Si los tipos de la familia de que acabamos de tratar tienen sus analogias por la uniformidad en la estructura $y$ en el género de vida, y no por el curatcter homo. géneo de las mariposas, los tipos de la familia de los quelo. marios no nos ofrecen semejanzas por ningun concepto. De los tres géneros que comprende, encontmmos en la mayor parte de las obras los zigenas reunidos con los esfingidos a causa de las antenas; $y$ los otros dos con los bombicidos, con 
los que tienen decididamente mucha afinidad. Aun tomando en consideracion las numerosisimas especies exóticas, ofrécesse sin cmbargo un trinsito tan insensible de un género á otro, que no se debe vacilar ni un momento en réunirlos en una familia: además, su separacion de los bombicidos proporciona un limite mas matural de esta última familia. Casi todas las mariposas pertenecientes a este grupo ofrecen una particula ridad que les es propia y nue por otro concepto indica una afinidad. Cuando se las coge entre los dedos aflojan las antenas $y$ las patas fingiéndose mucrtas, y dejan-salir de ambas una gotita de un jugo espeso amarillo; tambien le segregan por la herida del tórax cuando este se periora con un alfiler. Por lo demás, los tuelonarios, llamados tambion asos, son análogos por lo general en cuanto al desarrollo de la lengua, asi como por la presencia de ojuclos en la mavor jarte de las especies, por los pelos lisos del cuerjo, per ha manera de posar las alas cuando reposan, jor los colores casi siempre vivos $y$ chillones, y por tener en las posteriores una cerda prensil.

Las orugas, de diez y seis patas, no son nunca desnudas, hallándose a menudo provistas de pélos inuy fuertes y espe. sos. Las crisalidas no descansan munca en la tierra ni en los vegetales, sino hil aire libre y en muy diferentes tejidos.

\section{LOS ZIGENAS - ZYGAENA}

CARACTERES. - Estas bonitas mariposas se han llama. do carnerilos, à causa de sus antenas, un poco arqueadas, y gotitas ife sangre por las manchas rojas que tienen en las alas anteriores: los caractéres comunes à todas son los siguientes: lengua inuy desarrollada; dos ojuelos; cuatro espolones en los tarsos posteriores; dos nervios dorsales en las alas ante. riores, y.tres en las posteriores, que son rojas mas anchas y puntiagudats, preseniando además una cerda prensil: an. tenas no denticuladas, relativancnte largas y muy dilatadas por delante de la punta, que en los individuos muertos se rompen nuy fácilmente á causa de su base delgada: y por último un mechon en los palpos, que tienen la longitud de lis cabeza, y otro en la cara inferior de los muslos.

USOS, COSTUMBRES Y RÉGIMEN. - F.sta's Mariposas, que desde mediados de julio hasta agosto se posan en las mas diferentes fores silvestres, llaman nuestra arencion por su abdómen grueso, y sus bouitas alas posteriores rojus, mientras que las anteriores dienen puntos del mismo rolor sobre un fondo verde metrilico ó azulado. En los dins des. agradables permanecen quietas; pero cuando hace sol buscan Su alimento, reunidas á veces de cuatro en cuatro en las fiores y se alejan con vuelo pesado para buscar otro dejósito de néctar. Se posan aisladamente ó apareadas, en direccion opuesta, y no es dificil cogerlas con las manos. Hasta pueden encontrarse varias especies apareadas, resultando entonces mexclas que aumentan la dificultad para clasificar, segura. mente especies muy afines, sobre todo porque algunas de estas oirecen variedades de por si.

\section{EL ZIGENA DE LA FILIPENDULA - ZYGAENA FILIPENDULAE}

CARACTERES. - Esta especic ticne las alas anteriores de un verde azulado con seis manchitas carmesies del mismo tamano. Hay tambien individuos con las manchas $y$ las alas anteriores de un pardo de café.

USOS, COSTUMBRES Y REGIMEN. - La oruga se alimenta de las hojas del dicnte de lcon $y^{\circ}$ de otras yerbas. Como la mayor parte de estas orugas es de un amarillo claro con series de manchas negras; esti cubierta de prelos blandos j le gusta recoger su cabecita en el primer anillo del cuerpo.
Pasa el invierno siendo ya bastante adulta: y cuando en la primavera siguiente se ha alimentado aun algunas semanas, sube á un tallo y fabrica un tejido semejante a un papel de cola fuerte; en su parte superior es mas flojo; $y$ cuando en junio la mariposa despierta á nueva vida, saca al nacer la mitad de la cascarn de crisalida.

\section{EL SINTOMIS FEGEA-SYNTOMIS PHEGEA}

CARACTERES. - Esta mariposa de un color negro azU. lado con manchas blancas y una faja circular amarilla en el abdómen, se parece por su aspecto mucho á un zigena, pero difiere de el esencialmente en algunos puntos. P'or lo pronio faltan los ojuclos, y despues las antenas delgadas no se ensanchan hacia adclante; en cada ala solo hay un nervio dorsal y los pequeiros palpos están provistos de pelos cerdosos.

USOS, COSTUMBRES Y REGIMEN, - $\Lambda$ lli donde este bonito animal se encuentra abunda mucho $y$ ofrece el mismo género de vida que los zigenas, sulu que al coger su alimento lleva las alas un poco levantadas. La oruga, que igualmente inverna, aliméntase de liquidos; está cubiera en forma de cepillo por unos pelos pardo grises, de los cuales se sirve para fabricar un ligero tejido para la crisilida, que es parda y obtusa en ambas extemidades: solo descansa pocas semanas.

\section{EL OSO PARDO-ARETIA CAIA}

CARACTERES, - Cuando vemos que una serie de mariposas de colores claros, con puntos negros, y otra mas considerable aun, que ostenta los colorés mas vivos, se designán con el nombre de Osos, nos asombramos, porque no po. demos encontrar ninguna semejanza entre ellas y cl oso pesado y gruñidor. Conociendo sin embargo las orugas, observanos que el citndo calificativo es justificable, porque aquellas estan cubiertas de espresos pelos, largos y por lo regular oscuros, como los del oso. Todas pucden comer muy igilmente y descansan estiradas, pero segun la especic tienen un aspecto muj diferente. Estas mariposas se han dis. rribujuón en numerosos géneros, distinguiéndolas por caractéres muy marcados.

La especie que nos ocupa es de color vivo; las alas anteriores son de un pardo rojo aterciopelado con manchas $y$ fajas blancas: la cabeza y el tórax del dorso son de un pardo rojo; el abdómen de un rojo cinabrio y las alas posteriores del mismo color, con-manchas de un negro azulado. Lits antenas, blancas, son un poco mas gruesas en el macho por tener unos dientecitos.

USOS, COSTUMBRES Y REGIMEN.-Ta oruga se encuentra a menudo desde agosto, ; despues de invernar hasta majo, pues come torla clase de jerbas y arbustos. Se distingue de otras orugas de oso por los pelos negros de punta blanca ugue apenas dejan traslucir la piel del cuerpo; solo lateralmente y en los tres primeros segmentos, los pelos son de un color rojo pardusco. I a inariposa permanece oculta de dia: en las noches calurosas de junio y julio vuela lentamente y solo en este periodo se verifica el apareamien. to. La orugr aduita fabrica con sus largos pelos un ligero tejido en el çue la crisilida, negra y reeogida, jermanece pocas semanas ciebajo de la hojarasca. Bastante a menudo se presentan en su lugar cinco ó seis crisalidas negras, de las que in su tiempo salen unas moscas de color gris negruzco; son las llamadas tayuinas, que cn numerosas especies vagan por la jerha para depositar sus huevos en las mas diferentes orugas de mariposa.

Algunos congeneres vuelan cxeepcionalmente de dia cuan. 
do hace sol, como por ejcuujlo el magnifico use purpirren (aretio pierpuesea), ó la irirgen (callimerpha dominioula); pocas, verbigracia, la bandera espanola (callimurpha Hera) se dejan ver regularmente de dia mostrándose muy timidas y fugaces, pero la mayor parte descansin durante este tiem. po, cubriendo el abdómen con las alas en forma de techo.

\section{LOS CASTNIOS - CASTNIARI}

CARAC.TERES.-I Ios castnios se caracterizan por sus palpos divergentes, compuestos de tres artejos escamosos; trompar menos largan que el cuerpo; antcnas en forma de maza, cilindricas y munca ciliadas. Ias patas son escamosas, con las piernas provistas de dos espolones; el coselete es robusto y escamoso; el abdómen cónico, un poco mas corto que las alas inferiores; las alas anchas, cubiertas de escamas bastas, mucho mas grandes que en ningun otro género de lepidópteros; las inferiores presentan una crin, como en los esfinges.

DISTRIBUCION GEOGRAFICA.-I.OS castnios son exclusivamente propios de las regiones tropicales de Anrérica y de Australia.

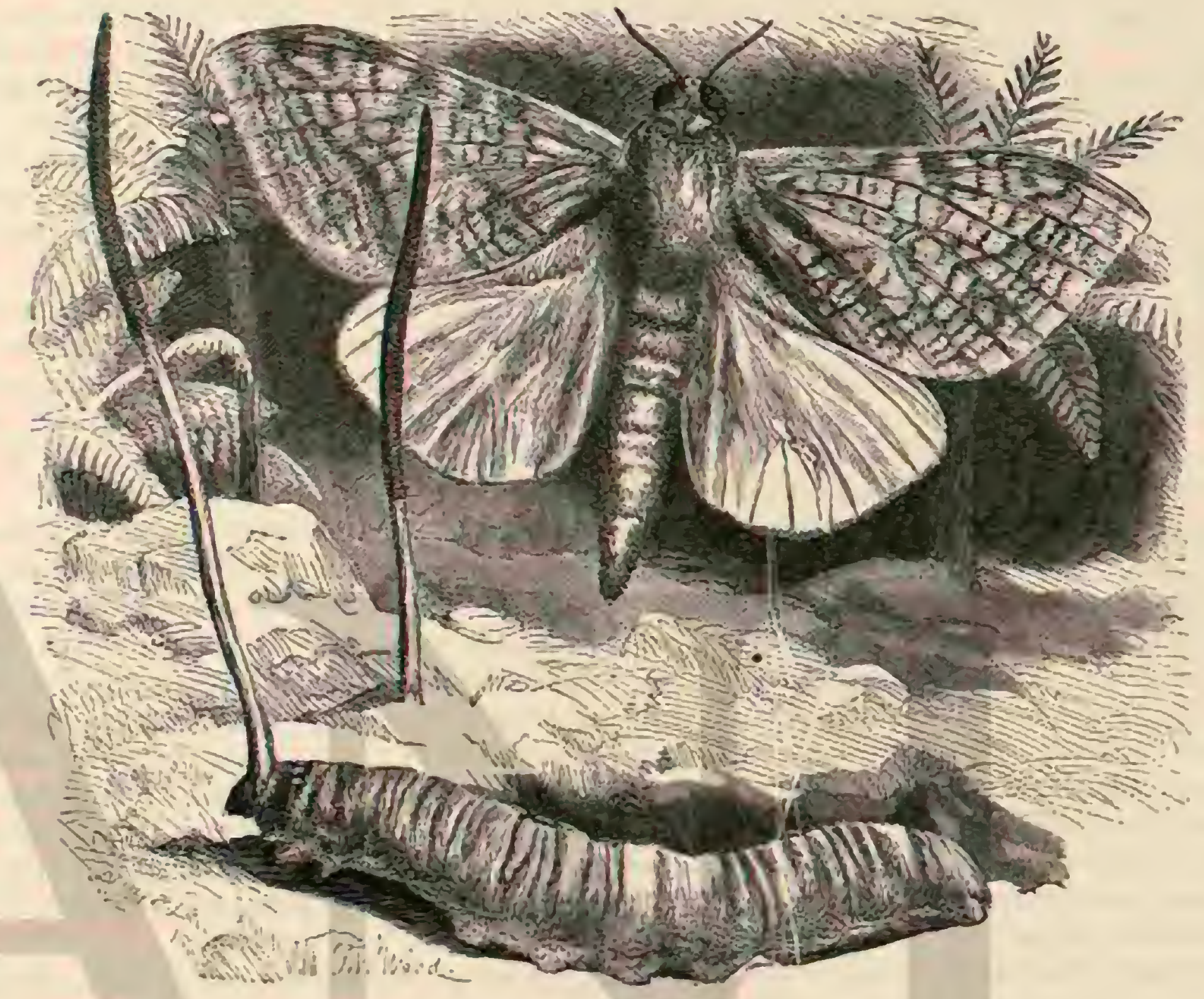

Fig. SG. - EL HEPIALO RABIDO

USOS Y COSTUMBRES. - I.os lepidópteros de este género vuelan en pleno dia con singular rapide\%; guistales reposar de plano sobre la tierra ó en el tronco de los árboles; $y$ a ciertas horas rcvolotean entre las fores, como los esfingidos.

I.as orugas viven en el interior de varias especies de bana. nos, en los bulbos de las orquideas, en las bromelitcens, en los cactus, etc

\section{EL CASTNIO LICO-CASTNIA LICUS}

CARACTERES. - El castnio licus (īg. $S_{5}$ ) es una mag. nifica especie que llama la atencion por el admirable conjunto de sus tintes: las alas superiores son de un negro pardo mas ó menos claro, con visos verdosos segun la manera de reficjarse la luz; van adornadas de dos fajas blancas, la primera de las cuales, casi recta, desciende del centro del costado hasta el ángulo intemo; la segunda, mas coria, se compone de seis manchas. Jas alas inferiores, de un pardo negro, presentan en su milad una faja blanca, que estrechin. dose al principio, se ensancha poco a poco hasta el angulo annl; por detrís, cerca del borde terminal se ve una serie de cinco ó seis manchas rojas, las tres del medio majores; el filete es blanco. La hase de las alas superiores es de un par- do pálido; la de las inferiores de un gris ligeramente pardusco; las manchas rojas no se distinguen bien por lit cam in. ferior.

DiTSRIBUCION GEOGR AFICA.-Fsta hermosa espe. cie habita en la Ansérica intertropical, y lay localiciades en que abunda mucho.

USOS Y COSTUMBRES. - Se ye it menudo ì éste lepidóptero revoloteando entre las flores: la oruga parece pruferir los bulthos de las orquidens.

\section{LOS BOMBICIDOS - BOM- BYCID压}

CARACTERES.-Ias mariposas que aun restan de atdómien grueso, de alas anchas, y de fuertes antenas en forma de peine en los inachos, pertenecen a la familia de los hombicidos, tan rica en especies como la anterior, y mas notable por la uniformidad de la estructura I.os bombicidos, en su mayoria, son de tamano regular, pero algunos le alcanzau extraordinario: son de color sucio pálido y opaco en las alas; carecen por lo regular de ojuclos y se distinguen muy genc. ralmente por singulares diferencias de ambos sexos en forma y tamaño. Las anterias, cerdosas de por sl, conservan su 
figura ó son denticuladas en la hembra, presentando en los machos dientecitos como los del peine, mis largos y bastante á menudo esjesos. Las anchas alas afectan regularmente la forma de tejadillo. El cuerpo está cubierto de pelos espesos y lanosos; es pesado en ambos sexos i causa de este prelaje, pero el macho le tiene a menudo delgado, al contritro del abdómen mucho mayor de la hembra, dilatado por numero. sos hmevos. A consecuencia de esto, los machos son superiores en agilidad $y^{*}$ en la rapidex del vuelo. Miuchos vuelan de dia continuamente entre las yerbas -y espesuras cuando se trata de encontrar a las henibras. Eštas no se alejan mucho del sitio en que uacieron, y muchas hasta no pueden hacerlo, porque les faltan las alas bien desarrollagias A causa de su pesadez dẹositan por lo regulas los huevos en montones, de modo que las orugas viven juntas en gran mimero, causando á menudo grandes periucios en los irbotes irutales $\mathrm{j}$ en al bosyue. Son muy diferentes entre si, pero todas se irasforman en crisálidas del mismo modo, fabricando uri tejido que fijan en un objeto de los/airededores.

\section{LOS SATURNIOS-SATURNIA}

CARACTERES. - Asi como los ornitóptcros y morfos entre las mariposas diurnas, y los esfinges entre los esfingidos, al antiguo género de los saturnios ocurá del mismo modo el primer rango en toda la fauilia y hastá en todo el órden, pues entré cllos encontramos no solaniente los gigantes de todas las nariposas, sino tambien furnias graciosaminte arqueidas en alas enormes cuyo centro se distingue ya por una mamcha cristalina, ó bien ocular. Son demasiado grandes para poider conservar la posicion horizontal; en las anteriores falta una celda apendiente; las postcriores, muy anchas, sobrsalen siempre inucho del abdómen; tienen solo un nervio dorsal bien marcado, y en las cuatró el quinto nervio longitudimal parie del angulo. anterior de la celda discoidea. I a serie doble de los largos dientes, mas pequenos hacia amlas extremidades, en las cortas antenas del macho, prociuce un contorne en forma de hojas.

DISTRIBUCION GEOGRÁFICA. - Los saturnios se encuentran en todos los contimentes en gran numero, sobre todo en América.

\section{EL SATURNIO ATLAS-SATURNIA ATLAS}

CARACTERES.-Ësta mariposa es la mias grande de todas; mide poco mas 6 menos un palmo de punta a punta de ala por 10",037 de longitud del cuerpo.

DISTRIBUCION GEOGRÁFICA.- Es propia de la China.

\section{EL SATURNIO DEL AILANTO-SATURNIA}

Como ya sabemos, las diferentes enfermedades que desde principios del quinto decenio de nuestro siglo ocasionaron gmandes cstragos entre los gusanos de seda, perjudicando mucho á cuantus se dedicaban ila cria, hicieron desear mas que nunca ol hallazgo de otros bombicidos, que quizis por el ecjido de sus orugas pudieran dar una scda que compen. sara cuando menos un poco la pérdida. Ias socieciades de aclimatacion existentes en todos los grandes Fstados de Europa se ocuparon tambien de esie asunto, y cuidaronse de enviar á buscar mrios hombiridos, en los que hacia tiempo se habia fijado la atencion, é hiciéronles producir seda por medio de una cria artificial. Desde entonces fueron muchos los aficionados que practicaron ensajos de cria con los hue- vos de unn th otra especic, obtenidos de las sociedacies con la condicion de publicar concienzudamente los resultados. Para Alemania, naturalmente, solo pueden adquirir cierta importancia las especies cuyas orugas se alimentan de las plantas propias de nuestros paises: y podriamos dar cuenta de ensayos muy notables, practicados con las mas diferentes especies, pero la falia de espacio nos obliga á ocuparnos solo de tres de las mas importantes.

Los primeros experimentos mas amplios practicíronsc con el saturnio del ailanto, llamado en Assam crya, cuya propagacion consiguió en $1 \$ 54$, por primera vez, la Sociedad de Paris. No puedo reconacer la diferencia que ultimamente se hace entre la symthia y la arindio, de las que la primera, se. gun se dice, come las hojas del ailantus glandulosa, y la segunda la del ricinus commursis. He recibido de la Sociedad de aclimatacion de Berlin huevos de la saturnia sym/ha: y ali. mentando las orugas con ambats plantas he podido obserar que prosjeran casi mejor con la última. Tampoco puedo hallar la diferencia que segun algunow naturalistas ofrece cl aspecto de algumas mariposas.

CARAGTERES.-FI bonito saturnio del ailanto tiene un color pardo de corzo vivo y aterciopelado, con hajas blancas; los bordes josteriores de las celdas cristalimas afectan la forma de luná, afreciencio un matiz amarillento; las oculares de lis alas anteriores son negras hicia afuera. En el abdómen se ven unos moñitos de pelos blancos.

USOS, COSTUMBRES Y REGIMEN, - El SAturnio del ailanto se desarrolla tan rápidamente que puede haber tres crias al hno si se le proporciona el alimento suficiente. lo que sin cmbargo solo puede hacerse en un invernadero. Por lo regular en junio, ó tambien en julio, sale! las orugas de la segunda cria; suponiendo un término mas largo, por ejemplo el rif de jutio, la primera muda se verifica el io del mismo mes, la ségunta el 28 , la tercera el $\mathrm{S}$ de agosto y la cuarta el 14 de este mes. Estos términos se fundan en experiencias. pero solo indican poco mas ó menos los intervalos, pues en ciertos casos podria liaber diferencias hasta de ocho dias.

Las orugas son de color amarillo verdosn y tienen además de las scis series de espinas carnosas unos puntios negros, dos en cada segmento entre las tres lineas superiores de espigas, tres alrededor del estigma orillado de negro, y ade más dos sobrepuestas en cada base del pie. Despues de la flitima muda adrquieren un viso blanco ó azulado. lass oru. gas se alimeniaban con mejor $\delta$ peor éxito ambien con cardos. Fin el otonio de $\mathrm{SG}_{4}$ habiendo comenzalo muy pronto las heladas de las noches, que destruyeron las dos plantas alimenticias citadas, me vi en el mayor apuro. Con mucho cuidado babia conseguido conservar gran número de orugas hasta mas alla de la tercem muda, y no pocas algun tièmpo despues de la cuarta. Estas últimas se ciejaron enganar en parte por las hojas del rius fyphison, algo semejantes $i$ las del ailanto 6 árbol de los dioses, y que habian surrido menos pror el hielo; las comian y obture unos treinta capullos de crisálida, aunque poco fuertes: estos se consersinron durante el invierno en una habitacion fria, y desde 12 de mayó del ano-siguiente aparecieron algumas mariposas ฤ̧ณ no pertenecian a las mas grandes. Cuando-con una temperatura demasiado baja no sc retarda el nacimiento, la crisálida solo réposa tres semanas y algunos dias. Los huevos necesitan unos catorce parn que salgan las oruguitas, si no hay obstaculo, amique la temperatura sea muy baja.

\section{ELSATURNIO DE PERNY-SATURNIA PERNYI}

CARACTERES. - Id sillurnio de Perny (preferimos el 
nombre genérico usidu en rez. del creado por Hubner de ankeliraa) debe su nombre a un relato del abad Pablo Perny, presentado à la Sociedad de Aclimatacion de Paris (1S70?), sicndo trasmitido it Furopa por mediacion del abad, y yque se hizo público por las relaciones mercantiles de los fabricantes de seda del pais con la China.

Esta bonita mariposa, que oirece la misma forma de la anterior, tiene las alas de un amarillo de cuero, cruzadas por una iaja trasversal posterior blanca, orillada lakia adentro de un estrecho burde pardo, y por otra anterior casi del todo parda, mas arquendi. Una mancha redonda vidriosa, circuida de un borde oscuro y de un anillo cortaclo blanco, ocupa la extremidad de cada celda discoidea. El borde anterior de las alas anteriores estí orillado ademis en la mitad de su base de un tinie blanquizco.

USOS, COSTUMBRES Y REGIMEN. - Tan luego cumo las mariposas se han desarrollado, los sexos se aparcan en seguida a la manera de los bombicidos, y solo por cxeep). cion quedan reunidos algun tiempo (de 40 a 50 hurass). Tress dias despues del apareamiento, las hembras depositan sus huevos, de color pardo, en montancitos, sobre las paredes del lugar donde se encuentran; y à los ocho ó diez dias salen las oruguitas, (que despues de la segunda muda adpluieren un color verde amarillento, el cual conservan desuues de las dos mudas restantes. $A$ cabo de unos 52 dias comienzan i tejer su capullo.

La oruga adulta tiene la cabeza de color pardo con manchas oscuras, por lo cual difiere de la del saturnio japonés, que es verde. Sobre los pequeños estigmas pardos se corre desde el cuarto segmento uma linea amarillenta rodeada de un borde pardo á lo largo del cuerpo, linea que se ensancha en la extremidad un poco triangularmente y rodea los dos lóbulos anales con un estrecho borde pardusco. Debajo de los estigmas se ve una serie de verruguitas azules, que en el dorso se prolonga desde el segundo segmento linsta el antepentilimo: tambien hay una serie doble de espigas puntingudas dirigidas hicia adelante, que rematan en botoncios azules; en los segmentos anteriores prarecen IIn poco mas fuertes, debiéndose esto mas bien al la posicion del cuerpo que a la realidad; tienen una manchita lateral plateada, y todas estain cubiertas de pelos cerdosos largos ó cortos en forma de maza. En todo el cuerpo se ven numerosns verruguitas amarillas. Lan oruga, muy perezosa, se agarm con fuerka ả las hojas; comc de dia y de noche con cortas interrupciones, durante las cuales deposita sus excrementos:y despues de cada muda devora ante todo su piel.

La mariposa tiene en su patria, lo mismo que en nuestros paises, dos crias al año: pero no todas las marijosas de la primera nacen de sus crisálidas, fenómelio que tambicn puede observarse en otros bombicidos que se distinguen de las ma. rijosias por cientas irregularidades en el desarrollo.

Scgun los relatos de Perny a la Sociedad de Paris, los capullos de la segunda cria con sus crisílidas invernan en las habitaciones, en la provincia de Kug Tschelu, evitancose por la regularizacion de la temperntura que las mariposas salgan demasiado pronto ó demasiado tarde. Nacen por abril, y las Tremiras fecundizad:as se ponen en cestos, dunde depositan sus huevos: $a$ las orugas, que salen al cabo de ocho $\delta$ diez dias, se les ofrecun ramitas de encinn: tan luego como han subido a ellas se coloca el cesto en los encinares donde snin hay aun arbustos, y cuyo suelo se limpia pira recoger ficilmente las orugas caidas. A este electo. y à fin de aluyentar las aves que persiguen à las oruggas, se tiene en cada plantacion un vigilante que debe cambien trasladar las orugas de un arbusto deshojado a otro cubierto de follaje. A los 100 ú 45 dias despues del nacimiento de las ongas, recógense por lo regu. lar capullos. los mejores se escogèn para continuar la cria; los otros se tuestan sobre troncos de bambú colocados sobre el fuego pan matar la crisalida. Despues se les deja unos ocho ó diez minutos en agua hirviente, añadiendo mas tarde una solucion de dos puñados de una ceniza especial en un jarro de agua. Esta ceniza se iabrica del modo siguiente: despues de recoger los granos para hacerla, los chinos secan los tallos al sol y los amontonan ó los encienden; la ceniza produce, segun supone el ab:ad, los efectos de la potasa. I.os capullos se reruclven entonces con una pala, hasta que los hilos de seda se separan y empiezan à envolverse en aquella; luego se cogen de cinco a ocho hilos, segun la fuerza del vejido que se quiere, se introducen en la primera abertura de la má(quina arrolladora y se abren los capullos.

lis segunda cria se trata del mismo modo que la primera. los clinos han hecho buenas ganancias durante los veinte años en que crian estc bombicido, aprendiendo toda clase de imañas de que aqui no podemos hablar. Aprecian la seda de esta oruga porque es mas filerte y barata que la del bom. bix de la morera. Los experimentos de cria hechos en varias regiones de Europa. tanto en edificios como al aire libre: han tenido los mismos resultados que en la China, quizicon la diferencia de que en nuestros paises las orugas no han nacicio al mismo tiempo ni con tanta uniformidad como alli, circunstancia que tal vez dependa de que muchos de estos luevos están a veces largo tiempo en la travesia. Si en po. cas palabras cito ayui mis experimentos de cria del ano 18 y comparandolos con los de un amigo. lo haggo para repro. ducir en lo esencial los resultados obteniclos tambien por otros; llamando al propio tiempo la atencion sobre algunas circunstancias importantes digmas de ser observadas en la cria de este bombicido.

Desde léjos recibi un número de huevos obtenidos de una cria del país; y habian reprosado lo mas diez dias, cuando el 23 de mayo las oruguitas salieron con bastante regularidad y prosperaron muy bien sin mascuichado cque darles un alimento abundante. El 31 de mayo observé la primera muda: el si de junio la segunda, del 13 al 15 la tercera, y i fines del mes la cuarta. En la noche del 2 al 15 de julio las orugas empezaron á labricar su tejiclo, lo que hacen siempre con algunas hojas de la planta alimenticia. Aunque segun ya he dicho las oruguitas nacicron bastanie igualmentc, dióse fronto el caso, que todo criador de onigas puede observinr, de que al. guna se retrassra en su desarrollo sin morir por eso. pues apcnas he perdido por la muerte en diferentes mudas una docena entre mas de cien orugas. Essas se hallaban al principio en una caja ventilada y cuando fucron mas grandes en dos; recibian ramas de encina de diferentes clases, colocadas en agua, y" çue se remojaban todas las mauanas, of cuando se renuraba el alimento; tenian un pequeño espacio para dormir y hallábanse expuestas todo cl dia al aire fresco. Cuando fueron creciendo y la continua caida de los excre. mentos impidió a los hahirantes dormir, llevé las dos cejas i una habitacion contigua. Algunos dias desfavorables produjeron una tardanza en la muda y disminucion del apetito en los individues sanos: y aquelles dias hube de escribir lo siguiente en mi libro de apuntes: percern muda desde el I 3 al 15: última muda a lines de junio. No he apuntado aquellos dias de mal tiempo sino como recuerdo. Ein lis sounda mitad de agosto nacieron brjo el cuidado de mi amigo todas las crisálidas excepto una Estas mariposas eran por cérmino medio mas peopucinas que las que él mismo habia criado. Ias orugas de su cria habian vivido en tal estado unos catorce dias nienos, y las crisalidas dieron a luz las mariposas mas pronto, pues ya antes del iz de agosto nacieron algunis. Listos resultados mas favorables solo podian reconocer por 
causa las tres circunstancias siguientes: las orugas tenian la prision mas espaciosa; una habitacion propia situada á oriente y mas humedad, pues se les daba todos los dias alimento fresco sumergido en el agua yo remojaba tan liego como el follaje se sécaba.

Precisamente por el hecho de que esta oruga de cabeza parda produce dos crias al año, la considero como la especie mas propia para la sericultura alemana en gran escala. Su cria debe verificarse sin embargo en habitaciones en que, cuando el tiempo no es favorable, cl desarrollo se pueda fa. cilitar por una temperntura artificial, de modo que el criador no se vea embarazado por cl alimento para la segunda cria. En los paises cálidos de Europa la cria del hombix de las more. ras no ha podido verificarse al airc libre y menos aun lo pol. dremos hacer con esta especie extraniera en nuestros pusis frios. Muy bien se comprende que no sea posible obtener dos crias al aire libre, y por lo mismo se ha hecho la proposicion de acostumbrar á este saturnio a una cria que deberia obtenerse en la mejor estacion del sũo, con locual no seri:t de temer la falta de alimento. Suponiendo que la mariposa pueda acostumbrarse de este modo, lo cual dudamos, los experimentos por este concepto me marecen muy supér. fluos, porque sa tencmos en la oruga de cncina de cabcza verde una especie que por sí misma vive en lí estacion que nos convienc; las condiciones desfavorables del tiempo, las persecuciones jor parte de las aves insectivoras no se evitan con tales cambios, y deberian hacerse sacrificios que apenas se compensan por una sola cosecha de capullos de seda. Debe criarse csta especie, por el contrario, poco mas ó menos como se cria el bombix de las moreras, y se ha de bus. car la ventaja en las dos cosechas; esto es lo mas natural, y tambien 10 mas razonable.

\section{EL SATURNIO JAPONÉS-SATURINIA XAMA-MAYU}

CARACTERES. - Esta mariposa se parece mucho i la especie china, solo que es variable en su color principal, jorque este puede pasar desde el amarillo puro al amarillo de cuero y al pardo, y además las manchas vidriosas son menos circulares y relativaniente mas jequeñas.

'Tambien la oruga ofrece la mayor semejanza con la de la especie anterior, pero es de un verde desvido y menos trasparente; la cabeza es verde, con las mismas manchitas plateadas en los lados de las espigas anteriores del dorso; algunas celdas aćreas cstán situadas por-debajo de la piel trasparcnte del cuerpo.

USOS, COSTUMBRES Y REGIMEN.- En el modo de proceder, y sobre todo en el desarrollo se obsernan dife. rencias mas escuciales entre esta especie $y$ la anterior. I as orugas jóvenes son muy inquietas lasta su prinicra muda, y se ahogan fácilmente en los rasos en que se les ofrece el alimento cuando pueden llegar à cllos, demostrando con esto su aícion al agua. Mi amigo antes citado, que segun los diferentes relatos que he leido obtuvo los resultados mas favorables alimentando las orugas en su primera juventud con las hojas del espino blanco, y tambien del sauce lanoso, me dio en dos diferentes años orugas que habian surrido la scgunda muda; las tratc del mismo modo que las orugas de encina de cabeza parda, les di la misma habitacion, pero no consegui que ninguna se crisalidarn, aunque no podian estorbarse en la prision a causa de su reducido número. Segun las siguientes experiencias, son mas sensibles que las anteriores y menos propias para dar pingüe ganancia, porque solo producen una cria al año. En esta especie los huevos imernan ye han de vigilar muy cuidadosamente para que no salgan las orugas antes de haber alimento para ellas. En tiempo favorable estas últimas mudan cuatro veces con intervalos de ocho a diez dias y se crisalidan por término medio el dia çuincuagésimo segundo, dando a luz 40 dias mas tarde la mariposa, que se ocupa mucho menos tiempo en el apareamiento que la anterior.

'l'ambien esta especic se ha importado de varios puntos de su patria i Europa y Alenania, pero anies que la anterior. Tengo á mi vista unos relatos del año 1866 segun los cunles Mach de Slatenegg, en la Carniola inferior, ha hecho experimentos de cria al aire libre con el mejor resultado, teniendo tal esperamaa de obtener buenos beneficios tambien para el porvenir, que solo se queja de la falta de hombres quue se ocujen en la cria. Ya hemos cmitido nuestra opjinion sobre este asunto, y solo podemos aconsejar á los que qquieran obtener la seda en grande escala, que se valgan para ello de mias especies de bombicidos al mismo ticmpo, if fin de que cada cual pueda clegir la que mas le convenga por sus con. diciones. Por nuestra parte nos decidiriamos en favor del saturnio chino, dado caso que algunos bombicidos importa. dos últimamente del norte de América no resultaran mas convenientes, cosa que sin embargo no creemos, porque el álamo y el sauce, arboles de que aquellos se alimentan, no sirven tunto como la encina yara la cria en cdificios; pero esta cria la consideramos en todas las circunstancias como la única conveniente en nuestro clima.

Tres saturnios sin puntos cristalinos en las manchas ocu. lares de las alas, de un bonito pardo, y sin capullos, que pudicran servir para la fabricacion de seda, son propios de Alemania: el saturnio de los pernles (salursia pyri), el saturnio del espino (snfurnia spivi), y el mas comun de cllos, el saturnio pecqueño (snturnia carpini). Sus orugas, verdes, tienen verrugas pedunculadas de un modo menos particular, pero ofrecen el caracier de las exóticas y se alimentan on el órden indicado de las hojas del peral y del ciruclo, del espino negro y de lás mas diversas plantas (rosales, hayas, encinas, etcétera).

\section{EL BOMBLX DE LAS MORERAS-BOMBYX MORI}

CARACTERES, - El bombix de las morerns ocupa hoy dia un lugar aislado en el sistema, porque el nombre genéricó de bomblyx, que linnco dió a toda la familia, se ha conservado solo para esa especie. Asi como las aves que mejor cantan ostentan el plumaje mas scncillo, del mismo modo la mas útil de todas las mariposas parece la mas humilde. Su tamano varia de $0^{4}, 040$ a $0^{*} .0455$ de ancho de junta á punta de ala; es de color blanco de harina, L negra en la doble serie de dientecitos de las antenas, çue son largas en ambos sexos. Las alas se distinguen por lo cortas; las anteriores tienen una punta falcifome, por efecto de una profunda escotadura arqueada del borde; una faja tmasversal de color amarillo pardusco se corre por las dos, cuando no falta.

USOS, CUSTUMBRES Y REGIMEN. - La mariposa se aparea apenas sale de la crisilida; la oruga desnuda, llamada conummente gusano de sedan, es la mas perfecta entre todas las de los boubicidos, ascmejándose por su aspecto exterior á las de los esfingidos, pres tienen en su parte posterior un corto cuerno y su cuello se ensancha casi- del mismo modo que en la oruga del esfinge. Es de un gris blan. quizco, presentando en el dorso manchas pardas ahorquilla. das y otms oculares de un rojo amarillo, asi como dibujos diversos en los lados de los segmentos anturiores. Su tinico alimento consiste en las hojas de la morera. Los capullos ovales, rodendos por fucra de ligeros hilos sedosos, son blan. cos ó amarillos, los dos colores en los que, como yin sabe. 
mos, se encuentra siempre la seda cruda. los capullos gemelos no son raros; tambien son de forma sencilla, y a pesar de eso salen de cllos mariposas.

Segun toda probabilidad, la mariposa es originaria de la China, patria de su planta alimenticia; con esta se disemino hácia el norte y el sur por los alrededores mas próximos, luasta que bajo ol reinado del emperador Justiniano, dos frailes persas importaron plantas de morera y siniente que habian robado $y$ escondido en sus bastones de viaje huecos, hallándose en Constantinopla. La seda se cultivó por primera vez en Luropa desde el año 520 despues de Jesu- cristo; esta industria fué hasta el siglo xul derecho cxclusivo del Imperio griego, en el que la isla de Cos representó el papel mas importante por tal concepto. Desde Grecia los arabes llevaron esta industria a España; y a mediados del siglo xı, gracias a la guerra que Roger II sostuvo contra el bizantino Manuel, inıportúse en Sicilia, extendiéndose poco i poco por l'lorencia, Bolonia, Venecia, Milan y cl resto de Italia: en ticinjo de Enrique IV se introdujo en Francia y desde ą̧ui mas hácia el norte. En Alemania se formó en $16 j 0$, en Baviera, lá primera sociedad para el cultivo de la seda. Federico el Grande hizo mucho por csta industria en

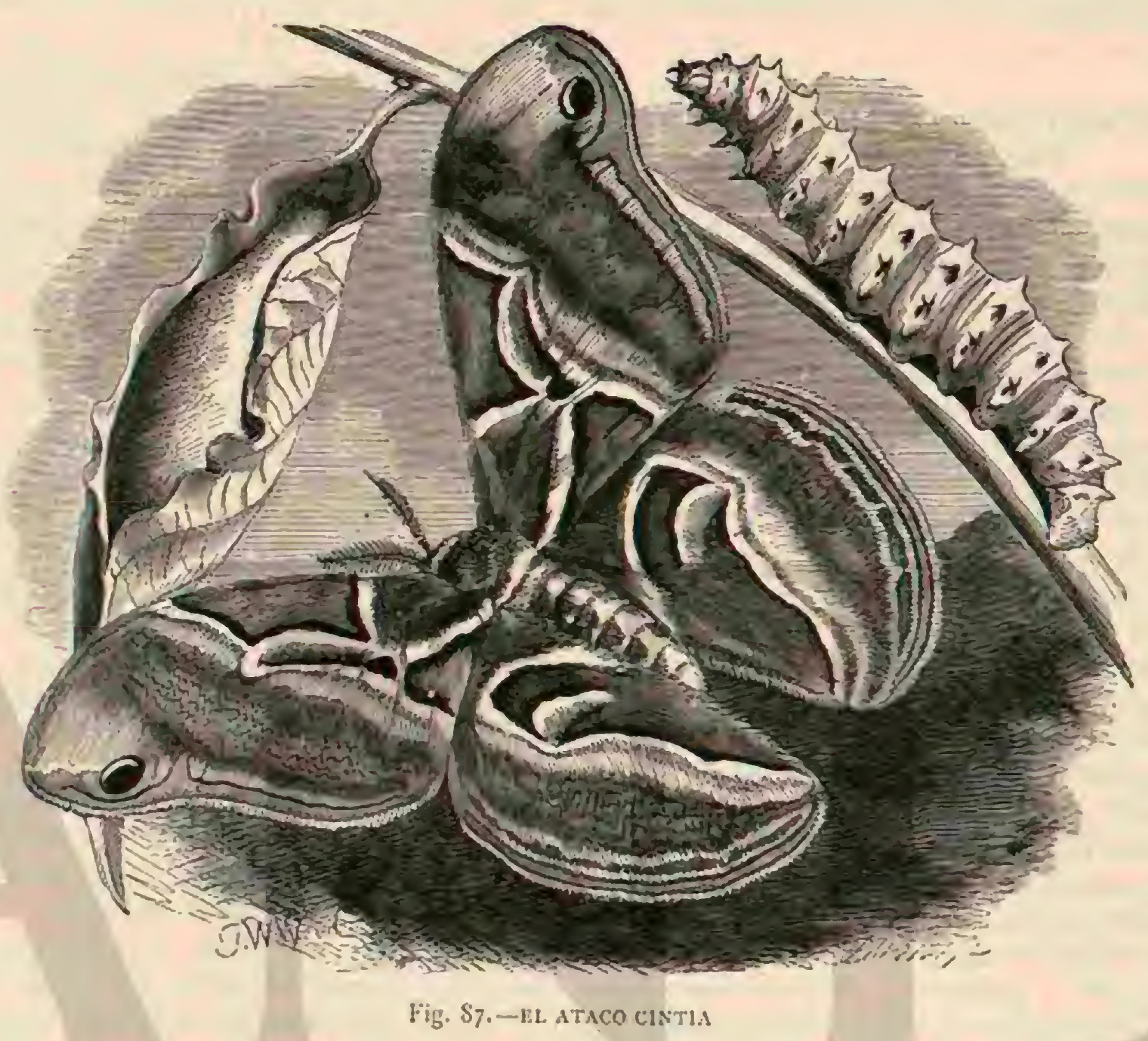

sus países, $y$ asi sé generalizó aquella en la segunda mitad del siglo pasado en todos los puntos de Alemania. I as guer. ras de la independencia dieron a ln nueva industria un golpe muy rudo, pues los tiempos no eran propios para cuidar gusanos de seda ni regar hojas de morera. I.os irboles se enrejecian sin propagarse; y apenas hacian caso de cllos mas que los chicquillos de los pucblos para coger sus dulces frutos. Vilimamente se volvió a tomar en manos el asunto, fa. vareciéndole los gobiernos, cuando menos el de Prusia. Ofreciéronse premios por cierto número de cajullos obtenidos; plantáronse en vez de àrboles aislados cercas de morera, que mucho mas ripida y cómodanente proporcionaban el alimento necesario: y así todo parecia marchar por el buen camino para que prosperase esta industria auxiliar, cuando circularon los relatos de los paises del sur de Europa referentes al cultivo de la seda y a los sintomas de enfermedad de los gusanoś, lo cual intimidó d los principiantes en Alemania. Entonces comenzaron los experimentus de cria con otros bombicidos desviándose la atencion pública del mas noble de todos; y' hé aqui porqué la Alemania no produce apsenas secla, al menos que sepamos, en proporcion a lo que se necesita en este articulo.

En la cria de estas orugas, una temperatura iguai poco mas 6 menos a $18^{\circ}$ Reaumur y un alimento seco son las condi. ciones esenciales de su prosperidad Se presentan igualmente solo una vez al año. Ia oruga adulta fija la sustancia textil, que sale de dos abarturas microscópicas del lado inferior, en una rama de la planta alimenticia ó en los emparrados que sé le ofrecen, y envuélvese con ella en forma de hilos aislados, los cuales se fijan cu una u utra jarte, formando su primera linea una especie de hamaca. Esta se hace mas y mas espe. s.. encierra el cuerpo de la oruga siempre mas estrechamente y le oculta por fin del todo á la vista del observador. Algun tiempo despues se oje cómo el insecto teje en el inte. rior, hasta que por fin reina calma completa y la crisálida qqueda formada. Los capullos mas fuertes, sea cual fuerc el sexo, se eligen para la cria; los de los machos son cilindricos en el centro, mas ó menos estrechos, y los de la hembm ovales. Los tejidos destinados para la fabricacion de la seda deben exponerse al calor del horno ó $t 1$ vipores cálidos de hgua, para que mueran las crisélidas y para que la mariposa al salir no destruyn el único hilo que tiene hasta 600 metros de longitud. I a primera tarea es la de desarrollar este hilo: al efecto se remueven los capullos en agua casi hirviente con escobas, hasta que la cola con quie estion uridos los hilos se disuelve. Los tejidos preparados de este modo se trasladan despues a utra caldera llena de agua caliente, que está en comunicacion con una devanadera cuya construccion puede 
ser de diferente clase. Como el hilo de un solo capullo seria demasiado fino se devanan, segun la nceesidad, de tres a ocho ó mas al mismo tiempo, que en el «conductor", pasando por anillos de vidrio, se reunen todos en un luilo á causa de la cola que aun tienen. En este trabajo, que regularmente se hace por muchachas, debe fijarse la atencion en la igualdad del hilo, que cuanto mas adentro está en el capullo mas fino es, exigiendo en su extremidad la reunion de hilos nuevos. I a cubicrta mas próxima de la crisálida no puede desarrollarse, pues sicmpre quedun cono unas membranas apergamimadas. De diez a die\% y scis kilógramos dé capullos crudos $\delta$ de siete a nueve tostados, dan desjues de devanados un kilógramo de seda cruda, cuyo tratamiento pertenece a otms industrias que no nos interesan aqui.

\section{EL GASTROPACO DE LOS PINOS-GASTRO- PACHA PINI}

CARACTERES,-Esta mariposa es de color muy variable, aunçue predomina el gris y el pardo en diferentes mezclas. Una manchita blanca en forma de media luma en las alas anteriores jo una faja trasversal irregular, mas estreclia o mas ancha, de color pardo rojo, son carnctéres distintivos.

USOS, COSTUMBRES Y REGIMEN.-El gastropaco de los pinos no es raro en ninguna parte donde existen estos írboles: su honita oruga es una de-lís mas temidas de los guarda-bosques. Se encuentra medio adulta, 0 aun pequeña en sus cuarteles de invierno, debajo del musgo, $y$ cn los terrenos poblados de írboles de sesenta i ochenta años de edid. Permanece en un agujero, enroscada en forma de muelle de reloj, siempre húmeda, y tambien se queda rigida cuando el hielo penetra en la ticrra. Si el frio desaparece recobm su agilidad, y' segun la temperatura sube mas pronto 6 mas tar. de, pero con seguridad cuando en el distrito el termómetro marea $8^{\circ}$ Reaumur. A fines de abril ha llegado a los conos de la copa de los árboles, y por lo regular no vuelve í bajar hasta joco antes de metamorfosearse. Sus dos colores princi. pales son el pardo y el pardó gris que alternan en diferentes matices y disposiciones; el cuerpo presenta en ciertos sitios pelos sedosos, con el mas magnifico brillo de nacir. Las incisiones del segundo y tércer segmento forman los llamados espejos, es decir manchas aterciopeladas de un arul metálico. Para crisalidarse fabrimn un capullo cerrado, no siempre entre los conos devorados, sino tambien mas abajo en el tronco, entre la corteza. A menudo no llegan à crisalidarsc, dándose el caso de que centenares de larvitas del icneumon se alinenten en su cuerpo y salgan por fin del mismo para trasformarse sobre la piel, lo único que queda de las pequeñas crisalidias de un blanco de nierc. Parece que has orugas enfermas, siempre inquietas, hajan de los árboles, pues he visto pellejos llenos de larvas de parisito en gran múmeto hasta la altura de un hombie, $\vec{y}$ mas abajo, en los troncos, observé que habia muy pocas de estas mariposas. I a crisalida sana necesita unas ires semanas para su desirrollo: de modo que la mariposa sale à mediados de julio.

l.a hembra mas grande es muy perezosa, y" no creo facil que el macho vuele de dia Que las mariposas emprenden a veces largos viajes es un hecho gue yo mismo reconoci hace tiempo por la circunstancia de haber encontrado un grupo de ocho individuos de ambos sexus posados en una campana en la torre de la iglesia, en una region muy distante de aquellas donde habia pinos. Tambien Ratzeburg hace mencion de al. gunos casos que indican tales viajes.

Poco despues del apareamiento, que por lo regular se ve. rifica la misma noche en n̨ue la mariposa nació, la hembra deposita de ciento a doscientos huevos en el tronco, un los conos ó en una rama, en grandes ó pequeños grupos. Estos huevos son de color verde claro, y grises en agosto, poco antes de nacer las orugas. Yit hemos visto antes que tienen sus aficionados entre los parisitos, de los que un telea se ha ob. ieniclo en número de doce individuos de un solo huevo.

I.a origuita se dirige en seguida i los conos, y los corroe solo al principio, pero pronto puede devorarlos del todo. Segun observaciones cuidadosas, se ha calculado que una orugi de regular desarrollo necesila por término medio mil conos hasta que llega a crisalidarse y que un oruga de medio tamaino derora en cinco minutos un cono, de lo cual resulta que grandes masas de estas orugas pueden ocasionar no poco daño. Desde el año 1770 tenemos noticias sobre lus estragros causados por esta oruga Un solo relati) de estos últimos tiempos que reciui de un empleado de la administracion de boscyues, puede darnos la prueba de las enormes legiones en que a reces se presenta este bombicido. En el distrito de Moellbitz, cerca de liurzen, recogieron en 1560 un quintal y cunrentin y nuere librus de lucros, sesenta y cuatro cele. mines de mariposas hembras y ciento veinticuatro de orugas, sin haber conseguido con esto dominar al enemigo. Aunyuc hace ya mucho tiempo gue la administracion de bospues vigila cuidadosamente y destruye un sinnumero de orugas en la primarera, poco lograria si la natusaleza misma no pusiera coto a una propagacion enorme por medio de muchas especies de icneunónidos y con el auxilio de una seta ( horry. tis barsiona) que crecen en el interior del cuerjo, produciendo una muerte segura: hasta se han encontrado ranas en los àrboles en que estaban las orugas en masas deriastr. doras.

\section{EL GASTROPACO ANULAR-GASTROPACHA NEUSTRIA}

CARACTÉRES. - HI macho, de color oscuro, prescna sobre fondo amarillo de ocre, lineas trasversales casi rectas y bastante paralclas, distinguiéndose por esto de una especie muy parecida (sastropacha costrensis).

USOS, COSTUMBRES Y REGJMEN.-Pocos serin los que no hayan visto en los troncos de los árboles frutales, f́ fines de mayo ó principios de junio, la oruga del gastropaco anular, de color azul claro con rayns pardas y ama. rillas, sobre cuyo dorso se corre además una inja central blanquizca, y cuya cabera azul tiene dos manchas negras, pues formando numerosos grupos nueve alegremente la par. te anterior de su ruerpo, cuando esta disfrutando de los calu. rosos rayos del sol. Esta oruga, llamada tambien de libren, i causa de sus fajas abigarradas, sale en la primavera de un anillo de huevos, casi tan duro como la piedra, que rodea una rama, en la que dificilmente se la distingue, a causa de la semejanza del color. Hasta la tercera muda poco mas ó me. nos, la oruga vive con sus hermanns, y" unos hilos plateados descubren el camino por donde suelen pasar. Solo cuando ha llegado a ser mas adulta y necesita mas alimento su dis. persa mas y mas. Despucs fabrica, con preforencia entre las hojas, un capullo cerrado, ammarillento por lo regular y empolrado, en el que la crisilida, de forma obrusa, é igualmente empolvada, reposa algunas semanas. I a mariposa sale en julio ó agosto: de dia permanece oculta perrciosamente, solo por la noche comienza \& aparearse.

Fsta especie y la anecrior, cuya oruga es mas honita y de co. lor pardo dorado, viven suciablemente en el cuforbio, y otros numerosos bombicidos de Europa y Amúrica han sido agru. pados en el género de los gastropacos, porque muchos de ellos tienen la costumbre de extender las alas en et estado de reposo, como la liueca que oculta sus polluelos. Ias alas 
de nuchos ofrecen ciertas diferencias en la disposicion de los nervios, pero todas las especies se asemcjan por los caractéres siguientes: dos alas anteriores, fuertes y relativamente cortas, ticnen doce nervios, ninguna celda apendiente $y$ un nervio dorsal no ahorquillado; las alas posteriores son an. chas, orilladas de cortas franjas, que carecen de la cerda prensil y tienen dos nervios dorsales. En ambos sexos, las antenas, cuya longitud varia, pudiendo alcanzar una mitad de la de las alas anteriores, presentan dos series de dicntecitos largos, en forma de peine, en el macho, siendo muy cortos en la incmura. Tos ojuelos no existen: los tarsos pos. teriores de las patas, cortas y fucrtes, carecen tambien de los dos espolones superiorcs.

\section{LOS SIQUINOS - PSYCHINA}

CARACTERES. - l.o5 siquinos constitujen un género interesante jor mas de un concepto; ambien se llaman por. indores de saco, porque las orugas cstin en un estuche fabricado con las mas diferentes materias vegetales, siencio la construccion muy variable, $y$ tan especial, que es preciso conocer el saco para poder distinguir con seguridad la mariposa de otra muy parecida. Una segunda particularidad es la de que la hembra carece de alas. ! muchas de ellas no abandonan el saco en que se crisalidó la oruga, asemejandose mas bien a una larva que á un insecto desarrollado y' menos aun i una mariposa. Otras ticnen patas y antenas y suelen posarse en la cara eaterior de su cuma. los machos, cubiertos por la regular de pelos, de colores oscuros y sin dibujos, son intectos alegres, que á mucha distancia olfatcan al otro scxo; acuden con rápido vuelo y penetran si es posible en la caja en que el coleccionador encerró uแa hembra perteneciente á su especie. Ias antenas tienen cerdas velludas dispuestas en doble serie: los palpos y la lengua faltan ó se atrofian mucho; las alas anteriores presentan un nerio dorsal, ahorquillado por lo regular hácia el borde; en las alas pestcriores hay tres de estos nerios y una celda jurensil. Por lo demás, la direccion de los nervios esta sujeta a viriaciones segun la especic.

USOS, COSTUMBRES Y REGIMEN.-Vuelan de dia y i la hora del crepusculo: cuando descarsan aproyan las alas en forma de tejadillo sobre al aludómen. Ademas de las dos citadas particularidades se obserna una tercera, aunque no en todas las especies, ý è la partenogénesis ó propagacion sin prévia fecundacion: hasta en una especie, el psjeke helix; que fabrica con granions de arena un saco bastante-parecido á la concha del género helix, ni siquiera se conocian aun los machos, hasta yue Claus (1866) los crió despues de haber reconocialo su existchcia por unas orugas tirolesas que se alimeutaron con el tescrium chrmadrys y el alyssum montamum. Las conchas de ambos sexos se distinguen por el me. nor tamano de la del macho y por la circunstancia de yue en este último el orificio superior lateral no se halla a mucho mas de una circunvalacion de disiancia de la descmbocadura, micutras que esta distancia en el saco de la henbra es casi kioble.

i mediados de junio todas las oruguitas se habian trasformitedo en crisálidas; el r. " de julio se presentó el primer macho; el 10 del mismo el segundo. Se distinguian por las gran. des alas anteriores de un pardo de chocolate oscuro, por el espeso pelo del cuerpo, que aredia $0^{n}, 003$ de largo; pero cran tan endebles que murieron ya al primer dia. Sobre la partenogénesis se hicieron además obseriaciones en la psyche unicolor, $P$. aiciella y $I$. afiformis, en ha talaforia netitella, solesobia lichenella, trisumetrella, y tambien en algunos bombicidos grandes.
Ias orugas de los siquinos necesitan, por su género de vida, las seis patas toracicas córneas para avanzar, arrastrando su pequeña casa consigo, pero las otras son sujérfluns, se atrofian en forma de verruguitas ó faltan del todo. Para crisalidarse la major partc de los sicjuinos abandonan su planta alimenticia y fijan la desembocadura anterior de su saco en un tronco de árbol, en alguna cerca de tablas, en una picdra, etc.; despues la oruga se revuelve dirigiendo la cabe7.a hacia la abertura posterior libre. Ia crisálida de la hembra, redondenda en ambos lados, se mueve poco, y aunque salga la mariposa permanece en el fondo de la concha, mientras que la del macho, prolongada y provista de anillos rle cerdas antes de dar al luz la mariposa, sale hasta una mitad de su capullo.

\section{EL SIQUIS UNICOLOR - PSYCHE UNICOLOR}

CARACTÉRES. - Iista especic, mas comun, puede darnos uma idea de tan interesantes mariposas. Fi macho, de color pardo negruzco, tiene las puntitas de las franjas blancas y algunos pelos del mismo color en el vientre; en los tarsos posteriores solo hay espolones en la extremidad. Ia hembra, de misero aspecto, $y$ que ofrece la forma de larva despues de salir de la crisílida, permanece siempre en la cxtremidad posterior abierta de su saco, y espera humildemente á que llegue un macho para aparearse con ella. El abdómen del macho puede estimrse muclio y extenderse para penetrar á mucha profundidad en el saco de la hembra, don. de se encuentra con la extremidad en forma de espiga del abdómen de la hembra. Fista carece de taladro; no tiene ojos desarrollados, ni antenas articuladas, ni patas de buena forma. Hemos dicho antes que en esta especie se ha observado la partenogénesis; no lo negaré, pero solo debo llamar la atencion sobre dos circunstancias propias para inciucir it error, y que exigen la mayor precaucion en tales observaciones. Verificado el apareamiento, la hembra se retira a la piel de crisálicia abandonada, jara depositar en ella sus huevos: es inuy fácil entonces recogerla y confundirla con una crisálida. Cuando mas tarde aparecen oruguitas de siquis, puede pretenderse fácilmente que estas se han praducido por la partenogénesis;perono solo la piel de crisalida se llena de hue. ros, sino que todo el saco aparece entonces á la vista $y$ al tacto relleno cual si estuviese habitado, creyendose tocar en 61 la crisilicia, circunstancia que hace posible otro engano. Los órganos genitales de la hembra están del todo desarrollados éindican decididamente que si se depositaron huevos sin privia fecundacion, los cuales á pesar de eso se desarrollaron, fué solo un caso excepcional. 'lan luego como las oruguitas han abandonado los huevos, cada una se fabrica su casita, que al principio solo se compone de los hilos de la sustancia textil; solo destues, $\mathfrak{f}$ medida gue se desarrolla la oruga, se entretejen objetos heterogéneos. Tengo sin cmbargo motivo para creer que en cicrtas especies el estuclue no se agranda agregándose material, sino que se consume.sustituyéndose por otro nuevo mas voluminoso. Durante largo tiempo el sitio en que mació la pequeña oruga sirvele de abrigo y parn nutrirse; poco a poco sepairanse y cada cual va por su camino.

De diferente modo se forman las condiciones en el génera fumca y en un tercer género, el epichnopieryx; cuyns especics tienen la hembra un poco mas desarrollada que en el géncro psycise.

\section{LOS LIPÁRIDOS-LIPARIDE}

CARACTERES.-El género de los lipáridos se distingue 
por las alas posteriores anchas, con franjas cortas, sin cerda prensil; cuéntanse dos nervios dorsales y seis 6 siete nervios mas; los correspondientes a los mimeros 4 y 5 se destacan muy próximos entre sí; el $\mathrm{S}$ parte de la basc, tocindo solo el nervio central superior, $\delta$ reuniéndose con él. Los ojuclos no existen.

Varias especies de este género han llamado la atencion a causa de los estragos causados por sus orugas, mas bien que por la sencillez de la mariposa.

\section{EL DASIQUIRO PUDOROSO-DASYGHIRA PUDIBUNDA}

CARACTERES. - Esta especie es un bombicido claro if oscuro, con dibujos de un pardo gris ó blancos; la hembra tiene unos colores mas mates y cónfusos que los det macho.

USOS, COSTUMBRES Y REGIMEN.-Vuela a principios de junio y no llama por nacia la atericion. Su oruga, en cambio, no solo se distingrue por su belleza, sino que a reces ocasioná considerables perjuicios en los bosques de hayas jóvenes. Tambien sé la encuentra en las encinas, pero. mas al norte de Alemania. Pertenece à las orugas de forma de cepillo y es por lo regular de color de azufre; solo tiene un tinte rojo en el pincel posterior dépelos (én la cola), jero i' veces tambien los otros pelos son de un honito viso sonrosado. Le gusta la posicion encorrada y entonces deja ver las inagnificas manchas de un negro aterciopelado que.hay entre los mechones anteriores. En su juyentud baja por un hilo cuando se sacude el arbusto donde se alimenta, pero si es adulta déjase caer libremente y queda enroscada en el suclo, hasta que crec pasado el peligro. Entonces se levanta y sube de nuevo à su vivienda. En octubre baja di la hojarasca del suelo para crisalidarse, encerrándose en dos tejidos cuyo interior es bastante ligero para que se trasparante la crisilida, que es de un pardo oscuro.

Segun cierto relato del jefe de guardabosnues Fickert, en Ruigen, donde la oruga se encuentra hace dos siglos, la es. pecie causó los estragos mas considerables en el caluroso verano de 1868 , despojando de su iollaje todas las hayas de la Stuwenitz en una superficic de mas de 2,000 hectarens; de manera que á fines dé agosto quedaron completamente desnudas. Despues de las hayas atacaron Jus platanos, las encinas, los avcllanos y todos los arbustos pequeños; por fin les tocó el turno a los alisos, alerces y abedules, y hasta corrojeron los bordes del fruto de los pinos, mientras que no perjudicaron en nada los serbales, aunque los habian ataca. do en otra ocasion antes que lus alisos y abedules. Se ha reconocido por experiencia á menudo que cuando un insecto forma masas extraordinariamente grandes no puede fijarse una regha respecio al órden de las plumus atacadas. El dasiquiro pudoroso estaba discininado por todo el bosque de la Stuwenitz; pero solo llamaba la atencion alli donde se reu. nia en grandes masas y propagabase poco a poco, aurique tan pronto como el follaje comenraba a clarear bastaban ocho dias para que se viern un espacio de 100 á 200 hectáreas del rodo desnudo de hojas. Los troncos estaban cubiertos entonces de una espesa capa de orugas que subian y ba. jaban jara buscar inútilmente alimento y que morian en grandes masas en el suclo, pues tan liego como tres ó cuntro orugas comenzaban a reñit cesaba todo movimicnto. Fn los sitios en que se encontraban dos agrupaciones de orugas, la aglomeracion cra tan sorprendente, que bajo una haya podian recogerse cinco ó seis celemines. Solo en dos sitios de poca extension bastaba cl alimento para una parte de las orugas hasta la hora de trasiormarse; en este punto metamorfoseabanse tambien por grandes masas en crisálidas, ianto en la hojarasca como en el musgo de los troncos.

\section{EL DASIQUIRO DE LOS SAUCES- DASYCHIRA SALICIS}

CARACTERES. - Este bombicido estå cubierto ligeramente de escamitas blancas y tiene un brillo sedoso; los dientes de las antenas $y$ unos anillos de las patas son muy peludos; de estas últumas solo las !nosteriores tienen en ta c.:tremidad espolones.

USOS, COSTUMBRES X REGIMEN.-Vucla durantc las noches calurosas de junio y julio, a menudo d miles, como fantasmas alrededor de los álamos de nuestros caminos, donde los persiguen los murciélagos de modo que las alas cortadas se encuentran esparcidas en la calle. De dir se les ve i mucha distancia en los troncos, y cuando los gorriones y otros pájaros se hartan de sus bandadas, caen medio muertos al suelo, donde magullados se revuelcan en el polvo.

La hembra tecundada fija sus huevos por peçucioos grupos entre la corteza de los troncos, colocaindolos en una sustancia inucosa de brillo scdoso, que les descubre á mucha distancia. En la primavera siguiente nacen las orugas, a reces tambien por el otoño, aunque entonces solo para su perdicion, porque el invierno las mata: son ligeramente peludas, con verrugas rojas, y llaman la atencion por una seric de manchas de un amarillo de azufre o blancas, situadas alredecor dél dorso.

A veces despojan los ảlamos y sauces de todo su follaje. A fines de mayo se encuentran las crisilidas, de un negro brillante j cubiertas de mechones de pelos; suclen hallarse detrás de algunos hilos en los troncos ó en medio de varias hojas de la planta alimenticia.

\section{LA PORTESIA DE ANO DORADO-PORTHESIA CHRYSORRHCEA}

CARACTERES. - Esta especie es como la anterior de un solo color blanco, pero tiene la extrenidad del abdómen de un pardo rojo; este remata en el macho en un mechon de jelos, y en la hembra en una especie de boton. Los dien. tes de las antenas son de un rojo amarillo de orin. Este género se distingue del anterior por tener en los tarsos posteriores, cerca del centro, un par de espolones; los nervios 6 y 7 de las alas posteriores nacen de un tallo comun y el ner. vio ro de las alas anteriores toma su origen en el 8 .

USOS, COSTUMBRES Y REGIMEN.-Fiste boimbicido se presenta al mismo tiempo que el anterior, tiene el unismo género de vida y solo sabe ocultarse mejor en la cara inferior de las hojas; no se limita tampoco i los sauces y álamos, sino que se encuentra en casi todos los árboles del bosque (encina, haj:a, olmo, sauce, espino negro), y tambien en la mayor parte de los frutales, rosales y otros arbustos de adorno de los jardines. En todos se encuentra a principios de julio la hembra ocupada en depositar sus hüevos, regularmente en la carn inferior de las hojas. Valiéndose de dos escamas de la extremidad abdominal saca los pelos de color pardo de orin del boton de dicha parte y coloca en ellos los huevos pucstos al mismo tiempo. Al catro de aigunos dias empleados en este trabajo, los pelos, que en la punta del abdómen formabin el boton, han desaparecido casi del todo; y la hembra queda a veces unuerta sobre el grupo de hucros. ó care exhausta á suelo. A los 15 ó 20 dias, es decir, á fines de junio, $\delta$ tambien mas tarde, nacen las oruguitas y co men las hojas que se hallan mas próximas. Son de un amarillo sucio en la cabeza; y la nuca y una serie de puntos en el dorso, negros. Poco á poco tejen un nido, que hacen siem. pre mas espeso cuanto mas se acerca la estacion fria, y que se distingue mejor a medida que cren las hojas; en fl se en- 
cuentra por lo regular la masa de los huevos. Al año siguien. te las orugas comen los capullos de las hojas, toman el sol cu las horguillas de las ramas y vuelven al nido viejo ó fabricin otro nuevo: que tambicn abandoman tan luegro cono han crecido. A fines de abril se verifica la segunda muda (la primera ya se efectuó antes del invierno), y a últimos de mayo la tercera. La oruga adulta es muy peluda y de color par. do oscuro, ticne desde el cuarto segmento una mancha lateral blanca en cada uno; ciesde el sexto al décimo dos fajas dorsiles rojas, un poco onduladas, y en el noveno y décimo una verruga central de un rojo de Iadrillo. En la primera mitad de junio se convierte en crisálida dentro de un tejido ligero trasparente, entre las hojas, siendo su color pardo negruz. co. Estas orugas son las que principalmente perjudican mucho nuestros árboles frutales, y a menudo demuestran el descuido de los propietarios, que en invierno podrian destruir tan ficilmente esos enenigos quemando los nidos; al mismo tiempo debe fijarse la atencion tambien en los arbustos y en las cercas vims, porque cuando estas se componen de espinos blancos, son verdaderos focos de estos insectos.

\section{LA PORTESIA CISNE-PORTHESIA AURIFLUA}

CARACTERES, - EI cisne, llamado tambien bombicido

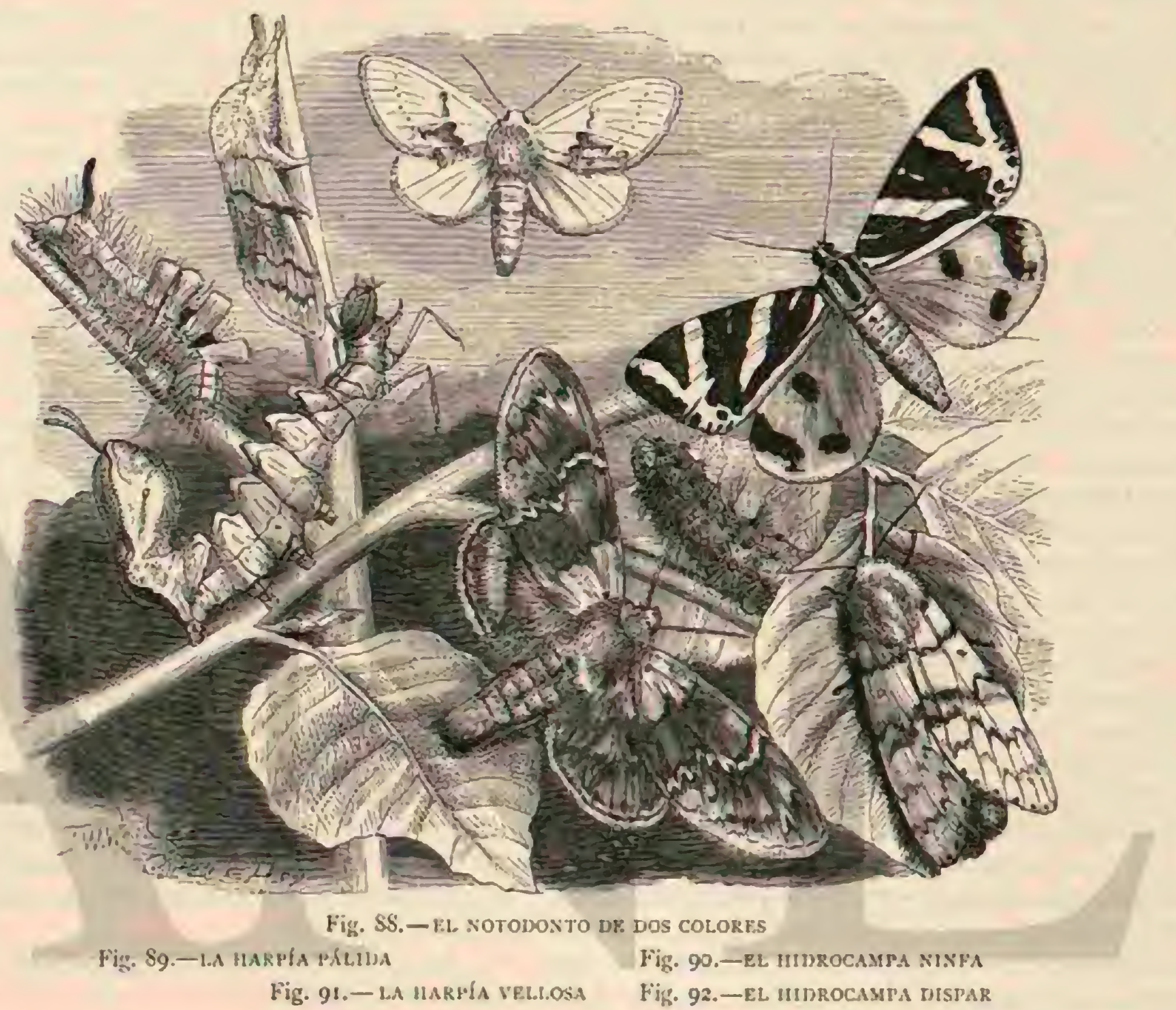

de los perales, se parece mucho i la portesia de ano dorado, solo que los mechones de esta son mas claros, de un amariIlo dorado, de modo que mas bien le pertenece el nombre del anterior, y ademis tiene en el borde interior de las alas anteriores una linea de franjas extremadiamente largas.

USOS, COSTUMBRES Y RÉGIMEN. - El género de vida y la historia de su desarrollo son casi los mismos que los de la especie anterior; el grupo de huevos, de un amarillo dorado, se encuentra en el bosque mas bien que en los jardines y las cercas, pero tambien aijui mas aisladamente. En un punto difieren ambos bombicidos esencialmente: despues de la jrimera muda, antes que principie el invierno se dispersan las oruguitas, y cada una busca en los escondites ordinarios un albergue donde fabricar un estuche blanco. Cuando adulta, es de color negro; tiene una laja doble de un rojo de cinabrio á lo largo del dorso, una sencilla por encima de los piés, una línea blanca ondulada en los lados, y en el cuarto segmento, en cl quinto $y$ el último, un mechon de pelos negros espolvoreados de blanco. Como es menos sociable que la especie anterior puede ayudar á esta en su obra de exterminio, pero nunca causar por si sola perjuicios tan grandes.

\section{LA OCNERIA DISPAR-OCNERYA DISPAR}

CARACTÉRES. - Esta especie se distingue por la disposicion de los nervios de las alas anteriores, en las que el nervio 10 sale del 7 ; en las alas posteriores los nervios 6 y 7 parten de un punto y no de un tallo comun. I os cuatro es. polones de los tarsos posteriores son comunes á ambos géne. ros. Muy bien aplicado tienen estos bombicidos su nombre, pues ambos sexos ofrecen un aspecto exterior tan diferente que el inexperto podria considerarlos como especies distintas. El macho, mas pequeño, de color gris pardo, presenta uma faja denticulada negra mas ó menos marcada en las alas anteriores, y largos dientes en forma de peine en las antenas, que afectan la figura de una oreja de licbre. I a hembra, muy pesada y perezosa, tiene las alas de un blanco sucio, presentando las anteriores fajas denticuladas negras semcjantes a las del macho yn unechon de pelos pardos en forma de boton en la extremidad del abdónen.

USOS, COSTUMBRES Y REGIMEN.-Ambos macen á fines de julio ó en agosto de la crisálida, que es de un negro mate. Se aparann de noche: apenas tiene el macho sus alas 
desarrolladas cuando empieza á volar con desenfrenada alegria, y' como una sombra pasa á nuestro lado, desapareciendo al punto, porque su ruclo de murciélago y la oscuridad, no nos permiten seguirle con h vista. Al dia siguiente se le encuentra en unn pared, en el ángulo de una ventana, donde reposa de sus ejercicios nocturnos; pero el mas leve estorbo basta para ahuyentarle, y asi sucede que en dias de sol ó calurosos vemos a estos lepidópteros en una eterna inquiciud. Muy diferente es el proceder de la hembra; pererosamente se posa en las paredes ó en los troncos de árboles y. cubre su grueso abdómen con las alas que no son nada bonitas. Si se puede sacudir el tronco donde se halla cae con la extremidad del al,dómen dirigicla hacia adelante, sin tomarse siquiera el trabajo de mover las alas parn eviar la caida. Solo a la hora del crepúsculo vespertino lernati fuenosamente sus "las y vucla alrededor de los árboles, sirviendo de buen bocado à los murcielagos. Asi pasa su corta vida de dia entregada a un perezoso descanso, de noche volando hasta que un macho la desuelve su tranquilidad; lo mismo la una que ol. otro se alimentan del rocio, pues nunca están cu las flores. Por fin deposita aquella sus huevos en un tronco de árbol. Como las dos esinecies anteriores, empieza por extender una capa de sustancia mucosa, á la cual se agarra la inferior de los pelos sedosos de su ano. Despues sigue una capa de huevos, otra de pelos, y asi sucesivamente hasta que un grupo considerable queda depositado. Cuanto mas numerosas se hacen estas aglomeraciones tanto mas escasean las hembras; los machos han desiymarecido antes del mundo de los viros.

Solo en la primavera siguiente se despierta la vida en los huevos si un cuidadoso agricultor ó jardincro no los ha des. truido a tiempo, en ruya operacion se necesita sin embarge, cierta precaucion. Aplastarlos en el mismo sitio en que se hallin no es ficil, porc|ue son muy duros y saltan de la masa elastica en vez de romperse. Es preciso, por lo tanto, quitarIns cuidadosamente, recogiéndolos sobre un papel ó tablita, etcétera, para quemarlos despues, pero poco s. poco, porque revientan jroduciendo un eștnllido.

En su blando lecho retoran alegremente las negras onguitas; se dispersan pronto, fuero siempre vuelven á encontrarse en la cata inferiór de las ramas para evitar la humedad. No son dificiles de cnntentar en cuanio al alimento, pues comen las hojas de los rosales en nuestros jordines, de las encinas en el bosque, de los sauces á oritlas del riachuclo y de - los álamos en los caminos réales, lo mismo que las de los mas difcrentes árboles frutales. Haj anos en que por su enorme multitud se trasformar en una plaga en regiones enteras.

Así. por cjemplo, los periódicos franceses decian el 14 de julio de 181\$: al.os hermosos encinares que se exticnden desde el Brabante hasta ha ciudad de Podenás, en el sur de Francia, han sido destrozados de un modo terrible por la oruga de la ocneria dispar. Despues de devorar no solo las hojas de las encinas. sino tambien las bellotas de este año y el siguiente (la fruta necesita un ano para madurarse), atacaron y destruyeron nuestres campos de maix y de mijo, nues. tras yerbas de heno y todas las frutas. I as casas inmcdiatas a los árboles estain llenas de estas orugas y no pueden servir de residencia á los desgraciados habitantes. Ni siquuiern han perdonado las cepas que hay en algunas partes de nuestro suclo arenoso. Yo mismo he observado en otra ocasion có. mo estos insectos se morian de hambre en el suclo despues de haluer despojado de su follaje un grupo de ciruclos, faltindoles la posibilidad de obtener mas alimento, pues no cmprenden grandes viajes en busca de el comootras orugas Fn $175^{2}$ existian en grandes masas en Sajonia, en los alrededores de Altenburgo, Zeitz, Naumburgo, Sangerhausen, y no solo despojaron todos los airboles frutales sino tambien bosques enteros.

I a oruga es de un pardo gris, con series de verrugas rojas y' azules, provistas de cerdas, y cuando es adulta tiene la cabeza gruesa, que saliendo de las espesas cerdas, la distingue fácilmente de otros congéneres. Para crisalidarse coloca algunos hilos entre los restos de hoja del último silio quue ocupó, b entre las hendiduras de los troncos; una vez convertida en crisalicla, agitase con fuerza si la tocan. Necesita solo algunas semanas para descansar.

El 28 de julio de 1864 se crió en Berlin un individuo de esta esperic, macho en el lado derecho $y$ hembra en el izquierdo. Siempre hay en el mundo rle los insectos una forma hermatrodita aunque no con la misnn reçularidad que en el caso presente. Hagen formó en 1861 un indice de las mariposas hermafroditas conocidas de el, y le resultaron 99, nimero que desde entonces ha ido en aumento, segun lo demuestra el caso presentc.

\section{LA OCNERIA MONJA-OCNERIA MONACHA}

CARACTERES. - I ocneria monja es digna hermana de la ocneria/dispar, tanto por su aspecto cxterior como por su proceder y d caricter danino de la oruga, que con preforencia sc alimenta de coniferas. Ia mariposa se presenta al mismo ticnupo que la precedente; tiene en ambos sexos las alas anteriores de lin blanco mas puro, con las fajas denticuladas negras, mas marcadas; las posteriores ligernmente turbias, y fodas cuatro provistas de franjas manchadas. I a hembri puede prolongar mircho la junta sonrosada de su abdómen, gracins'al taladro, cuando (quicre fijar sus hueros debajo dc la corteza.

Si la mariposa abunda mucho en un año, encuéntranse bastante à menudo viricdades del todo negras (ncucria eremita).

USOS, cOSTUMBRES Y REGIMEN. - I I mariposa suele estar siempre reposando pereyosamente en los troncos de los árboles, cerca de los bosques, pero el macho, mas ac. tivo que la hembra, vucla en los dias calurosos. Tambicn esta especie se aparea solo de noche. Segun ya hemos dicho, las henturas de ambas especies difieren esencialmente por la pucsta de los huevos.

A fines de abril ó á principios de mayo del ano siguiente nacen las oruguitas y permanecen reunidas de tno a seis dias antes de subir á los conos. En junio ó julio son adultas, de color gris verdioso, merclado con gris hianco y negro, presentando detris del centro una mancha clara. Se parecen mucho á la oruga de la ocneria dispar por la forma de la cabeza y del cuerpo y las cerdas de las verrugas. Culocándose detrás de algunos hilos sedosos se trasforman en el tronco en una bonita crisálida de brillo broncendo, con mechones de pelos blancos. Como en los árboles frondosos pueden renacer las hojas perciidas, sufren menos que los pinos por estars orugas.

Hasta el año $1 \$ 28$ consideribase a csta especie como cnemiga de los pinos; pero en 1852 ocasionó muchos estragos en los bosques de la Prusia oriental, de Liruania, Masuria y Polonia, demostrando que mucho mas le agrada el pino liso que el connun. Willkomm, à quien el gobiemo de Sajonia envió en 1863 á los bosques destruidos poco despues del suceso, dió un informe minucioso accrcá del asunto, fundándose asi en su propia experiencia, como en los datos oficiales de aquel distrito y en noticias de los cmplcacios. Fil 29 de julio de 1858 , dice el relato, fue cuando en el distrito de Schwalz, el mas meridional del bosque de Rothebude, se presentó la orneria monja de improviso, formando innume- 
mbles masas, impelidas por un viento sur. A las pocas horns la mariposa se diseminó sambien por los distritos limitrofes, en tal número que hasta la casá del guarda-bosque de Ragonnen quedó totalmente cubierta de estos insectos; mientras que la superficic del lago de Pillwung jarecia ocultarse bajo una capa de espuma blanca, í calusa de las mariposis alli ahogadas. Testigos oculares fidedignos con quienes hablé me aseguraron que en el hosque habia parecido estallar una tempestad de nieve. De las averigunciones de Schimmelpfen. nig resultó que la mariposa se habia encontrado hacia varios anos en los bosques particulares situados al sur del brezal de Bodschwingken, pero particulamente en los fronterizos de Polonia, aumentando all donde nada se hacia para su exterminio, mas un tan enormes proporciones que muchos propictarios, para librarse del insecto, hicicron quemar, en su desesperacion ( 1852 ), bosques enteros. Para que se forme idea del inmenso número en yute se presentaron estas mari. posas en $1 \$ 53$, hastara decir, que la masa de los huevos recogidos en el distrito de Rothebude desde el $\$$ de agosto lasta el i de mayo dcl año siguiente, pesaba unas 300 libras ó sean unos $150.000,000$ de huevos, prorque cada onza contiene cuando menos 15,000. Además se recogieron en el periodo del celo, que duró hasta el 3 de agosto, dos cclemi. nes y medio prusianos (unos $1.500,000$ individuos) de hembras. A pesar de esta enérgica medida volvió á presentarse en In primavern signiente tal nuimero de grupos de orugas hasta en los distritos tres y cuatro veces expurgados, que fuerza cra convencerse de que apenas se habia recogido la mitad de los huevos depositados. Esto se debia á la circunstancia de que, al contrario de lo siempre observado hasta entonces, la mariposa habia depositado sus huevos hasta en las raices y entre el unusgo de la hojarasca, asi como en los pinos, incluso sus copas mas altas, circunstancia quc naturalmente dificultaba mucho su recoleccion. No obstante, en casi todos los bosques donde la mariposa se habia presentado por masas, habianse examinado en una superficic de 14,500 inojadas todos los árboles, tronco por tronco, hasta una altura de cinco pies y a mayor elevacion con escaleras. No debo pasar en silencio la circunstancia de que en los bosnues de pinos lisos mezclados con la especic comun, y aun en los mas antiguos, los huevos estaban depositados casi sicmpre ciclusivamente en los pinos lisos, y raras veces en los otros, siendo asi que hasta entonces se habia observado lo contratio en los bosques compuestos de estas especies de árboles. In major parte de los huevos se encontró siempre en los pinos lisus, fuertes y anosos (hasta dos onzas en un tronco), a lo largo de lis raices y en el musgo. 'Iambien en los abedules y en las hayas se hallaban huevos. En los jinos estaban raras veces a mas altura de la de veinte piés, en los abedules de corteza muy hendida, solo a seis, y en las hayas a dicz piés poco mas of inenos.

En los pinos lisos, en cambia, se hailaban, como ya hemos dicho, desde la raiz hasta la copa Al exterminio de los hucros contribuycron esencialmente el pico abigarrado y adcunis los fringilidos, observindose tambien un gr:n número de larvis del derus alrededor de los montoncitos de hueros. A pesar de todo habia quedado una círa enorme "de esos montoneitos, jues segun el cilculo de schimmelpfennig se hubieran necesitalo por término medio cien iribajadores y veinte cupataces en el año siguiente pam poder destruir todos los grupos ú oruguitas recien macidas en solo una mojada de terreno. En tales circunstancias, Schimmelpfennig declaró en su informe del 15 de febrero de 185 w en el que pronosticaba sin ocultar sil enojo la destruccion de los bosques, la improsibilidad de matar las orugras recien nacidas, diciendo yue todo auxilio hamano seria insuficiente, jo (jue cuanto dinero se empleara para el exterminio de los insectos se gastaria en balde.

4No obstante, el gobierno dispuso la matanza de las orugas recien nacidas, que en cíccto se efectuó hasta el i $\$$ de mayo en el distrito de Rothebude, jero como em de esperar, con fucrass del todo insuficientes. Entonces se observó que las oruguitas recien nacidas comian con prefereucia en las hayas mexcladas en todas paries con los pinos lisos, y que solo cuando estos tenian sus retonos de mayo se dirigian à cllos y corroianlos de tal modo que no tardaban en secarse. Como cra de prever, la medida adoptada habia sido poco menos que inútil, pues las orugas se propagaron rapidamente por todo el distrito destruyendo hasta el 12 de julio, dia en que cesaron los estragos, segun un cillculo superficial, unas Soo mojadas de bosque cubiertas de pinos lisus. Ya entonces enfermaron muchas orugas y se presentó un sinnumero de icneumónicios (micrograster), cuyas peçuchas crisálidas blancas cubrian mas tarde como una capa de nieve todos los arbustos. A pesar de eso. las mas de lis urugas llegaron at crisalidarse, pues las mariposas nacidas cubrian los bosefues en masas no menos enormes que las del ano anterior.

- Durante el periodo en quue existian las orugas se observó que estas devoraban los conos de pino liso enteros, cortando los del pino comun por el centro y las hojas de abedul por el tallo, de modo que debajo de dichos árboles el suelo estaba sembrado de fragmentos de conos yo de hojas caidas. In los bosques donde estaban mezclados los pinos lisos con árboles de espeso follaje, estos no cran acometidos hasta que los jrimeros çuedaban clespojados, atacándose al mismo tiempo á las hayas; los sauces, fresnos, plátanos, ttc, que se hallaban en medio de las coníferas, no sufrian ataque alguno, mientras que los arbustos de bayas, etc, eran presa de las hambricn. tas orugns. Una helada bastante iuerte que hubo del 6 al 7 de junio perjudicó muy poco à estas larvas. No se observó que las orugas se dirigieran desde los puntos desprojados í los que aun conservaban su follaje; pero vióse que en todas partes cainu de los irboles despojados, reuniéndose en el suelo; muchas no llegaron à crisalidarse, y no pocas fueron devoradas por las ran:as. I.os árboles å cuyo pié habia hormigueros (formica rufor) (quedaron libres.

\$Como la recoleccion de los hucsos se verificaba demasiado lentamente, resolvióse quemarlos á principios del periodo del celo (desde el 29 de jutio hasta el 3 de agosto de 1553 ), y en I $\$ 54$ encendiéronse tambien grandes hogueras cn muchos puntos. Aunque tampoco esta medida turo el éxito deseado, resultó, no obstante, que las mariposas depositaron sus huevos en los sitios despojados de follaje, alli donde estabin las hogueras; de modo que em fácil destruirlos, sin mas que arrancar la coneza para quemarla despues. A pésar de esto, y aunque purecian grandes masas de mariposas en las hoguema, los huevos aparecieron despues del periodo del celo (1 854) en tales montones, upuc tra preciso desistir de su recoleccion, pues los ironcos de los pinos lisos tenian en toda la superficic una cispesa capa de ellos, de modo que los trabajadores po. dian quitarlas con las manos, cuando menos en los troncos en que el invierno anterior se habian arrancado las escamas de corteza para poder recoser mas ficimente los huevos. Lass copars, sin embargo, habian yucedado libres por esta vex lin cambio se encontraron numerosos montoncitos de huevos en yerbas de lodas clases, hasta en las plantas de tabaco (en Masuria se cultiva con frecuencia la nicusira rustica, solnce todo en los jardines de los empleados subalternos) y hasta en los tejados de las casas y en las cercas de tablas, toclos fenómenos unuca vistos hasta entonces. Para que se comprenda cuál seria lat increible masa de hueros de maripusa existentes entonces, bastarra citar el hecho de que centenares de hom- 
bres se ofrecieron a recoger luevos por el infimo precio de cuatro peniques por onza, mientras que en $1 \$_{53}$, al principio de la recoleccion, debiase pagar por la misma cantidad medio marco (2 reales y medio).

De tal mudo se acrecentó en mayo de 1855 la devastacion por las orugas, que no se recordaba haber visto nunca mada semejante. Hasta el 27 de junio, y solo en el distrito de Rothcbude, contibanse mas de ro,000 mojadas de bosque completamente despojadas, y además 5,000 invadidas de tal modo que tambien aquí debia esperatse encontrarias del todo asoladas. Los daños causados traspasaron con mucho los limites de lo que se calculaba; jues á fines de julio la mayor parte de los pinos lisos de todo el distrito estaban despojadas, los árboles muertos en una superficie de 16,364 mojadas, y en otra de $5, \$_{41}$ atacados de tal nado, qué jorobiblemente 1 a inayor parte debian perecer; solo 4,932 mojadas queclaron bastante libres. Schimmelpfennig calculó la cantidad de la madera resecada hasta el nies de setiembre en 264,240 toesas ó sean 16 toesas por mojada de dicha superficie. I ns orugas no se detenian ya à escoger entre las coniferas frondosas, viejas ni jorrenes, y hasta atacaban todos los plantios. Los pinos jovenes inclinaban sus copas bajo el peso de las ort. gas, cuyos excrementos llegaron por último á cubrir todo el suelo del bosque formando una capa de dos ó tres pulgadas, y en|muchos puntos hasta de seis:- caian continua mente como una copiosa lluvia de las copms de los arboles, ! pronto no se vio uinguna hoja ni tallos verdes en todo el espacio que alcanzaba la vista.

Ei) comunicante hace mencion despues de los estragos causados por cicrtos bostriquidos y concluye reproduciendo las cifras del relato de Schimmelpfennig del t, de octubre de 1862 , segun el cunl, en el distrito de Rothebude se habian perdido hasta entonces 290,000 ioesns de madern, de las que 285,000 fueron destruidas por la ocneria monjay 5,000 por los coleónteros. En pié habian quedado unos 153,000 troncos.

Ia superficie devaśtada era de 32,931 mojadas, y comprendia por lo tanto casi todo el distrito.

\section{EL CNETOCAMPO PROCESIONARIO-CNE- THOCAMPA PROCESSTONEA}

CARA CTERES. - Esta mariposa es de un color gris pardusco y ticne en las alas anteriores algunas lincas trasversa. les, mas oscuras y marcadas en el macho que en la hembra; lâs alás posteriores, de un blinco amarillunto, se distinguen por una faja trasveral confusa, tienen sietc nervios y se reunen por medio de una cerda prensil con las anteriores durante el vuelo, halláudose cruzadas jor doce nervios. En a.mbos sexos las antens llevan hasti la punta dos series de dientes; los tarsos posteriores solo presentan espolones en la extremidadi la lengua no ofrece nada de particular.

DISTRIBLCION GEOGRÁ FICA.-Iat especie està diseminada en el sur y noroeste de Alemania, mas bien en la llanura que en la montañ, y llega, segun Speyer, hasta cercar de Havelberg, su limitc.septentrional.

USOS, COSTUMBRES Y RÉGIMEN.-1 LanIgR vive en las encinas, y si alguna debe considerarse como venenosit, seguramente es esta. Sus largos pelos de punta blanca, que vistos con el microscopio presentan unas ramitas en su parte superior, contienen tanto ácido fórmico, que producen hasta en la piel menos sensible un agudo escozor. No faltan ejemplos de çue llegara al interior de cuerpos humanos ó de animales, produciendo las infiamaciones mas peligrosas de la mucosa, y hasta la muerte: unos buejes picados se volvicron verdaderamente rabicisos. I a oruga se encuentra en majo y junio y se llama procesionaria por la particular costumbre de marchar con sus semejantes en cierto órden cuando va en busca del alimento, volviendo del nismo modo \& su albergue. Nace en mayo de los huevos que la hembra fijo el verano anterior, en montoncitos de 150 is 300 , en la cortera de un tronco de encina, mezclados con pelos pardo-grises. Del número de huevos depende la importancia del grupo que se forma, no solo durante las seis semanas de la vida de oruga, sino tambien cuando son crisálicins, las cuales viven en la comunidad mas intima. Solo cuando son muy numerosas puede suceder que varias ingrupaciones que cn sus viajes se encuentran se reunan en una sola. La primera noche de su vida, y cunndo su número es reducido, acostumbma ia mar. char uma tras otra, pero en otro caso avanzan en cierto órden, formando como una cuña; en primer término via la que sirve de guia; despues dos, en la tercera fila tres, en la cuarta cuatro, etc., y de este modo se dirigen á la copn del arbol en busca de/ su alimento. En el mismo úrden comen y de la misma manera vuelien á su nido, que se halla en alguna cavidad del tronco, ó mejor en las ramas ahorquilladas. Aqui permanecen oprimidas una contra otra y fabrican un ligero iejido. Al principio canbian a menudo de residencia, pero mas tarde perimanecen siempre en el mismo punto, y el iejido se hace con las picles mudadas y los excrementos siempre mas espesos. lil viento dispersa los pelos contenidos en estos tejidos, los cuales caen sobre yerba que come el ganado, $\delta$ impelidos jor el aircllegan al estómago de los leñadores ú otras personas que almuerzan cerca de los árboles habita. dos por la oruga. Cuando reina la oscuridad las orugas abandonan su nillo en cuya partc inferior se ve un agujero que sin duda sirre de entrada y salida; se dirigen á la copa del àrhol; if lo mismo se repite todas las noches excepto los dos dias de enfermedad que siguen á cada muda. A reces se las ve tambien de dia comer en el suelo, quizas cuando se ven obligndas i abindonar el airbol y el nido por falia de alimento. Lste grupo ofrece un aspecto muy sorprendente semejante à una faja oscura ó å una culebra; y avanza con mucha lentitud, thando lineas onduladis. I a oruga tiene el dorso ancho, de color negro azulado, con verruguitas de un amarillo rojo, y como unas estrellas de pelos; en los lados son blanquircos. Cuando han llegado à ser adultas y à la longitud de $0^{\infty}, 039$ a $0^{\infty}, 052$, todas bajan al fondo del nido $y$ fabrican una serie de capullos estrechamente unidos contre si, de tal modo yue recuerdan las celdas tapadas de las abejas. En cacia cual descansa una crisailida, de color pardo rojo oscuro, cuyos segmentos abdominales tienen bordes agudos.

En julio y agosto. a la hora del rreptisculo, nacen las mariposas; y los machos comienzan desde luego a volar. He criado esta especic bastante a meriudo, pero nunca he visto un solo individuo at aire libre.

\section{EL CNETOCAMPO PINÍVORO-CNETHO- CAMPA PINIVORA}

CARACTERES. - Essta especic es muiy parecida ia lanicrior.

DISTRIBUCION GEOGRÁrCA. - Se encuentra en

la llanura del nordeste de Alemania, en el sur de Suecia y en los alrededores de San Petcrsburgo.

USOS, COSTUMBRES Y RÉGIMEN. - Vive del mismo modo que la especie anterior, pero solo en los pinos, observandose que la oruga no descansa exclusivamente en los troncos, sino tambien en cl suclo ó en las piedras, imcrnando en estado céc crisilidu. 
EL CNETOCAMPO DEL PINO DONCELCNETHOCAMPA PYTYOCAMPA

DISTRIBUCION GEOGRAFICA.-Esta especic, muy semejante à la anterior por su género de vidin, vive en las coníferas de la Europa meridional, sobre todo en los pinos. jỏvenes.

\section{LA HARPÍA GRANDE- HARPYA VINUIA}

Siguen al género anterior algunas mariposas que menos como tales que como orugas llaman uuestra atencion, porque sus larvas tienen en ve\% de los últimos piés dos apéndices filiformes dirigidos hácia arriba. Se les ha comparado con una horquilla, llamando a las orugas calas ahorgarilladus. Estas larvas pueden prolongar sus apéndices en forma de largo hilo delgado que pende como el cordon de un látigo de su mango, pero solo presentan estos hilos cuando se las irritn. Fin estado de descanso toman una posicion muy particular en la hoja del airbol que habitan. Descansan aproyindose en los piés ventrales y tienen la parte anierior y posterior del cuerpo levantadas, con la cabeza muy recogicia en el primer

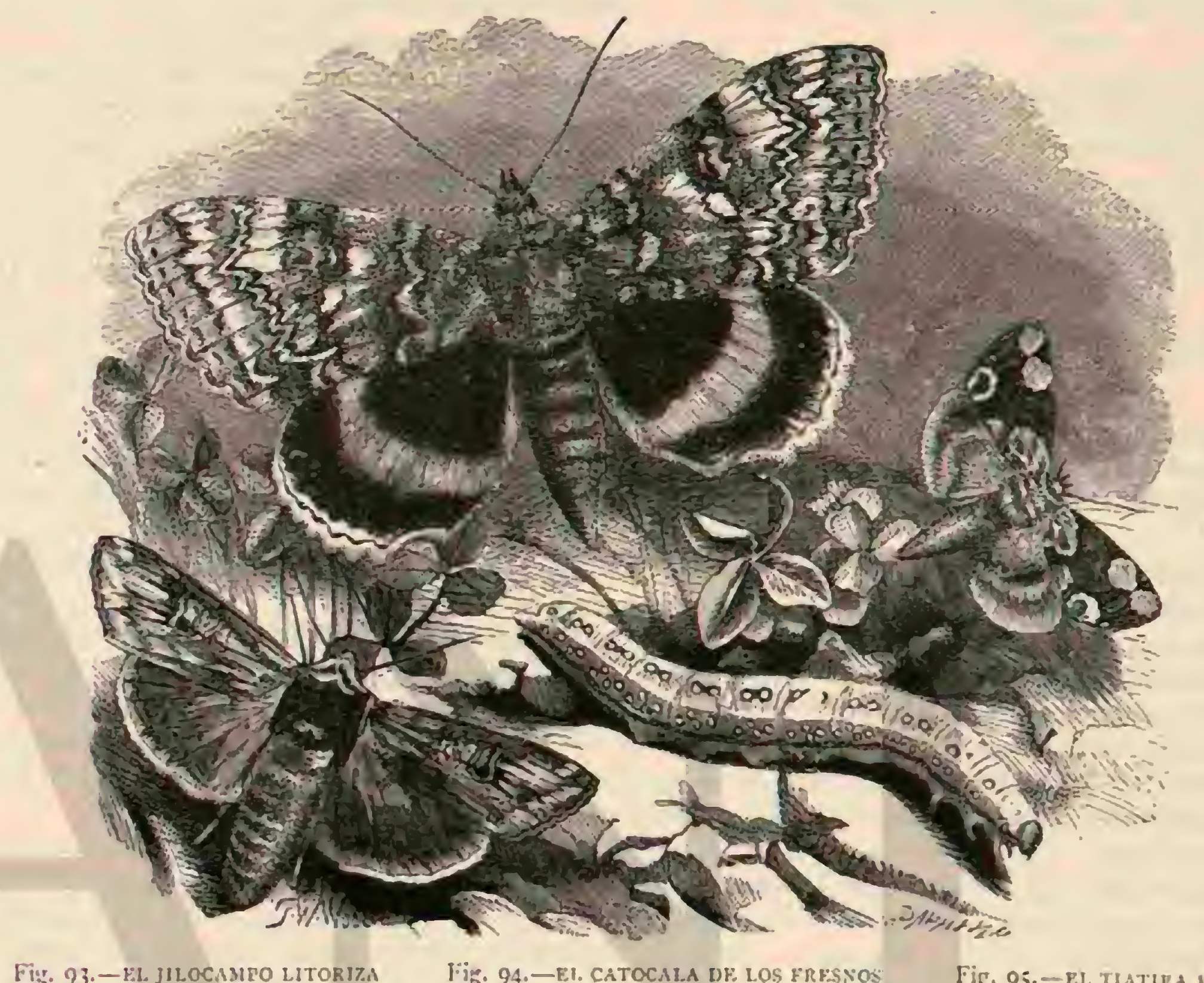

Fiv. 93.-LL JHLOCABIRO LITORI7A

ligh. 94. E E. CRTOCARA DF LOS FRPSNOS

Fig. 95- - EL THATIMA LATRS

segmento del cuerpo. Una de estas orugas pertenece it la es. pecie que nos ocupa.

CARACTERES, - La mariposa es blanca con los nervios amarillos y tiene manchas negras, en parte borradas, en las alas. Estas se apoyan sobre el cuerpo, y las patas anteriores, provistas de espesos pelos lanosos, se alargan mucho hảcin adelante.

La oruga es de un verde claro g tiene una mancha violatcea en forma de silla en el dorso, mancha que llega en el séprimo segmento hasta el estigma y' está orillada de blanco.

USOS, COSTUMBRES Y REGIMEN. - Se encuentra en julio y agosto en los sauces ó en las diferentes especies de álamos. Para crisalidarse corroe el tronco de su planta alimenticia y forma sobre el lecho cóncavo un icjido del color de los contornos; en invierno se encièrra aqui la crisilida. que es obtusa, de color pardo rojo. La mariposa nace en mayo, és muy perezosa de dia y repósa en los troncos, en los palos y en las tablas.

\section{LA HARPIA PÁLIDA-HARPYA PALLIDA}

CARACTERES. - lista mariposa (fig. So) difiere de la anterior asi por sus tintes como por su tamano, que es bas. tante mas reducido: el color dominame consiste en un gris pardusco muy claro, con varias manchas oscuras, casi negras; las alas posteriores son de un matiz mas pálido aun y tienen un filete pardo.

I.a hrva presenta varios hacecillos de pelos, que pudieran compararse por su forma con matas de yerba.

DISTRIBUCION GFOGRA FICA.-Fiste lépidóptero es propio de Europa.

\section{LA HARPIA VELLOSA - HARPYA PILOSA}

CARACTERES.-Se distingue principalmente este lepidóptero (fig. 91 ) por tener en el disco de las alas anteriores varios hacecillos de pelos; las piernas del segundo y tercer par son muy largas: los demás caractéres no ofrecen nada de particular.

DISTRIBUCION GEOGR ÁFICA. - La especie es bas. tante conocida en Europa.

\section{EL ESTAUROPO DE LAS HAYAS-STAURO- PUS FAGI}

CARACTERES. - Esta especic se parece a la harpin grande, pero es de color gris pardusco.

USOS, COSTUMBRES Y REGIMEN,-SU oruga per- 
tenece i la mas grotesca de todas las especies propias de nuestros paises; se posa en estado de descanso como la de la especic citada, pero ofrece un aspecto esencialmente distinto. Dos apéndices en forma de larvitas en la ancha extre. midad del cucrpo corresponden á los látigos de la harpia grande; pueden lemantarse automaticamente, pero carecen de hilos extensibles; los seis piés torácicos, muy prolongados, comunican á la origa, que es de un pardo de cuero, cierta semejanza con una araña Se encuentra en otono en las hayas $\delta$ encinas y toma una posicion amenazadora, que excita la risa, cuando se la molesta en su tranquilidad. Se crisalida antes de que llegue el inviemo, en una especie de espeso te. jido entre las hojis del suelo.

\section{LOS HEPIALOS - HEPIALUS}

CARACTERES.-Cuetro largo y delgado; antenas gencralmente muy cortas, moniliformes ó un poco dentadás; palpos vellosos y breves; alas prolongadis, en forma de hierro de lanza, estrechas y pocó consistentes; y atodómen muy delgaudo, son los atributos quic caracterizan a las especies de este género.

las orugis tienen forma prolongada y se nutren de raices.

DISTRIBUCION GEOGRAFICA.-Los hepialos están representados particularmente en Furopa y Arried.

\section{EL HEPIALO RÁPIDO-HEPIALUS VIRESCENS}

Caracteres. - Las alas de esta especie (fig. 86), en su estado perfecto, son de un color blanco plateado en los machos, con los bordes amarillentos; las anteriores de las hembras son amarillas adornadas de dos fajas oblicuas de un tiitte leonado; las posteriores son amarillas tambien, aunque imas pitidas y con ha extremidad rojiza.

DISTRIBUCION GEOGRÁFICA. - La especic designada con este nombre se ha descubierto, segun Mr. Wood, en la Nueva Zelanda.

USOS Y COSTUMBRES-Ias orugas de este insecto son completamente subterráneas, y se alimentan de raíces de plantas; todas ellas sé distinguen por su ligereza, y por la rapidez con que escapan cuando se las quicre coger. Los individuos perfectos vuelan con tal velocidad, que/al cruzar. los aires no se pueden distinguir sus formas. Las larvas no son solo notables por su forma ó colores, sino por una particularidad que llama mucho la atencion. «Sucede à veces, dice Mr. Ilood, que en algunos individuos ocupa un vegetal el sitio donde sucle alojarse el icneumon, en una de las extre. midades del cuerpo; y alli crece, alimentíndose a expensas del sér que le sirve de apuju. Luego se desarrolla, absorbiendo las partes grasientas del animal, hasta que al fin muere el insecto bajo aquel parásito, quedando casi convertido en una materia vegetal. El grabado que se acompaña representa muy bien el estado de la larva en semejante caso.

\section{LOS ZEUZEROS-ZEUZERA}

CARACTERES. - Las antenas de los machos de este género son pectineas en la base y setiformes en al resto de su extension; las de las hembras no ofrecen dicho caracter, y
solo son lanosas.

DistribUCion GEOGRAFICA. - Ias especies de este género son originarins de Europa.

EL ZEUZERO LEOPARDO-ZEUZERA CESCURI

CARACTERES. - Aunque este lepidóptero (fig. S2) no tiene brillantes colores, ofrecen sin embargo sus tintes un vistoso conjunto, particularmente por el dibujo de ins alas. Sus demás caractéres son los mismos que los del género.

DisTRIBUCION GEOGRÁficA. - La especie es propia de Europa.

USOS Y COSTUMBRES. - La mariposa se suele ver con frecuencia en el mes de julio, pero es muy rara antes de este mes. Algunas veces se encuentran numerosos individuos en una misma localidad; pero de pronto desajarecen y no vuej. ven a presentarse.

La larva se distingue por su color amarillo pálicio con una doble serie de manchas negras en cada segmento. Aliméntase en el interior de varios àrboles, pareciendo preferir siempre el manzano y el peral, en los cuales rausa no pocos perjuicios. Cuando se acerca el momento de mudar de estado, forma su capullo con materiales thas fucrtes que los empleados por oiras larvas, los cuales une sólidimente con la sustancia glutinosa que segrega su cuerpo.

\section{LOS ATACOS - ATTACUS}

CARACTERES. - El cuerjo de estos lepidópteros es muy grueso; las antenas cortas, con larges ramos en cada artejo de los nachos, y en forma de peine en las hembras; los palpos cortos y vellosos; el tórax redondeado; las alas extraordinariamente lángas, con una manchita diáfama que figura un ojo, dividida por una peguenăa nerviacion; el abdúmen es muy grueso y bistante corto.

Las urugas, muy gruesas y macizas, tienen tubérculos crizados cie espinas.

DISTRIBUCION GEOGRÁFICA. - Las especies de este género son óriginarís de Asia; pero tambien se encuentran en Luropa.

\section{EL ATACO CINTIA - ATTACUS CYNTHIA}

CARACTERES.-Esta magnifica especie (fig. ${ }^{8} 7$ ), una de las mas notables del género, puede considerarse como tipo. El color dominante de la mariposa consiste en un gris amarillento, con manchas y dibujos de un tinte violicco, blataco y negro, que contrastan con el del fondo; en la extremidad de las alas superiores se ven dos manchas diáfanas, y como trasparentes, divididas por una pequeina nervadura.

La oruga de este insecto es verde, con mezcla de negro, excepto en la cabeza y el último segmento, que son amarillos.

DISTRIBUCION GEOGRÁFICA.-Esta cspecie se encuentra en la China, de donde parece ser originaria.

\section{LOS NOTODONTOS - NOTODONTA}

CARACTERES. - L.OS insectos de este género tienen el cuerpo bastante grueso: antenas largas, pectineas en los machos $y$ dentadas en las hembras; alas anteriores provistas por lo general en su borde posterior de una prolongacion pequeña. l.25 orugns son comunmente lisas.

\section{EL NOTODON'TO DE DOS COLORES-NOTO- DONTA BICOLOR}

CARACTÉRES. - Los atributos de este lepidóptero (figura S8) son los indicados en el gánero, y' se le ha dado el nombre especifico que lleva porque predomiman en sus alas los colores escariata y verde, con manchas y rayas blanquizcas; en las alas posteriores ocupa el tinte escarlata la mayor parte: resaltando sobre este fondo tres ó cuntro manchas negras. 
DISTRIBUGION GEOGRAFICA. - Este lepidóplero habita en sarios paises de Europa.

\section{LOS NOCTUINOS - NOC- TUINA}

CARACTERES. - Los noctuinos constituyen una fnmilia muy considerable, cuyos tijos son en su mayoría de medìno tamaño: excepto unos pocos géneros, reconócense sin dificultad como pertenecientes à este grupo. lil cuerpo es por lo regular fuerte sin que se le pueda califiear de pesado; $\mathrm{cl}$ abdómen casi siempre puntiagudo, mas largo que el borde anterior de las alas posteriores; los pelos, espesos, forman bastante á menudo en el tórax y en el abdómen unos copetes de diferente forma. Los ojos, pelosos ó desnudos, brillan en la oscuridad; los ojuelos faltan solo en raros casos, pero están ocultos bajo espesos pelos. Las antenas, cerdosas, y un poco mas largas que la mitnd de las ulas :unturiores, se hallan sobre un artejo ensanchado y stuelen tener cerdas con pestanias; en los machos de pocas especies presentan dientecitos en forma de peine ó de sierra, provistos de pestanas en figura de pincel. Los palpos, mas ó menos desarrollados, sobresalen casi siempre de la cabeza; solo en un género, en el de los herminidos, alcanzan una longitud extrnordinaria. Lin casos muy raros, la lengua, que se puede enroscar, no alcanza su completo desarrollo, sino que es muy blanda ó falta del todo.

Las patas son fuertes, $y$ las posteriores mas largas que en los bombicidos; los tarsos anteriores cortos; los posteriores se prolongan mus que los muslos; estos últimos en su cara inferior y los tarsos en la superior, son mas 6 menos peludos, y raras veces están cubierios de escamis lisas; los tarsos de las patas posteriores tienen dos pares de espolones. En las fuertes alas anteriores, e] borde interior alcanza siempre mayor extension que el exterior; por lo regular presentan doce nervios, cuya direccion ofrece pocas diferencias. Respecto á los dibujos, en los cunles se deben buscar los distintivos mas ni. nuciusos para reconocer una especie, se usan expresiones que habrian de explicarse por un grabado. Las alas cubren en estado de descanso el abdómen, pero á veces tambien se po. san horizontalmente, sobre todo en los agrotis.

Ias orugas de esta familia forman tres grupos natumles. Por sus extranos pelos y sus diez y seis patas las unas se pa. recen mucho á las orugas de los bombicidos y descansan de dia en sus plantas alimenticias sin ocultarse. Las otras tienen igualmente diez y seis patas, pero sus pelos no son visibles: permanecen por lo regular ocultas de dia y solo salen de noclie para comer; este grupo es el mas numeroso. Las especies de un tercero tienen uno $\delta$ dos pares de piés menos; son desnudas, andan de dia libremente por las plantas alimenticins, y constituyen por el primero de los indicados caractéres el tránsito á los geométridos. Todas las orugas fabrican un tejido para crisalidarse, pero incompleto; las que descansan libremente en plantas los hacen en estas ó en la hojarns$\mathrm{ca}$ del suelo; las del segundo grupo le suclen fabricar debajo de tierra, de la cual toman particulas pam mezclar, uniéndolas ligeramente con su saliva.

A causa de la gran analogia de los noctuinos, los géneros tienen poca importancia en la clasificacion, $y$ nun los subgéneros han cambiado muchas veces, circunstancia que explica facilmente, aunque no justifica, la mala costumbre de los coleccionadores de dar á una narjposa su solo nombre, el de la especic.

DISTRIBUCION GEOGRÁFICA.- las 2,500 especies conocidas están distribuidas por todo el globo. Casi r,000 perteneren á Europa, circunstancia de la que podria dedu. cirse que las especies de mestro continente son las mejor estudiadas, mientras que en otros paises mas ricos en insectos muchas especies han pasado desapercihidas a causa de su género de vida oculto y de su exterior mas sencillo. Ademis no debemos olvidar que en los paises ecuatoriales mu. cho mas completanente bañados por el sol que muestras regiones, los nortuinos figuran en menor núnero que las mariposas diurnas, los grandes bombicidos y orms mariposas. De las especies alemanas, un cuatro por ciento invernan en el hucro, un 57 por ciento como orugas, $35 \mathrm{en}$ el estado de larva y solo cuatro como mariposas.

\section{EL DILOBO DE CABEZA AZUL-DILOBA COERULEOCEPHALA}

CARACTERES.-Empezamos con esta mariposa, que en diversas obms suele figurar entre los bombicidos, mien. tras que los naturalistas modernos la clasifican con los noetuinos. Ias antenas del macho provistas de fuertes púas como las de un peine, y el cuerjo grueso de th hembra, cubierto de pelos lanosos, son caractéres que no dejan de ofrecer afinidad con los de aquellos insectos si solo nos fijamos en el exterior. L.as alas anteriores, de un color de clocolate, mas claras en la parte del horde, están cruzadas por dos líneas trasversales muy denticuladias y próximas entre si, de color negro. Por la reunion de las dos manchas anteriores de un amarillo verdoso, y de otra, de forma redonda, con la mancha anular, se forma una grande, muy clara, que ai veres se civide en dos manchas en forma de rinones. Ias alas posteriores, de un gris blanquizco, tienen varias oscuras en el ángulo anterior; el ś́ptimo nervio se corre desde el ánguln anterior de la relda discuidea. Unos ojuelos pequeños, pal. pos cortos, y la lengun endeble y blanda, son carnctéres genéricos que solo pertenecen à esta especie.

USOS, COSTUMBRES Y REGIMEN.-La mariposa vucla desde setiembre, y pertenece nor lo tanto a los llamis. dos noctuinos de oloña: se posa de dia en los troneos de tirboles 6 en las paredes. En la primavera se presentan las orugas que son gruesas, de color blanco azulado, con franjas amarillas, y verrugas negras; á causa de tenor la cabeza azul se les ha dado el nombre que llevan. Viven en el espino necro y en los ciruelos, pudiendo perjudicar estos últimos cuando se reunen grandes grupos en los meses de mayo y junio. Una vez adula la oruga fabrica un capullo con pedacitos de madera, ó de la cal de una pared, etc., uniéndolos con su sali. m; en este capullo descansa cncerrada la crisálida, que es obtusa, de color pardo rojo.

\section{ELACRONICTO DE LOS PLÁTANOS-ACRO- NYCTA ACERIS}

CARACTERES. - Esta mariposa es de color gris blanquizco, y en las alas anteriores de un amarillento bastante turbio, salpicado de pardusco, pero de modo que las dos lineas trasversales $y$ las manchas anteriores se distinguen marcadamente como dibujos mas claros.

USOS, COSTUMBRES Y REGIMEN.—En agosto, $y$ mas aun ch setiembre, la bonita oruga llama la atencion en los platanos, porcue siempre se la ve descansando en posicion encorvada en la cara inferior de las hojas; on los bos. ques se encuentra tambien á menudo en las encinas. Es amarilla; tiene en los lados pelos de ese color, y en el dorso una serie de manchas blancas orilladas de negro. Recuerdo que hace años esta misma especie despojó completamente de su follaje un magnifico castaño situado delante de una casa de esta ciudad. Los insectos, casi desfallecidos de hambre, caye- 
ron sobre las cabezas de las personas que pasaban por debajo del árbol.

Ia crisálida inverna, y la mariposa nace en mayo $\delta$ junio del nno siguiente. I as orugas de todos sus congéneres llaman la atencion por sus colores abigarrados.

\section{EL MOMA ORION-MOMA ORION}

CARACTÉRES. - El tóras está cubierto de pelos erizados: el abdómen y las alas anteriores tienen sobre un fondo verde claro dibujos negros y blancos. En las últimas se dislinguen dos líneas trasversales de un negro oscuro y en el centro de la parte media, muy ancha, varios jeroglificos, que algunas veces componen una tercera lines irasversal. J.as alas posteriores, de color gris pardo, inas oscurns hacia fuera, tie nen una mancha dorsal blanca dividicia por una linea regra, y asi como las anteriores, presentan franjas manchadas de negro y blanco.

USOS, COSTUMBRES I REGIMEN. - lodenlos ver esta bonita mariyosa en mayo ó junio, a veces con mucha frecuencia en el bosque, en los troncos de áfboles, siempre con la cabeza inclinada. La bonita oruga se encuentra algunas semanas aisladn, y nas tarde reunida con otros muchos individuas en los arbustos y encinas, de las que baja por un hilo cunido supone algun peligro. Despues, cuando se hace mas grnde, busca la soledad y fabrica antes del invierno un capullo sólido paza la crisálicla. En el dorso es dé color negro aterciopelado, con los lados amarillentos; unas verruguitas rojas estan cubiertas de pelos de un pardo rojizo, y en el dorso del' segundo segmento, asi como del cuarto y' séptimo, presenta una grande mancha amarilla.

\section{LA HADENA BASILINEA- HADENA BASI- LTNEA}

CARACTERES.- Mientas que las orugas de los noctuinos hasta ahora descritos, $y$ 'de sus congeneres, son por 10 regular muj peludas, y con pocas excepciones habitan en plantas leñosas, sin ocultarse, la inayor parte de las orugas desnudas de los noctuinos que khora siguten solo son vistas de los que las buscan nucho en sús escondites. Se alimentan con preferencia de yerbas y gramineas; tolas tienen diez. y seis piés y se crisalidan en la tierra. Tambien las mariposas viven oculas; su actividad es nocturna, y las mas solo se ven cuando se extravian de noche en las habitaciones humanas, atraidas por la luz. A pesar de la vida oculta de la oruga, muchas descubren su presencia por el daño que causan en las plantas cultivadas, como sucede, por ejemplo, con las de la especie cuyo nombre es el del epigrafe y cuyo género de vida ramos á dinr à conocer en pocas palabras.

CARACTERES. - La hadena basilinea, de color pardo de cuero, a veces con un viso gris, tiene en el borde anterior y en la parte media de las alas anteriores un color pardo de orin. Ia mancha anular, y otra en forma de riñon, son gran. des, esta tíltima mas clara, particularmente hacia el borde. Del centro de la base de las alas parte una línea negra, d la cual debe esta especie su calificativo de basilinen. Las dos fajas trasversales, orilladas de un color mas oscuro, una linea ondulada y una mancha en forma de espiga se reconocen marcadamente. Varias manchitas negras, en forma de media luna, situadas entre los nervios, constitiyen el horde, juntamente con otras dos oscuras y una faja que orilla las franjas onduladas. En las alas posteriores, de un pardo amarillo bri llante, mas oscuras hácia el borde, el último nervio parte del ángulo anterior de la celda discoidea. Loz ojos son desnudos carecicudo de pestañas; la lengua es fuere; los palpos rema- tan en un artejo corto E inclinado. En el borde anterior $y$ posterior del tórax sobresalen en cada cual dos méchones de pelos; otros mas oscuros adornan el dorso de los segmentos abdominales tercero y' cuato. In mariposa mide $\left(0^{\circ}, 039\right.$ de punta á punta de ala.

USOS, COSTUMBRES Y REGIMEN.-Despues del apareamiento la hembra deposita varios huevos en tallos de yerba y en hojas, que mas tarde sirven de alimento á la orugra Estas yerbas pueden ser tambien especies de trigo, en cuyo caso las orugas corroen los gusanos aun blandos. Mientras lo permite el espacio se ocultan en la espiga y cncuéntranse dificilmente, porque su color difiere apenas del de aquella. Las orugas, que muchas veces se encuentmn en gran número, suclen posarșe en las paredes de las casas, y en las calles por donde han pasado los carros de trigo. En cautividad se alimentan con pan blanco, despues de invernar entre el trigo y lás yerbas. La oruga adulta se estrecha un poco hícia atrís y es de un color pardo gris pálido, "mu' poco bri. llinte, con cl dorso negruzco; la nuca, de un pardo rojo, presenta ires lineas blancas fo la valva anal es roja. Una serie de manchitas oscurns, situadas detris de los estigmas, yotra de la base de lós piés, se distinguen muy bien por debajo del vientre. La crisálida, de color pardo amarillento, remata en una verrugh, es áspera y esta provista de seis cerdas algo corvas.

\section{LA HADENA INFESTA-HADENA INFESTA}

CARACTERES. - Las alas anteriores de esta mariposa, de un gris amarillento, con manchas parduscas, presentan en la extremidad de la lineit ondulada un dibujo marcado en forma de $S$, y hacia aluera, hasta cl borde, un viso negruzco. Fn las alas pusteriores blanquizcas destacase una faja en el borde yna linen arqueada de color gris. El dorso del metatórax y los segmentos anteriores del abdómen llevan ligeros mechones.

USOS, COSTUMBRES Y REGIMEN.-Esta especie se asemeja mucho à la anterior por su géncro de vida. Cuando el trigo ustá segado alcanza ya un tamaño de $0^{n}, 015$, cae al sirelo y se oculta debajo del trigo cortado y de los pedazos de tierra, etc., alimentandose despues de gramine.ns, en el caso de que no sc la traslade con el trigo. Come hasta mediados de octubre, y en tiempo favomble hasta mas tarde, $e$ inverna en estacio casi adulto. En In prinavera siguiente sc alimenta durante algunas semanas de jerba y trasfórmase å mediados de mayo en una cristlida de color pardo claro, que remata en dos espinas cncorydas haicia afuera y rodeadas de algunas cerdis.

\section{EL JILOCAMPO LITORIZA-XYLOCAMPA LITHORHIZA}

CARACTERES. - Esta especie (fig. 93) ticne las alas superiores sub-dentadas, de un color gris ceniciento ligeramente sonrosado; las infcriores de un gris claro, con las nerviaciones negruzcas, lo mismo que una lúnula celular, una linea media sub-dentada $y$ un filete terminal.

DistRIBUCION GEOGRÁFICA-En Alemania, Inglaterra, Francia e Italia es donde se observa mas á menudo la especie.

USOS Y COSTUMBRES. - Desde los primeros dias de Ia primavera se ve ya aparecer esta mariposa, siendo acaso el primer noctuino que se encuentra. Por eso sin duda está revestido de una cubierta mas gruesa que la de otras especies, pues la necesita para preservarse del irio que todavia reina en la época de salir à luz. 
LA MAMESTRA DEL MELOCOTONERO-MAMESTRA PERSICARIAE

CARACTERES. - Este noctuino es comun y se recono. ce con seguridad por las alas anteriores, que son de un ne. gro azulado muy intenso, con dibujos amarillentos y con el borde ondulado; la mancha, en forma de rinon, blanca, se destaca marcadamente en el fondo oscuro.

USOS, COSTUMBRES Y REGIMEN.-SU oruga vire en ctono en las mas diversas plantas, prefiriendo, no obstanti, las de-nuestros jardines, donde se descubre sobre todo por los excrementos que se reunen en las grandes hojas. No vive oculta, y se reconoce por tener en forma de reborde la extremidlad del penúltimo segmento abdominal. Una mancha dorsal senicircular del cuarto y quinto segmentos, el borde posterior del undécimo y casi todo el duodécimo, asi como algunas lineas oblicuas que hay debajo de los estigmas, son de color pardo.

La crisálida, de un pardo negruzco, obtusa cul su parte aur. terior, tiene dos puntitas ahorquilladas é inverna en el suclo.

\section{LA NEURONIA POPULAR-NEURONIA POPULARIS}

Dos noctuinos muy graciosos, esencialmente distintos por su color y dibujos, macen de nrugas cuyo género de vida es tan uniforme, que dificilmente se pueden distinguir cuando se tienen á la vista al misnio tiempo. Ambos han causado ya grandes estragos en las gramineas de las praderas, de que se alimentan con abundancin: pues principian à comer por la base de la hoja, cuya punta se marchita pronto, no sirviendo ya para satisiacer su apjetito. La primera de estas dos especies es la indicada en el epigrafe.

CARACTERES. - Reunióse anses esta especie con los bombicidos, a causa de tener el tórnx cubierto de largos pelos, pero no pertenece a ellos, por mas que las antenas del macho estén provistas de dientecitos ó pias como las de un peine. Sus alas anteriores, de un bonito pardo rojizo, tiknen un viso rojo de flor de melocoton, siendo notables por las escamas blanco amarillentas de lodos los nervios, tanto que no se la puede confundir con otra espsecic. Ia hembra, un proco mas grande que el macho, tiene un taladro que puede prolongar mucho.

USOS, COSTUMBRES Y REGIMEN. - Deposita en agosto ó seticinbre sus numerosos louevos en la base de lab graminens. Las oruguitas nacen aun antes-del inviemo y pasan esta estacion en diferentes grados del desarrollo, segun la temperatura del otoño. El cuerpo es de color pardo de bronce brillante en la cara superior, limitada por los estigmas negros, y está cruzado por tres lineas longitudinales claras que parren del escudo de la nuca y se reunen on la extremidad de la valva anal. Se trasiorma en crisálida de. bajo de las piedras. De noche sale, y del modo indicado co. me en las gramineas de su vecindad, con preferencia en el trificum repens con vallico (lotisum tesmulentum). Yo no he conseguido criarla.

\section{EL CAREAS DE LAS GRAMÍNEAS-CHA- RLAS GRAMINIS}

CARACTERES, - Mas ditamada que la especie anterior por causa de su oruga, que es mas pequena, esta bonita mariposa estí diseminada mas hácia el norte. Asi como la ante. rior, tiene los ojos peludes y el tórax lanoso, sin moños; las antenas del macho presentan warias puías como las del peine. I.as : alas anteriores se distinguen por su color verdoso de Tомо II aceituna empolmalo, con dibujos muy variables. El centro y la mitad anterior de la parte del borde són regularmente mas oscuros gue el color del fondo y presentan tres manchas mas ó menos blancas. La anular se ensancha y reune con otra mas clara, en forma de riñon, por el nervio central casi del todo blanco. Las alas posteriores son de un gris amarillo blanqquizco y se hacen mas clams hácia la base.

USOS, COSTUMBRES Y REGIMEN. - En julio y agosto nace este gracioso noctuino desu crisilida, que es de

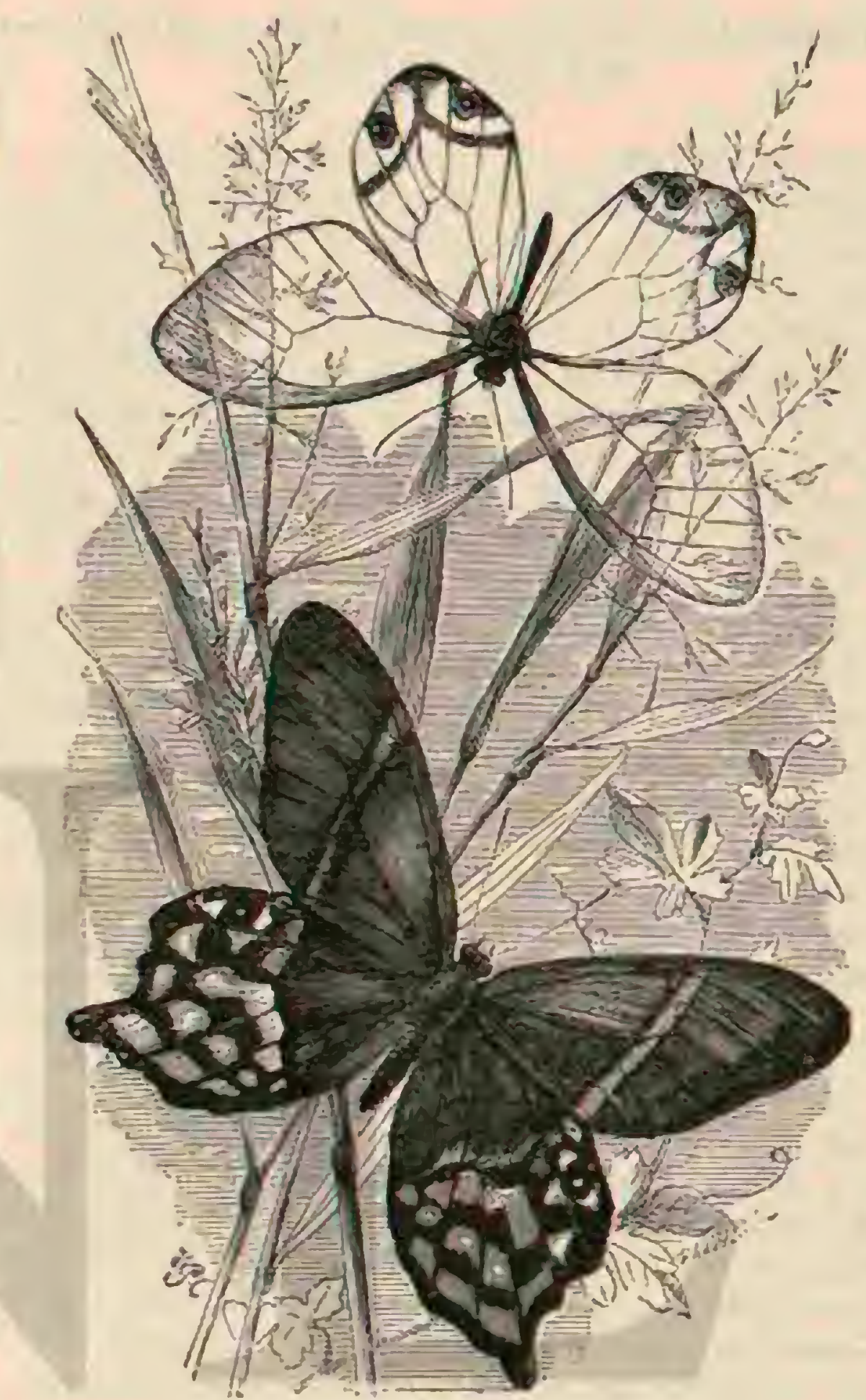

Fig. 96.-F.L HETYRA PIERA

Fig. 97.-8.I. MTHFRA LFSA

un pardo rojizo brillante y remata en dos puntitas ganchudas. Ia marijnsa vucla a veces de dia, cuando hace sol, entre las flores de las praderas.

Suecia y otros paises de la Europa septentrional, pero sobre todo la America del norte, han sufrido mas a menudo los ataques de las orugas de esta especie. Fn el año 177r lius crónicas hablan de estrigros muy sensibles causados por csita oruga en la region inferior del Weser: y mas tarde ( 1816 y isij) en la parte del Harz perteneciente al Ducado de Brunswik. Cerca de Bremen habian devastado en una noche dos mojadas de proderas, donde se hallaban oprimidas de tal modo que en el espacio de un palmo se encontraron 12 ó mas individuos. En la region de Harrburg presentaironse en I $\mathrm{S}$ G en masas increibles; los senderos que cruzaban por los pastos se cubrian de cadáveres, los cuales llenaban tambien los surcos abiertos por las ruedins. En el año siguiente despojaron del rodo mas de 3,000 mojadas de praderas, pues nada se habia hecho para exterminarlas, como no fucra perder el tiempo en consultas. Todas las medidas de preciucion adoptadas jara el año venidero fucron ya demasiado tardias, 
pues las orugas estaban reclucidas a su número normal. Suponiase que un aguacero de 18 horas de duracion, que cayó a mediados de mayo, haciendo salir de su cauce los rios y riachuelns, habia puesto coto à los estragos.

Conocemos ademas una marijosa pardo negruzca (ueuroniar irespitis) cuyas lineas onduladas y trasversales, asi como los bordes de las manchas, son amarillos, pero escasea mucho. Su oruga tiene el mismo aspecto que las dos anteriores y observa el mismo género de vida.

\section{LA BROTOLAMIA METICULOSA - BROTOLA- MIA METICULOSA}

CARACTERES. - Una impresion ésencialmente distin. ta produce of primera vistn li brotolamia meticulosa en la que el borde de las alas anteriores es denticulado, de un modo nada comun en los otros noctuinos. Son aquellas de un anarillo de cuero rojizo cun dibujos de un frardo aceitu. na en la parte centml, y en el estado de reposo se replegan un poco longitudinalmente. Las alas josteriores son de un anzarillo dé cuero claro, con manchas doradas mas oscuras en el bordé Gil dorso del tórax está provisto de una quilla longitudinal; los ojus son desnudos y sin pestaniasila lengua fucrte.

USOS, COSTUMBRES Y REGIMEN:- Este bonito noctuino se presienta dos veces al año, primero en mayo y junio, y despues en ngosto y seticmbre. Ja oruga de la segunda cria inverna Varia el color entre verde y pardo de cancla, con una linea lateral amasilia sobre las patas, otra mas larga é incompleta à lo largo del dorso, y dibujos angulosos oscuros abicrtos hària adelante.

Come iudp cinse de yerbas y se éncuentra aisladanente en la mayor parte de Alemania.

\section{LAS NONAGRIAS - NONAGRIA}

CARACTERES: - Interésante por el genero de vida de sus orugas es el género de las nonagrias, mariposas de un gris amarillo sin dibujos, semejante al de las cañas secas. 'Tienen los ojos desnudos sin pestañas, un inoñito que se destaca de la frente, debajó dél cual se oculta una placa córnea cuadrangular yue sobresalc horizontalmente; el dorso del tórax es convero y lanoso. Paril el coleccionador tienen la des. frvomble cialidad de volverse del rodo accitosas.

USOS, COSTUMBKIES X REGIMEN. - Vucla de no. che, desde agosto hasta octubre, cerca de los sitios donde mació; su área de dispersion es muy extensa, pero algunas especies solo. se encuentran en la Alemania del norte. Iss orugas practican galerias en diversas plantas, cuyas hojas presentan pronto un tinte amarillo en la punta. Como viven se. paradas de la luz, sus colore's son pálidos y" su aspecto vermiforme. Se trasforman en crisálidas en su estrecha prision, dispues de haber abierto antes una salida pam la mariposa. Segun la especie, la crisailida se halla cabeza abajo sobre este agujero ó cabeza arriba debajo del mismo.

\section{LA NONAGRIA DE LA TOTORA - NONAGRIA TXPHAE}

Caractéres. - A las especies nias grandes y diseni. nadas perteriece la nonagria de la totora, que mide $0^{\circ}, 039$ de punta á punta de ala. Ins alas anteriores son de un color de caña que varia hasta el gris rojizo, y parecen mas $\delta$ inenos empolvadas en el lado de los nervios, que son blanquizcos; tienen la punta obtusa y un borde bastante recto, ligeramente ondulado, en el que se ven dos series de puntitos negros. En ver de la linea trasversal anterior hay unos puntos negros muy aislados, y en lugar de la posterior, numerosas manchitas sustituyen la linea ondulada. Las alas posteriores, de color amarillento, tienen una faja oscura en el borde, cruzada por los nervios mins claros.

USOS, COSTUMBRES Y REGIMEN.-La oruga, de un color de carne sucio, vive en las dos especius de totora (Jypha dortifolion y angustifolia); tiene tres lineas dorsales claras, los estigmas negruzcos, el escudo de la nuca pardo, y la valva amal mas oscura La crisálida, delgada y de color pardo amarillo, suele estar con lia cabeza inclinada sotsre e] agrijero de salida. A pesar de la vida oculta de la oruga, no se halla al abrigo de las persccuciones; bastante á menudo se obtiene, de la crisálida (esta sola debe recogerse cuando se desen la mariposa) un icneumónido, exephorses (ichueumon) accupator.

\section{LAS LEUCANIAS - LEUCANIA}

CARACTERES. - Muy congenéricas de las nonagrias son las leucrnias, tanto por el aspecto y color de la mariposa como por las onigas, que en su major parte comen exteriormente las hojas de las granineas. Las mariposas carecen de la placa frontal, y de los dientes las antenas del macho, caracteres particulares que no permiten la reunion de ambos géneros.

\section{LA LEUCANIA EXTRAÑA-LEUCANIA} STRANEA

USOS, COSTUMBRES Y RÉGIMEN. - HSta especic la adquirido cilcrta celebridad bajo el nombre de sresinno de ejeritito anuericano (army aurm), por los estragos de la oruga, sobre todo én los estados orcidentales de la América del norte (1861). Esta oruga se alimenta, como la de nuestras especies, de graminens y ha destruido el poco tiempo praderas mus extensas; cuando le falta el alimento se dirige a otras partes y ataca tambien el centeno y el maiz. Segun noticias de aquel año, un ejército de estas orugas iranqueú en el espacio de dos horas la distancia de 60 varas inglesas (jards). las orugas avanzaban en tres cuerpos, y i veces veliselas enigrar a media legua inglesa de distancia de un sitio á otro. I a mariposa deposita sus huevos en julio y jusio en los tallos de yertas: y en la primavera siguiente se desarrollan las orugas. Yor esto se queman a fines de otoño ó en imvierno las yerbas en los puntos en (jue se presentan las orugas, como medida de precaucion contra futuris devastaciones.

\section{LA TRAQUEA DE LOS PINOS-TRACHEA PINIPERDA}

CARACTERES. - Esta especic es uno de los moctuinos mas abigarrados: se posa, con las alas en forma de tejadillo, en los troncos de pinos ó entre los conos, y rueia tambien de dia por su dominio en busca de los sauces en flor. Ape. nas se encuentran dos individuos del todo iguales; ial es la diferencia en el color y los dibujos. Generalmente las alas anteriores y el tórax, velludo, son de un tinte rojizo de canc. la mezclado de gris amarillento; cl matiz interior de las lineas onduladas es de un pardo rojo, y las manchas anteriores blancas. Ei abdómen y las alas posteriores tienen un solo color gris pardo oscuro. Los ojos son peludos: las antenas, cortas y delgadas, tienen pestanas en el macho; los palpos, cortos tambien, quedan ocultos por los pelos.

USOS, COSTUMBRES Y RËGIMEN.-TA aruga de esta espuecie ocasiono de improviso en el octavo decenio del 
siglo anterior, en los pinares de Francia y de Sajonia, tales derastaciones que las autoridades dispusicron se estudiase su historia yan poner coto, si era posible, a estragos mas sensibles. Al consultar varios documentos súpose que las mismas orugas habian devastado en 1725 los bosques de abetos enanos, de tal modo que en el espacio de quince dias, correspondientes al mes de julio, asolaron varios centenares de mojadas. Las orugas se hallaban en las copas de los àrboles mas altos y devoraban los conos emprezando por la punti; asi despojaron de! todo los árboles, que á los pocos anos murieron. En ayosto, las orugas dejaron de comer, cayendo en zales masos al suclo, que este se cubrió de una capa de cadaveres negros. In oruga sana no tiene nada de negra; su cuerpo verde está cruzado por varias líneas blancas en el dorso y una faja de color sıranja en los lados. En el año cirado sucedió tambien que en la Kurmark, en una parte de la nuera Marca y en la Pomerania anterior, asi como en la region de Ciorlitz, los bosques quiedaron asolados por esta oruga, y en particular por la del gastropaco antes citada. Descle enionces se ha presentado alguna vez, como por ejemplo en isos Y $\mathbf{I}_{15}$, en el territorio de Franconia; en el tiltimo ano en la Prusia Oriental; en el tercer decenio de nuestro siglo en P'o. merunia y Mechlenburgo, en la Marca del Uker; y en los alrededores de Berlin: en el quinto decenio, en Prusia, Posen y otra vez en la Marca de Brandenburgo. Las masas eran enormes, y dejaron para mucho tiemplo huellas de sus estragos. Sin llamar mucho la atencion, esta mariposa se encucr. tra desde mediados de mayo hastia fines de junio en zodos los pinares, con preferencia en los de? 30 à 40 mos de edad. I.a oruga adulta alcanza poco mas $\delta$ menos una langitud de $11 ", 0.35$ y baja al suclo para rmsformarse', delajo del musgo, en una crisálida verde al principio, y despues de un pardo oscuro que en el dorso del cuarto segmento abdominal presenta un hoyito limitado detrais por una jurominencia: esta crjsólida inverna. Ia naturaleza, sin embargo, conoce siempre medios para restablecer el equilibrio interrumpido, y de consiguiente mueren muchas de estas orugas por la temperatura fria, sin-contar las epidemias y miles de icneumóni. dos grandes y pequeños, que exterminan un gran número. Se conocen unos treinta diferentes parisitos que viven en esta especie y que casi todos llegan à su desarrollo en la crisálidn.

Cuando à fines de marzo ha brillado el sol varios dias seguidos, la tráquaea de los pinos sale ya en este mes, pero con seguridad al siguiente. Iin mayo la hembra deposita en los conos sus hucros, seis ú ocho en una filn.

'Todo el mundo conoce la voracidad de las orugas, casi proverbial, pero al hablar de ella piensa en las plantas de. adorno de su jardin, en la cosecha destruida de los árboles frutales, y en las devastaciones de los bosques. Solo el coleccionador y el que cria estos animales sabe que una oruga devora á la otra, cualidad propia sin embargo solo de algunas esprecies. Son de temer cstas orugas asesinas, pues si encierra una sola de ellas en una misma cajita con otros no cabe duda que en el camino devorars una parte de la coleccion tan penosamente adquirida. Yo no asegumria que en la na. turaleza libre estas orugas ataman a otras, porque se pueden escapar fácilmenic; pero en la cautividad es uno de los fenómenos mas ordinarios, sobre roda cuando muchas se hallan en una misma prision, aunque i ninguma falte el alimento vegetal. Delessert cita una obscrvacion çue hace resaltar todo lo horrible de esta voracidad. Una oruga asesina ( sropelosuma saldlitia), despues de haber engordado comiéndose una companera, fué encerrada con una segunda oruga ascsina (cos. mia trapezina), que empezó à devorarla por un lato, de modo que le silian las entmanas, por lo cual conicnzó i comer de atrás adelante. Para reconocer la resistencia vital de esta vicima sc le ofrecicron sus propias eniranas: y. la oruga las co. mió mientras que ella misma desaparccia poco à poco por atrís: solo cuando le quedaba la cabeza yo el scigmento del cuello cesaron los movimientos de sus maxilas. Esta doble comida ocupos al menos dos horas.

El género últimamente citado conticne varias especies, cuyas larvas pertenecen todas á las orugas asesinas, como por cjemplo la siguicnie.

\section{LA COSMIA DE LOS ÁLAMOS-COSMIA DIFINIS}

CARACTERES. - Ia mariposa, de formas graciosas, es de uu pardo castaño brillane con gris rojizo, sobre todo en el borde interior; el autcrior es de un gris amarillo con dos grandes manchas blancas. I a frente csta cubierta de escamas lisas; el tórax carece de mechones y presenta finos pelos; los jalyos, cubiertos de escaimas lisas, se dirigen murlio hácia arriba. Con dos congéneres que tambien habitan los álanos (cosmia afinis y prralina), los cuales se presentan en julio, la cosmia de los allamos es la mas rara, pero decididamente In mas bonita especie: la primera de aquellas tiene unas manchitas blancas inuy pequeñas en el borde anterior de. las alas anteriores, mientras que la segunda carece del todo de estas manclias.

USOS, COSTUMBRES Y REGIMEN.-La larv, bastante bonita por su aspecto exterior, vive en mayo en los alamos: ticne el escudo de la nuca de un pardo brillante, la cabeza de un pardo negruzco y lleva sobre un fondo verde amarillento cinco lineas longitudinales blancas yo unas verruguitas pardas peludas, situadas un manchitas blancas. En la trente hay una mancha clara en forma de horquuilla y los es. tigmas son pardos.

\section{LOS AGROTIS-AGROTIS}

CARACTERES. - Ulimamente se han reunido bajo este nombre genérico, que podria cambiarse por el de noctuinos agrestes, un gran nimero de noctuinos de los que muchos tienen urs asjecto sucio y color gris como el suclo en el que viven ocultos. Otros se distinguen por lo general entre los noctuinos á causa de tener las alas posteriores de color abigarrado, amarillas con una faja negra en cl borde. Se asemejan, aunque no sin excepcion, por los siguientes carnctéres: la estructura del cuerpo robusta; la cabeza y el tórax cubicrtos de pelos lisos, careciendo el filtimo de una quilla longirudinal afilada; los ojos son desnudos, sin pestañas: los palpos se dirigen hácia arriba con cl último artejo inclinado; el abdómen, desprovisto de mechones de plolos, is á menudo aplanado; los muslos peludos en su parte inferior: los tarsos medios y posteriores tienen espinas cerdosas: como en muchos otros noctuirsos, el séptimo nervio de las alas parte del ángulo anterior de la celda discoidea.

USOS, COSTUMBRES Y REGIMEN. - Se oculian de dia, y durante el reposo tienen las alas horizontales y so. brepuesias; cuando sc les inquieta de dia las mueven iemblorosamente antes de eievarse por el aire: vuclan a cierta distancia para volver i esconderse en el suelo. Sus onigas, desnudas y gordas, ugue solo comen yerbas $\delta$ gramineas, tie. nen el género de vida igualmente oculto; invernan sin excẹp cion, a menos que yo sepa, y se crisalidan en el suelo. De este modo se reunen muchas circunstancias que no dejan duda sobre su afinidad. El limitado espacio, desgraciada. mente, solo me jernite describir algumas de las especies mas comunes. 
EL AGROTIS PÁLIDO-AGROTIS PRONUBA

CARACTERES. - Esta especie se presenta en dos variedades: en la una (agrotis inmula) las alas anteriores son casi de un color pardo de cuero; la otra tiene en las citadas ahas un color pardo rojizo, ó pardo gris hasta negro, mezclado mas ó menos de ceniciento en la parte de la base y en la central. En ambas formas esta uiltima presenta mas 6 menos lineas trasversales oscuras. La mancha en forma de rinon es clara, con borde ossuro y con el centro salpicada de blanquizco; la linea ondulada llevi hàcia la base marcadas manchas negras. Mide unos 0", $05 \mathrm{~S}$ de punta á punta de ala.

USOS, COSTUMBRES Y REGIMEN.- Fste noctuino se encuentra en mayo $y$ junio en todas partes con bastante frecuencia. En sus expediciones nocturnas llega tambien a las viviendas humanas, donde por la noche se posa en -um rinconcito oscuro. su oruga, que es de color pardo sucio ticne una linea dorsal clara : en su parte superior xayitas longitudinales blanquizcas y en los lados otras oblicuas dirigidas Lncía abajo y aträs; ustos dibujos son mucho mas variados en los segmentos posteriores que en los antetiores.

Unas seis especies, de las que algunas se distinguen por unos colores muy bonitos é intensos, todas con las alas posteriores amarilias, se han separado de las otras bajo el nom. bre genuino de triphena.

\section{EL AGROTIS DE LOS SEMBRADOS-AGROTIS SEGETUM}

CARACTERES, - Esta mariposa, de aspecto sencillo, mide unos 11,044 de punta á punta de ala. Sus alas anteriores son de un jardo gris claro ú oscuro, con un viso amarillento en el macho. Las dos lineas trasversales, orilladas de un borde mas uscuro, estin poco marcadas en los individuos de color oscuro, mientras que las dus manchas anteriores se reconocen muy bien á causa de sus bordes negros. La linea ondulada es un poco mas clara y se corre bastante paralelamente con he orilla, excepto dos ingulos obthsos que forma hácia afuem. La linen del borde, se compone de triangulitos oscuros entre los nervios. En el macho lis alas posteriores se conservan blancas, excepto los nervios, salpicados ligeramente de amarillento, io mismo que el borde exterior. En la hembra parecen como ahumadas a causa de la mezcla. Las antenas del macho presentan hasta mas de la mitad unos dientes de peine en forma de maza siempre mas cortos y con pestanas.

USOS, COSTUMBRES Y REGIMEN.-No he querido pasar en silencio esta especie, porque su oruga, no solo se hace molesta sino muy danina toclos los años en los campos y jardines, ya en una ý otra region. Es de color pardo pilido de tierra, mezchado con mucho gris ó un poco de verde; la piel trasparente y muy brillante; el escudo de la nuca mas oscuro que el cuerpo. Las manchitas córneas ó verrugosas de los segmentos apenas son mas oscuras que el color del fondo y llaman poco la atencion. Su disposicion es la misma en todas las orugas de esta clase: en el dorso del scgundo y tercer segmenios se hallan cuatro en una liner tras. versal, y desde alli hasta el noveno inclusive, - se encuentran dos grandes verrugas mas distantes unia de otra; en el décimo no hay diferencia en la distancia de los pares y en el undécimo las verrugas antêriores estín mas desviadas una de otra. En cada una de estas plaquiras cómens, de las que hay tambien series en los lados, sale un pelo cerdoso. La orugn llega a una longitud de $\left(1^{\circ}, 052 \mathrm{y}\right.$ ' cl tallo es tan fuerte como el cañon de una pluma. Desde agosto hasta octubre, ó cuando el tiempo lo permite, tambien hasta noviembre, se alimen- ta de la colza, de varias especies de zanahorias y de coles, de patatas y de los sembrados tiernos en los campos y de toda clase de plantas en los jardines, sin dejarse ver, pues se oculta de dia bajo las piedras ó á poca profundidad en la raiz de su planta alimenticia y solo sale de noche para apoderarse de esta. La encontré bastante á menudo aun el 20 de julio en estado medio adulto: tiene un color oscuro y' visita las remo. lachas. En ninguna parte ataca las raices fibrosas, sino que come las plantas jóvenes por encima de la saíz, devorando la parte interior tierna ó bien ataca la planta desde arriba y penetra poco á poco en su cornzon. En la zamhoria y las patalas trabaja como la larva del abejorro, practicando agujeros y viaciando á veces las últimas del todo. Inverna en estado adulto y solo en raros casos llega á crisalidarse, ni menos aun á trasformanse en mariposa. Las orugas recogidas el 20 de julio en la remolacha estaban despues de crisalidarse en un vaso abierto sobre una mesa. En la noche del 15 de setiembre volú, con gran asombro mio, un agrotis de los sembrados, alrededor de mi lámpara y al examinar la vasija abiesta hallóse la piel de crisálida vacia.

Por lo regular las orugas se metamoriosean despues del in. vierno debajo de tierna, en la estacion en quve la col comien. za á florecer. La crisálida de forma recogida y color rojo amarillento brillante, remata en dos puntitas espinosas, cortas y un poco desviadas. De ella nace la mariposa al cabo de unas cuatro semanas.

Esta sencilla especie se encuentra desde la segunda mitad de mayo, pero con mas frecuencia en junio, aunque tambien se la ve en julio y agosto. En 1865 , año muy seco, la encontré hasta en seticmbre; el 8 de octubre vi una hembra re. cien nacida, $y$ el último del citado mes un inacho medio muerto débajo de la yerba. Estos individuos procedian sin duda ce una segunda cria, y sus descendientes debian invernar, desarrúllándose el año próximo.

El agrotis de los sembrados esta diseminado no solo por toda Europa, sino tambien por una gran parte del Asia, el sur dél Africa y el norte de América, perteneciendo por lo tanto decididamente á las especies cosmopolitas.

\section{EL AGROTIS DE LA EXCLAMACION-AGRO- TIS EXCLAMATIONIS}

CARACTERES. - No debe creerse que las quejas sobre los estragos causados en nuestras plantas cultivadas se refie. ren exclusivamente á la oruga que acabamos de describir. Hay otras varias del género ngrotis, que viven al mismo tiempo, ó algunas semanas mas tarde tambien y que uo son menos desagradables, como por cjemplo el agrotis de la exclama. cion, cuyas alas anteriores, de un gris rojo amarillctito, care. cen de dibujos y solo tienen tres manchas.

\section{EL AGROTIS DE COLOR DE CORTEZA- AGROTIS CORTICEA}

Caracteres.-Esta especie, un poco mas pequeña que la anterior, se distingue del agrotis de los sembrados solo por tener sus alas posteriores en ambos sexos de color pardo.

\section{LAS PLUSIAS-PLUSIA}

CARACTERES. - I.as plusias $\delta$ noctuinos dorados se caracterizan en su mayor parte por tener inanchas de un brillo metilico en sus alas anteriores: algunas podrian compararse por su figura con las letras griegas $g$, " ó $l$, y tienen todo el aspecto de una gruesa hoja de oro ó plata. Fin el abdómen, 
que es delgado, destácanse espesos moñitos. Los palpos, dirigidos hácia arriba, alcanzan en las diversas especies una longitud muy variada. En la magnifica plusia monela, que es de un color durado juilido, sobresalen, por cjemplo, como un par de sables corvos por delante y encima de la cabeza.

DISTRIBUCION GEOGRÁFICA.-Las plusias eastán distribuidas en todos los continentes y tienen numerosos re. presentantes en Europa.

USOS, COSTUMBRES Y REGIMEN.-EStos bonitos noctuinos colocan las alas en forma de tejadillo durante el reposo, y muchos de ellos vuelan tambien de dia Las oru- gas se caracterizan por tencr la cabeza pequeña y por su cuerpo adelgazado hária adelante, careciendo ademís de los piés abdominales anteriores. 'Todas viven libremente en las yerbas y fabrican en general un tejido alimenticio para la crisálida. Esta tiene el essuche de la trompa muy desarrollado y necesita poco tiempo parn su crecimiento.

\section{LA GAMA-PLUSIA GAMA}

CARACTERES. - la gama pertenece à las especies cu. ya ala anterior se distingue por tener una especie de gran le-

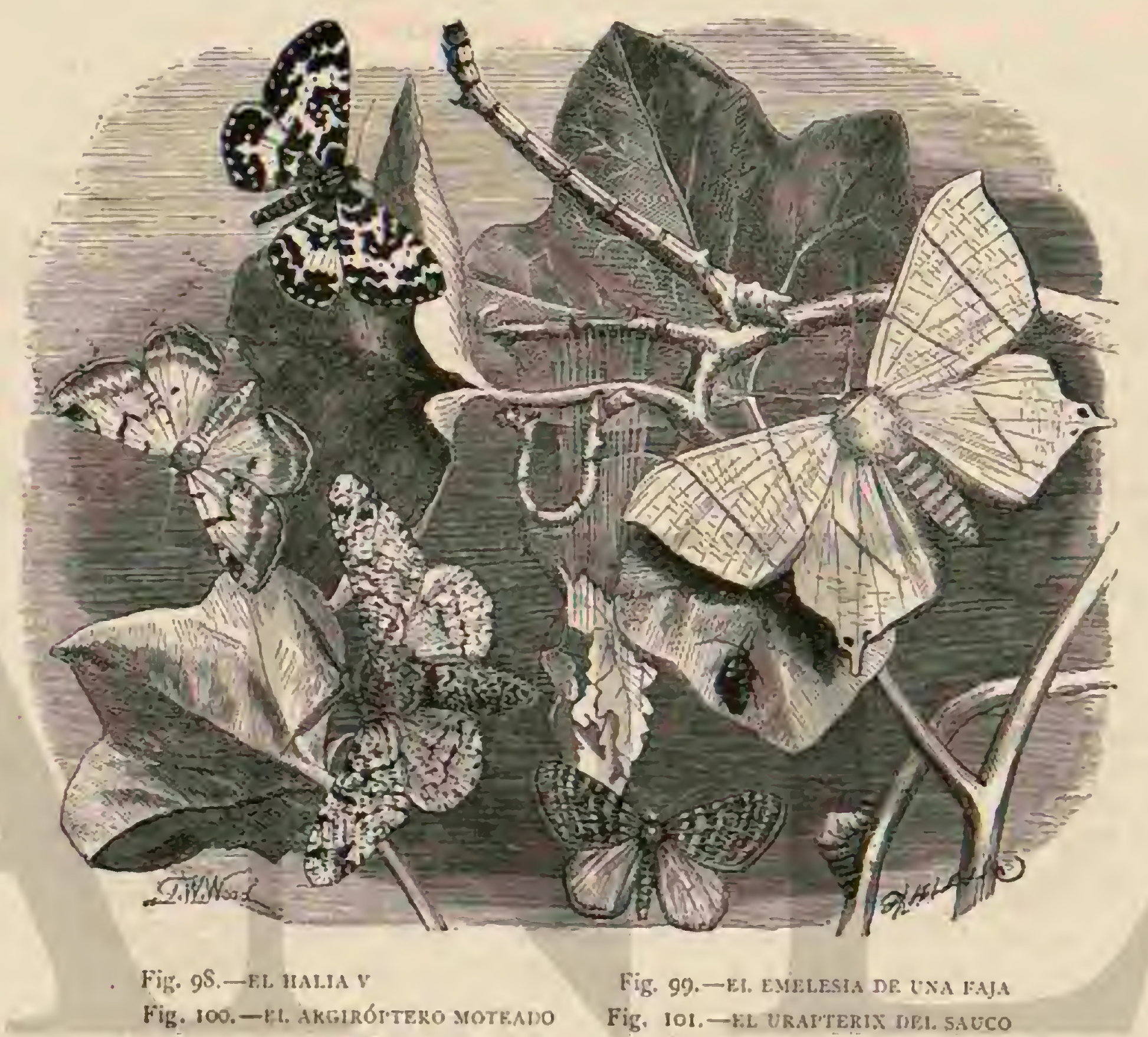

Fig. 102.-F.L ABKANAS DEL CKOSELLERO

tra platcada, semejante por su forma a la sr griega (gana). Las alas anteriores son grises, con dibujos como los del marmol, de color pardo, mas claros ó mas oscuros, con mezcla de pardo de orin; los dibujos, finos y claros, son plateados; las alas posteriores, de un pardo claro en la base, son mas oscuras hacia el borde.

DISTRIBUGION GEOGRÁEICA.-Fsta especic es lal rez la mas comun y mas diseninada de todas, pues se chcuentra hasta en el norte de América.

USOS, cosTUMBRES Y REGIMEN. - I a gama se encuentra en el campo y en el bosngue, en las praderas y los jardines, asi cuando luce el sol como por la noche; vaela ti. mida y rápidamente, y lith la miel en todas las fores posibles. Cuando se la molesta en su descanso clivase por el aire, pero vuelve a posarse pronto; solo cuando se crce segura oprime las antemas contra el pecho y coloca las alas en forma de techo sobre el abdómen, que es de un gris pardo. Is gaina no se encuentra solo i todas homs del dia, sino tambien en todas las estaciones del ano; durante los meses calurosos se las puede ver al mismo tienupo en todos los grados del desarrollo, por lo cual es dificil indicar con seguri. dad el número de las crias Por lo regular se supone que inverna en estado de orugra, pero el 7 de mayo de 1865 cogi una mariposa que por su aspecto nó era hija de la primare. m: mientras que ntra cogida en 1 . de octubre de $1 \$ 74$ debia haber salido hacia poco de la crisalida y sin duda no podria reproducirse sino despues del invierno.

La oruga, de color verde amarillento, con rayas longitudinales blancas, es mas estrecha en los segmentos. Aliméntase de las jerbas mas distintas, ocasionando à veces grandes estragos. Asi, por cjemplo, en i $\$ 2 S$ asolo en la Prusia Oriental los campos de lino, y en otras partes el cáñamo, la col, eic. Hace algunos años devastó repetidas veces los campos de remolacha en los ducados de Sajonia y de anhalt. De mas orugas cogidas en sauces yo crié este noctuino y. pude reconocer que la oniga se alimenta igualmente de una planta lenosa, cosa nunca observada hasta entonces.

\section{LAS CATOCALAS - CATOCALA}

CARACTERES.-1.os noctuinos mas grandes, y quc por sus alas posteriores ofrecen al mismo tiempro un caracter de. 
terminado, se designan con el nombre de catocalas, distin. guiéndose por sus colores amarillo, azul y' rojo.

\section{EL CATOCALA DE LOS FRESNOS-GATO- CALA FRAXINI}

CARACTÉRES. - Este catocala, el mas grande dic todos, pues mide (j)" 105, ó mas, de punta á pumta de ala, se reconoce fácilmente por la ancha faja de un azul claro que cruza las alas posteriores negras; las otras especies presentan en sus alas, amarillas á rojas, ademis de la faja negra del borde, una segunda mas ó menos denticulada en el centro.

\section{EL CATOCALA ROJO-CATOCALA NUPTA}

CARACTERES. - Está éspecie, una de las mas conunes, tiene las alas anteriores grises, reconociéndose en elths marcadamiente los dibujos que por lo regular se observan en los noctuinos, excepto una mancha anuiar y la de forma de espiga. I as alas posteriores tienen franjas blancas arqueadas sobre iondo rojo de sangre vimo. Por la faja central, un poco encorrada en ángulo, diñere de una segunda especie nus parecida (catorila elocran).

USOS, COSTUMBRES Y REGIMEN.-Desde media. dos de julio se ve este bonito insecto posado en los troncus de arboles, en las jaredes de las casas, etc, con las alas recogidas; estas son demasiado grandés para que se juedan colocar como las de las especies anteriores. Cuando álguien se acerca al sitio en que se haila, aléjase para buscar un es. condite mas oscuro, porque es tan timido como todos sus congéneres. Vuela por la noche alrededor de los árboles en busca de su hembin, que pone algunos huevos, pero nunca múchos, depositíndolos en la corteza de un tronco de álamo $\sigma$ de sauce.

Ias oruguitas nacen en la primavem y se alimentan de las hojas tiernas, haciéndose adultas à mediados de junio. De dia descausa en el tronco $y$ de noche sube à mas altura. Tiene poco mas $\delta$ menos el nismo color del tronco del ârbol, presentando en los lados una especie de franjas. Al co. ger una oruga de catocala se resiste noviendo la parte anterior y posterior del cuerpo lo mismo que un pez, y muerde si le es posible coger el decio. Debajo de la corteza del musgo ó de la hojarasca se rodea de algunos hilos y trasfórmase en una crisálida raquitica, cubierta de un polvillo azulado.

Del mismo modo proceden todos los catocalas en diver. sas plantas alimenticias (encinas, ciruelos, etc.). Las especies amarillas, mas raras en todas partes, no alcanzan el tamaño de has otras, midiendu por término medio $0^{\circ}, 052$ de punta á punta de ala. La América del norte alimenta igualmente muchas especies.

\section{LOS TIATIRAS - THYATYRA}

CARACTÉRES.-los lepidúpteros que forman este género tienen el cuerpo grande: antenas dentadas en los machos, con el último artejo casi desnudo y bastante largo; tórax ovalado; alas bastante anchas: patas anteriores o intermedias fasciculadas en los machos.

Las orugas son desnudas, $y$ tienen las patas anales extendidas durante el reposo. Algunas especies constituyen en cierto modo un segundo grupo que se distingue por ser las patas intermedias las fasciculadas.

DISTRIBUCION GEOGRAFICA.- 1.0s tiatiras se ellcuentran en una gran parte de Furopa.

\section{EL TIATIRA BATIS - THYATYRA BATIS}

CARACTERES.--Esta mariposa (fig. 95) llama la atencion por sus delicados tintes, muy semejantes á los de las fores del albérchigo. I a larva se distingue en particular por una protuberncia que lleva en th parte posterior de la cabeza, y por las prominencias triangulares que forman dos fajas á lo largo del cuerpo. El color de esta larva es al principio de un jardo oscuro, que palidece despues gradualmente. Las alas superiores del individuo perfecto tienen un fondo castaño muy delicado, que contrasta agradablemente con los puntos y rayas somrosadas que forman el dibujo; las inferiores son de un amarillo agrisado, con una linea ondulada en el centro.

DISTRIBUCION GEOGRÁFICA. - Esta especie es bastante conocida en Europa; pero en algunos paises, como por ejemplo en Inglaterra, escasea un poco.

\section{LOS UROPOS-UROPUS}

CARACTERES.- Los individuos perfectos de este género se distinguen principalmente por tener las antenas desnudas en la extrenidad.

Ias orugas son desnudas y se adelgazan posteriomente.

\section{EL UROPO VARIADO-UROPUS VARIEGATUS}

CARACTÉRES. - Esta mariposa (fig. 110) ofrecécolores sencillos, pero bónitos: las alas superiores son de un tinte castano, orilladas de verde $y$ blanco: $y$ las inferiores de un gris azulado, con filete amarillo $y$ mezcla de verde $y$ pardo. El tamaño de esta mariposa es bastante reducido.

DISTRIBUCION GEOGRÁFICA.-Habita en varios paises de Europá.

\section{LOS GONOPTEROS_GONOPTERA}

CARACTERES. - Las especies de este género se caracterizan en particular por su cuerpo robusto; las anteins son pectineas en los machos y vellosas en las hembras; los palpos largos, con sus dos primeros artejos gruesos: las alas anteriores son angulosas.

\section{EL GONOPTERO BOMBIX - GONOPTERA BOMBYX}

CARACTERES. - Esta bonita mariposa (fig. 111) tiene las alas superiores negras, con rayas longitudinales rojas $\mathrm{cn}$ la base, seguidas de dos grandes manchas amarillas; junto al borde se ven varios puntos blancos de forma irregular: las alas inferiores son rojas, con vetas negras y una faja del mismo tinte cn los bordes.

DISTRIBUCION GEOGRÁFICA.-Habita en Europa

\section{LOS HETERAS - HETERA}

CARACTERES. - Estos lepidópteros se distinguen por sener los paljos rectos y puntiagudos: las antenas casi filiformes; las alas anteriores tienen la extremidad cortada oblicuamente; las posteriores son desiguales y se jrolongan á veces como en forma de espátula.

\section{EL HETERA LENA - HAETERA LENA}

CARACTERES. - I as alas anteriores de esta mariposa (fig. 9j) son de un color gris uniforme, $y$ las segundas de un tinte azulado, con los extremos mas oscuros, adornadas ade- 
más de líneas y manchas blancas de forma irregular. La especie mide poco mas de a pulgadas de largo.

DISTRIBUCION GEOGRAFICA. - Esta bonita mariposa se encuentra en la América del sur.

En el mismo pais existe una variedad (fig. 96) conocida con el nombre de helera piera, q̨ue se asemeja mucho al heliconia trasparente, por tener sus alas esta cualidad, con un ligero tinte amarillo muy delicado; en las alas inferiores hay en el borde manchas de un matia anaranjado.

\section{LOS URANIOS - URANIUS}

CARACTERES. - No exageramos nada al decir que la única especie que representa á este género es el mas hermoso lepidóptero entre todos los conocidos. La oruga es tambien muy curiosa ; y cr cuanto à la crisálida, distinguese sobre todo por su forma angular, particularmente por su manera de suspenderse, que la comunica cierta semejanza con las especies diurnas.

\section{EL URANIO MAGNÍFICO-URANIUS MAG- NIFICUS}

CARACTÉRES. - Las alas de este precioso lepidóptero (fig. 84) son de un negro atercioplado, con la franja blanca; las superiores se prolongan y son rectas en el borde terminal, con fajas y estrías de un verde brillante; las de la base estrechas; la del centro ancha y regular desde el borde interno hasta la nersiacion media, quedando separada despues en dos partes por una mezcia de color negro. Las alas inferiores tienen una sola faja ciue ocupa la mitad de cada una; la parte superior es de un tinte azul, dividido por una gran mancha negra; en la inferior se ve una placa metálica de un color de oro brillante; la base de las alas, completamente metalica, presenta manchas negras entre una mezcla de verde y azul; el espacio terminal es de un blanco azulado ó verdoso en jarte y el resto dorado.

La oruga se distingue por su color negro, con fajas irregulares formadas de puntos blancos, verdes y amarillos.

DISTRIBUCION GEOGRÁFICA. - Drury dice que este lepidóptero es de la China: Cramer le supone originario de Bengala, y Bory de Saint-Vincent asegura que habita en Santa Elena. Ser de ello lo que fuere, lo cierto es que los ejemplares recibidos provienen todos de la isla de Madagascar.

\section{EL URAPTERIX DEL SA UCO - URAPTERYX SAMBUCATA}

CARACTERES. - No solo se puede considerar estal cespecie (fig. 101) como tipo del género, sino que es tambien sin disputa la mas notable. Sus alas son de un color amarillo de azufre, con algunas estrias oblongas aceitunadns; las superiores tienen el borde terminal algo dentado, con dos lineas verdosas y una raya celular. Ias inferiores son dentadias, y estan provistas de una cola que se adelgaza, precedicla de un diente fuerte en el que hay una mancha roja circuida de negro, il la que sigue una raja de este viltimo color, siendo la franja de un rojo ferruginoso. El cuerpo es de color azuirado: In parte anterior de la cabeza de un pardo canela: las antenas y los tarsos blancos.

La ortga es muy larga, ramiforme y afilada nnteriormente; la cabeza lenticular, ancha, y cortada ia escuadra en su parte anterior; las patas escamosas.

DISTRIBUCYON GFOGRÁFICA. - Es bastante comun esta especie en todos los paises de Europa, y sobre todo en las partes boreales.
USos X COSTUMBRES. - Los árboles que mas frecuenta la orugar de este lepidóptero son la encina y el ciruelo; tambien se la encuentra à menudo en el sauco y en el espino. Se la ve durante el mes de octubre.

\section{LOS GEOMETRIDOS- GEOMETRIDE}

CARACTERES. - Cieneraimente es dificil en las mariposas caracterizar las familias con pocas palabras, sobre todo cuando no se quiere prescindir del todo de las exóticas, porque los trảnsitos no permiten que los grupos sean bien limitados; y lo mismo sucede con los camctéres de la familia de los geométridos, que no pueden resunirse en una descrip. cion general. El tronco delgado de la mayor parte de las especies y las anchas alas, de las cuales las posteriores se igualan por lo regular con las anteriores por el color, asemejándose cuando menos respecto al dibujo, recucrodan a las mariposas diurnas, de las que sin enbargo se distinguen esencialmente por las antenas cerdosas en muchos machos, provistas de dientes en forma de peine. Por mas de un concejpto difieren de los noctuinos; no faltan las hajas trasversales en las alas, pero sí las manchas, en vez de las cuales figuran lineas. Las especies de abdómen grueso se parecen á menudo a los bombícidos, por lo cual deben tomarse en consideracion major número de caractéres, a fin de evitar confusiones.

los geométridos se parecen esencialmcnte por los caractéres siguientes: En su pequeña cabeza, que carece de ojuelos, sobresalen muy proco los palpos; la lengua, en cambio, ofrece los mas distintos grados del desarrollo. Ln el ala anterior se cuentan de once á doce nervios, entre ellos uno dorsal: raras veces hay solo die\%. El ala posterior, ancha, tiene cortas franjas, una cerda prensil, dos nervios dorsales, cuando mas, y ortos seis ó siete; de los dos primeros, el uno suele desembocar en el centro del borde interior y el segundo en el angulo interior. El nervio costal parte de la hase y toca regularmente el anterior de los nervios centrales á poca distancia de su origen, $\delta$ sale de este nervio mismo, circunstancia une ha obligado a los naturalistas modernos a fundar en ella dos divisiones principales.

USOS, COSTUMBRES Y REGIMEN. - I A mayor parte de los geométridos, en el estado de reposo, extienden siempre sus tiernas alas, aunque no tanto como remos cn las colecciones; algunos las tienen medio plegadas y levantadas, mientras que otras las colocan en forma de tejadillo sobre su abdómen. Muchas especies vuelan de dia, aunque es mus: fácil ahuyentarlas de la yerba ó de los arbustos; pero las mas despliegan toda su actividad durante la noche.

MIas bien por las ougas que por los individuos adultos estas especies difieren de las de otras familins. Ya dijimos anies que estas larvas carecen de los piés ventrales, excepto el uiltimo par; de modo que solo cuentan dice piés, rans ve. ces doce, propios para la locomocion. Agrảdales agarrarse con las patas anales á una rama para estirar todo su cuerpo al aire ó encorvarle tambien en forma de laro, de modu que toda la oruga, con su color pardo, que es el inas comun, se puede confundir fácilmente con una ramita. Algunas se fijan, como ciertas larvas de mariposas diurnas, por medio de un lazo en una hoja, para crisalidasse; pero la mayor parte se encierran con algunos hilos en hojas, tanto verdes como secas, $\delta$ penetran en el suelo. Si solo se toman un consideracion las especies alemanas, el 6,5 por ciento inverna en el estado de huevo, 35 como oruga, 58 como crisalida y solo 0,5 en estado perfecto.

Se conocen actualmente unas mil ochocientas especies de 
todos los continentes, de las que la menor parte excede de un tamano mediano (el Njotalemon Patroclus de Chima es el gigante entre todas). Linneo describió las que conocia en el grupo grometra y el género shalcena, terminando todos los nombres con aria ó ala, segun encontró las antenas en forma de peine ó sencillas. Los autores modernos han creado aqui, lo mismo que en todas partes, el mayor número posible de nombres geréricos.

Debemos limitarnos à unas pocas especies que representan las formas mas esenciales ú ofrecen un interés general por su oruga: pero sin regirnos por el órden cientíico, elegiremos una agrupacion conveniente pari nuestrus fines.

\section{EL ANFIDASIS DE LOS ABEDULES AMPHY- DASIS BETUIARIA}

CARACTERES. Eta especie pertenece por la estructura de su cuerpo á los geométridos seinejantes á los bombicidos, y es, á causa de sus alis anteriores prolongadas, una de las espccics mas grandes de nuestros paises. El color predoninante, que es blanco, se ve en todas jartes, sin exceptuar el abdónen, las ántenas y los piés, salpicado de un negro pardusco. Muchas motitas se reunen en algunas partes, sobre todo en el borde del ala anterior, formando manchas y lineas. Fil inacho, bastante mas pequeno, se distingue por tener el tronco mas dielgado y las antenas provistas en ambos lados de dientes en forma de peine, excepto en la punta.

La oruga, de igual grueso en torla la extension desu cuespo, tiene una profunda escotadura en la coronilla; en cada lado del octovo segmento presenta un nudito en forma de verruga, y tiene el color variable, dependiendo esto de la planta en que vive; puede ser gris verdoso y alguna vez. pardusco of amarillento.

USOS, COSTUMBRES Y REGIMEN. - Si bien se encuentra en los abejdules $y$ otros árboles fróndosos, prefiere, segun parece, la encina á todos, y er estado de descanso toma la posicion arriba descrita, propia de muchas orugas de geométridos. En setiembre if odtubre al canza su tamaño comple. to $y$ penetra en el suclo pari crisalidarse, aum antes del in vierno. En mayo ó júnio nace la mariposa, a la jue nunca se ve volar de dia, aunque a véces se la encisentra posada en un árbol del bosque, reconociéndosela por sus gtande's alas.

Otras especies mas congénericas, semejantes por suaspec. to tambien à los bombicidos y clasificadas últinamente en varios géncros, macen muy pronto de la crisáiida invernada; yo encontré ya en febrero el macho de la phigatia filosariu, cuya hembra carece de alas.

\section{LOS PLATIPTERIX-PLATYPTERYX}

CARAGTERES. - Los platiprerix tienen el cuerpo muy delgndo; cabeza diminuta; antenas contas, pectíneas en los machos; palpos muy breves y casi cónicos; alas grandes, con una prolongacion que afecta en cierto modo la forma de hoz en las anteriores.

\section{EL PLATIPTERIX UNGUICULADO-PLATYP- TERYX UNGUICULATA}

CARACTERES. - Se caracteriza esencialmente el macho de esta especie (fig. 106) por tener las antenas casi en forma de pluma. Los demás carnctéres son los indicados en el género. Su color es rojizo, con rayas y manchas oscuras; en el centro de las alas superiores hay otra muy marcada é inten$s a, y$ descle el borde inferior a la extrumidad se corre una linea anaranjada.
DISTRIBUGION GEOGRAFICA, - La especie es exótíca: labita en la América del sur.

\section{LOS ARGIROPTEROS-ARGY- ROPTERA}

CARACTERES. - Los palpos de estos insectos son ten. didos: el cucrpo delgado y largo; las alas anteriores mas bien estrechas que anchas; el vértice casi plano. Las especies de este género, nunçue de reducido tamaño, llaman la atencion por sus bonitos colores.

\section{EL ARGIRÓPTERO MOTEADO - ARGYROP- TERA PUNCTATUS}

CARACTERES. - Se ha dado á csta mariposa (fig. 100) cl nombre especifico con que la designan a causa del color cle sus alas, cuyo fondo blanco estí cubierto de manchitas ó motns negras, lo mismo en las superiores que en las infe. riores.

DISTRIBUGION GEOGRÁFICA. - Este insecto, vive en America, particularmente en los Estados-Unidos.

\section{LA HIBERNIA DESHOJADORA - HIBERNIA DEFOLIARIA}

CARACTERES.- El nacho ticne las alas grandes, pro. vistas de delgadas escamas, predominando en ellas cl color amarillo de ocre daro, todas cuatro tienen el centro oscuro salpicado de puntós, las alas anteriores se distinguen además por el ancho borde, de un pardo de orin en la parte central; las patas tienen escamas lisas, y las antenas dos series de dientecitoș. La hembra carece de alas y es amarilla, manchada de negro.

USOS, COSTUMBRES Y RÉGIMEN. - Sube de noche por el tronco de un árbol, con la esperanza de que el macho cumplira sus obligaciones, pues quicre que se la busque y este sabe encontrarla. Despues del apareaniento dęzo. sita sus huevos nisladamente ó en reducido número en los retoños de los árboles, à los que llega en poco tiempo á pié, gracias á sus largas patas. Cuando lo permite la temperatura, las oruguitas nacen ya á mediados de abril, ocualtanse bajo las. escamas de los capullos y convienzan su obra destructora antes de que el desarrollo de anquellas sea posible; en los airboles frutales llaman mas fácilmente la atencion, perjudican. do á veces mucho al propiciario, pero no tanto en los incultos, porque en estos la destruccion de los capullos frutales causa menos daño.

La oruga adulta tiene el dorso de colos pardo ruju, y- la mitad del vientre de un amarillo de azufre, con lincis de un pardo-rojo en cada segmento. Yara crisalidarse penetra en el suelo, construye con poeos thilos su pequeña vivienda y se trasforma en una crisilida roja parda çue remata en una punta espinosia

Una segunda especie amarilla del misno género (hibernia aurantiario), vuela al mismo tiempo que la anterior; y otras dos, una igualmente amarilla (hibernia progin:maria) ! otra de color gris blanquizco (hibernid leuenshicaria) se jresentan á principios de la primavera.

\section{EL QUEIMATOBIO DE INVIERNO-CHEI- MATOBIA BRUMATA}

CARACTERES. - lat alas tiernas y redondcadas del macho tienen algunas escamas de un gris empolvado; las anteriores, mas oscuras, son de un gris rojizo, con lineas tras- 
versales mas oscums y variables aun. La celda apendiente es grande, y los nervios i y 8 están separados; en el ala posterior la celda discoidea es mas larga que la mitad de las alas, y el único nervio dorsal desemboca en el ángulo falso. La hembra, que es de un gris empolvado. se distingue por sus alas atrofiadas, cada cual con una faja trasversal oscura, asi como las largas jatas, mancluadas de blanco.

USOS, COSTUMBRES Y REGIMEN. - El queima. tobio de invierno observa casi el mismo género de vida que la especie anterior, pero vuela mas tarde aun, pues su nombre especial cientifico designa el dia mas curto (bruma). Ia oruga, en cambio, abandona la planta alimenticia un poco antes, de modo que la crisálida descansa por término medio un mes mas. Otra diferencia en ambas esprecies consiste en que la oruga no se posa libremente en la planta alimenticia sino en restos de hojas recogidas y en parte secas. Esta especie devasta en el norte de Europa, y' se presenta en grandes masas en todas las cosechas de frutas. En la Alemania Central, por ejemplo, en la provincia de Sajonia, esta especie, lo mismo que la anterior, se encuentran bastante à menudo juntas en los árboles del bosque, pero el queimatobio solo causa danos en los frutales.

Las oruguitas salen del huevo a principios de la primavera; entonces son de un color gris y clespues de esa estacion de un verde amarillento con la cabeza y el escudo de la nuca negros. Despues de la segunda muda se pierde el negro: el color predominante es mas verde y una linea dorsal blanca, antes indicada, se marca mas. Despues de la última muda tiene una longitud de 0,026 , un color verde amarillento ó mas oscuro, con la cabeza de un pardo claro brillante y una fina linea, mas oscura en el dorso; esta última está orillada de blanco en ambos lados, y tambien hay otra linea clara por encima de los estigmas, que parecen puntitos oscuros. Esta eśpecie se distingue tambien de otras muchas orugas de greométridos por su aspecto vigoroso y fuerte. Cuando inas tarde, a principios de julio, abandona su planta alimenticia para trasformarse en crisálida á poca profundidad debajo de tier$r a$ adquiere un color pardo amarillo y presenta en la extremidad dos espinitas dirigidas hảcia afuera.

Para preservar los árboles frutales de los perjuicios causados por estas orugas se ha ensayndo hace tiempo el amillo de alquitran, que produce muy buenos efectos si se maneja de un modo conveniente: en Suecia se han cogido por medio de él, en un pequeño espacio, $2 \$, 000$ hembras. Se compone de una raja de papel del ancho de la mano, que se coloca de la manera mas cómoda para el trabajador al rededor de los troncos, de modo que por debajo de ella no puede subir nir. guna hembra Esta faja se cubre de una sustancia pegnjosa mientras dura el periodo def celo. Al principio se eligió al efecto el alquitran puro de pino, pero como era dificil de adquirir se sustituyó con otras inezclas que conservan mas tiempo su propiedad glutinosa, $y$ de las que, entre otras, he reconocido yo nismo como muy útil la que Becker de Juterbogk vende con el nombre de cole de brumata. Desde que los troncos de pinos se impregnan con alģuitran para preservarlos de las orugas de geométridos, sin fijar antes la faja de papel, se han fundado numerosas fábricas de dicha cola, entre las que la de Muetzell, en Stettin, produce la mejor, segun la opinion de muchos guaráa-bosques.

\section{EL BÚPALO DE LOS PINOS-BUPALUS PINIARIUS}

CARACTÉRES. - El macho es de color pardo negru\%co con manchas y rayas claras nuy variables; los dibujos tienen en la cara superior un co'or anarillo de paja y" en la inferior Toso VI blanco. En la hembra, mas variable aun, alterna cl amarillo rojo con un pardo rojizo; de modo que una vez predomina el primero y otra rè el segundo de estos colores. Lil género á que pertenece se caracteriza por una celda apendiente en las alas anteriores, por un nervio costal en las posteriores, que parte de la misma base, por icher la frente provista de escamas lisas, y las patas cortas, sobre todo en los tarsos posteriores.

USOS, COSTUMBRES Y REGIMEN. - Lil búpalo de

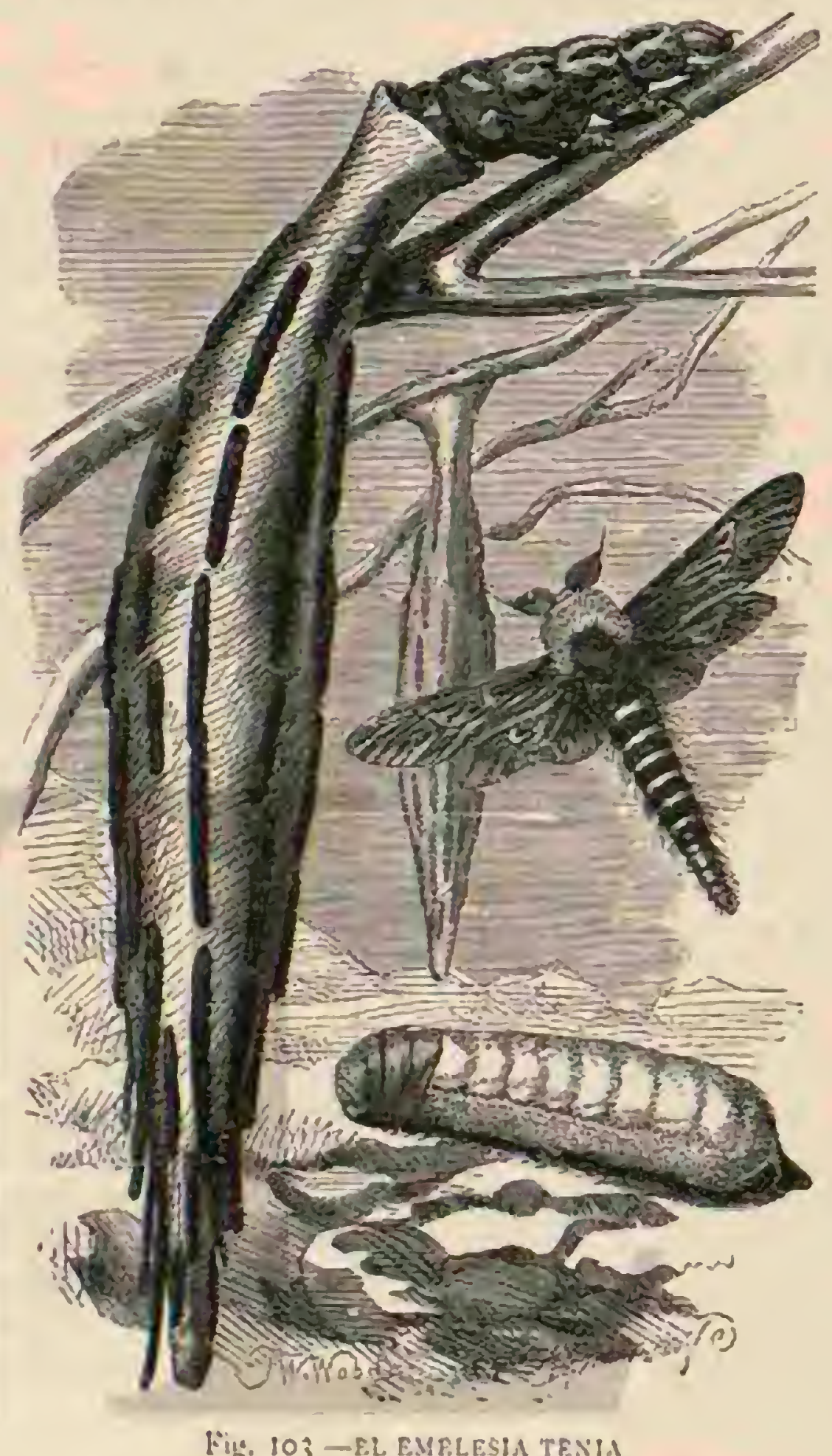

los pinos sabe elegir mejor el tiempo en que debe presentarse y llama la atencion de todos los que en un dia caluroso de junio se pasean entre los pinos, aunque solo sea para disfrutar de la iromática atmósiera, puies con movinientos rápidos \& violentos vielan, tanto el macho como la hembra, entre los troncos y conos de esos árboles. Hace varios años, en un dia caluroso de junio, al cruzar por un bosque, despues de una ligera Jluvia, y cuando el númern de estos insectos era mas considerable de lo que conviene a los guardahosques, vi centenares de individuos; rozabanne el rostro al vuelo, y llenaban el camino de tal modo, que à cada momento los pisaba; tambien abundaban en los troncos de los pinos. La hembra deposita sus huevos en la cima de esos árboles, y en junio nacen las oruguitas, que cuando existen en número considerable no llaman la atencion por sus estragos hrasta el mes de agosto. Ein setiemure se cuelgan como arañas de sus hilos, bajando por ellos, segun parece, parn divertirse, hasta que en octubre, ó tambien en noviembre, bajan de hecho a tierra para trasiormarse en crisálidas debajo del musgo ó de la hojarnsca. Ia oruga, de color verde y muy delgada, tiene tres lincas dorsales blancas y dos laterales ama. 
rillas que se continúan por la cabeza. 12 crisálida, al principio verde y despues parda, excepto los estuches de las alas, presenta en su extremidod una punta bipartida, $y$ siempre inverna. Al año siguiente no es seguro que nazca la maripo. sa, pues la oruga está expuesta à los ataques de numerosos icneumónidos, y en los años en que existe, sticede muy à me. nudo que ni siquiera llega a crisalidarse, porque una seta (bofryfis) que crece en su interior la mata sin remedio.

\section{LAS LARENTIAS - LARENTIA}

CARACTÉRES. - El género larentia, muy rico en especies, pertenece a un grupo en cusos tipos el nervio costal de las alas posteriores no parte de la base misma sino del nervio central anterior, á poca distancia del anngulo anterior de la celda discoidea. En el ala anterior hay otra celda del todo cerrada, y en la posterior una bijartida.

\section{LA LARENTIA DE ASTA-LARENTIA HASTATA}

Caracteres. - Esta especie es de color negro, con fajas y manichas blancas.

USOS, COSTUMBRES Y REGIMEN. - 1si como la especic anterior habita en el bosizue, pero no en todos, sino en aquellos donde predominan los arbustos y abedules. Aqui viela este gcométrido por el mes de mayo; es bastante vivaz. y timido. Su oruga se encuentra mas tarde entre las hojas caidas de los abedules, distinguiendose por sus repliegues trasversales de color pardo canda; en cada lado tiene una serie de manchis amarillas en forma de hurracura.

\section{LA LARENTIA TRISTE-LARENTIA TRISTATA}

CARACTERES. - Esta esprecie riene casi los mismos dibujos que la anterior, pero es mas pequenia.

USOS, COSTUMBRES Y REGIMEN.-Se la ve en la misma estacion, péro tambien antes ó despues, y así como la especie anterior, vaga por los trosques y espesuras. Unas la. rentins blancas ó amarillas, con hijas oscuras, mas numerosas o escasas, viven en la yerba de le terrenos humedos; y hiven si álguien se acerca, pero vuelsen á posurse okra vez. Se ve que les domima el miedo y que prefieren la oscuridad para volar 6 ir en busca de alimento ó de los machos.

\section{LA LARENTIA DEL QUENOPODIO-LAREN- TIA CHENOPODIATA}

CARACTERES. - El color predominante es el amarillo de cuero verdoso, con una faja ascura en los limites de la parte media en la hembra, y una mancha mas extensa, de color pardo amarillo oscuro en el macho. La forma de las alas anteriores, tas posteriores con el borde ondulado y dibujos diversos, son carnctéres que distinguen á otras muchas especies, las cuales tienen además dibujos mas bonitos y unos colores mas vivos.

USOS, COSTUMBRES Y REGIMEN. - La larentia del quenopodio habien en particular los jardines de los pueblos $y$ su vecindad; se posa en los paredes de las cuadras y en los troncos de árboles, pero to en la yerba; de modo que no es fácil encontrarla, ni tampoco se la ve siempre volar. No escasea en julio y agosto en ningena parte. Su oruga, que inverna, parece algo nudosa en los lados y tiene la forma aplanada desde arriba, siendo variable fror el color y los dibujos, pero en general de un gris parciusco $\delta$ pardo cancla; en el dorso tiene unos ganchos angulosos con la punta hácin adelante que cruzan una linea osrura; en los lados se ve otra denticulada, de color amarillo. Se alimenta de diferentes especies de quenopodio (chenofodium) en las que á veces forma grandes agrupaciones; para crisalidarse penetra á mucha pro. fundidad en tierra.

\section{LOS EMELESIAS - EMMELESIA}

CARACTERES. - No difieren las especies de este géne. ro de las del anterior por ningun caracter notable: el abdómen de los individuos perfectos, delgado y cónico, termina por un hacecillo de pelos quue tienden à levantarse; las alas, enteras y bastante ténues, presentan franjas interrumpidas; las superiores tienen lineas onduladas: Ins inferiores son siempre mas claras y de dibujos confusos.

Las orugas, cortas y atenuadas en las extremidades, se ca. racierizan por sir cabeza globulosa. Las crisalidas son pecuuenas $y$ agrudas en la extremidad.

DISTRIBUCION GEOGRÁFIGA.-Ia mayoria de las especies son propias de Europa: conócense muy poras cxróticas.

\section{EL EMELESIA DE UNA FAJA-EMMELESIA UNIFASCIATA}

CARACTERES. - Las alas superiores de este lepidóptero (fig. 99) son triangulares, de color pardo cancla, con el espacio niedio mas oscuro y uniforme, formando un ángulo obtuso: la raya celular es oscura, y sobre el fondo se extiende una inezcla de pardo gris mas claro; las alas inferiores son de un gris pardo pálido con lineas confusas; en la base existe un punto celular $\mathrm{y}$ dos ravas pamlelas poco intensas.

DISTRIBUGION GEOGRÁFICA. - Este insecto is muy comun en Inglaterra, en la Francia meridional y en Córcega.

\section{EL EMELESIA TÉNIA-EMMELESIA TOENIATA}

CARACTERES. - Este emclesia (fig. I03) se caracteriza por sus alas redondeadas; las superiores presentan una mezcla de blanco y pardo amarillento claro, con los espacios basilar y medio negruzcos; entre ellos hay una faja ancha y de un amarillo mas intenso; el espacio terminal es mas oscuro en la parte superior, y pálido en el centro. Las alas inferiores son de un gris pálido algo mas oscuro en el borde terminal, que va precedido de una fajita clara. No has punto celular bien marcado; toda la parte inferior es de un gris claro, casi sin dibujos. Solo el abdómen tiene en el borde dorsal anillos negros. Ia hembra es bastante parecida.

DISTRIBUCION GEOGRÁFICA.- Habita este lepidóptero en las partes montañosas del norte de Inglaterra, en Cumberland, Livonia y los Alpes.

USOS X COSTUMBRES. - Esta mariposa se deja ver durante los meses de junio y julio. Ia larva fabrica algunas veces un capullo con restos de maderas y hojas, los cuales une con las hebras de seda que va segregando. Muchas de ellas no se toman este trabajo, $y$ se introducen en los tallos de las plantas de la manera que ya hemos indicado en otro lugar, sufriendo alli su trasformacion. El grabado que se acompaña representa una larva en el acto de sacar una parte del cuerpo de su singular escondite para alcanzar el alimento.

\section{EL ABRAXAS DEL GROSELLERO-ABRAXAS GROSULARIATA}

CARACTERES. - Esste geoméricio no puede confundirse 
con otra mariposa, aunque no se tenga en cuenta la direccion de los nervios en las nlas. Sobre un fondo blanco estas presentan series de puntos negros, y en la base entre las dos últimas de estas series, asl como en los lados del cuerpo, se ve como tercer color el anarillo de jema (fig. 102).

USOS, COSTUMBRES Y REGIMEN. - De dia permanece en las espesuras y cercas, pero no tan oculta como otros muchos de sus congéneres; ampoco se oprime tanto contra las hojas, ni elige con tanto empeño la cara inferior de esaas para descansar. Cuando reina la oscuridad comienza à volar, y entonces se buscan los sexos. I.a hembra fecundada deposita en agosto sus huevos, de color amarillo de paja, en pequeños grupos, colncíndolos entre los nervios de las liojas de varias plantas leñosas, sobre todo de los groselleros, de los ciruelos y albaricoqueros de nuestros jardines, del espino negro y del espino cruzado. Las oruguitas nacen cuando mas tarde en la primera mitad de setiembre; mudan una ó dos veces de piel antes del invierno, y caen con las hojas ó antes que ellas para ocultarse en un escondite en el suelo. l'asado el invierno buscan su planta alimenticia, y cuando son muy numerosas no dejan ni una hoja sana, porque comienzan sus estragos antes de que estas se hayan desarrollado. Esta oruga nos ofrece un ejemplo raro de la igualdad de colores en la larva y en el insecto desarrollado. Tiene un fondo blanco con manchas negras y el vientre amarillo. A fines de mayo se ata con algunos hilos a un tallo de su planta alimenticia y trasfórmase en una crisálida recogida de color negro brillante en la que los bordes posteriores prominentes de los segmentos abdomimales tienen un color amarillo de yema. Esta graciosa crisálida solo descansa alyunas semanas.

\section{LAS EUPITECIAS-EUPITHECIA}

CARACTERES. - i causa de la uniformidad en el color y en los dibujos no deja de ser dificil distinguir las numero. sas especies de aspecto sencillo del género de las eupitecias. Se caracterizan por tener las alas posteriores muy jequeñas, con el borde truncado ó redondcado, pero no escotado; cl sexto y séptimo nervios parten de un mismo tallo; las anterio. res tienen una celda apendiente no dividida y el lílimo y sexto nervios no están separados. Ademas los muslos se ha. llan cubiertos de escamas lisas; la irente es mas estrecha que cl diametro de los ojos; los palpos no son visibles por arriba à causa de su pequencz: y las antenas tienen solo pestainas. Ias alas, en las que predomina el color gris, presentan una linca ondulada mas clara 6 mas oscura como dibujo principal; todas cuatro son visibles, distinguiéndose las anteriores por su borde exterior muy largo.

USOS, COSTUMBRES X REGIMEN-1 as orugas de muchas especies viven en flores jo frutas.

\section{LA EUPITECIA MARCADA-EUPITHECIA SIGNATA}

CARACTERES. - Esta mariposa es de un color blanco de leche; tiene en la parte anierior de las alas una nancha gris negruzea, $y$ en el borde una ancha linea ondulada de color gris rojizo.

USOS, COSTUMBRES Y REGIMEN.-Este geomé. trido, mas bien noctuino, vuela en mayo y junio por todas partes, aunque no en gran numero. Su oruga vive en las flores y simientes verdes de algunas yerbas; es de color blanquizco y se caracteriza por dibujos denticulados de un rojo claro.

\section{LA LITRIA PURPÚREA-IYTHRIA PUREU- RARIA}

CA R A CTERES. - Jas alas anteriores del macho son de un verde aceituna: las de la hembra a veces de un amarillo de ocre ascuro, con dos $\delta$ tres fajas trassersales purpúreas, que sin embargo no están siempre marcadas con igual perfeccion. Una linea en el borde y las fmnjas son igualniente de color purpúreo; tambien las alas posteriores, de un amarillo de ocre oscuro, tienen la faja central purpurea en la cara inferior, trasparente á veces; en la superior estan orilladas de franjas del mismo matiz. Ia celda apendiente no clividida de las alas anteriores se forma por el cruzamiento del undé cimo nervio con el séptimo y décjino, que salen por delante del ángulo de la celda discoiden. En el ala posterior el único nervio dorsal existente remata en el aingulo falso; el sexto y séptimo son pedunculados $y$ la celda discoidea se distingue por su corta exiension.

USOS, COSTUMBRES Y REGIMEN. - Hemos tenido ocasion suficiente parn conocer el gusto distinto de los geométridos respecto à sus usos y costumbres: Jos unos se ocultan de dia y solo son activos de noche; oiros vuelan lo mismo en la oscuridad que i la luz del sol, aunque prefieren esta; estos buscan la perba abundante; aquellos las cercas, las espesuras bajas, ó el bosque espeso. La especie que nos ocupar vuela en julio y agosto en los campos segados y en los anchos senderos de la campiña, posindose regularmente en el suelo; de modo que en rigor no se puede comprender lo yute busta en sitios tan escasos de Rores.

La oruga de este geométrido, que busca los sitios secos, se estrecha en los segmentos y tiene en el dorso, pardo amarillo, una faja longitudinal clara; los lados del vientre son amarillos. Vive en diferentes yertas.

\section{LOS MICROLEPIDÓP. TEROS}

CARACTÉRES. - Los microlepidópteros, que en los indices europeos representan en múmcros redondos la cifra de 2,700 especies por 2,583 de mariposas grandes, comprenden las mas pequenas y las de tamano mediano. Su cestudio ofre. ce virias dificultades, porque para observarlos en todos sus actos se necesita casi siempre un microscopio y otros aparatos a causa de la pequeñez de estos insectos. En todos los órdenes hay grujos de los que no agrada al coleccionador ocuparse, ni rampoco al aficionado, porque son de exámen dificil, y por cso dejan ese trabajo à uno í otro naturalista, siempre dispuesto a sacrificar en beneficio de la ciencia su actividad y su vista, contentandose con la seguridad de haber servido a aquella, como único premio de su constante celo. No obstante, su tarea promneve quiras una sonrisa de lástima de aquellos que sirven al genio del tiempo, á la utilidad real, y cuyo principio eel tiempo es orop parece servirles de norma.

\section{LOS TORTRICINOS-TOR- TRICINA}

Caractéres. - Siguiendo el ejemplo de Heinemann, comenzamos con la familia de los tortricinos, mariposas de mediano tamaño, y aun pequenas, que por el aspecto y forma de sus alas, difieren marcadamente de las otras, pudiendo considerarse á primera vista como una edicion en miniatura de los noctuinos las alas anterio- 
res prolongadas, tienená menudo ciesto brillo metalico glibujos abigarrados: el horde anterior es corto y se arquea en la base yor lo tanto los hombros son silicntes; además hay un nervio dorsal ahorquillado hácia lit base, y otros once nervios. Las alas posteriores, anchas, carecen de dibujos; no se hallan divididas, ni tienen una celda intercalnda, pero si una prensil; cuentanse tres nervios dorsales libres, y otros scis ó siete. las antenas, cerdosas, parten de una base gruesa, y no llegan à la longitud del borde anterior de las alas anteriores; los palpos, poco salientes, dirigen su corto arte. jo final niliforme harcia adelante ó hacia abajo: los ojuelos existen.

Para distinguir los numerosos géneros en que se ha dividido el llamado tortrix, debe tomnre én cuenta ia direccion de los nervios y fer si el central posterior de las alas posteriores está provisto en la base de pelos erizados ó no, y si la lengua forma espiral ó falta.

Parn clasificar las especies se examinan principalmente las alas anteriores: sus dibujos son muy rariables y por lo regular existe la parte uscura de la base, que cuando menos está indicada; después sigue una parte mas clara, a menudo en forma de faja ó de mancha, y por fin una faja oscura oblicua, que desde ál centro del borde anterior se dirige al ánguto anterior. Numerosas especies, sobre todo has que tienen la base del nervio central peluda en las posteriores, presentan en el borde posterior unos ganchitos, por lo regular pareados, cuatro entre la punta y el centro. que á veces tambien se continuan y se cuentan deșde la punta, porque aqui se presentan con mas regularidad. A menudo parten de cllos unas lineas chams de brillo metálico, las llamadas livens de flomo. Tha que desde el tercero y cuarto par se dirigen hacia al ángulo interior, encierran à menudó por encima del mismo una mancha oval ó cuadrangular de color distinto, el llamado disco, qué regularmente tiene entre los nervios una serie vertical de punios ó lineas longitudinales negras. De los dibujos propios de las alas anteriores de los noctuinos no se encuentra aqui nila mas jigera semejanza.

USOS, COSTUM BRES Y REGIMEN. - Jos tortricinos vuelan voluntariamente de noche, ipero hujen de las éspesuras de yerba donde, así como en los zruncos de l'os árboles, descansan de dia con las alas en forma de tcecho.

Ias orugas de los tortricinos provistas de die\% ye seis piés, tienen unos pelitos cortos (jue facilmente pasan resapercibi. dos; el escudo collar, regularmente sólido, está dividido por una raya clara y la válvula anal lleva una capa de quuitina. Arrollan por medio de hilos las hojas en que viven, por lo que han recibido el nombre de la familia; aunque si bien otras orugas tienen la misma costumbre, tambicn las hay que vi. ven en el interinr de las diferentes partes de las plantas, sobre todo en las frutas. Estas últimas orugas suelen abandónar su albergue para crisalidarse, mientras las que viven entre las hojas se trasforman tambien aqui en crisálidas. Solo en pocas especies se han observado dos criss.

Auncue las orugas de los tortricinos no viven sociablemente, como tantas otras de bombicidos, muchas llegan a ser sin imbargo molestas, y hasta peligrosas para el cultivo. Una oruga de tortricino, de color pardo negruzco ó gris, ataca las hojas de los rusales, no dejando desarrollarse ninguna flor si no se la cxtrae aisladamente y se la mata tan luego como se observa en los retonos la panlizacion del desarrollo. Otras especies viven de igual manern en diferentes clases de fruta, sobre todo en las que se crian en arbustos.

El conchilio de una faja, por cjemplo, en el estado de oruga, que es de color de carne, con la cabeza, el escudo collar y los piés torácicos de un negro briliante, ataca las flores y el fruto verde de las cepas, y' solo puede combatirse recogien. do ruidadosamente las crisalidas que invernan y que se fijan detris de la corteza, en las hendiduras de los pralos, etc.

Una segunda especie, menos extendida y mas escasa (gra. fibolitha bofrana): vive de igual modo, pero causa, segun se dice, mas daño á las repas de los jardines y a las de las casas que a las vides cultivadas en major escala.

\section{EL TORTRIX VERDE-TORTRIX.VIRIDANA}

CARACTERES, - Esta especie se reconoce fácilmeme por el color verde claro de la parte anterior del cuerpo y de las alas anteriores; el abcómen y las alas posteriores son de un gris brillante.

USOS, COSTUMBRES Y REGIMEN. - En mayo, chando los capullos de las dos especies alemanas de encina empiczan a desplegarse, vénse ya las oruguitas de los huevos invernados, y que penetran en los capullos. Mas tarde viven librementc en las hojas, las cuales arrollan tambien un poco; cuando deben crisaliclarse haillanse sus hilos pendienies de los irboles como telarañas. I a oruga, verde amarillenta, tiene In cabeza, el borde posterior del escudo collar, la vílvula anal y las arrugas negras, estas niltimas provistas de pelos parduscos. A fines de mayo ó á principios de junio se tras. forma en crisálida del modo indicado 6 en las hendiduras de la corteza. Poco antes ó despues del dia de San Juan se presenta la mariposa, mas raras veces tambien en julio. In mayo de 1863 las orugas aparecieron en tales masas en el jardin zoológico de Berlin causandotantos estmgos que las hojas viernas desaparecieron pronto, y tambien las de has hayas; tilos y otros árboles, que sin embargo mas tarde revisticron de nuevo su verdé follaje.

\section{LA RETINA RESINOSA-RETINA RESINELLA}

CARACTÉRES.-Ia retina resinosa pertencece à los tortricinos cuyas alas anteriores oscuras, se distinguen por numerosas limeas onduladas de brillo platcado y cuyas orugas perjudican de varios modos los retonos y la madera tiema de las coniferas. Es de un pardo oscuro intenso en las alas anteriores y lleva en ellas los indicados dibujos plateados.

USOS, COSTUMBRES Y REGIMEN. - Vuela ya en las hermosas noches de mayo entre los conos de los junos, donde produce gotas resinosas debajo de los grupos de capullos que deben desarrollarse en la primavera siguiente. Al examinar con detencion estos capullos se encuentra una galeria que llega hasta la méciula y est haljitada por una pequeña oruga, cuya actividad produce aquella resina. Esta secrecion se aumenta mucho durante el año siguiente hasta que por fin llega al taman̉o de una nuex, adquiriendo un color blanco sucio: se ve fácilmenti en la base del grupo de capullos, que mientras tanto se han desarrollado. Trascurren pucs casi dos anos desde la puesta de los huevos liasta la primavera, que es cuando la oruga, de color pardo rojo ama. rillento, de $1 "$ ",or 2 de largo, con su cabeza negra, se tras. forma en crisalida en la llamada agalla. Esta es negra y se desarrolla pronto si la oruga no contenia un huevo de la glyp ta resinanac: cuando se saca la crisálida de su lecho no se desarrolla nunca.

\section{LA RETINA DE LOS PINOS-RETINA BUOLIANA}

CARACTERES.- Este tortricino tiene las alas antericres de un rojo de castana vivo, con dibujos blancos plate.?dos, mientras que las alas posteriores y la cara inferior de todas las alas son de un gris rojizo sencillo. 
USOS, COSTUM BRES Y REGIMEN.-Iin julio, cuan. do los retoños de los pinos se han trasformado ya en madera, la hembra deposita sus huevos entre aquellos. 1.as oruguitas nacen aun èn otono y pican los capullos, que a consecuencia de esto segregan un poco mas de resina. Solo en mayo siguiente, cuando aquellos se han desarrollado en rétonos, reconócesé la influencia danina de las orugas, que en su juventud son de un pardo oscuro, y despues un poco mas clitas, con la cabeza bastante negra: el escudo de la nuca es negro y las patas torácicas del mismo color. Fl retono se encorra y conservase arqueado, mientras que la parte an. terior ilesa continua desarrollandose. A fines de julio la oruga se transforma en una crisalida de color pardo amarillo sucio: se situa con la cabeza cerca del agujero de entrada, y en el tiempo indicado nace la mariposa.

\section{EL GRAFOLITO DE LOS GUISANTES-GRA- PHOLITHA NEBRITANA}

CARACTERES.- Esta mariposa tiene las alas anteriores de color de corzo con brillo metalico; en cl borde anterior alternan desde la punta hasta detris del centro los blancos ganchitos costales, con pequenas lineas negras; cl disco, mas claro, esta limitado por dos linens de un amarillo azulado. I ass alas posteriores, negras con irillo bronceado. tienen las franjas de un solo color blanco.

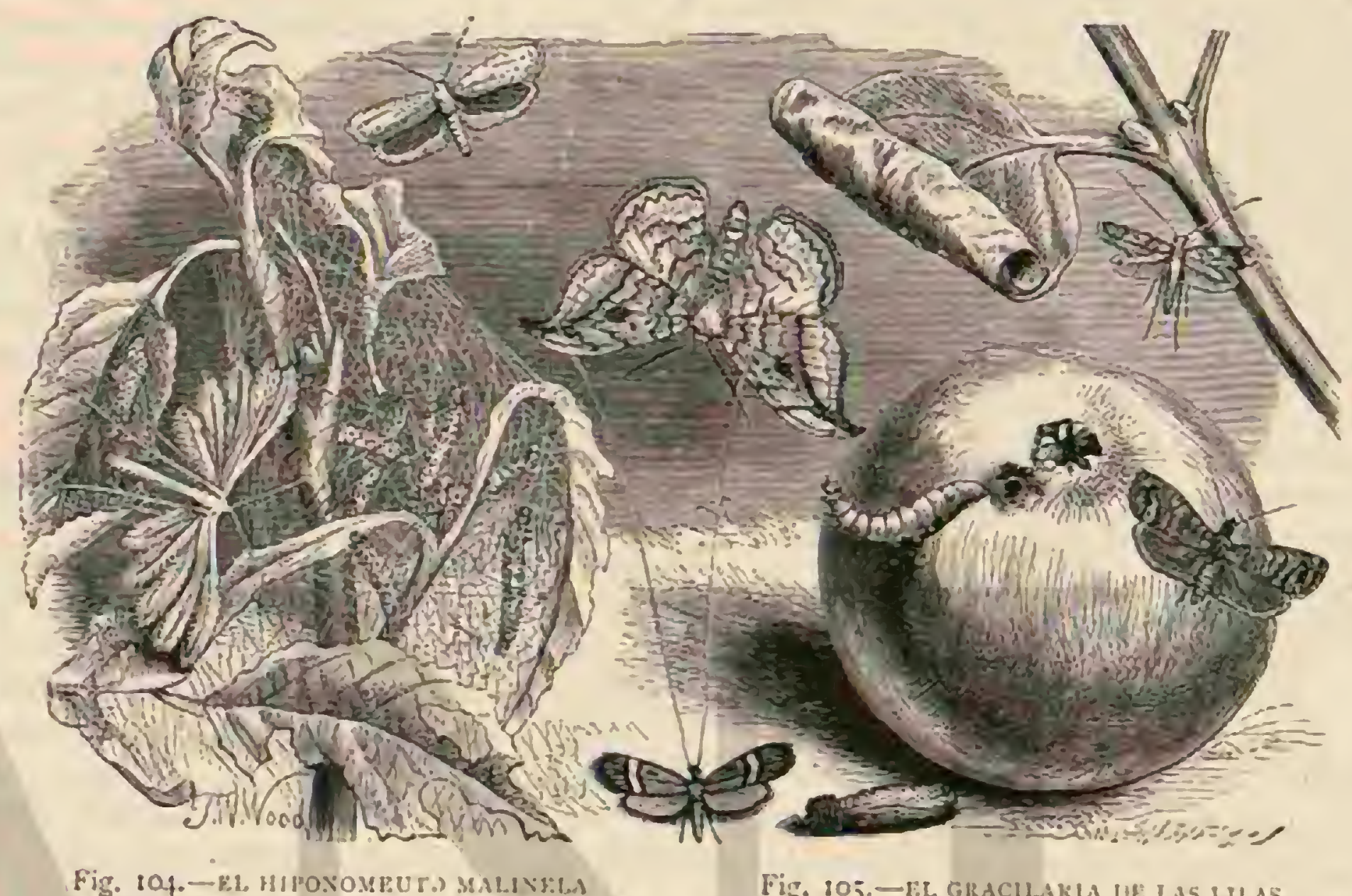

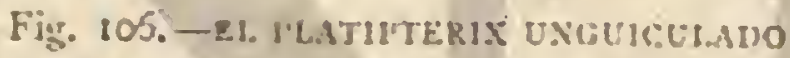

Fig. 107. - EL THES HORO HESTMU.ICTILO

Fig. 1OS. EL rHLALAS POMOS.

Fig. 109. - Y.L ADELA DEGFRELA

USOS, COSTUMBRES Y REGIMEN. - ESta especic se desarrolia de los llamados gusanos de los guisantes verdes. Ias diez patas que tiene la oruga, de un verde palido oscuro, el escudo de la nuca, la váliula anal $y$ las patas torácicas, demuestran sin embargo que no es gusano. Cuando álcanza una longitud de $U^{\prime \prime}, 00 S_{75}$ baja al suclo jara fabricar un capullo é inverna, pero hasta la primavera siguiente no se tmaforma en crisálida, $y^{\circ}$ en mayo sale la mariposa, que cn el tiempo de la florescencia visita los campos de guisintes yentejas. Aqui se verifica el apareamiento, y la hembra fe. cundada deposita sus huevos aisladamente en la base de las flores ó en las frutas muy tiernas.

\section{EL GRAFOLITO DE MANCHA SEMILUNAR - GRA PHOLITHA DORSANA}

CARACTERES.-Fsta especie ofrece el mismo aspecto que la anterior $y$ solo tiene además una mancla blanca semilinar delante del disco. Es un poco mas grande que da anterior y su oruga de un amarillo de naranja; tambien resaltan en ella menos làs vërruguitas, cada una de las cuales se halla provista de una cerda.

USOS, COSTUMBRES Y REGIMEN. - Fl gratolito de mancha semilunar parce menos conun que su congénere anterior. Las orugas de ambas especies atican !os guisantes, ocasionando considembles estragos cuando se presentan en gran número.

\section{EL GRAFOLITO DE LAS FRUTAS-GRAPHO- LITHA POMONELLA}

CARACTERES. - I AS alas anteriores son de un gris a\%. lado, con linens trasversales de color pardo y una mancha pardo oscura, orillada de rojo dorado y limitada hácia la base por un negro intenso. Las ains posteriores, de color pardo rojizo, tienen brillo metálico amarillento y franjas grises.

\section{EL GRAFOLITO DE LOS CIRUELOS-GRA- PHOLITHA FUNEBRANA}

CARACTÉRES.- Ista especie es mas pequeña fo de colores mas oscuros que los de la anterior.

USOS, COSTUMBRES Y REGIMEN. - IA OrUEa de la primer especic, que tiene igualmente die\% y sejs piés, es de un color sonrosado pálido ó amarillo rujizo, mas claro en cl vientre, con las verruguitas y la vilvula anal grises; las primeras estan provistas de largas cerdas. Ataca las nunzanas y peras, pero mas bien busca las pepitas que la carne. Los huevos se depositan en las frutas medio maduras y las manchitas negras indican el sitio por donde ha penetrado la oruga en el interior. Esta emernda se ensancha mas tarde para sacar los excrementos; solo en las especies de frutas en que li cápsula de las semillas es muy grande hay lugar para los excrementos, de modo que por fuera no se nota la presención 
de la oruga. Ins manzanas y peras picadas llegan antes á la madure\% y caen medio verdes de los irboles. En las frutas jue maduran muy pronto la oruga perece por lo regular, porque al comerlas se la encuentra y se la arroja antes de ser adulta; pero en la fruta de invierno, que se guarda en las despensas, sale por fuera, fabrica un tejido y se trasforma por mayo en crisálida, naturalmente sin haber vuelto á tomar alinento. Otras muchas orugis se metamorfosean al aire libre, con preierencia debajo de la corteza del respectiro árbol ó del musgo y los liquenes. Solo en los arboles trutales bien cuidados no encuentra un escondite para pasar el invierno, y entonces lo busca en el suclo. Cuando en el perio. do de su emigmaion están los troncos provistos de frjas de alquitran, reúnense muchos individuos dehajo de los mis. mos y fabrican sus tejidos blancos y-aplanados en in cara inferior de aqueltas. Iista circunstancia caflica cómo esas orugas pueden quediar cogidas en gran núnero. Al efecto solo se ha de tener cuidado de que en seicmbre no faten eı Jos árboles las citadas fajas; alli dondé no se necesitan contra las orugas de los geométridos basta poner trapos, de. bajo de los cunles se reune una inninidad de insectos, que despues pucden matarse todos á su tiempo.

La otra esplecie, el grablito de los cimiclos, escrasea bastante, aunque sú oruga habita muchos años en la mayoria de los ciruelos de cuya carne se alimenta, convirtiendo á menudo la mitad de la fruta en repugnante depósito de excrementos.

\section{LOS PIRALIDOS PYRALIDE}

CARACTERES. - I a jamilia de los piralidos comprende los microlepidópteros nias grandes, à la vez que los mas pequeíos, por lo cual ofrecen muclia menos uniformidad en il aspecto exterior que la familia precedente. Los caractéres generales se fundan sobre fodo en la direccion de los nervios de las alas Las anteriores, prolongadas y triangulares, culentan de once a doce, mas veces de nueve a diez; el 4 i's nacen uno cerca de otro, of en ur tallo comun, en el ángulo posterior ie la celda discoidica, y el 9 y 8 del 7 cerca del ángulo anterior. La distribucion desigial de los nervios 3 a 8 y sobre todo el mayor intervalo entre los 5 y 6 , distingue á los piralidos de la familia anterior $\xi$ de las dos siguientes. Además tienen alas con celda ciiscoidea no dividida; las posteriores, mas anchas, tanbien sin division, carecen dé la celdilla intercalada y tiener una cerda prensil; cuéntanse tres nervios dorsales libres y otros sicte, raras veces scis ó cinco. Las antenas son cerdosas; los ojos, desnudos, subresalen por lo regular en forma hemisférica; los ojuelos casi nunca faltan, $y$ deben buscarse por lo regular nuy cerca $y$ detrís de la base de las antenas. Los palpos varian mucho en tamano, forma y direccion; en general hay palpos maxilares ó secundarios, que tienen cuando mas tres artejos. I as orugas de los piralidos no difieren por su aspecto exterior ni por su género de vida de las de los tortricinos; son las que por lo regular invernan, haciendolo raras veces la crisilida, y nunca, segur parece el huevo ó la mariposa.

La familia se divide en una serie de géneros (p)ralibida, botide, chibnida, crambida, fhyride y grllerida) de los que describiremos alguno con pacos representantes.

\section{LOS PIRALIDIDOS-PYRALIDIDE}

CARACTERES. - Este primer género solo comprende trece especies alemanas y se distingue por dos nervios en las alas amteriores de los que el uno no es ahorquillado; el i se desvia del $S$; el nervio trasiersal es recto ó ligeramente encorvado; la celda discoidea es cerrada en las alas posteriores, y los palpos son iguales en ambos sexos. Encontramos algunas especies en nuestras casas, porque las orugas de las mismas no se alinentan de sustancias vegctales vivas.

\section{EL PIRALIS POMONA-PYRALIS POMONA}

CARACTERES. - Las alas anteriores son de un color amarillo claro con visos dorados; las inferiores de un tinte gris pardusco, con una franja mas clara. En la mayjor parte de las hembras, las listas de las primeras alas se pierden y dividen en manchas poco interrumpidas, ú bien se confunden enteramente con el color del fondo. Esta mariposa (fig. 10S) mide solo 96 so lineas.

DISTRIBUCION GEOGRÁFICA.-Esta especie habjta en el Cabo de Buena Esperanza.

\section{LOS HALIAS - HALIA}

CARACTERES.-Los insectos que forman este género Se caracterizan por tener los palpos mas cortos que el som. brerete; trompa salientey alas redondeadas.

\section{EL HALIA V-HALIA WAVARI}

CARACTERES.-Se ha dado à-este lepidoptero (figura 98) el nombre especifico que lleva por tener en las alas superiores unas manchas de un pardo oscuro que forman una figura semejante a la V. Fil color predominante de este lepidóptero es un blanco agrisado, con manchas pardas oscuras,

DISTRIBUCION GEOGRÁFICA.-Esta mariposa es bastante conocida en América.

\section{EL AGLOSO GRASIENTO-AGLOSSA PIN- GUINALIS}

CARACTERES. - liste piralidido tiene las alas de un gris rojizo con brillo sedoso; las anteriores presentan manchas en forma de faja trasversal, y otms hlanquizcas en forna de dados: las alas posteriores, de un solo color, se distinguen por tener unas franjas muy largas; la lengua falta, pero no los ojuelos; los palpos, salientes, están provistos en su parte inferior de cerdas y rematan en un artejolevantado, desnudo y cilindrico; los palpos maxilares son pequeios y filiformes. l.as antenas del macho se distinguen fácilmente de las de la hembra jar tener unos finos mechones de pelos; su extremidad abdominal tiene igualmente un mechon de pelos en rez. del taladro muy extenso de la hembra. I a mariposa mide de $0^{m}, 022$ a $1{ }^{\infty}, 030$ de punta a punta de ala.

USOS, COSTUMBRES Y REGIMEN.- En Marzo y abril, unas cuatro semanas antes del nacimiento de la mariposa, preséntase á veces la oruga, que tiene diez. seis patas y es de color pardo brillante. Se encuentra en las paredes de las despensas ó en algun rincon empolvado, ocupada en buscar un sitio conveniente para crisalidarse. Hasta entonces ha vivido oculta, alimentándose de manteca y de tocino, por lo cual prefiere habitar en las desjensas.

Desde los tiempos de Linneo, (1̧ue hablaba ya sobre el particular, se observaron varjos casos en que un hombre vomitó hasta siete individuos adultos de esta oruga. Fl fenómeno es bastante catraño, y vale la pena de estudiarle cuando haya ocasion, pues nadic ha podido dar hasta ahora una explicacion aceptable. 
LA ASOPIA DE LA HARINA - ASOPIA FARINALIS

CARACTERES. - Este piralidido, semejante á los geométridos, tiene las alas anteriores de un pardo aceituna con dos lineas trasversales irregulares de color blanco, que limitan un ancho espacio central amarillo; en las alas posteriores, que son grises, se reconocen tambien los restigios de dos líneas serpentineas claras. Los palpos erguidos, tienen escamas lisas y rematan en forma de hilo; la lengua existe, pero los ojuelos faltan.

USOS, COSTUMBRES Y REGIMEN. - La oruga vive en la harina. La mariposa tiene la particularidad de encorvar el abdómen en forma de ano hảcia adelante ciurante el reposo, como lo hace tambien un geométrido blanco con una fa. ja parda (cidaria ocellata). Vuela desde julio hasta sctiembre y se encuentra tambien al aire libre, porque su oruga no solo se alimentia de harina, sino tambien de la fécula contenida en los granus y de la paja.

Las orugas de este subgénero parecen despreciar en general el alimento vegetal fresco. Asi, por ejemplo, hace algunos años encontré en el bosque una copa de encina completa. mente seca y en ella un gran número de orugas pardo-negruzcas, de las cuales obtuve la graciosa asopin glanciralis.

\section{LOS BOTIDOS-BOTYS}

CARACTÉRES. - Esté género, muy rico en especies, de las que mas de ciento son propias de Europa, comprende los tipos del segundo grupo, que solo se distingue del anterior por la separacion de los nervios i y 8 en las alas anteriores. las especies, distribuidas en sumerosos subgéneros, ofrecen por su aspecto exterior mucha semejanza con los geométridos.

USOS, COSTUMBRES Y REGIMEN.-Muchas especies, sobre todo las pequeiras de color oscuro $y$ hasta negro, con dibujos blancos, vuelan solo cuando hace sol, se posan en terreno arenoso con las alas medio extendidas y buscan las flores por su miel, pero muéstranse siempre timidas y se dejan coger fácilmente. Otras especies, sobre todo blancas con lineas amarillas ó pardas en las alas, se encuentmn en los alrededores de los estanques y charcos donde abunda In vegetacion; vuelan al comenzar la noche en esos sitios, porque las plantas acuáticas ofrecen el alimento a sus orugas.

La mayoria de las especies, y entre ellas la mas grancie de todo el género, de color claro, ó mas bien amarillo, son mariposas nocturnas: descansan de dia oculzas en la espcsura, pero aléjanse cuancio se las inçuieta para buscar otro escon. dite. Algunas especies perjudican por sus orugas en ciernas circunstancias nucstros camṕos cultivados; pero entre ellas no se cuenta el botis del trigo (boty's frumentalis), como podria suponerse por su nombre: pues su oruga se alimenta de diversas cruciferas, que como mala yerba crecen en los cam. pos de trigo.

\section{EL BOTIS DE LA COLZA-BOTYS MARGA- RITALIS}

CARACTERES. - Este bótido tiene las alas anteriores de un amarillo de azufre sucio, con dos fajas interrumpidas trasversales, mas ó menos marcadas de amarillo de orin, y una linea oblicua de color pardo en la punta; aciemas tiene franjas del mismo color con inezcla de gris. Las alas posteriores, de un amarillo de paja brillane, son cortas y anchas, presentando una linea de color pardo de orin en el borde $y$ en el ángulo interior, $y$ una mancha gris parda $\mathrm{cn}$ las tranjas, que ofrecen un ligero viso gris. La frente, redondeada, es mas estrecha que los ojos y tiene ojuelos. Los palpos son cortos, provistos de escamas redondeadas; los maxilares son largos $y$ filiformes.

USOS, COSTUMBRES Y REGIMEN. - Fn junio $y^{\circ}$ julio estas mariposas vielan de noche por los campos, y la henibra fecundada deposita los huevos en los frutos de la colza, en cierta yerba (thlaspi), y en una esperie de mostaza (iberis). La oruguita se alimenta de las simientes abricndo en la fruta varios agujeros, de modo que esta puede adquirir el aspecto de una flauta. Ia oruga adulta puede alcanzar en setiembre un tamaño de $0 "$ ", or 75 de largo je es de un verde amarillo con cuatro series de verrugas de un pardo negruzco y una linca de puntitos oscuros sobre los estigmas; la cabeza y el escuda collar, divididos por tres líneas longitudinales, son negros.

En tierra fabrica un capullo sedoso é inverna en él como nriga. Algunas semanas despues, veintiseis dias antes de presentarse la marjposa, es decir en mayo, efectúase la meiamorósis. La crisálida, de un rojo amarillo, es mas ancha en el centro; la cabeza, puntiaguda en la extremidad posterior, está provista de un ancho estilo anal.

\section{EL BOTIS DEL MXJO-BOTYS SILACEALIS}

USOS, COSTUMBRES Y REGIMEN. - La oruguita de este bútido, semejante a la de la esprecie anterior, vive en los tallos del mijo, del lúpulo ó del càñmo, y puede perjudicar estas plantas.

\section{LOS CRAMBIDOS-CRAMBIDE}

CARACTERES. - 1.os palpos labiales son largos y están dispuestos horizontalmente como una trompa, apoyándose sobre ellos los maxilares en forma de pincel. Las alas anteriores, largas y' estrechas, tienen doce nervios, rara vez once, y el primero no es ahorquillado; en muchas especies se dis. tinguen por líneas longitudinales of manchas en forma de cuña, de color blanco sobre fondo mas ó menos oscuro, o por lineas de un brillo netálico y franjas en la orilla. L.as alas posteriores, muy anchas, y de un solo color gris, han de plegarse para que las anteriores puedan cubrirlas; su celda discoidea es abierta y en la base tienen un nervio central posterior provisto de pelos.

USOS, COSTUMBRES Y RÉGIMEN.- Estos piralidinos se encuentrm todo el verano en las jraderas y en los charos de bosque cubientos de jerba; huyen cuando se les itrqunieta para ocultarse de nuevo a cierta distancia; cuando reposan, las alas cubren como un manto el delgado cuerpo, $y$ llegada la noche comienzan á volar.

\section{LOS FICIDOS-PHYCIDE}

CARACTERES. - Este género se parece exteriormente mucho al anterior. Sus especies se distinguen por la celda discoider cerrada en el ala posterior y por tener menos nervios $(\mathrm{r}, 10.8 \mathrm{~g}$ ) en la anterior; los nervios 7 y s son pedun. culadós b́ se reunen del todo, mientras que la base del nervio central de las alas posteriores está cubierta de pelos. Los machos se distinguen muchas veces por unas formas particulares en la base de las antenas y por la figura diferente de los. palpos maxilares: en la hembra son de estructum regular.

USOS, COSTUMBRES Y REGIMEN.-Muchas especies descansan de dia del nismo modo qque los crambidos en. la yerba, en el follaje de las encinas ó en diversos arbustos. 
del bosque, pero solo se divisan cuando se sacuden los airbo. les obligándolas a huir ó a caer. Su género de vida es nocturno.

\section{LA GALERIA DE LA MIEL-GALLERIA MEL- LIONELLA}

CARACTÉRES. - Antes de concluir con los piralidinos haremos mencion de la galeria de la miel, especie del último género p̧equeño, que se distingue por los caractéres siguientes: los palpos del macho son cortos y rematan en un artejo puntiagudo, hueco y desnudo, mieneras que en la hembra están provistos de escamas y sobresilen de la cabeza. En el ala anterjot se encuentran 12,1 i $u$ lo nervios, de los que el I es ahorquillado en la base y el z y s pedunculados. En el ala posterior el nervio central posterior es peludo en la base; la celda discoidea estí cerrada del wodo ó solo en $5 u$ mitad posierior.

En la citada especie las alas anteriores, de un yris ceniciento, tienen el borde interior de un amarillo de cuero con man. chas de un pardo rojizo, este borde ess córto y ligeramente ondulado, con el angulo interior agudo: las alas posteriores del maclio son grises; las de la hembra, mas grande, blanquircas; la base del pié está provista en ambos seros de un diente éscanroso blanco.

USOS, costumbRES Y REGIMEN. - I A mariposa se presenta dos veces al año. en la primavera y despues des. de julio. la oruga, de color de hueso, tienc diez y seis patas: la cabera y cl escudo de la nuca son de un pardo castano, mas claro enla válsula anal; en cl segundo y tercer segmento hay unas verruguitas amarillas, con cerdas pareadas, reunidas en una especic de corona; en los otros segmentos se ruentan ocho de estas verrugas en cada uno. Esta oruga vive en las colmenas de la abeja, sobre todo en los panales viejos de cria; a veces ataca tambien los que cstán llenos de miely se alimenta de la cera, en la que abre galerias, indicando su camino por un tubo compuesto de un ligero iejido. Se han obenido ya mrias crias, alimentando la una con los érérementos de la anterior, cuya sustancia no parece diferir mucho de la cera Reaumur la alimentó muchus anos con cuero, trapos de lana, hojamsca, papel, ctc. Fs activa sobre todo de noche, debiéndose temer mas entonces sus ataques contra las abejas; podria destrozar toda una colmena si no se pusiera coto. I.a última cria inverna como crisálida en un tejido espeso, prolongado, de los que por lo regular se encuentran varios juntos. En este tejido permanece la oruga cuatro semanas antes de trasformarse en crisálida pirdo amarilla, aquillada en el dorso. Cuando esta ha descansado unos dicz y ocho dias st jresenta en mayo la mariposa que con agilidad se aleja á la carrera pam esconderse cuando la hiere la luz cel dii.

\section{LOS TINEIDOS - TINEIDE}

CARACTERES. - La mitad mas numerosa de codos los microlepidópreros se ha reunido en la familia de los tureidos que sin embargo no permite una descripcion general a causa de la gran diversidad en el aspecto exterior y género de vida de sus especies. Figurímonos los tipos primitiros: ustos tienen las alas estrechas yo puntingudas en forma lineal ó de lanceta, y sus franjas, muy largas, comunicanles un contorno semejante al del ala de mariposa. Enll cstado de reposo se agachan, cubren el cuerpo con las alas a manera de tejadillo, y entonces las largas franjas sobresalen á menudo en figum de cresta; otras especics se envuelven el curerpo como con un manto. Ias alas posteriores suelen ser de un color unifor- me, de ordinario gris y poco vistoso, en tanto que las anteriores, a menudo de colores vivos con magníficos dibujos de un brillo metálico, distinguen a los tineidos como las mas lindas mariposas. Desgraciadamente, esta belleza se sustrac à Ia vista á causa de la pequerie\% del insecto, no manifestándose en toda su magnificencia sino cuando se le mira con un anteojo. Las mas tienen antenas cerdosas de mediana longitud, ó a veces muy largas, pues en algunos machosalcanzan varias veces la largura del cuerpo, y en algunas especies presentan magnificos dientes. Los palpos suclen estar bien desarrollados y ofrecen muchas variaciones por lo que toca a la direccion y los pelos del artejo terminal, siendo por lo mismo de la mayor importancia como carácter distintivo; los palpos maxilares estan tambien muy desarrollados y sobresalen no rablemente. Jos pelos de la cabeza han de tenerse en cuenta, observándose si forman mono, mechones, ó si son lișos, asi como no deben olvidarse los del dorso y todos los detalles anílogos que solo no pasan desnpercibidos al ojo práctico, para poder distinguir con seguridad los numerosos géneros y las especies mas numerosas codavit. Anádase a esto la circunstancia de que en el ala posterior la vena $S$ está separada y se desvia de la séptima; que los tarsos posteriores ajenas son el doble mas largos (que sus muslos: que los ojos son desnudos, y que el último artejo de los palpos siguc la misma direccion que el principal, con lo cual tendremos los distintivos mas principales para el reconocimiento de un tineido.

USOS Y COSTUMBRES. - Esta variedad de forma en el asperto exterior de, las mariposis depende de la oruga, que tiene catorce $\delta$ diez y seis tarsos y de su método de vida. Unas permanecen unidas on un gran tejido; con el que rodenn ramas cnteras y pequenos arbustos como con un velo; otras envuclien rarias hojas ó una sola y se mueven en la galeria que de este modo se forma, siempre dispuestas á ba jar jor un hilo si se ven amenaradas de algun peligro. Ciertos coleóforos viven en una especic de concha que forman con el serrin de la planta que los alimenta, lievanclola consigo como el caracol; estas conchas pucden ser muy miadas, tanto por su figura como por su coloracion. Muchas viven a manera de mineros entre la piel superior é inferior de una hoja, practicando galerias especiales que adquieren como es natural un color especial, resaltando de este modo facilmente a la vista; alli se convierten tambien en crisálidas (Lithoro. lletis), o abandoman la galcria para hacerlo en el suelo ó construyen tambien un tejido en la parte externa de la hoja, en tanto que otras perforan simplemente las mas diversas plantas. Estas indicaciones bastarản para darnos una idea de Ia variedad de la vida de esas pequeñas mariposas, que han tenido illtimamente mas aficionados que antes.

No podemos tratar aqui detalladamente ni siquiera de los rasgos caracteristicos de algunos géneros, debiendo limitarnos a describir brevemente algunas especies de interés general, aunque una gran serie puede llamar muestra atencion por los estragos de sus orugas.

\section{LA POLILLA-TINEA}

CARACTERES. - En la especie fires de la clasificacion de los modernos papiliólogos sobresalen mucho los muy desarrollados palpos maxilares compuestos de cuatro â siete artejos; el sergundo artcjo de los palpos labiales se halla re. restido de cerdas en su extremidad; la lengun esta atrofiada; la cabeza se caracteriza poi su gran mechon de pelos y por su falta de ojuelos. Ias antenas, cerdosas, no alcanzan la longitud del ala anterior, ugue es prolongada y puntinguda, contando doce nervios, de los jue el tercero, cuarto ja quinto 
estan separados y el sćptímo desemboca en el horde anterior. El ala posterior se prolonga casi en forma de lanceta y tiene escamas y largas franjas.

Varias especies viven en nuestras casas.

\section{LA POLILLA DEL TRIGO-TINEA GRANELIA}

CARACTERES.-Es perjudicial en estado de oruga para el trigo de los graneros. Ia mariposa, que mide $\|^{n}, \mathrm{I}_{3} \mathrm{de}$ largo puede verse durante el mes de junio por todas partes. Yo la crié con hongos de encina y de los frutales. Sus alas anteriores en forma de lanceta obtusa, son de un blanco pla. teado con manchas de un pardo oscuro y hasta negto. Las franjas y bordes parecen mezclados con un color oscuro y la mancha mas grande se corre de ordinario desde la mitad del borde anterior, en forma de faja, hasta el angulo interno. I as alas posteriores son de un gris blanco lustroso homoge neo. Sus antcnas, negras y filiformes, alcanzan poco mas of menos dos tercios de la longitud de las alas anteriores; sus palpos cilíndricos son rectos y sobresalen poco del moño de la frente. En los tarsos, de un gris azulado, la falange inferior tiene dos pares de espólones de color blanco platerdo; los de los posteriores están revestidos de largos pelos blancos.

USOS Y COSTUMBRES. - Estos insectos se aparean apenas nacen, $y$ la hembra busca luego con preferencia los graneros, si es que no ha nacido en los mismos: pone de uno a dos huevos en un grano, sin cuidarse de qué clase es. Hícia mediados de julio termina este trabajo y lo paga con la vida. Alli se pueden ver numerosos cadítveres suspendidos de las telarminas. Al cabo de die\% a catorce dias nacen las

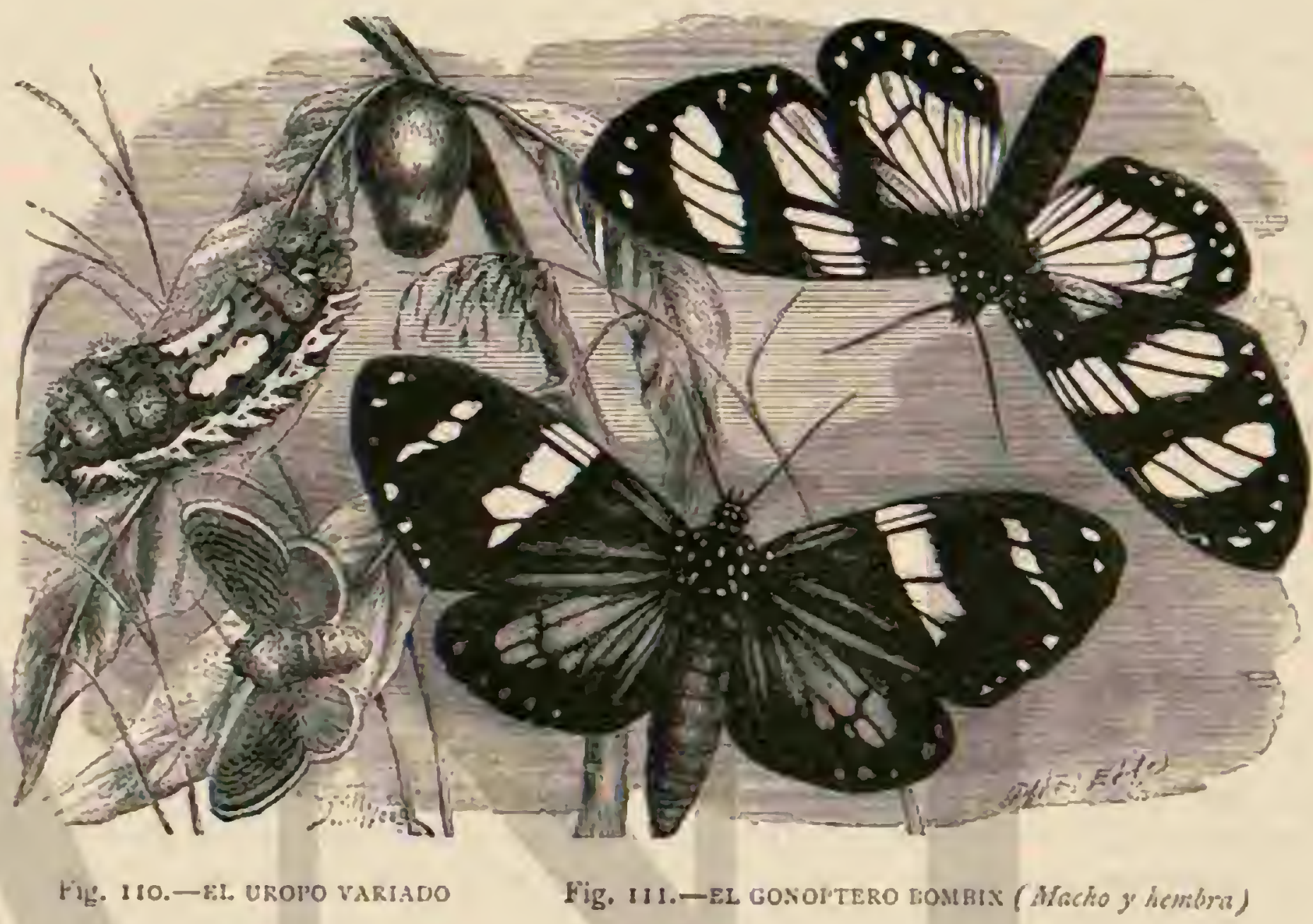

orugas, y en la tiltima semana de julio se las ve ya en los pequenos montones de estiércol, adheridas i los granos que roen y en grupos de tres 6 cuatro. Noo se limitan à un grano sino que corroen varios, uniéndolos luego con un tejido, bajo cuyo amparo comen descle fuera. La oruga es de color de cuerno, la cabeza y el escudo de la nuca mas oscuros, tic. ne 16 patas 5 alcanza una longitud de unos $0^{\circ}$, oro. A tulti. mos de agosto ó á primeros de setiembre comienza a inquietarse, corre de un lado a otro entre el trigo, dejando por todas partes hilos sedosos y busca un sitio conveniente para trasformarse en crisálida. Encuéntralo tanto en los granos vaciados como en las grietas de las vigas. En el capullo que forma con los residuos de las sustancias que ha roicto permanece hasta la primavera, y luego se convierte en larva, de un amarillo pardusco, cuya cabeza remata en punta obtusa. I os tejiclos se encuentran a veces enlazados en pequeños grupos.

- Dé las orugas de la polilla sabemos que causan estragos en nuestras habitaciones, en sitios donde no se las inquieta, como armarios, sillas y sofás tapizados, y cajones donde hay ropa de lana, asi como en las colecciones de historia matural, excepto las gcológicas. Alli donde abundan cuélganse en invierno de los techos, envueltas en pequeñas bolsas, donde se convierten luego en crisálidas. Se presentan dos especies mezcladas; una de ellas, la Tivera pellionella, de un amarillento lustroso como la seda, tiene en las alas anteriores uno o dos puntos oscuros en el medio, los que pueden no obstante faltar; la pelusa de la cabeza es de un amarillo de arciIla, y lits alas posteriores de color gris con un brillo amarillento. Fsta especic, la mas pequeña, micie de $0^{n}$, or I a $11^{m}, 0175$. In otra especie que tiene de $0=015$ i $0^{\mathrm{m}}, 022$, es la Tined tapetzella cuya pelusa es blanca en la cabeza; las alas antc. riores de un pardo violeta en la mitad basilar y luego de un blanco amarillento, adornadas en la punta con una mancha gris; las alas posteriores, grises tambien, tienen brillo anarillento. Esta especie reside preferentemente en los objetos de peleteria y en las pieles de los animales embalsamados. Ambas mariposas vagnn en los meses de junio y julio, y como ya se comprenderá se debe perseguirlas por todos los me. dios, pero de ordinario es dificil cogerlas, pues se ocultan con mucha rapidez. Asl que se ven las mariposas, es preciso poner la ropa todo lo posible á cubierto de las hembras que quierén poner, sacudir los colchones y con frecuencia los vestidos. Si se trata de articulos de peleteria se debe ante todo ventilarlos, envolverlos en un paño de tela, coserlos y esparramar polvo insecticida, guardandolos en un sitio bien cerrado ó ventilado. El olor de trementina y de todas las sustancias que la contengin, asi como los aceites minerales, repugnan a la polilla $y$ a todos los insectos, siendo por lo mismo el niejor preservativo indicado. En los rincones oscu. ros y polvorientos prosperan si hay en ellos objetos de lana ú otros alimentos convenientes. Esto era sabido ya de los 
antiguns: Aristótcles dice que los objetos de lana crian insectos, sobre todo si estín encerrados donde hay uma araña, poriue esta seca los objetos absorbiendo toda la liumedad de la lana. Hoy dia pensariamos que la arrina chupa la polilla.

\section{LA ADELA VERDE-ADELA VIRIDELLA}

Entre los variados recreos que encuentra el naturalista en la primavera al cruzar por un bosque frondoso, uno de cllos es contemplar las diferentes evoluciones de cierta jolilla que tiene la cabeza y los tarsos revestidos de una pelusa negra y un brillo verde metálico oscuro en las alas anteriores, espe. cie llamada adela serde (Adeli arividella). En las matas be visto revolutear centenares de estos insuctos com sus antenas levantadas perpendicularmente, mas notahles en la hembra porcute exceden bastante de la longitud de las nlas iniclicnalo en el macho mas del doble de las mismas. Durante el dia hasta la puesta del sol permanecen sobre las hajas de las encinas, formando grupos tan apiñados como lo permiten las largas antenas: llegada la noche dispérsanse en parcjas y se ocultan entre el follaje. En cicrtos años cstas mariposas abundan/mucho, encontrándoselas reunicha duraute las horas de sol por la tarde; en el resto del dia estin posadas sobre las hojas y mueven las antenas á compás. ú bien, como se ha observado con otros congéneres, visitan las fores y liban el néctar que constituye su régimen.

In adda degrela (fig. 109), especie parecida i la anterior, se distingue por su color rojizo y el brillo de sus escamas.

\section{LOS HIDROCAMPAS-HYDRO- C.AMPA}

CARACTÉRES.- los hidrocampas son lepidópletos de antcnas filiformes $\mathrm{y}$ algo pubescentes; palpos labiales muy jróximos en la hase; los maxilares bien mircados; trompa cielgada y corta; alas enteras; las inferiores simuadas ó mas an. chas que las supxriores. Los dos sexos se asemejan.

las orugas, lisas y lucientes, tierien colores opacos.

DistribUCION GEOGRÁFICA. - En Europa esti bien representado este género, y en la India se encuentran asimismo varins especies.

USOS Y COSTUMBRES. - Ias orugas de estos lepidópteros acostumbran it ocultarse debajo de las hojns que sobremadan en la-superficie de las aguas.

\section{EL HIDROCAMPA NINFA-HYDROCAMPA} NIMPHASA

CARACTERES. - Las alas superiores de esta mariposa (figura 90) son de un pardo cancla, ron manchas de un blanco puro; las inferiores son blancas, ofreciendo tambien man- clins irregulares.

DISTRIBUCION GEOGRÁFICA.-Inespecie es muy comun en Europa.

Usos X COSTUMBRES. - El hidrocampa ninfa frecuenta las orillas de los rios y de los arrojos, asi comn tamhien de los estanques: se le ve durante los meses de junio y julio.

Otra especie, el hidrocampa dispar (fig. 92), difiere algun tanto por sus colores; el maclio es de un tinte pardo negru\%$\mathrm{co}$, y la hembra de un gris blanquizco: en las alas superiores de ambos sexos se ven cuatro fajas trasversales de un matiz. pardo claro, y una mancha de un color mas intenso cerca del borde de la frente.

\section{EL HIPONOMEUTO MALINELA - HYPONO- MEUTA MALINELLA}

CARACTÉRES. - Este insecio mide $0^{\prime \prime}$, org y su rolor predominante es blanco, con un brillo scdoso. En las alas anteriores hay tres series longitudinales de puntitos negros, unidos con algunos otros cerca de las franjas del borde; las alas posieriores, blanquizcas en la raiz, tienen franjas de un gris claro homogéneo: y el abdómen es del mismo color (figu. m 104).

USOS Y COSTUMBRES. - A últimos de junin ó primeres de julio esta modesta mariposa sale y se josa de dia en los manzanos, pero por la tarde raga de un lado a otro si hay cntre las ramas tejidos ligeros. Fn tal sitio vive la oruga, que es de'culor gris pardusco con verrugas negras:al principio sc la re a través de unos delicados velos, semcjantes á las telas de amia, con los cuales envuelve las hojas que ha elegido para su alimento. Como se ponen varios huevos juntos y las orugas viven en comunidad, puede suceder que ramas ente. ras ce un manzano estén envucltas por el velo, dentro de] cual desajarece poco i poco el rerde de las hojas, no que. dando sino el usqueleto. Si las orugas, que se agitan vivamen. te en el nido, no están entregadas al reposo, como suele suceder despues de cada comida ó cuando nudan la piel, y se ven ameniazdas de algun ataque, cada cual se deja cner inmediatamente susprendida de un delgndo hilo, para huir à rápidos pasos por el suclo. Así que son adultas se encierran apiñadas en su tejido, el cual contiene en un monton varias bolsitas pegajosas, a través de las quue se ven las crisálidas, de color amarilió rojiro, tantas como orugas existian antes. Ias hembras fecundacias ponen sus huevos en la corteza de una rama, en montones oblongos. Segun se asegura, lís larvas salen al caho de unas cuatio semanas; pero como se las ve siempre en la edad adulta y a través del tejido, inclinome a creer que los huevos invernan. Vo he criado esta especic cn una mata de cspino negro. Otras viven en diversos arbustos, cuy'as ramás están a reces completamente deshojadas y del todo cnvueltas en los tejidos de estas orugas.

\section{LOS DEPRESARIOS - DEPRESSARIA}

CARACTÉRES.-Estos insectos representan entre las polillas al genero agrotis (Agrofis) por sus colores mas oscuros y alas planas, que se apoyan sobre el abdómen, muy conprimido; las anteriores son anchas y muy redondeadas ó truncarias en la parte posterior, mientras que las otras presentan una sesgadura en el borde. Sus grandes palpos se juntan y clevan mucho, ocultando una lengua cilindrica bicn desartolladi; en el vértice de su cabèn escamosa hay ojuclos. De las numerosas especies que invernan en estado de mari. posas, viven muchas en el de orugas en las flores y frutas de las umbeliferas, debiéndose considerar como nociva para la agricultura la siguiente:

\section{LA DEPRESARIA NERVIOSA-DEPRESSARIA NERVOSA}

CARACTERES. - Esta-especie, hicmulis daucella de Hubner, ofrece poco interés: tiene las alas anteriores de co. lor pardo gris rojizo: las venas, sobre todo \& lo largo del bor. de. parecen cubiertas de un polro negruzco, llamando la atencion principalmente for presentar un gancho de color claro en el ángulo, cuya punta se corre hicio el citremo del ala y cuyo lado mas largo es casi paralelo con el borde anterios. I as alas posteriores son de un borde gris; el artejo terminal de los palpos esti dos veces anillado de negrurco; $\mathrm{el}$ 
penúltimo, en forma de cepillo, se divide por un surco longitudinal. El ancho de punta á punta de ala es por término medio de 602015 .

USOS Y COSTUMBRES.-Estos insectos salen de sus escondrijos en invierno, mas tarde ó mas temprano segun la tempraratura, y la hembra pone aisladanente sus huevos en diversas plantas, entre las que merece citarse el comino, la ceunnthe aymatica (phillandrium aquaticum) y el sium latifolium. En el comino en flor se reconoce pronto la presencia de la oruga. De ordinario permanece en las umbeliferas, las cuales reune por medio de algunos hilos, devorando las flores y las scmillas tiernats; cuando estas ya no le bastan, toc tambien los tallos tiernos. Se ha dado el caso de que por culpa suya se haya echado a perder la mitad de la cosecha. La oruga, que tiene 16 tarsos, es muy vivaz, se agita con rapidez si la tocan $\delta$ desciende al suelo por un hilo, alejándose apresuradamentc. Lin cautividad sabe introducirse por las rendijas mas estrechns y ocultas. Despues de haber cambiado cuatro veces la piel, ya es adulta, habiendo necesitado desde la salida del huevo unas cinco semanas, si una temperatum desfrvorable no ha retardado su desarrollo. Mide unos $0^{\circ}$, o 5 y es de co. lores bastante abigarrados: una ancha faja lateral de un tinte naranja y los negros conductos acireos dividen el cuerjo en una mitad dorsal de un verde aceitumado y otm abdominal mas clarn; en aquella se se en cada-anillo, emperando por el cuarto, una scrie compuesta de cuatro rerrugas de un negto lustroso, con anillos blancos; sobre el penúltimo segmento hay cuatro, dispuestas en semicirculo abierto haicio adelante; sobre el segundo y tercero se cucutan seis en una linea trasversal. La cabeza, el escudo de la nuca y la vilvula anal son de 1 m nigro lustroso, las dos últimas estain rodeadas de un ribete amarillo rojo: aquella se halla divicida además jor una linea longitudinal de igual color. La mitad inferior del cuerpo se caractcrizat tamlien por varias series de verrngas.

Para convertirse en crisálida periora la oniga la planta yue la ha alimentado, hace un cómodo lecho y tapa el agujero con una cubierta oblicua. Si las orugas son muj numcrosas, se pueden contar trènta ó cuarenta igujeros en un solo arbus. to. Por lo demas, la inquicta oruga no se sobresalta fácilmente, segun he observado en las cautivas. Si no tiene un tallo apropiado para convertirse en crisilida, se encierra en las umbeliferas convenientemente trituradas y entretejidas, como lo hacen muchos congencres, ó bicul to hace libremente en la ticrra. En la época en que se recoge el comino, las orugas se han trasformado en crisálidas en los tallos, saliendo tambien algunas mariposas. En los primeros dias de junio obure y:a varias, procedentes de los tallos perforados que habia recogido. En otro año, en cambio, encontré todavia el 13 de agosto orugas y crisilidas en los tallos del acnanthe nuguticu, obteniendo de estas las primeras mariposas al cabo de dos dias. Asi, pues, las épucis de su desarrollo pueden maiar se. gun los años y las plantas; pero estas experiencias dificimen. te nos autorizarian i suponer que crian dos veces.

\section{LA GRACILARIA DE LAS LILAS-GRACILA-} RIA SYRINGELLA

Hace varios ahos llamó uni atencion en los pastos puibli: cos de'la ciuciad de Halle ha trasformacion de las hojas de los arboles, y despues de haber indagado la caus, lei en las 7.Sesiones de la Academia de Viena que las alamedas y los jardines particulares cran maltratados desde hacia mucho tiempo por un insecto, habiéndose heclso en francia la mis. ma observacion. Este insecto roc las hojas de un árbol $\delta$ ar. busto, las cuales pierden su forma y color natural; despues sc emroscan y al fu parecen quemadas. Ial causante es la dimi- nuta oruga de la especie gracilaria de less lilas (gracilaria syringella) (fig. 105), cujo aspecto solo ofende a la vista. Este insecto, de un verde claro, con I6 patas, vive hasta en grupos de 20 individuos, no solo en las hojas de la lila comun y peršh, sino tambion en las del fresno (Froximuscacelsjor). del Eronjmus europeus, del ligustro (Ligustrun zulgare) y de algunos otros árboles. P'rimero roen la membrama supcrior $y$ lucgo la parte carnosa que se halla debajo; la membrana inferior yueda siempre intacta y se ennegrece poco á poco. Despues de cambiar la primera piel abundoman su galería por la noche; y por medio de hilos consiguen recoger la pun. ta roida de las hojas Al cabo de dicz ó doce dias mudan la pici tres veces seguidas; luego buscan una hoja fresca, la tra. tan como á las otras y al cabo de igual tiempo bajan al suelo donde se convierten en crisalida en un tejido muy delgado. In crisilida, fusiforme, remata en punta obtusa; las antenas y los tarsos prostcriores alcanzan su desarrollo al cabo de 14 dias, y a últimos de junio of primeros de julio nace la mariposa. Esta revolotea por la noche alrededor de las plantas de que se alimenta para aparearse, y luego laxec los prejarativos de una segunda cria, cuyas orugas son las que causan los citados estrngos en las plamtas. Antes de la entrada del invierno se convierten en crisilidas, y en el próximo abril ó majo nacen las mariposas. Cada hembra puede poner por término medio roo huevos.

Esta linda mariposa es de color gris y tiene las alas poste. riores con franjas de igual color, muy largas. Las alas ante. riores parecen cruzadas jor seis fajas trasversales de un rerde plateado, siendo las tres posteriores mas finas e incompletas que las otras. Las antenas, anilladas de gris y blanco, alcanzan la longitud de las alas antcriores; sus palpos labiales, escamosos y delgados, arrancan a manera de sakble de la cabeza; lisa y redonda; su último artejo es puntingudo y mide la mitad de la longitud total; la lengua cilindrica y los palpos maxilares estån bien marcados.

Este insecto toma una posicion inuy curiosa cuando duerme de dia: el cucrpo se eleva oblicuamente y descansa sobre los dos tarsos anteriores, cuyas rodillas forman una linea divergente con la region frontal; los demaís tarsos no se ven porque se ocultan entre el cuerne y las alas El ancho mide por término medio de punta á punta de aia $15,0115$.

\section{EL COLEÓFORO DE LOS ALERCES-COLEO- PHORA LARICINELLA}

CARACTERES.-Esta especic es de color gris cenicien. to, con un lustre sedoso, algo mas opaco en las franjas. Sus largos palpos son ercetiles y alcanzan luasta liz raiz de las antenas, que niden la longitud del cuerpo.

USOS Y COSTUMBRES.-Comparece à primeros de junio en las montañas y en las llaumras de Alemania, donde cncuentra el alerce que le alinenta. Es muy jurobable que ponga los huevos alli donde ha de brotar él. Cuando en la primavera los arboles empjiczan à cubrirse de follaje. salen las jequeñas orugas y se introducen exclusivamente en lits hoias de la coja, cuya mitad terminal toma un color amarillo y sc eriza. No obstante, la orugra no jermanece en el misino sitio, sino que construye con las partes corroidas una pequeña bolsa para recogerse en ella. Es de color pardo rojo, mide unos $11 ", 00.45$ de largo y se caracteriza por su pequein calseza, asi como por sus ocho tarsos abdominales muy peyuchos. Antes de fin de majo es adulta, se adhicre i ma hojn, conviértese en crisilida, y al cabe de dos ó tres sumanas silc la mariposa por la cxtremidad posterior de la bolsa sin llevarse la cubierta de la crisalida. 


\section{LOS TEROFÓRIDOS- PTEROPHORID压}

CARACTŔRXS.-Debemos consagrar aqui algunas lineas tambien á los terofóridos, que constituyen la ultina familia de papiliónidos. Sus alas se dividen en dos largas franjas, de modo que pueden compararse con las barbas de dos plumas colocadas una junto á otra Las alas anteriores suelen dividirse en dos partes y las posteriores en tres, ó en otras especies en seis: no solo esto, sino tambien la diferencia en la direccion de las venas, seria motivo stificiente para separar aun varios géneros de los ýa existentes. El cuctpo, y princi. palmente los tarsos, se prolongan muciso; la cabeza es esféri. ca; la lengua cilíndrica y muy desarrollada; los palpos son salientes y están provistos de un largo artejo central. Los ojuelos pueden existir, pero tambien faltar.

USOS $Y$ costuMaRr.s.- I as ortigns, que tienen I6 patas, viven libremente en las plantas bajas ó arbustos, convirtiendose en crisálidas en icjidos fojos, y tambien en la tierrit.

\section{EL TERÓFORO ALUCITA-PTEROPHORUS}

\section{ALUCITA}

CARACTERES. - Esta especie no tiene ojuclos; las ala anteriores están dividiras desde el primer tercio en dos plumas puntiagudas, jero redondeadas en el angulo interno.

Lis muy numerosas especies fueron clasificadas por 7.eller en varios grupos, segun la direccion de las venas. Una de las especies mas commes y diseninadas es la siguiente:

\section{EL TERÓFORO TERODÁCTILO-PTEROPHO- RUS PTERODACTYLUS}

CARACTERES. - El cuerpo y las alas anteriores son de amarillo gris ó pardo cancla; cstas últimas con manchas oscuras en el borde y en el punto de division. Jas alas posteriores son grises y tienen franjas muy largas en la tercen pluma, carácter que distingue í esta especie del teróforo pardo. Oira especic muy fácil de reconocer es el teróforo pen. tadáctilo (fig. 107), por su color blanco nivco; es una de las especies mas grandes y mas extendidas, que habita en toda Europa, á excepcion del extremo norte. La oruga vise en los campos y en las setas.

\section{LA ALUCITA POLIDACTILA-ALUCYTA POLIDACTYLA}

CARACTERES. - Ias especies cuyan alas adquicren forma de abanico por dividirse cada una en seis plumas lineares hasta la raiz, y que tienen al mismo tiempo ojuelos, se han reunido recientemente para constituir con ellas la familia de los alúcitinos.

L.a graciosa alucita polidactila (Alucita polidactyla) comparte su aspecto con varias especies muy afines. El último artejo de sus palpos se dirige hácia arriba y es igual al pen. último por su longittud los nervios de las alas, de un gris amarillo pálido, presentan rayas trasversales oscuras.

DISTRIBUCION GEOGRAFICA. - In mariposa, que mide $0 \%$, or 3 de punta a panta de ala, está diseminada en la Luropa central.

USOS Y COSTUMBRES. - I a oruga vive en la flor de la madreselva (Lonicero pevidymenum ) en la que sé introduce en la parte inferior del tubo. Donde una ve\% anida se la encuentrn todós los años. En la tierra se convierte en crisálida.
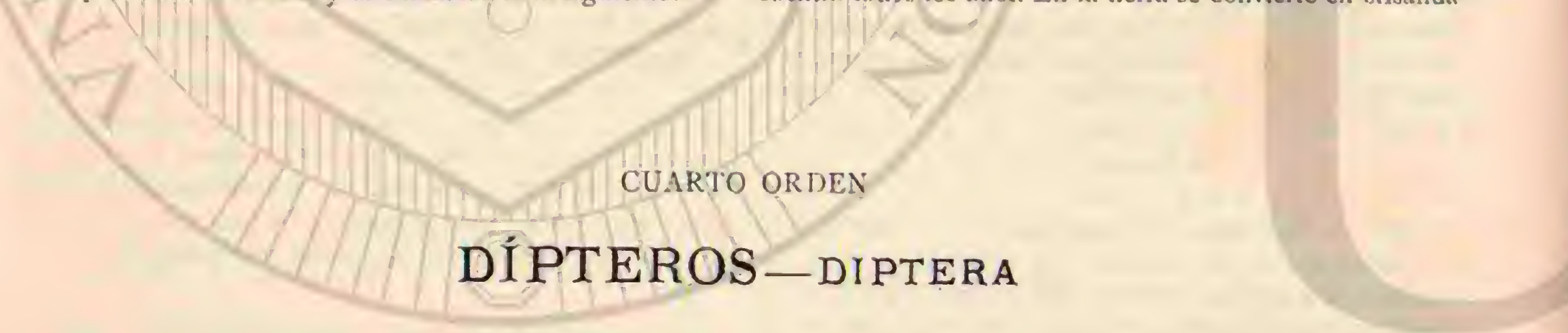

OBSERVACIONES GENFRALES. - Mosi\}uitos y moscas son dos nombres significativos cque parecen producir una sensacion desingradable, porque pensamos primero en los sanguinarios cinifes y luego en la impertinente mosca doméstica que todo lo ensucia. Ia tenacidad y la constancia son en todo cualidades del caracter de estos inséctos; pero de todos modos debemos estudiarlos de cerca, pues tambien perrenecen i lo creado y ocupan su lugar; $y$ asimismo tienen derecho a vivir, aunque no diviètan al rey de la creacion como la abigarrada mariposa ó la abeja que le proporciona su miel. ¿Quién puede olvidar que algunos de cllos nos atacan, eligiendo nuestro semblante para pasearse, mientras que otros consideran como una golosina nuestral sangre?

En la interesante obra de Monfer, que hemos tenido ocasion de citar muchas reces, el autor dedica s. esos insectos cuatro largos capitulos, ocupándose en el primero muy detalladamente de las moscrs, de sus buenas y malas cualidades y refiriendo cosas que maravillan acerca de su origen, pero conservando en conjunto la opinion raxonable. El capitulo mas largo trata de la utilidad de las moscas, fundada en la adivinacion de las cosas futuras, en la curacion de las enfer- medades y en la-alimentacion que proporcionan at otros animales. Cuando importunan al hombre ó at otros séres y vuelan a for de tierra anunrian lluvia ó tormenta. Segun los indios, persas y ergipcios, soñar moscas es presagio de una infausta noticia ó de una enfermedad; el que sueña que se le introducen en la boca ó $\mathrm{cn}$ la nariz ha de sucumbir al enemigo; pero las moscas no solo anuncian las tempestades y las desgracias, sino que curan tambien enfermedades. Algu. nas hay cuya picadura es mortal, fenómeno poco conocido todavia. El capitulo termina citando los numerosos casos en que Dios ha castigado con las moscas a nuchos hombres grandes, asi cono á pueblos enteros, entre los que figuran los egipcios del tiempo de Moisés. En el capitulo XIII trata agradablemente de los mosiquitos y al citar el nombre inglés Canopi (Canapé), lo hace derivar del griego Konopison, cuya palabra significa lecho para descansar provisto de cortinajes jara impedir el acceso á los mosquuitos (Korrops). Basta de digresiones.

CARACTERES. - Los dipteros de los naturalistas modernos se reconocen facilmente porque solo tienen dos alas, una trompa chupadora, que en los menos casos chupa la 
sangre, un tórax compuesto de trés anillos adheridos, tarsos con cinco artejos, y formas distintas en su desarrollo, el cual produce larvas, crisálidas y moscas. Fi tronco de los diptcros ofrece analogía en su estructura con el de los órdenes precedentes; la cabcza se comunica con el tronco por medio de un delgado fllamento pudiéndose mover de derecha a izquierda; el primero de los tres anillos torácicos no deja ver de ordinario desde arriba sino las depresiones de los hombros, en tanto que el segundo alcanza mayor desarrollo, por ser el que tiene las alas; el escudete está siempre bien marcado $y$ alcanza de ordinario una extension tan grande que oculta toda la region posterodorsal. Fl dorso de los tres anillos sucle llamarse escudo dorsal. En este órden se jresentan tambien toda clase de uniones entre la region toricica y la abdominal. El número de los segmentos, que en ciertos casos sirve para la clasificacion, varía entre cuatro y ocho, que suelen contarse en el dorso. A menudo sobresalen los órganos grenitales, muy variados en el macho y consistentes en un uviducto protráctil en la hembra. Los dipteros se asemejan á los himenópteros tambien por su aspecto exterior, pues si no están desnudos, hállanse revestidos de pelos ver dosos diseminados, 6 de una espesa pelusa lanosa, como se obserna, por ejemplo, en algunos ápidos, pero en cambio son muy raras las escamas, que se observan con frecuencia en los papiliónidos y coleópteros. Los tarsos se insertan en el cuerpo por ancas cilindricas y tienen un anillo en las malgas; las patas se componen de cinco artejos, el primero de los cuales sucle prolongarse, terminando con dos garras; entre estas hay \{ menudo una uñ rudimentaria, pero con mas frecuencia se hallan unos apéndices, con ayuda de los cuales las moscas corren por las superficies licas, con tanta seguridad como por las ásperas.

Ias alas, revestidas de una pelusa a veces visible, y otras microscópica, son trasparentés, algo enupañadas, ó con dibujos formados por manchas abignrradas. Dada la gran uniformidad que reina entre los dipteros, las alas tiencn una inportancin especial para la clasificacion por la disposicion de sus venas, lo cual nos obliga a describirlas, aunque sea bre. vemente. Predominan las venas longitudinales, y por lo mismo ambicn las células prolongadas. Observando atentamente, y aunque la ranificacion sea muy variada, se reconocen dos ramas principales que arancan independientemente de la rair, dcjando junto á esta un espacio libre mas grande ó mass pequeño. En todos los casos, estas dos ramas princi. pales están unidas por una vena trastersal. El borde anterior constituye la vena marginal, que suele rematar en la punta, pudiéndo tambien correrse álo largo de la misma; esta vena no se cuenta con las demás Inngitudinales. Es preciso recor dar que tres pertenecen à la rama anterior y tres \& la posterior, de modo que no se cuentan sino seis venas longitudinales, estando unidos ainbus troncos por la llamada pequeña vena trastersal. I $a$ primera longitudinal parte de la raiz del ala, dividiéndose pronto en una rama superior que desemboca siempre en el borde antcrior, sin presentar alli una lamina córnea, sino todo lo mas algunas grandes cerdas en caso de que estas revistan el borde anterior. I a otra parte, llamada rena subcosial, termina tambien en la vena inargi. nal, pudiendo no obstante dirigirse, tambien hácia la vena radical, que no arranca nunca de la raiz, sino del primer tronco, terminando en el horde anterior, y a menudo tam. bien en la primera vena longitudinal. la tercera, ó cubital, se ramifica siempre de la segunda y si esta falta, de la primera. En ambos casos termina sencillamente, pero puede tambien bifurcarse y desembocar en la siguiente por medio de la rama inferior. La cuarta vema longitudinal $\delta$ discoidea, es la rama superior del segundo tronco; cuando se corre en linea recta remata en el borde y á veces se inclina hácia la tercera vena longitudinal, en cuyo caso se llama terminat trasiersal, pudiendo descmbocar hasta en la cubital. Ia quinta vena parte de la raik misına, es de aquellas que no faltan nunca, y parece la mas fuerte del segundo tronco que es el mas poderoso apoyo de la superficic posterior del ala; termina en el borde posterior 6 en la vena amal, que parte de la misma, no llegando siempre hasta el borde del ala; si detrás hay otra vena longitudinal, esta parte de la raiz, pertenece al tercer tronco y se llama iena axilar. Donde hay una célula discoidea, como en cl ala de los mosquitos, resulta una ramificacion de renas longitudinales que no figuran en la serie, sino que se llaman segunda, tercera, etc., célula discoidea. Ademais de las venas que hemos citado, la trastersal posterior ó grande une á menudo la cuarta vena longitudinal con la quinta cerca del horde posterior, debiéndose consi. derar como bifurcacion de la primera; la radial delantera une en otros casos las dos nismas ramas, pero muy cerca de la raiz, como la radial posterior las dos siguientes; la que enlaza de un modo idéntico la subcostal con el borde anterior se llama vena trasversal humeral. Tos maturalistas estan me. nos acordes tociavía en la clasificacion de las células que en la de las venas; pero nos hemos limitado a esta breve descripcion, y añadiremos tan solo que las células no se consideran coino completamente cerradas sino cuando están circuiclas por todas partes de renas, mientras que se llaman abiertas cuando uno de sus lados toca en el borde del ala.

Muchas especies tienen detrás de las alas tambien una escanıa mas grande ó mas pequeña, simple ó doble, debajo de la cual se ocultan en parte ó en todo los erectores. Estos botoncitos pedunculados que ficilmente se echan de ver, como sucede, por ejemplo en los mosquitos, constituyen un órgano especial de los dipteros, cuyas funciones son muy variadas. Segun las modernas investigaciones de Landois, los erectores sirven para mover los anillos zumbadores en el aparato vocal. En el insecto que zumba, dice I andois, debemos tener en cuenta jrimero los movinientos de ciertos órganos cxternos, y despues la fuerza del zumbido. Si, por ejenuplo, venzos volar libremente por el aire un tálanno, oimos un zumbicio relativamente profundo $y^{\circ}$ observamos la impe. tuosa y trémula agitacion de las alas jo de los erectores. Si cogemos el mismo insecto de nodo que no pueda mover aqquellas, entonces sc oirá un zumbido mas alto, viéndose al mismo tiempo cómo los anillos abdominales se rozan convulsivamente entre sí; y por último, si se coge al insecto de mancera que no pueda mover ninguna de sus partes, entonces seri el sonido mas alto. I.os zumbidos profundos se producen en parte por las vibraciones de las alas, y por el roce de los anillos abdominales y de la cabeza, asi como por los cuatro conductos respiratorios del tórax, dos de los cuales se hallan en el anillo anterior. Iandois demostró lit verdad de este aserto por tres pruebas repetidas: puso moscas dentro de agua impidiendo de este modo el movimiento de los organos zumbadores y no obstante oyó sonidos; cortó del tórax de otra mosca todas las partes á excepucion cie los erectores del ala y no obstante reconocib que el tronco zumbaha; pero asi que tapó los conductos aéreos no oyó ningun sonido. En las moscas y mosquitos los conductos aéreos del tórax se han trasfomado en órganos vocales: en algunos los cuniro, en otros solamente dos, ya los anteriores 6 los posteriores. El aparato zumbador tiene poco mas ó menos la siguiente estructura: los numerosos conductos áćreos del tó. rax se reunen poco à poco hasta formar un solo conducto; este se ensancha en el extremo en figura de rejiga licmisferica, cuya abertura cxterma constituye al mismo tiempo el borde de los estigmas, y la rejiga traqueal se arruga a me. 
nudo formando graciosos foliculos. Estos se hallan separados por un arillo sumbador especial, situado inmediatamente debajo de la abertura de los estigmas. Asi pu•vs, cunndo el aire sale de las tráqueas ó es absorbido, muévense $y$ vibran los folículos de quitina de la cavidad vocal, $y$ como el sonido se produce por los órganos de la respiracion, puede tambien llamarse ros. La estructura de este aparato vocal es muy variada en los diferentes dipteros, pero no podemos describirlo agul mas detalladamente.

Fàltanos todavia describir brevemente la cabeza y sus órganos. Los ojos abarcan la mayor parte de la superficie de aquella; son desnudos ó estan revestidos de pelusa, tocéndose en varios machos en el vértice, mièntras que en la hembra estan siempre separados, aunque solo sea por una linea frọntal. De ordinario suelé haber tres ojuelos. Las partes bucales han sido descritas ya en otro lugar: en los mosquitos son mas córneas, en otros mas carnosas, pudiendo afectar formàs distintas, cómo por ejemplo de trompa 6 de cuchara. Para describir detallada y brevemente l.s varins regiones de la cabeza se han introducido denomimaciones especiales, llamandó chistoma la superficie que hay entre las antenas, los bordes internos de los ojos y el borde bucal; si estí revestida de una pélusa en forma de barba, llámasc esta mostacho en oposicion íla pelusa de las mejillas, desiguada con el nombre de barba. Los pelos que rodean los lados del epistoma se llaman ierdas, y si estas se hallan tambien en el borde superior de la boca, entonces se dice que este es cerdoso. Entre las cerdas del cuerpo, principalnente del abciómen, hay algunas caracterizadas por su grueso y longitud y que cuando merecén tenerse en cuenta se denominan marrochetas.

Por lo que toca a las antenas, que se hallan siempre en la línea divisoria entre el epistoma y la frente, pero que pertenecen en rigor à esta, pueden darse dos casos esencialmente distintos. En los llamados macroceros, remos que tiersen muchos artejos (hasta 36); son filiformes, cerdosas $\delta$ en forma de cordoin, siendo en el macho muy denticuladas. In los braquiceros, se halla sobre dos artejos cortos y amulares un tercero final mas grande y de forma muy variada, en cuyjo dorso hay cerdas, como por ejcmplo en todas las verdaderats moscas. El sitio qué ocupari, su estructura sencilla ó compuesta, su desnudé $u$ su pelusa, son caractéres sobre los cuales se fundan las diferencias genericas. Lintre his dos formas de antenas que acabamos de mencionar, hay otra intermedia que suele figurar al lado de la última. En muchos casos, el tercer artejo parece auillado, $\delta \mathrm{en}$ vez. de ta cerda tiene un estilo, una apófisis que no es cerdosa y que puede i su vez estar anillada. No obstante, en esta forma no se encuentran nunca mas de seis artejos."

Las larvás ápodas de los dípteros viven ell el agua $6 \mathrm{~cm}$ tierra, en las sustancias vegetales ó animales en putrefaccion, en las plantas vivas, á cuya descompósicion contribuyen, y además en calidad de parásitos en otras larvas ó en animales de sangre caliente, presentándose bajo dos formas esencial. mente distintas. Las mas desarrolladas entre ellas se reconocen por su cabeza cómea y sus partes bucales, nudimentarias; tienen labio superior é inferior; dos mandibulas, antenas y taubien ojos mas ó menos perfectos. Carecen de verdaderos tarsos, pero en lugar de estos tienen púas capilares 6 verrugas revestidas de cerdas, ųue en la locomocion prestan muy buenos servicios, pero sin que los insectos en cuestion salgan de su estado de larvas. En la segunda serie, mucho mas numerosa, de larvas llamadas acéfalas, no se distingue la cabrza, sino solo una extremidad aguda por un lado; $y$ obtusi, de ordinario truncada, por el lado opuesto. Jals siguientes partes del cuerpo son carnosas como el resto del mismo. Dos ganchos córncos que funcionan uno contra otro y yue penetran mucho en el interior, representan las partes bucales, destinadas para arrancar el alimento, y que sirven ademis para hacer resistencia durante la progresion. En semejantes larras se halla en la extremidad truncadn y mas gruesa, sobre unas prominencias cónicas ó verrugras, cierto número de conductos aéreos; dos de ellos, uno en cada lado del segundo anillo, estan ocultos. Por las investigaciones mas recientes se han hallado tránsitos entre ambas formas fundamentales, habiéndose hablado de esqueletos de la ca. beza de diferente estructura, pero aqui no podemos ocuparnos de estas pequenas variedades. Los dos puntos que acaba. mos de tocar se refieren no solo a la naturaleza exterior, sino tambien a la vida de las larias. Las que tienen cabeza cambian varias veces de piel si pueden obtener un alimento liquido; mientras que las acéfalas, en la majoría de casos, no cambian nunca de piel. Cuando se convierte en crisalida, la piel de la larva se cndurece, porque su forma se acortay ensancha formando los llamados tonelitos, en los que las prominenciass señalan los sitios donde la larn tenia las ver rugas con los estigmas. En tanto que todas descansan fuera del agua, las crisalidas de tipularios que viven en ella se mueven de igual manera que sus larvas. Las diferencias cque acabamos de citar entre las larvas y las crisilidas permiten deciucir una conclusion general acerca del insecto perfecto. De las crisilidas momias salen macroceros ó tipularios; de los tonelitos móscas ó braquiceros, pero no sin excepcion.

La círita de los dípteros no se puede calcular, dado el co. nociniento todhyia incompleto que tenemos de las especics existentes fuera de Europa, pero creemos que no alcanza a la de lós ápićos. Lat zona tórrida no posee ninguna familia exclusivamente, pareciendo estas mas diseminadas que las de otros insectos. Los dipteros figuran ya en los primeros periodos de la creacion; en las capas mas antiguas se encuentran aisladamente; son numerosos y estin bien conservados en los tersenos terciarios. De las 850 especies encontradas hasta aloora en el ambar, 656 estain clasificadas con séguridad.

\section{LOS TIPULARIOS - TIPU- LARI压}

CARACTERES. - Por variados que sean los caractéres en cuartio al tamaño, la estructura y el género de vida, los tipularios se reconocen fácilmente por su cucrpo prolongado, tarsos muy largos y filiformes, largos artejos de los palpos y antenas compuestas. El número de especies es muy considerable, habiendo quiza i,000 en Europa, de las que algunas se presentan a veces en immensas agrupaciones. I.os calendarios dicen que en 17,36 hubo en Inglaterra un número tan increible de mosquitos, que los que revolotcaban en las inmediaciones de un campanario parecian una columna de humo. Eil mismo fenómeno fué observado tambien en julio de r 12 en la ciudnd de Sagan, en Silesia, y el 20 de agosto de 1859 en Nuevo Brandenburgo. Semejantes ejemplos se refieren en muchos paises de Europa, aunzue no se Ita reconocido pósitivamente de que especie eran los dipteros que constituian las nubes. Se han encontrado las orillas de cicrtas aguas cubiertas de una capa de varios piés de alto, formada por los cadaiveres de las especies mas pequeiass, que miden li",0045. Todos los q̨ue viven, durante un ve. rano caluroso y húmedo, cerca de las aguas, saben cuàn molestos son estos atormentadores, pero nuchos ignoran que estos sanguinarios séres pertenecen cxclusisamente al sexo femenino, puesto yue los machos inofensivos se divierten danzando. Lin España y en la América del ser se llaman 
masunitos, y en Surimam iormefas ded diablo. I a plaga de los mosçuitos no es moderna sino muy antigna. Pausanias dice que los habitantes de Myus se vieron obligadas a luuir de la ciudad pror haber sobrevenido grandes bandadas de mosquitos. "Se dirigieron a Mileto, dice, y en mi ticmpo no qquedaba de la ciudad de Myus sino un templo de Baco. Osten-I ackien rérere ea cambio que en el año 1827 no habia todavia ningun mosyuito en las islas de Sandwich. Ln 1828 o 1830 fué abandonado en la costa de una de las islas un barco mejicano. Pronto olsservaron los habiantes que alrededor de aquel sitio compareció un insecto especial, sanguinario y aun desconocido. Este fenómeno llamó la atencion de modo que los indigenas curiosos se dirigian por Ia noche a aquel sitio para hacerse picar por arjuel extraño animalito. Desde entonces se extendieron los mosyuitos por las islas convirtiendose poco à poco en una plaga

Muchos mosquuitos viven en estado de larvas y crisálidas en el agua: algunos habitan en ella constantemente; otros salen a respirar a la superficie, haciéndolo à trarés de bran. quias exteriores ó de conductos respiratorios. Aquellos pueden estar revestidos de cerdas, que suclen hallarse en el pri. mero y el último anillo abdominal.

\section{EL MOSQUITO ANILLADO-CULEX ANNU- LATUS}

CARACTERES. - Esta especie representa a! genero de los culicidos, esto es, de aquellos mosquitos caracterizados por su larga trompa picadora, alas medianamente anchas, apoyadas del todo sobre el cuerpo y redondendas en la punta: tienen por In menos seis venas longitudinales de igual espesor/y revestidas de una espesa pelusa: los ojuclos no cxisten; un surco trasversal sc corre por el clorso del tórax. Solo en el macho los íspleros palpos, compuestos de cinco artejos, se prolongan mas allí cie la trompa, formando con losmechones de las antenas, de 14 artejos, una pelusa alrededor de la cabeza. Nunca se obscrvari la mismo en un mosquito que se posa sobre nuestra mano y que introduce su córnea trompa en un vaso sanguineo, porque estos son hembras, como ya hemos dicho, las cuales carecen del citado adorno capilar; pero si vemos hinchársele el vientre de sangre a cada succion, todos sabemos tambien que la irritante punzada es mas dolorosa cuando se mata al mosquito y la punta de su tromipa queda en la piel, que no cuando se le deja chujar hasta s]ue se harta. La citada especic se reconoce por los anillos blancos del abdómen y de las patas, por las dos fajas del dorso $y$ las cinco manchas oscuras de las alas. Representa i la mayor de las especies indigenas, pucs mide $u^{n}$, oog ó mas.

\section{EL MOSQUITO COMUN-CULEX PIPIENS}

CARACTÉRES. - Mas abundante todavia suelc presentarse esta esprecie en compañia de la anterior; es mas pequeกัa, con anillos mas claros y mas oscuros en el abdómen : pero cn los tarsos y en las alas, cuyas venas son pardas, faltan los dibujos oscuros (fig. 112 ).

USOS Y COSTUMBRES. - I as larnas de ambas especies viven à millones en las aguas estancandas. Fs curioso ver a estos séres suspendidos en el agua, con el conducto respiratorio del pentiltimo segmento abdominal inclinado hácia un lado y la cabeza hàcia abajo. I as maxilas estrin coninuamente en movimiento, produciendo de este modo un torbellino que lleva a la abertura bucal las particulas de inmundicia çue tiñen inmediatamente de negro los intestinus. De este modo $\delta$ levantándose con la parte anterior del cuerpo ! palpando con las antemas, perunancen estos insec tos largo tiempo suspendidos, y si el uno se acerca demasiado al otro, se agarran por la cabezn, pero sin emperar una lucha larga y séria. I.a nas ligem agitacion de la snjerficie hace bajar á todos al fondo, pero no están alli largo tiempo; del mismo modo que se han sumergido vuclven á subir ì la superficie, suspendiéndose de la misma por el conducto res. piratorio. Se sumergen aisladamente tambien sin ser asusta. dos, se arrastran por cl suelo, se echan de espaldas y eva. cuan.

Cuando llega la época se suspenden de la superficie en. corvados en rigura de interrogante; el cuerpo se agricta longitudinalmente detrás de la cabeza y por alli sale el mismo insecto, con la diferencia de que sus contornos son algo mas grandes. El cambio de piel se ha verificado. las antjguas curolturas flotan en el agua, se disuclven poco á poco y vuclven a ser devoradas por las larvas de tipularios y otros habitantes de aquella sucin morada. Cada una ha de cambiar tres veces de piel para alcanzar su completo tamaño, es decir, umos $0^{* 3}, 00875$. Asi que la piel se rompe por segunda vez en la nuca, cambia el género de vida que hasta entonces ha llevado el insecto: la esbelta forma desaparece y sustituyela otra mas tosca y algo comprimida en los lados. Ia crisúlida se suspende de los das conductos aéréos que se hallan detrás de la cabeza y se mueve arriba y alsajo por pasatiempo, como la larva. Entonces se agitan las larvas y las crisailidas en el acuario; el número de afjucllas disminuye y el de estas aumentaria otro tanto si una tras otra no se acercamn a un estado mas perfecto. Su hora ha llegado tambien: una grieta de ha picl libra al mosquito de su máscam. Salen primero seis larcros tarsos, luego un cueno delgado con dos alas. El animalito se apoya primcro sobre la flotante cnioltura que poco antes lo ocultaba todavia, y con la que tambien naufrnga si le sorprende un golpe de viento; en este caso ahógase si no se posa sobre los cuerpos que flotan; en estos descansa un rato de la fatiga y entre tanto desplega completamente las alas y clc. rase por fin en el aire para no volver mas al agua, que ya seria inhospitalaria. Solo la hembra que ha conquistado un unacho vuelve al liquicio elemento joco antes de morir para poner alli sus huevos. Con este objeto se posa sobre una planta desle donde puede alcanzar el agun con la punia del abdómen, ó solure un objeio floiante, cruza los tarsos poste. riorés en forma de $\mathrm{X}$ y cmpieza á poner. Entonces levanta al aire los tarsos posteriores, posicion en que a los mosquulos les gusta descansat; y al fin se ve en la superficic del agua un objeto puntiagudo por delante y detris, compuesto de 250 á 350 huevos. En el extremo inferior salen pronto las larvas j jas cáscaras de los huevus flutar en el agua hasta que esta las destruye.

Si se liene en cuenta que cada hembra pone por término medio 3 co huevos y que de estos salen en cuatro ó cine:o semanas otros tantos mosquitos aptos para la reproduccion, fácil es formarse una idea de las immensas landadas que se jresentan en los anoos himedos en que abundan los charcos, sitios donde cria y que por lo mismo favorecen su desarro. 110 y multiplicacion. I as hembras fecundadas de la tiltima cria invernan en los mas variados escondrijos, principalıwente en las bodegas, flara reproducirse en la primavera sjguiente.

En las islas Barbadas predominan tres especies, el Cudex malesius, el $C$. Irifur:atus y cl $C$. pulienris, que tienen foma de mosquitos. Estos atormentadores tienen tambien, sin $\mathrm{cm}$. bargo, su parte buena, a juzgar. por el plan curativo que empleó en Veracru\% con una señora el médico Delacoux. Ia pacienic estaba aletargada hacia doce horas a consecuencia de una inflamacion cerebral y presentaba sintomas de una 
jróximn muertc. Eil médiro desnudó a la enferma y dejola expuesta doce horas a las picaduras de los mosquitos; al calbo de este tiempo el letargo cesó y la enferma se encontró al dia siguiente, no solo entre los vivos, sino tambien notrblemente mejorada. En los años en que abundan los mosquitos, el humo o los cigarros de los fumadores sirven hasta cierto punto para alejar estos enojosos insectos, mas no para ahuyentarlos completamente. Aquel cuya piel sea insensible al aceite de clavel uintese con esta sustancia, que en algumas paries se llama grasa de mosquifo, y se preservar de las picadas mientras que el aceite despjida olor. El medio mas rápido y seguro para librarse del escozor de la saliva del mosuquito, se reduce à remojar la picada con espiritu de amoniaco.

\section{LAS TIPULAS - TIPULA}

CARACTERES. - El género de las lifulas (tipula), con sus numerosos congéneres, comprende los mayores mosqu:tos que se conocen, los cuales vigan por las praderas, por las matis y los troncos de los árboles, y que no pueden picar con su trompa corta y carnosa. Se les reconoce por el surco tmasuersal marcado que tienen en el centro del dorso, por sus alas con cuatro venas y en cuyas variaciones se han fundado numerosps géneros. In extremidad del cuerpo del macho está armada de una esprecie de temazas prensiles, y el abdó mer de la hambra remata en punta, formañdo dos válvulas.

\section{LA TIPULA COMUN-TIPULA OLERACEA}

CARACTERES. - En esta especie las antenas se compo nen de trece artejos; los jajpos tienen cuatro y terminan en una punta larga y filiforme; los ojuelos faltan; el primer artejo de las antenas se prolonga, el segundo se acorta y todos los demás estín revestidos de pelusa en la raiz. Las grandes alas, medio abiertas en el estado de descanso, tienen el primer nervio longitudinal doble, el segundo ahorquillado cerca de la punta, y el tereero sencillo; el cuarto, muy ramificado en la parte anterior, forma una celda discoidea completa, de la que se contiuúan tres ramis liasta el borde de las alas; la superior de estas mamas es pedunculada y ahorquillada. Eil quinto nervio longitudinal se encorva un poco por delante de la desembocadura, mientras que el siguiente es recto, asi como el pequeño nervio trasversal; el grande es oblicuo y forma un úngulo con el corto pedazo de la rama inferior del cuarto nervio longitudinal. Esta especie se distingue de las otras por tener un escuclo dorsal gris con rayas pardas, por el abdoimen de un pardo rojo y por el borde anterior, de un rojo de ladrillo en las alas, que son de un pardusco pálida. Las patas posteriores son casi tres veces mas largas que el abdómen, compuesto de nuere segmentos; la longitud de todo el cuerpio varia de $0^{m}, 022$ a $0^{m}, 026$.

USOS, COSTUMBRES Y REGIMEN. - Este mosquito tarda en presentarse; $y$ no vuela como otras muchas especies en mnyo, subiendo y bajando por los troncos de los árboles, pues no se desarrolla hasta julio 6 agosto de una crisailida cilindrica de color pardo claro, cuya parte del rostro parece una careta y esta provista en la frente de dos cuernos, los cuales afectan casi la forma de maza. Cuando en setien. bre se pasa por una pradera, estos mosquitos llaman al punto la atencion; en todas partes trabajan con sus largas patas de araña cu la yerba; 5 à cada paso se levanta alguno, rasando casi el suelo para volver a posarse otra vez en la yerba. Esto lo hacen pan depositar sus huevos, a cuyo efecto oprimen la extremidad abdominal en posicion casi recta contra el suelo, donde dejan los huevos.
De este modo continúán hasta laber depositado todos los germenes de su progenie en el seno de la tierra, y mueren despues de haber llenado este deber. Al calro de ocho dias nacen las larvas, $y$ cuando estas son un proco mas grandes, se las encuentra ficilmente en las capas superiores del suclo, ya en las praderas y jardines, $\sigma$ en los sitios luúmedos de los bosques. Son de color ceniciento, trasparentes, con repliegues trasversales y cortas celdas aisladas; la cabeza, de color negro, puede ocultarse en el jrimer segmento del cuerpo y tiene dos maxilas y antenas cortas; el cuerpo remata en una punta truncada, ligeramiente cóncava y orillada en el borde por seis espiguitas carnosas; entre las dos centrales y el dorso se hallan los dos cstigmas, que son grandes y de color negro. Mientras lo permite el tiempo las larvas se alimentan de las sustancias vegetales del suelo; luego adquieren ciertn rigidez y continuan en la primavera su género de vida, hasta que, pocas semanas antes de presentarse el mosquito, se tras. forman en la crișílida antes descrita.

Las larvas de las otras especics quc hasta ahora se cono. cen viven del mismo modo, y de algunas se dice que pueden perjudicar las jlantas cultivadas, corrojendo las finas raices fibrosas.

\section{LA TIPULA GIGANTE-TIPULA GIGANTEA}

CarActéres. - Ia especie designada con este nom. bre (fig. I I (4), una de las mas notables del género, es de color ceniciento; los palpos y las antenas de un tinte pardo; el tórax presenti tres tajas de este matiz, y otra iestacea por delante de las alas; el cscudo es de un amarillo pailidu; en el abdórnen se nota una línea dorsal y una faja a cada lado, de un timte pardusco, y una linea trasversal interrumpida del mismo color en cada segmento. Los piés son tentáccos; en las alas se ve una ancha faja pardusca dos veces escotada en el borde exterior; en el interior existen tres manchas mas pálidas. El macho de esta especie mide 12 lincas de largo $y^{5}$ Ia hembra io.

DISTRIBUCION GEOGRAFICA.-Este diprero habita cn una gran parte del globo.

USOS X COSTUMBRES.-La tipula gigante es completamente inofensiva cuando llega ia su estado perfecto, por mas que à la gente ignorante le inspire temor socar á cste animal; pero en el estado de larva suele ocasionar grandes daños, porquue se alimenta de las raices de la yerba, daindose el caso de que inutilicen asi la que debe crecer en los parques y jardines.

\section{LOS TENÓFOROS-CTENOPHORA}

CARACTERES. - A los mosquitos mas extraños y gra ciosos pertenecen los ienóforos, que tienen las antenas pro. vistas de fuertes puís en forma de peine, el taladro de la hembra saliente en figura de leana, y los colores mas vivos, predominando el amarillo y el negro.

\section{LAS ESCIARAS-SCIARA}

CARACTÉrres. - En la familia de los pequeños mos. quitos de color claro amarillento, cuyas larvas viven en gran número en las setas (mosquitos de setas, mycelophilida), hay tambien unas especies que á causa de sus alas oscums se han llamado mosquitos fómelures ó esciaras. Sus costados no son muy largos, como los suclen tener los micetofilidos; las antenas, delgadas y cubiertas de finos pelos, tienen 16 artejos, y los palpos solo tres, el último de los cuales se ensan. cha; los ojuclos se reconocen marcadamente; en la extremi- 
dad de los tarsos hay dos cortos espolones: las patas son corias; las alas, que en estado de descanso se apoyan hori. zontalnente en el dorso, tienen el ecreer nervio longitudinal ahorequillado, yo un pequeno nervio trastersal reune el primero con el segundo.

\section{LA ESCIARA MILITAR-SCIARA MILITARIS}

CARACTÉRES.-Fsta especie, que se encuentra en 20. dias partes, es del todo negra, con los ligamentos de los segmentos amarillos, color que desaparece mas y mas en los individuns muertos; ó solo se reconoce en los lados del cuerpo por unas manchitas. El cuerpo de la hembra remata en un taladro puntiagudo, $y^{\prime}$ el del macho en una gruesa ienaza de dos artejos, en cuyo centro sobresalen dos puntitas en el segmento ventral. El escudo dorsal, muy ronvexo y ovalado, es decolor negro brillante sin sutum trasicrsal $y^{\circ}$ estí cubicrio de pelos negros muy cortos. Ia liembra, de formas recogidas, ticne las antenas mas cortas que el macho $y$ mide $0^{m}, 00$ \& ó $0^{\infty}, 0045$, mientras que aquel solo alcanzas de $11^{18}, 003$ a $0^{7}, 0035$.

La larva adquiere cicrta celebridad cuando se presentan muchas, habiéndoscla llamado entonces en Alemania grusano de ejurcilo, gusano de guerra, gusano tragon ó serpicuti de cjircito. En 1603 se observó este finónieno pror primera ve\% en Silesia, repitiéndose de ver. en cuando en los ducados de

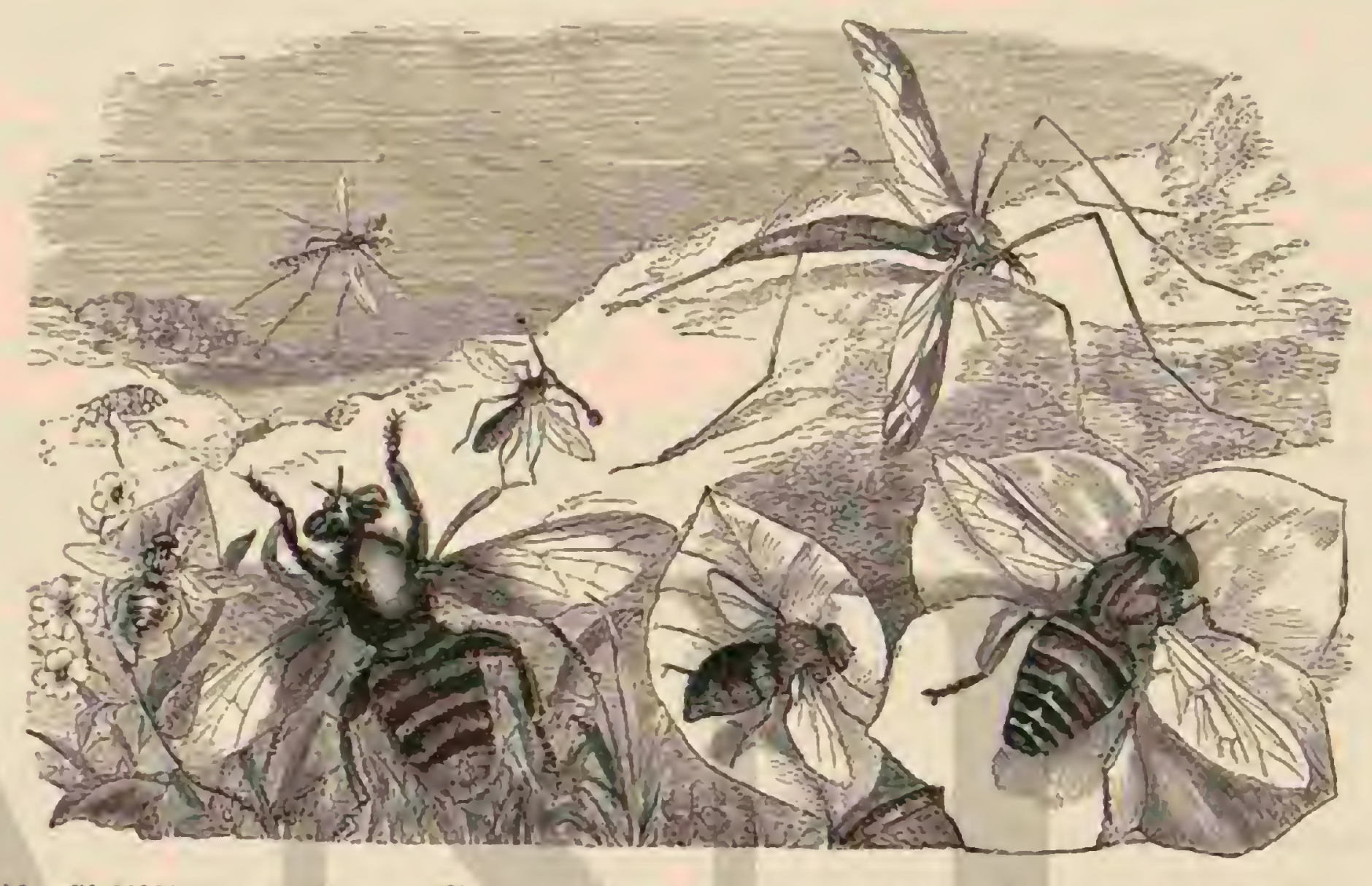

Fig. 112.-EL Mosnuito cosicx

Jig. 115.-lik. 18FMATOBO IRRTTANTE

fig. HS.-LA GLOSINA TSFTSE.

Fig. MJ.-EL DIOASIS LONGICORNE

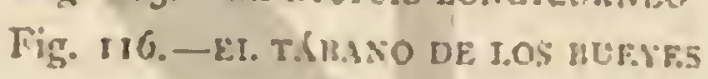

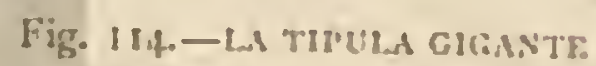

Fig. I19. - E.T. ASILIO ABEJORRO

Sajonia, en Turingia, Hannover, Norucga y Suecia, por lo cual llegó al fin à ser asunto de una discusion cientifica que duró hista d año i $\$ 68$. Solo entonces las incansables investigaciones del jefe de guarda-bosçues, Beling, dieron á conocer la causa de la cmigracion, demostrándose que la especic que se re cn el Harz es idéntica d la que Nowichi observo cerca de Kopalin, llamada sciarn militaris, y no la sciarn Tho. usá, como en opinion de Berthold, se crejó genernimente desde 1845. Algunos hombres, descosos de dar una explira. cion, dijeron lo que opinaba el jueblo de entonces, y aun de los últimos ticmpos, sobré este singular tenúmeno. Los unos aseguraron que la presencia de esta larva nnunciaba la guer ra: los otros que en indicio de buena ó nuala rosecha; segun los montaineses de Silesia, seria abundante si los insectos se dirigian en su emigracion baicin el valle, pero escasa si subian a las alturas: para los supersticiosos de la Selna de Turingia, lo primero signifientua la paz, y lo segundo la guerm. Otros seian en la presencia de esta larva la de in oracuio: ponian sus ropas en el camino por donde el insecto debia pasar. dibanse por ielices, paricularmente las mujeres cmbaraiadas, cuando crizabla por encima; el que no tenia esta suerte colssideraba el caso como indicio de una pronta muerte. Suponiendo que estuvieramos en julio 6 a principios de agosto, y que al decirnos, como en $1756 ! 1774$ á los habitantes de Eisenach, quie en el bosque inmediato se presentaba la larva de la esciara militar, nos fuéramos como la gente de entonces, pero sin preocupacion, á verla pasar, ¿qué observariamos?

Tosin V'T
Una especie de serpiente gris, de unos $3^{\circ}, 76$ de largo, no de igual anchum en toda su extension (de tres a cinco dedos) por una pulgada de gruešo, que no se mueve con la ligereza propia de aquel repiil al frasar entre la hojarasca ó sobre las jerbas, sino que se arrastra con la pesadez del camcol por lo mas oscuro del bosque. Se compone de miles miles de larmas palidas, que aciheridas entre si por la superúcie mucosa de su cuerpo, forman en cierto modo uma sola masa, en la que lá extrenidad que rejuesenta la cola puede levantarse un instante con un baston. Cada larra lace los movimiertos acostumbrados, sesultando asi la locomocion de toda la masa, cuya superficic produce a la vista d efecto de una corriente lenta. Segun las condiciones del terrenn, la marcha estí sujeta a muchas variaciones: los obstáculos péquenos se vencen pronio: los grandes producen una sepraracion fasajera; la hendidura causada por los cascos de un caballo, ú el surco que forman las ruedas de un carro. se framujucan bien pronto, como succde en los viajes de las orugas procesionarias. Tambien se ha olsservado que varios grupos se reunian en uno solo, pero no se ha jurobado que lo hagan en ticnupo determinado ni que sigan uma direccion fija, como dice haberlo visto la gente supersticiosa.

Las cuidadosas observaciones hechas durante muchos años al aire libre $y$ en cautividad han conrencido a Beling de que estos viajes tienen por objeto buscar pastos convenientes. La larva nacida bajo una capa de hojarasca húmeda, y fuera de la infuencia del sol, de unos montoncitos de hueros, es socin. 
ble por naturaleza y necesita para prosperar cierto grado de humedad; si esta es excesiva, cáusale tanto daño como la serquia. Su alimento se compone de la hojanasca en descomposicion; come las hojas blandas, dejando solo los nervios: los sitios himedos donde la hojarasca de varios años se ha reunido son los parajes en que mejor puede nacer. En el Harz, tales sitios están cubiertos particularmente de la hojarasca de has hayas, $y$ alli donde se encuentran estos àrboles se vemin con seguridad tambien las larras; si ya se han alejado, las hojas corroidas y los excrementos indiran que las larvas se hallan a corta distancia. En cstos puntos se desarrollan en el espacio de ocho à doce sernanas en el estado de husevos, tras. formanse en crisilidas, que descansan de ocho a doce dias, y despues salen á lur los mosquitos, siempre mas hembras que machos. El aparenmiento se verifica nunque da hembra no tenga desplegnadas las alas, porque los machos que se presentan antes busear muy pronto una hembra perezosa, que despues amástrá en pos de sf al mácho urido con ella $\mathrm{Al}$ cabo de tris dins no existe ga ningun mosguito, y junto à sus ca. diveres se encuentran los montonciros de huevos. Muchos años pueden pasar dándose estos casns, sin que un hombre sepa que existen esos pequeinos séres ya sen en sitios bastante frecusentaclos, ó en otros yue no to sean tanto.

Por este género de vida de la escitre militar, cuyo desartollo se verilica de un modo oculit puede suponerse que solo en casos excepcionales las larras se presentan públicatmente como gusano de ejercito, $\delta$ que algunas veces existen camo tales sin ser vistas. Ejemplo de trio de estos casos extepcionales es el que ofrece una agrupacion sumamente considerable de larms, que no hallandeya su alimento en cl sitio dunde uació se ve obligada à viajar. Cunnto mas desarrollada está la hrin tanto mas alimento necesita, de modo que por lo regruhr son individuos acultos los que emprenden las expediciones, hábiéndose observado que aigunos se crisalidaron durante el viaje mismo. Ademis la humedad ó la sequia pueden influir para uqu las larvas se alęien de los sitios acostum. brados. A prinera vista es un fenómeno extrano el hecho de que el gusano de ejerrsito de kopalin se haya visto en los pinares y que, segun observó Nowocha, la larva se alimente de los conos en descomposicion. Debenos tener en cuenta, sin embargo, que en tal estado lia diferencia entre las hojasy los conos no es tan grande $y$ que las larias de mosquitos $y$ de moscas no reparan mucho er la eleccion de su alimento.

Seria supérfluo indicar ąqui dónde y cuándo se presentó un gusano militar, porqque los autores que acabamos de citar han dado descripciones minuciosas, Beling en su \&Jardin zoo!ógicok, y otros en publicaciones separadas; pero en cambio completaremos en algunos puntos la historia natural de la esciara militar. Los huevos, al principio de un blanco briIlante, y mas tante negruzcos, son pequenisimos (se necesitan I 5 a 20 para llegar al tamaío de un grano de adormidera), y se depositan en grupos que contienen por término medio 100 de cada hembra. la cual los deposita en el sitio donde nació, cntre la hojarasca. Durante majo naocon las larvas, que cuando son adultas miden por término medio $6 ", 007$ : ticnen la cabera córnea y negra, dos ojos y maxilas denticuladas de trece segmentos vidriosos, por los cuales se trasparenta en algunas partes el contenido oscuro del intestino; hay seis verrugas carnosas de forma aplanada en la base de los tres segmentos anteriores $y$ dos en la extremidad; los estigmas son negros en los lados, y la supernicie muy lisa y pegajosa. Las larvas mas aduhtas pierden su aspecto vidrioso, vacian el contenido del intestino, tejen algunos hilos y se desprenden de la piel, q̨ue como apéndice reseco se conserva en la extremidad de la crisalida. Las larvas, nue se encuentran reunidas en gran número, son al principio de color amarillo blanco, pero tienen los ojos negros, y al fin se vuclven negruzcas en los estuches de las alas; poco antes de dar á luz los mosquitos dejan trasparentar el cuerpo negro, con las manchitas amarillas en el abdómen: miden de $\left(1^{m}, 00,3\right.$ a $0^{\circ}, \infty 4$, siendo el macho mas pequeno que ia hembra. A las larvas y crisálidas se agregan algunas larvas de una mosca, de la cyrlonesura pabulorum y varios congéneres mas peñuenos del moscardon azul, que se alimentan de las larvas en. fermas y de las crisálidas sanas. La esciara militar tiene por lo tanto una sola cria al año, que sin embargo sufre modificaciones por la temperatura.

La especie descrita no es la única que llama nuestra atencion; hay otras varias que, como la esciara de los perales, viven en estado de larvas en las peras verdes, impidiendo que maduren. Una gran especie con el abdómen amarillo es propia de la Luisiana, donde se la ve en grandes agrupaciones siempre que reinan peligrosas calenturas, y sobre todo la fiebre amarilla. Este ienómeno que aun no ha podido explicarse, es tan extrano, que la especir reronocida por Osten. Sacken como sciara se ha llamado mosca de la fiebre amari. Ila (jeblowi feiver Fig).

\section{LOS CECIDOMIOS-CEGIDOMYA}

CARACTERES. - Por mas de un concepto los cecidomios ó mosquitos de agallas ofrecen gran interés. Son peque. nos, con frecuencia diminutos y delicados; tienen las alas anchas y obtusas, muchas veces peludas, $y$ siempre provistas en el borde de largas pestañas: cuéntanse tres 6 cuando mas cuatro nervios longitudinales, de los que el del centro desemboca delante de la extremidad del ala, en el borde anterior. El nervio trasversal suele ser tan delicado que solo se distingue con una lur muy favomble. Los ojos, semilunares, se tocan en la coronilla de la diminuta cabeza; en la trompa, que es gruesa, sobresalen hácia adentro los palpos, de tres artejos, el última de los cuales sucle ser mas largo. Las antenas, en formá de cordon de perlas, varian por cl número de artejos, is menudo pedunculados y provistos de pelos dispuestos circularmente entre trece y treinta y seis; el macho suele tener uno ó algunos mas que la hembra. Fin esta últi. ma el abdómen compuesto de ocho segmentos es puntiagu. do, en aquel cilindrico, $y$ provisto en la extremidà de la tenaza consabida.

Distribucion GEOGRÁfica. - En Europa se conocen unas cien especies propias de este género.

USOS, COSTUMBRES Y REGIMEN - SU nombre genérico indica que las larvas producen en las plantas alimenticias ciertas deformaciones ó agallas; pero no to hacen todas, mientras que otras, que por su diferente estructura no han podido reunirse con este género, las forman siempre. Para hacer mencion de algunas de las especies mas comunes diremos que las excrecencias en figura de cebolla que se encuentran en la cara superior de las hojas de haya son efecto de la picadura de la cecidomya fagi; las de forma casi esférica que vemos en la superficie de las hojas del álamo tembloroso son producto de la cecidonyia polymorpha. In recidomyiz carpiscola hace nacer unas bolitas de color rojo de cereza en las flores de la zanahoria silvestre; cualquiera otra parte de las plantas puede estar habitada por diversas especies.

\section{EL CECIDOMIO DESTRUCTOR-GECIDO- MYA DESTRUCTOR}

CARACTERES. - Este mosquito debe examinarze en ambos sexos para conocerie á fondo. La hembra, mucho 
mas comun, varia en su longitud: medida desde la frente hasta el taladro extendido puede tener de ()$^{\circ}, 0027$ a $0^{\circ}, 00375$. El cuerpo es generalmente de color negro aterciopelado; todo el vientre, excepto una mancha negra casi cuadrada en cada uno de los seis segmentos centrales, las incisiones articulares del dorso y una linea central del mismo, son de un rojo de sangre; este mismo color se observa regularmente en la base de las antenas y en las depresiones de los hombros, en el individuo vivo, mientras que en el muerto desaparecen la mayor parte de los puntos rojos, cuando menos en el ab. dúmen. Unos pelos negros cortos cubren el cuerpo, y orros de un anarillo rojizo las antenas; las alas presentan un viso gris a causa cie unos pelitos que cubren su carn superior é inferior. I as antenas se componen de dos grandes artejos basilares y de 14 i 16 pedunculados ó regularmente de 15 esféricos. De los cuatro artejos de los palpos, el uno se pro. longa siempre mas que el anterior, y gracias á su movimionto tembloroso se reconocen fícilmentix en medio de ellos sobresale la trompa, corta y de color amarillo, que se puede recoger tambien en la cavidad bucal. El abdomen, compuesto de nueve segmentos, remata en un taladro muy movible. Entre las garras negras de las patas, inuy largas, se obscrvat un solo disco prensil. La longitud del micho es por lo reguliar de $0 \mathrm{~m}, 003$; su color negro es menos aterciopelado y tira mas al pardo; el rojo es mas claro; los pelos del cuerpo mas largos y solo negros en las alas, pues en lo demis predomina cl amarillo rojizo. Iil látigo de las antenas se compone regularmente de 16 artejos. I a diferencia mas extraña de los sexos consiste en la forma del abciómen. En el segrmento noveno, muy cortado, de color pardo amasillo, se inserta la tenaya, quue es de un rojo oscuro.

USOS, COSTUMBRES Y REGIMEN. - Est? especic no produce agallas, pero es una de las mas difamadas del géncro: los norie-americanos la han llamado mosquico de los heseses, pero sin rason, por creer equivocadamente que estos cnojusos insectos se habian importado en 1776 y 1777 con los fardos de trapos de Hesse, cosa que sin embargo no es posible, segun resulta de la historia del desartollo de que luego nos ocuparemos.

La larva adulta mide $0^{\circ}, 0033 \%$ : con un buen microscopio se distinguen en su parte anterior dos palpos carnosos, y en los lados de los doce segmentos del cuerpo, excepto al segundo, tercero y último, un pequcio estigma. Este caricter les scinala su puesto entre las larras de mosquitos, mientras que la falta de cabcial las hace aparecer como verdade. ras larvas de mosca, de modo que constituyen un ránsito entre las dos formas principales de que antes hablamos. Este perezoso insecto se cucuentra aisladamente ó en yrupus hasta de nucre individuos: siempre tiene la parte anterior dirigida hácia abajo entre el tallo y la hoja del centeno y del trigo - cerca de la rais, é por encima de uno de los nudos inferiores. Con el ticmpo adquicre una forma mas oval; retirase un poco la piel del cuerpo, y esta se trasforma poco a poco en una cubierta pardusca, en una crisálida en forma de tonel, que en rigor solo pertenece it las moscas. En tal esta. do inverna el insecto, y unos quince dias antes de presentarse el mosquito se encuentra en la cubicrta exterior la verdadera eristlida

En la segunda mitad de abril empieza el periodo del celo y dura unis cinco semanas, lo cuai no quiere decir que el mosquito vive tanto tiemplo, sino que nace en este periodo; cada individuo solo vive pocos dias. Despues de nacer se verifica el apareaniento y la hembra deposita de So á roo huevos aisladamente ó i pares, entrc dos nervios longitudi. nales de una hoja. La laria nace a los pocos dias y se fija en la base de la hoja. si los huevos se depositaron en trigo de invierno, la larva se encontrari en el primero ó segundo nudo ciesde abajo, pero immediatamente en la rair si la hem. bra eligió los sembrados de verano como nido para su cria. En ambos casos no mucte la planta, pero esta se debilita de tal modo que no puede sostener la espiga y se rompe ficilmente por el viento.

Hasta el 20 de junio la mayor parte de las larvas son adultas; las mas desarrolladas se han tmaformado ya en crisálidas, de las que en setiembre, $y^{*}$ aun i fines de agosto, nace la cria de verano. Las plantitas tiernas en que se halla la segunda cria, ó sea la de invierno, mueren casi todas, en lo cual consiste esencialmente el daño que estos mosquitos pueden causar, y no solamente en el norte de Aurérica, sino tambien en Posen, Silesia y en otras partes de Alemania. Por fortuna, este mosquito solo tiene dos crias, pero los hay tambien de tres $y$ cuatro, mientras que los de una cria al año son raros.

\section{LAS SIMULIAS- SIMULIA}

CARACTÉRES. - las simulias pertenecen it los mos. quitos mas perqueños y que mas se asemejan por su figura arqueada $a$ las moscas. Sus anchas alas tienen una punta casi angular; los nervios, pailidos, solo se marcan mis hácia c) borde; los repliegues tienen forma ahorquillada; en las patas, por lo regular manchadas, se ven mudos gruesos, y el primer artejo del pié es largo. En la caheza se notan las antenas de 11 artejos, los panjuos puntingudos de cuatro, un labio superior libre, adelgarado en forma de punta de puñal yo una trompa propin para picar. Los ojuelos ialtan. I.os dos sexos de uma misma especic se distinguen á menudo esen. cialmente y en el color yotros caractéres.

USOS, COSTUMBRES Y REGIMEN. - Las simulins SC presentan en considerable númcro y no se haria caso de ellas, á causa de su pequenez, si las scusibles picaduras de sus hembras no llamaran la atencion.

Muchos de los mosquitos de la América del sur, por cojentplo, la simulia fertinar, pertenecen i este género. I.as larras y crisailidas viren en el agua, donde se colocan en priedras, tallos de yerbas y otras plantas acuaticas, iabricando antes unos capullos en forma de cucurucho.

\section{LA SIMULIA DE COLUMBACH-SIMULIA COLUMBACZENSIS}

CARACTÉRES.-Esta especic no es idéntica, cono por lo regular se supone, il ta sinutia matulala de Afeigen: Śchi. ner la describió por individnos consersados en espiritu de vino que Kollar habia recogido en su misma patris, pero no sin observarlos antés en la Hatumleza libre. Segun dice, entre centenares die individuos no se encuentra ningun macho; la hembra es negruzca, cubicrta en todas jartes de un espeso polvo blanquizco y de pelos de un amarillo de metal, de modo que el escudo dorsal, sobre todo en su uirte anterior, adquicre un aspecto arulado de pizarm; el abdómen es de un blanco amarillo con el dorso pardusco, pero de nado que el color blanco amarillo sube bastante por las incisiones. Fn los individuos diserados solo la parte ventral sucle ser amarilla, yel dorso de un pardo negruzeo. I as intenas son del todo amarillas; los palpos de este color ó de un amarillo pardo; las patas blanquizcas en los individuos vivos y amarillentas en los muertos: las puntas de los muslos y de los metatarsos postcriores pardas; las patas anteriores pardo negruz.cas $y$ las alas vidriosas. El cuerpo mide $0^{\circ}, 00337$ ó casi $0=, 004$. Los numerosos nombres que muchas especies re- 
cibicron de los entomólogos, demuestran las dificultades que ofrece su conocimiento exacto.

USOS, COSTUMBRES Y REGIMEN.-Fsta especie es la mas conocida en Europa y toma su nombre de un pueblo del distrito de Passarowit\%, en Servia, donde la supersticion de los habitanies supone que el insecto debe su origen a una cuesa pedregosa en que San Jorge mató al dragon. En tales cuevas pedregosas se retugian los mosquitos cn ticmpo de tempestad, y' vuclven a salir despues en forma de nubes que parecen una nicbia En las-regiones de todo el Danubio inferior siembran ef terrot entre los hombres $y$ d ganado: asi, por cjemplo; el 26 de junia de 1813 se anunció en Viena que en el Banato y en una parte de Hungría muchos centenares de buejes y cerdos habian muerto én abrit mayo por esta terrible plaga. Apenas del tamaño de uni pul. ga, penetran en la nariz, en la boca y en las orejas del gana. (io, pican para chupar la sangre y atormentan de tal modo á los animales, que se vuelven verdadernmenie mbiosos, abriéndoselas sitios picados por el roce; et animal mas fuerte pucde morir atsi a las seis horas. En el hombre las simulias atacan con preferencin los ángulos de los ojos.

\section{EL BIBIO DE MARZO - BIBIO MARCI}

CARACTÉRES. - Pocos serản los que no hayan visto à principios de ha primavera los pesados mosquitos negros qque se' agarran i las puntas de las gramineas nun secas, ragan perezosamente yor los arbustos, sobre todo alli donde comienzan a presentarse los pulgones, y vuelan poco á poco con las patas pendientes cuando hacel sol. Si su número es considerable se les ve aparcados en los milsmos sitios, llaman. do la atencion por la gran desigtaldad de tales parcjas: es el bibio de marzo, mosca del todo negra con pelos del mismo color. El macho, mas pequeño, ticne ta cabeza grande, y acupada casi del todo por los ojos peludos; la hembra, mas mquitica, se distingue por su cabeza prolongata en forma de trompa, conservando por estu y por los pequeños ojos desnudos el caricter de mosquito. Fn el ingulo posterior de la cabeza se reconocen tres ojuelos; en la extremidad opuesta: lis antenas, pesadas: se componen de nueve artejos, que rematan en figura hentisférica; en la parte inferior los palpos tienen cinco artejos igualmente recogidos. El escudo dorsal, muy convexo, marca su primer segmento con dos hordes afilados çue forman un ångulo agudo: las patas son fuctes, y las posteriores mas largas; los muslos se distinguen for su forma de maza, y los tarsos anteriores por tener uma fuerte espina en la extremidad; las garras y los discos prensiles se caracterizan por su gran tamaño. Las anchas alas, obtusas por delante, y muy ahumadas, con el borde anterior, negro, parecell como pedunculadas: su primer nervio longitudinal desembora detras del centro del ala en el borde anterior, el seyundo falta; el tercero parte de la base del jurimero, se reune con él por un nervio trasversal oblicuo, y hasta llegar á este es mucho mas fuerte que en lo restante de su extension; el cuarto, bastante recto, se adelgaza de pronto por detris del nervio trasversal que se ahor(̨uilla mas adelante; el quinto envia desde su centro una rama hácia arriba, quic por medio del nervio trasversal posterior, que siempre existe, se reune con el cuarto formando por lo tanto una celda basilar posterior completa, mas larga que la anterior.

Despues del apareaniento la hembra deposita de 120 á 150 huevos en la hojarasca 6 en sustancias regetales en descom. posicion, y particularmente en el estiércol de raca y de oveja; los individuos muertos se pueden ver entonces en tales sitios. Los huevos, blancos y lisos, se adelgazan un poco hácia adelante y son en lo demás del todo cilindricos. Al cabo de tres o cuatro semanas salen las larvas, que tienen la doble longitud del huevo, $y$ adquieren poco á poco un color gris pardusco. Mudan tres reces de piel en intervalos de doce a quince dias, $y$ cuando son adultas alcanzan una longitud de $11^{n}, 015$ a $0^{n}$, or 75. Se componen de doce segmentos, de los cuales se destaca marcadamente la cabeza, casi esférica, presentando cada cual una corona de cerdas. Las partes bucales se componen de un labio superior que remata en seis dicntes, de maxilas córneas, de mandibulas con palpos de tres artejos y de un labio inferior sim palpos. Las antenas y los ojos no se ven. A los estigmas que hay á lo largo de los lados del cuerpo agrégase un par, tres veces mas grandes y de diferente estructura, en el dorso del último seymento, que remata en cuatro puntas espinosas. Las larvas invernan sociablemente en la tierra ligern cubierta de hojarasca y no se trasforman en crisalidas hasta febrero ó principios de marzo: esta crisálida, un poco arquenda, remata en dos puntas de $0^{\circ}, 0 S_{75}$ i $0^{\circ}, 011$. Unos quince dias despues salen las moscas del suelo, y en los cuadrós de los jardines se nutan entonces ficilmesnte lus agujeros cuando los hay en gran mimero; las hembras suelen presentarse primero, $y$ los machos una semana despues.

\section{EL BIBIO DE LOS JARDINES - BIBXO HOR- TULANS}

CARACTKRES. - Hay un gran múmero de especies de bibio que vivén del mismo modo, pero son todas mas pequeñas. El bibio de los jardines difiere mas aun por los sexos, pues el macho es negro y la hembra es de un rojo deladrillo.

USOS, COSTUMBRES Y REGMMEN.-1.alarn, negruzaci y muy semeịnte á la anteror, perjudica á veces mucho las plantas cultivadas. Asi por cjemplo, en abril de 1875 destrozó en nuestra region un cuadro recien plantado de espárragos, devorando las raices de las plantas.

\section{LOS TABANIDOS-TABA- NID死}

Aunque por su aspecto exterior son moscas perfectas, los tabånidos se emsforman como muchos mosquitos y sus hembras tienen la sed de sangre propia de estos, pudiendo atormentar mucho a hombres y animales. La siguiente especie nos servira para explicar cl carácter de toda la familia.

\section{EL TÁBANO DE LOS BUEYES-TABANUS BOVINUS}

CARACTÉres. - In la cabeza de esta especie, la mas comun de las 4006500 gue están diseminadas por todo el globo, sobresale el gran labio inferior, que es membranoso, como estuche de la trompa, pudiendo recogerse mas en estado de reposo; en su interior oculta las células picadoras, que segun la especie figuran en mimero de cuatro sí seis; los palpos maxilares tienen dos artejos; las antenas se aproximan mucho en la base, comproniéndose de tres artejos, pero como el tercero es á veres anillado, podria decirse que hay seis: In disposicion de los nervios de las atas, abiertas en estado de reposo, és caracteristica para la familia: el nervio costal pasa al rededor del ala; el tercer nervio longitudinal es ahorquillado, y su rama inferior se dirige á veces un poco hácin atrás. De la célula discoidea parten tres y de la base posterior uno longitudimal hácia el borde; anbas cólulas ba. silares son de igual longitud s están marcadamente separadas; la célula anal se prolonga casi hasta el borde de las alas: de 
las cinco del borde posterior, la primera esta à veces cerra. da. En las patas, que carecen de cerdas, sce ven tres discos prehensiles, como particularidad de ha familia. Esta especie, una de las mas grandes de nuestros paises, tiene los ojos desnuclos, y en los machos siempre se tocan en la coronilla: no hay apéndice alguno en la rama anterior del tercer nervio longitudinal; los tarsos son de un amarillo claro; en el ab. dómen, que se compone de siete segnientos y tiene una mancha dorsal triangular, predomina un color amarillo oscuro de cera. El escudo dorsal esti bastante cubierto de pelos amarillentos; las antenas, escotadas en forma de media luna, no son nunca del todo negras; las alas, de un gris pardusco, tienen los nervios de un parco amarillo (fig. 3r6). Esta descripcion me basta aun para distinguir la citada especic de otras muy parecidas, pero no podemos ocuparnos aqui de mas detalles.

USOS, COSTUMBRES Y REGIMEN.-Por un fuerte zumbido el tábano de los bueyes anuncia su presencia, cuando llega para atormentar al ganado en los pastos. Los animales mayores buscan la sombm para preservarse de los tibanos: que visitan con preferencia los sitios banados por el sol. Es curioso oixservar sus rápjiclas evoluciones: produciendo un fuerte \%umbido parecen sostenerse en el aire en un mismo sitio, y los movimientos de sus alas son tan ligeros que apenas pueden, verse cunudo el insecto se mueve de laclo; desaparece de pronto de nuestro vista y vuelve á presentarse un momento despues en otro punto. A esta danza singular acompaña á veces un concicrto nada desagradable cuando se reunen de diez à doce individuos. El tábano es muy timido ante el humbre, al que solo ataca cuando permanece inmóvil. Fn los dias destemplados suelen posarse en los troncos de los árboles, pero sicmpre estin alerta y escoppan por debajo de la mano cuando se les quicre coger. Tambien se alimentan muchos de las encimas enfermas.

La larsa se parece por sur forma y género de vida \&́ los mosquitos ierrestres: así como ella, se la ve reunida con sus semejantes en las prideras, donde se alimenta probablemente de has raices de las gramineas, pudiendo adelgazanse mucho cuando estira la parre anierior del cutrpo. La peqqueña cabeza de un pardo brillante, tiene dos antenas, palpos y dos ganchitos encorvados hácia abajo, que asi como las verruguitas carnosas del vientre sirven para la locomocion. Los doce segmentos del curerpo son grises y tienen los ligamentos negruzcos. I.a extremidad gruesa de la cola prescenta como estigmas dos espigas carnosas latcrales. Fu mayo la larva llega i la edad adulta despues de imvernar; muda la piel y se trasforma en una crisálida de color gris provista en el borde posterior de los ocho segmentos abdominales y fratnjas grises, y en cl uíltimo de unat corona de cerdas, con cuyo auxilio sale de la ticrra; dos prominencias le sirven para la sespiracion. En junio sale la mosca; la hembra fecundada deposita sus huevos en montoncitos de 300 i 400 , en tallos de gramineass y al cabo de diez ó doce dias nacen las larvitas, si no lo impiden unos pequeños icneunrónidos que de. positan los hucros en los de este tábano.

\section{EL CRISOPO CIEGO-CRYSOPS CCECUTIENS}

CARACTERES. - Al contrario de la cispecie anterior, que con gran ruido se accerca a su victima, otras dos moscas pertenecientes ia la familia atacan su presa con al mayor silencio y astucia, agradindoles mucho la sangre humana. la primera es el magnífico crisopo ciego, con sus dos ojos dorados. Tener dos ojos, $y^{\circ}$ sin embargo ser ciego, parece una contradiccion: pero sin duda se ha dado á esta mosca su nombre porque es ciega ante todo peligro que la amenace cuando una vec la empezado á clupar sangre. licene poco mas ó menos la forma de la esprecic anterior, en la que su abdómen, tambien deprimido, es nas redondeado por detràs y de igual anchura en casi toda su extension, midiendo solo 1)",00 8 i5 de longitud. El borde anterior es negro, asi como una faja trasversal en las alas; la parte anterior del abdúmen es de color claro; las antenas tienen la forma de lezna: tres ojielos bien marcados que faltan en los oiros tabánidos, y los espolones en la cxtremidad de los tarsos posteriures distinguen à este género del anterior.

USOS, COSTUMBRES Y REGIMEN. Esta mosca y algunas otras especies dificiles de distingnir se encuentran en mayo y junio chupando la micl de las flores. Su insolen. cia no conoce limites: la bonita mosca se posa, sobre rado en los dias muy calurosos, no solo en las partes desnudas del hombre sino tambien en las ropas, à través de las cuales chupa la sangre lo mismo que a través de la gruesa piel de los bueyces y caballos. lil calor de una tempestad prarece aumentar su audacia y sed de singte. En los citados meses se presentan los tipos de toda la familia; en julio ya han disminuido mas, y en agosto casi del todo, desapareciendo al fin, con pocas excepciones, de que son ejemplo esta especie y la siguiente. Segun las observaciones de Ciaenuicke, en I'rancfort sobre el Mein, el tálsano de. ojos azules (Rabamus ģaucoppis) parece volar solo en otoño.

\section{EL HEMATOPOTO PLUVIAL- HAMATOPO- rA PLUVIALIS}

CARACTERES. - Fsta esprecie, de color pardo oscuro, con dibujos grises, es mas grande que la anterior, pero mas delgadaj tiene las alas de un gris negruzo con dibujos daros, y ojos reticulares die color rojo en su mitad superior; carece de ojuelos, y de espolones en los tarsos posteriores. En el macho, el primer artejo de las antenas se dilata mucho; en la hembor es largo y delgado, y en ambos sexos el último artejo, en forma de lezna, presenta en la punta tres anillos. Los dibujos, de un gris claro, tienen en el escudo dorsal rayns longitudinales y en el abdómen series de puntos y de lineas trasversales, en las incisiones articulares.

USOS, COSTUMBRES X REGIMEN. I I mosca debe su nombre a la costumbre de ser mas impertinente cuando llueve un poco, ó tambien cuando amenaza una temprstad. Se reunen á veces de diez a veinte individuos debajo de un paraguas abierto: y entonces es dificil defenderse de ellos, pues uno ú otro sabe siempre encontrar la sangre, aunque ser a través de la ropa. Segun se dice, los renos de Iaponia sufren-murho los atapues de estos insectos, de tal manera que á veces todo su cuerpo esta cubierto de una costrá causa de las picaduras. El desarrolio de las dos citadas es. pecies es el mismo que et del tibano de los bueyes.

\section{LOS CENOMIOS-CCENOMYIA}

CARACTERES. - La cabera de estos insectos es peque. ina: las palpos prolongacios y cilindricos; las antemas no tienen apenas el largo de aquellia, y su primer artejo es prolongado; los ojos algo vellosos; el torax grueso; el escudo presenta dos puntas: el abdónen es ancho; el quinto segmento y los siguientes pequenos; las piernas terminan en puntas: las celdillas posteriores de las alas son cortas.

\section{EL CENOMIO FERRUGINOSO-CCENOMYIA FERRUGINEA}

CaRACTfREs.-Este diptero ticne la extremidad de 
las antenas negra, y en cl tórax dos fajas de vello blanquir. co; el cuerpo es ferruginoso; las alas amarillas; el abdómen oírece algunas manchas negras. Fiste insecto mice $7 \mathrm{u} \& \mathrm{li}$ neas de largo.

DISTRIBUCION GEOGRÁFICA.-Abunda en Furo. [ja, sobre todo en los meses de junio y julio.

\section{LOS MIDAS-MYDAS}

CAR ACTERES. - Jos midas se distinguen por su trom. pa corta, con labios terminales trianguhres y comprimidos. A estos insecios sejes ha dado el nombre que llevin por alusion a la longitud de las antenas.

\section{EL MIDAS GIGANTE-MYDAS GIGANTEA}

CARACTERES. - Fsta es la mas notable especic del género: en el cuerpo predomina el color negro; la barba es blancuizca; el tónx y al primer segnento del abdömen aterciopelados; los ptros de un azul metálico algo brillante, con visos verdosos; las alas negras; el borde intemo pardo en ambos sexos. El midas gigante tiene de 15,2 a lineas de largo.

DISTRIBUCION GEOGRÁFICA.-Este diptero habi12 en la América meridional, y se encuentra particulamente en al Brasil.

\section{LOS ASILIDOS ASILIDA}

Segun hemos visto, hs hembras de los tabanos necesitan sangre, aunglie no sea caliente ni roja, sino tal cono la conticne el cuerpo del insecto; sangre buscan los machos y las hembros de lis numerosas especies que se han reunido de la familia de los asilidos, $y$ en cuyos nombres, tales como mosin surilan, mosca lubo, mosm asesina y moska rapaz adivinamos el coracter de algunas tribus de este grupo.

CARACTERES. - Los asilidos se reconocen generalmente por su cuerpo raquitico y prolongado; tienen lis pa. tas fuertes, provistas entre las garras de dos lóbulos prehen siles; distinguense además por los pelos de ln barba y de las mejillas y por el último artejo de las anteras, que no suelc prolongarse y tiene una cerda en/su extremidad ó un estilo articulado; la trompa, corta y puntiaguda, está dispuesta horizontal ú oblicuamente, raras veces en sentido vertical; la mandibula inferior, en forma de cuchillo, solo tiene cuatro cerdas; el labio inferior es cónico, y en los palpos solo hay uno ó dos artejos. Los ojos de ordinario salientes, se hallan sepa. rados en ambos sexos por un surco en la coronilla, por lo cual la cabeza parece ancha y corta; los ojuelos estín dispuestos en una serie de tres, uño muy cerca del otrn, y i menudo en una prominencia. El atdómen se compone de ocho segmenios, el último de los cuales permite ver el Laladro y. los órganos genitales del macho. A causi de las escamitas humerales las alas quedan descubiertas; en el estado de descanso se apoyan sobre el dorso; tienen una tercera vena longitudinal ahorquillada, ó una celda discoidea, dos $\delta$ tres cuhitales y cinco dorsales, de las que la tercem y cuarta se estrechan à menudo ó se cierran, y: hasta son pedunçuladas. I.ai celdn anal llega hasta el borde, donde á peces se cierra.

USOS, COSTUMBRES Y REGIMEN, - I Aas larias que liasta ahora se conocen, de pocas especies, viven á poca pro. fundidad en el suelo, sobre todo en la arema humeda, eis mices y en madera muerta, de la cual se alimentan; son prolongadas y duprimidas: tienen la cabe\%a bien marcada, y estigmas por delante y por detras. Despues de mudar la última piel de larva se trasforman en crisálida.

CLASIFICACION.- - Los asilidos se dividen naturalmen- te en dos grupos, segun q̨ue el segundo nervio longitudinal termine en el borde del ala (leglogaster, damalis, ceraturgus, dioctria, dasypagon) ú en el primer nervio (Iaphria, asilus, ammatius), ó que la celda radial esté cerrada ó abierta. E] primero de estos caractéres facilita mucho la facultad de rolar, segun puede observarse tambien en numerosos géneros. Al segundo grupo pertenecen por lo tanto los attevidos rapaces de haibil ruelo, para los que apenas ninguna presa elegida es demasiado grande, fuerte ó dura; mientras que los del primer grupo son perezosos y persiguen su presa indefensa entre los tallos y las hojas.

\section{LA DIOCTRIA DE OELANDA - DIOCTRIA OELANDICA}

CARACTERES. - Lsta esprecic se reconoce fảcinmente por sus alas negras; el cucrpo es de un negro brillante, y las puntas, bastante Iargas, de un rojo amarillo; solo los piés y las puntas de los tarsos son negruzcos; la barbil, los bordes interiores de los ojos, algunas manchas en los lados del tórax, asi como dos fajas en el dorso, son de un amarillo metálico.

locw cuenta sicte especies europeas del género, que se caracterizi jor las antenas, de ordinario insertas en una prominencia de la frente y que tienen casi la longitud del tórax; el abdómen afecta la forma cilindrica y se arquẹa; las patas posteriores tienien pestains en su cara interior. Iia hemos dicho que el tercer nervio longitudinal desemboen en el borde extchior, $y$ aniadiremos que el color negro ó negro pirdusco de esta especic es propio tambien de sus otros congéneres. Ia mosca mide $0^{n}$, or 5 de longitud.

DISTRIBUCION GEOGRAFICA. - Esta especie, que toma su nombre de la isla de Oelanda, está discminada por toda la Europa, cxcepto en su parte sudoccidental.

lambien en la sumérica del norte se encuentran algunos répresentantes del género.

USOS, COSTUMBRES Y REGIMEN. - I A dioctria de Oelanda se encuentra en vemno i menucio en las espesuras. donde acecha los mosquitos y las pequenas moscas, sin perdonar tamporo a las aranas.

\section{LOS DASIPOGONES-DASYPOGON}

CARACTERES. - Los dasipogones son moscas de formas recogidas, cuyas anienas rematan en un estilo puntiagudo: se distinguen ademas de los anteriores por tener pelos cerdosos en la barba y un gancho en la extremidad de los tarsos anteriores.

DISTRIBUCION GEOGRAFICA.- lils especies se encuentman en gran número en todos los continentes.

\section{EL DASIPOGON ALEMAN - DASYPOGON TEUTONUS}

CARACTERES.- Esta especic, de $0^{\mathrm{m}}, 01520^{\circ 0}$, or 75 de largo, es de color negro brillante, con los tarsos, muslos $y^{\circ}$ antenas de un rojo de orin, y rayada de pardo en el dorso del tórax: los lados son de un amarillo metálico. El abdómen, mas deprimioio en la hembra. es cilindrico en cl macho, $y^{\circ}$ presenta en los lados unas manchás de un blanco plateado; las alas son de un gris amarillento.

DISTRIBUCION GEOGRÁFICA.-Lal esprecic abunda bastante en Alemania.

\section{LAS LAFRIAS - LAPHRIA}

CARACTERES. - I Ins lafrias tienen la celda radial cer- 
rada y carecen en el artejo fusiforme de la extremidad de las antenas de un estilo y' de la cerda, excepto una especie (/afhystin salustionlar) de la costa del Asia menor. Las latrias tienen el abdónen de igual anchura en toda su extension, un poco deprimido y á menudo cubierto de abigarndos pelos: agrádales oprimirle contra un tronco de árbol, con la cabeza dirigida hacia abajo y entreabicrtas las patas, en cuya posicion se ponen al sol para devorar la victima cogida. Si añadimos que tiene una espesa barba que llega hasta las antenas, habremos completado los caractéres que distinguen al géncro. En algunas especies la primera célula dorsal queda abierta, y en las otras se cicrra.

\section{LA LAFRIA AMARILLA-LAPHRIA GILVA}

CAR ACTERES.-Esta especie, de $\|^{m}, 013 \therefore 0^{\circ}, 0175$ de longitud, pertencece al primero de los grupos. Esti del todo cubierta de pelos regros mezclados en la cabeza: en el tórax y en la base del abdómen de pelitos blancos; en el centro del segundo segmento hay otros pelos de un rojo de orin muy vivo que no llega al borde lateral y se cxtiende hasta el quinto y sexto segmentos. De los artejos de las antenas el primero tiene casi doble longitud que el segundo, y el tercero, muy semejante á una maza, es mas largo que los dos primeros juntos. Las alas son turbias junto a los nervios. Esste audaz insecto chupa, del modo ya indicado, con toda comodidad, la sustancia de su presa, pero huye tan pronto como sc acera ailguien, produciendo un fuerte zumbido.

\section{LOS ASILOS - ASILUS}

CARACTÉRES.-Los asilos se distinguen de los ante. riores por la cerdir funal del tercer artejo de las antenas. IJos dipterúlogos como Wiedemann, Macquart y Loew, han di. vidido en numerosos géneros los muchos centenares de especies distribuidas por el globo, teniendo en cuenta la forma del abdómen y de los nervios de las alas; si existen tres celdas cubitales $\delta$ solo dos; $y$ si la segunda está provista de un apéndice ó no, etc. Los asilos tienen de comun con las la. irias la celda radial cerrada, pero se distinguen por tener dos celdas cubitales, ahorquillandose el tercer nervio longitudimal, micntras que la segunda no tienc ningun apéndice nervioso. Ademais de esto, la célula de las antenas es desnuda, y su primer artejo mucho mas corto que cl segundo, notán. dose tambien la falta de espolones en los iarsos medios, mientras que por lo demás las patas estan bien provistas de espinas ye de pelos.

DISTRIBUCION GEOGRÁFICA. - Se conocen algu. nos centenares de especies en todos los continentes, de las que ciento pertenecen a Europa, distinguiéndose casi todas por su sencillo color gris pardusco.

\section{EL ASILO ABEJORRO-ASILUS CRABRO- NIFORMIS}

CARACTERES.-Fsta especic, de color gris amarillo, tiene la cabeza de este ultimo tinte, asi como las depresioncs de los hombros, algunas myas dorsales y los úlimos segmentos del abdómen: la base del abdónien es de color negro par. dusco aterciopelado; las alats, que son de un amarillento de orin, presentan en la punta y en el borde postcrior algunas manchitas mas oscuras (fig. 119).

Estr especie, que mide de $0^{\circ}$, or 5 a $0^{\mathrm{m}}, 0$ of de largo, tiene muy pocos pelos en compamcion con otras especies.

DISTRIBUCION GEOGRÁFICA.-Se eneuentra en toda Euroga y llega hasta el centro de Asia.
USOS, COSTUMBRES Y REGIMEN.- lista mosca se encuentra á menudo al cruzar un compo segado; la remos elevarse a pocos pasos y huir volando hasia que se halla á cierta distancia. Por la noche le gusta descansar en troncos de árboles. Una vé encontré un individuo con las pastas rigidas, la extremidad abdominal cncogida y l.2s alas recogidas en el dorso, pareciendo mas bien un sér muerto que vivo. Para reconocerlo le cogi, pero al punto segregó un repugnante li. quido lechoso, sin moverse, obligiadome sin embargo i tirarle sobre la yerba. De este modo el insecto, que al parecer se habia dormido, se libró de mi sin morder ni resistirse.

In todas partes, en las espesuras, en los caminos, en las pendientes arenosas, $\delta$ en los troncos de árboles, las diferen. tes especies vagan en busca de su presa. De la roracidad y del carácter de araina de estas moscas se pucde juzgar por las siguientes palabms: CLa hembra mató despues del apa. reamiento al macho para chuparle la sustancia. Esto dice el relato de Jaenicke y' se lee debajo de una parcja disecada del asilus ganumus que se ve en la coleccion de Hoyden.

\section{LOS EMPIDOS-EMPID死}

CARACTERES. - LOS empidos ó moscas bailadoras constituyen una familia bien separada de otras, pero poco uniforme en sus esprecies. I.a cabeza, casi esférica ye pequéna, se destaca marcadamente del tórax; la trompa, que sirve parn comer, es puntiaguda y se inclina hicia abajo en forma de pico; el ruerpo es delgado, solore todo el abdúmen, que en la hembra remata en punta aguda, y en el macho en diferentes apéndices extraios; la completa desnudez. del cuerpo y las patas antcriores, prolongadas, conumican a varias de estas moscas rapaces el aspecto de mosuuitos: solo hay un nervio longitudinal ahorquillado y una célula anal, casi siempre muy corta y cerrada, provista en todos los casos de un largo tallo, carảcter distintion de las alas.

USOS, COSTUMBRES Y REGIMEN. - Desde prin. cipios de la primavera llama la atencion esta mosca por sus croluciones y cacerias, que debajo de los årboles ó de la espesura cjecutan á menudo con sus semejantes. Fintonces se aparean; y con frecuencia se ve á varios individuos reunidos, chupando un insecto cazado. Esta nosca coge su presa, que solo se compone de pequeños insectos, valiénciose de las patas, como toclos los asilidos en general, y puede ofrecer toda clase de trasformaciones: se ven los artejos de los pies muy gruesos, muslos y tarsos cubicrtos de espesas escamas, alguna que otra parte encorvada; y en fin, una variedad en la forma de las patas que dificimente se encontrará en una segunda familia. Muchas especios visitan con preferencia los eardos, la yerta de San Juan y otras plantas de las que a menudo vuelven a salir cubiertas del todo de pólen. las unas se presentan al principio de la primavera; las otras solo en otoño; algunas son activas de dia, mientras que muchas solo se agitan de noche como los mosquitas. I majoria es propia de las regiones frias y de las montanas. Las yocis larvas que hasta ahora se conocen distinguense por unas incisiones muy marcadas entre los segmentos del cuerpo, y viven en la tierra.

Segun la diferencia de los nervios de las alas dentro de los limites indicados, la familia se divide en numerosos géneros y estós en ui gran número de subgéneros.

\section{EL EMPIS DE DADOS-EMPIS TESSELLATA}

CARACTERES.-Esta especie, una de las mayores de nuestros paises, tiene un color gris pardusco, con tres rayas negras en al escudo dorsal; la base de las alas es amarilla, y el resto de un pardo claro, con manchas claras en forma de 
daclos en el abdómen. En el macho esta parte termina en una tenaza á modo de hacha, ! los ojos se tocan en la cor ronilla. la mosea tieue $\|^{m}, 013$ de largo y se presenta en mayo yo junis.

\section{EL ANTRAX SEMI-NEGRO-ANTRAXSE- MIATRA}

CARACTERES. - El antrax semi-negro tiene velos de este color, y solo en el túrax y el aboúmen hay algunos de un rojo amarillento. Jas alas son negris en la mitad de la base y vidriosas. El género se caracteriza ademís por los siguientes distintivos: de la gran ábertum bucal, la cabera, que es licmisterica, sobresale la trompa, puntinguda y de mediana longitud: las antenas, muy separadas una de otra, tienen el primer artejo cilindrico, el segundo en forma de diseo, el tercero én figura de cebolla ó cónico; el estilo final cucnta dosartejos. 1.os ojos, reticulares, estan en el macho en la coronilli, mas pricimos uno a otro que en la hembra, y ademàs se observan marcados ojuelos. El abdómen, compuesto de siete segmentos, es un poco deprimido, y en estado de descanso queda fácilmente cubierto por las alas medio abieras. Estas tienen el tereer nervio longitudinal ahorquillado y la rama superior nuy arquenda en forma de S; en la base liny is veces un ajxentice-neryioso; cl segundo jarte al jarecer del ecrecto, y el pequeno nervio trasversal se inserta verticalmente en el centro de la célula discoiden - selacerca un poco à la base. De la citada celda parten tres nerios; el último descle muy cerca eic la celda basilar; cuatro céltulas dorsales abiertas, una anal, que llega hasta el borde de las alas, y dos cubirales, complctan el crinjunto de los caractéres.

USOS, COSTUMBRES Y RÉGIMEN,-Con un vuelo sosteniđo pero ágil, esta mosca y otros coneréneres hacen sus eroluciones á poca altura del suelo, con preferencia en los sitios secos, teposasndo at intervalos en una piedra ó chupan? do con la trompa en un sitio húmedo para cobmr fuerzas. Cuando el tiempo es desagradable se las ve inmóviles en las hojas, en la yerba ó en el suclo, mas ó menos ocuiltas, sin huir aunque se/as toqué. l os antrax viren como parúsitos en las abrejas y otros himuenópturos y tambien en las orugas de mariposa. No conowo mas detalles sobre su genero de vida. Yo obtuse un individuo el a de abrit de 1858 de un capullo cuyo origen, sin embargo, no puedo indicar, porque lo encontré debajo de un arbusto en agusto. Del diferente tamano de la mosea, que varia de $0^{\circ}, 0045$ \& $16^{\circ}, 01.3$, resulia que la larria debe habitar en diferentes anfitriones.

Otras especies vuelan por las paredes viejas de barro habitadas por abejas, para deprositar sus hutwos, o buscan su alimento en las yerbas Eintre los antrácidios hay tambien especies mas grandes que en rez del color negro tienen un tinte rojo pardusco y constitujen el trinsito i los siguientes.

\section{LOS BOMBILIOS - BOMBYLIUS}

CARACTERES. - Estas moscas, que cuentan mas de 100 especies clistribuidas en el globo, tienem formas mas recogidas, parecidas en parte it las de los abcjorros; en el dorso presentan espesos pelos amarillentos, grises 6 de otro color, que fácimente caen. De los antrícidos se distinguen por la cabeza relativamente mucho mas pequeña, por las antenas muy próximas y por la trompa, dispuesta horizontalmente.

USOS, COSTUMBRES Y REGIMEN. - A principios de la primavera se juesentan los bombilios en los mismos puntos qque las especies anteriores, introducen á menudo su larga trompa en una for y producen un fuerte silbiclo. Re- cuerdan por este concepto a los esfingrios entre las mariposas, pues no se les ve posados, sino siempre en un morimiento sostenido liasta cuando comen, juero tambien descansan en las hojas ó en el suclo seco, y permancecen inmóviles en los mismos sitios cuando no hace sol. Una especic, el bomblylins seconsus, pertenece a las especies cubiertas de pelos grises amarillentos, y' es muy comun en Europa; lleva en la parte posterior de la caleza largos pelos negros y detris de los ojos otros del mismo colvr, pero mas largos aun. Los bonbilios se desarrollan del mismo modo que los antrácidos, pues viven como paråsitos en diferentes himenópteros.

\section{EL ESTRATIOMIS CAMALEON-STRATIOMYS CHAMALEO}

CARACTÉRES. - Fil estratiomis camaleon es una dé las especies mas notables de su género; la cabeza es de un color vivo amarillo; las gruesas mejillas salen un poco en forma de reborde y tambien la cam es del mismo color, exsepto uria estrecha rava longitudinal de un negro brillante. I os ojos, reticulares, se tocan en el macho en la coronilla. Fil último aricjo de las antenas se compone de cinco anillos y es un poco aplanado. I. tromya, angulosa y camosa, se recoge en estado de descanso y oculta en su interior dos cortas ct. lulas, que munea pican; los pequeños palpos se componen de dos artejos. Ista especie se designó con el nombre aleman de mosor de armas por tener el escudete, de un color mas 6 menos amarillo, provisto en sus ángulos posteriores de una espina en forma de lanza que se eleva oblicuamente. l'ámbien los dibujos del ancho abdómen, y las patas, excepto un anillo negro que hay alrededor del borde, son amariilos. En el estado de reposo las alas se aplanan solire el cuerpo sin cubrirle, porque este es muy ancho: su nerrio ra. dial Hega solo hasta la punta, y los longitudinales anteriores se oprimen de tal modo que la célula discoidea esta situada nuy adelante; de ella parten otros cuatro nervios pálidos, muy encorvados, que no llegan al borde de las alas; el tercer nervio es ahorquillado.

USOS, COSTUMBRES Y RÉGIMEN. - Fira el 27 de julio de $1 \$ 56$ cunndo emprendi una expedicion para coger insectos: hacia mucho calor, y toda clase de especies, sobre todo moscas, volaban activamente al rededor de la abigarnada alfombra de una rica regetacion. Una mosca en exiremo graciosa (strationy's furcula) estakin posada en el borde de un pequeño clarco en la cara inferior de una hoja de caña, poco mas ó menos à la altura de un hombre-sobre el nivel del agua, llamando tanto mas mi atencion cuanto que hasta entonces solo esta mosca habia visitado las flores con vuclo rápido, pero silencioso. Del todo convencido de la timidez de esta especic, acerquéme con cautela y consegui mi objeto. In inosca, no solo permaneció inmóvil, sina que continuó cu su ocupacion, que era poner huevos. Un objeto al parecer sedoso, que se reia detrís del insecto, iba aumceltando de volumen a medida que la mosca avanenba proco a poco: no pude observar mas á causa de la distancia, pero al fin cogi la mosca apoderándome de la hoja y los hueros, que eran cilinaricos, de color gris verdoso y de unos 11",00225 de largo. Los llevé a casa, y prontó observé que su color se oscureciai al cabo de unos diez dińs encontré -algunas pequeñas larvitas de forma de lanceta, pero muertas ya en su prision. Otra vez recogi, el 29 de mayo, una porcion de tallos de caña, en los que estaban adheridos los huevos del stratiomys longirornis; al cabo de orho dias nacieron las larvas que se pusicron en agua, pero no prosperaron; parecianse en un todo a la larva adulta y gustabales subir por las paredes de la vasija de vidrio, fuera del nivel del agua. Ia larva adulta de esta 
especie se adelgaza hácia las extremidades, afilándose en los lados, de modo que su corte trasversal se asemejaria poco mas ó menos al de una lentejia. De los doce segmentos del cuerpo obsérvase que en los cuatro primeros el borde anterior lel uno cubre sicmpre el posterior del que le precede; todos son de un color gris de tierra pardusco, con lineas longitudinales y puntitos negruzcos. Ia punta de las alas presenta una abertura respiratoria y está rodenda de uma corona de pelitos, mientras que el orificio anal se halla situndo un poco mas hảcin adélante. Fèn sus movimientos estas larvas se parecen mucho à las de los mosquitos arriba citadas. Haciendo evoluciones en forma de S y $\mathrm{C}$, con la extremidad caudal hácia arriba $y$ la caheza inclinada, suben $y$ bajan en el sgua, permaneciendo tambien it menudo en posicion vertical con los pelos caudales extendidos en la superficie. Tan luego como se sumergen estos uiltimos toman una forma es. férica y encierran una burbujita de aire de un brillo plateado, que es la provision para respirar, y la cual permite á es. tas. larwas permanecer largo tiempo debajo del agua. I a calueza, córnea y de color negro, ticne dos ojuclos y en la parte anterior una especie de pico junto a un par de maxilas movibles. La larva muda varias reces de piel; para trasformarse en crisálida abandona el agua y busca un escondite dełajo de alguna piedra. En tal sitio encontré el 12 de abril algunas larvas, a la distancia de dos metros del agua, por otro tanto de altura. Ias puse en una habitacion caldeada, sobre tierra bastante seca, en la cual penetraron un poco; y el 84 de tmayo se presentó la primera mosca, un macho del estrationys longicornis. No es sin embargo preciso que la larva salya del agua, pues tambien to hace la crisálida, ąareciendo en la superficic de la misma entre las lentejas $y$ otras plantas acuáticas. La ninfa, semejinte a una larm resecada, es corta, y su parte anterior se recoge de modo que afecta una forma algo angulosa, á lo cual se debe que los ganches córneos de la cabeza sobresalgan como espiguitas. A pesar de su género de vida, tnmpoco estos insectos estin libres de parisitos: de uno obtuve una esmicra de seis piés perteneciente á la firmilin de los calcidios.

\section{LOS SIRFIDOS-SYR- PHID死}

CARACTERES.-I.os sirfidos se distinguen como especies extrâns que no faltan en ninguna parte $y$ cosistitugen una de las familias mas numerosas entre las inoscas. Los tjpos, diferentes entre sí, se reconocen por su nervio longitudinal supernumerario, que atravesando el pequeho nervio trasiersal, se intercala enire el tercero y cuarto: dicho nervio no es nunca ahornuillado, pero í veces se arquea en su último tercio, sobre todo en el género de los cristalimos. In priniera célula del borde posterior está siempre cerrada, y la anal se prolonga hasta cl borde del ala. Fin todas las especies la cabeza, de forma hemisférica, tienc la anchura del escudo dorsal y es algo cóncavia ciebajo de las antenas, compuestas de tres artcjos, sobresale en la parte anterior de la can en forma de nariz; en la coronilla hay tres ojuclos marcados; los ojus, reticulares; se tocan en el macho: la abertura bucal es grande y suele ocultar por complete la trompa, carnosa y provista de anchas superficies absorbentes y de palpos no articulados.

USOS, COSTUMBRES Y RÉGIMEN. - I.OS sirfidos visitan con asiduidad las fores y los arbustos poblados de pulgones, y' se distinguen por su vuclo àgil é impetuoso. L.legado el verano, rense en las hojas, en medio de los pulgones, las larvas perteneciontes á las numerosas especies de sirfidos, cuyo color predominante es verde, mas ó menos mezclado de gris; se parecen mucho por sus formas y movimientos a las sanguijuelas. Su Rexibilidad y ligereza llega al mas alto grado, pues saben alargar su cuerpo en punta y contraerlo en ambas extremidades de modo que casi adquiere la forma de un bvalo. Se agarran por medio de unas ver. rugas carnosas que tienen en la parte posterior del cuerpo, mientras que la mitad anterior, adelgayandose mas y mas, eléase como un tenticulo al aire. En la extremidad anterior solo se distinguen dos ganchitos córneos, y en inedio, una plaquita cómea triangular. Con los ganchitos la larva se agarra, cuando ha extendido mucho el cuerpo, para soltar despues la extremidad posterior y ponerse en movimiento; con la plaģuiza atraviesa su victima, el incicfenso pulgon; recoge la parte anterior del cuerpo y chupa la sustancia, haciendo movimientos semejantes a los de la maza de una bomba. Al cabo de un minuto no queda del pulgon sino la piel, y si la larva tiene hambre, busca al punto uma segunda presa: las que son muy jóvenes se fijan por lo regular en el dorso de un pulgon para chupar la sustancia: Produce una inıpresion muy extraña observar la actividad de estos rapaces, al parecer del todo inocentes, entre los pulgones inofensivos. Atraviesan uno despues de otro sin piedad, y los chupan tranquilamente mientms toman su alimento, viéndose a menudo que el pobre pulgon pasa sobre su enemigo y se posa jacificamente a su lado, sin sospechar que un momento despues dejará de existir. Esta es una verdadera escena de extermi. nioj es el asesinato silencioso, despues de fingir un caricter pacifico é inofensivo. Veinte ó treinta victimas para una sola comida no es nada para uma larva adulta que repite estos icstines muchas reces diarias, descansando con preferencia a las horas del medio dia. No podremos extrañar esta voracidad si se refiexiona que la laria necesita pocas semanas para llegar á su completo tamano: despues abandona el teatro de sus hazañas y se fija en la cara inferior de una hoja, en la punia de un cono de jino ó en un tallo de jerba, donde pronto se encuentra su capulio verde pardusco, en forma de goth que cae $\delta$ de una lágrima, fijado con la cara interior en el objeto elegicio. En este capullo se forma la crisálida; poco à poco se oscurece mas, y al cabo de quince dias se levanta de su extremidad, mas, gruesa, una pequeña tap̧a, abriendo el camino el sér recien nacido.

\section{EL SIRFO DE MANCHAS SEMILUNARES- SYRPHUS SELENITICUS}

CARACTERES. - Esta especie, yue del moda descrito ha salido a la luz del dia, tiene la cabeza y el tórax de un verde azulado metálico: el escudete trasparente, de color amarillo pardusco, cubicrio de finos jelos, sin exceptuna los ojos: el abdomen, plano, es de un negro brillante, con tres pares de manchas semilunares blancas que en una especic análoga, casi unas comun (syrphus pyrastri), son de un color amarillo claro y están dispuestas en parte de un modo distinto. Ias antenas, oscuras, rematan el] un artejo oval que en su base tiene una cerda desnuda. las alas, tan claras como el cristal, y brillantes, se caracteriann, lo mismo quc en todos los congéneres, por el tercer nervio longitudinal, casi recto, por un nervio trasscersal pequeho gue desemboca en la mitad anterior de la célula discoidea, y por una radial abierta. Ia primera tiene casi la misma longitud que la primera dorsal, cuyo ángulo anterior superior es siempre agudo.

USOS, COSTUMBRES Y REGIMEN.-Cuando hace sol estas moscas vuelan muy vivamente, pero sin ruido, del mismo modo que es propio a todos los sirfidos. Permanecen mas o menos tiempo en un mismo punto en al aire, y van a 
posarsc despues poco á poco sobre una hoja ó una fior, para repetir luego la misma maniobra. En los dias desapacibles son tan perezosas como vivaces cuando hace sol. La hembra deposita sus huevos aisladamente en las hojas cubiertas de pulgones. El desarrollo es rípido y puede suponerse que hay varias crias al ario; por lo que no es fácil decir en qué estado estos animales invernan. Durante las inundaciones de la primavera he prescado larvis medio adultas: de modo que consta que estas habian pasado el invierno. El 4 de diciembre de $186 j$ encontré una hembra de aspecto aun muy juvenil, que se oprimia en la cavidad de una pared de barro; no hubiera podido asegurar si habia pasado en aquel sitio el invierno, pero me parece que esto sucede con muchas crisálidas, porque nuy di menido se encientran moscas recien nacidas al principio del año.

Si en las especies de militrepturs, condenadas a vagar eternamente entre las fiores de las gramintas, sobre todo en los melitreptus seriptus, mi tieniatus y otras, el cuerpo tiene una forma lineal, en el género bacciva se adelgaza de un modo extraordinario, pues remos que cl abdómen es pedunculado, lo mismo que en los géneros ammophila y tnpoxylon, entre los ásilidos. Con estas especies forman contraste los sirfidos mis recogidos y anchos, propios de nuestros paises, que son los siguientes:

\section{LAS VOLUCELAS-VOLUGELLA}

CARACTERES. - Varias especies de este grupo se parecen mucho á causa de sus espesos juelos á un abejorro; ade más se reconocen fácilmente por tener una celda mdial cerrada, y una cerda muy larga en el dorso del tercer artejo de las anienas, que en la hembra es un pocomas fuerte y esta cubicrto de pelos mas espesos que en el macho.

USOS, COSTUMBRES Y REGIMEN.-Estas moscas son timidas y fugaces, y muy silenciosamente vuclan de arbusto en arbusto en busca de la miel de las tores; pero muchas veces se las ve cuando produciendo un fuerte zumbido cruzan los aires como los tabánidos: yo creo que entonces se aparean.

Degeer y Reaumur encontraron ya en los nidos de abejor ros y avispas las larvas de las volucelas, es decir, de dos es. pecies: atolucela bombjlans y ciolucella plumala. Crichson, que turo ambas formas transitorias, dudó que fueran especies independientes considerando la última solo como variedad de la primera, sobre todo porque Boje habia obtenido ambas de un misino nido de abejorro. Si añadimos q̧ue 7eller cogió at fines de majo y principios de junio las dos supuestas especies en el acto del apareamiento, es decir, machos de ambas con sus hembras, no podemos dudar que solo la especie rundada por linneo es la que produce ambas variedades.

\section{LA VOLUCELA BOMBIFORME-VOLUCELLA BOMBYLANS}

CARACTERES. - Esta mosca se reconoce fácilmente por tener el cuerpo cubierto de spesos pelos, lo cual le comunica semejanza con el abejorro, tanto que la hembra puede entrar en las niclos de estos para depositar sus huevos sin que los habitantes legitimos se 10 impidan. El cuerpo es. negro, con la cara $y$ la frente de un amarillo de cera, y la mitad del abdómen amarilla, con pelos rojizos; el escudo dorsal está cubierto de pelos amarillos con el centro negro; el escudete es de aquel color; el abdómen tiene en la base nanchas laterales de igual matiz y està cubierto de pelos del mismo color; en los úlrimos segmentos hay pelos amarillos mas claros, casi blanquizcos (cuolucella plumsala): por las alas se corre desde el centro del borde anterior una faja oscura cortada, y tambien el nervio trasversal está orillado de tintes mas oscuros: la longitud de la mosca es de $\|^{*}, 014$ a ()$^{m}, 016$.

\section{LA VOLUCELA TRASPARENTE-VOLUCELLA PELLUCENS}

CARACTERES. - Esta especic, del mismo tamaño que la anterior, pero mucho mas comun, se reconoce por la base blanca del abdómen desnudo y por la base amarilla de las aias, con manchas oscuras.

\section{LOS ERISTALOS - ERISTALIS}

CARACTERES. - las numerosas especies de este género se distinguen de la anterior porque el pequeño nervio tras. versal oblicuo desemboca detrás del centro de la célula discoidea, y porque el tercer nervio longitudinal baja mucho hácia el borde jnterior, sicndo la célula radial tambien cerrada. I a cerda de las antenas es desnuda en algunas especies, mientras que en otras esti provista de espesos pelos plumosos.

\section{EL ERISTALO TENAZ-ERISTALIS TENAX}

CARACTÉRES. - El eristalo tenaz se encuentra ya á principios de la primavera, y pertenece á los insectos que antes del invierno visitan las florecitas aisladas. En 6 de octubre, cuardo ya habia helado algunas noches antes, encontré una mosca recion nacida con las alas no desarrolladas. El hombre inexperto la confunde con un macho de abejas; tanto se le parece por su tamaño, forma y zumbido, pero su naturale\%a de mosca resalta a primera vista, por tener solo dos alas, cuja estructura frermite reconocerla al punto cono eristalo; la especie es desnuda y la cerda de las antenas carece dé pelos; el dorso del líltimo artejo es casi circular. Como en todós los congéneres, los ojos están cubiertos de pelos negros, siendo solo visibles con el microscopio; ti resto de la cabeza, excepto una raya de color negro brillante en la cara, estŕ cubierto de unos pelitos amarillos y pardos, lo mismo que el tórax. El abdómen, de un pardo oscuro, se compone de cinco segmentos, $y$ tiene en los anteriores unas manchas laterales amarillas mas ó menos marcadis, presentando tam. bien hàcia afuera, sobre todo en el vientre que es un poco hueco, espesos pelos. I.os muslos posteriores, poco mas largos que los otros, se encorvan un poco, lo mismo que los tar5os, lo cual constituye una particularidad de todo el género; además presentan en el borde superior é inferior una secrie de cerditas negruzcas.

USOS, COSTUMBRES Y REGIMEN:-La larva vive en el cieno, sobre todo en los estercoleros al lado de las cuadras, y en otros sitios sucios, conociendose con el nombre de faria de cola de rata 6 de ratoncito, como la llaman en Silesia, sin que sepamos en qué sér alado se trasforma. Tiene la forma cilindrica y es de color gris sucio, midiendo en la edad adulta $0 ", 00175$; la cola es filiforme en toda su longitud. Ta extremidal anterior se recoge un poco en forma de repliegue y tiene los dos ganchos regulares; el vientre cstå provisto de series de cerdas que sirven para la lócomocion; la cola remata en una punta delgada de color rojizo, que puede sobresalir y recogerse. Cuando la larva habita en liquidos acuosos se suspende con la cola de la superficie para res. virar. Mas tarde se presentan en los sitios secos unas formas endurecidas, que son las criślidas, provistas de marcados repliegues y en su parte anterior de dos ajéndices en forma de oreja que tienen órganos respiratorios. $\mathrm{Al}$ cabo de doce $\delta$ ca- 
torce dias se levanta una tapita, dejando paso á la mosca. Los individuos que á principios de la primavem se encuentran en las flores $y$ en los sauces son probablemente los que invernaron en tal estado o quizás han nacido de crisálidas invernadas; es posible que la mosca inverne además como huevo.

\section{LOS HELOFILOS-HELOPHILUS}

CARACTERES. - Fil eristalo citado no es el único que debe su origen a larvas tan extranas: tambien otras pertene. cientes al género afue de los helofilos, los cuales difieren de los eristalos principalmente por tener la celda radial abierta y los muslos posteriores un poco mas gruesos, pero no denticulados. Algunas especies, como el helophilus pendulus, y el helophilus trivittatus, que se distinguen por su dorso rayado de arnarillo y el abdúmen provisto de manchas del mismo color, vagan al mismo tiempo con el cristalo tenaz á últimos de verano por las fiores y arbustos, y no se distinguen por nada de aquel en cuanto á su género de vida.

\section{LA CERIA CONOPSOIDEA-GERIA CONOP- SOIDES}

CARACTERES. - Este sirfido se distingue por el largo tallo en que se hallan las antenas y por las manchas amarillas sobre un fondo negro mate; las alas, medio abiertas y levantadas, presentan una raya oscura de color pardo. El género se reconoce por la extremidad blanca del último artejo de las antenas y por la primera celda del borde posterior, dividida en dos mitades por un apéndice nervioso que parte del tercer nervio longitudinal. En el macho se tocan los ojos en la coronilla, $y$ ademús el abdónen es del todo cilindrico, mientras quue en la hembra se ensancha ligeramente en el centro.

USOS, COSTUMBRES Y REGIMEN. - I a especiese encuentra a menudo al lado de las volucelas en las flores de ligustro; visita tanlbien los arbustos en flor y las partes enfermas de los troncos de árboles que contienen savin, pero solo se la re aisladamente. I.a larva, que se alimenta de madera podrida de los troncos de árboles viejos, se parece a las harvas de syrphus, pero tiene en vez de la colita un apéndice en forma de estilo que lleva los estigmas, y su superficie es àspera à causa de varias espinitas.

\section{LOS CONOPOS - CONOPS}

CARACTERES. - Por su aspecto exterior, por la disposicion de los dibujos y por la forma de las antenas que parecen pedunculadas, los conopos podrian confundirse fácilmente conl el género anterior si por otro concepto no difiriesen tan esencialmente que hasta sc ha debido constituir con ellos una familia independiente. La cabeza, bastante grande, es mas ancha que el escudo collar $y$ se distingue por tener la parte inferior de la cara dilatada; la abertura bucal es grande y de ella parte horizontalmente la trompa, que es córnea y angulosa y se prolonga mucho por lo regular. La frente, deprimida por detris de las antenas, es ancha en ambos sexos, provista en la coronilla de una vejiga trasparente que ocupa el lugar de los ojuelos. Las largas antenas estan muy cerca uma de otra en una prominencia, y forman una estrecha maza que se adelgaza en la extremidad, componiéndose de tres artejos. El abdómen, prolongado, se encorva en la punta hácia abajo, $y$ la hembra tiene en el vientre un órgano córneo, á menudo muy largo. En lo demás, las hembras se distinguen por la menor longitud de los lóbulos prensiles y de las garras de los piés, o por el quinto segmento, relativamente nass corto que en el macho. Fu las patas, Lastante largas y delgadas, los nuslos posteriores se ensanchan ligemmente, y en las garras de todos los piés se ven lóbulos prensiles muy desarrollados. Ins alas, largas y estrechas, tienen el primer nervio longitudinal doble con las dos ramas reunidas por un nervio trasversal; el tercer nervio es sencillo; la primera cúlula del borde posterior cerrada y pedunculada, como la anal, que se prolonga casi hasta el borde. Ya hemos dicho que los griegos empleaban el nombre genérico para designar los mosquitos.

USOS, COSTUMBRES Y REGIMEN, - Estas bonitas moscas se encuentran en las flores y parecen mas bien pere. rosas que vivaces. De varias especies se sabe que se desarrollan como parásitas en el abdómen de ciertos himenópteros, saliendo de esta parte á menudo medio ano despues de la muerte de su anfitrion. Yo descubri en la nuca de un lombus elegans, que habia estado en mi coleccion por $10 \mathrm{me}$ nos el tiempo citado, un agujero con la piel de crisálicia me. dio saliente, y en la misma caja el cadáver del conops aitfafus. La misma especie se crió tambien en la cuicsa antenuata y en una langosta (ocdipoda cyanoplera), el conops flavipes en una osmia, el conops chrysorrharus en el bemicx farsata, el conops auripes en un abejorro $y$ otras especics no citadas de la res. pa, oudinerus, pompilus audax, spher fluzipenuis. Respecto á los otros detalles, principalmente en cuanto a la manera de llegar el parásito à su anfitrion, no sé aun nada, pero sé jue. de suponer que depositan sus huevos en el insecto desarro. llado y no en la larva. Ademảs, el variado tamanio de las moscas de una misma especie parece indicar que no depende cada cual de una sola especie de insectos, sino que vive como parasita en varios, segun quedin demostrado ya pror el conopo myado (conops sillatus).

\section{LOS MIOPOS-MYOPA}

CARACTERES. - Ios miopos se distinguen de los conopos por tener la cerda dorsal corta en forma de estilo, compuesta de dos artejos en las antenas, por la existencia de ojuelos y por una trompa con dos ángulos.

\section{EL MIOPO DE COLOR ROJO DE ORIN- MYOPA FERRUGINEA}

CARACTERES.-Esta especic, que citamos entre algunas veinte propias de Europa, es de color rojo de orin brillante, con la cara de un amarillo dorado; en el escudo dor. sal hay tres rayas longitudinales negras, y en el abdómen fajas trasversales de un brillo sedoso blanco.

USOS, COSTUMBRES Y REGIMEN. - ES MUy curioso ver à las especies de este género posadas en una rama; con su voluminosa cabeza cchnda hácia atrás, ofrecen cierto aire amenazador, aunque su caricter es del todo inofensivo y pacifico. Tambien estos insectos, que vuelan à principios de la primavera, parecen vivir como parásitos en los himenópteros.

\section{LOS ESTRIDOS-CESTRIDE}

Bajo formas esencialmente distintas se presenia el parasitismo en una pequeia familia llamada de los estridos. I.25 especies visitan de diferente modo con preferencia los animales domésticos ungulados y la caza mayor; algunas se han dado à conocer tambien como parásitas de los roedores, y no cabe duda que atormentan igualmenteá otros mamiferos, solo que hasta ahora las moscas no se han podido observar. En los paises cálidos atacan á reces tambien al hombre; en 
la piel de la cabeza, en las fosas nasales, en las orejas y hasta en el estómago se han encontrado larvas llamadas en el Bra. sil urra, en Cayena ier macayue, en Costa-Rica toriel, entre los indios de Maynas suglacoru, en la Nueva Granada grusano peludo ó nuche, y que segun se dice pertenecen à un estrido humano (astrus hominis). Sin embargo, esto no es exacto; la verdad es que alguna especie que vive como paraisita en los bueyes, caballos, perros, nuulos, etc., ha llegado alguna vez por casualidad hasta of hombre.

CARACTTERES. - I Los estridos se distinguen por tener las antenas en forma de verrugas, insertas en una cavidad frontai y rematando en una cerda; la trompa muy atrofiada, apenas sirve para tomar alimento. Los ocelos existen. El abdómen, compuesto de seis seginentos; remata en el macho obtusanente, y en la hembra en un taladro. Los nervios de las alas se parceen mas a los de la familia de los núscidos. El nombre genérico de astrus, aplicado por Linneo, se con serva hoy dia solo para unas pocas especies, pues segun la direccion de los nervios de las alas, la forma de las antenas, de la bocil y de lit cara, se han constituido además trece géneros. Como el espacio no nos permite tratar de este importautisimo asunto tan minuciosamente como lo merece, nos atenémos a las investigaciones de F. Brauer, a quien se de. ben muchas explicaciones en este terreno misterioso, y que el citado naturalista consignó en su \&Monografia de los Estridos (Viena 1863), completándolos mas tarde en los \&Debates de la Real é Imperial Sociedad zoológico-botánicas.

USOS, COSTUMBRES Y REGIMEN. - Las larvas de las moscas de que tratamos viven debajo de la piel $y$ se ali. mentan de la sustancia supurada de las heridas que producen, ó se fijan en las paredes internas del estómago ó de los intestinos, cuando no eligen la cavidad masal ó bucal. En muchas de estas larvas se ha observado varias mudas de piel y en relacion con estas algunas trasformaciones de poca im. portancia. Cuando son adultas abandonan al animal que habitan para crisalidarse en el suclo. Las moscas viven poco tiempo, durante el cual nuchas vuclan zumbando con fuerza en las alturas desprovistas de vegetacion, cuando hace sol.

\section{EL ESTRO DE LOS CABALLOS-CESTRUS EQUI}

CARACTERES.--Esta especie es una de las mas comunes. La frente, mas ancha en la hembra que en el macho, y el dorso del tórax, están cubiertos de espesos pelos de un amarillo pardusco, que solo delante de las alas forman una faja negra. Las otras partes. llevan pclos mas claros y escasos; las patas y la mayor parte del abdónen son de color amarillo de cera oscuro en la piel. Las alas, ligeramente turbias, presentan una faja traswersal oscura y algunas manchitas; el cuarto nervio es del todo recto y' no existe el trasversal en la punta ni la primera célula dorsal cerrada. La mosca, que mide de $0^{\circ}, 013$ a $0^{\circ}, 0175$ de largo, descansa con la punta abdominal encogida $y$ con las alas entreabiertas (fig. 117 ).

Cuando la mosca nace obsérvase en ella una vejiga que cubre la frente $y$ la nuca como en los taquinos y otros múscidos en su juventud; desaparece cuando la mosca recien nacida se ha secado del todo, 5 entonces el insecto se lanza por los aires à fin de aparearse. Pertenece á las especies que buscan los puntos altos: en una cminencia estéril, nunca visitada por caballos, cogi el 6 de agosto uno de esos estridos. La hembra deposita sus hucvos aisladamente ó en corto nú. mero réunidos en la piel de los caballos, burros ó mulos, mientras estos se hallan al aire libre, en dias favorables: pero nunca los persiguen hasta la cuadra 6 al agua. El abdómen de la hembra contiene unos setecientos huevos, de forma extrana, cuyo color es al principio blanco y mas tarde amarillo. De ellos nacen al cabo de procos dias las larvas; que instintivamente se dirigen a la boca del animal que habitan, cl cual tas traga con el alimento; pero muchas no llegan al sitio de su destino. Despues de mudar dos veces de piel, la larva, de color rojo de carne, es un poco deprimida, y tience en los segmentos del cuerpo unas coronas de espinas dirigidas hácia atrás. En su parte anterior se distinguen dos verruguitas retráctiles yo dos ganchos córneos dispuestos trassersalmente, que sirven para agarrarse; en medio de estos ganchos se abre la boca en forma de una hendidura longitudinal In la extremidad anal, obtusa, hállanse en unos surcos trasversales las aberturas de los estigmas, dificiles de distinguir. Las larvas se agarran á reces reunidas en número de cincuenta á cien individuos en el estómago ó en el esófa. go de los caballos; chupan en la membrana mucosa á manera de las sanguijuelas, alimentindose de la sustancia supurada que segregan las llagas, y estas vuelven a curarse cuando la larva las abandona. Al principio, açuella crece rápidanente, cambiando tambien de sitio alguna ver, y al cabo de unos diez méses deja el estómago del animal atormentado, saliendo en mayo, junio 6 julio con los excrementos. Parece que su desarrollo se completa al pasar por los intestinos, pues solo en muy raros casos se ha conseguido criar moscas de las larvas extraidas del estómago de los caballos muertos por enfermedad. Llegada al suelo, la larva penetra en él í joca profundidad y se trasiorma en crisailida, cuyos úrganos respiratorios anteriores sobresalen en forma de dos orejas. Para el desarrollo de la mosca bastan en tiempo algo favorable, por térnino medio, seis semanas.

Se conocen además otros seis estridos que viven casi todos en el estómago de los caballos, pero en general solo en el de los ungulados.

\section{EL ESTRO DE LAS OVEJAS - ESTRUS OVIS}

CARACTERES. - Esta especie, perteneciente al segun. do de los grupos arriba indicados, es de color pardo y casi desnucla; su abdómen presenta dibujos que figuran dadas, los cuales se forman por escasos pelitos sedosos. La frentey el escudo dorsal tienen verruguitas negras $y$ las alas están provistas en la punta de un nervio trasversal.

\section{USOS, COSTUMBRES Y REGIMEN.- L I IROSCa SC} encuentra en agosto y setiembre en los sitios que suclen servir de pasto á las ovejas; se posan en las grietas de los muros ó en los troncos de árboles donde se dejan eoger sin resistencia La hembra fecundada deposita sus huevos en las fosas nasales de las ovejas, y las larvas que de ellas nacen suben hasta la cavidad frontal para alimentarse de la sustancia mucosa, cuya secrecion aumenta: raras veces se encuentran mas de siete ú ocho individuos en la nariz de una oveja. Dos ganchos córneos les sirven parn agarrarse. Al cabo de unos nueve meses son adultas, salen á favor de los estornudos del animal, penetran verticalmente en el sueloy se trasforman en crisálida, la cual necesita de siete á ocho se. manns para su desarrollo. Hace ya mucho tiempo que se sabe que el vértigo de las ovejas no es efecto de estas larvas.

Del mismo modo vive la larva del ass/rus maculatus en la cavidad nasal del búfalo jo del camello; la del pharyngomyia picta en la nariz y en el esofago del ciervo; la de la cepheno. myia mfibarbis en el mismo cuadrúpedo: la del c. stimulator en el corazon, y la del c. trompe ell el reno. 
EL HIPODERMO DEL BUEY - HYPODERMA BOVIS

CARACTERES.- Liste insecto es negro, con los tarsos y piés de un amarillo rojizo; el cuerpo está cubierto de es. pesos pelos; el segundo y tercer segmentos abdomimales son negros; la extremidad del abdómen amarilla, el resto blanco $\delta$ yris blanquizco; en el escudo dorsal resaltan algunos rebordes longitudinales marcadamente.

USOS, COSTUMBRES Y REGIMEN.-Esta esplecic y sus cungéneres vagan por los puntos situados a mucha altura. Las hembras depositan sus huevos como todas las de. mis, sobre la piel ó en los pelos de sus anfitriones. I a larva penetra en el tejido celular del dermis, produciendo solo con el tiempo la lierida que supura por la epidermis. la lar. va adulta cae al suelo, y en la superficie se trasforma en crisålida, que segun las circunstancias necesita de 4 á 6 semanas para su desarrollo.

Del mismo modo viven las larvas del hypoderma Diana y del $H$. Actieon: aquellas en el corzo, y estas en el ciervo; las del $M$. Parandieligen el reno. De un modo u otro los citados animales sufren los ataques de esos insectos y ni siquiern los rinocerontes y elefantes estin al abrigo de ellos. Brauer ha descrito el fharngrgobolus africanus sacado de la boca del elefante africano.

\section{LOS MUSCIDOS -MUSCID压}

Es dificil, en vista del poco espacio de que disponemos en esta obra, elegir en esta familia, la mas numerosa de las moscas, entre los miles de formas y especies, las cuales ofre. cen tal uniformidad, que es preciso caracterizar cada una minuciosamente para reconocerla con exactitud. La mosca doméstica que al hombre sigue por todo el globo, el moscardon azul, que en vernno ataca la carne, las moscas verdes doradas que se alimentan al aire libre reunidas en grandes bandadas, y todos aquellos centenares de especies que al profano parecen moscas domésticas, corresponden $a$ este grupo y representan el caricter de la familia.

CARACTERES. - Los múscidos tienen los siguientes caractéres comunes: las anienas, mas ó menos bajas ó deprimidas, se componen siempre de tres artejos: el último de estos, de forma diferente pero siempre aplanado, tiene en su dorso una cerda articulada ó no articulada, desnuda o con pelo. Ia trompa, angulosa, en raros casos córnea ó propia para picar, suele tener las superficies chupacioras anchas, palpos no articulados y dos cerdas en su interior. Lin el escudo dorsal hay una sutura trasversal, los piés tienen ade. más de las garras sencillas dos lóbulos prensiles, mas desarrollados á menudo en ol macho que en la hembra, que casi siempre es mas grande. A causa de las escamitas de las alas, muy desarrolladas en muchas especies y de la carencia de aquellas en otras, los muiscidos se dividieron en dos grandes grupos (Muscidac arlyplerce os aralypterce) y cada uno de estos en numerosos géncros, haciéndose esto menos para óde. ner una clasificacion matural gque para distinguir los muchos géneros y especies, por lo demás muy poco diferentes, y so. bre todo muy monótonos en sus colores.

\section{LOS TAQUINOS-TACHINA}

CARACTERES. - Todos los taquinos se parecen por te. ner el nervio trasversal de la punta de las alas bien marcado; jor la cerda de las antenas, desnuda cuando menos al pare- cer y articuladia, y por el abdómen compuesto de cuatro segunentos, de forma oval, corta y cónica, raras reces cillin. drica, en cuyo último caso su parte posterior parece cncorvada. Solo en pocas especies faltan las fuertes cerdas en el cuerpo. Los ojos no se tocan en la coronilla aunque se acercan en el macho, pudiendo ser desnudos ó estar provistos de pelos aterciopelados.

USOS, COSTUMBRES Y REGIMEN, - I AS mosins ripidias, asesinas ó dé orugas del género faguinra, con las que se reunen otras varias, pertenecen sin duda à las mas im. portantes de todas, porque ayudan a conserrar el equilibrio en la economia de la naturaleza. Sus larvas viven como parasisias, por lo regular varias a la ve\%, en otras larras, en las de las avispas, en las de ciertos coleópteros y cn otros insectos, sobre todo en las orugas de mariposa, impidiendo la demasiada propagacion de tales insectos. Por eso las especies mas pequeñas llaman nuestra atencion, pues vagan continuamente por la yerba y por los arbustos, donde las hembras saben encontrar sus victimas. Ias especies mas fuertes son mas visibles y se reconocen por su vuelo rapido y timiclo, así como por su carácter salvaje, al que se refiere. el primero de los nombies arriba citados y algunas denominaciones cientificas, como por ejemplo cehinomyia feror, c. fera y otras. Las relaciones de la larva con el animal que habita son diferentes segun la especie. Iass unas salen del cuerpo de la oruga y se crisalidan en ticrn; otras hacen lo mismo despues que la oruga se ha convertido en ninin; muchas se irasforman en la crisalida en las mariposas 6 en los capullos de ciertis avispas; y algunas por fin, nacen ya como larvas, en cuyo estado la hembra las deposia en su anfitrion.

\section{EL TAQUINO GRANDE-TACHINA GROSSA}

CARACTERES.- Esta especic, la mas grande de nuestros paises, pues mide $U^{\text {m}}$, or 75 de largo por $0^{\mathrm{m}}$, or 1 de ancho, tiene el abdómcn corto, de forma oval y color negro brillante, cubierto de pelos muy espesos y cerdosos; la cabeza y la base de las aliss son de un rojo amarillo; el artejo medio de las antenas, de un rojo de orin, es doble mas largo que el úlimo, que es negro y cuadrangular. I.os ojos soa desnudos y la parté anterior de la cara carece de pestañas.

\section{EL TAQUINO FEROZ-TACHINA FEROX}

CARACTERES.-Fsta mosca, que pertenece il los parisitos arriba citados, es de color pardo, con el abdómen de un rojo trasparente de orin, excepto una mya negra en el centro.

\section{EL SARCÓFAGO DE LA CARNE-SÁRCO- PHAGA CARNARIA}

CARACTERES. - Fil sarcófago de la carne varia mucho por el tamaño: el macho, siemure mas pequeño, apenas alcanza el tamaño de una mosca doméstica de las mayores, mientras que la heminn mide regularmente mas de $0^{\prime \prime}, 015$. 1a especie se reconocu por su cara de un amarillo pallido; el dorso es gris claro, con rayas negras; el abdúmen pardo, con visos amarillos y negros en forma de dados, y la raya frontal de un negro aterciopelado. In cerda de las anienas es nas gruesa en la mitad de la base; los palpos, en forma de maza, se insertan en la trompa, que es poco saliente; las cerdas del abdómen, casi cilindrico en el macho, afecta la forma de un óvalo prolongado en la hembra. En las grandes alas, la primera célula del borde posterior, abierta, desemboca a mucha distancia de la punta, mientras que el cuarto nervio longitudinal se encorva en angulo. 
USOS, COSTUMBRES Y REGIMEN.-Esta especic no se encuentra por lo regular en las casns, pero i menudo se la ve todo el año desde mayo al aire libre, en los troncos de arboles, en las flores, $y$ en fin, alli donde se encuentran sustancias animales $\delta$ vegetales en descomposicion.

Esta mosca, como todas las pertenecientes a su genero, no deposita huevos, sino que da a luz las larms que han salido de aquellos en el vientre de la madre. Reaumus observó ya este hecho en el sarcófago de la carne examinandole minu. ciosamente. El ovario se asemeja a una especie de vaso cuyas paredes afectan la forma de una taja arrollada en espiral; cuando se desenrosca tienc una longitud de $0^{\circ}, 065$, mientras que en su estado normal solo mide $0^{m}, 015$. En una faja de $\left(i^{m}, 0065\right.$ de largo se cuentan cien larvas tma-junto a otra; de modo que midiendo la longifud anterior se hallarian veinte mil larvas en un orario; cada cual esta contenida en una tenue membrana, y las que se hallan mas cerca de los oviductos alcanzan mayor desarrollo que las mas distantes. Si suponemos que ni siquiera la mitad de tan chome númcro consigue sobrevivir, suposicion que en nada podria fundarse, y que solo se desarrollan $\$, 000$, la fecundidad de estas moscas es aun asi enorme. Las larvas recien nacidas crecen ripidamente y alcanzari en ocho dias su mayor tamaño: son coniformes, de un color blanco sucio, con dios ganchos córneos negros; tienen la parte anterior puntiaguda y encima dos puntitas carnosas. En cualçuier rincon, $\delta$ a poca profundidad en el suelo, la larva se trasforma en una cristlida pardo negruzca, cuya extremidad abdominal, muy àspera, indica por una cavidad angulosa el sitio correspondiente de la lar. va. 1.as experiencias de Bouché no estin confornies con las de Reaumur y Degeer, porque observó que la crisálida descrnsa de cuatro à ocho semanas; que tambien la larva necesita inas tiempo para su desarrollo, y quie vive en matcrias en descomposicion, pero no en la carne, lo 'cual hace suponer que a veces se ha confundido esta especie con el moscardon azul. Las observaciones continuadis en diferentes múscidos han deinostrado que ofrecen gran diferencia los sitios donde se desarrolla una misma especie, y naturalmente la larva, à pesar de su nombre, depende nuy poco del alimento carnoso, que siempre escasea al aire libre. Mas tarde veremos, sin cubargo, que tambien hás cricepciones.

\section{LA MOSCA DOMÉSTICA-MUSCA DOMESTICA}

CARACTERES. - Lá mosca doméstica tiene la cerda de las antenas plumosa en ambos lados hàcia la punta; carcce de cerdas grandes en el dorso de los cuntro segmentos abdominales, y tambien de las aisladas en la cam interior de los tarsos medias; el cuarto nervio longitudinal de las alas se encorsa longitudinalmente hácia el tereero.

USOS, COSTUMBRES Y REGIMEN. - Sin exageracion puede pretenderse que ningun animal es tan fiel companero del hombre, aunque por lo regular muy molesto, y hasta en ciertos casos impertinente; á pesar nuestro, la mosca doméstica parece empenarse en perseguirnos por todas partes. Se amolda lo mismo á las regiones frias dé Laponia que a la vida agradable de los paises del Ecuador. Tódos conocemos sus malas cualidades, su impertinencia, su glotoneria, y su inclinacion á ensuciarlo todo; nadie podria encontrar ninguna rirtud en este insecto.

A fines del verano, sobre todo, cuando las noches y ma. banas frescas la obligan á entrar en las casas, se hace mas molesta en las habitaciones, pero no tanto para los habitan. tes del Narte y' del centro de Europa como para los del Mediodia. A. Young, en su interesante "Viaje por Francia, dice: «Encontré entre Pradelles y Thuyt\% numerosisimas moscas; bajo el nombre de «noscas» comprendo los miles ; miles de esos insectos que constituyen una verdadera plaga del clima meridional. Son uno de los mayores tormentos en Espana, Italia y los distritos de Irancia donde crece el olivo, no porque muerdan ó piquen, sino porque zumban é irritan. Ja boca, los ojos, las orejas y la nariz se llenan de moscas, que atacan todo comestible, los frutos, el azúcar y la leche, en tal número que no es posible comer si otra persona no se encarga de ahuyentarias. Con cierto papel preparado y otros inventos se cogen con tanta facilidad y en tal numero, que solo por desidia pueden propagarse de un modo tan increible. Si yo fuera agricultor en aquellas regiones, todos los años aljonaria cuatro ó cinco mojadas de terreno con moscas muertas. Aunque cuando está mas entrado el año llega un tiempo en que desajarecen, algunas se conservan tambien durante el invierno, si no precisamente en nuestras habitaciones, por lo menos en las cundras calientes; y en la primavera se presentan tambien al aire libre cuando liay dias hermosos. Algunas reces ofrecen un aspecto muy particular cuando estàn muertas: se las re abiertas de patas, fijas en las paredes 6 en cualquicr otro objeto, y con cl abdómen dilatado; la membra. na ligatoria de sus segmentos sobresale en forma de reborde y esta llena de setas nicroscópicas; de modo que el abclómen parece anillado de párdo y de blanco: al abrirle se ve que está invadido tambien por esos cuerpos, que hasta cubren el sitio ocupádo por el cadáver.

\section{LA MOSCA VOMITORIA-MUSCA VOMITORIA}

CARACTERES.-Esta especic se reconoce por las mejillas negras con pelos rojos, y por tener cuatro rayas negras, no muy niarcadas, en el escudo dorsal, en el que solo hay células, sin pelo alguno: los palpos son de un rojo amarillo: las patas negras; el audómen azul y la parte inferior de la cara hégruzca; estas últimas regiones del cuerpo presentan un marcado viso blanco; la hembra se distingue ademis por una faja frontal negra muy ancha, orillada de gris en los la. dos. Puede medir de $0^{\infty}, 00 S_{75}$ à $\|^{*}, 013$ de largo.

USOS, COSTUMBRES Y REGIMEN. - Pocos serin los que no hayan visto ya ese gran moscardon, que en seguida acude cuando olfatea la carne, aunque se halle a gran distancia, para depositar en ella sus huevos, y que penetra en nuestras habitaciones zumbando de continuo al chocar contra los vidrios de las ventanas, cual si quisiera romperse la cabezs.

la fecundidad de ambas especies es extraordinaria, por la infinidad de huevos que ponen las hembras y por la rapidez con que esta cria se desarrolla. La mosca doméstica deposita en un cuarto de hora pequeñas masas de 60 a 70 huevos de forma casi cilindrica, un poco puntiaguda en la parte anterior, por donde sale la larva: su piel brilla como el macar: I.os huevos de la mosca somitoria sicuen la forma algo en. corvada, como un pepino, y en la parte arquenda un reborde longitudinal. Tambien depositan los huevos en montoncitos de 20 á 100, con preferencia en la carne; la mosca doméstica los pone principalmente en el estiércol, pero las hembras de ambas especies no reparan mucho en la eleccion del sitio. La mosca doméstica, sin despreciar la carne, deposita tambien sus huevos en el pan ó el trigo, en rajas de melon, animales muertos, escupideras sucias, y hasta en el rapé cuando dejan las cajitas abiertas. Ia mosca vomitoria confia sus huevos al queso (las larvas saltadoras de éste no pertenecen sin embargo á ese múscido, sino à la piophila casei), à los cadáveres, y tambien a las flores extrninas de los estapelidos, etc. tas larvas, que nacen al cabo de 24 horas, son blancas, coniformes y truncadas en su parte posterior. Los 
excrenentos liquidos depositados por las larvas parecen apresurar la descomposicion del alimento, sobre todo de la carne. Pronto tienen perfomdos los objetos que habitan, $y$ aunque carecen de ojos huyen de la luz y penetran en aquellos. Un observador obligó à una mosca vonitoria a depositarsus huevos en un pez; al segundo dia despues de nacer, las latvas cran aun bastante pequenas, pero de 25 a 30 juntas pesaban cerca de un grano; al tercer dia, cada una tenia siete gtanos, por lo tanto en 24 horas habianse hecho 200 veces mas pesadas.

Hace tiempo que en Inglaterra ocurrió un caso espantoso, cuyos detalles confirmaron varias personas dignas de crédito; y en otros paises se han registrado tambien hechos que prue. ban cuan rapido es el nacimiento de cstas moscas, y hasta qué punto jueden ser peligrosas. Un pobre que a causa de su carácter infuicto no queria nunca permanecer en la casa de asilo de su parroquia, prefiriendo mendigar por los pue. blos vecinos, recibia linosnas que por lo regular consistian en pan y carne. Despues de satisfaccr su apctito, solia colocar el resto de la comida, subre todo la carne, en el pecho, entre la piel y la camisa. Cierto dia, despues de recoger una buena provision, y como se sintiern indispuesto, sentóse. á la orilla de un camino, donde a causa del calor del sol de aquella es. tacion (era á mediados de junio) la carne se descompuso pronto, llenandose de larvas de moscas. Estas comicron no solamente los pedazos de carne, sino gue atacaron tambien el cuerpo del infeliz, tanto que cuando unos transeuntes le encontraron estaba herido de tal manera que su muerte pa. recia inevitable. Despues de extraidas lo mejor posible las larvas, el enfermo fué trasladado à su pueblo, donde el mé. dico declaró que solo le quedaban algunas horas de vida: y en efecto, murió corroido por las larvas de mosca. Sin embargo, como no se puede suponer que hubicra permanecido varios dias enfermo en el camino, no es probable que las larvas pertenecieran á una de las dos especies de múscicios; sino a un sarcófago viviparo. En el Paraguay se han dado casos de que varias personas se vieran atacadas de iuertes dolores de cabeza, acompañados de copiosas evacunciones de sangre por la nariz, sin haber experimentado alivio hasta que por medio de estormudos hubieron arrojado algunas larvas de mosca. No sostendré que estas larias pertenecicran precisamente á las especies de que tratamos, porque hay otras que observan exactamente el mismo género de vida. Queda pro. bado, por ejemplo, que varias larvas del sarcófago de frente ancha fueron extraidas de hinchazones del oido: yo tengo dos individuos que por el tmamiento con bencina se sacaron de una inflamacion auricular muy dolorosa de un niño. En otro caso, tambien fué sin duda una larva de sarcófago la que hirió el angulo interior del ojo de un niño que se durmio al aire libre, y que de resultas perdió la vista. En todas las circunstancias se desprende de los ejemplos citados cuán peligroso es dormir durante la cstacion calurosa al aire libre, porque los peligros que nos amenazan por parte de unos séres inofensivos en lo demis, ticnen mavor importancia de lo que nosotros creemos.

En épocas anteriores no faltaba gente que pretendia que estas larns se formaban por si mismas en tos objetos en putrefaccion y que los gusanos que devoraban los cadácieres no cran otra cosa sino la prueba evidente de que el muertó habia sido un pecador. Hoy dia no hay hombre razonable que crea tales sandeces, pues ya se sabe que alguna ú otra mosca depositó sus huevos en cl cadaiver, aunque madie lo haya visto.

Cuando el tienupo es favorable y el alimento abundante. las larvas se hacen adultas en el término de 8 á 15 dias. Leuckart observó últimamente, en las del moscardon y de la bonita mosca domda (muser ciesarea), un hecho curioso reconocido ya en los estridos y en los pupiparos, de que luego hablaremos, y es gue durante el desarrollo se verifican trasformaciones en las partes bucales y en los estigntas. Para crisalidiarse, las larvas se separan y penetran en el suelo, si cs posible; pueden trasformarse también sin llegar á tierra, pero solo despues de mucha inquietud yisible molestia. I a mosca nace al cabo de dos semanas, sienupre de dia; nunca de no. che. Es natural que las larias adultas á fines de otono pasen el invierno en estado de crisalida, pero si dicha estacion es muy templada las moscas nacen pronto. Yo vi, por ejemplo, el 15 de enero de i $8_{54}{ }^{\circ}$ a las nueve de la mañana, un moscardon cuyas alas plegadas demostraban que acababa de salir de la crisálida. Además, resulta de lo dicho gue a causa de las varias crias al año las moscas se aumentarian en masais verdaderamente innumerables si no tuvieran tantos enemigos entre los hombres y los animales.

\section{EL ESTOMOXO PICANTE-STOMOXIS CALCITRANS}

CARACTERES.-Esta mosca, de color gris, se piarece mucho à la doméstica, de la cual difiere, sin cmbargo, por la trompa picadora que sobresale horizontalmente de la boca; además, la cerda de las antenas solo es plumosa en su parte dorsal y el escudo de las alas tiene tres rayas blanquizcas cortadas cerca cie la sutura. Tambien se pretende que al descansar siempre se posan con la cabeza hácia arriba, mientms que la mosca doméstica se coloca en sentido inverso, circustancia por la que los campesinos rusos saben distinguir facilnente ambas especies en sus habitaciones.

USOS, COSTUMBRES Y REGIMEN.-Esta moscase presenta a fines de verano en las habitaciones, sobre todo cuando se hallan cerca de las cuadras, y es de las gune chupa la singre.

La larva, coniforme y redondenda en su parte posterior, es de un color blanco de leche, lisa, brillante y bipartida en su parte anterior: mide $(1), 00875$ de largo. En verano yotoño vive sociablemente con las larvas de la mosca doméstica, en el estiércol fresco de caballo, pero se desarrolla mas lentamente que aquellas. La crisálida tiene un color pardo rojo pálido, con lineas trasversales, y los estigmas anteriores de la futura nuosca aparecen, como los de todos los múscidos, en el borde posterior del cuarto segmento del cuerpo, semejantes a cuernecitos coniformes dirigiéndose hácia adelante, mientras que los posteriores estrin alli donde los tiene la larva. La crisálida descansa de cuatro a seis semanas.

\section{LA GLOSINA TSETSÉ-GLOSSINA MORSITANS}

CARACTERES. - Lista mosca tienc poco mas ó menos el tamaño de nuestra especie doméstica; en la base del último artejo de las antenas presenta una larga cerda provista de dientes 5 en forma de peine; en el escudo dorsal, de color pardo castano, con polvillo gris, hay cuatro rayas longiudimales negras, cortadas en ambas extremidades; en el escudete, de un amarillo sucio, se ren dos manchas oscuras y algunos pelos cerdosos. El abdónnen, de color blanco amarillento, se conpone de cinco segmentos y tiene en los cuatro últimos unas tajas estrechadas en el centro; de modo que en eada uno solo queda una mancha central triangular gue conserva el color predominante. Las patas son de un blanco amarillento, un poco parduscas en la carn interior:y las alas iurbias (fig. 11 8 ).

USOS, COSTUMBRES Y REGIMEN, - Esta especie 
muy congenérica, pero mas bonita que la anterior, es tan temida en la zona cálida del Africa a causa de su picadura mortal para los animales domésticos, que la region donde habita se llama "pais de las moscass y todos la evitan como si en ella reinase la peste; cuando mas se atraviesa solo de noche. Como nuestros estomoxis, esias moscas se alimentan de la sangre caliente de hombres y animales, persiguiendo su victima con la misma pertinacia que nuestra especie, sobre todo en los dias calurosos. La picactura no causa daño al hombre ni á los animales salvajes, asi como tampoco a las cabras, los asnos y las terneras entre los domésticos, mientras que a todos los denris animales que acompanan al hombre les produce la muerte infaliblemente al cabo de mas ó menos tiempo, pero por lo regular poco antes, ó al principio de la estacion lluviosa. Una inflamacion de los ojos, secreciones acuosas de los mismos e infartacion de las glándulas salivales son los primeros sintomas crteriores del mal. Despues de la muerte, obsérvase en la carne un estado acuoso; cl corazon esta muy blando; la sangre disminuida y mas es. pesa que la clara de hucro; cl higido aparece dañalu, ú bien los pulmones; y solo el estómago y los intestinos no presentan ningun restigio de alteracion. Un perro sucumbe cuando bebe la leche de una vaca enferma, mientas que la de la ternera no le hace daño alguno.

\section{LOS HEMATOBIOS-HEEMATOBIA}

CARACTERES. - Los hematobios se reconocen porsu cabeza poco deprimida, casi esféricá el epístoma es saliente; la trompa sólida y prolongada; los labios terminales pequenos: los paljos, tan largos como la trompa, se ensanchan en forma dé maza; la frente es angosta; el tercer artejo de las anieuns doble del segundo.

USOS Y COSTUMBRES. - Estos dipteros no se muestran menos ávidos de sangre que los anteriores, segun lo in. dica ya su nombre; pero jamas los vemos en nuestras habi. taciones, pues parecen preferir las praderas.

\section{EL HEMATOBIO IRRITANTE-HEEMTOBIA IRRITANS}

CARACTERES. Este insecto es de color gris oscuro, con palpos negruzcos y en forma de maza: en el abdómen lazy una linea dorsal sin manchas; las piernas y los tarsos son parduscos. Este múscido mide 2 lineas de largo (fig. 115 ).

DISTRIBUCION GEOGRAFICA.- La especie es pro. pia de Europa, y ha siclo observada muy à menudo en Alêmania.

\section{LOS ANTOMIDOS - ANTHOMYIDE}

CARACTERES. - Los pocos múscidos descritos y sus congéneres son muy inferiores en número al gran cjército de los antomidos, que por su aspecto exterior, y en general tambien por sus colores, parecen ser moscas domésticas aunque dificren de ellas, al examinarlas mas minuciosamente, por la falta del nevio trașeersal en la punta de las alas. Son los verdaderos proletarios entre las moscas, en que relativamente fijamos menos la atencion y que a causa de su uniformidad ofrecen al mismo naturalista grandes dificultades:

USOS, COSTUMBRES Y REGIMEN. - Solo del gé. nero antomia se conocen mas de doscientas especies eu. ropeas, cuyas larras perjudican en parte las mas diferentes plantas cultivadas. Asi, por ejemplo, la enthomjia furasta se encuentra aisladamente en el corazon de la cebolla (allium cepa), y la anthombia ieparun, que tiene dos ó tres crias, desde mayo á octubre, en las mismas plantas, pero en otra especie; construye galerias en el campo de cebollas, perjudicando mucho estas plantas.

In anthomyia brassica perfora en estado de larra, desde junio hasta noviembre, los tallos de la col, y mata las plantitas jovenes: la anthomyia conformis mina en las hojas tiernas de la remolacha; la authomyia lactuca devora en agosto y setiembre la simiente de las lechugas, y otras viven del mismo modo en diversas plantas, pero la mayor parte eligen sustancias vegetales en descomposicion. 'Todas ellas, y centenares de otras especies de géneros, pertenecen á las moscas porque las escamitas de las alas cubren mas 6 menos completamente la bise de estas.

\section{LOS TRIPETIDOS-TRIPETINE}

CARACTÉRES. - Este grupo pertenece à lass numerosas especies que se distinguen por las alas oscuras ó bien pro. vistas de dibujos en figura de red, asi como por la forma extruña de sus antenas compuestas de tres artejos, $\delta$ la de la cabeza: el abdómen de las hembras tiene un largo taladro articulado.

USOS, COSTUMBRES Y REGIMEN.-Depositan sus huevos en las mas diferentes plantas vivas, como por ejen. plo en la for de los cardos, para que las larvas se alimenten de la simiente.

\section{LA PLATIPAREA PECILOPTERA-PLATYPA- REA PQECILOPTERA \\ CARACTERES. - Esta especie apenas es tan grande} como nuestra mosca doméstica; tiene la cabera, los lados del tórax y las patas de un pardo rojo brillante; la cara con las mejillas, las partes de la boca $y$ las antenas de un amari. llo de orin; el escudo dorsal gris, con tres rayas longitudimales negras; el escudete de un negro brillante; el abdómen, de un negro pardusco en la hembra, es en esia puntiagudo y de un negro intenso, con el taladro de un amarillo de orin: en el macho es obtuso en la extremidad y de forma cilindrica en toda su extension. I as alas son de un negro pardusco con manchas vidriosis; el primer nervio longitudinal es doble; el cuarto encorvado en su parte anterior; los dos trasrersales están muy próximos, y el pequeño se lialla detrás del centro de la celda discoidea. I a cabeza, mas ancha que el tórax; tienc la frente provista de cerdas negras. Las antenas rematan en un artejo puntiagucio eliptico, con cerda desmuda un su dorso. Las patas, mas bien pesadas quue ligeras, tienen, asi como los lados del abdómen, algunas células negras. La longitud es de $11^{\circ}, 0045 \cdot{ }^{\circ}()^{\circ}, 0051 \%$.

USOS, COSTUMBRES Y REGIMEN. - La larva de esta mosca ha llamado en algunas partes últimamentc la atencion de los jardineros. Poco despues de brotar los primeros retoños de los esparragos, es decir, a principios de mayo, la mosca se presenta y deposita sus huevos entre las escamas de la punta del retono. Al cabo de 15 a 21 dias, segun el ticmpo, nacen las larvas, que son blancas y penc. tran hacia abajo por el tallo hasia la parte fibrosa, cuyo viaje ejectuan en unos 15 dias, y entonces la larva ha llegado a la longitud de 0,0065 y se crisalida a principios hasta fines de junio, encontrándose oclio 6 mas larsas en un solo esparrago. Las plantas labitadas por las larias se atrofian pronto y ruélvense amarillas y pútridas aun antes de que los insectos se hayan trasformado en crisiliclas. Fistos tienen las extremidades negras y lo demàs de un amarillo pardusco asiz. brillante. En la primavera siguiente la mosea abre una escama en la region de la nuca y sale a la luz del dia. 
EL ESPILOGRAFO DEL CEREZO-SPILOGRAPHA CERASI

Tambien las larvas que muchos años se encuentran en las cerezas, por lo regular una sola en cada cual de aquellas, pertenecen à un tripetido.

I a hembra de esta mosca de las cerezas ó del espilógrafo diel cerczo pone sus huevos i primeros de mayo, al parecer cerca del sitio donde el tallo ha crecido, en la fruta sin madurar, que luego es agujereada por la larva al nacer. No obstante se ha instalado tambien en las frutas de algunos arbustos, como por ejemplo el lonicera xylosteum y tortarica y el Berheris anfgaris. Cundo ha saciado su apetizo con la parte carnosa del íruto y alcanza todo su tamano, practica un agujero para salir, cae al suelo, vaga alli algunas horas y trasfórmase en una pequeña cubeta de color amarillo, y no sale de ella hasta el año siguiente, en la citada época, el gracinso neuróptero. Este es de color negro hustroso; el escudo del dorso con rayas de un amarillo pardusco con tres fiajas negras, en las depresiones del hombro; el escudete, la cabeza, a excepcion de su parte posterior, y los tarsos, desde las patas, son de color amarillo. En el borde anterior de las alas, que sobresalen del abdómen, hay tres fajas trasversales oscuras, casi paralelas, las dos primeras se acortan, pero la tercera es completa y sé ensancha delanie por una fajita quue sobresale apenns de la cuarta vena longitudinal. La primera de estas, que es doble, se corre por la rama anterior hasta el borde; los dos surcos tmasversales del centro del ala se

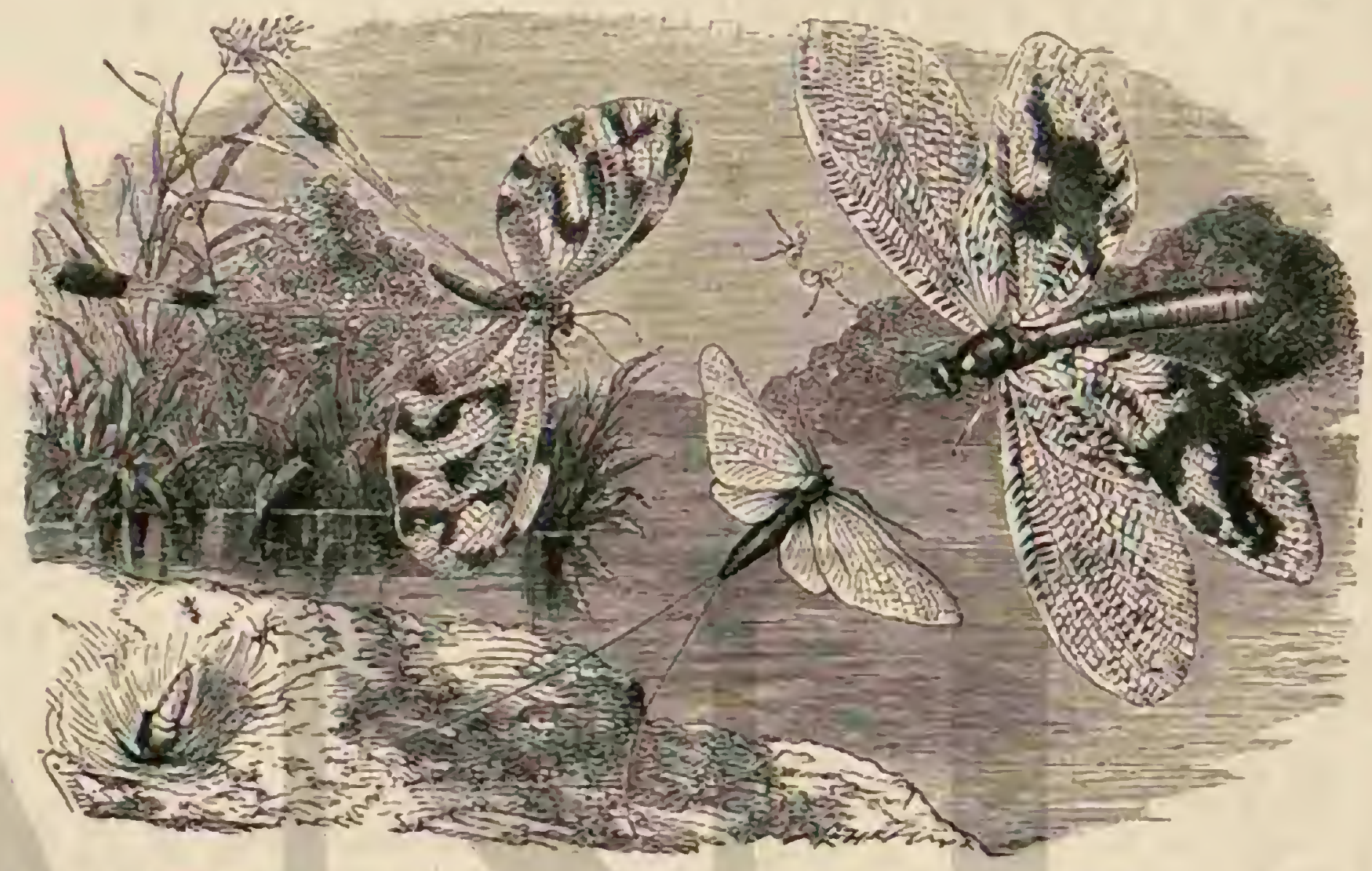

Fig. 120. -FL. SEROP'TERO COA

Fig. 121.-LA EITEMERA V'CLGAK

Fig. 122.-EL MHSMELEON LIHELLILOIH:O

desvian; la célula anal es mas corta que la radial, que la precede, y remata en punta. Este hermoso insecto no alcanua el tamaño del anterior.

\section{LOS DIOPSIS-DIOPSIS}

CARACTERES. - Los diopsis se distinguen por su cuerpo prolongado $y$ cabeza esferoidal; la trompa tiene labios ter. minales gruesos y largos: la cara convexa; el epistoma se prolonga oblicuamente hácia delante: la frente esti dilatada á cada lado en forma de cuerno recio y cilindrico, insertándose las antenas cerca de la extremidad de cada uno; el tóras, estrechado anteriormente, tiene los lados provistos de una pequeña pưnta cerca de la extremidad; el escudo termina en dos largas puntas vellosas; el abdómen, prolongado y deprimido por arriba, consta de cinco segmentos bien marcados; las nerviaciones mediastinas de las alas parecen reunidas; la primera celdilla posterior se estrecha un poco en la extremidad, y la discoidea se une á la basilar interna.

DISTRIBUCION GEOGRÁFICA.—- Las mas de las es. pecies son propias del continente africano; solo se conoce una originaria de P'ensilvania.

\section{EL DIOPSIS LONGICORNIO-DIOPSIS LON- GICORNIS}

CARACTERES. - El diopsis de cuernos largos (fig. 113) es de un color leonado rojizo; en la cara lleva una linea tras. Tомо VI versal parda; los ojos son negros, lo mismo que el tórax; el escudo amarillo; el primer segmento del abdómen negruzco; las alas un poco prarduscas. Fste diptero mide 3 y media li. neas de largo.

DISTRIBUCION GEOGRÁFICA.- Ia especie es propia de Guinea y del Senegal.

\section{LOS CLOROPOS - CHLOROPS}

CARACTERES. - Así se llaı́na unos neurópteros pequeños ó muy pequeños, que como sus congéneres afines los oscinos (oscinis), llaman la atencion mas de lo que se podria esperar de séres tan diminutos, no solo por su inmenso número sino por los grandés daños que causan en el trigo. Su cabeza hemisférica está en direccion trasversal; la parte in ferior de la carn se inclina poco hácin atrâs; los ojos, desnudos, tienen en vida del insecto un color verde; la frente es ancha en ambos sexos, cubierta de una fina pelusa, algo inclinada hácin adelante y provista por detrảs de tres ojuelos uzue se hallan solre una mancha triangular negra, mas ó menos ex tendida y perfecta segun la especie. Sus antenas, deprimidas, se insertan debajo de un arco de la frente; su tercer artejo casi circular, tiene cerdas desnudas ó en forma de plumon. Eis las alas, relativamente cortas, la vena marginal no llega sino hasta la punta; la primera vena longitudinal es sencilla; lats tres siguientes se corren en linea recta y las dos trasversas se aproximan en el centro del ala: la célula anal y la pos. terior de la base faltan. En estado de reproso las alas se apo. 
yan paralelamente sobre el dorso. Es dificil distinguir las numerosas especies. El cloropo de tarsos listados (Chlongs temiopus) es en su conjunto de un amarillo brillante, con to. das las antenas negras, asi como la mancha triangular del vértice que llega hasta la frente, reuniéndose en el lado opuesto con la faja negruzca del occipucio y alejándose hácin abajo de los bordes de los ojos. El dorso del tórax está cruzado por tres fajas negras y lustrosas, de las cuales la central se toca en sus extremos, en tanto que las dos extremas se acortan hácin adelante adelgazándose por atrás; tanbien se ve una raya negra junto-al nacimiento de las alas y pequeñas manchas de ese color en cada uno de los costados, pero de un tinte mas pálido. El escudo está rodeado de una serie de cerdas négras. En el abdúmen hay cuatro sesgaduras marcadamente separadas y en forma de fajas trasversales, de color pardo negro, terminando la anierior en cada lado por un punto. Los artejos de las patas, que son amarillos, parecen oscuros; los anteriores son negros, presentando en el macho un anillo central amarillo. Las alas son trasparentes.

Usos Y CosTUMBRES. - La larva blanca, que se en. cuentra en verano, causa por su succion en los tallos del tri. go y de la cebadn, una trasfornacion que los ingleses llaman gota ó podayra y que consiste en qué lis celulas alrededor del surco phano que produce comunmente desde la espiga hasta el priner nudo se dilatan; el talio parece doblado, manteniéndose blando y delgado en la parte opuesta y pudriéndose al fin. De resultas de esto la espiga, ó no sale por completo de la vaina $\delta$ no alcanza su complete desarrollo, si sale penosamente. Su larva, que mide $0^{n}, 045$ de largo, se convierte en crisilida junto al nudo superior, entre el tallo $y^{\prime}$ la vaina de la hoja, donde se la encuentra de ordinario aislada, $y$ en casos excepcionales tambien en la espiga. Al cabo de diez y siete a veintiun dias, la mosca se desarrolla, en agosto. I.a hembra pone entonces sus luevos en los sembrados de invierno, donde la larva se presenta del mismo modo que la del cecidomio destructor (cecidomyia destruetor), matando at veces las tiernas plantas artes que llegue $\mathrm{cl}$ invierno.

\section{EL OSCINO FRIT-OSCINIS FRIT} CARACTERES. - Está inosca, que mide apenas $0 \%, 001 \%$,
s de color negro lustroso.

USOS Y COSTUMBRES, - Segun las observaciones de Haberland, crin en Bohemia, por lo menos tres ieces al año, perjudicando la primera los sembrados de la primavera, la segunda los trigos maduros y la tercera los sembrados de invierno. Es muy notable que à pesar. del enorme número de algunos cloropos no causen sus larvas perjuicios considerables $A$ últimos del verano de 1857 se elevaron del tejado de una casa de Zittau espesas nubés asemejándose tan singularmente al humo, que se prepararon las bombas y cl agua para apagar el supuesto fuego. Iil examen deténido dió por resultado que millones de cloropos narigudos (Chlorops nasufa) habian salido por la abertura que dejó la falta de una teja, produciendo aquella ilusion. Al propin tiempo se encontró la misma mosea en otras casas de la ciudad en inmensas multitudes. En la segunda mitad de setiembre de $\mathrm{i} S 6_{5}, \mathrm{cn}$ contré en el tejado de una casa de campo ein el Harz, durnnte algunos dias, la misma especie en tan inmensa multitud ¿que las tejas parecian tener grandes manchas negras; cuandó hizo mas calor bajaron las moscas à las ventanas formando alli tambien grupos negros. Semejantes fenómenos se presentan aqui y allá con harta frecuencia.

\section{LOS FORAS - PHORA}

CARACTERES. - Extrañas nubes de moscas parecen à veces las especies del género phora y sus congéneres mas afines. Fstos insectos pequenos y jorobados, que corren for las hojas de las matas, por las vigas y los vidrios de las ventanas con un afan cuya causa no nos explicamos, están dis. tribuidos por toda la Europa en número de mas de ochenta especies. La cabera es inclinada y corta; el tóma arqueado, y el abdómen forma declive, lo cual produce precisamente el aspecto jorobado de todo el cuerpo. Ia cabeza lleva antenas cortas y en forma de verrugas; la cerda dorsal, ja des. nuda, ya revestida de pelusa, está levantada; los cerdosos palpos sobresalen tambien; los tarsos parecen robustos; las ancas.son prolongadas y los muslos comprimidos. El burde anterior de las grandes alas está provisto de púas; la segunda vena longitudinal se dilata mucho, y examinada detenida. mente, debe considerarse como la iercera, que à menudo se bifurca en la parte anterior extendiendo dos ramas pálidas por la superficie; la rama posterior no tiene sino dos venas; la célula anal falta siempre.

\section{LA MOSCA JOROBADA-PHORA INGRASSATA}

CARACTÉRES. - Esta especie es de color negro lustroso: ellabdómen de un gris matc; su primer ségmento tiene un borde blanco; los ojos están revestidos de una pelusa muy fina; las alas son trasparentes y amarillentas en la raiz y solo están cruzadas por cuntro venas longitudinales; la pri mera de las cuales (la rama superior de la tercera) es mas recta y, no encorvada en forma de S. Sus tarsos son negros, pero toman un color amarillento desde la mitad anterior de los muslos, llanando la atencion por estar revesticlos de fuertes cerdas, sobre todo en las ancas.

USOS, COSTUMBRF.S Y REGIMEN.-En la mayor parte de las comarcas de Alemanin, Suecia y Rusia, esta mosca pasa el invierno y el otoño en los arbustos y las plan. chas de madera, mezclandose con los enjambres de abejas para poner un huevo debajo de la piel de cada una de las larvas, bastante crecidas y no tapadas aun, lo cual hace introduciendo su oviducto entre dos anillos abdominales, para poner el huevo paralelamente al cje longitudinal de la laria de la abeja. Esta debe estar ya bastante desarrollada en el huevo, porque al cabo de tres horas rompe la envoltura $y$ se introduce inmediatamente en el cuerpo grueso de la larva de abeja, de que se alimenta. Crece con extraordinaria rapidez; cuarenta y ocho horas despues de salir echa ya la primera piel y está revestida de finas púas; $a$ las veinticuatro ha-alcanzado un grueso considerable; à las doce adquiere la segunda piel y su crecimiento se redobla, de modo que veinticuatro horas mas tarde alcanza casi la longitud de lim,0025; en otro tanto tiempo mide casi $0^{*}, 0035$, echa la tercera piel y. está completamente desarrollada. Es puntiaguda por delante, truncada por detris, y está provista de cerdas y de los dos conductos aéreos; los de la region anterodorsal sobresalen á manera de piramides. Doce horas despues de echar la última piel, su direccion varia en la larra de abeja, que parece sana y se ha encerrado tambien en su envoltura variando además su direccion en la célula, de medo que dirige la parte posterior del cuerpo hácia la tapa. Asi que la larva del parásito se ha vuclto sale por la extremidad del renerpo de la abeja, agujerea li tapa de cera que cierra la celdilla, cae al suelo, se convierte en crisálida en la carcoma, ó sale por la abertura del mismo y se trasforma en tierra. Doce dias despues sale la mosca, que inverna debajo de las escamas de la corteza. Estas interesantes obserraciones fueron hechas por Assmuss. La larva de abcja abandonnda por el parisito muere $y$ se pudre. In forn es de este modo un insecto peligroso para nuestras abcjas, dando origen a los llamados aenjam. 
bres podridos. Otras moscas jorobadas viven en estado de larvas en las sustancias vegetales en putrefaccion, y algunas se han encontrado como parásitas en las orugas de las inariposas, en las larvas de escatabajo y en los caracoles; de modo que en esto se nota poca conformidad, por lo cual difieren la conformacion de las venas de las alas y el método de vica de las diferentes especies.

\section{LOS PUPÍPAROS-PUPI- PARA}

CARACTERES.-Diferenciándose de todos los mosquitos y moscas hasta ahora descritos, tanto por su aspecto externo como por su desarrollo, los pupiparos (Pupipara) son dipteros, sobre los cuales se podria muy bien escribir todo un libro. Ia hembra no engendra sino un sér en forma de crisálida, una larva cuya crisilida se ha desarrollado en cl cuerpo de la madre, y que al narer es en rigor todavia una larm, de manera que el nombre que antes se aplicaba á esta interesante division no es yn apropiado, segun las mas recientes investigaciones. Ias especies que pertenecen a la misma vi ven en estado perfecto como parásitas de otros animales, sobre todo de sangre caliente, dividiéndose en tres géneros: Coriaceos ó Hitohioscides, Mescas y Braulos.

\section{LOS CORIÁCEOS Ó HIPOBÓSCI- DOS-CORIAGEA Ó HIPPOBOSCIDE}

CARACTERES. - Tienen el cuerpo córneo, coriáceoen el abdómen, comprimicio y dilatable; la rabesa, horizontal, ovalada y trasversal, se une estrechamente por su borde posterior en el tórax; los ojos son grandes y se hallan a los la dos; las antenas, muy cortas y cilindricas, pasan facilmente desapercibidas, porque están adheridas, rodenndo la abertura bucal con un borde en forma de cerco. La trompa forma el labio superior, con las mitades de la mandibula inferior, que lo rodean a manera de vaina; el inferior es muy corto, carecicndo por completo de palpos. Las largas alas no presentan venas marcadas sino en el borde extemo; a veces son cortas ó atrofiadas: sus pequeños erectores estain siempre libres y se hallan á cierta profundidad. Los tarsos se hallan bastante separados, porque el esternon es ancho; sus muslos son aplanados: las patas son cortas y fuertes; el artejo fimal el mas largo; las garras bipartidas y muy robustas.

USOS Y COSTUMBRES. - Semejante estructura permite ì éstos insectos correr con mucha destreza y mpidez de un lado a otro entre el pelaje de los caballos, ciervos, yamos y otros mamíferos, asi como par el plumaje de las aves. Ge neralimente anda especie vive en un animal determinado chupando su sangre; solo el lipopiena de los ciérivos (Lifopiena cerii) es una excepcion: mientras tiene alas vive como el ornitobio pálido (Ornitholico fallida), hasta el otono en las aves; mas tarde (¿despues del apareamiento?) pierde las alas y se convierte en parásito de los cierios, gamos y jabalies En otoño vaga a veces jor los bosques, y se posa en la cara y en los vestidos de los transeuntes, principalmente en los objetos de color pardo. Asi que llegué con cierto amigo st un territorio poblado de esos insectos escogicton para posarse el sombreso pardo y peludo de mi acompanantc, en tanto q̨ue yo quedé libre de su impertinencia. Sus paseos por el rostro no producen ninguna sensacion agradable.

El contenido del ovario de la hembra no pasa en el sneló fago (Mclophagus ocinus) de ocho huevos; solo la prole de una especie de estas moscas se limita à una cifra muy insig. nificante. Lina glandula grande y ramificada segrega un liquido que la larva que esta por desarrollar absorbe con avi. dez. Cuando nace representa un cuerpo ovalado y liso sin articulaciones, que oirece al principio un aspecto blanco. oscureciendose gradualmente mas y mas.

\section{EL HIPOBOSCO DE LOS CABALLOS-HYPPO- BOSCA EQUINA}

CARACTERES. - Esta especie conserva durante toda su vida las alas, caracterizadas por cinco venas longitudinales gruesas en el borde externo; la primera es doble, la se. gunda y tercera sencillas, la última sale de la segunda en el medio del ala, uniéndose en el borde con la vena del mismo léjos de la punta; las venas longitudinales cuarta y quinta parecen truncadas súbitamente junto a la pequeña vena tras. versal, siendo desde alli en adelante muy pilidas. El cucrpo es de un amarillo de orin lustroso, mucho mas pálido en el escudcte; las garras, desiguales y denticuladas, son negras. Faltan los ojuelos, y la corta trompa remata en punta obtusa.

Esta especie se encuentra con frecuencia en los caballos y' en las vacas, sobre rodo cn las partes del cuerpo menos re. vestidas de pelo, pero es dificil cogerla á causa de su superficie resbaladiza y de su destreza para deslizarse por todas partes.

En la especie lipóptena (Lipoptena) los ojuelos se ven claramente, pero en las alas, que mas tarde son frigiles en la rair, no se encuentran sino tres renas longitudinales.

\section{EL ESTENOPTERIX DE LAS GOLONDRINAS -STENOPTERYX HIRUNDINIS}

CARACTRRES. - Hsta especie, que se halla à menudo en los hirundinidos, se caracteriza por sus alas estrechas y en forma de ho\%, que apenas le permiten volar. En junio encontré una golondrina que habia caido al suelo extenuada, y como se dejase coger, halle en su cuerpo 24 estenopterix, precisamente todas hembras, de un negro lustroso, con el abdómen muy abultado y á punto de poner.

$\mathrm{Si}$ las especies que acabamos de mencionar recuerdan ya por su aspecto externo à los aricnidos, mas scmejanza ten. drán aun con los mismos las mosias de los murcrielngos, que carecen de alas y tienen los tarsos largos. Su cuerpo es tambien córneo, plano y comprimido: la cabeza, en forma de bacinete, se mueve con mucha libertad, pudiéndose recoger hácia atris en una profunda cavidad de la parte superior del mesotórax. I.os ojos son puntiformes ó faltan del todo; las antenas, en forma de dedos, se componen de dos artejos, in. sertändose debajo del borde de la cabeza. In trompa, filiforme, tiene los palpos muy grandes y en forma de cuña; los erectores del ala rematan en un boton esferico y se insertan en los costados. Debajo y delante del punto de insercion de los tarsos del centro se hallan en el borde de una cavidad dos órganos especiales en forma de cresta, cuyo objeto se ha explicado de muchas maneras y que al parecer sirven pam proteger los conductos aéreos.

Estos parásitos, que midén de $0^{m}, 00225$ a $00^{\circ}, 00,45$ de largo, y de color amarillo, viven en varias especies de murciélagos. Si se ponen algunos en un vaso a cuyas paredes no puedan agarrarse, procuran cogerse entre si y ruedan con tanta vive. za que casi parece que vuelan circulamente.

\section{EL BRAULO CIEGO-BRAULA CCECA}

CARACTERES. - Las varias particularidades de que 
hasta ahora nos hemos ocupado se reconocen de un modo notable en el liraulo ciego (Braula creca), que carece del erector del ala y vive en las abcjas, no debiéndosele confundir con la primera forma de la larva del Meloc. Su cabeza, marcadamente separada del tórax, es vertical y trianguhr, hallåndose revestida de pequeñas cerdas amarillentas; in parte interior de la cara está separada de la frente por una angulosidad que sobresale poco y presenta en el centro una linea muy sesgada en la parte inferior. Fil escudo de la cabeza, córneo y semilunar, se inclina un poco hácia abajo en ambos lados; los palpos son cortos y en forma de maza; la trompa cora y membranosa; el labio superior se halla encer. rado como en un tubo por las maxilas. I'recisamente alli donde otras moscas tienen los ojos, hay dos grandes fosis de las que parten antenas, compuestas de tres artejos, ocultindose en las mismas hasta el artejo fnal, que es esférico y tie. ne una cerda revestida de pelusa. I.os tres anillos torácicos forman un corro mesotórax comun que en la parte anterior es apenas mas ancho que la cabeza, pero que hacia atras se ensancha ligeramente nu dejando distinguir ningun escudo: en su parte inferior las caderas se aproximan mas que en los demás pupiparos. Los tarsos se diferencian poco entre si midiendo igual longitud; los muslos son gruesos; los tarsos algo arqueados; cuéntanse cinco artejos en las patas, los cuatro primeros trasversales; el quinto, muy ensanchado, tiene en suborde anterior unos 30 pequenos dientes cerdosos que forman como un peine, que puede recogerse y representa las garras. Delante de los mismos, esto es, en la parte cxterna del últimn artejo están adheridos dos pequeños lóbulos delgados 5 membranosos, provistos de pelillos. Por último, el abdómen se encorva en forma ovalada, por lo que el insecto alcanza su major anchum en el centro, componiendose de cinco anillos El cuerpo, i excepcion de las antenas, que son amarillas, iche un color pardo rojo lustroso: mide 0-,0or 5 .

USOS Y COSTUMBRES. - I.a especie que acabamos de describir vive principalmente en las abejas, rabajadoras $y$ machos, pero sobre todo en su reina, que à menudo está invadida por una infuiciad de estos parásitos, volviendo á cubrirse de ellos tan pronto como ha conseguido alejar los que antes tenia. El braulo ciego se fija en el escuda del dorso, trasladándose tambien de tma abeja a otra, gracias al contacto en que se hallan estas en su enjambre Cuando se ha saciado permanece horas enteras en un sitio léjos de su anfitrion, y muere a las pocas horas; solo los jóvenes braulos, que acaban de salir de la crisłlida, tienen mas resistencia vital, porque no.siempre se les presenta ocasion de instalarse en una abeja. Como la hembra, que en su doble ovario no tiene sino cuatro gérmenes, alimentados en el interior por su glándula läctca, yonc las larvas ya inaduras, que vienen i encontrarse en el fondo del enjambre ó en campo raso, el coleóptero va completo ha de esperar que una abeja se le acerque por casualidad. Cuando la larva nace es blanca y blanda, pero endurécese y se ennegrece pronto; vista con el microscopio se ve que tiene cl cuerpo ovalado, compuesto de once segmentos. Dos semanas despues la mosca alcanza su desarrollo. Hasta ahora no se conoce sino esta especie que habita en toda la Alemania. Francia é Italia, no habiendo sido observada todavia en Rusia a excepcion del mar Báltico.

\section{LA PULGA COMUN-PULEX IRRITANS}

CARACTERES. - Ya hemos visto que la falta de alas en un insecto no sirve de norma para su clasificacion en el sistema, pues hemos encontrado hasta ahora en todos los órdenes, y tambien en las moscas, individuos sin alas, como los hallaremos en lo sucesiro. Por lo mismo no parece justificado reunir todos los insectos sin alas en un órden especial, como han querido harerlo varios naturalistas. Ia naturaleza no ha creado sistemas sino especies, muchas de las cuales ofrecen dificultades al maturalista clasificador. A estas pertenecen las pulgas, que por su estructurn tienen semejanza con los hemipteros, y á causa de su tórax, dividiủo por tres anillos, con los ortópteros, pero que por su completa trasformacion y conformacion bucal deben clasificarse aqui. Su pequeña cabeza, estrechamente unida con el anillo del cuello, tiene ojos sencillos en ver de reticulados, y detrís de los mismos ocultan sus antenas, que se componen de tres y hasta de seis artejos; el cuerpo es muy comprimido lateralmente, articulado en los tres anillos toricicos, sin alas y provisto en los dos posteriores de apéndices en forma de líminas; sus robustos tarsos, cuyas caderns sobresalen mucho, facilitan el salto.

USOS Y COSTUMBRES. - Las pulgas hacen las veces de parásitos en los aninales de sangre caliente alimentándose de ella, en tanto que sus larvas viven de sustancias pu. trefactas y sobre todo del estiércol. Antes se clasificaban to. das en una especie, pero luego se ha probado que casi cada individuo invadido por las pulgas tiene además las suyas. Ia pulga comiun (Pulex irritans) es hastante conocida como cosmopolita; y su picadura es temida de las personas sensibles e irritables. Sus palpos maxilares constan de cuatro artejos, mientras que otras especies tienen diversa conformiacion. I a15 julgas molestan nucho, sobre todo en agosto y seticmbre. y en los paises calurosos mas aun que en nuestras zonas templadas. la hembra fecundada jone sus 12 huevos, relativamente grandes y oblongos, entre las grietas de las planchas de madera y en ins rincones polvorientos. Semejantes sitios se hallan sobre todo en las habitaciones de los niños, pero tambien en las casas recien construidas; y por eso se ha creido en otro tiempo que las pulgas nacian del serrin remojado con orines. I. cierto es que la basura de los cuartos, que en muchas partes se mezcla con serrin húnsdo, empleado para evitar el polvo, cjerce una especial atraccion sobre lis hembras, que están á punto de poner. En verano se nece. sitan 6 dias, y en invierno doble tiempo en las habitaciones caldeadas para que la larva se desarrolle en el huevo. Esta se presenta bajo la forma de un gusanito esbelto y blanco con antenas, dos maxilas y ojos; unas pequeñas cerdas late. rales facilitan su movimicnto serpentino, y al mismo tiempo su progresion. Rosel las alimentó con moscas, sangre secn y remojada, con lo cual iban adquiriendo color visiblemente. Al cabo de ir dias son adulins, expelen los excrementos, se vuelven blancas y prepáranse en una pequena cavidad un sitio para convertirse en crisálida. Cunndo ha perdido la piel que lleva detris se convierte en una hermosa crisálida, en la que se reconocen las distintas partes del insecto en que ha de convertirse. Poco a poco se oscurece mas hasta que en verano, al cabo de i d dias, sale el diestro gimnasta.

Toda la trasformacion dura pues unas cuatro semanas, y si es invierno, y las circunstancins favorables, mes y medio. El recien nacido se sirve inmediatamente de sus robustos tarsos posteriores, $\varepsilon$ impulsado por la sed de sangre, puede estar mucho tiempo sin comer, pero entonces pica de un modo tanto mas sensible, buscando á grandes saltos el objeto que ha de proporcionarle su alimento. Como ha nacido entre hombres y animales, sus esfuerzos quedan muy pronto recompensados. Introduce häbilmente sus agudas hojas j) chupa hasta saciarse sicmpre expuesto al peligro de que le cojan y de pagar su capricho con la vida. Cuando esta harto y se salva de la persecucion de que es objeto por la noche, al tratar de satisfacer su sed bestial, cumple con la ley de la naturaleza. Los machos son mucho mas pequeños que las hembras. 
Sabido es que hay personas que se ganan la vida adies(rando pulgas (enganchándolas à unos carritos, etc.): encierran primero estos insectos largo tiempo en unas cajitas, donde cada vez que intentan saltar les dan golpecitos en la cabeza, hasta que pierden esta costumbre; despues de cada representacion los ponen sobre el brazo y déjanlos chupar tanta sangre como pueden. Hé aqui una nueva prueba de que estos insignificantes insectos tienen uma inteligencia desarrollada que no es posible explicar por el solo impulso natural, como algunos han pretendido.

Prescindiendo de otras muchas especies de pulgas que viven en los perros, ratones, erizos, gallinas, etc, y que todavia no están bien clasificadas, hay en la América del sur una especie que en ciertos casos puede ser muy peligrosa para cl hombre y que a causa de la diferente estructura de sus órga. nos respiratorios, de la forma distinta de las maxilas y de los apéndices en forma de palpos que presenta en su labio inferior bipartido, ha sido separada de las pulgas y clevádosela ń la catcgoria de género especial. El rincoprion penetrante, pulga de las arenas, chichno, giger, nigua, bicho, etc. (Rhyychogrion penctrans) parece estar diseninado en la America desde el $29^{\circ}$ de latitud sur hasta el $30^{\circ}$ de latitud norte. Se encuentra por todas partes en las inmediaciones cie las casas y de las viviendas abandonadas, donde hay calor y sequedad, condiciones que le agradan mucho. Solo las hembras fecundadas penetran en la piel de los animales de sangre caliente y de los hombres, principalmente entre las unas de los piés ó en otra parte de los mismos. Los machos y las hembras estériles se alimentan de sangre, como las demás pulgas; el color desu cuerpo es, prescindiendo del contenido del intestino trasparente y oscuro, de color amarillento, y las hembras que se fijan en la piel, de color casi blanco puro. Al principio se asemejan ambos sexos por su tamano y mi. den por término medio ( 1 ",001, esto es, la mitad de nuestra pulga comun; pueden saltar, pero no à tamta altura como éstit: y ofrecen en su conjunto el mismo aspecto. El que quicra conocer al rincoprion en todas sus partes, y se interese en los relatos, algo contradictorios, que acerca de el tenemos, le aconsejamos el extenso trabajo publicado en IS64 por Karsten en el Boletin de la Academion de Moscou (xivini). Mientras la hembra permanece tranquila en la pie!, no irritada por la compresion ó el roce, su abdúmen sé dilata hasta alcanzar el tamaño de un guisante $\left(11^{\circ}, 005\right.$ de diámetro); mantiénese en tal estado largo tiempo, y no producc mas dano que un ligero escozor én la parte. En cambio la infa- macion aumenta considerablemente por el roce, y si uno se descuida prodúcense los efectos de que hablan los narrado. res. sobre todo porque otras hembras encuentran aquel sitio muy apropiado para instalarse. Las supurnciones malignas y la gangrena que luego se desarrolla exigen la amputacion de los dedos, habiéndose producido en cicrtos casos hasta la muerte. La dilatacion de la hembra que ha anidado debajo de la piel se verifica con mucha rapider, pero antes s-s preciso que se haya introducido hasta la punta del ano, que tapa en tal caso su morada. I as numerosas células ovaricas que se hallan en las bolsas cilindricas de su ovario, simplemente ahorquillado, se desarrollan alli lentamente, de manera que el huero mas maduro se halla junto a la salida, sicndo cxpulsado por la presion de los demás. Si no se la molesta, la hembra permanece en su vivienda hasta haber puesto todos los hueros, que van saliundo y no permanceen en el animal invadido, como la pulgn comun. La hembra muere despres y es expulsada luego de la herida en vias de curacion.

parece que el resto del desarrollo de la laria y de la crisilida no ofrece diferencias noiables con las de nuestra pulga comun.

De todos modos no es prudente permitirles que se instalen en nuestra picl, pues se necesita siempre cierta fucran de voluntad para no mascarse alli donde escuece; además, la presion externa puede irriar la herida, como ya hemos visto; y por último nadie sabe anticipadamente la resistencia que tiene su cuerpo para semejante mal. Por lo mismo son indis. pensables parn los habitantes de aquellos paises las médidas de precaucion indicadas por la experiencia. No es recomendable perseguir á la pulga que se halla á punto de introdu. cirse en la piel, porque en su ardor sabe abrirsc camino con sus partes bucales, penctrando cada vez. mas adentro; entonces se rompe fácilmente, y no pudiendo ser extraida sino en pedazos, initase mas la herida. Antes bien, mejor es dejar primero que se instale, para extraerla de la herida cuando se dilata, pero teniendo cuidado de no desgrarrar su abdómen, cuyas paredes son muy delgadas, pornue en tal caso una parte del animal que permaneciese en la herida la perjudicaria mucho. las circunstancias en que se desarrollan las larvas han desmentido que estas puedan producir tan malas consecuencias como algunos han pretendido. Por lo demás, cuando oimos semejantes historias no podenios quejarnos y si tolerar con paciencia los tormentos á que nos condenan nuestras pulgas; son molestas, pero en ciertos casos saludables y nunca peligrosas.
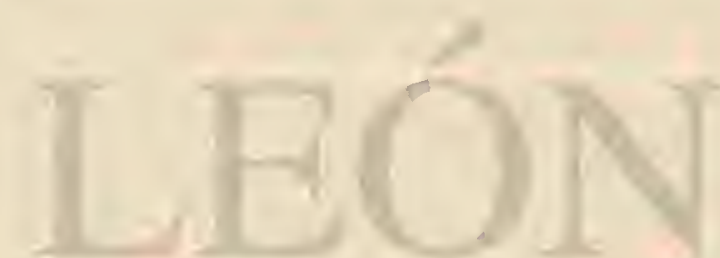

NEURÓPTEROS - NEUROPTERA

Al fundar estc órden, Iinvico reunió iodos aquellos insectos, cuyas alas, segun su denominacion, estản cruzadas por una red mas ó menos perfecta de vénas, asemejándose su estructura en lo esencial tambien bajo otros concentos, sobre todo por la conformacion de las partes bucales y el débil enlare del anillo torácico anterior con los dos siguientes. De resultas de esto, algunos insectos con alas, muy graciosa. mente reticuladas, como por cjemplo las libélulas y algunos congeneres cuya tmaformacion no es perfecta segun las tres gradáciones, han sido clasificados entre otros de trasformacion períecta. Luego se reconoció lo defectuoso de este plan y consideróse todo el órden como grupo de trínsito á causa de la diversidad de sus partes integrantes. No obstante, los neurópieros de tmsformacion incompleta, atendida su es. tructura interna, se pueden scparar y agregar al órden siguiente, como lo ha hecho Erichson, obteniendose la ventaja de que tanto este como cl que sigue permiten una clasificacion mas marcada que la que hasta ahora se ha podido 
hacer fundandose en la conformacion de las alas. Asi pues, sin rénunciar at la antigua denominacion, comprenderé bajo el nombre de neurópteros todos aquellos insectos que sufren una metamorfósis completa, yge fiewen las parles bucales pro. pins para morder, pero peco disnrvalladas, un protúrax libre $v$ las alas anteriores y posteriores membranosas é iguales.

Prescindiendo del protómx, que no salta mucho a la vista, los caractéres distintivos corresponden á los de los limenópteros, pero no es fácil confundir entre si los individuos de ambos órdences. I.os neurópteros son insectos prolongados, delicados y blandos, y ninguna especie está tan cubierta de una masa quitinosa como los himenópteros, á excepcion de una de las especies mas pequeñas. En concordancia con esto se halla tambien el desarrollo de las partes bucales, que se gun su estructura se consideran con mzon como propias para morder, pero que a menudo no pueden hacerlo á causa de su blandura. Además no es posible la confusion, dadas sus alas, provistas de numerosisimas cúlulas, de ordinario muy prolongadas y casi iguales entre si; $y$ atendida tambien la conformacion del mesotórax. Antes podia suceder que los inerpertos considerasen ciertos neurópteros, cuyas alas estain revestidas de una pelusa abigarrada, como micralepidópteros; pero aun admitiendo que las partes bucales estén atrofiadas, no se necesita tener una vista muy jerspicaz para reconocer la diferencia esencial de estas y ademots la diversidad de conformáción del tórax, lo cual desmnecerá ha duda de si tenemos a la vista neurópteros o microlepicúpteros. I os insectos perfectos de uste órden y del siguiente no se pueden distinguir con seguridad de los anteriores sin tropezar con dificultades, porque el carácter distintivo principal, tanto de los unos como de los otros, consiste en la trasformacion, que no se ve en el insecto períecto. No obstante, si recordamos que lis libelulas y efémeras, jumiamente con las especies mas afines, fíciles de reconocer, no sufren sino una trasformacion incompleta, agregindose no ya à cste sino al brden siguiente, desaparece tambien la dificulad y quedan señalados los limites deleste órden. Iis el mas reducido de todos, comprende unas mil especies yiga existia en los princros periodos de la creacion. En las capas mas antiguas se encuentran pocos restos fósiles, lo cual no débé extranarnos, dada la de. licadeza de la estructura de estos insectos: en cambio son bastante numerosos en el ámbar.

\section{LOS MIRMECOLEONES -MYRMECOLEON}

Los interesantes mirmecoleones se reconocen con bastante facilidad por sus antenas cortas, planas, comprimidas y cnsanchadas en la parte anterior un forma de cuna y por sus alas reticuladas, prolongadas, que rematan en punta son iguales entre sí; la extremidad de estas y la conforma. cion de las antenas son los dos signos caracteristicos diferenciales que saltan inmediatamente a la vista y que distin. guen a estos insectos de las afines libélulas. Sus ojos redon. dos son muy marcados y comunican à la cabeza un aspecto particular: sus maxilas cómeas son propias para morder. El segundo y' tercer artejos de los tarsos, que ofrecen la misma estructura, son mas cortos que el primero, y los espolones terminales de los piés no se encorvan a manera de gancho.

\section{EL MIRMECOLEON HORMIGUERO-MYR- MECOLEON FORMICARIUS}

CARACTERES. - Los caractéres distintivos específicos del mirmecoleon hormiguero son: algunas manchas oscuras en las alas; las venas de las mismas mas oscuras $\delta$ mas cla- ras: las antenas mas cortas que la cabcza y el mesotórax jun. tos. lodo el insecto es de color negrogris con manchas amarillas en la cabeza y en el tórax y de un pardo amarillo en los bordes posteriores de los segmentos abdominales y en los tarsos.

USOS, COSTUMBRES Y REGIMEN. - Vive principalmente en los bosques de coniferas de los terrenos arenosos de la Alcmania central y meridional, donde se le re desde julio hasta setiembre. De dia permanece tranquilo con las alas replegadas sobre el cuerpo, pero asi que se pone el sol cobra mas animacion, vuela con lentitud y parece mecerse en el aire mientras busca su alimento $\delta$ una hembra. En las vertientes soleadas, sobre todo al amparo de las raices de los arboles, la larva establece su domicilio, que consiste en un pequeño embucio en cuyó fondo se oculta con las tenazas estiradas acechando la presa. Esta consiste en hormigas y otros pequeños insectos que caen por casualidad en el cm. budo. Inmediatamente son cogidos y raciados. Ia parte su. perior de las tenazas representa la mandibula superior tridenticulada por dentro y cóncasa en la parte inferior para recoger las cerdosas mitades de la mandibula inferior, que juntas constituyen el órgano de la succion. Los palpos ma. xilares faltan; los labinles constan de un artejo muy grande y eliptico, î los que siguen tres mas pequeños, de forma cilindrica, encontrándose, no entre las maxilas y dirigidos hácia adehnte, sino situados lateralinente debajo de las mis. mas. En los ä́ngulas de su cabeza, grande y en forma de corazon, se hallan a cada lado siete ojuclos y antenas que no alcanzan ln longitud de los palpos labiales. Los tarsos terminan con dos grandes garras sin lóbulos prensiles. En su tosco cuerpo llaman la atencion el anillo anterior del protorax que se adelgaza a manera de cuello, el abundante pelnje que se presenta en mechones en las verrugas latera. les y la elevacion gibosa de la raia del abdómen. El último segmiento abdominal es esférico, pero no remata en una la. pinilla córnea, sino en verrugas revestidas de cerdas.

El mirmecoleon que acabamos de describir forma el embudo å fuera de empujar hácia atrás; abre su hoyo a modo de fosa circular, cuyo tamano estio determinado por el suỵo, y cuyo borde externo constituye al mismo tiempo el de su futura vivienda; en el centro hay por lo mismo un cono de arena truncado, pero el insecto sabe rebajarle de una manem tan rápida como ingeniosa. Alli donde ha escarbado, el primer circulo se ahonda con el abdómen; despues retrocede trazando una espiral cada ver mas estrecha; con sus tarsos delanteros dirigidos hácia adentro arroja la arena sobre su cabeza ancha, en forma de pala, y lánzala luego tan hábilmente $y$ con tanta fuerza que por lo menos va á caer a cinco centimetros de distancin del borde del embudo. De vez en cuando descansa, pero cuando está trabajando, sus ágiles movimientos producen una continua lluvia de arena. El cono interior disminuye á cada giro y desaparece por completo asi que el perqueño mirero llega al centro, donde se coloca, dejando sobresalir las tenazas. Para facilitar su trabajo, quue exige una gran fuerza muscular, no procede desde cl principio hasta el fin en la misma direccion, sino que se vuclve de rez. en cuando para que el tarso izquierdo preste el servicio de peon cuando se cansa el derecho. Si encuentra en su camino granos de arena mas gruesos, lo cual sucede á menudo, entonces se los carga separadamente sobre el dorso y los extrac. Se ha obscrvado que las tentativas sin éxito han sido repetidas con frecuencia, sin buscar otro sitio lasta que todos los esfuerzos han sido inútiles. Como la es. tructura del cucrpo de los mirmecoleones no les permite emprender largos viajes, la hembra previsora ha tenido cuidado de no poner sus huevos sino en la arena, donde su 
descendencia puede construirse la vivienda necesaria para su futura prosperidad. Es casi ocioso decir que el mirneco. leon no vive siempre en el mismo embudo; cuando crece necesita uno mas espacioso, prescindiendo de muchos accidentes que lo destruyen, 5 de la falta de alimento, que le obliga á practicar otro. El embudo de una larra adulta mide $0^{\infty}, 05$ de profundidad por $\left(0^{n}, 0,8\right.$ de diametro en el borde superior; pero estas dimensiones no son constantes y deprenden en parte de la maturaleza del terreno. El rapaz oculto en el fondo del embudo, no alcanza siemupre sin esfuerzos la presa que necesita; una pequeña oruga, cierta araña, ú otro animal mas grande que hayan tenido la mala suerte de resbalar en el abismo, yo no pueden agarrarse á las paredes para salir, oponen resistencia y se defiencien con mas valor que una hormiga ti otro insecto de igual tamaño. Bonnet refiere un interesante ejemplo que manifiesta no solo la resistencia vital del mirmecolcon, sino tambien la solicitud conmovedora de una araña por sus huevos. Una especic (Pardosa sacenta) de este grupo de asesinos vive debajo del follaje seco entre la yerba, y se re. conoce fácilmente por su ovario blanco del tamasio de un guisante, el cual llem en la primavera adherido al abdómen, guardindolo con mas afan çue un araro sus tesoros. Bonnet introdujo una de estas arañas en el hoyo de un mirmeco. leon; este cogió el ovario con mas rapidez quue la q̧ue empleó la araña para huir; el uno tiraba hácia abajo, y la otra hácia arriba; y al fun, despues de una luclıa tenaz, el saco se desprendió.

La amña, sin enbargo, parecia resuelta á no abandonar de esta manera su tesoro: cogióle con sus robustas maxilas y redobló sus ceśucrzos para arrancarlo de las garras de su adversario; mas a pesar de toda la resistencia y de un largo pataléo, el astuto enenigo lo hizo desaparecer debajo de la arena. Entonces intervino Bonnet con la fuerza, para que la infelir. madre no fuer tambien victima del vencedor por amor á su prole, pues voluntarianente no se hubiera alejado del sitio donde sabia que cstaixa enterrado su tesoro, y donde mas tarde hubiera sido tambien devorada.

El mirmecolcon se revuelca un cuarto de hora con una abeja, à la que se hayan arrancado las alas, y si se le echa un congénere suyo, procede del misno modo: sepultado en la arema, siempre tiene ventaja. Los cadáveres vaciados los arroja para que no le estorben en su camino. Asi pues, la constancia y la astucia han de suplir en el mirmecoleon á utras cualidades que la naturaleza no le ha concedido.

A primeros de junio las larvas adulias empiezan à convertirse en crisálidas. Por fin se ahondan algo mas profunda. mente debajo del vértice de su embudo, rcogen el extremo de su abdómen, cono un anteojo de larga vista en un tubo movible, 6 hilan con el mismo hebras blancas y sedosas que sostienen las capas de arena alrededor, formando una estera Roja La pared interna esta siempre muy bien tapizada. Por fin la piel de la larva se desgarra en la nuca, y por alli sale la crisálida. Esta es mas esbelta que la lara, de color amari. llento con manchas pardias; las rainas de las alas, de los tarsos $y^{\circ}$ de las antenas penden libremente en todas las crisálidas, y el cuerpo descansa en posicion recogida para que pueda caber en la esfera. Madurada en la arena, a menudó ardiente, rasga al cabo de tres semánas la envoltura de su crisálida, y al salir llénase consigo la mitad de la vivienda que antes ha perforado. El esbelto nirmecoleon no sale sino de noche, como animal de vida nocturna.

Un verano reuni varias bolas y todas las noches encontraba en la caja hasta ocho insectos recien nacidos, pero si los dejaba juntos durante toda la noche, estaba seguro de encontrar al dia siguiente algunos mutilados. Los pocos dias de vida que tienen los dedican á los deberes de la reproduccion. La hembra fecundada pone un escaso numero de huevos de unos $1^{n}, 00337$ de largo por $0^{\infty}, 00112$ de grueso y de cáscarn dura; son algo encorvados, de color anrarillento, $y$ rojos en el extremo obtuso. I as larias nacen aun antes que sobreven. ga el invierno, se instalan del modo que hemos descrito, y en la época en que no encuentran alimento aletárganse en el fondo de su embudo. Quizà no son todavia adultas en el siguiente mes de julio, pornque se encuentran al mismo tiempo larvas de distinto tamaño y crisilidas. No se han observado trasformaciones, al menos que yo sepa, en la piel de las larvins.

Del mismo modo vire la larma del mirmeleon hormign-lince (Myrmelenn formicalyn.x), muy semejante à la anterior, difiriendo solo un poco por su cabeza, y rue se presenta en Ale. mania juntamente con la especie ya descrita, distinguiéndose sin dificultad por sus alas no manchadas. En cambio, en los paises meridionales de Europa existen tambien otras especies cuyas larvas no praclicin pequeños embudos, sino que se ocultan simplemente en el terreno arenosa. A estas especies pertenece verbigracia el mirmelcon de largas antenas ( $\mathrm{My}_{\mathrm{y}}$ meleon ictragrammicus), cuyas antenas ilcanzan por lo menos la longitud total de la cabeza y del mesotórax, y cuyos espolones se encorvan en los tarsos delanteros. la larva se diferencin exteriormente de las anteriores pror tener los ojos sobre una pequcria gibosidad y el segmento terminal esférico del abdómen provisto de dos laminillas córnens, denticuladias en cl borde posterior: anda tanto hácia adelante como hácia atrá. Esta especie se encuentra tambien aislada en la provin. cia de Sajonia - En las comarcas mas calurosas hay mirne. coleones cuyo tanmaño es doble del de los nuestros, como

\section{EL MIRMELEON LIBELULOIDEO - MYR- MELEON LIBELULOIDES}

CARACTERES. - El mirmelcon libeluloideo (fig. 122), otra especie de las mas notables, se distingue por su cuerpo amarillo, listado de negro; las antenas de este vítimo color, nacen en un tubérculo amarillo, cubierto de un hacecillo de pelos negros; la cabeza tiene este linte en su parte anterior y es amarilla por encima, con una linea negra longitudirial: el coselete es velludo y amarillo; las alas de un color blanco gris, con las nerviaciones amarillas y manchas pardas, mas numerosas en las superiores que en las inferiores; en es. tas últimas hay-ademis dos fajas trasversales; las patas son pardas; cl abdómen negro. El tamaño de esta especie varia entre 20 y 22 lineas de largo, por 4 pulgadas y 6 lineas de punta á punta de ala.

DISTRIBUCION GEOGRÁFYCA.-Este neurópterose cncuentra en la Europa meridional y parece ser tambien muy comun en Oriente.

\section{LOS ASCALAFOS-ASCALAPHUS}

CARACTERES. - Como especies afines viven en el nediodia de Europa los ascalafos, que se diferencian por tener las antenas tan largas como cl cuerpo 6 mas num, cerdosas y terminadas en un boton ancho y comprimido; los ojos son reiculados y dividicios: la frente y' la coronilla cstán rcrestidas de una pelusa csuesa y larga; $y$ los cortos tarsos se caracterizan por tener dos robustas garras y espolones tcrminales. Como las alas, de las cuales la posterior es casi triangular, son todas de color, y las antenas se asemejan a los mismos organos de algunas mariposas diurnas, estos insectos se liaman en Alemania ascalafos mariposas. Ios machos ticolen tenazns en el extremo del abdómen, y con ellas cogen a las 
hembras en su rápido vuelo: una vez apareados se posan sobre una planta. Las larvas se asemejan por su indole á las del mirmecoleon. Ia cabeza, casi cuadrada y voluminosa en el ángulo posterior, está provista de seis ojuelos que se hallan sobre una prominencia en cada lado, detris de los órganos de la succion. Ia extrenidad del cuerpo es cilindrica y los costados presentan cerdas escamosas sobre verrugas pedunculadas. Los ascalafos viven entre la yerba y otras plantas, alimentándose de insectos, y en el mes de junio tejen tambien una blanda vivienda para su crisílida.

\section{EL ASCALAFO ABIGARRADO-ASCALAPHUS MACARONIUS}

CARACTERES. - La especie que habita mas al norte es el ascalafo abigarrado. Mide 0",0195 de longitud por 1",044 de ancho; es negro y esti revestido de una pelusa del mismo color; solo la cara es de un amarillo dorado. Las alas anteriorés amarillas en ln rair, están adornadas de dos grandes manchas pardas en el borde ahumado; las posteriores son de un pardo negro, con una línen central y una mancha terminal redonda de color amarillo muy viro.

\section{LOS CRISOPOS - CHRYSOPA}

CARACTÉRES. - l.os crisopos son pequeños neurópteros, que se diferencian notablemente de los mirmecoleones por sus antenas cerdosns, sin boton en la extremidad, $y$ en el estado de larva por sus órganos de succion no denticulados ¿Quién no conoce aquel diminuto insecto de ojos dorados, del colar del iris, que se instala en invierno en los aposentos de las casas donde hay jardines? Con las alas repleya. das a manera de tejadillo sobre su énerpo de color verde claro, aguarda la primavera para cumplir con los deberes de reproducción en el jardin ó en las matas del bosque. Desde este momento se deja ver hasta el otoño, encontraindoscle entonces en gran multitud, sobre todo en los encinares. El año $1 \$ 65$, que hi\%o mucho calor, encontré el dia 7 de noviembre un individuo que acababa de abanconar la crisalida. Para la mimdá crperta nunca pasa desapercibido que no todos los crisopos son cómpletamente iguales en tamaño y coloracion, por lo cual deben clasificarse en rarias especies.

\section{EL CRISOPO VULGAR-CHRYSOPA VULGARIS}

CARACTERES. - El crisopo vulgar (Chrysopa andgaris), llamado por Linneo, con otras especies, Hemerolinus perla, se caracteriza por sus alas trasparentes, cuyas venas son de color ierde, amarillo verdoso ó rojo encarnado uniforme; el cuerpo, de un bonito verde, presenta en torla su longitud una linea anarilla ó blanca; las antenas son de un amarillo páli. do, así como los palpos y los artejos de los tarsos. Lat ritiz de las garms se ensancha, formando gancho; el labio superior no esti sesgado y entre las antenas hay un punto negro.

Esste ncuróptero pone sus blancos huevos sobre las hojas de un modo singular. Primero comprime la punta del abdómen contra el objeto, luego la levanta lo mas posible extrayendo un hilo blanco y rigido en el cxtreino del cual se halla un nudito, esto es, cl huevo, que parece un hongo y que en otros tiempas fué descrito con el nombre de Ascophiorn orenlis. A su tiempo el huevo se agrieta en la parte superior $y$ del mismo sale un diminuto sér esbelto, que cuando es algo cre. cido se encuentra fácilmente entre los pulgones. Su seme. janza con el mirmecoleon no se puede desconocer, con la diferencia de que no tiene el aparato de succion denticu. lado y que los palpos labiales no alcanzan la longitud de sus cerciosas antenas. El cuerpo está menos revestido de pelusa, es mas esbelto; la extremidad del abdómen sirve para la locomocion y de órgano del tacto. 'Todas las especies se asemejan por su fondo anurillo sucio con manchas de un pardo violeta, $y$ no se distinguen sin dificultad por las variaciones de su dibujo, sobre todo el de la cabeza.

USOS $\mathrm{X}$ COSTUMBRES. - Con estas especies conocemos una tercera serie de larvas que se alimentan principal. mente de pulgones, contribuyendo mucho á contrarestar la extraordinaria multiplicacion de tales insectos, nocivos para las plantas, cuyo jugo chupan. Si el alimento abunda y la temperatura es calurosa, crecen con rapidez y crian varias veces al ano, lo cual explica porqué despues de un verano favorable hay una muleitud tan grande de moscas. La larva adulta hila en una hoja, ó entre las agujas de una rama de conifera, varias hebras sedosas, formando luego una vivienda bastante sólida, casi esférica, en la cual se convierte en cri. sallida. Por lo demás, segun mis experiencias, no todas las especies hilan. El crisopo vulgar se extiende por toda la Europa j otros en las demás partes del mundo.

\section{LOS HEMEROBIOS-HEMEROBIUS}

CARACTERES. - Se incurriria en error si teniendo solo en cuenta el nombre científico, se creyera que las especies de este género solo viven un dir. Estos insectos tienen las alas muy inclinadas a manera de tejado; la vena marginal de las anteriores no se corre simétricamente junto a la del borde inferior, sino que forma cerca de la raiz un arco hícia afuera; la vena longitudinal, mas próxima, envia hácia la superficie interna por lo menos dos ramas paralelas (sectores). Segun el número de estas y la direccion de la primera vena trasversal, entre la marginal y sub-narginal, se han clasificado recientemente varias especies.

\section{EL HEMEROBIO ÁSPERO-HEMEROBIUS HIRTUS}

CARACTÉRES. - Esta especie, que desde el mes de juLio no falta en ninguna parte de Alemania, se reconoce fàcilmente por las cinco ramas equidistantes y paralelas de su radio $y$ por las que están alternativamente manchadas de amarillo $y$ de un pardo negro en las alas antcriores. La mosca es de un pardo negro, à excepcion de los tarsos y de la region antero-dorsal que son de un amarillo pardo. La especie mide $10^{n}, 0065, y$ las alas anteriores $10^{n}, 008_{75}$. Sus antenas se asemejan á un collar de perlas.

USOS Y COSTUMBRES. - Las larvas del hemerobio se asemejan à la del crisopo por su género de vida, que es idén. tico, pero tienen los órganos de la succion muy cortos y anchos, las antenas gruesas, y los lóbulos prensores cortos en sus tarsos comprimidos. Nuchos de ellos se encierran en el interior de los pulgones que han devorado. No podemos des. cribir muchos tipos interesantes del mediodia.

\section{LOS NEMÓPTEROS-NEMOPTERA}

CARACTÉRES. - Los nemópteros forman un género que ofrece muchas analogias con el hemerobio: las antenas son casi filiformes; la boca se prolonga en forma de hocico; los palpos labiales son mas largos que los maxilares, y estos mas cortos que las maxilas: los tarsos constan de cinco artejos; el primero y el último bastante largos, y los otros muy breves; los espolones son cortos; las unas grandes.

Los nemópteros se distinguen sobre todo por sus formas graciosas y brillantes colores. 


\section{EL NEMÓPTERO COA-NEMOPTERA COA}

CARACTERES.-Seguramente seri esta la especie (figura 120$)$ que Fabricio quiso designar al cscribir alse antia rotundata, porque es la que mas marcado ofrece cste caricter. . Muy semejante este insecto al nemóptero lusitano, dis. tinguese notablemente, sin embargo, por los detalles del dibujo y la forma de las prineras alas, mas cortas y redondeadas, y á proporcion mas anchas; de modo que el borde costal, casi recto en aquella especie, es aqui cliptico. El cuerpo difiere poco por los colores, y en cuanto à las rayas y pun. tos, solo se distingue por ser unas y otros mas pequenos $y$ numerosos. El atributo mas no:able que ofrece este neuróptero consiste en el singular desarrollo de las alas posteriores, particularidad que se hace exlensiva, aunque no en tanta manera, i oiros neurópteros.

DISTRIBUCION GEOGRÁFICA.-Esta curiosa espe. cic ha sido hallada en la Morea, y particularmente en las is!ns del archipiélago. En estos puntos fué obsermảa por rarios naturalistas, y entre ellos por Mr. Olivier.

\section{LOS RAFIDIOS-RAPHIDIA}

CARACTERES. - Los rafidios, Ilamados asi por tener el primer anillo toricico prolongado y muy movible, pero sin representat un cilindro cermdo, como en los anteriores, por lo cual quedan libres las partes dorsales, estån representados por la siguiente especie.

\section{EL RAFIDIO DE ANTENAS GRUESAS-RHA- PHIDIA Ó INOCELLIA CRASSICORNIS}

CARACTERES. - La falta de ojuelos y de venas trasversales en la señal de color pardo rojo oscuro de las alas anteriores, que son trosparentes, distingue a esta especic de todas las demás, y dió motivo parn que Schneider la clevase, en una monogrấa, ấ la categoria de género especial.

USOS Y COSTUMBRES. - En el mes de junio vaga este neurúptero por los troncos de las encinas en busca de pequeños insectos. Si el rafidio descubre un mosquito 6 una mosea en sus inmediaciones, levanta la parte delantera del cuerpo, inclina la cabeza hàcia abajo é intenta en aquella po. sicion belicosa un ataque. Si la victima se mueve en el mismo instante, retrocede un poco antes de acometerla. Entonces introduce ávidamente sus dientes y chupa, los vuelve a retirar de vez en cuando, los sacude rípidamente uno contra otro como para afilarlos y continia su tmajo hasta no que dar nada ó solo la piel y las partes sólidns de la victima. Si se tienen dos cautivos en un reducido espacio, ai principio se esquivan, pero pronto se acometen y por último ol mas fuerte devora al mas débil si no se les proporciona de comer; uno solo puede ayumat varias scmanas. Su cabeza encogida pos. teriormente á manera de cuello y comprimida, alcanza por sus ojos salientes y grandes su mayor anchurn, llevando entre los mismos sus antenas filiformes que constan de numerosos artejos. Las partés bucales sobresalen poco á causa de su cortedad, teniencio palpos filifornes, los maxilares con cinco arzejos y los labiales con tres. La hembra se diferencia del macho por tener un largo oviducto dirigido hácia arriba, y ambos sexos se distinguen de casi todos los demás ncuróp: teros por la gran movilidad de los miembros.

La larva vive debajo de la corteza de los arboles ó entre su cubierta de musgo y liqquenes para alimentarse alli de inzsectos. Fs de forma eshelta y se caracteriza por la figura casi cuadrada de la cabeza y del primer anillo torácico, asi como por su única cubierta de guitina. En cada lado de la cabeza hay cuatro ojos; en otrns especies dos ó siete, y las antenas se componen de cuatro artejos. Sus rortos tarsos constan, además de las ancas, de tres artejos y terminan ell dos garras. A causa de su oculta morada, la larva de color pardo, rayada de'amarillo en el abdómen, raras veces se ve, j’ si hácil el medio dia sale a la superficie, procura ocultarse entre las es. carmas de la corte\%a si nota que la obscrvan. De ordinario solo vive una en cada tronco. Schneider observó uma larviı que mudó dos veces de piel, y supone que este fenómeno se repite con mas frecuencia. Además hizo la importante observacion de que una larvia que habia perdido el artejo de un tarso y otro de las antenas, los recmplazó durante el túltimo cambio de piel. Ia larva es adulta antes del letargo invernal, y en la siguiente primavern se ensanchan tumbien los otros dos anillos tomácicos para preparar la crisálida. La larva echa la última piel en abril ó mas tarde.

La crisálida no se diferencia de la mosca sino en el estado de reposo; el cuerpo se inclina poco hacia adclante $y$ las alas se desarrollan poco; en la hembra, el taladro se oprime $\mathrm{en}$ su major longitud contra el dorso, como la raiz del mismo en cl vientre. A los once 6 trece dias adquuiere color, parece despertarse y ya no tiene tranquilidad. Los tarsos, hasta entonces encogidos, se estiran y cmpiełan ả funciomar, y por último se levanta la ninfa y sale á luz. Alli se para conlas vainas de las alas separadas del cuerpo y permanece en tal posicion seis ú ocho horas como si quisiese reunir fucrats para hacer el último esfuerzo y librarse. Por fin la piel se resquebraja en la nuca y sale de la misma como otros insectos.

\section{EL SIALIS ACUÁTICO-SIALIS LUTARIA}

CARACTERES. - El sinlis acuático (Sinlis lufarior) recuerda jor su aspecto á los limnólilos, que pronto ciescribiremos y en cuya compañia vixe, tanio en las aguลิ estancadas como en las corrientes. Reprosa en las plantas acuíticas o vucla tambien pesadamente cuando los rayos clel sol le alientan. Aunque a veces se alcje con rajpidez un trecho de su sitio de descanso, parece un animal que se dejaria coger ficilmente. Carece de ojuelos y tiene un surco longitudimal en el vértice y una estrecha maxila inicrior en forma de lanceta; los palpos cuentan seis artejos en la mandíbula inferior. Como las depresiones de los hombros son muy marcadas, cl primer anillo torícico, adelgazado hácia atrás, parece un cue. 11o. Sus alas ahumadas son trasparentes y estan cruzadas por gruesas venas, caractéres que no se notan en los limnófilos. En los tarsos, el último artejo se ensancha en figura de cora7.0n. Il sialis acuático es de color negro pardo mate, con la raiz de la vena marginal de las alas anteriores de un anarillo pardo.

USOS Y COSTUMBREs. - En los meses de mayo $y$ junjo se encuentra esic neuróptero con bastante recućncia en los lugares mencionados en coda la Eurojia. Ia hemisa jecundada pone en las plantas ú otros objetos cercanos al agua unos 600 huevos ordenados en series. Son pardos, y de forma cilindrica; una de sus extremidades remata en una superficie redondeada, y la otra en unir prolongacion delgada en forma de pico. Al cabo de pocas scmanas salen las pequeñns larvas y se dirigen al agua en busca de alimento, ejecutando movimientos muy vivos, bien anden ó naden. Su gran cabeza y los tres anillos coricicos son córneos y todo lo demis blando; las apófisis laterales tubulares y movibles y lid larga cola sirven para respirar, pero al mismo tiempo para remar, juntamente con los tarsos. Lin el mes de marzo o abril del ano siguiente las larvas son ya de un pardo amarillo con manchas mas claras ó mas oscuras, yalcaman $11^{\text {ro }}$, or 75 de largo. Abandoman entonces el agua para crisalidarse tn el terreno húmedo de la orilla. 
EL SIALIS DE COLOR DE HOLLIN-SIALIS FULIGINOSA

CARACTERES.- ISSta especic, muy parecida a la ante rior, se distingue solo por su color mas oscuro, por los nervios de las alas, un poco diferentes, g por la estructura variada de la cxtremidad abdominal del macho.

USOS, COSTUMBRES Y REGIMEN. - Se jresenta regularmente quince dins mas tarde sjue la especie anterior.

\section{EL PANORPA COMUN - PANORPA COMUNIS}

CARACTERES. - Fiste nimal, qque intsoducc otrunucra seric de Formas, es un insecto particular, tue por su nsjyecto recuerda en cierto modo las sesias, y que durante el verano persigue a otros individuos de su clase en las espestras. Su nombre aieman de musca alel sscorpions se le dió porque el cuerpo diel macho, aunque no tiene el aguijon venenoso, remata en una especic de tenazas nudosas que se elevan verticalmente. Lin delgade\% del cuerpo, de las jiernas y antenas, Ia prolongacion de la cabeza en forma de pico, y las venas tristersales, relativamente cortas, en liss cuatro alas redon. deadas en su partc postcrior, apenas distintas entre si, son los corractéres mas distintivas del animal. Ademas son notables las pequeñas garras de los pies, provistas de una cresta, los fuerles espolancs en ha extremidad del tarso, y los marcados ojuelos. Vista por arriba, el escudo de la cabeza, de forma triangular prolongada, y por debajo la mandibula, que es largai, y el labio inferior soldado con ella, parecen un pico; la princra está provista de antenas de cinco artéjos y el último de tres; Ins mavilas, pequenas y' estrechas, estant armadas de dos dientes Este pequeño monstruo, que mide de $0^{\circ}, 013$ i $1^{12}, 015$, disimula el color del fondo, que es un negro brillante, porque los escuditos, las patas, el picó y los tres íltimos segmentos de la parte posterior del cuerpo del macho son amarillos 6 rojos.

DISTRIBUCION GEOGRÁFICA.- Westwood nos hat bla en una monognfía de este genero, compuesto de diez y nueve especies, de las que tres viven en Europa, siete en América, dos en lavi, uma en Madrás y las otmes en Africa

USOS, COSTUMBRES X REGIMEN. - LoS individuos cautivos de la especie panorpa contun-se alimentan de manzanas, patatas y carne cruda, y por lo tanto no son muy cxigentes; pero en la libertad, el parorpa demusestra su audacia é impertinencia, pucs no vacila en acometer á una libélula mucho mas yrande, haciéndola caer á tierra para in. troducirle el pico en el cuerpo. Lyonet fué testigo de tal atrevimiento. A pesar de que la mosca se veá menudo, y mas de una vez sorprende $\delta$ engaña al naturalista cuando inesperadamente sale de en medio de lás hojas, la larma y la crisá lida visen muy ocultas y' solo despues de muchos esfuerzos se consigue chicontrarlas. La hembra pone cuntro dias despues del aparcamiento, por la extrenidad del abdómen, un mon toncito de hruevos á una profundidad de dos milimetros $y$ cuarto, en tierra hímeda; 5 este montoncito es mas grande de lo que podria suponerse, á juzgar por el tamano del insecto. I.os huevos, blancos al principio, están cubiertos de venas prominentes en forma de red, que poco à proco toman un color pardo rerdoso; las laras salen ul cabo de ocho dias. Fistas últimas solo son peludas en la cabera y cn la parte anterior del pecho. Se alimemian de sustancias en descomposi. cion, y llegan al cabo de un mes á su mayor tamaño. I a cabeza afecta la forma de corazon; es de color pardo rojo y. está provista de antenas con tres artejos, dos ojos muy salicn. tes y fucrtes órganos de masticacion, cuyos palpos maxilares sobresalen mucho. De los otros trece segmentos, cubiertos de verrugas peludas, los tres anteriores estan provistos de piés córneos correspondientes al tórax, los ocho siguientes de piés carnosos y cónicos que corresponden al abdómen, y todos ienen, excepto el segundo y el tercero, un estigma en cada lado. Del tíltimo segmento la larva puede alargar cuatro tubos cortos que segregan un líquido blanco. A pesar de su perèa sabe evitar muy bien las persecuciones. Para tmsformarse un crisálida introdúcese à mas profundidad en el suelo, donde practica una cavidad oval, en la cunl permanece de 10 í 21 dias antes de mudar la piel de larva: pasados (juince mas sale a la luz del diat trasformada en mosca. Como la metamorfósis exige unas nueve semanas, es muy posible que los panorpas comunes se propaguen dos veces al año y que de la uiltima cria invencen ya larvas ó crisálidas. Haré mencion tambien de dos especies interesantes, afines de la especie anterior por la prolongacion en forma de pico de los órganos de la hoca y por la analogia de los demás caractéres.

\section{EL BITACO TIPULARIO-BITTACUS TIPU- LARIUS}

CARACTERES, - Es un insecto de $0^{\infty}, 026$ de largo, desde la frente linsta la extremidad de las alas, en estado de re. poso. A primeta vista parece un diptero á causa de las patas largas y delgadas y del abdomen, que forma como una línea con la extremidad encorvada hácia arriba, siendo sus cstrechas alas amarillentas. La cabeza, prolongada en forma de pico, tiene palpos maxilares, antenas y ocelos; los tarsos llevan es. polones largos, $y$ los piés tienen solo una garra. Fil color es amarillo de orin, que es el mesotórax y metatórax, asi como en las extremidades de los tarsos y en los trocinteres, pasa al pardo.

DISTRXBUCION GEOGRÁEICA. - Además de esta especie se conocen algunas otras propias de Australia.

USOS, COSTUMBRES Y REGIMEN. - Con vuclo icmbloroso y vacilante, el bitaco tipulario viga durame el crepúsculo por el aire, ó bien se agarra con sus largas patas anteriores í una ramita, cogiendo con las posteriores los in. sectos que se le acercan. Entonces se encuentmu los sexos, se njarean vientre con vientre, y entre tanto devoran la presa cogidis.

\section{EL BOREO DE LOS VENTISQUEROS- BOREUS HIEMALIS}

CARACTERES, - Lsieinsccto, que solomide de (1), 00337 a $0^{n}, 0045$ : es uno de los que buscin el frio, pues se le encuentra desde octubre hasta marzo y' à veces en la nicve de-tos ventisfutueros.

Las alas se sustituyen en la hembra por dos escamas, y en el macho por dos apéndices en forma de garras dirigidos há. cia arriba; las patas posteriores son muy prolongadas y propias para saltar, por lo cual Panzer llamó á este insecto grillo de pico (grillus strohoscideus), y en efecto no puede desconocerse cierta semejanza con una larva de grillo muy jóven. La licubra, en fin, tiene un largo tuho que sirve de oviducto: los ocelos faltan. El color predominante es un verie oscuro metálico; las piernas, los rudinientós de las alas y el tubo de la hembra solr de un amarillo pardiseo.

DISTRIBUCION GEOGRÁFICA.-Hace algunos años cogi cerca de Halle algunos boreos de los ventisqueros, en la depresion arenosa de una espesura de pinos socamada del todo por las minas de carbon.

Las larras viven en medio del musgo, y para trasformarse en crisálidas buscan los terrenos secos; segun se dice, son bastante parecidas a las del panorpa comun. 
Una segunda especie fuć descubierta tíltimamente en el sur de Nueva-York, por lo cual se le dió el nombre de boreus minorisudus.

\section{LOS FRIGANEIDOS - PHRYGANEID压}

CARACTERES. - Mientras que todos los neurópteros hasta ahora descritos tiench las cuatro alas iguales, no estando las posteriores plegadas, y las maxilas son córneas, en la familia de los friganeidos se observan cambios esenciales precisamente por este concepto. Las alas, peludas ó provistas de escamas, no presentan la forma de red; las posteriores, mucho mas anchas que las otras, se plegan en forma de aba. nico, quedando cubiertas por las anteriores, çue casi sicmure son de colores abigarrados y" que en estado de reposo se so. breponen en forma de teja sobresaliendo mucho del tronco. Las partes de la boca estan atrofiadas y las maxilas son menbranosas; la mandfbula $y$ el labio inferior se hallan soldados con aquella y no pueden clistinguirse de las maxilas. Los palpos tienen de dos a cinco artejos; los labiales siempre tres. Atendiclo el numero de los espolones de los tarsos en todas las patas, su distribucion y posicion diferentes en las diversas fases, se lann separado el género primitivo de Linneo Phygraner y algunos otros, formando diftimamente unos treinta, de los cuales, sin embargo, no podremos ocuparnos aqui. En canbio describiremos el limuofito rómbico (y'mno. philus rhombiciss) para formarnos una idea dè toda la familia.

\section{EL LIMNOFILO RÓMBICO-LYMNOPHILUS RHOMBICUS}

CARACTERES.-Esti especie se reconoce fícilmente por tener dos manchas blancas en cada una de las alas anteriores, cuyo color es pardo amarillo. El género, rico en es. pecies, se distinguc por los signientes caractéres. Los palpos maxilares del macho se componen de tres artejos y los de la hembra de cinco: los ocelos estin marcados; las antenas, cerdosas y tan largas como las alas anteriores, son ligeramente peludas y truncadas en la extremidad; los tarsos anteriores tienen un espolon, los medios dos, y los de las patas prosteriores cuntro.

DistRIBUCION GEOGRAFiCA.-Aunque los friga. neidos se encuentran en todos los continentes, habitan sin cmbarso con preferencia las zonas templadas.

USOS, COSTUMBRES Y REGIMEN. - Todos loS friganeidos ofrecen esencialmente semejanza en cuanto á su género de vida y su desartollo: este tiltimo es bastante cono. cido. lin mayo ju junio la mayor parte de cllos vagan por las orillas de las aguas corrientes y estancadas sin llamar nucho la atencion del naturalista ấ no ser que éste les busque expro. feso, pues su actividad solo empieza con cl crepúsculo. De dia se posan en las plantas acuáticas, o en la corte»a de los árboles ó bien se ncultan los mas debajo de ella. Cuando se les molesta $\delta$ inquieta deste fuera se escapan con vuclo rápido y corto prara pasarse de nucro en otros sitios análogos, si no lo hacen en la yerba; si se trata de cogerlos, ocúltanse a mayor profundidad en la jerba, y au en el suelo liso, saben critar que se les coja. Otros buscan la humedad en las hojas movićndose vivamente; todos parecen mas ó menos perezo. sos y pesados é indifurentes à cuanto pasa i su alrededor. El nombre aleman de moscas de primavern conviene á la mayor poute de cllos, aunqque algunos no salen hasta el otoño, presentandose entomres hastaute á menudo en los emcinares, 6 en bosques situados it bastante distancia del agua. No sé si se dirigen de noche hácia clla, ó si las larvas se contentan con la humedad, pero me inclino í creer lo segindo. Las larvas de la mayor parte de los friganeidos viven en el agtua y en nidos que ellas mismas se hacen. Estas orugas acuriticas, segun las llama Roescl, recuerdan mucho los siquis entre las mariposas como no pocos de los insectos aclultos á los ti. neidos. El limnónilo rómbico fabrica su capullo con materiales muy diferentes, ja de tallos de yerba dispuestos trasversalmente, ya de otros mas gruesos ó bien de otros mas largros longitudimalmente dispuestos, y finalmente con viruas de madera of pedaros de corteza colocados sin órden alguno. Habitante de todos estos nidos es la larva verdosa de color mas oscuro en su parte anterior, provista de seis patas y que como todas las demás tiene en su parte posterior dos ganchos córneos para sujetar su casita. Se fija en los cañaverales a poca altura sobre la superficie del agua; á fines de abril. y tambien en mayo empicza su tejido en plantas acuáticas y se encierra en su habitacion donde se trasforma en una crisáli. da prolongada y muy movible de la cual sale la mosca al cabo de quince dias.

\section{EL FRIGANEO RAYADO-PHRYGANEA STRIATA}

La larva del friganeo rayado (Phrrgineo strinta), especic muy comun en Alemania, es ya aclulta por abril. En el pri. mer segmento abdominal tiene cinco verrugas que pueden elevarse y bajarse. Cuandose la saca del agun, estas verrugas segregan humedad. En todos los otros segmentos se olsser. van dos hacecillos de hilos carnosos que pueden crguirse co. mo un copete de plumas y sirven para la respiracion. la larva no sale voluntariamente de su capullo; cuando se quiere que lo haga sin herirla ni matarja, es preciso tocarla ligera y cuidadosamente con un alfiler. De este modo sale aunque con resistencia, pero en seguida vuclve á entrar con la cabeza hácia adelante y se vuelve cuando se la deja tranquila. Si se la pone en un vaso con agun en la que poten toda clase de cuerpos ligeros que puedan servirle para la construccion de su vivienda, muévese horas enteras entre ellus sin fijarsc; pero cuando se le eligen objetos á propósito (jue, empapandus en agua, fajan à fondo, comienza al punio su obra, posaindo. se sobre uno de los pedacitos mas hargos; corta pirticulas de las porciones de madera 6 de las hojas $y$ las fija casi vertical. mente en los lados del jedazo que le sirve de cimiento, con. imuando en esta tarea hasta que ha formado un circulo, y con él el principio del capullo, que poco à poco llega á tener In longitud de la larva. Al principio se observan aun claros que se lleman y desaparecen mas tarite. Solo cuando el exte. rior está completamente cerrado, tapizacl interior con un fino tejido sedoso. Este tejido, que sirve para fabricar la cubiert:a exterior $y$ las paredes interiores, se produce lo mismo que en las orugas de mariposa, saliendo de las glindulas, que tienen un orificio en el labio inferior en medio de las maxilas ante. riores; las fuertes maxilas de la cabrea córnea separan el ma. terial para la construccion.

Antes de trasformarse en crisålida, la larva fija el capallo en una piedra ó en unn planta acuática, cerrando despuses las dos extremidades con una especie de enrejado, hecho con hebras de su seda, $a$ in de que el agua necesaria para la respiracion pueda penetrar sin que ningun insecto enemigo rapaz llegue á la indefensa ninfa. Como en maร\%o se encuentran ya sus capullos, parece que algunas cristlichas imernan, lo cual hacen tambien regularmente las larvas, plue casi siemprc se construyen su vivienda en julio. La crisálida, de un inlor blanco amarillento, tiene una faja latem negra en los cuatro últimos segmentos, en el durso las fibras estignáticas yo la 
cxtremidad dos espigas camosas. En la cabera, que es pe. queria, se notan principalmente los grandes ojos negros; en la parte anterior se ve una especic de pico, y sobre este un mo. nito de pelos. El pico se compone de dos ganchos cruzados de color pardo, situados debajo del labio inferior, carnoso y saliente; parece que representan la mandibula superior y que sirven para romper el enrejado, pues al nacer la mosca se quedan en el capullo. La mosca tiene poco mas ó menos el tamano del limnófilo rómbico, y como especie del género actual, Phryganea, esta provista de alas peludas, y adheridas al cuerpo; los palpos maxilarés están cași desmudos; cuén. tanse de dos à cuatro espolones en los tarsos, empezando por el primer par de patas, y la rama posterior de los cúbi. tos ó venas del borde inferior es sencilla en lás alas anteriores del macho, pern ahorquilada en las de la hembra. I a especie de que hablamos tiene el cuerpo de; color pardo oscuro; las, antemas pardas, con anillos negros; las alas pos. teriores del mismo tinte $\delta$ gris negtuzco, y las anteriores de un pardó claro canela, con dos puntos blancos, adomados cn la hembra de una faja longitudinal cortada. Ia dirección de las venass de las alas debe examinarse en todas estas especies mas minuciosamente de lo que nos permite el plan do nuestra obrá.

Para formarse una idea de los diferentes materiales cinpleados en la construccion por las larras reunióse una coleccion de capullos: los unos se comporren de granitos de arena ó bien de piedrecitas mas grandes; otros de conchas de caraco. les que perénecen sobre todo al géncro planorbis y que en partc pueden ustar aun habitadas. Hay tambien capullos en que se han mplendo conchas mas pequeñns; otros se componen de jarticulas veretales, pedacitós de jerba, caña, madern y corteza, y hasta lentejas acuáticas; las simientes representan tambien, segun la naturaleza del sitio, el papel principal. Excepto los capullos de conchas y caracoles, podemos cucontrar todas estis formas en nuestros rios y aguas estancadas, donde haya plantas. Los observadores se han convencicio de que el alimento de las orugas acuáticas se compone en primer lugar de sustancias regetales, y solo por excepcion de ciertos inimales. Es de suponer que una misun especic no emplea en todas partes exactamente el mismo material en la construccion de su vivienda; pero la forma es siempre la misma, ó cuando menos solo difiere muy poco, $5 i$ no lo exige el material cmpleado. Por lo demás, las especies, muy numerosas, no han sido observadas aun con la detencion necesaria para reconocer por el capullo la mosca, 6 joder fijar ciertas reglas. La graciosa concha del caracol antes citada es originaria del 'Tennessec y se consideró por el matu. ralista americano l.ea como producto de un caracol (zaliuta arerifera), hasta (jue otro observador, Bremi, la reconoció como obra artificial de un frigancido al que dió el nombre de Helicupsyche Shutherorthi.

Estos cipullos que se conscrmu abiertos en sus dós extremidades, están halitados por una larva que en la parte posterior se agarra con un par de ganchos, y cuando mas saca los tres siguiente's anteriores, provistos de una garra, pero no lo hace sino cuando repta por las plantas acuáticas ó nada cercin de la superficie. Algunos individuos no son tan aficionados al movimiento y por eso se fijan debajo de las piedras. Aunque las diversas especies difieren unas de otras, todas tienen los órganos de la masticacion, sobre todo las maxilas, mas desarrollacios en la larva que en la mosca; las antenas son pequeñas $\delta$ faltan por completo, y tambien es muy dificil reconocer los ojos. I.os siete primeros segmentos blandos del abdómen, comenzando por el segundo, tienen á cada lado, en el mayor numero de especies, de dos á cinco fibras ú copcits que se oprimen contra el cuerpo ó se levantan, sir- riendo de órganos respiratorios. Mudan varias veces de piel durante el desarrollo, y no cabe duda que entonces solo ruclven' á reconstruir su capullo cuando no tienen el espacio necesario. No es de suponer, como cree Rocsel, que falbriquen una vivicnda nueva.

Poco despues de despertar, en la primavera, las larras son adultas y desde mayo se presentan los friganes I as larvas se fijan entonces en una planta acuática, cerrando las dos aberturas del capullo: de algunas se dice que hasta construyen otro interior. A las pocas semanas nace el sér alado. Las hembras fecundadas ponen los huevos, en forma de aglomeraciones gelatinosas, en las plantas acuáticas y otros objetos que se hallen á poca distancia del agua.

Siebold ha demostrado que tampoco las larvas de estos insectos estân al abrigo de las persecuciones de los icneumónidos, pues algunos friganeidos, que habitan capullos lisos, se hallan expuestos á los ataques de un icneumónido de la especie Asrorolypus armatus. La hembra de este pequeño parísito se sumergor en el agua, permaneciendo bastante tiempo en ella para poner sus huevos en la larva. Esta sc desembaraza antes de morir de la nateria que le sirve para tejer y que sale de la extremidad anterior del capullo en forma de una larga faja, descubriendo asi las larvas picadas por, su enemigo.

\section{LOS ESTREPSIPTEROS - STREP- SIPTERA}

CARACTERES.-Mas bien como apendice que bajo la suposicion de una afinidad indudable, hare mencion en este lugar de los mas particulares de todos los insectos paraisitos, de los estrepsipteros: sobre cuya clasificacion no han podido los sabios ponerse de acuerdo hasta ahora. Los unos, sobre todo los/ingleses, les conceden el rango de órden indeitendiente; otros, entre ellos Lacordaire, los agrupan entre los coleópteros; y no pocos, como por ejemplo A. Gerstaecker, pretenden que en ninguna parte deben figurar sino entre los neurópteros.

Durante mucho tiempo, solamente los ingleses se digna. ron tomar en consideracion los estrepsipteros, hasta que, hace ahora 25 años, tambien los alemanes, Sicbold entre ellos, fijaron su atencion en esas especies, estudiando con afian su carácter y descubriendo mas de una verdad que liabia escapado á las miradas escudriñadoras de los natumlistas. Las larvins masculinas, $\delta$ las hembras vermiformes, mucho tiem. po desconocidas, que salen de entre los segmentos abiominales de ciertos himenopteros, fueron la princra causa del descubrimiento de estos interesantes insectos. En las especies Andreva, Halictus, Iespa, Odyrerus, Polistes, Sphex y Peloferes, hallaionse en particular los vestigios de aquellos parrisitos. Ochn ó diez dias mas tarde, cuando la larva del macho ha salido en parte del abdómon del animasl que habita, para trasformarse en crisálida, la parte anterior del prototórax, que se ha hecho córnea, elévase en forma de uma tapita, y el macho nace, para vivir solo pocas horas, que enplea en el apareamiento. En este corto rato se halla en la mayor inquietud, ruela ó repia continuamente, y si hace esto últi. mo, las alas anteriores, tan atrofindas como las posteriores desiurrolladas, se mueven sin cesar. Mientras vuela, cl cuerpo se mantiene vertical, con la cxtremidad encorvada hácia arriba, formando una graciosa figura de interrogante. Tambien al reptar levanta la punta de la cola, como lo hacen con tanta frecuencia los estafilinos, avanzando resueltamente con las cuatro patas anteriores, mientras las posteriores, que mas bien parceen servir de apojo al abdómen, se arrastran siempre. Al examinar este insecto extraño, obsérvase anic todo 
que los ojos son en extremo grandes, en forma de hemisferios, con facetas muy toscas, y que las antenns, casi sienure ahorquilladas, se componen de cuatro a seis articulaciones. Al rededor de la cabeza se estrecha el anillo del cuello, poco ancho; cl mesotóna; que tieue las alas anteriores atrofiadas, es cl menos desarrollado, mientras que el metatórax ocupa las dos terceras partes de la longitud del cuerpo, cubricndo de arriba abajo la base del abdómen, en la parte superior como una apónisis de figura cónica, separada por una sutura trasversal del resto de la parte posterior del dorso. La parte anterior y el centro de los costados afectan la forma de cilindros verticales movibles, mientras que la posterior parece peçueña y a modo de cuña. Los musios y los tarsos son cortos y aplanados: los piés mas anchos en su parte anterior, en forma de corazon, y membranosos en la planta, pero sin vestigios de garras. Solo algunos nervios forlalecen en forma de myos las alas posteriores, anchas en la base, comunicaindolas cl aspecto de un abáuico. El abdómen, compuesto de cuatro seymentos, reatata en los órganos genitales, que sobresalen en forma de gancho y que en estado de reposo se clevan hácia arriba. La cubierta hueca de la crisálida, que en la parte oculta conserva la piel blanda de la larra, subsiste en el ani. mal que la habita y forma en el abdómen de este una abertu. ra por medio de dos anillos.

Asi como ciertos siquinos entre las mariposas, las hembras de los esirepsipteros tienen, un caricter esencialmente disinto del de los machos alados y movibles. La larva madura sale tambien por medio del protórax y se ha desarrollado ya en el periodo del celo en un insecto completo que apenas difiere de la forma de larra, y quic permanece en la superficie del abdómen del animal que habita para espre. rar al macho. A causa de esta semejanza de la hembra con la larra, no fué posible en mucho tiempo explicar la historia del desarrollo de estos animales, hastá que el naturalista ale. man antes citado pudo demostrar que para la hembra no existe una forma mas perfecta. El protóras; que en otras especies es mas deprimido que en el estrepsiptero de Rossi, debe figurar como una cscama córnea mas deprimida que el resto del cuerno, que es cillindrico. En su borde anterior presenta una abertura bucal en forma de media luna, que por un estrecho esófago conduce a un intestino ancho y senci. Ilo, cuja extremidad ciega llega casi hasta la extremidad del cuerpo. Detrás de esta abcrtura bucal se corre un surco trasversal por el protórax, cuyos bordes se tocan al principio abriéndose mas tarde en forma de media luna. Este surco y la abertura genital forman la entrada de un ancho canal, que por debajo de la piel se corre casi hasta la parte extrema del abdómen y se distingue marcadamente del resto de este por su color gris plateado; se comunica con la caridad abdominal por medio de tres a cinco tubos cortos, encorvados hacia adclante, que libremente penetran en açuella; Sicbold la ha llamado canal de cria porque mas iarde recibe los huevos. EI desarrcllo de estos, que se hallan aistribuidus en todo el cuerpo, es muy lento, pero se verifica en el cuerpo de la madre: la larva, córnea y prolongada, tiene seis piés sin garras, dos cerdas en la cola, y órganos de masticacion muy poco desarrollados. Esta larva sale del canal y recorre el cuerpo de la hembra, circunstancia que ha dado lugar a que antes sc considerara como un paraisito de otro parisito. Observiciones posteriores han demostmdo, no obstante, que esta larm se conduce del mismo modo que la del meloido proscarabeo, y que asi como esta, se deja conducir a los nidos de los animales que habita, donde cada una de ellas se coloca en una larva de los mismos, en cujo cuerpo jenetra. Aqui la larva del estrepsiptero muda de piel cada ocho dias, adquiere la forma de gusano, tiene una boca bien marcada con dos maxilas atrofiadas, un intestino ciego sin vestigio de ano, y se compone por viltimo de die\% segmentos, de los cuales el primero, y mas grande, lo forma el protórax con la cabeza; este es abovedado ó cónico en la laria del macho y remata en punta en la cola; aplanado en la larva de la hembra, que tiene la extremidad del abdómen obtusa. Asi como en el exierior, reconócese la diferencia de los sexos tambien en el interior por el desarrollo de las partes genitales, lo cual demurestra que tambien aqui puede haber pirisitos que crecen sin perjudicar al sér en que viven. Poco despues de salir la pequeña abcja ó avispa de la cubierta de crisálida, aparece la larra madum del estrepsiptero como ya hemos indicado. Ifl estrido incompleto de las hembras que se procrean recuerda la pedogénesis, es decir, las larvas de ciertos cecidonidos que se jropagan en su primera juventud. A esta pedogéne. sis se sucle agregar en los estrepsiptcros, segun Sicbold, ia facultad de producir huevos fecundos sin prévia fecundacion, de los que quizás sc desarrollan los machos que abundan mucho mas, auncue su vida es muy corta. I as especies hasin ahora conocidas se han clasificado, segun la diferencia de Ins machos, en cuntro géneros: Xenus, Sifloss, Hntictopingyus y Elenelius.

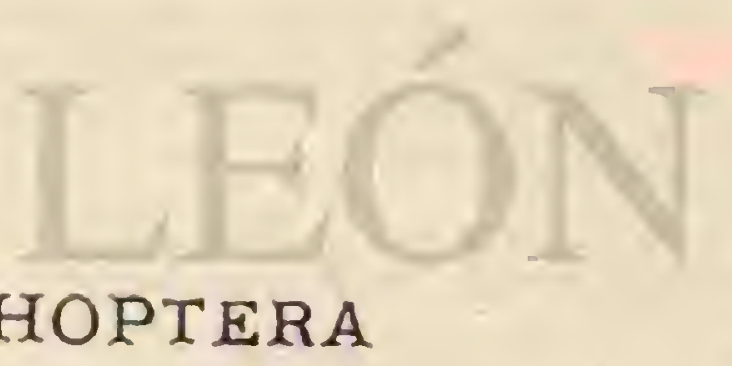

CARACTERES. - lodos los insecios hasta ahora descritus viveri primero como larvas y despues como crisálidás diferentes de aquellas, hasta que por fin mace el coleóntero y la mariposa, la abeja y la mosca; pero todos pueden reconocerse desde luega como lo que son, porque presentan marcadamente los caractéres del respectivo órden. Estos, sin embargo, cran menos pronunciados en los neurópteros: no se reconocian ya tau bien en la formacion de las alas, del protórax, del mesotórax y inciatórax, y' si solo en los órganos de la masticacion y" en la metamoriósis completa. "Todo el gran ejército de los insectos que nos resta describir, nace de una

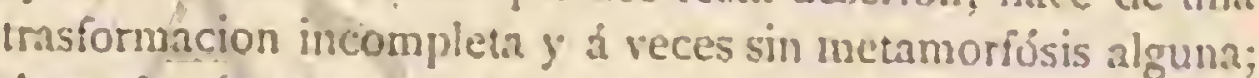
lienen los órganos de la boca apropiados para masticar ó ya en forma de pico para chupar, siendo estos los caraciéres distin. tivos mas esenciales de los dos úrdenes que aun nos resta describir. En cacia uno de ellos se encuentran con las especies aladas, otras sin alas: en el primero hay algunas en çue las alas anieriores se reducen à cubiertas córneas, y otras cn que todas cuatro se componen de una membrana delgada con of siz red de malla. Lin nuestra opinion, todos los insceros que 
sufren una metamorfósis incompleta ó nacen sin trasformacion alguna, y que estån provistos de órganos de masticacion, pertenecen á los.ortópteros.

Además de estos dos caractéres comunes à todos los ortópteros, la forma del labio inferior y la manera de articularse el abdómen, ofrecen otros dos generales de que solo diremos algunas palabras. La circunstancia de que en todos los verdaderos ortópteros de Linneo las cuatro maxilas de Ia mandibula inierior aparecen separadas y de que en otros (que nosotros reunimos en el mismo órden) se indican por lo menos dos mitades laterales por una cortadura en el centro de la parte de la lengua, parece señalar para este.órden la formacion de dos pares de maxilas inferiores que anles como en los cangrejos llagan á su désarnollo periecto. Otra particularidad propia del órden, consistc en la existencia de once segmentos abdomiuales (no todos visibles exteriormente), en la posicion de la abertura genital y la del ano en dos anillos diferentes, es decir, en el tercero de los posteriores y en el úlimó.

La larma carece de alas como sabemos, y solo despues de mudar varias veces de piel adquiere el nacimiento de ellas; mientras que el insecto desarrollado tiene alas. Cuando a! fin lás pierde, lo cual ocurre bastante a menudo, la distincion se hace mas dificil, pues entonces la larva difiere del insecto metamorfoseado solo por el menor número de artejos de lás anternas y de las facetas, caràctéres mas dificiles de reconocer. Muy a menudo el insecto tiene alas atrotindas, adaptandose las anteriores sobre las superiores, mientras que. en las larvas sucede lo contrario. Los ortópteros, cuya mayor parte tienen una forma prolongada, nos presentan, en porporcion $\{$ su número total de especies que se calcula en 5,000 , muchos insectos notables por su forma, color $y$ tamà̃o!

DISTRIBUCION GFOGRÁFICA. - las especies de este órden están diseminadas por todo el globo, aunque ciertas familias son propias en particular de las zonas callidas.

USOS, COSTUMBRES Y REGIMEN.-Muchos de es. tos insectos son notables por el hecho de reunirse un ntimero enorme de individuos de la misma especie, y como mu. chos se alimentan de sustancias vegetales y en todas has fases de su desarrollo no tienen nada que envidiar en voracidad á ningun otro insecto, llegan á ser en alto grado dañinos para cl hombre. Hay sin embargo tambien especies que como rapaces insaciables vagan por los aires, siendo útiles porque exterminan muchos paraisitos.

Los restos fósiles se encuentran en el terreno carbonifero. mas numerosos que los de ningun otro animal; tambien se hallan en la pizarra litográfica, y particularmenic en las capas terciarias y en el ámbar.

\section{LOS PERLARIOS-PER- LARIAE}

CARACTÉRES.-Hablaremos en priner lugar de aquellos ortópteros que, clasificados por la mayor parte de los autores en el ćrden anterior, se distinguen por sus cuntro alas iguales en ambos sexos y por su vida en el agua como larvas. Entre los perlarios citaré ante todo la perla de doble cola (Perla bicaudata): tiene la parte anterior del lomo de un pardo amarillo con dos manchas oscuras, una raya en el ceniro y los bordes del mismo color; la cabeza es de un rojo amarillo; el resto del cuerpo de un pardo amarillo mas vivo; las patas, de un tinte amarillento; las extremidades de los muslos y las cams de los tarsos mas oscuras. lin el macho se eleva la nozena hoja de la parte superior del abdómen en el borde interior y posterior, formando un estrecho liston; en la hembra esta dividida por unos hoyos poco profundos en tres lóbulos, mientras que la octava hoja abdominal se corta en ángulo recto. La hembrit mide casi $0 ", 022$ y el macho mas de $0^{\circ}$, o 15 ; las alas anteriores de aquella tienen $0^{\circ}, 02 \$ 25$ y las de este $U^{\prime \prime}, 022$. Además débo consignar que entre el radio y su rama, en el último tercio del ala anterior, solo se ve una rena tmsversal, mientras que entre el radio y la vena del borde hay cuando menos tres nervios trasversales; las maxilas son además nuy peņueñas y membmnosas; los últimos artejos de los palpos maxilares mas delgados, y la tercera articulacion de la pata mas larga que las dos anteriores juntas. Considerando todos estos caractéres será muy fácil distinguir la citada especie de otras muchas distribuidas vilti. mamente entre numcrosos géneros. Las dos cerdas de la cola, i las que el insecto debe su nombre, son propias de la mayor parte de las especies del órden, y se hallan en otros muchos perlarios, asi como la forma general del cuerpo, en el que el desarrollo casi igual de los tres segmentos del torax constituje un caracter de familia que raras veces se observa en los insectos alidos. Comiénzase a observar aqui una particulari. dad que despues se repite a menudo y es que en ciertas especies se atrofian las alas, con regularidad en algunos individuos, y rara vez en orros.

DISTRIBUCION GEOGRÁFICA. - pictet se ocupó en tSat particularmente de esta familia, describiendo cien especies đuue él mismo conoce, y veintiocho citadas por otros autores, las cuales no ha visto. De las primeras, veintisicteestán discminadas por lá mayor parte de Europa.

USOS, COSTUMBRES Y REGIMEN.-Fsios insectos acompañan d los friganeos y los sialidos, frecuentando los mismas sitios; sueten tener las alas oprimidas contra el lomo, y se les ve recorrer una corta distancia si àlguien los inquicta; ruclan puco, sobre codo de noche. Ias hembras adhieren los huevos a una depresion de su vientre, dejaindolos caer al agaa al volar sobre la superficie. Las larvas tienen gran semejanza con la mosca desarrollada, faltåndoles solo las alas y los largos pelos de los muslos y tarsos para poder remar con mas facilidad. En la major parte de los individuos reconócense en el limite inferior del tórax los copetes estigmáticos que les sirven para la respiracion. Permanecen con prefe. rencia en aguas corrientes, sobre todo en las montanas, debajo de las piedras ó en la madera, alimentándose de la presa que cogen: sus maxilas son por lo tanto mas fuertes antes que despues de la metamorfósis. Necesitan un ano para desarrollarse y quizas mas tiempo aun; poco a poco les crecen las alas atrofiadas, y jor fin salen del ayua por el tallo de una planta ó jor una picdra: de ellas nace la mosca, cuya vida es muy corta.

\section{LOS EFEMÉRIDOS - EPHEMERID压}

CARAGTERES.-los efeméridos pertenecen à un ségundo grupo de formas que, a pesar de toda su afinidad con los anteriores, tienen marcados caractéres particulares. El cucrpo delgado y casi cilindrico de estas moscas esti cubier. to de una jicl sumamente delgada, con cos ó res cerdas caudales articuladas, i menudo tan largas como el cuerpo: las cerdas cortas que ocupan el lugar de las antenas facil. mente pasarian desnpercibidas si no tuvieran las articulaciones de la base muy fuertes. 1.os ojuelos son por lo recrular grandes, pero á menudo solo hay dos: el mesotónx es casi tan largo como el protơrax. I as patas son muy delicadas y rematan en cuatro ó cinco artejos del pié, en cuya forma se funda 
una diferencia entre los dos sexos. jurcuue en las anieriores del macho los tarsos y los pies se prolongan de tal modo que cuando en estado de reposo se extienden hicia adelante podrian confundirse con las antenas. Los ojos, muy salientes, que ocupan casi toda la cabeza, constitujen el caricter dis. tintivo del macho. Como los ef́́meridos, ó moscas de un dia, merecen en efecto 'su nombre, y á veces npenas viven veinticuatro horas, no necesitan alimento, y aproveclian el breve rato de su vida para reproducirse; por eso las partes de la boca no se desarrollan y sus rudimentos se ocultan detrós de un gran escudo lipartido de la cabeza. Las graciosas alas elévanse verticalmente durante el reposo, oprimiéndose una contra otra; distinguense mucho por la proporcion en el tamano, pues un ala anterior es casi cuatro veces mas larga que una posterior, cujo lugar ocupa á menudo del todo. Lo mas intcresante en los efeméridos es cierta particularidad en su reproduccion, nunca observada en ninguna otra especic. 'lan luego como la mosca ha nacido de la crisálió, nuda por última vez la picl, incluso la de las alas, y despues que la llamada sulimigen ha permanecido un corto tiempo con aquellas horizontales, comienza a morerlas temblorosamente; al mismo tiempo separase primero la cexeremidad de la cola, avanz.ando poco á poco por la piel, y entonces las cspinas laterales de los bordes posteriores y de los segmentos abdominales impiden el retroceso de las partes que aranzan. Por estos esfuerzos del animal, que se oprime contra la cabeza y el pecho, la piel delgada del dorso y de la parte central del abdomen se rompe al fin: entonces se contrae sienupre mas hacia las alas, y cl dorso de la parte central del abdómen del efe. mérido, del todo desarrollado, aparece brillante en inedio de In abertura, hasta que por fin sale tambien la cabeza. I as alas se inclinan luego en forma de tejadillo sobre el cuerpo, y casi al mismo tiempo aparecen las patas anieriores: estas últimas se tiender casi en el instante en que las alas desarrolladas toman la posicion vertical en el aire. El insecto descansa entonces algunos seyundos; saca por fin la partc posterior del cuerpo con las cerdas y las patas posteriores: limpiase con las anteriores las antenas y la cabeza, y desaparece rapida. - mente de la vista del espectador: solo upueda la piel, con los bordes posteriores resecados de la cubierta de las alas. Recucrdo aun que en mi juventud, cuando miraba estas cosas de uma manera muy distinta que hoj; observé esıa mucin de la piel en el aire durante el vuclo. No sé si me he engañado, pero despues de lo descrito antes me parece posible que mi observacion fuera exacta. Para encontrar la diferencia entre la sub-imngen y la imágen se necesita alguna práctica; la primera parece mas pesada i causa de la anchura de la piel; sus cxtremiciades son mas gruesus y cortas, sobre todo las patas antcriores del macho; el color, menos marcalo, es mas sucio; en la inxagen, ó sea en el animal completamente desnrrollado, todos los contornos y formas se definen mejor; los colores son mas puros; lodo es mas brillante y vivo, y solo entonces llega à ser perfecta la rimágen demis, son caractéres infalibles, como Pictet lo ha explicado minuciosamente.

CONSIDERACIONES GENERALES. - LOS EjemEridos no eran desconocidos á los antiguos. Aristóteles cuenti que el rio Hipancs, que desemboca en el Bósforo, junto al país cie los cimerios, arrustra en el periodo del equinoccio unos objetus en forma de saquitos y del tamaño de los gmnos de uva, de los cuales sale un sér alado con cuatro patas, que vucla hasta la noche y muere al poncrse al sol: por eso se le Jlama nusca de un dia. Eliano dice que nacen del vino; al abrir la botella ó la bota salen los efeméridos, ven la lu\% del mundo y mueren.

La natufaleza les dota de la vida, privándoles sin embargo muy pronto de ella para que no conozcan su desgracia pro pia ni vern la de otro.

USOS, COSTUMBRES $Y$ REGIMEN.-En una tran. quila noche de majo ó de junio, cuando estas silñdes, como revestidas de su traje nupcial, é iluminndas por los rayos de oro del sol ponieute, se balancean en el aire cmbalsanado, ofrecen un espectáculo encantador. Semejantes a espiritus stuben y bajan sin movimiento visible de sus alas brillantes y apuran la alegrín y las delicias en las breves homs que median entre su aparicion y desaparicion, entre su nacimiento y su mucrte. Diriase que ejecutan una danza nujucial, aun. (juc, cosa extrana, entre los miles de machos solo hay pocas hembras. En nuestros paises pueden observarse mejor estos bailes en la efémera vulgar (Ëphemern inulgatn) (fig. 120), forque es la mayor y la mas comun en Alemania donde se presenta ya en majo, y á causa de su color oscuro resalta mas mientras ruela. Mide de $0^{\circ}, 087$ a $0^{\mathrm{m}}$, org sin las cerdas caudales, que en la hemlina tienen la misua lungitud mientras que en el macho alcanzan el duble; el color es pardo oscuro; una serie de manchas de un amarillo naranja, que a veces se reunen en la parte posterior del cucrno, unos anillos alternacivamente claros y oscuros de las tre's cerdins raudales, iguales entre si, comunican a este conjunto oscuro algun adormo: las alas anteriores, triangulares, llevan una esperie de redi de ¿'enas oscurns: son trasparentes en las mallas y presentan una faja central corta de color pardo. En cada pata se cuentan cinco artejos del pié; el segrundo de los cuales es casi nelue reces mas largo que el primero. I.os carnctéres impresos con letra bastardilla indican que ese caracter es propio de todas las esprecies del género ephemern, dividido últimamente en varios grupos. ¿ De dónde vienen estos fenomenales eféméridos? Salen del agua corriente, donde la larva pasó su vida como rapaz, despues que las hembras dejaron caer sus huevos en el líquido elemento. I a larva de esta especic tiene en cadia lado del abdómen seis copetes $\delta$ borlas estigmáticas. Ia cabeza acaba en su parte anterior en dos puntas y lleva ante. nas provistas de pelos finos, maxilas largas encorvadas en forma de ho\% hácia arrita y’ palpos maxilares tres veces nas largos que los labiales. Las paras, provistas de una garra, son lisas y cstán cubiertas de pelo; los muslos y tarsos de las antenas son mas fuertes y aptos para escarbar, pues practican con ellos tubos horizontales de $0^{\circ}, 052$ de largo, por lo regular muy cerca uno de otro, en las orillas arenosas de los rios, ó mejor de los riachuelos. La estrecha pared divisoria de estos tubos está perforada en la parte posterior, de modo que la larva no necesita moverse, ýa menudo queda destrui. da por el agua $s$ por el roce del animal.

Tas larvas del género Palinggentia escarban tambien, pero se distinguen exteriormente de las anteriores por dos hojitas estignaticas en los lados de la mayor parte de los segmentos abdominales; otras, de una forma mas aplanada 6 mas $\tau$. donda, viven libremente en el agua, pero las mas deben observarse aun minticiosamente antes que podamos completar nuestros conocimientos sobre las diversas especies de efeméridos. Ia palingenia de las orillas (Palingenia horaria) ticne un color blanco de leche, con un borde exterior negruzco en lis alas anteriores; los muslos y los tarsos de las patas anteriores son negros, y los primeros cinco ariejos del pié iguales en todas las patas. El género se caracteriza por las alas no trasparentes, sin manchas y con renas claras, asi coino por la cerda caudal del centro, que es mas corta, caractéres que se observan mas en el macho que en la hembra; esta no muda, segun se dice, por segunda ver, cuando menos en la especic de cola larga (falingenia longirauda), y además se coloca sobre el macho para el apareamiento, que se efectúa en el aire ó en la superficic del agua. 
Los efeméridos, yentre ellos las palingenias sobre todo, pertenecen á las especies que à causa de su cnorme número llaman la atencion general tanto mas cuanto que la vida de los individuos se linita à un tiempo sumamente corto. Los efeméridos no se ven mas que algunos dias ó noches del año, desapareciendo despues sin dejar vestigio alguno, hasta que vuelven a presentarse al ano siguiente Siempre se presentan en los mismos dias, á no ser que su grado mas alto de calor $\delta$ frio, la subida o el descenso de las aguas, y otras circunstancias aun desconocidas, apresuren $\delta$ retarden su añaricion. L os pescadores del Sena y del Marne esperan en. tre el 10 y 15 de agosto la especic que Renumur ciescribe como palingenia tirgo, y cuando lia llegado su tiempo suelen decir: «El maná comieriza á presentarse; cl mana ha caido esta noche en abundancia. Con esto quieren indicar la asombrosa cantidad de alimento que los cfeméridos proporcionar álos peces, los cunles llenan pronto las redés.

Reaumur observó estos insectos por primera vez en 1738 ,

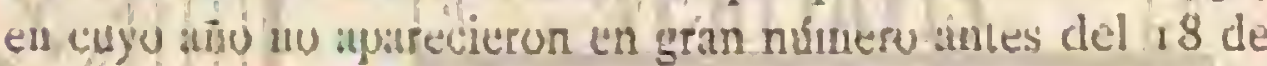
agasto. Cuando al ciin siguiente su pescador le dijo que las moscas se habian presentado, fletó una lancha tres horas antes de la puesta del sol, arrancó varios pedazos de tierra de la orilla, llenos de larras, y colocólos en un gran cubo de agua. Como este habia estado en ha-láncha hasta las ocho sin que saliera una gran multitud de efemeridos, y como amenazaba una gran tempestad, el celebre naturalista le hizo llemar a su jardin, situado i orillas del Marne. Antes aun de que la gente le sacara á tierra firme salieron muchos efentéridos. Cinda pedazo de tierra que sobresalia del agua estaba cubierto de cllos; los unos empezaban a salir de su residencia cenngosa, y algunos se disponian á emprender el vuelo, mientras que otros volaban ya por todas partes; debajo del agua se les podia ver en los diversos grados de su des. arrollo. Cuando se aproximó la tempestad el naturalista se vió obbligació à renunciar à tan bonito espectáculo, pero continuó sus òbservaciones cuando la lluvia hubo cesado. Al levantar la tapa con que se habia cubierto el cubo, el nú mero de moscas fúe muy considerable, aumentando i cada momento; muchas se alejaron volando, pero has mas ahogáronse en el agua. Los individuos ya trasformados y los que estaban metamorfoserindośe habian bastado para llenar el cubo; pero pronto aumentó su número, pues llègaban otros atraidos por la luz. Para impedir que se ahogaran, Reaumur hizo cubrir el cubo y poner la luz sobre ha tapa, mas apagironla al punto las legiones de insectos que à manos llenas podian quitarse del candelero.

Este especticulo alrededor del cubo, aunque interesante para el naturalista, era muy inferior al que se ofrecia à orillas del rio, donde le llamaron las exclamaciones de asombro del jardinero. QLosmillares de eíenéridos, dice Reaumur, que llenaron el aire sobre el rio y en la orilla donde yo estaba no se pueden expresar ni tampoco imaginar. Cuando la nieve cae en grandes y espesos copos, no intercepta tanto la luz. como los efeméridos. Apenas habia estado diez minutos en un escalon cuando inmediatamente se cubrió de estos séres, los cuales formaron una capa de dos á cuatro pulgadas de espesor; alrededor del escalon inferior, una superficic de cinco á seis piés estaba cubierta por todos los lados de efeméridos, que de contizuo sustituian is los individuos arrebatados por la corriente. Varias vices me ri obligado a retirarme de mi punto de observacion porque no pude soportar el turbion de efeméridos, que caia de un modo muy desagradable sobre todo mi cuerpo, cubriéndome la cara é introduciéndose por la boca y la nariz. No era nada conveniente tener la luz. en aquel momento; la ropa del hombre que la llevaba se cubrió a los pocos momentos de una nube de estas moscas. $\Lambda$ las diez poco mas ó menos terminóse el interesante espectículo, que algunas noches despues se repitio sin que se presentaran las moscas en tan gran número. Los pescadores calculan solo tres dias seguidos para la cnida del mana, aunque algunas moscas aisladas se presentan tanto antes como despues de este término. Sen cual fuere la temperatura de la atmósfera. fria ó calurosa, cstos séres vuelan invariablemente à la misma hora de la noche, es decir, despues de las ocho y cuarto 6 las ocho y media; a las nueve, poco mas ó menos, empiezan a llenar el aire; en la media hora siguiente se presentan cn mayor número y a las diez apenas se ven algunas, de modo que en menos de dos horas este inmenso cjercito de moscas sale del rio donde nace, llena el aire, se aparea y desaparece. Muchisimos caen al agua sirviendo de pasto á los peces, que a su vez penetmo en gran número en las redes del pescador.

Tambien yo tuve varias veces ocasion de observar al paso la palingenia de las orillas, por primera vez en Leipzig, dondc, como es sabido, no falta el agua contiente. A fintes ciel cuarto decenio de nuestro siglo observé alli esta especie, que en grandes tnasas se cogió á los faroles encendidos de los canales, masas que llegaron á tener la mitad del tamaño de un frabl. Sin duda se habia repetido el nismo fenóneno desde entonces muchas veces. En la primera semana de agosto de 1859 se vió en Halle la misma especie, que formaba co. pos como la nieve, alrededor de los faroles situados á la oriIla del agtia. El 26 de julio despues de las diez de la noche, se vió en un farol de nuestro mercado un esprectáculo semejante al hue describió el naturalista francés. Miles y miles de las citados efeméridos rodearon la luz, trizando circulos mas ó menos grandes, pero generalmente en direccion determinada. Lo cistraio fué que al continuar mi camnino no vi estas moscas én algunos faroles situados á orillas del Saale, mientras que el ya citado distaba bastante del rio El I4 y 15 de agosto de $18 ; 6$ se rẹpitió el mismo fenómeno, pero solo en algunos faroles en las inmediaciones del ngua.

Scopali refiere que las legiones de efeméridos quue todos los anos salen del Laz, rio de Carniola, proporcionan buen abono, del cuil se aprovechan los campesinos, y que estos creen haber recogido muy pocos insectos cuando el número de cargas no llega á veinte. El fenómeno conocilo en Humgria con el nombre de flor del Theiss, no es otra cosa sino una aglomeracion de la especie palingenia lengicauda en las orillas del citado rio.

Por lo demís, no son solo los pescadores de Francia los que saben aprovecharse de los éfeméridos (llamados tambien moscas de agosto, ó usando un término mas conocido, aust, porque casi siempre se presentan en dicho mes); tambien los de otros puntos se utilizan de esos insectos; encienden estropajos en sus barcas á fin de arraerlos, y como se queman las alas caen al agusa, donde sirven de sabroso pasto í los peces. 'Tambien mezclan sus cadáveres con barro $y$ hnoen unas bolas que sirven de cebo en la pesca.

\section{LAS LIBÉ LULAS - LIBELLULA}

Ins oncias de un riachivelo que suavemente se desliza por su lecho retozan con los tallos de las gramineas acuáticas que bordean sus orillas y de las cañas que sobresalen de la otra vegetacion, produciendo un murmullo sin que susurre el mas leve soplo de viento. Lina puerta de piedra da paso al rio por debajo del terraplen del ferro.carril, que como una muralla corta por su centro el paisaje; llenando de frescura las orillas, el riachuelo reaparece en el lado opuesto y prosigue silencioso su marcha, deslizaindose alternativamente en medio del abigarrado céspeci de las praderas $\delta$ de los verdes 
campos de trigo. Un sauce aislado, una vigorosa vegetacion de yerba, aqui ó alla una roja alfombra de flores acuaticas, $0^{\circ}$ un ranillete de sanguinaria, designan las evoluciones serpenlinas de un estrecho sendero; varios grupos de insectos vuclan a lo largo de sus orillas cubicrtas de Rores; las cañas, el sauce, el arco del puente que forman parte del paisaje, las ondas del riachuelo, ó bien un agua estancada en medio de una pradera; tales son los sitios misteriosos donde desde julio les agrada vivir á las libélulas, de cuerpo enjuto y imagni. fico brillo arul ó verde metilico. Con vuclo vacilante; que mas bien podria llamarse un aletco, pasan de tallo en tallo; ora se balancean sobre una hoja, ora se cogen à otra si la primera no les gustó, siempre con las alas en el aire como una mariposa diurna. Parece que solo vuclan para recrearse, aunque no se descuidan de coger, aqui un mosquito, alla una mosca, que desoran sin tardanza. Tal es la vida de un género de insectos que à continuacion examinaremos; otros mas grandes podemos observar en toda su actividad salvaje en los claros del bosque, cuando la atmóstera pesada y calurosa que precede a las tempestades, impide casi la respira. cion a nuestro pecho oprimido. Cuanta mas sofocacion sentimos, tanto mayor es la viveza con que pasa rozándonos la cara a cada instante un delgacio insecto de ripido vuclo: son las conocidas libélulas, llamadas por los franceses demoiselle.

Los movimientos son ligeros y igiles, los colores tienen un brillo sedoso, y las alas parecen un fino encaje; mas por su indole el insecto no tiene nada de una doncellita. Fil que ha estudiado la historia matural de Oken le conoce bajo el nombre de demonie brillante ó de agujos del diablo. El ingiés, siempre pràctico, les dió un nombre mas característico, llamándolas moscas dragones (Dragon-A3)s); cn una region de Alemania el pueblo las denomina nsepradoras, y en otra busra ojos $\delta$ caballos del cielo. Casi podria crecrse que con esos séres sucede lo mismo que con los gatos con su piel eléctrica: cuando se acerca la tempestad dominales una inņuietud invencible: aqui se ponc uno sobre algun tronco, ó en el camino, delante de nosotros, ostentardo el magnifico brillo de sus largas alas; y casi en el mismo instante elérase otra rez por los aires con mas rapide\% aun que antes. Alla se ve otro individuo que semejante a un ave de rapina se plecipita sobre una mosca, pero sin detenerse para comerla, devórala al vuelo, observando con sus grandes ojos una nueva presa. Mas de cuatro veces, alguna doncellita, adelantándose a mi, cogió una mariposa ú otro insecto que yo perseguia. A muchas les gusta volar continuamente en circulo, en particular sobre la superficie de las aguas, y entonces cogen todo cuanto rucla a su alcance, ahuyentando tambien de su dominio a algun individuo de su especie. De este modo divierten las doncellitas casi en todas partes, desde mayo hasta entrado el otoño, en los dias calurosos, al viajero que fija un poco su atencion en ellas, bien recorm la fria Iaponia ó ya la callida Nueva Holanda. Si el tienuno no es favorable permanecen quietas je se dejan coger mas fácilmente con la mano que cn otro tiempo con uma red, aunque se maneje con la mayor destreza. lin las diversas especies se observan muchas variaciones respecto al color, el tamano, la mamera de rolar y la estructurn de las extremidades, de lo cuni tmaremos despues.

CARACTERES. - Ia cabeza; un forma de hemisferio ó de cilindro, situada trastersalmente, esta libre sobre un curllo delgado, de modo que puede rolverse en rodos sentidos, cambiando asi à cada instante de horizontc á causa de la gran superficie de sus ojos. Ademís de los grandes ojos, los órganos de la hoca son los mas desarrollados y fuertes, condicion necesaria, atendida la rajacidad de esas ama\%onas acorazadas. Las anclias maxilas, armidias de muchos dientes Toso V! desiguales, pero afilados, forman unas fucrtes tena\%as; las maxilas inferiores apenas tienen la mitad de la anchura, pero rematan en un hacecillo die dientes mas puntiagudios aun, y estan provistas en su base de un palpo con un solo artejo; el labio inferior, que es abovedado, se adapta de tal modo al superior en su borde cuando la boca está cerrada, que ansbos quedan perfectamente unidos. Al lado de los dos ocelos superiores se ve sobre una gruesa articulit. cion fundamental una corta cerda de cuatro articulaciones, pero las antenas pasan desapercibidas fácilmente. El tórax no ofrece ninguma particularidad si se examina por arriba, pues el protórax, visto de este lado, presenta en muchos in. sectos menos desarrollo que el de los otros dos segmentos,

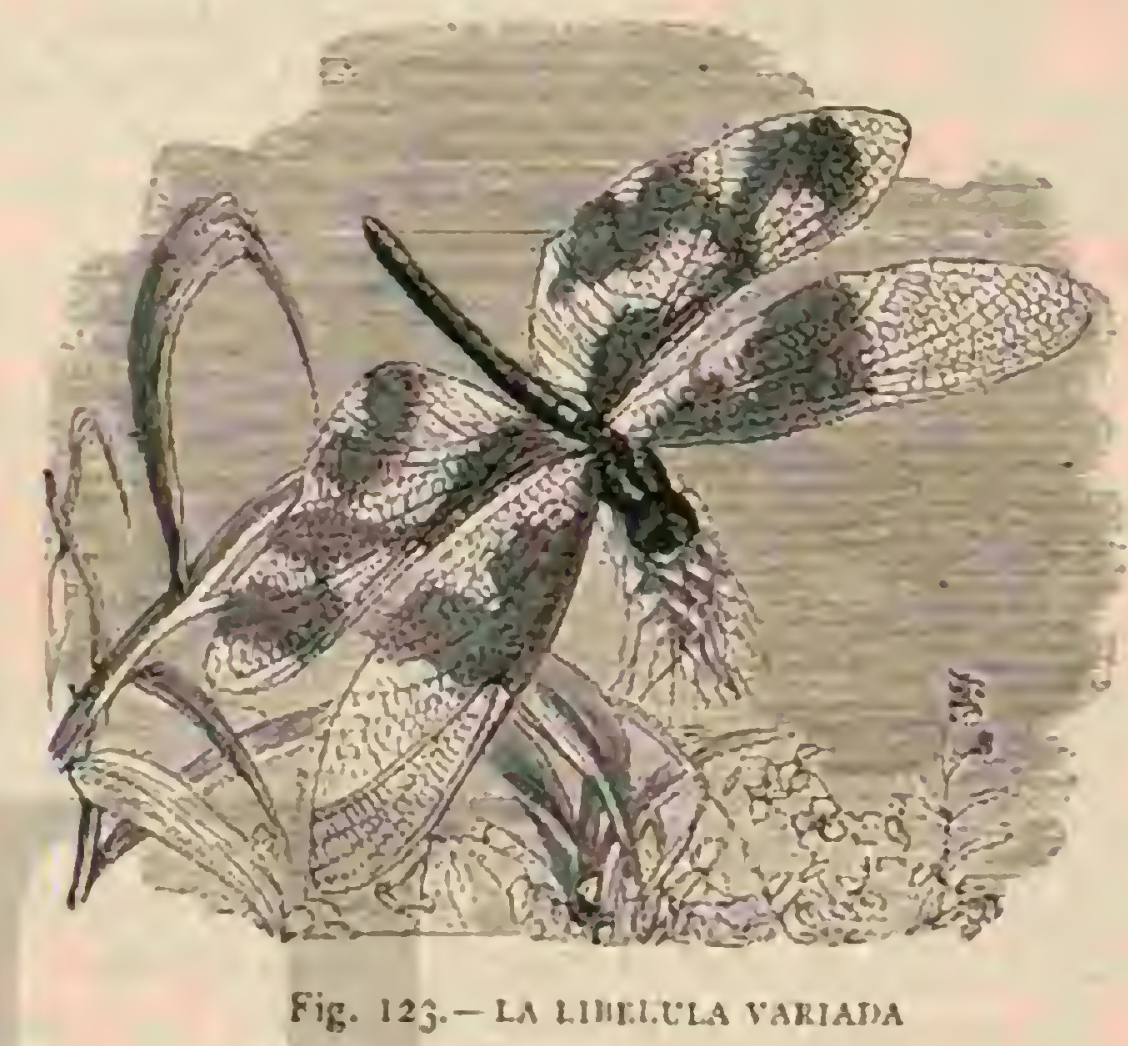

y Ia blandura en la linea central de estos tultimos, obsérviase tambien en muchos neurópteros y en otros ortópteros: si sc mira de lado presenta una estructura que solo es propira de esta familia Ios dos anillos posteriores estan dispuestos muy oblicuamente, segun puede verse por sus bordes latera. les, de modo que las alas se hallan situadas muy hacia atrís y las piernas muy hácia adelante: mientras que los lados de las extremidades anteriores preceden al punto en que se in. sertan las primeras alas. Dichas extremidades son las mas largas; los muslos y tarsos afection la forma cuadrangular, $y^{\circ}$ en su cara interior tienen espinas; en los piés hay tres articulaciones. Todo está constituido para que los mpaces puedan durante el vuelo oprimir con las patas la presa contra la boca; al mismo tiempo, la forma del mesotórax y del meta. tórax parece necesaria para dejar espario i los tendones. en figura de plato, que facilitan el vuclo rápido y continuo. Ias cuatro alas son casi del todo iguales en tamaño y forma y en la estructura de la graciosa rced de inallas, pudiéndose siempre reconocer marcadamente una mancha muy cerca de La punta. El abdomcn, compuesto de once segmentos y jrovisto en el penúltimo anillo de dos espinas en forma de estilo ó de hoja, no articuladas, que en el macho se trasforman tambien en tenazas, jrolóngase de un modo singular, afec. tando ea las especies del primer gencro casi la figura de aguja: ejemplo de ello se encuentra en la América del sur, en el Agrion Amalin, de Burmeisicr, que midiendo una longitud total de $6^{\circ}, 144$, el abdómen solo ocupa $0^{\circ}, 122$. Por lo demas sus colores son sumamentedelicatos y las extremi. dades estan poco conlazadas entre si.

USOS, COSTUMBRES Y REGIMEN. - MuY particular es la manera de acariciarse las libélulas y su modo de aprarearse. En las especies mas pequenas, de cabeza ancha, su modo de proceder puede ubservarse mas facilnente por- 
que el vuelo es mas acompasado y: lento: no recuerdo haber visto cómo se conducen las especies mas grandes de cabeza redonda. Cuando una libélula persigue a otra de cerca, su ruelo difiere del ordinario, siendo mas lento y tardio. El macho se remonta yrimero, y como retozando, coge con sus dos tenazas por el cuello á la hembra; esta encorva entonces su delgado abdómen hácia abajo, dejảndose sujetar en su extremiclad por un órgano en forma de doble gancho que el macho tiene en la parte inferior del segundo segmento, un poco dilatado y al parecer separado del abdómen. El apreton es tan vigoroso e intimo que no se juede dudar de.su objeto. Como el macho tiene los orificios de los testiculos situados en el noveno segmento del abdómen, el segundo anillo debe proveerse antes del apareamienio del licor prolifico sncándole de aquel. Terminado el acto, el nuacho de la mayor parte de las especies suelta la hembra y esta se agita entonces en posicion vertical sobre la superficie del agua, ó corta con el tubo que le sirve para la pusesta las plantas acuáticas, a fin de poner sus huevos.

Las larvas de las libélulas viven en los lagos, estanques y pantanos; asi como en las aguas corrientes, y son para los demás insectos yo parásitos que los habitan lo mismo que los tiburones para los habitantes del mar, es decir, rajaces temibles 6 insaciables. Aunque por las formas generales de su cuerpo se parecen á los insectos desarrollados, difieren no obstante, no solo por sus ojos màs pequeños, antenas mas largas y tronco mas recogido, sino tambien por dos caractéres esenciales, es decir, por los brganos bucales y por los respirntorios. El labio inferior se ha trasformado en un brazo prensil, que es la llamada máscara: y al companr este órga. no con un brazo, la estrecha parte de la base, que en estado de reposo se oprime por detrás de la garganta, forna el humero; la segunda, mas ancha y triangular, el antcbrazo; y la tenaza, destinada para coger la presa, la mano; pero como todo el órgano ocupa el lugar del labio inferior, sus partes pueden considerarse tambien análogas à las de este, en cuyo caso el húmero sustituiria à la barba, el antebrato a la lélygua, $y$ las renazas i la mandibula. Cuando estas, son pla. nas, de modo que todo el aparato en estado de reposo cierra la boca solo por debrjo, quédando invisible desde arriba la máscara, que se llama una plana, opónese à ella la de caseo, en la que los dos ganchos de la extremidad encajan con sus dientes uno en otro, se arquean y cubren durante el reposo la boca, no solo por debajo, sino tambien de lado y por arriba, como sucede en los géneros Libelluln, Cordulia y Épitheca. Cuando la larva persigue una jresa alarga la máscara y coge con las tenazas la victima, llévasela a la boca y la devora despues de haberla mascado rajpidamente con las maxilas Como animales acunticos, las larvas respiran por branquias: en las unas, esos apéndices aparecen exteriormente en figura de tres hojitas de forma oval situadas en la extremidad del abdómen y llamadas branquias caudales: en las especies mas grandes quedan invisibles, y denominanse, por el sitio en que se hallan, branquias intestinales. En las pare. des del intestino, por el cual se corren en toda su longitud los delgados "tubos respiratorios, se pierden los dos troncos principales de las triqueas, ramificindase elr numerosos repliegues membranosos. En el ano se ven tres vilvulas triangulares en forma de espina, que por medio de un pode. roso aparato muscular dejan entrar y salir el agua; de modo que no solo las branquias traqueales estan rodeadas continuamente por aquella, sino que tambien se producen al misno tiempo movimientos acompasados. Hace algun tiempo que tuve en invierno numerosas larvas de doncellitas en un acuario colocado en una ventana, $y$ bastante a menudo vi at una lanzar, con un ruido perceptible, un chorrito de agur, para lo cual elevaba la extremidad del cuerpo sobre la superficie.

Las larvas mudian varias veces de piel, aunque tengan ya los rudimentos de las alas. No sabemos aun con seguridad cuinto tiempo necesilan las diversas especies para su desarrollo, pero probablemente se verifica toda la metamorfósis en el espacio de un año y los individuos invernan siemure en estado de larvas. Hagen distingue scis diferentes formas fundamentales de larvas maduras (ninfas), de las que sin embargo solo podemos tomar en considerncion las de las especies de que hablaremos.

Cuando la larva se halla a punto de cambiar su género de vida acuaitico por otro mas perfecto en el aire, sube por una planta acuática, ó alguna estaca que se halle en el agua, etc; pero hay casos en que, poscida quizais de inquietud, ú obligada por el tiempo, vuelve da las ondas; sillega a fijarse fuera délagua, no está léjos el momento de su libertad. I.os ojos, hasia entonces tristes, comienzan a ser brillantes y trasparentes; la piel de todas las partes del cuerpo se reseca y ábrese por último desde la nuca hasta por delante de la cabeza, regiones que son las primeras en salir, seguidas de las patas, las cuales se agitan viramente en $\mathrm{cl}$ aire hasta que al fin, por efecto del cansancio, sucédese una iranquilidad general. Lnconces comicnza la segunda fase: haciendo un brusco movimiento, levintase la parte libre del cuerpo quue hasta entonces pendia las patas se cogen a la cabecera de la piel abandonada : y luego sale el abdómen, que estaba oculto. De este modo descansa In recien nacida sobre su última juel de lana, de lá gue solo falta la abertura longitudinal en la parte anterior. Las alas, huimedas aun, forman repliegues longitudi. nales y trasversales que se alisan mas por momentos, y al cabo de media hora escasa alcanzan todo su tamaño, desple. gándose sin ninguna rigidez, briliantes como la plata, â lo largo del cuerpo. Dos horas pasan aun antes de que el aire seque del todo ha humedad supérflua, comunicándoles la rigidez necesaria para su uso; pero se necesita todavia mas tiempo para que adquieran todo el brillo de sus colores. Una vez secas las alas, la aguja del diablo se lanza en el aire j comienza su ejercicio de rapiña, con mas perseverancia y agilidad que antes en el agua

Conócense en la actualidad de mil à mil cien especies diseminadas en todos los continentes, aunque se encuentren con mas abundancia en los paises cálidos: las especies tropicales no son sin embargo, salvo pocas excepciones, mas bonitas y grandes que las de las regiones templadas y irias. De dicho número, Europa alimenta unas ciento, - y entre ellas algunas que tambien se encuentran en otros paises, como por ejemplo la Libillula pedemontana, que es propia tambien de la Siberia, la Acschna juncia observada en la Transcausasia, el Anax Partlichope, que vive tambien en el Africa, y el Anax formosus, discminado desde la Suecin y el Ural por toda la Europa y el Africa.

\section{LOS ICTINOS-ICTINUS}

CARACTÉRES. - I os ictinos son ortóptcros de cabeza grande; ojos no contiguos: vértice bastante alto, con los. ángulos salientes; labio inferior casi tan ancho como largo, y redondeado en su borde externo; el abdómen presenta una dilatacion en el borde lateral del octaro segmento, la cual afecta la forma de una escama ó membrana ancha; los apén. ces superiores son casi semejantes en ambos sexos.

\section{EL ICTINO VORAZ-ICTINUS VORAX}

CARACTERES. - In cara de este insceto (fig. 125) es 
amarilla, con una faja tmsversa frontal y una mancha triangular negra; el vértice ofrece una escotadura excavada, j sus ángulos forman dos puntos; el protórax es negro por encima, lo mismo que el tórax, con dos rayas por delante de las alas; cl abdómen, grueso en la basc, se atenúa y dilata hácia la extremidad; las patas son negras, con los muslos algo rojizos; las posteriores tienen por debajo varias espinas mayores que las otms; las alas son trasparentes, y su base de un amarillo rojizo. Este insecto mide por lo menos $0^{n}, 09$ de punta á punia de ala, y mas de 0,,07 de largo.

DISTRIBUCION GEOGRÁFICA.-El ictino voraz se encuenta en varios paises de Europa.

Ias demás especies conocidas de este género viven en Africa; sobre todo en el Senegal y en Egipto.

\section{LOS CALOPTERIX-CALOPTERYX}

CARACTERES. - Los calopterix pertenecen al genero de los agrionidos, que se caracterizan por una cabear ancha, en forma de martillo; los ojos son de forma hemisférica y están muy distanies uno de oiro; el abdómen es cilindrico y delgado; $y$ el labio inferior tiene una gran escotadura en medio de las maxilas interiores; las larvas llevan branuuias caudales y máscarn plana.

En el subgénero citado, las alas, provistas de mallas angostas, estréchanse poco \& poco hàcia la base, y su color varia por el sexo, distinguiéndose en el macho una mancha. I.as espinas del segundo segmento abdominal tienen la forma de tenazas. De las observaciones anatómicis resulta que las larvas respiran no solamente por branquias caudales sino tambien por las intestinales; aquellas se componen de las largas aletas, es decir, de dos casi triangulares exteriores y otra un joco mas corta central, situada a mas altura. Una especie de careta hendida en su parte anterior, unas antenas que se insertan delante de los ojos sobre un artejo fuerte $y$ anguloso de la base, y otros siete mas largos que la cabeza, caracterizan a este insecto raquitico de paras largas, cuya forma no se observa en ningun otro género.

Una de las especies nas abundantes y diseminadas es el calopterix comun (caloplengit virgo). In hembra tiene las alas pardas, con puntos blancos, y el cuerpo de un verde meti. lico esmeralda; cl macho se distingue jor su color amul muy oscuro, de brillo metálico; sus alas son pardas, y por lo regular tienen el mismo brillo del tronco excepto en el sitio de las alas que es mas claro; hay sin cmbargo tambien individuos (que se han liamado immaduros, el Caloptery'x a'esta de Champentier), en que el brillo falta del todo, predominando asi el color pardo. La longitud del cuerpo es de $0^{n}, 0,435$ a $11^{\prime \prime}, 0.48$. Con csta especie no debe confundirse cl caloplerpx splendens, (fig. 124), que en julio 5 agosto se observa con cl calopterix comun; sus alas son mas estrechas y imsparentes, el macho tiene una faja trasversal azul por delante de la punta, mientras en la hembra son verdes.

\section{LOS LESTES-LESTES}

CARA CTÉRES. - Loslestes tiencu las alas mas estrechas, con la base en forma de mango y las mallas mas anchas. Las larvas, delgadas y enjutas, respiran solo por branquins caudales despees de la úluma muda, es decir, en el estado de ninfa; carecen de ocelos; tienen antenas delgadas de sicté artejos, en medio de los ojos, y una mascara muy larga y estrecha que en estado de reposo llega hasta los lados de las patas posteriores. Los cinco pénúlimos segmentos abdomimales, de igual longitud, tiencon unos aguijones laterales, cor- tos y rectos; en la cxtremidad vénse en medio de las tres aletas cinco cortas esprinas cáudales.

En mayo y junio el lestes espinoso (Testes sponssa) vucla en Alemania con bastante frecuencia. El cuento, de color verde csmeralda, mide de $\left(1^{\circ}, 03.3\right.$ á 1,",035: el del macho está cubierto en la parte superior é inferior del tórax, en los dos segmentos de la base y en la extremidad del abdómen, de un polvillo gris claro; las motas de las alas son pardas ó negras y están rodendas de un nervio blanco en el borde; el borde interior de las tenazas ticne dos dientes puntiagudos de igual tamano. Siebold observó la puesta de esta especie en um estanque lleno de juncos (Scirpus lacustris). Despues de efectuado el apareamiento de la manera dicha, el macho no suelta á la hembra, como lo hace el de otras especies, sino que la lienc sujeta por el cuello y la lleva a pascar. Ambos vuclan, reunidos asi sus cuerpos, pósanse sobre alguna planta acuática, y en sus actos parecen obedecer à una sola voluntad. El macho descansa con mas frecuencia en los juncos y con pre ferencia en las puntas de los mismos. Estas observaciones se refieren sobre tocio a las plantas que se hallaban fuera del agua. Cuando un macho se ha puesto sobre una hembra, esta última, colocada a la distancia á que la obligaba el abdómen de su conpañero, arquea el suyo hastante, fijando la punta del mismo por detrís de las patas; despues saca de las dos vaginas córneas laterales el tubo que sirve para la puesta, y apjlicale a la superficie del junco. A prenas hecho esto baja un poco por el junco, tmbaja de nucvo con suaparato de puesta y continua de este modo arrastrando al macho consigo, hasta que llega á la base de la plarta. Despues se alejan ambos para repetir la misma maniobra en otro junco. El tallo trabajaclo de este modo presenta una scric de manchitas blanco atnarillas; de arriba abajo se ve separada una fajita de la epji. dermis, que la parte convexa del órgano de la hembra ha vuelto á unir. Detrás de casi todas estas heridas distinguese en la espaciosa célula aérea del junco un huevo, estrechado por su extremidad mas puntiaguda, que es de color pardo oscuro en la parte posterior de la hendidura principal; la otra extremidad, un poco mas gruesa y redondcada, casi cilindrica y de color amarillo pailido, penetra en la célula. Esta última adquiere un color pardo sucio cuando los huevos están mucho tiempo en ella. A veces no sc encuentra ningun huevo en la abertura, lo cual indica que la hembra no ha tenido sin duda tiempo para depositarle, pues el macho no tiene siem. pre bastante paciencia para seguirla hasta abajo y emprende el vuelo antes de que haya recorrido todo el camino. Si las miradas del atento observador se fijan mas allá podrá ver tambien parejas en los juncos que sobresalen del agua, pero esto no es un obstieulo para que ia otra continue su camino hasta la base de la planta. Cunndo la hembra penetra en el agua el macho la sigue rápidamente, $y$, aquella no suelve á colncnzar su trabajo hasta ver à su compañero rodeado de agua. El macho arquea su abdómen lo mismo que la hembra, de modo que todas las parejas que se hallan debajo del agua y de las cuales Siebold observó un gran número, forman con sus troncos un doble ano. Por su brillo de plata ofrecen un aspecto sorprendente; en sus troncos, en las patas y las alas conservan una tenue capa de aire, necesaria sin duda par. respirar, pues algunos permanecen media hora debajo del agua, porque bajan hasta la base del junco y de consiguiente tambien al fondo del estanque. Llegados aqui ruelven à subir por el tallo y emprenden el vuelo apenas salen a la super. ficic del agua. Sucede con bastante frecurencia que en un mismo junco hay en la base una pareja y otra baja por el mismo Jado; en tal caso, esta última se dirige por el lado opuesto del tallo, contuuando despues su trabaja. Si el observador se acerca á los que se ocupan sobre la superficie; 
luwen en seguida, pero no asi los que se hallan debajo del agua: en esta se les puede inquietar hasta cierto punto, y entonces se agarran mas al tallo, pero si se remueve el agua con un palo suben con mas rapidez aun que por el junco para escapar. De las observaciones resulta ademàs que las hembras tienen gran necesidad de desembarazarse de sus huevos porque horadan la madera seca y otros objetos inconvenientes, mientras los machos se posan á reces como de costumbre en los blandos juncos. De la extremidad puntiaguda de los huevos salen las larvis, que en su juventud tienen las antenas mas largas y de forma diferente que las adultas.

I.os numerosos individuos que cual funs agujas retozan a los rayos del sól bailando por las cañas y sus alrededores y moviendo lentamente șus maynificas alas, 6 que cuando el liempo es lluvioso se posán con lis alas plegadas hácia arriba, pertenecen á diversos subgéneros, de los que el de los agrio nes (agrion) conticne el mayor nuinero de especies, Se reco. nocen por tener las alas provistas igualmente de tallos cuya seial 6 mancha solo llega a la longitud de una célula, y por los tarsos no ensanchados, pero con espinas, distinguiéndose principalmente por la forma del borde posterior de la parte anterior del dorso. Sus larvas desarrolladas se parecen á las del subgenero Lesies; la miscara, que en su parte anterior se éncorva en forma de casco, llega solo en su parte posterior hastal el centro de los costados; los rudimentos de las alas son un poco mas largos; las patas 5 las branquins caudales algo mas cortas y los segmentos del abdómen sin espinns. Dé la forma citada primitiva difiere esencialmente el Platjomemis pennipes por tener los tarsos blanquizcos en las cuatro patas posteriorés, $y$ aplanados en ambos sexos. Esta graciosa libélula que mide 0 \% 035 de largo, se reconoce además fácilmente por su tronco blanquizco con lineas negras.

\section{LOS ESCNINOS- ESCHNINA}

CARACTERES.-Fste género que comprende las especies mas grandes y al mismo tiempo mas salvajes de las libe lulas, cancterizase a primera vista por tener la cabeza gran. de de forma liemisférica; su parte principal estíl ocupada por los ojos que son brillantes y se tocan por delante de la coronilla; tal es su desarrollo que con una luz favorable se pueden reconocer sin microscopio las pequeñas faceias en su superficie abovedada La frente, dilatada en forma de vejiga y dividida por un corte trasversal, ocupa la tercera parte de toda la superficie de la cabeza; el labio superior, que afecta la forma de una visera de gorra, cubre los órganos de la boca desde arriba. Las alas posteriores tienen la base mucho mas ancha que las anteriores y todas cuntro ofrecen en el triángulo de las alas en la membrana ligatoria las diferencias mas esenciales de los géneros. El triángulo de las alas se compone de la superficie triangular, linitada jor venas mas fuertes, y que en el primer tercio de aquellas se extiende entre la cuarta y quinta vena longitudinales, procedentes de la base de las alas, y cuya punta sobresale hicia atrais. I a membiana ligatoria es una parte muy peçueña en forma de media luna, mas 6 menos marcada, en la base del ala, difiriendo del resto de la membrana por su color y naturaleza. I as larvas de rodos los escrinos respiran solo por las branquias intestinales y no necesitan por lo tanto las caudáles.

\section{LOS ESCNOS - ESCHNA}

CARACteres. - Los escnos son en Furopa los tipos mas grandes y abigarrados de la iamilia; solo una especie alcarza la Iongitud regular de $0^{n, 052}$ a $0^{n}, 065$. Este sub-géro se reconoce fácilmente por el color azul y amarillo del cuerpo, por los ojos, que en la coronilla se tocan en una li. nea, y por los cuatro triángulos bastante iguales de las alas. Las ocho especies alemanas no se distinguen fäcilmente.

I a larva se caracteriza por sus grandes ojos, y por sus oce. los poco desarrollados; las antenas, muy delgadas, tienen siete articulaciones; la máscarn es aplanada: los estigmas se ocul. tan en los segmentos del tórax, y los anillos del abdúmen ticnen espinas á los lados.

USOS, COSTUMBRES Y REGIMEN. - L L es encnos viven en regiones montañosas y cubicrtas de bosque casi siempre aislados, pues cada cual cruza contimuamente con ripido vuelo su territorio y no pernite que otro individuo penetre en él.

\section{EL ESCNO GRANDE- ESCHNA GRANDIS}

CARACTERES. - Mientras que varias especies de los escnos tienen en la parte superior de la frente una mancha oscura en forma de $T$, el escno grande carece de este distin. tivo, y en general presenta menos manchas en su cuerpo, cuyo culór es amarillo ó rojo pardo. En los lados del túrax haj dos fajas amiarillentas y en el centro del lomo, en medio de las alas que son amarillentas, y en el tercer segmento del abdómen! mrias manchas azules; el labio superior es de un solo color, la membrana ligatoria blanquizca; cada espina del micho, ilesprovista en la base de dientes, se redondea en la punta.

\section{LOS LIBELULINOS-- LIBELULLINÆ}

CARACTERES. - La mayor parte de los libelulinos tienen la base de las alas de color amarillo ú oscuro, pero en ninguno se ven colores metálicos. I.os ojos sé tocan en un punto de la calbeza; el borde posterior de las alas posteriores presenta igual forma en ambos scxos, y el triangulo de los últimos es de distinta figura que la de las alas anteriores. I as larvas tienen una máscara de casco, difiriendo por lo demás mucho de las diversas especies. Los caractéres del género, que comprende las libélulas propianente dichas y otros congéneres (Ephileca, Cordulia, Polyneura, Palposleura, etcétera), consisten especiaimente en que los lóbulos interiores del labio inferior son mucho mas cortos que los exteriores y se hallan soldados y provistos de palpos.

\section{LA LIBELULA DEPRIMIDA-LIBELLULA DEPRESSA}

CARACTERES. - la libelula deprimida tiene el color pardo amarillo, con manchas de este tinte ên los bordes ó en el abdómen del macho, que presenta una especie de polvillo de un bonito azul de cielo. Una gran mancha longitudinal y oscura de la base de las alas anteriores y otra trian. gular en la de las posteriores; una célula (célula basilar) de color pardo rojo, que en todos los cuatro lados se obserna entre la raiz de la tercera y cuarta vena longitudinal, y cuando menos dicz venas trastersales en el borde anterior de la base de las alas hasta su centro, distinguen esta especie de las numerosas que pertenecen al mismo sub.genero.

\section{LA LIBELULA DE CUATRO MANCHAS-LI- BELLULA QUADRIMACULATA}

CARACTERES.-Esta especic, que ya se deja ver en mayo, tiene la misma forma, tamaño y' color que la prece. dente, solo que el macho carece de la escarcha 2zul: debe su nombre à las manchas oscuras que adornan el centro de todas sus alas; la base es de color amarillo de azafran. 
USOS, COSTUMBRES Y REGIMEN.-Ambas eSpecies han llamado á menudo la atencion general por el in. menso número en que se presentan, para emprender expediciones á mucha distancia. Desde el ano 1673 se vieron mas de cuarenta de estas legiones, compuestas casi siempre de las libélulas de cuatro manchas, de las deprimidas, y á reces tambien de una especie de agrion. El naturaista Hagen antes citado, que adquirió muchos méritos por diversos estilos, y en particular por su estudio de estos insectos, nos habla de una agrupacion de la primera de dichas especies, que pudo observar a cierta distancia: En junio de is 82 , dice, anunciàronme a las nueve de la manana de un hermoso dia, que sobre la Puerta del Rey pasaba una inmensa legion de libélulas. Al medio dia me dirigi al indicado punto y vi que estos instectos continuaban entrando en la ciudad en nusas compactas. Para observar con mas detencion este interesante espectaculo sali de la Puerta y pucle observar los insectos desde una plaza descubierta. Bastaba trazar mentalmente una linea recta entre el punto en que me hallaba y Dervan para saber exactamente en qué direccion se movian las libé. lulas; en la Pucrta volaban a unos 30 pié; de altura, porque cl coronamiento del baluarte que alli hay impedia á muchas el paso. Hicia Dervan bajaban poco ì poco, segun podia calcularse por lus airboles; y alli donde empezaba el camino acercábanse tanto al suelo, que mi coche pasó por en medio de ellas. Muy particular y notable me pareció la gran regularidad con que volaban, oprimiéndose entre si sin desviarse de la linea. Formaban asi una fnja de unos 60 piés de ancho por ro de alcura, tanto mas marcada cuanto que a derecha é izquierda no se veia ningun insecto en el aire. I.a rapidez del vuelo era la de un corto trote de cabailo y no tenia nada de comun con el que por lo regular suele ser propio de estos insectos. Al observarlos mas de cerca noté que todos eilos parecian recien nacidos, lo cual no es dificil de re.

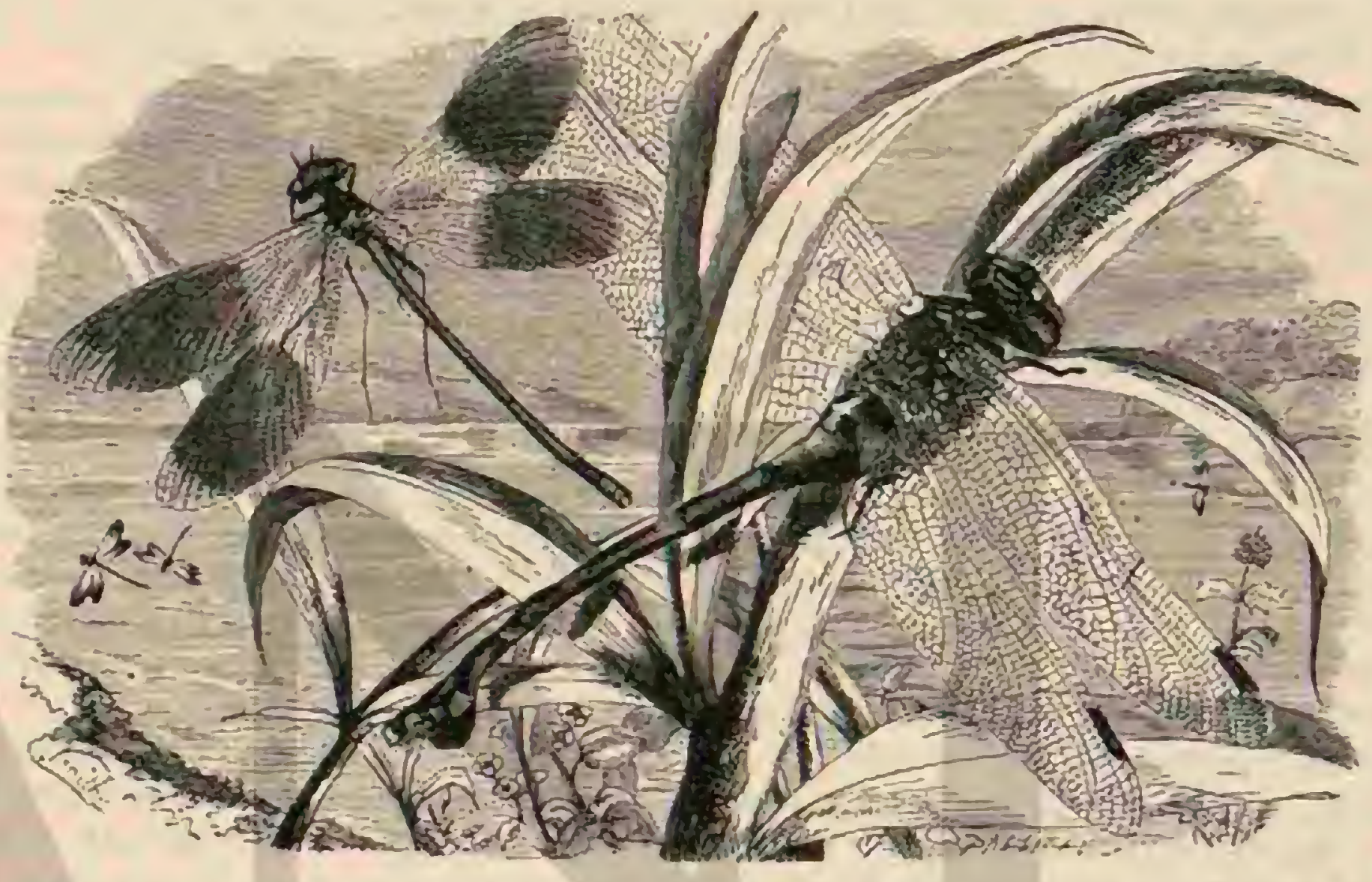

Fig. 124,E.L CHIOHTERIX ESH.F.IDIDO

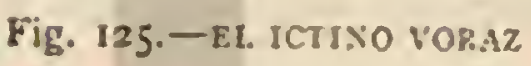

conocer por ei brillo particular de las alas en los individuos que acaban de abandonar la piel de ninfa Cuanto mas avancé en direccion opuesta i la marcha de los insectos tanto mas jóvenes eran los individuos hasta que al llegar á Derran descubri en el estanque de este pueblo el origen de aquella corriente de ortópteros. El color del cucrpo y la consistencia de las alas demostraba que la misma mañana debian haberse metamorfoseado. En la parte opuesta no se veia ninguna libélula: Ia corriente salia sin duda del estançue mismo, cerca de la orilla donde yo estaba y continuó sin la menor interrupcion hasta la noche. No me atrevo í inientar un cálculo sobre el numcro de aqueilos insectos. Bastante singular me pareció que uni parte de ellos pasara la noche en la zona de la ciucha mas próxima a la Puerta, cubriendo aqui las casas y los árboles de los jardines, hasta que prosiguieron su marcha á la manana siguiente en la misma direccion. Por un anuncio que publiqué en los periódicos recibi la noricia de que el cortejo habia pasado al dia siguiente sobre Karschan y que se le habia visto a unas tres leguas de distancia de Koenigsberg: no supe nada mas sobre la suerte de aquellos insectos.

¿Si comparamos los hechos obserndos, revélase desde luego sin duda un cambio instintivo de residencia, porque los insectos, contra su costumbre y antes de que en el punto donde nacieron faltara el aimento, abandonaroule en legrion ordenada, lo cual tambien es opuesto á sus usos. Debemos distinguir bien de tal bandada el enorne número de libélulas que muchos años observamos en las aguas, sobre todo cuando una primavera fria ha retardado su desarrollo y cunndo algunos dias calurosos producen de repente la metamorfósis atrasada. La inmensa legion que yo otservé siguió la direccion del viento, pero esto fué en mi opinion una casualitad, pues otrns agrupaciones que he vișto no procedieron asi. I a causa de estas expediciones no se ha explicado aun, pero su regularidad, uada conforme con la indole dé estos anima. les, hace suponer cierto fin. En el caso presente solo podumos creer que el agua donde, macieron estos insectos no habria bastado para la cria y que por eso cambiaron de sitio.

-El abate Chappe, que en 1 j7 I debió observar en Siberia el paso de Vénus, vió en Tobolsk una bandada semejante de la misma especie, de 500 varas de ancho, por una longitud que no se hubiera franqueado en menos de cinco horas, $y$ Mr. Uhler, de Baltimore, me dice, que en la América del norte, sobre todo en el Wisconsin, son muy comunes tales agrupaciones. Los individuos enviados no dejan duda de que açueila especie es idéntica á la nuestra; tambien en la América del sur se observin tales fenómenos. Del vuelo vigoroso de estos animales podemos dar una idea diciendo que se han visto libélulas volando en alta mar à unas 600 leguas in. glesas de la ticrra. 


\section{LOS EPSOCIDOS-EPSO- CID死}

CARACTERES.-Con los epsocidos, que se encuentran en las arboledas y espesuras, comienza la serie de las especies exclusivamente terrestres entre los ortópteros de alas iguales. La cabeza se ensancha hácia adelante por una frente dilatada en los lados y tambien en su parte posterior, de tal modo que cubre casi lodo el protórax. Delante de los tres ocelos se insertan las antenas cerdosas, que tienen ocho artejos y son mas largas que todo el cuerpo. Fil labio superior, que es semicircular, cubre las otras partes de la bocn; la mandibula superior es córnea y ganchuda; la inferior se compone de las maxilas membranosás, siendo la exterior ancha y la interior prolongada en dos puntas de palpos con cuatro artejos, y por último de un labio inferior bipartido $y \sin$ palpos. I ns alas cubren como un tejadillo el abdómen, corto, oval y compuesto de nueve segnicntos; sobress. len múcho de él y tienen pocos nervios; las alas anteriores presentan una gran marca de que carecen las posteriores, nas cortas y estrechas. En el último artejo de los dos del pié se ven dos garras cortas y una cerda

USOS, COSTUMBRES Y REGIMEN. - Estos insectos se alimentar probablemente de liyuenes, y no ofrecen ninguna particularidad en su estado de lavvas; en cambio debe notarse que la hembra cabre los huevos puestos en las hojas sobre un tejido de hilos que sale de su labio superior, procediendo cada especie á su manera. Así, por ejemplo, el epsoco de cuatro puntos (Psocus ogradripunelitus) oculta los suyus en las cavidades que hay entre los nervios de las hojas, rubriéndolas de modo que el tẹiido, visto i cierta distancia, afrece el aspecto de una escama de pez. Ya hemos visto algu? nos coleúpteros acuáticos que tejen con el misno fin, pero valiéndose de la extremidad del abdómen: no conozco nin. gun otro insecto metamorfoseado que teja con la boca.

Las numerosas esjecies han sido distribuidas por varios autores en diversos subgéneros; y solo se reconocen a menudo dificilmente por los nervios ó manchas oscuras ó por el color del cuerpo.

\section{EL EPSOCO LINEADO-PSOCUS LINEATUS}

CARACTERES. - Esta especie, la mayor de Europa, mide mas de $0^{\prime \prime}, 0065$ desde la frente hasta la punta de las alas; las antenas negras con la base de un pardo pálido, llegan á tener hasta $0^{\circ}$, or I de largo. Eil color del fondo del cuerpo es amarillenio; en el centro del lomo se ven manchas, en la frente docc rayas, y en el abdómen, que es de un amarillo viro, varios anillos de color mas ó menos negro. Las patas, de un pardo pálido en la cara anterior de los muslos, pre. sentan manchas negras. I.as alas anteriores, claras como el cristal, carecen de todo matiz, 6 solo tienen en la celdilla del centro algunas manchitas poco marcadas, yotra en el borde posterior, que tambien puede prolongarse en forma de faja, sin llegar sin embargo al borde anterior.

\section{EL TROCTES EMPOLVADO-TROCTES PUL- SATORIUS}

CARACTERES. - Esta especié pertenece tambien á la familia que nos ocupa: su cuerpo prolongado, aplanado desprovisto de alas, con su color pardo amarillento pálido, la comunica mucha semejanza con un piojo, del cual sin embargo se distingue esencialmente por los órganos de la boca y' por las antenas cerdosas, bastante largas. loos muslos pos- teriores son mas gruesos, y los jiés presentan tres articulaciones. Puede medir $0^{\circ}, 0016^{\circ} \mathrm{g}$ de largo.

USOS, COSTUMBRES Y REGIMEN, - Corre coll suma rapidez y habita con preferencin las cajas descuidadas de las colecciones de insectos $y$ sobre todo en la juntura de las tablas donde se extienden las mariposas para secarlas; roe los bordes de las alas ó devora pedazos enteros de la superficie de las mismas; pero los perjuicios que causa en las colecciones son de poca importancia, porque en los rincones empolvados encuentra alimento suficiente.

\section{LOS TERMITINOS-TER- MITINA}

CARACTÉRES. - Los termitinos pueden llamarse tam. bien hormigas blancas, pues asi como estas, habitan nidos comunes formando grandes agrupaciones, hallandose en sus colonias, además de los sexos alados y apios para la propaga. cion, individuos desprovistos de alas é infecundos; en cuanto a lo demis, difieren de aquellos himenópteros por la forma de su cuerpo, por la metamorfósis incompleta y otros puntos esenciales. Desgracindamente son muy escasos aum nuestros conocimientos sobre esos interesantes séres de las régiones cálidas, aunque algunos viajeros antiguos, como por ejemplo Koenig, Smeathman, Sauvage, Saint Hilaire, etc., han hablado sobre ellos, y por mas que últimamente Lespés, Bates, Fritsch, Federico Mueller y otros, fijaron su atencion en esos insectos, observándolos en su misma patria. Sin embargo, las regiones inhospitalarias donde viven, poco propias para una observncion cuidadosa, como las exigen unos séres que viven tan ocultos: las formas tan diversas de una misma especic, y la presencia de varias de estas en el mismo sitio, son circunstancias que dificultan en extremo las averiguaciones. Por es. tas causas, y porque el género de vida de todos no es el mismo, solo podemos trazar una descripcion general de esos insectos; para dar una idca mas minuciosa de cllos necesitariamos mayor espacio del que nos permite el plan de nuestra obra.

Los termitinos tienen el cuerpo prolongado, poco mas $\delta$ menos de la nisma anchura en toda su extension, de forma oval aplanada y abovedada por abajo; la cabcza, que está libre, se inclina en sentido oblicuo ó vertical hácia abajo, y el tórax ocupa casi toda la longitud; las patas tierien cua. tro artejos: $;$ las cuatro alas, en los individuos en que existen, son de igual tamaño, largas y' endebles, con una sutura trasversal en la base: estín cruzadas por siete nervios longitudinales, de los que parten otros oblicuos, paralelos ó sencillamente ahorquilládos. La forma de la cabe\%a, relativamente pequeña, convexa en su parte superior y aplanada en la inferior, varía segun las especies, pero la parte situada detràs de los ojos se redondea siempre en forma de semicírevlo; una depresion longitudinal, mas ó menos marcada, la divide en tres partes casi iguales. Los ojos, casi siempre grandes, son salientes y se tocan en su parte interior con un ocelo, de los que en general solo existen dos, mientras que las especies Termopsis y Hodotermes carecen de ellos del todo. Muy cerca de los ojos se insertan las antenas en forma de cordon, presentando de $x_{3}$ a 206 $2 \tau$ artejos, $j$ son un poco mas largas que la cabeza los órganos de la boca están muy desarrollados: el labio superior, dilatado en forma de concha, es de figura muy variable; las maxilas, cuya extremidad es obtusa, están provistas en su borde interior de cuatro á scis dientes; la mandibula inferior se compone de una maxila interior que termina en dos dientes y otra exterior en forma de sable, situnda á mas altura, hallándose provista de palpos 
con cinco artejos; cl labio inferior jresenta cuatro lóbulos, de los cunles sobresalen poco los palpos de tres artejos. Los tres segmentos del tórax, de igual tamaño, son inucho mas anchos que largos, y están cubiertos de una hoja plana de quitina que sobresale unuy poco lateralmente; el primero difiere hasta cierto punto de los otros, sirviendo de caracter distintivo en las diferentes especies. Las jiemas son delgadas, pero fuertes, y los lados de cada par se tocan. En la cara superior del abdúmen se cuentan diez anillos, y en la inferior solo nueve. Ias alas se oprimen durante el reposo hori. zontalmente sobre el cuerpo, sobresaliendo de él mucho. El color de los termitinos ofrece poca variedad y suele extenderse en cada individuo por todo el cucrpo, ofreciendo todos los tintes, por un lado hasta el negro, y yor el otro hasta el amarillo. Segun la edad, los individuos de una misma espe. cie son de diferentes colores: los recien nacidos se distinguen por su tinte amarillo de marfil viejo; los sexos difieren por las escanias abdominales; en el macho las seis primeras son de igual longitud y las dos siguientes mucho mas cortas, mientras que la hembm tiene las cinco primeras iguales y la sexta mas grande, de forma variable, segun la especie, hallándose las dos siguientes atrofiadas; la novena lo está igualmente en ambos sexos, y además dividida.

Las larvas de que nacen los insectos desarrollados que acabamos de describir soil al principio pequenas, delicadas y muy peludas; las partes del cuerpo, muy poco separadas, forman en cierta manera un todo, siendo los ojos muy poco marcados yj las antenas mas cortas: no existe ningun vestigin de las alas. Estas aparecen poco it poco despues de varias mudas, $y$ la piel del cuerpo se trasparenta, pero reconócese por su poca solide? que aun no lia llegado à su perfeccion. Por fin apuntan las alas en los lados del cuerpo, llegando hasta el sexto anillo del abdómen; j: entonces tenemos el estado de la ninfa, que aguarda la última parte de su meta. morfósis.

Con el nombre de rey y reina se designan por lo regular los habitantes de un nido de termitinos encargados de la reproduccion: sin duda han sido machos $y$ hembras apareados que perdieron sus alas; las segundas tienen á menudo $\mathrm{cl}$ abdómen tan dilacado como la garrapata (ixodes ricinus) y lleno de sangre. Ia dilatacion es debida al crecimiento del animal ó a la extension de las membranas medias, pues las hojas de quitina de los segmentos no cambian, hallảndose que estín situadas como manchas oscuras a mucha distancia sobre esa bolsa de color blanco amarillento sellena de hueros. La reina se conoce solo en -muy pocas especies.

Además de las formas hasta ahora descritas hallảnse en cada nido, y en mayor número, los individuos que llaman trabijindoris y soldaibs; unos y otros carecen de alas y difieren por la forma de la cabeza jo el tamanoo. El trabajador del todo desarrollado es algo mas pequeño que el individuo con álas, antes descrito, y tambien mas corto; la cabeza, dispuesta casi verticalmente, carece de ojos en la mayor parte de las cspecies, siendo un poco mas convexa, pero por lo demis de la misma forma que en los individuos alados. El tónx, siempre sin alas, difiere esencialmente; el protómx es muy estrecho y los segnentos siguientes apenas se distinguen de los anillos del abdómen. Lespés, que lizo un eximen anatómico de los trabajadores, halló los indicios de órganos scxuales, cunto masculinos como femeninos. Antes de la primera muda los termitinos trabajadores no se pueden distinguir de los que alcanzan el desarrollo sexual, pero poco á poco se reconocen por las mudas las diferencias de los primeros, asi como tam. bien por la situacion de la cabeza y la formacion del tórax.

Los soldados son mas grandes que los trabajadores y tienen la cabeza en extremo desarrollada, de modo que a me- nudo ocupa la mitad de todo el cuerpo, cambia en sus contornos y en la superficie segun la especie. En todos sobresalen las maxilas con aspecto amenazador, llegando it la tercera parte de la longitud de la cabeza, cuando no son mas largas; mientras que la mandibula y el labio inferior casi se atrofian. En los soldados halló tambien lespés indi. cios de ambos sexos. Las larvas de los trabajadores jo soldados solo empiezan a distinguirse despues de la segunda muda.

Hagen, al hablar del subgénero eutermes, hace mencion de otra esperie de séres fabulosos, cuya cabeza se prolonga en su parte anterior en figura de llariz, y que por sus demás formas deben considerarse como pertenecientes á una de las clases descritas: el citado observador las llama nasuf;.

Los huevos tienen una forma cilindrica, i veces corra; son redondeados en sus extremidades y variables por el tamaño eu la misma especie.

USOS, COSTUMBRES Y REGIMEN.-Por lo que toca al género de vida de los termitinos en general, consta que los individuos sexuales $y^{\circ}$ los trabajadores $y^{\prime}$ soldados infecundos pertenceen i un Estado cuya residencia, ntendida la forma y construccion, llamaremos cl nido. Ias dos últimas castas, con sus individuos de diferentes edades, habitan esa vivienda con una reina por lo menos, aunque esta última no se ha encontrado siempre; mientras que los machos y las hembras aladas solo se ven por temporadas, segun parece, al principio de la estacion lluviosa. Tan luego como los últimos están del todo desarrollados, y cuando el nido se llena con exceso, tanto de individuos sexuales como de hormigas, ve. rificase el apareamiento, ya en el aire, $\hat{b}$ bien despues de volver los insectus á tierra, rotas ya las alas por la sutura trasicersal. Bates que los observó en el Amazonas, dice que vuclan por la mañana, cuando el cielo está nubiado, ó por la noche si esta es húmeda. Fin el último caso, las luces de las casas lus atraen como a todos los insectos que vuclan de noche. Miles y iniles penetran por puertas y ventanas; forman como una nube y hasta apagan las lamparas. Rengger habla en su Virzje al faraguna' de la admiracion que produce el aspecto de una bandada de estos insectos, que salen de la tierra y a la luz del sol parecen componerse de hojitas de plata. C. Fritsch, que ha vivido tres anos en el Africa del sur, solo habla del vuclo de los machos, observado por él. Eléranse por la noche, dice, formando espesas nubes sobre el nido, $y$ entonces ofrecen un aspecto casi fantístico, cuan. do á la luz del crepúsculo, semejantes á un vapor blanquizco, agitanse de un lado á otro y danzan en medio del enmarañado ramaje de un árbol caido. Por lo demas son malos volado. res, y no se fian de sus largas alas. Cuanclo se encuentra un macho alado fuera del nido yj se tmata de cogerle, esfuérzase por quitarse las alas, revolviendo vivamente el cuerpo para poder huir con mas rapide\%.

Estas noticias demuestran que las diferentes especies tienen tambien por tal concepto costumbres distiutas. M/uy pocas escapan durante la danza nupcial de sus numerosos encmigos, aranas, lagartos, sapos, nuurciélagos y chotacabras, que se precipitan voraznente sobre su presa; las pocas que sobrevipen se hacen rejes y reinas de una nueva colonia jon caso favomble se puede ver i sus majestades, con unos pocos trabajadores, echar los cimientos para el futuro nido. La circunstancia de que el macho sigue viviendo, y que por lo tanto tambien un rey habita el nido, es uno de los fenó. menos, en el estado de los termitinos, que hasta ahora no ha podido explicarse y que induce a suponer una fecundacion rápida.

Los trabajadores y soldados, y quizás tambien sus larvins mas desarrolladas, son los que proveen de alimento a los in- 
dividuos que no pueden buscarlo pror si mismos; llevan los huevos a los diferentes compartimientos del nido, reparan los desperfectos, abren una salida para los individuos alados, y ocúpanse en otros quehaceres anílogos. Salen á trabajar fuera del nido, mas por lo regular cubren sus galerias con una taja y coustruyen su vivienda principalmente de noche. Respecto al nido obsérvanse las mayores diferencias entre los termitinos: un número considerable de especies construye los montones conocidos hace mucho y en cierto modo célebres. Al térmite belicoso (Termes oellicosus), my diseminado en el Africa, se refieren numerosas noticias, entre las cuales los relatos de Smenthinan y Sauvage son de gran valor. Los nidos se componen, segun la descripeion de los citados naturalistas, de montones provistos en su interior de muchas prominencins, que mejor pueden compararse con un monton de heno, y que se encuentran mas numerosos en país llano, cuando este se ha preparado para el cultivo, y cuando la madera cortada no se ha utilizado. Los montones déstruidos por las copiosas lluvias, $\delta$ en las cercanias de las ciudades, por los niños que sobre ellos juegan, se hallan abandonados, pero si tienen auí las torrecitas y puntas que forman el principio de tal construccion, siguen creciendo. Una torrecita se elem junto á otra y los intervalos se llenan; en cada una se halla una cavidad que abre el canino al interiot del monton 6 forma la extremidad de una senda para circular por el interior. Cuando el monton tiene la forma de los del heno ha llegado a su completo desarrollo y à una altura vertical de $3^{m}, 76,6$ mas de 5 metros, por una circunferencia de $15^{*}, 70$ a is $S^{7}, 83$. El material se compone principalmente de barro, que segun la naturaleza del suelo tiene un color diférente y se amasa con la saliva de los insectos; la arena no sirve para estas construcciones, porguie no se puede unir con la suficiente consistencia. La solidez de estas construcciones de barro es tal, segun la opinion de numerosos observadores, que podrian sostener nas hombres ó animales sobre la superficie de los que caben en el interior. Tres hombres necesitaron dos horas y media para abrir dẹl todo uno de estos montecillos; que á causa de su dureza estain al abrigo de la destruccion por has copiosas lluvias de açuellas regiones, ó por el choque de arboles caidos. Al quitar la yerba y la maleza alrededor del montecillo vénsé varias galerías de barro que conducen i los troncos de árboles recinos; cstas galerias miden a veces mas de $0^{\circ}, 3^{\prime}$ de diámetro; poco á poco disminuye su dimension y se ranifican en las extremidades. Al examinar la comuni. cacion con el nido hållanse muchas cavidades, las cuales dan entrada à los caminos que oblicuamente bajan al interior: estos caminos desembocan en las celdillas $y$ se apoyan en columnas de la roca, en las que se ve cierto número de espacios arqueados; éntre ellos están la vivienda rèal y otras varias. Los alrededores del montecillo se reducen a un terraplen de barro de $0^{\circ}, 157$ a $0^{\circ}, 47$ de grueso, y contiene celdas, cavidades y galerias que se comunican entre si ó que se corren desde el pić hasta la cima, hallándose en relacion con el interior de la cúpula. En la base, a la altura de $0^{\mathrm{m}} .31$ a $n^{\star \prime}, 628$ sobre el nivel del suelo, en el interior del monte. cillo, hállase la cámara real rodeada de otras celdillas, llenas de huevos y de hijuelos de distintos tamaños, segun si desar. rollo. Pasaremos en silencio las otras noticias de Sneathman sobre la construccion y' el diverso material que halló on el niclo, porque es probable que este relato contenga muchos errores.

Leichardt observó formaciones parecidas, es decir conos

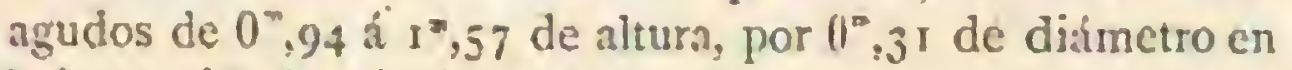
la base, aislados ó dispuestos en filas como edificios de un aspecto extraño. Epp creyó ver sepulcros al encontrar las viviendas de témites en la isla de Banka. Golberry hace mencion de unos nidos particulares que se comunican con los de la especie Termes mordar: en una base cilindrica de 6" ${ }^{\prime \prime}, 94$ a I" $^{\prime \prime}, 95$ de altura apóyase un techo de forma cónica que por todos lados sobresale $11^{m}, 05, y$ que quizas son los ni. dos de térnites quue Lichtenstein llama seliformes. Bates ( naturalista del Amazonas ) eligió en particular para sus observaciones la especic termes arenarius, porque en acpuellas regiones construje en mayor numero los montecillos, que son bastante blandos y pueden cortarse con un cuchillo. allodo el gran distrito mas allá de Santarem, continúa el citado au. tor, está cubierto de espesos montecillos, reunidos todos por un sistema de calles protegidas por una bóveda del mismo material de que se componen aquellos. De este modo todos los individuos de esa especie de térmites pueden considerarse como una sola y gran familia, explicándose asi el sistema empleado en la construccion de los nidos. Los hay de todos tamaños, desde los mas pequeños á los mas grandes, ofreciendo á la vista los diversos grados de su desarrollo. Encuéntranse: ${ }^{\circ}$ montecillos nuevos en que solo viven al. gunos soldados y trabajadores, que se comen las raices de la verba; $20^{\circ}$ montecillus mas desarrollados, donde tambien viven solo algunos de aquellos individuos; $3 .^{\circ}$ montecillos de pocas pulgadas de altura, que contienen algunos huevos, con los trabajadores y soldados correspondientes que sin duda trajeron aquellos de un nido demasiado lleno; $4 .^{\circ}$ grandes montecillos con numerosos huevos en diferentes celdillas $y$ larvas pequeñas en todos los grados de su desarsollo, pero sin reina ú inciicios de una celda real: $50^{\circ}$ montecillos muy pequeños con cierto número de individuos sexuales alados, algunos trabajadores $y$ soldados, pero sin huevos, larras, ninfas ni reina; $60^{\circ}$ montecillos casi desarrollados sin reina $\delta$ celda tenl, y'si solo con un número de larvas casi adultas y con ninfas; $70^{\circ}$ montones del mismo tamaño con nimfas y animales sexuales; 8. " montecillos con reina y rey en una esmaciusa celda cerca del centro de la base, construida con material diferente del enspleado en las otras partes. Es muy grueso y coriácco, mientras que el resto forma una masa granujienta que dificilmente se reduce á polvo. Bates encon. tró tales montecillos siempre atestados de esos insectos: algunos se ocupaban en trasportar los huevos desde la celda de la reina a todas las partes del nido y hasta la cúpula; las larvas recien nacidas y otros individuos en diferentes grados del desarrollo oprimianse en todas las celdas con las cabezas dirigidas una contra otra, y se ocupaban sin duda en comer. En las mismas celdas comian juntas larvas muy pequeñas y endebles de la casta de los trabajadores, soldados muy jóve. nes que solo se reconocian por la forma de la cabreza, y otros muchos individuos de mas edad, asi como ninfas muy delgadas y débiles, mas pequeñas que los trabajadores adultos.

Bates reconoció con bastante seguridad que entre los insectus jóvenes no existe ninguna distincion, lo cual resul. ta de que ninguna parte. de ellos se nutre en las diversas celdas de un alimento distinto. En una colina con una reina solinn hallarse por lo regular, además de los soldados y tra. bajadores, huevos y larvas pequeñas $y$ algunas veces un par de ninfas, pero nunca térmites alados, y dicho naturalista no podria decir si de tal unonton sale jamis una bandada. En el contenido del montecillo hay tal irregularidnd, $f$ las ninfas lo mismo que los individuos sexuales se encuentran tan mezcladas con larvas en las mismas galerias, que no tendrá minguna importancia conocer el monton del cual sale la bandada. Algunas ninfas, $y$ hasta individuos sexuales desarrollados y larvas, pasan desde los nidos demasiado llenos à otros recien hechos; los caminos cubiertos solo son prolongaciones de las galerias de un nido.

Asi como muestras hormigns, muchos térmites no cons. 
truyen su nido fuem del suelo, sino que le ocultan debajo de tierr, dirigiéndose por galerias subterráneas á la nuadera y otros objetos que pueden atacar con sus dientes. Fin las re. giones arenosas del Africa se han encontrado a mucha profundidad, debajo de la superficie del suelo, galerias endurecidas en forma de tubos, obra de los termites, aunque ahora no se ve uinguno de esos insectos en los mismos parajes, porque la vegetacion ha desaparecido; la raiz rodeada por uno de esas tubos estaba roida por dichos insectos. Pallme habla de una especie que en el Kordofan vive en la arena humeda y construye galerias que despues se endurecen. A pesar de todos sus esfuerzos para encontrar su vivienda, no logró descubrirla por sus excavaciones, pero cuando ponia una caja cerca del sitio donde en su opinion se hallaba algun nido pronto encontraba centenares de térmites debajo del foncio de aquella. l'ambien fiogel encontró, durante su viaje por el interior del Africal, entre Mursuk y Kuca, galerias de 0,026 á $0^{\circ}, 06 \$$ de diaimetro, que casi siempre se eleviban vertical. mente a $(1 \neq, 047$ de profundidad en la arema: pareciéronle obra de una especie de termes muy comun en Bornu, que como otras muchas tienen costumbre de rodear la madera, las ramas de árboles y los tallos con una capa de tierra, para roerlos despues bajo la proteccion de csta cubierta. En los boscjues halló galcrias de una circunferencia considerable, que antes rodeaban gruesos troncos de arboles. Al construir en luisiana un pozo se reconoció la profundidad a que penetran los térmites, hallándose a mas de ocho metros de profundidad sarias galerias, que se consideraron como obra de una especie del subgénero Hodotermes.

Hace poco que Federico Mucller publicó observaciones in-

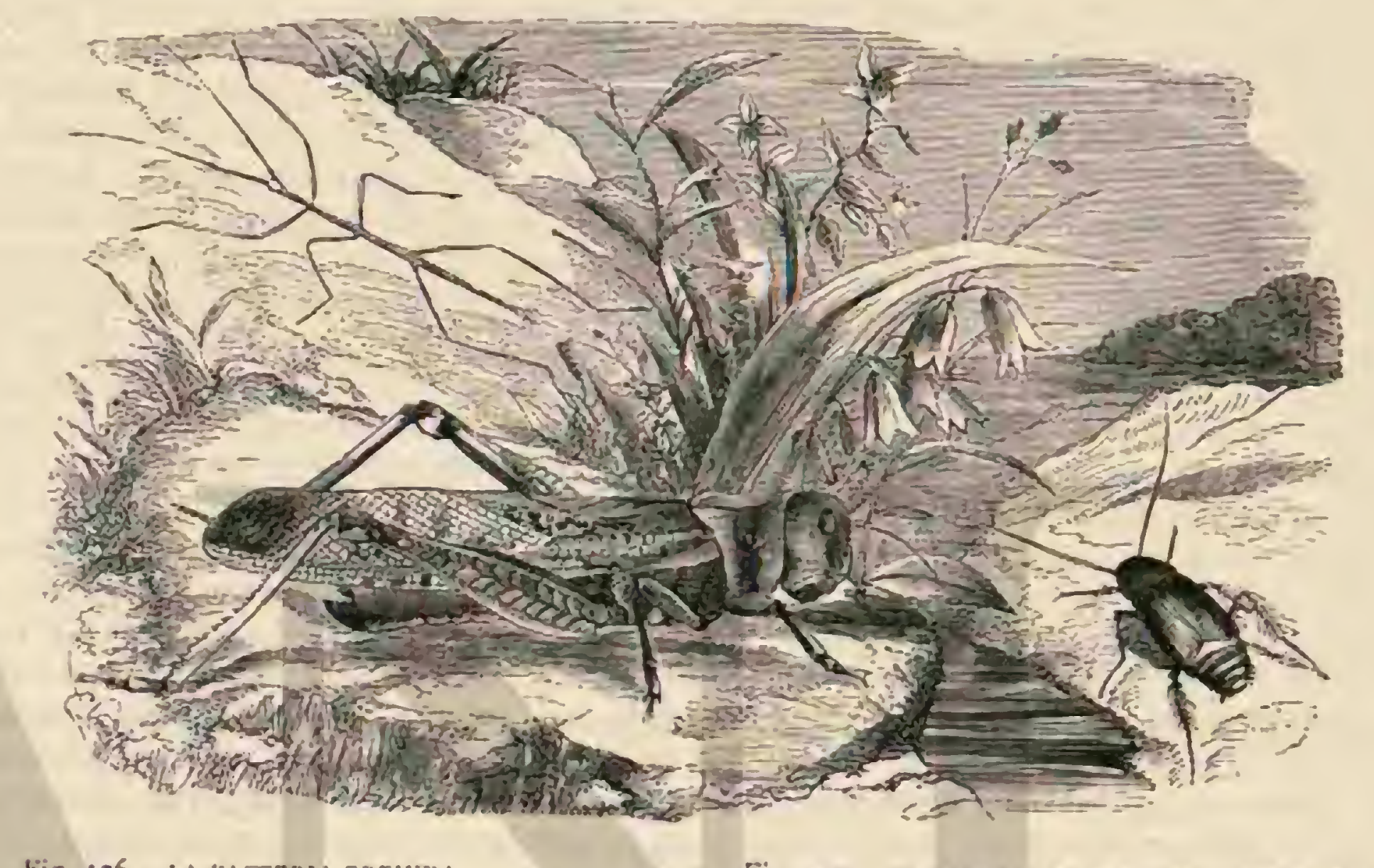

Fig. 126. - LA B.ACTERAS OREJUDA

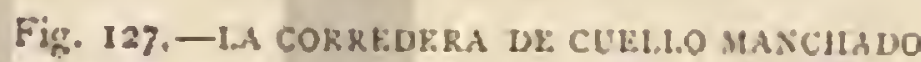

Fig. 12S. - FL HIJPOHA EMIGRANTE

teresantes sobre los térmites americanos, describiendo entre otros el nido de los llamados por él termes Iespest, especie muy semejante al fermes similis, mucho mas pequeña, y en la que en el segundo artejo de las trece ó quince de las antenas el diametro longitudinal es mucho mayor que el latitudinal. Fstos nidos son, así como - los del térmite belicoso, descritos por Smathman, unos de los mas particulares: tienen la forma de un grueso salchichon ó cilinciro de poco mas ó menos un palmo de largo, alrededor del cual se oprmen, separadas por ligeros surcos, unas prominencias planas en forma de cinturon, de las cuales de nueve a doce ocupan el espacio de $0^{0}: 10$. Solure estas prominencias circulares se corren otras longitudinales estrechas, de poco mas ó menos $0^{\mathrm{m}}$, or 2 de ancho, \& lo largo de las cuales prolónganse en el centro va. rios surcos: de quince a veinte de estas prominencias ocupan el espacio de $0 ", 10$; y no son siempre parnlelas ni tamploco estain dispuestas en intervalos regulares. Tanto las prominen. cias longitudinales como las trasversales aparecen menos marcadas en los nidos viejos que en los nuevos: cuandó estos últimos se resecan, atbrense angostas grietas i lo largo de los surcos que recorren las prominencins longitudinales y de los cuales sepáranse las circulares. En ambos lados del nido se ve casi siempre una especie de apófisis cortas y en la extremidad de una de ellas una pequeña abertura redonda, única entracla de esta viviuda subterránea. Si se practica un corle longitudinal en el nido, observase que se compone de tantos

томо VI pisos separados por paredes divisorias horizontales como pro. minencias circulares hay exteriormente, las cuales corresplonden í los pisos del mismo modo que los surcos circuiares a las paredes divisorias. Las grietas que se forman al resecarse el nido corresponden al las galerias de circulacion que se corren por debajo de los surcos longitudinales y' circulares. Cada piso tiene la forma de una caja plana, con la pared posterior ventrulla y contornos casi circulares, a no ser que causas exteriores hayan modificado el plan. En cada piso el suclo y el techo están reunidos por una gruesa columma, mas ancha en su base y en su extremichád, situada en el centro ó inas o menos cerca de la periferia. Al pié de la columna hay una abertura redonda que solo da paso á un insecto á la vez prara dirigirse oblicuamente al piso inmediato; si baja, siguiendo la misma direccion que tomó al subir, llegrara casi sicmpre a la salida situada al pic de sa columna, de modo que el camino clue desde el piso superior se jrolonga hasta el inferior forma una linca ó escalera de caracol, aunque no muy regu. lar, a causa de la desigualdad en la posicion de las columnas y altura de los pisos. la primera pared delyada de cada piso nuevo se compone casi siempre solo de los excrementos de los térmites, que suelen agregar capas mas gruesas de tierra, sobre todo en el tabique exterior, limitado por los surcos lon. gitudinales, ţue se cubren tambien con excremento. En otras partes, sobre todo en las paredes divisorias, la tierra esta me\%. clada con parte de ayuel y hojitas delgadas. Este nido artifi- 
cial se encuentra ì la profundidad de medio palmo $\delta$ umo, bajo la superficie del suelo. En su construccion se practica una cavidad que forma un espacio de un dedo de ancho al. rededor del nido, el cual, por ciertos ramales en la extremidad superior é inferior, se comunica con las paredes lisas de la citada cavidad; de umo de esos ramales, raras reces de varios, parte una senda que desde el piso inferior condure a unos tubos del grueso de un coñon de pluma, cubiertos de una capa de excrementos, que se corren à larga distancia por lierra, ensanchándose en muchos puntos eu forma de pequenoas cámaras irregulares. Fstos tubos conducen i los troncos de àrboles viejos, bajo cuya corteza encuéntrase á reces el ecrmes Lespesi, y sin duda tambien otros nidos. Mueller hace. esta suprosicion porque nunea encontró juntas las diferentes castas, raras veces una reina, y menos aun larvas pequenas cerca de cllas. Cundo se abre un pequeño agujero en la jared del nido se puede ver a los soldados que cuidadosinnente examinan el desperfecto, $y$ a los trabajadores que con sus excrementos proceden á la reparacion; pero si de un piso se desprende un buen pedazo de la pared, tos habitantes se retiran á los pisos mas próximos, cerrando al poco rato las entradas con dicha inateria. De este modo es fäcil defender el nido piso por piso contra los enemigos yue penetrán.

Respecto á las viviendas del térmite construidas en forma de nido en los árboles, y citadas yn por otros autores varias veces, Federico Mueller nos suministra detalles del todo nue. vos, no aplirables á todas las especies, pero si a la de la América del sur, observada por él. Asi como ciertas hormigas de nuestros paises abren galerias en la madern de los árboles, del mismo modo lo hacen varias especies de térnites, como por ejemplo las del sub-género caloterme. Algunas parecen atacat con preferencia cicrtas maderas, aun las mas duras, de los árboles casi samos. Isa pared de las galerias está tapizada casi Siempre de una delgada capa de excremento, sobre la cual se acumulan á veces otras en la extremidad de las galerias. Cuando la poblacion que ocupa un espacio aumenta mucho, las galerias se aproxinnan mas entre si, las paredes divisorias se adelgazan y desaparecen del todo, de manera que la capa de excrementos llega pur fin a formaren vez. de In madera las paredes divisorias. Esto es lo que se observa en los troncos de àrboles habitados por cl eutermes, especic muy afine del termes Riper/u, cujn construccion recuerda la miga de un pan poco compacto ó una esponja. Cuando estas aglomeraciones de excrementos no se limitan al interior del àrbol y salen del mismo, fórmanse los \& nidos arboricolas esféricos que por lo tanto no son en su origen otra cosa sino el basurero de una poblacion de eutermes, aunque sirve despues para la cria de los huevos y parn la subsistencia de las larmas. Fistos nidos se constituyen por consiguiente desde el interior del árbol hảcia fuera y no al contrario.

Cuando se corta un pedazo del nido los trabnjadores SC retiran de las galerias abiertas, en las que se presentan pe. queños soldados de cabeza puntiaguda en gran numero, los cuales comienzan i exploralo todo con sus antenas; al cabo de algun tiempo vuelven los trabajadores; cada cual examina el borde de la abertura que debe cerrarse, y muy pronto levantan sobre ella una pared. Despues vielven al interior del nido iodos juntos, oprrimiéndose unos contra otros, ó ruelven otra vez jara examinar su obra y perfeccionarla en caso de necesidad. Algunos trabajadores colocan tambien pequenos pedazos de la pared vicja en las recien construidas. Los soldados se han retirado al principio del trabajo al interior, excepto algunos que de vez en cuando tocan a los tmbajadores con sus antenas cual si quisieran animarlos en su tarea. Fn los troncos gruesos el nido solo ocupa un lado mientras que en los mas delgados le rodean por completo.
Uno de los nidos mas grandes observados pror Mueller representaba una masa irregular de $0^{\circ}, 94$ i $\mathrm{I}^{\prime \prime}, 25$ de diametro, que rodeaba dos troncos derribados. I a superficie presentaba unas prominencias planas irregularmente reunidas, que por su color negro y la forma esférica podian muy bien compa. rarse con la cabeza de un negro. Cuanto mas vicjo es el nido tanto mas oscuro y sólido se hace; en los nidos antiguos es preciso coger el hacha para separar un pedar. I a parte stl. perficial solo contienc trabajadores y soldados y en dicicm. bre, es decir en el periodo del celo, térnuites alados; despues se ven larvas mas pequeñas; haicia el centro, grandes masas de huevos, y al fin de rodo el rey y la reina.

Aunque las opiniones de los distintos autores difieren bastante en algunos puntos resprecto al género de vida dle los térmites, todos estàn conformes en que muchas especies son las mas terribles plagas de los paises tropicales, plagas que asombrar á todo viajero. Cierto quue no atacan á la persoma como otros muchos animales inútiles ó venenosos, pero se presentan en inmensas legiones, que destruyen en poco tiem. po toda una propiedad, ropas, libros $y$ hasta las vigas de una habitacion, procedicudo con tal sigilo y astucia que solo se advierte el desperfecto cuando ya no es tiempo para impedirlo, cuando cl techo cae sobre las personas antes que se piense. D'Essayrac de Lantrec, que himo un viaje por el Sudan, habla minuciosamente de las hormigas blancas, llamadas alli arda. Su tamanio es el de una hormiga comun, y se alimentan con preferencia de madera, pero destruyen tambien todo objeto que se ofrece á sus maxilas: es dificil preservar de su alcance el cucro, la carne, el papel, los libros y el calzado. Ln una noche destruycron un atlas encuadernado y la mitad de un estuche de anteojos, sin que se advirtiera el daño hasta que se cogió el libro á fin de examinarlo. Para llegar á él, los ardas habian tenido que perfornr el suelo de la habitacion y un banco de tierra;y por fuera no se vió ningun desperfecto, pues los térmires habian penetrado por debajo del atlas, destruyendo las cubiertas y las primems hojas. Los subios preservan sus objetos poniendolos sobre tablas suspendidas con cuerdas del techo de la casa i en otras rugiones, para librar los útiles de caza de los agucios dientes de esos voraces insectos se han de poner en un cubo de agua. Un árabe durmió cerca del Burnu sin saberlo sobre un nido de térmitcs, y al despertar por la minana, vióse desnudo, pues los insectos habian destrozado toda su ropa. Segun las noticias de A. Brelrn, el 15 de agosto de i $\$_{50}$ las aguas del Nilo Arul, crecidas por la inundacion, habian elerindo el dia anterior hasta el palacio del bajá una colonia de térmites que se abrieron camino por el suelo de ln sala, presentándose $\mathrm{cn}$ tal numero, que todos los presentes se vieron obligados à huir. Al dia siguicnte, el baji hizo practicar un profundo agujero en el suelo para poder destruir todo el nido. A la attura del nivel del rio vióse una enorme mole animada que solo se componia de térmites; parecia ser el centro de la colo. nia y de aqui partian de todos lados anchos canales por los que entraban y salian continuamente nuevos cjércitos de estos insecios. La mole se hundió en el agua, $y$ el hoyo practicado en la sala se llenó de cal, mas por la noche, los térmites salieron de tres agujeros en mucho inayor número aun, de modo que los criados debieron trabajar largo tiempo para reunirlos con escolas y poncrlos con palas en los cubos. A.

Forbes, al examinar su habitacion despues de una ausen cia de varias semanas, halló algunos muebles destruidos, descubriendo numerosas galerias que conducian á varios cuadros colgados en la pared; los cristales parecian muy oscuros y los marcos cubiertos de polvo; Forbes quiso limpiarlos, y no fué poco su nsombro al reconocer que solo estaban alli los vidrios, pegados en la pared y circuidos de una sustancia pe- 
gajosa, propia de las hormigas blancas. Los marcos de madera, las tablas de la mayor parte de los grabados habian desaparecido, y el cristal se sostenia solo con la sustancia pegajosa. Segun el Morning-Herald (diciembre de 1814), hasta la magnifica residencia del gobernador general en Calcuta, que costó enormes cantidades à la Companinía de las Indias Orientales, estuvo á punto de ser minada por los térmites. En un buque de guerra inglés, cl Allion, se habian fijado de tal modo, que fué preciso desarmarlo.

Un escrupuloso registro que las autoridades holandesis practicaron en l'ernate, porque la destruccion de ciertos ob. jetos de bronce se atribuyó á un descuido de los empleados, prucba que ni aun el metal esta libre de la accion del penetrante ácido de los térmites. Los cañones de hierro que cstaban en los baluartes se encontraron cubiertos de galerias de esos insectos y de orin. Bory de Saint Vincent encontró en lle de France, en los bosques de la isla, varios troncos de árboles grandes cruzaclos por nidos, quue perteneren on su opinion a la especie termes destrublur, llamada alli Karia. Este térmite destruye á menudo los mas bonitos árboles en poco tiempo, y hasta las vigas: cierto empleado, para cubrir un déficit considerable de madem en los almacenes reales, atribuyó la pérdida si los térmites, lo cual indujo al ministro ì enviarle una caja con limas para limar à los harins los dien. tes, advirtiendo que el gobierno no estaba dispuesto á tolerar en lo sucesivo tales destrucciones.

USOS Y PRODUCTOS. - No solamente los cmpleados monopolizadores, sino tambien los indigenas de los paises donde se encuéntran los térmites, utilizanse de estos insectos como alimento. Cógense en el periodo del celo con tallas de yerba, a los cuales se agarran los soldados, ó bien se abren agujeros en las viviendas de las especies subterráneas, etc. En marias regiones de Java véndense en el mercado con el nombre de Laran, y tambien se buscan los nidos para dar las larvas á las ares de jaula. Ya hemos dicho que sirven de alimento á numerosos animales, $y$ solo aniadiré que entre los mamiferos, los armadillos y homigueros se alimentan prin. cipalmente de esos insectos. Por esto, y porque destruyen ciertos vegetales, los térmites tienen muchá importancia en la economia de la maturaleza, aunyuue no agradan, como otros muchos animales, al \&senoor de la creacion\&, al hombre, tan impotente para combatirlos.

C.LASIFICACION. - Ias cien especies próximamente de térnites descritas por Hagen en una ú otra casta (pues muy' pocas se conocen hasta ahora del todo) se dividen en cuatro subgéneros, que fácilmente pueden distinguirse Dos especies presentan lóbulos pegajosos entre las garras y nervios en el borde de las alas; la llamada calotermes tiene orelos, mientras que la de los temopsis carece de ellos. 1.os lindetermes carecen de lóbulos pegajosos; y el subgénero de los termes, ef mas rico en especies, se reconoce por la existencia de ocelos, por la falia de lóbulos entre las garras y por los nervios en el borde de las alas.

\section{EL CALOTÉRMITE DE CUELLO AMARILLO} - CALOTERMES FLAVICOLLIS

CARACTERES. - EI calotérunite de cuello amarillo, que como habitante de los paises del Mediterrineo es una de las dos especies que se encuentran al sur de Europa, solo se conoce como insecto alado ó como soldado, mientras que no se han visto aun los trabajaciores, ni la reina ni la construccion de su nido. Los alados son de color pardo castaño os. curo, con la boca, las antenas, las patas y el protórax aunarillos; las alas, que de punta a punta miden $\|^{\circ}, 020$, son ligeramente ahumadas; su cabeza cuadrangular de mediano tamaĩo y un gran escudo del cuello, escotado en su parte anterior, les cancterizan por lo demás. L.os soldados que miden $0^{\prime \prime}, 002$ mas de longitud, es decir de 7 a 9 , se distinguen por su cabeaa cuadrangular muy prolongada, con grandes maxilas, las cuales estion provistas en su lado interior de dientes angulosos en la base, y son una mitad tan largas como la cabe 7.a. Esta especie no sc ha mostrado muy danina hasta ahora.

\section{EL TERMITE BELICOSO-TERMES BELLI- cosus}

CARAGTERES. - Vil termite belicoso, llamado asi por Smeathman, no difiere del termite fatal (tromes fotalis) de Fabricius, que se encuentra en toda la costa oriental del Africa, desde Abisinia, y tambien i los grados de latitud correspondicntes a la costa occidental, y es una de las mayores especies conocidas, pues mide $0^{\circ,}, 018$ de largo por $1^{\circ}, 065$ á $6^{m}, 080$ de punta á puntia de las alas; se conoce esta especie en todas las costas.

\section{EL TERMITE OBESO - TERMES OBESUS}

CARACTERES. - De esta especie que debe su nombre á Rambur, y que es propia de las Indias Orientales, solo se conocen los individuos sexuales, y nada se sabe sobre su género de vida. El macho mide $1^{*}$, on 1 de largo por $10^{n, 048} \mathrm{de}$ ancho de punta á punta de las alas. lil cuerpo es de un pardo de pez; el escudo, que afecta la forma de carazon, tiene el borde amarillo, y en el tórax se ve una mancha en figura de ancla, del mismo color. Ia boca, las patas y la cara inferior son de un amarillo de ocre; las antenas presentan anillos claros, $y$ las alas son blancas con viso amarillento.

\section{EL TERMITE TERRIBLE-TERMES DIERUS}

CARACTERES. - Ins ninfas y la reina de esta especie no se conocen ain. El color del cuerpo y cl de las alas es pardo de café, y en la coronilla hay una mancha; las antemas, el escudo del ruello, la parte inferior del cuerpo $y$ las patas son de un rojo amarillo.

DISTRIBUCION GEOGRÁFICA. - Esta especie vive en el Brasil y en la Guayana. Segun Burmeister, vive en agujeros subterrancos y debajo de las piedras, alimentandose de las raices de árboles en estado de descomposicion.

\section{EL TERMITE LUCIFUGO-TERMES LUCI- FUGUS}

CARACTERES. - Fsta especie, de color pardo negruzco, está cubierta de pelos pardos: las extremidades de los tarsos y de los piés son amarillentas, las de las antenas y palpos, blanq̨uizcas El cuerpo tience de $0^{m}, 006$ a $0^{\circ}, 009$ por $0^{\circ}, 01 S$ a U $U^{\circ}, 020$ de ancho, de punta á punta de las aloss.

DISTRIBUCION GEOGRÁ FIC A.-EI térnite lucifugo es la segunda especie curoper que á menudo habita con el térmite de cuello amarillo, muy semejante, las paises del Medierráneo; encuéntrase a la altura de 1,094 metros subre el nivel del mar ca la isla de Madera; y han penetrado hasta Rocáfort y la Rochelle en Francia, en cuya iltima ciudad ocasionó grandes perjuicios en las vigas que forman parte de los cimientos. Lista circunstancia es tanto mas curiosa y ex. traña cuanto que en los otros continentes todas las especies se encuentran solo hasta el $40^{\circ}$ de latitud norte y sur.

USOS, COSTUMBRES Y REGIMEN.- Lespés ha hecho últimamente la descripcion ya conocida, de este termitino, la cual reproduciré aqui en extracto, puesto que siem- 
pre hemos dado la preferencin á las especies curopeas. Los individuos sexuales antes descritos nacen de dos formas de ninfas, distinguiéndose la primera por los rudimentos de las alas, largos y anchos, que cubren toda la parte anterior del abdómen; y la segunda, que es mas rara y gruesa, por los mismos rudimentos muy cortos, situados lateralmente. Ambos empiezan desde julio à presentarse en el nido, y pasan por lo tanto el invierno como crisálidas; la primera se trasforma a fires de mayo en insecto alado, mientras que los individuos de la segunda forma no ven la luz hasta agosto del año siguiente, necesitando por lo tanto 20 meses para su desarrollo descle la puesta del huevo. Igual tiempo se calcula parn los neutra, segun se. Hlaman los trabnjadores y soldados no desarrollados sexualmente. Desde el invierno hasta marro se encuentran en el nido las lárvas mas jórenes de todas las castas, y que Lespée designa como primer grado del desarrollo.

Son muy perezosas; se apoyan contra las paredes; $y$ hasta que no han llegado i la longitud de $1^{m}, 002$ se asemejan tanto, que aun no se puede saber qué individno nacerá de ellas. I a lasva del segundo grado de desarrollo, es decir, ia que ya ha mudado una ve\% de piel, mide de $0^{\prime \prime}, 002$ a $0^{\circ}, 003$, ofreciendo dos formas. I.as unas se parecen por el tórax a los trabajadores, pero reconócense facilmente por su figura, por sus movimientos caclazudos, y por tener la cabeza mas pequeña, de color blanco mate se trasforman en junio en trabajadores ó soldados Las otras tiene el tórax mas ancho, asi como los dos segmentos siguientes, en los que ya comienzan a presentarse los indicios de las futuras alas, por lo cual estas larvas se parecen mas á los individuos sexuales. Este segundo grado del desarrollo aparece ya en inviemo, pero predomina tan luego como el primero ha desaparecido, porque de este nacen, por la muda de la piel, las larvas de $10^{\%}, 004$ o $0^{\circ}, 006$ de longitud, gue en la primera forma se. parecen ya bastante á los trabajadores y soldados; en la segunda las ninfas ofrecen el tercer grado del desarrollo, que pronto sucede al anterior. Las larvas del primer grado tienen las antenas de 10 artejos, las del segundo de 12 \& $14, y$ las del tercero de 16 . Todo el año se encuentran trabajadores y soldados en cl nido, pero escasean on el mes de junio, primero los unos y despues los otros; enflaquecen y presentan los vestigios de la vejez, pues ha llegado para ellos e] tiempo de dejar su puesto a las generaciones mas jóvenes. Segun hemos observado ya en la descripeion general, los soldados difieren de los trabajadores solo por el gran tamaño de la cabeza y de las mandibulas; aquella es tan larga como ancha y de forma cilindrica; estas son negras, encormdas hácia arriba en forma de sable, desprovistas de dientes y la mitad menos largas que la cabeza. Los trabajadores, en quienes recnen casi exclusivamente todos los quehaceres, tienen la costumbre de moverse solo en galerias cubiertas, lo cual, sin embargo, no lo hacen sino para impedir la entrada del aire fresco, pues temen la luz. Lespece puso varios nidos en rasijas de vidrio $y$ no pareció que a los trabajadores les molestara mucho la luz del sol que por el lado del cristal penetraba en una galeria. Por lo regular construyen el nido en el tronco cortado de un pino, á veces en las encinas, sabucos ó tamarindos; pero siempre en la madera muclle y humeda situada a poca altura del suelo. I as pequeñas socieda. des que cuentan uno, 6 cuando mas dos anos de existencia, viven debajo de la corteza, pero despues penetran en la madera. I.as galerías conducen desde la periferia al centro, y al mismo tiempo interesan las raices, que en los pinos se corren casi á flor del suelo. No son regulares, y muy á menudo las larvas que se alimentan de madera, sobre todo las de los jilóáasos, son los inquilinos de los térnites, mientras que las cavidades mas anchas de los capricornios sirven de cel. das. Si no encuentran estos trabajos preparatorios, construyen sus galerias con cierta regularidad, abriéndolas en medio de los anillos anuales y dejando estos como paredes divisorias. Unas aberturas redondas bastante grandes para dejar paso a uno ó dos trabajadores establecen la comunicacion entre ellos. Toda la parte interior del nido está cubierta de una capa lisa de color pardo claro, que segun las observaciones hechas en los individuos cautivos, resulta componerse de los excrementos.

Lespée encontró en algunos troncos de árboles junto á los térmites un nido de hormigas, separado del de aquellos solo por una delgada pared divisoria, observacion que tambien se ha hecho por algunos autores al encontrar térmiles arborico. las exóticos, y la cual demuestra que la gran enemistad en que riven ambos grupos de insectos no hace perder el instinto para la construccion de los nidos. Jos dos bandos cstablecen sus colonias en los sitios convenientes, sin cuidarse de si el enemigo ocupa las inmediaciones. Cuando I.espée ponia un pedazo de nido, con sus insectos, en sus vasijas de observacion, los trabajadores empezaban desde luego à cons. truir galerín' en el fondo de aquellas, fijando despues el nido en las paredes. En las regiones de Francia a que se extienden las observaciones no faltan en los restos de pinos cortados, porque se ncostumbra á dejar los árboles intactos en el suelo y esta es quizá la mizon principal porque las casas de Burdeos no son visitadas por los térmites, aunque en algunos puntos se han reconocido sus huellas. Para poder cons. truir sus viviendas necesitan tambien alimentarse, pero de esto se cuidán otra vez los trabajadores. Cuando se rompe un pedazo del nido dé modo quue el aire pueda penetrar, buscan los objetos mas diferentes y mas á mano para remendar en seguida al desperfecto: por eso se encuentran raras veces nidos donde no haya suficiente excremento para tap:zar las paredes ó cerrar las aberturas. Los remiendos se hacen con el imayor órden, sin la intervencion de los soldados. Estos no répresentan nunca el papel de capataces; toda su atención se fija en los trabajadores y los huevos. Al abrir una celda llema de estos, acuden precipitadamenie y se llevan cinco 6 seis à la vez. Lespée puso un dia cierto número de huevos, encontrados en el campo, en una de sus vasijas, y sus habitantes los ocultaron al poco rato en el interior del nido. Rueven vió tambien una ninfa frente á un trabajador, comiendo el alimento que este arrojaba: pero cree que este fenómeno es una excepcion. Ademis de los casos citados no pudo observar la manera de alimentarse, ni vió tampoco que se prodigaran cuidados al rey ni á la reina, aunque es preciso que cuando menos para las larvas jóvenes se haga algo en este sentido: pero es muy dificil observarlo. Por su parte, Lespée cita ejemplos que no dejan duda de que los trabajadores cuidan tambien de la cria. Lamian las ninfas, y cuando alguna de estas se habia herido, caso muy frecuente, cuidátranla dos ó tres trabajadores. En la última muda de las larvas de trabajadores y soldados observó varias veces que los trabajadores adultos las ayudaban á despojarse de su primera cubierta, pero nunca lo hacian cuando las ninfas se trasformaban en individuos sexuales, aunque tambien entonces se notaba siempre una agitacion muy viva en todo el nido. Los trabajadores tienen ciertas costumbres que aun no se han podido explicar: en medio de una ocupacion, $y$ tambien cuando no hacen nada, empinanse de repente sobre sus patas y golpean diez ó doce veces el suelo con la extremidad del abdómen.

Los soldados destimados á velar por la seguridad de los demás, se presentan amenazadores contra cl hombre, à me. nudo grotescos, pero nunca son peligrosos. lespée alargala a menudo el dedn, y no mordian, sin duda porque no les ern posible abrir las tenazas lo bastante para coger la piel. A pe. 
sar de su valor son bastante torpes, a causa de su ceguedad, y manifiestan mas furia de la que pueden experimentar. Casi siempre permanecen inmóviles en las galerias ó celdas, pero cuando se abre el nido, corren sin saber adónde, con las maxilas abicrias. Si se les irrita toman una posicion en extremo grotesca: preparan sus tenazas, levantan la parte postcrior del cuerpo, avanzan a cada instante para caer sobre el enemigo; pero cuando lo han intentado varias veces en vano, golpean con la cabeza cuntro veces en el suelo, produciendo un sonido agudo, que antes se tomó por silbido. Cunndo Lespé abria la pared divisoria entre dos hormigueros próximos, trabábase una lucha encarnizada: la hormiga cogida era muerta sin remedio, pero el soldado debia su. cumbir tambien por lo regular, pues las compañeras de aque. lla acudian en su auxilio y acosaban en gran número al cnemigo hasta que perecia.
Ias larvas viejas permanecen regularmente reunidas en las estrechas galerias, y los soldiados casi sicmpre en los exircmos de las mismas; aquellas huyen tan luego como peneira la luz, y las ninfas hacen lo mismo. Cada vez que mudan de piel se observa una gran agitacion, que parece fundarse principalniente en que los recien nacidos, sobre todo los que han pasado por la última muda, buscan un sitio solitario donde fuera de la confusion de la mayoria puedan dejar en. durecer su blando cuerpo, $\delta$ donde a los individuos alados les sea mas fácil alcanzar el desarrollo de sus alas, que es cosa de una hora. Los trabajadores que acaban de desarrollarse, asi como los que han concluido de mudar de piel, son del todo biancos, y necesitan algunos dias antes de ser aptos para trabajar. Los individuos scxuales pierden mu. pronto las alas y viven tambien reunidos opriniendose unos contra otros. I.espée no los viú volar al aire libre hasta que

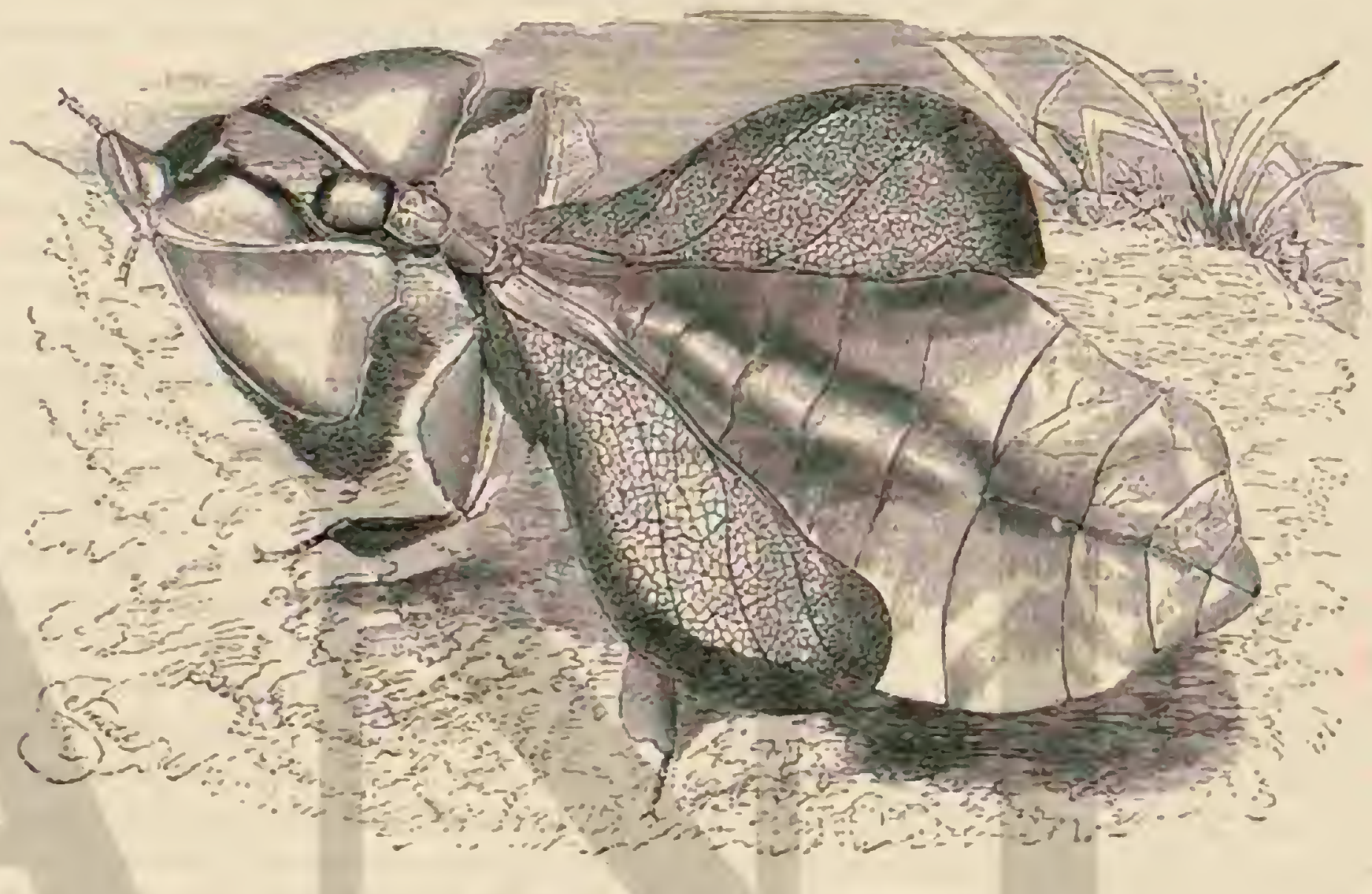

Fig. 129.-F.1. 111.10 110JA.SECA

hubo abierto un nido: sus cautivos murieron en julio. Cuanro ta vasija estaba expuesta al sol, las hembras salian a la superficie del nido, perseguidas por los machos, muy excita. dos, casi siempre por uno, raras veces por dos; ibnn tan i su alcance, que porlia creerse que con las maxilas habian cogido la extremidad del abdómen. El apareamiento no se pudo observar ni en los cautivos ni en los individuos libres, y por lo que he lejdo sobre este particular esioy seguro quue no se vérifica en el aire, sino en tierra, despues de perder las alas, $y$ siempre en un rincon oscuro ó de noche. Esta apasionada persecucion del macho, observada igualmente en otras especies, $y$ el temor que a estos insectos infunden toda la vida la luz y el aire, indican bien á las claras que no imitan à las abejas como hijas de la luz.

Parece que rara vez se encuentran las reinas: en lo que I espée dice de ellas hállanse muchas contradicciones. Segun asegura, encontró los huevos sicmpre unidos en masa, y nunca guardados por una reina, lo cual le induce á creer que fueron puestos por los individuos scruales que se aparean en agosto. Despues de buscar mucho logró al fin encontrar, el $2 \$$ de julio, dos parejas en un mismo tronco de árbol, cada cual en su celda particular, pero que se comunicaban entre si, de modo que probablemente habitaban alli juntas dos colonias, lo mismo que en el caso antes citado. En las celdas habia trabajadores, soldados, larwas y huevos, pero ninguna ninfa Li exámen anatómico de la hembra demostró que los huevos no podias ser puestos por ella. Es noviembre encontró cambien en un pequeño nido una hembra que tenia en el ovario huevos con cascara. Varias rejnas se encontmron en diciembre, marzo y julio, acompanadas ó no de un rey. Aquellas crecen mas y mas con la edad, no habitan singuna celda separada, sinn una galeria mas jrofunda juntas con el rej; muy vivaces, se pasean á pesar de su gordum con mucha agilidad, 5 hasta un año despues de la última muda no comierzan la puesta de los huevos que dura poco tiempo y se verifica en julio, segun parece.

A pesar de los estudios y averiguaciones de aigunos observadores, la naturaleza oculta en su actividad muclios nisterios, tales que la razon humana no podria descubrir sin una observacion incansable; esto lo ha demostrado otra ver. la vida de las liormigas blancas, pareciendo decir á todos los estutliosos: buscad y encontrareis!

\section{LA CORREDERA ALEMANA-BLATTA GER- MANICA}

CARACTERES. - Este insecto es de un color pardo claro; la hembra, un poco mas oscura que el macho, tiene en el escudo del cucllo dos lineas longitudinales negms. El abdúmen plano y amarillento del macho está cubicrto por 
las alas, excepto las dos hojas del ano: la parte anterior ne. gruaca de la hembra sobresale un poon de las alas en cada lado y no alcanza su longitud.

DISTRIBUCION GEOGRÁFICA. - Prusianos Ilama en Rusia el hombre del pueblo $a$ los insectos que el labrador austriaco designa con el noinbre de rusos y que tanto aqui como alli, $y$ aun en otras muchas partes, molestan en extremo en las casas. Los rusos creen que despues de la guerra de los siele años las tropas los importaron a su vuelta de Alemania, 6 por lo menos que hisia entonces no se cunocian en San Petersburgo. Los austrincos justifican la aplicicion del nombre que emplean asegurando que unos trabajadores de Bohemia los impontaron en el Austria inferior, 5 que de aqui los trajeron unos subditos rusos empleados por los fabricantes de vidrio en elase de jornaleros. Er hecho siguiente denuestra con cuanta faciliciad la corredem alemana, pues de ella se trata, puede trasportarse de un sitio à otro. En una cerveceria de Breslau las correderas habian aumentado de tal modo que corrian por las mesas de la casin subian por los vestidos de los huéspedes y se ocultaban con preferencia bajo los cuellos de las levitas. Encuéntranse tambien en Siria, Eigito, en el norte de Africa y en las revgiones mas diferentes de Alemania. En Nordhausen se las conoce hase unos cincuenta y cinco años, enconträndoselas át menudo, con no poco desagrado, en las fábricas de aguardiente; en Halle se las ve aisladamente en la Casa de huérfanos de Francklin y en la fábrica de azúcar situada fuera de la ciudad, liace unos vante anos: su número es alli cnorme: En Hamburgo son muy molestas en muchas casas y Walte dice que en Passau cstos insectos obligan a menudo a los inguvilinos á dejar la casa. Hárento asi en la estacion ́ria, dejándolo todo nbierto, $y$ al cabo de algunos dias los insectos inueren, probablemente por el brusco cambio de temperatura: de modo gue los habitantes pueden volver a entrar en la casa. la circunstan. cia de vivir al descubierto demuestra que solo el cambio de temperatura ó la corriente de aire frio las mata, y no el rigor del invierno, pues se las encuentra en muchos sitios de mues. tros bosques alemanes. Yo las cogi en los alrededores de Halle y uno dé mis anigos cerca de leipzig.

USOS, COSTUMBRES Y REGIMEN.-Segun marece, la hembra hace menos uso de sús órganos para el vuelo que el macho; al cabo de quince dias busca los favores del otro sexo; ambos se acercan por detras retrocediendo casi cl cuerpo, pero permanecen muy poco tiempo unidos. Poco despucs se dilata mucho el abdómen de la hembra, aumentando el volímen poco á poco hicia atriss, y al cabo de una semana, con corta diferencia, se ve en la punta del abdómen un cuerpo amarillo redondeado que parece querer salir; debe ronsiderírscle como un huevo aunque tenga un tamaño extraordisario en comparacior con la madre. No se ha averiguado aun cuánto tiempo lleva esta el supuesto hucro visiblemente. consigo, jero no cabe duda que varins semanas y mas tiempo que la otra especie de que á continuacion hablaremos. Por fin lo deja caer en un rincon $y$ muere poco despues. Se ha observado tambien que algunas hembras ponian un huevo poco desarrollado y despues otro mas perfecto; pero por regla general debe suponerse que solo pone una vez. Al exaninar mas minuciosamente este huevo de $0^{2}, 006$ de largo por la mitad de ancho $y$ de color pardo, se ve/solo cirteriormente una sutura enlazada en uno de los largos bordes, y marcadas fajitas trasiersales en los lados; pero en el interior presenta un estructura maravillosa; una pared divisoria longitudinal lo divide en dos mitades iguales de las que cada una tiene I 8 compartimentos correspondientes á las fajas trastersales exteriores, con un huevo blanquizco longitudinal; cuanàn este se halla mas desarrollado ticne una larva blanca cuya cara abdonimal está dirigida hácia la pared divisoria. Ia madre deposita por lo tanto de esta manera treinta y seis liijuclos en una gran cáscara de huero, regularmente uno al lado de otro, y es de suponer que solo deja caer aquella poco tiempo antes de quue los hijuelos estén desarrolladus. Estos salen cuando han llegado á la madurez por la sutura enlazada con la cipsula. Hummel pudo hacer en San Petersburgo, hace ya mucho tiempo, una observacion interesantisima. Para conocer el género de vida de estas correderas habia encerrado en una vasija de cristal, hacia mas de una semana, una hembra en que la cápsula del huevo estaba visible, cuando en la mañana del $\mathrm{t}^{\circ}$ de abril le trajeron otra cápsula que al parecer cra del todo fresca, y la cual colocó en la misma vasija con la hem. bra. Apenas lo hubo hecho asi la cautiva se acercó á la cápsula para examinarla, la volvió de todos lados, sujetóla por fin con las patas anteriores $y$ la abrió por la sutura en toda su extension. Tan luego como la abertura se ensanchó salicron las blancas larvas, siempre juntas de dos en dos. La hembra las ajudó con los palpos maxilares y las antenas, y en pocos segundos se aparearon alegremente sin hacer caso ya de su mádre adoptiva. Habia $3^{6}$, todas blancas, con ojos negros: pero pronto se volvieron verdosas, tomando despues un tinte negro con niezcla de amarillo. Comicron todas las migas de pan que se habian puesto pam la hembra; y todo esto fue obra de diez nimutos.

Cuando la larva ha sufrido seis mudas, en cada una de las cuales renparece por poco tiempo su primitivo color blanco, queda trasformada en corredera apta para propagarse. En n. gor deberíamos hablar de siete nudas, porque la primera piel queda en la cápsula del huevo, por lo cual es fảcil no verla. Al cabo de ocho dins efectúase la primern, ó mejor dicho segunda muda; diez dias mas tarde la siguiente, y unos quince dias despues la tercera. Al salir de la piel vieja que siempre se abre por el dorso, la larva es al principio delgada y mauitica, pero pronto adquicere su forma plann, y poco á poco tambien el color oscuro, del cual se destacan despues el borde amarillo dél escudo collar y los dos segmentos siguientes del tórax. Con la cuarta muda, es decir, unas cuatro semanas mas tarde, todas estas partes se ven aun mas marcadamente; cuatro semanas despues desaparecen con la quinta muda los rudimentos de las alas. Ja larva se trasforma en ninfa y vive en tal estado otro tanto tiempo ó seis semanas. Despues de haberse desprendido de la última piel, la corredera necesita diez. ó doce horas para adquirir todo su color, comenzando por las patas y las antenas. El desarrollo no es tampoco aqui regular, como en todos los insecios.

La especic alemana cone, por decirlo asi, todo cuanto juede comer un insecto, en particular pan, y eon jurefurencin el blanco, mientras que no busca la harina, despreciando tambien la carne cuando tiene otra cosa. Humel los vió à miles precipitarse en botellins que habian contenido aceite y raspar el barniz de las puertas hasta el cuero, pero nunca observó que la una se comiese á la otra. Chamiso dice que en alta mar se abricron unos fardos que debian contener arrozy trigo y se encontraron en ver de estos cereales correderas alemanas. Pueden ajunar tambien mucho tiempo.

Entre las numerosas especies congenéricas hay tambien algunas correderas que, evitando en parte las casas, solo ha bitan un los bosques, distinguiéndose por la estructura de las alas.

\section{LA CORREDERA DE LAPONIA - BLATTA LAPPONYCA}

CARACTERES. - En esta especie, las alas anteriores de la hembra, que son amarillas con puntos negros, solo alcan- 
zan, asi como las posteriores, it la extremidad del abdómen, micntras que en el macho se prolongan mas. Esta corredera es de color pardo claro ú oscuro, con un borde claro trasparente; el escudo del cucllo alcanza una longitud de $0^{m}, 07 r \%$

USOS, COSTUMBRES Y REGIMEN. - Lista corredera se encuentra en nuestros paises en todos los bostues, pero es dificil cogerla a causa de su rapidez. En Laponia penetra en las habitaciones, $y$ juntamente con el silfa laponica podria devorar en un solo dia toda la provision de jescado fresco.

\section{LA CORREDERA MANCHADA-BLATTA MACULATA}

CarActeres. - En esta especie, que solo mide $0^{m}, 006_{5}$ de largo y con lo mismo de ancho, las alas posteriores quedan mucho mas cortas que las anteriores, cuja longitud iguala á la del abdómen. Este insecto, de forma oval, es de color pardo oscuro, mas claro en la extremidad de los costados y en el burde exterior del escudo-collar; las alas anteriores son amarillas, excepto una mancha negra de la mitad posterior de las últimas. Yo le encontré en los alrededores de Halle, muchos años en gran número, retozando alegremente en las moreras.

Los caractéres del sub-género blatta son los siguientes: la cabeza se oculta del todo bajo el escudo-collar, ancho en la parte posterior y muy prolongado en forma de ingulo; asi como en todas las correderas, la coronilla está muy hácia adelante y la boca bastante hácia atras: en la escotadura de los ojos, que tienen la forma de riñones, hay anteuns cerdosas que miden cuando menos la longitud del cuerpo. Las cuatro alas, de las que las anteriores forman elitros coriaceos con nervios prominentes se apoyan sobre el abdómen, que es aplanado, sobresaliendo el lado izquicrdo, con if borde interior, sobre el derecho, y estrechándose las anchas islas posteriores por varios repliegues longitudinales. En los muslos, que son aplanados, se ven siempre algunas espinas, mas numerosas en los tarsos, bastante prolongados; la quinta articulacion del pié está provista de un lóbulo agarradizo. Los machos se distinguen de la hembra jor su menor tamaño $y$ forma mas esbelta, $y$ por tener un segmento supernumerario en el abdómen; por lo demás, la últimn escama del vientre afecta igual forma en ambos sexos, solo que es plana y' mas ancha en la hembra; tanto en esta como en el maclio se ven largas puntas articuladas en la extremidad del abdómen, pero aquel carece de estilo.

\section{LOS PERIPLANETAS -PERIPLANETA}

CARACTERES:- Este sub-género se distingue del anterior solo por tener da última escama del vientre bastante plana, provista de dos largos estilos en el macho, mientras que en la hembra el nismo segmento se eleva en forma de quilla.

\section{EL PERIPLANETA ORIENTAL-PERIPLA-} NETA ORIENTALIS

CARACTERES. - El periplaneta oriental es bien conocido, al menos exteriormente, de todos los que habian junto a una tahona, en un molino, cn una cerveceria, ctc.: no se le encuentra nunca al aire libre, y si solo en las viviendas hu. manas donde molesta à sus moradores. Los individuos pequionos son las larvas sin alas, mientras que los adulios se presentan bajo dos formas. Los machos tienen las alas de un pardo de pez, provistas en su extremidad posterior de nervios dispuestos en forma de abanico y que cubren parte del abdómen: las hembras son de un color negro brillante y solo tienen én el tórax globos laterales en ver. de alis.

DISTRIBUCION GEOGRÁFICA. - Ei periplaneta oriental, que tambien se llama corredera ú escarabajo, deberia ser origimario del Oriente, á juagar por su nombre cientiíco, aunque faltan las pruebas para sostenerlo con toda seguridad. Solo se sabe que lo mismo en las Indias orientales que en América, y no solo en las ciudades de la costa, sino tambien en el interior y en toda Furopa. es mas ó menos comun. Agridale habitar los buques; $y$ su modo de desarro. llarse por medio de la cápsula de los huevos es del todo propio para poderse jropagar con las mercancias por todas partes.

USOS, COSTUMBRES Y REGIMEN. - las noticins sobre la existencia de este insecto en Furopa datan de '35 nños. No me atrero á determinar si es cierto, segun se pretende, que la corredera alemama ha reemplazado á la especie oriental en algunas partes; solo sé que en Hamburgo por ejemplo habitan las dos especics y molestan mucho a los habitantes. De dia no sale nunca; permanece escondida en los agujeros de las paredes y en los rincones oscuros. Al limpiar un cuarto de mi casa, poco usado, encontrábase á reces debajo de la alfombra una lrembra ó un macho aislado, ó bien una larva, pero siempre solo un individuo, sin que pudiéramos explicarnos su presencia alli, pues en todos los demis sitios no se veia ninguno. Como siempre me llamaban para coger aquellos insectos, cicrto dia dejé escapar uno para observarle. Con la rapidez del rayo corrió á lo largo de una jared, desapareciendo en un rincon por un prequeno agujero que hasia entonces no se habia visto; asi como el raton, el periplaneta supo encontrar el mismo camino por donde habia venido, descubriendo asi su verdadero domicilio. Debajo de la habitacion habia. una tienda de comestibles, donde los insectos buscaban su alimento; y en sus expediciones noctumas habian llegado poco á poco hasta mi casa; varios penetraron en el citacio cuarto, y algunos debie. ron morir alli de hambre, pues tres $\delta$ cuatro lices se encontraron sus cadaveres entre las cortinas.

De noche, solure todo desde las once, se puede rer a estos inscctos tan ariscos vagar en no escaso número por los sitios que habitan, lo mismo nue los grillos; asi como i estos les agrada el calor, por lo cual cligen con preferencia las cocinas y los parajes situados cerca de los hornos, en las panaderias y cerrecerias. Preséntanse principalmentc en los meses de junio y julio; llegado este tiempo, siempre se verin en el sitio habitado por ellos individuos de todos tamanos, desde el de una pequeña chinche hasta los que miden una longitud de $0^{\mathrm{m}}, 026$; todo lo cramiuan, ý retunense principalmente alli donde encuentran un sitio húmedo, pan ú otro alimento. Si el observador hitce ruido al acercarse huyen con una rapide\% y agilidad que demuestran st timide\%, pero que tambien producen en el observador una sensacion en extre. mo desagradable. La lur que de improviso aparece les es. panta tanto como el mas leve rumor; lo caal se reronore ficilmente, pues una mosca qute ruele, un grillo, etc, les induce i emprender la fuga.

Cunndo con el mes de abril llegra el tiempo de la puesta de los huevos, las hembras fecundizadas se dilatan muclio en la extremidad del abdómen. In caipsula de que hemos hablado aparece pronto y sobresale cada rez. mas de la extremidad del cucrpo á inedida que sce endurece y adquicre poco a poco un color negro. I a capsula de esta especic tiene tambien una pared divisoria longitudinal, jero en cada mitad solo hay ocho celdillas de ovarios. La puesta se efectua en agosto, $y^{\circ}$ las larras nacen muy pronto, segun opinan algunos: mientras que otros, con quienes no estoy conforme, aseguran 
que tardan un año. 'Tambien en esta uspecic sé encontró una hembra que puso dos cápsulas de huevos, una el 21 y la otra el 29 de junio; á los dos dias estaba muerta en el cristal que le servia de prision. $\mathrm{N}$ salir los hijuelos queda la primera piel en la cipsula, y despues mudan seis veces, pero a intervalos mas largos que los observados en la especie alemana. Pretendese que la primera muda se efectúa al cabo de un mes, y las oiras con intervalos de un año, de modo que el insecto deberia llegar à la edad de cinco antes de propagarse. No he fracticado ninguna prueba sobrc el particular, pero creo que ese término es un poco exagerado.

I a costumbre que ticnen esos insectos de buscar sitios húmedos y lamer cerveza puede utilizarse para su exterminio, a cuyo efecto se colocan trapos hümedos en donde se reurén y entonces es fácil matarlos. Si se pisa una hembra de periplaneta óyese-un fuerte ruido, semejante al que se pro. duce al reventar una pequeina rejiga de pez.

\section{EL PERIPLANETA AMERICANO-PERIPLA- NETA AMERICANA}

CARAC'rERES. - Hosta especic se distingue por un color pardo rojo, mas claro en la parte inferior del cuerpo, que mide unos $\left(0^{m}, 034\right.$ : el escido collar que en sus contornos se parece al del periplaneta oriental, presenta una faja clara debajo del borde postcrior.

Tambien esta corredera, cuya hembra tiene las alas del todo desarrolladas, se ha fijado en las ciudades de las costas curopeal y tambien en el interior, causando perjuicios en los invernaderos. Asi, par cjemplo, los franceses se quejan sobre este jorticular; y en la propiedad de Borsig, en Monbit, los periplanetas americanos destruyeron las raices y las Mores de las orquideas. A menudó llegan individuos muertos con los fardos de tabaco remitidos á Europa.

\section{LA BLABERA GIGANTESCA-BLABERA GIGANTEA}

CARACTERES. - Ta blabera gigantesca, llamada tambien en las Indias Orientales tamtur, porque en sus expediciones nocturnas emite un sonido semejante al que producen los dedos al estirarlos, tienc el escudo rollar trasversalmente eliptico, roteado de un fino reborde; carece de espinas en los muslos y de lóbulos prehensiles entre las garras, pero tienc una marcacta planta de los piés. Es un inscecto de $0^{\infty}, 05^{2}$ de largo, prolongado y mu plano, de color pardo sucio, con una ligera aja en el centro de los elitros y una mancha negra, casi cuadrada, en el escudo collar.

Numerosas especies exóticas son congenéricas de la bla: bera gigantesca por faltarles los lóbulos prehensiles y por tener ambos sexos alas. Hay además otras especies en que las hembras solas, ó tambien los machos, carecen mas ó menos de alas destrrolladas. En todos estos casos es dificil distinguir la larvi del insecto perfecto, nunque todos los naturalis. tas han hrllado algunos camctéres distintivos.

DISTRIBUCION GEOGRÁFICA.-En la América del sur la blabin gigantesca visita con frecuencia las casas.

I.a generalidad de las correderas (blatlina) es propia, asi como los rímites, de las regiones cálidas. Lo mismo que estos, viven ocultamente, y se les parecen además si no por su exterior. á lo menos por la estructura interna. En las formas descrias, todos los blatinos ofrecen gran semejamza; los caractéres generales de todos estos insectos consisten en la posicion lit la cabeza, que no siempre esta cubierta del todo por el escido collar; en la delgadez de las patas, anchas y feas, y en las que todos los piés, sin excepcion, tienen cinco artejos; en el cuerpo aplanado y las largas antenas cerdosas, que, sin embargo, no llegan siempre á la longitud del cuerpo; y por último, en las espinas articuladas en la extre. midad del abdómen. Los órganos de la boca estan en todos muy bien desarrollados; las maxilas estan provistas de cuatro dientes o de seis; una maxila exterior prolongada, en forma de pico, de la mandibula inferior, unos palpos de cinco aricjos, propios tambien de las familias siguientes; un labio inferior dividido en cuatro partes, siendo las dos exteriores de doble tamaño que las anteriores; y palpos labiales de tres artejos, caracterizan á los blatinos como ortópteros de prime. ra categoria.

\section{LOS MANTÓDEOS - MAN- TODEA}

En esta familia, propia principalmente de las regiones cálidas, sc rcuncn algunos géneros de insectos que a continuacion describiremos.

\section{LOS MANTIS-MANTIS}

CARACTERES. - La cabeza, triangular, csta dispuesta del mismo modo que en los blatinos, es decir, con la coro. nilla dirigicia mas hácia adelante y la boca mas hácia atrís; llevan tres ocelos y por delante de los mismos las antenas verdosas. El protórax, que afecta la forma de baston, puede ser de ver y media á tres veces mas lango que los otros dos segmentos del tórax juntos, redondeado en la parte posterior, ondulado en los bordes laterales y mas ancho sobre el punto en que se insertan las patas anteriores; los lados de estas son muy largos y trilaterales; los tarsos encajan como la hoja de un cuchillo en el mango, en una seric de espinas que hay en el muslo, rematando en una espina falciforme, que constituye un peligroso órgano prehensil. El abdómen prolongado en ambos sexos, y siempre mas grueso y pesado en la hembra, cubre en esta, bajo una profunda escotadura de la penúltima escama abdominal, un corto tubo en forma de gancho, que sirve para la puesta; mientras que el macho tiene en la extremidad dos estilos que una vez secos se rompen fácilmente y faltan por lo tanto i menudo en los indiviouos de las colecciones. Las alas y los clitros, muy diferentes por su forma, y los últimos tambien por su estructurn, solo son análogos en cuanto a los nervios, de los cuales los mas fuertes son longitudinales, mientras que los mas delgados son trasversales, representando en su conjunto umas manchas de forma cuadrangular á veces extranias. Los dos pares de alas son, en algunos individuos, mas cortos que el abdómen, pero por lo regular, cuando menos en los machos, alcanzan mayor longitud, dando buenos caractéres distintivos para la clasiticacion de las diversas especies.

\section{EL MANTIS RELIGIOSO-MANTIS RE- LIGIOSA}

CARACTERES. - El mantis religioso es uma de las es pecies que, á causa de su naturaleza algo coriacen, tiene las alas anteriores un poco sucias y una membraua córnea del mismo color detris de la vena longitudinal principal; la parte del borde no es mas gruesa que la contigua á dicha vena, y tanto esta como aquella tienen un solo color; la mayor parte del ala, situada por dctrás de la vena principal, clarea po. co a poco mas hácia el borde posterior, donde es vidriosa. En esta especie el color del cucrpo está sujeto á muchas variaciones: puede sur amarillo pardo, ó del todo verde, y en 
los bordes de las alas, del protóms, y en las patas, de un amarillo pardusco.

Los dos pares posteriores de patas son en todas las especies de mantis largos y delgados, con cincoartejos en los piés.

DISTRIBUCION GEOGRAFICA. - Fil mantis religio so se encuentra en casi toda la Europa meridional y en Africa; se le ha visto en Friburgo, en el Breisgau, y en los alrededores de lirancfort sobre el Mcin, cuyos puntos se consideran, además de la Momvia, como el limite mas septentrional de su área de dispersion.

USOS, COSTUMBRES Y REGIMEN.-El mantis religioso es por sir criterior uno de los insectos mas particula. res que se encuentran en Europa; y por su nombre ha dado origen id las mas extrainas suposiciones. Fnere los griegos la palabra merntis en su acepcion masculina (o mantis) significa un profeta, pero tambien la emplearon como femenina para designar este insecto ó una especie muy congenérica. Fi natumlista inglés Moufet, citado ỹa varias veces, que vivió it fines del siglo swi, quiso buscar la razon de ser de este nombre y halló tres. Essos insectos anuncian la primavera, porque son los primeros que se presentan: esto se funda en lo dichn por el poeta Anacreonte, pero tanto este como el naturalista incurren en un error, segun veremos despues. Dicese tam. bien que esos mantis presagian la escaser, segun la doctrina de Celio y de los Escolísticos: mas aqui se ohserva atra inexactitud, probablemente debida a la circunstancia de laaber con esos insectos langostas, cuya presencia puede causar fícilmente una escase\% de alimentos. Mas razonable parece la tercera explicacion en la que tambien se funda el nombre aleman de aduradora de Dios, el de los labradores

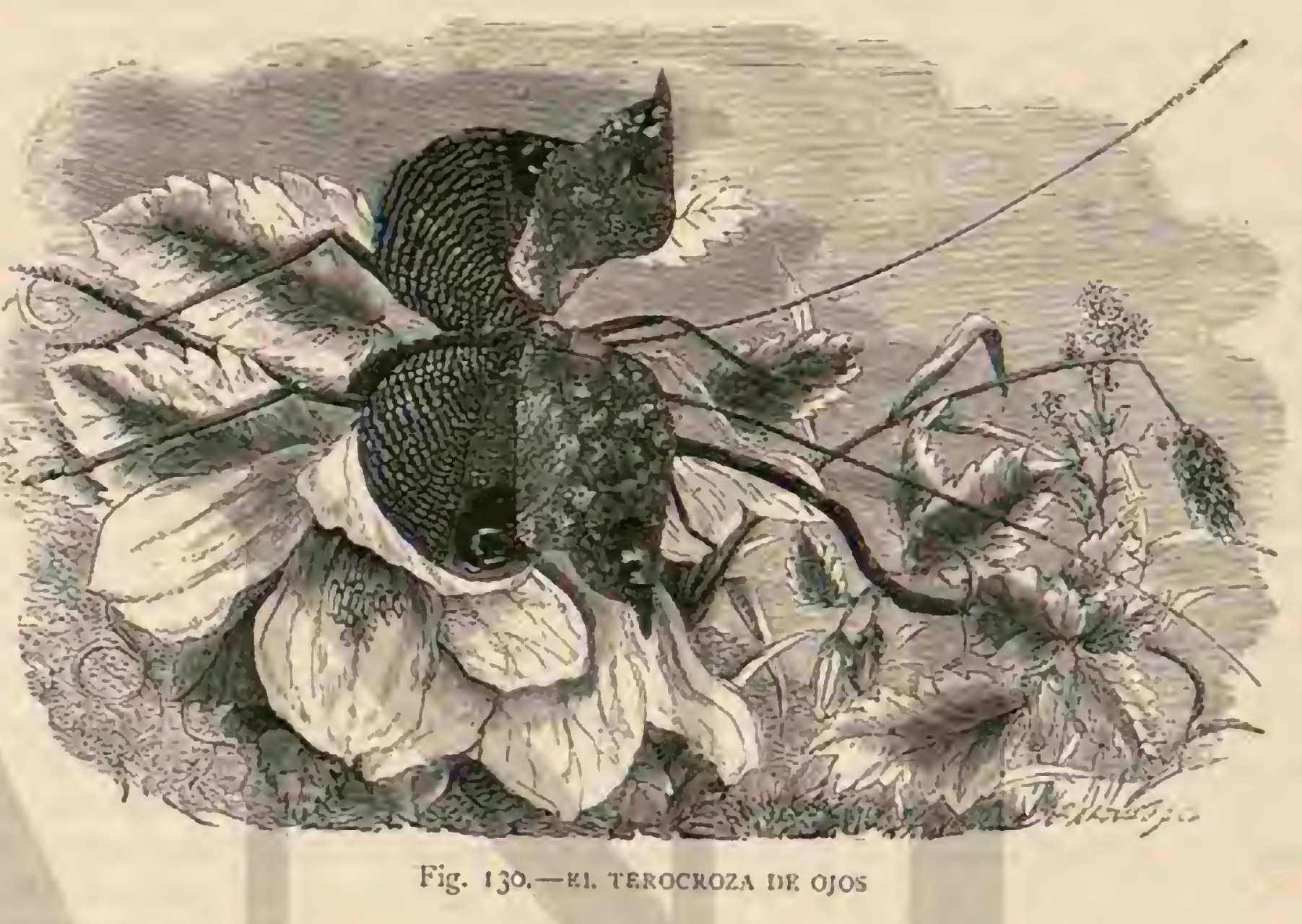

provenzales pregadiou (priedieu), d de los españoles alaba at Dios, y otros, porque el animal eleva las patas anteriores del mismo modo que el suplicante las manos, ýa la manera de Tos profutas, que en tal posicion suclen ofrecer á Dios sus oraciones. En concepto del citado naturalista, el mantis recuerda no solo por eal posicion el profeta, sino tambien por todas sus posturás; no juega como otros, ni salta, ni tampoco es retoron, sino que demuestra en su lenta marcha moderacion y cierta dignidad. Se le considera profeta (divino), porque si un niño le pregunta qué camino debe seguir, indicaselo levantando la una o la otra pata anterior, con la particularidad de que muy raras veces $\delta$ nunca engana.

Opiniones como esta túltima solo podrian formarse en una época y entre pueblos que todo lo creian por las apariencins exteriores, y en que se consideraba devotos y hunrados á los que parecian seflo. En nuestro mantis, aquella posicion que en un hombre puede significar derocion, solo encubre la astucia y el engaño. De color verde, como las lrojas de los arbustos en que vive, permanece horas enteras inmóvil enta mismn posician con el largo cuello érguido y: las patas prehensiles tendiclas, demostrando con esto su paciencia y astucia. Cuando una mosca, un colébtero ú otro insecto que cree poder dominar se acerca a bl, siguele con la mirada moviendo la cabeza, se desliza tambien con la mayor precaucion, como los gatos, en direccioná su victima, y sabe aprovechar el momento en que pueda hacer uso de sus patas. La desgraciada victima queda cogida entre las espinas de una de Toso V1 las patas, otra vicne en auxilio de la primera, y la fuga es im. posible. Recogiendo los brazos, el rapaz. lleva la presa á la boca, cómela con toda comodidad, y hecho esto, la adoradora de Dios limapia sus patas con la boca, las antenas cerdosas con aquellas, y suelve a tomar sus posicion anterior para esperar una nueva presa.

En los tíltimos dias de agosio de 1873 encontré esta especie bastante á menudo en el montu Calvario cerca de Bozen; vingaba particularmentc entre ln malcza y los arbustos. Cuando cogia algun individuo se agarraba de tal modo con sus patas a mis dedos que necesitaba alguna precaucion para desprenderle sin herir su cuerpo blando y delicado por demás; se adheria con tenacidad á la ropa, y agarribase siem. pre i otra parte de la mano cuando la habia obligado a soltarse de la que ocupalas; no rausaba sin embargo impresion dolorosin.

Varios observadores han reconocido los mantodcos. Roesel hizo venir algunos mantis religiosos de francfort para observar el apareamiento; a este cfecto encerró algumas parejas en una jaula llens de artemisia y utras plantas que cligen para su morada; pero pronto se ví́ obligado á separarlas, pues desde el primer momento, rigidos é inmóviles, hiciéronse frente como dos gallos, levantaron sus alas para golpearse con la rapider del myo y con toda la furia posible con las patas prehensiles, y se mordieron sin piednd. Kollar no fué mas feliz con el mismo experimento: encontró los insectos posados uno junto á o:ro sejun lo hace tambien el panorpa 
comun: despues la hembm devorial macho, !mas tarde a otro que se puso tambien en su jaula.

Hurtson, segun nos refiere Burmeister, estaba sentado una noche a eso de las nueve delante de la puerta de su casa de canupo, cerca de Buenos Aires, cuando de repente los agudos gritos de una arecilla (Serpophoga suberisfosto) llamaron su atencion, pues partian de un airbol vecino. $\mathrm{Al}$ acercarse observó con gran asombro que el ave parecia estar adherida à una mun, moviendo con violencia las alas. l'arn poder examinar el fenómeno, Hudson habia buscado una escalera y entonces vió cómo un mantodeo se agarraba con sus ctintro jatas pasteriores à la rama, abrazando con las anteriores à la avecilla de tal modo que las cabczas cie ambos estaban oprimidas la una contra la oira. I f picl de la del ave estaba ya desgarrada y el cránco roido. Burmeister nismo sc convencio de este hecho cuando 212 manana siguiente Hudson le presentó los dos animales. El citado naturalista describió despues esta especie en ambós scxos (el individuo que habia mueró al ave era una hembra); la especic hasta entonces desconocida tiene $0^{\circ}, 0,8$ de largo, $y$ es de color verde claro; y Burmeister le dió el nombre de mantis argentino (mantis argentima). El macho tiene las alas claras como el cristal, sobresalen poco del abdómen, y sus nervios son verdes, excepto la vena principal anterior, de un tinte amarillento. Ia hembra carece de alas y ticne en lugar de las anteriores solo unos apéndices enrejados, coriáceos, de $0^{\text {it }}, 026$ de largo. Consta por lo tanto por esta noticia el hecho de que los man. todeos son bastante atrevidos para sorprender y matar a las aves dormidas, exponiéndose al peligro de que estas les maten de un par de picotazos.

I a fecundidad de los mantodeos es bastante considerable y. la manera que tienc la hembra de pegar sus huevos muy prolongados en paquetes grandes ó pequeños, en un tallo ó en una piedra, no carece de interés. J os huevos están colocados con bastante regularidad en series uno al lado de otro, reuniéndose despues por una secrecion glutinosa que se endurece, ya en forma de escamas ó de hojas. Jesjues que la hembra ha colocado seis if ochio hucros en una línea trasversal, uno junto da otro, prosiguicndo en este trabajo hasta que depo. sita de diez y ocho a veinticinco de estas-series trasversales, fórmase un paquete de huevos en que tocios se hallan en posicion rertical, reunidos por la sustabcia glutinosa que forma como unos compartimientos. El lado exterior escamoso del paquete presenta ligeros surcos longitudimales que marcan las cabczas de los huevos. Tales paquetes forman en las superficic llana de una piedra una figura aplanada, pero en los tallos redondos de una planta una sujerficie abovedada y no se distinguen esencialmente en las diferentes especies por su color, estructura y forma.

Que una hembra no f́brica un solo hacecillo es cosa que se pudo suponer ya por el cjemplo de otros insectos que ponen los hucros aglomerados; y Zinmermann observó el hecho en el mantis de la Caroliua, en la América del norte. El cirado autor recibió un mantodeo el 2 de octubre, lo colocó en una gran maija y diólc alimento; al dia siguiente habia puesio los huevos, pero no murió, como se esperabn, sino que devoró todos los dias algunas doceras de inoscas, y a reces grandes langostas; algunas mnas pequenas y hasta un lagarto que era ires veces mas largo que él. No aceptaba la presa una vez abandonada, porque ya estaba muerta. Pronto se dilató su abdómen y el 24 de octubrejpuso por segunda ver, pero un hacecillo mucho mas pequeỉo. Despues de este trabajo, que duró algunas horas, el mantis comenzó otra vez á comer todo cuanto se le ofrecia en séres vivos. De nuevo se dilató el abdómen haciendo esperar una tercera puesta de huevos, pero los rigurosos frios de noviembre la malograron sin duda; y el mantis murió el 27 de dicho mes sin laber puesto por tercera ver. El 26 de mayo salicron los primeros huevos, y el 29 los segundos, que habian sido pucstos tres semanas despues. Zimmermann comunicó esta observacion por escrito ì Burmeister, enviandole las prucbas, que aun se conservan entre los ricos tesoros del Real Museo roologico de Halle.

Despues del invierno salen los insectos de su cuna y umudan por primera vez de piel, micntras abandonan la cáscara del huevo. Hace varios años que un amigo me trajo uma agrupacion de huevos de Espana; y cuando a fines de junio y a principios de julio nacicron algunos mantis religiosos, fue tanto mayor mi asombro cuanto que habia pensado que los huevos no podrian desarrollarsc. I.os pequeños insectos hicieron la mismo que los de Roescl: mordiéronse unos a otros, pero no quisieron coger las moscas que les ofreci, ni tampoco las cogieron cuando los puse en libertad, dejándo. los correr por las ventanas: murieron a los procos dias, des. pues de divertirme mucho, tomando las mas grotescas posiciones; su alegria y su modo de proceder revelaban à la vez timides y atrevimiento. Pagenstecher logro conservar sus cautivos hasta agosto, y pudo observar algunas mudas; la segunda se verifice quince dias despues del nacimiento $y$ la tercera dos semanas mas tarde; de modo que probablemente mudarán siete veces, aumentando en cada una los artejos de las antenas y prescntándose al mismo tiempo los rudimentos de las alas y los ojuclos. Los piés tienen desde un principio cinco artejos. Los mantodeos acaban por lo tanto su vida en el trascurso de un año.

Numerosas especies que en lo esencial presentan la misma estructura y en la cabera una apófisis dirigida hácia adelante en forma de juñal, ó provista tambien de dos puntas, y que en la extremidad de los músculos tienen una membrana inclinada hácia atrás, han sido reunidas en un género, bajo el nombre de bates. Otras en que las antenas de los machos se distinguen yor una doble serie de dientes en forma de cresta constiiuyen el sub-gúncro cmpusa, que con una especie (cmpusa pauperata), está representado tambien en la Europa incridional.

\section{LOS FASMODEOS MODEA}

PHAS-

CARACTÉRES. - Los fasmodeos, sumamente afines de los mantis por habitar las regiones cálidas y por su extrano aspecto, estaban agrupados antes con ellos en la clasificacion, pero tienen tautos caracléres distintos, que la ciencia moderna ha debido separarlos. En el desarollo del mesotórax d expensas del protórax, en la carencia de las patas prehensi. les, y casi siempre tambien de las alas y del apéndice en forma de baston en la mayor parte, ó en la figura de hoja en algunos. existen diferencias que á primera vista se reconocen. Cierto que la cabera, oral tambien en los individuos de este grupo, está dispuesta oblicuamente, pero la boca cae hícia adelante: los ocelos existen, pero no siempre, en las especies aladas; los ojos son salientes; las antenas cuentan de nueve a treinta. artejos; y por último, los órgnnos bucalcs presentan un gran desarrollo; en ellos predomina el labio inferior grande con sus roluminosos lóbulos inferiores; y los jalpos labiales ocupan casi todo el sitio de los pequeños palpos maxilares. El mesotórax es por lo regular el mas desarrollado, pero se rige por la ley de formacion de las otras partes del cuerpo, siendo de consiguiente redondo ó plano, segun la figura del insecto; las patas y las alas se hallan, en las especies que tienen estas últimns, en la extremidad posterior del incsotórax; solo 
un reducido número de fasmodeos (phyllism) presenta el metatórax tan grande como el mesotórax; en las especies no aladas es mas corto y de la nisma forma que en la anterior; y en las aladas mas largo. El abdómen suele ser cilindrico, lo mismo que el tóras, ó bien de forma aplanada ó tan del. gado como una hoja, distinguiéndose en el dorso nueve segmentos, y en el vientre solo siete ú ocho; el seitimo de la lembra es grande 5 af́cta la forma de pala; la octava placa abdominal del macho llega á ser bastante larga para cubrir el último segmento y hasta sobresalir de él. Otra diferencia sexual, consiste en el hecho de que el macho, que siempre es mas peçueño, tiene la abertura de los órganos genitales en la penúltima placa abdominal; mientras que la hembra la lleva en la anterior. Como ya hemos dicho, muchas especies carecen de alas en todos los grados de su desarrollo, y en este caso se presentan las mismus dificultader que en las correckeras cuando se trata de distinguir las larras de los individuos sexuales no alados; estas dificultades son de mas consideracion aun, porque muchas larvas tienen espinas ó a jéndices membranosos en varios sitios del cuerpo ó en las partes que mas tarde vuelven á jresentarse, desapareciendo asi las amalogias que antes cxisticron. I.as alas anteriores suelen ser cortas, cubriendo solo la base de las posteriores; estas en cambio llegan bastante a menudo casi hasta la extremidnd del abclómen; tienen un borde muy estrecho, apergaminado y colomdo, pero la parte de la cintura muy ancha y membranosa; la disposicion de la red nerviosa es en toda el ala casi cuadrada. Gran variedad se observa respecto a las patas: pueden ser largas y delgadas, ó anchas en diferentes sitios, ó bien estar provistas de apéndices afectando la figura de hojas. I.os cinco artejos del pié, el primero de los cuales es el mas largo, y un gran lóbulo redondo en medio de las garras, son caractéres comunes a todas las especies. Ias delgadas patas anteriores tienen casi siempre en la base de los muslos una profunda curvatura para la cabeza, a fin de que al estirarse puedan oprimir aquellas una contra otra, pósicion que gusta mucho à estos insectos para descansar; gracins a csto y i su color prardusco se les puede confundir con una rama seca. En esta particularidad debe verse uno de los medios defensivos que la naturaleza concede à menudo, con preferen. cia à los inseccos mas débiles, para preservarlos en su dominio de las asechanzas de sus encmigos.

USOS, COSTUMBRES Y REGIMEN. - LOS fasmodeos habitan en el ranaje inferior de los arbustos cuyas hojas comen de noche, mientras que jasan el dia descansando perezosamente. I.as hembras dejan caer uno a uno los huevos, y de ellos salen al cabo de setenta á cien dias los hijuelos, que crectn rápidamente. De las numerosas especies solo dos pertenecen à la Luropa meridional, mientras que casi todas las demás habitan las zonas cólidas. R. Gray describe en un trabajo sobre esta familia $\left(1 S_{\mathbf{5} 3}\right)$ ciento veinte especies: $y$ Westwood aumenta este número considerablemente en su catálogo del Museo Britanico ( 1859 ). La tercera parte pertenece al hemisferio occidental, micntras que el resto es propio del oriental. Su tamano y desarrollo van en aumento conforme nos acercanios al Ecuador. Alli se ven formas de baston mucho mas largas que las de cualquice otro insecto: asi. por ejemplo, la hembra de la especic Cyphocrania acanthopus, propia de Java, tienc 0 , 0065 de diometro por una longiud dc $U^{\prime \prime}, 215 ; y$ la hembra de la especic Bactria aurita (lig. 126) que carece de alas y es propia del interior del Brasil, tiene $0^{\prime \prime}, 00325$ de ancho por $11^{\circ}, 2,40$, hasta $0^{\circ}, 314$ de longitud, cuando se la mide con las patas tendidas. Fin la cabera llevan un par de apendices grandes y anchos en forma de oreja, $y$ en ellomo, en medio de las patas posteriores, una gran espina vertical.
El fasmodeo de Rossi (bucillues Russii), una de las pocas especies europeas, vive en Italia y en el sur de Francia. El cuerpo, muy seco, carece de alas, de espinas y de apéndice, y la cabeza de ocelos. Estos caractéres, las cortas antenits en forma de cordon, y la extremidad abdominal, puntiaguda en la hembra y abultada en el macho, son los distintivos del subgenero. El cuerjo liso y brillante, de color verde parcius. $\mathrm{co}$, con la çuilla central poco prominente en los dos segmentos posteriores del tórax; antenas de :9 artejos, tres ó cuatro dientes en el lado inferior de las patas medias y scis en el mismo sitio de las posteriores, son los caractéres de la especic. Eil macho llega à $0^{\prime \prime}, 0.88$ y la hembra in $0^{\circ}, 065$ de largo.

El sub-género hactrin, muy rico en especies, difiere del anterior por ser las antenas cerdosas, ó en forma de hilo guve por lo menos tienen la longitud del tómx; de las esperies no aladas se distingue por iener el primer artejo del pic mas largo que los tres siguientes juntos. I.os fasmas (phasma) son jor lo regular especics abigurradas propias de las is. las de la Sonda y de la América del sur, reconociéndose por las antenas cerdosas muy largas y por tener las alas de igual longitud.

Mientras que todos los fnsmodeos hasta aloril descritos pueden considerarse como eramas ambulantes, los otros se deben designar como hojas ambulantes á causa de sus formus aplanadas y anchas y de la estructura de las patas, que es en un todo análoga, segun lo demuestra la especic fhyllium siccifolium (fig. 129) propia de las Indias orientales: el color verde del cuerpo de esta especic se vuelve amarillo en los individuns muertos; este insecto dificre además de sus congénères por los cinco dientes de la parte anterior, por los muslos anteriores y por la falta de lins alas posteriores en la hembra. En un scgundo sub-gencro (prisopus) las antemas son filiformes, y' mas largas que la mitad del tórax.

\section{LOS ACRIDIODEOS- ACRIDIODEA}

Sigue ahora el numeroso ejército de los ortópleros salta. dores, que en lenguaje popular se designan con nombres muy distintos, como langosta, grillos, saltamontes, caballitos, nulos del diablo, etc. Todos ellos aliméntanse con preferencia de plantas, y muchos pueden llegar á ser en alio grado peligrosos para el hombre á causa de su enorme número, aunque no desprecian, en su romcidad, ni sun a sus semejanics IIi a otros insectos. Son cantores incansables y que viven en medio del verano y del otoño, en los bosques, campos y praderas, produciendo su carncteristica música, cada cual a su modo. De aqui viene su nombre aleman de Shrecke, que en su origen significa gritar, zumbar y rugir. Como es de suponcr, se les conoce desde las érocas mas remotas, aurquic se les haya confundido mucho unos con otros, segun resulta de los datos de Aristóteles, quien dice que producen su canto por el roce de las patas, y que depositan los huevos por meciio de un tubo debajo de ticrsa, donde se desarrullan los hijuelos. a Cuando la langosta sale del suelo es perquena y. hegra, pero pronto se rompe la cascara, y el insecto crece. s" Los entomólogos modernos distribuyen codas las langostas en tres familists, a saber: acridiodeos, locustinos y grillodeos: y' en este b́rden cxaminaremos varias especies algo mas detalladamente.

'lodos los oriópteros saltadore's cuyas antemas, marcada. mente articuladas, no exceden en longitud de la mitad del prolongado cuerpo, cuyos piés iguales se componen de tres artejos y cuyas fatas posteriores sirven para saltar, por tencr el muslo grutso y el tarso largo, pericuecen a los accidiodons 
o langostas propiamente dichas. Son los mejores salıaclores de la familia y franquean, como la pulga, uma distancia 200 veces nayor que su propia longitud. La cabear está colocada verticalmente: pero la frente no forma siempre una linea recta, porque a veces (como en los truxalis) se prolonga con la coronilla en una apónisis córnea. Los ojuelos faltan solo en pocas especies; cerca de los dos superiores, sobre una base en forma de copa y un segundo artejo en figura de puchero, insértanse las antenas, que tienen de 20 î 2 at artejos y son de aspecto diferente. Cuando el labio superior, es. cotado en el centro, se oprime contra el inferior, cuyos lóbulos interiores son muy pequeños y están oculios, se ve muy poco el resto de los órganos de la masticacion en extremo desarrollados; lo mismo sucede con las maxilas, de punta negra, $y$ con la interior del labio inferior, que remata en dos dientes negros y curn maxila exterior se puede adaptar en forma de casco sobre aquella por lo cual tumbien se le ha llamado caseo. El tronco, muy comprimido interalmente, es mas ancho que altn.

De los tres segmentos del tórax, el protórax es el mas desarrollado y cambia de forma en los diferentes sub-géncros, aunque en casi todos los casos se observa la tendencia a inclinarse hácia atrís sobre la base de las alas, prolongándose en la superficie superior en los rebordes longitudinales cuyo centro és el mas desarrollado. Ta parte superior es mucho mas perfecta que la inferior, en el mesntórax y metatórax, que son mas cortos; la primiera es mas ancha que la segunda. El abuónen, cónico, y mas ó menos aplanado, como el pecho, se estrecha poco à poco hảcia arriba, contando en ambos sexos nueve seymentos, el primero de los cuales se reune intimamente con do tórax en su parte inferior. El abdómen es el distintivo mas marcado de los sexos. Alli clonde es mas delgado y puntiagudo se forma una especie de vilvula grande, triangular ó puntenda, cuya extremidad se cleva hicia arrika y contiene los órganos genitales; junto á ella se ven dos especies cortas, de un solo artejo, yertre ellas, en la base, otra vilvula mas pequeña y triangulas cierra el ano por arriba. El tubo que a la hembra sirve para la puesta no sobresale nunca ui se compone de vályulas laterales, sino de àn estilos superiores y dos inferiores que rematan en un gancho obtuso, de modo que la vagina al cerrarse aparece armada de cuatro ganchos dirigidos hácia afuera. Ias cuatro alas tienen por lo regular la misma longitud, pero diferente anchura, porque las anteriores son un poco mas anchas que la parte del borde de las posteriores; ambas están cruzadas por las venas en forma de red; las anteriores, en todo ó en parte coriaiceas, deben servir de cubiertas; lis posteriores se replegan longitudinalmente cubriéndose con los bordes posteriores. In pocos subugénerus las alas anteriores se atrofian por excépcion, $y$ en algunos faltan del tolo, ya solo en la hembra ú ambion en el nincho.

De los tres artejos del pić, el primero, mas largo, tiene en la planta tres lóbulos membranosos; el siguiente uno en foruna de cojin, y el tercero atro redondo en medio de las dos caras de los muslos posteriores; los machos, pero exclusivamente ellos, se rozan con las alas anteriores, pro(úciendo asi los sonidos agudos, poco duraderos, la cura interior de aquellas tiene una especie de liston circular cuya parte inferior es la mas saliente: con el microscojio se verà en la parte de su base, que puede ponerse en contacto con la cubierta de las alas, una seric de dientecitos obtusos en forma de lanceta, dispuestos en pequeños hoyos. En las alas anteriores los nervios longitudinales, sobre todo uno, sobresalen en forma de revolver; por el roce muy rípido de los musios con los elitros, estos, como membranas delgadas que son, se ponen en movimiento ondulado, $y$ entonces resuenan exactamente lo mismo que una cuercin de violin que se toca ra con el arco. Cuando estos insectos producen sus sonidos tienen las alas un poco flojas, á lo cual se debe que aquellos senn mas claros: ó mas ó menos agudos segum el tamaño y el grueso de los elitros, por lo cual los acridiodeos grandes producen los tonos mas bajos que los pequeños, influyendo en ello esencialmente el mayor 6 menor número de nervios de las alas. Ias especies diferentes cantan cada cual á su modo, de manera que un oido príctico puede reconocer algunos insectos, sobre todo los del subgénero gomphocirus, por el tono que producen. l.os mejores músicos son por lo tanto aque. Hos que tienen los órganos mas desarrollados, como por ejemplo los de la especie gompthocerus srizssus. Iin tas hem. bras, los dientecitos de los muslos se hallan por lo regular demasiado hácia abajo, de modo que no pueden producir el sonido.

Otra particularidad muy curiosa es el hoya rodeado de un anillo córneo, y cubierto en la delicada membrana que se ve en ambos lados del abdómen de los acridiodeos, muy ccrca de la parte posterior del tórax. En medio de dos apuólisis córneas que nacen de la cara interior de la membrana hállase una pequeña vejiga llena de liquido, la cual se comunica con un nersio que sale del tercer nudo del tónax y que forma aqui otro, remiatando en finas fibras nerviosas. Segun las investigaciones de J. Muller, continuadas por Siebold, este aparato solo puede ser el oido de esos insectos.

I a reproduccion de todos los acridiodeos, al menos de los de Europa, es análoga, y puede describirse en pocos pármfos. En otono la hembra fecundada deposita los huevos, de los que algutos estan reunidos por una materia peyajosa que se endurece ya en tallos de yerba ó bien á poca profundidad debajo del suelo, medio preferido sobre todo por las especies grandes. La madre mucre; sus huevos invernan, y solo en las regiones meridionales las larvas tienen aun tiempo de salir, lo que por lo regular no hacen hasta la jprimavera próxima. Por sus colores poco determinados, por la falta de alas, por las antenas un poco mas pesadas y cortas y por el menor tamano se distinguen del insecto desarrollacio, cuyo estado alcanzan despues de varias mudas, à fines de julio ó en agos. to. En este tiempo comienzan a cantar anunciando sus bodas. Solo los acridiodeos aumentan à reces en número tan enorme que se presentan en bandadas, poniendo à contribucion regiones mas ó menos extensas.

I'arece que el Africa estaba expuesta en las épocas mas remotas à las devastaciones de cstos animales, de los que la Biblia, Plinio y Pausanias hacen ja mencion. Cuando Adanson, en 1750, llegó al Senegal, presentóse antes de desembarcar, á las $S$ cle la mañana, una espesa nube que oscurecia el cielo. Era una bandada de langostas que volaban à la altura de 120 á 180 jiés del suelo, y que al bajar cubrió una exten. sion de algunas leguas. Aqui descansaron, comieron y prosi. guieron despues su camino Esta nube fué traida por un fuerte levante y vagó toda la mañana por aquella region. Despues de haber comido la yerba, las frutas y las hojas de los arboles, tampoco perdonaron las cañas que formaban el teclio de las chozas.

A fines de marzo de 1724 presentaronse en Berberin las primerns langostas, despues de haber reinado muchios dias el viento del sur, y á mediados de abril su número habia alumientado de tal manera, que formaba nubes que oscurecian el sol. Cuatro semanas despues se extendieron por las Ilanuras de Metidja y de los alredecoores, para depositar sus huevos. Al mes siguiente se vió la cria, que cubria centenares de metros cuadrados: despues, prosiguiendo su camino en linea recta, treparon à los artholes, paredes y casas, destruicndo todas las hojas que encontraban. Parn impedir su marcla, 
los indigenas abrieron fosos, llenándolos de agua, $y$ forma. ron además una linca de montones de madera y otros combustibles, encendiéndolos despues; pero todo fué inútil; los fosos se llenaron de cadáveres y los fuegos se apagaron. Al calso de algunos dias siguieron nuevas bandadas de acridiodeos recien macidos que roian las ramas de los árboles cuyas hojas y frutos habian devorado ya sus antecesores. Asi vivieron los insectos poco mas de un mes hasta que estuvieron del todo desarrollados, haciéndose mas voraces y actiros aun, lasta que for fin se dispersaron para poner sus hueros.

Un relato de los últimos tiempos se refiere à un acridiodeo del Africa meridional (sryllus drirastator de Lichtenstein) quu parece mas interesante porque nos da à conocer el género de vida de esta plaga, que siempre vuelve en ciertas épocas. liritsch dice: «ns huevos de estas langostas se depositan reunidos ell número de 30 i 60 bajo una cubierta parda, en pequeños agujeros redondos en el suelo, practicadios por la hembra en la pendiente de una coliria ó en una ligera elevacion del suelo, probablemente para proteger los huevos de la infiuencia peligrosa de la lluvia. Los agujeros se cicran por ol viento y la tierra oprime los mazos longitudinales de huevos que asi pueden estar varios años sin perdér la facultad de desarrollarse. Sin embargo, tambien pueden producir lus jeq̨ueños ya en la próxima estacion lluviosa, es decir al cabo de algunos meses; de modo que la region que apenas se ha recobrado de la devastacion de estos insectos voraces, que. da infestada de nuevo por ellos. In humedad parece tener gran importancia en su desarrollo, pues en una serie de años secos no se oye nada de los grillos devastadores. La gente

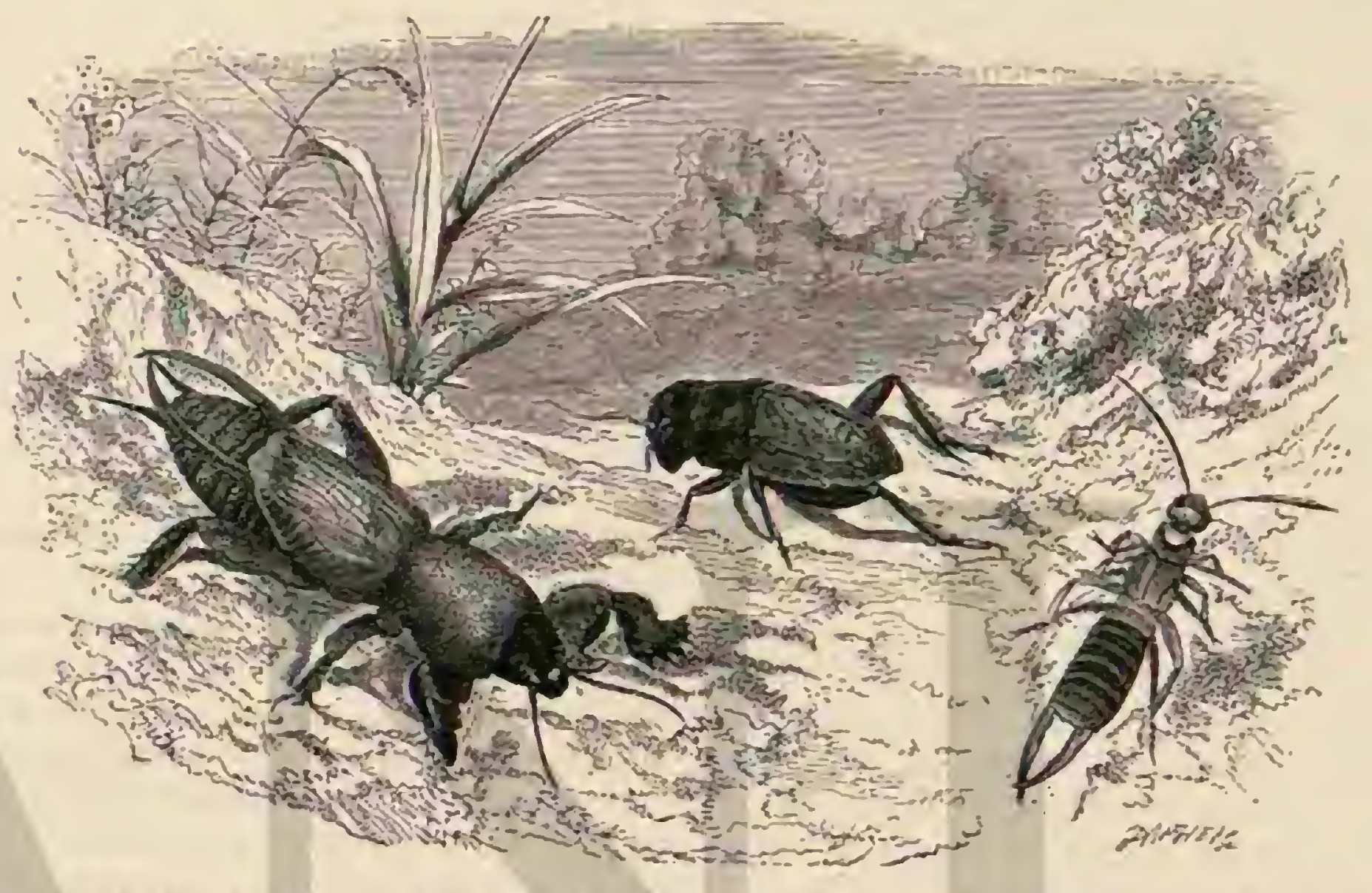

frig. I3T. TiL LISILLO KEAR.

Fig. 132.-EL GRILlo CAMPESTKE

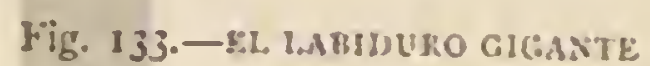

yuc se ocupa en la cria de ovejas y que quizas ha perdido por la falta de agua la mayor parte de sus rebaños, saluda entonces la presencia de las langostas con cierta satisfaccion, como señal de tiempos mejores, que pondrín término à la scequia periódica: sacrifica a los alados saqueadores su pequeno jardin penosamente cuidado, y espera que asi prosperarin los animales y brotarin de nuevo los manantiales.

Win 1863 terminó un periodo de varios años de sequia en cl sur de Africa, durante el rmal no se habian presentado en ninguna parte langostas. Desde 1862 a 1863 la mas icrrible carencia de agun amenazó destruir todo gérmen de vida, y pasabra el tiempo sin que se viera nimguna langosta en el suclo duro y seco. Sin embargo, cuando á fines del ano 1863 comenzó à llover copiosamente, las langostas se presentaron en legiones innumerables, cual nunca se habian visto, cu. briendo en el estado de larvas inmensas extensiones. Estas larvas son en su juventud de color pardo rojo con mntices négros, y los campesinos holandeses del Cabo las llaman poni lentjes, es decir levilas rojas, ó hefgrnger, peatones, porque ya cn su jurentud revelan distintamente la inclina. cion a viajar. El primer calificativo es al mismo tiempo una alusion a los soldados ingleses con sus uniformes rojos, en extremo odiados por estos holandeses del Africa, y la comparacion es tanto mas exacta cuanto que iambien las langostas jórenes marchan en columnas cerradas, formando com[xañas. En los años favorables para la especic se ven cjércitos enteros en marcha, que casi siempre siguen ciena direccion, la cual solo cambian furzosamenic. Cuando los insectos llegan a las aguas estancadas, suelen franquearlas; las primeras columnas perecen, pero los demís prosiguen su marcha pasando sobre los cadáveres de sus companeros; siempre evitan el agua corriente.

Por la noche hacen alto los viajeros, se posan sobre los arbustos de los contormos y destruyen todo lo ąue hay de verdura: cuando el campesino ve que las langostas se encaminan hácia su jardin intenta desviarlas de su curso, para lo cual se lanza á caballo por detrás de cllas, agitando i dere. cha é izquierda un trapo grande. Cada ve\% que pasa asi por el ejército de los insectos, aléjase una parte de los enemigos, y esto puede repetirsc tantas veces que al fin todo el ejérci. to se desvia. Si el hombre ataca por delante al cjército los insectos saltan de lado, pero los posteriores empujan á los anteriores, de modo que la corriente se cierra detrás del jinete.

MIudando rurias veces de piel los grillos demstadores crecen ripidamente, hasta que por fin, en la última muda, adquéteren su color gris rojizo, asi como las alas, que les sirven de mucho para satisfacer su inclinacion a viajar. Lil canpuesino holandés les llama springiaaner cuando alcan\%an su mayor desarrollo, y lémelos mucho por su hacienda, pues sabe que su aparicion amenaza destruir todo el adorno de los campos. Al ver las oscuras nubes de langostas apnatecer en el horironte, apela al ústimo desesperndo medio defensivo: enciende en un jardin el mayor número de hogueras 
posible para reclazar con el humo á los insectos, pero tam. poco este medio suele producir buen resultado. Cunndo el viento es fresco viajan i mucha altura pueden franquear grandes distancias, pues entonces se dejan llevar del todo por su corriente, mientras que si esta es algo fuerte, avanzan mas ó menos en direccion contraria. Si hny calma, su vuelo se reduce à saltar á poca altura del suclo, parándose siempre parte de la vanguardia en tierra para formar despues la retaguardia. Ia continua subida y bajada, el chirrido de los millares de alas y el rumor que producen las maxilas en el suelo causan un estrépito particular, dificil de describir; y que puede compararse con el que produce una fuerte granicida al tocar en tierra. Tambien las consecuencias de su aparicion se parecen álos terribles efectos de ese fenómeno de la naturale\%as

Los mismos insectos compensan la pérdida cnorme que ocasionan en sustancias vegetales, confrmando aquella sentencia de la hiblia que dice: El alimento salio del devora$d(r$, , pues hombres $y$ animales se aprorcchan de las langostas para alimentarse. Los indigenas las tuestan un poco al fuego y cómenlas en número increible, dejando solo las jatas posteriones y las alas, 6 nada. El sabor es tepugnante, $y$ la sustancia alimenticia muy escasa. En los caballos sin embargo, producen el mejor efecto, pues engordar y las comen tambien con gusto. Es singular que los campesinos holandeses crean genemlmente que los caballos se énvenenan cunndo comen las hembras que aun no han depositado sus huevos. Diodoro Siculo que vivió en tiempo de Julio César, conocia ya este aprovechamiento de las langostas, pues dice lo siguiente: Los comedores de langostas son una tribu de africinos que habitan en los limites del desierto, hombres pe. queños, facios y muy negros. In la primavera los fuertes vientos del oeste y del sudoeste les llevan una infinidad de langostas del desierto. Estos animales son muy grandes y sus alas tienen un color sucio. Los indigenas obtienen casi para todo el año un alimento abundante y se coyen los insectos del modo siguiente: toda la superficie de un gran valle se cubre de leña, muy abundante en el pais; tan luegó como se acercan las bandadas de langustas se enciende el combustible, producicndo tal humo, que cuantos insectos pasan por el sitio caen al suelo; y de este modo se continua varios dias hasta que grandes montones de langostas cubren la tierm Entonces se ponen en sal, y asi se conservan, evitando la descomposicion. Los citados indigenas no tienen ni ganado ni mas alimento que las langosias.

Tampoco la América, sobre todo la meridional, está cxenta de esta plaga. Por ia noche, dice Temple en su priaje al Perú, ofrecióse d nuestra vista, a cierta distancia, ó en la llanura, un espectáculo extrnordinario: en vez del color verde de las hojas de árboles y de la yerba. solo observamos una masa de color igual, pardo rojo, de modo que alguno de nosotros creyó serian matorrales iluminados por el sol; pero eran langostas. Estos insectos cubrian literalmente el suclo, los àrboles y arbustos, hasta donde la vista podia al. canzar; el ramajc de los arboles se encontmba bajo una mole de langostas, como agobiado por el peso de fuerte nevada ó de un exceso de frutas. Pasamos por en medio del espacio que ocupabar los insectos y se necesitó una hora larga antes de llegar á terreno despejado, aunque viajśbamos con la velocidad ordinaria.

Un inglés poseia en Conchos, en la América del sur, grandes plantaciones de tabaco: y como al llegar habia oido decir que algunas veces se presentaban grances bandadas destructoras de langostas, reunió todas las plantas de tabaco en número de $\$ 0,000$ cerca de su casa, a hin de poder protegerlas mejor. Todas crecian y pruspemban perfectamente, alcanzando ya la altura de 30 centímetros, cuando cierto medio dia oyóse el grito de: $x_{i}$ Ias langostas vienen! El plan. tador salió presuroso de la casa y las vió reunidas en una espesa nubc alrededor de su vivienda; la bandada aumentó muy pronto, extendiéndose sobre el campo de tabaco; cubrióle del todo, cual si se hubiera tendido una alfombra de color pardo, y á los 20 segundos, es decir, apenas medio minuto, volvió á elevarse tan bruscamente como habia venido, para continuar su marcha; pero de las 40,000 plantas de tabaco ya no quedaba mstro. En Doob (Calcuta), Playfair observó cierto dia, cerca de un pantano, un inmenso número de pequeños insectos negros, que en un vastisimo espacio cubrian el suelo, y al examinarlos mas de cerca, vió que cran langostas pequeñas. Esto sucedió el 18 de julio de i\$12, y aun se recordaba nuy bien que cuntro semanas antes ( 20 de junio) se habian presentado grandes bandadas de langostas. Al cabo de pocos dias, estos insectos jovenes, desprovistos de alas, avanzaron hácia la ciudad de Etaweh, destruyendo los rampos y trasformándolos pronto en una playa desierti, sin que ningun esfuer.o de los campesinos, ni aun el fuego, bastaran para exterminarlos, pues avanzaron nuevas bandadas. Aun cuando carecian de alas habian devorado las hojas de todos los arbustos y de todos los árboles. A fines de julio desplegaron con la primera lluvia sus alas, las cabezas ad. quirieron un color rojo oscuro, y empezaron a volar en handadas; pero el 31 de julio los vientos los hicieron desaparecer de repente! Ninguma descripcion sobre las destrucciones de estos terribles insectos es tan exacta como la que nos da el profeta Joel (cap. II, a a 10), y por eso la recomendanos al lector.

I as crónicas antiguas de Furopa, sobre todo del sudeste del continente, contienen numcrosas descripciones de los perjuicios causados por las langostas en Alemania;y cada año los periódicos publican nuevas noticias sobre el particu. lar. Durante este siglo, solo la Rusia meridional fué invadida en los años $1800,1801,1 S_{3}, 1812$ á i $\$ 16,1 \$ 20$ a $1 \$ 2 z$, 1829 a $1831,18_{34}$ a $18_{3} 6,1 S_{44}, 18_{47}, 1850,1 S_{51}$ y $1 S_{59}$ i 1861. En todas partes la langosta emigrante (Pasligtylus migratorius ú Cidipoda migratoria) (fig. 12S) representa el papel principal, debiendo considerarse como su patria los paises en que todos los años se reproduce, es decir, la Tartaria, la Siria, el Asia Menor y la Europa meridional. En la Rusia central se encuentra en cicrtos sitios, pero solo en los otoños y primaveras muy calurosos. En la Marca de Brandenburgo se presentó algunas veces a principios del sexto decenio de nucstro siglo y ademas en $18 ; 6$, en $1 \$_{5} 6$ cerca de Breslau y en $1 \$ 59$ en la Pomerania, más allí del Oder. La linea septentrional de su àrea de dispersion pasa desde España por el sur de Francia, Suiza, Baviera, Turingia, Sajonia, La Marca, Posen, Polonia, Volhinia, el sur de Rusia y la Siberia meridional hasta el norte de la China. Yo mismo cogi algunos individuos cerca de Seesen, en el Ducado de Brunswik, yen el ca. mino de Halle à Petersberg. Algunas bindadas se han ob. servado tambien en Suecia, Inglaterra y Lscocia. Al vir cosas ian inauditas sobre las langostas, quizas podria creersc, con Plinio, que son animales de 3 piés de largo y de tal fuerza que las mujeres se sirven de las patas conso de sierras, y esto con tanta mas razon cuanto que los árabes les han atribuido en su poético lenguaje, los ojos del clefante, la cerviz del toro, las astas del ciervo, el pecho del leon, el vientre del escorpion, las alas del águila, los muslos del camello, los piés del avestruz y la cola de la serpiente. De todo esto, empero, solo encontramos la cabeza dispuesta como la del caballo. Eil co. lor de los mas grandes acridiodtos de Europar no es igual en todos los individuos, y parece oscurecerse mas : i medida que avanza la estacion. Lin general predumina en las partes supe. 
riores el verde gris y en las inferiores el rojo de carne, pero aquel pasa gradualmente a verde pardusco, y este al rojo $\delta$ amarillo. Jos muslos pasteriores tienen dos iajas trasversiles oscuras, los tarsos un viso amarillo rojo, y los elitros son parduscos, con manchas mas oscums. Como camctéres del subgénero considéranse las antenas filiformes, no puntiagudas; el pecho liso, no encorvado; la cabeza vertical yo obtusa en su parte anterior, mas ancha que el cuello; y los bordes laterales de este último redondendos.

El apareamiento dura de 12 à 24 horas. Siete dias despues la hembra manifiesta inquictud, no come ya y busca un sitio donde deposita sus huevos, por lo regular \& 39 milimetros de profundidad bajo tierra, la cual debe ser bastante ligera para que paeda penetrar tanto. Un montoncito de huevos contiene de 60 a 100 y el ovario por término medio 150: de lo cual resulta que debe depositar por la menos dos de aquellos si quiere completar la puesta, lo que siempre hace cuando el mal tiempo ó la falta de alimento no lo im. piden. Se ha observado un apareamiento repetido, pero no es de creer que esto seri necesario; si por excepcion se verifica, explicase por el número exiraordinario de los animales. Koerte encontró en 1826 , cuando los montoncitos perjudican tanto en la Marca de Brandenburgo, varias parejas reunidas desde el 23 de julio hasta el so de octubre, de modo que la puesta de los hueros ocupa un espacio de casi tres meses. En la primavera nacen tambien los hijuclos durante durantc dos ó tres semanas, obedeciendo d las influencias atmosféricas, pues mas que otros muchos insectos las langostas exigen un verano y otoño calurosos y secos para prosperar. Cuando es. tas condiciones se reunen en ciertos territorios, preséntanse con regularidad las langostas, si las habia el año anterior. Esta opinion convicne con el aserto antes citndo de Fritsch, pues un verano caluroso y seco tiene para nuestras regiones septentrionales una significacion del todo diferemte que un verano sin lluvia en el Africa meridionai.

I a larva pequeña es de color blanco amarillenio, pero se oscurce muy pronto, tanto que al cabo de cuatro horas tiene un time gris negruzco. Hasta la segunda muda, que se verifica en cinco semanns, conserva este color, mezclado con matices blancos en tl abdómen. Entonces busca los retonos mas tiernos para nutrirse, y pasado este tiempo, la bandada se extiende mas y mas, notåndose mejor sus daños segun adelanta el crecimiento, que es bastante rapido: mudan aun dos veces. Unos quince dins despues de la cuarta muda, en la que los rudimentos de las alas aparecen ya bastante desarrollados, suben por los tallos, se cuelgan de las patas poste. riores, $y$ solo necesitan de 30 \& 40 minutos para desprenderse de la última piel: entonces despliegan las alas. Puede parecer en la major parte de casos que la falta de alimento obliga á las langostas a emigrar, jero cs de suponer que asi como en otros insectos, tambien en la langosta es innata una inclinacion i viajar, cuya mzon hasta ahora no ha podido explicarse.

Una forma mas pequeña, confundida con otra especie, Pailuglylus ijverascens, que habita con preferencia en Africa, Espania, Francia y el sur de Alemania juntamente con su congénere mas grande, yo que cn 1875 y $18 \% 6$ ocasionó gran. des destrozos en varias provincias prusianas, nn es una especie ináependiente, segun las últimás observaciones.

Otra especie mas pequeña de color pardo, con las alas posteriores de un rojo oscuro, habita las pendientes secas bainadas por el sol en nuestras montanas, $y$ llama la atencion por el ruido con que á la luz del sol vuela a corta distancia para escapar del hombre nue se acerca; por esto se le ha llamado langosta ruidosa (Pailytylus stridulus). En Alemania viven ademas varias especies que se distinguen por la aspereza del cuerpo yo por tener una aguda guilla centml en el escudo co. llar, por lo cual se las ha dado el nombre de Octipoda. Sus alas posieriores orladas de negro, son rojas $\delta$ azules. A este grupo pertenece el edipodo de fajas (Oedipoda fasciuta), de color gris ceniciento con dos fajas oblicuas oscuras en Ins elitros y casi siempre tambien en los muslos posteriores. Muchos individuos tienen las alas posteriores de un azul claro, y se han designado generalmente con cl nombre de Oedifoda crerulescens; ntras se distinguen por tener la parte azul del ala roja, por lo cual se llamaron oedipoda fascinita ó germanuca. Estos insectos se han visto bastante a menudo aparendos, $y$ pueden representar dos especies. Habitan las pendientes lanñadas por el sol, los linderos de los bosques y sitios análogos, pero nunca las praderas.

Fil sub-género gomphocerus (stemoholhrus de Fischer) comprende aquellas de nuestras especies que con preferencia ha. bitan las praderas y el césped. 'Tienen la superficie del cuerpo plana, pero nunca áspera, y se reconocen casi siempre por ser la parte anterior de la cabeza mucho mas salientc que en el límite de la coronilla; delante de cada ojo tienen un hoyo estrecho, longitudinal, bistante profundo, 6 donde este falta un agudo reborde; $y$ en muchos, (gomphocerus mifus y gomiphocerus sibiricus), las cortas antenas se ensanchan junto ála punta, de modo que adquieren la forma de lanceta. Por lo demás este sub-género es análogo al anterior. Las es]recies del gompliocerus lineatus, que tienen de $0^{\circ}$, or 3 a $0^{\circ}$, or 8 de largo, son comunes en todas las praderas, $y$ á veces tanto, que estos insectos, aluuyentados por las pisadas de un hombre, suelen producir un verdadero estrépito. Estas especies tienen las patas rojas, y verde la cara exterior de las patas posteriores; de este mismo color es todo el resto del cuerpo excepto las lineas longitudinales amarillas que se corren por la coronilla y el centro del dorso; las alas anteriores llegan hasta la extre. midad del abdómen, no se distinguen por su forma segun los sexos, y son de color de orin con una mancha blanqquizca oblícua. Los hoyitos del borde de la coronilla estan marcadamente desarrollados, y la callosidad de la frente llega lassta la boca.

No menos comun es la especie gomphoceros' grossus, que como la nnicrior habita las praderas de toda la Europa. En ella vemos en rez de los hoyos à cada lado de la coronilla saliente un reborde agudo $y$ otro a los lndos de la callosidad de In frente, que llega hasta la boca; un liston menos marcado se corre á lo largo de las mejillas, de modo que los lados de la cara están cruzados cn linea recta por un hojo longitu. dinal que por arriba empieza con el de las antenas. El color del fondo es un verde aceituna; las partes inferiores de un rojo de sangre y los muslos de las patas posteriores an11arillus, lo mismo que el borde exterior de los clitros verdes que sobresalen de la extremidad del abdómen. La longitud del cucrpo es de $0^{\circ}, 015$ á $0^{\circ}, 016$. I ms demás especies no se reconocen sin una descripcion muy minuciosa.

In langosta italiana (calosienus iralicus) se encuentra no solamente en Italia sino tambien en el sur de Rusio: hasta Siberia; en Alemania, por ejemplo, en la Marca, Silesia, Sa. jonia y Austria: en $\mathrm{IS6}_{3}$ se vieron en Crimea grandes bandadas. Coino se desarrolla con preferencia en los bosques y en las montanas cubiertas de estos, perjudica mas bien á los árboles ýa las cepas en for que á las yerbas y al trigo. Ya en abril, y aun antes, salen las larvas de los huevos Pallas observó à esta especie en la Rusia meridional, y dice de clla poco mas ó menos lo siguiente. En ticmpo caluroso esta en movimiento por la mañana muy temprano: tan luego como el rocio se evapora, y a la salida del sol cuando no hay lıumedad. Al principio aparecen algunos individuos, como batidores que preceden i las bandadas, las cuales descansan aun en 
el suelo, oprimiéndose por lo resular al pié de pequeñas colinas $\delta$ biem en toda especie de plantas y arbustos, donde se distribuyen en grupos. Poco despues, todo el ejército se pone en marcha en línea tan recta que apenas se observa una saliente; parecen una bandada de hormigas, y todos siguen sin tocarse el mismo camino. Sin descanso, y con toda rapide?. posible, casi a la carrera se dirigen a un mismo punto sin saltar, á no ser que se les persiga; en este caso se dispersan, pero pronto se les ve reunirse de nuevo y continuar el viaje en la direccion anterior. Asi marchan desde la mañana hasta la noche sin descansar, franqueando un camino de cien brazas y mas en un día. l.es gusta unucho pasar por caminos y campos despejados, pero cuando un arbusto, una espesura 6 un foso les ofrece una dificultad siguen la linea recta pasando por encima ó por entre ellos. Solamente los pantanos y los rios oponen grave obstaculo á estos insectos, que segun parece tienén gran aversion a mojarse. Sin embargo, a menudo intentan llegar á la otra orilla valiéndose del ramaje jo cuando algunós tróncos lan caido en cl agua, formando un puente, se aprorechan de ellos para pasar. A menudo se les ve descansar sobre tal puente, como si les agradase la frescura del agua. Hácia la puesta del sol, toda la handada se divide en peunenos grupos it fin de buscar un albergue para la noche, y no continuan su marcha en los dias frios ólluviosos. El género de vida descrito es propio no solamente de las larvas de la langosta italiana, sino tambien de lodns las especies que en estado petfecto se elevan en bandadas. Desde mediados de julio se desarrollan en cllas las alas y cntonces se dispersan mas, efectuándose el apareamiento y la puesta de los huevos, por lo cual algunos hijuclos stlen ya en otoño, cuando las condiciones son favorables. La especie se asemeja mucho á Ia anterior en tamano y forma, pero sécaracteriza en particu. lar por una protuberancia verrugosa entre las ancas anteriores, yor ser la coronilla redondeada, menos saliente'y por su ancho protórax Agudos dientes en el borde interior de las maxilas superiores y de la interior de la mandibula inferior, y la forma esférica de la extremidad del abdómen en el macho, completan los caractéres distintivos del sub-género. F.n la cirada especie, las tres quillas del escudo collar se desarro. llan de un modo bastante igunl, y las tres impresiones trasversales ondulacias del mismo están situndas en su primera mitad. El cuerpo y los elitros, que llegan hasta su extrcmidid, son de un amarillo sucio salpicado de pardo. El borde inicrior de las alas posteriores es de un rojo sonrosado, lo mismo que la cara interior de los muslos posteriores, mientras que la otra cara es de color amarillento ó tiene unas fajas oscuras.

Solo las especies mayores cuyas cortas antenas no son pun. tiagudas y cuyo protórax tience en su parte infurior dos verrugas, mientras que en la superior se eleva en forma de quilla central ó solo en la parte anterior en figura de cresta, han conservado el antiguo nombre del sub-género Acridiums. Los acridios pertenecen a las regiones callidas de ambos hemisfe. rios y son sobre todo los que sirven de alimento á los indigenas del pais que habitan. I.a línica especie, cuya àrea de dispersion se extiende hasta el sur de Luropa, es la langosta de Tartaria (acridium lafaricuss) perteneciente a un grupo en que la quilla del protórax es igial y tiene en su parte anterior tres depresiones trastersales, mientras que la protuberancia del pecho afecta la forma de una prominencia recta, un poco mas gruesa en su parte anterior. Su color es gris amarillento, con manchas mas oscuras en los elitros y en la parte de la sutura; en las alas posteriores resalta una mancha oscum en forma de arco. El macho alcanza una longitud de $0^{\prime \prime}, 039$ y la hembra de $0^{\circ}, 065$.

En la coleccion del Museo de Halle se encuentra un individuo de otrn especie muy parecido (acridüum peregrinum) que se extiende por toda el Africa. In la etiqueta dice: «Cogido en marzo en el Sur.... (el nombre mal escrito del buque) a 40 leguas de distancia al oeste de las islas Canarias; formaba grandes agrupaciones que se dirigian al Africa 》

\section{LOS TRUXALIS - TRUXALIS}

CARACTÉRES. - Un aspecto muy distinto ofrece el subgénero de los truxalis, muy rico en especies, pur la forma particular de la cabeza. Esta parte se eleva hícia adclante y hácia arriba á mas ó menos altura, en forma de cono trian. gular en su extremidad, ya cóncavo ó convexo en la superficie superior, y que se oprime lateralmente donde se insertan las antenas que son planas, triangulares, con la punta semejante $\dot{3}$ la de un estoque. El cuerpo es endeble y prolongado; las alas, que sobresalen de él, tienen la extremidad pun. tiaguda; los muslos posteriores, angulosos, son medianamente gruesos: y en una palabra, todo el conjunto de estos insectos raguiticos comuriciles un aspecto inty fantistico.

\section{EL TRUXALIS NARIGUDO-TRUXALIS NASUTA}

CARACTERES. - En el sur de Francia, Italia y Hungria, vive el truxalis narigudo, en el que la parte de la cabeza que sobresale del borde del protóras es cuando menos tan larga como la linea central de este, cuyo borde posterior tambien se prolonga en forma de àngulo. La punta de la cabeza es cóncara, y en sus tres lados se adelgaza hícia delante; en la parte posterior del pecho no hay protuberancia. Fl macho mide $0^{\circ}, 039$, es de color verde, excepto las alas pos. teriores, que son claras como el cristal con la base de un amarillo claro; la hembra, que mide $0^{\circ}, \mathrm{I}_{3} \mathrm{mas}$, presenta en el tóraxy los elirros fajas pardas, las últimas de las cuales tienen manchís blancas.

\section{LOS TETRIX - TETRIX}

CARACTERES. - Mientras que en lodas las especies hnsta ahora descritas la parte anterior del pecho es truncada y deja en completa libertad la cabera, en otras se eleva el borde anterior del pecho de modo que la boca puede ocul. tarse en él.

A estas especies pertenecen, entre otras, los tetrix, en los que el borde pastcrior del escudo collar se citiende hasta la extrenicad del cuerpo ó mats alli. I.ats alas estån casi del todo cubiertas por esta prolongacion triangular, puntinguda en el centro del cscudo collar, por lo cual los clitros solo cxisten en forma de hojitas cúrneas, de modo que estas especies no pueden producir ningun ruido. Los ojos están muy altos; por delante del escudo collar y al lado de tas antenas; que son filiformes. Los muslos pusteriores son muy gruesos. A causa de su reducido tamano y de su vida nuy oculta, los tetrix recuerdan en cierto modo á las pulgas.

\section{EL TETRIX COMUN-TETRIX SUBULATA}

CARACTERES.-El tetrix comun es el mas grande entre las especies alemanas, aunque solo mide, curndo mas it", or I, j no escasen en ninguna parte. Eil escudo collar está cortado cu su parte antcrior en linea recta, clévase en su centro en forma de quilla poco prominente y' se adelgaza en figurn de espina, sobresaliendo mucho de la extremidad del abdómen. Los lados del borde posterior, que no se prolongan, parecen dos dientes, por lo regular triangulares. El color del cuerpo es un gris pardo, d menudo con un viso amarillo pálido, gque 
siempre se observin en los puntos oscuros de las antenas. Yo he encontrado con frecuencia larvas invernadas, $y^{\circ}$ por lo mismo creo que estos insectos pasan por lo regular el invierno en estado de larva.

\section{LOS LOCUSTINOS - LOCUSTINA}

CARACTERES. - I os locustinos se reconocen por sus antenas largas y cerdosas y por los cuntro artejos de todos los piés que tienen igual forma. In cabera, dispuesta verticalmente, sobresalc un poco en la coronilla; los ojos son hemisféricos, y carece casi siempre de ojuelos. El protórax, en forma de silla de montar, suele extenderse hảcia airás sobre la base extrema de las alas. Fstas ocupan los lados del cuer. po, se cubren entre si con los estrechos bordes interiores, formando asi en la parte de su base como un angosto tejadillo aplanado; el abclómen se redondea y tiene en su mitad mayor diametro; en el macho remali en espinas, à veces encorvadas en forma de gancho; en la hembra termina por un tubo mas ó menos corto en forma de sable, de modo que la diferencin entre los sexos puede observarse con facilidad. El ullimo artejo de los piés carece de garras y lóbulos prehensiles. Los machos no producen el chirrido con los muslos posteriores, sino rozando una base de los elitros con la otra. Ei celitro ir. quierdo, que al mismo tiempo es el superior, tiene en su base una fuerte vena trastersal que casi afecta la figura de dos eses sobrepuestas, mas marcada en la cara superior que en la inferior $y$ que por numerosos surcos trasversales adquiere el aspecto de una lima. I a parte triangular del elitro derecho, que está fijado horizontalmente sobre el dorso, presenta una mancha menbranosa delgada, circuida por todos lados de fuertes nervios, y gue se llama espejo; por detras hay otra mas pequeña de la misma forma $y$ trasparencia. Al producir el chirrido los elitros se levantan, y cuando la vena trasversal del izquierdo se roza rápidamente con los bordes del espejo, las finas membranas regulan el diapason, reforzando el tono. Una excepcion de la regla encontramos en algunas especies, cuyos elitros se dilatan en forma de espiga, pudiendo producir tambien las hembras el chirrido, por ser la disposicion de los clitros completamente distinta. I.os locustinos tienen en las patas anteriores otra particularidad: $\mathrm{en}$ la base de los tarsos presentan exteriormente dos profundas hendiduras ó ca. vidades que en el interior se cierran por una membrana delgada. En medio de ambas aberturas ensánchase en forma de vejiga el tronco principal de los zubos áreos pertenecientes at las patas anteriores, $y$ un nervio que parte del primer nudo del pecho se ensancha alli tambien, dando origen á unos ele mentos nerviosos de formacion particular, dispuestos en series y rodeados de pequenas vejigas claras y trasparentes como el agua. Siebold ha examinado detenidamente la es. tructura de estas formaciones, y las considera como órganos del oido en esta familia.

DISTRIBUCION GEOGRÁFICA.-los locustinos habitan en todo el globo.

USOS, COSTUMBRES Y REGIMEN.-El desarroHo de estas langostas no las distingue esencialmente de la familia anterior: el largo tubo que sirve a la hembra para la puesta indica que esta no deposita sus huevos en tallos de yerba, sino en el suelo y a mayor profundidad que los acridiodeos. Los locustinos, sobre todo los verdes, habitan con preferencia las espesuras y los àrboles, cuyas hojas comen; mientras que los de color pardo, buscan las plantas bajas, sobre todo de noche. Como solo podremos hablar de algunos de estos insectos, me parece conveniente ocuparme tan solo de varias formas muy diferentes.

томо VI
La hembra adulta (hetraies espinoso, hetrodes stinulosus) se distingue de los otros congéneres por tener los muslos posteriores delgados, los tarsos provistos de espinas muy libres, el hoyo calloso cubierto en la base de los tarsos anteriores y muy corto el tubo que sirre para la puesta. Fista especie es de color amarillo cerca del borde posterior y el collar pardusco. El sub-género à que pertenece se caracteriza por la falta de alas en ambos sexos; las anienas se insertan en medio de la frente debajo de los ojos, viéndose en medio de ellos una prominencia; el protórax es muy grande, y el tórax muy ancho.

Otros varios locustinos presentan la misma estructura del cuerpo, pero tienen algunos indicios de alas.

Otra especie, llamada por los entomólogos meconena ir rism, que representa un sub-género, es un pequeño insecto delgado, de color amarillo verdoso, que habita con preferencia las encinas. Es muy comun en nuestras regiones y su larva se encuentra ya á principios del verano. Asi como lodos los lacustinos, es perezoso y pesado: yo no le vi volar nunca. Al sacudir los árboles que habita cae sin servirse de las alas, $y$ al parecer no produce chirrido, $\delta$ quizas lo haga solo un la espesura; muy a menudo sube y baja por los troncos. Una vę observé el is de octubre, cómo la hembra habia penetrado con su corvo tubo de puesta a bastante profundidad en la corteza para depositar sus huevos. Este insecto figura a la cabeza de una larga serie de especies cuyas antenas se insertan en medio de los ojos y en la extremidad de la fren. te, y cuyos hoyos auditivos tienen un borde eliptico; además se distingue por no tener en el pecho prominencia alguna, y por una especie de espiga obtusa en la frente.

Ias especies exclusivamente verdes del sub-género Pibyloptera se distinguen por tener los elitos extendidos como una bonita hoja verde en forma de lanceta á los lados del cucrpo, sobresaliendo mucho dé éste: pero la mayor parte de las especies tienen las alas posteriores mas largas aun; sus nervios afectan la forma de red como en la especie Pliglloptera mayrifolia, propia de la América del sur; otras veces presentan manchas abigarradas muy graciosas, como la especie Plyolloptera fenestrata propia de Borneo y que alcanza casi doble tamaño qque la anterior, es decir, $6,0,0,8$ de largo y en los tarsos anteriores tiene espinas nudosas. Fn la mayor parte de las especies, no obstante, los cliuros presentan un nervio longitudinal del que parten algunas ramificaciones mucho mas finas.

Mas numerosas son las especies distribuidas en muchos subgéneros en que las antenas se insertan en el mismo sitio, mientras que en los conductos auditivos los tarsos anteriores afectan la forma de estrechas hendiduras. Solo haré nencion aqui de los dos subgéncros curopeos mas comunes. El uno. decticus, se reconoce por tener la parte superior de la cabeza obtusa, de modo que no sobresale del priner artejo de las antenas; por las espimas largas y movibles de que estan provistos los lados internos de los tarsos anteriores, y sobre todo por los dos lóbulos prensiles libres en el primer artejo de los pies posteriores. Las especies tienen todas el color pardo verdoso ó pardo gris, y en algunas las alas estan atrofiadas. Ia major de todas, el dectious ierruciarorus, insecto de $\|^{\prime \prime}, 026$ a 6,030 de largo, está diseminado por el norte y centro de Europa y se encuentra en las praderas y en los campos de alfalin. Hace algunos anos que le vi con frecuencia entre las achicorias cultivadas, pero runca visita las espesuras, al me. nos que yo sepa. Ios cuatro rebordes de los tarsos posteriores estan provistos en su mitad posterior de espinas, y los anteriores de tres series de otras movibles; en las ancas hay una sola espina. I a coronilla y la frente están separadas por una linea trasversal, á la altura de la base de las antenas; y 
en el protónx sé ve una prominencia longitudinal. El color del cuerpo varía mucho, predominando un verde claro ú oscuro con visos rojizos, 6 con mas frecuencia pardos, con manchas de este color en los largos elitros, mientras que la cara interior, $y$ sobre todo el vientre conservan un tinte mas claro, es decir amarillento. Poco mas 6 menos a la segunda mitad de abril salen las larvas, que mudando por primera vez al cabo de cuatro semanas, lo han hecho la segunda a medindos de junio; entonces se pueden distinguir los sexos por el corto tubo abdominal de la hembm, y en agosto ambas han llegado i su completo desarrollo, los machos empiezan en seguida sur canto: la hembra se aproxina $y$ anuncia su presencia agitando sus largas antenas. Tan luego como el inacho se convence de que su compaúera viene animada de buenas intenciones, recibela producienda suares sonidos amorosos. Pocos dias despues busca la hembra un sitio conveniente, con preferencia en la yerba y deposita sus cincuen. ta huevos, Al coger un individuo adulto, muerde con tal fuerza que la piel se llena de sangre, quedando cogidos la cabeza y el esófago del insecto, de modo que es preciso arrancarlós con fuerza.

Al morder expele un liquido pardo, el cual no sé si produce efectos jara curar la mordedurá.

Mas conocida aun es la especie locusta airidissima, insecto de $0 \%, 026$ de largo, que en algunos puntos, por ejemplo en Leiprig, se conserva por los niños en pequéñas jaulas de alambres; cógenlos en los campos de trigo ya maduro. Muy divertido es su canto, que se puede expresar por las silabas sik, sik. Los largos elitros y el cuerpo son de color verde puro, y solo las partes horizontales del dorso son parduscas. Tambien la cabeza tiene á menudo un color rojo de orin. El tubo abdominal de la hembra alcanza la longitud del cuerpo excepto la cabeza.

Este insecto huye de la luz del sol y busca la sombra debajo de las plantas. Cuando se descubren sus sitios favo. ritos, busca los sanices, abedules $y$ otros àrboles, posíndose sobre todo de noche $\dot{a}$ - mucha altura en el ramaje para cantar.

Las otras especies igualmente verdes y menos cxtendidas, no deben confundirse con lá anterior: la langosta terde de cola (locusta caudala), que hádemás de algunas diferencins en la estructura del abdómen sé distingue por su canto esencialmente distinto, pues produce el rumor de una rueca sin qque se puedan distinguir los sonidos aislados. La langosta cantora (locusia cantans) se distingue, además de las diferencias anteriores, y el color verde oscuro de su cuerpo, por los cortos elitros que sobresalen poco del abdómen del ma. cho, por el menor tamaño $\left(v^{\circ}, 022\right)$, y por otras particulari. dades, de la langosta varde ce cola. No sube can tanta frecuencia a la cina de las plantas, llegando solo á la mitad de sil altura; es muy timida, advierte pronto la presencia del hombre y guarda en seguida silencio. A causa de esta prudencia y de su color es dificil cogerla; produce su chirrido sobre todo despues de la puesta del sol y antes de su salida, siguiéndose los tonos muy rapidamente. Despues de emitir tres $\delta$ cuatro sonidos acomnasados, sigue otro mas alto, prolongado y un intervalo, despues del cual el chirrido empieza de nuevo. La vor puede traducirse por las silabas rross'ss'ss... ssit. El chirrido varia mucho sobre todo en cautividad. Esta especic parece habitar con pieferencia en Suiza, Westfalia y Holstein, aunque tambien se encuentra en Sajonia, abundando en los contornos de Tharand mucho mas que la langosta verde grande. Todo el subgénero difiere del anterior por la falta de los lóbulos en la base de los piés posteriores, pror la punta mas estrecha de la cabeza y por un estilo mas largo del ano.

\section{LA TEROCROZA DE OJOS-PTEROCHROZA OCELLATA}

CARACTERES. - El cuerpo y la cabeza de este insecto (figura I 30 ) son de un pardo rojizo; el protórax ligeramente granuloso; los clitros opacos, muy anchos, ovalares y terminados en punta, siendo de un leonado rojizo con algunas fajas longitudinales negruzcas en su cara interna; hảcin la mitad tienen una mancha irregular blanca, trasparente y visible por ambos lados. Cerca de la extrenidad, y tanto encima como debajo, se ve otra mancha circular, de un negro aterciopelado, con puntitos blancos en su borde exterior. Las alas sou oblongas, mas cortas que los elitros y mucho mas largas que anchas; su coloracion es la misma por ambos la. dos, teniendo nerviaciones trasversales muy numerosas, rodeadas de un tinte negruzco; en su extremidad aparece una mancha a manera de ojo, de un leonado rojizo, circunscrito interiormente por un ancho semicirculo de un negro atercio. pelado y en cuyo centro se ve un semicirculo de un hermo. so color blanco, sobre el cual se advierte otro mas pequeño, y detris de ellos una estrecha línea negra trasversal con al. gunos puntos blancos irregulares. Las antenas son mucho mas largas que el cuerpo y de su mismo color; las patas de un leonado pálido; todos los muslos algo espinosos por debajo; las piernas posteriores canaliculadas por encima, con las dos carenas superiores algo espinosas.

El tamaño de esta especie suele ser de zo líneas.

DISTRIBUGION GEOGRÁFICA. - Habita generalmente en Cayena.

\section{LOS GRILLODEOS-GRYL- LODEA}

En los matorrales secos, campos arenosos, pendientes de montañas bañadas por los rayos del sol, en Europa y Asia, un insecto de cabeza gruesa y negra practica galerias en el suelo para refugiarse en ellas cuando le amenaza un peligro, pasar alli los dias frios y lluviosos y morir en su escondite. El poeta que le canta llàmale con mucha razon el egrillo perezoson; el naturalista, no acostumbrado à moralizar, le da el nombre de grillo campestre (gry/lus campestris). Los agujeros no son mucho mas anchos que la circunferencia del in. secto; se prolongan primero horizontalmente en el suelo y se inclinan despues, terminando en hoyo. Se construyen con preferencia en el periodo en que el macho empieza a cantar, es decir, á principio de la primavera, y solo están habitados por un individuo. A menudo se traban luchas, pues á todos los grillos les gusta utilizarse de una guarida ya hecha; cuando en ella encuentran otro individuo, ninguna de ambis par. tes cede voluntariamente; se muerden y empujan con la ca. beza, y cuando la victoria es tan completa por una parte que el adversario queda muerto en el campo de batalla, el otro devora su cadáver. Al macho le agrada asomar la cabeza en su agujero para cantar y nunca se alcja mucho de él, para poder refugiarse en seguida, pues los grillos tienen precaucion extriordinaria, que podria llamarse miedo. Cuando el macho canta para llamar a la hembra entreabre múcho las patas, oprime el pecho contra el suclo, levanta los elitros un poco y los roza rápidamente uno contra otro. Solo cuando cesa de cantar recoge los elitros. La hembra oye el canto de llamada pero no se sabe aun cómo, porque la abertura de los tarsos anteriores falta en todos los grillos. Lo cierto es que la hembra se acerca y toca al macho con las antenas para advertirle de su presencia; este guarda entonces silencio, el apareamiento se verifica montando el macho sobre la hem- 
bra, costumibre que parece ser propia de todas las langostas. Ocho dins despues la hembra comienza en el fondo de su sivienda a poner los huevos, que salen en múnero de 30 á la vez Su owrio contiene unos trescientos y antes que todos se hayan depositado la hembra se aparea varias veces con el macho. Al cabo de unos quince dias salen las larvas, que permanecen reunidasal principio, y ya empiezan a practicar agujerns. Despues de la primera muda se dispersan mas, sin alejarse sin embargo at nucha distancia del sitio donde nacieron: habitan en escondites debajo de las piedras, donde buscan su alimento, que se compone de raices. Pasan el invierno en un estado de desarrollo muy diferente. En I 867 , año bastante desiavorable, encontré a mediados de octubre en los dias calu. rosos larvas con rudimentos de alas y cortos tubos de puesta, que por lo tanto estaban ápunto de sufrir la primern muda. Fristch y Roesel opinan que el insecto se desarrolla con la cuarta muda, pero últimanente se aseguró que la larva muda diez veces, lo cual me parece muy exagerado segun todas las otras cxpcricncias.

Con la primavera despiertan tambien los grillos no desarrollados y cada uno procura hacer una vivienda para si solo. Ningun grillo inverna cuando es adulto, pues con el periodo del celo termina tambien su existencia. Afortunadamente habita en terrenos que sirven de poco al hombre, pues à no ser asi podria perjudicarle destrozando las raices. Respecto á los caractéres, solo tenemos que añadir que el color de la cara inferior del muslo posterior es un negro brillante: la hembra tiene a veces los tarsos rojos. Aunque no es posible confundir esta especic con otro insecto, debemos determinar los caractéres del género que se refieren à quince esp̧pecies europeas y muchas exóticas. Consisten en tener la cabeza voluminosa y redondeada en el protórax; el cuerpo, cilin. drico y pesado, remata en dos largas espinas articuladas, y en la hembra presenta además el tubo recto que sirve para la puesta; todas las patas tienen tres artejos en los piés; las últimas sirven para el salto, $y$ las alas posteriores ofrecen una estructura particular; su borde anterior córneo rimata en punta y. se replega por debajo de otras puntas que sobresalen mas ó menos de los elitros, los cuales se apoyan sencillamente sobrc el corso.

\section{EL GRILLO DOMÉSTICO-GRYLLUS DOMES- TICUS}

CARACTERES. - El grillo doméstico, mas peqqueño $y$ gracioso que el precedente, es de color pardo de cuero, amarillento en las patas y en la cabeza; en esta última presenta una faja trasversal parda, y en el escudo collar dos manchas triangulares. La extremidad de las alas posteriores sobresale del cuerpo, constituyendo en la hembra dos apéndices mas de los tres ordinarios. I a longitud de este insecto es de $0^{\prime \prime}, 0175$ a $0^{7}$, or 95 .

USOS, COSTUMBRES Y REGIMEN.-Por su indole sociable, por sus salidas nocturnas de su escondite, por su aficion al calor y á los mismos alimentos, el grillo doméstico se parece mucho al periplaneta oriental en cuya compania se le encuentra á menudo en los hornos, molinos, cervere. rias y cuarteles; en estos últimos suelen sazonar á veces \&con La pequeña langosta, el caldo demasiado claro. Un solo individuo interrumpe con su canto melancólico el silencio nocturno de un modo bastante agradable, pero si tiene muchos compañeros pueden desesperar álas personas que todas las noches se ven obligadas á oirlos. Los sonidos se producen por el macho del mismo modo que por el grillo campestre, pero son mas débiles a causa del reducido tamaño del insecto y de los rebordes mas espesos del nervio en los clitros.
Nunca en mi vida tuve mejor ocasion de obscrar los grillos en su género de vida que durante mi juventud, cuando pasaba las vacaciones de la canicula en casa de this alsue los. La oscura cocina de la antigua casa pastoral de Gross. goerschen era para los grillos agradable residencia ! por élla pasaba yo a veces con mi abuela di la hora de xcostarme. Miles de grillos se pasenban por alli, muchos de ellos muy pequeños, y otros del todo adultos segun los grados del desarrollo. En todos los rincones resonaba el canto, aqui una voluminosa cabeza llenaba un agujcro de la pared, pero retirábase timidamente tan luego como la luz se acercaba: mis alla paseábase toda una jrogenie en busca de alinento, demostrando no obstante á cada momento su timidur. No era nada fácil coger con la mano uno ó dos de los peqqueños insectos que vagaban libremente ó pasaban solos por castalidand, pues se sustraen à la persecucion por su gran ligereja y mpidez. en la carrera; tambien saltan, pero su pesadez les impide franquear as mucha distancia. Yo encontré pronto un sitio que no ofrecia dificultad para la caza; en el hogar habia una caldera de cobre, con tapa de madera, de la cual solo se hacia uso de rez en cuando, $y$ en cuyo fondo queda. ba siempre un poco de agua $y$ un calor agradable, por lo cual acudian alli numerosos grillos, que natumimente no podian volver á salir, siendo muy fácil cogerlos con las manos. Muchas veces tuve el capricho de encerrar marios individuos asi cogidos en una vasija bien tapada por arriba. ! con frecuencia observé \&i la mañana siguiente que ninguno de ellos estaba intacto; por lo regular les faltaban patas, antenas, y hasta pedazos del cucrpo y extremidades que habian desaparecido. Era que impulsados por su voracidad! el enojo que les causaba verse todos encerrados en tan re. ducida prision, se habian devorado en parte. Si enionces hubiese sabido lo que mas tarde suje, habria podido probar yo mismo la exnctitud del aserto de los que dicen que los grillos, asi como los cangrejos, pueden sustituir las extremidades que les faltan por otras nuevas, mientras no hayan concluido la muda.

Como mis visitas en la cocina y mis cacerias tuvieron lugar en junio, debi desechar la oninion de los que creen que solo en este mes y en el siguiente se depositan los huevos: yo supongo que la puesta se efectúa durante todo el periodo en que se oye el canto del grillo.

El apareamiento se verifica del mismo modo que en la especie campestre. Ia hembra pone unos huevos longitudinales y amarillos dentro de su agujero $y$ al cabo de dicz $u ́$ doce dias salen ya las larvitas que mudan cuatro veces é invernan en estado incompleto: despues de la tercera muda se ven apuntar ya las alas y en las hembras un corto tuba de puesta Supónese que la duracion de la vida no excede de un año, en cuyo tiempo la hembra pone huevos y mucre cuando ha concluicio la provision del ovario.

\section{EL GRILLOTALPA VULGAR Ó GRILLO REAL - GRYLLOTALPA VULGARIS}

CARACTERES. -Si hemos de juzgar por los muchos nombres que el pueblo ha dado a esta especie, debe ser la que excita el interés general, ya por el daño que causa ó por su aspecio extraño, pues representa la caricatura del topos. En cuanto a Jas formas del cuscrpo, solo diré que en la parte posterior las puntas de las alas se dirigen en linens argueadas hasta el centro de las espinas de la extrenidad del abdómen; en la parte anterior sobresalen-además de las antenas los palpos maxilares, de cinco artejos, y en la coronilla se reen dos ojuelos brillantes. El cuerpo, de calor pardo, está cubierto, excepto los ojos, las patas ! las alas, asi como la 
parte del dorso oculta por estas, de un pelo muy corto y sedoso de color pardo gris (fig. 131). I. ^ hembra carece del tubo para la puesta y se distingue del otro sexo por la forma diferente de la última escama del abdómen.

USOS, COSTUMBRES Y REGIMEN. - El grillotalp: habita con preferencia los terrenos arenosos, y agrádanle mas los secos que los húmedos. En las llanuras de la Alemania del norte se observa por lo tanto con mas frecuencia que en el sur montanoso. Se le teme con razon en los puntos donde habita; y solo divergen mucho las opiniones sobre la clase de daños que ocasiona. La opinion general de que come las raices ha sido refutada últimamente por varios observadores, los cuales pretenden que se alimenta de lombrices larras y hasta de su propia cria, y que solo causa perjucicios al cortar la raiz de las plantas que están sobre el nido, ievaintandó de continuo el suelo. Ambas partes tendrain razon: pues asi co mo las otras langostas son plantivoras, sin perdonar por eso a otros insectos de que pueden apoderarse, asi tambien el grillotalpa vulgar. Como vive cusi exclusivamente debajo de tierra, aliméntase de larvas y de las raices subterráneas de las plantas. Noerdlinger nos cita un ejemplo evidente de la voracidad verdaderamente asombrosa de este insecto. Un grillotal. pa que habitaba en un jardin quedó partido en dos mitades por un golpe de azadon; y cual no seria el asombro del jardinero al ver, un cuarto de hora despues, que la mitad anterior del insecto se ocupaba en devorar la posterior. Así como todos los grillos, tambien este es muy timido y se retira al mas leve rumor, ocultandose en seguida cuando se le hace salir de su agujero ó se le arroja en tierra al tratar de remontarse por los aires, como lo hace en el periodo del celo, sin que esto pase de ser una tentativa. Orra especic, propia del Japon y del Archipiélago indio, parece ser nuy diestra jor este concepto, pues Martens dice que penetra hasta por la noche en las habitaciones.

El apareamiento se verifica en la segunda mitad de junio y en la primera de julio, siempre de noche y en sitios ocul. tos, por lo cual no se le ha podido observar nunca Los machos producen de noche un ligero chirrido que se, ha com. parado con el zumbido lejano del chotacabras ( Caprimulyus europans). Ia hembra deposita sus numerosos huevos en un agujero que tiene varias galerias en forma de caracol, las cuales conducen á una cavidad de la forma y el tamaño de un huevo de gallina, situada a unos $6^{\prime \prime}$, ro, 6 por lo menos $v^{n}, 05$ debajo del suelo. Las paredes, humedecidas por el insecto, son tan lisas y sólidas que con un poco de precaucion se puede sacar todo el nido con la tierra que le contiene. De este nido parten en distintas direcciones varias galerias, que exteriormente tienen una anchura de $1^{\text {th }}, 0$ r $9, \mathrm{y}$ algunas de ellas se inclinan hácia abajo para servir de refugio á la hembmen caso de peligro, $\delta$ desviar la humedad si es demasiado inten. 52. Esta guarida se encuentra siempre en sitios descubiertos, bañados por los rayos del sol, reconociéndose principalmen. te por los espacios en que ha sido arrancada la regetacion. El número de huevos depositados por la hembra es de doscientos, por término medio, pero tambien se han hallado mas de trescientos en un nido: una cifra menor que la primera indica que la hembra no ha terminado aun la puesta, que se efectúa á intervalos. Ta hembra no muere despues de poner; permanece inmóvil cerca del nido en una galéria vertical, con la cabeza levantada, como vigilando su cria. Si por lo tanto se ha pretendido que incuba, adviértase que este túrmino estả muỵ mal ap̧licado, porque puede inducir á erro. res. Cierto es que vive aun despues de nacer los hijuelos y que devora muchos de estos, pero dudo que pase el invierno en galerias casi verticales con la cabeza levantada; mas bien creo que inuere antes de comenzar la estacion fria.
Los huevos, de cáscara sulida, son de color pardo amariIlo verdoso, de forma longitudinal y ligeramente aplanados: al caho de tres semanas salen á luz las larvas, lo cual puede ocurrir a mediados de julio aunque mas tarde se hallan tambien huevos recien puestos en algumas partes. Ratzeburg encontró una vez huevos el 6 de agosto. Fin las primems tres $\delta$ cuatro semanas los hijuelos permanecen reunidos, sin escarbar, y se alimentan de los restos vegetales od de las raices vi. vas de los alrededores del nido. Despues de la primera muda muéstranse mas vivaces $y$ se dispersan; en los últimos dias de agosto efectuase la segunda, $y$ á fines de setientbre la tercera, despues de la cual los insectos alcanzan por término medio una longitud de $0^{\circ}, 026$. Para pasar el invierno penetran a mayor profundidad en la tiern; suelen despertar en primavera, mudan luego por cuarta ver, y' entonces se distin. guen ya los rudimentos de las alas. A fines de mayo, ó un poco mà tarde, halllase el insecto del todo desarrollado, que a causa de su gran escudete se ha llamado tambien cangrejo de tierra. En todos los demás continentes hay cspecics muy parecidas.

El género citado y algunos otros constituyen en su con junto la tercera y última familia de los ortópteros saltadores, es decir, la de grillodeos (Gryllodea), que viven debajo de tierra y se distinguen de los grupos anteriores por la forma cilíndrica del pesado cuerpo y por la circunstancia de no pasar el invierno en estado de luuevo.

\section{LAS FORFICULAS- FORFICULA}

CARA CTÉRES، - El labiduro ó forficula gigantesca (For-

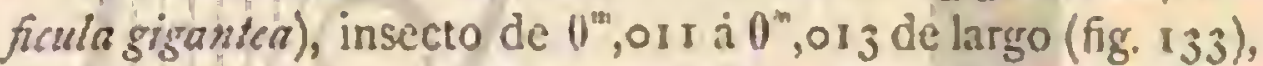
nos dará idea de una pequeña familia diseminada por toda la tierra. Algunos naturalistas ingleses quieren erigirla en órden independiente; mientras que otros in consideran como formada por coleópteros, lo cual no debe extrninarse, puesto que aun en 1775 . Fuesslin los agrupó bajo ese nombre al fin del órden de los coleópteros.

A incdiados de julio, al levantar algunas piedras en una desierta superficie arenosa, cerca de Halle, salió una forficula espantada por la súbita claridad, y buscó presurosa otro es. condite, mas no pudo hallarle; siguiéronla algunas hembras mas pequeñas y una crisálida; $y$ tanto por cl color claro de los adultos como por la presencia de la ninfa reconocl que aun no habia alcanzado su desarrollo completo. El cuerpo, excep. to una mancha parda del centro del abciómen, $y$ una faja del mismo color en cada clitro, que con interrupciones se continuaban hasta el escudete, eran de color amarillo. I as tenazas son caracteristicas para todas las forficulas, pues sirven para la defensa, asi como tambien para plegary desplegar las alas. El que quisiera admirarse de oir decir que las forficulas vuelan, solo debe examinar un poro mas minuciosamente el centro de su dorso. Detrás del escudete se ven dos placas cuadrangulares, sin duda elitros coriaceos, que parecen rematar en una puntita obtusa de color mas claro. Esta opjinion sin enibargo è errónea, porque las dos puntitas se hallan debajo de los elitros cortados en linea recta y son la única parte visible de las alas posteriores, mur anchas y replegadas del modo mas gracioso. Cada uno de esos apéndices se compone de la parte corificea en la base del borde anterior $y$ de otra membranosa tres veces mas larga, de forma semi-oval.

En la parte membranosa el ala se divide en un campo anterior de doble anchura de la escama coriácen, y la otra esta provista de nervios en forma de radios. Estos últimos salen 
en número de ocho del nervio principal, y van ia la extremi. dad de la escama coriaicea; unos nervios tmsversales regularmente dispuestos sirven de apoyo á la membrana en la direccion opuesta. Cada uno de los radios tiene una manchita córnea y ligeramente arqueada en su centro: para desplegar las alas, el borde posterior se dobla hasta esas manchitas hi cia arriba (primera posicion); despues el ala se replega en forma de abanico (segunda posicion): este abanico se dobla for debajo de la parte ancha del campo anterior del ala (tercera posicion); y por último, este se dobla longitudinalmente por debajo de la escama coriacea que se inantiene visible (cuarta posicion). I a cabeza, libre y un poco inclinada, afec. ta la forma de azadon y carece de ojuclos, pero en los lados tienc ojos redondos, debajo los cuales se insertan las antenas, que tienen de doce á cuarenta artejos. Las partes bucales no difieren esencialmente de las de los ortópteros anteriores, solo que la barba es cuadrada y cubre casi toda la region inferior de la cabeza, mientras que el labio inferior se compone solo de dos glóbulos redondeałdus. El abdómen, casi siémpre un poco mas ancho en la extremidad, y redondendo lateral. mente, se compone de nueve segmentos, pero en la hembra se atrofian dos del todo, el víltimo en la cara inferior. Las numerosas especies se distinguen por sus tenazas diferentes, aun en los sexos de una misma; por los artejos de los piés; por la forma mas ó menos perfecta de las alas y del coselete, y por otros caractéres bien marcados que han servido de base para la formacion de varios géneros. La forficula gigantesca tie. ne en el centro de las tenazas un diente; las de la hembra, mucho mas cortas, no presentan ninguno detrais del centro. Las antenas se componen de veintisiete a treinta artejos.

Lista interesante especie se encuentra aislada en Europa (Alemania, Inglaterra, etc, etc.), pero tambièn en cl Asia y en el norte del Africa.

\section{LA FORFÍCULA AURICULAR-FORFICULA AURICULARIS}

CARACTERES. - I.a forficula auricular ó comun ticne un color pardo oscuro brillante; las patas, los bordes del escudete y la base de las anienas, que tienen quince artejos, son amarillos y la cabeza de un rojo de orin. En el último segmento del abdómen se ven algunas pequeias prominencias. Jar tenaza del macho es aplanada en la base y siempre denticulada, pero despues cilindrica, sin dientes; el centro esta muy encorvado hácia fuera. Las de la hembra se tocan en su cara anterior y se encorvan en las puntas ligeramente liácia arriba. El tamajo varia de $0^{m}, 00875 \& 0^{\circ}, 015$; la hembra es sicmpre mas pequeña.

DISTRIBUCION GEOGRÁFICA. - La forficula auricular habita en tocia la Europa, pero á nadie le gusta verla.

USOS, COSTUMBRES Y REGIMEN. - El jardinero conoce muy bien este insecto porque destroza sus mejores clareles y georginas: por eso coloca pezunas huecas de cabra ó de vaca, etc., sobre lus palitos que rodean las plantas, i fin de atraer al insecto a un escondite agradable, del cual lo saca para matarlo. Al indio no le gusta comer las uvas cuan. do una forficula sale del racimo; $y$ la cocinera ccha con re pugnancia la colifor en la olla si al limpiarla ha visto al pardo insecto con sus amenazadoras tenazas. El campesino debe proteger sus oidos contra el insecto para que no entre y le destroce el timpano, aunque á pesar de su nombre, la forfi cula auricular no tiene nada que ver con nucstras orejas. Puede ser que al hombre que duerme sobre la yerba se le haya introducido alguna ver en los oidos, porque le agradan tales escondites oscuros; pero ya en otro lugar hemos indicado los peligros que amenazan por otra parte a tales imprudentes y lo mejor es por lo tanto no dornir en tierra al descubierto. La forficula auricular pasa el invierno en estado perfecto para propagarse al ano siguiente; y segun la temperatura despierta mas ó menos pronto. En $10^{\circ}$ de febrero vi un macho que subia lentamente por un tronco de árbol; algunos años mas tarde (1874), el 19 de tebrero, hallé debajo del musgo, en terreno arenoso y húmedo, un montoncito de huevos ama. rillentos, guardados por una hembra. Si eran de esta, la temperasura benigna habia apresurado sin duda su salida; pero como no estaba seguro, me llevé huevos y hembra á mi casa. Los primeros eran muy elásticos, estaban del todo secos, y fué preciso sacarlos con un pincel de la arena. Con esta llené despues el fondo de una botellita, para poner en ella la forficula, y dejé caer los huesos, en número de doce à quince, que se diseminaron por el fondo de la rasija. De este modo debia reconocer si la forficula cra la madre, pues habia leido que esta reune ell monton los huevos dispersos. Era ya de noche cuando efectué esta operacion, y la forficula estaba demasiado preocupada por el cambio para hacer caso de otras cosas; pero à la mañana siguiente los huevos formaban un montoncito $y$ hallitbanse cubiertos por el pecho de la cuidadosa madre, que casi siempre permanecia en esta posicion cual si quisiera incubarlos. Cuando estos tomaban una posicion muy oblicua, inclinándose hácia la pared de la vasija, la hembra los colocats en el lado opuesto, en una ligera cavidad practicada antes en la arena; y en una palabra, mostraba la mayor solicitud por su progenie. Quizis contribuya al desarrollo de los huevos lamiéndolos, ó de algun otro modo particular.

El cáliz. de una flor fresca de primsulis chinensis, las partes blandas de una mosca aplastada, y algunas larvas de insectos constituian antes y ahora el alimento de mi cautiva. El 7 de mazzo se presentaron las primeras larvitas blancas, y poco despues todos los hueros habian desaparecido. Debo notar que su reducida prision se hallaba cerca de la ventana de una habitacion bien caldeada, y u ue el 5 de mayo de 18,6 encontré una madre con sus hijuelos al descubierto.

Las larvitas se cocultabar á menudo debajo de la madre 6 pascàtansc sobre ella, procediendo muy libremente, y pronto royeron las flores de la primula. Lil 30 de marzo humedeci un poco la arena, y como algunas gotas de agua no fueron absorbidas con bastante rapider, los pequeños, insectos, hallando demasiada humedad, se colocaron en las paredes de la botellita, cosa que ya habia observado en algunas larvas, pero nunca en la madre. En esta ocasion solo conté siete larvas cuyo tamaño diferia poco. Las mas grandes median sin tenazas $U^{*}, 006$ de largo. Una de ellas se habia escapado de la prision, yo mas tarde la encontré en una maceta próxima. No pudc observar si la madre hatria atacado à la cria. Degeer encontró en su tiempo támbien una pequeña fimilia de forficulas, y dice que la madre murió poco despues de haber salido los hijuelos, que devoraron el cadaver y tambien dos de sus hermanos, muertos casualmente.

El 21 de abril di a mis cautivos una habitacion mas grande, y entonces no encontré mas que tres larvas, observando que la arena estaba muy revuelta; al mismo tiempo afiadi un macho que habia encontrado debajo de la corteza de un árbol, y el cual se manifestó indiferente con sus compañeros; toda la sociedad experimentó por lo demás una sensacion muy fastidiosa. Despues de pasar algunos dias sin observarios encontré, el ig de mayo, el cadiver de la hembra mutilado en su parte anterior, y las dos larvas que aun existian ocupadas en roer en el mismo sitio el cuerpo del macho muerto; parecióme que tambien habian comido las pieles que antes vi, pues ya no cstaban ahora. Su longitud ern de 9",009, sin las tenazas, y marcadamente se reconocian ya los rudimentos 
de las alas. I.as maté para conservarlas en mi coleccion como productos de mi propia cria.

Tenemos en la forficula auricular, y sin duda tambien en cada especic de este grupo, otro ejemplo de las que viviendo al aire libre con el periplaneta oriental y el grillo doméstico, $\tan$ aficionado a nuestras habitaciones, forman una excepcion de esa regla general entre los insectos, segun la que la madrc no ve $i$ sus hijuelos: la forficula vive bastante tiempo en compañia de su progenie, sin que se haya podido encontrar hasta ahora la razon de este fenómeno excepcional.

Además de la citada especie, hállanse otras dos mucho mas pequeñas en uuestros paises, de las cuales sin embargo no podcmos ocuparnos, por interesante que sen el género de vida de esta familia, á juzgaŕ por las noticias anteriores.

\section{LOS TRIPIDOS -THRIPIDE}

CARAC̣TÉRES.-Haliday agrupó bajo el nombre de Iysampiera cicrto número de insectos pequeñisimos que pur la forma general del cuerpo y la movilidad de su delgado abdómen aseméjanse a las forficulas, y i los blatidos por tener la cabera dispuesta oblicuamente de arriba abajo y hicia atrás. Sin embargo, ofrecen tantas particularidades, que no se puede agruparlos con unos ni con otros. Los entomólogos alemanes modernos los reunen bajo el nombre de trípidos con los ortópteros, aunque la forma de la boca es esencialmente distinta, haciendo que estos pequeños séres formen el iránsito, entre el órden que nos ocupa y el siguiente. Ia cabeza es cilindrica, porque la boca se prolonga en forma de trompa; las mandibulas, bastante largas, se insertan en el labio superior y están provistas de palpos de dos $\delta$ tres artejos; los palpos labiales tienen dos. Estos insectos chupan pues su alimento que se compone de jugos vegetales. En medio de los grandes ojos sobresalen en la coronilla las antenas de nueve artejos a lo sumo, y por detrás de cstos pueden descubrirse tambien ojuelos, todo con ayuda de un buen microscopio, pues la mayor parte de estos pequeños seres ni siquiera llegan a la longitud de $\left(1^{\circ}, 00225\right.$, c.cediendo raras veces de esta medida. El protórax es mas estrechn que los dos segmentos siguientes del tórax en los que se insurtan las alitas en forma de lanceta en extremo angostas y provistas de largas franjas: todas cuatro son muy sólidas y apenas necesitan nervios; a menudo presentan manchas ó fajas abi. garradas; apóyanse sobre el abdómen, y se atrofian sambien mas ó menos, ó faltan del todo. Otra particularidad de estas especies, que habitan toda clase de flores, es la de que los piés no rematan en garras, sino en discos redondos, que segun la noticia de Kerby produce unas cosquillas muy molestas cuando en dias calurosos se posan estos insectos en la cara del hombre. Es posible que sean mas numerosos en Inglaterra que en Alemania, donde no be hecho aun mas observaciones.

Segun la distinta configuracion del abdómen, los tripidos se dividen en dos géneros, en uno de los cuales la citada parte se compone de dier. segmentos, que en ambos sexos rematan en una especic de tubo; mientras que en el otro género el Litimo segmento contiene un órgano semejante com. puesto de dos válvulas laterales.

\section{EL TRIPS DEL TRIGO - TRIPS CEREALIUM}

CARACTÉRES. - Esta especie purtenere al segundo de los géneros citados; solo las hembras tienen alas. los individuos adultos son de color rojo de orin, $y$ hasta negro. Solo los piés de las patas anteriores y las membranas ligatorias, entre los segmentos del abdómen, ofrecen un color amarillo de paja. La larva es de un amarillo de naranja vivo; en la cabeza, una parte del protórax y una extremidad del abdó. men son negras; las antenas y las patas presentan anillos cla. ros que alternan con otros oscuros. A la cuarta muda vénse en las hembras los rudimentos de las alas que llegan hasta la mitad del abciómen. Su color palidece, excepto en los ojos, que tienen un tinte rojo oscuro: los movimientos de esta es. pecie son pesados y torpes.

USOS, COSTUMBRES Y REGIMEN.-Estos insectos se hallan con frecuencia en grandes masas en las espigas del trigo, y tambien entre las hojas y el tallo, por lo cual destruyen numerosas simientes. Es muy probable que el insecto desarrollado inverne $y$ deposite en la primavera sus huevos en tales sitios.

\section{EL HELIOTRIPS DE COLA ROJA-HELIO- THRIPS HAMORRHOIDALIS}

CARACTRRES. - Los individuos adultus de estit especie tiencu un color pardo negrurco excepto la parte posterior del abdómen, que es de un rojo pardo; las antenas y las pa. tas son de un amarillo pálido y las alas de un blanco sucio; tiene cuando mas una longitud de $0^{\circ}, 00112$.

USOS, COSTUMBRES Y REGIMEN. - El heliotrips de cola roja vive todo el año en las plantas de los invernade ros bien calidos: prefiere la planta india ficus retusa y la begonia cebrina; se hija en la cara inferior de los retoños tier. nos, que se marchitan por la pérdida de savia; el insecto sucle chupar de noche y entonces se aparea tambien en esto tiempo. Ia henibra fecundada deposita sus huevecitos, blancos y ovales, casi siempre aisladamente, en la cara inferior del nervio central de las hojas. Al cabo de ocho ó diez. dias salen las larvitas, que son de un color amarillo rojizo pálido; carecen de ojuelos y de alas, y tienen las antenas blancas, distinguiéndose solo tres artejos. Fn intervalos de igual duracion mudan tres veces, adquuieren en la última muda los rudimentos de las alas y son en tal estado de crisalida muy activas; no toman alimento, porque todo el cuerpo está rodeado de una membrana cermada. Al cabo de cuatro dias la crisúlida cornienza á tomar un color mas oscuro; solo las antenas, las patas y las alas se conservan blancas. Seis ú ocho dias mas tarde, cuando ha abandonado la piel de ninfa, el insecto desarrollado adquiere todo su color y la facultad de propagarse.

Esta y otras muchas especies que el jardinero reune bajo el numbre de moscas negras, causan bastante perjuicio en los invernaderos á causa de su abundancia.

\section{LOS TISANUROS - THYSA- NURA}

CARACTÉRES. - Bajo el nombre de tisanuros reunió Iatreille una seric de insectos particulares en un órden inde. pendiente, que se distingue por la carencia total de alas, por tener grupos de ojuelos desde los ojos, antenas largas y apén. dices correspondientes en la extremidad del cuerpo; los tegumentos del cuerpo, prolongado en extremo y blando, son particulares. Estas especies viven muy ocultamente. Burmeister jué el primero en clasificarlas entre los ortópteros, pues su reu. nion con otros órdenes de estructura muy diferente, fundada en que los tisanuros no tienen alas ó no pasan por una metamorfósis ó su inclusion en el órcien independiente de los åp. tcros (agtera) ó ametabolos (amelaticla), puede aprobarse aun mucho menos Se dividen naturalnente en dos fumilias: la de los lepismátidos y la de los poduridos. 


\section{LOS LEPISMÁTIDOS - LEPISMATIDA}

CARACTÉRES. - Los lepismátidos tienen el cuerpo prolongado, ligeramente convexo en su parte superior, cubierto de tiernas escamas con viso metálico, de un modo tan delicado como las alas de las mariposas. En la cabeza inclimada se ven largas antenas nudosas de muchos artejos y detrás de estas cierto número de ocelos. En los órganos masticadores sobresalen los palpos maxilares, compuestos de siete artejos; los labiales solo tienen cuatro. Los tres segmentos del tónx, sobre todo el primero, se distingue de los diez del abdómen por su mayor tamaño, y recuerdan álos blatidos. Los muslos son gruesos; los tarsos cortos, provistos de una espina en su extremidad; los piés de dos ó de tres artejos y con garras; la extremidad del abdómen remata en cerdas articuladas de un numero impar.

\section{EL LEPISMA DEL AZÚCAR - LEPISMA SACCHARINA}

CARACTÉRES. - Esta especie, una de las mas disemi. nadas y conoridas de los cocos lepismáticos, es un animalito muy ágil, cubierto de escamas blancas en sus partes superio. res, $y$ de un color amarillo en las inferiores, en las patas y las antenas. Las tres cerdas caudales miden casi la misma longitud; cuéntanse dos artejos en los piés, yen los palpos maxilares cinco; las maxilas, formadas por una exterior cónicin y otra interior ganchuda, carncterizan sobre todo al lepisma del azúcar. Despues de varias mudas, que no producen ningun cambio en la forma, llega a su completo desarrollo y es apto para propagarse.

USOS, COSTUMBRES Y RÉGIMEN.-Este pequeño insecto se oculea con preferencia en las despensas y en las casas vicjas, donde sin embargo no se le recibe muy bien, pues se le acusa de causar tantos perjuicios como la polilla en la lana, en los tejidos, en el papel y hasta en el cuero.

\section{LOS PODURIDOS - PODU- RID}

CARACTERES. - Bajo formas mas variadas se presentan los poduridos, cuya cabeza se prolonga en linea horizontal; el tronco es cilindrico; el protórax mas corto que cada uno de los otros dos segmentos del tórax, iguales entre si; el abdómen se compone de seis 6 de tres segmentos. En la parte anterior de la cabeza se insertan las antenas, q̧ue son fuertes, con cuatro ó seis artcjos, y detrís de estos, en grupos, los ocelos, dispuestos de cuatro en cuatro ó de ocho en ocho y hasta de veinte en veinte. Las partes bucales, aunque cxisten, son dificiles de reconocer $y$ carecen de palpos en la mandibula inferior. Las patas, algo pesadas, rematan en una sola articulacion del pié, bipartida y provista de uña Para saltar se valen del apéndice ahorquillado de la extremidad del abdómen. La elasticidad es tañ notable, que a una especie, el poduro acuá. tico (poduera aquatica), la superficie del agua le sirve de punto de apoyo.

USOS, COSTUMBRES Y REGIMEN. - Todos los poduridos necesitan para su bienestar cierto grado de hume. dad, y por eso se les encuentra bajo la hojarasca mojada, de. bajo de la corteza de árboles en putrefaccion, cn el agua, en el hielo $y$ sobre la nievc. La mayor parte de ellos ponen numerosos huevos de una pequeñez microscópica Nicolet, á quien debemos minuciosas averiguaciones sobre estos séres interesantes, encontró en una hembra r, 360 huevos, que suelen ser lisos, pero a veces tambien ásperos, ovales, prolongados ó esféricos. Primero se desarrollan los ojos; des. pues se rompe a menudo la membrana del huevo, y una mitad anterior $y$ posterior quedan adheridas a las respectivas partes del embrion. Las patas y las antenas aparecenal principio como bolsas no articuladas, y desde la puesta del huevo hasta que se desarrolla el embrion pasan unos doce dias. Los hijuelos, que son pequeñisimos, tienen una cabeza relativamente grande y el abdómen corto. En la siguiente muda, la cabeza adquiere su forma invariable; $y$ despues sucédense otras muchas con intervalos de doce à quince dias.

\section{LA DESORIA GLAGIAL-DESORIA GLACIALIS}

Caracteres. - Esta especie, una de las mas interesantes, tiene las antenas de cuntro artejos, la horquilla abdominal recta y siete ocelos à cada lado de la cabeza.

DISTRIBUCION GEOGRAFICA. - Fn una region donde el sol no toca, donde solo hay agua, hielo $y$ piedras, $y$ donde apenas puede calentar la capa inferior del aire, vive cl pequeño insecto negro y peludo que debe à su primer descubridor, Desor, su nombre cientifico. Hace unos treinta y cinco años que se le encontró en el monte Rosa, poco despues en el ventisquero interior del Aar, $y$ mas tarde en los de Grindelwald.

USOS, COSTUMBRES Y REGIMEN.-Nicolet, que hizo varios experimentos con desorias glaciales, vió que es. tån bien en el agua de 24 grados centesimales y que resisten hasta los $3^{8}$ grados; los mismos individuos que liabian sido expuestos à la temperatura mas calurosal hizo Nicolet helar en - I I grados cents., dejándolos diez dias en el hielo; y cuando este se desheló volvieron à saltar alegremente; una nueva prueba de la resistencia vital en los animales mas pequeños y delicados, resistencia que no se imaginaria. No sé si esta especie es la misma que á reces se presenta en Alemania, pues no conozco ninguna de las dos por haberia vis. to yo mismo.

\section{EL PODURO VELLUDO-PODURA VILLOSA}

CaRAGTERES. - Esta especie es una de las mas abigarradas, pues tiene el cuerpo de color rojo amarillo, cubierto de fajas negras. Agrádale vivir en las espesuras debajo de la hojarasca, en companía de la siguiente especie.

\section{EL PODURO APLOMADO-PODURA PLUMBEA}

CARACTERES. - El cuerpo de este poduro está cubierto, no solo de pelos sino tambien de escamas; tiene antenins muy prolongadas, aunque solo de cuatro artejos, una larga horquilla abdominal, y cl tercer segmento del abdómen de notable longitud. Esta especie y la anterior miden hasta $0^{\circ}, 00337$.

Al examinar los lugares fétidos encontramos numerosos séres semejantes que por sus caractéres principales se dan a conocer como poduridos, aunque cada uno tiene sus particularidades, por lo cual los naturalistas se vieron obligados a formar con el primitivo género podura de Linneo unn serie de nuevos géneros.

\section{LOS MALÓFAGOS-MAL- LOPHAGA}

Los ortópteros se ofrecen â las miradas del naturalista 
en tierra firme y en el agua, en fiores y arbustos, asi como en las susiancias vegetales en putrefaccion, en la oscuridad de nuestras habitaciones y en las regiones aéreas.

Tanto en las verdes alfombras de las praderas, como en las profundidades de los valles; asi frecuentan los eternos campos de nieve como las cimas de las montanas, y hasta se introducen en las partes accesibles de los animales de sangre caliente. Hay entrc ellos tambien parasitos que, sin embargo, no se alimentan de la sangre, sino de los pelos de su piel, como los tricodectos, $\delta$ de las partes bilandas del plumajc: como los tocóforos. Los malófagos, segun puede llamárselos, dindoles un nombre comun, se parecen por su forma exterior á los piojos tanto que nada mas fácil que confundirlos con ellos; mas á pesar de esto. el entomólogo no puede agruparlos con ellos, porq̨ue no chupan sangre, y for lo tanto es distinta la configuracion de su boca. I ass hembras ponen tambien sus huevos en pelos ó plumas, y los hijuelos que salen tienen exactamente la forma de los adultos, pero solo desprues de algunas mudas adquieren el color y toda la solidez de sus tegumentos. Como la mayor parte de estos insectos apenas ticne la longitud de $0^{\prime \prime}, 00225$, viven siempre ocultosy suelen abandonar los animales en que habitan cuando estos mueren; los mas no son vistos del naturalista sino cuando este los busca con empeño sin temer las grandes dificultades que su examen ofrece. Nitzsch ha dedicado 30 años de su vida á este estudio con su acostum. brada solicitud, dejando á su muerte descripciones y numerosos y excelentes dibujos de unas 60 especies de tricodectos y 400 de tocóforos, descripciones que solo últimamente, es decir hace 36 años, fueron publicadas por Giebel (Insecta spison, Leipzig, I 86.4).

CARACTERES. - Ios malófrgos carecen de alas y de ojos compuestos; tienen el cuerpo plano, cubierto en su parte superior, del todo ó parcialmente, de placas córnens; el resto del cuerpo es membranoso; la cabeza, cónica y en forma de escudo, se prolonga horizontalmente con las partes bucales en su cara inferior. Ias maxilas afectan la forma de ganchos cortos y fuertes, à veces denticulados en su carn anterior. las mandibulas, casi siempre muy pequeñas, tie. nen, en los unos, palpos dé cuatro artejos, mientras que en los otros carecen de ellos. Los labios superior é inferior, provisto el ultimo regularmente de cuatro artejos, se reconocen con facilidad. Las antenas se componen de tres, cuatro $\delta$ cinco artejos, $y$ ofrecen muchas variedades segun el sexo y la especie. Fl tórax se compone casi siempre de dos segmentos, porque los dos posteriores están soldados. El abuómen tiene nucie ó diez, de los que los del centro son siempre los mas anchos. Las patas suelen ser cortas, pero fuertes; los muslos jlanos y comprimidos; el pic tiene dos artejos y remata en dos pequeñas garras en los tocóforos, mientras que los tricodectos solo tienen una movible, propia para trepar. Los malóngos con antenas filiformes de tres ó cinco artejos y sin palpos maxilares constituyen la familia de los filopicridos (philoptevide) que contrasta con los lioteidos, cuyas antenas de cuatro artejos afecian la forma de maza j cuỹas maxilas estån provistas de marcados palpos. En ambas familias se encuentran tricodectos y tocóforos; en el sentido antes indicado.

\section{LOS TRICODECTOS-TRICHODECTES}

CARACTERES.-I,OS pilivoros de la primern familia, que habitan en los mamiferos carniceros y roedores domésticos, constituyen el género de los tricodectos, los cuales se distinguen jor sus antenas de tres artejos, por tener una sola garm en cada pié y espinas de uno 6 dos artejos en el antepentil- timo segmento del abdómen de la hembra, que rematr en dos lóbulos. I a especie trichudectes lafus 6 fiojo de los perros se caracteriza por sus cortos piés con una garra muy corva: la parte anterior de la cabeza se corta y el angulo posterior de cada segmento del alddómen es agudo. A las especies de piés delgados y de garras casi rectas pertenece el fiojo de las cabras (trichodectes dimax), cuya cabeza se corta tambien en la ancha parte anterior $y$ cuyos dos últimos artejos de las antenas tienén igual longitud; y al piojo de las raias (trichodectes sraiaris), con la cabeza bilateral estrechada en su parte anterior.

Los caractéres de las especies irichodeciés longicornius (fig. 138 ) que es parásita del cierro y la trichodectes egui (fig. 139), que vive en el caballo, son los ya indicados prara el género, diferenciándose únicamente entre si por algunas variaciones de color.

\section{LOS FILOPTEROS - PHILOPTERUS}

CARACTERES. - Los plumivoros del antiguo género phibopterus se dividen actualmente en cinco géneros. I.os docúforos (áocophorus) se carncterizan por tener un apéndice movible delante de las antenas. Muchos viven en las aves de rapiña, sin haberse cncontrado aun en las palomas y gallinas. El docóforo adulto, en cambio, vive en las plumas de la cabeza y el cúllo de la oca doméstica Las especies que carecen del apéndice movible por debajo de las antenas tienen costas últimas filiformes 6 iguales en ambos sexos; la parte posterior de la cabeza redondeada, lo mismo que fa extrenidad del abdómen del macho (uirmus), en contraste con la jarte posterior de la cabeza, que es augulosa fgonioco. les): las antenas del macho adquieren ia forma de tenazas por una apofisis lateral en el tercer artejo. I as especics en que la parte anterior de la cabera es angulosa en el segmen. to final del abdómen, y en la hembra verrugosa, pertenecen al género goniodes; mientras que aquellas en que la parte posterior de la cabera es redondeada, y la extremidad del abdómen escotada en el macho, constituyen el género lipeurus. Uni especie del género goniodes, el goniodo falcicornio (fig. 14 I): es de color amarilio con manchas pardas en los lados, de modo que en cada segmento del abdómen un punto conserva el color predominante.

\section{EL FILOPTERO DEL CISNE-PHILLOPTE- RUS CYGNI}

CARACTERES. - Fosta especie (fig. 137) tiene el cucrpo bastante ancho: In cabeza consicierable; las antenàs semeinntes en ambos sexos: el último anillo del abdómen de los ma: chos entero y redondeado. I a cabeza, el tórax y las patas son de un castaño brillante, y el abdómen blanco con su primer segmento, asi como una mancha humeral del segundo y tercer par de jatas, castaño.

Este filoptero es parásito del cygmus Bercickii y del mnser segetum.

\section{EL FILOPTERO ARGULO-PHILLOPTERUS ARGULUS}

CARACTERES. - Vil cuerpo de este insecto (fig. 140) es mas estrecho que el de la especie anterior; la cabeza de mediano tamano; las antenas semejantes en los dos sexos, a veces mas gruesas en los machos y otras reces ramigeras: el último anillo del segmento de istos entero y redondeado. Este especie es parisita del cuervo. 


\section{LOS LIOTEIDOS - LIO- TEID压}

A los pilivoros de la familia anterior siguen como pertenecientes á los lioteidos los griropos (grophrus), que se distinguen por tener los piés de una garra y carecer de palpos labiales; los palpos maxilares son cónicos y en cada lado de la cabeza hay una profunda escotadura, en la que encajan las antenas. Dos especies (syropus oaralis y garopus gracilis), viven en los conejos de Indias.

I.os lioteos (Liotheum) plumivoros, muy ricos en especies, tienen las maxilas denticuladas, los palpos labiales de dos artejos, y en su mayor parte estin provistos de ojos, de dos garras y de un lóbulo prehensil en cada pié; se distinguen de un modo muy variado unos de otros por la forma del tórax y la cabeza y por la disposicion de las antenas, de modo que Nitzsch los ha dividido en seis sub.géneros de los que,-sin embargo, no podemos ocuparnos aqui. Solo diré que a este grupo pertenecen, entre otros, las especies menopon pallidum (fig. ${ }^{1} 3^{6}$ ) y trinotum conspurcalum y otros muchos parásitos, que con algunos lipeuros y otros dos filopteudis habitan nuestra gallina doméstica; en ambas familias aumentarán aun mucho las especies tan luego como los naturalistas fijen su interés en ellos.

\section{HEMIPTEROS-HEMIPTERA}

\begin{abstract}
CARACTÉRES, - Lo mismo que en el órden anterior, este comprende insectos muy diferentes por su cstructura in. terior y solo semejantes por la forma de la boca y la metamorfósis incompleta. Todos los insectos que tienen una trompa para chupar, cuya estructura ya hemos descrito en otro lugar, $y$ cuyas larvas se distinguen de los insectos desarrollados solo por la falta de las alas y en ciertas circunstan cias por algunos artejos menos y mayor níncro de géneros, pertenecen a los rincotos 6 insectos de pico (rivihota). En algunos faltan las alas del todo; en otros solo en las hembras, por lo cual no se verifica en rigor ninguna metamorfosis en ellos. Las cuatro alas, en las especies que las tienen, pueden ser iguales y entonces, por lo regular, de membrana delgada, con nervios longitudinales (por excepcion todas las cuatro pueden estar formadas por una piel sólida mas coriácea), $\delta$ bien desiguales, en cuyo caso las alas anteriores son
\end{abstract} mas sólidas, compuestas de quitina en la mayor mitad de la base; las posteriores son de membrana delgada y se trasforman en élitros que, à causa de su naturaleza, se han llamado semielitros, dándose por esto á todo el órden el nombre de hemipteros, pero sin razon, porque soio unas pocas especies del órden estan provistas de alas anteriores de tal estructura. Por lo tanto, repitense aquí las mismas proporciones respecto a las alas, que en el órden anterior: algunos rincotos con elitros y protórax libre se oponen á otros con alas iguales y protórax menos separado; y hay tambien especies desprovistas del todo de alas. La cabeza se inserta con su base mas 6 menos profunciamente en el torax y tiene unas antenas pequeñas $y$ " ocultas, ó bien tharcadas. A reces solo hay ocelos, pero con frecuencia vénse tambien ojos de tamano regular $y$ un pico muy próximo, cuya parte visible se compone esencial. mente del labio inferior trasformado en una especie de tubo. El abdómen se compone de $i$ à 9 segmentos cuyos estigmas están situados en la cara del vientre. En todas las especies has patas estan igualmente desarrolladas, tienen un trocínter del muslo y dos ó tres artejos en el pié; aunque en las mas de las especies sirven para andar, se encuentran tambien tales que son propias para coger la pared, saltar y nadar.

Se conocen actualmente cerca de 12,000 especies de rincotos, diseminadas por todos los continentes. Este número, sin embargo, no llega ni con mucho á la realidad, porque hasta ahora solo se han examinado las mas importantes que se hallan fuera de Europa. I as especies fósiles no faltan en la formacion del Jura; pero son mas variadas y numerosas en los terrenos terciarios y en el àmbar.

\section{LOS PEDICULINOS-PE- DICULINA}

Parece del todo justificado clasificar aqui los insectos de este órden, que durante largo tiempo han sido agrupados por los sistematicos entre las especies de que acabamos de hablar, es decir, con los verdaderos piojos, esos atormentadores del hombre y de los mamiferos. Todos los parásitos de seis patas en las aves, sin embargo, aunqque tienen por lo re. gular el nombre de piojos, no chupan sangre sino que pertenecen à los filoptéricios.

CARACTERES.-Los pediculinos, ó piojos, no tienen alas; las antenas son filiformes, de cinco artejos, excepto en el piojo del mono ( Aediculus currggaster.), en el que solo hay tres; los piés tienen dos, de los cuale's el último es ganchudo y puede doblarse contra el penúltimo, permitiendo asi al in. secio irepar. Lal cabeza, situada hurizontalmente hácia adelante, carece de ojos $\delta$ los tiene muy pequeños y sencillos; las partes de la boca solo son visibles cuando el animal come. Esta se compone de un cono blando, corto y recogible cuyo borde anterior estri rodeado de series de ganchitos. En este tubo cncajan como en una vaina ntros cuatro pequeños y córneos que de dos en dos se reunen en uno estrecho y otro mas ancho; el tubo interior sobresale nucho, introdúcese en la piel y sirve para clupar la sangre; la corona de ganchos de la vaina exterior del pico sirve al insecto para agarrarse y para cerrar herméticamente la bomba, produciendo, sin duda, entonces la impresion desagradable, pues todo el mundo creerá por lo que siente que el piojo come y no pica. El pequeño tórax solo presenta ligeros indicios de tres segmentos, que en el género Hiematopinus, muy rico en especies, sepáranse marcadamente del abdómen, oval ó redondo. En algunas especies del género pediculus el abdómen, casi siempre oval, permite reconocer por varias estrecheces, mas ó menos marcadamente, nueve segmentos, y es bastante tras- 
parente, de modo que se puede ver el intestino, sobre todo cuando está lleno de alimento.

Los piojos se propagan por huevos, en forma de pera, cuyo número es excesivo. la hembra los adhiere à la base de los pelos, y el calor de la traspinimcion animal los desarro. lla al cabo de ocho dias. Por una tapa sale el pequeño piojo á la extremidad superior, trasformándose en adulto en mas ó menos tiempo; pero siempre rápidamente y segun parece sin mudar. Leeuwenhoek ba calculado que una hembra puede presenciar al caiso de ocho semanas el naciuniento de cinco mil vástagos, lo cual demostrará que no muere despues de haber puesto los huevos. Muchos mamiferos, como cerdos, rumiantes, solidungulados, roedores y monos estan infestados de piojos, cada cual de una especie determinada, ó de dos a un tiempo: el hombre alimenta tres.

\section{EL PIOJO DE LA CABEZA-PEDICULUS CAPITIS}

CARACTÉRES. - El piojo de la cabeza vive principal. mente en las cabezas de los niños sucios. ES de color aunarillo gris, mas oscuro en los bordes de los segmentos abdomimales, y tiene un tórax bastante cuadrado. En el macho, mas pequeño, la cabeza se separa marcadamente, y se le reconoce muy bien por el órgano genital, que sobresale en forma de espina, indicando su prosicion que en el apareamiento le cu. bre la hembra. Fista pone despues unos iso huevos, cuyo contenido es propio para la propagacion al cabo de cuatro semanas.

\section{EL PIOJO DE LOS VESTIDOS-PEDICU- LUS VESTIMENTI}

CARACTERES. - Hay una segunda especie, un poco mas delgada y grande, que no tiene parduscos los bordes posteriores de los segmentos abdominales: es el piojo de los vestidos, que se alimenta en el cuerpo humano, sobre todo en el pecho y la espalda, ocultándose en la ropa; esta especie es la que molesta a los soldados en campaña y' en los cuarteles. Ia delgader del insecto consiste, no solo en ser el cuerpo mas angosto y la cabeza muy estrecha en su interior, sino en las incisiones de los segmentos. Las hembras ponen los huevos entre las costuras de la ropa blanca, y hé acqui porqué esos incómodos parásitos anidan con preferencia alli donde aquella no se inuda tantas veces como lo exige el aseo. De la llamada cenfermedad de piojos so ó eftiriasis, Moufet nos refiere hechos pasmosos, dando las cxplicaciones mas extrañas, indicando la existencia de una especie llamada fediculus tabessentium, piojo que nadie habia visto. Diodoro, quien dice que los langostifagos del Africa mueren los mas de esta eniernedad, llama á los parásitos que salen del bajo vientre y del pecho, causando al principio la misma impresion que la sarna, «piojos alados. \& Como la citada en. fermedad no ha vuelto á presentarse nunca desde los tiempos en que se emite un juicio bajo el punto de vista cientifico, dicho piojo y sus efectos quedarán sumidos probablemente en una oscuridad inpenetrable.

\section{LA LADILLA COMUN-PHTHIRIUS INGUI- NALIS}

CARACTERES. - I ladilla difiere esencialmente de los piojos por la forma del cuerpo y además por la circunstancia de que en las patas anteriores solo hay un artejo en el pié. Este parásito blanquizco de $11^{\prime \prime}, 00 \mathrm{r}$ I de largo por casi la misma anchura, tiene un tórax que apenas puede dis- tinguirse del abdómen, que es cuadrado, y entre los segmen. tos de este unas espigas carnosas laterales cubiertas de pelo. Este repugnante sér se oprime con las patas contra el cuerpo, penetra á mucha jrofundidad y produce una sensacion muy desagmable; excepto la cabeza, fijase en todas las partes del cuerpo cubiertas de pelo. Antes se combatia con fricciones de ungiuento de mercurio, pero desde que se conocen los aceites minerales, consiguese el mismo fin sin que se necesite mudar la propia piel.

\section{LOS HEMATOPINOS - HÆMA- TOPINUS}

CARACTERES.-El género de los henmatopinos se caracteriza por la proporcion del tórax en el abdómen, y se dis. lingue por su riqueza en especies, que llenan á nuestros animales domésticos de verdaderos piojos. Además de los pilivoros, en of perro vive el verdadero piojo canino (hematopinus piliferus) (fig. 135), en la cabra la especie hematopinus slenopsis, en el cerdo la magnifica urines (fig. 134 ), en el ca. ballo y el asno el hematopinus macrocephalus; $y$ las vacas alimentan hasta dos especies, hematopinus lenvirostris y otra mas pequeña, hemalupinus corrysternus.

\section{LOS COCCINOS-COCCINA}

CARACTERES. - Si de las especies de que acabamos de hablar no hemos podido decir nada interesante sino sobre parasitismo en su forma mas comun, la familia de los cocci. nos en cambio, llamados tambien siojos de escarlata ó de: escudo, ofrecen muchas particularidades, siendo una de ellas la diferencia completa del macho y de la hembra de la mis. ma especie no solo por la forma exterior sino tambien por el modo de desarrollarse. Las hembras producen larvas movi. bles en las que pueden distinguirse en la cara inferior de la cabéza antenas y un pico; en el cuerpo, en forma de escudo y articulado por estrecheces, seis patas con piés de dos ó tres artejos y una $\delta$ dos garras. El pico exterior, compuesto de tres artejos, 5" que no se puede recoger como en las especies anteriores, oculta en su interior tambien cuatro cerdas; estas parten de la cabeza y penetran á mucha profundidad en el cuerpo, donde forman un lazo, volviendo despues a la cabeza. Por esta estructura, que tambien se observa en la familia siguiente, los coccinos pueden prolongarse en extremo $e$ introducirse a mucha profundidad en las plantas, de cuyo jugo se. alimentan exclusivamente estos insectos. L.as antenas tienen Ia forma de cordon ó de hilo, y en las mudas aumenta poco a poco el número de artcjos, sin alcanzar á pesar de cllo mucha longitud. Ios ojos son sencillos en hs especies en que existen. Las larvas corren al principio ágilmente por la planta de que se alimentań para buscar un sitio conveniente, donde se agarran con su pico y en el que mueren despues. Cuando le han encontrado cmpiezan a crecer y à tomar figura; pero jamás adquieren alas. Despues del apaàreamiento se dilatan mas y mas y no se ve ya ningun artejo en la superficie superior ni en la inferior; en esta ullima, las antenas y patas que antes podian distinguirse comienzan á desaparecer. Entonces depositan sus numerosos huevos en una especie de tejido resistenie, á veces blanco, $y$ despues de morir permánecen sobre ellos, como escudandolos: muy raras veces caen. Cuan. do el tejido se hace visible exteriormente y por lo tanto el borde del cuerpo no se oprime ya contra la planta, puede suponerse que la hembra ha muerto. Antes de que los hijuelos, despues de salir del huero, abandonen su cuna, ya han mudado una ver. Ëstas son las noticias generales sobre la heınbra. 
Muy diferentes son las condiciones en el sexo masculino. La larva del macho, al principio parecida it la de la hembra, solo que es mas delgada y pequeña, se agarra con el pico y crece, pero fabrica una especie de capullo, $\delta$ segrega de su superficic una cubierta, como sucede tambien a veces con las larvas femeninas; despues se trasforma en una crisalida, de la que nace un delicado sér con dos alas, el cual sale por fin de la extremidad posterior del capullo y se distingue por tres divisiones principales del cuerpo; las anteriores son cerdosas 6 en forma de cordon; los ojos séncillos; el pico atro. fiado; los piés bien marcados; y á menudo hay dos largas cerdas caudales, de cuyo centro sale el largo órgano genital. El macho, que escasea bastante, vive solo corto tiempo; se conoce por lo tanto en muy pocas especies, y hasta es posible que falte en algunas.

Por las condiciones vitales que acabamos de indicar, algunos géneros se diferencian esencialnente. Asi por ejemplo, en el género aleurodes ambos sexos se parecen casi del todo; en el géneru dorlhesior lạs hembras consernan su actividad hasta la muerte, pero de lo dicho resulta que tambien en este caso quedan muchas averiguaciones por liacer. Ia major parie de los coccinos pertenecen à las regiones cálidas, pero como en estas hay abundancia de otros insectos mas fáciles de observar y de coger, debemos ver en estas circunstancias una razon mas para que sean escasos nuestros conocimientos sobre estas especies tan pequenas comn interesantes.

¿Quién no ha visto ya los restos pardos casi esféricos del lecanio de las encimas (lecanium ouercus) entre la cortera de añosos troncos de encina, à menudo dispuestos en seriés que se conservan muchos años? Mientras viven las hembras, que afectan la forma plana de un escudo, y que en su estado de larvn tienen antemns de ocho artejos, nadie fija su atencion en ellas; los machos se distinguen por tener dos cerdas caudales. Un insecto del todo semejante, el lecanio de la vid (lecanium aitis), vive en las cepas viejas, sobre todo cuando los restos de la hembra cubren un cojin blanco como la nieve, que puede descomponerse en hilos análogos a los del tejido de las aranas.

\section{EL LECANIO DEL QUERMES-LECANIUM ILICIS}

Bajo el nombre de quermes, baya carmesi, grana ihermes, Kermes tinclorm, etc., recibese del archipiélago griego, y sobre todo de Gandia, una materia colorante conocida ya de los griegos y romanos antiguos. Esta materia parda, en forma de concha, que tratada con vinagre produce un color rojo con el que tinen á menudo los gorros de los griegos y turcos, pertenece al lecanio del quermes, insecto que vive en una especic de encina (quercus cocrifera) aunque mas a menudo se encuentra en arbustos añosos, los cuales se hallan cubier tos de este cóccido esfenio, muy semejante al lecanio de las encinas de Alcmania. Segun que la temperatura es mas $\delta$ menos suave en el invierno, la cosecha del Kermes abunda mas $\delta$ menos, recogiendose mucho si la primarern pasa sin hielo y nieblas. P'or lo regular solo hay una cosecha at año, y solo en casos muy favorables dos. A principios de marzo los diminutos insectos son mas pequeños que un grano de nijo, y en abril llegan a su tamaño mas considcrable que es el de un guisante. A fines de mayo se encuentran de 1800 i 2600 huevos debajo de los restos de la hembra, muerta poco despues de la puesta. En este tiempo los jastores, niños 6 mujeres recogen los Kermes, dejandose crecer parn este trabajo las uñas y alcanzando tal habilidad que en ciertas circunstancias recogen en un dia dos libras.

\section{LA COCHXNILLA DEL NOPAL-COCGUS CACTI}

CARACTERES-El cóccido mas célebre es la cochini1la. El macho, de color rojo carmesi, tiene dos alas no trasparentes, y antenas de dicz artejos; la hembra, que ofrece el mismo color, estí cubierta como de una especie de cscar. cha. Este insecto habitaba primitivamente en México, donde se le conocia con el nombre de nopal. Desde alli se diseninó hasta varios paises occidentales, a España, Argelia, Java y por fin tambien à Tenerife (fig. 143 ).

Desde 1526 , este precioso insecto, que secado en planchas de hojalata calientes, puede reblandecerse con agua tibia, reconociéndose aun entonces las formas de su cuerpo, cons. tituje un importante articulo de exportacion para Mféxico. Aunque ya Acosta dió a conocer en 1530 el origen animal de estos granos pardo rojos, cubiertos de un polvillo blanco, de los que cuatro mil ciento pesan una onza, y por inas que otros naturalistas habian confirmado el aserto, durante largo tiempo predominó la opinion de que cran de naturalcza vegetal; de modo que aun en 1725 el holandés Melchor Dirujechir hizo una apuesta que le habria costado toda su fortuna si su generoso adversario no hubiera renunciado à ella. Para decidir este litigio apelóse à los tribunales; tomáronse informes de los que en México se dedicaban á la cria sobre la naturaleza de los animales en cuestion, y por último re: sultó que las cochinillas eran insectos.

Fxcepto en la estacion lluviosa, la cochinilla se encuentra en los diferentes periodos de su vida en la planta materna, la cual cubre en cicrtos sitios casi del todo con sus secreciones blancas. Ia hembra deposita alli sus liueros abandonàndolos en este refugio; asoma el pico en la planta y cae muerta al suelo. Al cabo de ocho dias salen los hijuelos, semejantes a la madre, pero estan cubiertos de un largo vello sedoso. Fn dos scmanas mudan varias veces de piel, alcanzando to. do su desarrollo. Ias larvas del macho se forman con el capullo abierto por detrás y descansan ocho dias como la crisálida. Los machos mueren inmediatamente despues del apareamiento, mientras que la hembra vive aun quince dias para depositar sus huevos. Como el desarrollo solo exige pocas semanas se obitencn varias crias, para lo cual se recoge cada vez cicrto número de larvas y las hembras moribundas. Puche crió la cochinilla en el tercer decenio de nuéstro siglo en un invernadero, cerca de Berlin, $y$ obturo cuntro crias con un calor continuo de $16^{\circ}$ à $20^{\circ} \mathrm{R}$. Para el desartollo de una cria se necesitan seis semanas, de las cuales ocho dias se halla en el estado de huevo, quince en el de larva y ocho en el de ninfa; la vida durn otros quince para el insecto desar. rollado. En agosto se obtiene In tiltima cria, y dumnte el in. vierno quedan fecundizadas las hembras que no depositan sus huevos hasta febreró. Los mexicanos dedicados á la cria llevan todos los insectos destinados para esta con las hojas de la planta a sus casas, donde se conserian frescas mucho tiempo, tan luego como llega la estacion lluviosa, volviendo á ponerlas en las plantaciones apenas cesa. Con mas trabajo se recoge de la epanka cucincllifera que crece al aire libre, la llamada cochinilla salmaje, Grana siliestre, que segun dicen los mexicanos da mas cosechas y representa sin duda otra especie y no una variedad de la anterior.

Cuando solo México producia este importanie insecto, se exportaban á Europa todos los años ochocientas mil libras, que importaban casi siete millones y medio de florines ho. landeses; y durante la permanencia de Alejandro de Humboldı en la América del sur, la exportacion anual era todavia de treinta y dos nil arrobas, que valian medio millon de li. bras esterlinas. Del sur de Espana, donde segun hemos dicho se cultiva tambien la cochinilla, y del sur de Tenerife, 
donde á causa de la frecuente enfermedad de la vid ya no se obtienen de esta los resultados suficientes, la exportacion en 1850 ascendió a mas de ochocientas mil libras de cochinilla, que se recibió en Inglaterra. Quien sepa que en una libra se cuentan setenta mil de estos diminutos insectos secos podrá formar idea del enorme número de los que se matan anualmente. Los llamados zurrones españoles en los que se despacha esta mercancia se componen de pieles rescas de buey con el pelaje hácia dentro.

En la cochinilla que se compra se ven los diminutos insectos secos del tamnio de medio guisante, en cuya superficie se distinguen aun muy bien las incisiones trasversales del abdómen. Exteriormente tienen un color pardo, negruzco, cubierto de un polvillo mas ó menos blanco; interiormente el color es purpúreo oscuro, line la saliva de rojo, y segun se dice, conserva esta cualidad mas de cien años. Cuando se mojan con agua caliente pueden distinguirse por lo regular las patas y las anteuas, y eul la masa roja gránosa que puede sacarse del cuerpo Reomamey ha reconocido los hnevos.

En el comercio se distinguen varias clases, segun la procedencin: Is coctivilla fina, Grana fina, é mestion, que se cria en la provincia de Honduras; la cochinilla comun, grana sifiestre ó copresiona, compuesta de granos mas ó menos pequeños, segun la diferencia en la preparacion; y la cochinilla renegri. da, una clase que parece ser de color pardo oscuro porque se matan los insectos en agua caliente perdiendo así su capa de polyo, mientras que la clase que le conserva se llamajas. piada los insectos de esta última se matan en hornos calien. tes, de modo que no se borra el color blanco. Puede suceder, no obstante, que los granos se calienten demasiado, adquiriendo un color negruzco, y esta clase se llama mérra; otra que se compone de individuos grandes y peq̨ueños ó deteriorados, tiene el nombre de granilla. Como la clase blanca era mas buscada que las otras, adulterábase poniendo en sitio húmedo los granos que habian perdido el polvo blanco, por espacio de veinticuatro à cuarenta y ocho horas, y mezclandolos desjues con talco molido.

\section{EL CÓCCIDODEL MANÁ-COCCUS MANIPARUS}

Caracteres. - La piel de la hembra de esta especic es de color amarillo de cera cubierto de una especie de plumon blanco; el otro sexo no se conoce aun.

DISTRIBUCION GEOGRÁFICA.-El cóccido del ma. ná vive en los alrededores del monte Sinai, en los tamariscos del mana, donde produce por su picadura la secrecion del jugo, que se seca y cae si no le disuelve la lluvia.

\section{EL CÓCCIDO DE LA LACA-COCGUS IACCA.}

CARACTERES. - Esta diminuta especie se distingue por su cuerpo en forma de lanceta; tiene dos largas cerdas cau. dales, seis patas y antenas de cinco artejos, provistas de tres cerdas en forma de ramas.

DISTRIBUCION GEOGRÁFICA,-Este cóccidoes propio de las Indias orientales.

USOS, COSTUMBRES Y REGIMEN. - El cóccido de la laca produce por su cuerpo la laca roja; sus secreciones son las que bajo diferentes formas circulan en el comercio bajo los nounbres de gelatina ó goma laca. Las pocas no. ticias que tenemos sobre el género de vida de este insecto no estån acordes $y$ además dejan inucho que desear. Segun Kerr y Roxburgh, vive como parásito en algunas especies de higueras (Ficus religiosa é indica) y en tres diferentes nimosas; segun Carter, cerca de Bombay habita en la Anona squa-
mosa.
Tan luego como las hembras se han agarrado at las plantas dilatanse, y perdiendo las patas y las antenas adquieren una forma casi esférica; en el viltimo caso presentan una estrechez. visible en la extremidad anterior. Esta dilatacion se relaciona con la formacion de la laca, porque esta cubre el insecto del todo, pero ligeramente, de manera que no impide la respiracion. Segun las observaciones de Cárter, las larvas salen dos reces al ano; el macho desarrollado se presenta mas tarde que la hembra, y segun la estacion bajo dos diferentes formas, es decir, en setiembre sin alas y en marro alado, y muy semejante al macho de la cochinilla. Despues del aparea. miento muere en la materia segregada rápidamente por la hembra. I a laca está contenida en el ovario; la goma se for. ma por las secreciones de la piel despues cie cogerse el insecto á la planta que habita. En los capullos de laca se han criado varios parissitos.

\section{LA DORTESIA DE LAS ORTIGAS-DORTHE- SIA URTICAE}

CARACTERES.-MUcho difiere el aspecto de las hem. bras hasta ahora descritas, del que ofrece la dortesia de las ortigas, que con su secrecion blanca cubre todo el cuerpo cxcepto las antenas y patas, formando una especie de tubo, y nunca se agarra de tal modo que permanezca en un mismo sitio. La cabeza, situada en el escudo collar, se prolonga hácia atrás y tiene antenas de ocho artejos, puntiagudas y de color negruaco, asi como las patas, que rematan en una gar. ri. La cubierta, de un blánco de cera, que en el vientre forma una placa, se encorva en la parte posterior sobre la del dorso y está cortada formando un ancho borde; el macho tiene antemas cerdosas de nueve artejos; ojos aglomerados; dos alas con escamitas; y en la extremidad del abdómen, que es ovinl, un copete de largos hilos blancos.

Estos insectos se encuentran en julio y agosto con bastante frecuericia en algunas partes de Alemania, en la ortiga grande.

\section{EL PORFIROFORA DE POLONIA-PORPHY- ROPHORA POLONICA}

CARACTERES. - Mrucho tiempo antes de la importacion de la cochinilla americana conociase ya en Europa el porfi. rofora de Polonia, llamado tambien cochivilla de Polonia 6 sangre de San.Juan, cuyo nombre se le dió porque se recogia igualmente en junio. El macho, de color rojo, tiene antenas en forma de cordon con nueve artejos, ojos granujientos, garras sencillas, alas peludas en el borde anterior hasta mas alli del centro, y un largo copete de hilos. la hembra, de forma hemisferica, tiene antenas cortas de ocho artejos y solo una garra en cada pie, pero en las patas anteriores son anchas.

DISTRIBUCION GEOGRAFICA.-Se encuentra cerca de Dresde, en la marca de Brandenburgo, en Pomerania, Mecklenburgo, Succia, Prusia, Polonia, Rusia, Hungria y otros paises.

USOS, COSTUMBRES Y REGIMEN, - Vive en la raiz de algunas plantitas comunes, que crecen con preicrencia en la arenn, sobre todo en las especies Steranthus perennis, Herviaria glabra, Pariefaria y otras.

Tos dos sexos están encerrados en su estado de larva en una membrana esférica, en la cual permanecen inmóviles introduciendo el pico en la rair de las plantas. Al cabo de quince dias se abre la piel, la de los machos, que son mas pequeños, antes que la de las hembras; pero estas últimas salen ya adultas, mientras que el macho continúa en estado de laria. Esta se rodea de una materia lanosa, trasfórmase en 
crisalida y sale al cabo de quince dias desarrollada. Antes de que se conociera la cochinilla verdadera, mucho mejor y mas importante, de modo que un rey de Polonia percibió, solamente por los derechos de aduana de la cochinilla, sesenta mil florines. De Podolia se han exportado, segun se dice, to. dos los años mil libras, al precio de ocho á diez horines polacos por libra.

\section{LOS ALEURODES-ALEURODES}

CARACTERES. - Por la forma igual de ambos sexos, jrovistos de cuatro alas, el género de los aleurodes constitu ye el trálusito à los afidinos, con los que sin embargo no pueden reunirse, en la opinion de Burmeister, porque la larva se parece á los cóccidos; mientras que Hartig es de parecer barata, la de Polonia constituia un articulo de comercio

contrario. De los seis artejos de las antenas el segundo es el mas largo y los piés están provistos de dos garras.

\section{EL ALEURODES DE LA CELEDONIA-ALEU- RODES CHELIDONII}

CARA CTERES.-Este cóccido, que solo mide 0",00r12, es de color blanco verdoso, $y$ tieme en las alas dos fajas largas poco marcadas. Linneo la describió ya como tinen proletella, comprendiéndola por lo tanto entre los tineidos ó po. lillas.

USOS, COSTUMBRES Y REGIMEN. - Abunda bas. tante en Europa y se sitúa con preferencia en la cara inferior de las hojas del chelidonium majus, cubriendo su cuerpo con las alas en forma de techo. Cerca del insecto se ven unos pequeños circulos cubiertos de un ligero polvo blanco, en los
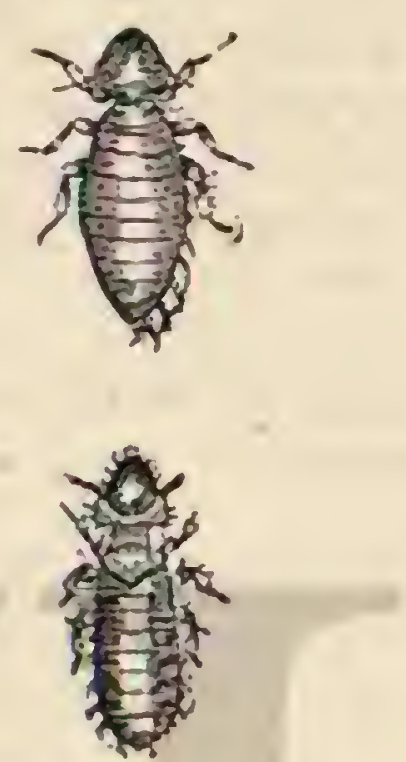

Fig. 135. -EL. LIOTEO PŔLIDO

Fig. ISO.-E]. FILUPTERO SRgGil.o
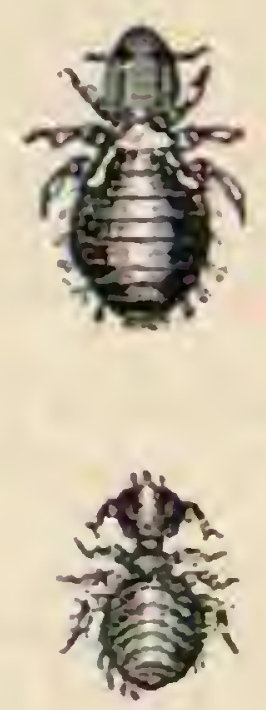

Fig. 1 37. - EL FIL.́́PTERO DEL CISN:

Fig. 141.-E.1. GON1010 BALCICORNO cuales se hallan los huevos, primero amarillos y despues pardos.

\section{LOS QUERMESIDOS- CHERMESID压}

Algunos cuantos géneros que se suelen agrupar con la familia siguientc, son para nosotros una familia nislada, constituyendo otro transito entre los verdaderos cóccidos y áfidos. Segun yat hemos dicho mas arriba, nuestros conocimientos sobre todas estas especies particulares son aun demasiado defectuosos para poder clasificarlas ahora de un modo natural y definitivo. Trảtase de los dos géneros chermes, segun la acepcion de Kaltenpach, y fhilloxicra, cuyo desarrollo ofrece nuevas particularidades aun mas extrañas.

\section{EL QUERMES DE LOS ABETOS-CHERMES ABIETIS}

CARACTERES. - La especie mas conocida, y que ha sido objeto de observaciones muy minuciosas, es el quermes de los abetos, que no dividiremos, como Ratzeburg, en especie verde (viridis) y roja (cocrincus). Este insecto, desprovisto de alas, tiene el tamanto de un granito de arema: el cuerpo dilatado, las patas cortas, trompa larga, $y$ una cubierta blanquizca lanosa. Por su aspecto exterior se asemeja bastante á una hembra de cóccido; se agarra á la base de un retono de abeto (pinsus picen), que en la primavera siguiente debe desarrollarse en el llamado rretoño de mayo». Aqui inverna, y tan luego como despierta de su letargo comienza
A chupar. Entonces crece, muda varias veces de piel, reno. vando cada una su cubierta lanosa, y mantienese siempre en el mismo sitio. Despues comienza á fabricar la graciosa ngalla en que debe desarrollarse su progenie, yá fuerza de chu par corta el cje del retoño. Antes de crecer este, el quermes de los abetos enpieza á poner sus huevos, de cáscara dura, que poco á poco se reunen en número de 200 , depositados en parte en los hilos lanosos que han caido de la piel A esta extrema fecundidad corresponde un ovario de mucho desar. rollo, en cada uno de cuyos lados se reconocen con el microscopio de veinte \& veinticuatro oviductos. Despues que han salido las larvitas de los primeros huevos, la madre muere, terminado su trabajo. Poco mas ó menos en la se. gunda mitad de mayo todas las larsas han salido y suben entonces á la punta del retono, introducen en él sus trompas y gan á espacios sendosos dentro de una espiga que se parece cesivo las copas de los pinos jóvenes, perjudicando en extremo su desarrollo regular.

Las Jarvas que viven en las agallas son mas delgadas que la madre y mas activas, plaes cambian á menudo de sitio; así como aquella están cubiertas de hilos lanosos blancos, pero mas cortos. Mudan varias veces, adquuieren rudimentos de alas, pero nunca el tamaño de la madre, y quedan por fin con las patas recogidas, agarrándose solo con el pico triangular. mente en el mismo sitio hasta que la espiga se abre por grictas trasversales. Entonces, es decir, en la primera mitad de hecho esto mudan la piel por última vez y se trasforman en quermes alados, que se oprimen uno contra otro, pero pronto completan la deformacion empézada por un lado. Al fin lleá un ánax. Estas espigas cubren á veces en un número exagosto, salen muchas y agarranse en las agujas; apenas han 
se dispersan en todas direcciones. Al cabo de pocos dias pueden verse algunos en una posicion del todo natural, pero muertos, y detriss de ellos un montoncito de huevos que dejan precisamente la misma señal que los puestos por las ma. dres invernadas. Su número es mucho mas. reducido, porque tambien el ovario tiene menos oviductos. Los hijuelos que pocas semanas deapues salen de los huevos son, despues de pasar el invierno, las madres de que hablamos al principio de nuestra descripcion. A pesar de los esfuerzos mas repetidos no se ha logrado hasta ahorn encontrar tos machos, $y$ por lo tanto solo podemos suponer que en estos piojos se verifica el parto virginal y que Ja segunda criz está destinada a la propagacion de la especie.

\section{EL QUERMES DE LOS ALERCES-CHERMES LARICIS}

El quermes de los alerces, una segunda especie, si posible es mas discminada que la anterior, propágase sin formacion de agailas y libremente en las agujas, que se vueven amarillas por los pinchazos; hay varias crias, aladas y no aladas, pero se han de hacer observaciones mas minuciosas para poder explicar del todo su género de vidia

\section{LA FILOXERA DE LAS ENCINAS-PHYLLO-} XERA QUERCUS

CARACTERES, - I a filoxera de las encinas ha llamado ultinamente la atencion de los naturalistas por la historia de su desarrollo tan extraña como la han indicado primera mente Ballbiani y Lichtenstein. En la primavera, poco mas 6 urenós el zo de majo, segun escribe-el segundo desde Montpellier, vense en la cara inferior de las hojas de la encin comun (quercus pedusculuta y piblescens) unos piojos alados que por su forma recuerdan el quermes de los abetos. El tórax es negro, la cabeza ancha, el abdómen y las cortas patas de color rojo mas ó menos amarillento. En las anténas recogidas, solo se reconocen tres artejos, el último de los cuales es dos veces mas largo que las otros dos juntos, presentando en su primer tercio exteriormente una prominencia en forma de diente. Las alas anteriores tienen en su borde una seizal amarilla rojiza y, tres nervios oblicuas muy sencillos; en las alas posteriores solo hay dos longitudinales. Los pequenos insectos corren por todas partes, y depositan en la cubierta lanosa de las hojas tiernas unos huevecitos amarillentos. Seis ú ocho dias mas tarde salen a luz unos piojos blancos no articulados, con el cuerpo semcjante al de los cóccidos. Se agarran chupando 5 producen unamclias amarillas en cuyo centro se encuentra un piojo que cliando despues de algunas mudas ha, llegado á ser adulto y ligemmente verrugoso, deposita á su alrededor en forma de anillo de 30 a 40 huevos. De estos se forma de igual modo una se. gunda cria ys asi varias sucesivamente hasta el mes de agosto; las posteriores, sin embargo, son menos numerosas, y todas sin aýuda de un macho. En el cirado mes se cucuentran entre los individuos alados algunos sin alas, procedentes de larvas que no pueden distinguirse en su primera juvientud.

En una noche, a principios de sctiembre, desaparecen, segun la noticia de Lichtenstein, todos los individuos aladós que se dirigen hácia el sur, donde en grandes masas vuelien a reunirse en la encina coccifera, que crece cn las montanias en forma de arbusto. En seguida depositan algunos huevos de dos tamaños y de los que los mayores conservan un co. lor amarillo claro, mientras que los pequenos se ruclien rojizos. I.os séres que á poco rato se desarrollan de estos huevos guardan proporcion con ellos por su tamaño y color; son en extremo vivaces y no tienen la menor señal de pico, pero en seguida al nacer se distinguen marcadamente los sexos. Los hijuclos son los machos que se aparean con varias hem: bras y mueren despues; las hembras son mas grandes y viven algunos dias mas, hasta que cada una ha puesto su última huevo de invierno en medio de las escamas de los capullos 6 en la corteza: este huevo es relativamente grande y de co. lor amarillo. En la primavera siguiente el huevo de invierno produce un sér vivo que despues de varias mudas se trasforma en un piojo hembra, el cual deposita, en los primeros dins de mayo, en los tallos ó en la cara inferior de las hojas, por medio de un capullo que acaba de desarrollarse, de 150 i 200 huevecitos blancos: despues de esto muere. Cuatro ó seis dias mas tarde aparecen pequeños piojos lisos que se agarma con la trompa á las hojas, crecen muy rapidamente, adquieren despues de algunas mudas rudimentos de alas, y haciendo luego uso de los órganos del ruelo, marchan à las encinas de las regiones septentrionales 6 a nuestros jardines. He observado à mediados de julio de is 86 á este insecto cercal de lirfurth y en los alrededores de Naumburgo, y no puedo suponer que el viaje descrito a las encinas meridionales eśnecesario parn el desarrollo, pues no me parece creible que desde el centro de Alemania se dirijan a la encina coccifera cjue sula se encuentra en las montañas de la Europa me. ridional.

\section{LA FILOXERA DEVASTADORA-PHYLLOXE- RA VASTATRIX}

La filoxera yastatrix ha excitado últimamente por sus nu. merosas devastaciones, sobre todo en las vides francesas, mucho mas interes, aumentando al mismo tiempo la importancia de la especie anterior, porque por esta última se esperabá conocer la historia del desarrollo de tal enemigo de la vid, lo gue en este último tiempo se ha logrado efectivamente. Conocido ya desde mucho tiempo en la América del norie $(1853)$ este parisito recibio del entomúlogo oficial de los Estados Unidos Asa Fitch el nombre de pemphigus rititalii. Como se dudó de la exactitud de su clasificacion como afi. dino, Schimer fundó en esta especie el nuevo género dactylosphera, cuyo nombre debia indicar los pelos en forma de maza en los piés, que sin embargo tambien se encuentran en otros cóccidos. Cuando en 1863 el mismo insecto se encontró en los invernaderos ingleses considerandose como especic nueva por Westwood, este le dió el tercer nombre de peritymbia isitsana; y en 1868 , Planchon le aplicó otro, el de pliylloxern iastatrix. Este último se ha liecho ya tan popular, que dificilmente se pondria en vigor la ley establecida por los entomólogos de dar la preferencia al nombre mas antiguo.

Como filoxera el paraisito visita sobre todo el país de Avignon, donde sube y baja por los valles de los rios, habiendose extendido en el espacio de ocho años de tal modo yue casi la tercera parte (unas 750,000 hectárens) de todos los viñedos de Francia son visitados por el insecto y se hallan en parte devastados. Cuando la filoxera apareció de repente en 1869 á mucha distancia de las regiones que hasta entonces recorria, es decir, en los alrededores de Ginebra, se quiso averiguar la causa de un fenómeno ian sorprendente, fayorecido por la circunstancia de que tambien se habia presentado en las escuelas de agricultura de Annaberg, cerca de Bonn, y de Klosterneuburg cerca de Viena, y entonces se averiguó que este insecto habia sido importado en Europa con cepas americanas. Listas averiguaciones fucron confirmadas despues por las ya citadas de Lichtenstein respecto al nombre.

La filoxera desprovista de alas, que aun no ha llegado á 
su desarrollo completo, tiene un color amarillo paròusco é inverna en las hendiduras de las raices de la vid, casi siempre del grueso de un dedo, pero tambien mas delgadas. Despues de despertar mas 6 menos pronto, segun la temperatura del suelo, cambia su piel verrugosa y oscura por otra mas fina de color amarillo, se agarra chupando en las raices y llega pronto á su completo tamaño de $0^{m}, 001750$ poco mas. Los ojos compuestos se distinguen marcadamente; las antenas tienen tres artejos, dos cortos y gruesos en la base, $y$ uno mucho mas largo surcado trasversalmente, que en la extremidad está provisto de una cavidad en forma de cuchara. Todos los individuos, q̨ue resultan ser hembras, depositan cada cual treinta ó cuarenta huevos de color amarillo de azufre, que luego se oscurece, y de los que al cabo de ocho dias nacen los hijuelos amarillos. Estos se-muestran al principio inquietos, pero cuando han encontrado en una miz vecina un sitio conveniente se agarran chupando, mudan tres veces de piel, crecen rápidamente y ponen al cabo de veinte dias otra vez huevos, lo mismo que la madre, sin aỵuda de un macho; de este modo continúa la propagacion, produciéndose de cinco á ocho crias seguidas durante el verano; de modo que se supone que una sola hembra que ha pasado el invicrno, suponiendo el desarrollo de todos los huevos, puede ser madre de algunos centenares de millones de individuos en un solo verano.

En medio de las últimas crias se presentan algunos individuos de un aspecto algo distinto. La mitad superior de sus extremidades presenta verrugas, dispuestas regularmente, que solo se hallan indicadas en los individuos de las crias anteriores; la cabeza es mas pequeña; el artejo final de las antenas mas largo; en el tórax salen rudimentos de alas; las cuatro que ciespues de la última muda se oprimen contra el cuerpo, sobresaliendo de él mucho, tienen los nervios relativamente fuertes. Los individuos alados de ambos sexos se desarrollan mas pronto que los no alados y tienen en el estado de larva mas movilidad, pues abandonan poco antes de la última muda las raices y suben á las cepas para desarrollarse del todo alli. Al principio no se habia fijado la atencion en ellos; pero en 1876, M. P. Boitcau hizo de ellos una descripcion independiente de aquella de que tomamos las siguientes noticias sobre el desarrollo de este insecto tan notable. In filoxera alada, que por las corrientes de aire puede ser empujada á larga distancia del sitio donde nació, pone por término medio cuatro huevos en las mas diferentes partes de las cepas, sobre todo en la bifurcacion de los nervios de las ho. jas, $y$ muere despues. Fistos huevos difieren por su forma y naturaleza de los que se encuentran en las raices y tienen. dife-

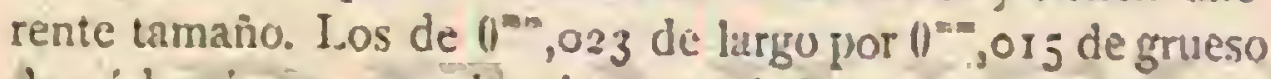
dan á lu\% a poco rato hembras no aladas que necesitan la fecundacion; los mas pequeños, de $0^{\text {m+r }}, 020$ de largo por $0^{-\infty}, 082$ de ancho, dan los machos, mas raros y no alados. Eśtos últimos no han sido observados por Boitenu, quien solo dice que Baibiani ha visto fecundar dos hembras seguidas por un macho. La hembra vivaz y muy activa, tiene $0^{\text {mon }}, 03^{8}$ de largo por $10^{\circ / 0}, 015$ de grueso, es un poco mas prolongada que las de las raices, de color amarillo claro y' con el pico atrofiado. Su abdómen contience un solo huevo, que no solo le llena sino que llega hasta el tórax; es el llamado huevo de invicrno, que se deposita en la parte posterior de las galerias formadas en la madera por la separacion de la corteza vieja de la nue. va, para lo cual se necesitan por lo tanto cepjas de cierta edad. En la madera mas vieja Boiteau no pudo encontrar huevos de invicrno. Ademas de los fecundados depositanse otros que no lo están, de un color amarillo vidrioso, los cuales pueden secarse al caloo de algunos dias, mientras que los otros adq̨uieren pronto un color verde accituna, con manchi- tas oscuras. Son cilindricos y redondeados en las extrenida-

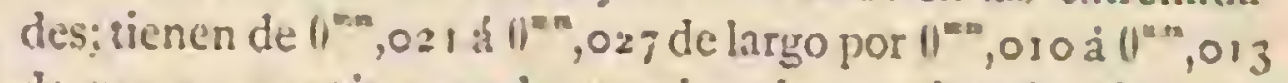
de grueso, y estain pegados en el suelo, en el techo ó en las paredes de aquellas galerias. En la primavern siguiente cada huevo presenta una filosera de la misna naturaleza que la de las raices. Balbiani encontró varios individuos sexuales en las raices, suponiendo por esto tambien la propagacion sexunl subterrinea. Las observaciones de Boiteau, sin embargo, hacen creer mas bien que solo la crudeza del tiempo habia obligado à los insectos á ocultarse đebajo de tierra. De este modo ya se han confirmado las suposiciones hechas sobre la especie anterior.

Hace mencion además de un fenómeno que aun carece de explicacion suficiente. Poco despues del descubrimiento de la filoxera se encontro en los sitios infestados (aunque sulo aisladamente en Francia, pero con mas frecuencia en América) la cara inferior de las cepas cubierta de numero. sas agallas características, las cuales ofrecen gran semejanza con las monstruosidades de otras varins plantas y que provienen de los filoptos, poco estudiados hasta ahora Se abren en la parte superiór de la hoja, mientras que en la inferior se ensanchan en forma de una vejiga plana y están cubiertas extcrior $\varepsilon$ interiormente de una infinidad de apéndices velludos. El espacio interior contiene una filoxera sin alns, $y$ a veces tambien dos ó tres, y al lado de ellas se ve cirrto número de la misina naturaleza que las halladas en la estacion anterior en las raices. Varios naturalistas han demostrado que se trata en este caso de la filoxera devastadora, aunque nadie ha podido explicar el hecho. Como la estacion fria obliga a los individuos sexunles á refugiarse en el suclo, tambien en este caso es posible que influyan condiciones desconocidas que obligan á los insectos à abandonar las raices y buscar un albergue en las hojas.

Las devastaciones que las filoxeras ocasionan en las cepas muy infestadas solo se observan en el segundo año exteriormente, porque entonces las hojas se vuelven mas pronto amarillas, se cnroscan por los bordes y caen. las mismas ce. pas quedan en la primavera siguiente atrasadas; cchan retoños mas cortos y producen menos uvas, que maduran dificilmente y tiencn un sabor acuoso. Al cxaminar las raices, las dilataciones irregulares, pero siempre longitudinales, en forma de morcilla, que se hallan en las extremidades de las fibras, demuestran la presencia de la filosera. Estas deformaciones se producen por el insecto, que chupa casi siempre al principio del verano, cuando despues del sueno invernal necesita mas alimento. Unas manchas amarillas en tales sitios demuestran, hasta sin microscopio, cómo las mismas filoxe: ras se han reunido en montones. Al cabo de algun tiempo las raices fibrosas se descomponen, $y$ tambien las mas fuertes empiezan à entrat en putrefaccion y la corteza cac á pedazos: la filoxera se ha extendido entonces en todas direcciones hasta las cepas vecinas, aun sanas; la enfermedad se propaga desde este foco circularmente siempre á major dis. tancia. En la propiedad de muchas especies de cepas americanas de producir rápidantente raices en extremo abundantes se funda la major resistencia de estas, en comparacion con las cepas de nuestros paises, à los cfectos de la filoxera.

No por el aspecto exterior de las cepas, sino por las cuida. dosas investigaciones de las personas encargadas por la Can. cilleria del Imperio Aleman de preservar lo mejor posible este país de las tristes experiencias de los viticultores de Francia, se ha hecho constar en $18 ; 6$ la presencia de la filoxern en algunos importantes establecimientos de plantas de Erfurth y Klein.Flottbeck, y en varias especies americanas de cepas en los alrededores de Stuttgart. Aunque en algunos de estos sitios el enemigo existe desde hace lo menos 
diez años, no ha logrado propagarse, sin que se sepa hasta ahora el por queé, y por eso la experiencia ha de excitarnos í tomar medidas, aconsejándose á todos los viticultores la mayor precaucion. Segun el género de vida hasta ahora conocido, lo propagacion de este enemigo es fácil, primero por la especie alada, y despues por la que carece de alas y ataca las raices.

Aunque en Alemania el clinia es menos cálido, está expuesta tambien al peligro de una devastacion por la filoxera, como la ocurrida en limencia. Todos los medios hasta ahora ensayados para exterminar este enernigo subterraineo no han

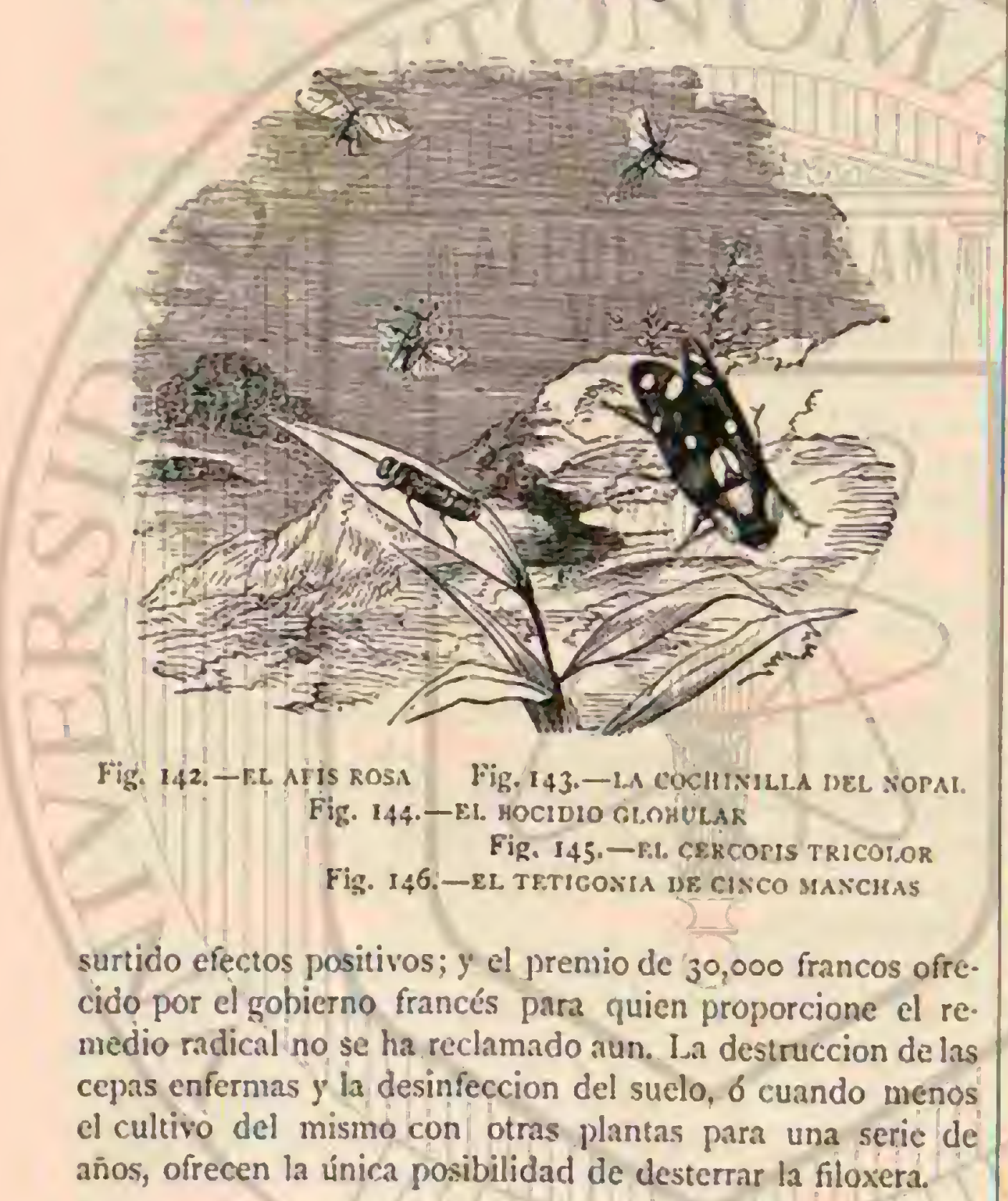

\section{LOS AFIDINOS - APHIDINA}

CARACTERES. - Los afidinos forman otra familia de los piojos que se alimentan de jugos vegetales, pero no viven solamente en las hojas, sino tambien en las puntas de los re. tohos, en los capullos, en la corteza; y hasta subierráneamicnte en las raices, ó en el interior de agallas producidas por la picadura. Los especies de la familia pertenecen a los insec205. mas delicados, que raras veces alcanzan una longitud de $0^{m}, 0065$. I a cabera, prolongada y mas ancha que larga, ticne en la parte anterior antenas de 5 i 7 artejos de diferente longitud; en el borde posterior 6 inferior hay un pico de 3 artejos, por lo regular muy corto, pero casi siempre mas largo que todo el cuerpo y que en el estado de descanso se oprime contra la garganta, mientras que se endereza en angulo casi recto tan luego como empieza su actividad, en cuyo caso las tres cerdas de su interior suben y bajan de continuo. En los lados de la cabeza sobresalen mucho los ojos que son reticulares. I.os afidinos alados tienen ademas tres ocelosen la coronilla, y el anillo collar no alcanza la anchum de la cabeza, mientras que en las especies sin alas es mas ancho, distinguiéndose apenas de los segmentos siguientes $y$ del abdómen, tanto menos cuanto mas engorda el afidino. En los individuos jóvenes se reconocen en el abdómen mas ó menos marcadamente nueve segmentos, entre los cuales los del centro ocupan la major circunierencia. Para el género mas abundante en especies, Afhis, son caracteristicos unos apéndices laterales de la parte superior del sexto segmento, dirigidos hácia arriba y llamados trompetas de miel, porque pueden segregar un líquido dulce y lo hacen efectivamente cuando las hormigas, muy aficionadas a este excremento dulce, se acercan para lamer. Además de estos tubos $\delta$ trompetas sobresale casi siempre una llamada colita como apéndice del último segmento del abdómen, que es el único del todo des. arrollado en los individuos adultos. Las patas son relativamente largas y delgadas; los piés tienen dos artejos y dos garras. Cuatro alas en extremo delicadas, que brillan con to. dos los colores del arco iris, son propias de casi todos los afidinos sexuales, pero faltan con frecuencia en las hembras y machos, mientras que los individuos neutros de una misma especie están provistos de alas ó carecen de ellas. las anteriores son mucho mas largas que las posteriores, de modo que en estado de descanso sobresalen mucho de la extremidad del tronco. Las alas estan cruzadas por un solo nervio fuerte, longitudinal, paralelo con el borde anterior, situado i poca distancia, $y$ que en las alas anteriores remata en una hojita cónica, la llamada serial de las alas. De este nervio longitudinal parten algumas venas oblicuas sencillas ó ahorquiladas, de las que en las anteriores la exterjor se considera como radio y la siguiente como cubito. La direccion de estas pocas veces es en los afidinos menos constante que en la major parte de lus otros insectos, de modo que el ala i\%. quierda puede diferir de la derecha. Los mas de los afidinos tienen el color verde, cubierto á menudo de una especie de escarcha, susceptible de quitarse, pero esta secrecion puede aumentar hasta formar un verdadero pelo lanoso.

A pesar de la gran abundancia de afidinos, a pesar de los muchos perjuicios que causan en el reino vegetal $y$ a pesar de la atencion que desde fines del siglo xvil fijan en cllos los naturalistas, como por ejemplo t ceuwenhoek, Renu. mur, Bonet, 1)egeer, Balbiani, Leuckart y muchos modernos, todavia es una verdad lo que Degeer ha dicho sobre ellos: eSon del todo propios para trastornar el supuesto sistema de la generacion, y la mente de aquellos que se esfuerzan por averiguar los secretos de la naturalera.

\section{LOS AFIDOS Ó PULGONES - APHIS}

CARACTERES. - Al hablar de los afidinos propiamente dichos ó fiojos de lurs hojas, pensamos en el género de los áfidos, que se compone de casi trescientas cincuenta especies europeas, las cuales se reconocen por las antenas de siete artejos mas largas que el cuerpo; tienen la señal de las alas análoga y de su centro sale el radio, dividido por el cúbito en tres partes; tambien están provistos de una colita en el abdómen.

USOS, COSTUMBRES X REGIMEN. - Se fijan en las puntas de los retonos, en los capullos $y$ hojas de las plantas fibrosas y yerbas: toman su nombre casi siempre de la planta que los alimenta, sin pertenecer por eso a ella exclusivamente, y arrollan muchas veces las hojas para chuparlas en comun. Asi, por ejemplo, en el arbusto llamado felota de nieze vive la especic aplis bilumrni, en los manzanos, perales $y$ en el endrino, el aphis mali, de Fabricio; en el serbal silvestre, el aphis sorti; en los cerezos, el aphis scrusi; en los groselleros, el afhis ribis; en los guisantes, arbejas y otras numerosas papilionáceas, el aphis ulmarice de Schrank. Para formar una idea de estas especies basta examinar el afis de las rosas (aphis rose) (fig. 142), que se encuentra en cual. quier rosal; y por lo tanto me limitaré dar una corta descripcion del género de vida de los áfidos.

En la primavera, mas ó menos pronto, segun la tempera. 
tura, salen de los huevos, pegados en la cara inferior de las hojas ó en las ramas, los áfidos sin alas; mudan cuatro veces antes de ser adultos, pero cambian la forma de su cuerpo muy poco; la citada colita idquiere despues de la tikimat muda contornos mas marcados y los colores se hacen por fin mas intensos $\delta$ tambien cambian. El desarrollo, si las condiciones son favorables, puede efectuarse en 10 ó 12 dias. La hembra adulta sin alas no pone huevos, sino que da ¿luz hijuelos vivos sin ayuda de ningun macho. La pequein larva sale con las extremidades oprimidas contra el cuerpo, y aun no tiene libre la cabeza cuando estira vivamente las patitas, se agarra y acaba de salir del vientre de la madre; esta ni siquiera retira las cerdas de su trompa de la planta de que se alimenta y siente por lo tanto muy poco los dolores del parto. El hijuelo se encuentra exactamente en la misma situacion que la madre cuando esta habia salido del huevo, se agarra chupando, crece ripjadunente, inuda cuatro veces la piel, y la henbra pare, cuando alcanza su desarrollo, hijuelos vivos. Supónese que cada nodrizn, segun se ha llamado á estos áfidos viviparos, da \& luz por término medio de $3^{\circ}$ \& 40 hijuelos antes de morir. Cuando las condiciones vitales arriba indicadas faltan temporalnente, retardase tambien el parto, $y$ la prole es menos numerosa. El sitio quc habitan estos chupadores tan voraces deja muy jron. to de dar el alimento necesario, porejue la pereza de estos séres les impide emigrar; pero tambien podria perecer por un acciclente toda la familia a la vez. La naturaleza ha teni. do por lo tanto la prevision de asegurar los individuos de toda la especie: cuando la colonia de afidinos se ha hecho mas numerosa, preséntanse en medio de las nodrizas indivi-

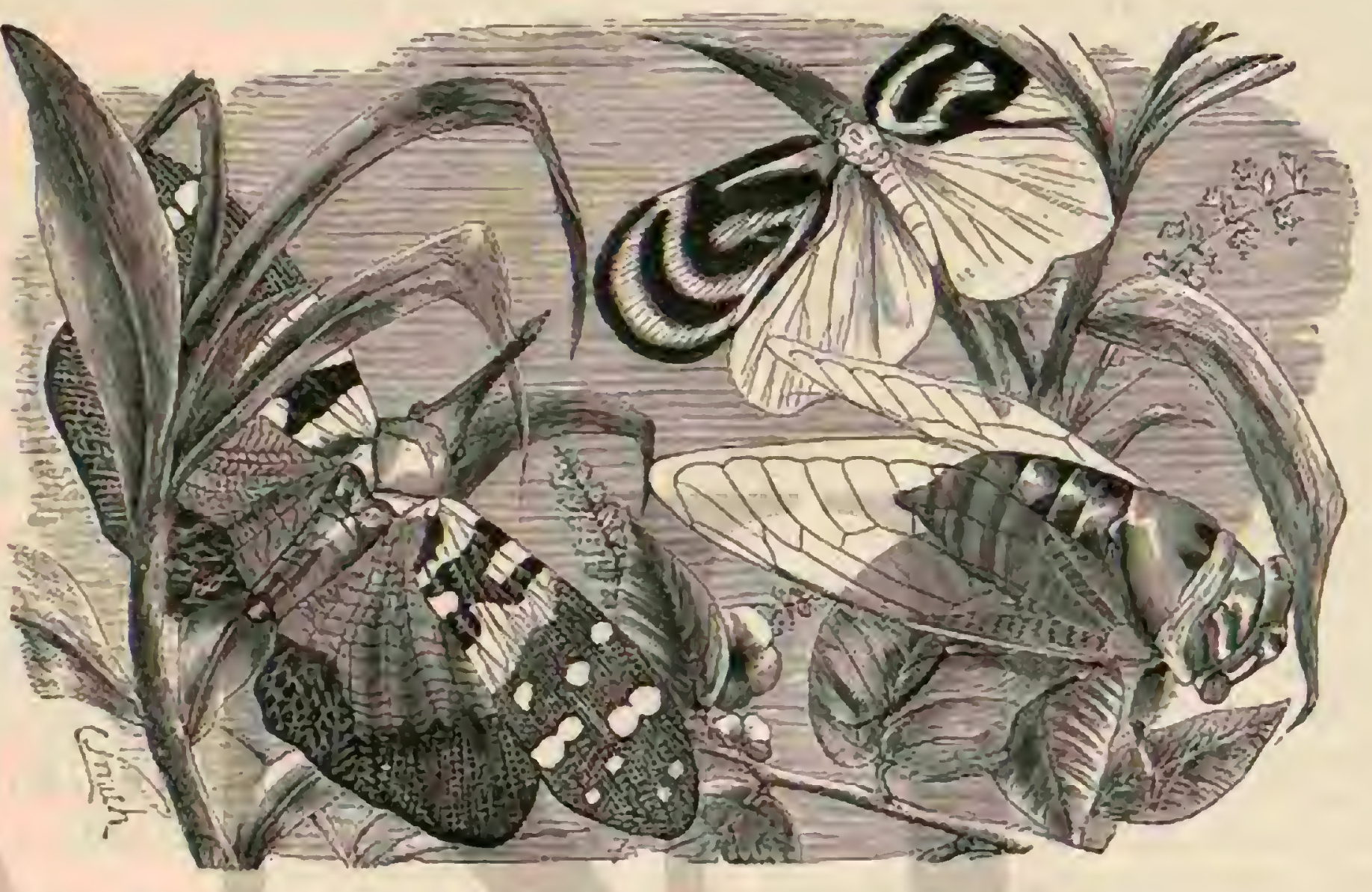

Fig. 14j. - EL BOTKROCERO MANCHABO

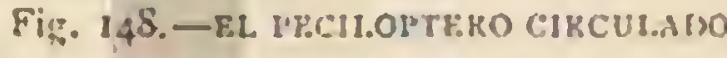

Fig. 149. -LA CIGAREA IHE, FRRSNO duos alados, nacidos como larvas sin alas, y que ahora se sirven de estos órganos de vuelo para fundar nuevas colonias lejos de la patria; $y$ apenas se han fijado en otro punto. repitense las mismas condiciones que antes. Las nodrizas dan à luz primero áfidos sin alas, y despues alados.

Fste procedimiento para la diseminacion de la especie recuerda el vuelo de las abejas' y hormigas, que si bien se verifica de oiro modo, tiende al mismo fin.

Véase pues de qué manera tan maravillosa viven los áfidos todo el verano y otoino mientras encuentran alimento; pero despucs de salir à luz las nodrizas escasean mas, formándose en su mayor parte hembras sin alas, y muy aisladamente nachos alados mas pequeños, que tambien nacen vivos. Pronto se aparean, y aquellos ponen sus huevos en tallos de plantas a otros sitios abrigados. Estas hembras son verdaderos individuos sexuales que dificren por su cstructum de la nodriza y no pueden parir hijuelos vivos. Steenstrup compara esta propagacion con la de muchos animales inferiores en los que intervienen una 0 varias formas, que difieren de los demás por algunos conceptos, pero tienen al mismo tiempo la facultad de jropagarse sin macho. Eil céle. bre naturalista danés ha dado i esta clase de reproduccion el nombre de cambio de generacion.

Como en los afidinos de que acabamos de hablar solo al principio de la estacion fria se verifica la reproduccion sexual por la puesta de huevos, cfectuándose despues por cier- to número de partos neutros, parece que en la propagacion de estos insectos solo la temperatura fria influye en los cambios de condiciones. En pro de esta suposicion tenemos tambien la circunstancia de que en nuestros invernaderos mas calurosos la propagacion sexual puede desaparecer del todo; por otra parte, el pastor protestante Kueber logró á principios de este sigio conservar una colonia de afidos cuatro años, solo por el nacimiento de nodrizas. No faltan tampoco ejemplos de que en sitios muy abrigados algunos áfidos se conservaron al aire libre en otro estado que en el de htrevos.

Asi como otros insectos, que a veces se reunen, formando masas innumembles que asombmn al espectador, tambien los délicados áfidos poblaron á veces el aire en forma de nubes, como por ejemplo la especie pempligizus hursarius en Suecia, el 7 de octubre de rS46. Intre Brujas y Cinte se presentaron en 18 de seticmbre de $1 \$ 34$ nutes de afidinos, dejandose ver al dia siguiente en la úleima ciudad en tales bandadas desde las siete de la mañana hasta la noche, que la luz del din se oscureció; el 5 de octubre toclo el camino que desde la ciudad conduce a Amberes estaba ennegrecido por estos animales, que despues se dirigicron à Emkloo, obligando í las personas a proteger sus ojos, y $\{$ taparse con pañuelos la boca y la nariz. El g de octubre, Mooren se en. contró cerca de Alast en medio de una bandada de áfidos, que tres dias despues se presentaron muy numerosos. Desde 
el 17 al 21 de junio de $1 S_{4}$ i pasó por varias regiones en Inglaterra tambien el afido de las habas (athis fabre). Estos cjemplos pueden servir para formarnos una idea de fenúmeno tan inexplicable.

Respecto à la infuencia dañina de los aifidos en las plantas, claro es que la continua extraccion de jugos debe debilitar no solo las partes infestadas, como retoños y cajullos, sino iambien tocia la planta. Por el desastollo interrumpido se prociucen monstruosidades de todas clases (agallas) entre las que el enroscamiento de las hojas es una de las menores; las hojas y las plantas caen sin madurat; on otros casos la corteza y las raices son atacadas, y el resultado de todo es la muerte parcial ó total de la planta. Al mismo tiempo que los insectos toman cominuamente alimento, scgregan una abun. dante sustancia liquida, glutinosn, tmsparente coma el agua, y con elia ensucian las hojas y otras jastes de la planta, que se cubren como de un barniz. I a lluvia disuclie una jarte de esia capa. pero condúcela a otras partes de la planta - tambien le cambia a vecus el color y en tudos los cásós esta sustancia impide la respiracion de las hojas.

Estos insectos, pues, y no las abejas y otras especies golosas, entré las que las hormigas son lns mas comunes, son los que perjudican las plantas. Si ese mani de que hemos hablado, que siempre es jroducto de los dfidos y de los. cócidos, aunque no se les rea, porque están sitmados.a mas. alturn. se designa como rocio de niel, segun tengo rnones para creer, otro fenúmenn parecido, juero mas raro, que nada. tiene que ver con los afidos, merece con mas motivo aquel nombre, lo cual debo advertir para evitar confusiones por este concepto. Por causas hasta ahora inexplicables prodúcense unas gotitas trasparentes de miel, semejantes a perlas de rocio, que brotan de la cpidermis de la cara superior de los retonos y hojas, y airaen á los insectos golosos, pero nunca $\dot{a}$ los áfidos.

Las plantas perjudicadas por los afidos ofrecen un estado cnfermizo qute jara los embriones puede producir enfermedades muy variadns, y aunque no pretenderé que codras tienen su origen en las destrucciones de los áfidos, creo, sin emtargo, que las favorecen.

Ahora bien, despues de probar cl cardcter en extremo da. uino de los áfidos para las plantas, nuestro interés exige preservar de cllos los cultivos, sobre todo el de árboles frutales y rosales, lo mejor posible contra estos parásitos. Un amnnte de las rosas, que en mi Entomología para jardineros y aficio. nados a Rores habia buscado sin duda en vano un medio parn conseguir el fin indicado, me escribió proco mas ó menos lo siguiente: Me levanto todas las mañanas una hora mas temprano, examino mis rosales y' aplasto los áfidos con los dedos donde los encuentro, limpiando las hojas diespues con agua de jahon. Cuando nis vecinos comparan sus rosales con los mios, manificstan el mayor asombro por el aspecto que preseritan, Fi que ticne icmpo y un numero no demasiado exresivo de rosales, jucde hacer lo mismo, pero en niro caso ese medio no seria suficiente, sino que lo mejor es regar las plantas con agua de jabon ian luego como los áfidos comien. zan a presentarse. Además de los áficos hay otras varias esfrecies que hasta ahora ban figurado entre las de la familia, pero no cabe duda de yue cuando se estudie su géncro de vida, reconociéndose que el desarrollo es del todo riterente, se hara una separacion, como ya se practicó con otros varios.

\section{LOS LACNOS - LACHNUS}

CARACTÉRES.-I.OS lacnos, Jamados inmbien piojos arboricolas, pertenecen a los afidinos mas grandes y de estructura mas pesada: sus antenas tienen solo seis artejos, $y$ en ve\% de lns trompetas de miel, glándulas en forma de jorobas; $\mathrm{cl}$ cúbito esti dividido en tres partes en las alas anteriores, y el radio parte de la punta de la sevial de las alas en forma de línea.

\section{EL LACNO PUNTUADO-LACHNUS PUNC- TATUS}

CARACTERES.-De las die\% y ocho cspeciesalemanas elegiremos al lacno puntuado para representar todo el géne. ro. I a especie es de color ceniciento, con las patas pardas, excepto la base de los muslos que es amarillenta; sobre el abciómen se corre una serie de puntos negros aterciopelados.

USOS, COSTUMBRES Y REGIMEN.-Esté piojo se encuentra descie jrincipios de la primarera en los retonios de las ramas de las orillas de los rios, y por sus secreciones atrae rumerosos himenópteros y hasta abejas domésticas.

\section{EL LACNO DE LAS ENCINAS-LACHNUS QUERCUS}

CARACTÉRES. - Fstn especie esta mas diseminnda que la anterior y en otono llama la atencion por su gran número en el ramaje de las encinas. 1.os individuos tienen un pardo oscuro brillanté y' miden por término medio $0^{10}, 006$. Las antenas tienen el sexto artejo mas largo que el penúltimo y se mueven continuamente. Los individuos mas cortos y alados, de (im, oorra de largo, son negros y peludos; los individuos sexuales carecen de pico desarrollado. Si las observaciones de Heyden sobre csta especie no se fundinn en un error, será exacto que d sénero que nos ocupa no se desarrolla del mismo modo que el anterior.

\section{LOS ESQUIZONEUROS - SCHI- ZONEURA}

CARACTERES.-Esté genero, que se camcteriza por las antenas de seis artejos, por el radio que parte del centro de las alas y por el cúbito bipartido de las alas anteriores, se reune tambien con los áfidos, pero parece ser mas congenérico en muchos conceptos de la filoxern que de los afidinos; varias especies ofrecen interés general.

\section{EL ESQUIZONEURO LANÍFERC-SCHIZO- NEURA IANIGERA}

CARACTERES. - Esta especie pasa por el enemigo mas pehigroso del manzano en el que, reunida en cocos $\delta$ en seriés, chupa la corteza de la madera jóven, produciendo asi enfermedad. Tambien en los postes de madera vieja se fija cuando estos han sufricio por el frio ó por otra causa; impide la cicatrizacion de la herida, practicandose un escondite que casi hace imposible su persecucion. Los individuos sin alas son de un amarillo de piel hasta pardo rojizo; en el lomo, sobre todo en la extremidad del abdómen, estan cubiestos de lana blanca que resalta fácilmente à la vista del observador. Jos ojos son pequeños; las cortas antenas son de un amarillo pálido; las patas mas oscuras en las rodillas. Fi pico tiene la longitud del cuerpo, atrofinindose y encogiéndose mas tardc. la longitud del cuerpo es por término medio de $0^{\circ}, 0015$. I.os piojos negros alacios, de un color de chocolate en el abdómen, se distinguen por los ojos grandes, antenas mas cortas aun; las patas trasparentes son pardas, mas oscuras en los muslos y en las punias de los tarsos; tambien ellos están cubiertos de un pelo blanco y lanoso. Como estos animales dejan una 
mancha roja de sangre al aplastarlos, los alemanes les llaman piojos de sangre.

USOS, COSTUMBRES Y REGIMEN. - En la primavera se presentan nodrizas que sin duda han invernado en su seguro escondite en el tronco del árbol, paren hijuelos vivos, y estos hacen lo mismo, de modo que durante el verano se verifican ocho crias. En otoño se presentan los individuos alados en medio de los sin alas, se agarran por algun ticmpo chupando al lado de estos, pero cuando los cinco ú siete huevos han madurado en el ovario, emprenden viajes parn. fundar nuevas colonias. Paren entonces dos clases de piojos grandes en extremo delicados, con las partes bucales atrofiadas, probablemente individuos de ambos sexos, cuya hembra pone huevos ó un solo huevo invernal. El mejor medio contra este enemigo es el de cortar los puntos enfermos de los árboles pintíndolos despues con cal, y cubriendo además con ella el suelo alrededor del árbol.

\section{EL ESQUIZONEURO LANUGINOSO-SCHIZO- NEURA LANUGYNOSA}

Un segundo congénere mas inofensivo se ha hecho notar por sus cxtranos efectos en las hojas de olmos. Ias hinchazo. nes de las hojas producidas por este piojo ocupan poco á poco toda la hoja, de modo que por fin cstas adquieren un color pardo, y cuelgan como bolsas del tamaño de una nuez y mas del ramaje, al que quedan agarradas aun despues de la caida de las hojas sanas; en estas deformaciones, que son peludas en la carn superior de las hojas del mismo árbol, observanse cambicn agallas lisas.

El insecto labra ai fin su capullo en un agujero irregular por el cual salen hijuelos alados y no alados, cuyo color negro está mas $\delta$ menos cubierto por un pelo lanoso blanq̨uizco mas azulado en los últimos, mas blanco en los alados y mas espeso en la extremidad del cuerpo. No se sabe nada mas sobre la suerte de estos afidinos.

\section{EL TETRANEURO DE LOS OLMOS-TETRA- NEURA ULMI}

En las hojas de olmos se nota otra agalla lisa del tamnño de una judia que se levanta sobre la strperficie de la hoja, no solamente del arbusto, sino tambien del olıno. Su color, al principio rojo, conviertese en amarillo y se abre en julio por una hendiciura irregular en la coronilla para dar paso al te. trancuro de los olmos. Este insecto es desnudo y negro, de un verde oscuro en el abdómen; está provisto de alas, tenien. do las anteriores el cúbito sencillo, mientras que las poste. riores solo llevan una vena oblicua; las antenas tienen seis artejos. Lá causa de la agalla es un afidino sin alas, como rerde y pelado, de forma esférica, cuyo desarrollo y el de varios otros congéneres es diferente del de los álidos.

\section{LOS PÉNFIGOS-PEMPHIGUS}

CARACTERES.- Liste género se distingue del anterior por tener dos nervios oblicuos en las alas posteriores.

\section{EL PÉNFIGO DE BOLSA-PEMPHIGUS BURSARIUS}

CARACTERES.- Esta especie, cuando es alada, tiene l.s antenas ligeramenic anilladas, con el sexto artejo puntiagudo y mas largo que el anterior. Is madre primitiva, no aiada, es muy gruesa y está cubicrta de una lana corta y blanca; sus antenas muy cortas, solo tiencn cuntro artejos, de los que el tercero es el mas largo. Este insecto mide unos $0^{\mathrm{m}}, 005$. Vive por lo regular en los nudos de los tallos de las hojas del olmo, que a fines de vemno se abren por una hendidura longitudinal para dar paso á sus habitantes alados.

USOS, COSTUMBRES Y REGIMEN. - Varios natUralistas anteriores, como Reaumur y Degeer, habian reconocido que el desarrollo de estos insectos, agrupados antes con las dos especies anteriores, era distinto que el de los que habitan en hojas y troncos, pero solo tiltimamente Derbes ha logrado completar ent parte nuestros conocimicutos sobre el género de vida de estos insectos. Si de las observaciones hechas en el pénigo del terebinto pudiésemos colegir las que se refieren á otras especies del género, resprecto ad la historia de su desarrollo, diriamos lo siguiente: los individuos sexuales se presentan en la primavera; viven poco tiempo y nose alimentan, porque las partes bucales están atrofindas. Despues del apareamiento la hembra pone un huevo del que se desirrolla el individuo que hemos llamado nodriza; carece de alas, y sus descendientes alados invernan. La agalla en que habita nuestra especie se forma jor la jicadura de un solo individuo pequeño y no alado, cuya costumbre de chupar en el mismo sitio ocasiona el estado enfermizo del tejido celu. lar y una protuberancia que elr cierto tiempo, es decir, casi siempre a fines de mayo, alcanza su mayor desarrollo, conteniendo no solo la madre primitiva, $y^{\circ}$ alguma vez dos, sino tambien gran número de hijuclos nacidos vivos y que echan alas despues de las mudas. Estos individuos alados que nunca tienen el tamaño de su madre, son à su vez nodrizas; no depositan su progenie en las células hasta que estas se abren, y entonces salen para desembarazarse de sus hijuelos en otro sitio. No se sabe aun si estos individuos alados y posteriores son los que invernan en tal estado, habiéndose reconocido que despues de la estacion fria dan a luz en las grietas de la planta que los alimenta individuos sexuales sin pico ni alas, de los que los mas pequeños y delgados son los machos. Es. tos últimos mueren inmediatamente despues de aparearse, mientras que las hembras se cudurecen bajo la forma ciel huevo que en su abdómen se desarrolla, sirviendo asi de abrigo, aun despues de su muerte, al único hijuelo, como sucede con los cóccidos.

De dicho huevo sale la madre primitiva á que nos referia. mos al principio de nuestra descripcion.

\section{LOS SILIDOS-PSYLLID在}

CARACTERES. - Un reducido numero de péqueños hemijteros podria considerarse como perteneciente à los ep socidos, antes descritos, si no nos fijàramos en sus partes bucales, pero en estas hay un pico que carnctcriza al grupo? además ho son propias para mascar: ambos sexos tienen alas y palas posteriores que sirven para saltar. Ln la coronilla se ven tres ojuelos muy distantes entre si; las patas, de regular longitud, se carncterizan por los dos artejos del pié y por los glóbulos prehensiles que hay entre las garras. La facultad de saltar distingue suficientemente á cítos insectos para no confundirlos con las especies anteriores.

USOS, COSTUMBRES Y REGIMEN. - LOS silidos chupan igualmente jugos vegetales, y sus larns, cuyas patas són aun mas cortis, ,y que en las antenas carecen de artejos, producen a menudo gran detrimento en las Aores de las plan. tas de que se alimentan.

Los dos géneros Liavia y $P_{s y} /$ a son los mas diseminados.

$$
\text { LAS LIVIAS - LIVIA }
$$

CARACTERES.—Las livias tienen antenats (que no'al. 
canzan la longitud del cuerpo, y sus ojos son lisos. En ha li. via de los juncos ( Tivin junsorum), que mide $0^{\circ}, 00225$ de largo y tiene la cabeza de color pardo y el tórax de un amarillo de orin, debemos rer el representante del género en Alemania. Este diminuto insecto, que se distingue además por tener las antenas blancas en el centro y negras en la punta, vive en las flores del junco articulado (iuneus artimilatus y' (amproingus).

\section{LAS SILAS - PSYLLA}

CARACTERES. - Fste genero se caracteriza por las an. tenas cerdosas, que tienen cuando menos la longitud del cuer. 10; los ojos son reticulares, redondus y mlientes; $y$ las alas anteriores, cuya menibrana es clara, parecen inas endebles que las de las livias. I.a especie Psjlla gevista tiene en la parte anterior de la cabeza dos protuberancias, $y$ unas fajas parduscas en las alas: el cuerpo es de color rerde claro.

USOS, COSTUMBRES Y REGIMEN. - Segun In indica el nombre, esta espiecie vive en las hiniestas; $y$ tambien en los perales y manzanos, con otras espécies del mismo gé nero. La especie Psylla pyri ensucia con sus excrementos los tallos de las hojas y las ramas, cubriendolos de una sustancia glutinosa buscada por las hormigas. La especie Psjlla moli se encuentra durante el otono ya desarrollada en has hojas amarillas de los manzanos, mientras que la larna chupa en los capullos y en los tallos de las fiores.

\section{LOS CICADINOS} DINA.

\section{CICA -}

CARACTERES.-La serie de hemípteros de que hablaremos, asi como la de los cicadinos, presentan, por diferentes que sean sus éspucies, los siguientes camctéres conumes: las alas son cortas y rematan siempre en una cerda; el pico, si tuado muy atrás, es grueso, y las cuatro alas pueden ser iguales ó desiguales. Todais las esjecies se alimentan de jugos vegetales, yj difieren esencialmente de las especies du órden hasta ahora descritas por no agarrarse para chujar siempre en el mismo sitio: introducen el pico tan pronto cn un lugar como en otro, : solo algunas vects se reunen muchos individuos en una planta.

\section{LOS CICADELINOS-CICA- DELLINA}

CAR ACTERES. - 1-25 especies mas pequenas han sido separadas de las otras como familia indęendiente, distinguiéndosc por los siguientes caractéres comunes: la cabeza sobresalc librencute hácia delante; junto à los ojos elevanse las antenas de tres artejos, siendo el último cerdoso; puede haber dos ojuelos ó ninguno: el protórax; sencillo por lo regular, llega en su parte posterior hasta el escudete del segundo segmento, deiando á este por lo tanto descubierto. Las alas anteriores son curiáceas y las patas posteriores, prolongadas en sus tarsos, son propias para saltar.

USOS, cOSTUMBRES Y REGIMEN. - Lstas cespecies, que suelen pasar del salto al vuclo, y que habitan en gran número la Europa, no producen ningun sonido; todas pasan su corta vida en silencio.

\section{LOS TIFLOCIBOS-TYPHLOCYBA}

CARACTERES. - Eiztre los cicadelinos mas graciosos por sus matices y su forma figuran los tiflocibos, llamados asi por lin carencia de ocelos; son especies que apenas alcanzan la longitud de $0^{\circ}, 003$.

El cuerpo, bastante angosto, se adclgaza en forma de cuña de delante atrás, la coronilla sobresale y se redondea; la frente ligeramente convexa está soldada con las partes que la rodean. A pesar de su solider, las alas anteriores son en extremo delicadas y los largos tarsos posteriores están provistos de fuertes espinas.

DISTRIBUCION GEOGRAFICA.-I Los tiflocibos son propios de la América del norte, del Asia septentrional y so. bre todo de Europa.

USOS, COSTUMBRES Y REGIMEN.-Muchas especies se encuentran en gran número en una jlanta determinada, como por ejemplo la cigarra de los rosales (Typhlog. ba rosa). Segun lo indica su nombre, vive con preferencia en los rosales en los que estos insectos se fijan tranquilamente, formando lineas de color amarillo de limon; pero cuando se sacude el arbusto todas saltan y vuelan iltededor, volviendo sin embargo á posarse pronto; en los dias de sol ejecutan estos movimientos yoluntariamente para su recreo. la hembra tiene, como las de todas las demás especies, su tubo visible en la extremidad del abcónen, tubo que introduce en la madera blanda para depositar sus huevos, con lo cual produce una dilatacion que poco a poco va en aumento. Las peçueñas larvas quedan ocultas, alimentáncose del jugo y adnuuicren despues de varias mudas rudimentos de alas, y solo cuando estas viltimas están del todo desarrolladas llaman la atencion de li persona acostumbrada à observar unos séres tan pequeños:

\section{LOS TETIGONIOS - TETTIGONIA}

CARACTERES. - I.os tetigonios se distinguen por tener la frente dilatada en forma de vejiga, y por las largas cerdas de las antcnas; las ancas posteriores son trasversales; los tarsos posteriores triangulares, cubiertos de espinas, y las alas anteriores largas y estrechas.

DISTRIBUCION GEOGRÁFICA.-Las mas de las 400 especies conocidas son propias de la América delsur, siendo la mas notable de ellas la tettigonia uninyuesignata 6 de cinco manchas (fig. 146).

\section{LA LEDRA OREJUDA-LEDRA AURITA}

CARACTERES.-En las cspecsuras mas altas de las encinas se ve la major especie alcmana desde setiembre ya desarrolladir. Los bordes laterales del escudo collar, levantados en forma de orejas, y la cabea, cnsanchada en figura de disco, afilada y saliente en los lados, comunican á esta especie, yue es de un color oscuro de corteza, un ispecto muy singular. Los tarsos posteriores sc hallan provistos de fuertes espinas y se ensanchan hácia fuera en forma de un reborde afilado, mientras que los costados son inasversales. El sur de Asia y la Nucva Holanda poseen varias especies afmes.

\section{EL AFRÓFORO ESPUMOSO-APHROPHORA SPUMARIA}

CARACTERES. - El afróforo espumoso es de color amarillo gris, excepto dos fajas poco marcadas, claras, çue adornan las alas anteriores. Caracterinase esencialmente portener la coronilla trilateral, separada de la frente, que es convexa, for un reborde afilado; el escudo collar es septagonal, las curtas ancas afectan la figura de codo; los tarsos son cilindricos y tiencen tres fuertes espinas. 
USOS, COSTUMBRES Y REGIMEN.-Muy extraña es la vida de la larva del afróforo espumoso que produce en las raices ó cn algunas plantas de las praderas, sobre todo en la especie lychusis fuscuculi y tragofon prasense, la liamada salita de cuclillo, materia espumosa de que el insecto toma su nombre. En otono la hembra deposita con su largo tubo abdominal los huevos entre las hendiduras de la corteza; y de estos huevos sale en la primavera siguiente una larva verde adelgazada hácia atràs y aplanada en el vientre, la cual se coge á la respectiva planta para alimentarse. I a sustancia sigregada por este insecto no se presenta, como la de los áfidos $\delta$ pulgones, en forma de gotas pequeñas y glutinosas que atraen à otros séres, sino como una espuma blanca se. mejante á la producida por el jabon ó á la saliva destimada a jroteger la larva, pues que la cubre del todo preservándola asi de sus enemigos. Cuando hay muchas larvas reunidas en un sauce viejo, las numerosas burbujitas de espuma caen como gotas, sobre todo cuando un cielo muy despejado anuncia una temperatura calmosa: entonces se dice que tel sauce llora. Solo cuando la larva ha pasado por las mudas sale in. mediatamente antes de la última de su cubierta, y vinga por los arbustos y yerbas vecinas mientras que la sustancia espumosi se seca.

\section{EL AFRÓFORO DE LOS SAUCES-APHRO- PHORA SALICIS}

CARACTERES. - Una especie mas prolongada de color gris amarillo, la cigarra de los sauces (aplsophore salicis de Fallen, ó lacrmans, de Ebersmann), produce en el condado de Ohrenburg el mismo fenómeno que el afróforo espumoso en Alemania. En Madagascar se encuentra otra especic en las morcras, de las cuales, cuando el calor del sol es muy fuerte, cac, segun se dice, hasta una verdadera lluvia, procedente de las larvas, que se agarran en gran número alrededor de los retoños mas fuertes.

\section{LOS CERCÓPIDOS-CERCOPIS}

CARACTÉRES.-Fin los cercópidos, la frente dilatada sobresale del borde anterior de la coronilla, algo mas corta por esta razon. y que tiene en un hoyito central los ojuelos. E] escudo collar tiene en su borde anterior dos incisiones y solo se cuentan seis ángulos, a causa de la disposicion del escu. dete pequeño; y como las alas anteriores son bastante anchas y abigarradas, los cercópidos parecen menos prolongados que otras tsplecies. Los costados posteriores son cortos y cónicos, y los tarsos posteriores, angulosos, estan rodendos en su extremidad de cerdas.

Numerosas especies do estas cigarras están diseminadas por todos los contincutes, y entre ellas las majores de toda la amilin, que habitan las regiones cilidas.

\section{EL CERCÓPIDO DE DOS FAJAS Ó TRICOLOR - CERCOPIS BIBITATA}

CARACIFRES,-ESta especie propia de Java, es de co lor negro brillante, y tienc en cada una de las alas anteriores dus fajas trasiersales (fig. 145).

\section{EL CERCÓPIDO DE MANCHAS DE SANGRE - CERCOPIS SANGUINOLENTA}

CARACTÉRES.- No necesitamos ir á paises lejanos para ver representantes del género que nos ocupa. Un gracioso insecto de apenas 0 ", oro de largo habita en algunas partes de Alemania, donde se le ve en los arbustos, en los que tranquilamente se posa en la cara superior de las hojas, llamando à mucha distancia la atencion del observador por las tres manchas de color rojo de sangre en cada ala anterior. La especie lleva por lo tanto con razon el nombre de cercopido de manchas de sangre, pero tiene aum muchas hermanas muy parecidas, de las que se distingue por la circunstancia de que la mancha anterior ocupa la base, la siguiente, redonda y mas pequeña, el centro, $y$ la posterior toda la anchura en forma de faja.

Es muy timido pues tan luego como álguien se acerca des. aparece de un poderoso salto, haciendo brillar sus magnificns alas á los rayos del sol.

\section{LOS MEMBRACINOS- MEMBRACINA}

CARACTERES.- Otra especie, por término medio no mas grande que las ya descritas, $y$ de colores mas monútonos, verdes ú oscuras, se ha reunido en la familia de los membracinos of cigarras de joroba, porque su escudo collar sobresale del resto del cuerpo en las formas mas diversas, presentando protuberancias y apéndices a menudo muy extraños. La cabeza estí situada mas hácia abajo; la frente no se separa marcadamente de la coronilla, porqque ambas están soldadas; entre los ojos, reticulares, hay dos ojuelos; y las antenas, muy cortas, se ocultan por debajo del borde de la frente. Las alas anteriores son i menudo tan tenues y traspa. rentes como las posteriores, lo cual sucede siempre cuando por prolongaciones del escudo collar están cubiertas del todo. Las cortas ancas de las patas medias se acercan mucho entre si, y las anteriores se prolongan trasversalmente.

DISTRIBUCION GEOGRÁFICA.-LOS membracinos están diseminados casi exclusivamente en la América meri. dional.

\section{EL CENTROTO CORNUDO - CENTROTUS CORNUTUS}

CARACTERES.- Esta especic, de un negro mate, cu. bierta de pelos blancos sedosos, pertencee à un género único entre los membracinos, por habitar en todos los continentes: se encuentra en otoño con bastante frecuencia en Alemania, particularmente en los avellanos. Su escudo collar tiene en los hombros un cuerno corto y se prolonga por un apéndice ondulado sobre el dorso hasta la extremidad del abdómen. Ias cuatro alas son nuy tenues: los tarsos, largos y den. ticulados en el borde, distinguen a esta especie de la de otros paises, siendo de advertir que ia prolongacion del escudo collar pasa por encima del cosclete, pero sin cubrirle, as como tampoco la base de las alas. Las larvas, de color abjgarrado, tienen cortas espinas en la parte superior del cuerpo.

\section{LOS HETERONOTOS - HETERO- NOTUS}

CARAGTERES.-Fn los heteronotos, géncro exclusivamente americano, el escudete tiene una prolongacion posterior en forma de cilindro hueco ó de vejign, que se corre por encima del dorso y cubre del todo el cosclete, produciendo las formas mas extrañas.

\section{EL HETERONOTO RETICULADO-HETERO- NOTUS RETICULATUS}

CARACTERES. - Lsta especie tienc una dilatacion cn 
el escudete, que es puntuado y en figura de red; en el centro y en la extremidad presenta como un nudo, rematando aqui en tres puntas espinosas. In la parte anterior se caracteriza por tener cinco rayas longitudimales, de las cuales las tres del centro se extienden hasta la cabeza, reuniéndose en ella. Cada uno de los nudos lleva una linea trasversal cortada en el cen. tro, $y$ las tres espinas presentan puntos de color blanco. Las alas anteriores, trasparentes excepto en el borde anterior, que es de color pardo rojo, escotadas en el ángulo interior, y cruzadas por nervios ahorquillados, ocultan el abdómen, que es de color pardo sucio. En otras especies, el escudete tiene diversas formas extrañas.

\section{LOS HIPSAUQUENIOS HYPSAU- CIENIA}

CARACTERES - En estos insectos la citremidad anterior se acerca mucho a la posterior del escudete, que es aplamado, cunno se observia en la especie hypmusienia balista, propia de la Colombia; otra especie nuy semejante, que vive en el Brasil, distinguese por sencr un nudó doble, que en el centro de la parte horizontal del escudete se levanta lácia la punta anterior. Todas estas singulares protuberancias podrian considerarse como adorno, de la misma manera que en los coleóptcros, pero aqui exceden a toda ponderacion como for maciones de las mas caprichosas.

\section{LOS MEMBRACIDOS}

MEMBRACIS

CARACTERES. - I.os nnembracidos, propios de ln Améca del sur, y representados por unas cien especies, tienen el escudcte casi siempre levantado a mucha altura, en forma de un reborde casi afilado, de manera que los lados se aplanan mucho; dicha parte presenta varias fajas blanco amarillas ó rojas, muy rariadas; los tarsos anteriores se ensanchan en forma cliptica y los posteriores están provistos de fuertes es. pinas. Una especie, el membracido clevado (ncmbracis eleia. ta), tiene el escudete en forma de casco, de color negro mate, con la parte anteriór y la punta blancas; y otras especies pre. sentar una prominericia en forma de dientes. El memuracis cruenla, que podria llamarse por su forma surro frigio, tiene matices rojos.

\section{EL HEMIPTICO PUNTUADO-HEMIPTXCHA PUNCTATA}

CARACTERES. - Esta especic, tal ver la mas grande del órden, es de color pardo; el escudete está cubierto de puntos verdosos; los bordes interiores y las alas anteriores son de un color sucio, con rajas pardas, cosa que no se observa en nim. guna de las especies anteriores; ademas, las patas posteriores no se notan por su curtedad, como en los congéneres mas aines, los umbonios (umbionia) en los que del centro del escudete se cleva una espina.

\section{LOS BOCIDIOS-BOCYDIUM}

CARACTERES.-Fstos hemipteros tienen la cabeza an. cha, frente estrecha y'vértice plano: al jrotórax no se pro: longa por detrás; los elitros rodean los lados del cuerpoy sus nervaduras llegan exactamente á la extremidad; las patas, largas y delgadas, carecen de espinas en la punta; las piernas y los tarsos tienen casi la nisma longitud.

De las dos especies comprendidas en este genero, la mis conocida es el hocidio globular (fig. 144).

DISTRIBUCION GEOGRÁFICA.-Este insectoes ori. ginario del Brasil.

\section{LOS PECILOPTEROS -PEEILLOPTERA}

CARAGTERES. - Estos insectos tienen el cuerpo largo y delyado; frente estrecha y bastante prolongada, antenas largas 6 insertas por debajo de los ojos, el protórax mas corto que el mesotorax; y este último bastante convexo; los clitros y las alas son muy grandes y rodean el cuerpo en toda su extension; las patas delgadas y bastante cortas; las piernas carecen de espinas,

De las seis especies comprendidas en este género, el pecilippero circulado (fig. 148) puede considerarse como tipo.

DISTRIBUCION GEOGRÁfrCA.-Li! Brasil es la patria de este insecto.

\section{LOS BOTRIOCEROS-BOTHRIOCERA}

CARACTERES.-Se distinguen principalmente estos he. mipteros por tener la frente redondeada en su parte anterior, formando como un circulo; las antenas se insertan en un hoșo profundo situado delante de los ojos. El caricter dis. tintivo de estos insectos consiste en la especie de tubo que forma la prolongación de la cabeza.

Ia especie tipica de este género es el botrivcero manchato (fig. 147).

DISTRIBUCION GEOGRÁFICA. - kista especie es tambien originaria de América, y abunda sobre todo en el Brasil.

Ademas se encuentran numerosos géneros en qৃue el escu. dete oculta del todo las alas anteriores; pero debemos limitarnos a los descritos, que bastan para dar una idea de la riqueza en formas de esta familia.

\section{LOS FULGORINOS - FUL- GORINA}

CARACTÉRES. - Como en los membracinos, en la familia de los fulgorinos la cabeza representa el papel principal y de clla depende en gran número de especies la forma del cuerpo, aunque nunca adquicre la propiedad de dar luz como un farol, segun se crejó gencralmente en otros tiempos. Aunque estos insectos no tienen brillo en ninguna parte de su cuerpo ni producen chirrido, se les ha conservado su nombre de fulgorinos, del mismo modo que la conocida fresa tiene todavia su antiguo nombre alcman de baja terristre, aunque hace tiempo no se la considera como tal; otro tamo sucede con otms muchas cosas, que despues de bautizarlas se han conocido mejor, y a las cuales se habria dado con mucho gusto otro nombre si la fuerza de la costumbre no do. minara tambien en la ciencia. In forma de la cabera, cuyas protuberancias no son propias de todos los fulgorinos, se distingue sin embargo de todas las demás cigarras, por la circunstancia de que todas sus partes, es decir la coronilla, la frente y las mejillas, estan separadas unas de otras por añlados rebordes y de que alli donde unas trasformaciones particularcs no son la base de este caracter principal, toda la ca. beza conserma la forma angulosa. Allado de cada uno de los pequeños ojos reticulares se ve hacia el interior un ojuclo, que sin embargo puede faltar tambien del sodo; en las mejillas elevanse las pequeñas antenas, apenas visibles; el escudete es sencillo y no presenta ningun a jéndice ó protuberancia; las alas anteriores, membranosas en unas especies, son en otras mas sólidas que las posteriores; en un tercer grupo, coriaiceas y abigarradas, están cubiertas en su base por una escamita que a los membracinos falta siempre, cuando menos 
en todos los casos en que el escudo collar cubre la base ó toda la superficie. I as ancas del centro son prolongadas y se desvian mucho; los tarsos trilnterales tienen a menudo espinas, $y$ los postcriores ángulos en la punta de su corona espinosas. Muchos fulgorinos segregan de entre los segmentos del abdómen una materia blanca parecida i la cera, que cuando abunda mucho forma como una especie de moño, renovindose tambien cuando se gastn. Los fulgorinos pertenecen particularmente à las zonas tropicales y solo muy pocos se encuentran en Europa.

\section{EL CIXIO NERVIOSO-CIXIUS NERVOSUS}

CARActeres. - Esta especie, cigarra de $0^{\prime \prime}, 00717$ de largo, es un insecto prardo, con los bordes de la cabeza amarillos y alas trasparentes con manchas y puntos pardos. L.2 coronilla es angosta $y$ tiene ojuelos; una frente romboidea, y antenas en forma de intoncio, que asoman por debajo de unos ojos salientes, carncterizan la cabeza; el coselete es romboidco; las alas, que sobresalen mucho del cuerpo, de forma triangular, tienen nervios divididos en figura de horquilla.

Aun hay en Alemania algunas especies de este género, dificiles de distinguir, $y$ à las que Burneister ha dado el nombre de cixios. El género de este nombre se agrupaba antes con el llamado Flata, cuyas especies sin entrargo solo se en. clientran entre los trópicos; algunas se parecén á las maripo. s.s por sus grandes y abigarmadas alas; otras tienen como una capa de escarcha. Asi, por ejemplo, la especie fiatu limbiata produce la llamada cera blanca de China.

\section{EL SEUDOFANO EUROPEO-PSEUDOPHANA EUROPAEA}

CARACTÉRES. - Esta especie, que es una cigarrita de $0^{m}, \operatorname{co} 575$ de largo, de color verde de yerba, cuyjas alas anteriores trasparentes están cruzadas por nervios igualmente verdes, es el único representante curopeo de su género que, excepto en la Nueva Holanda, se encuentra en todas partes, y cuyas demás especies son análogas à la presente por su color verde. La cabera, que caracteriza al género, sobresale en forma de cono: la coronilla está cruzada por una quilla longitudinal; y la frente tiene un reborde.

USOS, COSTUMBRES Y RÉGIMEN, - El seudofa no curopeo se encuentra sobre todo en las praderns donde abunda la jérba de San Juan y la manzanilla bastarda, asi como en otros sitios cubiertos de yerbas, propios de algunas regiones de Alemania. Se han encontrabio individuos aisladosno léjos de Leejprig y Halle: yo los observé cerca de Naum. burg: y un amigo mio en la frontern norte-oriental de la provincia de Sajonia: mas hácia el sur aburda bastante.

\section{LAS FULGORAS-FULGORA}

CARACTERES. - Este género presenta las formas mas perfectas y grandes, entre otras la especie fulgora candiclaria, que tiene la cabeza prolongada en forma de sable. El cuerpo es de color rojo de minio; las alas posieriores de un rojo ta. drillo con la punta negra; las anteriores, de un verde carde. nillo con matices amarillentos.

\section{LA FULGORA DEL FAROL-FULGORA LA- TERNARIA}

CARACTERES, - Esta especie, conocicia bastante por: los grabados, llama la atencion por la gran maza deprimida en figura de silla de montar, formada por la coronilla y la frente. Esta cigarra, que mide $0^{\prime \prime}, 00 \% 8$, es de color amarillo verdoso, con matices negros, sobre todo en el angulo exte. rior, ancho y redondeado, de las alas posteriores, casi bipartidas, y en las cuales se ve una bonita mancha ocular grase. El abdómen segrega con abundancia una materia blanca como la creta. Desde hace mucho tiempo los sabios han dis. cutido sobre la propiedad de lucir atribuida a esta especie, y no admiten la opinion de muchos naturalistas modernos, por lo cual se necesitan aun observaciones despreocupadas para establecer la verdad del hecho.

DISTRIBUCION GEOGRÁFICA.- La fulgora de farol es propin de la América del sur, sobre todo de Surinam, pero no parece abundar en ninguna parte; los indios la consideran como venenosa

\section{LOS CANTORES - STRIDU-}

\section{LANTES}

Los estridulantes ó cigarras cantonas justinican cuando menos por un concepto su nombre; pues los nachos producen sonidos que pueden considerarse como chirrido, zumbido, etc., segun la opinion del que los oye. Verdaderamente poética fué la opinion de los antiguos griegos sobre estos animales: segun una de sus fábulas, dos músicos, Eunomo y Ariston, competian en su arte, y una cigarra, poniéndose en el arpa sobre una cuerda rota, decidió la victoria. Por esto se consideraba entre los griegos à la cigarra puesta on un arpa como simbolo de la música. Los poetas celebraban a los insectos en sus cantos elogifíndolos como los séres mas félices e inocentes. Asi, por ejemplo, Anacreonte les dedica una oda en la que dice: «; Feliz te considero, cigarra! porque en los árboles mas alios, cntusiasmada con un poco de rocío, cantas como un rey: Tuyo es cuanto miras en los campos; tuyo todo cuanto traen las estaciones; amigos te son los habitantes del pais, porque á nadic causas dano; y los mortales te veneran como deseado mensajero del verano; las musas te quieren $y$ te quiere el nismo Febo, ol qque tic ha dado tu clara vo\%. I Profeta cres entre los hijos de la tierra, y cantor feliz sin sangre en la carne! iCasi te pareces á los dioses! Menos delicado parece cl elogio por parte de Cenarco de Rodas, quien dice que las cigarras son felices porçue tienen las mujeres mudas.

Virgilio demostró menos interés por las cigarras, pues suspira al oir su voz, que produce ruido en la espesura; $y$ tam. poco los autores sucesivos la juzgaron muy agradable. Chaw dice: "En los meses calurosos del verano là cigarra produce desde el medio dia hasta la noche un ruido tan desagradable que inolesta al oido. Es el insecto mas enojoso cuando po. sado en una rama interrumpe la siesta. I a especic felix de los griegos debe producir un sonido mas suave y armonioso, pues de no ser asi, los excelentes oradores que se han comparado con las cigarras no jueden haber sido otra cosa sino charlatanes y vociferadores. Debe repetirse en este caso lo que hemos dicho al hablar de las langostas: cada especie en. tona su melodia: del carácter y de la instruccion musical del que escucha depende la impresion que en él produce el concierto. Los griegos llamaban à las cigarms, segun hemos di. cho, tetix; conservábanlas cautivas en jaulas, por su canto, $y$ tambien las comian. Aristóteles dice que las larvas de las cigarras son mas sabrosas antes de abrirse su cubierta, j que al principio los machos, y mas tarde las hembras preñadas, tienen mejor gusto.

Pasemos ahora á la descripcion del aparato musical del insecto, del que ya los antiguos tenian una ides, pues Aris- 
tóteles dice que los sonidos se producen por medio de una membranita extendida en un segmento del abdómen y por la compresion del aire. Eliano dice: "Otras ates cantoras cantan como el hombre con la boca, pero las cigarras to hacen con las ancis."

CARACTERES.-Dos grandes escamas coriaceas que sin articulacion están soldadas con el metatórax, reciben todo el vientre en la parte de su base; cada una de ellas cubre una gran abertura circular en el primer segmento del abdómen, cerrada en su fondo por una delicada piei; por arriba, en la cara exterior de cada anillo, se inserta hicia el dorso un marco córneo, soldado en varios puntos con las paredes interio. res y sobre el que se extiende una membrana mas sólida de repliegues longitudinales. I as alas laterales del anillo, que en el dorso remata en su parte anterior en tres globos, pro. tegen este órgano sin tocarlo. En el fondo de cada una de las escamins, oculto debajo de los muslos posteriores recogidos, hállase it cada lado el estigma en forma de una hen. didura muy larga. En el rigido borde de quitins se insertan las cuerdas yocales, cuyos bordes interiores vibran por el aire comprimido. Frente d este estigma, trasformado en una especic de laringe, se ve la cavidid del tambor con la membrana replegada. Por la respiracion pónense en movimiento las cuerdas vocales y la nembrana en forma de concha que hay en el marco, asi como el tambor en el rondo de la gran caviclad, dando a los sonidos mucha mas ruerza. En las moscas se habló de una estructura nuy parecida. Respecto a la del cuerpo, la cabeza se prolonga en la cigarra muy rams veces hacia adelante; por lo regular, al borde anterior y posterior de la coronilla descubren dos arcos iguales, $y^{\circ}$ dos surcos trasversales dividen su estrecha superficie en tres partes: en in central se rentres ojue. los. En medio de los ojos reticulares, nuy salientes, elévanse las antenas, cerdosas, cortas, $y$ con sicte artejos. De las cuatro alas quie en forma de tejadillo cubren el tronco cónico, las anteriores alcanzan una considerable longitud, son vidriosas y peludas, observandose esto ullimo, sobre todo, th las especies africinas; los nervios se extienden en ramas ahorquilladas sobre la superficie. Las larvas se sirven de las patas anteriores para escarbar en la tierm, donde Jas unas pasan varios años de su vida y las otras están únicamente en la edad adulta; las especies de un tercer grupo solo en in. vicrno chupan la raíz de las plantas fibrosas.

USOS, COSTUMBRES Y REGIMEN.-Las cigarras son insectos tínidos y perezosos, solo mas activos cuando les loca la luz del sol. Introducen su pico en los retoños de las plantas tibrosas y chupan el jugo. Despues de la picadu$m$ sale tambien, produciendo en ciertas plantas el mand. I) mismo modo introducen lus hembras su tubo hasta la médula para clepositar los huevos. Los hijuelos salen al nacer en seguida de su cuna y chupan por fuera el árbol.

Conócense de cuatrocientas à quinientas especies, de las que is habitan al sur de Europa, pero la mayor parte de las otras la zona cálida, extendiéndose por el sur hasta los $40^{\circ}$ de latirud y por el norte à mucha mas altum.

\section{LAS CIGARRAS-CICADA}

CARACTERES.-El género-cisada, llamado por Fabricius tefigonia, se dividió últimamente en varios subgéneros, de los cuales no podemos ocuparnos. Para representarle bas. ta la especie siguiente.

\section{LA CIGARRA ESPECIOSA-CICADA SPECIOSA}

CARACTERES. - Fste bonito insecto negro iienc una mancha mas pequena en la parte anterior del escudo collar y una faja mas ancha en la parte posterior; el dorso y los lados del abdómen en los seǵmentos quinto i sejutimo son amarillos; los rehordes del centro del dorso, los bordes exteriores de las alas anteriores y los nervios son de un rojo de sangre; el borde exterior de las alas anteriores y el de las partes posteriores blancos.

DISTRIBUCION GEOGRÁFICA.-Este magnifico insecto habita las islas de la Sonda, y cuando hay muchos jun. tos producen un chirrido que se oje a la distancia de algu. mas horas, aturdiendo á los que le ojen de cerca.

\section{LA CIGARRA DEL QUEJIGO-CICADA ORNI}

CARACTERES. - la forma extrania del cuerpo, que es pardo con manchas amarillas y pelos blancos; los muslos anteriores, poco desarrollados, y los ir puntos pardos caracterizan esia especic.

DISTRIBUCION GEOGRÁFICA. - Fista cignrm es propia delsur de Europa, donde suele vivir en el quejigo. De las heridas que infiere á los árboles para su propia alimentacion sale el mani, sustancia glucosa que tal ver. se halle igualmente en otras especies de serbal; con mas 6 menos abundancia esta contenida asimismo en el jugo de las zamahorias, cebollas, apio, ctc. Aunque segun se dice, el maná mas fino se produce por las picaduras de cigarra, la major parte provieric de incisiones artificiales que en julio y agosto se hacen en la corteza.

El macho levanta un poco el abdómen para bajarlo en seguida y repite rapidamente este movimiento hasta que el sonido pasa il un chirrido sin interrupcion con el que termina el canto. "His strident arbusta Ciendis, dice Linneo de esta especie, probablemente la misma de que habla Virgilio. De otras especies muy parecidas à la anterior yque en parté muy dificimente pueden distinguirse de ella, unas cuatro son propias de Alemania I a especie ricada homatodes, se ha éncontrado cerca de Wurtzburgo; la pledeja en la inmedia. cion de Ratisbona; y la afra (lo mismo que concinna) y otra especie no lejos de Heidelberg, en Erlangen (Suiza franca). La cicada montrna esta disemimada por toda la Europa y cl norte de Asia: no solo se ha cogido en algunos puntos sep. tentrionales de Alemania, como Jena, Naumburgo, Jresde y Breslau, sino tambien aislada en los alrededores de Insterburgo, en Prusia, cerca de San Petersburgo y en Suecia. En la América, y sobre todo en el Brasil, tan rico en insectos, abundan especies análogas y mas grandes.

\section{LOS HIDROCORES-HIDROCORES}

CARACTERES. - A las especies que acabamos de des. cribir, y que túnto entusiasmaron á los poctas de la ancigicicdad, deben seguir, segun los naturalistas, los insectos de pico, que por su género de vidia en el cieno de los charcos alejan toda idea poética Los hidrocores ó chinches acuáticas de que aqui se trata se parecen i las cigarras por sus antenas cortas de tres á cuatro artejos, ocultos debajo de los ojos, pero difieren de ellas por sobresalir el pico, no en la base de la cabeza, sino en la punta, por téner la coronilla soldada y por su rapacidad. los colores y formas són bas. tante monótonos.

DISTRIBUCION GEOGRÁFICA.-Los hidrocores ha. bitan las aguas estancadas de ambos hemisferios, tanto en la parte septentrional como en la meridional; las especies propias de las regiones cálidas ni tienen colores mas brillantes que las de la Furopa templada ni se distinguen por la belleza de sus formas, pero si por su tamaño. 
USOS, COSTUMBRES Y REGIMEN.-Las larias que en la primavera salen de los huevos, mudan varias veces de picl hasta el otono, época en qque alcanzan su mayor tamaño. Se alimentan de toda clase de parásitos, á los cuales atra. viesan con su pico para chupar el conienido. Ocultos en el cieno de los charcos pasan aqui el invierno, y se propagan al año siguiente, ó cuando menos, esto es lo que se ha observado en nuestras especies europeas. Los adultos tienen la facultad de volar, pero nunca lo hacen sino de noche. Parece que muerden fuertemente con su picolos dedos del que quiera privarles de su libertad. Los hidrocores se han dividido en tres familias.

\section{LOS PEDIREMOS-PEDI- REMI}

CARACTERES. - Una cabeza grande y ancha, situada oblicuamente hácia abajo y atris y sin ocelos; frente ancha $y$ redondeada, con un pico grueso y corto que solo llega hasta el centro del jecho; patas posteriores mas ó menos aplana. das, provistas en un lado ó en los dos de los tarsos y piés de una especie de pestañas; y el cuerpo prolongado y aplanado, son los caractéres de los pediremos 'ó notonectinos (Nito. nectini). Esta última calificacion parece, sin enbargo, menos conveniente, porque muy pocas especies nadan de espaldas, mientras quue todas, gracias á sus patas en forma de remo, lo hacen muy bien en la forma oräinaria.

\section{LOS CORIXAS-CORIXA}

CARACTÉRES. - Ia excesim longitud y el ensancha. miento en fonna de cono del tercero y penúltimo artejos de las antenas; los piés anteriores de un solo artejo, provistos de iuertes cerdas, muy aplanados, $y$ sobre todo un escudito invisible, porque le cubre el protórax, caracterizan el género de los corixas, muy rico en especies.

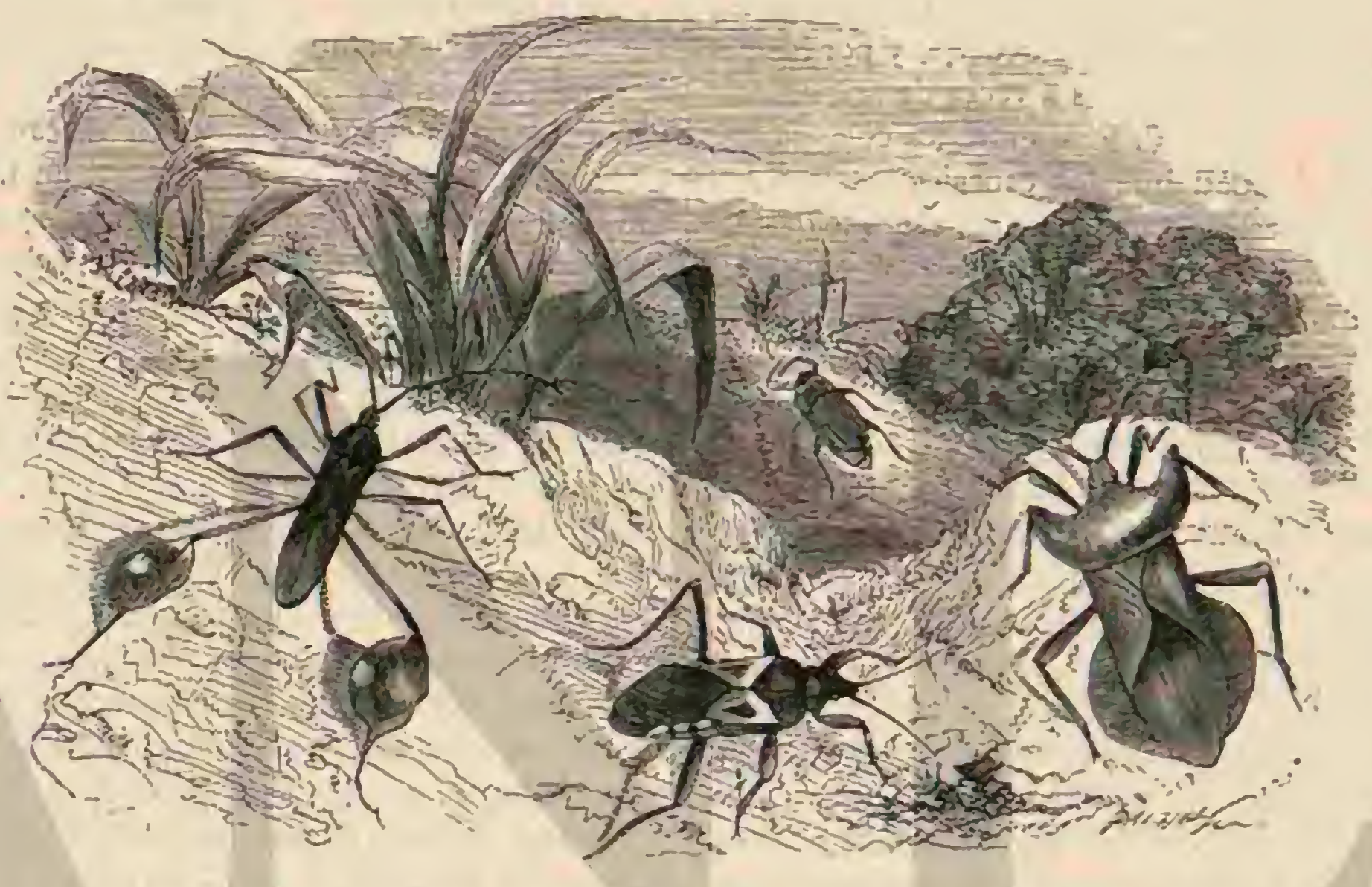

Fig. 150.- EL עLACTOR UILINEADO

Fig. 151. - EL NRPיA CENICIENTO

Fig. 152.-1:1. DOLABER DE COSTADO AGUDO

Fig. 153.-E.t, HFasATOCliRo 8), Axrr.ojos

\section{EL CORIXA DE GEOFFROY-CORIXA GEOFFROYI}

CARACTERES. - En el dorso, que es aplanado, y en el cuerpo, cuya longitud es de unos $0^{\circ}, 012$, predomina cl color negro verdoso; el escudete presenta por lo menos quince lineas onduladas amarillas, y las alas anteriores están salpicadas de este último color. Ia cara inferior del cuerpo es tambien amarilla, con manchas negras en la base del vientre y del pecho. Por la forma de cuchillö de las patas anteriores esta especie se distingue de otras muy numerosas y semeantes, pero en su mayor parte mas pecqueñas.

USOS, COSTUMBRES Y REGIMEN.-Las hembras de los corixas depositan en la primavera sus huevos, reundos en grupos planos en las plantas acuáticas. Los huevos de dos especies mexicanas ( $C$. mercenaria y femorata), se re. cogen y preparan de varias maneras como alimento.

\section{EL NOTONECTO COMUN-NOTONEGTA GLAUCA}

CARACTERES, - Esta especie nada por lo regular de espaldas. El tórax, amarillo y plano, se dirige hácia arriba, y el dorso presenta una quilla obtusa. Este hidrocoro parecido por su forma á una pequeña lancha, sube $y$ baja por medio de sus patas posteriores elásticas y fuerter, que tambien le sirven para volver á su elemento cuando se le ha sacado á tierra firme. El vientre esta cubierta de espesos pelos, en los que se encierra el aire necesario para la respinacion. Cuando el notonecto le ha respirado todo vuelve á la superficie del agua para tomar nueva provision. Sobre el dorso, que es de un amarillo verdoso, resalta por su color negro aterciopelado el escudito, que es grande, y triangular. Las cuatro patas anteriores, bastante iguales entre si, tienen solo al parecer dos artejos en los piés, con dos garmas; pero un cxámen minucioso permite reconocer que existe una tercera, muy cor. ta, solo visible por la cara inferior, mientras q̨ue la segunda y al mismo tiempo última del pié remata en las patas poste. riores sin gatra.

USOS, COSTUMBRES Y REGIMEN. - A principios de la primavera las hembras depositan sus huevos, de forma oval y color amarillo claro, en la parte inferior de una planta acuática ó en cl suclo, reuniéndolos en grupos que afectan la figura de disco. Al cabo de unos diez, dias aparecen en las extremidades libres unos puntos de color rojo viro, y pocos dias mas tarde, es decir, aun en mayo, salen las larvitas, se. 
mejantes á la hembra por su forma y género de vida, pero son de color amarillo de ocre y carecen de alas. Hasta el mes de agosto mudan tres reces, presentando al fin los rudimentos de las alas, aunque muy cortos Con la cuarta muda el insecto alcanza su mayor desarrollo, pero necesita aun bastan. te tiempo para adquirir todos sus colores y dureza: pasa el invierno aletargado en el cieno. Simpson dice haber observado en setiembre de 1846 a a orillas del Mississippi, una ban. dada de esos insectos que formaban en los aires una linea de veinticinco leguas inglesas de longitud. Una especie muy análoga, que los mexicanos llaman mosquito, se utiliza por ellos para alimentar las ares; y con los hueros confeccionan una especie de tortas llamadas fiautle, que segun se dice tiene sabor de pescado.

\section{LOS NEPINOS-NEPINE}

CARACTERES. L I inmilia de los nepinos se caracte riza por tener la cabeza, pequeñ y cstrccha y por las jatis anteriores, propias para coger una presa; una parte de estos hidrocoros recuerda por la forma de su cuerpo y por los pelos de las patas posteriores, provistas a veces de una especie de pestanias corinceas, ciertos ditiscos entre los coleópteros; nadan con la misma agilidad que las especies anicriores; $y$ otros, en cambio, se arrastran lentamente por el iondo del cieno de las aguas, dejando ver a intervalos en la superficie su delgado tubo respiratorio en forma de larga cola.

\section{EL NAUCORIS COMUN-NAUCORIS CIMI- COIDES}

CARAGTÉRES. - Esta especie, que pertenece al primero dé las citados grupos, tiene de $0^{\circ}$, or r $a 0^{m}, 013$ de largo; el cuerpo es de forma oval y aplanada; el dorso ligeranente convexo, s de un color pardo verdoso, mas oscuro en el escudito y en los clitros. Los cortos tarsus de las patas anteriores encajan en los inuslos, en su parte inferior, cual la hoja de un cuchillo en su mango, constituyendo los órganos con. que el insecto coge su presa. In cabeza es casi tan ancha como el escudete cateciendo de ocelos; las antenns tienen cuatro artejos, ocultos en un hoya debajo de los ojos.

USOS, COSTUMBRES Y REGIMEN. - Ia hembra deposita igualmente sus huevos en forma de torta en las plantas acuáticas; afecta la figura de un cilindro ligeramente encorvado y cortado oblicuamente, con la punta libre. Los hijuelos adquieren despues de la tercera muda los rudimentos de las alas. En el otono salcu estos insectos de noche a menudo del agua, y se limpian los pelos del abdómen con las patas tan fuertemente que se oye el ruido que producen.

\section{EL BELOSTOMA GRANDE-BELOSTOMA GRANDIS}

CARACTÉRES.- Lista especie cs la mas grande de todo el órden, pues mide $0^{\infty}, 0105:$ en la extremidad del abdómen, que es aplanado, tiene unos apéndices en forma de lanceta cuyo destino aun no se conoce. En las hembras de algunas especies afines se ha observado la costumbre particular de reunir los hueros igualmente en forma de torta, la cual llevan consigo en el dorso, como por ejemplo la especic diplonychos rusticus, propia de las Indias orientales.

\section{EL NEPA CENICIENTO-NEPA CINEREA}

CARACTÉRES.-El nepa cenicienio pertenece al segun. do de los grupos ó géneros arriba indicados, las anțenas tienen tres artejos, los piés solo uno, $y$ las patas anteriores están provistas de una garra sencilla. Excepto la parte superior del abdómen, que es de un tinte rojo vivo de minio y que por lo regular no queda visible, el color del cuerpo es pardo negruzco á menudo manchado por el cieno. El hilo de la extremidad del abdómen, que llega a la mitad de la longitud del cuerpo, se compone de dos partes huecas hácia dentro y que oprimidas estrechamente forman el tubo respi. ratorio, cuya punta saca el animal con frecuencia à la superficie del agua (fig. 151).

USOS, COSTUMBRES Y REGIMEN. - Ilegada la primavern, la henbra deposita sobre las plantas acuáticas sus huevos, que presentan en la extremidad unos apéndices en forma de siete radios. Las larvas parecen mas anchas que largas y e! tubo respiratorio es mucho mas corto que el individun del todo desarrollado.

\section{LA RANATRA LINEAL-RANATRA LINEARIS}

CARACTERES. - El género á que pertenece esta especie tiencesencialmente los mismos caractéres que el anterior, distinguiéndose de él solo por ser los costados de las patas anteriores cuando menos seis veces mas largos que los trocánteres; los tursos llégan apenas a un tercio de la longitud de los $\mid$ muslos y los piés anteriores carecen de garras. I a mantra lineal tiene el cuerpo muy prolongado, cilindrico, de color gris amarillo sucio; en la pare superior del abdó. men es rojo, en lós costados amarillo y en las alas posterio. res de un blanco de leche.

USOS, COSTUMBRES Y REGIMEN, - Asi como la especie anterior, tambien esta se desliza lentamente por el fondo del agúa poco profunda en busca de alguna presa; sucle estar cubierta de unos diminutos cuerjos en forma de pera y de: color rojo, que son las ciscaras de unos pari. sitos fertenecientes al género Hydrascina. Ia hembra pone igualntente sobre plantas acuáticas; sus huevos tienen dos apéndices cerdosos. I.as larvas nacen a los quince dias, pero en mayo no han llegado aun à la longitud de $0^{m}, 013$ y carecen todavia de tubo respiratorio exterior; en agosto alcanzan doble longitud, y con las mudas adquieren los hilos caudales; los rudinacntos de las alas no aparecen hasta la tercera muda. Unas especies muy parecidas habitan en los otros continentes.

\section{LOS PLOTERES-PLOTERES}

I a naturaleza, que en la formacion de sus criaturas nunca procede a saltos, ha creado en los ploteres ú corredores del agua un grupo de hemipteros que por el género de vida se parecen à las especies acuáticas, nientras que por las formas del cuerpo se asemejan mas à las terrestres, constituyendo asi un trínsito natural de estas á aquellas. No se les encuentra nunca dentro del agra, pero sí en la superficie. Procediendo exactamente como en invierno una alegre sociedad de patinadores, que hacen sus ejercicios en un estanque helado, estos hemipteros de patas largas y delgadas corren sin hiclo y sin hierro debajo de los piés sobre la superficie tran. quila del agua en que se refleján los rayos del sol, ora dis. persindose en todas direcciones, ora volviendo i teunirse en un mismo punto. Pam descansar mantiénense otra vez como enclavados y parecen esperar solo una ocasion de em. plear sus ardides, pues cuando el observador se acerca cm. prende la fuga, con preferencia contra la ligera corriente cuando un riachuelo les sirve de escena para sus juegos. Los individuos adultos estan provistos de alas y sc sirven de ellas, segun lo demuestra el hecho de hallarse en algunos 
los charcos de los caminos. I os amojuelos formados por el agua que bajan de la cresta de las montañas les sirven tam. bien de albergue, aunque su verdadera residencia debe bus. carse en todas las charcas grandes y en los remansos de las aguas corricntes; los limnołates habitan hasta en la superficie de los mares tropicales, alejándose á mucha distancia de la costa. Los alegres viajes de estos hemipteros les sirven no de diversion sino tambien para la caza de los peçueños insectos de que se alimentan. Cogen su presa casi siempre con las patas anicriores que no se emplean en la carrera, aunque no tenga la estructura de patas prehensiles.

CA RACTERES. - En los diversos géneros las seis patas no siguen la misma ley de formacion; suelen insertarse muy al borde del cuerpo, y en el pié hay solo dos artejos, provisto siempre el último de dos garras en una escotadura que hay delante de la punta. En todas las especies la cabeza alcanza casi la auchura del protórax el cual sobresale horizontalmen. te sin estrechamientos en forma de ruello: las antenas solo tienen cuatro artejos, pero estrin marcados y no ocultos. Los ocelos faltan en la mayor parte de casos. El estuche del pico llega hasta el protórax, se oprime mucho contra el cuerpo, sin encajar en ningun surco y se compone de tres artejos, siendo el central por lo menos cuatro veces inas largo que el último. El cuerpo, prolongado y estrecho, nunca muy aplanado, está cubierto de una especie de pelo aterciopelado que en la cara inferior presenta un vivo brillo plateado. Los elitros y las alas faltan a reces, $y$ los primeros con menos frecuencin, porquue casi siempre son mas cortos. Las hembras depositan sus huevos longitudinales, dispuestos en series, en las plantas acuaticas, y las rodean despues de un tejido.

\section{EL LIMNOBATES DE LOS ESTANQUES -IIMNOBATES STAGNORUM}

CARACTERES. - Esta especie se caracteriza por tener la cabeza larga, ensanchada en su parte anterior y sin ocelos: los ojos, réticulares y muy salientes, se hallan situados casi en el centro; el pico sobresale muy poco de la cabeza y todas las patas tienen una forma casi igual. Fste pequeño insecto, que mide $0^{\circ}, \mathrm{or}_{3}$, carece de pelos; su color es pardo negruzco excepto la base del cetalotorax y del escudcte que tiene un tinte rojo de orin, y las patas, que son de un ama. rillo pardusco; los elitros presentan nervios longitudinales de color mas claro.

DISTRIBUCION GEOGRAFICA. - El limnobates de los estanques se encuentra en todos los punios de Europa.

\section{LOS HIDROMETROS - HYDROMETRA}

CARACTERES, - Ios hidrometros $\dot{0}$ corredores del agua se distinguen por tener las patas anteriores mas cortas. El jrotórax, en extremo grande, cubre el mesotórax hasta la punta del escudetc; el abdómen es angosto, de igual anchura en toda su extension, aplanado por arriba y muy consexo en su cara inferior. Las antenas tienen cuatro artejos en for. ma de varas; y oiros antos constituyen el estuche del pico, pero solo al parecer, porque el cefalotorax se inclina al prin. cipio, doblandose hácia atris. Casi siempre hay dos ocelos bien marcados: los elitros, del todo coriáceos, se prolongan regularmente hasta la extremidad del abdómen, que está muy escotado para recibir los órganos genitales, compuestos en el macho de tres articulaciones y en la hembra de dos. Los costados de las cuatro patas posteriores, risibles por arriba, producen en los respectivos sitios del cuerpo un marcado ensanchamiento.
Las larvas se distinguen de los hemijteros desarrollados por tener los piés de un artejo y por la carencia de alas: su desarrollo parece ser muy desigual, pues se ins encuentra aun en la primavera.

DISTRIBUCION GEOGRÁFYCA.-De las numerosas especies de hidrometros, solo una docena, poco mas $\delta$ menos, son propias de Europa.

USOS, COSTUMBRES Y REGIMEN.-LOS hidrometros viven reunidos en bandadas.

\section{EL HIDROMETRO DE LOS PANTANOS -HYDROMETRA PAIUDUM}

CARACTERES.-El hidrometro de los pantanos, una de nuestras especies mas comunes, se caracteriza por las arrugas trasversales en la parte posterior del escudete, provisto de tres quillas longitudinales y en su parte anterior de una protuberancia nudosa; cl abdómen remata lateralmente en ambos sexos en dos puntas corvas mas largas en el macho que en la hembra. Este hemiptero, que mide mas de $0^{\circ}$. o 4 , es de color pardo negruzco con una línea blanca amarillenta en el borde del abdómen.

\section{LOS VELIAS - VELIA}

CARACTERES. - FI los velias, los ojos, reticulares y salientes, tocan en el borde anterior del escudete, de forma pentagomal, y que en su parte anterior presenta dos hoyitos latcrales, cubiertos de pelos platendos; la posterior oculta el coselete; la cabe\%, que es trilateral, carece de occlos: las patas, de igual longitud, rematan en tres artejos del pić: y el abdómen, muy recogido, se cleva en los. lados en forma de reborde.

\section{EL VELIA VAGABUNDO-VELIA CURRENS}

CARACTÉRES. - Fsta especie es de color amarillo de naranja en el vientre, incluso el reborde lateral; solo los ángulos de los segmentos y las puntitas casi cónicas del ano, son negros, como las demás partes del cuerpo. los muslos posteriores, muy gruesos, provistos en su parte interior de varios dientes, distinguen al macho de la hembra.

USOS, COSTUMBRES X REGIMEN.-Fstos graciosos hemipteros corren a intervalos contra las corrientes de poca fuerza y se encuentran en toda la Europa, mas á menudo sin alas que en estacio perfecto.

\section{LOS RIPARIOS-RIPARII}

USOS, COSTUMBRES Y REGIMEN.-I OS riparios que constituyen otro trinsito de los verdacieros hemipteros terrestres, viven a la orilla del mar $\delta$ de las aguas interiores, donde se les ve correr con suma rapidę, gracias à sus largas patas posteriores provistas de espinas, por lo cual es muy dificil cogerlos. Por su ligereza en los movimientos y" su rapacidad, en las inmediaciones del agua son mas afines de los ploteres que de los hemipteros terrestres, que se alimentan mas bien de sustancias vegetales.

\section{LOS SALDAS - SALDA}

CAR ACTÉRES. - Fste subgénero es cl mas rico en espe. cies, las cuales se camcterizan por un pico triarticulado que llega hasta la parte posterior del pecho; tienen dos ocelos y antenas de cuatro artejos insertas en el centro por delan. te del borde anterior de los ojos, que son reticulares: las 
piés de las artejos, rematan en garras $s i n$ discos, viendose algunas celdillas prolongadas en la delgada membrana de las alas anteriores. La cabeza es corta, y a causa de los ojos salientes algo ancha, siempre mas que el escudete en su parte interior: todo el cuerpo afecta la forma de un óvalo prolongado.

\section{EL SALDA ELEGANTE-SALDA ELEGAN- TULA}

CARACTERES. - Esta especie cs de las mas pequeñas, pues solo inicie $1 ", 003$ de largo: tiene un color negro mate, y la parte superior está cubierta de pelos amarillentos lisos; las patas y unos anillos de! segundo y cuarto artejos de las antenas son amarillos; los elitros tienen el borde de este color, con dos puntos blancos.

\section{LOS REDUVINOS-REDU} VINI

CARACTEREs.-La cabeza se estrecha en forma de cuello por detrás de los ojos, que son salientes; el protórax está divididido por un estrechamiento trastersal en una par. te anterior, casi siempre mas angosta, y otra posterior, mas ancha; es reciondeado lateralmente y constituje el carácter. mas esencial de los reduvinos ó hemipteros rapaces. Ias antenas, en forma de látigo, tienen cuatro artejos, entre los que a seces se intercilan otros mas cortos; de modo que su nimero pucde elevarse de cinco à ocho; y en un género, por la subdivision de los artejos principales, á treinta. Detrás de un surco trasversal la coronilla presenta en una protuberancia dos ocelos. El pico, encorvado casi siempre y corto, se compone de tres artejos y queda libre. De las patas, caracteris. ticas en general, solo podemos decir que rematan en tres artejos del pié, el último de los cuales no lleva disco; distinguense en particular las posteriores por st gran longitud, sin ser por eso delgadas, plies los muslos se ensanchan, y están provistas de espinas de formas muy diversas.

USOS, COSTUMBRES X REGIMEN. - TOdos los reduvinos andan con lentitud a pesar de sus largas patas: permanecen ocultos de dia, y solo de noche salen en búsca de su alimento, que se compone de pequeños insectos, sobre todo de moscas. Algunas especies exóticas son muy temidas por su aficion á la sangre caliente de los animales y del hombre: asi, por ejemplo, dicese que la especie arilus serratus, que está discminada por toda la América, produce una conmocion verdaderamente eléctrica por su sensible picadura. Es probable, pero no seguro, que este insecto sêa el mismo que bajo.el nombre de Winhuka, en los Andes de Chile, o con el de Rinhuia en la república Argentina, obliga á la gente durante el verano i salir de sus casas cuando quiere entregarse de noche al descanso. La mayoria de las especies, incluso las mas grandes, habitan en los países cálidos. Fieber enumeró en 1861 treinta y cuatro especies europeas, distri. buidas en 1 s subgéneros.

\section{EL REDUVIO SUCIO-REDUVIUS PERSO- NATUS}

CARACTERES,-Esta especie, de color pardo negruz$\mathrm{co}$, con las patas rojizas, tiene unos pelos blandos en las antenas y en el protórax, que presenta cuatro protubernncias: el insecro debe sul nombre, no muy lisonjero, à una particularidad de lá lariá, que suele vagar por los rincones empolvados, cubriendo todo su cuerpo de basura, tanto que su verdadera forma queda oculta como bajo una careta. Su manera de andar tiene tambien algo de extraño, pues apenas adelanta un pié se para un poquito, mueve el segundo, in. clinando el cuerpo al lado opuesto, y de este modo avanza á intervalos con un continuo movimiento de las antenas. Cuando se le ofrece una mosca doméstica ú otro insecto pequeño se acerca, lo mismo quue el individuo adulto, ì cortos pasos, examina la presa tocándola con las antenas, $y$ precipitase despues sobre ella para devorarla.

DISTRIBUCION GEOGRÁFICA.-EI reduvio sucio pasa en Alemania el invierno en estado de crisálida, pero tambier se encuentra en Africa, donde quizás las condiciones de su metamorfósis ioman otra forma por efecto de la temperatura mas alta.

USOS, COSTUMBRES Y REGIMEN。-Habita aisladamente las casas y sitios donde hay basura, persiguiendo, segun dicen, como larva, las chinches domésticas, lo cual no me parece irobable, pues si tal hiciera, no seria por gustarle el cuerpo Raco de las chinches, sino por aficion á la sangre, y fácil le seria extraer este noble jugo sin ir á buscar las ba. suras. El antiguo nombre del género reduvio se ha conserva. do uiltimamente solo para algunas especies que se caracterizan por tener el protúrax sin espinas, estrechado en el centro, y' por las garrns no denticuladas en la base; los piẻs son propios para andar, y tienen una planta larga, estrecha y carnosa en la cara interior de las extremidades de los cuatro tarsos anteriores.

\section{LOS HEMATOCEROS -HAMMATOCERUS}

CARACTERES. - Tos hematoceros tienen in superficie del cuerpo granulosa y bastante velluda; cabeza grande, con una gran prolongacion cilindriforme por delante de los ojos; cuello muy corto; ojos grandes y salientes; antenas de cuatro artejos; pico corto, muy arqueado; el protórax afecta la forma de un trapecio prolongado, que se redondea un poco en la parte posterior; el esternon y el vientre tienen su disco apjanado; los elitros son tan largos y anchos como el abdómen; los bordes de este último cortantes; las patas fuertes, vellosas y de regular tamanoo las cuatro jiernas anteriores presentan en su extremidad una ancha foseta esponjosa, de
forma ovalar.

\section{EL HEMATOCERO DEANTEOJOS-HAMMA- TOCERUS CONSPICILLARIS}

CARACTERES. - Este insccto (fig. 153) es de color ne. gro mate; la parte coriácea de los elitros blanca, con una mancha irregular en su disco; à cada lado del abdómen hay otras cinco rojizas, $y$ una semejantc en los muslos anteriores; pero mas pequeña y apenas aparente.

DITRIBUCION GEOGRAFICA.-Esta especie es africana: se encuentra igualmente en Cayena.

\section{EL HARPACTOR SANGUINEO- HARPACTOR CRUENTUS}

CARACTERES. - La mas bonita de las especies alèmamas es $\sin$ duda la de este nombre: mide $V^{\prime \prime}$, or 7 de largo, $y$ su cuerpo, de color rojo de sangre, tiene en el vientre tres series de puntos negros: otra de manchas del inismo color adorna el reborde aplanado del abdónsen; la cabeza y las an. tenas son igualmente negras.

El harpactor sanguineo pertenece à un género muy rico en especies que se caracteriza por las garras denticuladas 
de tocios los juies, propias para andar; las alas anteriores, peludas en su mitad anterior, son mas estrechas que el abdómen; los muslos posteriores mas gruesos; la cabeza de igual anchura en toda su longitud, estrechada solo en su parte posterior, y el cuello corto.

USOS, COSTUMBRES Y REGIMEN.-Esta especie se encuentra en verano con bastante frecuencia en las flores visitadas por numerosas moscas y abejas. Ia he visto w veces volar cuando el sol calentaba mucho y al cogerla experimenté la fuerza de su picadura.

I a mayor parte de los otros reduvios europeos son mas pequeños y viven ocultos en la yerba, raras veces en los arbustos; los hay tambien que se distinguen por tener las alas atrofiadas.

\section{LOS MEMBRANÁCEOS- MEMBRANACEI}

CARACTERES. - Cierto número de hemipteros, por lo regular muy pequeños y que se caracterizan por tener el es. tuche del pico de tres artejos oculto en un surco de la garganta, por carecer casi sicmpre de los ocelos, y por compo. nerse los piés de dos artejos, sin discos junto à las garras, se han reunido en una familia llamada de los membranáceos, porque el protórax, los elitros y el abdómen están provistos de apofisis y procuberancias membranosas, a veces en forma de vejigas quue a muchas especies comunican una forma extraña.

\section{LOS TINGIDOS-TINGIS}

CARACTERES. - Sin fijarnos en algunos pocus géneros, el mas importanic de los cuales, el de los syries, cuenta en América con numerosos representantes nque se caracterizan por tener las patas anteriores propias para coger la presa, ${ }^{\prime} 110$ carecer de ocelos, nos ocuparemos en primer lugar de los tingidos, animalitos en extremo graciosos, y que dificilmente se observan al descubierto porque apenas llegan it la longitud de 0,004 . En medio del escudete tienen una protuberancia callosa $\delta$ en forma de vejiga, yue cubriendo el escudito se prolonga hảcia atrás, y lo mismo que los elitros, convexos y provistos de nervios reticulares, se ensancha lateralmente en forma de hoja; esto y la extremidad en figura de boton de las delgadas antenas, constitujen las particularidades de estos bonitos hemipteros.

USOS, COSTUMBRES Y REGYMÉN.-TA maYor parto de las numerosas especies viven en localidades determinadas.

\section{EL TINGIDO AFINE-TINGIS AFFINIS}

CARACTERES. - El tingido afine se distingue por el color pardo del cuerpo; tiene unos bordes membranosos tras. parentes, con nervios pardos; las puntas de las antenas son mas oscuras; y una mancha en forma de estrella adorna el centro de cada elitro. Las cinco largas espinas de la frente son comunes a la mayor parte de sus congéneres.

USOS, COSTUMBRES Y REGIMEN, - Estc hemiptero vive reunido ron sus semejantes en tierra, $y$ á menudo se le encuentra en las rajces de las gramineas.

\section{LOS ARADES-ARADUS}

CARACTERES. - Estos insectos, de forma muy aplanada, con la superficic del cuerpo oscura y rugosa, viven ocultos debajo de la corteza de los árboles muertos. Su cabe. za, casi romboidea, remata en su borde anterior en una pun. ta obtusa, en cuya base hay una escotadura en la cual se insertan las gruesas antenas de cuatro artejos. El pico llega hasta la extremidad del protórnx ó algo mas allá en cl escudo collar, un poco mas estrecho en su parte anterior, se ven varios rebordes longitudinales, y en la parte coriácea de los elitros algunas gruesas venas longitudinales.

\section{EL ARADE DE LA CORTEZA-ARADUS CORTICALIS}

CARACTERES. - En esta especie predomina el color negro; solo la base de los elitros es de un blanco amarillento; la parte posterior del coselese y los ángulos de los seg. mentos abdominales de un tinte amarillo sucio. El tercer artejo de las antenas, de un color muy oscuro, es mucho mas corto que el segundo; el protórax tiene una escotadura lateral y es denticulado; el coselete es igualmente escotado. Ta. les son los caractéres de esta especie, que no escasea cn ninguna parte. Las hembras son mas grandes que los machos y ticnen el cuerpo mas ancho.

\section{LA CHINCHE COMUN-GIMEX LECTU- LARIUS}

CARACTERES. - Unica en su género es la chinche comun, tan difamada y conocida de los antiguos griegos con el nombre de kuris, y por los romanos con el de cimex, por lo cual parece justificado que el antiguo nombre genérico tmaferido por I.innco à un múmero extraordinario de especies muy distintas por sus formas, se conserve exclusivamente para esta especic. Unn de sus particularidades consiste en que se alimenta de sangre y otra en que carece de alas; las antenas son cerdosas y de cuatro artejos; el pico es triangl. lar y oprinido, ó encaja un un surco de la garganta; carece de discos en las garms. El cuerpo, sumamente plano, mide cuando menos (1),004 de largo y es pardo rojo claro, cubriéndole espesos pelos amarillentos. Los lóbulos redondios en ambos lados del escudito pequeño deben considerarse como los restos de los elitros.

USOS, COSTUMBRES Y REGIMEN, - La hembra deposita en cada uno de los meses de marzo, julio y setiembre unos cincuenta huevos cilindricos, de color blanco, de $1^{m}, 001$ I 2 de longitud; los pone en las grietas de las paredes de las habitaciones, sobre todo detras del papel pintado $y$ de las tablas, ó en las rendijas de las camas, es decir en el mismo sitio donde las chinches permunecen ocultas de dia La última cria, sin embargo, perece casi siempre, y solamente los individuos adultos que para su ciesarrollo necesitan once meses, invernan y pueden soportar mucho frio. I.o mas desagradable en estos insectos, es que retardan su actividad hasta la noche, para molestar al hombre en su sueno. Muy bien puedo creer que, segun se dice, atraidos por la traspiracion de las perso. nas dormidas déjanse caer del techo, pues yo mismo vi cierta noche como una chinche llegó de esta manera a una taya de café caliente. A pesar de su gran aficion à la sangre pueden ayunar mucho tiempo. Leunis encerró una hembra en una caja bien tapada, y al abrirla, á los seis meses, no solo la en. contró viva aun, sino rodeada de algunos descendientes, que asi como la madre se trasparentaban cual si fuesen de vidrio. Por lo muy fecundas, y por su facilidad para trasladarse de un sitio á otro, las chinches son los mas molestos de todos los parásitos, sobre todo en las ciudades grandes, donde el numeroso vecindario de las casas dificulta su persecucion radical. Durante mis estudios en Berlin pude observar cuan esca. sos son los efectos del sencillo blanqueo de las habitaciones 
para ahuyentar à estos parásitos. Lin el taller muy limpio de un encuadernador vi una pequena shinche que con el lomo pintado de blanco se paseaba alegremente por la jared. Una mercla de vitriolo entre la cal produce ya mejores efectos, despues de limpiar bien todas las hendidums con clara de huevo, polvos insecticidas y aceites minerales, cermindolas despues. Estos medios empleados con energia pueden limpiar por fin las habitaciones, à no sor que las circunstancias sean muy desfavorables, jero no bastan para proteger al via. jero rue por su mala estrella se hospeda en una fonda poblada de chinches. En este caso, la lu\% encendida impide, segun he oicio asegurar un riarias paries, que esos vampiros atormenten à las personas dornidas.

Nadie sibe de dande han renido las clinches; pues aùn no esta demostrado que las Indias orientales slan, como va: rias veces sé ha pretendido, la patria primitiva de esos para. sitos Los antiguos griesos y romanos los conocieron, segun ya hemos dicho, y les temian murho, aunnue atribuyéndoles toda clase de virtudes medicinales. En el siglo $x t$ aparecieron en Listráskurgo: pero la pretension de que hasta 1670 no llegaron a 1.óndres, por conducto de los hugonotes expulsados, se refuta fácilmente, pues ya en 1505 , dos damas de aquella capith habian considerado su picalural como indicio de la peste. Cuando hace años yo mismo buscaba excrémentos de murcielagos en el desvan de una iglesia para atonar mis flores, me admiró mucho encontmr pieles de chinches de todos tamaños. En nquel sitio habitaban decidiamente las chin. ches en la madera vicja, tomando su alimento en los murcié lagos: Ahora bien, como lambion se las enctrentra en galline. ros, palomares y en nidos de golondinas, es muy probable que primitivamente hayan vivido al descubierto como parisitos de los mas diferantes animales de sangre caliente, llegando poro a poco á ponerse en contacto con el humbre, sobre todo por medio de los nocturnos murciélagos, porque puedic suponerse que mas de una chinche habrí salido de su escondite agarrada al cuerpo de un murcielago antes de comenzar este sus expediciones nocturnas. Ebersmano distingue una especie rusa de $11 ", 0337$ de largo yide color amarillento de lodo, con cl abdómen cubierto de arrugas tras. versales, y a la cual da el nombre de cimbir cilintus.

\section{LOS FITOCÓRIDOS-PHY- TOCORIDE}

CARACTÉRES. - Todos los pequeños hemipteros delicados y blandos que en verano retozan en las lores y yerbas cor una-agilidad extrañ à muchas especies del grupo, y que siempre estan dispuestos a clevarse en el aire con silencioso vuelo micntras que el astro del dia ilumina con sus calurosos rayos la tierra, insectos que con preferencial se alimentan de miel, pertenecen à la familia de los fitocóridos ó capsinos, familia representada por especies relativamente mas numerosas en las regiones templadas que en las callidas; en Liuropa se conocen unas trescientas. Estos insectos, de color verde claro, que presentan i menudo graciosisimos matices abigarrados, no hubiernn podida reunirse en un grupo si no fuese anåloga tambien la estrictura de su cuerjo. la cabeza triangulis, con la corouilla trilateral, caracteriza particularmente a un género (miris); en otros se encorvn hácia abajo y esta soldadia con la frente, que se dirige hacia adelante. L.os ojos son reticulares, pero carecen de ojuelos; l.25 antenas cerdosas, con su segundo artejo inas largo $y$ á reces mas grueso, alcancando la longitud del cuerpo, o mas, rematan en dos artejos finisimos. El pico, muy oqurimido, llega hasta la extre. midad del pecho y' se compone de cuatro artejos de igual longitud; el escudito, no muy grande y triangular, queda siempre visible; los elitros, blandos y coriáccos, jresentan un repliegue paralelo al borde $y$ dirigido hácia $\mathrm{el}$ escudito, repliegue que separa una placa longitudinal en forma de trapecio, llamada el clavo (clianus); la parte restante forma un triángulo llamado el cuero (corrims) en cuyo lado mas corto, dirigido hácia la punta, toca un lóbulo mas delgado casi sicmpre, de un color particular y scparado por un repliegue; este lóbulo, al que se ha dado el nombre de cuna (cureus), ó tambien apéndice, es carácter distintivo de la familia; yartiendo de él se continúa la membrana (membrana). Fin esta última se ve una vena arqueada que salc del borde de la cuna y vuelve á ell ramificándose por delante de la extremidad en otra rama pequeña, de modo que forma dos celdas desigua. les. In el caso de faltar esta membrana, no existen tampoco las alas posteriores, siempre muy delicadas. Los piés, á veces en extremo pequeños, presentan tres artejos, separados poco marcadamente, y unos discos diminutos entre las garras. Esta blandura del cuerpo y poca solider en la insercion de las pa. tas no se observa en iningun otro grupo de hemipteros.

\section{ELCALOCORIS RAYADO-CALOCORIS STRIA- TELLUS}

CARACTERES.-Esta especie nos puede servir para formar una idea de la familia en cuestion. Pertence al gé. nero phyłosoris, dividido últimamente muchas veces, y al grupo calocoris en el que la callosidad de la frente se prolonga en ángulo hasta la coronilla; la nuca es convexa y no presenta ningun ruborde; el artejo de la base de las antenas sobresale de la cabern que es casi pentagonal; el pico llega hasta el segundo anillo abdominal; el escudo collar, q̨ue ticne form de trapecio $y$ en su parte anterior un reborde, avanza en los, lados en línea recta y la base de los piés de las patas prosteriores es mas corta que el artejo siguiente. II cuerpo tienc un color de naranja $\delta$ amarillento claro y está cubierto de pelos blanquizcos; los matices del escudo collar son negros, así como en los clitros.

DISTRIBUCION GEOGRAFICA. - El calocoris rayado, que mide mas de $0^{\text {m }}, 00 \%$ de largo, se encuentra en toda Europa.

\section{LOS MIRIS-MIRIS}

CARACTERES. - Los niris, delgados, de un color verde sucio, se distinguen de los otros por su cuerpo muy estreclio y por la diferente configuracion de la cabeza. Ill cránen, trilateral y puntiagudo en su parte anterior, llevin en su borde lás antenas, quue salen de un grueso artejo.

\section{LOS CAPSOS-CAPSUS}

CARACTERES.-I os capsos, 6 sean las especies de los fitocóridos de forma oval, de color pardo, negruzco of rojo, se caracterizan por tencr la segunda articulacion de las ante. nas ensanchadas en forma de maza, y el cucrpo cubierto de puntos gruesos.

\section{LOS LIGEODOS- LYGEODES}

CARACTERES. - La mayor parte de los llamados hemípteros longos ó ligeodos viven debajo de las piedras, entre las planias y el musgo y en los troncos de árboles, donde corren en busca de su alimento que se compone de insecios 
y de jugos vegetales. Salen muy poco à la luz del dia. La mayor dureza de los tegumentos, la existencia regular de cinco nervios en la membrana, la falta de la cuña en los eljo tros, y en fin, las antenas filiformes, un poco mas gruesas hácia la punta, son los caractéres que distinguen à estos insectos de la familin anterrior. Las antenas se muestran en las mejillas y estản situadas casj siempre debajo, ó cuando mas sobre la linea que se tira desde el centro de un ojo hasta la base del pico. Las proporciones de los cuatro artejos de las antenas varian tanto en los diferentes espacios como en los del pico, aunque el penúltimo suele ser mas largo que el úl. timo. Entre los tres artejos del pie el del centro es el mas corto; el último tiene garras y discos. Algunos carecen de ojuelos, pero en la mayor parte estàn bien marcados, y exac. tamente al lado de los ojos que son reticulares.

\section{EL PIRROCORIS SIN ALAS-PYRRHOCORIS APTERUS}

CARACTERES. - A las esprecies sin ocelos pertenece el conocido pirrocoris sin alas, hemiptcro caracterizado por el color rojo de sangre y negro del cuerpo, asi como por la falta de la membrana de los elitros $y$ de todas las alas posteriores. Los pirrocoris diseminados en los continentes, se distinguen solo por el reborde afilado del escudo collar del género laryus, propio de la América Central; se asemejan por el segundo artejo de las antenas, mas corto que el primero, y por la falta de los ocelos.

USOS, COSTUMBRES Y REGIMEN.-Los pirrocoris sin alas llamados en algunas partes tambien franceses ó soldados, se reunen todo el verano en bandadas en la base de los tilos ti olmos añosos, contentándose tambien con uno jo. ven en caso de no tener otros ả su disposicion. 'Tan luego como ha pasado el invierno, por lo regular en marzo, abando. na poco a poco sus escondites y se desliza aisladamente en los sitios preservados de los vientos frios. Cuanto mas benigno es el tiempo tanto mas llaman la atencion, y desde mediados de abril los adultos suelen aparearse. Karas veces se reune el macho mas de una vez con la hembra mientras que esta permite un apareamiento repetido; este puede durar hasta $3^{6}$ horas. Despues se encuentran debajo de la hojarasca hímeda 6 en las raices subterraineas de los troncos añosos, unos huevos de color blanco de perla, y mas tarde larvitas del tamaño de una cabeza de alfiler junto á otras-mayores. Los hijuelos tienen el abdómen dél todo rojo y los rudimentos de las alas negros; despues de tres mudas llegan à su completo desarrollo y adquieren la coloracion definitiva. Los elitros se prolongan y cambian el color negro por el rojo, trastormándose en una especie de capote con dus manchas negras redondendas como botones; tienen un borde ancho $\delta$ estrecho en la extremidad, $5 \mathrm{el}$ abdómen, que antes era rojo, toma un color negro brillante; solo los bordes late. ralcs y algunas fajas trasversales de la extremidad del vientre conservan su color primitivo. Ia cabeza, con las antenas y el pico, son de un negro brillante; el protórax ad̄quiere tambien pronto este tinte en su cam superior é inferior y solo conserva bordes rojos.á su alrededor; las patas son negras en los individuos pequeños. Entre estos pirrocoris, que parecen larvas aunque sean del todo adultos, en las regiones meridio nales hay algunos alados. Los adultos han perdido su color particular: mientras que las larvas lo producen por tres gín. dulas de la parte superior del abdónen, dispuestas en el centro de los tres segmentos medios. Si se les irrita, aunque sea poco, percibese un olor penetrante que se exhala al salir de la gländula central una gotita de un liquido desco. lorido que proco á poco se evapora. Cuando se aumenta la irritacion oprimiendo una larva $\delta$ cortándole una pata ó una antena, de la glándula posterior sale en forma de chorro un liquido que tiene el verdadero olor de la chinche. En los individuos adultos se nota al principio un olor acre que sin embargo se desvanece pronto, encontrándose enton. ces has glandulas vacias.

Los pirrocoris retozan durante todo el verano, aunque sean mas bien perczosos que activos; en sus pequeños pascos se paran a menudo, pero no para descansar sino para recrearse. Algunas veces se reunen dos ó tres individuos al rededor del cadảver de un insecto, aunqué sen de su propia especie, para chuparle el jugo; y en la cautividad los grandes atacan anmbien á los jequeños y los chupan. Debajo de los elitros hay a veces numerosos aradores que se alimentan a costa de aquellos. Grandes y pequénos buscan los escondites convenientes tar luego como la estacion iria lo exige: ofreciéndose de este modo el caso, muy maro entre los hemipteros, de que invernan en los mas diversos grados de su desanrollo.

\section{EL LXGEO CABALLERO-LIG AEUS EQUESTRIS}

CARACTERES.-Otro ligeo es propio de Alemania, el ligeo caballero, que mide mas de $10^{\circ}, 0 \mathrm{r}$, habia à menudo, reurido con otros muchos, los troncos de encina desprovistos de corteza, por lo cual, así como por su bonito color, es una de las especies mas particulares de toda la familia. In superficie de sta dorso, que tiene la forma cliptica prolongada, es de un color rojo de sangre $y$ negro, y en la membrana de los elitros, que es negra, orillada de blanco, se ve una manchita blanca en el centro. Fl género de los ligeos (yrgeus) a que pertenece este insecto, se distingue por estar reunidas las dos venas interiores y los dos segmentos de esta inembrana por su nervio trasversal, por tener la paste curiácen de los elitros mas córnea y la coronilla provisa de dos occlos.

Todos los demais géneros se sustraen à nuestra observacion por su vida oculta; entre ellos tigura tambien el de los faquimeros (fachimerus) muy rico en especies, que se distinguen por las venas longitudinales no reunidas en la parte principal de los elitros, que por lo demás tienen ia misma estructura que en el género anterior, y por estar los muslos anteriores mas 6 menos manchados.

\section{LOS COREODES- COREODES}

CARACTERES.-Entre todos los hemipteros tertestres cuyo estuche del pico se compone de cuatro antejos y cuyo escudito no llega al centro del ahdómen, los cureodes presentan la mayor variedad de formus y pueden caracterizarse en general solo por tener las antenas de cuatro artejos insertas en el borde de la coronilla, y los piés provistos de garms con discos. Además tienen siempre dos ojuelos y en ln membrana de los elitros muchos nervios prominentes divididos á menudo en forma de horquillas. Ambos sexos se distinguen fácilmente por la forma del último segnento abdominal, que en el macho es mas grueso y está cubierto desdce abajo por una especie dic vilvula, mientras que en la l:embra está hendido longitudinalmerite.

En Europa apenas viven 60 especies, al paso que la fami. lia tiene en América numcrosos representantes, que por su tamano y forma pertenceen à los hemipteros mas grandes j: bonitos: unos ensanchamientos en forma de hojas en los tarsos posteriores ó en uno ú otro artẹo de las antenas, un protórar ensanchado por apéndices, muslos posteriores en extremo gruesos y provistos de espinas, y unos bordes laterales 
afilados y encorvados hacia el abdómen que sobresale de los elitros, son los canctéres distintiros de esta familia de hemip. teros.

USOS, COSTUMBRES Y REGIMEN.- Cuando en nuestms regiones todos los insectos se retiran y cesa su acti. vidad; cuando comienzan los frios dias del otonoo, y cada cual busca sitios abrigados, sobre todo debajo de la hojarasca, para pasar el invicrno, los coreodes mas grandes, reunidos con los pentatómidos, ofrecen un curioso espectáculo cuando en una tarde de sol, que en dicha estacion aun podria llamarse hermosa, se examinam los sitios indicados inquietando á los insectos que aun 120 se han entregado á su sueño invernal. Parece entonces que no les agrada mucho i estos hemip. teros la visita, pues algunos de ellos se remontan por los aires, escapando asi con mas segutidad y rápidez que silo hicicran a pié. En verano permanecen en las coplesuras y en la yerba, persiguiendo su presa; vuelan tambien viramente \& la luz del sol, peró segun parece, mas bien para escaparse de las persecuciones que pam divertirse. Mertenecen por lo tanto i. los hemípteros que llaman la atencion del amigo de la naturale. za, turque no sea naturalista, mucho mas que la mayor parte de las familias hasta ahora descritas.

\section{LOS COREOS - COREUS}

CARACTERES. - El género principal de los coreos se ha dividido hoy dia en mrios sub-generos de los que el Syro. inaslis con casi todos los coreodes propios de nuestras regio. nes, pertenecen à la subdivision que se caracteriza por tener los ojuelos distanies unos de otros, el ríltimo artejo de la base corto y grueso, y el pico auálogo por su longitud al de los pentatómidos, prolongåndose mas allá del mesotórax.

\section{LOS SIROMASTES-SYROMASTES}

CARACTERES. - Este género se distingue entre los grupos citados por ser la cabeza bastante cuadrangular; la base de las antenas muy prolongada hácia adelante; el abdómen ancho, mucho mas largo que las alas; y el segundo arte. jo de las antenas apenas mas largo que el tercero.

\section{EL SIROMASTES ORLADO-SYROMASTES MARGINATUS}

CARACTÉRES.-En esta especie las prominencias de la base de las antenas se ensanchan hacia adentro en forma de espina; la superficie gris rojiza del cuerpo parece mas os. cura, por tencr unos puntos finos de color negro entre los artejos: el último es el mas oscuro y los dos anteriores los mas claros; la parte superior del abdómen es de un rojo inas puro, y. In membrana de los elitros de un color de bronce brillante.

USOS, COSTUMBRES Y REGIMEN. - Este hemip. tero se encuentra en toda la Europa en las mas diferentes espesuras; é inverna en estado perfecto para propagarse en la primavera siguiente. La larva es mas pesada y torpe.

\section{LA VERLUSIA RÓMBICA - VERLUSIA RHOMBICA}

CARACTERES. - La verlusia rómbica tiene cuando mas $n^{\circ}, 0$ II de largo y se reconoce fácilmente por cl abdómen casi romboidal, muy aplanado y cóncavo en su parte superior. En esta especic las prominencias de las antenas no se trasforman en espinas.

USOS, COSTUMBRES Y REGIMEN.-Habitacon preferencia los fosos at lo largo de los pinares, donde en los dias de sol trepa por los tallos de yerba ó de otras plantas.

\section{EL BERITO MOSQUITO-BERYTUS TIPU-} LARIUS

CARACTERES.- Este animalito, de color gris claro, mas oscuro en los bordes exteriores, tiene cinco puntos en los clitros, y los trocínteres son gruesos; de modo que este insecto parece tener poca analogia con el siromastes orlado, mas a pesar de esto, solo una diferencia caracteristica los distingue, $y$ es la proporcion longitudinal del segundo y ter. cer artejos de las antenas, siendo el primero mucho mas largo que en el segundo.

Este cjemplo demuestra cuán dificil es la clasificacion de los corcodes.

USOS, COSTUMBRES Y REGIMEN.-E! berito mos. quito vaga con algunas otras especies afines debajo de los montones de heno, asi como en los enebros y la maleza, y parece aprovecharse muy poco de sus largas patas; es perezoso y déjase coger fäcilmente.

\section{EL' DIACTOR DE DOS LINEAS-DIACTOR BILINEATUS}

Car Actéres. - En esta especic exótica, propia de las regiones cálidas, el cuerpo es de color verde metálico, con abundantes matices amarillos; las patas son de este mismo color; unas dilataciones en forma de hojas en los tarsos posteriores, de un tinte pardo, con manchas amarillas, y los cli. tros de un pardo negro.

DISTRIBUCION GEOGRÁficA.-La América del sur, tan rica en insectos, alimenta tambien esta especie.

\section{LOS ESCUDADOS- SCUTATI}

CARACTERES. - Bajo esta denominacion se reunen por último todos aquellos hemipteros cuyo escudito del dorso sobresale cuando menos del centro del abdómen y hasta lo cubre del todo. En la cabeza, triangular, con los ojos reticulares, se inserta el protórax; las antenas tienen de tres a cinco artejos; en el estuche del pico hay cuatro, siendo el segundo por lo regular mas largo; las patas no ofrecen nada de particular; en los piés se encuentran dos ó tres artejos con discos. La mayor parte de las especies tienen una marcada parte de quitina y una membrana en los clitros; solo en las q̨ue tienen el escudito muy grande, compuesto de quitina, se reduce al borde anterior de los elitros no ocupado por ayuel. El contorno general del cuerpo simila una elipse, y por los lados salientes de la parte anterior del dorso, que es irregularmente exagonal, ả un escudo de armas. En el tórax, siempre muy grande, obsérvase en el segundo y tercer seg. mentos, al lado del estigna, un gran replicgue ondulado, que constituye el orificio de la glándula fétida. El abdómen se compone de seis grandes segmentos y de un septimo escotado que conticne los órganos genitales. Una quilla de la cara inferior del abdomen se prolonga desde el segmento há. cir el pecho; el primero sobresale y llega con su punta, en forma cie puñal, hasta el borde posterior del protorax; en el centro de cada segmento abdominal, d poca distancia del borde lateral, hállase á cada lado un estigma, que solo en el primero se oculia á veces en la membrana ligatoria y en el séptimo desaparece del todo. Las diferencias sexuales son análogas a las que se observan en los coreodes: una hendidura longitudinal en la hembra; y una especic de válvulas laterales que en su parte superior y posterior rematan en un gancho, formando el estuche de la verga en el macho. 
USOS, COSTUMBRES Y REFIMEN. - I.OS escudados hahitan con preferencia en las jlantas bajas; alcrunos ocultus, pero los mas en la superticic, donde sus colores abigarrados llaman fícilmente la atencion. I as especies mas gratudes viven en ärboles y arbustos, donde se alimentan de bayas, confundiendose por su color con las verdes hojas. Respecto al género de vida, menos oculto, se parecen mas á los fitocóridos, y por su tamaño llaman casi nas la atencion que estos, aunque solo ticnen la mitad de representantes ( r $_{50}$ ) en Europa. Invernan en estado perfecto debajo de la hojarasca. I a hembra fecundada pone à principios de la primavera sus huevos ovales 6 casi esféricos, provistos de una tapita y reunidos en forma de una prequueñn torta, en los sitios que habita. Las larvas, casi circulares, mudan varias reces, cambiando poco á poco de forma y de color; crecen duranté cl rerano, y á principios del otoß̉o alcanzan su major tamano, nutriéndose con preferencia de jugos vegetales, sin des. jreciar por eso el alimento animal. Su pereza innata dismi. nuye un poco con el desarrollo de las alas y pucde converlirse hasta en actividad hajo los rayos del sol.

\section{EL EURIDEMA DE LAS COLES-EURYDEMA OLERACEUM}

CARACTERES.-Esta pequeña especie, gracioso insecto de $0^{\circ}, 006_{5} 6$ mas, se distingue en la hembra por sus matices rojos y en el macho por los colores blancos sobre fondo metálico, verde azulado en la parte superior. Muchos se quejan de este hemiptero porque destroza las hojas tiernas de col extrayendo su jugo.

USOS, COSTUMBRES Y REGIMEN. - Degeer asegura que a veces ha causado grandes perjuicios en Suecia en las citadas plantas. En Alemania no sucle presentarse en tan crecido número; y como no se alimenta exclusivamente de

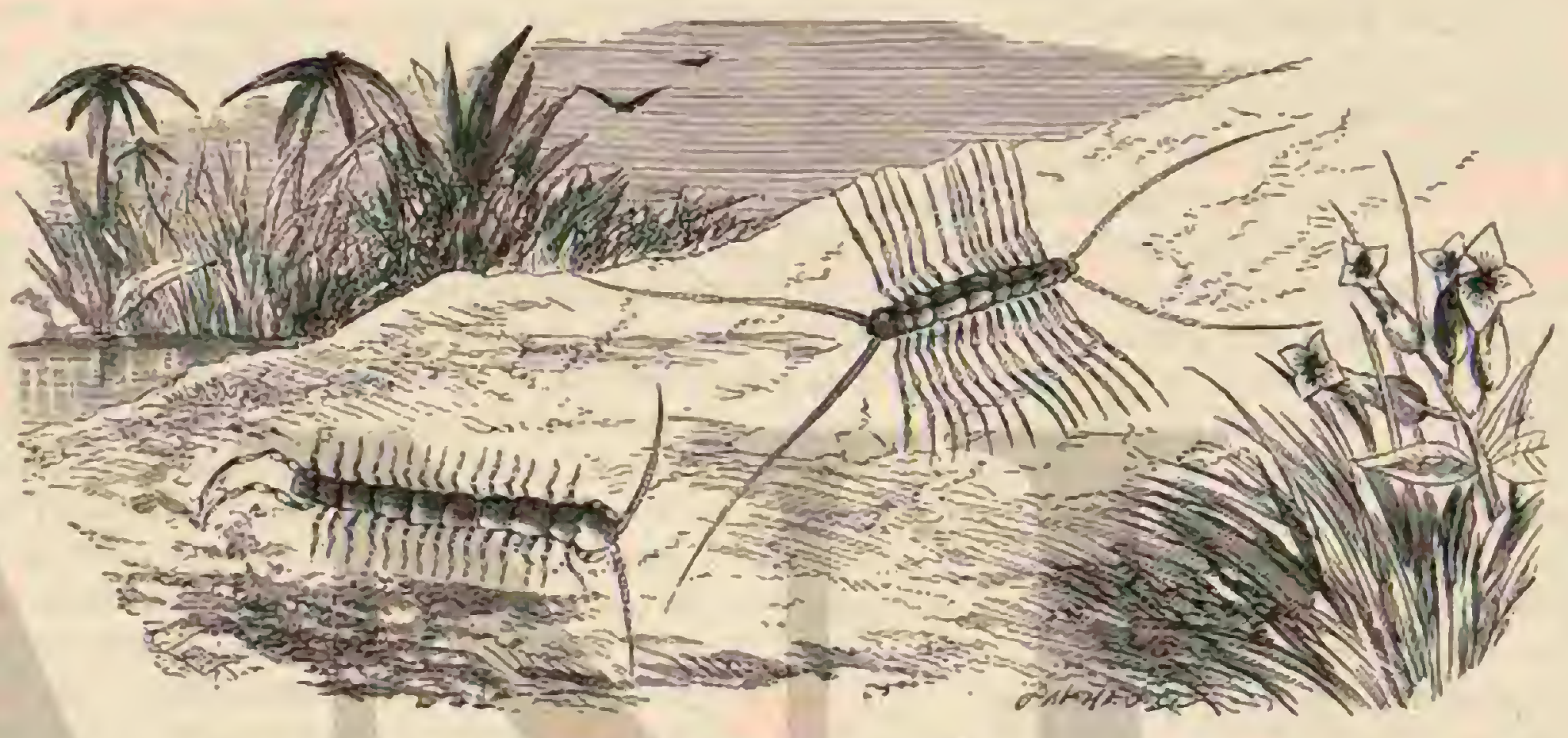

Fig. 154. - R.L. LTTOHO IH: CABELA KOJA

Fig. 155.-E1. ESCUTIGEKO NOHL: coles, sino tambien de otras plantas, y coge asimismo insectos, segun he observado algunas reces, no pertenece en mi opinion á los verdaderos enemigos de la agricultura.

El grupo de los escudados á que pertenece esta especie, es decir, el de los cidnos (Ciduus), separado por Hahn bajo el nombre de Straction dil cimex, se distingue por una marcada protuberancia trasversal del escudo collar, por la cabeza pequeña y triangular, por faltar la quilla del tórax y por acner numerosas espinas en las patas.

\section{LA ELIA PUNTIAGUDA - ELIA ACUMINATA}

CARACTERES. Fis uno de los escudados mas comu. nes, que en todas partes se encuentra en los linderoś y cla. ros de los bosques, y con menos frecuencia en los campos y praderas: se caracteriza por su singular delgadez. y' por tener la cabcza estrecinda en forma de cono, lo cual le distingue de todos los demás congéneres de la familin. In superficie del cuerpo es de color amarillento pálido, con puntos oscuros y tres lineas longitudinales blanñuizcas en el dorso.

\section{EL PENTATOMA DE PIÉ ROJO-PENTATOMA RUFIPES}

CARACTERES. - Este hemiptero solo difiere en rigor de una seric de otros semejantes por el ensanchamiento latcral del escudo collar:tiene de comun con la especie anterior el largo pico delgado, cuyo primer artejo encaja en un surco, y el vientre desprovisto de quilla; el segundo de los cinco artejos de las antenas es mas corro que el primero; la super- ficie del cuerpo presenta puntos negros y las demás partes son de color aimarillento ó pardo rojizo, con brillo metálico, excepto la parte suprerior del abdómen, que es de un negro brillante; las antenas, lis patas y la punta del escudito, ofrecen un rojo mas ó menos marrado.

USOS, COSTUMBRES Y RF.GIMEN.-Esta especie vive con preferencia en los abedules, pero tambien en varios arbustos: trepa por los troncos de los-árboles y segun dicen es útil en los bosques, porque extermina las orugas. Cuando se sacude con fuerza un abedul para hacer caur los insectos que en el se encuentran, esta especie no la hace como otras muchas, sino que baja volando y produce un fuerte aumbido.

\section{EL ACANTOSOMA DENTICULADO- ACAN- THOSOMA DENTATUM}

CARACTERES. - Esta especie presenta un fenómeno raro entre las nuestras por tener una quilla en la parte infe. rior del tórax y del abdómen, carácter que se observa en muchas especies exóticas, sobre todo en las que el estuche del pico se distingue por su grueso y longitud. F.l acantosoma denticulado es de color verde amarillento. excepto la punta roja del vientre, mas oscuro en sus partes superiores y con unos pumtos negros. De los dos últimos artejos de las antenas el segundn tiene la longitud del cuarto, mientras q̨ue el tercero es un poco mas corto.

USOS, COSTUMBRES Y REGIMEN.-Esta esperie está diseminada por toda Luropa, pero segun parece solo habita en los abedules. 


\section{LOS DOLADERS - DOLADER}

CARACTERES. - I a cabcza de estos insectos afecta la forma de un cuadrilongo; las antenas son grandes: cl pico muy corto; el protórax se dilata en los lados, lo mismo que los bordes del abdómen que se asemejan á una hoja muy ancha; las patas son de un tamaño rejular.

\section{EL DOLADER DE COSTADO AGUDO-DOLÁ-} DER ACUTYCOSTATA

CARACTERES, - Este insecto (fig. 152) es rojizo o de un pardo ferruginoso; los bordes aplamados del abdómen ofrecen cuatro fajás trnsversas de un rojo mas pálido; los muslos son de un pardo ó rojo ferruginoso.

DISTRIBUCION GEOGRÁFICA. - Habita en Borneo.

EL EURIGASTER DE LOS HOTENTOTESEURYGASTER MAURUS

CARACTEREs.-En los escudados hasta ahora descritos y en sus numerosos congéneres, el escudito ocupa la parte mas pequeña del abciómen y no oculta la pieza córnea de los elitros; pero hay una serie de especies, propias de los paises calidos, en que llega hasta la extremidad del abdómen, dejando lithre hícia los lados solo una estrecha parte de los elitros. Iis eurigaster de los hotentotes ofrece un ejemplo de esta particularidad: esta especie es de color amarillento, pardo negruzco ó negro, con ó sin manchitas laterales claras en la base del escudito, que es aquillado longitudinalmente en cl centró.

USOS, COSTUMBRES Y REGIMEN. - Vive menos en ha espesurns que en yerbas y otras plantas bajas, $y$ tambien le gusta ocultarse debajo de las piedrás, etc.

\section{LOS ESCUTELÉRIDOS-SCUTEL- LERA}

CARACTERES. - Algunas especies de las Indias Orientales, de un magnifico a\%ul metálico con manchas amarillas, de dorso muy convexo y vientre aquillado longitudinalmehte, pertenecen al género de los escuteléridos y constitujen por su brillo exterior un digno final de esta-division.

Del gran ejército de los insectos hasta ahora tan generalmente despreciado, y cuyo número no ha podido evaluarse todavin, una jeçueñisima parte ha pasado á nuestra vista, de. mostrando de un-modo suficiente que muchos de los inismos, ya por su aspecto exterior, ya por su asombroso instinto artístico, ó bien por ș poderosa unflucncia en el equilibrio de ta naturaleza, merecen en alto grado nuestra atencion. Los gu- sanos de seda y las abejas, cuyos productos tienen gran valor para el hombre, las langostas, los iérmites y hemipreros acuicicos, que en algunas regiones sirven de alimento a cicrta clase de la poblacion, mientras que otros, como por ejemplo las cantáridas, se emplean como remedio eficaz, figuran en primera linea cuando se trata de la utilidad que nos reportan. Mucho mas larga es la última seric descrita, y que comprende las especies inútiles, molestas y dañinas: los parásitos que atormentan á hombres y animales domésticos; los destructores de la propiedad humana de toda clase $y$ sobre todo los pequeños enemigos de la selvicultura. Cuánto pueden conseguir estos animalitos tan pequeños por la reunion de sus fuerzas y su perseverancia, harto nos lo prueban, no solo las devastaciones en campos y praderas, cn jardines y bosques, sino los cstragos causados por coleópteros, orugas y larvas del abejorro:y la destruccion fabulosamente rapida de los cuerpos vegetales y animales por las hormigas, los térmites, lamelicornios, larvas de moscas y otros, sin contar las maravillosas construcciones de los insectos sociables, como por ejemplo de las hormigas, avispas y abejas. En medio de estos dos grupos descritos figura aquel pueblo de insectos considerados hasta ahora ni como daninos ni comoútiles, y que por lo tanto se mantiene en un terreno neutral, porque no nos hacer dano ni tampoco nos reportan beneficios palpables. Sin embargo, todos los hombres sensatos están acordes en que ni una sola de cstas especies, aunque sea la mas pequeña, es supérflua, porque nada de supérfluo cxiste en la creacion.

Si por lo tauto los insectos parecen muy dignos do atencion, no solo por su caracter útil 6 danino, sino tambien como séres destinados para nuestro recreo ó para dar vida y variedad al conjunto de la naturaleza en cuya economia son necesarios, nos será licito expresar el deseo de que en lo futuro se fije en ellos mas la atencion que hasta ahora, para que puedan llenarse los grandes claros que existen en la entomoloyia. Nuestros conocimientos sobre las mariposas grandes son los mas completos, y los mas diferentes naturalistas curopeos se esfuerzan con aficion y actividad en com. pletar tambien la historia del desarrollo dc las mariposas pequenas. El segundo lugar, por el interés general que ofrecen, ocúpanie los coleópteros, sobre todo en cuanto al desar. rollo de sus larvas y crisalidas. lodos los demás órdenes excitan la atencion muy aisladamente, pero deben interesar nos mas en general para que el conocimiento de ellos pueda igualarse con el que tencmos de los otros dos órdenes. Sicmpre es dificil descubrir un nucvo insecto en Europa; en los otros continentes faltan aun muchisimos por conocer, y tambien de muchas especies europeas carecemos de noticias sobre su clesarrollo y género de vida.

Necesitaremos por lo tanto entregarnos aun largo tiempo al estudio mas atento para elevar la historia matural de los iusectos a un grado de períccion como el que se ha obtenido respecto i los vertebrados.

\section{MIRIAPODOS $\mp$ MYRIAPODA}

CARACTÉRES. - A unos quinientos ó seiscientos arti. culados lucifugos que en los paises cilidos se encuentran en mayor número $y^{\prime}$ tamano que en nuestras regiones, se les ha dado el nombre de miriápodos, no para significar que tengan precisamente mil patas, sino un determinado número. Muchos segmentos de piel dura, casi iguales entre si, cada uno de los cuales tiene dos, y hasta cuntro patas articuladas, provistas de una garra, y una cabeza marcadanente sepaurada, constituyen el cuerpo uniforme de estos animales, que exteriormente ofrecen una diferencia esencial si se compara con el de los insectos, porijue, excepto la cabeza, todos los seymentos son iguales, desapareciendo por lo tanto del todo ia 
diferencia entre un protórax con alas y solo seis patas, y un abdómen desprovisto de estas. Ia cabeza tiene en la frente, ó por debajo de su borde dos antenas filiformes ó cerdosas, raras veces un poco mas gruesas en la punta, y á cada lado un grupo de ojuelos en diverso mímero, que en algunas es. pecies faltan del todo $y$ en un género (scutigera) se sustituyen por ojos reticulados. Los órganos masticadores de todos los miriaipodos se componen eseucialmente de las maxilas ganchudas, que se insertan a mucha profundidad en la hoca, y de una valusula bucal inferior compuesta de cuatro partes, cuyas dos latcrales corresponden á las maxilas interiores y las dos del centro al labio inferior de los insectos, pero todos carecen de palpos.

Cuanto menor es la semejanza que ofrecen los miriápodos con los insectos por su aspecto exterior, tanto mayor es su semejanza por la estructura interna. El cuerpo tiene tràqueas ramificadas que por fuern se abren en estigmas bien marcados cuando estos se hallan entre las hojas del dorso y del vientre, ó mas ocultos debajo de los segmentos. El intestino delgado es casi siempre tan largo como el cuerpo, en cuyo caso se corre directamente desde la boca hasta el ano. El corazon está representado por un vaso lumbar cuyns cámaras se rigen en su número por el de los segmentos del cuerpo. A lo largo del vientre se corre el tronco de los nervios, provisto aqui de numerosos nudos situados í menos distan. cia unos de otros que en los insectos, segun puede suponerse yna a primera vista por el número mucho mayor de segmen. tos. En este grupo rige lo mismo que en el anterior, en cuanto á la estructura de las glảnclulas salivales y de los ór. ganos sexuales.

Las hembras de los miriipodos dejositan sus huevos en sitios determinados que les sirven de residencia, como por ejemplo debijo de las piedras ó de la hojarasca lúmeda, en la madera podrida, en los troncos viejos de árboles, etc., y de ellos salen, por lo que ha podido deducirse de las observaciones incompletas hechas hasta ahora, hijuelos apodos qute á la primera muda adq̨uieren tres pares de piés, $y$ en cada una de las siguientes algunos mas, los cuales, asi como los segmentos que los llevan, se intercalan entre los ya existentes; tambien dan á luz hijuelos que nacen con scis ú ocho piès. Segun Gervas y Lucas, en el género de las escolopen. dras las hembras paren hijuelos que tienen ya todos los segmentos. Como por las repetidas mudas aumenta tambien el número de ojos, cl desarrollo parece efectuarse esencialmente del mismo modo que ya hemos observado en los poduridos; pero atendido q̨ue una misma especic está provista de mas $\delta$ menos anillos y patas, segun el grado de su desarrollo, el plan de algunos sistemáticos, que quieren caracterizar el género por el número de patas, parece fundarse en razones muy poco segurns.

] os miriajpodos son, unos plantivoros y otros carnivoros. CLASIFICACION, - I os naturalistas no han podidoponerse de acuerdo aun respecto al lugar que corresponde i los miriápodos entre los demís articulados. Unos los reunen con los cangrejos, teniendo en cuenta los tegumentos duros del cuerpo, las numerosas patas y la amalogia exterior de cictas formas; otros los agrupan con las arañas ó los clasifican en un órden nada natural, el de los desalados, idea que desde un principio no tuvo tantos partidarios en Alemania como en Francia E Inglaterra. En el primero de dichos paises se ha preferido constituirlos, siguiendo el cjemplo de Lench, en clase indeprendiente, que debe seguir à los insectos y forma cl tránsito á los cangrejos, distinguiéndose por los caractéres siguientes. Los miriápodos son articulados terrestres que tienen la cabera scparada con dos antenas, órganos bucales masticadores y numerosos anillos en el cuerpo, casi iguales entre si, de los que cada uno tienc cuancio menos un par de piés propios para andar. Los miriápodos carecen de alas, respiran por tráqueas y llegan á sêr adultos por medio de una metamorfósis completa.

Algunos restos fósiles aislados se han encontrado en las capas del Jura, pero son mas numerosos en el àmbar: las especies aun existentes se dividen en dos órdenes muy raturales.
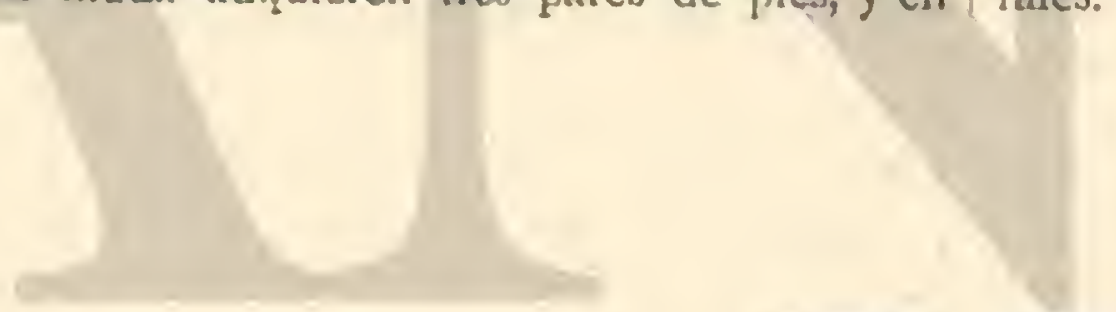

PRIMER ORDEN

\section{QUILOPODOS-CHILOPODA}

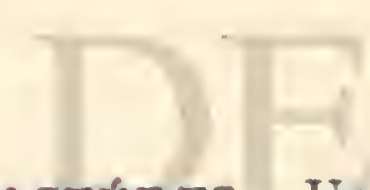

RES. - Un cuerpo largo, aphando, cuyos seglientes en los lados, y una cabe\%a escutiforme, dispuesta horizontalmente, caracterizan á los quilópodos. Debajo del borde de la frente se insertan las antenas, de catorce á veinte artejos, que preden afectar la forma de cordon y ser fili formes. lintre los organos masticadores las maxilas estan medianamente desarrolladas; la parte céntrica de la válvula bucal se limita a dos pequeños troncos, dispuestos uno junto a otro, mientras que los laterales se compoinen de una jieza principal mas grande y de otra biarticulada, provista en su extremidad de una superficic esponjosa cortada oblicuamente. En los dos pares anteriores de piés las partes bucales ticnen unos importantes órganos auxiliares; el primer par, poco des arrollado, adrquicre por el atrofiamiento de sus costados ce aspecto de un segundo labio inferior en que las extremida- des libres aparecen hasta cierto punto como palpos. 1.os dos piés siguientes se asemejan á una fuerte temaza, cuyas pun. tas en forma de garra, exprelen por un pequeno orificio un veneno en la herida que infieren, y que produce en cl hombre una irritacion dolorosa, aunque no la muerte. Todos los demás piés, excepto los dos últimos pares, son por lo regular iguales y se inclinan mas hácia atrís; el penúltino es muy largo, y mas aun el último, que en linen recta sobresale de la extremidad del cuerpo: los muslos, muy fuertes, tienen por lo regular numerosos dientecitos, de modo que estas patas adquieren el asjecto de un órgano prehensil, y como tal sirven á veces. Cada segmento del cuerpo se compone de una hoja lumbar y orra abdominal, reunidas en los lados por una piel delgada en la quue al mismo tiempo se muestran las patas, y en la que cada segundo segmento tienc un estigma. El ovario de la liembra presenta como una bolsa aislada muy 
larga, en forma de intestino, de la cual salen uno ó dos oviductos cortos, y está jrovista de una doble bolsa espermatica; en el último segmento del abdómen hay un orificio, asi como en los órganos genitales del macho, no visibles exteriormente. l'ampoco se aparean estos animales, segun la observacion de Fabre, sino que los machos depositan su liquido espermático en hilos, extendiendole como las arnias en el suclo para que la hembra le pueda recibir en la abertura sexual.

USOS, COSTUMBRES Y REGIMEN.-I,os quilópodos se mueven haciendo ondulaciones con el cuerpo como las serpientes, sobre todo cuando se les asusti en sus escondites, en cuyo caso vuelren al punto $\{$ la oscurichat. Su alimento se compone en particular de amilas, aradores y pequeños insectos de todas clases, que-vagat por los sitios que habitan y mueren pronto de su mordisco renéluso.

\section{LOS ESCUTIGEROS-SCUTIGERA}

CARACTERES. - En mas de un concepto los escutigeros se distinguen entre los miriajuodos por sus ojos reticula. res salientes; las antenas y patas son muy largas, y las últimas se agrandan siempre hácia atris, hasta que al fin toman la forma de dos largos hilos: alcanzando mas de la doble longitud del cuerpo: los estigmas cstán situados en la linea central del dorso, en el centro de cada placa; la cabeza se dilata entre las antenas, y en ambos lados por detras de los ojos; el cuerpo varia en el mimero de sus segmentos segun se uniren por arriba 6 por abajo, distinguiendose orho placas lumbares y quince estrechas abdominales que no llegan al borde lateral. Desde la tercera í la quinta articulacion de las patas se ven agudas espinas.

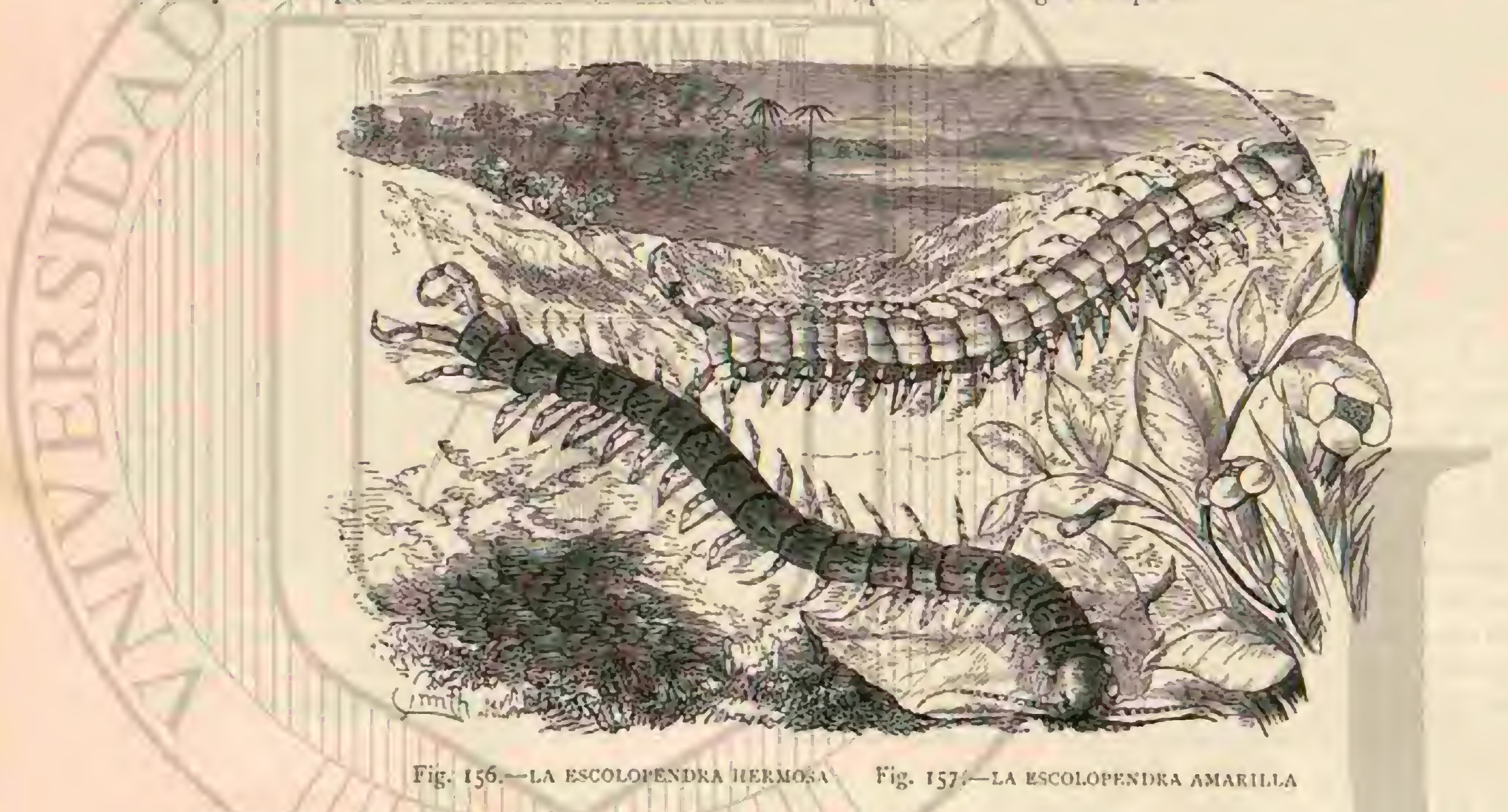

DISTRIBUCION GEOGRÁFICA.-Tos escutigeros están discminados en reducido número de especies en todos los continentes : pero cxcepto dos europeas, todas son propias de las regiones collidas.

USOS, COSTUMBRES Y REGIMEN. - Estos insectos habitan en particular en la madera vieja, y con gran agilidad suben por las paredes verticales cuando de noche abandonan su escondite. Pierden con facilidad las patas, y por eso son puco propios para conservarse disecados en las colecciunes.

\section{EL ESCUTIGERO ARACNOIDEO-SCUTIGERA COLEOPTRATA}

CARACTERES.-El cuerpoes de color amarillo pálido, $y$ en el dorso hay tres lineas longitudinales de un negro azulado: esta especie mide $U^{\prime \prime}, 026$ de largo. Lin todas las patas el turcer artejo, y en las posteriores el suarto, tienen anillos de un negro azulado.

DISTRIBUCION GEOGRAFICA.-Ul escutigero aracnoideo, que tiene una larga serie de otros nombres, habita cn la Furopa meridional y en el norte de Africa; y Perich le encontró tambien en liridburgo ( Wurtemberg) debajo de las tablas de una habitacion.

\section{EL ESCUTÍGERO NOBLE-SCUTIGERA NOBILYS}

CARACTERES. - Este escutigero (fig. 155) tiene la cabeza pequeria, ovalar, con una fajita negra que va desde el

labio hasta cerca de las antenas y el borde inferior de los ojos, y otra mas clara que pasa i la cara superior de la cabeza; antenas muy largas y pardas; cuerpo largo, fusiforme, con la cuarta placa dorsal guarnecida de numerosos dientes espiniformes, carácter que se observa en otras placas, siendo todas ellas de un pardo claro con el centro amarillo; los piés largos; las ancas de un pardo amarillento, anilladas de azul en su extremidad; los muslos verdosos, débilmente anillados y los tarsos de un rojo pardo oscuro. Esta especie mide $U^{n}, 054$ de longitud, siendo la major que se conoce.

DISTRIBUCION GEOGRÁFICA. - Es propia de la India y de la isla de. Francia.

\section{LOS LITOBIOS-LITHOBIUS}

CARACTERES.-I.os litobios, que en Alemania se en. cuentrais en los troncos de los árboles muertos ó en los sitios luímedos, entre la hojarasca y debajo de las piedras, no solo en la llanum sino en las cimas mas altas de las montanas; como por cjenplo, en los Alpes, constituyen el grencro de este nombre. Se reconocen en el estado adulto por los quince segmentos del cuerpo que, bastante iguales en el vientre, se componen ell cl dorso de seis placas cortas y nueve mas largas; tienen quince pares de piés propios para la marcha; antenas en forma de cordones, un poco mas delgadas hicia la puuia, compuestas de 22 a 40 artejos: y en fin, varias aglomeraciones de ocelos compuestos de to i zo en cada lado. 
EL LITOBIO DE TENAZAS--LITHOBIUS FORFICATUS

CARACTÉRES. - El litobio de tenazas llega à la longitud de 0 ", 026 y tiene la cibera de color pardo brillante; la parte superior del cuerpo y las antenas son rojizas. Estas últimas constan de numerosos artejos y presentan muchos pelitos.

USOS, COSTUMBRES Y REGIMEN.-Mucho divierten las evoluciones serpentinas y la ligereza con que estos animales procuran huir de la luz cuando se les molesta; en este caso tambien corren hácia atrås si se les toca, sirviéndo. se al eferto de las cuatro últimas patas, que por lo regular se arrastran. Además de la citada especic, que está diseminada por toda la Europa y las ishs Canarias, otras muy análogass habitan en el sur del citado continente, en Africa, América y Australia.
Algunas han sido sepamdas del grupo, como el género in. dependiente Henisops, porque en cada lado de la cabeza no tienen sino un ojo.

\section{EL LITOBIO DE CABEZA ROJA-LITHOBIUS RUBRYCEPS}

CARACTERES. - 'liene este litobio (fig. 154) ln cabeza grande, subcuadrada, y rojo oscum: los ojos pequeños en numero de 14 pares; el labio aplanado y puntuado profundamente; 14 dientecillos negros y agudos; el cuerpo accitunado por debajo; cl labio y las mandibulas lconados, y los últimos pares de pies ampliamente anillados de negro. Mide $\left(0^{\circ}, 03^{6}\right.$ de longitud.

DISTRIBUCION GEOGRÁFICA.-Fsta especie procede del mediodía de España

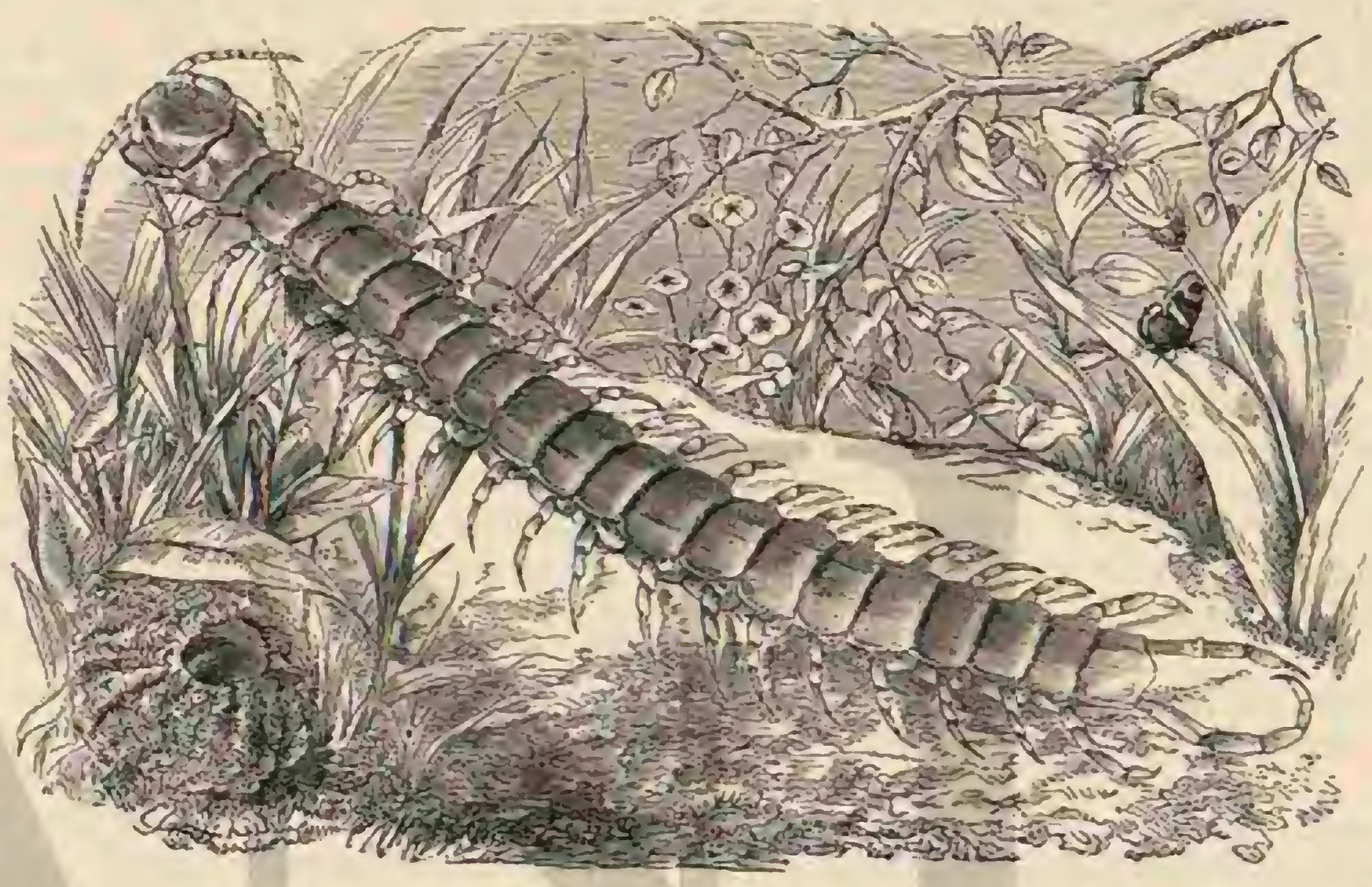

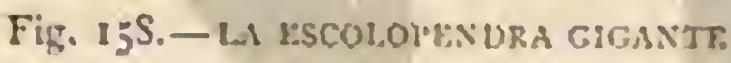

\section{LAS ESCOLOPENDRAS-SCOLO- PENDRA}

CARACTERES. - Litobidos propiamente dichos ó escolopendras se llaman actualmente las especies que se distin guen de las anceriores por el reducido número de los artejos de las antenas, difiriendo tambien por tener menos ojos y mas segmentos. Las antenas se componen de I 3 á 20 artejos: los otros carnctéres principales consisten en tener cuatro pares de ojos, 2 I de patas y otros tantos segmentos, de los cuales el segundo es siempre mas estrecho que los siguientes. Las tenazas venenosas están muy desarrolladas. Las especies, no muy numerosas, ofrecen en general tantas particularidades que los sistemáticos se han visto obligados á dividir el género primitivo en otros varios.

USOS, COSTUMBRES Y REGIMEN.-T'Odos estos miriajpodos son rajaces y alcanzan á menudo un tamaño considerable. Alejandro de Humboldt vio cono algunos muchachos indios.sacaron de su agujéro, jara comérsela, una escoloperidra de $6 ", 47$ de largo por mas de $66^{\circ}, 013$ de ancho.

\section{LA ESCOLOPENDRA DE LUCAS-SCOLOPEN- DRA LUCASI}

CARACTERES. - La cabeza, que afecta la forma de corazon, y el cuerpo son de un color rojo de orin; en la parte supe. rior de cada uno de los segmentos, excepto los dos últimos, se observan dos lineas cieprimidas divergentes, $e$ iguales depre. siones que, sin embargo, no forman lineas coherentes, se encuentran en la cara inferior. Los lados del cuerpo forman un reborde, y las patas laterales de la válvula ciel ano, redondeada ligeramente en su parte posterior, rematan en sencillas espinas. Ias patas posteriores, algo comprimidas y relativamente delgadas, tienen ta la parte superior de los muslos un reborde provisto de dos ó tres espinitas, viéndose otras dos en la cara inferior; las placas de los dos pares anteriores de patas que sirven il la boea estín provistas de cinco dientes cada una.

DISTHIBUCION GEOGRAFICA. - Tsta especie se en. cuentra en las islas de Francia, Borbon y otras del Océano Indico.

Una especie parecida de la América del sur, probablemente la que llatuan scolofendra Brandtiona, lleyó hace tiempo viva á mis manos, habiendo sido imporzada entre un fardo de campeche.

\section{LA ESCOLOPENDRA HERMOSA-SCOLOPEN- DRA FORMOSA}

CARACTERES. - Esta escolopendra (fig. 156) tiene la cabera cordiforme; las vinzas rojizas; el horde de los segmen. los verde; los priés anarnujados; diez dientes negros distintos; 
los piés posteriores orillados; el borde interno del primer artejo con cinco espinas en dos series alternas; la superficie inferior con seis series. Alcanza l", ros de longitud.

DISTRIBUCION GEOGRÁFICA. - I a escolopendra hermosa procede de la India.

\section{LA ESCOLOPENDRA AMARILLA - SCOLO- PENDRA LUTEA}

CARACTERES. - Distinguese esta escolopendra (figura 157) por tener las antenas, el cuerpo y los piês de un color leonado claro; la calieza, las pinzis y los apéndices anales de un anaranjado oscuro; diez dientes obtusos poco distintos: el priner ariejo de los piés posteriores subaplanado; cuatro espinas negras en el borde interno, la apicial prolongada y aguda, y otras dos en la carz inferior. Su tamaño no pasa de $11 ", 13$.

DISTRIBUCION GEOGRAFICA. - Esta especie se encuentrá en lás Antillas.

\section{LA ESCOLOPENDRA GIGANTE-SCOLOPEN- DRA GIGAS}

Caractéres. - Fsta especie (fig. 158) tiene los seg. mentos de ángulos redondeados, pardo ferruginosos, amarillos por detrás; las antenas, los palpos, y los piés testicceos; estos, excepto el par anterior, espinosos en su artejo basilar; el libio ferruginoso; las mandibulas tambien lo son en su base y negras en su extremidad; todo el cuerpo está fina. mente punteado. Llega á tener $0^{\circ}, 2 S$ de largo.

DISTRIBUCION GEOGRÁFICA. - Ia escolopendr gigante es propia de Venezuela.

\section{LA ESCOLOPENDRA ANGULOSA-SCOLO-} PENDRA ANGULATA

CARAGTERES. - Los de esta escolopendra (fig. I 60) son: color verde oscuro; la cabeza, el segmento basilar, el labio $y$ las mandibulas anaranjádas; estas últimas salpicadas de negro; los piés amarillos con su parte posterior verde; los segmentos aplanados; la parte anterior de su borde angulosa, focho dientes penquenos é iguales. Mide $0^{m}, 12$ de longitud.

DISTRIBUCION GEOGRÁFICA.- Habita en la isla de la Trinidad.

\section{LA ESCOLOPENDRA VARIADA-SCOLOPEN-} DRA VARIEGATA

CARACTERES. - El color de este miriápodo-(fig. 159) es castaño oscuro, con la frente 5 las patas posteriores de cada segmento dorsal, el labio, las mandibulas y la superficie ventral de un anaranjacto brillante; las antenas aceitunadas, y los piés con fajas anaranjadas oscuras.

DISTRIBUCION GEOGRÁFICA. - Habita en Demerara.

Mientras que en la mayor parte de los litobidos los estigmas tienen la forma regular de ojal, en muchas especies propias de la Nueva Holanda y de la China ofrecen la figura de harnero, por cuya razon las ha reunido Gervais en un género independiente, Heterostemin; algunas otras, entre ellas varias europeas, son en un todo análogas á las escolopendras verdaderas, pero se han sejarado de ellas por la falta de los ojos, formaindose un género independiente, Cryptopss. Tambien hay especies de $2 \hat{3}$ pares de piés, por cjemplo el escolopendropsis de Bahia (scrilependropsis hahiensis), que tiene cuatro ojos en cada lado; el escolopocriptops rojo (scolopocrylops rufa), del Africa, sin ojos; $y$ hasta existen especies con 30 pares de piés (Neripportion). Muy curioso es, en fint, el eucoribo de cascabel (eucurylus crotalus) (fig. 161) de Puerto Natal, por tener ensanchados los tres últimos artejos de las patas posteriores en forma de hojas, constituyendo un apéndice con el que el animal produce un rumor extrano por el roce. Su cuerpo, de color de orin, mide (1",og de largo y está provisto en su cara superior de siete quillas longitudinales.

\section{LOS GEÓFILOS-GEOPHILUS}

CARACTERES. - Los geófilos son quilópodos largos, muje estrechos, en figura de linea, que tienen de 40 a $75 \mathrm{seg}$ mentos y antcnas de catorce artejos, careciendo de ojos. l.os segmentos parecen componerse cada uno en su parte supe. rior de dos piezas desiguales, mientras que las placas del vientre son sencillas. EJ último par de piés remata en garras, ó bien forma una especie de palpos desprovistos de ellas. Algunas especics son fosforescentes en la oscuridad; otras, como por ejemplo, el geófilo de Gabriel (geophilus Gobrielis), que habita en los paises del Mediterráneo, y tiene mas de 160 pares de piés, segregan de unas glandulas un abundante liquido rojo dé púrpura. Excepto en el Africr meridional y Madagascar, hállanse geófilos en todas partes, siendo subre todo numerosos en Europa. La longitud de las antenas, la forma de la cabeza, el desarrollo de los pies bucales y el número de los ségmentos del cuerpo constituyen toda clase de difurencias entre las muchas especies, á menudo muy semejantes unas î otras, y cntre las que el geófilo de antenas largas (geophilus longricormis) (fig. 362) pertenece á los mas comunes: quizás es lá misma especie que Linneo y sus sucesones citaron como-la escolopendra eléctrica (scolopendra elestrica). Las antenas, cubiertas de pelos finos, son cuatro veces mas largas que la cabeza la cual es de figura oval; sus artejos, inas largos que anchos, no están formados como un cordon, y. los tres o cuatro áltimos son mas delgados que los anteriores. Esta especie, de color amarillo, tiene unos 55 pares de piés y alcanza la longitud de $11{ }^{m}, 078$.

USOS, COSTUMBRES Y REGIMEN.-El geófilo de antenas largas se encuentra en las raices y tubérculos de varias plantas, remolachas y zanahorias; destruye estas últimas, segun las observaciones de Kirby, abriendo gran numero de galerins en todas direciones de las raices. En esta ocupacion le ayuda seguramente la escolopendra aplanada y otros pará. sitos, que por su actividad de mineros y con sus excrementos producen una rápida descomposicion. El geófilo de antenas largas, procediendo como las lombrices, sale de sus escondites cuando todos los séres esperan hace mucho tiempo una lluvia refrescante, y entonces puede suceder que obligado por el hambre se precipite sobre una lombriz diez veces mas grande, estrechándola a pesar de su resistencia entre sus anillos como los pitónidos á sus infelices victimas; pero no la ahoga, sino quue la mata á picotazos y mordiscos con ayuda dé su veneno.

Scoutetten refiere en su periódico de medicina que se pu. blica en Metz un caso en extremo particular: hace varios meses que cerca de Metz una mujer de $2 S$ años sintio un picor muy molesto en la nariz, acompañado de una secrecion mucosa, y- despues frecuentes áblores de cabeza; - estos eran al principio soportables, pero pronto fueron mas fuertes y' se repiticron mas a menudo. Los sintomas no cran regulares ni en su duracion ni en su naturaleza: la paciente sentia a menudo como unos pinchazos mas 6 menos fuertes en la base de la nariz y en la region central de la frente, acompanados de dolores agudos, que desde la sien derecha se corrian hácin la cabeza, extendiénclose por toda esta parte. 
La abundante secrecion mucosa obligaba á la enferma ì so. narsci contimuamente, y entonces salia de la nariz una sangre de olor muy desagradable los ojos lloraban de continuo y los vómitos se repetian á menudo: algunas veces los dolores cran tan agudos que la cuferma los comparabí con martillazos aplicados sobre el cerebro. Despues se le descompusieron las facciones, contrajéronse las mandibulas, las renas de la region de las sienes se movian mucho, y los sentidos del oido y la vista se irritaron de tal modo que el menor ruido y la luz se hacian insoportables. Otras veces la infeliz era presa de un verdadero delirio; oprimiase la cabeza con las manos y salia de la casa sin saber donde buscar auxilio. Estos accidentes se reppetian cinco ó seis veces de dia ó de noche, y uno de ellos duró con cortas interrupciones, hasta quince dias. No se habia emplcado un tratamiento médico metódico. Por fin, al cabo de un ano de sufrimientos, estos sintomas extraordinarios de enfermedad cesaron de repente, pues al estornudar una vez la enferma salió un insecto que cayendo al suelo, se enroscaba con gran agilidad en forma de muelle de reloj; conservóse vivo varios dias en un poco de agua y solo murió al ponerle en espiritu de vino. Tenia (1), 058 de lirgo, un color amarillo ; 64 segmentos con patas. Los inteligentes en la materia dijeron que pertenecia á la especie teophilus electricus, mas en vista del grabado que se hizo queda en duda si aquel insecto era el geophilus carpophiliss.

Uno y otro se distinguen del geófilo de antenas largas por tener las suyas en forma de cordon, dos ó ires veces mas largas que la cabeza, y por los segmentos del cuerpo, mas numerosos. Koch dice que el geónilo eléctrico descrito por él tiene 74 segmentos; Leach asegura que el geófilo curpófilo, al que gustan las frutas dulces, despide luz eléctrica.

\section{EL GEÓFILO DE CUMING-GEOPHILUS CUMINGII}

CARACTERES.- - Este geónlo (fig. I6S) se distingue por tener la cabeza nuy convexa, redondeada por detris; las mandibulas negruzcas; el labio liso; todos los segmentos muy cortos y convexos; la superficie dorsal llena de numero. sos surcos irregulares; las placas dorsal y ventral atrofiadas; los apéndices estiliformes dẹl ano delgados; la escama anal convexa, subcordiforme, reciondeada por detrís, con dos pequeñas placas marginales á los lados, y i o r pares de piés, desnudos, con uñas negras. Tine $0^{\circ}, 135$ de largo.

DISTRIBUCION GEOGRÁFIGA.- Esta especie se encuentra en las islas Filipinas.
CARACTÉRES. - En su aspecto exterior los diplopodos ó quilugnatos (chilognatha) se distinguen esencialmente por la cabe\%a dispucsta verticalmente; el cuerpo es cilindrico ó semicilindrico; los anillos, mas ó menos numerosos, llevan des. de el sexto ó sétimo dos pares de patas cada uno; la cabeza, relativamente grande, se divide en la coronilla cn parte supe. rior y anterior, rematando esta liltima en un reborde libre, y en dos partes de las mejillas, que en el occipucio se insertan ligeramente. En dos hoyos de la frente hällanse las antenas, a cierta distancia una de otm, por lo regular un poco mas gruesas hacia adelante y casi siempre tienen siete artejos; encima ó detrás de ellas estan las aglomemciones $\delta$ series de ocelos que sin embargo jueden faltar del todo; en el primer caso se oprimen a menudo de tal manera que a primera vista podrian considerarse como ojos reticulares. I os órganos de la boca están auxiliados en estos insectos por las cuatro patas anteriores; se componen en cada lado de un disco en forma de cojin quue sirve de superficie masticadora, y de un diente, que constituye las maxilas y se inserta en la parte superior del disco $y$ de la válsula bucal; esta se compone de una piěa principal triangular, puntiaguda en el centro, y de otras dos que/se insertair hácia adclante y cuyas puntas tienen casi siempre una maxila atrofiada pero movible como labio inferior, con el que estain soldadas las maxilas inferiores. Los segmentos del cuerpo varian por su número de 9 i $80 y$ no son constanies para una misma especic porque aumentan con la edad. Segun que cada uno de los anillos sea de figura circular y solo abierto en el vientre por una ligera hendidura, ó bien forme un semicirculo que aun recoge los bordes latera. les, resultan las tres formas principales en que se basa la estructura del cuerpo. Como las patas anteriores no se trasforman en partes bucales, la superior de sus anillos alcanza un completo desarrollo aunque solo llevan, como algunos de los segmentos siguientes, un par de patas cortas y delicadas de la misma naturaleza que las otras, que en doble uúmero parten de los anillos siguientes. Muy cxtrairas son las proporciones de los órganos genitales. En ambos sexos desembocan en las ancas del segundo ó tercer par de patas, de modo que sus conductos se corren por detrás hàcia adelante, porque los ovarios de la hembra y las vejigas espermáticas del macho se hallan cu la parte posterior del cuerpo. En cambio, el miembro del macho no se encuentra en el orificio del depósito espermático, siro en el sétimó segmento ó delante del mismo, ó en algunas especies delante del ano. Antes de aparearse el macho debe proveer por lo tanto su miembro que se compone de dos vergas, de liquido espermático. Los estigmas estån muy ocultos cerca de la base de las patas y envian sus canales separados hácia los órganos internos. Las aberturas en los lados del dorso, de todos ó de algunos segmentos, que Treviranus ha designado como estigmas, segregan un liquido cáustico, que es la defensa de estos animales.

DISTRIBUCION GEOGRÁFICA. - Los diplopodos habitan en todos los continentes, frero en Luropa y en las regiones templadas son de reducido tamaño, mientras que en los paises calidos hay especies de casi un pié de largo y del grueso de un dedo, mas corpulentas que cièrtas serpientes.

USOS, COSTUMBRES Y REGIMEN.-Sin despreciar 
a los cadiveres, parecen preferir el alimento vegetal; habitan por lo regular en escondites oscuros, aunque no tan exclusivamente como los quilópodos. Ias hembras depositan sus huevas en montoncitos, en cavidades subterrineas, y los hi. juelos nacen con tres ó seis segmentos, pero siempre muy rollo. cortos; pasan por numerosas mudas, en las yue se intercalan otros segmentos en los ja cxistentes. Carecemos sin emhargo de observaciones mas ninuciosas sobre ciertas particularidades y sobre la duracion de cada estado del desar-

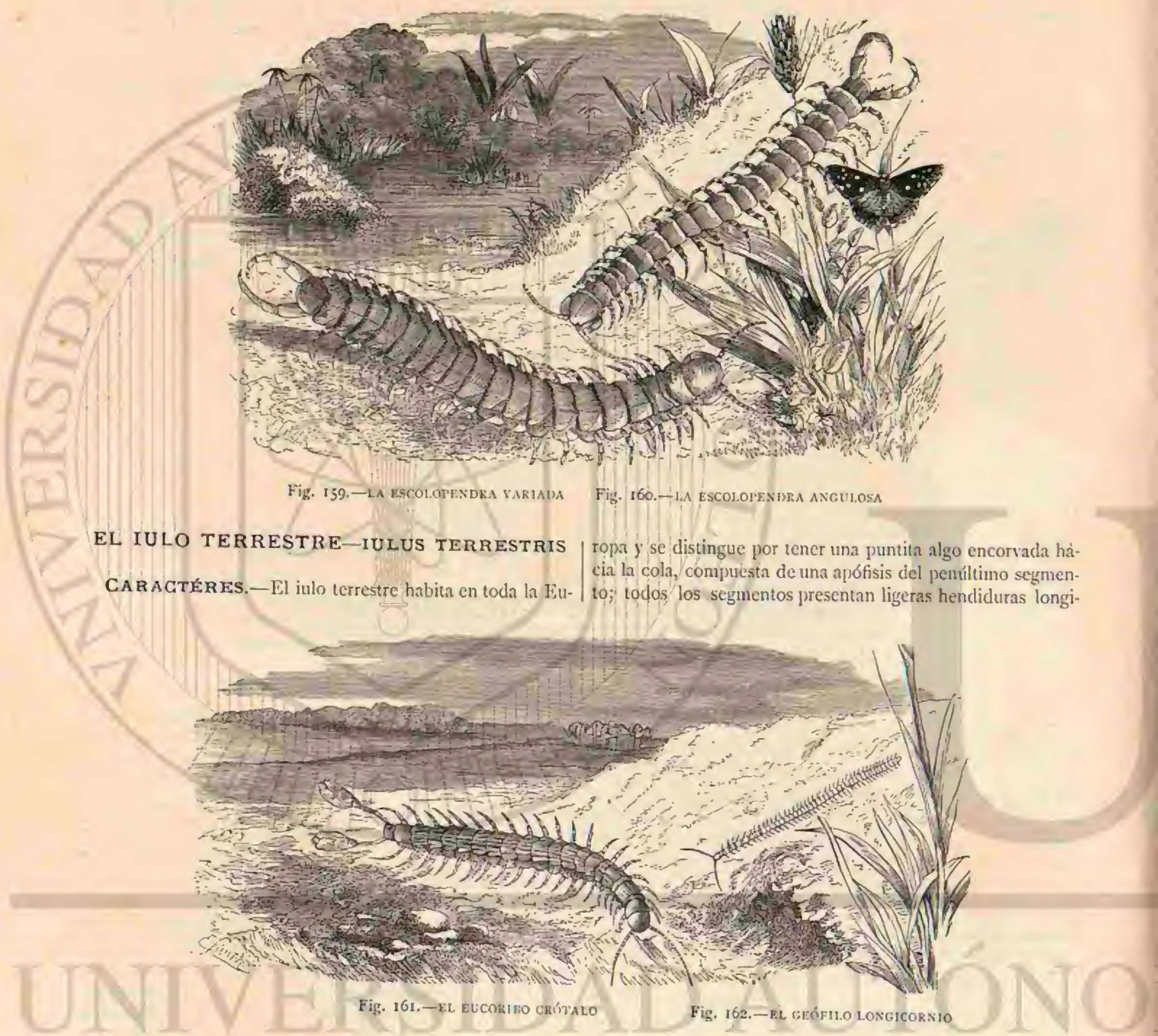

tudinales, $y$ en el dorso se ve una doble faja amarilla que resalta marcadamente del color pardo claro ú oscuro del cuerpo; los $2 \$$ ojos de cada lado forman un triángulo y están dispuestos en sicte series (fig. I65).

USOS, COSTUMBRES Y REGIMEN:- Cuando á fines de la primavera buscaba onugas debajo de las piedras en las montañas desprovistas de vegetacion, encontré los cadaveres de estos animales, divididos a menudo en fragmentos grandes ó pequenos de color gris de plomo; al sacu dir encinas jóvenes caen con frecuencia estos insectos viros y' permanecen enroscados como un muelle de reloj, con la cabeza en el centro, mientras temen un peligro. Cuando no se les molesta recóbranse poco á poco de su temor y din media vuelta à fin de apoyarse sobre mas de cien patitas que se tocan en la linea central del vientre. Semcjantes á una serpiente, deslizan el cuerpo, parecido al de la lombriz, sobre la superficie del suelo ó del tronco de un árbol; y si se fija mas la atencion en el movimiento, se verá como alterma. tivamente se cxtiende un grupo de patitas fuera de los bordes del cuerpo, formando con este un ángulo obtuso, mientras que las extremidades de los intervalos conservan stu posicion vertical, produciéndose asi un moviniento ondulado que comenzando por la cabeza se comunica poco á joco á todo el cuerpo y la cola. Las hembms deprositan sus numerosos huevos en una cavidad subterránea, $y$ al cabo de pocos dias salen los hijuelos, que tienen dos patas y una longi. tud de $17-, 00225$, no habiendo sido observados aun porque siempre se mantienen ocultos. Ios autores distinguen deter- 
minadamente una especie algo mas grande bajo el nombre de iulo arenoso (isfus snlmionis), que segun ellos, difiere de la anterior por tener dos lineas dorsales rojas y mayor múmero de segmentos.

\section{EL IULO PUNTUADO-IULUS GUTTULATUS}

CARACTERES, - Iil iulo puntuado, nuestra especic mas pequeria, afecta la forma de un hilo delgado, de color pardo pálido, con una serie de manchas de un rojo de sangre en cada lado del cuerpo: se encuentra en algumas partes en gran numero, en jardines y campos, donde ocasiona perjuicios por varios conceptos.

USOS, COSTUMBRES Y REGIMEN.-Este insecto causa los mayores daños en las simicnes que germinan, sobre codo en las pepitas de calabaza, impidiendo que las ha. bichucias, y en particular las zamahorias, lleguen á desarro- llarse. Ademais perjudica las mices carnosas de las huertas, los frutos caidos y sobre todo las iresas que están maduraindose.

Se conocen además mumerosas especies, tal vez 150 , con 6 sin espinas en la extremidad y que todas tienen un número considerable de ocelos; las placas de las patas son fijas, y cl primer segmento del cuerpo mas largo que los otros. Otras especies que ofrecen casi la misma estrtictura exterior difieren, sin embargo, por tener las antenas y patas mas lar. gas y movibles, asi como por otros carncléres, debiéndose fa ello que se hayan distribuido últimamente en varios géneros.

\section{EL IULO DE PIÉS ANILLADOS-IULUS ANNULATIPES}

CARACTERES.-Los de esta especie (fig. I64) consisten en tener el borde posterior de los anillos de un castaño

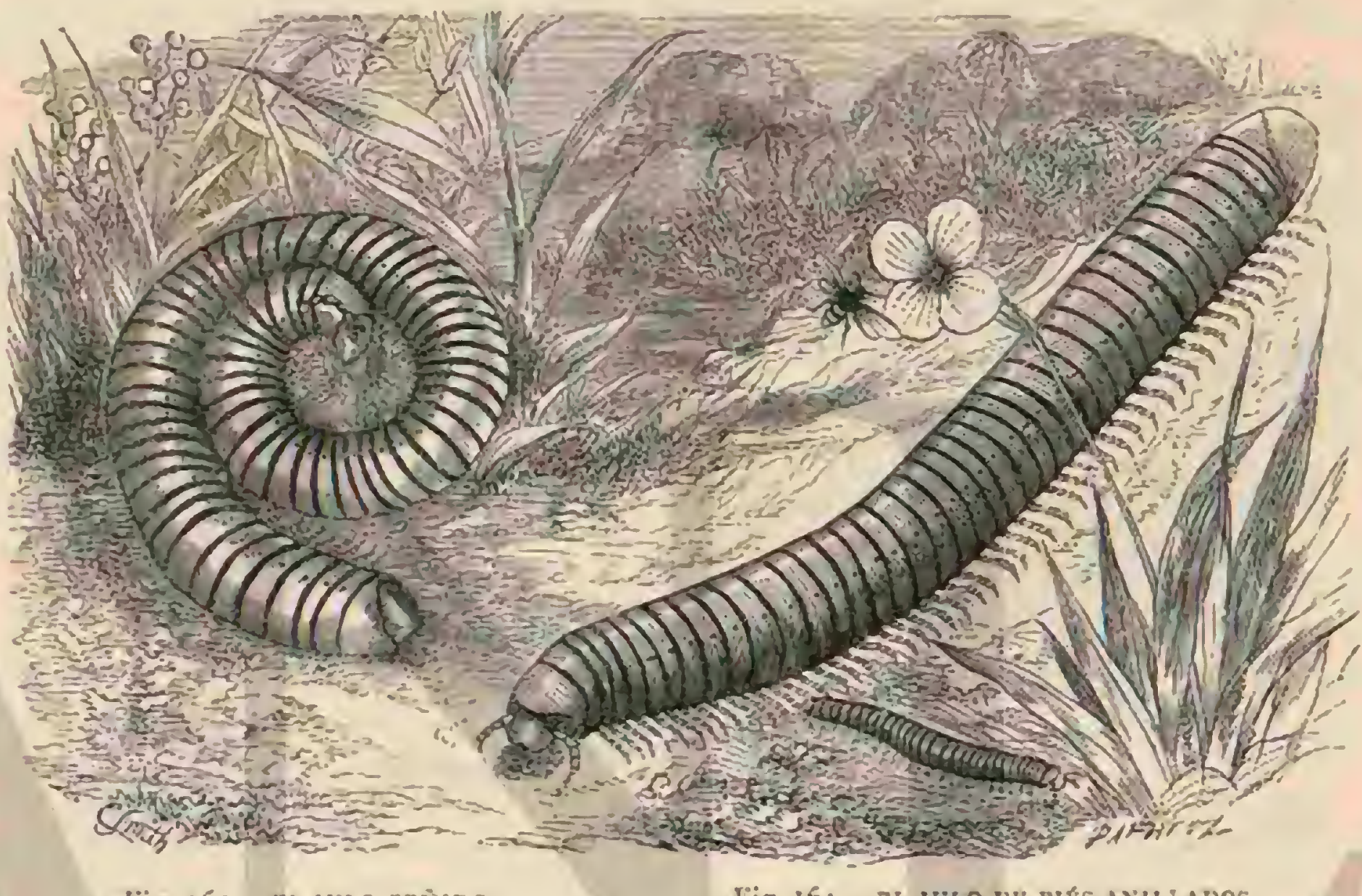

Fig. 163. - RL IULO CENIIDO

oscuro: sesenta y ocho anillos; su parte anterior marcada de pliegues trasversales numerosos y finos, la posterior lisa; en los piés lleva anchos anillos de color de carne; el color get néril del cuerpo es parcio, y su longitud $0^{m}, 2$

DISTRIBUCION GECGRAFICA.- Este iulo pertenece al Africa meridiona!.

\section{EL IULO CEÑIDO-IULUS CINCTATUS}

CAR ACTERES. - 1.OS individtoos deesta especie (fig.163) se distinguen por tener 75 segmentos; el cuerpo furruginoso, con una estrecha línea blanca al través de cada segnento; los piés pardos, con una ancha faja en medio de cada anillo. Su longitud viene a ser de ()$^{\text {tw }}$, 24.

DISTRIBUCION GECGRAFICA.-Fi iulo ceñido habita cn la India oricnial.

\section{LOS POLIDESMOS-POLYDESMUS}

CARACTERES. - Los polidesmos afectan una forma esencialmente distinta por la circunstancia de que los anillos dejan de ser cilindricos ó circulares y de que las patas no se tocan en la linea central del vientre, quedando mas
Fig. 164.-EL IULO DE PIÉS ANILLADOS

Fig. 165, - EL IULO TERRPSTKP.

visibles en los lados del cuerpo. Gerwais observó polidesmos planos (polidesmus complanatus) recien nacidos, sin haber visto la salida de los huevos: comprendiendo la cabeza y el ano tenian siete segntentos y seis patas 'Tres semanas des. pues uno de ellos presentabs dier. segmentos, ú ocho sin la cabcra y cl ano, y seis pares de patas, uno en el primero, otro en el segundo, lo mismo qute en el tercero, dos en el cuarto y el resto en el quinto segmento. Fil autor consideró este individuo como macho, porı̨ue una hembra hubicra tenido en el respectivo segmento igualmente dos pares; en el macho, sin embargo, las vergas no estaban aun desarrolla das. El polidesmo aplanado aduito carece de patas en el priner segmento y en los dos últimos, presentando en cada uno de los otros tres un par en el anicrior y despues dos pares: los ojos no cxisten. Los lados de los anillos, gue sobresalen en forma de placas, son redondeados en su parte anterior y angulosos en la posterior; el penúltimo se eleva por medio de un diente central sobre el anillo del ano; y la supernicic de color gris pardusco de pizarra propia de todas las especies es un poco áspera, por tener ligeras prominencias en forma de puntos.

USOS, COSTUMBRES Y REGIMEN. - Ëste polidesmo se encuentra en codos los puntos de Europa, debajo de la hojarasca himeda, de las piedras, $y$ de la corteza de irbo. 
les: aliméntase a reces de mices jugnosas, por ejemplo de zanahorias, y se enrosca i la manera de los iulos, como un muclle de reloj, cuando se le inquicta en su escondite.

El género es rico en especies, algunas de las cuales alcanzan en ciertos juntos un tamaño considemble, distinguiéndose unos de otros por la forma del borde aplanado, la punta del penúltimo segmento, y otros caractéres de poca importancia, por lo cual se han agrupado en varios subgéneros.

\section{EL POLIDESMO DIADEMA-POLIDESMUS DIADEMA}

CARACTERES. - EI color de asta-especie (fig. $r(66)$ es un rojo cancla finámente granuloso en la jarte superior del cuerpo y en la cabeza, que parece coronada por el primer anillo, cuyar quilla, continuando la de los demas, no se in. terrumpe por delante, donde tan solo es algo mas baja y forma una especie de diadema ó corona; las quillas laterales de los anillos se insertan en la cara lateral de estos, siendo bastante gruesas y muy levantadas, casi aliformes y muy próximas entre si. Este individuo mide $1{ }^{\prime \prime}, 025$ de largo.

DISTRIBUCION GEOGRÅFICA.-Procede de Gibraltar.

\section{EL POLIDESMO GRANULADO-POLYDESMUS GRANULATUS}

Caracteres. - Este polidesmo (fig. I67) ticne el cuerpo cubierto de pelos corios de color pilido, rojo por debajo y los pies mas pálidos; la cabeza parda, guarnecida de penuenos pelos recios; el labio inferior blanco; los segmentos del cuerpo bastante convexos con gramulos redondeados, salientes, obiusos, muy juntos y situados trasversalmente en

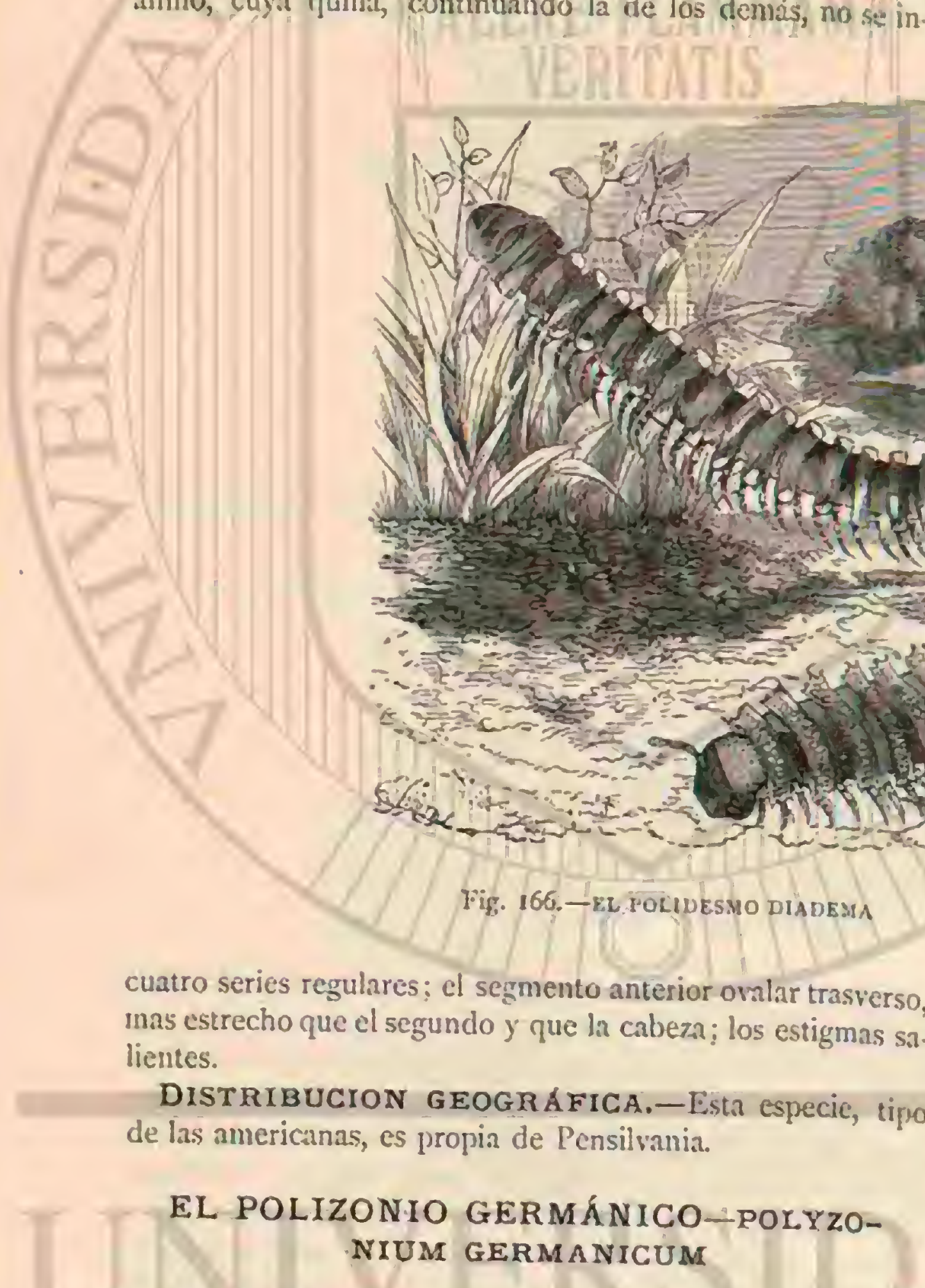

CARACTERES. - Algunos curiosos miriápodos se dis tinguen de todos los demás por el cefalotórax único, que, en la relacion con las partes bucales, soldadas entre si, for. ma un tubo propio para chupar, por lo cual se ha elegido esta especic como tipo de una familia independiente.

La única especic curopea observada hasta aliora en Alemania, Polonia y el Cáucaso, el polizonio aleman, que solo alcanza $11^{\circ}$, or 3 de longitud, es de forma un poco aplanada y ticne. unos 50 segmentos; las partes superiores son lisas, blandas y de color claro de orin; las inferiores de su cuerpo tienen un tinte blanquizco. Los segmentos, excepto los tres primeros, cada uno de los cuales tiene un par de piés, ápodos los dos últimos, estan provistos de dos pares de patas, y no forman circulo en su corte trasiersal, sino una eliprse. Los ojos estản situados en la frente, en dos grujos de tres, y el iubo chupador es aqui mas corto que en las otras especies exóticas de la finmilia, con las que el polizonio aleman ticne de comun la incultad de poder segregar de entre los anillos del cuerpo un líquido techoso.

Como es dificil conservar viros estos diminutos insectos en cautividid, tampoco se ha podido observar bicn en esta especie el desarrollo desde el huevo. Waga, gue hizo esfuer7.0s par conseguirlo, cucontró cierto dia en un vaso tuna hembra enroscada en forma de espiral, alrededor de un mon. toncito de hucros muy diminutos, de color claro, que ligeramente unidos, separaronse en varios grupos al tocarlos. Ocho dias despuces ( 7 de junio), llaģa encontró todavia la hembra en la misina posicion, pero los huevos estaban casi todos diseminados, siendo su número de 5o. Con el microscopio reconociéronse solo en algunos varias sombras mas oscurns, pero al cabo de tres dias se observo, sin necesidad del instrumento, que algunos de los huevos se dividian en dos partes. En medio de las cascaras veiase un cuerpo plano enroscado casi en circulo, que parecia escotado en un punto de su circunferencia. Pronto se distinguió un sér escamoso y encorrado, casi tan ancho como largo, provisto de seis patas y de antenas, pudiendo reconocerse tambien el principio de los ojos, por algunos pelitos cortos que cubrian el cuerpo medio trasparente, provisto de cinco segmentos. 
En este grado de desarrollo, el diminuto sér movia continuamerrte las antenas, pero no podia servirse aun del todo de sus patitas, las tiltimas de las cuales emn fijas: el insecto estaba boca arriba y no le era posible volverse. 1.125 de junio ha. llaironse aun huevos cerrados y otros que acababan de abrirse, asi como hijuelos de seis y de ocho patas, mas como se pusiera el vaso al sol, dejandole en el mismo sitio mucho ticmpo, todos los animalitos muricron.

\section{LOS GLOMERINOS-GLO- MERINA}

CARAC'TERES. - Ios miriapodos hasta ahora descritos no tienen un aspecio muy agradable para el observador, pero no sucede lo mismo con la última familia, que es la de los glomerinos. Figúrese el lector uno de esos pequeños mamiieros de la especic armadillo, medio enroscido, pero sin co. la ni hocico, que tiene en cambio patas mas numerosas y formas mas pequeñas y delicadas, cual corresponde al insecto, y podrá formarse una idea de estos séres extraños. Vistos por encima son muy converos: lienen la cubierta dura, y la cara abdominal ligeranente cóncara, son blindos y están provistos de muchas patas, casi de la misma estructura que vemos en las del armadillo.

Estos insectos, cuya cabeza se inclina hácia abajo, cuentan de doce a trece segmentos, siendo el segundo y último los mas largos, y' el primero mas angosto y' pequeno, estrechán-

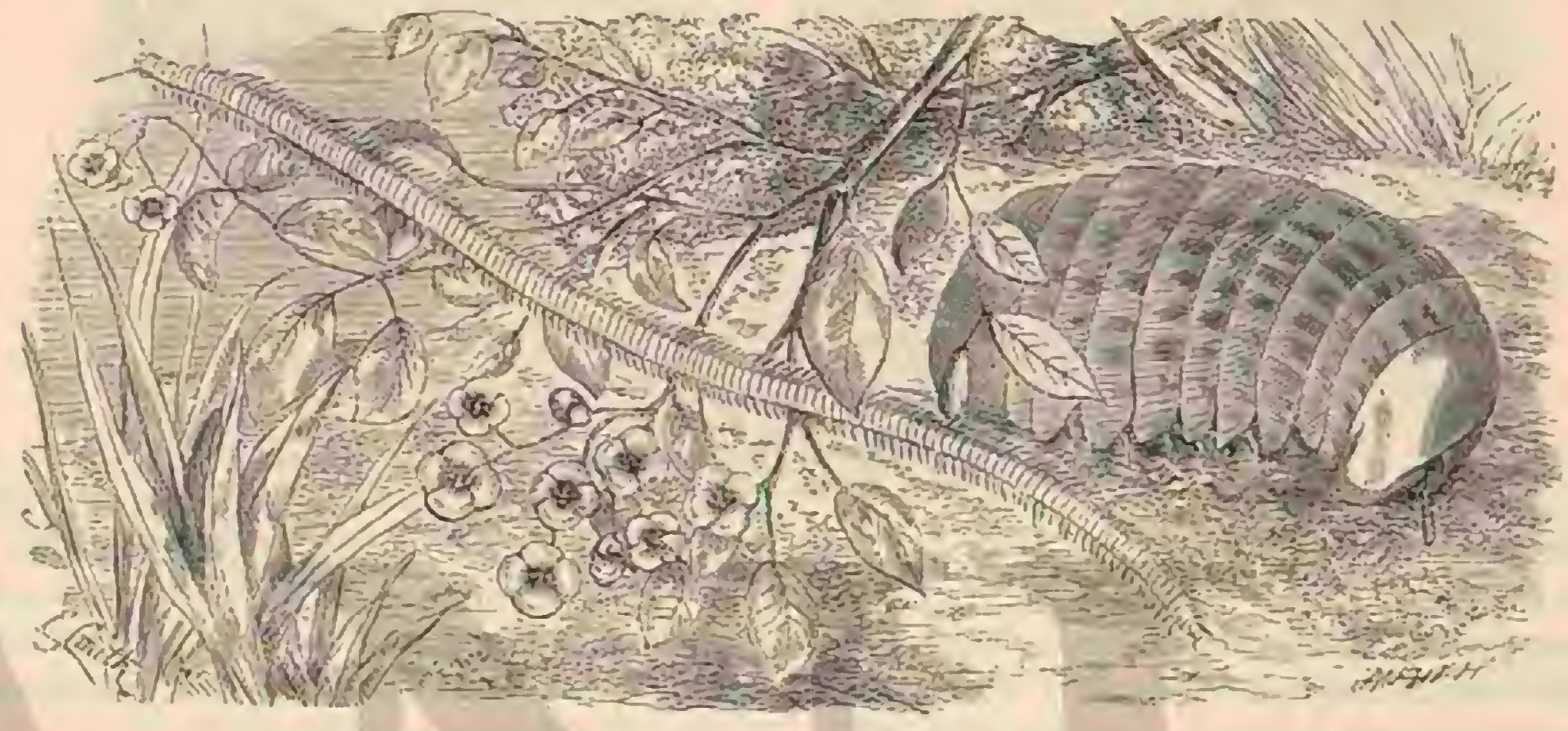

Fig. 16S. -F. GEREH.O DE CBMISG

dose todos hicia los lados. Cunndo estos insectos se hallan en peligro, enróscanse de tal modo, que toda la superficie del cuerpo representa una coraza esferica. Al contrario de todos los demis miriajpodos, obsérvase que los machos de esta especic tienen en la extremidad del cuerpo dos órganos en forma de pié, mientras que las aberturas sexuales están situadas por lo regular, asi en machos como en hembras, debajo de una especic de escama que hay en la base del segundo par de patas.

\section{LOS GLOMERIDOS-GLOMERYS}

CARACTERES. - I.as únicas especies de toda la familia, propias de nuestros juises, pertenecen al género de los glomeridos que se caracteriza por tener doce segmentos, diez y siete pares de patas, y en cada lado una serie trasversalmente arquicada de ocelos; las antemas se inscrtan en la frente y se distinguen por la prolongacion del tercero y sexto segmentos.

USOS, COSTUMBRES Y REGIMEN.-Estos animales, del todo inofensivos, se encuentran aislados ó en pequeños grupros debajo de las piedras $y$ la hojarasca, en sitios himedos é incultos, con preferencia en los hosques. Son en extremo perezosos, y suelen entregarse al descanso en una cavidad subteranea; pero se les ve ä veces deslizarse en linea recta, como los iulos, aunque sin ondular el dorso. Sin $\mathrm{cm}$ bargo, apenas recelan algun pcligro enróscanse y se dejan caer à menudo rodando por alguna pendiente. Su alimento se compone de restos vegetales en descomposicion. Accrca de su desatrollo faltan datos, pero sábese que mudan lo mismo que sus congéneres, penetrando al efecto en tierra hasta que el cuerpo se ha endurecido.
Fig. 16g. - IA 7.FRONIA COMPRIMUAA

\section{EL GLOMERIS ORLADO-GLOMERYS IIMBATA}

CARACTERES. - Esta especie iene un color pardo negruzco brillante, orlado de amarillo en los bordes visibles de todas las placas del dorso. Este insecto cambia varias veces de colores, no solo en vida, sino despues de muerto; de modo que es fácil que se confundin las nombres de esta es pecie con los de orras. A menudo se ven individuos cubier tos de manchas oscuras y clarns que imitan casi el jaspeado del mirmol.

DISTRIBUCION GEOGRÁFICA.-Esta especie se halla por el mediodin hasta Italia y el Asia Menor.

\section{EL GLOMERIS PUN TUADO-GLOMERYS GUTTULATA}

CARACTÉRES.-Una segunda especie, mas rara, es el glomeris puntuado, insecto algo mas pequeño, casi del mismo color; aunque tiene á veces cuatro puntas de un rojo amarillo en el primer segmento, y dos en cada uno do los siguientes.

Ademis de las dos especics citadas se encuentra alguna otra aisladamente en la Furopa mcridional.

Unos glomerinos mucho mas grandes que los europeos, pues alcanzan la longitud de $11 ", 05$, por su correspondiente anchura, habitan en Africa y Asia, es decir en los paises cá lidos de estos contincntes, distinguiéndose por tener trece segmentos, veintiun pares de patas, grupos redondos de ocelos en cada lado de la cabeza, y las antenas casi sicmpre en forma de maza. Pertenecen i los géncros Sifherotherium, Zephronice y otsos. 
LA ZEFRONLA COMPRIMIDA-ZEPHRONIA COMPRESSA

CARAGTERES. - Los segmentos dorsales de esta espe- cic (fig. 169) están cubiertos de puntitas diseminadas: y el último del cuerpo comprimido lateralmente con algunos puntos escasos. Mide 1)",015 de largo " "1",000 de ancho.

DISTRIBUCION GEOGRAEICA.-Fsta zefronia procede del Cabo de Buena Esperanza.

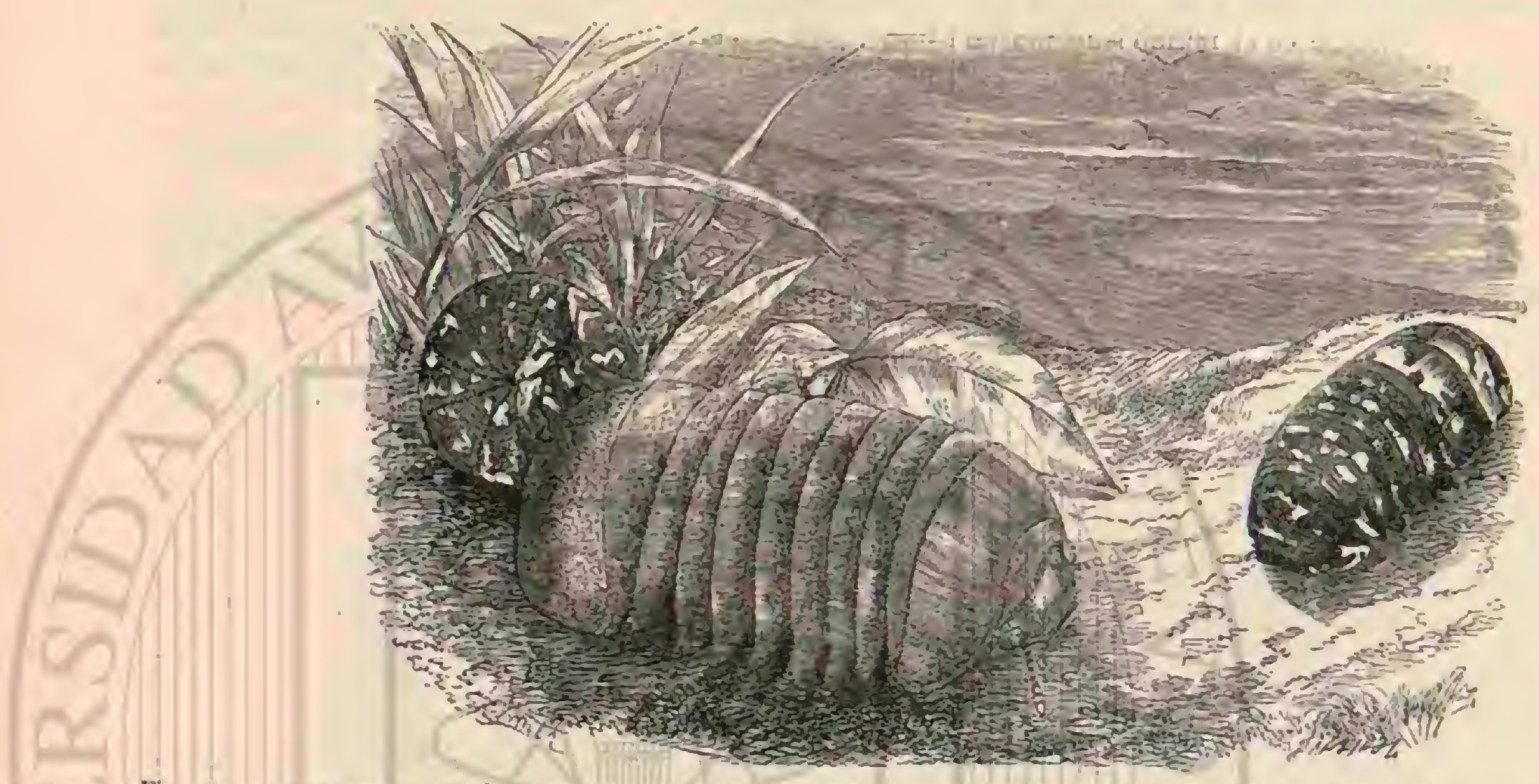

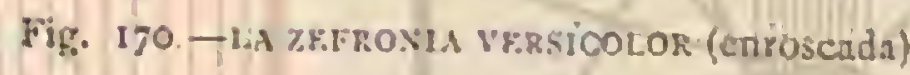

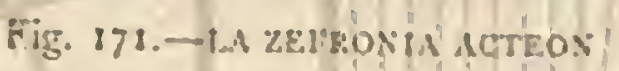

Fig. 172.-LA grirosia vrestcolon (extendida)

Conócense otras dos especies, recientemente descubiertas, que son la zefronia Acteon (fig. iji) y la \%. versicior (frigs , 10 y 1,2): la primera, indicada por la Sra. Ida Pfeiffer, tiene la superficic del cuerpo muy suave y brillante, siendo su color amarillo pálido con varias manchas diseminadas. Ia segunda tiene tambien el ctjerpo muy suave, y de un precioso color amarillento con manchas y rayas de un negro intenso; la parte anterior de la cabeza, los ojos, las piernas y las an. tenns adquieren un tinte vercle pálido $\mathrm{cn}$ los individuos que se conscrvan.

La zefronia Acteon es propia de Madagascar, y la Z. versicolor habita particularmente en Ceilan.

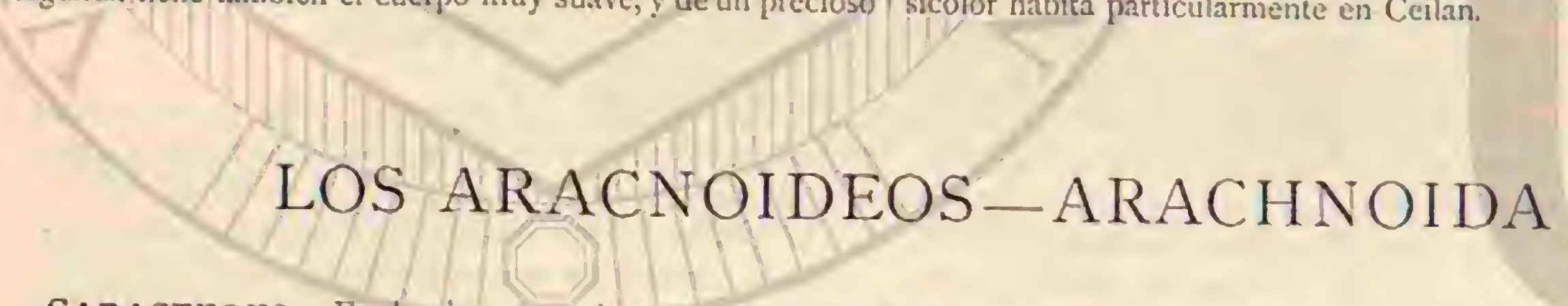

CARACTERES. - En los insectos el cuerpo se divide en tres partes diferentes, de las que la central lleva seis patas y casi siempre tambien alas; en los miriápodos, el cuerpo se divide en muchos anillos iguales con un número correspondiente de patas y la cabeza muy separada, provista de antenas; en los articulados que los naturalistas agrupan con los aracnoideas estos caractéres cambian otra vez de aspecto. El cuerpo se divide en una pieza anterior, llamada el cefalotórax, y en abdómen: salvo pocas excepciones, el primero se compone de cuatro segmentos del todo iguales, quie forman como un todo no dividido, cuya placa dorsal representa un gran escudo mas ó menos convero, el cual cubre la base de todas las extremidades, mientras que su cara inferior ó el pccho, circuido de los costndos de aquellas, queda reducido casi siempre á una pequeña circunferencia.

I.os cangrejos tienen iambien su cefalotórax, que segrun lo indica el nombre, representa una soldadura de la cabeza y del tómx. No sucede sin embargo así con los aracnoideos, en los que la calreza no alcanza su desurollo, segun lo demuestran los ojos y las antenas. El mímero de ocelos varia de dos á doce ó faltan tambien del todo, y no ocupa nunca un sitio determinado, sino que se agrupan en las diversas especies de una manera muy caracteristica, particularmente en la region anterior del cefalutúrax. Debajo de la parte anterior libre se inserta un par de extremiciades que varian por su forma en los diferentes aracnoideos, y que, por su empleo y asyecto exterior, deben considerarse como mandibula inferior, aunqque no lo sea en realidad, pues sobresale de la abertura bucal y recibe sus nervios del nudo superior, como las antenas en los articulados hasta ahora descritos. Estas antenas, que sinen por to tanto de maxilas, se han llamado an. tenas maxilares, considerảudolas como carácter distintivo de los aracnoideos, que carecen de las verdnderas. Además de las maxilares existen cinco pares de extremidades, de los cuales los cuatro posteriores ofrecen el aspecto de brganos de la locomocion, aunque solo sirven para esta los tres últimos. Sin embaryo, como los anieriores hacen las veces de mandibula inferior y presentan otra forma en los diversos órdenes, at hablar de ellos deberemos ocujarnos otra vez del asunto. En este lugar solo diré que los úrganos masticiedores encierran, en la mayoria de los aracnoideos quie se alimentan de sustancias animales, armas renenosas, con las cuales concluyen ripidamente con su presa. El abuónen es articulado á veces, pero forma mas á menudo una sola pieza y carece siempre de patas. I a respiracion se efectúa por pulmones en figura de bolsas replegadas, por tráqueas que ofrecen el grado mas inferior del desarrollo, ó por la piel. Comprendenos por lo tanto en los aracnoideos los articulados de cabeza soldnda 
atrofiada, con antenas maxilares y ojuelos en el cefalotórax, provisto cuando mas de cuatro pares de patas que nunca existen en el abdómen; y que respiran por pulmones, por triqueas ó por la piel. No sufren ninguna trasformacion durante su desarrollo, en el sentido de la metamorfósis com. pleia de los insectos.

Para terminar esta brevisima descripcion general de los caractéres de los aracnoideos, hemos creido oportuno incluir dos grabados en que se representan los órganos principales de algunas de las especies mas notables de la clase.

las tres primeras figuras del primer grabado representan los ojus de los licosos, los de los saltadores y los de los nops.
- En los tres cibujos de la segunda línea se figuran los ojos de los hersilios y de los disderos.

En la tercera serie se representan los cuemos de los saltadores y de los argirometras y los labios de los linifios. En la cuarta los piés de los licosos, de los saltadores y de los tejenarios; y en últimotérmino figura el singular doble peine del escorpion, órgano situado en el primer anillo del abdómen, y cuyo uso no es bien conocido. Consiste en dos proyeccio. nes unidas por su base al abdónen y provistas de apéndices dentados, en numeto variable.

El segundo grabado representa los palpos de los aracnoideos machos.

\section{ARTROGASTROS - ARTHROGASTRA}

CARACTERES. - Un abdómen marcadamente articulado, soldado casi siempre en toda su anchura con el cefalotórax, y por lo tanto fijo, caracteriza las especies superiores de los aracnoideos, cuyo aspecto cxterior y estructum general presentan tal variedad que los sistematicos modernos las han dividido en cuatro órdenes El reducido espacio de que disponemos para describir toda la division, solo nos "permite tratar de las familias de los artrogastros.

\section{LOS SOLIPUGOS - SOLI-}

\section{PUG㞋}

CARACTERES.-T.OS solipugos ó arañas cilindricas, llamadas solifugos, se distinguen esencialmente de todas las especies del órden por el hecho de no limitarse la articulacion al abdómen, puesto que se extiende a la parte anterior del cuerpo. En esta hay una cabeza oval, como podria llamatse: cuya mitad anterior, mas grande, se compone de las tenazas, dispuestas verticalmente y muy fuertes, $y$ de la base hinchada di modo de rejiga de las anteras maxilares. In parte inferior de la tenaza, asi como la superior, estánprovistas en el borde interior de fuertes dientes, yo pueden moverse en senido vertical. Dichn cabera tiene en el borde anterior de su cam superior dos ocelos, y en la parte inferior dos pares de nuxilas ó mas bien sus palpos, de la misma estructura de las patas, pero desprovistas de garras. Cada par de las patas verdaderals, yue remata en dos largas garras, se inserta en un segmento particular del tórax, separado mas marcadamente en el Jado abdominal que en su cara superior. Fi abdónen se compone de nueve segmentos y cestá provisto, asi como todo el cuerpo, de un espeso vello, mientras que las extremidades presentan largos pelos rigidos, algunos de los cuales alcanzan una longitud particular. Además se observan en los lados de las patas prosteriores delicadas formaciones membranosas, que en figura de placas triangulares sé insertan en un delgado tallo: la respiracion se efectún por triqueas. En toda la estructura del cuerpo los solipugos guardan un término me. ciio entre los insectos y las aranins.

\section{EL SOLIPUGO ARAÑA-SOLIPUGA ARANEOIDES}

CARACTERES. - Esta esuecic (fig. 173), propia de la Rusiameridional, y que tambien se encuentra en Egipto, segun Pallas, tiene un color amarillo de orin, las tenazas plardas y el abdómen del mismo tinte; las antenas maxilares presentan en su cara interior tuertes espinas de color pardo aceituna. Koch publicó los grabados de un grain numero de especies, casi todos muy semejantes entre sí, pero como solo se tuvic. ron por modelo individuos disecados ú conservados en espipiritu de vino en las diferentes colecciones, queda la duda de si son cfectivamente especies distintas, no reconociéndose, por ejemplo, si un graleodes arahs difiere en re:ulidad del galeo. des ó solipugo aracnoidco.

USOS, COSTUMBRES Y REGIMEN.-Pallas refiere cosas raras de este último solipugo que, liamado por los kalmucos bu-rhorgoi (gusano mágico) ó mandehi-lin-chorgoi (gusano migico comun) y por los kirguises kara-kurt-bie, es tan temido en las estepas de la Rusia meridional, como en otras partes el escorpion. I.os indigenas abandonan la region en que a menudo se presenta este insecto, peligroso para el hombre y sus ganados Cuando los camellos, ovejas y carneros se entregan alli al reposo, al aire librc, durante el verano, esos insectos acuden, y agarrándose à las reses les introducen sus tenazas, que sin duda contienen veneno. Iil vientre se hincha, y con harta frecuencia sucumben los animales mordidos, por efecto de la ponzona. Como los solipugos liabian con preferencia en las caủas, llegan con estas à las chozas construidas con ese material, y de este modo pónense en contacto con el hombre, mucho mas de lo que á él le conviene; ocúltanse, como los escorpiones, en la ropa, y obserran en ge. neral el mismo género de vida. Segun la supersticion de los kaimucos, se necesita para la curacion de la herida venenosa, leche de una mujer que por primera vez hava parido, habiendo sido anies casta doncella, ó a faita de este medio, el pulnon y el cornzon arrancado de un animal negro (perro $\delta$ gato viro) que se colocan sobre in mordedura. Los médicos de Sarepta aconsejaban en tiempos de Pallas fricciones de aceite de nuez ó de oliva mezclacio con alcanfor. I a picadu- 
ra es en extremo dolorosa y produce una fucte irritacion, parailisis, dolores de cabeza yesmayos pasajeros.

El solipugo araña habita en las hendiduras del suelo, en regiones donde abundan los caraverales, 6 permanece de dia oculto bajo una piedra, si no se introduce en algun sótano; de noche sale en busca de una piedra, y entonces puede encontrar grandes escolopendras y coleópteros ramaces, enenigos tan fuertes como él. Inis maxilas en forma de pic se mueven continuamente, y cuando tocan un objcto despiden al punto una luz fosforescente. Asi como el elefan. te levanta su trompa cuando con clla toca un objeio que no le inspira seguridad, del inismo modo el insecto lcvanta sus an-

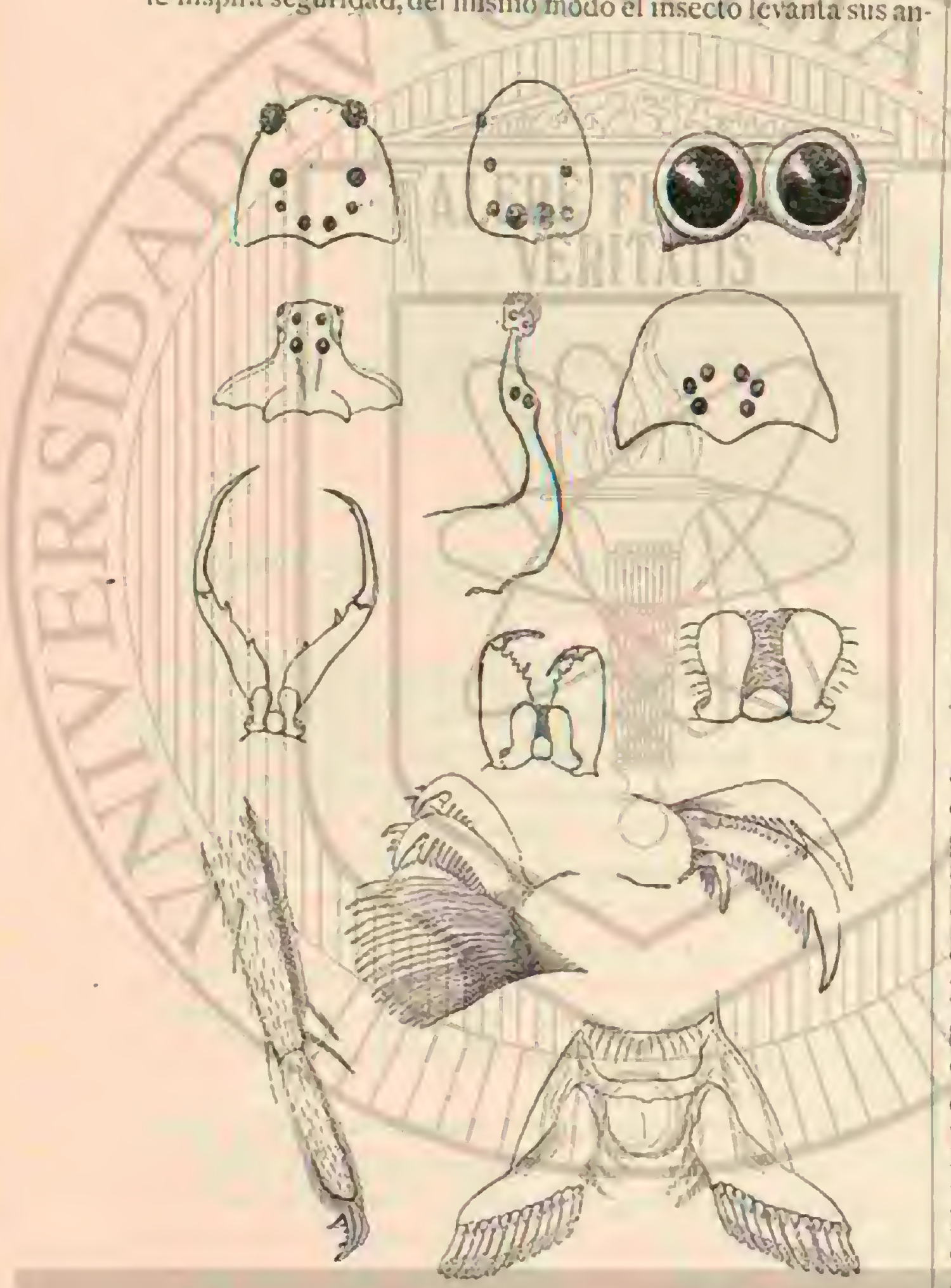

tenas inaxilares; pero una ver. averiguado lo que es, precipitase de un salio sobre da presa introduciendo en clla sus tenazas. Se han hecho varios experimentos que demuestran la ferocidard de los solipugos. Ln individuo de $k^{\text {", }}$, 52 de largo atracaba $a$ todo insecto que se le poura delante; á un lagarto que, sin co. la, media $1 "$, o78, acometióle sin vacilar, hizo presa en su lomo, introdújole las garras en la nuca y deroró todo el cuerpo, dejando tan solo algunos huesos. Otro dia mató una rata recien nacida, comiéndola i poco rato. Despues lc presentaron un murciélago de $11^{\circ}, 105$ it $0^{\circ}, 131^{2}$ de punta punta de ala, y aurque se movin vivamente, ol solipugo se precipitó sobre el, agarrindoscle de tai modo al cuello, que el murciélago no pudo librarse a pesar de todos sus esfuerzos. Mas tarcie cogió un escorpion de $6^{m}, 105$ de largo por la base de la colia, la cual arrancó a mordiscos, comiéndose las dos partes; pero esta victoria solo fué casual, pues, habiendo atacado otro dia à un segundo escorpion, este lo cogió con las tenazas, clavindole el aguijon renenoso, y a los pocos instantes sobrecogiéronle convulsiones y murió. El ca- pitan Hutton nos habla de una especic indin, para la cual propone el nombre de graleodes s'orizx, y que quizas es la nisma que Herbst llama galeodes fatalis; sobre la que ha liecho observaciones interesantes, gue respecto á su audacia y vo. racidad confirman las noticias que acabamos de dar.

El alimento regular se compone de insectos de todas clases, cujos cuerpos chupan y mascan completamente. Tampoco perdonan à los de su especie, sino que luchan á vida ó muerte, devorando el rencedor al vencido. En cambio, la hembra, segun costumbre de las amñas, cuida con la mayor solicitud sus hijuelos. Hutton tuvo una hembra cauliva que muy pronto abrió una galeria en el suelo, depositando mas de cincuenta hucros blancos, los cuales guardaba sin mover. se del sitio. Al cabo de quince dias nacieron los hijuelos: que durante tres semanas, hasta la primera muda, permanecieron inmúviles, comiendo despues alegremente en su prision: crecicron muy pronto, sin que se hubiern podido ver de qué se alimicutabin.

Lois treinta especies, poco mas \& menos, basta ahora co. nocidas, y que, asi como los escorpiones, pertenecen exclusivamente a los paises calidos, fucron agrupadas por algunos autores bajo el nombre antiguo de solpuga, pero Kocls las distribuye en cuatro géneros que se distinguen por el número de articulariones del pie: segun él, las especies que en dicha parte tienen cuatro, en el segundo y tercer par de puatas, y siete en el cuarto, constituyen el género solpuga, propio casi ex. clusivamente del Cabo de Buena Esperanza; las que de un modo correspondiente llevan dos y tres artejos, el género galiodes. En el género vhax los piés divididos en cortos artejos no tienen garras, y en el llamado gluvia se componen de un solo artejo largo y delgado. I as especies de este viltimo género se tiallan sobre todo en México; una de ellas (galeodes, striolata), habita en Portugal, siendo esta última, con el galeocio griego, los únicos representantes de la familia en Europa $A$ una de estas dos últimas especies se referian tambien varias roticias de Eliano ! Plinio, el primero de los cuales dice: "Algunos naturalistas pretenden que en la isia de Zante las personas mordidas por los falangios sc quedan rígidas, tiemblan y provocan, experimentando al mismo tiempo dolores en los oidos y en las plantas de los piés. Mas cxtraño es aun el hecho de que, los que penetran en el agua donde los mordidos se han bañado, sufran los mismos accidentes En otro pasaje el mismo autor refiere que en la India hay un pais í orillas clel rio Astabas llamado el Desierto, donde nadie habita. En un caluroso rerano los mosquitos oscurecen alli el aire y un sin número de cscotpiones y falangios cubren el suclo. Al principio, segun cicen, vivió alli el hombre y soportó algun tiempo la plagn, pero curno esta firese en aumento, todos los habitantes abandonaton el pais. Plinio dice. de los falangios que las lacmbras incuban en su guarida gran número de luevos, y que no se conocen en Italia. Cuando aiguno ha sido envenenado por una picadura, cairanle enscñindole otro animal de la misma especie, parn lo cual se conserman individuos nuertos. Tambien se mucle la piel que dejan en la muda y se toma el polvo como remedio. Estas y otras noticias demuestran de un modo suficiente el temor que desde la antigüedad han infundido estos amenoideos.

\section{LOS ESCORPIONES-SCORPIONIDE}

Entre todos los articulados apenas habra uno que desde la antigüedad haya dado origen í iantas fabulas como el escorpion. Por todas sus condiciones este animal es propio para que se le considere como el simbolo de la malignidad, díndole por companero el genio del mal, Tifon, en ha mitología 
del antiguo Egipto. Algunos filósofos griegos supusieron que los escorpiones nacen de los crocodilos en descomposicion; Plinio dice que provienen de cangrejos marinos sepultados, y que no salen a lu\% sino cuando el sol pasa por el signo de Cáncer: segun el aserto de Paracelso se reproducen de escorpiones putrefactos, añadiéndose tambien que ellos mismos sc matan. Mucho circuló la fábula de que el escorpion, rodendo de un circulo de fuego, prefiere matarse con su aguijon antes que sucumbir i los efectos del calor, cuando no puede huir. Los exprerimentos hechos por los naturalistas posteriores sobre cste particular han demostrado de un modo suficiente lo absurdo de esta opinion. Algunos autores mas modernos hablan de escorpiones de mas de seis segmentos en la cola, $y$ de otros con dos colas; Mloufet llegó hastia dar el grabado de un escorpion con alas. En muchas obras se dice que el uso de la yerba dasiliz es sumamente eficaz para volver í la vida a los escorpiones mucrtos; y hé aqui porqué el célebre A. de Ha. ller, que vivió en la primera mitad del siglo pasado, para re. futar tales absurdos, dijo que en el cerebro de álguien se habia desarrollado un escorpion por abusar de la yerba basilia. Estas y otras opiniones sobre el escorpion y la circunstancia de figurar zambien en el Zodíaco demuestran el gran interés que desde la antigüedad excitó en el hombre, aunque siempre le miró con temor, exngerando á menudo sus cualida. des, segun lo han demostrado con el tiempo numerosos experimentos.

Los escorpiones tienen en el aguijon encorvado de la punta de su abdómen un arma venenosa, infaliblemente mortal para otros séres semejantes á cllos, y que en animales mas grandes, y aun en el hombre, en casos particulares, produce efectos peligrosos, cuando no la muerte. Cerca de Montpellier hay dos especies, una de cllas el pequeño escorpion europeo, scurpio europazs, cuya picadurn no ha producido en las personas heridas un resuliado funesto, por(nue el eaceite de escorpiont cura pronto el mal. Lil escorpion campestre (buthus occiranus) es inucho mas grande y peligroso: un perro picado cuatro veces en el vientre comenzó á tambalearse al cabo de una hora, arrojó todo el contenido de su estómago y además una sustancia pegajosa, por fin le acometieron convulsiones, arrastróse sobre las patas anteriores porticr. my murió cinco horas despues del envenenamiento. Otro perro, picado seis veces, aulló otras tantas, pero conservóse sano: cuatro horas despues se obligó a varios escorpiones if herirle dic\% veces mas, y á pesar de esto no sufrió ningun daño: tomaba alimento cuando se lo ofrecian, aun conociendo que ib.s a ser picado. Fill otro experimento se reunió i itres escorpiones con un raton; este fué jicado, chillo, mató a los insectus yo murió. Cicrto dia un hombre fué mordido en el dedo pulgar, y pasaron diez y ocho horas antes de que llegara el médico: el brazo se linchó mucho; enrojeciose la piel, $y$ frecuentes convulsiones atormentaron al hericlo, que delimba y provoé á menudo, saliendo de un desmayo para carer én otro. Al cabo de cinco dias mejoró el paciente, pero pasó mucho tiempo antes de que sanara del todo. Cujyon liabla de cinco casos un que ha inuerte sobrevino doce horas despues de la picadura, y de otro en que el herido sucumbió en seguida, mordido por una especie mas grande. bl venéno es un liquido claro como el agua que fácilmente se seca; tiene un sábor agrio y es soluble en al agua, pero no en alcohol ó éter puro.

Los escorpionés, así como los quilópodos, permanecen débajo de las piedras, en la madera podrida, en los agujeros $y$ otros escondites oscuros, pero, agradindoles el calor, penetran á menudo en las viviendas liumanas, donde se esconden en las camas, en las ropas y el calzado. Cuando los viajeros que deben pasar la noche al descubierto, encienden la indispen- sable hoguera, preséntanse, entre otros articulados nocturnos, algunos esconjiones de los cuales se hace preciso defenderse, por un medio í otro. Asi el caminante, como el hombre que trabaja al aire libre, pueden acercarse al insecto sin saberlo, y entonces no es fácil evitar una pieadura, pues los escorpiones quieren defencierse. Ia picadura es en extremo dolorosa; produce inflamaciones locales, pamlizacion, calenturn, desmayos y vómitos, segun cl tamaño del animal, la irritabilidad de la persona y la temperaiura de la region, pues ya se sabe que todas las infamaciones son mas graves en los paises cilidos que en los templados. Las especies europeas son las que hieren menos; las africanas y asiáticas, hal vo\% á causa de su mayor tamano, lo hacen mas profundamente. Antes se solia emplear el llamado accite de escorpion, que es aceite de oliva en el que se han dejado morir algunos escorpiones: deciase que era bueno para cumar la herida, y uste remedio se usa todavia en algunas partes. Los alcalinos, como amoniaco, ceniza de tabaco, etc., calman mas cficazmente el dolor y la inflamacion, y una jequeña dósis de ipecacuana los vómi. tos. Los indigenas del Africa, que en muchas regiones de este continente suiren las picaduras de la especie srortio ater, se ponen una venda muy apretada sobre la herida, y sin mas que esto la cierran, curindose al fin. Extraña es la circunstancia de que el organismo humano pueda acostumbrarse con el tiempo al veneno del escorpion. Una segunda herida tiene los efectos menos violentos y duraderos que la primera, $y$ la tercern es aun menos peligrosa que la segunda. Se refiere que un individuro, habiendo querido observar este fenómeno en su persona, logró pronto no experimentar sino un dolor pasajero por la picadura.

No sucede lo mismo con los insectos de toda clase, y sobre todo con las aranias, que constituyen el alimento favorito de esa especie danina que encuentm en sus exprediciones nocturnas. El escorpion corre entonces con mucha rajjidez y agilidad, a reces de lado ó hicia atris, lleva la cola encornada hácia arriba por uncima del dorso, y sicmpre ticne su arma preparada para coger con sus tenazas lo que puede. Iuego levanta la prest, aunque se resista, dirige los ojos hácia arriba, $y$ la infiere en el pecho con sumo acierto $y$ seguridad la picadum mortal. Despues de algunas convulsiones la victima inuere; el escorpion la lleva à su boca y chupa su contenido mascíndole tambien por completo en ciertas circunstancias.

Los escorpiones viven por lo regular en los paises cálidos y' en las partes mas calurosas de las regiones templadas y por lo tamio faltan del todo en Alemania.

\section{EL ESCORPION CAMPESTRE-BUTHUS OCGI- TANUS}

CARACTERES. - Lina de las especies mas comunes de la Europa del sur que viven en Francia, Espaina, Berberia y generalmente en todos los paises del Mediterránco, pucde servirnos para dar una idea de la estructura del cuerpo de todas las restantes de la inmilia. I ass dos grandes tenazas de cangrejo representan los palpos de la mandibula inferior, y. su corto artejo bucal, muy grueso, que por encima no es visi. ble, la mandibula inferior misma. Il sugundo horde maxilar hace las reces de patas anteriores, cuyas ancas en forma de placas, asi como las del siguiente par de verdaderas patas, se cxtienden hícia adelante por una apófisis que constiuye el labio inferior. Estos dos primeros pares se colocan en la linea central del cuerpo, mientras que los otros dos se des. vian y reciben entre si un segrnento toricico de muy diferente forma en las varias especies. Cada una de las ocho patas remata en dos garras. Aunque las tenazas recuerdan mu- 
cho a primera vista las de los cangrejos, difieren sin embargo csencialmente de las de estos por la circunstancia de que el dedo exterior es movible por una articulacion contra el otro, soldado con la mano, y no viceversa, como en los cangrejos. Las dos puntitas que se ven delante del borde an. terior del cefalotórax son las antenas maxilares, que en su punta tambien rematan en tenazas. El tronco del escorpion se divide en un cefalotórax cuadrangular, entero y un poco mas ancho ell su parte posterior, y un abdómen no separado visiblemente de aquel, compuesto de trece segmentos, de los cuales los últimos seis forman una cola nudosa que remata en el aguijon venenoso arqueado. La abertura doble del agui-

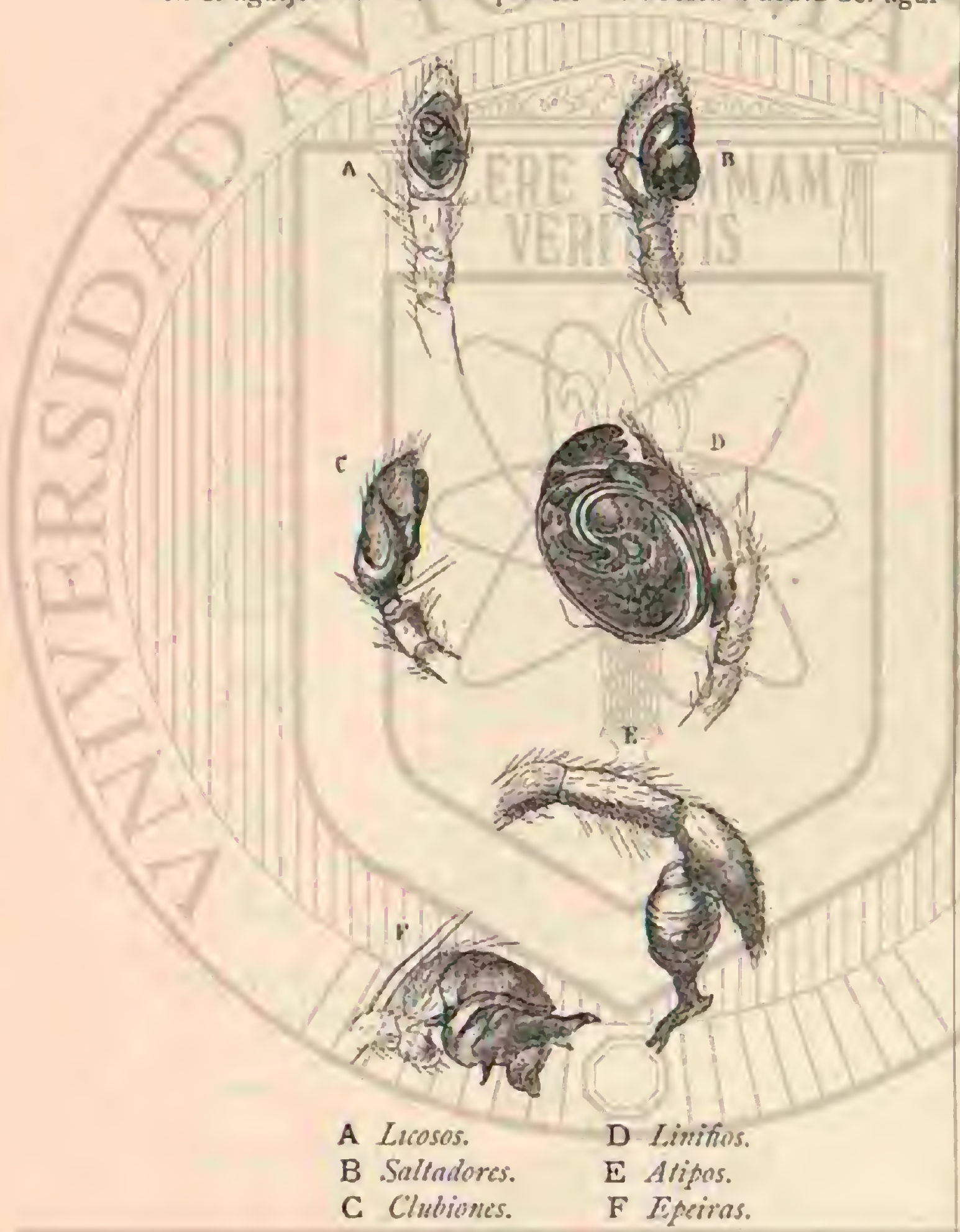

jon que oculta las glíndulas vencnosas solo puede verse r.nn el microscopio. En la cara abdominal del primer segmento det abdómen hállanse cubiertas de dos placas las aberturas sexuales; en la extremidad del segmento siguienté se ven las llamadas cierlas, que se componen de dientes fijos, en forma de peine, en estrechas hojas de varios artejos, cuyo número varia segun la especie y la edad; rematan en el bor. de exterior en forma de hoyos y estin sostenidos en su base, tanto en la carn interior, como exterior, por botoncitos triangulares cónicos ó esféricos. No se conoce su verdadera aplicacion, pero supónese que sirven en el apareamiento como auxiliares de las patas, $y$ para subir por superficies lisas y verticales. Por detris de las dos ciertas que no faltan á ningun escorpion, hállanse, en cada uno de los segmentos abdominales siguientes, dos aberturas hendidas y oblicuas, que conducen como estigmas a los cuatro pares de las bolsas pulmonares replegadas. Los ojuelos están siempre sobre el cefalotórax; en los lados de dos rebordes longitudinales se ven à derecha é irquierda del cefalotórax de dos á cinco ojuelos mas pequeños, cuyo número difiere mucho en las diferentes especies, y hasta en una misma y aun en ambos lados de un solo individno. Como la superficie del celia. lotórax es muy granujienta, se necesita gran atencion para encontrar los ojuelos laterales ó no confundirlos con alguna de las verrugas brillantes. I.os tegumentos del cuerpo se com. ponen de placas duras de quitina; en cada segmento hay una superior $y$ otra inferior, reunidas con las inmediatas por membranas blandas: solo la de la coia constituye una excepcion. Ia superficie del cuerpo es brillante ó mate, casi siem. pre áspera, granujienta ó verrugosa, con rebordes, y en ciercos sitios tambien cerdas. El color pasa del amarillo pardo al negro mas intenso, encontrándose tambien individuos que sobre un fondo claro jresentan matices negros. El macho difiere de la hembra por tener la cola mas larga, las tenazas mas anchas y los dientes de los ciertos mas numerosos.

El intestino de los escorpiones, hablando solo de paso de su organizacion interior, consiste en un tubo sencillo, bastante cilíndrico, que en lis punta del penúltimo nudo de la cola descmboca hácia afuera. Iil vaso del dorso, compuesto de ocho camaras, forma un verdadero corazon que no solo desde las extremidades anterior y posterior, sino tambien de amibós lados, envia fuertes arterias á los órganos del abdómen, pero sobre todo a los respiratorios, siendo conducida al cornzon la sangre que vuelve del cuerpo por unas venas particulares. Yerificase, por lo tanto, una verdadera circulacion de aquella, mejor que en ningun otro articulado, $y$ por lo tanto la respiracion se efectúa por medio de pulmones. Estos se componen de cuatro pares de bolsas membranosas, cuyns partes exteriores forman repliegues oprimidos entre sí: son las llamadas placas pulmonares. A los grandes nudos nerviosos del ccfalotórax, que proveen á las antenas maxilares $y$ i'las patas de nervios, siguen otros siete mas pequeños, correspondiendo los cuatro últimos á la cola.

Ios órganos genitales de la hembra tienen la forma de tres angostos tubos longitudinales reunicios por otros trasversales en cl abdómen, sirviendo como centro del desarrollo, no solamente a los huevos, sino tambien a los hijuclos, pues las hembras paren, como ya lo sabia Aristóteles, hijuclos vivos. En las primeras semanas estos tienen la picl blanda y rodean a'la madre, sin que se la rea alimentarlos; pero la hembra enflaqquece cada vez mas, y al fin muere cuando estos se hacen independientes y se dispersnn. Es un espectículo curioso ver i. la madre rocieada por todas partes de sus numerosos hijnelos (20 a jo) en las posiciones mas diferentes, y observar la pacifica reunion de unos insectos cuya natumleza se opone a toda sociabilidad.

USOS, COSTUMBRES Y REGIMEN.-Se han hecho los mas variados experimentos para averiguar qué intervalos median entre las mudas y cual es la duracion de la vida de los escorpiones; pero siempre sin resultado, porgue estos no se conservan en la cautividad mucho tiempo, aunque se les alimente bien. Fuessly cuidó algunos individuos (que por su grueso abdómen consideraba como hembras fecundadas. A principios de agosto, es decir, à los cuatro meses encontró á uno de los individuos cubierto completamente por unos veinte pequeũos escorpiones que tenian la punta de la cola y la region de los ojos de un tinte pardusco, $y$ que excepto por su tamañoy su color claro se asemejan en todo à la madre. Agarrá. banse ásta ya en el dorso 6 en el vientre, sin désurenderse ninguno, por mucha que fuese su vivera (fig. 175). Unos doce dins despues de nacer mudiron por primera rez, adquiriendo todos un color algo mas oscuro, y entonces se les vió alcjarse de la madre, dispersindose por todas partes. La hembra murió pronto muy enflaquecida; y la misma suerte turo otra que solo habia parido cuatro hijuclos, aunque con un abundante alimento se conserró muy bien ciurante seis meses. Los indi- 
rojo vivo, liso y brillante, y en los lados muy oscurn asi como los bordes de las tenazas en toda su extension. En medio de la parte superior de cada segmento abdominal, desde el segundo, se ve una prominencia cortada, mientras que los bordes pesteriores se levantan en forma de liston. En la cara inferior de la cola, çue es nudosa, elevanse desde el segundo segmento un reborde lateral y tres rebordes longitudinales en el centro. 'lodas las extremidades, y sobre iodo las tenazas, tienen largos pelos. Herbst describe minuciosamente esta especic, siendo singular que su relato, en todos los detalles, pueda referirse à tres indivicuos de la coleccion de la Unirersidad de Halle que Burmeister trajo del Brasil.

El tercer grupo (centrurini) se distinguc por los siguientes carretérc:- un pequeno esternon triangular mas lägo que ancho, dos series de dientes en cl dedo movible de Jas ante nas maxilares y uma en el fijo, un borde anterior recto on el cefalóórax, una espina debajo de la base del agujon venc. noso, tres grandes ojuelos principales y uno 6 dos secundarios, y wríltimo los dedos cónicos de las tenazas $A$ este grupo pertenece cnire otros el escorpion americano (centruras mmeribums) que es delgado en sus extremidades, de color gris amarillo con bonitas manchas negras, y de unos (i), ${ }^{\circ}$, de longitud. El escorpion de los hotentotes (centruris hetfentiturs) es de color mas oscuro, y al mismo ticmpo inty ielgddo, y mide hasta 1)", 105 .

Fil escorpion campestre (influtus ocritanus), descrito yo dibujado for Herbst bajo el nombre de ssorpio tunetanus, periencceal último grupo (androtonius), cuyas especies tienen el pequeino esternon triangular, puntiagudo ú obiuso en su parte anterior, mientras que en la posterior es recio en toda su cxtension; ambos dedos de las antenas maxilares estin pro. vistos cadia uno de cios series de dientes, las tennzas de los palfios son cónicas y los estigmas grandes. En los bordes taterales del cefalotórax; cortado en linea recta en su parte anteriok hay tres ojuclos principales $y$ dos secunciarios i cada lado. El color del cuerpo es de un rojo amarillo claro; tres quillas se corren por la parte superior del abiómen, y en su ültimo segmento las dos latemies se aproximan entre si Unas series de granitos en forma de perlas - trazan graciosas figuras sobre la parte superior del cefalotóns, particularmente una que viche á formar una especie de s no cerrado en el centro. Por detrís de los ojuelos laterales fórmase i cada lado un reborde que al principio se corre en linea recta hácia atras, prolongaindose despues en línea recta hasta el borde nosterior.

\section{EL QUELIFERO CANCROIDEO - CHELIFER CANCROIDES}

CARACTÉRES.-Por sus grandes tenazas cl quelifero canctoirieo 6 escorpion de los libros parece un escorpion sim cola, micatras que sin aquellas se parece por el tamal:o, color y cosiomos generales del cuerpo, muy aplanado, al tipo comun. Su abdómen se compone de 1 I segmentos de igual longitud; el cefalotórax, provisto solo de dos ojuelos, presenta sureos trasversales; los palpos de la mandibula inferior se desarrollan en poderosas tenazas, mientras que las anicnas maxilares estain atrofiadas y no sirven para mascar, sino para chypar. No solo se distinglie esta especie por la falta de las cierus en la base del vientre y de las glándulas venénosas en claalquiera jarte de su cuerpo, sino tambien por lá estructura interior, que sin embargo no se ha examinado aun completamente. No respiran por pulmones sino por tráqueas que salen de dos estigmas laterales en el primer segmento del aboómen en forma de troncos cortos y anchos, los cuales se ranifican por todo el cuerpo. El intestino no se corre cn. linea recta, sino que forma un nudo delante del intestino grueso, ensanchándose este en forma de bolsa. Esta cspecic tiene además glíndulas textiles, que cerca de la abertura genital desembocan en la parte inferior del segundo segmento abdominal. Iil quelifero se parece generamente mas á los acarinos que i los esconjiones por su estructura interna (figura 174$)$.

USOS, COSTUMBRES Y REGIMEN. - El quelifero canctoideo habita las casas viejas, en medio de libros cmpolvados, en las carpetas de los hertarios y en has cajas de las colecciones de insectos, donde persigue á los piojos acarinos y otros pequeños insectos, no causando por lo tanto ningun daño en aquellas; léjos de ello, merece la proteccion del naturalista. Es muy curioso ver a este insecto correr por los rincones al abrir una caja, pues se mueve de lado como un cangrejo y anda hacia atris lo mismo que hácia adelante; agita sus tenazas a derecha 6 irquierda y no puede oponer ninguna resistencia cuando se le quicre coger; la hembra pone unos veinte huevos.

Unos escorpiónidos semejantes del mismo tamaño, que se encuentran al descubierto debajo del musgo, de la cortera de los árboles, etc., pertenecen à otras especics, como por cjemplo, el quelifero cimicoideo (chelifer cimicordes), que tiene las tenazas mas cortas y el abdómen oval y sin ojos; 6 el escorpjion de la corteza (obisium: muscorum ú obisium corticalis), cuyo cefalotóras no presenta ningun surco trasversal, pero si cuatro ocelos, siendo el cuerpo delicado, de color pardo negruaco brillante, mas claro en las tenazas y casi blanco en las patas, ctc. Otras espuccies del mismo género de vida están diseminadas por toda la tierra, y existian ya en los periodos prinuitios de la creacion, pues se encuentran á menuda sus restos en el ámbar.

\section{LOS PEDIPALPOS-PE- DIPALPI}

Algunas formas en extremo intercsantes de las que desgraciadanente solo se conoce el aspecto exterior, y que antes se reunian bajo el nombre de género Phalangium, habi(an en los paises cólicios de ambos hemisterios.

\section{EL TEL.IFONO DE COLA-THELYPHONUS CaUdatus}

CARACTÉRES. - El telifono de cola, llamado tambien mata.msujers de cola, representa una de las formas citadas: es de color pardo nscuro y tiene $0^{\infty}, 032$ de largo. Habita en Java, y su picadura se teme tanto como la de sus congéneres en otros paises. Sin cmbargo, solo puede picar, como nues. tras arañas, con las antenas maxilares, de dos artejos, que rematan en una garra, pues falta el aguijon venenoso de la extremidad de la cola. Los palpos de las maxilas inferiores afectan la forma de brazos nuy recogidos y fuertes tan largos como el cefalotórax; se ensanchan en el trocainter de los muslos hacia adentro, y tienen una fuerte espina que remata en tenazas gruesas y cortas en la parte de su base; las maxilas estan soldadas. lil segundo par de palpos maxilares. aunque semejante a las patas, es mucho mas largoy delgado que estos y termina en pićs de ocho artejos. El cefalotórax, oval, ticne ocho ojuelos, de los que dos, así como en los escorpiones, ocupan la coronilla, contándose tres à cada lacio del borde lnteral; el abdónen, de doce segmentos, afecta casi la forma comun: los tres últimos anillos se estrechan en forma de espiga y dam salida a un hilo articulado. La estructura interna hace resaltar aun mas la semejanza con los escorpiones. El abdómen, aplanado, presenta en la base dos pares de estigmas, que albren la salida a otras tantas bolsas 
pulmonares, pero en cambio faltan aqui, lo mismo que en el género siguiente, y no de igual modo que en los escorpiones, lus nudos nerviosos del abdómen. Desde los grandes nudos del cefalotórax se corren hácia el abdúmen dos troncos principales que solo en la extremidad se dilatan en forma de un pequeño nudo.

USOS, COSTUMBRES Y REGIMEN.-Del género de vida de estos escorpiones, no tenemos noticias. Una especie habita en México, otras muy semejanntes son propias de las regiones calidas del Asia.

\section{EL FRINO DE BRAZOS LARGOS-PHRXNUS LUNATUS}

CARACTERES, - El frino de brazos largos representa la oira forma y'a mas semejante a las arañas. Tambien aqui

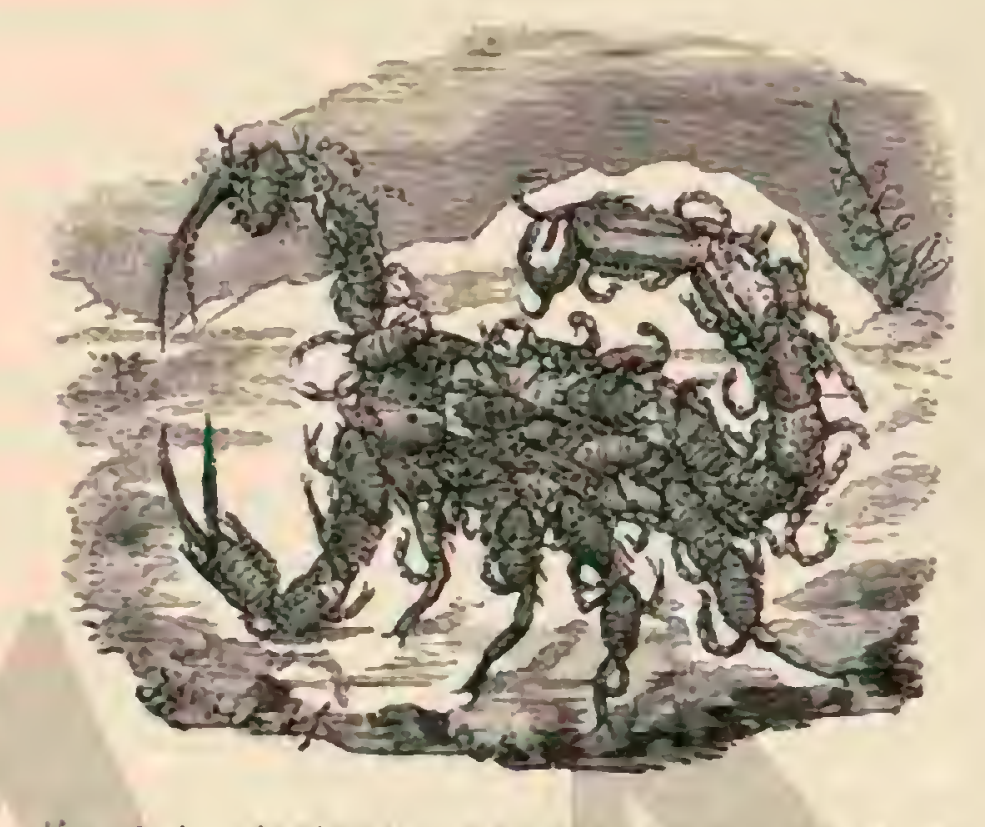

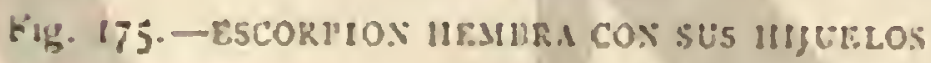

se hallan las segundas maxilas en forma de largos latigos, y el segundo par en ligura de brazos largos ó cortos, provistos de mas 6 menos espinas, que rematan en una sencilla garra. Entre la parte de la basc que forma las mandibulas hay una espina movible de la barba; las antenas maxilares tambien rematan en una sencilla garra y contienen probablentente las glándulas venenosas. En el cefaloiórax, que casi afecta la forma de un riñon, los ojos se distribuyen de modo que dos se hallan en el borde anterior y tres dispuestos triangularmente en cada lado, por manera que todos los tres grupos liguran un triảngulo obtuso cuyo ángulo plano está formado por los dos ojuelos anteriores. Como el abdómen, de once artejos, se estrecha en su parte antérior, el cuerpo se asemeja al de las arañas. Los frinos respiran sin cmbargo igualmente por pulmunes, yue en la base del vientre desembocan en cuatro estigmas.

Las hembras paren hijuelos vivos, circunstancia que demuestra la mayor afinidád con. los escorpiones. El frino de brazos largos, especie propia de Surinam, tiene un color pardo amarillo, los muslos de las tenazas naucho mas largos yue los de las patas y desprovistos de cspinas, los tarsos son casi de la misma longitud $y$ junto if la punta presentan varias espinas muy largas. No se comprende que Gervais diera un grabado de eșta esjecic bajo el nombre de phrjyus rinifor. mis refiriéndose a otros de Herbst que sin embargo en nada se parecen al suyo. Nuestra especie se encontró tn 1872 viva en la fábrica de colores de Schramm, cerca de Ofienbach, a donde se la habia importado con una mercancia de Santo Domingo. Las otras especies se disinguen principalmente por la forma de los brazos, mas cortos y provistos de mas espinas que les hacen parecer mas amenazadores.

Los frínidos y telifónidos se han reunido en el órden de los pedipalpos, distinguiéndose por las patas anteriores pro. longadas en forma de antenas, por las maxilas provistis de garras y por el abdómen compuesto de once a doce sergmentos.

\section{EL FRINO PALMEADO-PHRYNUS PAL- MATUS}

CARACTERES. - Este insecto (fig. 177) tiene el cefalotórax reniforme, con granulaciones vellosas, asi como las del abxiómen, cujo órgano es ovalar y deprimido; cl antebrazo liso, hinchado, algo rnmiforme y con cinco dientes agudos; a cada lado del gincho digital hay dos espinas basilares.

DISTRIBUGION GEOGRÁFICA. - Este frino habita en las Antillas.

\section{LOS FALANGIDOS-PHA- LANGIDE}

Si los aracnoideos hastia ahora descritos, casi exclusivamente propios de los paises meridionales, se observan muy poco à causa de su vida nocturna, las especies de que vamos á ocuparnos se dejan ver con mas frecuencia, constituyendo la familia de los filangidos diseminada en las zonas templa. das, y subre todo en la América. Estos insectos, tan propios de Alemania como de las partes septentrionales y meridionales de Europa y de la América del norte, tienen el cuerpo pequerio, oval y articulado, suspendido entre sus patas en extremo largas y delgadas cuando andan por el tronco de un árbol, por un muro ó por el suelo, pero lo hacen apoyaindose en el vientre cuando reposan con las patas estiracias. 'lodo el mundo los conoce bajo uno i otro nombre, como aincer, sastre, sapatero, espiribu, muerie (fauchesur de los franceses) y otros. Los muchachos dicen que el tronco tiene un gusto dulce como una nuez, y no faltan golusos que hacen la frruce. ba, asegumndo á sus companeros que el hecho es exacto. En tal ocasion reconocen que las largas patas delgadas cren muy facilmente de las ancas carnosas, y que algunas horas despues se mueven convulsiramente cual si estuvicran aun vivas. Se ve a estos insectos reposar de dia en los rincones oscuros de las casas $\delta$ al descubierto, no muy ocultos, ó bien andar lentamente como sobre zancos; pero de noclse muéstranse mas activos; retozan entre si de todas maneras, provocándose unos a otros, se agarran con las patas, y persiguense: pero mas biein se ocupan en buscar los pequeños insectos y los granos que les sirven de alimento. El sastre se precipita como un gato sobre su presa fo la masca rápidamente. Segun la opinion de Goednrt, pasan tres años antes de que los individuos nacidos de unos huerecitos blancos lleguen despues de varias mudas a su completo desarrollo. Parece cque el frio les molesta poco, pues se les incuentra á mucha altura en las montañas, y hasta en los Alpes de Suiza se: observa el upilin glaciolis a una alcura de 3.344 metros.

Estas especies sc agrupaban antes con las que acibanos de describir bajo el nombre genćrico de phalangium: pero separadas mas tarde, conservaron para los unos su nombre, recibiendo de los otros el de apilio. Ultimamente se hizo una nueva subdivision para ciertas especies.

\section{LOS OPILIOS-OPILIO}

CARACTERES. - Ios sasites, d los que conservaremos el nombre que Herbst les ha dado, ofrecen los siguien. tes caractéres: cuerpo grueso, rodeado por las largas patas como por radios, un poco isspero en el cefalotórax y de forma oval, pero no sicmpre bien marcado; cl abdómen es convexo 
y tiene seis segmentos. Por mas de un estilo la naturaleza se ha mostrado muy madrastra para estas especies: solo hay dos ojuelos en el centro del cefalotórax; y dos estigmas situados en las ancas de las últimas patas, son los únicos orificios de las trángueas, por medio de los cuales el animal respira. Las antenas maxilares, de tres artejos, penden por delante de la boca y rematan en una pequeña tenaza; los palpos maxilares se componen de seis artejos filiformes desprovistos de espinas, de los que el primero se inserta en el lado exterior de las antenas maxilares; el ultimo remata en una-fina garra como el siguiente par de maxilas, que tiene la forma de patas. Estas últimas alcanzan una longitud como en ningun otro articulado y aunque terminan con diez á quince artejos delgadísimos del pié, contienen como órgano del lacto numerosos nervios, segun lo demuestran las convulsiones de las patas separadas del cuerpo. Todos se insurtan en ancas camosas que están oprinidas unas contra otras; el último par no es mas grueso ni está mas separado que los otros.

Por su estructura interna los opilios se asemejan esencial. mente a las arañas. De los dos nudos nerviosos que hay encima y debajo del esóngo, el viltimo, mas grande, provee $i$ las pitas y al abơómen de nervios. El estómago, situado en la parte anterior del abdómen, da salidà à numerosos apeéndices en forma de intestinos ciegos, es decir, que de su parte superior salen cuatro series de bolsas cortas y cie los lados tres pares largos auce pasan por todo el abedónín. El vaso del dorso se compone de tres rentrículos is solo por sus dos ertremidades puntiagudas puede salir la sangre. Lo mismo que en todas las arañas articuladas, has partes genitales se abren tambien aqui en la base del vientre, $y^{\prime}$ el macho tiene la particularidad de poder hacer salir un órgano en torma de espiga. Los naturalistas distinguen numerosas especies ba. jo los nombres populares arriba indirados; casi todas tienen 12. parte superior de un gris amarillo, con manchas nass ó menos oscuras; las partes inferiores, casi blancas, se distinguen mas ó menos dificilmente.

La especie mas diseminada, á la que se aplican con preferencia aquellos nombres, se llamó por Linneo phalangiuns opilio, y por Herbst ofilio fariefinus; mide mas de $0^{\circ}, 005$, tiene el cuerpo de color gris amarillo, y presenta en las ancas, en los muslos y en el cefalotórax vorias espinitas. Lina especie muy parecida que muchos consideran como el macho de la anterior, es el opilio cormutus, que se distingue por una apófisis córnea detrás de la base de las tenazas de las intenas maxilares.

Numerosos opilios semejantes viven en Europa y América. Otras especies, de las que sin embargo ninguna se encuen. tra en Europa, se caracterizan por las patas posteriores desvindas, con muslos mas gruesos; los palpos son aplanados, desprovistos de espinas cerdosas; el cefalotórax es cuadran. gular, y el abdómen muy pequeño. Pertenecen al géncro cos. metus y algunos afines.

\section{EL GONILEPTES DE PATAS CORVAS - GONYLEPTES CURVIPES}

CARACTERES. - Las especies mas particulares de la familia son propias de la América del sur y pertenecen al género de los gonileptes. La especie de que nos ocupamos se compone casi exclusivamente de un cefalotórax de piel dura y de color rojo pardo, que cubre el aldómen casi complétamente: unos espesos granitos de color amarillo claro y dos espinitas en la prominencia de los ojos, en forma de una horquilla, hacen que la superficie sen aspera y abigarrada á la ve\%. Como en todos los congéneres, las patas posteriores, prolongadas, se desvian mucho una de otm, salen de ancas muy gruesas y presentan en el macho fuertes espinas de las que la hembra apenas tiene vestigios, llevando en cambio en algunos segmentos del abdúmen verrugas cspinosas.

DistRIBUCION GEOGRAFICA. - El gonileptes de patas corvas es propio del Brasil y de Chile; mas parece que las otras numerosas especies del género no tienen el área de dispersion muy extensa.

USOS, COSTUMBRES Y REGIMEN._El géneto de vida es análogo nl de nuestros opjilios, aunque se eucuentran con menos frecuencia en las casas. Como animales nocturnos, permanecen de dia detrás de la corteza, debajo de los troncos cortados, en agujeros subterráneos y en otros escondites oscuros, donde encuentran tambien otros animales lucírugos que les sirven de alimento. Se les encuentra alli reunidos en pequeñas familias, de modo que tambien manifestan cierta inclinacion a la sociabilidad.

\section{LOS SEGADORES - PHALANGIUM}

CARACTERES. - Por lo tínico qque se diferencia este género de los demás de la familia es por tener el cuerpo ovoideo ú orbicular, los piés iguales, y el abrómen libre.

DISTRIBUCION GEOGRAFICA.-LOs segadores son frecuentes en Europa.

\section{EL SEGADOR DE PIES LARGOS-PHALAN- GIUM LONGIPES}

CARACTERES. - Esta especic (fig. 178) se distingue por tener el cuerpo testíceo en su parte media y blanco por debajo; el tórax rugoso con dos escotaduras anteriores entre otras tres menos avanzadas, el abdómen anguloso y los piés muy largos.

DISTRIBUCION GEOGRAFICA.-Liste insecto abunda principalmente en la Europa septentrional.

\section{ARANAS PROPIAMENTE DICHAS -ARANEIDA}

Aqquellas peq̨ueñas amigns de las tiniebias que llamamos arañas, se carncterizan por la costumbre de acechar malicio. samente su press desde un escondite : por la mutua encmistad de las hembras con los machos, que lasta se ha hecho proverhial en Alemania, donde la frase \&enemigos como las arañas indica el sumo grado de cnemistad entre dos hombres. Estos dos rasgos caracteristicos, asi como su aspecto exterior, podrian granjear à estos insectos el carino del hom. 
bre; pero muy al contrario, este huye de ellosy los desprecia, aunque solo jor preocupacion. Si ahora pretendo erigime en su protector, hágalo al recordar lo que en mi juventud me enseñó mi inolvidable abuela, quien opinaba que el miedo infundado era tonto, sobre todo tratindose de pequeños parísitos, y que se debia ciesterrar del hombre, y sobre todo del nino, no por la instruccion sino por el ejemplo. Cierto dia que observó mi terror, el cual di á conocer como lo ha. cen los niños, no solnmente me reprendió mucho, sino que quiso al mismo tiempo hacerme comprender lo absurdo de mi miedo. Cogió una araina de las muchas que habia en una de las paredes de la vieja casa pastoral, hizomela ver en la mano para demostrarme que cra inofensiva, $y$ llamó mi aten- cion sobre su nido artificial y su modo de ca\%ar las moscas, tan perjudiciales para las uvas madums, y luego volvió a poner la arana en su sitio.

Si todos los que educan y enseñan hiciesen lo mismo, mucho disminuiria el número de las maturalezas nerviosas por estupide\% é ignorancia, que al ver una oruga, un abejon, etc. sufren convulsiones.

A pesar de su exterior extraño y de algunas cualidades desagradables, pero que no ofenden al hombre, las amñas ofrecen no solo en la estructura del cuerpo, sino tambien en su gémero de vida, bastantes puntos interesantes para considerarlas dignas de obscrvacion en inn alto grado como los otros articulados, lo que ya reconocian los antiguos. Segun cierta

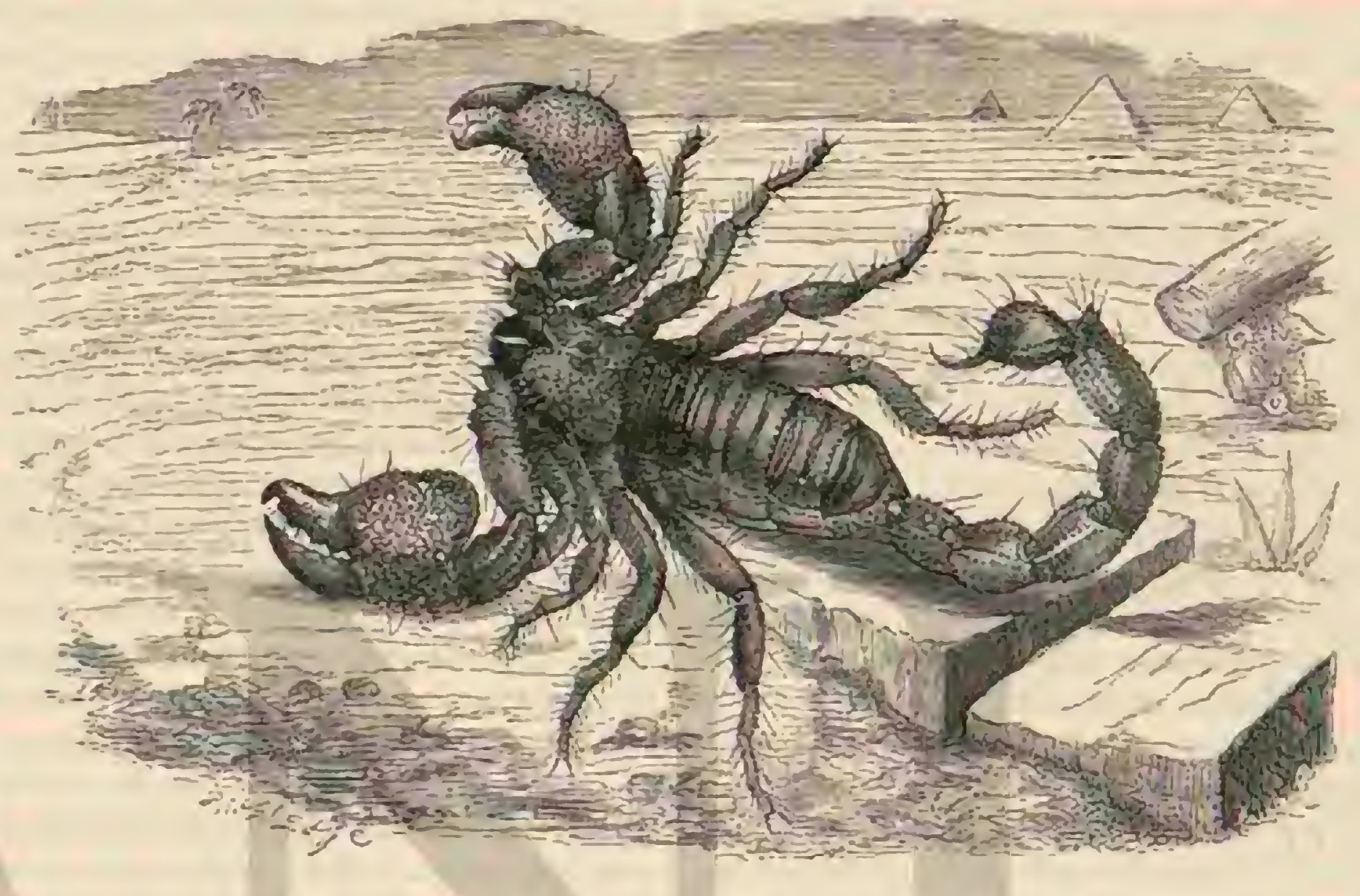

Fig. 176. - EL ESCORHON DE LAS ROCAS

tmdicion griega, Aracne, hija de Idmon, habia aprendido de Minerva el arte de tejer, atreviéndose luego á desafiar i su divina mastra en este arte. En vano la diosa, tomando la forma de uma vieja, inientó disuadirla; el trabajo empezó, y Aracne hizo un tejido artístico que presentaba las historias amorosas de los dioses; pero irritada Minerva rompió el tejido y Aracne se ahorcó en su desesperacion. La diosale devolvió la vida trasformándola én araña para que pudiera ahorcarse á su antojo. El rey Salomon recomendó á sus cortesanos la aratha como símbolo de la aplicacion, de la aficion à las artes, de la prudencia y de la virtud. Tambien Aristóteles, el mas antiguo naturalisia, fijó su atcucion en las arañas, dando ș co. nocer su origen, alimentacion, apareamiento, trabajos y ene. migos. Moufet dijo en $16 \hat{34}$ que era señal de cobardia y de. bilidad despreciar las aranas, y una pobreza de espiritu no admirar sus bonitas obras, 6 retroceder 1 la vista de una teje. dorn tan lábil.

CARACTERES. - La estructura cxterior es tan conociสn, que al ver las ocho patas de su cuerpo, dividido en solo dos partes, sin mas segmentos, se está seguro de tener á la vista uná arafia. Ėn la cara superior del cefalotórax se encuentran los ocelos, parecidos á perlas montadas. Debemos fijar la atencion en su numero, posicion, distancia, tamaño y direccion para distinguir los muchos géneros. El número de ojos es en la mayor parte de las arañas de ocho, pero tambien se encuentran seis, en raros casos dos y en algumas especies que habitan debajo de tierra (Anthrobia mammuthico, Stelita te. uaria, Hadites fegenarivides), no existe ninguno. Las antenas miaxilares se componen de un artejo bucal fucrte, surcado en la cara interior y de ntro en forma de garra recogible, que lo mismo que el diente venenoso de las serpientes, está perforado. Dos glándulas venenosas en forma de bolsas ciegas lon. gitudinales segregan un penetrante liquido que se inocula en Ia herida hecha con aquellas garras. Los palpos maxilares se componen de seis artejos y forman en su base, como en los escorpiones, la mandibula inferior misma. En estos palpos se advierte una particularidad propia de tedo el órden. En la hembra acaban siempre en una garra provista ó desprovista de dientes, mientras que esto mismo sucede rarns veces en el macho, en el que, al contrario, el artejo de la extremidad se ensancha poco a poco en forma de maza, la cunl está llena en su inicrior de un liquido semi-trasparente. Despues de la penúltima muda se forman en el macho los conductos espermáticos que oirecen viria conformacion y salon des. pues de la última muda à la superficic por medio de una hendidura de la piel exterior. El artejo anterior toma mas ó me. nos parte en esta tmsformarion por el desarrollo de cerdas, espinas, dientecitos y otras formaciones córneas. A continun. ción veremos cuál es el fin del citado órgano. El último far de maxilas acaba, lo mismo que las verdaderas patas, en dos garras articuladas en forma de peine y tienen tambien por lo demàs la figura de aquejlas, dividiéndose en sicte artejos, de modo que se consideran como patas, atribuyendo à las arañas sencillamente ocho organos de movimiento. En la base de las cos garras citadas se encuentra la llamada garra rudimenta. ria que solo falta en ciertas especies. En la base del abcómen 
reunido con el cefalotórax por medio de un pequerio tallo se encuentran entre los estigmas que dan salida i las bolsas pulınonares las aberturas sexuales, que en la hembra suelen reunir los estigmas trasversales en forma de hendidura trasversal.

Precisamente delante del ano, que afecta la forma de tubo, hillase en el admirable órgano textil la segunda particularidad de todo el órden. En ghindulas de muy variada forma, que ocupan diferentes posiciones en medio de los intestinos, y de las cuales, segun Siebold, hay cinco clases, prodúcesc un liquido que al aire se endurece en figura de hilo elistico, seco ó glutinoso, ó tambien semejante a un barniz: es como el hilo sedoso que sale del labio inferior de las origas de mariposa. Fin el caso que nos ocupa, la sustancial textil se copelc por numerosos agujeritos microscópicos que hay en las llamadas verrugas textiles, sumilandose í los de un harnero. Casi siempre se ven seis de estas verrugas, pareadas, dos delante, dos detrás, y las dos últimas en los lados, aunque tambien se encuentran en nienor númeru y en formalmuy diferente; por la fuerza muscular se pueden volver hácia adelante $y$ hácia atrás, hácia adentro y hícia fuera, salir ó recogerse. En muchas arainas hay un par de verrugas textiles de varios artejos, que como colitas sobresalen de la extreniidad del abdómen, y que probablemente intervienen en la disposición de los hilos sin jroducirlos de por si. Ins verdaderas verrugas textiles, cónicas ó cilindricas, tienen una base mas grande rodeada de un anillo córneo y peludo y de una superficie algo convexa, que, semejante à un cepillo, estả cubierta de un gran número de puntas de forma particular llamadas cerdas 0 tubos textiles. Estas se hallan a inenudo en anillos regulares, ó tambien están dispuestas irregularmente; las grandes, mas cerradas, forman los orificios de las glindulas textiles ó el barnero. Varian por la distancia que las separa, pór la disposicion y el número, no solo en las diferentes es. pecies sino taubien en las varias verrugas de una sola espiccie. En ciertas obras se exagera el número, como sucede con el cálculo de Renumur, fundado en la suposicion errónea de la igualdad de todas las verrugas. Segun las averiguaciones de Blackwail, en los epeiras asciende cuando mas á mil; en la Tegenariá no pasa de cuatrocientos; en los pardosa saccata ni siquiera llega à trescientos; en los segestria senoculala aje. nas se cuentan ciento, $y$ muchas especies pequeñas tienen aun menos. No debe creerse que en la formacion de un hilo han de funcionar todos los tubos textiles; la araña puede, por el contrario, valerse de uno 6 varios à su antojo, y' segun que el hilo sea para uno if otro fin.

El tegumento de quitina del cuerpo de las araías presenta muy diforentes grados de dureza y es en nuestras especies generalmente mas blando que en muchas cxóticas, entre las que hay algumas de piel muy dura, pero siempre la placa dorsal y el tórar son, despues de las garras, las partes mas sólidas de todo el cuerpo. La superficie esta cubierta de pelos mas ó menos espesos, largos y cerdusos, ó mas gruesos, y entonces aterciopelados; a veces tambien hay espinas que menudo afean mucho el aspecto del individuo. Los colores, por lo regular oscuros, pero a menudo tambien mas claros $y$ abigarrados, parecen impropios para servir de caractéres distintivos, porque son muy irconstantes en una misma es. pecie, sobre todo segun la cdad.

Por lo que toca à la estructura interna solo diré lo siguiente: Sobre el esófago se halla el gran ilion principal soldado con dos nudos nerviosos, y que envia sus nervios á los ojos y à las antenas maxilares. La médula del vientre se compone de cuatro nudos que proveen à las otras extremidades y envian los grandes hilos al abdómen, que se extienden al rededor de los intestinos, órganos sexuales y respiratorios. Estos últi- mos presentan formas mas variadas de lo que se suponia en un principio y difieren en cada especie, de modo que yn no puede admitirse una division en araias con pulmones y arañas con tráqucas, como latreille la jropuso al principio. En la mayor partt de casos, además de los pulmones se encuentran tambien triqueas, por lo cual aquellos se han considerado como trasformaciones de estas, designándoselos con el nombre de triguias de abarico. Fistas se abren en la parte anterior del vientre en dos hendiduras oblicuas, cuyo borde anterior se ensancha formando una prominencia, y cuya pared interna, al principio en extremo delicada, está cubierta despues de hilos de quitina, semejantes a pelos. El fondo de la bolsa pulmonar esta provisto tambien de pelitos sólidos, que alternan con saquitos triangulares planos en número muy variable en las diversas especies, y de este nodo forman la figura de un abanico. Este órgano respiratorio está situado en parte en una ligera depresion de la piel, y cl resto penctra en el cuerpo grasoso del abdómen. Ambas triqueas de abanico estain reunidas por un ligamento en el que se insertan músculos Los migálidos tienen un segundo par de pulmo. nes, cuyos, orificios se hallan detrís del primero, mientras que cn las otras arañas se encuentran, además del primer par, triqueas quie se dirigen sin ramificaciones hasta las extremidades del cuerpo, a las patas, maxilas, palpos y músculos, ó bien ramificadas en forma de árbol, como en los tomisidos, abriéndose hácia afuera en dos estigmas separados, pero con mas frecuencia en una hendidura trasversal por delante de las verrugas textiles. El vaso dorsal que en medio de una placa en figura de hoja vemos en el segmenio abdominal de muchas aranas al trasés de la piel trasparcutc, ananca del nacimiento de aquel, envia un tronco principal hácia el cefalotórax, va. rios tubos interales a las bolsas pulmonares, y tres mas grandes por cada lado hácia el higado, rematando en la partc posterior en un tubo sencillo. los órganos de la digestion comienzan con un esófago córnco en su parte superior al que sigue la panza; detrás de esta el esófago se divide en dos $\mathrm{m}$ mas, que volviéndose hricia adelante reúnense en el esióma. go en forma de anillo. Del estómago parte un corto apéndice, mientras que cuatro largos tubos retorcidos llegan hasta el nacimiento de las patas, donde se vuelven haicia abajo, reuniendose otra vez, y enviando hácia atrás dos ayendices en forma de intestino ciego. Por el abdómen se corre un intestino sencillo rodeado de numerosos lóbulos y lobulitos y de un higado pardo que vierte sus secreciones en aquel. Por debajo de los lobulitos del higado se ramifican los tubos que segregan la orina y que inmediatamente desembocan en el intestino ciego por debajo del ano.

USOS, COSTUMBRES Y REGIMEN, - Como mpaces que se alimentan de toda clase de insectos, las aranas no pueden vivir sociablemente, sino que deben permanecer solas, haciéndose aun la guern en ciertas circunstancias. Lcvingstone encontró en el Africa meridional una especie reunida con inuchas de sus semejantes, y sus nidos juntos en tal nu. mero, que el tejido ocultaba del todo el tronco del árbol ó las ramas de una espesura. "lambien Darwin habla de un gran epeira negro con manchas de color rojo en el dorso, que en considerable número vive sociablemente cerca de Santa lie, en los Estados de la Plata, donde fabrica, como todos los cpeiridos, un - vido vertical; cerca de este se ven algunos mas, separados uno de otro por espacios de unos $6_{3}$ centimetros, pero reunidos por medio de hilos comunes de mucha longitud. Esto es lo que observó Darwin en unos grandes arbustos que estaban rodeados de nidos, y no pudo inenos de admirarse al ver esta armonia de las arañas. 'leniendo en cuenta, sin embargo, que en aquellas regiones, tan abundantes de insectos, elalimento nunca escasea y que tambien 
en muestros paises se aglomerari en sitios farorables los nidos de otras especies, no debemos reconocer en este fenómeno ni siquiera una excepcion de la naturaleza envidiosa de las aranas.

La araña pertenece a la clase de tejedores pobres, y tmbaja como estos para ganarse la vida, pero debe economizar el material y el alimento cuando abundan, porque cuando es casen tambien hay poco de aquel, y porque el hilo una vez. salido del cuerpo no puede volver á él. A reces podria pare. cer lo contrario cuando la arana sube por un hilo que se acorta siempre, pero luego se verá que lo recoge con las patas y lo lleva consigo. Así como en las diversas avispas, cada cual construye el nido á su modo, y así es que tambien difieren las arañas por su manera de tejer. Las unas, como el conocido cpeira comun, hacen una rueda; las otras, como la araña doméstica, fabrican un tejido mas espeso, y algunas forman con el suyo como una bolsa, etc. Además de estas arañas, hay otras muchas que no se sirven de lazos para cn. ger su presa, sino que la acechan al descubierto en sitios convenientes, apoderandosc de su victima á la carrera ó al salto. Las arnnas tejedoras se aprovechan de su habilidad para bajar por un hilo cuando quieren trasladarse de un sitio a otro: muchas especies vuclan con ayuda de estos hilos en los hermosos dias de otoño, franqueando largas distancias por el aire. Pero todas sin excepcion, es decir las hembras, se sirven de los tejidos para resguardar los huevos, porque á pesar de su crueldad, pueden servir de verdaderos modelos en cuanto al carino hácia su progenic. Menge, que observó la puesta minuciosamente en dos casos, la describe del modo siguiente. Cuando umn hembra conoce que llega su ticmpo, prepara un nido hemisférico de hilos, bien libres como en las amñas corredorns, ó ya fijos en el tejido 6 en otro lugar conveniente. Cuando el nido está acabado, la hembra se pone encima, y seguidamente salen los huevos de la abertura de Ia vagina, formando un montoncito redondo. Al cabo de po. cos momentos de descanso lanza algunos hilos, pero por los movimientos inseguros $e$ indeterminados nótase que aun no tienen por objeto tapar la puesta, y que aun se han de hacer otras cosas importantes. De repente, la hembra coloca el vientre otra re\% sobre los hucros, y por la hendidura de la vagina expele un liquido claro con el cual los cubre, y que es absorhicio al punto por cllos sin que se moje el tejido. Con este baño, los huevos aumentan de volúmen de tal modo que ya no cabrian en el vientre de la madre. Menge cree que el línuido proviene de las bolsas espermáticas, entonces muy ensanchadas: que está merclado con la esperma del macho, y que soles de esie modo se verifica la verdadera fecundacion. Por lo pronto la araña queda inmóvil y cansada sobre los lineros, pero despues taja el nido con su tejido. Esta cubierta solo es sencilla, pero muy espesa en las arañas corredoras, componiéndose de dos capas hemisféricas ligeramente reunidas; la madre la fija por algunos hilitos cletajo del vientre y la lleva consigo; muy pocas especies abren agujeros sub. tcrríncos para permanecer en ellos hasta el nacimiento de la progenie. Tambien varias especies de las que construyen re. des fabrican nidos pam los huevos, que penden en sitio se. guro, y los vigilan ó bien los llevan consigo. Todas estas aranas ponen sus huevos generalmenter mediados del verano, y los hijuelos salen al cabo de tres ó cuntro semanas, cuando la temperatura es favorable. I.os atfidos, tsibilelos y orbitelos ponen sus huevos casi siempre a fines del verano, colocando su nido en sitios abrigndos, donde invernan. De estas arañas, algunas que aun no han llenado el objeto de su vida, pasan alguna ve\% el invierno, mientras que la cria, aun no adulta, de las otras, permanece dumnte el invierno aletargada en los escondires ordinarios.
Degeer, que observó la salida de los huevos, no dijo sin razon que la ciscara es la primera piel de la araña y el naci. miento la primera muda, pues con el desarrollo del embrion, el contenido del huevo su cáscara son por fín la jequeña araña misma; pero aun no puede moverse, porque la cásca. ra la oprime. Rómpela jor fin la parte anterior del ccfalotórax con sus repetidas dilataciones y contracciones, y la cabera, cubierta de una nueva piel con los ojos, es ya visible; poco despues aparece todo el cefalotórax con las patas, y por último el abdómen. Este rodea el resto de la yema; la araña recien nacida, aun débil, está rigida; estira sus palpos y patas, mas apenas se mueve, y no puede tejer ni correr, pues los órganos que sirven para esto se hallan cubiertos por la

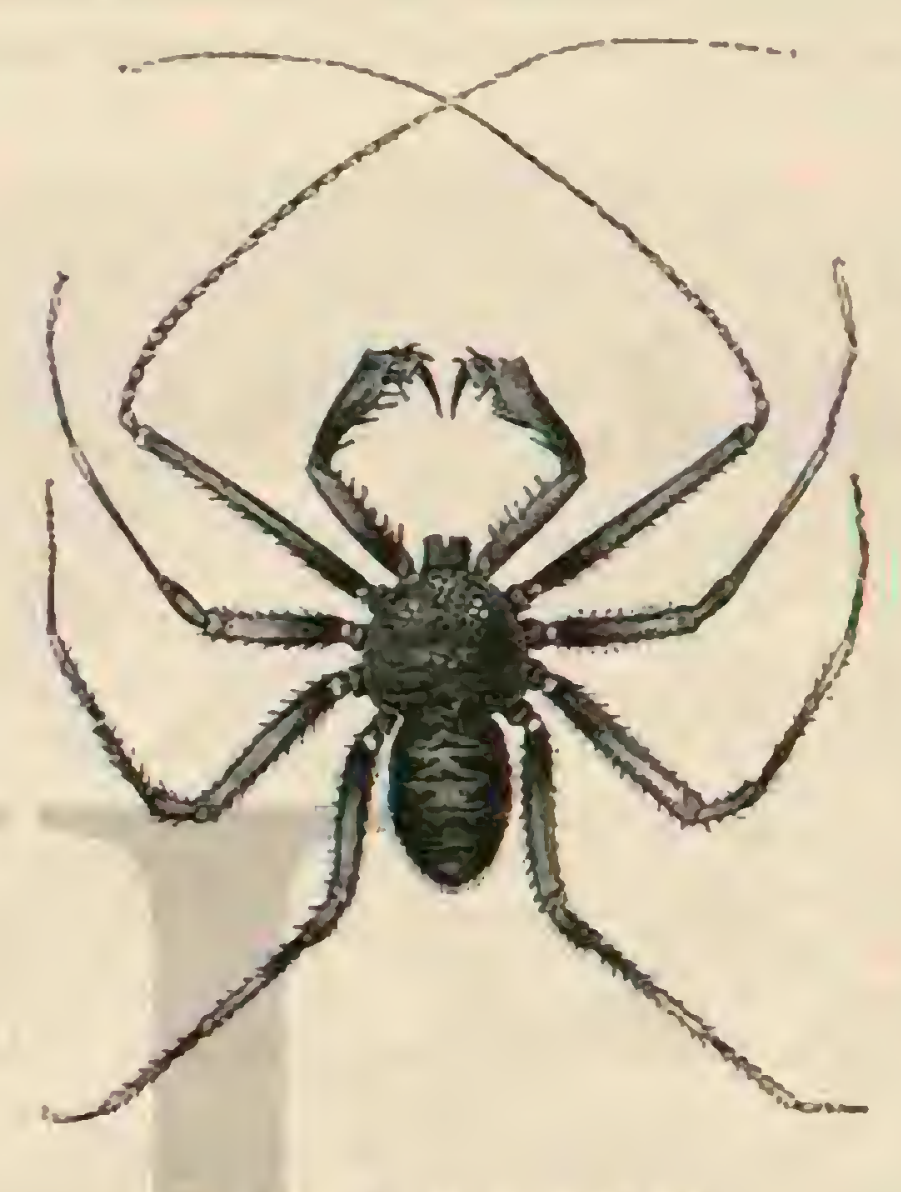

lig. 177. - EL FRINO PALAEADO

piel; desarrollada en lo demis del todo, no le es posible sin embargo abandonar su cuna hastil que sufre una muda completa que segun la iemperatura se verifica en unos ocho dias. Despues de mudar descansa poco ticmpo para recobrar las fucrzas; algunas horas despues comienza i pascarse alegre. mente, teje sus hilos y ejerce su oficio de rapaz. Mudando repetidas veces las arañas crecen rapidaniente, si el invieno no ocasiona una tarcianza. Es dificil averiguar cuảntas veces mudan, porque las observaciones seguras solo jueden hacerse en las arañas cautivas, de lns cuales las mas perecen si no pueden obtener su alimento exactamente como lo obtienen en libertad. Por lo regular se supone que con la cuasta muda se completa el desarrollo y que cntonces las extremidades perdidas no vuelven a reproducirse.

La manera de aparcarse estos insectos no está bien explicada todavia; pero de las observaciones hechas resulta lo siguiente: Cuando el macho quiere aparearse se acerca con gran prudencia y lentitud á la hembra para reconocer si esta aceptarí sus caricias, ó si le considerara como buena presa para devorarle. I a hembra indica sus sentimientos amistosos colocandose boca arriba, desjues de lo cual el macho se aproxima, y con las dos puntas de sus palpos, que sirven de intermediarias para trasladar la esperma, teniendo en las di. ferentes especies rariadas formas, loca la vagina de la hem. bra en la base del vientre; en este acto la extremidad de los palpos se dilata marcadamente, y mientras dura ambas partes no hacen caso de los objetos que las rodean; la misma manio. bra se repite varias veces con breves intervalos; pero despues el macho se aleja presuroso para no ser devorado por la hem. bra. Esto es ln que se ha observado en orbitelos jo tubitclos, 
pero no se vió que el macho tocara con las puntas de sus palpos en la base de su vientre para proveerse alli del licor prolííco. Por eso se arraigó la opinion de que en dicha parte no hay ningun orificio, y que las bolsas espermáticas, poco retorcidas, se comunican interiormente con las puntas de los palpos maxilares Sin embargo, esto no es exactu: la abertura sexual no lalta en la base del vientre ciel maclso.

Conócense actualmente unas mil especies de arañas, diseminadas por toda la tierra; algunas especies (Lycosa blanda, Melanophora blanda y otras) se encuentran hasta la altura de 3,125 metros sobre el hivel del mar, aunque prefieren los paises cúlidos a los frios, segun lo demuestra la rariedad de arañas, algunas muy grandes, que habitan aquellas regiones. Decididamente el número de las especies conocidas no llega ni con mucho a las que en rèlidad existen, pues últimamen-

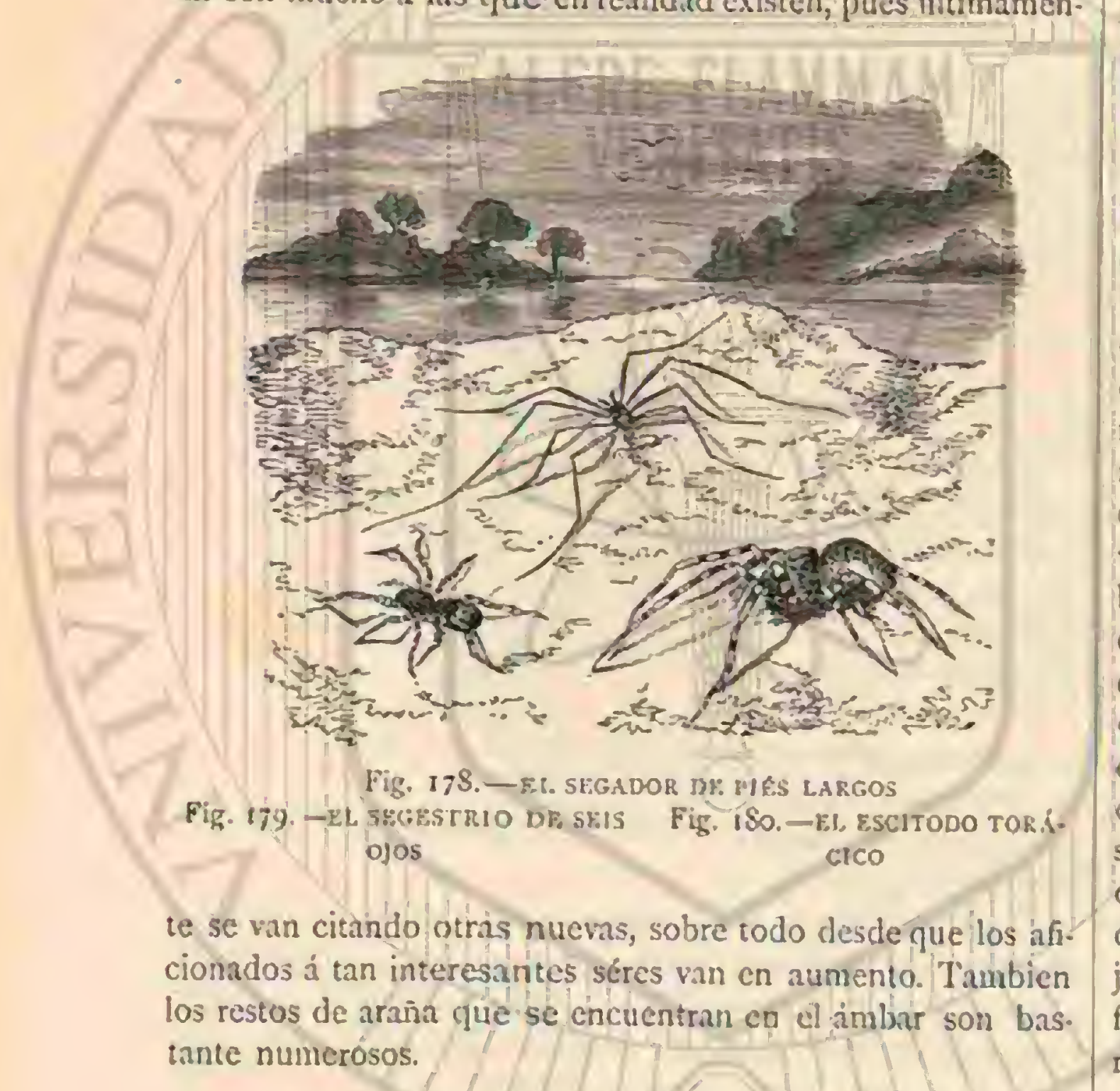

\section{LOS MIGALIDOS - MIGALID左}

Estas son las mas grandes de todas las amnas, pues su cuerpo mide $00^{\mathrm{m}}, 05$ o mas, ocupando, no obstante, cuando exticnden sus patas gruesas y peludas, un espacio lungitudinal de $0^{\prime \prime}, 18$. Viven en los páses cálidos de ambos hemisterios y se conocen bajo el nombre de arañas asesinas, de bosgick ó de pijaro (Mygrale), porque la señora Merian, Palisot de Beaubois y otras las acusan de haber devorado pajarillos, tales coma los colibrís. Otros maturalistas han negado el hecho, pero á decir verdad es innegable. Bates vió á una de estas arañas apoderarse de tal presa, aunque no puede decir si era cl migale comun ú otro de sus numerosos congéneres. Sobre la profunda hendidura de un grueso tronco de arbol veiase una téla de araña muy sólida y de color blanco, de cuya parte inferior, algo desgarrada, pendian dos pajarillos (fringilides). El uno estaba ya muerto; el otro, situado debajo del cuerpo de la araña, parecia moribundo. Cuando Bates hubo espan. tado al insecto cogió la avecilla, que pronto murió en sus manos, cubierta de un líquido sucio semejante d la saliva "que el monstruo habia expelido. Bates dice que su obser. mcion habia sido nueva para los habitantes del Amaronas, que llaman á estas arañas, mada cscasas en el pais, aranhas carangucxeiras (arañas cangrejeras). Es de suponer, sin embargo, que no muchos migálidos pueden alimentarse de pajjaros, porque las menos de las especies son las que viven en árboles y arbustos, habitando las otrns en agujeros de los muros, en los techos de las casas y las paredes, ó debajo de las piedras y en galerias subterráneas. Por este último concepto se distingue una especie de color pardo, el my yale biondii, que se reconoce fícilmente por las fajas amarillas de las patas, $y$ la cual es propia de la América. Esta especie, que habita en galerías subterráneas, tapiza espacios de hasta $\|^{\circ}, 60$ con un tejido sedoso, poniéndose por la noche al acecho en la entrada; pero al acercarse un hombre se retira al interior de su guarida. Tambien en el Africa meridional los migálidos que habitan debajo de las piedras parecen ser mas numerosos que los que viven en los bosques. Con gran agilidad y saltando procuran escapar cuando se les quiere coger, y están siempre dispuestos á introducir sus afiladas garras maxilares en el dedo que hallen á su alcance.

El primer antor que habló de los migálidos, llamados por los brasileños Nhamdu gunacu, fue Jorge Maregrabe, natural de Sajonia, que en ${ }^{6} \sigma_{3} 6$ fue al Brasil con el conde Juan Mnuricio de Nassau-Siegen, à quien los holandeses habian enviado alli con un numeroso ejército para defencter sus conquistas contra los españoles. En la obra médica y de historia natural publicada en el Brasil por Maregrabe, este describe muy bien al migale, diciendo que se alimenta de moscas y otros insectos, y que vive mucho tiempo, pues habia tenido varios individuos mas de dos años en una caja, donde mudaban a su debido tiempo. La piel que dejaban tenia la forma de una araña, porque solo estaba hendida la parte inferior. A esta noticia se agrega la siguiente nota de Juan de Laet: 4. Habia recibiơo una de estas arauas vivas del Brasil, y pro. curé alímentarla con moscas, pero nunca las comió, y enfiaqueciendo poco á por.o, murió á los pocos meses. En su pri. sion no tejia nunca, pero tan luego como encontrabur ocasion de escaparse y llegar à la ventana, comenzaba á tejer. Langsdorf, quien niega que las cangrejeras del Brasil devoren pajarillos, opina que su mordedura produce en el hombre fuertes irritaciones, lo cual confirmó últimamente Fritsch refiriéndose à las especies africanas, pero añadia que no es peligrosa ni mortal, si bien deja una cicarriz nuuy parecida á la que produce una cortadura. Mr. Bates observó que los hijos de cierta familia de indios tenian muy poco miedo á los migálidos, pues una vez los encontró conduciendo un gran migale, atado con una cuerda como un perro, por toda la casa. El naturalista se admiró mucho de este hecho, pues al disecar un individuo, los pelos cerdosos que se le introdujeron en la epiclermis de sus declos causáronle una scrasacion que segun dice jodia volver loco á un hombre.

Hace algunos años que en Dantaig se encontró en un bu. que cargado de carbon: procedente de Inglaterna, un mygale avicularia vivo, que el 10 de setiembre de 1862 se entregó al profesor Menge quien lo conservó casi un año vivo. Repro. duzco las observaciones hechas por este natumlista, con tanto mas gusto cuanto que es muy entendido en esta materia. (1) La araña fué colocada en una gran vasija de cristal cilindrica, cuyo fondo se habia cubierto con musgo y algodon y algunos peclazos de corteza de jino. Por logeneral mantenirse oculta durante el cia, y solo de noche se paseaba lentamente. Si la tocaban con el dedo $\delta$ con una pluma retrocedia rápidamente; intentaba trepar por las paredes de su prision sin lograrlo, y por eso se podia dejar destapada la vasija sin temor de quue se escapara. Poco á poco cubrió el musgo y la corteza con un tejido de hilos finos y blancos, sin fabricar una vivienda para si. Una tegenaria ciallis que se le ofreció el pri. mer dia quedó al punto aplastada por sus maxilas y devorada 
por completo; un segundo individuo de la misma especie su frió la misma suerte, $y$ de un epeira solo quedaron las patas y parte del abdómen : el migálido no hizo aprecio sin embargo de un moscnrdon ni de un opilio, pero devoró en cambio un diplópodo (porcellio scalere). Colocíbase sobre un platito de porcelana que se lé habia puesto en el agua y chupaba el contenido de la victima. El 18 de setiembre se le ofreció una rana de $\left(0^{m}, 04\right.$ de largo, que por la noche aun estaba intacta, pero à la maũana siguiente faltaba ya la mitad. Mascó la rama, reduciéndola a una papilla, la cual engulló con piel y luuesos, pero arrojó estos últimos con los excrementos en pedaros de $0^{-}, 0065$. Poco despues se le dicron dos pequeñas ra nas acuáticas, un sapo $y$ dos tritones, pero todos quedaron sanos y salvos; peor fué la suerte de una pequeña rana terrestre que el $j$ de octubre se ofreció ia la araña; á los pocos mo. mentos esta habia introducido las maxilas y las garras en la parte anterior del dorso, de manera que los ojos del pobre batracio dirigian tristes miradas al vientre de la araina. Esta mascó y chujó desde las nueve de la maủana hasta la misma hora de la noche, dejando esta ve\% los muslos posteriores y los intestinos. Un pequeño sapo que al principio se paseaba alegremente por el vaso, se encontró al cabo de algunos dias con el vientre oprimido contra un pedazo de corteza y como muerto. Al sacarle se vió que estaba atado con hilos y moribundo á consecuencia de algunos mordiscos. Cuando la araña estaba satisfecha oprimin el vientre contra el suelo permaneciendo dias enteros como aletargada. Comió ademàs de las ranas varios escarabajos, de los cuales arrojaba con los excre. mentos los pedazos de la piel, y cuando las ranas ya no po. dian cogerse, algunos comzones de pichon. Al ofrecerle con

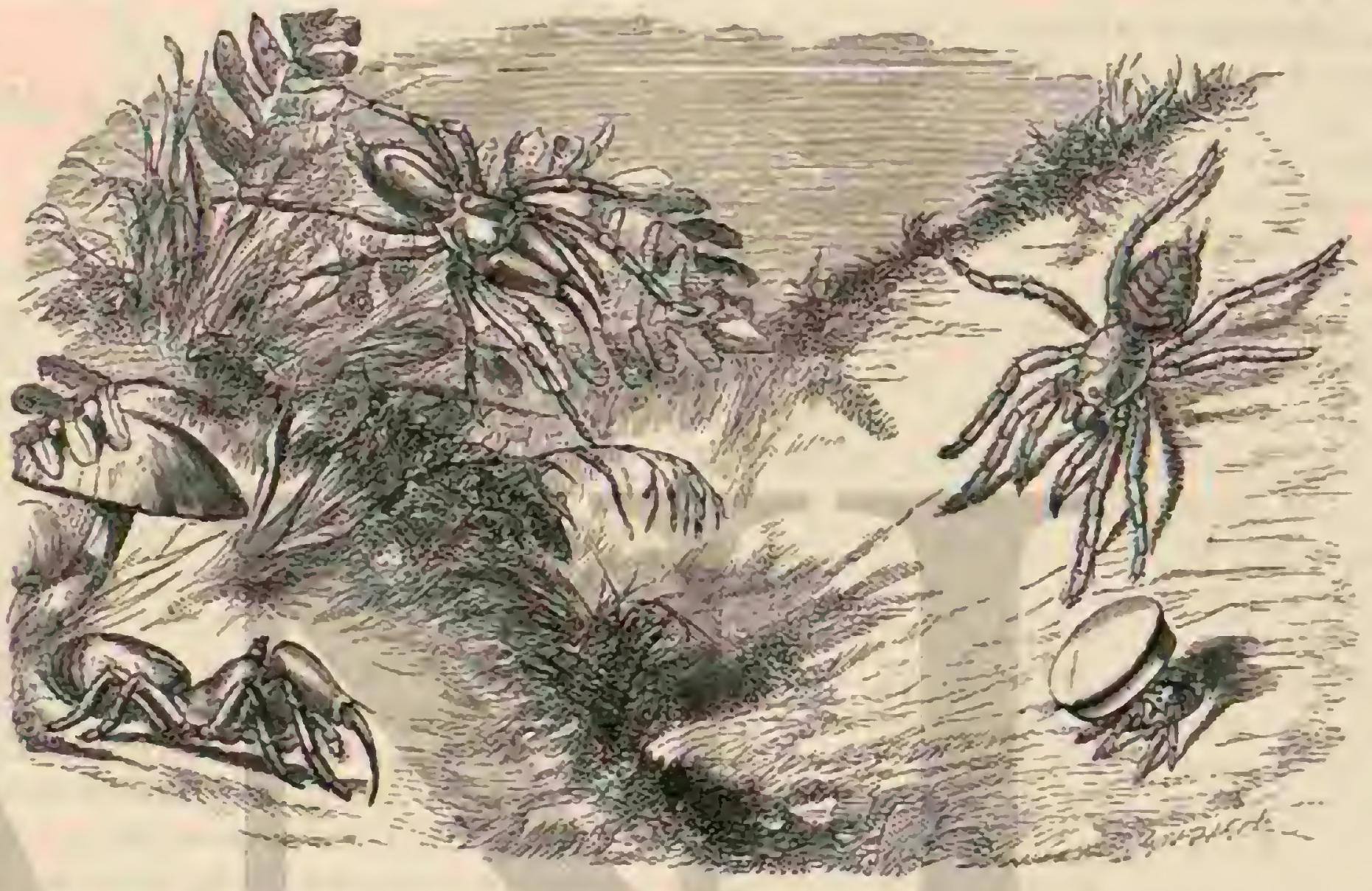

Fig. 1S1.-ES. ATHO COLOR DIS PY?

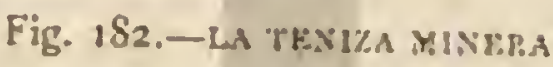

una pinza un cscarabajo ó un moscardon no retrocedia como al principio, sino que se enderezaba y mordia muchas veces la pinza sin tocar la presa que se le ofrecia. En enero de $186_{3}$ se habia roto el músculo del artejo de la garra maxilar derecha de la que desde entonces no pudo servirse, y a partir de aquel dia, tampoco comió. I as arathas domésticas que se habian puesto en su prision y que al principio huyeron espantadas, corrian despues al rededor del migálido, y un macho se atrevió a morderle algunas reces en una de las puatas estiradas, huyendo sin embargo apresuradamente, de lo cual no tenia necesidad, pues el migálido no hacia caso alguno. El ${ }_{3}$ de junio se le ofreció un pajjaro pequeño, pero no lo tocó á pesar de un ayuno de seis meses. Úna hembra cie la arnna domés. tica mordió á la avecilla en la nuca y comenzó á chuparla, llenindose de tal modo de sangre que esta podia verse por la jiel trasparente del ahdómen dilatado. El pájaro tenia una herida de unos $f^{\circ}, 002$ de ancho. y.murió despues, pero en opinion de Menge, menos á causa de la mordedura que por falta de calor y de alimento. Fl zS de julio el migálido estaba boca arriba, conio muerto, pero à la manana siguiente se observo un cambio esencial; la parte anterior del cuerpo habia mudado de piel y cuando despues la araña se hubo desprendido cel todo de ella, el pellejo presentaba la forma de todo el animal excepto el abdómen hendido y seco. Las anienas maxilares $y$ las ancas de las patas anteriores eran del todo blancas; los pelos, antes parduscos, tenian el color pardo negro, y en algunas lineas que se corrian en direccion determi- nada de las patas faltaban dos pamlelas en la parte superior de los muslos, una hateral, y dos en las rodillas y los tarsos; en vez de la garra maxilar enferma veiase una protuberancia an. gulosa. Como la araña habia permanecido todo el dia y aun los dos siguientes sin moverse, se la puso en espiritu de vino, creyéndola muerta; acjuí se movió un pocn, y por lo tanto sacáronla al punto, lavindola con agua, pero entonces murió realmente. 8

El migale esta cubierto de pelo neyro, jardo de hollin ó rojizo en los artejos extromos de sus patas, ensanchados y aplanados. Como caractéres esenciales del género de los migalino5, muy abundante en especies, considémnse los ocho ojos de casi igual tamaño dispuestos en forma de $x$; las patas muy gruesas, cubvertas de largos y espesos pelos, cuyo par anterior es á menudo tan largo como el posterior; el macho se caracteriza por los conductos espermáticos retorcidos en forma de espirales y muy salientes, y por los dos ganchos encorvados en el segundo artejo de los tarsos de las patas an. teriores.

Ians especies del género mygale y otras pocas tienen cua. tro bolsas pulmonares $y$ cuatro estigmas en la base del vientre; solo hay cuatro verrugas textiles, de las que dos son pequeñas; y las antenas maxilares tienen un artejo que se do. bla hácia ahajo y no hảcia adentro contra el de la base. Estas especies constituyen por lo tanto, con algunas afines, en contraposicion de todo el otro ejército de las arañas que solo tienen bolsas pulmonares, el grupo de los tefrafneumunes ó 
arañas de cuntro pulmones, de las cuales las llamadas araros minerns (elenisa) están representadas por pocas especies en Europa y exclusiramente en el sur. listas se reconocen adenás del caracter principal por las patas, adelgazadas ha. cia la punta, por una serie de espinas que hay debajo de las antenas maxilares, y por la placa dorsal de forma oval, re. dondeada yor detrá; los ojos estin dispuestos poco mas ó menos como en el migale.

\section{LA TENIZA MINERA-CTENIZA FODIENS}

CARACTERES. - La teniza minera tiene un cúcrpo par do rojo casi desnudo y ofreci el aspecto de un disclerino. En la punia del abdómen'tlene dos colitas que representan las verrugas textiles antes citadas, en forma do tubu y que no contienen hilos (fig. 182 ).

USOS, COSTUMBRES Y REGIMEN.-La teniza mi. nera, uropia particularmente de la isla de Córecga, fija st domicilio en una pendiente escarpada sin jiedras ni vegeta cion, y porlo tanto, donde no se empape el agua de da lluvia. Aquí abre en direccion horizonial una galeria de mas de ()$^{m}, \sigma_{3}$, bastante ancha, para poderse mover cómodamente, y tapirala con un tejido sedoso parn que no pueda lundirse. Su major arte se muestra en la entrada de este tubo que se cierra por medio de una apa circular provista de una especie de muesca con que cncaja en la entrada de la galeria esta tapa, compuesta cxteriormente de tierra y por dentro de un tejido secososo, esta enlazada en su parte superior con cl tubo, j: se cierra por su propio peso cuando se ha abierto. Sauvage reconoció la significacion de esto: habiendo encontrado una de estas tapas, quiso abrirla con uma aguja, $y$ ob. servo con gran asombro una marcada resistencia; una hendidura le permitió reconocer en el interior una araña que, echada boca arriba, oprimiase con todas sus fuerzas contra las paredes del tulio, sujetando con algunas patas la tapa, th cuyo efecto hay en cl borde de esta unos agujeritos en cl te jido. Cuando despues de ahrir y cerrar varias veces la tapa la araña debió declararese vencida, tetiróse al fondo de su vivienda, pero cada vez que se movia la jucrtecilla salia para sujetarla de nuevo. Sausage sacó por fm la parte anterior del tubo con el cuchillo, y micntras tanto la arana no se movió de la tapa. A no ser para sus expediciones nocturnas no abandiona nunca su domicilio, que gracias a la tapa le ofrece seguridad contra los ataques de los enemigos. En el fondo de la galeria se encuer.tran tambien los luevos, y mas tarde los hijuelos durante su primera juventud, hien vigilados por In madre. Si se la pone à la luz del dia, y sobre todo á los rayos del sol, la teniza uninera sc debiliia pronto z' parece como paralizada.

\section{EL ATIPO DE COLOR DE PEZ-ATXPUS PICEUS}

CARACTERES - En la Europa meridional se encuentran algunos congéneres de la especie anterior, pero tambien mas al norte. y en Alemania se observa, aunque raras veces, una especie de esta tamilia, que es el atipo de color de prea ó el atipo de Sulzer, arania subterrinea de $0^{\circ}, 0175$ de largo, que se distingue por tener el cefalotórax casi cuadrangular, con las garras maxilares muy largas y dos colitas en la cxtre. midad del abiómen (fig. 1SI).

USOS, COSTUMBRES Y REGIMEN. - Yo encontré hace algunos anos en otono una tela de esta especie: el teji do, en forma de tubo, estaba en direccion rertical, en un terreno socasindo por los ratones, y media $0^{\circ}, 34$ de largo por casi $0^{\circ}, 022$ de diunctro. Este tubo cra áspero exteriormente por las particulas de tierra pegadas, pero en el interior fino, tapizado de un tejido sedoso. No he visto aun la araña nisma.

\section{LOS DIPLEUMONES- DIPLEUMONES}

CARACTERES.- Todas las aranas que ahora siguen respiran solo por dos bolsas pulmonares y en patte tambien por triqueas; doblan las garras de las antenas lácia adentro y pueden distingnirse por su género de vida en sedentarias y. r'agahumdas. Las primeras construyen nidos ó habrican cuando menos hilos en los que acechan su presa; las últimas no hacen tejidos, sino que cogen su alimento al paso ó saltando. Las primeras se dividen, segun la diferencia de sus nidos, en varias familias.

\section{LOS ORBITELOS-ORBI- TEL死}

CARACTERES. - Los orbitelos tienen todos ucho ojos, de los que los cuatro del centro, que al mismo tiempo son los mas grancies, están dispuestos en cuadro, 6 bien los de la frente se hallaná mas distancia unos de otros que los de la coronilla; los otros cuatro estàn por pares en los laclos, a mas cistancia. Eil primer par de patas, bastante gruesas, es mas largo que todos los otros y despues signe por este concepto el segundo par. Ia hembra se distingue, excepto en un género (kefraymalka), por su abdómen grueso casi estęrico, y por las garras de los palpos, provistos de varios dientes.

USOS, COSTUMBRES Y REGIMEN. - Los orbitelos tejen telás verticales que parecen una rueda apoyada por radios, estando los títimos reunidos por hilos circulares ó espirales. Al lado de esta red ó en su centro, esperan con paciencia hasta que un insecto queda cogido en ella. A fines del verano, ó en otono, la mayor parte han llegadu con la última nuda à su desarrollo completo; las hembras ponen bolsitas de huevos, envueltos por lo regular en hilos lanosos amarillos en sitios abrigados, y mueren antes de la llegada del invierno.

\section{EL EPEIRA DEDIADEMA-EPEIRA DIADEMA}

CARACTERES. - El cpeira de diadema llamado tambien arnîa de cruz, la especie mas conocida, puede servirnos para formamos una idea de todos estos tipos. Las manchitas claras en forma de cruz sobre fondo parclo claro í oscuro, me\% clado de gris en la parte superior del aboómen, que es grueso $\mathrm{y}$ brillante, han valido a la esprecie su segundo nombre. Ademås tiene otros puntos y manchas de color casi blanco que rodean un espacio triangular. En la parte superior del cefalotórax se ve en cada lado una faja arqueada, y en el centro una recta, todas tres de un color pardo negruzco. Fi macho es mucho mas pequeño, pues solo mide $t^{2}, 011$. En todas las especies del genero chior, muy numerosas en f,uropa, el tercer par de patas alcanza mas de la mitad de la longitud del primero; y en el macho, el conducto espermático, corto y ancho, afecta la forma de un platillo. El primer par de verrugas liene la forma de conos obtusos; el posterior es un poco mas corto y las de harnero se dirigen hicia dentro; el centro es triangular, esta comprinido lateralmente y los harneros se oblicuan hácia adentro (fig. 183 ).

USOS, COSTUMBRES Y REGIMEN. - El epeirn comun vive en jardines, espesuras y bosques de coniferas, en 
la mayor parte de Europa, y fija su domicilio casi siempre at una altura de $0^{\prime \prime \prime}, 031$ a $0^{\circ}, 157$ sobre el suelo, con prefe. rencia en los alrededores de los fosos, pantanos y" lagos, y en gencral de los sitios donde pueden abundar las moscas y mosquitos.

A principios de mayo, los hijuelos salen de los huevos y permanecen unos ocho dias juntos en forma de ovillo, hasta que se ha verificado ia primera muda. $A$ principio la cabeza y las patas son medio trasparentes y blancas; el aldómen de un amarillo rojizo sin manchas; los ojos estin rodencios de anillos rojizos $y$ las patas cubiertas de pelos finos. Con las diversas mudas aparecen poco á poco los dibujos, a los cuales se debe que las arañas adultas sean las mas bonitas de nues. tras regiones. "Tan luego como los hijuelos se han dispersado cada cual fabrica su nido, qué por su pequeñez llama menos la atencion que los de ()$^{*}, 316$ mas de diametro, de los individuos adultos. Ia cleccion del sitio en que debe fijar su vivienda parece inspirar algun cuidacio á la araña, pues corre mucho tiempo por los objetos antes de comenzar su obra, y en efecto debe mirarse mucho, porque segun el sitio ha de proceder de un modo diferente, antes de tender los hilos exteriores que forman el marco para todo el tejido, afectando la figura de cuadràngulo $\delta$ triånguio. Por lo regular fija un hilo en un punto elevado, y bajando por él, imprimele la direccion conveniente, en cuya operacion su cucrpo se bambolea de continuo.

De gran importancia es el primer hilo trassersal interior; para tenderle como una cuerda entre dos troncos de pino distantes quizis of centimetros uno de otro, la arañ debe logmr su fin por dos medios diferentes. En un caso ha de fijar el hilo en el segundio árbol, avinzando á pié, aunque la distancia sea muy grande, pero entonces el hilo se haria demasiado largo. Se sabe que ciertas arañas producen hilos por las verrugas textiles, lanzindose despues al espacio con ellos; el epeira de diadema puede producir quizas tambien tal hilo y esperar hasta que su extremidad libre se fije en un objeto distante. Kerby nos habla de una interesante prueba que hizo para obtener una seguridad por este concepto. Puso un epeira de diadema en un palo de cuatro piés de largo, colando éste en medio de un vaso con agua; la araña bajó por el palo con su hilo, pero al tocar con las patas anteriores el agua volvió á subir. Esto se repitió varias reces, hasta que cansado el observador, abandono al insecto algunas horas. A su vuelta no le encontró ya en el palo, pero observó que desde la punta del mismo se dirigia un hilo a un armario distante 2 centimetros. Kerby encontró alli la araña, y condenóla a repetir la maniobra, poniéndola otra vez en el palo despues de quitar el hilo. Al principio empe\%ó á subir y bajar por el palo, pero al fin descendió en dos hilos, que imantenia separados con las patas posteriores, y llegando al suelo rompió el uno, dejảndolo Rlotar. Kerby, no qqueriendo confiar å la casualidad ci fijar este hilo flotante, recogió su cxtremidad con un pincel y le arrolló algunas veces, tendiéndole despues bien tirante. Ja arana, que mientras tanto llegó otra ver.á la punta del palo, examinó cl hilo con las patas, y como le pareciese bastante seguro avanzó -por él, reforaándole con nuevos hilos parn llegar sin accidente al pincel. El otro medio de llegar á un objeto distante consiste en colgarse la arana de un hilo en el que comienza a bambolearse y continuia hasta llegar al punto deseado. Cuando por fin el marco está construido de uno ú otro modo, la amña, corriendo por él, forma un diámetro desde cuyo centro construye los radios, reuniéndolos despues por círculos. El primero contiene poco mas ó menos ia extension que puede ocupur con las patas estiradas, y se compone de hilos secos, mientras que los otros son glutinosos con unos nuditos muy finos y numero- sos, para que los insectos que se acerquen queden cogidos mas fácilmente, como el pajjaro en la liga. Una red de $3^{6}$ i 39 centimetros de diámetro contiene, segun cailculo aproximado, 120,000 de esos nuditos.

La red queda terminada y aunque los radios y circulos no parecen hechos con exactitud matemática, no son por eso menos admirables, sino un clocuente testimonio del extroordina. rio instinto artístico de la araña. Esta construccion tro sirve para cuidar la progenic, sino para la conservacion de la vida, tanto del macho como de la hembra. En medio de su tejido, que por lo regular queda terminado en una noche ó un dia, despues de una ligera liuvia en los meses de mayo ó setiembre, el epeira de diadema pernanece con la cabeza inclinada, ó si le conviene mas sitúase en una extremiclad de la red, de. bajo de una hoja 6 en otro sitio abrigado que siempre está en comunicacion con el centro por unos hilos muy tendidos, los cuales sirven de alambres telegrificos, anumciando al punto à la ariña la llegada de una presa. Cuando una mosca ha terido la mala suerte de chocar con la red, enredándose mas y mas al esforzarse por recobrar la libertad, la amna se precipita desde su acecho, pero á intervalos, porque siempre obra con prudencia y llega pronto al centro. Descie aqui se dirige al punto donde la mosca patalen con todas sus fuerzas, pero ya comienza á cansarse, y le aplica un mordisco que pronto la deja inmóvil. Segun las circunstancias procede de un modo diferente: cuando tiene mucha hambre empieza en seguida á comer ó bien rodea la inosca con una aucha faja de hilos dejándola pendiente por lo pronto; a veces se la lleva d su escondite para comerla alli con toda comodidad, mascándola y chupaniola despues mezclada con saliva. Por eso se encuentran pedacitos de quitina en los excrementos, del tamano que lo permite la abertura del esófago. También se ha observado que cuando una araia ve en su tela una presa que no le conviene, ayúdala cuanto puede para que escape, rompiendo aligunos hilos. Esos pequeños mosquitos que a veces en gran número cubren toda la red y disminu. yen la fuerza glutinosa de la misma, no solo ofrecen poco alimento á ia araña, sino que tambien la obligan á dejar su tela y fabricar otra. No tiene auxiliares como algunos epciridos de las Indias occidentales en cutos nidos Darwin encon. tró arañitas que sin ducla se alimentan de los cautivos que á la propictaria de la tela perecen demasiado pequeños. Algu. nos observadores afimman, y otros niegan que el epeira de diadema remienda una red rota; yo creo que, asi como la araña misma, conoce mejor la conveniencia de un sitio que el observador humano; en ciertos casos preferirá componer el tejiclo, mientras que en otros fabricará uno nuevo. Ia ma. ncra de proceder del epeira de diaclema difiere mucho en el caso de peligro segun las circunstancias. El medio de que sucle valerse para escapar consisic en bajar por un hilo, del cual queda colgada en el aire cuando esto le parece suficien. te, $\delta$ bien se deja caer al suelo fingiéndose muerta, para volver despues tranquilamente a subir. 'Tambien he observado que por un ancho hilo llega al suẹlo y emprende despues rápidamente la fuga a la carrera. Este uiltimo medio parece emplearlo cumado la sorpresa es inesperada Es muy probable que uno de los medios de que. esta especie se vale para librarse de un enemigo, que observó Darwin en una araña brasilena, y jue podemos ver igualmente en nuestro equeira, consista en agitar todo el tejido con tal violencia, con un movimiento tembloroso de adelante atrás, que casi desapace a la vista del observador. Firitsch nos labla de un orbitelo africano que se distingue tanto por su tamano como por el brillo de sus colores; dice que es poco mas $\delta$ menos tres veces mas grande que nuestra araña de cru\%: que presenta en su abdómen, escotado en los bordes, unas fajas oblicuas 
de color amarillo de naranja ó negro; y que cuando se columpia en su ancha tela, estirnndo sus largas jnatas anilladas de rojizo y de negro, ofrece un aspecto mangnifico.

En otono, las arañas de cruz abundan mucho en ciertas regiones, encontrándose por cada macho de diez a quince hembras. Ratzeburg observó el 15 de setiembre el apareamiento, y sobre él nos dice poco mas ó menos lo siguiente. A la hora del medio dia, siendo el tiempo hermoso, vi en un claro del bosque una pareja de arañas que parecian en. ienderse; la hembra bajó poco a poco del centro de su tejido, saliendo al encuentro del macho, que respetuosamente esperaba en una extremidad de la tela, sin atreverse a dirigirse hácia el centro. Despues la hembra se colocó boca arriba, con la cabeza dirigida hácia adelante y recogiendo las patas cual si estuviese nuerta. El macho avanzó ilgunos pasos en
In misma posicion en que se hallaba la hembra, it la cual examinó abrazánclola desde abajo con sus largas patas: he cho esto, que sin ciuda era una caricia, la cual duró un cuarto de hora, el macho saltó de repente sobre el pecho de la hembra, naturalmente boca abajo; levantó su abdómen y tocó con la punta de los palpos la vagina de la hembra Al cabo de medio minuto bajó, alejándose presuroso, mientras que la hembra se dirigia lentamente hácia su tela. Pasado un cuarto de hora repitióse la misma maniobra, con la dife. rencia de que el macho, despues de dar varios saltos sobre el pecho de la hembra, volvia á retirarse cada vez. Esto duró poco mas $\delta$ menos una hora, pasada la cual la hembra volvió á su sitio y el macho se dirigió à una icla próxima, donde permaneció quieto aquella tarde y la mañana siguiente. Ratzeburg alega que esto último no puede ser exacto, porque
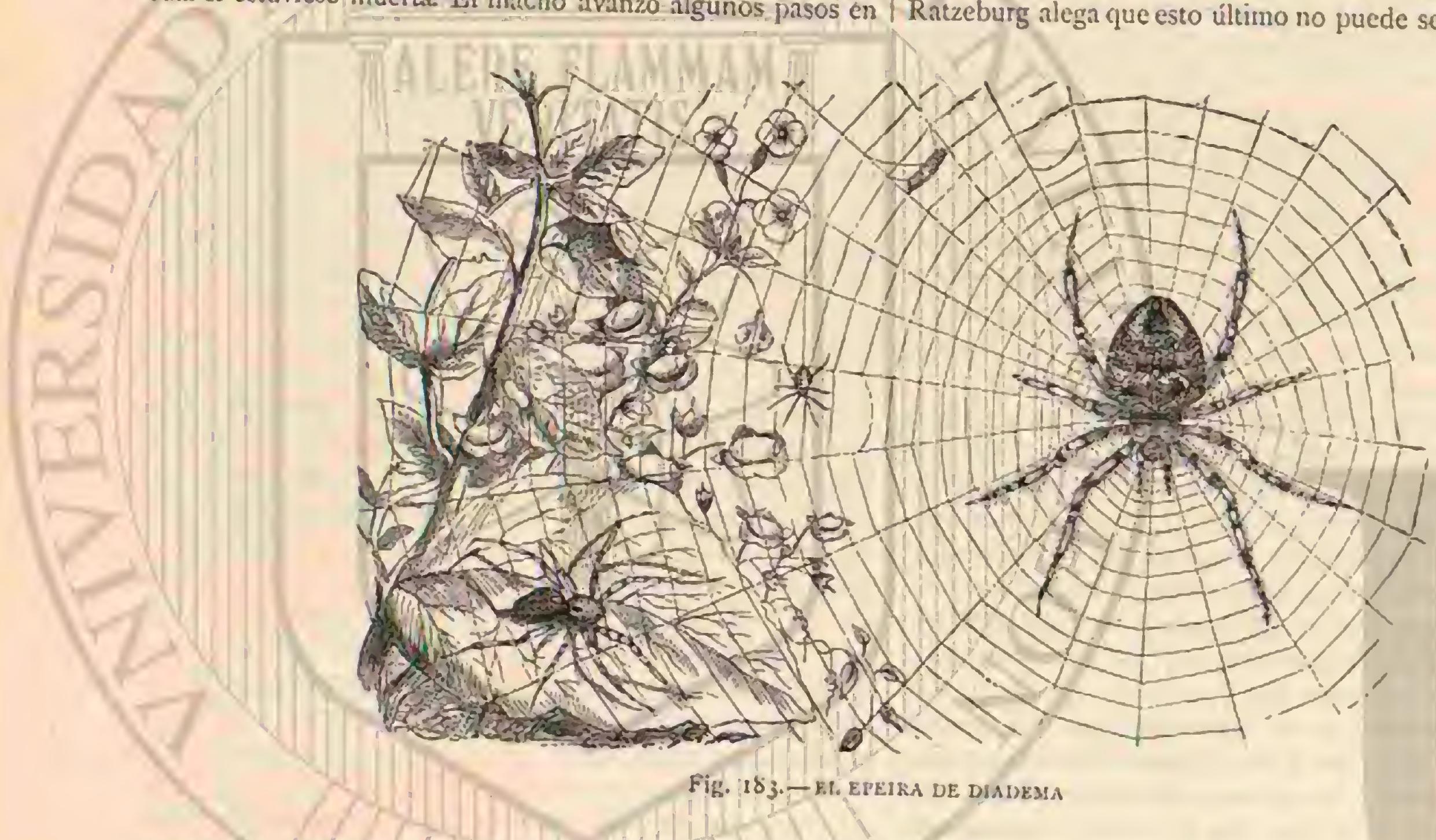

supone, sin razon, que el macho no fabrica telas, sino que
obscrva una vida vagabunda Las noticias de Menge sobre el mismo asunto difieren en algunos puntos poco esenciales; de manera que no parece haber poreste concepto completa regla fija. A fines de otono los huevos, de color amarillo, se depositan en un sitio abrigado; el abdómen de la hembra enflaquece de tal modo que casi no se la reconoce: y antes de llegar al invierno la araña muere. Los cpeiras de diadema, que en invierno se encuentran muy raras veces debajo de la curteza de los arbolès 6 el musgo, son individuos que no han llegado id desarrollarse.

Del género efeirn existen aun especies del mismo tamaño en Europa; hay otras mas pequeñas como el epeira bicornio (fig. $1 S_{4}$ ) que abunda en Alemania y Francia, y otras por fin se han distribuicio últimamente cnire otros géneros que se distinguen por la posicion algo diferente de los ojos y otros caractéres.

\section{EL TETRAGNATO EXTENSO-TETRAGNA- THA EXTENSA}

CARACTERES. - Esta especie se distingue entre los orbitelos particularmente por tener el abdómen muy prolongado, las patas muy largas, que se prolongan hácia adclante en estado de descanso y las posteriores hácia atris, sucediendo lo mismo con las antenas; los ocho ojuclos, iglales entre si, es. tin dispuestos en dos series; aparendos uno tras otro y a

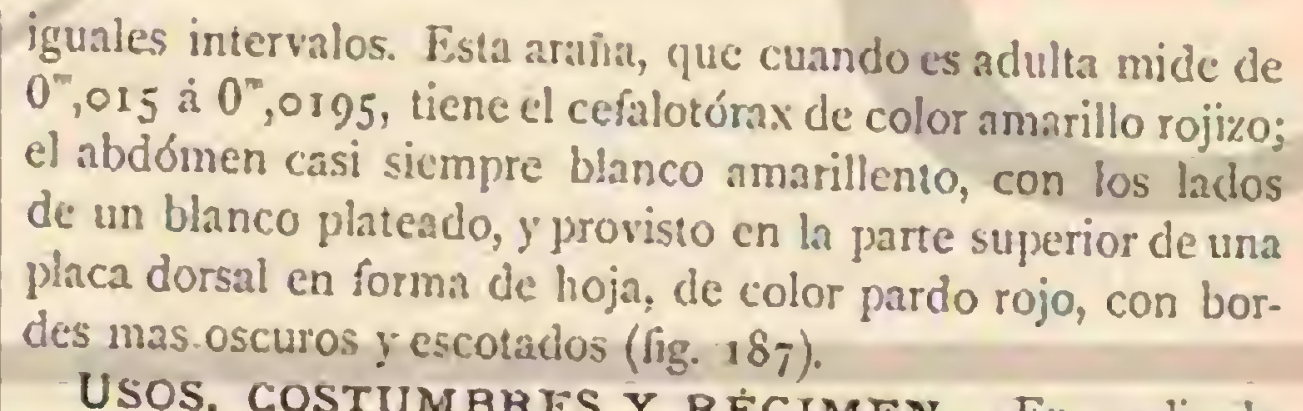

USOS, COSTUMBRES Y REGIMEN. - En medio de los tallos de cañas, cocos ú yerbas, a orillas de los jantanos u otros sitios humedos, esta esperie fabrica una red vertical en cuyo centro ó cerca de la misma acecha su presa. Cuando se la quiere coger huye con la rapidez del rayo y se oculta delajo de las hojas. Igual ligereza y audacia suele ciesplegar para coger su presa, a la cual nunca rodea de hilos. A mediados del verano los individuos son adultos; en el apareamiento el macho se coloca debajo de la hembra con la extremidad del abdómen levantada, mientras que su compañcra inclina la suya un foco hácia abajo. El macho no demuestra ningun temor de la hembra, jo es al contrario, impertinente. los hueros se depositan en un nido hemisférico situado en un tallo, y los hijuelos salên a luz en el inismo año; á veces vuelan colgados en hilos por el aire, y se ocultan a principios del invierno en las cañas.

\section{LOS GASTERACANTOS-GASTE- RACANTHA}

CARACTERES. - Lin los paises cáliclos de ambos he- 
misferios viven nunerosas especies de orbitclos en extremo particulares, de los que los gasseracantos son quizás los mas diseminados. Su abdómen, mas largo que ancho, visto por arriba, parece una hoja de quitina aplanada, con varias depresiones en forma de cicntrices; y en el borde hay à menudo espinas cortas ó largas. Lns patas son relativamente cortas, y los ojos están dispuestos como en nuestras amias de cruz, cun la sola diferencia de que los ojuelos de la coronilla están nas desviados. Segun los coniomos del cuerro obsérvansc las figuras mas variadas: en una especie (gasteracantha orcuata), el aparato textil sobresale en forma de una espiga obtusa en la cama inferior del vientre, que presenta una protuberancia trastersal; y las largas espinas encorvadas que se hallan en el centro del borde posterior del abdómen difieren por su forma mas 6 menos corva en los diversos individuos.
Esta especie tiene un color de sangre claro; cl cefalotórnx, q̧ue es peludo, y el aparato textil son de un neuro brillante, mientras que las manchas en forma de cicatrices en la parte superior del dorso, $y$ las seis esplinas, cuyo primero $y$ ultimo par parecen puntas, son igualmente negras, con un viso rojo.

La especie vive en Java, donde parece abunda, pues hace algunos años se recibieron de alli numerosos individuos para el muséo zoológico de Halle.

\section{LOS TERIDIDOS-TERI- DIDE}

CARACTERES. - De los ocho ojos desiguales los cuatro del centro están dispurstos en cuadro, pero los de la frente

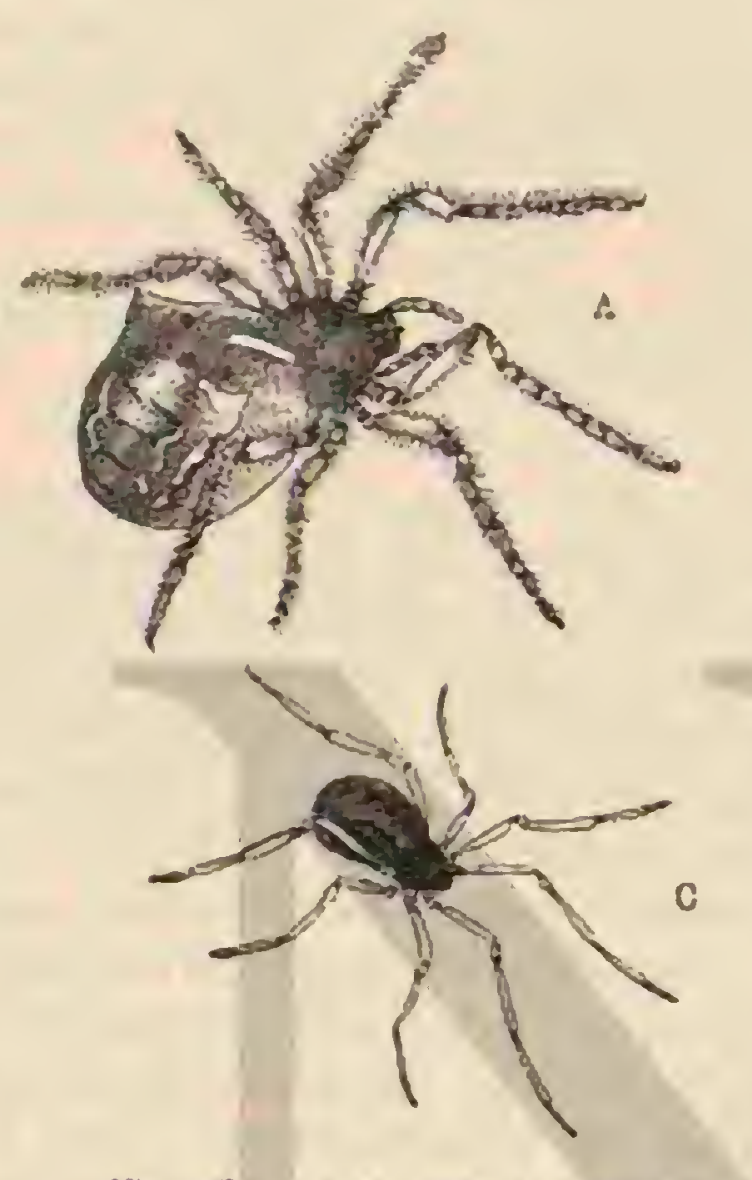

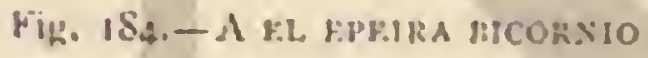

Fig. 1S5. - B EL I.1SHHO MONTANES

estản mas próximos entre si que los de la coronilla, mientras que los pares de los lados casi se tocan. El abdómen es en la mayor parte de las especies muy ronvexo; las patas del par anterior son mas largas y delgadas que las otras, ofreciendo desples mayor longitud el cuarto par, luego el segundo, y por fin el tercero.

USOS, COSTUMBRES Y REGIMEN.-LOS terididos ó aranas tejedoras fabrican en la espesura ó entre la yerba una tela horizontal, cuyos hilos se corren sir órden en todas direcciones y que forman un nido bajo el cual en el periodo del celo el macho y la hembra viren sociablemente, pero fuerat de este tiempro solos; otras especies tejen hilos aislados horizontales ó verticales, ó tambien los arrastran en pos de si sin tejer un verdadero nido (pachygnatha), pero los que tejen con mas abundancia, fabrican debajo de la cubierta una pequeña red horizontal en forma de rueda, y junto á ella, en verano,-una tela en forma de campana para la cria $y$ en la que la hembra guarda uno ó varios inontoncitos de huctos. Todas estas arañas suelen agarrarse boca arriba con las patas en la tela, acecharido en esta posicion su presa, de modo que con razon puede decirse que viven debajo de su red.

\section{EL LINIFIO MONTAÑÉS-IINYPHIA MONTANA}

CARACTERES. - Esta especie se asemeja poco mas ó menus al tetragnato extenso, pero solo alcanza una longitud
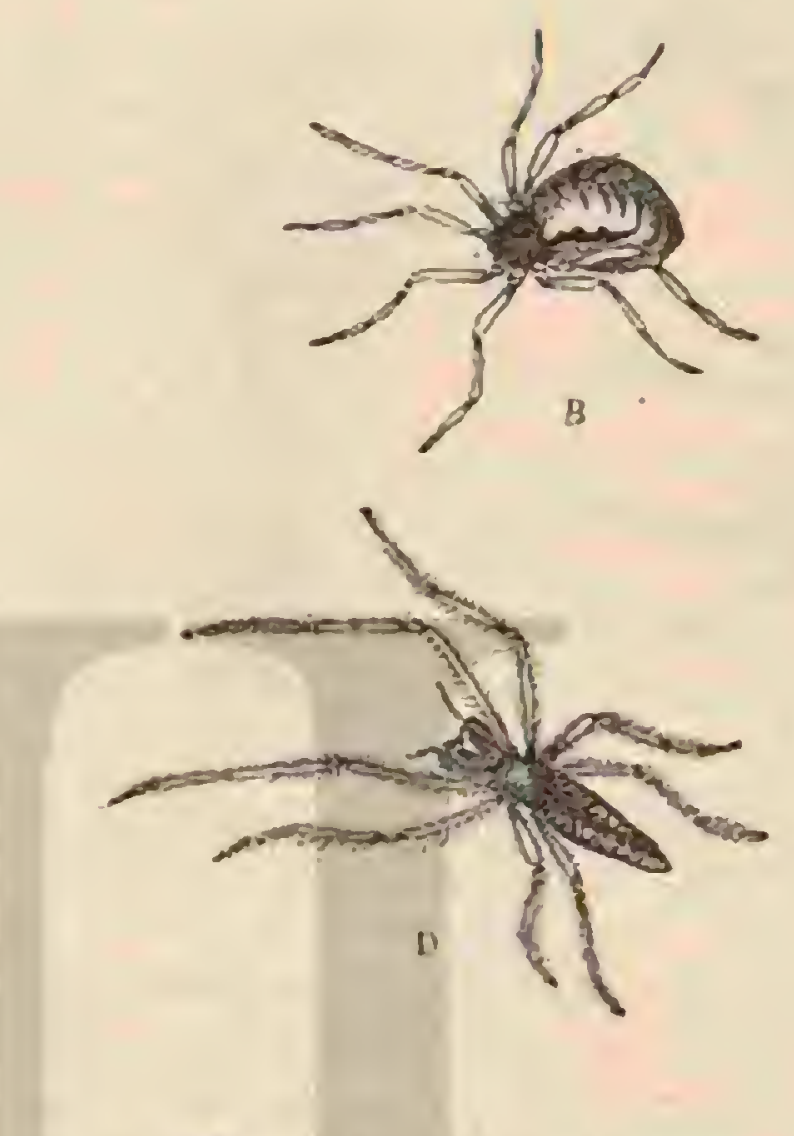

Fig. 186. - C E.J. 1.INHFIO DE B'AJAS

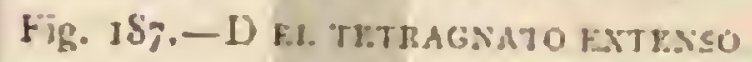

de $0^{n}, 007$ a $4^{n}, \circ c 8$, y ro cstira sus patas cuando reposa. Fi cefalotórax es pardo, con bordes mas ó menos oscuros; el abdómen blanco, provisto en su parte superior de un escudo longitudinal, pardo en el borde y escotado: el vientre, de un pardo oscuro, tiene cuatro manchas blancas. I.as patas, amarilientas, presentin en los muslos, en los tarsos y en los piés posteriores dos anillos de un pardo negruzco; en las extremi. dades de las rodillas $y$ de los otros artejos del pic hay un anillo del mismón color. Los ojos de la frente y de los lados, todos del mismo tamaño, dispuestus en dos series, forman una linea ligemmente arqueada hảcia adelante, mientras que los ojos de la coronilla, mas grandes y mas desvindos uno de otro que los de la frente, están situados en una linea casi recta (fig. 185).

USOS, COSTUMBRES Y RIEGIMEN. - El linifio de las montanas vive tanto en los parajes llanos como en los montañosos, $y$ fabrica un nido en los jardines, en las cmpalizndas ó en casas viejas, así como en sauces luecos y en los bosques, donde preficre la maleza. La tela se compone de una cubierta horizontal, sobre la que se extienden numerosos hilos en todas direcciones; la araña se agarra boca arriba en la cara inferior del tejiclo, retirándose cuando se la inguvicta. Si un insecto queda cogido on los hilos, enredindose en la cubierta mas espesa, la araña deja su sitio y precipitase sobre la presa, pero no la persigue mas ailla de los limites de su tejido si aquella lograt escapar. Chupa ol contenilo de la victima: pero no la inasca. En los sitios favorables se ven á menudo nume. 
rosos nidos en una superficic, situados unos sobre otros, ofreciendo un aspecto magnifico cuando están cubiertos del rocio de la mañana. Varios naturalistas aniguos y modernos han observado repetidas veces el apareamiento de esta especie, y Menge describe los preparntivos del mismo por parte del macho. El 14 de mayo de $1 \$_{5} 6$, un macho acababa de fabricar su pequeño tejido triangular, semejanteá un puente, en el que se colocó apoyándosc solure el abdómen, y moviendo este de atris adelante hasta que apareció una gotita de esperma del tamaño de una cabeza de alfiler en el borde del tejido. Despues se dirigió por debrajo de la iela tocando alternativamente con los jalpos que sirven de conducto para la esperma, hasta que los ganchitos que en aquellos se en.

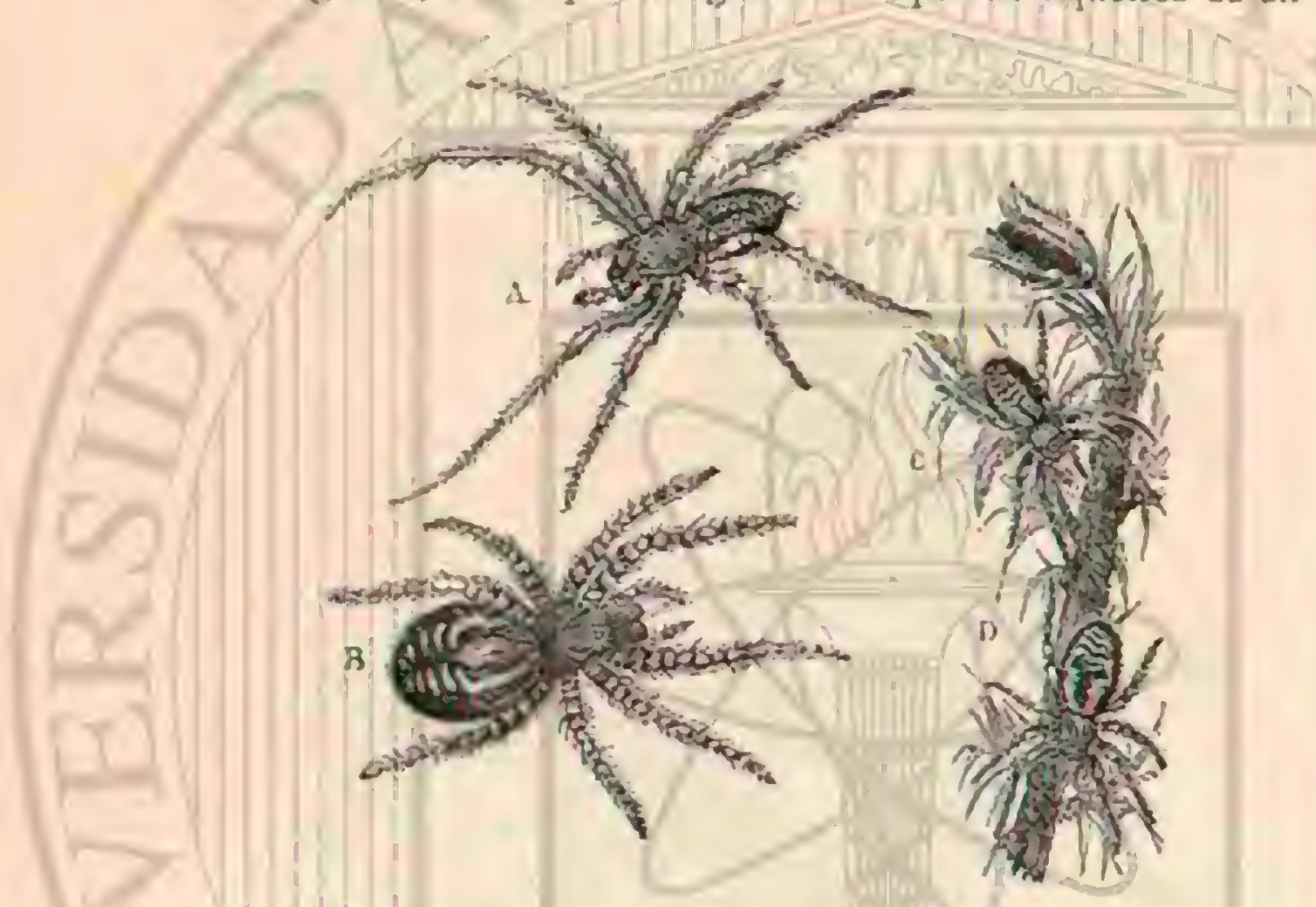

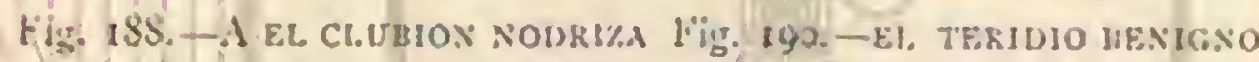
Fig. I\$9. - B EL Cr.UBIOS +EROZ (C., Hembra. D, Macho)'

cuentran la hubieron absorbido. El ibdomen se hallaba nientras tanto cn movimiento, sin que se manifestase la excitacion con que despues, pecho contra pecho y vientre contra vienire, los ganchos se introdujeron en la vagina de la hembra - Intes que el macho prueda cfectuar este acto, ha de lu. char á menudo a vida ó mucre con otro rival.

La hembra deposita en junio unos cien hucros en un nido ligeramente cóncivo, detrajo de lí cortena de los árboles ó en un rincon abrigado, cúbrele de ligeros hilos y le guarda con el carino maternal propio de las aranas: los hijuelos salen à luz en julio.

\section{EL LINIFIO DE FAJAS-IINYPHIA FASGIATA}

CARACTERES, - Fista araña (fig. 186) se distingue por su abdómen ormlar, algo puntiagudo hácia el ano, recogido en los hados, y ms alto hácia el coselete; adórnanle fajas rojas y: blancas, verdes y amarillas; en el centro del dorso hay una de este último tinte que se corre hasta el ano; en sus bordes presenta lineas de un rojo bermellon, ạue por la manera con que se combinan forman como una cruz doble: la region de las hileras está manchada de un pardo rojizo; el coselete es verdoso; las patas verdes excepto los tarsos y las articulaciones, que ienen un matiz amarillo. Esta especic mide 5 lineas.

DISTRIBUCION GEOGRÁFICA. - Ei linifio de fajas se encuentra en el nuevn continente; es bastante comun en la América sententrional y en Georgia.

\section{EL TERIDIO CORONADO-THERIDIUM REDIMITUM}

CARACTÉRES. - Lista graciosa araña de unos $0^{n}, 00516$ de largo, varia mucho por su color y dibujo, y ticne por lo mismo varios nombres. En su primera juventud es casi blanca y trasparente excepto la parte superior del abdómen, que tiene manchas negras; pero á fines de junio, en julio y agosto, se encuentran en el mismo sitio arañas de un color amarillo pálido (theridium lineatum) ó unas (jue en el abdómen presentan un circulo sonrosado (thiridium redimitum) ó una mancha oval en vez de la circular (tieridium ozatum), ó en fin, especies en que el matiz. rojo no es completo, por tener un viso verde. Además se encuentran machos que en la parte superior del abdómen jresentan una mancha oval roja, divi. dida por dos lincas trasversales amarillas. Fuera de estas diferencias en los individuos que tienen el color de un blanco amarillento, los bordes del cefalotóras y una linea central, así como varios puntitos redondos en el abdómen, la extre. midad de los palpos y de los tarsos son de color negio; en el pecho, que es amarillo, asi como en el dorso, se ven tres fnjas de este color, y al rededor del ano cuatro puntitos blan. cos sobre fondo negro. Por su posicion los ojos recuerdan los de la araña de cruz, con la diferencia de que los cuatro iguales del centro forman los ángulos de un cuadrado.

USOS, COSTUMBRES Y REGIMEN.-Todos los teridios son mas perezosos que la mayor parte de las otras amñas y se dejan coger ficilmente.

Iil teridio coronado pertenece à las pequueñas arañitas gor. dás que habitan toda clase de plantas bajas en las que reunen un par de hojas con algunos hilos irregulares pam coger aqui pequeños insectos. Ia madre coloca la bolsita de huevos, que son esféricos y de color azulado, sobre una hoja y la guarda hasta one los hijuelos han salido. El macho habita en el periodo del celo el mismo nido que la hembra pacificamente.

Además de las especies citadas, merecen mencion el feridio rayado (fig. 193), bastante extendido por Furopa, el den. tellado (fig. 104), propio de Francia é Inglaterm, el heuigno (figura 190), que habita en dichos paises y en Alemania, el neriudo (fig. 195), abundante en Suecia, y el grusso (fig. 196), que vive sobre todo en Grecia. El género de vida de todos estos teridios es inuy análogo al del coronado, y sus carnctéres especificos ofrecen poca variacion para que nos detengamos en detallarlos.

\section{EL LATRODECTO DE TRECE MANCHAS- LATRODECTUS TREDECIMGUTTATUS}

CARACTERES. - Entre las numerosis especies de la fa. milia haremos mencion del latrodecto de trece manchas, propio de la Europa meridional donde se le llama malmigsatln, aunque el hombre del pueblo no designa con este nombre una especie determinada. Ia que entre los maturalistas tiene este nombre es de una longitud de $\left(0^{\circ}, 0\right.$ I 3 , de co. lor negro de per.y provista en el abdómen, esférico, un poco puntiagudo en su cara posterior, de trece manchas de tamaño y forma diferentes, y de color rojo de sangre, de las que dos pertenecen al vientre. Los ojos del pequeño cefalotórax, iguales entre si, están dispuestos en cios lineas rectas, los exteriores muy cerca del borde y los de la frente mas ajproximados uno al otro que los de la coronilla.

USOS, COSTUMBRES Y REGIMEN.-Esta graciosa amina se hizo desde ijS6 mas generalmente conocida en Toscana y sobre todo en el mes de agosto se la temia mucho à causa de su mordisco venenoso. En España solo llamó la atencion desde 1830 , porque entonces se presento en gran número en Cataluña, asi como en $1 \$_{33}, y$ despues en $1 \$_{4} 1$, precisamente los mismos anos en que las langostas habian causado tantos estragos. El miedo a esta araña parece fundarse mas bien en la supersticion e ignorancia yue en la 
observacion exactin, y al cabo de tres ó cuntro dias los efectos del veneno desajarecen, segun se dice, cuando el cnfermo suda con abundancia.

I.a malnigratta fija su residencia entre piedras ó en cavidades del suelo sobre las que extiende algunos hilos, precipitandose con un atrevimiento desenfrenado sobre los insectos que en ellos se enredan y que á consecuencia de la eficacia del veneno quedan dominados fácilmente aunque sean mur superiores en tamaño á la araña, la cual destruye sobre todo gran numero de langostas. I a hembra rodea sus numerosos hueros, que á menudo exceden de 200 , de un capullo csférico un poco puntiagudo en un lado y muy compacto, de color pardo de café claro y de $0^{\star}, 013$ de diámetro. I.os huevos no estån aglutinados, pero tampoco libres, sino reunidos por hilos invisibles; pues cuando se tira del uno el otro sigue como las perlas de una sarta. Totti cree que una hembra fabrica tres capullos, el primero con 400 y el tiltimo con 100 huevos, de morin que el mimero total de estos asccnde ria à mas de $j 00$, prueba de gran fecundidad que no debe admirarnos, puesto que las langostas las ofrecen un alimento abunciante.

\section{LA TEGENARIA DOMESTICA-TEGENARIA DOMESTICA}

CARACTERES. - Todo el mundo conoce las telas de amña triangulares que abundan en los rincones de las cuadras, iglesias, graneros y en general en todos los espracios que no se limpian a menudo, y que casi siempre tienen el asjecto negro por el polvo que en ellos se ha depositado. Los cliferentes nombres que la tegenaria domestica ha recibido, como por ejemplo, araña doméstica, amña de las ventanas ó de los rincones, indican el paraje en que habita.

No solo se halla diseminada for toda la Europa, sino tambien por el norte del Africa; inverna entre nosotros cuando es jóven y alcanza por término medio en junio su completo desirrollo; el macho mide entonces $10^{\circ}$, o i y la hembra de $\|^{\prime \prime}, 01 \%$ a $^{\prime \prime}, 0195$. El color del fondo del cuerpo es amarillo de ocre con matices pardos. En el ceralotorax, el borde y una faja central de la cabeza, separada del dorso por una depresion trasversal, varias lineas en forma de radios, y d cada laclo tres manchas lunares, son mas oscuras; en el abdómen se ve una linea central de un rojo de orin 6 amarillo pardo, una seric de manchas, tambien amarillas, y unas espesas lineas oblicuas pardas en los lados. Las patas, que tienen un color amarillo de ocre, y cujo tercer par es mas corto que los otros, que orrecen igual longitud, están provistas de anillos oscuros denticulados. Las dos verrugas textiles supariores sobresalen de la superficie oval en forma de colitas. USOS, COSTUMBRES Y REGIMEN. - Cuando la araña quiere fabricar su fejicio, oprime iodo el aparato texti] de su cuerpo a varias pulgadas de distancia del rincon contra la jared, se dirige en ángulo a la opuesta y fija aqui el hilo a la misma distancia reforzándolo, como el mas importante. con dos ó tres mas. Despues llena todo el espacio triangular con hilos algo mas cortos, fijándolos todos como el primero en las dos paredes. Hecho esto cubre el tejido con otros trasversales, y para si misma teje en el rincon un tubo abierto jor ambos lados, con el que se enlaza el tejido circutar como en un corto tallo. Como la arana clige con preferencia los sitios en que hay agujeros y grietas en la pared, el tubo desemboca en alguna cavidad a la cual se retim la araina en caso de peligro. En la parte anterior del tubo acecha à su presa, coge al punto la mosca ó mosquito que cae en la red y los lleva a su cscondite para comer con comodidad.

Ya hemos dicho anies que cada araina debe ser econóni- ca con su material textil, porque su preduccion depende del alimento, y por eso no trabaja cuando la tempestad o la lluvia pucden destruir su trabajo. Hé aqui sin duça por qué la naturalezi debe haber dotado i este insecto de esa facultad de prever los cambios de tiempo. Por eso se han considerado las arañas como barómetros, de los cuales se hacen deducciones sobre la temperatura probnble, segun la actividad ó pereza de esos insectos, segun que se retiran ó salen de su escondite, por su posicion en la tela, etc. En todo caso las arañas son muy sensibles á los cambios de temperatura, los cun. les indican seis ú ocho horas antes que ocurra la mudanza de ticmpo. Las observaciones hechas se han rejerido sobre todo a la araña de cruz $y$ a la especic que nos ocupa. Cuando la araña de cruz rompe los hilos principales de su tela en cierta direccion, ocultandose despues, ó cuando las arañas domes. ticas se retiran à la profundidad de su tubo dirigiendo su abdónen hicia cierto lado, puede darse por seguro yuc pronto soplark un fuerte viento en aquclla direccion; pero si la araña de cruz vuelve à fijar los hilos del marco, poniéndose al acecho, ó la doméstica sale á la entrada de su tubo, estirando las patas con intencion dc coger alguna presa, puede contarse que volverá a reinar tmncquilidad en la atmósfera. Muchos habian atribuido un exingerado don profético i las arninas, don que otros les negaban del todo; en I794, cuando el prestigio de que gozaban las arañas parecia perderse, volvió a prevalecer otra vez por el siguiente hecho: El jefe del ejército francés revolucionario, Pichegru, estaba convencida de que nada podria lograr contra la Holanda inundada y ya estaba disputsto a retirarse, cuando ol ayudante general Quatremere d'Isjonsal, prisionero de los holandeses en Utrecht, le avisó que las aranas le profetizaban que dentro de diez dias, con seguridad helaria. Pichegru se armó de paciencia, sobrevino el frio, y el cjército avanz\& sobre el hiclo hasta Amsterdam. Isjonval, que habia dado la importante noticia, guiảndose por las amñas, fué llevado en triunfo à Paris.

Decididamente fué una araña doméstica, ó una especic muy afine la que el desgraciado rey Cristian II de Dimamarca domesticó en su calabozo, y que contribuýb bastante á refre. nar las pasiones del tirano; conocia su voz y siempre acudia cuando le llamaban para darle algo. Ahora bien equién fué mas aborrecible, aquella pobre araña, que di un desgraciado pudo distraer un poco, ó el cruel carcelero, que segun dicen mató al insecto al descubrir su amistad con cl cautiro? Cuando el res, anciano y débil, nada déseaba ya sino la muerte, intibascle con mas consideracion. A menudo hablaba entonces, con lágrimas en los ojos, de da amistad de su araña, ciel consuclo que le habia ofrecido su presencia, del cariño que profesalon al insecto, $y$ del desesperado dolor que el endurecido carcelero le causó con su muerte.

Usos Y PRODUCTOS. - I as telaranas, sobre todo las de la especie doméstica, se han empleado tam. bien jara fines medicinales. Despues de quitarlas bien el polvo sobre una silla de rejilla ó un harnero de alambre, córtanse en finas particulas, mercladas con manteca, se comen con pan, lo cual es un cxcelente remedio para las calenturas intermitentes. Mas conocido es el electo que las telas de araña producen, bien limpiadas de polvo, mara atajar la sangre. Tambien se ha intentado lavarlas como los hilos de seda, pero esta materia especial nunca podra obtenerse en ta] cantidad que pueda utilizarse por la industria.

\section{LA AGELENA LABERINTICA-AGELENA LABYRNITHICA}

CARACTERES. - Esta especie es de cstructum mas sólida que la araia doméstica (tiene de $0^{\circ}, 0 \mathbf{I}_{3}$ á $0^{\circ}, 022$ 
de largo), y ofrece la misma forma; el cefalotórax es de co. lor gris amarillo, con dos fajas longitudinales de un pardo negruzco, ! hácia los ojuelos laterales remata en punta. El abdómen es de un gris mezclado de negro, presentando en su centro una faja de pelos de color gris rojizo, que remata en una inancha de color de narnnja sobre las verrugas textiles salientes, $y$ de la cual parten por los lados cinco ó seis fajas de pelos del mismo color que se dirigen oblicuamente hicia adelante. Las ancas y los muslos son amarillos; los otros artejos de las patas de un amarillo rojo y los puntos de un rojo pardo. Los ojuelos, bastante grandes, cstán dispues. tos como en la especie anterior, con ha diferencia de que los de la coronilla se hallan sibuados mas hácia atris. Como el último artejo de las verrugas textites tiene doble longitud que el anteriot, la colita resulta muy desarrollada. El vítimo at- tejo de los palpos del macho es corto y grueso, no mas largo que el tercero, mientras que en la arana doméstica es casi vez y media mas largo (fig. 199).

USOS, COSTUMBRES Y REGIMEN. - Ia agelena laberintica fabrica debajo de yerbas y de la inaleza en sitios bañados por el sol, su tejido horizontal en forma de hamaca, que termina en un tubo cilindrico muy abierto, de varias cir. cunvoluciones, donde se pone al acecho; por arriba le cubre y entreteje con hojas secas para preservarse de la llusia y de los rayos del sol. Cuando hace buen tiempo la agelena laberintica se pasea a menudo por su tejido, cuyo ancho borde se comunica con los contornos por medio de unos hilos de mas de $0^{m}, 30$ de largo. Es sumamente agil en sus movimientos y muéstrase muy ávida de presas. Rara vez abandona su te. jido, $y$ prefiere remendarle cuando obsersia algun desperfec-

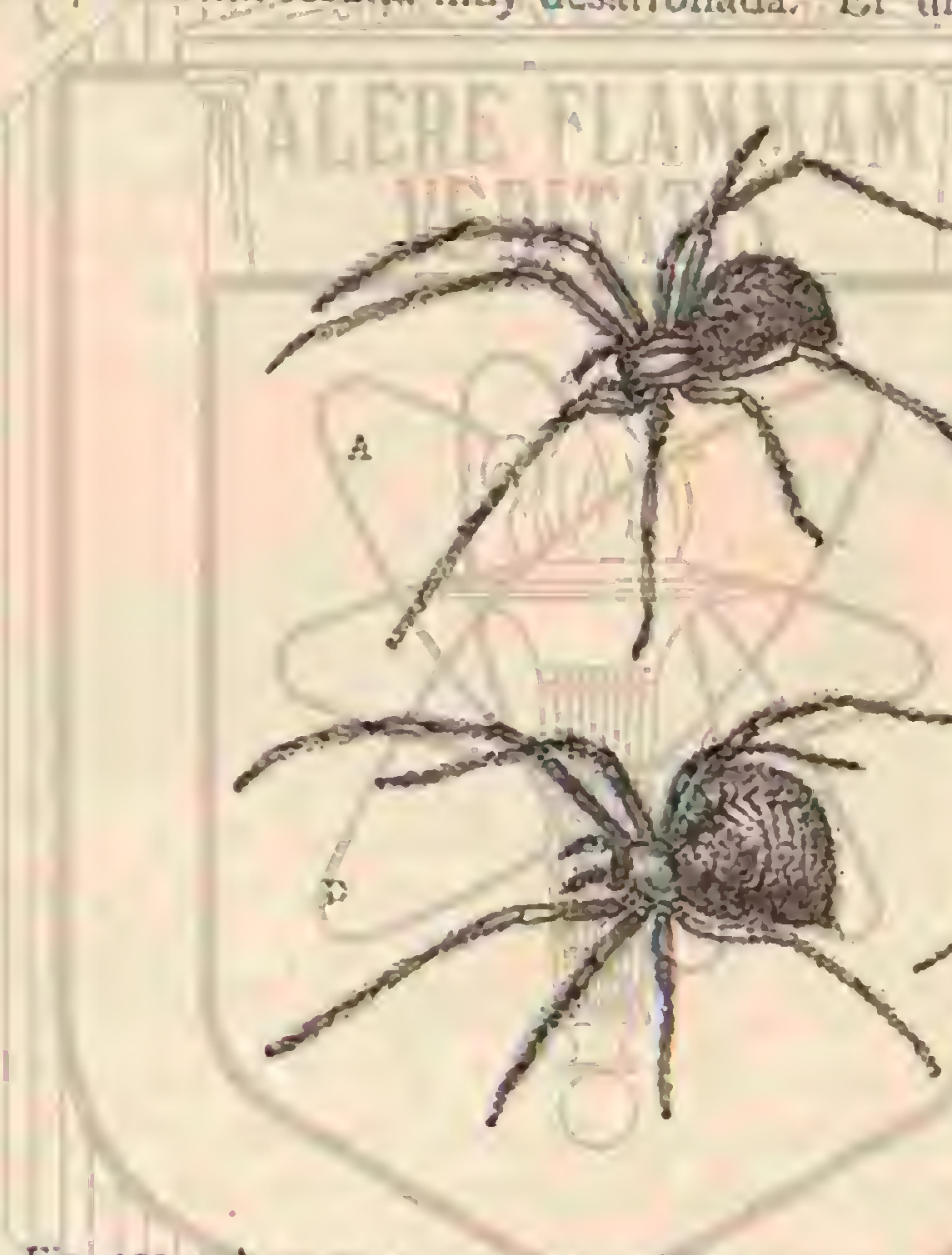

Fig! 191-A \&. TERIMก ksหano (Hembra) Fig. 194-D EL TERITIO DENTHLLWO
Fig. 195-E H.t. Tr.mino Nerveno

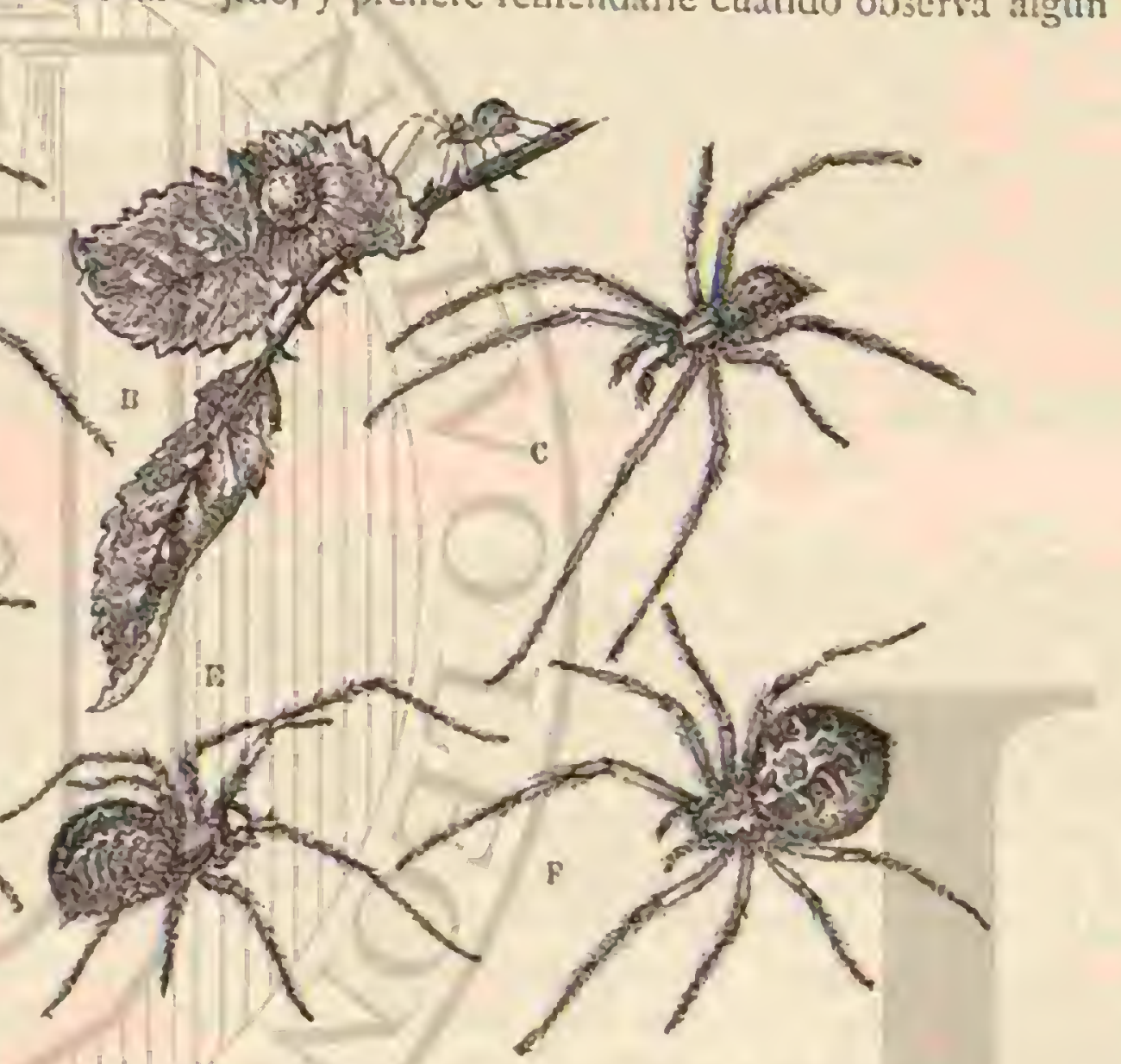

Fig. 192. - I NIDO

Fig. 193. - C EL Trkinto RAYsiro (Mrcho)

Pig. 196. - F I:L TrRRISHO GRURSO to. En julio y setiembre se verifica el apareamiento en el sitio habitado por la hembra. Estn pone despues un numero relativamente reducido $(60$ a 70 ) de huevos grandes en una especie de tubo compuesto de varias capas y cuya pared interior se halla tapizada de terroncitos de tierra y restos vegetales de los contornos. Este tubo queda prendiente cerca del nido donde la madre lo guarda con todia solicieud. Lsta araña tiene un área de dispersion muy cxtensa, pues se encuentra en Inglaterra, Suecia, Alemania, Francia, Hungria, y sin duda tambien Rusia. En el primero de dichos paises el aparea. micnto se verifica, segun las observaciones de Listers, en el mes de mayo, y la cria inverna, protegida por espesos hilos, en los agujeros de las paredes y detrás de la corteza de los irboles; mientras que en Francia y en Alemania invernan los huevos.

La agelena saxátil (fig. 200) es una especic afinede la labe. rintica, de la cuai difiere por sus patas algo mas cortas, y por el dibujo que presenta la parte superior del cuerpo.

Los dos citados suingéneros y aigunos otros afines, que se distinguen por la garm rudimentaria provista de cinco a ocho dientes, se han reunido en el grupo de las agelenas que per. tencece à la fomilia de los ciràsidos.

\section{LOS DRASINOS-DRASSIN E}

CARACTERES.-I.OS drasinos constituyen un segundo géncro de la misma familia: tienen el refalotórax y abdómen cilindricos 6 en forma de óvalo prolongado; las patas cortas; en los piés falta casi siempre la garra rudimentaria : las yesrugas textiles, cilindricas, pueden ser de igual tamaũo, ó las inferjores mas salientes; los ocho ojuelos se distribuyen de un modo diferente en la parte superior del cefalotónx, en el que la cabeza se desvia mucho menos marcadamente que en las especies anteriores.

\section{LA ARGIRONETA ACUÁTICA-ARGYRONETA AQUATICA}

CARACTERES. - Ninguna especic de rodo el grupo ofrece por sul géncro de vida tantas particularidades interesantes como la argironeta acuática, insecto que sé distingue desde luego pror su exterior, pues tiene una garra rudimen. taria con varios dientes en los piés y la parte anterior del cefalotórax muy convera separada del resto por un surco trasversal, de modo que forma una especie de cabear; habiase agrupado antes con las agclemias, pero teniendo en cuenta los demás caractéres, parccé mas propio agregarla to este grupo. Contra la regla geneml en las arañas, el macho es mas grande que la hembm, pues mide $0^{\circ}, 015$; y esta solo $11^{\circ}$, or 2. De los ocho ojos, de igual. tamaño entre sí, los cuatro anie. riores forman un arco encorvado hnicia adelante $y$ los cuatro posteriores otro hácia atrís, difiriendo ambos por la circuns. tancia de que en el anterior los ojos están menos distantes que en el posterior; los ojos del centro se hallan en uma jro- 
minencia en forma de cojin;y los laterales sobre una protu. berancia oblicua. Los dos artejos cilindricos de los palpos del macho son un doble mas largos que anchos. En ambos sexos el cefalotórax, casi desnudo, de color rojizo de orin en los lados, es en la parte posterior pardo; al rededor de la frente pardo negruzco; cn la region superior esta provisto de radios negros, y en la anterior de tres linens longitudinales del mismo color. El abdómen, de un pardo accituna, hállase cubierto de pelos aterciopelados de color blanco gris, sobre los cuales se ven dos séries de puntos. Estos se hallan à me. nudo tamibien en otras arañas y marcan el sitio donde se in. sertan los músculos que al tmvés del abdómen pasan hasta el vientre.
USOS, COSTUMBRES Y REGIMEN. - I. amì que acabamos de describir vive casi continuamente en al agua y respira al mismo tiempo por bolsas pulmonares y tráquens; por estas en el cefalotorax, segun parece, yo pror aquellas en el abdómen. I as tránqueas parten de unos cortos troncos en forma de pincel, situados detras de los pulmones, y no se ramifican. Por su aspecto exterior puede confundirsela ficilmente con otras especies de araña (Cluihiong atrox, Drassus brunnews, sericens y otras), aunque difiere esencialmente de todas por su género de vida. Flige siempre aguas estancadas ó cuando menos de corriente lenta, donde abundan los acarinos y pequenos insectos, lentejas y otras plantas acuáticas. Alli construye su nido y se aparea, pero tambien puede vivir

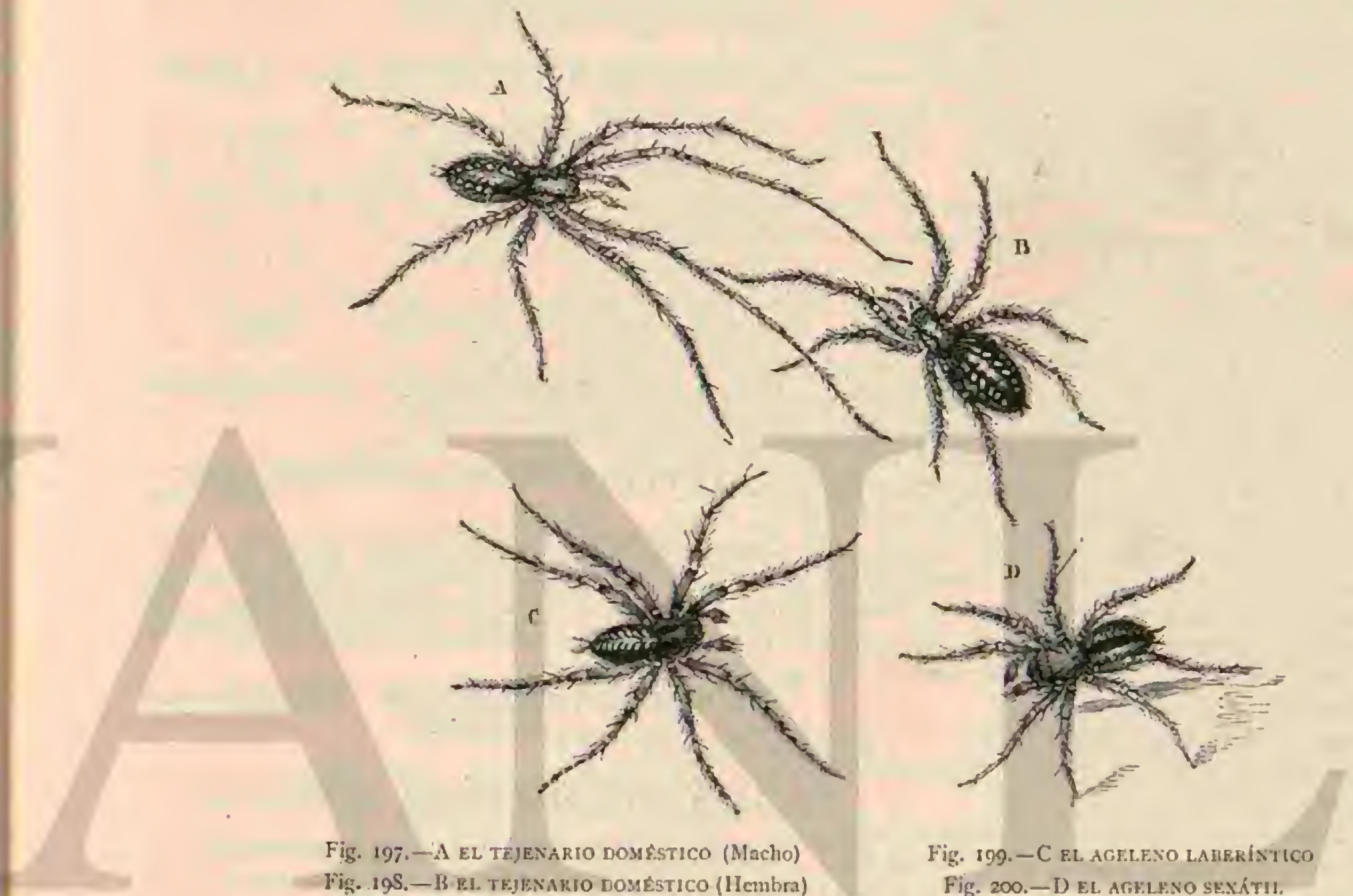

corto tiempo fuera del agua, pues Geoffroy vió como atguna de estas aminas salia is tierra en persecucion de una presa, volviendo despues á su elemento, y Walkenaer observó en ciesta ocasion una muda fuera del agua. In araña ofrece un aspecto sorprendente cuando nada, pues una ténue capa de aire rodea su abdómen, yue brilla como una burbuja de mercurio (de aqui el nombre de argironeta, ua rociecida de plata y rjue descubre la presencia de los pequenos insectos, que sin esto no se verian. Fista capa aérea está separada del agua por una especic de barniz; y cuando se ven arañas acuáticas sin su adorno plaieado, seguro es que estån enfermas.

Cuando el pequeño insecto quiere fabricar su nido, sale : la superficic del agua, y poniéndose cabeza abajo con el vientre hŕcia arriba, saca la puñta del abdómen del aguá, abre las verrugas textiles y vuelve rapidamente a la profundidad. De este modo lleva, además de la capa de aire que roden el abdómen, una burbuja pequeña ó grande en la extremidad de aquel, lo cual naturalmente no puede hacer sino por medio de la sustancia textil que sale de las verrugas como una especic de barniz, y aplicada con las patas posteriores cierra el aire de la burbuja preservandole del agua; de lo contrario, el aire subiria al punto hảcia arriba. Despues repite su primera maniobra, busca una segunda burbuja y sigue en esta ocupacion hasta dejar hecha una especie de cumplanat de buzo con la abertum hácia abijo, del tatutúu de una nucz. Varios hilos dan la solidez necesaria à la construccion, y otros, tendidos en todas direcciones por delante de la entrada, sirven de trampa para la presa; pero la araña no se limita á esperarla en su guarida, sino que la persigue á nado. Cuando ha cogido una victima sube con clla por el primer tallo y la devora en la superficie del agua, ó bien lo hace en su campana de buzo, of la guarda como provision en su hilo cuando ha satisfecho su apetito. In cautividad las arañas fijan su campana en las paredes de su prision; de Troisvilles observó varias veces que, cuanda no las ponian plantas, cruzaban el agun con hilos, fijando en ellos su nicho. Este no presenta en ningun caso cl aspecto de un tejido; siempre parece como una masa blanca, espesa y barnizada. En la época del aparcamiento, que se verifica en la primavera y en setiembre, la capa aćrea es menos regular: entonces dicha capa deja en descubierto una mancha romboidea en el dorso, mientms que en el pecho, vientre y en la extremidad del abdómen se aglomera el aire en mayor cantidad. El 
macho construyce entonces tambien su campana cerca de la hembra, pero mas pequeña, reuniéndose ambos nidos por una galeria cubierta. Lignac vió algunas veces, pero solo en la primavern, tres nidos juntos, que pueden separarse, sin cmbargo, con la misma rapidez con que se reunen cuando las aranas disputan, jues en dicho tiempo están muy excitadas y se traban luchas en uno if otro nido; pero cuando la parcja se ha formado, vive en perfecta asmonia. La hembra pone sus huevos en una burbuja de aire que despues rodea con la tela, fijando este nido esférico, un poca aplanado, en una planta acuatica 6 dejándolo pendiente en su campana, sin perderlo nunca de vista. Fsto último fué lo que observó Troisvilles con sus cautivas: el 7 de junio salieron las amnas jequenas, que subian à la superficie para respirar: algunas construyeron pequeinas cumpanas en una phanta que encontraron en su prision, mas no por eso dejaban de entrar y salir en el nido donde nacieron; otras sc precipitaban sobre el cadáser de una larma de libélula, arrancando un bocado, comó los perros. El quinto dia mudiron de piel, dejando ilotar esta en la superficie del agua.

Los nidos de estas aranas sirvenles tambien para pasar el inviemo. Degeer cogio en setiembre un macho y pudo conservarlo cuatro meses en uma vasija llena de agua, aqui consiruýo una campana muy delgada, del tamano de medio hue. vo de paloma, que por medio de hilos -angulosos fijó en la pared de cristal. En medio de esta campana, llena de aire, veiáse a la araña con la cabeza levantada $y$ las patas recogidas contra el cuerpo. El $1_{5}$ de diciembre la abertura inferior apareció cermada, y la araña permanecia inmóvil en su burbuja; al comprimir esta se rompió, dejando escapar el aire; $y$ entonces la araña abandono su vivienda destruida. Cuando Degeer la echó un quilópodo acuático, cogióle en seguida y chupó su contenido. Al cabo de trés meses de ayuno manifestålase aun muy visazy dispuesta a comer. Fucra de su campana la arana acuòtica inverna por lo regtilar en alguna concha de caracol vacia, cuya abertum cierra con un tejido artificial.

Nuestra especie parece pertenecer mas bien á la Europa septentrional; escrsen en el norte de Francia y no se la encuentru en el sur.

Los otros drasinos, muy numerosos, distribuidos en varios subgéncros, vivén én sú mayoria ocultos debajo de las piedras, en el muscro, en las grietas de las paredes y de las hojas y detris de la corteza de los árboles viejos. Aqui, sobre todo, se ven unos cuerpecitos blancos sedosos, semejantes á hotones de camisa, un poco cóncavos en el centro y ligeramente bordeados en su contorno: son los nidos de huevos de varias especies de este género. Lina de las mas comunes se encuentra en tales escondites en nuestros jardines, $y$ á menudo tambier en las casas; es la llamada araña de seda

\section{EL CLUBION DE SEDA-CLUBIONA HOLO- SERICA}

CARACTÉRES. - El clubion ó araña de seda se reconoce por ener un tegumento escamoso de color blanco amarillento, que cubre el fondo pardo córneo del cefalotórax, cuya forma es oval y prolongada; al abdómen, de color pardo rojo, tiene la misma figura; las patas son de un blanco verdoso irasparente, con la punta negruzca; los órganos de la boca son negros. La hembra mide $1^{\prime \prime}, 0065$ a $1^{\prime \prime}, 011$, y el macho cuando mas 1, m, $008 ; \mathrm{S}$. El subgénero à que pertenece se caracteriza por ocho ojos muy distantes, cuya serie ante. rior forma casi una linea recta, $y$ la posterior otra ligeramente curva hácia atrás, hallándose estos ojos mucho mas desviados. Las verrugas textiles tienen igual longitıd; las patas carecen de la garra rudimentaria; el labio inferior tiene una forma casi lineal, y las antents maxilares se estrechan mucho en el oentro.

USOS, COSTUMBRES Y REGIMEN. - El clubion verde construye una bolsita que tanto se distingue por su finura $y$ brillo de plata, como por su trasparencia, y sale por la abertura timidamente cuando se ha molesta. Sus nidos de huevos en forma de botones suelen estar debajo de la corte2a. Fn el periodo del celo ambos scxos habitan una bolsa que tiene una pared divisoria para formar dos compartimientos, es decir un piso superior y otro inferior. A fines de junio la hembra deposita 50 huevos, los cuales no abandona por ningun concepto; cuands mas, se retira en caso de peligro al fondo de su habitacion. A los clubiones les agradia salir en busca de los nidos de otras aranas para poner sus huevos.

\section{EL CLUBION NODI ZA-CLUBION NUTRIX}

CARACTERES. - F.sta araña (figg. I $8 S$ ) tiene el abdó men oval, convero y mas grueso un su parte anterior, de un color verdoso oscuro uniforme, con cuatro puntos fundidos en el céntro del dorso; el coselete es verde, de un tinte rojizo en su parte anterior; las mandibulas grandes, fuertes y de un color rojo en la mayor parte de su longitud, y negras en sus extremidades, como la de las patas y de los palpos. Esta especie mide 9 lineas de largo.

DISTRIBUCION GEOGRAFICA. - Este aragnido habita en varios paises de Europa.

\section{EL CLUBION FE.ROZ-CLUBIONA FEROX}

CARACTERES. - Este araznido (fig. 189) tiene el cefaloturax en forma de corazon, de color pardusco amarillento pálido, y revestido de largos pelos negros; $\mathrm{cl}$ abdómen es de un tinte pardo oscuro, con manchas irregulares. Mide poco menos de media pulyada.

DISTRIBUCION GEOGRÁFICA. - Se encuentra en los sitios que habitan los otros clubiones.

\section{LOS DISDERINOS-DYSTERINE}

CARACTERES. - Los disdcrinos colocan sus tejidos de. bajo de las piedras, hendiduras, cañas, etco, en forma de tubos de espesa seda. Estas cspecies solo tienen seis ojos: el cuerpo cilindrico; las patas cortas pero fuertes; la garra rudimentaria existe, pero con un solo diente; los palpos de la hembra están provistos de una garra, sin cliente. Estas especies constituyen el tercer géncro de los tubitelos (rubitelce, drassida), que fabrican nicos en las formas ya descritas: lienen ocho ojos, raras veces scis; $y$ patas no sicmpre provistas de garras rudimentarias, siendo las centrales mas cortas. Ias especies pertenecientes á este grupo se reconocen fácilmente por los carnetéres indicados, sobre todo por los seis ojos que en el subgénero segrestria tienen casi igual tamaño y están dispuestos de modo que cuatro se hallan en la parte anterior en unà série apenas nrqueada, mientras que las otras dos laterales están hácia atrás; en el subgénero dysdera hállanse de manern que dos ojuelos mas grandes se hallan en la frente, dos mucho mas pequeños en la coronilla y á cada lado, en medio de estos, un ojo lateral del tamaño del borde de la frente.

\section{LA SEGESTRIA DE SEIS OJOS-SEGESTRIA} SENOCULATA

Caracteres.-Esta especie, una de las mas disemi- 
nadas y comunes, que mide de $0^{*}$, oro a $0^{\circ}$, or 1 de larga, se distingre por su cuerpo prolongado. El cefalotórax, de forma oval, y de color pardo de pez, tiene casi doble largo que ancho, truncado en su parte anterior y posterior; al abdómen, cilindrico, de color amarillo pardusco, está provisto de pelos y lleva en el dorso matices de un pardo oscuro, formados por una serie longitudinal de seis 6 siete manchas mas peqquenas hácia atris y rẹnidas por una faja central. Los lados del vientre y' el pecho estain salpicados de manchas pardas oscuras: los tarsos presentan dos en las puntas de los nuslos, que tienen un anillo negro (fig. 179).

USOS, COSTUMBRES Y REGIMEN.-La segestria de seis ojos vive debajo de las piedras, la corteza de los irboles y el musgo, en las grietas de los muros y en los techos de paja, donde construye un tubo blanco de regular longitud, abierto en ambos lados, y en cuya entrada tiende varios hilos en todas direcciones, que sirven para coger la presa, la cual arrastra inmediatsmente al fondo del tubo. I a araña se muestra en sus ataques atrevida y ágil, pues acome. te a insectos mucho nıas grandes $y$ fuertes, $y$ hasta no vacila en habérselas con una arjspa, temida por la mayor parte de las otras arañas. A mediados del verano, los hijuelos salen de la bolsita de huevos, y permanecen al principio en el nido de la madre. Walkenacr pudo reconocer que esta especie cra muy insensible al frio, pues observó en enero de $15_{30}$ unล ลกเท็ล แกนy vivaz, aunque el termómetro marcaba hacia ocho dias it grados bajo cero. El mismo autor pretende tambicn q̨ue en esta especie, lo mismo que en la argironcta, el macho es mas grande que la licmbra, pero no lo confirman otros.

Uno de los congéneres mas afines es una araña que en Cuba vive debajo de las piedras; se la describió bajo el nombre de nops gunnabuence (fig. 209), y se distingue de las otrás arañas por tener solo dos ojos.

\section{EL DISDERO ERITRINO-DYSDERA ERY- THRINA}

CARACTERES. - El cosclete de este amgnido es grande; las patas y los palpos brillantes, de un color rojo vivo: el abdómen es de este mismo tinte, aunque algo mas pailido, $\delta$ bien de un gris rojizo: la forma de esta parte es oval y pro. longada; los ojos blancos. Fil digital del macho está provisto de un conjuntor auxiliar, en forma de cono prolongado y puntiagudo: las patas no tienen mas que dos garras pectineas. lista especie mide 6 líneas de largo (fig. 2ir).

DISTRIBUCION GEOGRÁFICA.-El disderocritrino no es mro en el mediodia de Fspauna, cu toda Francia, en el norte de Africa y en Figipto; pero 130 se encuentra en Suecia y en los paises frios.

USOS, COSTUMBRES Y RÉGIMEN.- Este aragnido es errante; se le suele encontrar desde majo hasta noviembre. Intrépido y fero\%, acometc á menudo a otras especies de arañas, y acostumbra à encerrarse en sacos sedosos debajo de las piedras. Enemigo declarndo de las hornigas, establece su nido en el interior mismo de los hormigueros, y protegido suficientemente contra los ataques de estos heteroginidos por el saco en que se oculta, deposita alli sus hueros.

\section{LOS ESCITODOS - SCYTODAS}

CARACTERES.-Estos aragnidos tienen seis ojos, prúximos yo dispuestos por pares; los dos anteriores sobre una linea trasversal; los laterales separados de los anteriores, y en una linea longitudinal inclinada, de tal modo que prolongåndola forma un ángulo cuy̧a pllinta esta por delnnte. El labio es trianguliforme, mas alto que ancho, comsexo y cnsanchado en su base; las maxilas, estrechas y prolongadas, se inclinan sobre el labio y son cilindroideas; las patas finas y largas; las del primero y cuarto par casi iguales entre si; la tercern es la mas corta.

DITRIBUCION GEOGRAFICA.-Se encuentran estas arañas en casi todo el globo.

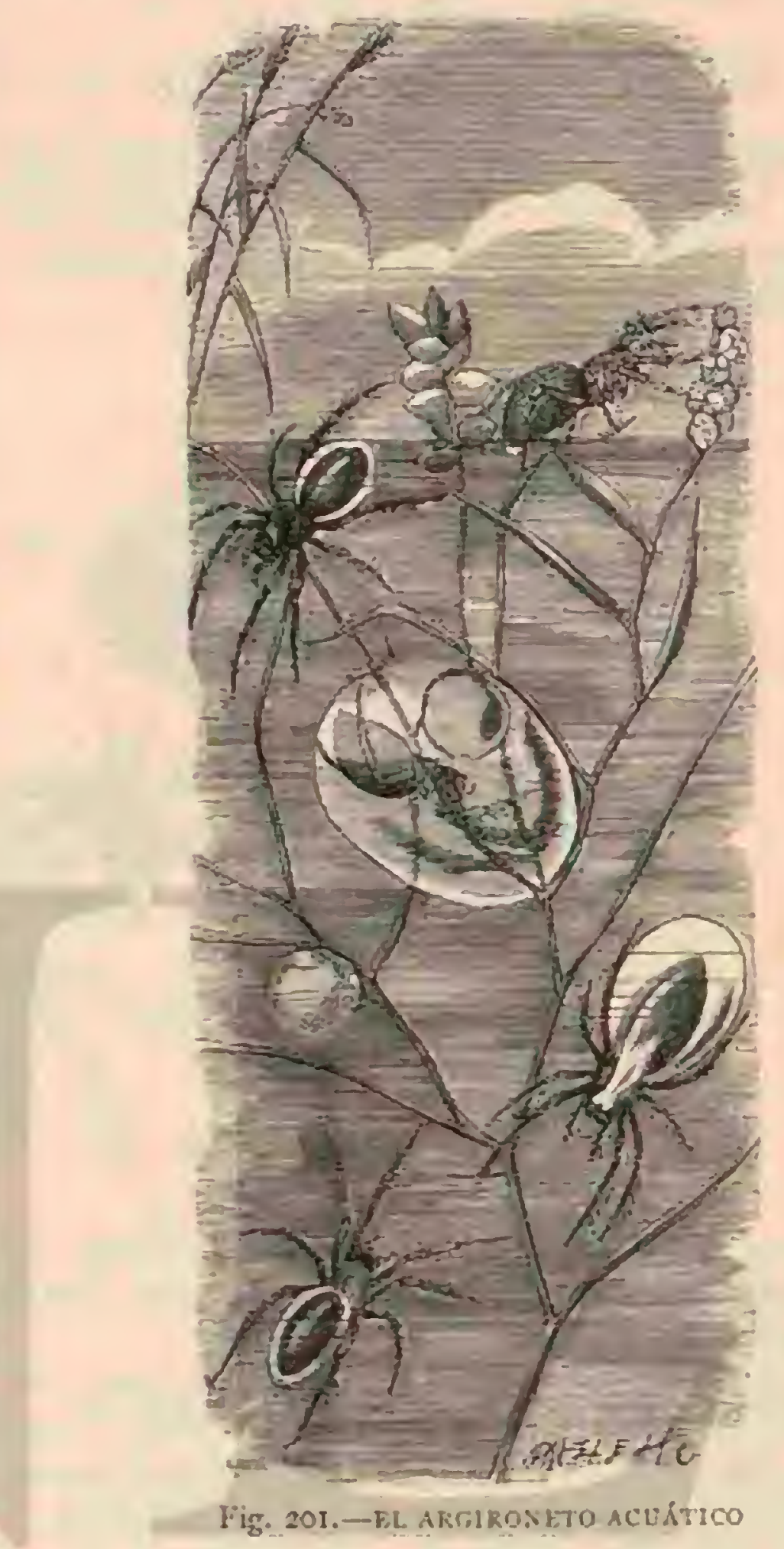

USOS Y COSTUMBRES. - I os escitodos vagan lenta. mente cie un punto á otro, y lienden hilos lácios que se cruzan en todos sentidos y en planos difcrentes. Fil cannullo que fabrican es redondeado y está cubierto de borra.

\section{EL ESCITODO TORÁCICO-SCYTODE THO- RACICA}

CARACTERES. - El color predominante de esta arana es un blanco rojizo pálido; las mandibulas, el coselete y el abdómen tiener manchas negras muy distintis: las patas es. tán orilladas de negro $y$ blanco. Fil coselete es muy convexo: los ojos figurnn en número dé seis; las mandibulas, dirigidas hàcia delante, son pequelins, y se estrechan en su insercion; están cubiertas en cierto modo de una epidermis de color pálido y blanco rojizo, como el resto del cuerjo, con ипа mancha negra intensa en el centro; cuando existe la úngula es pequeña; los ojos son amarillos y brillantes; el vientre de un rojo pálicio sin manchas; las patas prolongadas y finas. Mide unas 5 lineas (fig. 180).

DISTRIBUCION GEOGRÁFICA.-Donde mas parere abundar esta especie es en liuropa y Africa.

USOS Y cosTUMBRES. - lin mayo, julio y seticmbre 
se sucle encontrar esta amàn en el interior de Jas casas, jamis al aire libre; y se ha observado que lleva su capullo en las mandibulas. Véase lo que dice un observador: «El 9 de sede ureme abri uno de estos capullos; los hijuelos, en número de unos tremta, habian nacido ya, $y$ aunque blancos, perci los adultos. El capullo es domen las rayas negras que tienen cubierto de seda lácia poco compacta.h

\section{LOS DRASOS-DRASSUS}

CARACTÉRES. - Ios drasos se caracterizan esencial. mente por sus maxilas dilatndas en el centro; el labio es oval yerior prolongado; las patas cortas; el cosclete tiene la parte an.

\section{EL DRASO BRILLANTE-DRASSUS FULGENS}

CARACTERES. - Esta pequeña especie (fig. 206), no menos admirable por su industria que por sus colores, se ca. macteriza por su abdómen oval ó prolongado, que se arquea aumentando de grueso hácia la parte posterior y es puntiagudo en el ano; el dorso está cubierto de pelos de color amarillo de oro, verdosos ó de un azulado oscuro, con cuatro rayas cobrizas en el centro, $y$ otras dos mas cortas en la parte anterior, cerca del cosclete. Fistas rayas se destacan sobre un fondo negro violaceo, que forma como dos regiones trasversales del dorso; entre ellas y la parte posterior, hasta el ano, el matiz es mas pálido; pero todos estos tintes ofrecen un visa irisado, como el de ciertos colibries. El vientre presenta pelos verdosos sobre un fondo negro; el coselete, de forma

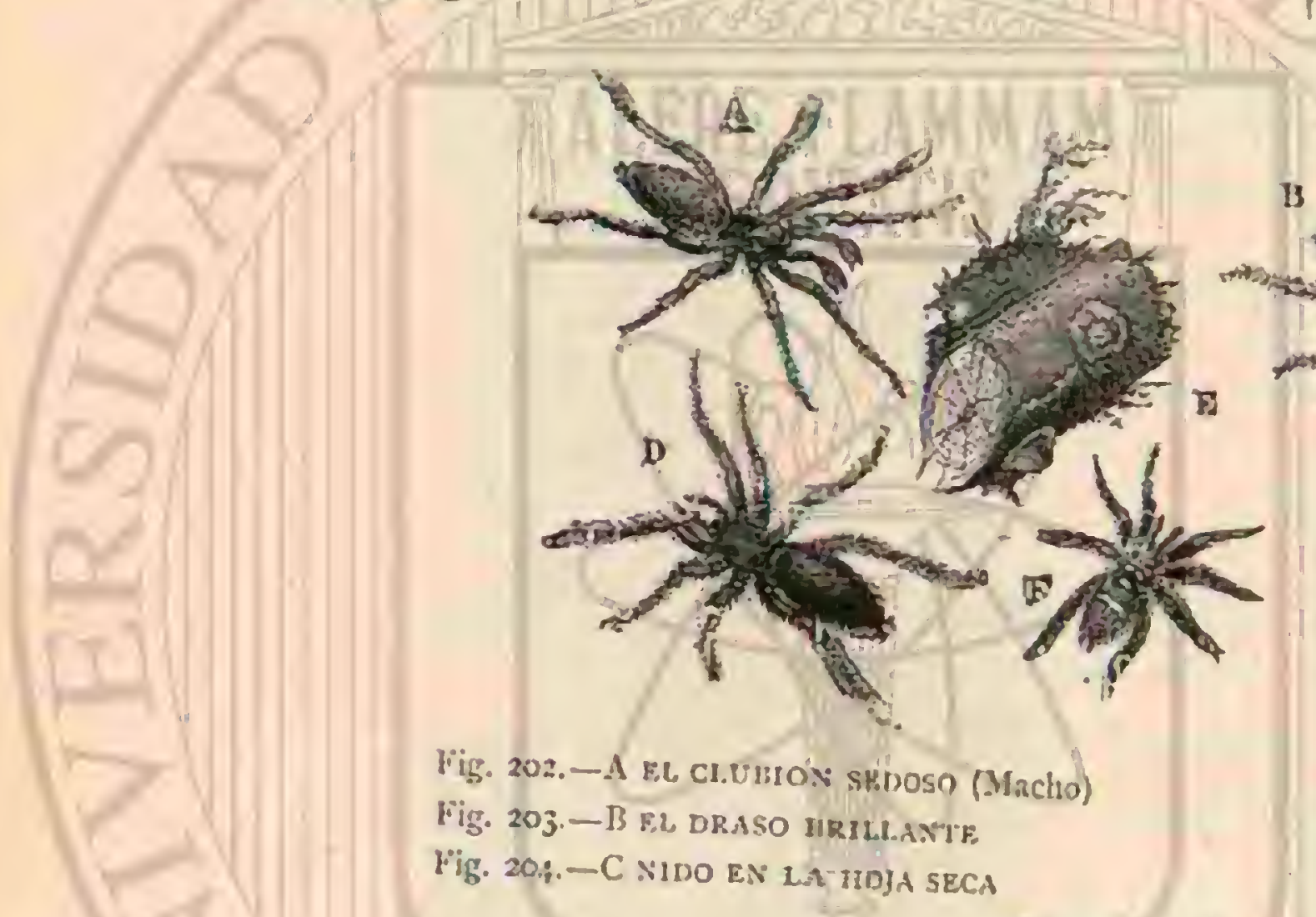

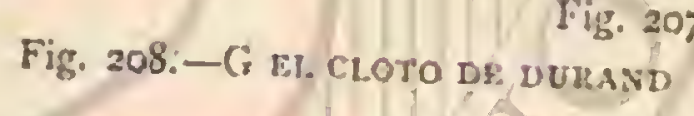

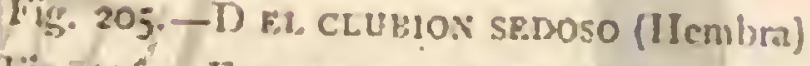

Fig. 206. - E HUEVOS DEPOSITADOS

Iig. 207. -F ER. DRasO SEDOSO prolongada/y color rojizo, se halla cubierto de un velio brillante, amarillo verdoso; las tibias son-algo gruesas; y las de las patas anteriores de color pardo.

Fl unacho se ascmeja a la hembra, pero el abdómen es mas. prolongado y cilindrico; sus jalpos tienen la radial provista en el lado externo de una apófisis fina, en forma de gancho Y puntiaguda. Los pelos, que forman los mas bellos colores de este aragnido, son caducos. El segundo par de patas es mas largo que el primero. El tamaño de esta especie varia entre 2 y uncdia y 3 lineas de largo.

DISTRIBUCION GEOGRÁRICA.-Habita en el antiguo continente: Francia y Mlemania parecen ser los paises de Furopa donde mas $i$ menudo se observa la especie.

USOS, COSTUMBRES Y REGIMEN. - El draso bri llante construye en la yerba, y en las cavidades cie las picdras, una especie de tienda formada por una tela fina, $y$ compacta; su forma es oval y tiene dos salidas. Esta tela contiene otra de un tejido mas fino y compacto, la cual afec. ta la forma de una bóreda; la hembra se coloca debajo de su capullo, que mide cos? de una linea y tres cuartos de diametro, componiéndose de dos partes, una especic de copa su opérculo; la primera, de forma hemisférica, es profunda y de notable blancura, componiéndola una película delgada de un iejido tan compacto como el de una hoja de cebolla. lin aquella copa es donde deposita la hembra de quince à veinte hucvos de un tinte anaranjado, los cuales distan mucho de llenar la cavidad del capullo, que la heinbra cierra despues con un opérculo ú hoja plana pegada solo por los bordes, de tal modo yue se pueda desprender. El aragnido piedra con una tela de un pero antes cubre la cavidad de la piedra con una tela de un tejido licio y trasparente, formán. dose asi sobre la bóveda un segundo espacio que comunica con el primero. La hembra suele fabricar su capullo en las cavidades de las piedras, con la superficic plana vuelta hacia arriba y la convexa hácia abajo. $\Lambda$ últimos de julio es cuando este aragnicio fabrica su capullo, y si se le coje inmediatamente antes y se le coloca en un tubo de cristal, puede el observidor ver como lo teje. Primeramente forma el tuho en que debe apoyarse; despues la parte convexa del capullo; y cuando ha depositado sus huevos, elabora el opérculo que le debe cerrar. Algunas reces se encuentra en este último una pequeña larva amarillenta, que es la de un icneumon, el cual consigue introducir uno de sus huevos en cl capullo del aragnido; la larva que nace, se alimenta entonces de la sus. tancia que la rodea, antes de llegar al estado de ninfa.

El draso brillante se encuentra \& menudo en los matorrales y en las yerbas.

\section{EL DRASO SEDOSO-DRASSUS SERICEUS}

CARACTERES. - El dmso designado con este nombre (Gg. 20\%) tiene el abdómen negro, cubierto de un velo sedoso; el cosélete, la boca y las patas son de un rojo leonado en los individuos jóreries, $y$ de un pardo oscuro en los de mas edad El tamaño de esta especie es de 5 lineas de largo.

DISTRIBUCION GFOGRAFICA. - Esia anan habita en Europa: parece bastante comun en Suecia.

USOS Y COSTUMBRES.- Se encuentra el draso sedoso en las casas y en los huecos de los árboles; pero en julio agosto se oculta tambien debajo de las piedras, donde teje un capullo de tierra, muy grande, oral, liso en su interior, y 
cubicrto de seda blanca, sin fabricar capullo. En la primem edad los hijuelos son del todo blancos; luego adpluieren un tinte rojo, y entonces comienzan a ennegrecerse los muslos.

\section{LOS CLOTOS-CLOTHO}

CARACTERES. - Los clotos tienen los ojos dispuestos en dos lineas, de las cuales la posterior estí muy encorvada por delante; los dos ojos anteriores medios son mas grandes tjue los otros, y los posteriores están muy scịarados entre si. Lil labio, ancho en st base, se adcigara en la extremidad, rematando en punta; las mandibulas son cortas, muy inclinadas sobre el labio, conniventes y redondendas en su extremidad; las patas del cuarto par se prolongan bastante mas que las otras, y son casi iguales cntre si.
USOS Y COSTUMBRES. - Fstas amias construyen su nido debajo de las piedms $y$ detris de la iela que labitan con sus hijuclos.

\section{EL CLOTO DE DURAND-CLOTHO DURANDII}

CARACTÉRES. - Eil abdónren de esta especiē (fig. 208) es oval, prolongado, agudo hacia el ano, negro y con cinco manchas amarillas que figuran, si se unen por lincias, un pentảgono cuya punta se dirige hácia el ano; el coselete es mucho mas ancho que largo, en forma de media luna y de color pardo negruzco, orillado por una linca de un amarillo claro; los rentáculos son ovales y largos. El tamano, en ambos sexos, es de 5 lineas.

DISTRIBUCION GEOGRÁFICA. - El cloto de Durand está diseminado en el antiguo continente; parece bastaute comun en liuropa y Africa, y muy conocido sobre todo en
Fispana y Egipto.

USOS Y COSTUMBRES. Este aragnicio, dice Mr. Dufour, forma en la superficie inferior de las grandes piedros, 6 en las grietas de las rocas, un capullo en forma de concha, de una pulgada de dianietro; su contorno presenta scis ó siete escotaduras, cuyos ángulos únicamente estan fijos en la piedra por medio de hacecillos de hilos, al paso que los bordes quedan libres. El tejicio es de una textura admirable por su ?elicadeza, y segun la edad de la obrera, presenta major ó menor número de dobleces. Cuando el aragnido es jóven aun, no teje simo dos telas; pero despues, y creo que a cada muda, añade cierto número de dobleces; por último, llegado el periodo de la reproduccion, forma un compartimiento indepen. diente, mas suave, donde debe encerrar los sacos de huevos y los hijuelos que salen á luz. Hasta lines de diciembre ó el mes de cnero no se verifica la puesta. Cuando termina, la hembra sale de su domicilio para ir a cazar: lo hace por una de las escotaciuns de su tela; y apenas los hijuelos se hallan en disposicion de poder vivir sin los cuidados maternales, van i establecer en otm parte su domicilio; mientras que la nadre termina su vida en su sedoso pabellon.

Cuando esta araña divisa una mosca que pasa cerca de su tela, sale presurosa, coje el insecto con sus patas anteriores, y haciendo un movimiento circular con la extremidad die su abdómén, enruelve a su victimis en la tela. El cloto de Durand no chupa al parecer los insectos; diriase que le ofende muclio la luy y ceme el calor.

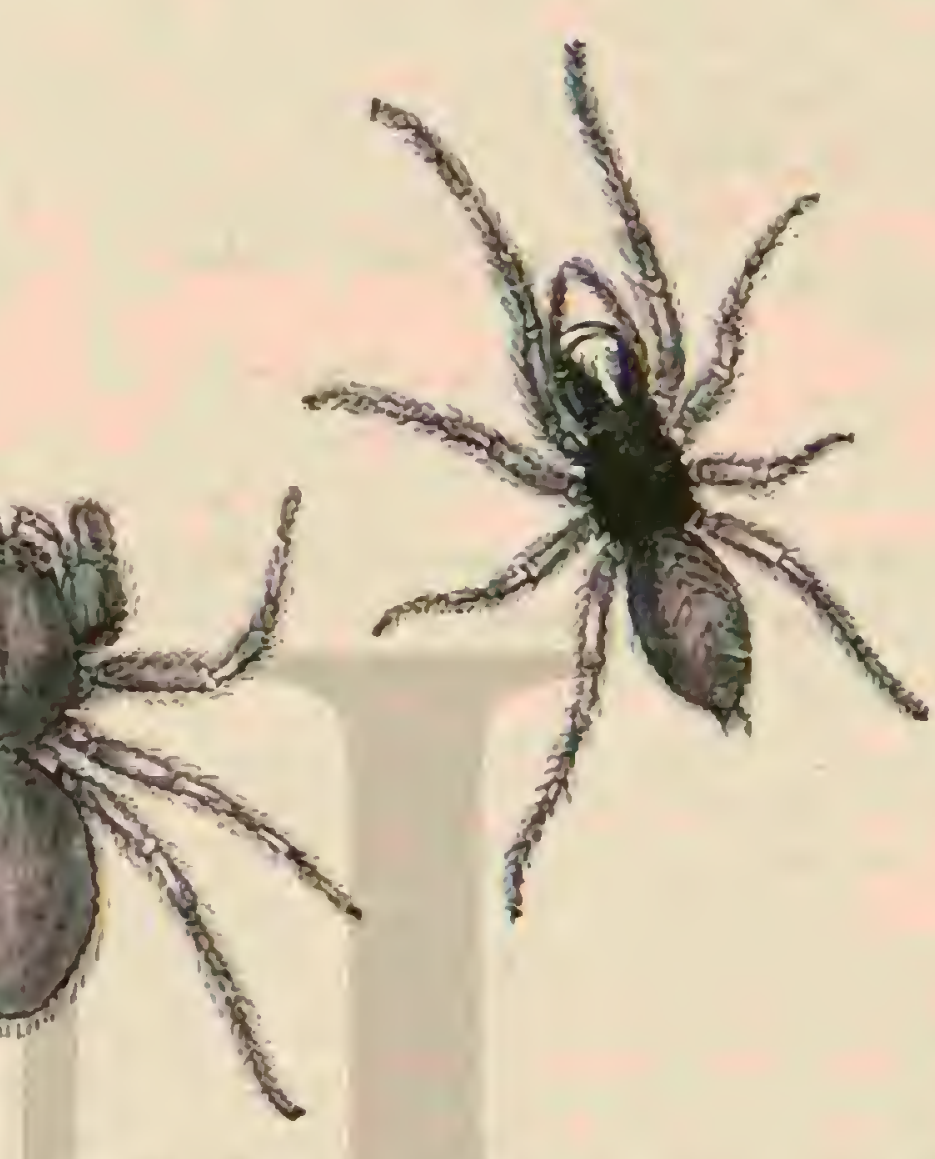

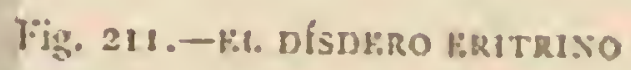

\section{LOS OTIOTOPS-OTIOTHOPS}

CARACTÉRES. - A Mro. Mac Leay se debe el conocimiento de este género, compuesto de amgnidos que se distinguen por los siguientes caractéres. 1.os ojos, en numero de ocho, forman tres lineas; los dos posteriores son mas grandes, y están muy atrás en la cabeza, uniéndose de tal modo entre si, que parecen no formar sino uno solo. Fol labio es prolongado, triangular y cónico; las maxilas, anchas y triangulares, se comprimen en su insercion, truncindose en linea recta en su cxtremidad; las patas anteriores tienen sus primeros artejos muy protuberantes; las del jrimer par son las mas largas.

Usos Y costumBRES. - L.os otiotops liabitan debajo de las piedras.

\section{ELOTIOTOPS DE WALKENAER-OTIOTHOPS WALKENAERII}

CARACTERES.-Distinguese esta especic (fig. 210) por tener las patas del par anterior palpiformes, con seis artejos: el metatarso y el tarso son corios; este último tienc su extremidad redondeada $!$ sin garm: en el segundo par, el femura! es protuberante; los palpos son delgados y sedosos, insertándose en la base de las maxilas; las mandibulas cortas, trasversas y verticales; el gancho pequeizo y horirontal; el coselete, bastante jrolongado, aiccta la forma ovalar y convexa, ofrecicndo un r:olor rojizo: el abdómen es prolongrado y ovoi. 
deo, negro yelloso: las hilcras pequeñas. El tamaño de este aragnido es de 5 lincos.

DISTRIBUCION GEOGRÁICA.-La especic es projia del nuevo continente: se encuentra en cl archipiélago de América y en la isla de Cuba.

USOS Y COSTUMBRES.-Este aragnido vire comunmente debajo de las piedras, y sobre todo en los parajes donde hay mucha espyesura.

\section{LOS TOMÍSIDOS-THOMI- SIDE}

CARACTERES. - Uni considumble nimero de arañas que habitar sobre todo en Europa y Anérica, sin faltar del todo en Jos demás continentes, difiere de las demás por su proceder y por su cuerpo casi siempre aylanado. Sel les ha designado con el nombre de tomisidos, y tambien de aranas cungrigus, dinulules este uiltimo calificativo por su semejanza con dichos crustácéos; estiran como estos sus largas patas y se mueven con la misna facilidad hácia adelante que hácia atrís 6 de lado.

Los tomisidos yue permanecer en acecho en los tron. cos de los árboles tienen un color que apenas difiere del de la corteza; $y$ una especic (bomisüs 6 starnscus zirescens), de color blanco verdusco, se oprime estrechamente contra las Aores de la yerba de San Juan, de modo que los insectos que se acercan en muchos casos no sospechan el peligro que les amenaza:

Los ocho ojos de los tomísidos están dispuestos en dos limeas argueadas que encierran una media linea abicrta por dęrás.

USOS, COSTUMBRES Y REGIMEN.-Se les encuentra en los troncos de átboles y en las hojas, pero sobre todo en las flores, donde acechan su presa. Les gusta acercarse de frente al insecto elegido, cogerle por la nuca y matarle de un mordisco. A menudo retroceden para esperar los efectos del ataçue, y solo empiczan á chupar su sangre cuan. do muere. Por lo regular rienden algunos hilos para bajar ú preparar su camino. En el tiempo dé Ja puesta muchas especies habitan entre hojas recogidas, en las flores de la yerba de San Iuan ó de otras plantas que en Isu interior tapizan con un tejido mas ó menos espeso: otms se buscan sitios abrigados debajo de picdras para depositar sus bolsitas de huevos, las cuales guardan con cl carino maternal acostum. brado.

Segun la posicion poco variable de los ojuelos, el tama. no proporcional de las patas, la cxistencia o falta de lit gurra rudimentaria, jen este caso de mechones de pelos en la cara inferior de las puntas de los piés, y por último la forma del abdómen, los tomisidos se han distribuido en generos y subgéneros de los que el thomisus ocupa el primer lugar.

\section{EL TOMISO VAGABUNDO-THOMISUS VIATICUS}

CARACTERES:-Elegimos, como representante del ciaado géncro, cl tomiso ingabundo, gue por su color y matices variables se ha considerado por algunos autorés siempre como otra especic, reconociéndose por lo tanto con muchos nombres. Fs de color pardo amarillento claro, con una mancha en forma de horçuilla en cada borde lateral del cefalotórax; el uibujo, mas claro hicia atrás, se ensancha poco à poco, presentando en cada lado tres puntos y se corre por el dorso, en cuyos costados blanquizcos se cruzan líncas oblicuas. Ias patas, amarillas, sobrc todo las anteriores, tie- nen en la hembra manchas y puntos pardos; en el macho las cuatro anteriores son desde la base hasta las rodillas de color pardo de orin $\delta$ negrurco, y despues amarillas sin manchas, como las siguientes. El macho mide 0 " 005 y la hembra $0^{m}, 00 \%$. Las patas carecen de garra rudimentaria y tambien del mechon de pelo en vez de la misma; los dientes de la garm de los piés son corvos; las garras de las patas tienen varios dientes; los ojos anteriores forman un arco apenas visible, $y^{\circ}$ las cuatro del centro, al mismo tiempo las mas pequeña, figumn un cuadrado.

DISTRIBUCION GEOGRÁFICA. - El tomiso vagabundo esta diseminado desde Suecia por toda la Europa hasta el Egipto.

USOS, COSTUMBRES Y REGIMEN.- Fste insecto es mas bien perezoso que vivaz; agrádale vivir entre las hojas, y se rodea de algunos cortos hilos. En mayo ó á principios de junio la hembra deposita tambien sus huevos, encerrin. dolos en una bolsita redondeada con las paredes nuy tendidas, y guárdalos con tal solicitud que ni por el contacto huye lil desarrollo de los hijuelos parece verificarse de un modo muy desigual; en otoño se ven individuos de diferentes tama. ños, que cn sus hilos cruzan el aire.

El fenómeno de las telamanas volantes, llamadas tambien hilos de otonio, arerano iolanle, hilos de María (fils de la Vierge.) de los franceses, se conoce lace mucho tiempo, pero aun no se ha cxplicado del todo. Miles y miles de hilos relucen a los rayos del sol de otono cual si fuesen de plata, sobre los campos y praderas, en las espesuras y matorrales, vierdose pendientes como largas banderas en los árboles y otros obje. tos altos; algunas veces vuelan cual blancos copos por el aire destacíndose marcadamente en el cielo azul. Solo en tiempo muj hicrmoso se produce este fenómeno, y hé aqui porqué esos hilos y copos, que solo se ven algunos dias, ya muy en trado él año, y que en cierto modo recuerdan la belleza del verano, se llaman en Alemania, no sin razon, y sin querer aludir con ello a las personas, el averano de las mujeres vicj25. 'Todo el mundo, y hasta los niños, conoce el origen del fenómeno: y nadie le considera como una traspiracion de las plantas, conıo se creyó en tiempos pasados. Pero ¿jpor qué se ren estos hilos precisanente en otono y no en verano, cuando en todas partes se encuentran los mas diferentes tejidos de aranas? El obserndor atento no prodrí menos de reconocer que los tejidos de que ya hemos hablado difieren unticho por su naturaleza de los de las telarañas de otoño: los primeros sirven para retener la presa de las especies-sedentarias que los hicieron, pero los segundos, solo indican el camino por donde ha paszdo el cjército de arañas grandes y pequeñas y no tienen por objeto coger insectos, porque los insectos que los fabriciron observan un género de vida vagabundo y no hacen nidos. Estas aranas solo llaman la atencion en dicha época del año, porque en este ticmpo se han dispersado mas y' mas mara buscar sus cuarteles de invierno, y solo cuando el tiempo es hermoso se dan \& conocer por sus hilos, porque ninguna especie teje en tiempo desfarorable. Cuando el rerano es muy propio para el desarrollo, en octubre, que sicmpre sucle traer algunos dias calurosos, estas arañas llaman mucho la atencion, pues entonces existen en mayor número que en los anos en que el tiempo no favorece su prosperidad. Si por lo tanto consta que las telaramas de otono sénalan el camino por donde han pasado esos insectos vagabundos, menos para buscar su alimento que para dispersarse, refugiándose en sus cuarteles de invierno, podremos pasar aun mas allá y atribuir tambien à estos séres cierto instinto de viajar, como lo hemos reconocido yn en otros muchos insectos. Como rapaces que son no pueden permanecer juntos en grandes bandadas, tanto menos, cuanto que sus hermanos sedentarios, 
domésticos hasta cierto punto, dependen de ciertos lugares. Sin embargo, como las arañas carecen de las alas de los insectos emigrantes y el viajar por su propio pié de poco les serviria, utilizanse ingeniosamente de sus hilos para cruzar los aires. ¿Cómo lo hacen? Basta observarlas un poco para comprender pronto su astucia. Todos los objetos que sobre. salen del suclo, los guardacantones de las calles, las estacas y maderos, y tambien las punias del ramaje de los arbustos y árboles, están cubiertos en el otoño de las telas de diversas arañas pertenecientes a las especies vagabundas, y que aun no han llegado á la edad aduita. Cuando una de ellas desea emprender su viaje aéreo sube al punto mas alto del sitio en que se encuentra, levanta el abdómen, que al parecer está nas alto que la cabeza, lanza un hilo de sus verrugas textiles, tiende las patas y comienza su marcha aérea. White refiere que cierto dia, hallandose leyendo en su habitacion, vió de pronto en su libro una araña, que despues de avanzar hasta la extremidad de una hoja lanzó un hilo y siguió con ell rápidamente. Sin temor ninguno y con toda comodidad tiende todas las patas y abandónase al azar sin saber á dónde llegará. El hilo se mueve con lentitud, conducido por una corriente de aire, que siempre existe aunque nosotros no lo notemos;y es posible que el hilo negativamente eléctrico, sen atraido por la clectricidad positiva del aire. Quizis sa la cixcursion bastante corta, pues el hilo se agarra en cualquier objeto, obligando a la arana a ponerse de nuevo en pié; pero a reces el hilo la conduce a bastante distancia. Darwin observó, hallindose á unas 60 millas marinas de la costa, miles de pequeñas aranas rojizas que llegaban de esta manera al buque; y Lister las vió volar repetidas veces a mucha altura sobre el punto mas elevado de la catedral de York.

Para que el viaje aéreo no dure eternamente la amña se vale de un medio muy sencillo cuando quiere bajar; bastale subir por su hilo y trasformarle en un copo blanco, para vol. ver poco a poco al suelo, como con un para-caidas. Estos copos caen a reces por el aire en número sorprendente, y muy á menudo se encontrará en ellos uma amña. Varios naturalistas han observado hace mucho tiempo la produccion de estos hilos, mientras que otros la negaban; pero hasta el đ̧ue no es maturalista puede convencerse facilmente por sus propios ojos, si dedica algun tiempo a observar las aranas en los sitios indicados, cuando la luz toque precisamente en los individuos que lanzan su hilo, porqque la finura de este lo hace invisible en condiciones desfavorables. Por mágica que sea la belleza de ese mar de tejidos esfericos que se exticnde sobre los campos y praderas, y que cubiertos por el rocio parecen piedras preciosas, pueden sin embargo perjudicar mucho en las praderas de las regiones donde se recoge tarde la última cosecha del heno, porque este se impregna poco a poco de humedad de tal modo que no se puede secar de dia. Este es el único perjuicio que ocasionan estas aranas, las cuales trabajan por lo demás en interés de los agricultores. En primavera, cuando las arañas abandonan sus cuarteles de invierno, repitese el mismo fenómeno (jue el del everano de las doncellas», pero cn menor escala, y no solamente en nuestros paises, sino tambien en el Paraguay, donde Rengger las olsservó y sin duda tambien en otras partes.

\section{EL TOMISO DE CRESTA - THOMISUS CRISTATUS}

CARACTERES.-Fl tomiso de cresta (fig. 212) tiene el abdómen deprimido en el dorso; el vientre suele ofrecer co munmente colores leonados, pero que varian desde el blan. co hasta al pardo, presentando un espacio mas claro que afecta la figura de una cresta ó de un plumero extendido; en las patas hay lineas pardas, leonadas en las hembras y mas oscuras en los machos; el abdómen de cstos viltimos afecta una forma oval mas prolongada. Ia hembra mide 4 y media lineas de largo, y el imacho 3.

DISTRIBUCION GEOGRAFICA.- Este aragnido habita principalmente en Europa y Africa; parece ser muy comun en Succia, Alemania, Francia y ligipto.

USOS, COSTUMBRES Y REGIMEN. - Iil tomiso de cresta se mucre con pesader y lentamente; ocíltase debajo de las piedras y de las cortezas, y sobrevive a los frios mas rigurosos, por lo cual varia mucho de color; pero la estructura notable de su dorso se manifiesta desde la primera edad. Como las patas de este aragnido no son muy prolongadas, su marcha es torpe. Enciérrase entre las hojas, y tiende hilos aislados, al rededor de los cuales se suspende algunas reces.

Ia hembra deposita sus huevos en un capullo aplanado, de tres lineas de dianzetro, cujo tejido abulta mucho cuando conticne los huevos, presentando entonces eminencias redondeadas. Ia madre se coloca sobre el capullo, y no le aban. dona aunque se la toque; algunos contienen hasta ciento veinticinco huevos de un blanco amarillento; y si esta es la regla para todas las hembras, se explicaria por ques abundan tanto los individuos de la especie: jero es de creer que solo haya tantos en casos excepcionales.

\section{EL TOMISO DE CAMBRIDGE-THOMISUS CAMBRIDGII}

CARACTERES. - Esta especie (fig. 213) tiene el abló. men de color amarillo de azafmu, con dos rayas de un rojo sanguineo cerca del coselete, y otras ocho trasversales en los costados; las patas y los nuslos son de un tinte vercle; las piernas y los tarsos amarillos, estos últimos anillados de rojo; los palpos tienen el digital corto, oval y de color anaranjado. Lil tamaño de este aragnido es de unas 4 lineas de largo.

DISTRIBUCION GEOGRAFICA.- Lsta araña se cncuentra en la América septentrional, y particulamente en Georgia.

USOS Y COSTUMBRES.-Se suele encontrar esta especie en los troncos de los àrboles y en las flores.

\section{EL TOMISO DE CIDRO-THOMISUS GITREUS}

CARACTERES.- lista especie (fig. 214) corresponde al grupo que llaman algunos autores de los globulosos: el abdómen es corto, convexo y muy ancho cn su parte posterior, que se redondea y carcec de tubérculos: los ojos laterales de la linea anterior son prominentes, pero no mucho mas grandes que los otros: en cl abdómen hay duce puntos hundidos en el centro, dispuestos en ingulo ó en pirámide, de color verde púlido, blanco ó amarillo uniforme; todas las pattas son verdes. Esta especic midic 4 lineas de largo.

DISTRIBUCION GEOGRAFICA.- Este aragnido se halla diseminado por toda Luropa.

USOS Y COSTUMBRES. - \& He jresenciado, dice Degeer, el apareamiento de este tomiso con el que algunos llamaban uniclicole, y entonces reconoci que estos dos aragnidos tan diversos al parecer, constituian una sola especic. I I hembra suele frecuentar los rosales y otras flores, donde se oculta para devorar las abejas y otros insectos cuando estan ocupados en chlipar el néctar. Cuando ha puesto, no abandonia el capullo, aun cuando hayan salido a lu\% los hijuclos. Al acercarse el momento de poner se situa en la hoja de un arbol ó de un arbusto, la cual dobla convenientemente. 


\section{LOS FILODROMOS-PHILODROMUS}

Caractéres. - Los atributos esenciales de las especies de este género consisten en tener el coselete aplanado; abdómen corto, muy ancho en su parte posterior; las patas de los pares medios mas largas que las otras; el labio es trinngular $y$ truncado; las mandibulas son cilindroideas.

\section{EL FILODROMO DESIGUAL-PHILODROMUS} DISPAR

CARACTÉRES. - I a hembra de esta especie (fig. 218) tiene el abdómen piriforme; cubierto de pelos cortos, agrisados en el centro de la jarteanterior y uegros ó pardos en los lados: el coselete, en formn de comzon, es agrisado, con dos fajas pardas longitudinales; las patas finas y verdosas; los muslos estan manchados de negro.

El macho (fig. 216) tiene el coselete y el abdómen de un pardo negruzco, orillados ambos de blanco; las patas y los palpos rerdosos; estos últimos muy largos. Este aragnido mide 3 lineas de largo.

DISTRIBUGION GEOGRÁFICA.-La especie está diseminada en todo el antiguo continente.

\section{EL FILODROMO PÁLIDO-PHILODROMUS PALLXDUS}

CARACTERES. - Estr especic (fig. 220) tiene el coselete mas ancho que el abdómen, y de un color pálido agrisado; el

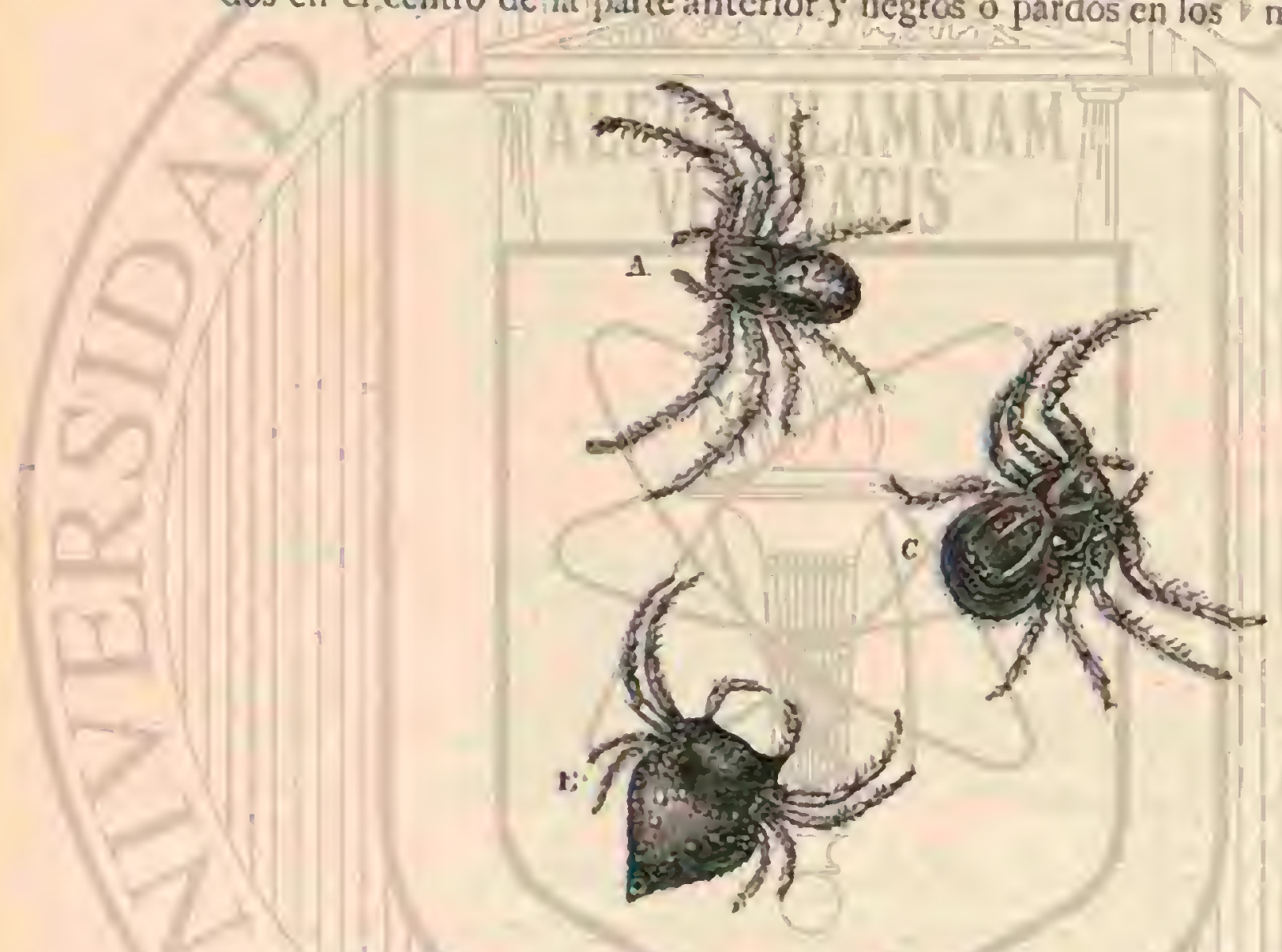

Fig. 212. - A E. TONHSO DE CRESTA Fig. 215.-E EI. ARK1S 1.ANCERO

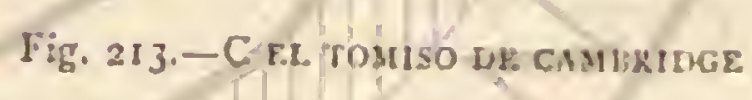

Fig. 214.-B EL TOMISO IHE CIMRO

(B Macho, D Hemibra) vientre es ovoideo, prolongado, deprimido, y puntiagudo hácia el ano; en la parte anterior presenta una ligera iscotadu: $\mathrm{ra}$, ó una pequeña depresion, $y$ a cada lado hay dos manchas de un negro muy vivo; el vientre, las patas y los palpos son de un amarillo pálido. Mide dós líners de largo.

DISTRIBUCION GEOGR Á FICA.-Este filodromo estå diseminado en los diversos paises de Europa.

\section{EL FILODROMO OBLONGO-PHILODRO- MUS OBLONGUS}

CARACTERES. - El filodromo oblongo (fig. 219) dificre de la especie anterior por tener el abdómen muy prolongado y cilindroideo, con el fondo de color anarillo $y$ una mya lon. gitudinal parda en el centro, la cual se adelgnza en su parte posterior; en los lados hay otras dos mas estrechas, y en cl centro del dorso varios puntos pardos; el vientre es de un gris blanco uniforme. El filodromo oblongo mide poco mas de 3 lincas de largo.

DISTRIBUCION GEOGRÁFICA,- Habita en Europa $y$ es bastante comun en Alemania y Suecia.

\section{LOS ESPARASOS - SPARASSUS}

CARACTERES. - Los ocho ojos que tienen los esparasos, bastante aparentes, estín dispuestos en dos lineas en la parte anterior del coselete, sicndo la primera la mas corta; el labio es breve, ancho, semicircular ó clipsoidal; las maxilas rectas como los lados paralelos y la extrenidad redondeada; las patas robustas y divergentes, son poco desiguales entre si.

DISTRYBUCYON GECGRÁFICA. - LOS esparasos se encuentran en una gran parte del globo.

\section{EL ESPARASO ESMERALDA-SPARASSUS SMARAGDULUS}

Caracteres. - I a hembra de csta especie (fig. 217) tiene el coselete, las patas, las mandibulas y el abdómen de un color verde muy delicado: el vientre es del mismo tinte, pero mas júlido; el abdómen oval y prolongado; el coselete Se arquea y redondea on su parte posterior.

El macho adulto tiene el abdómen oval y cilindroideo, con cinco fajas alternativamente amarillas y purpureas que se corren en toda la longitud de aqquel; el vientre es rojizo en los lados y de un verde sucio en el centro; cl coselete, las patas y los palpos verdes. Fil tamano de ambos sexos es de 6 linéas de largo.

DISTRIBUCION GEOGRAFICA.-El Esparaso esmeralça es una especie propia del antiguo continente, y bastante comun en Francia, Suecia y Alemania.

USOS, COSTUMBRES Y REGMEN.-Se encuentra esta especie en los jardines y en los bosques, corriendo sobre la yerba, sobre todo en majo, junio y julio, en este último mes se suele ver el capullo grande $y$ verde de la hembra, que contiene algunas reces ciento cuarenta huevos. 


\section{LOS LICOSIDOS-LYCOSID屃}

OBSERVACIONES GENER A LES. - Mejores acronaUtas que los tomisidos ienemos en la familia de los licosidos ó citigrados, llamados tambien aranias lobos, y que por el considerable tamaño de algumas de sus especies representan en nuestras regiones templadas a los migálidos de los paises tropicales. Los licosidos agrupados en el género /jeosa, sub. dividido últimamente en muchos subgéneros, están disemimados por toda la cierm y son muy propios para infundir una preocupacion, despertando un odio instintivo contra todas las amias por su asperto exterior, su tamaño, la rapidez de su carrera, sus bruscos movimientos, y el impetu con que se precipitan debajo de una piedra cuando se les inquieta en su esconditc.
Fritsch hace mencion de una especie del Africa meridio1 al cuyo abdómen tiene el tamaño de una avellama grande y cuyas partes centrales miden la anchura de unos $0^{n}, 157$ de punta á punta de garm. Mas facil es recibir una picadura de esta araña que no de los migálidos, porque le gusta visitar las casas. Segun el citado autor, para la persona que cestá sentada tranquilamente en su estudio no es nada agradable oir de pronto un ruido particular, y al volverse ver uno de csos monstruos pasearse por las cortinas. Muchos licosidos viven en agujeros subterríneos cuyas paredes tapizan con su tejido. Los unos llevan las bolsitas de los huevos consigo en el vientre ó permanecen sobre ellas como si las incubaran; otros las cuelgan en las agujas de los pinos ó de las plantas bajas.

CARACTERES. - En los licosidos se obsermn algunos

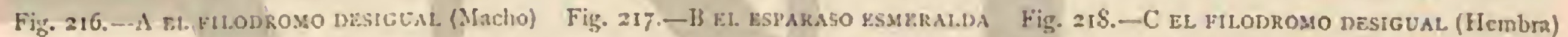

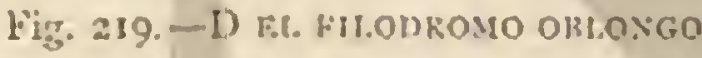

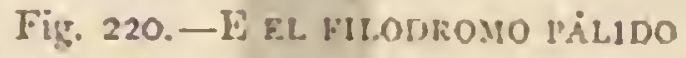

caracteres muy particulares que los distinguen á primera vista. El cefalotórax se estrecha mucho hácia adelante y se eleva á lo largo del centro en forma de quilla obtusa; los ojos están dispuestos en tres series; cuatro son pequeños, muy oprimidos en una linea casi sicmpre recta en la parte anterior, dos mucho mas gtandes, próximos entre si, situados detrás; los dos últimos son tambien grandes, pero mas distantes uno de otro. De las patas delgadas el uiltimo par lo es mas que los otros, pero sodas rematan en dos principales y en una garra rudimentaria sin dientes, que solo cn un genero (aora) falta del todo. Los palpos de la hembra están provistos de una garra denticulada.

\section{EL DOLOMEDO ORLADO-DOLOMEDES FIMBRIATA}

CARAGTERES. - Muchos licosidos habitan con preferencia los sitios húmedos y pantanosos y comen tambien de. trás de su presa á cierta distancia por la superlicic del agua, aunque sin sumergirse: á estas especies pertenecen entre otras el dolomedo orindo. Tiene la cara superior del cuerpo de un pardo aceitunado, presentando en ambas mitades un ancho borde blanco 6 amarillo. Tambien se ven á menudo en el centro del abdómen cuatro series longitudirinles de puntos plateados; las dos exteriores, compuestas de sicte puntos, se extienden en toda la longitud, mientras que la del centro solo tiene tres ó cuatro poco marcados en la mitad posterior. El pecho es amarillo, con un borde pardo; el vientre está rayado de gris y de negro; las patas, de un tinte amarillento, tienen pelos negros y puntas espinosas (fig. $22 \mathrm{r}$ ). El género dolomedes se distingue por tener sus individuos dos dientes largos y corvos en la garra rudimentaria; los cua. tro ojos anteriores son pequeños y están situndos a cierta altura en la superficic do la cabeza, que forma un declive, y los cuatro posteriores, muy grandes, forman un trapecio corto, cuyos angulos posteriores estin i doble distancia que los anteriores. Lin borde lateral claro del fondo aterciopelacio constituye un rasgo distintivo del cefalotórax y del abdómen de todas las especies del género.

USOS, COSTUMBRES Y REGIMEN.-En junio SE encuentran ya los hijuelos á menudo en diferentes plantas de las regiones pantanosas. La hembra fecundada alcanza a menudo la considerable longitud de $11^{\circ}, 026$, mientras que el macho so! o mide $0^{\circ}$, or r. La bolsita de huevos pende en forma de tejido ligero y blanco en un tallo, que el insecto vigila de continuo.

\section{EL DOLOMEDO ADMIRABLE - DOLOMEDES MIRABILIS}

CARACTÉRES,-Este aragnido (fig. 222) dificre por varios caractéres muy marcados de la especie anterior. El 
coselete es corto y en forma de comzon; el abdomen, muy jrolongado y cilindroideo, se estrecha posteriormente, ! presenta á los lados una faja íestoreada de un blanco nurvivo en el centro hay varias placas mas oscuras, de un bonito leo nacto carmelita: el labio, prolongado y de forma cuadrads, es grueso y mas alto que ancho; los ojos laterales de la línea anterior igualan en tamano á los de la central. Esta asaria mide unas 5 lineas.

DISTRIBUCION GEOGRAFICA.-El area de disparsion de este aragnido es muy externsa, pues se halla diseminado por tocio el antiguo continente.

USOS Y COSTUMBRES - Bien merece este aragnido el calificativo con que se le distingue, porque es en efecto admirable por su industria. Ia hembra pone len el mes de agosto. : entonces rodea lis extremidades de las ramas ó de las yerbas con una tela en forma de cupula o de globo, tin zmande como el puno y abienta por su parte inferior; en medio de ella coloca su capullo, que es globuloso, de un color blanco algo amarillentn y del tamaño de una grosella. Cuan. do el dolomedo admirable sale de su albergue, lleva siempre consigo su capullo, oprimiéndole entre su pecho y una partc del vientre con sus mandibulas y sus palpos. Mientras está en su nido, no se aparta jamás de los hijuelos hasta que han salido a luz: cuando se halla sobre su cipullo no le asusta nada; déjase coger anies que abnnconarle; pero en cualquier otra época, muésirase salvaje y huye con rafjide\%. Los hijuclos al nacer permanecen aglomerados en uma de las mitades del capullo abicrto, ó en un lado del nido; si se sacude este, los pequetos abandonan al punto aquel sitio, y vingan por todo el interior de la tcla, mientrus que la midre suele hallarse en la superficic exterior, sin que se pueda obligarla à dejar su nido $\delta$ á penetrar en el. La puesta varja entre ciento y ciento circuenta huevos segun la edad.

\section{LA PARDOSA DE SACO-PARDOSA SACCATA}

CARACTERES. - I ans especies que tienen una garra rucimentaria sin dientes, cabeza muy estrecha jo dejrimida en su parte anterior, y unos dibujos en forma de radios en el ceialotórax se han agrujado ultimaneate bajo el nombre genérico de pardosa.

La mas diseminada de todas las especies es la pardosa de saco, que en su jurentud figura entre los atrevidos acronautas y yue á principios del año siguiente es uno de los artro. podos que al despertar de su letargo invernal se presentan en sitios caldeados jor el sol. Mide cuando mas $0^{\circ}, 0065$ de largo; es de color pardo gris y tiene una mancha longitudinal amarillenta en la parte superior del cefalotórax, Dira ahorquillada y negra en la base y dos series de otras negras en el dorso del abdómen; las patas son de un amarillo pardusco, con anillos negros.

Hay varias especies muy parecidas que observan el mismo género de vida (Pardosa montana, arenaria y otras) y que sin descripción detallada no pueden distinguirse fácilmente, por lo cual los autores las hau dado á menudo el nombre de Ir especic que nos ucupa, aunque sin razon.

USOS, cOSTUMBRES Y KEGIMEN. - Pstas pardosas viren en sitios húmedos y secos explestos à los rayos del sol y no me atrevo a deteminar si por la residencia po. dria reconocerse la especic; creo, por el contrario, que todas se encuentran mas ó menos mezcladas.

Eil apareamiento se verifica muy pronto, pues en la segun. da mitad de mayo se ve a la hembra correr entre la hojarasca, con una bolsa aplanada de huevos en el vientre. Los hijuclos nacidos permanecen algun tiempo en la bolsa y suben tam. bien al cuerpo de la madre. Una ver que eché varias de es- tas arañas en espiritu de vino, me asombré bastante al en:contrar en la botella un gran número de lijjuelos que en su agonia habian salido probablemente de la bolsa.

\section{LA TARÁNTULA DE APULIA - TARANTULA APULIAE}

CARACTERES.-E! nombre que Linneo dió a la taraintula de Apulia ha sido aplicado últimamente á un género en que se reunen todos los licosidos que presentan en comun los caractéres siguientes: la superficie anterior de la cabeza se inclina vericalmente hácia adclante, y a cicria altura, sobre una callosidad trasversal, tiene los cuatro occlos anteriores, penueños y de igual tamaño entre sí. I a posicion de sodos se parece mucho i la del género anterior, con la única diferencia de que los posteriores se aproximan un poco mas entre si yo à los anteriores. Los piés tienen una garra rudimentaria sin dientes. En el cefalotórax se ven casi siempre tres fajas longitudinales claras; en el abdómen hay unas manchitas oscriras, á menudo poco narcadas, ó una uancha langitudinal oscura en forma de cono $\delta$ de huso en medio de los lados mas oscuros y cubiertos de una especie de escarcha.

I.a tárántula de Apulia mide en el sexo femenino hasta $0 \%, 037 ;$ es de color de corzo, presentando en el abdómen algunas lineas trasversales negras orilladas de blanco rojizo, y en el vientre una faja central negra. Los puntos claros del cefalotórn: que es negro, tienen tambien un color rojizo.

DiSTRIBUCION GEOGKAFICA.-Esta tarintula vive no solamente en la Apulia, con gran frecucncia en los alre. dedores de Nipoles $y^{\circ}$ de Tarento, sino ambien en otros punios de Italia, Jispaña y Portugal.

USOS, COSTUMBRES Y KEGIMEN.-Todas las taríntulás prefieren los sitios secos bañados por el sol; la hembra coloca su bolsita de huevos en las verrugas textiles.

La tarintula de in Apulia practica en las pendientes incul. tas un agujero en la tierra, refuerza la entrada con plantas secas entretejidas de modo que se eleve sobre el suelo en forma de un pequeño terraplen, y tapiza el interior con una sustan. cia que al calor del sol se endurece como la piedra. I 2 posi. cion inclinada y el terraplen que rodea la viviènda protégen. la contra la humedad y contra los objetos que pudieran cacr en ella. De dia no es fácil que la araña salga, hasta despues de ponerse el sol: entonces acecha en la cutrada, y cuando cierra la noche vaga por los alreciedores en busca de su presa; apenas coge un insecto llévale à su vivienda y le devora con toda comodidad, arrojando á la entrada las partes que no puede cumer. Varios autores dicen que las aranas salen tambien de dia fuera de sia vivienda cuarndo se sopla con un iallo de paja en el agujero, imitando el zumbido de la abeja, lo cual sahen hacer muy bien los campesinos de la Apulia.

Desde ociubre hasta la primavera la guarida csta cerrada con una masa de inda clase de sustancias vegetales reunidas enire si por hilos. Fn la primavera puede suceder que el campesiro al labrar la tierra destruja muchos agujeros de la tarantula antes de que esta haya despertado de su letargo, pero entonces no maniniesta inclinacion a morder, pareciendo solo enojada porque se la obliga a salir i la luz del dia. Su paso es inseguro y vacilante; parece que yá no sabe ì dónde ir, $y$ segun pretende Baletta no se conoce ningun cjemplo de que la taråniula haya mordido à ningun hombre en otono ó la primavera. Rossi dice que la bolsa de hucros que esta araina lleva, como ya hemos dicho, en la extremiciad del abdómen, es blancr y tiene el doble tamaño de una arellana, conteniendo de 600 a joo hueros blancos del tamaño de un grano de mijo. Los hijuelos salen à luz en agosto $y^{\prime}$ 
seticmbre, y suben alternativamente al dorso de la madre, hasta que llegan is ser independientes y se dispersan. Asi por este concepto como por otros muchos la temida tarintula ofrece por lo tanto los mismos fenómenos que sus muchos congéneres en las regiones de la Europa meridional y septentrional, y es tan poco peligrosa para el hombre como aquellas.

VENENOSIDAD. - Ninguna cspecie de araña ha dado lugar a tanto clamoreo como la tarintula por causa de su mordisco renenoso, y dificilmentc se habrán propagado iantas noicias falsas sobre ningun otro insecto. Jan tarintula, con varios congéneres, pertenece al antiguo género lycosa, nombre originario del italiano. Bajo la denominacion de tarantela se comprendia primitivamente una araña venenosa (llamada iambien solofizsi) que vive particularmente cerca de Tarento y a cuya mordedum se han atribuido los fenómenos mas extraños. Ulises Aldrovandi, que en su historia natural de los insectos ( 1602 ) ha recogido todo cuanto hasta entonces sé hahia escrito sobre las arañas, trata detalladamente de los efectos de la picadura de la tarintula y de los medios de curarla. Segun él, apenas se contaba un acto humano, por tonto y pueril que fuese, que no se atribuyem á los efectos de esa picadura; y al hablar de los pacientes dice que los unos cantan sin cesar, rien, lloran ó exhalan quejidos; otros se sienten dominados por un sucño invencible ó una gran agitacion; los mas padecen vómitos; muchos bailan ó sudan; y no pocos son presa de un temblor continuo ó palpitaciones de corazon, $\delta$ bien experimentan otros malcs, de los que resulta su antipatia contra los colores negro y azul, mientras que les gusta el rojo y el verde. Para curar á los picados por la tarántula se han de tocar en cualquier instrumento dos inclodias, la "pastorily y la tarantela, muy recomendadas en las diversas obras que tratan del asunto. Desnues el enferno empieza a bailar, hasta que, sudando al fin copiosamente, cae exhausto al suelo. Entonces le llevan á la cama para que duerma, y al despertar ya está curado, sin saber qué le ha sucedido. Puede haber, sin embargo, recaidas, susceptibles de repetirse por espacio de 20630 años y hasta toda la vida. Además se pretende que en la canicula la picadura es mas peligrosa; que puede ser mas grave la de una araña que la de otra, y que la especie de la Apulia no es peligrosa cuando se la lleva á Roma, 6 mas al norte. Semejantés necedades se creinn aun en este siglo, no solo por cl pucblo, sino hasta por algunos médicos ilustradisimos; pero de ello resultó una ventaja, y es que muchisimas personas verdaderamente instruidas se ocuparan del fabuloso insecto, reduciendo los efectos de la picadura á su verdadera medida. Un hidalgo polaco, Borch, in. dujo à fines del siglo pasado á un napolitano, haciéndole un presente, à que se dejase picar en el dedo en su presencia. Conseguido esto, la mano se inflamó; jos dedos se hincharon; y. el paciente experimento en cllos una fuerte picazon; pero al poco tiempo curó del todo. Lecon Dufour, y últimamente José Erker, confirman por experimentos hechos en su misma persona que la picadura de la tarintula es del todo inofensiva.

Los datos referentes al baile de la tarantula, observado en verano, il carmaralefto delle donse (el pequeño carnaval de las inujeres) se remontan nada menos que al siglo $\mathrm{xr}$, $\mathrm{y}$ ofrecen un carácter muy distinto cuando se lee la historia del kbaile de verano en la Edad media, so de la cual-resulta yue en Dinamarca, Suecia, Inglaterra, Francia y Alemania se observan fenómenos del todo semejantes á los que produce la taríntula de los italianos. Todas las expediciones de bailes de aquella época perdieron su imprortancia ante el baile llamado de San Juan, que nada tiene que ver con la picadura de la taraintula ý que fué epidémico en r 374 á orillas del Rhin, del Mosela y en los Paises Bajos. Jórenes y ancianos, mujeres y niños, simtiendo los cfectos de la enfermedad, abandonaron sus hogares y fuéronse \& viajar, bailando de ciudad en ciudad. En Aquisyran, Colonia, Met\%, Mastricht, Lieja y otras poblaciones, veianse en las calles, iglesias y otros sitios, gentes que bailaban como salvajes, dando furiosos saltos, hasta que hombres y mujeres cainn rendidos de cansancio. La buena crianza y la moralidad se olvidaban del todo en esta inexplicable demencia. Con el nombre de baile de San Victor esta epidemia se deçaró en otras jartes, rẹpitiéndose en algunas mas tarde, bajo la forma de peregrinaciones.

A la misma familia, aunque á otros géneros, pertenece sin duda una parte de las raras aranias de que nos hablan los vinjeros à paises callidos, y que estan desfiguriadas por protu. berancias córneas, dilataciones en forma de vejigas, excre. cencias y ensanchamientos de las patas, necesitandose muy buena vista para reconocerlas como arăas. Estas especies procuran utilizarse lo mas posible de su forma desfigurada, pues recogiendo su cuerpo en forma de un bulto disforme, permanecen en la bifurcacion de una rama, en uma bendidura de la corteza $\delta$ en otro sitio semejante siempre al acecho, hasta que la presa se aproxima descuidadamente; pero entonces la agilidad de la araña sorprencle, anto mas cuanto que el bulto deforme no inducia a suyoner que fuesc un sér vivio.

\section{LOS ATIDOS-ATTIDE}

CARACTERES. - La carencia de garm en los palpos de la hembra y tambien de la rudimentaria de los piés, que cuando existen son delgadas y tienen cortos dientes, isi como las extcriores presentan á veces pelos en forma de plu. mas; la facultad de saltar, y las proporciones particulares de los ojos, caracterizan esencialmente i esta última fimilia. Los cuatro ojos de la scrie anterior, sobre todo los dos del centro, son muy grandes; los dos anteriores latemles y los posteriores de la coronilla iguales entre si, y con pocas excepciones (salticus) situados a la misma distancia, mientras que los ojuelos laterales que en linea casi recta están dispuestos en medio de açuellos, se distinguen por su pequenea I as patas son fuertes $y$ llegan a su mayor longitud en cl par posterior. Las aminas, en su major parte pequeñas, y bastante á menudo adornadas de graciosos dibujos abigarrados, fabrican en las plantas ó piedras un nido sedoso en forma de bolsa oval ó redonda, doncie las hembras conservan sus huevos.

\section{EL SALTADOR ESCÉNICO--SALTICUS SCENICUS}

CARACTERES. - En majo y en junio, los machos, que solo miden $0^{\circ, 00516}$ de largo, presentan palpos desarrollados que con las antenas maxilares sobresalen mucho. I.os dibu. jos ce este pequeño insecto varian algo: el cé́alotórax sucle ser oval, un poco estrechado hacia atrás; sobre un fondo ne. gro presenta dibujos blancos, formados por unos pelitos que figuran una ancha faja lateml; en la cara hay por detris de los ojosanteriores una mancha ahorquillada que tambien puede ensancharse en forma de cruz. El abdómen largo y ovalado ticne el dorso de color pardo aterciopelado ó negro brillante, con cuatro anillos blancos cortados, que mas bien parecen fajas: á menudo se observan además pequeños di. bujos angulosos de color amarillenio. Fin el vientre predomina el color gris blanco; el pecho es negro con pelos blancos; y las patas parduscas con escamas blancas en el centro de los muslos. La heinbra es $0^{n}, 00225$ mas larga que el macho. 
USOS, COSTUMBRES Y REGIMEN.- EI saltador escénico se presenta ya en los primeros dins de la primavera en las paredes y ventanas donde da $\mathrm{el} \mathrm{sol}$, buscando por todas partes las moscas. Cuando ve alguna se acerca; segun el caso, un poco mas, para precipitarse de un salto sobre el dorso, asegurándose en su caida por medio de un hilo. Una ó dos picaduras bastan para que la mosca no pueda oponer resistencia; entonces baja sobre su víctima y chupa su conte. nido. Los movinientos de estas arañas tienen algo de muy grotesco, pero el que fija un poco su atencion en ellas no po. drá desconocer su astucin y su verdadero plan de ataque para apoderarse de una mosca. Asi, por ejemplo, la baranda de una escalera al aire libre puede servir de escena para la actividad de la araña; en el lado donde da el sol agradales á las moscas y otros insectos posarse, pero en la parte opuesta ya está en acecho un saltador, cual si sujiera que el lugar es á propósito para una buena caza. Desde el punto en que se halla deslizase sobre la baranda para caer precisamente sobre la mosca y poder saltar sobre ella desde un punto elevado. No obstante, se ha equivocado en la direccion, pues viene a dar delante ó detrás de la victima: entonces vuelve á bajar con cautela y busca el medio de corregir la falta, con lo cual cae exactamente junto á la mosca que sin cuidado se pasea En línea paralela, la araña sigue a su futura presa, y vuélvese como ella, de modo que casi podria creerse que ambas se mueven por una misma roluntad. Alguna rez se levanta tam. bien la mosca para colocarse detràs de la araña, pero esta se vuelve con la rapidez del rajo para no perder de vista su víc.

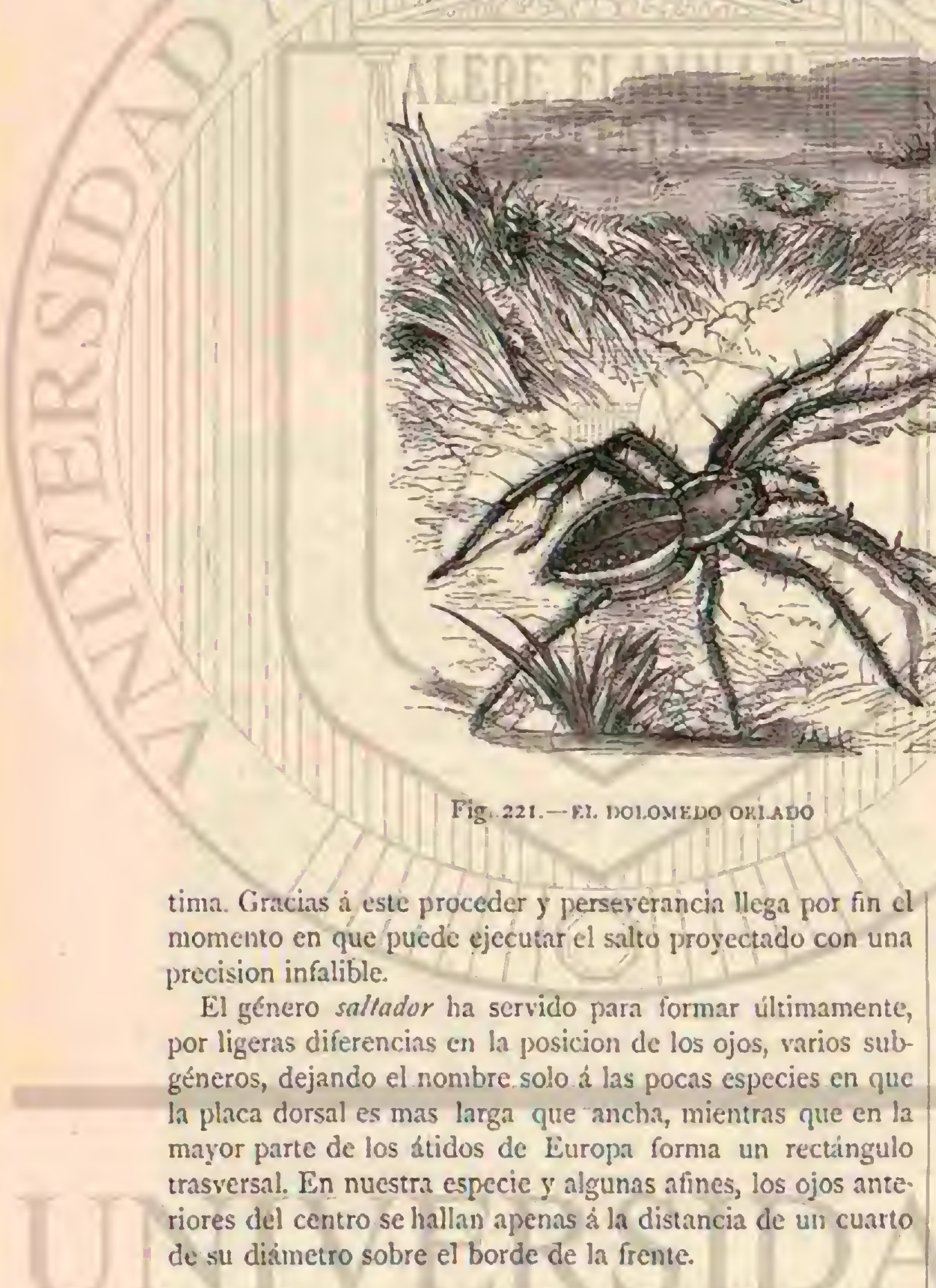

\section{EL SALTADOR DE PIÉS GRUESOS-SALTI- CUS GROSSIPES}

CARACTERES. - Esta notable especie (iig. 223) se caractcriza tambien por su abdómen corto, oval, ensanchado en su centro y agudio en la parte posterior; es de color pardo negro, con seis puntos hundidos en el dorso; el cosclete de primido y de un pardo castano: los ojos están guarnecidos de pelos de un blanco amarillento; las jatas son cortas y robustas, de un pardo castaño, con las anteriores muy protuberantes. Las maxilas, grandes y redondeadas, tienen un tintc pardo, bordeadas por una linea amarilla ó blanca; el abdómen, de fondo negro, está cubierto algunas veces de pelos leomados; los palpos son rojizos.

DISTRIBUCION GEOGRÁFICA. - Francia, Suecia y

Alemania son los paises donde parece abundar mas este arag nido.

Usos X costumbres.-Segun Degecr, esta-araña. se lanza de improviso sobre su presa apenas la divisa, $y$ la puede alcanzar á pulgada y media de distancia.

\section{EL ERESO DE COLOR DE CINABRIO-ERE- SUS CINABERINUS}

CARACTERES. - Por la belleza de sus especies distínguese el género eresus, que esti representado en el sur de Europa, y con menos frecuencia en el centro del continente: reconócese por las formas recogidas del cuerpo: el abdómen es casi cuadrangular; las patas cortas $y^{\prime}$ gruesas; $y$ la posicion de los ojos difiere esencialmente de la de las especies anteriores, porque los exteriores de la sêrie anterior están muy distantes de los del centro y son los mas grandes con los dos de la serie siguiente.

El ereso de color de cinabrio, que mide casi $0^{\circ}$, oro, es una de las arañas mas bonitus de Europa. Tiene el color negro aterciopelado; el centro del abdómen, de un rojo carmesi muy vivo, presenta cuatro puntos negros que forman un cuadro; las patas anteriores tienen anillos blancos; las posteriores son de un rojo escarlata hasta la mitad.

DistRIBUCION GEOGRÁFICA. - Aunque Italia y otros paises meridionales se indican como patria de este insecto, le he cogiclo tambien cerca de Halle y le recibi de 
pueblos vecinos, donde se le habia encontrado en sitios andlogos; de modo que parece habitar las rocas bañadas por el sol en las orillas del Saale.

Algunos átidos mucho mas grandes, del tamaño y forma de las especies de nuestros paises, y tambien otros que casi se parecen a las hormigas, habitan en gmn número en los jaises cálidos de ambos hemisferios.

\section{LOS VOLTEADORES - VOLTITARIX}

CARACTERES. - Se reconocen estos aragnidos por sus patas prolongadas, de un grueso regular, y propias para la carrera 6 el salto; los palpos son largos y filiformes; $\mathrm{cl}$ último artcjo tiene la digial proco protuberante en los machos, y algo dilatada en las hembras.

\section{LA VOLTEADORA HORMIGA - VOLTITARIA FORMICARIS}

CARACTERES. - El coselete cie estearagnido (fig. 227) es de color negto, y se levanta en forma de joroba: el abdómen, prolongado y fusiforme, tiene si mitad anterior de un tinte leonado rojizo, con dos fajas trasversales pardas; la mitad posterior es negra; las patas rojizas, lo mismo que las mandibulas, que se prolongan mucho en el macho; en las patas se observan algunas manchas negras. El macho de esta especie mide 3 lineas de largo.

DisTRIBUCION GEOGRÁFICA. - Esta especie es bastante comun en Francia y Suecia.

USOS Y COSTUMBRES. - Segun los observadores, esta mana se oculta debajo de las piedras y en las caviòndes de

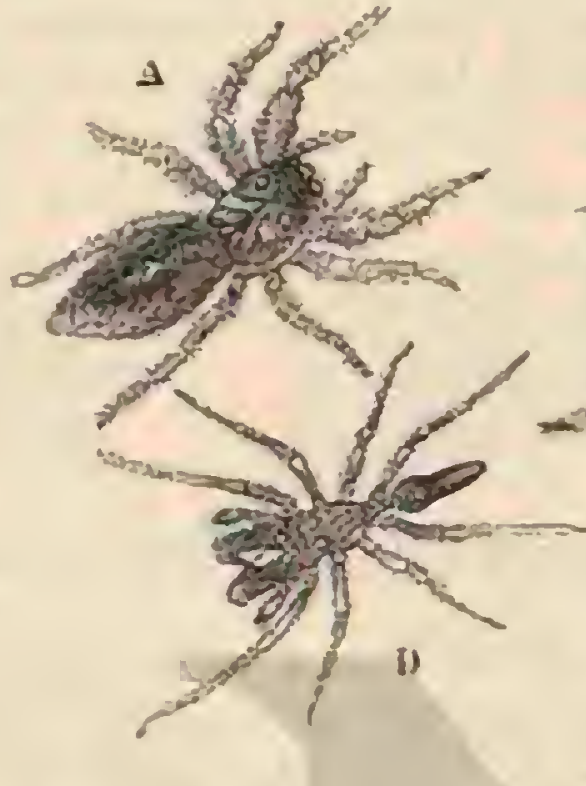

Fig. 223.A EL. SALTAIOK IHE JIES GRLFSOS

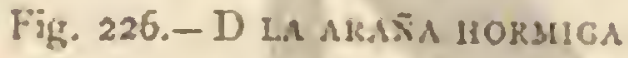

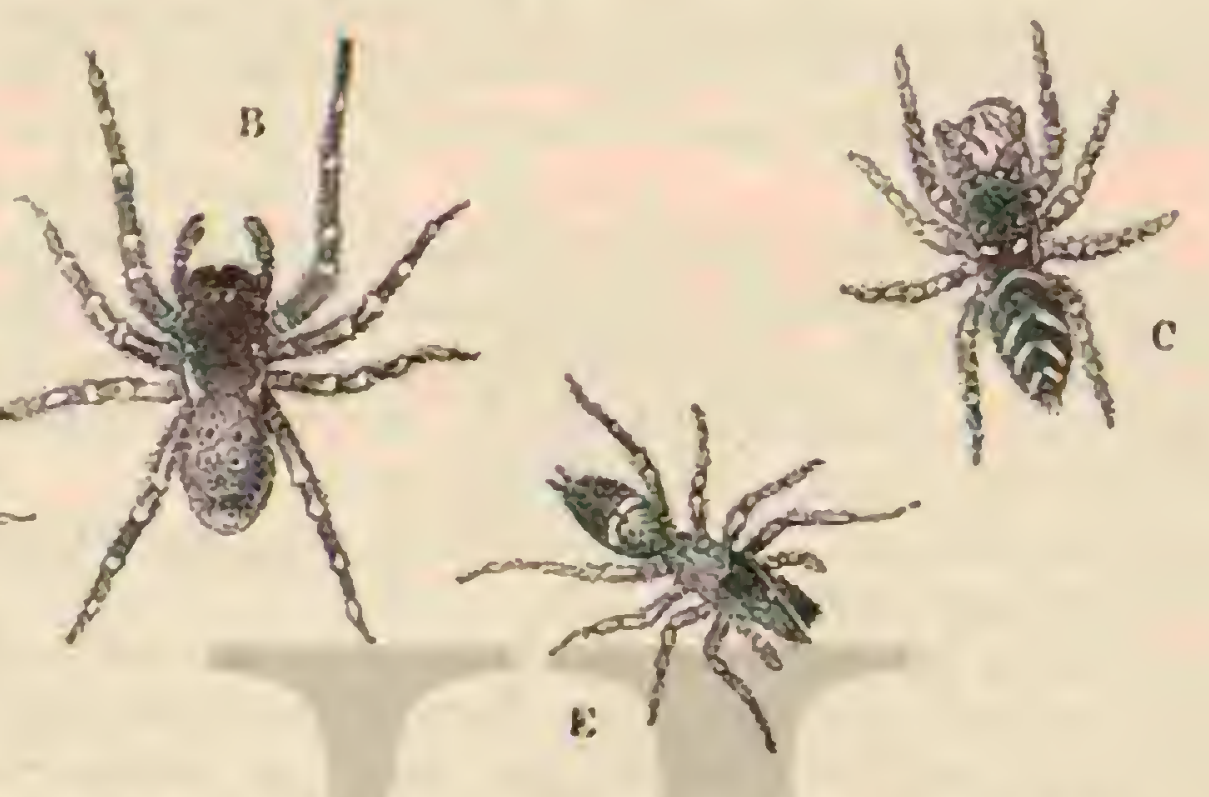

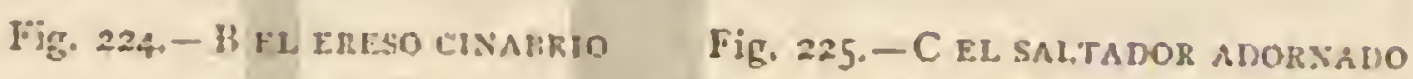

Fig. 227. - H. LA TOLTEAHOKA HORMIGA los árboles, donde teje un pequeño capullo de seda blanca, abierto por ambos lados, que le sirve de albergué, y del cunl sale presurosa cuando observa que la han visto, cieslizandose hasta el suclo por medio de un hilo de seda fijo en su ana. Acostumbra á formar además otro capullo en el nuevo sitio donde se esconde, mas en el primero es donde cambia de piel. Cuando anda se detiene de ver en cuando, con las patas levantadas, y luego las agita de arriba abajo cual si fuc. sen antenas; en tal monento no parece tener sino seis patas y se asemeja completamente a una hormiga. Tambien tiene In faculind de mover en todos sentidos su abdómen.

la araña hormiga (fig. 226) es otra especie afine que se distingue sobre todo por sus grandes mandibulas y su abdómen atenuado. Lista especie es propia de Bengala.

$$
\begin{aligned}
& \text { in' } \\
& \text { de } \\
& \text { ic: } \\
& \text { en } \\
& \text { on } \\
& \text { te- } \\
& \text { uy } \\
& \text { os } \\
& \text { es } \\
& \text { e- } \\
& \text { e- } \\
& \text { un } \\
& \text { te } \\
& \text { y- }
\end{aligned}
$$

cuéntranse solbre todo en la América meridional, en el Jirasil y en Rio Janeiro.

\section{EL ARKIS LANCERO - ARKYS LANCEARIUS}

CARACTERES. - El arkis lancero (fig. 215) iiene un color leonado: Ia configuracion del cuerpo es bastante singular: cl abcóncon, de un tinte mas oscurn, es corto, ancho y hueco en su parte anterior: que se redondea en los lados, disminuyendo bruscamente para terminar en punta en la pos. terior; de este modo ofrece la forma reyular de un corazon. y tiene sus bordes adornados de manchitas redondas de un amarillo pálido, en número de unas diez je seis; hácia el centro se ven otras tres; las dos mas cxternas, de mayur tamaño, forman el principio de dos lineas longitudinales ce diez manchas amarillas, cinco a cada lado, que se reunen en àngulo en el ano. El coselete, de un sintu leonado rojizo, es ancho y está dividido por un surco trasversal; la parte anterior en que se halla la cabeza jroyecta á cada lado una punta arqueada de coler rojo oscuro. Los ojos medios de la parte inferior son mas pequeños que los otros: el labio y las maxilas son rojos; las patas anteriores presentan varias espinas; las posteriores, finas y cortas, carecen de ajuellas y no tienen ampoco pelos. El arkis lancero, única especie que representa el género, mide aj lineas de longitud total.

DISTRIBUCION GEOGRAFICA. - Parcee que este aragnido es originario del Brasil ! Rio Janeiro.

USOS Y COSTUMBRES. - I as de esta especic no han sido suficientemente estudiadas. 


\section{ACARINOS - ACARINA}

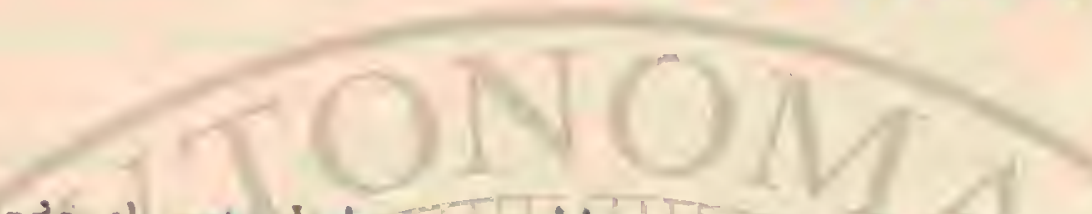

Casi todo el resto de tos aricnoideos se conare por el nombre de mitas ó andores y garrapatas (acarinos); aunque solo muy poćs especies se distinguen yor sil aspicto exterior, de módo que los naturalistas solo han hecho hasta ahora observaciones muy defectuosas sobre su género de vida, cuando precisamente en este órden se abre ancho campo, por demis interesante, aunque dificil, para la inteligencia humana.

Los acarinos forman un mundo sumamente rico de las formas mas variadas y de gran importancia por su género de vida, siendo un grupo de arachoideos en su mayor parte microscópricos. Pocos llegan à un tamano que permita a la vista inexperta reconocerlos como insectos; y sin embargo, coIIso muchos son socinbles reínetsse en inmenso nuimero, asemejandose a objetos deformes y movibles, $\mathrm{t}$ una especie de polvo, ó á las mas diversas sustancias vegetales. Solo recordaremos que la mita del queso (acaro domestico) y la es. carcha blanca de las ciruelas pasas no se compone siempre de azicar sino de millones de pequefios acarinos. Por eso y mas aun porque como parisitos viven en hombres y animales, $y$ à menudo ocasionan enfermedades dolorosas y repuguantes, son en sumo grado dignos de toda nuestra atencion.

CARACTERES:-Además de su tamaño mas reducido, los acarinos se distinguen de las verdaderas arañis por su aspecto exterior y por no tener el cuerpo articulado. Su cefalotórax está soldado completamente con lel abdómen excepto en algunos casos en que un surco trasversal en el dorso indica el limite. En la extremidád anterior del tomo hay dos ocelos, rara.s veces cuatro, que sin embargo faltin á menudo tambien del todo. Sobre las partes de la boca, propias en unos para morder $y$ en los otros para chupar, indicaremos lo necesario al hablar de las familias; la misma variedad ofrece el primer par de palpos maxilares; el segundo, en cambio, afecta, como en las verdaderas aminas, la forma de patas, pucs asi en unos como en otros insectos parecen existir cuatro pares de patas.

Fl intestino de los acarinos se corre en linea recta hácia Ia abertura del ano situada muy hácia adelanie en la cara del vientre; aunquue en el menor número de especies afecta la forma de un tubo corto y sencillo, en la mayoria de casos el estómago tiene á cada lado tres apendices en forma de intestino ciego que presentan muchas diferencias respecto is su division y direccion. La respiracion se efectún por tríqueas, excepto en los sarcoptidos, en los que aun no se ha encon. trado ningun órgano de ella; estas tráqueas casi siempre se extienden en forma de copete desde el tronco principal, que desemboca en el estigma y que no se ramifica mas. Suelen existir solo dos estigmas, ya ocultos cerca de la base de las antenas maxilares $\delta$ bien situados libremente en el laajo exterior del cuarto 6 tercer par de patns: no se ha encontrado hasta ahora cl vaso dorsal.

Las aberturas genitales se hallan en el lado del vientre, mucha distancia del ano, y $\mathrm{cn}$ el maclio hasta cerca de la boca. Los acarinos se propagan por medio de huevos; los lijuelos que salen à luz mudan varias veces de piel y difieren al principio esencialmente de la hembra por su forma, en particular a causa de faltarles un par de patas; de modo que en esto recordamos la metamorfósis incompleta de los insectos, pudiendo hablar de una forma de larvas, y muchas veces de varias. Para caracterizar este grupo en general, di. remos que los acarinos son aracnoideos que tienen los órganos de la boca chupaciores ó masticadores; el cuerpo no articulado; cl segundo par de maxilas en forma de patas; respiran en su mayoria por tráqueas y llegan á la edad adulta por una metamarfósis incompleta.

\section{LOS TROMBIDIDOS - TROMBIDIDE}

CARACTÉRES-Ios trombididos se caracterizan por las antenas maxilares en forma de garra $\delta$ de alfiler; los palpos maxilares son cortos y recogidos y rematan en dos extremidades opuestas una a la otra en forma de tenazas; las patas, nuy pesadas, son propias para la marcha; el cuerpo, blando, tienc casi siempre colores nuy vivos.

USOS, COSTUMBRES Y REGIMEN.-I.os trombididos viven en plantas 6 en la tierra; corren casi siempre con mucha rapidez, y durante una parte de su jurentud viven como aracnoides de solo seis patas en otros artropodos de sus contornos mas próximos. Los que habitan las plantas observan muchas veces un género de vida análogo, la mismo ņue los pulgones: fabrican una cubierta sedosa muy delicada en la cara inferior de las hoj̣as en que viven; chupan el jugo; se propagan; producen enfermedades en la planta cuando la colonia aumenta mucho, 6 forman unas protuberancias en forma de agallas, que les sirven de albergue.

\section{EL TROMBIDIO COCHINILLA-TROMBI- DIUM OLOSERISEUM}

CARACTERES. - El trombidio cochinilla es un acarino de color rojo escarlata, que mide poco mas de $11^{m}, 00225$ de largo: despues de llover se le re en toda clase de plantas. El cuerpo, blando, en forma de pera, es muy convexo y ru. goso; el pico se compone de dos antenas maxilares muy pe. querias en figura de tenazas y está casi envuelto por el labio superior; al lado de estas se encuentran los palpos de cuatro artejos, provistos en el penúltimo de un gancho y sobre estos dos ojos. Los piés rematan en dos garras. Pagenstecher ha publicado últimamente una descripcion minuciosisima sobre la anatomia y el desarrollo de estos insectos, pero no podemos ocuparnos aqui mas detenidamente solre el particular.

USOS, COSTUMBRES Y REGIMEN.-Jas larnas, que tienen seis patas y han sido descritas antes bajo nombres genéricos particulares, viven como parisitos en pulgones y otros insectos; los acarinos adultos persiguen a las pequeĩas orugas. 
En los paises cálidos se encuentran especies mas grandes, hasta de $11 ", 008$; su dorso no es aterciopelado, á causa de la prolongacion de sus espesos pelos; la piel es sedosa, y en ella se ven algunos copetes mas largos en la cara inferior de las patas. En Guinea habita el trombidio de los tintoreros (fromlidium linclorium) que se emplea para teñir de rojo.

\section{EL TETRANICO DE LOS TILOS-TETRANY- CHUS TELARIUS}

El ramaje de los ásboles, y en particular los troncos de añosos tilos, presentan a veces un aspecto singular, cuando privados de sus hojas tienen de arriba abajo, en el lado expuesto al sol, un tejido que brilla como el hielo. Al examinar este fenómeno mas de cerca se ven millones de acarinos debajo de este tejido sedoso, que les protege para pasar alli el invierno. Existen ya en el verano, pero viven entonces en la carn stiperior de las hojas, bajo un tejido, alimentandose de su jugo; aqui se les encuentra á centenares en las hojas en todos los grados de su desarrollo y con sus huevos; tambien extienden sus tejidos sobre las ramas cuando abundan mucho, pero entonces no se distinguen tan bien ti causa de las hojas.

CARACTERES. - El tetranico de los tilos de que aqui Se trata tiene apenas $0^{\$}, 00812$ de largo, y es de color amarillo de naranja; cl tronco, oval y provisto en cada lado de una manchita de amarillo de orin, está cubierto de pelos finos. Las antenas maxilares tienen la forma de alfiler; los palpos maxilares son cortos; de los dos pares anteriores de patas, el anterior es mas largo, hallándose situndas a mucha distancia de los dos posteriores. En la parte anterior del dorso se distinguen, con ayuda de un buen microscopio, dos pequeños ocelos.

USOS, COSTUMBRES Y REGIMEN.-Segun preten.
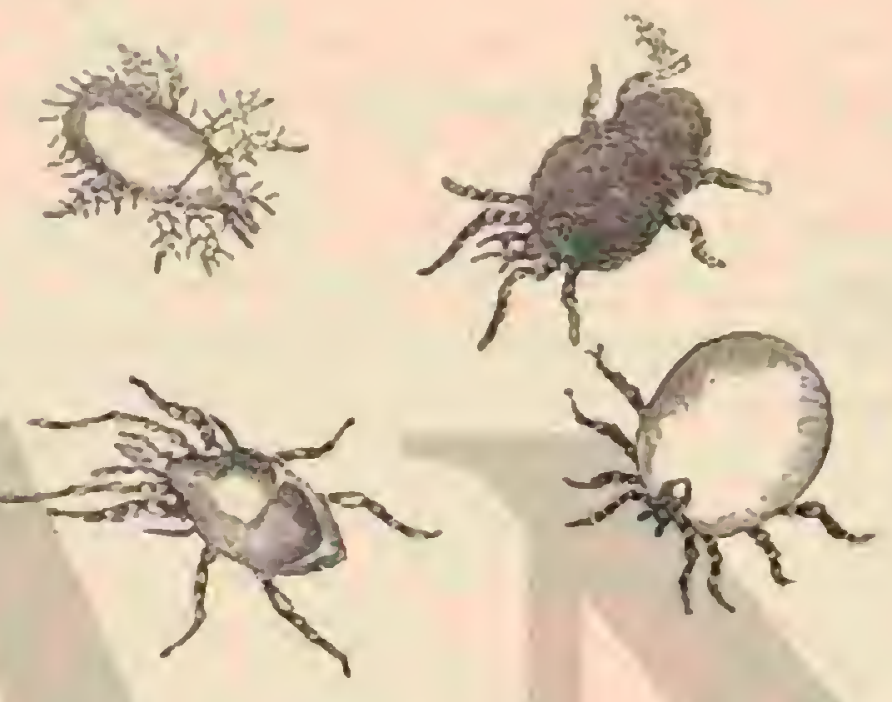

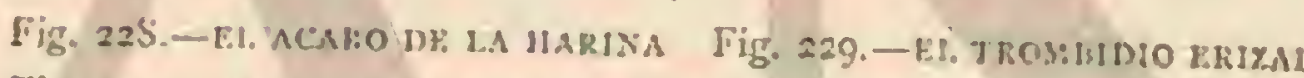

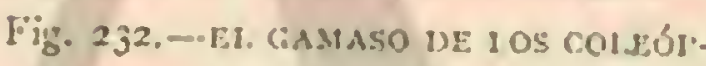

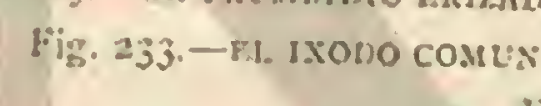

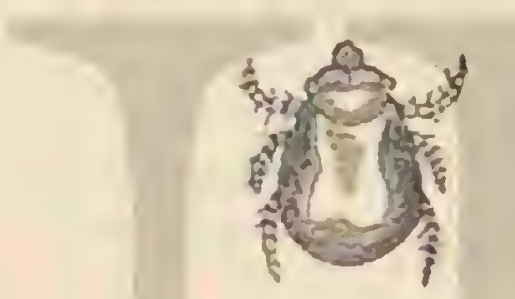

$$
\text { TEx:OS }
$$

de Linneo, éste acarino causa daños à verces en las plantass de los invernaderos; pero conso en muchas de aquellas la carn inferior de las hojas cstá infestada de una infinidad de parásitns, podemos suponer que entre ellas hay diversas especies, aun $n o$ bastante reconocidas, que producen en las plantas una enfermedad (la grise de los franceses), cuyos sintomas con. sisten en marchitarse las hojas, adquiriendo un color gris. Es posible quc el llamado acarino de otoño (lepfus aufumanalis), en el çuc solo se han visto seis patas, pertenezca como forma de larva al citado género. En julio ó setiembre se le encuen. ira en gran-nimero en la yerba sect, en los tallos de trigro, etc. Ć irmade el cuerpo de los segadores ó de otras per. sonas que imprudentemente se echan en la yerba habitada por esos insectos, que parecen puntitos rojos.

De parecido modo que las garrapatas, introducen su pico en el cuerpo y causan una picayon en extremo desagmdable; pero se les puede matar fácilmente con bencina ó con cocimiento de tabaco. White encontró piedras cubiertas de los huevos de este acarino, y al cxaminarlos mas minuciosamen'te reconoció que antes se hahian descrito como una planta de flor oculta (caferisen pinforme).

A este grupo pertenecerán tambicn los acarinos, cuyo nombre genérico shly'rofus se ha formado descomponiendo el nombre phito coptes. Fn las mas diversas plantas producen por su picadura unas protuberancias en forma de agallas que casi siempre se distinguen por una capa camosa, y que algunos consideraron allfes como setas. Los acarinos microscópicos se han observado hasta ahom demasiado poco para poderles distinguir ya como especies.
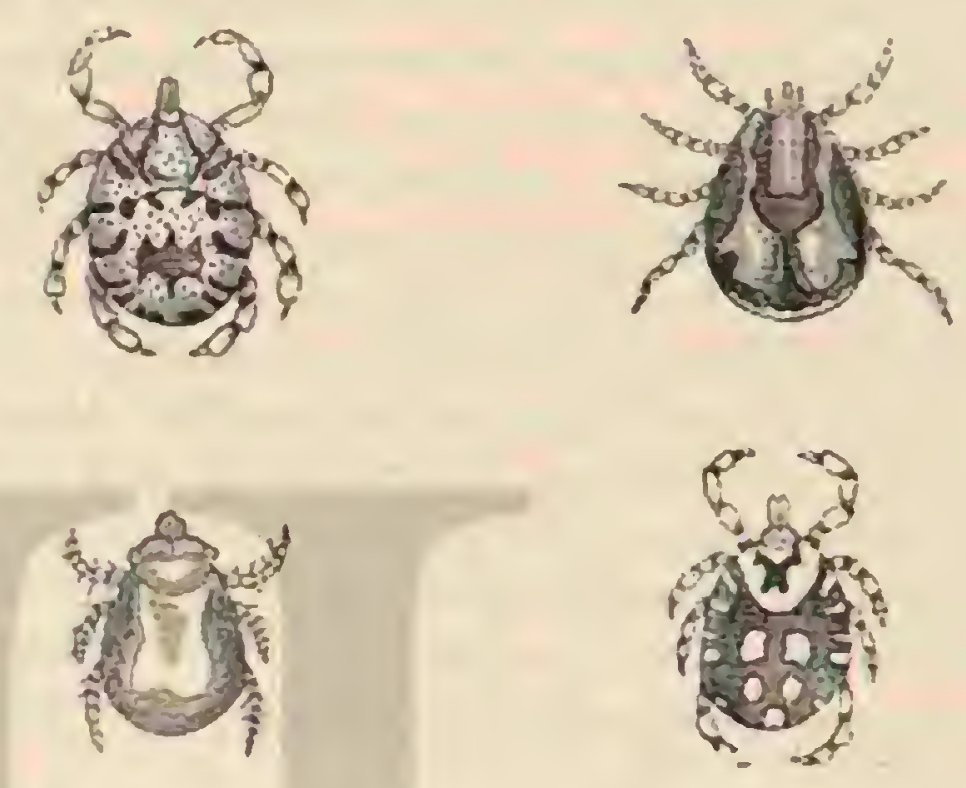

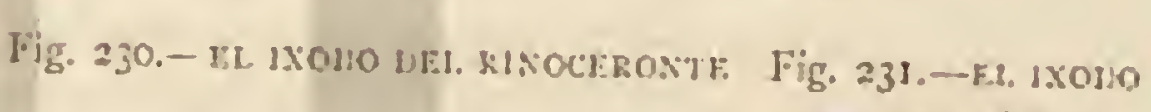
IEL IITOFIJANO

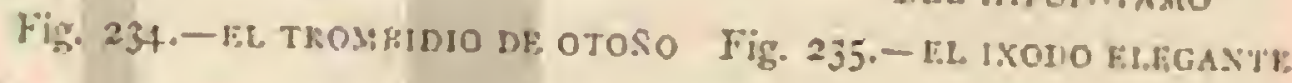

\section{LOS HIDRARACNIDOS HYDRARACHNIDE}

Muy diferentes, y cn extremo particulares, son las condicio. nes en qque viven los hidraracnidos $\delta$ acarinos acuáticos, ciue habitan exclusisamente en el agua, asi estancada como corriente, habiéndose hallado algunos hasta en el mar. la mayor parte de estos insectos nicroscópicos ofrecen el aspecto de bolitas de color rojo escarlata, y algunos vercloso: con ayuda de sus pratas peludás nadan sin salir jamás à la superficie del agua para respirar, y como carecen de branquias, es probable que sus trinuens puedan recibir el aire de la misma agua y que tengan la estructura semejante a la de algunas larvas de libélulas. La historia de la vida de los acarinos acuáticos es rica en fenúmenos extraños; asi, por ejemplo, hállanse varias especies en que los dos sexos ofrecen formas inuy variadas: mientras que las hembras conservan la forma esférica que es la regular, los machos rematan en una apéfisis en figura de coln, de modo que se les podria considerar como formaciones completamente distintas. "lodos, sin embargo, conservan los caractéres juincjpales: patas de siete artejos, con cerdas natatorias movibles, que aumentan en longitud desde adelnnte atris; antenas maxilares en forma de garra ó die sable; paljus maxilares cortos y salientes, y dos ó cuatro ojos en la coronj. lla Despues del aparenmiento, a menudo muy particular, las hembras depositan los huevos en los tallos de las plantas acuáticas ó en la casa inierior de las hojas, donde se ercuentran reunidos por una especie de gelatina. Varias hembras 
dẹositan á menudo los hucros en las mismas hojas ó tallos. Al cabo de algunas semanas salen los hijuelos, provistos solo de seis patas y de una trompa relativamente muy desarrollada que cmplean para cogerse à los hemipteros y coleópteros que habitar con cllos el ngua y en los que pasan su vida como parásitos. Cuando llega su tiempo, abandonan el animal que habitan, mudan de piel, acórtanse sus patas y bajan al fondo del charco para descansar como crisílidas. Por fin se abre la picl, y el acarino que hasta cntonces tenia seis patas sale ahora provisto de ocho, siendo su boca del tamaño regular. Parece que algunos sufren despues otra muda, despues de la cual llegin a ser adultos, mientras que oiros pasan toda su vida como parasitos, segun se observa, por ejemplo, en la es. pecie Hidrarachnd cmiharim, que Baer vió en las branquias de las conchas comunes de rio; esta larva se habia descrito antes como parasito particular bajo el nombre de Arhlysia. Otras especies, en fin, viven libremente como larias; y solo en su ustado de ninfas se trasforman en paraisitos.

I.os hidraracnidos se han dividido en varios géneros, de los cuales el alax y al nesar son los mas ricos en especies. El prinero se distingue por tener el tronco oval, mas $\delta$ menos truncado en su parte posterior; los ojos muy distantes uno de otro y con un ángulo lateral; la trompa corta, y los palpos ell forma de huso de mediana longitud El pien se compone de un labio en figura de lanceta, dos maxilas de la misma forma, algo corvas, una lengua pequeña, palpos de cuatro artejos, provisto el penúltimo de dos dientecitos, y un gan cho dirigido oblicuamente hácia abajo.

Los diminutos insectos pertenecientes á este grupo madan lentamente con preferencia en las aguas tranquilns, donde tambien descansan con las patas exteudidas cerca de la su. perficic.

Una especie, el atax de piés esninosos (alux spinipes), se caracteriza por su tronco casi esférico y blando, comun. mente redondendo en li parte posterior, por su color rojo sucio y por la posición particular de las patas.

Fil arenuro rojo (arrenurus abslergens) ticne el tronco bastante aito, pero un poco aplanisdo en el dorso y con una (iepresion en forma de arco abicrto hacia atrás, cuya extremidad es mas ó inenos angulósa en los lados; una cruz negra de varios brazos en el dorso caracteriza a esta especie, que es muy comun. La hembra deposita sus huevos, que re. matan en punta, en el cuerpo de cicrto népido. Los hijuelos salen al cabo de juince dias y sufren varias mudas antes de adquirir el aspecto de la madre.

los hidraracnos (hydrarni/bna) se distinguen por tener cuatro ojos; en muchos de ellos el pico es muy salientey nadan con sumn agiliciad subiendo $y$ bajando en seitido vertical; algunas especies podrian verse por un observador atento, porque no son muy pequenas y se distinguen por sus colores abigarrados.

\section{LOS GAMASIDOS- GAMASID压}

CARACTERES. - I.os gamasidos tienen las antenas maxilares en forma de tenazas; los palpos prolongndos haicin ade. lante y compuestos de artejos bastante iguales; las patas peludas, casi sicmpre de igual longitud y forma, provistas en su extremidad, además de las garras, de un disco; los ojos faltan.

USOS, COSTUMBRES Y REGIMEN.-Estos pequenos acarinos habitan como parksitos en otros animales, y ha. llanse particularmente en varios insectos de vida subterrá. nea, en ares y en murciçlagos. No se fijan en un mismo sitio, como las garrapatas, sino que corren con gran destrema en la piel de los animales que habitan, colocándose constantemente en los palpos y is veces tambien en las patas anteriores.

Una de las especies mas comunes es el gamaso de los coleópteros (gamnsils colcoptratormm), diminuto insecto bastante duro, de color amarillo rojo, y de unos doce milimetros de longitud (fig. 232), que à menudo insade en gran numero el vientre de los necróforos, coprófingos, abejorros y otros insec. tos, sobre todo cuando estos han permanecido mucho ticmpo debajo de tierra. Kairby dice que, segun varias observaciones, los abejorros, atormentados por los acarinos, penetmn en los hormigueros, donde escarban y patalean para que salgan las hormigas, las cuales se precipian sobre los acarinos j los devoran. libmndo asi al abejorro de sus atormentadores. Es posible que este hecho se haya observido alguna vez, aunque no se puede suponer que los abejorros se migán por costumbre de este medio para librarse de los acarinos. Estos abandonan el insecto cuando muere; pasan sin duda su primera juventud en la tierra humeda y solo mas tarde se albergan en un coleóptero, un abejorro ú otro himenóptero que se aproximeá ellos. El gamaso de los coleópteros tiene las patas anteriores mas largas que todas Jas otras, mientras que las dos siguientes son las mas gruesas: el cefalobórax está separado del abdómen por una depresion transcersal y en los hombros se nota una grande cerda movible; caricter observado en algunas otras especies, mieniras que en la mayor parte falta. He hallado un acarino semejante en ciertos coleópieros exúticos de nuestras colecriones, y tengo una moscon (del género gystonerurn) que, excepto la cabeza, las patas y las alas, se halla cubicrta de tal modo de acarimos de un color gris amarillo, que no se puede reconocer ni un punto de su verdadera superficie. Fste acarino piertenece á otro généro de forma mas prolongada.

\section{LOS DERMANISOS-DERMANYSSUS}

CARACTERES. - Las especies de este género se caracterizan por la piel blanda del cuerpo y por las antenas maxilares, de diferente forma en los dos sexos. llienen una arompa larga, movible, encorvada hácia abajo; los palpos maxilares presentan marcadas articulaciones, entre las cuales la de la base es mas gruesa que en los gamasidos; las patas son de igual longitud, pero las cuatro anteriores, mas fuertes, tienen el disco mayor que las otras; todas se insertan muy cerca una de otra en cl borde del pecho.

Una especie, el dermaniso de las aves (dermanyssus arium) atormenta tambien á reces à las arecillas enjauladas durante la noche. Cuando, por ejemplo, se nota en un canario cierto malestar: observándose que revuelve mucho las plumas con el pico, se le deben poner cañitas huecas para posarse, y entonces se vera, al examinarlas, que del interior caen acarinos rojos de diferentes tamaños. Estos diminutos insectos se ocultan durante el dia, como las chinches en sus escondites, pero salen de noche para satisfacer en la pobre arecilla su apetito. Limpiando a menudo las ciñas, pronto se puede exterminar du estos paraisitos, gue muchas veces quizás penetran con la arena que se pone en las jaulas de los pájaros. El mismo dermaniso, gue mide $10^{n}, 00135$ de largo, se oculta tambien, segun parece, en los paloniares y gallineros para chupar de noche la sangre de estas ares; j hasta se le ha encontrado en el hombre, en protuberancias de la piel, que producen una picazon insoportal)le, hecho demostrado hasta la evidencia por Vogel. Otras especies se albergan en diversos pajaros, y una en los matones.

I'ambien los murciélagos lienen en sus membranas y en las orejas varias especies de aracnoideos que pror eso se han 
llamado acarinos de murciélagos: se han distribuido en va. rios generos de los que el pieroptus parece ser el mas comun. El cuerpo blando, que casi afecta la forma de una pera, tie. ne patas gruesas, provistas de grandes garras y de un disco; las cuntro posteriores se insertan a gran distancia de las anteriores; y los palpos maxilares rematan en un artcjo muy prolongado.

El teropo comun de los murciélagos vive principalmente en la especie respertilio murinus y por eso se la llama pteropitus écstertilionis. Nitzsch demostró por el estudio anatómico su propagacion. Cuando en junio de $1 \$ 25$ abrió varias hembras inuy hinchadas encontró casi siempre tres hijuelos, y en un caso hasta cuatro, en diferentes grados del desarrollo; en los mas imperfectos solo podian reconocerse seis patas lisas, no articuladas, dos palpos, tambien sin articulaciones, y un cuerpo cortado en su parte posterior en linea recta; los individuos mas desarrollados tenian ocho patas articula das provistas de discos y de cerdas, y el cuerpo algo puntiagudo en su parte posterior. Las hembras dan a luz, por lo tanto, hịuelos vivos, uno cada vez, que primero tienen solo seis patas $y$ despues ocho.

\section{LOS IXÓDIDOS-IXODID平}

CARACTERES.-Los ixódidos ó garraparas difieren por mas de un concepto de los otros acarinos, tanto que algunos maturalistas han hallado razon bastante para incluirlos en un órden independiente de los aracnoideos. Su cuerpo apla. nado, masó menos oval, aunque cubierto de piel córnea 0 coriścen, posee tal grado de clasticidad que, en individuos de $y^{\prime \prime}, 00225$ de longitud pueden ensancharse hasta alcanzar el tamaño de una pequeña habichuela, cuando se dilatan con la sangre de un animal. En la mayor parte de casos, ta cubierta de quitina presenta la forma de un escudo, que, redondeado hácia airas, cubre bajo varias formas la parte anterios del dorso, escotándose tambien un poco en su parte anterior, para recibir la trompa, muy desarrollada, Esta se dirige en estado de descanso hácia adelante y se presenta como una cabera separada, lo que en realidad no es; porque los dos ocelos, cuando existen, se notan mas 6 menos marcadamente en una escotadura lateral del escudo córneo. Fu otros casos, este escudo cubre casi todo el dorso del cuerpo, aunque tambien aqui se redonden en su region posterior, En la parte de la boca, la barba se inserta en forma de una hoja de quitina movible; los dos palpos forman un ángulo-recto cuando el insecto se mucre, y oprinien las restantes partes de la boca, en el estado de reposo; se componen de cuatro artejos de los que los últimos oprimen el penúltimo en forma de una pequeña tapa: el labio inferior es cóncavo en su par. te mas baja, acioptando la forma de surco, y está provisto de dientecitos en la cara inferior de su cxtremidad; las antenas maxilares encajan en los surcos del labio inferior y se com. ponen, cada una, de dos artejos.

Cuando la garrapata quiere morder, agarra con las patas la piel del animal en que hace presa é inclina la trompa verticalmente hácia abajo, la oprime contra el punto en que ha de introducirse y clava en la carne los extremos de los ganchos de las antenas maxilares, abriendo asi camino hasta el labio inferior: los dientes, dirigidos hícia atrás, im. piden que puedan volver a salir de la herida. Despues que la trompa ha penetrado hasta su base, los ganchos de las antenas maxilares, se enconan, en forma de ancla, à derecha é izquierda; los palpos maxilares se oprimen á ambos lados de la herida contra la carne, y la garrapata se halla en la posicion conveniente para chupar, de manera que ya no puede quitarse forzosamente, sin dejar en la rarme in trom. Toso V'l pa. El Úrgano chupador se compone de una fina membrana de quitina en forma de campana. Ias patas tienen en todos estos animales igual forma; son delgadas y en la extremidad, ademås de dos garnas afladas, están provistas de un disco que permite á la garrapata quedar adherida al objeto, una vez cogido, aunque sea con un solo pie. Los dos únicos es. tigmas estån en una hojita de quitina que a cada lado, por detris de las patas posteriores, se ve fácilmente en el borde del cuerpo: mientras. que la abertura sexual, en forma de hendidura, debe buscarse en medio del pecho. Los ixódidos jórenes tienen solo seis matas, y asi como los de ocho, recorren las yerbas y la maleza, hasta encontrar un animal para habitar, del que, por lo menos las hembras, chupan la san. gre. Tambien el macho, siempre mas pequenio, sabe encon. trar una hembra para aparearse, hecho que ofrece no poco interés, y que no se ha comprendido bien hasta los últimos tiempros. El macho sube al vicntre de la hembra, vuelve la cabcza, oprimiendo la extremiriad dẹ abdómen de aquella, extiende sus patas, agarrándose con los discos y garras a sus ancasé introduce la trompa en la vagina. Aqui se adhiere exactamente del mismo modo que la hembra al chupar la sangre de un animal ó de un hombre, y' se ha supuesto que en esta clase de apareamiento, cue Degeer ya conoció, las partes grenitales del macho tienen su orificio en la trompa, No sucede, sin embargo, asi. Pagenstecher ha demostrado por lo contrario, anatómicamente, que las partes sexuales internas obedecen á la misma ley de formacion en los machos que en las hembras; y que tambien en aquellos el orifi. cio, aunque mas angosto $y$ menos marcado, se halla en el pecho. No puede suponerse por lo tanto otra cosa, sino que al agarrarse el macho i la hembra accrca su abertura sexual lo bastanté à la vagina de aquella, para que pueda intreducirse el liquido espermático en ella. Fil pastor protestante Muller de Odenbach, a quien debemos numerosas observa. ciones interesantes y fidedignas sobre los insectos, habia fijado en su tiempo la atencion sobre este particular y nos habla de una observacion muy curiosa. Intentó separar de la hembra un macho apareado, para reunirle con otra, pero co. mo no lo consiguiera, trató de matar aquella, creyendo que el macho la soltaria entonces voluntariamente. Al efecto hirió la supuesta cabeza de la hembra con un cuchillo puntiagudo, sin tocar al macho. Eiste emperó un seguida à tem. blar, recogió las patas y murió, estrechamente unido à la hembra, al cabo de pocos minutos, agitindose convulsivamente; mientras que la hembra herida sobrevivió algunos dias. Mas tarcie vió a un macho aparearse con tres hembras, una despues de otra, permaneciendo con la última cinco dias con sus noches. De la vagina de la hembra fecundada, los huevos salen en gran número, se adhieren unos con otros y envuelven parte del insecto.

\section{EL IXODO COMUN-IXODES.RICINUS}

El irodo comun ó la garrapata de los perros, a la cual se refieren las observaciones anteriores, fué conocida ya por Aristótcles con el nombre de kroton, y por Plinio con el de ricinus; el último dice que esta denominacion, empleada primitivamente para designar la semilla accitosa del árbol maravilloso de ligipto, fue aplicada despues a este odioso insecto. Cuando P'lutarco, á fuer de observador sagaz comparó el ricirus con los aduladores, cuyas alabanzas una vez ojdas, no se rechazan con gran facilidad, bien podemos suponer que sus contemporancos conocian este insecto y sus costum. bres. Despues que Degeer hubo dado el nombre de ricinus a cierto género de piojos y de acaros se llamó á la especie de que hablamos acarus riciums, hasta que Iatreille se vió precisado 
à distinguir varios géneros de acarinos, y la dió el nombre de ixodes ricinus. Ixodes significa pegajoso, agarradizo.

CARACTÉRES. - No es posible describir el ixodo comun con pocas palabras, pues Papenstecher supone, en su excelente trabajo acerca de esta especie, tres grados de desarrollo, con siete formas diferentes; crejendo lo mas probable que entre estas existen tales diferencias que los autores antiguos hubieron de considerarlas como especies distintas.

En el primer estado la garrapata comun solo presenta scis patas, ningun distintivo sexual y ninguma placa con estigmas; y hasta al examinarla anatómicamente se echa de ver la falta completa de órganos réspiratorios, carácter observado igualmente en todas las demás especies de acarinos que tienen seis patas. El cuerpo en un principio aplanado, se dilata en forma oval, y ndquierc entonces un aspecto esencialmente distinto, cuando cl estómago está lleno de sangre. Papens. techer observó esta forma menos desarrollacia en el nioxo de las encinas (myoxos guercinus), en la ardilla comun y en el topo; pero solo en individuos aishdos. Quierc cxplicar esta escasez, por la circunstancia de haber examinado en general pocos vertebrados para poder encontrar esos parásitos; y porque en el caso de que en su primera juventud maguen estos libremente, lo efectuaràn mas bien en el suelo q̨ue en la verba.

En el segundo grado del desarrollo, precedido de una muda hasta ahora no observada, se encuentran los estigmas con seis placas respectivaunente y ocho patas. Por minuciosas mediciones de la longitud de todas las patas y por otras observaciones, Papenstecher cree poder justificar la supiosicion de que, en la muda, se desarrolla el último par de patas, I que no se intercala el segundo, como hasta ahom se creia. Tambien en este grado de desarrollo faltan los órganos sexuales internos y externos. El modo de ser de las garrapatas de ocho piés, que aun no han llegado à su desarrollo sexual, es del todo análogo al de los adultos: arrástranse lentamente por la yerba y por la maleza de los bosques, agarrảndose todos los objetos que hallan à su paso, si bien es dificil divisarlas á causa de su pequeñez.

Estaciónanse con preferencia en una region, mientras que en otra no se encuentran. Recuerdo muy bien que en mi juventud, un bosquecilló cerca dé Naumburgo, á orillas del Saale, gozaba de mala fáma da causa de estos insectos: porque no era fácil dar un pasco sin recoger cuando menos una garrapata. En cierta ocasion senti en el sobaco izquierdo un dolor pasajero, pero violento, que podria comparar unuy bien à un pinchazo: pero como en el citado sitio nunca habia experimentado tal, me volvi pensativo, procurando descuhrir la causa. Pronto encontré al ixodo, que acababa de penetrar entre mis ropas; pero ignoro cuál seria su grado de desarrollo. Debo añadir que mojándolc con un poco de aceitc, se obliga al animal i soltar rápidamente su presa y que con la bencina muere instantáneamente. En los alrededores de Halle, esta especie no parece abundar; mientras que, segun las observaciones de Papenstecher, se encuentra mas frecuentemente en las cercanias de Heidelberg, donde vaga por los senderos frecuentados por los animales de bosque, agarrándose sobre todo $\dot{a}$ las ardillas $y \dot{z}$ las aves. Besde fines de setiembre, las garrapatas no desarrolladals se encuentran muy aisladamente al aire libre, $y$ desde octubre esca. sean asimismo los adultos de ambos sexos; tambien se encuentran con frecuencia individuos en el segundo grado del desarrollo, rellenos de sangre y', como es consiguiente, de otro aspecto, arrastrándose pesadamente por el suclo, aunque con mas frecuencia adheridos al cuerpo del hombre y en toda clase de mamiferos; sobre todo en los persos y ardillas, it cuyas úl. timas se agarmon con preferencia en parrpados y labios. Ia última muda, y con ella el tránsito á la edad adulta, se verj. iica de noche, por lo cual Papenstecher no pudo observarla á pesar de lodos sus esfuerzos.

En cl último grado del desarrollo se presentan, además de Las dos formas, dependientes de la circunstancia de estar el intestinn vacio ó lleno, la del sexo; porque el macho que nunca se la visto hinchado, ofrece otro aspecto que la hembra en ayunas y que la bien alimentada. En él casi todo el dorso está cubierto de una hoja de color pardo de pez, brillante, un poco peluda y provista de hoyos deprimidos, la cual es mas de la mitad mas larga que la de la hembra; el lado del vientre presenta rebordes trasversales, entre la abertura sexual 5 la del ano; distinguiéndose además de la hembra por una trompa mucho mas corta. Opino que el ixodo orillado (i.20des warginalis; , de Hahn, que se encuentra representado en algunas partes, no es sino el macho de la especie comun.

La hembra tiene una placa dorsal, un poco estrechada hácin adclanie, que deja libre la mayor parte del tronco. Cuando esiá repleta de sangre tiene un color que desde el blarico pasa á un rojo carnoso hasta convertirse en pardo: en esca forma el animal ha llamado siempre la atencion.

El ixodo comun se encuentra, en ambos sexos, en estado de ayuno, ragando al aire libre; pero siempre dispuesto á hacer presa en hombres $\delta$ animales; la hembra para engordarse de este modo y el macho para aparearse con ella. Una henbra adulta llega, adherida à un perro, on nueve dias, à una longitud de $0^{\circ}$, or I por una anchura correspondiente; $y$ adquiere tanta elasticidad que, al caer al suclo, rebota como una pelota de goma. Su color suele ser, en el perro, gris de piedra, con brillo grasoso. Aumque la garrapata se desarrolla ripidanente en circunstancias favorables, su género de vida la condena a largos ayunos, por lo cual la duracion de su existencia se prolonga por têrmino medio, desde mayo hasta octubre.

\section{EL IXODO RÓJO VIOLETA-IXODES RE- DUVIUS}

CARAGTÉRES. - Esta especie, confundida por varios autores con la anterior, es en mi opinion del todo diferente de ella. Poseo varios individuos que recogi al aire libre juntamente con hembras muy flacas de la especie anterior. 'To. do el animal es rojo, cubierto en el escudo dorsal y en alguuas partes de las patas como de una escarcha blanquecina, y lleva en la parte del cuerpo que queda libre del escudo dibujos longitudinales.

Esta garrapata se halla particularmente en los carneros, como ya se ha dicho, pero tambien en perros, sobre todo en los de caza y en los bueyes.

\section{EL IXODO ELEGANTE-XXODES VENUSTUS}

CARACTERES. - Esta especie (fig. 235) es de un negro brillante con el borde externo amarillo, llevando una man. cha roja, oblonga y orillada de amarillo en el dorso, y detrás de esta, otra del mismo color, trasversal y cuadrilobada; las patas son de un pardo rojizo, anilladas de amarillo: mide $U^{m}, 005$ de longitud.

DISTRIBUGION GEOGRÁFICA. - Esste ixodo es abundaute en el Senegal.

\section{EL IXODO DEL RINOCERONTE-IXODUS RI- NOCERINUS}

CARACTERES.--El cuerpo de este insecto (fig. 230) es pardo castaño, adornado por encima de manchas mals 0 
menos grandes, matizadas de anırillo leonado con un gran número de puntitos pardos; el borde posterior del dorso tie. ne otras dier manchas del mismo color dispuestas en scmicirculo; las patas son pardas.

DISTRIBUCION GEOGRÁFICA.-El individuo descrito procede del Cabo de Buena Esperanza.

USOS Y CCSTUMBREs. - El célebre viajero Sparrmann, que los ha cogido en algunos rinocerontes, dice que estaban fijos en las partes genitales de dichos animales, por ser mas blanda la piel en este sitio que en el resto del cuerpo. Anade el citado viajero que, cuando estos insectos están repletos 4 hinchados, su cuerpo adquiere un volumen cuntro veces mayor $y$ al mismo tiempo se alarga un poco.

Existe otra especie afine à esta, que suele fijarse en el cuerpo del hipopútamo (fig. 23I).

\section{EL AMBLIOMA AMERICANO-AMBLTOMMA AMERICANUM}

En la América meridional $y$ en otros paises cálidos viven en gran número ixodidos del mismo tamaño y forma, pero en su mayor parte de colores ahigarrados, sobre todo rojos, con matices mas claros ú oscuros, distinguiendose, sin embargo esencialmente de nuestros ixodidos por llevar en el centro de los costados del escudo, en una escotadura, ojos que se presentan como un punto claro, poco visible.

Koch reune las numerosos especies bajo cl nombre generico de amblyomma, que indica, como caricter para la hombra, un tronco elástico, casi unicoloro, y un escudo dorsal cubierto de una especie de esmalte blanco ó amarillo sobre un fondo oscuro.

A estc grupo pertenece, entre otros, el amblioma americano que es el que nos ocupa, y que, i juagar por sus nombres vulgares de nigue, ligua, pigue, se ha confundido muchas veces con el cichao (rhyrschoprion penctrans). Es una de las garzapatas mas comunes y conocidas en América, que a ma. nera de nuestras especies molesta $a$ los hombres y animales, causando grandes dolores à los caballos en la region de los hipocondrios. Este ixodo que mide de $0^{\circ}, 0225$ á $0^{\circ}, 003$ es de forma corta y oval, de color rojo pardo sucio, con puntos muy finos en la superficie y rodeado de un surco. Ia hembra tiene la punta del escudo de un color amarillo claro, que no tiene el macho. Sin duda pertenecen iambien a este grupo las dos especies que Bates encontró ian numerosas en los-alrededores de Villa Nova, en el Amazonas inferior. Los sitios mas altos y secos de aquella region son en todas partes arenosos, orillando altas yerbas los caminos abiertos por medio de la vegetacion arbórea. Estos sitios están poblados de carrpalos, ixodos feos que permanecen posados en las puntas de las yerbas y sc agarran a los vestidos de los transeuntes. Bates necesitó todos los dias una hora, para espulsir estos enojosos insectos de su cuerpo, cuando volvia de una espedicion. Distingue dos especies, que, sin embargo, se asemejan por tener una trompa corta y' gruesa, por los tegumentos córneos del cuerpo, y por su género de vida. Chupando la sangre, pocos dias bastan para trasformar su cuerpo plano en esférico. No sc experimenta malestar ni picor, pero producense tumores dolorosos cuando se arrancan los animales violentamente, porque entonces su trompa se queda en la carne. Pasa obligarlos à desprenderse se les moja con jugo de tabaco. Cuando andan por la yerba solo se sirven de las patas anteriores, mientras que las otras, tendidas siempre, están prontas jara coger una victima. I a especic mas peque in tiene un color amarillento. A menudo se agarran al viaje ro docenas de individuos y cuando estản repletos de sangre alcanzan el tamaño de los perdigones del número S. I a mayor especie, mas escasa, alcanza el tumano de un guisante. De esto resulta que las garrapatas de otros puntos no difieren en nada de las nuestms, en cuanto a su género de vida.

Otms especies, propias del Africa, del Asia Menor y del sur de Europa, que se distinguen por sus ojos salientes de forma emisférica y brillantes; por tener una gran placa triangular de quitina y por los estigmas en forma de hendidum, se han reunido en el género hyulumma; mientras que otros de nuestros insectos, mas cortos, y que difieren algo de la forma descrita por los órganos de la boca, se han separado en otro grupo.

\section{EL ARGAS DE PERSIA-ARGAS PERSICUS}

Por la superficic dorsal, en forma de escudo y algo estrechada hácia adelante, y por la trompa corta, inserta en la cara del vientre, las argas difieren esencialmente de los ixodos hasta ahora descritos. Cuéntase pocas especies, entre las que que la llamnda s chinche venenoso de Minnas, el Mallei ó el argas de Persia, ha adđ̧uirido una triste fama \& causa de varias fabulosas noticias de algunos viajeros. Deducicias todas las exageraciones acostumbradas en tales casos, solo resulta verdad que esta garmapta vive en l'ersia, así como en el Egipto, de donde recibi algunos individuos. Andan por las paredes de las viviendas humanas, donde á la manera de las chinches chupan de noche la sangre de las personas, produ. ciendo una herida dolorosa, y desaparecen sin dejar huclla. El que conoce la plaga de chinches de nuestras regiones podri creer en las palabras de Kotzebue, quien asegura en su \$ Viaje por la Persia que á causa de estos pamísitos, poblaciones enteras se han visto obligadas a salir de sus casas. Segun noticias, en Miana, donde los cmbajadores europeos so. lian pernoctar, el mismn insecto solo busca à los extranjeros $y$ á las 24 horas de haber picado han ocurrido casos de inuerte; pero estos deben atribuirse sin duda a la calentura pútrida, tan peligrosa para los extranjeros. In temible garrapata ticne un aspecto algo rejugnante, y me recuerda por su conjunto el feo sapo de celdas.

CARACTERES. - Toda la superficie dorsal del cuerpo, que es pardo rojo, estil cubierta de numerosos hoyitos blan. cos redondos, de los cuales, los del borde y del centro posterior del cuerpo, están dispuestos en sćries longitudinales, y los demas, un poco mas grandes, que pertenecen a la parte posterior del dorso, en lineas trasiersales, aunque en rigor no puede hablarse de un verdadero úrden en su disposicion. Los ojos faltan. Por este caricier y por su forma, la citada espe. cie ofrece semejanza con otra que es propia de Alemania y de la que damos á continuacion algunas noticias.

\section{EL ARGAS DE FORMA DE CONCHA-ARGAS REFIEXUS}

Parere que esta especie vive de un mocio muy análogo al de ha chimshe iencnosa de Persia. Visita las viviendas humanas ocultandose de dia en las grietas de las paredes, y se alimenta de la sangre de las palomas, que mueren a consecuencia de la picadura. Asi lo dice Latreille al hablar de este acarino, y tambien otro autor francés, Hermann que en su QMemeria apterologicas. (Strasburgo, isos) llama á la especic Phymchoprio: columiluce, manifestando su admiracion de que nadie la cite, pues, su padre la conoce ya hace 30 años como peligroso parásito para las palomas. Hasta hace algun ticmpo indicábase la Francia é Italia conno patria del argas de concha, Herrich-Schaefier supuso que tambien puede encontrarse en Alemania, lo cual se ha confirmado bajo circuns. 
tancias interesantes en varias regiones de nuestro patria. En Cameos, en Westfalia, se encontró esta garrapata, segun informe del doctor Boschulte, à principios del año 1859 y tam. bien en anos anteriores, en la parte superior de una casa de piedra, en las paredes de varias habitaciones revestidas de papel pintado, y sobre todo en su dormitorio que ocupaba el centro de una torte y' que por medio de una ventana esturo en comunicacion hasta 2857 con un palomar vecino. La garrapata se colocaba en las paredes de las dos citadas liabitapo se podi modo que á cualtquier hora del dir, y en todo tiempo se podia coger sin gran trabajo uno if otro individuo, $y$ la circunstancia de encontmrlos de todos tamaños, indicaba una abundante propagacion, a pesar de que habia pocos mabitantes en la casa $y$ de que ninguna paloma entraba alli de forma dé conchs cuantos individuos se veian. Un angas. mano ceŕra del pul qu hia agarrado en la palma de la pando su alimento o ve vinterisiete minutos chu luntariamente cuanclo hubo llegado a se desprendió vo queña habichuela.

En $16_{3}$ el pastor protesiante de liriedeburgo, a orillas del Sazle, entregó dos argas vivos al museo zoológico de Halle, dando otra vez con su relato una prueba de las intimas rela. ciones entre el citado argos y las palomas. Hasta el año 1857 existió debajo de la habitacion en que se-presentaban los parisitos, un portal en cuyas paredes habia nidos de palonia. Despues el portal se irasformó en habitacion, sobre la cual dormian unos niros. Aqui se presentaban las garrapatas y tambien algunos en el piso inferior. De dia pernanecian ocultas y solo de noche se paseaban por las paredes 6 el techo. Cada ver. que veian una lua se paraban, y al tocarlas fingianse como muertas. Gracias á este proceder, ofrecian un medio para exterminarlas, pues, antes de acostarse la gente, pasábase la luz por las paredes y quemábanse cuantas se veian, algumas noches pocas, pero otras hasta diez y ocho. Recordamos aquí el medio de que hablamos al describir las chinches, y es dormir en una habitacion iluminada, medio que tambien en Persia se recomienda contra las argas. Nunca se pudo averiguar de donde venian las garmpatas, nunca se vió una grande $y$ otra pequeña, pues todos tenian por térnino mecio de $U^{\prime}, 045$ á $U^{n}, 065$. La mayor parte de los incividuos que se cogian en las personas encontrábanse en los piés y en las manos, circunstancia que indica que los argas no buscan el calor de la cama como nuestros chinches. La lesion ofrece el aspecto de un pumtito rojo sin inflamacion alrededor, pero produce una fuerte picazon, menos en el sitio mismo, que en la direccion de las venas: asi, por ejemplo, una picadura en medio de los dedos ocasiona picor en lodo el brazo hasta los hombros, si es en el pié, el dolor llega hasta la espalda. Si el paciente se rasca aumenta la fuerza de la irritacion y se extiende cada vez mas, inflamándose los contornos de las venas sobre todo en los niños, que suelen separarse de la cama con marcadas infiamaciones. En una niria de cuatro a cinco años preséntanse en la muñeca y en el antebrazo hinchazones seincjantes a las ampollas que produce una quenadum. En cierias circunstancias, los efectos duran ocho dias. De todo lo dicho podria deducirse que la picadura de nuestro argas no es menos sensible en nuestro clima templado que los del argas de Persia en aquel pais cálido. Hace dos años que observé en Eisleben, en una mampara, un argas de forma de concha en extremo grande, y a mis jreguntas contestóse que esta inampara habia estado en un palomar. Además de su gran temor á la lu\% estas garrapatas se distinguen por una inmovilidad que raya en terquedad. Durante algunos minu. tos mantiénense en el mismo sitio, de modo que se las puede creer muertas y al echarlas ell espiritu de vino no mueren ni una sola pata, mientras que cualquier otro insecto hace codos los esfuerzos posibles para escapar de la muerte.

CARACTÉRES. - Foste ixiodido tan interesante, que segun las observaciones hechas se halla tambien en otras regiones de Alemania, siendo igualmente paraisito de las palomas, tienen la superfície del cuerpo cóncava, con algunos hoyos, de los que los dos mas grandes y omles se hallan un poco por delante del centro, mientras que la mayor parte de los otros, pequenos y blanquizcos, rodenn en forma de corona una placa dividida en su centro por una marcada depresion longitudinal. La cara superior es de un amarillo de orin; el borde exterior del cuerpo, la cara inferior $y$ las patas, de un blanco amarillento, cuando el animal está en ayunas. Ias patas se insertan en ancas lijins, muy próximas entre si y rematan en dos garras muy corras, sin discos, que no existen en el fítimo artejo del pié, si bien se comunican con él por medio de dos anillos delgados, adquiriendo por esta circunstancia mayor agilidad. Un poco por delante de las primeras ancas se halla en una cavidad la trompar, que es corta y prolongada horizoritalinente; tiene la estructura ancha descrita, aunque difiere por algun detalle poco esencial, como, por ejemplo, tener el último artejo de los palpos maxilares en figura de lezna, $y$ el primero en forma de escama. Para hacer uso del liftimo artejo la garrapata le dirige verticalmente hacia abajo como en los ixiodos, cuya estructura parece reprcducirse igualmente en las demás partes del cuerpo. Además de los dos argas citados solo se conocen con seguridad dos especies, el Argas fischeri, del Egipto, y el Argas maari. tianus, de la isla cuyo nombre lleva; pero solo se han observado exteriormente, como la major parte de los acarinos, asegurándose que el último vive en las gallinas, cuya muerte pcasiona á veces. El Argas Sreigryi del Eigipto se ha clasifi. cado por Koct con el nuevo gúnero Ormithodoros, porque prescentá en la cara inferior del cuerpo ojos bien marcados.

\section{LOS SARCÓPTIDOS-SAR- CORPTIDA}

CARACTERES. - Los sarcóptidos pertenecen álas especies mas pequeñas del órden y se caracterizan por su cuerpo de piel blanda, reforzado á veces por algunos rebordes de quitina que presentan una forma oval proloigada. Los ojos faltan; la superficie esta cubierta de pelos cerdosos a menudo muy abundantes; las patas, cuando no estån atrofradas, rematan en un disco; las antenas maxilares terminan en una tijera ó punta de alfiler y pueden recosrerse, en este último casu, en un tubo membranoso. También la organizacion interna de estos séres microscópicos es incompleta. Has. ta ahora no se ha encontrado ningun restigio de órganos respiratorios, y si solo un nudo nervioso sin ranificaciones. Leyehig ha logrado tambien encontrar órganos digestivos.

A pesar de ello, estos acarinos son molestos y perjudicia. les en los mas diversos comestibles y hasta en el cuerpo hu. mano.

\section{EL ACARO DOMÉSTICO-ACARUS DOMES- TICUS}

CARACTERES. - El I acaro doméstico parece $\mathbf{a}$ la simple vista un puntito claro dificil de reconocer, pero con el microscopio se ve que es un diminuto insecto de cuerpo bipartido, grueso, brillante, prolongado y cubierto de largas cerdas, con las antenas maxilares en forma de tijera y pro. visto de patas de cuatro artejos quue rematan en un disco de tallo largo. 
USOS, COSTUMBRES Y REGIMEN.-Miles de individuos habitan en al queso rancio y duro como la piedra, el cual trasforman con el tiempo en polvo, mezclado con los excrementos y pieles de los acarinos; pero esto es precisamente lo que desean ciertos aficionados, que aprecian mas el queso cuando mas acnros contiene.

\section{EL ACARO DELA HARINA-ACARUSFARINAE}

CARACTERES. - Esta especic se parece mucho à la anterior, pero no tiene el cuerpo bipartido.

USOS, COSTUMBRES Y RÉGIMEN. - A nadic le agrada ver este insecto, porque es un indicio seguro de la mala calidad de la harina y proque en algunos casos hace desaparecer del todo montoncitos de trigo (fig. 228). El polvillo reseco que cubre los frutos dulces tales como las ciruelas, pasas, higos, dátiles y otros, no se forma siempre por la secrecion de la sustancia glutinosa, sino a menudo por millares de acarinos que pertenecen à varias cspecies del género givy. phagus (golosos).

Desde que la enformedad de las patatas se ha hecho cues. tion del dia en el terreno econúmico, algunos naturalistas franceses (Guerin-Méneville) hablaron de un acarino, acartis (lyroglyphus) fecula, del cual, sin embargo, no se sabe aun si es causa ó consecuencia de la enfermedad: jo creo lo ultimo.

Este insecto cubre en forma de un polvo gris las patatas que por su aspecto parecen ciel todo sanas; pero en menos de ocho dias se desarrolla á millones en las patatas verdaderamente enfernias, econtrindose en ellas en todos los grados del desarrollo, desde los mas pequeños hasta los adultos, incluso las hembras fecundadas y las parejas que se ocupan en aparearse. Numerosos insectos rapaces de las mas diferentes órdenes se presentan pronto para cebarse curando abunda la cosecha.

Fn las colecciones de insectos se encuentra otra especie (acarus destructor) que suele producirse en los individuos grasosos de aquellas, y que puede ser á menudo muy dañino cuando no se retiran pronto los ejemplares infestados; un montoncito de polvo alrededor de la aguja con que se clava el insecto, descubre la presencia de los acaros.

En los barriles de cerveza, en los bordes de los jarros de leche sucios, en la carne resecada, en medio de las simien. tes, etc, se encuentran otras especies, que dan a conocer la asombrosa extension y variedad de los acarimos.

\section{EL SARCOPTO DEL HOMBRE - SARCOPTES HOMINIS}

Durante siglos énteros los sabios, y principalmente los médicos, no llegaron jamis a estar acordes sobre la naturaleza de esa enfermeciad tan enojosa, y hasta repugnante, de la epidermis, cuyo nombre de sarna tiene en todas partes una signiticacion muy desagradable. Desde que las muchas enfermedades de la piel se han distinguido mejor, estudiándose sus causas mas minucjosamente, se ha demostrado hasta la evidencia que la sarna se produce por la actividad de ciertos acarinos en la epidermis, y por eso nunca será una crupcion cutáńca, sino que se comunica por contagio exterior inmediato, por medio de las ropas, camas, eic., que trasmiten los acarinos $\delta$ sus hueros de una persona a otra. El animal que cn el hombre produce la cirada enfermedad se llama el sarcopio, nombre moderno cientifico, introducido por Raspail, y' inas propio cue el antiguo, acarus scabizi de Fabricius, porque la instruccion insuticiente de este uiltimo entomólogo hace dudiar sohre si turo cfectivanente à la vista el animal de que hablamos ú otro muy semejante del que aun se consersa la especie.

la sarna se presenta bajo la forma de prominencins lineales (galerias) diseminadas casi siempre en las diversas partes del cuerpo cubiertas de una epidermis delgada, como la de la muñeca, el codo, la rodilla, etc. : cada una de esas promi. nencias indica un sitio irritado, $y$ en su conjunto aparecen segun la sensibilidad del eniermo y la region de la piel bajo la forma de verruguita, vejiga ó pústulas. Cuando los sarcoptos se han ingerido en la piel, penctran mas 6 menos oblicuamente en la epidermis, segregando un liquido catistico que produce las citadas prominencias Al principio de liaberse declarado la sarna no se encuentm ningun sarcopto, ya porque han penetrado a mas profundidad, 6 bien porque se han alejado de nuevo, pues todos los acarinos jovenes, tanto los machos, como las hembras no fecundadas, observan una vida ragabunda y abancionan sus galerias para practicar otras. Fstos individuos son particularmente los que prociucen la inso. portable picazon. En cambio las henbras adultas abren galerias mas largas (de nido), las cuales no aluandonan ya; depositan en ellas sus huevos, y se las encuentra muertas en la extremidad cerrada de su retiro. Tampoco se hallan los sarcoptos, por lo menos con regularidad, cn las escamas y costras (escaras); en estos dos casos debe buscarse la causa de no habérseles reconocido durante anto tiempo como autores de la enfermedad.

Del modo indicado sucede en la sarna regular que se encuentra en el hombre: alli donde las condiciones de la poblacion son mejores no tiene que estar mucho tiempo sin auxilio del médico; pero tambien pucảe suceder, en caso de descuido que el mal no pase de cierto grado, porque una irritacion de la piel demasiado fuerte no conviene a esos inseclos y favorece muy poco su propagacion, habiéndose conocido hombres que tuvieron la sarna algunos años sin que esta adquiriese un carácter esencialmente distinto del regular. Cuan. do en cambio los sarcoptos se encuentran en circunstancias muy favombles, es decir, cuando la piel à cnusa de su natu. ralceza se irrita menos, no siendo la constitucion del resto del cuerpo muy sensible á los efectos del mal, y cuancio ningun tratamienio entorpece la artividad de los insectos durante meses enteros, la sarna aumenta hasta lo increibic. Las numerosas crias que se siguen ripidamente, no encontrando lugar para la construccion de sus nidos en los sitios que con preferencia eligen, se ven entonces obligadas á practicar las galerias en las partes del cuerpo libres. Por la continua initacion que ocasionan en la piel los sarcoptos produceu al mismo ticmpo una renovacion extremadamente rápida de los elemen tos de la epidernis. mientras que los tejidos mas antiguos de la misma, cruzados por numerosas galerias cortas y agujeros desvianse juntamente con las madres primitivas de los mas recientes, quedando adheridos sin embargo it los inferiores por medio de la humedad que desde abajo penetra por la masa porosa. En csta formacion de escam y en su major ex. tension sobre el cuerpo se funda el carácter de ta asarna es. carosa, micho mas rara pero ambien mas pertinaz; esta forma parece como producida por otros acarinos y sucle observarse en nuestros animales domésticos (caballos, cerdos, perros, gatos y concjos), designándose con el nombre de roña.

Hasta ahora se han visto poros casos de este mal, diseminados en toda Europa, habiendo observado que las personas atacadas eran siempre pobres mal alimentados, estúpidos y apáticos. El mayor numero de casos $(\overline{5})$ se contó en Noruegâ, en una poblacion muy iníestada por la sarna; y en el centro de Alemania hubo cuatro; mientras que en Francia, Suecia, Dinamarca jo Constaminopla solo se dió respectivamente un caso. En Nonega, Islandia, en las islas de leroé y 
Groendlandia, $\delta$ sea en regiones enteras donde la poblacion es muy sucia, parece probable que la sarna escarosa se haya declarado con mas frecuencia; y podernos suponer que en tiempos anteriores, cuando la curacion de las enfermedades se hallaba en un grmn atraso, debió propagarse aun mucho mas el mal. Tambien es posible, pero no puede probarse con seguridad, que la fabulosa enfermedad de los piojos de que nos hablan los autores antiguos, haya sido la sarna, por lo menos en casos aislados.

R. Bergh nos habla minuciosamente de un caso de sarna escarosa observado por ćl, y de su informe reproduzco en extracto las noticias referentes a nuestros acarinos. Un pedazo de la parte mas vieja y superficial de la capa escaro$\mathrm{sa}$, de un milimetro cúbico 5 ocho diermiligramos de peso, contenia dos hembras, ocho hijuelos de seis patas, veintiun individuos grandes y pequenos, seis huevos, cincuenta y ocho cáscarns y unos $\mathrm{r}, 030$ pelotes de excrementos de todos tamaños; mientras que en un pedacito de la capa inferior era mucho mas reducido el número de estos animales.

Los excrementos son de muy diverso tamaño y forma, por lo regular redondos y prolongados, lisos ó granujientos, de color amarillo pardusco. Los hucvos son casi ovales, una tercera parte mas largos que anchos (por terrmino medio $11^{\circ}$, oo I 5 de longitud) y circuidos de una piel incolora, gruesa y poco trasparente. Por lo regular se puede observar el desarrollo desde la primera posicion de la cabeza y extremidades de seis patas, de las que las posteriores estan cruzadas. El huevo se abre regularmente por dos hendiduras longitudinales y desiguales para dar paso al hijuclo: que aparece despues replegado y rugoso. Los restos de los acarios que en gran número se encuentran en todas partes de la capa escarosa se componen principalmente de las pieles abandonadas, reconocién. dose sobre todo por los bordes de quitina que se hallan en la superficie del vientre del insectó, en los cuales se apoyan Las extremidades, y tambien por los anillos amarillentos de los últimos Los individuos muertos suelen hallarse casi siem. pre completos.

CARACTERFS.-Por lo que toca á los sarcoptos vivos, preséntanse bajo tres diferentes formas principales, es decir, como machos de ocho patas, provisto el par posterior de piés con discos, como hembras del mismo número de patas, cuyas cuatro posteriores están provistas de cerdas; y en fin, como larvas de scis patas. Segun ya hemos dicho las extre. midades se apoyan en rebordes de quitina; las patas anteriores en uno comun, ahorquillado, y cada una de las-otras en uno particular; el del segundo par de estas es mas fuerte $y$ largo que los de las patas posteriores. Los tres rebordes de los pares anteriores de las hembras y de los hijuelos son escotarlos en la parte posterior. Cada pata se compone de cuatro artejos, el ifltimo de los cuales tiene en su centro un disco de tallo largo o una poderosa cerda; ademis se observa en los diferentes artejos, cerdas en número determinado, to mismo que en las otras partes del cuerpo. Este se halla dividido en dos partes desiguales por una inaccion trasversal.

El macho se reconoce por los discos de las patas posteriores; tiene en el dorso dos largas cerdas $y$ en la region de los hombros tres pares de espigas cortas y gruesas; en la parte posterior del cuerpo hay a cada lado una serie oblicua de tres ó cuatro escamas grandes triangularés y mas atras otras regulares. En varios de ellos se ven numerosos replicgues. La hembra de un color mas amarillo, tiene detrás de los puntos de los rebordes de quitina anteriores la abertura de la vagina, en forma de hendidura longitudinal; la supericic del dorso está rodeada de escamitas planas triangulares, y mas hácia atrís de cuatro series de espinas casi cilindricas. Las larvas difieren de las hembras adultas por su menor ta. maño, por la falta de la abertura sexual y del par de cerdas por delante de la misma, $y$ además por los repliegues de la picl, que afectan la forma de concha mientras que en aque. llas se extiende en figura de arcos. Bergh indica además ciertos caractéres distintivos entre los tres gradios del desarrollo de las larvas, haciendo notar que las hembms preponderan mucho menos que los machos: esto se lo dijeron otros auto. res, que se han engañado al suponer que los machos son muy raros, de lo cual se deduce que confundieron en parte ambos sexos.

\section{EL DEMODEX DEL HOMBRE-DEMODEX HOMINIS}

A principios del cuarto decenio de nuestro siglo Heule y Simon descubrieron en los folículos de los pelos de la piel humana un acarino que excitó el interés general y fue desig. nado con numerosos nombres, siendo el mas antiguo el de acarns folliculorum: esta especie puede ofrecer tambien otro aspecto en los perros, gatos, etc, infestados por la roña. I.ey dig se rió obligado à examinar este insecto, por haber observado en el vientre de un murciélago de Lurinan (Phyllasto. ma hoslatum) una inflamacion del-tamaño de un guisante lleno de una materia blanquizca compuesta de grasa y de un sinnúmero de acarinos; una pequeña cantidad de esta mate. ria, vista con el microscopio, presentaba centenares de estos diminutos insectos. (Demodex plyyllos tomatis).

CARACTERES, - El denodex del hombre tiene la boca compuesta de una trompa y de dos palpos, ásperos por de. lante en su parte inferior; las patas, cortas y gruesas, rema. tan cada una en cuatro garras. Varios observadores dicen que presenta unos surcos muy finos en la parte posterior del cuerpo, pero Léydig dice que se hallan en la anterior, generalmente mas anchas en este insecto que en el demodex de los perros (demadiex conis). La especie que nos ocupa, se caracteriza sobre todo por tener una cresta membranosa á lo largo de la parte anterior del dorso, y una depresion con re. borde oblicuo entre la cresta y las patas. Leydig describe la forma de la boca y de las extremidades mas detalladamente que otros observadores, porque el reconocimiento de séres tan pequenos ofrece grandes dificultades.

USOS, COSTUMBRES Y REGIMEN.-El demodex del hombre se encuentra en los folirulos de los pelos y sobre todo en los de las orejas y de la nariz, que se designan como espinillas. Estus no son acarinos, sino gotas de sebo cuya extremidad exterior se ha ennegrecido con el polvo, pero en la profundidad de estos foliculos vive el acarino microscópico. Un cuerpecito en forma de corazon, que siempre se encuentra al lado de un demodex, ha sido considerado por Leydig y Simon como liuevo, del cual nace una larva de seis patas. Este huevo tiene otra forma en las otras dos especies antes citadas. Por todo esto vemos que la naturaleza no se limita á producir parásitos visibles que invaden el hombre y los animiales, sino qque tambien crea parisitos tan pequeños que no podrian descubrirse sin el poderoso auxilio del micros. copio. 


\section{LOS LINGUATULIDOS — LINGUATULIDE}

Un reducido número de parísitos, que por su forma vermiforme y por su género de vida se han clasificado antes entre las lombrices intestinales, constituye ahora un órden de los aracnoideos, el de los lingruatulidos, compruesto de una sola familia del mismo nombre, llamada tumbien la de los pentastomidos (pentastomide), pues las averiguaciones de Beneden, Schubart, Leuckart y otros han demostrado por la estrucura interna y por la presencia de dos pares de patas su afinidad con los acarinos. Por una trasformacion retrógradia, estos séres, acarinos por su estructura, han vuelto à la forma y al género de vida de las lombrices y constituyen de este modo un tránsito entre los eutrópodos y aquellas.

CARACTERES.-Dos pares de ganchos prehensiles en forma de pik, articulados al rededor de la abertura bucal, que carece de inaxilas, $y$ la falta de triqueos, caracterizan estos parasitos de forma prolongadas y anillados, en que el macho, essencialmente mas pequeño que la licmbra, tiene su abertura sexual cerca de la boca, mientras que en aquella se halla en la extremidad del tronco, donde al mismo tiempo desemboca el ano.

\section{EL PENTASTOMO TENIOIDEO-PENTASTO- MUM TAENIOIDES}

CARACTFRES, USOS Y COSTUMBRES.-EI Dentastómo tenioideo se encuentra principalmente en la cavidad nasal $\delta$ entre las celdas del esferoides del perro, y del lobo, en estado de adulto; aisladamente se le ha visto tambien en los caballos, mulos y cabras. Los huevos depositados, de los que algunas hembras tienen 500,000 , llegan con la secrecion mucosa al aire libre, y por lo tanto tambien a las plantas, con las cuales penetran en el estómigo de los conejos, licbres y oiros animales, pero raras veces en cl del hombre. Tan luego como el embrion abandona el hucio penetra lo se encierra en su capullo, en el cual sufre varias mudas a nunera de metanórfosis, cambiando de forma. Al cabo de unas seis semanas se ha desarrollado, adquiriendo considerable tamano:tiene ya los cuatro ganchos de la boca y numerosas articulaciones denticuladas del cuerpo, y entonces sale de su capullo. Én tal estado, se le encontró en col higado, y considerado como otra especie, diósele el nombre de pentastomo denticulado (pentostomusu denticulatum). En este grado del desarrollo, aun incompleto, el insecto emprende otra vez sus viajes y perfora el higado, causando la muerte del sér atacado cuando se reunen muchos individuos. Cuando en tal estado llega a la cavidad bucal de un perro que coma el higado de un conejo ó de una liebre, penetra en las paries del crảneo, desarróllase, y á los dos ó tres meses se convierte en pentastomo adulto, cuyo nombre científico significa animal de cinco bocas, pues à cada lado y un poco hácia atras de la boca, rodeada de uma prominencia circular dura, se encuentran dos hendiduras, de las que salen los gauchos prehensiles y en las que pueden recogerse. El cuerpo blanco amarillo, tiene forma de lanceta; es liso en el vientre, un poco abovedado en el dorso y anillado por numerosos réplic. gas trasiersales. La hembra alcanza de 70 a 130 milimetros de largo, mientras que el macho solo mide de $S$ i 10. P'ocos pentastomos tenioideos producen un la caridad nasal ó frontal de un perro inflamacion y dilatacion de las membranas mucosas, pero cuando se reunen muchos individuos aquella es tan dolorosa, que el perro se vuelve rabioso y puede considerarse entonces como hidrúfobo.

Se han encontrado tambien otras especies hajo diversas condiciones, como en la boca de los crocodilos, en los pulmones de las serpientes de artejos, en pitónidos y crotálidos, y hasta en el higado de negros egipcios; a estas especies se les ha dado nombre sin conocer su historia naturn, como la de la especie anterior, la cual debe bastarnos para formarnos idea de estos seres interesantes.

\section{mismo que la trichina por el intestino y llega al higado, donde

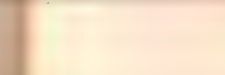
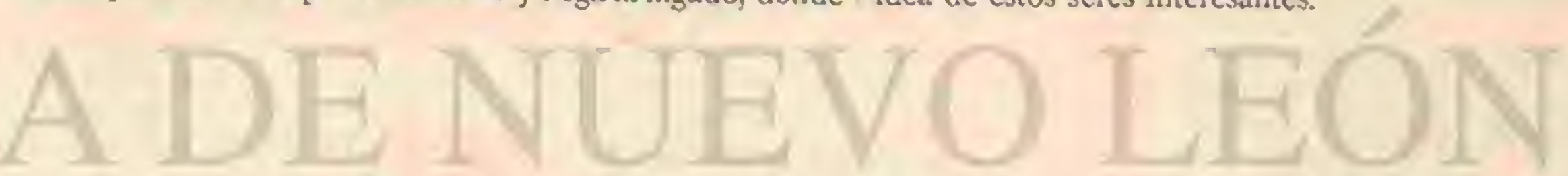

QUINTO ÓRDEN

\section{PANTÓPODOS-PANTOPODA}

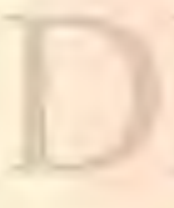

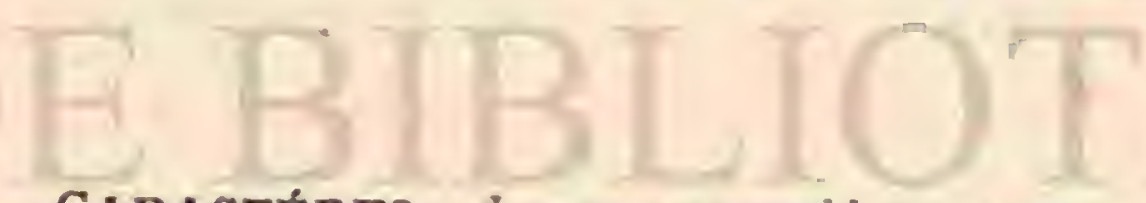

CARACTÉRES. - Los pocos aracnidos que nos quedan por describir se habian clasificado por Milne Edwards entre los crustáceos, y solo últimamente, despues de reconocerse, su desarrollo y estructura extensa, los sistemáticos se han visto obligados á reunirlos aqui. I.os paniópodos se encuentran en las playas, debajo de las piedras y en medio de algas con las cuales flotan ó agarrados tambien ả otros

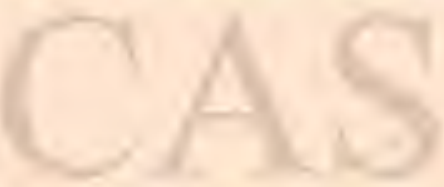

animales. Este insecto se compone principalmente de patas de muchos artejos, pues el abdómen desaparece casi del todo, y el cefalotóras, de cuatro artejos, solo sirve de purr. to de apoyo a las extremidades. A los lados de un tubo chupador, en forma de cabeza, se insertan las antenas maxilares, en figura de tenazas; á veces son sencillas, yả menudo no existen, como sucede con el primer par de palpos maxi. 
lares, mientras que el siguiente par ts de la misma estructu. rat que las otras patas, compuestas de siete artejos, rematando en una fuerte garra. En el borde anterior del cefalotórax hállanse en una especie de corcova cuatro ocelos.

El iniestino se corre en línea recta desde la boca hácin el ano, pero no forma a pesar de eso un tubo sencillo, porque el estómago, muy estrecho, está provisto en cada lado de cuatro protuberancias en forma de intestino ciego, de las cuales el par mas corto penetra en la cavidad de las antenas maxilares y cada una de las siguientes hasta el antepenúltiino artejo de las patas correspondientes; sus paredes en las que abundan las gländulas, hacen las veces de hígado. Los órganos genitales se hallan en el macho y la henibra en el cuarto ó quinto artejo de cada pata, de mólo que su número asciende á ocho, el liquido espernsitico sale de la punta del citado artejo, pero los huevos se expclen por una abertura de cada segundo artejo, pasando á un órgano en forma de pata que se inserta en la parte anterior del cuerpo, donde quedan achieridos hasta que salen los hijuelos. Los órganos de la circulacion de la sangre han sido descubiértos última. mente por \%enker bajo la forma de un corazon de tres ventriculos, pero los órganos respiratorios en cambio falian, de modo que probablemente estos ánimales respiran por la gruesa piel del cuerpo. Los hijuelos no adquieren hasta despues de repetidas mudas la forma de los padres, pues nacen sin artejos, con las antenas maxilares que á veces rematan en una especie de largos látigos y con solo cuatro patas.

\section{EL PICNOGONO LITORAL-PIGNOGONUM LITTORALE}

CARACTERES. - El picnogono litoral alcanza una lon. gitud de $0^{m}, 013 y$ vaga por las costas de los mares europeos, sobre todo por al del Norte; se le encuentra debajo de las piedras y en medio de las algas; y tambien se le lia visto agarrado en peces. I as antenns maxilares y los palpos de la nandibula inferior no existen; la superficie del cuerpo. de color amarillo de orin, mas 6 menos pálido, es mate y gra. nujienta; los artejos del muslo están provistos en las puntas de dos protuberancias on forma de verrugas.

\section{EL NINFON GRACIOSO-NYMPHON GRACILE}

CARACTERES. - Esta especie se distingue de la anterior por las antenas mas anchas en forma de tenazas, por los palpos de la mandibula superior, delgados, con cuatro artejos y por las patas filiformes, muy largas. Alcanza una longitud de poco mas de $11 ", 005$ y se encuentra bajo las mismas condiciones en las costas europeas. En el centro del cuerpo hay un par de patas que solo se encuentran en la hembra y que sirven para llesar los huevos. El primer segmento del cefalotórax se prolonga extremadamente en compania de los otros, estrechándose en el centro. Los cuatro ó cinco artejos de las ancas, que se insertan debajo del artejo del muslo contribuyen esencialmente á ha prolongacion de las patas y garras; y los piés mas largos que la trompa son otros tanios caractéres distintivos del género.

En el género ammothoa las garras de los piés son mucho mas cortas que la trompa y los palpos se componen de ocho artejos lin otros géneros de este grupo, de los cuales no podemos ocuparnos, estas proporciones vuelven a ser otras.

Por útimo, diremos que recientemente se ha formado el órden de los tardigrados, clasificándolos entre los aracnoideos, mientras que antes se agrupaban entre las moscas. En estos séres microscópicos ambos sexos están reunidos en un individuo; el cuerpo, prolongado y vermiforme, no está dividido en dos partes, y tiene en su parte anterior un tubo para chupar, del que parten dos maxilas en forma de puñales. Los cuatro pares de patas están atrofindos, no tienen artejos y rematan con garras; el último se inserta en la extremidad del cuerpo. Los tardigrados tienen un anillo esofocal, cuatro nudos nerviosos y un intestino, pero carecen completamente de los órganos respinatorios y de los que sirven para la circu. lacion de la sangre.

Se alimentan de especies animales peq̨uenas, que como ellos viren entre el musgo $y$ las algas, sobre todo en los espacios cubiertos de esta vegetacion; algunos habitan tambien en el agua y se lan distinguido por la circunstancia de que en ciertos periodos, cuando les falta la humedad necesaria permanecen como muertos, si bien vuelven à reponerse apenas reciben aquella. Se han reconocido varias especies, distribuidas en varios géneros, de los que el macrobiotur es quizás uno de los mas diseminados.
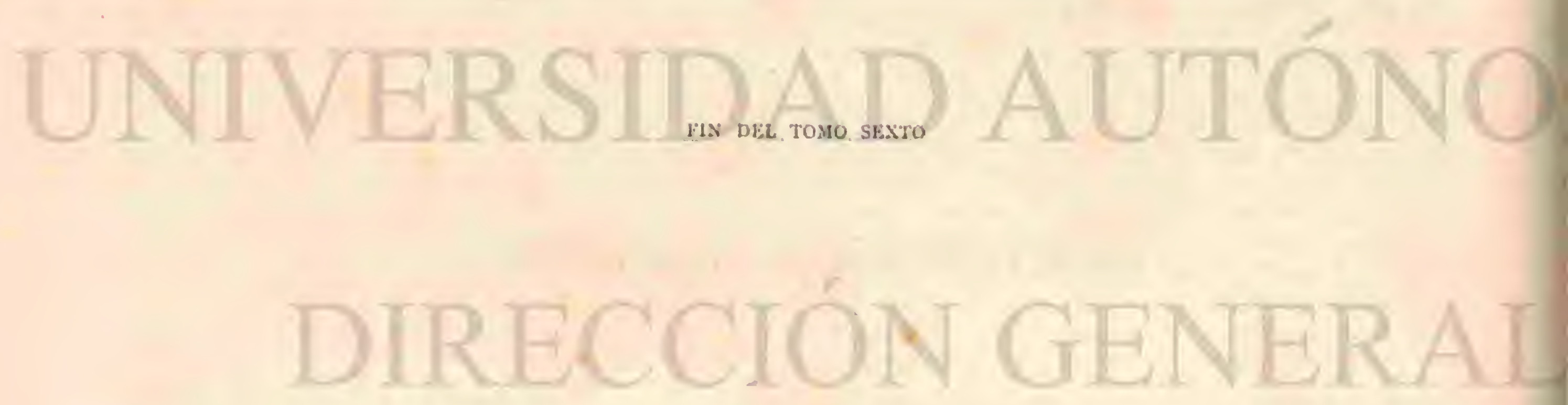


\title{
IN DICE ALFABETICO
}

\author{
DE LAS SERIFS, ÚRIENES, FABHLIAS, GKNYROS Y ESPECIFS CONTENIDOS FN FL TOMO SEXIO
}

Abeja doméstica y9

Abejas parásitas 115

Abejorros 106

Abejorro de las piedras 108

Idem de los musgosidem

Idem de los jardines idem

Idem oriental idem

Idem terrestre idem

Abraxas del grosellero 228

Acantocino ebanista 82

Acantosoma denticulado 331

Acáridos 376

Acaro doméstico 382

Idem de la harina $3^{83}$

Acilio surcado is

Acridiodeos 293

Acriote de los sembrados $i 7$

Acronicto de los plátanos 217

Adela verde 236

Adolias 180

Adolia espinoso idem

Afrdinos 314

Afidios 154

Afidos 314

Alodios 33

Afodio escarbador idem

Afroforo de los sauces 319

Idem espumoso 318

Agelena laberintica $36 \mathrm{r}$

Agenias 139

Agloso grasiento 232

Agras 9

Agra varinlado idem

Agraulis 187

Idem moneta idem

Agrilinos 44

Agrilino de dos manchas idem

Agrotis 221

Idem de la exclamacion idem

Idem de las cortezas idem

ldem de los sembrados idem

Alantos 170

Alanto escrofulario idem

Alcione 190

Aleurodes 311

Alisios 156

Alisio manducadora idem

Alotrias $15 \mathrm{I}$

Alticidos 9 I

Altica slerícea idem

Idem de las encinas 92

Alucita polidáctila $23^{3}$

Amblioma americano $\$$

Ambliteles $16 \mathrm{I}$

Amofila arenosa 14

Indienas II I '

Andrena cenicienta 112

Idem de muslo pardo idem

Idem de Schrank idem

Iden ovina idem

Andricos 149

Anfidasis de los abedules 226

Aníriso 176

Anisoplios $3^{8}$
Anobios 53

Anobio abigarrado 53

Idem del pan idem

Idem rayado idem

Idem terco idem

Anoma capataz 131

Anomalones 159

Anomalon circunflejo idem

Antias 10

Antidos 114

Antocaris Aurora i $8 \mathrm{r}$

Antófilos 99

Antoforos 109

Antoforo de las paredes iden

Idem de pelos bastos idem

Idem truncado idem

Antomidos $25 \mathrm{~S}$

Antonomos 70

Antrax semi negro 250

Antreno de los museos 28

Antribinos 70

Antribo albino 77

Apatos 115

Apaturas is 6

Apatura iris idem

Apiones 65

Apion del sol idem

Apodero de los arellanos 66

Idem de cucllo largo idem

Aquerontia Aropos 196

Aracnoideos 342

Arades 327

Arade de la corteza idem

Arañas propiamente dichas 350

Argas versa 381

Iden de forma concha idem

Arginis i 82

Idem Aglaya $18 \hat{j}$

Idem de raya plateada idem

Argironeta acuática 362

Argiropteros 226

Argiroptero moteado idem

Arkis 375

Arkis lancero idem

Aromia almizclado 99

Artrogastrós $3+3$

Ascalafos 265

Ascalafo abigarmdo idem

Asilidos 248

Asilos 249

Asilo abejorro idem

Asopia de la harina 233

Aspidolofos SS

Aspidolofo ancho idem

Atacos 216

Ataco cintia idem

Atagenos 27

Atageno de las pieles idem

Atalia de la colza r 69

Atelabo curculionoideo 66

Ateuco sagrado 32

Atidos 373

Atipo de color de pez 356

Atoo àspero 45
Atta caberudo 137

Avispas $12 \mathrm{I}$

Avispa alemana 122

Idem comun idem

Idem media idem

Idem roja idem

Avispon 121

Balanino de los arellanos 70

Banco falcador 158

Baridios 13

Basos 158

Baso de señal blanca idem

Belonogastro 124

Belostoma grande 324

Rembex 142

Idem comun idem

Beriro mosquito 330

Bibio de marzo 246

Idem de los jardines idem

Bioriza sin alas I 50

Birros 28

Bitacn tipulario 268

Bituro tomentoso 28

Blabera gigante 290

Blaps enlutado 54

Blasfofago de los pinos 75

Idem menor idem

Bocidios 320

Bombicidos 203

Bombilios 250

Bombix de las moreras 206

Boreo de los ventisqueros 268

Bustricos 75

Bostrico tipógrafo 76

Bostriquidos 74

Botidos $=33$

Botis de la colza idem

Idem del mijo idem

Botrioceros 320

Bracones 155

Bracon palpebrador idem

Braconidos 153

Braquiceros 68

Braquinos 9

Braquino estrepitoso idem

Braquitarsos 77

Braulo ciego 261

Bréntidos 76

Briseis 190

Brotolamia meticulosa 220

Bruco de los granos 85

Idem de los guisantes idem

Idem de patas rojas idem

Bruquidos $\mathrm{S}_{4}$

Bupalo de los pinos 227

Buprestidos 42

Idem propiamente dichos 43

Calandridos 73

Calcidios 152

Calcis clavipedo 153

Calcoforidos 43

Calcoforo Mariano idem 
Calcosomas 39

Calcosoma atlas idem

Calicodomo de los muros 113

Calidio variable 81

Calígrafos 90

Calocoris rayado 328

Calopterix 227

Calosomas 8

Calosoma asesino idem

Idem inquisidor idem

Calotérmite de cucllo amarillo 285

Campanotos 89

Campanoto hercúleo idem

Cantíridas 50

Cantárida vejigatoria 59

Cantores 321

Capricornios 77

Capsos 328

Carabicidos 6

Carábos idem

Cárabo de las huertas

Idem dorado idem

Idem dorado de las montanas 8

Careas de las gramineas 210

Cásidos yz

Casido nebuloso idem

Castnios 203

Castnio lico iden

Catagramas i 88

Catagrama climene iden Idem lica idem Idem, paloma idem

Catocalas 223

Catocala de los fresnos 224

Idem rojo idem

Cecidomios 244

Cecidomio destructor idem

Cefo pigmeo 166

Celioxis 116

Cenomios 243

Centroto cornudo 310

Cerambícidos 78

Cerambicinos 79

Cerambix héroe idem Idem labradoridem

Cerceris 143

Cercópidos 319

Cercópido de manchas de sangre idem

Ceria conopsoidea 253

Cerocoma de Scheffer 58

Celonio dorado $\$ 0$

Ceiosias I 86

Cetosia Dido 187

Centorincos 73

Centorinco de cuello surcado idem Idem asimile is

Cicadelinos 318

Cicadinos idem

Cicindela campestre 4

Cicindélidos idem

Cigarras 322

Cigarra especiosa idem

Idem del quejigo idem

Cimbex de los abedules ifo

Cinipidos 147

Idem falsos 150

Cinipes 149

Cionos $7 t$

Ciono escrofulario iden.

Cirestis 188

Cirestis tiodamas idem

Cixio nervioso $32 \mathrm{I}$

Clavigero amarillo 20
Cleridos 51

Clitos 81

Clitros $\mathrm{S}_{7}$

Clitro de cuatro puntos 88

Cloriones 140

Clorion azulado idem

Idem lobado idem

Clorops 259

Clotos 367

Cloto de Durand idem

Clubion de seda ${ }_{3} 6_{4}$

Idem nodriza idem

Idem ferozidem

Cnemido:os 16

Cnetocampo del pino doncel 215

Ideni pinivoro 214

Idem procesionario idem

Cóccido del maná 3 to

Idem de la laca idem

Coccinos 308

Cocinelas 94

Cocinela de pústulas 94

Idem dispar idem

Cocinélidos 93

Cochinilla del nopal 300

Coleófero de los alerces 237

Colébuteros 1

Colete rudo 113

Colliris de cuello largo 5

Conops 253

Coprófagos 32

Coreodes 329

Coreos 330

Coriáceos 261

Corixas 323

Corixa de Geofiroy idem

Corredera alemana 287

Idem de Laponia 285

Idem manchadal 289

Cosmia de los álnmos $22 \mathrm{I}$

Cosmisonas $8 \mathbf{3}$

Cosmisoma de Cayena idem

Coso de los sauces 201

Crabrones 144

Crabró cabezudo idem

Crambidos 233

Crioceros 87

Criptidos 157

Criptocéfalos 88

Criptorinco de los alisos $i_{2}$

Criptos 161

Cripto de tarsos blancos 162

Crisidos 145

Crisis 146

Idem azul idem

Idem comun idem

Idem fúlgido idem

Crisocroas if

Crisocroa de Bugneti idem

Crisoforos 40

Crisoloro crisocloro idem

Crisomelas 89

Crisomelinos 86

Crisopo ciego 247

Cucuyo 46

Curculioninos 61

Chinche comun 327

Dacilidos 48

Dacilo cervino idem

Danais I 82

Idem arquipo idem

Dasipodo de piés erizados II
Dasipogones $24^{5}$

Dasipogon alenıan idem

Dasiquiro pudoroso 210

Idem de los sauces idem

Demodex del hombre ${ }_{3} 3_{4}$

Depresarios $2 ; 6$

Depresaria nerviosa idem

Dermanisos 3 TS $^{\mathrm{S}}$

Dermestes del tocino 26

Dermestidos 26

Desoria glacial 305

Diactor de dos lineas $33^{\circ}$

Diastrofo del glechomá 150

Idem de los zarzales idem

Dicranorino de Smith 40

Dilobo de cabera azul 217

Dinasta Hércules 39

Dinastidos 38

Dortria oelándico $24 \mathrm{~S}$

Diopsis 259

Idem longicornio idem

Dipleumones $35^{6}$

Diplopodos 3.37

Diplópteros 117

Dipteros 238

Disderinos 364

Disdero eritrino 365

Diticidos 13

Ditico orillado idem

Doladers $3 \mathbf{j}^{2}$

Dolader de costado agudo idem

Doleras 168

Dolornedo admirable 371 Idem ornado idem

Donacias 86

Dorcadiones 82

Dorcadion cruzado idem

Doriforos 90

Dorilidos 13 I

Dortesia de las ortigas 310

Drasinos $3 \mathrm{G}_{2}$

Drasos 366

Draso brillante idem

Idem sedoso 322

Ecitones I 33

Ecodoma cefalotes I 34

Edicros 1.46

Edicro luciente idem

ldem sonrosado idem

Efialtos 163

Efialto emperador idem

Filafros 6

Elafro de ribera idem

Elampidos 146

Elatéridos 44

Elia puntiaguda 33

Emelesias 288

Emelesia de una faja idem

Emitelo arador 162

Empidos 249

Limpis de dados ióem

Epeira diadema 356

Epinefele hiperanto I9:

Idem janira idem

Epselánidos 20

Epsócidos 2 So

Epsoco lineado idem

Ereso cimabrio 37 it

Ergates carpintero is

Ericinos 193

Eristalos 252

Eristalo tenaz idem 
Escarites 10

Idem gigante

Esciara militar 243

Escitodos 365

Escitodo torácico idem

Escrinos 278

Escnos idem

Escno grande idem

Escolia hemorroidal 136

Escolopendras 335

Escolopendra amarilla 336

Idem angulosa idem

Idem de Lucas 335

Idem gigante 336

Idem hermosa 335

Idem variada 336

Escorpiones 344

Uscorpion campestre 345

Escudados 330

Escutcleridos 332

Escutigeros 334

Escutigero aracnoideo iden Iden noble idem

Esfegidos 139

Esfex idem

Esfinge convólvulo 197

Idem del euforbio idem

Idem del laurel rosa idem

Idem de los pinos idem

Idem de los sauces 196

Esfingidos 195

Esmerintos igs

Esmerinto de los álamos idem

Idem de los tilos 199

Idem de mancha ocular idem

Esmicra clavipedo 153

Espaniscos 159

Esparaso esmeralda 370

Espatio clavado 156

Espilografo del cerezo 259

Espondilo buprestido 79

Lisquizoceros 170

Esquizoneuros 316

Esquizoneuro lanifero idem Idem lanuginoso $31 \mathrm{~T}$

Estafilinidos 19

Estafilino de alas rojas idem Idem de pelos cortos idem

Idem de rayas doradas idem

Estauropo de las hayas 215

Estenopterix de la golondrina 261

Estilbos I 45

Estilbo espléndido idem

Estomoxo picante 257

Estrangalio armado 80

Estratiomis camalcon 250

Estrepsipteros 270

Estridos 253

listro del caballo 254

Idem de las ovejas idem

Euclens 199

Euclea de Dumoulin_idem

Fufolos 64

Fufolo de Linneo idem

Eumenidos it?

Eumenes IIS

Eumeno pomiforme idem

Eupitecias 229

Eupitecia marcada idem

Limplea emperador i 8 ?

Euquiro longimano 42

Euridema de las coles 331

Lurigaster de los hotentotes $33^{2}$
Eurigonos 193

Eurigono opalino idem

Evisniados 153

Evanios idem

Exentero orillado $15^{8}$

Exetastes 159

Falangidos 349

Fasmodeos 292

Feno asectador 153

Feno de fecha idem

Ficadenones 16 I

Ficadenon comun idem

Ficidos 233

Figites $15 \mathrm{I}$

Idem escutelario idem

Figitidos idem

Filanto triangular 3.43

Filios 203

Filio hoja seca idem

Filoberto horticola $3^{8}$

Filobios 62

lilodromos 370

lilodromo desigual idem

Idem oblongo idem

Idem pálido idem

Filonto de color de bronce 20

Filopteros 306

Filoptero árgulo idem

Idem del cisne idem

Filoxera de las encinas 312

Idem devastadora idem

Filotreca de los Sotos 92

Fitocóridos 328

Foras 260

Forculas 302

Forficula auricular 303

Formicidos 124

Frigánidos 269

Frigánco rayado idem.

Frino de brazos largos 349

Frino palmeado idem

Fulgoras $32 \mathrm{I}$

Fulgora del farol idem

Fulgorinos 320

Galeria de la micl 234

Galerucos 90

Gamásidos 378

Gasteracantos $35^{\mathrm{S}}$

Gastropaco anular 206

Idem de los pinos idem

Geófilos 336

Geófilo de Cumming 337

Geométridos 225

Creotrupos 33

Geotrupo estercolatio 34

Idem primaveral idem

Idem tricornio idem

Girinos 16

Girino zambullidor idem

Gliptas $\mathrm{I}_{3}$

Glipta resinosa idem

Gloméridos $34 \mathrm{I}$

Glomerinos idem

Glomeris orlado

Idem puntuado idcm

Glosina tsetse 257

Golint 40

Gonileptes de patas corvas 350

Gonopteros 224

Gonoptero bombix idem

Gracilaria de las lilas 237
Grafolito de las frutas 238

Idem de los guisantes idem

Idem de los ciruelos idem

Idem de mancha semilunar iđem

Grillodeos 300

Grillo doméstico zor

Grillo real idem

Hadena basilinea 218

Idem infesta idem

Halias 232

Halia V idem

Haliplos 16

Harpactor sanguinario $\$ 26$

Harpalos is

Harpalo Eneas idem

Harpia grande 215

Idem pólida idem

Idem vellosa idem

Heliconias : 82

Heliotrips de cola 304

Helofilos 253

Hematobios 258

Hematobio irritante idem

Hematoceros 326

Hematocero de anteojos idem

Hematopinos 305

Hematopo fuvial 247

Hemerobios 266

Hemerobio áspero idem

Hemipteros 307

Hemiptico puntuado 320

Hepialos 216

Hepialo rápido idem

Hesperidos 194

Hesperio coma idem

Heteras 224

Hetera lena idem

Heterio cuadrado 25

Heteroginos 135

Heteronotos $3^{19}$

Heteronoto reticulado idem

Hibernia deshojadora 226

Hidraracnidos 377

Hidrobios 18

Hicirobio oblongo idem

Hidrocampas 236

Hidrocampa ninfa idem

Hidrócores 322

Hidrofilidos 17

Hidrofilo de color de pez idem

Hidrometros 325

Hidroo caraboideo 18

Hidroo negrisimo idem

Hidróporos 15

Hileos 112

Hileo grande $1 \geq_{3}$

Hilobios $6_{3}$

Hilotoma de los rosales 170

Idem del espino agrio idem

Hilotrupo doméstico SI

Himenópteros 94

Himenópteros $16 ;$

Hipoboscidos $26 x$

Hupobosco del caballo idem

Hipodermo del buey 255

Hiponomento malinela 236

Hipsauquenios 320

Histeridos 24

Histérido del estiércol idem

Hormigas propiamente dichas 129

Hormiga roja idem

Idem! sanguinea 130 
Ibalia de forma de cuchillo $15 \mathrm{t}$

Icneumones 157

Icneumones 360

Icreumon fusorio 168

Idem pisorio 160

Icneumónidos 156

Ictinos 276

Ictino soraz idem

Ilibios 16

Ilibio negro idem

Inquilinos 150

Insectos 18

Itomias 187

Itomia traspatente 188

I ulo ceñido 339

Idem de piés anillados idem

Idem puntuado ider

Idem terrestre $33^{8}$

Ixódidos 379

Ixodo comun idem

Idem del rinoceronte 380

Idem elegante iden

Idem rojo-violeta idem

Jenoceros 77

Jenocero brillante idem

Jilocampo litoriza 2 is

Jilocopos no

Jilocopo viólácco idem

Julodidos 42

Julodis fasciculado idem

Lacrios 316

Lacrio puntuado idem

Idem de las encinas idem

Ladilla comun 308

Lafria amarilla 249

Lamelicornios 31 .

Idem pleurosticticos 35

Lamia tejedor 82

Lámidos 82

Lampiris comun 49

Idem noctíluco idem

Iarentias 228

Larentia de asta iden

Lasios 130

Lasio negro idem

Idem brillante idem

Idem orillado idem

Latrodecto de trece manchas 360

Lebias to

Lebia de cruz pequeña idem

Lecanio de quermes 309

Ledra orejuda 318

l.epidópteros 171

Lepismátidos 305

Lepisma del axúcar idem

Leptalis 181 Idem espio idem

L.eptinotarso de diez lineas 89

Leptocirco curio 17

Lepturinos 80

Lestes 277

Letro de cabeza grande 34

Leucanias 320

l.eucania extraña iđem

Libelulas 274

Libela de cuatro manchas $2 ; S$

Idem deprimida idem

Libelulinos idem

Licenos I9:

Liceno Adonis 193

Idem Icaro idem
Licosidos 371

L.idas 166

Lida campestre 166

Idem de cabeza roja $\mathrm{I}_{\bar{j}}$

Idem de los perales idem

Idem de los rosales idem

Idem estrellada idem

Idem hipotrótica iden

Ligeodos 328

Ligeo caballero $\hat{3} 29$

Limenitis del álamo \& 56

Limnobates de los estanques 325

Limnofilo rómbico 269

Linas 88

Eina del álamo idem

Idem del chopo iden!

Linguatúlidos $\overline{3} \delta \bar{\xi}$

Linifio de fajas 360

Idem montaniés 359

Lioteidos 307

Liparidos 209

L itobios 334

Litobio de cabeza roja 335

Idem de tenazas idem

Litria purpúrea 229

Livias 317

Lixos $6 \hat{3}$

Lixo parapléctico idem

locustinos 299

Lofiros de los pinos 167

Lucano ciervo 29

Macrocentro marginador 154

Macroceros 109

Macrocero de antenas largas idem

Macrofios 170

Macroglosos 199

Macrogloso de cola de paloma 200

Idem de D Diego de noche idem Idem fusiforme idem

Malacodermos 48

Malofagos 305

Mamestra del melocotonero 2 I9

Manticoras 5

Manticora maxilar idem

Mantodeos 290

Mantis 290

Idem religioso idem

Mariposas diurnas 175

Marpesias 1 SS

Marpesia Tetis idem

Masaris II 7

Mecanitos is

Mecanito marseo idcm

Megaquilos 114

Megaguilo centuncular idem

Meguera 192

Melectas $1: 6$

Melecta luctuosa idem

Idem puntuada idem

Meligetes de la colza 25

Melinos I 4 I
Melino campestre idem

Idem arenoso $\mathrm{I}^{4} 2$

Meliponas 104

Meliridos 51

Meliteos 183

Melitófilos 39

Meloinos 57

Meloe abigarrado $5 S$

Idem proscarabeo idem

Melolonta comun 35

Idem curtidor 33
Membracinos 319

Membracidos 320

Membranáceos 327

Merilégidos 111

Mesosteno gladiador 162

Meteco paradójico 56

Microgastros 154

Microlépidópteros 229

Midas 248

Idem gigante idem

Migalidos 354

Milabridos 59

Miopes 253

Miope de color rojo de orin idem

Miros $3^{2 S}$

Mirinpodos $33^{2}$

Mirmecoleones 264

Mirmelenn formicario 264

Mfirmica fugaz 133

Idem roja 132

Idem agricultora idem

Mirmicidos $13 \mathrm{~s}$

Moma Orion 218

Monédulas ${ }^{4} 42$

Monédula vespiforme idem

Morfidos 189

Mormolice fantasma 10

Ilosca doméstica 256

Idem jorobada 260

Idem vomitoria 256

Mosquito anillado 248

Idem comun idem

Muscidos 255

Mlutila europea 136

Naucoris comun 324

Necidalo major 80

Necroforo comun 22

Nematos 168

Nemato de los sauces idem

Idem rojo amárillo idem

Nemeobios 194

Nंemópteros 266

Nemóptero coa 267

Neoptolemo is9

Nepinos 324

Nepas ceniciento idem

Neuronia popular 219

Neurópteros 263

Ninfalidos 182

Ninfalos 189

Ninfalo Polus idem

Ninfon gracioso 386

Nitidularios $=5$

Noctuinos 217

Nómadas 116

Nómada de Roberjeot idem

Nonagrias 220

Nonagria de la totora idem

Notodontos 216

Notodonto de dos colores idem

Notonecto comun $\$^{2} 3$

Oberea de los avellanos 84

Ocifo comun 20

Ocneria dispar 2 I I

Idem monja a 12

Odacantos 9

Odacanto melanuro 10

Odineros 117

Odinero antilope idem

Idem de las paredes idem

Idem de patas espinosas idem 
Orionidos 158

Ofiones 159

Omofrones 5

Ontofagos 33

Opilios 349

Orbitclos 356

Orictes rinoceronte 39

Orquestos ix

Orquestos de la haya idem

Ortopteros 271

Oscino frit 260

Osmias I I 4

Osmia roja idem

Osmodermo ermitaño $4^{t}$

Oso pardo 202

Otiorinco negro 62

Otiotops $3^{6} 7$

Oxibelo comun $\$ 44$

Oxiporo rojo 20

Panorpa 265

Pantopodos 385

Papilio hector 177

Idem macaon $1 ; 6$

Idem de vela 177

Idem sarpedon idem

Pararges 192

Pardosa de saco 372

Parnopo de color de carne 145

Paropsis go

Pasálidos 30

Pecilonoto de los tilos 43

Pecilópteros 320

Pedero de ribera 20

Pediculinos 307

Pedipalpos 348

Pediremos 323

Pelopeos 140

Pelopeo azul iden

Idem destilatorio idem

Idem espirifex idem

Idem silbador idem

Penfigos 317

Penfigo de bolsa idem

Pentastoma de pié rojo 331

Pentastomo tenioideo $3 \delta_{5}$

Pepsis $: 3^{S}$

Periplanetas 289 Idem americano 290

Perlarios 272

Pignogono litoral 386

Piéridos 178

Picris idem

Idem de ln colza 179

Idem de la nabina 180

Idem de has coles 178

Idem de los árboles I 80

Idem epicaris 18 I

Pimelios 55

Pimelio distinto idem

Pimplarios 157

Pimpilo investigador $16_{3}$

Piojo de la cabera 305

Idem de los vestidos idem

Piralididos 232

Piralis Pomona idem

Pirrocoris sin alas 320

Pisodos 65

Platiparca pecilopicra 258

Platipterix 226

Platipterix unguiculado iden

Plectroderos $\mathrm{S}_{4}$

Plectrodero listado idenı
Ploteres 324

Plusias 222

Plusia gama 223

Podilegidos 105

Poduridos 305

Poduro velludo idem

Idern aplomado idem

Polidesmos 339

Polidesmo diadema 340

Polilla 234

Polilla del trigo 235

Poliomato de verga doradia 192

Polizonio germánico 340

Pompilidos 137

Pompilos idem

Pompilo coniun $13 \mathrm{~S}$

Idem noble idem

Ponera armada 130

Ponéridos idem

Porfirofora de Polonia 310

Portesia cisne 211

Idem de ano dorado idem

Priamo i 96

Priocnemes 138

Priono curtidor 78

Prionidos idem

Proctotrupidos $15 t$

Psiliodes de cabera dorada 9 I

Pulga comun 262

Pulgones $3^{1}$.

Pupiparos 261

Queimatobio de invierno 226

Quelifero cancroideo 348

Quelonarios $20 \mathrm{I}$

Quermesidos 311

Quermes de los alerces. 312

Quilocoros 94

Quilocoro de dos pústulas idem

Quilópodos 333

Rafidios 267

Rafidio de antenas gruesas idem

Ragios 8o

Ragio indagador idem

Ranatra lineal 324

Reduvidos 326

Reduvido sucio 326

Retina de los pinos 230

Idem resinosa idem

Rinquitos 67

Rinquito de los abedules idem

Idem de los álamos 69

Idem cónico idem

Idem delos manzanos idem

Idem bronceado idem

Ripifóridos 55

Riparios 325

Risas 162

Risa persuasorio idem

Rirotrogo solsticial 3i

Rodocera Cleopatra is I

Idem del crucero idem

Rodito de los jazmines r 50

Idem de los rosales idem

Kogas 155

Rutélidos 37

Saldas 325

Salda elegante 326

Saltador escénico 373

Idem de piésgruesos idem

Samótila àspera iqo
Saperdos $8_{3}$

Saperdo grande idem

Idem de los chopos $\delta_{4}$

Saprinos 25

Sarcófago de la carne 255

Sarcoptidos 382

Sarcopto del hombre ${ }_{3} S_{3}$

Satiridos I $S_{9}$

Saturnios 204

Saturnio Atlas idem

Idem de Perny idem

Idem del ailanto idem

Idem japonés 206

Segadores 350

Segador de piés largos idem

Segestria de seis ojos $3^{64}$

Selandrias 168

Selandria adumbrado idem

Idem de cuernos amarillos 160

Semele 190

Sesias 200

Seudofano europeo $32 \mathrm{I}$

Sialis acuático 267

Sialis de color de hollin 265

Silfidos 22

Silfos $2 \overrightarrow{3}$

Silfo de cuatro puntos 24

Idem negro $=3$

Idem toracico 24

Silidos 317

Silas 318

Simulias 24

Simulia de Columbach iden

Sintomis feger 202

Siquinos 209

Siquis unicolor idem

Sirex comun $\mathrm{I}_{5}$

Idem gigante iden

Sirfidos 251

Sirfo de manchas semi lunares idem

Siromastes 330

Siromastes orlado idem

Sitaris de los muros to

Sitones listado 6I

Sulpugos 343

Solpugo araña idem

Tabánidos 246

Tábano de los bueyes idem

Tais hipsipila 177

Taquinos 255

Taquino grande idem

Idem feroz idem

Tarántula de la Pulla 372

Tecla de las encinas 102

Tegenaria doméstica 361

Telefórinos 50

'Telifono de cola 348

Tencbriónidos 54

Tenebrio molinero 55

Teniza minera 356

Tentredinidos $16 \%$

Tentredos 160

Tentredo escalar idem

Idem de cuernos amarillos 170

Idem verde idem

Teras terminal i 50

Terididos 359

Teridio coronado 360

Térmite belicoso 285

Idem lucffugo idem

Idem obeso idem

Idem terrible idem 
Termitinos 280

Terocroza de ojos 300

T'erofóridos 238

Teroforo alucita idem Idem terodáctilo idem

Teromalos 152

Tetigonios 318

Tetragnato extenso $35^{8}$

Tetrameros 6I

Tetramorio del césped $x_{3}{ }^{2}$

'Tetranico de los tilos $3 \pi 9$

Tetraneuro de los olmos 310

Tetrix comun 298

Tiatiras 234

Tifias 136

Tiflocibos 318

Tincidios 234

Tingidos' 327

Tingidó afine idem

Tino ladron 52

Idem amarillo de laton idem

Tipularios 240

Tipulas 242

Tipula comiun idem

Tisanuros 304

Tonisidos 368

Tomiso de Cambridge 369

Idem vagabundo 368

Tortricinos 229

Tostrix verde 230
Toxotos 80

Traquea de los pinos 220

Traquisinos 44

Tricodectos 306

Tricodes 52

Tricodes apiario idem

Tricóndilos 5

Tricóndilo áptero idem

Trifonidos $15^{8}$

Tripetidos $25^{8}$

Tripidos 304

Trips del trigo idem

Tripoxilones 143

Tripoxilon comun idem idem de tarsos blancos 144 Idem de frente dorada idem Idem fugazidem

Triquios $41^{1}$

Triqujo listado idem

Troctes empolvado 280

Trombididos 376

Trombidio cochinilla idem

Troquilo apiforme 201

Truxalis 298

Truxalis narigudo idem

\section{Uranios 225}

Uranio magnifico idem

Trapterix del saúco 225

Uropos 224
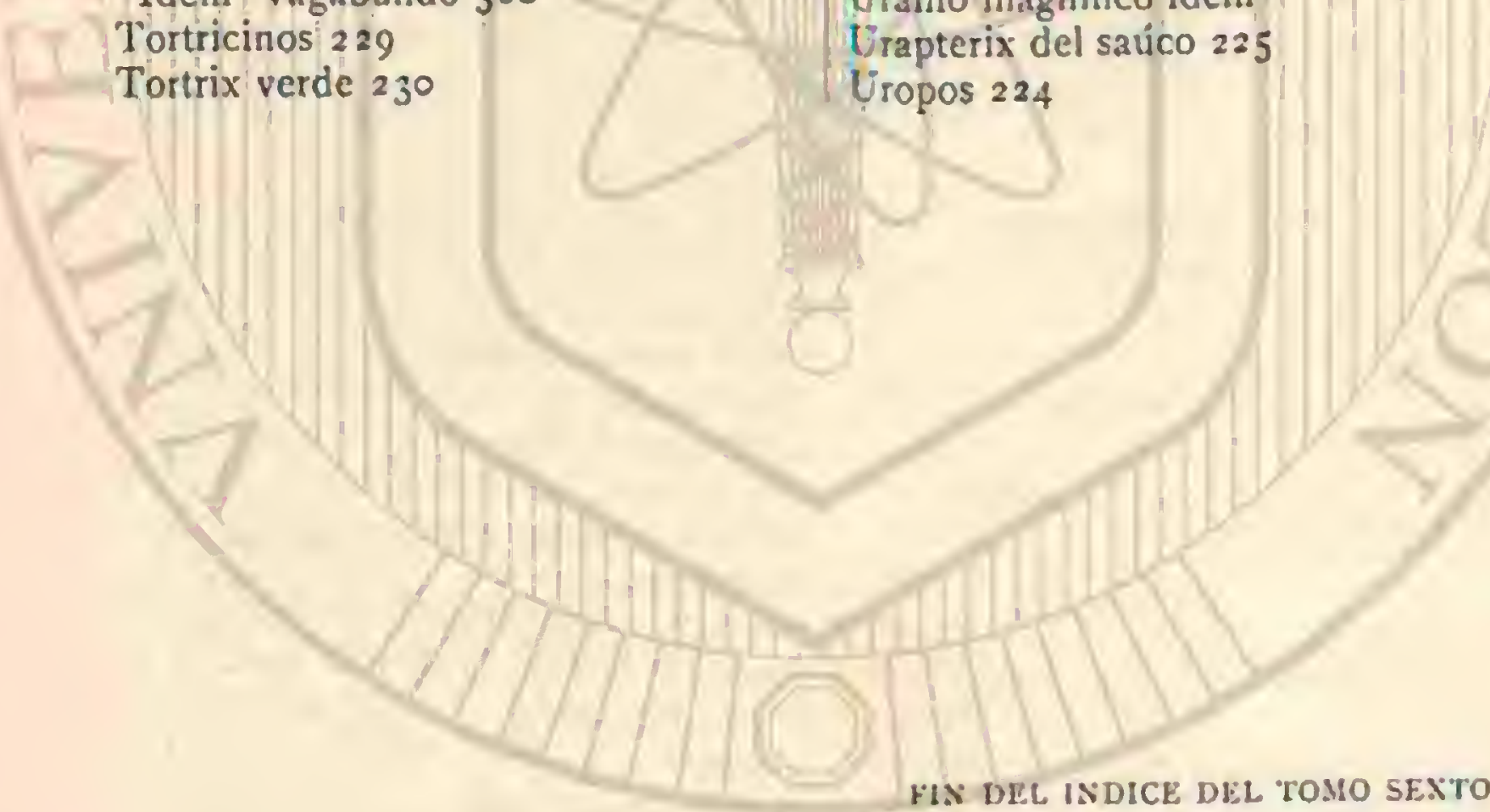

HIS DEL INDICE DEL TOMO SEX'TO

Uropo variado 224

Vanesas 184

Vanesa Io idem

Idem Antiope 185

Idem Atalanta i 84

Idem de las ortigas I $\$ 5$

Idem de los cardos 184

Idem de muchos colores 185

Velias 325

Verlusia rómbica $33^{\circ}$

Véspidos 117

Volteadoras 375

Volteadora hormiga idem

Volucelas 252

Volucela bombiforme idem

Idem trasparente idem

Xifidrios $\mathrm{x} 66$

Xilotrotos 200

Tabros II

Zabro del trigo idem

Zefronia comprimida 342

Zeonias 193

Zeonia de Bates idem

Zeuzeros 216

Zeurcro leopardo idem

Zigenas 202

Zigena de la filipéndula idem
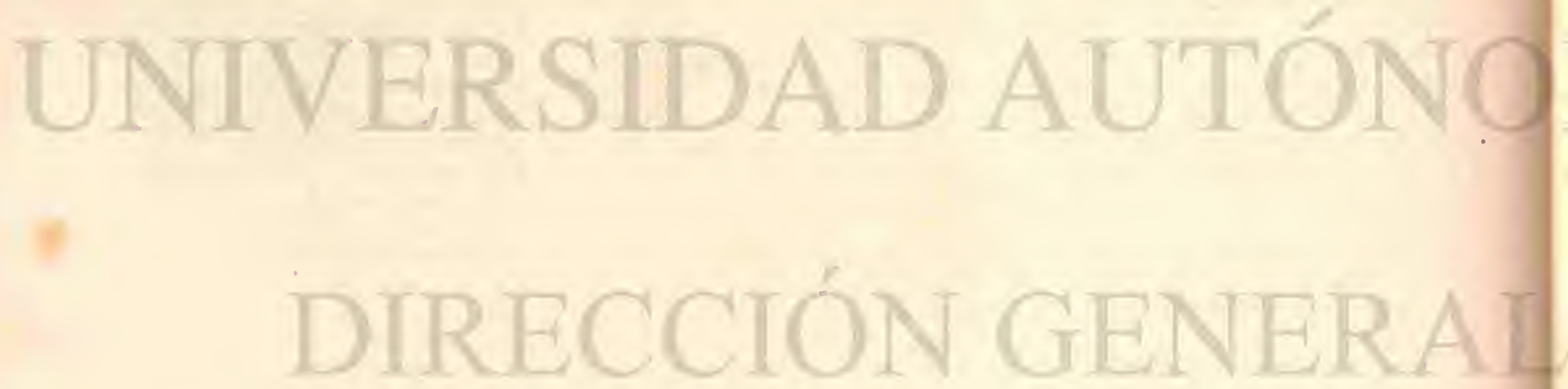


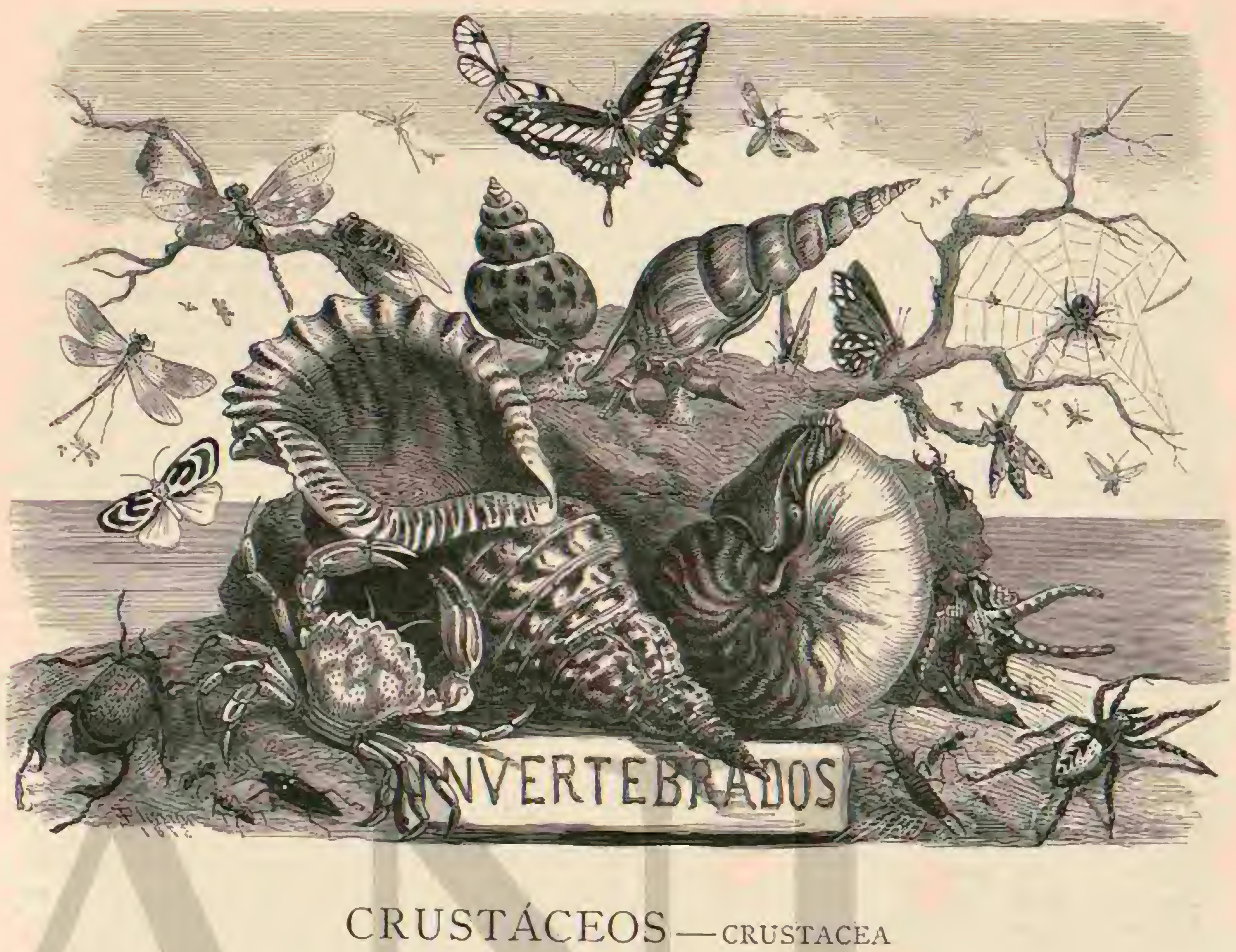

CONSIDERACIONES GENERALES. - Dentro del importante grupo de los artropodos, al que pertenecen tambien los quilópodos y aracnoideos, los crustaceos acupan un lugar bien determinado. Asi como aquellos, tienen el cuerpo articulado, tanto en el tronco como en las extremidades, y son análogos por la estructura y disposicion de sus diversas partes; pero sus particularidades son generalmente propias de los animales que viven en el agua. Aunque muchas larvas de insectos vivan largo tiempo en el agua, y por mas que algunas de sus especies desarrolladas, arncnoideos y acarinos, puedan sumergirse hasta cierto punto en el líquido elemento, reconócese no obstante su naturaleza de animales aćreos; sus órganos respiratorios revelan siempre que solo son propios para funcionar en el aire, y muchos coleopteros y aracnoideos hasta se llevan siempre cicrta cantidad de aire a las profundidades para satisfacer su necesidad de respirar durante su estancia en un elemenio que en rigor no es el suyo. No sucede asi con los crustáceos, que respi. ran en el agua y están provistos al efecto de branquias que por lo pronto podemos comparar con las de los peces, aunque mas tarde serh preciso describirlas mas muluciosariente.

Cierto número bastante considerable de crustáceos, sobre todo de los grupos de los isópodos y decápodos, se han adaptado en el trascurso de lö siglos á la vida terrestre $y$ respiran aire, aunque sus órganos respiratorios han conservado el aspecto de branquias.

Otro caricter de los crustíceos desarrollados que no observan la vida de parisitos consiste en tencr mas de cuatro pares de patas; de modo que mada tan fácil como reconocer superficialmente un artrópodo que llega a nuestras manos como crustáceo: con tres pares de patas es un insecto; con cuatro un aracnoideo. Tampoco se les puede confundir con un quilópodo, porque este tiene la forma de lombriz y carecc de branquias exteriores. I.os regumentos epidérmicos de todos los artrópodos, y por lo tanto tambien de los crustíceos, se componen de cierta sustancia de una composicion quinica especial, de la quitina, pero muchas especies de los segundos tienen una coraza mas sólida, reforzada por una capa de caliza. A csto se reduce todo cuanto podemos decir en general sobre los crustáceos, pues por mriados que sean los insectos, aventijanlos por tal concepto, no solo en cuanto se refiere î su estructurn, sino tambien por su género de vida. Propios de la alta mar, asi como de las costas, encuén. traseles á las mas diversas profundidades en que generalmente puede permanecer un animal vivo. Una serie de órdenes se han acostumbrado al agua dulce, tanto corriente como estancada, asi cristalina como llena de sustancias en putrefrccion. Algunos salen de su verdadero elemento, para introducirse debajo de las piedms y la maleza; mientras que otros emprenden largos viajes sobre superficies arenosas, jo marios cangrejos suben á las palmeras para comer su dulce fruta. La mayor parte de los crustaceos viven como rapaces, por lo cual tienen los órganos de los sentidos muy desarrollados, maxilas fucres, tenazas y cxtremidades robustas; tambien hay numerosas especies en que la articulacion del cuerpo, al principio bien dispuesta, no llega i su completo desarro. llo; y otras que como parrisitos viven en peces, en otros crustáceos, ó tambien en gusanos, pareciendo ser solo unas bolsas inanimadas.

CARACTERES. - Ia suma de conocimientos anatómi- 
cos que deben posecrse para comprender los caractéres de las diferentes divisiones, de los órdenes y grupos de la clase, puede adquirirse con mas facilidad cxaminando minucio. samente el cxterior é interior del cangrcjo luuvial (aslaiss finviofilis) que ficilmente podemos obtener. Los lectores que hayan estudiado ya los insectos y aracnoideos hallaran tanto mas facil la descripcion que vamos a ofrecerles, cuanto que no tendrin que tomarse el trabajo de comparar.

Fl cangrejo huvial, particulasmente, visto porarriba, aparece romo formado de dos partes principales del cucrpo; la anterior, el cefalotórax, se halla cubierta en su parte superior por el escudo dorsal compuesto de una picza; so encorva lateralmente hicia abajo y llega hasta la catremidad del cuerpo, donde se insertan las patas:- Ia anterior del escudo dorsal remata en la copina fronial, en cuya base se hallan los dos ojos, dispuestos subre dos tallos fijos, $y$ que pueden girar en diversos sentidos ó recogerse en dos medios surcos. A la simple vista, y mejor aum con un nioroscopjo de poco aumento, nos ronvencemos de que la superficic de los ojos no es lisa, como la córnea de los nuestros, sino que está compuesta de faceras, en perfecta armoniz conl los ojos de los insectos. Muchó siento no poder ocuparme de la naturalea de los órganos de la vista, porque no seria posible sin descender a los mis circunstanciados detalles: Solo diré que el cangrejo fluvial ve sin duda muy bien con sus ojos, y que asi como los otros crustáceos de csiructurn andoga, divisa á bastante distancia tanto á sus enemigos como a su jresa. Hácia adentro y debajo de los ojos hóllanse las gran. des antenas exteriores, cuyos gruesos artejos de la base están cubiertos de una escama movible y provistos del latigo compuesto de muchos anillos pequeños. En la base de estas antenas se ven dos prominencias cónicas que se comunican con una glindula verde interna, pero cuyo uso no se conoce aun bastante. Las antenas interiores se hallan en medio de las anteriores y su base presenta látigos. Dentro de la base de estos estín los órganos del oido.

Para dar una idea de estos úrganos, en extremo notables y curiosos en el cangrejo fuvial y/ sus congéneres en general, debo permitirne una digrésion. Como todo órgano dél sentido, el del oido se compone tambien de un aparato que recibe y trasmite las impresiones exteriores, pudiendo compararse con un instrumento tisico construido para cierto fin, y ademàs de un nervio por medio del cual dichas impresio. nes se trasladan al cerebro. I n estructura del órgano del oido debe ser á propósito para que vibren en él fácilmente las ondas sonoras, y llega da ser tanto mas perfecto cunnto mas leves son las intermisiones de dichas ondas, a las que puede corresponder de diferentes maneras; asi como tambien cunn10 mas en relacion éstén las modulaciones del aparato auricular con las delicadas partes del nervio auditivo. Lin apéndice en forma de pelo que, puesto en vibracion por las ondas sonoras, trasmite estas à un nervio que se oprime en su base, puede ser por lo tanto un órgano auditivo, aunque muy incompleto á causa de su sencillez. Con arreglo á este principio estàn construicios los órganos del oido en todos los crus. táceos congenericos del cangrẹjo fluvial: cll la base de sus antenas interiores hay una bolsita cerrada 6 con una hendidura que se abre hácia fuera, en cuya pared interior hiny. algunas ó muchas series de pelos en forma de plumas $\delta$ sencillos. las vibraciones del agua que llena la cavidad cerrada, $\delta$ las de la que se halla en la cavidad abierta, se trasmiten a los pelos, y su efecto aumenta por las llamadas piedras audifiáns. El concicnzucio observador de estos órganos, profesor Heuscu, vió como un pequeño cangrejo marino se llenó las orejas de casquijo, pam sustituir asi las piedras auditivas yue habia perdido. Muy interesantes son tambien los experimentos hechos por Heusen para convencerse de que los cangrejos ojen, it cuyo efecto sirvióse, de un eritino que se encuentra cerca de Kiel, del Palcemon anknnarius. "Cuando se colocan individuos jóvenes recien cogidos en el acuario, dice, cada sunido que se produce desde el suelo 6 las paredes del depósito les obliga al instanteà saltar fuera del agua, mientras que permanecen tranquilos siempre que las paredes no cmi. tan ningun sonido. Mejor podria demostrarse aun la facultad auditiva, poniendo a estos animales varins horas en agua sala. da con una mercla de estrignina; entonces hasta los sonidos mas leves en la casa, en la mesa ó en el depósito producen otros sonidos reflejos, es decir, obligan á los crusticeos à moverse involuntariamente, y por los sonidos repetidos se puede hacer saltar a los animales con la misma frecuencia con (que se aperciban de aquellos.

Otros experimentos dieron á conocer de qué modo los crustáceos perciben los sonidos: en la hipótesis de que estos animales oigan lo mismo que el hombre, debia suponerse que los pelos auditivos, de diversa longitud y grueso, vibran produciendo sonidos de diferentes tonos, lo cual pudo convenir con el resultado de los célebres experimentos de Helmholt? sobre la aucicion en general.

Volvamos al cangrejo fluvial: si examinamos el lado inferior, desde las antenis hasta abajo, veremos la abertura bucal ro. deada de numerosas partes movibles. Ademís del labio superior, dispiesto irasiersalmente por delante de la bora, pertenecen a las partes de esta nada menos que seis pares de órganos; lu los cliales los tres primeros corresponden a los de los demas artrópodos descritos al hablar de los insectos: la mandibula superior, muy fuerte, està provista de un palpo movible, y además hay dos maxilas inferiores, la se. gunda de las cuales corresponde al labio inferior de los insectos. Las maxilas ausiliares $\delta$ piés maxilares, son en su principio y pósicion patas, pero no sirven para la locomocion, sino para sujetar el alimento, mientras que la mandibula su. perior sé emplea en la masticacion prévia. Digo préria, porque la verdadera masticacion se verifica por unos dientes particulares.

A las mavilas auxilinres siguen cinco pares de patas de las que, lis tres anteriores, están provistas en su extremidad de tenazas. Al considerar que en los insectos los tres pares de patas pertenecen al tórax, y que á ellos corresponden en el cangrejo fuvial las tres maxilas auxiliares, resulta que el segmento del cefalotómx; que tiene los cinco pares de verdade. ras patas, no debe comparnise con el pecho, sino con el abdomen de los insectos, yo que por lo tanto, la llamada cola del crustácco es un nuevo segmento del cuerpo no existente en la rlase de los insectos, y que llamamos el past.abdimen. En el escorpion, dicha parte del clicrpo existe como una llamada cola. I.os anillos del post-abdómen tienen apéndices en forma de pies, en medio de los cuales se fijan cn la hem. bra los huevos puestos; en el último anillo, en cuya parte inferior se abre el intestino, estos apéndices adquieren la forma de anchas aletas, y de este modo el cangrejo fiuvial presenta desde las maxilas superiores hasta dichns aletas un mismo órgano fundamental, sumamente variado por su forma y destino.

Las branquias aparecen fijas en la base de las patas: cuando se cortan las hojas latemles de la coraza, libres en su parte inferior; el agua peneira en ellas junto a los órganos de la boca yo puede salir hácia bajo y por atrais, pornue el continuo movimicnto de los palpos maxilares auxiliares, pro duce una incesante renovacion; el movimicnto de las demás partes de la maxila auxiliar sustituye aqui a la respiracion pulmonar interior de los animales superiores. Pascmos ahora al exímen de los mas importantes órganos internos. 
Fl aparato digestivo empieza yor detris de la abertura bucal, en forma de un esiffago quue pasa a un estómngo espacioso, conrexo haicia arriba; su superficic interna está provis. ta de una serie de prominencias, rebordes y dientes moridos por músculos particulares, que continúan la masticacion consenzada por las maxilas superiores.

Muy conocidas son las llamadas fiedras, dos formaciones calizas en forma de lentcjas, situadas en el interior del estómago, y que despues de la muda anual se gastan en la reproduccion de la coraza. Desde el estómago se corre por el abdómen un iniestino delgado, casi recto, que fácilmente puede arrancarse con la extremidad de la cola, operacion que nunca se deberia olvidar antes de hervir los cangrejos. El llamado higado, que produce una especie de jugo gástrico, extiéndese en ambos lados del estómago y se reconoce fácilmente por su color verdoso y su estructura fibrosa y lobular.

Al abrir el crustáceo por la parte del dorso, separando con una buena tijera la coraza para retirar lo mas cuidadosamente posible la parte superior de la misma, se encuentra cu la mitad de la linea central cl corazon, de color blanquiz. co, que remata en varios ventrículos, y desde el cual deben continuarse tambien los rasos priucipales. Recordaremos que tambien este órgano es anólogo al llamado vaso dorsal de los insectos, asi como quue en ambas clases de animales es igual la direccion de la circulacion de la sangre. Esta úl tima, de color blanquizco, sale del corazon, recorre el cuerpo y vuelve por las branquias al punto de partida.

Fil cangrejo Ruvial pertenece a las especies en que, convi niendo con la figura prolongada, el sistema nervioso cxiste en forma de una especie de escala de cordones bien desir rollada, como por cjemplo en los palemones, micritras que en los cangrejos, cuyas formas ofrecen en su conjunto notable cuntraste con las de aquellos, tambien el gran simpitico, ó la cadena de los gainglios presenta una figura recogida. Asi como en la mayor parte de los demís crustaceos, en la es pecie del cangrejo fluvial se distinguen los sexos; $y$ sin fijarnos detenidamente en los órganos internos de la reproduccion, podemos reconocer fácilmente la diferencia sexual exterior. En los machos, el primer pié del post-abdómen se trmsforma en la base del quinto par de patas, en una especie de apén. dice exterior de los conductos espermáticos internos, que en cada lado afecta la forma de un medio surco. Las aberturas de los oviductos se hallan en la base del tercer par de patas. El desarrollo por que pasa el cángrejo fiuvial en el huevo es esencialmente análogo al que hemos observado en el insec. to. De una faja en estado decmbrion se furma el lado abdominal; por una hendidura se forman las llamadas protuberancias embrionarias, primern disposicion para la estructura bilateral simetrica, en la que despues se produce la division de los segmentos primitivos por varios grados hasta llegar a su desarrollo. El cangrejo fuvial sale del huevo en un estado que no le sumete a una metamorfósis como a muchos insectos y crustaceos: pero su muda anual recuerda la metamorfósis de los insectos. Todos los artrónpodos que no mudan de piel no pueden pasar de un tamaño determinado desjues de su irasformacion y cuandosu esqueleto epidérmico adquiere cierta solidez, pues nunca crecen mas. Los crustaceos que perriódicamente mudan de piél adiquicren con esto la facul. lad de crecer toda su vida. Si txaminamos ahora algunos centenares de abejorros, vemos que han nacido de su estado de larra con escasas diferencias de amaño, las cuales no se compensan durante el corto periodo del celo. Lin pequeño crustaceo tiene en cambio la esperanza de llegar á ser muy smande, si una imprudente coonomia politica no le entregia ya en su jurentud al cocinero. Nucstro asombro es grande al reconocer la posibilidad de que cl cangrejo pucda despo. jarse todos los años de su rigida coraza, pero crece de punto cuando vemos que tambien los órganos mas finos, las antenas, los ojos y las branquias, cambian sus tegumentos y que hasta el intestino toma parte en la muda. Reaumur ha observado ya en la primera mitad del siglo pasado la muda del cangrejo fuvial, de la que hizo una descripcion minuciosa. Al efecto puso sarios individuos en vasijas de cristal perforadas colocindolas en agua corriente. Si consideramos que tam. bien la piel del estómago y los dientes gảstricos cambian, fácilmente se comprendera que el cangrejo no debe tener gran apetito pocos dias antes de la muda, acompañada siempre de grandes molestias. ¿Quién pensari en comer cuando todos los dientes se mueven? Tambien se puede presagiar el acontecimiento por el tacto; al oprimir el esqueleto epicérmico con el dedo, cede un poco, sin duda porque ya antes ha disuelto una parte de la sustancia caliza. No podenos hacer, al menos que yo sepa, una comparacion que se funde en el análisis quimico. Poco despues el cangrejo manifiesta inquietud, roza las patas unas contra otras, se echa de espaldas, trabaja con todo el cuerpo, consigue romper la piel yue en el dorso reune la coraza del cefalo:órax con el post-abdamen, y al propio tiempo se levanta la gran coraza dorsal. A los primeros esfuerzos siguese un rato de descanso, pero pronto empieza el animal otra vez á mover sus patas y todas las partes del cuerpo, y entonces se ve cómo la coraza del cefalotórax se eleva mas y mas, y cómo aumenta la distancia entre las patas. En menos de media hora el cangrejo ha salido de su picl, oprimiéndose primero por la parie de la cabeza hicia atrís parn sacar los ojos y las antenas, y des. prendiendo despues sus patas del angosto estuche. Ista úl. tima operacion es la que mayores dificultades ofrece y suele darse el caso de que el animal pierda alguna cxtremidad: ni siquiera podria conseguir su objeto si la piel de las patis no se abriera en toda su longitud; pero una vez terminado este trabajo tan dificil, y sin duda doloroso, el aninal sale rápidamente de sus tegumentos. Primero asoma la calkeza, por debajo del escudo dorsal, y la cola sale despues facilmente de su estuche. In cutvierta abandonada queda del todo intacta, excepto la hendidura de la cola.

El cangrejo que acaba de salir de su cubierta tiene los tegumenios blandos, pero a los pocos dias adquieren la solide\% del primer esqueleto epjéérmico. El periodo de la renovacion y del endurecimiento se prolonga en los crustáceos de cola corta, ó cangrejos, mucho mas tiempo, y en este perio. do se acultan en las grietas ó debajo las piedras, cuando no en agujeros subterrineos.

la que lablamos de la muda regular de la coraza cpidérmica, podemos oruparnos tambien de la sustitucion al parecer voluntaria de las extremidades $\delta$ de las patas casualmen. te perdidas, segun se observa í menudo en los crusticcos superiores. Todo coleccionador sabe que los galateidos y porcelanas, en particular, deben tratarse con la major pre. caucion si se quiere cvitar que pierdan cntre sus manos algunas ó tambien todas las palas. Es dificil decir si el hecho se funda exclusiramente en el llamado libre albedrio, ó es efecto de malicia, miedo ó terror, ó bien resultado de unir especie de convulsion, como el vómito de los intestinos en los holotúridos, aunque creo que sea lo último, pucs una convulsion rompe la pata cerca del tronco, cuando la extre. midad ha sufrido daño. Los pescadores de cangréjos y lan. gostas pretenden que cl animal cogiclo por una pata se des. prende de ella para escapar, asegurando sobre todo que las langostas al oir los truenos durante la tempestad, 6 los caijonazos, pierder sus patas á causa del espanto; pero esto no pasa de ser un cuento. 
Ias obsermaciones mas seguras sobre el particular, sc deben å Ieach, y Bell las cita en st aHistoria Natural de los crustáceos pedunculados de Inglaterra. Dice que abando nan, no las antenas, como tambien se ha pretendido, sino solo las patas, inclusas las tenazas, de las cuales se desprenden fäcil $y$ voluntariamente, habiendo algunas especies, como

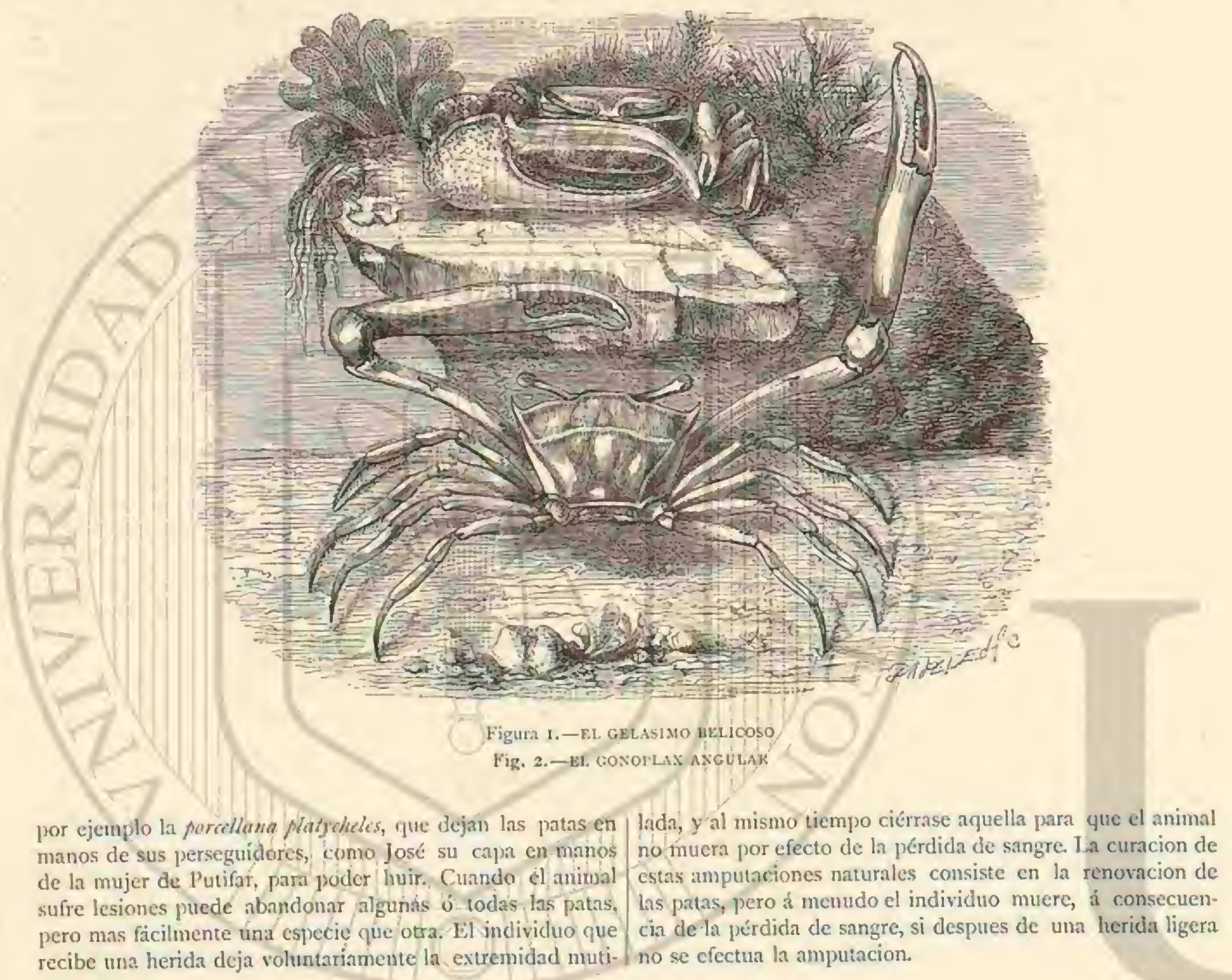

\section{UNIV \\ DECÁPODOS DECAPOD兔}

CARACTÉRES. - El cangrejo futvial, intes descrito, es un representante de esta division que comprende los crustáceos mas desarrollados: se caracteriza porsus ojos movibles y pedunculados y por el célalo tórax fijo, que soldado del todo, estr cubierto por el gran escudo y tiene cinco pares de patas. Los órganos bucales se componen del labio superior, mandibula superior, dos pares de maxilas inferiores, tres de maxilas auxiliares y sus branquias en forma de copetes ó de hojas, encerradas debajo del escudo dorsal en cavidades particulares.

El major desarrollo de los decipodosse reconoce al com. pararlos con los otros crustàceos; y aqui debemos decir algo sobre este punto, aunçue nos refiramos solo a los rasgos principales. Un animal esta mas desarrollado que otro, cuanta major es su actividad; pero esta depende de la buena estructura de los órganos de los sentidos, que deben darse cucnta del mundo exterior, y de la fuema del cuerpo. Y'or ambos conceptos los decapodos ocupan el primer lugar, pues en ningun otto órden encontramos ejemplo de tanta astucia para coger la presa ó emprender la fuga; ninguna otra especie es tan sutil para observar los objetos que la rodean. Esta propiedad tan favorable de less órganos de los sentidos, yobre todo de la vista, se une en los decípodos con la mayor resistencia del esqueleto epidérmico y el mayor desarrollo de los músculos sobre todas las especies de la clase. Cierto que muchos decápodos sacados del agua parecen tener una es. 
tructura pesada y apenas pueden levintar sus poderosas tena. zas, pero no se les debe juzgar entonces, sino cuando están en el elemento liquido, donde son tanto mas ligeros, cuanto mayor es el volúmen de agua rechazada por su cuerpo. Los movimientos de muchos decaipodos, ast como los del cangrejo luvial, son en extremo ágiles y rípidos cual el rayo.

Además de estas particularidades, propias de todo el órden, las relaciones entre los grupos que le componen oúreren sumo interés, sobre todo por la diferencia entre las especies terrestres y las acuáticas. Los decipodos son tanto mas ágiles $y$ aptos para correr y trepar, cuanto mas corto y ligero es el post-abdómen. Esste último hace en el cangrejo fluvial las veces de un fuerte remo; y las grandes langostas (palinuros y homaros), consus fuertes músculos, pueden aplicar con él vigorosos golpes. Ese apéndice no sirve, sin embargo, para la carrera, y por lo tanto se comprende que los crustáceos que carecen de él anden y trepen mejor. Los crustáceos de cola larga, macruros, y los de cola corta, ó cangrejos, constituyen por consiguiente dos subdivisiones naturales de los decapodos, entre las que, como sucede en todo el sistema del reino ani. 1mal, sc intercala un grupo de trảnsito, por decirlo asi, sin carácter, el de los anomuros. Entre estos cangrejos, los que tienen las pratas mas ágiles y que mostrándose infieles a su elemento nativo, á pesar de sus branquias, habitan en tierra firme, ocupan el primer lugar.

Todos los séres vivos ofrecen una prueba de que los terrestres son superiores a los acuáticos, generalmente, por su energía vital y actividad. Para comprender las ventajas de la vida al aire libre, solo debemos fijarnos en la circunstancia de que en este elemento cl oxigeno se aspira con inucha mas abundancia que en el agua, y por lo tanto la sangre cs mucho mas caliente y el sistema nervioso mas enérgico. Podemos tambien esperar, por lo tanto, en los cangrejos que tienen la facultad de vivir mas 6 menos tiempo en tiern firme, un aumento correspondiente de la actividad de los sentidos, un instinto mas sutil, y en una palabra, el mayor desarrollo en todo el sér del crustácco.

\section{LOS CANGREJOS-BRACHYURA}

CARACTERES.-Segun ya hemos dicho, túna subdivi sion de nuestro órden se compone de los cangrejos ó braquiuros, en los que la cola, nque en el cangrejo fuvial hemos designado como post-abdómen, tiene la forma de placa y se dobla por debajo del cefalotórax. Las hembras se distinguen de los machos por la mayor anchura de esta placa de la cola, que sc desarrolla a atenudo en una especic de caroleta en la cual, con ayuda de los apéndices filiformes, semejnntes á patas, la hembra lleva los huevos hasta el nacimiento de los hijuelos. El cefalotórax es corto, a menudo mas ancho que largo, y comunica á los animales un aspecto muy particular, por tener toda clase de prominencias y espinas. Ia mayor parte de los bmquiuros andan de lado y ofrecen entonces, sobre todo cuando corren, un aspecto grotesco. Los soldados alemanes que cncontré en Dalmacia los llamaban con voz de mando, diciendo: ¿ Paso lateral, marchen! A sun. que los cangrejos adultos tienen la cola muy atrofiada, en los individuos jóvenes alcanza bastante desarrollo, dando lugar a que su forma, que tambien se observa en la mayor parte de los otros decápodos, se haya designado con un nombre particular (zoca). El aspecto es por cierto bastante extraño; el largo apéndice en forma de pico, la poderosa espina dorsal, $y$ la cola, deben desaparecer en párte 6 se atrofian; $y$ el cefalotúnx tiene una figura del todo diferente antes de que salga el cuerpo del cangrejo. Púcde decirse por lo tanto que el braquiuro de cola corta es en su juventud un macruro de cola larga; y esta forma se observa en los hijuelos de todo el órden de los decápodos. Mientras que la mayor parte de los cangréjos y macruros viven en tierra, exceptuándose única. mente la familia de los caridinos, las larvas que acabamos do citar con el nombre de soen, nadan libremente en el agua; va. gan en la superficic del niar ó casi siempre cerca de las costas, â jocos piés de profundidad, no aisladas, como podria creerse, sino en gran mumero de individuos, en su mayor parte microscópicos. Por lienos que estén los lagos y estanques con las especies mas varindas, la monotonia de sus habitantes contrasta con la increible diversidad de la vida debajo de la superficie del mar. Las larviss de crustaceos comparten con la mayor parte de sus compañeros la cualidad de ser tan trasparentes que no descubren su presencia por nada, $\delta$ cuando mas por los ojos, en extremo grandes atendida ia proporcion del cuerpo, y a menudo brillantes. 


\section{LOS CANGREJOS CUA- DRANGULARES}

La familia de los cangrejos cuadrangulares ticne el cefalotórax poco mas o menos de esta forma, truncado trasiersalmente en su parte anterior. A ella pertenece una serie de

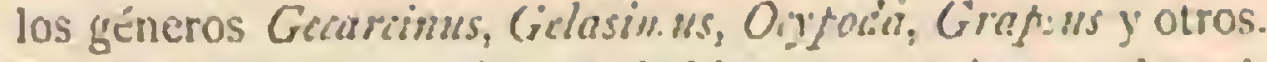
Las especies de los primeros habitan en agujeros subterra. neos.

\section{LOS GECARCINOS-GECARCINUS}

USOS, COSTUMBRES Y REGMMEN.-Poeppig, des-

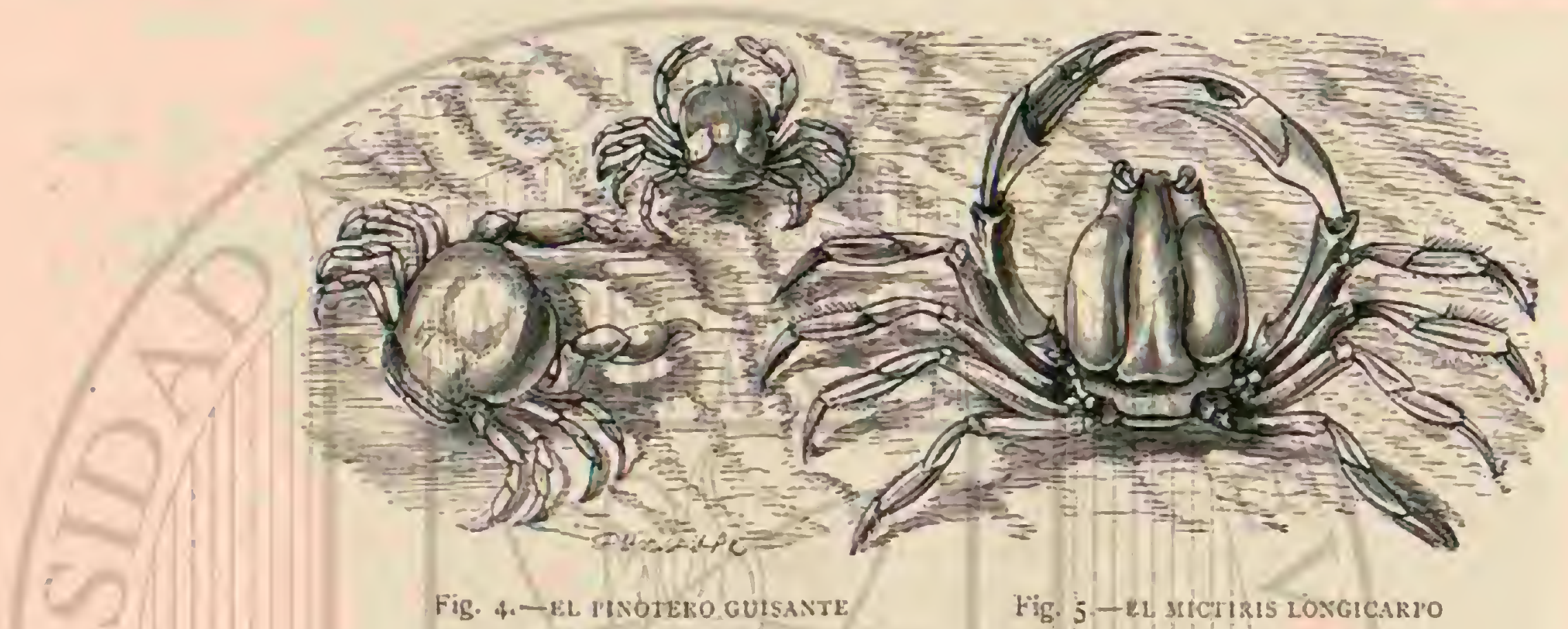

cribe la vida de los gecarcinos ó cangrejos terrestres del de los árboles ó practicando agujeros de considerable profuninodo siguiente: Habitan con preferencia en los bosyues didad. Muchos no afrandonan las llanums en parte pantanohumedos y frondosos, ocultandose por debajo de las raices 1 sas que hay cerci del mar; otrus viven a bastante distancia

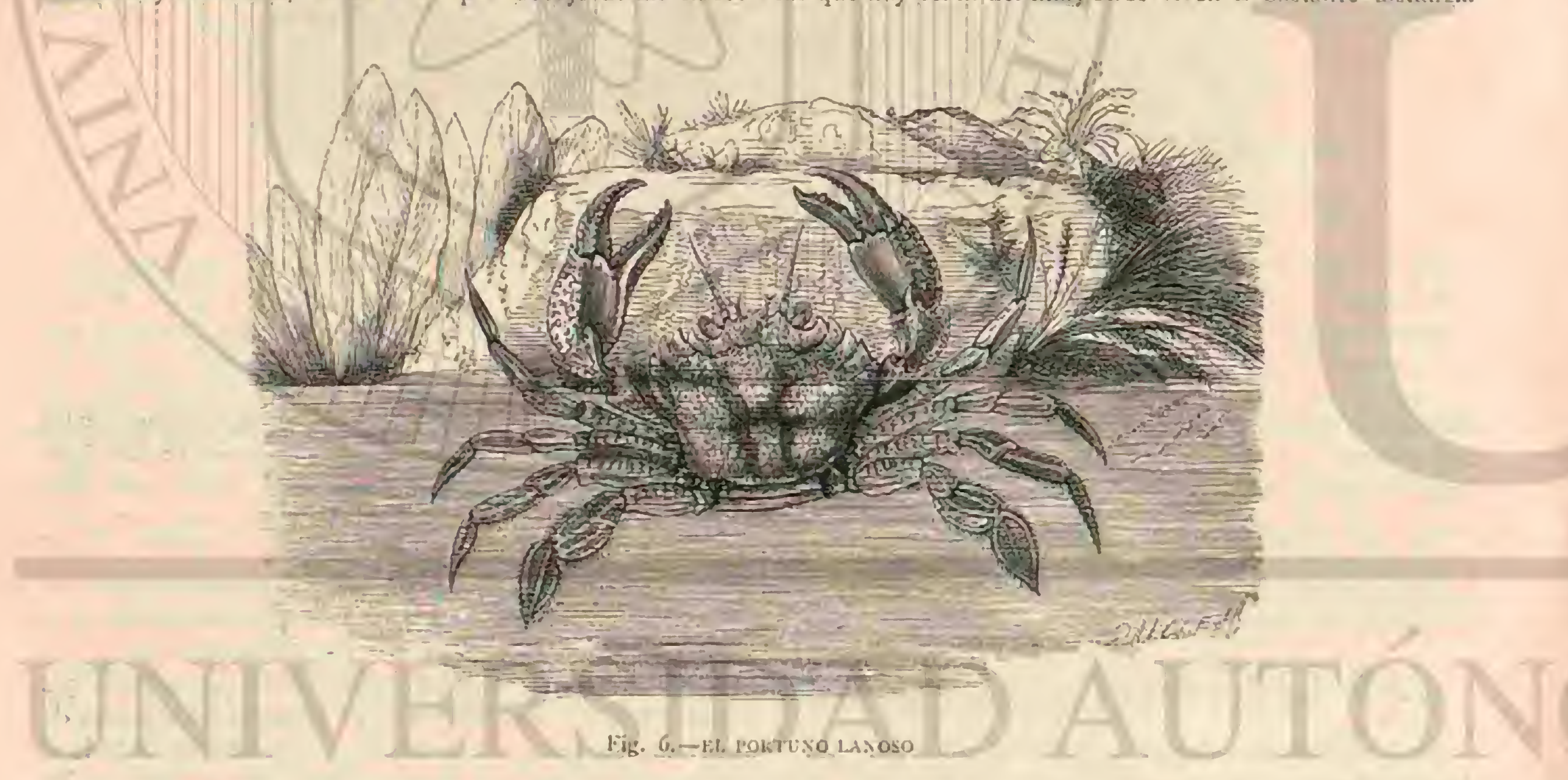

del mismo, y hasta en montahas cscarpadas ye pedregosas. Lin las rocas de caliza de Cuba desprovistas de agun, y cubicrtas de bosque bajo, que solo en algumos sitios tienen tierra vegetal, se encuentran durante ocho meses del ano grandes cangrejos terrestres, que haciendo ruido en la hujarnsca pueden asustar al viajero: se dicfienden con gran ralor cuando son descubiertos. Se les ve con frecuencia, aunque siémpre aislados, pues solo son sociables en el periodo del celo. Bas tante a menudo se hijan en sitios sucios, allado de las cloacas de las plantaciones y sobre todo en los cementerios. Fo las In dias occidentales se cree generalmente, $!$ sin duda con ratzon, que se abren comino hasta los cadáieres mal enterrados parn devorarlos. De aqui la aversion que casi todas las chlases de In poblacion tienen à cste alimenso, y que es muy fundada
Fil gecarcino comun (gerarinus ruriola) se encuentra cu todas las islas de las Indias occidentales y en las costas del continente vecino. Una vez al noo abandona su residencia, que dista una $\delta$ dos horas de la costa, y se dirige hácia el mar. En febrero se ven los primeros de estos viajeros, yue aunfue siempre aumentan en mimero no forman sun. ca aquellas legiones tan considerables de que nos hablan los antiguos, y que sin hacer caso de destructores ataques seguian siempre avanzando sin temor $y$ sin critar obsta. culo alguno; léjos de ello, cominuaban su marcha por encima y por en medio de las viviendas, donde se les veia con mucho gusto, porque perseguian las ratas y serpientes. Todo esto son rabulas ó exageraciones indignas de refutarse. Fi vinje dura hasta abril: llegados i la costa, los gecarcinos se 
abandonan a las olas, pero evitan todos los sitios donde es. tas son muy violentas y no permanecen nunca mucho tiempo en el agua. Se retiran de esta tan luego como las hembras han depositado sus huevos, que adheridos con una especie de cola cubren en gran número la parte superior del abdómen. En mayo y junio emprenden el viaje de vuelta y entonces no se pueden comer, pues por una parte, la carne muscular ha disminuido mucho, y además el grande higado, que en todos los cangrejos y langostas constituye la única parte co mestible del cefalotórax, ha cambiado su sabor habitual por otro amargo y penetrante, aumentando mucho el rolúmen.
Algunas semanas bastan para restablecerse; a mediados de agosto, el gecarcino se oculta en una cavidad bien tapizada de hojarasca, cierra la entrada con mucha precaucion y surre la muda, que parece exigir un mes. Cubierto de una piè! mus delgada y sensible, con venas rojas, el gecarcino se ericuen. tra hasta principios de setiembre en su escondite, y entonces se le considera como una golosina. P'rotegido por una coraya sólida vuclve á salir, pero mas de noche que de dia; engor dà hasta enero, y entonces es cuando vuelven a efectuarsc las trasformaciones descritas. Brown asegura en su «Histo. ria natural de la Janaica y cue los gastrónomos de aquella isla

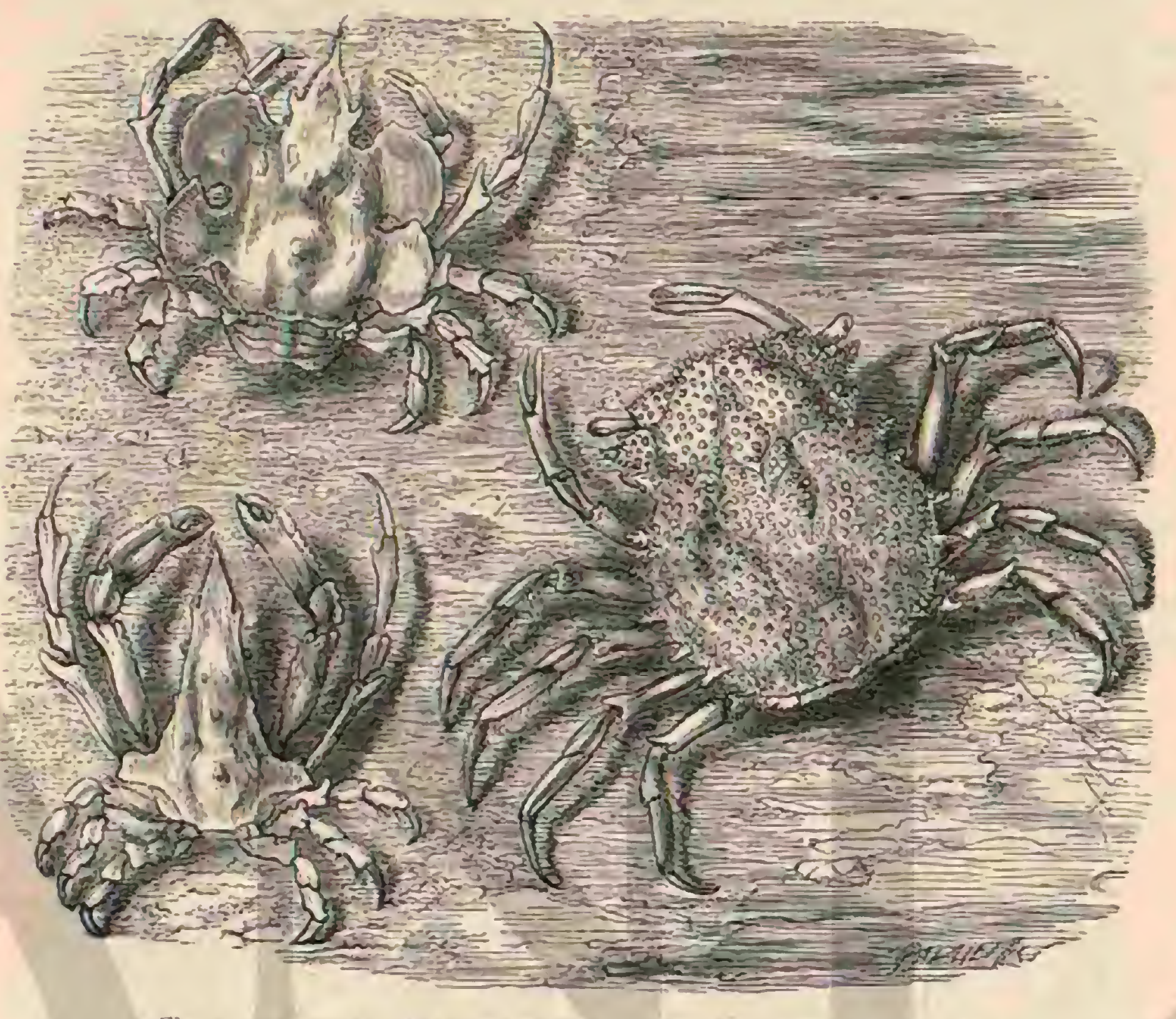

Fig. 7. - LA MICASA TUHSRCULOSA

Fï. 9.-T.A PARAMICIPA FILIRA
Fig. S. - LA MICIRA DE. CRESTA consideran el gecarcino cogido a tiempo y bien guisado como el mas sabrosu de todos sus congeneres y que en verdad me. rece este buen concepto.

\section{LOS GELASIMOS-GELASIMUS}

CARACTÉRES. - Las hembras de los gelasimos tienen la tenaza del todo negra; en el macho, una de las ramas esti sumamente desarrollada y cl animal se sirve de ella para cermar la entrada de su guarida. Mientras que los unos solo buscan la orilla mas llana para sus paseos y cacerias, otros demuestran sus habilidades en el arte de trepar. Asi, por ejemplo, Fr. Muller, el ilustre naturalista que hace tanio tiempo vive en el Brasil, habla de una cspecic graciosisima y vivaz de esta familia que sube á los arbustos de mangle parn comer sus hojas. Con sus cortas garras, en extremo puntiagudas que pinchan como alfilcres cuando corre por la mano, trepa ágilmente ả las ramas mas delgadas. El inismo observador ha estudiado muy minuciosamente los órganos particulares que permiten i estos séres, alejados de su verdadero ciemento, conservarse al aire libre. Muchos pueden llewar c:l su cavidad branquial una cantidad de agua que en vez de vaciarse al salit á tierra, extiéndese como una fina red por la cornza y vuelve por medio de los movimientos del apúndice. de las patas maxilares cxteriores, que produce su juego en la hendidura de la entrada, á la cavidad branquial. Pasando co. mo una delgada capa sobre la cornza vuclre a recoger oxigeno y puede servir de nuevo $1 \mathrm{~m}$ la respiracion. 4 En un aire muy humedo, dice el citado sutor, la provision de agua contenida en la cavidad branquial puede conservarse horas enteras y solo cuando se acaba levanta cl arimal su coraza para introducir por detrás aire en las branquias. Entonces respirn: en efecto, lo mismo que las especies que pertenecen al género siguiente. Ia especie ripo de este género es el gelasimo belicoso representado en la figura 1.

\section{LOS GONOPLAX - GONOPLAX}

CARACTERES. - los gonoplax se caracterizan en particular por su cefalotórax aplanado, que afecta la forma de un cuadrilatero trasversal, un poco mas ancho por delante que por detris: en medio de un borde anterior presenta una protuberancia muy marcada; los ojos estin situados en la punta de unos pedinculos largos que se extienden hasta los ángulos extcriores del caparazon; las antenas quedan descu. biertas; las exteriores son sedosas y muy visibles, con los tres 
primeros artejos mucho mas gruesos que los otros; las inter- macho son prolongadas, las patas raquiticas por lo general; sus medias son bifidas en su extremidad, y durante el reposo en- articulaciones forman ángulo, y la cuarta esla mayor de todas. cajan en un pequeño hucco que hay debajo de la caperuza. Los piés-maxilas exteriores están próximos; las pinzas del

Los gonoplax habitan en las costas de Francia é Inglaterra. Mr. Roux dice que estos crustáceos no salen nunca del

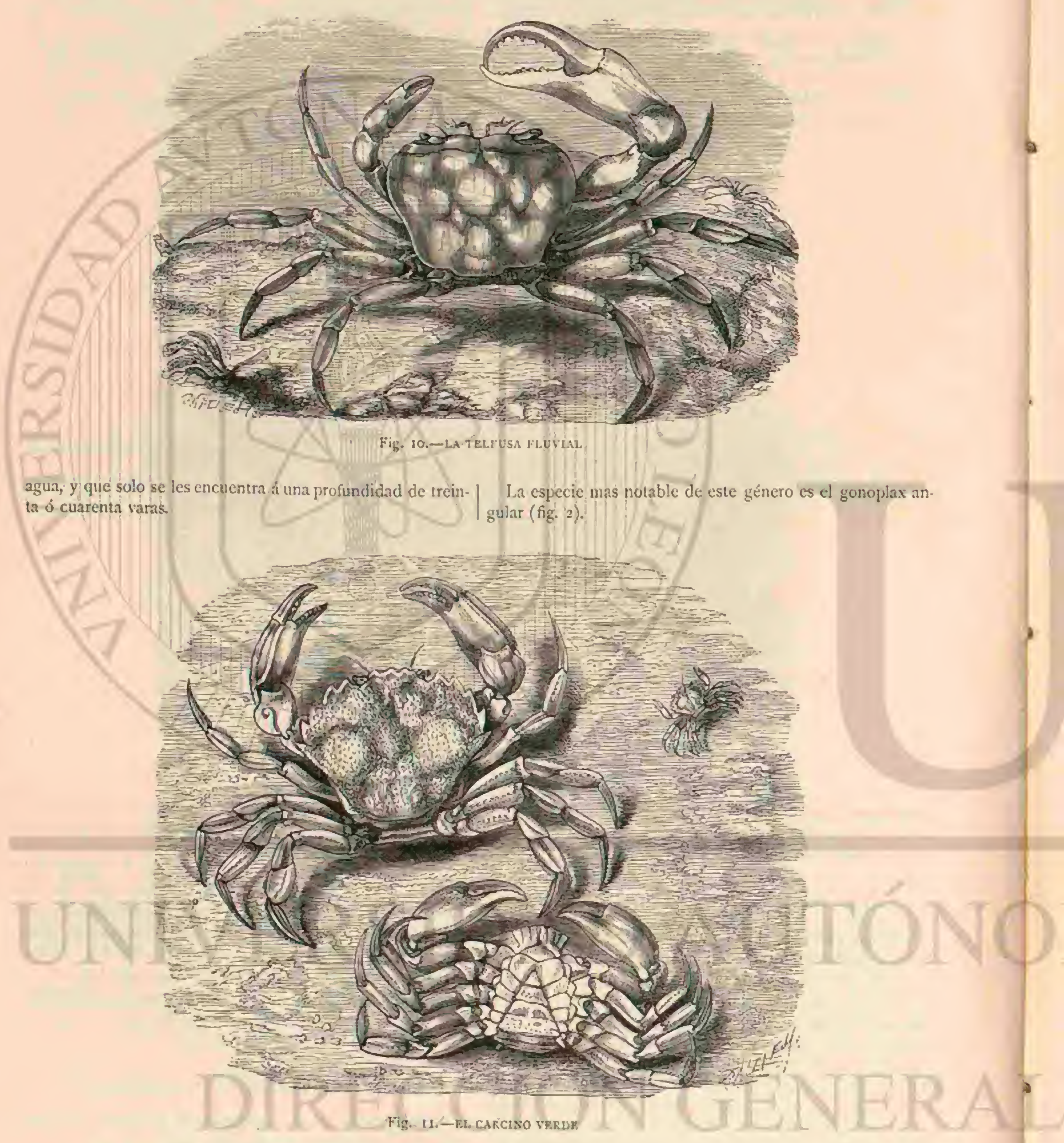

\section{LOS GRAPSOS - GRAPSUS}

CARACTÉRES. - I.os gmpsos ticnen el caparazon plano, deprimido, liso y cuadrado; ha parte anterior $y$ lateral de Ia concha presenta algunas veces tres dientes dirigidos hácia delante; los ojos ocupan los ảngulos externos; hallándose si- tuados en una cavidad trasversal; las anteras cstin en el borde inferior de la frente; las laterales ó externas tienen siu nacimiento en la base de los ojos, y las intermedias se insertan en una pequena cavidad de la caperuza. Los piés.maxilas exteriores están separados en su base; las pinzas son iguales, bastante gruesas, protuberantes y lisas; los brazos, deprimidos 
en la parte superior, terminan en el mismo lado en una cresta; las patas, aplanadas, lisas, y estriadas al través, terminan en una uña algo curva, aguda, y espinosa por sus carns.

Las esprecies de este género se encuentran principalmente en el Brasil, en las Antillas, en el mar Rojo, en el Océano, en el Mediterráneo y en el Ocćano Indico, siendo una de las mas conocidas el grapso pintado (fig. 3 ).

\section{LOS OCIPODOS - OCYPODA}

Los ocipodos 6 cangrejos arenicolas, son unos animales exclusivamente terrestres y muy ágiles, que en el agua apenas pueden subsistir un dia, puesto que mucho antes de trascurrido este se debilitan en exiremo, cesando todos sus movimientos voluntarios. Tambien reciben el aire por una abertura muy oculta que puede cerrarse por detrás en la cavidad respiratoria.

\section{LOS PINOTEROS - PINNOTHERES}

CARÁCTERES. - Los pinoteros ó igilantes dé concha, aunque difieren por su forma redondenda de los demás cangrejos cundrangulares, se asemejan à estos por algunos caractéres esenciales de los órganos de la boca y cle la cavidad branquial; en sus conchas viven varios moluscos marinos; $y$ como el tegumento epidérmico, por efecto de su blandura, no les ofrece el suficiente abrigo, lo encuentran en el seno de sus amigns. Los antiguos consideraban como tal amistad la relacion entre el cangrejo y la concha, toda vez que esta daba su proteccion al cangrejo blando, y en cambio, el ani-

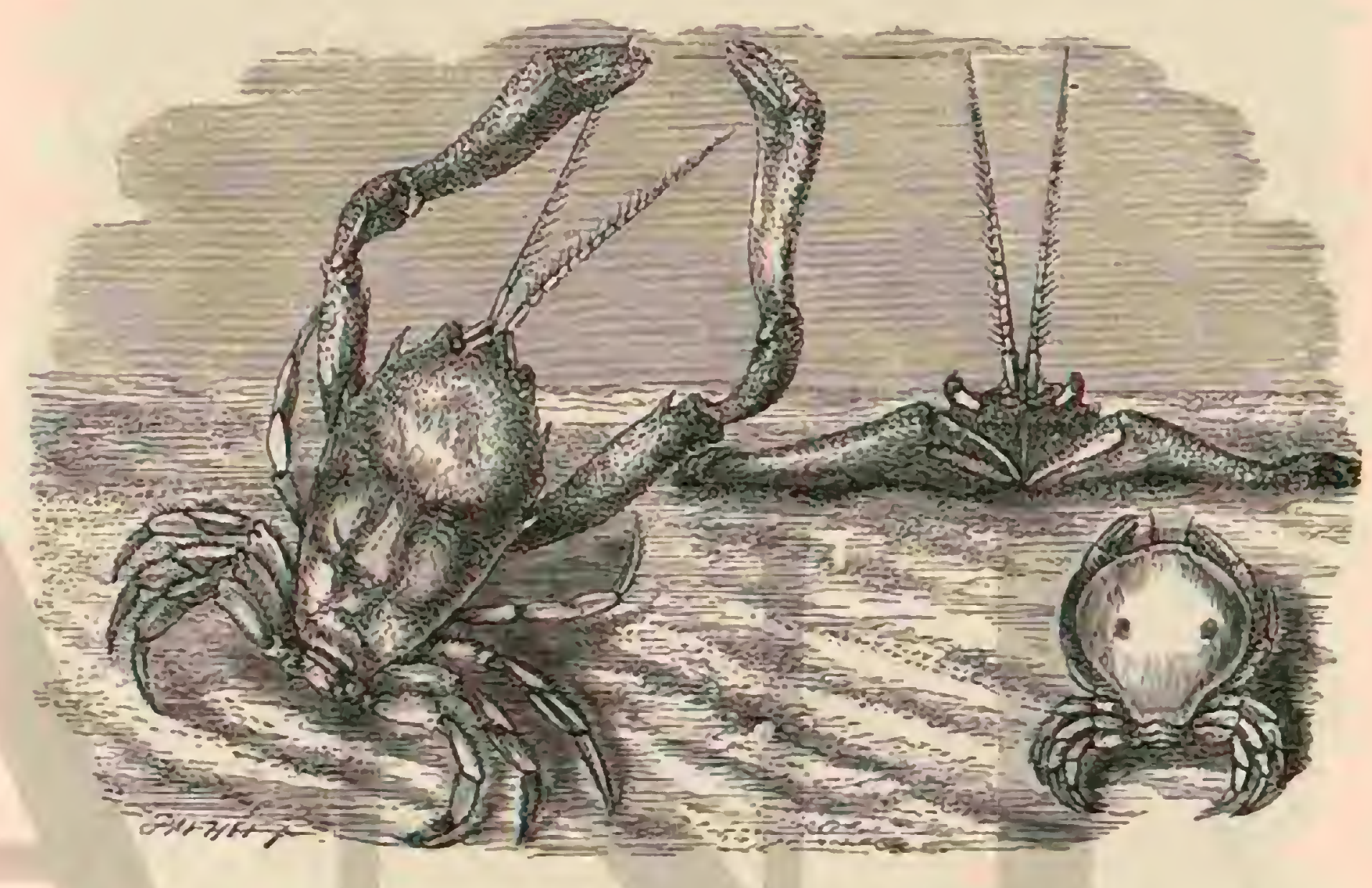

lig. 12.-EL CORISTE. Drs s.

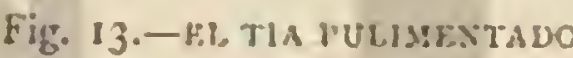

mal dotado de excelente vista, advertia a aquella oportunamente los peligros.

La especie que ha dado lugar a la fábula es el pinotero de los anfiguos (finnotheres ateferum), propio del mar del Norte y del Mediterráneo, y que con preferencin vive en la pinn escamosu. Otra es el pinnotheres fisum (fig. 4); prefiere los nautilos, pero se encuentra a veces tambien en el cardin. Sin duda cambian su residencia como el ermitano, cuando el espacio llega á estrecharse demasiado: pero el conocido naturalista inglés Hyndemann, encontró una vez en un cardio, que aun no media tres lineas de longitud, un pinoteto yue con las paras estiradas no alcanzaba casi mas dimension.

\section{LOS MICTIRIS-MICTIRYS}

CARACTERES. - Este género estableciclo por I atreille, es sin disputa uno de los mas curiosos de la familia: el raparazon, casi ovoideo, blasdo, membranoso, y un poco mas ancho que largo, presenta una trüncadura en la parte posterior; la separacion de las regiones está bien marcada con lí. neas profundas; las antenas intermedias tienen el primer artejo mas bien longitudinal q̨ue trasversal; los ojos, saltones y gruesos, estån bastante próximos, sostenidos por un peciún. culo corto y globuloso: los artejos inferiores de los piés.maxilas externos son muj anchos, foliaccos y velludos por el borde interior; las garras son grandes y salientes, formando hacia cl centro un recodo muy pronunciado; las patas disminuyen progresivamente de longitud.

Los mictiris habitan en el Oceano austral, en donde es bastasste comun la especie conocida con el nombre de mic. tiris longicarpro (fig. 5).

\section{LOS CANGREIOS AR- QUEADOS}

En la familia de los cangrejos arquuendos reúnense los géneros que tienen el ceinlotúrax ancho y redondcado en su parte anterior.

\section{LOS TALAMITAS - THALAMITA}

La major parte de las esperies de este grupo son buenas madadoras, lo mismo que todos los de la familia. Los talamitas tienen las tenazas nuy prolongadas; el artejo en que estän se citiende mucho mas allá de los lados del cefalotórax y' está cubierto en el borde anterior de algunas espinas. Del mismo modo el artejo de la mano, que se inserta en la anterior, es bastante largo y tiene por fuem espinas; los siguientes pares de pies son mucho mas cortos, y el tílimo artejo del segundo, tercero y cuazto es puniagudo en forma de tallo: en el viltimo hay un par de piés: el cxpresado artejo se trasforma en una hoja ancha y ural. 


\section{LOS PORTUNOS - PORTUNUS}

CARACTÉRES. - Los portunos tienen las patas natatorias de una estructura muy parecida entre sus especies: seis de estas son propias del mar del Norte y nueve del Mediterrineo. El portunsus marmoriss se encuentra en Venecia, frecuentemente en los grandes terraplenes del Lido, llamados murassi, donde sube a la muralla y hasta visitia la inmediacion de los edificios de la ciudad; hallase tambien en el puerto de Trieste. as, dice Martens en su (Wiaje i Venecia, suma- mente timido, $y$ al acercarse álguien, se precipita en seguida al mar; de modo que pasé horas enteras sin que de ciento pudiera coger uno solo. Cuando les corté la retirada al mar. ocultaronse en las hendiduras de las piedras, con mucha facilidad, á causa de su cuerpo aplanado: cntonces amenazaban con su afilada tenaza y antes se la dejaban arrancar que salir de su escondite. l. Ias otras especies de este género son tambien animales vivaces, muy astutos y en caso de necesi. dad valientes, sobresaliendo entre ellas el portuno lanoso (fi. gura 6).

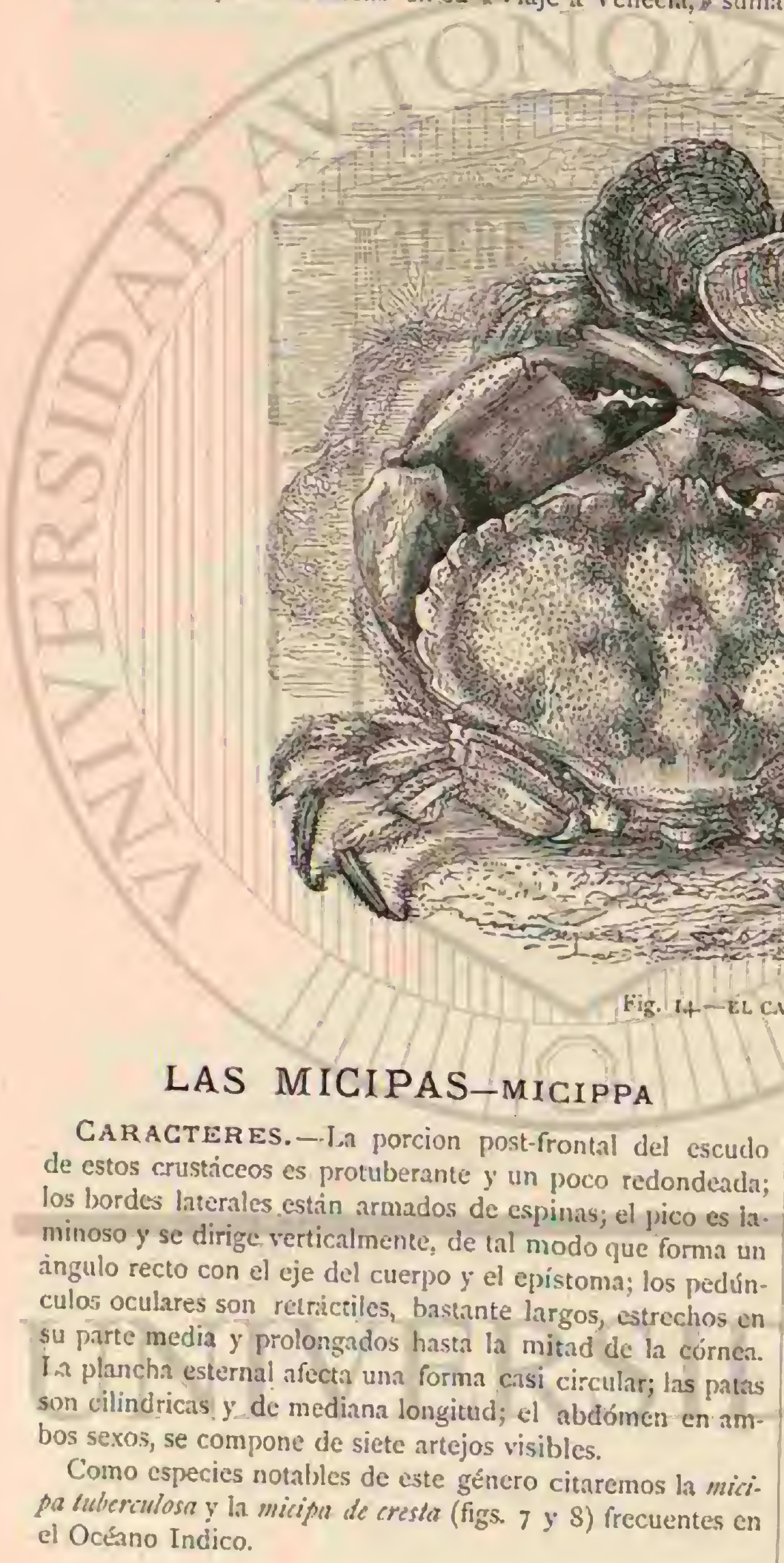

\section{LAS PARAMICIPAS-PARAMICIPA}

CARACrTERES.-Los crustáceos ņue forman estegencro difieren de las micipas por iener el cefalotórax casi tan ancho como largo; sicndo el tipo de este género la paramiipa filira (fig. 9), cuyo cuerpo bastante ancho, casi es redondo, y esti cubierto de numerosas protuberancias de diversos tamaños, asi corno de pequeños tubérculos; los piés-masilas son relativamente pequeños. Se encuentra en las islas Filipinas.

\section{LAS TELFUSAS-TELPHUSA}

CARACTERKS.-Tienen el caparazon deprinido, liso y ел figura de cora\%on, truncado en la parte posterior con una impresion en forma de $\mathrm{H}$, que se halla en el centro, e indica la separacion de las regiones en aquella parte; los ojos están separados; los laterales snstenidos en pedúnculos cortos, gruesos y colocados en una fosa ovalada y irasversal. Las antenas exteriores son muy cortas y estan insertas cerca de los pedúnculos oculares, debajo die los cuales se adaptan; los pies-maxilas exteriores se hallan muy inmedintos $\mathrm{y} \mathrm{cu}^{\mathrm{co}}$ bren exactamente la boca; las pinzas son fucrtes, desiguales agudos $y$ dentodos prolongados, puniagudos y dentados en su lado interno.

Iars principales especies de este género son comunes en el mediodia de Italia; se las encuentrn asimismo en las aguas de Egipto y en la costa de Coromandel.

La langosta fluvial de Belon, Rondelet y Ciesner, es la especie tipica de este género (tig. 10). Tuvo gran celebridad las virtudes medicin particularmente entre los griegos, por fue emblema de la constela la atribuian; y aun parece que Plinio, Dioscórides, Plinio, Dioscórides, Aricena y otros muchos sabios de la an. iguedad la mencionan; se la ve representada en muchas medallas antiguas y en esprecial en las de Agrigento en Sici- 
lia. Segun refiere Eliano, la langosta de rio presiente como la tortuga y el crocodilo los desbordamientos del Nilo y gana las alturas inmediatas con un mes de anticipacion. Es comun en los rios y particularmente en los lagos y cráteres de antiguos volcanes; en Roma se come en todas épocas del año y aun en los dias de abstinencia; pero prefieren à las que acaban de tener la muda, como sucede tambien con otras especies de crustáccos, ó bien las que se hallan próximas à ella.

Cuando las llevan al mercado, forman con ellas cuerdas, pero cuidando de atarlas a cierta distancia unas de otras, at fin de que no puedan comerse ó devorarse. Segun Belon, los campesinos de algunos puntos las comen crudas, y aseguran que su carne es mas agradable de este modo que cocida. Los árabes llaman saraha á este crustáceo, pero como dan igual nombre al ocipodo del país, parece que esta voz es simó nima de turiuni que sirve à algunos viajeros para designar tanto à los cangrejos terrestres como á los de rio.

\section{LOS CARCINOE-CARCINUS}

CARACTERES. - Ios carcinos tienen la frente tripartida, saliendo por encima de las órbitas, y formando con la par-

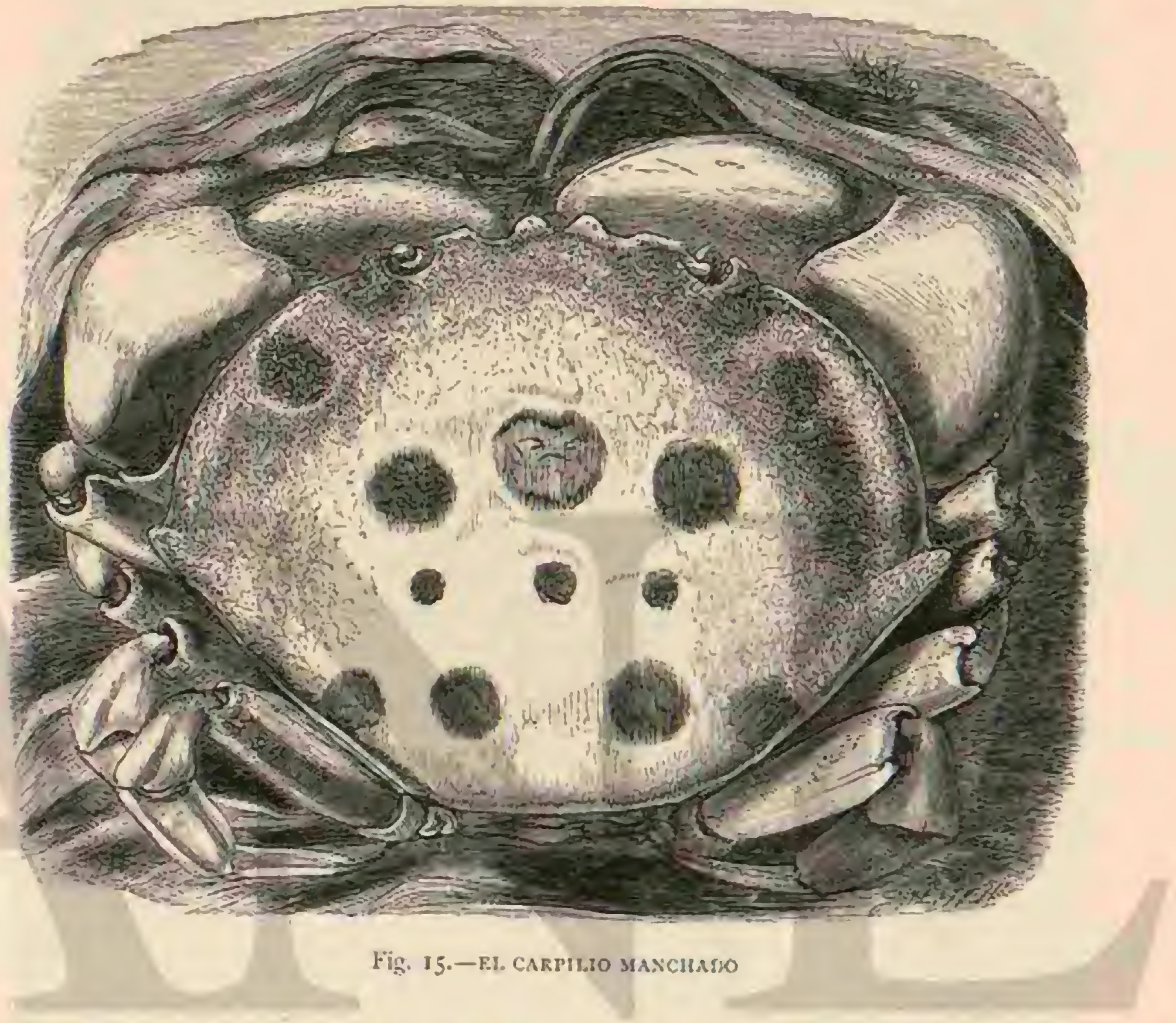

te anterior de los bordes laterales una linea arqueada pro. vista de cinco dientes delgados. El artejo final del último par de patas es, como en las anteriores, muy comprimido, pero estrecho. Ial especie carcinus menas (fig. 11) es quizás el cangrejo mas comun de los mares curopens. Segun las no. ticias antiguas, cada año se exportaban desde Venecia å Istria, donde servian de cebo para las sardinas, 139,000 barriles de So librns cada uno; 38,000 de hembras con huevos, y $\$ 6,000$ - libras de individuos de cascara blanda (los molecrhe, que fritos en aceitc son un marjar favorito de los venecianos).

- 'Todos los años se vendian como alimento en Venecia y en tiern firme, ascendiendo, segun se dice, los productos de esta venta a medio millon de liras venecianns. Aunque so. bre este particular no encontramos noticins modernas, lee aqui to que dice el citado autor. Eesde el principio de la primavera hasta el otoño todos los terraplenes y lagunas: y hasta los canales de la ciudad están llenos de estos animales grotescos. Cuando álguien se acerca á cllos corren con gran agilidad de lado solure el cieno, penetrando ripidamente en él; cuando se les corta la retirada enderezan las tenazas y las ciersan con ruido, dispucstos a vender su vida lo mas cara posible. Aunque estos animales son muy sociables, cuando estan cautivos, se cortan en poco tienpo con sus tenazas casi todas las patas. En una habiticion bien fresca he tenido a menudo varios dias algunos de ellos, como animales domésticos, y observé que puestos al sol, mueren al momento: de modo que este es el mejor medio de matar sin lesion un individuo destimado à una coleccion.

Bell describe del modo siguiente el género de vida de esre cangrcja: \&is sirn duda cl cangrejo mas conocido en nuestras costas y se encuentra en todas partes en gran número: en In playa arenosa se oculta, por lo regular cuando baja Ia marea, debajo de las piedras, y si se le molesta, procuraya' nar lo imas pronto posible su elemento 6 penetra apresud. damente en la arena. No se limita á los espacios arenosos; $i$ menudo se le coge con la red á bastante profundidad, pero prefiere aquellas á otras localidades. El género de vida de peride de la facultad de poder permanecer mucho tiempo tuera del Igua, como sucede con nuestra especie, si bien no puede vivir a gran distancia de la costa como los gecarcinos.

- Ia clase baja de la poblacion de la costa come con frecuencia este cangrejo, q̧ıอ por su exquisito sabor tambien se lleva al mercado de Lóndres. Aliméntase sobre todo de. huevos de los peces, de caridinis y otros cangrcjos, asi como del pescado muerto y de otras sustancias animales. Los hijos de los pescadores suelen cogerle sirviéndose de un peda\%o de los intestinos de algun pajaro ó pez, fijos en la extremidad 
de una cuerda como cebo. Los cangrejos se dejan enganiar y por este medio se obtienen en múmero considerable.

Despues diremos de que modo nuestro cangrejo engaina á su pequeña presa.

\section{LOS GORISTES-CORYSTE}

CARACTERES. - Listos crustáceos tienen cefalotórax muy estrecho y oblongo, y que termina en un pico truncado por delante; los ojos, bastante separados, se hallan en pedinculos gruesos; son casi cilindricos - algo cortos; el tercer artejo de las patas-maxilas extcriores es mas largo que el seguncio, estrecho y terminado en punta obtusa, con una escotadura en su borde interno; los pies anteriores, grandes é iguales entre si, son cilindricos, dos veces tnas largos que el cuerpo en los machos, y de la misma longitud que este en las hembras; los otros terminan en una uña prolongada, iggda y surcada longitudinalmente.

Fistos crustáceos viven en el Mediterráneo y en el Océano: su especic mas conocida, el coriste dentado (fig. 12) jerma. nece de ordinario en las aguas á pocas varas de profundidad, y. se distingue por la lentitud de sus movinientos. Acos.

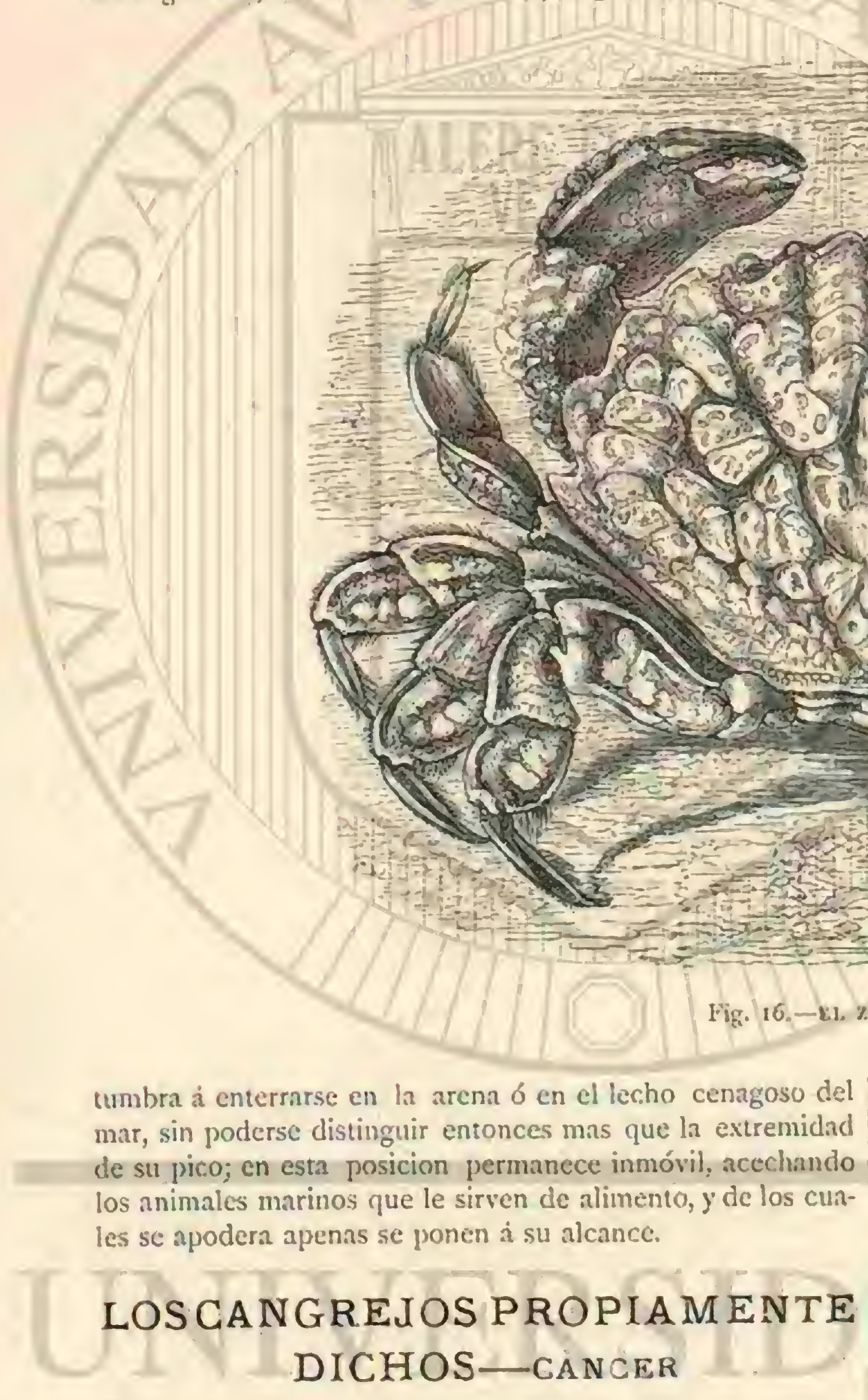

CARACTÉRES. - De los géneros de igual estructura que los anteriores en el último par de patas, ó sea tos que tienen el último artejo delgado y' puntiagudo, mencionaremos el cangrejo paguro (anner pagurus) (fig. 14) que, menos frecuente en el mar Adriático y Mlediterrineo, es un habitante algo mas conocido en las costas del mar del Norte La frente, que sobresale mucho, presenta tres dientes, á los que siguen nueve lóbulos obtusos á cada lado de los bordes literales. Eil color del cuerpo es pardusco en la parte superior, y en la inferior mas chro; los bordes de las tenazas son negros. El cangrejo paguro, cuya anchura llega a medir mas de 30 centimetros, es una de las especies mas comunes, $y$ a causa de su tamano $y$ buen gusto, el mas buscado en el mar del Norte y en las costas inglesns. P'refiere las rocas de la profundidad à la playa. En Inglaterra se le coge á menudo con unos cestos pariculares de mimbre, en cuyo fondo se coloca el cebo, consistente en peces de -ningun valor. 1.os machos, entre los que hay individuos de 12 libras, sienen mejor sabor y por ello son preferidos á las hembras.

\section{LOS CARPILIOS - CARPILIUS}

CARACTERES. - Este género fué creado por Leach; tomando por base el que Linneo formó con el nombre de cancer. El cefalotórax de estos crustảceos es oroideo y muy convexo: los bordes latero-anteriores sun obtusos, y terminan por detrís en una esperie de tubérculo redondendo. Las patas son mas largas que en la generalidad de los cangrejos, las manos muy abultadas, y su gruesa es desigual; los dedos, gruesos y redundos, carecen de estrías y su punta us obuusa; presentan, por lo menos en un ládo, dos ó bres tubérculos gruesos y redondendos. Fil trea de dispersion de las especies de este género es muy extensa; unas habitan en las aguas de las Antillas, otras en el Océano Indico, y las demás en el mar Rojo. La mas notable de todas, el carpilio manchado (figura 15 ), si no fuera por las manchas particulares que adornan el caparazon, pasaria lácilmente desapercibido à la vista cuando permanece del todo inmovil, porque es tan re- 
donco y suave, que se asemeja a un guijarro pulimentado / como coralinas, algas y 7.oófitos; $y$ en tal caso apenas se pue por la accion de las olas. Muchos individuos están mas of de reconocer el animal. Las manchas que se ven en el capemenos cubicrtos de productos vegetales y animales, tales razon son de un tinte rojo brillante.

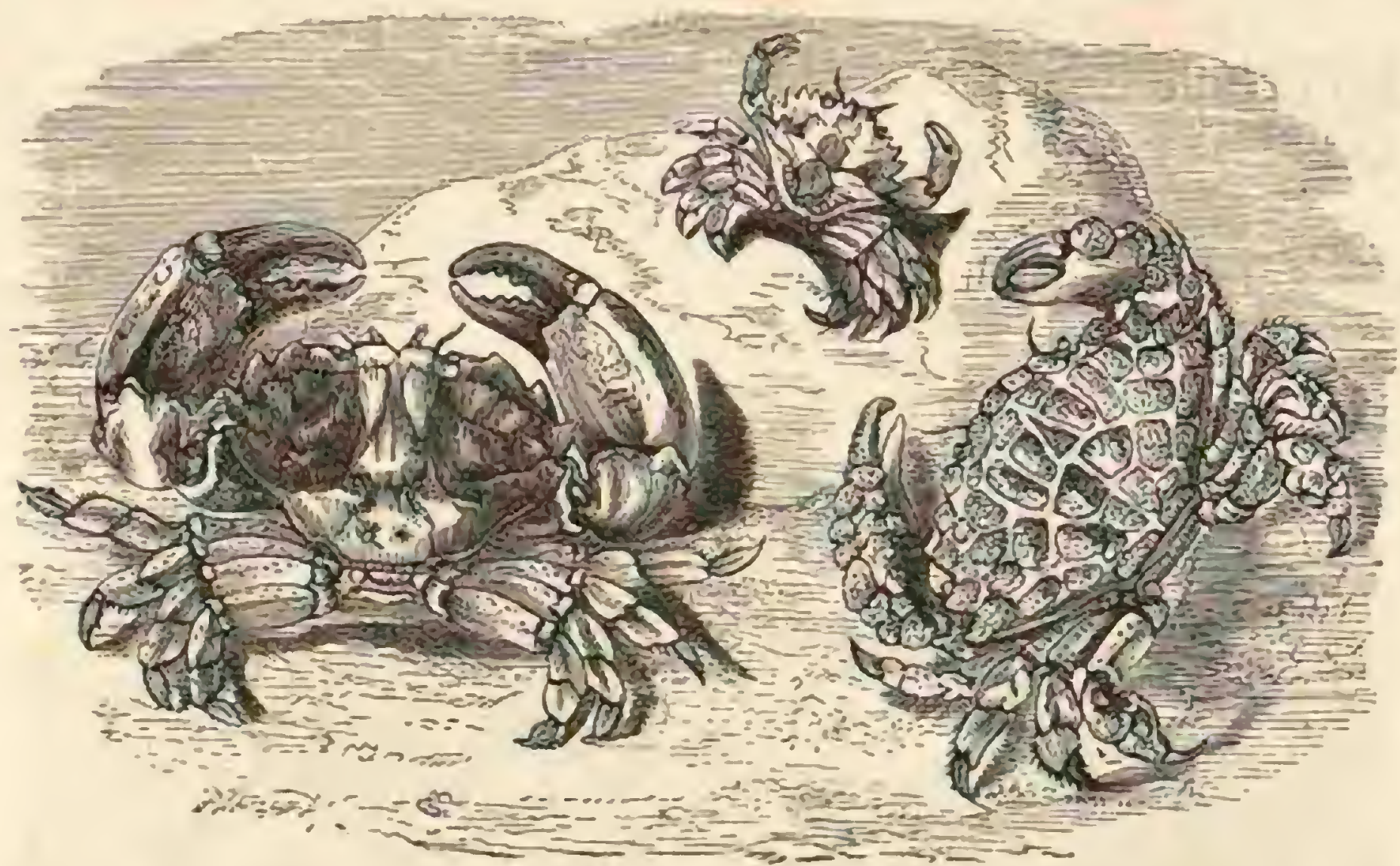

Fig. 17. -IAS PIRIMPI.A DFNTICLLADS

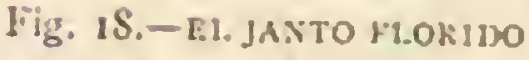

Fig. 19.-E. \%OC1MO r'UNTLIDO

Otro género, el sozymus, se distingue de los anteriores por $/$ cavada como una cuchara. Una de sus especies, el socimo la ,orma de sus pinzas, cuya cxtremidad se dilata y està so- rugoso (fig. 16) llama la atencion por las singulares protube-

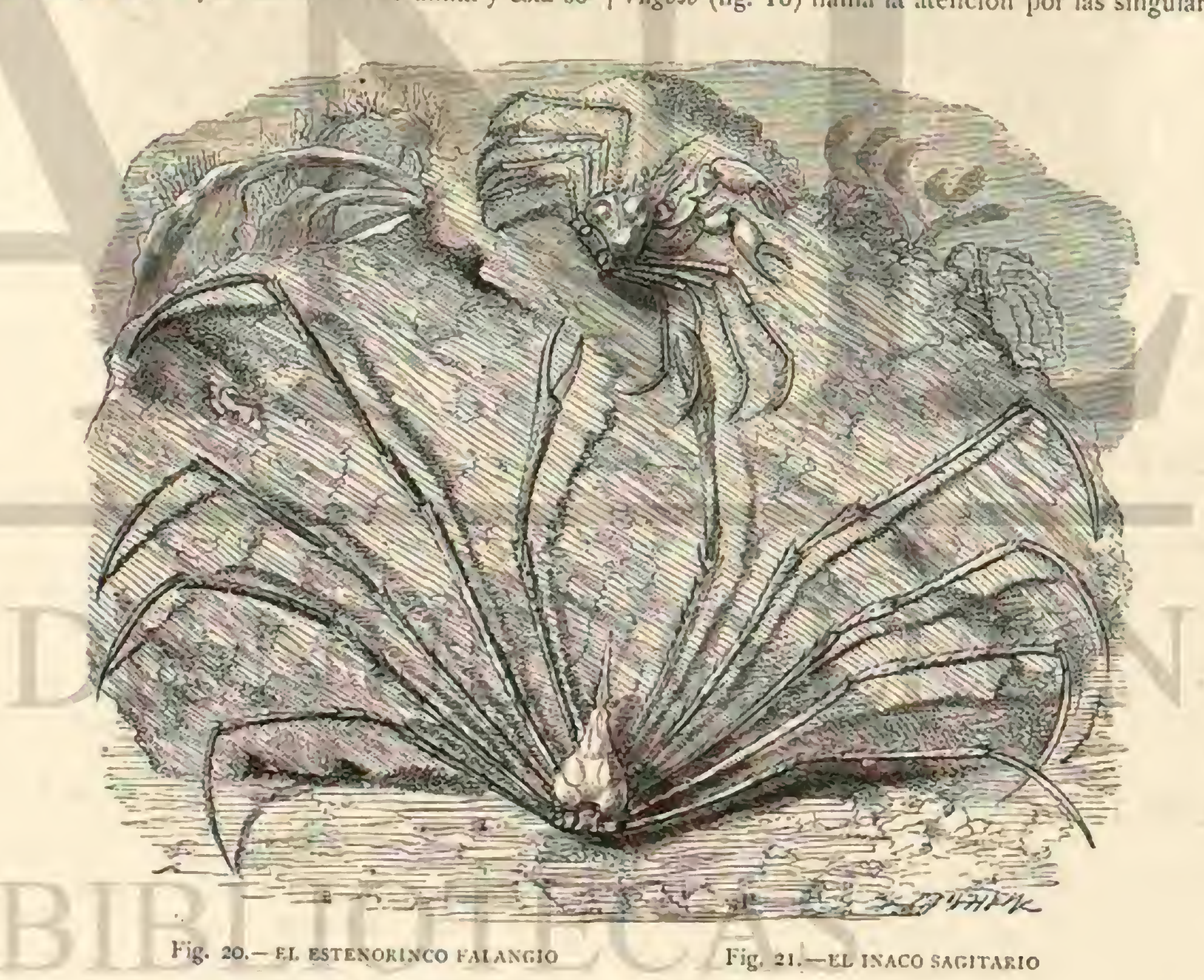

rancias que ofrece el cefalotórax, y que cubren tambien las garms y las piernas. Fil conjunto del cuerpo es un poco me. nos ovalado que en los cangrejos propianente dichos.

El zocimo rugoso habita en el Océano Indico, en cuyas aguas se encuentra tambien otra especie afine, que es el zocimo puntuado (sosymus functata) (fig. 19).
Haremos tambien mencion del género de las pirimelas (fig. 17), que viren en el Canal de la Mancha, y cuyo cefalotórax es casi tan largo como anclio, y del de los jantos, cu. ya especie mas comun, el janto Rorido (fig, i $\$$ ), hahitante asimismo de las costas de Inglaterra, tiene la forma del cuerpo aplanada, y el escudo notablemente fuerte; la fuerza Tono lit 
muscular de las extremidades es tambien notable, si se atiende al reducido tamatno del animal. El color predominante del cefalotórax consiste en un pardo rojizo, que tira al negro en los lados; los dedos tienen este último tinte.

\section{LOS CANGREJOS TRIAN- GULARES}

I.os cangrejos cuya forma es próximamente triangular y la parte de la frente puntiaguda y pronunciada se llamain cangrejos triangulares. No nadan, sino que se deslizan, pré sentando, por sus patas, à veces prolongadas, un aspecto se. mejante al de una araña. Asi se observit principalmente en las especies Sicnorhynchus \&́ Knachus, cuyos individuos son tan perezosos y tardios en sus movimientos, que suelen agarrase siempre á coda clase de algas y esponjas, las cuales crecen á menudo hasta el extremo de rodear todo el cucrpo del animal. Es posible que esto les ocasione muchas incomodidades, pero tambien les sirve de abrigo, puesto que les oculta á la vista de los numerosos enemigos que les amenazan constantemente.

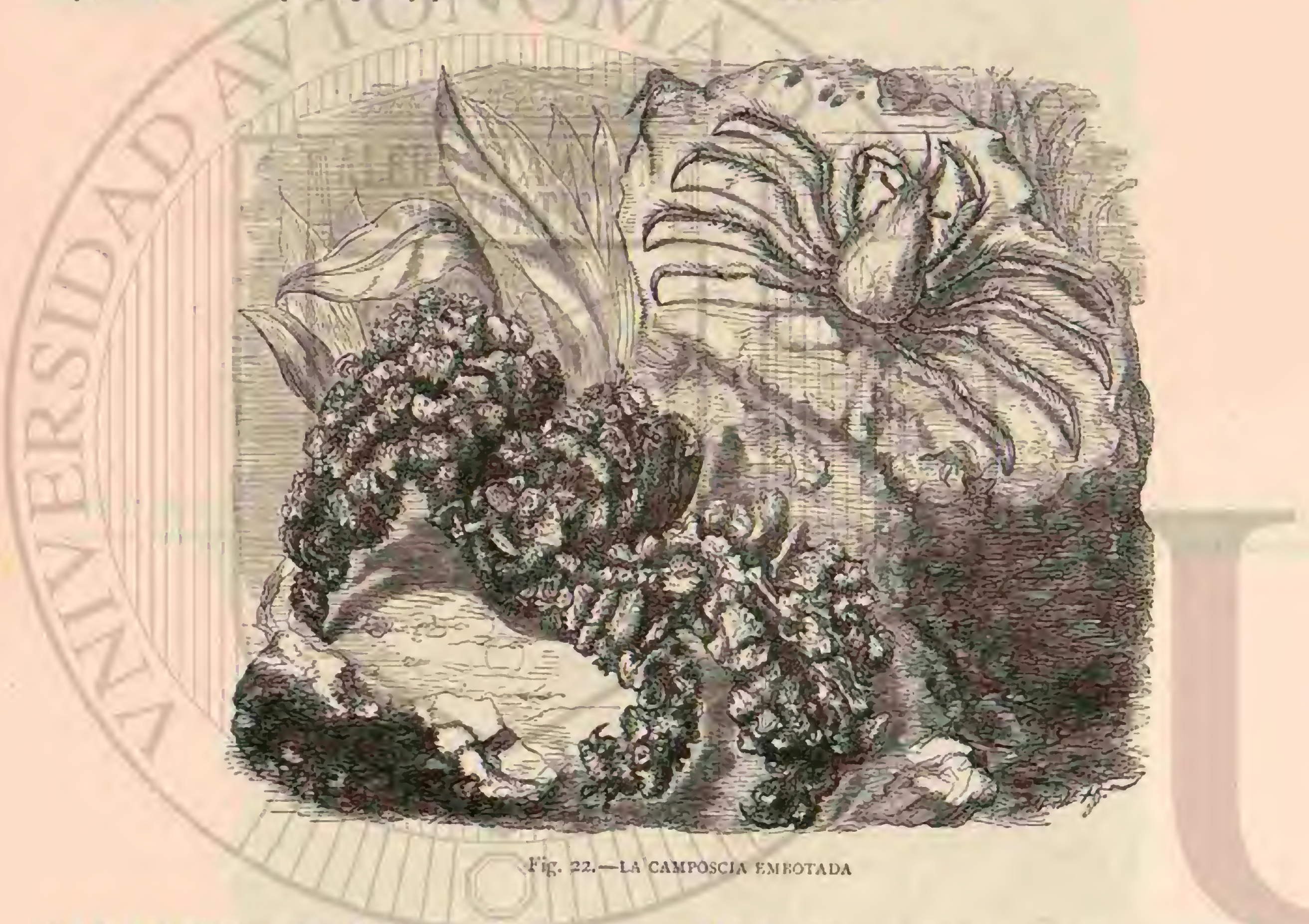

\section{LOS ESTENORINCOS-STENORHYN- CHUS}

I.as especies mas limpias son las del género estenorinco que se caracteriaan por tener la espina de la frente muj pro. longada. Lo nismo al andar que en estado de reposo, no suelen tocar el suclo con el cuerpo, sino que se sostienen sobre sus largas patas, dejando jendientes las tenazas verticalmente desde el artejo de la mano. El estenorinco falangio (fig. 20) es cl tipo de este género.

\section{LOS INACOS - INACHUS}

Las especies de este género (fig. 2 I), diferente de los demás por tener la frente mas rorta y el segundo par de patas mas ruerte, están siempre cubiertas de toda clase de algas y de animales Diatómeas, pólipos, infusurios, ascidios y utros, cubren las exiremidades del cangrejo como con césped, no sin gran provecho del animal, que lleva su colonia como una huerta, de la que coge con su tenaza lo que necesita para su alimento. El doctor Eisig reficre haber visto repetidas veces como el inaco ha arrancado itroidos de otros sitios, y los ha fijado en sus espinas yo pelos, trasplantándolos en cierto modo a su jardir portátil. No podemos duciar de la exactitud de esta interesante observacion, conocida la astucia extraordinaria de estos crustíceos.

Otros dos géneros de los cangrejos triangulares son los lissa (ing. 24) y fism, que se distinguen por la menor longitud de sus patas y por el encorvamicnto de su cuerpo. casiatrofia. do. Algunas especics de estos géneros, propias del Mediter. ráneo, suelén estar cubiertas de cal modo de esponjas, jóli. pos, etci, que el animal apenas queda visible bajo los parasitos. En este caso la extmordinaria peréát del animal permite el desarrollo de las larmas de esponjas, que casualmente se fijan en él, perro sienupre se conservan limpios los órganos de la boca y las tenazas. Hemos tevido ocasion de observar en una colonia de pólipos (astruides calycularis) un pisa que buscaba cuidadiosamente con las tenazas su alimento y lo lle. vala con agilidad yracia a su boca; alguna que otra vez cogia tambien un bocado de in provision que llevaba encima.

\section{EL MEYA ESQUINADO-MAJO SQUINATUS}

La especic mas importante es el meya esquinado (fig. 26) que habita principalmente en el Mediterráneo, hasta Trieste. Todos los años se trasportan muchos nillones de individuos à los mercados de las ciudades litorales del Mediterraneo, casi siempre en grandes cestas ligeramente trenzadas, en las que 
los animales, que miden unos 11,11 de longitud, forman una verdadera confusion de cuerpos y patas. Son apreciados, especialmente en las cocimas de la clase baja, que tiene costumbre de asar en la misma piel del animal ciertas viandas, obteniéndolas asi muy sabrosas. Los antiguos refieren accica de estos crustáceos muchas historias extrañas, asegurando que son astutos $y$ aficionados a la muisica; tambien se les ha representado en muchas monedas.

\section{LAS CAMMOSCIAS-CAMPOSCIA}

CARACTERES.-El caparazon de estos crustáceos es protuberante y casi piriforme, aunque truncado en su parte anterior; tienen el pico rudimentario, sobresaliendo apenas del ángulo interno de las úrbitas; los njos están situados en pedúnculos bastante largos, curvos por delante y muy gruesos en su base, que pueden doblarse lácia atrás $y$ no son re. trictiles; las antenas internas se doblan tambien un poco hácia delante; las fosas donde se insertan carecen de un tabique longitudinal, formando solo una cavidad cuadrilá. tera. El primer artejo de las antenas, largo $y$ delgado, se prolonga casi tanto como el piro, $y$ tiene en su extremidad un tronco movible que esta del todo descubierto; el episto. ma es casi cuadrado; las patas-maxilas externas, muy largas, terminan con una una cilindrica, algo encorrada en la base.

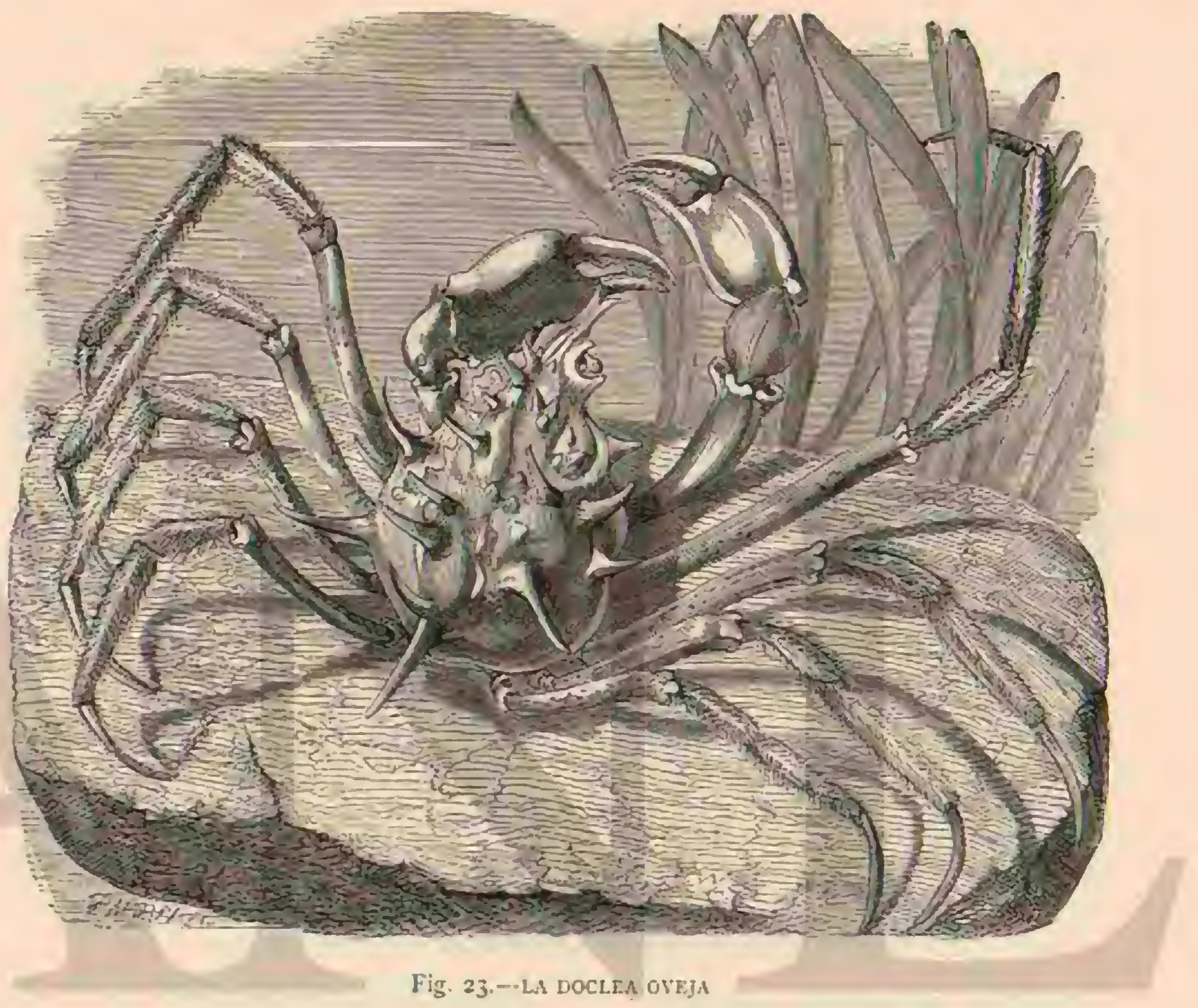

LA CAMPOSCIA EMBOTADA-CAMPOSCIA RETUSA

CARACTERES. - Fsta es la especic (fig. 22) que principalmente representa el género, y sus caracteres son los mismos. Su color es amarillento.

DISTRIBUCiON GEOǴRAFr.A.-No se sabea punto fijo cual es la patria de este crusticco.

\section{LAS DOCLEAS-DOCLEA}

CARACTERES.-Distinguerse las docleas por su caparazon casi globuloso, velludo ý mas ó menos cubierto de espinas: sus bordes laterales se dirigen hácia el interior del cuadro bucal; el pico es corto y muy estrecho; las órbitas avanzan oblicuamente hácia delante, $y$ en ellas sc acomodan los ojos, que son muy pequeños y no tienen ninguna señol de espina en el ángulo anterior de su borde superior; el artejo basilar de las antenas externas sobresale mucho del ángulo anterior de los ojos, y termina casi en punta por debajo de la frente. El epistoma, poco desarrollado, es mucho mas ancho que largo: el tercer artcjo de las patas-maxilas cxte- riores es casi cuadrado y' se dihata un poco por fuera. Las patas anteriores son enciebles y muy pequeñas, y las siguien. tes, por el contrario, largas, delgadas y cilindricas; las patas del segundo par se prolongan tambien mucho, $-y$ - las siguien. tes van disminuyendo poco á poco de longitud. La forma y disposicion del abdómen es variable; en las hembras se com. pone algunas veces tan solo de cinco artejos visibles, y otras ticnen sicte, lo mismo que los machos.

\section{LA DOCLEA OVEJA-DOCLEA OVIS}

CARACTERES.- Este crustácco (fig. 2.3) se distingue en particular por el considerable tamaño de sus garras y la robustez de las piernas, cubiertas de numerosas espinas; otro de los caractéres mas notables consiste en las formidables y agudas puas que irradian de diferentes puntos del cuerpo, ofreciendo alguma semejanza con las del puerco espin; los ojos no son muy prominentes, y quedan casi cubiertos por cl escudo.

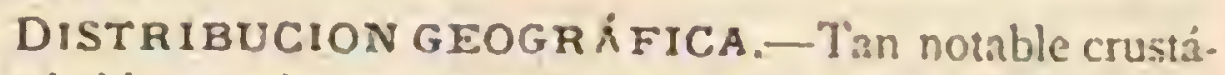
ceo habita en el mar de las Indias: parece abundante en las aguas de la China y en rilipinas. 
USOS, COSTUMBRES Y REGIMEN, - Esta doclea parece preferir los parajes mas profundos del mar, y se fija à menudo en los banros de ostras. Como ya se comprenderá, atendida la considemble longitud de las piernas, los movimientos de este crustáceo son muy cachazudos, de tal modo que cuando anda el animal, parece que se cae. E.l alimento de la doclea consiste comunmente en pequenos moluscos y otros animales marinos.

Créese que este crustaceo inverna, durante la estacion fria, en las masas de cieno, pues cuando se le coge a principios de la primavera se encuentra su escudo lleno de las mismas sustancias que se hallan en el lecho del mar.

Otro género notable de este grupo es el de las periceras, cuya especie tipo, la pericera de tres espinas (fig. 27) debe su nombre à la forma particular de su cuerpo; el pico, y la singular modificacion del escudo la comunican el aspecto de una figura triangular.

Lste crustaceo se encuentra en las aguas de las Antillas.

\section{LOS CORINOS - CHORINUS}

CARACTERES. - La gran desproporcion que comunmente cxiste entre las patas diel segundo y tercer par del ma. cho, $y$ la disposicion del tronco movible de las antenas internas, es lo que principalmente caracteriza a los corinos. El cefaloturax es mas largo y estrecho que el de los mejas; el
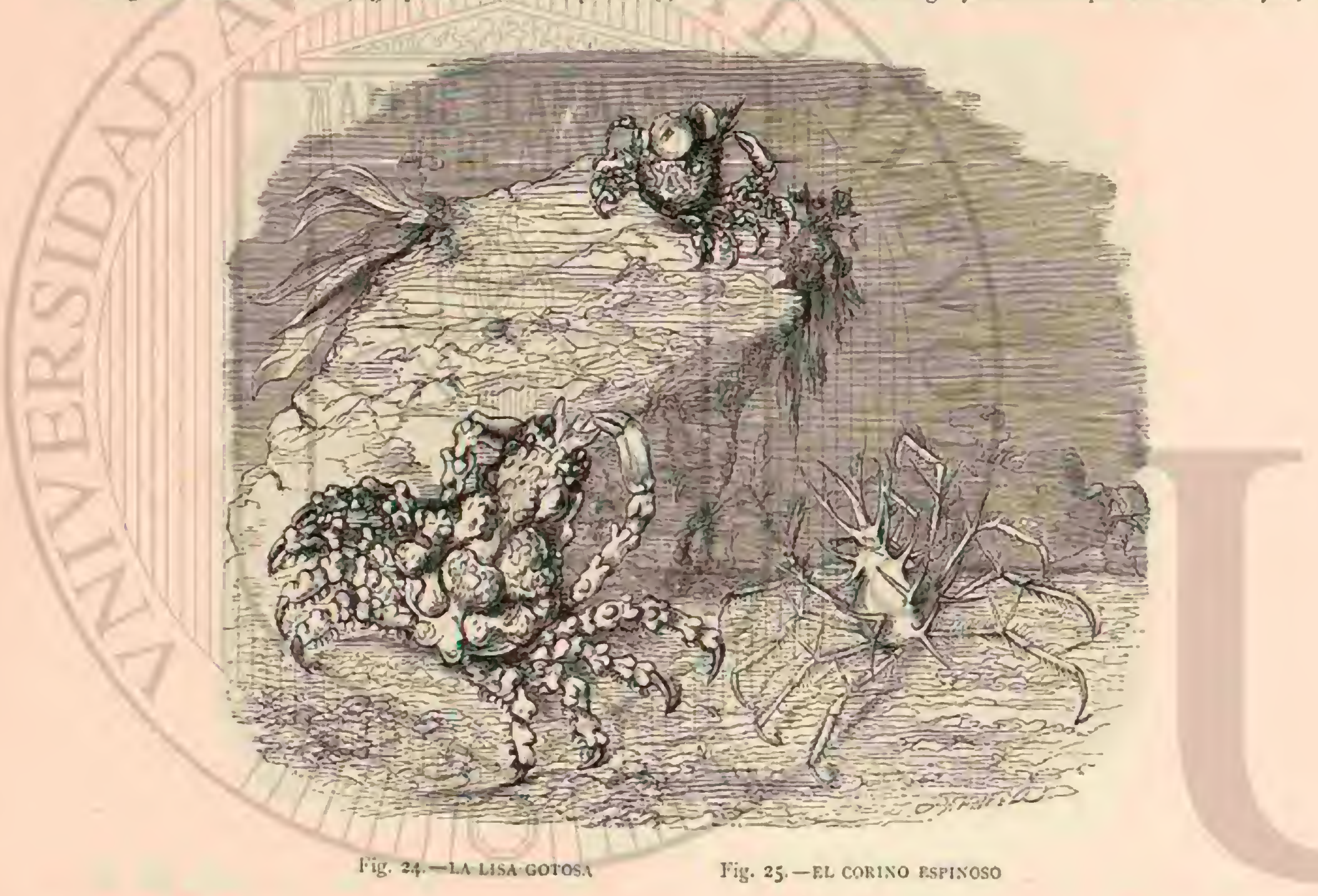

pico está formado por dos cuernos gruesos, puntiagudos y horizontales; los ojos son retráciles; las patas anteriores mas largas que todas las demis, especialmente en los machos: y la uña que las termina, muy encorvada hácia dentro y den. tada, remata en punta.

Los corinos están diseminados en las aguas de las Antillas y de Asia.

\section{EL CORINO ESPINOSO-CHORINUS SPINOSUS}

CARACTERES. - Este curioso crustricco (fig. 25) no se confundira seguramente con nirguna otra especie, a cau. sa del simgular aspecto que ofrece en su conjunto, paréciendo su cuerpo una masa irregular de la que se proyectan es. pinas por todas partes; las garras son nuy endebles; los'ojos están situados sobre largos peduinculos.

In figura representada en la parte supperior del grabado, corresponde tambien al género chorinus; aunque parece muy desemejante, porque se representa a cste crustacco con el cuerpo cubierto de sustancias marinas. No lleva nombre específico por no haberse convenido aun cuál será el mas apropiado para designar á este crusticeo.

\section{LOS CRIOCARCINOS-CRIOCAR- CINUS}

CARACTER ES. -- F.stos crustáceos se distinguen-por las cavidades orbitales, que tienen casi la forma de un tubo dirigido hácia fuera, largo y deprimido en su extremidad; el pedúnculo ocular, largo y delgado, se inserta de tal modo, que queda del todo descubierto, pudiendo doblarse hảcia delante y' aplicarse en toda su longitud conira el borde exterior del artejo basilar de las antenas externas. El criocarcino cornudo (fig. $2 \$$ ) único representantc de este género, se caracteriza esencialmente por las dos puntas que parten del pico a manéra de cuermos; el cuerpo es tambien espinoso, aunque no. tamto como en las especies anteriores: los ojos están situados én pedúnculos regulares.

El criocarcino cornudo habita en las Nuevas Hébridas.

\section{LOS ACANTONIX-ACANTONYX}

CARACTÉRES. - I.OS acantonix tienen el cefaloiórax prolongado y espunoso: el pico horizontal, compuesto de dos cucrnos planos y divergentes; las órbitas son circulares y es. 
tán del todo ocupadas por la base de los pedúnculos; las pa. tas son cortas y bastante gruesas.

En las costas de Nápoles y en las Antillas es donde parecen abundar inas las especies de este género, siendo la mas conocida el acunsu: ix listalo (fig. 29).

\section{LOS LAMBROS-LAMBRUS}

CARACTERES.-Fstos crustáceos están cancterizados por iener las regiones del céalotórax muy marcadis; los ojos sostenidos en un pedíncula corto y grueso; las antenas exteriores muy cortas, los piés interiores tienen mas de doble longitud que el caparazon y estin colocados en ảngulos rec. tos y los piés siguientes son cortos. Las lambros viven en el Mediteráneo, en el Occiano Indico y en el mar Rojo.

\section{EL LAMBRO DE MANOS ESPINOSAS-LAM- BRUS SPINIMANUS}

CAR ACTERES. - Fil lambro de manos espinosas (fig. 30) tiene el cefalotórax cubierto de tubérculos, y terminado en su parte anterior por una especie de pico; las pinzas son griesas, angulosas, y presentan muchas rugosidades formadas por numerosas espinas.

En la isla de Francia es donde se ha observado particularmente esta especie, que suele vivir á grandes profundida

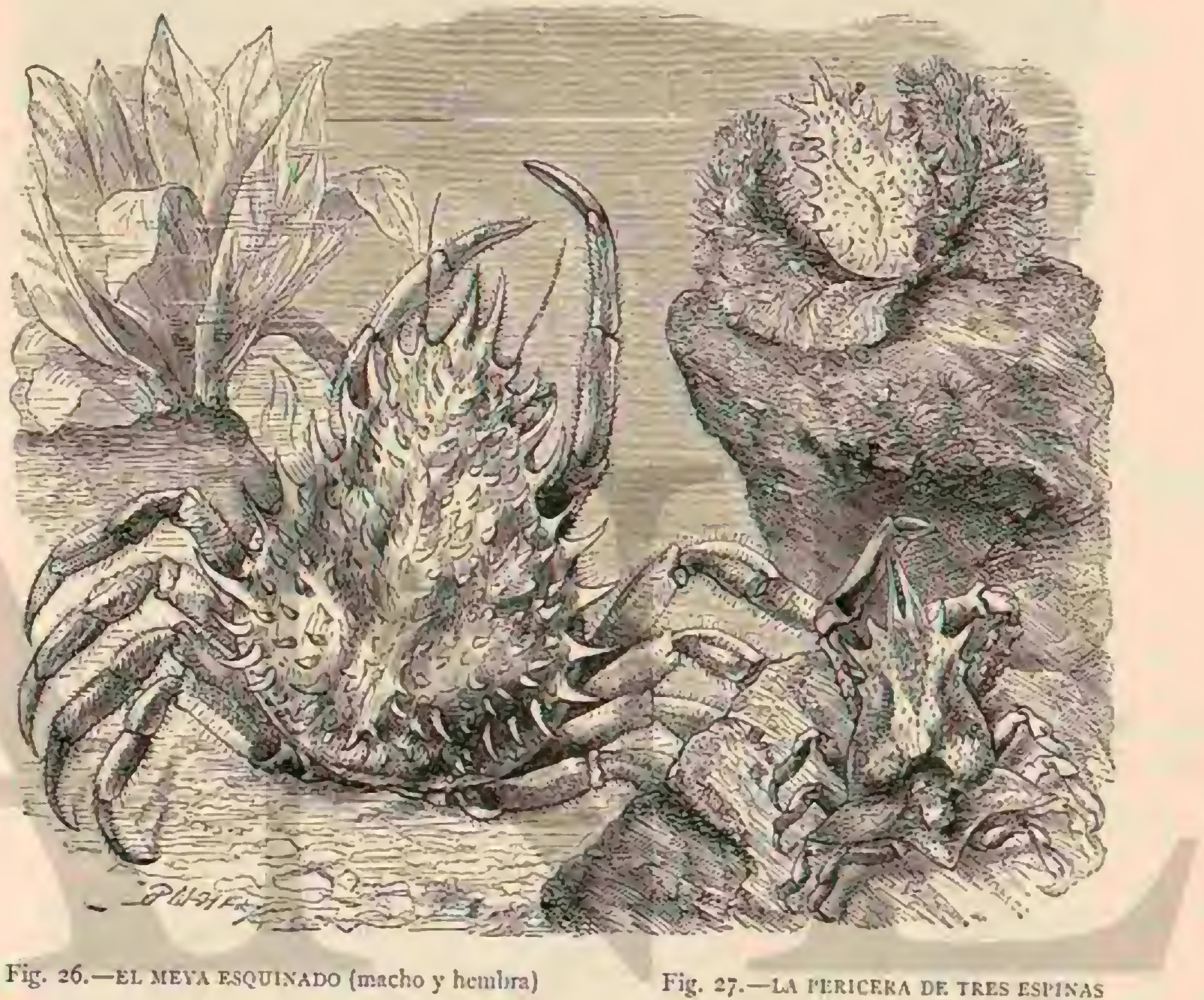

des, y se la encuentra casi siempre entre las rocas, donde acostumbra ocultarse entre el cieno ó las plantas acuáticas.

\section{LOS EURINOMOS-EURYNOME}

CARACTERES. - Fil cefalotórax de estos animales imita la forma de un triảngulo de base redondeada, es muy desigual y se halla cubierto de asjerezas; el pico es horjzontal y está dividido en dos cuernos triangulares; los ojos son pequeños, sus órbitas están hundidas, y su borde superior, que es muy saliente, se halla separado del ángulo exterior por una hendidura.

listos animales viven en el Canal de la Mancha, y en las costas de Normandia, figurando principalmente entre ellos el eurinomo rugoso (fig. $3 \mathrm{r}$ ), crustáceo de reducido timaño, que se reconoce desde luego por su agradable color rojo; to da la superficic del cuerpo está cubierta de numerosos tubérculos.

\section{LOS PARTENOPES-PARTHENOPE}

CARACTÉRES. - Tienen el caparazon rombóideo y' muy irregular por debajo, prolongåndose en un pico por delante y en angulos lateralmente; los ojos son abultados y estan sostenidos por pedúnculos cortos y colocados en hoyuelos laterales; las antenas exteriores son en extremo cortas y sus dos últimos artejos, especirlmente el de la base, muy grue. sos; las garras son desiguales y inuy grandes, con las articulíciones angulosas y cubiertas de tubérculos, de rugosidades y de puntos; estas garras terminan en dedos cortos é incli. nados hácia adentro; las demás patas son igualmente rugo. sas, de mediana longitud y van disminuyendo de tamano, empezando á contar desde el segundo par. Se encuentran estos crustáceos en el Océano Indico y en ti Atlántico. In especie mas notable es el partenope hórrido (fig. 32), uno de los crustaceos mas singulares y de mas extrnordinario aspecto. cuy'o cénaloiorax se asemeja a una figura de circo lados, mas ancha que larga, y cubierta de una serie de las más extrañas protuberancias que imaginarse pucde, las cuales alternan con rugosidades, puntos y espinas de las mas variadns formas; el pico, corto y puntiagudo, presenta un sólido diente entre las antenas; las garras son muy anchas y desiguales, con las articulaciones angulosas, y provistas tambien de bérculos; las patas posteriores son relatimmente pequeñas, 
pero fuertes, y armadas tambien de agudas espinas. Todo este conjunto hace de estc crusticeo un aninal verdaderamente formidable, yo seria ficil cogerle impunemente con la mano, cuando se pudiera defender.

\section{LOS CRIPTOPODIOS - CRYPTO- PODIA}

CARACTERES. - I.as especies de este género dificren

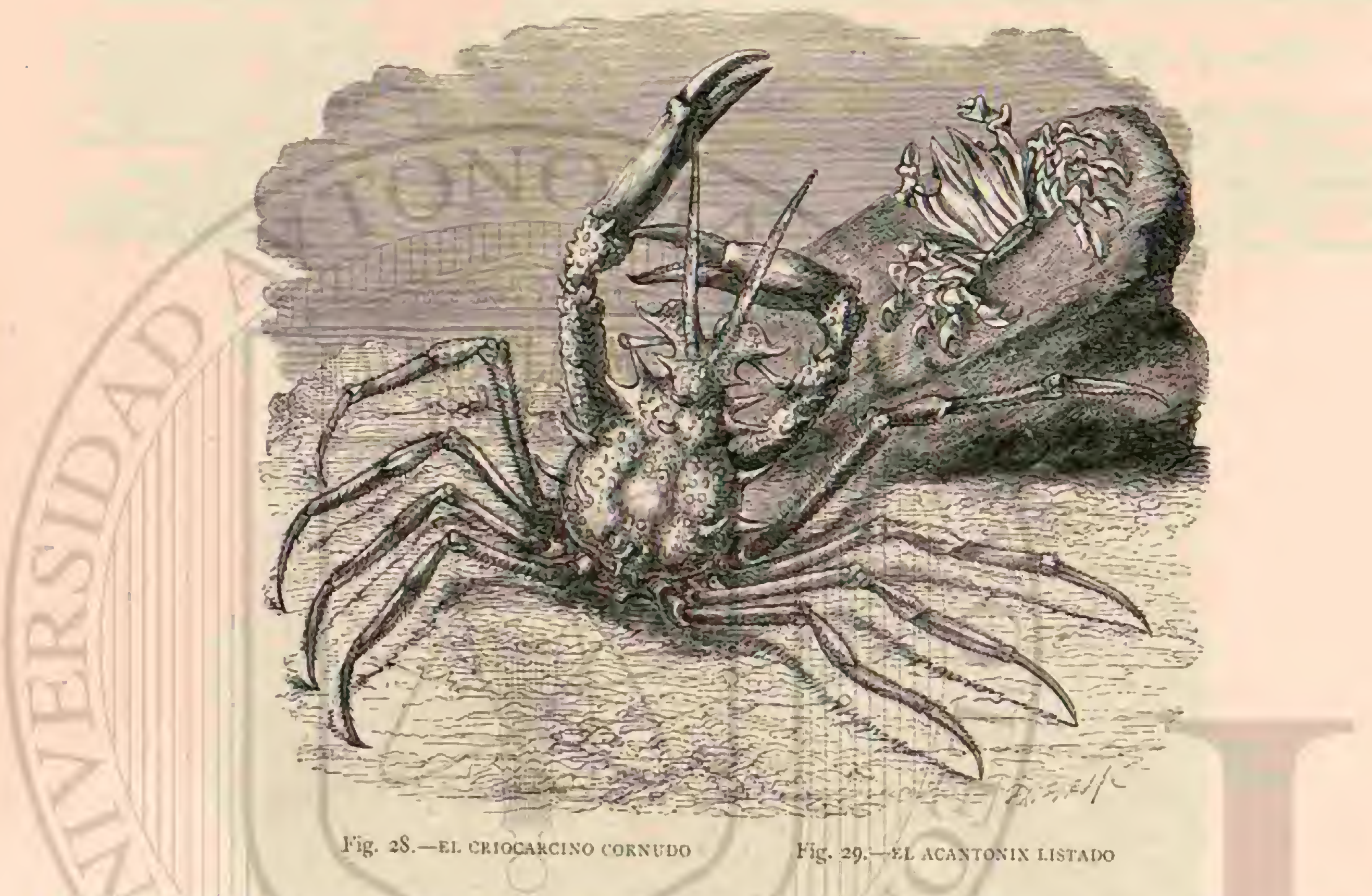

de las de los anteriores por ciertos caractéres bien marcados: ras, puedén reconerš̀ debajo de dos bóvedas formadas, una todas las patas de estos crustáceos, a excepcion de las gar- a cada lado, por la prolongacion lateral posterior de la con-

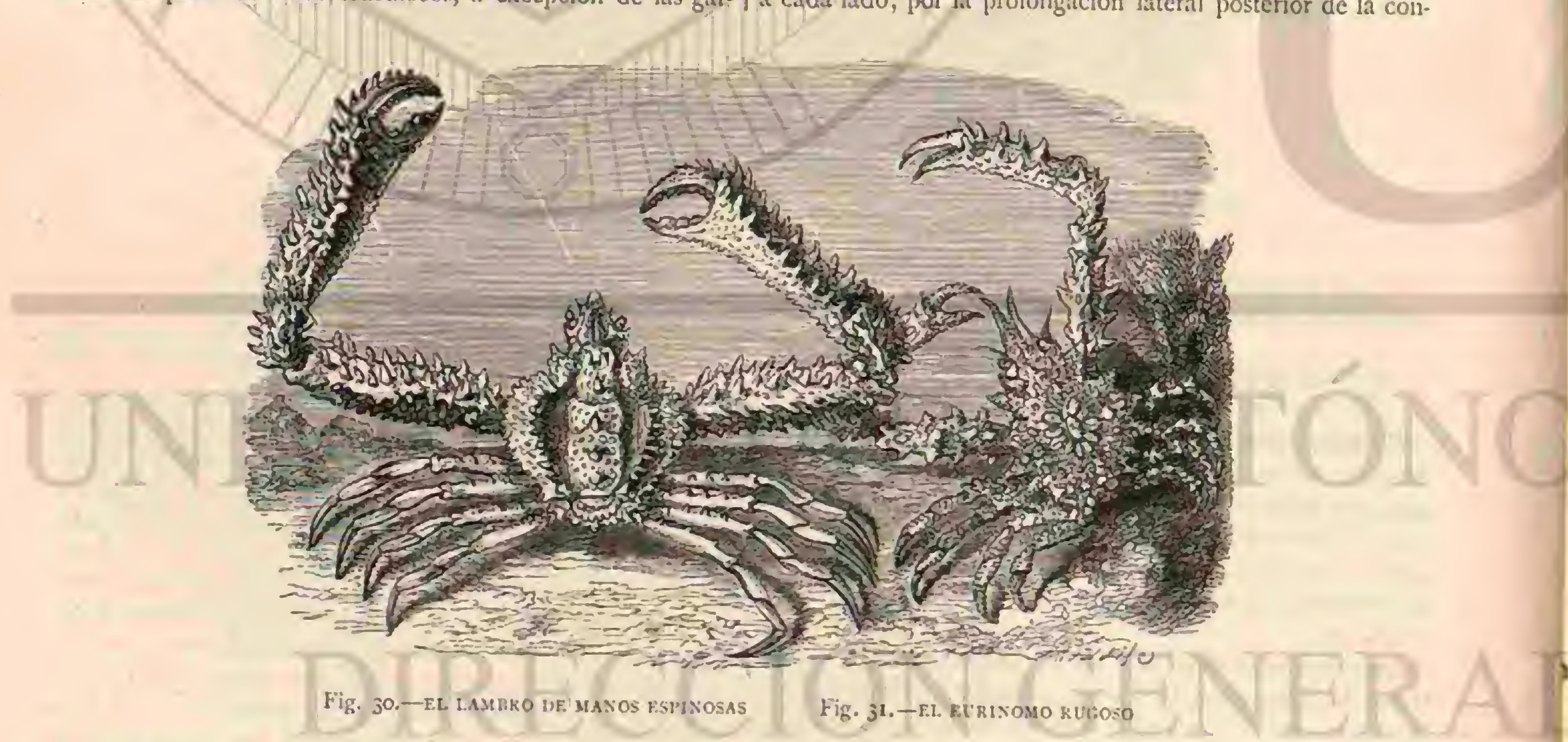

cha ó cubierta; de modo que cuando se mira el animal por encima en el momento de contraterse, no se ve ninguno die dichos órganos, por lo bien que aplica sus extremidades contra la cara anterior del cuerpo. I.os criptopodios jueden ocul. tarlas tanto mejor, cuanto que el corte superior de has pinzas constituye una cresta, por su clevacion, su compresion y las escotadums del borde. A semejante estructura deben estos animales haber recibido el nombre de grallos de mar, y tanbien el de cangrejos àcrgonsosos. Todo el contorno del cefin. lotómx aparece dentado.

Este género no esta representado mas que por una especie, el iripteptadio alinicadato (fig. 33). y vive en el Occiano Indico. 


\section{LOS ETRAS - ETHRA}

CARACTERES. - El cefalotúrax de cstos crustacens es una tercera parte mas ancho quue largo, yáfecta la forma de un óvalo regular; es muy cunvexo por encima, y sus bordes laterales son dentados; los piés maxilas exteriores cierran completamente el cuadro bucal, y el peto esternal es mucho mas largo que ancho; todas las patas presentan una cresta cortante por encima. Los etras habitan en el Océano Indico y en los mares de Africa, distinguiénoose entre ellos él elra deprimido (fig. 34).

\section{LOS GANGREJOS RE- DONDOS}

Fstos crustáceos se distinguen por tener el cefalotórax redondeado, sin frente saliente yo por la abertura triangular de su bocs.

\section{LAS CALAPAS-CALAPPA}

Es muj particular el aspecto de la calapa granujienta (in.

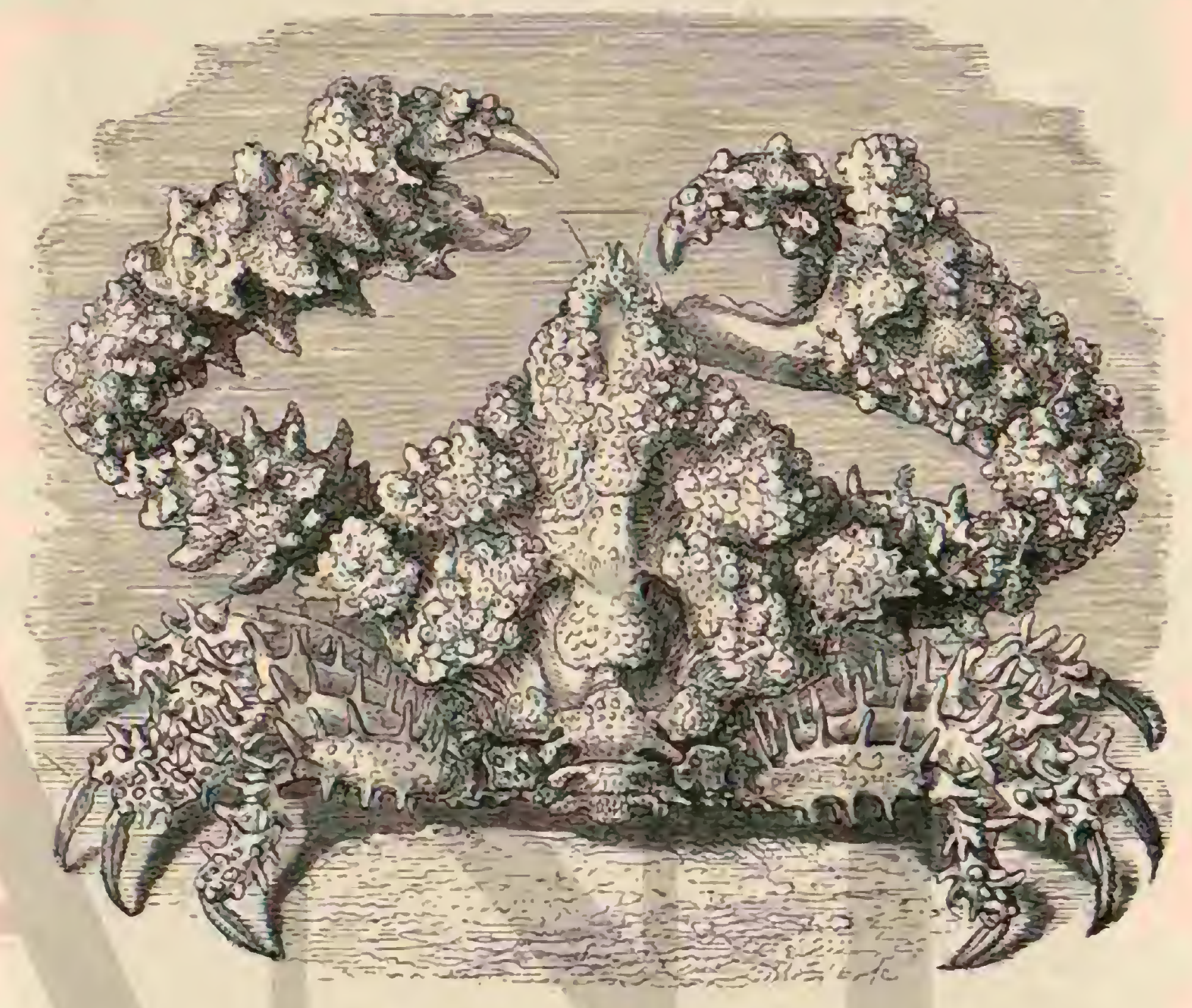

Fig. 32. EI. PARTENOTE UÖRRIDO

lappagrasulata), llamada tambien imngrejo zergonsoso (fig. 3i) porque con sus grandes ienazas se cubre, por decirlo asi, la cara. Ias especies del género pertenecen a los mares caiicios y la de que hablamos es como el último centinela del Medi. terráneo. Como animal muy perezoso, permanece dias enteros en su mismo sitio, oculto de tal modo en el suclo, que únicamente sobresalen la parte superior del escudo dorsal, la parte de la frente con las cortas antenas y el borde superior de las tenazas. Entonces se reconoce la ventaja que reparta al cangrejo el desarrollo de esta última parte yu su extraña posicion: pues, por delante de los órganos de la boca y los orificios de las branquias hay una cavidad separada, descle la que el agua penetra en las últimas sin mezclarse con cuerpos sucios. El color immarillento ó rojizo de cste cangrejo, con manchas oscuras, es causa de que á menudo no se le descubra fácilmente en el suelo arenoso. Son notables tambien las especies calapa de cresta (fig. 35) y calapa atma. da (fig. 36), ambas jropias de las aguas del Japon y de la China.

\section{LAS LEUCOSIAS-LEUCOSIA}

CARACTERES.-Los crustáccos quue forman este género se distinguen por su cefalotórax prominente casi globuloso, un poco mas estrecho en su parte anterior y con una prolon. gacion algo levantada, en cujar extremidad estan la frente $y$ los ojos; el aparato bucal es triangular, y la porcion anterior de sus bordes laterales se confunde con la protuberancia del caparazon: las patas del primer par son gruesas: la mano proruberante y la una corta, un poco doblada y guarnecida de dientecillos obtusos; las otras patas son mucho mas cortas, $y$ van disminuyendo notablemente: todos los sermentos del abdómen del macho, excepto el prinero y el último, cstán soldados en una sola pieza.

I as leucosias están distribuidas en las costas del Mediterráneo, en Nucra Guinea y en las de la India, siendo de notar entre ellas la leucosia urano (fig. 40), originaria de Filipinas, y la leucosia moteada (fig. $3^{8}$ ) de Nueva Guinea.

\section{LAS MIRAS - MYRA}

CARACTERES.- Distinguense las miras por tener el palpo de sus patas-maxilas exteriores un poco dilatado en su parte inferior, terninando por fuem en un ribete poco arqueado que se estrecha gradualmente hácia la punta; la mano es delgada: In uña corta, fuerte y' con dientes poco comprimidos; las patas son cortas. I a mira fugaz (fig. 39) se distingue por la excesiva longitud de los brazos, y por la forma 
irregular del cefalotórax: las antenas externas no se ven bien cuando se mira al animal for arriba: las extremidades anterior ! posterior del escusterninan en punta.

Este crustadceo se encurstra en las islas Filipinas.

\section{LOS TIAS-THIA}

CARACTERES. - I Los tins se caracterizan por su cefalotórax de forma orbicular, truncado en la parte posterior; los

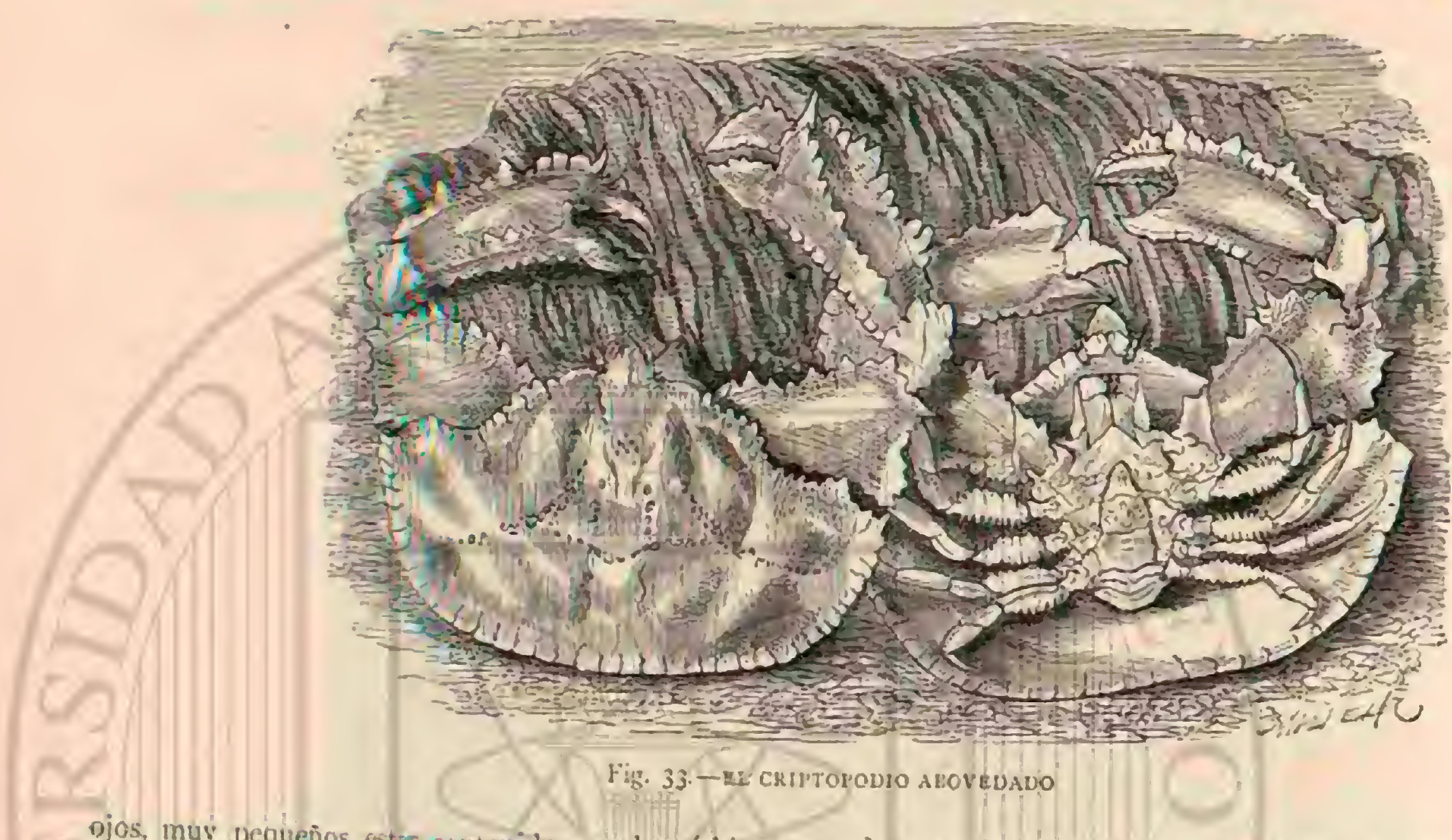

Djos, muy pequeños, estro contenidos en las órtrias, cuyo f rores són [ucstañosás por ambos lados; bastante largas, con

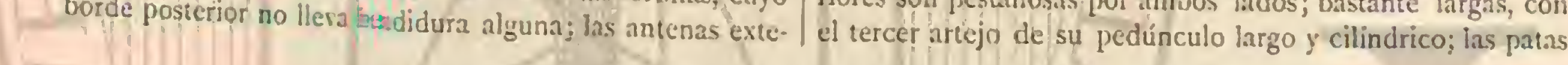

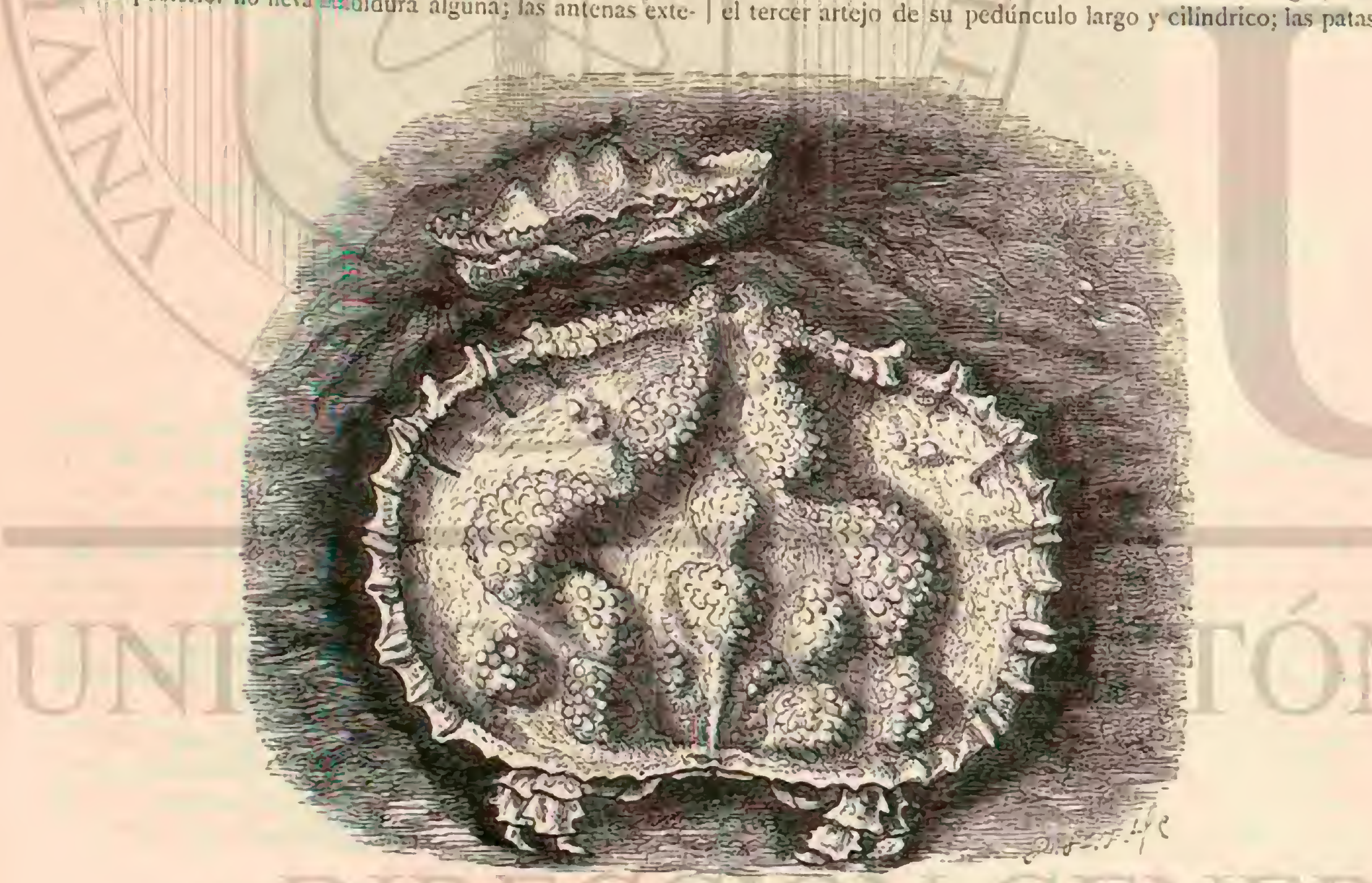

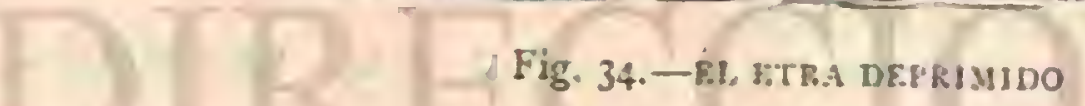

del primer par son un pooi mas lägas en los nachos y ticnen las manos aplanadas: co las de los demás pares, el tarso jo amudo: sal y arovendo; anterior also saliente: cuadrado y el quinto el tercero mucho mayor; el cuarto cas cuadrado y el quinto trianelar. In especic tipo de este gene- ro es el tha fulimentado (fig. $1_{3}$ ) que vive en las costas euro. pers.

\section{LOS IFIS - IPHIS}

CARACTERES. - LOS ifis están provistos de un capara. zon que afecta la forma de un rombo, de lados redondeados, 
prolongándose horizontaimente $y$ al traves elz forma de una espina gruesa. El ifis de siete espinas (fig. 4 t) debe su nom. bre $a$ las siete agudas espinas ó ptias que proyecta el capara. zon: por lo general figuran en numero de siete; pero hay especies mayores que presentan nueve; los brazos son largos I' muy delgados, y los dedos de las garras muy endebles.

En las rostas de la India es clonde se coge generalmente este crustáceo.

\section{LOS IXAS - IXA}

CARACTERES.- - I.os ixas son particularmente notables por la forma de su caparazon cuya parte media es casi esfé- rica, $\delta$ mas bien eliptica trasversalmente, prolongandose a derecha é izquierda en una porcion cilindrica; la carn superior del cefalotórax esti surcada mas $\delta$ menos profundamente por dos canales que separan las regiones brancjuinles de las medias; la frente aparece levantada y bastante ancha; las or. bitas presentan dos hendiduras por debajo; las patas son filiformes. I as proyecciones cilindricas del ixa cilindrico que se notan à los lados del cuerpo de este crustáceo (fig. 42) constituyen su carácter mas notable, debiéndose i ellas que la anchura de dicha parte iguale casi á tres veces la longitud; las patas son largas y endebles.

Habita en varios puntos de Asia; se le encuentra en las Indias $y$ en Filipinas.

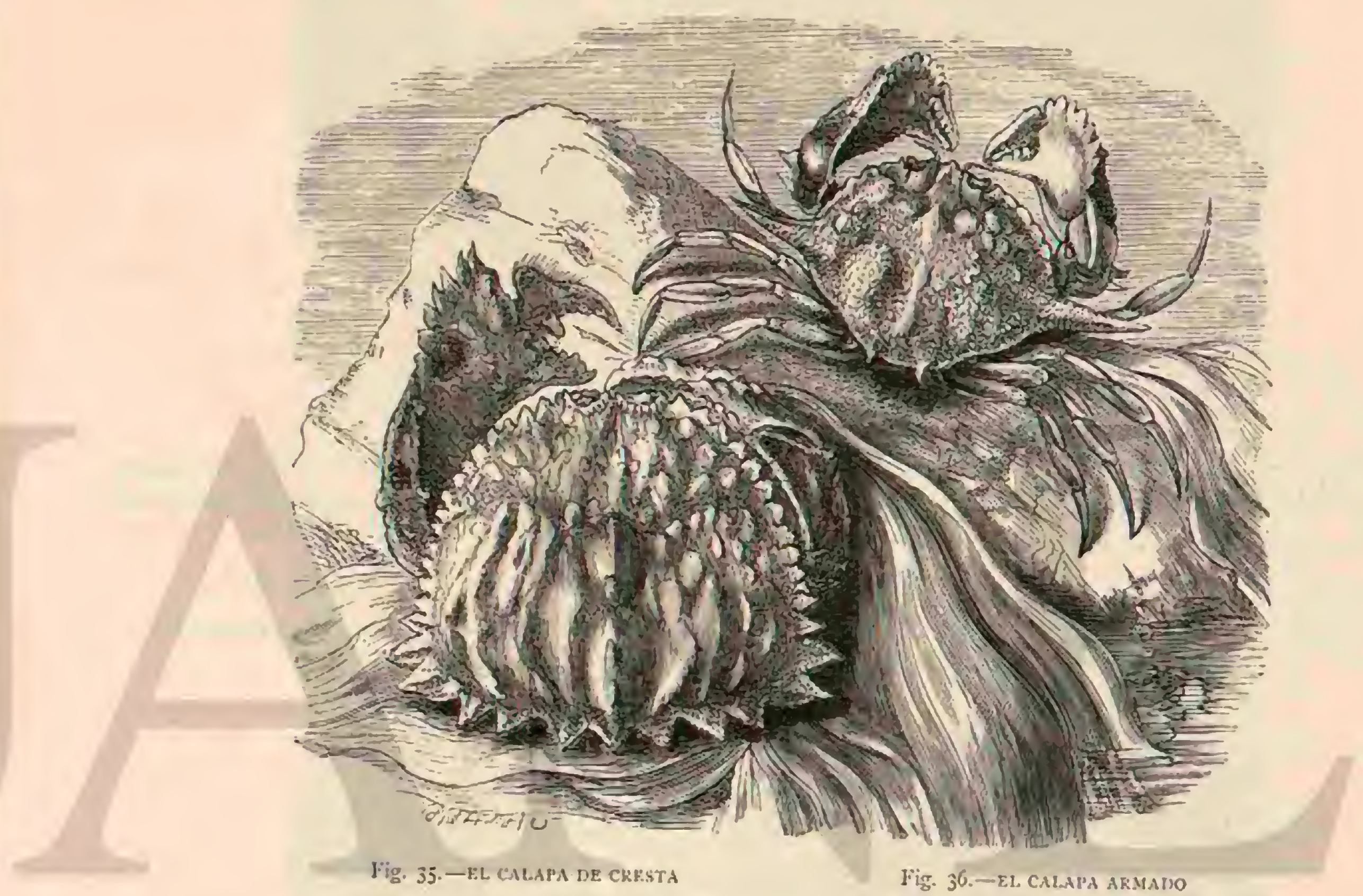

\section{LOS NURSIAS - NURSIA}

CARACTERES, - Los crusticeus azrupados en este gé. nero tienen el cefalotórax algo prolongado, en forna de pico, nfreciendo sus bordes postcriores, que son dentados, una escotadura; el tronco externo de las patas-maxilas exteriores se dilata un poco; los piés del primer par son angulosos; el úl timo artejo del abơómen del macho está provisto de una punta pequeña en su borde posterior.

La especie tipo de este género es la nursia granujienta que se distingue sobre todo por la singular estructura de su cefalotórax, que forma como unos dobleces $y$ ángulos de caprichosa forma (fig. 43).

Se ha encontrado este curioso crustáceo en las aguns del Océano Indico.

\section{LOS DORIPAS - DORIPPA}

CARACTERES.-Tienen el cefalotórax algo deprimido, mas ancho por detrás que por delante, truncrido y espinoso en la parte anterior, y sinuoso en la posterior; su superficie Tомо Vil presenta prominencias $\delta$ tubérculos que corresponden exactamente â las regiones propias ó partes que están situadas debajo: presentan ademis dos grandes aberturas oblicuns, vellosas en el horde, y que se commican con las cavidades branquiales; se hallan situadas debajo de la concha, una à la derecha yo otra á la izquierda de la boca; la porcion interior y posterior del cuerpo esté truncada, formando una ranura donde recibe el abdómen doblado, cuyas piezas son nudosas y tuberculosas.

Las especies que componen este género se encuentran principalmente en el Mediterrineo, en el Océnso Indico y en los mares de Asia, figurando principalmente entre ellas la doripa lanosa (fig. 45), cuyo nombre especifico to debe a tener su cuerpo cubierto de una espesa capra de pelo corto: à cada ládo de la concha, y en la base de las patas-máxilas, se ve una abertura cerrada en parte por una membrana, por la cual entra y sale el agua que el crustáceo necesita; las pratas, notables por su estructura $y$ dipposicion, son desiguales en tamaño; las de los dos últimos pares se clevan sobre el dorso, yell sus extremidades existe una especie de gancho, que d animal puede emplear como arma ofensisa.

Esta especie parece comun en el Mediterraineo. 


\section{LAS CAFIRAS-CAPHYRA}

CARACTERES. - I os de las cafirns son: caparazon lampino, cuadrilátero, un poco mas ancho que largo, saliente $y$ recortado en el horde anterior; por la parte de atrís se presenta cortado á escuadri, ý por arriba es muy poco convexo; las antenas exteriores son cortas, sciáceas, están insertas encima de las intermedias y én los ángulos externos de la cavi-

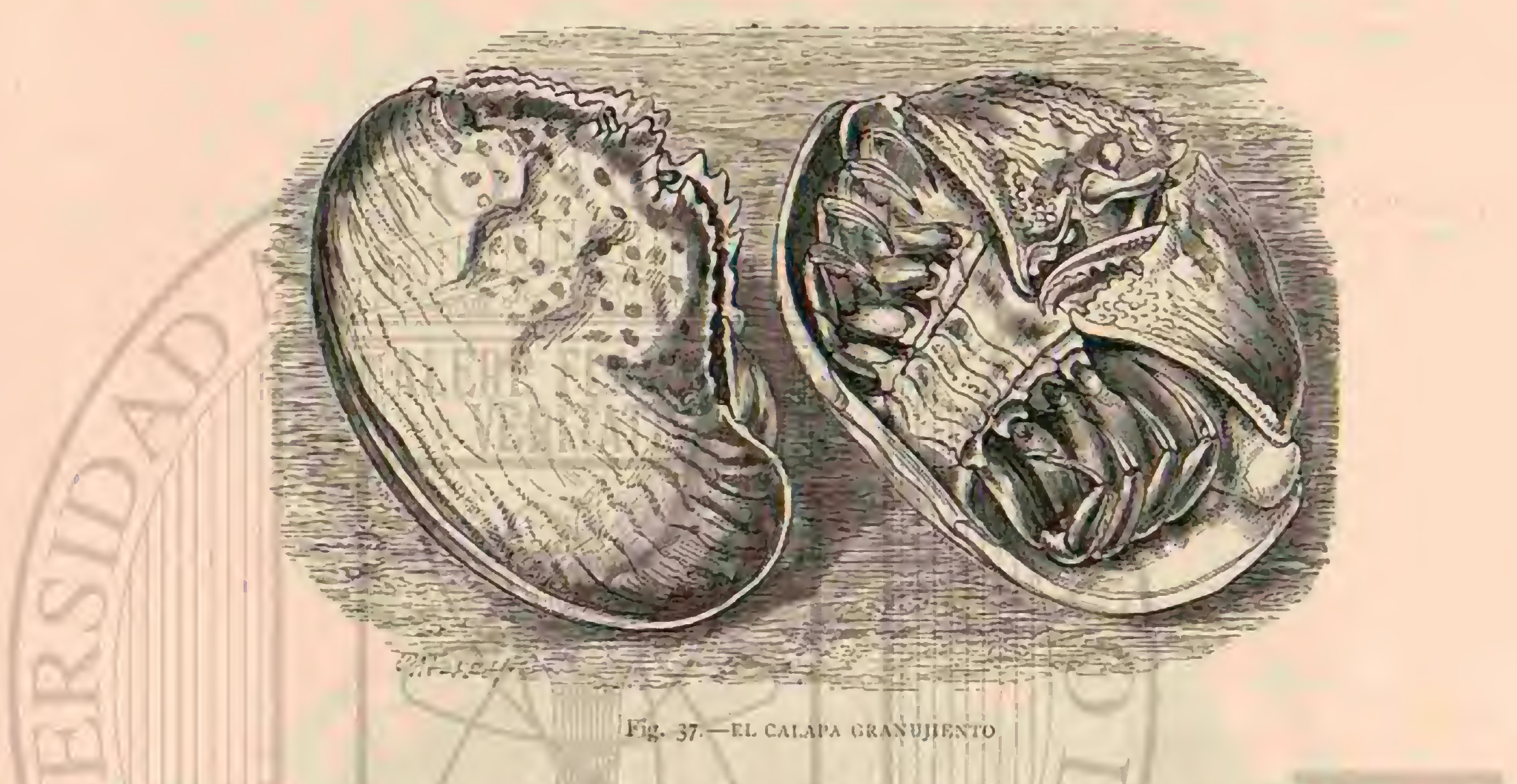

dad bucal: Las interiores están insertas đatirajo de la caperuza, en sus cavidades trasversales; los ojos estin sostenidos en pedúnculos cortos y gruesos, y pueden esconderse en parte

en las fosas orulares: los piés-maxilas exteriores son vellosos, con clsegundo artejo ensancliado, algo salienie y redondeado in su extremidad superior interna, las pinzas son cortas, igua.

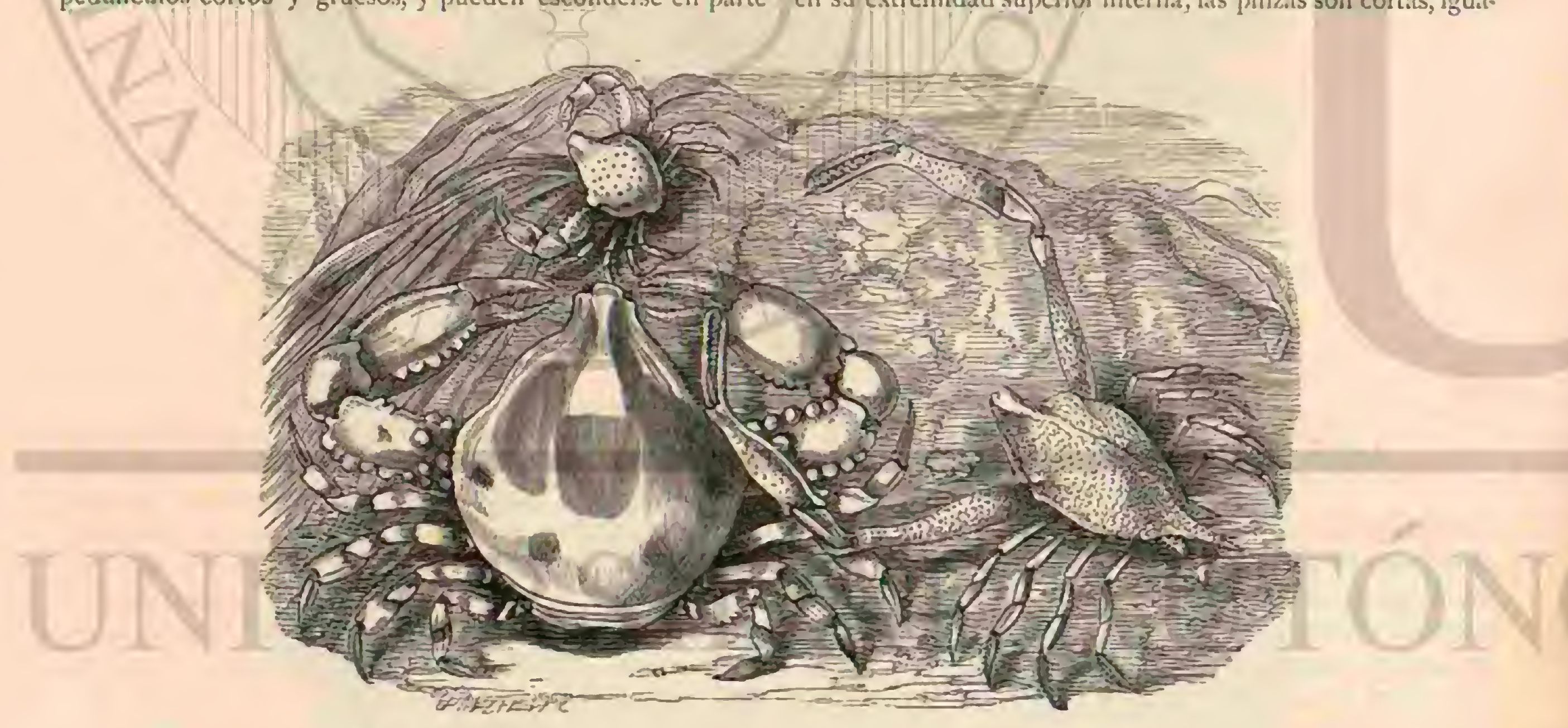

Fig. 3S. - I.A Lr.ticosia MOTEADA

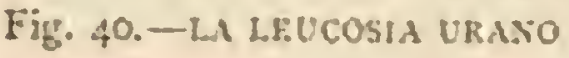

Fig. 39. - LA MIRA FÚGA

les y de tamaño mediano en las hembras; las patas son semejantes y van disminuvendo de longitud a contar desde las. primeras: terminan en un garfio doblado hicia dentro y velludo. El abdómen se presenta doblado, terso y compuesto de siete segmentos en las hembras.

Estos crustáceos habitan en la Nueva Irlanda, donde se encuentra la cafira de Roux (fig. 44) que además de tener todos los atributos del género se distingue por su reducido tamaño. 
Como ejemplo podemos citar el galena dorsal (fig. 46) y el galena liso (fig. 47 ).

DISTRIBUCION GEOGRÁFICA.-Estas especies son propias de las Indias orientales.

\section{LOS LUPAS - LUPA}

CARACTERES.-El caparazon es aplanado y mas an- cho que largo: los ojos mas gruesos que su corto pedúnculo; los piés-maxilas tienen el tercer artejo casi cuadrado; las patas del segundo, tercero y cuarto par terminan en una una. - Ias especies mas conocidas de este género son el lupa peldyico (fig. 4S) y el lupa forceps (fig. 49).

DISTRIBUCION GEOGRÁFICA.-El lupa pelágico parece propio de las Indias orientales; cl lupa forceps habita en las Antillas.

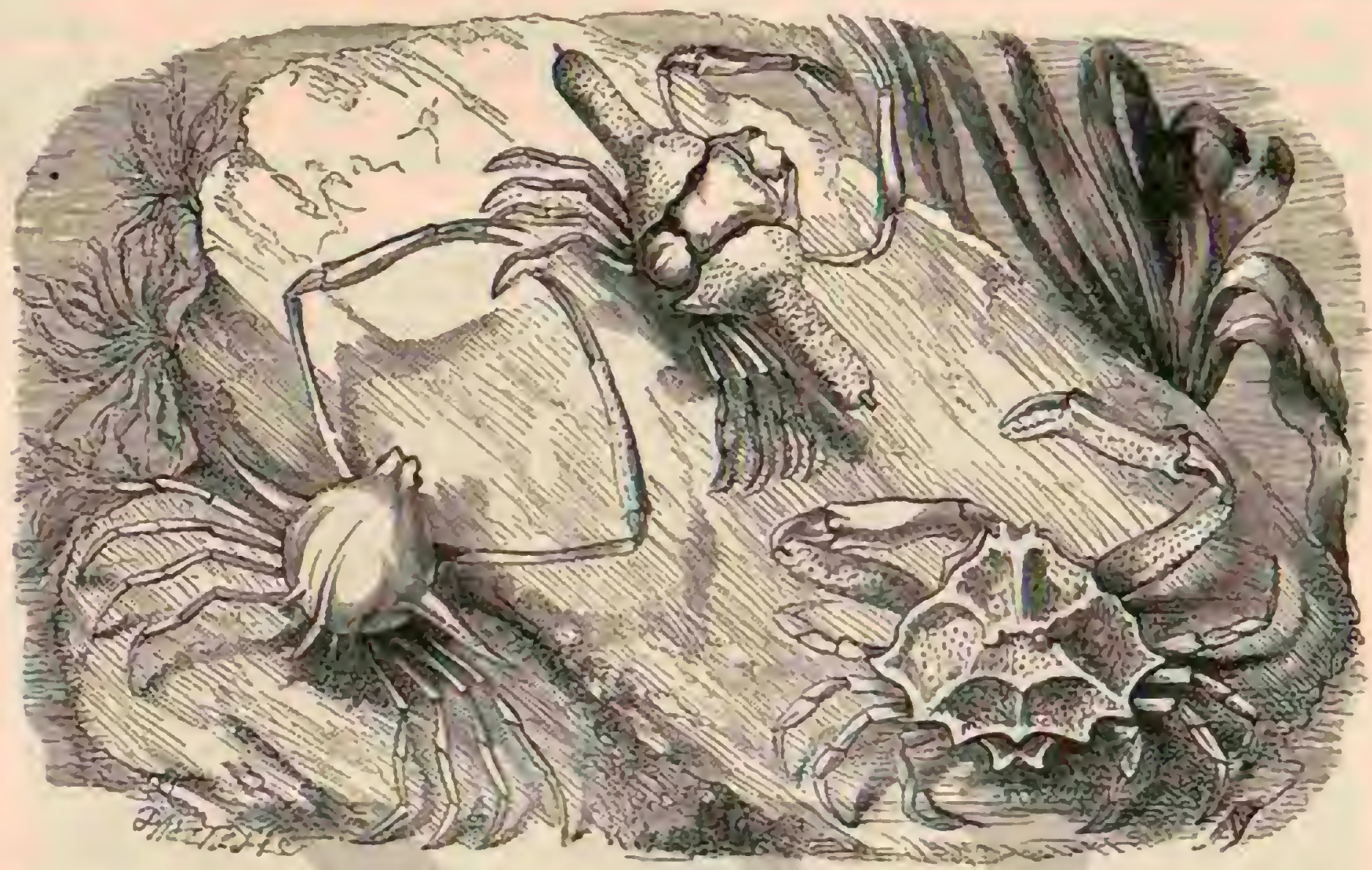

Fig. 41. -HB. HIS DE. SIETH ESPINSS

Fig. 42.-Fis. 8xs crustortco

Fig. 43.-ba Nursta GRanujestTh

\section{LOS POLIBIOS-POLYBIUS}

CARACTÉres. - El caparazon de estos crustáceos es plano, orbicular, con el borde anterior arqueado: los ojos están sostenidos en peduinculos cortos; las antenas exteriores son cortas y sedosas; el abdómen de la hembra es ancho y

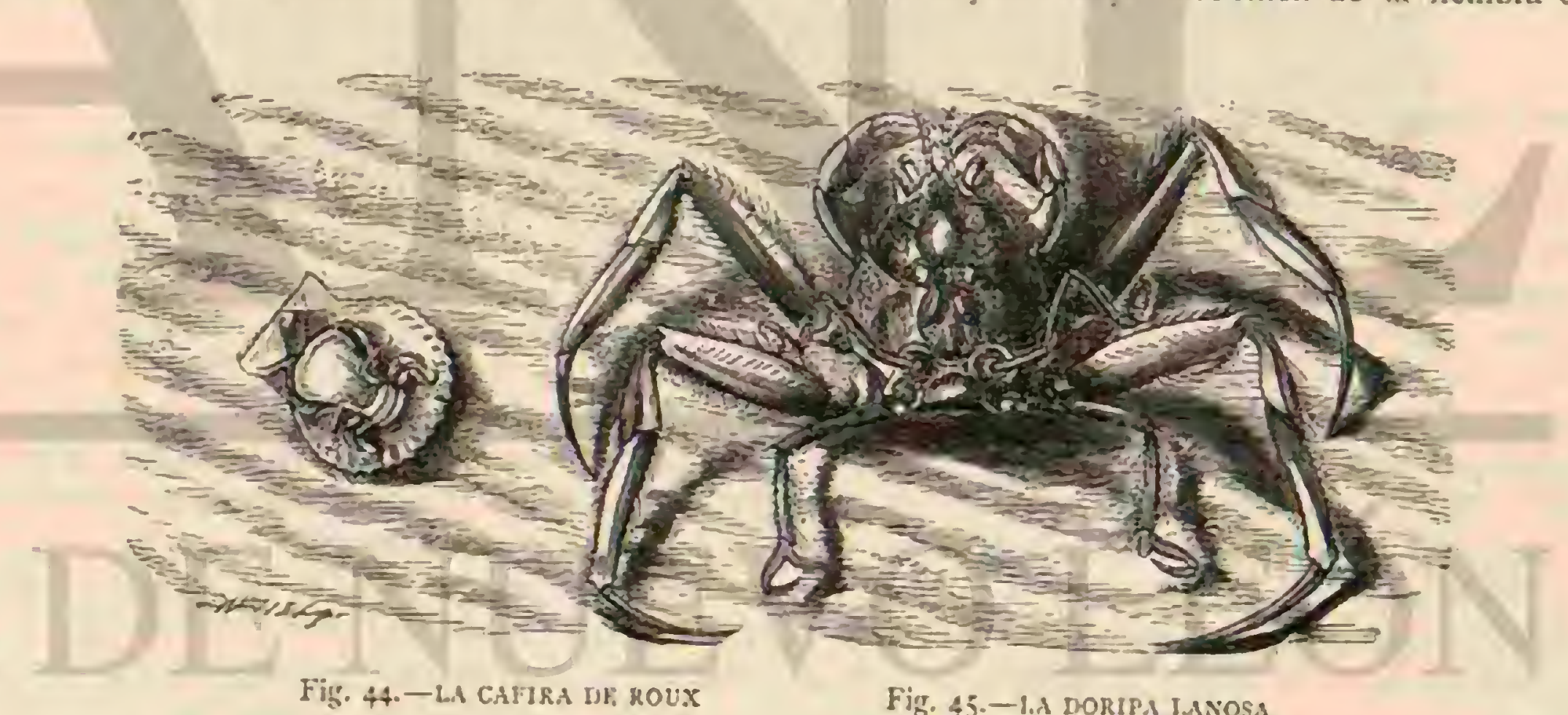

Fig. 44.-LA ChIIRA IS, hOUX

Fig. 45.-PAd DORIPA InNOSA

ovalado, y el del macho un poco mas estrecho y puntiagudo. La única especie que se conoce de este género es cl polibio de Henslow (fig. 50).

DistriBUCiON GEOGRÁFICA.-Fste crustícco se encuentra en el canal de la Mancha.

\section{LOS PODOFTALMOS - PODOPH- TALMUS}

CARACTÉRES. - I as especies de este género se caracterizan sobre todo por la singular manera en que están dispuestos los ojos, la mas propia para mirar en todas direcciones, sin que el animal necesite moverse; los órganos de la vision están situados en pedúnculos extraordinariamente largos. El podoflalmo itgiga es la única especie que representa al género (fig. 51).

DISTRIBUGION GEOGRÁFICA. - Se ha encontrado este crustáceo en las aguas de Inglaterra.

\section{LOS DROMIAS-DROMIA}

Hemos llegado à las especies que ticnen las patas sobre la cara superior del cuerpo, y que se llaman dromias. Fl quinto par de patas, $y$ à veces el cuarto, se insertan á mas altura hácia el dorso, de modo que estos animales forman el tránsito á la próxima subdivision de los decápodos. Una especie, el dro- 
mia sulgar (fig. 53) cstá cuhierto, cxcepto en la punta rojiza de las terazas, de varias espligas y pelos, y generalmente tambien de cieno y de toda clase de animales y plantas, lo cual exige limpiarle cuidadosamente antes de colocarle en una coleccion. 1.o mas particular en las costumbres de esta especie, es veria llevar sobre si una especie de techo para resguardinsse, lo cual explica la utilidad y el empleo de las patas dorsales; esta cubierta está formada casi exclusivamente de esponjas, sobre todo de la especie Sule rites romuncula ó de la Spongelin for. llescens. La esponja se oprime con su superficic exterior intimamente contra el escudo dorsal, y cubre completamente al cangrejo, sin impedir sus movimientos. Igrnoramós si la esporja se coloca por casualidad sobre el dorso del cangrejo, como sucede con el Sulkriles domuncula en las conchas habitadas por los paguros, 6 si el cangrejo mismo coge la esponja y la coloca sobre sí. El segundo caso no es tan extrano como parece, porque la esjonja solo está sujeta por las patas dorsales, y hemos notado con frecuencia que el crustácco puede dejarla caer en la fuga cuando se le acosa brus. camente. Lo cierto es que el crusticeo experimenta la necesidad de llevar tal cubierta, porque en el acuario, cuando se le priva de la esponja, se cuelga algunas algas del dorso, ofreciendo entonces un aspecto sumamente grotesco.

Para completar lo que hasta ahora hemos dicho sobre los cangrejos, reproducimos la siguiente descripcion de sus cos. zumbres, publicada en el conocido periódico inglés Cham.

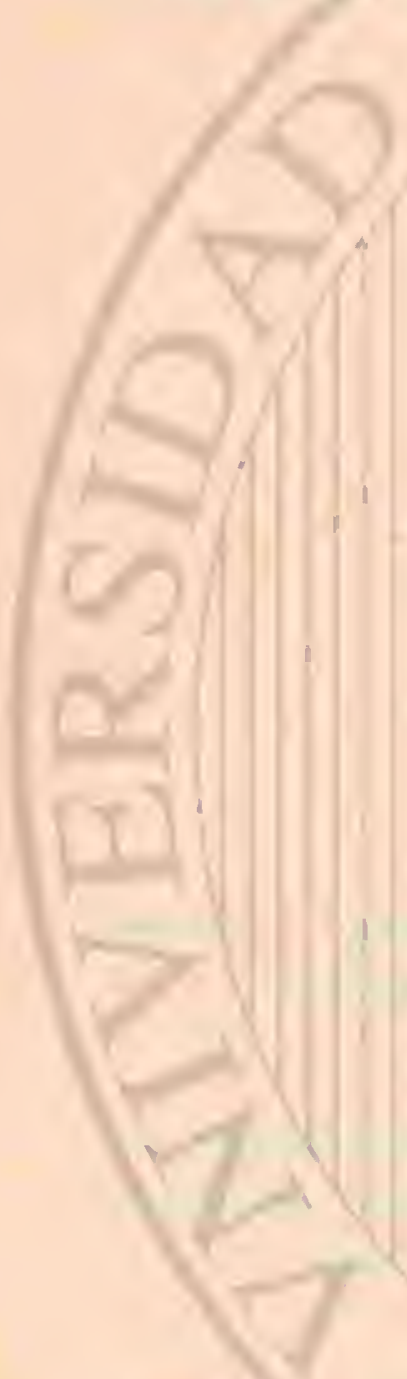

bers fournal y reimprosa en el Auslond: al os naturalistas han obscriado en un punto de la costa inglesa el proceder del ta litro, ņuc igualınente pertencé á la clase de los crustáceos. Ocupados casi por completo en la obserracion de estos extraños y pequeños séres, no habiamos reparado en varias formas, que, cono unas sombras, aparecian en las olas; nuestro amigo nos llamó la atencion por algumas observaciones. \&.Ahora, dijo, pueden ustedes hablar tanto como quieran, pero no se muevan de si sitio, pues el movimiento de un brazo ó de un pié, y' hasta el volver la cabera, nos privaria de un espectáculo interesante. Mientras hablaba, vimos un cringrcjo serde, uno de àuellos animales de la costa que no logran Ilamar la atencion, por mas que se hayan visto infinitas veces. Tenia poco mas de $0^{2}, 003$ de auchura. yen efecto era un sér mu! pequeno que nada interesante ofrecia por su extcrior. Acercibasc lentamente à la arena, que solo en al. gunos sitios se humedecia con las olas, $y$ parecia examinar sigilosamente sus contornos. Un gran molusco venia y se alejaba con las aguas, ! sobre este animal se precipitó el cangrejo; un momento despues vimos como arrancaba pedazo por pedazo la carne del molusco para lleviársela a la boca. Cuando hubo tomado algunos pedinzos, se dirigió lentamen. te hácia la arena seca, como si el alimento no hubiese sido de su agrado. Pasando por los sitios humedos, un talitro se deslizaba hacia algunas matas de yerba marina, sin sospechar la presencia de su enemigo. Las movimientos del cangrejo fueron entonces muy curiosos: observaba al talitro y acercábase lentamente, poniendose al acecho detrás de una espesura de serba marina, con la habilidad de un caza- dor experto. Unas ocho pulgadas de espacio le separaban de su victima y ya solo se trataba de aproximarse mas, pero el talitro mostrábase receloso, acordandose sin duda de percan. ces anteriores. Al poco rato el cangrejo abandonó su cscon. dite, yacurrucàndose se dirigió con cautcla hàcia la presa. Cuando estuvo à diez centinetros de distancia, el talitro dejó de conzer, dirigiéndose hácia el cangrejo. Solo un momento habiamos separado nuestra vista de los combatientes, y, al mirar de nuevo, cl cangrejo habia desaparecido, no siendo posible decir lo q̨ue era de él. La arena estatsa en todos los alrededo. rés llama y descubierta, excepio el espacio ocupado por un poco de yerba marina. Al examinar el sitio mas próximo, vi. mos en la arena, cerca del talitro, un bulto que se levantaba lentamente, como movido por una fuerza subterrínea, y entonces salió el cangrejo de la arena en que se labia escondi. do para no ser visto de su adversario. Despues de haberse tendido, avanzó dos ó tres pasos y de repente se lanzó sobre el talitro como el gato sobre el raton. Las garras, semejantes á manos, se introdujeron jor debajo del cuerjo de la victima yara sujetarla; y una vez despedazada, el cangrejo comenzó a comer. Mientras turimos toda nuestra atencion fija en este cangrejo: no vimos algunas docenas de ellos ocupa. dos del mismo modo y que á poca distancia de nosotros estaban cazando. Uno de estos nos divirtió mucho: era un in. dividuo de gran tamaño, que con cxtremada precaucion salia del mar, mas cuando hubo avanzado un poco, dctírose como indeciso. A los pocos momentos penetró de repente en la arena y ciesapareció de nuestra vista; pero no tardamos en divisar los puntos movibles en la arena, que cran los ojos 
pedunculados del cangrcjo oculto, observando cuanto sucedin i su alrededor.

* Solo despues de haber permanecido algunos ninutos sin movernos, el cangrejo salió de la arena y continuó su caceria. Hubiérase podido creer que habin estado meditando sobre el camiro que debin seguir para llegar al logro de su intento. Al ver varios talitros, precipitóse rápidamente en medio de ellos, $y$ los animalitos se dispersaron en todas direcciones. Al principio no pudo coger uno de ellos, y entonces penetró en la arena, permaneciendo inmóril al acecho. Al poco rato los talitros volvieron à reunirse, pues no vieron ya ninguna cosa que les inquietase cr el mismo lugar donde se les habia sorprendido; saltaban alegres por encima del cangrejo, y' este se lesantaba poco á poco en la arena para prepararse al aıaquc. Sin embargo, como los talitros, al dar sus fantásticos saltos no tienen ninguna seguridad de caer de pié $\delta$ de lado ó boca arriba, á menudo han de esforzarse bastante para recobrar el equilibrio; : el cangrejo espera tal ocasion para apoderarse de su victima. Algunas veces se acercan dos cangrejos del mismo tamaño uno a otro, extendiendo sus garras, como un atleta sus puños, y entonces luchan un rato; mas por lo regular el uno se retira, cual si estuviera contento de haber demostrado ya su fuerza. Cuando un cangrejo se ve amenazado por un palo, despiértase en él todo el valor que le excita a la lucha. A poyàndose en las patas postcriores, riende las tenazas hácia el enenigo con tal fuerza ylue se oye

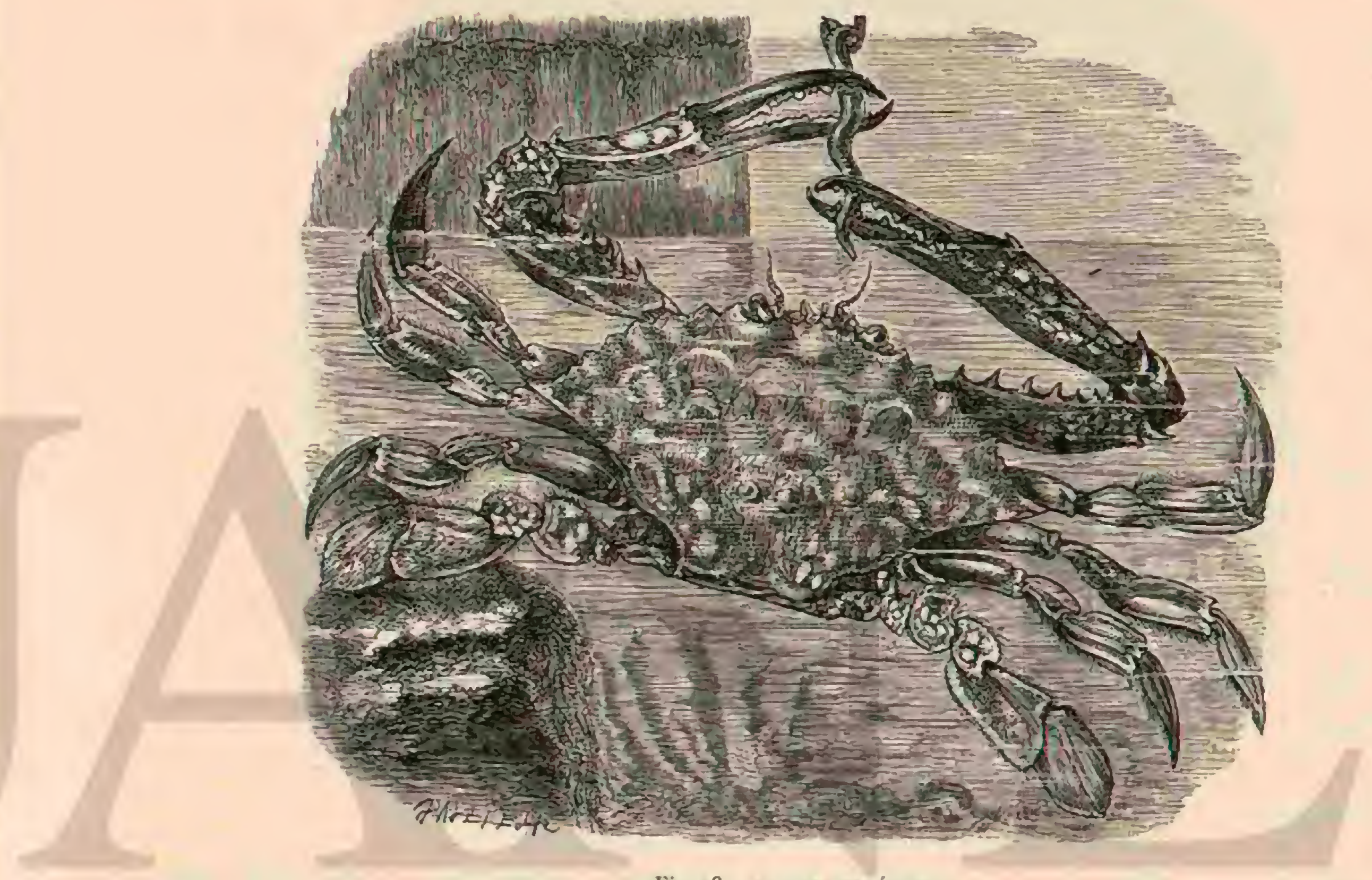

Fig. 4S. - EL LLPA TELĹGICO

distintamente el ruido que producen, $y$ cuando se agarra al palo se le puede levantar en el aire.\$ Puedo contirmar por mi propia experiencia la exactitud de la mayor parte de los detalles de esta descripcion; recomendando d cuantos visiten la costa arenosa, la observacion del género de vida de estos animales, lo cual les servirá de recreo. En las costas pedregosas del Mediterránco podemos distraernos del mísmo modo con el grapsus íarius, cangrcjo cuadrangular muy astuto, abigarsado, de regular tamaño, que caza en la orilla y sabe introducirse en los agujeros y grietas de las rocas con la agilidad de un raton.

\section{LOS ANOMUROS-ANOMURA}

CARACTERES. - Entre los cangrejos y los macruros se ha introducido un grupo de tránsito, al de los anomuros, nombre muy dificil de traducir. Poeppig ha propuesto que se les llame crustácens medios. Su posicion intermediaria se determina principalmente por las proporciones del postabdómen, que es mas grande que en los cangrejos, aunque no llega a la circunferencia que liene tel de los macruros; cuando sucede asi los tegumentos son biandos. Ya hemos visto que los dromias difieren por las patas dorsales de los verdaderos cangrejos, á los que siguen algunos otros géneros de los mares curopeos, como por ejemplo el siguiente.

\section{LOS HOMOLOS - HOMOLA}

Un gigante de este género, el homolo de Cuvier, es una especie rara del Mediterrínco. lo compré hace anios en el mercado de Niza un individuo yue con las patas iendidas medía unos tres piès.

Tambien son de notar el homolo barbado (fig. 52 ), cuyo distintivo consiste en formar el caparazon una especic de pico, estando casi siempre cubierto de agudas espinas, y el homolo nudoso (homola ribarius), cuyn contormacion es de las mas singulares (fig. 54). Su principal carícter consiste en estar todo él tan cubierto de tubérculos, gue mas bien parece una piedra cubierta de productos marinos, que un crustaiceo. Hahita en Colombia.

Además de cstr especie y de los litodidos (Jithodes) (fig. 55) que tienen tambien representantes en nuestros mares, cl lec. tor encuentra en las colecciones algo completas el rangrejo rana (fig. 5i), de forma muy particular, y otros géneros de este grupo propios de los mares tropicales. 


\section{LAS ALBUNEAS-ALBUNEA}

CARACTERES. - Los crustáceos de este gênero tienen el caparazon de forma ovalada, algo convexo, un poco estrecho por detrás y truncado en su parte anterior; los ojos están sostenidos en pedúnculos que afectan la forma de escamas; las antenas intermedias son mucho mas largas que las laterales y se insertan debajo de los ojos, lns pies anteriores terminan en una pinza triangular y están provistos de un dedo movible muy corto; los del segundo par rematan en una lamina en forma de segurr; el abdómen es corto, y su artejo terminal ovoideo. Como tipo de este género citaremos la albunea asiatica ( fig. $5^{6}$ ), que vive en las aguas de Asia.

\section{LOS REMIPES - REMIPES}

CA RA CTERES. - Las antenas laterales $e ́$ intermedias de estos crustáceos son cortas, casi de igual longitud, salientes y algo encormadias; las patas-maxilas exteriores terminan en un garfio, y los piés del primer par en láminas puntiagudas. Ja especie mas curiosa de este género es el remipes oval (fig. 59) que se distingue por sus antenas cortas, y por la

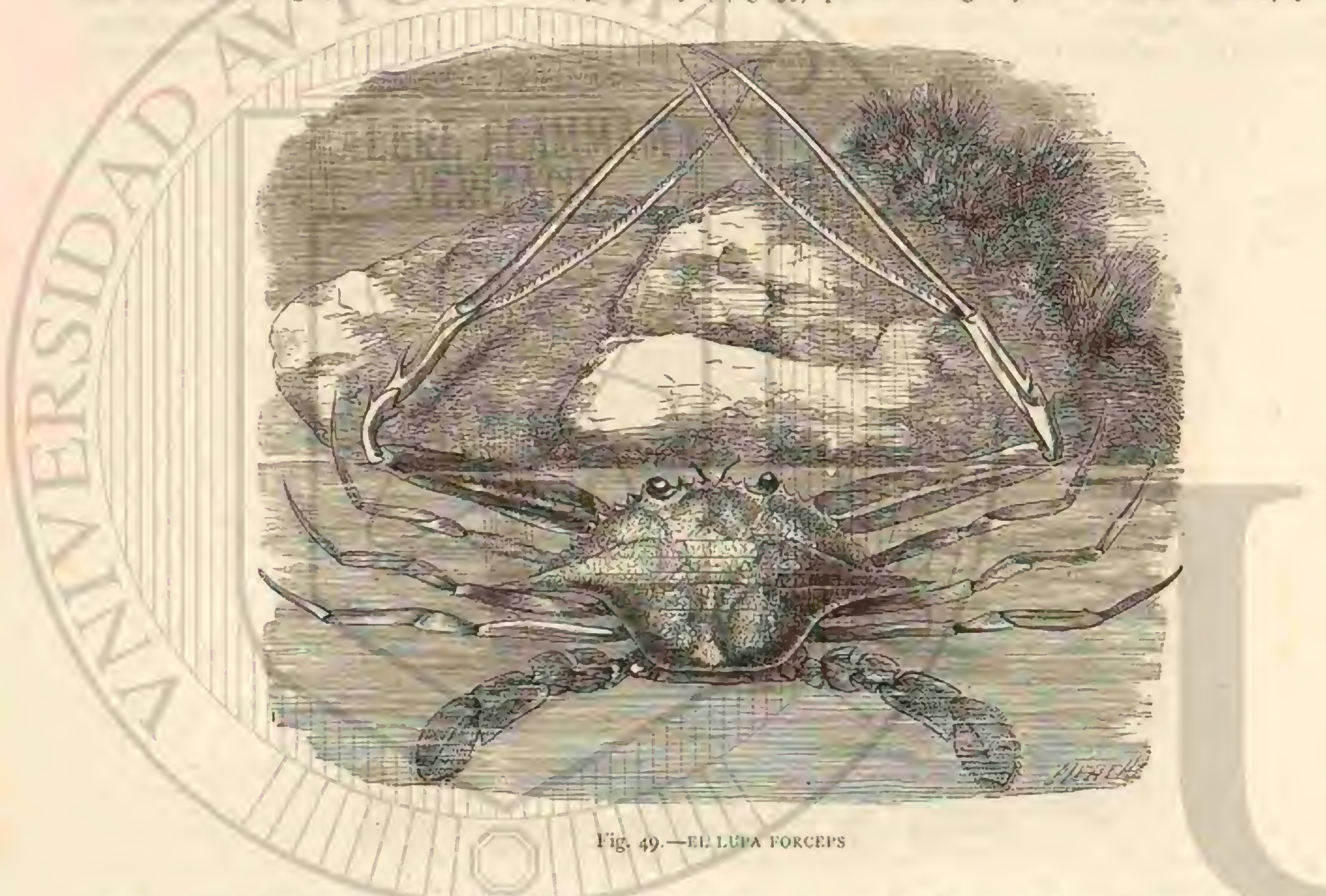

curiosa modificacion que sufren ios piés, ofreciendo la forma de remos, ๖ sirviendo mucho á cste crustáceo para nadar; el cayarazon es convexo y constituye un óvalo bastante regular, a cuyo carácter debe principalmente este crustáceo el nombre especifico con que se le designa. Su tamaño es siempre reducido.

Esta especie es propia de la Nueva Holanda.

\section{LOS PAGURINOS-PAGURINA}

CARACTERES. - Tanto por sU estructum como por su género de vida, la familia de los cangrejos ermitaños (pagrzrina) merece nuestra atencion. Su cefalotórax es prolongado y los pedúnculos de los ojos, largos y salientes, lo cualle sirve de mucho para observar desde su vivienda cuanto pasaa su alrededor. 'Tambien las patas de las tenazas son largas, fuertes y de un desarrollo regular y simétrico, caraicter que se observa en muchos cangrejos, pero que en las especies que nos ocupan se nota en muchas partes del citerpo, hallinduse en relacion con el género de vida. Los dos últimos pares de patas tienen forma de muñones y garras cortas, con las que se cogen a su concha de caracol, asi como con los muñones de las extremidades del post-abdómen. Iass patas de los ermitaños y de los otros anomuros, aunqque se desig. nen con el nombre de muñones, no deben considerarse sin embargo como atrofiadas; son propias para el género de vida del animal, y sirven, segun nos demuestra el dromia, para llevar objetos y agarrarse. El post-abdómen de los paguros se prolonga en forma de saco; solo tienen por encima algunas placns duras, y una piel tan blanda, que los animales necesitan otro abrigo. Istos crustaceos, conocidos en las costas de todos los mares, tienen la costumbre de albergarse en las conchas de los caracoles, pero no matan al molusco, segun se habia dicho: limitanse á usurpar su vivienda abandonada. El cangrejo busca una del tamaho necesario para que no solo pueda colocar bien en ella su post-abdúmen, sino tambien tener sitio para retirarse del todo en el interior. Agarraindose con sus munones a las espirales de la concha, it la que algunas especies pueden igualmente adherirse, sujétase de tal manera, que casi nunca se logra sacar un individuo vivo y entero: antes se deja despedazar, porque ya se rompen las tenazas que son la parte del cuerpo que mas fácilmente se puede recoger $\delta$ el cefalotórax se separa del postabdómen. Cuando una concha es demasiado estrecha, el animal se ve obligado a salir en busca de otra. Ins especies que se encuentran en nuestras costas, y sobre todo en $\mathrm{cl}$ Mediterrineo, se ven á menudo en una situacion muy peli. grosa, porque una esponja (Suberites donumula), se agarra 
precisamente á estas conchas de camcol habitadas por los ermitaños. Cuanto mas el cangrejo viaja en su vehículo, tanto mas prospera la esponja, que pronto cubre la concha con una sustancia ispera, de color amarillo rojizo; esto llega pror fin á ser muy peligroso para el habitante, y si este no se escapa con tiempo, la esponja tapa de tal modo la salida de la vivienda, que el crmitnño ya no puede salir. Se les en. cuentra muy á menudo en tan triste situacion, จุuedándoles aplenas un agujerito, por el que, con sus ojos pedunculados pueden distinguir algo de lo que pasa en el exterior y buscar con las puntas de su tenaza un escaso alimento, hasta que por fin mueren de hambre.
Numcrosas especies son, asi como muchos cangrejos, animales terrestres, y tambien buscan en su mayor parte con. chas de caracoles pertenecientes al género bulimus, las cua. les llevan consigo en sus penosos viajes, á veces muy largos. Todas estas especies son propias de los climas cálidos; las que se hallan en nuestros mares pertenecen al género pagurus.

\section{EL PAGURO DE PRIDEAUX-PAGURUS PRIDEAUXII}

CARACTERES. - La mayor parte de los paguros propiamente dichos viven en la playa, y en ciertos puntos la

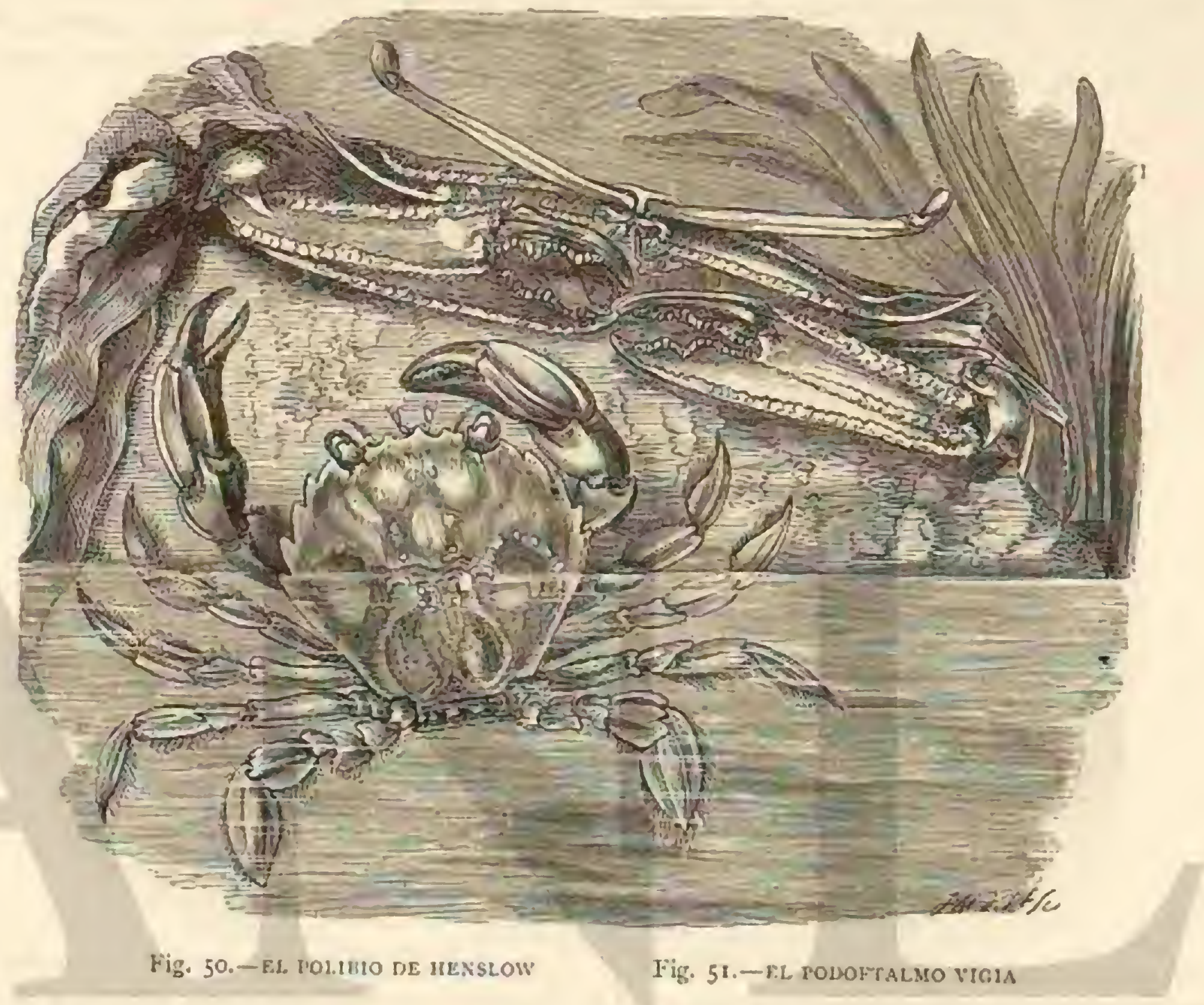

invaden de tal modo, que forman un verdaciero caos. Nues tra especie, en cambio, vive á mayor profundidad; es un erinitano sobre cuya cubierta se halla casi siempre un prólipo perteneciente a la familia de los bonitos soras marinos, la actiuia de manto (acivin palliata). He recibido algunos individuos con sus eternos huéspedes, cogidos con la red arrastradera en las profundidades del ancho camal de Zara: abunda mucho cerca de Nảpoles. En esto tenenios un nuevo ejemplo de la extrana manera de unir su existencia unos séres orgainicos del todo diferentes. El conocido naturalista ingles (josse que ha adquirido grandes méritos, en particular por la introduccion de los acuarios, y que ha hecho una serie de preciosas observaciones sobre los animales que en ellos icnia, refiere lo siguiente sobre la existencin de aque. llos: «El comprifero de la anemona, que lleva el nom. bre de M. Prideaux, de Plymouth, su descubridor, vive exclusivamente en la profundidad del agua. Se le ha encontra. do en varios puntos de nuestra costa, pero invariablemente con la misma compañia. Yo creo que el cangrejo vive siempre solo con la animona y esta solu con él. Cierto que lior. bes cita ejemplos de haberse extraido la una sin el otro con la red, pero yo diria que esto solo sucedió cuando el ruido de la arrastradera esjantó al cangrejo ohligandole d huir $y^{*}$ abandonar is su amiga. Ia anémona pertenece á la familia de los sagartios, de color magnifico y de una forma extraña; es por lo regular de un pardo rojizo en su parte inferior, mientras que hácia la superior el color se cambia en un blanco de nieve; todo el cucrpo está salpicado de manchas purpúreas, sonrosadas y rodeado de una orla de color escarláta pálido. Las antenas y el disco son de un blanco puro; este ultimo ofrece la particularicind de no ser de forma circular coma en las otras amémonas, sino longitudinal, prolongándose su base en dos lóbulos laterales. El animal clige siempre para fijarse el borde interior de una concha de caracol; los dos lóbulos del pié rodean poco a poco la abertura de aquella orla, se tocan en el borde exteriory' se unen, formanclo de este modo un anillo.

\$ A menudo nie he preguntado con gran interís cómo se estableceria el eguilibrio por la proporcion del tamano entre la actinia de manto y la concha, en el sucesivo desarrollo de la primera, pues sin ducla existe tal proporcion entre ambos, porque las anémonas de manto pequeño se encuentran en reducidas conchas y las adultas en grandes. El ermitaño puede trasladarse de una vivienda pequeña a otra mayor cuando no tiene suficiente espacio; y como sabemos (pue su conpaỉero, el ermitaño Bernardo (fagurus Bermhardus), (fig. j\$) 
lo hace por lo regular, suponemos naturalmente lo inismo del ermitano de Pridenux. Pero suponiendo esto equé se hace de la actinia de manto? Cuando los cangrejos camlian de domicilio $y$ abandonan a las ancmonas, las rclaciones entre ambos cesan, y por lo tanto seria preciso encontrar los unos sin las otras: sin embargo, mo succde asi.

"Por otra parte, si tambien la anćmona puede mudar de habitacion, ¿de qué modo busca una nueva concha? Si abandona su antigua vivienda al mismo tiempo con el cangrejo, continuando luego su existencia en las mismas condiciones, ¿cómo se explica que jos actos de esos dos séres obedezcan a una misma voluntad? ¿cómo se comunican entre sf sus pensamientos? Lin anémona no se agarra al cangrcjo, sino ála coucha, y siendo ambos independientes en sus morimientos, ¿cuál de los dos toma la iniciativa? ecuál buscia la nueva vivienda y cuándó sigue el uno al otro? Todas estas pregun tas me hice yo con gran interés hasta que hallé alguna solu. cion.

5. 16 de enero de 1859 cogi con lazos un individuo me dio adulto de la especie Adamsia palliata; estaba en una concha algo pequena (Notica monilifera) habitada por un paguro de Prideaux que parecia sobrado grande para estar alli. Puse los dos en un gran acuario bien arreglado, con las mejores condiciones, y tuve por primera vez la suerte de co. lonizar el cangrejo y la actinia en el acuario. Ambos gozaban de excelente salud y parecian cstar muy á su gusto; pero al cabo de tres meses noté que el aspecto de la adamsia no era ya tan satisfactorio. Tambien el cangrejo dió á conocer mas tarde que su concha era ya demasiado estrecha, pues sacaba mucho la parte anterior de su cuerpo; pero no me atrevi à ofrecer al ermitano otra concha de caracol, porque temia que apoderándose de ella abandonara á su amiga y esta muriera.

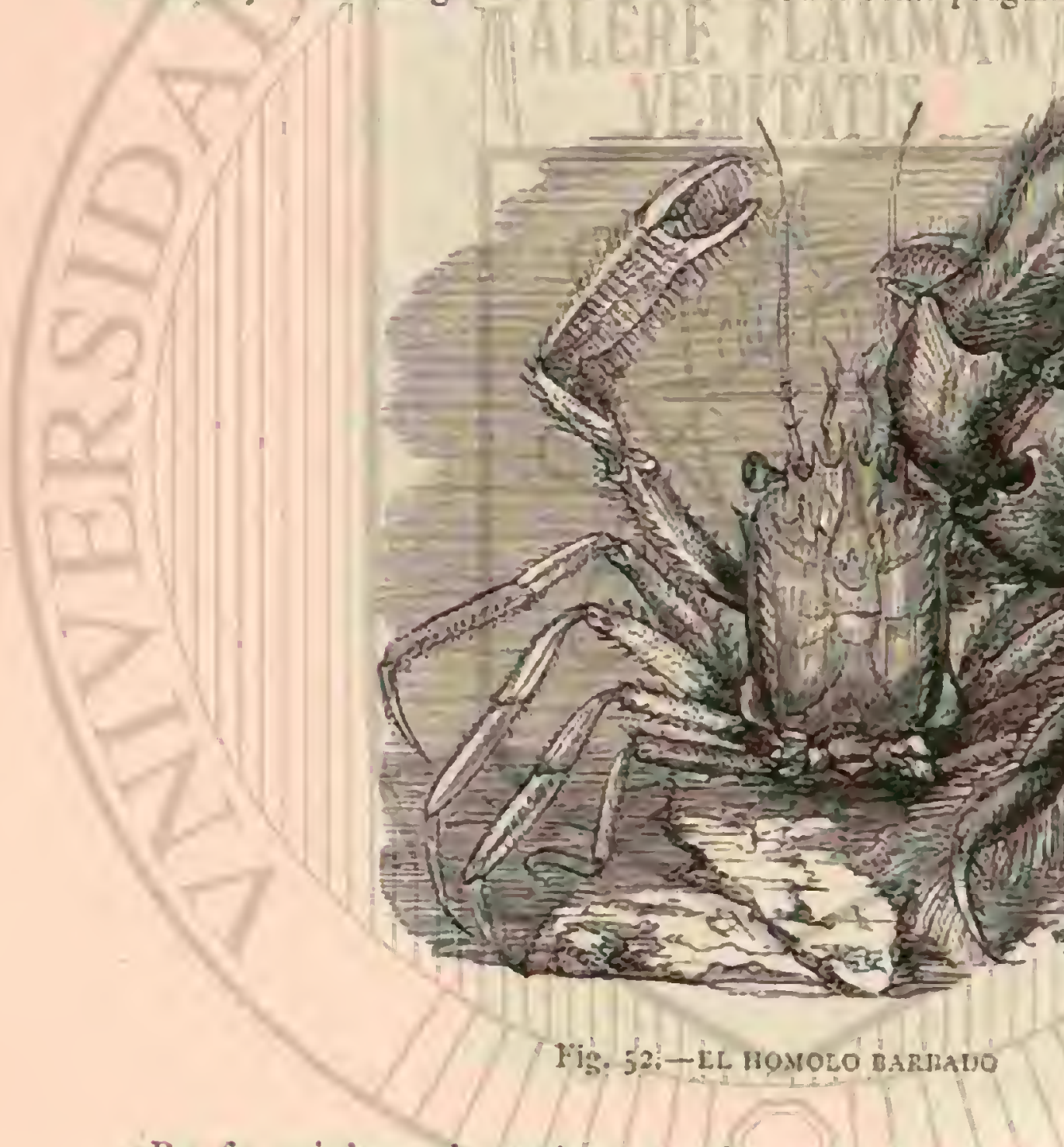

- Por fin, mi deseo de resolver un enigma científico se antepuso a mi sentimiento; la cosa valia mas que un animal, $y$ for lo tanto saqué de mi coleccion la concha de una natica adulta y echéla en el acuario cerca de los dos animales. El ermitano, hallando pronto la concha, conenzó inmediatamente à examinarla; pero no se condujo como su hermano Bernardo, el pagurus Bernharaius, porque este, sin grandes cumplimientos, hubiera entrado en la nueva casa: mientras que mi prisionero volvis la atiertura de la concha hacia arri. ba, recogió tanto el labio exterior romo el interior, valiéndose ce una garm arrastró el objeto por el fondo del aciiario. Algunas veces la soltaba y despues de examinar el interior continuaba su marcha. Una ocupacion me obligo à alejarme; y cuando al cabo de una hora volvi, encontré al erinitano instalado cómodamente en su nueva casa; la vicja estaba abandonada á cierta distancia. Rápidamente la revolvi para ver qué se habia hecho de la actinia, pero no la encontré; en el mismo instante el ermitaño se acercó casualmente á la pa. red del acuario, y entonces vi con satisfaccion que la antigua rmistad no se habia interrumpido. La adamsia se ngarraba con un lóbulo al pié de la nuevn concha, $y$ sin dudn tambien con el otro: pero no pude convencerme de ello por no permitirlo la posicion de la concha. Al examinar entonces los animales con el microscopio, observé que la actinia, valién. dose de una pequeña superficie de la parte media de su dis- co, estaba adherida en el lacio inferior dèl cefalotórax del cangrejo, en medio de la base de sus patas.

- El hecho de agarrarse la actinia al cangrejo es excepcio. nal, ý por. eso me ircino á considerarle como medio de que se sirve aquella para trasladarse de la conclia vieja á la nue. va y tomar una posicion cómoda. De aqui résultó necesariamente que tan luego como el cangrejo vió que era conveniente la nueva concha, tanbien la actinia turo conociniento de esta circunstancia: en las dos horas siguientes ocupóse en separarse de la concha vieja, para trasladarse despues, cogida al pecho de su protector, a la nuesa casa, donde empezó a fijarse otra vez del mismo modo que lo estaba antes.

"Once dias despues de esta observacion hice otra prucba interesante para el estudio de tan extraina anistad. La acti. nia no presentaba tan buen aspecto desde que habia cambiacto de habilacion: unas veces ocupaba en fa concha mayor extension y otras menos; pero con mas frecuencia veiala pendiente de lá concha. El cangrejo, en cambio, parecia estar nuuy a su gustó, y no mostró ninguna inclinacion ia volver á 5u casa antigua. Eal a de mayo encontré la actinia separada de la concha y en cl fondo del atcuario, debajo del cangrejo, el cual huia cuando se le molestaba, abandonando à su com. panera. Entonces crei que mi prisionero estaba perdido; pero fué grande mi asombro cuando al enbo de pocas horas vi à In actinia otra vez. bien adherida á su antiguo sitio en la con. 
cha, ofreciendo entonces mejor aspecto que algunos dias an. tes. Pero, cosa extraña, habia tomado una posicion muy diferente de la que solia tener en la otra concha; en esto crei ver una prueba de inteligencia, lo que me propuse desde lisego averiguar.

\Levantando la concha cuidadosamente con una tenaza hasta la superficie, separé la actinia dejándola caer al fondo, y despues puse la concha con su inquilino cerca del animal. Apenas el cangrejo tocó la actinia, cogióla primero con una tenaza y despues con las dos, lo cual me bastó para adivinar al punto lo que trataba de hacer. Con mucha destréza comen. zó á elevar la anemona sobre la concha; habíala encontrado con el disco de los piés hácia arriba, y' su primera diligencia fuć volverla del todo; despues, cogiendo la actinia alternativamente con las dos tenazas, y pellizcindola, al parecer asaz sordamente en la carne, elevóla de modo que pudo oprinir su pié contra la parte de la concha que solia ocupar, es decir contra el labio inferior; de este modo la sujetó unos diez. minutos sin moverse, y luego desvió cuidadosamente sus tenazas una despues de otra. $\mathrm{Al}$ ponerse en movimiento tuve el gusto de ver como la actinia estaba agarrada mucho me. jor y en sitio conveniente. Dos dias despues, la actinia volvió a caer; encontréla en una hendidura y la puse en el fondo: $y$ apenas la vió el cangrejo, repitió la maniobra descrita para volver à ponerla en su sitio. Sin embargo, observé que la actinia estaba cnferma, pues apenas podia sostenerse en su

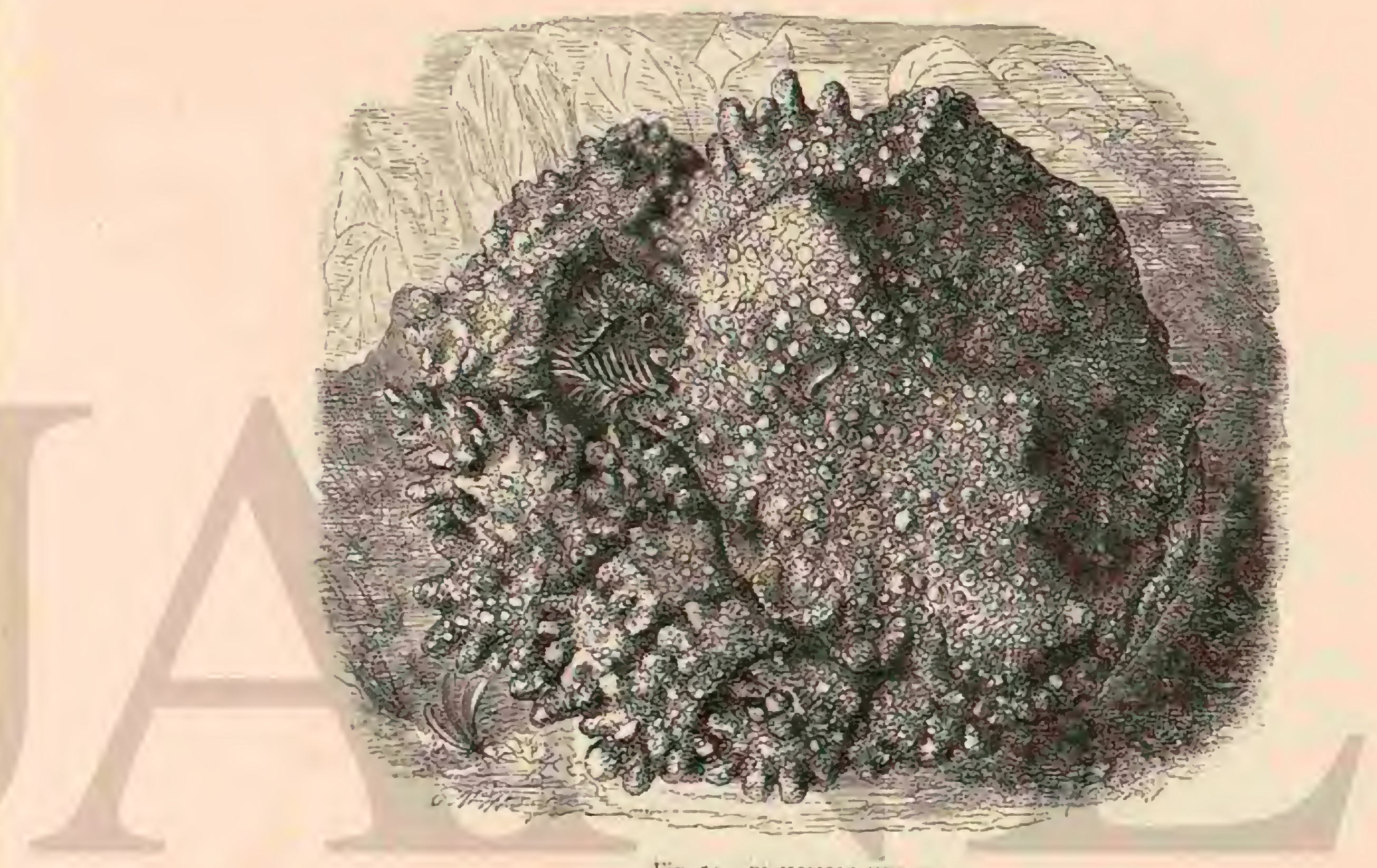

Fig. 54. - FL HOMOLO NUUNoso

sitio. L2 actividad instintiva de estos dos séres se revela claramente, sobre todo en el cangrejo, que parece apreciar la compania de su hermosa huéspeda, amnnue tan diferente de él por su naturaleza. Nuestras últimas observaciones nos abligan á suponer que las temazas del cangrejo sirven sicmpre para trasladar a la actinia de manto de una concha a otra.

Puedo confirmar y completar estas interesantes observaciones por las que yo mismo hice en el acuario de Nápoles. Al ver los cangrejos en su suclo natural, es decir en la arena fria, al punto se comprende porqué la actinia coge la concha de modo que su boca esté dirigida hacin abajo. El paguro de Prideaux remueve con sus maxitas auxiliares la arena de tal modo que sicmpre pasa, una corriente por la abertura de su boca, lo cual le proporciona la ocasion de co. ger algun insecto. Tambien la actinia aprovecha la oportuni dad, pues abre la boca $y$ despliega los tentaculos con tanto mas afan, cuninto mas su anfitrion remueve la arena. Los pa guros no proceden sin embargo asi cuando tienen á su dispo sicion algun alimento sólido, tal como peces muertos ú otra cosa anäloga. No he observado lo que prefiere la actinia, pero si he visto que se tienen mucha envidia entre si. Muy á menudo un in lividuo pequeño perseguido por uno grande, que quiere quitarle su bocado, si le alcanza, cógele con la tenaza, pero si el pequeño conserva libre una parte de su arma sabe manejarla de tal modo que el agresor sc ve obliga. do i retirarse sin liaber logracio su objeto. No he podido explicarme que ventaja reporta la actinia al ermitaño de Pri. deaux, que si la dejase quectaria del todo abandonada; pero claro es que el cangrejo se acostumbra a la actinia y la cuida del modo indicado por Gosse solo porque le reporta algun provecho.

Debemos hacer mencion de dos géneros agrupados por los sistemáticos, bien con los paguros ó ya con la division siguiente: son estos las forcelanas y galadicas. Unas y otras ticnen grandes jinzas y el último par de jatas muy poco desarrollado, recordando á los anuros y cangrejos por tener el postabdómen muy oprimido contra la parte inferior del ce. falotórax. La porcelana tiene esta parte oral, corta y plana, y sus tenazas son mucho mas largas que el cucrpo. En nuestras costas, y sobre todo en el Mediterráneo, habita una pequeña especie con pinzas ó garras anchas (porcelliaria platychicdes) (fig. 60), pequeño crustáceo sicinpre cubierto de cieno à causa de los pelos que le cubren. Fl cefalotórax de las galateas es prolongado y oval, y en la mayor parte de las especies tic- 
ne surcos tmsversales, como por ejemplo en las llamadas galathea squamifera (fig. 6x) y otrigosa.

\section{LOS MACRUROS-MACRURA}

CARACIERES, - Con las galateas hemos llegado á la tercera gran division de los decápodos, a los macruros ó cangrejos de cola larga: tienen el postabdómen muy desarrollado, tan largo ó mas que el cefalotórax, y provisto en sus siete segmentos de un par de extremidades; las de los dos posteriores forman con la última parte del cuerpo una larga aleta caudal. En todo to demás podemos referimos al cangrcjo fluvial, antes descrito.

\section{LOS ACORAZADOS-LORI- CATA}

CARACTERES, - I a familia de los acorazados se distingue por tener los tegumentos del cuerpo muy duros y el post. abdómen sumamente grande. Los cinco pares de patas no rematan en tenazas, y solo una articulacion afecta la forma de garra.

\section{LAS LANGOSTAS-PALINURUS}

CARACTÉRES.-El género mas importante es el de la

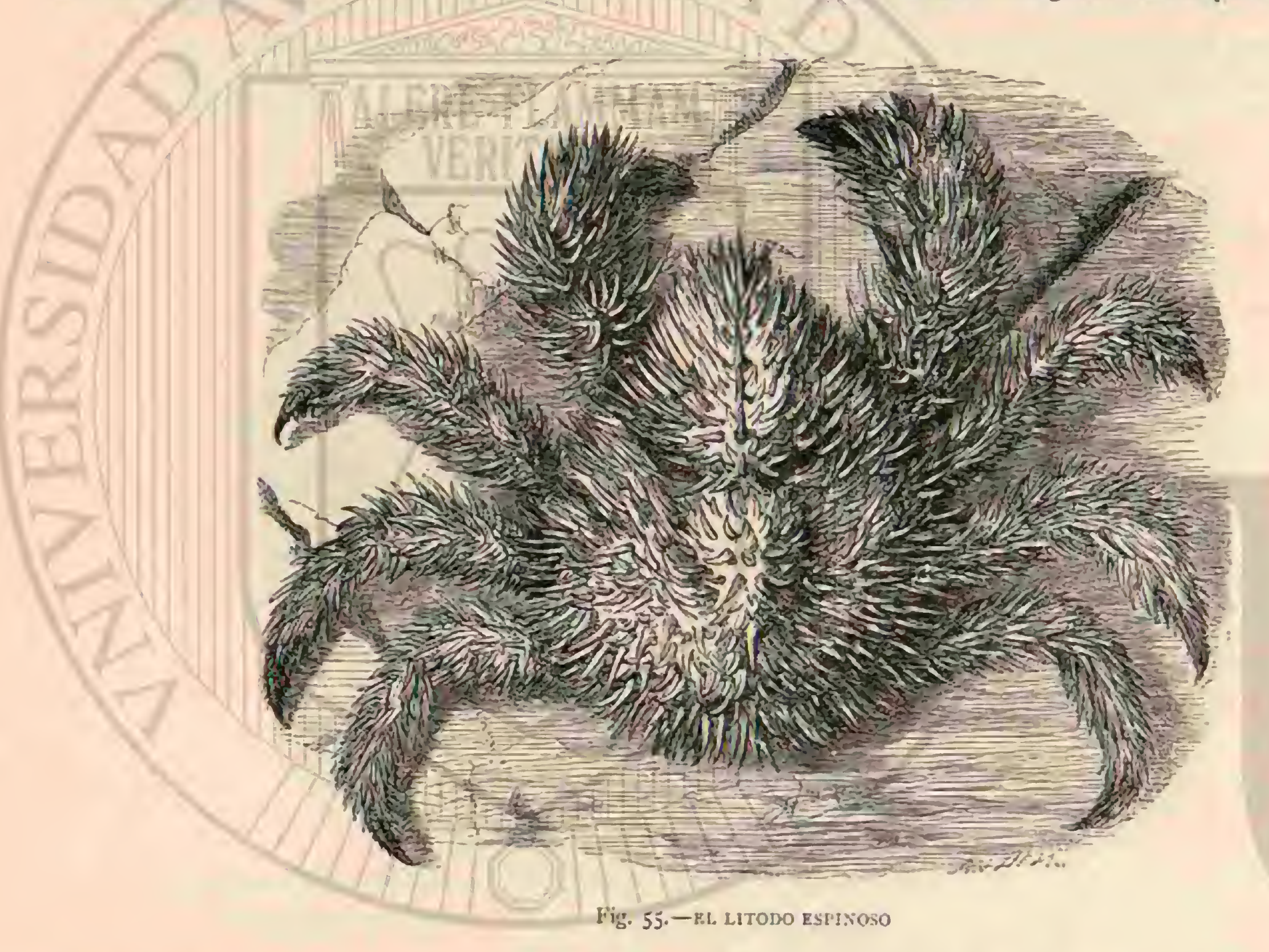

langosta, distinguido por las antenas exteriores mas largas que el cuerpo, con las articulaciones del tallo grueso y espinoso y provistas de un largo látigo.

\section{LA LANGOSTA COMUN-PALINURUS VULGARIS}

CARACTÉRES. - La langosta conun (ing. 62) se cncuentra con mas frecuencia en el Mediterránco, jero tampoco falta en la costa occidental de Irlanda y de Inglaterra, constituyendo buen articulo de trifico del mercado de Lóndres. Tiene el borde anterior del cefalotórax provisto de dos fuertes espinas y presenta otras en toda la superficie del cuerpo, micniras que el postabdómen es liso. Su longitud puede liegar à $\|^{\infty}, 40$ y es de color violeta rojizo vivo, que pronto se convierte en azul intenso cuando se pone el cangrejo recien cogido à los rayos del sol; mientras que el color natural se conserva bastante al secar el esqueleto cpidérmico di la sombr.

USOS, COSTUMBRES Y HEGIMEN. - Esta especie que en algunos individuos colosales llega á tener un peso de doce a quince libras, abunda mucho mas en el Mediterráneo que el cabrajo (homarus rm/garis), al que sustituje en la mesa. La langosta prelicre el fondo pedregoso, áspero y cubierto de plantas marinas a muy difcrente profundidad. En Dalmacia hállase principalmente en los alrededores de Lessima y de Lissa, micntras que en direccion á la Istria disminuye mas y mas: yo lat he observado á profundidades de 2 á 20 brazas.

PESCA. - La langosta se coge de dos maneras: una de ellas, la mas prosaica, consiste en sumergir una red de mas de un metro de altura por treinta y uno de largo hasta el fondo del mar, donde debe permanecer durante la noche. Como las mallas son muy anchas, los peces y los grandes cangrejos, que en la oscuridad penetran en ellas, intentan atravesarlas forzosamente; las langostas procuran vencer el obstáculo, pasando por encima con sus corpes patas, y entonces se-enredan. A primera hora de la mañana debe sacarse la red, pues de lo contrario, los peces rapaces y los delfines devorarian los cautivos. Cierto que al sacar la red, sobre todo cuando contiene buena presa, se ofrece al ob. scriador un curioso espectáculo, pero mucho mas interesan. te es la pesca de la langosta a la luz del fuego. Me encontre con otro maturalista cn la isla de Lessina, en la quinta Mil. na, del profesor Boglich, muy inteligente en la fauna animal 
del Adriático: su casa estaba situada en un magnifico golfo, y como reinaba compléta calma y la noche era hermosa, resolvimos pescar cuando la oscuridad fuese completa. Se preparó una lancha, examinamos el tridente con que se debia pescar y carróse de leña la proa de la embarcacion. junto á un fogon de hierro colocado en la extremidad de la barca; un remero solo la impelió lo mas silenciosamente posible á lo largo de la costa pedregosa, obedeciendo át las miradas $y$ ademanes de nuestro patron, que empujaba su tridente, ejecutando con la mavor seguridad las mas pequeñas evoluciones que eran necesarias para colocar el arpon todo lo vertical posible sobre la presi. Chispeaba el fuego, ilu. minando no solo la superficie y reflejándose mágicamente en la costa salvaje y escarpada, sino tambien la profundidad; de modo que todos los objetos que solo tenian algunas pulgadas de largo podian distinguirse y reconocerse perfecta. mente. Estos animales parecen aturdirse por el inusitado brillo de la luz, que á muchos sin duda sorprende durmiendo. Los peces en particular, permanecen siempre inmóviles, y tambien las langostas, que á pesar de su prudencia, se dejan entonces sorprender. Era un verdadero placer inclinarse so. bre el borde de la barca y contemplar aq̨uel mundo misterioso que se agitaba ostentando sus maravillosos colores. Va habia cierto número de peces, y tambien un ejemplar colosal del caracol llamado de tinta, cuando nuestro amigo Boglich hizo otra vez una sena, indicando un sitio en la profundidad

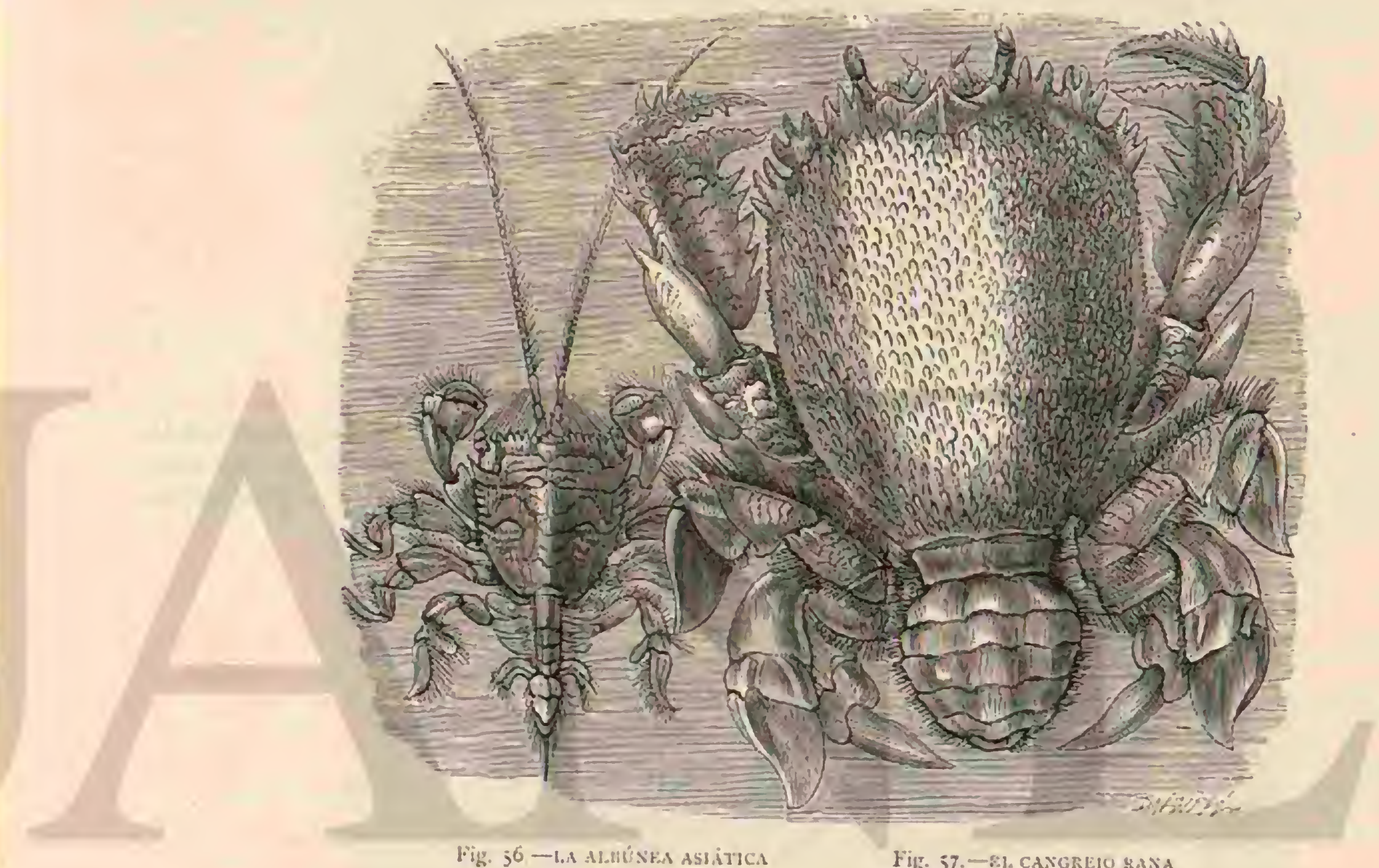

cubierto de espesas algas. Alli, casi cubierta de plantas, ocultando el postabdómen en uma hendidura, yjugando con las largas antenas, veiase una magnifica langosta; algunos - momentos despues el tridente fatal cara cón la mayor rapide\%.sobre el crustáceo, que moviéndose convulsivamente en su agonia quedó muerto à nuestros piés. Fra mas de la me. dia noche cuando rolvimos, yo para arreglar i la mañana siguiente una langosta destinada à la coleccion, y los demás para preparar con parte de nuestra pesca nocturna una suculenta comida, sazonada con buen vino de Dalmacia. Una tercera langosta cogida en la red y del todo intacta, esturo algunos dias atada con una cuerda en el mar. Aunque tenia bastante espacio para moverse permanecia muy quieta, tal vez porque no se le ocultabal lo desesperado de su situacion.

CAUTIVIDAD. - Las langostas se encuentran ahom a menudo en los acuarios con cabrajos y cangrejos paguros. Sigun observó el guardian del acuario de Hamburgo, à ve ces producian ciertos sonidos, pero solo cuando sus grancles antenas hacian bruscos novimientos, por ejemplo, cuando rechazaban, al comer, los ataques de sus compañeros. Fl profesor Mocrius, entonces en Hamburgo, cura atencion llamó el guardian, oyó tambien estos sonidos, y dice que se asemejan al chirrido que se jroduce al oprimir el cuero de una bota contra el pié de una mesa ó silla. Las langostas emiten el chirrido tambien cuando las sacan del ayuda, y entonces resuena con mas fuerza que cuando se hallan dentro. A la sazon se reconoció que el aparato con que se producen los sonidos cra una hoja redonda que se inserta en la inferior de los artejos movibles de las antenas exteriores. El chirrido se produce al pasar una placa peluda sobre la superficie lisa del anillo fijo con que el primer artejo movible de las ante. nas esta reunido. Fstos sonidos y la manera de producirse nos recuerdan un pez. marino (daitjloplerus), que tambien deja oir un chirrido con las superficies articulares de la tapa de las branquias y además nuchos insectos que producen ruido semejante.

Los que se esfuerzan en criar con resultado toda clase de animales propios para la alimentacion, á fin de abaratar su precio, de tal modo que el pueblo pueda comprarlos, han fijado su atencion tambien en las langostas. El profesor Corte en Francia, y Erco en Trieste, han estudiado mucho el asunto, pero aun no se ha citado el caso de una cria conı. pleta. En cambio los experimentos de Corte vinieron á confirmar una observacion hecha ya antes, y es, que las langostas 
recien salidas de los huevos, tienen gran semejanza con los filosomas descritos como género independiente de crustáceos. Su cuerpo delyado, en forma de hoja, se compone de dos partes principales; tienen largos pedúnculos en los ojos,
Fatas prolongadas y una longitud que varin de $\left(1^{\circ}\right.$, or a $0^{\text {" }}, 04$ (fig. 76). No se ha conseguido aun trasformar la cria sacada de los huevos al estado de filosomas perfectos, aunque de la comparacion de estos, tanto con los acorazados adultos,

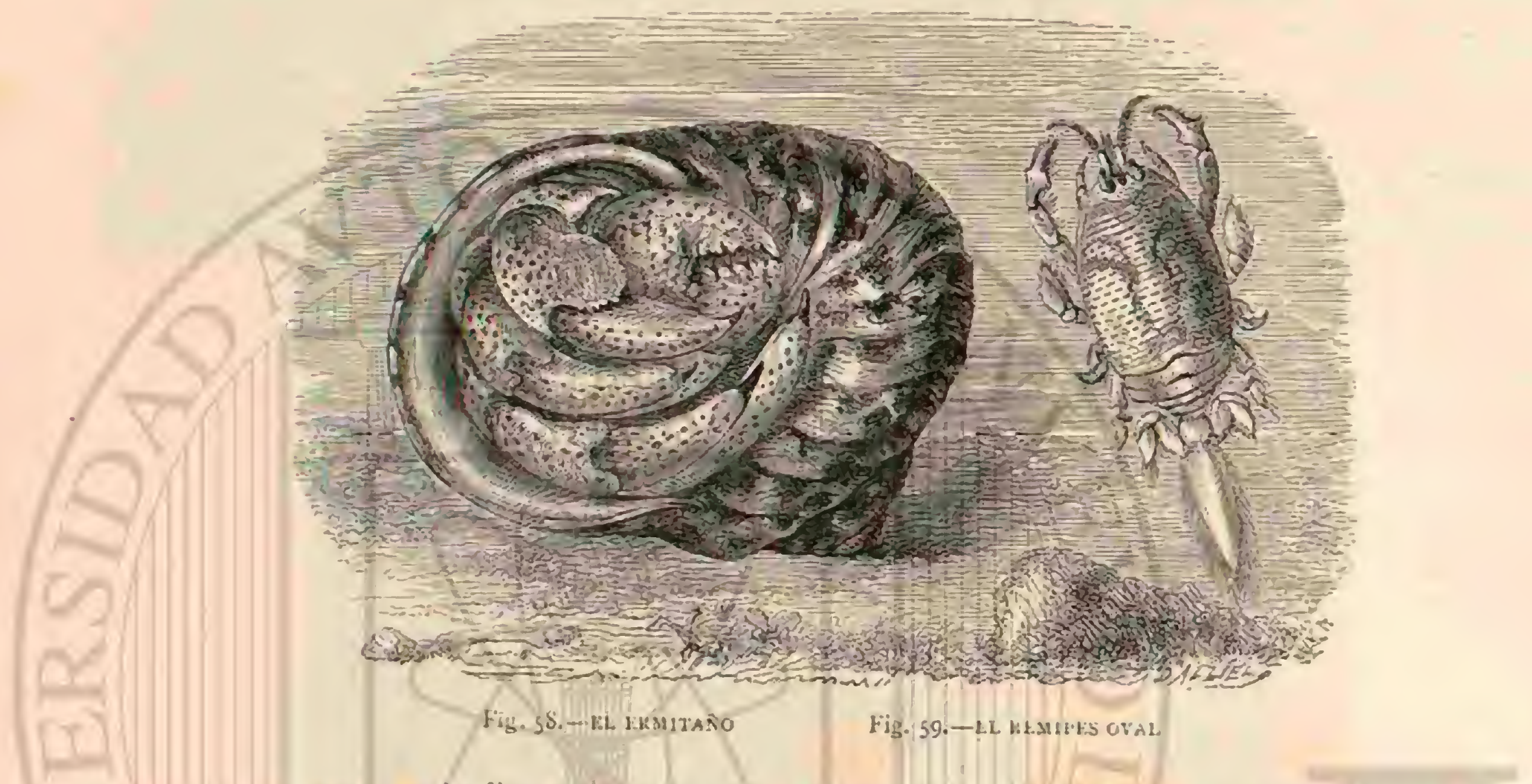

como con la cria, resulta que los filosomas son las larvas de aquellos cangtejos. Richter, el uítimo que ha tratado acerca ce este particular dice: $\& \mathrm{E}$ línico camino del todo seguro

para resolver este problema seria obscrvar el desarrollo de los respectiros animiales en el acuario; pero estas pruebas nunca darán resultado' porque apenas se pueden proporcionar las

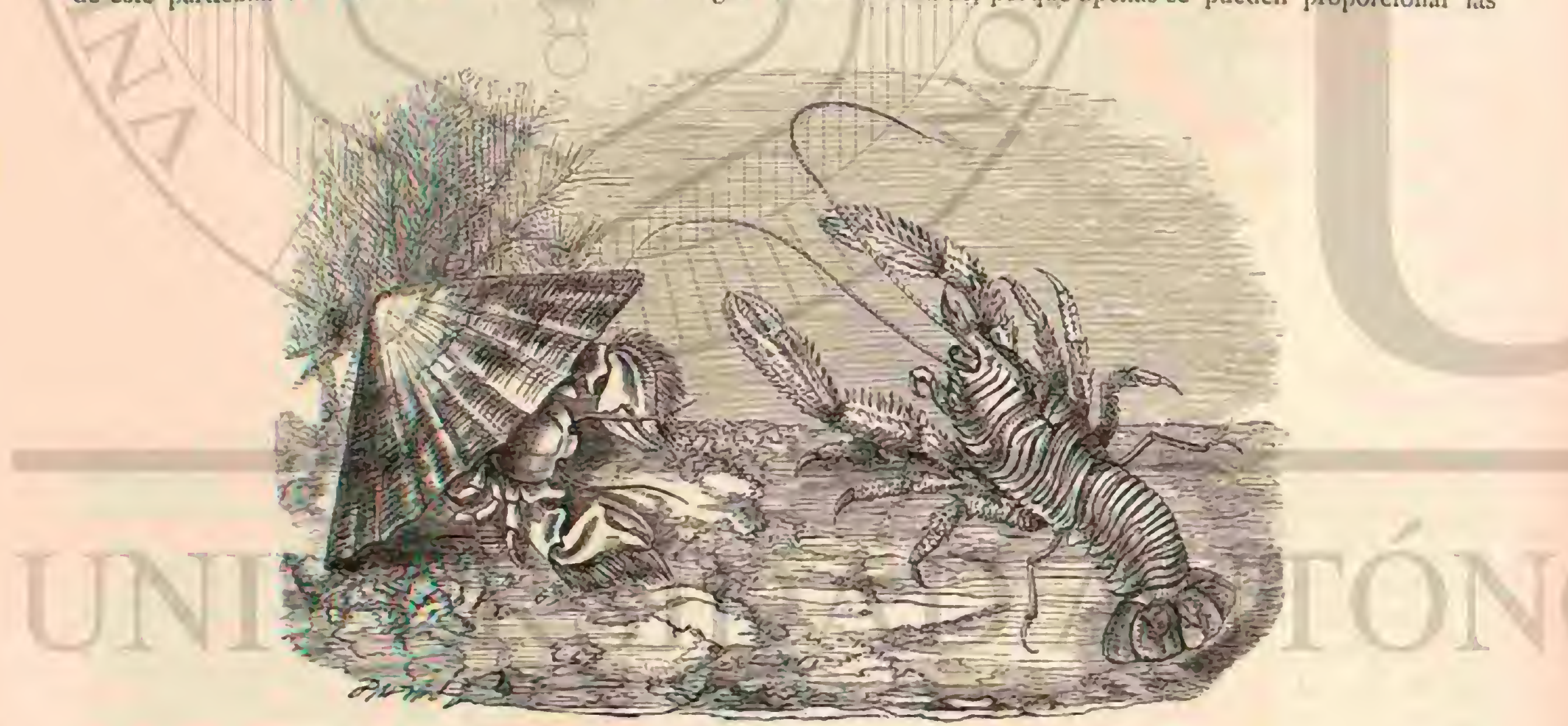

Fig. Ga-LA FORCELANA DE GARRS A.TCHAS

Figg. 61. - LA CNLITEA KLCOSA

condiciones necesarias para la existencia de estos animales en todos los estados. Los acorarados ádultos son habitantes de la costa; sus lanas, en cambio, los filosomas, puieblan principalmente de noche la alta mar, y no los parajes tran. quilos, como podria creerse por la delicadeza de su cuerpo, sino precisamente aquellos en que la corriente es mas vio. lenta. Las especies de tráusito sin duda viven en el fondo del mar a considerable profurdiciad, pues no se cogen en las aitas aguas ni enl la costa. $\$$ A pesar de esto, queeda de. mostrado, segun hemos dicha gue los filosomas pertenecen á los acorazados, no solamente del género palinurus, sino tambien de los otros géneros. De estos hay aun otro en el Mediterranco.

\section{LOS ESCILAROS-SCYLLARUS}

CARACTERES. - Este género se caracteriza por los cortos pedúnculos de los ojos, que se insertan en el dorso; jor las antenas en forma de hoja, y que carecen de látigo, $y$ en fin, por el cefalotórax cuadrangular, ancho y plano. Una 
especie que es propia del Mediterraneo, la seyllarus archus (fig. 63), crustaceo bastante comun, alcanza l" 30 de largo.

\section{LOS IBACOS-IBACUS}

CARACTERES. - I OS ibacos se caracterizan tambien por su caparazon mas ancho que largo, con una prolongacion laminar á cada lado, que cubre la mayor parte de las patas: estas prolongaciones son mayores por delante que por detrás; en ambos lados del cuerpo se ve una profunda hendidura que divide dichas prolongaciones en dos partes iguales; las órbitas no estan situndas muy cerca del ángulo externo del caparazon, sino bastante scparadas dé élą el abdómen es muy corto.
I.a principal especic de este género es el ibaco motcado (fig. 6f) que se cncuentm en los mares de Austmlia.

\section{LAS CALIANASAS - CALLIANASSA}

CARACTERES. - Este género se compone de especies de caparazon joco prolongado, liso y' terminado en un pico pequeño; los piés del segundo par son didáciilos; las patâs anteriores muy desiguales; el abdómen, grande, bastante an. cho, y casi membranoso, está provisto en su extrenidad de laminas foliaceas, las de los lados muy anchas y redondendas, $y$ la intermedia casi triangular. Como tipo de este género podemos citar la calianasa suliferránea (figr. 66), que tiene la costumbre de introducirse en unos hoyos que practica en la

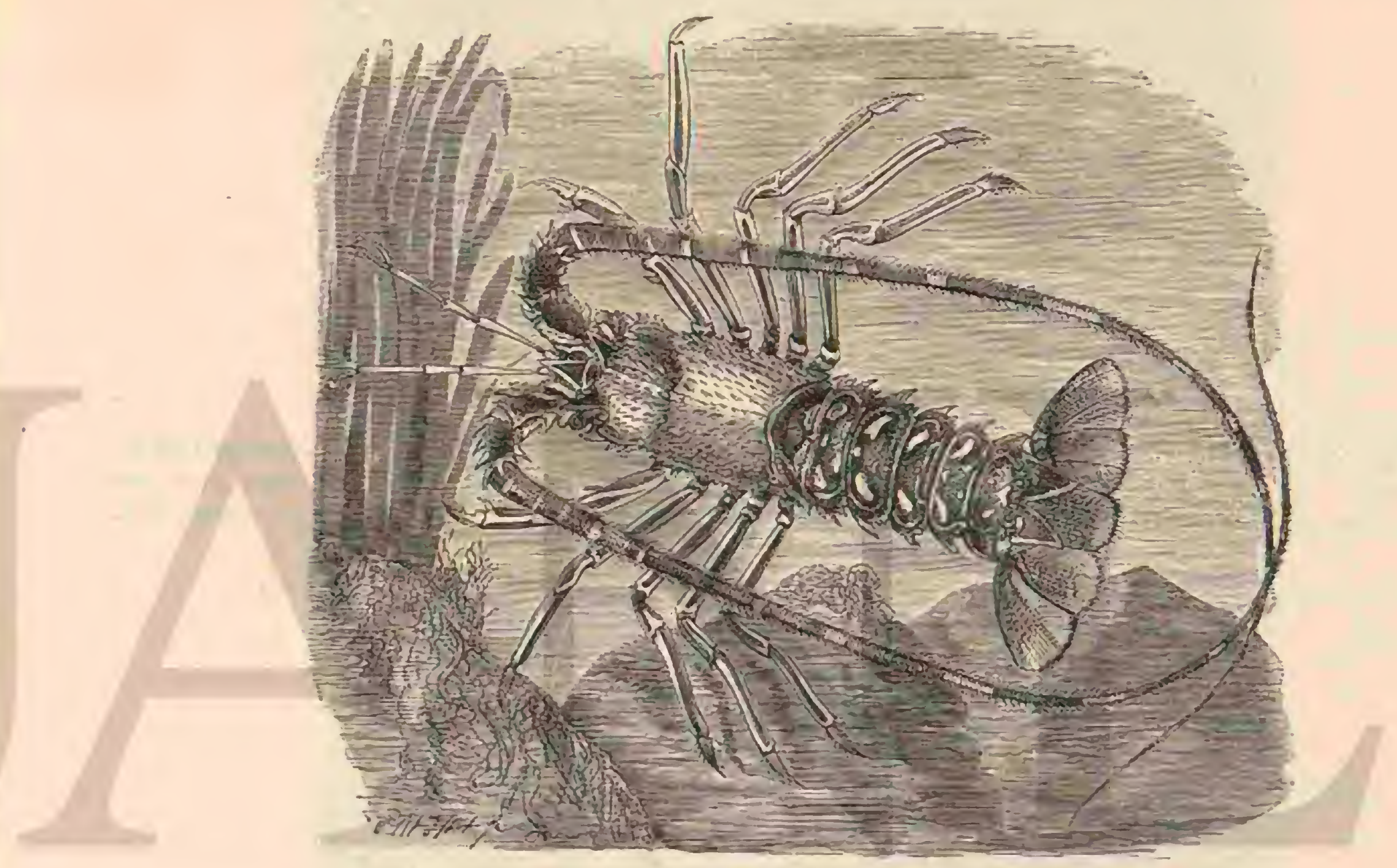

Fig. 62, - i.s LAsigos7s cosis

arena i poca distancia de la orilla del mar, eligiendo sicmpre los parajes mas cenagosos.

Otro género afine, el de los axios, se caracteriza por la lentitud de los movimientos de sus individuos. entre los cuales figura el axius sfirhynchus (fig. 65), crustáceo tan pe. sado que apenas puede correr ó andar. Abunda en las costas de Inglaterra.

\section{LOS CANGREJOS PROPIAMENTE DICHOS-ASTACINA}

CARACTERES. - La tamilia à que periencec el cangrejo fluvial comun y sus congéneres mas afines, puede llamarse la de los cangrejos propiamente dichos: se reconocen por el cefalotórax un poco comprimido latemlmente y protegido lo mismo que el post-abdómen, por una coraza bastante sólida. Fil primer par de patas tiene siempregrandes tenazas; el segundo y terecr par estin provistos tambien de ellas en algunos géneros, pero son pequeños.

\section{EL CANGREJO FLUVIAL-ASTACUS FLU- VIATILIS}

Como ya hemos descrito mas arrihn las proporciones anatómicas de estos séres, solo nos queda que añadir algo sobre su genero de vida y ảrea de dispersion.

USOS, COSTUMBRES Y REGIMEN,-Vive con preferencia en agras corrientes, sobre todo en las orillas verticalcs, donde puede ocultarse de dia en las mamas de los árboles que tocan el agra. Aqquellos que en su juventud se han quitado clandestinamente las bo:as para jescar cangrejos, saben sin embarga que este crustaceo vive tambien en los sitios llanos de las orillas, debnjo de las piedras. El cangrejo es poco exigente en cuanto i su alimento, y prefiere la carne podrida á la fresca, por lo cual debe recomendarse a todos cuantos comen cangrejos hervidos que dejen lo mas intactos posible los estómagos de los mismos. Asi como todos los artrópodos que se alimentan de cadíveres y de otras mate. rias impuras, el cangrejo fiuvial parece dotado de un olfato muy fino: ó por lo menos le atrae la carne podrida que se pone como cebo en las redes. Su alimento ordinario se com- 
pone sin embargo de conchas, caracoles, larvas de insectos las que la una es roja y la otra pardusca, solo la uiltima se y en algunas ocasiones de pececillos. Los cangrejos viros tienen un color verdoso, pero si se les pone al sol se vuelven rojos, como algunos de sus congéneres. De las dos materias colorantes qué existen en sus tegumentos epidérnicos, y de

\section{destruye por el calor, aunque predomina la otra.}

Las aglomeraciones calcåreas de las paredes del estómago, llamadas «ojos $\delta$ piedras de cangrejo», figuraban como lapides ú oculi cancri asłaci, entré los muchos remedios de la medici.

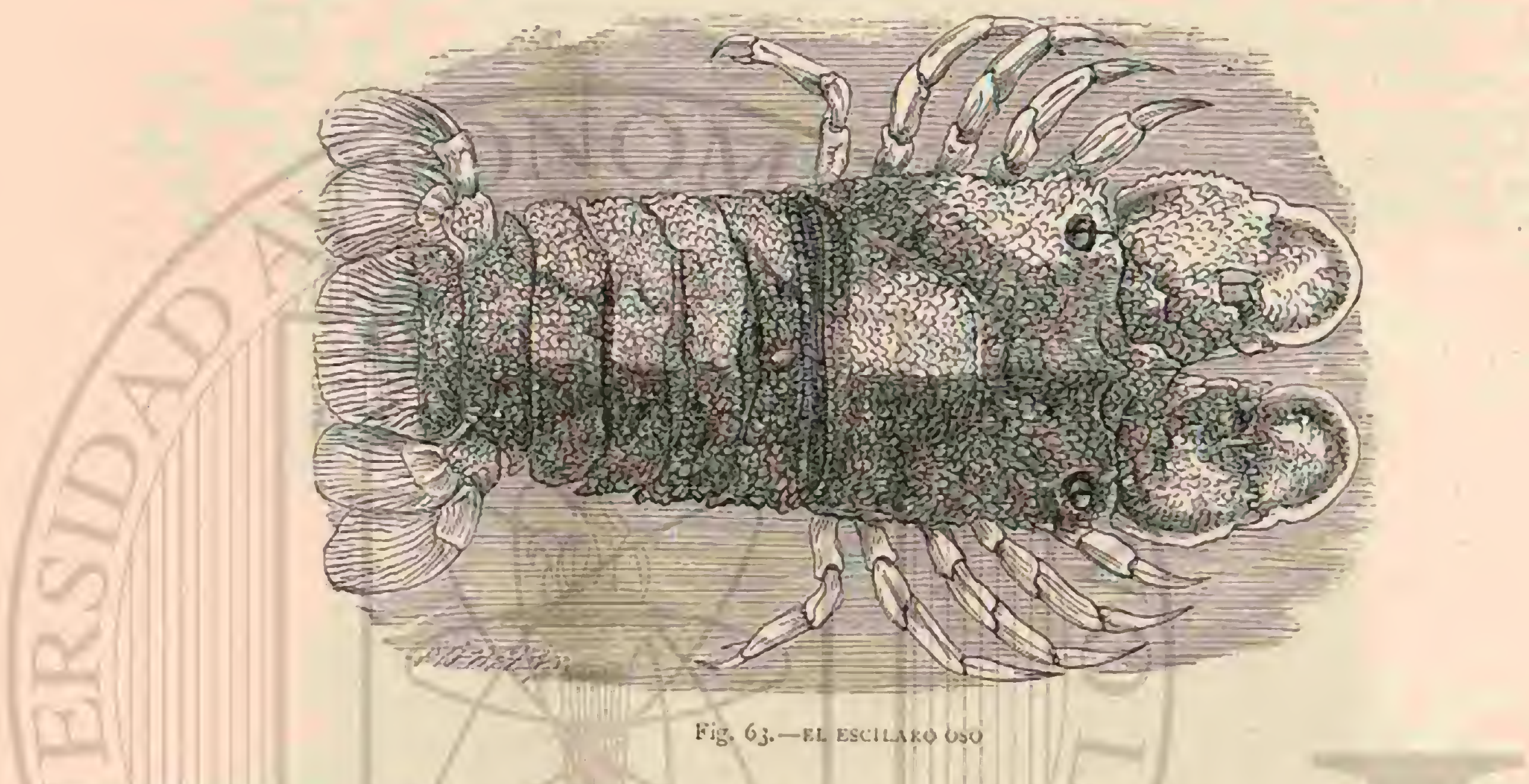

na antigua, ahora casi olvidados, aunque el pueblo los considera eficaces todavia. Así, por cjemplo, formaban parte del célebre polvo tranquilizador de Stahl: créese que reduci-

dos a polvo producen el mismo efecto que una serie de remedios que mas ficilmente pueden adquirirse, como por ejemplo la magnesia calcinada; en algunas farmacias se ha-

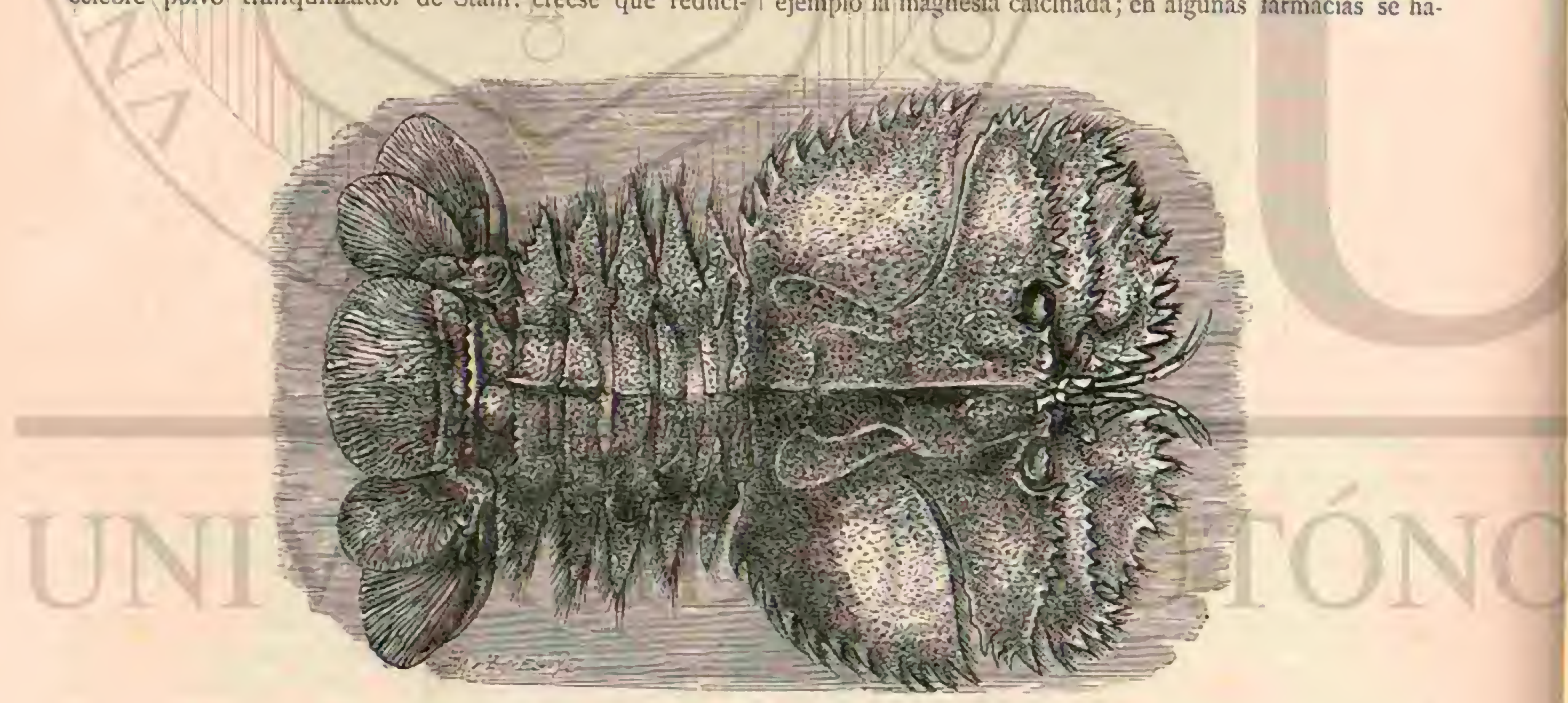

Hig. G.4. - R.L BBACO MOTzano

llan aun, $y$ se compraban antes, sobre todo en Astracan. En el Volga hay tantos cangrejos que se ies dejaba y deja podrir en varios montones en la orilla, para proveer las farmacias rusas, extrayendo los \&ojos fácilmente de entre los restos. Fl cangrejo comun está diseminado por casi toda la Europa. Su limite meridional llega hasta el lago de Zirknitz, en Carniola, coniprendiendo Niza, todo el territorio del Pó y hasta Nàpoles. En la Rusia meridional se encuentra cerca de Nikolaiew, en el territorio del Buj. Los cangrejos fluvinles del Niester, Nieper y del Wolga, de Crimea y del Cáucaso, y de algunos otros territorios de la Rusia meridional, que se han descrito como tres especies distintas, difieren $\tan ^{y}$ paco del cangrejo comun, que solo preden considerarse como variedades. Sin embargo, la acepcion de especie y variedad no está bien determinada, $y$ por lo tanto podemos conformar. nos con la clasificacion antigua, comprendiendo por variedad una forma de animal que solo difiere por caractéres poco importantes de la especie jurimition, con la que sin embargo se relaciona por tránsitos directos.

En el curso de nuestra obra hallaremos aun bastante es. 
pacio y tiempo para ocuparnos mas minuciosamente de esta y otras cuestiones importantes que constitujen la ciencia de la historia natural.

\section{EL CANGREJO DE LAS PIEDRAS-ASTACUS SAXATILIS}

CARACTERES.-En el sur de nuestro continentc habita el cangrejo de las piedras que difiere del comun por el color pardo amarillo y otros varios caractéres.

DISTRIBUCION GEOGRÁFICA - Ei zoólogo Grube de Breslau confirmó la presencia de este cangrejo en el sulitario lago Vrana, de la isla de Querso; este lago situado so- bre el nivel del mar y circuido de montañas, parecia muy poco poblado: con una variedad de gobios y algunos sollos, halláronse numerosos cangrejos en las piedras. Mas tarde se sacó tambien de una profundidad de 57 metros un pequeño cetopodo. Quizas se pregunte cómo el cangrejo y sus semejantes han llegado a. estas aguas solitarias, que no tienen ningun affuente: el hecho ocurre en todos los puntos por aislados que estén, y en rigor solo podria contestarse recordando las leyes generales de la distribucion geográfica de los séres, y los fenómenos y fuerzas naturale's que en ellas influyen. En el caso presente podemos suponer, por lo pronto. que las islas de Istria y de Dalmacia quedaron separadas del continente en una epoca primitira, aunque no demasiado re-

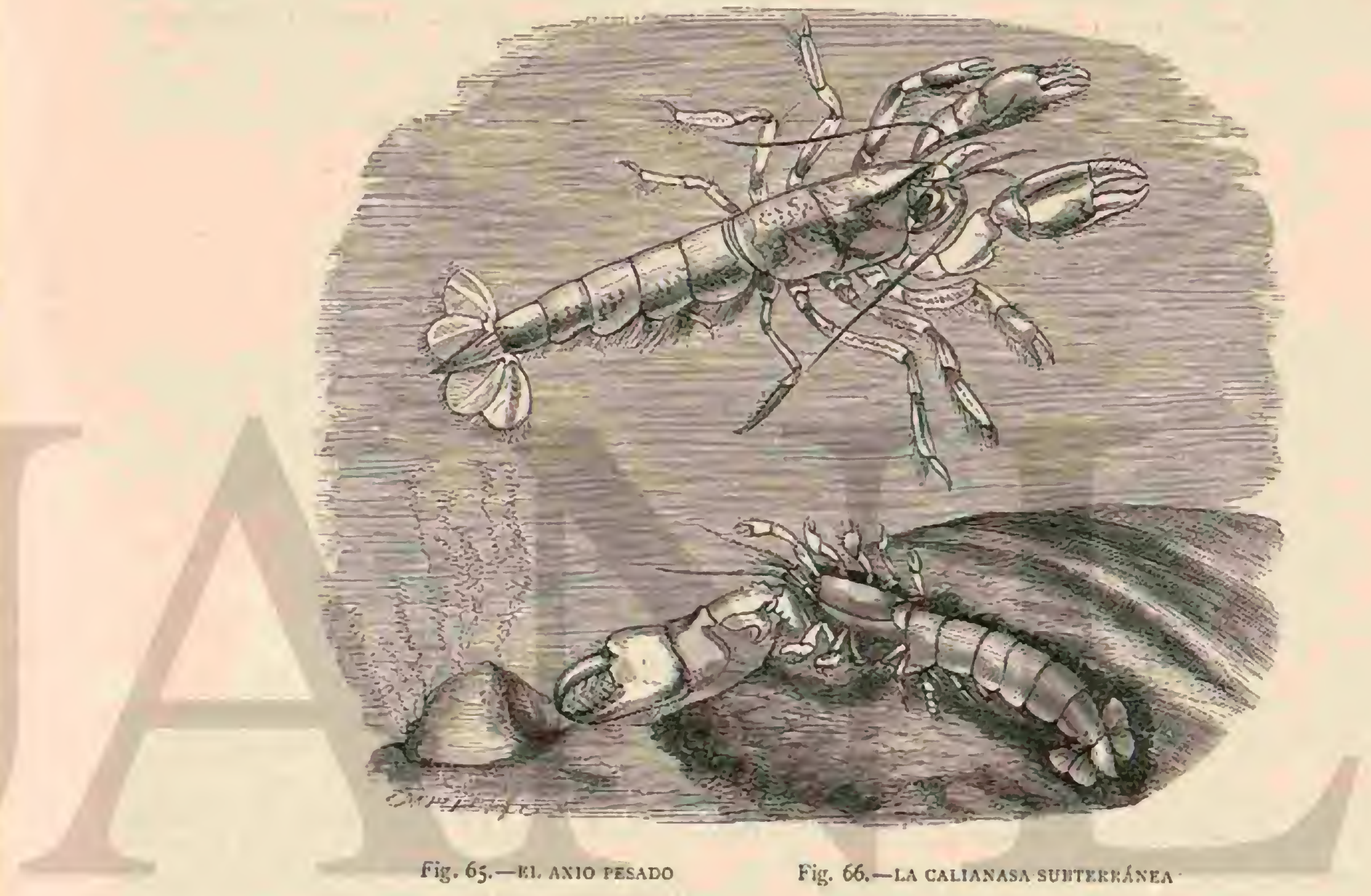

mota, a causa de violentos terremotos, adquiriendo entonces su forma y nivelacion actuales. Muchos animales de tierra firme se aislaron por esta causa, obedeciendo a las leyes a que están sujetos todos los séres habitantes de la tierra y delas aguas dulces, que no vuelan.

Las dos especies citadas son muy congenéricas de la especie encontrada en la América del Norte, en Chile y en la Nueva Holanda.

\section{EL CABRAJO Ó CANGREJO MARINO-ASTA- GUS MARINUS}

CARACTERES. - lambien el cabrajo (fig. 6\%) se distingue del cangrejo fluvial por caractéres tan poco importantes que apienas se debe agruparle en otro género. Tiene el apéndice frontal mas estrecho; $y$ la escama en la base de las antenas extcriores, que en los cangrejos de rio afecta la forma de hoja, es angosta y dentiforme.

DISTRIBUCION GEOGRÁFICA.-El cabrajo comun de los mares europeos se encuentra desde la costa de No. ruega hasta el Mediterráneo, donde sin embargo abunda mucho, mientras que las costas de Inglaterra, y sobre todo las de Nonega son su verdadera patria. Aquí se encuentra con otros muchos animales marinos, con preforcncia en la inmensa extension de agua que corre á lo largo del continente, precinitandose en el Océano.

PESCA. - Ias costas pedregosas de Inglaterra son los sitios donde se cogen los cabrajos. Los jescadores se sirven de cestos parecidos a los que se usan para la pesca de los cangrejos, $\delta$ tambien de redes longitudinales con la entrada en forma de embudo. En estas trampas entra de noche. En ningun pais de Europa es tan grande el consumo de cabrajos como en Inglaterm. Hace ya veinte años que de Escocia y las Islas Británicas se recibian anualmente unos $150,000 \mathrm{in}$ dividuos en Lóndres; la importacion de Noruega es mucho mayor; este pais envia todos los años, cuando menos, 600,000 individuos con destino il Lóndres, sirviéndose para el tras. porte de pequeños buques, rápidos, provistos de un doble fondo para depósito de los cabrajos. El concurso principal se hace desde el mes de mayo al de agosto.

Segun las observaciones de Saunder, traficante de pescado, apuntadas por Bell, el cabrajo no se aleja mucho del sitio donde nace: Saunder, hombre experto en la materia, asegu. ró que por el color y el aspecto del cabrajo podia reconocer- 
se su procedencia. La reproduccion del cabrajo europeo es análoga i la del americano, del cual hablaremos despues. Es un hecho extrano nue las larvas de ambas especies difieran mas unas de otras que los individuos adultos.

Calculando el consumo de cabrajos para el norte de Europa en cinco ó seis millones de individuos al año, podemos deducir la extraordinaria fecundicad de este animal. La hembra pone mas de 12,000 huevos, los cuales fija en su post-abdómen, llevándolos consigo hasta pocos momentos antes del nacimiento de los hijuelos. Es ciaro que solo una pequeña parte escapa de los peligros, á pesar de que la madre los proteje; refugianse debajo de su cuerpo, y segun aseguran los pescadores, la hembra conduce cuando menos una parte de sus hijuelos. Poeppig sefiere, tomando la noticia de Penuant, que en toda estacion, sobre todo ea invierno, se cogen hem. bras cargadas de huevos, que, sin embargo, no se desarrollan en los meses frios, circunstancia que ofreceria una excepcion extraña respecto á la reproduccion de los crustriceos y todos los artrópodos en general. Fl observador inglés anade que la muda no se verifica en el mismo ano, despues de poner. Ios hueros como es regla en todos los crustaceos; tambien se supone que en la edad adulta la coraza no se muda, ó solo á grandes intervalos, porque en el cefalotórax de individuos muy grandes se agarran a veces conchas y cirripedos.

Por las cuidadosas observaciones hechas últimamente sobre el género de vida y la reproducción del cabrajo norteamericano (homarus americanus), la propagacion se verifica, segun la costa, desde abril à setiembre, y parcce que á este efecto las hembras visitan sitios menos profundos. Los hijuelos nadan libremente apenas nacen, cuando tienen las pa-
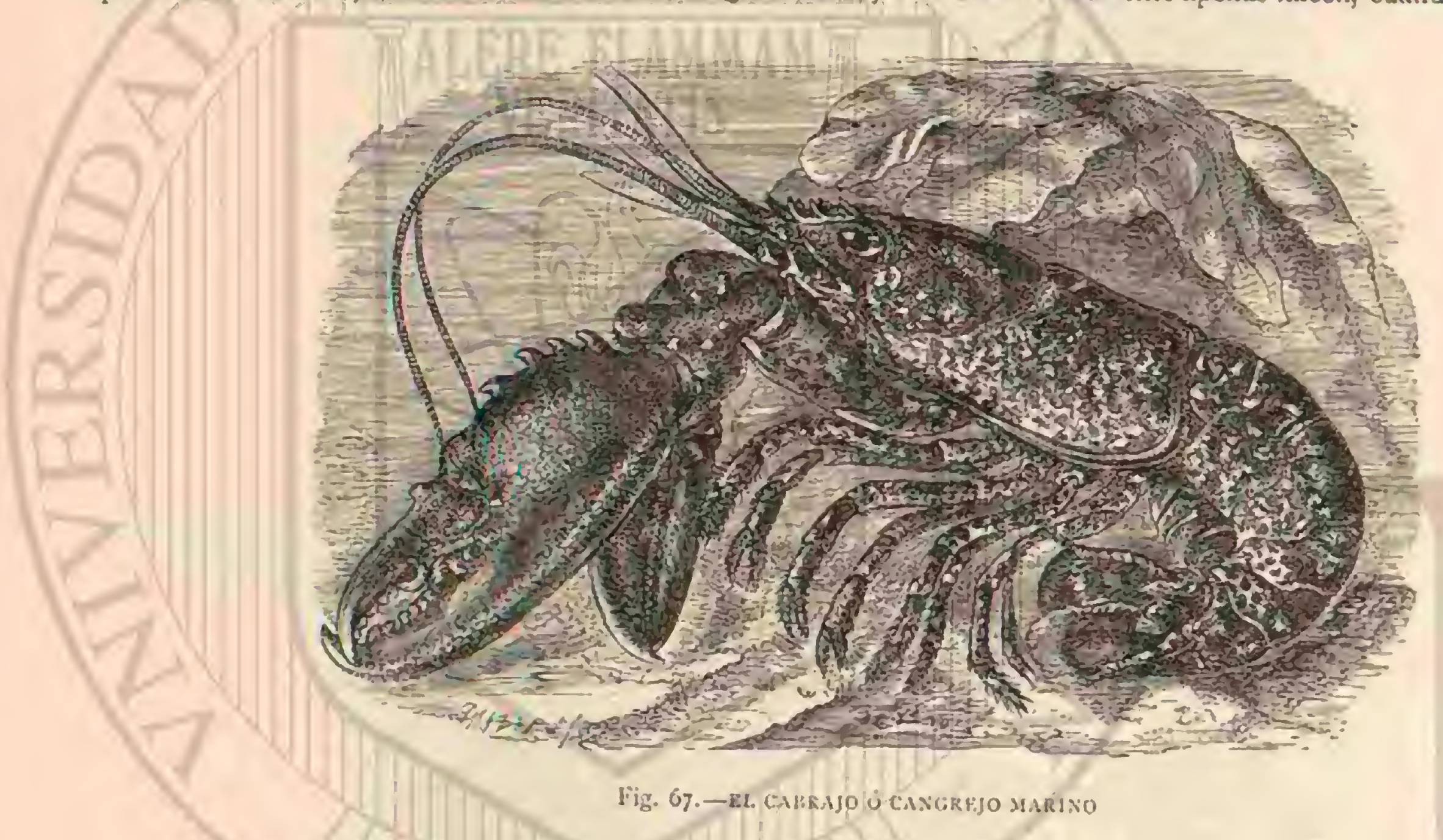

tas hendidas y gran semejona con los hijuelos de los quiso. podos, lo mismo que cuando ofrecen el aspecto de los adultos y alcanzan una longitud de g lineas. Como, vagan en manadas, los peces devoran un ntineto extraordinario de ellos.

El consumo del cabrajo en la América del Norte es muy superior al europeo: en Boston sólo se venden todos los años un millon de individuos. La pesca en las costas americanas se hace casi exciusivamente con cestos, como en Inglaterra (colster-pots), poniendo varios ccibos.

\section{EL NEFROPS DE NORUEGA-NEPHROPS NORVEGICUS}

Entre los cangrejos de la familia de los astacinos de gran valor económico, merece mencionarse tambien el nefrops noruego, crustáceo que se distingze por su cuerpo delgado y sus fuertes tenazas. La verdadera natria de esta especie es la costa de Noruega, donde he haltido individuos de mas de $0^{*}, 30$ de longitud; pero no recuerdo haberle visto en el mercado de Bergen ó de otra ciudad litoral de Noruega co. mo mercancia, y por lo tanto parae que escisea bastante. En cambio se cogen muchos en la gran bahia que desde el Adriatico se extiende hasta Fiume pudiendo decirse nue se le lleva a quintales al mercado de Trieste bajo el nombre de scampo. En el resto del mar AGriaitico y en el Mediterrảneo no abunds tanto, de modo que no es articulo constante en los mercados.

\section{LOS CARIDINOS--CARIDINA}

CARACTÉRES. - I a familia mas rica en especies, entre los macruros, es la de los caridinos, de la que, solo de los mares europeos, se han descrito unas noventa especies. los tegumentos córneos de su cuerpo, elásticos y comprimidos lateralmente; la gran escama que sobresale del tallo de las antenas exteriores: el color en extremo delicado y bonito que ofrecen algunas de sus partes, mientras que otras son trasparentes como cristal, y una extrema agilidad en los mo. vimientos, caracterizan los tipos de este grupo. Precisamente en él la clasificacion de los géneros y especies, exige un estu. dio penoso y detenido, en el que debe tomarse en consideracion la naturaleza de las maxilas, de las branquias, antenas y patas. Algunas especies son, sin embargo, tan comunes, y se cogen y comen tan á menudo, que nos remos obligados a hacer mencion de ellas, juntamente con otras que se distinguen por su genero de vida.

\section{LOS CRANGONES-CRANGON}

CARACTERES.-De los restantes caridinos, el género de los crangones, y algunos afines, se distinguen por tener las cuatro antenas insertas en linea, mientras que en aquellos, las interiores están situadas á mayor altura que las ex. teriores. 


\section{EL CRANGON COMUN-CRANGON VULGARIS}

CARACTERES. - Inas costas arenosas y llanas, sobre to. do las del mar del Norte y de Inglaterra, estan pobladas por el crangon comun, que los ingleses llaman garnate, granale, shrimp, y los franceses crevelte. Ofrece un carácter comun con las demás especies, y tiene incompletas las tenaas del primer par de patas, que es mas grueso que los otros; en can?bio difiere por el cuerpo que es casi liso. Solo en el ceralo. tórax presenta tres espinas (fig. 68).

USOS, COSTUMBRES Y REGIMEN.-Gosse ha heclso una interesante descripcion de la pesca de ește crusticeo, dảndonos a conocer al mismo tiempo las particularidades de su vida. "Veamos, dice, cómo procede el pescador, y qué debe hacer el caballo, con que penetra en el mar, hasta que el agua llega sa su vientre, sacindole despues y dirigien. do sus pasos desde una extremidad à otra de la orilla, cual si tratara de labrar la arema. ¿Por que el pescador obscrva con tanta atencion al caballo? Examinemos primero lo que hace: llama al muchacho que monta cl cuadrúpedo y baja con rapidez por la orilla, de la que yia regresa el animal con su pequeño jincte. Vamos tambien alli y cerciorémonos.

„El pescador es cortés y" nos comunica el secreto, que deja de scrlo cuando llegamos á dicho sitio. El caballo arrastra en pos de si una red, cuya abertura está fijada en un marco de hierro longitudinil; la parte posterior de la red remata en punta, pero no está ligada con mallas, y sí solo con un cordon. El marco de hicro mantiene abierta la embocadura de la red, y pasa por el fondo del agua, mientras que el caballo. con cuyo aparejo se comunica aquel, avanza con regularidad. El fondo arenoso está poblado precisamente alli, de una especie de cangrejo, bueno para comer, el crangon comun, ó segun le llama el pueblo de esta region, el crangon de la arena, para distinguirle del crangon de las rocas (palaemon serratus).

El caballo que cira del peside aparato, penctrando hasta

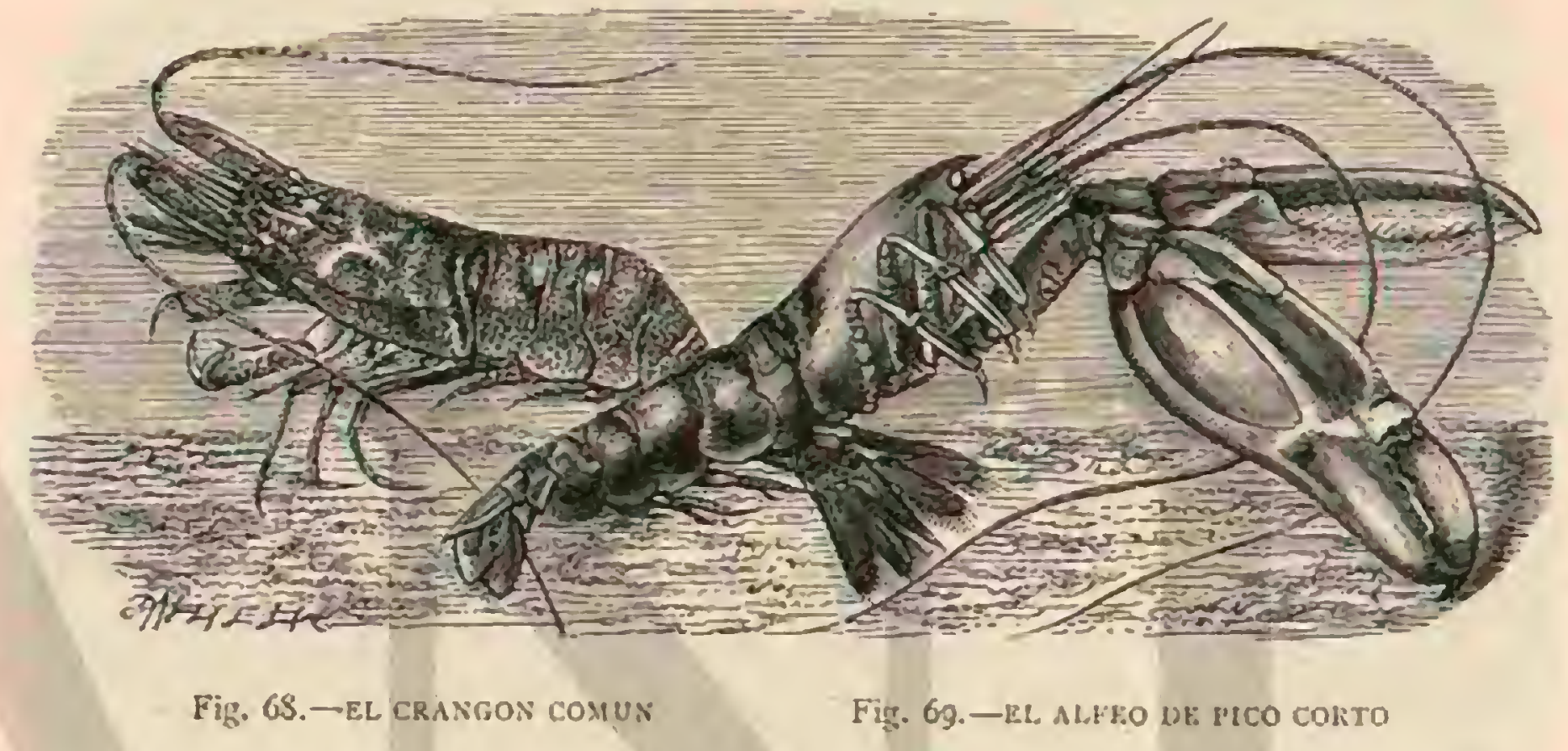

un metro de profundidad en el agua, efectua un trabajo muy penoso, y experimenta especial placer al salir á tierra firme, donde se detiene tan luego como la red arrastradern ha lle. gado á la orilla. El pescador extiende un paño sobre la arena, desata el cordon y racia el contenido de la red sobre el paño. Hay mas de dos arrobas, y como el pescador es benévolo y está de buen humor al ver su buena pesca. nos atrevemos á proponerle un negocio. A cambio de una pequeña moneda nos permite recoger todos los animales y objetos que no son crangones. Estos últimos son muy bonitos. Pell dice que su longitud puede ser de $0^{\prime \prime}, 006$; pero los mas pasan de $0^{m}, 00 S$. La mayor parte son hembras, cuyos huevos se encuentran entre las jatas rudinentarias del post-abdóneı. El crangon es menos gracioso que otros muchos caridinos; tiene un color pardo pálido que tira un poco al verdoso; pero al examinarle mas detenidamenic se ve una aglomeracion de manchas negras, pardas, grises, y de color de naranja, que cxaminadas con un buen microscopio afectan la forma de estrella.

DEs muy divertido ver la ngilidad y rapidez con que el crangon se coloca en la arena. Cunndo cl agua tiene solo dos pulgadas de profundidad, el animal se deja caer tranquilamente al suelo; entonces se re elevarse por un momento, como una pequeña nube de polio, y el cuerpo baja de tal manera que el dorso se confunde con el suclo. En tal instante se comprende la utilidad del color de este crustáceo, pues las manchas de diferente tono de pardo gris y rojo, se asemejan de tal modo al color uniforme de la arena, que un momento despues de haber visto al crangon penetrar en esta, ya no se le distingue. Solamente los ojos, situados en la extremidnd de la cabeza, aparecen como dos centinelas; asi permanece cl animal guicto y tranquilo, sin sospechar el riesgo, hasta que le recoge el hierro de la red.

Fn todas partes se cogen los crangones de un modo semejante, aunque regularmente los pescradores pobres no hacen la pesca con ajuda de un caballo, sino que arrastran cllos mismos la red, mas pequena, fija cu un marco de hierro $\delta$ de maders.

\section{EL LISMATO DE COLA SEDOSA-IYSMATA SETICAUTA}

Uno de los caridiños mas bonitos, afine de los crangones, es el lismato de cola sedosa, que solo habita en el Mediterráneo y se caractcriza por un color rojo de coral, con fajas lon. gitudinales blanquizcas.

\section{LOS ALFEOS-ALPHEUS}

CARACTERES.-I.os crustáceos comprendidos en este género tienen las antenas insertas en dos líneas, estando las internas por encima de las externas; el pico muy pequeñoy chato; las patas robustas, sin señal de apéndices ni de palpos; las de uno de los tres primeros pares son muy fuertes, y las de los tres últimos, siempre monodáctilas. En el alfeo de pico corto (fig. 69), tipo del género, la extremidad del cefalotórax se proyecta sobre los ojos en forma de gancho; el pico es muy pequeño, y hasta parece que algunos individuos carecen de él; las patas del primer par son sicmpre muy sólidas, y una de las garras es siempre mucho mas an. cha y poderosa que la otra. 
Donde mas abunda esta cspecic es en las aguas del Japon; pero por regla general se encuentra en todos los mares cålidos.

\section{LOS PANDALOS-PANDALUS}

CARACTERES. - Los pandalos tienen el caparazon largo, cilindrico, dentado en su cxtremidad y terminado en in parte anterior por un pico largo y comprimido: las antenas superiores, mas corfas que todas y bifidas, estan sostenidas en un pedúnculo compuesto de zres artejos; las patasmaxilas exteriores se forman de otros tres visibles, de los cuales el primero es tan largo como todos lós demás réunidos, y los otros dos iguales chitre si, cubictos de pequenas espinas en todas sus partes; los piés del primer par, bastante cortos, carecen de pinzas y ticnen el ríltimo artejo puntiagudo.
I.a especie tipica de este-género es el pandalo de cuernos anillados (pandalus annulicomis) (fig. i1); y tambien se conoce otra que es el P. numal.

\section{LOS PENEOS-PENCEUS}

CARACTERES. - El caparnzon es cilindrico, comprimido, dentado y velloso, terminando anteriormente en un punto puntiagudo; los ojos, casi globulosos, están sostenidos en un pedúnculo muy corto; las antenas medias son bifidas y las exteriores sedosas, hallindose provistas en su base de una cscama grande y muy larga.

El penco caramote (fig. 7o) es objeto de una pesca considerable, y sc hace de él un consumo enorme, no solo en las costas, donde se utiliza su carne como alimento, por ser muy sabrosa y delicada, sino tambien para salarlo y expedirlo à Levante, sobre todo à Grecia.

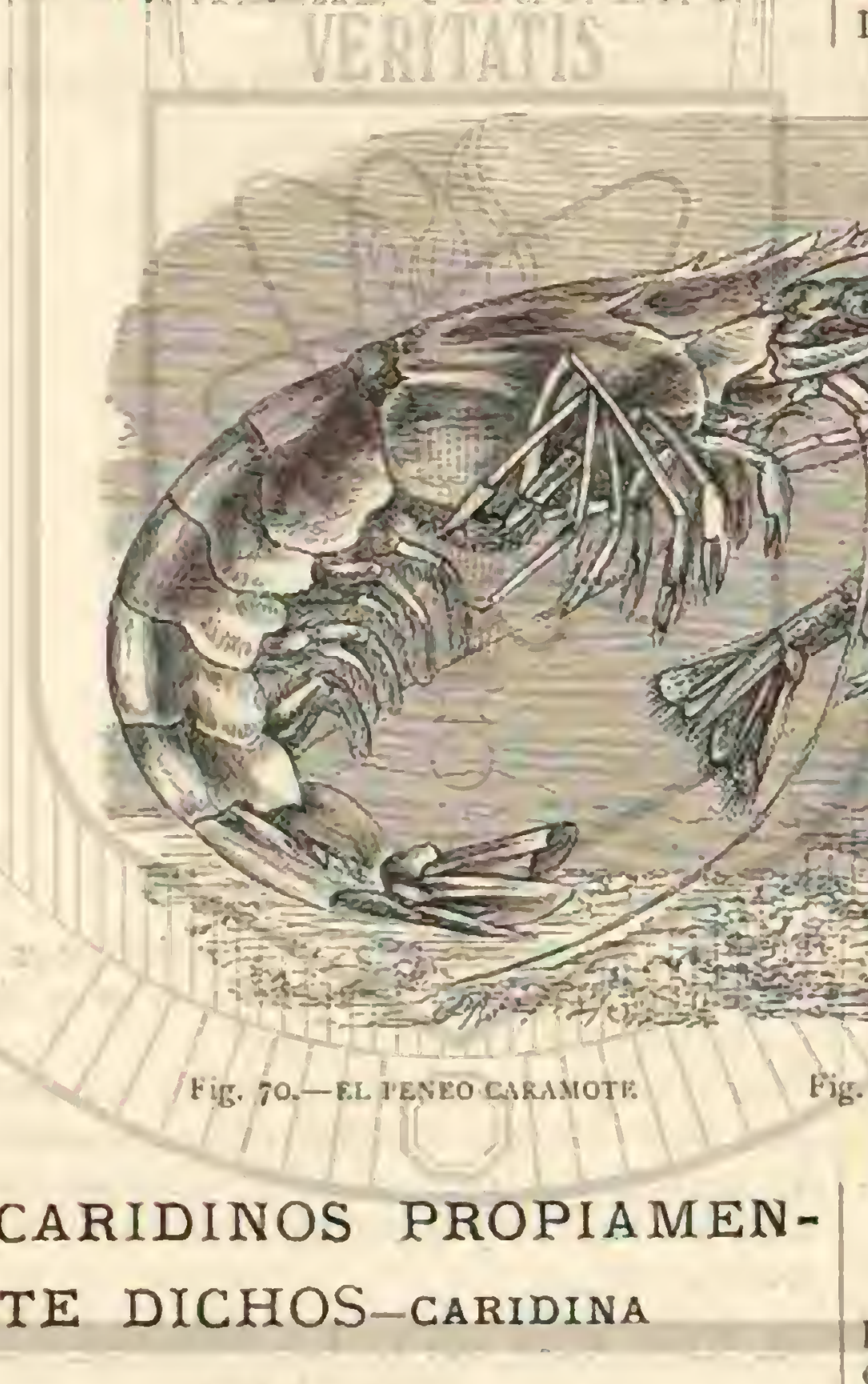

Solo algunos caridinos viven en las aguas dulces, como por cjemplo el género eavidisa en dos rios de la Francin meridional $y$ en otros puntos del sur de Europa.

Probablemente una cspecié atrofinda del mismo es el troElocaris Schmidtio que-vive en las aguas de-lás-grutas del Karst, por ejemplo en la cueva de Adlsberg. Ei atrofiamiento reside en los ojos, cuyos órganos disminuyen en casi todos los animales subterrincos y hasta desaparecen del todo.

\section{LOS PONTONIAS-PONTONIA}

Volviendo á los caridinos habirantes del mar, haré mencion, dejando a un-laco algunas otras especies, dé la llamiada ponforia tyrrhena, que se distingue por su especial género de vida. Tiste crustácece, que se encuentra, aunquıc no muy à menudo, en el mar Adriátice y en el Mediterráneo, vive por le regular como parásito en la pinosa escamosa, otro de cuyos huéspedes hemos mencionado tambien al hablar del finnosheres: sin cmbargo tambien se oculta muy a menudo en esponjas.

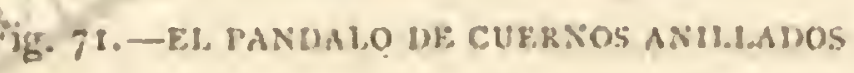

\section{LOS TIPTONES-TYPTON}

CARACTERES. - La especie typlon spongicoln cstá rcpresentada por un animal que casi exclusivamente habita las esponjas. Las itnazas del segundo par de patas están muy desarrolladas, y una de ellas, mas grande que la otra, alcanza casi sicmpre a dos terceras partes de la longitud del cuerpo. Su color es pardusco claro, y las hemhras adultas se distinguen por el rojo de minio ó casi de coral del gran jostaldémen.

USOS, COSTUMBRES Y REGIMEN.-Cuando estos pequeios seres, que apenas tienen una pulgada de largo y que ofrecen un aspecto extraño con su gran tenaza, se espantan ó irritan, cierran los dedos de dicha parte, produciendo el mismo sonido que cuando hacemos castañetear el dedo indice con el pulgar; mas no por eso atacan numea al hombre.

\section{LOS CAMARONES-PALAEMON}

CARACTERES. - No mas valerosas que las anteriores son las diferentes especies del género de los camarones y de otros afines. Su cefalotórax remata en su parte anterior en un pico en forma de sable, cuyo borde superior es denticulado. Al describir el camaron de sierra (falaemon serratus), Gosse compara estos animales á un guerrero, pero csta comparacion 
no es fundada. Dice que en su coraza las placas encajan de tal modo que el animal, como un verdadero soldado, anda, come y duerme siempre armado. Haciendo abstraccion de este belicoso aspecto, en este crustacco no hay energia, ni vilor; $y$, a pesar de las repetidas observaciones efectuadas en diversos individuos puestos en acuarios, nunca se ha visto que uno tan solo se sirviern de su lanza, al parecer tan peligrosa, para el ataque ó la defensa. Fl observador inglés dice que solo el aspecto del arma amenazadora basta para atemo. rizar á muchos encmigos del pequeño cangrejo que pronto emprenden la fuga. Este camaron abunda de tal modo, sobre todo en la costa septentriomal de Francia, y mas hácia el este, cn el mar del Norte, que constituye un importante articulo alimenticio. Esta especic y otros camarones, de los que el falaemon squilla es el que mas abunda en el Meditersineo, adquieren un color rojo cuando se cuecen, mientras que la mayor parte de los otros caridinos, asi como el crangon co. mun, pierden su color en el agua caliente.

Solo en el acuario pueden observarse las costumbres de los caridinos. lin el mar apenas se ven los mas de ellos, a causa de su trasparencia y por ser uny rípidos, pero en ciutividad se hacen mas familiares, aunque nunca picrden del todo su timidez. Son en extremo bulliciosos y siempre cortan su clemento valiénduse de las maxilas auxilines, ó de las tenazas. Vagando juntos por el depósito se disputan los bacados, sin trabar por eso encarnizadias luchas, como los paguros.

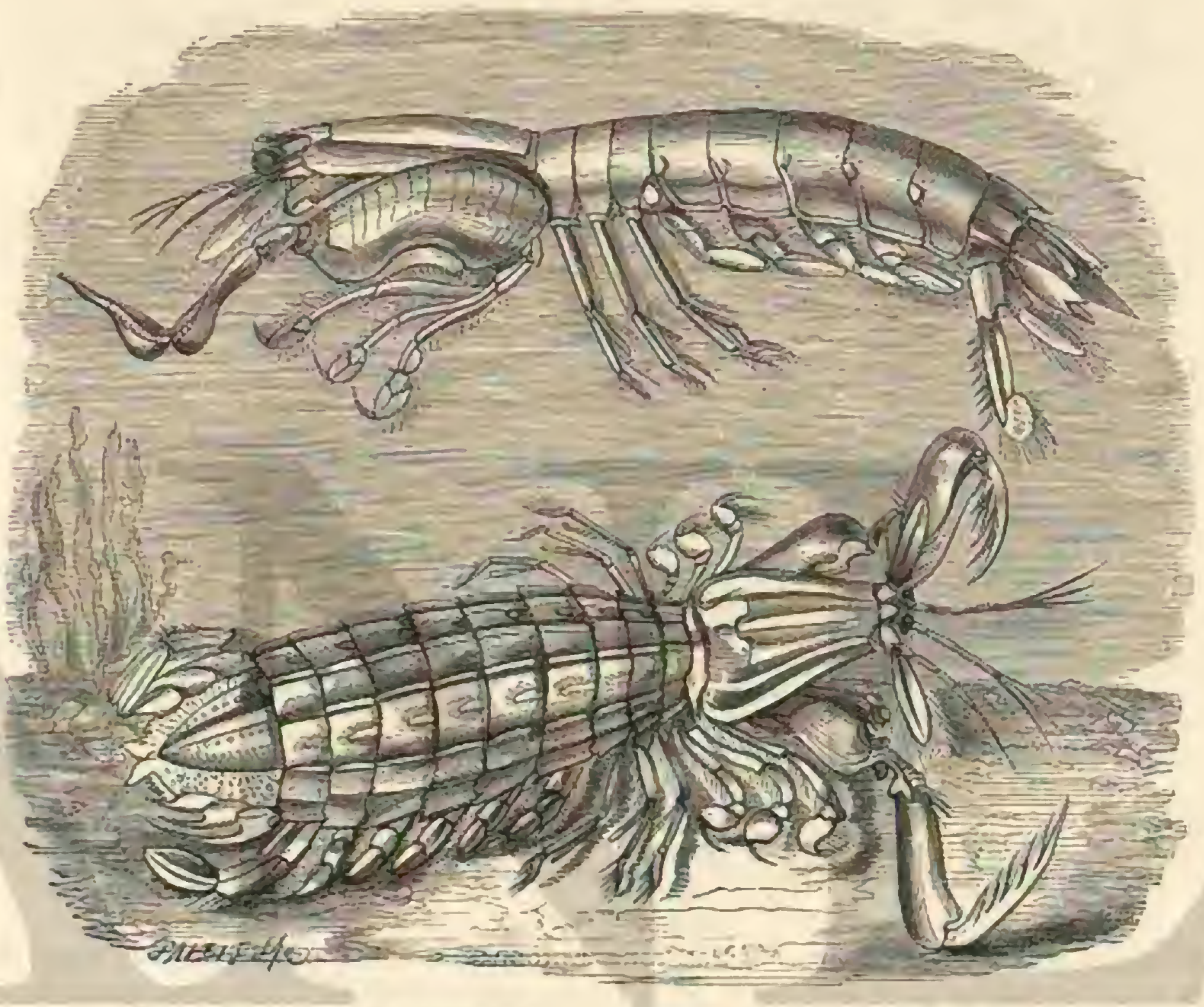

Fig. 72. - R.I. GOSOD.CTILO cotoso
Fig. 73.-LA ESQUILA MANTIS

\section{LOS ESTOMATÓPODOS STOMATOPODA}

Siguen al órden anterior algunos pequeños géneros, pare cidos $\{$ los decipodos por tener los ojos pedunculados y movibles; pero diferentes por la articulacion del cuerpo, y por la posicion y forma de las branquias. Entre cllos figuran en primera línea los estomatópodos.

CARACTERES. - A presar de no habernos podido ocupar de la descripcion detallada de las formas del cuerpo y de los puntos importantes relativos a la clasificacion, hernos dado una serie de descripciones, a mi entender interesantes, sobre el género de vida de los crustíceos superiores, suficientes para ilustrar al amigo de la maturaleza; pero si deseare mayor número de datos sobre los diversos cambios de formas, puede coger una especic de estos estomatópodos, como la galera 6 squilla mantis del Mediterráneo (fig. 73), examinarla un poco inas ciefenidamente $y$ compararla con el cangrcjo flurial. Esto le servirá de metódica preparacion para hacerse despues cargo de formas mas complicadas, entre los cangrejos inferiores. Sin conocer los medios y los úrganos vitales, la existencia no puede comprenderse. Entre todos los crustáceos superiores, con ojos pedunculados, la esquila mantis es la pue ofrece los segmentos del cucrpo mas independientes unos de otros, efecto de su diferente desarrollo caracteristico: y sobre todo, las extremidades, llegan a presentar una organizacion en extremo particular é interesante. Fin la parte anterior se hallan los órganos para divisar, coger y desgarrar la presa; en la central, las patas; y el abdómen, prolongado, provisto de una ancha aleta y oprimido sobre la parte inferior del cefalotó rax, sirve para los rápidos movimientos natatorios. B. escudo dorsal, tan desarrollado en los decápodos, se reduce à una placa horizontal, casi cuadrangular, que deja libres, tanto las regiones anteriores, como los cuatro sexmentos posteriores del cefalotórax, cuyas partes por lo mismo pueden moverse independientemente; los grandes ojos se insertan en el anillo auterior y movible, al ņue sigue el que lleva las antenas.inte. riores; su tallo delgado, provisto de tres artejos, tiene tres puntas en forma de látigo. En las antenas exteriores que se insertan debajo del escudo dorsal, hay un apéndice largo, perteneriente al tallo. Los labios y las partes de la boca, correspondientes á las inaxilas superiores é inferiores del cangrejo fluvial, solo pueden reconocerse detalladamente ull-lus in. 
dividuos vivos ó conservados en espiritu de vino, pero no en los disecados; por lo demás son poco diferentes. En cambio, la serie de maxilas auxiliares, ó patas mnxilares, alcanza al número de cinco pares, por la tmaformacion de las dos extremidades correspondientes al primero y al segundo par de patas en los decrijoxdos: todas estas maxilas auxiliares, excepto el primer par, están provistas de un artejo con garra que encaja en ellas como la hoja de un cuchillo; un par sobre todo, se trasforma, á causa de su longitud y fucrza, asi como por los largos y puntiagudos dientes del artejo de in garra, en un excelente ófgano para atacar y coger la presa. In los insectos rapaces (manlis y otros) hallanse tambien cstas patas con las que se coge el álimento, pero ningun otro artróprodo cuersta tal número junto à la boca. Al segmento libre, es decir, no cubierto por el escudo dorsal, que lleva el último par de maxilas auxiliares, siguen orros tres muy fuertes, cuyos apéndices tienen otra forma que la observada hasta aqui y sirven de aleias $y$ de patas. Il gran post-abdómen es el verdadero órgano de la locomocion y remata en una ancha aleta. Los apéndices, en forma de patas, de los cinco primeros segmentos de este post-ablómen, tienen branquias que afectan la figura de copetes. Su extension corresponde á la celeridad en la circulacion de la sangre y a la creciente necesidad de respirar que se revela del modo mas enérgico en animales tan viraces y de tan fuertes músculos como los de la esquila mantis.

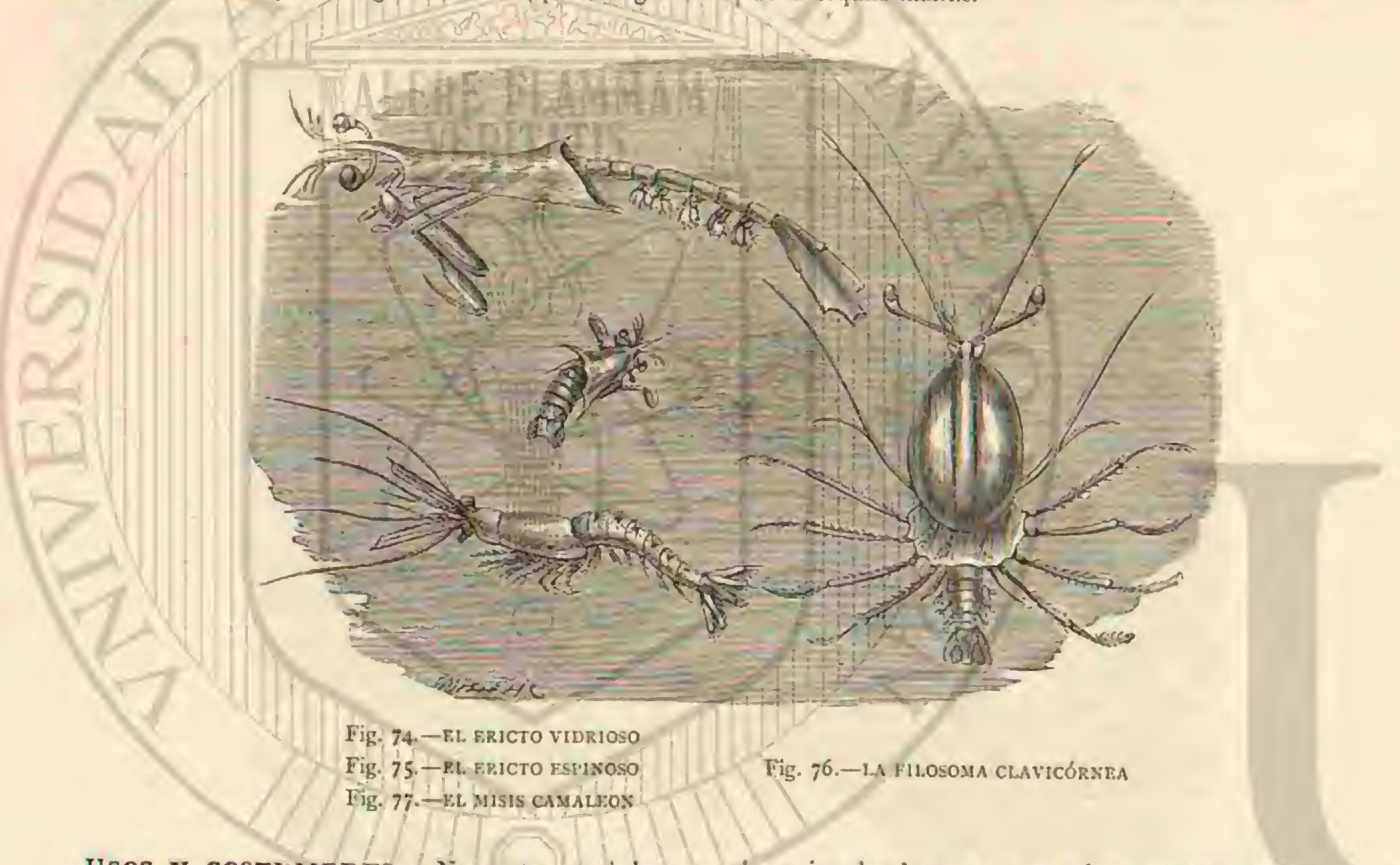

USOS Y cosTUMBREs. - No pertenece à las especies mas vivas de su clase, cundo menos en cautividad, donde casi nunca nada; mas bien anda con auxilio de sus tres pares de patas. Muy a menudo se sirve de las maxilas auxiliares, bastante movibles, para limpiar las diferentes partes de su cuerpo, pudiendo alcanzar con ellas hasta la superficie de la cola.

La galera del Mediterráneo mide una longitud de $-f^{n}, 18 y^{\circ}$ es llevada como articulo productivo y apetitoso à los mercados. Una especie mas pequena, la esquila de Desmarest, de $n^{\prime \prime}$, io de largo, se encuentra tambien en el Mediterráneo en el Canal de la Mancha. Los animales permanecen por lo regular ocultos entre las piedras y algas, de modo que en el acuario se puede observar cómodamente cuál es la habilidad y el modo variado con que utilizan las extremidades que rodean su boca. Se limpian de continuo y extienden una ú otra de sus patas sobre el dorso para rascarse en parte a la que aparentemente no pueden llegar.

\section{LOS ESQUIZÓPODOS- SCHIZOPODA}

CARACTÉRES. - La familia de los escruirónodos comprende una seric de pecueños crustáccos de escudo blando, propios de alta mar, y que, vistos superficialmente, se parecen à los caridinos. Sus patas maxilares, como las propiamente tales, tienen igual formacion, llevando hàcia fuera un apéndice largo y articulado, por cujo motivo aparecen hendidas.

Ya en la descripcion de especies groenlandesas publicada en 1 iso por el predicador y misionero Oton Fabricius, se consignó que los misis, juntamente con algunos otros animalitos, constituyen el alimento principal de la ballena de Groenlandia (Balcue mysticelus). Maravilla el considerar cómo estos pequeísísimos seres, que no alcanzan una pulgada de largo, pueden servir de alimento esencial i animales tan enormes, sirviéndoles para la produccion de tan grandes cantidades de grasa. Abundan tanto, sin embargo, en los mares grocnlandeses, que la ballena solo ha de abrir la boca para tragar miles de gotas de grasa,-juntamente con el agua. Entonces utiliza las láminas córncas, detràs de las cuales queda la presa reducida á una masa. Se diria que los cangre. jitos son atraidos por el brillo y las fibras de las hojas que forman las liminas y penctran voluntariamente en la enorme boca de la ballena.

Asi como el género mysis (fig. 77), tambien cl leurifer care. ce de branquias, presentando una forma tan diferente y rara, que los coleccionistas no han podido ponerse aun de acuerdo respecto á su clasificacion. Semejantes á centinclas avanzados, las antenas y los ojos se hillan en el borde anterior de 
un segmento de la cabeza muy prolongado Muy separada | auxiliures apareadas. A estas sigucn inmediatamente algunos de ellos, es decir, alli donde la parte anterior del abdómen se une con el cefalotórax, que está comprimido lateralmentey se ensancha hácia adelante, hállase la aberturn bucal, rodea. da de las maxilas, oprimidas en un copete, y de otras cuatro pares de patas. El post-abdómen ofrece el mismo aspecto y estructura que el de los decairodos. Tambien los leuciferos son habitantes de alta mar y pertenecen á los muchos animales que por su fosforescencia le hacen brillar.

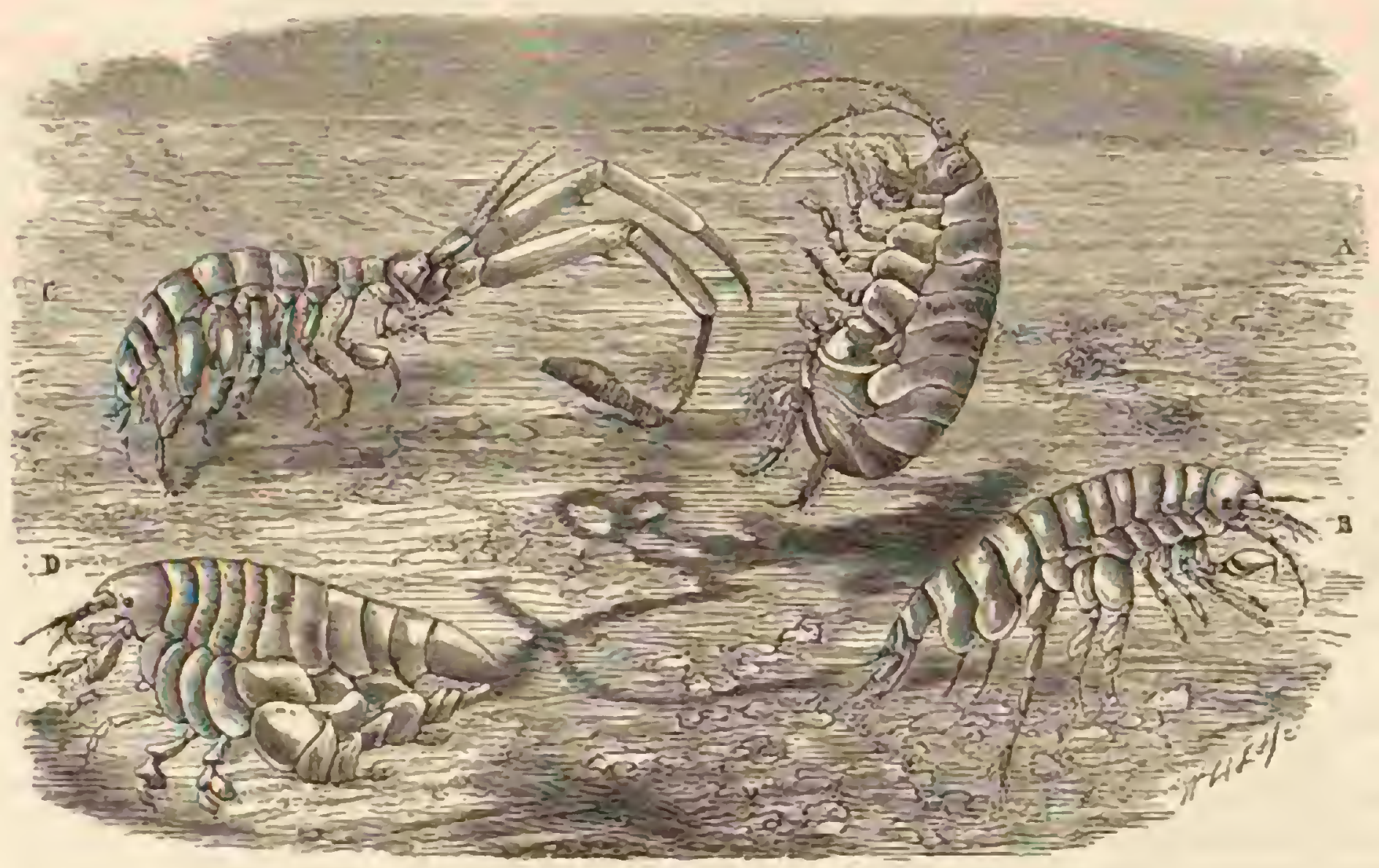

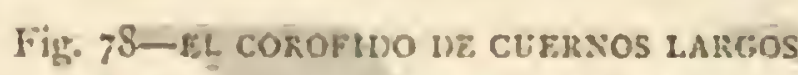
Fig. SO. - LA LISIANASA ARENARIA

Fig. 79. -E: TALitho IANrostA

Fig. SI.-I.A LISIANASA DE. I.AS COSTAS

Al terninar esta parte de mi obm, creo oir preguntar a guras y generales por este concepto, aunque podemos supomuchos de los lectores á qué edad llegan los individuos de ner que los mayores viven cuando menos algunos años, como este órden, mas desarrollados. No pueden darse noticias se- podria deducirse de algunos fenómenos. Cuando, por ejem.

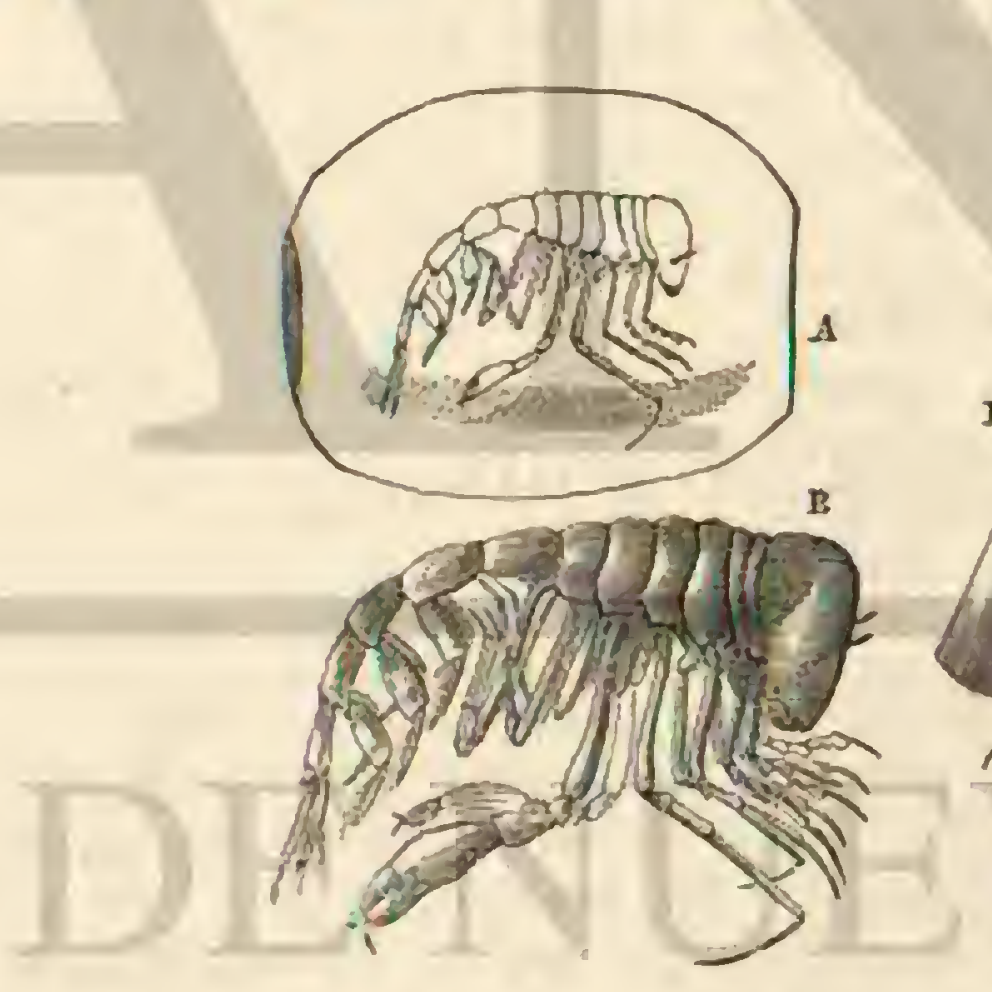

Fig. S2. -A B LA FRONBMA SEBENTAKL

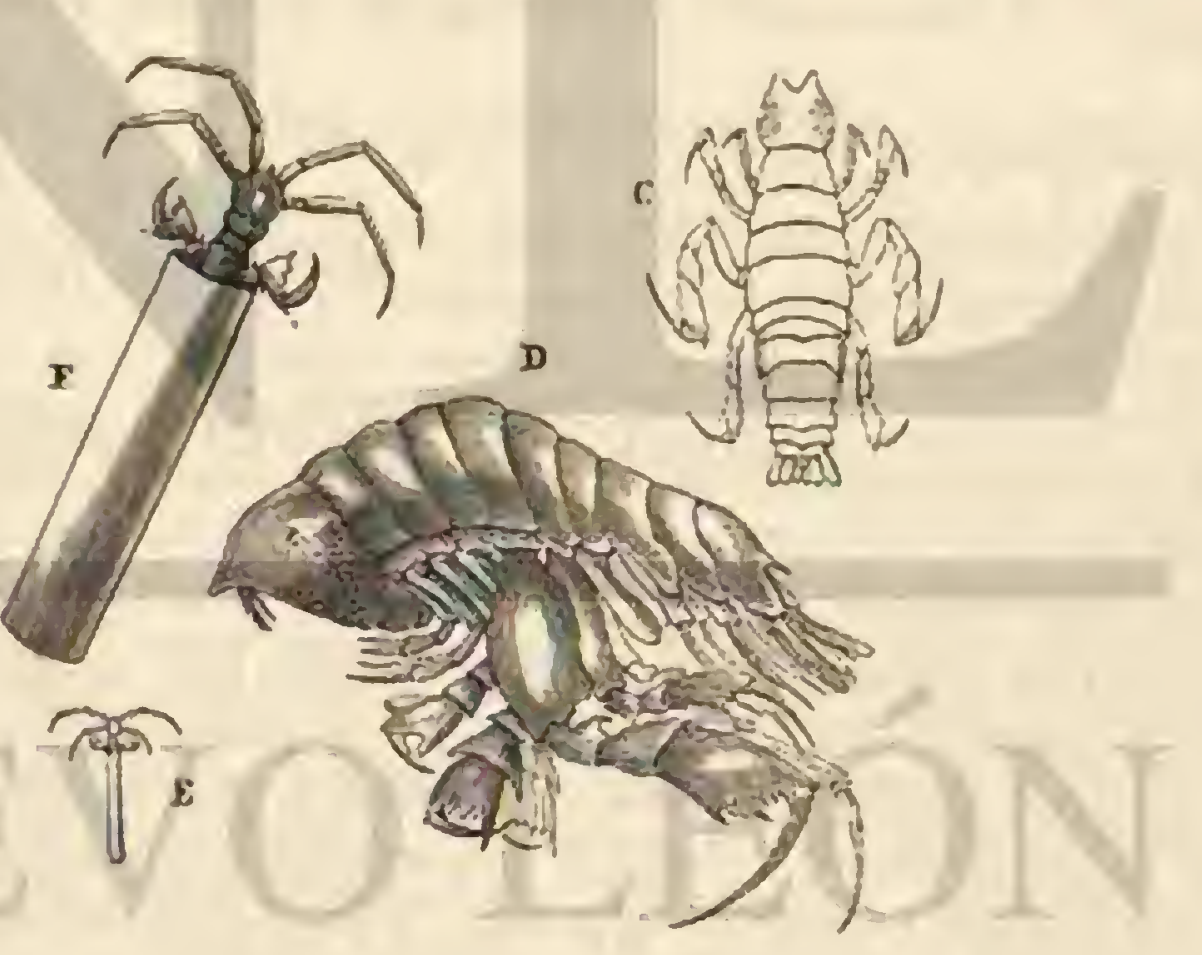

Fig. S. $_{3}$-C D EL DACTII.GCERO DE NIZA

Fig. $S_{4}-E$ F p. cerapo tunus.á

plo, la dromia a'udgaris esta cubierta de una grande csponja, esta (segun mis observaciones acerca del desarrollo de la esAongria, desgraciadamente muy lento), se ha fijado ya algunos aios antes en el cangrejo. Esta prueba no es, sin embargo, verdadera, en todas ocasiones, pues ya indique antes la probabilidad, $\delta$ cuando menos posibilidad, de que la dromia se fije voluntariamente una esponja mas desarrollada cn el dorso. Bell, en cambio, habla de un individuo perteneciente á los cangrejos triangulares, de la especie hyas araneus, en cuyo dorso se habia fijado una ostra de S centimetros de largo y 6 años de edad.

\section{LOS-ERICTOS-ERICTHUS}

CARACTERES. - Distinguense los erictos por su caparazon grnnde, convexo y revestido de prolongaciones espiniformes; cubre por dentro la base de los pedúnculos oculares $y$ de las antenas, y se extiende por detrás, mas ó menos léjos, por encima del abdómen, que es corto y grueso; los ojos son abultados, en forma de pera, y no están situados solire el tronco delgado y prolongado; los piés-maxilas del primer par son muy delgados y mediannmente largos; las patas prensiles estín poco desarrolladas; las patas torácicas de los tres 
últimos pares están tambien poco desarrolladas y carecen a veces de apéndice en forma de punzon; tambien suelen presentarse completamente rudimentarias; el abdómen es ancho y corto; las falsas patas de los primeros pares son grue- sas y terminadas en dos grandes láminas ovaladas, sobre una de las cuales se encuentra una branquia rudimentaria

Se han visto los érictos en los mares del Asia, y particu. larmente en el golfo de Bengala.

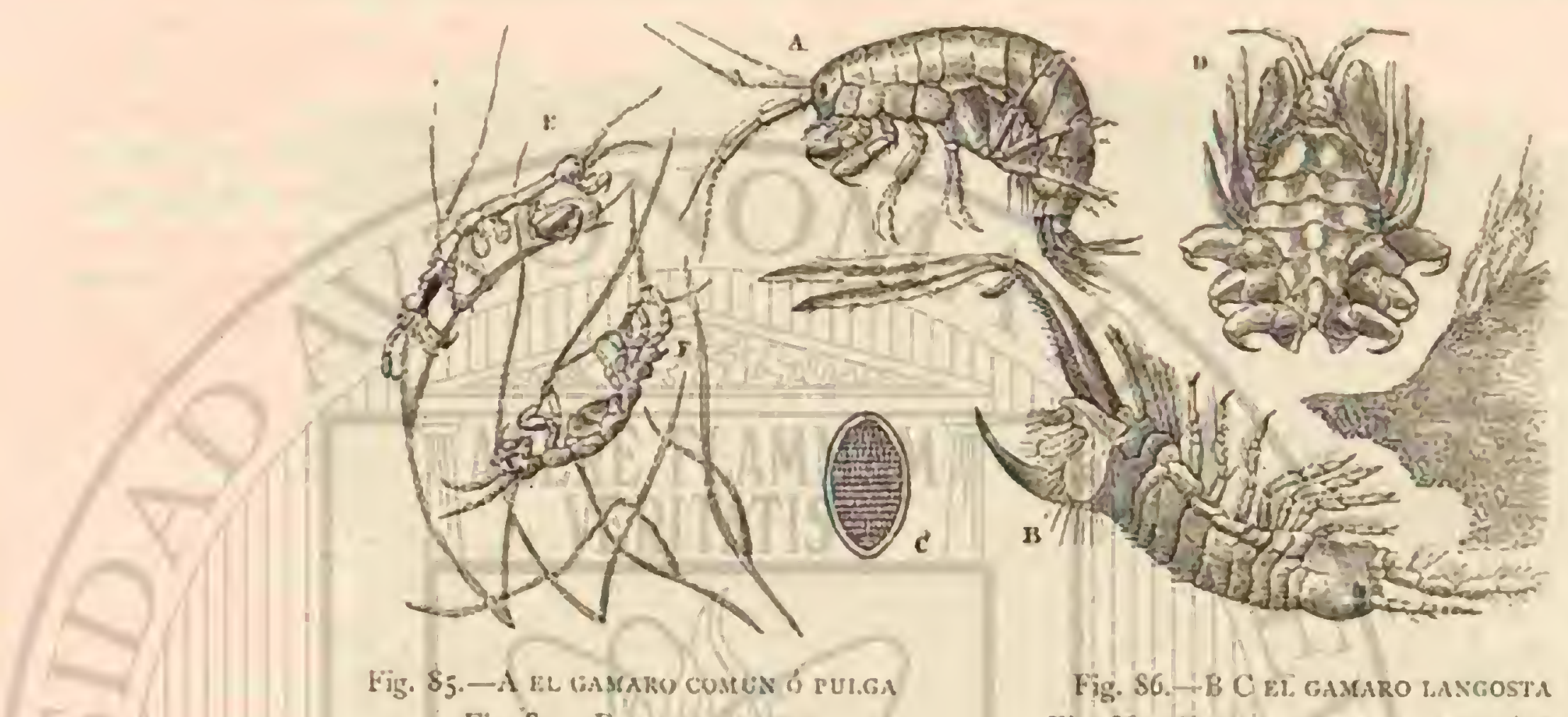

Fig. 87. D R.1. CIAYO OVAL

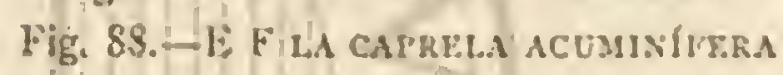

El ericto vidrioso (fig. 7.7) y el espinoso (fig. 75), que se distingue por las agudas espinas de que está crizado su escudo, son las especies mas notables de este género.

\section{LOS GONODÁCTILOS - GONODACTYLUS}

CARACTERES. - Ias especies de este género se distinguen por la forma de las pinzas y de los dedús; estos tienen en su nacimiento la forma de nudos, terminándose en una punta comprimiảa, rects ó poco encorvada; la ranura del artejo precedente se ensancha en șu crtremidad y es sim plemente estriada, sin espinas ni resortes; los ojos son grandes y redondos; el cuerpo es casi cilindrico, y generalmente liso, excepto tn los útimós segmentos; los del tórax son proporcionalmente cortos y mas transyersales. Citaremos, como especie típica, al gonodáctilo gotoso (fig. $7_{2}$ ) que se caracteriza por los grandes tubérculos que presenta en sus micmbros, algo semejantes á los que produce la gota, á lo que debc este animal su nombre especifico. Encuéntrase en todos los mates de los paises cálidos.

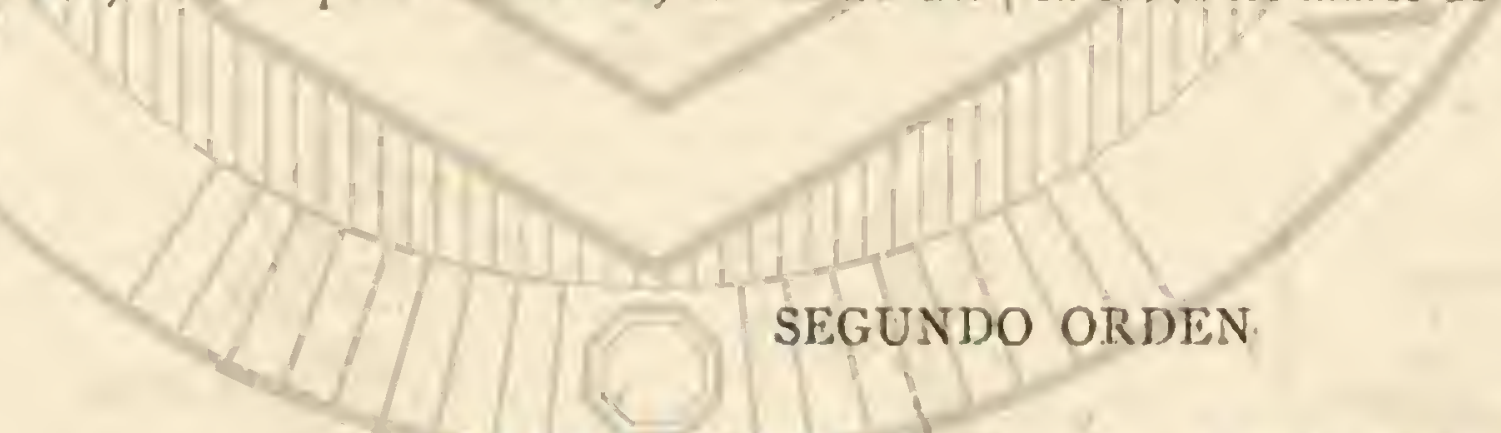

ANFIPODOS A MPHIPODA

CARACTERES. - Los anfipodos llamados tambien cangrejos pulyas, se encuentran diseminados por todo el globo, y viven casi siempre reunidos en considerable número. Han recibido su segundo nombre, a causa de la cxtmordinaria agilidad con que nadan y saltan en tierra firme, $a$ menudo a una altura cien veces mayor que la de su cuerpo. Muchos tienen los lados de aquel comprimidos, asemejándose por este carácter á los caridinos, de los que sin embargo difieren, así como de todos los demis decipodos, por la articulacion de su cuerpo. Para entrar en comparaciones, en la descrip. cion que vamos a trayar seria conveniente tener el gamaro comun (grammarus pulex) (fig. 85), ú otras especies congené ricas, todas muy abundantes en Alemania, especies que suelen vivir á miles debajo de las piedras, la madera y las sustancias regetales en descomposicion, en el fondo de aguas corrientes y en las orillas de los lagos y grandes estanques.

El que haya estudiado la articulacion de los decipodos y los insectos, se complacerá en comparar esta nueva forma de crusticeos con las ya conocidas. De los tres segmentos del torax en el insecto, el anterior se ha soldado completa- mente en el gamaro comun, con la cabcza, que ticne dos ojos no pedunculados, compuestos de facelas, clos pares de antenas, y además de los tres pares de maxilas, uno de patas maxilares. I os dos segmentos libres del tórax, ofrecen la misma estructura que los cinco del abdómen, y por lo tanto existen siete pares de patas para la locomocion. Siete segmentos forman tambien el post-abctómen que por lo regular no se separa marcadamente; todos, excepto el uíltimo, tienen asimismo patas, cuyos tres primeros pares se distinguen por su forma y destino de los tres últimos; los urimeros proveen de agua á los órganos respiratorios, que en forma de hoja se insertan en las patas de los segmentos anteriores del cuer. po. Es ficil observar el grado de actividad de estos animales, que generalmente suelen pernanecer quictos. I a necesidad de respirar es en ellos muy marcada, pues mueren fácilmente en el depósito cuando no se cuida de su limpieza. Si se les coloca en vasos ó en acuarios de borde llano se reunen mápidamente en su parte baja, donde por sus movimicntos favorecen la absorcion del airc.

Los mas grandes anfipodos alcanzan mas de 0 ", oz de 
longitud, pero la mayor parte apenas miden $0^{\circ}$, or y nuchos no llegan á esta dimension.

USOS, COSTUMBRES Y REGMMEN, - Solo algunos pocos viven en el agua dulce. Las numerosas especies que habitan en el mar, pernnanecen en parte. cerca de las costas, yo se las designa con el nombre de salladores de la arena, o. bien en alta mar; otras construyen sus nidos con sustancias vegetales, ó abren gnlerías en el cieno y en la arena. De las averiguaciones del żoólogo danés Kroyer, resulta que los mares árticos albergan numerosas especies, y casi siempre en asombrosas masas de individuos. Se alimentan con preferencia de sustancias animales en descomposicion y son por lo tanto de muchisima utilidad. Ios cadiveres de los grandes delfines yo ballenas, que abandonados à una lenta putrefaccion producen en las aguas pestilentes emanaciones, y ocasionan la muerte de multitud de crias de diferentes animales, son presa de millones de anfipodos que en breve rato los reducen a esqueletos. Prestan por lo tanto como agentes útiles de la naturaleza, los mismos servicios que $\mathrm{cn}$ las regriones tropicales los buitres, pero absorben, sin duda, mucha mayor cantidad de materins dañinas que estos últimos.

\section{LOS GAMARINOS-GAM- MARINA}

CARACTERES، - Fin los grmarinos, ó cangrejos pulgas, propiamente dichos, los dos pares anteriores, de los siete arriba citados, del cefalotórax son patas prensiles con la garra doblada solsre el tarso. Los que pueden saltar tienen el cuerpo comprinido; ! los pares posteriores de piés rudimentarios con que saltan afectan la forma de estilo. Fin una rápida ojenda acabamos de observar los caractéres particulares del gamaro pulga comun.

USOS, COSTUMBRES Y REGIMEN.-Habila en el fondo de aguas poco profundas, pero limpias; con preferencia bajo grandes piedras y peda\%os de madera, alimentindose en prarticular de sustancias vegetales; reduce, por ejemplo, con gran maestria i esqueletos, las hojas que en otoño caen a las aguas. Al levantar una de las piedras que sirven de abrigo á estos animales, se les encuentra regularmente en grandes masas, oprimidos uno contra otro, grandes y pequetros; mas ajenas se les inquieta, se dispersan con la mayor rapidez en todas direcciones, para ocultarse detrís del pri mer objeto que hallan a su paso. Jos que han quedado ad. heridos á la piedra levantada, intentan recobrar la libertad por medio de movimientos enérgicos del post-nbámen y se abalanzan lateralmente, sin que en rigor pueda decirse que saltan para volver a su elémento salvador. Si no puedén lo grarlo pronto, se secan sus branquias, y tambien su cuerpo at poco rato, sobre todo cuando hace sol. La causa de su ràjida fuga no es solo el temor á la persona que se acerca, sino á la luz; pues si se les coloca en un depósito, lo primero que hacen es buscar un sitio lo mas oscuro posible, debajo de una hoja ó de una piedm. El invierno lo pasan los gamarinos ocultos en el cieno y en la arena, dejándose ver de nuevo en los primeros dias calurosos, cuando comienzan á reproducirse. Entonces se les encuentra á menudo aparen. dos, pórque el macho sujeta con tenacidad á la hembra con sus pratas anteriotes por espacio de muchos dias: I.a hembra es mas pequeña que el macho. Los hijuelos se desarrollan en unas bolsas en las patas de la madre, la cual los conduce en ellas durante los primeros dias que siguen à su nacimiento. En caso de peligro, se ocultan en las patas de la hembra, costumbre que tambien se ha observado en anfipodos mari nos, romo por ejemplo, en el grmmarus Insusta: de la costa europea (fig. S6). He observado que el gamaro pulga era un alimento muy conveniente para mis proteos, que rehusan cl alimento muerto, $y$ no aceptan jequeñas lombrices sin repugnancia, pero si les dan gamaros se hartan á mas no poder: estos mismos anumcian al proteo su presencia, haciendole cosquillas en la punta del hocico al pasar junto á él.

Se han descrito además del gamaro pulga, algunas pocas especies congenéricas que habitan las aguas dulces de Furcpa: las del mar son muy numerosas.

Ya comprenderá el lector, sabiendo de antemano que de los verdaderos anfipodos se cuentan nada menos que ciento treinta y siete especies, habitantes de la costa inglesa, que vamos á limitamos a la descripcion de pocas formas. Naturalmente elegiremos de ellas las que mas llaman la atencion, y que se encuentran siempre al pasenr por la playa, ya en Brightor $\delta$ en Helgoland, ya en el Lido, cerca de Venccia. Alli se ve, en todos aquellos sitios de la orilla del mar donde se descubren las algas, al talitro langosta (talitrus 10custo) verdadera especie de la playa (fig. 79), lo propio que a su companero el orquestia de la costn (orrhestia litoralis), que se distingue de aquel esencialmente por la estructura de las patas maxilares.

El talitro langosta no penetra nunca en el agua, sino que la va bordeando, ó durante la marea permanece en la extensa linea formada por las algas, siendo arrojado despues á la arena por las olas. Estos animales saltan en ella, à menudo hasta un pie de altura, en tan increible número, que nuchas veces se ve yia desde alguna distancia su movible masa. Esto, sin enbargo, solo acontece en tiempo caluroso. En invierno se ocultan en las costas septentrionales; se les ve en los montones de algas en descomposicion, arrojados por la marea alta fuera del verdadero dominio de las aguas.

El orquestia de la costa, antes citado, es un compañero comun del talitro, aunque no tan numeroso: prefiere generalmente la costa pedregosa, á donde aquel no le sigue.

\section{LOS COROFIDOS-COROPHIUM}

CARACTERES. - Constituyen un grupo bastante nume. roso de los anfipodos las especies que construyen galcrias, 6 nidos. Estas especies están provistas, casi siempre en la extremidad posterior de su cuerpo, de órganos ganchudos, por medio de los cualeș, se agarran en los allhergues que se construyen con fragmentos de piedra ó de madera y masas de cieno. Nadan, sin embargo, muy bien, y por la forma plana de su cuerpo se asemejan a los isópodos.

Los difcrentes corófidos que buscan el material para construir sus casas, como el corofido de cuernos largos (fig. 78 ), son animales inofensivos, pero no puede decirse lo mismo de la especie chelurn terebrans, nue juntamente con un isó. podo de que mas tarde volveremos á ocuparnos (limnoria lignorum), abre galerias en los diques y terraplenes, gale. rias que alcanzan desde la superficie à cicrta profundidad.

Hasta ahom se le ha obscrvado en las costas meridionales y occidentales de Europa, en las Indias y en la América del norte. Lo único que parece evitar es la madera impregnada de creosota.

Podriámos llamar al queluro un parísito vegetal, porque sc alinenta de sustancias vegetales, y bajo este punto de vista deberia considerarse como tránsito à los parásitos entre los anfipiodos

\section{LAS LISIANASAS - LYSIANASSA}

CARACTERES. - Se asemcjan à los talitros por la estructura de sus pratas, de las cuales ninguna cs prensil; Jas 
dei primer par son bastante luertes, casi cilinäricas en toda su longitud, y terminan en un artejo corto y casi inmóvil; la forma de los diferentes apéndices de la boca es, al contrario, la misma que en las langostas, y las antenas algunas veces muy cortas, siendo siempre las superiores for lo menos tan largas como los pedúnculos de las inferiores, y terminando en dos pequeños troncos anillados.

Las dos eapecies mas conocidas de este género son la lisianasa arenaria (fig. 8o) y la lisinnasa de las costas (figura $8 \mathrm{r}$ ).

\section{LOS CERAPOS-GERAPUS}

CARACTERES. - Los cerapos tienen las antenas superiores gruesas, the largas como las inferiores y pediformes; los piés del primer par pequeños, los del sequndo muj" gran. des, con una mano ancha, aplanada y triangular, provista de un pulgar biarticulado, correspondiente à una punta bas. tante pronunciada, que sustituye al dedo inmóvil de los crustácens comunes. El cuerpo es prolongado y lineal; la ca. beza termina en un diminuto pico; los ojos son prominentes. La especie ilamada cerapo tubular (fig. 84) distínguese por el notable desarrollo de las antenas, y por tener en los primeros pares de patas garras pequeñas. Otra de las particularidades de este crustáceo consiste en que fabrica una especie de tubo en el cual introduce su cuerpo, tubo que se compone de sustancias vegetales. Algunos han creido que este tubo cra el albergue abandonado de algun anélido; pero las observaciones parecen demostrar que el aserto no es exacto.

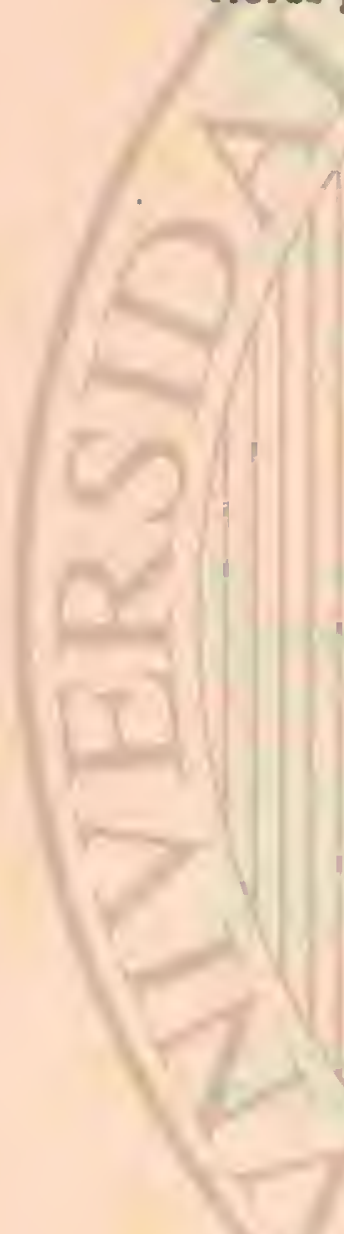

Este singular crustäcen abunda mucho en las rostas de los Estados-Unidos, y vive entre los sertularios, los cuales constituyen su principal alimento, segun dicen los observa. dores. Parece que no se le encuentra sino a grandes profundidades.

\section{LOS DACTILÓCEROS-DACTYLOGERA}

CARACTERES. - Las antenas superiores de estos crus: ticeos son grandes y en forma de cuchara; las diez patas propiamente dichas, monodáctilas y compuestas de cinco artejos aplanados; el cuerpo oblongo, algo arqueado y re. dondo i los lados; la cabeza se prolonga por delante en forma de hocico; ia cola presenta cinco segmentos casi cuadrangulares, y ternina en dos láminas oblongas y velludas; con otra intermedia corta, aplanada y redondeada en su extremidad. El dactilócero de Niza (fig. 83 ) es la especie mas notable del género.

\section{LOS HIPERIDOS - HYPE- RIID Æ}

Estos anfipodos viven como parisitos en otros animales y se distinguen por sus ojos enormemente desarrollados, carric ter que podria extrañarnos tratindose de parásitos, que necesitarian poco esos órganos, si no se vieran obligados a cam. biar de cuerpos pam buscar su alimento. El género hyperia y' sun congéneres, viven en las cavidades, en forma de bolsa, que vemos en la cara inferior de las medusas y su indole es tan tranguila que se dejan llevar sin resistencia por los animales que habitan. No sucede asi con la especie phronima sedentaria (fig. 82), perteneciente i la familia de los fronómi. dos, que está diseminada por todos los mares europeos. $\mathrm{Ca}$ racterizase zoológicamente por la forma de la cabeza, mas ancha en su parte superior; pero sobre todo, por un par de jatas provistas de fucrtes tenazas.

Su género de vida es en extremo raro; elige individuos de los géneros doliolum y pyrosoma, vicilndolos de tal modo, que solo queda la cubierta, como nido 6 galeria. Por esn sc ve obligada a cambiar de sitio; en cuya ocasion se ngarm con las tenazas al animal, que le sirve de alimento; rema con el post-abdómen extendido y provisto de tres pares de patas natatorias. Mas raro en las costas del mar del Norte, abunda en el Mediterráneo, donde en la primavera se puede coger todos los dias en el puerto de Mesina. Tambien en Napoles abunda todo el invierno.

\section{EL TAUMOPS TRASPARENTE-THAUMOPS PELLUCIDA}

CARACTÉRES. - Un animal extrano, congenérico de los hiperidos, fué descubierto por la expedicion de Challenger, en el Océano Aulántico, al sudoeste de Gibraltar, a la profundidad de dos mil ciento ochenta metros: era el taumops trasparente. Este auimal gigante, entre los anfipodos, tiene la longitud de $0^{n}, 08+$ a $11^{m}, 10_{3}, y$ sus ojos que ocupan toda la parte superior de la cabeza, miden $0^{4}, 020$ de largo por $0^{\star}, 026$ de ancho. Segun dice uno de los zoólo; ros de la 
expedicion, Willamoes.Suhm, es trasparente como el cristal; solo el ovario tiene un tinte sonrosado; y el color pardusco una linea que se forma en las paredes de los ojos, por un apéndice de quintina lan frónima tiene una cabeza muy grande $y$ cnormes ojos compuestos de facetas; pero el taumops trasparente la supera por este concepto. Casi podria dudarse de la exactitud de la noticia, segun la que, este animal vive à una profundidad de dos mil metros, á que apenas llegará el rayo de luz; $y$ la suposicion de que el individuo haya entrado en la red en las regiones superiores, parece mas probable por la circunstancia de que en otra ocasion, varios de estos animales se cogieron de noche en una red arrastrada por el buque. Los tres pares de apéndices, en forma de ho. jas, que presentan los segmentos centrales del cuerpo, son órganos respiratorios; en medio de aquel, se halla él sistema nervioso en forma de un cordon nudoso.

\section{LOS LEMODÍPODOS - LAEMODIPODA}

CARACTERES. - A los anfipodos siguen, como del todo congénericos, los lemodipodos, semejantes por tener la cabeza soldada con el primer anillo del pecho; mientras que se distinguen por el atrofiamento completo del post-abdómen. Por lo regular hállanse en dos segmenios del abdómen, branquias en forma de hojas, en ver. de las patas. Tambien el segundo segmento del tórax está soldado estrechamente con la cabeza, carícter que comunica á estos animalitos un as- pecto idéntico al que tuvieran con el primer par de patas en la garganta. Deben distinguirse dos géneros principales, muy diferentes por su aspecto y modo de ser.

\section{LOS CAPRELAS - CAPRELLA}

CARACTERES-E! primer género, el de las caprelas, comprende especies de cuerpo delgado, prolongado y filiforme. Los dos primeros pares de patas tienen el penúltimo artejo mas grueso que los tres posteriores, en los cuales aparece mas prolongado. Las numerosas especies miden de $0^{\mathrm{m}}, 003$ i $0^{\circ} .013$ de largo, y viven en las algas de los mares, ofreciendo un espectáculo muy interesante al observador. Son verdaderos gimnastas entre sus companeros de la misma clase, pues se mueven con ln agilidad de los monos en el ramaje de los bosques submarinos. Siempre ágiles y actiros, se distinguen ventajosamente de los tipos del otro género. Como tipo de cste, citaremos la caprela acuninifera (fig. 88).

\section{LOS CIAMOS-CYAMUS}

CARACTERES. - El cuerpo de estos animales es oval y aplanado y la parte de la cabeza pequeña y estrecha; los tres pares posteriores de patas son cortos y fuertes.

Viven como parásitos en los delfines y grandes ballenas a cuya piel se agarran, sin ofrecer gran interés para el observador. El ciamo oval (fig. $S_{\boldsymbol{\gamma}}$ ), conocido con el nombre de piojo de ballena, es la principal especie del género.

\section{ISÓPODOS - ISOPODA}

CARACTERES. - La disposicion general de las partes del cuerpo de los isópodos se asemeja á la de los anfipodios Su cabezan tiene un par de ojos fijos; los siete anillos libres del tórax llesan patas casi del mismo aspecto, que raras veces sematan en tenazas; los segmentos del abdúmen existen en ulinero de seis, carácter muy importante de todos los isópodos, que por lo demís suelen tener el cuerpo aplanado, trasformandose las patas del post-abdómen en placas dobles quue sirven de órganos respiratorios. Las hembras presentan en las -patas del pecho unos apéndices en forma de hojas, qque for-man una cavidad para los huevos y los hijuelos en los primeros dias de su existencia. Los hijuelos se parecen mucho ¿ los adultos, pero no tichen aun el número compléto de segmentos del cuerpo y de extremidades. En su generalidad, los isópodos son crustáceos pequeños, que miden por lérnino medio de $\left(1 \bullet, 0015\right.$ a $0^{\circ}, 0026$. Como se alimentan con preferencia de sustancias en putrelaccion, observan diferente género de vida; encuéntranse lo mismo en el agua dulce que en la salada, y asi en tierra firme como en los sitios secos y húmedos. Aunulue los mas viven libremente, hay entre ellos parísitos que viven en otros crustảceos y en peces.

\section{LOS ONISCODEOS-ONIS- CODEA}

CARAGTERES. - Ia familia de los oniscodeos ó isópodos terrestres se caracteriza principalmente por sobresalir Toso VH el ulltimo par de patas rudimentarias en forma de estilos en ambos lados del abdómen. Tambien por su género de vida difieren de las otras especies como habitantes terrestres que casi siempre se hallan en los sitios húmedos, debajo de las grandes piedras, en bodegas y otros sitios anailogos, donde como animales lucilugos, que necesitan siempre el aire, pa. san su vida en toda comodidad. De sus patas rudimentarias, solo la hoja interior tiene la piel delgada, sirviendo de órgano respiratorio; la exterior, de consistencia mas sólida, forma una tapa encima de la otra para inipedir el resecamiento. Las especies de los géneros oniscus armadillidium: y otros que habitan en sitios del todo secos, tambien baiados por el sol, parecen tener la facultad de respirar por branquias, $y$ ademas por la via aérea, pues en la tapa exterior de aquellas se ven espacios aéreos muy rumificados, que por hendiduras se abren hácia afuera. Hay unas especies muy conocidas, repugnantes para las personas demasiado delicadas, y son los oniscos de los muros (onissus murarius) (fig. 90), los porcelios de las bodegas (oniscus sablier) (rig. 92) y las ligins oceinicas (ligio ocennica) (fig. 93), qute asi como los demás tipos de su grupo no pueden enroscar su cuerpo plano. Esta faculead la tienen los armadillos, de los cuales el arrnadillo officinarum constituin antes, bajo el nombre de millepedis, un remedio muy usado, aunque segun parece poco eficar, que se vendia en las farmacias. Cuanto se ha dicho sobre el hecho de que, despues de comer algunos oniscos se ha dado el caso de que varias personas experimentasen fuertes sintomas de envenenamiento, no merece crédito, porque segun 
dice Martiny, autor de tima historia natural de les animales importantes para la medicina, los inofensivos oniscos se to. man en muchns regiones como remedios populares, en gran cantidad y sin malas consecuencias.

\section{LOS ASELINOS-ASELLINA}

CARACTERES. - Los aselinos $\mathcal{U}$ isónodos acunticos se distinguen de las especies del grupo ninterior por tener el

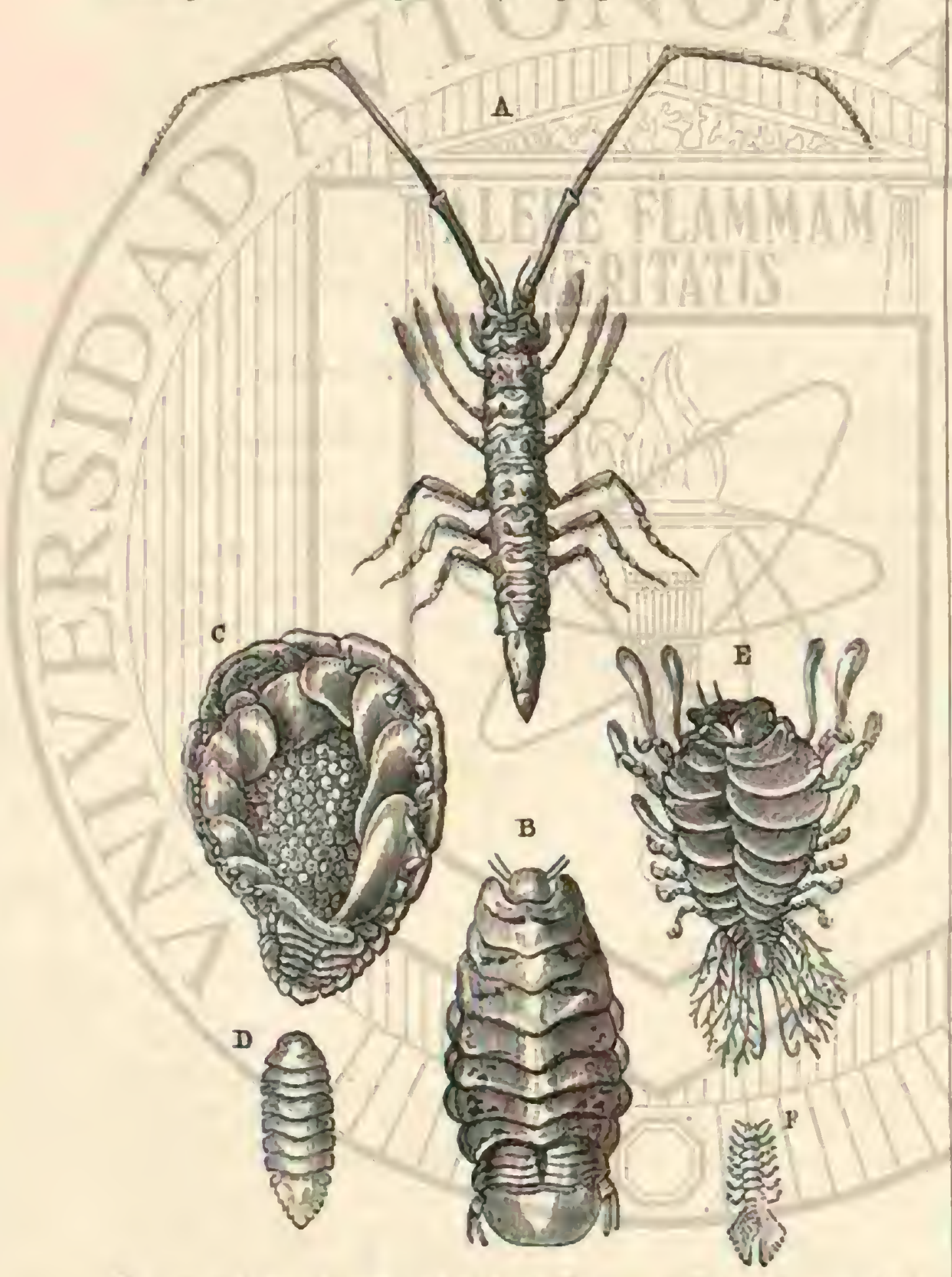

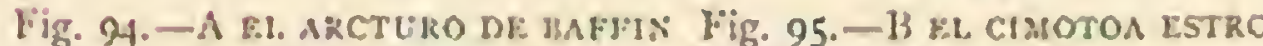
Fig. 96. -C D EL hOH'HO UE d.OS CANGKi:jos (1)

Fig. 97.-E I EL IONE TORÁcico (macho y hembm) (2)

cuerpo mas prolongado $y$ por la aproximacion de los seg. mentos del abdómen, excejto el último, que afecta la figurn de escudo. En el aselo acuático comun todo el abdómen se compone de un solo segmento gradual en forma de escudo. liste animal que mide $11 ", 0013$ de largo se encuentm por todas partes en los estanques y pozos, Los otros géneros de los aselinos habitan en el mar, siendio de los mas ricos en especies los llamados idolea y asclus (fig. 91). La mayor parte de estos animales son inofensivos y carecen de importancia esencial; solo uno; la limnorio terelurans (fig. Sg), que alcanza una longitud de $0^{\circ}, 002$ ta $0^{\circ}, 0<4{ }^{11}{ }^{2}$ y que es propio de las costas inglesas, perece ser muy dañino, porque destruye la madera que se halla debajo de la superficie del agua.

(1) La figum $C$ representa la henibra de cste bopiro de mucho mayor tamaño, y ucha de espalda para que be vea ha masa de hucvos que conriene.

(2) Esta figrura està representada tamlien cie mayores dimensiones, para que se pucta formar mejor idea de su est nuctura,

\section{LOS ARCTUROS - ARCTURUS}

CARACTERES. - Los arcturos son notables por la forma de sus segundos y tcrceros piés, que dirigidos baicia de. lante, terminan en un largo artejo velloso, un poco unguiculado; los dos anteriores se aplican contra la baca y tienen unas y los seis últimos son bastante fuertes, ambulatorios, dirigidos hácia atrís y bidentados en la extremidad.

Se encuentran estos crustáceos en los mares del Norte siendo el arcturo de Baffin (fig. 94) ln especie que presenta mayor desarrollo; el cuerpo es largo, y' los primeros pares de patas parecen orillados de pluma en sus extremidades; las antenas, notablemente largas, sirven de órganos prensiles á este crustáceo; y' con cllas se apodera de su presa.

\section{LOS ISÓPODOS NADA- DORES}

CARACTERES. - Ias siguientes familins pueden agruparse como isópodos nadadores, porque los pares posteriores de las patas nidimentarias, que son plamas, forman con el último segmento del cuerpo una nleta. Entre estas especies, los esferomas (sphacroma) son crustíccos muy diseminados en las costas, sobre todo de los mares de los paises cálidos, donde se encuentran en masas innumerables. El esferoma de las costas europeas (sqhacroma serratum!) se encuentra en todas partes en las orillas pedregosas, en et limite del agua. Vive siempre debajo de las piedras y se enrosca cuando se le toca. Tambien se acostumbra al agua sucia. Le he visto en la travesia desde el Kerkin à la bahia de Sebenico, en Dalmacin, cuyn bahia se confunde joen ó poco con el mar y cuya agua es apenas salada. En las aguas de Carniola se encuentra tambien un esferoma (monolistra socer).

\section{LOS CIMOTOADOS- CYMOTHOADE}

CARACTERES. - I a familia de los cimotoados 6 isópo. dos peces se compone principalmente de especies que viven como parasitos en la piel ó en las branquias de los peces. Ial pequeña cabeza $y$ las grandes garras los distingue de la familin anterior: a ellos pertenecen los isópodos mayores, que miden $0^{\circ}, 05$ ó mas. Como tipo de esta familia puede citarse el cimoter estro (fig. 95).

\section{LOS BOPIRINOS-BOPY- RIN I}

CARACTERES. - Un atrofiamiento particular y una diferencia scrual muy extrana carncteriza à los bopirinos, isópodos que viren como parásitos, principalmente en la cavidad branquial de los caridinos, y segun mis observaciones, tambien, aunque raras veces; en las porcelianas. In presencia de estos incómodos huéspedes se reconoce por la dílatacian del cefalotórax, ocasionada siemure por las hembras, mucho mayores que los machos, y que, despues de agarrarse, se inflan de tal modo que no se las reconoce y pierden soda simetría. Los niachos son mucho mas pequeños y conservan su articulacion graciosa; siempre se fijan en la cara inferior de las hembras. El bopiro de los cangrcjos (fig. 96) es una de las especies mas singulares de la familia. Otra especie notable, propia del género ioné, es el sonés arácico (fig. 9i), el 
cual se distingue por los apéndices laminares ocultos debajo del abdómen. El ione es tambien parisito, y se oculta entre el caparazon y las partes carnosas del cancer subterrancus, donde forma un tumor en un lado del cuerpo. Parece que ambers sexos se alojan en el mismo sitio, $y$ (que los machos no se separan nunca de sus hembras, una vez hecha su eleccion.

\section{LOS PRANIZAS - PRANIZA}

CARACTERES.- Èstc género no puede clasificarse sistematicamente entre las familias citadas de los isopodos, pero es añne de ellas; los pranizas se asemejan a los decápodos por todo su aspecto y por tener soldados los segmentos del tórax de la cabeza, pero presentan entre otros distintivos los ojos fijos de los isópodos, ofreciendo un cjemplo mas de la increible diversidad del tipo de los crustaceos. Durante su juventud tienen la cabeza pequeña, grandes ojos y una trompa para chupar: viven como parásitos en diferentes peces ma rimos. En tal estado permanece la hembra, de la que cl macho se distingue por tener la cabcza cuadrangular y muy grande, asi como por sus poderosas maxilas superiores. El aspecto del macho es tan diferente del de la hembra, que aquel se ha considerado hasta ahora como género independiente (ansens).

No sé concluir mejor la descripcion de los isópodos que reproduciendo una observacion de mi amigo Fritz Muller, consignada en su obra "Parn Darwin», y que se refiere a la existencia de dos formas de machos para una sola especie de hembras. Es un isópodo provisto de tenazas, del género /17nais, clasificado por los sistemáticos juntamente con el aselo acuático. Dice en la introduccion, al hablar de las dos formas de machos, que en todos aquellos crustaceos tn que las tenazas aiectan la figura de mano $\delta$ de tarsos, aquellas son mucho mas fuertes en los machos que en las hembras, adquiriendo a menudo un tamaño desproporcionado. Fl gelasimo nos ha dado un ejemplo de esto. \&Otra particularidad de los machos, continua Muller, consiste á menudo, en presentar un excesivo desarrollo de varios delicados hilos en el látigo de las antenas anteriores. Muller y otras autoridades cientificas los consideran como órganos del olfato ó del tacto, muy desarrollados, upinion que se confirma por el hecho, de que tanbícn en otros casos los machos se rigen por el olfato al buscar la hembra.

\&Los machos jórenes de la especie tanais se asemcjan à las hembras hasta la última muda çue precede ì su estac̀o adul. to, pero entonces sufren una trasformacion notable. I o mas extrano es que en tal ocasion tamhien se presentan bajo dos formas diferentes. Los unos tienen poderosas tenazas muy movibles, con dedos largos, y en ver. de un solo hilo olfntorio, como lo tienen las hembras, de doce á diez y siete, situados de dos en dos ó de tres en tres en los artejos del látigo de las antenas; lns otros conservan la forma pesada de las tenazas de la hembra, pero en cambio sus antenas están provistas de hilos olfatorios mas numerosos, dispuestos en grupos de cinco it sicte.

- Era natural pensar que dos diferentes especies, con hembras muy parecidas y machos muy clistintos, vivian juntos, ó que los machos, en rez de presentarse bajo dos formas marcadamente distintas, solo cran variables dentro de cicrtos limites. No puedo suponer ni lo uno ni lo otro. El tanais vive entre una espesa capa dic plantas acuáticas que forman una cubierta de una pulgada de grueso subre las piedras, cerca de la orilla. Al poner una porcion de esta capa verde en un grande vaso de agua marina pura, pronto sus paredes se ven cubiertas de centenares y hasta miles de estos pequeños isóno. dos pesados y blanciuizcos. Yo he examinado miles de ellos con un sencillo anteojo microscópico y muchos centenares con el microscopio, pero no he podido observar ningura diferencia entre las hembras, ni forma alguna de tránsito en los machos.

No podemos permitirnos en este lugar, como nuestro paisano en el Brasil, explicar el diferente desarrollo de los órganos prehensiles y de los olfatorios, á fin de apoyar con esto la teoria de Darwin.
CARACTERES. - La mayor parte de los crustáccos pertenecientes á esta gran division tienen la cubierta en forma de escudo ó de concha, que saliendo de la piel del dorso sucle protejer el cuerpo, excepto las partes de las extremidades; pero ademas de esta cubierta, que no es propia de todos los géncros, se distinguen de los otros crustáceos por ser menos marcadas las divisiones del cuerpo y por la carencia mas ó menos completir de un tórax con sus cxtremidades. Faltan por lo tanto á menudo las que corresponcierian a las maxilas auxiliares de los decapodos, y con ellas muchar veces tam. bien el segundo par de las maxilas inferiores. Tanto mas des. arrolládas están las extremidades de la parté posterior del cuerpo, que para distinguirla de la cotrespondiente en los insectos hemos llamado post-abdónen. No empleamos sin embargo esta cxpresion en absoluto, porque es extraña al lenguaje. 'Todas las extremidades, $\delta$ solo las anteriores, afectan la forma de hoja, y se trasforman en branquias y alctas.

USOS, COSTUMBRES Y KEGIMEN. - Su género de vida es sumamente monótono y no da lugar à brillantes des. cripciones: pero en cambio, ciertas particularidades extrañas en la manera de reproducirse y desarrollarse excitan nuestro interés. En la mayor parte de los branquiopodos las hembras existen en gran numero, mientras que los machos escasean, $y$ aun de algunas de las especies mas comunes hasti ulti. mamente no se han encontrado los machos; los de otras solo se encuentran un corto tiempo del año; mientras que du. rante los demás meses no se conocen los machos de varias generaciones. Tambien se ha observado que la mayoría de especies de los otros órdenes viven en agua dulce, lo cual revela una separacion del tronco primitivo de los crustácéos, y en efecto, los mas antiguos que hasta ahora conocemos, los trilobites, son los mas afines de un grupo de los branquiopodos, es decir, de los filópodos.

\section{LOS FILÓPODOS - PHYL- LOPODA}

CARACTERES. - La familia de los filópodos compren. 
de los mas grandes braquiopodos hoy dia existentes y solo ctsenta algunos géneros, que sin embargo se distinguen por muchos conceptos. Su cuerpo, de piel delgada, està cubierto casi siempre de una cornza en forma de escudo ó figurando dos tapas, y presenta en los numerosos segmentos del postablómen de 10 a 60 pares de patas matatorias en forma de hojas, con apendices branquiales. Ios individuos jórenes ca. recen del escudo y de las numerosas articulaciones y extre. midades, ofreciendo un asjecto extmino por las grandes antenas que sirven de remos y que desaparecen mas o menos en los individuos adultos.

USOS, COSTUMBRES Y RÉGIMEN. - Nadan boca arriba; y por su repentina alsundancia en sitios donde en muchos años no se habia visto ninguno, asombran à todo aquel que no sabe que sus huevos conservan la facultad de desarrollarse, aunque hayan estado algunos ainos en seco. Fisto puede decirse sobre todo del braquipo, que suele presentarse en las praderas despues de las inundaciones.

\section{LOS BRAQUIPOS-BRANCHIPUS}

CARACTERES. Fil géncro de los braquipos pertence á su segundo grupo, cuyas especies tienen los njos pedunculados y movibles, y el cuerpo no protegido por una cornza. I.a mayor parte de las 18 especies conocidas viven en el agun dulce, pero la mas interesante de todas es el braquipo salino (branshipus salinus ó artemia salina) (fig. 99), que no solo $\mathrm{cn}$ el mar, sino tambien en los lagos salados del interior abunda inucho. Esta especie solo mide algunos milimetros de longi. tud. Yo la encontré en los cubos de lejia salada bastante

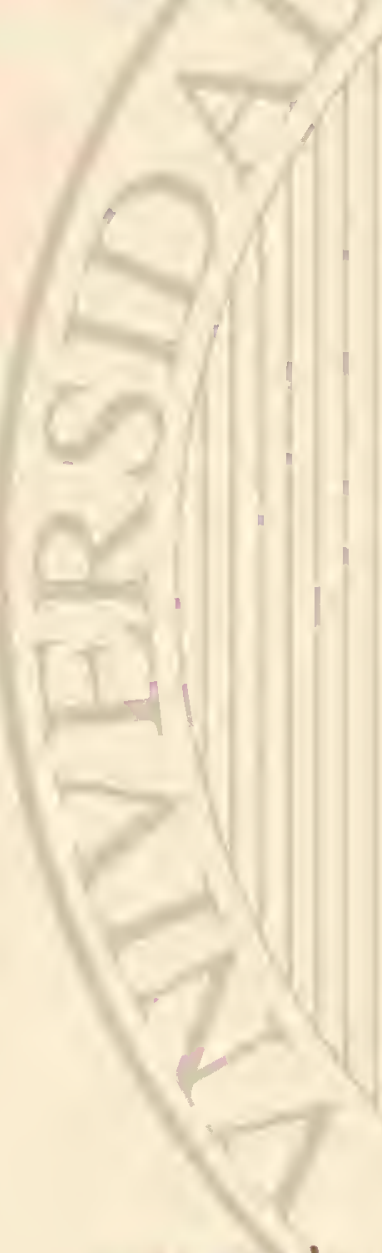

concentrada, de las salinas que hay cerca de Greifswald, donde me dijeron que la muerte de las artemias es una señal de que el agua salada se ha concentrado bastante por la evaporacion al sol, para que se pueda hervir. In las salinas de la Francin meridional, en los altededores de Trieste y de Odesa, en las salinas naturales de Adana, visitadas por el conocido viajero Kotschy, en los lagos de bicarbonato del Egipto, segun refiere Schmarda, y en algunos otros puntos, se ha encontrado esta esjecie. Vogel la descubrio en su viaje al interior de Africa, y describióla bajo el nombre de artemia Ondneyi; con el de gion de Fersan es conocida en los lagos del liczzan y se come mezclada con dátiles como una especie de papilla.

El braquipo salino es una de las especies en que últimamente se ha observado con regularidad la ireproduccion por hueros, sin concurso de los machos, ó la llamada partenogénesis. Las noticias de Carlos Viogt y de Siebold quien estudia hace aisos el asunto, nos dan al mismo tiempo otras explicacionces sobre la existencia y género de vida de estos anima. les. Vogt habia recibido de Cettc varios individuos encerrados en vasijas, que estuvieron 36 horas en camino, y los cuales puso en un acuario lleno de agua de nar de la misma ciudad; alli jusicron luevos y nacicron las larvits. "Hasta ahora, escribe Vogt desde Ginebra, no he podido encontrar, entre todos los individuos, un solo macho, mientras que en la especie brunchipus diaphanus, recibidas el ano anterior, y procedentes de una charca situada en el monte Jura, unos 4,000 piés de elevacion, los machos y las hembras existian en un número poco mas ó menos igual. No dudo que las artemias llegaran aun viras á Munich en vasos cerrados.
Reproducimos ahora el relato del célcbre zoólogo de Munich. "Fácilmente se comprenderf, dice, con cuanto placer acepté una invitacion que se me hizo para observar por fin las interesantes artemias; à vuelta de correo contesté afirmativamente, y el profesor Vogt cumplió mi deseo con la mayor amabilidad, remitiendo el 23 de agosto cierto numero de estos filópodos vivos a Berchiesgaden. Las artemias habian llegado tambien vivas en una vasija bien cerrada. En extremo sorprendido y lleno de alegria conté setenta artemias adultas y algunas que no lo eran del todo; pero todas estaban alegres, y entre ellas retoraban muchos individuos recien nacidos: solo cinco cadáveres encontré en el fondo de la vasija. Debo añadir que esta contenia tres cuartas partes de agua marina $y$ una de aire. Todas las artemias adultas de este envio eran hembias. Parece por lo tanto gue los lagos salados de Cette, asi como los estanques de Ville Neure, cerca de Marsella, de los que Joly tomó su material de ob. servacion, son los parajes en que la artemia salina se propaga solo por la generacion universal. De csta generacion exclusivamente femenina se producian hueros, que no se depositaran por que los animales murieron antes; otm clió á luz. hijuetos rivos en gran núméro, pero no se desarrollaba nin. gun macho. El extmono hecho de que varias hembras de la misma cria pusieran huevos ó dieran á lur hijuelos vivos, puede atribuirse segun el citado naturalista a la circunstancia de que, en los últimos, las glándulas para la produccion de la reiscara de los huevos están menos desarrolladas. \&La puesta, dice Sicbold, no se efectúa en la mrtemia salina hasta que las glíndulas que dan la cáscara se han desarrollado de tal modo que pueden segregar la cantidad necesaria de sustan. 
cia, pues solo entonces los hucvos podrain adiquirir una cás. cara sólida y duradera. De tal ciscara sólida y resistente depende que los huevos tengan la cualidad de poder conservar su facultad de desarrollo aun despues de resecarse on el cic. no $y$ al cabo de mucho tiempo.

«Cuando, en cambio, cl clesarrollo de las citadas glandulas no se ha verificado debidamente, faltan las condiciones para qque la cáscara sea sólida y duradera. I.os huevos de las artemias que se hallan en este caso tienen solo entonces una càscara delgada, de lo cual resulta que las influencias favorables para el desarrollo del embrion pueden producir fäcilmente sus efectos sobre el contenido del huevo, apresurando asi el desarrollo de aquel. Recordamos el caso, bastante fre. cuente en todo gallinero, de la puesta de hueros de cáscara blanda, debida al estado enfermizo, que disminuye la secre. cion calcarea en los oviductos.
Sicbold que obturo artemias y hueros de las cercanias de Trieste por conducto del doctor Syrski, bien conocido de los naturalistas, obtuvo una cria exclusivamente femenina. Yo he podido completar las observaciones sobre el género de vida de esta especie, que reproduciré, con tanto mas gusto, cuanto que contiene mucho de instructivo sobre los otres filo. podos. Mi principal cuidado, dice Siebold, para conservas la cria de artemias, se redujo á sustituir el agua evaporada del depósito por agua de mar, despues de reducir su contenido de sal á cierto grado, añadiendo agua destilada, sin of. vidarme nunca de remover bien esta solucion salada varias veces antes de mezclarla con el agua habitada por los animales, y permitir llegara á clla un poco de aire atmosférico.

\$No cré necesario cuiclar de mi colonia de artemias, porque habia observado que el canal alimenticio de estos

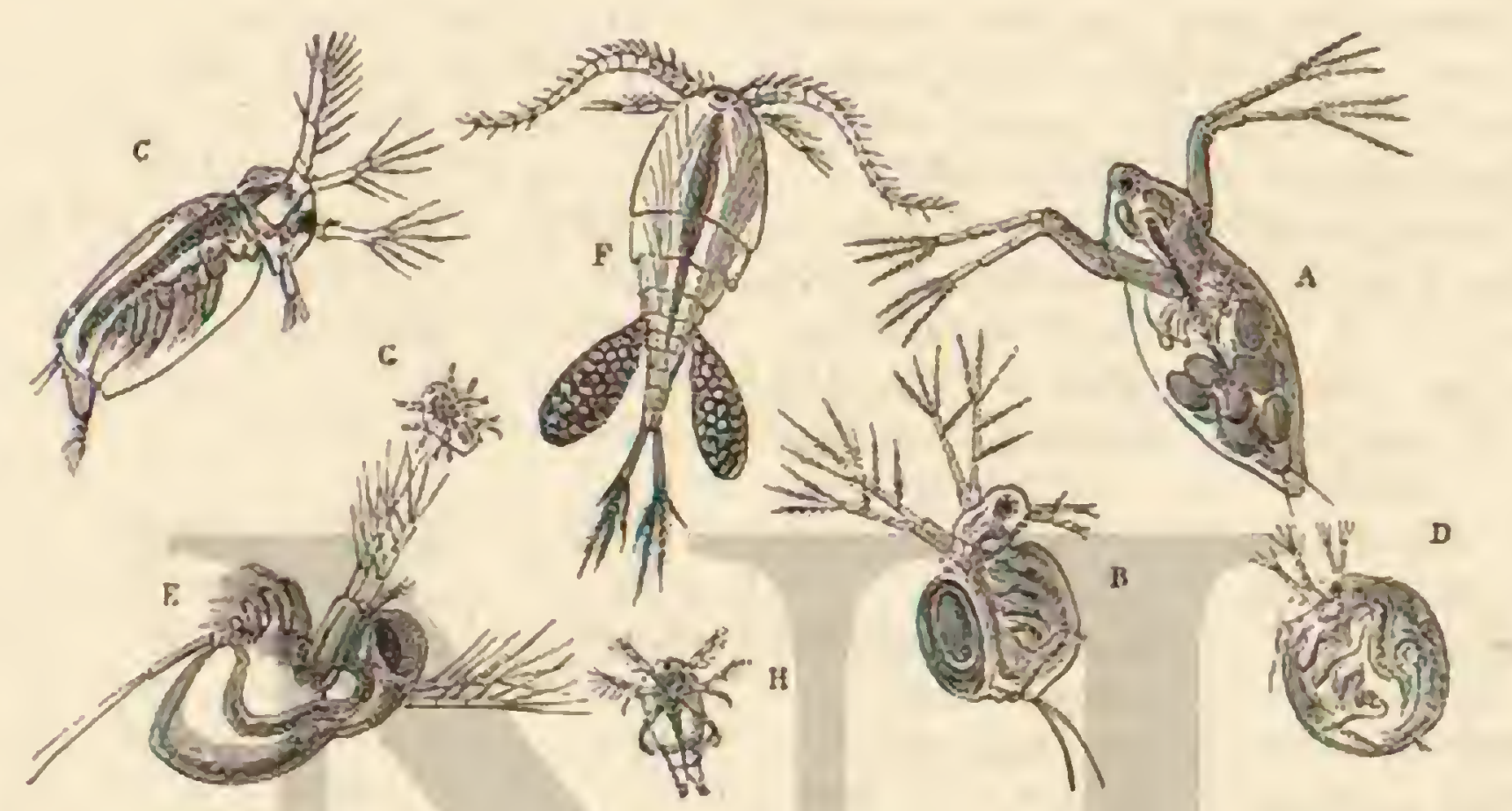

Fig. IOI. A EL DAFYTO PULGA Fig. 104. - D EL LINCEO R.STRRICO

Fig. 102. - B LA MOISA DE mKANǪUIAS

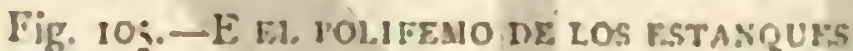

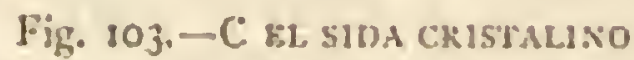

Fig. 106. -F G H 8.1, ciclore comus animales estaba siempre lleno de particulas de cieno desde la cavidad bucal hasta el ano. Con mucha frecuencia y du. rante largo tiempo se ve á estos cangrejitos ocupados en recoger el cieno, el cual remueren con los movimientos rápidos de sus patitas, que nunca descansan. Este cieno pasa entonces por delante de la boca y penetra en el vientre del crustáceo. Sin duda las artemias, lo mismo que otros filópodos, recogen y devoran ciertas sustancias del cieno. Muy á menudo observé que estos animalitos permanecian largo tiempo en el mismo sitio del fondo, y que entonces mante. nian su cuerpo vertical: colocados, por decirlo asi, de cabe za, los movinientos de sus patas continuaban sin cesar, abriendo poco á poco un verdadero hojo en el cieno revtuel to, en el que la extremidad de la cabeza penetraba mas y mas. Varios individuos se revolvian de improviso, tocando el suelo en la superficie de su vientre, en cuya posicion permanecen las artemias en el mismo sitio largo rato ó se arrastran lentamente surcando el cieno; sin duda recogen entonces tambien alimento.

DEstos vivaces cangrejitos nadaban con bastante ravidez en todas direcciones de su depósito, dando volteretas, à lo que parecia por pura diversion, cual si se hubicran querido provocar, volviendo á dispersarsc con la rapidez del rayo. $\mathrm{Al}$ cruzar incansables el agua, no pierden la ocasion de devorar.el alimento qque les viene à la boca. Sin duda alguna tragau de continuo las particulas de cieno por necesidad, aun que sus órganos digestivos solo puedan asimilarse una muy pequeina parte de las sustancias recogidas como nutricion. La extraordinaria cantidad de excrementos que las artemias dejan caer en el fondo de su prision, indican la enorme vo. racidad de estos séres.

xValiéndome del procedimiento ya indicado, lie conseguido criar muy bien los embriones de artemia. Solo algunos individuos murieron en los diferentes depósitos en que habia colocado los que me servian para mis observaciones.

Mientras escribo estas lineas se reciben noticias importantes para la doctrina de la variabilidad de las especies, adqui. ridas por el jóven naturalista ruso Schmankewisth sobre la artemin salina de las fuentes saladas, que hay cerca de Odesa. Al desmontar un terraplen salieron muchos de estos can grejos de un paraje lleno de sal reposada del Liman de Kujalnik (Lago de Kujalnik); y despues de la reconstruccion del terraplen, $y$ cuando el agua saladn se hulo concentrado por medio de la cvaporacion, la arlentia salina se trasformó despues de varias generaciones, en ta artemia Mishlhansenii que, por la falta de los apéndices y de las cerdas de la cola. y a causa de su menor tamaño, puede considerarse. segun estas observacioncs, como una forma degradada bajo condiciones vitales desfavorables.

Schmankewitsch obturo esta trasformacion tambien por medio de la cria artificial, concentrando poco á poco el agua salada de las vasijas de cria; por el tratamiento contrario, es decir, haciendo perder poco á poco la intensidad de las sa. les, logró trasformar la arlemia Muhlhausenii en arlemia sa. lina.

En la cria artificial de esta última en agua salada, que poco a joco se iba descargando de sales, el naturalista obtu. vo una forma con los caractéres del Branieliphs Schaefferi, 
que en cierto modo podia considerarse como una especie nueva de branchipus.

.En general las especies del género artemia son propias para el desarrollo progresivo en una concentracion de agua salada disminuida por grados, hallándose las condiciones necesarias para ello en la maturaleza libre, en aquellos charcos que despues de cierto número de años pueden convertirse en depósitos de agua dulce por las continuas filtraciones del suelo salado. En efecto, la artemia salina vive aun en los charcos salados, donde en el agua poco concentrada se encuentra el branchipus spinusus, y en la que es aun mas Roja ol branchipus fero. $y$ otra especic particular que tiene los apéndices caudales encorvados ell format de gancho: es el branchipus medius.

Otras observaciones se refieren is la influencia que la temperatura y los diferentes grados de intensidad de la sal ejercen en la propagacion. Es preciso estar muy obcecado por la creencia en la estabilidad, para no querer considerar thles ejemplos como prucbas en favor de la variabilidad de la especie, ese punto esencial de la doctrina dé la generacion. Muy notable es la relacion que el brachions salimus y al. gunos otros cangrejos parecen tener, segun las observaciones del butunico Federico Unger, con la tridicion de Afrodite, «nacida de la espumas lin su viaje á Chipre, el citado naturalista visitó las pocas ruinas de fabricas célebres, tales como los santuarios de la diosa del amor en Chipre; y habienda refiexionado en aquellos clísicos lugnres sobre las causzs que pudieron haber dado origen à la fábula, se fijó en la verdádera formacion de la espuna.

RHe reconocido sobre todo, dice Unger en su descripcion de la isla de Chipre, que en una de las costas de Pafos, an. tiguo santuario de Afrodite, se produce una formacion espu. mosa de tal naturaleza que apenas se hallaria otrasemejante: y por 10 tanto es posible que haya contribuido esencialmen. te á que riaciese aquella idea.

Durante mi primera estancia en Larnaca fije mi atencion en la espuma que en el mes de marzo y á principios de abril, muy abundante, orlaba la orilla del próximo lago sala. do. Esta espuma se extiende como una blanca faja movible, y al examinarla mas de cerca, parece compuesta de pequenas lurbujitas de un blanco de nieve, muy oprinidas y bas. tante sólidas. Al recogerla, to que hice con una red de insectos, $y$ al tocarla, observé que la fina espuma contenia un gran número de granitos que al contacto parecian de arena.

Al examinarla en mi casa, vi con gran asombro que estos granos cran millares de huevos muy superiores en volúmen i la sustancia blanquizar que les rodeaba; $y$ con bastante facilidad reconoci que estos huevos emn del todo buenos, como los de un crustáceo, es clecir de un pequenio cangrejo comun en anuella region (filumnas hirlellus). La enorme cantidad de estos huevos induce $\mathfrak{a}$ suponer que este cangrejo viene en el periodo del celo desde el mar vecino al lago salado, para poner. Solo una puigada cúbica contiene mas de un millon de huevecillos, y como además, la orilla del lago está cubierta en el espacio de media legua de una capa de aquellos, de una pulgada de espesor, puede calcularse la extraordinaria fecundidad de estos crustáceos.

MAdemás de estos huevos del pilummus, la espuma contenia una sustancia blanca y mucosa, que en ini concepto debe considerarse como el verdadero substmto de la espuma, sin el que seria imposible su formacion. I.a mayor parte de esta sustancia producia dos animales, dos especies de cangrejos, que, alli dondé se encuentran, siempre abundan mucho, y son la artemia satina y cierta especie de cypridina. Logre sacar de ambas especies unos ruerpos bastante ilesos de individisos, pero un la mayor parte solo fragmentos que fácilmente pudieron reconocerse despues de encontrita el pumo do comparacion. Cuando se sabe que la artenia, tanto en sali nas artificiales, como en las naturales, se encucntra en ial abundancia que existen mas cuerpos animales que gotas do ngua; y si se tiene presente que este crustáceo, aunque muy pequeño, casi microscópico, puede servir de alimento en el interior del Africa, se comprenderá que su presencia y" su descomposicion pueden formar una grande cantidad de sustancias mucosas en el poco profundo lago salado de Laruaca. Lo mismo debe decirse de la cipridima que, sin embargo, es en rigor un animal marino y solo casualmente se encuen. tra en este lago salado. Despues de hacer mencion de las formaciones análogas de la orilla, en las cercanias de Pafos, donde todos los años, en la época de las tempestades de invierno se recogen, sobre todo en la colina donde en tiempos remotos esturo el templo de Afrodite, espesas masas de espuma blanca, que el viento lleva á menudo hácia el interior de la isla, el autor concluye de este modo: "Se comprende, por lo tanto, que la aglomeracion de la espuma de mar en esta orilla es un fenómeno que, hoy, como antes, llama en extremo la atencion, siendo muy posible que diera origen - la fábula del naciniento de Afrodite, tanto mas, cuanto que, en efecto, debe considerarse como una senal de cestraordimaria fecundidad que se prestalo mas que ninguna otra \& sugerir la ingénua idea de aquel pueblo, dominado por la religion de la naturaleza.

\section{LOS APOS-APUS}

CARACTÉRES. - Suspendamos nuestra excursion al templo de la diosa del amor, para seguir un camino mas pro. saico ocupándomos del apo, que se distingue por sus ojos fijos. El cuerpo de las dos especies conocidas, propias de la Europa central, está protegido descle arriba por una ancha cubierta en forma de escudo, en cuya parte anterior estan los dos ojos casi soldados. Estas especies cuentan nada menos que sesenta pares de patas branquiales, de las que el undécimo de la hembra esta trasformado en dos bolsas pectorales para la recepcion de los huevos.

USOS, COSTUMBRES Y REGIMEN.- Habitan en pequeños espacios de agua estancada, y cuando esta se ngota mueren todos los individuos, conservindose la especie por los huevos contenidos en el cieno endurecido. Hasta el ano 1856 no se conocian los machos; y el descubridor celebró mucho que, el dia mismo en que hizo su hallazgo, se cumplieran precisamente cien años desde la fecha en que se publicó la primera monografin acerca de la especic apus cancriformis (fig. 98). En 1756 el naturalista Schnefier, predicador protestante de Ratishona, habia dado primero en Jengua latina $y$ despues en alemana, la primera descripcion detallada acerca del apo. A pesar de haber estudiado mintrciosamente por espacio de cuatro años este animal, no habia logrado descubrir los machos.

Otro género con ojos fijos es el limnaisa, el cual tience el cuerpo encerrado en un escudo bipartido, cuyas dos partes se tocan y fijan en el dorso.

\section{LOS EULIMENES-EULIMENE}

CARACTERES. - El cuerpo de estos crustíceos es oralado, oblongo ó lineal; la cabeza presenta ojos negros is sus lados, sostenidos en pedúnculos grandes y cilindricos; las dos antenas, casi filiformes, son un poro mas largas que la cabeza y se insertan entre los ojos. Entre el cuarto y cl décimo par de patas se vé una pieza globulosa, y otra mas pequena llena de una materia negruzca y de la cual parte 
un hilo semejante a una tripa. Iatreille opina que es el oviducto.

Los culimenes se crian en el Mediterraineo.

Estos pequeños crustáceos viven en aguas dulces 6 saladas: nadan siempre de espalda con mucha velocidad, ayudandose de sus patas branquiales, y parecen ser carniceros. los hijuclos sufren notables metamórfosis: en la primera edad se observa que su cuerpo, en vez de ser prolongado, ofrece la forma del de las arañas; despues de la urimera muda, la cabera presenta tres ojos distintos, aunque todos sesiles, y el abdómen sé prolonga y bifurca al principio. Cuando mudan por scyunda vez, aparece el primer par de patas foliaceo, y comienzan à verse otros sicte rudimentarios; y' por zíltimo, la conformacion del pequeño animal acaba por ofrecer los caractéres del adulto.

I.os huevos que depositan las hembras conservan la facultad de poderse desarrollar mas tarde si las circunstancias son favorables, aunque hayan estado largo tiempo en seco.

Una de las principales especies del género es el eulimene diáfano (fig. 100) que abunda en los alrededores de Ginebra.

\section{LOS CLADOCEROS - CLA- DOCERA}

Un hombre muy entendido en muchas especies animales, entre otras, en estas, el profesor Leydiger, de Bonn, describe de un modo muy interesante las condiciones vitales de la familia de los cindoceros, llamados tambien pulgones acudticos, ó deffidos. "A primera hora de la manana, y' sobre todo en las. noches calurosas y tranquilas, lo mismo que cuando el ciclo está nublado, estos animalitos, de los que los mayores, raras veces tienen mas de $0^{\circ}, 006$ de largo, nadan en la superficie del agua, pero bajan il la profundidad tan luego como el sol brilla con alguna fuerza en el liquido espejo. Muchas especies prefieren permanecer cerca del fondo cenagoso; pero, ya porque suelen reunirse en considerables legiones en las aguas estancadas ó de corriente lenta, ó bien porqque, segun muchos pretenden, comunican al agun un color determinado (1), debian llamar precisamente la atencion de los naturalistas hace mucho tiempo; se comprende sin embargo, que solamente los observadores acostumbrados á mancjar el microscopio se hayan ocupado detenidamente de ellos. Pero precisamente para los zoólogos que no solo toman en consideracion el aspecto exterior de un animal, sino tambien se interesan por la estructura interna y el género de vida, cl estudio de estosanimales es en alto grado curioso. En muchos puede examinarse, gracias a la tmsparencia de los tegumentos, toda la organizacion del animal vivo, casi del mismo modo que en aquellos modelos de máquinas que bajo uma cubierta trasparente y brillante permiten ver al observador la composicion y juego de las partes aisladas. $Y$ rambien aquellos que no scan zoólogos, se verin agradablemente sorprendidos, cuando en un animal examinado con el microscopio puedan observar los movimientos de los ojos y del canal alimenticio, las pulsaciones del corazon, los glóbulos de la sangre, que como perlas pasan por cl cuerpo, y cuantos órganos funcionan.

Sin embargo, na todos se sienten inclinados, ó quieren descender à estudiar los cuerpos orgánicos por amor á los mismos, ni i reflexionar solure los séres animales que, segun dijo el poeta, constituyen el pensamiento mas elevado (ute animó à la naturaleza ch su creacion. Fil interés que insjuira $\mathrm{cl}$ mundo animal se rige $\mathrm{en}$ la mayor parte de los honbres,

(1) Afirmu cate hecho: la superficic de pequemos estanques, puecte aciquirir un color amarilio rojizo for el gran númeso de pulgones acuá. licos. solo por los servicios que pueda prestarie cada uma de las especies que le componen. "lanto mas me complace poder dar á los amigos de la naturaleza una noticia sobre los dafi. nidos, cuanto que quizás por ella sabrain en adelante apreciarlos mas. Durante una larga estancia a orillas de los lagos de las montahas de Baviera y del de Constanza, he olservado que los cladoceros y ciclópidos (órden siguiente), constituyen al alimento casi exclusivo de los peces mas aprecindos on el pais. Yo abri un gran número de los citados peces y sicmure halle que el contenido del estómago se complonia exclusivamente de estos crustácéos microscópicos, que, atendida su abundancin, deberian considenarse como la pollacion principal de las citadas aguas. Si se reffcxiona, por cjemplo, sobre la iniportancia que tiene para los habitantes del pais el coregoro de Wartmann, del que todos los años se cegen mas de cien mil individuos en el lago de Constanza, se compren. derá que estos pequeños crustáceos, apenas apreciados, son de gran utilidad para el hombre por servir de alimento á to. dos los peces.

Yo puedo confirmar en un todo lo que ni colega ha dicho sobre el interesantc espectáculo que ofrece un cladocero colocado bajo un microscópio, aunņue sea de poco aumento. 'Todos los años observo como, precisamente en estas demos. traciones, mis estudiantes y otros amigos de la maturalén prorumpen en exclamaciones de asombro y de admiracion. Para poder observar estos animalitos y otros análogos debe. mos valernos de un cristal provisto de un surco, en el cual se puede colocar tambien el cladocero boca arriba.

El aspecto de los animales no puede ser mas extraño. Sobre el tronco, protegido por una cubicrta biparticla, sobresale una cabeza abovedada, con una especie de casco y un picn; debajo de la extremidad de este se insertan las antenas interiores, que rematan en hilos tactiles muy delicados y nerviosos. Debajo de la parte convexa superior se ve el ojo grande que puede girar por medio de varios músculos. Las ańtenas exteriores están trasformadas en poderosos órganos ramificados, propios para remar, y cuyos golpes facilitan el salto, semcjante al de las pulgas. Muy ocultas debajo del casco de la cabeia y de una escotadura anterior hällanse las partes de la boca, compuesta de labio superior y de dos mandibulas. Ia cubierta bipartida es una superficie membmanosa de la parte del cuerpo, que corresponde al torax de los insectos. Precisamente en estus animales no puede desconocerse cier. ta semejanza con las alas de los insectos, con las que tambien se han comparado las partes laterales de la coraza de los decápodos Solo en algunas larvas irnsparentes de insectos se puede observar el corazon y la estructura interna de un animal vivo con tamta claridad como en los claojoceros. Está situacio en la linea central del cuerpo, en el dorso, y ticne casi sicmpre la forma de una vegiga redondeada. Por una hendidura en forma de boca recoge con rápidas pulsaciones la sangre, para empujarla al lado opuesto por una segunda hendidura hácia afuera. Como órganos respiratorios sirven los apéndices en forma de hojas de los cuatro a seis pares de patas. Tambien estos crustáceos tienen un post-abdómen que corresponde à la cola del cangrejo fluvial, situadolibremente debajo de la cubierta y que temata en garras ó en dos cerdas caudales; sirve de órgano para la locomocion.

Ios cladoceros machos son todos mas pequenos que las hembras y se distinguen en su mayor partc de las demais cspecies por ser distinta la forma de las antenas interiores y por el primer par de patas construido en forma de órgano agarradizos. Las hembras jonen, como ya se sabe hace nu. cho tiempo, dos clases de hueros: los de verano y los de in. vierno, distinguiéndose estos tílimos por ser la cascarn mas fuerte. In puesta de estos huevos depende mucho menos de 
la estacion que de la presencia de los machos; pues los llamados huevos de verano se forman y desarrollan sin ser fecundizados, y recuerdan por lo tanto los de la reina de las abejas, de los cuales nacen los machos de estos insectos, ó el embrion de los pulgones, del cual se desarrolla la generacion de verano. Tan luego como en cierta estacion se presentan los machos de los dafinidos comienzan á verse los huevos de invierno, en forma de paquetitos muy singulares, en el llamado efipio (silla de montar). Toda la cáscara ó parte de la misma se separa, y encierra como cubierta de abrigo dos huevos ó todo un paquete; en esta cubierta consérvanse aque. llos, aunque se agoten las aguas, y á pesar del frio, caurante la estacion invernal, y por eso su nombre de huevos de in. vierno es del todo apropiado.

Los numerosos géneros difieren particularmente por un diverso numero de patas y por la formacion de los brazos para remar. Asi por ejemplo, el sida (fig. 103 ) tiene seis pares de patas y una cola prolongada; el daphinia (fig. 101) solo cinco, y la cola doblada hácia adelante. De este género, el cladocero comun y el cladocero grande se consideran como las es. pecies mas diseminadas. Muy afine del género daphnia es el acantliocer:us. Los linceos (fig. 104) tienen solo cuatro pares de patas y el cuerpo esférico. Por la reduccion de las cubicr. tas a sencillo espacio los géneros polyphemas (fig. 105) y bythotreplees son de aspecto extraño. Leydig descubrió este último en el estómago de los coregoros pescados en el lago de Constanza y como no logró cogerlos vivos en las capas superiores del agua, es de suponer que, lo mismo que aquellos peces, vive con preferencia en la profundidad. 'Teniendo en cuenta la proporcion de la cubierta con el cuerpo, hemos dicho que

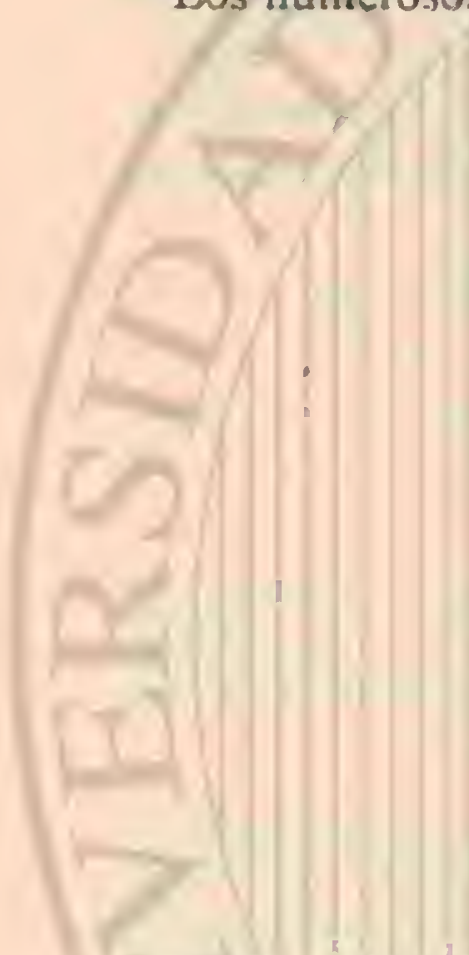

Fig. 107.-A E. FIPRIS MOYYOCLO Fig. 10S.-B.EL ClPR1S AUORNADO Fig. 111.-E ER CITERE INONINADO Fig. 114,-H EL CIPRIDINO de MCANDRE.

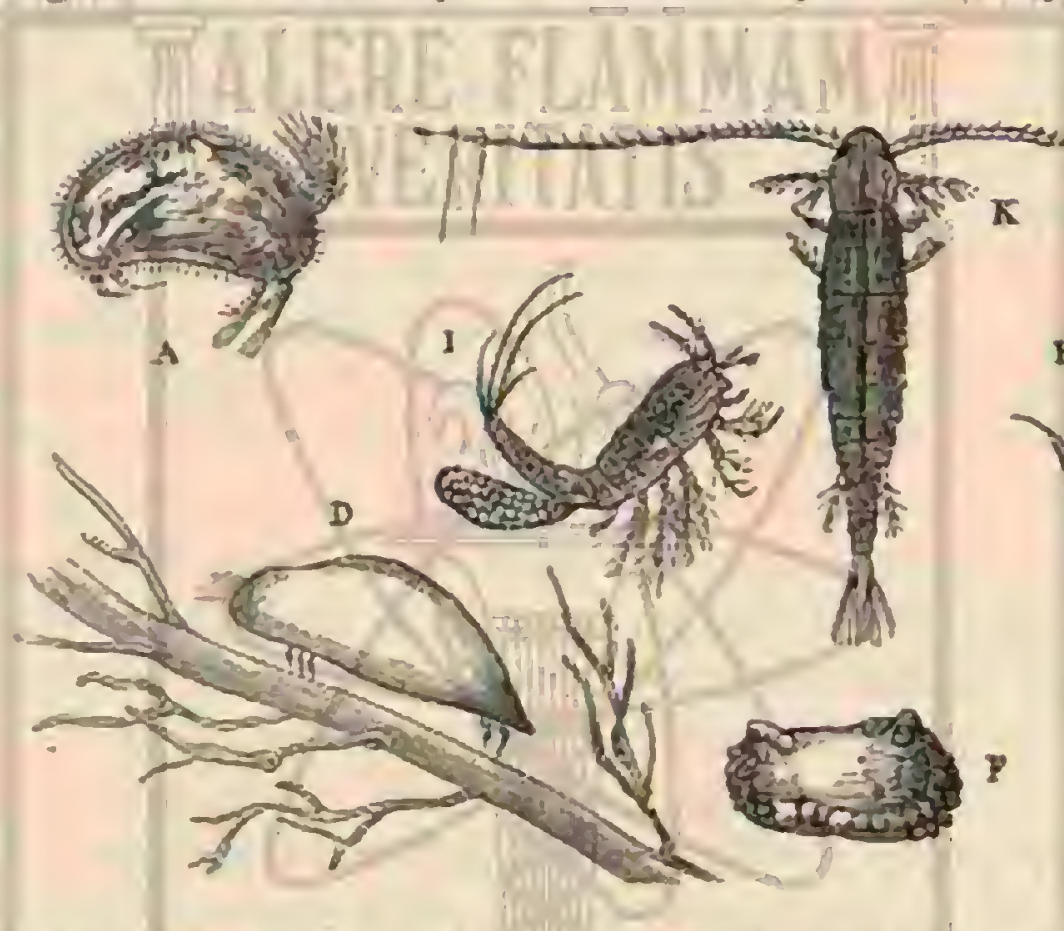

Fig. 112. - F \& CITERE DE JONGS

Fig. $115 .-1$ 1.L castocianto prequrso

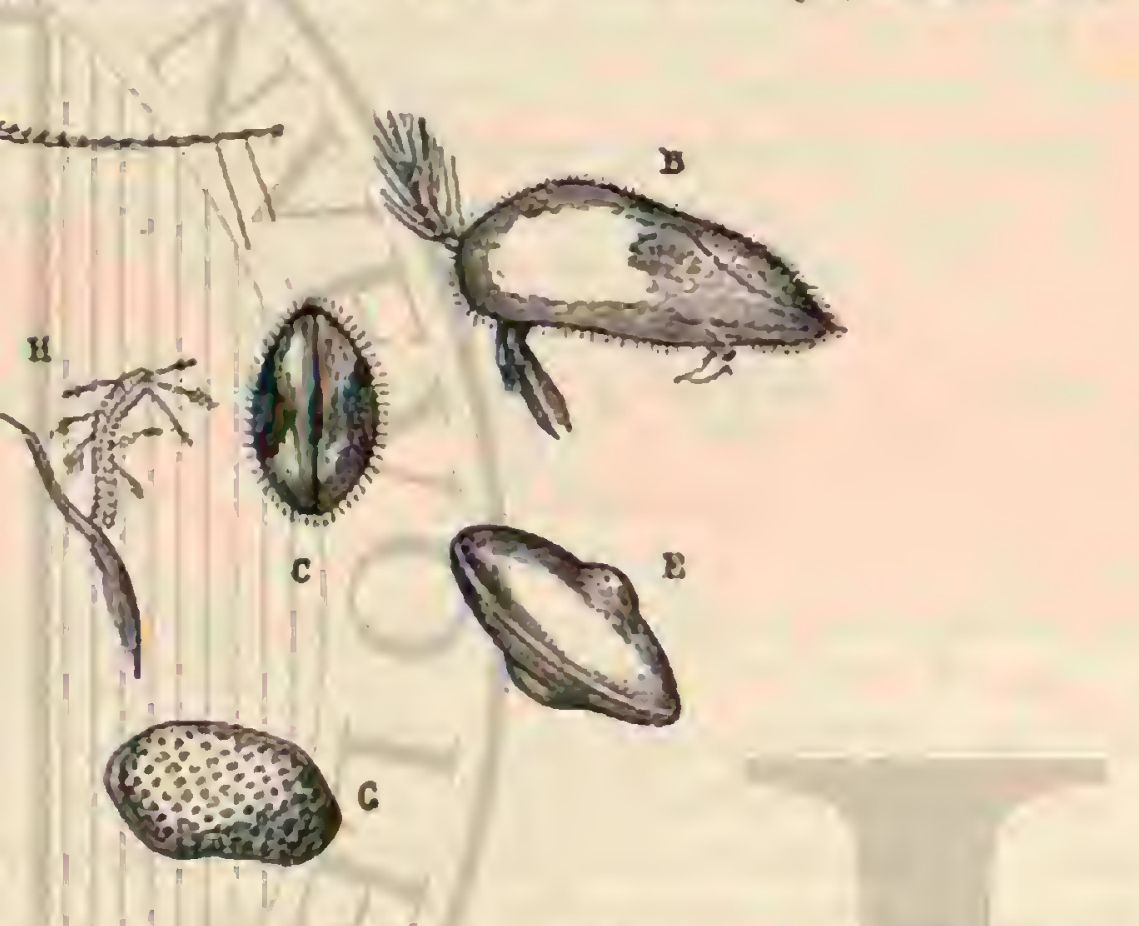

aquella es rreducida", aunque este término quizas no sea apropiado. Si aplicámos á los dafinidos la doctrina de la descendencia quizá seri exacto suponer que las especies de escudo pequelio y reducido son las que mejor han consersado su semejarza con sus antecesores. Esta opinion parece confirmarse por la extructura de uno de los dañnidos mas bonitos y notables, de la especie lepthodora hyalina que hace tiempo es conocida superficialmente y que Waissmann des. cubrió ha poco en el lago de Constanza, habiendola visto en los de Italia dos veces.

Este diminuto ser mide algunos milimetros, $y$ al contrario de los o:ros dafinidos es raquitico y prolongado, ofreciendo u»a marcada articulacion en la cabeza, tórax y abdómen; la parte posterior afecta la forma de escudo, que cubre mas 6 menos cl abdómen, dejando libres los últimos segmentos bien desarrollados del mismo; las antenas exteriores se extienden lateralmente y se caracterizan por su musculatura $y$ por su orla de cerdas plumosas; las patas prolongadas hácia adelante forman un aparato para coger la presa. Como entre los crustáreos y en otra clase de animales, numerosos ejem. plos hacen suponer, con seguridad, que el cambio observado en la articulacion del cuerpo de este crustaceo, indica una trasformacion verificada en el curso de los tiempos. Weissmann tiene motivo para considerar la forma raquitica y articulada del genero leptodora como un carácter heredado de sus ascendientes, y he aqui porque la especie que nos ocupa ofrece particular interés. Weissmann dice lo siguiente sobre su género de vida y su irea de dispersion: \&Aunque solo pocos natumlistas lo han visto, la lepthodora hyalina parece tener una area de dispersion muy extensa, y abundar mucho en todus los sitios donde habita. Cierto que viviendo de la rapina, nunca pirede presentarse en tales masas como los animales de que se alimenta, es decir, principalmente los ciclópidos, pero P. E. Muller dice que es muy comun, y aun. que yo las haya buscado muchas reces en vano, en otras ocasiones recogi mas de cien individuos en unas dos horas. Yo pesqué casi sicmpre nuy cerca de la superficie con la red fina, y creo, con Muller, que esta especie no baja nunca à la profundidad, pues su poca fuerza para remar no le permite viajes á tal distancia, y en todo caso no pociria emprenderlos diariamente. Sin embargo, deben alejarse mas ó menos, pues obscrvé que de dia solo por excepcion se mantienen en la superficie, mientras que de noche solo se ren aquí. Evitun la luz intensa y cuando la del sol es muy brillante de scguro no se encontrará ningun individuo en la superficie. Cuando lucia la luna, apenas pescaba, mientras que siempre cogia muchos individuos con cielo nublado 6 en noche os. cura.

; Podria ser, sin embargo, que este temor a la luz solo fuera aparente, porque los ciclopidos de que se alimenta la leptholora ofrecen las mismas particularidades al bajar y subir, y es de crecr, por lo tanto, que estos son realmente los que temen la luz. Es fácil reconocer en un acuario que aquella influye mucho en los ciclopidos, porque estos sicmpre se rcunen alli donde produce un fuerte refiejo; pero huyen de la luz directa del sol ó de la que es demasiado intensa.

* En la lepiodora no he obiervado que buscase con insistencia la lur, ni tampoco lo contrario.

2.P. F. MLuller ha dividido ja los cladóceros en dos grupos, segun su residencia, en pelagicos y costeros; la leptodo. ra pertenece al primer grupo, pues toda la estructura de su cuerpo la obliga á vivir en agua limpia, sin plantas, y por lo 
tanto no se encuentra cerca de la orilla, en el lago Constan. za cuando menos solo se ré alli donde el aguá es mas profunda. Solo rema con las antenas y á intérvalos, como todos los dafinidos, avanzando lentamente; su gran trasparencia, merced i la cual se hace casi invisible, es sin duda condicion necesaria para la existencia de esta especie demasiado pesa. da para perseguir su presa. Acecha sus victimas y se parece inucho por este concepto a la larva de la especie cosethra flumieorıis (una mosca célcbre por su trasparencin), aunque no alcanza ni con mucho a la leptodora.

Asi como la larva del rosethra, la lepiodora permanece extendida horizontalmente en el agua, y espera a que la presa se enrede en sus patas prehensiles. Si en la cosethra unos aparatos hidrostáticos particulares, es decir, grandes vejigas traqueales, aseguran el cuerpo en su posicion horizontal, en la leptodora, el intestino estomacal esti situado de tal modo hacia atris, que mantiene el equilibrio con el pesado tórax y la cabeza.

4n los individuos cautivos se vé marcadamente como uste animal comienza i madar. "Tan luego como las algas y cuerpos extraños flotan en el agua, agárrase i ellos con los bra. 205 gue á los leptodoras sirven de remo; pero jamis intenta

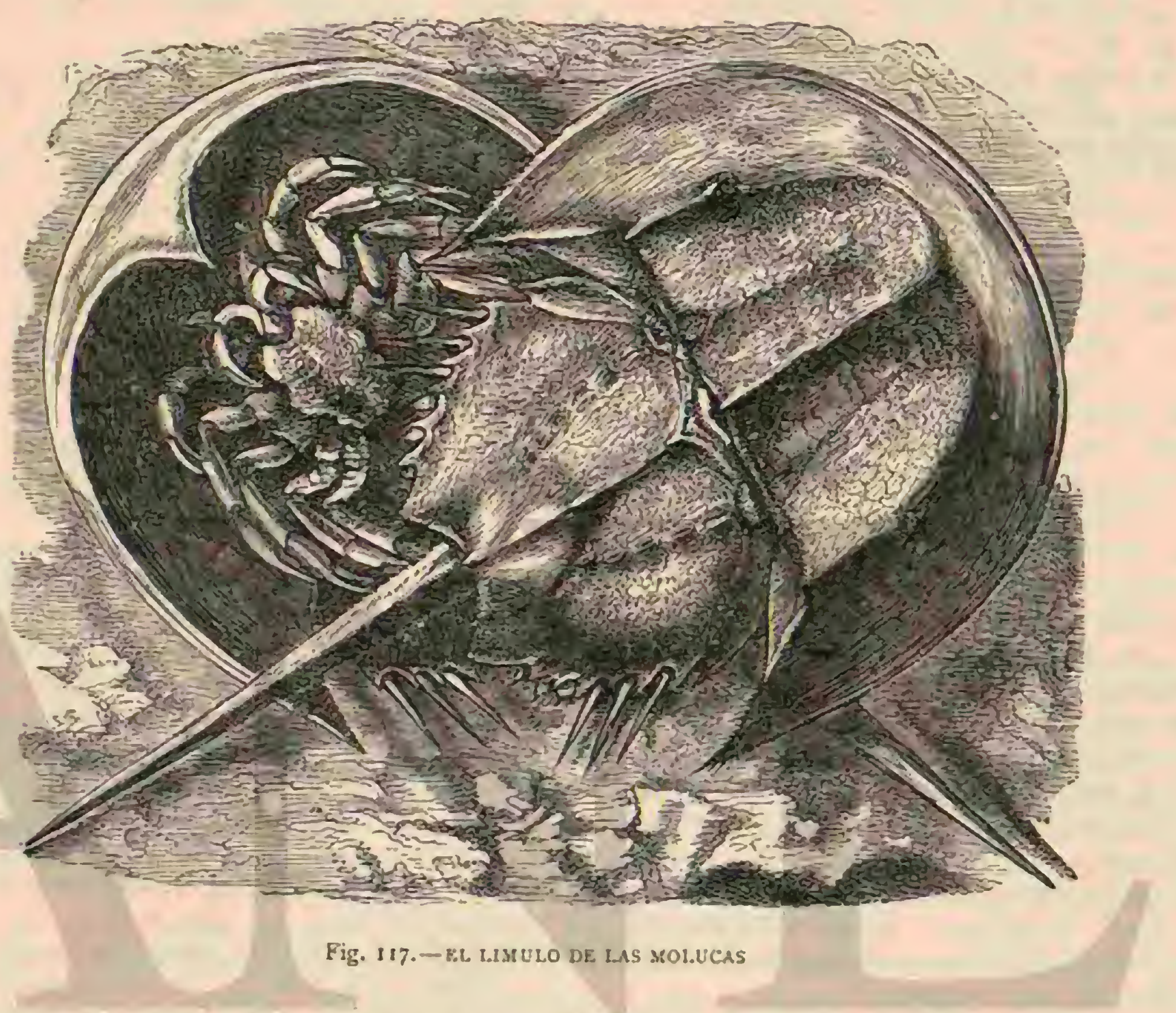

servirse de las patas para trepar, y solo en caso de apuro, cuando quedan agarradas en alguma parte, procum avanzas con ayuda del abdómen, cuya extremidad adelanta por debajo de la cabera. Muy a menudo se produce en esta especie una seta (saprolegoria), que crece con la piel por dentro, ocasionảndola poco á poco la muerte.

La leptodora se lia encontrado hasta ahora, no solo en los lagos de Constanza y de Ginebra, sino tambien en los daneses y suecos, cerca de Cahne, y para no omitir nada, en el foso de circunvalacion de la ciudad de Bremen. En América se le conoce en el lago Superior.

Pocos cladóceros de los ujue habitan en el mar se conocen hasta ahora.

\section{LOS OSTRACODEOS-OSTRACODEA}

CARACTERES. - En las mismas aguas en que prosperan los anfipodos se encuentran tambien unos animalitos muy vivaces, de la familia de los ostmcódeos, que por la cubierta bipartida qque rodea todo su cuerpo tienen cierta semejanza exterior con las conchas. Al nadar, lo cual efectuan dando rápidos golpes con las antenas, que sirren de rêmos, ayudanse tambien con las patas posteriores, que sobresaliendo del borde de la cubierta del cuerpo, perniten al observa. dor darse cuental de que no pertenecen a un molusco. Fil genero gy ris (figs. 107 a 109), cl moina (fig. 102), con numerosas especies europeas, pertenecen al agua dulce; el opridina (fig. 1 14) el citeres (figs. 110 \& 1 13), el canto canpus (fig. 115) y otros al mar. Los ostracodos hoy existentes solo miden algunos milimetros de largo, y muchos apenas medio de longitud.

Existen numerosas especies fósiles cuyos restos se han conservado a causa de su mayor solider; y en táles masas se amontonaban en la orilla de los mares antidiluvianos, que ciertas capas calcireas han adquuirido romo \& cal de ciprididinos un aspecto caracteristico: el tamaño de esas especies era un poco mayor.

\section{LOS TRILOBITES-TRILO. BIT 在}

De los artrópodos hoy existentes, los crustáceos hasta shora descritos, y sobre todo los filópodos, parecen ser las especies mas congenéricas del grupo de los trilobites, que se oírecen como los mas antiguos representantes antidilurianos de los crustáceos y de los artrópodos en general. Su parte superior estaba protegida desde amiba por una cubierta probablemente bastante sólida, de cuyos segmentos, el anterior, que 
ienia los ojos, destacábase como un grnn semicirculo o como una pieza en forma de media luna. El cuerpo estaba dividido por dos surcos longitudinales paralelos, en una parte media clevada y dos lóbulos laternles, rematando á menudo en un gran segmento en forma de escudo, el llamado pigidio. Del hecho de que estos animales podian enroscarse, y de que en los muchos miles de individuos minuciosamente examinados no se han encontrado restos de extremidades, debe inferirse que toda la parte inferior $y$ las extremidades tenian la piel blanda.

Los restos fósiles y el género de vidi de los filopodos actuales justifican la suposicion de que los trilobites vivińn en las orillas poco profundas del mar, y sociablemente. Su areá de dispersion era muy extendida. Mejor conocidos son por las capas de la llanada cal de tránsito, que se encuentran en Rusia, Succia y Bohemia ba deposicion de estas capas jre. cede à la formacion del terreno carbonifero, y como ya en las capas inferiores que no contienen restos de otros seres vivos, se encuentran trilobites, cstos se consicieraban hasla lus últimos tiempos, no solo como los mas antiguos artrópodos, sino como los primitivos representantes del reino animal. Como sin duda eran animales bastante bien dotados respecto is su organizacion, ofrecian una prueba en apoyo de la doctrina, segun Ia cual, los reinos orgánicos no se han desarrollado poco a poco de seres sencillos y de los mas inferiores. sino que han sido creados en sus diferentes divisiones, al mismo tiempo plantas y animales con una estructura relativamente superior! La doctrina opuesta, por la cual se supone la lenta perfeccion de los seres vivos mas inferiores, demuestra nece. sariamente, segun lo hace ver su fundador Darwin, que at juzgar por la náturaleza de las capas de la costra del globo, el mundo vivó debió existir al principio con sus elementos mas rudimentarios. Al fín de nuestra obra veremos hasta que punto este aserto se la confirmado por las averiguaciones mas recientes. I.os trilobites continuan siendo lo que hasta ahort son, es decir, los mas antiguos :utrúpodos conocidos. Un género, el paradcivides, no podia enroscarsc:y algunas de sus especies alcanzabain una longitud de 07,3. El género calymenc contaba especies cuyo cuerpo, protegido por una cubicrta dura, podia enroscarse Fi ilustre historiador de los trilobices, Barrande, de Praga, posec una de las colecciones mas completas de estos cristáceos.

'Por primera vez hemos dirigido aqui mua mirada al mundo primitivo, á los restos de una vida pasada. Solo al profano podria parecer que el estudio de este asunto debe ser ageno ă una descripeion de la vida actual; pero ha de comprender que para el perfecto conocimiento de las especies que nos ofrecen condiciones de afinidad con un origen comun, es pre. ciso descender à este, pues de lo contrario, el órden de la creacion actual, y en general el sistema serian incomprensibles. Con las formas y la estructura, cmpero, se han podico trasmitir tambien las costumbres, pero solo cuando la organizacion $y$ el géncro de vida no han debido alterarse forzosamente por el cambio de las condiciones cxteriores. I a distribucion geográfica, punto importante en la vida de las especies, encuentra su explicacion ciclusivamente en las edades del mundo primitivo, en las dislocaciones de los mares, islas y continentes, en que de grado 6 por tueraa debicron comar parte las especies animales En adelante volveremos por lo. tanto á menudo à la interesante vida primitiva para buscar las explicaciones sobre la afinidad y las particularidades de los tipos del mundo viviente actual, comparándolos con los fósiles, estudiando la relacion de estos con los objetos y la naturalera que en aquel entonces les rodeaba. Solo de esic modo comjrendemos el mundo viviente como una unidad y no como una sola coleccion de curiosidades sin rélacion.

\section{LOS PECILÓPODOS- POECILOPODA}

Los trilobites que ofrecen puntos de contacto con los braquiópodos actuales nos obligan å presentar aqui un sub-órden de animales cangriformes, que como órden independiente, el de los pecilópodos ó cangrejos de las Molucas, pertenecian hasta ahora al grupo de los crustáccos.

Consideremos primero su aspecto exteriọr.

Iin los grandes acuarios se ven ahora i menudo estos animales, de forma aplanada, de $0^{\prime \prime}, 30$ a $0^{\prime \prime \prime}, 60$ de largos, y que tienen la figura de una cacerola provista de un largo mango: se llama limulas (limulus).

Fianninemos un individuo por su parte superior. El cuerpo estácubierto de dos escudos; el primero, mas grande, tiene la forma de media luna, $y$ sus ángulos rematan en una espina; las partes laterales se extienden desde dos bordes longitudinales provistos de espinus, un los que tambien sé hailan los ojos, compuestos de facetas y que casi afectan la forma de rinones; qutos dos sencillos, mas próxinos entre si, se hallan mas hacia el borde anterior. Con la coraza, que cubre el cehalotórax, está reunicio por una articulacion casi lineal el es. cudo posterior, poco mas 6 menos sexigonal, provisto de dientes y defuertes espinas laterales, y cn el cual se inserta igualmente por medio de una asticulacion la larga y puntiaguda espina caudal. Cono estos animales acostumbran d trepar a menudo lentamente por lás paredes de las grandes vasijas de vidrio que suele haber en nuestros acuarios, no falia ocasion para observar las articulaciones del lado abdo. minal, dispuestas de un modo muy particular, y al mismo tiempo su uso. Aunque no estamos acostumbrados a cn. contrar la abertura bucal de los cangrejos en la extremidad anterior, en el caso presente nos asombra liallarla aun mas distante, rodeada de seis pares de extremidacies que rematan en tenazas. El par anterior, que al mismo tiempo es el mas corto, se halla delante de la boca, y corresponde probable. mente $a$ las antenas. Los tres pares siguientes, que en un todo se parecen à las patas con iemazas de los decápodos, se distinguen por tener los lados de forma redondeada, cubicrtos de muchas pequeñas espinas, con las que el extrano animal masca. El lado de las dos patas siguientes presenta una estructura diferente, mientras que los de las otras se parecen a las de las antcriores.

Tambien en la cara inferior del escudo semilunar se inserta la tapa grande, que se adapta sobre los cinco pares de extremidades del abdómen, las cuales sirven de remos y de branquias d́ la rc\%.

I a espina caudal, en cuya base esta la abertura del intestino no existe aun en los hijuelos al salir del hucro, ni tan. poco las patas natitorias posteriores, aunque aquellos tengan por lo demas el tipo de sus padres. Por este conjunto extc: rior, y sobre iodo, en vista de los escudos cangriformes y de la distribucion y número de las extrenidades, los zoólogos se vieron obligados a clasificar los limulos entre los crusta. ceos, aunejue no resultaba marcada afinidad con una de las tan numierosas especies de cangrejos sin embargo, cicrtos caractéres de las extremidades anterioris; sobre todo del corazon y del vaso de la sangre, asi como el sistema nervio. so, que solo hace poco tiempo se examinaron minuciosamen. te, han demostmdo una afinidad cvidente de estos extraños animales con las aranas escorpimiformes. De este hecho y de la comparacion con formas primitivas de la época de los trilobites, al parecer afines de estos últimos, se ha deducido que las limulas son el resto de una tribu, con categoria de clase, que antes del desarrollo de los verdaderos crustaccos 
y de las verdaderas amñas se formó 6 separó de los mas an. tiguos atrofiados que poblaban el mundo primitivo.

La distribucion geografica de las pocas especies del génenero actual de los limulos, no se comprenderia sin remontarnos à los periodos geológicos pasados. Lna especie, el limulus polyphemus, habita en la Florida, en la Carolina y en las Antillas; las demàs en las costas de las Molucas (fig. 117), de China y del Japon. Una cmigracion de uno à otro de estos territorios, con la correspondiente formacion de razas y especies, no es posible, á causa de la profundidad de los mares que los separan, y ningun hombre de recto juicio imaginará una creacion especial para cada punto. Los limulos de los Océnnos Atlántico y Pacífico deben estar separados, por lo tanto, cuando menos desde la época en que el istmo de Pr. namá se clevó como un terraplen que separa los dos mares, es decir, desde principios del periodo terciario; pero solo en las capas de una época mucho mas remota, en la pizarra de la formacion del Jura, en Solenhofen, se encuentran los restos de animales que se parecen á los limulos. I.a rareza de los mismos y su falta completa en todas las capas posteriores, debe explicarse por el género de vida de nuestros limulos; pues sin duda tambien las especies fósiles que han desaparecido sin dejar vestigio eran habitantes de las costas arenosas. los restos de cstas especies no se conservin, porque la atmúsfera y las olas las destruyen, mientras que las que se sumergen en la profundidad penetran en el cieno y se conservan para satisfacer la curiosidad del hombre cientifico.

Pocppig escribe lo siguiente sobre el género de vida de esta especie:

«Nada mal y repta con mucha lentitud, mas á pesar de ello, cuando el cielo esta nublado sale á menudo á ticrra fir. - me, arrastrindose, y entonces seméjase á un escudo movible. En el mar peramanecen casi exclusivamente en sitios profundos; no pueden soportar el calor y penetran en la arena cuandoen sus expediciones les sorprende la lu\% del sol. Su alimento es solo animal.

\section{QUINTO ORDEN}

\section{ENTOMOSTRÁCEOS-ANTOMOSTRACA}

Este variado grupo de crusticeios verdaderamente microscópicos, que cuando mas alcanzan una longitud de i i 3 centimetros, comprende géneros que viven libremente, en cuyo caso están provistos de órganos bucales y bien articulados; y otros que por su género de vida parasítico pierden toda articulacion anterior, convirtiendose las partes bucales en una trompa chupadora. Las trasformaciones de los individuos adultos de estos numerosos crustáceos parásitos son tan notables, que cuando á últimos del siglo pasado y en el primer decenio del actual llegaron á conocerse, no se les consideró como artropodos hasta que la analogia de sus formas en la jurentud, con las de otros cangrejos inferiores, demostró à los zoólogos que lo eran. Una serie continua de especies de transito prueba que pertenecen á un mismo grupo, con las esprecies de vida libre del género syclops y otros. Esta variedad de formas impide expresar en pocas lineas los caractéres aplicables à todos, confesion que la ciencia natural debe hacer al constituir todos los Ilamados órdenes, ó como quiera que se llamen los grupos congenéricos.

Nos diferenciamos por este concepto esencialmentc de los excelentes roólogos del tiempo de linneo y de la época que a este siguió, pues se contentaron con una descripcion lo mas breve posible. Desde entonces se han reconocido, ade. más de los caractéres típicos, que llaman à primera vista la atencion en los géneros y especies, y que podrian reunirse en un catálogo regular, muchas formas internedias y de tránsito, tanto que los datos recogidos respecto i forma, estructura y género de vida, solo son aplicables a las especies, por decirlo asi, tipicas. Esto podria decirse tambien de los entomos. triceos.

Llámanse asi porquue su abdúnen bien separado del cefalo. tórax tiene patas ramificadas $\delta$ hendidas. No existen nunca los órganos respintatorios particulares; pero los tegumentos del cuerpo, compliestos de una membrana delgada, que nunca se ensarcha en escudos y' corazas, permite en todas las especies el cambio de gases necesario para la respiracion. Aun debe anadirse respecto à las formas que nadan libremente, que sus antenas anteriores constituyen un poderoso par de remos; y que rematan en figura de horquilla, en cuyas purtas se insertan varias cerdas caudales. El desarrollo esta en relacion con una metamoriósis particular, como retrógada en muchos cangrejos parásitos, y que se resuelve por un atrofiamiento de ciertas partes. Las larvas, de cuerpo ovalado, con un solo ojo frontal y tres pares de extremidades alrede. dor de la boca, se consideraban, segun sucede con muchas formas de los animales jóvenes superiores, como género independiente, con el nombre de sauplius. Una serie de escudos se relaciona con la formacion lenta de los seymentos del tórax, del abdómen y de sus extremidades, que se desarrollan por el estilo de los capullos de las Rores. Sin embaryo, des. pues de la primera muda, ó cuando están bastante adelantados, muchos crusticeos parásitos pierden toda articulacion de su cuerpo, que adquiere la forma de huevo, mientras que las patas se conservan comn pequeños munones, ó bien des. aparecen completamente. En estos parásitos, fijos durante toda su vida en el animal que habitan y atormentan, desaparecen tambien los ojos que de tanto les servian durante su juventud; las buenas cualidades del individuo no pueden desplegarse ya; no llegari jamás á sur un verdadero entomos. traceo, que hasta su muerte retoza alegremente en el agua;y en ve\% de esto se ha convertido en un animal voraz $y$ torpe que vive á costa de la sangre de otro.

Actualmente se habla en el mundo cientifico del desarro. llo de nauplius en algun crustáceo inferior y del desarrolbo de soea en los crustácéos superiores, el cual dimos á conocer al hablar de los cangrejos propiamente dichos. Nuestro amigo Federico Mueller, cuyas observaciones y noticins minucio. sas hemos reproducido repetidas veces, emitió la opinion de que los cangrejos inas inferiores, con los que en los tiempos antidiluvianos comicnza la vicla de la clase, tenian esta forma de nauplius. No podia esperarse encontrar conservados unos cuerpecitos tan finos para confirmar tal suposicion, pero un notable descubrimiento de Mueller ha renido en apojo del hecho. En la suposicion, fundada en muchos hechos po. 
sitivos, de que los estados del jesarrollo de los animales hoy existentes recuerdan los de las especies antidiluvianas, el naturalista que buscaba una confirmacion de la doctrina de Darwin, esperaba encontrar algun crustáceo superior cuyo desarrollo no solamente pasase por la forma del coct, sino que, comenzando con la forma de manplius, nos representara como un resumen completo $y$ breve de todo su desarrollo

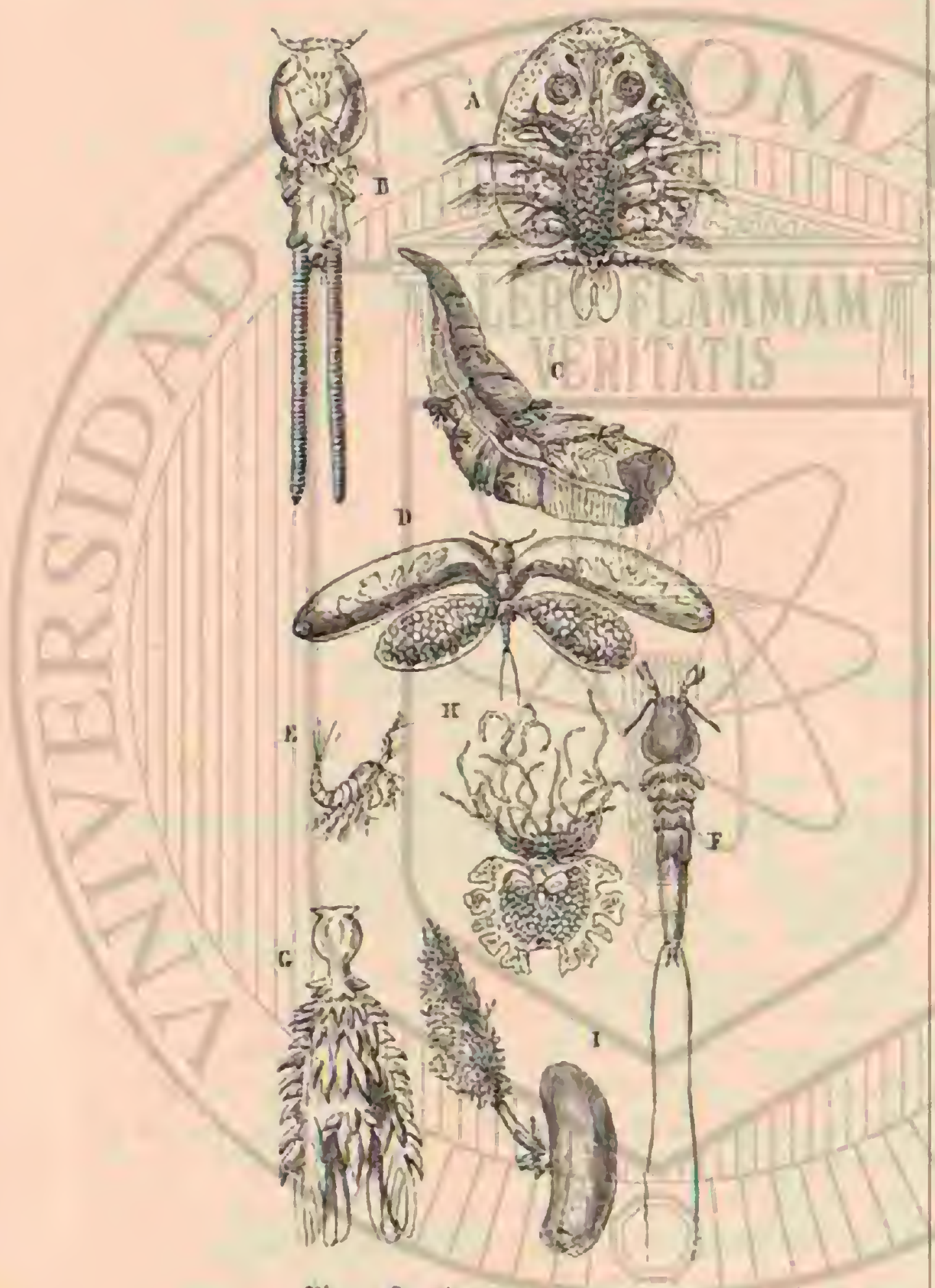

Fig. 118. $-A$ E. AkCtio Hojoso

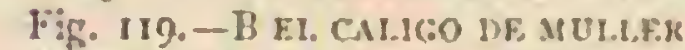

Fig. 120. - C Flo Nicotor. DEL. CAsckejo (tamaño matural)

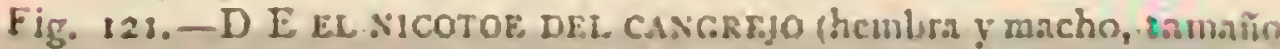

Fig. 122-F EL DIQBETESTIO DILESTUKION amplia(t) Fig. 123.-G E. COSDRsCANTO Di: B.OS 7.:OS

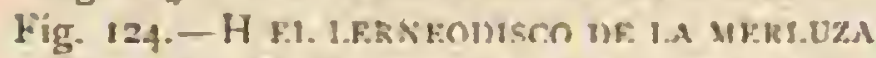

Fig. 125. - I IA 3ACULTSA JE IA NERTUZA

E historia primitivos. Mueller buscó y encontró un candino que nace del huevo hajo la forma de noufflies, $y$ solo de esta pasa i la de zoca.

\section{LOS COPÉPODOS-COPE- PODA}

Los copépodos 6 entomostriceos que nadan libremente tienen los órganos de la boca propios parn mascar. Clans, que ha estudiado estas especies, describe su género de vida del modo siguiente: \&abitan tanto las aguas dulces cubiertas de vegetacion, como los lagos y el mar, en cuya :auna infinitamente rica $\&$ inagotable estos animales tienen una gran importancia para la econonsia de la vida Aqui se presentan, no solamente bajo las formas mas variadas, y ofreciendo un cambio extrnordinario de las condiciones de la estructura, sino tambien en grandes masas y cnormes agrupaciones, de las que los peces y hasta los mas grandes animales acuáticos pueden alimentarse. En los lagos de Baviera y en el de Constanza, los ciclópidos constituyen, segun L.eydig, con los dafinidos, el alimento de los peces mas apreciados. Roussel de Vauzene dice al hablar de la especie celochilus australis (fig. 116), que estas formas se aglomeran a miles, formando bancos en que el agun adquiere un color rojizo. Como estas noticias han sido confirmadas por Goodsir, apenas podemos admirarnos de que los mas pequeños crustáceos constituyan el alimento de los séres mas enormes, tales como las ballenas. Segun refiere Goodsir, los pescadores de Firth of Forth designan con el nombre de maidre una inmensa exterision que con los cirrifuedos, moluscos y anfipodos se compone principalmente de entomostráceos. Con tales hechos no necesitamos ya detenernos en demostrar la importancia de estos perqueños crustíceos para la creacion.

Dos copéjodos se alimentan de sustancias animales en desconuposicion ó de séres mas pequeños, que cogen viros. $\mathrm{Ni}$ siquiem perdonan a sus propias larvas y progénic, hecho de que tódos los dias podemos convencernos por el contenido intestinal de los ciclópidos. La locomocion y la residencin varian segun las familias y el régimen alimenticio. Los calissidins y los pintelides, prolongados j enjutos, son los mas hábiles nadadores y habitan casi todos en el mar; surcan el agua con la rajidez. del rnyo, saltando ligeramente; y para descansar de su ejercicio se fijan en un punto, sosteniéndose solo en el agua jor el rapido movimiento de las placas de las maxilas superiores, con las cuales atraen su presa.

Otrás son las condiciones vitales de los cirlifidos (fig. 106). Tambien estos saltan mucho, pero no producen remolinos con sus maxilas, sino que se cogen con las cerdas de sus pe. queñas antenas à las plantas acuáticas. Sin embargo, los harfactides y piltidius dependen mas de las plantas acuáticas,y for eso se encuentran las especies de agua dulce de esta fumilia con mas frecucncia en los charcos y ícsos poco pro. findos, donde abunda la vegetacion: mientras que los marinos se hallan menos en alta mar que cerca de la orilla, en medio de toda clase de plantas marinas, asi como en la marlera en descomposicion, y entre los serfuralinos y tuhuInrinos (animales inferiores polipiformes). Los coriecidos viven lo mismo que los calánidos, como excelentes nadadores, en la alta mar; pero su cuerpo recogido, la forma de las partes bucales, su antena prehensil y su residencia, nos hace sospechar, que viven algun tiempo como parásitos. n

Una especic que ante todo merece mencionarse entre esta multitud, y que por si sola llama la atencion, es el cangrejito de zafir (sappliring fulgens), cuyo cuerpo, ovaly aplanado, midc unos $11 \%, 003$ y medio de longitud. Aunque muy á menudo le he observado yo mismo, reproducire la bonita descripcion de Gegenbaur: Cuando el mar está sereno, dice, y se fija la vista en la profundidad, obsérvase á menudo un espectáculo, inferior quizás en grandiosidad á muchos fenómenos del mundo marino, pero que pocos le igualan por su gracioso 5 agradable aspecto. Vése de pronto una intinidad de puntos luminosos, semejantes á chispas, y que parecen fáciles de coger, pero que a menudo se producen á muchis brazas de profundidad; saltan en lodos senti. dos y brillan con los mas variados colores, a\%ul de zátiro, verde dorado 6 purpúreo; y estos colores cambian y aumentan en intensidad à cada momento. ¿Una josforescencia del mar en pleno dia! Cada movimiento produce de nucvo el fenó. meno, hasta q̨ue un nuevo viento riza la superficic del mar, encrespando las olas, y entonces todo el espectículo se des. vanece en la profundidad. Gegenbaur, que hizo esta obser. vacion en Mesima, añade que una fosforescencia tan intens. 
solo se notó en enero, pero que se ve mas débilmente con alguna frecuencia. Yo he observado, no obstante, este curioso espectáculo en todos los hermosos dias de marzo.

Solo el macho de la zafirina es fosforecente, y segun dice Gegenbaur, la capa quue separa la coraza membranosa es la que produce el fenómeno. Todo el precioso juego de colores puede observarse con el microscopio, de cuyo exámen resul.

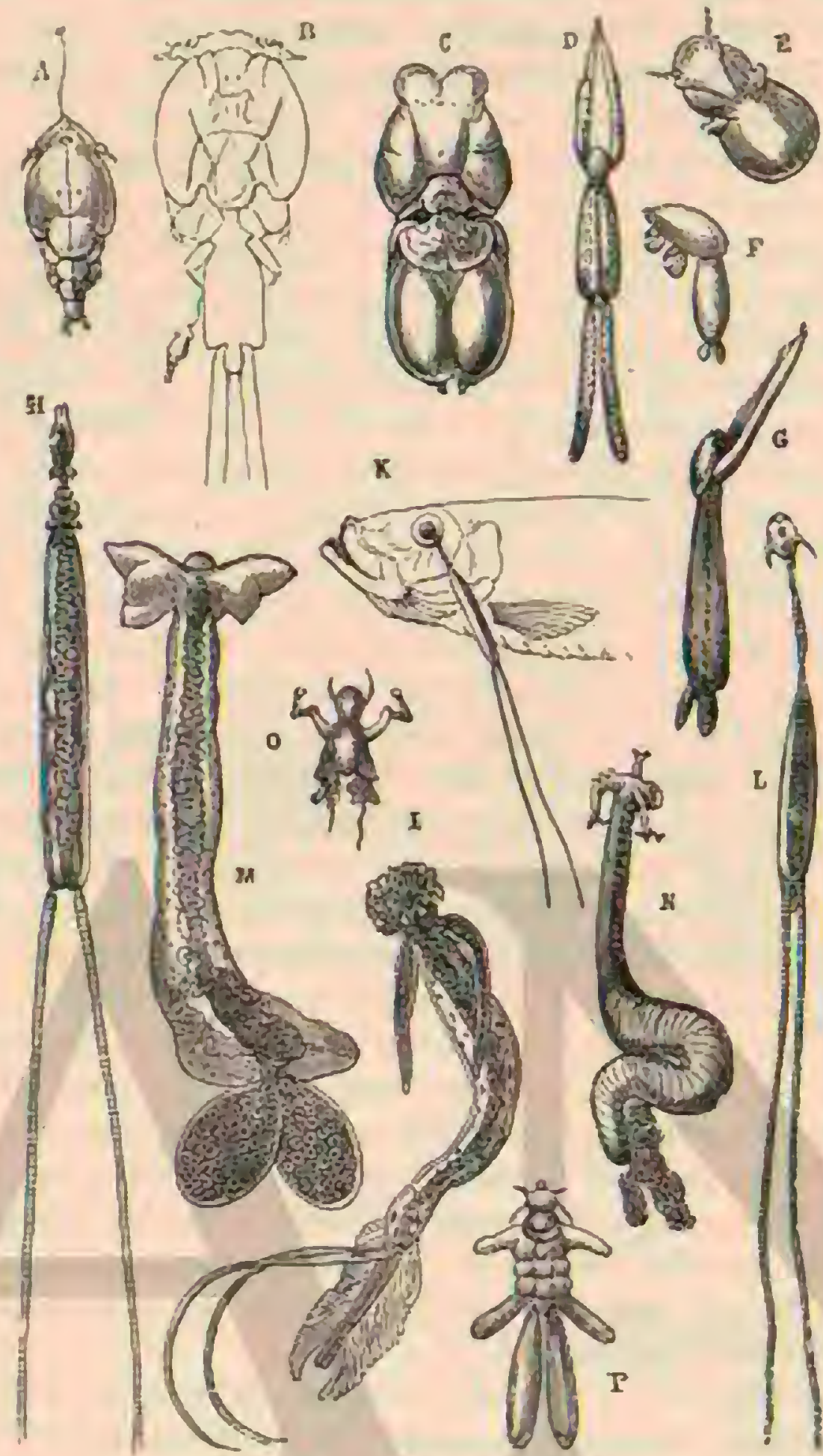

Fig. 126-A EL CALIMO DER LA CAMALLA

Fig. 127.-B EL MISMO, ADHFRIDO $A$ UN CAR.ICO

Fig. 128. - C EL CECROIO DE LATKFILL.F.

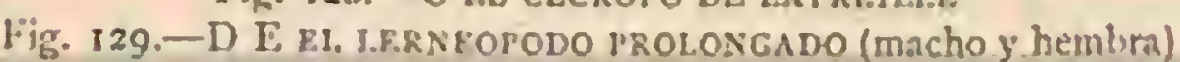

Fig. 130. F G FI. IERNEOPODO ESTRELIATO (macho s hembra)

Fig. IZI.-H LA PENEILA FILAMENTOSA

Fัg. 332. - I LA PE.NEJ.1A DE. SAETAS

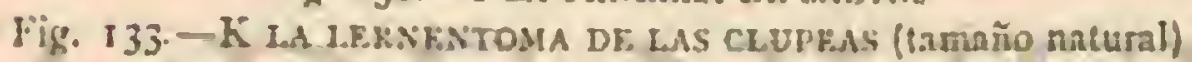

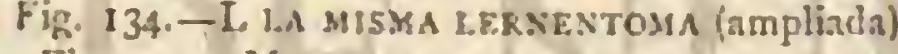

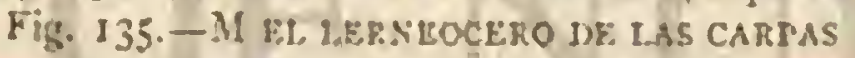

Fig. 136. - N LA 1, BRAEA DEL BACALAO

Fig. 137. - O LA LEKS'EA DF, L.OS GOBIOS

Fig. 138. - F IA LERNEAA RADIADA

to que cada celda irradia independientemente los suyos. ه Asi, por ejemplo, se ve el amarillo en medio del rojo, y este en medio del azul, aunque el fenómeno puede extenderse tambien a las celdas inmedintas; del borde de una que era arul, este color pasa à la siguiente, que hace un momento era roja, $y$ de este modo su color se difundu á veces sobre una gran extension. A menudo aparece de pronto $\mathrm{cn}$ una misma celda una mancha sin color en el centro ó en el bor. de, ora grande, ora pequeina, mientras que el resto brilla todavia con todos los tintes. Si la luz interceptada un momento, refleja despues directamente, la mancha despide un brillo metálico, mieniras que las restantes partes, de distintos colores., se oscurecen al punto.
DLos espacios de tiempo en que se suceden los fenómenos son de muy diversa duracion: con frecuencia cambia en un segundo tres veces el color, y á menudo un solo tinte dura varios segundos. Si muere el individuo, en cuyo caso el contenido granoso de las celdas radiantes se reune en el centro, el jenómeno termina por completo. Resulta de ąqui que en este caso se trata de una reftexion de los rayos de luz en aquella capa granosa de las celdas, $y$ no de una llamada fosforescencia propia. Sin embargo, el autor no quiere sostencr que los zafirinos no pertenezcan a los animales nocturnos radiantes, entre los cuales fueron clasificados por Thompson y Ehrenberg.

En cuanto precede hemos dado á conocer una serie de grupos con categoria de familias. Los habitantes del agua dulce se han reunido antes bajo el nombre genérico de $g$ ilops, distinguiéndose por un solo ojo frontal. Las hembras tienen por lo regular uno of dos ovarios. Listas especies labitan en todas paries las aguas estancadas. Un género que vive con prefencia en el mar, y nauy afine del anterior, es el harpacticus. Un periódico inglés, el Ausland, ha dado cuenta del descubrimiento de una especic propia del agua salada y perteneciente al último género. El yoúlogo noruego Sars, extrajo de la parte mas profunda de un lago interior un poco de cieno, y con gran asombro le encontró lleno de una especic de pequeños ciclopodos rojos, en los que enseguida recono. ció la especic marina harpacticus chelifer. La existencia de este crustrácco le admiró tanto mas, cunnto que á pesar de las especies de agua dulce halladas luego, hubo de reconocer por el-sabor que el agua cra salobre. La analogia de los crus. táceos descubiertos por Loven, en los lagros interiores de Suecia, con las especies de agua saliada del alto Norte, es otra de las evidentes pruebas de que los verdaderos animales marinos pueden acostumbrarse en ciertas circunstancias á vivir en cl agua completamente dulce. El lago en que Sars pescó está situado tan cerca de la costa, que cualquicra alta marea ó violenta tempestad podia llenarle. Otras especies de agua saladn penetrarian probablemente al misno tiempo en el lago, pereciendo poco à poco, á medida que el agua per dia su contenido en sal; pero el pequeño copepodo, sin tras. formarse anatómicamente, se adaptaba a las nuevas condi. ciones.

Haremos mencion adeniás del género notodelphys, cuyas especies, sin ser verdaderamente parásitas, viven en el manto y en la cavidad branquial de los acidios, grupo de moluscos que mas tarde describiremos.

\section{LOS PARÁSITOS-PARA- SITA}

En los crustáceos parásitos, un par de antenas y otro de patas maxilares; $\delta$ algunos de cllos, trasfórmanse en órganos prehensiles; mientras que en las maxilas sucle haber en un tubo chupador una especie de estiletes propios para pinchar. Todos cstos crustáceos toman su alimento de otros animales, sobre todo de peces. Su relacion con estos últimos ofrece los mas diferentes grados, desde la completn movilidad que les permite abandonar á su antojo al anfitrion, hasta la vida mas sedentaria, que obliga al naturalista á practicar una incision en la rabeza de aquel parn obtener el parásito ileso, pues penetra del todo en la carne del ser que habita. Con esta vida sedentaria siempre se relaciona una metamorfósis retrógada que hace desaparccer la estructura primitivamente articulada del cuerpo, cuando menos en el sexo femenino: el cuerpo se ablanda, convirtiendose en vermiforme, $\delta$ ad. quiere la figura mas grotesca, por la formacion de toda clase de protuberancias iudosas ó lobulares. Con frecuencia su. 
cede que los machos, aunque no llegan a ser tan deformes como sus feas companeras, quedan convertidos en pigmeos y se dejan arrastrar por las hembras, agarrándose á ellas.

Entre los crustáceos parisitos, nuestras especies de agua dulce se distinguen por su mayor movilidad y por la frecuencia con que cambian de domicilio, como sucede con el argulus folinceus(fig. I I 8). Esta especie tienc el cefalotórax en forma de disco con el abdómen bilobado; dos grandes ojos compuescos sobresalen en los lados de la cabeza; y á las partes buca-

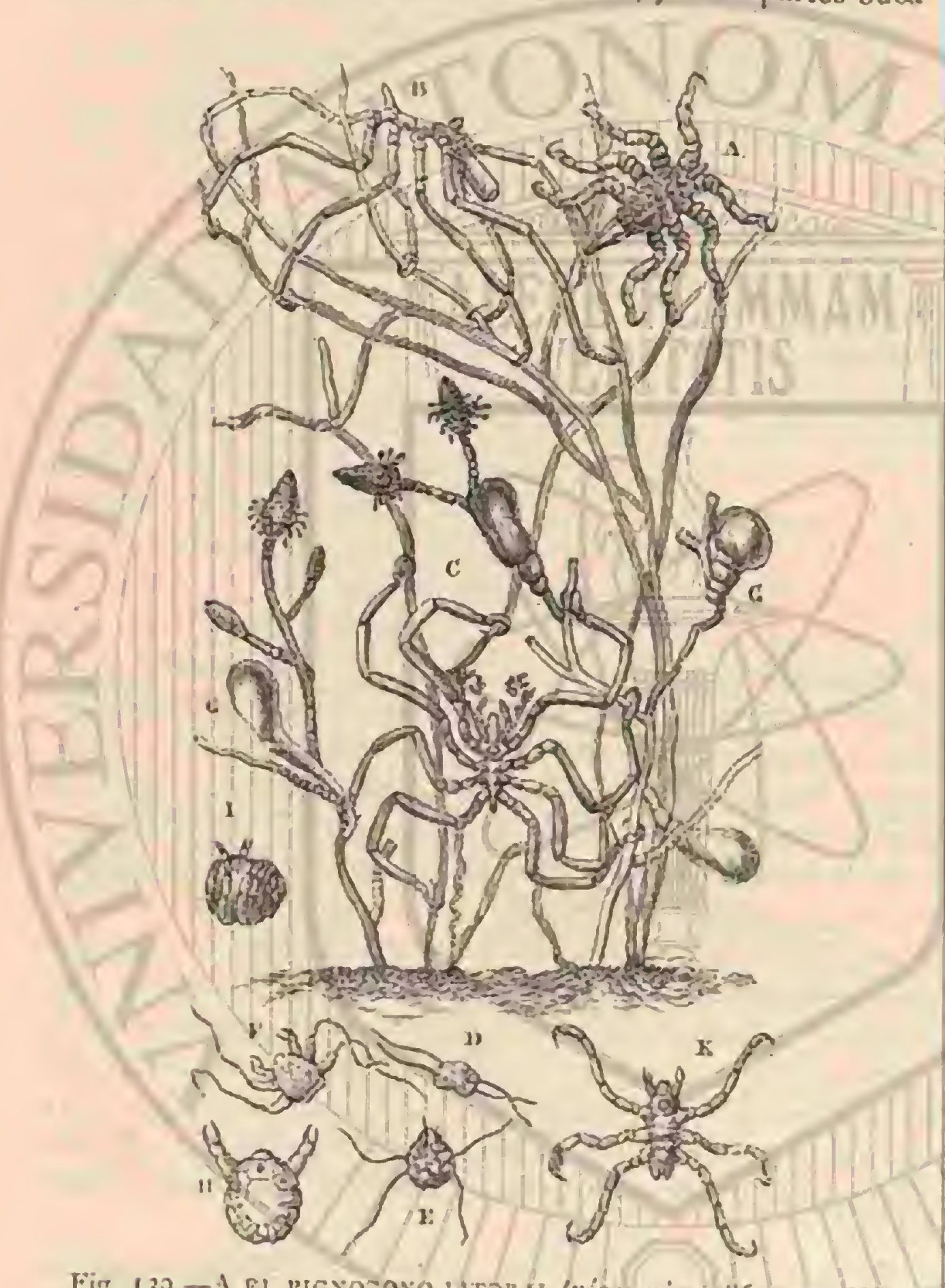

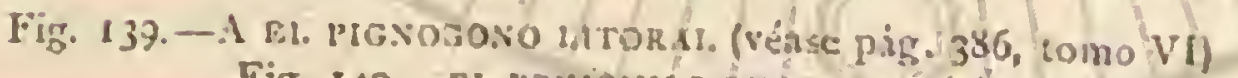
Fig. I40.-EI. MOxinur.o ruRlukfó (1)

les y patas maxilares siguen cuatro pares de patas natatorias prolongadas y hendidas. Segun indica su nombre aleman de piojo de canpa, el argulus foliaceus habita con preferencia en nuestras especies de carpas; pero muy à menudo tambien, segun Claus, en los boquerones y con menos frecuencia en los sollos, pércas y en la trúcha salmonada. Hasta se encuentra en pequeños sapos y ranas; y el citado observador vió como se fijaba con jredileccion en el axolotl. \& Los argúlidos, dice Claus, se alimentan con preferencia del plasma de la sangre, es decir del verdadero liquido de esta, abriéndose camino por inedio del aguijon, y sobre todo con sus mandibulas y maxilas puntiagudas. El perfecto desarrollo de los órganos del sentido y de las patas natatorias demuestra que se tienc $\mathfrak{a}$ la vista un paràsito tan solo estacionario (2) que

(1) B. Macho. C. Hembra. D. F. I. Lin sus diferentes estados. G. Encerrado en protuberancias de la Coryma "exims. II. Hijuclo casi completo. I. Sepamdo de la Corgna. $K$. Antes de su madurez.

(2) Los lectores que quicran conocer lodos los parísitos del reino animal en sus diferentes graros de parasitismo, deben adqquirir la inte. resante obra de P. I. Van. Benteden, titulacla, Los parásites del reino animal.s Lsiprig, IS66. El sutor dexlica su primer libro á los animales que toman en parte su alimento de otro animal, contra la voluntal de éste. «Tal parisito, dice, no vive á expenass rbel cuerpo de su antitrion; torlo lo que exige es un alliengue ó el exeeso de alimento de agquel. llegada la hora del apareamiento y de la puesta de los huevos, abandona su domicilio y vaga libremente (3). Tambien la estructura del canal alimenticio, con sus numerosos intesti. nos ciegros ramificados, puede permitir sin duda que, à una abundante comida, siga un largo ayuno, sin disminuir la energia vital del individuo. Fn efecto, he observado que el argula bien alimentado puede pasar muchos dias y hasta semanas separado de su anfitrion sin alimentarse, y sufriendo en este tiempo varias mudas; despues, cuando vuelve al cuerpo del pez, llena de nuevo los numerosos apéndices de sus intestinos con jugo alimenticio.

Como las noticias que tenemos sobre la reproduccion de los animales inferiores son en su mayor parte aun muy in. completas, nos aprovechamos con gusto de otras observaciohes que Claus ha hecho sobre este punto en los caligidos.

En cunnto al periodo del apareamiento y de la reproduccion, dice, puedo asegurar que no se limita á la primavera, sino que varias crias se siguen en veranoy otono. A fines de abril y primeros de majo observé la primera puesta, sin çuerer decir con esto que no pueda efectuarse una 6 varias semanas antes. la progénic nace al cabo de un mes, ó poco mas, despues de la puesta, y necesita de seis a siete scmanas para desarrollarse y poner i su vez los primeros buevos.

- A mediacios ofines de julio, por lo tanto, la generacion joven produciria en verano sus huevos, y los descendientes criarian i fines de scticmbre. Debo añadir que esta limitacion periódica de las crias es susceptible de aiterarse por el hecho de que la hembra del argulo puede ponir por segunda vez, y probablemente varias, sus huevos. Muy á menudo vi una hembra de argulo fijarse, inmediatamente despues de la puesta, en el integumento del per (los huevos se fijan en pie. dras y otros objetos sólidos), renovando al cabo de algun tiempo su provision, es decir, madurando una multitud de pequeños embriones. Asi sucede que desde julio hasta fines de octubre se puede observar la puesta. Tambien los machos tiener una energia vital correspondiente, y puecien iecundar durante una vida de muchos meses toda una scrie de hem. bras, lo cual explicaria en cierto modo que el número de machos sca mas reducido.

Ios caligos (fig. I 19) ticnen el cuerpo aplanado y el cefalo. tórax grande en forma de escudo. La familia comprende los crusticeos parisitos que se distinguen por una vida activa y por el gran desarrollo de las garras de los órganos prehensiles. Habitan la piel, las aletas y sobre todo, las brancquias de los mas diversos peces inarinos. Ias hembms, que por lo regular tienen los dos ovarios existen en mucho mayor número que los machos.

El lernanthropus, pertenece is la familia de los dichelestina (fig. 122). En el pequeno cefalotórnx se ven tres pares de órgamos prehensiles; las patas anteriores del abdómen están casi atrofiadas, y las posteriores se trasforman en grandes placas. Los machos de toda la familia, bastante numerosa en especies, que habitan tanto en peces marinos, como en los de agua dulce, no se han podido observar aun.

De la lamilia lerneconemida fjamus nuestra atencion en una bracliella que puede figurar dignamente entre las hembras aqui descritas. En la base del céfalotórax, que se extien-

No succde as! con Ins mutualistas, es decir, con los animales que vi. ven unos sobre otros sin ser parísilos: varios de cllos se arrastran; otros se prestan mútuos servicios, algunos se cxplotan, no pocos se proiegen, y en fin, hos haj que están unidos por los vinculos lle la simpatia. I

(3) Los verdaderos parisites son. stgun Beactien, los animales que viven á expenens del ctierpo de su prójimo y cựa intencion é la de ex. plntarle econòmicatmente, sin poner en peligro su existencit. La cVida de los animales tme numérosos cjemplos, con sus diferentes gradus.

(Nobs ded Antor). 
de en forma de lombriz, bay un par de patas maxilares, prolongadas como brazos, que están soldadas en su extremidad y presentan açui un disco cliupador que el animal introduce en la piel de su anfitrion. Excepto en los pequeños organos bucales, todo vestigio de articulacion ha desaparecido.

Ia familia lemacerida se caracteriza por tener unos apéndices y protuberancias particulares en la cabeza; en el cuerpo del hamobaphes, que tiene unas dilataciones en forma de bolsas, hállanse dos ovarios retorcidos á manera de rizos; de este cuerpo se destaca marcadamente una parte delgada en figura de cuello, cuya region superior se encorva hácia atrís, mientras que toda la extremidad anterior se introduce desde este ángulo en cl vaso de la sangre, qué se corre entre el corazon $y$ h has branquias de los peces que el parásito elige, mientras que cl resto del pesado cuerpo descansat entre las branquias.

El lemainéma inonlaris elige oqro órgano delicado para su residencia, introduciendo su cabeza en los ojos de los arenques, de modo que forma un apéndice repugnanie.

Tambien las especies del género pensuella (figs. 13 I y 132 2) desmienten las palatiras del poeta: ${ }_{i} \mathrm{O}$ h si supieras cuan tranquilo se tialla el pececillo en el fondo del agua! Deci. mos esto, porque el cefalotórax, cubierto de abundantes ramas é introducido á mucha profundidad en el cucrpo del $\mathrm{pe}_{3}$ no debe causarle ninguna sensacion agradable.

Muy pocos de estos parásitos viven en otros animales qque los peces. A ellos pertenece el herpyllobins, que se fija en varios quetópodos de los mares septentrionales: la parte anterior de su cuerpo se desarrolla en forma de una placa irre. gular, que se introduce por completo en el cuerpo de la victima; un cuello en forma de tallo reune aquella parte anterior con el abdómen, dilatado en forma esférica, y en el que no faltan los ovarios, propios para reproducir una numerosa descendencia.

Finalmente, haremos mencion de algunas especies, cuyas formas representamos en los grabados adjuntos y que podrán dar al lector una ligera iden de la singular estructura de estos animales. 'Tales son: los nicolves (figs. 120 y' 121) paråsitos de los cangrejos y langostas; los condracantos (fig. I23), que lo son de los zeos á peces de San Pedro; los lerneadiscos y joculinas (figs. 124 y 125) que los son de las merluzas; los calimos (figs. 126 y 127 ) de las caballas y tambien de otros parisitos, es decir, de los caligos; los cecropos (fig. I 2 S), parásitos del atun y del rodaballo; los lerméprodos (figs. I29 y 130), de los salmones y bacalaos; las levurnio mas (figs. 133 y 134), de las sardinas y demás cupleidos; los lerneoceros (fig. 135), de las carpas; las levneas (figs. 136 , ${ }_{37}$ y 138$)$, del bacalao y de los gobios; los foxiguilos (fig. 140), los acteres (fig. 141), de las percas; las aucorelus (figs. 142 y 143 ), las lamprogrlinas (fig. 346), de los ciprinos y finalmente los trayseliastes (fig. I45).

No dudamos que muchos icctores apartarán la vista con disgusto de este cuadro. Esa multitud de animalejos extravagantes, verdaderas caricaturns, que sin gozar de la vida, sirien solo de tormento ì otros séres, no deben producir, considerados en si, una impresion agradable. A pesar de esto, no podian faltar en el gran cuadro en que hemos tratado de representar la lucha por la existencia y los combatien. tes que en ella toman parte. I.lenan un vacio que existia y que han sabido conquistar; y solo por su conjunto se pueden explicar, comprender y apreciar. Muchas veces aun, en el curso de nuestra descripcion, nos veremos obligados a ocuparnos de formas $y$ condiciones parccidas. 1.os cirripedos, llamados asi por las articulaciones en forma de ramas que prescnta la extremidad de sus paras, están sugetos á una trasformacion en extremo particular; y á causa de la secrecion calcúrea de su cubierta se han colocado en todas las colecciones antiguas entre las conchillas. $\mathrm{Ni}$ aum Cuvier los reconoció por su verdadera-13aturaleza, y solo cuando los grados de su desarrollo ofrecieron un indicio imposible de desconocer, se les consideró cono los animales que en realidad son. En el estado que sigue inmedintamente al salir del hnevo, el ser, que affecta la forma de pern, hallándose provisto de uri ojo frontal y tres pares de extremi dades, con los que alegremente rema por el agua, tiene la mayor semejanza con los peçueños entomostráceos. A pesar de su viracidad, es posible que el impetuoso jóven se trasforme en un viejo malhumorado; $y$ en efecio, despues de algunas mudas hace los preparativos para fijarse por el resto de su vida. Con la muda que precede a la fijacion, la cubierta del cuerpo adquiere cl aspecto definitivo de la de los ostracódeos. Las antenas, que sobresalen bastante, sirvenles parn cogerse al animal primero, fijándose despues en êl por medio de una sustancia segregada de glándulas particuculares.

En la coraza menbranosa, que entonces se separa mas, depositanse capas en figura de hojas calcáreas, que pronto
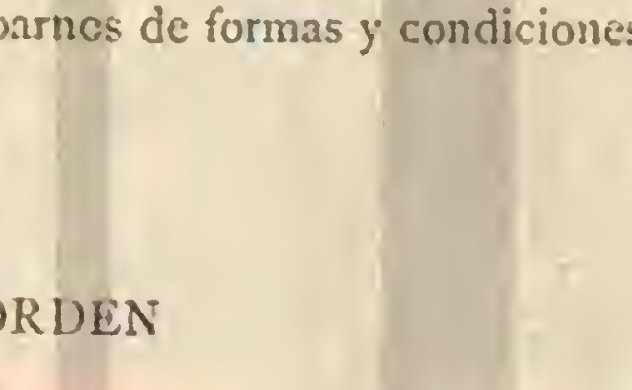

CIRRIPEDIA 
animales se desarrollan los gansos berniclas, supersticion que hoy dia no puede ya prevalecer. Se fijan con un tallo elástitico musculoso, y tienen el escudo plano y irilateral. Por el número de las hojas calcáreas y su major ó menor desarro. llo sé distingue toda una seric de géneros, siendo los mas comunes el lepas y el olion. Poco mas 6 menos la mitad de de todas las especies de lepadidos se fija en objeios flotantes en el agua, en las quillas de los buques 6 en animales que muy d meando cambian de residencia. Asi, por ejemplo, el

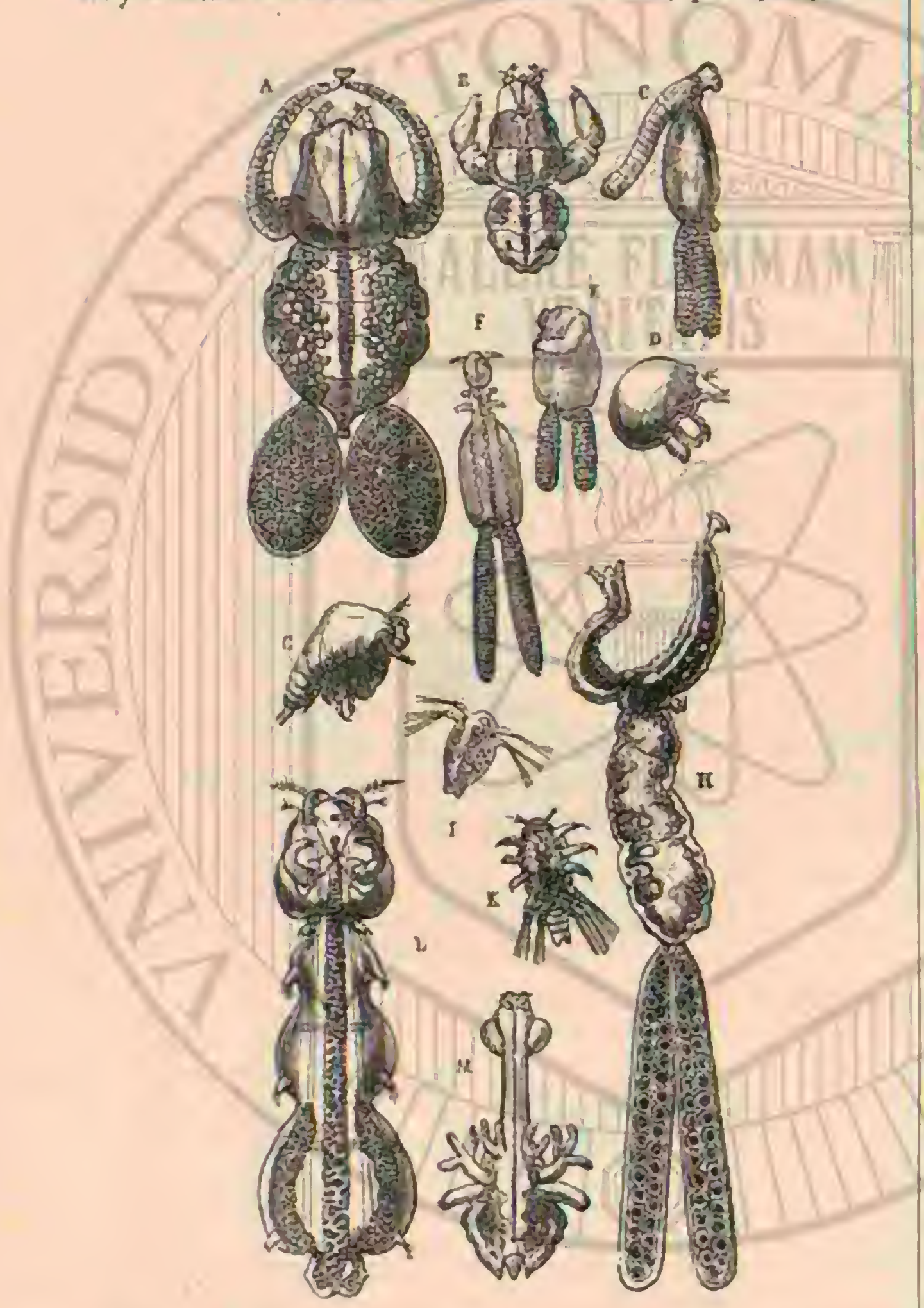

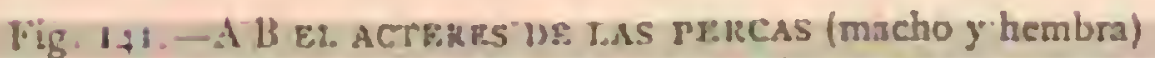
liig. I42. - C () los ANCORH.1.A 1)R GANCrios (hemabry y macho) Fig. 143-E in sicorfis R Uroosa (macho)

fiu. I A - F C EL LERNRSTOMa COKNUDO (hembra y macho) Fig. 145 - - II I K F.LTKAqUELIASTES

Fig. iq6.-1, I.A IASPROGLENA DONCEI.IA (hémbira)

Fig 177 . - M EL LERNENTOMA ASEl.INA (heimbra)

ane'arma squalicola vive como parisito en los tiburones, en cuya piel se fijan con su tallo; y el lepas anserifera, con algunas otras especies, se halla como apendice ordinario en los buques que regresan de casi todos los mares meridionales y tropicales. Oira especié, el lepars pectinala, se encuentra en objetos flotantes en toda la extension del Océano Atlíntico, desde el norte de Irlandia hasta el cabo Horn. En la costa de Calabria y en el golfo de Niápoles hállase a menudo la piedra ponez cubierta del lepas anatifera, especie que parece depender de los vientos y corrientes, y que hace largos viajes en aquella. I.as especies scalpellum son habitantes del agua profunda; los pollicipes y otras viven en la costa. Entre los géneros que no cambian de residencia con el objeto que les sirve de base cuéntase el lithothrya, que se fija en rocas de caliza, corchos y pedazos de coral.

\section{LOS BALANIDOS-BALA- NID蚱}

Los balanidos se fijan en otros objetos con la superficie externa de su cubierta, que tiene forma de cilindro ó de cono y pucde cerrarse por medio de una tapa membranosa provista de dos pares de placas. Listo se observa, por ejem. plo, en el halames halaroides, que visita la costa, tan luego como comienza la marea baja. Asi se preserva del peligro de resecarse, y enciérrase tan bien, que ni los mas ardientes rajos del sol pueden perjudicarle. Esta misma especie su. cumbe ell agua salobre, mientras que otras prosperan en ella. Darwin encontró en las islas de Falkiand una especie, en las rocas de la desembocadura de un rio, que tan pronto vivia en agua dulce como en agua salada. Una de las especies mas comunes, que se distingue por su color rojo pailido, $y$ hasta purpúreo oscuro, y por la variedad en la forma, es el balanus fintinnabulum. Su verdadera patria se extiende desde Madera hasta él Cabo y desde California lasta el Pe. rú. Amenudo/se halla en asombroso número en los buques que desde el oeste de Africa, las Indias orientales y occidentales, y la China, vuclven il los pucrtos europeos. En un buque que habia visitado primero el Africa occidental y despues la Patagonia hallóse la especic balamus psittarus, fija en el balanus tintinnabulum.

Mucho carino parecen profesar á varias ballenas ciertos balanidos, y tambien á veces los lepodidos. En la ballena de Groenlandia llamada Kepurkak, y en individuos aun muy jóvenes del diadema halaenaris se encuentran con tal regularidid, que los groenlandeses pretenden y juran que los hijuelos están ya cubiertos de esas especies en al rientie de su madre. Alugumas orns, la coronula balaesaris y la tsubici. sella habitan al parecer exclusivamente en la ballena aus. tral (leinbalaenn australis). Al contrario de esta, la del extremó Norte nunca cstá infestada de cirripedos, $j$ cn ningun cachalote se ha tncontrado, segun Eschricht, un solo bala. nido. Eil citado naturalista de Copenhague demostró que el conocimiento de estos parisitos es de gran utilidad para la historia natural de las ballenas. \& A cada especie de estos cetaceos, dice, pertenece otras de cirripedos, y estos ocu. pan tambien diferentes partes del cuenpo bastante determinadas. En las ballenas del Mar Austral se ijjan con preferencia en la parte superior de la cabeza, sobre todo en la llamada corona; las tubicinelas habitan exclusivamente en esta parte, mientras que los arviculos se fijan además en los aletas caudales y pectorales. En el Keporkak, la diadema no se fija nunca quizás en la parte superior do la cabeza, sino con preferencia en la superficic abdoninal y en las aletas. En las ballenas meridionales el color blanco producido por las tubicinelas y los ciamos, visible en la cabeza del cetíceo al respimar, fué desde un principio para los pescadores la señal característica para reconocer la especie de ballenas Hemos hablado antes de los lepaadidos parásitos, y tanto para conocerlos en sus formas particulares de tránsito, como à causa de su posicion intermediaria entre su grupo.y los rizo cefalos, darcmos a conocer aun dos especies pertenecientes álos lepadidos. La una llamada cochlorine amata, por su descubridor Noll, se encuentra en la concha del haliotis tubercuIato: estos crustáceos, que solo tienen algunos milimetros de Jargo, se fijan en una cavidad en forma de botella, cuy:a entrada es alguna hendidura. Su manto esta cubierto de espinas de quitina, las cuales servirán jrobablemente para abrir la cavidad en la dura concha; otras mas largas, que se ven en la entrada del manto, empléanse quizás para mantener abierta y limpia la desembocadura de la galeria, pues de lo 
contrario la interceptarian los numerosos animaluchos que se fijan en los caracoles. $\Lambda$ unque las partes aisladas del cuerpresentan diferencias en los géneros que viven al descubierto, todo el conjunto se rije sin embargo por la estructura de los lepatidos; solo se ven trasformaciones resultantes de la residencia jo de la construccion de la vivienda. Otras especies, los coclorinos y los haliotis, solo difieren en que estos carecen de las placas calcáreas, con las cuales se acorazan sus companeros, que viven libremente y han de buscar su alimento.

Del todo diferentes son las condiciones de la especie aneInsma sumenlicela. Fil individuo descrito primero por Darwin es sin duda un lepadido, pero no solo carece de las hojas calcircas del manto exterior: sino que tambien sus extremi dades han degenerado en cortos munones sin cerdas, y los órganos bucales están poco desarrollados. Darwin dice que el aniasma toma su alimento de la superficic de la piel del tiburon, pero no sucede asi, porque el tallo de ese crustáceo penetra a mucha profundidad en la piel del mismo y ademis se forman numerosis protuberancias en figura de raices, que prolongadas y ramificadas lateralmente penetran en la carne de aquel. En inmediato contacto con los jugos, las raices recogen este liquido y alimentan el cuerpo del parásito. Asi se explica que i medida que aquella formacion de raices se desarrolla, los órganos destinados por lo regular a recoger el alimento se atrofian.

Los órganos digestivos, por el contrario, han desaparecido, excento algunos vestigios que se conservan en los rizo-cefalos; y el animal que en su juventud se legitima como crustácco, adquiere la forma pesada de un saco despues de fijarse en su

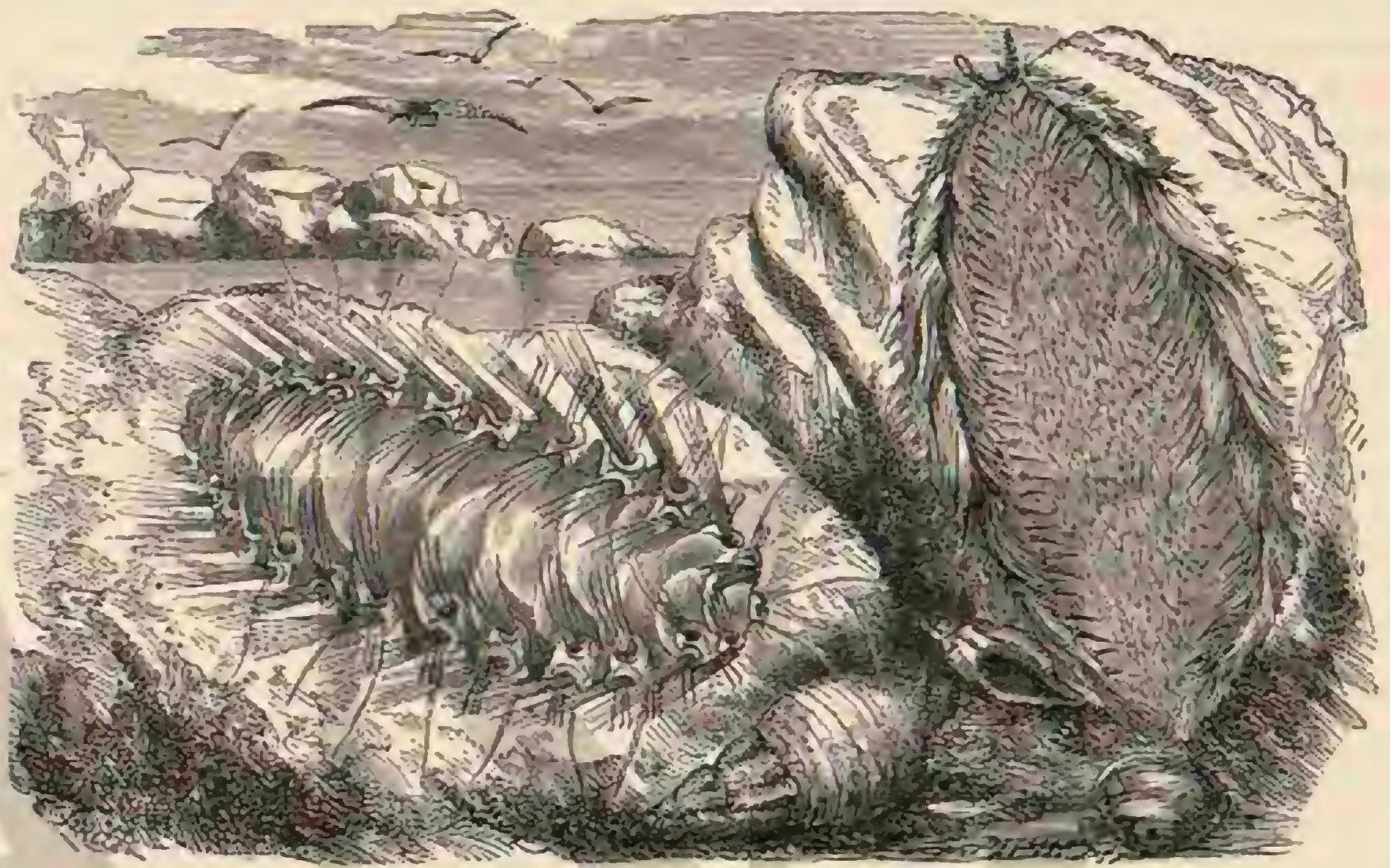

Fig. 14S. - EL. AFRODITA ERIZADO

Fig. 149. - F.1. AFRODIt's roro

anfitrion, que es un crustaceo superior. Hasta aqui se efectía 1. trasformacion, que es una metamorfósis retrógrada, de modo que estos animales se han considerado mucho ticmpo como tremalodes.

Los hijuelos tienen al nacer la forma de naupios y se parecen mis a los de los rerdaderos cirripedos. Desgraciadamente la historia de su imsformacion no está bastante explicada lederico Mueller demostró en especies del Brasil que de las partes en que esos seres se fijan, consideradas antes como boca, aunque en realidad corresponden al tallo de los lepadidos, bajan unos tubos cerrados, ramificados en forma de bolsas, por el interior del anfitrion, rodeando su intestino o extendiéndose entre los tubos del higado para apropiarse los jugos de la victima. De este modo el parasito no necesita ónganos digestivos propios; el animal en que se fija hasta su muerte se encarga de todo el trabajo para la prejaracion del alimento

Lalespecie mas comun de nuestras cosias es la saculina carcini del cangrejo comun, en curos hjuelos hace años-reconoci por primera vez la naturaleza del cangrejo. Encontré en la playa de Wangerooge a los cangrejos infestados por saculinos en" tal número, que despues de cada marea alta pude recogerlos a docenas. En cambio, cuando, hace algunos anos estaba recogiendo con mi amigo Cossmann animales marinos inferiores en el Helgoland, nos vimos obligndos á revolver centenares de cangrejos en la llamada roca de los saculinos, mas alla de la duna, antes de encontrar un solo individuo con el parásito que buscábamos.

Otro género, el pelígaster, se compone de especies que viven como parasitas, principalmente en los paguros: tienen la forma de saco prolongado y sus raices se trasforman $\mathrm{cn}$ una masa esponjosa que pencetra en el anfitrion para absorver sus jugos. La especic peldogyster curralus se halla con fre. cuencia en el paguro de Prideatix, propio del Mediterrínco.

Una especie muy afine del peldogaster, la parthenopea suhterranea, habita en el cangrejo llamado callientassa.

Cual si no pudiéramos separarnos del parasitismo, debemos añadir aun, pars completar la historia natural de los ri\%ocefalos, que con bastante frecuencia vive en ellos un lissópodo perteneciente a los bosirinos, el liviope, y que otras dos especies se utilizan de las raices de la sacculina furfirra, que vive como parisito en un pequeño paguro: fijüudose debajo de la saculina la roba el alimento que le proporcionan sus raices ; ocasiona su mucrte. Pero esto no basta, las raices crecen tambien sin saculina y adņuieren, scgun dice Federj. co Mueller, una extension extmordinaria, sobre todo cuando el hisópodo que de ellos se alimenta es un bopyras. La naturaleza produce, pues, aunque no precisamente bocas, órganos que hacen las mismas funciones, y que luego han de perecer, cuando los cuerpos à cllos pertenecientes están ya putréfactos hace mucho ticmpo. 


\section{LOS ANELIDOS}

Un nuevo mundo viviente, se ofrece ahom \& nuestra vista: pero solo para los que buscan con interés su existencia porque numca puede llamar la atencion como los - mamíferos, aves, peces, insectos y hasla crustácuos, todos los cuales estamos acostumbrados î vêr tan á menudo, que hasta sis viriedad nos parece muj natural. El nombre de gúsano sé emplea para designar algo despreriable, misero é indigno de atencion, y al hablar dé estos seres, la gente piensa por lo regular en la Iombriz de lluvia, ųuc desamparada se revuelve en el polvo seco, ó bicn evócase el recuerdo desagradable de una sản guijuela, de las trichinas ó de la carne infestada de los portúnidos. Estas son impresiones poco agradables, si no repugnantes, y que no convidan mucho a un estudio mas minucioso.

Y a pesar de esto, repetimos que con los gusanos se abre todo un huero muncio para los amigos de la naturaleza, mundó que por la variedád de la estructura, del género de vida y del área de dispersion, aventaja i la mayor parte de lós grupos del ruino animal; relacionindose por una parte, a causi de la sencillez de la estructura y la pequenez unicroscópica, con los infusorios; por otra con los moluscos; y confundiénduse, en fin, con otra division de sal modo, que diti cilmente puede distinguirse de los verdaderos artrópodos. En la profmudidad de los mares viven los unos; otros en sus orillas; no pocos en la tierra; y varios hasta suben à las copas de los arboles de los bosques tropicales. bil hecho de que muchos llegan in introducirse en los intestinos de toda clase ce animales, y desgraciadamente tambien en los dethombre, ensancha su área de dispersion, dificultando no poco su eximen f su clasificacion sistemitica. Cómo han combiado los tiempos desde linneo! Lintoneds se enscinaba que habia seis clases de animales: mamiferos, aves, anfibios, peces, insectos y gusanos. Cuantos animules se rcunicron en bl gran mundo de los gusanos! iY con que seguridad se sabia que estos tenian un cornzon con un solo ventriculo sin nuricula, sangre fria y blanquizca, y cu vez de antenas una especie de hilos para el tacto! Estas palabras debian referirse á la lombriz de lluvia, al caracol, al asterio y al pólipo. En cl sistema del gran retormador de la zoología, Cuvier, los gusanos no constituyen un punto nuy débil. Una division, la de los gusanos articulados, cujo cuerpo se compone de anillos, se agrupó, segun este naturalista, y con mucha razon, despues de los artrópodos; la de los gusanos intestinales, y otros tenian su lugar entre los holoturidos, con los que solo guardan una relacion muy problemática.

Actualmente se tmata de reconocer si los gusanos deben reunirse con los artropodos en un gran grupo, ó si deben formar una division independiente de la misma categoria de los vertebrados y artropodos. Al fijar nuestra atcucion en los gusanos ó anélidos bien conformados, en esos numerosos séres provistos de cerdas, de los que, por decirlo así, nos da ligera idea la lombriz de lluvia y sus congéneres mas afines de nuestros paises, pero qque han adquuirido su verda. dero desarrollo en el mar, parece natural la inmediata re. union con los artropodos. Cuvier, y todos los que en este punto. siguicron su sistema, tenian razon; pero estos anḱli. dos tienen una relacion tan inmediata é inseparable de todos los otros no articulados, de los que una parte presentan los vestigios de una organizacion inferior, que en este caso tambien los últimos necesariamente deben higurar en linea con los anélidos articulados, y en union de estos con los artropodos mas superiores. Ja mayor parte de los zoólogos no judicton resolverse á dar este paso.

Si tenemos presente la obsermacion que se debe hacer en laś grandes divisiones del reino animal, es decir, que los séres de organizacion inferior llegan a tenerla superior, y ha. ciendonos cargo además de que los nuevos principios y' teo. rias cientificas evigen la desigualdad y la cxplican satisfactorianente, comprenderemos que la unidad interior de una série de animales que comenzando con especies no articuladas, adquuicre en los anćlidos articulados un caraicter nuevo, oireciendo al' fin los insectos mas desarrollados, es una necesidad que tambien debe encontrar su expresion en el sistema. Fin rigor deberia inventarse para la afinidad de los andidos y artropodos un nuevo nombre comun.

Tomando en consideracion esta unidad sin duda seria permitido, y hasta es conveniente para la mayor claridad, admitir junto á los verdaderos artropodos un tipo de los gu. sanas, y liuscar para el mismo algunos distintivos caractcristicos

La palabra gusano parece despertar en todo el mundo la idea de un cucrpo simetrico, mas ó menos prolongado, ya cilindrico como en la lombriz de lluvia, ó bien complletamente plato, conno le vemos en las articulaciones de la ténia. Por Jo regular, los tegumentos de la piel son blandos, y en general, ciertas partes de la superficic presentan á reces pelitos brillantes. la carencia de estos órsanos microscópicos en todos los insectos aracnoides, miriápodos y crustaceos contrasta con la abundancia que ofrecen en los anćlidos. Con la picl suele cniazarse un tubo compuesto de los músculos que se cruzan trasversal y longitudimalmente. las contracciones del cuerpo, los movimientos serpentinos al nadar y los de las partes aisladas del cuerpo, por ejemplo de los munones membranosos, en los que se hallan las cerdas, se producen por dicho tubo, siendo necesario para que se éfectuen que los tegumentos membranosos no lleguen it trasformarse en esqueleto como en los artrópodos. 'lambien saben todos que el gusano no tiene patas, y que sus movimien tos son serpentinos; algunas especies ondulan en sentido horizontal como las serpientes, $\delta$ bien se mueven como las sanguijuelas. Iluchos anélidos. se sirven para la locomocion de unas prominencias de la piel y del tubo muscular en forma de munones, en los cuales hay cerdas aisladas ó haceci. llos enteros de ellas. Por último, tambien se ren discos chupadores que pueden ser auxiliares de la locomocion en ancilídus parásitos, asi como en ayucllos de vida libre.

Cuando el cucrpo del anélido presenta una articulacion, distinguese esencialmente por tál concepto de los verdaderos artrópodos, : causa de tener los anillos de igual forma ú homónomos. Los segmentos que en un principio se presentan en los artropodos como homónomos, se desarrollan en el individuo adulto de un modo muy diferenie, segun el princi. pio de la distribucion del trabajo. 1.a clase inferior del anélido articulado se reconoce desde luego por la analogia 6 completa semejanza de los anillos del cuerpo. En el insecto siguen a la cabeza los segmentos del tórax, que principal. 
mente contienen los poderosos muisculos de las patas. y despues vienen los segmentos del cuerpo, en los que se hallnn la mayor parte del intestino y los órganos genitales. El anelido no llega munca á presentar tau marcada separacion en diferentes partes del cuerpo, 6 mejor dicho, en los casos en ‘ue alcanza tal separacion es porque se ha desarrollado poco a poco en verdadero artrópodo.

El sistema nervioso de los anćlidos superiores no puede distinguirse del de los artrópodos si no nos fijamos en aquellas contracciones de los ganglios abdominales que se relacionan con la concentracion del cucrpo en las cangrejos aracnoideos, ctc. Numerosos anćlidos inferiores solo tienen uno ó dos ganglios en la region de la nuca, con dos nervios que partiendo de ellos se corren a lo largo del vientre. Ios órgnnos de los sentidos, subre todo lus ojos, estan desarrollados segun que el género de vida de los respectivos anelidos es mas 6 menos lilure y crranic. Asi como los coleópteros y crustáceos que habitan en cavidades oscurns tienen li vista mas 6 menos atrofiada, tambien los ancilidos nue se retiran al interior de otros animales fierden necesariamente la consistencia normal de los órganos de los sentidos.

Sobre el aỵarato digestivo de todos los anélidos en general apenas hay algo que decir. Muchos gusanos parisitos carecen del todo de intesturo; tienen la ventaja de no necesitar comi. da, y se alimentan à pesar de eso a expensas de su anfitrion por medio de una absorcion involuntaria de la piel. Otros anćlidos inferiores tienen un intestino semejante $\{$ una bolsa, y algunos en forma de red; cn los cue digieren ripidamente es delgado y corto; los que lo hacen con lentitud, tomando de una ver gran cantidad de alineuto, como las sangujuelas, tienen una dilatacion ó ensanchamientos correspondientes del estómngo, por decirlo asi. El sistema de la circulacion de la sangre es proporcionado al desarrollo del intestino: en muchos gusanos superiores se pucde observar en individuos vivos hasta en los mas minuciosos detalles, viendose que la sangre, por lo regular rojiza, está encerrnda en algunas arterias y muchas venas. Esta separacion, ya completa, ó cuando menos relativa, en la que las arterias funcionan en lugar de un corazon, es otra particularidad caracteristica, cuando me nos de estos anélidos articulados. Como órgnno respirntorio sirve, ora toda la superficie de la jiel, ora unos apéndices en forma de branquias, 'ó bién existen órganos internos en forma de vasos, que prodrian compararse con los vasos aćreos de los insectos, puesto que introducen à mucha profundidad en el cuerpo ol agua que sirve para ta respiracion.

Los órganos genitales mas complicados, propios precisamente de los anćlidos inferiores, alternan con los mas sencillos; y en estos séres remos tambien todas las formas posibles de la reproduccion, asi como en el modo de vivir, formacion por medio de capullos, metanoriósis. desarrollo con cambio de formas (cambio de generaciones), parasitismo desde el huevo hasta la muerte ó solo en la juventud, $\delta$ en cualcyuier otro periodo de la existencia; en una palabra, aqui observamos todos los estados posibles y todas las formas en el genero de vida y el desarrollo.

Despues de cesias indicaciones no debemos extranar que la colase de los anélidos se haya dividido en tantas, y que dentro de ellas se encuentren contrastes mucho mas notables que en los grupos de vertebrados \artróp̧odos Los crustáceos parásitos han demostrado suficientemente cuiles son las diferencias y trasformaciones producidas por cl parasitismo que se limita los tegumentos de oiros animales: mucho mayores debenser por lo tanto las trasformaciones respecto i la estructura $y$ al desarrollo en los anélidos que en el interior desus anfitriones encuentran albergue y alimento en los mas diversos brganos. Por lo ianto podriamos inclinarnos \& styoner, con todos los roólogos, que los llamados anélidos intestinales constituyen una clase bien decterminada en sus limites. Sin cmbargo, laciencia moderna ha rechnzado esta opinion que se funda en una consideracion parcial sobre la residencia, y en la pue los sistemaiticos se lian hecho culpables de grandes inconsecuencias. I.os anćlidos intestinales son tan diferentes entre sí como los que pasan toda su vida al aire Jibre, y las formas de trinsito de los unos a los otros son mucho mas numerosis de las que antes hemos encontrado entre lus crustuiceos parásitos. Uno de los naturalistas mas modernos é instruidos que se ocujan de los anćlidos, el doctor Ehlers, forma nada menos que ocho clases. De todos estos grupos tendremos que hablar, de algunos muy minuciosamente, y siguiendo el cjemplo de otros zeólogos, sin considerarlos como clases.

\section{LOS ANÉLIDOS ANI- LLADOS}

CARACTÉRES.- Dicese que el cuerpo de los anćlidos pertenecientes of la primera clase se compone de una serie de anillos ó segmentos visibles exteriormente, de cuyos surcos in:ermedios unas paredes divisorins membrnosas se extien. den mas ó menos profundamente en la cavidad abdominal. Fil mímero de estos seginentos homónomos es del todo inde. cominado. In boca se halla sienupre detrás del primer segmento, en el vientre, y en la mayoria de las especies la primera parte del intestino puede prolongarse y salir en foma de una trompa, propia para escarbar 0 coger la presa. li grado superior de los anćlidos anillados se démuestra sobre todo en la forma y en el desarrollo de su sistema nervioso, por el cual resulta ser del todo afine al de los verdaderos arté. podos. Debemos esperar, por lo santo, que en la cnergia y iariedad de las manifestaciones vitales lany ambien una semejanza correspondiente con los artrópodos de superior or. ganizacion. Aprenas convendria scguir tratando de cllos en gencral, antes de conocer cierto númcro de formas y de grupos, para que podamos reproducir nuestras noticias con un material suficiente de observaciones. Ia lombri\% de lluvia y la sanguijuela se nos presentan como tipos de dos divisiones principales, yue deben distinguirse por los órganos del movimiento. I a primera, sin embargo, solo puede servirnos imperfectamente de modelo, porque es jreciso examimarla muy unuciosamente para reconocer la existencia de las cerdas caracteristicas en el grupo. Pertenece i los quetópodos, cuya particularidad consiste en tener cerdas insertas directancnte en la piel, $\delta$ en numerosas salientes en forma de piés nue en los mosimicntos sirven de apojo, de emprije ó de remo. $A$ continuacion de cstas especies se agrupan los himativeos. 


\section{PRIMERA SUBCLASE-QUETOPODOS}

CARACTERES. - Segun acabamos de indicat, los quetópodos se distinguen por tener unos hácecillos laterales ó grupos de cerdas en los que el microscopio nos descubre una serie de las fonuas mas graciosas, ganchos, Tanzas, flechas, cuchillos, peines, remos lisos y surcados, y otros instrumentos punzantes y cortantes en miniatura. Las, formas mas sencillas, que simplemento merecen el nombre de ganchos y cerdas, son propias de los lombricinos; las mas pequeñas, puntns, dientes, dientecillos, hojas cortantes y afiladas, son un adorno de la mayor parte de los habizantes marinos del grupo. Solo algunos de los afroditeos rapaces hacen uso de sus cerdas cuando rodean su presa como las serpientes, hiriéndola con aquellas armas; por la pasicion de las cerdas en hacecillos, creeriase mas bien que en rigor son órganos de la locomocion.

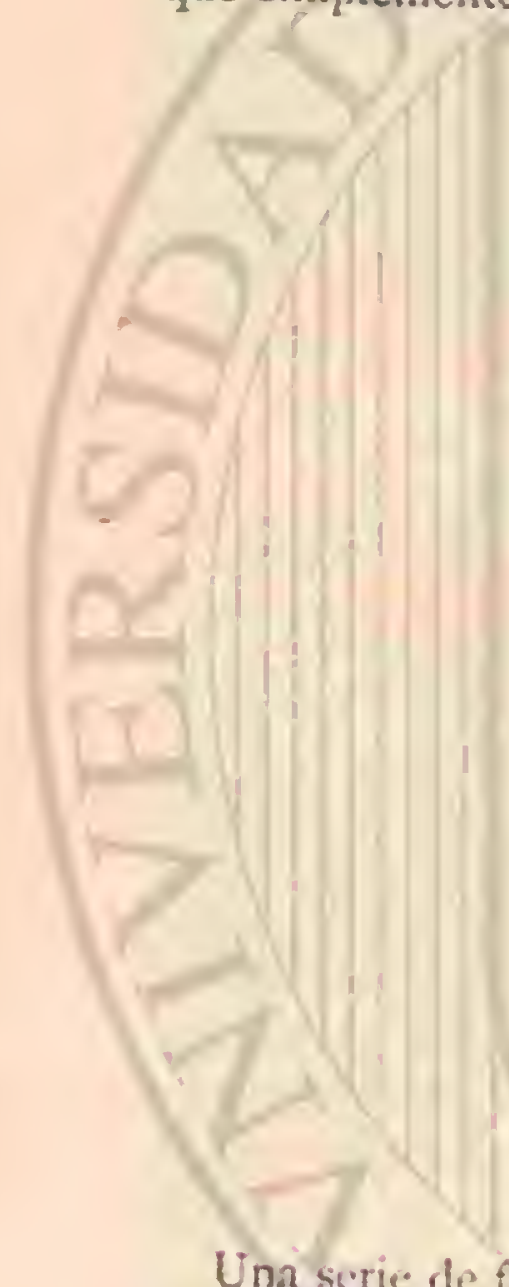

Una seric de iamilias habita libremente en el mar; en las especies que tiencu branquias, estas se hallan en los muñones del dorso, y sus segmentos siencn il menudo cerdis dol tacto anilladas. Ia extremidid anterior, que corresponde a un segmento y subresale de la boca, tiene ojos y antenas ó tenticu. los, y en cuanto no son planiforos cogen su presa con aguclas maxilas ganchudas y dientes, que se ven al salir la trompa. I.a mayor parte de estos quetópodos errantes ostentan colores de brillo metálico: su piel reluce como un vestido de seda, ! las ucerdas reflejan diversos tintes. Los diferentes géneros se distinguen por la forma y disposicion de las ramas de los piés, de las antenas, branquias y sedas.

\section{LOS AFRODÍTEOS -APHRODITEA}

CARACTER ES. - I la calyeza de los quetópodos suclen figurar los afroditeos cuyo dorso esta cubierto de grandes es. camas llanadas elitros (clytro), y que en la cabeza ticnen por lo regular tres antenas, una central, y' dos laterales. 'Todas las especies se hallan provistas de dos 6 cuatro njos, que a veces ocupan la punta de pequeños tallos ú tuberculos f que siempre son pequenos. Fn muchos generos se desarrolia, además de las cerdas sencillas y compuestas ordinarias, una cubierta de largos pelos que, sobre iodo en los lados, presenta los mas magnificos colores del iris, complarables solo con los que remos en el espléndido plumaje de las aves tropicales, y que forman una especic de capa sedosa que cubre los elitros dorsales completamente. Por dectajo de esta

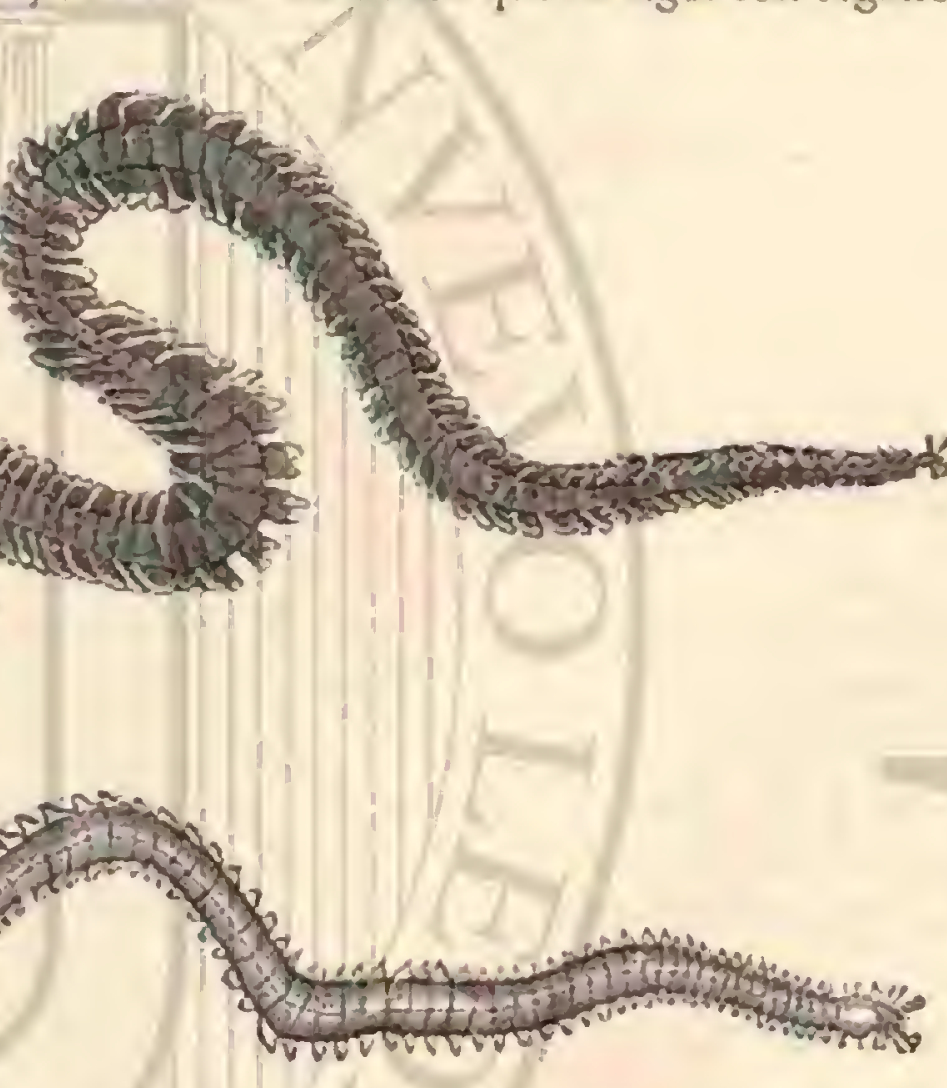

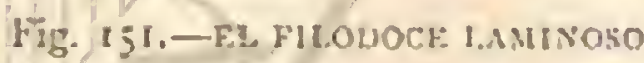

cubierta, y a través de varias aberturas, pencetra el agua hasta las branquias pequeñas, situadas cucima del tentáculo superior de los segmentos. Entre las particularidades de la cstructura interna de los afroditeos debe mencionarse sobre rodo la mmificacion del intestino. Entre las especies cubicrtas de pelo en el dorso, pertenecientes al género apisrodites, el afrodita erizado (apleredite uculeafor) (fig. 148), que alcaniza medio pié de longitud, es propia de todas las costas europeas, y cl afrodita topo (fig.-149) de las oceánicas. De dicho género, el hermione se distingue por la falta del pelo dorsal jo por orros caractéres de proca importancia. Una de las especies mas comunes del Mediterráneo es el Jermione hystria. Fil lector no debe admimese de la cxtrana reunion de un bonito nombre cie mujer con el del puerco espin, cuando sequa que si se limpia el anétido, cubierto de cieno por lo tegular, ostenta su agradable forma cxterior en todo su brillo. I as espinas de la hermosa hermione son sin embargo peores que las de un puerco espin, porque estin provisias de ganchos que se agarran y penetran en la piel. A pesar de esto, los peces roraces, sobre todo en el Norte, las merluzas y abadejos en el Mediterríneo, $y$ los pequeños tiburones, devoran con mucho gústo esta cspecie. Jil que ha tenido una ver. en sus manos la pared estomacal, semejante á un pedizo de cuero de botas, com: prenderá que no debe temer las espinas de los hermiones.

Schmarda, sobre todo, ha observado magnificas formas de esta familia, durante su virije al rededor del mundo, en todas las costas de los mares tropicales, y las representó en un li. bro especial de cromos con loda la belleza de sus colores; pero ninglin pincel llegga à reproducir el brillo del viso meta. lico que se cambia a cada movimiento. 


\section{LOS NEREIDOS-NE- REI DEA}

CARACTERES. - Una verdadera familia tipo es la de los nereidos, à cuyo carácter de rapaces se agrega una continua actividad y rapidez en los movimientos. I a especie nereis inserta ticne en la cabeza dos antenas interiores y dos cxterio. res y en sus lados los cirros tentaculares; la trompa jurolongada presenta dos grandes maxilas en forma de tenazas, que se mueven horizontalmente una contra otra como los órganos bucales de los artrópodos; $\mathrm{y}$ además se ven algunos dientecitos. Una serie de géneros, se asemeja al nereis por la pre. sencia de las gruesas antenas exteriores; el género nereis cstá representado por mas de So especies; entre estas citaremos el nereis enganoso (fig. 150) que abunda cn las costas francesas.

Fn la especie heturenereis Smardae se presenta una forma muy rara en el grupo que nos ocupa: los segmentos de la mitad posterior del cuerpo difieren del todo por su figura de los de la anterior, que tiene exactamente la forma de un nereis, hallándose unida, por decirlo así, à una mitad posterior extraña, provista de remos y cerdas. Esta especie, hallada cerca de San Vanst en el fondo del mar, cubierta de yerba marina, alcanza $0^{\prime \prime}$, ir de longitud, presentando 35 anillos en la parte anterior del cuerpo, y $\$ 2$ en la posterior, proporcion numérica semejante á la de otras especies.

Los eunices tienen dos ojos y cinco antenas situadas en una sola seric trastersa; el anillo bucal estí provisto de dos tentaculos; las branquias son pectineas en un solo laco; las

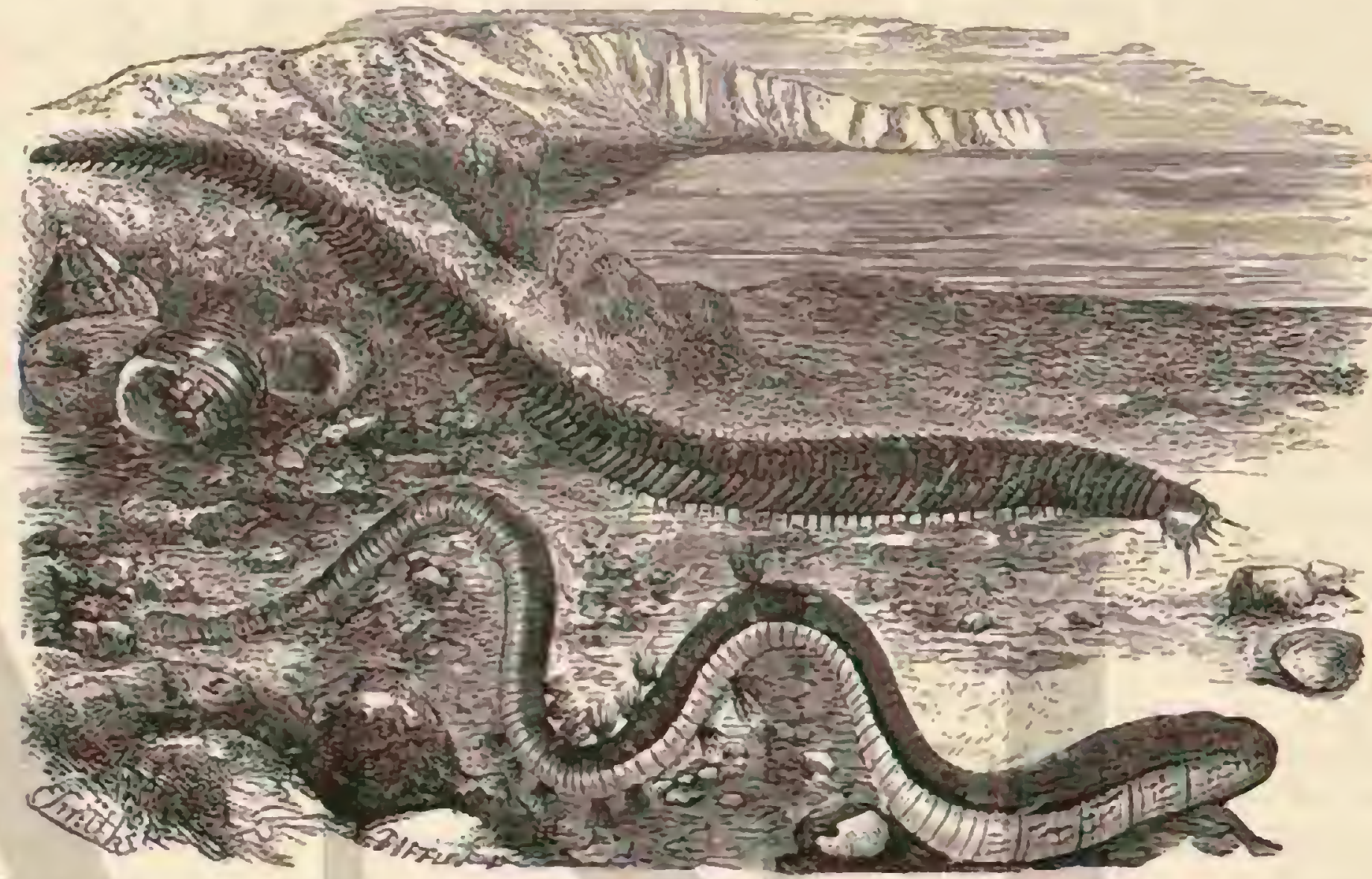

Fig. 152-ri. Eusicf. Gronintesco

fig. 253.--ER AREXICOL DE. ZOS YESCANOKHS

sedas compuestas, con un apéndice corto en forma de cucharon. La especic mas notable de este género es el eunice gigantesco (fig. 152), propjia del Océano Atlántico.

Como géneros afines de esta familia, mencionaremos además el de los cirratulos, y el de los silis. Ia principal especie del primero, el cirratulo Medusa (fig. 155), Hcva este nombre á causa de los numerosos cirros ó apéndices filiformes une se proyectan en los lados del cuerpo, sirviendo á la ver. de órganos de la locomocion y respiratorios, segun se ha in. dicado antes; estos singuiares apéndices parien de los seg. mentos alternados, y se continúan en dos series à lo largo del dorso, casi hasta ta extremidad del cuerpo. Mirados con una buena lente, se vé circular la sangre por las paredes trasparentes de estos cirros. Las lineas negras en forma de media luna que se ven a los lados de la cabeza, no son segurnmente ojos, comó algunos han creido, ni ocultan tampoco estos órganos. Este anćlido mide unas a puigadas de largo, y es de color casi rojizo.

Los silis tienen la boca armadia de una trompa medianamente gruesa, dividida en dos anillos; el segundo menor, jo dublado en el orificio: cuyo borde superior presenta un cuernecito sólido que se dirige hácia adelante. Carecen de maxilas: tienen tres antenas, largas, delgadas y moniliformes; no hay branquias; las patas son de tres clases: las primeras, sin sedas, constan de un pas de cirros tentaculares á cada lado, otras son ambulatorias y las últimas tienen dos hilos moniliformes que las terminan. El cuerpo es lineal y se compone de muchos segmentos; la cabeza es redondeada y esta libre por delante; à los lados presenta cos lóbulos que se pueden considerar como rudimentos de antenas exteriores. la especie rifro de este género es el silis manchado (fig. 154), habitante de las costas de lisancia é Inglaterra.

\section{LOS FILODOCEOS - PHY- LODOCEA}

CARACTERES. - I Aas especies de esta familia tienen los ienticulos dorsales y abdominales ensanchados en forma de hojas, y cl cuerpo muy yrolongado, compuesto de numero. sos anillos que le sirven de remos. Asi, por ejemuplo, el phlyllo. door laminosa (igg. 151), de las costas inglesas y francesas, cuenta de trescientos á cuatrocientos segmentos, y Quatrefages asegura que alcamza mas de $0^{\text {m}}, 60$ de longitud.

USOS $Y$ COSTUMBRES. - Rymer Jones tiene raron cuando dice que esta especie salue nadar con la mayor gracia. Asi como otros muchos anélidos rapaces, permanece de dia tranquilamente en su escondite, solo á favor de la oscuridad sale en busca de su presa, y entonces todo el cuerpo ejecuta movimientos ondulados horizontales, con cl apoyo de los re. mos. Estos se alargan y encogen del mismo modo que en los miriapodos, es decir, en ondas que desde atrńs corren hácin adelante; todas estas partes, que se mueven sin cesar, caun. bian de continuo de posicion para recibir bien la luz, y en- 
tonces el cuerpo, cuya mayor parte es verde, brilla con todos los colores del arco iris, particularmente el violado, azul y oro.

Otra especie que habita en la costa de Sicilia, la forrea ar. frea: es tan tmsparente que en sus movimientos en el agua, solo se ven los ojos como dos puntos rojizos, y dos séries de otros puntos violáceos, que son órganos en forna de glándulas en la base de los muñones de los piés. El naturalista parisiense antes citado se convenció de una manera muy curiosa de que csos dos ojos șon excelentes órganos de la vista. I a rentajosa propiedad de estos consiste primeramente en queel aparatorefractor en el ojo humano, la córnea y además el humor acuoso; cl cristalino y ol humor vitreo reffejen una imagen verdadera y fiel de los objetos. Cuando un ojo de buej, recien cortado, de cuya parte posterior se quita bien la grasa, se coge por alli, colocíndolo delante de los ojos y dejazdo pasar la luzal tarés, por la via natural, los objetos que tencinos a nucstro frente, los arboles, tránscuntes, ctc., se representan en miniaturi, y ell posicion invertida en la retina. Elzoblogo obsersó con el nicroscopio el ojo de la torrea, y en su retina vió projectarse la imágen mas gmciosa y exacta de una parte del paisaje que delante de la ventana del obscrvador se estenciia. Una de las condiciones jara la perfeccion del órgano visual se llemaba muy hien; y la otra, la retina, para recoger la imágen, $y$ un ncrvio óptico para trasmitir la impresion al cerebro, exisian tambien. Anadiremos que igual perfeccion de estos órganos se observa en la major parte de los quetopodos cuyo genero de vida es libre.

\section{LOS GLICEREOS - GLYCE- REA}

CARACTÉRES. - Una impresion del tocio diferente pro. duce la familia de los glicereos. Los segmentos des su cuerpo, que es prolongado, afectran la forma cónica $y$ están provistos todos de anillos. Estas especies pueden prolongar una trompa verdaderamente colosal en proporcion a su th: mairo, cubiena de toda clase de verrugas y dientecitos. Fá. cilmente se observa cómo se sirven de la trompla cuando se les sorprende en la orilla del mar, débajo de las piedras, en suclo arenoso; sirveles para penetrar en éste, para lo cual la estiran y encogen con volenciá. A su género de vida oculto y lucífugo, convicne tambien el color poco vivo del animal.

DISTRIBUCION GEOGRÁFICA.-Lil áren de dispersion del génern glycern es muy considerable; se le conoce en la Nueva Zelanda, Valparaiso, el Peru, Groculandia y el Cabo Norte; varias especies son propias de los mares del ccntro y sud de Luropa.

\section{LAS ARENÍCOLAS - ARE- NICOLA}

CARACTERES. - Con la especic arenicola piscatorm (1ig. 153 ) llegamos á una familia bien limitach, cuyos individuos observan un género de vida parecido al de los glicereos. In citada esjecie se habia considerado hasta cl tiempo de Lamarck, comolombricino. El cuerpo, muy adelgazado hácia adelantc, se divide en tres partes principales; alcanza una longitud de ()$^{\mathrm{m}}, 22$ y varia mucho por el color, predominando los tintes verdosos, amarillentosy rojizos, pero tambien hay individuos muy claros y otros de un negro oscuro. Los matices de estos colores están evidentemente en relacion con la natura. lear que le roden, porque la variedad clara solo se encuentra en terreno casi exclusivamente arenoso, y la negra en el cenagoso, formado por una mezcla de sustancias en descompo- siciun. Yo encontre estas arenicolas oscuras, con un viso verdoso, en el puerto de Niza. La trompa, parecida à una copa, mede salir de la pequeña cabera triangular; los segmentos anteriores del cuerpo solo presentan en el dorso los haceci. llos de cerdas insertos en tubérculos, deirás de los cuales, en los trece segmentos medios, se hallan los arbolitos branquiales ramificados de un modo muy gracioso.

Fil útimo tercio del cuerpo es casi cilindrico, sin branquias ni tubérculos de los piés.

USOS Y COSTUMBRES. - In arenicola de los pesca. dores vive en casi todas las costas de Europa y de Groenlandia: en muchos terrenos arenosos de la costa se encuen. tra en enorme número, con preferencia en la zona situnda enire los limites de la alta y la baja marea. Atendido que los pescadores la emplean como cebo, se la persiguc con grande aficion. Su pesca, aunque no dificil, exige sin embargo cierto conocimiento de su género de vida. Como los lombricinos, farrenicola devora grandes espacios del suclo en que vive, provejendo asi su estómago de las sustancias orgánicas necesarins para su alimento. Sale a la superficic, lo mismo que la lombriz de llivia, para clesembarazarse de la arena que ha tmancio. Fstos exrrementos descubren al anélido, seúalando la lextremidad de su galería, yue penetra á gran profundidad en el suelo; apenas sospecha el peligro, la are. nicola baja al fondo con la mayor destreza. Es preciso, por lo tanto, sondear hasta el fin del agujero que hay entre las dos aberturns de la galeria, y aun asi revuelvesc la arena i menuda sin cncontrar nada. Sacada de su escondite, la arenicola se mucre muy lentamente, segregando entonces un líguido de color verde amarillento jue mancha la mano del que lo toca. Si se la deja en la arena, comienza al punto a penetrar en clla, en cuya operacion se observa que los seg. mentos anteriores disminuyen uno despues de otro, formando una circunferéncia; de inodo que cada uno puede recogerse cn el inmedinto. Fin esta forma, la extremidad anterior parece truncada, mientras que los segmentos forman un cono regular, y de este modo se constituye el aparato taladrador. El gusano oprime la cabeza contra la arena, y con un fuerte empuje del cono se abre camino à cierta distancia; pero como el espacio asi ganado seria demasiado estrecho e impediria al anélido desplegar sus branquias, le cusancha dilatando los segmentos inmediatamente despues de prolongarlos. Despues sigue el cuerpo y vuelve á rep̧etirse la misma maniobra. Mientras penetra la parte anterior de apuel, segrega una sustancia glutinosa, por lo gue la capa interior de la arena se amasa en forma de un iubo liso, de paredes delgadas, que, sin embargo, son bastinte fuertes para impedir que se hunda la galeria. Lista es entonces suficientemente ancha para permi. vir al agua, desprovista de arena y de cieno, penetrar hasta las branquins. I a subida de la arenicola por el tubo, se efectua naturalmente con ayuda de -los hacecillos de cerdas.

\section{LOS CLIMENIDOS-CLY- MENI 压}

CARAGTÉRES. - I a fnilia de los climenidos, se com. pone de especies que se caracterizan principalmente por no tener tan niarcadas las regiones del cuerpo como has arenicolas: á ella pertenece el género arenia, cuyo cuerpo presenta solo dos divisiones: la parte anterior, de un tinte rojizo, sucio, altera la forma muchas veces por estrechamientos y contracciones: la posterior, mas larga, es de un rojo amarillento.

USOS Y Cost UMBRES.-Quatrefnges, que observó à este animal en las costas francesas, dice que á menudo le ha 
encontrado en una arena tan lavada y pura, que parecia in. posible que el animal pudiera alimentarse. Todo el intestino estaba relleno de esta fina arena, por lo cual er mayor aun la gran fragilidad del cuerpo. Ni un solo cjemplar estaba bien conservado.

I.os animales que acabanos de describir y sus fanmilias, ya no se pueden reunit, en rigor, sistemáticamente con los quetópodos de branquias dorsales y de un género de vida libre: porque en su cucrpo se reconocen bien varias divisio. nes; pero mada podemos decir acerca del particular, pues los respectivos sabios que se ocupan de esta parte de la historia matural no están aun conformes sobre el arreglo. Tambien aqui la naturaleza avanza por trinsitos insensibles y toda nuestra obm de divisiones se reduce á escogitar un medio para facilitar el estudio y syudar la memoria.

\section{LOS QUETOPTÉRIDOS - CHAETOPTERIDA}

J legando al grupo de las familias que se llaman tubicolas (fubicolie), ó anélidos de branquias, intercalamos, antes de ocupramos de cllos, cuando menos una de las formas del todo diferentes, la de los quetoptéridos.

CARACTERES. - El único género, el de los quetugheros, se caracteriza por tener en el cuerpo tres regiones del todo diferentes. I a parte anterior puede compararse con la de las sabelas, de que mas tarde hablaremos; la cabeza forma como un cmbudo escotido en el dorso: despuces siguen nueve segmentos, con murones de piés planos yrolongados que en el borde superior llevan un hacecillo de cerdas pardas. Muy rara es la trasformacion de los cinco segmentos que componen la parte media del cuerpo: desde el primero las muñones de los piés sobresalen mucho en forma dè un par de antenas lisas en la parte anterior del cuerpo, nientras que las ramas inferiores de estos piés se ensanchan en forma de gorgucra, cerrada en la region del vientre. Los muñones de los piés superiores del segundo anillo forman una cresta dursal que se reune con los muñones anteriores, y entre ellos y las ramas inferiores, trasformadas en lóbulos trilate. rales, la piel estí en extremo dilatada y és de un color negro violiceo. In los tres segmentos siguientes solo soluresalen los lóbulos trilaterales de la parte inferior. I a mitad poste. rior del cuerpo, en fin, se compone de unos cincuenta segmentos en extremo anchos, con los munones de los piés prolongados.

In especic descrita, inctupterus pergamentnceses, que mide $11^{\prime \prime}, 22$, se encuentra en las costas de Normandia y en el Mediterraneo, donde habita a bastante profundidad, en unas galerias de unos treinta y dos centimetros de largo, compuestas de varias capas semejantes á pergamino amarillento y grucso, y por lo regular fijos en algun objeto sólido. Cunndo se sacit cl gusano de su tubo, es muy poco divertido para el observador; y dificulta el exámen anatómico una abundante secrecion de cierta sustancia mucosa espesa que se adhicre á los dedos é instrumentos.

La cirada especie y otras del género chatopterus, que se encuentran en el golfo de Nảpoles, se distinguen por su pro. piedad de brillar. Sergun las observaciones de Panceri, es preciso irriar á los animales para que ofrezcan el fenómeno. Entonces se extiende la materia radiante en forma de nube en cl agua; el animal brilla con una viva lu\% arulada, y en un espacio oscuro con tal fuerza, que se pueden reconocer los objetos y ver la hora en el reloj. Nuestro amigo y colega de Nápoles, que hace años observó repetidas veces los fenúme- nos mdiantes de los animales inferiores, ha demostrado que en algunos quetopteros, sobre todo en el chatopterns irariopedatus, que forma sus tubos con'granos de arena, ciertas celdas y glindulas son las que producen la materia radiante.

Respecto al género de vida del chatoplerus perganienta. calls, y it la manera de apoderarse de él sin lesionar la galeria ni el animal, debemos noticins exactas a l.acaze-1)uthiers. Si se le busca en la playa durante la marea baja encuéntmsele á menudo en espacios cubiertos de zostera marima, y en la arena que tiene fondo cenagoso. Cuando las aguas se han retirado completamente se le encuentra tambien, en medio de los tubos de la bonita sabella paionina, notables por su longitud y color pardo. El animal forma un tubo no mas largo que su cuerpo, abierto en ambas extremidades y que penetra en el suelo en forma de $U$; durante la marea baja se le llena de agua, y el anćlicio puede proseguir sin dificultad sus movimicntos respiratorios dentro de su espaciosa viviendil Pura obtener el animal y la galeria ilesos, es preciso descubrir el tubo, mientras que un ayudante sujeta las dos extremidades del mismo.

Podemos hacer mencion de algunas otras familias que tienen las branquiass en forma de arbolitos ó copetes fibrosos en la extremidad de la caber.a. Ia boca desprovista de dientes, y una trompa que no puede prolongarse, lo cual indica un género de vida mas pacifico que el de la major parte de las especies errartes con branquias dorsales: en esta suposicion nos confirma el hecho de que visen en tubos y solo por fuerza se alejan de cllos.

\section{LOS HERMELACEOS - HERMELLACEA}

CARACTERES. - Entre unas ostras recien desembarcadas recibí una masa irregular, compuesta de arena y aubos arenosos que constituian toda una colonia de fiermella nlico. lakn. Los tubos, formados por granitos de arena, estabun sobrepuestos sin órden ninguno, pero quedando libre su des. enbocadura Cada uno estaba constituido independientemente de los otros por su habitante: y la arena acumulada en lus espaciosos huecos, hatuia formado una pasta bastante complacta por su mezcla con una sustancia pegajosa. Como esto molestaba nucho á los animales, halsianse retirado à sus escondites, y por detrís do la critrada de cada tubo se veia una capa de brillo metailico. Colocados en una vasija con agua de mar, prontd experimentaron los anelidos la necesidad de ponerse en comunicacion con el mundo cxterior; a poco vióse aparecér en la abertura de un tubo como dos pe. nachos dé finos hilos, y por fin se dejó ver la cabeza, pero retiróse al tocarla ligeramente; de modo que para satistacer la curiosidad fué preciso romper todo el tubo y poner el ani. mal en una vasija pequeña, donde pronto se trançuilizó.

La extmina forma de la cabera es debida à quue las dos grandes antenas se sueldan y tienen en su superficic truncada algunas series de cerdas planas, anchas, y en parte denticu. ladas de este modo se trasforman en una especie de tapa que cierra la entrada del tubo. Probablemente los dos pena. chos que hay en los lados de la parte inierior de la boca hacen las veces de órganos respiratorios, pero las verdaderas branquias aparecen de nuevo en la misma forma y posicion que en las especies de tranquuias dorsales, es decir, en forma de lengüetas en todos los segmentos provistos de niunones de pié. El suerpo remata en una parte cilindrica no anillada y desprovista de cerdas. 


\section{LOS TEREBELACEOS -TEREBELLACEA}

CARACTÉRES. - Una de las familias mas ricas en especies y en formas, del grupo de los quetópodos, es la de los terebelaceos. Su cuerpo, prolongado, pero muy contrictil y blando, es redondo, mas grueso en la parte anterior; y en la cabeza hay una serie trasversal ó dos monitos laterales de tentáculos, tan numerosos en algunas éspeciés, como por cjemplo en la tereliella sublitosa, comun en el Meciternineo, que es muy dificil contarlos, porque estás en continuo movimiento; se acortan " prolongin y parecen vivir en sí como en su mayor parte tienen el color antarillento rojizo, presentan un conjunto bastante gracioso. Las verdaderas especies primitivas tenian en los segmentos posteriores del cuerpo varias branquias, que en la especie terebilla connclislegn (hig. 156) forman tres arbolitos graciosamente ramificados. Los munones superiores del jué de todos los terebelaceos tienen moñ. tos de pelos cerdosos.

USOS Y COSTUMBRES.-Todas las especies emplean el material que tienen à su alcance para construir sus gale. rías 0 tubos. La tercliella emmalina, del golfo de Vizcaja, forma con pedacitos de concha y de arena unos tubos muy frágiles. La ya citada terchella conchiliga, comun en todos los mares del centro de Europa, debe su nombre á la predileccion que manifiesta por los fragmentos de conchas para la construccion de su albergue. Las recientes observaciones de Ehlers demuestran, sin embargo, que tambien cmplean otro inaterial. I os tubos estån provistos de numerosos apéndices
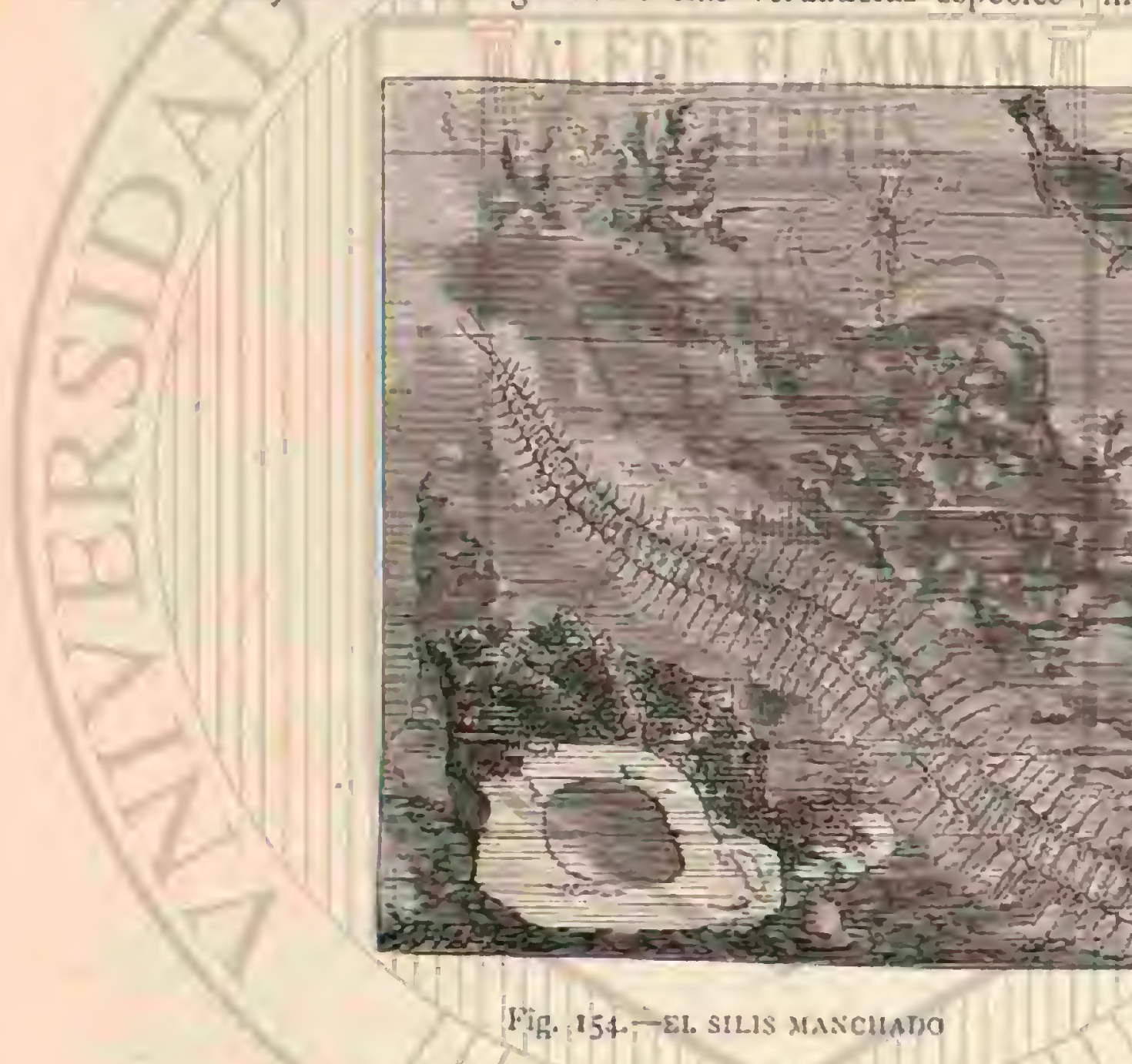

Hig. 154-21. smLis maxcuatio

huecos, para resguardar los tentácuios; $y$ Ehlers dice lo siguiente: En el Barico de cangrejos situado a pocn distancia de Spicherooge: desprovisto de agua duranté la marea baja, y que está cubierto casi del todo por las construcciones de la Sabellariu spinulasa, se ve como sobresalen estos tubos con sus apéndices, de muy variada forma, it mas ó menos altura en direccion vertical. A primera vista parecen vacios, pero al levantar cuidadosamente el terreno en que sobresalen, aunque penetrant muclit profundidad, sc puede ver el habitante, que por lo regular se retirn al fondo del tubo, y que pertenecen à la especic Immie (terchella) fonshiliga.

* ia un pequeño acuario con buena rentilacion, los animales encerrados en sus tubos se conservaban muy bien vivos, permitiéndome observar como estos anélidos forman sus galerias. In construccion difería de la de los individuos li. bies, pues a veces agregaban en las dos extremidades del tubo apendices filiformes, siendo asi que, en los de la especic libre, solo se hallan en ia parte yue sobresale del suelo. Algunas reces uno ú otro individuo prolongaba tambien el tubo mas allá de la desembocadura provista de apéndices; esto lo hacen tanto en libertad como en el acunio.

- En la eleccion de las materias empleadas en la construccion, estos anćlidos no parecian muy cxigentes en el acunrio; mientras que en los tutios extraidos del terreno libre, la parte introducida en el suelo se componia exclusivamente de grnnos de arena, y solo el pedazo saliente estaba cubierto de los mas variados fragmentos.

Los animales sacaban por una abertura del tubo las largas antenas, buscando con ellas el material que debia cmplearse en la construccion. Al ofrecer al anélido alguna piedrecita ó un iragmento de concha (los pedazos de vidrio no cran aceptados casi nunca), el animal lo tomala con mayor ó menor número de tentáculos, introciucialo en el tubo, y entonces casi siempre recogia aquellos. Al poro rato aparecian de nuevo fuera del tubo, seguidos de la parte ante. rior del animal; cate llevaba el pedazo cogido con el lóbulo de la cabcra ó en los elitros abidominales, separados de los segmentos anteriores Entonces cl anélido llegniba como á tientas hasta el borde del tubo y colocaba el frigmento en el sitio elegido, soltándole bruscamente; despues se retiraba, dejando en el tubo el material aiberido en su lugar. De este modo se agregaban los granitos de arena y framentos pequeños á la entrada del tubo. En raros casos, cuando el fragmento no estaba bien pegado, el anélido se clenaba varias veces, y valiéndose del lúbulo de la cabeza y de los escudos abdominales anteriores trabajaba para cnlazar mejor las par. ticulas colocadas.

\$Cuando se ofrecia al anélido un pedazo demasiado grande para que pudicra introducirlo en cl tubo, por ejemplo la mitad de una concha, la parte anterior del gusano se acercaba al fragmento, los tentáculos le aproximaban à ln entrada del tubo: y cntonces el animal pasaba sobre él la superficic ventral y le adheria asi nl tubo.

Ne estas observaciones resulta, que en la construccion de 
los tubos, los tentículos qque presentan en toda su longitud un surco luciente, solo se emplean para buscar y eleyir el material; hecho que sobre todo se reconoce cuando el animal recoge con ellos granos de arena en el cieno, $\delta$ toma el fragmento elegido acercindole á la extremidad de la cabeza. Los tentáculos no se emplean para la construccion propiamente dicha; el animal adhiere las particulas aisladas, cubriéndolas con una sustancia glutinosa que pronto se endurece y refuerza la base del tubo. Esta sustancia es la secrecion de unas glindiulas de la piel, sobre todo numerosas en la superficie luciente de la cabeza y de los lóbulos laterales de los otros segmentos, asi como en los escudos ventrales y en las antenas. Esas glàndulas se adaytan sin duda á la pieza cogida, con auxilio de los labios que rodean la abertura bucal. De este hecho me convenci ofreciendo al anélido, sacndo del tubo, y que cntonces hacia todos los esfuerzos posibles para formar una nucva cubierta, un fragmento de vidrio granuloso: entonces vi cómo el lóbulo de la cabeza cogió el objeto, opriniéndole contra la abertura bucal; al retirarlo de aqui observé que tenia ya una cubierta membranosa semejante á la sustancia cmpleada en la construccion y que constituye la parte de la pared del tubo fabricado por los animales. El grano ó particula, provisto del cemento, se coloca por medio de las escamas ventrales y del lómulo de la cabeza en el lugar elegido por el gusano, que de este modo puede prolongar el tubo ó reparar un desperfecto.

Rymer-Jones describe del modo siguiente la manera de proceder de otra especie de terebelacios, la terehella figulus, en la construccion de sus tubos. \& El material de construccion es cieno ; al sacar el animal del tubo se contrae y enrosca, pero pronto los tentáculos empiezan à buscar á su alrede. dor, atrayendo todo aquello que pueden alcanzar. Cuando el animal ha descansado por la mañana, trabaja el resto del dia, pero con mas aficion por la tarde. Unos tentáculos recogen cieno, los otros granos de arena y fragmentos de concha, y todo lo recogido de esta manera se acerca al cuerpo por la contraccion de los tentáculns. Durante este trabajo, la parte anterior del cuerpo se dilata cierto número de veces por mi-

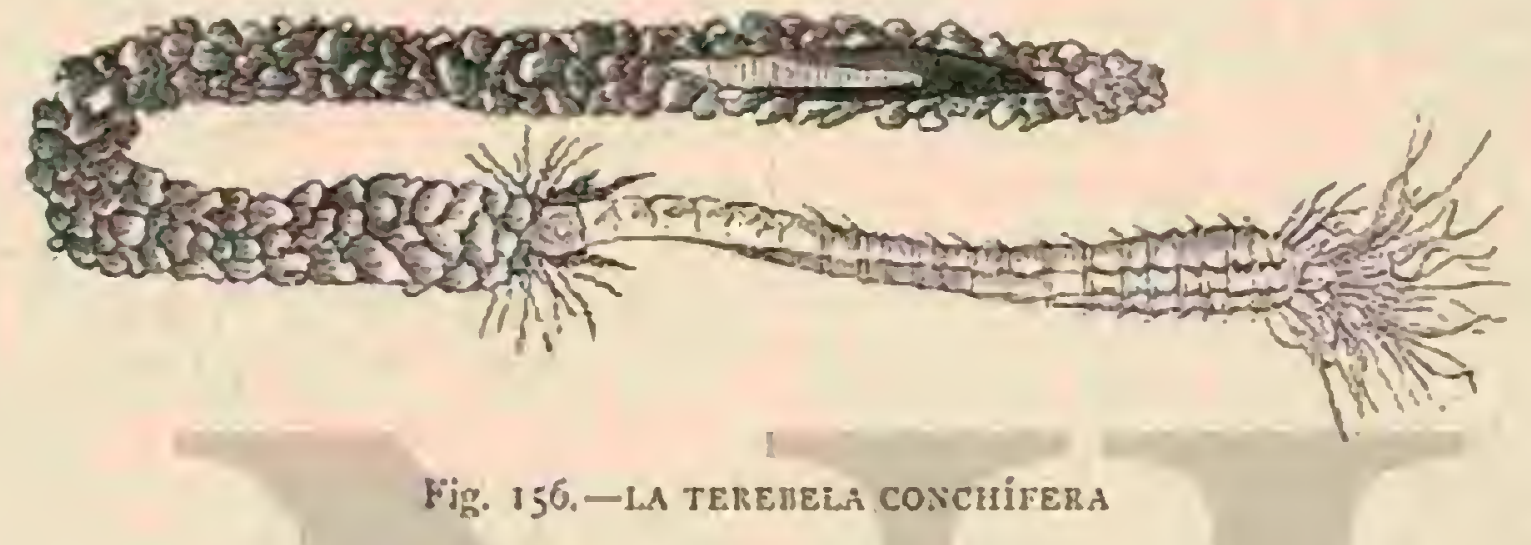

nuto y otras tantas efectúa un movimiento ondulado desde atrais hacia adelante, expeliendo entonces el animal de diez. i doce particulas del material de construccion, yrobablemente despues de haberlas preparado de aniemano con la boca. lil labio inferior alisa segun parece la parte recien construida ó la enlaza con el resto del tubo. No cabe duda que el anélido inga primero el inaterial de construccion.

dios tentaculos de la térebella figulus varian en múmero de 25 a 50 ; son bastante fuertes, y estirados del todo miden por lo menos 9 pulgadas, es decir dos veces la longitud del cuerpo; de modo que pueden extenderse en un considera. ble espacio: contraidos iienen un color pardusco $\delta$ rójizo carmesi, pero desarrollados se parecen á una crin de ca. ballo blanquizca.

- Causa asombro ver cómo la atencion del pequeño obrero puede fijarse al mismo tiempo en tan diferentes trabajos. Una parte de los tentaculos busca material, otra lo recoge, y una tercera lo trae d la casa ; algunos depositan su carga, otros In levantan, y el anélido mismo se ocupa mientras tanto con gran aficion en preparar el material en la boca, arrojarlo des. pues para colocarlo en su sitio ó bien en alisar la pared recien construida y aspera.

La tercbilla nebulosa, llamada asi porçue puede rodearse con el caos de sus tentáculos rojizos como con una nube, fabrica, solo para albergarse temporalmente, unos tubos muy frágiles y galerias cubiertas que á menudo se encuentran abandonadas debajo de las piedras de la orilla. Mas häbil y movible que sus hermanas, puede servirse de sus tentäculos, segun dice Quatrefages, como de unas cuerdis vivas para elevarse con ellas.

\section{LAS SERPULÁCEAS- SERPULACEA}

CARACTERES. - En la gran familia de las serpulàceas Tosso VII las branquias se hallan en la extremidad anterior y el agua, puesta en movimiento por los pelitos de las mismas, conduce i la abertura bucal, situada inmediatamente debajo de ellas, el alimento necesario. El lóbulo de la cabeza, separado en otros grupos, está soldado aqui con el primer segmento, y la cabeza asi formada, queda independiente del resto del cuerpo por una especie de ancha gorguera. Muj extmna es la diferencia de cerdas que consiste en que las de la mitad anterior del cuerpo son pelosas, en el vientre ganchudas, y en la parte posterior pelosas orra vez.

En el gran género serpula vemos una ó dos de las fibras branquiales trasformada ell una taja en figura de maza, sujeta por un hilo que, cuando el animal se retira à su tubo, sirve también para protegerle. El detrille microscópico de estas tapas es muy importante para distinguir las especies; en algumas ofrecen un agradable aspecto, por presentar unos dienrecitos $\delta$ apéndices en forma de corona, espinas novib!es y otros órganos parccidos. Ia formacion de tubos calcircos cs otra variedad en este género. Todas las especies comienzan a vivir libremente y están sujetas á una metamorfósis. Mucho antes de terminar esta, el animal jóven segrega un subo cal. cáreo, al principio cilindrico y abierto en ambos extremos $A$ medida que cl anélido crece, se prolonga y ensancha aguel, y apoyado al principio en toda su longitud en la base, se apla. na en el lado inferior, adquiriendo en la superficie libre fajas, repliegues y rebordes, ó en algunas especies dientes y escotadurns en la region de la cabeza; en varias de ellas, la parte que crece despues se eleva libremente en figura de espiral sobre la bisc. Fin la secrecion y forma casi del tubo intervicne principalmente la base de las branquias y la gorguen, que en este trabajo representan funciones análogas a las del lla. mado manto de los moluscos en la formacion de la concha.

Las numerosas especies de serpulaceas cstan distrionidas en todos los mares y ofrecen un aspecto muy curioso cuando sacan la parte de la cabeza y despliegan el abanico branquial, compuesto de tibras amarillas, rojas à abigarradas. Tambien 
los vasos de la sangre, que son trasparentes, presentan dibujos muy graciosos; en algunas especies la sangre es verde; en otras rojiza ó amarillenta; ; en algunas, por tíltimo, del torbo descolorida. Como tipo de este género haremos mencion de la sérpula de anillos plegados (fig. 158).

Eil género sabella muy afine del sérpula, construye por la secrecion de cierta sustancia glutinosa unos tubos que se conservan elásticos, y que à veces, por cjemplo en la bonita saliella issispira, propia del Meditcraneo, ticne el aspecto coriácco: en otros casos aseméjanse á los de las terebelas por estar culiertos de arena y fragmentos de concha. Tam. bien es de notar la sabella ivdica (fig. 157) propia de los mares de la India, y que asimizmo construye tubos elísticos.

Entre las especies mas notables figuran sohre todo las del género anflicora, que en nuestras costas se hallan en increib)e número, aunque $n$ son visibles sino para el zońlogo que las busca, pues solo miden algunas líneas de largo y habitan en el cros mas intrincado de plantas acuáticas; sobre todo de algas Cunndo se deja un manojo de estas plantes, con la arená y el cicno, en un plato, por espacio de una a dos ho. ras, pronto, salen, obligndos por la necesidad de respinar, muchos diminutos cangrejitos y pequebos gusanos que se reunen en el borde del plato para recoger aqui el oxigeno del aire. Puede darse por seguro que entre ellos se hallará tambien una especie del género anficora, de cuyas diferen. cias especificas no nos ocujamos aqui. Bebe suponerse que, - al contririo de los oiros serpuláccos, lít salido de su tubo membrinoso, segun suele hacerlo tambien en estado normal, para buscar alimento y compania. Hemos dicho que la vista de las esjecies con branquias estí generalmente poco desarrollada: de csta regla la anfhicora cs una somprendente cxcepcion, pues no solo tienc ojos delante sine tambien detrás. Cuando en I $S_{4} S$ obscrvé esta especie, descubierta por Ehrenherg cerca de Helgoland, y en las islas de Feroe, pareciame que la extremidnd sin branquias era la cabeza, pries segun observé mul il menudo despues, en $186 \%$, el animal lleva siempre dicha extremidnd de frente, armstrando las branquias en pos de sí como una escoba. Sin embargo, î menu. do se observa lo contrario, porque el animal reune la particular ventaja de no tener necesidad de volverse, porque tambien detris de las branquias hay un par de ojos, y porque los muiones del pié y las cerdas prestan su servicio tanto hacia adelante como hicia atrás. Mas tarde reconoci que habia confundido la cola con la cabeza, segun resulta del carricter del intestinn. Tambien la posicion de dos verrugas que se hallan detrás de las branquias, y que proba. blemente son órganos del oido, habla en pro de esic último ascrto. Sen como fuere, podemos recomendar á torin aficionado á divertirse en observaciones microscópicas que fije su atencion en la anplicorn viva.

Hemos descrito hasta ahora cierto número de especies, muy reducido en verdad, en proporcion al total de ellas, pero tal vez suficiente para poder atrevernos a trazar una descripcion general del género de vida de los quetópodos marinos de branquias dorsales y de branquias cefálicas. Permitasenos seguir por lo pronto otra vez. al excelente conocedor de estos animules, Mr. de Quatrefages,

Un gran múmero de estos quetópodos pucde permanecer desde una marea á otra en el cieno $\delta$ en la arena descubierta de agua, o tambien en tubos libres, pero ni uno solo vive fuera de la region de la alta marea ó de la zona á que llegan las aguas. Alas especies que habitan a mayoraltura pertenecen los airodites, los nereidos y arenícolas. Solo en los pisos inferiores de la zona de la marea baja se encuentran algunas especies de los glicereos y climénidos: excepto cierto número de las que, como los serpuláceos y hermeláceos, habitan en tubos sólidos, la mayor parte de los quetópodos penetran en el suelo y viven en la arena, en el cieno 6 en una mezcla de ambos, cubiertos y descubiertos dos veces al dia por la marea alta Esto, sin cmbargo, solo puede decirse de las costas en que el flujo sube considerablemente. En el Adriático, donde apenas se eleva uno 6 dos piés, la mayor paste de los anillados permanecen siempre debajo de la superficie del agua. Sin duda los mas practican sus galerias en el suelo, en esta \%ona superior, agradándoles mas el terreno que por una meacla de arena y de cieno adquiere cierta solidez, sin oponer por eso obstáculo i los trabajos de los mineros. En ninguna parte se reunen mejor estas condiciones que en las praderas submarinas cubiertas de la yerba llamada zostera y que ofrecen rico botin al naturalista. Estas praderas atmen $\dot{a}$ las especies plantivoras, 2 las cuales siguen las camivoras. Los escondites predilectos son las grietas de las rocas, donde muchos de los mas delicados silideos, de que lucgo hablaremos, y de pequeños nereidos, se ocultan con las anficorinas entre lats algas. En todas partes donde estas plantas se han fijado en lo mas fuerte de las olas se puede estar seguro de encontrar esos pequeños anillados. En el agua libre y en las inmediaciones de la costa no se observa ficilniente segun se comprendera ninguna especie; pero en cambio, la alta mar conviene a cierto número de generos y especies, por ejemplo a la trasparente torren ritrea, y sobre todo a los heteronereidos, que por slis anchos remos de la mitad posterior del cuerpo son muy buenos nadadores.

Perci tampocio estas especies pelígicas permanecen siem. pre en alta mar, ó por lo menos Quatrérges vió que algu. nas; que por lo regular viven léjos de la costa y que perte. necen al géncro de los heteronereidos, la buscan en e] periodo del celo, arreglándose á manera de los otros habiiantes de la misma. En cambio, los anillados, que regularmente se encueniran ell la playa, parecen retirarse a mayor profundidad y a-mas distancia de la costa en la estacion desfavorable, cuando mucha agua llovida se mezcia con la capa superior de agun marina: la dulce puede producir en muchas especies el éfecto de un veneno; algunas mueren al instante en ella, $y$ otras despues de hacer varios movimientos convulsivos.

Para el observador y coleccionador la construccion y formacion de las galerias y de los tubos ofrecen un gran interés. Ya hemos descrito antes algunos detalles de este trabajo: las galerias en la arena y en el cieno se practican con la trompa; contrayendo el cuerpo, el anélido impele hácia adelante el licpidio de aquel, formado por una especic de sangre, $y$ hace salir de este modo la trompa con violencia. Este órgano pe. netra del todo cn el suclo, y como regularmente al salir tiene mas grueso que el animal, éste avanza fácilmente al recoger la trompi, maniobra que puede rẹetirse muy rápidamente. Asi es como un anélido de varios centimetros de largo pue. de penetrar en el suelo al cabo de pocos minutos ó segundos. En la mayoria de estas especies mineras no se hace nada para la conservacion de los tubos de las galerias, pero algunos nereidos las revisten de una ligem capa segregada por el cuerpo, que esencialmente es de la misma sustancia que la de los tubos de las sabelas y quetópteros. Por diferentes que sean estos tubos, en todos los casos se forman por secreciones de los animales; pero entre ellos y los individuos que los habitan nunca cxiste una union tan intima como entre la concha y el caracol ó los moluscos, que las tienen soldadas.

Segun las muchas observaciones hechas en los anillados hasta ahora descritos, se han dividido en carnivoros (rapa(es) y limivoros (limiora): mas esto no parece en general cxacto, mientras con estos nombres se quiere designar el gru. 
po de los quetópodos de branquias dorsales y el de branquias cefálicas, porque entre los primeros hay limivoros y' entre los últimos carnivoros, aunque estos se contentan con la presa pequena que llega al alcance de los órganos bucales. Su utilidad para el hombre se linita a su cmpleo como cebo. Ni aun los chinos, que son muy poco delicados para el alimen. to, han llegado is comer esas especies; solamente los indigenas de las islas de Fidji y de Samon se utilizan para su cocina de un anillado, comun en sus costas.

Las noticias adquiridas sobre el genero de vida de estos animales, por las observaciones hechas en individuos libres, pueden completarse con las que se han practicado en las especies cautivas en los acuarios grandes ó pequeños, donde se pueden tener juntas las mas diferentes sin temor de que se ataquen ó devoren unas á otras. A la mayoria no les gusta evidentemente la clara luz del dia, sobre todo los rayos direc. tos del sol. Los que viven libremente buscan en seguida un escondite; los habitantes de tubos permanecen retirndos todo lo posible en el fondo. Solo cuando en los depósitos pequenos, donde se les conserva para el estudio, se produce una descomposicion muy marcadi para los órganos del olfato, intentan huir a todo trance del foco pestilente, y entonces abandonan su retiro, asi los anélidos de tubos como los serpuláceos; mientras que en su residencia natural nunca lo intentan. Su marcada aversion à la luz directa no es suficiente motivo para considerar á la mayor parte de los anillados ma. rinos como animales nocturnos; mas por la eleccion de su residencia podria creerse asi.

Gracias á las averiguaciones mas recicntes, hechas en las profundidades del mar, podemos alıora completar y' genera. lizar la descripcion anterior. Sobre tocio notables son los re. sultados obtenidos por Ehlers de los anélidos que le fueron entregados por la expedicion del Purcupins, la cual pudo probar que aun a profundidades de 2,435 brazas $(4,318$ metros) viven quetipodos, y que solo las familias de los telesudos y hermelizeos, que decididamente prefieren la costa, no tienen especies i mas de 300 brazas de profundidad. Solo una, syllis aby'ssicola, sc encontró à mas de mil; la mayor par. te de las que se hallan mas a fondo se encuentran tambien mas arriba de la linea de 100 brazas, $y$ aun de las especies que hasta ahora solo se han hallado como habitantes de la profundidad, debe dudarse si algunas veces no visitan fondos mas bajos.

Despues que Moevius clasificó los animales marinos en especies eurifermas y estenotermus, segun que encuentren las condiciones para su existencia en limites de temperatura muy vastos ó muy réducidos, Ehlers prosignió este estudio, demostrando en especies de las costas curopeas, desde el Mediterráneo hasta el circulo ártico, que los anélidos con gr.m esternon horizontal, es decir, los que se conservan en temperaturas muy diferentes, tienen al mismo liempo la mayor extension vertical. «Como cjemplo mas caracteristico, dice Ehlers, haré mencion del tevehellisles stroemsii: esta especie se encuentra como companem del cangrejo euritermo, nephrops noriggius, en el Adriático, donde Grube la vió en la playa de la isla de Lussin, y yo en la region costern, no léjos de Fiume, en una region calurosa y exputsa a grandes variaciones de temperatura: niientras que por otra parte se encuentra en las costas árticas, igualmente en la playa.

Sin animo de sobrecargar la memoria del lector con muchos nombres, citaremos tambien el hecho de que muchas formas àrticas se hallan, como los estenotermas, en las mas profundas aguns meridionales, lo cual nos induce a preguntarnos si hemos de considerar tales parajes como puntos aislados, ó si mas bien debemos creer que esas formas árticas se trasladan a las costas septentrionales por medio de aguas frias que a considerables profundidades se extienden desde el norte hácia el sur. Se ha tratado de comparar la existencia de esos animales con la de iguales especies alpinas que viven aisladamente en las cimas de nuestras mas altas montañas, separadas por valles y llanuras donde no se encuentran los séres de que hablamos; pero la comparacion no podria adnitirse sino en el caso de justificarse la creencia de que los parnjes meridionales del mar profundo, en los que encontramos formas árticas, estuviesen rodeados de masas de agua de tal temperatura que no pudiesen vivir en ellas las respectivas especies árticans. Tal suposicion, no me parece, sin embargo, fundada; muy por el contrario, del mismo modo que remos entre las islas de Feroe y las de Shetland, animales árticos que con la corriente fria de las protundidades del mar llegan desde el norte, podriamos figurarnos que, a causa de una gran cxtension de masas frias de agua, la forma ártica puede prolongarse por una inmensa área de dispersion.

4Solo bajo un concepto seria dido sostener dicha comparacion. Si ahora nos explicamos casi siempre la diseminacion aislada de las formas alpestres por el cambio de temperatura ocurrido al terminar el periodo glacial que obligó á los animales hoy alpestres à penetrar en los valles donde desapare. cian los ventisqueros, podriamos suponer respecto à la extincion actual de los séres árticos que en una época anterior estos animales habitaban en las costas europeas del mar del Noric, pero que al liegar una corriente tibia superficial, la del grilfstream, se vieron obligados a retirarse a los sitios en que el mar conservaba una temperatura baja: fuera del círculo ártico, estos sitios son genernlmente los mas profundos del mar, en los cuales no influye la corriente cilida. Haré mencion tambien del antiroe Sinrci, forma comun en las costas articas, que se encontró i una profundidad de 1,215 brazas a una temperatura de $2 \%$ s centig. delante de la costa irlandesa y por Sars a una profundidad de 300 brazas frente i la de Noruega; para mi tiene mas importancia este anélido porque pertence á los animales qus se encuentran en el Báltico y que Loven designó como formas árticas que en aquel mar se conservaron cuando este quedó separado del Artico.»

Atendido que muchos quetópodos alcanzan su mayor desarrollo en el ilto norte, fenómeno - que tambien se observa en otros animales vertebrados, de esperar era que sucediese lo mismo con las especies que viven a grandes profundidades, pero Ehlers ha demostrado precisamente lo contrario: todos los anćlidos que habitan la profundidad del mar sun perpueños en rompraracion con las especies congenéricas de la zona ärica. Ias causas no se explican bien, pero puede suponerse, con gran probabilidad de acierto, que la falta $\delta$ escasc\% de alimento producen la atrofia. En general, al ob. servar la vida de los anélidos en las regiones superiores, involuntariamente nos vemos inducidos á creer que la mayoria de las especies que pasan su vida en los profundos y ascuros abismos no permanecen alli por su voluntad.

Sin duda es mucho mas dificil para los quetópodos que habitan profundidades del mar subir il las costas bajas que hacer lo contrario: Nuestro colega Ehlers se inclina á supo. ner una relacion en ambas direcciones para explicar el hecho extraño, citado ya por nosotros al hablar de los crustáceos que habitan las profundidades, de que el oscuro abismo no haga percier el color ni la vista à aquellos quetónodos. Una sola especie, la ciega syllis alyssicola, nos ofrece un ejemplo de que en las profundidades del mar donde falta la luz hay quetópodos ciegos, cuyas especies congenéricas siempre tienen ojos.

Aun à mayores profundiclades que las ya indicadas, se en. 
cuentran todavia quetópodos muy bien organizados. Un anélido perteneciente al género myriocliele fué extraido con su tubo cenagoso por la expedicion del Challenger, en el mar Austral, de la enome profundidad de casi 6,400 metros.

Hemos hablado ya de la facultad de brillar de un quetópodo, del chaclopierus, $y$ ahora añadiremos que umbien otros tipos de esta clase brillan en ciertos casus ó segregan una materia luminosa, como en aquella especie, en varios poljcirrus y odontosyllis: este brillo proviene de unas celdas mucosas: mientras que en el polynoc unos nervios particulares situados en las escamas dorsales son el foco del brillo ra. diante, en el syllis, segun observaciones de Quntrefages, se produce por los núsculos.

I a historia natural y lá biologia de Ia mayor parte de los animales inferiores, asi como también de los quetúpodos, son muy incompletas sin el conocimiento de su desarrollo. En los guetópodos marinos los sexos están separados, $y^{\circ} \mathrm{cn}$ general se observa que todo el huevo con la piel se trasior. ma en hijuelo. Ia superficie entera ó una parte de este huevo se cubre de pelitos, y entonces el pequeño sér conien\%a como larva, una existencia independiente. Antes de que pueda distinguirse una separacion de los óryanos internos, las larvas empiezan à revolverse y agitarse con ayuda de aquellas pelitos; pero à menudo sucede, como se ha visto en el género arenicola, que están encerradas con los huevos en una masa gelatinosa. Cundo la larva se prolonga, los pelos quedan linitados á una sola region ó bien ocupan otra ó al. gunas mas. A medida que avanza la articulacion, que se presentan los tuberculos, $y$ en ellos los hacecillos de cerdas, aparecen tambien el intestino y los ojos, mientras que los
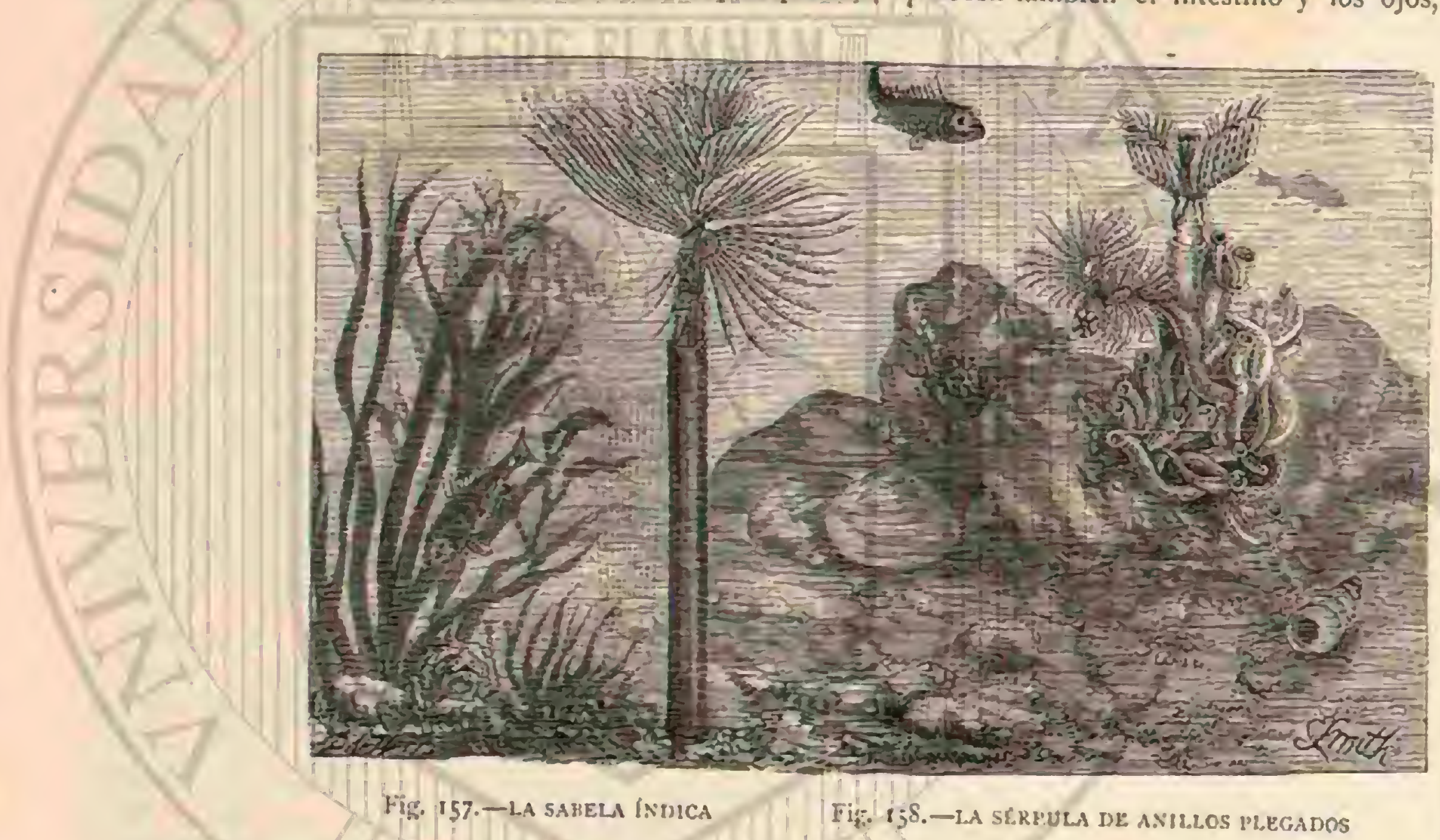

Fig. 157-LA 5ABELA INDICA

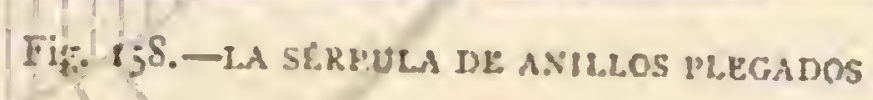

anillos de pelitos dejan de verse cada ver mas la meianor. fósis consiste por lo tantó en qué los órganos interinos des tinados para la vida de larsa, ceden su sitio poco á poco a los definitiros. Debe notarse tambien aqui que las especies mas tarde sedentarins y que se rodean de un tubo, están en cierto modo mejor organizadas en la juventud que en la eảad madura. Ias larias de las terebelas y de otras especics tienen ojos y viven generalmente como los quetópodos de branquias dorsales mas perfectas. Su desarrollo está por lo tanto en relacion con una metamoríosis retrógmada.

Vamos á ocuparnos ahora de la propagacion neutra de los silideos: figurémonos una hembra de anélido cuyo cuer po se prolonga en seis articulaciones, y estas con sus vistagos ó retonos en el verdadero senticlo de la palabra. El primer retoino que se forma en la extremidad posterior de la hembra, se desarrolla poco à poco, y entre tanto nacen un segundo, tercero y cuarto; hasta que, al salir el quinto, el primogénito ocupa el último lugar entre sus hermanos, formando al mismo tiempo el eslabon mas largo de esta cade. nn. En el sitio en que el retoño debe separarse de la hembra insértase la cabeza del hijuelo. Ln esta trasformacion de articulaciones enteras de la madre en hija sucede que esta última ja esta llema de huevos, aunque el caso de que el mismo animal produxca aquellos por via sexual, y al mismo tiempo retonos, parece ser el mas raro. La regla es mas bien que el individuo antcrior ó la nadre sea neutra, mientras que los retonos se desarrollan en machos ó hembras. Lo mas claro é instructivo de este procedimiento se observa en el género astoljtus. La cabéza del individuo anterior, del awtolytus comalus, se distingue por la posicion, forma y longitud de las antenas y ientáculos del retono inasculino, y este á su vez del de la hembra. Machos y hembras nacen por lo tanto exclusivamente como retoños, mientras que su progencratria neutra debe su sér solo a los huevos de la generacion sexual. Teneinos aqui un ejemplo muy claro del llamado cambiu de generacion, tan comun en el mus. do de los animaies inferiores Este cambio es un inodo particular de reproducirse y propagarse, segun el cual el individuo que se desarrolla en el huevo nunca llega a tener la forma y el valor, es decir, la importancia fisiológica del individuo sexual si no se propaga por la via neutra, por medio de division y formacion de retonos 6 por producirse interiormente embriones, volviendo solo por estos sus vástagos a la generacion sexual. La especie se compone, pues, no solo de Tos dos sexos, sino tambien de los individuos de, la generacion intennedia que igualmentese distingue por una formacion muy particular. Tan sencillo y... comprensible es en cl género astolytus el cambio de generacion como en los demas casos que podriamos citar. Las dos generaciones que carbin son aqui ya tan difurentes, que antes de reconocerse el hecho de que pertenecieran a una sola especie, se las des. cribia como géneros distintos. Fl individuo neutro, como autolyus, el macho como folybostrichus, y la hembra como
sacousereis. 


\section{LOS LOMBRICINOS- LUMBRICINA}

CARACTERES. - Una tercera division de los quetópodos comprérde los lombricinos, es decir, todas las especies cuyas cerdas no se insertan en tubérculos y que no tiencn ni antenas ni ningun otro de los ajuéndices de los anillos, tan variados en los grupos anteriores.

Ia mayor parte de esta division esta formada por las lom. brices de lluvia, que se distinguen desde luego por sus numerosos seginentos cortos; en la cabeza hay un lóbulo en forma de cono, que constituye una especic de labio superior; las cerdas, ganchudas, están dispuestas en dos ó en cuatro series, que sobresalen muy joco de la piel. Fuera del llamado labio que forma la extremidad del cuerpo, las lombrices de lluvia no tienen órganos particulares de los sentidos, ni ojos, ni orejas; y a pesar de esto son sensibles a la luz. W. Hofimeister describe en una monogratia has lombrices de Alcmania del modo siguiente: \& El que se ha ocupa. do en observar el género de vida de estos animales, habrá notado que sou sumamente sensibles á la luz. Una llasna les hace retroceder rápjidanente i su escondrijo, aungue se acerque con el mayor cuidado, si bien parecen necesitar cierto tiempo pam percibir la impresion, pues en el primer momento suelen noverse á pesar de la llama. Despues se paran de repente cual si quisieran escuchar y solo entonces se retiran, con un rápido movimiento, i sus agujeros. Una vecz percibida la impresion, ya no se detienen, aunque se apague al punto la lur, sino que por el contrario, el brusco contras-

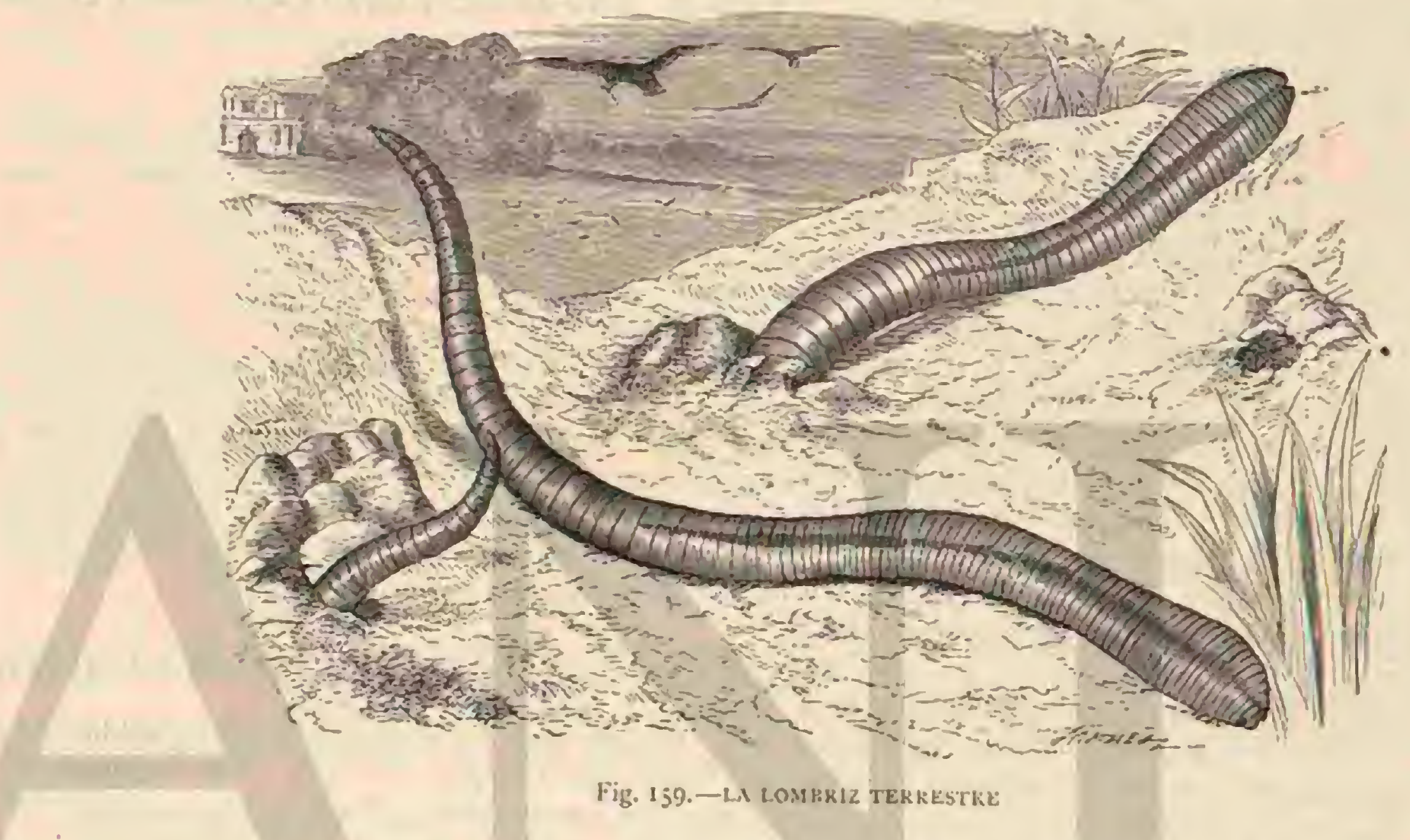

te parece apresurar su fuga. No todo el cuerpo, sino solo los dos primeros anillos en que se hallan los ganglios perciben la impresion. Un gusano que habia introducido la calse. za en el igujero de un recino, ó estaba oculto debajo de un pedacito de madera, soportó la llama muy cerca de su cuerpo, pero desaparecio en seguida al levantar la cabeza. Cuando se trata de dibujar las formas de la boca de una lombriz en una labitacion alumbrada por el sol, colocindola al efecto en una copa con agua, siempre se observarí que se dirige hacia el lado opuesto a la luz.

I. mayor parte de los lombricinos lleman su ancho intes. tino poco mas'ó menos como los arenicolas, pero solo devoran las grandes porciones de tierra abundante en mantillo, para nutrirse de las sustancias vegetales y animales contenidas en alla. El citado autor dice del Iumliricus ngricola, la especie mas grande $y$ fuerte de Alemania, que en terreno fértil a menudo alcanza una longitud de unos cuarenta centimetros. - La tierra abundante en mnntillo, dice, les hasta; buscan tambien vegetales en descomposicion, y cuando no los encuentran, introdúcensé con este objeto en cuantos agijeros hallan i su alcance. Nadie ignora que las lombrices de lluvia se llevan de noche los tallos de paja, las plumas, hojas, etc. que por la inainana vemos en el suclo de los jardines, cual si los hubieran puesto alli los niños. Pocos, sin embargo, habrản visto cómo, con órganos tan débiles, una lombriz pucde manejar objetos tan grandes: pero quien ha notado la resistencia que opone cuando se trata de sacarla de su agujero, no admi. rari la fuerza muscular de un animal compuesto de misculos y de picl. Coge una gruesa paja pror su centro y tira de ella con tal fuerza que la dobla y la introduce en el agujero; una ancha pluma de gallina es introducida siu dificultad en el esconcirijo, y del mismo modo arranca una hoja verde de un arbusto. I Al hablar de la actividad de los órganos de los sen. tidos de la lombriz de lluvia, debemos referirnos tambien á su género de vida: pero antes convendrà decir ajgo sobre sus caractéres anatónicos. Lo que antés indicamos sobre los rasos de la sangre, se explica muy bien en individuos peçuenos de nuestra especic comun: a la simple vista distinguese a traves de la piel la arteria principal sobre el intestino y su contenido zojizo. A pesar de su sangre roja, la lombriz. in figurado casi dos mil años entre los animales sin sangre, hasta que Linneo la fijó un lugar entre los que la tienen blanquiz. ca $y$ fria, $y$ un corazon con ventriculos, pero sin auriculas. Así vemos que todo conocimiento, aunq̧ue en apariencia sea el mas sencillo, requiere tiempo para madumrse. Al vaso dorsal corresponde en el vientre una segunda arteria principal, reunida con la primern por una serie de renas trasversales. Cuando se introduce una lombria rápidamente en espiritu de vino $y$ se la abre en seguida, puede verse que una infinidad de pequeñas venas parten de las principales para alimentar el cuerpo en las mas finas ramificnciones. Los legumentos de ia piel sirven de órganos respiratorios. Las lombrices y sus congéneres son hermafroditas. No todos los géneros de la familia de los lombricinos icenen blanquizca ó amarillenta la 
region glandulosa, que comienza en el anillo vigésimoquinto y remata en el vigésimonoveno, ocupando de cuatro á diez segmentos; j que sirve para sujetarse el macho y la hembra mutuamente en el apareamiento.

La lombriz comun pasa el invierno aislada ó reunida con otras de sus semejantes à una profundidad de seis i ocho pies bajo tierra, sumida en un largo sucino. El calor de la prinavera la despierta y entonces vuelve á la superficic. No le agrada el dia, pero durante el crepúsculo matutino y el respertino, $y$ hasta muy entrada la noche, sobre todo despues de una ligera lluvia, abandona su escondite para buscar alimento ó reunirse con alguna de sus companeras.

A pesar de su carácter parifico y modesto, la muerte acecha bajo mil diferentes formas a las pobres lombrices, que pueden compararse a seres oprimidos a quienes ni sinuiera se permiten sus reuniones nocturnas y silenciosas.

a l a lombriz, dice su biógmó, es uno de los animales que mas expuestos estan a las persecuciones. El hombre la mata porque la acusa del destrozo de sus pequeñas plantas; entre los cundrúpedos, los topos, musamñas y crizos, se alimentan de ella; y es innumerable el ejército de ares que procuran su exterminio, porque no solamente las rapaces, nadadoras y pantanosas, sirio tambien las granivoras considéranla como: una golosina. Los sapos, triones y salamandras. _la acechan de noche, y los peces persiguen à las especies que habitan en los rios y en el cieno del mar. Mayor es aun el número de los unimales inferiores que se alimentan de lombrices. Los grandes coledpiteros corredores se ocupan de noche continua. mente en el exterminio de estos animales tan indefensos, de los que se apoderan fácilmente y mas aun de sus larvas. Sus enemigos mas encarnizados parecen ser sin embarigo las grandes especies de miriopodos: al escapar de estos se las ve a menudo salir en pleno dia de sus agujeros, perseguidas jor algun enemigo.

Ia iamilia de los lombricinos se divide, segun la naturnleza del Jóbulo de la cabeza y la disposicion de las cerdas, en una serie de géneros, de los que solo el lumbrious cuenta veinte especies: de estas, sin embargo, unicamente dos ó tres, como por ejemplo la lumbricus anatomicus y lumbrinus agricula (fig. 159), cstàn diseminadas por toda la Alemania. El Iumbriaus futidus, la especie de mias bonitos colores, que tiene el cucrpo cruzado por fajas amarillas y rojas, prefiere las re. giones arenosas y se encuentra à menudo, particularmente en la Marca, debajo del mantillo. El lumbiricus puter, de color pardo rojo, con iajas mas claras, se mueve con gran mpidez cintre la madern podrida; el lambricus chlorolicus, de color verdoso, solo se ha visto hasta ahora en el Harz, en el fondo de aguas estancadas, en praderas de terreno arcilloso y en las orillas arenosas de riachuelos y rios.

Leydig ha descrito minuciosamente la estructura y el gé-, nero de vida del flsteoryites Menkeanss, especie muy delgada, y una de las mas raras lombrices de Alemania. Vive principilmente en los pozos, sobre todo en la region del Sur, y al parecer ocúltase durante el invierno lo mismo que las especies terrestres: abunda mas en mayo y junio.

En el acuario, dice Levdig, cuyo fondo cenagoso está cubierto de piexiras conservibanse muy bicn durante largo ticmpo. Casi sicmpre se escondian debajo de las piedras, en. lazandose por lo regular unas con otras. Cuando el tiempo era fresco of lluvioso permanecian ocultas, mientras que en dias muy calurosos y cuando amenazaba una tempestad salian regularmente, vagando inquietas por el depósito. Todo el otono y el invierno mantuviéronse invisibles, y solo en marzo se dejaron ver. Comó las valisnerias que habia en el acuario perdian poco a poco sus races, sin que otro animal hubiera podido ser el culpable, debe suponerse que al phreorictes se alimenta de sustancias vegetales. A causa de la gruesa piel y de la delgada capa de músculos, los movimientos del animal son un poco torpes. I a observacion de Ley. dig de que el animal no vive solamente en los pozos, sino tambien en aguas estancadas poco profundas, queda confirmada, porque le he encontrado en bastante número entre lis plantas acuáticas superficiales de un depósito del jardin botảnico de Cracovia.

Vemos por lo tanto que varios géneros muy afines de la lombriz, comun, como el phreoryctes y el criodrilus lacuus, propio del lago de 'legel, cerca de Berlin, pueden ser verdaderos habitantes del agua. A estos siguen algunas familias notables por su pequeñez y por estar provistas á veces de pe. los cerdosos.

\section{LOS TUBIFICINOS - TUBI- FICINA}

CARACTERES. Lina de las especies mas comunes de esta familia es el fubifex riaulorum, pequeña lombric de unos dos centinctros de larigo, de color rojizo trasparente, que por miles y miles de iridividuos se encuentm en el fondo cenagoso y puirido de fosos y riachuelos. Sicmpre tienen la parte anterior del cuerpo en el cieno, donde abren un espacioso tubo; mientras la posterior sobresale y está en continuo movimiento para la respiracion. Por lo regular se oprimen de tal manera que la supjerficie del cieno presenta un color rojo,y cuando ílguien se acerca cautelosamente no se inquietan, pero tan luego como se dn un golpe sobre el agua, todas las lombrices desaparecen al punto ocultindose a varias pulgadas de jurofundidad en su fétido escondrijo.

\section{LOS NAIDINOS - NAIDINA}

De un modo muy distinto se conducen los naidinos, del tocio trasparentes y limpios. Si se saca de un estanque ó foso cubicrto de lentejas acuáticas (limma), una pequeūa parta de cstas plantas, cuando se llega á casa se puedie estar seguro de encontrar cuando menos algunas, sino muchas de estas graciosas lombrices; que con ayuda de sus cerdas ganchudas ó pelosas se deslizan como serpientes entre las mices de las lentejas ó en el caos de los hilos acuaiticos.

CARACTERES. - Va se describió en el siglo anterior h nais froboscidea, llamada asi a causa de una estrecha prolon. gacion, en forma de tentículo, del lóbulo de la cabeza, con la cual sonden el terreno. Esta especie y otra sin lengua, con el sugmento de la cabera sencillamente redondeado, tienen dos ojos; esta última y algunas otras presentan en cl vientre dos series de cerclas pelosas y largas. Fon las dos ciradas especies y' otras congenéricas las venas anteriores de los masos de la sangre, que fácilmente se reconocen por su color amarillento, sobresalen aun de la abertura bucal de la region in. ferior de su extremidad anterior. Diferente es esta tilima parte en el género cirnetogastel, del cual una especie casi tan trasparente como el cristal (chatogastel dighthamis) se encuentra à menudo, cuando jóven, como parásita en nuestros caracoles acuáticos. Su cabeza está truncada verticalmente y acaba con la abertura bucal, por detris de la que se ve un esófago cubierto de muchas papilas y que en parte puede sa. lir. Otro carácter distintivo del género es que solo tiene cer. das ganchudas. Todos estos gusanitos se pueden recomen. dar mucho para el eximen microscópico, porque el animal vivo es fäcil de colocar en el aparato, y se pueden observar infinidad de pequeneces de la organizacion, compensindose el trabajo del eximen por el curioso aspecto que ofrecen. 


\section{SEGUNDA SUBCLASE-HIRUDINEOS}

Es mas fácil hallar protectores para las lombrices de lluvia, 6 ser toleranic con los crustáceos parásitos, que como caricatums y ejemplos de las trasformaciones retrógradas mas extranas nos divierten $\epsilon$ interesan, que no buscar amigos para los hirudineos $\delta$ samsuijuelos. Todo el mundo piensa, al hablar de las sanguijuelas, en los verdaderos chupado. res de sangre, que si bien no desagradables por su aspecto, suclen iuspirar repugmancia. Sin embargo, estos conocidos y voraces representantes de su division constituyen solo un reducido numero, y entre otros muchos pueden excitar por la elegancia de su forma y dibujo un interés mas viro. Consi. derados como partes del todo, los hirudineos llenan tamuien su mision en la gran economia de la naturaleza, y aunque se distinguen menos por su extmino género de vida, nos ayudan tambien á comprender un gran grupo de verdaderos anélidos intestinales. Tan intima es la relacion de los hirudincos y los llamados anćlidos chupadores (trimalodes) por su estrucıura y género de vida, que con justo motivo pueden reunirse estos últimos anćlidos no anillados con los hirudineos en una sola clase.

lil examen superficial de cualyuier individuo demuestra que los hirudineos son verdaderos anelidos anillados, $y$ la amatomia nos revela ademas que tambien participan de la propiedad de los quetópodos, segun la cual los órganos inter. nos mas importantes se repiten en los segmentos siguientes. La ausencia total de muñones de los piés 6 tubérculos, y el tener por lo regular discos chupadores en la extremidad anterior, y siempre en la posterior, los caracteriza como division independiente que a menudo se llama tambien la de los arélidos lisos.

Cientifica y prácticamente es natural que empecemos por In familia de las verdaderas sanguijuclas (Mirmdinea). Los anillos, estrechos y visibles exteriormente, no son en estos hirudineos los verdaderos segmentos: segun resulta de la distribucion y repetición de los órganos internos, solo cuntro ó cinco anillos forman un segmento. El lóbulo capital esta soldado con el segmento de la cabeza en un disco prensil anillado; el disco chupador posterior está casi siempre separado del cuerpo por una estrechez, y por encima desemboca el intestino. El esófago puede salirse, de modo que se forman tres repliegues, á menudo denticulados.

\section{LAS SANGUIJUELAS MEDICI- NALES - HIRUDO MEDICINALIS}

CARACTERES. - Ocupemonos ante todo un poco minuciosamente de ias sanguijuelas medicinales (fig。 160): unas especies pertenecientes al género hirudu, y que para inferir la heriảa de que quieren chupar la sangre están provistas de numerosos dientecitos agudos en los repliegues maxilares, de forma semicircular; ademàs se distinguen por la considerable anchura de su estómago, en el cual hay numerosos compartimientos laterales. Debenos, 110 obstante, examinar mas de cerca estas y otras particularidades de su estructura.

I as sanguijuclas medicinales tienen diez ojos distribuidus a pares en los ocho anillos anteriores. El microscopio nos permite ver que el borde de la cabezi de la sanguijucla tiene uma infinidad de órganos muy prarticulares en forma de copas, que por su maturaleza y su abundancia de nervios parecen órganos de los sentidos. Fs dificil distinguir si por medio de ellos el disco de la cabeza se trasforma en un órgano de tacto muy sencillo 6 si las copas son una especite de órganos del olfato.

Las llamadas maxilas de las sanguijuelas se componen de una masa nuscular en forma de semicírculo. Las fibras musculares se cruzan de modo que las maxilas se mueven como una sierra, y los 60 á 70 dientecitos fijos en el borde piuchan y desgarran a la rez. I as maxilas están dispuestas del modo indicado en la herida caracteristica, que presenta tres mdios. Al esófago sigue el estúmago, provisto de once pares de ventrículos cicgos: naturalmente dehemos considerar como estó. mago todo el espacio que al chupar se llena a la vez, lo cual se verifica hasta la extremidad del último par de largas bolsas ciegas, que al lado del intestino, corto y estrecho, se extienden hasta cerca de la extremidad posterior del cuerpo; $y$ atendido que, tanto las jaredes de estr como las del estóma. go son elásticas, compréndese que la sanguijucla pueda aumentar toda su circunierencia, mientras chupa, hasta ser triple y cuadruple. La sangujuch medicinal tiene el sisicma de la circulacion de la sangre muy complicado: los que se inte. resan en observar sus condiciones, que en la especie conuu dificilmente pueden explicarse, procuran obtener individuos claros y trasparentes de la especie de hirudineos neplielix i'ulgaris, muy diseminada; $y$ en un tubo de viclrio se ve al trasluz con el microscopio toda la circulacion de la sangre que fluctua de un lado $i$ otro.

l. sanguijucla medicinal es hermafrodita, como todos los hirudineos; la abertura masculina se halla entre los anillos vigésimocuarto y vigésimoguinto; la fomenina entre el vigésimonono y trigésimo. In descripcion de la puesta de los huevos $y$ la formacion de las capas de los mismos exige un exámen general, en el yue podemos guinrnos por la exacta descripcion de Salzwciel (en el Aresliusd de 1862).

USOS, COSTUMBRES Y REGIMEN.- Nuestras San. guijuclas viven con preferencia en los estanques de fondo cenagoso y en los pantanos, y nunca se hallan en sitios donde el suclo sen arenoso; buscan ante todo las aguas tranquilas y cubicrtas de plantas. Fuera del agua no jueden vivir mucho tiempo y mueren cuando aquella se agota; pero pueden prolongar su cxistcncia gracias at la secrecion mucosa. De dia, y sobre todo en tiempo caluroso, madan vimulente; pero si el cielo está nublado y el dia es frio se enroscan de tal modo que ocultan la cabeza en la cavidad del pie, alec. tando entonces la forma de una lira. I o mismo sucede por la noche y en otoijo, en cuya estacion penetran en el cieno cuanto es posible.

Su alimento cxiclusivo es la sangre de los vertebmdos ó los jugos análogos de los invertebmdos. Se ha pretendido que en caso de necesidad se agarran unas å otras, pero estos casos deben ser muy raros; tan dudoso me parece como el aserto de que chupan la sangre de cadáveres de animales. Lo que si se ha visto es que se agarran por lo regular alos animales vivos, varios de los cuales son sus propios enemigos, como, por ejemplo, los carncoles acuáticos. La muda, que segun algunos observadores se efectua con intervalos de al- 
gunos dias, solo se verilicó una vez en varios meses sègun lo vió Martini en individnos adultos. ela muda duró unas dos semanas, dice, y durante este tiempo las sanguijuelas permanecicron tranquilas, oprimiéndose entre si; con frecuencia estaban en el fondo del depósito bocat arriba, como se observa regularmente en sanguijuelas muertas. No vi morir á nin. guna durante este periodo; $y$ todas inudaban al mismo tiempo. El agua renovada á menudo no parecia perjudicarlas ni desagradarlas. La piel que dejan es una epidermis muy fina que despues de limpia queda aun trasparente y blanca, y que vista mas de cerca presenta todas las prominencias y cavidades del cuerpo: sepírise á veces en pedazos y otras en toda la extension del animal. Debe distinguirse bien de la muda la solidificacion de la sustancia mucosa, que se verifica continunmente y que it menudo envielve al anelido en hilos ó fajas.

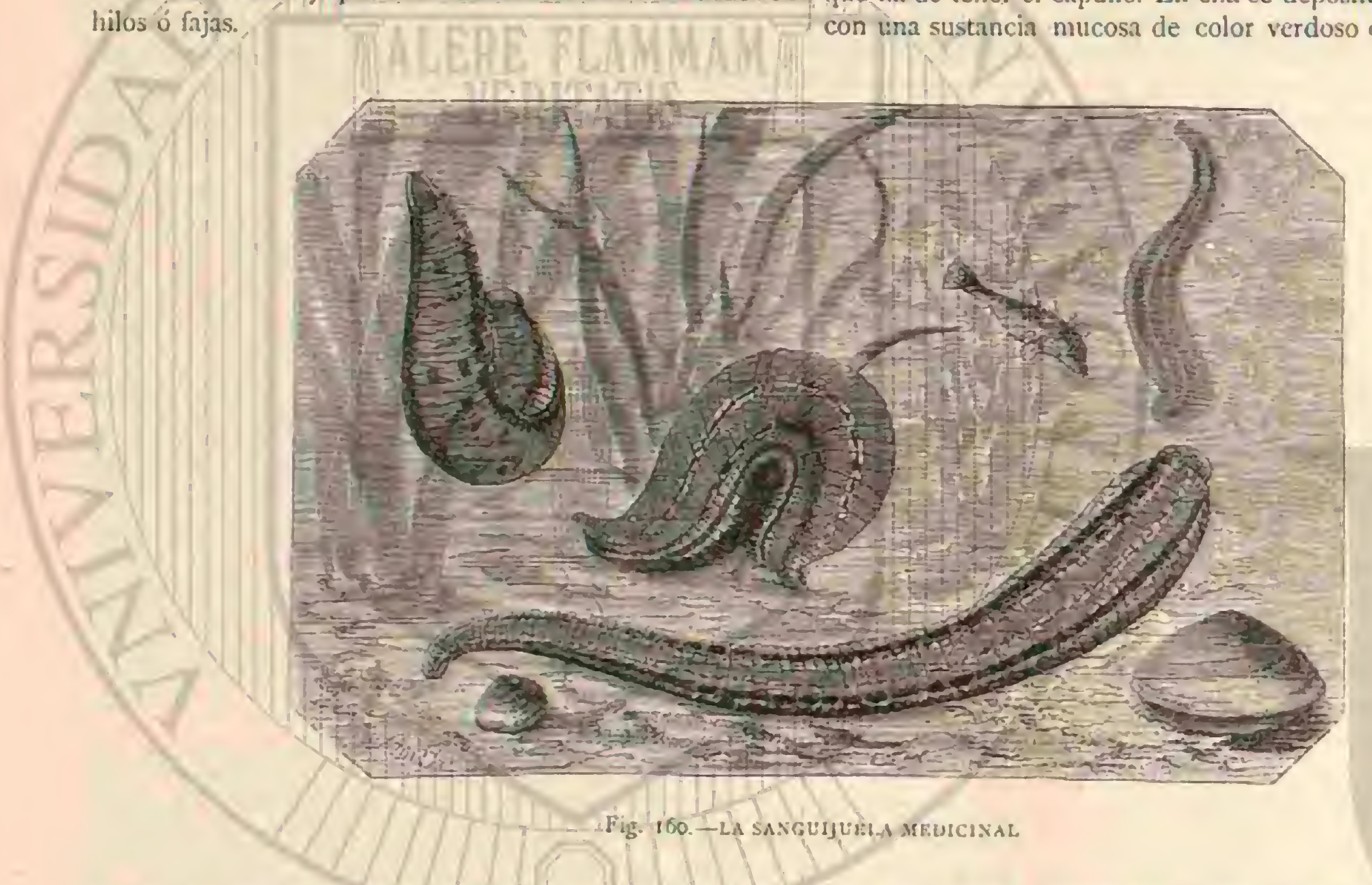

diez a die\% y seis yenitas no visibles sin el auxilio del microscopio, $y$ al mismo tiempo la sarguijuela forma con la boca al rededor de aquellas una cspuma blanca semejante a la saliva, que por lo regular ocupa la circunferenciat de un pequeño huevo de gallina. lucgo se retira al capullo, retuerce por dentro la abertura abandonada y sale completamente de aquel, repitiendo la misma operacion por fuera. Despues permanece asi algunos dias junto al capullo. Este último adquicre luego su tamaño natumal, resecíndose la espuma en forma dé una cubierta esponjosa; y cuatro ó séis semanas despues de la puesta salen los hijuelos. Son fi. liformes y claros, pero se parecen en lo esencial à los adultos. Su desarrollo se verifica muy lentanente: cuando mas, hasta los tres años no sirven para el uso medicinal, álos cinco llegan à su completo desarrollo, y segun se dice, jucden vivir hasta veinte.

CRIA. - Como nosotros no hemos risto aun criadero alguno de sanguijuelas, tomaremos tambien ahora por guia al citado autor del Ausland. To mas favorable para conservar las sanguijuelas es un estanque naturah, qque sin embargo no debe carecer de las siguientes cualidades: el fondo debe ser ligero ó cenngoso; el agua clara y tibia, libre sobre todo del a contacto de ciertos árboles que puedan comunicarla un sabor particular, como por cjemplo alisos, que no gustan á las sanguijuelas en el estado libre En el cstanque no debe haber
\$Despues del apareamiento que se verifica ca la primave. ra, la sanguijuela busca un sitio etevado sobre la superficic del agua, y alli abre con la cabeza galerias. En las orillas de los estanques y pantanos donde hay muchas sanguijuelas se ven cenienares de aquellas a pocos centimetros debajo de la superficie del suelo. Algunos dias despues del último apareamiento se preparan en seguida su lecho, pudiendo suponerse que desde las últimas semanas de mayo hasta principios de junio se ocupan en este trabajo. A fines de junio empiezan a formar sus capullos ó cápsulas de huevos, que poco mas ó menos tienen la forma de una bellota. La sanguijuela cxjele al efecto una humedad mucosa verde, que parte de su boca y llega hasta la desenbocadura del conducto de los huevos a lo largo de fa cubierta anular cuya longitud es la que ha de tener el capullo. Eir ella se depositan, juntamente con una sustancia mucosa de color verdoso ó pardusco, de peces roraces ui grandes ranas, que persiguen à la sangui. juela; ademís se las debe preservar de las aves pantanosas y acuáticas, de roda clase de gallináceas, de las ratas terrestrés y acuáticas, y de los grandes caracoles. Sin embargo, tales estanques, ųue cuando cstán poblados se llaman esfanques de saugruijuslas, son muy raros y es preciso malerse de los artificiales para formar colunius de sanguijuelas, construyén. dolos de la manera mas conveniente. Para esto no se puede menos de elegir los sitios donde hay una afluencia natural de agua templada $\delta$ donde es posible obtenerla artificialmente, porque ese fluido es una cosa esencial, tanto por su existencia como yor su calidad. En tales sitios se establecen por lo regular varias colonias de sanguijuclas, separadas por un camino de un metro de ancho, de manera que se pueda circular cómodamente airededor de ellas. Cada una de estas colo. nias necesita un foso cuadrado de tres a cinco metros, cuyas orillas estén cubiertas de césjxid hasta la alura de un metro; en el fondo se extiende una mezelá de barro y tiersa de curbera, formando con ella una capa de treinta y dos centimetros de elevacion; y en el centro practicase una cavidad de medio metro cuadmdo parn ofrecer a las sanguijuelas, en años muy secos, su último refugio. Alli donde la naturaleza no proporciona la corriente de agua cual se necesita, empléanse tubos de madera cerrados por finos harneros para impedir que las sanguijuclas se escapen. Parece ventajoso poner en 
estas colonias algunas plantas que al parecer gustan ii las san. guijuclas, como pror ejemplo varios arbustos de sauce y una que otra planta de acoro. Atendido que en estos depósitos se pueden tener hasta seis mil sangujjuelas, que estas, ó por lo menos la majoria, permanecen largo tiempo en ellos, es preciso cuidar de su alimento, para lo cual se cchan en el estanque pececillos y ireza de la rana verde acuática, ó a falta de esto, puede utilizarse tambien sangre, etc. La freza sola no sirve para la alimentacion de las sanguijuelas, perosi los jequeños renacuajos que de ella nacen. Hace poco tiempo que el periódico de la Sociedad protectora de los animales llamó la atencion pública sobre una horrorosa barbarie de que se hacen culpables algunos de los que se dedican á la cria de sanguijuclas. A los caballos y asnos destinados a la matan7a, hacenlos entrar en los estanques para servir de alimento a miles de sanguijuclas al mismo tiempo; pero como arquellos oponen demasiada resistencia, se emplean vacas.
Atendido que la capa de agua de estos depúsitos no seri en invierno muy profunda, ofreciendo de consiguiente un abrigo muy dudoso contra el hiclo, debe aconsejarse en 20. dos los casos cubrirla durante la estacion fria con ramas de abeto y hojarasca. Una precaucion debe observarse en la construccion de estos depósitos, y es no situarlos demasiado cerca de otras aguas, porque fácilmente podria suceder fjue las sanguijuelas penetraran por el fondo para recobrar su li. bertad. Esto es cuando menos lo que ha resultado de diver. sas observaciones.

Si se quiere conservar las sanguijuelas para el uso doméstico debe obserwarse que estan mejor en una gran vasija ci. lindrica que se llena de agua de rio hasta una tercera parte o poco mas, tapándola despues con trapo de hilo. El agua solo se muda cuando se observan indicios de su descomposicion, y entonces debe tenerse cuidado de que la fresca tenga la misma temperatura. En invierno esta temperatura solo
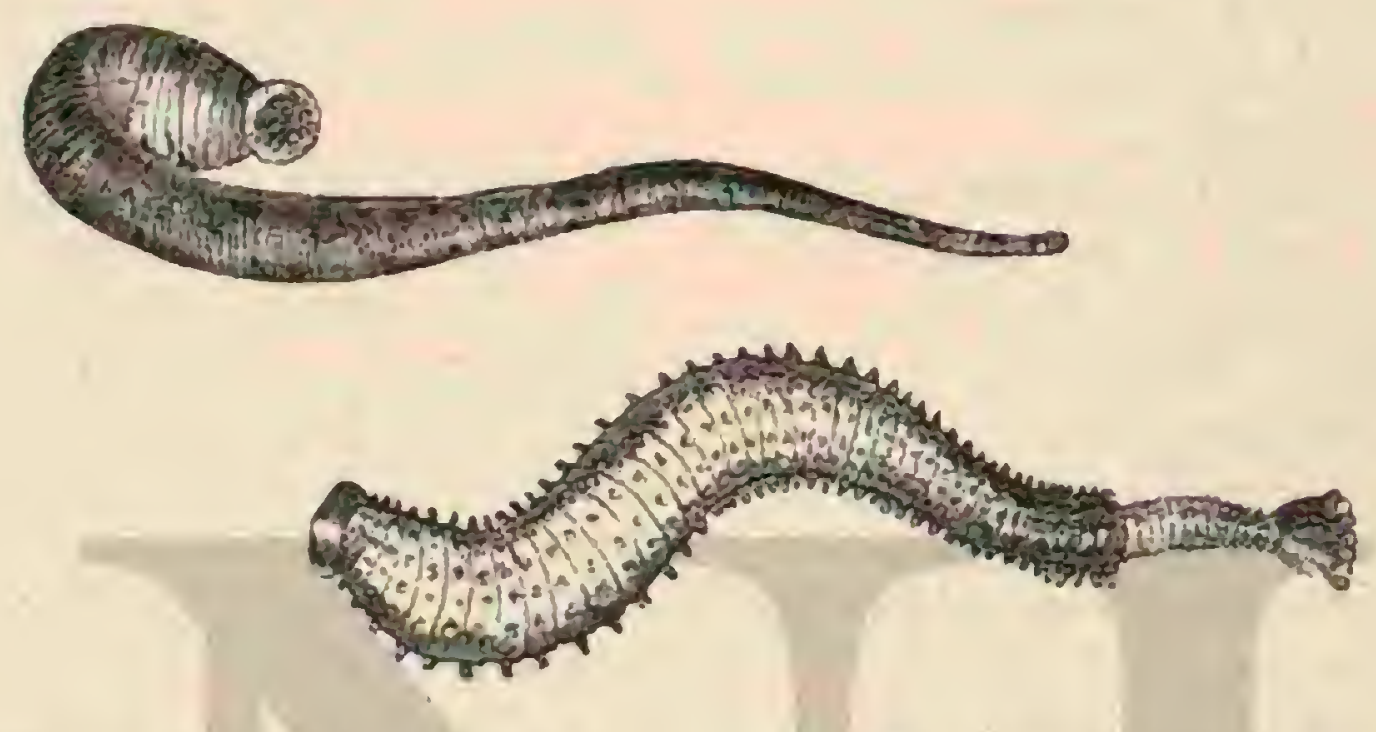

Fig. 161.-2L. Henoris Savgujuleh

Hig. 162.- R.L ALBIOS VERRUGOSO

debe ser de pocos grados sobre cero, y en verano igual i la del agua corriente.

En cuanto à la construccion de un depósito para mayor número de sanguijuelas, haremos mencion por lo menos de un inétodo. Se toma un barril de madera blanda, que por medio de una tabla vertical perforada por varios agujeros se divide en dos partes iguales. Un compartimiento se llena à unos quince centimetros de altura con una meacla de barro y de tierra de turbera $\delta$ de césped, echando despues el agua necesaria, no solo para que se cmpape bien, sino para que el húido esté a varios centimetros de altura en la segunda di. vision, que por lo demás queda vacia. En este lado del barril se practica, si es posible en la parte inferior, un agujero, que se cierm con un tapon de corcho, por el cual de vez en cuando se saca el ggua para sustituirla con fresca. Despues se ponen las sanguijuelas en un barril de mediano tamaño, que puede contener hasta mil, y se cierra con un trapo de hilo.

La mejor sayon para coger las sanguijuelas y conservarlas mucho tiempo es el otoño, pues entonces se hallan mas fuertes y sanas. Tambjen las que se adquieren en la primarera pueden servir, aunque con menos seguridad; mientras que las que se cogen en el verano no son buenas para conservarse mucho tiempo ni para el trasporte. Por lo que hace $a$ la pesca de las sanguijuelas, esta se verifica del modo siguienté: los pescadores se introducen con las piemas des. nudas en el agua habitada por estos anélidos y las inquictan todo lo posible revolviendo el fondo, ó de otro modo; la san. guijuela sale entonces à la superficie del agua y puede cogerse con la mano 6 con una red de mallas muy finas, $\delta$ bien se fijan en las piernas desnudas de los pescadores de donde se retiran con la precaucion necesaria para sus órganos chupadores. Ias que han comenzado à chupar, lo cual no suce-

Toso VII de con frecuencia, deben rechazarse. Cuando se recoge un excesivo número de sanguijuclas, transpórtanse il las regiones donde no existen ó han sido exterminadas, lo cual exige la mayor precaucion.

Las mas de las sanguijuclas que se usan en Alemania pro. ceden de Polonia, de las ironteras de Rusia, de Hungria y de lurquia lil sistema de trasporte reconocido como el mejor consiste en poner un núnero no muy crecido de sanguijuclas en sanquitos de hilo, siempre liumedos, los cuales se colocan en hamacas sujetas en un coche con buenos inuelles y que pueda cerrarse por todos lados. Los traficantes al por inayor de Alemania las envian à sitios no muy distantes, colocando de 60 a 120 individuos en un saquito de lino, que rodeado de musgo se coloca en una cajita con agujeros.

I.ras sanguijuelas que se usan en Europa se distinguen en dos especies principales, con algunas sub-especics y variedades, à saber: la sauguijucla medicinal ó alemana (hirsdo medicinalis), y la oficinal of hungara (hirudo officinalis), pero debe notarse que no se han hallado distintivos anatómicos para establecer diferencia en estas esjecies, y que las variedades de un color se confunden de tal modo, que las supuestas especiesy sub-especies en rigor no forman mas que una sola. I.a variedad llamada livodo medicinalis tiene $\mathrm{cn}$ el vientre manchas negras y á veces toda csia parte ofrece dicho color, hallandose diseminada por casi tocia Luropa, pues se encontró en Alemania, Irancia, Dinamarca, Suecia, Rusia é Inglaterra. La otra mriedad principal, hirudo officiwalis, tiene el vientre de color verde accituna sin manchas, y pertenece á la Furopa meridional. En enorme número se halla esta sanguijuela en los pantanos situados cerca de Esseg en Eslaronia.

Fuera de Europa hay una serie de especies que tambien son propias para el uso medicinal: en Argelia yen Berbe- 
ria se halla el hiruto tractina, que sobre todo en el noroeste de Marruecos se coge con regularidad, exportándose por Cibraltar á Inglaterra y á la Amériga del sur. En las pose. siones francesas del Senegal se usa cl pequeño hirado myso. melis, que segun contrato con los negros se vende en los hospitales. In la India, es decir. en Pondichery, se encuen. tra otra especie, hirudo granuloza: pero tiene el defecto de ser demasiado grande, y muerde de tal modo, que cuesta mucho trabajo atajar la sangre. Tambien la Américia del norte tiene algunas especies propias.

\section{LOS HEMOPIS-HAMOPIS}

Las especies mas ronocidas, entre las sarias que representan este género, són el hemopis sargraijuela (fig. I 65 ) y et hes mopis iorax, llamada vulgarmente sangrijuela de cotiallo 6 sangujiueló negra, especie gue tiene el cuerno menos plano, no denticulado en los bordes, y los dientes mas obtusos, Lambien se caracteriza por su color mas oscuro, casi negro; las fajas longitudinales del tórax no existen; y los costados están orillados por una linea amarilla.

En el norte de Africa estos animales son una terrible plaga para los caballos y lueyes, como lo demuestra el médico frances Giuyon en un detallado informe. En un buey se cn. contraron veintisicte individuos diseminados en la boca, en la cavidad esofngal, en la laringe $y$ en la faringe; horas despues de la muerte del animal estaban aun agarradas chiupando sa sangre é introduciendo la cabeza alternativamente en una de las numerosas heridas que cada, una de las sanguijuelas habia hecho. Ahora bien, aunque no debe tomarse al pié de la letra lo que dice el pueblo al asegurar que seis do estas sanguijuclas bastan para matar un caballo, es sin em. bargo positiso que pueden causarle tormentos horribles.

\section{LOS ALBIONES-ALBIONE}

CARACTERES. - Los anélidos que constituyen este género tienen la boca muy pequeña, colocada en el fondo de la ventosn bucal, hácia el borde inferior; esta rentosa consta de un solo segmento, muy cóncaro y en forma de arcabur. Ias maxilas solo estin representadas por tres puritos salientes poco visibles. Tienen seis ojos colocados trasversalmente detras del borde superior de la ventosa. El cuerpo es cilíndrico, un poco cónico, adelgazado por delante, y se compo. ne de muchos anillos, generalmente erizados de tuberculos. puntas $\delta$ verrugas.

El esótago es largo y muy estrecho; los estómagos media. namente anchos, se distinguen poco y estín reducidos i $\mathrm{um}$ tubo longitudinal, sinnoso en sus bordes y mas ancho por detras, No tienen nas que un intestino ciego bastante ancho, y tan largo como el recto.

Los albiones habitan en el Mediterráneo y en el Océano. El albion marino, el albion terrugoso (fig. 162) y el allsions de los preces, son las especies mas conocidas del género; la última debe su nombre á la particularidad de haberse encontrado en los escualos.

\section{LOS AULACOSTOMOS - Aulacostomum}

CARACTERES. - A menudo se confunden con el heunopis voraz, llamado tambien sanguijucla de los caballos, cl genero y la especic aulacostomum gulo, cuyo cuerpo. verde y negruzco, se adelgaza mucho hácia un lado: que ticne los dientes mas escasos y obusos; y el estómago provisto en la extremidnd de dos estrechas bolsas ciegas.

\section{LOS NEFELIS-NEPHELIS}

CARACTERES.-El habitante mas comun de nuestros estanques y de muchas aguas corrientes cubiertas de cañas y de hojas de rosa acuática, es el nefelis vulgar, sangui. juela de $0^{\circ}, 005$ de longitud, con el cuerpo aplanado y la seric de anillos poco marcada; tiene cuntro pares de ojos y el esórago denticulado. Ya hemos dicho antes que los indivi. duos jóvenes de esta especie de color rojizo trasparente, cmn propios para observar la circulacion de la sangre.

No podemos concluir este capitulo mas oportunamente que con la descripcion de aquellas pequenass sanguijuelas del Ceilan, tan difanadas, de las que Schmarda dice lo si guiente en su obra titulada Viaje al rededor del Globo: A.as continuas molestias quec ocasionan los escarabajos y mosquitos, verdaderas plogias, son poca cosa en comparacion de las que en todas partes sufre el viajero al cruzar hosques y praderas, donde abunda una especie de sanguijucias terres tres, el himedo colanica, de los autores antiguos. Se ocultan en la yerba, debajo de las hojas caidas y de las piedras y hasta en árboles y arbustos; son en extremo ágiles en sus movimientos, y es probable que oliateen su presa ya desde alguna diseancia. Tan luego como divisan un hombre ó un aninal, acuden por tocias partes y precipitanse sobre su pre. sa. A mérudo, apenas se siente que chupan la sangre, pero i las pocas horas se han rellenado de tal modo ņue caen pór si mismas. Los indigenas que nos acompañaron cauterizaban las heridas con cal, que llevaban á prevencion, o bien con su saliva despues de inascar un poco de betel, porque asi equivalia á un caustico. Parecióne natural que esta sanguijuela produjese una fuerte inflamacion, y fácil mente me expliqué la causa de las profundas úlceras que va rios indigenas temian en los piés. Muchos opinan que el jugo de cierto limon (cirnus iuberosites), es buen especifico. Esto podrá ser muy bucno para obligar á las sanguijuelasá soltarsupre sa; pero necesariamente ha de producir en la herida una irrita. cion. Lo mas desagradable es la particularidad de qque esos anćlidos buscan con preferencia la parte en que sus predecesores encontraron buen pasto, porque la piel mas irritada y ardiente bajo la cual se halla la sangre coaguiada, los atrae. Para preservarse de los ataques de estos pequeios, pero terribles encmigos, es de todo punto necesario resguardar sobre todo los piés, poniéndose tambien polainas de cuero 6 medias muy gruesas de lana encima del pantalon, y attindolas por debajo de la rodilla. Esto último nos pareció suficiente y mas cómodo, y siempre llevábamos un par de reserva, porque fácilmente se rompen en la espesura 6 se desgastan con el roce. A menudo encontré docenas de sanguijuclas en la ligadura esforzándose por penetrar. Durante la marcha no surrimos tanto, siendo de notar que el jurimero de la fila es el que menos padece, pues cuando las sanguijuelas han olfatcado una vez su presa se precipitan con mayor voracidad sobre las siguientes. A pesar de toda nuestra precaucion nos caian a menudo en la nuca, en el cabello ó los brazos, porque no solamente viven en la yerba, sino tambien en los ár. boles, de los que se dejan caer sobre los hombres ó animales que pasan

\section{LOS GLEPSINEOS - CLEP- SINEA}

CARACTERES. - Tambien podemos hablar de una segunda familia que habita en nuestras aguas dulces, y cuyas especies se caracterizan por su cuerpo corto y plano que se adclgaza hảcia adelante poco i poco y termina en el disco 
prensil que lleva en los ojos. El esófago, desprovisto de maxilas, puede prolongarse en forma de trampa.

\section{LOS CLEPSINOS-CLEPSINE}

Varias especies del género clepsine se encuentran en las hojas de las plantas acuáticas y' debajo de las picdras: son de color gris amarillento ó blanqquirco, y reconócense en particular porque tan luego como se las coge enroscan su cuerpo, encogiendo tambien un poco sus bordes laterales. Manifies tan mucha solicitud con su cria; llevan los huevos en el vien. tre, y los hijuelos nacidos permanecen mucho tiempo juntos con la madre, agarrindose a ella con el disco posterior. Es un curioso espectáculo ver de dia á quince de estos animali tos sacar la extremidad de su cabeza por debajo de la henzbra como polluelos de la clueca, volviendo a reunirse con ella si se les aleja.

\section{LAS PONTOBDELAS-PONTOB DELLA}

CARACTÉRES. - Un clepsineo es tambien la puntob della muricaka que se distingue por sus discos muy fuertes, por las prominencias de la superficie de su cuerpo y' por su color gris verdoso: agrádale vivir en las rayas. A juzgar por su manera de proceder en cautividad es un animal perezoso y estupipido; su fuerte musculatura le permite mantenerse estirado horixontalmente bastante tiempo, apoyaindose solo en el disco posterior; mas prefiere estar pendiente recoriendo la extremidad de la cabeza como lo liacen las marnotas. Quizh́s no hacemos justicia á esta esprecie al motejarla de perezosa, pues tambien las rayas permanecen de dia casi inmó viles, mientras que durante el crepuisculo muéstranse alegres $y$ activas; de manern que és de suponer que su huésped tiene las mismas costumbres.

\section{LAS MALACOBDELAS-MALACOB. DELLA}

Las sanguijuelas qque regularmente permanccen en el agù libre $y$ solo algunas veces se fijan en vertebrados para chupar su sangre, tienen sus congéneres mas afines en los géneros que como parásitos habitan en la piel de los peces ó tambien en los crustáceos; pero mientras que en las sangui. juelas libres son anillados, en los géneros siguientes la piel es blanda $y$ lisa, sobre todo en las malacobdelas, que como paraisitos viven en algunas conchas.

Para clasinicar las sanguijuclas pur la refacion que guardan con los animales que les sirven de alimemto, se ha de tener en cuentis que algunas solo se albergin algun tiempo en los de sangre caliente y apenas pueden llamarse parásitos; otras no se encuentran sino en la piel de vertebrados de sangre fria; y varias, en fin, viven como parisitos en crusticios y moluscos. Generalmente se observa que el organismo de un animal se relaciona hasta cierto punto con el medio en que habita; y esta proporcion se presenta tambien en grado descendente en los grupos de sanguijuelas $y$ en las clases de animales en yque viven como parásitos.

La malacobdela que termina la serie de las sanguijuehs y que vive en la cavidad de las conchas, particularmente de las especies Venus y Cyprina, se asemcja á un tremotodes del género amphistomum, que se halla en el estómago de nuestros rumiantes, mas bien que á una sanguijucla, y apenas tiene con esta mas caraicter distintivo comun que el intestino con doble abertura. Los otros caractéres, el cuerpo no anillado, etc., nos conducen a los verdaderos ancelidos intestinales del grupo de los tremalodes, cuyo origen no se puede explicar. De estos últimos nos ocuparemos al tratar de la clase de los anćlidos planos.

\section{LOS BRAQUIÓPODOS - BRACHIOPODO}

Este calificativo es errónco y falso, defecto comun entre los nombres empleados en la historia natural, por cuanto debe indicar una particularidad caracteristica del grupo de animales que por él se designa. Antes se partia de la suposicion de que aqui se trataba de moluscos, y como entre estos figuraba la clase de los cefalópodos y la de los gasterónodos, buscábase un nombre anȧlogo que expresara la particularidad de la nueva division, comparada con las anteriores: pero sus especies no tienen brazos, ni piés que pudieran equipararse con los órganos de movimiento, ni tampoco órganos prensiles $y$ dispuestos al rededor de la boca como en los ce. falópodos, ni piés que pudieran compararse a la base del caracol ó el pié acunado de las conchas. Los naturnlistas an. teriores les atribujeron una cualidad que no existe y en la cual creian, porque otra analogin, solo aparente, les indujo á ello. Designose con el nombre de braquiópodos à un grupo de animales mucho mas numerosos en los terrenos fósiles que en nuestros paises, grupo cuyas especies, por tener una concha bipartida parecen sumamente alines de los moluscos de concha, tanto que hasta los últimos tiempos se los consideraba como una sola subdivision que tenia la importancia de un órden de aquella clase. En dos úrganos enroscados en forma de espiral, situados junto a la abertura bucal, creiase ver los úrganos que sirven para coger el alimento, recordando quizás los cirripedos que Cuvicr consideraba entonces tambien como moluscos. Fsta epuivocacion cra tanto mas fa. cil, cuanto que hacia unos veinte años que los animales no se obscrvaban casi nunca vivos: hasta nuestrn época no se demostró que los supuestos brazos prensiles no eran otra cosa sino las branquias. Y tanto mas impropio era el nombre apli. cado por la supuesta afinidad con los moluscos, cuanto que las averiguaciones del americano Morse $y$ del ruso Kowa. lewsky, no publicadas basta $1 \delta_{73}$ y $18^{3} 4$, confirmaron la opinion emitida ya una ver por el ingenioso Stecnstrup, de que los braquiópodos son anélidos trasformados, lo cual se demostró por-la anatomía y la historia del desarrollo. Resulta de estas lineas que poco tendremos que decir de la actividad y de las costumbres de estos séres, los tịos mas enojosus del mundo animado.

Por fortuna, bajo cierto punto de vista son dignos de nuestra consideracion. Fis preciso comprender en primer lugar su estructura y condiciones, y cuando sepamos esto veremos que los braquiópodos son el principio y simbolo de la estabilidad. En su extremado quictismo, desde las mas remotas épocas de la creacion animal han estado sometidos al la accion de las olas y al peso del mar sin cambiar esencialmente de forma. La época de la Moreseencia de la clase ha pasado hace mucho, pero en otro tiempo, no solo las especics sino tambien el número de individuos abundaban de tal manera, que en ciertos puntos formábanse gruesas capas de roca con sus aglomeraciones, siendo su existencia para el geólogo un medio indispensable para determinar el órden en que se siguen las mas antiguas formaciones de montañas. Imporian. tes deducciones pueden hacerse al observar la amalogia de los braquioppodos actuales con sus antecesores de los mares primitivos; pero su verdadero origen, su verdadern afinidad continúan ignorados hasta nuestros dias, y solo el hecho de su cxistencia en perfecto desarrollo en las capas mas antiguas de los terrenos induce à suponer que muestra llamada fauna primitiva, es decir la fauma que hasta ahora hemos conside. 
rado como tal, ha teniclo una serie tan larga y antigua de an. tecesures como la que se ha observado en nuestros tiempos.

Tambien el profano en la ciencia, al observar superficialmente estos animales se inclinaria a considerarles como afines de las conchas; pero si se examinan con mas detencion reconócense las diferencias mas importantes, tanto en la concha como en el animal, sin que los tipos intermediarios hagan presumir que una clase tiene su origen en la otra. En cambio la comparacion con los anélidos anillados hecha por Morse ha sido muy fructuosa, sobre todo porque nos ayuda i comprender tales resultados. Fin los braquiópodos no es el género de vida de los individuos lo que mas interesa; sino la historia del desarrollo de toda la clase, que nos da una idea del de los individuos, en particular bajo el punto de vista científico. De esto hablaremos mas adelante.

\section{LOS TEREBRATÚLIDOS TEREBRATULIDA}

Comenzamos nuestra descripcion con la fanilia mas dise. minada en el mundo actual que es la de los terebratúlidus En todos los géneros la desigualdad de las dos mitades de la concha llama desde luego nuestra ateucion; la una es ventruda, mas grande que la otra, y está perforada en el pico; por el agujero sale un tallo corto yervioso con que el animal se agarra á los objetos submarinos. Si cn las conchns abandonadas por el animal se trata de separar las dos partes, se verá que están reunidas cerca del pico, prorque un par de dientes de la mas grande encaja en unos hoyós de la menor, observándose además que no pueden separarse como las conchas de los moluscos, aunque no tengati el ligamento clástico de estos. De la posicion del animal y de la colocacion de sus partes resulta que la mitad mas grande, que es ventruda, corresponde al abdómen, mientras que la otra debe considerarse como cubierta dorsal. Desde ln region en que esta última recibe los dientes de la otra mitad parte una cspecie de lazo de una sustancia calcáren, que se dirige hácin el borde opuesto y libre. En el desarrollo $y$ la forma de csta parte de la concia se han hallado caracteres fundaunentales para determinar las familias $\mathrm{y}$ establecer sus subdivisiones. En los restos bien conservados de las conchas de los braquiópodós fósiles reconócense tambien perfectamente la forma y estructura que acabamos de indicar, pudiendo hacerse deducciones res. pecto á la naturaleza de los importantes órganos i que la clase debió su nombre cientifico. Las dos partes de la concha se abren y cierran por medio de músculos, que exigen una descripcion demasiado minuciosa para que podamos ocupar. nos aqui de ellos. Para la descripcion general tomare por tipo el género Thecidium.

La parte calcárea sirve de apoyo à dos apéndices labinles o brazos enroscados en forma de espiral, que presentan largas franjas; estos brazos ocupan la mayor parte de la concha, saliendo de la boca, debajo de la cual están reunidos por una especie de juente membranoso igualmente franjeado. El talio retorcido de los brazos solo puede moverse un poco, $y$ tambien las franjas, que son bastante rigidas, pero todas las partes están cruzadas de canales, por lo cual son propios para servir de brganos respiratorios. Se ha demostrado que dichos brazos no pueden considerarse como tales, pues solo las es. pecies de la familia de los rinconélidos pueden sacarlos de la concha, y no sirven para coger el alimento; por un lado están cubiertos de pelitos, como la mayor parte de tales órganos respiratorios; y gracias a la corriente de agun, que remueven, el alimento llega hasta la abertura bucal. El intestino es cor. to, con la extremidad ciega.
Las partes de que hasta ahora hemos tratado, $y$ que al abrir la concha son las que mas llaman la atencion, están rodeadas de dos délgadas hojas del manto y se estrechan mucho contra las conchas, separándolas. En unos ensanchamientos cóncavos de estas hnjas hay tambien órganos genitales de la mayor sencillez. Los sexos se distinguen, reconociéndose en algunos casos por la forma diferente de la concha.

Entre los órganos secundarios se cuentan dos tubos membranosos, brillantes en su interior, que reciben en su extremidad libre y abierta los huevos para conducirlos hácia afuera. El macho tiene tambien los correspondientes conductos. Hacemos mencion de este minucioso detalle anatómico porque de la comparacion de los cios embudos con los lla. mados organos segmentales de los anélidos se ha obtenido una importante prueba de la afinidad de ambos grupos.

Iista añnidad se confirma esencialmente tambien por la historia y el desarrollo de la metamorfósis de los braquíbpodos, y de consiguiente, antes de dar á conocer el àrea de dispersion y el género de vida oculto de algunas especies, trataremos mas de cerca estos puntos.

Hasta hace muy poco tiempo solo teniamos noticins minuciosas, solbre un braquiopodo del Meditcráneo, el thecidium mediterraneum, descrito mas abajo detalladamente, pero estas noticias, debidas al zoólogo jarisiense Iacaze-Duthiers, no daban i conocer toda la marcha del desarrollo. Los luevos que deben producir penetran en una bolsa formada por el lóbulo inferior del manto, á la cual llegan tambien las dos franjas inas próximás de los brazos, que en su extremidad se dilatan, formando dos protuberancias alrededor de las ćuales se agrupan los huevos, y con las que cada embrion se enlaza por medio de un corto ligamento. Despues de tomar la for. ina de un bollo. cl embrion adquiere el aspecto de un corto anillado. Seguib observó Lacaze-Duthiers, el apéndice supe. rior es el tallo que sale de la nuca, y por inedio del cual el pequeño sét se fija en las franjas. Ia parte anterior, mas pequena, ofrece el aspecto de una cabeza, y ticne cuatro puntos oculares y un hoyo, que es la futura boca. Dos segmentos mas gruesos forman el centro del cuerpo y m apén. dice pequeño la extremidad del mismo; todias estas partes están cubiertas de pelitos.

Morse y Kowalewsky han demostrado cómo se verifica la metamorfósis. La parte posterior sirve para fijarse; la cabeza y el anillo, en forma de collar, bajan hasta una prominencia formada por los segmentos siguientes; esta prominencia crece mas y mas hácia arriba y forma los dos lóbulos comparados tantas veces con el manto membranoso de las conchas, $y$ los cuales producen la secrecion. El individuo jóven, recogiéndose en si mismo, por decirlo así, se despide de la vida libre para entregarse, bajo su extraña forma, a una vida de ernitaño. Kowalewsky, que hizo sus observaciones en el genero argiope, dice que las larvas librés, tripartidas, tienen en vez de la cabeza y del segmento collar, como se ve en el thesidium, una especie de seta cubierta de pelitos; la parte central, y al nismo tiempo la mas grande del cuerpo, tiene dos missculos que mas tarde bajan hácia el tallo; el repliegue memumnoso circular, dirigido hácia alajo con los hacecillos de agujas salientes, no presenta aun el menor indicio de que mas tarde la extremidad posterior, sencillamente redondea. da, se trasformarí en tallo. Fsta larva no solamente puede compararse con la de un quetópodo sino que lo es efectivamente; pero sufre una metamorfósis retrógrada; el animal se fija por medio del tallo, y la region nembranosa del seg. mento se vuelve en parte para convertirse, en la cubierta que en los moluscos constituye el manto, desapareciendo la seta de la cabeza.

IEn el último periodo del desarrollo nada recuerda ya un 
anillado, pues la parte posterior se trasforma en tallo, con el actual y antigua y de sus modestas manifestaciones vitales, que el animal se fija para siempre; y la cubierta bipartida sirve para proteger al cuerpo, que por lo demás queda indefenso contra peligrosos intrusos.

\section{LAS TEREBRATULAS -TEREBRATULA}

Para que el lector sepa que son los braquiopodos, comspletamente desconocidos de los profanos en la ciencia, 10maremos como punto de partida la familia mas diseminada del globo, que es la de los terebratulidos. Conocidas las relaciones, muy particulares, entre ellos y los anillados verdaderos, y despues de explicar su estructura, podremos ocuparnos un poco mas detalladamente de suárea de dispersion à cuyo efecto nos serviremos tambien de los representantes de algunas otms familins. En mi viaje à Noruega, en $x \$_{50}$, ture ocasion de adquirir individuos vivos sacados con la red del fondo del mar.

El Oexfjord, situado a pocas leguas mas al sur de Hammerfest, resultó ser muy rico en terehrótulas iltreas yo terebrafulinus caput serpentis (fig. 164). Mis observaciones, publicadas poco despues, se han completado mas tarde con las noticias de Barett sobre el genero de vida de esta última especie. Esta especie, dice, se ve mas á menudo que cualquiera otra y deja ver tambien mas los cirros; se encontró en todos los puntos de la costa noruega, aunque en reducido nimero, a la profundidad de 30 i 150 brazas, y fija con frecuencia en una especie de coral llamada oculina. L Los cirros de la

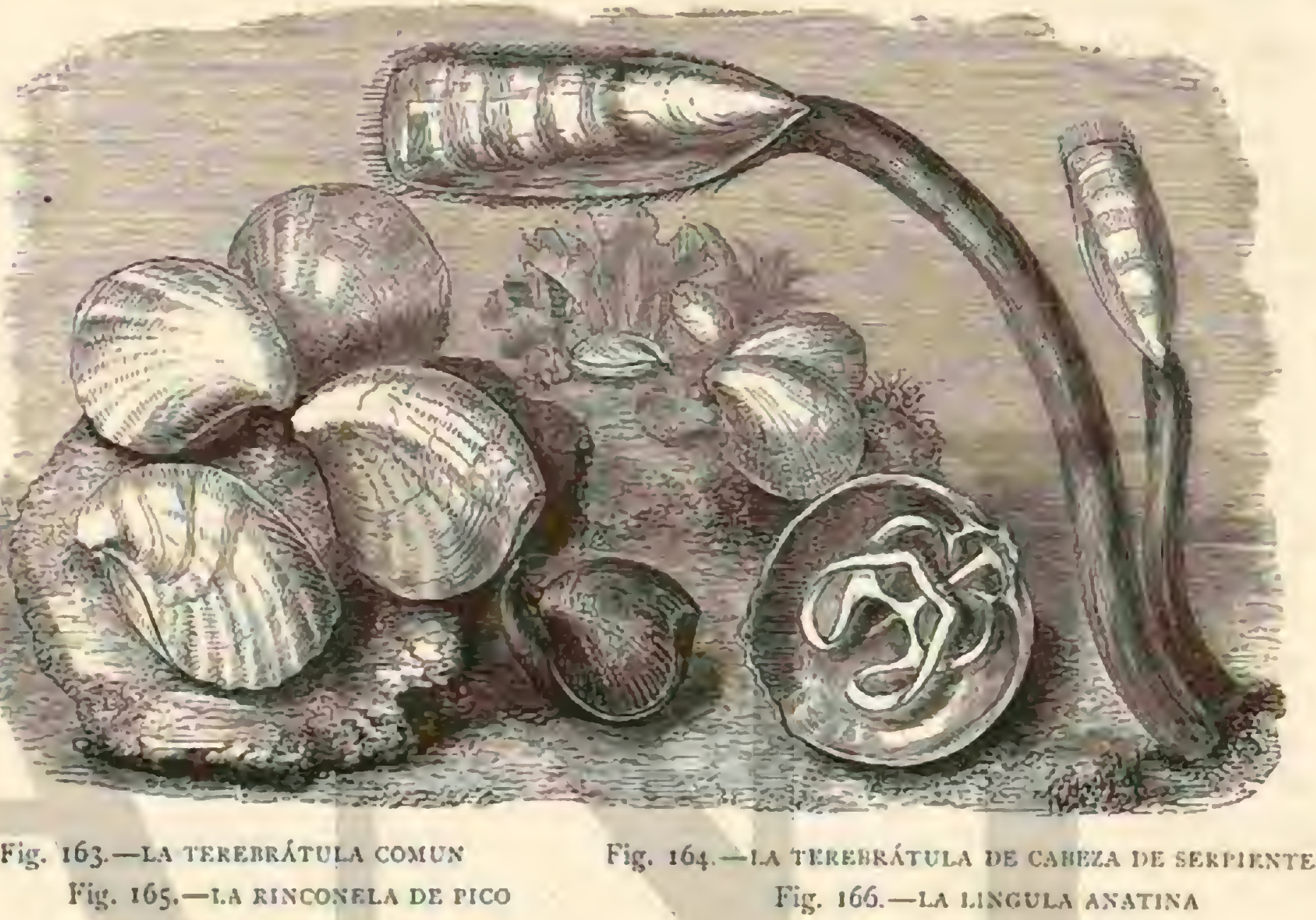

parte superior de los brazos son mas cortos que los de la inferior: estos animales estaban en continuo movimiento, y a menudo vi que conducian pequeñas particulas a la canal que tienen en la base. Cuando se les ponia en una vasija con agua de mar abrian poco á poco su concha: Los individuos que habian quedado fijos en otros objetos manifestaban una singular disposicion para moverse sobre los músculos de su tallo. Los individuos sacados con esta parte podian moverse en todos sentidos sin serles necesario cerrar la concha. Al tocar algunos de los cirros retirábanse en seguida y la concha se cerraba para abrirse poco despues Cinndo los brazos están recogidos, los cirros se encorvan hácia adentro; pero al abrirse la concha se ve como se levantan y enderezan; á menudo, sin embargo, observé que el animal antes de abrir la concha saca algunos cirros moviéndolos en todas direcciones cual si quisiera averiguar si amenazaba algun peligro. Solo en una ocasion distingui una corriente que penetraba en medio de las dos scries de cirros. Yo habia intenthdo-asegurarme de la existencia de corrientes, colocando con un pincel pequeñas cantidades de añil en el agua que rodeaba al animal; tres veces se recogio con violencia y en. tonces vi algunas particulas de aniil pasar por la base de los cirros en direccion á la boca. Inútil parece repetir que es. tas corrientes se producen por los invisibles pelitos.

Barett dice tambien lo siguiente de otro terebratulido de la costa septentrional, Woldhecinia cranium. \& Le halle va- rias veces entre las islas de Vigton y el Cabo Norte, en las profundidades de 25 \& 150 brazas, fijo en piedras y otros objetos. Pertencece á los terebratulidos; y los apéndices de la boca están fijos en este esqueleto calcáreo de tal modo que el animal solo puede mover los cabos enroscados en forma de espiral. Se ha supuesto que estas espirales unidas pueden desenroscarse como la trompa de una mariposa, pero nunca he observado tal cosa. Esta especie es mas vivaz. que la terburatulina cafut serpentis; se mueve a menudo en el talío y cxcitase mas fácilmente. Los cirros no sobresalen del borde de la concha antigua, y se encorvan hàcia atras cuando esta se cierra.

Fn el limite de esta familia figura el género thecidium, caracterizado por el desarrollo muy particular de la armazon calcirca. En el mundo actual solo tiene un representante, el theidium mediterraneum, que I acaze-Duthiers ha descrito en una de excelentes monografilas. La cubierta dorsal cons. tituje para la abdominat, mucho mas grande, una tapa casi plana, de la cual no se destaca el ligamento libremente, sino que se mantiene reunido con clla por una red calcáren. El citado nutor dice lo siguiente.

a La concha del thecidium se fija en cuerpos submarinos: encontré muchisimas en objetos que las redes de los pesca. dores de coral sacaban del fordo del mar, en el espacio comprendido descle el golfo de Bona hasta cerca ciel cabo Rosa. La proíndidad a que se pescaba era de to à jo bra- 
2as. Como ya habia recogido muchas muestras para el estudio de la fauna animal de las rocas de coral de Córcega, pues proponiame extender mis observaciones á las costas de Argelia, a la isla de Cerdeña y a las Baleares, sorprendióme el reducido múmero de terebratulas, que formaba un contraste con las grandes moles de la especie thecidium. A reces encontré en una piedra, del tamaño de dos puños, de zo á $3^{\circ}$ individuos. Muy fácil es observar los animales vivos; yo los conservé asi mes y medio, pero mudando diariamente el agua en que se hallaban. Es de todo punto necesario, no obstante, desprenderlos de los cuerpos en que se han fijado, porque están habitados por toda clase de animaluchos: esponjas, anćlidos, pequeños crustáceos, etc, que pronto strcumben, $y$ ensuciando el agra del acurio, ocisionan tambien la muerte de los tecidios.

4 En los primeros dias despues de pescados, los tecidios se abrian mucho en los grandes barriles donde se hallaban con las picdras; pero despues de aislarlos y ponerlos en vasijas pequeñas, no se abrian ya tanto. Ia pequeña concha dorsal se levainta hasta formar un ángulo recto con la ventml, pero el mas ligero movimiento basta para qué se cierre con la rapider del rajo. Los tecidios son muy sensibles a la luz. Un dia vi cri una grande vasija varios de estos animales con la concha abierta, y accrquéme con mucha precaucion; pero como mi cabeza produjese sombra al inclinarme para ver meior, cerriaronse al punto los individuos tocados por aquella In un tecidio ablerto se distinguen, gracias il ha mucha separacion de lis conchas, todas las partes, viéndose muy bien varias franjas y los brazos. I a superficic interior de la concha e:I que se npoya el manto es tan blanca, y este último tan trasparente, que los ligamentos calcireos y las prominen. cias de las cunchas se divisan perfectamente sin que se dis. tinga el manto. Esto me sorprendió de tal modo, que hube de preguntarme si habia en efecto una cubiertà blanda sobre las partes calcáreas que reia

- La concha es rasas veces blanca y lisa exteriormente, pues por lo regular esta cubierta de plantas ó animales; mas parece natural que las conchas lijadas grarden la misma proporcion respecto al desarfollo de parásitos que cualquiera otro objeto que á estos sirva de base Sin embargo, no solo el exterior estå ocupado por tales séres, sino que las conchas estản perforadas en todos sentidos por algas parísitas que a veces comunican à la concha un aspecto verdoso. \# Esta última observacion de Lacaze-Duthiers deberia rectificarse, pues no las algas, simo mas bien una especie de esponjas del género iña, penetra en las conchas de los tecidios lo mismo que en la de los moluscos.

la familia de los terebratúlidos no se ha encontrado en las capas mas antiguas, es decir, las paleozóicas, pero si en las llamadas devónicas. Puede considerarse como efecto de una extraña apatia, ó si se quiere de resistencia vital, que algunos géneros por ejemplo el tereluatula y el waldheimia, se hayan conservado en todas las formaciones sin cambiar nunca, no como unicos testigos de la primitiva creacion de su clase, sino como representantes de otras cuatro familins. Sin embargo, mientras que estas últimas se extinguen tanto mas fácilmente, cuanto mas jóven es la formacion, segun dice el excelente conocedor de la clase, Suess, los géneros rhyncho. mella, carmia, discina y lingula figuran como únicos represertantes de sus familias ell todos los ticmpos, como árboles despojados de sus hojas. En la familia de los terebratulidos ha sucedido lo contrario; su árbol ha dado retonos hasta en los últimos periodos del mundo, y cuenta actualmente diez géneros, cuya àrea de dispersion se extiende por todos los mares.

Habitan con preferencia las grandes profundidades, condi- cion comun á todos los braquiópodos cuyas conchas son muy calcáreas, gruesas y no trasparentes.

\section{LOS RINCONÉLIDOS 一RINCHONELID压}

Esta familin, cuyo origen es aun mas antiguo que el de la anterior, no esti actualmente representada mas que por cuatro especies: debe su nombre al género mas importante, Rhymrhonella, que pertenece á los organismos mas antiguos, pues desde el periodo silúrico se propaga por todis las formaciones. La especic rhyuchonella psittacea, que aun hoy existe, presenta los apéndices carncterísticos mas marcados, en forma de pico, debajo del cual se encuentra la abertura para el tallo. Las dos partes de la concha están reunidas del mismo modo que en los terebratulidos; el armazon, empero, solo se compone de dos hojitas, cortas, estrechas y corras, hijas en la region del centro. Barett hizo en su viaje á Es. candinavia algunas observaciones sobre el área de dispersion y el género de vida de la citada especie. \&Se encuentra vi. $\mathrm{ra}$, dice, aunque no con gran frecuencia, en las regiones mas septentrionales, sobrétodo cerca de Tromsoe, á una profundidad de 70 a 150 brazas; la concha sin el animal se ha recogido cerca de Hammerfest en el cieno. Me parece muy dificil observar esta especie, porque sensible á todas las im. presiones, cierra suiconcha al hacer el mas minimo movimiento. Los brazos ensanchan sus espirales bastante para que las franjas lleguen hasta el borde de la concha. Yo he observado esta especie, d menudo abiern, pero nunca he visto que sus brazos se desenroscaran.

\section{LOS CRANIDOS-CRANIIDE}

Si nós ocupamos ahora del género crania, no lo hacemos porcué su actividad vital ofrezca interés, sinó porque su distribucion geológica, pasada y actual, lo exigen asi, y por. que solo á causa de sus diferencias podria formar una familia Su concha se fija en cuerpos submarinos por la parte ventral; la dorsal tiene la forma de tapa, y ambas están unidas solo por medio de músculos. Sus brazos carnosos, en fi. gura de espiral, solo se apoyan en un apéndice en forma de nariz, en el centro de la concha. Ia mas conocida de las cuatro especies cxistentes es la cranias anómala de nuestros inares septentrionales, que casi- sieminre se encuentra asocia. da con la teribratula caput serpentis, aunque no la sigue á la América del Norte ni al Mediterráneo. Aun no se la conoce en el estado fósil, y Suess ha supuesto por lo tanto, que su origen data de una éfoca mas reciente, por cuanto los feno. memos que permiticrón á la terebratula caput serpentis llegar à la América del Norte, y que parecen haber consistiđo en la formacion de una cordillera de islas que juso en comunicacion este continente con el nucstro, indican que la especie no existió antes. En cambio su presencia en el golfo de Vigo revela que, cuando menos en parte, presenció la lenta retirnda de la fauna septentrional de la Europa central.

Los cranios de los periodos anteriores no se hallan nunca en considerable número, pero su série se continua sin inter. rupcion desde el periodo silúrico. Nuestros museos conticnen aun poco material para hacer evidentes los trámites de estas especies, pero precisamente en el terreno de la averi. guacion comparativa, el porvenir exije una tarea que promete justo premio. Hasta joodemos añadir que ya se han inaugurado los primeros trabajos, porque uno de nuestros naturalistas modernos, Kayser, encontró on $1 \$ 7$ I en sus averiguaciones sobre los braquiórinodos de las capas devónicas del 
Eifel una confirmacion continua del punto principal de la doctrina del oxigen $y$ de la variabilichad de ias especies.

Los braquiópodos de que hasta ahora hemos tratado son propios, asi como los otros de concha calcárea, con pocas excepciones, de las profundidades del mar; pero no sucede asi con otros dos grupos, los lingulidos y los discinidos, cuyas conchas son de naturaleza córnea, y que habitan con preferencia en gran mimero las orillas de los mares de las regiones mas cálidas.

\section{LOS LINGULIDOS-LIN- GULID死}

El género mas conocido de esta fanilia es el fingula, cuya concha, delgada y córnea, es casi clística y de color verdoso; sus partes no encajan una en otra; son casi iguales $y$ tampoco presentan en su interior apófisis para apoyar los brazos, gruesos y carnosos, en forma de espirales. Suess dice lo siguiente al hablar del área de dispersion de las eśpecies de lingula: "Este género se halla, asi como el discine, en las capas fósiles mas antiguas, y en número bastante crecido de especies. Desde el periodo primitivo se ha conservado en todas las formaciones hasta la actualidad sin presentar en cualquier época un maximo notable. - Hoy dia no existe nin. guna especie de lingula en los mares europeos, pero en las costas americanas se encuentra la lingula promidata en la que Morse ha hecho observaciones-interesantes. Su manto tiene dos veces la longitud del cuerpo ! no se fija: es movible, como gusano, y tiene la facultad propia de ciertos aneli. dos, es decir, la de fabricar tubos de arena. Tanto en estado natural como en la cautividad, cuando se les proporciona arena, practican cavidades, à las cuales se retiran, formando con las cerdas del borde del manto una especie de fino harnero, para impedir que con el agua penetren gramos de arena en las branquias. Los tubos sobrepuestos ofrecen el aspecto de una terebela.

Morse npina que la linguha pyramialuk no vive mas de un ano. Varios centenares de individuos recogidos en junio 6 julio cran todos de igual tamano y sus conchas presentaban igual grado de frescum, por lo que fué natural suponer q̨ue todos tenian la misma cdad. Los incividuos recogidos y conservados en verano murieron à fines de setiembre, presentando fenémenos semejantes á los quue, segun las averigunciones de Williams, se manificstan en la muere natural de ciertos anillados (Nais arenicola).

De la sencillez de la concha de las especies de liugula azue mejor pueden compararse con las formas cartilaginosas de. ciertas branquias, y de la presencia del género, en las mas antiguas capas que contienen braquiópodos fósiles, deducimos que son las mas alines de sus antecesores vermiformes. Al mismo tiempo debemos suponer un periodo incalculable durante el cual se verificó lo trasformacion que nos revela el desarrollo de las formas actuales. Precisamente en el hecho de que esta irasformacion se efectuó ya en las épocas primitivas mas remotas, cesando solo despues de sufrir una metamorfósis retrógada, debemos buscar la causa de la persistencia de la clinse dentro de sus límites, persistencin que no tiene ejemplo. De este modó la trasformacion de las es. pecies, sin adquisicion de órganos nuevos y esenciales, ofrece todo el caracter de un desarrollo posible, segun lo lian demostrado los estudios de Kayser, y como lo confirmarán las observaciones que siguen haciéndose en este sentido.

De la comparacion y condiciones de la residencia de los braquiópodos actuales y de la naturaleza de las capas donde se hallan los tipos fósiles de esta clase, Suess- ha hecho deducciones muy interesantes y probables sobre la profundidad $y$ las condiciones de las orillas de los mares primitivos. La presencia de los lingúlidos y discinidos, su asociacion y el material que los encierra, demostratuan marcadamente que sicmpre se han mantenido à poca profundidad. De esta circunstancia puede colegirse la existencia de continentes, ó cuando menos grandes grupos de islas, con orillas arenosas y llanas, ya antes del periodo carbonifero. In supasicion de que existian profundos y anchos mares se aviene; no solo con la creencia general apoyada por muchas observaciones geoló. gicas y paleontológicas, sino que se demuestra tambien particularmente por la distribucion de braquiópodos íbsiles de concha calcárea. Recordamos ademas quue á las deducciones anteriores precedieron otras análogas respecto á la naturalcza del mundo primitivo, hechas en vista de la estructura y de las condiciones de afinidad de los extraños crustáccos llamados trilobites (pág. 57).

\section{ROTÍFEROS}

Los crustảceos no: han conducido á regiones dé la fauna animal inferior, donde a la simple vista solo se pueden reconocer los contornos exteriores de los diversos seres con alguna exactitud. En el mismo caso nos encontramos respecto á una numerosa clase de animales, cuya existencia, precisamente $a$ causa de su pequeñez y de los sitios que habitan, está relacionada del modo mas intimo con la de los infusorios, ocupando una posicion muy singular en el mundo actual de los séres vivientes. Un célebre autor aleman, Cristiano Godofredo Ehrenberg, nos ha demostrado en su obra elos infuso. rios coino organismos perfectos:, que descie la invencion del microscopio, ya por mera curiosidad para distraer la vista y el ánimo, ó bien por aficion á la ciencia, la gente se familiarizaba poco á poco con la vida de lo infinitamente pequeño hasta que él mismo, el grande naturalista, zuvo la suerte de arrojar una nueva luz sobre ese mundo microscópico, reciucirle á un sistema y separar los rotiferos, como clase independiente, de los verdaderos infusorios. No agui, sino al hablar de estos últimos, deberenos dar i conocer algunos puntos de la historia del descubrimiento, de la cual resulta que ya en i68o Lecuwenhock, el fabricante de anteojos de Delit, vió algunas formas de rotiferos y los describió muy bien.

Los rotíferos, cuyas especies mas grandes alcanzan una longitud de medio milimetro, $\delta$ poco mas, tienen, cosi sin escepcion, un cuerpo trasparente, en el que pueden observarse mientms vivo, hasta las partes mas internas de los órganos. I.os tegunentos de la piel tienen tal solidez, que su eximen bajo el microscopio no ofrece ninguna dificultad, con tal que el observador sea un poco hábil. Ya he dicho antes que la observacion de muchos peçuenos crustáceos, por ejemplo de los cladoceros nos ofrecen el espectáculo mas curioso, $y$ anadiré que la mayor parte de los rotiferos interesan por el mismo concepto cn igual grado L.a forma y estructura tienen sin embargo un tipo tan particular, que nuestm descripcion no satisiaria al lector que no pueda compamarlas con algo conocicio, hasta que un naturalista le presente uno de estos séres graciosos y vivaces bajo cl cristal de un microscopio de trescientas veces de aumento. Los rotiferos ofrecen con toda la variedad de formas exteriores tal semejanza en la estructura, que al conocer uno se conocen todos. El tipo del género es el rotifero amarillo (fig. 167 ).

\section{LOS NOTEIDOS-NOTEIDE}

Consideremos uno de los noteidos 6 rotiferos escudiformes, el noteus quadricornis, en el qque los tegumentos que ro- 
dean la parte del cuerpo han adquirido la forma de una coraza. En esta liltima se observan numcrosas diminutas prominencias, $y$ hay moivo para creer que tanto los tegumentos de la piel en forma de coraza, como los blandos, se componen de quitina, esa sustancia caracteristicá de los insectos. La corrza del rotifero qque nos sirve de modelo está en su parte anterior graciosamente escotada y provista de apéndices en forma de cuernos, pudiencio ocultarse debajo de ella la parte anterior del cuerpo, cubierta de piel blanda. Cuando nada $y$ come, el animal despliega su órgano rotiforme. Dos lóbulos carnosos y retractilis por el juego de los músculos presentan en su borde libre una serie de delicadas pestañas que pue. den ponerse en urovimiento á voluntad del animal, yque en su conjunto parecen en muchos rotiferos dos ruedas que girasen rapidamente sobre su cje.

Este fenomeno; que ha dado nombre a la clasc, es para todo aquel que le ve por primera re? tan sorprendente, que no podenos extrañar que hasta los últimos tiempos se considerase casi como un milagro; y aun en $18 I_{2}$ hịciéronse suposiciones sobre si seria un verdadero moviniento rotatorio. Se ha buscado una serie de explicaciones para este fenómeno, comparindolc entre otros con el juguete óptico que consiste en hacer pasar por una estrecháa abetura una série de figuritas en varias posiciones, lo cual produce el mismo efecto que si se movicra una sola. Eirenberg dice a Cada pestanal gira sencillamente en su hase como el brazo de un hombre en su articulacion, deseribiendo de este modo con sit punta un circulo; $y$ atendido que todas funcionan a un tiempo, producese en aquél una curiosa actividad; porque las pestañas se aproximan y alejan alternativamente, y $\mathrm{cl}$ movimiento aseméjase al de una ruedn, tan luego como todas las pestanas giran en igual direccion. Sin duda se trata de éfectos de óptica muy rápidamente seguidios, de tal modo que producen el efecto de un solo movimiento continuo. En el Notens observamos en medio de los dos grandes glóbulos de ruedas un cono cubierto tambien de pestañas. El órgano rotifero presenta numerosas mriaciones en 54 desarrollo; pero la forma mas diferente seri sin duda la de la Jlosendaria ormata.

Gracias al movimiento de los órganos rotatorios, estos seres nadan con suma gracia, formando um ligeto remolino en figura de espiral. Al mismo tiempo las pestañas del embudo conducen a la boca del diminuto sér el alimento, sobre todo cuando el rotífero se ha fijado en algun sitio pror medio de las tenazas que tiene en su extremidad posterior. Si entonces se echa en la gota que conticne el rotifero, colocada en el objetivo del uicroscopio, una imateria colorante ligeramente distribuida, como por ejemplo añil ó carmin, se putede obscrvar el rapido movimiento de las pestauns y la aglomeracion del alimento delante de la boca.

Los rotiferos están provistos de un par de maxilas: las del woteus tienen poco mas ó menos la forma de manos; pero en otros muchos individuos aseméjanse à una tenaza punti. aguda; en todos los géneros afectau una forma tan determi. mada, que consituyen distintivos no menos caracteristicos que los dientes de los máníferos, pudiendo deducirse tam. bien por ellos el género de vida del animal. Acuérdome aun recibió de aplicado discipulo del profesor Ehrenberg, iste recibió de punto muy lejamo una botellita con agta, en la cual debia haber un rotifero; la persona que lo habia enviado descaba saber de que especie ern. A pesar de lo mucho que se observó con el microscopio, no se pudo descubrir nada: aunque fue enviado á gran velocidad, ya habia muerto sin duda "Sin enbargo, las maxilas deben existir, aunque lo demás del cuerpo no exista ya , decia mi profesor; y en efec. to, cuando se hubo examinado el agua cuidadosamente, en- contratronse en la última gotita los órganos buscados, que permitian la segura clasificacion de la especie.

En el centro del Noteus hay un intestino ondulado de bas. tante desarrollo. En todos los rotiferos puede verse el interior del estómago y observarse cómo el alimento recogido está en continuo movimiento circular, gracias a las pestanias de la pared intestinal, cuyo movimiento sustituye al peristál. tico de otros animales. Dos apéndices en forma de alas, que se insertan en la parte superior del intestino, pueden compa. rarse con las glándulas salivales. Ningun rotfícro tiene un sistema vascular independiente, ni tampoco un órgano en forma de corazon como existe en todos los artrópodos. El liquido de la sangre se halla libre en la cavidad abdominal que rodea los intestinos, y no se concentra, á causa del ağua recogida por el animal. A menudo se observan movimientos convulsiros en los rotiferos, que disminuyen considerable. mente la circunferencia de su cuerpo. Esio no puede verificarse de otro modo que por la expulsion de una gran parte del liquido contenicio en el cuerpo, en cuyo lugir penetra probablemente agua por una abertura de la nuca cuando cl cuerpo vuelye a dilatarse. Por extraña que parezca esta difusion de la sangre, obsérvase no obstante una cosa análoga en otros séres inferióres, por ejemplo en los pólipos, $y$ debe consicierarse como un hecho. Otro retroceso regular de la sangre se verifica por dos canales sinuosos, los cuales desembo. can en una vejiga que de vez en cuando se vacia.

Nuestro notens tiene un ovario muy desarrollado. Durante largo tiempo consideróse a los rotiferos como hernafroditas, porque no se encontraban órganos genitales del macho: pero hl fin resultó que de casi todas las especies descritas solo se habian visto las hembras, y que los machos, tan raros, ymas escasos aun que en muchos crustáceos inferiores, difieren de aquellas del modo mas extraño por su estructum. En todos se observa que el intestino csta atrofiado en parte o del todo, impidiendó a cstos séres comer; de modo que representan en general un papel muy subordinado; segun parece, las hembras los toleran muy corto tiempo, y despues ya no se les vuclve à ver.

\section{LOS HIDATÍNIDOS HYDATIN尼A}

A la familia anterior, cuyns especies se distinguen por tener el pié mas largo anillado, provisto de un estilo en la extremidad, sigue la de los hidatinidos, que carecen de escudo y tienen el pié corto. La especie nas comun, hydafina scusa, se halla con frecuencia por millunes de individuos en aguas estancâdas y en depósitos siluados al aire libre. Ehrenberg ha hecho varias observaciones sobre la estructura complicadn de estos séres microscópicos.

En pequeños tubos cilindricos de cristal, dice el citado autor, del grueso de un cañon de pluma, se pucden observar muy bien, a simple vista. Si tienen alimento depositan pronto sus huevos en el fondo de! agua como es fácil ver con una buena lente, ó con el microscopio, en el tubo cilindrico de cristal. Con la punta de una pluma dispuesta en forma de pincel se pueden sacar para pronerlos en un vidrio plano $y$ observarlos al descubierto. Al cabo de dos ó tres dias nótase un gran aumento en el numero de individuos: y si se fija la atencion en estos diminutos séres con interés, no se puede menos de réconocer en ellos la inteligencia, el librealbedrio, la facultad de darse cuenta de los lugares y cierta sociabilidad. Se podrá llamar a estos fenómenos instinto ó darles otro nombre; pero de todos modos es una actividad del espiritu que solo por vano orgullo estimamos en menos de lo que vale 
realmente. Debemos aijadir aqui, para completar nuestras noticias anteriores sobre la estructura del notcus, que en todos los grandes rotiferos se ha descubierto en la region del esóiago y de la nuca una considerable masa nerviosa correspon. diente al anillo esofígico de los artrópodos; y, en relacion con esta especie de cerebro, ojos con verdaderas lentejas prismiticas que sirven para reflejar los objetos. Sobre la propagacion de la hydatina scuta, que raya en lo fabuloso, leemos lo siguiente en la gran obra de Ehrenberg sobre los infusorios:

«Un sér microscópico formaba ya, dos ó tres horas des. pues de nacer, los primeros embriones del huevo, $y$ t las veinticuatro ví cómo de los huevos depositados por dos individuos (formacion embrionaria) resultaban ocho hijnelos, cuatro del mayor y dos del mas pequeño. Dada esta reproduccion diaria de cuatro huevos, de los que nacen hijuelos que se reproducen á su vez, resulta que en diez dias seguidos puede obtenerse un total de $100.048,576$ individuos de una sola hembra, yá los once $4.000,000$.

Estos cálculos son inciertos, sobre todo tratíndose de es- pacios de tiempo mas largos, porquie semejante fecundidad nunca dura mucho tiempo en el mismo organismo; pero cuancio se quiere explicar la presencia casi repentina de grandes y enormes agrupaciones de individuos, las experiencias indicadas permiten al observador comprender cuán ma. ravillosas son las leyes ordinarias de la naturaleza.s

Entre los hidatineos se encuentran varios gigantes de la clase pertenecientes al género notomata, uno de cuyos carac. téres distintivos es el grande ojo solitario. El notomata myrmeleo, muy diseminado, es en extremo voraz, cualidad que se manifiesta ya en las maxilas, semejantes â unas tenazns. Esta especie se halla provista de los organos mas importantes, y en sus incansables expediciones se pueden observar muy bien a la simple vista con toda claridad. Ja tenaza parte de una cavidad bucal en forma de embudo, y à ella sigue un delgado esófago, en cuya extremidad hay dos pares de glándulas dobles, las salivales. El estómago es un cuerpo irregular esférico; cl intestino desemboca, unido con el ovario, en la cloaca; y asi como en la mayor parte de los notómatas,

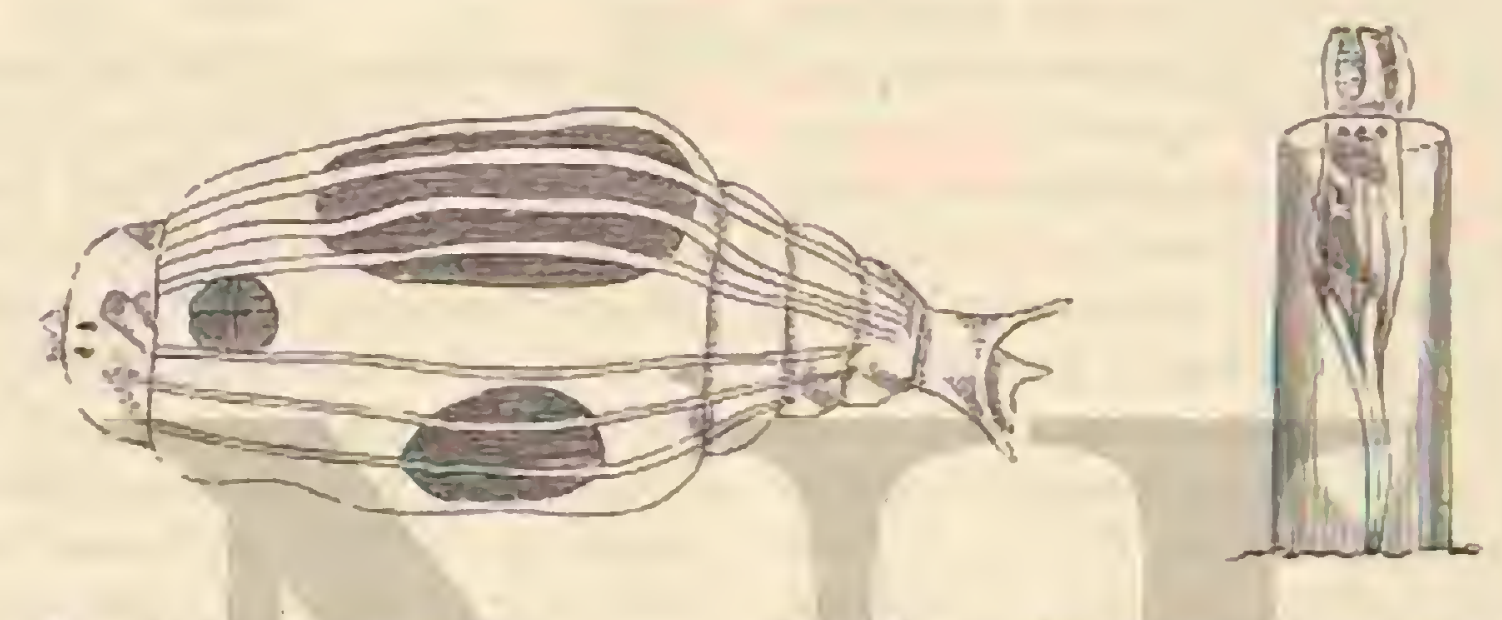

Fig. 16\%.-EL ROTIFERO AMARILLO

los vasos están muy desarrollados, lo mismo que la vejiga contraictil.

\section{LOS FILODÍNEOS-PHI- LODINEA}

A esta familia pertenecen los rotiferos mas conunes y de que mas se ha tratado, en los que primero se reconoció el moviniento rotatorio, y los que con mayor frecuencia y facilidad se puede observar.

Entre ellos el género retifer se distingue por tener dos ojos situados en una trompa frontal y por un pié terminado en una especie de horquilla, que asi como en toda la familia, puede salir y entrar á manera de anteojo de larga yista: Al rotifer iulgaris se refieren los repetidos relatos que circularon durante siglo y medio, en los cuales se hablaba de ruedecitas giratorias y de la milagrosa resurreccion despues de una mucrte de muchos años. Inaverdadera residencia del animal son las aguas estancadas, en las cuales, situado entre los hilos acuáticos y las algas, puede aglomerarse de tal modo que cubrn esos vegetales como con una costra de moho; pero, asi como miles de organismos, al secarse su morada se propaga con el polvo que le rodea, impclido por los vientos en todas direcciones y por todos los continentes. Al secarse los charcos y pantanos donde habitan los rotíferos, estos se contraen en forma de bala y resécanse por fin, adhericlos á un grano de arena ó à una particula vegetal, reduciéndose á un polvito sin forma. Juguetes de los vientos, con ellos se diseminan por toda la tierra, yendo á fijarse entre los liquenes y en el musgo de la corteza de los árboles, pero particularmente en el musgo de los tejados; se les encuentra en todas partes; habitan en la choza mas humilde $y$ en los pa-
Fig. 10S. - EL ESTLFASOCERO DE EICHORNI lacios, tan pronto como sus tejados estan ya bastante ruinosos parn poder conservar su vegetacion musgosa. En tiempo seco los rotiferoș reposan; con la humedad y la lluvia récobran nueva vida. Con ayuda del microscopio podria verse cómo se dilatan poco á poco y se redondean, quedando algunas partes trasparentes; la humedad penetra en el cuerpo, y sus órganos se destacan siempre mas marcadamente á medida que se llena de agua. El pié, que antes hemos comparado con un anteojo de larga vista, sale poco á poco, cual si el individuo quisiera reconocer con cautela el sitio en que se halla; hasta que por fin, ejecutando un visible movimiento rotatorio interno, la cabeza aparece con las ruedas, y el animal recobra nueva vida al cabo de un sueño mas ó menos largo. ¿Estabia muerto cuando despues de resecarse durante meses enteros puede vivir nucramente? Claso es que no; la vida solo se habia interrumpido, casi completamente, pero sin producisse ninguna descomposicion ni trasformacion quimica El hecho de que las partes mas finas del tejido puedan conservar la vida à pesar de un resecamiento tal vez absoluto, se puede comprender por lo que ja hemos visto en las ranas y en los peces. Solo quedan sumidos en una especic de rigide\% que interrumpe el curso regular de la vi. dai pero despues todos los órganos vuelven is funcionar de la misma manera.

\section{LAS TUBICOLARIAS- TUBICOLARIA}

Como representantes de esta última y numerosa familia de rotiferos, cuya mayor parte de especies habitan en tubos, debo mencionar tambien las floscularias (foscularia). L.o mas notable en ellas es la trasformacion extrema del órgano 
rotatorio: en re\% de este vemos en las cinco prominencias cónicas, situadas en el borde de la cabezn, unos hilos largos y' delgados à los que no puede darse el nombre de pestañas, porque son rigidos y casi fijos. En el embudo bucal se en. cuentran próximameruc las pestañas, cuyos movimientos atraen el alimento. El animal está rodeado de una fina cubierta gelatinosa a la que, como lo efectuan los pertenecien. tes a otros géneros, pueden retinarse las articulaciones del pié. Tambien ofrecen ciertas particularidades los conoquilos (conochilus), a causa de una rubierta comun. Gracias à esta cubierta todo un numero de individuos se encucntran en una esfera gelaunosa tlotantc, de tal modo que sus cabezas sobresalen de la superficie de gelatina. Se distinguen asimismo por la actividad de que están clotados; cuando tstos autumales aunan todós sus csituerzos, poner en movimicnto giratorio la esfera de que ya se ha hecho mencion y que para cllos viene à ser un mundo.

Conocemos ya en mi opinion suficientemente los rotifcros, part poder ocuparnos de las rclaciones que guardan con otrits clases de animales. Se les ha llamado crustáceos pestañeados para indicar que alguras de sus cualidades, por ejemplo, el pie hendido en su extremidad y algun tanto articulado, y su piel quitinosa, que a veces constituje unalcorara, recuerdan \$los artroprorios acuaticos, aunque las pestanis de que comple. tamente carecen les comumican un caracter del todo distinto. Varios naturalistas atribuyen la mayor importancia á estc caracecr, es decir à los órganos provistos de pestañas, tanto internos como externos, que representan un gran papel en la vida de los rotiferos, y en su opinion no es ménor la de los ca. nales acuáticos que vemos en los anélidos. Estos maturalistas nos ofrecen iel instructivo ejemplo de una clase de animales bien constituidos, en cuya division no observamos las formas de tránsito á las grandes agrupaciones que siguen ó preceden; solo nos conducen á tiempos pasados, al mundo primitivo. en el que las relaciones de afinidad encontraron sin duda su expresion en las formas mezcladas e intermedias, ahora cxtinguidas. Desyraciadnmente no podemos esperar en este caso explicaciones fundadas en futuros descubrimientos tosiles, dada la delicadeza de tan diminutos séres. Para la comparacion recomiendo sin embargo, las aves, cuya exis tencia actual está bien constituida en simisma, aunque hace poco que unos restos de tiempos primitivos nos han dado evidentes pruebas de su primitiva afinidad con los reptiles.

\section{ANÉLIDOS ESTRE-}

\section{LLADOS}

Cuando en la primavera de 1852 visite por primera vez la isla de Lesina (Dalujacia) para cstudiar alli los animales inferiores, sobre todo los anélidos, mis amigos Botteré y Bo glich me condujeron al golfo Socoliza, en cuya orilla debiamos recoger un gran número.

Habiamos revuelto ya bastantes piedras y hallábanse varios quetópodos en las rasijas, cuando a un pié de profundidad debajo del agua vi, casi oculto por una grande piedra, á un animalillo de color verde muy pronuncindo, que se moyia como un anélido. Al levantar la piedra el supuesto gusano presentó una irompa, terminada en dos alas laterales, propia de un anélido muy poco visto de los zoólogos: era la honellia airidis. Conservé esta especic en el depósito por espacio de un dia, y no nos cansibamos de observar sus ex. tranos morinientos. Una materia colorante verde que se disuclie en el espiritt de vino, en el que puse despues el anima, teudia el cuerpo y la trompa: el primero está cubierto de muchas rerrugas pequenias y puede efectuar los mas variados movimientos y contracciones, es ya esférico ya oral, ó bien se presenta en ligeras ondulaciones que desde su parte posterior a la anterior se extienden hasta la trompa

No es menos raro ver el desarrollo que adquiere su cuerpo, que de la longitud de algunos centímetros, en los individuos grandes de unos 0",08, puede extenderse a un metroy medio ó mas. I a abertura bucal se halla en el fondo de la trompa y la del ano en la extrenidad posterior. Caracteristi. cas son adcmás dos cortas y gruesas cerdas situadas á poca distancia de la extremidad anterior.

Mi bonelia no hacia otra cosa sino desarrollarse y con. tmerse: los zoólogos que la han observado y disecado tampoco refieren de clla otra cosa. Mas tarde se demostró que en la playa de Socolizza es una de las especies mas comu. nes, pero huye de la luz del dia y agridale solo la del crepúsculo matutino. Se la encuentra sin cimbargo, en todas ocasiones escarbando en las piedras y mezclada con arena, desde meaio pic hasta un pié de profundidad. Segun hasta hoy sabienos, se la halla desde Fiume hasta las islas Ba. learcs.

La bonelia es uno de los animales vermiformes cuya clasificacion ofreció dudas á los \%oúlogos durante mucho tièm. po. Su piel fucite y coriácen, algunas condiciones de su organizacion, la faculiad de contracrse mucho y de recoger del todo la tronipa, recuerdan de tal modo a las holoturias, que deben considenrse como un transito entre estas y los anćliclos. Nos permitiremos agruparlos como órden, á continuación de los verdaderos anillados, pues algunas especies merecen este nombre por los anillos superficinles de la piel oscura. Por lo demás son unos séres en extremo particulares, segun ya lo demuestran sus formas. Viven muy retindos y suiren por lo que hasta ahom se sabe, irasformaciones extra. nas. Como no son dañinos ni útiles; y su género de vida es silencioso, la mayor parte de los habirantes de la costa no los conocen.

\section{LOS FASCOLOSOMAS - PHASCOLOSOMA}

Este género pertenece à una familia diseminada por todos los mares: la mayor parte de sus especies, asi como las de otro género, habitan en galerias que practican en piedras y rocas. Algunos por cjemplo la phascolosoma granulatum, que tiene de $0^{-}, 0_{3}$ a $0^{\circ}, 05$ de largo, encuéntrase á miles en localidades farorables de la costa, y en las bahins bien resguardadas de Dalmacia Nu es fácil apoderarse de ellos aunque se les haya cogido por la trompa, pues dilatan su parte posterior, y antes se dejan hacer jedazos que ciarse por vencidos. Es preciso, por lo tanto, romper las duras piedras con el martillo, en cuyo caso se matan muchos individuos. Cuando por fin se han reunido algunos en un depósito, aburre observarios: al principio permanecen como muertos, ofreciencio la forma de un pequeño salchichon y con la trompa del todo recogida. Al cabo de algun tiempo parece como que empiezan a desarrollarse, pero despues de repetir de 20 ¿ 50 veces la teniativa, es muy raro que dejen ver la última extremidad de la trompa, provista de apéndices en forma de dedo; yi una vez la presentan, de seguro vuclien á retirarqu un momento despues. No debe olvidarse, sin embargo, que la situacion de estos animales en una vasija abierta y clara, difiere mucho de la que ocuparian en un tubo de picdra, por delanie del cual las algas rojizas y verdosas comu. nican á la luz un tono agradable; pues aunque carecen de ojos son muy sensibles a los efectos de la luz. 


\section{LOS SIPUNCULOS-SIPUNCULUS}

CARACTEHES. - Istas especies se distinguen por tener una trompa que pueden recoger, $y$ la abertura intestinal mas próxima a la extremidad anterior que a la posterior, por lo que el dorso tiene gran importancia. Además de estos caractéres, comunes tambien al género anterior, el sipunculo tiene en la piel surcos longitudinales ó trasversales, presentando dibujos que simulan una red. Fn los mares europeos viven el sipunculus mudus, que mide una longitud de $00^{\circ}, 1_{5}$ y el eremita (fig. I7I) que tiene de li" :20 á $0^{\circ}, 25$.

\section{LOS PRIAPULOS-PRIAPULUS}

Ofrece este gencero (fig. 160) una estructura sumamente rara, con caractéres muy particulares. En la parte anterior del cuerpo ligeramente ensanchada en forma de rlaza, se encuentra la trompa, en ruya superficic anterior trun. cada halllase la abertura bucal que es bastante grande. Los surcos longitudinales de la trompa están cubiertos de puntitas agudas; cl verdadero cuerpo a uarece separado de aquella por una estrechez, y tambien presenta marcados surcos. La cola figura como un apéndice, y en el punto de su naci. miento hallnse la abertura intestinal. Ehlers ha recogido todos los datos posibles acerca del área de dispersion ý género de vida de los priapulos. Ia primera parece limitarse a la costa de los mares septentrionales, hallándose con mas frecuencia estos anélidos à medida que se aranza hrócia el Norte. En toda st área de dispersion, desde Groenlandia, Islandia y Noruega, hasta las costas británicas, el priapulo vive en el fondo cenagoso a diferentes profundidades. Practica, por medio de la trompa, galerias de la longitud de su cuerpo, que se reconocen exteriormente por $m$ montoncito, $y$ en ellas permanece quieto, mientras que la cola sobresale en el agua "odos los observadores que han tenido ocasion de examinar ejemplares vivos, dicen que estos recogen la trompa cuando se les molesta, alargándola cuando reposan, poco mas $\delta$ menos como lo hacen los sipunculos. En un priapulo que se conservó tres scmanas en un acunrio no pudo obscrvarse nunca que inientará tomar alimento. Cuando hacia so!, el animal parecia mas agil; recogia la trompa y alargaibala alternativamente; y encorvaba el cuerpo y contraiale, sin órden alguno en sus movimientos. Por lo que toca al alimento, no cabe duda que el priapulo es plantivoro, pues asi lo demuestra el contenido de su estómago.

\section{LOS TALASEMOS-THALASSEMA}

CARACTERES, - I a boca de estos anélidos es muy pequeña: estŕ contenida en la base de un tentáculo ancho, corvo y abierto por la parte inferior. Presentan sedas lisas, rectas, aplanadas, que forman en la parte posterior del cuerpo dos lineas circulares, y tambien dos sedas mas fuertes y encorva. das inmediatas una á otra, colocadas en la extremidad anterior. El cuerpo es muy blando, de figura casi cilindrica, ob. tuso por atrís y mas delgado por delante, y consta de una multitud de anillos apretados, poco distintos, rodendos cada uno de un círculo de papilas glandulosas y salientes, sobre todo en la parte posterior del cuerpo. Hl ano es pequeñoy circular.

El talasemo brevipalpo (fig. 170) es la especie tipica del género, $y$ habita en las costas europeas.

\section{ANÉLIDOS REDONDOS}

El objeto de esta obm, que no es otro sino la descripcion de la «vida de los animalesh, puecie alcanzarse mas ó menos en las clases superiores, sin tomar por eso en consideracion las trasformaciones de la organizacion interior, que cambian con las condiciones de la vida exterior. A pesar de csto, en todos los grupos caracteristicos, aun en los maniferos, he. mos dado á conocer las particularidades amatómicas que podian servir de apoyo jara las manifestaciones vitales; $y^{\circ}$ en su consecuencia describiéronse los dientes, los tegumentos, los órganos de la locomocion, y en fin, todas aquellas parti. cularidades nque desde luego pueden interesar, y por las cuales, hasta el profano en la materia, puede reconocer diferencins y establecer sus comparaciones.

Cuanto mas avanzamos en el mundo de los animales inferiores, tanto mas cesa aquella diferencia, bastante justificada entre los caracteres externos é internos, necesarios para la descripcion de la vida. En aquellos casos en que se ha debido cmplear el microscopio para las averiguaciones cientificas, háse utilizado con preferencia para poder asegurar hasta cierto punto que ningun tegumento ó repliegue rodea el cuerpo, ó por lo menos que no era óbice para determinar los caractéres. Asi pues, en la clase de quue vamos a ocuparnos nos veremos precisados con major fundamento á dar á conocer la estructura interna para comprender los cambios exteriores; deberemos seguir la senda intrincada, y con fre. cuencia poco agradable, que nos traza la historia del desar. rollo; porque la «vida de muchos anélidos redondos consiste en la lenta perfeccion de las formas relacionada con el cambio de residencia Nos veremos obligados á seguirlos tambien desde la carne del animal en que vivió, al intestino de otro animal ó del hombre; desde el agua al vientre de un sér animado; desde el suelo húmedo, $\{$ un pulmon de rann; desde la cavidad abdominal de una oruga ó langosta, a la tierra.

Vencida ya la repugnancia natural que el asunto pueda inspirarnos, convendremos en que estas trasformaciones $y^{\circ}$ emigraciones de los anélidos intestinales, son en alto grado interesantes é instructivas. Tambien se demostrará, dê qué modo la ciencia ha logrado descubrir, no sin penosos experimentos y costosas averiguaciones, el tiempo que necesitan para desarrollarse casi todos aquellos parisitos del cuerpo humano, de los que algunos pertenecen al número de los enémigos mas peligrosos para nuestra vida; y cómo la ciencia ha podido explicar el origen de todos ellos. Fn la descripcion de estos anélidos y de otros congénericos deberemos atenernos con preferencia á la excelente obra de Rodolfo Leuckart: \&Los parásitos del hombre, y a otra parecida de Schneider. Estos autores han estudiado el asunto de tal mocio en sodos sentidos, que nadn casi me quedia que hacer sino citarlos literalmente ó citractar su descripcion.

Los anélidos redondos, llamados tambien anclidos de hilo ó nematodes, tienen un cuerpo en forma de hilo ó de tubo, nunca anillado y que siempre carece de piés; la piel es fuerte y lisa; y el tubo muscular, reunido inmediatamente con ella, tiene a menudo mucho desarrollo.

Para no incurrir en la monotonia de una descripcion difusa, y por conrenir mejor para el conocimiento de las condiciones vitales de estos anúlidos, empezarcmos con el huevo, describiendo el desarrollo de un nematodes en el mismo. Elegimos uno de aquellas especies de ascariformes que con casi absoluta regularidad se encuentra en el mairtir de la ciencia, en la rana, es decir, el nematorix.

El huevo afecta la forma de un elipsoide; el embrion contenido en él tiene dumnte corto tiempo un color claro, pero poco despues se cubre lentamente de una capa compuesta de grandes celdas. Eintonces presenta una depresion, principio de una prolongacion siempre mas pronunciada, y la futurs 
cola se dobla sobre la parte anterior del cuerpo. Ias grandes celdas ceden poco i poco su puesto á otras mas penqueñas y a una sustancia particular, y al mismo riempo despréndese de la superficic del cuerpo del embrion, nue sicmpre se prolon. ga, encorva y enrosca, una cielicada piel del todo trasparente, que es en rigor el primer órgano que queda. Pronto se obserforma el borde anterior, truncado, una depresion que se trasnacer, ademàs de bucal, y en el gusanito maduro, próximo ả esti acabado de la piel y del tubo muscular trasparente, no tura bucal, rodeada de tres el intestino. Empieza con la aberestos sigue un esbofa tres jurominencias en forma de labios; a saliente saliente con sus paredes granujientas y un corto tubo final que desemboca por delante de la extremidad de la cola en el lado del vientre.

En este estadó riacen la mayor parte de los nematodes:y ahora deberemos fijamos en su desarollo en general, el cuál se efectia en una misma residencia, mas por lo regular con un repetido cainbio de las condiciones exteriores. I as tras. formaciónes que sufre el intestino se manificstan particular: mente en los contornos de la boca y de esófago; los labios, dientecitos, rebordes y dilataciones en forma de buche en el tubo esofágico, pueden constituir sefiales caracteristicas para las diferentes familias. La sangre, descolorida, circula libre. mente en la cavidad abdominal. Un órgano muy importante para toda la division, es el que se halla en las llamadas lineas laterales; consiste en dos series de ceidas nue, cerca de la extremidad anterior, se continuan cn dos canales, y por debajo del esófago tienen una desembocadura comun: constiiujen un órgano respiratorio y puede compararse con los riñones. Los sexos se reconocen casi siempre por distintivos exteriores: los machos son mas pequenos y-tienen apéndices en la parte posterior del cuerpo. Ia mayor parte de los nematodes ponen huevos: pero en muchas especies los cumbrio. nes se desarrollan en los conductos; de modo que el nacimiento de los hijuelos es simultáneo casi siempre con ta puesta, resultanco de aqui que aquellos nacen, como si dijéranos, vivos. Es tan rara una diferencia esencial entre este procedimiento y la puesta de los huevos, que ambas cosas pueden suceder alternativimente. Lambien estas condiciones son propias en rigor/de la vida de los nematodes, en los que veremos, por ejemplo, que algunas hembras se trasforman en uma especie de bolsa inerte en la que los hijuelos pasan el periodo de su juventud.

\section{LOS UROLÁBEOS-URO- LABEA}

El mar, ese gran foco de toda la vida, alberga la mayor parte de una fanilia de que solo se conocen muy pocas especies de ncmatodes libres: son los urolábeos, animalitos delgados, trasparentes y microscópicos, algumas de cuýas especies, provistas de varias pequeñas cerdas de la extremidad anterior, recuerdan los quetópodos, que tautos represcntantes tienen
en el mar.

\section{LOS ENOPLOS-ENOPLUS}

In mayor parte de los géneros descritos por varios autores bajo diferentes nombres deben agruparse, segun .Schneider, en el género de los enoplos, uno de cuyos carnctéres esendes consiste en unos prequeñisimos tentáculos que salen dase de rganos pertenecen tambien las celditas arriba mencionadas. Muchas especics tienen en la boca pequecias espinas huecas, y no pocas presentan en la extremidad caudal una glándula textil particular que se abre por debajo de la cola. Tan luego como el animal ha fijado su cola en una base, dice Schneider, prosigue su marcha, dejando en pos de si como rastro una secrecion en forma de hilo claro como el vidrio, y á menudo varias lineas. Una edtremidad del hilo está fija, y en la otra el animal nada libre. mente en el agua. Los enoplos marinos adultos parecen vivir a mas profundidad que los que se hallan en el estado de larva. Dicho naturalista vió estos últimos cerca de Helgoland a poca profundidad, $y$ hisia en la superficie, trepando por las algas, mientras que los individuos adultos solo se hallaron a la profundidad de dos a tres brazas.

A las especies marinas siguen algunas otras de agua dulce, gue, con otros nematodes microscópicos, fueron reunidos por zoólogos antiguos y modernos bajo el nombre de leptoderos acuáticos, cuyo nombre no debe emplearse ya científicamente. Fjecutando movimientos serpentinos pululan en el fondo cenagoso de los estanques ó entre las rajces de las lentejas acuáticas: la vista experta los descubre cuando se extiende sobre un cristal, una pequeña porcion de cieno que contenga restos de esas plantas infusorias.

Segun ha demostado Buetschli la separacion sistemática intentada por el naturalista inglés Bartian, en la clasificacion de los nematodos marinos y los de agua dulce, no es admisible Los sistemáticos tropezaron siempre en la clasificacion de toda especie con la cuestion de la residencia del animal. En clianto a la fuerza de vitalidad de estos pequenisimos anelidos, Buetschli dice lo siguiente: \& Debo dar à conocer una obseriacion de otra clase sobre la afinidad de las especies terrestres y miarinas, observacion que al mismo cicmpo explici en algo las diferentes condiciones viales con que estos séres pueden existir. Cuando practicaba mis averiguaciones recibi de un amigo un porcion de yerhas halladas en el puerto de Korhaven, entre las piedras, en un sitio que el agua cubre dumnte la marea alta. En la tierra adherida á las raices de esta jerba encontré cinco nematodes terrestres, entre cilos el mas comlin de sus congéneres, el dorlaimus papilatus. De aqui resulta que una inundacion pasajem en el terreno habitado por estos animales no les perjudica; de mo. do que tambien las especies de agua dulce pueden acostumbrarse sin dificultad il la vida marina, y no me parece imposible que muchas de cllas se encuentren tambien en el agua

Respecto al àrea de dispersion de los nematodes no parásitos y a los que segun Buetschli, pertenecen poco mas ó menos todos los géneros, excepto el Rhahdivis (pelodera, lep. todern), dicho naturalista resume del modo siguiente sus ob. servaciones: en rano busqué estos nematodes de género de vida libre, con pocas excepciones, en el agun; en el cieno $\delta$ en la tierra, que por sus emanaciones parecieran hallarse en estado de descomposicion; jamks pude encontrar un solo individuo en tales sitios. Fn cambio desarróllase una rica forma de estos animalitos en el agua, pero con preferencia en la corriente, tanto en el limo y otros fondos, como entre las piedras y plantas acuáticas, y en la espesura de las algas. Ias especies terrestres deben buscarse princjpalmente en las raices de diversas plantas, sobre todo de los musgos y setas, asi como en muchas fanerogáneas. Vemos además que es tos animalitos evitan el suelo cenagoso, mientras que el barro mezclado dé arena, ó la arena pura les agradan mucho.

Todas estas observaciones, y otras de Schneider que mas abajo reproduciremos, se han hecho en la Alemania Central; pero sabemos por las de otros autores que no solo en Fran. cia, sino tambien en las Indias Orientales $y$ en el Norte de América se encuentran especies del todo anólogas. 


\section{LAS ANGUILULAS-ANGUILLULA}

Sin atenernos á las carnctéres en extremo minuciosos de la zoologia descriptiva, trataremos ahora de algunos nematodos microscópicos de general extension, que Schneider agrupó bajo los nombres genéricos de pelodera y leptadera y que casi exclusivamente viven, cuando menos durante un periodo de su vida, en sustancias en descomposicion. Su cavidad bucal está provista de varios nuditos: el tubo esofágico se dilata en forma esférica; $y$ á él sigue el largo intestino. 1.os huevos de la hembra se hallan poco mas 6 menos en el cen. tro del cuerpo, en dos tubos que se reunen en un marcado orificio. La especie mas célebre de este grupo, observado ja inuchas veces en el siglo anterior, es la anguilula del vinagre (anguillula asceti), que hasta los últimos tiempos se conside- raba como diferente de la anguilula del engrudo (anguiliula glutinis de los autores), hasta que Schneider demostró que la especie, muchas reces observada por él, puede vivir en ambas sustancias. El engrudo mismo no es condicion vital para las anguilulas, sino las setas microscópicas que pronto se forman, y cuyo desarrollo se favorece mucho cuando se echa un poco de vinagre en el engrudo. Al observar detenida. mente el vinagre se ve que las anguilulas escasean mas aun de lo que indican los observadores antiguos. Se ha creido encontrar la razon de esto cn que el vinagre no se hace ya de vino: en cierto modo este parecer es exacto. En el vinagre de vino 6 de cerveza que antes se usaba quedaba probablemente mucha azúcar y albúmina, es decir sustancias favorables para la formacion de setas y tambien para las an. guilulas, porqque estas no pueden hacerse adultas ni propa-

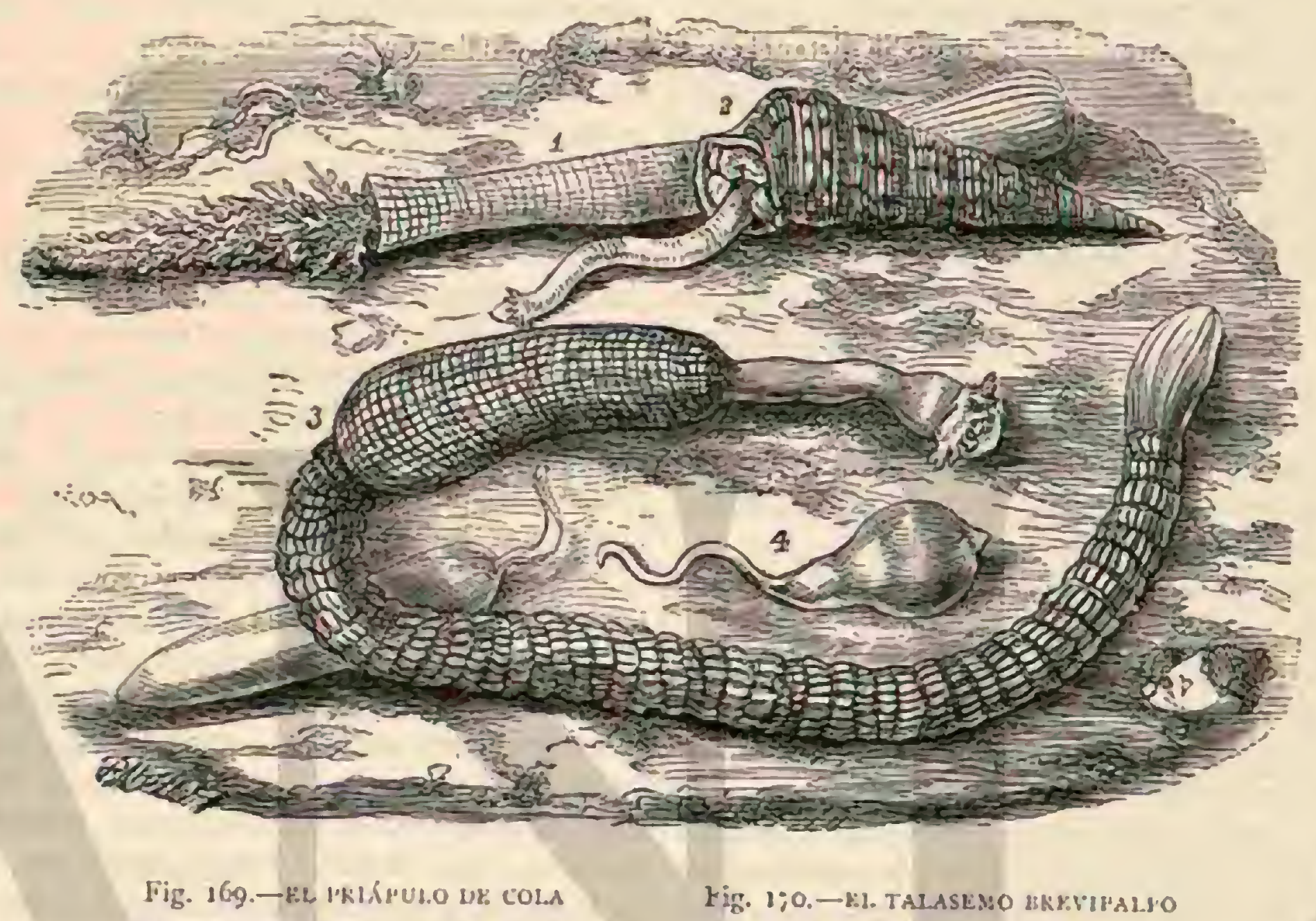

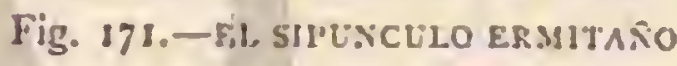

Fig. 1\%2.-EL SITUXCUR.O DESTUDO garse en vinagre puro, sino entre las setas que les ofrecen un alimento carbónico. El vinagre que circula en el comercio no contiene probablemente nunca individuos adultos, $y$ si solo larvas, a menudo muestas; al destapar una botella de vinagre vemos con frecuencia qque parecen vivos, pero suelen confundirse con los esquueletos membranosos que flotan en el liquido. La madre del vinagre, como se llama comunmente, contiene por lo regular en cierto grado del desarrollo, nume rosas anguilulas. Nunca he logrado criar estos animalillos en el engrudo hecho con puro almidon cocido; es indispensable mezclarlo con cola ó en general con una sustancia carbó. nica. El nombre científico que este animal lleva hoy dia es el de leptodern axoplita.

Casi tocias las demás especies de leptodera y pelodera habitan en la tierra humeda y en sustancias en descomposicion. Schneider conservo nuchos años en macelas y visijas de barro llenas de tiurra varias colonias de estos séres, para observar sus extranas condiciones vitales, que se manifiestan durante una emigracion. « Cuando se pone en una rasija con tiern un pedazo de carne podrida, $\delta$ se mezcla aquella con sangre, leche, etc., se puede estar seguro de obtener las es. pecies pertenecientes á estos grupos; con tierra extraida de diferentes sitios, del cieno, de las aguas, de la madera podrida, arboles huccos, de jardines, campos, etc., he obtenido las diversas especies. Para conservar la humedad necesaria es preciso humedecer siempre li tiema ó conservar cubierta la vasija, siendo de advertir que la descomposicion no debe llegar à un grado excesivo, y que los animales mueren tam. bien cuando se empapa la tierra con mas agua de la que le es dado absorber. En estos experimentos los animalillos pueden pasar por los tres grados del desarrollo, cs decir, el embrion se trasforma por una muda en larva, que difiere de los individuos adultos por la forma de la boca, a menudo cerrada, y por la falta de órganos sexuales, debiendo sufrir otra muda para llegar il la edad adulta. En la libre naturale$z a$, sin embargo, estas trasformaciones se verifican durnnte una emigracion. En todas las partes en la tierra y en el agua se encuentran larvas neutras de rostos animales diseminadas en gran número, pero tan luego como cerca de ellas se forma un foco de descomposicion se dirigen á él, atraidas, quizás, por el olfato; aqui se hacen adultas, y los hijuelos que nacen desarróllanse en el mismo sitio. Cuando estos han vi. vido algun tiempo en aquel foco pestilente se despierta en ellos la inclinacion a viajar, que les induce á emprender la marcha, diseminándose en todas direcciones. I.as hembras dan a luz entonces hijuelos que tambien siguen a los emigrantes. Esta emigracion por tierra furme dura cierto tiempo, lo cual se explica por la circunstancia de que los embriones se reunen en grandes grupos, protegiéndose por su propia humedad y por la «que produce su cuerpo alternativamente 
por la evaporacion. Fin este viaje los embriones entran en el estado de larvas haciéndose doble mas grandes que los que hasta dicho periodo han vivido en sustancias pútridas. Ia piel del embrion se separa, pero la larra no la abandona, por la cual forma una cubierta del todo cerrada, aunque no impide que pueda moverse libremente y continuar su viaje. Sin embargo, luego adquiere cierta rigidez y se prolonga; y si tal estado dura mucho ticmpo, la larva muere. Mluy distinto es el resultado cuando los cmbriones se resccan durante el via. je, lo cual, muy léjos de perjudicarlos, contribure á su conservacion. Al resecarsé entran en el estado de larva y la piel embrional forma uná cubierta para las larvas. Cuando haj humedad reviven, y si cesa resecanse. Para yue las larvas crezcan y puedan llegar á la edad aduta es preciso absolutamente que vivan en algun paraje humedo; aqui se abre Ja cubierta, coman alimento $y$ se verifican todas las trasformaciones por médio de las cuales llegan a ser adultas. Las lar. vas que se mueven libremente olfaean a mucha distancia un foco de descomposicion. Cuando en una rasija grande, llena de tierra, se deja desartollar una colonia de estos séres, las larvis se dispcrsan si cesa la descomposicion. Cuando la tiérn es húmeda y se echa en ella, nor ejemplo, algunas gotas de leche, al cabo de una horn se encontrara cu. bierta de larwis Este experimento, que de un modo tan sorprendente demuestra la presencia de pequenisimns orga. nismos, se practicó, segun Schneider, hace ya casi cicn años, por un tal Roffordi. Cociendo almidon con agua y vinagre puro, este engrudo, encerrado en un saquito de hilo, en una maceta con tierra húmeda, se hallara a los diez ó doce dias Heno de anguilulas.

En algunas otras especies de ambos géneros se ha observado que alguna ve\% cambian la vida libre jor el parasitismo en la gran limaza negra y en la lombriz de lluvia, para abandonar su anfitrion otra ver. cuando las condiciones exteriores son farorables.

Del parasitismo voluntario 6 fortuito de nuestras leptode. ras, al parasitismo regular y necesario, solo hay un jaso, del cual nos ofrece ejemplo el nematodes llamado ascriris vigro ¿enosi, cuya historia es, por ló curiosa, superior á todo cuanto se haya visto hasta ahora en este terreno. I a especie ci. tada tiene de $0^{\circ}, 0010$ a $0^{\prime \prime}, 0012$ de larga y se encuentra a menudo en el pulmon de los sapos y ranas. Se ha comprendido sicmpre entre los ascaridos, pero la forma caracteristica de los labios de este género no existe. Es muy probable que el animal sea hermafrodita. Desde el sitio ocupado por la hembra, que siempre está repleta de sangre, sin que se ob. serve en las ranas ningun sintoma, los hijuelos se trasladan al inicstino del anfitiun, y por un conducto muy natural al aire libre. Segun el ejemplo de otros nematodes deberia su. ponerse que estas pequenisimas larvas vuelven directa 6 in. directamente a la rana, convirtiendose en ascaris nigrueno. sa; pero en esto nos enganariamos mucho, pues se conscrvan como generacion libre; no se vuelven hermafroditas, como el animal de que toman su origen, sino que se desarrollan, a mediados del verano, en machos y hembras del tamaño de medio milimetro, ofreciendo todos los caractéres de una leptodera. Asi por su género de vida en el cieno yien la tierm húmeda como por su estructura, la generacion, que nunca se inclina al parasitismo, difiere de ln parisita como dos especies de géneros diferentes una de otm, $y$ solo por sus des cendientes ruelven al punto de origen del circulo del desar.

Despues de salir los hijuelos de los oviductos de la heinbra, la madre se sacrifica del todo por su cria. Alimenta la progenic con su sangre; todos sus órganos internos se descomponen y nada queda de la piel, que constituye una cu- bierta sin vida al rededor de los animalitos. Este periodo de la vida dura algun tiempo, pasado el cual salen de su tubo y permanecen algun tiempo, quizis semanas enteras, en la tierra húmeda, desde donde se trasladan á los pulmones de las ranas, en los cuales se desarrollan en ascaris nigrorenosas.

Añadamos ahora que entre las anguilulas no hay solo pa. rásitos animales, sino tambien vegetales, a los que Schneider quiere limitar el nombre sistemático de anguillula. Ia anguillula tritici, conocida desde 1743 , produce en el trigo una enfermedad particular, llamada tizon. En las espigas enicrmas, dice Kuehn, los granos pierden su forma en parte ó por completo; son mas pequeños, redondeados y negros, componiéndose de una cascara gruesa y dura, cujo contenido se reduce a una sustancia blanca y pulverulenta.

- 1l humedecer esta sustancin con agua dividese en finas particulas, que, vistas con el microscopio, resultan ser anguilulas, las cuales pueden llegar poco i poco à vivir y comien. zan a morerse vivamente. Los gisanitos contenidos en el grano de trigo del todo desarrollado son neutros. Cuando el grano penetra en el suclo húmedo, se reblandece $y$ des. compone; los gusanitós contenidos en él, hasta entonces resecos, reviven con la humedad, $y$ la cubierta podrida les permite abandonarla y diseminarse por el suelo. Cunndo llegan á una planta jóven de trigo trepan por clla, y si el tiempo es seco, guarécense en los ángulos de las hojas sin noverse ni dir señales de vida; pero cuando llueve, y a medida que crece él tallo suben siempre mas arriba, - hasta llegar al ángulo de la hoja superior, dentro de la cual se forma la espiga que aun está en los principios de su desar. rollo. Isos gusanitos que penctran producen un crecimiento anormal de las partes de la tlor, poco mas ó menos como el que observamos en las agallas, debido à las larvas de in. secio; fórmase una protuberancia redondeada, y en su cen. tro se hallan los gusanitos, que se desarrollan rapidamente hasta su estado normal. I.as hembras depositan gran número de huevos, y asi como los machos, mueren muj pronto. Fn tanto, crece la protuberancia, hasta que, llegada la época de la madurez del trigo, alcanza casi la dimension de un grano ordinario. Ia antigua generacion de las anguilulas ha muerto ya entonces; los embriones nacieron hace tiempo de los huevos, y constituyen ahora, como larras neutras, el contenido pulverulento y fibroso de la agalla. Esta se seca con los gusanitos, al parecer muertos, formando dẹpues los liamados granos del trigo. Cuando estos granos caen con los buenos en la tierra húmeda, repitese el mismo desarrollo circular.

En algunas yerbas las anguilulas producen tambien fenómenos análogros: Kuchn ha reconocido una anguilula como causa de la descomposicion central del cardo. El curso de la vida en esta cspecie parece scr exactamente el mismo que el de la anguilula del trigo, pues se observa igual muerte ficticia, la de los gusanitos en las fores secas, y su resurreccion repentina con la humedacl. Como el tiempo húmedo favorece el ascenso de las anguilulas por los tallos, explicase porqué la enfermedad de esta planta se extiende anto, sobre todo en años húmecios. Tambien entre los diferentes enemi. gos de la zanahoria figura una anguillula, y segun otros un fytenclats. De las noticias anteriores resulta riue son hembras las que se agarran a las fibms de la rair para chupar, dila. uindose en forma de saņuitos ovales de $10^{m}, 75$ lineas de largo por casi media linea de ancho. Bueischli, refiriéndose a las observaciones de "Th. Stein, dice lo siguiente: En rigor, lo que hasta ahora se ha visto solo son burbujitas, en las que, segun Schneider, nada puede distinguirse $y^{3}$ del intestino, de los mísculos, de los vasos ni de la cstructura especial de 
los óvarios. Los individuos jórenes no se han visto aun hasta ahora, y por lo tanto queda en duda si estas burbujitas constituyen efectiramente todo un nematodes dilatado ó solo una parte del mismo. Segun la observacion de Stein, lállase en cada una de ellas un gusanillo, que por la espina bucal se reconoce decididamente como un blemehus, cuyos caractéres indican un macho. Stein dice no haber observado munca tal macho, y quizis el caso presente es análogo al interesantisimo fenómeno descubierto por Leuckast en el trichosomum crassicauda, es decir, la presencia del macho dentro de la hembra.

- Repetidas veces se ha hablado de la resurreccion de los rotileros y de los nematodes microscópicos, pero no será inoportuno ocuparnos un poco inas de este extraño fenómeno. El célebre Necdham, descubridor de la anguilula del trigo, habia dado en 1744 al naturalista inglés Bakeralgunas de las agallas del trigo, y aun al cabo de veintisicte años, en 1771, este último logró harear revivir á los animalitos humedeciendo las agallas. La resurreccion al cabo de reinte anos del resecantiento se ha confirmado. Sin duda influyen mucho en sentejante resultado los medios que se enplean para la conservacion. Uno de los mayores adversarios de la llamada reproduccion voluntaria $\delta$ primitiva en el siglo anterior, el sagaz Spallanzani, sabia ya, que una de las condiciones esenciales para la existencia de los rotiferos y anguilulas que viven en el musgo de los tejados, era la de que su cuerpo estuviera mas ó menos cubierto de musgo ó de arenn. Baker dejaba secar y hunedecia despues los mismos individuos, obtenien. do siempre igual resultado, solo que el húmero de los rest. citados se reducia siempre mas, no llegando ninguno de ellos i. revivir por décimasevta vez. En éfecto, los animalitos soportan extraordinarias vejaciones. Davaine, que ha explicado la historia natural de la anguilula del trigo, puso larras de tres años de edad en la unqquina neumítica, despues de obtenido el absoluto rescamiento del aire, y cejólas alli cinco dias. La mayor parte de las larvas revivieron despues de permanecer tres horas en aglia pura. Muy distinto resultadu se obser. va, no obstante, en los individuos adultos que solo cstán escasamente dotados de esa resistencia vital, que generalmente no se manifiesta sino en los anguilulidos cuya residencia esta expuesta al cambio de lemperatura. Para obtener resul- tacos favorables, al resecar las anguilulas parece ser condicion necesaria rodearlas de finos granos de arcna, i juzgar por el hecho de que esos diminucos séres, á causa de la irregularidad de la superficie y de la consiguiente distribucion irregular del agun, pueden seguir la humeriad que poco a noco des. aparece, y contraerse lentamente. Si se quiere resecarlos en una supperficie de vidirio, despues de la evaporacion de una gota de'agua pura, y cuando este experimento se efectua en un espacio bien calceado, el fin de la evaporacion se verificá con tal rajidez, que los gusanillos y rotiferos quedan de repente como pegados, resultando de aqui que la piel y otros órganos se rompen necesariamente.

\section{LOS ASCARINOS-ASCA-} RINA

E! tipo de la fanilia siguiente es la lombriz intestinal, ó ascaris lumbricoides. En todo individuo de esta especic un poco grande vénse en la abertura bucal tres labios particulares, que aun á la simple vista se destacan marcadamente del cuerpo. Lno de estos labios ocupa el centro del lado dorsal, y los dos restantes se tocan en la linea central del vientre. Lil exámen microscópico permite reconocer que los labios ţenen en dos hoyitos laterales un órgano del tacto pequeñi- simo, en forma de cono. Fn todos los ascarinos, la diferencia de tamano entre la hembra y el macho es muy marcada; es. te último, mas pequeno, se reconoce además jor tener la extremidad posterior del cuerpo arqqueada en forma de gancho. Por desgracia la historia natural de los ascarinos, y entre ellos precisamente la de la especie mas importante, el asca. ris lumbricoides, no es bien conocida todavia.

Esta especie es uno de los parásitos mas comunes del hombre, en farticular de las razas caucisica y negra, á las cuales acompaña por todo el globo. Aunque por lo regular se hallan en reducido número, dáse con bastante frecuencia el caso de reunirse algunos centenares, y á reces se cuentan maś de mii ó de dos mil de estos desagradables huéspedes.

la residencia ordinaria es el iniestino delgado, desde donde penetran a veces en el estómago. Los individuos mas grandes pueden alcanzar una longitud de $0^{n}, 016$ : $0^{\circ}, 018$, y hasta se han encontrado en el higado. No nos es posible ocuparnos en detalla las circunstancias bajo las cuales pueden ocasionar hasta la perforacion de las paredes intestinales y abdominales, invadir la vejiga, ctc. La importante cuestion de cómo el hombre se comunica la lombriz intestinal no está resuelta aun del todo. Los huevos que con los anéli. dos llegan al aire libre tienen una gran resistencia contra todo el rigor de las intemperies y la accion de los liquidos; se desarrollan asi en el agua como en la tierra humeda, y parecen llegar al iniestino humano del mismo inodo que la ténia de los gatos, bajo la forma de un pequeño sér de me. nos de medio milimetro de longitud. En cuanto a la suposicion de que los pequeños parisitos penetran en el cuerpo humano encerrados aun en la cáscara del huevo, I.euckart dice lo siguientc: "Con la gran abundancia de ascares $y$ la inmensa fecundidad de sus hembias, que todos los años po. nen unos sesenta millones de huevos, estos se encuentran naturalmente en todas partes. Para confirmar este aserto no necesitamos ni siquicra referirnos a los excusados y estercoléros, ni lampooco, segun se ha hecho, a las comunicaciones secretas de nuestros pozos con las cloacas vecinas ó al abono de nuestros campos. Desde los numerosos focos de infeccion mas pequeños, los huevos de la lombri\% humana se disemi. nan por la lluvia y otros agentes a mayor distancia; á pesar de todos los rigores del vicmpo, etc., conservan muchos años su fuerza de desarrollo; y â causa de su pequeñez dispérsanse fácilmente de una ú otra manera; de modo que en los campos, en los jardines, $y$ hasta en la casa, el hombre está expuesto a su invasion. No es preciso entrar en detalles, pues toda clase de alimento, y hasta cl agua que sacamos del riachuelo para calmar nuestra sed, puede contener un huevo que haya conservado su fuerza de desarrollo. Cuanto mas se diseminan los hueros, ó lo que es lo mismo, cuanto mas densa es la poblacion infestada por el ascaris lumbricoideo, menor es el cuidado en examinar el alimento, y menos la limpieza de los parajes en que el hombre vive, mas frecuente sera la invasion. Sin cmbargo, a pesar de las muchas razones que hacen admisible la suposicion del contagio de la lombriz directamente por los huevos, y que explican la presencia de estos parasitos en los niños y campesinos, en clases pobres y en los pueblos incultos, varias recientes ob. serraciones no la confirman. Parece, no obstante, que antes de fijarse en el hombre, tambien el ascaris lumbricoideo busca, como la major parte de los otros parísitos, otro animal, que aun no se conoce.

Despues del hombre tambien el cerdo recibe la visita del ascaris lumbricoideo; en raros casos la lombriz de los perros y de los gatos (ascorris mrsta.r) se introduce en el hombre. Ia resistencia vital de los huevos ciel ascaris de los gatos es muy extraordinaria, pues desarróllanse aunque se tengan en 
espiritu de vino, trementina ó ácido de cromo. Otra especie, cl ascaris megalocéfnlo, invade los caballos y bucyes. Las hembras de esta especie, que à menudo se reunen en número de mil, alcanzan una longitud de $0^{2}, 36$.

\section{LOS OXIURIDOS - OXYURIS}

CARACTÉRES. - Un segundo parésito del hombre, muy comun, pertenece al género de los oxiuridos. Todas las especies son anélidos pequeños que cuando mas miden de $0^{\circ}, 02$ á $0^{n}, 03$; tienen la cola en forma de lezna y los 12. bios poco desarrollados. Ins hembras del-axiuris vermicula. ris llegan á $0^{2}, 010$ de largo y los machos a $0^{m}, 004$ - Alligen con suma frecuescia á los niños y adultos, ricos y pobres, y pertenceen a los parásitos mas desagradables y molestos. Tambien para ellos estál demostrado que, en el curso normal de su desarrollo, los huevos pasan hácia afuera y vuelven á tomarse por la boca. Las corrientes de aire pueden disjersarlos a los mas diferentes objetos, y asi el hombre como el animal pueden contribuir del modo mas variado a st propagación, porque la pequeñez de los huevos les favorece; para comprenderlo basta recordar las moscas y el contacto de estos insectos con los alimentos del hombre y los objetos mas sucios. Solo el mayor aseo, y esto no siempre, pueden preservarnos del contagio. Con toda fruta no bien lavada nos amenaza el peligro, y Leuckart llega a sostener que la harina con que lós pamaderos suelen cubrir el pan está infestada de embriones de oxiuridos, porque los huevos que se encuentran en el trigo pueden soportar, á causa de su pequenez, los procedimientos del trillar y de la molienda.

\section{LOS FILÁRIDOS- FILARIA}

La perniciosa lombriz de Medina pertenece al género filaria, caracterizado por tener el cuerpo filiforme, micntras que la cabeza saria mucho, segun la presencia ó falta de labios y nuditos. Los machos se distinguen por la extremidad de la cola, retorcida en forma de espiral. Conocemos unas cuarenta especies de estos filíridos, que habitan en mamiferos y aves, debiendo suponcrse que los hijuelos emigran cuando tienen un tamano inicroscópico. Sobre la historia del desarrollo y el género de vida de la renombrada lombriz de Mcdina ó de Guinea (filaria medinensis) carecemos aun de noticias. Solo podemos decir que despues de fijarse en el tejido celular del hombre alcanza una longitud de 3 a 4 metros por $0^{n}, 002$ de grueso, produciendo con su presencia peligrosas úlceras. En los paises húmedos tropicales, excepto América, tanto los blancos como' los negros, sufren los ataques de este animal. Despues de coger la lombriz en la herida abierta, procurase enroscarla en un rodillo, operacion que ocupa varios dias; $y$ si por desgracia se rompe la lombriz, el resultado, segun se dice, suele ser funesto, pues se ocasionan peligrosas infiamaciones. Un caso acaecido hace algunos años en Pesth demuestra, sin embargo, que esta inflamacion no. se presenta siempre, pues dos lombrices de Medina que de. bian extraerse de un tártaro se rompieron, y á pesar de esto curó la lıcrida sin novedad. El filárido de Medina es viviparo. y dicese que al nacer los hijuelos producen una violenta infiamacion. Es bastante probable que contribuyan á ella, pero debe creerse que su desarrollo se verifica fuera del hombre, aunque no sabcmos si con el agua que se bebe penetra en el cuerpo, ó si, como la trichina, sale del estómago $\delta$ se introduce directamente en la piel.

I, a llamada lombriz de Loa es un filarido: nide $0^{n, 05}$ de longiiud, y hállase con bastante frecuencia en la niña del ojo de los negros, causándoles horribles dolores.

Repetidas reces se han encontrado, en el cristalino de ell. ropeos que padecian cataratas, unos gusanillos de pocos milimetros de largo que parecian filáridos, pero sobre cuyo origen nada se sabe aun.

\section{LOS ESTRONGILIDOS- STRONGYLIDEA}

Mejor informados estamos, gracias à las observaciones incansables de Leuckart, de la historia de los estrongilidos, porque cuando menos pueden observarse directamente los periodos del desarrollo de algunas especies, haciéndose de aqui deducciones respecto á las demás. Un carácter impor. tante de esta familia es que la extremidad posterior del macho está rodeada como de una gorguera en forma de escudilla ó de paraguas, àyojada á menudo en una especie de costillas. Habitan con preferencia los mamíferos y se encuentrnn, no soló en los intestinos, sino tambien en los pulmones y otros organos. Huésped bastante comun en el intestino del perro es el dochmius frigonocephalus, cuyos huevos se des. arrollan en la tierra humeda en pocos dias en forma de un gusanillo pequetro de medio milímetro de largo. Su cuerpo, bastante recogido, se adelgaza un poco en su parte anterior, prolongándose en una cola bastante larga, cuya punta scparase en forma de un apéndice particular. Crece mudando varias veces, pero pierde despues sus dientes esofágicos: entonces deja de comer y crecer, si bien vive aun semanas y meses enicros en el limo en qque se halla. Cuando llega directamente ál estómago ó intestino de un perro, muda de nuevo y adquicre su forma y tamaño constante.

Esta emigracion y trasformacion es muy propia para expli. car la presencia de uno de los parisitos mas peligrosos para el hombre en los paises del Nilo: nos referimos a la especie dochmius dradenalis que por las observaciones de los yrofeso. res Billroth y Griesinger, en Egipto, tiene hoy una triste celcbridad. Segun pudieron reconocer estos naturalistas, en los paises del Nilo, la cuarta parte de la poblacion, por to menos, padece una enfermedad que, acompañada de los sintomas de Ia ancmia y de la clorosis, produce evacuaciones sanguincas intestinales, y con harta frecuencia ocasiona la muerte de las personas. La única causa de esta enfermedad es el doshmius duodenalis, caractcrizado por agudos dientes, y que se encuentra por miles de individuos en el intestino delgado; se alimenta de la sangre y ocasiona evacuaciones de esta por las heridas 6 inflamaciones que causa. Del mismo modo que el perro queda infestado por esta especie á consecuencia de be. ber agua en los charcos cenagosos, el hombre es atacadoá su ver poríue en los palses cálidos bebe aguns sucias.

Un congénere afune del dochmius es el eustrongliss, represcntado solo por el eustrangolus gigras, cuya hembra alcanza la longitud de un metro. Los lobos, perros, zorros y osos de trompa son los animales en cuyos rinones se fija con preferencia, pero tampoco el hombre esta libre de ellos. Por fortuna, estos casos son muy raros, mas aun de lo que se cree, pues muchos informes son ralsos. El célebre médico cirujano, doctor Brenser, de Vien, ha dado if conocer en su libro: aLombrices vivas en hombres viros, $\Rightarrow$ de un modo muy inte. ligible, una scrie de errores, intencionados 6 no, gque sc trasmitiendo de unos á otros y que solo son absurdos, creidos sobre todo por las mujeres. La mayor parte de estos casos son muy dudosos. Una de las especies que se habia clasifica do como eustrongins gigas, y gue una mujer, segur se dice, habia tenido en su cuerpo, resultó ser un intestino de pato. 
Un cuadro algro modificado del curso del desarrollo presen. tu la pequeña especie ollulasus tricuspis que difiere algo en $\mathrm{el}$ curso del mismo, aunque pertenece tambien a la familia de los estrongilidos. Los machos y las hembras, estas tiltimas de un milinetro de largo, habitan en gran número en los in testinos de los gatos. Sus hijuelos salen hácia fuera por la via natural; ya resecados, esperan á que los coja el mton, en cuyo estómago penetran como las trichinas en los músculos de otros órganos; alli se rodean de una cápsula, y en ella permanecen mas ó menos tiempo. Cunndo el maton tienc la suer te de que ningur gato le devore, los paraisitos no llenan el objeto de su vida: pero si el roedor es presa del carnicero, el letargo cesa; los parisitos reviven con el jugo estomacal del gato, $y$ de una manera muy poco poética man à terminar sus dias en el intestino de este animal. El raton es el medio por el cual el olulano penctra en su verdadero anfitrion.

Muy parecidio, pero un poco mas agradable es el curso de la vida del cucullamus elegrans, parisito de los peces, que ha sido bien observado por Leuckart: su cavidad bucal conticne una cápsula cliprica con gruesas paredes pardas. Las hembras de los cuculanos, dice el citacio autor, paren hijuclos vivos, que ya en el vientre de la madre salen de las delgadas cáscaras de huevo, encontrandose à miles en los individuos de uno á dos centímetros de largo. Preservados por una piel gruesa, los gusanos llegados hácia afuera, permanecen á menudo varias semanas viros y moviéndose en el agu, el ticm po suficiente para encontrar un animal que les sirva de medio para penetrar en los peces. Los gusinos suelen introducirse en los pequeños ciclopes, que en grandes agrupaciones habi. tin nuestras aguas. En los acuarios pequenos la emigracion se verifica comummente al cabo de pocas horas y con frecuencia en tal múmero que los intrusos pueden contirse it doce. nas; cuancio la cirra de los parísitos cxcede à la de los anfitriones, suelen morir al fin del desarrollo embrionario sin causar la muerte de los séres que atormentaban.》 Los agusanillos sufren en su primer anfitrion varias trasformaciones internas y externas, y no alcanzan la longitud de dos milimetros, pero su desarrollo completo se verifica despues que los ciclopes han sido devorados por un per, que por lo regular es la perca Ruvial.

Iil último estrongilido de que aun debemos ocuparnos seri conocido de unuchos aficionados a las aves. Es el syngamus tracheali, el gusano de la tringuen de las aves, huésped muy fatal para los gallineros. El nombre genérico se refiere á la particularidad de que en la parte habitada por los individuos adultos, es decir, en la tráquea de varios animales débiles y jórenes, el parásico está sienupre apareado, el macho adherido it la hembra en matrimonio indisoluble. Parece que el sjugramas se puede resistir con frecuencia, mientras no se presenté en gran número, pero á veces se reunen tantos individuos en una sola ave, que no solo produce inflamaciones en la tráquea, por la irritacion y la evacuacion sanguinea, sino que ambien sofoca a su anfitrion ocasionándole terribles tormentos. Yo extraje de la traquea de una chocha nada menos que 65 pares de synga. mus. Fihlers nos ha explicado la sencilla emigracion del jardsito. Una tos acompañada de la expulsion de algunos gusanos, es la señal mas segura de la presencia del terrible huésped en el ave. Los hucros maduros pasan sin duda, por la tos ó los esfuerzos de la deglucion, desde la tríquea á la cavidad bucal, siendo tragados por el ave; y tan luego como existen la humedad y el calor necesarios, desarróllanse al aire libre á los ocho dias en pequenos embriones filiformes, que tienen la cabera obrusa y la cola puntiaguda. Para nacer es precisa la directa emigracion en las aves, la cual se efectía probablemente de modo que al recoger el alimento los huevos quedan agarrados en la laringe y los embriones se desarrollan en la tráqquea, convirtiéndose en individuos adultos. Esta observacion indica algun tanto un medio, dice Ehlers, para preservar las aves de la propagacion excesira, y entonces peligrosa, de estos parásitos, pudiendiose tomas medidas de precaucion. Una observacion minuciosa de las aves que tienen tos, y en las que el exámen de los excrementos descubre con la mayor seguridad la presencia de estos parásitos, un cuidadoso aislamicnto de los individuos enfermos, y medidas oportunas para gite en las regiones infestadas no se compren aves, pueden por lo pronto ser eficaces. Cuando la enfermedad se presenta en mayor cxien sion deberån tomarse diversas medidas, segun la localidad, para impedir que con los excrementos se ensucien los platos de comer ó que se formen en sitios húmedos del suelo tocos de cria, que siempre pueden infestar à las aves. Asi, por ejenuplo, la costumbre que tienen muchos de los que crian aves de poner cadáveres de las mismas en las crias de gusa. nos de harina para cebarlas, es muy propia para propagar los hucros de singamus contenidos en los cuerpos de pijaros, y que pueden desarrollarse muy bien en el estiércol húmedo y caliente, pasando despues á las ares cuando se les da el alimento.

\section{LOS TRICOTRAQUÉLI- DOS - TRICHOTRACHELIDE}

Ningun anclido intestinal ha ocupado santo la atencion pública desde i $\$ 60$ como el mas peligroso de todos, la trichi. na (irichina sfiralis) que con algunos otros géneros, entrc ellos el tricocéfalo, que tambien pertenece á los parásitos del hombre, forma la familia de los tricotraquélidos. Fl curso de la existencia de la trichina se rige por las mismas condiciones que en los nematodes hasta ahora descritos, puesto que durante su juventud no sale nunca de su anfi. trion para desarrollarse, sino que desde el intestino del hom. bre ó del animal que labita trasládase a los músculos: pero las condiciones vitales son en general análogas a las que hemos dado a conncer para los nematodes anteriores. Fil peligro de que repentinamente se vió amenazado todo el mundo por la trichina contribuyó mucho á que se venciera la repugnancia que inspimba la observacion y el conocimiento mas minucioso de los nematodes. Puede asegurarse que la trichina fué despues de su aparicion el asunto mas comun de las conversaciones en la mesa y en la calle. Una seric de invasiones de trichina scmbraron realmente el terror, y el sér que hasta entonces no bubia llamado la atencion llegó á ser el inas conorido de su clase, gracias i las aperiguaciones sobre su naturaleza y desarrollo, y i los medios puestos en practica para preservarse de él. Publicáronse varias mo. nografias rientificas, entre las cuales las de Leuckiart y Pagenstecher ocupan el primer lugar; son tratados populares para tranquilizar é instruir al pucblo; uno de cllos, el de Virchow, se propagó por muchos niles de ejemplares. Jos gobiernos dieron instrncciones para que se vigilara el trífico de carne, y hasta se fundó en varios Esstados del centro de Alemania un nuevo empleo, el de examinador de trichimas en favor de muchos maestros de escuela de los pueblos, à los que las trichinas (esto es lo único bueno que podemos decir de ellas) han proporcionado un aumen. to de salario, por su trabajo de examinar los cerdos que se matan.

Los casos probados de la presencia de trichinas en los músculos del hombre solo datan de unos 40 años: el naturolista inglés Owen las dió en i $\delta_{3} 6$ el nombre de frivisiun 
sfiralis. Con estc calificativo quiere indicar la semejanza del gusanito enroscado en la cápsulá con un pelito en espirnl: la palabra griega thrix; frichos, significa el pelo. Los parisitos, aunque se encontraban en gran número, parecian inofensivos; y en efecto la enfermedad puede vencerse con la encapsulacion. Solo ocho años mas tarde se reconoció que aquellas trichinas son en su jurentud nematodes; su presencia en el hombre parecia sin embargo anómala; túvose de ellas la opinion que algun tiempo antes se habia tenido tambien de otras lombrices intestinales del hombre y del animal, y' que en cierto estado del desarrollo equivocan a menudo el camino natural, penetran en anfitriones que no convienen a su desarrollo, y degeneran.

Al mismo ticmpo se observó que las trichinas mismas se gregan su cajpsula. Mas tarde reconocióse por varios experi. mentos hechos repetidas reces, que tanto en los intestinos del raton como en los del perro, las trichinas importadas con la carnc abandonaron'su cảpsula, crecieron, y en poco tiempo hiciéronse adultas. Tambien se observói un hecho mas importante respecto a la infeccion con trichinas, y es que los individuos nacidos en el intestino del animal no cmigran hácia afuera, sino que se dirigen i los músculos del anfitrion. El primer caso no:able de una enfermedad de trichinas con resultado mortal para el hombre, se reconoció el 27 de enero de i $\$ 60$ en Dresde, donde el prófesor Zenker pudo apreciarla en toda su importancia. La completa explicacion siguis pronto, favorecida desgraciadamente por multitud de casos aislados y de graves epidenias que causaron numerosas victimas, danciose el caso que de 159 enfermos muriemn 2S. La gran propagacion de los parísitos permitió reco. nocer, en Hamburgo, que el cerdo que ocasionó la infeccion se habia comprado en Valparaiso y que ta came de! mismo sirvió de alimiento a la trijulacion del buque durante la tra. vesia. En general se demostró muy pronto que la causa principal de la intróduccion de los parisitos en el luombre era el cerdo; pero de este asunto trataremos de nuevo al estudiar las cualidades y condiciones vitales de la trichina mas' minuciosamente.

I.as trichinas adultas, 6 las llamadas trichinas intestinales, viven solo en el intestino del lombre y de varios inamiferos y aves donde se desarrollan del todo, se propagan y mueren poco á poco. Las hembras raras veces iniden nierios de $0^{*}, 003$, mientras que los machos tienen solo uno y medio de largo. Fil desarrollo y el apareamiento se verifican en el intestino con tal rapidez que la nueva generacion se forma ya a los quince dias de la importacion de la anterior, pudiendo reconocerse por lo tanto los prarisitos a la simple vista. En anbos sexos la boca se halla en la extremidad anterior, desde donde el cuerpo aumenta en volumen por igual hasta el cen. tro, para estrecharse otra véz liacia la extremidad posterior, que es redondeada I a aberturn de que.salen los embriones nacidos del huevo en el oviducto se halla a poca distancia de la extremidad anterior: la cxtremidad caudal del macho se distingue por tener dos prominencias en forma de espiga. Las trichinas que se introducen en el intestino del hombre y de ciertos animales, no pasan desde aqui à los músculos, sino que permanecen en ál, bajo condiciones normales, unas cinco semanas ó mas: los hijuelos producidos por cada hem. bra pueden calcularse en algunos miles. En la parté inferior del tubo largo, en cuya parte superior se forman las celdas ovarias, los embrioncs se encuentran estrechamente oprimi. dosy los maduros para nacer llegan á la longitud de un décimo de milimetro. Solo permanece corto tiempo en ellugar de re. sidencia de sus padres, asi es que su biograio pudo poner el siguiente epigrafe al capitulo que trata de su primera juventud: e Ias trichinas en la emigracion. El contenido de este capitulo es sin embargo muj dudoso; pues parece que solo excepcionaimente llegan a los vasos de la sangre con la que se distribuyen por otras partes del cuerpo. Es mas probable, por el contrario, que voluntariamente sigan su marcha por el liamado tejiclo ligntorio que rodea y traspasa los músculos. Cuanto mas circuidos están estos por dicho tejido, tanto mayor es el húmero de trichinas que en ellos penetran; pero sucede generalmente que la emigracion á las partes muy desviadns del tronco es muclio menos frecuente que i las cercanas. El diafragma, los músculos masticadores, y hasta los que sirven parn la respiracion, que trabajan continunmente ó casi de continuo, son los mas expuestos. Debe suponerse que el morimiento de los mísculos mismos contribuje à que las trichinas puedan avanzar. Con el fin de la emigracion co. mienza el periodo de \&las trichinas de los músculos, de las cuales nos dice Virchow:

Cuando una trichina jóven ha penetrado en una fibra musculosa, avanza por lo regular a cierta distanria, rompe los tejidos finos de las fibras y produce asi rarios desperfec. tos en su composicion, sin que se pueda dudar que tambien toma alguna parte del contenido, pues tiene boca, esófngo é intestino; crece en pocas semanas mucho, y po: lo tanto, preciso es que tome alimento, el cual no puede obtener simo en las partes que la rodean. Cuando airca innediatamente la sustancia muscular $\delta$ la materia carnosa, produce al mismo tiempo una irritacion en las regiones inmediatas.

Para comprender estos efectos es preciso figurarse la composicion de los músculos.

* A la simple vista, toda la carne está formada por peque. hos hacecillos de fibms dispuestos paralelamente uno junto i otro 15 enlazados por un fino tejido. Cada uno de estos ha. cecillos puede descomponerse en otros mas delgados, y estos i. su vez en fibris, que vistas con el microscopio parecen tambien compuestas. Exteriormente tienen una cubierta ci. lindrica sin esiructura, en la cual está la verdadern sustancia camosa compuruesta de diminutos granitos, dispuestos longitudinalmente en la forma de finisimas fibritas (fibrillas primitivas), que en los lados tienen la figum de hojitns (discos carnosos); en medio de cllas se ven á cortos intervalos ciertas formaciones, que son los llamados cuerpecitos musculares. E] efecto destructor que causan las trichinas se reconoce principalmente en la verdadura sustancia carnosa y sobre todo en los granitos, fibrillas primitivas y discos. Estos desaparecen poco á poco de la fibra, ya medida que se extinguen, aquella enflaquece mas y mas. El efecto irritante sc observa mas en la cubierta yen los cuerpacitos musculares, sobre todo en el sitio donde el parásito se fjo: aqui la cubierta se dilnta poen í poco; los granos de los cuerpecitos musculares aunientan en número; estos últimos adquieren mayor tamaño; en medio de ellos se deposita una sustancia mạs fuerte; y de cste modo se forma alrededor del animal una masa mas espesa en la que pueden distinguirse la cubierta exterior y la protuberancin interna.

- Cuanto mas crece el animal, tanto mas se enrosca; y encorvando la extrenidad de la cabeza y de la cola, mantiénese en forma de espiral como un muelle de reloj. Este procedimiento se efectur sobre todo en la tercern ó quinta semana despues de la enigracion; pasado este tiempo la caipsula adquicre masor grueso, consolidándose particularmente el conteniclo. El centro de la cápsula en que se halla el animal enroscado, vista con un microscopio de poco aumento, parece una masa esférica ú oval en la que se divisa el parasito marcadamente. Por encima y debajo de este punto se ven por lo regular dos apéndices que hajo la luz indirecta parecen oscuros y con la directa blanquizcos; adelgázanse poco á poco y rematan en una extremidad redondeada ú obtusa. A me- 
nudo ofrecen la mayor semejanza por su forma con la esco. tadura del ángulo interior del ojo; su longitud es muy diferente, y a menudo desigual hasta en la misma caipsula. A reces faitan del todo y esta última forma un sencillo óvalo o es obtusa y hasta deprimida en las extremidades. Las partes de la fibra muscular anterior que sobresalen de ella se atrofian mientras tanto. pero en cambio vénse en el tejido que á veces la rodea una gran protuberancia y hasta el desarrollo de vasos nuevos.

Estas trasformaciones duran meses enteros y despues se verifican otros cambios en las cápsulas. 1.0 mas frecuente es que se depositen sales calcireas, y tambien, segun se dice, que las cápsulas queden rodeadas de creta. Cuando la masa calcairea aumenta demasiado, cubre por fin todo el animal, de manera quie ni aun con el mictoscopio se puede ver nada de él. Entonces se ve una cáscara calcáren, como la de un huero de are.

No se sabe aun cuánto tiempo la trichina puede conservarse en este estado completo de capsulacion, sin perder la facuitad de propagarse cuando se fija en un intestino conveniente. Sin duda años y hasta decenios enteros. Los hombres y animales que han pasado por la dolorosa enfermedad producida siempre por una numerosa emigracion de trichina, y cuyas fibras musculares se han sustituido por formaciones nuevas, no sufririn ya mas de los huéspedes que en sus cuerpos se albergaron.

Hé aqui ahora el curioso caso que se refiere solsre el particular. En I 845 , despues de girar una visita à his escuelas de cierta ciudad de Sajonia, las siete personas que componian la comision almorzaron cn ura fonda, donde se les dió longaniza, jamon y vino blanco y tinto. 'Todas enfermaron; cuatro murieron; y como una octava persona que solo habia bebido un raso de vino tinto no habia tenido ninguna consecuencia, creyóse en un envenenamiento por el otro vino; nada se probó, prero las sospechas contra el fondista fueron tales que se vió obligado d emigrar. En i $\mathrm{SG}_{3}$, uno de los qque habian curado resolvió que se le operase en un tumor del cuello, y el profesor Singenbeck reconoció en el músculo abierto una masa de trichinas encapsuladas, asi como todos los sintomas de la enfermedad. El suptiesto envenenamiento no era pues otra $\cos a$ sino la trichinosis (enfermedad de trichinas).

Para que la trichina muscular llege á ser adulta es preciso que penetre en el intestino del hombre ó de ciertos animales. Segun los resuliados de experimentos hechos liasta ahora, este tíltimo periodo del desarrollo y de la vida se verifica en los siguientes animales: en los cerdos, conejos, liehres, conejos de Indias, ratones, ratas, perros, gatos, erizos, temeras, grajos, palomos, gallos y gallinas. Esta lista probablemente podrá aumentarse aun. Sin embargo, en ninguna ave se verifica una emigracion de ese parásito à los músculos; los cone. jos, licures y-terneras, que suelen servir de alimento al hombre, solo en circunstancias muy particulares estan expuestas à la trichina y no pueden considerarse como fuente del contagio para el hombre. Todo el mundo sabe que las medidas de precaucion deben concentrarse en el cerdo, pero el raton y la rata, derorados alguna ver, parecen ser i menudo los intermediarios de la infeccion.

Como habitante inoiensivo del hombre citaremos el triconocéfalo (trichuscephalus dispar) que puede tener mas de tres centimetros de largo; la parte anterior del cuerpo, que contiene el csófago, relativamente largo, es peliforme. la posterior gruesa y reclondeada. El triconocéfalo se encuentra por lo regular en el intestino ciego, con la misma frecuencia que el ascaris; y con igual facilidad se pueden tragar sus huevos, los cuales se conservan meses enteros y hasta uno ó dos años en el aguz y' en la ticrra, verificandose el clesarro. llo muy lentamente. Fiste puede interrumpirse cuando el huevo ó el embrion se resecan. Como. segun hemos dicho, es muy probable que el desarrollo se verifique sin animal intermediario, existen todas las probabilidades de que aun el hombre mas aseado, no se libre del todo al comer y beber.

\section{LOS GORDIÁCEOS-GOR- DIACEA}

Por nuchas particularidades interesantes de la estructura y genero de vida, se distingue la familia de los gordiriccos. Hace ya siglos que el gordiáceo, conocido desde los tiempos de linnco con el nombre de gordius ausurtious, se cita en las obras de historia natural. Gesner nos ha conservado su nom. bre de sternera acuática (1550), aplicado sin duda en remotos tienıpos por el pueblo. Enlazamientos y anudamientos extraños que los animales aislados ó reunidos forman en cl fondo de las aguas, podian compamrse al nudo gordiano; tal nudo fué tambien el género llamado actualmente mermis por el pastor protestante Goeze de Quedlimburgo, autor de la excelente historia natural de los anélidos intestinales que creyó no poder resolver el enigma de su género de vida, relacionado con emigraciones en ciertos insectos.

Distinguimos, entrc los gordiàceos, dos gúneros; del uno, gordius, se encuentran en Alemania varias especies, que antes se reunian bajo el nombre de gordius aquaticus o ternera acuática. La longitud media del macho es de diez a quince centimetros, aunque algunos miden mas de treinta; la hem. bra alcanza unos diez. El grueso de los machos de mediano tamaño varia entre dos quintas partes y la mitad de un milimetro; las hembras son un poco mas volunimosas. El color, por lo general pardo, presentia muy variados tintes; los machos son casi siempre mas oscuros y en general ticnen un color negruzco gris de raton brillante ó negro pardusco intenso, que en algumas partes del cuerpo puede pasar tambien a' un negro puro. El color de la liembra cs sienpre mas claro y no brillante, pasando desde el amarillo isabela, hasta un intenso amarillo pardo. Por la línea central del vientre y del dorso se corre, asi en los machos como en las hembras, una raya longitudinal oscura que se distingue hasta en los individuos mas negros. En el adulto, el intestino esta sicmpre atrofiado y parece que en este periodo de su desarrollo toma alimento. Volveremos a este punio despues de conocer la metamorfósis de la ternera acunitica No podemus imaginar que el gordiaceo se alimente por la sola absorcion de la piel en animales que viven libres. Un caracter general del género gurdius consiste en tener el macho la extremidad caudal hendida en forma de horquilla.

Las terneras acuaticas adultas pernanecen en aguas poco profundas, estancadas y corrientes. Siebold dice lo que sigue sobre su género de vida: “En una cxcursion zoológica al lindo valle de las Praderas, en la Suiza francesa, enireStreitberg y Muggendorf, examiné en un pequerio valle lateral, los charcos que habia formado un riachuelo crsi seco, y en ellos vi un par de gordios vivos aue me indujeron a fijar mi particular atencion en estos animales. Mi trabrjo no quedó sin recompensa, pues habiendo visitado algunas veces dichos parajes, obture de cincucnta a sesenta individuos. Entre cllos hallé las dos especies, el gordius aguaticus y el gordius swbobifurcus: pero la primera mucho inas escasa que la segunda, predominando en ambas los machos. Necesité cierta atcucion para encontrar estos anélidos, pues ern fícil no verlos, á causa de sus oscuras colores y de sus movimientos serpentineas y lentos. Muchos solo salian de las piedras y raices con la extremidad 
anterior del cuerpo, ó estaban ocultos en el cieno de la orilla, siendo entonces mas dificil aun el encontrarles.

Como no ignoraba que tenia $\mathrm{a}$ la vista par.sitos emigrantes, busqué en las iumediaciones del sitio donde labia encontrado estos anélidos, para obtener los animales de que habian salido, y pude obsermr tambien, varios coleópteros del género de las correderas, $y$ de los que algunos se habian ahogando; alsti el ablómen ì todos estos coleópteros, obteniendo, en efecto, de una feronin melnuaria un gordius aguaticus macho.

"Por otra circunstancia pude explicarme la frecuencia con que los gordiaceos se encuentran en los alrededores de Streitberg. El administraclor de correos y fondista del citado pueblo, conocia nuy bien los anelidos que con tanto interes buscaba, pues segun me decia se encontraban con bastante frecuencia en el depósito del pozo, detrás de su casa sabia tambien este sujeto que los gusanos llegaian cón el agua corriente de las cancrias, por lo que habia recomendado a sus criados que examinasen siempre el agua sacada para beber, a. fin de evitar que el anélido filiforme penctrara en un vaso. Este detalle me obligo i examinar varios depósitos del pueblo, y en ciecto, asi obtuve algunos gordios masw. Por todo esto, Siebold sió confirmado el aserto de que una vaquera que vomitó una temera acuatica de algunos centimetros de largo, habiala tragado al beber agua.

Segun dejanos consignado mas arriba, los gordios adultos nó son parásitos; pero la mayor parte de stl vida, es decir, hasta que llegan á dicho estado, viven en ciertos animales. Las estudiosis observacioncs de Meissner mos han ilustrado sobre la emigracion de las larvas de los insectos. Los peque. ños gordios que salen ciel huevo, tienen die? y ocho milimetros de largo y son muy extraños, al decir del observador, tanto por șu diminuto tamano, en proporcion a los gordios adultos, que alcanzan un pié $\delta$ mas de largo, como por su forma y organizacion, que catisan asombro. Su cuerpo cilindrico se compone de la parte anterior, mas gruesa, y de un apéndice en forma de cola, mas delgado. Del cucrpo truede destacarse una especie de cabeza cubierta de dos círculos, cadil uno de los cmales tiene seis ganchitos; cuanoo se despliega del todo, sobresale una trompa córnca. Con estas uinicas armas, los pequeños séres perfaran la cáscara de su huevo; pero como centenares de individuos permanecen tranquilamente en el fondo del acuario, es evidente que no buscan en una emigracion sus anfitriones, sino que esperan \& que estos mismos se acerquen ta ellos. Meissner puso una infinidad de larras acuáticas y de moscas en el depósito donde se hallaban los pequeños gordios, que entonces efec. turaron su emigracion. Buscan los sitios mas delicados en las articulaciones de las patas, donde se introducen practicando un agujerito con su aparato ganchudo: despues recogen y' prolongan lis cabeza por entre las fibras musculares de las patas, para recorrer nsi todo el cuerpo de la larva del insecto; al hin entréganse al reposo encapsulandose poco mas ó menos como la trichina muscular. En los insectos delicados producen exactamente el efecto de la trichina, resultando de aqui que, despues de la inmigracion de unos currenta jóve. nes gordios no tardan en inorir.

Por lo que toca al género de vida y a las emigraciones ulterores, Vellot nos informú sobre el particular en $18 \%$, despues de haber examinado varias especies en su patria (Grenoble). Parece que en libertad desprecian las larvas de los efeméridos; las del gordius penetran en las de mosquitos de los géneros coretina y chironomus; pero estos son perseguidos por varios peces, resultando de aqui que los pequenos gordios llegan al intestino de nuestros peces de agua dulce. Aqui, en la mucosa del intestino, se rodean de una nueva cáscarm ó ciste, permaneciendo en tal estado cinco ó seis meses, para trasformarse despues por ullima vez. Salen de su cascarn, abandonando con los excrementos el intestino de su anfitrion; cxtienden su cuerpo, hasta entonces recogido, y alargan el aparato ganchudo de la cabeza. Entonces, al principio de la vida libre, la ternern acuńtica posee un canal alinenticio como los demás anélidos filiformes; mas por el desarrollo progresiro del sistemn nervioso y de los órganos genitales, el intestino se estrecha y la abertura bucal desaparece del todo con el esófago.

Del segundo género de los gordiáceos, los mermis, las dos especics con mas frecuencia observadas, el mermis alkions y el nigrescens, habitan en la tierra húmeda de los jardines. Las hembras mas grandes pueden alcanzar de $11^{n}$,oro i $10^{\prime \prime}$, o I l de largo. Se presentan, sobre todo en verano, des. pues de haber llovido por la noche, en la superficie del sue lo, dul que salen a reces à centenares y miles. Tambien su género de vida pone a prueba la paciencia del observador, pues permanecen por lo regular enroscados tranquilamente en el suelo, bien aislados ó reunidos en masa. Si se moja la tierra donde se hallan suelen ponerse lentamente cn movimientó y permanecen algun tiempo en la superficie Cuando se les toca, intentan escapar, ejecutando movimicntos mas rápidos. Tanbien en el agua se conservan muchos dias.

1)e una forma muy particular son sus huevos, pues tienen la figura de lentejas con dos apendices que rematan en borlas. In el mermis alhicans los hijuelos solo salen en la primavera siguiente, de los huevos puestos en verano: despues de una breve permanencia en ticrra, buscan larvas de insec. tos, en cuyd cavidad abdominal penetran; en tal ocasion pueden emprender vinjes muy largos, relativamente. à su ta. mano, pues solo miden 1",ooro; y hasta pueden subir á los árboles, puesto que se encuentran larvas con bastante frecuencia en el interior de la oruga de la especic carfusapsa fomo$\pi a$, que vive en el interior de las manzanas y peras. Sin embargo, las larvas del mermis suelen hallarse mas á menudo $\mathrm{cn}$ las orugas de mariposas, asi como tambien en ortóp. teros, colcópteros, diptcros y locústidos. En estas esjecies, los mermidos pasan su edad de larva sin encapsularse: por fin perforan la piel de su anfitrion, llegan dila ticrra húmeda, mudan de piel y se propagan.

\section{LOS ACANTOCÉFALOS -ACANTHOCEPHALI}

L.os acantocéalos pertenecen todos al género Eechiror\%y chus, cuyas especies se caracterizan por tener una tromja rubierta de varias ó muchas series de ganchitos. Cuando esta trompa no está dilatada en forma de bola, lo cual se observa en muchas esperies, el animal se puede prolangar y recoger como un dedo de guante, en cuyo caso los dientecitos dirigidos haicia atrás se enganchan y desengauchan. Los iegumentos de la piel, gruesos y sólidos, y la separacion de los sexos, son caractéres que corresponden à los otros anélidos redondos: pero obsérvase una diferencia esencial en la falta de un intestino y aparato digestivo particulares.

Cuando son adultos solo viven en el intestino de verteturados, y asi vemos que la especie mas grande, echinorhynchus grigas, que tiene el grueso $y$-la longitud del-ascaris, se fija en el intestino delgado del cerdo, aunque para llegar á este sitio debe hacer emigraciones semejantes á las ya descritas. Por Leuckart se sabe que el echinorlyneliss froteus, comun en varios peces, pasa su jurentud en el intestino del gamaro, que le traga encerrado aun en la casscara del huevo. Otra es. pecic, el echinorloynchus polimorfus, se desarrolla y acaba su vida en el intestino del pato. Fin diversos peces marinos, por 
ejemplo el lenguado, se encuentran en los intestinos y en el tejido celular del higado, desde febrero hasta abril, equinorincos muy pequeños de i a 2 milimetros de largo, cuyo orígen no se ha explicado aun. In posibilidad de que penetren por la piel y por la carne no parece 'tan creible como la suposicion de que desde el intestino comiencen su cmigracion y solo en el de otro pez ó de un are acuática se desarrollen hasta ser adultos.

\section{LOS PLANARIDOS-PLANARIA}

En todas las clases del rcino animal cuyos tipos no conocemos, por no encontrarlos con frecuencia, ó porq̣ue no son Ĺtiles ó daninos de un modo muy evidente, no nos orientamos por una descripcion general que supone una infinidad de observaciones aisladas, sino que seguimos el camino por donde la ciencia ha llegado a sus recopilaciones. Decir que los planaridos 6 anélidos aplanados son regularmente planos, es lo mismo que si dijeramos que los anćlidos redondos suelen tener una forma redondeada; pero debe añadirse que muchos anélidos planos son redondos en el corte vertical. Nuestra idea no se aclara tampoco mucho por lo que hemos dicho respecto á que los planaridos tienen un cuerpo blando fácil de romperse; $y$ como la mayor parte de los lectores no han visto probablemente nunca uno de esos séres, creo de todo punto preciso tener à la vista cuando menos una especie de esta grande division de animales inferiores, muerta ó viva Por fortuna no debemos apelar á una ténia conservada en espiritu de vino, pues podemos encontrar graciosos séres en la hermosa natumleza libre. El que habita en los alrededores de estanques y otras aguas estancadas cubiertas de cañaverales, ó en cuya superficic se balancean las anchas hojas de las rosas narinas; el que puede pasearse por las márgenes froridas de un riachuelo cujo cauce esti cubicrto de grandes fragmentos de arenisca, y se hace acompañar por una persona práctica, podrá encontrar el verciadero tipo de un plana rido. En los alrededores de Gratz, por ejemp?o, mi anterior residencia, hállase tanto en el Meur como en vinios riachue. los que en él desembocan, y en algunas aguas que cru\%an las praderas, una especie muy conocida en el pais. Alli doncle la corriente no es tan rápida y donde las piedras pueden repo. sar algun tiempo, basta lerantar algunas para encontrar la fla. naria gronocephala, de color verdoso ó verde pardusco. Oprimiendo su ancha superficie abdominal 6 planta contra la

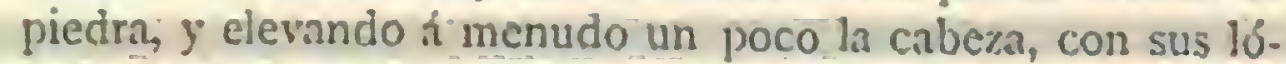
bulos laterales en forma de orejas, se la ve deslizarse por el fondo. Casi podriamos confundirla con una especie afine de las limazas, aunque la mayor parte de los observadores la tomarian por un andido si no hiciesen antes un exámen minucioso. De la relativa delicadeza de su cuerpo nos convenceremos á menudo cuando al sacar con los dedos, 6 con una pinceta, los individuos pequeños para ponerlos en una bote. Ila vemos que la menor cosa les hace dano. Entonces, ó al disecar los planaridos cogidos, reconócese tambien que sus órganos internos no están contenidos, como la mayor parte de los anillados, en una cavidad abdominal, mas ó menos espaciosa, y rodeada de un tubo muscular membranoso, sino que se hallan rodeados de una sustancia espesa.y fibrosa que lléna todo el cuerpo. Hé aqui porqué se designan estos anélidos con el nombre de paresechimatosos que sin embargo no significa ya nada.

Las mismas pruebas que hemos hecho con el planarido elegiclo por nosotros, no encontrado aun en el resto de Alemania, se pueden hacer con las otras especies, en las ténias, distomos y otros de estos animales. No la residencia, ni la circunstancia de que viven de parásitos en otros animales, sino aquelios caractéres referentes á forma y estructurn le dan el rango de una clase diferente dentro clel atipos de los anélidos. Por lo que toca cmpero à la reunion sistemática de familias de un género de vida libre con otras parisitas, hacemos en ellas la misma observicion interesante y que nos obliga á pensar en la verdadera naturaleza de sus condiciones de afinidad, como en los anélidos redondos, y como ya hemos dicho en las sanguijuclas. Ios trinsitos son tan in. sensibles en las formas, y de tal nodo cambian en los para. sitos los periodos de la vida libre, que solo podemos explicarnos el parasitismo, suponiendo que es debido à una invariable costumbre de adopcion. Fijémonos algunos momentos mas en estas consideraciones, que nos permitirán sondear mas el fondo de la variedad, y clijamos para ello uno de los cjemplos mas sencillos: la rana y sus huéspedes pará. sitos. En este batracio sc albergan unas quince especies; $y$ en el ejemplo que citamos se pueden dar los siguientes ca. sos posibles. Primer caso: Una pareja de ranas se crió de un modo incomprensible, casi milagroso, y en cllas se encontraron al misino tiempo todos los parrísitos. Segundo caso: Segun dice L. Agassiz, en muchos sitios convenientes que reunian las condiciones apetecidas, formàronse muchas ranas, y en todas cllas se encontró algun anélido intestinal. Tercer caso: Ni las ranas ni sus anélidos intestinales se formaron de repente $\delta$ de un modo incomprensible, sino que las ranas por una lenta trasformacion de vertebrados inferiores peciformes y sus anélidos intestinales dè mismo modo, lo cfectuaron lentamente por la adancion de anélicios en un principio libres al género de vida parásito, siendo posible en este caso que estos anelidos hajan existido en parte ya en los antecesores de diferente forma de las ranas, mientras que la otra parte solo se ha presentado en ellos tales como son hoy dia.

Solo podemos hablar sobre el tercer caso porque en los otros dos nos falta la fe necesaria para creer en ellos, pues tambien la teoria de Agassiz sobre las causas del origen y de la distribucion geográfica de los animales carece de todo fundamento científico. Para comprender, sin embargo, que un anélido intestinal tuvo hace muchos siglos antecesores que vivian libremente, no es conveniente explicar en seguida una de las éprecies inas complicadas en su curso de desarrollo. En cambio, es muy admisible la idea de que una especie de sanguijucla, que alguna vez vive en peces, pueda trasformarse en verdadera parísita. Figurémonos que esta sanguijucla, habiendo vivido algun tiempo en aguas donde escaseaba la pesca, y viéndose obligada a buscar en diferen. tes sitios su alimento, es trasladada a una agua en que abundan mucho los peces. Entonces puede formarse una variedad que de tal modo se arostumbrará á la vida perezosa en los peces, que asi en su-Jégimen alimenticio, como en su lo. comocion, sufrira trasformaciones del todo comprensib!es y previstas Cuando el aisiamiento de la variedad se prolonga bajo condiciones igualmente favorables, y mientras que tal vez la especie madre que vire en las aguas escasas de peces ha perdido poco il poco sus costumbres de parísita, puede suceder nue en el trascurso de los siglos, la variedad, al principio poco diferente, se haya trasformado en nueva especie bien caracterizada por su géncro de vida y estructura, llegando a ser por lo pronto un parísito exterior (ecto-pa. risibo). El que admita la exactitud de estas sencillas hipótesis, a las que en realidad nada se puede objetar lógicamente, deberá deducir como consecuencia que todos los anélidos parásitos fueron en un principio libres. Para el b́rden siste. mítico resulta de aqui la importante consecuencia de que los anélidos de un género de vida libre, deben clasificarse en calegoría superior á la de los parásitos, porque estos pue. den provenir de aquellos. Todos los parásitos pierden à 
causa de su género de vida ciertas perfecciones externas 'é internas de sus congéneres libres; sus colores palidecen y" acaban por desaparecer del todo; los órganos de la locomocion ó de los sentidos se atrofian ó dejan de existir; el sistema nervioso pierde su sensibilidad; el aparato alimen. ticio deja de ser complicado; y en una palabra, bajo las condiciones mas monótonas para la existencia, el organismo se simplifica $y^{\circ}$ las especies inferiores constituyen entonces géneros que mas tarde se han separado del tronco primitivo.
Resulta de aqui que à la cabeza de la clase de los plana. ridos debemos colocar los turbelarios, que si por una parte recuerdan los infusorios, ofrecen por otra el desarrollo supe. rior dentro de la clase. A ellos siguen los trematodes ó lombrices chupadoras, no solo semejantes a los turbelarios sino tambien a los anillados de forma de sanguijuela. El gínero de vida de muchos es medio libre cuando menos, aun en el estado adulio, mientras que en el tercer órden, en los técridos, representa el mayor grado de la trasformacion retrógma y del atrofiamiento.

\section{PRIMERA SUBCLASE-TURBELARIOS}

Continuando las observaciones con que comenzamos al tra. tar de la planaria, diremos que cuando mada libremente en el asua, su movimiento regulary continuo, sin fuerzas para reinar, llama nuestra atencion; solo cuando el animal encorva la cabeza ó la cola, el cuerpo obedece a la evolucion. El microscopio/demuestra que la planaria esta cubierta del todo de fimisimos pelitos, cuyo continuo moviniento permite al cuerpo deslizarse tranquilamente por el itgua. No se sabe aun de qué nodo el animal se para; pero en todo caso el nombre elegido por Fhrenberg parece cxacto, pues recuerda el remó. lino de agua formado por el animal y que de continuo le rodea.

Iis natuml que con tan delicada organizacion los turbe larios vivan con preferencia en el agua, tanto estancida como corrienic; abundán en el agua dulce, pero encuéntranse masas innumerables en el mar. En cualquier punto de la costa marina donde haya agua salobre $y$ una regetacion de espesals yerbas y algas, seguro es encontrar una poblacion de tur. belarios tanto en el mar Artico como en los mares tropica. les. Muchos habitin solo entre el delicado ramaje de las algas en golfos bien preservados, conde el impetu de las olas no es muy fuerte; otros sc encuentran en las ramas de las duras coralinas y algas calcáreas, entre las que su delicado cuerpo esti al abrigo de los mas fuertes golpes de los cachones. Cuando una costa escarpada es de tal condicion que las plantas no pueden fijarse, los turbelarios pueden vivir, i pesar de esto, ocultándose en las pequeñas grietas $y$ hendi. duras apenas visibles. Tomando en consideracion que una parte aunque pequeva de estos animales habita en tierra lir. me, es decir, alli donde las cortezas de los árboles en los invemaderos, \& en los paises tropicales húmedos, están libres del resecaniento, y que una especie del Brasil hasta bus. ca las lombrices de lluvia debajo de tierra, debemos admirar la elásticidad de esta clase de organismos. Si la compamcion de la musarana enana con el elefante y la ballena producen asombro, nucho mas importantes son las proporciones que hallamos en el seno de los turbelarios, pues aigunas especies del sub-órden de los nemertineos niden ro metros de largo; de modo que comparadas con las mas pequenas estin en la proporcion de $45,000 \mathrm{~A} \mathrm{~s}$.

\section{NEMERTINEOS - NEMERTINEA}

Fijemos nuestra atencion ahora en este grupo. Todos los nemertineos tienen el cuerpo en extremo prolongado, casi nunca del todo plano, y sí solo en el lado del vientre, un poco deprimido. En el borde anterior tienen por lo regular dos aglomeraciones de ojos; en la extremidad de la cabeza, en el lado inferior, hay dos aberturas, una de las cuales conduce al intestino y la otra 2 la cavidad interior, donde se ve una trompa muy particular. Esta trompa puede alargarse con gran rapidez y á buen trecho, alcanzando hnsta dos terceras partes de la longitud del animal, y la usa como órgano de ataque. En algunos géneros del grupo aropla la trompa presenta al salir una punta calcárea. Un cuidadoso observador de estos animales, Maximiliano Schulize, vió repeidas veces cúmo el pequeno tetrastemsma obseurum, propio del Bảltico, y' que tiene mas de $0^{m}, 002$ de largo, alargó su trompa con la rapidez del rayo, hiriendo a los animales que se le acerca. ban. \&Cuando un animal queda traspasado por la trompa, esta se recoge poco d poco, aunque sin soltar, sin embargo, su presa, y entonces el nemertinco, penctrando en la aber. tura practicada por su órgano, introdúcese en el animal herido cuyo contenido devora: de los crustáceos solo deja el esqueleto quitinoso hueco. Con bastante frecuencia se reunen alrededor del animal perforado varios nemertineos, que por diferentes sitios emprenden su ataque con la trompay se reparten la presa. Con gran habilidad saben elegir la par. te abdominal mas blanda del animal para introducir su dardo. Ademis de la punta principal existen otras varias irregulares, que el nemertineo guarda como de reservin, pero se gastan poco i poco sin que se haja observado aun cómo.

Debemos llamar la atencion del lector sobre algunos caractéres importantes del organismo. Ias dos dilataciones de la extremidad de la cabeza, reunidas por una especic de puente 
trasversal con los dos cordones que de ellas siden y se corren a to largo del cuerpo, son el sistema nervioso, que por la forma y posicion representa el tipo primitivo de los anillados y artrójodos. Los órganos ondulados son los llamados vasos acuáticos que vemos en el cuerpo de los planáridos y ofrecen una forma particular de los órganos respiratorios. En los planarios parisitos parecen servir de órganos segregatorios.

\section{LOS NEMERTIDOS - NEMERTES}

El género tetrastemma, con el que reanudamos estas observaciones, es uno de los mas diseminados: sus pequeñas especies que en parte apenas miden algunos nilimctros, viven con preferencia entre las algas.

Una segunda division (anopla) reunc los géneros sin armas, es decir, sin espina en la trompa; a estos pertenecen varias especies gmandes, como por cjemplo pulia, liemertes y mecklia: en los fondos cenagosos se halla entre el césped la meckelin somatotoma, larga, aplanada y blanquirca. Is palabra somatotoma significa la que parte su cuerpo; y en ciecto, sucede por lo regular que estos animales, que ticnen de $10^{m}, 020$ i $0^{\circ}, 060$ cie largo por $0^{m}, 006$ a $0^{\circ}$, soro de ancho, se rompen al menor contacto un poco brusco. Esto parece en parte un acto voluntario y puede explicarse por los llamados movimientos de reflejo, contracciones involuntarias y convulsivas causadas por el sistema nervioso. Inuitil parece decir, sin embargo, que los músculos y diversos órganos se rompen muy fácilmente. De los pescadores que en Dalmacia y en Trieste me tmjeron del golfo de Muggia la meckelin somatotoma no recibi nunea un individuo ileso. En las cxcursiones que yo mismo emprendi solo obtuve alguna cuando la aislabs inme. diatamente del mar, colocándola en una espaciosa vasija. Hay dos medios de conservinla bastanic entera para la coleccion: despues de vaciar lo mas lentamente posible el agua marina, se la cubre de pronto con abundante agua calienté $\delta$ bien con espiritu de vino. Yo prefiero este último método, sobre todo para los pequeĩos nemertineos, porqque à menudo en su agonia que solo dura algunos segundos, estiran su trompa sir tener tiempo de recogerla.

Otra especie muy comun es la polia.erucigera, llamada asi porque el cuerpo, de color verde sucio, adornaclo con fajas y anillos blancos, tiene en la cabeza una cruz: su longitud es de $0^{\circ}, 040$. Tambien tiente la costumbre de alargar á menudo su trompa antes de morir en la cauividad; este órgano, filiforme, tiene unos $0^{\circ}, 015$ de largo, y apenas un milimetro de grueso. Se encuentra esta especie con mas frecuencia en pedazos de roca en que otros animales han practicado ya agu. jeros y galerias, sobre todo en la caliza y en la creta. Entre los tallos del césped tiene tambien su escondite laberintico donde se halla con una infinidad de otros anélidos y sobre todo pequeiros crusticeos. Como aquel, muy comun en el Mediterrineo, se rompe facilmente, la polia puede sacarse bastante ilesa. Mas dificil es, por supuesto, cxtracrla de las galcrias de las rocas, pero tambien en este caso la caza se facilita i menudo por los trabajos preparatorios de las vivas, que segun veremos en otro lugar, perforan la mas dura roca calcàrea.

Los mas grandes nemertineos hasta ahom observados sc encuentran en la costa inglesa. Ia descripcion de uno de ellos iué hecha por Rymer.Jones, quien tomó por guia al es?udioso coleccionador Davis Nosotros la copiamos de un libro del primero, que el autor escribio hace ya veinte anos para sus compatriotas con el titulo de «ida ilustrada de los animales.8

8Puse un individuo de cstos extraños séres, dice Davis, en una gran fuente de loza llena de agua, para observar mejor su género de vida. Alguno procedia como una sanguijuela; sacaba una parte del cuerpo fuera del agua, y extendiase despues a la distancia de uno $\delta$ dos piés del borde de la fuente colocada sobre la mesa. A ciertas horas, sobre todo de dia, manteniasc recogido y tranquilo, a no ser que se tocara la fuente, lo cual parecia molestarle mucho, á juzgar por el estremecimiento de todo el cuerpo, y por la contraccion de la extremidad de la cabeza generalmente un poco prolongada. Por la noche no recogia tanto el cuerpo, y por lo tanto ocupaba mayor espacio en la fuente; pero si se acercaba una luz hacia movimientos como para contracrse; de modo que, aunque no pude ver sus ojos, me convenci de su gran sensibilidad a los efectos de la luz Por la mañana cl cuerpo presentaba á menudo la lomma de espiml; y una vez tuve la satisfaccion de hallarle enroscado en toda su longitud en dicha forma. Me alegré infinito de ello, porque me pareció hallar la solucion de uma dificultad que me preocupaba en extremo, cual era saber de qué modo un cuerpo tan blando y delicado, largo y al parecer nada flexible, se movia de un sitio a otro. Entonces, al verle en tal posicion, me convenci de que el animal la toma cuando quiere cambiar de residencia; pues de este modo no solamente ha dado a su cuerpo la menor circumierencia josible, sino que tambien cada parte de la espiral, puesta en movimiento de un modo conveniente, debe contribuir al avance de todo el cuerpo en su excesiva longitud, sin exponerle al peligro de romperse.

¿La longitud del cuerpo no se puede calcular en el nemerlis vivo, porque al tocarle se contrae y estira continuamente con una facilidad increible; cierto dia observé cómo una parte de la extremidad anterior se cxtendia a casi tres piés de distancia de la fuente sobre la mesa, y si se molesta. ba al animal, contrainse rapidamente. 'Teniendo en cuenta su grueso cuando se encoge y estim, debo suponer quic el animal puede prolongarse de veinticinco à ireinta veces mal de lo que alcanza en su estado normal.

\El color cambia notablemente, al contraerse ó estirurse, formando una faja oscura ò una rojiza, que expuesta à la lur. del sol aparece cubierta de un vello muy delicado de color purpúreo; la extremiciad de la faja es casi negra.

- Despues de haber observado de este modo el extraño ani. mal por espacio de unos quince dias, renovando diariamente el agua de mar, púsele en una botella, no sin muchas precauciones, aunque tenia el cuello muy ancho. Cuando lo hube logrado, anadi espjiritu de vino; el animal se movió convulsi. vamente; contrajose mucho en proporcion i su longitud, y presentó en la extremidad de la cabeza una trompa de ocho pulgadas de largo, órgano que numca havia dejado ver hasta entonces.

- Como habria sido imposible calcular la longirud del animal en vida, medile despues de muerto, y vi que sin contar la trompa alcanzaba mas cie veintidos piés de largo. No exagero al decir que el animal vivo hubiera podido estirarsc llegando al cuf́druplo de esta longitud. \$ Pondriamos en duda esta noticia si nuestro autor no se refiriera al testimonio de los pescadores que conceden á cste anélido una longitud de doce a quince brazas, es decir, hasta unos treinta metros.

En los acuarios debe proporcionarse a todos estos nemer. tineos grande espacio para ondular al redecior de las piedras, segun lo hacen en libertad, porque de lo contrario solo se veria un nudo dificil de desenredar.

Debemos abstenernos de la descripcion de otras muchas especies conocidas hasta hoy, tanto mas cuanto que el ge. nero dic vida de estos animales es muy monótono, poseyéndose solo algunas noticias sobre la historia de su desar. rollo. 


\section{LOS MICROSTOMEOS- MICROSTOME压}

Entre el órden de los nemertineos y el siguiente, dos reducidas familias de turbelarios microscópicos ocupan una posicion intermedia la primera es la de los microstomeos propia, sobre todo, de las aguas dulces. Elijo para la descrip cion el stenostonum monucelis que hace años descubri cerca de Gratz y que me interesa porque posee un órgano que hasta ahora solo se encontró en los turtelarios marinos. Por su estrecha abertura bucal, y el esófago angosto, en un cuer po prolongado, asi como otras particularidades anatómicas, se debe agrupar en el gênero sterossonum. Una vejiguita clara, situada delante dé fa boca, es un órgano en forma de ojo, tai vez, cl del oido, y segun ya hemos dicho solo se co nocia hașta ahora en algunos géneros que habitan en el mar. Para el inteligente, la presente forma es un tipo de transito al gênero mónocilis. Obscrsamos además cn este animalito un vaso ondulado cuyas ramificaciones solo se distinguen en algunas partes con ayuda de un nicroscopio de mucho aumento. Pero lo que mas interesa y nos recuerda a los anillados naris, autolyos y myrianida, es la presencia de retonos en la extremidad posterior. En junio, en cuyo mes observé continuamente esas especies, raras veces encontré un sér aislido, sino por lo regular un animal anterior como madre: y otro posteriór como hijo ó retono. I. a madre procura al mismo tienıpo conservar su especie de atro modo, es decir, por la puesta de huevos.

Esta formacion de retonos distingue tambien at un género afine, de la misma forma del microstomo linear, que luabita en la Alemania central y tambien en la costa del Bàltico.

Una segunda familia, compuesta solo de pocas especies, pero interesante por su estructura, forma el género dimiphilus, descubierto por mi hace treinta años en las islas de Fe. roc, donde pude cxaminar la huna marina inferior de aquellas lejanas regiones, fauna muy rica por la infuencia calorífera del Gulf Stream, lo mismo que la de Noruega. Durante la marea baja examiné las orillas pedregosas del golfo de 'Thorshaven, $y$ vi que la cosecha de moluscos y anélidos era sicmpre muy abundante. Entre los últimos figuraba la peque. ina especie de que hablamos, de dos milimetros de largo, de color rojo ladrillo ó naranja, que vire sociablemente debajo las piedms y se distingue de las demás de su clase por la cstructura del intestino. Este puede compararse hasta cierto punto con el de los nemertineos, y tanto por esta circunstancia como por la separacion de los sexos, demuéstrase la afinidad de los dos grupos; mas por toda la forma del cuerjo y el conjunto que ofrece a primera vista, recuerda mas bien al géncro borfex del b́rden siguiente. El dinoplsilus zorlicoides, parece estar muy diseminado, porque se le ha visto cerca de Ostende. Otra especie he liallado en la costa de Nápóles, donde abundan mucho los turbelarios.

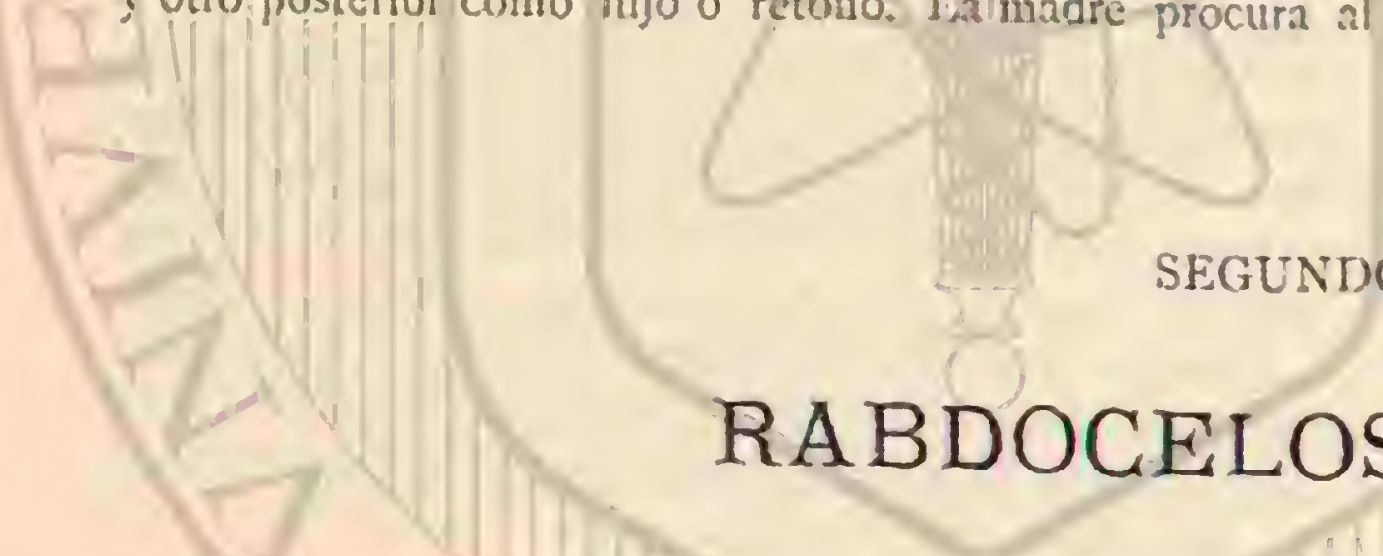

El úrden de los rabelocelos comprende casi solo turbela rios microscópicos, cuyo intestino consiste en uma sencilla bolsa ciega, la cual se comunica con un esófago musculoso y muy fuerte Si empleo la palatura bolśa ciega, deho modificar sin embargo un poco su acepcion, en vista de recientes é importantes descubrimientos. Es cicrto que en la matyor parte de los rabdocelos el alimento se aglomera como en un saco; mas a pesar cie ello, no debemos atenernos, para la mayoria de estos anélidos, à la idea de que este saco es análogo al estómago de una ternerá ó al nunestro, es decir, un espacio vacio con ciertiss redundeces particulares. El espacio estomacal ¿' intestinal esta por el contrariolleno de una masa semejante a la clara del huevo que forma parte del organismo, y en unedio de la cual el alimento se introduce, por decirlo asi, para ser digerido. El descubrimiento es de importancia, poryue confirma el aserto enunciado primeramente por mi, es decir, que los turbelarios son los congéneres mas afines de los infusorios All hablar de estos conoceremos con mas minuciosidad el aparato alimenticio, í la verdad tan diferen tc. Otra particularidad propla de ambas clases, es decir, de los infusorios $y$ turbelarios, y sobre rodo de los rabdocelos y del órden siguiente, es que en la piel existen un sinnúmeró de pequenos órganos paliformes que parecen segregar un liquido cáustico, el cual sirve sin duda para aturdir y envenenar la presa.

Para la clasificacion de los rabdocelos en familias, tómase por guia la posicion y naturaleza de la boca, del esófago y de los órganos genitales'hermafroditas, muy complicados. En la mayor parte de casos el eximen exterior no basta para determinar la especic, siendo preciso apelar a la anatomia microscópica. I.o mejor seri desarrollar los caractéres de las familias en algunos géneros tipicos.

En los estanques y fosos y en el mar, viven las especies del género prostomum. Estos diminutos séres, nuy àgiles, presentan en la extremidad anterior, que es puntiaguda, una trompa semejante \& la de los nemenineos, juces asi como esta, haillase en una cavidad particular, no se comunica con el intestino y solo sirve para apoderarse de la presa. La abertura bucal está distante de la extremidad anterior, en el lado del abdómen, y de ella puede salir el órgano esofígico musculoso con el que el animal se agarra á la presa, sobre todo á los crustáceos microscópicos, para chupar su contenido. En la extremidad posterior del cuerpo, mas gruesa, y que casi afecta la forma de naza, hay un agudo aguijon en una vaina que parece comunicarse con los órgnnos genitales, pero que sirv tambien para la defensa del individuo, segun hemos podido reconocer. He observado á menudo una especie, a la cual di el nombre de prostomsum furiosum, porque tan pronto como se ve algo apurada ó en situacion crítica, pincha furiosamente con el aguijon, lo mismo gue una avispa al ser cogida.

Una forma muy particular tiene el género convoluta; estos animales arquean las partes laterales del cuerpo hácia abajo tomando asi la forma de un cucurucho de papel. La cavidad bucal, en forma de embudo, se laalla en el vientre, y junto a ella hay una vejiguita que probablemente es el órgano del oido. En los mares septentrionales vive la comolufa parado. *a, de varios nilimetros de longitud y de color pardo. Otras 
especies se han descrito, propias del mar Adriático; ninguna vive en el agun dulce.

Pasando en silencio una série de géneros que otros y yo hemos observado en el Mediterrineo, llegamos í uno de los mas importantes y ricos en especics, al mesnitomum. Ia abertura bucal de las especies, que en su mayor parte son aplanadas, está por lo regular en el centro del vientre, en al. gunas junto al mismo, y en otms detras. En la cavidad bucal se ve la extremidad del esófago, en forma de una cabeza esférica, órgano prensil y chupador muy eficar, que sirve para coger la presa y extraer su contenido. Una de las especies mas bonitas es el mesos/omam Ehrenbergä, que casi alcanza un centimetro de longitud y que en la primavera y en el verano abunda en las praderas inundadas y en los estanques de fondo cenagoso cubiertos de canas y juncos. Aumque es irasparente como cl cristal y al parecer muy quebradian, nada con la mayor destreza y rapide\%. Por lo regular corta tranquilamente el agua con algunos movimicntos ondulados de los lados del cuerpo, ó se desliza por los tallos de las plantas; pero si algo la molest., sobre todo un encuentro brusco con algun coleóptero, se mueve, casi temblando y con la misma rapidez y habiliclad de una sanguijucla, trazando lineas serpentinas. Muy curioso es ver como se apodera de los dafnidos y cipridos para chupar su contenido: cógelos poco mas ó menos como se roge una mosca con la mano: arquea los lados del cuerpo, y juntancio sus dos extremidades forma una cavidad al rededor de la presa. Al principio el crustáceo co. gido se resiste con todo vigor, pero jurcnto el mesos/omum logra aplicarle la poderosa cabcza de su esúfingo. Los esfuerzos del ciánido para recobrar la libertad resan pronto; su vampiro vuelve a estirarse, y a menudo vi como un segundo mesostomo acompano al vencedor pacificamente en su fes. tin.

Una de las formas mas cxtrañas es el mesosfomum letragonum de un centimetro de largo y de color amarillo pardo, que a orillas del Elba encontré, despues de las inundaciones, en pequerios estanques secos durante el verano. La posicion de las dos manchas oculares negras y la de la boca es la misma que en el mesostomum Ehrenicreii.

Cuando se observa esta especie en un cristal de ruloj, cu. bierta con un poco de agua, se ve que es delgada y plana, pero tan pronto como nada libremente sobresale de cada lado del cuerpo un lóbulo en forma de aleta, que desde la extremicad anterior puntinguda se dirige hácia la cola, igualmente puntiaguda.

Como esta especic y la mayor parte de las otras del me. sustomum viven en aguas que temporalmente se agotan, supónese que su conservacion se efectua del mismo modo que la de los crusticcos inferiores que hatitan con ellos los mismos sitios y que tambien se presentan despues de las inundaciones y aguaceros como por un milagro. I.os rabdocelos ponen huevos duraderos de cáscara sólida que conservan mucho tiempo la facultad del desarrolio. Yo he visto algunns especies en pequeñas charcas de frocos pies cuadrados de extension, de cuyo fondo llevé algunos fragmentos i mi casa desjues de haber estado secas por efecto del calor durante semanas enteras, $y$ tuve la satisfaccion de que los huevos de un mesostomum contenidos en el barro seco se desarrollaran al cabo de pocus dins despues de haberlos co. locado en el agua. Los huevos de la mayor parte de los me. sostomum tienen forma de discuy una depresion en el centro.

En muchas especies se forman temporalmente huevos blandos y trasparentes, de los que salen ya formados del vieutre de la madre los pequeños rabdocelos que nunca pasan por una metanórfosis.

Lo mismo sucede con la familia schirostomem, llamada asi por tener sus especies la boca hendida situada delante de los ojos. A poca distancia detrás de estos se halla el disco chu. pador, semejante al esófago de los mesostomos.

Otra familia ticne por tipo el géncro avotiex cuyna especies se caracterizan jor su esúfngo musculoso en forma de tonel y situado detrás de la abertura bucal, que se halla en un lado de la parte anierior del cuerpo. Las especies de arortex no exceden por decirlo asi del tamano microscópico, to que quiere decir que las especies mas grarides pueden reconocerse por el naturalista aun a simple vista. En este caso se encuentra por ejemplo el rortir truncatus, especie muy comua de color negro parduzco, con la extremidad anterior truncada, y el iurlex airidis, especie bonita de color verde que vive so. ciablemente; es uno de los pocos animales inferiores cujo color verde se produce por la iglomemcion de los cuerpecitos de clorofila que tambien hacen las plantas tan agradables à la vista. Taubien cxiste un parásito en el grupo al que pertenece el género vortex; es el amoplodium, cuyo animalito vive en la cavidad abdominal de los holotúridos pertenecien. tes a los moluscos de piel espinosi.
Mas grandes y fáciles de observar son los tipos del tercer órden cujo nombre sistemático de dendrocelo designa la forma particular de su intestino ramificado en figura de arbo!.

Una abertura situada en el lado central conduce i una cavidad en la que está récogido en estado de descanso un órgano esofagico muy extensible. Este sale luego que el animal se prepara para comer y no parece sino que ticne vida por si propio. Al practicar el exámen anatómico, esta trompa esofágica ofrece el aspecto de un anélido independiente, de color blanquizco, pues entonces continúa aun bastante tiempo sus movimientos. El intestino que sigue ơ se inserta en este esófago, y que mas bien podria llamarse espacio para la digustion, se compone de una rama principal que se dirige hảcia adelante y de otras dos extendidas haicia atrais con mayor ó menor número de ramificaciones, que rematan todas en el extremo ciego. Iin los dendrocclos propios de agua dulce todas las especies se hallan provistas de dos ojos en la extremidad anterior, pudicndo agruparse con el género pla. nariar. Una de las especies mas grandes, que alcan\%a mas de dos centimetros de largo, es la planaria laclea que como rasi todas las otras vive debajo de las piedras, en medio de las hojas de las canas y en la cara inferior de las hojas de la rosa marina.

Es propia sobre todo para poder formar una idea, sin lesio. narla, de la nigura del intestino ramificado. Fn este intestino se reconoce ya el color negruzco à la luz directa, pero se ve 
que es mas intenso cuando se examina en un cristal, con anteojos de aumento y a la lu\% indirecta. Tambien esta especie tienc la costumbre de fijar sus huevos en un capullo redon. deado, del tamaño de la cabeza de un altiler grande, sobre las piedras y plantas.

Antes se condensaban todas las planarias pardas observadas en el centro y Sur de Alemania como una sola especie, planaria lorba. Yo he demostrado que ademas de la planaria yonephala, citada ya, se encuentran cuando menos tres diferentes especies pardas en nuestro pais, las cuales se reconocen por sus formas exteriores y sobre todo por particularidades anatomicas constantes. Su proceder en libertad y cautividad ofrece muy poco interés. Tan hiego conjo se les pone en un acuario muéstranse inquictas algun tiempo y cruzan el depósito en todas direcciones, pero despues buscan los escondites mas oscuros y permanecen todo 10 quiutos que es posible.

Lo miśno puede decirse tambien dal segundo género, propio de nuestro pais, del polycelis. El penueno polycelis nigra que alcanza hasta un centimetro de largo és muy comun en la llanura y en las aguas estancadas, y tiene, lo mismo que la otra especie, mushos ojos. Todo el borde de la extremidad anterior esta provisto de una serie de 30 a 50 . El polycelis migra, ancho y redondeado en su parte anterior, y del todo negro, es el mas comun, y además se encuentra una variedad pardusca. In otra especie, el polvielis cornula, vive con pre ferencia en las aguas de las alturas: y se encuentra, por ejem. plo, á millones en los riachuelos de las montaias de Estiria; tambien vive en la selva de Turingia. Es una de las nuas graciosas especies, y se distingue por tener dos lóbulos en la cabeza, que la prestan gran semejanza con algunas lima zas. Cierta noche llevé á mi casa numerosos individuos de esta especie en un raso y à la mañana siguiente halléle cubicrto de telaranas, sobre las cuales se paseaban las planarias Estos tejidos sulo podian ser segregados por los animales, y es de suponer que lo hacen por una glindula propia de la especie, situada cn cl vientre.

Sin duda un número infinito de especies afines de las ya descritas se extiende por todo el globo, por lo menó yo encontre algunas nueras en las pocas excursiones que hice a Corfú y Cefalonia Una abundancia mucho mayor de este grupo nos ofrece el mar. Las planarias marinas se asemejan poco à los géneros arriba descritos, hallándose las diferencias mas importantes en el detalle anatómico de los órganos genitales. En la mayor parte de especies hállanse en el lado dorsal, cerca de la extremidad anterior, numerosos ojos dispuestos en dos aglomemciones, no del todo simétricas, pero en un ơrden caracteristico para cada especie. El cuerpo es casi siempre plano y ancho, á menudo trasparente, y de bonito color. Los animales tienen el aspecto tan delicado que apenas se comprende como pueden resistir á menudo el impetu de las olas. Durante mi permanencia en Cefalonia me ocupé bastante ciempo en la observacion de estos seres. La ciudad de Argostoli está situada en un golfo muy poco pro. fundo en ciertos sitios, y cuyo fondo está cubierto de espesas esponjas y algas; encargué a un pescador que sacara un monton de estas plantas, cogilas sin cuidado alguno para llevarlas a mi domicilio, y dividiéndolas en pequeñas porciones las puse en un vaso. Al cabo de pocos minutos las planarias sa. lian ilesas. Sin duda estos géneros (thy'snosoom, Lepioplana), son de los mas graciosos labitantes del mar. Una especic, el thysarozoon, muy comun cerca de Niapoles, tiene el dorso cubierto de muchas séries de apéndices en forma de franjas de color oscuro, y mide unos tres centínetros. En la extremidad de la cabeza tiene un par de repliegues en forma de orejas, dispuestos oblicuamente hácia arriba, $y$ en los cuales el sentido del tacto parece concentrarse mucho. El lado ventmal es de color blanco puro. Las planarias presentan su mayor variedad en el Mediterríneo, proporcionando con otras especies a las orillas de las aguas de Nipoles yo de Sicilia gmndes atractivos para el naturalista. 'Tambien el tranquilo golfo de Villafranca, cerca de Niza, ofrece al amigo de esta fauna ani. mal oculta el mas rico botin de diminutos seres. Schmarda nos ha dado á conocer muchas graciosas formas de los mares meridionales.

Muy dignas de mencion son las planarias terrestres que por ahora se han reunido bajo el nombre de groplana. Y'a en el siglo pasado el célebre zoólogo danés, Oton Federico Muller descubrió una especic que vivia en tierra firme, en el suelo húmedo debajo de las piedras, y a la cual dió cl nom. bre de plamaria terrestre. Tiene un cuerpo casi cilindrico, solo en el lado ventral un poco aplanado, y mide unos $0^{\circ}, 016$ de longitud por uno y medio de ancho; el dorso es de color gris negruzco; la cara inferior del cuerpo, blanca; y en la extremidad anterior hay dos manchitas negras, en forma de ojos. Muy pocas reces se ha visto esta especie en Francia y Alemania, sin duda porque estas regiones templadas no le son favorables. Una sola especie se ha descubierto mas tarde en Alemania, es decir, en las macetas del invernadero de! jardin bosanico de Gijessen, donde se describió bajo el nombre de gedésmos lilinentus. Cuando la tierra de las macetas no es bastante húmeda, el animal penetra en la profundidad, pero ruclie á la superficie tan luego como la tierra se lumedece los individuos tienen $v^{*}, 012 \mathrm{de}$ largo. El dorso es de color amarillo sucio ó de un pardo rojo, con dibujos seme. janies á los del nårmo!. Ademástiene en el dorso dos lineas paralelas de color pardo rojo que se corren por todo el cuerpo y una mancha oscura en el centro del mismo; esta láltima correspondé a la posicion de la trompa esofigica. Los dos ojos son muy marcados en la extremidad de la cabeza.

Mljentras que en nuestro pais solo se encuentran muy pocas de estas formas, clos viajes del naturalista ingles Carlos Darwin, dice Maximiliano Scluulze, nos han dado á conocer una rica forma de planarias terrestres en las húmedas regio. giones de las selvats virgenes de la América Meridional. Si debia sorprendernos la particularidad de que algunos aućli. dos del órden de los turbelarios, que en nuestras regiones estamos acostumbrados a ver siempre en el agua, j que à causa de su cuerpo en extremo blando y delicado, parecen estar destinados a vivir exclusivamente en ese elemento, existan en numerosas especies como animales terrestres, no menos debian admirarnos los detalles que recibimos sobre el considerable tamaño de esos séres, sus colores abigarrados y la forma de los nemertineos que tienen la organizacion in. terna de las planarias de nuestras aguas dulces. El deseo de adquirir noticias mas minuciosas sobre la historia natural de estos habitantes de la selva virgen quedó satisfecho por nuestro amigo Federico Afuller, gracias at los informes de un cmigrado aleman que, hacha en mano, buscaba una nuesa patria Este emigrado, docior en medicina, observó trece es. pecies de las notables planarias terrestres así en los alrededores de la colonia de Blúmenau como en Desterro. Habitan con preferencia los sitios un poco húmedos, ocultándose debajo de la madera, de la cortera y delas jiedras, y en medio de las hojas de las bromeliáceas, pero no en el ägun que en ellas se recoge. De dia descinsan al parecer y soló salen de noche. Lil doctor aleman quiso asegurarse de si las planaria. terrestres tienen pelitos en la superficie del cuerpo, como sus congéneres acuriticas. "A falta de microscopio, escribe, y re. cordando un experimento de que se habli en los tratados fisiológicos de lieclerico Muller, (1) cubri de harina un indi-

(1) El que quica cercioranc coja una rana cualquicsa. ábrale ta bo. 
viduo muy grande de le especie geoplana nufixentris y pude ver cómo aquella avanzaba continuamente en el dorso, mientms que en la parte ventmal se movia un poco hacia atras, circunstancia que pareció confirmar la existencia de los pelitos.

4La geoplana subterrínea, añade el mismo autor, que vive debajo de tierra, me ofreció tambien un interés particular. pues en ella vi ensancharse de nuevo el circulo de las condiciones vitales con que estos séres pueden subsistir. Des. pues de encontrar planáridos en el agua clara de la fuente de la montana, debajo de las piedras de la costa marina, lo mismo que en las algas floiantes en medio de los océanos; despues de anunciarsenos el descubrimiento de una rica forma de planáridos terrestres, que se ocultan en el musgo húmedo, debajo de las piedras y la corteza, y suben hasta las copas de los árboles de la seiva virgen, donde entre las hojas de las bromeliáceas encueutran un asilo siempre húmedo, ahnra encontmmos tambien planáridos subterráneos, companeros de las lombrices de lluvia y de las larvas del abejon. Al contrario de sus congéneres terrestres, ricos en colores $y$ cn órganos de la vista, este geoplana, que vire en la oscuridad, carece de colores y de ojos:y por su forma caterior alćjase mas que ninguma otra especie de la forma tipica de los planaridos. Su cuerpo, igualmente estrecho, muy largo, y en las extremidades redondeado, tiene una longitud de $0^{\prime \prime}, \infty 06$ i $v^{\circ}, 00 \$, y$ hasta l,", or 1 , llegando ajenas a uno y medio de an. chura, por todo lo cual ofrece en un todo el aspecto de un limestino. Vive principalmente en terreno cenngoso ó arenoso, pero tamtien se halla en tierm firme en compañia de una lombriz de lluvia (lumbrious corethrurus). De extrañar es que un animalito tan blando, que apenas soporta el mas ligero contacto, pueda existir en este elemento y abrirse camino. Esta dificultad queda rencida por las lombrices, las cuales perforan el suelo de tal modo, que asi como lit espon. ja están cruzadas en todas direcciones de galerias lisas de diferente anchura El planárido manifiesta su agradecimiento devorando las lombrices, ó mas bien chupa su contenido. No ern dificil suponer este alimento al examinar el interior de la scoplana: pero tambien he hallado individuos que tenian cogida con la trompa una pequeña lombrix, y cuyo intestino comenzaba á llenarse de sangre fresca.

Fin los bosques húmcdos de Ceilan se han descubierto tambien planáridos terrestres, entre los que las especies pertenecionte al género liffoliums se distinguen por la facultad de colgarse de un hilo sacado de una secrecion mucosa de la superficie de su cuerpo. Por las observaciones mas anriguas de Dalyell, sabiamos que ciertos planarios marinos iabrican tales hilos en el agua.

\section{SEGUNDA SUBCLASE - TREMATODOS}

l'anto las sanguijuelas como las planarias conducen al maturalista, si toma en considencion el organismo de los géneros uno por uno, y sobre todo las condiciones vitales. al grupo de los trematodos ó anélidos chupadores, sobre cuyos limites sicmpre han estado las autores bastante acordes. Casi todos ticnen la forma de hojas, son aplanados, no muy largos, ! están provistos en su parte anterior, en el centro $u$ en la region posterior, de varios discos chupadores. El canal digestivo ticne siempre una sola abertura bucal y es por lo regular ahorquillado. Los vasos de la sangre no existen al parecer, pero si un aparato bucal que desemboca en la parte posterior del cuerpo; asemejase al sistema de vasos acuaticos de los turbelarios, pero es un órgano sc gregatorio. l.os sexos estín reunidos. L.os trematodos mas desartollados se llaman parisitos exteriores y no sufren me. tamorfósis; los géneros inferiores se hallan sometidos à una trasformacion nuy complicada con cambio de generaciones; frasan su juventud en 7 m animal, y trasládanseà otro definitivamente para llegar a la edad adulta. La observacion que hicimos al hablar de la distribucion de los animales de forma de sanguijuela, es decir que las sangtijuelas mas deșar. rollidas van con los animales superiores, mientras ųue las menos perfectas dependen de los inferiores, se repite en los trematodos en otro sentido. I.os individuos mejor dotados dependen exclusivamente de preces, ! los menos farorecidos se albergan en las mas dif́crentés clases de animales, aun. que los que estån sujetos á una metamorfósis y emigracion

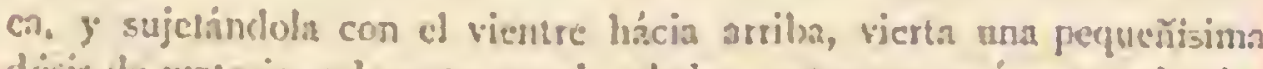
dosis ife uraferia colorante en el paludar: entunce verí como el color pair i las regiones pnsteriures de la boca por miedio be la scrividad in. visilife te los pelitios. se atienen esemcialmente á la regla que rige para los filiformes, es decir, que el periodo de la juventud se pasa en ánimales inferiores, y la edad adulta en vertebrados.

El género conocido hace mas tiempo, descrito ya en el siglo pasado, es el tristomsum 6 epibdello, Hamado irissomm por tener tres pequenos discos chupadores en la extremidad interior, mas arriba de la abertura bucal. En la especie epih della hippoglossi, parásito mas abundante del lenguado, la pequeña abertura bucal esta situada detrás de los dos discos chupadores anteriores; muy notable es el disco posterior, pues al examinarle mas minuciosamente con un microscopio de poco aumento se descubren dos grandes ganchos y uno muy pequeño. El profesor van Beneden de Lovaina, á quien debemos las areriguaciones mas minuriosas snbre este animal, inventó un medio tân sencillo como ingenioso para conservar los epjibdelas vivos varias semanas en su habitacion, poniéndolos todos los dias en una ostra fresca. El anélido toma a menudo la posicion que ambien agrada a la sanguijuela, fijando la extremidad de la cabeza en tel disco posierior; asi mismo prolonga el cuerpo como las singuijue. las, ó bren le dilata, aunque sin extenderle tanio como aquelias. Fil color es blanco, como la cara inferior del lenguacio en que habita.

Al géncro cpibdella siguen otros que tambien se distinguen por tener sugran disco chupador en la extremidad posterior, y luue excitan nuestro interes, menos por su género de vida que por sus formas, a veces muy graciosas. Para demos. tmarlo solo haremos mencion de algunas especies. Asi, por ejemplo, se encuentra con bastante frecuencia en el trigla hirnsdo el trichegus tuhipurus, quizis el único trematodo que tienc ojos en estado adulto: su número es de cuatro $y$ hállanse situados entre los dos discos anteriores grandes $y^{\circ}$ la muy peq̨ucia abertum bucal. El cuerpo, de forma eliptica, 
remata en un gran disco chupador, que parecido i una ro setil se apoja en nueve rebordes en forma de radios y esta rodeado de una orla frangeada.

Uno de los animales mas estraños de este grupo es el rclatella anelisuevlo, cuya boca esta rodeada de una comisa de antenas con pestañas. Eil cuerpo oval, del todo plann y de color blanco, esta muy escotado en su parte posterior el gran disco chupador se inserta en un tallo que sale del ángulo de la escotadura. En esta especic el órgano chupador está aproyado en ocho rádios, y circuido de un delicado borde membranoso: el animal, asido a cl, pucde moverse con libertad y rapidez en todas direcciones sobre el tallo cxtensible y clístico: es una de lós pocos trematolos que viven en el interior de los anilios, entre los pertenecientes al généro dymente que subsiste encerrádo un tubos

El espacio no nos permite, cual deseariamos prescntar el cuadro de otros géneros, ni siquicra el del usonella gue por lo demís es muy notable. Las especies que a él perte. necen se fijan en los criligos y lerneos que viven como para sitos de los peces, habitan en estos crusticeos yo aprove chan de los caligidos como medio de locomocion: los peces son exclusivamente su alimento.

Citaremos/ahora algunos cjemplos de otra familia, rica en especies, cuyos individuos tienen en la extremidad posterior virios disc,os absorbentes, que por lo regular son ocho, dis. puestos en dos filas. Eutre esios se encuentra uno de los fenómenos mas maravillosos de la zoología, el llamado animal doble (diflozom parndoxwm): rórmanle dos mitades exactamente iguales de las que cada una contiene todas las propiedades de un sér completo; en renlidad son dos individuós distintos, que estan unidos por el centro de su cuerpo, no á modo de los gemelos siancses, sino en forma de cruz.

Cada una de sus dos extremidades anteriores puntiagudas tienen una abertura bucal y un par. de pequeños discas chupadores. Por medio de cierta presion puede observarse el intestino, compucsto de un iubo contral y de numerosas ramas laterales cue, al igual de los demas órga. nos, se hallan en cada nutal independientemente. En la extremidad posterior de cada individuo unense bajo una depresion dos órganos aprehensores, compuestos de cuntro discos absorbentes, y apoyados por partes duras en forma de hevi. lla. Cada una de las dos mitades del animal doble presenta un completo aparato genital hermafrodita, identico à los de los demás trematodos.

Dicho animal vive en las branquias de varias de nucstras esprecies de ciprinidos, por ejemplo, del bremo, del gobio y del foxino. Dos decenios despues de su descubrimiento era esto un enigma hasta que von Siebold vino a encontrar la solucion de un modo sorprendiente, al notar que en las branquias del último de los citados peces acompañaba siempre al diplozoon oiro parásito, ó sea un anélido conocido ya entonces con el nombre de diporpa. a Al comparar mas minuciusamente ambos parásitos pronto se echó de ver la relacion de la diporpa con el doble diplozoon, pues, tanto las extremidades bucales con los dos discos laterales, como los intestinos de ambos eran perfectamente anälogos in todas sus partes. los órganos insertos en la extremidad posterior de la diporpa eran tambien de la misma naturaleza que los ocho de que el diplozoon esta provisto en cada una de las propias extremidades. Aparte del doble cuerpo del diplozoon, existen otras diferencias entre ambos animales: la dijporpa no presenta ningun vestigio de órganos genitales, mientras, que el diplozoon los muestra en anbas mitades de su cuerpo; aquella es siempre mucho mas pequeña, y finalmente, tiene un disco chupador por detris del certro de la cara ventral, en el sitio en que están soldados los dos cuerpos del diplozoon.

Esta última noticia no es del todo exacta, segun el recien. te relaio del naturalista Keller, el cual crió diporpos de los huevos del diplozoon de agua pura, y observó la union de dos de aquellos parisitos. El hijuelo se desarrolla en unos quince dias dentro de un huevo prolongado y provisto de un largo hilo córneo: mide unos $0^{n}, 0026$ de largo, tiene jestanias y dos ojos, y en su extremidad posterior solo se observan un par de órganos aprehensores. «Lstos animalitos, cuando sin. len de los huevos son extremadamente vivos; siempre en continuo movimiento, ya se deslizan lenta y sosegadamente por el agua, ó bien madando de un modo mas regular, desplegan extraordinaria mpidez: ora se avalanzan hacia adclante, ora retroceden haciendo las mas variadas evoluciones, ó girando sobre si mismos. A veces parece que se paran, pero, observidos con el microscopio, se les ve mover con mas ó menos rapidez la cabeza y la extremidad posterior, encorracias una sobre otra en 111 estrecho circulo, ó bien extender sus pequeños ganchitos sobre los tallos, en cuya ocasion sobresalen bastante Liempo de las paredes laterales del cuerpo.

Cuando estos diminutos séres no tienen oportunidad alguna de fijarse en las branquias de los peces, à las pocas horas se debilitan y, mueren muy pronto, sin duda por falta de ali. mento y porque la duracion del periodo del celo es muy corta. 7.eller no pudo ver directamente cómo se fijaban en cl animal que habitan, pero en julio y agosto encontró is menudo en las branquias del phozinus learis hasta ciento y mas diporpas, entre ellas algunas que sin duda acababan de ocupar su sitio. Ia diporpa desarrollada tiene la forma de lanceta y es aplarsada i en la superficie central tiene un pequeño disco chupador, yn el dorso, algo mas atrás, una protuberancia en forma de espiga. Hasta ahora se habia crejdo que lits diporpas se junzaban con sus discos para la formacion del animal doble, pero Zeller ha demostrado que cada individuo recoge con su disco la espiga dorsal del otro. Esta remion, sin embargo, solo se verifica al cabo de algunas semanas ó meses, durante los cuales las diporpas aisladas, asi como el diplozoon, absorben la sangre de las branquias. Ia única y extrana trasformacion de las diporpas aisladas consiste en la disposicion del segundo par de órganos prensiles; y à menudo tambien del tercero en la parte posterior.

Otra forma, muy sorprendente de por si, aunque no reunida con el animal doble, es la que nos ofrecen las branquias de la merluza vulgar (merlucivius evilgaris), en la cual habita el muthocofjle merinccii. Apenas habri otro trematodo que tenga medios tan distintos como este para asirse \& su anfitrion, aunque los dos pequeños discos de la extremidad anterior no son de gran efecto, pues cuando existen empléanse principalmente para fijar el disco y la abertura bucal on el acto de tomar el alimento. El animal tiene, sin cmbargo, un par de cxcelentes órganos aprehensores situados en la pro. longacion del cuerpo que afecta la forma de tallo; estos dos órganos son convexos por arriba y planos por abajo, presentando en cl lado inferior cuatro ganclios, y un plequeño disco chupador con tallo. En la extremidad posterior se ven ademis tres pares de discos pedunculados dispuestos simétricamente. Las dos lineas onduladas que desde el esófago pasan por el cuerpo, cruxíndose cerca de los dos grandes órganos prensiles, forman con sus ramificaciones el intestino.

El anćlido de que acabamos de hablar es en cierto modo una variedad artificial y de un conjunto mas sencillo que el de otra especie que tambien podiamos elejir, el dactylocotyle pollaciii, especie que habita en las branquias del merlango polaco (merlangus pollnchius). De todos estos trematodos conócense en general los mas desarrollados y no sujetos á 
una metamorfósis: represcntan unos treinta géneros, que el naturalista yue forma sus colecciones en da costa, ficilmente podria aumentar en un doble ó triple; pero el fin de nuestra obra no seria mas completo por la enumeracion y descrip. cion de otros.

Solo de dos formas haremos aun mencion, atendido que por su residencia tienen afuidad con la division siguiente, como parásitos internos; son ol polysfumum inlegerrimum y el aspidugaster anichirola. De este viltimo conocemos la anato mia y algunas fases de su desarrollo; pero nada se sabe de sus cmigraciones; vive en la bolsa del corazon de algunas de nuestms conchas.

Zeller, en cambio, nos ha dado a conocer, con su minucioso estudio la notable trasformacion y emigraciones del polistomsm ivfrgerrimum, que vive en la vejiga de las ranas. Dicho animal tiene el cuerpo plano, un poco anillado, y alcanza una longitud de $0^{\circ}, 008$ i $0^{\circ}, 010$. Se distingue de la mayor parte de los trematados por el intestino ramificado y provisto de muchas circunvolnciones, y se le reconoce mas especialmente por el gran disco situado en la extremidad posterior, en el que se liallan tres pares de chupadores y uno de grandes ganchos. I.os jolistomos depositan, segun jarece, directamente en el agua los huevos de un color pardusco y visible a simple vista, de quue esta provista su vejiga. Esta operacion la ejectuan, encontraindose en su estado natural, en primavera, cuando las ramas han abandonado sus cunrteles de invierno. Segun el estado de la temperatura trascurren de quince $\mathrm{a}$ cuarenta dias hasta el del nacimiento: asi puede observarse en los hijuelos criados dentro una habitacion en agua pura. Al aire lire, en cambio, pasarian, segun Zeller, de seis à ocho semanas a Lincontré á este anélido maduro y pronto á nacer, dice el mismo, colocado por lo regular de tal modo en el hucro, que su disco caudal; estaba dirigido hácia la extremidad opuesta. En esta última, el huevo se abre por medio de una tapa de bordes irregularmente denti. culados. La tapa es pequeña, y el anélido tiene por lo mis. mo algunas dificuliades, para salir de la estrecha abertura; de modo que, á menudo, arrastra la cascam del hucvo a cierta distancia.

\& El animal cuando sale del huevo, es en extremo vivaz y movible; nada bulliciosanente con ayuda de la orla pestaùeada, contrayendo y prolongando el cuerpo, encorvándole yevolviéndole, ó bien gira rápido como el rayo, con la cabeza dirigida hácia abajo, y da verdaderas volteretas: así retozan estos anélidos horas enteras, en su clemento. \& Cuando joven, este anélido, se distingue por muchos conceptos del adulto: en primer lugar por la orla pestancada que descle la cabcza corre por los lados, y despues por la falta de discos chupadores en el grande disco posterior. I as diez y seis ganchitos finos de que este se halla provisto, se conscrvan tambien en el animal desarrollado. El tránsito al género de vicha de parísitos parece que solo excepcionalmente se efec. tua por emigracion á ranas de uno \& dos años; pero si, con gran regularidad á renacuajos, en los que los polistomos pequeños (cosa bastante rara), fijan su residencia, eligiendo la cavidad branquial. Entonces se- despojan del emblema de la juventud, la orla pestancada. Desgraciadamente Zeller no logró averiguar el camino por donde los parásitos llegan des. de la cavidad brañuial, a la rejiga. A ese grado de su oscura exisiencia llcian los cuatro ojos de que sin duda se sirvicron en su vida libre.

Hemos llegado por fin al grupo de los verdaderos trematados, llamados endoparásitos, que se distinguen de los anteriores por la mayor sencillez de los apamtos anarndores y chupadores en general, y por la falta de pequeños discos chupadores en la cabeza, en particular junto i la boca. Llaman nuestra atencion en mayor grado, porque entre ellos se en cuentran los mas importantes parisitus de los animales do. mésticos y del hombre; y porque su desarrollo y el trinsito de las formas juveniles al estado adulto guardan relacion con hechos muj particulares, cuya observacion es muy dificil; pero cuya esplicacion es grata é interesante. Entre todos los anélidos intestinales, estos trematodos, sujetos à una metamorfósis, son los que primero se conocian; y cllos bueron los que, juntos con algunos animales inferiores, indujeron a Stecnstrup a concebir la fecunda idea de la propagacion por medio de generaciones cambiantes, ó en una palabra, ta la teoria del cambio de generaciones.

El género mas importante propagado en muchas cspecies, es el disfmmm. Ocupémonos ante todo de una determinada, para orientarnos acerca las particularidades del género é his. toria de su vida y desarrollo, eligiendo á este efecto el distumum cchinafum que en estado adulto habita cl intestino del pato, del gurrion y de otras aves. Es un distomo, es decir, un animal con dos bocas, porque ademas del disco bucal, tiene un segundo disco mas grande en el vientre. Posce un intestino ahorquillado, en cuja extremidad posterior se abre un canal, al que desembocan los dos grandes vasos seyregatorios laterales. El calificativo de erhinatum, ó espinoso, se le ha dado a causa cie las espinas que tiene en una especie de gorguera de la cabeza; pero la parte anterior del tronco esta tambien cubierta por completo de circulos de pequeñas espinas. 'Todos los distomos y' géneros afines producen numerosos huevos. Cuando estos llegan del intestino del pato al agua, conienza su ripido desarrollo: sale de ellos una larva pestañeada que en seguida se transforma en otro sér, despojaindose de las pestañas. Ya se comprenderá que esté animal no es ningun distomo. 1.a cabeza, en la que se halla la abertura bucal, esta separada del tronco por medio de una incision; este último, provisto de un par de prominencias cónicas, se prolonga inmediatamente en una especie de cola la boca y el csólago conducen à un intestino sencillo con extremidad ciegn. Este vảstago del distomo, no cambia ya ș forma, ni se transforma nunca en animal del género de aquel al que debe su existencia. Es por el contrario una generacion inicrmedia, $y$ solo la generacion producida por él, cierra, una veradulta, el circulo del ciesarrollo, la generacion intermedia de que nos ocupamos, ha sido llamado redia; tambien se ha aceptado para tales estados el nombre de nodriea ó tubo embirional. No vive libremente; pues, al silir del cmbrion pesiañeado se fija en $v$ dentro-del cuerpo de nuestros caracoles acuáticos; a medida que su cavidad abdo. minal crece rápidamente, fórmase en criadcro de una gene. rácion de insectos muy raros que de tal modo llenan el cuer. po de su progeneratriz, es decir de la notrien, que bajo su presion se seca el iniestino de esta y en muchos cnsos yueda de la nodriza solo la piel, extendida en forma de un largo saco, llamado tubo embrional.

Esta segunda generacion, tan luego como ha nacido, pro. cura volver al agua. Parecida por su cabeza y tronco, al distomo espinoso, se distingue, sin embargo, esencialmente por una larga cola de remo en extremo móvil, la que utiliza durante las semanas que cuenta de vida libre. Hace algunos decenios, antes de que se tuviem idea de su origen y trnsformacion, eran ya conocidos estos animales á los que se designaba con el nombre de ecercarios\%. Ofrecen la particularidad de que, llegado el tiempo oportuno, buscan de unero i las mismas especies de moluscos en que han nacido. fijảndose entonces con el grande disco chupacior de que está do tado su vientre en la piel de los caracoles, y rozindose por medio de bruscos movimientos de la cola de remo, simbolo cie su existencia movible. La superficic de su cuepjo segregra 
una caipsula trasparente, en la cual permanecen enroscados, cual si se hallaran bajo un disco de cristal. Se parecen del todo al disiono espinoso, con la sola diferencia de que las pequenas espinas del tronco y los órganos genitales no estan desarrollados aún. l'a podemos suponer lo que pasará en los ciracoles para que beneficien a las larsas del distomo espinoso. Las aves que buscan su alimento en las aguas, entre ellas el pato, comen los caracoles, y en el intestino de aquel animal termina en pocos dias el desarrollo de los distomos, inmigrados involuntariamente.

Este desarrollo y emigracion se han observado tambien paso a paso en algunas otrns especies. Asi, por ejemplo, ha nodriza perteneciente al circulo de desarrollo del distomum retusun, propio del intestino de la rana, vise en la limaza ce. nagosa (limncicus stagmalis): con especialidad en el higado. los cercarios cie cola, provistos de una espina bucal, se encapsulan tambien en los limneos, 6 en las larras de insectos acuáticos; pero pueden tambien prescindir de este anfitrion intermediario y desarrollarse directamente en el intestino de las ranas, donde al cabo de trece dias llegan á la edad adulta.

Desgraciadamente no conocemos, ó es por lo ménos solo de un modo incompleto, la historia natural de los distomos mas importantes, a causa de su carácter peligroso para los animales comésticos y para el hombie. Casi en toa cria de corderos conocen los pastores los estragos que el distomo cel lígado (distomum hepaticum) catsisa en el ganado. Esto animal, quc alcanza la longitud de casi tres centímetros, ticne su cuerpo en forma de hoja, con la extremidad inferior cónica y bastante gruesa, y està cubiezto de espinas escamiformes, que, al avanzar en las galerias de la hiel, prestan grandes servicios. Los discos chupadores están situados uno cerca de atro, y son relativanente pequeños y débiles. Las habituales residencias del distono del higado son las gale. rias de la hiel en numerosos animales plantivoros, sobre todo en los corderos, asi como en el hombre. Su àren de dispersion se extiende, no solamente por toda la liuropa, sinó iambien por el Ergipio, Groenlandia y el Norte de América. No es estraño qué los corderos importados de Australia lia. yan traido sus parisitos. Para estudiar bien, dice leuckart lus fenómenos vitales, y solre todo los movinientos de los distomos del higado es preciso esaminarlos io mismo que las ténias y otros anélidos intestinales, seguidamente de la inuerte de su anfitrion, $y$ antes de que por la infuencia del frio hayan entrado en apluel estado de rigidex en rue á primera visia parecen mas bien una hoja marchita gue un aninual vivo. Cierto que sus movimientos no son entonces muy rápidos y variados; pero, a pesar de esto, son hastante estranos, y suficientes para explicar lo preciso acerca la exisrencia de estos seres y su distribucion en el higado de los animales en que viven. Al avanzar por las galerias de la hiel del higado su actividad principal se ejerce con sus discos chupadores por la parte anterior cónica del cuerpo. Pe. netra a manera de cuna y arrastra en pos de si el resto del curerpo, cuyos bordes estan doblados ó enroscados. A pesar de todos estos medios, dice lecuckart, la locomocion en los estrechos canales seria imposible, si la superficie del anćlido no estuviera provista de las espinas arriba citadas, las que, teniendo las puntas hicia atris, impiden todo movimiento retrógrado y conviertén las contracciones del cuerpo, por mas ó menos extendidas que sean, en movimientos progresivos.»

La suposicion de que el distomo del higado se alimenta de la hiel es del todo errónea, segun ha demostrado I cuc kart. Recibe al contrario en su intestino, ramificado del mismo modo que el de los dendrócelos, la sangre de su anfitrion y la sustancin de la pared interna de las galerias de la hiel ó ciddus cpileliales. Claro esta que el higado debe destruirse poco á poco, cuando el número de distomos que en el habita es considerable. Las galerias se encienden, la circulacion de la sangre se dificulta, a causa de la continua presion, la secrecion de la hiel se estorba; circunstancias que se manifiestan con la falta de apetito, rayuitis é hidro. pena. Por fortuna, los casos de enfermedad producidos por el ciistomo del higado en el hombre, son muy raros. Los extragos que causa entre las manadas de corderos son $\mathrm{cn}$ cambio bastante grandes, para que se le considere como uno de los parásitos mas ierribles. Produce enormes masas de huevos que, de las celdas epiteliales, pasan por lo regular a la vegiga de la hiel, donde puecien reunirse á millones, siguiendo despues su camino por el intestino del anfitrion para llegar mas tarde al cxterior. En el agua se desarrolla en ellos un embrion cubierto de blandos pelitos y provisto de una inancha ocular en forma de cruz. Q Para ver el tegumento del mismo en plena actividad, dice leuckart, es preciso observarle al nacer. Despues de levantar por medio de vigorosós movimientos la tapa de la cáscara, penetm con ayuda de los pelitos; quue al contacto del agua empieza i moverse, nor la abertura de la tapa, para abandonar con pasmosa rapidez su habitacion.

¡Con el cuerpo extendido avanza sin descanso á nado, ya en direccion recta y girando continuamente por su cje longitudinal, yn describienda circulos ó arcos. El cuerpo tiene en tal estado una forma córnea y una longitud de $0^{\circ}, 0013$. Cuando el embrion choca con algun objeto, permanece al. gunos instantes, como en actitud de examinarle, antes de empezar de nuevo sus movimientos. Al describrir en el agua un arco ó circulo, el cuerpo se encorva tanto mas, cuanto mas corto deben ser aquellos. A veces se observa al cmbrion girar sobre si mismo con el cuerpo del todo encorvado: cuando este movimiento se ha prolongado sin descanso unos 20030 minatos, disminuye poco á poco hasta que por fin termina del todo. Los pelos se erizan y caen desplues que el aninal se lin contraidio con mas ó menos violencia en for. ina de masa oval, $\delta$ ha efectuado quizis tentativas para reptar.

No se conoce aun la suerte ulterior de cstas larvas, pero puede suponerse que pasan en su anfitrion intermediario un cirso de desarrollo muy parecido al de los demís distomos, cuyas formas jovenes viren primero libremente en el agua, e inmigran despues a los caracoles. No cabe duda alguna, continúa el citado autor, acerca del modo con que los distomos pequeños pasan à su anfirrion definitivo que les recoge regularmente con el alimento que le sirre de pasto. Se ha evidenciado por cierto numero de observaciones que algunos corderos que permanecian cn un pasto sospechoso un corto espacio de tiempo, muricron por ciecto de la putrefaccion del higado, cxcepto aquellos que dejaron de pastar por en. contrarse enfermos of por otros motivos. Tambien se sabe que algunos ganaderos ingleses para evitar la competencia, renden sólo animales á los que antes han infestado de distomos del higacio conduciéndolos a pastar a determinados lugares. En muchos casos se ha observado que scis semanas despues que abandonaron las praderas sospechosas se presentaba la enfermedad de los distomos en los corderos. Segun noticias de un naturalista francés, Francia cuenta ya cu este siglo nueve ainos en los que se han presentado distomos del higado; de lo que puede deducirse los estragos que estos causan en determinadas épocas. Aquellos anos fueron los siguientes: $1 \$ 09$, I $\$ 12,1 \$ 16,1 \$ 17,1 \$ 20,1 \$ 29,1 S_{30}$, I $\$ 5 j$ y I $\$ 5 \%$ En los alrededores de Arles perecieron 300,000 rorderos y en los de Nimes y Montpellier ;0,000. Fin el higado de un solo animal se hran encontrado, segun dice, á veces mas de 1,000 de estos parásitos; pero parece que su número raras veces excede de 200 . 
Lin huésped, mucho menos peligroso, muy congenérico a) distomo del higado, y que, con este, habita la misma area de dispersion, es el cistomum laniculatum que tience de 0 ", oo 8 a $0^{\circ}, 010$ de largo. Se encuentra por lo resular en reducido múmero, circunstancia que unida id su pequeñez y i la falta de las espinas del cuerpo, contriburea que se le tema mucho menos. El curso de su vida parece ser semejanic al del dis: tomo del higado y comienza con el periodo de la larra pestañead. Su inmigracion en el hombre es en exiremo rara.

No podemos abandonar aun el género disfoman sin dete. nernos a describir antes algunas especies que dependen especialmente del hombre. En una ocasion se encontró un pequeño distomo en el ojo de cuatro individuos. Otro de estos animales habita el intestino de los egipcios; pero no es ni frecuente ni peligroso. Un tercero, el distomnem hiemato. birm, mueve, sin embargo, mas poderosamente nuestro interés, ya porque en él aparecen los sexos separados, ya porque es uno de los parásitos mas peligrosos de los fellahs y coptos de? Egipto. El macho tiene un centimetro y medio de largo, la hembra es un poco mas delgada y de mayor extension. El disco chupador se halla cerca de! borde anterior. Segun las averiguaciones de algunos profesores, empleados en la escuela médi. ca de Alejandria, sobre todo Bilharz, cuando menos la mitad de la poblacion adulta de la raza egipcia padece a causa de este anélido, el cual permanece en los vasos venosos del bajo vientre y sobre todo en la uretra. Las enfermedades causadas por él acaban á menudo con una debilidad general y con la inucric. Los hijuelos de este distomo nacen en gran número die los hucvos depositados en los órganos enfermos; pero un sin numero de huevos sale ambien al exterior contribuyendu de un modo mas q̨ue suficiente á la propagacion de esta cnformedad tan general.

"Seria de sumo interés, dice I.euckart, averiguar los caminos por los que el distomum hanalobism penetra en el cuerpo humano. Como el género de vida y los alimentos de los egip. cios son muy sencillos, quizás no sea esto muy dificil; por lo menos asi opina Griesenger, gran conocedor de los estados médicos del Egịjo, á ciusa de largos años de experiencias, y naturalista nue ha adquirido grandes méritos por la explicacion de las enfermedades de entozoos del Oriente Segun cree esté médiro, contestando à la pregunta relativa a lit importacion del distumum incmatolium, tenemos principalnente que lijarnos en tres cosas: en el agua del Nilo que se bebe sin filtrar, en el pan y el trigo y quizas tambien en los dátiles que forman un objeto principal de halimentacion, y en los peces que en estado casi descompuesto se comen con gusto por los fellahs. Parece justificado tomar en considemcion las hojas y raices crudas que constituyen el alimento esencial de los egipcios pobres. Como precisamente las cla. ses inferiores de la poblacion son las que estan inf́stadas por el distomum hematobium, la suposicion de que este alimento importa encapsulados los anélidos pecqueños, a causa de los caracoles $\delta$ insectos casualmente adheridos, es quizis mas probable que la idea de que proceda de los peces que, cunndo menos en muestros paises, raras veces estan habitados por distomos encapsulados.

Completaremos nuestros conocimientos relativos á los tre. matodos, sujetos al cambio de generaciones, arrojando uma mirada sobre dos géneros muy afines al distomo. Monosto. mum se llaman las especies que solo tienen un disco chupa. dor que rodea la boca. De estas, el monostomsun mutabile, que mide algunas lineas de longitud, habita en gran número de aves acuáticas. El desarrolllo diel huevo es cxactamente ańlogo al de los distomos de las ranas y parece que en el estado de cercarios penetran en las fosas nasales de estas ares (garzas reales, pollas acuaticas, patos, etc.), y desde aqui á las denás cavidades del cuerpo.

El otro género, último de los trematocios, el aushisfomurm, tiene un gran disco chupador en la extremidad posterior. F.l amphisfomm sublaratum que vive en el intestino grueso de las ranas, sobre iodo en la rana verde acuática, pasa su priméra greneracion, en estado de cercario, libremente en el agua, $y$ en diferentes insectos acuáticos y moluscos, entre otros en las conchas del género gyolas. Otras dos especies cuya historia no se ha averiguado nun, habitan en nuestros rumiantes.
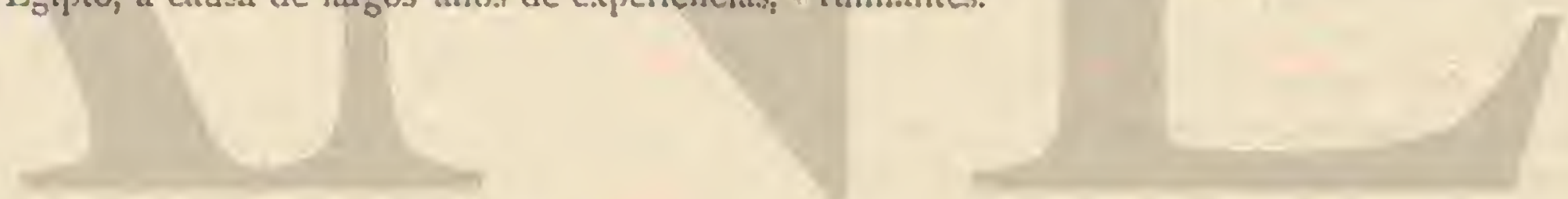

\section{TERCERA SUBCLASE-CESTOIDOS}

Ei conocimiento cle los cestoidos se ha generalirado tanto como el de las trichinas, por cuyo motivo podenos detenernos a tratar mas circunstanciadamente de su género de vida. loda mujer casera amante del aseo de su cocina debe conacer los cestoidos, sus trasformaciones y sus emigraciones involuntarias; : fijarse sobre todo en la composicion del extraño sér á qué se da el nombre de ténia ó lombriz solitaria, cual si fuera un solo animal, asi como en los viajes por él efectuados en sus jeriodos juvenules. Preciso es confesar que la ténia conservada con espiritu dentro de una lomba de vidrio segun se'vé en los musejs, ofrece un aspecto algo repugnante. Pero no es necesario pensar solo en los cestoidos que invaden nuestro cuerpo. Los perros, gatos, ranas y peces nos los ofrecen en buena eleccion. $Y$ sin embargo, entramos involuntariamente en relacion con estos huéspedes de la becada comiéndolos como una golosina al saborear ciertas paraes del ave. Esto nos imp:lsa a emprender sin vacilar la des. cripcion, para la cual detemos ante todo iormarmos una idea de las partes componentes de la llamada lombriz solitaria, colonia ó aglomeracion de animales, segun veremos, cuy'a importacion solo puede explicarse bien por la historia de su desarrollo. Fijémonos, por lo pronto, en el grupo de los verdaderos cestoidos (temaden), al que pertenecen tambien algunas especies que habiian en el hombre; clegimos este grupo porque su historia matural es conocida con todas sus particularidades: mientras que el porvenir debe dar aun las explicaciones completas respecto à los oiros grupos.

Todo el mundo sabe cómo la ténia se encuentra en el hombre, y en muchos animales la «cabera, con su cucllo corto y filiforme $y$ sus articulaciones, pero no todos saben con exactitud lo cque se entiende bajo la palabra articulacion. I a cabeza de la ténia está provista en varias especics de una corona de ganchos sobre una prominencia pequeña en forma de trompa que le sirve para fijarse mejor en tal ó cual intes. tino de su anfitrion involuntario. Seria sin embargo un error creer que las especies no provistas de una corona de ganchos 
son por eso menos tenaces: la mojor prueban de ello es la ténia que ataca al hombre, la ténia mediocanellata, para ruja cxtirpacion deben emplearse genernlmente, aunnuc carece de dicha corona, meciios mas enúrgicos que parn extrnet la tinis sollium, provista de espinas. Alrededor de la cabeza tiene cuatro discos chupadores que como órganos prensiles produ. cen el mismo efecto que los discos ventrales de los trematcdos. En vano se buscara una abertura bucal 6 un intestino en la ténia, quue asi como los equinorincos tiene el feliz privilegio de no necesitar comer y de alimentarse bien à pesar de eso absorbiendo alimento con toda su superficie. En la capa superior de la piel, llamadaruficula, hay un sin numero de finos tubos $\delta$ canales de poros, de los cuales sobresalen delicados hilos de protoplasma de la eapa celular que se balla debnjo. Por estos hilos pasa cl liquido que nutre a la téniay que lleno de granitos grasosos se exticnde en algurios cestididos directamente por el cuerpo. Ien otros parece existir un sistema de rasos destinados à reribir y distribuir el jugo alimenticio.

En los animales mas desarrollados apenas podria demos. trarse que absorben líquidos por la pjel, mientras que en los inferjores esta facultad existe bajo muchas formas segun la maturaleza de los tegumentos del cuerpo. No podemos recharar la idea de que los antecesores de las ténias, convir. tiéndose poco á poco en parisitos, dejaron de tomar el alimento por la boca parn absorbcrle involuntariamente por la piel, y que cl intestino, no solo dejó poco a poco de funcionar, sinno que desapareció por fin del todo.

Segun hemos dicho antes, la parte que sale ininediatamente de la cabeza y yue carece de toda articulacion se suele llamar rcuellow, jero ya veremos que pertenece en rigor a la cabeza. Al cuello siguen las llamadas anriculaciones\%. que se inserhit inmediatamente en aquel, hallándose apenas separadas unas de otras; cuanto mas se alcjan del cuello, tanio mas marcadas son; y en la extremidad de la ténia, alli donde segun dicen se knaduranx, solo estin unidas ligeramente: de modo que aisladas 6 unjadis de dos en dos y de tres en tres, salen del hombre atacado Todos cuantos conocen por experiencia la tenia. saben que las articulaciones son retonos de la extremidad del animal, sobre todo de la cabeza y del cuseIlo, que se separan, y que todos los remedios para extmer el parásito no sirven de nada mientras no s.alga la cabeza, pues toda la cadena se reproduce de nuevo. Sin embargo se vaciló en considerar a la ténia como una raiz animal, porque precisamente las arriculaciones de las especies que con mas irecuencia se observan no parecen tampoco individuos independientes. No se mueven apenas, $v$ to hacen solo como órganos separados; y lo mismo que toda la formacion de que se sęparan, no tienen ni boca ni canal alimenticio, ó aparecen solo, como por ejemplo en la ténia de la rana, cual sencillos tubos de ovarios. Otra cosa sucede con muchos géneros de cestodiclos de los peces, cuyas articulaciones separadas con. inuan viviendo dias enteros, y ejecutan rápidos novimientos. Todas las dudas desaparecen, sin embargo, cuando se ob. servan estas llamadas articulaciones, comparindolas con cl cambio de generacion, y con las de otros inuchos animales, en particular de los trematodos, pues entonces resulta que la ténia se compone de clos clases muy diferentes de indi. viduos.

En los trematodos hemos examinado la generacion de la madre que es tubiforme, y la segunda de los cercarios descendiente de la primera, que desde luego conviértense en individuos adultos.

l.os cercarios se forman como cubriones ó retonos internos. En la tẻnia, la generacion de la madre es la cabeza, con su cuello no articulado, cuy'o origen pronto cxaminarcmos y que algun tiempo existe sola, es decir, sin retonos. Cuando la madre de la ténia se ha fijado en su anfitrion con la cabe «a, da principio à la formacion de una descendencia que en figura de retonos se presenta poco á poco en la extremidad posterior. Fstas llamadas articulaciones de ténia, aunque po. co independientes á menudo, parecen representar en rodo caso los individuos sexuales, la forma mas desarrollada con que termina la fase de la reproduccion y del desarrollo. I.as manifestaciones vitales de las ténias son en todos los grados del desarrollo an poco limitadas, que prescindiendo de la antigua opinion, por demás errónea, podremos considerar como individuo, no toda la forma de la ténia, sino la articu. lacion madura de la misma. La actividad de la ténia se reduce i prolongarse ó contrnerse; movimicnto que se comunica a todas las articulaciones La cabcza, como individuo del órden inferior de los progeneradores de la cadena de articulaciones, es al mismo tiempro una especie de órgano al servicio de ln rair. y por lo tanto está compuesta de dos clases de individuos de diferente forma, que en esta reunion constituyen tambien una unidad. Fsta opinion, con la que debemos fanilia. rizarnos jara comprender muchos hechos de la fauma animal inferior, puede explicarse por las sociedades que forman varios insuctos, como las abejas y otros himenópteros. Toda la agrupacion de abcjas es una unidad à la que varias especies de inclividuos contribuyen por una actividad del todo distinta. Esta comunidad mas libre en sus articulaciones, nos da mas clara idea de aquellas colonias orgánicas reunidas de los cestodidos y de muchos séres polipiformes, en z̧ue el individuo éxiste mas bien aparentemente que en realidad, viendose en ver de lós séres liures unos sustitutos muy imperfectos y dependientes de aquellos. Aqui no podemos menos de recordar aquellas palabras del poeta: procurn siempre formar un todo; s si tú mismo no puedes serlo, reúnete con un todo como mienibro útil». Todas aquellas variadas comunidades animales carecen de la racultad de resolver, que debe carac terizar el Úden superior de un Estado. Pero ; cómo divaga mos al hablar de la ténia! Hablibamos de sus miembros úti les, que cuando alcanzan todo su desarrollo se cambian, gracias a una produccion abundante de huevos en el circulo en que se mueve la especic. En las prineras articulaciones planas de la ténia se reconoce por lo regular a la simple vis. ta el ovario, compuesto de un tronco central y de ramas irregulares que se dirigen á los dos lados. Este úrgano está relleno de huevos á través de cuya ciscara, gruesa y a me. nudo doble, distinguese un pequeno sér esférico, provisto de tres pares de ganchitos. El que cono\%ca la historia del desarrollo de los otros anélidos intestinales, y examine los cestoidos yue hasta entonces no conocia, comprenderá por qué es tán sólici: la cubierta y la estructura de los cmbriones. I.a observacion nos permitira reconocer además que estos huc. vos.Hegan en grandes masas al aire libre: que tambien los cesioidos pueden resistir todos los rigores de la intenuperie, lo mismo la humedad cue la sequia, y el contacto con sustancias fermentadas y en descomposicion, sin que estas influencias afecten su interior; que están destinados á introducirse por cunlquier accidente en un animal; y que entonces el em. brion, provisto de seis ganchos, se libra, y con ayuda de sus seis lancetas se dirige, en cl interior de su anfitrion, á un órgano determinado. A la esfera de este desarrollo, al yqte se adclantan las harvas emigradis, provistas de seis ganchos, pertenecen aquellas especies nite durante casi todo un siglo se habian designado bajo el nombre de canélidos de vejigay como géncros independientes, yique tambien el profano conoce bajo las denominaciones de cisticercos y cenuros. Se les llamaba anćlidos de vejiga porque su cuerpo está lieno de un líquido acuoso, y porque la comparncion mas superficial
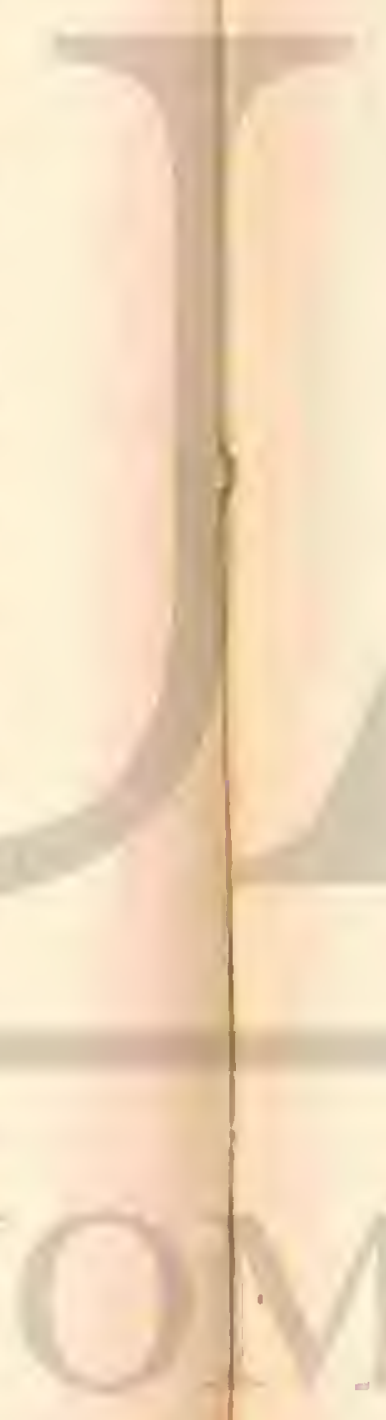
de sus cabezas, que no son otra cosa sino verdaderas cabezas de ténia, explicó hace mucho tempo su verdadern afinidad con los cestoidos.

Cuando hace treinta años se comenzó à observar las emigraciones de los anélidos parásitos, supúsose que los anélidos de vejiga relacionados de un modo tan evidente con los cestoidos, no eran otra cosa sino individuos extraviados que en su cmigracion se habian convertido en órganos inconvenientes, enfermizos é hidrónicos. Ios cisticercos, mas conocidos, llegaban a la carne y no al intestino; su existencia ern nuy misera y llegaron á carecer de todo al fin de su vida. Kuechenmeister tiéne el mérito de haber puesto en su lugrar la controversia sobre la relacion de los anélidos de vejiga con los cestoidos de vejign, determinándola por muchos expe. rimentos, de modo que consta quue la forma del ancelido de vejiga es el estado normal del desarrollo firopjo de toda una serie de cestoidos. No debemos extranar, pues, que se incurricra en semejantes errores. Cuando nuestro amigo Kuechenmeister se presentó en la reunion de naturalistas, en Gotha (I 851 ), poseido del fanatismo de la conviccion, expu. so su teoria, anunciando que despues de repetidas pruebas habia logrado criar del cisticerco de un conejo una hermosa ténia en el intestino de un perro; y él mismo se ofreció á repetir el experimento durante los dias de la reunion. Con otro naturalista mas jóven tuve el honor de ayudar á Kuechenmeister. Habia cisticercos de conejos, pero ninguno de perro, y como Kuechenmeister creyese que tambien jodria hacerse con un gato, cogióse un macho enorme, muy arisco: ataronle en un saco y nos dirigimos à un desvan, cuyas habitaciones esiaban a disposicion de los naturalistas, para introducir los

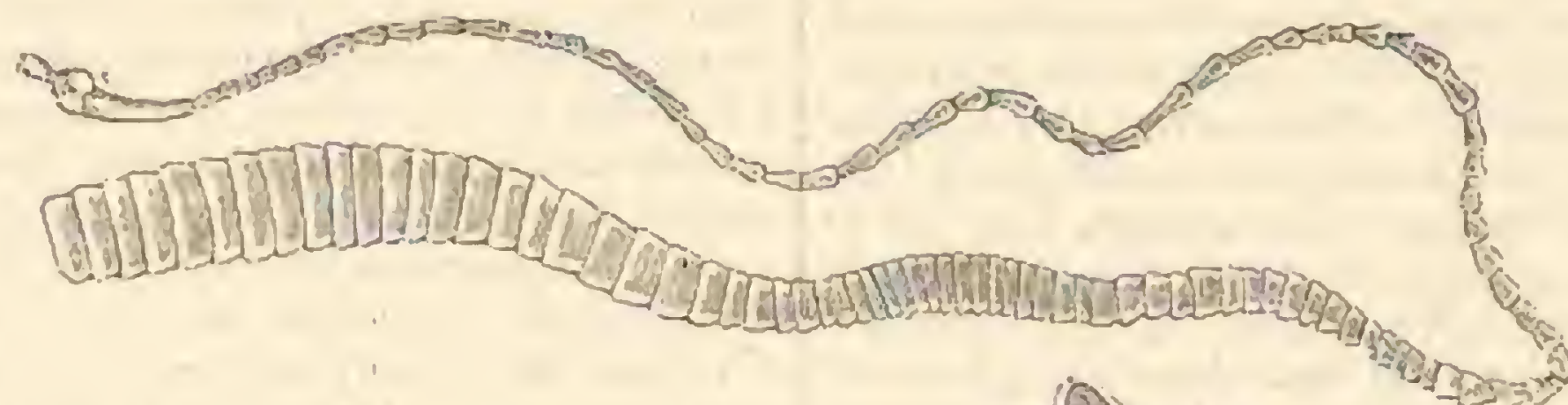

Fig. 173. - LA TENIA JOROSA

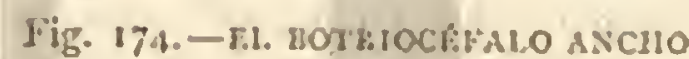

cisticercos en el gato. El carnicero, no obstante, parecia poco dispuesto a ser el anfitrion; aranaba y mordia, y arrojaba siempre los cisticercos que le poniamos en la boca. Por fin logramos la introduccion forzosa; al cabo de dos dias dióse muerte á la victima de la ciencia, y no se halló el menor restigio ni de los cisticercos ni de los principios de las ténias. Naturalmente, aquella prucba única no impidio el progreso del conocimiento exacto de estas relaciones. Comprendiúse que ciertos cisticercos solo pueden desartollarse en ciertos animales.

Los experimentos comenzados por Kuechenmeister, cuyo buen éxito debia depender mas ó menos de la casualidad, se continuaron con afan en todos sentidos. Primeramente era preciso averiguar en el intestino de qué animal el cisticerco que vive en otro animal se desarrolla en colonia de cestoidos; y despues se debia saber de qué modo las larvas provis. tas de seis ganchos pasan su vida hasta su trasformacion en cisicerco. Los hijuclos encerrados en los huevos no macen al aire libre; es preciso que estos lleguen al cstómago de un animial determinado, por ejempló, los de la ténia del gato al estómago de un raton: los de los cestoidos de los perros al estómago del conejo $\delta$ de la liebre, para abrirse aqui bajo la influencia de los jugos gástricos a las procas horas y dejar salir al cmbrion, provisto de seis ganchos. Estas larvas, que entonces están libres, muy pronto comienzan la emigracion, perforan las paredes estomacales y llegan á los organos mas diferentes, donde debe clectuarse una trasformacion en ellos.
Con mas frecucncia el fin àce esta emigracion es el higado. Algunos penetran en los huesos, y cl cisticerco de los cordcros suele introducirse hasta el cerebro. Cuando ha llegado al tin de su viaje y despues de desembarazarse de los ganchos, entonecs inútiles, rodéase de una cápsula en la que inide poco mas ó menos la décina parte de un inilimetro. Ha entrado en un segundo periodo de su vida, en el que se tras. forma en el llamado anélido de vejiga. En el interior del cuerpo redondeado se concentra un liquido, que es el que le dilata mas y mas en forma de una vejiga, en cuya pared se desarrolla una red de vasos claros como el agua, que indican el procedimiento orgánico.

Muy pronto aparece, sobresaliendo hácia el interior de la vejiga, una espiguilla, que es el principio de la cabera de la ténia; es hueca hácia afuern, y ascmépase al dedo de gunnte recogido; en esta cavidad se hallan los discos clapadores y la corona espinosa, de modo que al salir de la espiga estas partes se dirigen hácia afuera, y entonces, naturalmente, la superficie de la espiga vuclta hácia adentro sirve de eje. En niguma especies pueden formarse numerosos retoños de cabezas $\delta$ tambien solo vejigas, de las que cada cual produce una de aqquellas. Nos fijaremos mas minuciosamente en estas producciones al hablar de las respectivas especies. El cestojdo se mantiene en estado de anélido de vejiga mientras deba estar en el sitio donde.se forma la rejiga El cisticcrco del cerdo no se trasforma de ningun modo en los inúsculos cn que fija su residencia: el del conejo, que vive en el higa.. 
do ó en el mesenterio, no cumple con el fin de su vida cuando el animal sucumbe de muerte natural. Pero si la came de cerdo infestada y vendida en el mercado, se conne cruda ó mal preparada por el hombre; si el conejo pasa al estómago de un jerro, ó si el raton, que tambien tiene un cisticerco propio, penetra en el cstómago de un gato, efectúase el trảnsito del cisticerco al verdadero cestoido. Ia primera trasformacion es la salida completa de la cabeza, a la que pronto sigue la segunda con la cual desaparece la vejiga de la cola, que sencillamente se digiere I a cabeza con su cucllo es un ser independiente; la generacion intermedia de la madre, que desde el estúmago del animal habitado pasa hasta cierta parte del intestino, donde se fija y produce la generacion final, representa los individuos sexuales bajo la forma de retoños y articulaciones. De consiguiente, para resumúr en pocas pala. bras lo anteriómente dicho, en la vida de la ténia se suceden los siguientés estados, con repetido cambio de residencia. el embrión de seis ganchos; el cisticerco; la cabeza de ténia sin articulaciones; el verdadero anélido con cadena, y la articu. lacion aislada 0 individuo sexual; pero atendido que la larva de seis ganchos pasa directamente á la vejiga, la cabeza de ténia se forma en esta como retono, el cual constituye el suelo en que se desarrollan las articulaciones. En rigor deben dis. tinguirse tres gencraciones, de las cuales solo la última esta desarrollada sexualmente, mientris que las dos anteriores son losigrídos preparatorios.

\section{LOS TENIA DEOS - T.FNIADEA}

Hecha esta descripcion comprenderemos fácilmente bajo qué condiciones se encuentra una serje de especies del género tenia (figs 173 a 176 ). Examinaremos por lo pronto na. rias cuya formn de anélido de vejiga, designada antes con el nombre de cysticerius, se compone de una vejiga con una sola cabera, aunque las mas importantes son las que con mayor frecuencia se fijan en los hombres. La especie conocida hace mas tiempo y mejor estudiada es la ternin soliuns, cuýr longitud alcanza de dos à tres metros, siendo su cabeza semejante a la de un alfiler de mediano tamaño. En la pro. minencia de la frente tiene una corona de dos clases de ganchos, los cuales se distinguen muy bien, por sir forma recogida, de los de otras fanins conqque se ha querido agrupar la lombriz solitaria del hombre. El cucllo tiene poco mas ó menos $0^{\circ}$, or 5 de largo y el número de las articulaciones maduras $y$ no maduras que forman la cadena asciende a sicte í ocho, cuando no mas. In forma de las articulaciones es muy diferente en las diversas partes; solo la illtima es decididamente prolongada, ramificióndose el omrio mas y mas, a medida que aumenta el grueso de la ciscara de los huevos. Basta ver tal articulacion madura para poder decir con seguridad si el inaividuo atacado por - la sólitaria tiene la fenia solium ú otra especie. El ovario de la trenia solium solo presenta á cacla lado de siete a dicz brazos que à su vez se ramifican.

Es cosa bien averiguada que el hombre sufre, con el cerdo, la invasion de este cestoido, hecho que ha quedado fuera de toda duda por minuciosos experimentos, repetidos siempre con el mismo resultado. Muchos cerdos grandes y pequenos han sido sacrificados desde el quinto decenio de nuestro siglo para observar la enfermedad ocasionada por los cisticercos, despues de introducirles cierto número de arti. culaciones maduras de la icesia solium.

Practicada esta operacion necesitanse dos meses y medio para que los cisticercos se desarrollen en los músculos del cerdo. No se han encontrado solo en este mamifero, segun dicen, los cisticcrcos de la ténia, sino tambien en otros ani- males, como por ejenplo en el mono y el perro. Es cosa averiguada que hasta en rl hombre, cuando por cualquiera casualidad ha tragado los huevos, se desarrollan esos parásitos regularmente en los músculos, pudiendo además encontrarse en el corazon y con bastante frecuencia en el ojo y en el cerrebro.

Para cerciorarse de que en un caso dado el cisticerco del cerdo se trasforma en el hombre en trin solium podian hacerse tragar cisticercos, voluntaria ó involuntariamente, a fin de observar las consecuencias: Kuechemmeister que tantos méritos ha contmido por su estudio de los cestoidos, turo la idea de propinar á criminales sentenciados a muerte cierto número de cisticercos en una buena sopa merclada con pedazos de salchichon, sin que los reos lo supieran; al practicar la autópsia reconoció la existencia de los cisticereos y el principio de la transformacion. Otro naturalista encontró por poco dinero un pobre que sometiéndose à sus instrlicciones adquirió ta ténia comiendo; y en fin, el amor á la verdad y à la ciencia indujo a varios zoólogos a servirse de su misma persona para hacer los experimentos sobre los cisticercos y la ténia. Parece que desde la introduccion de aqquellos en el estomago, hasta la hora de separarse la primera articulacion madura, deben trascurrir de tres meses a tres y medio. la té nia puecie llegar á la edad de ro á 12 años, $y$ hasta parece pasar dé este término cuando se reunen todas las condiciones de bienestar.

Un segundo cestoido que habita en el hombre es la tic. mia mediocantiata que puede tener 4 -metros de largo, sien. do mas gruesa, fuerte y actima que la especie que acabamos de describir. Ambas pieden distinguirse muy fácilmente, porque la cabeza de la trensin mediocancliata carece de la corona de gánchos, presentando solamente los cuatro discos clapadores muy fuertes. Sin embargo, cada articulacion madura puede reconocerse, porque el ovario tiene de 20 a 35 ramas laterales paralelas. El área de disjuersion parece ser tan extensa como la de la especie anterior. Desde largo tiempo se sabe que los abisinios sufren mucho por la invasion de un cestoido, segun las noticias de los viajeros antiguos y modernos, á consecuencia de la costumbre de comer la carne cruda. J.os mahometanos y curopeos que no la comen de este modo están exentos de la ténia, que sin cmbargo, se presenta en seguida cuando adoptan la costumbre de los abisinios. Estos no comen carne de cerdo, sino de cordero y buej: Otros informes médicos mos dicen que los niños se iniestabar de la ténia despues de comer carne de ternera picada, lo cual indujo a Leuchart a suponer que el cisticerco de la fenia medioranelioto habitaba en los musculos de la ternera, cuyo hecho confirmaron los experimentos hechos en este sentido.

Debemos abstenernos, por lo tanto, asl de la carne cruda de ternera como de la de cerdo. Parece quue las terneras y los becerros infestados del todo pror cisticercos se encuentran muj raras reces, circunstancia que sin duda es la causa prin. cipal de que el estado de cisticerco de la tarnia medjosanelinfa del hombre fucra ignorado durante nucho tiempo. A la manera de alimentarse los rumiantes debe atribuirse la causa de que estén muclio menos expuestos al peligro de devorar articulaciones enteras de ténias con miles de hueros, mas no por eso se ha de tener inenos cuidado. La fanin mediocaneliafa es sin duda la forma mas comun del cestoicio, y hasta puede introducirse por la proca carne de cerdo que sa pone en el salchichon, como sucede en Turingia; mas fa vorable para la propagacion de la esprecie es la carne cruda picada de ternern.

Entre las ténias en su estado de anélido de vejiga, análogo al del cisticerco, es decir, al en quue la vejiga solo produce 
una cabeza de ténin, podemos citar aun algunas especies uropias de los perros y gatos. La tania marginata, que puede llegar á la edad adulta en el perro, no es peligrosa para el hombre en tal estado, pero alguna ver. su cisticerco, que por lo regular vive en el higado de los rumiantes y cerdos, y que por el sistemático antiguo se conocia bajo el nombre de cysticercus tenuicollis, hallase igualmente en el hombre. Ia ténia mas comun del perro es la ternia serrnta, caracterizada por una serie doble de grandes y pequenos ganchos; en estado de cisticerco vire en los conejos y liebres. I.os muchos experimentos hechos en los perros y conejos en que se crió la tenia serrata han contribuido con preferencia s la expli. cacion de la historia natural de los cestoidos. I a especie mas comun en el gato es la tenia crassicollis, que tiene la cabeza fucre y el cuello corto y grueso. El proverbio que dice, cuando el gato no esta en casa los ratones bailan, no se refiere en modo alguno al cisticerco contenido en el raton (al llamadn gesticercus forinloris), ruyo mejor tiempo comienza cuando el gato ha comido al raton.

Un cestoido muy interesante á causa de su estado de cisticerco, y aun mas difamado, es la tenin canurus, que solo en el perro llega á la edad adulta. Conocemos este grado del desarrollo desde hace poco tiempo, es decir, desde que comenzaron los experimentos sobire los cestoidos: pero ya hace mucho que se observó el estado de anélido de vejiga bajo el nombre de cenuro (cirnssrus), que, viviendo en el cerebro de los corderos, produce el vértigo en estos animales. Se ha dado a conocer el curso de la enfermedad, uaturalmente tambien por medio de experimentos: en los corderos en que se introdujeron los respectivos huevos manifestáronse al cabo de iq dias los primeros simtomas del vértigo, hallandose entonces en su cerebro las vejiguilas del taınaño de un guisante, en que se han trasformado los embriones de 6 ganchos. En estas rejigas, sin embargo, no se forma, como en el cisticerco, una sola cabeza de ténia, sino un grujo de tres ó cuatro, y muy jronto, desarrollándose mas y mas en algunos sitios de la vejiga, aparecen otros grupos, 6 bien salen nuevas cabezas en medio de las ya existentes, mientras que la primitiva se ensancha de modo que su número puede ascender por fin à varios centenares. Ia pre. sion y la irsitacion que el cenuro ejerce en sus alrededores, froducen aquellas inflamaciones y debilidad del cerebro, que ocasionar el vértigo de las ovejas y por último su muerte. La repeticion de la enfermedad solo puede prevenirse algun tanto enterrando cuando menos las cabezas de los carneros muertos, a fin de que no las devoren los perros. En el pueblo donde pase mi ninez habia continuamente carneros que padecian el vértigo; el inatadero se hallaba situado apenas-a un cuarto de hora de distancia, y en el parecian darse cita todos los perros de corral y de pastor que se soltaban de noche ; y entonces nadie tenia la mas remota idea de que precisamente estos perros pueden volver à llevar el mal a los pasios, al corral y al establo. Ahora, la vigilancia es tal, que solo por medio de perros forasteros puede propagarse el cenuro. La disolucion de la vejiga de esa especie se verifica muy rápidamente en el estómago del perro; todas las cabecitas quedan en libertad; cada cual funda una colonia dé articulaciones, y del solo huevo que se desarrolla resulta una descendencia multiplicada muchos miles de veces.

Un parisito del hombre, no muy comun, pero en cicrtos casos bastante peligroso que causa la muerte $y$ habita tambien en algunos animales (rumiantes, cerdos, monos), es el equinococo (eihirococis, del sistema antiguo): tiene la forma del cisticerco de un cestoido que asimismo vive en el perro y que se designa bajo el nombre de fania echinocacus; es tan pequeño (mide poco mas de $0^{\circ}, 00 ;$ de largo por un tercio de milimetro de ancho) que escapo al exaimen de los observadores anteriores, habiéndose descubierto solo tambien por el moderno estudio de las condiciones vitales de los cislicercos.

Difiere esencialmente de todas las otras ténias por la circunstancia de que ya ell la tercera articulacion se hace adulta, siendo aquella tan larga como las dos primeras con ia cabeza. La vejiga quee nace del embrion, con seis ganchos, es, asi como la del cenuro, el sitio donde se producen muchisimas cabecitas; pero no se forman directamente en la parte de la vejiga, sino en ch́psulas particulares, que nacen de la pared, y en cuya superficie exterior se desarrolla el principio de la cabecita bajo la forma de un apéndice. Este apéndice se recoge entonces en el interior de las capsulas de cria, en las que penetran por fin las cabecitas de ténia col. gadas de delgados tallos. Cada una de las caipsulas contiene a menudo de doce à quince cabecitas, raras veces veinte, $y$ tiene de (1),001 á uno y medio de diàmetro. Muy diferente es, sin cmbargo, el tamaño de la vejiga del equinococo antes de producir las capsulas: Leuckart las vió del diametro de $0^{m}, \infty 0 \mathrm{r}$, habiendo encontrado otras del volúmen de un lavevo de gallina. Al lado de estos equinococos sencillos que acabamos de describir se encuentra otra especic compuesta en la cual se forman otras nuevas vejigas, llamadas sccundarias, ya hácia afuera ya hácia adentro; de modo que entonces la ve. jiga primitiva encierra toda una descendencia de otms iguales i ella. Muy à menudo ternina con estas últimas el desarro1lo, no formandose cappulas con cabecitas ni en las rejigas primarias ni en las secundarias. Toda la formacion parece entonces menos un cuerpo animal parasitico que un scncillo hidátido.

Entre los parásitos humanos, dice leuckart, no hay otro que pudiera compararse al equinococo por la sariedad de su distribucion. Hasta el cisticerco del cerdo, que con ran hemos clasificado entre los helmintos, at causa de su residencia en tan diferentes órganos, es muy inferior por este concepto al equinococo. Apenas hay órgano del cuerpo humano que no le sirva alguna vez de morada, $y$ hasta penetra a veces en los huesos. Sin embargo, no todos los órganos al. bergan à ese anélido con igual frecuencia. El equinococo iene, asi como el cisticerco, residencias favoritas, ademàs de las que busca con menos frecuencia; pero las preforidas por ambas especies son muy diferentes. El tejido celular de los músculos, que el cisticerco elige ante todo, solo en raros casos es morada del equinococo. Lin el cerebro, y sobre todo en el ojo, el cisticerco se encuentra con mucha mas frecuencia que el equinococo, que en cambio clige los intestinos y sobre todo el higado, donde alcanza a menudo el tamano de una cabeza de niño. Probablemente el perro es el único animalen que habita la fenice echirococus, que con él se propaga por tódo el globo; péro en ninguna parte constituye una plaga tan temible como en Islandia, donde, segun se dice, ocasiona la muerte de la quinta ó sexta parte de toda la poblacion.

\section{LOS BOTRIOCEFÁLIDOS-BO- THRIOCEPHALIDE}

La historia de los cestoidos, cuya vida está relacionada con la existencia de nuestros animales domésticos y de nuestro propio cuerpo, debe completarse, pasando por alto.álgunas formas menos importantes y conocidas. con una especic perteneciente à otro género y familia, el hothriocephalus la. tus (fig. 174). Los hotriocéfalos, que difieren de las ténias, tienen una cabeza aplanada provista en cada ladó de un pro. fundo hoyo chupador longitudinal. La mayor parte de las 
especies viven en estado adulto en animales de sangre fria, sobre todo en peces; $y$ algunas en aves y mamiferos: la mas importante es naturalmente la que habita en el hombre. Ningun otro cestoido de esta última especie llega á la lon. gitud del bofliriocephalus lahus que alcanza de 5 a 8 metros de largo, y tiene de tres á cuatro mil articulaciones cortas y an. chas; la cabeza mide 1" chr $\varangle$ El área de dispersion del botriocéfalo, dice Leuckart, es mucho mas reducida que la de la taria solium. Fuera de la Europa este anélido no se ha observado aun nunca con seguridad, $y$ aun en nuestros paises solo se encuentra en ciertas naciones, sobre todo en la Suiza occidental y en los distritos limitrofes de Francia; en Ginebm, segun se dice, casi la cuarta parte de los habitantes padecen del botriocefalo; en las provincias Norte occidentales y septentrionales de Rusia, en Suecia, Poloria, Holanda y Bélgica hállase tambien el botriocéfalo, pero con menos frecuencia que en los paises antes citados. Tambien en Alemania se observa en algunos distritos, sobre todo en la Prusia oriental y en Pomerania.

\ace ya inucho tiempo se observó que los sitios y regiones en que viven los botriocéfalos son aquellos en que mas abunda el agua. Habitan varios puntos de la costa, como las provincias del Báltico, y los paises del golfo de Botnia y de Finlandia, ó bien las llanuras immediatas à los grandes lagos y rios. Compréndese que muchos lanyan procurado rélacionar esta circunstancia con la presencia de nuestro cestoido, alegaindose entre otras cosas que la alimentacion con peces era una causa principal 6 cuando menos favomble el desarrollo del botriocéfalo. Hasta se aseguró que los cul-

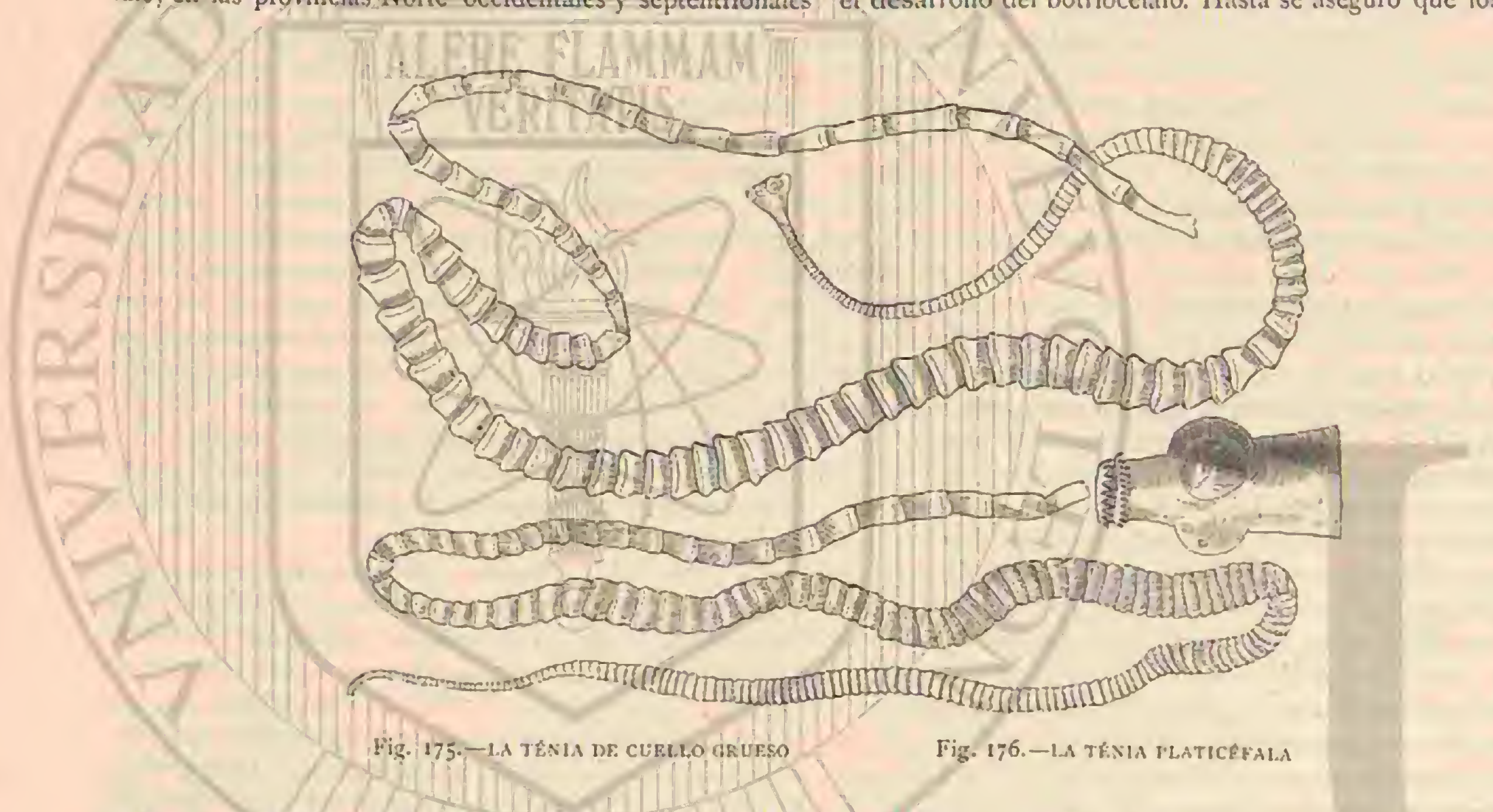

pables eran ciertos peces determinados, precisamente los mas gustosos, es decir, los salmones'y las iruchas. Sin embargo, no se sabe aun si con tal suposición se ha dado en lo justo.

Desgraciadamente solo se conoce hasta aliom una parte de la historia del desarrollo del botriocéralo; el que comienza en los huevos solo se verifica despues de haber pernanecido muchos meses en el agua. Al través de la cáscara se divisa cl cmbrion de seis garkhus ugue ya hemos observado al hablar de las ténias; pero al nacer, en cuyo instante se levanta una tapita especial del huevo, no sale una larva desnuda; sino cubicrta de largos pelitos, que durante cuatro ó seis dias se mueve lentnmente en el agur, perdiendo despues aquellos. Como los mismos sabios están muy poco acordes aun sobre la suerte ulterior de las larvas, pasamos por alto aqui sus suposiciones y pareceres. En el intestino del hombre el botriocéfalo se conserva hasta veinte años, más por lo regular este término es mucho mas corto y tambien es facil desembara. zarse del cestoido, porque se fija con menos fuerza.

Al lado del botriocéfolo comun se ha réconocido aun otra especie con seguridad como parásito del hombre: es el bothriocephalus cordatus, que en el norte de Groenlandia acosa al hombre y al perro. Sin duda en el curso de los años se ampliarin las observaciones con noticias de otros continentes.

Los demas géneros de la familia de los botriocéfalos viven desarrollados, ya en peces, ya en ares acuaticas, en las que penetran con aqucllos I.as articulaciones del cuerpo son en la mayor parte de las especies poco marcadas; hasia pueden limitarse a una sencilla repeticion de los órganos genitales, sin señal visible exterior, hecho de gran importancia tcóricn, que nos obliga a referirnos al género carjopliyllacus, que, à pesar de ser esencialmente ténias, no son, sin embargo, articuladias; tienen los órganos genitales sencillos y pueden llamarse trematodos sin aparato digestivo. Las especies de la familia tetropliylliden, cuya cabera esta provista de cuatro discos chupadores muy movibles, a menudo pedunculados, y cuyas articulaciones maduras viven bastante ticmpo aisladas, recuerdan í los trematodos mucho mas gue las verdaderas te. nias.

Todas habitan en peces, principalmente en tiburones $y$ rayas, en cuyo intestino penetran con otros peces que constjtuyen el alimento de aquellos.

Al termimar esta parte de nuestra obm, abundante en materia, tenemos la esperanza de que los lectores que no se hayan desanimado ante los epigrafes y por el contenido poco -agradable en si, habrán encontrado, por el interés dé la relacion de los hechos, una compensacion completa de la falta de todo atractivo poético. En general recordaremos que las supuestas disonancias en la naturaleza se compensan cuando el hombre, colocándose en una atalaya, procura espaciarse en mas cilatado horizonte. Un foeta aleman, Rueckert, dice: EI que encuentra el tono propio del canto universal, no oirá en él ninguna disonancia, sino solo trínsitos.» 


\section{LOS BRIOZOIDOS- BRYOZOA}

Los briozoidos han tenido la suerte de muchos grupos de animales acerca de los que los maturalistas no pudieron en mu- cho ticmpo ponerse de acuerdo en cuanto al lugar qque debian ocupar en el sistema. Su tamaño microscópico; la existencia de dos copetes ó una corona de antenas quue roder su abertura bucal; y sobre todo el hecho de encontrarse siempre estas especies en raices animales ó colonias cuya formacion ofrece
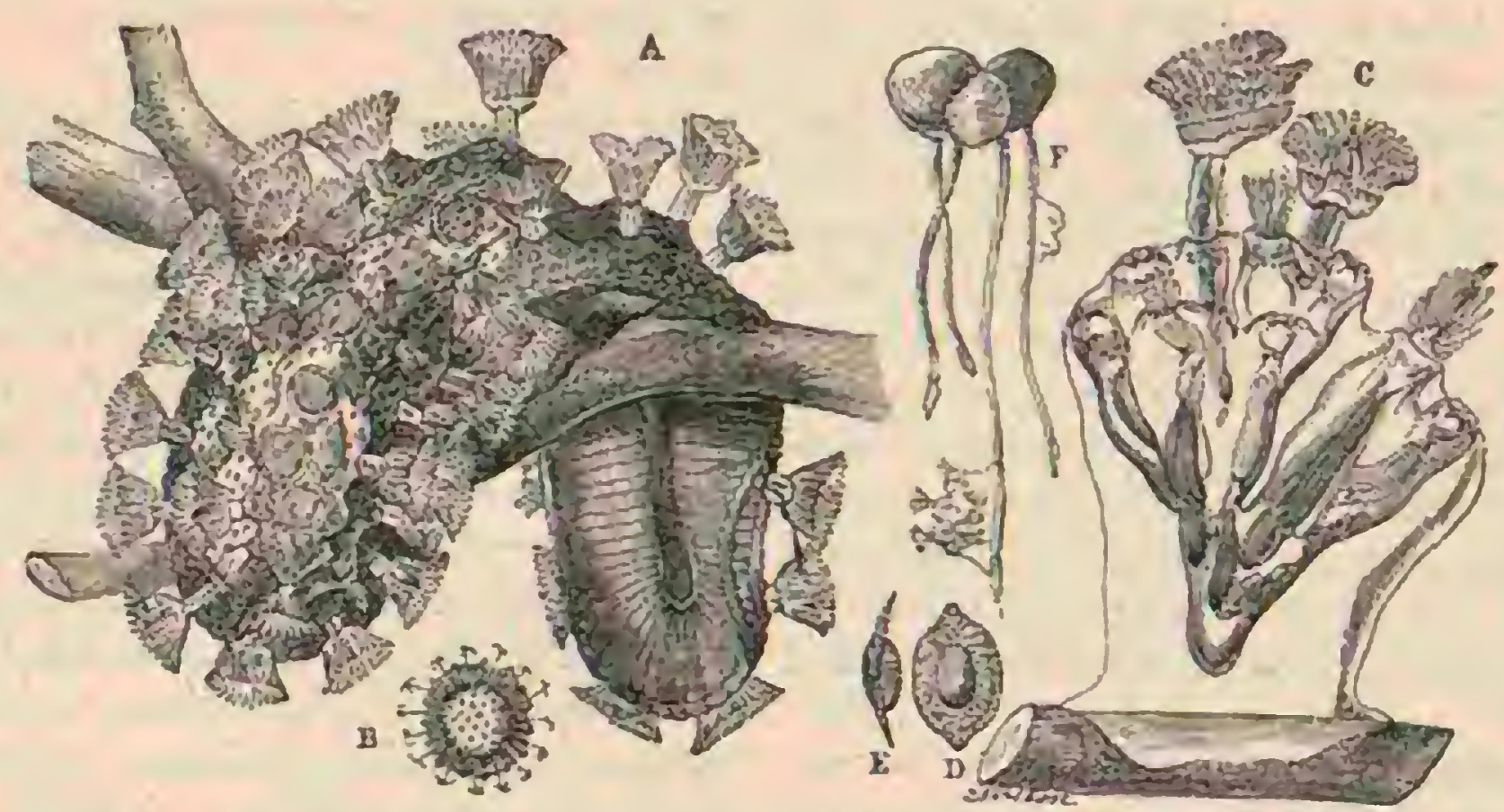

Fig. 177.-A Y li CRISTATEI.A MOHOSA

Fig. IFS.-C, D, E y LOFOYO CKISTALBNO

una marcada analogía con las raíces de los verdaderos póli. pos, hicieron que pareciern exacta la clasificacion de la mayor parte de los naturalistas antiguos, que los agruparon entre los pólipos. El cételure zoólogo Milne Edward, creyendo ver en la forma del intestino y en otros varios caractéres una afinidad con los acididos, reunió ambas clases bajo cl

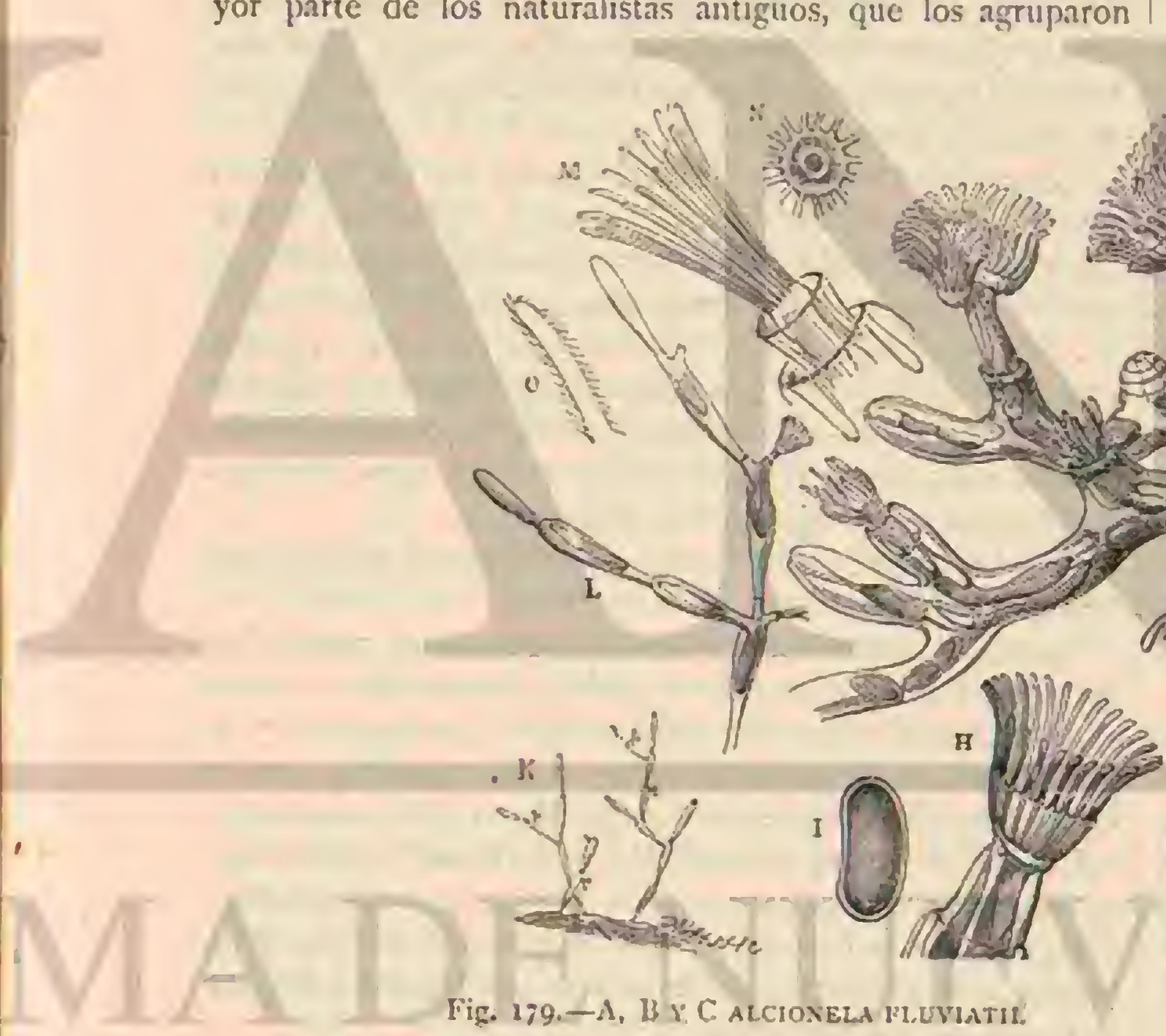

Fig. 18I. - H V I FREDERICILA SULTANA

nombre de moluscoidus; pern Carus dice con razon, en una de sus mas recientes obras sistemáticas, que ela completa falta de una parte del cuerpo animal, separada extcriomente, es la que dificulta y hasta improsibilita una union directa de la estructura de los moluscoidos con el plan de organiyscion de los moluscos. Nosotros ramos aun mas allá, pues ni siquiera concedemos las relaciones entre los briozoidos y los acididos. Desgraciadamente no desaparecen por eso las dificultades sistemáticas, y apenas hay razones que positivamente obliguen á considerar los briozoidos como rama del tronco de los anćlicios. Cárlos Vogi ha dicho en cierta ocasion con mucha gracia, que cuantos sistemáticos busquen una diagnosis que reuna los grupos heterogéneos de todos los anélidos y' animales que lo parecen, solo podrán fijarse en el hecho de que la longitud de la lombriz es diferente.

En los casos en que la anatomía de los animales adulios no nos sirve para determinar la afinidad, el desarrollo nos ofrece por lo regular algunos indicios. Schneider quiere deducir de la comparacion de la lara llamada geplonautes, perteneciente a un briozoido marino, el membranipora pilosa, con larvas de los bonélidos, Ja afinidad de nuestras especies con estos anclidos, y tambien ve en la estructura de los briozoidos una marcada analogía con los sipimculoidos. Sin descender a estas comparnciones particulares, he creido deber citarlas aqui para orientarnos mejor.

Examinaremos la estructura de los briozoidos en una cs. 
pecie propia de las aguas dulcés de Belgica, en la paludicella Eirrenbrergij. El cuerpo presenta una celdilla bastante prolon. gada, de paredes rigidas, excepto en la parte anterior, donde son tan elasticas, que pueden recogerse por medio de varios músculos, entre los que hay uno muy fuerte que libremente se extiende por el cuerpo, llegando casi a la extremidad de la celdilla. En la extremidad anterior se halla la abertura bucal, rodenda de una corona de tentáculos ó antenas con pestañas. El intestino, que comienza con un esófago musculoso, esta pendiente como un lazo, con el estónago, en la cavidad ab. dominal, y remata un poco mas abajo de la boca; el resto, del todo libre, solo se fija ligeranente en la pared abdominal por una especie de cordones mas cortos. Fin todas las celdas adultas se désarrollan en la pared dos aglomeraciones celtulates; de la superior salen los hiveros, mientras que en la inferior se forman los cuerpecitos espermáticos. Lós briozoideos son por lo tanto hermafroditas; la fecundacion de los huevos se verifica por los cnerpos espermáticos que se desarroilan muy cerca de ellos y fotan con los huevos libremente en el liquido abdominal.

Estos son los caractéres uniformes y esenciales de la cstructura de un grupo de animales del que se conocen unas 1,700 especies, entre fósiles y vivientes, aumque llaman poco la atencion en su conjunto, á pesar de las aglometnciones de jndividuos! Algunos géneros cubren en el ngin dulce las raices y los taillos de las anémonas, formando chpas del grueso de un brazo, pero su maturaleza y sus colores son tales, la estructum graciosa de cada individuo escapa de tal modo á la iniracla, que tampoco por estas masas llaman la atencion. De una extrema virieciad y gracin admirables son las raices de los brio. zoideos marinos, que tambien se encuentran con extraordinnria frecuencin: elévanse en las basés mas diferentes como graciosos arbolitos $\delta$ formaciones que sé ramifican en figura de lorquillas, is bien reptan en un sitio determinado. Otras se enlazan como frinas redes ú ofrecen el aspecto de césped y musgo reunidos, ó forman hojas que sobresalen en uno $b$ en ambos lados de los copetes branquiales.

Con la red se coge a menudo en las costas del Atlántico y del Mediterrineo, el limmado coral de red, quie no es coral, sino un verdadero briozoido, cuya colonia ofrece el mas gracioso aspecto. Cuando esti fresco, las raices, semejantes a una red en forma de copa, ó formando muy variados repliegues y rizos, le dan el aspecto de una masa organica rojiza, de la cual sobresalen las delicadas partes anteriores. Los individuos aislados solo pueden reconocerse bien con un alleojo de bastante aumento. Las raices despojadas de sus par. tes blandas, limpias y expuestas al sol, tienen un color blanco brillante. En ellas prepondera la masa intermedia calcárea que reune los individuos, y cuyas relaciones con las partes pertenecientes a los individuos aislados son muy análogas á las de los pólipos, de los cuales hablaremos despues. Los pe- queños orificios que como puntitos vemos en las hojas abicrtas pertenecen á los individuos aislados; sus paredes son las extremidades trasformadas en esqueleto, es decir, las cipsulas, à que se retiró la parte anterior correspondiente.

Un grupo de los briozoidos, el de los leprálidos, se distingue de los retéporos y otros por la particularidad de que los individuos solo se encuentran en un lado de la rai\%, es decir, en capa sencilla.

I a conservacion en estaclo fósil se debe al endurecimiento y á la osificacion de la mayor parte de la pared abclominal, que se trasforma en una celda donde puede recogerse la parte anterior del animal que siempre queda blanda. La forma tan variable de las raíces depende de la manera especial de formarse los retoños, pues cuancio el sér nacido del huevo se ha fijado, la raiz se produce por la formacion de aquellos. Los retoños ocupan en cada género y especie ciertos sitios y $u n a$ posicion determinada respecto al individuo 6 madre, $y$ de este modo resultan, a causa de pequenas diferencias, las mas veriadas formas en las colonias. Como cada individuo de estos produce en cierto tiempo huevos y espuma, la maturaleza parece haberse cuidado con la mayor solicitud de la propagación de la especie. En la orilla del mar se puede adquirir en pocos dias una rica cosecha de briozoidos; solo se necesita tener algunos montones de algas para encontrar casi ent todas las partes de las hojas de estas plantas cicrtas especies; y alli dónde el fondo del mar no es demasiado estéril y desfavorable, las piedras y las conchas de caracoles están cubiertas de raices de briozoidos que, sin embargo, no se des. cubren á menudo sino despues de un examen minucioso con un anteojo de bastante aumento.

Las especies mas notables del género de los leprílidos son la lepralia de Ladsboros' (fig. 214) la lepralia espinifera (fig: 215 y 216 ) y la lepralin de tres espinas (fig. 217 ); conócen. se además otras especies designadas con los nombres de letralia de condia (fig. I $8_{3}$ ), lepralia adada (fig. 1 \$ 4 ), lepratia de un cuerno (fig. 185), lepralia de Gattje (fig. is6), lepralia de Hydman (fig. IST), lepralia personal (fig. ISS), lepralia E'ariolosa (fig. I 89 ), lepralia nilida (fig. 190), iepralia de Malus (fig, 191) y lepratio discreta (fig. 192).

Podrit formarse idea de estas especies por el grabado que las representa.

De lo dicho resuita que estos séres no tienen mucha importancia en el gran concierto del mundo orgánico; pero su número considerable, los detalles sobre sus úrganos y su diversa manera de propagarse ofrecen tal. variacion, que su estudio podria ocupar muchos años de la vida de un naturalista, segun lo demuestran los voluminosos escritos que tratan de estos séres. Los caractéres principales para la division sistematica se han tomado de la naturaleza de la boca y de la corona de tentáculos, segun se verí por algunos ejempios que presentaremos al lector.

\section{FILACTOLEMATOS-PHYLACTOLÆMATA}

La mayoria de los briozoidos de agua dulce pertenecen al órden de los llamados filactolematos, cuya boca cstấ provista de uma tapa en figura de lengua. Sus branquias afertan in forma de herradura y estan rodeadias en su base por una piel en forma de copa. Ias celdillas son del todo blandas y córnens, no encontríndose por lo tanto en estado fósil. Un génern muy particular es cl crisfatella (fig. 177), cuyas especies constituyen agrupaciones de discos que no se fijan sino buscando la luz; reptan y avanzan lentamente. Ahora se preguntara como lin sér de tantas cabezas logra reunir todas las vo- 
Mucho mas numerosas son las familias que carecen de la tapa de la boca llamada epistómo y que tienen por lo tanto dicha parte descubicra. Sus branquias no afectan la forma de herradura y los tentáculos estín dispuestos en figura de un disco. El nombre sistenático parn este órden es el de y'mnolémafa que significa falta de cpistómo. A las pocas especies de agua dulce de este grupo pertenece la faludicella (fig. $\mathrm{r}_{32}$ ) en la que la corona branquial puede salir incom. pletamente y parece rodeada por lo tanto tambien, cuando se halla mas extindida, de una especie de doble gorguera.

Distlnguense tambien entre estos briozoidos las alcionellas, cuyos tubos en vę de ramificarse forman una masa redon deada de aspecto esponjoso, y en las que se considera como á tipica la alciunela fluriatil (fig. 379 ); las plumatelas, casi dia famns, provistas de tentáculos retrictiles en número de cincuenta que están guariecidos de pelos vibrátiles y cuyos movimientos determinan rádios en el líquido, conduciendo asi los alimentos i su boca; $;$ de las que es la especie mas conocida in siumatela companuda (fig. 180); y la fredericila que se distingue por tener una serie de tentáculos dispuestos en forma de embudo y cuya especic típica es la fredericilo sultona (fig. 181 ).

Otro grupo muy numeroso de los gimnolematos figura con los quilostomos, de cuya naturaleza la furstra folicisen, comun en nuestros mares $y$ la fasstra devitioula (figs. 205 a 207), pueclen darnos una iden. Las celdas constituyen la parte del animal que se endurece, yá la que puede retirarse la anterior blanda, lo cual se verifica por una aberturn transversal en la gue se encuentra una tapa clástica en forma de labios. Ios individuos pueden por lo tanto encerrarse dentro de este capullo; los géneros que no están provistos de una tapa paricular contraen la hendidura transversal por medio de mísculos. Las colonias de la flustra producen lóbulos ranificados en forma de hojas y compuestos en ambos lados de una capa de individuos estrechaniente oprimidos. Las celdas se transforman en una pared calcárea no muy fuerte, de modo que cuancio estàn frescas toda la raiz conserva mucha elasticidad.

Merecen tambien consignarse aqui las carbaseas (fig. 208); los diacoris (fig. 210) que presentan las celdillas separadas, cada una cnlazada con otras scis por medio de tubos (figu- mientos de las colonias. Además de los huevos se forman en la cavidad abdominal de las cristatelas, $y$ en general de la mayor parte de los filactodematos, unos cuerpos particu. lares en figura de lentejas, los llamados estatopiastos, que en otono, cuando mueren las raices, quedan libres y pasan el invierno en el limo del fondo de las aguas. Fn la primavera pasan a las celdas que forman la protuberancia que rodea el exterior de la lenteja; esta se liena de aire; los es. tatoplatos salen á la superficie, y de ellos nace en algunos géneros un individuo jóven, mientras que en nuestrn cristatela se producen tres que constituyen el principio de una nueva vida

I os lofofos constituyen otro género, cuyo polífero afecta la forma de saco y es muy gelatinoso. Le representa en particular la especie lofofo cristalino (fig. 1;8). ósil. Un especies sino bus- ra 211) : las membraniporas (fig. 213), en cuyogenero se observan celdillas irregulares con bordes bastante levantados. Esencialmente distinta es la proporcion que se observa entre la parte recogible y la celular en el género bubuliforn; la desembocadura esti en la extremidad y pasa sin estrecha. miento à la parte anterior que es blanda. El género que es uno de los muchísimos llamados ciclostomos, forma con sus raices incrustaciones en forma de fuentes con los individuos dispuestos como rídios.

Los naturalistas se han visto obligados á reunir con los briozoidos, antes descritos, algunos géneros mas, cuyo caracter mas notable, en su opinion, consiste en tener la abertura anal dentro de la corona de tentículos. Elijo precisamente el animal menos conocido hasta ahom, agregado a este grupo, porque hace poco tiempo quic me ocupé mimuciosnmente de él.

Se trata del género loxesuma para el que propongo el nom. bre de animal de cuchara, porque no solo la forma del loxosoma cochclar, sino tambien la de la mayor parte de las otras especies, vistas de lado, se ascmejan muchisimo a dicho objeto, sobre todo cuando los tentáculos estan recogidos. Str cuerpo se compone del tronco y del tallo; la parte anterior del primero presenta una corona de ocho á doce tentáculos, pro. vistos de una doble série de largas pestanias. Ia abertura bucal se halla en cl borde superior del disco de los tentáculos, y la del ano un poco mas arriba del centro ciel mismo. El tallo, fuerte, bien provisto de músculos, se fija por su extremidad en forma de pie, y semejante á un disco chupador, en el sitio elegido por el mismo animal, apoyado por la se. crecion, sin duda pegnjosa, de una glándula del pié. Todo el animal es bastante transparente y observa una vida muy mo. desta y oculta en el mar.

Hasta ahora solo se habian visto individuos aislados fijos en anélidos y briozoidos. Yo descubri en Nápoles una fuente inagotable que me ofreció miles de estos animales para cxaminarlos. Viven en tales masas en las galerias y cavidades, asi como en las depresiones de algunas esponjas córnens (caco spongria y enospongia), que aunque es dificil reconocer los individuos en su conjunto, aparecen como una capa blanquizea de las galerias de la esponja. Si bien pueden moverse 
lentamente, parece que se alejan poco ó nada del śitio, una vez ocupado; encuentran sin dificultad sts alimento, porque la continua corriente del agua que pasa por las cavidades de
Ia esponja habitada por ellos, les provee sin cesar de alimen: to microscópico. Este alimento es conducido á la boca del animal por las largas pestañas de los tentículos y por medio

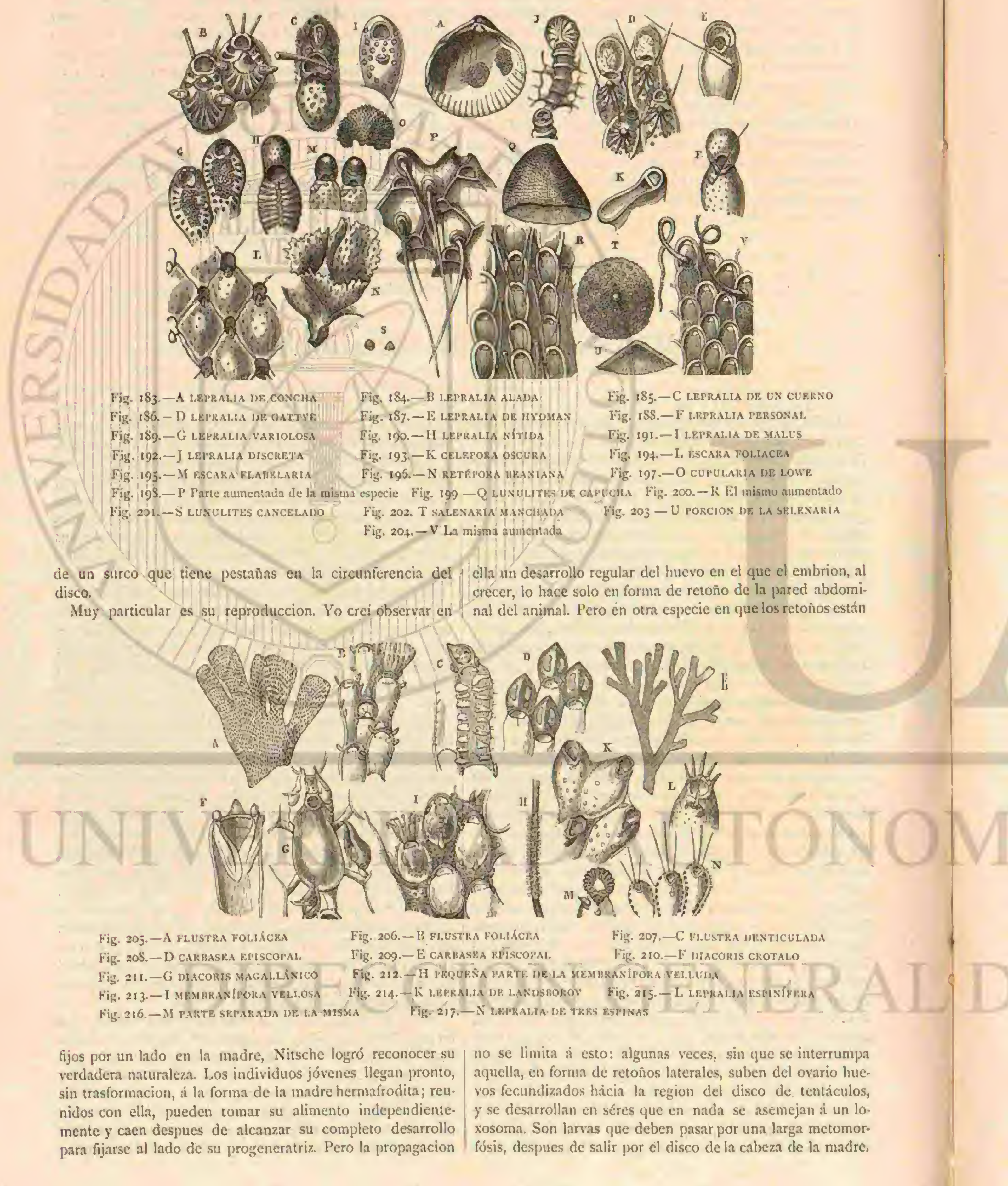


El cuerpo es plano, casi escudiforme, rodeado en su borde por una prominencia con pestañas. De los órganos internos se conocen, ademís del corto intestino, dos grandes cuerpos llenos de trolas muy prisınáticas y de una materia colorante negruzca. Parece que son, ó se trasforman, cn órganos de la vista. De otras cuatro partes en forma de riniones que se en. cuentran en el disco, supongo que son el principio de los tentículos. Espero que pronto se podra observar esta larva en su trasformacion al loxosoma sedentario.

las particularidades detalladas en la formacion de retonos ofrecen la mayor analogia con los surcos y la formacion de hojas cmbrionales en el desarrollo del huevo; pero si, segun las leyes de la doctrina del origen, las larmas que pueden moverse nos dan un indicio de la idea que debemos formarnos de los antecesores de los loxosomas, los retonos laterales nos ofrecen un excelente ejemplo del flamado desarrollo abreviado. Segun toda probabilidad, este último modo de propagarse es uni propiedad ulterior de los loxosomas y seria muy interesante demostrar si en alguna especie existe uno ú otro modo de reproducirse. En las especies obserndas por mi en los meses de invierno siempre se verificó la formacion mas viva de los retoños laterales, pero solo en el loxosama singular puede seguir al mismo tiempo el desarrollo de las larvas libres. Yo creo justificada la suposicion de que la propaga. cion por medio de las larvas libres esta desapareciendo como resto de tiempos y formas remotas; mientras que en un periodo futuro la produccion de los retonios laterales resultará mas ventajosa y útil. Aquel de mis lectores que se haya ocupato de la doctrina de la descendencia y del darwinismo, comprenderá si considera la formacion de las larvas libres como un retroceso que, se presentari con tanta menos fre. cuencia, cuanto mas tiempo se efectue la reproduccion por medio de retoños laterales, tan conveniente para la conservacion de ln especie, $i$ pesar de que en general la formacion de retoños es la mas antigua propagacion.

Este estudio del problema mas importante de la roologín me excusara de haberme ocupado de los loxosomas mas de lo debido.

Para completar hasta cierto punto la serie de estos curiosos animales, haremos mencion de otros géneros, por ejemplo: las celeporas (ing. 193), que por la agrupacion irregular de sus celdillas forman un polipero frágil, membranoso y como esponjoso: las escaras (figs. 19.4 y 195), cuyo polipero es calizo con expansiones comprimidas y ramosas; las cupurlarias (fig. 19j), de polipero plano, de forma redondeada $y$ ¿ veces cóncavo; los lumulites (figs. 199 á 201), género muy atine al anterior, y las seicnarias (figs. 202 à 20 f), briozoidos de aspecto orbicular en su estado libre.
Para poder hacer con la necesaria aptitud el eximen dctallado de los moluscos, basta poseer esa pequeña suma de conocimientos y experiencias generales que se adquieren en el trascurso de la vida. A la simple vista de un caracol ó de una conclia descúbrese fảcilmente la presencia de uno de esos animales blandos ó moluscos, cuya denominacion se funda en diferencias marcadisimas, que les distinguen de los vertebrados y artrópodos. En la suposicion de que el caracol y la concha sean congéneres, debemos, sin embargo, notar que el primero tiene una cabeza provista de antenas y de ojos, mientras que en la segunda en vano se buscarian tales órganos. La présencia de una concha en un caracol de las viinas no impide al observador lego ver en él al congénere mas próximo de la limaza desnuda. $Y$ aun cuando las opinio. nes se multiplican indefinidamente al visitar la costa, y los mercados de las ciudades marinas exhiben cada dia nuevas y mas variadas formas de moluscos; no por esa dejan de dis tiimguirse, al ser examinados y comparados, de los rinos vertebrados y artrópodos, sin excluir á los anélidos.

Cierto es que en un gran número de moluscos se observa la separacion entre la cabeza y el tronco, pero el conjunto aparece mas abultado que en los denas animales de que ya tenemos conocimiento. En vez de añuella articulacion presentan á lo mas la disposicion para clla, al paso que en el artró. podo domina enteramente $y$ es propiedad caracteristica de los vertebrados, por la separacion de su columna vertebral y de sus extremidades articuladas y movibles. El inolusco carece de una forma determinada, á diferencia de los vertebra. dos, en los cuales depende del esqueleto huesoso interno y de los artrópodos, en los cuue se halla constituida por los tegumentos endurecidos de la piel.

los anćlidos mas sencillos figuran como medios superficiales de tránsito entre estas dos últimas clases y la de los molusros. En cuanto a la cáscarn de la concha, este adita. томо VII mento, auncue segregado y producido por el cuerpo, se hallan en tan ligera relacion con él que no admite comparacion alguna, como el esqueleto interno ó externo. Este último es, en toda la acepcion de la palabra, una parte del organismo. Los huesos crecen y se alimentan; el coleóptero no puede extraerse de su esqueleto membranoso; cuando la coraza del cangrejo pierde su adhesion, cae para ser sustituida por otra; relacion intima que no existe entre el molusco y su concha. Esta es un producto segregado, que, aunque puede engrosarse por la produccion de nuevas capas y ensancharse por el aumento de una sustancia calcárca en los bordes li. bres, solo está unido en limitados puntos con el animal, sin que tome parte en el cambio de materias vitales, como objeto inanimado y muerto. Un caracol puede sacarse de su concha cortando tan solo un pequeño músculo, que con ella te une, lo cual seria una usurpacion de los derechos de la naturaleza, que, por medio de ella, ha querido librar del peligro la vicia del molusco; solo en los tegumentos de la piel de muchos de estos animales se hallan secreciones de hojas córneas y calcirens que al causa de su situacion, semejan jedazos de esqueleto y de luesos internos, aunque en lo esericial están conformes con aquellas formaciones de cascarar externa.

Para explicarnos los carnctéres generales de los moluscos, preciso es, por lo tanto, que nos atenganos a los que carecen de concha, despojando de ella à los que la tienen. En tal caso se nos presentan como animales no articulados, de gran pesadez, á juzgar por su asprecto, y de una forma que se opone frecuentemente a la simetría de su disposicion na. tural. La piel es mucosa, blanda, y prolongada en lóbulos y repliegues, á manera de manto, hajo el cual envuélvese el cuerpo total 6 parcialmente. Nada mas fácil que formarse una idea de esta particularidad principal de los moluscos; cuando el caracol se retira a la concha, un grueso lóbulo 
membranoso se coinca por encima de la cabeza: este lóbulo es un pedazo de manto. Al sacar la cáscara de una pechina, cl cuerpo aparece cubierto por cada lado de un grande lóbuIo membranoso: estos lóbulos son las dos mitades del mismo manto. Toda formacion de concha sobresale del manto, so. bre todo en sus bordes libres.

Los moluscos mas desarrollados, cuyo cuerpo mide con frecuencia I, 2$\}$ mas metros, y algunos de dimensiones gigantescas, hasta seis y mas de longitud, poscen los órganos de los sentidos casi tan perfectos como los vertebrados mas desarrollados, y están dotados de una fuer\%a muscular proporcionada à su tamaño. Fn cambio, hay otros de formas casi microscópicas y muchos parecen pertenecer a los turbelarios. Ni la estructura, ni el género de vida, ni él área de dispersion de este grupo pueden presentarse en una descrip. cron general. Despues de haber hecho notar la importancia de los tegumentos membranosos, indicaremos solaments que In parte principal del sistema nerviosu consiste en un anillo esofáyico con el que los otros nervios y gangliones distribuidos en el cuerpo estan relacionados. la presencia de órganoside las sentidos se rige por el grado de desarrollo del cuerpo en general, y por la residencia y género de vida: de suerte que solo se citan muy pocós éjcúplos de acéfalos con ojos. Hstos animales no necesitan buscar su presa y su alimento, sino que se les proporciona por medio del continuo movimiento de unos pelitos de que se halla cubierta la superficic del cuerpo. No obstante, todos los carncoles, y sobre todo los llamados de tinta. muy desarrollados y rapaces, buscan el limento con al auxilio de sus ojos. En todos los moluscos, y principalmente en los órdenes superiores, es muy perfecta la urganizacion del aparato alimenticio y en ruanto a los que desmenuzan ó tritumn alimentos sólidus, estàn provistos dé óganos de especialisima aptitud para sus funcionce.

Ultiunamente han podido aprovecharse esos órganos para el conocimiento de su sistcma natural, del propio modo que en la dentadura cie los mamiferos se reconocen mucho tienpo hả su género de vida y su posicion sistemítica Siendo mu!y vornces los moluscos, necesitan, no solamente un intestino espacioso, sino tambien una abundantc cantidad de los jugos que principian $y$ farorecen la digestion, y asi tienen muy desarrolladas las glindulas salivales y el higado, ó sea las glandulas que producen la saliva y la hiel.

I a circulacion de la sangre se verifica por un corazon compuesio de un veniriculo y de dos auriculas, en el que la sangre entra del órgano respiratorio, para volver al cuerpo en un estado renovado convenientemente para la alimentacion dej organismo. Los órganos respiratorios, casi siempre bran. quias, están muy desarrollados y ofrecen a la caracterizacion muchos puntos de apojo por la varicdad de su posicion y forma. Asinismo el otro grupo de órganos pertenecientc al Jado vegetativo de la vida, es decir, el de los órganos geritales, sucle ser muy desarrollado.

Mas paseiuos ahora al estudio de los grupos aislados, pain dar uni idea de todo lo expuesto y demostrar cómo las formas hermafroditas alternan con sexos separados, presenándonos aqui el cambio de generacion, alli la metamorfó. sis, y en otro grupo, el desarrollo sin trasformacion: al pro. pio tienipo explicaremos las relaciones de los moluscos, tan to las que guardan entre si, como las exteriores.

Los aficionados a curiosidades y productos de la naturn. lera, han coleccionado, hace ya algunos siglos, con preferencia las conchas de caracoles y de acefalos para recrearse con sus abigarrados colores y la riqueza de sus formas. Nosotros licmos pasado lace mucho tiempo de este punto de vista parcial; y sin concienar a los amigos de las bonitas co. lecciones de conchas, no deben en rigor contentamos estas, mas que cualquiera otra coleccion de pezuñas ó de cascos. pues lins conchas nos explican la vida y la actividad del animil mucho menos que las partes de menor importancia de que hemos hablado.

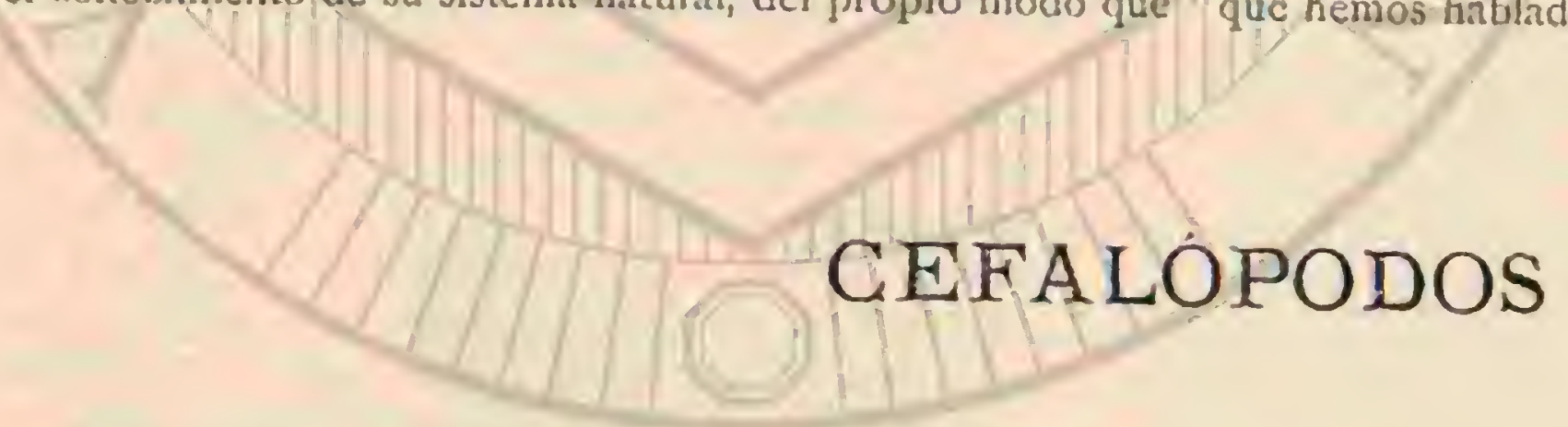

A las impresiones inextinguibles de un viaje a Italia pertenece, no solo el primer aspecto de las islas Borromeas, de ins editicios de Florencia, del Coliseo, del Vesubio en el fondo de la perspectiva del golfo de Nápoles, y de las ruinas del templo de P'astum, sino tambien la primera visita de un gran mercado de pescacio, como todos los dias'sc ven en Trieste, Génova, lioma, Nípoles, ctc., que causa honda sensacion en el ánimo. Alli estan acumulados los tesoros de los mares, détrás de los cuales aparecer los vendedores, en mangas de camisa y con el gorro rojo, ofreciendo su mercancia con gritos atronadores. Todo se encuentra alli clasificado segun su tamaño y especie: en rededor de los exquisitos peces de mesa se oprimen los cocineros de las mas nobles casas y mas de un caballero die buen aspecto, cuya esposa permanece to. davia en el lecho, hace por si mismo sus provisiones. En bancos inmediatos vése colocado el atun; despues siguen las tiendas, en que se exponen las especies de los horrorosos tiburones y rayas parn los paladares menos delicados, entre ellos figuran la raya electrica, el ángel del mar y otros monstruos. Con gran habilidad se les quita la dura piel y su carne lienc cntonces un aspecto apertoso, al que no corresponde despues el gusto. Pero por hoy prescindiremos de los peces y de los magnificos colores que ostentan parte de ellos: pasemos igualmente a lo largo de los muchos cestos de las vendedoras de conchas, caracoles y de otros frulli si mare, asi como de algunas mesas, cuya alta categoria se demuestra por el techo que las cubre y" en las que se nos presenta una mercancia del sodo cxtraña \& i Calamari! : Calamari! ¡O che bel calamari! :Seppe! :séppe! idelicatissime sepiolej Asi resuenan incansables las voces estentóreas a nues. tros oidos. Uno de los voceadores ha fijado yasu vista en nosotros; cree que quicremos comprar para nuestra cociua y algunos vagabundos son rechazados para dejarnos puesto. Nos accreamos, y el pescador lemanta por los brazos polipiformes un delgado calamar de un pié de largo. «iE muto frescol dice, y para demostrar que lo esta y que se conserva vivo tocinvia, le cia con la punta del cuchillo un ligero pinchazo. ¡Cosa extraña! Con la rapidez del rayo pasa una nube colorenda de imarillo y violeia solure la piel, cuyo fondo blanco se tine con los colores del iris y esta cubierta de finas $y^{\circ}$ pequeñas manchas. Viéndonos indecisos, el revendedor echa el calamar en el monton con sus compañeros, y, continuando los elogios, se dirige á otra clase de su mercancia, a las sepias. De un barril yque esta en el suelo saca pieza por picza, abre con un corte el lomo de cada una, de un blanco brillante, quita, revolvicndo el interior, una parte de los in. 
testinos con Ia bolsa de tinta, limpia el animal con amua y lo pone sobre la mesa.

Nosotros, como naturalistas extranjeros conocidos aqui hace wucho tiempo, nos vemos precisados a jagar en la fonda por un precio curadruple del que tienen en el mercado, los individuos yque elegimos para hacer su clasificacion y estu. dio. Fintre las obras de que nos servimos para tal objeto, es ura de ellas el litoro del senor Verany, de Niza, sobre los cefalópodos del Mediterrånco, en el que todas las especies que en este mar se encuentran se han descrito en su forma y género de vida, segun las observaciones de aquel naturalista, hechas durante muchosaños y representadas magistral. mente en cromos. Otra de dichas obras versa sobre la pequera Seprila Rondeletii, por la que nos orientaremos respecto al cuerpo y los órganos exteriores de los cefalópodos. Esstos noluscos, asi llamados por la notable distincion que existe entre su tronco y su cabeza, tienen esta coronada de apéndices que sirven de órganos prensiles y de movimiento. Rodea el tronco un manto, al que siguen en la cara dorsal los tegu. mentos membranosos de la cabeza, formando'en el vientre una bolsa abierta, de la que sobresale la extremidad estrecha de su órgano en forma de embudo. I a cara dorsal se reconoce ficilmente por la proximidad de los dos gran. des ojos.

Todas estas regiones y partes exigen, sin embargo, mas escrupuloso eximen, porque en sus diferencias se basan las particularidades de los varios grupos y géneros de que esta clase se compone. I.os brazos que circujen la boca son de naturaleza muy sólida y musculosa, extensibles, y de una movilidad tal, que su juego, en las especies de mayor tamaño, semeja las circunvoluciones de un grupo de serpicntes entre lazadas. Todos los cefalópodos, excepto el nautilo, están dotados de discos chupadores, de una utilidad excelente para asir la presa y para deslizarse: hállause comunmente sobre un tallo corto y unusculoso, y su circunferencia está formada por un anillo cartilaginoso, lleno de fibras tambien musculosas. Cuando el anillo se adapta á un objeto plano y los mús. culos sobresalen un poco, el aire rarefacto del hueco intprime el disco re tal modo, qute, al hacerse esfuerzos parn extmer el animal viro, suelen romperse algunos de los citados órganos. Del propio modo, cuando un grupo de céalópordos está en actividad, primero se les arrancarán las brazos que obligarles á abandonar su presa. Muchos géneros poseen ademàs unos ganchos de puntas córnens. «Los movimientos de los discos chupadores, dice Collmann, no consisten solamente en la accion de asir y soltar, sino que tambien se exticnden y deprimen sin coger presa alguna. Al estirarse ofrecen al aspercto de un capullo y - Iuego vuelsen a abrirse a medias 6 coinpletamente, mas ó menos á cada lado; á roluntad del nnimal. Cada cisco, provisto de un aparato particular de musculos y nervios, obra con entera indenendencia de los demás, de manera que, mientras los unos funcionan, los otros permanecen libres. 13 los bmzus estan dispuestos con rigurosa simetria y se numeran, á partir del dorso, con las designaciones de prinero, segundo, ecreero y cuarto par: el ultimo se halla à derecha é izquierda de la linea central del vientre. Todos cllos estiu unidos cn su base por una nembrána çue en algunas especies se extiende hasta la punta de los mismos. Esta membrana sirve, segun parece, con preferencin, para formar sobre la presa, hecha con los brazos, una cavidad que la encierra por todos lados y en la que la victima, asida por los dientes del cefalópodo, muere in la mayor brevedad.

Al abrir el animal los brazos, se ve prerisamente en el centro de un circulo la abertura bucal rodeada de una especie de labios. Ein ella se hallan has dos maxilas de color pardo negruzco, y que, correspondiendo al caraicter ropriz de nuestros animales, son grandes, sólicias y afiladas; la maxila inferior es mas ancha y sobresale mas que la superior; esta, tanto en estado de reposo, como en el acto de la masticacion, encrjada en las hojas laterales de aquella; y por medio de ambas los animales de que nos ocupamos pueden corroer la cabeza de grandes peces y hasta el cerebro. Bajo la corona de los brazos, la cabeza esti inclinada por ambos lados hnicia el lomo, como una esiera. En el interior del indicado punto hallase una especic de cráneo, del cual son continuacion inmediata las dos cápsulas cartilaginosas de los ojos en forma de escudillas. Los ojos, cxcesivamente grandes y brillanies despiden un fuego siniestro, $y$, cn cuanto a la cara dorsal del tronco, no ofrece nada de particular. Lin los lados llevan nuestras sepiolas un par de lóbulos membranosos, casi circulares, en rigura de hojas, que se llaman aleias, y sirven, tanto para la locomocion acompasada, como para posicion regular. La extension de estos apéndices es muy diferente segun los géneros: asi, son mas desarrollados en los de cuerpo prolongado y adelgazado, y en los que tienen los ár:gulos y hojas laterales en forma de fiecha (loligo). En el borde libre del manto, que se cncuentra en la cara inferior, obsérvase la extremidad adelgazada del llamado embudo. El animal hace un uso muy importante de este órgano, pues con su auxilio separa el manto para alejar su borde del tronco jo dar entrada al argua en el fondo de la bolsa. Practicada esta operacion, vuelve a cerrarse el manto por medio de dos botones cartilaginosos, encajados en unas depresiones de la pared abdominal, $y$, con un brusco movimiento, empuja cl animal fuertemente el agua hácia la gran desembocadura oculta en el manto: de modo que el liquido sale formando un chorro tan estrecho como la abertura del embudo. El im. pulso de la salida es tan violento, que hace madar con ha rapidez de una necha à las especies mas delgadas de los refalópodos.

Para conocer la situacion de los úrganos respimtorios, ó sea de las branquias, es necesario cortar y colocar de lado li hoja libre del nunto de la parte abdominal: los lados de la cavidad abierta parecen entonces un órgano rizado, en el que la sangre sufre las trasformaciones indispensables para la respiracion.

listo nos demuestra la clasificacion que de estos arimales hacen los naturalistas, al distinguirlos con los nombres de dibranquiados y tetrobranquindos. A la primera division pertenece la sefiula.

Ademas del intestino desemboca en el cmbudo, en la mayor parte de los cefalópados, el conducto de otro órgano importante, ó sêa de la bolsa de tinta, glíndula que segrega una masa negra pardusca. Esta se vacia a volunad del animal, yasta una perjucha cantidad de tinta para envolverle en una nube oscura que le oculta, instantaneamente if la vista de sus perseguidores. De aqui el nombre de carusoles de fista, ó mas impropiamente peces de finsa, con que se ha designado a estos animales. I.a sustancia que forma el punto de union se conoce bajo el nombre de sepia aplicible desdo la antigüedad a las especies fósiles.

En muchos ejemplares que se han conservado cn esjiritu de vino, nótase todavia que la piel esta salpicada de finas manchitas de color violeta y parduscas; pero esto no da ninguna idea del maravilloso juego de colores que ostentan los animales viros. Los cambios de colores a que están siıjetos, dependen de la intensidaci de la luz, de su actitud de ataque y de otra mulitud de circunstancias. El cuerpo, de un fondo blanģuecino brillante y transparenic en los sitios mas delgados, tórnase: á reces pálido cuando el animal se halla fatigado. ostentando entonces un lustre rojizo, amarillento ó violeta. Al excitarse nuevamentc, se dibuja en algunos puntos una 
nube de colores, espesa en el centro y diáfana en los bordes: su color es pardo ó violeta. I ans nubes y fajas colorndas recorren todo el cuerpo, se unen, se dilatan y van acompnña das regularmente de una fosforescencia general, de un brillo radiante y de los colores de! iris extendiclos por toda la piel: ial fenómeno es una verdadera tempestad, con todos los sig nos de la ira y de la escitacion nerviosa. Hay dos causas mecinicas de este bellisimo juego de colores. En la piel se hallan unas celdas rellemas de una sustancia colorante levemente esparcida; cliando estas celdas, en estado de reposo, por la elasticidad de su cubierta, han adquirido el meno rolúmen, la sustancia colorante, recogida en jequeños urumos da muy escaso colar a la sujerficic. Dichas celdas, to mismo que los colores, pueden ersancharse; sin etnbargo, por lis numerosas fibras musculares que $\mathrm{cn}$ forma de radios se insertan en ellas. La inútua presion de unas hojitas finas situadas por debajo de las celdas produce la union de los colores del iris con el de la sustancia colorante: asi se csplica fisicamente la doctrima de la interferencia de la lev. Las cromolitografias de Verany dan alguna idea de la extrema belleza de estos colores. Aun cuando no es posible deternimar el verdadero color de los cefalópodos predominan ciertos tonos en las diferentes especies, distinguiéndose entre si por su brillo y dulicadcya particulares ó por sus frecuentes canbius de colores. Solo útimamente, desde que en algunos grandes acuarios se tienen tambien cefulopodos, el público puerle ver este espectáculo. Como al describir las especies se ho de tratar mas minuciosamente del géncro de vida, solo haremos aqui algumas observacioncs Los cefalópodos son exclusivanzente habitantes del mar, como lo fueron en todas las épocns; muchas especies son sociables y emprenden por lo regular excursiones; entonces abandónan las profundida des del mar y acércanse à la costa. Verany ha llamado sin embargo la atencion sobre el hecho de que el no hallarse ciertas especies sirn an meses determinados ell las pescade. rias no deprende de sus viajes, sino del uso de ciertas, redes quue solo se emplean en cierta estacion del año El Histiotere this Ruicpeli que habita las mas urandes profundidades se pesca, por ejemplo, solo en mayo y, sctiembre, meses en quc se baja la red a profundidades de 2,400 piés, para la nesca de cierta especie del sparis introdontus.

l'odos los cefalópodos son carmivoros y mapes, y deroran una infinidad de peces, crusticcos, carncoles y conchas; son tan voraces que se precipitan sobre los animales de su propio género cogidos en el anzuelo y que salen con cllos á la superficie. Las especies que reptan en las rocas y en medio de las algas, cerca de la costa, acechando su presa, tienen muchos apéndices filiformes, los cunles dejan thotar $i$ tin de atraer a sus victimas. Por fortuna el daño que causan se re prime por una serie de animales importantes, como, por ejem plo, varias.ballenas y truchuclas que se, nutren casi exclusiva mente $\delta$ con preferencia de cefalópodos, sin contar que va rias especies sirven de alimento tambien al hombre.

Como los cefalípodos son los moluscos mejor organizados, llegan tambien al mayor grado de fucrza, volúmen longitud. Keforstein, en su excelente obra sobre los molus cos, la reproducido las noticins de los tiempos antiguos y modernos referentes a este tema, separando lo cierto de lo falso. "Desde la antigüedad, dice, se ha creida que hay ce. halópodos de gran tamano que pueden hacerse peligrosos pam el hombre, $y$ hasta las tradiciones septentrionales sobre el octópodo, que sirvió á Oken para dar nombre á toda la clase de los cefalopodos, se han creido en otra época muy generalmente. En los últimos tiempos se demostró que muchas de estas noticias eran solo fábulas que carecian de todo fun. mento cientifico, habiéndose supuesto, entre uiras cosas, yuc ningun cefalópodo alcanzaba mas de tres ó cuatro pies. Aho. $\mathrm{m}$, sin embargo, se sabe que hay especies de gran tamaño entre estos animales; pero las noticias sobre ellas son iun insuficientes, y en muchos casos no es dado determinar si cstos cefalópodos son individuos en extremo viejos, y por eso tan grandes, como sucede en los peces, que asi como los àrboles crecen continuamente, ó si pertenecen à especies que por vivir en alta mar han escapado a nuestra observacion, pero que siempre alcanzan, al llegar à la edad adulta, un tamano enorme. I a primera suposicion me parcce la mas probable y explica tambien la poca frecuencia de estos colosos, porque muy pocos escaparian á los numerosos cnemigos, alcanzando á mucha edad. No quiero decir con esto que en alta mar no se oculten, sobre todo en sus profundidades, muchas especies de cefalóprodos de cuya existencia no tenemos aun ninguna iden, $y$ que pueden distinguirse por su gran tamaño.

Dristóteles habla ya de un loligo que tenia 5 varas de largo, y Plinio hace mencion de las noticias de Trebio Ni. ger. isegun las cuales un pólipo gigantesco se acercó de noche a la costa para saquear los depósitos de pescado. de donde ahuyentó : li los perros con sus bufidos y sus brazos. La cabeza de este animal, que se ensenó a Lúculo, era tan grande como un barril de quince ánforas, y sus brazos, que un hom. bre npenas podia abarcar, median treinta piés de largo: en sus depresiones (discos clapudores) cabia muy bien una urna de agura Del mas grande de los cénlópodos, el octópodo, llamado tambien krake, se han conservado noticias de Noruega, debidas a Olaus Magnus y al obispo Pontoppidan. Segun el ufltimo, cuando los pescadores obscrsan gmn abundancia de peces y estos huyen, saben muy bien que se acerca el octópodo. Entonces clévase sobre las olas una nube inmensa, que con frecuencia sobresale 30 piés de la superficie. In las depresiones quec forman las asperezas de la masa, que tienc la forma de una roca, ha quedado agua, y en esta se ven saliar preces. Poco á poco se desarrollan las colinas y montañas de aquella especie de isla a una altura cada ver. mas escarpada; desde el interior cléranse brazos semejantes a los tentảculos de un caracol, mas gruesos que un mástil de mesana, y bastante poderosos para coger un coloso qque lleve cien canones $y$ hundirle en la profundidad. Se extienden por todos lados, juegan unos con oiros, inclinanse en la superficic del agua, vuelien a levantarse y tienen toda la movilicad de los brazos de cualquier otro pólipo. Un hijuclo de este animal monstrunso se habia encallado en 1860 en Nord land (Noruega), segun dice Frus, entre has rocas de un estrecho golfo, el cual quedó obstruido con el cuerpo. Los brazos rodeaban las rocas y los arboles; estos últimos fueron arrancados de raiz por el animal, agarrado de tal modo en las piedras que no era posible de ningun modo desprenderle.

Tla mayor parte de las noticias acerca de estos jólipos gigantescos se encuentran en la historia batumal de Montfort sobre los moluscos. En clla se refiere que un monstrun marino, en la costa de Angola, esturo á punto de hundir un buque en las profundidades, lo cual indujo a la tripulacion salvada á conmemorar el recuerdo de aquel peligro con un cuadro yne se coloco en la capilla de Santu Tomas en San Malo. Montínt rejroduce además un informe del capitan de un buque, el major Dens, quien le habli de un pólipo que, cerca de Santa Helena cogió con sus brazos dos marineros del buque; uno de sus tentáculos, que se enredó en el aparejo, fué cortado, y entonces vióse que media veinte y cinco piés de largo y tenin varias series de discos chupadores.

lis un animal de poco menos tamanio debió haber pertenecido al brazo cque, segun dice un pescador de ballenas, sacó en el mar Austral de la boca de un cachalote y que media 
de No-

pidan.

gmn

qque se

nube

superfi.

masa,

en csta

linas $y$

da ver.

cjontes

ástil de

ue lle-

ienden

isuper-

movili-

1clo de

Nord-

un es-

Los

fueron

odo en

nderle.

pólipos

ontfort

in $\mathrm{ma}$ -

dir un

ulacion

con un

en San

itan de

o que,

ros del

cjo, fué

diés do veintitres piés de longitud. Sin embargo, estas y otras noti cias merecieron tan poco crédito, que todos los rełatos en que se hablaba de especies de esta clase de mas de algunos piés de tamaño se consideraban como fábulas.

Mas tarde Steenstrup reprodujo las noticias acerca de los pólipos gigantes, asegurando que los monstruos marimos encallados en 1639 y 1790 en las costas cie Islandia, de los que el último tenia un cuerpo de tres brazas y media de largo, eran indudablemente cefilópodos; opinaba tambien que ta la misma clase pertenccia el llamado fraile marino cogido en $1546 \mathrm{cn} \mathrm{la} \mathrm{Sonda,} \mathrm{y} \mathrm{que} \mathrm{medín} \mathrm{ocho} \mathrm{piés} \mathrm{de} \mathrm{largo.} \mathrm{Algun}$ tiempo despues, Stecrstrup mismo recibió los restos de un pólipo gigantesco que en 1853 habia encallado en Jutlandia: teria la cabera tan grande como la de un niño y su cubierta dorsal córnea media seis prés de largo. Harting habló tambien en 1860 mas minuciosamente acerca los restos del fers de linta que se encuentran en los museos de Utrech y Amsterdam. La noticia mas notable y reciente sobre uno de estos animales gigantescos la debemos al capitan Bouye, del aviso francés Alecton, que obscrvó al animal en 30 noviembre de 186 a cerca de T'enerife. Fil aviso encontró entre Madera y 'lenerife un monstruoso pólipo que nadaba en la superficie del agua. Este animal media de cinco á seis metros de largo, y sus terribles brazos estabin provistos de discos; tenia un color rojo ladrillo, ojos enormes, de espantosa inmovilidad; el peso del cuerpo, en forma de huso muy cillatado en el centro, debia llegar á dos mil kilógramos; y las aletas, redondeadas en la extremidad posterior, eran enormes. Se intentó coger al animal en un lazo y matarle à tiros, pero el capitan no se atrevió à exponer la vida de sus marineros, haciéndoles emprender la caza en una lancha que el animal fácilmen. te hubiera podido destrozar con sus temibles brazos. Despues de una persecucion de tres horas, solo se obturo una parte de la extremidad posterior del mónstruo. Ahora bien, si las observaciones modernas no han confromado las tradiciones acerca del octópodo nos han dado, sin embargo, un informe seguro acerca de los cefalopodos gigantescos, de veinte piés y mas de largo, que pueden ser peligrosos para el hombre mismo y para las pequeñas cmbarcaciones》. Aun en los últimos tiempos en 18 ity 1875 , se han cogido en la costa oriental de la América del Norte calamares cuyos brazos median nueve ó diez metros. Segun el cálculo de Ke. ferstein se conocen unas 2,000 especies de cefalópodos, de las que 2 I $\$$ pertenecen is la crencion actual.

PRIMER ORDEN

\section{DIBRANQUIADOS - DIBRANCHIATA}

Hemos clegido antes un dibranqquiado como punto de partida para nuestra descripcion, $y$ comprendemos bajo tal denominacion los cefalópodos cuycs brazos, dispuestos en circulos alrededor de la boca, tienen discos cliupadores, $y$ que en la cavidad del manto presentan dos branquias, una á la derecha y otra il la izquierda: todas estản provistas de una bolsa de timta. Una gran mayoria de las especies actua. les, es decir 232 , pertenecen á esta division, que a juzgar por los restos geológicos es la inas reciente.

Las siguientes descripciones se han tomado con preferen. de la espléndida obra de Verany, completandolns con nues. tros propios datos y las de Collmann que bemos recogido en los animnles viros del acuario de Dorhn en Nảpoles.

\section{LOS OCTÓPODOS - OCTOPODA}

En este grupo se comprenden los cefalópodos de ocho piés: casi todos, tienen un tronco en forma de bolsa y ocho brazos, no encontríndose nunca en ol dorso del manto una secrecion de cáscara. I a mayor parte de los octónodos viven cerca de la costa $y$ andan mas bien que nadan. Su vivienda habitual son los agujeros y hendiduras de la rocn, desde las que acechan su presa; pueden reptar en todas direcciones, pero prefieren moverse de lado; entonces extienden los bra\%os, levantan la calocza, apoyan el cuerpo un poco sobre el cuarto par de brazos $y^{\circ}$ dirigen la abertura del embudo a un lado. Ejecutan el movimiento lateral de preferencia con los dos pares centrales de bra\%os, mientras que los superiores é inferiores solo se emplean alguna ver, segun lo exige el terreno. Tanto en el agun, como fuern de ella, avanzan con bastante rapidez; voluntariamente no abandonan nunca su clemento, sunque algunas especies pueden vivir horas enteras fuera del agua. Su iustinto para volver al mar, cuando se les ha llevindo á cierta distancin en tierra lirme, es admirable; sin ver el agua se dirigen por encima de montones de pie dras directamente á su elemento. Hoy dia aun se designan en las costas de Italia (y tambien en España) algunos géne. ros de octopus y cledine con el nombre que ya les dieron griegos y romanos, polfu, fonife, fulpo (animal de muchos piés). La mayor parte de las especies del género orlupiss tienen el cuerpo redondendo en forma de bolsa, y' sus brazos, ya muy desiguales, cubiertos en su carn interior de dos sc. ries de discos chupndores.

La especie mas comun y extendida, que alcanæa taunbien las mayores dimensiones, es el pulpo rulgar (octopus ivulgo. ris), de color gris blanqquizco, que cuando se irrita presenta tintes pardos, rojos y amarillos, cubriéndose además toda la parte superior del cuerpo de prominencias verrugosas. El distintivo mas imprortante de la especie consiste en tres gran. des tentículos en cada ojo. El area de dispersion de la especie se extiende, no solo jor zodo el Mediterráneo, sino por todas las costas del Atlantico, cerca de las islas de las Indias Orientales y Occidentales y en los alrededores de la isla de Fimncia.

Habitan en un fondo pedregoso y se ocultan por lo regular en agujeros $y$ hendiduras, en las que su cuerpo blando y elistico peneira con facilidad. Alli acechan a los animales de que Se alimentan; apenas los divisan abandonan cautelosimente su escondite y jrecipitansc como el rayo sobre su victima, envuélvenla con los brazos y la sujetin por medio de los discos chupadores. Se dirigen á nado sobre su presa, siempre de espalda, y llegados al punto donde se halla, giran con una rapider inconcebible, abriendo los brazos para asirla. A veces fijan su residencia á cierta distancia del terreno pedregoso, en algun fondo de arena; $y^{\circ}$ entonces forman alli un escondite. Con suyda de los brazos y discos reunen piedras en forma de un eráter, y en él esperan con paciencia á que pase un pez ó crusticco, del cual se apoderna diestramente. Verany ha 
observido varios de estos rapaces cerca de Villafranca; y con facilidad se pueden estudiar sus usos y costumbres en cl acua. rio de Nipholes. Collmann dice lo siguiente: QUno de los pulpos del acuario habia coustruido tambien un escondite entre las piedras colocadas en los compartimientos de agun; parecia un nido y su abertura estaba en la partc superior. Las piedras, que formaban un monton situado cerca de la ventana del depósito, tenian distimto tamaño, que variaba desde el de una manzana hasta el de un adoquin de quince centínetros de dingonal. En esta guarida el cuerpo del animal estaba casi sicmpre del todo oculto; solo la cabera sobresalia, mientras los brazos se apoyaban como una corona de serpientes sobre la abertum. Fiste escondite parcein ser muy cómodo para el animal, pues solo una vę le lo abandonarle, al separar una parte de las piedras. Entonces salió el pulpo furioso nam reunirlas de unevo. Hahiamos desmontado nina parte de la guat rida parn ver como este molusco, blando y sin huesos lleviba las pesadaś piedras, algunas de las cuakes, muy grandes, se colocaron en el centro dal compattimiento vecino, a bastante distancin: Tan luego como nos hubimos alejado, el animal comenzis su obra: agarróse d cada piedra cual si quisiera devo. rarla y la iestrechó de tal modo contra su boca que casi desajareció entre sus brazos; cuando el animal creja estar bastante firme soltaba un par de brazos, $y$, oprimiendolos contra el suelo, impulsnda el cuerpo con su peso hácia atris. las piedras del tamaîio de un puno se trasportaron con rapidezy sin gran trabajo, las grandes, elnpero, exigian otro proredimien to. El animal las cogió por el ángulo mas estrecho, oprimién. dolas contra la abertura bucal: al mismó tiempo, el cuerpo se introdujo, por debrio de la carga, para colocarla en la linea de equilibrio; lerantóla despues balancéndola, y cuando por fiu se estableció aq̨uél, dos brazos se soltaron para empujar la masa informe dél animal y la piedra.

- En verano, los individuos jóvenes se acercan umbien i has orillas cubiertas de guijarros, y a veces se les encuentra en el fondo cenagoso, donde se pescan por to regular con la cuerda, pero sin anzuelo, atando en lugar de éste, cualguier cebo blanco con una piedrecita. El pescador tiene en cada mano una cuerda y la pása lentanerie por el agua mends profunda; apenas el pulpo divisa el cebo, precipitase sobre él y se deja conducir lentamenté á la superficie, desde donde se le coge con una pequeña red para echate en la lancha. Los pescadores que de noche pescan toda clase de animales a la lü de las antorchas, cscena que antes he descrito, sutletr coger individuos mas grandes. En Niza, donde los octó podos jóvenes se acercan en verano á la playa, cubierta de guijarros, pude observar tambien otro método de pesca. En la cuerda, provista de plomo, se fija un corcho que lleva raríos anzuclos y esta cubierto de un pedazo de jaño rojo. Lá cuerda se lanza a la mayor distancia posible, atrayéndoia despues poro á poco á la orilla. Eil octópodo se precipita sobre el ceboy por lo regular queda cogido siempre.

* Así los muchachos callejeros como las personas acomodadas se ocupan en las hermosas noches del estio en esta pesca. Atendido que cuindo se les coge se conservan bastante tiempo ágiles $y$ vivaces, intentando hábilmente la fuga, es preciso matarles en el acio. A los pequeños se les parte la cabeza, matando á los grandes de una cuchillada. 1.os hi. juelos constituyen un alimento muy sabroso; la carne de los individuos viejos y grandes que pesan mas de una libra es dura y muy inferior a la de la sepia y del calamar. 1 il mayor ejensplar que cerca de Niza rogió un pescador, no sin gran. des esfucrzos, tenia tres metros de largo y pesaba cincuenta libras. Los individuos de treinta libras no son raros.

"Segun hemos diclio, los animales jóvenes son los que en particular se acercan à la costa, de modo que tambien que- dan descubiertos entre las piedms durante la marea baja. Grube describe la pesca de los mismos cerca de Sim Malo; mientras que ajudado de uno de los marineros revolvia los pedazos de roca sin gram resultacio, el otro vagaba por los alrededores en busca de pulpos. Yo mismo sorprendi uno cie estos oczópodos que estaba cscondido, pero cuyos trmos sobresalian en parte del pedazo de roca. Mala fué su suerte, pues mi companero, despues de arrancarle del suelo, donde intentaba asirse con toda su fuerza, le arrojó tres ó cunirn veces contra la roca hasta que apenas se movió; volviendo despues el saco de modo que las branquias quedaron visi. bles, se sacaron todos los intestinos, reuniendo por fin el in. dividuo con los demás que se habian pescado. En tiempon de la marea baja un hombre coge í veces cuatro ó cinco de estos pulpos, mas parecen servir aqui solo de cebo para el anzuelo, y no parit cumer como en Italia. \&

Fischer ha publicado ofservaciones muy interesantes acer. ca el género de vida del oclopus ïulgraris en ol grande acuario de Arcachon. en la costa francesa. En el verano de 186 - habia sicte individuos en el acunrio: y en las divisiones de los grandes' dénósios de pescados abrióse para cada cual uma vivienda en los pedazos de roca. Cuando uno abandonaba su escondite para eximimar cl agujero ocupado por otro. este último se irritabn en extremo, cambiaba de color é impeclia la entrada con uno de los brazos del segundo jar; pero unnca se trababa una lucha formal. lil segundo par de brazos. el mas largo, se emplea sobre todo en el ataejue ó la decensa, y con los dos primeros el animal examina y toca los obje. tos. De dia los octópodos se mueven poco; pero ì veces eje. cutan una maniobra muy particular, sacudiendo con violencia y circularmenté sus brazos, que entonces se curoscan y enlazan:

Los cambios de colores se presentaban al parecer tempo. ralmenic sin causa visible. Lina vez vió cl observadur como en un ocispodo adnuiricron el cuerpo y la cabeza un color rojo pardo intenso, mientras que la oira mitad se mantenia gris. Los cautivos, muy vomces, se alimentan de conclass, y todos los dias se les ofrece cierto numero de ellas de la especie cardiun edule. Se apoderan de las mismas y las llevan a la boca, ocultandolas con los brazos y la picl. Despues de un tiempo indeterminado, pero, cuindo mins inde, al cabo de una hora, volvian a echar las ciscaras abiertas y vacias, pero de? todo ilesas. Como la concha arriba citada no se cierna del todo, era posible chupar poco i pocu su contenido. Para cerciorarse del hecho Fischer ufreció a los vetópodos otra con. cha, un grande pectucoulus que se cierra con mucha fuerza y. herméticamente: los octópodos hacian lo mismo que con los cardios, y al cabo de tres cuartos de hora tambien los-pectículos estatran nacios y las cáscaras intactas. Como de cite morlo nada se podia lograr, se ofreció a los octópndos su ali. mento favorito, es clecir, cangrcjos: tan lucgo como cl octó podo vió al crustáceo (carcimus maremas) iproximarse is su guarida se precipitó solbre él cubriéndole del todo con la membrana y brazos. Estos envolvian la victimn de tal mancra, que no podia defenderse; dumnte un minuto el iufeliz. cangrejo intentó mover las patas, pero desjues permaneció tranquilo y el octópodo se lo llevó á su esconditi lintonces vióse, a traves de la piel de la membrama, que el cangréjo (o) maba diferentes posiciones; al cabo de una hora ha comida terminó; la cornza dorsal estiba vacia y separada de los in testinos reunidos con el cefalotórax; todas las patas habian sido rotas en su base; los músculos de las pratas y una parte de los intestinos no se veian ga, pero ninguma parte del es. queleto membranoso presentatan lesion. Tamproco cintunces se pudo comprender cómo el octọpodo mati su presa. Despues de la comida arroja los restos delane de su vivienda, fou- 
bre con ellos parte de la cntrada, atrayéndolos con los discos chupadores. Todos los ojos sobresalen de este marapeto, acechando nueva presa.

I. a violencia y rapidez. con que los octópodos cogen sus victimas y las oprimen contra su tronco, el cambio de los colores durante el ataque, y las verrugas que se presentan en la picl prestan if estos animales un aspecto verdaderamente sal. vaje. Sin embargo, cuando estan satisfechos dejan que los cangrcjos se paseen cerca, y hasta los tocan; estos, por el contrario, temen cvidentemente, perdiendo su acostumbrado atrevimiento: parece que se han abandonado à su sucrte, cual si estuvicran bajo aquella infuencia nágica que domina á los animales pequeños cuando se ven amenazidos de sus cnemigos. Collmann nos ha dado una descripcion muy interesante del octópodo comun, ó pulgo, por los ejemplares que existen en el acuario de Dohrn: Mucho descaba, dice, concrer la maturale\%a de estos animales. Hay, en efecto (segun las (rádiciones del Kiarlien), algo de salvaje, atrevido y rapa\% en su caricter. ¿lienen efectivamente algo de la naturaleza del tigre, ó sucede precisamente lo contrnrio? Confieso que me inclimaba à suponer lo último, pues el cuerpo blando, so. bre todo de los animales sin vida, confirmaron mi escepticismo. El pulpo recien muerto que, echado en un cesto ó en tierra, se ofrece à los compradores, no produce ni el mas minimo efecto. Fil cucrpo es liso y los brazos están entre. lazados en suaves circunvoluciones; no tienen en apariencia nada de peligroso; pero por la observacion de los animales vi. ros mi menosprecio se ha convertido en opuesto sentimiento. $Y$ en efecto, los pulpos son quizás los animales mas valerosos y pendencieros que respiran en el agua; atrevidos y rápidos en el ataque, y de una variedad soprendente en los movimientos, tienen una fwerza enorme en los blandos brazos sin liuesos.

Feferire uno de los hechos que he observado delante de los compartimientos de agua del acuario. De otro depósito se habia puesto un grande calorajo en el de los pulpos; se le envis por decirlo asi al desticrro. Antes habia vivido en el deprósito mas grande del acunrio, pero á causa de haber muer. io it uno de sus semejantes se habir cantado la antipatia del guardian, que lo expulsó de alli por precision. En aquel depósito grande hahia, además de tiburones y rajas eléctricas, cuntro magnificos ejemplares de tortugas marimas, muy aficionadas a las ostras y los cabrajos: la una, del tamaño de un plato, parecia tener apetito para comerse aquel cabmjo y quiaas no habia apreciado bastante las armas del crusticeo Este cogió la cabeza de la tortuga con su tennza, aplastánciola en la serdadera acepcion de la palabra. "lodo el mundo sabe cuanta es la durera delerineo de estos animales, y puede for marse por esto idea de la chorme fuerza de la tenaza del cabrajo. Es cicrto que el cabrajo cra un ejemplar colosal, pero - a pesar de esto, la manera de defenderse demuestra una res. petable actividad en sus tenazas.

\$ Ahora bien, este cabrajo fué puesto en el depósito de los pulpos que observaron con la mayor atencion al intruso, rodeandole en anchos circulos. En esta acasion todo el comportamiento de estos animales demostraba algo de provocativo. Cautelosmmente, cual si quisieran acercarse h́ hurtadillas it un chemigo, se dirigieron hícia el cangrejo, sacudiendo los brazos por encimn de èl como látigos, aunque se retirnban lentamente cuando les enseñaba su coraza ian dura como el imeso, ó las poderosas tenazas.

Droco ś poco se calmó su excitacion, pero uno de los pul. pos hizo esfuerzos para acercarse mas y mas; por fin pareció yue tambicn él labia cambiado de parecer $y$ permaneció del todo indiferente. El cabrajo se retiró un poco, abandonándose al descanso, por su desegracia demasiado pronto, pues, un mo- mento despues, el pulpo ja le tenia rogido, envucleo entresus brazos y estrechado dejaindole del todo indefenso. Fin este momento acudió el guardian, cogió los animales, enlazados como serpientes juriosas, y libró al cabrajo.

IEl guardian, un naprolitano de pura raza, supuso, con la mayor serguridad, y haciendo esos expresivos ademanes que caracterizan al italiano del sur, que el pulpo sin duda habria desgarrado al cabrajo si él no le hubiera salvado. Yo, sin conbargo, tenia mis preocupaciones sobre estos pulpos, de masa blandal y gelatinosa: ni siujuien me parecian peligrosos. A pesar de las tradiciones sobre el caricier peligroso de estos animales, y á pesar de la lucha que acaló de desarrollarse ante mi vista, permancci indeciso, aunque el guardian me refirió las cosas mas horrorosas. Para observar el curso del suceso volvi á menudo al depósito. Al raho de unz hora me pareció que la inclinacion à la lucha se despertaha de nuevo en uno de los pulpos, y en efecto, poco despues se verifico un nuevo ataque. Desgraciadamente no pucle averiguar si em el mismo de antes; casualmente estalsa solo en el acuario y me guardé bien de mezclarme en el combate; lo que a mi me interesaba era el modo de luchar y el éxito de la refriega, siendome del todo indiferente cual de los dos cxtraños gladiadores sucumbiria. I) el mismo modo que la úlima ve\%, y como los brazos del pulpo rodeaban en circunvoluciones convulsivas al cabrajo; alli se soltaba uno para ajudar en otro punto a los otros. La masa total parecia compuesta del cefalópodo, pues del cabrajo solo se veian jeque. nas partes. I.os combatientes nadaban por el fondo revolviendo la arena; pero de repente se abrió el bulto y el pulpo cruzó rápidamente a traves del agun arrastrando, aunque no victorioso, al cangrejo en pos de si. Fil crustíceo habia cogido un brazo del pulpo en la base cerca de la cabeza, oprimiendo sus tenazas de tal modo que temi una amputacion instantánéa. Pero con gran sorpresa mia, la sustancia del pié, fuerte y' marecida en elasticidad al cauchuc, soporta la terrible presion. Fin cl entretanto el pulpo atormentado de dolores cruzaba el agua en todas direcciones con intencion de desembarazarse de su adversario. El cal)rajo fue lanzado varias veces contra las piedras que compjonen las paredes del depósito, y esto le obligó por fin á abrir su tenaza. Des. pues, ambos se retinron a diferentes rincones del depósito. El crustáceo permaneció como tranquilo observador en un rincon oscuro, mientras que el pulpo se agarró a una de las prominencias pedregosas, comenzaudo incesante juego con sus brazos que, ya se enroscaban, ó extendian lentamentc examinando orn este ora otro punto de sus contornos.

biun el brazo oprinido que habia sido cogido con la tenaza se movia con gran sorpresa mia. Yo csperaba, en analo. gía con la naturaleza de un vertebrado, una parálisis completa; jero no observé ningun vestigio de ella. Estos organismos tienen cualidades müy particulares en sus vasos de sangre que a los animales mas desarrollados faltan del todo en tal grado. Cada parte del sistema mal es contractil, de modo que sin corazon tambien se puede verificar la circulacion de los jugos. lista naturaleza explica ficilmente que al cabo de pocos dias haya desaparecido toda huella de la lucha.

3.1 a manera que tuvo el pulpo de comenzar la lucha $y$ la actividad con que maniobró, aunque sin resuliado favorable, habia modificado un poco mi menosprecio. No pude menos de reconocer el valor del animal, yademis que la rapidez de los movimientos habia siclo muy notable. Mientras tanto continuaba la guerra contra el intruso; el guardian habia separado varias reces en los dias siguientes a los dos adversarios, pues luciraba un solo pulpo, mientras que los otros permanecian del todo pasiros; pero una vez solo se logró la separacion, despues de que el mbrajo hubo perdido una de sus tenazzss. 
\$ Pira poner coto \& la continua persecucion, el cabrajo fué conducido al depósito inmediato, separado de los dos anteriores; pero lque sc comunicaban por una ancha puerta y una sólida pared de cemento que sobresalia unos dos centimetros de la superficic del agua. La esperanza de proteger aqui al crusticeo contra los pendencieros pulpos fué inútil; en el mismo dia, uno de ellos escaló la pared, atacó al cabrajo, que nada temia, y, despues de un corto combate, le partió completamente por medio. El ceinlópodo habia logrado la sorpresa, y en menos de cuarentia segundos, el victorioso habia comen. zado y concluido la lucha, empezando á devorar is su cnemigo.

3. Este proceder del pulpo me cra un alto grado interesante: al fin de la lucha demostró una actividad del cerebro muy superior al instinto, revelando inteligencia. El julpo habia visto quizás que el calinjo era conducido por el guardian al depósitó vecino, ú olfateó por medio del agua corriente la presa. Sin decidir cuál de estas dos suposiciones es la mas exacta, podemos afirmar que el pulpo reconoce por cualquie. ra inyzestion de sus sentidos la ajroximacion de una presa que no divisa, y da por fin un salto en el aire en aquella direccion. Precipitarse sobre una presa visible seria un acto del instinto; pero hacerlo contra un enemigo que no se halla is su alcance, $y$ con las circunstancias arriba citadas, es $\sin$ duda inteligencia tinas bien que instinto.

- Para apreciar bien este fenónemo debemos tomar en con sideracion, sia embargo, lo siguiente: desde que se instaló el acunric, los pulpos vivian junzos con dos cabrajos en muy buenn armonia, asi como con algunos pequenos peces que desde el primer dia fueron sus companieros. El tercer cabrajo les cnusó, sin duda, una impresion diferente: parecióles un intrusa; y todo competidor nuevo que les quiere disputar el aire y el espacio excita su in y su odio.

$\$$ Durante uni estancia se quisieron poblar los dos depósitos con otros varios pulpos de la misma especie, pero el experimento fracasó dél todo: todos fueron muertos y devorados por los antiguos, que en cadnlucha quedaron victoriosos, aun con adversarios mas fuertes. El intruso es siempre inferior y siempre se lialla en una situacion menos favorable que los primeros habitantes, que como señores del campo de batalla son valerosos y audaces por los résultados obtenidos en combates anteriores, conociendo además el terreno. El recien llegado se encuentra solo en un territorio extranjero, frente a muchos agresores, cuya nanera de combatir no conoce. Naturalmente estas condiciones le infunden tentor, por lo cual piensa mas en la fuga que en la defensa, y de aquí el desgraciacio fin de la lucha. Ios pulpos odian á todo sér que con ellos quicra habitar el mismo espacio; no es el hambro la que les impulsa, pues se les alimenta con abundancia; es solo el odio que en todas partes se acrecienta en la lucha por la existencia. Sin embargo, la aversion y la tendencia a ma tar no son los rasgos fundamentales de su carícter, segun lo demuestran de un modo suficiente en otras cosas. Conocen a suguardian $y$ le distinguen tambien de otras personas, mani. festindole carino: rodean con suaves y afectuosas circunvo. luciones su mano ó el brazo desnudo, é intentas coger len tamente la golosina con la que durante un rato les provocas.

Como Collmann ha observado tambien el juego de los colores y el comportamiento para con los companeros de cautividad mas minuciosamente que Fischer, reproducimos tambien esta interesante parte de su descripcion. «El ani mal tiene la facultad de cambiar su color, desde el gris mas claro, hasta el pardo mas oscuro; el color sc cambia en esta ocasion ripidamente ó se fija en un tono determinado; puede presentarse ya solo en el tronco, ya en los brazos; en una pa labra, el pulpo parece írbitro absoluto de su colorido. En los ataques arriba citados contrn el cabrajo, toda su piel cra oscura, sobre todo, durante la lucha. Cuando se acerca á hurtadillas a su enemigo, cuando quiere arrebatar al guar. dian un cangrejo, ó bien cuando entre si se persiguen rêtozando, coda la influencia que ejerce sobre el color se hace visible. Este cambio de colores es sin duda para los animales excelente arma para engañar al enemigo. Cuando los pulpos permanecen entre piedras grises adoptan el color gris; es sin embargo dificil decir si lo hacen voluntariamente ó ả consecuencia de reflejos en los nervios; entonces el animal, con los brazos recogidos y el dorso encorvado, parece talmente una picdra.

El carmbio de colores es al mismo tiempo un excelen. te medio para auxiliar la mimica de estos animales. Los pulpos son quizás los animales mas vivos del mar; están siempre en movimiento (r) y son mucho mas viros que los calimares En la transparencia de la piel y en la desnudez de todo él cuerpo es fácil -seguir los estados de excitacion en quel se halla este animal, y pronto se reconocera que tiene una mimica muy expresiva, y que pueden manifestar muchas impresiones. Para tales observaciones era propio, sobre todo, el pulpo citado, que en su guarida de piedra estaba continuamente cerca de la rentana. Cuando se acerca. ba alguno de sus hermanos, dejaba ver, segun la distancia, una exuresion muy marcada de enojo.

Primero lerantaba la extremidad de algunos brazos en direccion al sitio por donde llegaba la visita, y extendiale lentamente, pero con vigor. Mas brusca era la amenaza cuando un par de brazos se lanzaban hácia afuera como un láaigo: entonces el animal levantabase al mismo tiempo un poco en la profundidad de su guarida, cual si se preparase a la defensa; oscurecianse alyunas partes de su cuerpo, y le re. corrian sómbras pardas, desapareciendo con la misma rapidez con que se presentaban. Si estas señales de enojo no ahusentabar á los impertinentes companeros, ó cuando un espectador zocaba con la mano el cristal, como yo lo hacia con frecuencia, entonces el cuerpo se levantaba a mayor altura; las prominencias que rodean los ojos dilatábanse; el color se oscurecia; un par de brazos se levantaba, mientras que los otros, desligándose sobre las piedras, fijaban sus discos chupadores, tan pronto en un sitio como en otro, para levantarlos poco despues con violencia. Tales ademanes amenazadores iban acompanados siempre de ronqzuidos, y $\mathrm{cl}$ agua entraba en mayor cantidad en el manio: este se dilataba, y la actitud era cada ver mas amenazadora, contribuyen. do h́ ello, no poco, el violento surtidor de agua que salia del embudo como de una bomba.»

Entre las utras especies del género didopiss haremos mencion del pulpo de brazos largos (oclepus macropis), que se distingue por este caricter. El cuerpo alcanza un longitud de $0 ; 075$, mientras que el primer jar de brazos mide hasta un metro. Por su genero de vida en libertad y por su proceder en cautividad difiere de su congénere anterior. Vive en las cavidades de las rocas situaclas à mas profundidad, y sólo en el fondo cenagoso. En una vasija grande llena de agua de mar vive varios dias sin alimento y sin hacer ningunat ten. tativa de fuga. Lina de las especies mats honitas, pero muy raras, es el oclopus calcoubutus que se distingue por tener unos rebordes membranosos en la cara abdominal, los cuales se cruzan en forma de red. Solo algunas veces se le ha sacado de muy grandes profundidades agarrado a peecs yue se habian cogido con al anzuelo.

(1) Estu no icbe entenderse por un conthuo mgar. l'ermanecen al contrario horas y dias enterus en un mismu sitio, pero observan con gran atencion todo lo que pasa $\mathrm{i} s u$ alrededor y cjecutan ligeros movinientos con las lirazos, como los hace el gato con la cola. (Niriz did Astos.) 
El género elerome difiere del octopus principalmente por la circunstancia de que sus brazos tienen una seric de discos chupadores. I a especie mas comun es el cledone de almi\% cle, (eledone moschata). Su cuerpo es en extremo variable, pues unas veces afecta la forma de bolsa prolongada o de huevo, $\delta$ bien es redondeado \& puntiagudo, liso $\delta$ verrugoso, segun el antojo del animal. Caracteristico es tambien el gran tamańo de la abertura del manto que llega hasta el dorso. Los pequeños ojos salientes pueden cubrirse del todo con los párpados y tienen un iris muy variado. Fi color predominante, que es gris, presenta unos tintes sonrosados ó rojiros. Unas manchas negruacas simétricas y un borde azulado de la mernbrana que se extiende entre los brazos son otros caractéres de la especic, la cual debe su nombre á cierto olor de almizcle bastante marcacio.

Parece que solo se encuentra en el Mediterrineo, pero aģui es muy comun en todas las costas. Por lo regular vive en un fondo cenagoso de ro a 100 metros de profundidad, se encuentra tambien entre la arena y los guijarros en todas las estaciones, pero mas raras veces cn rocas. Como no es posible estudiarla en libertad, es preciso limitarse i la obser. vacion de los individuos cautivos, que pueden obtenerse muy fäcilmente, porque se pescan en gran número con la red. Fu el estado de descanso se agarra con ajuda de los discos en el suclo, y toma con la cabera y el tronco poco mas 6 menos la posicion que tambien gusta al octopus indyaris; entonces

1,os

están

ue los

mudez

tacion

à que

ifestar

ropio,

Ira es-

cerca.

ancia,

$\cos \mathrm{cn}$

ndiale

cuan-

n lá:i-

n poco

se d la

- le re.

rapi-

ojo no

do un

hacia

or al-

se; el

ientras

us dis.

o, para

manes

s, y cl

dilata-

buyen.

alia cel

5 men-

give se

ngitud

liasta

proce-

ive en

y sólo

e agun

na ten.

o. muy

r tene

cunles

a saca.

que se

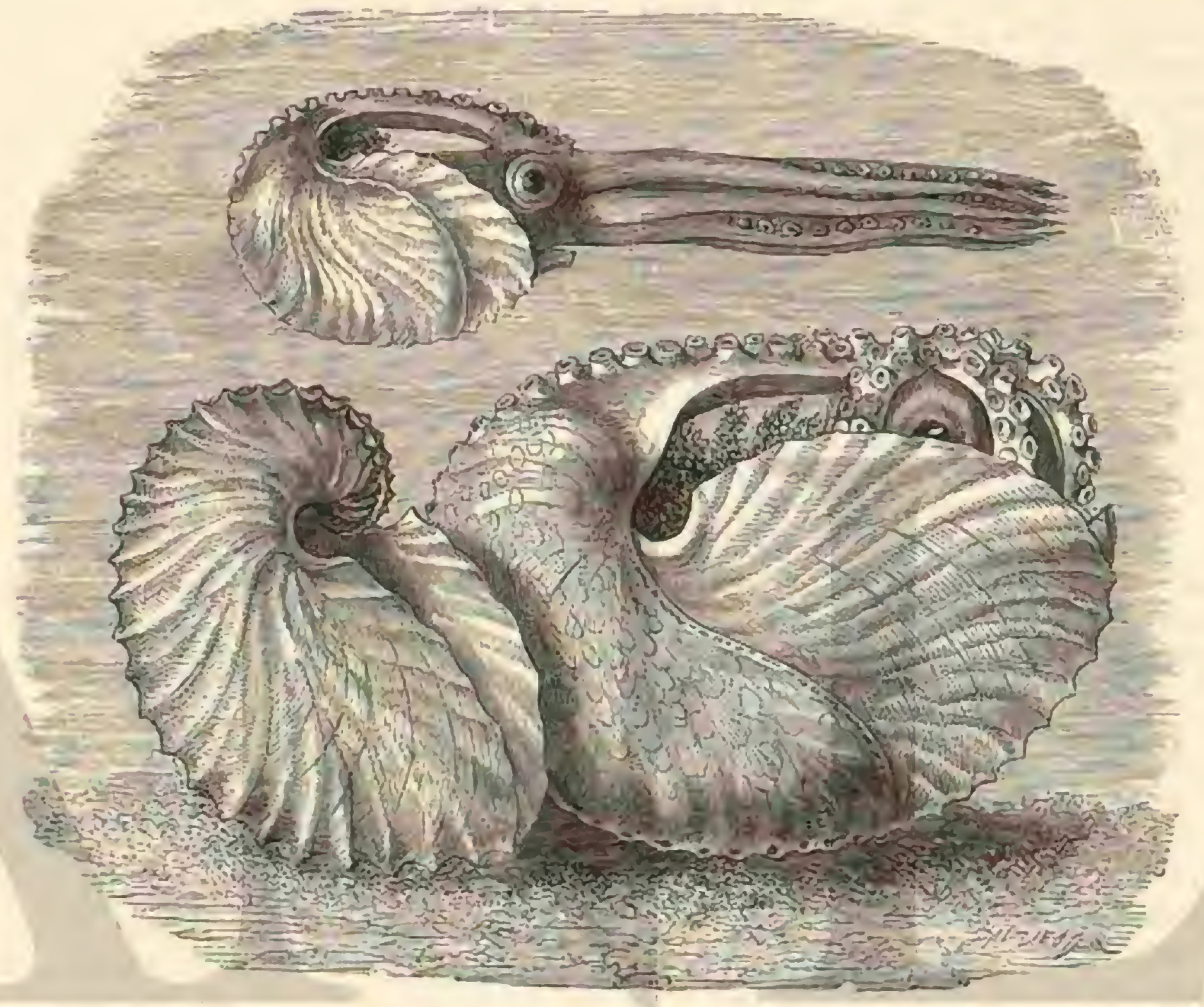

Fig. 218. - H. ARGONALTA AKGOS

las extremidades de los brazos son libres $y$ la abertura del embudo se prolonga lateralmente. Lìn esta posicion el animal pasa las tres cuartas partes de su vida, y se puede admirar la asombrosa rapidez con que cambia los colores. A la mas minima molestia un color oscuru recorre con la rapider del rayo todo el cuerpo, desapareciendo sin dejar una huella. Verany cree haber visto alternar con este estado una especie de somnolencia. La posicion es la misma, pero las extremidades de los brazos están mas recogidas hícia el cuerpo, in pupila se contrace, y la respiracion, la entrada y salida del agua se verifican mas lentamente. El color regular es un gris annarillo ó gris pardo, pero siempre fattan las manchas cista nas; el oido y la vista permanecen insensibles y el observador puede acercarse al depósito, gritar y hacer ruico sin que el numal despierté. Pero al mas pequeno golpe contra el brazo, por ligeramente q̨ue se le toque, el animal despierta al momento, y en todo su sér se verifica un cambio no:able. El eledone endereza rapidamente el cuerpo, casi vertical. mente por enciuna de la cabeza, $y$ le hincha un poco dindole una forma puntiaguda; toda la supericic de la piel toma un color amarillento, las simétricas manchas negruzcas se presentan, y ent todas partes se clevan verrugas cónicas. El iris se contrace y adquiere un color amarillo de azufre intenso; sale el agua ron violencia del embucio, y la respiracion se hace mas irregular. De tiempo en tiempo se recoge una can. tidad de agua en el manto que despues sale como un surtidor de dos á tres metros de distancia fuera del depósito, por mas que ha de pasar por una capa de agua de 30 centimetros. Tambien al ofrecer Verany al eledone un cangrejo vivo, le vió tomar una posicion que revelaba excitacion; se cubrió de proubcrancins, dando ì la piel el color del vaso en que se hallaba, probablemente para no causar sospecha al animal i quien querin engainar y atacar.

A veces, sohre todo de noche, el eledone se escapa de su depósito, ya porque el agua no basta para la respiracion, ya porque el animal busca la libertad. Se conserva entonces varias horas en tierra firme; tambien soporta un ajuno de diez dias.

A pesar del olor muy sensible de almizcle, el eledone se lleva en gran número á los mercados. Su carne no es tan dura como la de las especies de oclopus del mismo tamaño. pero es menos sabrosa. Por lo demás solo se presenta cn la mesa de las clases pobres.

Una tercera forma, célebre ya en la antigüedad, y muchas 
veces descrita, es el a gronaufa argo (fig. 2 I S), del quue hasta ha. ce unos veinte años se conocia solo la hembra provista de una bonita $y$ delineada concha. De ella tambien trata la siguiente descripcion, pero de las diferencias muy notables del macho hablaremos despues, al tmar de los caracteres sexuales de los machos de los demás cefalópodos. En el cuerpo de forma redondeada, se notan la pequeña cabeza y el embudo, muy desarrollado $y^{\circ}$ largo, pero sobre todo el ensanchamiento lobuloso del par superior de los braz.os. El color es en extremo brillante y bonito: el naturalista napolitano Sangiovani la ha descrito del mocin siguiente: las partes inferiores y laterales del tronco son de un color de plata pardusco que segun la direccion y fucran de los rajos de-luz se cubre, ora de un ligero tinte azul parecido al nzul de mar, or: de un tinte gris o rojizo. Tambien se observan en esta superficie de tan variados colores uruchos puntitos brillanies, amarillos y castaños ó sonrosados; y cuando mayor es el movimiento, tanto mis bonitos son los tintes. Hil conjunto de estos lobulitos de color que se extienden sobre un fondo brillante dé plata camunica a la piel de aquellas partes del cucrpo un viso sonrosado, con un sin numero de puntitos de color, entre los cunles se observan algunos dispuestos simétricamente y rodeados de un circulo plateado. Las partes dorkales y la superior de los lados del argonautason de un bonito verde, que se puede oscurecet y se obscrva sobre todo de noche. il color plateado de la parte inferior de los costados se continua en fajas hricia la parte superior de los mismos que es yerdosa, de modo que aqui alternan los colores. Ia natumleza adornó esia parte del cuerpo del argonauta con varias cerdas de un color amarillo claro y hasta de ocre, mezcladis con otms de un tinte castaño.

Algunos individuos presentan en ciertas partes una especic de glóbulos de color, dispuestos en el centro de pequeños circulos rodeados de celdas de diferente matiz y que adornan la piel como pequeñas rosas; colores parecidos se extienden sobre la cabcza y los brazos.

La concha del argonauta argo, que se distingue por su elegancia y esbeltez, es bastante clástica, porque contiene abundante materia orgánica: pero tiene nucha mas resistencia que las conchas mas delgadas de otros moluscos, por ejemplo de los terópocios. Se compone de una soln cavidad y se retuerce en forma de espiral, de modo que las circunvoluciones anteriores estan cubiertas por la última. Ia relacion en que el animal se halla con la concha es única c1r su clasc, porque en ningun punto está unida con ella, ni tampoco la forma del primero, cuancio se saca, parece corresponder à la de la segunda. Por lo tanto explicase que antes se tuviern la ider que ha predominado hasta estos últimos tiempos, de que el argonauta habita la concha de una especie extraña, no conocida, del mismo modo que el ermitaño. Sin embargo, sie encontró que la concha es una secrecion de los brazos, que la cubren desde afuera, sosteniendola en esta posicion. Ia concha se forma por lo tanto desde la superficie exterior, y cuando sufre desperfectos se remiendan exteriomente, cubriéndose el cuerpo de una picl quue se mantiene elastica.

- menudo se encuentran dibujos del argonauta en una posicion que el animal no puede tomar; estos dibujos res ponden à una fábula que se ha creido desde Aristóteles has ta nuestros tiempos, segun la que, cuando el argonanta nada en la superficic del mar, eleva sus dos brazos en forma de vela, sirviéndose de ellos como ia tal. Segun vió Vernany, en tiempo de calma, sube de vez. en cuando, pero no para servirse de sus brazos como de velas, sino para emplearlos à guisa de remos: el animal de quue habla se dirigió de esta manera a la orilla, donde se pudo coger. Cuando quieren nadar debajo del ingua,-à la manera de los otros cefalópjodos, empujando el agua del embudo, colocan los grandes brazos de tal modo sobre las partes laterales de la concha que esta se cubre casi de todo.

En el Mediterráneo el argonauta argo abunda, sobre todo en la costa siciliana y en el golio de Tarento. En el Adriático, la isla de Lisa es el punto mas septentrional donde no escasea, aunque los ejemplares que de alli se reciben son bastante pequeños.

\section{LOS DECÁPODOS-DECA- PODA}

Fin el segundo grupo $\delta$ sub-órden se reunen los cefalópodos provistos de discos chupadores que además de los ocho, órganos de locomocion de la cabeza de los octópodos, tienen dos órganos prolongados compuestos de un largo tallo liso, en cura extremidad hay $n$ na placa provista de discos. Regularmente estos dus brazos prehensiles de diferente estructura se insertan en estuches particulares, en los que pueden reco. gerse en parte; pero no se emplean como órganos de locomocion, sino prehensiles Todos los decápodos tienen en el dorso una concha calcairea ó córnea.

La mayor parte de las especies viven en alta mar y se acercan solo alguna vez is la costa, viajando por la regular en numerosos grupos. Perseguidos por los grandes peces, salian de la superficic y encallan á menudo en los bancos o en la arilla Como difieren mucho por su área de dispersion y géncro de vida, preferimos tambien en este caso las descripcionies parciales \& las generales.

Empecennos por el género de las graciosísimas sepiolas (fig. 220 y 221). La sefiola Rondeletif presenta como caractéres genéricos cuerpo corto, redondeado, con una aleta semicircular en cáda lado; la concha dorsal, cómea y Rexible, tiene solo Is mitad de la longitud del cuerpo. Nuestra especie pertenece à los cefálópodos mas pequeños, porque los ejemplares cuya longitud total, desde la extremidad posterior hasta la punta de los braros prehensiles extendidos es de $0^{\circ}$, I 6 , ya son raros. Los ejemplares de la pescaderia de Trieste raras veces llegan

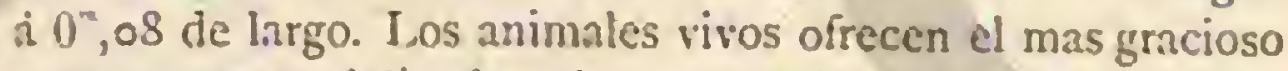
aspecto por su delicado color sonrosado y por su gran trasparencia. Se encuentran en todas las costas del Mediterraneo, y hasta yo les he cogido una vez con la red en el puerto de liries. te. Una rariedad mas grande vive en el fondo cenagoso, a la profundidad de 90 a 100 metros en compañia de los eledones; otra prefiere el fondo arenoso y las rocas cubiertas de algas. larece ser un animal sedentario que no viaja en grupos, y que se coge en todas las estaciones, aunque nunca en gran numero. Nada con mucha gracia, valiendose de las aletas, hảcia atrás ó hácia adelante: los brazos prehensiles están por lo regular del todo recogidos, y la cabeza se halla, por decirlo asi, entre los hombros. La carne es muy apreciada.

No hacemos particular mencion del género rossia, muy afine del sefiola, por la circunstancia de que los pescadores no reconocen ninguna diferencia entre ambas formas: pero csto lo hacen por excepcion, pues los pescadores suclen ser naturalistas muy superficiales y poco fidedignos.

Uno de los decaipodos mas importantes de que en muchas obras populares y elementales se imta con mas frecuencia es el género sepia ó jibia (sepia), con cuyo nombre se designa tambien el jugo de tinta y el color fabricado con él, y cuya concha dorsal calcárea es conocida cuando menos de todos los iarmacéuticos bajo la denominacion de os sepici (hueso de sepia). Las sepirs tienen el cuerpo oral, prolongado, un poco aplanado y circuido en toda su circunferencia de una alcta. La especie mas diseminada y comun, sobre todo en el 
Mediterráneo, es la sepia comun (sepia officinalis). Sus brazos son de mediana longitud, $y$ los prehensiles mas largos que el cuerpo, con la extremidad en forma de lanza. I a concha dorsal, que tiene la extremidad redondeada é igualmente afilada, se inclina hácia la cabeza; en la otra extremidad hay unn escotadura, donde se ve una espina inserta en la linea central. Fäcilmente se distinguen las tres capas de la concha: hácia fuera se ve una calcárea, fuerte y delgada, con la superficie gramujienta y revestida de ligeras prominencias; la capja central es una delgada hoja córnea, cuyo inayor espa. cio está ocupado por numerosas hojitas calcáreas dirigidas oblicuamente hácia arriba, y que reunidas entre si constitu. yen la tercera capa. Con estas hojitas se fabrican polvos den. tíricos, que tambien sirven para pulimentar y alisar muchos objetos.

En el estado de descanso predomina en toda la superficie corsal un color amarillento sonrosado con visos de arco iris y manchas blancas en la linea central. lar cabeza es un poco colorada; los globos de los ojos azulados; y los ojos verdosos, provistos tambien de manchas blancas en deterninado órden y numero en los diferentes pares. Las aletas, que parecen una prolongacion de la piel dorsal, son trasparentes, de color violeta, y están cubiertas de pequenans manchas blancas opacas. Además de este color regular se observan otras combinaciones parecidas. A veces presenta tambien toda la superficie dorsal marcadas prominencias cónicas cu. biertas en seriẻs longitudinales paralelas á los lados: pero cuando el animal se irrita todo el dorso se llena de prominencias irregulares de un bonito color castaño oscuro y de brillo metálico ó de un rojizo de cobre. Desde la cabeza y á lo largo de los brazos, cuyas manchas blancas tambien adquieren un color rojizo de cobre, se produce entonces un brillo verdoso, mientras que los globos de los ojos despiiden reflejos platcados, sonrosados, azules y verdes. la aleta cambia muy poco, mientras que la cara abciominal presenta nur. cados colores de arco íris, cruzados por rayas grises mas ó menos marcadas. Cuando la irritacion se nitiga, las promi. nencias desaparecen en el tronco, persistiendo aun lạs que rndean los ojos. Tambien la cabeza conserva sus manchas, pero un gran número de cerdas colorantes se contrnen en el cuerpo; pequeñas manchas blancas se presentan en la línea central, y los bordes del manto se cubren de finjas irregulares blanquizcas un poco corvas.

Al sacar la sepia del agua, el dorso aprarece por lo regular rayado de pardo; poco á poco se contraen las cerdas colorantes, la piel toma un matiz amarillento y pierde paulatina. mente su tinte, asi como la cara inferior su brillo metalico; $y$ cunndo el juego de las celdas colorantes cesa, adquiere un color blanco leonndo.

Los ojos: muy variables en todos los cefalópodos, parecen estar sotnetidos particularmente en las sepias a la influencia de los diversos objetos que puedan producir excitacion. El ojo de la sepia tiene un aspecto en extremo particular; la pupila es muy estrecha y arqueada: el fondo del ojo es de color negro oscuro, y, desde la parte supuerior, la niña esta cubierta de un lóbulo membranasa provisto de celdas colorantes; este lóbulo pende hasta el centro de la pupila y podria llamarse un párpado superior; el inferior es mas estrecho y blanqquizco. Cuando el animal está excitado y se halla en el periodo del celo, la pupila se dilata extraordinariamente y se redondea, is la ver que los párpados se contraen mucho.

Nuestra sepia, que por término medio mide $0 \mathrm{~m}, 15$ de largo, permanece siempre cerca de la orilla, con preferencia en el fondo cenagoso y arenoso, donde se la encuentra todo cl año y se la coge con red. El método mas usado y divertido para pescarla en la primavera consiste en salerse de un ani- mal que sirva de cebo, como por ejemplo una hembra, la cual se ata à una cuerda; ó bien se pone una figura de madera en forma de sepia, a la que se sujetan algunos pedacitos de espejo. La hembra, que se reconoce por su cuerpo mas ancho y por carecer de la linea blanca en el borde de las aletas, se engancha por la extremidad posterior á un anzuclo, y cntonces se larga la cuerda, de modo que el animal pueda moverse y nadar libremente, pero sin perderse de vista Parece que el anzuelo no le causa ciolores, pues le soporta varias semanas seguidas. la sepia nada entonces ji avanza con ayuda de sus brazos inferiores, que en una posicion horizontal del cuerpo deja pendientes de la cabeza, sirviéndose de ellos como de dos poderosos remos; con las aletas, que estìn en continuo movimiento, conserm el equilibrio, utilizándose tambien de los seis brazos superiores, que estrechamente oprimidos entre si se extienden horizontalmente. Durante el movimiento de avance la cabeza está recogida en parte en la cavidad del abdómen; la parte central del borde libre del manto se oprime mucho contra la base del cmbudo, y el agua entra solo de lado en las branquias; los hoyos prehensiles estin ocultos en sus estuches. Cuando qquiere nadar hácia atrás lo hace con ayuda del embudo como los otros cefalópodos, y los brazos estin reunidos entonces en forma de un har. Cuando la hembra atada a una cuerda de anzuelo pasa junto à un macho oculto en su guarida, ó que nada, este se precipita como una flecla sobre ella y recógela con sus brazos. El pescador atrae entonces suavemente la pareja, se apodera de ella por debajo del agua con ayuda de una pe. queña red, y expone à la hembra de nuevo á tan bruscas declaraciones de amor. Los mejores resultados se obtienen á la luz de la luna. Muy parecida es la pesca con la figura de madera y los pedazos de espejo; el muneco se arrastra en pos del barco, las sepias se precipitan sobre él y son agarradas.

Fuera del agua, la sepia muere muy pronto: si se la toca produce una especic de crujido con los dientes y sacada del agua bufa con mucha violencia arrojando aire por el embudo. los discos chupadores son muy fuertes y quedan pegndos atm despues de la muerte, aunque haya cesado ya el juego de las celdas colorantes. En una vasija estrecha no se conser. van mucho tiempo; cuando el aire contenido en el agua no satisface ya sus necesidades respiratorias, segregan en gran cantidad su tinta á consecuencia sin duda de paralizaciones, y mueren promo si no se cambia el agua. Eil mismo observador que ha proporcionado las noticias ya indicadas sobre el pulpo de los depósitos de Arcachon, cerca de Burdeos, da algunos detalles interesantes sobre las sépias que alli se tienen cautivas. Las reproducimos bastante integras, nunque se encuentran algunas repeticiones, porque completan esencial. mente las noticias de Verany. Las primeras sepias pescadas para el acuario y colocadas en el depósito grande, se mostraron muy tímidas, envolviéronse en nubes de tinta y se ocultaron bajo objetos flotantes, donde en posicion horizontal, y tocando con el vientre casi al suelo, permanecieron inmóviles. Al cabo de algunos dias de descanso se las trasladó a un cajon del acuario y aqul parecieron acostumbrarse al cambio de su residencia.

Ia posicion ordinaria de la sepin es la horizontal en la que el cuerpo se halla en su perfecto equilibrio. I os movimientos de ondulacion de las aletas sostienen al animal libremente en el agua, pero a menudo he visto tambien que ni siquiera necesitan ejecutar esos ligeros movimientos de remo para sostenerse en su posicion acostumbrada. Los brazos juntos figuran como tres bordes, de los que el superior está formado por los dos primeros pares de brazos; el cuarto par, que es el mas lango s ancho, forma con su borde exterior los otros dos rebordes. Las paredes interiores de estos últimas brazos se to. 
can, sus extremidades libres sobresalen de los otros y se enroscan ligeramente. Esta reunion de los brazos en forma de una especic de pirámide deprimida de atrás adelanie comunica á las sepias un aspecto particular, $y$ quien las ve se asombra de la semejanza de su cabeza con la de un elefante: los tres pares superiores de brazos representan la trompa, y la extremidad inferior del cuarto par se parece completaniente ála mandibula inferior.

En esta posicion los brazos prehensiles no se ven; haillanse recogidos y enroscados en la cavidad formada por los otros entre las bases del tercer para y del cuarto. Mirando por ia cara abdominal se ve en momentos dados como lasepia deja pendiente el cuarto par de brazos, en cuyo coso parecen dos protuberancias blanquizcas. En la posicion de descanso, de la cunl podémos formarnes una idéa por la descripcion ante. rior, los brazos superiores se entreabren á veces, levantåndose verticalmente como dos tentáculos: á reces tambien el animal deja pendiente el cuarto par, volviendo a colocarlé pocos momenios despues en su posicion anterior.

Lo que Fischer nos dice sobre los movimientos de la sepia no está del todo conforme con la descripcion de Verany. Distingue un movimiento mas tardio y otro rápido; cl primero se verifica con la misma facilidad hácia atrás como hácia adelante; cuando el animal aranza, el cucrpo gueda en posicion horizontal con los brazos unidos é inclinados; solo sus extremidades se encorvan un poco por la resistencia del agua. En el movimiento retrógrado la pirímide de brazos se levanta mas hácia el eje del cuerpo. Las vibraciones de las aletas, que solo en este movimiento moderndo son activas, empiczan de nuevo cuando el animal quiere nadar häcia
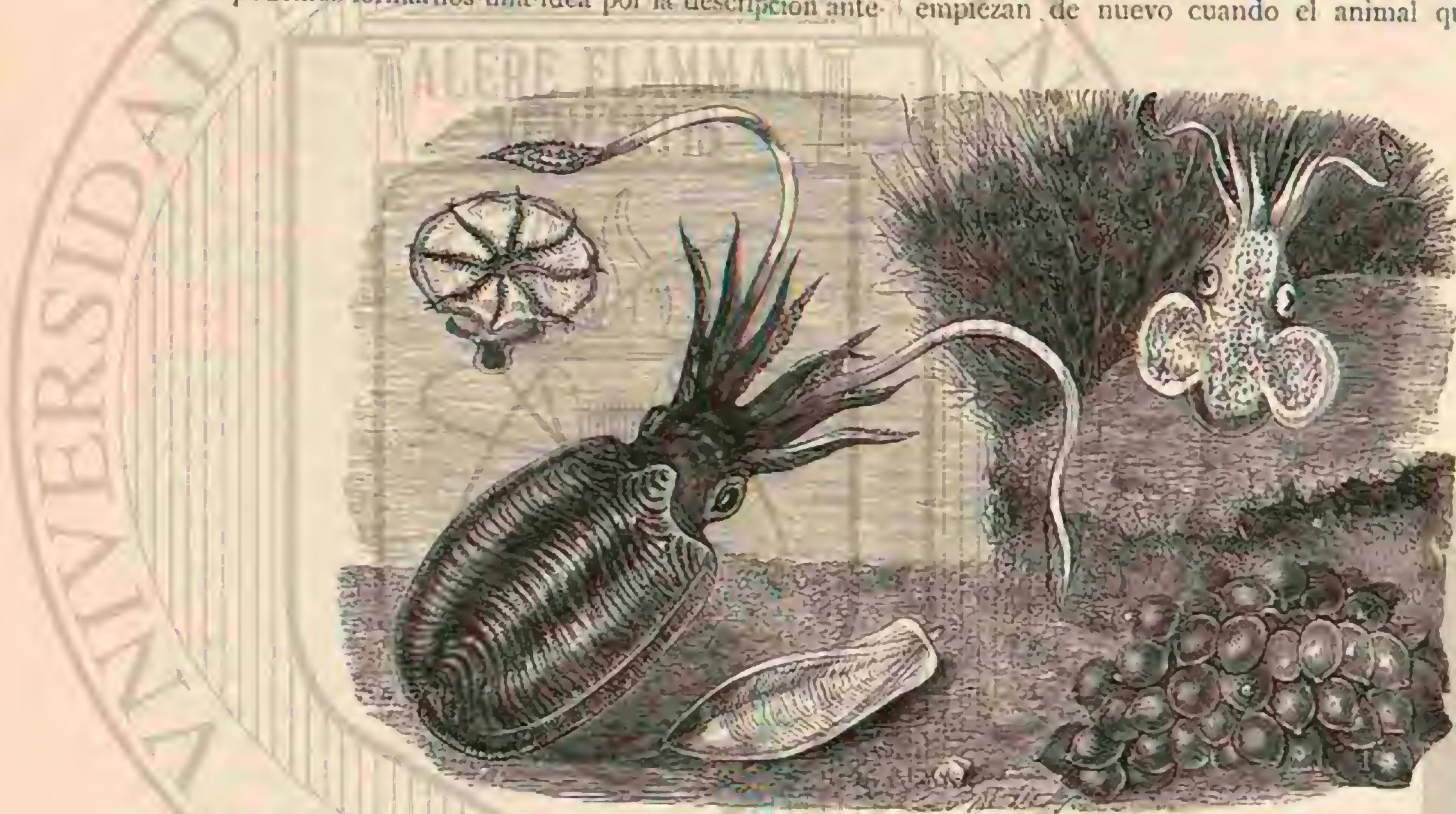

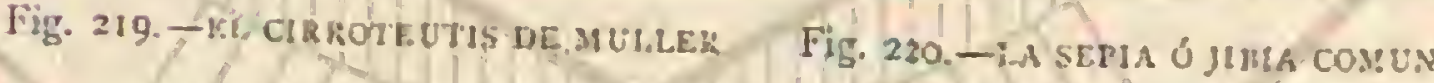

Fig. 221.-1,A SEPHOLA DH. ATLÁNTICO

atrás y vice-versa. LL/ movimiento se apresura notablemente apenas la sepia sc espanta ó excita; cutonces retrocede à intervalos, extiende los brazos y rtielve it unirlos de repente; las aletas permanecen inmóviles y se doblan haicia el vienere; al abalanzarse el animal franquca de un salto una gran dis. tancia. Fil observador de Arcachon considera el embudo como órgano auxiliar en este ligero movimiento, y dice que solo en el tiempo mas rapido la actividad cs eficaz. lo que yo he visto se aviene con este relato.

- Fil uso de los brazos prehensiles, continúa Fischer, me fue del todo desconocido hasta que tuve la satisfaccion de verlos cierta mañana en movimiento. En una division del acuario habia, desde hacia un mes, una sepia de mediano tamaio y durante todo este tiempo no habia comido. Se puso en el compartimiento un pez vivo del género caran.x, de conside rables dimensiones, $y$ sin sospechar nada, paseábase por el depúsito, acèrcándose al escondite dè la scpia. Aprenas ésta le hubo visto, desplegó con asombrosa rapidez y destreza sus brazos prehensiles, y extendiendolos cogió ál pez járat atrácrle á la boca; estos brazos volvicron à desaparecer al punto, pero los demás estrechaban la cabeza y la parte anterior del desgraciado pez. Los dos pares superiores estaban en las es paldas, $y$ los dos inferiores debajo del vientre de la victima, en el que se fijaban con los discos.

\$El pez estrechado de este modo no pudo moverse; pero la sepia, en cambio, ya segura de su presa, no la solto, y a pesar del enorme peso llevóla en todas las direcciones, nadando con facilidad y sin descansar, en el fondo ó entre los pednzos de roca. Sostenia al pez horizontalmente dejándole caer al cabo de una hora; el cráneo estaba abierto y el cerebro y parte de los músculos devorados:

Las sepias que en los grandes depósitos del acuario de Nápoles se colocan regularmente en compañia de estrellas de mar, se acostumbran muy pronto á su-nuero estado; solo manifiestan su enojo vaciando abundantes cantidades de timta cuando el guardian, para ofrecer al público un intere. sante espectáculo, las toca con un baston. No les agrada mo. verse; lo mismo que los octópodos, no persiguen su presa sino que la acechan. Cuando no están inmóviles sosteniéndose libremente, $y$ á menudo un cuarto de hora en el agua, perinanecen en el fondo, ya durniendo, con los ojos cerrados, ó bien conservándolos entreabiertos, cual si dormitasen; a veces dejan el párpado sujerior abierto, y nirando hácin ar. riba. Si el fondo de su depósito se compone de arena 6 pequeños guijarros, se cubren del todo, como to hacen los lenguados y rayas cuando están en acecho, colocando piedrecitas con las aletas sobre su dorso. En esta ocasion adaptan su color de tal modo al de los contornos, formando manchas verdosas y grises, que hombres y animales se enganan y no los divisan, a menos que la sepia se precipite de repente sobre su presa.

Ademås de la sepia comun, haillansc en el Mediterrảnco 
dos especies de color mas delicado y bonito que suelen ha. bitar en el fondo cenagoso en compania de los eledones; se venden alguna vez en los mercados, y son muy apreciadas por su carne tierna. Se llaman sepin elegans y sepin hiserialis: la primera tiene una piel trasparente por la que se ve en los individuos vivos el hucso dorsal, que con la espirn saliente en su extremidad posterior, constituye el mejor distintivo de la especie, cuya longitur, sin contar los brazos prehensiles

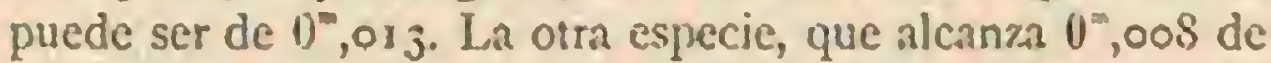
largo, lleva el nombre de biserialis, por tener dos series de manchas blancas en el dorso.
Despues de la sepia, el género de los calamares (Joligo), es el mas importante. El cuerpo cilindrico, carnoso y desnudo, se prolonga y adelgaza en punta en su parte posterior, $y$ las

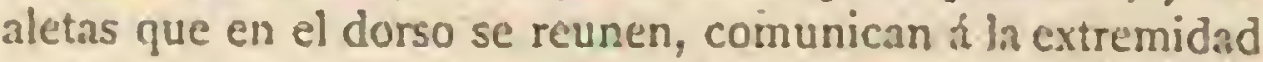
posterior casi siempre la forma de una punta de flecha alada. En el dorso hay un hueso córneo y flexible en forma de Recha. La especie mas comun, designada como tal por el sistema, es el calamar vulgar, loligo imulgaris, el calamaro de los italianos. Sus aletas forman un romboide que se extiende sobre dos terceras partes del tronco; el primer par de brazos es el mas corto; $y$ despues siguen en longitud el cuarto,

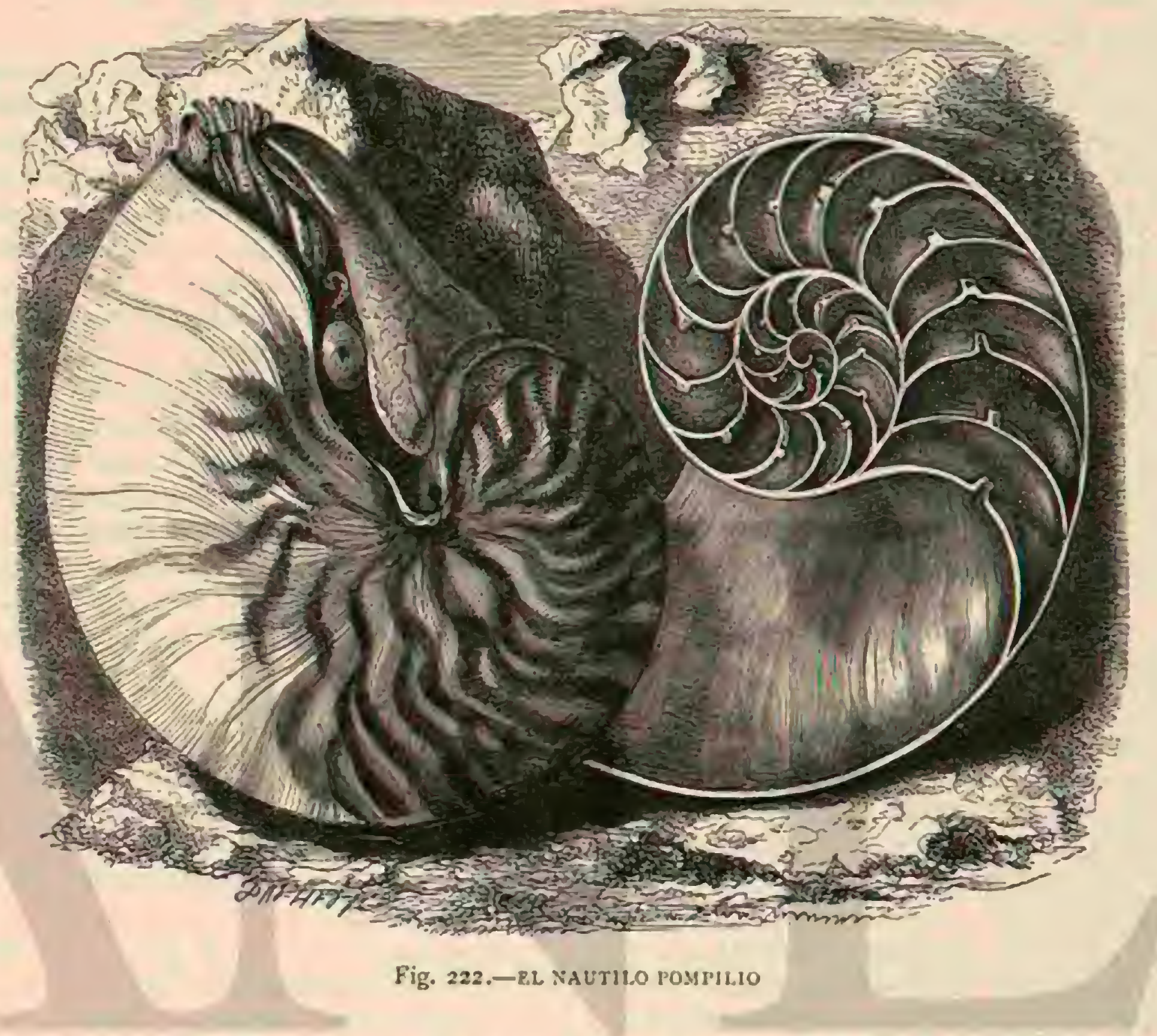

segundo y tercero; los prehensiles tienen vez y media la lon. gitud del cuerpo, $y$ sus extremidades ensanchadas estan provistas de cuntro series de discos muy desiguales. Ia particularidad especial del color consiste en que predomina un tinte carmesi muy brillante.

En el Mfediterráneo y en el Océano el calamar está generalmente muy diseminado. Se le encuentra en todos los pun. tos, pero abunda mas en otoño, cuando emprende viajes formando grandes agrupaciones. A veces se cogen muchisimos en las redes colocadas para el atun, $y$ de noche tambien con la red llamada mageliera. Con esta se sacan todo el año de los fondos cenagosos y arenosos, siendo mayor el número durante el plenilunio: es dificil pescarle con la lanza y el an. zuelo. Las emigraciones del calamar se rigen principalmente por las expediciones de los pececillos de que se alimenta. Ulega bastante à menudo á tener un peso de veinte libras; pero hállanse individuos mas grandes; mientras que la longitud media, sin contar los brazos prehensiles, suele ser de $0^{\mathrm{m}}, 020$. El tamaño que alcanzan las hembras es un poco mayor que el de los machos; pero estos individuos colosales solo se encuentran por lo regular cuando han encallado en la playa y muerto. En tal ocasion Verany, pudo obtener un huc. so dorsal de $0^{-}, 075$ de largo. Los individuos de mediano tamaño se prefieren à los otros grandes ceíalópodos comesti-

bles, sobre todo a la sepia, á causa de su sabor y de su carne tierna.

Tambien el calamar fué durante ini estancia en Nápoles un huésped comun del acuario, aunque no constante, $y$ demostraba como hijo de la alta mar una indole del todo distinta de la de sus congéneres de que acabamos de tratar. Asi como el calamar comun y otros varios loligidos, vive sociablemente, y por eso se suelen coger muchos individuos en las redes. A menudo se reciben grupos de diez á diez y seis individuos que se echan en el depósito grande; pero desgraciadamente se cunservan solo pocos dias; sus movimientos son monótonos; no hacen mas que cruzar de continuo el espacio en diversas direcciones, buscando siempre la luz entre la ventana exterior y la pared de cristal. El movimiento se reduce á un gracioso remar, que podria compararse con el de las aves acuáticas: para retroceder se comunican impulso con el embuỏo, y sus brazos se extienden horizontalmente; al avanzar, la cabeza está mas alta que el tronco y vice-versa al retroceder. Evitan cuidadosamente el contacto con las paredes del depósito; al acercarse á una, todo el grupo cambia casi en el mismo instante de direccion. Mientras que los octópodos y sepias se acomodan en el acuario para muchos meses, $y$, segun he observado en los octópodos, hasta intentan reproducirse, los calamares no se manificstan contentos; ni en Ar- 
cachon ni en Nảpoles se ha logrado obligarles á comer. Al cabo de cuarenta y ocho horas de cautiverio, durante las cuales no descansan, los morimientos son mas pesados y vacilantes; los animales parecen atontados, chocan entre si, y mueren.

De las otras especies solo mencionaremos algunas de las mas frecuentes $y$ grandes. El calamar de flecha (loligo sagitafa), tiene las aletas cortas, redondeadas en su parte superior y en forma de corazon; el cuerpo es trasparente y los brazos prehensiles, delgados, poco retráctiles y con la maza ancha. El juego de sus colores es mas variado yue en el calamar comun, con el que comparte su áren de dispersion en sitios donde se encuentran eledones y otros tantos cenlópodos. Por lo regular, solo se les coge aisladamente, pero como i veces entran por grupos en la red, parece que emigran temporalmente. Los vendedores no los niezclan con el calamar comun porque tiene muy mal gusto: Con el calamar de flecha se ha confundido it menudo una especie mayor, el loligy toldzrus, que, sin embargo, tiene el cuerpo mas pesado y que facilmente se reconoce por los brazos prehensiles no retríctiles que en toda su longitud estín cubiertos de discos chupadores y en su extremidad no se dilatan en forma de maza. Tambien esta especie se pesca, todo el año, algunas veces en el Mediterrineo, en general acompanada de peces que se sacan con el anzuelo y i los cuales se han agarrado; a menudo se encalla zambien. Su longitud, por término medio, es de $0^{\circ}, 020$, aunque tambien se encuentran individuos que pesan reinta libras. Su carne es muy dura y de mal coiner, tanto cjue en algunos puntos no se permite llevarla al mercado.

Los naturalistas modernos no clasifican estas dos títimas especies entre los verdaderos loligidos, sino con el género ommitostrefes que, con otros, tiene de comun la estructurn particular del ojo. Este carece de toda piel córnen, y tam. bien de una camam anterior; de modo que la lenteja ó el cristalino esti en contàcto inmediato con el agua.

Unino de estos géneros es el loligopsis, representado por una especie muy notable en cl Mediterrineo, el loligopsis vicranis. El cuerpo de este animal es gelatinoso y trasparente; el tronco, estrecho y prolongado, separado de una manera muy marcada de la cabeza, está cubierto en su initad posterior del disco de las aletas redondeado en forma de corazon. La cabeza, de forma esferica, es mas anchin que el tronco; los ojos son grandes y desproporcionados; los brazos aumentan en longitud y grueso desde el dorso hácia abajo; pero lo mas notabie, son los dos brazos prehensiles, pues miden casi un metro, mientras que toda la longitud del cuerpo, hasta la extremiảad de los otros brazos es de unos 15",030: solo tienen el grueso de una fina cuerda que en su extremidad afecta la forma de maza, provista de discos.

El género de vida del calamar de Verany corresponde à su trasparencia y sunve color azulado, pues habita en alta mar durante la calma de la estacion benigna en medio de los tenóforos y medusas del Mediterráneo. Todos estos animales de alta mar se distinguen por su trasparencia. Esta cualidad se nota mas aun en el loligupsis atermicularis encontrado cerca de Mesina, que por la falta de toda celda colorante aseméjase å un pedaro de hielo, y casi no seria visible en el agua si no se descubriera por los dos ojos negros.

En warios géneros de los calamares propiamente dichos, afines por su forma y género de vida, y que se han llamado calamares de gancho, los brazos están provistos, además de los discos, de unos ganchos córneos. El género mas rico en especies es el onychosesthis, cuyos brazos prehensiles solo llevan ganchos. De las dos especies propias del Mediterrineo el onycroteuthis lichtensteinii tiene en cada brazo prehensil dos series compuestas de doce ganchos, movibles en todas direc. ciones, curgo tallo está rodeado de una especie de estuche membranoso. Las aletas afectan, asi como la extremidad del cuerpo, la forma de una punta de flecha afilada.

El área de dispersion de esta especie demuestra, lo mis. mo que la de otras muchas, que estamos aun a oscuras sobre las verdaderas causas de la distribucion. Parece nlimentarse del sparus loops, a cuyas bandadas sigue, pero aunque este sargo es muy frecuente cerca de Génova, el onichoteuthis lichtensteinii no se coge nunca allí. En Niza, en cambio, donde el spariss boops se pesca en redes desde febrero á mayo, las cuales se tienden de noche cerca de la costa, hállase tambien este cefalópodo, que, sin embargo, no es comes. tible.

Los calimares de gancho que en los brazos prehensiles solo tienen discos chupadores, pero en los ocho restantes cuen. tan ademas ganchos, se agrupan en el género enoploteuthis.

Las especies de otro géncro, el de los rirrotentis (fig. 21g) se distinguen por tener los brazos enteramente reunidos hasta su extremidad por una membrana interbranquial, cuya forma se asemeja à la de un paraguas.

Pam la explicacion de algunas formas fósiles, tiene gran importancia la espirula (spirula). Este decajodo, que por muchos conceptos se distingue de los ahora existentes, es notable tambien por tener una bonita concha en forma de espiral, aplanada y compuesta de una serie de cámaras situadas una tras otra Por todo el lado abdominal se corre ún tubo llamado sifon, del cual hablaremos mas detenidamente al tratar de los tetrabranquiados. Esta concha, blanquirca, con brillo nacaridlo, está oculta parcialmenté en la parte posterior del manto, mientras que la otra sobresale de una hendi. durn del mismo.

Soló se conocen tres especies, entre ellas una propia del Atlántico. Aunque las conchas se encuentran á menudo en las playas meridionales, solo han llegado á manos de los naturalistas cuatro ejemplares del animal completo. No debe asombrarnos esto, despues de leer lo que Willamoes-Suhm, de la expeciicion de Challenger, escribe acerca de este particular: «escibamos, dice, a la vista de la costa de Banda Neira, á una profundidad de 360 brazas, y la gran red fué sacada al fin, completamente llena de toda clase de tesoros, que desde luego se vaciaron en un cubo lleno de agua de mar. Al examinar el botin con el profesor Thomson, para ordenar poco á poco ac̣uel caos, llega á mis manos un pe. queño cefalópodo del que veo sobresalir la concha de la spi. rula; lleno de alegria, se lo doy á Thomson, pero al mirarle mas de cerca, notamos que ya debia haber estado cn el estómago de un per muy grande, probablemente un macruro, que al ser pescado habria vuelto á vomitarlo, casi en seguida de haberlo tragado, pues la epidermis de todo el manto del animat estaba desgastada por el jugo digestivo, mientras que en la parte inferior $y$ en los lurazos hallábase ilesa, lo inismo que las otras partes del animal. Esto prueba que el individuo fué tragado en el mismo momento en que la red lo cogib, y como estos peces siempre salen de la profundidad conl el intestino muy saliente tanto de la boca como del ano (1), era tanto mas fácil que un animal tan liso como la espirula volviese á ser arrojado al punto. El hecho revela tambien de un modo indudable que la espirula debe vivir en profundidades regulares de 300 ì 400 brazas, donde pro. bablemente sabe evitar con gran destreza todas las persecu. ciones, evitando tambien la red; pues nadie ha sacado una

(r) A causa de la presion disminusila del agrua y del aire, á lo cual se dete que el gas contenido en la vejiga natatoria se exsienda. (Noto itcl autor.) 
espirula del fondo del mar antes que nosotros que tambieu debemos su pesca a una feliz casualidad Por mucho que buscibamos nosotros mismos en la playa y por minucioso que fuera el examen de los individuos sacados à la superfi. cie, en ninguna parte se halló un vestigio del animal de la espirula. En las costas de Fidchi y de Cabo York enseñé ì los inuchachos la concha ofreciéndoles una pieza de oro si me traian el animal correspondiente; pero en la mayor parte de los casos me dijeron que para aquella concha no habia animal; algunos quisieron ir á buscarle, pero volvian siempre con las manos vacias.

Hemos pasado en silencio un punto muy importante de la historia natural de los cefalopodos dibranqquiados, es decir, Ia diferencia de sexo. En la mayor parte de los cefalópodos no se observa ninguna diferencia esencial, si no se los examina con mucha detencion. Cierto que en general se sabe que, por ejemplo, el macho de la sepia se reconoce por las líneas blancas en las aletas, y quue las hembras de los calamares tienen un cuerpo mas largo; pero la circunstancia de que en los machos uno de los brazos es siempre de distinta estruc. tura que los demás $y$ sirve de órgano genital, no se ha echa do de ver, por extmino que parezca, hasta los viempos mo dernos. Solo Aristóteles, el célebre observador ingenioso, tuvo noticia do ello, ya en el siglo IV antes de nuestra era, pero sus breves indicaciones no se comprendieron. El argonauta y algunos octópodos (octopus carena y (remoclopus riolacius) son los en que mas se nota la estructura diferente del respectivo brazo; el primero tiene brazo izquierdo, y los dos uiltimos tienen brazo derecho, los que no se desarro llan del modo regular, formándose en ve\% de ellos una rejiga en forma de pera, çue aungute por lo general se parece a los otros brazos y tiene tambien discos, difiere de aquellos por la posicion particular de los mismos, por su longitud, por un apéndice filiforme, y sobre todo por su estructura interna. Esa vejiga se llena de licor espermático, se rompe al efectuarse el apareamiento y permanece en la cavidad del manto de la hembra aun bastante tiempo en toda su frescura y movilidad, hasta que se ha efectuado la verdadera fecundacion. La independencia 6 individualidad aparentes de este brazo son tales, que algunos de los naturalistas mas célebres, entre ellos Cuvier, le consideraban como anélido paraisito dandole el nombre de hectocotylus. Collmann dice que la larga vida del brazo aislado se explica de un modo satisfactorio por la naturaleza de los vasos de la sangre y de los numerosos gangliones. Sin embargo, se puede pretender que mada hay en el mundo orgánico aislado y sin preparacion, y alli donde la creacion actual no es suficiente à llenar los claros, tos periodos anteriores tuvicron una superabundancia de formas de tránsito, tanto por los órganos como por los organismos. En el caso presente las minuciosas comparaciones de Steenstrup han demostrado que el brazo llamado hectocotylus de los cefalópodos arriba citados es solo el extremo grado de una formacion propia de los machos de todas las especies: todos los machos de cefalónpodos tienen un llamado brazo hectocotilizado.

En el calamar es el cuarto de la irquierda el que esta irnsformado, de modo que los discos chupadores que en el brazo derecho disminuyen en tamaño hasta la punta, desaparecen aqui en un lado, á bastante distancia antes de llegar a la punta, hallandose en su lugar uma scric de papilas cónicas dispuestas en forma de cresta. En la sepia, el cuarto brazo izquierdo es el que ofrece tambien la diferencia, y en los géneros uetopus y cledonce, el tercer brazo derecho esta hectocotilizado en su extremidad por una especie de disco clupador y en toda su longitud por la formacion de un repliegue membranoso.
Como segun hemos dicho mas arriba, en el periodo actual de la tierra los dibranquiados predominan de tal modo que el segundo órden casi desaparece comparado con ellos, sera quizas conveniente dar aqui algunas noticias sobre la reproduccion y el desarrollo de los cefalópodos dibranquiados que ofrecen muchas particularidades interesantes. Aristóteles ha hecho ya observaciones sobre el singular brazo y apareamiento, resultando de ellas que ha visio una especie con brazo hectocosilizado sin que se pueda reconocer por su corta descripcion la especie. \& Los polipodos, sepias y loligidos, dice, se agarran boca con boca con los brazos enlazados. 1)espues que el púlipo ha apoyado la llanada cabeza (el abdómen) en el stelo, $y$ extendido los brazos, ol otro indivi. duo se fija en él con los suyos tambien abiertos, de modo que los discos chupadores se cubren. Muchos pretenden ambien que el inacho tiene una especie de órgano genital en uno de los brazos, es decir, en el que se hallan los mas grandes discos; exre órgann se extiende en forma de un cuer. jo nervioso hasta la mitad del brazo y penetra despues. del todo en el eminudo de la hembra. I as sepias y los loligidos, en cambio, nadan con las bocas oprimidas y los brazos enlazados en direccion opuesta; de modo que tambien sus cmbudos se tocan: cuando nadan, el uno se mucve hácia adelante y el otro hácia atras. Carolini despues de confirmar lo que Verany ha referido sobre la pesca del macho con las hembras reclamos, dice: (I.as union con ol macho es tal, que las aberturas de ambos embudos se cubren. \# Hasta la visita de Fischer en Arcachon, ningun autor moderno habia con. firmado las noticias anteriores: Fischer cogió en dicho lugar con la red dos sepias de un tamano algo desigual, cuyos bra. zos estaban estreclanmente culazados de manera que las mandibulas parecian tocarse. Al separar la parcja dieron a conocer su enojo por la abundante secrecion de tinta. Apenas se hubieron colocado en un barreno cogiéronse de nuevo, cuya escena se repitió despues varias veccs.

Para las observaciones mas completas el acuario de Dohm me sirvio de mucho, pues yo mismo puedo afirmar por propia experiencia lo que Colimann refiere sobre la verdadera lucha de la pareja de pulpos. a lo que yo he visto, dice, y lo que en la coleccion roológica me designaron como aparea. miento es una terrible lucha á vida 6 muerte, un combate que quiras mejor hace resaltar la fuerza salvaje y la agilidad de esos séres. Yo mismo experimentaba inquietud, pues pa. reciome que los animales iban a devorarse en la verdadera acepcion de la palabra, y solo me tranquilicé despues de haberme convencioio del vercadero fin de este desafio. In es. cena era la superficie interior de la ventana, precisamenic en frente del escondite que en unn de los riscones habitaba el pulpo ya mencionacio. Este permaneció como espectador del codo indiferente aunque los otros dos luchaban muy cerco de el sin hacer aprecio de los que miraban. Una parte de sus brazos parecia soldada con la ventana por los discos, mien. tras que otros se extendian hacia la pared pedregosa para buscar nueros puntos de apoyo. y los demás enroscándose con furia, procuraban sujctar el cuerpo ó los brazos del ad versario. Chispcaban los ojos, los cuerpos de un color pardo oscuro se oprimian, furiosos movimientos respiratorios $\mathrm{cm}$ pujaban el agua por la embocadura del embudo, y a manera de serpientes deslizábanse los brazos en todas direcciones, cogiéndose á la superficie del manto para arrancarse en seguida con una violencia espantosa, de tal modo que la picl de uno de los animales se despedazaba. Tales son los juegos amorosos de los pulpos. Una hora quizás observé los biuscos movimientos de estas cabezas de (Gorgona, sin ver aun el fin verdadero de la lucha; los animales se cansaron por último de la pelea, pero yo no pucie olvidar este espectaculo. Coll- 
mann busca la razon de esta salvaje y cruel lucha amorosa en el hecho de que la hembra se opone á la introduccion del brazo hectocotilizado en la cavidad respiratoria, sea por la hendidura del manto, sea por el orificio del embudo, pues entonces la hembra del pulpo experimentaria la misma sen. sacion que un hombre â quien introdujeran un objeto en la tráquea ó en la laringe. Puede ser que esta opinion sea exac. ta, aunque el éxito de la cuession no es tan terrible como se piensa el excelente observador, que cree que la hembra quizis rompe en su furia y necesidad el brazo del esposo. Yo fui testigo ocular de que despues de la introduccion del res. pectivo brazo por la hendidura del manto en la cavidad branquial se produjo la calma, y de que al cabo de media hora, poco mas 6 menos, separaronse los dos, conservando. el macho su braźo genital.

No sucede to mismo con las especies arriba citadas en que el brazo hectoco:ilizado entrechado en lá base se rompe fícilmente.

Los huevos de los dibranquiados suclen estar encerra. dos, aislados ól reunidos en unas cubiertas ó caipsulas longitudinales pedunculadas. I a sefio fija/ sus hueros, 6 mas bien las negras cappulas, aishadas ó en grupos, en las algas, yerbas marinas, en fragmentos de madera ó en ramas cortadas fiotanes en el agua, haciéndolo de modo que las catre. midades ánorquilladas del pedúnculo rodeen en varias circunvoluciones estas partes. La fijacion se verifica mientras el animal abraza aquellós objetos. «En el tremoctopus riolareses, dice Koelliker, la imporiancia que tienen los brazos es de mucha mas considencion aun, jucs en estn especie todos los huevos, reuniclos en forma de racimo, estin sujetos durante el desarrollo de los hijuclos por unos doce discos infe. riores de un brazo, en cuya posicion el citado bulto solo puc. de llegar con ayuda de uno ú otro de los brabos.)

"Eín el género loligo los huevos no pernanecen aislados con el sepia, sino que se juntan en largas cherdas compues. ras de tres $\delta$ cuntro series de los mismos, de modo que los tallos de todos los huevos estån dirigidos hácia adentro, pero las extremidades redondas libremente hácia afuera. Io mismo que los tallos, se oprimen tambien los huevos estrechamente, aplanándose mas ó menos, en las partes que se tocan. Este cordon de huevos podria compararse a uria panoja de mair que solo se compusiera de cuatro series de granos. Todos los huevos de un cordon, de 45 i 100 , estín circuidos de una cubierta comun que les rodea como el pulgar de un guante al dedo correspondiente, y que es trasparente y de un color pálido. Algunos cordones de hucvos, de 5 á 20, cstán reunidos en masa, porque las extrenidades inferiores de las cubiertas comunes de cada uno se enlazan enire sf. Tales masas de huevos proceden probablemente de una sola hem. bra; ésta no las lleva consigo como lo hace el argonauta, en la parte posterior de su concha, ni las fija en plantas ú otras partes, sino que las abandona al capricho de las olas. Ios pescadores de Nápales los conocian muy bien y me los tra. jeron en considerable número, sobre todo en mayo y junio: los llamaban noia di calanaron. El animal que esta desarroliandose, y encermdo aun en ia cubierta del huevo, ofrece un aspecto particular: cuando su desarrollo se halla tan ade. laniacio, que la cabeza y el tronco, los ojos y los brazos pue. den distinguirse ya muy bien, reconociéndose el hijuclo co. mo un cefalópodo, en la parte anterior de la cabeza, por debajo de la boca, sobresale una voluminosa bolsa, el saco de la yema Esta formacion se ha verificado por la circuns. tancia de gue se desarrolla primero el manto en el centro de un disco embrional, y en la circunferencia del mismo, las partes de la cabezn, situadas al principio de la circunferencia, se aproximan entre si por encima del tronco y separan al mismo tiempo la bolsa de la yema. El hijuelo parece estar entonces pendiente por la cabeza de la cirada bolsa.

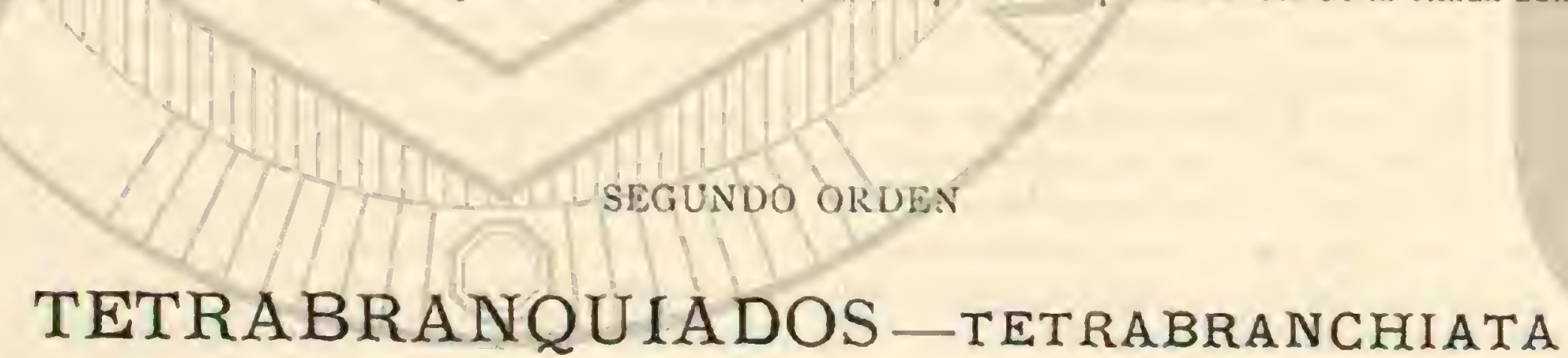

El único género naudilus, con pocas especies, se aistingue en la creacion actual por tan diferentes cualidades de los dibranquiados, que solo parn si exige la categoria de un órden. Encontramos la explicacion de este aislamienio en la historia primitiva de nuestro gloho, de la que resulta que el nawtilus es uel último de los mohicanos" el vástago de una sribu an. tes muy diseminada y rica, pero que ahora estí destinada a extinguirse. Comenzaremos por la descripcion del nautilo vivo, pasando despues una revista a los cefalópodos fósi. les, tanto de los tetrabranquiados como de los dibran. z̧uiados.

Las partes blandas del nautilo raras reces han llegado å las inanos de los naturalistas, siendo por lo mismo mayor la abundancia en nuestras colecciones de las bonitas conchas, que micien unos 1$)$, o1 5 y pertenecen por lo regular al mausilus pompilius (fig. 222). Este forma una espiral, en la citada especie; de modo que las circunvoluciones anteriores se cubren del todo por las posteriores. Al examinar la gran desembocadura de la concha ilesa, y que en su parte exterior es de un color blanquizco de porcelana con rajas trasversales rojas, obsérvase que ul espacio anterior, que en su cara interior reluce con los bellos colores del nácar, está situado detrảs de una pared trasiersal cóncava; de modo que el animal solo fija su residencia en una parte mas corta, aunque volumino. sa de su concha, y no pasa como nuestros caracoles por todas las circunvoluciones. En el centro de aquella pared tras. versal, hay, sin embargo, un agujero que nos invith i exami. nar mas de cerca la cavidad que forma, à cuyo efecto debe practicarse un corte trasversal por la concha, inmediatamente al lado del eje, y enionces se ve que la pared divisoria que separa la vivienda del animal. está precedida de toda una serie de tabiques que dividen la circunvolucion de la concha en otras tantas camaras, por las que se, extiende un tubo que sale del citado agujero y se llama sifon. El fin de estas cinaras, sin embargo, y el sistema de su desarrollo; solo se explica por el conociniento mas minucioso del ani. mal y de las relaciones en ugue se halla con la concla. Segui. remos para esto las excelentes averiguaciones de Keferstcin.

Ein el órden general de las partes del cuerpo, cl animal del mautilus es naturalmente análogo à los otros cefalópodos; por lo tanto, existen la cabeza, el embudo y el manto. La primera, sin embargo, no tiene brazos con discos chupado- 
res, sino que aq̨uellos afectan la forma de tentáculos, y pueden recogerse en estuches que en circulos concéntricos éinterrumpidos, en el lado abdominal del embudo, rodean la abertura bucal. Los estuches de los dos tentaculos superiores forman una especie de ancha caperuza que cubre la ca. beza cuando el animal se retira a la concha. El embudo está hendido longitudinalmente en la cara ventral, y puede cerrarse, por lo tanto, sin mas que sobreponerse estas dos hojas entre si, y por este concepto es un órgano de locomocion mucho mas débil que en los dibranquiados. En el fondo del manto hay a cada lado dos bránquians que llevan por consecuencia una mayor complicacion de los vasos de la sangre entre los órganos del cornzon y los respiratorios. La extremidad posterior se redondea longitudinalmente, segun lo de. rnuestra la forma de la cámara en que el animal habita; este se coloca de modo que el embudo se encuentra en el lado convexo de la concha. Debemos acostumbramos, por lo tanto, à la opinion, no admisible a simple vista, de que la bó. veda de la concha es el vientre.

Como el género de vida de este animal que tan pronto se mantiene en la profundiàd del mar, como nada en la superficie á pesar de su pesada conclua, no puede comprenderse sin conocer su relacion con aquella, y la manera con que esta última se forma, oigamos la explicacion de Keferstein, gue por primera vez nos la da satisfactoria:

6. Todas las conchas de los tetrabranquiados tienen su parte posterior mas antigua dividida en cámaras fror medio de una seric de paredes divisorias, y el animal se encuentra solo en la camara anterior mas grande, y por lo regular tan profunda une puede retirarse completamente al fondo del mismo modo que un caracol. No obstante; cuando se extiende, es preciso que el borde del manto sobresalga un poco de la desembo. cadura de la concha, porque este borde forma la capa exterior de la conchn; en las conchas del nautilo se ve muy if menudo, precisamente en la desembocadura, una faja de cierta sustancia organica de color jardo, como señal de que cuando vivia cl animal, el borde del manto estaba adherido cn este punto a la concha. Al abandonar el animal en su lento des. arrollo las partes posteriores de la concha, que entonces se disgregan en cimaras aéreas, no'se retirn, sin embargo, del todo de las mismas, pues una apófisis delgada tubiforme de la bolsa del cuerpo, el sifon, queda continunnente en ellas; periora este objeto la septa y ticne, asi como el resto de la epidermis del animal, la facultad de segregar la sustancia nacamda, de modo que en el sitin donde el sifon perfora la septa (pared), esta ultima está provista de una apófisis tubiforme de diferente longitud, formada por el sifon, y que se llama cucurnelu sifonol.y Hay un número bastante considerable de caracoles, segun mas tarde véremos, nue solo habitan la parte anterior de su concha, cerrando las circunvoluciones anteriores por una serie de paredes trasversales. In a particularidad de los tetrabranquiados no se funda por lo tanto en la existencia de las cámaras de las conchas, sino en la comu. nicacion de todas ellas con el animal por medio del sifon, asi como en el hecho de que aquellas cstán llenas de aire para estos animales que con frecucnciaviren en las profundidades del mar. Creo que todos los naturalistas están conformes en que estas camaras están llenas de airc en el uautilus pompi. lims, que por lo regular se encuentra à profundidades de treinta brazas. En los ejemplares examinados seguidamente des. pues de ser cogidos no habia agua. Para explicarse la for. macion de las camaras acreas del mautilus que vive en un fondo de treinta brazas, es decir, bajo una presion de agua de mas de sếis atmósferns, es muy importante el conocimiento de una circunstancia que hasta ahora apenas se habia com. prendido de este modo. Es la soldadura anular ciel animal con la concla. Por medio de dos grandes músculos del cuerpo se fija el animal en ella; i la altura de estos músculos se suclda ademis el manto con una estrecha faja alrededor de la con cha, no para sostener el animal, sino para impedir que el agua que entra libremente por la desembocadura, penetre en la parte postcrior de la superficie del manto. La parte de la superficie corpórea, siruada por detrás de este anillo, segregn el aire que encontramos en las comaras, y el anillo impide que el aire se escape por delante, entre el manto y la concha; con este aire el animal toma impulso continuamente en la concha hacia delante, avanzando on ella del mismo modo que el carncol en la suya, prolongándose al mismo tiempo la concha de continuo en su desembocadura. Los puntos en que se fijan los músculos del cuerpo y tambien el anillo, siguen natural mente poco a poco creciendo en su parte anterior, y consumićndose en la posterior, segun Reaumur lo demostrb en los músculos de las conchas. Asi se ven en la concha del nautilo, en la prolongacion de los músculos y del anillo, marcadas fajas paralelas al borde anterior, como señales de la continua progresion. De este modo, cl nautilo se aleja del aire sin ce. sar con la secrecion constante de la última pared divisoria y crece al mismo tiempo mucho, como la mayor parte de los caracoles, ensanchándose la concha hảcia delante de un modo considerable en relacion al desarrollo del animal. Sin embargo, como casi todas las conclitas hacen alternar los tiempos del desarrollo con los dei descanso, segun lo demuestran en los caracoles, a la simple vista, las prominencias de los orifi. cios, que con ciertos interválos se repiten; y como sabemos que nuestros caracoles terrestres continuan por lo regular creciendo en la primavera, comprendese que suceda lo mismo tambien con el nautilo. Cuando este descansa en su desarro. Ilo, sin segregar yo aire ni avanzar en la concha, fúrmase en la extremidad posterior del animal, detrás del anillo, una capa nacarada, que es la pared divisoria, asi como en la parte del manto situada delante de aquel sucede lo mismo continuamente. Tas paredes divisorias indican por lo tanto el descan. so periódico del animal. No puedo determinar, sin embargo, cuantas veces se repiten tales estados de repaso; podria ser qque una vez al año, como en la nayor parte de los caracoles, en cuyo caso por el número de las paredes se reconoceria al punto la edad del nautilo.

Como la formacion de ias cámaras aéreas se verifica por las partes posteriores del manto, el sifon sirve para conservar el aire en cllas: $y$ a causa de la porosidad de la concha debe efectuarse un continuo cambio del aire contenido en las cá. maras y' del agua. La sustitucion necesaria se verifica por el sifon por medio del voluminoso raso de la sangre. De un modo análogo se introduce el gas en la vejiga natatoria de los peces; en que esta no se halla en relacion con el tubo eso. fágico por medio de la secrecion de la sangre. Del hecho de que estos animales, ainade Keferstein, a peesar de vivir de ordinario en la profundidad, donde permanecen iranquilamente, desplegando sus tentáculos como una actinia, ó reptando por medios que no puedo explicarme del todo, se encuentren muy a menudo nadando en la superficie, resulta con certeza que los nautilos necesitan en efecto el aparato natatolio de las cámaras aéreas, conservado por el sifon. Segun lo que diecn Rumph y Bennet por su propia experiencia, y Proseh jor las indicaciones de los balleneros daneses del mar Austral, cuando el nnimal mada ó flota, sale por la des. einbocadura de la concha con los brazos extendidos, pero retirase al fondo de la concha y desciencle rápidamente á la profundidad cuando teme que se le coja. Esto apenas lo podriamos comprender si el peso de la concha y del animal. que no son propios para nadar, no se sostuviera en gran parte por las cámaras aéreas. Keferstein llega al resultado 
de que cuando en la parte posterior del animal se encuentra aire debajo del anillo, y este aire se comprime ó extiende cuando el animal se recoge 6 se prolonga, debemos ver en esta circunstancia el medio por el que el animal, cuyo peso es a causa de las camaras atereas poco mas ó menos igual al del agua cuyo espacio ocupa, puede hacerse mas leve $\delta$ mas pesado que la masa del agua que desaloja por medio de pe. queños movimientos.

Las noticias que hemos reproducido, suministradas por el médico holandés Rumph hace doscientos años en su célebre "Crabinete de curiosidades de Amboina\%, y que se refieren al nautilo, han sido apenas completadas por observaciones mas modernas. El citado naturalista dice: "Cuando este carncol nadá en la superficie del.agua, alarga la cabcra con todas las barbas (brazos) y las extiende sóbre el agua; de modo que há circunvolucion posterior sobresale siempre de la misma; pero cuando repta en el fondo, ocupa la posicion inversa; levinta la barba hácia arriba, y con la cabeza o los brazos hàcia abajo, avanza con bastante rapjidez. Casi siempre está en el fondo del mar y entra a veces en las bircas. Cuando despues de una temintstad el mar vuclve a calnarse, se les ve nadar en grandes grupos en la superficie, y esta es la prueba de que tambien en la profundidad viven sociablemente. Se les encuentra en todas las partes del mar de las islas Molucas, y tambien en la region de las Mil islas, a la viśta de Batavia y de Java, aunque en los mas se encuentra la concha vacia, pues el animal nismo se coge raras veces cuando penetra en las nasas. Hste animal se come como los otros mariscos, pero su carne es mucho mas dura y dificil de digerir.

Rumfin ha hecho tambien una descripcion de los proce dimientos para sacar de las conchas la capa exterior hasta llegar à la nacarina, y trasformarlas luego en aquellos vasos para beber, mas caprichosos que cómodos, que se encuenImn aun á menudo en los gabinetes de curiosidades antiguas. Cuando estan ya limpias de esta manera, se cortan en la region posterior de modo que las cuatro 6 cinco cámaras de esta partc quedan visiules; despues se sacan del todo'los tres $\delta$ cuatro segmentos, ahriendo en la circulacion mas interior un jaso, y jor luera se cortan toda chase de figuras cu. briendolas de hollin mezclado con ceray aceite, cuya mezcla contribuye à que las figuras iengan un brillo negro.y

las pocas especies conocidas del género nautilus perteneccn á los mares tropicales; pero en cierta época, en los periodos fósiles mas antiguos, desde la llamada formacion silú rica hasta despues de aquel periodo en que tuvieron su origen las poderosas capas carboniferas, los cefalópodos nautiliformes predominahan exclusivamente, $y$ aun nos asombra la variedad de esa clase, muy superior a la de los tipos actuales. Se han descrito unas 1,600 especies fósiles, distinguién- dose por la forma de la concha en general, por la posicion del sifon y por la forma de las paredes divisorias y de la linca de la soldadura con la concha. Todas están provistas de camaras; y de los restos de su concha podria deducirse con se. guridad que su género de vida era semejante al de nuestros nautilos actuales, asi como que la concha servia, no solo de abrigo, sino tambien de aparato hidrostático. El grupo mas antiguo es el de los nautilidos, que tenian una de las extre. midades de la concha del todo enroscada, y estin represen. tados aun por el nautilo; mientras que el otro se nos presenta en el género orthoceras. La concha de las numerosas especies es prolongada en línca recta y se conocen ejemplares de dos metros de largo. Por esta forma el género orthocera viené à ser à los nautilicos enroscados y cortos, lo que los loligidos á los géneros sepiola y ortopulus; probablemente han sido los mas activos habitantes de la alta nar, mientras gue las formas pesadas, como el nautilo, permanecian cerca de la rosta.

Mucho mas rico en especies es el género de los amonitidos, cuyas especies tienen las paredes divisorias arqueadas en muchos sentidos, presentando lineas muy rizadas, regularmente lobulosas, y soldadura con la concha exterior. 'Tambien se encontraban antes de la formacion carbonifera, pero llega a su innyor desarrollo el género ammonites en la formacion del Jura y de la creta, desde cuya remota época data la ripida decadencia de los céalópodos tetrabranquiados.

Como sohre el género de vida de los individuos de las especies fósiles solo podemos hacer suposiciones sobre los objetos que las rodean, restaurados por la fantasía, y de la comparacion con congéneres hoy existentes, debemos creer que con los ammorites ha sucedido lo mismo que con los rautilos, Sabemos, sin embargo, que no solo el género de vida de los individuos, sino tambien la duracion de los géneros y especies son de suma importancia. $Y$ en este concepio los ammonites llaman toda la atencion; pertenecen a los pocos grupos que con abundancia y regularidad se encuentran en las capas de varias formaciones del globo, donde las especies limitadas desaparecen del todo, sustitu. jéndose por formas de trảnsiro.

A los ammonites siguen los belemrites que constituyen el trånsito directo a los dibranquiados actuales. Los belemni. tes, con el género principal del mismo nombre, tenian una concha interna cubierta del manto, provista de cámaras y de un sifon de forma arqueada. En su cxtremidad posterior se encuentra un estuche calcareo mas grueso, que casi siempre aparece solo, y en ciertos terrenos calcáreos con gran frecuencia. Hace muchos siglos que estos llamados rajos de Jispiter llamaron la atencion del pueblo, que los interpretaba à su manera.

\section{CARACOLES}

Tenenuos á la vista el simbolo de la cachaza y de la enojosa circunspeccion, un animal de mas vientre que cabeza; repta penosamente sobre una planta aplanada, llevando sobre el dorso la concha espiralada no simétrica, que contiene - una bolsa iniestinal. El hombre inclinado al misticismo po. dria ver, como Gustavo Carus, algo de mistico en los movimientos cachazudos peculiares de los caracoles, y tambien citar i Goethe que hace decir a Mefistofeles en el Blocksberg: éVes venir alli al caracol que se acerca reptando, y que con sus cucrnos me olfatea? Aunque quiera no puedo evitarle. To

Sin embargo, para nosotros, el caracol no debe ser otra cosa sino el representante algo misterioso de una clase de animales á la que solamente los insectos son superiores en raricdad y en número de especies, clase que dentro del considerable grupo de los moluscos se distingue por determinados caractéres. Fis exacto que el caracol tiene una cara, mias para ello sc necesita una cabeza, y porque los caracoles tienen 
una parte mas 6 menos marcada como tal, se les ha llamado tambien cefalóforos (cephalophorn). Se asemejan en esto, como ya sabemos, á los cefalópodos, yue à su vez se distinguen por los brazos. De la comparacion mas superficial con una conchilia resulta que la existencia de la cabeza es carácter importante para los caracoles, pues en las conchilias se buscará en vano una cara 6 una cabeza, por to cual ocupan una posicion mucho mas inferior, que se manifiesta además por su género de vida. La locomocion de los caracoles es muy caractcristica; se valen para ella de una planta particular $\delta$ del pié, disco muscular, longitudinal que en las especies desnudas, sobre todo, parece ser el vientre, y al que los caracoles en general deben el nombre de gasterópodos, usado tambien con frecuencia. Aunque los movimientos ejecutados con ayuda de este órgano son por lo regular inuy lentos, hay sin embargo varios grados en esta lentitud: cuanto mas estrecho y largo es el pié, tanta mayor es la rapidezy vice-versa. Los músculos que forman ol pie suelen correrse longitu. dinalmente. Cuando se hace reptar un caracol en un cristal, se re, segun Johnston, ‘cómo por una serie de movimientos ondulados que en la planta se continuan desde la cola hácia la cabera, y que segun la expresion de Swammerdan similan el oleaje del mar, el gasterópodo avanza acompasadamente mar. cando su camino, en el caso de que sea un caracol terrestre, por una faja platenda de una sustancia mucosa que segrega, jara que sean menos sensibles las asperezas del camino. ¿Quien no habrí observado aun al caracol terrestre en su marcha? I os habitantes del agua se mueren exactamente del mismo modo, ora asciendan por las escarpadas pendientes de las rocas, ó recorran stis guaridas entre la yerbit marina y los corales. Por último, podemos observar en todos nuestros caracoles acuaticos ó terrestres ese órgano tan importante para los moluscos y que ofrece un tipo característico. En los caracoles de concha forma en la parte anterior un grueso repliegue, que como un collarin puede rodear la cabeza y por detrís pasa a una especie de bolsn neutral donde se hallan una gran parte de los intestinos; asi como en la mayor parte de los caracoles desnudos no se destaca mucho del tegumento general del cuerpo, y nunca esta cerrado en el lado del vientre.

Como la cabeza y las partes que en clla se encuentran, por cjemplo los ojos, en cicrtos grupos inferiores apenas se conocen cual divisiones particulares del cuerpo, y como esas partes pueden faltar tambien, los órganos internos se hallan sujetos en su desarrollo á las mayores variaciones, tales como no se encuentran en las clases superiores de los cefalópodos ni en la inferior de las conchilias la lengua y el iutestino, y ademàs el anillo esolágico no varian y los órganos genitales se hallan muy desarrollados. Estas variaciones en la estructura llamain nuestra atencion, sobre todo por estar rela. cionadas con trasformaciones esenciales referentes à la figura exterior, de las que depende un cambio del área de dispersion y de género de vida. La mayor parte de las ramas del ironco de los caracoles son acuáticas, y de estas pertenecen à su vez las mas al nar. Pueblan en él todas las zonas, desde el limite de la marea alta hasta la profundidad, y se les re hasta en alta mar. Ninguno de los cefalóforos marinos se ha desarrolla. do mas que las especies que respiran por bránquias; las que respiran aire son habitantes del agua dulce de ticra firme: $y^{\circ}$ en esta considerable rama se ha reconocido en particular la mayor facilidad para adaptarse a las diversas condiciones. Por este concepto los gasterópodos se han desarrollado mas que los cefalópodos, que desde las épocas mas remotas, des. de su aparicion en la cscena de la vida hasta ahora han hecho progresos relativamente escasos en su organizacion. Cicrto que en los caracoles no se ha demostrado el verdadero pro- greso, es decir un desarrollo intelectual paralelo à la perfeccion que consiste en respirar aire: nuestros gasterópodos terrestres son tan estrípidos como la gran mayoria que sigue manteniéndose del alimento salado.

Los danos y la utilidad de los caracoles, su manera de luchar entre si y con otros animales, son cosas que se explicarán mejor en la descripcion especial; mas para comprender las descripciones es preciso examinar minuciosamente la concha. Ya hemos dicho que la de todos los moluscos no puede compararse con el huevo vivo de los vertebrados, sino que es una secrecion y por lo tanto una materia muerta. To. das las conchas son, sin embargo, no solamente sustancias inorgánicas, sino que tienen una base animal, segun puede observarse de dos maneras. Al examinar con el microscopio los huesos en desarrollo de los gasterópodos, 6 conchilias, que llevan concha, se ve a esta viltima al principio como un ensanchamiento flexible, membranoso, nุue mas y mas se sepa. ra del manto; la capa superior se trasforma en epidermis, que, sin embargo, en muchas conchas desaparece por el roce, mientras que en una scric de cefaloforos conchilias es muy marcada, cuando menos en los bordes de las conchas. La capa situada debajo de esta epidermis, compuesta de células, llena sus partes celdosas poco a poco de cal carbónica y por este sistema del desarrollo resulta lógicamente que deapues que las celdas se han llenado de cal, las partes mas finas de las capas interiores de la concha forman como cuerpecitos prismáticos 6 rombóideos. La epidermis se pro. duce solo en los bordes libres del manto; pero despues que en el resto de la superficie de aquel, dicha capa de celdas se ha desgastado, fórmase otra nueva y de este modo la concha se agranda y completa. Como los colores de las conchi. lias solo estan contenidos en las capas exteriores de la caliza y se segregan por el borde del manto, resulta que las con. chas deterioradas pueden remendarse desde adentro, pero jania aplanarse ni llenarse otra vez completamente: las partes remendadas quedan sin rolor. El experimento puede hacerse facilmente en un caracol de jardin sin hacer daño al animal.

El otro medio para reconocer la base animal de la concha de los moluscos es mas sencillo: solo se necesita poner un pedazo de aquella en un icido rarefacto; entonces se disuelve la cal y el esqueleto orgánico queda, dando á conocer que, no la cal, sino la base animal, comunica a la concha su forma. Cuando las celdas y membranitas, entre las que se de. posita la cal, son muy delgadas, las conchas adquierén el brillo de perla con los colores del arco iris. 4 Cuando estas conchas se deterioran por el aire, dice Gray, dividense en muchas escamas delgadas en forma de hojas de color de perla y de un brillo plateado. Los rhinos saben esto y utilizanse de las particulas de las conchas deterioridas, emplearidolas como phata en sus acuarelas. Jo mismo me he servido de este polvo plateado, que Reeves llevo a Inglaterra con buen éxito para pintar peces. No tiene todo el brillo de la plata en hojas pulverizadas, pero ofrece la ventaja dé no altérarse en el aire. I a masa principal de todas las manchas de moluscos es la cal carbónica; la proporcion de esta cal con la sustancia organica, es en nuestros cefalóforos y conchilias alemanas de 92 a mas de 99 por ciento, segun la especic $y^{\circ}$ la naturaleza del suelo.

Ruego ahora al lector que coja la concha de uno de nuestros mas grandes cefalóforos, por ejemplo la del caracol de las vi. ñas (fig. 226), para adquirir algunos conocimientos preparato. rios necesarios. Al colocar esta concha de modo que la punta esté dirigida hácia nosotros, la parte afilada y ventruda de la embocadura està á nuestra derecha; al ponerlo de modo que la punta esté dirigida hàcia arriba y la desembocadura hácia 
la cara, vemos que las circunvoluciones se corren de derecha a izquierda. Tal concha se llama circmizuelia a la derechn, asi como la otra, lógicamente, es una concha cirrumergelto it ia iaquieria. La gran mayoria de las conchas de caracol espiraladas se dirigen con sus circunvoluciones a la derecha, aunque entre las especies que regularmente ofrecen ial formacion hay ejemplares de circunrolucion opuesta, $y$ estos se encuentran precisamente entre los caracoles de las viñas con bas tante frecuencia. I.os coleccionadores de conchilias buscan, como es natural, tales excepciones, y Johnston refiere, en su introduccion á lá conchealogía, una historia muj intere-

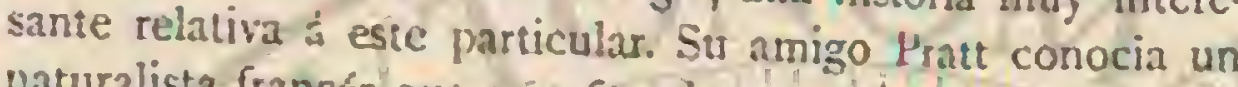
naturalista francés que sé esforzaba para obtener una cria de caracoles de circunvoluciones opuestas para venderios con ventaja a los coleccionadores de curiosidades: pudo adquuir una pareja viva, y con ella una familia muy numetosa, cuyos individuos todos tenian las circunvoluciones contrarias á la regla, manifestándose asi desde su meimiento.

En la desembocadura le nuestro caracol de las viñas (itelix pontatia) distinguimos el borde bucal, corno circunferencia completa de aquella, y en este borcie, la mitad exierna como labio caterior ó derecho de la mitad interior llamada unbio in. terior. En el caso presente estos labios pasan uno à otro sin interrupcion y solo por una dobles del interior se cubre una deptesion que hay en muchas conchas, Hamada ombligo. fodis las circunsoluciones que sobre este úleimo se elevan que, cuando se sier juntan en el helix fornatio de tal modo embocidura, se ve una la concha desde la punta hácia la des. o matenatico cuando erdadero cje o hrso yue es imaginado en una escale circumoluciones no se tocar como de sus congéneres caracol. El helix pomatia y la mayor parte ciletargo invernal con la abertura de su concha durante cl letargo invernal con una tapa. Para verle constantemente es preciso buscar una faludina, si no se vive en la costa del mar. La citada especie liene en el pié un disco córneo, y otros muchos gasterópodos uno calcáreo en el que, asj como en las conchas, se distinguen las circunvoluciones y los apéndices anales. Por regla general, alli donde el aire y el agua alternan en el dominio, segun la expresion de Martens, la tapa es el medio mas sencillo para que el animal, retirado en su concha, impenetrable a los liquidos, pueda cerrarla her. méticamente y vegetar en la humedad hasta que el tiempo sea mas favorable, interrumpiendo entre tanto toda actividad. Este disco es propio de todos los cefalóforos de las costas.

Por la notable belleza de muchas conchas, por su limpieza y buena conservacion, es fácil comprender que los naturalistas del siglo pasado, en su afan de coleccionar, se ocuparan sobre todo de las conchilias; pero ya en el mismo siglo, el docto adversario de Linneo, el cura protestante Klein, de Kanigsberg, atacó la ligereza de muchos de estos aficiona. dos. i La mayor parte, dice, se recrean sin juicio (sine pliflo. sophin) en la increible variedad de las conchilias, juegan con ellas y las piden, como los chiquillos ins nueces y los ricos las piedras preciosas; pocos son los que piensan en la historia natural, El que obra un poco mas cuidadosamente, pone en sus conchas un rótulo con un bonito nombre, como lo hacen los holandeses; pero evitan las dificultades de una descripcion, pues expresar determinadamente en palabras convenientes Intas tormas, tantas diferencias de colores $y$ tantas partes de la concha, seria superior a las fuerzas de un naturalista comun (avilgaris philosophi). i Segun el inismo autor, es mucho mas dificil aun encontrar los verdaderos ca. ractéres distuntiros de las especies. El reverendo Klein po. dria increpar hoy dia con mas motivo à los clasificadores que se mezclan en asuntos de ciencia sin que se les pida su intervencion.

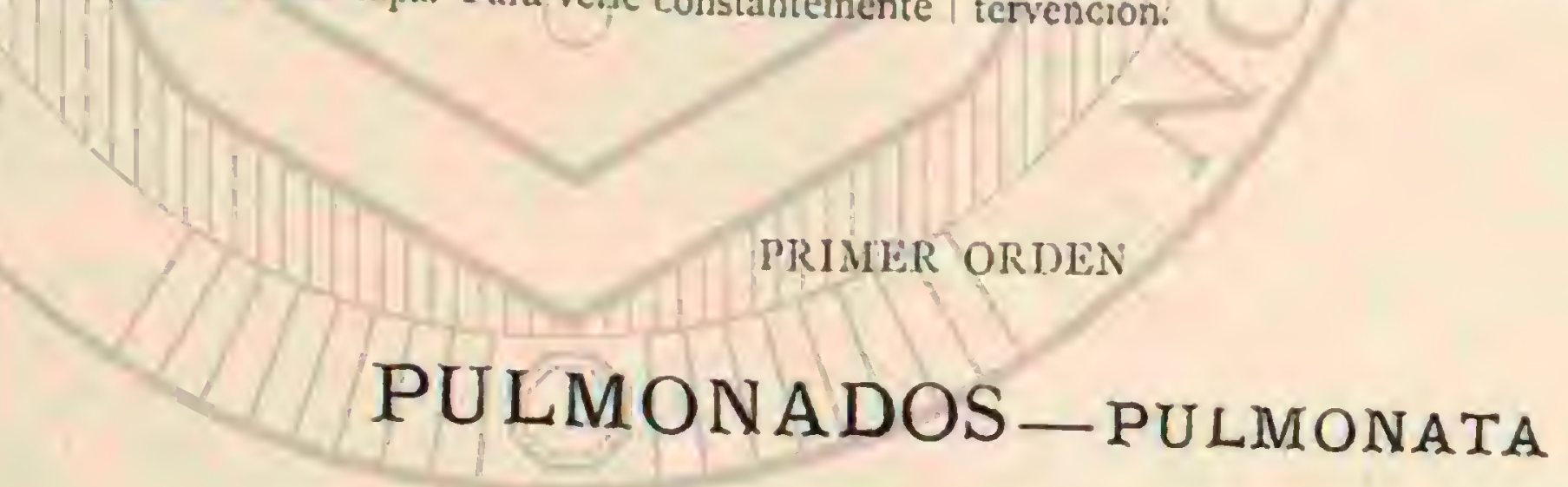

el tubo en qie se hallan los intestinos: esta parte del tubo membranoso es la que en el helicido se retuerce en espiral y no sale de la concha. El cuerpo esta reunido con esta solo por un musculo llamado misiwio ded eje; que se inserta en el huso, mas arriba de la primera circunvolucion, y con él se romunican algunos otros músculos que se exitenden en la extremidad anterior, los cuales solo en parte se encueutran en las limazas y sirven para recoger la extremidad de la cabeza y el hocico.

Para disecar los cefalóforos es lo mas conveniente ahogarlos en el agua ó tenerlos diez 6 doce segundos en agua hirviente, esperando el momento en que estén del todo estimdos: no se deben matar con espíritu de vino. Las especies arriba citadas son las mas propias para el experimento. Es fácil sa. car los carncoles de concha escaldados de su cubierta, porque el músculo del eje se ha separado. I en el agua, y hasta el lego podri darse cuenta, despues de algunas tentativas, de las proporciones mas importantes de la estructura interna, valiéndose de este sencillo liquido. En este trabajo no es preciso extenderse is un órden sistemático determinado de los órganos, sino proceder sencillamente, una vez. sacado el helix de su concha. Una tijera fina y dos pincetas 
pequeñas bastan. Como ya en el aumal vivo hemos reconocido la abersura pulmonar, empezamos con ella á examinar la cavidad; seguimos el grueso tronco formado por la reunion de muchos rasos mas finos, extendidos en forma de red hácia cl lado irquicrdo, y llegamos à la auricula y al rentriculo del corazon, encerrado en una bolsa. En el animal vivose puede sin atormentarlo, romper fácilmente, lo cual no gusta, un pedazo de la concha, de tal modo que se observan los latidos del corazon. Los vasos de la sangre que salen de este órgano no nos llaman ya la atencion desjues de habernos convencido de que el corazon recibe aquella del órgano respiratorio y la hace pasar al cuerpo. Este corazon, propio de todos los mo. luscos, se llama arterial, mientras que el de los peces, por el cual la sangre procedente del cuerpo se hace pasar al brgano respiratorio, se llama renoso. Despues de retirar la cavidad pulmonar y el corazon, intentamos sacar entero sodo el canal digestivo. Como la abertura bucal tampoco ofrece duda, co. menzamos por ella, despues de haver abierto desde arriba la piel de la parte anterior del cuerpo en el animal del todo es. tirado.

I a cavidad bucal estí rodeada de una espesa masa musculosa llamada laringe; sobre la entrada de dicha cavidad y por detrás del labio hay una mandibula superior surcada, casi semilunar. En la base de la cavidad bucal existe un órgano muy complicado, la lengua, de cuya disecacion mi. nuciosa, muy dificil, no podemos ocuparnos aqui. En cam. bio, el inexperso podrá sacar de un disco adlierido a clla una hoja clarn, trasparente, la hoja de moler, que vista con el mi. croscopio ofrece uno de los aspectos mas graciosos, porque esta cubierta de numerosas series trasversales de dientecitos compuestos en su mayor parte de quitina mexclada de un poco de sustancia huesusa. 'Todos los cefalópodos y gasterópodos tienen esta hoja, de cuja existencia j uso mejor podenuos convencernos en nuestros caracoles acuaticos. Cuando algunos de estos se tienen en un vaso en cuya pared al cabo de algunos dias se lan fijado plantitas verdes micros. cópicas, los carncoles están casi siempre ocupados en lamer 6 mas bien moler este alimento con la lengua, la cual prolongan y recogen. Johns describe mas minuciosamente el acto de comer. Cuando un gasterúpodo plantivoro está ocupado en comer, alirga la lengua espinosa y la despliega hasta cicrta extension, prolongando al mismo tiempo tambien el labio en cada lado, por cuya causa la lengua se comprime y adquiere la forma de cuchara Los labios cogen entonces el alimento, lo hacen avanzar: sujetíndole con la lengua espinosa yo oprimiéudole al mismo tiempo contra la maxila superior, cortindose entonces un pedacito con los dientes, que ¿ reces producen un marcado crujido. Fl alimento jasa luego à lo largo de la lengua, cujos dientecitos agudos le trituran; despues llega al estólungo, tanto por al movimiento peristáltico del organo, como por la fuerza resistente de los músculos inmediatos. Está descripcion es exacta, no sola. menic respecto à los pulmomados, sino tambien para los plantivoros del órden siguiente, cuyos tipos carnivoros estan provistos, en su mayor parte, de una trompa de particular organizacion, que contiene ha-lengua. I.a imporiancia de este-órgano para la vida de los caracoles es evidente y ha llegrado a ser uno de los mejores distintivos caracteristicos, i causa de la diferencia en la formacion de los dientecitos, formacion que corresponde al género de vida y al alimento; y tambien por la facilidad con que se conserva, encontrándose aun muchos decenios despues de haberse resecado el animal. Por detrás de la laringe sigue el delgado esófago, que pasa al sencillo estómagg. Al abrir un caracol recien muerto, se notan dos lóbulos sobrepuestos al estómago y un poco irregulares, las glandulas salivales, cuyos orificios, tam- bien muy marcados, se abren en la cavidad bucal. Seguid:zmente, por deirás del estómago, el intestino está rodeado de una masa verdosa, del higado, en cuy'a sustancia hace algunas circumroluciones para pasar despues, dirigiéndose liácia delante y á la derecha, al lado de la cavidad pulmonar, al intestino recto, que desemboca junto al orificio respiratorio. Alli se halla tambien la desembocadura del conducto que segrega la sustancia del rinon, que es de forma obtusamente trilateral 6 de habichuela, y se halla á poca distancin del cornzon. Segun vemos, los aparazos, por medio de los cuales los caracoles disirutan de la dicha de gastrónomos contentos consigo misinos y con el mundo, existen en el mejor desarrollo.

La parte mas importante del sistema nervioso, el anillo esofágico, se reconoce à la simple vista, al examinar la laringe y el esófago. Al disecarla no es necesario proceder con mucho tiento, porque la sustancia nerviosa, en si muy delicada, esta circuida de unos estuches muy sólidos. Ios ojos, situados en la extremidad de los grandes tentáculos, se han descrito ya minuciosamente por el gran disecador de animales inferiores, Swanmerdam; y hasta con demasiada deten. cion, pues reconoció en el caracol de las viñas una hume. dad acuosa delante del cristalino, lo mismo que observamos en el ojo liumano. Sin enbargo, a pesar del gran desarrollo de estos ojos, el excelenté conocedor de los cefalóforos ter. restres, Martens, solo les atribuye una reducida actividad. 4En nuestros caracoles terestres, dice, se han examinado anatónicamente órganos de la vista; pero esta úluma debe limitarse á un grado nuy reducido, consistiendo mucho en la sensacion general del tacto, porque deben tocar con sus ojos los objetos para examinarlos $\delta$ encontrarlos. Nunca pude obserrvar que uno de nuestros cefalóforos vicra un objeto, aunque fuese a muy corta distancia; lusta un limax rufus que expuse al sol, muy próximo à la som. bra, no logró cncontrar esta, aunque al principio tomó vilrias direcciones, las cuales no scguia, sin cuda para buscar un sitio mas conreniente. Como órganos del oido se encuentran en el animal que nos sirve de muestra dos veji. guitas en la parte anterior del anillo esofágico, que se ven mas fácilmente en otros gasterópodos, por cjemplo en las limazas y planorbis. l'odemos decir aqui que tambien los cefalópodos tienen en el cartilago que rodea el cerebro unos órganos del oido muy desarrollados.

El que ha llegado hasta aqui, ya disecando el helicido por si mismo, \&l obscrmndo â una persona práctica, habrå visto y'a varias veces los órganos genitales tan marcados y desarrollados como el apiuato digestivo. Todos los pulmo. mados son hermafroditas, y sus órganos masculinos y femeninos están enlazados y reunidos de una manera particular. Lo mas notable es la glandulá hermafrodita, órgano en forma de racimo, oculto en las circunvoluciones superiores del higado, $y$ en el que en los mismos compartimientos de la glándula se producen tanto los huevos como la esperma. La abertura sexual se halla en el lado derecho del cuello á poca distancia del gran tentaculo: entre las partes situadas derrảs de ella se nota un órgano en forma de saco, de paredes gruesass, en cuyo interior hay un órgano calcáreo en forma de Recha, de puñal 6 estilete: es la flecha del amor, de cuyo uso hablaremos despues. Los mas de los pulmonados her. mafroditas cfectuan un apareamiento alecrnativo, y como ambos individuos son del todo iguales, puede suponerse que tambien se fecundizan alternativamente. Falta aun sa. ber, sin embargo, si despues del acto poseen uno y otro lue. ros fecundos Tampoco puede darse contestacion á la pregunta de si se efectua una fecundacion intima del nismo individuo, pues el aserto de que aquella solo se funda en el 
contraste de los individuos y de las sustancias segregadas por ellos, no caplica nada, si no es solo la circunscripcion del hecho con que una anticuada filosofia llamada natural se ha engañado à si misma. Solo en el género linnaus de los pulmonados acuáticos funciona un individuo como macho y o:ro como hembra, colocindose el primero sobre la segunda. Con bastante frecuencia, sin embargo: el primer macho se hace hembra para un tercer individuo, y asi consecutivamente: de modo que seis ư ocho individuos se reunen como una cadena, funcionando tuicamente el inferior como hembra, el superior solo como macho, y los del centro de ambas maneras.

Podemos suponer que los pulmonados acuáticos y los terrestres oirecen, scgun el contraste de-su residencin, grandes diferencias en su género de vida, contraste que influira tanto mas, cianto que estos animales andan tan poco que les es imposible evitar por medio de enigraciones 6 de una rajpida fuga los riggores é influencias régulares 6 casuales del climá, que segun se sabe se notan nucho mas en tierra firme que en el agua. Martens, uno de los naturalistas de la expe. dicion prusiana al Asia oriental, ba cscrito una excelente obrita sobre las condiciones de la distribucion geografica de los cefalóforos terrestres y de aguia dulce de Europa, de cuya obrita tomaremos la major parte de nuestras noticias. Là nnturaleza de los gasterópjodos terrestres exige pues, segun ya hemos dicho, que fijemos nucstra particular atencion en los hechós y en las leves de su área de dispersion. Ia importancia de estas obsermciones se ha demostrado en toda su evidencia solo en el últimn decenio, porque segun parece, deben ser decisivas para el conocimiento exacto de los hechos mas recientes que á nucstro continente comunicaron su formin definitiva. Hablaremos por lo tanto aqui, antes de examinar los nombres y caractéres de las familias y de los géneros en general, sobre estos puntos.

QTambien los cefalóforos terrestres, dice Martens, necesi tan bastante humedad para la vida activa. Los menos preșervados, como los desinudos y las especies de los géneros cubiertos solo inconoletamente (1testacella y otros). mueren muy pronto en la sequin; las especies pequenas, por ejem. plo, puestas en una caja de carton, al cabo de veinticuatro horas. Tambien el bulimus gallina sultana, de boca ancha, muere a los pocos dias en los sitios que no son del todo hú medos. Fn general parece que todas las especies de conchas brillantes y trasparentes necesitan mucha humedad, que tambien agrada á los gastcróporos. En cambio, todos los cefaloforos terrestres que deben soportar mucha sequia tienen una concha opaca de color mate y casi sin epidermis. El color abigarrado del manto que rodea á los moluscos es propio tambien de los cefalóforos que viven en la humedad. Fiste carácter esti en relacion probablemente con la trasparencia de la concha, que permite penetrar la luz hasta el manto; en codos los gasterópodos de concin gruesa, esta es de un solo color, regularmente pálido, y en los que la tienen delgadn, y que nunca salen a la luz del dia, como por ejemplo los vitrinos, tambien de un solo tinte, pero oscuro.

SAnque tambien los gasterópodos arriba indicados so. portan dias enteros la luz mas viva del sol, dan á conocer sin embargo el cartcter general de los moluscós, pues per. manecen todo el tiempo inmóviles, con la abertura estrecha. mente oprimida ó cermda por una sustancia mucosa endurecida, para preservarse de la evaporacion. Solo en las horas de la noche, y mientras dura la humedad del rocio de la mañana, se pasean por los contornos. Todo coleccionador de caracoles sabe que los encuentra mas numerosos por la mañana y despues de llover. En Italia el helix adspersa se busca de no. che con la linterna, $y$ en Espana, el caracoleto encuentra por la mañana muy temprano el gran helix laclea y el alonestis, muy numeroso en las sierras mas secas, mientras que durante el calor del medio dia el viajero no ve uno solo. Hasta el helix desertorism, que Ehrenberg encontró con una liquena y una araña, como únicos habitantes del desierto, cerca del Oasis de Júpiter Amon, no vive del todo sin hu. medad, circunstancia que se demuestra porque precisamente en el citado punto se encuentra una planta que solo crece mientras está mojada. El cefalóforo deberá tambien sufrir interrupciones muy largas y frecuentes en su actividad vital, pero con la ventaja de despertarse siempre, cuando la planta que le sirve de alimento está húmeda y en sazon.

Despues citaremos algunos ejemplos para demostrar que el género de vida de los pulmonados, rigiéndose por la mayor ó menor humedad, está en cierta relacion con la forma de la concha y la anchura de su orificio. Ahom craminaremos mas detalladamente las disposiciones que el animal toma jara fiksur los liempos secos y calurosos. Scguimos para esto ¿ Daring, observador moderno y muy concienzudo.

- Antés de entregarsc el animal al estado de reposo, dice el citado autor, permanece algun tiempo en la parte anterior de la descimboradura y segrega aqui, en la superficie del cuerno que se halla en contacto con el ano, una sustancia mucosa, en cuya cara exterior, al evaporarse el agua, se forma una delicada membrana que poco á poco se espesa hacia acentro: es el llamado epifmgma falso (al contrario del epifragma invernal del grupo fomatia), que al principio está provisto de una abertura correspondiente al la pulmonar, y que, despues de haberse cerrado esta, toma la forma de una tenue mémbrama trasparente y trasversal sobre la desem. bocadura de la concha, separando el espacio interior de la misma del aire exterior. Despues de la formacion de esta membrana, para la que, reconociendo una diferencia relativa entre ella y el rerdadero epifrngma de invierno, proponemos el nombre de neumofragma, el animal se desprende poco a poco de la mayor parte del aire reunido en su cavidad res. piratoria y se retira mas hicia dentro contrayendo mas el volúmen de su cuerpo. A consecuencia de esto se forma en la cubierta un espacio aéreo impregnado de humedad entre el neumofragma y el cuerpo del animal. Con bastante frecuencia obsérriase, además de esta membrana exterior, otra formacion membranosa situada mas hácia adentro, formacion segregada siempre cuando la primera sufre algun desperfecto por una infuencia mecànica, ó cuando, segun suele suceder a menudo, se seca por el calor, presentando pequeñas hendiduras.

Por muy conveniente que sea la formacion dd ncumo. fragma, en ningun caso formara una separacion completa entre la capa, cerca del interior de la concha, y el medio exterior. A causa de la evaporacion de la humedad en la superficic exterior y la sustitucion de la misma por la sustancia de la capa aúrea interna, sin fijarnos en otros fenómenos de la actividad respiratoria del animal, no del todo interrumpida, que producen una renovacion del aire necesario para la respiracion, efectúase un cambio continuo, aunque limitado en cierto modo, de la humedad hácia afliera. Este cambio se alimenta por los jugos del ánimal y disminuye siempre mas el volúnen del mismo. Se observa por lo tanto que su cuerpo se retira siempre mas a las circunrolucioncs interiores de la concha, mientras que la capa interna del aire aumenta de volímen, disminuyendo en igual grado la actividad vital del individuo que parece sumergirse en un profundo sueño. El movimiento del corazon disminuye muy rápidamente y la actividad de la caridad pulmonar, comprimida en un pequeño volúmen, se limita á su mininum. \$El animal debe permanecer en tal estado mientras no se 
verifica ningun cambio en la sustancia acuosa de la atmósfera; pero tan luego como la iension del vapor aumenta de nuevo, como suele suceder por lo regular cuando amenaza lluvia, pronto se observa una actividad vital redoblada del organismo, muy sensible para tales fenómenos La cantidad de humedad que por medio de la difusion sale continuanenio hicia afuera, se reduce bastante, cesa poco a poco del todo y cambia por fin en una corriente opuesta. Entonces se observa que el cuerpo, recogido en las circunvoluciones interiores de la concha, aumenta de tamaño, avanzando mas y mas hácia la desembocadura de aquella, porque el animal ensancha su cavidad pulmonar, y recoge en ella la capa aérea, contenida en la concha; asi aumenta su rolúmen hasta que, llegando con la superficie del cuerpo al neumofragma, destruje este y sale de la concha.8

Si las obseriaciones anteriores sobre la humedad necesaria para la vida se refieren preferentemente á los pulmonados terrestres, ambos grupos, tanto los uiltimos como los acuatiCos, ofrecen interesantes pruebas, respecto a sus relaciones con los grados de la temperatura. Fil calor les conviene, no siendo demasiado seco. En ciertas fuentes de aguas terma. les se encuentran aigunas especies a uma temperatura de 40 y mas grados Reaumur, mientras que otras se distinguen por la facilidad con que soportan el extremo contrario. "Mu chos cefalóforos, continúa Martens, pueden resistir un frio excesivo, sobre todo el pequeño arion horlessis, el arion lenellus y los vitrinos, que varias veces he sacado con los dedos rigidos y frios, por debajo la capa de nieve; en el Kesselberg, cerca del Kochelsee, en la Baviera superior, encontré el 24 de diciembre el helix rupestris y la clausilia parula expuestos al aire en las paredes de roca, libres de nieve, a causa de su posicion vertical sobre un suclo helado. I os gasterópodos mas septentrionales son todos pequeños y tienen la concha delgada. Parece por lo mismo que precisamente esto y su reducido iamaño son necesarios para soportar el frio y que la concha dura produce efectos contrarios. Asi como en el clima frio y templado los cefalóforos evitan las influencias perjudiciales del invierno cerrando su concha con la tapa ú ocultándose en el suelo, los cefaloforos terres. tres de las regiones tropicales pasan el verano, lo inismo que muchos reptiles é insectos, retirándose debajo de la tierra ó de las piedras ú ocultos en la cara inferior de las ramas.

El tercer importante agente de la propagacion de los séres, la luz, influye, sin embargo, menos que la humedad y el calor, produciendo efectos esenciales, solo cuando estí acompariada de aquellos dos otros factores. Es en extremo interesante la infiuencia variab!e que la luz y el calor juntos ejercen en el color de los céalóforos terrestres. "Fn las conchas pálidas de los cefalóforos que viven en la oscuridad, cuyas conchas podrian llamarse mas bien descoloridas que blancas, se notan los diferentes tránsitos posibles, bien que trasparentes, de los gasterópodos propios de la sombra; y de este color al blanco de creta espeso que reune todos los abigarra. dos colores y a los matices de los caracoles terrestres que bus. can el sol, existen toda clase de gradaciones.

Alli donde la luz infuyc con demasiada fuerza, blanņuea los cefalóforos vivos, mientras que en otros casos solo sucede esto en las conchas racias. Asi, por ejemplo, con bastante frecuencia se encuentran en sitios muy expuestos al sol, ejemplares del todo blancos y sin brillo, helix pomatia y hortensis, que en la coleccion solo permiten se les distinga de los ejemplares desgastados por el tiempo, por el brillo de la cara interior de la desembocadura, donde la concha siempre está en contacto con las partes blandas. El helix deserto. rum que en las inmediaciones del Cairo y de Alejandria se presenta pardo, en el desierto es casi siempre de un color
Blanco. Mauricio Wagner encontró el helsa hieroglyphicula, en Argelin, en la sumbra del coplus upurtio, presentando fa. jas continuas, mientras que en los sitios expuestos al sol ofre. cia siempre fajas interrumpidas $y$ borradas en ciettas partes. D'Orbigny vió el bulimus deralictus en las montanas de Cobija, en Bolivia, adornado de vivos colores; mientras qque al pié, de dichas montanas, donde la region, por falta de lluvia, solo les ofrece liquenes, era del todo blanco. Tambien el bulinus sporaticus es de un solo color en las pampas de Bue. nos Aires, mientras que en Bolivia, en el límite de los bos. ques, presenta rayas negras muy marcadas. Lil bulimus citrimus (fig. 224) debe mencionarse asimismo aqui, lo propio que el decollatn, furlula y australis.

Del eximen de esios y de nuchos otros ejemplos, resulta que los cefalóforos terrestres son propios para demostrar cómo el color está sujetoà la infíuencia directa de la luz. Encuéntmnse, sin embargo, entre ellos numerosos cjemplos para denostrar ofro hecho observado tambien en diferentes clases de animales, es decir, la analogia del color de su cuerpo con el del es: pacio en que habitan. I.os cefalóforos terrestres tienen en su mayoria un color pardo de ticrsa; los vitrinos, el arion hortensis que vive debajo las hojas humedas y descompuestas, negro $;$ brillante como cstas. Si el citado autor ha querido evi. denciar, aunque con cierta reserva, la razon de que la luz reRejada na perdido en estos casos tales efectos, estamos del todo conformes. Sin embargo, nos inclinamos a la opinion expuesta por Haecken, en una obra muy combatida al par que muy elogiada, opinion que es extensiva a todos los fe. nómenos idénticos del reino animal y muy digna de llamar nuestra atencion. El citado autor dice que la analogia del color de muchos animales con el de su residencia, puede explicarse tambien por la circunstancia de que, precisamente los individuos que presentan tal analogia en los colores, deben escapar mas fácilmente à las asechanzas de sus enemigos, que los que presentan un contraste de colores con el que distingue al punto donde residen. Existe pues una ex. clusion constante de individuos abigarrados, en tanto que los ejemplares que presentan color análogo al de su residencia, se conservan, y con ellos la variedad preferida por su tinte.

Como todas las conchas de cefalóforos son calcárcas, y su matcria no se produce en el organismo, sino que se introduce desde cl exterior, resulta lógicamente que alli donde la cal falta en absoluto, no puede haber caracoles de concha. Esta dependencia se echa naturalinente de ver en los cefalóforos terrestres. H'or lo que respecta a la extension, al número de los individuos, í la solidez. y espesor ó finura de las conchas, el suelo calcáreo y las montanas de caliza son de sima importancia. "La diferencia, dice Derring, que suele notarse en individuos de una misma especic que habitan parajes de variada naturaleza geognóstica, tiene su ori. gen en la circunstancia de que los individuos que se presentan en formaciones pobres en cal, tales como el granito y otras, son siempre mas trasparentes, mas abundante su sustancia orgánica, y por lo tanto, de un color mas intenso, asi como es menor la solidez de la concha. In cantidad de cal necesaria para la formacion de la nacarina, no solamente se extrae del alimento, sino que el animal la obtiene corroyendo las picdras calcáreas, ó, donde estas faltan, conchas de otros individuos de la misma especie. Alli donde faltan, como sucede, por ejemplo, en el territorio de las formaciones de cuarzo granitico, las mezclas calcáreas fáciles de resolver, el animal no tiene ocasion de procurarse abundantes cantidades de cal, y por lo tanto se ve imposibilitado de construir la capa de nacarina con la misma solider. que los individuos de las formaciones abundantes en cal. Aparece, como en los individuos que han habitado en ambas residencias, con 
la capa epidérmica regularmente rica en sustancia orgánica; tiene un desarrollo bastante igual, mientras que la capa interior de nacarina, abundante en cal, presenta una diferencia en punto á solidez; esta es de un quilate por ciento de sus. tancia orgånica, en favor de los individuos que acusan una formacion primitiva montañosa, circunstancia que al mismo tiempo explica la delgadez de la concha en los últimos, su gran trasparencia y su color iutenso.» Al tratar acerca del modo con que los cefalóforos terrestres, a los que anteriormente nos hemos referido, y de los que tambien nos ocuparcmos con especialidad, eligen su residencia, y acerca del punto en que viven y los medios con que se les tiene que buscar, ce deremos la palabma uno de los decanos en esta especialidad, al ingenioso Rossmoessler. eMuchos reptan con preferen cia en las plantas, en tas que eligen como sitios faroritos la cara inferior de las hojas y los ángutos de las ramas; otros prefieren fijar su residencia en la superficié ó debajo de la hojarasca; muchos pasan su oculta existencia debajo de la espesa alfombra de musgo que cubre las piedras y los tron. cos de arboles; y no pocos se encuentran debajo de grandes piedras en companía de las lonbrices de lluvia y de los miriópodos, en cuyo caso, á menudo no llegamos a compren. der como un animal tan delicado $y$ de concha tan endeble, ha podido penetrar debajo de una piedra á veces enorme. Mas de una especie de caracoles no se creyb, í lo que parece, bastante segura, rctirándose a gozar de una vida realmente subterránea. Examinemos, empero, algo minuciosamente; y una tras otra, las residencias de estos celalóforos.

* Como el alimento de estos séres, es decir, de los cefalófo. ros terrestres, se compone casi exclusivamente de sustancias vogetales, podemos suponer desde luego, que los mas de ellos se fijan en plantas, ó cuando menos, próxinos a las mismas. Para dar en primer lugar una iden geneml me refiero á Pfeiffer, quien dice: que la mayor parte de los cefalóforos se encuentran en los bosques de hayas, en los encinares, y en las coniferas. Yo digo que las regiones donde existen bosques de espeso follaje, con productos de cunchilia, son siempre preferidos á los de coniferas. Por lo demás la noticia que di al isegurar que habia encontrado mas conchilias en las regiones llanas, se ha confirmado tambien respecto a los bosques, pues siempre halle los que pueblan los montes mucho mas polures en conchas que los de las llanuras. Anguí viven los caracoles a escasn altura en el tronco de los àrboles, prefiriendo la espesura baja, ó fijando su residencia en las yerbas silvestres 6 en el suelo. No he podido averiguar aun con seguridad si los caracoles prefieren en los bosques ciertos arbustos. Cuando encontré con frecuencia uno ú otro arbusto, espesura 6 cerca muy poblado de ellos, me jareció que esta circunstancia debia atribuirse, mas bien áotras causas, que a la clase de plantas qque poblaban aquellas espesuras ó cercas. Cuanto mas espeso y umbroso es un arbusto, y cuanto mas cubierto $y$ húmedo es el sitio en que se encuentra, tanto mas gustan de él los cefalóforos. Parecen, sin embargo, scrles mas convenientes las espesuras, como por ejemplo de cormus sangruinea, rubus, acer, corydus, etc, que están rodeadas de enredaderas de lúpulo y entremezcladas con otras yerbas altas. In ellas se fijan en tiempo seco, en la cara inferior de las hojas, ó se ocultan en la hojarasca que cubre el suelo: el que no sepa buscarlos aqui ó tema quizás penetrar en la espesura, llegari a convencerse de que no existe ningun caracol. En general, cuando mas seca y calurosa es la temperatum, á tanta mayor profundidad deben buscurác los caracoles; pero despues de una lluvia templada es cuando se echa de ver el número de cetalóforos que se encuentran al rededor y en el interior de la espesura, oíreciendo notable contraste con su escaser en tiempo seco: entonces salen todos de sus escondites para recrearse con las gotas de agua y la húmeda temperatura, prometiendo al observador una abundante cosecha, si hace caso omiso de las gotas que dejó la lluvia, las espinas y las ortigas.

7. Cuando sc han examinado las ramas y las hojas de tales arbustos, no debe descuidarse examinar tambien cl suelo al rededor de los mismos, que por lo regular está cubierto de musgo, piedras y hojas caidas; porque en él vive mas de un caracol que raras veces sale a la luz del dia, í cuyo número pertenecen con especialidad los vitrinos. Tambien las tapins ó cercas pueden ser compandas á las espesuras, por lo zque atañe á la presencia de los cefalóforos: las de los jardines húmedos situados en la llanura suelen verse muy pobladas, sobre todo despues de haber llovido. En los jardines hay sin enbargo otros sitios donde pueden buscarse caracoles; tales son, las cercas de boj, sobre todo en una temperatura calurosa y seca, los rincones no limpios de la yerba inútil, los sitios en que steleamontonarse esta, y en fin todos los lugares angulosos, oscuros y húmedos. Por eso no debemos olvidarnos de levantar en un jardin toda tabla que por largo tiempo haya estado en un mismo sitio, si queremos coger los caracoles que infaliblemente se encontrarín en la mara inferior de aquella. Pureden emplearse por lo mismo las tablas como trampas, para atraer y coger los caracoles.

in in los bosgnes de mucho follaje, el suelo aparece por lo regular cubierto de una capa de hojarasca, de musgo, de pie. dras y de tamitas. Por eso se encuentra en ellos gran número de cefalúfuros que pueden recogerse con toda comodicad, examinando primero la superficie ó cubierta y las plantas bajas, sacando despues la hojarasca para apoderarse de los gasteró. podos que viven debajo de la misma. En tal ocasion se ha de tener cuidado al levantar las piedras grandes, porque son la vivienda favorita de muchos caracoles. A menudo estas piedms ó los viejos troncos están cubiertos de uma espesa alfombra de musgo; esta puede quitarse fácilmente en grandes pedazos para descubrir mas de un caracolito.

sina vez en el bosque, no debemos olvidarnos de examinar cuidadosamente los troncos de árboles medio podridos ó los árboles viejos y liuecos. Encima, y en el interior de los nismos, viven muchos gasterópodos, sobre todo clausillas, pupa y zertigo: puede hacerse saltar la corteza, especialmente en tiempo húmedo, de troncos ó árboles viejos, y en el estrecho espacio comprendido entre la corteza y la madera se encuentra á muchos caracoles, sobre todo de los géneros iertigo y carychium. Si se ofrece la ocasion de examinar regiones pedregosas, se encuentra por lo regular abundancia de bonitos caracoles. Principalmente en las partes de oriente $y$ de occidente, que por lo comun se conservan durante mas tiempo húmedas, $y$ en las hendiduras, en particular las que estan cubiertas de musgo $y$ de líquen humedecido por el agua, viven muchos gasterópodos, sobre todo algunas especies de los géneros heliax y clausilla.

\section{LOS HELÍlCIDOS-HELI-} CIDE

CARACTERES, - Ocupémonos ahora algo mas miluciosamente de los grupos subordinados y de algunos de sus representantes, en primer lugar de los helícidos ó curacoles cirsulares. Forman con algunas otras fanilias, la division de los estilomáóferos, con cuyo nombre se designa la josicion de sus ojos en la punta de los dos ientaculos posteriores, huecos y retráctiles. Todos sienen una concha espiralada, espaciosa, propia para recoger el cuerjo, y que varía tomando todas las formas posibles, desde la plana hasta la punti- 
aguda y larga. Se han descrito unas $₫, 600$ especies vivas, de las que mas de 1,600 pertenecen al género helix. De las especies mas comunes en la Furopa central, el helix fomatia ya nos ha ocupado mas arriba. Todo el mundo conoce la stancie concha esférica, rentruda, amarillenta ó pardusca, que los especialistas llaman \&cubierta y perforadas, porque el ombligo estrecho que se extiendic en el eje, está cubierto por el ensanchamiento del borde del huso. Este aninal no depende de los vinedos, aunque en primavera gusta en extremo de los capullos de las cepas, en las que puede causar bastante perjuicio. Por el contrario, se encuentra en todas partes en las regiones secas, con preferencia en las colinas donde prosperan las yerbas y las espesuras. A causa de su tamnno $y$ de su utilidad ha sido con mas frecuencia objetu de obsersaciones y de averiguaciones. P'erienecé á las especies que en otono, despues de haber, penetrato de medio hasta un pie de profundidad en el suelo, con preferencia bajo el musgo, cierran su concha con una sólida tapa calcárea. El animal se interna en la concha, dividiendo el intervalo entre la tapa y el clerpo, por medio de una ó varias mem. branas. Dumnte este periodo que por lo menos dura seis meses, la respiracion y la actividad del corazon no están in.

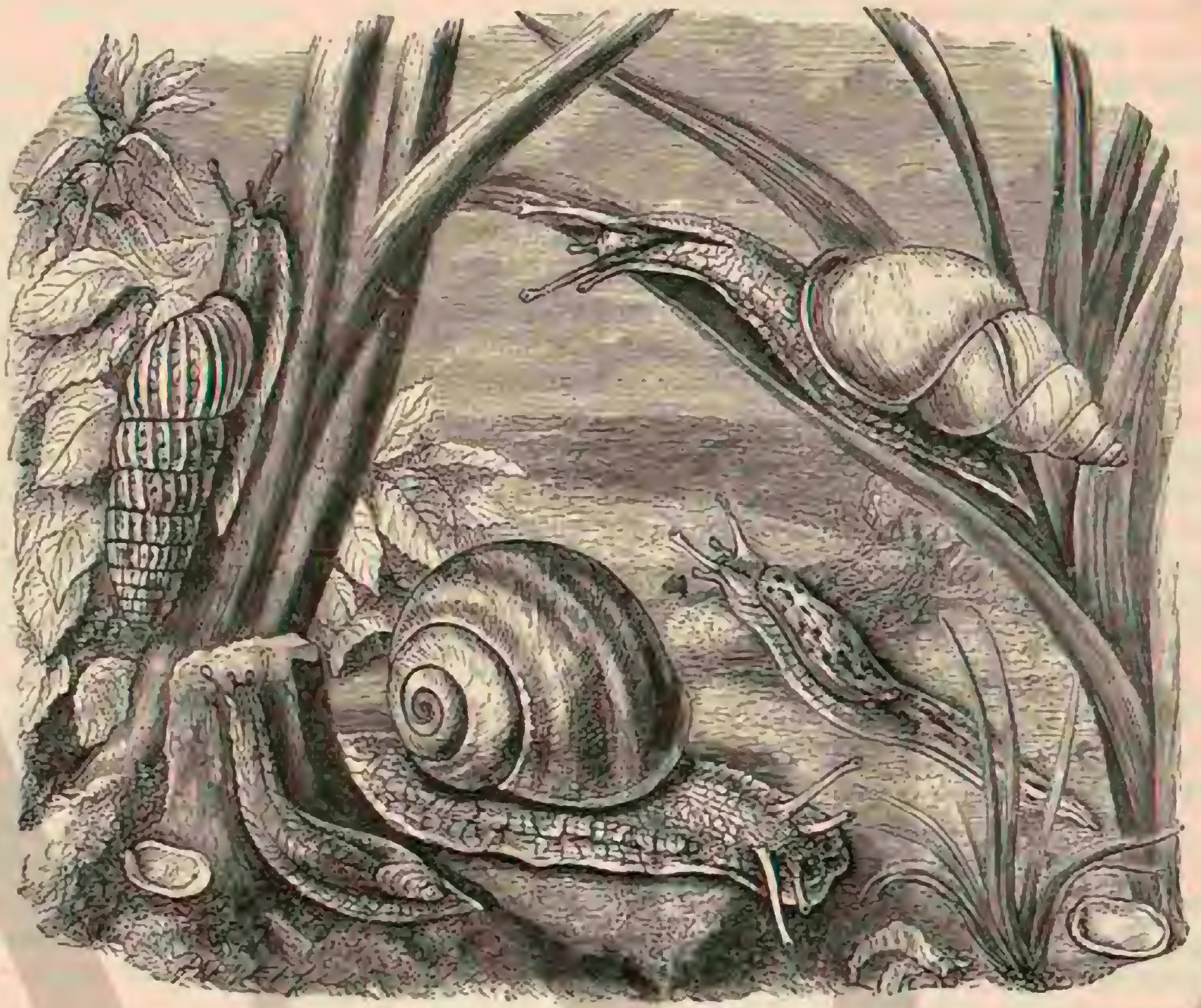

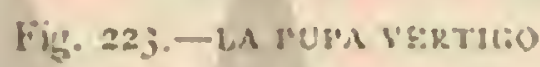

Fig. 224.-Fil. HULiso CHTRIso

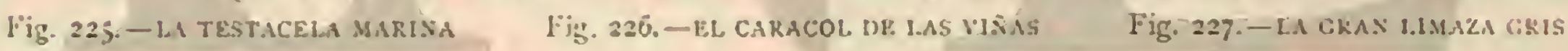

terrumpicas. Cicro que la iapa calcairea no tiene abcrtura de ningun género, como en algunas otras especies se ha observado; pero, en cambio, es lan porosa, que la renovacion de los gases puede verificarse al través de ella y de las de. más membranas delgadas. Listableceremos una comparacion, observando que tambicu el polluelo está en relacion con el airc atmosférico, al través de la cáscara, durante su desarro. tlo en el huevo. Pero como en todos los ànimales de sueño invernal, ambien en el helix pomatia y sus congéneres la res piracion es escasa. Despues de trascurridos algunos hermo sos dias de marzo, dins aun no excesivamente calurosos, enconiré el pulso en estado muy irrégular, de unas doce á trece pulsaciones por minuto, mieniras que, pasado el sueño invernal, el numero de aquellas se clevaba á treinta. Dc to. dos modos, noté que en pleno invierno la actividad del corazon es mucho mas pequeña: un observador inglés pretétlde que à mediados del año el corazon cesa por completo de latir y la circulacion de la sangre se interrumpe; un naturalista aleman, Barkow, que se ha ocupado ninuciosamente de los fenómenos del sueño invernal de los animales, dice que las pulsaciones no cesan del todo, pero que la bolsa pul. monar está cerrada y la respiracion queda interrumpida. Yo creo gue la respiracion no se inicrrumpe nunca por comple-

Tono VII to. Fl alimento contenido en el estómago, de que el animal se proveyó oportumamente para el inviemo, es digerido en. tonces; despues el estómago se llena de una sustancin pardusca, la hiel El calor de los meses de abril y de mnyo des. pierta la actividad de la vida; el corazon late con mas encrgia, y el animal se ve obligado, sin duda por la creciente necesidnd de respiracion ó por cl hambre, i oprinir con su pié las tapas membranosas. Estas no se rompen; se reblande. cen fícilmente y no requieren grande's esfuertos para arjartar la tapa calcárea de la desembocadura Esta no está soluada, sino que forma una especie de tap̧on plano, cuyo borde sc cierra herméticamente.

Los dias y semanas que siguen inmediatamente al despertamiento del sueno invernal, se enuplean por nuestro caracol en devorar las yerbas tiemas. Solo en los dias humedos de mayo y junio verifican su aparcamicnto. acto acompañado de los preparativos mas cxtraños y de las mas raras circunstan. cias. Johnston habla jocosamente, con resjecto al papel qute. segun se dice, representa en esta ocasion la flecha amorosa. "Cuando los poetas enamorados, dice, cantan la aljaba y las flechas de Cupido, usan expresiones de las que algunos na. turalistas serios han echado mano en la cescripcion de varios helicidos (helix poniatio y otros). La estacion les obliga $x^{\circ}$ 
efectuar cl apareamiento, y entonces la pareja que va á veri. ficarle se adelanta, lanzándose de tiempo en tiempo pequenas flechas. Iistas fiechas se asemejan algo a una bayoneta y se enruentran colocadas en una casidad de la aljaba, situadat en el lado derecho del cuello, desde la que son lanzadas, cunndo los animales estan i dos pulgadas de distancis uno de otro. Una ve\% cambiadas las flechas, ha nacido entre estos dos séres el carino y el apareamiento es la consecuen. cia.

No puede negarse que el disparo de la llecha es uno de los preparativos, pero solo forma la primera escena de este cuadro. Esta escena comicnza á menudopor una especic de danza circular, propia de los caracoles, por la que se rodean estos animales aliernativamente unos a otros, formando circulos cada ve\% mas pequeíos. $\$$ menudo, sin embargo, la manera de entablar este género de relaciones es, segun Johnston, menos formal. Cuando estos animales se han al. canzado, ponen las jlantas de los piés una sobre otra, apo. yándose con su extremidad en el suelo; los movinientos ondulantes de los muslos, son entonces vigorosos en extremo; tócanse los tentáculos, se encogen y se extienden de continuo, Y rozan sus labios de una manera que Swammerdanı compara al besuqueo de los palomos. Despues de estos y otros preparativos, yediante ciertos mosimientos, despiden flechas, que, regularmente, penetran en los órganos scxuales; pero que á menudo se introducen, tambien, junto á ellos en la piel, ó se desprenden, sin producir resultado alguno. Re. sulta de aqui que la importancia de estas flechas para el acto del apareamiento, cuya parte principal comienza desde este instante, es en todo crso muy pequeña, pudiéndose apeuas considerarlas como órganos de la irritabilidad.

Ios huevos del helix pomatiu tieñen tres lineas de diá. uretro, y como estån rodeados de una criscara blanca revestida de cristales calcáreos, es por lo mismo bastante sólida. «Estos huevos se depositan en gran número, dice Keferstcin, en pequeñas cavidades subtcráneas, abiertas por los mismos caracoles. Li parte anterior del cuerpo penctra, hasta donde puede salir de la concha, en el suelo blando $\mathrm{y}$ húmedo, y forma de este modo un agujero redondo de una pulgada a una $y$ media de profundidad, cuya abcrtura queda cerrada en su parte superior por la concha del caracol. Penetrando jor este medio en la cavidad, el animal deposita en uno ó dos dias sus 60 a 80 huevos. Entonces cierra el agujero con tierra, allanando la superficie de modo que el nido de los huevos sea dificil de encontrar, si no se le reconoce poco despues de la puesta por la tierra levantada. EI desartollo en el huevo dura unos reintiseis dias. Mas ade. lante, al hablar del caracol agreste, daremos a conocer algu. niss particularidades del desarrollo de los pulmonados terres. tres. Hasta muy entrado el otorio, tanto los adultos, como los jóvenes, son muy voraces y comienzan á aletargarse al comenzar el invierno.

Fi helia pamutia ha sidio desde antiguos tiempos en la Alemania central una comida favorita, sobre todo en el periodo de cuaresna. En Suiza y en las regionés danubianas, se les cria y engorda en huertas construidas al efecto. Pero pasó ya el bucn tiempo, en que el helix pomatia se criaba en lare. gion de Uilm, en esta clase de huertas, por los campesinos, los que exportaban anualmente mas de $4.000,000$, en barriles de à 10,000 ó mas cada uno: por el Danubio hasta mas alla de Viena. Lin Stiria, donde tambien se comen en cantidades bastante considerables, se les recoge sencillamente en otono, provistos ya de tapas, conservandolos entre la arena. Como es consiguiente, esta se reseca un poco en invierno, lo que la gente explica, dicicudo que los caracoles la comen, sin poder jndicar por eso cómo pueden hacerlo al través de la tapa. En nuestros paises se les come hervidos; ignoro si constituyen inayor golosina, guisándoles de otro modo.

En la Alemania meridional, linda con el territorio del heli. fomatio el área de dispersion del helix adsfersa, propio con preferencia de la Europa del sud. is un poco mas pequeño, su concha parecida a las de la especie anterior esta provista de fajas $y$ salpicada de blanco y amarillento. Constituye un importante alimento de las clases bajas de la poblacion de la Europa meridional, sobre todo en Italia. En las cocinas pirblicas de las grandes ciudades se les hierve en calderas, y en Nápoles, he dado it menudo gracias al cielo de no verme obligado \& beber cl caldo que el lazsnroni recibia como añadidura de la racion adquirida mediante una pequeña moneda de cobre; caldo que apuraba, cual si fuera el liquido mas cxquisito. Fijándonos en la venta de esios comestibles, genemlmente tan propagados, que solo cuesta el trabajo de recogerlús, y en su sencillo guiso, nos dámos razon del atractivo o̧ue en estas regiones tiene la holganza y la mendicidad. Un men. digo experto sabe procurarse en todas ocasiones algunos soldis para la comida; en esta reune, no solamente carne y un buen caldo, sino por anadidura, y como postre, un gran pedazo de sandia, que junto $i$ las calderas donde se hierven los caracoles, exhiben con rerdadero arte los rendedores. Y'a en la antigiledad se criaron y engordaron, además de esta especie, muchas otras, importadas en parte. Segur refiere Plinio, Fulvio Lippino fué el primero que poco tiempo antes de la guema pompejana se ocupó de la cria de caracoles y en cuadras separadas teria los caracoles blancos de la region de Reate, los grandes de lliria, los del Africa, distinguidos por su fecundidad, y los muy apreciados de Solitania. Se llegó å inventar una pasta de mosto, harina de trigo y otras sustan. cias, para engordar los caracoles y criarlos sabrosos. No puede decirse cuales fucron las especies extranjeras que se criaron, y si cntre ellas frguraba algun bulimes y achatina del Africa; sin embargo, parece, segun la obscrvacion ce Kobelt, que la cochlea maxima illyrica, tan apreciada jor los romanos, era el helix sercern:nda, congenere de nuestro helix pomatia, comun en Dalmacia, y que aun hoy dia se considera alli como una golosima. En Venecia se coge con preferencia la pequena helix pisana, que en enorme numero vive en las plantas de las dunas eEste gracioso caracol tienc la forma del caracol comun de los jardines, sin llegar por eso à su tamaño. Este atuimali. to ticne la desembocadura interior de la concha sonrosada, con la capa exterior blanca, adornada de fajas de un pardo amarillo que, diferentes en casi lodos los ejemplares, se corren, á manera de un pentágrama, $\delta$ se prolongan de arriba abajo, formando como un follaje, $\sigma$ bien se conrjonen de puntos $y$ de lineas trasversales, i menudo de colores muy viros y otms reces muy pálidos: tambien pueden faltar del todo. Estos caracoles se llevan en gran numero à Venecia, dondè se guisan con la concha, con ajo picado y accite, ven. diéndose en grandes fuentes, durante el verano, en todos los mercados (segun Martens).

«Por toda la Italia, dice hobelt, además del helix adspersa son muy apreciados como alimento el helix naticurides y el heliv icrmiculata. El primero, llamadoen Italia del sur en todas partes la tafudata (la tapadir), es sobre todo apreciadu; pero no es fácil recogerio; pues este carncol permanece casi rodo el año oculto a algunas pulgadas de profundidad en el suelo, y solo despues de las tuertes lluvias de otono, sale para des. aparecer luego er fébrero. Cuando se le coge con la mano, segrega, produciendo un ruido muy sensible, cierta cantidad de espuma de la abertura respiratorin; de modo que esta quic. da del todo oculta. No conozco otro cefalóforo terrestre que esté provisto de igual arma defensiva. Desgraciadamente esta arma es la quue causa su pérdida, cuando tiene que habérscias 
coll el hombre; pues la espuma se nota ya á cicrta distancia y el ruido se oye a algunos pasos.

rambien los gasterópodos icrrestres representan un papel principal en Nipoles, sobre todo el helix ligata que se tme de los Apeninos; pero no por eso dejan de encontrarse las especies arriba citadas, que se comen en rodia la Italia, en especial los colosales helix lucorms del monte Gargano que tambien se venden públicamente. Llamin la atencion del extranjero los marnssta, que con un hornillo de piedra en la cabeza cruzan las calles ofreciendo al público su mercancia. El hornillo está adornado de flores y à su alrededor fijan los vendedores pedaros de pan. Cuando se presenta un parroquiano, bajan el hornillo cuidadosamente de la cabeza, el vendedor coge un pedazo de pan y saca de la caldera la cantidad de caracoles pedidas

Segun el mismo observador el consumo de caracoles terrestres es mayor en Palermo que en toda la Italia. En mis expediciones al monte Pellegrino, dice, encontré siempre un gran número de caracoleros, cuyos cestos contenian a menudo una ahundante cosecha. Estos hombres estin provistos de cortos hierros corvos con los que revuclven la escasa iierra que existe entre las rocis calcárens perforadas. El ma. yor número de caracoles se encuentra en los agujeros medio llenos de tierra de las mismas rocas. In ellos se presenta el helix zermiculafo, naticoides y of helix mazzullii que, segun parece, se limita al monte Pellegrino. Esta tíltima especie, en extremo apreciada, está oculta en mayor número en las rocas, en agujeros que, segun las observaciones de Doderlein, practica ella misma, constiruyendo uno de los fenómenos mas notables en el género de vida de los caracoles. I a piedra calciren gris blanca del Pellegrino contiene partes yue fícilmente se descomponen bajo la infuencia del aire, y a consecuencia de esto los bloques de que se compone toda la suprerficie del monte estín perforados del modo mas sorprendente. Con particular frecuencia se encuentran galerías que pasan de una à oira extremidad, teniendo à menudo algunos pies de largo, pero solo pocas pulgadas de ancho. lin la parte superior de estas cavidades, es ciecir, en partes donde la lluvia no puede labet producido ningun electo, se encuentra cierto número de galerias verticales abiertas en la piedra, por lo regular bastante circulares, y de algunas pul. gadas de profundidad; de modo que la piedra parece un enorme panal de abejas. En el fondo de estas galerias se encuentran siempre carncoles, sobre todo el iclix maszullii, pero con mayor frecuencia el irelix sienna, a veces en núntero crecido en la misma cavidad.

yen un principio me pareció de todo punto increible que los cefalóforos abrieran estos agujeros; pero es por otra parte impositble que estos puedan ser producidos por los efectos del ticmpa: además son del tado lisos en su interior. Considerndos como du un fenómeno hijo de da casualidad, hay que comvenir en que se presentan con demasiada frecuencia y regularidad, y sus dimensiones corresponden exactancnte à las de sus hahitantes. Queda en pić por lo tanto Is suposicion de que los caracoles mismos han abierto cen el trascurso de muchis generaciones, estos agujeros, y que aun prosiguen su trabajo. Si no me engaño, ambicn un naturalista frances ha observido en ia costa occidental de Francia, agujeros parecidos abicrtos por el helix horlcirsis.

D. Anadiré ahora que los individuos que viven en los agu. jeros, se distinguen de los que viven libremente, por una forma cónica mas prolongada. Puede presenderse con seguridad que el helix massmllï,por efecto de este género de vida, se ha trasformado en una especie diferente del helix adsfersa. Los individuos que goran de una vida libre se accrean mar. cadamente is su especie primitiva, aparecicudo el helix mas- sullii como una varieciad local que por efecto del cambio en su género de vida, ha adquirido caractéres distintivos, constantes y noiables. Se nos ofrece aqui una nueva prueba para demostrar la exactitud de la palabra de Cocthe: an El género de vida influye poderosamente en todas las formas.

Tres esperies mas grandes y muy comunes, comparten con el helix pomalia casi la misma área de dispersion: de lo que la mayor parte de nuestros lectores alemanes pueden convencerse con facilidad. El helix arbustorum, tiene un color pardo castaño en el fondo y salpicado de numerosas lincas irregulares de un amarillo pajizo. Lil borde de la boca esta provisto siempre de un labio blanco y brillante, y el cuerpo es de un color negro azulado con la planta mas clara. Liste animal fija su residencia en los jardines, en los linderos de los bosques y en las cercas, en puntos huimedos, en el suelo ó en plantas bajas. El helix nemorolis se distingue por un gran número de variedades de la concha. Esta es de un rolne aniarillo slaro, muy vivo ó pardo rojo, yo se reconoce fácilmente por el borde bucal y por la pared de la desembocadura que son de un castaño oscuro. Los conqui liólogos mencionan unas to sariedades de esta espnecie muy danina para los jardines. La tercera de las citadas especies es el helix hortensis, cuya concha no difiere de la de la anterior por la forma, el color y los matices, sino por ser, regu. larmente, algo mas delgada y tener el borde lucal casi siempre de un blanco puro. A pesar de su nombre se en. cuentra raras veces en los jardines, y' no obstante las muchas descripciones minuciosas hechas acerca de las variaciones die los colores, no se han cmitido aun las verdaderas y decisivis observaciones acerca de la mezcla y la formacion de las varicdades relativamente a las dos últimas especies. Cuarenta años han trascurrido desde que manifestó este deseo Russ. maessler. \& Sin duda que cste trabajo fucra recompensado, dice este autor, trabajo que por otra parte es ficil de hacer, á causa de la frecuencia de ambas especies, pudiendo averiguarse entonces qué posicion ocupan los hijuelos, respecto a sus padres, en cuanto á las mumerosas sariedades, y observar si todos los caracoles de una misma cria se pareren entre si y si se asemejain mas al padre ó à la madre. Al efecto serin preciso recoger caracoles que se encontrasen apareados, colocarles aisladamente en jaulas convenientemente preparadas, y cuidar los huevos obtenidos del modo mas conveniente à su estado natural. lissto último ofreceria ciertas dificultades, auncjue no invencibles, segun lo ha demostrado la experiencia. Jas dos mas principales medidas de precaucion que hay que observar son las de conservar la tierra de la jaula medianamente húmeda y preservarla del mal olor. Fui, hace poco tiempo, al menos que jo sepa, el primcro que turo ocasion de observar el apareamiento de un helix nemantis con un pequeno helix horlensis amarillo. La opinion emitida jor varios autores de que el color de las conchins depende de la naturaleza del suelo, y' que, en su consecuencia, en un terreno margoso se vuclven rojas en ver de amarillas, no sc ha confirmado segun mis observaciones. Listas son, segun se ve, propasi. ciones propias para experimentos que deberian practicarse en jardines zoológicos, pero que tambien cualquier hombre es. tudioso y desormpado pucde emprender. Los resultados de estos cxperimentos se aceptarian ahora con gran interis por la ciencia, que los utilizaria para ulteriores fines.

\section{LOS BULIMOS-BULIMUS}

CARACTERES - El immediato género, mas rico en especies, es el de los bulimos, ó cefolofores glutones. Este anjmal no se distingue csencialmente del helix; su cuncha es casi siempre de forma jrolongacia, con la desembocadura oral. 
DISTRIBUCION GEOGRÁFICA. - lass mas de las 20 especies conocidas se parecen mucho en sı género de vida ia los helicidos. Algunas pertenecen á Europa, ozras son tropicales, propias solure todo de la América del sur. Dióse primero este nombre á una especie que se encuentra en Cayenin, al bulimus hemastomus (boca sonrosada), especie poco agradable por su extremn roracidad; las restantes no merecen consignarse, excepcion hecha del bulimo citrino (fig. 224), ni mas ni menos que la inayor parte de los restantes gasteró. podos.

USOS, COSTUMBRES Y REGIMEN.-Muy notable es el regular desgaste de la punta de la concha en el bulimus decollatus, propio de la Europa meridional. Esta punta cac así que el animal ha salido de la concha, dirigiéndose hácia el exterior y cerrando el espacio abandonado, de parecido mado que lo éfectío el nasitifus, es decir, por medio de una pared divisoria trasversal. Acerca del género de vidia de los bulimos, auenas podemos anadir otros detalles. Nada diremos acerca le la exactitud de la noticia de que en algumás partes de Inglaterra el pequeno bulimus acatus y el helis airgata, son de gran importancia para la cria de carneros. La yerba es tan corka, el numero de los caracoles tan asombroso, que es de todo punto imposible comar los carneros la prinura, sin devorar al mismo tiempo grandes masas de los últimos. Lla carne mas sabrosa de carnero, dice Borlase, se conside. ral la de ovejas pequeñas, que por ló regular pacen en pastos connunales, en los que la arera apemis estí cubicrta de un césped corto. De esta arena salen caracoles helicidiformes de diferentes especies y tamaños, adultos youvenes y hasta los mas pequenos, que, ajenas frera del huevo, se discminan por la llanura a primera hora de la mañana, sirviendo de alimento í los carneros, mientras que ellos buscan el sujoj.

\section{LOS AGATINOS-ACHATINA}

CARACTERES. - Tos agatinos se caracterizan por tener el piré puntiagudo y comprimido, asemejändose por ló demás al género felix. La concho se distingue de ha delos bulimos, sobre todo, por el huso libre, truncado en su paric inferior. De la Alemania central, extendiéndose por la Francia y hasta la Suecia, se conoce solo la pequeña ncliatiua Iuliriea de tres lineas de alturn, que vire debajo de las pie. dras y el musgo, y generalmente en parajes húmedos. Las mas de las especies prefieren, segun se dice, las cercanias del agua. Pertenecen principalmente al Africa y à la Améri. ca tropical, y entre cllas figuran los mas grandes y bonitos cefalóforos terrestres, como la achatiun immaculata, mauritia"ur y perdix. La suposicion de que esta última pudo figurar entre las especies criadas y cingordadas por los romanos no es probable.

\section{LOS SUCINEOS-SUCCINEA}

CARACTERES, USOS Y COSTUMBRES.-La mayor parte de las especies de sucineos, ó caracoles de ámbar, dependen mucho del elemento liquido, segun puede deducirse de su concha delgada con circunroluciones y' su gran desem. bocadura Su dependencia del agua, no es sin embargo igual, sino que se rige precisamente por el ancho relativo de la desembocadura de la concha. la succinea Pfeifferi, cuyo orificio tiene una gran superficie, se encuentra siempre en las inmediaciones del agua, en la cual penetra à menudo para nadar como los sinneos. ela succinea amphibia, dice Doring, que tiene la desemboctdura de la concha relativamen. te mas pequeria, no manifiesta tambien tanta inclinacion al agua, pero tiene gran necesidad de los pamjes húmedos, los cuales comparte algunas veces con su congénere la succinen Pfejfferi, alejándose raras veces mucho del extremo limite de la regetacion de canas y otras plantas acuaticas. Sin embargo, tambien visita los arbustos y los árboles que se hallan a unos 30 pasos de distancia. Major diferencia en ia forma cxterior se nota entre los dos tipos citados y la succimea dblon. gra, que tiene la desembocadura relatimmente mas pequena: es un cefalóforo terrestre que, al contrario de las otras dos formas, sube a mucha altura de la montaña, donde por lo regular se encuentra en las cercanias de los riachuelos, y con gran frecuencia tambien i larga distancia de ellos en parajes secos.

\section{LOS VITRINOS-VITRINA}

CARACTERES.-Tambien los vitrinos, que tienen la concha pequeña, delgada y tmsparente, en parte cubierta por una apófisis del manto, son dignos de citarse aqui, jorque las especies de este género, propias de uuestrns paises, nos ofrecen completa semejanza con los sucinos por el género de vida y' la forma de la concha. Muy pequeña es la desembocadura, dice Daring: que observamos en la ritrina pellu. cida, y muy grande la de la sitrina clunga/a; esta siltima y sus especies áfines solo se encuentran en bosques muy hú. medos, casi sicmpre entre el musgo y la hojarasca de las orillas de los riachuelos: por lo regular se oculta durante los meses calurosos del verno á mucha profundidad debajo de tierra. La ritrinu pelluciala se halla con frecuencia en lo. calidades mas desfarorables que en tiempo sereno estain cxpuestas i los rayos del sol.

Lin contraste con este género otros dos prefieren à los parajes húmedos, las regiones montanosas y secas, y sobre todo los terrenos pedregosos de los Apees j de la Europa meridional.

\section{LAS PUPAS-PUPA}

CARACTERES. - Este géneto no comprende ninguna especie de mas de $0^{n}, 025$ de altum. La mayoria solo ticnen de $6^{\prime \prime}, 010$ a $0^{\prime \prime}, 015$ de largo, y muchas de ellas se distinguen por su tamaño casi microscópico. Su concha es ovial ó cilindrica, y la desembocadura esta provista casi sicmpre de dientes. Aunque tambien la superficie de la concha es muy variable, lisa ó surcada, siempre afecta la forma cilindrica, $y^{\circ}$ lo mismo sucede con-las especies mas numerosas del género siguiente. Meréce consignarse aq̣ui la pupa rértigo (fig. 223), cuyo pić es siempre muy corto ý puntiagudo por detras, y los tentaculos inferiores sumamentc breves.

\section{LAS CLAUSILIAS - CLAUSILXA}

CARACTÉRES.- Hstas conchas se distinguen por sus numerosas circunvoluciones y por tener la punta delgada, pero obtusa. Detris de la desembocadura hay un aparato especial, el llamado huesecito de serrar, que consiste en una placa ensanchada en la exrremidad libre y soldada con es huso por medio de un ligamento elístico. Cuando cl animal se retira al fondo de la concha el huesecito la cierra, siviendo de tapa, y si sale, la placa sé oprime contra un hojo correspondiente. De las chusilias se conocen cerca de cuatrocientas especies vivas que cstán diseminadas hasta la Alemania cen. tral; pero la verdadera patria de las clausilias es la Dalmacia, donde algunas de las esprecies mas comunes se en. cuentran á cada paso, en las rocas y los muros. Con mas frecuencia se las ve aun cerca de las escasas aguas y fuentes de esa provincia, tan rica en piedra. Se presentan en mayor 
múnero despues de una lluvia refrescante, pero pueden re sistir el calor y la sequia por ln desembocadura muy estrecha de la concha, es decir, por la reducida superficie de evapora. cion. Aunque todos los caracoles terresires, fuera del periodo de ur sueño invernal ó de verano, se conservan meses enteros sin alimenio $y$ sin sufrir daño alguno encerrados en su con cha, las clausilias se distinguen mas aun por su resistencia vital. Consta que los individuos de la slausitia almissana re cogidos por mayo en Dalmacin no se despertaron hasta el otono del ano siguienic; y tambien que una grande especic de lulimus que desde Valparaiso se llevó á Londres, en vuelta en lana y encerrada en una caja, resucitó despues de su sueño de veinte meses. De varias especies meridionales de helix se refieren cosas semejantes.

\section{LAS LIMAZAS - LIMACEA}

CARACTERE:-En la familia de las limazas podemos reunir todos los pulmonados, que parecen caracoles desnudos y çuc carecen en efecto de la concha, 6 tienen oculta in el escudo del manto, en la region anterior del dorso, una pequeña placa calcárea, ó bien se hallan provistos de una con.

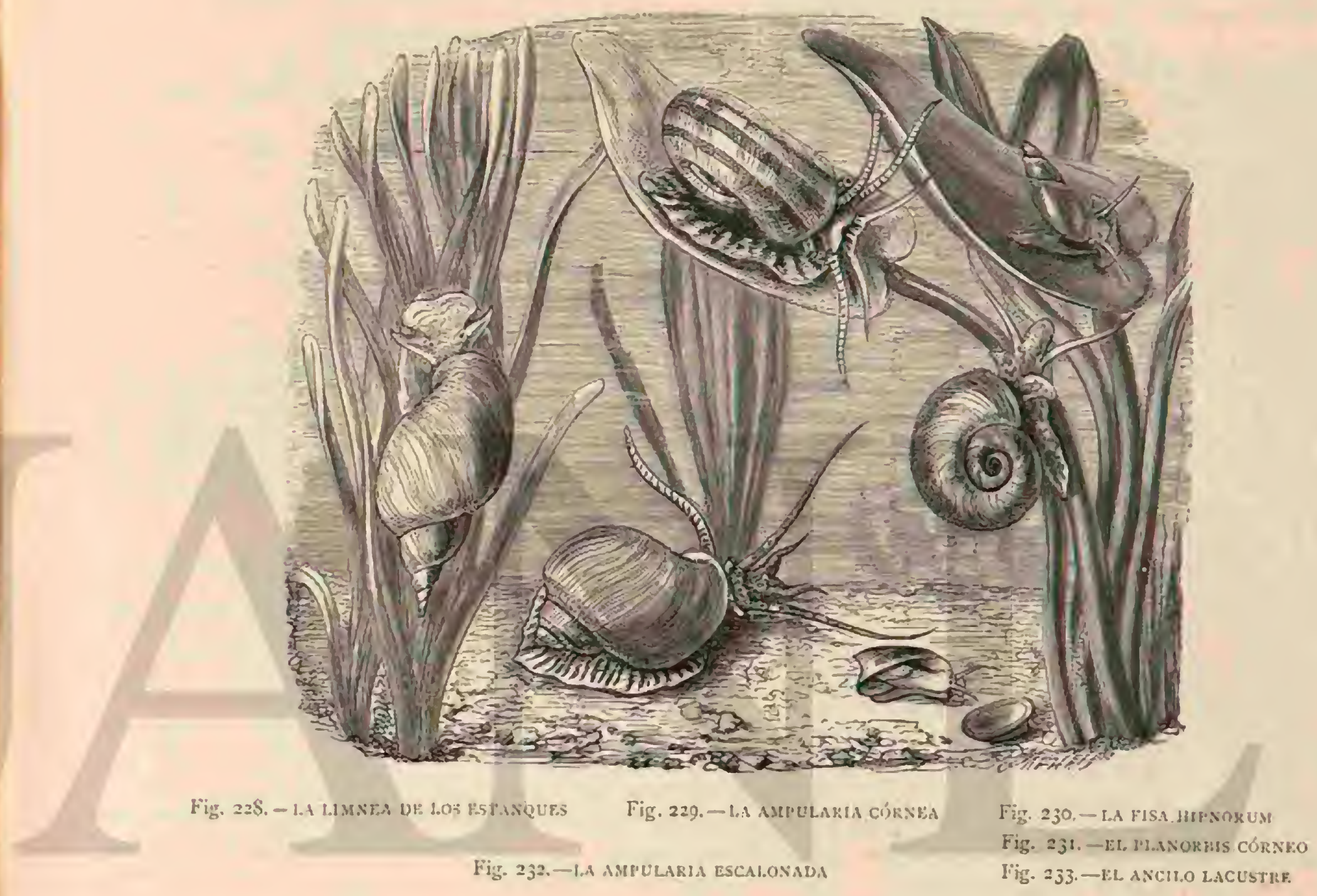

cha pequeña que cubre la menor parte del cuerpo. Nuestras limazas de los caminos y de los campos son tipos muy conocidos de este grupo; estas ulttimas especies se asemejan mucho $\mathrm{i}$ los helícidos con los que tienen de comun, entre otros caractéres, la forma de la lengua y la posicion de la abertura pulmonar y de la sexual. En el escudo, es decir, en el manto cortado que cubre la cavidad pulmonar, hay unos cuerpos calcareos, separados por una concha rudimentaria en forma de placa. Las primeras especies se lan Ilamado arion, y las últimas lima.; $\sigma$ limazas propiamentc dichas. Fl arion $\mathrm{cm}$. firicorum alcanza una longitud de cinco pulgadas y presenta muy variados colores, desde el negro hasta cl rojo amarillo. Vive con preferencia en los bosques frondosos y en los coniféros que no se resecan. A menudo, segui dicen, se ve cm plear este caracol por el pucblo como remedio para toda clase de enfermedades, sobre todo contra la raquitis; mas it pesar de haber estado muchas veces entre los campesinos, no he conocido una verdadera ajllicacion de este cefalóforo como medicamento, ni tampoco de otros caracoles desnudos. Las grandes limazas (limur. marinus) (fig. 227), stelen ser de color gris salpicado de negro y se reconocen par la quilla rugosa y blanquizca de la extrenidad posterior. "Tambien viven ais-

ladamente, sir causar dano. I a pequeńa limaza (limav ayreslis), que apemas alcaura una pulgada de largo yq que riene cl color gris, con los tenticulos negros, es en cambiu cul ciertos periodos sumamente peligrosa para los sembrados y las legumbres. Se aparian durante toda la estacion favorable, y cada animal pone en verano, segun se dice, varios centenares de hueros. Estos se encuentran, sobre todo en la concha, al pie de las paredes de los jardines, reunidos en montones de unos 20 poco mas ó menos. Hace años que he observado la marcha del desarrollo de este animal. Cuando el embrion adquiere sus contornos y la forma de caracol, ofrece el gratlo mas notable de su desarrollo, pero aun no tiene corazon ni vasos de la sangre, nunque existe ya un liquido semejante a ella, el cual es impelido por la contraccion de un apéndice en forma de vejiga desde atrás hácia adelante y vice-versa Un órgano cxtraño es tambien el que en el cmbrion, encerrado aun en el huevo, sirve provisionalmente para orimar y que puede compararse con los llamados \& cuerpos de Wolffy, los órganos urinarios embrionales de los vertebrados. $A$ un den. tro de la meinbrana del huevo, el hijuelo adquiere in forma completa de caracol, demostraindonos cómo en general, en todos los pulmonados, no se verifica una trasformacion esen. 
cial despues del nacimiento. Aquellos órganos provisionales, la rejiga caudal contráctil y el urinario, han desaparecicio del todo antes de] nacinziento, sustituyéndolos el corazon y los verdaderos riñones.

Con este ejemplo quisiera demostrar cuán relativas son las denominaciones tan usadas, y al parecer del todo terminan tes, de «desarrollo con metamorfósis y «desarrollo sin metamorfósis \%. I a limaza salvaje sufre sin duda una trasformacion en el huevo, porque alli riene órganos internos y externos que no necesita en el estado de adullo, lo mismo que el re. macuajo no necesita ya en su major edad la cola que sirve de remo. Bajo estc punto de vista la diferencia entre el desatrollo con metamorfósis y el sin metamorfósis, que, en concepto de los zoólogos sistemniticos, se funda en la existencia ó falta de la membrana del huevo, noparece tener importancia.

En el génefo festasella, la forma del cuerpo se parece bas. tante a la del limax, la abertura puimonar y la del orificio se encuentran, sin embargo, en ta extremidnd posterior del cuerpo, cubiertas de un manto nuy péyueno que contiene una concha oralada con una diminuta espiral. Los informes sobre el género de vida de estos anmuales, de los que una especie, la testacella haliolidea, se cncuentra en la Francia ineridional, fueron reunidos hace tick po por Johmston. Distinguese entre las limazas la testacella, que penetro on el suelo, donde es el tertor de la lombriz de lluvia, a la cual persigue: durane su vida sufre trasformáciones correspon. dientes à sulorganizacion. Su cuerpo es mas cilindrico que el de la limaza, y en vez de un escudo del manto, limitado solo a una parte del cuello, todo el cuerpó está encerrado en una pequeña piel coriácen, jara preservarle de una presion casual y comunicarle la fuerza suficiente para escarbar. La diferencia mas marcada se encuentra, sin embargo, en los órganos digestivos. Fn la boca no hay ninguna mandibula córnea denticulada, ni tampoco una lengua granujienta y espinosa; pero entre dos labios verticales sobresale uma pequeİa irompa cilindrica, para cuyo movimiento existe un músculo que constituye la parte mas notable en su estructura;este mus. culo es grande y cilinarico, y extendiéndose a lo largo de todo el vientre, se fija en el lado izquierdo del clorso por una docena de fajas carnosas muy marcadas, sobreponiendose casi verticalmente al inúsculo principal del cuerpo. El tamano y la solider de dicho misculo demiestra su gran importancia; y su actividad es de dos clases. Cuando la kestacella divisa una presa le es preciso sorprenderla 6 atraparla de improviso; pues la lombriz, una vez en movimiento, es mucho mas rajpida ṇue su eneniga. Pero la ventaja de esta última consiste en poder alargar rapidamente la trompa, fror medio de ag̣uel músculo, y de agarrarse en un momento à su presa. Fintonces se recoge por el mismo músculo, sujetando i lia victima, á pesar de todos sus esfuerzos para librarse. Un obscrvador, Sowerby, se asombró al ver cómo la féstacella seufulum, animal que por lo regular es tin cachazudo en sus movimientos, alargó de improviso su lengua (trompa), blan. cr, surcada y retrictil, apenas divisó una lombriz, y la cogió rápidamente, aunque era mucho mas grande y al parecer mas fuerte, sujetandola de tal modo que no pudo huir à pesar de sus esfucrzos. I.a especie tipo del género tistacella es la testacela marina (fig 225). que parece sobre codo abun. dante en el mediodia de Francia.

\section{LOS AURICULÁCEOS- AURICULACEA}

Con la familia de los auriculiceos volvemos á los pulmonadas, cuzo cuerpo puede retirarse del todo a una concha espiralada; esta última es sólida y gruesa, de varios colores; tiene la última circunvolucion muy larga y una espiral pequena. El labio inferior se distingue por repliegues y prominencias en forma de dientes. El animal tiene solo dos tentaculos córneos, en cuýn basé, hácia adentro, se hallan los ojos. El scurabus imbirium (caracol de los aguaceros) debe su nombre, segun Rumph, ả la siguiente circunstancin: Estos caracoles se encuentran en la costa maritima debajo de hojas y de madera putrefacta, tanto en la playa como mas en el interior, $y$ hasta a menudo tambien en montañas tara vez visitadas por el hombre $y$ a las que tampoco es probable que los cefalóforos puedan dirigirse rápidamentc. Se cree, por lo tanto, que el viento los levinta cuando hay fuertes aguaceros en la playa volviendo á lanzarlos á la montaina. A mi, sin embargo, ne parece mas probable que en las mismas montanas se producen por la lluvia, porque se encuentran pequeños y grandes. 8

Se conocen mas de 200 especies de auriculiceos, pero solo unas pocas son propias de Europa. A estas últimas pertenecen varios de los caracoles emanos (arychium), animalitos muy pequeños, que apenas miden algunos milimctros de largo Y fijan su residencia como los auriculáceos en general en un terreno muy humedo, cubierto de musgo, hojas y madera putrefacth, sin ofrecer fenóntenos notables en su modo de vivir. El gênero mas rico en especies es el Auricula, que al mismo riempa es al mas diseminado. Agunas especies (aurioula scumbus y auricula minima) viven en sitios húmecios en la superficie del suelo; oira (auriula Juba) se encusentra en los parajes arenosos inundados por el mar: muchas (auricula myosuris, suniformis, nifius y otras) se obscrvan solo en la playa del mar en compañia de verdaderos habitantes marinos, y algrmas especies sud-americanas por fin han adoptado el género de vida de los pulmonados de agua dulce habitando cono estos los rios y lagos. Si los zoólogos sistemáticos se han fundado en esta variedad de la residencia para dividir el benero en lo que llaman sub-géneros, cargando el catálogo zoológico de nucros nombres, no han jrocedido con acierto. Dejándonios guiar por la iden de reconocer el origen de estos animales, probablemente comun, como punto de partida para la formacion de grupos (géneros, familias; ctc.), no podemos atribuir ninguna importancia à la diferente residencia, por cuanto su adopcion no influye en las particularidades anatómicas ni en las formas. Ia cxistencia de las especies de un mismo género en tierra firme, en el agua dulce 6 salada, solo prueba la poderosa faculiad de aciajuarse a cualquiera de estos elementos. P'or su locomocion muy particular se distingue el pédipes, congenérico á las auriculáceas, y que solo se encuen. tra en los paises tropicales. El pié está dividido por un surco trasversal en dos mitades desiguales. Cuando quiere avinzar se fija con la mitad posterior de su pié, adelantando la ante. rior hasta donde lo permite el surco, que cede marcadanente en esta ocasion. Entonces el animal recoge la mitad posterior hasta que toca la anterior, avanzando por lo tanto con el cuerpo la misma distancia que media entre estos dos puntos, y despues da el segundo paso del mismo modo. Este movimiento, semejante al de las sanguijuelas y de ciertas orugas, se efectúa con lal rapidez yue solo algunos molusros son 54 . periores en agilidad al pédipes. Nuy parecido és el modo de moverse de la fufa pagndula, como debemos añadir, segun Johnston. para completar las primeras noticias arriba indi. cadas sobre las pupas. Este animalito, de tres milinetros de largo, y que se ha encontrado en Francia, Suiza y Austria, es en extremo pequeño relativamente a la concha, cuja desproporcion, sin embargo, se compensa por la mayor fuera de los músculos del pié y del tallo que se encuentra entre el cuerpo y la articulacion de aq̨ucl. Cuando el animal anda, la desem. 
bocadura de la concha esti verticalmente en su dorso, mien. tras que las circunvoluciones se hallan en sentido horizontal, un poco oblicuas hácia la derecha, y a pemas à bastante altura para no tocar el suclo. Fata posicion de la croncha es bastante particular, pero mas lo es aun la actividad del pié, pues esi todu esfuerzo para ayamar, la extremidad de la cola se Jevanta un poco al aire doblándose despues contra el suelo, para dar un empuje mas poderoso al pié ó al cuerpo, nientras que solo los movimientos ondulados se propagan ripidamente desde la extremidad de la cola hácia la cabeza.

\section{LAS LIMNEÁCEAS- LIMN㞎ACEA}

CARACTERES.-Con el grupo que acabamos de citar, las limneicens ó pulmonados acuáticos tienen de comun la particularidad de que los dos tentáculos no son huecos y recogibles y que los ojos no se hallan en la punta sino en la base de los anismos en la parte anterior.

\section{LAS LIMNEAS-LIMNAUS}

CARACTERES. - Ill género qque da nornbre à todo el grupo es el de las limneas ó carncoles del limo (limuscrus ó limnea). El animal, casi siempre puntuado de amarillo, tiene los tentáculos triangulares y aplamados. Su concha es por lo regular delgada y' trasparente con-circunvoluciones inclinadas à la derecha; estas últimas se ensanchan bruscamente, y la ultima, ventruda, es casi siempre la parte mas grande cic toda la concha, formandola a veces del todo.

USOS, COSTUMBRES Y REGIMEN. - Estas conchas visen con preferencia y muy a menudo en el agua dulce con fondo cenagoso, donde liay una abundante vegetacion de plantas acuáticas de dierentes especies. Se las ve reptar ora en el suclo ora en los tallos y en las hojas; agarmdos con frecuencia tambien por debajo de la superficie y con la concha hicia abajo, nadan a flor de aguı. De esta facultad participan en comun los demás gasterópodos. «uchos de estos animales, dice Johnston, pueden subir á la superficie, donde en posicion inversa, con el cuerpo y la concha hicia abajoy con el pie dirigido hacia arriba, se sirven del aire como de un sendero, reptando en el como en tierra firme. A menudo se puede ver a los aplidios y otros moluscos desnudos cómo se pasean de este mocio en los charcos de la costa. Sin umbar. go, los pulmonados de nuestras aguas dulces $50 n$ los que tienen mas facilidad para esta singular locomocion. Fàcilmente se puede ver à las limneas y planorbis cómo en los dias de verano se pasean ó euelgan en la superficic de los pantanos y cstanques. Mientras están pendientes de este mo. do cambian de improviso su posicion; hajan rapidamente al fondo y ruclven a elerarse a la superticie, subiendo por cualquier objeto súlido. A veces, sin embargo, los he visto subir directamente por el agua, hecho que solo pucdo explicarme suponiendo que tienen la facultad de comprimir el aire cuando bajan y extenderle cuando quieren subir libremente por el agua En mi concepto esta explicacion es satisfnctoria, sobre todo porque ambien se conlirma por la actividad de la vejiga de los peces como un aparato hidrostático; mas por lo que toca al hecho de que las limneas y otros gasterópodos se mueven en la superficie que forma el limite entre el aire y el agua, no conozco ninguna explicacion que haga del todo comprensible este fenómeno. En la planta del pie se observan ligeros movimientos ondulados que sin embargo aqui no pueden tomarse en consideracion. Muy atendible es el hecho de que aquella está cubierta de pelitos, pero 110 se comprende cómo el animal pucde pararse de repente en sus movimientos. Lo mas dificil, sin embargo, es explicarsè de qué manera estos gasterópodos se adhieren a la superficic nisna. No parece sino que cl aire ejerce una atrac. cion, yo antes de bajar el animal al fondo necesital librarse de la influencia de esa arraccion. Me ha parecido que, cuardo la planta del pié sobrenada en la superficie, se poné cóncava como la palma de la mano, de manera que cl animal flota cual un barco. Como su peso especíico es escaso, basta una cavidad muy pequena para sostener el caracol en la superi. cie del agua; cuando la superficie cóncava se allana por medio de insensibles contracciones del borde de la planta, el animal se sumerge al momento. Esta sérá la explicacion mas sencilla y razonable.

I a concha de la limnea stagnalis (fig. 228), muy comun en todas las aguas estancadas, alcanza una longitud de $6^{\text {m", }}, 06$ a $U^{\leftarrow}, 0 \%$ El animal es de un gris amarillento sucio ó verde aceituna oscuro, salpicado cie puntitos amarillentos; la planta es siempre mas oscura, con el torde claro. I a diferencia de cdiad influye mucho por este concepto. liambien la forma de la concha esta sujesa a grandes variedades, de modo que algunos zoólogos se han complacidoen dar, á nada menos que seis de eptas variedades, nombres latinos particulares. Hasta la delgrada capa negra de barro, indujo à los estudiosos conquiliólogos a considerar al limneo de cierto estanque como una especie independiente. Ins mismas localidades que la especie arriba citada habitan viras varias, como el limneo de los pankssos y el limmed comus, que por la forma de la con. cira se asemeja mucho à la limna stugnalis; mientras que otra especie conocida, la limsued auricularis, difiere por su concha dilatada en forma de vejiga y por tener casi siemure depresiones dispuestas en forma de entcjado.

Todas las limneas depositan sus huevos en forma de freza compacta y vermiforme ú oval en toda clase de objetos que hallan en el agua, por lo regular en la cara inferior de las hojas flotantes de las plantas acuaticas. Desde mayo hasta agosto depositan ia memudo hasta 20 de estas frezas, de las que cada una contiene de 20 a 1 jo huevos. Tanto la puesta como el desarrollo de los embriones, nue giran por medio de pelitos, se pueden observar fáciluente en los ejemplares que se tienen en rasos.

Hemos cilado antes algunos ejemplos jor los que podian conocerse las relaciones entre la forma de la concha y el gènero de vida. Daring observa, sin embargo, que tambien en los representantes del genero limmea pueden seguirse de un modo muy interesante dichas relaciones alternativas entre el género de vida y el ancho relativo de la desembocadure El representante de una de las dos series paralelas de formas que deben distinguirse es el fimnara slagralis, y el de la otra el limbnà courisularis. Aquella pertenece mas a las aguas estancadas y cenagosas, y la segunda a las corrientes Como, sin embargo, la separacion de las aguas corrientes y estancadas no es marcada, no puede faltar en las dos diferentes series de formas aquel contraste con el género de vida: no se presentaba constintenente, sino que à menudo ambas se encontraron una al lado de otra, conservando empero su tipo de forma con pocas variaciones. Cuando se com para1, no obstante, los numerosos datos de diferentes observadores, démuéstrase en cierto modo, que una forma suelc encontrarsc mas en el agua estancada y la otra en la cor. riente, fenómeno que quizas no es demasiado cxtraño.

ligurémonos una limnea de los estanques trasladada i una corriente muy violenta: las circunvoluciones jprolonga das serín una especie de palanca de brazo largo; tl agua la arrojara de un lado à otro, y la concha ha déser el major obstáculo para la locomocion del animal, impotente contra 
la fuera de las ondos. Esta desproporcion no existe parn la concha de la limncas a suricularis que por su forma del todo desarrollada se comprime en figurn hemisférica;y he aqui porqué la limnea de las estanques no se halla nunca en las corrientes impetuosas y si la limnea auricular. Esta última sin embargo, no encwertra ningun olssticulo al trasladarse à un agua estancada, donde al contrario se encuentra con gran frecuencia, aunque casi sienıpre con una forma variada. Hace mucho tiempo que se conocian ciertas especies de limneas que muy á menudo abandonan el agun para vivir mas 6 me nos licmpo fuera derella en ticrn firme. Fsto sucede entre las limneas verduderas, sobre todo en la formn limndea clongata que en muchos sitios give constantemente en praderas pantanosas. Una especie muy rifine (limiter sibessian), manifiesta la misma inclinacion vivir fuera del agun. Con mucha me nos frecuencia sale lasimnen folustris y nunca la abandona la linncen stagmalis. Asi se demuestra tambien aqui que solo las especies que tienen 12 desembocadura de la concha rclativaunente mas pequeña pueden existir fucra del éemenio líquido. Este mismo fenómeno se observa en el subgénero qulunria, én el que solo las limures ucimuta y fimuca perigra, rams veces la limma imlgaris y la limmen brvin, pero nunca la lim. man auricularis viven fuera del agua. Mras abajo conocere. mos el cambio al otro extremo. la adaptacion a la cxclusiva respiracion en el agus

\section{LAS AMFIPEPLEAS - AMPHXPEPLEA}

CARACTERES. - Tambien la amfipeplea tiene los tentáculos triangulares, conprimidos y cortos, y los ojos situa. dos en la cara interior de la base de aquellos. Muy particular es el manto que ensuelve toda la conclia. En Europa y tambien en la América central, solo se encueustra una especie, la amfipeplea mucosa (amphipeplea glutinosa), que alcanza un centimetro de longitud. Su concha, casi esférica, es en extrerno delicaria, muy pulimentada y brillante, a con. seciéncia del continiso roce con el manto, que es de un ne gro de mármol salpirado de puntos amarillos. Cuando el animal está tranguiló on cl agua ro se ve nada de la concha, y entonces asciméjaste a una mucosidad, lo cual ba criga. ñado a mas de un conocecior que inesperndamente encoutró este raro cefalóforo. Pero aun cuando se ha reconocido el caracol como inl, es posible confundirle con las esperies del género physn, que tambien tienen la facultad de envolver ta concina con el manin y que pertenecen a los habitantes co munes de nuestras aguñs estancadas, fosos, etc. Tambien cllas tienen una concha delgada y trasparente, en la que las circunvoluciones sun muy cortas; el animal se reconocc, cximinado nuinuciosamente, pror sus largos tentáculos en forma de ierdas. Algo peor sucedio, segun Kossmaessler, al célcbre Jraparnard, quien confundió el manto mucoso del animal con una capa de excrementos.

\section{LOS PLANORBIS-PLANORBIS}

CARACTERES. - Alli donde se encuentran las limneas puede contarse con seguridad tambien con planorbis, cuya concha está arrollada en un disco plano, en el que se yen las circuuvoluciones, tanto por arriba, como por abajo; cl animal, bastanie delgado, iene en la cabera un lóbulo escotado en su parte anterior y dos tentáculos largos en forma de cerdas, que cnsanchíndose un poco en la base pueden recoger. se. El pié es bastantic corto, truncado en su parte anterior y redondeado en la posterior.

La especie tipica es el flanorbis cirmen (fig. 231).

USOS Y COSTUMBRES. - Por su area de dispersion gérero de vida, por sus movinientos y la manera de subir à la superficie del agua, los planorbis se asemejan mucho à has limneas. Agrádales por lo tanto el agua dulce estancada, con iondo cenagoso, y en la que hay muchas plantas acuáticas. sobre todo lentcjas. Pertenecen con preferencia al hemisicerio septentrional y a la zona templada. Ls fácil reconocer si éstản circunvueltos á derecha ó izquierda, porque el borde esterior de la desembocadura es un poco mas largo que el interior. Fn algunas especies la concha es aquillada, como por cjemplo, en el planorhis marginatus, muy comun, y pro. pio mas bien de las reyiones llanas que de jas montañas, y en el planorbis carinatus, que es mucho mas raro, pero muy extcndido, y vive particularmente en las aguas de corriente lenta y en los estanques y grandes fosos. La concha mas aplanada es la del planorbis iortex; en el gue forma un disco cormpleto, un poco cóncavo en su parte superior, y del todo plano en la inferior. Los huevos de todas las especies se depositan del mismo modo que los de las limneas, pero no en fremas longitudinales sino redondas y planas.

\section{LOS ANCILOS-ANCYLUS}

CARACTERES. - A nuestros pulmonados acuáticos partenecen tambien los ancilos, género cuyas pocas especies tienen una concha en forma de plato, en la cual solo se re conoce la sental de las circunvoluciones.

Una delas dos especies mas comunes vive en aguas es. tancadas, y, la otra en las corrientes, donde adherida casi siempre al la concha, en las hojas y piedras, observa un género de vidal muy monótono y perezoso. Entre los cefalófo. rostenestres y de agua dulce no hay viro con esta forma de concha, que sin ambarzo, se observa en algunas especies de Esparia, Americn, Cuba y Nueva 7clanda. Muchos zoólogos clásifucan el género anejlues entre los cefalófcrcs qu!e respiran por bringuias. A pesar de numerosas observaciones, no afir maré haber visto con seguridad debajo del lorde del manto una cavidad pulmonar, pero a decir verdad, no he ballado brannuias, y por orra parte la historia de su desarrollo habla en pro de la clasificacion entre los pulmonados. Este desar rullo es mas sencillo q̨ue el de los cefalóforos con brånquias, aunque tambien se encamina por sendas particulares. En la conchạ del cmbrion del ancylus lacustris (fig. 233), compuesta de finas partes calcireas, una curva que no se desarrolla indica las circunroluciones. Fil borde del manto sobresale al rededor del de la concha; en la cabera hay dos tentriculos, que tienen en su base los ojos y además la abertura bucal. En la mayor parte de las regiones es fácil procurarse los ancilos adultos, examinando las plantas en las aguas estancadas, $6 \mathrm{cn}$ lus rios, las piedras y las estacas de las orillas.

- Ocupindonos orra vez en la particularidad mas esencial de los jutmonados, cual es la dé respirar por inedio die pul. mones, y poder vivir las mas de las especies en tierra firme, diremos que se nota un fenómeno semejante al que hemos observado en los crustáceos adaptados a la vida terrestre y al aire liture No es dudoso que todos los animales terrestres han tenido especies acuáticas como antecesores; por eso los tipos anfibióticos de los grupos de animales mezclados de séres acuáticos y terrestres, llaman nuestra particular atención, porque los organismos especiales de los géneros anfi. bios prometen explicar el tránsito de un elemento de residencia, al otro, que lentamente se verifica. Fl ciecano de la z.oologia, Tonh Siebold, ha publicado últimamente sus interesantes observaciones, dảndonos à conocer la facultad de adaptacion de los moluscos de agua dulce pulmonados, es decir de los limneaceos, en cuya descripcion no se explica, sin embargo, segun vera el lector: la formacion de los pulmonados de los 
cefalóforos con bránquias, de que mas tarde hablaremos, si. no de una adaptacion, por decirlo asi, retrógrada de órgano pulmonar al agua

Wisité, dice Siebold, el Fercheusce, poco profundo y no muy exterso, situado cerca del Sechaus, que se distingue por su agua clara de color verde mar, y cuyo fondo esta cubierto en todas partes de grandes piedras. Sobre estas se paseaban numerosas limneas (limnan murindaris), de las cuales ni una sola intentó subir â la superficie del agua clara para recoger aire fresco en su cavidad pulmonar. Permanecia con toda intencion bastante tiempo ell este lago, mas á pesar de mi gran paciencia y atencion, y de la extremada claridad del agua, no vi que ni uno solo de estos numerosos pulmonados subiera nuuca a la superficie para respirar. Fsta permanencia constante de pulmonados debajo el agua, llamó tanto mas mi atencion, cuanto que en mis visitas anteriores a las aguas estancadas de las llanuras de Berlin, Koenigsberg y Dantzig, habia podido observar bastante is menudo, y muy distinta. mente, cómo subian y bajaban las limneas y planorbis pul. monados pam respirar. Pero las obsermaciones continuadas arirmaron al zoólogo de Munich que «en el profundo lago de Constanza, en el llano Fercheusee, en los sitios poco profundos del Kanigssee y en el agua de corriente rapida de un acueducto situado cerca de Reit, los pulmonados de los géneros limnaa y flanorlis habian olvidado, segun parece, del todo servirse de sus pulmones como de tales, no cm. p!eándolos para respirar aire.

Lstas observaciones de Siebold, interesantes ya de por si en cuanto al género de vida de nuestros pulmonados acuá. ticos, y con las que cnlaza sus instructivas consideraciones sobre la facultad de adaptarse, en el sentido de la teoria de la trasformacion, adquieren un caricter del todo diferente, segun las averiguaciones hechas con buenos resuliados por Simroth en el verano de I\$74, en Estrasburgo. Debo á ha pluma del jóren naturalista la siguiente descripcion, que se. guramente agradara á todos los amigos del mundo vivo, no solamente á los que quieren adquirir conocimientos, sino tambien á los que desean explicarse lo que pasa a nuestro rededor.

Entre nuestros pulinonados, los que han fijado su residencia en el agua dulce se distingmen en parte por una extraña trasformacion de sus órganos respiratorios; pero todos demuestran por la estructura de su cuerpo y por la forma del desarrollo, una afinidad muy aníloga á la de los representantes mas notables de los prosobranq̧uiados quue con ellos comparten el elemento vital, es decir, el cefalóforo de los pantanos (palu. dina). La facultad de servirse en sus viajes por la profundidad, a pesar de la tentitud de sus movimientos, de la respiracion por medio de pulmones, débenla al aire encerrado en I. cavidad pulmonar, que disminuye de tal modo su peso especifico, que solo por esta circunstancia, sin recurrir á la locomocion por medio del pić, se elevan á la superficie. Al llegar aqui se forma con los bordes de la abertura respiratoria, hasta entonces herméticamente cerrada, un embudo abierto que se nivela en la misma linea con la superficie del agua, dando entrada en la cavidad pulmonar al aire, pero nunci al agua. Para que sen posible abrir con tanta exactitud cl orifi. cio respiratorio, y a fin de que el caracol reconozca la distancia del mismo y de la superficie liquida, existe, al jarecer, un órgano especial descubierto por I.acazc-Duthiers. Un pequeiro ganglio envuelve un canal membranoso corto y con pestañas, que se halla precisamente en el ángulo del manto, delante del orificio respiratorio.

Si de este modo se han cumplido las condiciones que permiten la respiracion pulmonar de animales tan lentos en el agua como estos caracoles, en los planorbis se reunen mas condiciones para facilitar y perfeccionar la vida acuática; el orificio respiratorio, en forma de embudo, corresponde aqui solo á la mitad anterior de toda la abertura de la cavidad pulmonar. La mitad posterior forma una para si, y ambas están separadas por una prominencia que divide en dos el fondo de la cavidad respiratoria en tocia su longitud, y, por lo tanto, tambier la abertura. Encierra principalmente cl in. testino. Paralelamente à esta prominencia, cóncava en su parte superior y en forma de surco, se corre un ensancha. miento de la cavidad respiratoria que se adapta a los espacios, dividiendo aquella en dos partes, una anterior con la entrada en forma de embudo, el espacio pulmonar, y otra posterior, el espacio branquial. En este último se ve ademíts un marcado repliegue longitudinal en el borde supcrior y posterior, repliegue que debemos considerar como compuesto de hojitas, para deducir de el las bránquias de la paludina. En la entrada del espacio branquuial, en la parte anterior del mismo, hay un apéndice principal que, saliendo de la prominencia divisoria, es por lo regular pequeño ye de poca importancia, pero puede extenderse, i causa de sus numerosos msos, por una corriente de sangre, hasta una gran formacion parecida á una cuchara Entonces se dirige con su lado cóncavo hácia atrís, y no solo sirve de superficie respiratoria, sino que conduce tambien el agua al espacio brançuial. De este modo el caracol tiene una verdadera respiracion doble, de la que se sirve por lo regular del modo siguiente: cuando se encuentra en la superficie, abre su orificio pulmonar $y$ deja entrar aire en los pulmones; y si quicre bajar al agla, cierra la citada abertura, en cuyo caso parte del aire se esca. pa, produciendo un silbido análogro al que emite el género limmer. Iandois ha considerado últimamente este sonido como voz de caracol. Entonces la masa principal de la sangre es empuiada al espacio branquial, pues el apéndice membranoso se dilata j comicnza la respiracion acuática.

Cuando el caracol vuelve a la superficic y respira el aire, se ve cómo el apúndice se baja y comprime, deduciéndose de esto que la sangre llena principalmente los vasos de la cubicrta pulmonar.

Esta notable estructura justifica orra suposicion respecto á la afinidad del planorbis $y$ de la paludira. No solamente existen las relaciones ya indicadas entre el reborde branquial de aquel y la bránquia de esta, sino que tambien aquel apéndice vuelve a encontrarse en la paludina, aunque no puede dilatarse ni prolongarse, sirviendo solo para la conduccion del agua. Tambien se encuentra una division que corresponde al espacio pulmonar, con la sola diferencia de que su abertura no forma ya un cstrecho embudo, sino que se ensancha en una larga hendidura, con lo cual el espacio pierde su facultad de respirar el aire.

Deberiamos deducir de esta descripcion que los pareceres liasta ahora admitidos sotire las condiciones del origen de cufaloforos en cuestion, serian crróneos. No obstante, parece conveniente acepiar por lo pronto los datos de Simroth, quien dice que tanto el género de vida como la afinidad de nuestros gasterópodos les hacen aparecer bajo un punto de vista del todo nuevo.

Con lo dicho hasta aqui no hemos podido tomar en consj. deracion sino un reducido número de familias ó de géneros de los paludinos, pero añadiremos á las particularicades referidas algunas consideraciones generales concernientes en parte, no soiamente à los carncoles, sino á todo cl reino animal, induciéndonos â cllo particularmente este grupode los moluscos. No tomando en cuenta algunos anélidos, por ejemplo las lombrices de lluria, apenas hay otm division del reino animal mejor desarrollada, cujos tipos dependan tan directamente de la localidad, encontrándose al mismo tiempo en 
tan extraordinaria variedad de especies y de tormas, como los pulmonados. A causa de los pocos medios auxiliares de que disponen para moverse, son los que menos podrian inclinarse á ensanchar suárea de dispersion; y por tanto puede esperarse que las leyes en que su distribucion geográfica se basa, sean mas sencillas $y$ se definan mas claramente çue en los animales que con una organizacion de semejante desarrollo disponen de medios mucho mas numerosos para cambiar de residencia. Tenemos los datos referentes a este punto recogidos con inteligencia y completados por Keferstein, aunque en la explicacion de los hechos vemos las cosas. bajo el punto de vista opuesto.

Ya hicimos mencion de la infuencia del clima y del suelo al hablat del area de dispersion de los pulwonados. Henios hecho ver que un terreno calcáreo es para ellos en -extremo favorable; pero se nota menos esta influencia en las especies del helix y del limax, que cu las del clavisilin y del fripa, segun lo demuestra la abundancia de clausilias en Dalmacia. Que el calor, ese poderoso auxiliar de la vida, limita el área de dispersion en las alturas de las montañas y hácia los polos, es un hecho confirmado naturalmente tambien por la disminucion de los pulmonados en dichas regiones, segun puede notarse especialmente en los pulmonados terrestres; pero esta es una ley que se consiciera demasindo en general. Sumamente curioso es el hicho de que precisamente en las islas encontramos la mayor patte de los pulmonados, hallándose en el grupo de Madera $13+$ especies, en Cuba 300 , en Jamaica 250 , el mismo número en las islas de Sandwich y mas de $35^{\circ} \mathrm{en}$ las islas Filipinas. De la comparacion de estas es. pecies con las de los continentes vecinos, resulta que las comunes figuran en muy reducido wúmero, ó faltan por completn, ó las hay que por su extensa área de dispersion merecen el nombre de cosmopolitas, siendo por lo tanto el niar un límite casi absoluto jara el sistema actual de la dis. cribucion geogratica de los pulmonados, y sobre todo para su aislamiento en islas y archipielagos. Las altas cordilleras lan producido, segun notamos, una division parecida. Ast, por ejemplo, en la America del norte se han enconimdo al oriente de las Momtafias Pedregosas 309 especies; en el occidente 94, do las que solo diez son comunes á ambos territorios; y casi exactamente lo mismo sucede en los territorios de la América del sur separados por los Andes.

L.os grandes géneros ricos en especies, como el helix bulimus y otros, estan diseminados casi por todo el globo; los pequeños, compuestos de una especie, ú de muy pocas, y los que no hemos citacio, se encuentran distribuidos casi por igual en las islas y en los continentes; y por lo tanto vemos en este hecho una gran supremacia de las primeras respecto el área de dispersion; pero tambien algunos géneros notables la tienen solo insular, como por ejemplo las doscientas sietc especies del género acliatizcl!a, perteneciente â los helícidos que viven exclusivamente en las islas de Sandwich. "Se observa por lo tanto cada vez mas, dice Keferstein, cómo las islas, en todias las proporciones de las faunas de pulmonados, se igualan con los grandes territorios que comprenden las faumas continentales, siendo por consiguiente las islas muy preferidas a los continentes en propor. cion a su cxtension territorial, y l.ns cefalóforos terrestres son los mas sujétos al aishamiento, mientras que los limneaceos se diseminan con mas frecucncia por varios territorios. Con su acostumbrada sagacidad, continúa Keferstein, Dar. win explicó esta singular área de dispersion de los pulmona. dus y otros habitantes de agua dulce. Mientras que los pulmonados de agua dulce, à causa de sus residencias limitadas invariablemente, por odas partes, tienen á primera vista muchas menos probabilidades de ensamchar su área de dis. persion que los pulmonados terrestres, Darwin demuestra que su freza, fijada en plantas, puede ser llevada fácilmente a mucha distancia por las aves acuíticas, jo que por este mismo medio liasta la cria se irasportaria a grandes distancias. Darwin vió como un pato elerándose del agua llevaba en el pié lentejas acuáticas, y como unos carncolitos recien nacidos se fijaban en gran número en la misma parte de dicha ave, que rolaba sobre el agua. lyjell, el célebre geólogo inglés, observó además en un dytisiuss agarndo cl anij/rus, que de consiguiente pudo trasladarse por medio del coleóptero descic unas aguas a otras, y Darwin demostró además con experimentos que los pulmonados que se aletargan y' están cerrados por la tapa pueden soportar muchos dins el trasporte en agua marina. Todas estas condiciones obran exclusiramente, $\delta$ cuando menos con preférencia, en favor de la diseminacion de los habitantes de agua dulce, y no pode. mos admirarnos de encontrarlos esparcidos generaimente por territorios mas grandes $y$ hasta independientes.

Keferstein, explicando por estas y otras circunstancias el arrea de dispersion, á menudo tan extensa, de los animales en general y de los pulmonados en particular, deduce la úl. tima racon de la existencia de las especies aisladas de la hipótesis de los centros de la creacion. Segun esta hipótesis, que entre los naturalistas modernos, cuando menos los de Alemania; no cuenta numerosos partidarios, cada especie, tal coino es, fué creada con todos sus caracteres bajo cicrtas condiciones expansivas; mas por lo general dentro de limites constantes, una sola vez y en sitio determinado. Esta hipótesis se aparta de la idea, clara y comprensible, y que debe considerarse brjo el punto de vista científico; que demuestra cl modoide haterse efectuado esa creacion, suponiéndose ndemás por ella que cada especie conquistó en el trascurso de los siglos desde el primitiro punto originario, y en todas direcciones, su area de dispersion. Con clla se va mas adelasite que el venerable Linneo, quien se figuraba que toda la superficie del globo estaba cubierta en las épocas mas remo. tas por un inmenso océano, excepto una sola isla, en la que habia lugar suficiente para todos los animales, y en donde las plantas prosperaban. Una alta montaña, elevándose hasta la region de las nieves, como por ejemplo el Ararat, habria sido suficiente, con sus zonas sobrepuestas, para satisfacer las diversas necesidades climatológicas de los séres vivientes. Desde aqui, las plantas fueron dispersadas en todas direcciones por los vientos y los animales emigrantes; mientras que ei lento descenso de las aguas dejaba poco á poco descubierto el continente. Suponiendo la creacion parcial en los mas diversos puntos de la superficie dal globo, se refuta algun tanto lo imposible de ian pueril idea de Linneo; no obstanic, es mas cómodo aun figurarse, con Agassiz, la im. comprensible fuerza creadora de cada especic aislada, tan extendica, que puede formar en muchos puntos igualmente farorables, otros individuos de la misma especie. Con esto se pone término á todas las divagaciones, siendo inútil la [rucba referente i los paises y aguns ahora separados que albergan especies iguales, prueba en que se han hecho al parecer progresos sorprendentes desde algunos años; no nece. sita por lo tanto ninguna cxplicacion, bastancio solo la fe.

Por lo que hace a nuestros pulmonados, la hipótesis de los centros de la creacion supone, por cjemplo, que si de las 134 especies del archipićlago de Madera solo 2 I se encuentran cn Europa, las 113 restantes se han creado tales como son propiamente en aquel punto, con todos los carac. teres que actualmente presentan.

A nuestro modo de ver, la hipótesis de la crencion de las especies actuales no satisface por ningun concepto, porque la explicacion que da es incomprensible, y por lo tanto nada 
cientifica. Damos major importancia, como se la dan los conquiliólogos, sobre iodo Rossmaessler lace ya mas de treinta años, a los fenómenos de aclimatacion y adajtacion. Y cuando los cefalóforos de las Canarias y de la isla de Madera difieren tanto de los de los continentes africano y europeo, esto no es sino una prueba de diferentes actos de una creacion $y$ tumbien del hecho de que la parte norte-occidental del Africa estaba separnda de las islas Canarias y del archipiélago de Madera mucho antes de que comenzara la trasformacion de especies anteriores comunes en la fauna actual de caracoles. Tampoco nos cabe duda, aunque sin considerarlo como articulo de fe, sino iundaindonos en los fenómenos de la historia del desarrollo y de la formacion de las variedades, que han cxistido dichas formas primitivas. El área de dispersion de los pulmonados actuales, partiendo del supuesto de la estabilidad de los archipiélagos y de los continentes, es de todo punto inexplicable, como lo com. prendera fácilmente todo naturalista. Los partidarios de la doctrina de Agassiz admiten tantos actos de creacion cuantos sc descan, y si el helix ponatio se encuentra mas aca y mas alla del Camal, no se necesita la prueba, hace tiempo demostrada, de la union de la Gran Bretaña con el conti. nenie en épocas remotas, sino conocer las circunstancias que anui dieron origen a la primera aparicion del animal, y que alli habrín producido tambien sus efectos.

El arrea de dispersion del reino animal de hoy dia adquiere un aspecto del todo diferente cuando tomamos en consideracion las últimas trasformaciones zoológicas de la superficie del globo. Asi se ha hecho en los últimos tiempos con excelentes resultados, aunque por lo jronto sc reduzcan estos principalnente i demostrar que el sistcma antiguo de enumerar las áreas de dispersion como parte esencial de la geografia animal, juntamente con las hipótesis de la creacion, se considera como del todo insuficiente. Por esto se hacen esfuerzos para averiguar las razones efectivas de esta área de dispersion, deduciendo por medio de la geologia la forma anterior de la superficic de la tierra, y explicando por la misma y por las trasformaciones y separaciones efectuadas mas tarde, la distribucion geogrảica actual.

Para dar una idea de cómo la investigacion y descripcio. nes de los cefalóforos y de sus conchas, al parecer infecundas de por si, conducen por el contrario a las mas interesantes deducciones geológicas, estudiaremos lo observado por Bourguignat en la distribucion geográfica de los cefalóforos terrestres y fuviales en Argelia y en las regiones vecinas. El lector no llevara $\mathrm{i}$ mal que en algunos puntos dejemos de ocuparnos de la verdadera vida de los animales para, buscar en nuestra descripcion las consecuencias que esa vida tiene para otras ramas de la ciencia. El autor francés habla de los moluscos terrestres y de agua dulce en general, es decir se ocupa tambien de las conchas, pero la importancia de las especies no pertenecientes álos pulmonados es insignificante en lo que se refiere a las cuestiones que aun estin jor resolver.

Lo que en la distribucion actual de estos animales rige para la Argelia puede hacerse extensivo asimismo á Marruecos y Túncz. Pasando revista al gran conjunto de la fauna argelina de moluscos, y considerando las residencias res. pectivas de estos animales, se ccha de ver que alli donde en el centro de la regencia de Argelia se extiende la region du las mesetas, hállanse series enteras de moluscos de cuncha pesacla y gruesa y de una desembocadura de forma particular: que a ambos lados de dicho centro y paralelamente $\{$ las mesetas se extienden dos zonas de moluscos de concha nudosa o trasparente tambien de formas caracteristicas; y por último, que no solo es ia costa del Mediterráneo, sino tam- bien los linderos del gran desierto, al sur de la segunda cordillera del Atlas, donde se encuentra todavia una serie de cefalóforos costeros, las mismas especies cuyas conchas pueden recogerse tambien en las orillas de los lagos salados que hubo en la meseta, y que por lo tanto vivian alli cuando aquellos estaban aun llenos de agua. El desierto mismo se caracteriza por la carencia casi compleia de la vida actual y pasada. Al cruzar aquellas regiones se pasia por lo tanto desde el Mediterráneo por una zona de la fauna costera. despues por una de montanas y otra de mesetas, y al bajar hácia el desierto hällase de nuevo la \%ona montañosa hasta licgar à la ribereña. Segun antes hemos dicho, los mas de los gasterópodos de las mesetas se distinguen por sus conchas gruesas y fuertes, por su espeso borde bucal y por algunas prominencias ó dientes enl la desembocadum. Extrano es que los cefaloforos fósiles que en las mismas localidades vivian ya en el período terciario, tengan los mismos rasgos caracteristicos. Resulta de aqui que las mismas condiciones que han conunicado a los cefalóforos actuales de las mesetas de Argelia su tipo paricular, influjeron ya en ąquel período paleozóico y se han conservacio sin alteracion.

A ambos lados de las mesetas se encuentran pues dos extensas zonas con otra fauna de cefalótoros, llamada por Bourguignat forma montañesa, porque corresponde exacta. mente a las series de montañas y valles, que desde Marruecos se prolongan hácia Túnez, casi paralclamente \& las mesetas. A la extension y naturaleza de estos paises monta. nosos se debe que su fauna animal sea la mas rica: y muy superior á la de moluscos de las otras zonas. Como en los valles y las alturas, los bosques y las praderas, el terreno calizo alterna con el granitico, prodúcese una gran variedad entre estos caracoles, sobre todo en los que habitan los valles, que contrastan con las especies de las alturas; pero como los tipos naturales se repiten en ambos lados, hállanse tambien en las dos zonas paralelas las mismas esjuccies caracteristicas, en particular los lielix y el sonites carmiroro. Las es. pecies que viven en los valles 6 al pié de las montañas, son por lo regular de aspecto calcáreo, y de conchablanca mas ó menos rayada, ó bien frágil y á menudo aspera; las de las alturas y de los bosques son casi siempre de mediano tamaño y tienen uma concla delgada y trasparente, á veces aquillada, cuya desembocadura sin reborde particular suelc ofrecer poco desarrollo.

En cuanto al tercer grupo, el naturalista francés llama la atencion sobre el leecho de que á to largo de la costa de to. do el Mediterráneo encontró ciertos cefalóforos casi exclusivamente pulmonares que segun parece no pertenecen ninguna fauma ni pais en particular. Solo se les encuenira i lo largo de las costas y rocas, exclusivamente en las regiones donde prevalece la infuencia del mar, 6 tambien en las que antes han sido orillas del mar. Cuando cxcepcionalmente sc les encuentra mas en el interior, de seguro han seguido un malle ó alguna corricute de agua en las que el mar cjerce aun su influencia: su áreal de dispersion tiene sus limites alli donde esta influencia cesa. Como Bourguignat es partidario de la hipótesis de los centros de creacion, distingue de las especies cosmopolitas, es decir de las que se han di. seminado por toda la costa del Mediterráneo, las que no traspasan el territorio de su creacion, como por cjempllo el helir Inctea. Este cefalóforo, caracteristico del gran centro espanol, se encuentra en casi tocia ia periferia de este llaniado centro de creacion desde Túnez, Argelia y Mar. ruecos hasta los Pirineos Orientales. En la Argelia, estas dos especies de cefalóforos costeros vivian no solo en toda la costa del Mediterráneo, sino tambien en el limite septentrional del Sahara, al pie de la segunda cordillera del Atlas, y 
hasta en los bordes de las mesetas. Este hecho zoologico innegable demuestra que alli donde se encuentra una serie de estas especies costeras debe haber existido antes una playa maritima Aunque otros hechos indican tambien la union antigura de España con el norte de África, ninguna otra cir. cunstancia lo prueba tan evidentemente como el àrea de dispersion ya citada de los pulmonados; i lo inenos para los maturalistas que prescinden de la creacion repetida de una misma especie en diferentes puntos.

Al principio de la época actual de nuestro continente, cuando las especies modernas acababan de ser creadas segun las opiniones de Bourguignat y de Keferstein, 6 en nuestra oppinion se liabian desarrollado ya en su aspecto actual, el norte del Africa era una pieninsula perteneciente $\{$ España; no existia el estrecho de Gibraltar, y cl Mediteráneo se comunicaba con el Occenn jor el gran desierto, que era entonces un dilatado mar. En aquella época tanbien las mesetas de Argclia estaban ocupadas por grandes lağos de agua salada que poco á poco se han désecado y adquirido su aspecto actual. Du ranté cl lento desecaniento efectuóse tambicn la aclimatacion de aquellos caracoles costeros; pero es muy extraño que ustos umportantes cambios de la residencia no causaran con sidembles trasformaciones en la estructura interna de las res pectivas especies; mientras que en inuchos ccílóforos terrestres encontramos muy singulares formaciones y variedades segun las diferentes residencias. Con todo, no debemos perder de vista que al comparar la faum esparibla de moluscos con la de Argelia se observa una analogía casi completa, circunstancia a que se debe que la fauna animal argelina aparezca como un sencillo apéndice de la española, y Espana como el centro de creacion cuyos radiós se extendian en épocas remotas sobre la peninsula de Angelia; y que muchas es. pecies cspañolas estén representadas en Argelia solo por otras llamadas andilogas. Si con cste término no sc expresa ninguna otra idea sino la de Bourguignat, es decir, la de que ciertas especies españolas no sc encuentran en Arge lia, pero que están representadas por formas muy alfines, esto es decir muy poco, pues no se hace mas que circunscribir una condicion efectiva. El hecho se explica sin embargo, si con los partidarios de la doctrina de la meta. morfósis, podemos suponer que una de las dos formas analogas es una ramificacion efectiva producida por las condi. ciones del clima y de la adaptacion, ó que ambas sacan su origen directamente de una tercera forma. La ciencia no puede aun ni con mucho probar este orígen en todos los casos; pero cuando el espíritu de invéstigacion se dẹa dominar por este pensaniento y espcra reemplazar con lo comprensible lo que parece milagro, la ciencia misma se ensalza, $y$ el interés por sus resultados acrece cada vez mas en el gran circulo de sus amigos. Por lo demás creo que tambien Bourguignat quiere dar à la cuestion poco mas $\delta$ menos el mis. mo sentido, porque en otro pasaje reconoce que un cefaló. foro que descle el punto montañoso de su salida baja a la llanura, puede estar sujeto en el trascurso de los siglos da ta. les influencias modificadoras, que las innovaciones que en él se notan se fijan poco il poco, acabando por formar lo que efectivmente se llama una especie nueva. Fsta idea eleva. da sobre la vida animal tiene tal importancia para nosotros, por las controversias de la zoologia, que crecmos se nos dispensarion las digresiones sobre nuestro tema especial.

Sin seguir el área de dispersion de los pulmonados por toda la superficie del globo, diremos a conocer, cuando me. nos, sirviéndonos de las noticias de Keferstein, el caracter de la gran zona curopeo-asiática que mas nos interesa «Es el inayor centro que habitan los pulmonados, dice cl citado na. turalista, pues comprende toda la Europa, el Africa mas al norte del Atlas, el norte de Egipto, el Asia Menor, la Siria, Persia, el Asia septentrional, el Himalaya y las montañas que se extienden hasta el centro de la China; de modo que ocupa todo el antiguo continente septentrional casi hasta los $30^{\circ}$ de latitud norte. No hallando ningum obstacculo, la forma tipicamente uniforme del pulmonado se ha extendido por este territorio, y como el Ural no constituye límite natural para casi ningun órden de animales, tampoco los Alpes, los Balka. nes y el Cáucaso pudieron oponer una resistencia escncial a la propagacion de los pulmonados. Además de las islas del Mediterraneo, corresponden á esta provincia la Gran Bretaña Y la Irlanda, que en un remoto periodo de nuestra creacion actual estaban unidas al continente, $y$ además la Islandia, al paso que la Groenlandia pertenece mas bien a la América; e] lapon, por lo que hasta ahora puede juzgarse, deberia formar una provincia independiente. Nuestra airea de pulmonados se extiende por lo tanto descle el clima cálido de la Argelia jor los paises templados, hasta las regiones mas frias del norte de Siberia y de la Laponia, y claro es que las grandes diferencias en el clima deben producir otra muy grande en la abundancia de la fauna de pulmonados. Aunque encontremos en los paises del Mediterráneo unas Soo especies de estos animales, en Alemania 200, en Noruega 50, en Iaponia 16, y en el extremo norte de la Siberia nadia mas que 5, al examinar mas minuciosaniente las faunas de pulmonados de aque. llos paises remos que son restos degenerados de las de los cálidos/y que no pueden tener una posicion independiente, asi como tampoco la tienen las faunas del Bático, escaso de sal, en proporcion a las del miar del Norte. Los pulmonados de Alemania se encuentran tambien casi todos en Italia; los de Noruega y de Laponia en Alemania y por lo tanto observamos, solo en el sur nuevas especiés; mientras que las septentrionales tambien se conservan aqui. En el norte, en cambio solo se ven las que ia conocemos en el sur, sin que haya otras especificamente septentrionales.

4.s natural, dice el autor en otro pasaje, que en los diferentes purtos de esta extensa provincia se encuentren gran. des diferencias en la riqueza de la fauna y en menor grado también en la composicion de la misma, pero esencialmente observamos una asombrosa analogía y vos causa admiracion encontrar entre los pulmonados del territorio del Amur tres cuartas partes, y entre los del Tibet la mitad de las especies diseminadas en Europa. $*$

De las comparaciones complementarias minuciosas, y por lo tanto muy precisas de Bourguignat, resulta además que para la Europa la cordillera de los Alpes ha sido el punto de salida de la propagacion. No podemos creer, conio po. driamos deducir de las palabras de Keferstein, que todos los pulmonados europeos se formaron como especies separadas en el sur de los $A$ lpes, emprendiendo despues su riaje hàcia el otro lado de los mismos, sino que la emigracion turo su origen en los Alpes; tampocónos fijamos en la extension primitiva sobre el territorio alpestre mismo. En todo caso, à la naturaleza climatérica y geológica de las llanuras del centro de Europa jy de los paises norte-europeos se debe que el numero de las especies que haicia ellos emignron quedara reducido y no se aumentara por la aclimatacion, micntras que las pendientes meridionales tan surcadas de los Alpes y los paisces del sur ofrecieran en el mas alto grado las condiciones necesarias para la trasformacion y la multiplicacion de las especies. Si á pesar de esto, los pulmonados de la Europa meridional no han alcanzado la relativa variedad de los que soa propios de los archipiélagos del Africa occidental, esto puede cxplicarse por razones cientificas sin que haya necesidad de cortar el nudo gordiano con las hipótesis sobre la creacion. Indiquemos tan solo que por la reducida concur. 
rencia de otras clases de animales, los cefalóforos de la isla de Madera', los limneáceos y varios mas, apenas tenian que luchar por la existencia, mientras que la fauna animal euro. pea debia ganar su terreno paso d́ paso, quedando los pul. monados reducidos á un papel pasiro.

\section{LOS NEUROBRANQUIOS -NEUROBRANCHIA}

CÅRACTERES. - Algunas familias se parecen à los pul. monados por su respiracion aérea y por la estructura de su órgano respiratorio, pero por sus formas y por la separacion de los sexos se asemejan ya al órden siguiente. Se les llama neurobranquios porque, segun ya hemos dicho, respiran aire atmosferico por medio de una red de vasos. Todos tienen una concha "con circunvoluciones, que puede cerrarse por medio de una tapa. Su boca se prolonga a menudo en un largn hocico y la cabera esti provista de tentáculos.

USOS Y COSTUMBRES. - 'odas las especies viven en tierra firme, sobre todo en las regiones tropicales húmedias.

\section{LOS CICLOSTOMIDOS -CYCLOSTOMIDA}

CaRACTERES. - Las especies mas numerosas son las del grupo de los ciclostomidos que se distinguen de los otros ncurobranquiados por la estructura particular de la tapa. Del género principal, grolostoma, se han descrito mas de mil quinientas especies, pero de ellas encuéntranse muy pocas en Francia, en Suiza y en la parte meridional del centro de Alemania.

\section{EL CICLOSTOMA ELEGANTE-CYCLOSTOMA ELEGANS}

CARACTERES. - Fl mas comun entre estos cefalóforos, bastante raros, es el gracioso ciclostoma elegante, qৃue debe su sobrenombre a la cualidad general de todos sus compañeros del género de tener una concha de bonita forma que en esta especic esta cruzada por lineas en forma de espiral, muy regulares, y por fajas trasversales cortadas. Rossmaess ler ha hecho una minuciosa descripcion de las particulari dades de esta especie maravillosa, segun la llama. [II animal, dice, es en extremo timido, $y$ al inas leve contrcto se situn rapidamente al fondo de la concha, cerrándola con la tapa muy sólida y dura Los tentáculos solo son contráctiles y no retráctiles, pues al recogerse no desaparece primero la punta, sino la base y cuando estan del todo recogidos ln punta obtusa se halla en la frente junto al ojo. Lins arrugas angulosas de las antenas facilitan mucho la contraccion de los tentriculos. Ios ojos se hallan en la extrema base de los tentículos, no son muy perqueños y de un negro brillante.

"Cuando el animal avanza sobre un cristal húmedo absor. be la humedad y recoge tambien al parecer mucho aire, pues el liquido absorbido con la boca se divide á manera de remolino en numerosas burbujitas. Loda la cabeza ó trompa está provista en su parte superior de arrugas angulares marcoudas, irregulares, y en la parte inferior al rededor de la depresion de la boca provista de arrugas reticulares.

\$Mchos pretenden que la locomocion de este notable animal se efectia fijando alternatiramente la trompa y la planta del pié, pero no es así. Durante la marcha, pues tal puede Hamarse su movimiento, la trompa esti en actividad, aunqque solo subordinada. Iass dos prominencias en forma de morcillas en que la planta del pié esta dividida por un profundo surco longitudinal, funcionan efectivamente como dos piés, segun podenjos reconocer muy bien cuando el animal se mueve en la superficie del cristal; si permanece quieto, ambas prominencias estan oprinidas contra el cristal, y el surco divisorio se nota solo como línea longitudinal; pero cuando quiere avanzar se levanta poco i poco una prominencia del cristal, adelauta una linea de distancia y se oprime contra la superficie, repitiendo despues lo propio con la otra prominencia. Este movimiento se verifica, sin embargo, con bastante ligereza y el animal es superior en rapidez. i los helicidos. La trompa contribuye tambien is la locomocion, facilitando la marcha; mas no parece ser esencial para ella. Al cerrar la concha con la tapa, que en la locomocion se posa sobréla parte posterior del pié: el animal procede como otros cefalóforos de estructura anäloga, es decir, dobla la planta trastersalmente de modo que sus dos mitades se oprimen una contra otra y se retira cerrando la concha herméticamente.

* Respecto as su viracidad he observado en mis cautivos lo contrario de los helicidos, pues todos mis ciclostomas son vivaces de dia, mientras que de noche descansan en su concha bien cerrada.y

De los géneros afines solo haremos mencion del fomatios, propio de la Furopa del sur, que tiene la concha en forma de tóras y surcada. De la familia de los helicinidos, citaremos el género helirina, muy rico en especies; Europa no pasee ninguna forma, pero si una tercera familia, la de los aciculidos, con cuatro especies del género acne. Estas tienen una pequeña concha de forma casi cilindrica, con tapa delgada y trasparente. Fl animal está provisto de dos tentículos delga. dos cilindricos, hallándose los ojos en la base de la parte posterior. Son pequeños caracolitos muy graciosos, de algunos milimetros de alto, que viven debajo de la hojarasca y del musgo, con preferencia en las raices de arbustos.

Tambien el género amphullaria (fig. 229 y 230) es un tipo de trånsito entre los pulmonados y el órden siguiente; pero se inclina mas hácia el túlimo, porque sus especies tienen pul. mones y branquias a la vez, pudiendo respirar por lo tanto, altemativamente en el aire y en el agua. De mas de 50 especies conocidas solo sabemos que viven en las aguas dulces de las regiones cólidas de America, Africa y las Indias Orientales, y que durante la estacion calurosa deben esperar la estacion lluviosa en el cieno seco. Algunos individuos que el cono. cido naturalista francés D'Orbigny encerró en Buenos Aires en cajas, vivieron hasta trece meses. En el fondo de la cavidad branguial, que se abre hicia afuera por el lado derecho, hay una serie de hojas branquiales, y en la tapa de la citada caridad se ve una gran abertura que conduce a otra cavidad de la misma extension que la inferior; pudiendo cermarse y servir de pulmon.

\section{LAS FISAS-PHYSA}

CARACTERES. - Las fisas tienen la concha oval oblon. ga ó globulosa, con frecuencia muy delgada, frágil y lisa; la abertura es longitudinal y se estrecha superiomente; el borde recto y cortante, con la última vuelta de espira mayor que las otms reunidas. Aunque la mayor parte de las especies se caracterizai por su manto franjeado con largos apéndices filamentosos, no sucede asi en la fisa hipnorum (fig. 232), que tiene los bordes de aquel completamente lisos, siendo muy aplanado: los tentáculos se distinguen por lo largos y delgados; la concha es muy tenue, y su abertura redondenda. Este molusco existe en una gran parte del globo: en general las fisas viven en las aguas dulces estancadas $y$ corrientes. 


\section{SEGUNDO ORDEN}

\section{PROSOBRANQUIOS -PROSOBRANCHIA}

CONSIDERACIONES GENERALES. - Constituren esta nueva division, casi todos los cefalóforos marinos provistos de una concha de estructura unas sóliảa, y que, atendicasu enorme area de dispersion, sualimento y genero de viday su utilidad, présenta una variedad correspondiente'a su número. La antigliedad solo se comó interés por ellos, impulsada por el lujo ó por la golosina, si ya no por las absurdas fábulas relativas á una tó otra especie. Durante el trascurso de la Edad Media sucedió, poco mas ó menos, lo mismo. Solo cuando se hubo abicrto à través del mas el camino de las In. dias, of a las islas en que abundan estas especies, y cuando algunos amigos de la naturaleza, tales como médicos y empleados, distraian útilmente jangos años amargados por la nostalgia en aquella nueva y espléndida naturaleza, hubo quiten se ocupó con preferencia de las conchas de moluscos; las colecciones se llenaron y pudieron darse abundantes de. talles acerca de las conchas, preciosas descripciones sobre el género de su viưa y utilidad de los aninales que las llevaban, descripciones y detalles que pasaron a ser propiedad del mundo cientílico. No obstante, los aficionados à los moluscos en Europa, y sobre todo en Holanda, solo se fijaban en el brillo y los colores de la concha, yumph se queja en su "Gabinete de curiosidades de Amboina, de que sus compatriotas creyesen que aquellas se encontraban ya tan briIlantes y bellas en la playa como en el mar. En 28 años de penosos trabajos solo habia recogido 360 especies de los contornos de Auboina. El buscarlas en la costa pedregosa es tan enojoso, dice, $y$ ofrece tantos inconvenientes, como cl hacerlo en la playa arenosa, pues por lo que toca a esta última. continuamente se ha de tenrer al caiman, y guardarse tambien de los charcos pantanosos; a fin de no pisar las agudas espinas de los manzanos marinos, 6 el pez venenoso llamado Jean Sarangi. En la costa pedregosa no hay que temer al caiman, peroen cambio los piés se lastiman con los coralesy crizos marinos. Fstos y otros peligros, asi como los trabajos que ocasiona la limpieza y pulimento de las conchas, no deja de hacerlos presentes a sus colegas fque seguramente viven con toda comodidad en Holanda. Desprénclese de lo dicho que la conquiliologino ciencia de las conchas de caracol, se cultivó desde el último tercio del siglo xvir por numérosos aficionados à la naturaleza, ajcanzando cierto desarrollo, á causa de las condiciones que estos animales reunen, mucho antes que la entomologia, si por ambas comprendemos, mas el conociiniento de las especies que la anatomia: pues tenemos ya cn el siglo xvir excelentes trabajos solbre la anatomin de los insectos.

El verdadero conocimiento científico no comenzó, sin embargo, hasta el primer decenio de nuestro siglo, por los tra bajos del gran Cuvier; y desde entonces hemos alcanzado tambien en esta parte de la zoologín, como en todas las demàs, conclusiones hasta cierto punto definitivas.

CARACTERES. - Despues de lo que ya hemos observado, acerca de la estructura de los pulmonados, no necesitamos una nueva explicacion relativa a los prosobranquios cefalóforos. Reanudamos nuestras observaciones con los cefalú. foros, porq̨ue sus órganos respimtorios son bránquias que estin ocultas debajo del repliegue del manto ó en una caridad, accesible por un agujero, una escotadura ó un tubo. L'n un macho de Ja litoridisı Gaudichandi, extraido de su concha, podemos estudiar las proporciones anatómicas mas inportantes, en las que tambien hallaremos la razon del nombre de prosobrannuios con que se les designa. El que conoce las partes de que se compone el helix pomatia, comprenderi sin dificultad àlguna la estructura y situacion de los úrgnnos de cualquier otra cefalóforo. La cabera se prolonga en un hocico de inediana longitud, en cuya extremidad se encuentra la abertura bucal. Tsste hocico no tiene la propiedad de serr recogido, aunque por lo regular puede acortarse y se encuentra en nuichos generos de este órden, mientras que en otros aparece la trompa Esta última es de una prolongacion tubiforme, a menudo muy considerable, y lleva tambien en su extremidad la abertura bucal, que puede recogerse. No obstante, la trompa no es otra cosa que un hocico prolongado, efecto, sin duda, de que su piel exterior es de la misma naturaleza y el mísino color yque el resto de la piel de la cabeza. Fi pié de este animal es bastante pequeño, si bien lleva la ancha planta que caracteriza á la mayor parte de los cefalóforos. Encima y unido a el se encuentra el músculo con el que el animal esta unido á la concha. Al abrir la cavidad del manto, se presenta à la derecha la superficie interna del lóbulo de que aquel esta provisto, junto con otros importantes órganos. En la posicion natural, se encuentra mas hácia la derecha el intestino, con el orificio anal. A su lado existe una gländula llamada glándula mucosa. Los caracoles pueden segregar de ella gran cantidad de una sustancia espesa, casi lfquida, que tambien emplean, en caso necesario, como medio de defensa. I a glándula de algunos géneros segrega el jugo de púrpura, y parece ser el mismo órgano de que hablaremos minuciosamente en su lugar respectiro. Mas hácia el lado izquierdo se encuentra la bránquia, en forma de peine, compuesta de estrechas hojitas aisladas, y, por detrás de ella, el corazon, que se compone de dos divisiones, el ventrículo y la auricula. Todos los gasterópodos en que, como en este, la bránquia está situada delante del corazon, y por consiguiente la auricula delante del ventrículo, se llaman prosobran. quios. Desde el corazon se extiende la sangre por medio de arterias particulares en el cuerpo. En la mayor parte de los cefalóforos no existen, segun parece, venas provistas de paredes particulares, por las qque la sangre pasa al órgano respiratorio, sino que la sangre prosigue su curso por sencillos conductos en iorma de vasos ó cavidacies de sustancin corporal; y en muchos casos se ha demostrado que por medio del riñon puede recogerse agua, para la sangre, ó segregarse sangre muy diluida en agua. Relacionado con la comunicacion que las grandes venas tienen con el exterior, se halla un organo que nos da razon de la facultad que poseen muchos moluscos, asi como la mayor parte de los prosobranquios, de dilatar el pié, cuyo conocimiento es imprescindible para la compren. sion exacta de diferentes variaciones de forma y movimientos del aninal. En una serie de géneros se ha descubierto que 
el pié tiene una abertura que conduce en esta parte del cuerpo á un sistema tnuy ramificado de canales, que ponen en comunicacion la cavidad venosa con el cuerpo. Al desarrollarse el pié de la concha, el animal recoge agun por aquella abertura, racilitando esta operacion la longitud que adquiere el pié y que no guarda uinguna proporcion con la anchura de la concha. Al recoger dicha parte, el agua vuelvé á salir. Agras. siz y otros llevaron á cabo su experimento decisivo sobre este particular con la gran natica heros. Al poner un cjemplas de este cefalóforo con el pié recogido, cn un vaso lleno de agua hasta el borcie, el animal desplegaba todo el pié, sin notarse el mas minimo cambio en el nivel del agua. Este despliegue no pudo verificarse, de consiguiente, por una sencilla exten sion de los tejidos del cuerpo, sino porque el pié recogia el agua como una esponja, dilatandose por este medio hasta adquirir su asombroso tamaño. Exactos resultados dieron otros numerosos experimentos efectuados con cefalóforos y conchas, y que se obserman por mcdio de tubos de vidiio gradundos: los movimientos de estos animales debajo del agua no se dieron nunca á conocer por el nivel de aquella, a pesar de la absorcion y la secrecion verificadas. Recomendamos para tan sencillos como instructivos experimentos nuestras grandes conchas fluviales $y$ de estanque.

\section{LOS TENOBRANQUIA- DOS-CTENOBRANCHIATA}

El núcleo de los animales pertenecientes it este grupo, unas $\$, 000$ especies, ch tan grande, que nos vemos obligados á reunirlas tambien en varios grupos muy desproporcionados por lo que respecta á su extension. La mayoria de los de que nos ocupamos, es decir, de los que aparecen en primera linea esti formada por los tenobrannuiados. En las noticias generales acerca de este grupo y los siguientes nos atendremos á la descrijucion de Keferstein, fundada en una implia consideracion de los resultados cientificos; y seguiremos cas sicmpré literalmente, por lo que respecta á los caractéres, al citndo autor 6 á Philippi.

CARACTÉRES. - En todos los tenobranqquiados la cavidad respiratoria se halla en la nuca y contiene una gran bránquia, junto á la cual hay otra mas pequeña rudimentaria, que es la bránquia secundaria. En la parte anteriory lado izquierdo, el manto se prolonga en nuchos tenobranquiados en forma de un surco cóncavo en su parte inferior: es el sifon ó tubo respiratorio, que conduce el agua à la cavidad respiratoria. En otros falta este apéndice. Para una exacta apreriacion es secomendable reunir las familias, dotadas $\delta$ nó de sifon respiratorio, sobre todo porque tambien en la concha existe un carácter distintivo para ello; pues en el caso de que exista tubo respiratorio, tienen en la desembocadura un apén dice tubiforme ó una escotadura. Los sexos aparecen siempre separados, $y$ los inachos se reconoren generalmente por los órganos genitales, que sobresalen mucho en el lado derecho del cuello.

Estos animales son, ya plantivoros, ya carniroros: los últi mos se distinguen regularmente, por tenet una trompa ó un sifon respiratorio. Nos ocuparemos de las familias en las que la desembocadura de la conclia carece de escotadura, o de canal, y que en su mayor parte sou plantivoms. In la clasificacion de las especies aisladas se manifestarà en qué concepto la membrana destinada al roce, es carncteristica para las familias y los subórdenes.

En las paludináceas (paludinacea) el animal tiene un hocico corto, que no se puede encoger, dos ientáculos largos $y$ delgados, en cuya base se insertan exteriormente los ojos.
La membrana de roce es larga y delgada, y se halla en parte situada en la cavidad destinada a los intestinos; lleva en la liner central una serie de dientes y á cada lädo tres series de ganchos. Todos los cefalóforos en los que la lengua presenta tal estructura se llaman tenioglosos (kemioglosia).

\section{LAS PALUDINAS-PALUDINA}

CARACTERES. - Las paludinas son propias de nuestras aguas dulces corrientes y estancadias. Su concha es oval ó de forma esférico-cónica, con las circunvoluciones muy convexizs, reunidas por una profunda sutura, y con una tapa córnea rajada concéntricamente.

USOS, COSTUMBRES Y RÉGIMEN.-Rossnaessler describe del modo siguiente las condiciones vitales de estos cefalóforos. «Las paludinas viven en fosos, charcos, estanques ; rios, sobre todo en el hemisferio septentrional, con menos frecuencia en el meridiunal, donde las sustituyen las ampularias. Por lo regular permanecen en cl fondo de las aguas, reptando en el limo y en los tallos y hojas de las plan. tas. Cuando los rayos solares producen mayor grado de calor suben tambien á la superficie, donde á veces, à semejanza de las limueas, se pasean con la concha dirigida hácia abajo. El animal no puede salir tanto de la concha como los limneos; y en esta ocasion levanta la tapa inserta en la cara superior del pié, posándose con este detrás de la concha, cuya última circunvolucion convexa descansa cntonces sobre aquella Cuando el animal ruelve à retirarse à la concha, la planta se dobla por el centro cerrándose como un libro.»

\section{LA PALUDINA VIVÍPARA-PALUDINA VIVIPARA}

CARACTÉRES. - In mas grande de las especies de nuestro pals, la paludina vivipara, alcanza una altura de casi 07,004. Tambien en ella, como en otras especies, las hembras son, segun se dice, un poco mas grandes que los machos; pero la concha no presenta ningun distintivo cuando el animal es adulto. "Durante todo el verano, el ovario se pucde encontrar lleno de embrione's y de huevos en los mas diferentes periodos del desarrollo, porque cada vez no sale á luz mas que un hijuelo. El embrion maduro, al nacer, tiene ya una concha de cuatro circunroluciones y de tres líneas de largo pror otms tantas de ancho. La tapa es muy tenue y presenta ya compleios los anillos concéntricos qque adq̨uirió por su desarrollo paralelo al de la conchas.

\section{LA PALUDINA AGATINA-PALUDINA ACHATINA}

Tambien la paludina agatina vivipara, mas pequeña que la especie anterior, tiene en su ovario embriones y huevos del todo desarrollados. Este animal prefiere el agua corriente y se encuentra en el Elba, el Spree, el Klin y el Danubio.

Pequenas son las diferencias que se notan en las demás especies, ya en la forma de los dientecitos $y$ hojitas, ó en su posicion alternativa.

\section{LA PALUDINA IMPURA-PALUDINA IMPURA}

CARACTERES. - la tercera de las especies comunes en la Europa central, es la paludina impura, llamada asi porque su concha trasparente, lisa, brillante $y$ de color amarillento claro, está cubierta de una cara que varia segun la naturaleza del agua.

Oportuna ocasion sé nos ofrece parn volver á ocuparnos 
de las observaciones del doctor Simroth acerca de los pulmonados acuáticos y las paludinas, y para continuarlas segun sus propias noticias recientemente publicadas. Nos habin explicado dicho naturalista, cómo el aparato de la respirncion atmosférica se trasforma en el órgano branquial de la palu. dina de una manera del todo opuesta á lo que se creia en general, respecto a que nuestros pulmonados son los descendientes de cefalóforos de bränquins, y que los actualmente existentes, de estos uiltimos, carecen de ellas, Simroth nos dijo que el embudo de la entrada pulmonàr en la paludina se habia ensanchado en una larga hendidura.

Con este ensanchamiento, continúa tambien aquel órgano del sentido, descubierto por Lacaze-Duthiers, perdiendo su destino en la respiracion atmosférica retrogresira, y haciendose rudinentario, avanza de un modo correspondiente, teniendo lugar en su consectiencia una dislocacion notable de todo el sistema nervioso, dislocacion que solo de este modo puede explicarse. A estos indicios de una proxima afi nidad, hay que rinadir muchos otros. Ia boca, que en los verdaderos cefalóforos terrestres tiene sólo una fuerte maxila extendida trasversalmente sobre la entrada, permite el retroceso de aquelia en los pulmonados acuáticos, contando en cambio con dos mas pecuenas laterales, como se nota casi siempre en los prosobranquios. En estos animales ta hendidurn horizontal de la boca se trasforma en vertical, presen. tando ya el género planorbis marcadamente el tránsito al hocico del género paludina. Ray-Lancaster ha demostrado últimamente que los dos glóbulos membranosos, que en los pulmonados acuáticos cubren la abertura bucal, deben pro. venir de un cordon embrionaria con pestañas n̨ue á manera de velo (axlusin) orilla la cabeza del caracol jóven. Este velo fal. ta en los pulmonados verdaderos, mientras que se presenta perfectamente desarrollado en los embriones de los prosobranguiados (véase despues el genero siermétus), en los que, sin cmbargo, clesaparece mas tarde sin dejar huella, excepto en la paludina. En esta sin duda le corresponden dos globbulos membranosos parecidos, como en las limnea y planoribs. situados lateralmente al hocico. Isel mismo modo los pulmomados acuáticos y los prosobranquios difieren de los embriones de los cefalóforos terrestres por la falia de la vejiga caudal, hallíndose los segundos provistos de clla.

Simroth, demostrando tambien, por la estructura de los órganos genitales $y$ el modo de efectuarse el apareamiento, la posicion intermediaria de los pulmonados acuáticos, presenta este prob!ema a la consideracion de los estudiosos, quienes sin duda no se han fijado aun en si el origen de una parte de los prosobrançuiados se remonta tal vez à pulmonados acuáticos parecidos á los actuales. Por ingeniosa que sea esta suposicion, opónense a ella casi todas las observaciones que se han hecho, respecto a las relaciones que existen entre los animales terrestres y de agua dulce con los habitantes del mar. Aqui deben tomarse tambien en consideracion las numerosas observaciones que Yheringi ha hecho acerca de! sistema nervioso y otros órganos de los moluscos. Consta, segun este autor, que los pulmonados acuaticos, deben tener otro origen que los cefalóforos terresires; y precisamente tambien ha podido deducir la prueba de le diferente natumleza de las cavidades respiratorias.

\section{LAS MELANIAS - MELANIA}

CARACTERES. - Ias melanias son muy "afines de las paludinas por su estructura y manera de vivir. Este género es muy rico en especies, que con preferencia habitan las aguas de la zona cálida, y cuya concha de muy variadas formas, está fubierta casi siempre de una capa negra y lisa.

\section{LOS VALVÁDOS - VALVATA}

CARACTERES.-Tambien este género es muy afine de los dos anteriores. Le componen pequeños cefalóforos que casi exclusivamente se encuentran en las aguas dulces de Europa y de la América del norte. Suelen prolongar sus bránquias en forma de peine, similando un penueño plumero de la cavidad branquial. Una de las especies que mas abunda es la aroliata fiscinalis.

En los géneros que á continuacion siguen y que ya se han clasificado entre los paludináceos, el animal se parece en estado adulto al de los géneros anteriores; pero su desarrollo es mas complicado, porque los hijuelos están provis. tos, como los de casi todos los cefalóforos marinos, de dos grandes lóbulos bucales con pestañas, qque les permiten nadar con agilidad.

\section{LAS RISOAS-RISSOA}

CARACTERES. - Por su pequeñe\% y gracia se distingue el género risad, rico en especies, cuya mayor parte tienen la concha en figura de torre, la desembocadura oval y una esspecie de a pa córnea de la misma forma. El hocico de este animal parece una trompa y es escotado; los tentáculos, filiformes, tienen doble longitud que aquel.

USOS Y COSTUMBRES. - Considerndo el género $r i$ sod con cierta amplitud, tal como los roólogos especialistas modernos consideran la familia de los risoidos, se han descrito unas 500 especies, inclusas las fósiles, pertenecientes á el. No debemos extrañar, por lo tanto, que el estudio de este solo géncro haya ocupado exclusiramente á un naturalista como Schwarz von Mohrenstern de Viena, quien dice al hablar de estas especies: «Su alimento principal consiste en algas marinas, por lo cual se les encuentra con mas frecuericia en la zona de las limnarias. Son ágiles y libres en sus movimientos; y reptan con bastante rapidez, moriendo los tentáculos alternativamente hácia adelante y atrís. En algunos se ha observado la facultad de moverse á la inversa, con el pié hácia arriba en la superficic del agua; y segun las observaciones de Gray, la risoa para tiene la facultad de tejer hilos glutinosos, con los que se fija en las yerbas marinas para resistir el impetu de las olas, $y$ al mismo tiempo para poder cambiar de residencia con mas seguridad. Se les encuentra à todas las profundidades, hasta las de 105 brazas, aungue la mayoria vive en las regiones superiores.

-Su patria son los climas templados, pero se les halla tambien aisladamente en la mayor parte de los mares, y solo las formas prolongadas de risoidos pertenecen exclusivamente i los mares ćlidios, mientras que los de concha delgada, sin prominencia bucal, sc encuentran mas bien en el Norte. La riqueza en formas que el Mediterránen ofrece, en cujo mar se encuentran la major parte de especies mas grandes y mas desarrolladis, demuestra que la verdadera patria del rison (propiamente dicho) es la parte meridional de la zona templada septentrional.

\section{LOS LITORINOS-LITORINA}

CARACTÉRES.-Constituyen las especies del géneto lilorina, caracoles de la costa, verdaderos animales anfibió ticos. El de que vamos á ocuparnos tiene un hocico corto, redondo, largos tentáculos fliformes que sustentan los ojos en la parte exterior de la base. Ia concha, de borde grueso, es de una materia semejante á la porcelana y por lo regular afecta una forma esférica.

USOS, COSTUMBRES Y REGIMEN. - Se conocen 
mas de cien especies en todos los mares, yue viven la mayor parte del tiempo fuera del agua, en la zoma de la orilla, á que solo llega la marea aita, 6 solo las olas en su fuerte empuje. Iohnston dice: L Ins especies de liforina, comunes en la costa británica, parecen preferir los sitios en que sola la marea alta puede cubrirlas; he visto miles de sus hijuelos en cavidades de las rocas y a algunos piés de altura sobre el límite de la alta marea. Sin embargo, los úrganess respiratorios son, como siempre, las brínquias; y merece aqui llamar nuestra atencion la hipótesis de I.amarck, para preguntaunos por qué estos moluscos, tan avidos de aire, no han adquirido aun pulmones, como los kelicidos; porqué no salieron del todo á ticra firme: porqué la concha no se ha aligerado para permitirles mayor agilidad en los movinuientos, y porqué, en fin, los ojos, situados en la base de los tentáculos, no se han elevado aun á major altura, para poder observar el espacio y evitar los peligros. Lamarck, contra el cual se dirige el ataque del inglés, es el autor de la doctrina de la trasforma cion, que por Darwin se engrandeció y estableció ciemúficamente. Hoy ya no es tan-fácil venir a un arreglo con I.a. marck, como lo ha efectuado Johnston. Dado el caso de que animales que respiran por medio de bránquias deban trasformarse en el trascurso de los tiempos, de modo que puedan respirar aire, esto se puede verificar por dos medios. El caso presente, el mas sencillo, caso que tambien se ha dado en los cangrejos terrestres y en otros crusticeos, de un modo altamente satisfactorio, consisirà en que los brganos respi. ratorios anteriores no cambien de iorma, sino que su superficie adquuiera otra naturaleza, la cual puede describirse mi-

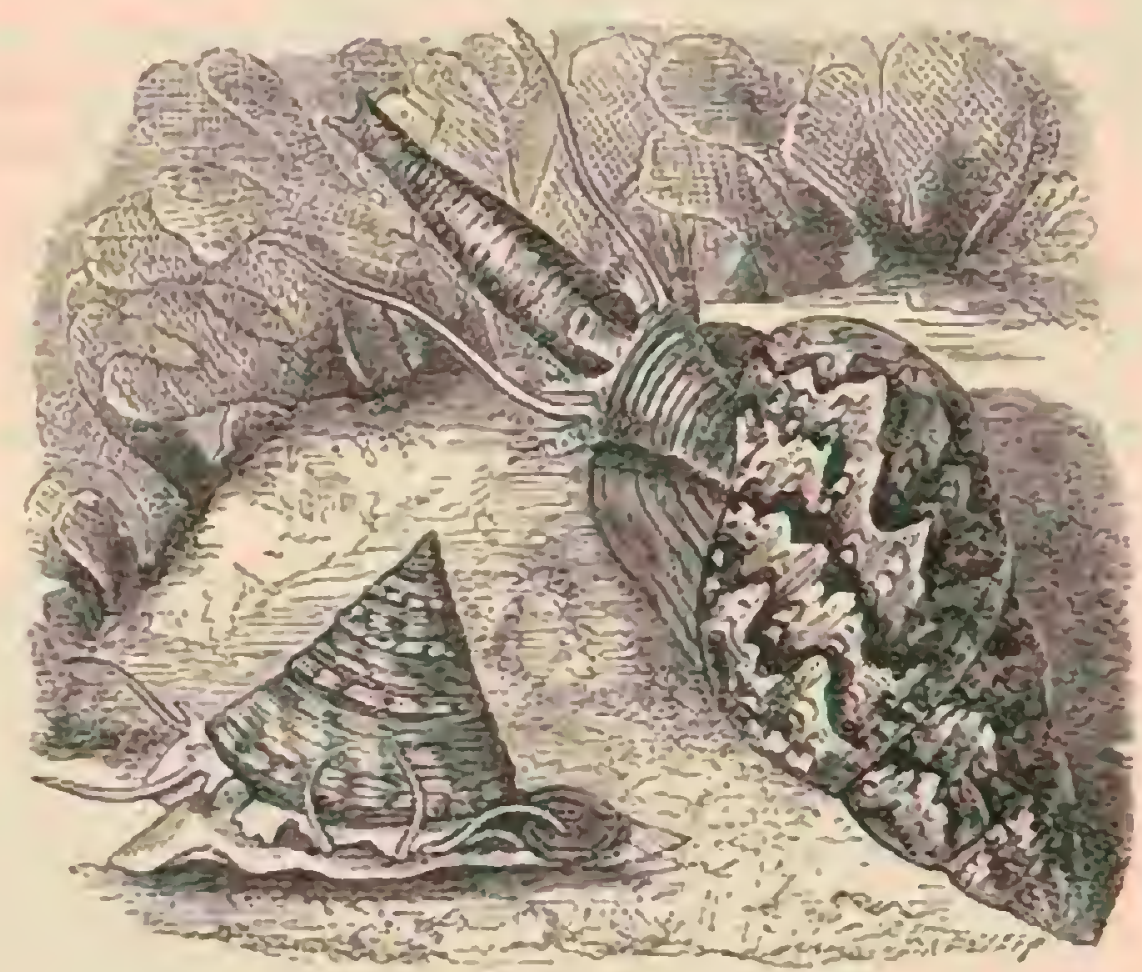

Fig. 234.-LA CANTAIHDA CONUS

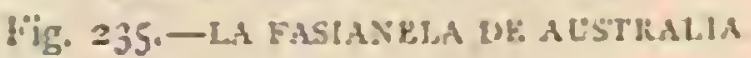

nuciosanente: el órgano respimatorio acuático conserva la forma de hrárquia, aunque en realidad se ha trasformado en liránequia y pulmon, $\delta$ solo en pulmon. Ya anteriormente hemos apreciado el caso opuesto; es decir el caso en que varias

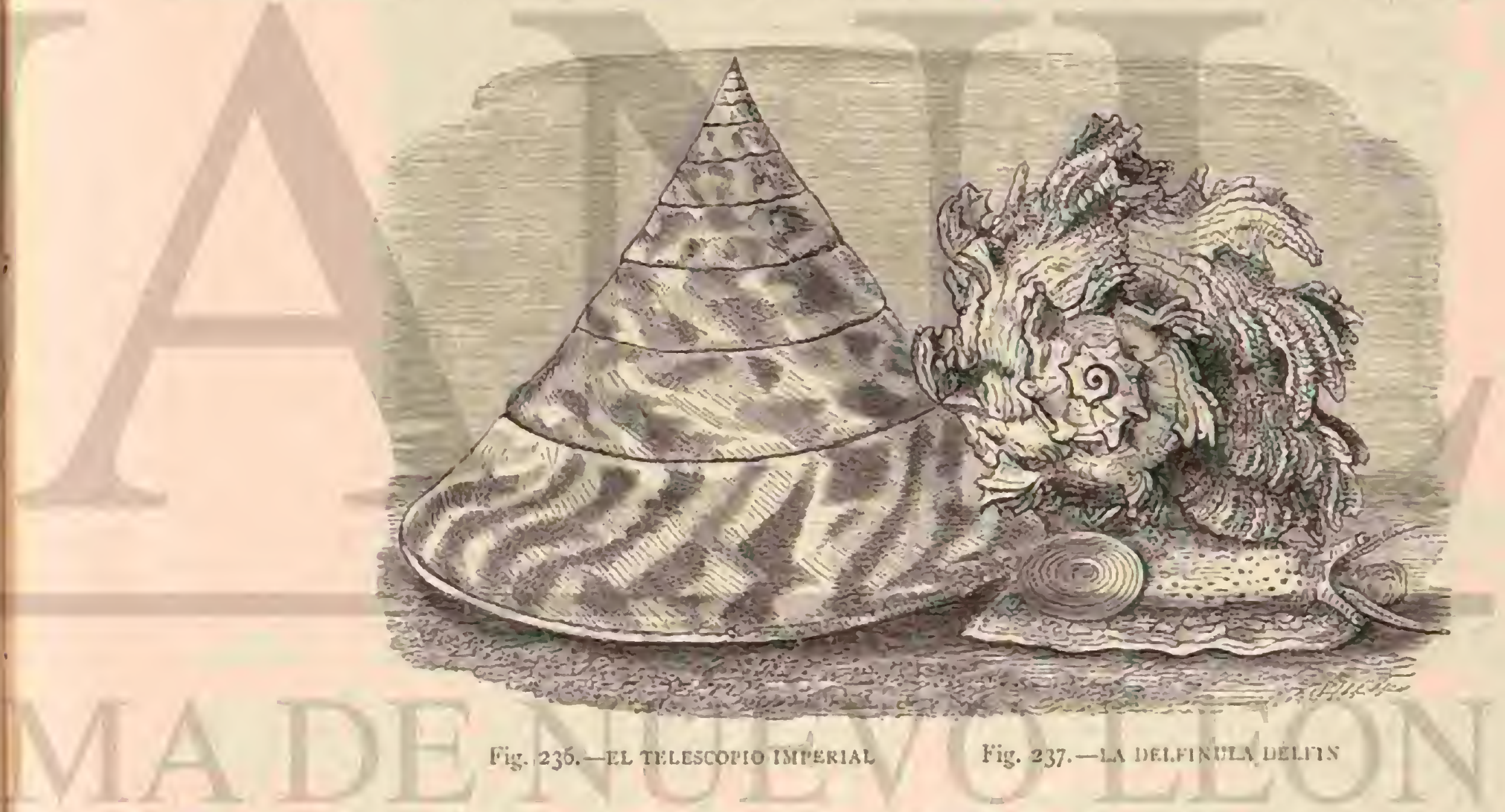

especies del yénero limnea que respiran aire, se han adapta. do a la respiracion en el agua, sin grancies cambios en su cavidad pulmonar. Solo en el caso anterior, mucho mas dificil, se reune á la atraccion fisiológica, una morfológica, es decir, la que concierne á la forma y á la estructurn que mas llama nuestra atencion. Pero, en general, al ucuparnos de las ideas de lamarck y Darwin no debanos dejarnos confundir por las preguntas referentes a puntos de que por athora no podemos darnos cuenta por añella hipótesis, sino que debemos atenernos a los hechos qque por ella se reducen a su causa $y$ à sus relaciones. Los litorinos son una prucba clocuente, en cuanto atañe á la respiracion ýa sus órganos, de la extraordinaria facultad que para adaptarse cuentan estos animales. A la pregunta de porqué los litorinos no se han rue!to mas ligeros y porqué sus ojos no han ascendido in. scnsiblemente hasta las puntas de los tentaculos, contestaremos con entera tranquilidad, diciendo que lo ignoramos; pero con la circunstancia de sulue en lo observado no vemos ninguna razon de gran peso contra las hipótesis de la trasformacion y del origen.

Segun anteriormente dijimos, los litorinos permanecen pocas veces mas abajo ó con irecuencia mas arriba del limite de la marea alta, donde se abnudonan á una sonolienta inaccion, cuando el agua cesa por mas tiempo de subir. Pa. rece que algunas especies pueden quedar sumidas en un lctargo invernal, fuern de los limites del agua. Cimy refiere que muchos individuos de la litorina fetrea y algunas otras cspecies, viven en la costa inglesa en tal estado. Las encontró algunos piés mas arriba del limite máximo del agua, fijas en la roca. Fil pié estaba del todo recogido, y un borde mem- 
branoso llenaba el espacio entre la roca y el latio exterior de la concha; solo las bränquias estaban humedecidas y la bolsa branquial no contenia la gran cantidad de agua que es. tos animales suelen depositar en ella. Gray los observó en tal estado de letargo mas de una semana. Colocándolos en agua de mar, recobraron por algunos minutos toda su actividad.

\section{LA LITORINA LITORAL - LITORINA LI-} TOREA

Una de las especies mas comunes y propagadas es lá lito- rina litoral. eVire en el agua poco profunda, en las algas, piedrasyempalizadas; permaneceà menudofuern del ngua mucho tiempo, en un mismo punto, agarrada á ias piedras y estacas; al volver á ella lleva consigo provision de aire. Cuando poco despues de sumergirse se la inquieta, salen burbujitas de aire ála superficic. Sus movimientos son lentos; al reptar, las dos mitades de su planta trabajan alternativamente, mientras que la mitad derecha se ensancha hácia adelante y la izquierda se acorła hácia atrás; cn cuja ocasion se forma en la parte posterior un repliegue, mientras q̨ue en la anterior la planta avanza con ondulaciones alternativas. Un individuo

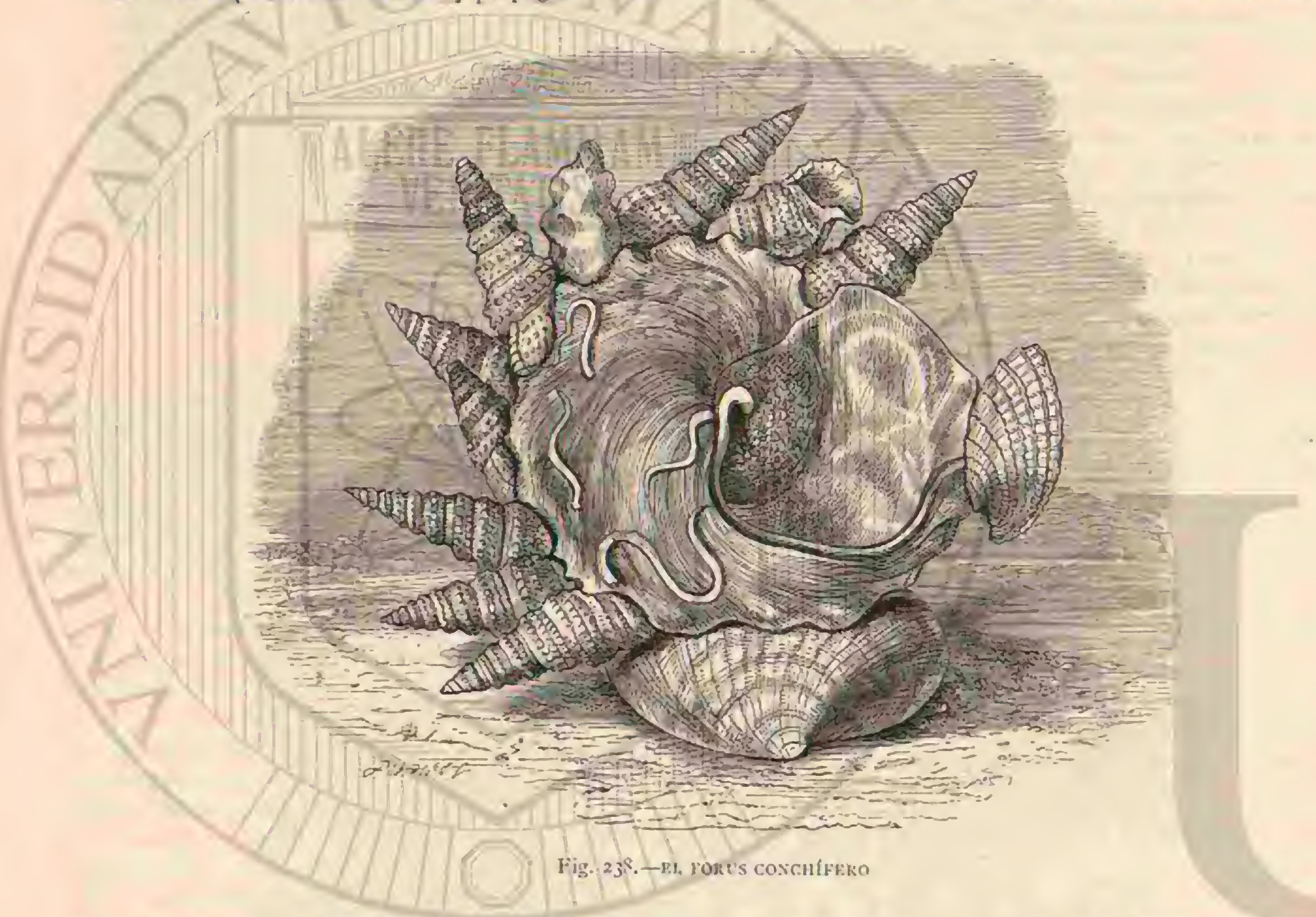

de mediano tamaño, al subir y bajar en la pared de cristal de un acuario, lo cfectuó con la rapidez media de $0^{\circ}, 005$ por segundo. Recorreria por lo tanto en una hora, 8 metros.

NEl alimento de la litorina litoral consiste en sustancins animales y vegetales. La vimos nutrirse de algas en el acua. rio; pero tambien comia las capas de plantas y animales microscópicos, dejando las huellas de su lengua ( radula), en forma de dibujos, en la pared de cristal. Eu Inglaterra se arrojan estos caracoles en los criaderos de ostras para purgar al fondo de plantas marinas. Estas plantas son perjudiciales porque dan lugar á la formacion de limo. En nuestros acunrios vimos tambien comer á las litorinas comunes carne cruda de mamiferos.

En Holanda se come la litorina, segun Swammerdam refiere en la e Biblia de la Naturaleza. En la pescaderia de Lóndres se venden desde marzo i agosto semanalmente unos 2,000 bushels $(46,13$ litros $)$ y en los restantes seis meses unos 500 (segun Majer y Mocvius).

I.a litorina litoral es uno de los moluscos que mas abundan en el hemisferio septentrional. En el Bâltico llega, segun las noticias de Mayer y Movius, hasta las costas orientales de Bornholmo y de Rugen. Al este el quilate de sal del agua es para ella demasiado reducido. In las costas del Schleswig-Holstein abundan mucho. Viven cn el mar Blan- co; y en el Oceano Atlintico se la encuentra desde Groen. landia y el nordeste de América hasta Portugal; tambien se conoce en el Adriático.

Los huevos de las litorinas se componen de pequeñas bolsitas de jema y de gran cintidad de clara de huevo, cuya capa exterior se cndurece en forma de cáscara. Un monton de estos hueros está reunido por una sustancia gelatinosa, parecida á la clara del huevo, por medio de la cual aquellos se fijan en las algas $\delta$ cn las rocas; los hijuclos alcanzan ya en los huevos un desarrollo avanzado y los de muchas especics nacen vivos.

Mayer y Mavius refferen que la litorima obtusa pare des. de la primavera al otoño hijuelos vivos, y quue aun en noviembre se encontró en el acuario, al lado de una hembra, cierto múmero de individuos jóvenes.

\section{LAS LACUNAS - LACUNA}

CARACTÉRES. - El gênero lnenssa, afune de las litorinas, se distingue por tener una corta circunrolucion, con el labio inicrior ancho y plano, y el cxterior afilado. La cabeza es truncada y corta; los tentáculos afectan la forma de lezna y en el dorso del pié se ven dos largas apófisis en forma de fajas. 
USOS, COSTUMBRES Y REGIMEN.-Majer y Mce vius dan las siguientes noticias acerca del género de vida de la lacum diantionto, propia de las costas de Europar y de la America del norte.

«Es un cefalóforo muy virar; cuando se le echa de espaldas vuelve a salir ripidamente de su concha, se extiende tanto como puede, alarga la parte anterior de su cuerpo hácia un lado, y trabaja con los tentáculos extendidos para tomar su posicion natural, en cuyo caso aquellos se apoyan i veces en el suclo para ayudar. Tambien le agrada madar bocia arriba en la superficic, y cuando se sumerge ripida. mente, lleva en el pié hueco y cncorvado una burbuja de aire rodeada de una sustancia mucosa.

* Como al reptar las mitades laterales del pié avanzan alternativamente, el caracol se mueve de un modo vacilante, trabajando vivamente con los tentáculos, que ya se encorvan hasta la concha, ya vuelven á extenderse como un látigo.

E.l animal vive en las regiones de la regetacion marina; $y$ segun la obsersiacion de loven, adquicre un color verde cuando come algas pardas, tomando un tinte sonrosado si las come rojas.

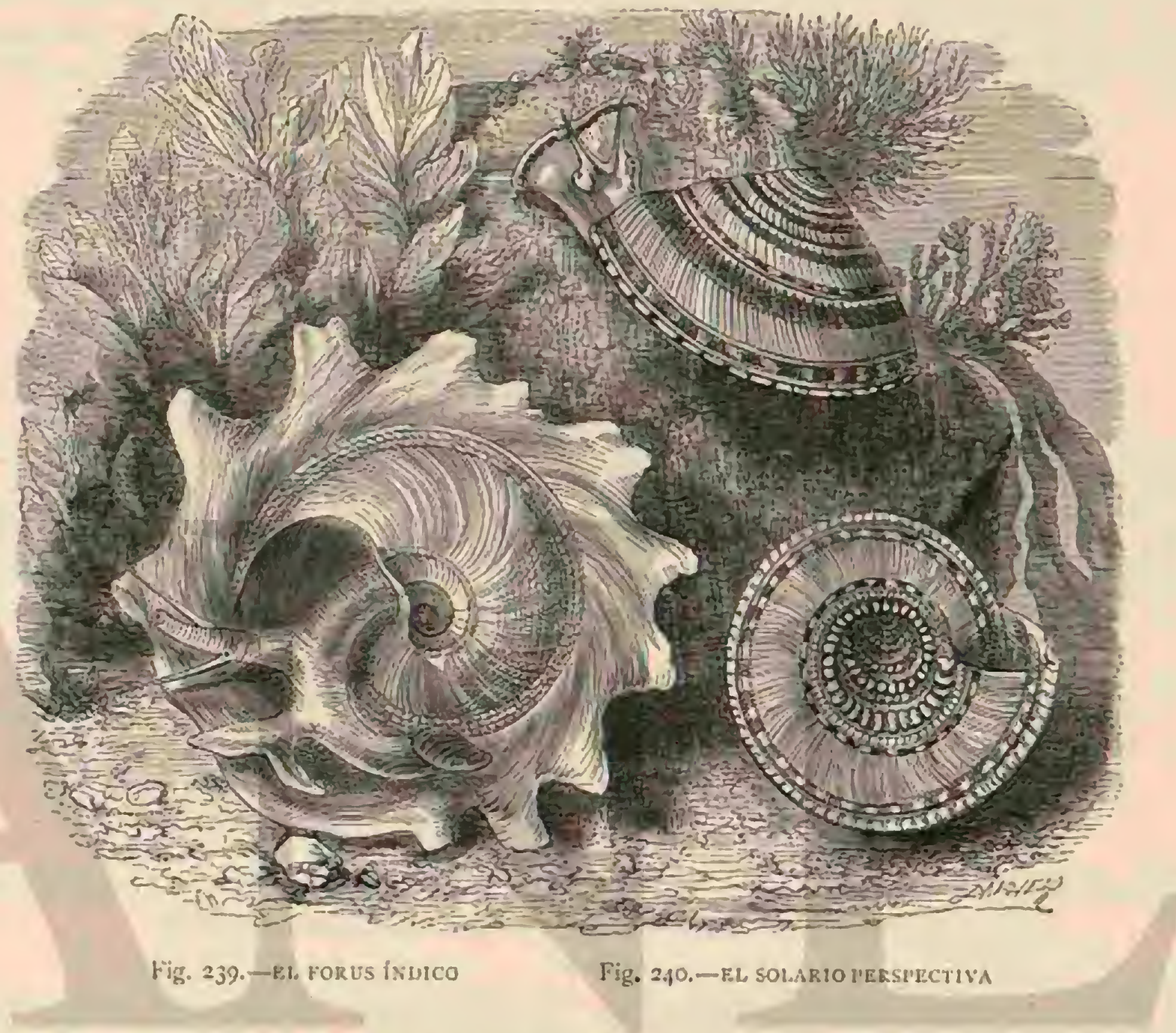

\section{LAS CANTÁRIDAS-CANTHARIDA}

El atributo distintivo de estos moluscos consiste en que la columnilla ó eje ofrece hácia la base una pequeña prominencia 6 vestigio de diente semejante al de las monodontas, de las que hablaremos despues. Algunas especies son propias de todos los mares. Como tipo del genero citaremos in rankirida cumsn, que abunda enlasaguas del nueso continente (fig. 234).

\section{LOS TELESCOPIOS - TELESCOPIUM}

Su concha no es anacarada: el cono muy alto, con numerosas vueltas de espira y estrias. El color de las conchas es un violeta pardo. El telescopio imperial (iig. 236) es la especie mas notable por todos conceptos entre todas las del género, y hasta de la familia. Distinguese sobre todo por cl agradable coniraste que forman con el color violiceo del fondo, los visos rojizos semejantes å llamas que realzan el conjunto. Este precioso molusco se encuentra solo en la Nueva Zelanda: pero escasea mucho, a lo que dicen los naturales.

\section{LOS SOLARIOS - SOLARIUM}

CARACTÉRES. - Una pequeña especie, muj buscada para las colecciones, es el solario, cuya concha en forma de peon\% esta provista de un ombligo tan profundo yue pernite ver todas las circunvoluciones. Aunque se encuentran algunas veinte espacies en los mares tropicales, no se tienen noticias suficientes, ni sobre su estructura ni acerca de su géncro de vida. El solario perspectiva (fig. 240) se cita como tipo por diversos autores.

\section{LOS FORUS-PHORUS}

Los forus ticnen la concha umbilicada, deprimida, con espira poco alta y aglurinante; el opérculo afecta la forma de espiral. De las dos especies comprendidas en este género, la una es el furus conchiffero (fig. $23 \$$ ), muy notable por su costumbre de incorponr à su propia concha cuerpos extrninos, como, guijarros, conchitas, etc I a segunda es el forus indieo (fig. 239), que se encientra particularmente en las aguas de in India, y ofrece la misma particularidad de que hemos hecho mencion. Los forus habitan en los mares delos paises mas cálidos.

\section{LOS CAPÚLIDOS - CAPULIDX}

CARACTERES. - Varios génerns han adquirido por la 
forma de su concha el nombre de axpulididos ó cefolififoros de capucha. La desembocadura de aquella es muy ancha, de borde entero y desprovisia de tapa. La punta, á menudo no șimérica, por una jeçueña circunvolucion media 6 entern. La especie mas conocida es la captiha hingyara (cupulus hunnariens) del Mediterranco y del mar del Norte la base de la concha, como en casi todos los cefalóforos de esta especie, afecta la forma de herradura, $y$ en ella se inserta ef mus" desarrollado músculo de la conchita:

(josse refiere que ha recibido a menudo el nombre de sgorro de la libertad (cas of libert), uno de los cefalóforos mas. raros del mar templado septentrional, de Weymouthy ' 'enby, donde se cogrio à la profundidad de 30 á 50 brazns. $4 \mathrm{El}$ ani. mal vivo, dice, vale algo por su concha de bonitos matices. lil color es por lo regular amaritlo pálido, cl del manto son. rosado, con una bonita franja anaranjada. La cabeza, grue sa, lleva dos tentáculos con los ojos en su base. Tuve un ejemplar bastante tiempo en el acuario: pero no me sirvió para ilustrarme mucho sobre este animal; el caracol estaba siempre con el ficten con que fuć cogido, y solo accidental. mente se mavia un poco hácia uno ú utro lado. El borde franjeado de la concha estaba tan estrechamente oprimido sobre su base, (que no se podia llegar hasta el animal; solo alguna vez levantaba un poco el borde, permitiendo al obsersador una ripida mirada

\section{LAS CALIPTREAS - CALIPTRAA}

CARACTERES. - Este género, afine del anterior, es de aquellos cuya concha está dividida en su interior por una hoja

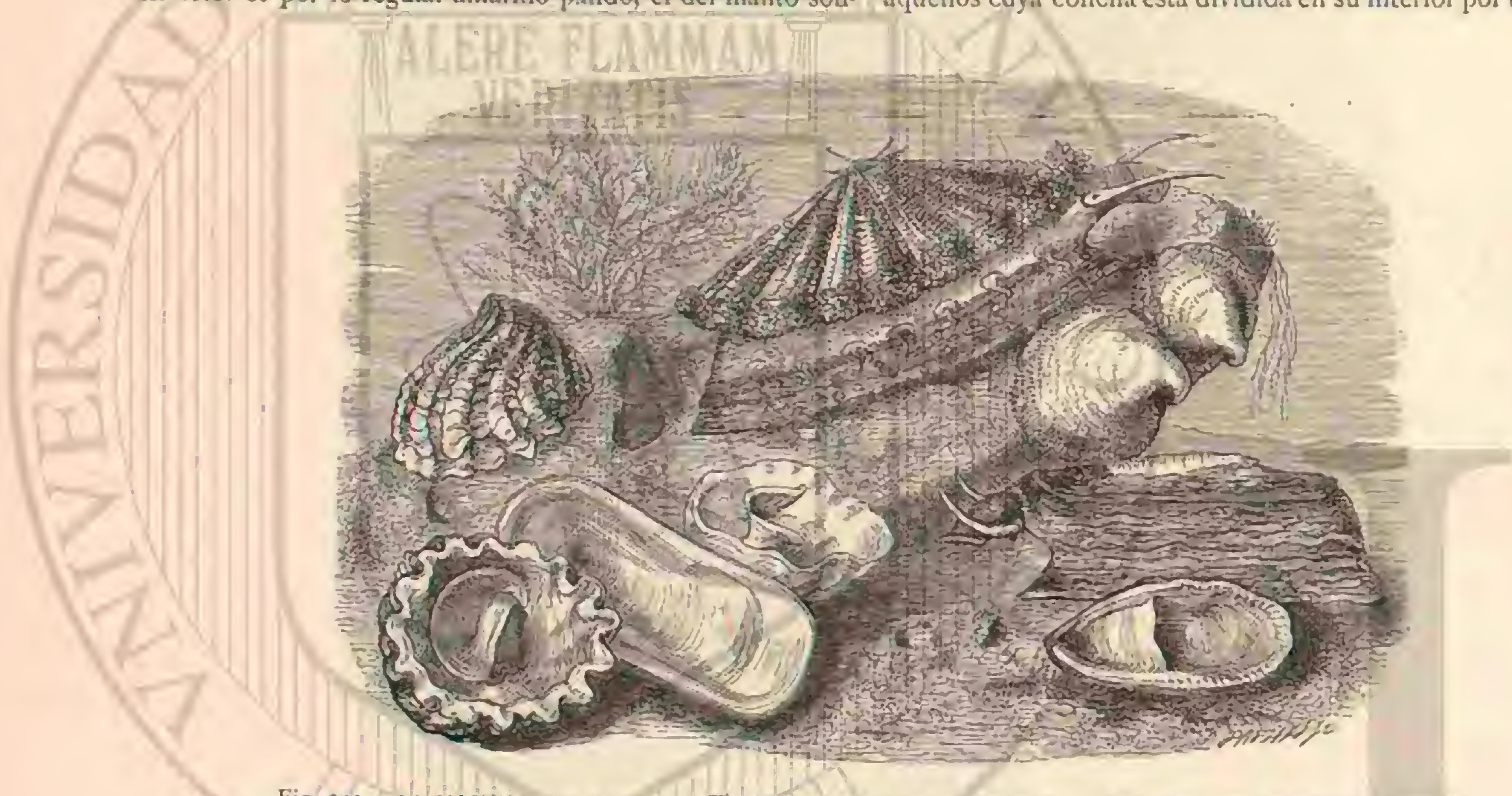

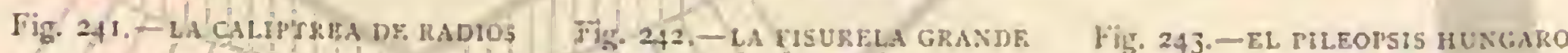

Fig. 244 - LA CALITRREA RSHIOSA

particular. Aqui cuelga desde la circunvolucion central prominente una hoja calcárea en forma de cucurucho cortado por el centro, cuja hoja está soldada con el lado derecho. El género es notable tambiẹn porque el animal produce con la planta del pić en el cuerpo extraĩo en que replosa (lo mismo que algunas especies de capullidos) una placa calcárea. Al contrario de la major parte de los moluscos que ya no hacen caso de los huevos despues de depositarlos, obsér. vase en el género caljptrea una solicitud para la cria que recuerda da de las clepsinas. Las caliptrens parecen incubar verdaderamente sus huevos, segun Milne Edwards observó hace ya muchos auos en especies del Mediterráneo. La ma dre coloca los huevos debajo del vientre, conservíndolos entre el piê y el cuerpo extraño en que descansa; de modo que su concha no solo la cubre y protege, sino que tambien preserva a su progenie. Los hijuelos se desarrollan bajo este techo inaternal nute no abandonan hasta tener suficiente fuerza para jijarse en la piedra y hasta que su propia concha es bastante dura para ofrecerles abrigo. Jos huevos en nú. mero de seis á doce se hallan encerrados en uinas cápsulas elipticas aplimadas de diversa forma, que se encuentran sobre todo entre los cefaloforos carnivoros. Seis a die\% cápsulas constituyen una puesta y están reunidas entre si por un tallo, de modo que parceen una especie de plumero. De las nume. rosas especies que representan al género, considéranse como
Fig. 245.-RL YAKMÓRORO AUSTRAL

tipicas la caiphrea de radios (fig. 2f6) y la caitplrea espinusa (figura 249).

\section{LAS FISURELAS - FISSURELLA}

Las fisurclas son unas bonitas y pequeñas conchas adorna. das de diversos colores: afecian fa forma ce un cono oblongo muy abierto por debajo y perforado en la cima. Lil animal es prolongado, con la cabezar truncada por delante y provista de dos tentáculos cónicos; las bránquias son pectineas en su parte superior; forman una prominencia a cada lado del cue110 y corresponden á uma obertura superior de la concha; el manto es muy ancho y el pié grueso. la especie tipo es la fisurcla grande (fig. 242) de los mares de liuropa, y tambien dela India.

\section{LOS PILEOPSIS - PILEOPSIS}

Su concha es univalva, en forma de cono oblicuo, encorvada hácia delante, con el rértice casi en espiral; la abertura redondo elifutica; el borde auterior agudo, mas corto que el oiro y un poco sinuoso, y el prosterior redondendo; jresenta una impresion muscular prolongada, arg̨ueada, trasversal y situada debajo del limbo posicrior. El animal tiene dos tentáculos cónicos, en cuya base exterior aparecen colocados los 
ojos; las brániuias están en linea debijo del borde anterior de su cavidad, cerca del cuello. Los pilcopsis son basiante pequeños. Las ocho ó diez eśpecies vivas que representan el género éstán diseminadas en casi lodos los mares, sicudo la mas conun en nuestras costas, y que se considera cono la lipica, el pileopsis hưngaro (capulos hungaricu) (fig. 243).

\section{LOS PARMÓFOROS-PARMOPHORUS}

l.os parmóforos constituyen un género afme al anterior, ${ }^{\circ}$ se caracterizan por su concha prolongada muy deprimida, clipeiformu, con la punta muy inclinada hácia atrás, sin agu. jero ni escotadura, cubierta en gran parte por los bordes retorcidos del manto; la abertura es tan grande como la concha; los bordes laterales rectos y paralelos; el posterior redondea- do; y el interior cortante. La especic mas notable es el parmoforo austral (fig. 245) que se distingue por la forma particular de la concha, muy semejante a la del pico de un pato. El color del animal es negro; los ojos estin en la base exterior de los téntáculos; la concha tienc un tinte amarillo muy pálido. En general este molusco liabita en los mares de los paises mas cilidos: se le ha encontrado en Nueva Zelan. da, en el mar Rojo y en el Cabo.

\section{LAS NATICAS-NATICA}

CARACTERES. - Este género, rico en especies, forma el centro de otra familia. Su concha es esférica ú oral, con la desembocadura semicircular; el labio exterior, afilado y liso en su cara interior, y el interior calloso. Ya hemos hecho

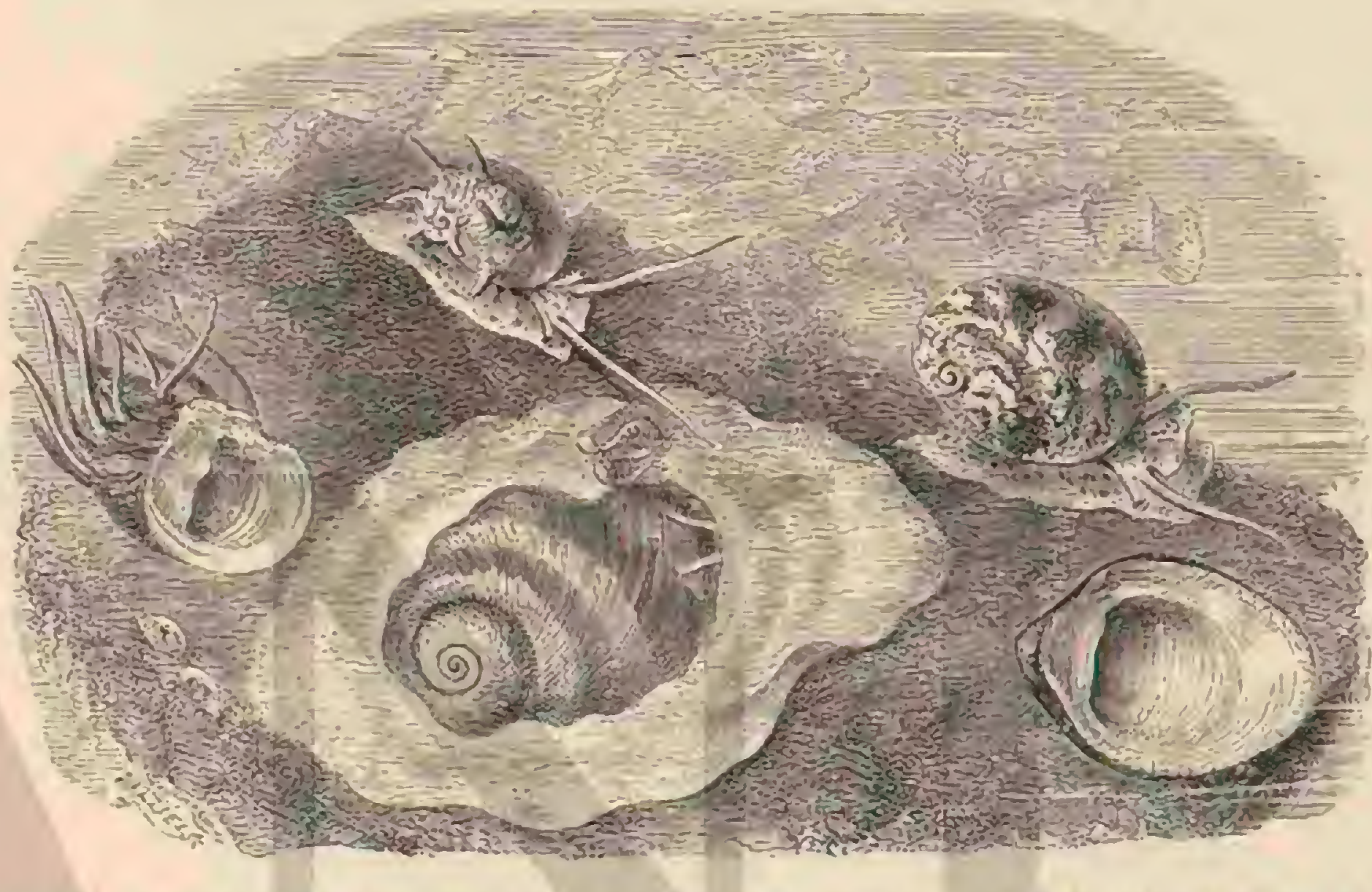

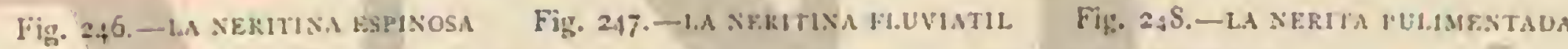

Hig. 249. - IA vartes castaina

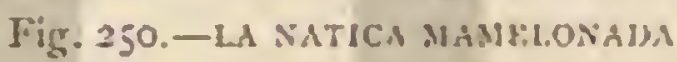

mencion de la facultad del animal de dilatar el pié hasta un tamano extraordinario, ausorbiendo agua. Se sirve del mismo para penetrar en la arena y cubrir del todosu presa, pues son carnisoros, que atacan particularmente à otros cefalóforos, perforando las conchas de los mismos circularmente. Un zoólogo inglés dice çue devoran con preferencia peces muertos y otros animales cucallados en la orilla. En su consecuestcia pertenecen a los caracoles poco numerosos, que, por la falta de un canal o escotadum en la desembocadura, mas bien deberian considerarse como plantivoros. Muy extraña es su freza que durante mucho tiempo se ha considerado como un animal parecido i los pulpos. Gould la describe del modo siguiente: "lis una masa arenosa adherida en forma de una ancha ciscara, con una abertura en el fondo y cortada en un lado. Tiene el grueso de una ciscara de naranja; es muy flexible y no se rompe cuando esta húmeda. Vista al trasluz, apharece ltena de celdillas dispuestas en series aliernadas; cada una de estas celdas contiene un huevo gelatinoso, con cl centro amarillo, que es la cáscara embrional. Se encuentran á menudo a mediados del verano, con frecuencia en toda superficie arcnosa, donde vive una especie de natica.

Entre las doscientas especies marinas, poco mas $\delta$ mcnos, que se conocen, una de ellas, la natia helicoides, figura al mismo tiempo como habitante del mar y del agua dulce. Descubierta primero en el interior de la Nineva España, se la en contró despues a una profundidad de jo brazas. la nalica castaña (nig. 249) y la naticu mamilonada (igg. 250) merecen consignarse tambien aqui.

\section{LOS VERMETOS-VERMETUS}

Los yue cn una costa pedregosa se ocupan en recoger plantas y animales, y hara tener mas libertad en los movimientos se quitan el calzádo, verán á menudo sus jiés en. sangrentadus. Hay, como por cjemplo experimenté en la orilla pedregosa y llana de la magnifica colina del Canon en Corfú y segun Lacac-Duthiers en una ensenada del hermo. so puerto de Mahon, hay sitios que están cubiertos completamente de tubos calcáreos, mas ó menosirregulares, de gran solidez y de una desembocadura tan afilada, que solo el amor i la ciuncia ayuda a sobrellevar los tormentos que ocasiona csta especie de alfombra, que parece compuesta de espinas y cuchillos, cuando se recorre en busca de plantas y animales. No tenemos à nuestra vista un gusano de la famila de las sérculas, sino el vermeto (jermicfus) (fig. 252) con sus conchas, uno de los moluscos cuya forma extrana y diferente al parecer, se alcja mucho de sus congéneres mas afincs, aunque Ia disecacion del animal aduito, y sobre todo el curso del des. arrollo, nos explica la vercindera natumleza de estas formas difcrentes. 
Seria dificil determinar por las conchas vacias, que en la mayor parte de las especies (por ejemplo reermetus gigas y aermetus trigueter) son blancas y en otra, muy abundante en el Mediterráneo (resmetus subrancellahus), negras, la clase de ani. males á que pertenecen. Ia parte con que principia, soldada siempre con la base pedregosa, tiene circunvoluciones regulares en forma de espiral, lo mismo que en la turritela; pero despues de cierto número, el tubo se ensancha, tomando una forma regular, y cono hay diversas especies de anéliclus del género sércula cuyos tubos calcareos tienen circunvoluciones

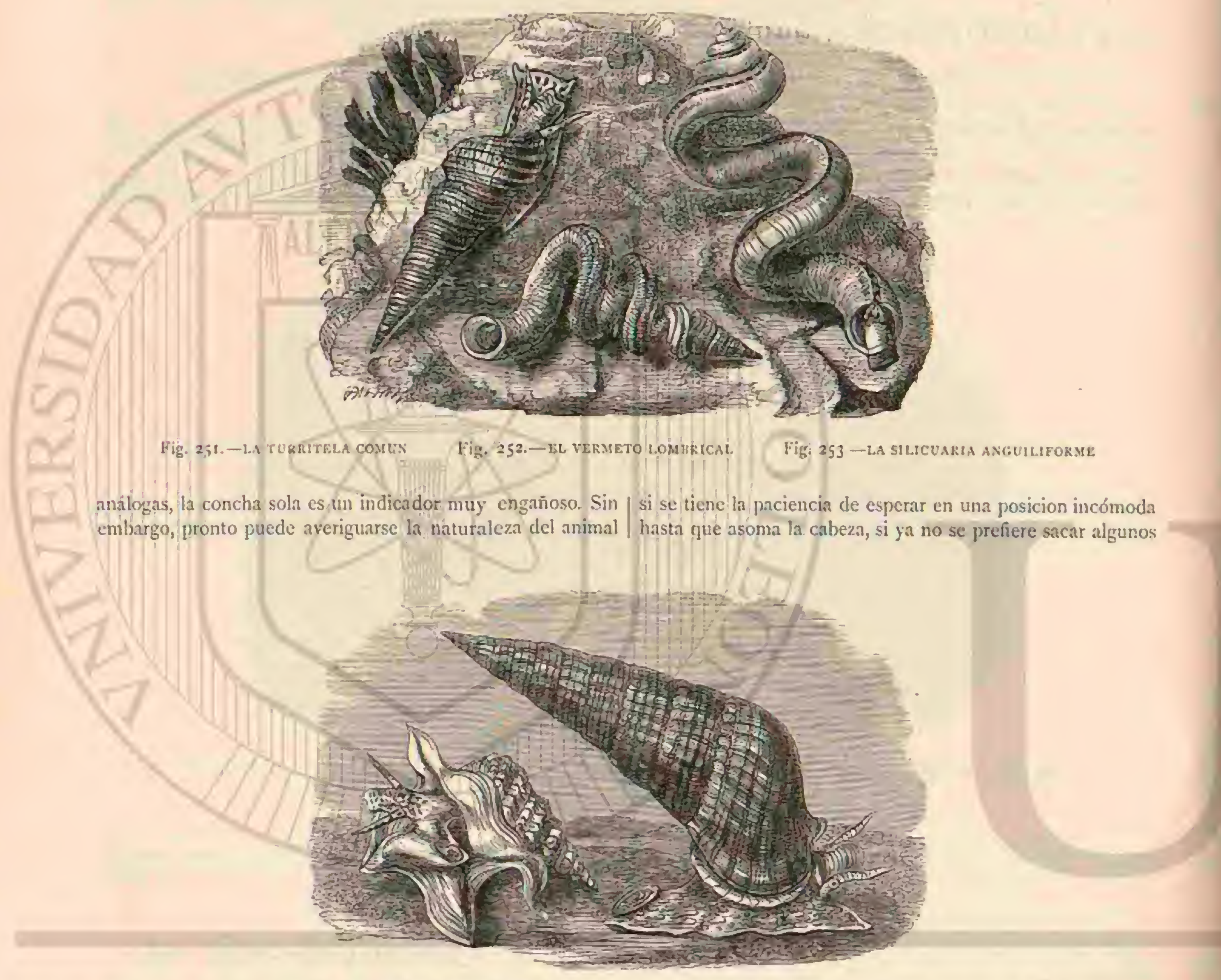

Fig. 254.-EL ESTHOM HO PIL DH. PELICANO

con un pedazo de su base para llevarlos á casa en una gran vasija, observando entonces con comodidad, sus muy débiles manifestaciones ritales. El vermeto puede rctirarse à mucha profundidad en su tubo; cuando se dispone a salir aparece sobre la abertura de la concha una especie de tapon, en cuya superficie superior redondeada y lisa se encuentra una peque. ña placa cornea. El pié y la tnpa de otros muchos cefalóforos marinos presentan precisamente el mismo aspecto en estado de la mayor contraccion. En el caso concreto, sin embargo, el pié conserva esta forma, tambien despues de salirse. Tans. bien hay una pequeña escotadura entre la base del pié y del cuerpo, lo mismo que en las púrpuras, y unos tubos que despues describiremos. Ia cabeza, muy pesada, dilátase por el grau desnrrollo del esófago que por tener dos tentáculos con los ojos situados en su base, confirma el caracter del caracol. Los dos óryanos anteriores filiformes no son arterias sino sencillas jrolongaciones del labio. La cabeza pucde observarse
Fig. 255. - EL CERITIO PALUSTKE

tanto mas minuciosamente si el animal, mas valeroso que todos los demás gasterópodos, no se retimal punto á su concha cuando se le toca sino que, como dice Lacaze-Duthiers, muerde los objetos blandos que se le ofrecen sujctándolos con bastante fuerza. Debo anadir aqui, que nada se sabe sobre el alimento de los vermetos, pero es probable que sean carnivoros y que se alimenten de los animales que pasan por encima de su concha. Numerosos anélidos y crustáceos se encuentran siempre en sus inmediaciones.

Ia cabeza y el pié pưden énvolvèrse del todo por el manto, que afecta la forma de bolsa. Al cortar esta, aparece en el lado izg̨uierdo la brénquia en figura de peine y prolongada.

El mas sencillo exámen nos demuestra que el aparente anélido es por todos conceptos un céaloforo que pertenece al grupo de los prosobranquiados: al comparar la parte posterior del cuerpo que contiene los órganas genitales y el higado, con la misma division observada en otros gasterúpodos 
de concha larga, la diferencia es de muy poca consideracion. Muchas reces la historin del desarrollo y la metamorfósis de los animales inferiores, de los que nos ocupamos en este tomo, ha debido suspender el interés que en tantos animales superio. res despiertan las variadas costumbres y los instintos. Sobre todo hemos visto cómo los animales que no se mueven de su residencia sufren a menudo unas trasformaciones verdaderamente asombrosas, en cuyo trascurso se hacen mas y mas desconocidos, negando el origen y la afinidad. Aunque el género zermelus no llega hasta aqui, su reproduccion y desarrollo ofrecen, sin embarge, bastantes particularidades interesantes. Como verdadero prosobranquiado, tambien en este género se distinguen los sexos, pero atendido que su reunion inmediata solo podria verificarse por una casualidad, cuando los individuos se fijan uno junto á otro, ó sobrepuestos, no se efectua ningun apareamiento, sino que la fecundacion se confia al acaso y á la intervencion del agua. En cierta esta. cion, es decir, en los meses de verano (y quizas tambien en invierno), las hembras se encuentran ocupadas en la puesta de los hueros; en todas partes donde hay colonias de vermetos, el agua que los rodea debe contener nillones y millones de elementos espermáticos iecundantes, y muchos de ellos penetrarán, si no casualmente, por lo menos con seguridad, en los tubos de las hembras. Los gasterópodos de vida libre no suelen abandonar sus huevos al capricho de las olas, sino fijarles en cualquier parte de un modo determinado. La hembra del vermeto, como no puede moverse libremente, conserva los huevos en una serie de cápsulas, on forma de rejiga, que en la concha están fijas en unos tallos, y contienten cada una de ro a 30 huevos. La primera de estas cipsulas se deposita mas cerca de la desembocadura; es la mas grande, y aumenta su circunferencia con el desarrollo de los em. briones. Aunque el órden de los órganos que se desarrollan en el huevo no es del todo igual en los diversos grupos de gasteropodos, el pić y la llamada vela, y despues el wanto y la concha, suelen aparecer primero. Lo propio sucede en el vermeto. La vela se compone tambien de dos lúbulos se. micirculares en ambos lados de la boca, cuyo borde està provisto de largas pestañas. Los hijuclos manifiestan ya actividad en enero, y el admirado observador puede ver cómo cl animal se mueve en el liquido ovario. El pié del vermeto pequeirn presenta al nacer tanto desarrollo como pueda esperarse de cualquier otro gnsterópodo. Los órganos que adcmås se ven en el embrion son los tentáculos, los ojos, el manto y el esófago, en el centro del cuerpo el estómago, y en la parte posterior el higado. Lo que sobre tocio llama nuestra aten. cion es la graciosa concha con sus circunvolucjones à la derecha que caracteriza mejor al animal como verdadero caracol.

De este modo el pequeño vermeto abandona el huevo y el capullo, y nada como todos los ceíalóforos, con ayuda de las velas, libremente en el mar. Lstá provisto ya del músculo de la concha, y puede recoger con gran facilidad las velas, oculiandolas en todas las demás partes blandas de la concha. Su trasformacion y el desarrollo de aquella no se han observado directamente, pero bien se deduce lo que debe pasar para que llegue a su forma definitiva. No es improbable que los pequerios animalitos que à la simple vista aparecen como puntos, repten todavia algun tiempo libremente con ayuda del pié, cuando la vela la perdido sus pestanas y desaparecido; si viven aun durante este periodo, crecen algunas circun. voluciones de la concha. En todo caso semejante estado no durara mucho tiempo; el pic se contrae tambien, mientras que la concha se fija de un modo desconocido en la roca, efectuandose el desarrollo en adelante, por lo regular, longitudinalmente.
Parece que en todos los mares cillidos viven especies de iermetus, descuidadas sin embargo hasta aliora por los co. leccionadores de conchas.

\section{LAS SILICUARIAS-SILIQUAKIA}

CARACTEIZZS.-Un género aline, representado en el Mediterráneo, es el de las silicuarias, cuya concha, irregularmente circunvelta, esta hendida en el lado derecho en cor. respondencia con una hendidura en el manto. No se fijan en piedras sino en esponjas y en el pólipo llamado escorcho ma. rino. In especie propia del Mediterrineo es la siliguaria assguiliforme (fig. 253).

\section{LAS TURRITELAS - TURRITELLA}

CARACTERES.-Los zoólogos forman con los géneros citados una familia particular (iermetncea), ó la reunen con la de las turritelacias (turribellacea). El género de estas últimas constituge el llamado furritella (fig. 25r). La concha afecta la forma de torre y se compone de numerosas circunroluciones, hasta 30 , provistas casi siempre de surcos traspersales; tam. bien la tapa córnea, en figura de espiral, cuenta muchas. El animal tiene la cabeza prolongada con el hocico largo y es. cotado, el borde del manto estí provisto de franjas y ademis de esto se re sobre la nuca un repliegue membranoso franjeado.

Se conocen unas- 10 especies de todos los mares, siendo las mas conunes y grandes las de las regiones cálidas. Los animales son carnivoros, pero perezosos, y salen rarns veces de su concha.

\section{LOS CERITIOS-CERITHIUM}

CARACTERES. - $\Lambda$ caUsa de la semejanza de la concha podemos agrupar aqui el género cerithium, muy rico en especies, y que en la época paleozoica tuvo aun mas repre. sentantes que en la creacion actual. Una diferencia esencial de la concha consiste en el canal de la desembocadura corto y eruncado, ó mas largo, encorvado hácia atras.

Son plantivoros y casi siempre viven en el mar, aunque tambien se-encuentran en las lagunas, en el agua salobre y en las desembocadunas de los rios. Ciertas diferencias en la forma de la lengua de las especies de agua salada indican que tambien existen otras en el régimen alimenticio y en el genero de vida: pero carecemos de observaciones por este concepto.

Lil ceritio falustre.(tig. 255 ) es una de las especies mas 110 tables del género.

\section{LOS LITIOPAS-LITIOPA}

CARACTERES. - Lin género muy afine del anterior es el de los litiopas, pero, segun dice Troschel, han perdido nucho de su interés descle que se sabe que tambien otros cefalóforos forman tribus para fijarse. Sin embargo, posecn esta facultad en tan alto grado, que nos parece oportuno repro. ducir la descripcion de Iohnston fundada en observaciones de otros. Es un gasterópodo muy pequerio, nacido entre las algas, en las que debe pasar toda su vida. El pié es de estructura regular, pero estrecho y corto, y el arimal podria desprenderse fácilmente por las olas del punto en que se ha fijado, si no tuviera otros medios de apoyo. Asi como la araira, teje su téla con un liquido glutinoso, segregado por cl pić, para impedir su caida a la profundidad, $y$ ascyurarse del medio de volver a su sitio anterior; pero cuando el hilo se 
ha roto $\delta$ el animal cree conveniente abandonar su sitio para buscar otro, ct hilo juede reanudarse í desprenderse. En este caso, casualmente 6 con intencion, una burbujita de aire sale sin duda de la cavidad branquial, elévase lentamente por el agun, y como el caracol se ha rodendo de sustancia mucosa, esta se prolonga en un hilo que ì menudo sulse con la burbujita. lintonces tiene el animal una boya y una escalera en la qque vuelve is subir, esperando á que la burbujita se ponga cu contacto con las algas.

Otro caracol, que tambien tcje, cs un ceritio tropical (serif: lium truncatumi) que vive en los pantanos y en las desenubcaduras de los rics y puede colgarse por medio de un hilo pegajoso en las ramas y raices de los árboles. Tambien nues. isa Plissa fonlinalis puede bajar a la profundidad por un hilo pendiente de la superficie, asl como muchos caracoles ter restres (por ejemplo el megralomastoma de los bosques de San Vicente) pueden formar con una secrecion gomosa de su piel una hila, con cuyo auxilio bajan de los árboles y pendientes por un camino mas corto del que habian subido.

\section{LAS LAMELARIAS - LAMELLARIA}

CARACTERES, - Citaremos tambien la reducida familia de los masenias (masseniada ó lamellarida) para dar á

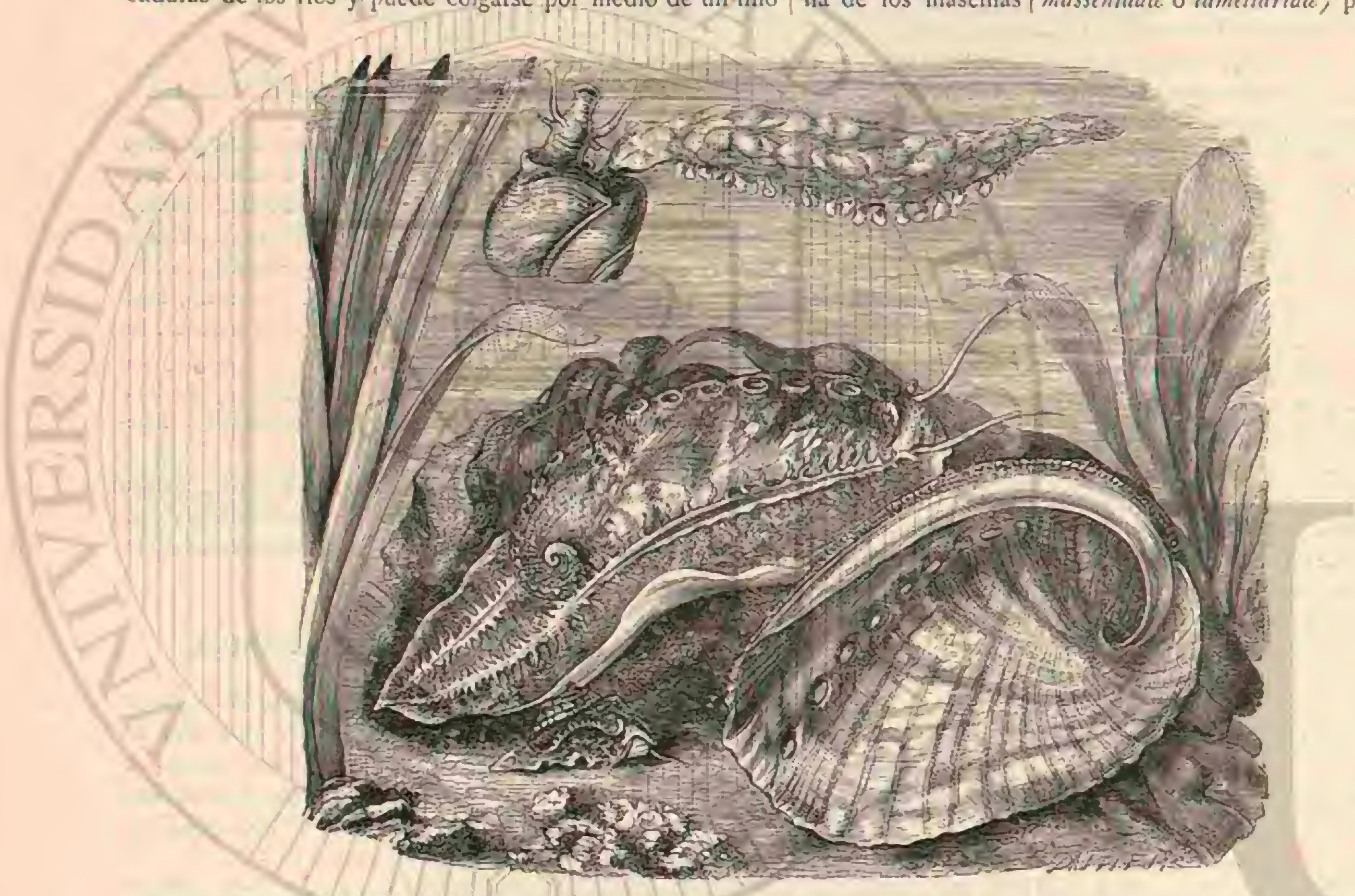

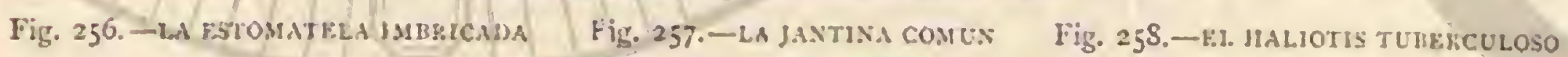

Fig. 259. -EL IIALIOTIS ORRJA DE BAR

conocer la extraña adaptacion de colores en el género la mellaria, del que nos labla Giard. Estos cefalóforos tienen una concha delgada, córnea y oculta en el manto, de modo que parecen caracoles desnudos; viven por lo regular en las ascidias compuestas, de las cuales hablaremos despues. Giard dice que, cerca de Roscoff, ha recogido centenares de indivi. duos de las dos especies lamellaria perspicua y lamellaria. tentnivilata, habiéndole admirado siempre la facultad de es tos séres de adaptar su color á los mas diferentes objetos de los contornos. Muchas veces, despues de poner varias colo. nias de ascidias en cl acuario, se encontraron por la mañana cinco ó seis lamelarias cuya presencia no se habia advertido \& causa de la igualdad de sús colores con los de las ascidias. Sin embargo, no tievien, como los cefalóforos, la facultad de variar su color rápida y soluniariamente sino que se necesita bastante tiempo antes de que se establezca la armonia con los contornos.

Cuando la lamellaria ferspicua vive entre las piedras, presenta un color gris con manchas blancas, pardas y negruzcas; pero si se la encuenera en la ascidia roja (leprotimum fulgidum ), tambien el cefalóforo es de un bonito color rojo, y se necesita alguna atencion para distinguirla de su base, en la que se eleva muy poco. Fn otras ascidias de distinto color, Giard encontró los cefalóforos cambiados del modo correspondiente. lo mismo podemos decir de la otra especie, que, sobre todo en el Ieptoclimum perforatum, casi no puede des. cubrirse.

Al comparar la adaptacion de los colores de la lamellavio ó el cambio de los de la sepia, asi como de utros cefalófo. ros, resulta esencialmente una considerable diferencia. Cierto que en ambos casos se nos presenta la quue llaman cmmascuraia (minicry, mimetinse); pero la sepia se disfraza para engañar á su presa, cuidandose únicamente despues de su seguridad, mientras que el cefalóforo de que hablamos solo emplea la enmascarnda como medio de seguridad y defensa. Aunque las ascidias compuestas, en las que vive con preferencia, sirven de alimento $i$ algunos cefalúforos rapaces, el múmero de sus enemigros no es considerable, mientras que la carne de la fameellario tiene sin duda muchos mas atractivos. Menos persecuciones sufre en las plantas y rocas, a cuyos colores se adapta.

La explicacion de todos estos ienómenos es dificil, pero en la mayoria de.casos basta apelar al principio de Darwin sobre la cria voluntaria natural. 


\section{LAS JANTINAS-JANTHINA}

Pasamos en silencio toda una serie de géneros sobre cuyo género de vida no tenemos ninguna noticia particular, y que no creemos necesario enumerar. Hemos terminado, por lo tanto, con la division de los prosobranquiados que carecen de sifon respiratorio, y que à causa de la forma de su lengua se han agrupado bajo el nombre de teniocloros $A$ estos prosobranquiados, sin tubo respintorio ni escotadura, pertenecen tambien dos familias compuestas de pocas especies, enire las que, la de los jantinidos, excita mas nuestro interés.

CARACTERES.-El género mas conocido es el de las jantinas, (fig. 25i) que tienen la concha mas ténue, ventruda y de color azulado, casi de la forma de los helicidos.

USOS, COSTUMBRES Y REG GIMEN.-Viven todos como carnivoros de alta mar: cuando se les inquieta, y, pro. bablemente tautien, cuando yuieren aturdir a su presa, segregan un jugo de color purpúreo para enturbiar el agua. Se distinguen principalmente por la llamada abalia aglomeracion de vejigas fijadas en su pié y con la cual se sostienen en la superficic del mar.

Antes de dar a conocer las curiosas observaciones de Lacaze-1)uthiers sobre la janthina del Mediterráneo, valdria la pena de reproducir las noticias sobre observaciones anteriores: parn lo cual copiaremos literalmente las palabras de Johnston. elil género jonthina tiene sin duda, entre todos los gasicrópodos, el mas notalile apamto para la locomocion. Al principio se les consideraba como exclusivos habitantes de los mares tropicales, pero mas iarde se descubrieron al. gunas especies en el Mediterrineo y en las costas de Inglaterra. Su residencia es el alta mat donde nadan lentamente. Fn la parte posterior de su pié se halla un grande apéndice de vejigas llamadas con mucha razon por Fabio Columna spumn cartilaginea (espuma cartilaginosa), porqque las vejiguitas son tan trasparentes como las de la espuma, mientras que la cubierta es cartilaginosa y membranosa Pendiente de estas burbujas de aire, la jantina nada fácilmente, imprimiendo la direccion con ambos lados del pié. Solo cuando la tempestad es violenta, el cefalóforo se abandona \& su capricho encallándose en la orilla hospitalaria. Asegurábasc que, sin el aparato para producir las burbujas, el animal no poutria permanecer en la superficic; que solo se fijaba ligera. mente con el pie; y que, cuando el animal se retiraba a la concha, hacialo sulo en parte. Fil uaturalista inglés Coates, habia indicado de una manera bastante exacta otras particularidades; pero Lacaze-Duthiers, durantc su permanencia en la costa africana, cerca de Iacalle, turo ocasion de hacer las observaciones mas precisas. Cederemos la palabra á este autor.

Ruertes tempestades del Noroeste habian encallado un gran número de aprestes expumosos de las jantinas en la playa arenosa de la bahia de Bonlinff, cerca de Lacalle, y entre ellos encontré un buen numero de individuos vivos. Me interesaba observarlos, y poniéndolos en acuatios con agua pura y frescat, jude ver como reparaban su concha, des compuesta por la tempestad y por el chonue contra la prilla. Al prrincipio me arimiró obscrvir corno todas las jantinas que habian perdido por completo las burbujas de aire, permanecian en el fondo del agua, aunque estaban alegres; vi tambien que algunas de las mas vivaces subian, no sin esfuerzos, con ayuda del pié, por las paredes de los depósitos de cristal, y que alcanzaban la superficie, inclinándose hácia atrís, pero nunca podian llegar à componer su concha del ıodo, y al fin bajaban pesadamente al fondo. Jamás las vi nadar a la manera de tantos cefalóforos, contrayéndo y ensancliando el pić. Es posible que no suceda lo inismo en alta mar, pero sodu parece indicar yjue el animal $y$ la conchá pesan demasiado para poder nadar sin su aparato. Tebe notarse adenats que los animales mueren muy ripidamente en el fondo del agua.

\Los vanos esfuerzos que los aninales hacian para llegar à la superficie, ó para remendar sus desperfectos, me obligaron á ponerlos en la posicion que, segun parecia, buscaban. Lo mismo que mis antecesores habia reconocido que no existe

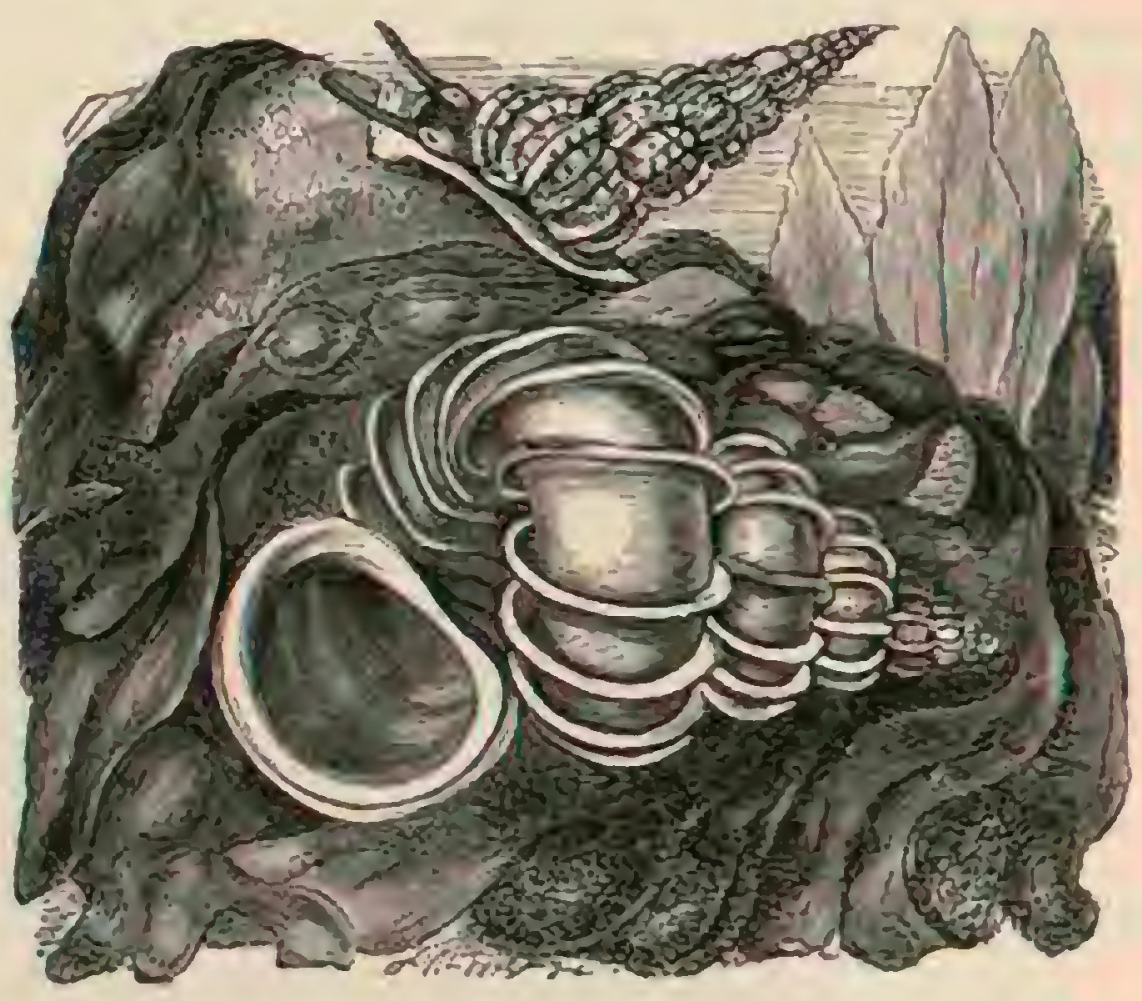

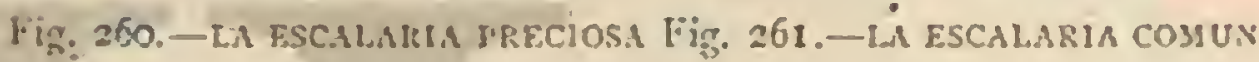

relacion orgánica entre cl aparato de las burbujas y el cuerpo, que aquel se fija sencillamente en el pié, y que, por consiguiente, el aire encerrado no puede proceder del cuerpo, sine que csta contenido mecinicamente en las burbujitas. Debia buscarse por lo tanto el medio ó el mecanismo por medio del que el animal puede encerrar. el aire en las vejigas. Al examinar detenidamente la parte anterior del aparato mas próxiima à la cabeza, se pueden contar muy bien las vejiguitas, reconociéndose su tamaño, forma yosicion. De consiguiente, puede obscrvarse el procedimiento, cuando el animal trabaja $\mathrm{cn}$ la construccion y engrandecimiento del aparato.

El pié está dividido marcadamente en dos compartimientos; el posterior, mas grande, y en el tue se fija el aparato, es plano; el anterior se redondea por delante y forma, doblando lns bordes hácia abajo, un canal que a cada instante varia de figura. Esta parte anterior, movible, construje el aparato del modo signiente: primero se prolonga hácia adelante, en. córvase, inclinảndose à derecha ćirquierda, hácin arribn, recoge con su parte cóncava la anterior del aparato y oprimese estrechnmente contra el mismo.

Resulta de aquí, quc el pié, elevaindose por encima del agua y cncorvandose, encierra una burbujita de aire, segregando alrededor de la misma una cubierta mucosa; cuando baja, inclinase hácia el aparato y oprime la burbujita bácia la parte anterior de la misma. Los movimientos del piése repiten por el mismo órden, y de este modo se agregan las burbujitas. I a sustancia mucosa, al principio blanda, se consolida pronto en el agua, y pudiera tomarse en tal estado por una masa cartilaginosa. Para seguir observando la construccion del aparato, Lacaze-Duthiers puso à las jantinas en un gancho de alam. bre, colocándolas à la misma distancia de la superficie en que el animal se encuentra cuando nada libremente con la bolsa. El cefalóforo comenzó al punto á salir de la concha, y á ensanchar su pié, trabajando del modo descrito. A medida que las burbujitas se aumentaban, el aninal se hacia mas ligero, pero no pudo sostenerse en la superficie ó alcanzarla antes de çue el aparato llegase a tener su tamaño correspondiente. 
Con la cantidad de la secrecion mucosa sucede lo mismo que con la materia textil de las aranas; el pié no la segrega sin interrupcion, $y$ lo hace solo por necesidad. Por lo demás el aparato es tan frágil y se halla expuesto a tantos peligros, que los animales casi siempre estarán ocupados en remendarlo.

Otra particularidad de la janiina es la de que fija los huevos en pequeñas cápsulas en la cara inferior del aparato; pero no se ha observado aun de que modo procede en esta operacion. Solo una casualidad podrá dar explicacion del hecho, porque Lacaze Duthiers, tan práctico en el tratamiento de otros animales marinos, no logró, á pesar del mayor cuidado, conservar sus cautivos con vida mas de algunos dias. I as especies de alta mar no pueden conservarse en los acua rios, sobre todo porque les falta el alimento conveniente, sin contar la limpieza que exigen en cuanto a la nutricion.

\section{LOS ESCALARIAS-SCALARIA}

CARACTERES. - Por la estructura muy parecida de la lengua, las escalarias (fig. 261 ) son muy afines del grupo anterior. El animal tiene la cabeza prolongada, $y$ los ojos se hallan en la base de los tentáculos, que son delgados. El pié es pequeño; la concha blanca, y semejante d la porcelana, afecta la forma de torre. I.os coleccionadores de conchilias apreciaban sobre todo las especies cuyas circunvoluciones tenian surcos trasrersales que no se tocaban, como la sealaria pretiosa, (fig. 260)

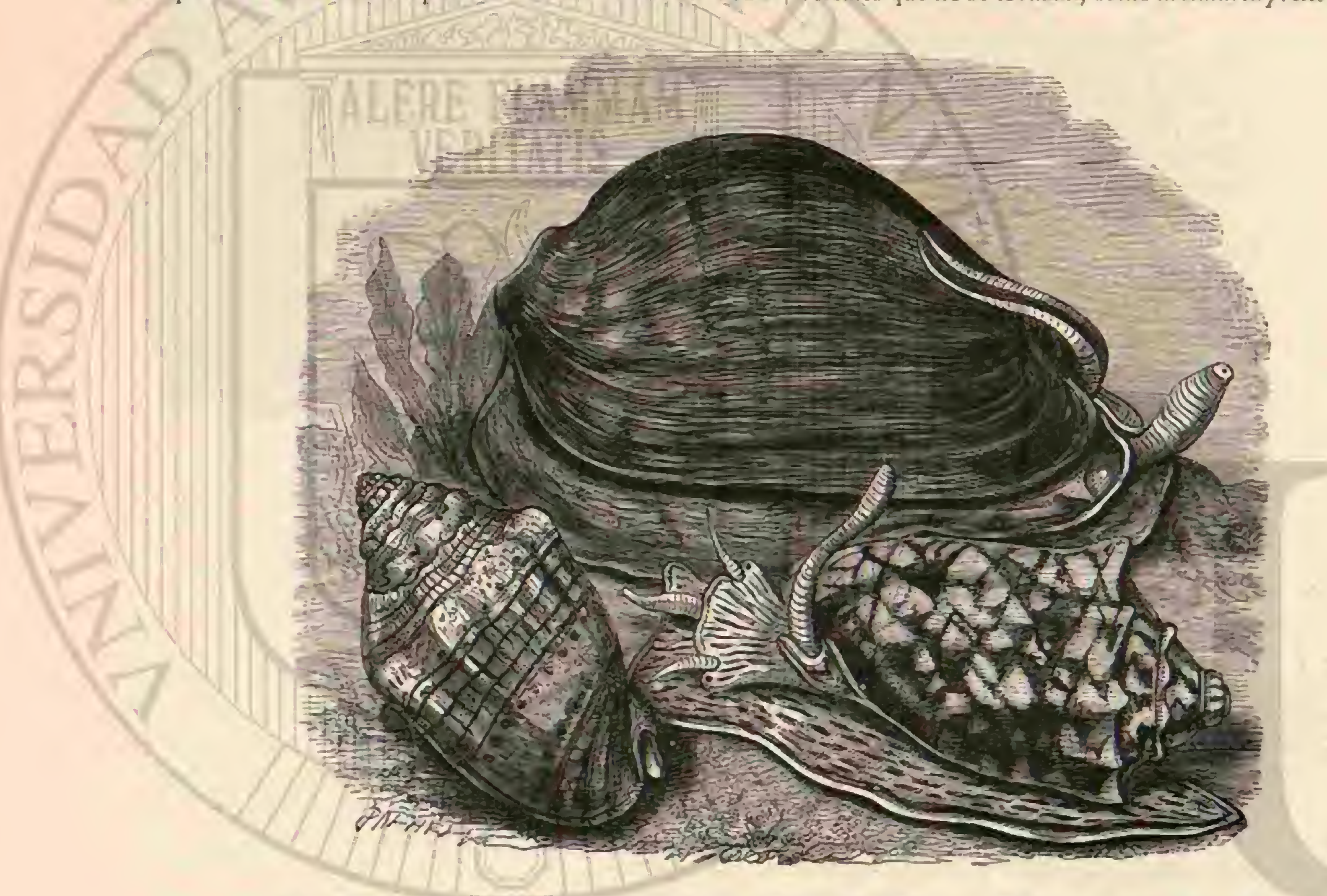

Fig. 262. - LA voluts ivstas

Fig. $26 j$ - I.A YOLUTA NETrtino

Fig. $2 G_{4}-2$ voluts juiso

por la que los fanáticos conquiliólogos de Holanda pagaban algunos centenares de florines. Tambien estas especies son carnivoras y pueden segregar un jugo pupúreo.

Los pocos gasterópodos carnivoros hasta ahora citados, indican, por la estructura de la lengua, mas bien una afinidad con los plantivoros, con los que asimismo se asemejan $\mathrm{cn}$ general por la falta de un canal ó de una escotadura de la desembocadura de la concha. Solo los ceritios ofrecen dificultades respecto a la clasificacion, por el aspecto de la desembocadura de su concha. Sin embargo, las llamadas excepciones son ventajosas á la ciencia sistemática. Las familias siguientes se reconocen exteriormente por el sifon respi: ratorio, con el que, segun ya hemos dicho, esta unido un canal interior ú escotadura del orificio de la concha. Ias conchas siempre circunvueltas pueden cerrarse a menudo por una tapa córnea. Habitan sin cxcepcion el nar y son casi todos carnivoros.

\section{LOS CEFALÓFOROS DE LENGUA ESTRECHA}

Las fnmilias de que ahora nos ocuparemos, inclusa la de los muricidos, se designan con el nombre de cefalóforos de lengua estrecha, porque esta, angosta y larga, solo lleva dos series de placas; la central no tienc cl borde antcrior do. blado, y el posterior está provisto de agudos dientes.

\section{LAS VOLUTACEAS-VO- LUTACEA}

CARACTERES. - Las roluticeas toman su nombre de los profundos repliegues oblicuos que se forman en el huso y por los cuales los conquiliólogos antiguos se guiaron para la clasificacion, aunque estos animales no prescentan una analogia completa. De las verdaderas voluticeas se distinguen los géneros marginelia, áoluta (figs. 262 a 26.4), cymbium y mifra, estos últimos por el peçueno pié ancho. Ia mitra episcopal (fig. 266) es la especie tipjica de este último género.

USOS, COSTUMBRES Y REGIMEN.- MuY poco Sa. bemos acerca del género de vida, $y$ solo se tienen varias no. ticiass sobre el uso de algunas especies y el valor de las conchas para los coleccionadores de los tiempos antiguos.

Rumph, describe, por ejemplo, el gran cymbium acthiopi- 
cum del modo siguiente: «Cuando este cefalóforo se eleva en | vista de ninguna tapa. Los caracoles mas grancies tienen de el aire, aseméjase bastante á una cota de malla ó á una túnica 15 á 19 pulgadas de largo y 9 de ancho. Los indigenas ponen imperial. Las circunvoluciones apenas ocupan en un lado de tnda la concha sobre el carbon, asan la carne y la comen; de la concha la mitad de la anchura; $y$ en ella se encuentra un las conchas mas grandes extraen las circunvoluciones interioanimal grande, de carne dura, de color gris, no estando pro. $\mathrm{res}$, y con las exteriores hacen platos y fuentes, utensilios muy

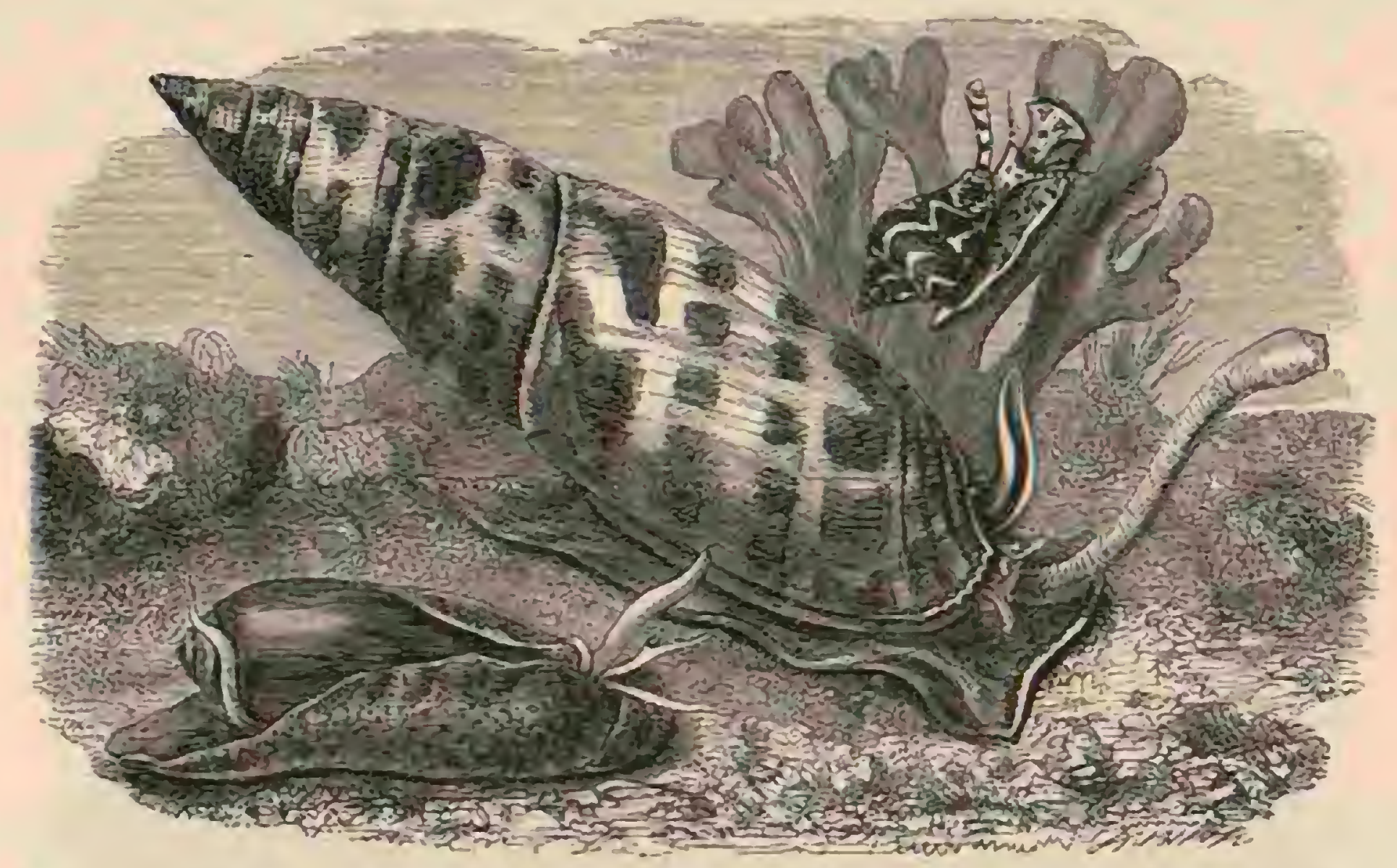

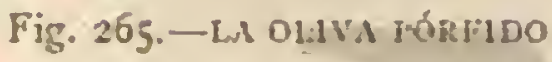

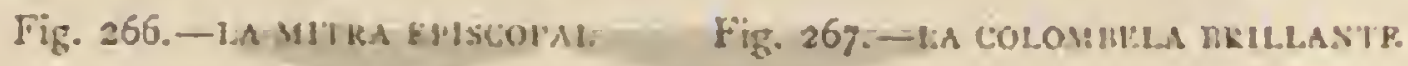

útiles porque no se rompen fácilmente. Cuando los indios han comido de ellas, las emplean para sacar el agua de sus barcos. Los chinos llaman á este caracol euerne de Rey y saben hacer de su circunvolucion interior bonitas cucharas que sin embargo sirven mejor al que come con la mano izquierda."

Aunque estas y otras noticias no ilustmn en nada la histo-

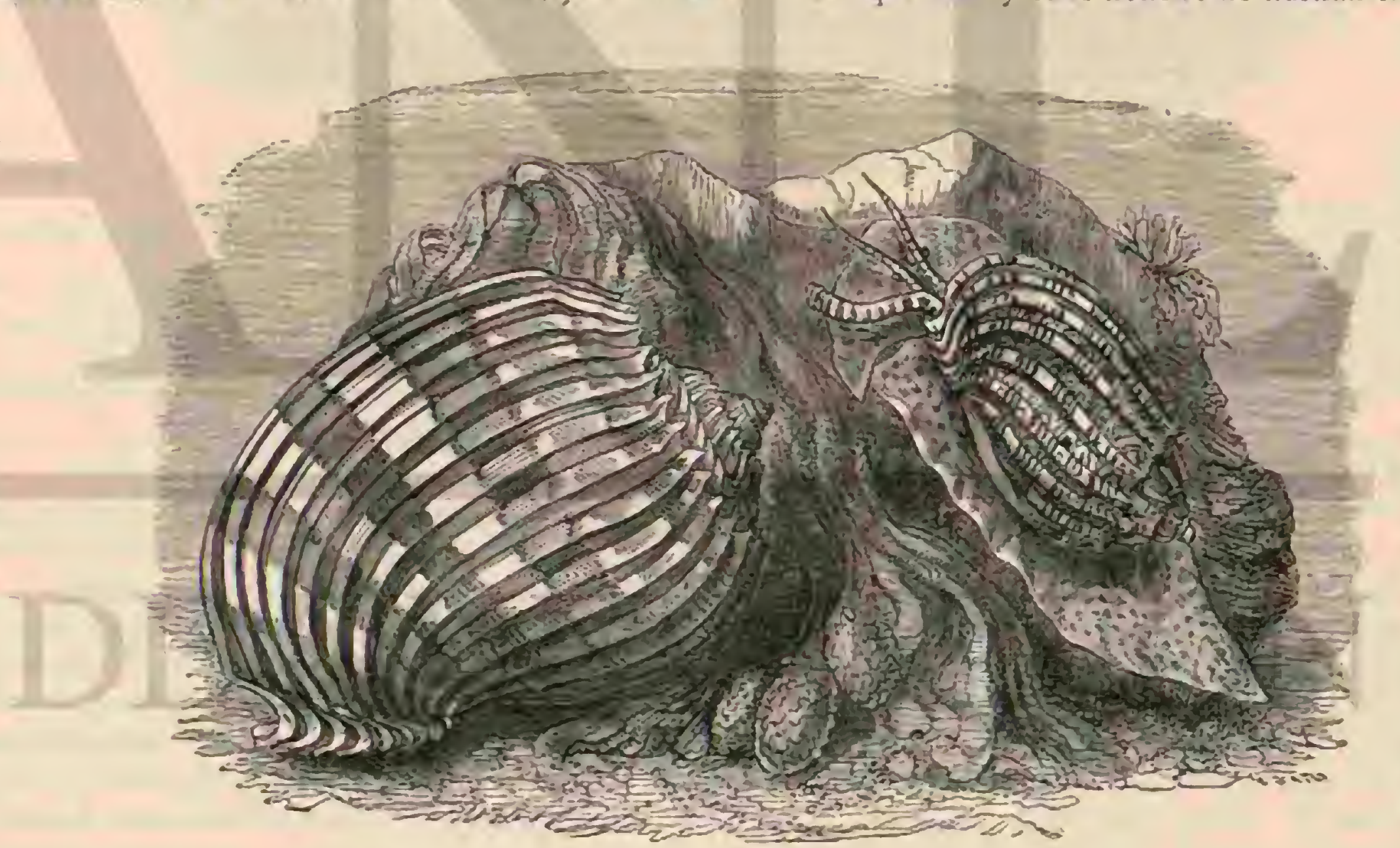

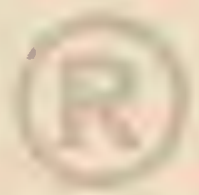

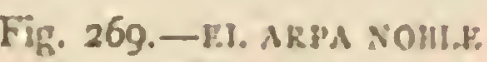

Fig. 26S. - RI. ARB' COMU:

ria natural, son digmas sin embargo de citarse, porque nos permiten dirigir una ojeada sobre la industria inferior y artistica de los pueblos. Causa asombro observar hasta que punto la vida de las poblaciones insulares y costeras de las regiones cálidas se facilita $y$ embellece por ha abundancia de moluscos grandes, comestibles y útiles.

La concha del género mitra es casi fusiforme, con una larga circunsolucion puntinguda. El animal tiene una trompa desproporciomadamente larga, y segun la noticia de Rumplh, pucde causar peligrosas heridas con las armas interiores de sur boca; cl citado autor dice que algunas personas han muer. to de ellas. El que trata de comer ha mitra sufre por lo regu. lar vómitos mortales.

\section{LAS COLOMBELAS-COLUMBELLA}

Ias colombeizs son conchas cortas, pequeủas, bastante gruesas, muchas veces estriadas trasversalmente y muy va 
riadas en sus colores. El animal es un traquuelipodo, cuya cabeza lleva dos tentáculos con los ojos situados en su parte media inferior; tiene un sifon sobre la cabeza para la respiracion, y un opérculo eliprico y nuy pequeño unido al pié. Se encuentran estas conchias en los mares cilidos, y por lo regular en las aremas, algunas veces en gran número. En los terrenos terciarios existen varias especies fósiles

Ia especic tipica mas notable es la colombela brillante (iolumbella fulgurans) (fig. 26i).

\section{LAS OLIVAS - OLIVA}

CARACTERES. El género olivi constituye el tronco de otra familia. La concha se asemeja muclio a la de la porcelana, porque tambien estí arrollada, aunque las circunvoluciones cortas quedan visibles por suturas que afectan la forma de surcos siempre profundizados. La superficie es lisa y brillante. El animal tiene un pié ovalado, muy ancho, que se dobla lateralmente sobre la concha hacia atrás y la alisa.

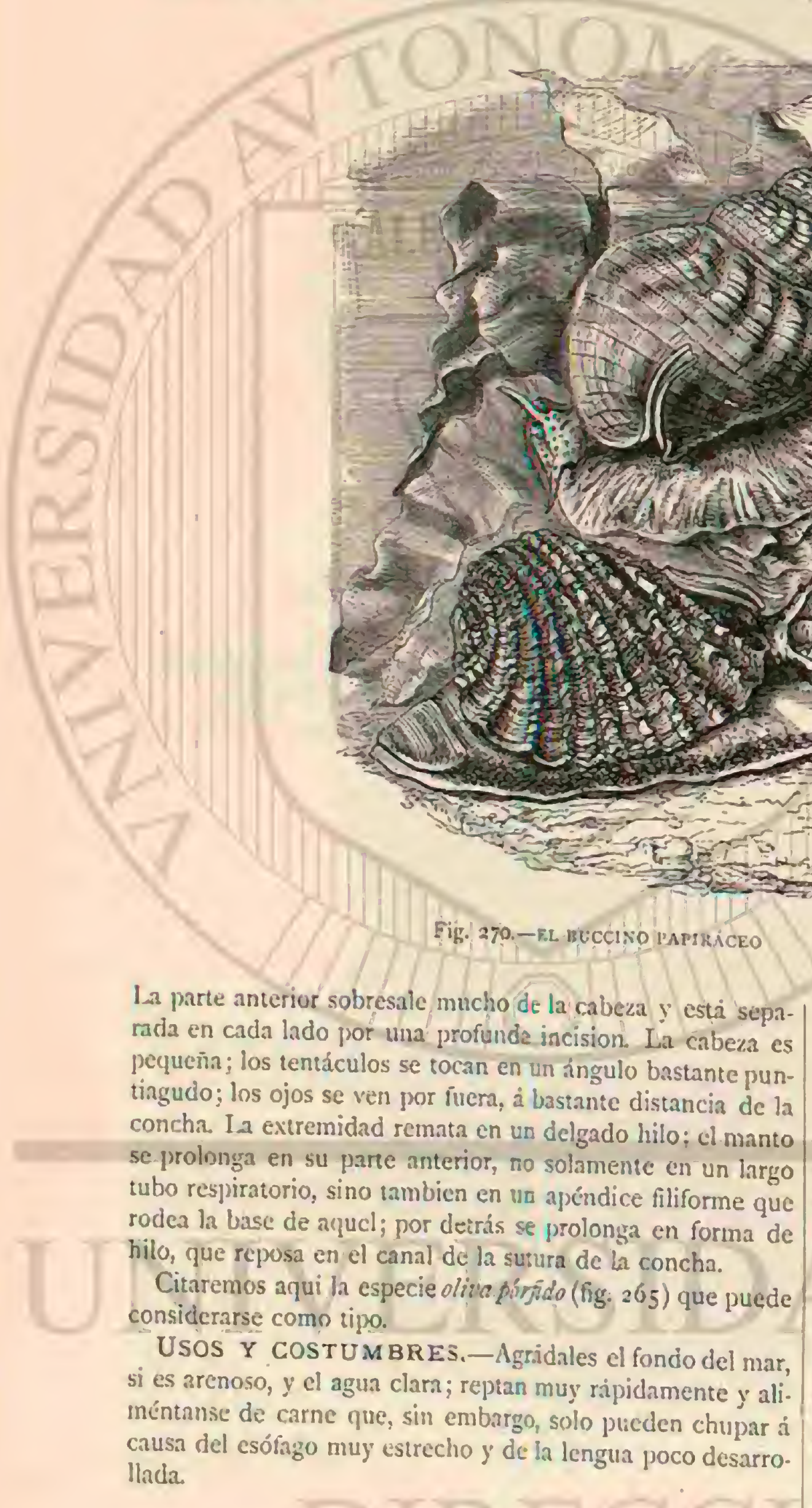

Fig. 271. - EL CONCOLEL'A HERUANO

\section{LAS ANCILAS-ANCILLIA}

La parte anterior sobresale mucho de la rabeza y esta sepaera en cada lado por una profunde incision. La cabeza es oje tocan en un angulo bastante pun, a bastante distancia de la ing tubo respiratorio, sino iambien en un apendice filiforme gue rodea la basce de alpucl; por detrás se prolonga en forma de hilo, que reposa en el canal de la surura de la concha.

Citaremos aqui la especie olive piroido (fig: 265 ) que puede USOS Y COSTUMBRES. - Agridales el foncio del mar, si es arcnoso, y cl agua clarn; reptan muy rapidamente y ali plicenen chupar llada.

CARACTERES. - Un pié de la misma naturaleza y una concha semejante, cuya sutura no tiene sin embargo la forma de surco, caracterizan principalmente a las ancilas, animales vivaces, que al parecer jurefieren el fondo cenagoso. Su estruc tura especial explica que puedan recager su enorme pié en la concha.

\section{LAS ARPAS - HARPA}

CARACTERES. - Tambien las especies del género harpa tienen un pié muy grande, mucho mas largo que la concha, y' que puede extenderse y alcanzar doble longitud. Ias bonitas conchas ovales, mas 6 menos dilatadas, se reconocen fácilmente por los surcos paralelos y de borde afilado.

Citanse como especies principales, entre las existentes hoy dia, el arpa comun (fig. 268) y el arpa molle (fig. 269). USOS Y COSTUMBRES.-Rumph ha observado ya que estos animales que viven en el Océrno Indico y en el Paci. fico, pueden, al contraerse con violencia, lanzar la parte pos. terior del pié Oken, fundandose en las observaciones de Quoy y Gaymard, refiere lo siguiente sobre esta mutilacion voluntaria \& I o mas asombroso en este animal es la separacion de la parte posterior del pié. Jos animales son muy ági. les; en los acuarios salen al punto de la concha f ensucian el agua con la sustancia mucosa. Aperias se les inquieta hacen algunas contracciones y arrojan el cuarto posterior del pié, que aun se mueve algunos momentos. Parece que el animal no se encuentra luego muy bien, ó cuando menos se oculta bastante tiempo en su concha. Esta sepamcion, quue se efectua con el mas ligero esfuerzo, no parece una fractura, sina solo un corte, y i pesar de eso, no se observa en ninguna parte la linea de separacion. Por fin hemos encontrado lit ra\%on; pues trasiersalmente se corre por el pié un gran con. 
ducto de agua, de modo ąue esta parte se debilita, separán. dose por una fuerte contraccion. De cincuenta individuos, hemos obsermdo en cuarenta esta separacion. A Aunque esta parece efectuarse voluntariamente, no es de suponer que en estos moluscos, como tampoco en los holuturidos, se trate de una convulsion debida al sistema nervioso. La parte perdida, segun se dice, fórmase pronto de nuevo, á pesar de su tamaño.

\section{LOS BUCINIDOS-BUCCINIDE}

CARACTERES. - Un habitante comun del mar del Norte, el bucino ondulado (bucinum undatums), sirve por lo regular para caracierizar la familia de los bucinidos. El caracol de la concha de estos moluscos es conitorme ý pequeño en proporcion á la última circunvolucion. Ia desembocadura acaba en un corto canal encorvado hicia arriba. L.a con. cha, que llega á tener ocho centímetros de altura, es oval cu. neiforme, ventruda y con rebordes en las circunvoluciones convexas, longitudinalmente irasversales, prominentes y de finas líneas. El animal tiene la cabeza plana, truncada en su parte anterior, en cuyos dos ángulos se insertan las antenas, bastante prolongadas. Por fuera, en la base de las mismas, se hallan los ojos. El gran pié es redondeado en su parte pos. terior $y$ cn los ángulos anteriores.

El huccino papináceo (fig. 270) es una de las especies que se consideran como tipo del género.

USOS, COSTUMBRES Y REGIMEN. - No es fácil permanecer algunos dias a orillas de muestros mares septentrionales, sin encontrar, entre los objetos arrojados à la orilla por el mar, el ovario de estos animales, amarillento y de forma de un racimo. Cada una de las bolsas coriáceas tiene la mitad del tamaño de un guisante y es de forma esférica com. primida. Un fuerte ligamento las reune en una masa redon-

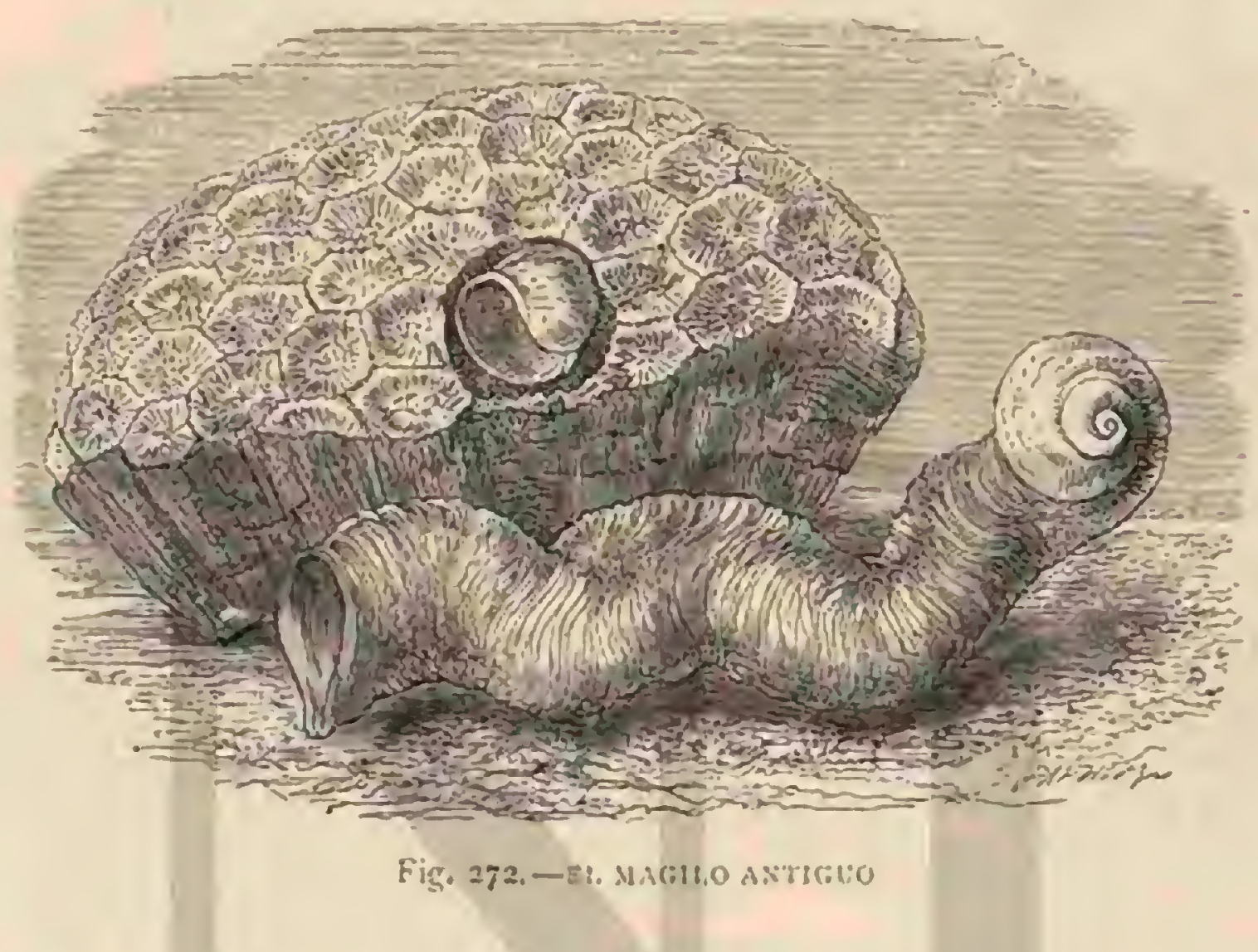

deada llamados ellis, abola de jabon marino», porque los navegantes se sirven de ella para limpiarse las manos. Estas masas de ovarios se fijan por los caracoles en diferentes cuerpos submarinos, piedras, jedazos de madern, ostras, etc., y las paredes de las cápsulas son al principio tan delgadas y tras. parentes, que sin dificultad se ven los huevos encerrados en ellas. Cáda una contiene el asombroso nímero de 600 a 500 huevos; pero mas asombroso es que un reducido número de caracoles, unos cuatro a doce, macen de la cápsula. Los conocidos naturalistas noruegos Koren y Danielssen observaron el desarrollo de los embriones, pretendiendo que el hijuclo no nace de un huevo como en los demás animales, sino que se reunen de cuarenta a ciento cincuenta huevos para tras. formarse despues en un solo embrion. Resultó, sin embargo, que el procedimiento es otro, aunque no menos extraño. La disposicion del embrion, toma su principio en la materia de un solo huevo, pero tan luego como los primeros órganos aparecen, entre ellos, sobre todo, la vela, de que ya hemos hablido al tratar del género iermefus, el pequeno animal hace uso de la boca $y$ del intestino, $y$ come con verdadera voracidad los huevos que le rodean y que no han llegado á desarrollarse Su cavidad abdominal se llena por esto de tal modo, y la cana llega a ser tan delgada y trasparente, que bien se puede perdonar el error de que el pequeño ser es un conglomerado de muchos huevos; estos sirven, por lo tanto, sencilla. mente de alimento, y en tal caso reemplazan à la llamada yema alimenticia, es decir, á la parte de la yema de un huero que en el trascurso del desarrollo no se trasforma directa- mente en los tejidos y sustancia corpórea del embrion, sino qque se dijiere como alimento en el intestino del jơven animal. Los huevos contenidos en las cipsulas son al principio de igual naturaleza y no se conoce la verdadera causa porqué solo aquellos pocos se han elegido para el desarrollo.

De las otras especies de bucinum, propias de los mares de las regiones mas cálidas, no si conoce el desarrollo, pero puede suponerse que sigue el mismo curso.

El bucino ondulado permanece cerca de la costa arenosa, donde á menudo se fija con ayuda del pié. Issto lo hace para perseguir las conchas que alli residen (pecten coperinlaris), especies de mactra, tellina, zenus y otras. Segun se dice, se apodera à menudo de la primera, introduciendo el pié entre la concha abierta, con riesgo de que esta le oprima fuertemente. De todos modos, el ataque á la concha se hace regularmente perforando, segun lo efectua tambien la major parte de los gasterópodos carnivoros. Los pescadores persiguen con afan al bucino ondulado, ja como enemigo peligroso de la ostra comestible, ya para emplearle como cebo. Jonsthon dicc sobre este particular: «En Puerto Patrick, donde el bucino ondulado tiene el nombre de grallina de liucki, se recoge al efecto en cestos, en los que se ponen pedazos de peces, y que â la distancia de un cuarto de legua del pucrto, ó del Castillo Viejo, se bajan à una profundidad de diez brazas para coger los caracoles que han entrado, atraicios por aquel cebo. De cada caracol pueden hacerse los cebos para dos anzuelos; de modo que, calculando el número de estos en 4,500, parn todos los barcos que los echan diariamente, mientras dura la pesca, 
se cogen 2,250 de estos grandes caracoles, lo cual representa al año un total de nada menos que 70,000 . Sin embargo, aunque esta cantidad se recoge en su mayor parte en un pe. queño espacio, estos animales parecen abundar mucho.

\section{LOS CONCOLEPAS - CONCHOLEPAS}

Este animal tiene el pié enorme, fijo en la concha por un músculo en forma de herradura, y provisto de un opérculo córneo, delgado y recto. La concha es gruesa, oval, combada, con una abertura tan grande, que se parece à la de un pileopsis: no se han encontrado estas conchas mas que en las costas del Perú.

Ia única especie que representa el género es el conicolepr feruano (fig. 271).

\section{LAS EBURNAS-EBURNA}

Este animal se asemeja bastante i los buccinos; el pié, agudo por detrás, está provisto de un opérculo bastante desarrollado; la concha tiene la forma de la de las olivas, sin pliegues en la columnilia. Ias pocas esprecies compren.

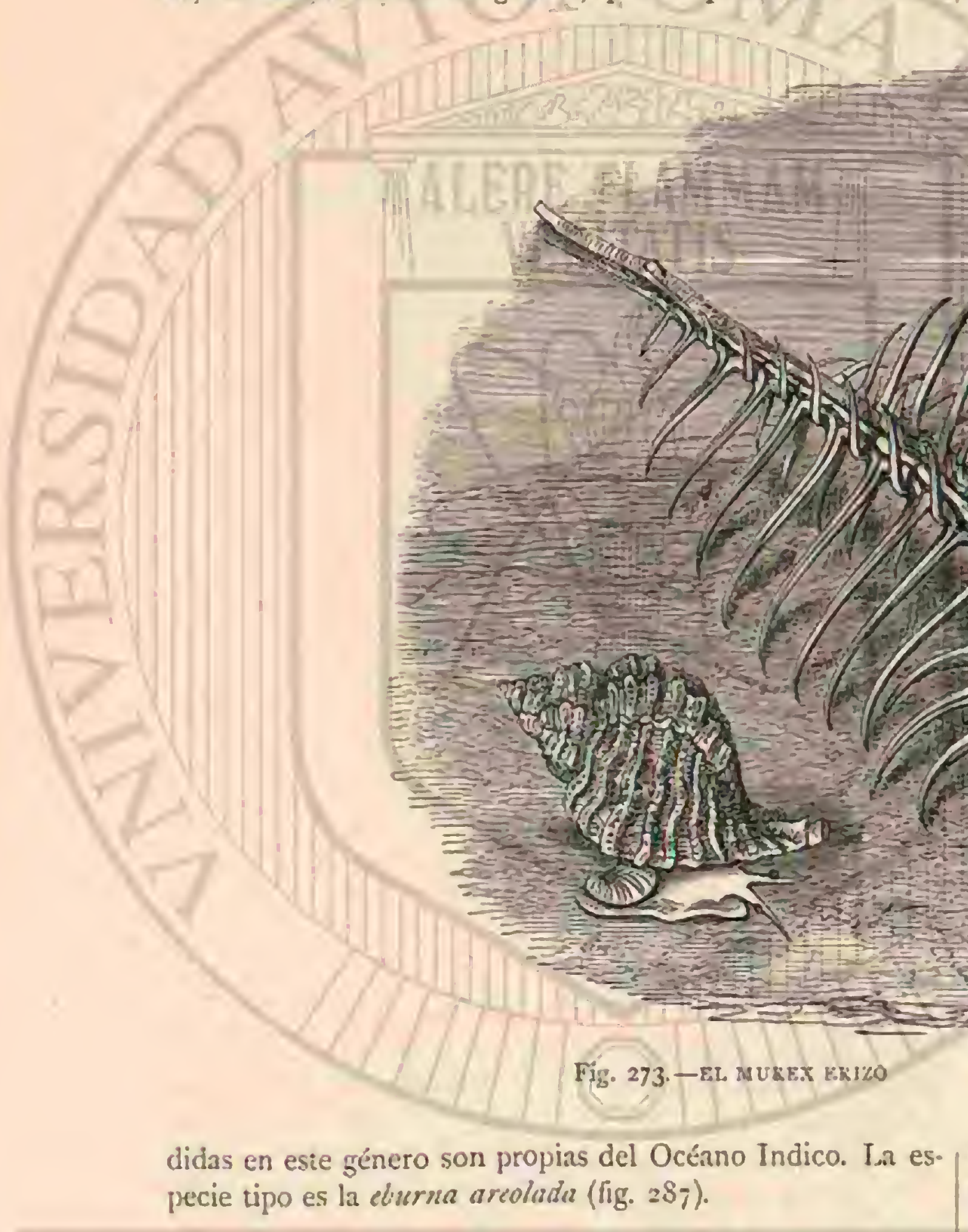

\section{LOS TEREBRAS - TEREBRA}

Ia concha de estos moluscos es muy prolongada y agu da, componiendose de un gran número de vuelias de espira. El animal tiene la cabeza grande, cilindráced, provista á cada lado de un tentáculo corto y cónico; el pié es brevey grueso, y se adhiere con fuerza i los cuerpos, hallándose provisto de un opérculo córneo: habita en los mares de Africa, de las Indias, y de la Oceania.

Ja terebra manchada (fig. 288 ) es la especie mas notable como tipo del género, ys se encuentra particularmente en Africn.

\section{LAS NASAS - NASSA}

CARACTERES. - A los bucinos sigue el género nassa: con profunda escotadura en el canal y' con el buzo replegoso. Para nosoitos la nasa reticulada (nassa reficulata), llamacia asi por la concha provista de una red casi regular de surcos longitudinales y irasversales, es la mas importantc. Mayer $y$ Marius han descrito muy exactamente su género de vida.
هIas nasas son camivoras: ya hemos visto que atacaron a estrellas de mar vivas, y que solo retrocedieron por la fuerza de los movimientos de estos animales. Cuando si ceha carme al acuario, la olfatean muy pronto, pues enseguida se ponen cn movimicnto para buscarla. Las que están próximas à la superficic del agua se dirigen hảcia-abajo, otras que están subiendo, vuelven á bajar. Muchas levantan el pié fijado en el cristal y déjanse caer al suelo. De este modo consiguen acercarse mucho al alimento olfateado, y liego continuan su camino reptando. Ias que están ocultas en el cieno del fondo, salen y se dirigen hácia la carne.

El órgano con cl que la nasa oliaten la carne parece ser el tubo respiratorio; le alarga y mueve en todas direcciones. No avanza en linea recta hácia la carne, sino que se dirige à la izquierda, ó à la derecha, y hasta á veces se vuelve, pero entonces advierte muy pronto que se aleja del alimento olfateado, y vuelve á emprender su anterior camino. Todos sus movimientos hacen suponer que la lu\% no es la que las guia, sino otro moior, que se extiende como sustancias de olor, y como estas influye en un órgano del sentido. In el momento en que el caracol toca por primera vez la carnc, nótase un estremecimiento en las antenas y el tubo respiratorio, y la trompa, un tubo de color rojo claro, sale de la boca y se introduce en la carne. 'Todis las nasas del acuario se reunen muy" 
pronto alrededor de la carne; cada una queda firme en su puesto y solo los tubos respiratorios se mueven continuamente.

y La nasa se sirve á veces de su pié para coger el alimento y sujetarlo. Una nasa acababa de encontrat un pedazo de carne, cuando se presentó tambien un foliemon syuilla (un garnélido), pasa cogerlo con sus temazas; pero la masa le envolvió la mara con el pié, y no la soltó aunque el palemon quedó mucho tiempo tomando parte en el festin.

\section{LAS PÚRPURAS-PURPURA}

REPRODUCCION. - Si arriba hemos dicho que probablemente tambien en las demás especies de luccirumm, el desarrollo de los pocos hijuelos se efectua á expensas de ta mayoria de los huevos, debemos confirmarnos en este parecer por la observacion de que lo mismo sucede tambien en otros caracoles, como por ejemplo en la púrpura lapillus, muy congenerira al hurinn, y que tiene la misma área de dispersion. Las cápsulas ovarias de estos gasterópodos, se encuentran fijas tambien en piedras y otros objetos, asemejindose á una peçueña botella fija por su delgado cuello. Cada cápsula estí cerrada herméticamente y llena de un liquido gomoso, claro como el agua, en el que flotan de 500 i 600 huevos. Los mas de estos no llegan, sin embargo, al fin de su destino, pues suelen servir de alimento. Todas las especies del genero se distinguen por su lentitud y pereza; la purpura lapillses, jertenece $i$ las que durante dias y semanas enteras permanece en un mismo sitio. Segun las observaciones de Steentrup esta especie parece estar representada tambien por algunas formas pequeñas, que se encuentran en los troncos y ramas del coral de abanico (gorgorsia flabellum) y otras gongonias de las Indias Occidentales. Se mantienen firmes en su sitio y oprimen el borde del manto de tal modo contra las ramas del coral, que las envuelven completamente, mientmas que la capa superficial blanda de la gorgonia, rodea la concha hasta que por fin solo queda un peq̨ueño agujero para la comunicacion entre el caracol y el inundo cxterior. Poco mas ó menos como estas especies, que viven en los corales córneos Rexibles, otra, la firpura madreporarum, habita en los corales pedregosos de la India

\section{LOS RIZOQUILOS-RHIZOCHILUS}

Hay dos géneros muy añnes al de la purpura, y que al fijarse sufren las mas extrañas transformaciones: son el magilus y rhisochilus. Libres al principio, nosolamente se hacen sedentarios, sino que su concha sufre tales cambios en su ligura, que varia del todo su régimen alimenticio y.su género de vida. Continuaremos la descripcion que Stecnstrup ha hecho sobre este punto. Los hijuclos del rhisaclishus Anifipathum se parecen tanto a las púrpuras, que se les puede confundir con los individuos jórenes de muchas especies de este género. La concha del animal tiene $11^{\circ}$, o 15 de largo al nijarse; la desembocadura longitudimal es redondeada hácia arriba, puntiaguda hácia el corto canal, y los dos labios del todo sencillos, hasta el tiem. po en que los animales se fijan; entonces se prolongan tanto en el interior como el exterior, comenzando it rodear las ramas de coral. Cuando mas tarde se cxamina el estado de la concha, obsérvase ya una extrańa trasformacion, sobre todo en los labios. Estos son protuberantes; han recogido una ó varias ramas de coral, acercándose uno a otro, ỷ por la continua secrecion calcárea, el animal ha cerrado por decirlo asi, la abertura de su propia concha.

A menudo varios individuos se han fijado tan próximos entre si, que la concha del uno cerraba en parte la desembocadura del otro, aunque dejando siempre bastante espacio para que pueda salir un tubo rjue tiene gran semejanza con el de un anélido, como por ejemplo del género serpulr. Como los corales córneos, segun veremos despucs, se componen de un eje mas sólido $y$ de una sustancia mas blanda y carnosa que rodea a aquel, esta viltima debe comarse en consideracion cuando, con Stcenstrup, queremos formarnos una ider completa de la vida del rhisochilus, pues cuando los individuos pequenos existen ya en las espesuras de antipntes rodeadas de sustancias animales, y mas tarde se fijan en los troncos de coral, que aun se hallan en tal estado, natumlmente la capa blanda de la cubierta del pólipo ejercerá una influencia esencial en los caracoles parásitos. Aunque el maturalista danés solo tenia a su disposicion troncos de antipates resecados, el hecho se podia hacer constar sin embargo con seguridad. "lodos los rhizoihilus fijados estaban cubiertos de la masa blanda resecada de los pólipos. Al fijarse el rhizochilus, queda cubierı poco í poco por los pólipos, que mas y mas sc extienden, $y$, a medida que estos crecen, el caracol prolonga aquel tubo y tiene entonces un género de vida sin duda muy diferente del de los otros congéneres, cuya descripcion queda reservada para observadores futuros.

\section{LOS MAGILOS - MAGILUS}

De cste género, cuya manera de proceder es análoga á la de los arriba citados y no menos singular, solo existe una especie que se encuentra en el mar Rojo. El inagilo se introduce en las moles del coral pedregoso; pero mientras que en los rizoquilos solo el canal sé jrolonga en un estrecho tubo, aqui toda la dusembocadura se alarga como una especie de ancho cucurucho. Lil concha primitiva y la parte interior del cucurucho se llenan poco á poco de caliza; el animal avanza for el tubo, a medida que este se prolonga, y segun que el co. ral se extiende. Como los rizoquilos, no se hallan aislados en su vida de parásito, pues al contrario, ticne un tránsito, en las especics de púrpura que viven en los madreporos;el iránsito de los caracoles libres al magihus antiguus (fig. 272) no es tampoco brusco, sino que tienc como género preparatorio el lepir-conchus. Tambien estos animales viven en el interior de otros pedregosos, pero su concha no se prolonga nunca en tubo. El lepro-conchus es por lo tanto el estado de juventud del magilus.

\section{LOS MUREX - MUREX}

CARACTERES. - El géneto murr: rico en especies, tiene el borde exterior rodeado de una prominencia que en el desarrollo ulterior queda en las circunvoluciones, que afectan la forma de fajas longitudinales prominentes, que parecen formar repliegues ó son denticuladas. Cuando menos tres serics de estas prominencias se corren hasta la punta de la espiral. Ias dos especies mas importantes de este género son el murex erizo (fig. 273) y cl murrex espinoso (fig. 274) que viven particularmente en el Océano Indico.

DISTRIBUCION GEOGRÁfiCA.-Entre las especies que tienen largas espinas y el canal muy largo el murca bran. daris es la mas comun en el Mediterráneo.

USOS, COSTUMBRES Y REGIMEN. - Vive en el fondo cenagoso $y$ se pesca en grandes masas para llevarle al mercado.

Otra esperie, el murex trunndus, tambien uno de los caracoles mas comunes del Mediterrineo, que vive en el fondo pedregoso, ticne un canal encorvado de mediana longitud y solo protuberancias obtusas en las prominencias.

Al describir los murex, Kumph habla de las llamadas unas de mar ú ong:r, es decir, de las tapas de la concha. Como cu. 
riosidad daremos algunas noticias sobre las aprecinciones que de estas especies se hacian en los tiempos antiguos. «Tal znguis 6 uña se llama una myrx marina, y es en toda la India un conocido sahumerio, porque en todos los polvos para perfumar constituye el principal ingrediente. Hablo de los polvos desinfectantes que los médicos llaman thymiamata y que se arrojan sobre carbon encendido. Entre estos, el ungui es el elemento principal, como el áloe entre las pildoras. La uña de mar por si misma no tiene olor agradable, puses cuando se romje en pedazos, ponienciolos sobre el carbon, percibese primero un olor como el de la gamela irita, que sin emhargo se inclina pronto al del ímbar, ó, segun Dioscorides, al de la secsecion glandulosa del castor, no muy agradable mientras se quema soló pero que, cuando se mezcla coll otros perfumes, comunicales mucha fuerza y dumcion.
La mayor parte de los sahumerios se componen de maderas, resinas y jugos que tienen un olor muy desagradable, y es preciso mezclarlos con la uña de mar para que aquel sca mas fuerte $y$ duradero. Esta una de mar podria comparar. se al contrabajo de la música, que mientras se oye solo no tiene el sonido agradable, pero mezclado con otros tonos produce una suave armonia que realza mas aquellos. \$ Los charlatanes indios muelen un poco de ony'x del murex ramosus sobre una piedra, sy le propinan como remedio contra el cólico y el dolor de vientre, empleando tambien el humo para curar los males de la matriz, en cuyo último caso, sin embargo, se debe quemar sobre un fuego muy vivo.h Es una suerte que hoy dia no tengamos necesidad de servirnos de las tapas de caracol, ni para perfumes, ni para medicina.

Un detalle de mas importancia, que se relaciona con la

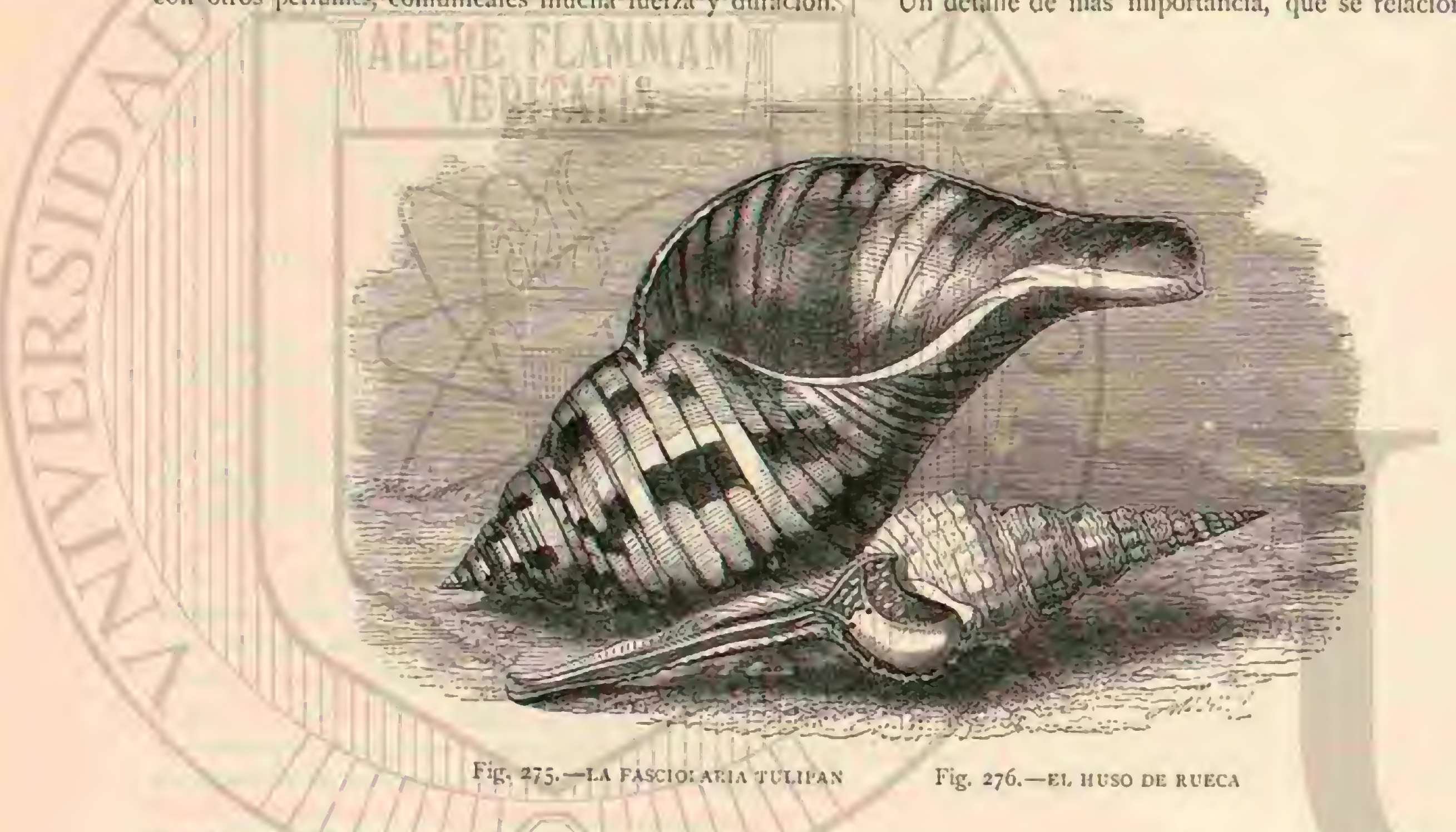

historia natural de los géneros furpura y murex, es el que se refiere al color de purpura, sobre cuya fabricacion y particularidades existe toda una historia, que Lacaze. Duthiers ha esclarecido con sis excelentes averiguaciones. Cuando este raturalista, se hallaba en el verano de $\mathrm{i} \delta 58$ en el puerto de Mahon, donde con aynda de un pescador buscaba toda clase de animales marinos, abserró que su auxiliar se tenia la ropa, trozando leiras y figuras toscas con un peciacito de madera,y aparéciendo los caractéres al principio amarillentos. "Se vol. verán rojos, dijo el pescador, tan luego como el sol los haya tocado\%. Al decir esto, mojó la madera con la secreción gomosa del manto que habia arrancado de un caracol, que enseguida pudo reconocer el natumlista como pirpurn haneasforna. El zoólogo hizo teñir enseguida tambien su trage, observando que bajo la influencia de los rayos del sol se desarrollaba un olor en extremo desagradable é intenso, produciéndose luego un tinte violacco muy hermoso. Esta fué la causa de otras averiguaciones que dieron los mas preciosos resultados.

Segun se sabe, hace tiempo que se emplea la púrpura de los caracoles como sustancia para teñir. En cambio sabemos por los autores griegos y romanos que la fabricacion de púrpura era un importante ramo industrial, y que solamente los grandes y ricos podian darse el orgulloso jombre de purpurados (purpurati), a causa del alto precio de la sustancia. Hoy dia solo remos en las islas y costas apartadas algunas

gentes pobres tenir su ropa blanca con la púrpura del caraco que, en la antiguedad, cuando los colores de la quimica moderna no se conocian aun, debió tener un valor tanto mas crecido, cuanto que sus tintes y la cualidad de su dura. cion dependian del sol. A principios del siglo pasndo, el cúlebre observador de los insectos, Reaumur, se ocupó en la costa de Poitou de los caracoles de púrpura. Tambien oliservó que la sustancia teñia de violeta, pero es extraño no reconociera que la produccion del color dependia de la luz, creyendo que en clla influia el aire. Tales y otros errores fueron cometidos tambien por otros autores, en cuyos relatos se encuentra la noticia de que el color de puirpura ticne su origen de un pez; mientras que otro dice que se extrae de una concha encontrada por los pastores.

Por lo que toca a las particularidades de la materia purpúrea, al sacarla del órgano en que se halla, y que mas abajo describinos, es blanca ó amarillenta, segun las csprecies de fiopura y de murci; al exponerla á los rajos del sol toma al jrincipio un tinte amarillo de limon, luego amarillo verdoso, despues pasa al verde y se trasforma por fin en violeta, que se oscurece mas y mas, cuanto mas se expone di la influencia del sol. Depende de la cantidad de la sustancia sacar el matir de violeta desenclo; el tintorero experto tiene por lo tanto todos los grados de sus matices en su mano. Para obtener la sustancia es mejor servirse de un pincel un poco duro, con el que se saca, para ponerla enseguida sobre los géneros que se 
han de tenir. Lacnze-Duthiers, no solamente zoólogo, sino tambien artista, vió que la materia purpúren es, seyun nuestras experiencias modernas, una sustancia fotográfica en alto grado útil. Hizo en este concepto una serie de experimentos con muy buenos resultados, de los que tengo, mientras escribo esto, varias pruebas a la vista. Naturalmente, In tintura de púrpum no tiene un porvenir nuevo, pero el zoólogo parisiense crec que el tresporte de fotografias, por medio de la púrpura, sobre latistas y géneros finos de scda, sobre abanicos y otros articulos de lujo, seria muy apreciable por la extraordinaria deli. cadeza de los tintes.

Nos resta examinar ahora el órgano de que se segrega la púrpura. Para tenerlo bien á la vista es preciso rompler la con. cha y sacar el animal, como se hace generalmente con todo

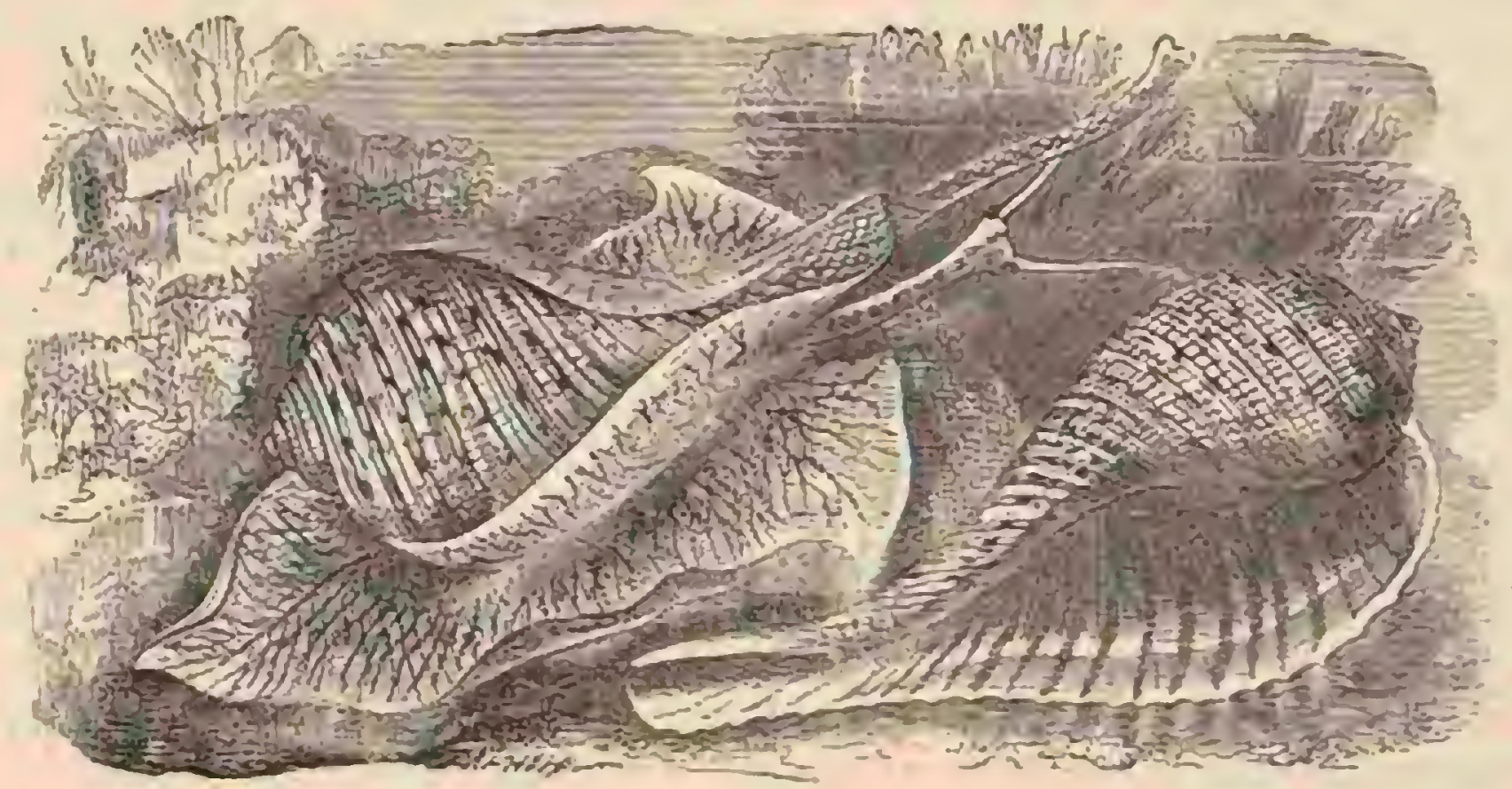

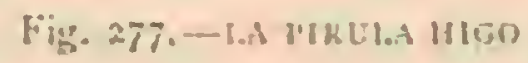

camcol que debe disecarsc. Sugun hemos visto, yueda ileso dejaria arrancarse todo el pie y la cabeas. Entonces se ve en tan luego como estí cortado el músculo que se inserta en el el animal desnudo cómo cl bordedel manto ste extiende sobre lusso. No es posible extmerle de la concha entero, pues antes la region de la nuca: a la irquierda se encuentra la prolonga-

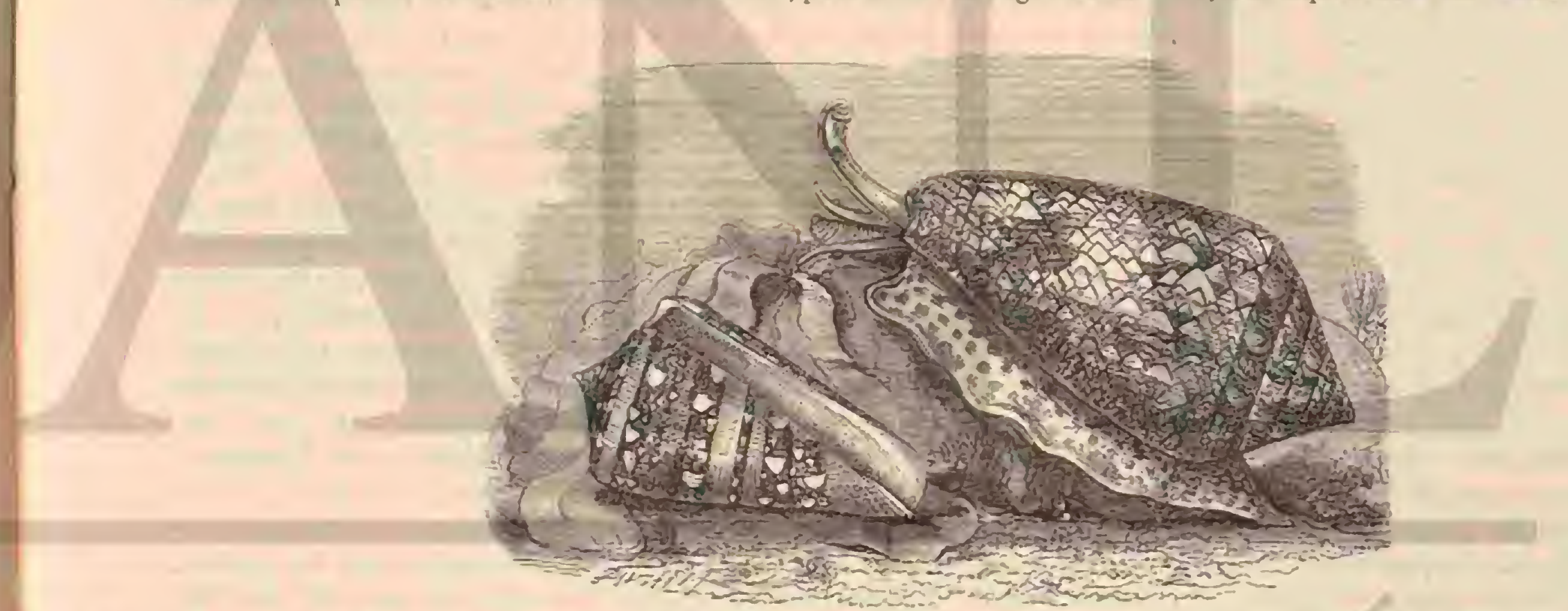

A D

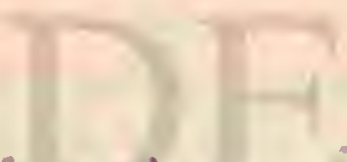

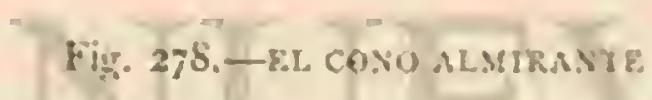

cion en forma de surce por la ruge el agua jenctra en la bránquia. Festa se distingue à la simple vista, $y$ un poco mas à la derecha de ella hay uma fajat verde amarillenta. Abriendo cl manto de adelante atràs, à lo largo del lado derecho de la brinquia, hållanse, allevantar los lúbulos, las partes de que se trata, y a demás, al lado ce la glándula amarillenta, cl intestino y' el conducto de salida de los organos genitnles. Parn coger. la sustancia púrpurea no se necesita nada mas que pasar el pincel por la ghíndula amarilienta, llamada glascosta de fírpura. Sin embargo, el citaco atutor llama la atericion sobre la circunstancia de quue la mayor parte de los camcoles, yo quizas todos, pueden segregar del manto un liquido mucuso (que por su origen es comparable con la sustancia purpúrea, mieneras que solo en algunos géneros, en los verdaderos caracoles de purpura, se encuentra la facultad de adquirir bajo la influenria de la luz del sol el color violiceo. Aqui se trata por lo
Fig. 279.-E. Coso Mosnico

tanto de pequeñas diferencias de la composicion quimica, tan ligeras que apenas pueden expresarse por palabra y cifra $y^{\circ}$ solo se presentan en la exrema diferencia del eiecto.

Aunque antes hemos visto que el color de que se trata es violàcco, volveremos :i las explicaciones de Lacaze-Duthicrs sobre las particularidades que ofrece, por mas que esto parezar del todo supérfluo, porque todo el mundo tiene ja idea del color cuando dice: csta ó aquella cosa es violáccí Al pre. sentar el naturalista parisien sus dibujos y fotografias le dijeron: esto es violáceo, $y$ la púrpura de los antiguos era el rojo, y la de Tiro el color de sangre. Para designar la púrpura romana de hoy dia se habla de un rojo vivo que se obtendria par un fondo rojo de cinabrio cubierto de carmesio Varios pintores de aupellos á quienes se invitó d indicar cl color de un vesticio de purpura romana cran de opinion del todo distinta. Como las especies de carncoles examinadas daban sin 
excepcion por resultado un color violáceo, aunque de diferenies tintes, se trataba de comparar estos hechos indudables con las noticias que en los antiguos autores se han conservado sobre la púrpura. En cllas se ha encontrado, como cra de esperar, que conocian todos los tintes; que por fin se fijaron en el violaceo, y que tambien los colores obtenidos por la mezcla de la sustancia de varias especies de caracoles y por la fabricacion, colores que se designaban con el nombre de púrpura, solo se diferenciaban por la major $v$ menor intensi. dad del violaceo y del brillo; asi como por otms cualidades ulue nada tienen que ver con el color primitivo. Una mezcla favorita era la de las materias colorantes de las especies de firfura y murex, que se apreciaban mucho como color de amatista Sin cmbargo, predominaba mucho la moda por que debian regirsé los sintoreros, y es probable que. se prefiriesen sobre todo las mriedades antiliciales que mas se acercaban al rojo. En mi juventud, dice un romaino, era moda la púrpura violeta, de la que la libra valia cien denarios (unass 106 pesetas); poco despues se usaba la purpura roja de Tarencia, Yinas tarie la púrpura doble de l'iro, que costaba 1,000 do. narios la libra. los restidos de púrpura doble llamados dibigha eran de sumo lujo; se teninin dos veces, aumentando de este nodo su belleza y precio. Lacaze-1)uthicrs al recopilar sus averiguaciones llega al siguiente resultado: ฉ Desean. do determinar la significacion de la palabia púrpusa como color, nu dirigi à la pintura. Examine cuadros de nacstros, rogue a varios pintores tau habiles como instruidos me indjcaran el tono, el tiute que emplearian para representar un vestido de púrpura. Siempre hubo grandes dudâs y dificultaces, jero al fin predominaba el rojo. Consulté la historia de In pintura $y$ hallé la misma inseguridad respecto a la púrpurn. Fundíndonos en los experimentos y en las noticias de los autores antiguos comparados con aquellos, nos parece sin embargo evidente que los pintores que debian emplear la purpura hubieron de nariar el tinte segun los periodos diferentes. Cuanto mas profundizamos la antiguiedad, tanto mas predominante es cl tinte violeta, y cuanto mas nos acercamos al contrario a la época de Plinio (So despues de I. C.) tanto mas predomina el rojo; pero hasta el tiempo en que ya no se servia de la púrpura obtenida de los caracoles, el tono principal del color debia ser mas ó menos vio. láccó.

Si no olvidamos que en algunos cuadros hechos con la sustancia de puirpura de los diferentes caracoles obtuve tonos y reflejos azulados y rojizos, y si tenemos presente ademís que a los antiguos les gustaban mucho los vestidos de purpura en que se reflejaban varios tintes, al representar vestidos siempre debera cubrirse el fondo violáceo de rojo y azul; cosa que sin duda corresponderá a los tintes vivos y brillan. tes de que hablan Plinio y Séneca.

Ias especies de murex con que Lacaze-Duthiers hacia sus experimentos cran murex brandaris, murex trunculus y murex erinaceus, de los que los primeros son muy comunes en el Mediterrineo, mientras que el tercero pertenece $i$ la costa atlintica de lirancia; se parecen del iodo por la estructura de la glándula colorante. Lo mismo pasa con las dos especies de pirpsura, pirpura inchemasluma y purpura lasillus, pertenecientes la primera al Mediterríneo $y$ la otra al Atlántico; probablemente, todas las especies de estos dos géncros están provistas de la glándula de purppuru. Comparando la descripcion que Plinio hace de los caracoles empleados en la tintorería, resulta que los antiguos designaban nuestro género actual de pirpura con el nombre de buccimus, pero el mure. con el de firpura. Las fabricas de esta sustancia se exten. dian por toda la Italia y Grecia; una de las mas grandiosas existia en Romn, donde de las conchas de los animales utili. zados se formó el Monte Testiceo. Yo mismo he reconocido en la primavera, en $386 \%$, en Aquilea, el lugar de una antigua fibrica de sirpiera. Segun se sabe, Aquilea ha estado mas expuesta a las tempestades de la emigracion de los pue. blos, que ninguna otra de las célebres grandes ciudades de la antigüedad. Solo existen algunas columnas y restos del grandioso acueducto; la ciudad, ó lo que antes lo era, se ha trasformado en vinas $\delta$ campos. No se puede recoger ni un punado de tierra sin encontrar en él los vestigios de una gran civilizacion pasada, y en gran número se presentan estos objetos cunndo los campos se labran a mayor profundidad. El administrador de la Hacienda de Monastero, pueblecito que se halla en el territorio de la ciucad destruida, me habia dicho que su gente, al labrat un trozo de campo, habia encontrado tambien grandes montones de conchas de caracol, y gue probablemente alli habia estado la pescaderia y el mercado de conchillas, Sin embargo, los miles de conchas y fragmenios que vi, snlo pertenecen á las esperies murix hrandaris y murex trinculus, de modo que no puede haber duda sobre la razon por que alli se hallan amontonados.

\section{LOS HUSOS-FusUS}

A los caracoles congenéricos del murex, pertenece tambien el grande génuro de los husos (fig. 276). El animal tiene una calbeza muj pequena, los tentículos se tocan bajo un ángulo agudo y llevan los ojos en la mitad de su altura. El pié es tambien relatimmente pequeño. Ia forma de huso de la concha debe su origen a la espiral puntiaguda, muy estirada, y al canal larga que sale de la base Solo pocas especies de inediano tamaño habitan en los mares curopeos, como por ejemplo, el fusus antiquns. Como toda una seric de otros moluscos, esta especie reside en el Norte, es decir, en la costa escandinara y escocesa à reciucidas profundidades y baja en las partes meridionales del Atlántico á regiones siempre mas profundas. Johnston dice que la concha del huso se emplea en las islas de Setland como lampara y da la siguiente descripcion de sus huevos. Ia masa de los huevos en su conjunto representa un cono obtuso de $0^{\circ, 0}, 07$ de altura por $0^{\circ}, 05$ de ancho, que con la superficie ancha de su base esta fijado en el agua profunda. Este cono se compone de un múmero de grandes bolsas reunidas de un modo regu. lar por un fucrte ligamento cartilaginoso; cada celda tiene poco mas ó menos la forma de una una, convexa por fueray cóncava por dentro, de una fuerte jicl cơrnea caterior hendida en su borde superior, pero con la abertura tan estrecha que no puede penetrar nada mas que el agua necesaria pasa la respiracion del anima! jóven. En esta capa embrional exterior y solo ligeramente reunida con ella se halla una bolsa de Torma parecida, del todo cerrada, que se compone de una membrama tan delgada y trasparente que no opone ningun obstáculo al oxigeno contenido en el agua. Su contenido es al principio liquido y granoso, pero pronto se descubren puntos oscuros, y por fin se desarrollan en cada bolsa de dos á seis pequeñuelos que cuando ha llegado su tiempo solo pueden lograr la libertad rompiéndose ó disolviéndose la bolsa interior. Las cajpsulas ovarias del lusso de Noruega y del huso de 'lurtoni son mas sencillas; sc parecen á botellas comprimidas con cuello corto.

\section{LOS PIRULOS-PYRULA}

Un género del que hace unos 30 años solo se conocia la concha es el pyrula, llamado tambien por la forma de su concha higra (ficus ó fucula) (ing. 277). In concha, que en su bise remala en una canal, carece de proninencias; tiene una espji. 
mal corta y un huso plano. Jas especies pertenecen á las costas tropicales de la India, $y$ a las de la América central, donde el nuturalista danis Ocrsted observó individusos viros de esta especic, cuya estructura es muy notable. Visto el animal vivo por su parte superior, cuando esti en movimiento, distinguese como una orla parda muy ancha, cubierta de manchitas regulares mas claras, que rodea la concha y la cubre en parte. Al observar el animal superficialmente, es fícil la suposicion de que la concha, como se ve en el género natica y otros, se apoye sobre un pié grande, pero no es asi; cste rodea la conchn, como ficilmente jodemos convencermos si se vuelve el animal del otro lado. Eintonces se ve que es el borde libre del manto, que arjui se ha desarrollado de un modo muy particular: este borde, que en los gasterópodos solo aparece en general como una estrecha orilla en el borde interior de la desembocadura, se prolonga en algunos de estos moluscos y se dobla sobre la superficie exterior de la concha. Mas alrajo la porcelana nos demostrari hasta qué grado esto puede verificarse. 'Tambien en las pirulas se ha efectuado tal desarrollo, en el mismo grado que la porcelana, pero de un modo muy diferente, pues la prolongacion se ha efectuacio preferen temente en direccion horizontal, como una orla plana musculosa y muy ancha que encierra del todo el pié y se halla en una misma linea con CL. Esta parte del borde del manto, al ceñirse estrechamente al rededor del pić, forma en cierto modo una continuacion del mismo y es propia como órgano de movimiento d causa de su fuerte estructura musculosa; el animal repta jor medio de ella del mismo modo que con el pil.

Observemos todavía un poco al animal desde abajo. Una larga punta saliente pertencec tambien al manto y es el cauce que conduce el agua á la brinquia; por delante del pié sobresale la jequeña cabeza coniforme, que llena los tentaculos, igualmente coniformes, y en cuyo lado exterior se hallan los ojos. Desgraciadamente no tenemos noticia alguna sobre el verdadero género de vida de este animal tan extraño. Oersted no dice si puedc ocular todo el borde del manto $\mathrm{cn}$ la concha, lo que, sin embargo, parece indudable por los experimentos hechos por Agassiz en especies americanas solore la recepcion roluntaria de agta en el cuerpo y la fa cultad de los tejidos de dilatarse que depende de aquella.

\section{LOS PLEUROTOMAS-PLEUROTOMA}

Algunas de las inmilias siguientes de moluscos se reunen bajo el nombre de pleurotomas; su lengua tiene dos series de largos dientes huecos, provistos a veces de ganchos, $y$ de los que cada uno tiene en su base un largo hilo musculoso. Como es natural, estos dientes sirven para recoger el alimento, pero segun parece nadie ha observado directamente el modo como ia lengua se cunplea ca este caso.

\section{LOS CONOIDEOS - CO- NOIDEA}

Entre los pleurotomas, la familia de los conoideos octipa el primer lugar, no soln por la multiud de las especies de lís que ahora se conocerán unas $\$ 00$, sino tambien a causa de la belleza de la concha, que perienece das favoritas y predilectas de los coleccionadores de conchas.

Como especies tipicas se hace mencion del cono aimirante (fig. 27S) y del conm mosniro (fig. 279).

Por un ejemplar del cunus codonulli se pagaron en otro tiempo 300 guineas $(7,200$ irancos). La concha de los conoideos es generalmente conocida. lis enroscada y por lo regu- lar de una forma cónica inversa, pues la espiral es tan corta que á menudo solo sobresale muy poco de la parte ó vuclta posterior de la tiltima circunvolucion. I a desembocaciura es una estrecha hendidura Inngitudinal con el labio exterior sencillo, de linea recta, que ilene por arriba un vestigio de canal. El animal presenta un pié largo y estrecho que lleva una tapita angosta en forma de una La cabeza es pequeña, de figura de hacha, los tenticulos son pequeros y cilindricos, y cerca de su punta se hallan los ojos. El tubo respiratorio es corto ó bien llega á la mitad de la longitud de la concha. In los conoideos, como en los otros caracoles enroscados (olisa, ygraa), las circunvoluciones se siguen tan estrechamente, que si conservasen su grueso frimitivo, t1o quedaria bastante lugar para los intestinos. Sin embargo, podemos reconocer los cortes trastersales, y, por la comparacion de individuos viejos con otros mas jóvenes, que las paredes de la concha, de un grueso igual en los segundos, vuelien a disolverse mas tarde. De las tres capas de la concha, anatómicamente demostradas, solo queda la interior.

En la obra de Johnston (Intraducion d in conguiliologia), con frecuencia utilizada por nosotros, y muy abundante en materia, se hace la suposicion de que algunos crustáceos ermitanos tienen la facultad de disolver las conchas de carncoles habitadas por ellos. Esto es decididamente errónco: la destruccion de la sustancia de la concha, observada con mucha frecuencia, se debe casi siempre : uma esponja (sulierites domucula ) que se fija en las conchas de caracoles habitadas por crustáceos. Tambien un pólipo sociable de la familia de las actinias produce la disolucion.

I as observaciones sobre los conoideos, que habitan á bas. tante profundiclad, por lo regular en un fondo cenagoso, son tan escasas que ni siquiem se sabe que es lo que comen. aSegun se asegurn, dice Philipi, se alimentan de plantas, cosa que sin embargo no se aviene con la estructura de su lengua. Rumph afirna que varias especies son comestibles, lo mismo que los huevos del conus marmorntus: Elstos últimos, dice, forman una masa que ofrece el aspecto de un ovillo desarreglado, es una sustancia cartilaginosa de color blanco, que tiene muy bucu gusto, asi como tambien el animal mismo. El citado autor habla de bonitos objetos de adorno que en otro tiempo se fabricaban con csas conchillas en las Indias orientales. Con mucha frecuencia se recogen para hacer anillos, usados no solo por los indigenas, sino tambien por los holandeses. Estos anillos se hacen sin herramientas, pues los indios sacan la cabeza de la concha molién. dola sobre una piedra aspera hasta que por dentro se ven rodas las caridades de las circumroluciones; despues rompen la parte posterior de la concha con picdras ó la tmbajan con una lima delgada lasta que adquiere la forma de un anillo. De cada camcol solo pueden hacerse dos de estos anillos, que son blancos, lisos y brillantes como marfil, pues las manchas negras dul caracol no penetran en el interior $y$ pueden quitarse. Algunos hacen estos anillos lisos; otros los cubren de dibujos en forma de hojas; y muchos saben hacer el trabajo con tanto arte, que dejan en el anillo un cuadraclo prominente con una mancha negra, cual si fuera una sortija serdadera con una jiedra momada.

El célebre coleccionista y conocedor de conchas, Clicm. nitz, enumera en un apindice al capirulo títulado \&Cimma de noredades de Rumphs una serie de conoideos raros, y sus propietarios. El burgo-maestre d" Aquet d' Delft cra en 1766 el único posecdor del (Almirante de Orange. 3o Mas precioso que este, y el mas caro de todos los caracoles em el "Almirante en jeft. Por el Almirante verdadero se ofre. cieron en vano 500 florines. Todos estos ejemplares son de primera calidad, y para tener un gabinete de valor es preciso 
tratar de obtener cstas conchas, aunque es dificil encontrar las. Sin embarga, no solamente entre los conos, sino entre los demás géneros hay caracoles raros De lo dicho resulta que esos coleccionadores aficionados, y úitiles por sus obras, carecian en rigor de todo fondo cientíico. Tampoco cu nuestro siglo friezn tales aficionados à la naturaleza, cuyo solo objeto es aşuirir animales raros; pero por encima de ellos hay millonts de hombres que con los productos de la naturaleza procuran tambien adquirir su conocimiento, $y \mathrm{ch}$ esto consiste el progreso que la humanidad ha conseguido desde contonces en este terreno.
Casi mas rico en especies es el género de los pleurotomas propiamente dicho, cuya concha tiene una espiral larga y como carácter distintivo un borde esférico hendido en la des. embocadura.

\section{LOS CIPRIDOS-CYPRID.E}

El resto del grupo, caracterizado por tener un sifon respi. ratorio, se distingue además por una membrana muy prolongada de la lengua, con siete dientecitos ó placas en cada fila: estas especies son las de los cipridos.

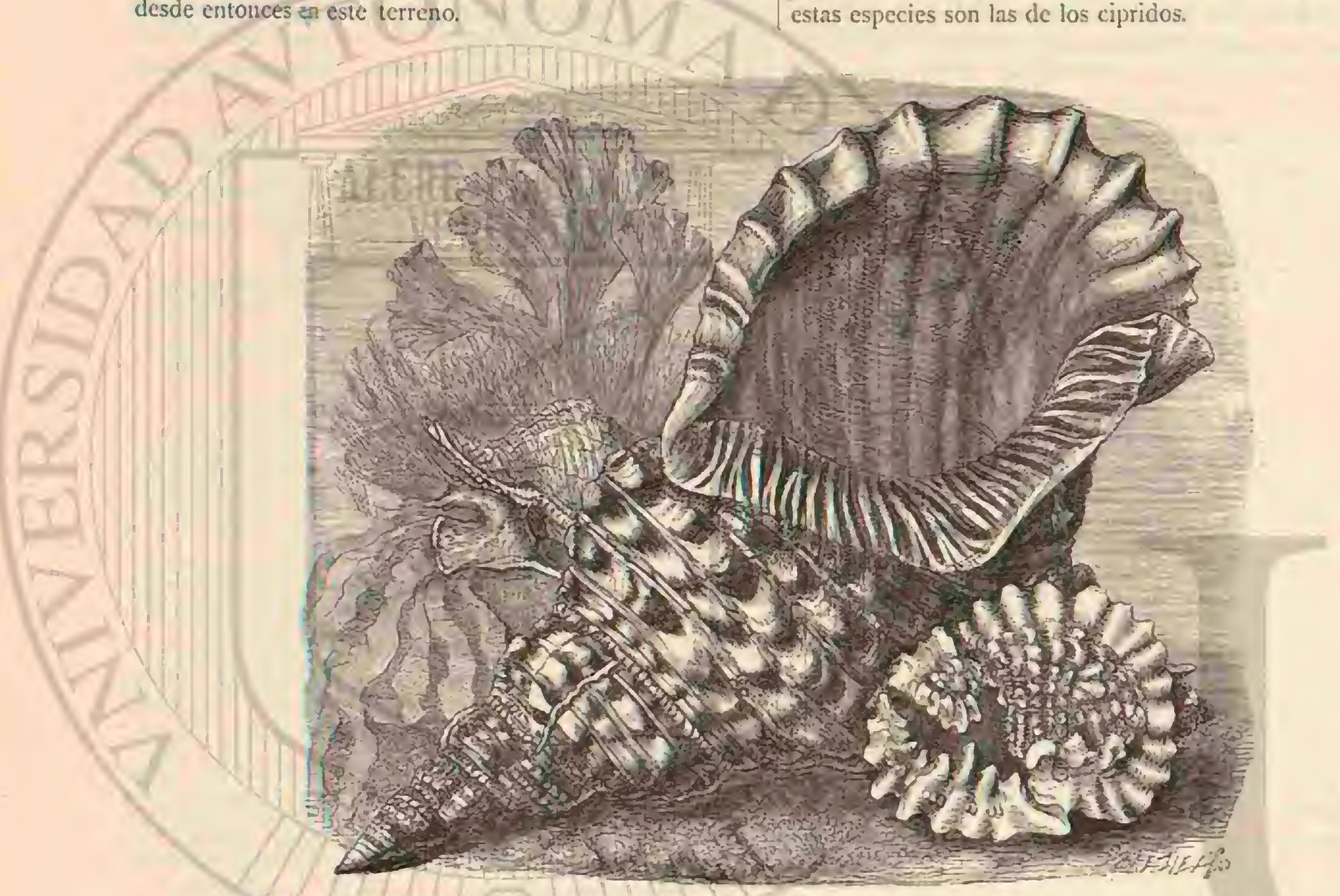

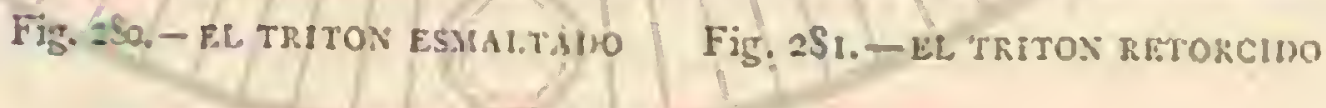

Fig. 2S2, - Ro. TRITON TUHKC Culonso

\section{LOS CIPREOS - CYPRAEA}

Los cipreos, ó porcelanas, forman el grueso de una de las familias mas importantes de los caracoles, $y$ tomando en consideracion la importancia que el cauris tiene en la economia, puede llamarse hasta la mas importante. Los anima les de este géreso j de sus afines tienen ln cabeza bastante gruesa, con tentieulos largos, delgados y poco separados, en cuya base exteriog se hallan los ojos sobre una prominencia El manto se extiende mucho por ambos lados y puede do. blarse de tal inodo que cubre la mayor parte de la concha ó toda ella, comuricandola un brillo particular, por cuya cualidad, asi como por su color muy vivo y abigarrado, ó bien muy delicado, ha llegado à ser uno de.los géneros mas favoritos en las colecciones.

Reproducimos aqui la descripcion minuciosa y acertada de

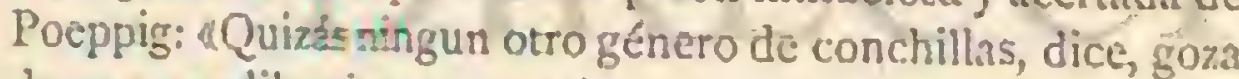
de una predileccion tan antigua y general, ora por su gran d abundancia, ora por su belleza verdaderamente notable. En todas las regiones del globo, y aun entre los pucblos bárbaros, figura como un adorno de las habitacione's of personas, algunas especies circulan, segun costumbre antiquisima de muchos paises, conso moneda de calderilla. Las conchas de estos caracoles merecen tal invor por varias razoncs: agradan por su graciosa redonder, se puteden pulimentar fácilmente, dejandolas brillantes; son tan duras como el mármol, y os. tentan los colores mas viros. Tambien llaman la atencion bajo cl punto de vista cientifico, pues en las diferentes fases de su vida, cambian de forma del inodo mas notable, $y$ segun antiguamente se creia crecian por leyes del todo particulares. De las variedades for la edad pueden demostrarse cuando menos tres grados. Las conchas jórenes son lisas, de un solo color gris, ó provistas cuando mas de tres fajas trasversales poco marcadas. El borde del huso es liso y convexo hácia arriba, cóncavo hácia abajo, y el horde exterior delgado. En una edad algo mas avanzada, ambos lados del borde de la boca se dilatan ya tanto que se puede distinguir el carácter genérico, y al mismo tiempo el manto adquiere grandes ensanchantentos laterales, que hácia arriba cubren la conchay depositan una capa mucosa mezclada de cal, que se endurece en la capa mucosa supecrior, tomando un color del todo diferente. Esta capa no tiene, sin embargo, aun el espesor de la concha perfecta; inmbien carece en este periodo el borde de la desembocadura de los repliegues trasversales. I:as conchas del tercer periodo, $y$ por lo tanto, del todo trasformadas, se reconocen por la aproximacion de los lados del borde de la desembocadura, que tienen gruesos repliegues, por el espesor de la capa superior de la concha depositada, 
por el manto doblado, y en fin por una faja mas clarn, que corriendo en el dorso de la conchilla llega por arriba y por abajo à la desembocadum: probablememente señala el sitio en que los lóbulos del manto doblado se tocan por sus bordes; csta taja no se ve nunca en las conchas de formacion re. ciente. En las especies que en gran nimero nos traen de los mares mas calidios, los coleccionadores aficionados no hallan dificultad en reunir series enteras de ejemplares para expli. car esta formacion.

2. Otro fenómeno no del todo extraordinario, pero mal en tendido, indujo à los naturalistas antiguos à creer que ya el desarrollo de la concha debia verificarse en los cipreos por leves del todo diferentes que eri otros moluscos, ó bien que la concha hasta st mudaba periódicamente como el caparazon de un crustíceo. Al observar el lado de la descmbocadu- ra de un cipreo, nos pecurre maturalmente quie cl desarrollo en la concha no puede verificarse aqui del modo regrular, es decir; por la formacion de una nueva circunvolucion del labio exterior ensanchado, porque este, no solo se encorva casi en rectángulo mas alla de la desembocadura y liacia el borde del huso, sino que se enrosca tambien hácia arlentro. Si en el caso presente el desarrollo se verificara a lo largo del borde, necesariamente la desembocadura se cerraria en poco tiempo. Ahora bien, como de la misma especic se tenian conchas bastante pequenas con el horde bucal desarrollado, y como, no conocienco los verdaderos señales de la diferen. cia de cdad, se las consideraba como jóvenes, para explicar el desarrollo, por lo demás incomprensible, suponiase que el animal disolvia periódicamente todo el borde bucal, deposi. tando una nueva circunvolucion, formaba otro borde bucal

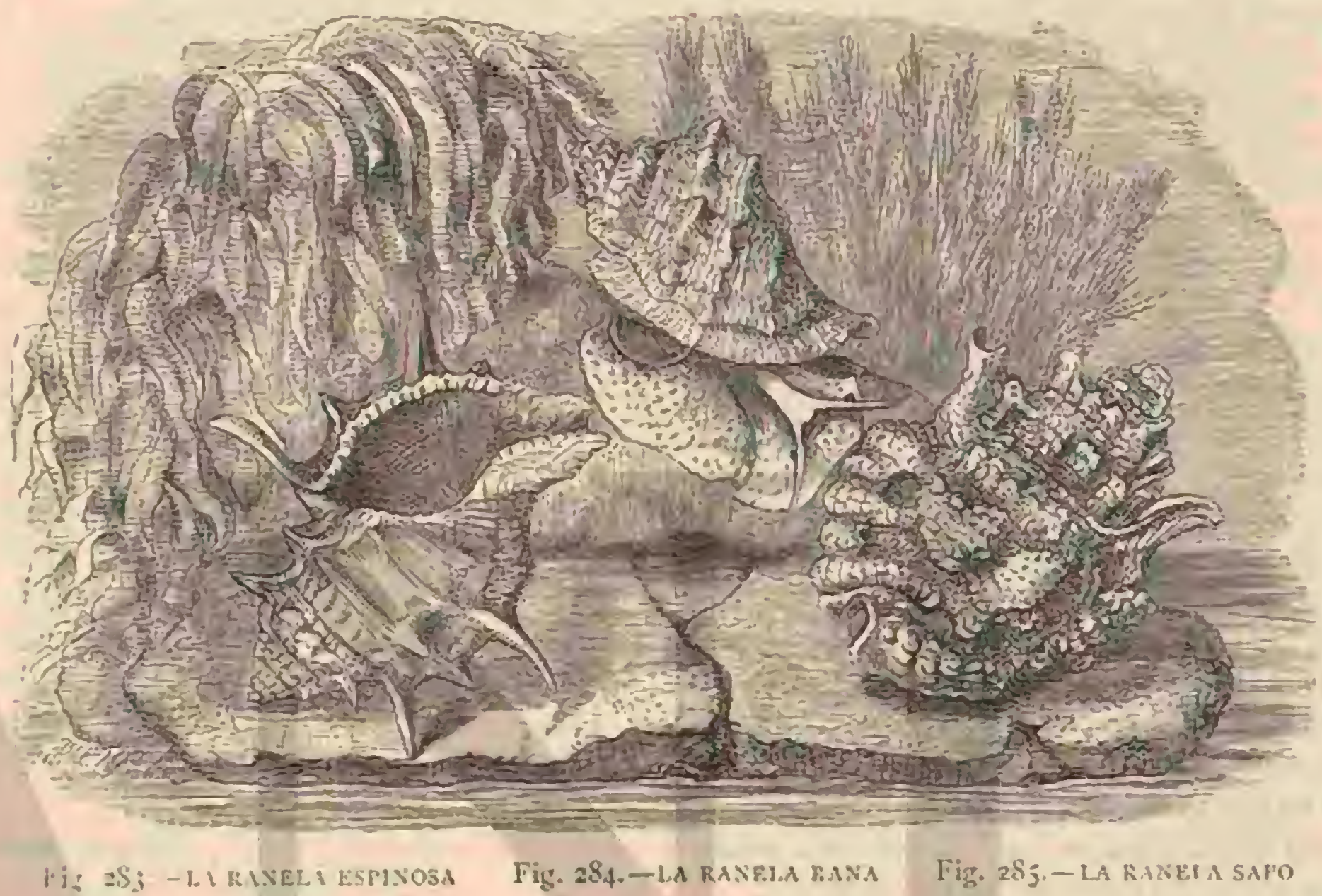

y a!canzaba asi el tamaño regular de la concha. Ya antes habiase desistido de la idea de que elanimal salia de la concha, demasiado estrecha; pero tanto una como otra hipótesis es inexacta. Al enunciarlas se ha olvidado que entre todos los séres orgánicos, tanto plantas como animales, existen en una misma especic individuos grandes y pequeños, irregularidades que si bien no pueden explicarse, se encuentran sin duda en iodos los séres poco desarrollados, y sobre todo en los moluscos. Un cipreo atigrado de dos pulgadas de longitud, con los hordes bucales próximos, enroscadas y provistos de repliegues trasversales, es aduito del mismo modo que un individuo de doble tamaño; vivirá sin aumentar nunca el volúmen de su concha, una vez. llegadio al tamaño que le corresponde individualmente.

Rumph ha dado una explicacion diciendo que la prominencia de la desembocadura solo se forma cuando el desarrollo la terminado: reproducimos aqui su descripcion del cipreo atigrado, con observaciones mas generales sobre el género y su utilidad. Cuando habla de hembras to hace en el sentido de que las conchas mas ligeras y lisas suelen conside. rarse como tales, y dice: a Este caracol es el mas grande y hermoso de su géncro, porqque tiene casi el tamaño de un pequeño puño, y el dorso, muy redondo $y$ liso, cubierto de espesas manchas negras, pardas y amarillas, presentando cn toda su longitud una linea dornda, que, sin cmbargo, no se encuentra en todos los ejemplares. Cuanto mas iguales son las manchas negras, ianto mayor es el precio de este carncol.
- Cuando los cipreos se sacan del mar brillan como un espejo; por lo que hace al vientre ó la parte inferior del caracol, no es muy liso, pero sf tin plano, que juede servirle de apojo, siendo además blanco y brillante. Del animal mismo solo se ve un lóbulo tenue, salpicado, casi del mismo modó quue la concha, de manchas negras, pardias y. amarillas, con nirns mas pequeñas blancas. El individuo que se considera como hembra tiene una concha delgada y ligera que adyuicre casi su tamaño completo antes de que se enrosque uno de los lados de la desembocadura, que es tan afilada y del. gada como el pergamino. Esta concha presenta bonitas manclias negras, amarillas y' azules, y cuanto mas predomina este lítino color tanto mayor es su precio. Se encuentra en las costas de arena blanca y donde hay peñascos aisla. dos, en los cuales permanecen yor lo rugular oculans debajo de la arena; toda la parte de la concha que sobresale de ella hicesc áspera y pierde sus colores brillantes, pero cuando hay luna nueva óllena salen de la arena y se fijan en los peñascos. Cuesta mucho trabajo sacar el animal de modo que la concha conserve su bonito brillo. El medio mas séguro es el de echar el caracol en agua caliente, sacar lamta carne como sca posible y colocar la concha en un sitio frondoso para que las hormigas devoren el resto de la carne. Cada dos ó tres años es preciso ponér estas conchas medio dia en agua salada, lavarlas despues con otra fresca y secarlas al sol.

Rumph refiere además que este cipreo y otros solo sirven 
de alimento á las clases mas pobres, y' que á menudo produce malas consecuencias. Los indigenas tienen por regla que todos los caracoles lisos y brillantes, con manchas rojas, no son comestibles, pero que todos los de concha áspera y espinosa son un buen alimento.

La especie mas importante de su género es el ippreo moreda, llamado tambien cauri. Este cipreo es blanquizco 6 amarillento, de forma oval ancha, provisto en los lados de la extremidad superior de cuatro prominencias obtusas, y alcan. za una longitud de $I^{\prime \prime}, 05$ à 2 metros. En mayor número se le encuentra en las islas Maldivas, donde, segun noticias de los antiguos, se recoge dos veces al mes, es decir, tres dias despues de la luma nueva y tres despues de la llena. Es pro. babie, sin embarso, que tambien se le pueda enconirar en los otros dias del mes. De las citadas islas se le exporta Bengala y Siam, pero con preferencia al Africa El emporio principal del comercio africano de cauris es Zanzibar. Desde ia costa oriental del Africa marchan hace siglos grandes caránnas con este articulo, que al mismo tiempo es dinero y mercancia, dirigiendose al interior. Las embarcaciones europés toman cargamento en Zanzibar para trocarlos en la costa occidental por oro en polvo, martil y aceite de palmera. I a célebre obra de viajes de Barth da noticia del asombroso comercio que con este dinero se hace entre los negros del Africa central. En Gure, 700,000 conchas valian 330 thalers (unos 1,070 francos), es decir, 2, 1 20 concluas el valor de un thaler, y'la renta del soberano subia a 30 millones de conchas. Su valor depende naturalmente del piecio de lis plaza, de la importacion y de la distancia. Porl lo regular estản enfiladas $i$ centenares en cordones para abreviar las manipulaciones de pago. En muchos puntos no se procede sin embargo, de éste mado, y los miles de conchas se han de contar una por una. Segun las noticias de Beckmann en r 793 , en la isla de Ceilan estaba el emporio mas importante para los cauris, que sc exportaban en cestos ó fardos de 1,200 conchas cada uno, ó en barriles: estos últimos iban destinados á Guinea. Durante algun tiempo todo el tráfico áricanó de esclavos se hizo por medio del cauris, recesitándose tan solo 12,000 lifbras pam comprar de 500 á 600 esclavos. Hàcia mediados del siglo xint el precio se habia doblado, y entonces, cuando todas las costas estuvieron infestadas de la concha moneda, esta fué sustituida por otros medios de pago.

\section{LAS OVULAS-OVULA}

Haremos mencion tambien de este género mas afine de los cipreos. El animal tiene la misma cstructura de aquellos; la concha es enroscada y se adelgaza cu ambas extrenidades, rematando en una canal. Rumph nos habla de la óvula ovjforme, que tiene la concha blanca por fuera $y$ violeta por dentro, siendo muy apreciada por los habitantes de la isla Corea. Solo los jefes y guerreros que podian presentar algunas cabezas de los enemigos tenian derecho para llevar esta concha en el cuello; tambien servia para adornar los escudos.

\section{LOS TRITONIOS-TRITONIUM}

Ios tritónidos reunicos por los conquiliólogos antigúos re. gularmente con los caracoles espinosos, difieren de ellos, no solo por la estructura de la lengua, sino tambien por la forma de la cabeza. Esta es grancie y sobresale de en medio de los tentáculos, que, largos y coniformes, tienen los ojos hácia fuera, poco mas ó menos á la mitad de su longitud. De la hendidura bucal que se encuentra en la parte inferior de la hoca, el animal puede sacar una trompa bastante larga. La concha se parece a la de los caracoles espinosos, pues se prolonga en su parte inferior en una canal, presentando prominencias sin espinas que se hallan sobre las circunvolucio. nes, $\delta$, con menos frecuencia, aisladas. De las numerosas especies que forma este género, solo haremos mencion de las principales; i saber el triton esmalicide) (fig. $2 \mathrm{So}$ ), el triton reforcido y el fuberculoso (figs. 281 y 282). Del género principal de los tritónidos, el rribnio mudifero es propio del Mediternneo. Es la buccina de los antiguos de la que se dice: Jiuccina jam prisios cogelual ad arma Quirites (La bocina llamaba ya à los ancianos Quirites í las armas). T'ambien otras especies mas grandes se empleaban y se emplean aun como bocina de guerra, sobre todo el tritomiums arariegafum. Ninguno de los maturalistas modernos ha podido completar las noticias de Rumph sobre esta especie. Los individuos mas grandes de ella, dice, tienen mas de pié y medio de largo y de seis á siete julgadas de alto. Su exiremidad esta por lo regular un poco rota, y la concha cubierta de gruesos granos blancos y rojos que primero deben ablandarse con aicido clorhidrico y sacarse cespues con un cuchillo. Estos caracoles se cuentan entre los mas raros; $y$ limpiados valen hasta en las mismas islas por lo regular 2 y medio florines (unos 2 I reales). En la isla de Amboina raras veces se encuentran: los mas de ellos proceden de las islas del Sudeste. Habitan en la profundidad del mar, pero á veces penetran tambien en los cestos destinados para la pesca. I os alforeses, habitantes salvajes de la isla de Corea, emplean estos caracoles en vez de bocinas, practicando una abertura en la circunvolucion del centro.

- Al aplicar estas conchas al oido se percibe cierto sonido sordo, y lágente cree que esta es señal de la legitinidad de la concha, porque en ella se oye, por decirlo asi, el rumor del mar. Esta cualidad no se limita sin embargo a estos caracoles, pues todas las grandes conchas son una buena caja de resonancia para los sonidos mas diversos; pero reinando un silencio absoluto, el fritoniun zurirgalum no puede producir el citida rumor.

Todo el mundo sabe qué papel representaban los tritones en los cuadros, estatuas y relieves de la época del Renacimiento. ¿Quién no los conoce? Los tritones moltetudos, montados en delfines, seguian a la bella diosa del mar, Galatea. ¿̨uien no ha visitado algun parque con sus grutas al estilo de aquella Época, y donde los verdaderos tritonios y otras conchas grandes aparecen entre corales y formaciones estalactiticas?

\section{LAS RANELAS - RANELLA}

Este genero tience la concha oval ú oblonga, deprimida y acanalada en la base; en su parte exterior se advierten dos rodetes; la abertura es redondeada ti oval, y dichos rodetes son rectos ú oblicuos y forman uma fila longitudinal en cada lado de la concha. Las especies que le representan cuyo nú. mero no pasa de diez $u$ doce, son todas propias de los ma. res de la India, de la China y de Nueva Holanda. 1.a ranela espinosa (fig. $2 \$_{3}$ ), la ranela rana (fig. $2 \$_{4}$ ) y la ranela sapo (fig. 285 ), son las que distinguen principalmente los autores.

\section{LOS DOLIOS-DOLIUM}

Eil género de los dolios es intcresante por varios conceptos. La concha es delgada, ventruda, á menudo casi esférica, con la desembocadura ancha, escotada por debajo y no prolongada en canal; el labio exterior, por lo regular ensanchado, presenta surcos en toda su longitud. Il animal tiene un jisé longitudinalmente oval, grande y grueso, provisto en su parte anterior de una especie de orcjitas, y que puede dilatarse 
mucho para recibir una gran cantidad de agua. La cabeza es plana y ancha, y forma enire los tentáculos una línea casi recta. Fstos son largos y tienen los ojos en la parte exterio de su base ensanchada. El tubo respiratorio, grueso y bastante largo, apóyase sobre la concha. Tambien la trompa es muy grande y gruesa. Todas las especies, excepto una sola, habitan los mares meridionales.

Esta especie única, el dolium galen, propia del Mediter rinteo, es el caracol mas grande de este mar, y fué la causa de un descubrimiento muy notable. Cuando cl profesor Troschel se ocupaba en Mesina en investigaciones zoológicas, observó en un gran individuo de la citada especie que, tan luego como se le irritaba, extendia su trompa que tenia medio pié de larga, y arrojaba por la abertura bucal un chorro de u1 liquido clara como el agua a un prie de distancia. Con gтал asombro se observó que la picdra calcárea del suelo hervia al contacto con el liquuido, y que, la supuesta salisa, era por lo tanto un fuerte àcido, que segun el análisis contenia de tres á cuatro pror ciento de ricido sulfúrico ytres por ciento de ácido clorhldrico, los cuales eran segregados por glin. dulas situadas al lado de las salivales. Estos ácidos no sirven sin embargo en la digestion para disolver la cal recogida con

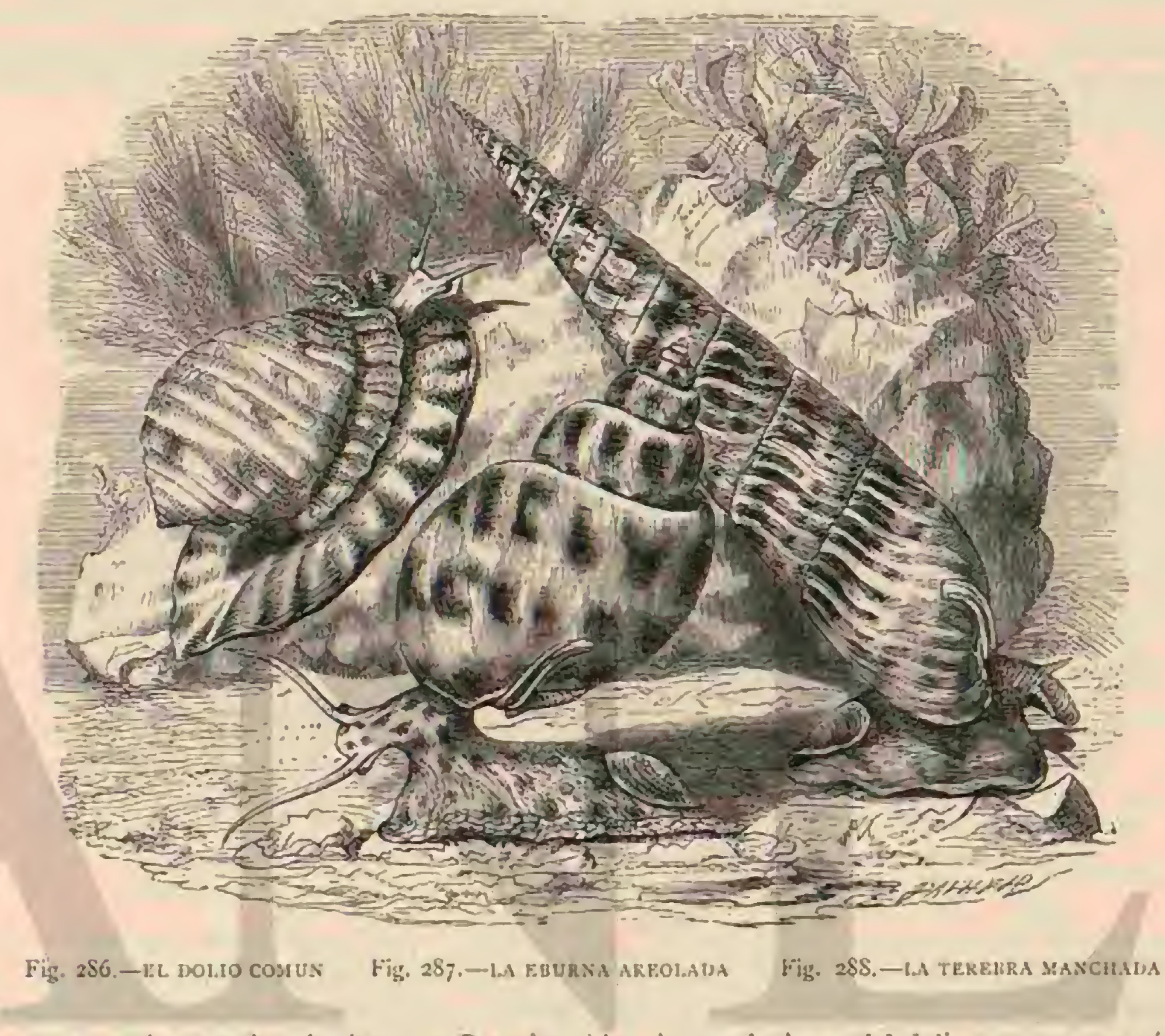

el alimento, y segun muchas pruebas hechas por Pancri en Nàpoles, tampoco es probable que sirvan de medios defensivos lil liquido de las glíndulas, segun parece, es mas bien un producto destinado á segregarse por el cuerpo. El citado zoúlogo mapolitano ha demostrado que una serie de otros caracoles de los géneros cassis, cassidaria y trilonicum yoseen el mismo órgano para la secrecion del ácido sulfúrico. Todo csto es por demis interesante bajo el punto de vista fisioló gico; pero falta mucho aum para uquedar bien explicado. El conocido cónsul austriaco y lingüista, doctor $G$. de Hahn, ha procurado demostrar de un modo muy ingenioso que el dolio era el modelo de los ornamentos espiralados de las columnas jónicas. Asi como ahora los pescadores napolitanos, dice el citado autor, hacen con las conchas de caracoles y conchillas de su playa, bonitos festones para adormar con ellos las iglesias en dias féstivos, del mismo modo en la antigúedad los habitantes de las costas se habrán valido ya de los graciosos prociuctos de sus playas, cuando se trataba de adornar los santuarios de sus dioses. Entre las conchas del Mediterráneo se distingue sin embargo el dolio, caracol caracteristico de este mar, no solo por su tamano, que à veces llega al de la cabeza del hombre, sino tambien pror la belleza de sus espirales y surcos. \$ De la interesante comparacion de la forma artistica con el producto natural se quiere deducir que las circunvoluciones del dolio, tanto por su número como por la estructura de su espiral corresponden à la llamada voluta del capitel jónico; que con el lado interno del borde exterior de la concha se pueden construir cunndo menos aproxima. damente, las curvas de reunion de ambas volutas, las cuales se corren por-encima del canal del capitel jónico; que los listones convexos de la cara exterior de la concha se irasforman en la interior en estrias, ofreciendo estas gran semejan. za con las de las colummas jónicas; y que hasta su número corresponde poco mas ó menos al que se encuentra en las citadas columnas.

\section{LOS CASSIS-CASSIS}

Los cassis tionen de comun con los dolios las pasticularidades del pié, grande tambien, con ensanchamientos laterales; la tronina muy larga; y los ojos, situados en la base de los tentáculos, como pequeños pedúnculos. El manio de los cassis forma por encima de la cabeza un apéndice en figura de velo, que se prolonga en un largo tulo respiratorio apoya. do en la concha; esta es panzuda y tiene una espiral corta. La desembocadura, por lo regular angosta y lincal, presenta en su parte inferior un corto canal que se inclina en ángulo agudo sobre el corso. El labio inferior tiene un doblez mus 
desarrollado, y' arrugas y repliegues en è borde del huso; cl labio exterior se cnsaucha hácin fuera y es denticulado a menudo por dentro.

Rumph habia observado ya, gque en estes caracoles, así co. mo en los cipreos, el desarrollo puede rerificarse por una disolucion de las prominencias labiales anies formadas, segun hemos cxplicado ya minuciosanente, sirviéndonos de las palabms de Poeppig. e Como las circusvoluciones que se forman de nuevo, dice el antiguo autor, se sobreponen al la. hio antiguo, el animal podri necesariameste desembarazarse de todos los obstarculos. Esto puede rerse muy bien al romper la concha, pues entonces se obserra en la parte anterior de has circunvoluciones un sim múnem de pequeños vestigios dul antigun labio que en la parte anterior de las circunvoluciones se notan tambien claramere. i Ias especies entre las que el cassis cornudo se distingue por el tamaño y espesor de la concha, viven por lo regular á poca profun. didad cerca de la playa, en un fondo arenoso. donde, persiguiendo las diferentes conchiferas, penctra del todo ó casi del todo. Para conservarlos en las colecciones, solo se recomendaban los ejemplarcs cubiertos del todo por la arena, pues aquellos cuyo dorso sobresale de ella, tienen cieno y un aspecto desagradable.

\section{LOS APORAIS-APORRHAIS}

Con los aporais hemos llegndo à las dos familias gue antes, cuando solo se tomaban en consideracion las conchas, llamábanse teroceros, pero que, segun à continuacion vere. mos, difieren esencialnente por sus partes blandas. La con-

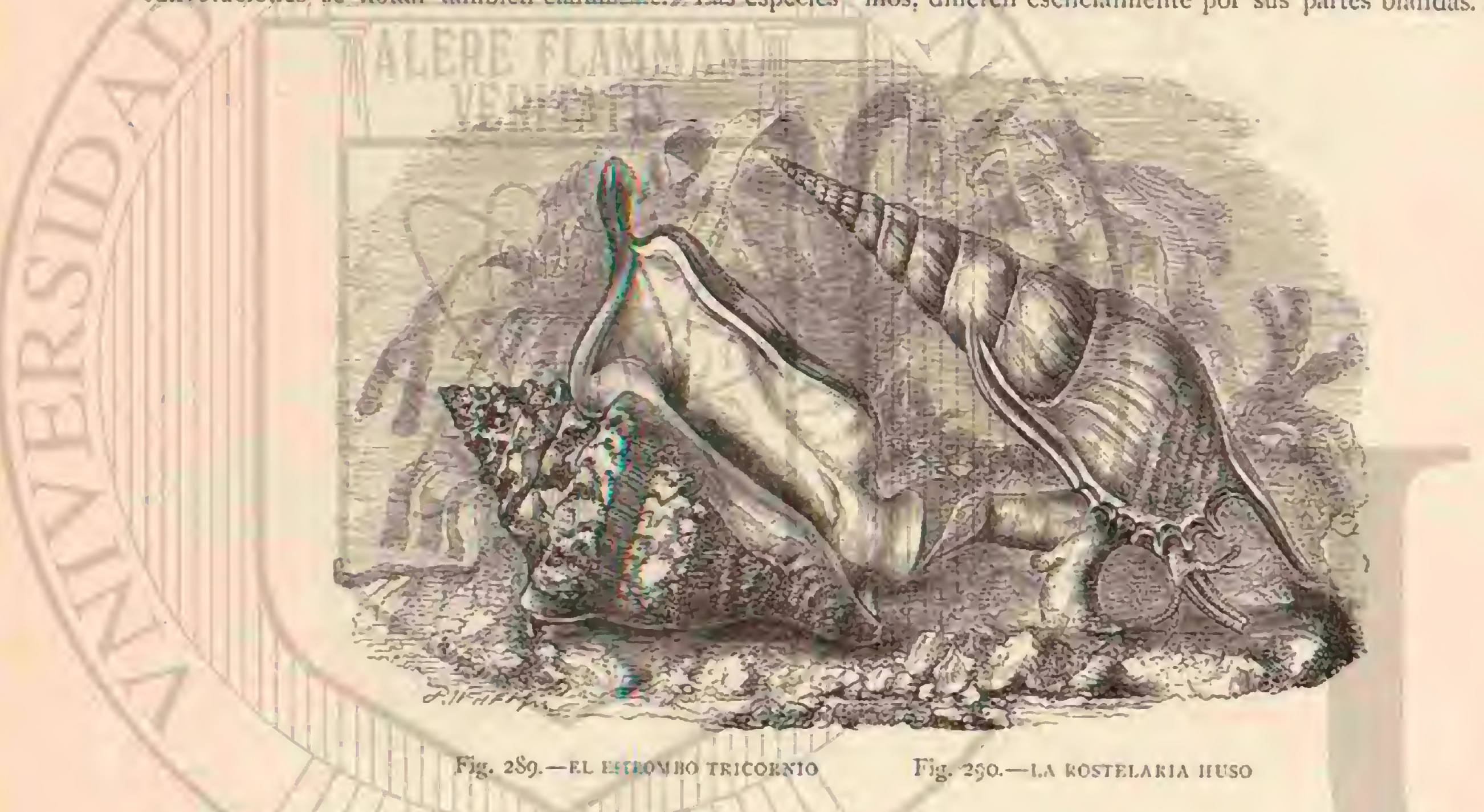

cha de las pocas especies de apomis, entre las que el pueden por lo tanto reptar, pero en cambio sallan, es decir, aporrhais pes pelecani (pié de pelicano) abunda mucho en los mares curopeos, es fusitorme jo remata en la hase en urna canal, ó mas bien en una ancha punta surcada. En todos los reroceros la concha jóven difiere mucho de la adulta. lil labio cxterior tiene al principio el borde entern y-solo proco a poco se desarrollan los diferentes apénüices y dedos con sus surcos y dobleces. El animal tiene la cabeza prolongada en un hocico aplanado escotado en sus penc anterior. Los largos tentaculos filiformes llevan los ojos por fuera en una prominencia fil pié pequeno se redondes en ambos lados, pero es. muy propio prara reptar. El Eanto del animal adulto no se ensancha mucho, pero se peolonga en puntas alli donde las tiene la concha, siendo de stponer que tengn mas desarrollo en el periodo en que estas partes de la concha se forman.

\section{LOS ESTROMBOS-STROMBUS}

Iil animal de este genero y del de las terocéros propuamente dichos, que juntos forman la familia de los verdacieros terroceros, tiene una forma muy particular. El pié que se dobla casi en ángulo recto, es un poco aplazado, redoncleado en el borde, con su parte anterior mas curs y escotada, y la posterior muy larga, provista en la extremidad de una tapa córnea, casi íalciforme, que no pucde cerrar la desembo. cadura. A causa de esta estructura del pise ios animales no culocan la parte posterior del pié delante de la anterior, to. mando impulso para lanzarse. Rumph ha hecho una descrip. cion muy detallada de este órgano. Es un carácter particular de este géneio, dice, tener en la desembocadura una especic de piernerila larga, que, por su color y forma, parere un ónix marino. En el lado exterior presenta agudas puntas, por debnjo es puntiaguda, y jor arriba fijase en una carne dura, semejante por su forma á una manila. Con este úrgano, el animal, no solo se mucre, sino que se defiende y desvia 10 . dos los obstriculos que se oponen á su marcha.) Cuando el cirado observador puso-algunos de estos animales, que él llamaba esgrimadores (fugiles), con otros caracoles, en una fuente, los yrimeros pronto ceharon fuera à los segundos con sus impetuosos movimientos. Dice tambien que esta esjecie, comun cerca de Amboina, se sucle comer, pero que produce con frecuencia una traspiracion de olor-desagradable semejante al de los machos cabrios.

Volvamos ahora a la descripcion gencral de los estrombos. La cabeza ticne dos pedúnculos gruesos y cilindricos, en cuya extremidad están los njos, por lo regular muy grandes y de viros colores, mientras que los ientriculos sobresalen de la cara interior de cstos pedúnculos en forma de delgados hilos. En medio de los ojos, la cabera se prolonga en un largo hocico no retráctil. Lil manto ts gnrande, pero muy delgado, y liene un apéndice filiforme que se encucntra en la canal superior de la desembocadura de la concha. 
La concha de las especies de estrombos remata en su parte inferior en un corto canal; el labio exterior, que se ensancha por lo regular en forma de ala, puede prolongarse por arriba en un lóbulo, pero nunca estí provisto de largos apréndices ó dedos.

Las mas de las serenta especies conocidas pertenecen á los mares tropicales. Fl estrumbio tricornio (fig. 289 ) es la mas curiosa por su estructura: una de la mas comunes, el estrombo gigante, se recibe en gran número de las Indias occidentales, doncie bastante á menudo se adornan con sus conchas los cuadros de los jardines: tambien se utilizan para hacer cestas y jarrones de fores. La concha alcanza la longitud de un pié y puede pesar mas de cuatro libras. Para comprender cómo estos animales á pesar de su carga pueden saltar, se ha de sener presente lo qque ya hemos dicho al hablar del pe- sado caparazon de diferentes crustáceos, es decir, que las proporciones del peso varian en el agua en favor de los séres vivos que en ella habitan. Entre las especies mas conocidas merece citarse tambien el estrombo fie de pelicuno (fig. 254).

\section{LAS ROSTELARIAS - ROSTELLARIA}

Los moluscos que forman este género tienen la concha en forma de huso y turriculada, terminando por abajo en un canal en forma de pico agudo; su borde derecho es cntêro ó dentado, mas ó menos dilatado con la cdad en forma de ala, y con un seno contiguo al canal. El molusco es espiral, prolongado, con un pié cividido en dos partes, la una posterior, cilindrácea, truncada oblicuamente y provista de un opérculo cúrneo, unguiforne en esta truncadurn; la otra

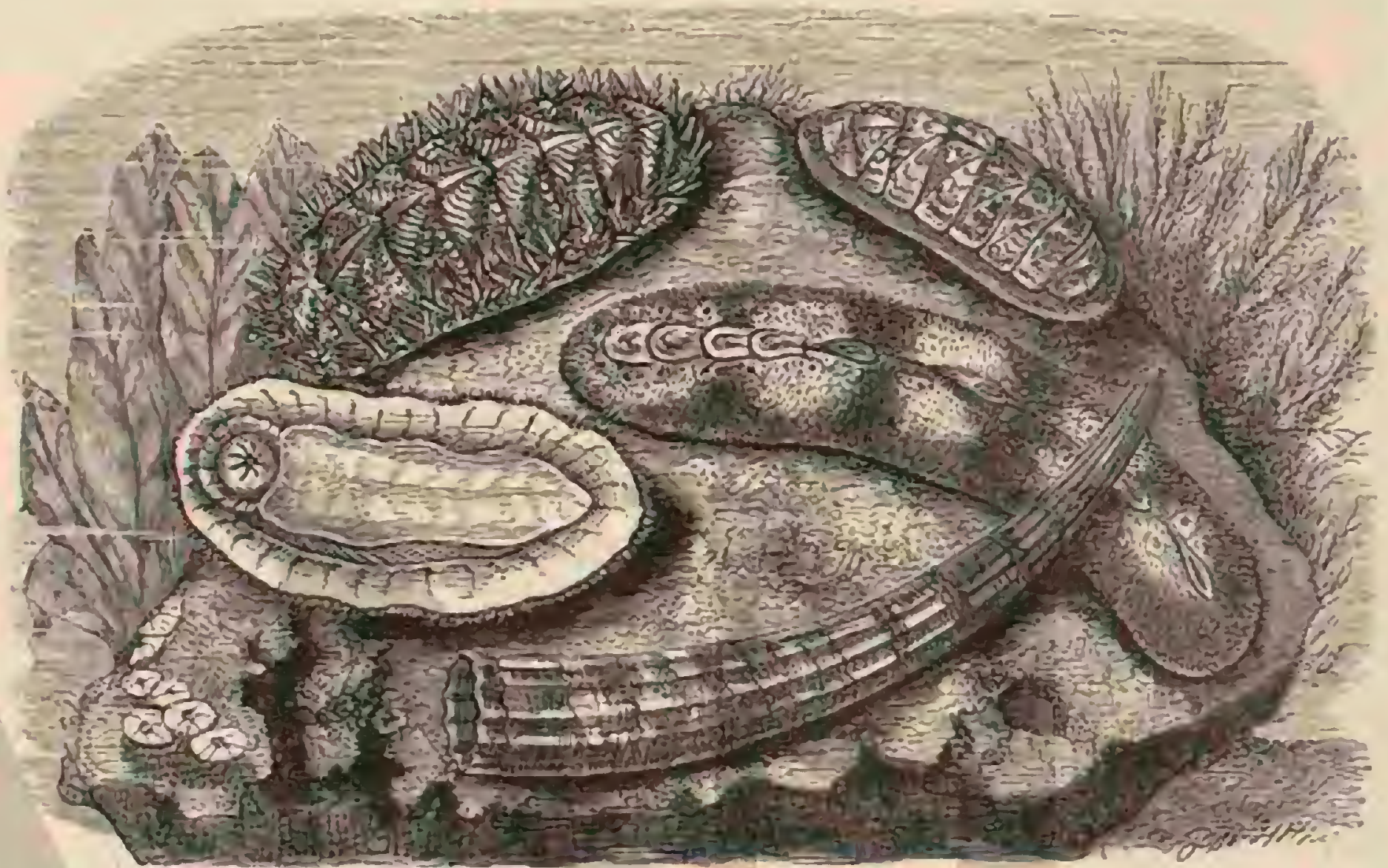

Fig. 291.-EL กุU1TON ESCANOSO Fig. 293.-12. nUUITON IIE ESPINAS CORTAS
Fig. 292. - EL CQUITON MARMOREO

Fig. 29.4 $\rightarrow$ EL QUUTOX Dr. liAJAS

Fig. 295. - F.1. DF.XTtALIO ARก̨UKADO

parte del pié es plana, redondeada por delante, y puede servir al animal para asirse á los cuerpos sólidos; la cabeza es gruesa, forma hocico con trompa hendida por delante, $y$ presenta dos grandes tentáculos divergentes, cilindráceos y bifurcados, cuya rama incerna es mas delgada y aguda, y la externa está truncada por su extremidad y con un ojo encima de esta truncadura.

Los autores citan como especic tipica y de las mas iniportantes por su forma particular la rosiclaria hisso (fig. 290), que se ha encontrado en las aguas de la China: solo se conoce una especie en el mar Rojo y otra en el Mediterráneo.

\section{LOS TERÓCEROS-PTEROCERA}

Los teróceros, entre ellos la garra del diallo, solo se diferencian de los estrombos por la forma de la concha, presentando el labio exterior, en el individuo adulto, una marcada escotadura, $j$ un ala con dedos en su parte inferior: éstos dedos, que al principio tienen surcos, se cierran desprues del todo.

\section{LOS RIPIDOGLOSADOS -RHIPIDOGLOSSATA}

Con este nombre designa 'lrachel el sub-órden siguiente, á causa de la naturaleza de la placa. Siempre se hallan mas Tомо VII de sicte series longitudinales de placas ó dientecitos, y además se agregan en los lados de cada serie trasversal numerosas hojitas estrechas, dispuestas uma junto à otra, en forma de abanico. En el dorso hay una gran cavidad respiratoria, que contiene las brinquias, compuestas de dos hojas Ia concha y el pié son de forma muy variada, peso la primera tiene el borde de la desembocadura siempre entero, sin canal 6 escotadurn, y el pié es de gran tamano. Todos los animales pertenecientes a cste grupo son plantivoros, $y$ viven, en su mayor partc, en las costas pedregosas.

\section{LOS NERITIDOS-NE- RITID压}

Ia familia de los neritidos comprende lambien numerosos habitantes de agua dulce, casi todos del género de las neritas. Fl animal tiene in cabeza ancha, plana, en forma de corazon invertido, en cuya cara inferior se halla la placa grande, cubierta de repliegues y con dus largos tentáculos puntingudos. Por fuern, en la base de los mismos, se hallan los ojos sobre un corto pedúnculo. I a concha es hemisférica y sin ombligo en su parte inferior, con la desembocadura circular 6 semi-circular. La tapa calcárea tiene por dentro un apéndice que, al desaparecer la concha, se extiende por detrás 
del borde del huso. Como especie tipica citan los autores la nerita pulimentada (fig. 248). Se ha querido separar genéricamente las especies marinas de las de agun dulce, pero sin mz.on fundada. Casi trescientas especies se hallan diseminadas por todo el globo; entre cllas, la nerita de los rios (nerita $f$ tu. aratilis), es muy comun en la Europa central; es un animalito de unos $\left(0^{n}, 008 \text { de alto por } 1\right)^{n}$,oro de ancho, que se encuentra en las piedras y plantas acuáticas de los rios y riachuelos, estanques y pantanos. Su concha, cubierta de una especie de red rojiza ó violácea, es delgada, pero de una solidez poco comun entre nuestras conchillas de agua dulce. Asi como en muchos géneros de animales cuyas especies se encuentran anto en el agua salada como en la dulce, del mismo modo entre las neritas cuéntase cierto número de formas de agua salobre, y otras uque habizan cu aguas de muj diferente coim. posicion quimica la llamada nerifa menor es una sencilla variedad de la nerita dé lós rios, que abunda mucho en los lagos de Mansfeld.

El notable fenómeno cirado antes, al hablar del desarrollo de las bocinas y púrpuras, de que solo pocos enibriones se desarrollan a costa de los numerosos huevos, se repite tam. bien en la nerita de los rios. En las capsulas ovarias, de for. ma esterica, y que solo miden un nilímetro de diàmetro, hállanse de cuarenta á sesenta huevos, de los que uno solo se desarrolla en embrion, alinentíndose de las otras yemas. De este modo llega á ser tan grande que por fin llena toda la capsula, y sale de ella levantánde la tapa hemisférica. Al salir ya tia desaparecido la vela que tenia durante su vida embrionaria.

\section{LAS NERITINAS-NERITINA}

Thas néritinas, conchas de bonitos colores, prescntan la forma sub globulosa, a menudo aplanada por debajo, con el borde recio, dentado en su interior; el opérculo es córneo. Habitan en las aguas de casi rodos los paises del globo, y la mayor parte de las especies viven en los rios; péro tam. bien hay algumas marinas.

Como tipos mas notabies del género eitaremos la neritina

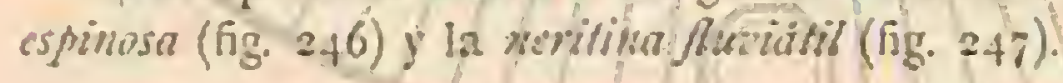

\section{LAS NAVICELAS - NAVICELLA}

liste género, compuesto de unas diez y ocho especies, que liabitan principalmente en las aguas de las desembocaduras de los rios del Asia oriental y de la Polinesia, donde representa à las néritas, llama nuestra atencion porque en él observamos una nueva modificacion de la tapa. Esta última, de sustancia calcirea, no desempeña las funciones á que por lo regular se halla destimada, sino que se oculta del todo en la carne del pié, recordando en cierto modo aquellas conchas de las limazas que durante toda la vida quedan cubiertas por el manto en forma de una secrecion de figura de escudo.

\section{LOS TURBINOS-TURBINA}

Iista familia, segun dice Philipi, no existe desde el princi. pio de la creacion, pero si en las capas inferiores a las carboniferas que hasta alsora se habian considerado como las mas antiguas entre las que contienen animales fósiles. El nombre de turbinos solo pertenece en rigor a los géneros cuyas conchas tienen una forma mas ó menos marcada de trompo; pero los tránsitos de estas formas \& otras mas aplanadas y hasta del todo planas, con una estructura esencialmente aná. loga a la del animal, son tan continuas, que no se debe limitar la fanilia á aquellos géneros. Es necesario, sin embargo, que esta generalizacion, segun demuestra Philipi, solo se entienda por lo que hace à las especies fósiles.

El que haya tenido ocasion de ver en un gran museo z.oologico 6 paleontológico los numerosos géneros y especies citados por Philipi en su manual, se convencerd de que la limitacion de familias y géneros se funda en un convenio en el que à menudo sirvieron de guia ląs mas insignificantes ca. sualidades. Los que menos trabajo dieron it los naturalistas de antaio, son los géneros de animales y las plantas que por decirlo asi se han consolidado durante millones de años. Darwin y sus partidarios han demostrado qué idea debemos formar en tales casos de la desaparicion de las formas de tránsito. Las especies y los géneros cuja separacion nunca ha sido una primitiva, simo una que poco à poco se ha desarrollado, satisfacen a los naturalistas que se contentan con buenas descripciones; mas al que quicra conocer à fondo cl origen y la formacion de los séres vivos, ofrécenle mayor interés precisamente los grupos de formas en que la va. riedad $y$ multitud se relacionan por medio de trinsitos. Hemos creido conveniente llamar la atencion sobre esta circunstancia, aunque el plan de nuestra obra no nos permita dar una explicacion mas amplia sobre la comparacion.

\section{LOS TURBOS-TURBO}

Entre los verdaderos moluscos que afectan la forma de trompo podemos citar con Oken, el género de los turbos. El animal tiene la cabeza prolongada on un hocico; en el lado exterior de los largos tentáculos se hallan los ojos, que son pedunculádos, y en medio de los tentáculos sobresnlen dos lóbulos fromiales. En cada lado del pié hajo por lo regular tres hilos y con frecuencia una piel franjenda. I a circunferencia de la concha se redondea siempre y la desembocadura es casi circular, con la tapa gruesa y calcárea. Antes se vendia en las farmacias la tapa del turbo rugosus y de varias especies tropicales bajo el nombre de «ombligo marino" (umbilicus marinus), como remedio contra la acedia. Muchas especies de estos moluscos plantivoros sirven de alimento al hombre, $y$ las gruesas conchas de las mayores tie. nen importancia para ciertas industrias.

Los chinos, sobre todo, las emplean para incrustar en los muebles los pedazos brillantes que se asemejan mucho al nácar. Rumph cita como principal especie el furbo olearius, que vive formando grupos entre las rompientes de las costas pedregosas de las islas Mrolucas, por lo cual es difícil obte. nerla. Otra especie, propia de las Indias orientales, el turbo paymdus, se distingue por su gran resistencia vital; lsabita cllcre los escollos fuera de la superficie del agua, pero tambien junto á las rompientes. Rumph conservó algunos ejemplares, recogidos en la plaza de Nusanive, mas de 7 meses sin agua in alimento, y uno de ellos vivió aun despues de un año de prision. Sin seguir el ejemplo de Rumph y de sus contempo. ríneos, que consideraban como inútiles para la ciencia las pequeñas especies de los turbos y de todos los demas generos, a pesar de que a ellos pertenecen especies importan. tes, nos abstenemos, sin embargo, de hacer su cnumeracion y pasamos al género siguiente.

\section{LAS DELFINULAS-DELPHINULA}

Este género se compone de moluscos de forma cónica aplanada, con cl ombliga profundo y la desembocadura circular. El animal no difiere esencialmente de los otros turbónidos, pero no tiene lóbulos frontales ni hilos laterales. La tapa es delgada, circular y córnea. Puede considerarse como tipo del géncro la delfinula delfin (fig. 237). 


\section{LOS TROCOS-TROCHUS}

Fste género, muy afine del anterior, comprende especies de conchas cónicas 6 de forma de trompo, pero con la circunferencia mas ó menos angulosa: In desembocadura es deprimida, y el carácter distintivo para las conchas de ambos géneros consiste en tener açuella romboidea. Se han descri. to mas de 200 especies de trocos de todos los mares; la mas bonita de las pocas europeas es el trishus zisiphinus. El modo de moverse este animal puede observarse muy bien mirándole con un anteojo de aumento cuando repta en la pared de un cristal. Entonces se vé que avanza adelantando una y otra mitad longitudinal, aunque la superficie de la planta no está dividicla. Gosse compan este movimiento con el de un animal que intentara andar en un saco elástico. Sin embargo, tiene el mismo modo de moverse, que las facianelas propias de la costa francesa aunque mas marcado, estando dividido su pié por un surco longitudinal; dicha locomocion es probablemente una cualidad mas general.

\section{LOS HALIOTIS-HALIOTIS}

A causar de las numerosas formas de trínsito fósiles, los haliotis u orejas marinas (fig. 259) están en relacion tan natural con los géneros anteriores, que no es necesario hacer de ellos una familia independiente. La concha apenas tiene ya una semejanza con las formas mas prolongadas de los turbinos; parecida hasta cierto punto i la oreja humana, es plana $y$ tienen la forma de puente. I.as circunvoluciones crecen con tal rapider, que la última forma la parte mas grande. Por fuera, la concha no es bonita, y á menudo presenta arrugas $\delta$ fajas verdosas y rojizas; la cara interior, sin embargo, ofrece los colores inas magníficos del arco iris, entre los que predomina el verde cobrizo; y tambien el animal está adornado de bonitos apéndices, elevándose sobre el repliegue del unanto, que sobresale de la concha, franjas é hilos verdes y blancos. los haliois viven en la playa, pero en sitio que no queda del todo en seco durante la marea baja. Les gustan las orillas pedregosas, y de dia permanecen ocultos debrjo de las piedras, mientras que de noche se ali. mentan de algas. Mas de jo especies están diseminadas en los mares de las zonas cálidas y templadas. El canal de la Mancha es su limite septentrional. El halioles twberculela (fig. 258), que ofrece todos los caractéres exteriores de su género, es muy comun en el Mediterráneo; y en el Adriático se encuentra mas allá del centro de la costa de Dalmacia. En la playa de Lesina he hallado pequeños individuos debajo de las piedras.

\section{LAS ESTOMATELAS-STOMATELLA}

Las estomatelas tienen la concha orbicular í oblonga, auriforme é imperforada; la abertura entern, mas ancha que larga ; el borde derecho dilatado y abierto. El animal es ova. lar, oblongo, deprimido, con un pié ancho, listado algunas reces por los bordes; la cabeza es ancha y aplanada; esta provista do un par de tentáculos graides, en cuya base externa se observan dos pediculos oculiferos; la cavidad bran. q̨uial es serncilla, no está hendida y contiene además, à la izquierda, una gran brinuguin compjuesta de dos hojillas casi iguales.

Todas las especies son propias de los mares de la India y de la Nueva Holancia, siendo la especic tipo la estoma. uela imbricada (fig. 256), que se distingue por su color rojizo pálido, y gris cn la parte exterior.

\section{LAS EMARGINULAS-EMAR- GINULA}

I a concha de este género, igualmente plana, tiene en la linea central un incision profunda que parte del borde anterior. Taubien de este género se halla una especié, la cmarginula reticuladla, en todas nuestras costas; el gracioso animalito, que tiene $15^{\circ}$, or $\$$ de largo, habita en el fondo del mar, cerca de la playa. Solo en el reflujo mas fuerte, en el mar del Norte y én el Atlíntico, saleá veces fuera del agua. Segun dice Gosse, observar à esta especie en el acuario es poco interesante á causa de su gran pereza. Nos dispensamos por lo tanto de la enumeracion de otros ggéneros afines, poco diferentes por la formacion de la concha.

\section{LAS PATELAS - PATELLA}

Este género, del que se conocen mas de rov espsecies, forma de por si un tercer sub-órden de los terópodos que por la posicion de las bránquias lleva el nombre de sido. branguio. Ia concha es plana, de forma cónica, con abertura oval y el huso dirigido hácia delante. En la cara interior se ve una incision que casi tiene la forma de herradura, $y$ en este punto se fija el músculo que reune el animal y la concha. La cabera de aquel se prolonga en un hocico corto 5 grueso con dos largos tentáculos puntiagudos, en cuja base exterior están los ojos. De los órganos interiores merece especial mencion la- lengua, en extremo larga y provis. ta de scis series de dientecitos.

I a mayor parte de las patelas habitan la zona de la playa, muchas la region descubierta regularmente en el reflujo. Las patelas nunca se fijan del todo en un mismo punio, mas se asemejan por su pereza é inmoviliclad á los géneros sedentarios. \& El mismo animal, dice Johnston, se encuentra dias y hasta años enteros exactamente en el mismo lugar. Despues de haberse fijado en su juventud, raras veces cambian de sitio, pues el borde inferior de su conclua se adapta a todas las irregularidades de la roca. Renumur ha olservido que se necesita un peso de 28 a 30 libras para vencer la fuerza de la patela vulgar. Este asombroso vigor in un inimal tan peque. ño no depende de la naturaleza muscular del pié, ni dé la introduccion mecánica de su superficie en los poros de las pie. dras, ni de la formacion de un vacio debajo de la conchn; Reaumur ha refutado todas estas explicaciones por medio de algunos experimentos. Cortando el animal en dos mitades $y^{\circ}$ haciéndole además proiundas incisiones horizontales para destruir los mísculos de la planta y llenar de aire los vacios por debajo la concha, la fucrza de adhesion seguia siendo la misma, $y$ aun la muerte no la destruia. Depende solamente de una especie de liga ó cola que, aunque invisible, produce un efecto considerable Tocando con el dedo una parela en Ia superficie de la jlanta con que se ha fjajado, nótase una adhesion muy fuerte, aunque no se ve ninguna materia: pero si se moja la misma parte con un poco de agua el dedo ya no se adhiere, porqque la cola se ha desleido. El agua es por lo tanto el mejor agente, $y$ con clla los animales pueden hasta separarse de la roca. Durante la tempestad, ó cuando ame. naza un enemigo, el animal se adhicre as su base: cuando ha pasado el peligro, segrega un poco de agua de la planta del pić, por cuyo medio la cola se disuelve y el animal adquiere la facultad de separarse y moverse. Tanto lit sustancia glntinosa como el agua que la disuelve son segregadas por un número infinito de glandulitas, y como ha patela no putede producirlas tan sipidamente como se gastan, la fuerza de adhesion del animal debe destruirse arrancándole dos $\delta$ tres veces seguidas del punto donde descansa.» 
Por ingeniosa que parezca esta teoria, no podemos sin embargo conformarnos con clla: yo creo que la facultad de adherirse consiste solo en la asombrosa fuerza con que el animal se fija. Si se sorprende una patela que se halla sobre la superficie del agua se la encuentra à menudo con la concha del todo levantada, y entonces un leve empuje basta para hacerla caer si no se la deja tiempo de oprimir la concha contra la roca por medio de la contmecion del pié. Además de esto, seria muy extraño que en el momento de segregarse la liga pudiera tambien fijarse el cuerpo en la roca; los esfuer2os, por lo regular inútiles, para separar la patela ilesa de la piedra, nos demuestran que la mayor dificultad consiste en levantar el borde de la concha, que por cierto no podria fijarse tan rípidamente por medio de la liga.

Sobre el género de vida de la patela vulgar, comun en las costas europeas, cierto señor Lukis ha hecho interesantes observaciones en la isla de Guernesey. "Para evitar todo error cn el cambio de sitio de las patelas debe observarseal mismo individuo, y entonces se verí que siempre vuelve í su punto favorito, donde el borde de la concha se acomoda perfecta. mente á todas las irregularidades de la roca. Entonces un golpe repentino horizontal basta para dislocarle. I los pesca-

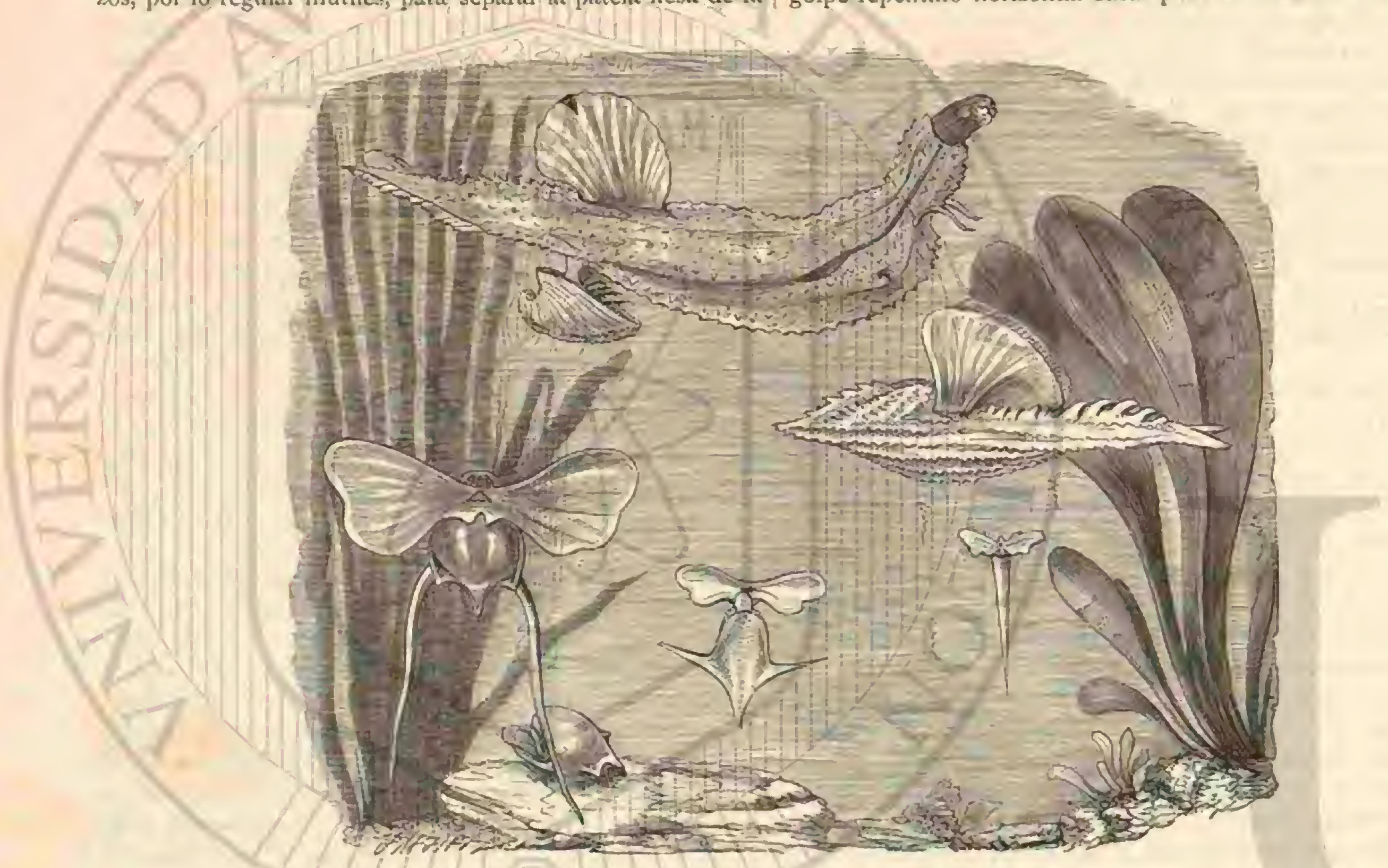

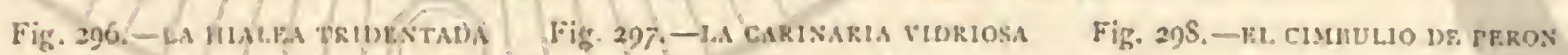

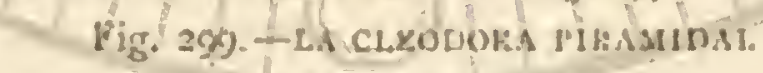

Fig. 300.-8.1. CKESELS A1.ZANAtוo

dores y otra gente pobre que buscan la patela como alimento saben muy bien que puede cogerse mas fucilmente de noche que de dia, y es jrobable que de noche vayan en busca de su alimento por debajo del agua. Iil movimiento de la patela es lento, y, cada ver que quiere fijarse, el borde de la concha se oprime contra la piedra, que cuando es blanda recibe las impresiones de los dientes del borde, de mocio que su camino queda visible a la distancin de algunas varas. Eil sendero de la patela en el granito y otras rocas duras ofrece a primera vista el mismo aspecio, pero difiere mucho al exanimarlo minuciosamente. Al observarlo por primera vez, una gran parte de una piedra de sienito de grano fino estaba cubierta de las huellas de este caracol, mientras que el resto parecia como barnizado con una delgada membrana de una especie de fuco, sin huella algum en su superficie. Al principio no pudo encontrarse ninguna patela, pero pronto se encontro una hendidura en la roca, en la que se habian fijado cinco ó seis patelas, de las qque cada una ténia su camino recto al sitio de pasto. Las huellas en la roca resultaron ser los restos de las algas que á los caracoles habian servido de alimento en sus expediciones. Despues se examninó el borde de la superficic cubicrta de vegetacion, que tambien se encontró corroido, llevando la scnal de la extremidad exterior de la conchas
Ia especie de que hablan estas noticias es un alimento no muy sabroso, pero muy requerido de las clases pobres de las costas curopeas, y, segun se dice, los indigenas de la Tierra de liuego se alimentan exclusivamente de una ó de sarias especies.

La major parte de estos animales tienen una concha muy dura, mientras que la patella pellurida del mar del Norte y de la costa noruega la tienen delicada y trasparente. Eil color depende de la base. Las que se encuentran en los troncos oscuros de los fucos son de un color de cuerno pálido, mientras que las del ramaje son de un bonito color de púrpura, con lineas longitudimales de un azul pálido. Esta esprecie pertenece á las que habitan la region mas profunda de la playa, y que nunca esta descubierta de agua.

\section{LOS QUITTONIDOS-CHI- TONID死}

Nuestros lectores habràn notado quo los moluscos hasta alsora descritos no se parecen casi cn mada á otras formas primitivas de animales en el sub-órden que nos ocupa; algunas particularidades de las especies adultas, y ciertos rasigos del desarrollo, recuerdan los artrópodos. El género principal 
del grupo es el de los quirones (chiton). Visto por arriba, el animal parece á primera vista una patela plana y oval; pero pronto nos convencemos de la completa diferencia, sobre todo en las conchas. listas níltimas, que cubren el dorso del caracol, se componen de ocho placas trasversales movibles, que permiten al animal cnroscarse. De estas placas sobresale el borde del manto, que es liso $\delta$ presesta prominencias, escamas, pequerias papilas $\delta$ espinas. Si se vuelve de otro lado cl animal, su ancho pié nos recuerda otra vez las patclas. En Ia parte anterior, dirigida hácia abajo, se halla la abertura bucal; la cabeza está representada por una prominencia semicircular sin tentáculos ni ojos; y, cosa rara entre los moluscos, el orificio anal se halla opuesto à la abertura bucal. En cada lado de la extremidad posterior, entre el pié y el manto, hay una serie de hojitas branquiales.

A estas importantes diferencias, agréganse las condiciones particulares de la propagacion. Parece que los sexos están separados. El desarrollo puede observarse hasta ahora en el shiton marginatus, propio del Norte, donde lo examinó el naturalista sueco I.ovén. İl embrion aparece primero conio un cuerpo esférico de $0^{m}, 008$ de diámetro, cuya mitad ante. rior, mas pequeña, separase de la posterior por un circulo de pestañas, debajo del cual se ven los ojos. En un grado posterior del desarrollo, el dorso aparece dividido en ocho pro. minencias trassersales; el pié se separa marcadamente de resto del cuerpo, y la parte anterior estí cubicrta del todo de finisimas pestañas. La boca ha tomado la forma de una de presion un poco mas hicia adelante de los ojos. Mas tarcle, el circulo de pestanas y los ojos desaparecen de la parte anterior, quedando solo la prominencia que rodea la boca; y el dorso se cubre de pedazos de concha.

En su género de vida, los quitones se parecen mucho á las patelas, con las que compiten, sobre todo, por su inmo. vilidad. No dependen generalmente de una zoma determinada, aunque los mas pertenecen á las regiones superiores y soportan muy bien el reflujo. A causa de haber algunas pequeñas aberturas en el borde, se ha supuesto una region aérea; pero esto no está confirmado: en las patelas, en los liturinos y muchos turbones, vemos que la faculad de abandonar durante mucho tiempo el agua, no depende precisamente de la existencia de pulmones al lado de las bránquias. De las muchas especies que representan al género, citanse como las mas notables el quiton escrmoso (fig. $29 \mathrm{r}$ ), el quiron marmireo (fig. 292), el quilum de espinas cortas (fig. 293) y el quiton de fajos (fig. 294). Ia primera de estas especies se encuentra cn los mares de la América meridional; la segunda en las aguas de Nueva Holanda; la tercera en las costas de Africa y la uiltima en el Canal de la Mancha y en el Océano del Norte.

\section{LOS HETERÓPODOS}

\section{HETEROPODA}

Esta nuevn division de los moluscos nos conduce á la alta mar. Desnudo del todo, $\delta$ provisto de conchns delicadas y trasparentes, el cucrpo de los heterópodos es de sustancia gelatinosa y trasparente, por lo cual, juntamente con otros numerosos habitantes del mar, constituyen uno de los fenómenos mas intercsantes entre los moluscos.

Traitase ante todo de averiguar las particularidades que a este gruyo dan el valor de un órden independiente. Aunque á causa de habitar en el Océano muchos de estos animales no se han observado y descrito aun; no cabe duda que la multitud y variedad de las formas son muy inferiores a las de los cos órdenes primeros.

\section{LAS ATLANTAS-ATLANTA}

Lista familia es la que mas estrechamente se une con los dos órdenes primeros: se compone esencialmente del género allanta, cuyas especies miden algunos milimetros de diámetro, $y$ que a primera vista se reconocen como caracoles d causa de su concha espiralada, en cuyo dorso se cleva una fina placa en forma de cresta; en la ancha desembocadura el animal puede retirarse del todo, asi como salir para comer y moverse: en estas especies obsérvanse tambien diferencias caracteristicas. I a cabeza se prolonga en un hocico, en cuja extremidad se halla lá abertura bucal; en la parte superior de aquella se distinguen partes importantes del sistema nervio so, es decir, los ganglios superiores del esófago que pueden compararse con el cerebro de los animales mas desarrollados, y además los órganos de los sentidos principales, las regiguitas del oido, los ojos muy grandes, y por delante de estos los tentáculos. Recordando que en muchos gasterópodos de los otros dos órdenes descritos, la planta está dividida por sur- cos longitudinales ó trausversales, fäcilmente comprenderemos que solo se necesitaba un paso para que en los heterópodos la planta adquiriern una forma del todo diferente, trabajara de un modo muy distinto. Vemos en vez del ancho pié de los otros caracoles, unido regularmente por la cabeza, una parte del todo separada de aquella y dividida en tres segmentos. El primero de estos es comprimiclo en los lados, y constituyen el órgano mas importante para nadar, es decir la quilla, que, muy movible, puedc inclinarse a derecha é izquierda. P'or detras de la izrilla se encucntra un disco chupador, con cuya ayuda el animal puede fijarse en objctos flotantes sobre todo en las algas. El tercer segmento, la cola, esta en las atlantas tambien muy desarrollado; llern en el dorso una tapa plana y' córnea que como en los otros cara. coles puede cerrar la concha Ia estructura interior de lits atlantas y de los demás heterópodos se parecen tanto a la de los otros caracoles, que omitimos describirla minuciosamente. Tambien el desarrollo es muy andólogo. Ia larva de las atlantas tiene pestanas bastante desarrolladas, con lóbulos muy escotados, y mientras que en los primeros órdenes las larvas se transforman en séres mas fuertes y resistentes, las de los heterópodos se conservan durante toda su vida muy delicadas.

Las atlantas se encuentran en gran numero en todos los mares cálidos y templados. Las mas conocidas, sobre todo por las excelentes averiguaciones de Gegenbaur, son las dos especies que con muchos otros animales de la alta mar son arrojadas á menudo por la tempestad al estrecho de Nessina; estas son la allanla Peronis, con la concha clàstica de color amarillo de cuerno, y la Rislanta erandrenis, con la concha frágil y casi trasparente. Fil diámetro de las conchas mas grandes es en aquella de $0^{\circ}, 009$ y en esta de 10. Sus 
movimientos los cjecutan por medio de las quillas $y$ de la cola, y el animal nada como todos los heterónodos con el dorso hàcia abajo. Keferstein, que observú a las atiantas viras, dice que los morimientos de las mismas hacen la misma impresion que el revoloteo que los terópodos cjecu. tan con sus remos en forma de alas. Los movimientos se eje. cutan á intervalos por medio de una. especic de saltos. Al hablar del huso del disco chupador, con el que los animales se fijan, el citado autor dice: "Cuando los animales se conservan en una vasija, es fúcil obserrarlos en esta josicion, y entonces se nota que se fijan con bastantc fucra. En alta mar se agarran de este modo a las algas ú otros objetos hotantes, del mișno modo que las sanguijuclas, sirviéndonos de la expresion de Adams.

Cunndo se inquieta a las allantas ó quieren bajar da jro. fundidad, retiranse del todo en la concha, oculfando primero la cabeza, despues la alcta y por fin la extrenidad exterior del cuerpo, que cierra la concha herméticamente por medio dé la trupa

Como en todos los heterópodos, en las atlantas se distinguér los sexos, pero solo por la existencia de cicrtos órganos genitales del macho, que en la liembra faltan. So debemos hacer mucho caso de la noticia de cierto naturalista que dice que, en las atlantas, las hembras son muy inferiores en número a los machos; pues ningun otro autor lia observado esta desproporcion. Los huevos se depositan probablemente como en los otros terópodos en largos cordones, libremente en el agua. Gegenbaur dice que los individuos cautivos nunca ponen huevos, pero que las larvas se cogen en los diferentes grados de su desarrollo, con la red fina, en la superficie del ägua.

\section{LAS CARINARIAS - CARINARIA}

Estegénero es afine por muchos conceptos de las atlantas, pero por otros importantes caractéres constituye el trúnsito a la tercern forma principal de los heterópodos. "Tambien las carinarias tienen una concha muy delgada, vidriosa y espiralada con una ruelta mus rapicia, de modo que la última desembocadura es muy/superior en circunferencin y espacio a la circunvolucion. En esta concla, sin embargo, solo hay sitio para el llamado núcleo, que se compone del higado y de los intestinos; mientras que las bránquias sobresalen del borde. La mayor parte del cuerpo constituye una masa fusiforme en la que la parte anterior corresponde a la cabeza de Ia atlanta y la posterior à la cola de la misma. En la base de la cabeza se ven dos largos tentáculos, detrís de los cuales se hallan los ojos. En el apéndice redondo del vientre se re. conoce al purto la quilla ó la aleta con el disco chupador. Ka aleta, dirigida hàcia arriba, dice Keferstein, permite al animal aranzar, lenta, pero continuamente. Ia cola se mueve tan pronto a uno como á otro lado, y todo el cuerpo se agita constantemente, pero los movimientos del amimal, cuando avanza, son torpes y pesados. Segun resulta de esta descripcion, puede moverse con la misma facilidad hácia atrás que hacia adclante, y en efecto, asi se observa en la locomocion.

In especie mas notable $y$ magnifica, aunque tambien la que mas escasea es la carinaria vidriosa (fig. 297).

l.as atlantas, al retirarse del todo en su concha, pueden protegerse cuando menos en algo contra los alaques, sobre todo de los pequenos crustáceos roedores, pero las carinarias, caș del todo desnudas 6 indelensas, están cxpuestas a lodas las agresiones de los crustáceos, de los peces y de sus propios congéneres. Estos enemigos parecen atacar con preferencia el núclco de los intestiros, cosa que muy fácilmente se cxplica por la trasparencia casi completa del resto del cuerpo. Tam. bien el hecho de que á menudo falte igualmente la cabera, en cujo estado de mutilacion el arimal se mueve aun mucho tiempo, se debe atribuir á que los ojos, semejantes à globulitos brillantes, llaman la atencion de los enemigos. Como, segun hemos dicho, los individuos mutilados viven aun mucho tiempo y se mutven despues de haberse cermado sus heridas, se comprende el error de algunos naturalistas, que designaban estos cuerpos mutilados como géneros nuevos.

Numerosas carinarias cogidas por Gegenbiaur en marzo depositaron un gran número de huevos, calculandose que una sola hembra puso en 24 horas varios miles. Estos huevos, que forman cordones, se componen de una sustancia parecida á la clara del huevo, y por fuera tienen una capa un poco enciurecida que ficilmente se rompe. Los cordones son cilindricos, de $0^{n}, 001$ á $0^{n "}, 002$ de grueso, y del todo lisos en la superficie; los huevos están dispuestos en uma sola serie, muy próximos el uno al otro. Diez y ocho horns despues de la puesta el embrion se mueve ya dentro del huevo por medio de las jesrañas; Cregenbaur pudo observar tambien el desarrollo hasta la formacion de la vela, que se extiende en dos lóbulos; esto sucedia poco mas ó menos al tercer dia, pero despues los embriones morian por lo regular, aunque se turiese el major cuidado.

Fintre las conchillas, antes muy apreciadas, figura tambien una carinaria india, por la cual se han pagado hasta cien guineas.

\section{LOS TEROTRAQUEOS - PTERO- TRACHEA}

La tercera forma principal de los heterópodos es la de los terotráqueos que son del todo desnudos. Ia diferencia entre ellos y las carinarias consiste esencialmente en que el núcleo intestinal, que aqui tiene la figum de un grano de trigo, no esta contenido en una bolsa particular, hallándose solo cubierto por una concha. El largo cuerpo cilindrico se continúa por delante en una trompa delgada que por detrís remata en una cola nuy fina; en la cara inferior se ve una aleta en forma de hacha, y en la supcrior, por lo regular cerca de la extremidad posterior del cuerpo, hállase el núcleo intestinal, que es fusiforme y queda descubierto en una mitad. En el estado normal, los animales tienen además un apéndice caudal filiforme contricili, en el que, á intervalos regulares, se ven dilataciones en forma de nudos de color pardo 6 rojo oscuro.

Ios terotriqueos arentajan á sus congéneres en voracidad, y asi como ellos, mueven la trompa en todas direcciones para buscar alimento; desenroscan y recogen continuamente la lengua, entreabriendo los dientes laierales como unas tenazas. Por estos movimientos de los dientes y de la lengua cogen y sujetan la presa, que poco á poco es conducida al esófago. Keferstein vió ause los terotraqueos llevaban su presa mucho tiempo consigo, lo cual ha becho creer en la noticia errónea de que estos animales chupaban sus victimas.

La propagacion de los terotráqueos es en un todo seme. jante á la de los otros heterópodos: Gegenbaur dice que, en. tre estos, son los mas desartollados, porque la íalín de toda coricha permite una iorma mas libre; esta opinion, fundada en nuchos cjemplos del reino animal, apóyase tambien en el hecho de que en los terotráqueos la diferencia entre ambos sexos es la mas marcada; la hembra carece del todo de la ventosa, y el macho tiene además de esta un órgnno genital muy desarrollado. Ios cordones ovarios de los terotráqueos se parecen mucho á los de las carinarias; son de diferente longitud, bien cilindricos ó ya un poco aplamados, componiéndose de una sustancia vidriosa, endurecida en la super- 
ficie, y encierran las yemas dispuestas en una sola serie Segun parece, la puesta de los huevos se verifica todo el año con seguridad, por lo menos desde setiembre à marzo.

\section{LOS FILIROES-PHYLLIRHOE}

- Hacenos mencion tambien de este género, cuyas especies son desnudas y trasparentes, y en particular del filiroc bucéfalo, en el que Panceri ha observado la propiedad de brillar. El animal no alcanza apenas $0^{\circ}, 03$ de largo; es comprimido lateralmente, y está provisto de dos largos tentaculos. En el Mediterráneo se coge á menudo en la superficie, con una red fina, pero pasa desapercibido con frecuencia à causa de su excesira trasparencia, tan notable, que se podria lecr á través del cuerpo. El citado zoólogo se convenció de la propiedad que tiene el animal de brillar en la oscuriảad, cuando movia el saso ó tocaba el molusco, que tambien parecia despedir luz, como otros muchos animales, cuando se le ponia en agua dulce. El fenómeno cra mas completo si se cubria el animal con una disolucion de amoniaco; entonces todo el cuerpo fosforecia, despidiendo sus grandes tentáculos una viva luz azul que pronto se apagaba con la vida. Panceri ha observado que la luz sale de las celdas nerviosas, sobre todo de las que se hallan superficialmente debajo de la piel, y depende de una sustancia que, aun despues de la muerte del aninanl, pruede hacerse radiante por la irritacion, sobre todo en el agua dulce. Es extraño que la electricidad, que por lo demits es bastante poderosa para excitar la encrgia de los nervios, no tenga in. fluencia en este fenómeno.

\section{CUARTO ORDEN}

\section{OPISTOBRANQUIOS-OPISTOBRANCHIA}

Volvemos de la pleaniar à la costa, sobre todo à las abigarradas praderas de las algas, à las magnificas alfombras de plantas sumergidas en el agua, que, tantas veces sedujeron nuestras miradas, cuando las observábamos desde la lancha que lentamente surcaba el agua; aqui encontramos otras agrupaciones de moluscos, que en su major parte recuerdan por su cuerpo desnudo nuestras limazas, aunque son superiores por su graciosa estructura, numerosos apéndices que sirven de bránquias, $y$ la belleza de sus colores.

Aunque el número de especies conocidas de los opistobránquios apenats asciende a mil, la estructura de su cuerpo, su forma y su manera de vivir ofrecen, sin cmbargo, considerables diferencias; por una parte pertenecen á generos muy desarrollados y afines de los órdenes anteriores, mien. tras que por otra hay muchos quie, alejảndose de su carácter de moluscos, se parecen mas bien á los anélidos y carecen a menudo de bránquias internas y externas.

Siguiendo la excelente recopilacion de Bronn, transcribiré ante todo, los caractéres generales del órden, puesto que lo dicho antes bastará para reconocer las relaciones.

Los opistobrínquios son moluscos marinos cuyos caractéres mas esenciales y constantes se fundan en la respiracion acuática, en la disjosicion de la cimara anterior y del tron$\mathrm{Co}$, que hace volver la sangre de las brínquias, y por último, en su hermafroditismo. Casi sin excepcion son de forma prolongada y desnuda; solo en un corto número encontmremos conchas en forma de escudo o espiraladas, pero nunca tau completas como las observadas en los órdenes anteriores. Tambien puede decirse que casi sin excepcion, tienen un par de tentáculos ye en la boca dos palpos labiales ó un apéndice membranoso que se parece à las velas de las larvas. La abertura bucal está cubierta de un lóbulo en forma de vela, y sobre el se hallan los tentículos. Ia circulacion de la sangre se verifica por medio de venas, las cuales llevan la sangre á la bránquir, descle donde se dirige al corazon.

Podemos hacer mencion aqui de una particularidad que esté órden tiene, comun con la major parte de los otros moluscos y de la que depende el aspecto extcrior, que tantas veces cambin en un mismo individuo: es la relacion directa del sistema vasal de la sangre con la parte exterior. Por una abertura penctra el agua directamente hasta la sangre, y gracias a un conducto esjecial, los vasos de aquella, que cruzan como las cavidades de una esponja el dorso y el pié, se pueden llenar y vaciarse a voluntad del individuo. Aunque este es el sistema principal de la circulacion de la major parte de los ostiobránquios, algunas especies del órden constituyen una excepcion de la regla, porqque ga no tienen órganos respiratorios independientes, cuyas funciones deben ser desempenadas por la picl desnuda del dorso.

El sistema nervioso estí por lo regular bien desarrollado. La parte mas importante, el anillo esofágico, se suele compo1zer de tres pares de gánglios reunidos por haces de nervios, de los cuales separanse los principales para los órganos de los sentidos, para la parte del manto y la del pié; por lo regular están en relacion con ellos unos nuditos nerviosos, de los cuales se proveen las partes de la boca y el canal alimenticio de los finos hilitos nerviosos. En el desarrollo de los ojos, los ostiobránquios son inferiores tanto a los pulmonados como $a$ la major parte de los pectinibrániquios y a los heterópodos, cosa que esta en rclacion con su necesidad de reptar y su alimento vegetal. Solo en algunas cspecies en. contraremos la taculiad de nadar por medio de ensanchamientos del pié en forma de aletas.

Los órganos genitales son hermafroditas. Los huevos se depositan en gran mimero envueltos en una sustancia mu. cosa, en la que los embriones que se mueven por medio de pestanas permanecen hasta trasformarse en larvas. Fistas se distinguen por su caracteristica vela, por una concha espira. lada que puede contener todo el animal, propia tambien de los moluscos que mas tarde son desnudos, y por un pié provisto de una tapa. De este modo sale la larva de la capa mucosa de los hueros, nada libremente, echa despues la tapa y la concha, y cmpicza a usar su pié que poco á poco se trasforma en una ancha planta; esta al principio separada se suelda mas y mas con el resto del cuerpo.

En el indice que Bronu hace de los ostiobrainquios se enumeran nada menos 26 familias qque con 122 géneros; naturalmente se nota la necesidad de una division de ordenes en sub-órdenes. Es claro que con la importancin de los órganos respiratorios y por que su posicion y forma se reconocen fia- 
cilmente, siempre hay que recurrir à ellos cuando se trata de una clasificacion sistemaitica. "Este grupo de moluscos, dice Bronn, ofrece de por si uno de los ejemplos mas bonitos de una serie ascendente por medio de la separacion de la division del trabajo, por el desarrollo de órganos independientes, por la concentracion $y$ la internacion de su posicion en un desartollo progresivo del organismo, sobre todo en las branquias. El principio lo forman los rodopos que carecen de disco, bránquias, vasos y hasta de corazon. Primero funciona la piel del dorso, despues aumenta su superficic de contacto con el aire pór la formacion de diferentes apéndices; eștos se ramifican mas y mas y se trasforman en verdaderas brin. quias; las bránqquias distribuidas sobre todo $\mathrm{cl}$ dorso se concentran alrededor del ano, buscan despuces proteccion por debajo del manto, primero á lo largo de ambos lados del cucrpo, y se limitar despues al lado derecho donde poco a poco se forma una cavidad branquial poco profunda con descmbocadura ancha. Por stra parte se ciesarrolla la concha espiralada, para la proteccion y recepcion del animal, trasformandose de rudimentaria, interna y córnén, en una exteman

Nos hemos adelantado por estas acertadas palabras á

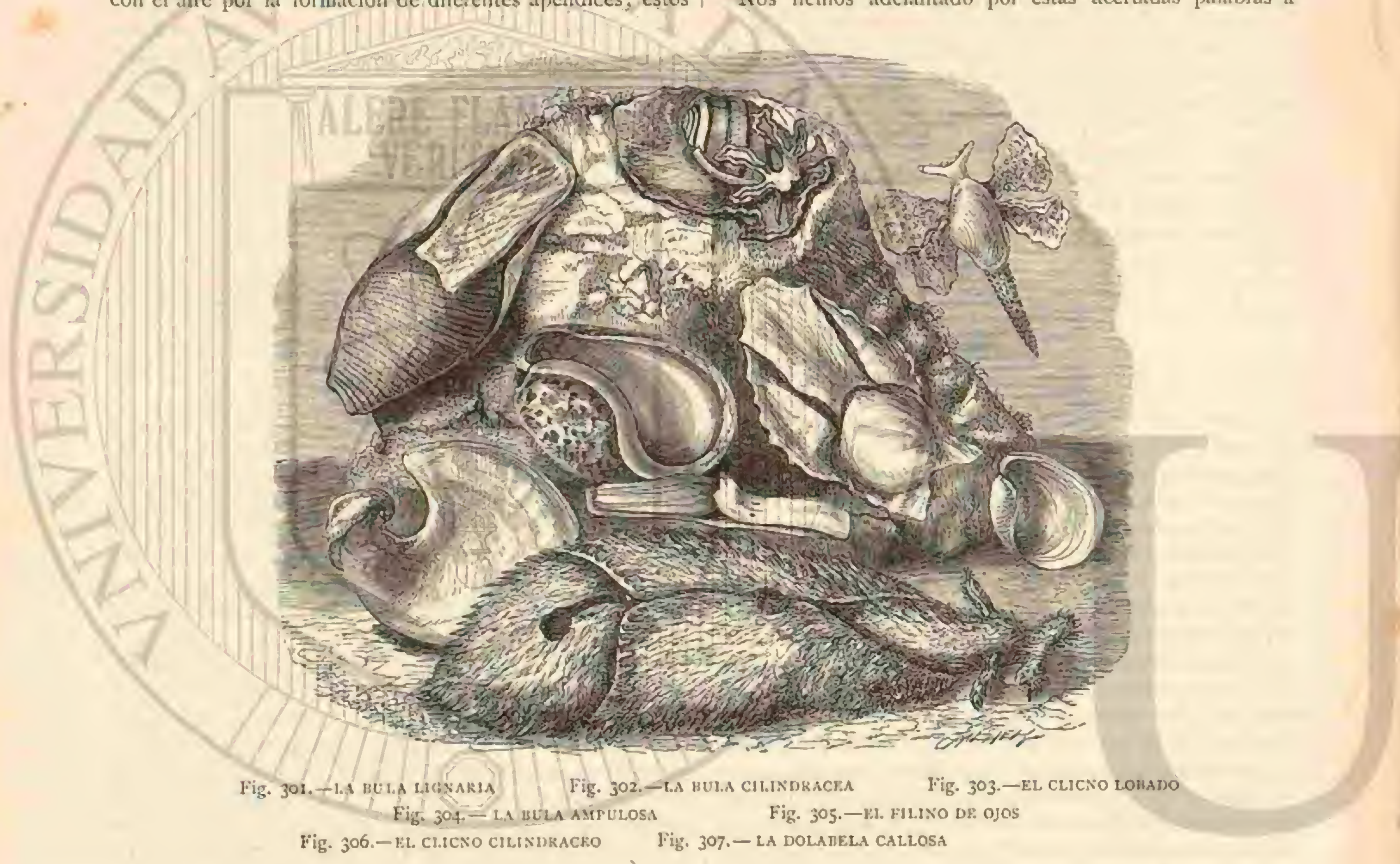

nuestra descripcion. Expresan el resultado de un minucioso exámen de toda la seric de los ostiobránquios comenzando por los menos organizados. La disposicion de cstn ohra no nos permite proseguir este camino, pero no hemos querido dejar de indicar cómo para in verdadera comprension de csta parte del mundo vivo es de absoluta necesiclad el ascender de las formas menos organizadas à las superiores. Aquellos ostiobránquios cuyas brinquias se encuentran bajo el borde del manto pueden llamarse moluscos de hroinguins culiertas ó de brinumions laterales. Es preferible sin embargo el primer nombre, porque en todas las familias de este grupo las bránquias están mas ó menns cubiertos, mientras que en una sola se hallan decididanente en los lados.

\section{LOS BULÁCEOS-BUL- LACEA}

Ia familia de los buliceos se compone de géneros en los que las brinquias se hallan en el dorso y por el dorso están cubiertas. Casi locios tienen una concha exterior à menucuo tan grande que todo el snimal puede retirarse en ella.
De las treinta especies que comprende uno de estos géneros, el de las bulas, las tres mas conocidas son la liula ligmarin, de Linneo (fig. 301), la hula ampulesa, del mismo autor (figtura 304 ) y la luta cilindsáced (fig. 302)

\section{LAS ACERAS-ACERA}

Tenemos en las costas europeas algunos representantes distinguidos de la familia que nos ocupa y" daremos á conocer sus particularidades en una especie comun del mar del Norte, del Bälico y del Mediterrainco, la acera hullata, sirviéndonos de guia la magnifica obra que Mever y Mrevius han publicado sobre los ostiobránquios de la ensenada de Kicl y curo texto nos servirá despucs muchas veces al hablar de los gimnobránquios.

El animal de las acerns es prolongado, casi en forma cilíndrica; la cabeza es deprimida y obtusa por delante; el pié tiene grandes lóbulos redondeados que pueden descubrir la minor parte de la concha. En la extremidad posterior del manto hity un apéndice filiforme: este hilo sale del borle del manto y por la hendidura posterior de la concha puede ensancharse y contraerse. Soure su uso no se ha hecho nin. 
as linin-
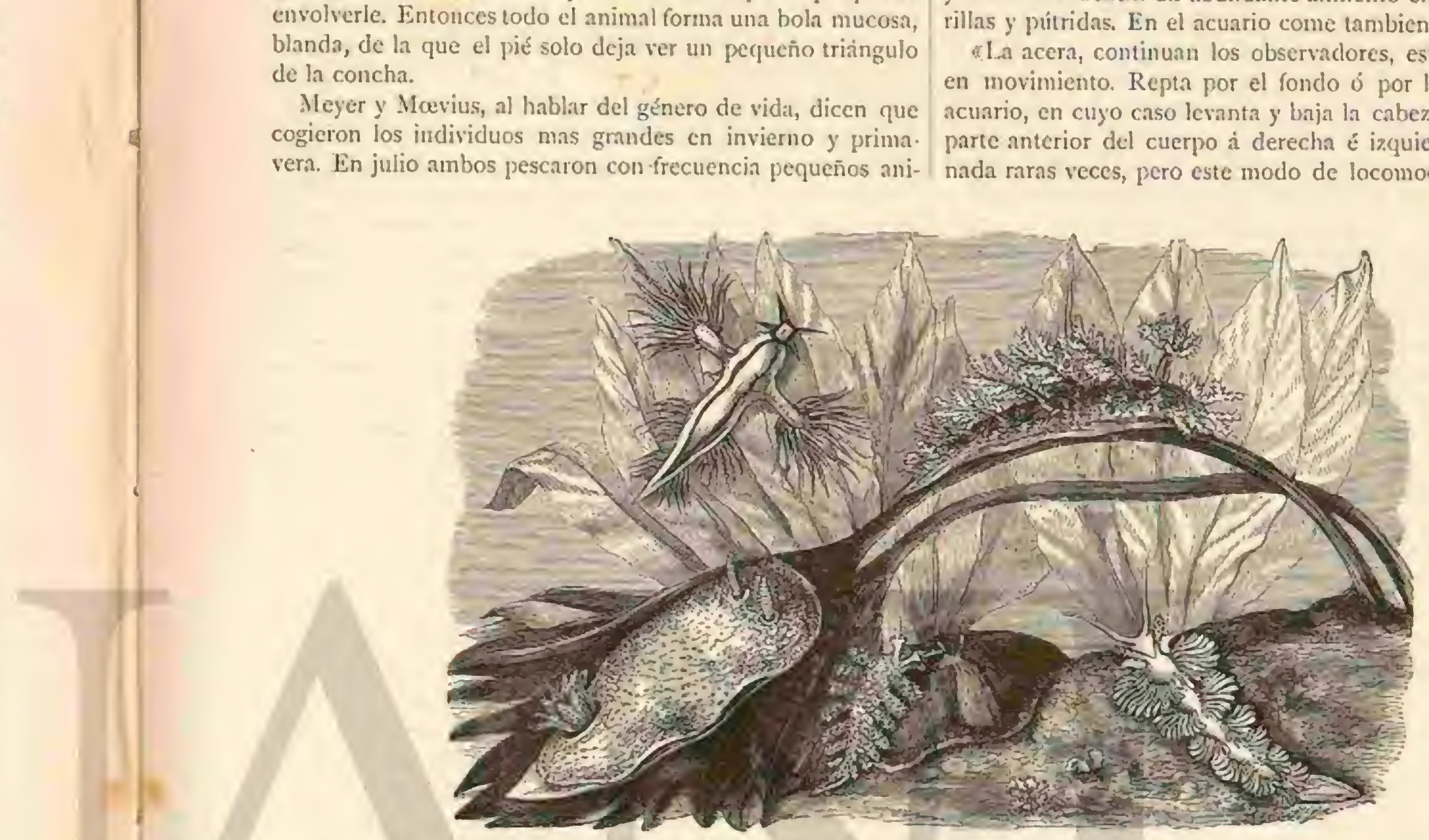
sube entonces siempre a mayor altura del agua y queda sus. pendido en las posiciones mas graciosns en medio del líquido clemento. Cuando estos movinientos han llegado a su mayor rapidez, cl pié da dós á tres fuertes golpes por segundo, separándose de hal modo del cuerpo oue forma una superficic cóncan hácia abajo. Al mismo tiempo la parte anterior del cucrpo se encorva un proco, ora hícia adelante ora hácia atrás, duranti cuyo movimiento cl atimal baja cada ve\% un poco, subiendo sin embargo oblicumente con cada golpe del pie extendiclo.

Cuando estos vivos movimientos se han prolongado algunos minutos, los golpes se hacen mas débiles, y el caracol baja lentamente; á veces, antes de tocar cl suclo, vuclve a elevarse por algunos golpes fuertes, pero yn no a la altura anterior: las fuerzas se extinguen, y' cl animal baja al fondo, moviendo solo algunas reces los bordes de los lóbulos del pié; despues envuelve con ellos la concha y empiezat por fin á reptar de nuevo.s

Los autores de esta detallada descripcion creclr que quiass las inclinaciones amorosas, en la primavera, producen estos movimicntos, porque precisamente en febrero, cuando los sentantes Narius enada de es al liaforma ci Hte: el pić scubrir la terior del del borle cha puede seciro nin. se con.

ion por dos del joco i da con Ir conanimal, en แIna

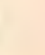

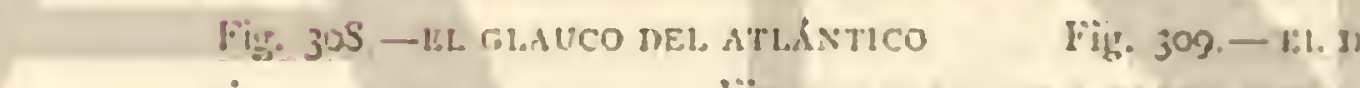

Fig. 311,-EL DORIS VERkUGOSO

y curioso, podria llamarse un vuelo dentro del agua. La con. cha amarilla se desliza con creciente rapider hảcia adelantey atris, la parte anterior del cuerpo hace movimientos acompasados, los lobulos del pié se separan y ruclven à recogerse, siempre a mayor distancial y con mas fuerza, hasta que por fin sus golpes impulsan todo el cuerpo hácia arriba. El mimal

gunn observacion, pero sin duda recuerda el apéndice caudal
de los tcrotrátqueos. I a concha es delgada, córnen, elastica y oval. Los grandes individuos de la especie citada se estimuy desarrollado, sirve, lio solo para reptar, sino para nadar quieta, encoge todo al cuerpo de tal modo que el pié puecle blanda, de la que el pié solo deja ver un pecqueno triangulo Mejer y Movius, al hablar del género de vida, dicen que ula ligna. males de solo 0־,003 a 0",005 de lirgo y muchas conchas de mediano tamaño entre yerbas marinas pútridas, rircunstancia de la que puede deducirse gue la acera vive de una primavera a la otra. Fön la ensemada de hiel es una de las espe. cies mas commes en los fondos cenagosos, cubiertos de yerha marina, prefrriendo sobre todo la region donde ésta ha muerto y donde encuentra un abundantc alimento en las hojas amarillas y puitridas. En el acuario come tambien carnc.

"la acera, continuan los observadores, está casi siempre en movimiento. Repta por el fondo ó por las paredes del acuario, en cuyo caso levanta y baja la cabeza, y encorva la parte anterior del cuerpo a derecha é iaquicrda. lil animal nada raras veces, pero este modo de locomocion, particular 
gunas horas, en fuentes con un poco de agua. Eintonces salen los unas de los caracoles y reúnense en la superficie, mientras que los anélidos se ocultan en el fondo del mar. Muchos de estos últimos, que habitan en sustancias puitridas, se aglomeran debajo de las conchas vacias, que se recogieron del fondo, tan pronto como el cieno pasado por el arnero se pone en fuentes planas en un sitio claro.

- En el agua poco profunda, donde las plantas marinas crecen hasta cerca de la superficie, una bolsa sencilla sujeta en un aro con mango, puede servir para coger los caricoles. I as piedras cubiertís de algas se cogen desde la lancha con ganchos para examinarlas al paso. Si el agua tiene poco fondo se pueden buscar en dichas piedras conchiferos, y ane. lidos en la arema, of pequeños crustíceos y carncoles en los charcos.

Para péscar en la superficic empléase una pequena bolsa poco profunda de tal muy friso, sujeta a un aro de nadera. F.sta brolka se fija en ln popa de la innrha, nueneras esta avan. zi. lentamente, y el contenido, lavado varias veces, se examina despues con el microscopio.

* Parrásicar el agua de la profundidad empleamos una pequéna boniba de cobre, en la qué se nja un largo tubo de goma de media pulgada de dianetro con las paredes de un cuarto de pulgada de grueso. La extremidad exterior del tubo está cerrada por un vaso cónico de cobre, cuyo fondo tiene unos agujeritos, gracias a los cunles solo pueden penetrar pequchos cuerpos en el tubo. El agua extraida penctia en una bolsa de iul fino que pende en el agua, para que lós aniniales delicados no puedan lesionarse por el roce con el tejido. Al uso de esta bontba debemas el descubrimiento de forminiferos vivos en el puerto de Kiel.

- Las especies que nos conviene conservar mas tiempo visas se echan en vasijas de vidrio que se cierran con tul $y^{\prime}$ se colocan en el cubo. Esto úitimo afecta la forma de barco y contienc una tabla horizontal cun agujeros a los que se adaptan las vasijas de vidrio. Mientras uluestra lancha esta anclada, el cubo hotn a su lado y' se sumerge sieminre de modo que las rasijas esten debajo del agua. Cuando la Lan. cha avanza, dos hombres suben el cubo sóbre cubierta hasta que la embarcacion se detiene otra vez.

E Lu csas vasijas de vidrio cubiertas de tul 6 de lienzo llevamos nuestros animales en cestos divididos en compartimientos, $y$ asi llegan vivos a Hamburgo para conservarlos en acuarios, donde se pueden hacer observaciones mas minuciosas.

\section{LOS CLICNOS-CLICHNA}

De este género, afine al anterior, y que se caracteriza por tener la concha libre, el clicrio truncádo pertencecé los mares del Norte y tambien á la ensemada de Kiel. Sabemos que este pequeño caracol que puede retirarse del todo á su concha, ia cual mide $0^{\circ}, 005$ de largo, repta muy vivamente por las jerbas y plantas; le gusta penetrar en el cieno del fondo del acuario; y no cscasea en los sitios profundos y cenagosos de la ensenada de Kiel.

l'uede considerarse como tipo el ilieno cilindráseo (figu. m 306$), y$ merece mencionarse como i cspecie notable el slicno lobado (fig. 303).

\section{LOS FILINOS-PHILINE}

La tercera especie trasladada del punto de Kiel a los acua rios de Hamburgo es el filino abierto, perteneciente $\dot{a}$ un grupo en que la concha está envuelta del todo por el manto; los bordes laterales del pie se ensauchan y la cabeza carece de tenticulos. La especie de que se trata, y que se encuentra desde el Bíltico hasta el Adriático, alcanza una longitud de unos $11^{\prime \prime \prime}, 015$, pero solo cuando se estira para reptar. I a conclia ténue y ligeransente enroscada, liene una desembocadura de color blanco de leche y transparente, con un brillo de macar. lista cualidad de brillar con los nas bonitos colores verdes y rojos consiste en la circunstancia de que, con las finas lineas redondeadas, se cruzan otras, visibles solo con un buen ante. ojo de aumento, hallindose la concha cubierta además de espesos poros finos. El animal tiene sobre su fondo oscuro un color blanco de leche $\delta$ amarillento con punios blancos y transparentes. La especic mas notable es el filino de ojos (iig. 305 ).

A tines de Julio algunos filinos cogidos hacia poco, depositaron sus huevos, envueltos en sustancias mucosas claras como el agua, de forma oval, y que hotan libremente. Bri el mar el anmal habita los sitios profundos cubiertos de cieno. En los acuariós se oculta casi siempre en el limo y a vecrs vuelve d aparecer solo despues de muchos meses. De noche suben por la pared del acuario, pero vuelven á ocultarse enseguida cuando se les expone a la lux. Estan provistos, por lo tanto, como otros muchos animales sin ojos, de la facultad de sentir la lu\%, lo que solo quiere decir que la lua influye de otro modo sobre ciertos nervios de la piel, que la oscuridad.

\section{LAS APLISIAS-APLYSIA}

Este género forma el núcleo de una familia que con prefe. rencia trabita los mares cólidos. En las historias de mágia del tiempo de los emperadores romanos se luabla repetidas veces de la liẹure mariria (lipus marinus). Apulejo se liabia casado con una viuda rica, y como pagase á un pescador para que le proporcionara aquellos animales, hirose sospechoso y se le acusó de haberse valido de la magia. Mientras la liebre marina sacada del mar vivió, se atormentaba a la victima, obligándole a tomar las secreciones del animal. Aun hoy dia los pescadores llaman á este molusco liebre marina, y en algunas costas de Inglaterra tambien vaca marina: la cabeza del animal, del todo desnuda posteriormente, justifica estos nombres. Tiene cuatro tentấculos, dos planos y triangulares y dos recros que se parecen mucho a las orejas de una liebre. Por delante de los últimos se encuenuran los ojos, y en el contro del dorso, el escudo del manto que contiene una concha ligeramente convesa, córnea ó calcirea, j’ que en su parte poste. rior se continua en un corto tubo por el cual dagua penetra en las branquias. Las extremidades interiores de estas sobresalen por lo regular del bords del escudo, pero, asi como la mayor parte del dorso, pueden cubrirse por medio de dos apéndices membranosos en forma de ala, con los que el animal ejecuta movimientos ondulados. Parece que no es exacto que las liebres marinas puedan nadar por medio de estos apéndices, pues los animales son demasiado pesados para esto y los apéndices ticnen poco desarrollo. Cuando no se la inquieta, el cuerpo de la liebre marina parece lleno y elástico, pero tan pronto como se coge un individuo para ponerlo en una vasija, pierde, no solo el agua que dilata el cuerpo, sino tambien un liquido de color violiceo oscuro que igual. mente se distribuje por tlagua, segregändose en tal cantidad por los bordes del manto, que el animal queda oculto en êl.

Interesantes son las noticias del quimico Ziegler sobre las relaciones de la secrecion de la liebre marima con la anilina. Llama à la sustancia, color rojo óviolíceo, liquido de anilina de un alto grado de concentracion, que en doble concepro sirve al animal de medio defensivo, pues puede enturbiar el cl agua para ocultarle a sus enemigos y tiene además las cualidades renenosas de la anilina, exhalando un olor parti. 
cular y repugmantc: propio del molusco. Ya en $1 \$_{2} \delta$ el cé. lebre conquiliólogo fiancés Fúrrussac llamó la atencion sobre la mpidez con que la materia colorante se descompone, tan luego como el animal la segrega, $y$ dice que esta descomposicion puede retardarse y hasta impedirse del todo merclando el liquido con un poco de décido sulfúrico. El citado guimico cree que seria fácil obiener esta materia colo. rante en grande escala, porque la liebre marina se encuentra en tal abundancia en las costas portuguesas, que cuando la tempestad las arroja a la orilla, infectan por su descomposicion de tal modo el aire que los habitantes temen el desarrollo de enfermedades epidémicas; hay cjemplo de liebre marina que da liasta dos gramos de color puro y seco. Las reacciones quimicas de la secrecion de la licbre marina, conirmaban al parecer la suposicion de que estos colores animales eran verdaderos colores de anilina, iguales á los que artificialmente se aplican de la benzolina. He tenido entre las manos muchos individuos de la especie aplysin dejilans que alcanza medio pié de longitud y es propia de las costas meridionales de Europa, pero nunca he notado escozor en los puntos de la piel que se ponian en contacto con el animal, ni cl olor repugnante que se altribuye à la liebre marina. Fista, sin duda, no dcbe tener tan mala fama, y seguramente no merece el nombre depilans (esquiladora), que se le ha dado, creyéndose que quien la eocaba perdia hasta los cabellos. Sin embargo, parece (que algunas especies tropicales producen por el contacto escozor.

No solo la forma exterior y el alimento de las aplisias invitan i la comparacion con los mamiferos plantiroros, sino tambien su estómago, compuesto de varios compartimentos, recuerda viramente ia aquellos. El esófago se abre en una ancha panza membranosa, de la que el alimento llega al segundo estómago, provisto en sus paredes de muchos cuerpecitos cartilaginosos de forma piramidal, que sin duda producen el mismo efecto que los dientes estomacales de los crustacens. Tambien la tercera division, mas pequeña, está provista de tales dientes; el cuarto éstómago, por fin, tiene la forna de un intestino ciego. Como la liebre narina necesita mucho alimento, que se conipone de algas gruesas, se la encuentra casi siempre paciendo. Ia especie nencionada sube á menudo tan cerca de la playa, uuc, al rellujo, permanece en perjueños charcos apenas húmedos, pero tambien baja à varias brazas de profundidad.

\section{LAS DOLABELAS-DOLABELLA}

liste género es propio de las \%onas cailidas y muy afine à las aplisias. In dolnbela de Rumph llega a una longitud de $11^{\circ}, 20 \AA 0^{\circ}, 25 \%$ 'se distingue por tener el escudó en la extremidad posterior redundeada, y en él una concha del todo calcărea. El tipo de este género es la dolabia callosa (figura 307).

\section{LOS PLEUROBRANQUIOS - PLEUROBRANCHUS}

Los pleurobránquios se distinguen de los apliciaseos por no tener cubiertas las bránquias por un escudo particular, sino situadas libremente por debajo del horde sencillo del manto, en el surco formado por este y el pié. De los pocos géneros que forman csta familia, el de los pleurobránquios es el que conocemos mejor, à causa de una excelente monografia que sobre todo trata de la especic pleurobranshus anuronfiucus propia del . Mediterráneo.

Los pleurobránquios tienen un cucrpo poco mas $\delta$ menos oval; desde arriba se parece it un disco aplanado en el ajue el dorso conrexo se cleva como un escudo carnoso. Bajo el borde exterior de este escudo del manto salen dos tentáculos hwecos que se componen de hojuclas delgadas enroscables. Mas hicia abajo, pero aun por encima de la boca, se cucuen. tra un lóbulo membranoso, trilateml, mas ancho por délantc que por detrás. Los ojos se hallan en la base de los tentaicu. los y se presentan como dos puntos negros muy peņueños. En las especies fleurohranchus aurantianas y vecllatus, el prie no es tan ancho como el escudo del dorso, mientras que en el pleurobrinquio de Perron, propio del mar Austral, sobresale en todas las direcciones.

Cuando el pleurobrínquio está eı movimiento sc adapta a tocias las irregularidades de los cuerpos por los que pasa, su icjido es tan blando que casi a cada momento le permite variar su fonma general. En este estado, los téntáculos, la rela bucal y la bránquuia tambien se despliegan. Sabemos que la hinchazon voluntaria del cuerpo de los moluscos depende de la recepcion de agua. Incaze-Duthiers compara el escudo del pié del pleurobránguio con esponjas que se pucden llenary vaciarse, de modo que al volumen del cuerpo puede variar en un doble y triple. Un Jrgano en extremo sensible es la vela, que se halla jor crucima de la boca: cuando el animal repta, baja esta parte y la empuja lentamente por la superficic de los cuerpos por los que se arrastra. El aspecto del animal es elitonces muy particular, presentándose la vela como una especic de trompa que sale del borde interior de la verdadera trompa. I a extrema sensibilidad de este órgano si explica por la abundancia de nervios de que esta provisto.

Como la vela es sin duda el verdadero órgano del tacto no podemos menos de supaner que los lamados tenticulos tienen oira significácion para el animal, sobre todo porque siempre los lleva encorvados hicia atrás y nunca se les ve palpar en realidad un objeto. Y en efceto, un naturalista in. glés ha designado los tentáculos de los moluscos como órganos del olfito. Lista suposicion es tanto mas probable en los pleurobránquios, porque aquí este órgano se compone de una hoja enroscada y cure forma un tubo abierto pror arrilias y en la base, por el que pasa, con ayuda de las pestañas mi. croscópicas, una continua corriente de agua. Corresjonde por lo mismo en alto grado ì las exigencias đque, segun ląs expe. riencias de la anatomia comparadar, debe cumplir un órga. no de olfito.

Sobre el arcat de dispersion de las especies observadas, Isacaze-Duthiers refiere lo siguiente. Cerca de Ajaccio, en Córceuga, encontró en las rocas el pleurobranedous ocillaturs, que muy facimente se reconoce por las vivas manchas blancas sobre un fondo pardo mezclado de rojo. En cambio, predomi. na en Mahon, en las Baleares, la especie de color de naranja

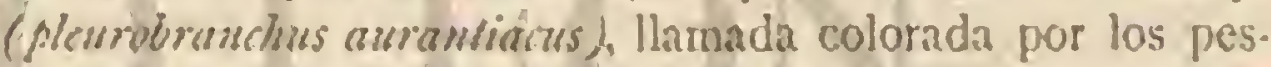
cadores españoles: Em fácil cogerla y se conservaba muy bien en cautividad, en la que tambien se propagaba. Aunque en su residencia natural buscan los escondites, no tcmian mucho la lux; a menudo llegaban hasta el horde del agua del vaso, doncle con preferencia depositaban los huevos. Al tocar un pleurobránquio, ó al levaniar rápidamente la piedra bajo la cual se oculta, se enrosca y se deja caer, costumbre muy ventajosa para el coleccionndor, porque no seria posible arrancar estos tiernos animales de las piedras, si como tamtos otros moluscos se agarrasen à ellas.

Ia época del celo de los pleurobránquios observados en el puerto de Mahon, acontecia en julio y agosto, y el citado na. turalista cree yue cada individuo deposita varios cordones de huevos. Fija el principio del cordon ell una piedra situada á poca profundidad y repta despues alrededor de este punto de partida en espiral, segregando una sustancia mucosa. Fl cordon es de $0^{3}$, o 1 de alto $y^{\prime}$ déc color de naranja. 
Lil Mediterrineo y los Océanos meridionales aibergan a\% gunos otros géneros parecidos al pleurobrinģuio, asi por ejem. plo el pleurobranthéa, que, entre otros caractéres, se distingue del pleurobrnáquio por la falta completa de una concha, mientras que el escudo dorsal, como aquel, tiene una conchn rudimentaria. Ia umbrella, distinguida jor un pié inuy grande, tiene cl manto pequeño, cubierto de una concha casi del todo plana y provista en el centro de ura pequeña puntita oblicua. La umbrela mediterránea, que tiene varias pulgadas de largo, se encuentra tambien en el Adriatico, al menos hasta Lissa.

\section{LOS GIMNOBRANQUIOS-GYMNO- BRANCHEA}

Más numeróso que el grupo anterior es el sub órden de los gimnobrnaquios, moluscos que si bien en estado de embriones y larvas están provistos de una delicada concha, la pierden prónto y quedan del todo dessudos en estado desarrollado, sin tener una concha rudimentaria. Cuando, como sucede en la mayoria, tienen bránquias, estas són del todo descubiertas, y se presentan como apéndices en forma ce borlas, hojas y árboles en la piel dorsal. Segúmos en la descripeion de cuatro de las familias mas importantes, la obra ya mencionada do Neyer y Micevius.

\section{LOS DORIDIDOS - DORIDIDA}

En la familia de los dorididos las bránquins, en forma de plumas ó de hojas, están dispuestas alrededor de la abertura anal situada en el centro de la parte posterior del dorso $y$ que forma una graciosa roseta.

\section{LOS DORIS - DORIS}

El género de los doris es uno de los mas numerosos on especies y a él pertenecen en gran número los gimnobrán quios mas grandes. El cuerpo es oval, convexo por arriba; el manto cubre el dorso y la cabeza, sobresaliendo del borde del pie. Todns las especies tienen la parte anterior del dorso provista de tentáculos llamados dorsales, que pueden reco. gerse en cavidades particulares; su piel está revestida de extrañas secreciones calcäreas de forma determinada.

La especie doris filosa y otras dos que viven cerca de Kiel carecen de los paipos bucales. Los tentáculos dorsakes ofrecen la particularidad de muchos gimnobránquios que consiste en estar provistos de repliegues oblicuos. Este doris debe su nombre á la particularidad de tener la superficie dorsal cubierta de papilas córneas de distinto tamano. El animal, que alcanza una longitud de mas de $0^{\circ}, 02 \mathrm{O}_{3}$ se cogió por los zoólogos citados en la primavera y el otono en las algas y yerbas marinas de las partes arenosas y pedregosas de la ensenada de Kiel, y durante semanas enteras se conservó en los acuarios con la furcellaria, ceramium y zostera, es decir, con una de las plantas marimas mas comunes. Aqui depositaba tambien en setiembre $y$ octubre sus huevos en cordones mucosos trasparentes como el agua.

Al lado de esta especie se presenta un doris afine, cuyo dorso tiene igualmente verrugas, pero el color rojo, midiendo de $0^{n}, 025$ de largo. Ls menos vivatz que ha especie anterior, $y$ permanece en el acuario por lo regular tranquilo entre la yerba marina. Algunos cjemplares que se pusieron en un acuario construido para mimales de la costa de Bornholmo se conservaron en el agun poco salada, del mismo modo que en la de Kicl.
Una tercera especie, muy comun en los mares septentrionales de Europa, es el doris murinata, de color blanco ó blanco amarillento, trasparente en el dorso y con los ienticulos de un amarilto naranja, hallindose acpuel cubierto do verrugas en forma de masa obtusamente redondeada (figura 310 ).

A las especies mas grandes pertenece el doris tuberculado cuyo dorso está cubierto de verrugas, pequeñas que alcanza una longitud de (1)

\section{LOS DOTOS - DOTO}

Distinguense particularmente las especies de este género por la estructura de los tentículos, yue son muy delgados y pueden recogerse en una especie de estuches que se projec. tan en la parte anterior del cuerpo. Los dotos parecen bas. tante comunes en las aguas del Canal de la Mancha. La especie mas curiosa es el doto coronado (fig. 312).

\section{LAS ANCULAS-ANCULA}

Del géncro anterior difieren las anculas por tener dos ten. táculos anteriores y unos apéndices en forma de estilo en la base de los tentáculos posteriores, que corresponden por su estructuria a los dorsales de los doris. Las brànn̨uias están dispuestas en un arco circular por delante del ano, frente al cual se elevan unos apéndices en forma de maza, un poco aplanados. A las-regiones antes citadas pertenece la ancula mohuda, cujo color predominnie es un blanco de leche trasparente. Su delicádo cuerpo ofrece un aspecto muy gracioso entre las plantns marinas verdes $y$ pardas, por las que repta con bastante vivacidad.

\section{LAS POLICERAS - POLYCERA}

El cuerpo de este tercer género de los dorididos es prolongado, redondeado por delante y puntiaguco por detrás. El carácter principal consiste en las verrugas, mas largas en la cabeza y al lado de las bránquias, que en el borde de la frente, donde sobresalen como cuernecitos. Una de las esprecies que se encuentran cerca de Kiel, lo pulpcera ocellata, fué causa de que se reconociera un interesante carácter especial. Todas las especies de policeras de la costa inglesa, entre ellas tambien la citada, tienen en la piel pequeñas es. pigas calcireas. la diferencia mas notable entre los individuos de la poljeera osellata, que se encuentra en la ensenada de Kiel, y los del mar del Norte, consiste en la íalta de aquellos cuerpos calcireos. "Si algunos de estos cuerpos, continuan Mejer y Alarius, se encontrasen en los individuos de la poljcera ciellara que habitan entre el mar del Norte y la ensenada de Kiel, la opinion de que la existencia o falta de los mismos no produce diferencias especiales quedaria del todo contirnada, y esto le hemos visto ciectivar mente cl segundo dia de P'entecostes de $186_{\mathfrak{j}}$, en el estrecho de liaenoe. Apenas habiamos anclado nuestro yacht, despues de navegar durante una-mañana muy fria, echamos la red de fondo, y a la jrimera vez sacamos individuos que tambien reconocimos como propios de la ensenada de Kiel; entre ellos se hallaron aigunos de la especie folycera ocellata, que, sin embargo, sè distinguian por tener manchas amarillas mas vivas sobre un fondo mas oscuro que el de los indivi. duos de Kiel. Todos tenian espiguitas calcireas en la piel, y es de suponer que la desigualdad en el agua y su salobriclad es la causa de esta diferencia, aunque se opone $a$ tal suposicion la falta de cuerpos calcáreos en individuos de una pequena ensenada de la isla de Samsoe, mas prósima aun al 
mar del Norte que el pequeno Belt. Creemos que la fuerte corriente en el grande y pequeño Belt, es sobre todo una condicion importante de la mayor semejanza de su forma con las de la zona del mar del Norte comparadas con formas de animales que habitan las ensenadas tranquilas de la parte occidental del Bålico. 2.

Dejemos á un lado las causas de la existencia ó falta de aquellos cuerpecitos calcireos, y atengámonos al hecho. Vemos sma cualidad que una especie tiene en comun con todas las demás de su género y que desaparece bajo influencias desconocidas; vemos como se forma una variedad qque solo necesita un aislamiento completo delárea de disprersion de su especie ordinaria para trasformarse tambien cu especie: Ia existencia de cuerpecitos calcireos, hace suponer una actividad muy enérgica y particular de las celdas de la piel, actividad que debe tomarse en consideracion, lo mismo que otros miles pequeños detalles que sirver para distinguir las especies de plantas y animales poco desarrolladas. Estos viltimos nos darin amm, mas de una vez, ejemplos chocantes de la nulidad de los llamados caricteres de especic.

\section{LOS EOLIDIDOS - EOLI- DID压}

L.a tendencia de la piel dorsal â formar excrecencias verrugosas, se manifiesta en algunos géneros de tal modo, que se los ha reunido en la familia de los eolididos, cujos órganos respiratorios son aquellos apéndices y papilas dorsales.

\section{LOS DENDRONOTOS - DENDRO- NOTUS}

Liste género se distingue por los apendices arboriformes dispuestos simétricamente. In especie derdronulus arbores. cens (fig. 309), muy comun, es uno de los gimnobránquios mas bonitos. Llega a una longitud de casi $0^{\infty}, 03$ y medio, y se reconoce fácilmente por su color rojo carmoso. Su cuerpo es muy enjuto y se adelgaza poco á poco hacin atrís; su major adorno son los arbolitos, que forman un semicirculo de 7 à 9 por encima del borde anterior de la cabeza, y de 5 a 6 pares a lo largo del dorso. Tambien los tentáculos tienen un tronco ramificado en el que pueden recogerse. El pié es mas estreclio que el dorso y truncado en su jarte anterior; sus bordes laterales se estrechan it veces de tal modo que se presenta como una quilla aguda. El animal prefiere trepar por las delgadas ramas de las algas, y á menudo sube hasta la punta, lcrantando libsemente la parte anterior del cuerpo para moverse à uno î otro lado, ó buscar un objeto sólido que le facilite continuar su marcha. Mejer $y$ Mavius vieron al dendronoto con tiletlos frecuencia que otros gimnobránquios, adherido tranquilamente $\mathbf{z}$ la pared del acuario. Cuando na. da en la superficie, el pić se ensancha mucho, ó sus bordes laturales se acercan, formando la planta un surco. Al nadar, lus arbolitos dorsales penden oblicuamente hácia ajuera y hácia abajo: cuando el caracol repta con el cuerpo cstirado en linea recta, se inclinan ligeramente hacia atras, y si este dá una vuelta, sepiranse en todas direcciones. Por sus movi. mientos ligeros, por su color y forma graciosa de los arbolitos, este dendronoto es uno de los animales marinos mas bonitos.

Cerca de Kiel se le encontrú, con mas frecuencia en invierno, en los árboles puestos cn la parte interior de la ensenada yara la cria de mitilos, y' se conservaba muy bien en acuarios llenos de piantas frescas y en descomposicion. F.s generalmente bastante comun en las costas septentrionales, y yo mismo ic he encontrado en las islas de feroe.
Los naturalistas citados no pudieron confirmar la noticia del zoúlogo inglés (irant, respecto a que el dendronotus arbnreseens puede producir débiles sonidos; pero como se asegusa lo mismo de otro gimnobránquio (reolis pustata), parece que hay en esto algo de verdad. Se supone que los duros órganos bucales producen estos sonidos.

\section{LOS EÓLIDOS - EOLIS}

Eiste género, numeroso en esprecies, que forman el nuicleo de la familia, tiene por carácter principal las papilas dorsales dispilestas simétricamente y que son de un grande interés fisiológico à causa de su estructura. En cada papila se cxticnde un tubo que por su naturaleza parece ser una parte del higado y esta en comunicacion con el canal alimenticio, ra. mificado en forma de airbol. Hácia la parte superior de la papila, el tubo del higado se comunica con unas verruguitas pequenisinas de las que puede salir un hilo que al punto produce escozor y probablemente sirve de medio de ataque $y$ defensa. Ia figura 310 representa el eolis papiloso.

Fintre las especies de eólidos de la ensenada de Kiel, Mejer y Mcevius han descristo mas mimuciosamente estc cólido papiloso: que en el citado punto alcanza mas de $0^{\circ}, 05$ de longitud; pero se encuentran en las costas inglesas individuos gigantescos de hasta $00^{m}, 15$ de largo. Su color es por lo regular un gris pardo, y su géncro de vida el siguiente: trepa con lemtitud y permanece à menudo inmóvil ; en el estado de descanso se recoge, baja los tentículos posteriores y deja pendientes las papilas. Las juntas de los lóbulos del pié y de la parte posterior del cuerpo solo sobresalen de las papilas cuando el animal repla estirindose. Si se le pone de esjaldas contráese mucho, se enrosca como un eriro fo cubre la region ventral de papilas. Sube con menos frecuencia que otros eó. lidos para nadir.

Su aliunento se compone de sustancias animales, y' sobre todo le gustan las actinias; si encuentra un individuo pequeio de la especie actinia plumosa, comienza por practicas un el borde del pic un agujero scmicircular que va ensanchaindose siempre mas; luego recoge, con la boca dilatada, lodo el resto de la presn y la devora poco á poco, sin que se vean los movimientos exteriores produciuos por la deglucion. Cierta tarde un gran cólido papiloso estaba cerca de una actinia plumosa, casi an corpulenta como él, y vióse como introdu. cia su boca en el borde del pié de su victima. Apenas habia comenzado su banquete, cuando se acerró un segundo j; por fin, un tercer companero para tomar parte en el festin. Al cabo de cuatro horas no quedabn ya ningun vestigio de la actiuia. Los naturalistas citados creen probible que el cólido ocupa. do ell devorar su jresa, atraiga à sus companueros por la saliva que segregan comiendo. Para buscar su alimento, los tentaculos anteriores te jrestan buen servicio; palpra en todas las direcciones y se retira bruscamente al tocar la presa; mien. iras que no lo hace cuando se encuentra con otro eólido ó cuando toca el fondo del raso. Tan luego como los tentá. culos han tocado el alimento, la boca se dirige hacia ellos. Mientras el animal come, cl cuerpo está recogido y descansa, las parvilas ligeramente sobrepuestas y encorvadas.

Sabre la reproduccion del élido papiloso se refiere lo si. guiente. Agunos animales quic desde mediados de enero vivian en el acuario, depositaban en febrero sus hueros en la pared de vidrio. listos son esféricos, la jema es blanca ó ligeramente rojiza. Forman un cordon que se laslla en una faja mucosa, clara como el agua, por medio de cuyo borde toda la masa se hija en plantas, piedras y otros efectos. Fil 15 de marzo un individuo deposito un cordon en forma de una espiral cncorrada de ires circunvoluciones. Fl a de mayo un 
grande animal depositó un cordon cuyo número de hueros ern por lo menos de 60,000 .

Dos otras especies muy comunes son el eólido de Drum. mod y el blanco. Este último tiene la piel tan delicada que las partes internas trasparentan marcadaniente en muchos puntos, y todo el animal adiguiere un viso verdoso cuando repta por la yerba marina. En algunos cordones de huevos se contaron hasta 40,000, pero los animales mismos, alimentindose de ellos, se oponen as una propagacion muy crecida.

\section{LOS GLAUCOS - GLAUCUS}

El cuerpo de los ghaucos es prolongado, sub.cilindrico y gelatinoso; termina posterinrmente por una cola delgada y en forma de lezma: su ratheza es corta y está provista de cuatro tentáculos rónicos colocados por pares: las aletas branquiales son opuestas, palmeadas y digitadas en su parte superior; laterales, horizontales y en número de cuatro pares; los tres pusteriures son casi sesiles; Jos orificios de la generacion y el ano se hallan colocados lateralmente. El animal es muy notable, tanto por su forma particular, como por los hermosos colores de que êstí adornado. Bste molusco nada lentamente en la superticie del mar, valiéndosé de suśbrinquias, y sicm. pre vielto de espalda. Las dos principales especies son el Slowico del Atlóntico (fib. $3 \mathrm{CB}$ ) y cl glanco rodindo.

\section{LOS TETIS-TETHYS}

Una especic cle este género, la leshys fimbria, que á inenudo alcanza $0^{m}, 30$ de largo, es un gimnobríncuio prophio exclusivamente del Mediterríneo y que por la posicion de sus bránquias recuerda mucho á los dendronotos, pero recibe un aspecto muly particular por la grande vela de la cabera, rirculirmente redondeada, que se forma de los lóbulos natatorios de la larva.

Grube nos ha dado una descripicion muy explicita de su género de vida segun las observaciones hechas en un indivi: dıo que en Trieste le diú un pescador: «era, dice, en extremo vigoroso y provisto de todos los apéndices laterales del dorso que en otro tiempo se han descrito y representado como parásitos de este molusco: estaban hinchados casi en forma de pera ó de rábano, un poco estrechados en la base, dispuestos a pares por delante de las brinquias a lo largo de los lados del dorso, disminuyendo hácja atras en tamaño y extendidos como remos. El cuerpo, tambien hinchado, casi sin color y trasparente como las brínquias, resaltaba de un modo maravilloso de los apéndices, que eran de un rojo pálido en l,2s puntas, provistos en el centro de manchas de un rojo muy oscuro y de las oculares negruzcas del dorso: cchado de espal. das se movia continuamente con cierta gracia, encorvando el cuerpo de tal modo que la extremidad del mismo tomba los bordes laterales de la rela. En esta posicion, el animal pare. cia un martillo en el que la rela representaba la maza y cl cuerpo el mango; pero tan luego como se habia tranquilizado un poco, el pié se ensanchaba en forma de una profunda fuente oval cuyos bordes laterales eran mas altos que el anterior $y$ el posterior. Despedia una viva fosforescencia lo mismo cuando jo tocaba al animal que cuando solo movia la mano en su vaso de agua. A pesar de que rellové el agua en el vaso, hastante espacioso, el animal murió durante la noche; á la mainana siguiente los apéndices habian caido y estaban sin morimiento, aunque conservaban su color.

No es extraño que un molusco tan grande, acostumbrado al agua mas pura de alta mar, y que necesita mucho la respiracion, haya vivido solo algunas horas en un vaso estrecho. Aun en los grandes acuarios, en un cambio contistuo de agua, los tetidos raras veces sobreviven algunos dias a su cautividad. Algunas reces la falta de alimento jropio es la causa, pues en Nápoles he visto individuos magnificos de un pié de largo y observé que no comian; pero sobre todo se pier. den por los choques con las paredes del acuario, como suele suceder con todos los moluscos de la alta mar. Al principio se agitan con rigorosos movimientos, pero al cabo de algunas horas manifiestan gran cansancio y no pueden resistir las corrientes que comunican los depósitos de agun: se oprimen contra las piedras y permanecen indefensos en los rincones.

\section{LAS ELISIAS-ELYSIA}

Con este género llegamos al grupo en que las bránquias, como ayéndices particulares, empiezan á desaparecer mas y mas. En el género de las elisias se comprenden las especies cuya cabeza no está separada marcadamente del tronco y en cuyos lados del cucrpo sobresalen dos lóbulos membranosos quie se reunen por detrás y sirven de órganos respiratorios, segun se deduce de la existencia de un gran vaso sanguineo ó varios, que penetran en dichos lóbulos desde el dorso, ra. mificindose en renitas mas finas, propias para la respiracion. Desde el Mediterráneo hasta el mar del Norte se encuentra la magnifica elisia verde, color predominante en la cabeza, mientros que en los tentículos de la parte superior del dorso $y$ de la superficie exterior de los lóbulos membranosos es un negro aterciopelado que tira á verde ó a pardo. El color principal del pié es un verde accituna. Por toda la piel se hallan diseminados unos puntitos brillantes, verde-azulados y rojo-buanquizcos, de un lustre metalico. Hstos efectos de colar se producen por unas celdas en cujo inierior luce el verde esmeralda mas viro y el azul záîro mas bonito. Otras dos especies de celdas pequenas tienen un brillo plateado ó cobrizo muy yivo.

En sus movimientos, esie bonito animal toma posiciones muy diferentes. Si repta por el suelo, se estira por lo regular en toda su longitud y avanza con relativa rapidez; cuando lo hace por la pared vertical del acuario, se vale à menudo de los lóbulos membranosos, con cuya planta se agarra. Segrega gran cantidad de sustancia mucosa, que al tocar la piel con una varita $\sigma$ un pincel puede sacarse en largos hilos fuera del agua. De estos hilos mucosos los moluscos se cuelgan a ve. ces libremente en el agua.

Aunque sabemos que los colores con que se suele pintará estos animales son exagerados, no podemos menos de rejroducir lo que dice Grube, para llamar mas la atencion sobre estos magníficos animalitos que con facilidad pueden cogerse y observarse en cautividad. Entre otras especies, dice el citado zoólogo, descubri en San Nicolo (en ln isla de Querso en el Quarnero) una nucva elisia, la élisia esplendida, de una belleza tan rara, que verdaderamente me causó asombro. Al principio solo vi en una cavidad profunda, no muy accesible i la luz, un cambio notable de negro, intenso, azul claro $y$ color naranja, pero luego observé que alli se movian varios de estos pequucinos gimnobránqquios, de tres ó cuatro lineas de largo por dos y media de ancho. Solo cuancio salieron los individuos uno por uno pude reconocer mas exactamente la distribución de los colores. El cuerpo y sus grandes lóbulas laterales eran de un negro aterciopelado; cl borde extremo de los últimos y la parte bucal, de un amarillo naranja, pero la cara exterior de cada lóbulo presentaba una ancha faja azul de Ultramar, y debajo de esta otra mas estrecha de un verde claro plateado, en cuya parte inferior se veia una seric longitudinal de puntitos parecidos. La faja, de color narnnja, pasaba por detrís à la correspondiente del otro lado, y la azul era 
cortada, destacindose graciosamente una mancha oval blanca entre los tentáculos, cuỹa cara interior tenia el color blanco, mieneras que estos órganos eran negros en lo demás, con las puntas azules. Median la cuarta parte de la longitud total, y tan pronto se inclinaban hácia adelante como se entreabrian, $\checkmark$ bien formaban uma espiral plana de la circunvolucion.

\section{LAS PONTOLIMAZAS-PON'TOLIMAX}

Volvamos otra ver al acuario de Hamburgo, tan instructiro para nosotros por sus habitantes de la ensenada de Kiel, porque debemos ocuparnos de una especie que, mas aun que la elisia, recuerda por su aspecto a las turbelarias. Pertenece al género de las pontolimazas, de la familia de los pontolimacidos, que carece del tocio de tentáculos y de bránquias. El cuerpo es prolongado, la cabeza se ensancha lateralmente y sus bordes presentan una cresta membranosa. La pontolimara de cabeza ancha (pontoliusax capilutus), que está diseminada en la mayor parte de los mares europeos, alcanza una longitud de $0^{\circ}, 008$. En el centro del dorso tiene una prominencia y entre esta y la cabeza una depresion. Ia mayor parte del dorso es de un color pardo con puntos de un amarillo claro. La citada prominencin es amarilla.

lil pequeño molusco se encuentra en toda estacion en la yerba marina, y se conservó repetidas veces durante meses enteros en pequueñas vasijas con toda clase de algas. Repta lentamente por las plantas, se suspende de la superficie del agua y sube a veces hasta elli. Cuando se le toca se contrae, por lo rual es muy fảcil no verle cuando se saca con las plan. tas del mar; Meyer y Mcevius observaron tambien que esta especie, puesta en agua dulce, segrega una gran cantidad de sustancia murosa blanquizca de un penetrnnte olor de harina podrida.

\section{LOS SINAPTOS-SYNAPTA}

Sin descender a las averigunciones sistemáticas, un poco dificiles, terminaremos la historia de este grupo de los gimnobranquios con la descripcion de uno de los moluscos mas notables, animal tan diferente de los demis de su clase, que indujo à su descubridor, uno de los naturalistas mas célebres é ingeniosos de nuestro siglo, a emitir una hipótesis por la cual una de las lejes mas importante de la naturaleza, basada en el hecho de que una cosa solo puede derivar su origen de otra igual, ó cuando menos muy semejante, se trastornó completamente. La historia yo el descubrimiento de la entoenncha mirnhilis, ó, segun ahora se Ilamá, helicosyrim parasitu, son por muchos conceptos tan instrúctivos, y nos permiten hacer tan interesantes observaciones sobre las relaciones de dependencia de los animales, que nos parece necesario ocuparnos algo minuciosamente de este asunto.

Desde mediados del cuarto decenio de este siglo hasta mediados del quinto el gran fisiólogo y zoólogo Juan Muller, de Berlin. se ocupó casi cxclusivamente en el estudio de la anatomia y de la historia del desarrollo de los equinodermos, clase de animales poco desarrollados de que mas tarde háblarémos. Un sitio jarticularmente favorable para estas averiguaciones era y' es 'T'rieste. En los dias lluviosos o cuando el mar está agitado, la pescaderia nos provee de un material abundante para el lipiz, el cuchillo y microscopio; pero, cuando el mar está en calma nos invita a hacer cxcursiones i la bahia de Muggia, de cuyo fondo cenagoso la red arrastradora saca un rico botin. Sobre y en este cieno viven miles y millones de sinaptos, equirodermos de forma de ans. lidos. Para comprender lo siguiente, solo tenemos que saber que la cavidad ventral del animal está cruzada desde la boca por un intestino, en cuya parte anterior existe una division marcada jor dos hinchaones en forma de anillo yue resulan ser el estómago. Tambiè se corren por el mismo logitudi. nalmente dos vasos de la sangre, de los cuales el uno débe llaurarse por su posicion viso ventral. Estos y otros muchos habitantes de la bahia de Muggia los recibian los naturalistas por conducto del pescador Frusing de Zaule y de su familia, que los llevaban diariamente á Trieste. Juan Muller se valia del mismo medio cuando no necesitaba cogeranimales microscópicos de la superficie del mar. En algunos sinaptos obsersó un tubo, una de cuyas extremidades cstaba en intima relacion con el vaso ventral del equinodermo, mientras que la otra flataba libremente en la cavidad abdominal del mismo. La naturaleza anatómica del tulio llamó pronto la atencion del observidior, quien reconoció que aquello era un fenómeno muy extraño, acreciendo su asombro al encontrar en el tubo, huecos, de los que salieron caracoles perqueños, pavistós de curscha, pié y vela. El descubridor se pregunió naturalmente si no tenia á su vista un caso de parasitismo. Sin embargo, el tubo que producia caracoles le pareciós tan diferente de tal molusco, que no pudo considerarle como caracol, trasformado quizás por una metamorfósis retrogresiva, y por otra parie, la relacion entre el sinapto y el caracol era tan íntima al parecer, nue rechnzó del todo la idea de que se tratase de un parásito, procurando demostrar en una obm muy ingeniosa que el tubo era un producto del simapto. Despues, observando que el fenómeno solo se presentaba en un sinapto entre ciento, salió del laberinto de hechos contradictorios, no por la atrevida suposicion de que se trataba de una especic de cambio de generacion, sino juzgando que el organismo tenia la facultad de pasar á otro tipo. El tubo se trasformó para el gran naturalista cn un órgano del sinapto, y este descubrimiento le halagó anto mas, ell cuanto creyó haber encontrado un medio de prescindir de la suposicion de las generaciones esponiánens, suposicion que en rigor no le agradabi Con frecuencia oimos repetir las palabras de Junn Muller sobre el hecho de que la crea. cion de cada especie era sobrematural, es decir, oculta jara la observacion y la explicacion de la ciencia. Ahora tenia a su vista un caso que, si bien inaudito, no era del todo contrario á las leyes de la naturaleza, puesto que liabia al parecer otros muchos ejemplos del cambio regular de la generncion, que reamudaba la formacion de un nuevo tipo animal en una forma ya existente. Juan Afuller ereyó jor lo tanto tener a su vista una ampliacion del cambio de generacion: Estamos acostumbrados en este terreno, dice, à muchas cosas milagrosas, que, sin embargo, deben obedecer á la misma ley; y aun eran de esperar descubrimientos asoinbro. sos. Sin embargo, esto parecia demasiado violento, de modo que la hipótesis sobre el sér enigmática en el interior del sinapto, aunque llamaba mucho la atencion, no encontró partidarios.

Varios zoólogos intentaron descubrir la verdad, y entre ellos con mas persevernacia Alberto Baur, que vivió algunos meses cerca de la playa de Muggia para estudiar del todo la historia natural del sinapto, lo cual le permitió descartar la parte milagrosa de los iniormes sobre el tubo del sinapto y la creacion de los caracoles pequeños, dejando, sin enbargo, a otros naturalistas la tarea de averiguar cómo inmiglaba el caracol parásito, pues el tal tubo no era oira cosa. Fiste problemn, par cuya solucion la Academia de Berlin ofrecio un premio, no se ha resuclto aun.

Los sinaptos que habitan en el cieno se sacan por medio de una especie de ancla envuelta en estopa, que desde la barca se maneja como una red. Los animales, cuya piel está provista de ganchos, quedan agarrados à la estopa; pero no 
se obtiene nunca un simapto entern, pues por efecto de una convulsion nerviosa quedan divididos en pedazos de 2 a 6 centimetros de largo, y entonces se ha de cxaminar la cxtremidad de la cabeza ó la regrion del estómago plara cncontrar los tubos, trabajo muy penoso, porque de cien sinaptos solo uno contiene el parásito. Alguna vez, Baur encontró en un sinapto dos $\delta$ tres $y$ hasta cuatro tubos; pero tambien le ocurrió el caso de examinar en rano 500 ó 600 individuos. En su excelente trabajo publicado por la Academia I.copol. dima, Baur dice: r Para observar tan solo una vez el cuerpo del tubo, es necesario récoger un gran número de sinaptos y examinarlos todos. Su trasparencia-permite, sin cmbargo, ver los tubos sin que haya necesidad de abrirlos Al principio, encargué a los mismos que habian cogido los animales jara Juan Muller, que me llevaran á Trieste el major número posible de indiviatos, pero pronto me confenci de que el matcrial asi obtenido no bastaba ni sinuiera para un exánen superficial. Por eso resolvi nermanecer durante des meses en Zaule, en cuyo tiempo tuve alquilada una barca para la pesca, neccsiando una tripulacion por lo menos de dos liombres. Cunnto mayor es el número de ganchos en el ancla, y mejor cuvuelta esta en estuja, y cuanto mas profuncio es el fondoldel mar, tanto mas abundante es el botin. In un viaje pude obtener hasta acho ejemplares del tubo, y:a enteras ó mutiladas, pero algunas se empleaban para pescar otras. 1

Hechas estas observaciones, pasemos por fin á la descrip. cion del molusco parásito, tomando por guia al efecto las noticins de Batur.

Li cuerpo del molusco parisito es prolongado y cilindrico, y no se, distinguen el dorso ni el vientre; ni el lado derecho ni el irquierdo, y rampoco tiene apúndices; la extrensidad anterior afecta la forma de boton, siendo la del cuerpo espiralada é irregular. El color del dorso es amarillo pardusco, por lo cual se puede reconocer el tubo al través del cuerpo trasparente del sinapto. Por término medio todo el tubo mide $0^{m}, 02$ y medio de largo, y su organizacion es niuy par. licular. 'liene en la extremidad anterior una abertura Yiucal que conduce $\mathfrak{a}$ un intestino cjego. El scgundo segmento del cilindro encierra un omrio muy extensa con una glándula de color blanco, y deșpues sigue un espacio en el que naduran los hueros que se separan del orario. Fn una dilata. cion esférica se prepara el sémen, y la extremidad abierta del cuerpo permite á los productos sexuales penctrar libremente en la cavidad abdominal del sinapto. Fl tubo se fija en un raso de la sangre situado en el lado rentral del intestino del anfitrion, de modo que parece formar un todo organico; pero en realidad solo se fija mecinicamente, como se ob. serva en muchos parisitos, por cjemplo en los peltragastos. En una palabra, el cueryo del tubo pende del vaso de la san. gte del simapto y se alimenta por medio de su ábertura bucal y cavidad intestinal de la sangre de su anfitrion.

I.os movimientos del animal tubiforme que pucden observarse al abrir un sinapto fresco se limitan \& encorvar su cuerpo y recogerle lentamente, tomancio la forma espitalada de un tiraburon; pero de todos los fenómenos virales que ofrece el tubo, los mas importantes son los que se refieren a la propagacion. Ein el periodo del celo el sinapio y el parásito están independientes uno de otro. Iuan Muller no co. nocia aun el desarrollo del sinapio, pero Baur le ha estudiado completamenic y demostrado que el sinajto solo se pro. paga en la primavera, mientras que el tubo lo hace en todos los meses, cxcepto en invierno. La masa de huevos del parásito que se desarrolla en su cavidad abdominal se com- pone de un gran número de bolas de las que cada una contiene unos veinte huevos ó embriones. l.as larvis que se desarrollan de aquellos no permiten cludar de que la hembra es un molusco. Tienen una concha de circunrolucion regular que se cicra por medio de una tapa calcirea y en la que pueden retirarse lil plié del animal es bilobado; el dorso remata en un lólulo frontal provisto de algunas cerdas rigidas, jor detris de las cuales dos pequenas prominencias forman el principio de los tentáculos. En el interior se ve una cavidad cerrada aun, que mas tarde se trasforma en intestino, y por debajo dos vejiguitas auditivas. Toda la superficic no cubieria por la concha presenta espesas pestaías. Ia tras. formacion de esta larva en el parisito tubiforme no ticne igual entre los caracoles y solo puecie compararse con la me. tamorfósis retrogresiva de muchos crustaceos parasitos. El molusco adulto no tiene corazon, ni sistema rasal ni nervioso, ni órgano de los sentidos, y la comparacion con otros fenó. inenós semejantes, aunque un tan extensos rutri los gasteró. podos, nos conduce a los prosobránquios, con los que por lo regular se reunen las entoconchas, si no debemos dar moon à Baur, quien designa los gimnobránquios como congéneres mas afines del notable parásito. Sobre la metamortosis, cl citado naturalista dice lo siguiente:

Ror lo que toca a la trasformacion á que la larva está sonietida necesariamente, para poder llegar à ser el caracol tubiforme, podriamos formarnos una idea de esta metamorfósis suponicndo (lo que sin embargo no puede demostrarse), que sea sencilla. El pequeno cuerpo de larva se desprenderi primero de su concha, perdera su cavidad respiratoria y creceri por lo regular longitudinalmente. Ias vejiguitas auditivas y los apéndices en forma de tentáculos desaparecerán, el cuerpo se hará cilindrico, de modo que el dorso fo la planta no se distingan, y por fin, con el desarrollo de los ór. ganos sexusales, el crecimiento longitudinal se rerificará de inodo que la abertura de la cavidad del abdúmen, que mas tarde será la sexual, se desvie poco á poco de la cara inferior de la parte anterior del cuerpo, acercindose a la extremidad posterior del mismo. Consecuencia de ln tmaformacion seria tambien que la espiral unilateral de la entocousho (nombre con (que Baur solo designa la larra) se trasforme en la de dos lados de los caracoles tubiformes (llamados por Baur lielicosyrina\%). Es natural que esto solo sean suposiciones fundadas en hipótesis y analogias indeterininadas. \#

Desgraciadamente no sabemos aun uada mas sobre la tmsformacion y la inmigracion de estos parisitos. Fs probable que las larvas al despedazarse los sinaptos voluntaria ó involuntariamente, lleguen al agua libre, yo por medios desconocidos penetren despues de algun tiempo en un anfitrion. Baur deduce de la constancia del punto en que se fija el parásito, que la inmigracion debe verificarse en un tiempo en que los sinaptos casi inevitablemente ofrecen este punto al parásito. a Cuando la larva del parásito penetra en un sinapto joven hasta la cavidad abdominal, fijándose en el vaso inferior de la sangre, la consecuencia seri que en el sinapto adulto, el parásito, micntras tanto trasformado y desarrollado, nunca podrá estar fijo á gran distancia de la extremidad postcrior del estómago, hácia el ano, pues toda la region posterior del anfitrion, en la que casi nunca sé encucntra un fiarisito, no existia aun cuando este inmigró.

Al hablar de la clase de los equinodermos, encontrarcmos otra vi\% los sinaptos, y describiremos su metamorfósis, muy notable, siguiéndola nasta el punto en que los individuos jórenes, que viven en el cieno del foncio del mar, parecen mas propios para la inmigracion del helicosirinx. 


\section{TERÓPODOS-PTEROPODA}

Los habitantes del interior comprenden por la palabra «caracol un molusco provisto de una cabeza bien marcada y que repta con una ancha planta; pero nosotros estamos preparados, por lo ya dicho, à modificar muchissimo esta idea, strgerida por las formas llamadas tipicas. Sabemos que el reino animal y sus divisiones aisladss no se crearon por un molde, sino que se efectuarun trinsitos de lo inferior in lo superior, de lo proco desarrollado a lo mes perfecto; y que depende mas ó menos de la voluntad del observador, el grado á que debe atenerse en esta abundancia de formas, para fijar ciertos carnctéres por los cuales se procura determinar los de las grandes divisiones, por ejemplo, las clases, mientras que en realidad no hay nada constante, siendo casi todas otras tantas exccpciones de la regla.

Esto último se debe decir tambien de los terópodos, que segun Brown son «moluscos reptadores, poco desarrollados aun en la cabeza, en los tentàculos, en el pié por lo regular, en las brainquias $y$ a menudo tambien en el manto. Este nuevo órden carece de las particularidades que caracte. rizan una cabeza de caracol. Solo la abertura bucal indica el punto en que deberia comenzar la cabez; tambien dos ó tres tentáculos, poco desarrollados, nos sirven para orientarnos. Los órganos internos ofrecen en todas partes puntos de comparacion con los que tienen los otros órdenes, pero una cosa esencialmente nuevin son las aletas laterales que, ora salen en la parte anterior del cuerpo correspondiente à la cabeza, ora mas hácir atràs, en la region q̨ue corresponde al cuello de los otros caracoles. San delgados lóbulos membranosos cruzados por fibras musculosas que se mueven como las alas de una mariposa, a menudo tambien con la misma rapidez, y q̨ue han dado origen al nombre de farfalle di mare (mariposas de mar) con que los pescadores del Mediterraineo designan a estos animales.

En cuanto á los caractéres en general, solo diremos que por la estructura de sus órganos genitales son muy congenéricos á los moluscos hermafroditas, y que por la naturalezas delicada de su cuerpo y sus alctas son animales pelígicos que viven nadando en la alta mar. En la descripcion de sus usos y costumbres seguircmos por lo regular literalmente las noticias de Gegentraur.

\section{LAS HIALEÁCEAS-HYA- LEACEA}

In familia de las hialeaiceas se caracteriza por dos aletás, una separada de la otra hasta la base, soldadas mas ó menos por la parte inferior de su borde exterior con el lóbulo medio, órgano que corresponde al pié de los otros moluscos. Su cuerpo está rodeado de una concha delgada, córnea ó calcarea, en la que las aletas pueden recogerse del todo.

El género hyalea (fig. 296) tiene una concha bastante esferica con desembocadura estrecha $y$ hendiduras laterales, en cuyo fondo están las bränq̧uias. De estas profundas incisiones salen á cada lido dos consiclerabies lóbulos que se doblan, ja sobre la superficie ventral, ja sobre el dorso del animal, $y$ forman mientras este vive una capa de la superficie de la concha. Auncque los hialcos como todos los terópodos tienen en su anillo esofágico un sistema nervioso central bien desarrollado, estan provistos solo escasamente de órganos de los sentidos.

Los géneros rlcodora (fig. 299) y creseis (fig. 300) tienen la concha prolongada con desembocadura estrecha $y$ sin hendiduras laterales. La concha del primero es angulosa, la del segundo cilindrica. Su manto tiene procos apréndices que no se doblan sobre lia concha. En los cortos tentáculos que se encuentran en la nuca del animal se hallan ojos en forma de puntos.

4.os huevos de los terópodos del grupo de los hialeáceos se depositan en sencillas cáscarns trasparentes de dos á tres líneas de diametro y de una longitud a menudo de varias pulgadas, J.os cordones mismos no se fijan i modo de otros gasterópodos marinos en objeto injo, pues quedan á merced de las olas, en las que se desarrollan en embriones, que al salir de la concha continuan el género de vida de sus padres. Gegenbaur logró durante su cstatncia en Messina conservar en vasos de cristal un número de terópodos que siempre depositaban con abundancin un número considerable de cotdones de huevos. Pudo averiguar que lahyalea eridentata pone en dos dias unos 200 huevos, la hyalea gyilliosa 60 i $S z$, y las sleodio ras otros tantos. El embrion sale al séptimo ú octavo dia de su desarrollo, de su císcara especial, y subiendo y bajando por el estrecho tubo del cordon busca la salicia al agua libre, parn comenzar alli su vida de larva. In corona de pestañas de que esta provisto en su parte anterior se hace poconi poco oval, y se forman en ella dos escotaduras que constituyen los lóbulos de la vela; esta es muy desarrolladil en la larva del genero creseis que à menudo se encuentra en innumerables masas en el mar.

\section{LOS CIMBULIÁCEOS- CYMBU LLACEA}

La familia de los cinbuliáceos se caracteriza por el ensanchamiento de las aletas, de base espaciosa, y por tener una concha interna plana, compuesta de sustancias trasparentes y cubierta del zodo en su estado normal por un lóbulo delgado del manto; este lóbulo es tan tierno y delicado: quue solo raras reces pueden obienerse individuos bien conservados. In la pesca, el animal suele separmise á menudo del todo de su cu. bierta, con tanta mas facilidad, cuanto que el verdadero cuerpo, rodeado de su concha, no está unido con ella; siempre trasparente, es como un cartilago blando, y pertenece por su naturaleza quimica a los cuerpos quitinosos, que, aunque propios sobre todo de los artrónodos, se encuentran tambien aqqui, en los anćlidos, moluscos y otros animales poco desarrollados.

Un genero perteneciente á los gymbullacen, muy interesante por la forma de su cuerpo, es la firdemannia. 
Las observaciones de Gegenbaur se refieren a la ticdeman. mia neapolitana. 1il cuerpo, que forma un óvalo plano, presenta por delante una marcada prominencia y se adelgaza hácia atras en un borde aplanado. Esta forma depende de la concha, que es trasparente $y$ está rodeada del todo por el manto, que, à la mas minima lesion, se disuelve al punto, dcjando solo escasas huellas de la forma anterior del cuerpo. Las aletas estản soldadas completamente entre si; un apéndice que parte del centro del borde anterior de las alctas, $y$ que alcanza una longitud de $0^{\mathrm{n}}, \mathrm{O}_{2}$ y medio, rematando en dos lóbulos, es la trompa, órgano muy poco movible Casi todo el animal es trasparente y flama la atencion en el mar solo por sus movimientos. Los intestinos, de color pardo oscuro, se reunen, como en los címbulios, en un núcleo pun. tiagudo y trasparente por la capa del cuerpo.

Varias especies de tidemánias tienen en su manto manchas amarillás y pardas, las cuales se trasforman del mismo modo que los extraños cromatóforos de los cefalópodos. Gégenbaur dice sobre esto lo siguiente: ¿Si se observa algun tiempo minuciosamente una tidemánia viva, nótase cómo el manto y el borde de las aletas, en vez de las grandes manchas pardas, solo tiene finos puntos negtos, y cómo despucs de algun ciempo estos puntos se agrandan poco is poco, haciéndose mas claros, para trasformarse al fin en las grandes manchas pardas. Mas interesante es la observacion de este fenómeno bajo el microscópio, con el cual se cree tener à la vista el mas bonito juego de cromatóforos, pucs la celda de color toma á veces las formas mas extmragantes. I a rapidéz de la contraccion es muy diferente, $y$ dura desde medio minuto a tres cuartos de hora ó mas. N El cimbulio de Peron (fig. 298 ) es una especie muy notable gue habita en el Mre. diterránco, en los inares de Amboinay de la Nueva Holanda.

\section{LAS LIMACINAS-LIMACINA}

A los géneros provistos de concha pertenecen tambien las limacinas que tienen la concha espiralada á manera de lós caracoles, forma que separa este género de todos los demís. Se han descrito diez ó doce especies de los mares mas dife. rentes, pero ninguna es tan interesante como la limacina ártica de la costa de Groenlandia, cujo género de vida describe Oton Fabricius del modo siguiente: «Se sirve de su concha como de un barco, y moviendo sus aletas levantadas hácia adelante rema muy bien. La extremidad abierta de la concha-representa la proa, la opuesta la popa, mientras que el borde de la espiral hace las reces de quilla; pero nunca he observado que el animal sacase una parte del cuerpná guisa de vela de la superficie del agua. Cuando esta cansado 6 se le toca, recoge los remos, penetra del todo en la concha $y$ baja al fondo, donde descansa un corto tiempo sobre la quilla $\delta$ la coronilla, pero nunca sobre el ombligo; sube remando en direccion oblicua, y llegado à la superficie muévese en línea recta. \& Fabricius afirma que esta limacina ártica se lla. ma rcomida de ballena», y que constituye el alimento principal del finwal (balicnoptera boops) y de la ballena de Groenlandia (balana mysticetus.).

\section{LAS CLIOIDEAS-CLIOIDEA}

Ias clioideas tienen el cuerpo desnudo, por lo regular fusiforme, con una cabeza bien marcada, hallandose en el cuello dos aletas. Caracteristico es tambien un apéndice, por lo regular en forma de herradura, que sobresale en el lado ventral entre ambas aletas, y que juntamente con otra protu. berancia, en forma de punta, se presenta como la planta trasformada de los denas moluscos.
Con estas palabras se caracteriza el gran género clio, añadiéndose que no existen brazos provistos de ventosas. Los animalitos llegan á una longitud de $0^{n}, 01$ á $0^{n}, 03$ y pueden, cuando de repente quieren bajar, recoger las aletas en repliegues y retirarlas, juntas con el apendice ventral y toda la cabeza, en el abdómen. De todas las especies se nombra con mas frecuencia el clio boreal, muy comun en el mar de Groenlandia, y alimento acostumbrado de varios peces voraces, de la gaviota de tres declos y tambien de las ballenas arriba citadas.

\section{LOS NEUMODERMONES -PNEUMODERMUN}

Este género se parece esencialmente al anterior, solo que en la cabeza tiene dos tallos provistos de ventosas que pueden recogerse en la parte de la cabeza. "Tambien se encuen. iran en la extremidad posterinr unos apéndices menbranosos y rugosos que sirven de bránquias, $\delta$ en su lugar, (como en el pneuniodermon ciliatum del Mediterráneo) una corona de pestañas muy desanrollada. Gegenbaur descubrió en la piel de estos animales numerosas glándulas pequeñas, de cuya secrecion hacen uso para su delensa. Cuando se irrita a un individuo recien cogido, cuyas glándulas tienen un color blanco, cuando están llenas, toda la superficie del cuerpo destila una sustancia a veces blanquizca que forma como una mernbrana, la cual se puede arrancar á pedazos.

Este cxperimentó puede repetirse varias veces en interva. los de dos'a seis minutos, pero cada vez con menor Exito, y por fin pasan horas enteras hasta que las glandulas vuelven a llenarse de la sustancia suficiente. No me atrevo at determinar si esta secrecion es un excremento 6 un medio defensivo; quizás sea lo uno $y$ lo otro, pues cuando el animal ne. cesita defenderse, segrega la sustancin al mas leve contacto de la piel con un cuerpo estraño. Cuando se reunian varios individuos en la misma vasija con voraces terotráqueos ó gimnobránquios, cstos últimos atacaban pronto á los neumo. dermos que á pesar de su destreza no podian escapar de sus adversarios. Cada vez que uno de cllos se aproximaba á un neumodermo, este se cnvolvía en una nube, escapsánciose cuando menos por algun tiempo: pero despues de repetir va. rias veces la misma estratagema, la secrecion faltaba, y el mas fuerte hacia presa del mas debil.

Las ventosas con sus tallos suelen estar recogidas, y es di. ficil obligar a los animales a presentar todo el aparato chu. pador. Gegenbaur no observó nunca que se hubiesen agarrndo á un objeto por medio de los discos chupadores.

El desarrollo de los neumodermos difiere no solo del de todo los terópodos, sino tambien del de todos los demás caracoles. La larva que nada libremente por el mar es al principio de forma cilindrica prolongada, y está circuida de tres coronas de pestañas, de las que la primera corresponde a la vela de los otros moluscos. A cada lado de la boca hay una espiga cubierta de ganchos que tambien se conserva en el neumodermo adulto. En cstado de reposo estas espigas están recogidas como cl dedo de un guante; pero si se enderezan son propias para el ataque y la defensa, aunque no se han hecho observaciones directas sobré su uso. En todas las es. pecies desaparece la corona central de pestañas, $y$ cn las mas tambien la tercera, en cuyo lugar se desarrollan las bránquias.

Para completar las noticias sobre los terópodos en general, diremos que están diseminados en todos los mares, desde el Polar hasta el Ecuador, siendo esencialmente pelágicos. Su existencia en las costas de Niza y de Messina depende principalmente de las corrientes del mar. Aunque en el Mediterráneo se cogen muchos individuos de dia, los más pue- 
den considerarse como animales nocturnos $\delta$ crepusculares; en las latitudes meridionales, sobre todo, no parecen jresen. tarse hasta despues de la puesta del sol. El natumlista francés Orbigny, que mucho tiempo los observó en los mares tropicales, refiere que nunca ha cogido un solo individuo de dia; pero anade que á las cinco de la tarde, cuando el ciclo está nublado, dos $\delta$ tres especies, sobre todo hialeos, comienzan à presentarse en la superficie del agua, pudiendo enton. ces cogerse pequeiios terópodos. Las grandes especies no se presentan hasta entrada la noche; entonces no es dificil apo. derarse de los neumodermos, de los clios y de las cleodoras. Algunas especies, por cjemplo la liyalen halantium (ahora balantum como género), propin del golfo de Guinea, se pescan en las noches oscuras. Ias especies van desapareciendo en el órden que llegaron, y å media noche solo se observan algunos individuos que han tardado en retirarse; varios se quedan tambien hasta el amanecer: pero despues de rayar la auro. ra no se ve ya ningunn. Cada especie se rige en su aparicion $y$ desaparicion por ciertas horas, $\delta$ mas bien por cicrtos grados de oscuridad.

Orbigny cree poder deducir de esta costumbre que cada especie permanece a cierta profundidad, donde la fuersa de la luz se debilita hasta cierto punto, $y$ que se presentaria en la superficie mas á menudo si aqui reinara poco mas $\delta$ me. nos la misma oscuridad que cuando el sol se ha puesto. Si los terópodos permanecieran toda la noche en la superficie del mar, podria creerse, con Rag, que se presentaban con la puesta del sol para buscar su alimento ó respirar, lo que, sin embargo, no es probable, porque de dia viven y respiran muy bien en la profundidad. Mucho mas natural es la opinion de que buscan siempre el mismo grado de oscuridad que de dia reina en la zona que habitan. La objecion de que faltándoles los órganos de la vista puedan ser tan sensibles a la luz, no es fundada, pues vemos en muchos ejemplos del reino animal go vegetal que esta sensibilidad no depende de la existen. cia y perfeccion de los órganos de la vista. El topo no huye de la luz, porque tiene buenos ojos: el temor a ella produce el atrofiamiento de la rista, asi como en sentido figumdo los que temen la luz tienen la razon debilitada.

Respecto ì las excursiones de estas especies, el naturalista francés observó que, en el Pacífico, los terópodos no se acercaban nunca á la costa mas que á diez leguas de distancia, $y$ mucho menos aun en el Atlántico. Ya hemos dicho que los terópodos de los mares templados, y añadimos ahora de los septentrionales, no son tan escrupulosos respecto á la luz y a la tierra firme.

Los terópodos pueden avanzar 6 mantenerse en el mismo sitio, moviendo continuamente sus aletas como las mariposas sus alas. Las aletas trabajan con gran agilidad y ligereza, y segın su posicion, el animal avanza, sube ó baja, teniendo el cuerpo siempre derecho 6 ligeramente inclinado. Cuando durante sus movimientos se les estorba, las aletas se doblan ó se recogen como en los hialeos, y el animal baja al fondo. los hialeos nadan mas rapidamente que las cleodoras, muy lentamente lo hacen los neumodermos y los eliones.

Los icrópodos son carnivoros, segun resulta del exámen de su estómago; se alimentan de varios moluscos y de los pequueños crustáceos que en inmenso numero habitan la superficie del mar.

\section{LOS DENTALIOS - DENTALIUM}

Antes de pasar á los conchiferos de dos raluas, debemos ocuparnos de una de aquellas formas de animales quue han sido objeto de polérnica entre los zoólogos sistemáticos. I.os dentalios (fig. 295) se conocian ya en los tiempos de Rumph;
Linnco los agrupaba con las sérpulas, y Cuvier los reunia con los anillados. Mas tarde, cuando se hubo reconocido con seguridad su naturalean de moluscos, clasificaronse con los moluscos de ventosa y las fisurelas, hasta que, hara un año, el mas excelente de los anatómicos de moluscos actuales, Lacaze-Duthiers, demostró que el dentalio reune caractéres de molusco y de conchifero: que la historia de su desarrollo ofrece algunas particularidades de los anillados, y que respecto a la clasificacion sistentática, quizás seria lo mejor agrupar los dentalios a la cabcza de los llamados moluscos acéfalos. Hizo al mismo tiempo una descripcion minuciosa del dentalio vulgar de la costa francesa, de modo que las noticias seguras que del animal tenemos, debemoslas al zoólogo parisiense. A pesar de ello, scinalamosá los dentalios este lugar porcue en ningun periodo de su vida tienen una concha de dus valvas, yo porque su lengua, provista de una placa, es uno de los órganos mas importantes del tipo de moluscos. Sin entrar en detalles, debemns indicar, no obstante, algo sobre la estructura del cuerpo, para comprender la historia del maravilloso desarrollo y el género de vida, que se distin. gue por muchas particularidades interesantes.

La concha de los dentalios tiene la forma de un colmillo de eléante algo encorvado, y esta abierta en ambas extremidades. En su posicion acostumbrada, el animal llena este cono hueco, con el que solo esta soldado por medio de un estrecho anillo musculoso del manto. El arco convero es el lado ventral: el manto es 11 ma larga bolsa cuya abertura ante. rior puede cersarse por un músculo; con el resto del cuerpo solo está soldado en los dos tercios de su longitud. La parte anterior del tronco se halla separada de la posterior por una pared divisoria, cortacia por los dos vasos de la sangre y el intestino. Por arriba, en la primera division, hay una prolon. gacion bucal rodeada de un apéndice de hojas, y en una di. latacion la lengua con su placa. Los dientecitos estan dispuestos en dos series longitudinales, $y$ toda la lengua aseméjase al órgano análogo de las moluscos.

La cxistencia de este órgano es decisiva para confirmar nuestra idea sobre la afinidad de los dentalios, porque todas las partes de los moluscos se presentan bajo las formas mas diferentes, mientras que la region de la lengun y de los órganos trituradores solo varian dentro de límites muy reducidos. Aunque debemos suponer á los dentalios congéneres tanto de los moluscos como de los conchiferos, no cabe duda que existian muchas mas formas de trảnsito entre los denta. lios y los últimos, que entre ellos y los verdaderos moluscos. La cuestion de la major ó menor afinidad no tiene otro sentido, $y$ debe aconsejarse al aficionacio á la roologia juzgar siempre las proporciones y principios sistemáticos por esta regla.

Debajo del nacimiento del canal intestinal se halla el pié, que es hueco cn toda su longitud. Dilatándose con sangre, puede prolongarse $y$ salir de la abertura anterior del manto: despues conoceremos su uso. Se parece mas bien il pie de los conchiferos que á In planta de los moluscos ordinarios.

Ia abertura amal está en la cimarn posterior del manto, que en el dorso contiene tambien la glándula genital. I.os sexos son separados. El cuerpo está cruzado por canales de la sangre, grandes y anchos, sin órganos que representen el cornzon. Los b́rganos respiratorios faltan; en cuanto à los de los sentidos, existen dos rejiguitas auditivas situadas sobre los gånglios que se hallan en el pie; tambien hay dos copetes de tentáculos con pestañas, que pueden salir à gran distancia de la abertura, naturalmente dentro del manto.

No hay necesidad de extenderse en mas detalles, y por lo tanto pasaremos i la historia del desarrollo. Segun ya hemos dicho, los dentalios son de sexo separado. Del huevo sale una 
larva oval y prolongada; los seis $\delta$ siete anillos de pestañas diseminadas al principio en todo el cuerpo, se reunen luego en el centro del animal, y entonces parece que solo existe una ancha faja de pestañas. Ya antes se ha formado en la extremidad anterior una pequeĩa depresion, de la que se eleva un mechon de pelitos movibles. Mientras la parte anterior se recoge, la posterior, mas délgada, se prolonga; la concha afecta la forma de una delicada cscama en figura de silla de montar; cuando se prolonga, la prominencia cubierta de pestañas se retira, y por debajo de ella sale el pié. En el último estado que Lacaze-Duthiers pudo observar la cavidad del manto, sobresalia un poco de la concha, y de ella partia el pié á mucha distancia. Los órganos internos se hallan dispuestos tambien, en su major parte, sobre todo el ganglio del pié y-las rejiguitas auditivas!

Reproducimos literahmente la descripcion del observador francés sobre el género de vida de los dentalios, porque es una de las mejores acerca las costumbres de este animal tan poco desarrollado.

* Los dentalios habitan en gran número las costas septen. trionalés de la Bretaña, pero no debe creerse que es fácil apoderarse de cllos, pues es preciso snber cómo y donde viven. Como ture el innjor deseo de estudiar el animal, busque alli doade habia conchas vacias, pern en vano. L na mar un poco inquieta me proveró de un animal vivo, $y^{\text {entonecs pude }}$ obscrvar sus costumbres y todas sus condiciones vitales. Cuando lo levanté y lo recogí, vi qué se esforzaba en penetrar enl fondo del vaso. Volvi á joncrlo en uno de los charcos de la playa y observé como poco à poco penetraba en la arena, y entonces supe que en adelante tenia que buscar al animal en el suclo misino de la playa

Lil animal no penetra verticalmente en la arena, sino que sigue una direccion oblicua trazando un angulo de $45^{\circ}$. Sin embargo, ha direccion y profundidad dependen un poco de la naturalean de la arena; no puede vivir en la capa cenagosa, negruzca y à menudo fétida que por lo regular se halla por debijo de la capa superior arenosa de la playa. Tambien torna una direccion nas yertical cuando la capa de arena se láce. mas delgada; crtonces es casi siempre mas dificil encontrarle porifue esta del todo oculto y nada descubre entonces su presencia Por lo regular su concha sobresale unos dos milimetros de la superficie del fondo, pero a menuda la punta llega apenas a la superficic de la arena, por lo cual se comprende fícilmente ąue el agua descubra al animal al mas leve movimiento. Sin embargo, vuelve a penetrar seguidamente en el suelo, alarga el pie, le introduce en la arena, y en algunos minutos se endereza, quedando como plantado. Cuando se tienen muchos individuos es dificil distinguir en el fondo los muertos de los que sobreviven, y de esta particularidad me aproveché para hacer mi observacion. Coloqué un gran nu. mero de denialios sobre una superficie de arena humeda $y$ pronto reconoci que los que no penetraban en ella cstaban moribundos ó mucrtos.

-Cuando durante el reflujo el agua no cubre ha superficie de la arena, el dentalio penetra del todo en ella y desaparece Anadire una observacion que se refiere a la major parte de los animales que se ocultan asi, y que es importante para has zreriguaciones cientificas, asi como de un ralor práctico. El momento mas favorable para recoger en el reflujo los anima. les que habitan el suelo de la playa, es el que precede inmediatamenic al flujo, debiéndose esto \& que, cuando el agua baja, queda aun mucha humedad en la arena y por algun tiempo los animales se encuentran aun en condiciones bastante farorables. Pero muy jronto, i medida que el agua baja mas, la humedad desaparece, en cuyo caso los animales cambian de sitio y van en busca de in lugar mas húmedo. En- tonces todos los animales que se ocultan en la arena de la playa, sea cual fuere su clase, descubren su presencia por sur$\cos$ y morimientos. Asi sucede tambien con el dentalio que tambien revuelve la arena. Al principio solo hace un pequeno surco que podria confundirse con el de la pandora (pequeño conchifero). Este último, sin embargo, siempre abre un camino sinuoso, porque una valva es plana y la otra corva. Tan luego como se conoce esta señal ya no es fácil enuivocarse $A l$ principio los dentalios descubren su presencia por un surco en la arena; despues aparece la concha como plantada en la playa; luego sobresale del todo y el animal cae sobre la arena. Cuando hube conocido esta circunstancia, en un solo refujo pude recoger facilmente 200 individuos. El dentalio es por lo tanto un animal que vive relativamente a grandes profundidades y que solo puede encontrarse durante los grandes reRujos. Por lo regular penetra en la arena poco gruesa, y nunca la encontré en la muy fina. I.os individuos que se conserraban mucho tiempo vivos parecian encontrarse muy bicn en la arena compuesta de perqueños fragmentos de conchn; en la mas fina, cuyacapa inferior se hacia cenagosa y pútricla, los animales morian pronto. Al penetrar en la arena, el dentalio se sirve de los dos lóbulos laterales del pié que liacen el ofi. cio de dientes de ancla, de modo que despues de alargar d piéle contrac para que todo el cuerpo avance.

Despues de dar i conocer estas observaciones, por las culalés se ve que el agua entra por la extremidad anterior y vuclvé a salir por la abertura exterior, junta con los exicrementos y los productos genitales, pudiendo el animal servirse cn esta ocasion del pié como de una maza, I acaze. Duthiers dice que le parece probabie que por la corriente regular dirigida desde adelante hicia atrás, penetre taribien el alimento en la boca; pero ambien los tentáculos pueden servir para buscary atraer penuenos animalios propios para el alimento.

Sobre la sensibilidad y los nervios es fácil observar que el dentalio siente la influencia de la luz: se ve como recoge el pié á los'myos del sol, y que cuando alguien se acerca al animal con una lur, se retira a su concha. Esta circunstancia esti en relacion con una particularidad de su gériero de vi. da, y es que cambia de sitio por la noche, sobre todo al principio de la misma. Habia observado que los animales qque están en vasijas producen un pequeño golpe; fije mi atencion en esta circunstancia y reconocí çue el pié, al pc. netrar en el suclo, clevaba la concha que al caer ocasionaba el ruido; luego observé que por la tarde cambiaban de lugar. No quiero pretender que se muevan solo ad esta hora, pero me parece indudable que los dentalios son activos, sobre todo de noche.

$\$$ Tambien la reproduccion ofrece algunas particularidades notables. Ja cópula no se verifica, porque no existen órganos genitales exteriores y los individuos ni siquiera se acercan uno á otro. I:os dentalios se pueden observar con la mayor facilidad, de modo que no es posible enganarse en este concepto. Coloqué mis dentalios en platos blancos, renovando á menudo el agua, y al cabo de algunos dias podia estar seguro de que pondrian huevos, lo cual hacian regularmente desde las dos hasta las cinco de la tarde; "solo note una excepcion en los individuos expuestos demasiado al sol. Los huevos se vaciaban à la misma hora, y tambien el liquido espermático salia por la abertura posterior de la con. cha. Ia fecundacion queda por lo tanto abandonada á la casualidad, como en la mayoria de los moluscos acéfalos. Aquí el macho, alli la hembra, se deseinbarazan de los productos de sus órganos genitales, y estos productos pucden encolntrarse 6 no precisamente, como en algunas plantas els que el pólen cae al suelo, diseminándole los vientos. Cuan. do estos son contrarios, el pistilo de los individuos hembms 
queda sin fecundar, asi como con una corriente desfavorable de agua la hembra no puede producir nada, porque los huevos no se desarrollan. En este caso se comprende cuán útiles deben ser los vivos movimientos de los cuerpos espermáticos, que deben buscar el huevo á cierta distancia para fecundizarlo. El ticmpo en que se observó la propagacion de los dentalios fué desde principios de mayo hasta mediados de setiembre.

\section{LOS CONCHÍFEROS- CONCHIFERA}

¿Quién no ha leido la subline poesia die Rueckert: «Ia piedra preciosa $y$ la perla, que se refiere al desarrollo de su existencia y i su laberintico viaje por la vida? La ligrima de un ángel cayó al mar para ser recibida en el seno de la concha y endurecerse poco á poco, mientras que la frel madre cruza por aquellos espacios \& donde ocultos en las grutas cristalinas, géneros enteros de séres vivos se burlan de las averiguaciones $y$ del descubridor. ¡Cuàn bella es la poesin y cuan verdadera! $Y$ sin embargo; por lo que toca al conchifero, apenas contiene un rasgo tomado de la naturaleza. Todo es fantasín, todo simbólico para las condiciones hu. manas, y hasta tan poco determinada deja el poeta nuestra idea sobre la fiel madre de la perla, que debemos creer que un triton puede tocar en ella sus melodias. Ahora bien; estas frases poéticas é indeterminadas expresan fielmente el poco conocimiento de los conchiferos entre los legos en zoologia Estos animales tan ocultos á la vista que es preciso buscarlos muy cuidadosisimamente, son para la mayoria de los hombres un enigma misterioso. Muchos han visto sobresalir del fondo cenagoso de un agua poco profunda centenares y miles de conchíferos en una posicion un poco oblicua, sin que hayan podido averiguar si sobresalian con la parte an. terior 6 la posterior del cuerpo. Una ostra abicrta no ofrece casi ningun punto de observacion para orientarnos acerca las partes de su cuerpo, de modo que la mayor parte de los que la comen, la tragan sin conocimiento alguno anatómico ni sistemítico.

El que recoge una concha de conchifero puede examinarla tanto como quiera por todos lados, y, cuando mas, adivinará en que punto poco mas ó menos estaba la boca del animal. Ia circunstancia de que los conchiferos son tan perczosos, con raras escepciones, contribuye á que los conozcanos muy poco. Su modo de alimentarse no les obliga à luchar por la subsistencia; atacados, solo se defienden cerrando la concha; y ni siquiera la época del celo les hace-abandonar su solc. dad. Poco interesaria el asunto si nos limitasemos á la biografia de los conchiferos en su eseremada uniformicad; pero otra cosa será si los cónsideramos bajo el punto de vista descle el cual intentamos penetrar en las particularidades de la misma estructurn, comparar las organizaciones superiores é inferiores y esplicarlas una por la otra. Nuestros conchíferos de agua dulce, por ejemplo, son de gran valor para la cuestion mas importante de.la zoologia actual, para el cambio y el cesar. rollo de especies nuevas. Antes de que Darwin diese á conocer su importantisima hipótesis, el ilustre Roosmaessler se vió ya obligado, por el estudio de aquellos conchiferos, a emitir la tésis de que las llamadas especies no eran nada constantes, si no que pasaban de una á otra y se renovaban por continuas adaptaciones, conservando parcialmente los caractéres here dados. Valdra por lo tanto la pena, para el amigo de la naturaleza, de examinar una vez minuciosamente un conchífero para conocer exactamente la clase.

Despues de haber adquirido algunas conchas racías, asi como individuos vivos del conchifero comun de los rios ó estanques, empczamos en ellos nuestro estudio. ela idea general de un conchifero, dice Brown, puede ndquurirse figurandose un libro encuadernado puesto con el dorso hácia arriba y con la extremidad superior hácia delante. Ias dos tapas corresponden ia derecha é izquicrda á las dos valvas de la concha calcárea, las dos hojas siguientes de ambos lacios is los lobulos del manto del animal, la tercera y cuarta hoja de cada lado á los dos pares de brínquias del mismo, $y$ el resto interior del libro al cuerpo del animal. Sin embargo, estas hojas, desde la exterior de cada laclo, disminuyen en tamaño liasta el cuerpo, de modo que las dos valvas conve. sas de la concha encierran todo el resto como el manto las bránquias. Todas estas partes estan soldadas en su borde superior como las hojas de un libro encuadernado. Espliquémonos estas palabras en un conchífero muerto, empezando por el ánima. El borde de la hoja que cubre el cuerpo en cada lndo y se halla mas próxima i la concha, es decir, el borde del manto, está fijo por lo regular à lo largo del borde de la concha, pudiendo separarse fácilmente con una plegadera. La extremidad posterior de cacia una de estas hojas estí cubierta de verruguitas muy sensibles, propias de todos los conchiferos que introducen en la arena la mitad anterior del cuerpo. No todos los conchíferos tienen los bordes del manto libres, como el que examinamos; en algunos estan so!dados a mayor ó menor distancia. El manto forma en su extremidad posterior tubos, y es el órgano que segrega la concha:

Debajo del manto, a cadin lado, se encuentran las dos hojas iranquiales, muy desarrolladas en nuestra concha de agua dulce, $y$ en general tan caracteristicas é interesantes que de cllas ha recibicio toda la clase el nombre de lamelibránquios (Iamellibransliana). En medio de estas hojas, haicia adelante, se halla el pié en forma de cuña, de cuyo uso podemos convencernos en individuos vivos, puestos en un vaso con agua cuyo fondo esté cubicrto de arena. Tan luego como el conchífero reconoce que hay tranquilidad a su alrede. dor, abre la concha, y el ángulo anterior del pié aparece como una lengua entre los bordes del manto. El pić sale mas y mas en los individuos grandes, alcanzando una longitud de cuatro a cinco centimetros; en seyuida penetra en la arena, y el animal tiene fuerza para levantarse sobre el pié; penetra con la extremidad anterior en el suelo, $y$ su huella queda marcada por un surco. El uso y la posicion entre las otras partes del cuerpo, demuestran que el pié del conchifero corresponde à la planta de los caracoles. Además del pié, vemos en nuestro conchífero los músculos por medio de los cuales se cierran las dos valvas de la concha. Mientras el animal vive, esta no puede abrirse sin emplear mucha fuerza, $y$ a menudo se rompe la concha sin que los músculos cedan. EI uno se halla delante de la bota y forma por su lado inferior, con el pié, el escondite para la abertura de \$a.boca; el otro estrá situado debajo del intestino, que, despues de haber pasado por encima de él, se encorva un poco hicia abajo : se presenta por detrís del múscula.

En vano se buscaria una cabeza. Los conchíferos $y$ los moluscos, cuya descripcion nos resta hacer, no ticnen ninguna parte separada del resto del cucrpa que merezca este nombre: no existe, ó bien es tan imperfecta, que, segun hemos visto, se ha dado tambien á muchos moluscos superiores, de la clase presente $y$ las que siguen, el nombre de acé́alos. Hé aqui porque al principio no podemos orientarnos en el cuerpo del conchifcro. Pasando un cañon de pluma sobre el borde anterior y superior del pié, hallaremos con seguridad la abertura bucal situacia en un ángulo oculto. La cavidad bucal de los conchifteros no tiene órgano alguno 
para la trituracion de los alimentos, porque todos estos animales solo se nutren de plantitas microscópicas y de otros organismos inferiores. A la boa sigue un esófngo corto $y$ ancho que se ensancha en el estómago. Al lado de este, hàcia arriba, se encuentra el higado, y desde el estómago baja ol intestino å la parte del cuerpo que sigue al pié hácia atràs y hácia arriba. Despues de dar una 6 dos vueltas en forma de lazo, se dirige en linea recta á la extremidad posterior airavesando en su camino el corazon.

Dos pares de loojas trilaterales a cada lado de la boca se llaman tentáculos bucajes ó tambien apéndices labiales.

El sistema nervioso de los conchíferos es del tódo igual al de los moluscos; la anologia es tan completa, que los conchiferos tienen hasta las conchitas auditivas en los gánglios del pié, segun facilmente puede abservarse con el microscopio en los embriones y muchos géneros. Desde el tercer par de gainglios penetra una rama nerviosa ó unas verruguitas 6 palpos del horde posterior del manto. Fncontramos por lo tanto una série de lus úrganos mas importantes reunidos en la cabeza de los moluscos, dispersados aqui en el conchifero de una extremidad del cuerpo i la otra, circunstancin que constituye una de las pruebas mas sorprendentes y sencillas de la tésis general de que la formación de la cabeza en el reino animal se funda en una concentracion, é indica por lo tanto un grado superior de desarrollo.

El corazon con su auricula derccha é izquierda está encerrado en una delgada bolsa en el dorso, e impele la sangre hácia el cuerpo; antes de que esta se traslade desde el cuerpo à las bránquias, debe pasar por un órgano muy voluminoso, descubierto por Bojanus. Por una abertura puede recojer agua y distribuirla en el sistena de los rasos de la sangre, circunstancia que explica la facultad de dilatarse de nuestros animales. Tambien se han descubierto varias aberturas en el manto y en el pié, por medio de las ruales el liquido compuesto de sangre y agua puede volver á salir. Si se saca re. pentinamente del agua un conchifero que ticne el pié muy tendido, lo contenido en el cuerpo sale con impetu en forma de varios chorros, tan fuertes, que á menudo se déstroza la superficie dél pie del manto; a las aberturas constantes y normales pertenece, sobre todo, la del borde del pié. A elia conduce un considerable canal con la red extensible de esta parte del cuerpo, que puede cerrarse hácia el canal de salida cuando debe verificarse el hinchamiento, mientras que se abre cuando el pie ha de ocultarse debajo de la concha. Recordamos otra vez los experimentos de Agassiz arriba citados.

Muy sencillos son los órganos genitales de los conchife. ros, pues se limitan á las glàndulas interiores y se hallan siempre en la parte del cuerpo que hácia arriba sale del pié.

No podriamos, sin embargo, comprender cosa alguna de la econonia vital del conchífero si no supiéramos nada de la actividad de los pelitos movibles de la superficie de su cuerpo: toda la superficie interior del manto, la de las bránquias y de los tentŕculos labiales están cubiertas de pelitos movibles sumamente activos, que producen corrientes regulares y continuas, por medio de las cuales se proveen del alimento necesario, no solo las brånquias, sino tambien la boca. I as pestañas que producen dos efectos en el sentido opuesto, segregan las sustancias digeridas é inutiles por el tubo ó la hendidura superiores. En los conchiferos que llevan en las bránquias sus huevos hasta el nacimiento de la progénie, el trasporte y la fecundacion de aquellos se verifica tambien por medio de estas corrientes. En una palabra, toda la existencia del conchifero depende de la presencia y buena conservacion de aquellos pelitos invisibles. Por lo demàs, una corta observacion basta para convencernos de que el cambio del agua dentro de la concha no se verifica exclusivamente por medio de los pelitos. Sin causa alguna exterior el conchífero cierra de ver en cuando de repente la concha, haciendo salir violentamentc el agua conterida entre las hojas del manto y de las bránquias; la apertura de la concha se verifica despues lentamente. Sabemos que muchisimos moluscos pueden fa. bricar una concha por las secreciones de su manto: el man. to del conchífero segrega en la superficic exterior y en los bordes libres una materia calcárea que se acumula en forma de concha. Ias dos valvas de la misma se componen por lo regular de dos capas diferentes; la primera segregada por los bordes del manto se compone de celdas $\delta$ bolsitas prismáti. cas llenas de cal carbónica y dispuestas verticalmente sobre la superficie del manto; la interior se forma por un gran número de ensanchamientos sobrepuestos, en medio de los cuales hay capas de cal; tan pronto la exterior como la interior 6 nacarada pueden formar la sustancia principal de la concha. Ya hemos clicho que ambas valvas en su superficie interior solo están soldadas con el animal por los apéndices de los músculos y en su borde por una epidermis qué sale de los bordes del manto. Esta epidermis cubre tambien 1a superficie exterior de las conchas, pero se desgasta siem. pre de nuevo en muchos conchíferos. Las conchas están unidas por un ligamento elástico, independiente de la voluntad de] animal, y que por su elasticidad abre la concha. Esto explica porque los conchiferos muertos suelen estar abiertos: los músculos que en vida se contraian por la voluntad del animal, paralizando temporalmente los efectos de ligamento, han perdido su fucrza. In la mayor parte de las conchas de conchifero se hallan por delante del ligamento las dos coronillas, dos prominencias dirigidas hácia adelante de las valvas, de modo que por ellas y el ligamento es fảcil instruirse sobre la posicion del animal. Naturalmente, es de todo punto necesario saber que el borde en que se encuentra el ligamento, es el borde dorsal y el opuesto el ventral. El ala anterior, se halla por delante de las coronillas y es por lo regular mas redondeada que el posterior, situada por detrás de las coronillas.

En el punto donde el ligamento reune las dos valvas, estas tienen a menudo una especie de dientes que encajan unos en otros. Toda la reunion de las dos valvas por el ligamento de los dientes se llama la cerradura. Caractéres importantes de los conchiferos son tambien varias depresiones y dibujos de la cara inferior de la concha; son estas las depresiones mus. culares y la del manto. Todos los conchíferos que tienen tu: bos respiratorios y falsos, presentan la impresion del apéndice de estos músculos, que atravicsan aquellos tubos, en forma de una escotadura del borde del manto abierta hácia atris.

Teniendo presente que por la uniformidad del alimento recogido por la actividad de las pestañas, la diferencia de plantivoros y carnivoros no existe en rigor; que el sistema nervioso y el órgano de los sentidos están recogidos en los limites mas estrechos, y que ni siquicra el periodo del celo es capaz de dispertar á los conchiferos de su apatía, desde lue. go se comprende que no podemos esperar la variedad de aquellas funciones vitales exteriores, relacionada en otros gru. pos de animales con la variedad de las necesidades vitales. In uniformidad interna de los conchiferos dificulta ademas mucho su tratamiento sistemático. Sin embargo, por mas que no se quier profundizar esta parte de la Historia Natural, no hemos podido menos de echar una ojeada sobre la clasifica. cion de los grupos de animales y el resultado del conocimiento de todas sus condiciones de vitalidad internas y externas. Por lo pronto suponemos que las 4,500 especies de conchiferos conocidos difieren mucho por su forma exterior, asemejändose esencialmente por la analogia de la estruc- 
tura. Desde luego vemos muchas adaptaciones muy notables á las condiciones exteriores, por las cuales las valvas, el pié y el manto sufren una trasformacion. Sin embargo, para juzgar de la mayor 6 menor perfeccion de un conchifero debemos atenernos a varias de las formas mas conocidas. Tomemos algun conchifero de rio ó de estanque (unio anodonta) que nos ha servido para explicar la estructura, y además una ostra. Ia concha del conchífero de rio parece ser la mas perfecta por su estructura regular, su lisura y limpicza. Las dos valvas de la concha de ostra son desiguales, y demasiado macizas en proporcion al animal; en algunas ostras fósiles, sobre todo, la secrecion de las capas calcáreas es tan voluminosa que parece haber necesitado toda la actividad vital del conchífero. El unio esth reunido con la concha por medio de dos músculos simétricamente desarrollados, fuertes, pero no voluminosos; mientras que la ostra se cierra con uno solo, aunque herméticamente y con mucha fuerza; pero teniendo en cuenta la posicion de las otras partes del cuerpo, los dos músculos son mas ventajosos. Lo extrano es que en ningun conchifero se hallan los órganos de los sentidos tan desarrollados como en un género provisto de un músculo, lo cual basta para dificultar la clasificacion sistemática. Ni en el unio ni en la ostra se encuentra en la estructura del manto un carácter determinado parn su clasificacion en el sistema, pues en ambos el manto se extiende de adelante atrás. En muchos otros géneros, sin embargo, se suelda de tal ma- nera en los bordes, que por delante solo q̨ueda una hendidura para dar paso al pié y por detris uno ó dos tubos 6 hendiduras para la respiracion y la salida de los excrementos.

Por su desarrollo, los unios y los anodontos difieren esencialmente, no solo de la ostra, sino en general de los otros congéneres de su clase, sucediendo en esto lo que con otros muchos animales habitantes del agua dulce $y$ de tierra firme. En la historia del desarrollo de estos animales se presenta á menudo la particularidad de no existir el estado de larva, caracteristico de las especies marinas afines, produciendose a menudo un desarrollo general superior. Hablando en general, los conchiferos marinos son por lo tanto inferiores a los de agua dulce; los de un músculo, inferiores á los de dos; los que tienen la concha irregular, menos perfectos que aquellos en que es regular y bien desarrollada; y los de manto abierto, inferiores á los que le tiennen cerrado en parte. In gran diferencia en la locomocion, 6 lo que es in mismo, en el desarrollo del pié, hace mas dificil la clasificacion de las familias. Tanto en los conchiferos con dos músculos (dimyaria) como en los de uno (monomyaria) la locomocion puede ser completamente nula, y como ademis la comparacion de los géneros actuales con los fósiles, en los conchiferos, arroja una luz muy vaga, podemos indicar con alguna seguridad su lugar en los órdenes, pero respecto à la clnsificacion ulterior, debemos opinar, con Philipi, que la de las familias por los grados de perfeccion no es posible.

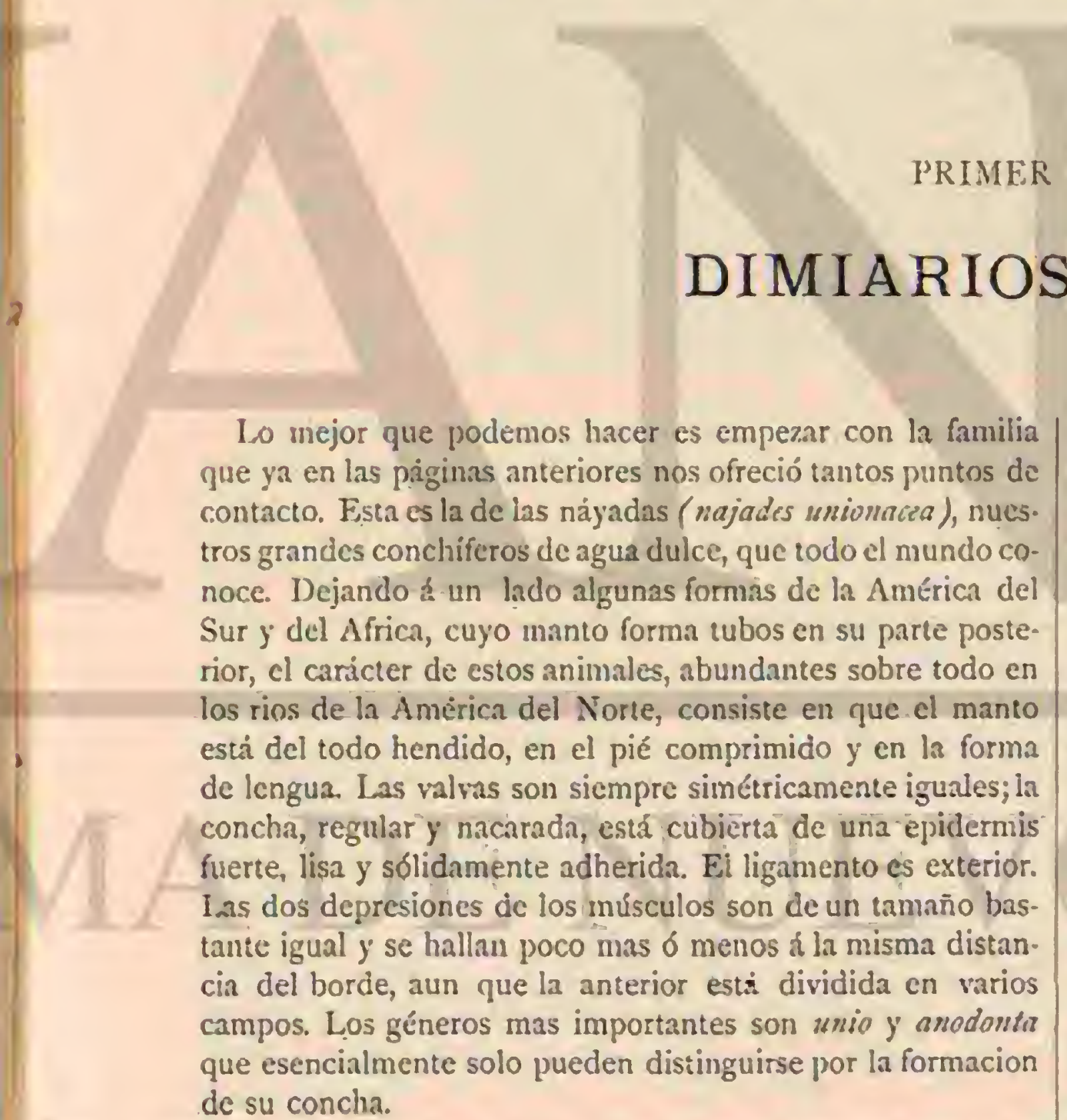
de su concha.

\section{LOS UNIOS - UNIO}

El caracter mas importante de los unios es que la abertura de la concha tiene en cada valva, por delante, un diente sencillo $\delta$ doble, rayado $\delta$ escotado, $y$ por detris, debajo del ligamento, en una valva, un diente laneliforme, mientms en la otra hay dos paralelos al borde.

Se conocen varios centenares de especies vivas de todos los continentes y zonas, 6 cuando menos se han descrito tantas formas como especies, pero quien lea el tratado de Ross- maessler snbre los unios curopeos, publicado en r $\$ 44$, se convencerá de que muchas especies solo son variedades. Aun cl que haya estudiado muchos años los unios y anodontos, $y$ adqquirido cierta práctica en su distiucion, se verí indeciso cuando se proponga determinar por las descripciones y grabados de los libros de ensenanza zoológica, las especies recogidas en los alrededores mas próximos. De estas descripciones regularmente puede aplicarse todo y nada. eNo solamente cada arroyo, dice Rossmaessler, rio y estanque tienen sus formas particulares de unins y anodontos, sinn que a menudo se presenta el fenómeno de que con el cambio del cauce del rio en anchura, profundidad, naturaleza del suclo, y con la mayor ó menor rapidez de la corriente, cambian las formas de los conchíferos. En los grandes estanques ó lagos, la orilla opuesta a la corriente reinante del aire tiene à inenudo formas del todo diferentes de la otra, por lo regular mas profunda. El que por si mismo recoge sus anodontos $y$ unios á centenares en los sitios que habitan, ó los recibe en abundancia de sus amigos, con exacta indicacion del sitio en que se reco. gieron, no se admira tanto de hallar las especies de formas mas 6 inenos tipicas, como de ver alguna vez exactamente las mismas formas que ya recibió de otra parte.»

Reproduzco esta notable confirmacion de la teoria de las trasformaciones y este parecer sobre el desarrollo y la vida de las especies, porque la del individuo es de menor interés. Rossmaessler deinuestra en toda una-serie de ejemplos tales tránsitos y creaciones de nuevas especies derivadas de las antiguas. «Parece que la naturaleza, continúa, para formar una especie nueva é introducirla poco á poco en la serie de 
las antiguas, se sirve del medio de cambiar y trasformar todos los individuos por las condiciones diferentes del desarrollo, hasta quue por fin, con la edad, adquieren un aspecto extraño. Fn las primeras generaciones esta trasformacion individual en los padres, no se traslada todavia á sus descendientes, sino que cstos se presentan otra vez fieles a su tipo antiguo, pero durante su desarrollo se trasforman bajo las mismas condiciones que sus padres, hasta que en las generaciones posteriores la trasformacion se nota tambien en los hijuelos. Rossmaess. ler recuerda el conocido hecho de que los piés de los chinos, atrofiados artificiałmente, tambien en los niños recien nacidos se inclinan al atrofianiento; y que los indios que desde su niñez se estrectan la cabeza, comunicandola mas altura, nacen, por fin, con tales cabezas. Fsta teoria ha obtenido uiltimamente el apoyo mas sólido, pór la abundancia de pruebas luse Darwia ha reurido para la trasmision por herencia y la consolidacion de nuevos caractéres y cualidades, por las condiciones bajo las cuales se verifica voluntaria ó involuntaria. incutela lyropagacion.

Las formas del unio de las aguas de la Alemania central que mas pueden designarse como especies, son el amio tumihais, priforum y crassus. Una descripcion de sus diferencias poco marcadas nos seria muy conveniente despues de lo que arriba hemos dicho. "Aun arrojando pór la ventana de 20 à 30 diferentes formas, dice Rossmaessler, sacaria de mi coleccion de 4 a 6 mas. De las citadas cuatro especies tengo cuando ménos 200 variedades, diferentes casi todas taubien por su forna; y de estas podian obtenerse cunndo menos ditz especies 6 tal vej, al tratar de clasificarlas, llegaria uno í desespetarse.p Pespues nos conduce el citado autor a las orillas del lago de Worth, cerca de Kalgenfurt, en Carintin, para demostrar la formacion de una nueva especie con un ejempio determinado. Reproduciremos todo este pasaje de la tan instructiva iconografia de los moluscos terrestres y de agua dulce, porque imprime una direccion determinada á nuestra idea sobre las especies, y nos impulsa a meditar y comparar.

《El lago de Worth cerca de Kalgenfurt, dice Rossmaessler, ha producido el unio platirinco; $y$ un puede demostrarse si ha dado tambien el de los pintores. Al abrir el camal que desde el lago conduce á la ciudad, llenábase con el hgua del lago, y naturalmente esta (iebia ad nquirir poro à poco una naturaleza variada. Es tanto mas trançuila cuanto mas öistante se halla del nacimiento del lago, porģue el canal no tiene salida; sus orillas, bien conservadas, forman un declive regular; su anchura es de $\delta$ a 10 pasos, poco mas 6 menos; y su profundidad de unos 3 piés. Al llemarse el canal con el agua del lago, naturalmente debian llegar i él algunos conchiferos cu. yos descendientes encontramos en algunas partes del mismo. Ahora bien, en el canal, donde predomina marcadamenic el unio de los pintores no se encuentra ningun unio platirinco, habitante del lago, y en este viltimo ni un solo unio de los pintores. No será por lo tanto una hipótesis demasiado atrevida suponer que el unio platirinco, muy afine evidentenente del unio de los pintores, haya vuelto à la forma del último despues de haber salido de las condiciones particulares de su desarrollo en el lago y de haberse trasladado á una nueva esfera. Paralelamente con el camal, extiéndese á media hora mas del Sur del lago, el arroyo del Glanfurt, que por la continua renovacion de sus aguas debe parecerse mucho mas al lago que el canal, aunque no tenga la misma naturaleza, á causa de su continua corriente. La diferencia es bastante grande para que el unio platirinco, que nunca se encuentra en el arroyo del (ilanfurt, sea la especie intermedia del unio de pico largo. El unio cncorvado del lago (fig. $3_{4}$ ) se encuentra en algunos ejemplares muy modificado; en cambin hay muchos de una pequeña forma, del unio bátavo (fig. $3^{1} 3$ ), $y$ a una hora de distancia, arroyo abajo, encontré solo este último, tambien modificado; las otras especies habian ya desaparecido. Y ahora, pregunto si pueden desearse explicaciones mas evidentes sobre la relacion de afinidad de las formas de conchifero de nuestras aguas, tan distintas por mil conceptos. Que se me demuestre con razones desde luego comprensibles que mi deduccion es falsa y que los conchiferos del lago de Wœrth, del canal citado $y$ del arrojo de Glanfurt no están en ninguna relacion de origen entre si, y entonces, pero solo entonces, me avendré á reconocer como tales á las numero. sas especies que ciertos señores inventan.»

Muchas especies de unios producen perlas, pero el mas abundante en este precioso producto es el unio margaritifero. Sobre las conchas con perlas tenemos una excelente obra de Teodoro de Hessling, de la cual tomamos, en su mayor parte literalmente, las noticias sobre los unios margaritiferos y las aviculas. Fundandose en la intima afinidad de los unios, el cuncito que el citado naturalista ha trazado del unio marga. ritífero es mas ó menos váliclo para los demás.

El unio margaritifero se distingue entre todos los conclif. feros de agua dulce de Alemania por el grueso despropor. cionado de sus conchas, que en algunas regiones llegan á una longitud de 5 a 6 pulgadas. Fl àrea de dispersion de este molusco es muy extensa; vive en las costas occidentales de Irlanda y en los rios del Ural, prospera lo mismo en la provincia escandinava, como en la Rusia septentrional hasta el nar Cilacial, y habita tanto las desembocaduras del Don como los rápidos arrogos de los Pirineos. Al contrario de los otros moluscos que prefieren un suelo calcíreo, los unios margaritiferos solo se encuentran bien en las aguas que tiencn su origen en la montaña primitiva y en otros terrenos montañosos, ricos en silex y muy pobres en cal, y que pasan continuamente por regiones de esta naturaleza geognóstica. Hessling dio impulso á un exámen minucioso de las aguas de la Selva de Baviera que se distinguen todas por su dulzura y se expresa del modo siguiente sobre la influencia de las mismas sobre el reino animal. En todas partes se nota, lo mismo que en el reino vegetal, una falta extrañ de las especies en los organismos, tanto superiores como inferiores. Las aves del bosque se llegan en el periodo del celo asiduamente à las habitaciones humanas, para recoger y llevarse el mortero de las paredes. Las payesas recogen y truecan por lino cascaras de huevo para sus gallinas, que de otro modo ponen sus lauevos sin cáscara. El ganado que se alimenta con brezos y filicedos, jerbas que nunca tocan los animales de los opulentos pastos de los Alpes, produce bueyes con los huesos tiernos y con una carne sabrosa. Pobres son los rios en animales inferiores; $y$ pobres en peces; algunas especies de estas últimas, entre ellas truchas de una carne exquisita, y los cangrejos solitarios, son casi los únicos compañeros del unio margaritífero.

Estos arroyos escasos de cal en los que vive y crece el unio margaritifero, dice Hessling, cruzan tranquilamente por las alfombradas praderas, ricas en llores, ya entre sotos de fresca verdura 6 a lo largo de los linderos de frondosos bosques, ya entre colinas y montañas fértiles de las que algunos alegres riachuelos toman su origen; sus orillas están póbladas de sauces y alisos vigorosos, al rededor de los cuales retozan las impertinentes libelulas; los molinos con su monótono ruido, interrumpen el sosegado curso de los arroyos: pero estos se precipitan tambien con la rapidez de la flecha por estrecios desfiladeros, entre paredes pedregosas, escarpadas y sumidas en melancólicas sombras; corren por un cauce pedregoso y revuelto, en el que gigantescas rocas de granito elevan sus venemables cabezas. l'or lo regular no se encucntran en estas aguas los unios margaritíferos, si no despues 
que han salido de la montaña. Los sitios favoritos de estos animales son charcos de mediana profundidad con un fondo de silex granitico y de arenn, con preierencia en los ángulos $y$ rincones de los riachuelos, bajo la sombra fresca que reina en medio de las raices de los alisos y sauces; pero tampoco huyen de los sitios anchos, en el centro de los arroyos, sobre to. do en los puntos donde estos dan vueltas, y donde los rayos caloriferos de la aurora interrumpen la sombra de la orilla. En cambio critan un fondo cenagoso ó puramente pedregoso, poblado de plantas acuáticas, y sobre todo los sitios cn que desembocan las aguas ferruginosas ó procedentes de pradems infestadas de inusgo.

Aqui viven, ya aisladamente $\delta$ con pocos compnñeros, ya en colonias compactas que constitujen en cierto modo el empedrado en grandes distancias de los arroyos, ora á grande; ora a pequeña profundidad. Siguiendo la corriente del agua cstán metidos con la mitad ó dos terceras partes de su concha en la arena: en esta posicion las extremidades de la concha, abiertas á media pulgada, recogen el agua que pasa por encima y vuelven i arrojarla mezclada con los excre.

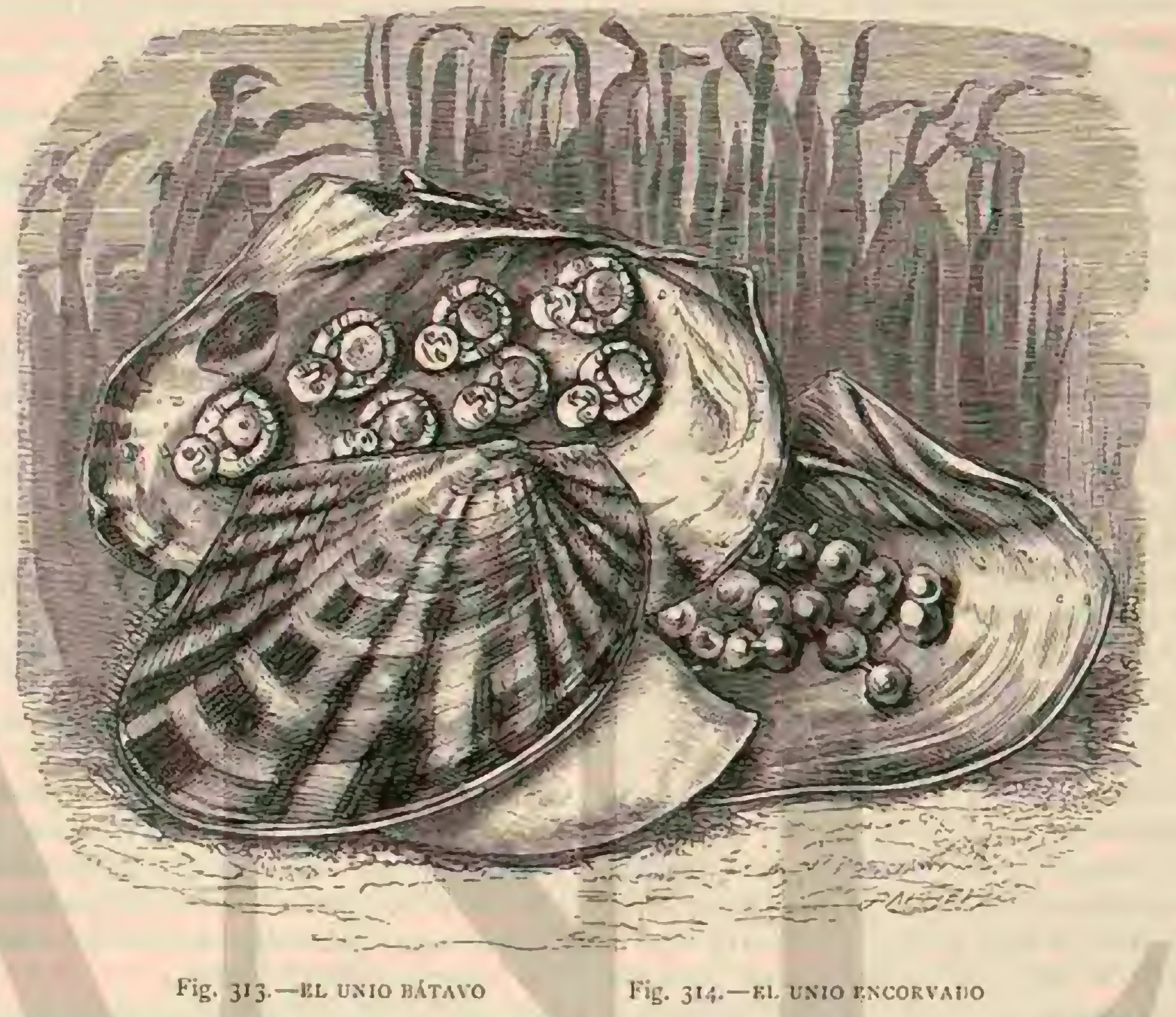

mentos en un surtidor a menudo tan fuerte que muchas veces la superficie del arrojo forma una especic de torbe. llino. Fstos movimientos de las branquias son mas viros bajo los rayos del sol ó en una temperatura subida, duran y descansan alternativamente horas enteras, cesan por lo re. gular del todo en la oscuridad y se hacen mas raros durante varios dias cuando el tiempo está nublado.

A pesar de la gran pereza de estos animales, se notan sin embargo marcados vestigios de una facultad de locomocion. Los conchiferos que despues de pescados vuelven a echarse al agua, han avanzado al dia siguiente hasta cl centro del arrojo, segun lo demuestran los surcos que dejan en pos de si; pero aun esta locomocion no es excesiva y los movimientos carecen de viveza; los conchiferos marcados con una señal se encuentran á menudo despues de 6 u 8 años ca. si en el mismo sitio en que se depositaron, si no se to han estorbado las infuencias exteriores. Sus viajes nunca se extienden a grandes distancias; por lo regular, y cuando mas, a 20630 pasos.

El guardabosque llaliher de Hohemburgo, este excelente observador, refirió à Hessling que un conchifero, desde las ocho de la manana hasta las cinco de la tarde, emprendió un viaje de dos piés y medio de distancia. Cuando despues de cada intervalo volvia a moverse, necesitaba para una distancia de la longitud de su concha 3 minutos. Estos viajes solo se verifican en la arena donde el conchifero puede abrir sus surcos, mientras que los que habitan un fondo pedregoso no pueden moverse. I.a locomocion se verifica en dos actos marcadamentc distinguibles: el pié estendido por medio de las valvas penctra con su punta en la arena, alargándose $y$ contrayénciose alternativamente. Despues de un intervalo, empieza una viva corriente de las bránquias, y despues de uno ó dos minutos se estrecha el tubo anal, los tentáculos se contraen, y el agua recogida sale de aquel como impetuoso surtidor; al mismo tienıpo se cierm la extremidad posterior de la conclas, pero vuelve á abrirse pronto. La parte libre del pié que se encuentra fuera de la concha, queda immóvil, la parte interna hace seguir a aquella recogiéndose. Despues de otro intervalo corto, vuelve i verificarse el primer acto.

De este modo los animales tienen una larga vida, si no la ponen fin las inundaciones de la primavem, la avaricia del hombre, las persecuciones de la nutria, de las urracas, cuer. vos y cornejas. Pero 110 solamente el hombre los persigue á causa de las perlas, sino tambien para satisfacer costumbres supersticiosas. En la selva de Baviera hay la creencia de que una raca antes de parir necesita una perla buena: aun las señoras, por lo regular las solteronas, dan en muchos puntos a los perros cachorros una perla preciosa en aguardiente para que queden pequeños; álos caballos y perros que pierden la vista se les pone polvo de las conchas machacadas en los 
ojos. El cuerpo del conchífero se considern como buen cebo para los peces y cangrejos y como buen alinento para en. gordar los patos y los cerdos. No se sabe la edad á que pue. den llegar estos conchíferos, pero se cree que por túrmino medio llegan à la de 50 à 60 años. Sin embargo, los conchiferos marcados con el número del año han demostrado que pueden alcanzar la edad de 70 á 80 : la creencia en una edad superior, aun hasta 200 años, será siempre problemá. tica y debe aceptarse solo con precaucion.

Todos los rasgos esenciales de cste cuadro, trazado de un modo tan interesante por Hessling, se confirman en las demás náyades de nuestras aguas corrientes y estancadas; pero debemos completarle con algunas noticias de la historia de desarrollo y de la propagacion, que si bien se refieren prin cipalmente al unio de los pintores, pueden aplicarse sin em bargo, con algunas modificaciones, á todas las náyades, y serun Hessling, en particular al unio margaritifero. Inútil parece observar que este $y$ sus congéneres no emprenden largos viajes para cfectuar su apareamiento: la propagacion se verifica cí los meses de verano, y los huevos nosalen hácia fuera, sino que se conservan en los espacios huecos de las hojas branquiales 6 interiores. El liquido espernático de los machos sale primero libremente y se recoge por las hembras con el agua neccsaria para la respiracion, que pasa á los mismos espacios branquiales en que se hallan los huevos. Estos últimos, que al salir del ovario tienen un diametro de $0^{\mathrm{m}}, 005$, existen en tal número, que con ellos las bránquias cxteriores se dilatan, formando prominencias de varias lineas de grueso. Despues de la fecundacion, el huevo se cubre por cierta parte que tiene la forma de.un escudo, con pestanlas en extremo cortas y tiernas, las cuales ponen al embrion en continuo inovimiento giratorio. Este fenómeno chocante, quizis el primero en su género, se observó ya por el gran Lecuwen. hock. Algunos de estos conchíferos, dice, se abrieron en presencia del grabador para que dibujase los hijuclos tan luego como se sacaran de su depúsito; pues dejándolós aislados solo algunas horas, habrian perdido su forma rerdadera. Los conchiferos én embrion se pusieron en un tubo de vidrio bajo el microscopio, y entonces presencié con asombro un espectículo magnifico, pues cada uno, encerrada en su membrana particular, giraba lentamente, lo cual puede observarse hasta tres horas, siendo tanto mas extraño, cuanto que los pequenos conchíferos, durante todo el movimiento, permanecian sicmpre en el centro de la membrana como una esfera que gira sobre su eje. Estc espectaculo extmordinario no solaniente me divirtió a mi, sino tambien à mi hija y al dibujante, durante tres horas, y lo considerábamos como e] mas interesante que puede haber.

El holandés se contentó con la sencilla descripcion de lo que le ensenaban sus imperfectos instrumentos; mientras que, aun en este siglo: un célebre naturalista supuso una fuerza migica indefinible, para explicar el movimiento giratorio del embrion de los conchiferos y moluscos en el huero. Estos movimientos se prolongan aun bastante tiempo despues de haber comenzado la formacion de la concha. Cuando duran. tc la observacion se rompe la membrana del hucvo $5 \mathrm{el} \mathrm{em}$. brion se pone en contacto con cl agua, la concha se abre de repente, y el pobre animal se esfuerza cuanto puede para cerrar las valvas. Los cmbriones se trasforman en larvas libres despues de haberse reforzado un poco en este grado de su desarrollo. Creo que no despertarí oposicion el que dé à es. te estado el nombre de larva, pues ninguno de los órganos del conchifero adulto se ha desarrollado, y ni siquiera la concha presenta su forma definitiva; la larva tiene un solo músculo para cerrar la concha, mientras que el individuo adulto esti provisto de dos. No labiéndose apreciado bien este hecho, deciase antes que nuestras náyades nacian con una forma muy parecida á la definitiva del cuerpo, mientras que yoo, despues de muchos experimentos; obtuve el resulta. do contrario. Dehe notarse, sin embargo, que las náyades, asi como los pulmonados, carecen del órgano caracteristico de los moluscos y conchiferos marinos, es decir, de la vela. En los pulmonados, el desarrollo se simplifica por no existir el estado de vela; en las náyades tambien ha desaparecido, pero en cambio se han presentado otras particularidades. Me permito hacer además otra indicacion. Generalmente los monomiarios se consideran como los conchiferos inferiores, y predominan tambicn en los periodos geognósticos anterio. res, complarados con el actual; el órgano que sirve para fijarse es un hilo, y alli donde se encuentra, en el embrion $y^{\text {ia }}$ larva, sirve á menudo para reconocer la edad geognóstica y. el grado sistemático inferior. ¿Serian estas condiciones de las laryas de las nayades reminiscencias de la época primitiva de los conchiferos?

Flemming ha establecido un principio muy notable para coniparar las larvas de nuestros conchiferos fuviales con los marinos, por las ideas sobre la embriologia inferior. Para decidir, sin embargo, con seguridad, se necesita explicar de que modo esta larva de náyinde, tan parecida al animal adulto, se metamorfosea en el estado perfecto; jero aqui se nota un gran vacio en la historia de la vida de este animal. Solo nos dice el naturalista que las larvas que salen de las brinquias de la madre viven como parásitos en peces.

Despues de conocer la estructura, el género de vida y el desarrollo del unio margaritífero y de sus congéneres, nos ocuparemos de las perlas, siguiendo otra vez, casi literalmente, la descripcion de Hessling.

Ins perlas son las concreciones libres que se encuentran en el aninal, compuestas de la materia de las conchas. Sus cualidades, el brillo de sus aguas, la redondez $\delta$ lisura, el tamaño $\delta$ el peso, dependen mas 6 menos de su composicion y estructura, que es anailoga a la de la concha. Las perlas se componen, por lo tanto, de finas membranas orgánicas y de una sustancia calcárea depositada dentro ó en medio de aquellas. La perla perfecta carece de todo color particular; solo tiene los visos de la capa nacarada de su concha, y por lo tanto tambien su estructura. Su brillo suave, blanquizco lechoso, claro como la plata y luciente como los colores mas delicados del arco-iris, sus aguas mas puras, dependen del modo de hallarse depositada la cal y de la trasparencia de sus membranas: el primero les da el juego de colores; la se. gunda la suave luz que tan poderosamente atrae y seduce la vista de los mortaics. Las perlas orientales superan das latrus en brillo y belleza, porque sus cajas columnares, asi como las nacaradas, carecen casi del todo de color y permiten el paso a la lu\%, lo cual no sucede con las capas cóluminares de color del unio margaritifero. Una de las perlas orientales mas magnificas se encuentra en la coleccion de objetos na. turales de los hermanos Zosima de Moscou; es del todo re. donda, no perforada, del mas hermoso brillo plateado, $y$ tiene

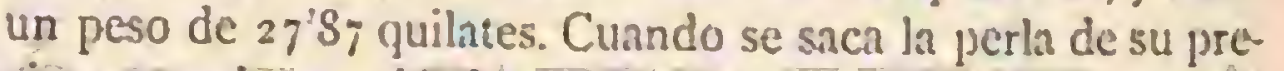
cioso estuche, poniéndóla sobre un fino panuelo de batista, rueda como una bola de mercurio ofreciendo los colores mas magnificos. Todos los ejemplares de gran tamaño, hasta el de una nuez: y mas, son perlas americamas y persas. Las curopeas, sobre todo las de Baviera, alcanzan el tamaño de un gran guisante ó de una pequeña habichucla, mas por lo regular no exceden de la dimension de una cabeza de alfiler.

La cuestion del origen de las perlas es tan antigua como el conocimiento dc su existencia. Reproduciremos cuando menos algunas de las tradiciones recogidas por Hessling, aunque la major parte de ellas se refieren a las perlas de los 
conchiferos marinos. In las noches benigmas de vernno algunas gotas de rocio se deslizan del cielo para fecundizarse en el seno del conchíero, abierto por los benéficos rayos del sol. Esta antigua tradicion de los indios circuló por toda la antiguiedad hasta mediados de la Edad media. En el dia del mes Nisan ( 24 marro), dice el sabio hebreo Benjamin de Zutela, los conchíeros recogen las gotas de lluvia, y en el mes lisai (mediados de setiembre) los buzos encuentran en cllos las piedras preciosas, $y$ aun en nuestros dias existe entre los indigenas de aquel pais la misma creencia sobre la formacion de las perlas. En diferentes formas alegóricas este mito sobrevive en las obras de los poetas y' en los monumentos del arte; y en inspirados versos le cantaba el alqquimista Augurello. Véase lo que dice Rueckrt: * Entonces pensé en mi origen celeste: un ángel llora mi debilidad, y una gota debió caer á las tinicblas. 'Iambien los ángeles lloran á veces a escondidas, pero sus lagrimas son beneficiosas para el mundo, porque de ellas salen estas perlas. Ia lägrima hubiera desaparecido en las aguas del Océano, si el mar, conociendo su origen divino, no la hubiese recogido en una concha, separando esta gota de las que procedian de una fuente menos noble. Con las siguientes palabras encargó a la con. cha el cuidado de la perla: «En tu seno solitario debes conservar el gérmen precioso jo cruzar cuidadosamente las aguas hasta que se haya desarrollado. Y cuando en tus entrañas la perla se haya formado y llegue su hora de salir, debes abrirte para darle paso. b

En San Petersburgo se conserva en una galeria un cuadro en el que Cupido, cerniéndose en las nubes, dispersa gotas de rocio, que unos amores que nadian en la superficie del mar recogen en conchas, en las cuales se trasforman en perlas. En Deggeldorf, punto principal de la Sclva de Baviera, celebre en otro tiempo por sus perlas, la iglesia tiene en su cielo raso un cuadro que representa cómo la leche gotea del seno de la Reina de los cielos, y cayendo en conchas soste. vidas por ángeles se trasforma en perlas.

Sin embargo, tambien los elementos, la tempestad y los vientos, los rayos y los truenos, segun se creia en la Edad inedia, producen perlas en los conchiferos, en los que pueden penetrar á manera de piedrecitas del mar parn recibir en el molusco su brillo y lisur.

No nos oruparemos en dar cuenta de qué modo se explicaba en el último siglo el origen de las perlas: pero en los años que precedieron ì la época en que Hessling comenzó sus inturesantes averiguaciones, la teoria sobre la formacion de las perlas, generalmente aceptadn, reconocia que unos parásitos que vivian en el conchifero cran la única causa de la formacion de las perlas. Precisamente el asunto es tan inte. resante, que creemos conveniente reproducir en este lugar toda la parte correspondiente de la obra de Hessling.

El mérito principal de haber encontrado en las perlas pa. rảsitos con sus huevos se debe sin duda à J. de Philipi. Unos experimentos hechos con muy distinto objeto llamaron por casualidad su atencion sobre el origen de estos paraisitos. Entonces recogió un número conveniente de pequeñas perlas del manto de algunós moluscos, y a fin de hacer un exámen minucioso de la sustancia interior rompió algunas, poniendo otras en ácido de/salitre rarificado. Las perlas que por.algun tiempo se habian expuesto à la infuencia de este ácido perdian mas ó menos pronto, segun su diametro, toda la sustancia calcairea, conservando sin embargo su forma anterior; dilatábanse un poco en burbujas gaseosas y pre. sentaban un número de capas membranosas muy finas que rodeaban un marcado núcleo central de materia orgánica.

Otro hecho que en esta cuestion pareció importante à Phi. lipi fué la presencia irregular de estas perlas en individuos de la misma especie de conchiferos recogidos en diferentes localidades. Cuando Philipi tuvo un gran numero de individuos de la especic arodonfa ygnea, de los estanques de Racconigi, se asombró del gran número de perlas existentes, soldadas con el interior de la concha ó envueltas en el manto, mientras que algunos años antes solo muy raras veces habia encontrado perlas en los anodontos y unios de algunos lagos y rios de Lombardia. Las perlas de los estanques de Racco. nigi son pequeñas, de forma regular, y constituyen un articulo de comercio. Philipi encontró una perla completamente redonda, del tamaño de un cañamon grande, en el borde musculoso del manto, precisamente en el sitio en que suelen hallarse las perlas en el unio margaritifero. Con la abundancia del anodonto de Racconigi coincide además la de una especie de anélidos intestinales del distomo duplicado que parece no habitar con los conchíferos del lago de Varesse en la Lombardia. Cuando Philipi sacaba de la concha las concreciones en apariencia mas recientes, y; despues de prepararlas bien, las ponia bajo el microscopio, reconocia los restos de pequeños distomos que habian servido como centro de la materia calcárea. Tambien en las otras perlas que se encuentran aisladamente en el manto de los anodontos, Philipi encontraba un contenicio orgánico como núcleo, por lo cual decia que el centro de las perlas ofrecia el carácter de un sér orgánico muerto, y que este sér era un anélido intestinal. Fil centro de las perlas se componia siempréde un parasito, y la abundancia de las perlas estaba en relacion directa con la de los parásitos en el manto de los conchiferos inargaritiferos.

Philipi habia indicado ja otro parásito como causa de la formacion de las perlas, y este parásito adquirió major inportancia por los trabajos del doctor Kuechenıneister, quien no dudaba que en muchos ejemplares del conchifero del Elster un parásito formaba el centro. Este parrsito, un arac. nido acuático, es el alax ypsilophara, llamado tambien linno chares ancilorlic. Vive en estanques cenagosos y raras veces sube à la superficic; permanece por lo regular en las capas de agua superiores al limo, es decir con preferencia al nivel de la mitad posterior del cuerpo de los conchiferos; donde tambien Kuechenmeister, encargado por el gobierno sajon del exámen de los bancos de conchíferos cerca del instituto balneario de Elster, encontró los mas de los individuos emigrados. Cuando este aracnóide, que tiene ocho patas, es adulto, vaga por el agua y depasita sus huevos en el manto de los unios. Los huevos envueltos por el conchifero en una membrana, se trasforman en aranas de ocho patas, que salen al agua para volver á fijarse en el manto desjues de permanecer poco tiempo en aquella; la cria que solo tiene seis extremidades, nuda la piel en una mémbrana recibida otra viz por' el conchifero; despues los hijuelos rompen la membrana y salen con ocho patas al agua a fin de aparearse. Kuechenmeister consideraba la membrana formada por el conchifero al rededor de la piel del atax como el centro de la perla.

A Hessling se debe el mérito de haber reducido à sus modestos limites la verdad de esta teoria, aunque no nicga que los citados parásitos pueden alguma ve\% ser la causa de Ia formacion de perlas en las mas diferentes especies de náyades, pero asegurando que estas condiciones no pueden aplicarse al verdadero unio margaritifero. "Examiné, dice Hessling, unos 40,000 individuos abiertos, ya por mi, ya por los pescadores, para buscar este parásito, y ni en un solo unio observé tal insecto, huevo ó cualquiera señal de su existencia. Lo mismo me sucedió con los conchiferos margaritiferos de otras regiones, por ejemplo de Bohemin.

Sin embargo, las perlas del unio margaritifero que se forman en el manto tienen un nuicleo, y el naturalista de Munich 
ha recogido del modo siguiente los resultados de sus fatigosas observaciones sobre el origen de las perlas, al que parecen contribuir causas externas é intcrnas. Las primeras son mas raras y dependen de la particularidad que ofrece el sistema de los vasos de guedar abierto hácin afuera Por esta callsa penetran con el agua cuerpos extraños en el cuerpo y sc depositan sobre fodo en el manto, donde se rodean con la sustancia de las capas de la concha. La segunda causa, interna, está en relacion con las projorciones de formacion y desarrollo, con la concha, porque casi siempre algunos pedacitos de una á cinco líneas de largo, de la sustancia de que se compone la epidermis de las conchas, forman el centro de las perlas. Ias perlas cuyos centros se hallan en la capa del manto que segrega el nácar de la concha, recibirán tambien esta cubierta de nácar y se trasfomarán en perlas Hlamadas de agua pura, mientras que las que se encuentran en la parte del manto que segrega la capa epidermal y media, no pueden llegar a ser preciosnis. De la obra de Hessling resulta tambien que la division de las perlas en maduras y no maduras no es exacta, porque no puede hablarse en rigor de una madurez, ó mas bien, si se quiere, lodas las perlas cstain madurando mientras se hallan en el animal; una perla que apenas se ve con el microscopio, es tan madura como la jerla mas magnifica de la corona de un rey. De la cantidad de sus capas resulta su tamaño y forma, de la cualidad de las mismas su valor.

Comparada con las enormes sumas que circulan en el co. mercio con perlas marinas, desaparece cisi la reducida renta que dan lás perlas fuviales. En Sajonia se recogieron des. de 1826 hasta 1836 , 140 perlas de un valor de Si thalers. IA pesca de perlas en Baviera díó en los 43 años desde $181 .+$ hasta 1857 el resultado de 158,850 perlas. A causa de estos escasos bencficios de los margaritiferos fluviales, se ha pensa. do hace muchisimos anos en aumentar la produccion de las perlas, sobre todo en las fuviales, 6 , segun dice Hessling, en obligar á los conchiferos a formar perlas en nenos tiempo y mayor cantidad. En el siglo pasado Linneo ofreció vender como secreto un procedimiento de cria artificial de perlas por medio de la perforacion ó de lesiones en la conchi; mas a pesar de algunos informes emitidos sobre este particular, no se conoce aun el verdaderó método de I inneo. Un segundo modo de producir perlas en los conchiferos consiste en introducir cuerpos cxtraños entre el manto y la concha, con $y$ sin lesion de esta última Hace muchos siglos que los chinos se sirven de este método: el relato del cónsul inglés de Ningpo, Hague, y delmédico americano-Mac-Gowan sobre este ramo de la industria, relato reproducido por Hessling, dice lo siguiente:

* Esta industria se limita á dos puntos cerca de la ciudad de Tetsing, en la parte septentrional de Tschehing: durnate los meses de mayo y junio se recogen con cestos grandes cantidades de conchiferos (anodonta plienta) del lago Tai-hon, en la provincia de Kiang.Hon, eligiéndose los individuos mas grandes. Como por lo regular suclen padecer un poco á causa del viaje, se les deja descansar algunos dias en cesti. tos de bambú sumergidos en agua. Despues se introducen en la concha abierta granos ó cuerpos diferentes en forma -y sustancia. Los mas comunes se componén de una masa de pildoras humedecida con el jugo del fruto del. arbol del alcanior.

Las formas que mejor adniten la capa de nácar sc importan de Canton y parecen componerse de la conclia de la avicula margaritifera; tambien se emplean pequeñas figuras, representando por lo regular a Buddha sentado, asi como peces; estas figuras se fabrican con plomo. La intro. duccion se verifica con gran precaucion: abrese la concha cuidadosamente con una paleta de nácar, y la parte no fijada del conchifero, se descubre dé un lado con una sonda de hierro. Los cuerpecitos extranos, figuritas, pildoras, etc, se in. troducen despues con la punta de una canita de bambú, y se colocan en dos series paralelas sobre el manto ó el lado li. bre del animal. Hecha esta manipulacion en un lado, se re. pite en otro. Atormentado por los cuerpos cxtraños el ani. mal se oprime convulsivamente contra las valias, sujetando de este modo las formas en su sitio. Despues se colocan los conchíferos unos tras de otros en canales, depósitos $\delta$ estanques, i la distancia de 5 a 6 pulgadas uno de otro $y$ a una profundidad de 12 piés en cl agua, à veces en número de 50,000 individuos. En noviembre, al cabo de die\% meses, segun unos, ó segun otros á los tres años, se abren las conchas con la mano, el animal se saca $y$ las perlas se separan por medio de un afilado cuchillo. Cuando el centro de aquellas se compone de nácar, no se extraen, pero si son de barro ó de metal se sacan, y despues de llenar el hueco con resina fundida se cierm la abertura artificialmente con un pedacito de nácar. Estas perlas son poco inferiores en brillo y belleza â las sólidas, y pueden venderse á un precio muy equitativo. Los plateros adornan con ellas diademas, brazaletes y otras joyas para señoras. Las capas de nacar que se han formado sobre imigenes de Buddha se fijan como amulctos en las garns de los niños. Se dice que 5,000 familias de los pueblos 'Ischang- $K$ wan y Tschangugan se ocupan en este ramo de la industria. A los que no saben tratar bien los conchiferos se les mueren á veces un diez. por ciento, mientras que otros mas liábiles no pierden ni uno solo durante toda la estacion.

Hessling ha probado el valor de este método chino en nuestros unios margaritiferos. Se introdujeron igualmente cuerpos extranos redondos, de alabastro ó marfil, y otros semi-esféricos de vidrio, colocándolos entre el manto y la concha de los animales que se depositaron en el agna corriente det Instituto fisiológico de Munich y' en los arroyos dc que se habian sacado: pero resultó quue estas especies no ernn propias para tales experimentos. Hessling ha demostrado tambien que la proposicion de Philippi y Kuechemueister, encaminada í promover la iumigracion de los parásitos en los margaritiferos, para obligarlos á formar las perlas con mayor frecuencin, es del todo impracticable, pues nunca se obtendrian resultados que reportaran ganancias materiales. Deberiamos fijar por lo tanto nuestra atencion en el aumento natural de las perlas. a La proporcion desfavorable, dice Hessling, de que en 2,215 concliferos se encuentra una perla de mediana cualidad y en 2,708 solo una buena, depende exclusivamente de la materia colnrante oscura jropia de nues. tro margaritifero, $y$ esta materia colorante depende a su vez. del alimento, sin el cual no puede subsistir el individuo. Dicina materia epidérnica comunica el impulso para la formacion de la perla, pero impide que todas las perlas producidas en el animal puedan ser preciosas. Si por lo tanto, de cualquier manera se logra el aumento de la formacion de perlas, tambien acreceria la produccion de las de color, porque el alimento es el mismo y debe serlo. Fl limite de la produccion de las perlas preciosas deperide, por lo tanto, de las condiciones vitales del animal nismo, y estas no pueden cambiarse esencialmente sin poner en peligro la existencia del conchifero.

Las últimas paiginas de la obra conticnen indicaciones sobre la cria racional de las perlas, y varios consejos por los cuales se recomienda reducir el animal lo mas posible al estado de su naturaleza primitiva. Las reglas necesarias para la cria y la pesca de las perlas, son las que a continuacion reproducimos.

Respecto a los animales, debe tenerse en cuenta sobre 
todo su alimento y la propagacion. De la gran cantidad de agua que un solo animal necesita para su alimentacion, resulta que los individuos en general exigen para conservarse sanos, cantidades suficientes de agua de la natumleza qui mica conveniente, y que por lo tanto todas las causas que les privan de aquella ó la disminuyen, como la sequia, el riego de las praderas, etc., pueden perjudicarles. Además se demostró cuán poca sustancia orgánica necesita el agua para la alimentacion de estos animales, y que precisamente la materia colorante, unida quimicamente con estas sustancias orgánicas, impide con mucha frecuencia el desarrollo de perlas bonitas despues de haberse trasformado en sustancias animales. Es preciso, por lo mismo, tener limpios los arroyos de formaciones vegetales y del limo en que estas se descom. ponen, 6 sacar los animales de las partes del arroyo en cuyo fondo crecen los citados organismos vegetales. Lo mismo debe hacerse en puntos donde hay confluencias de canales de riego, praderas cubicrtas de musgo, de letrinas ó de desperdicios de fábricas. La experiencia confirma la exactitud de esta tésis: en numerosas aguas se encuentran á grandés distancias animales muy vicjos cuya concha esta cubierta de musgos y algas, por ejenulo de las especies de fontinales; estas son de por si pobres en perlas, y cuando las tienen producenlas por lo regular malas. Is cosa bien sabida de los pescadores, que en los arrojos de un agua fresca de fuente $y$ de fondo limpio, las conchas son negras y sus animales blancos, lo mismo que sus perlas. Por falta de la materia colorantc, que en el anirual no puede depositarse, los órganos se destacan de la concha oscura, micntras que en los artoyos alimentados del agua impura de las praderas, las conchas son de un color mas claro, y los órganos èstán mas carga. dos de color a causa de la materia colomnte superflua que diche depositarse en elia. Aunguc estos animales produzcan perlas, son por lo regular de mal color.

Ademas se la dado gran valor a la circunstancia de que los arroyos estuvieran libres de arbustos en sus orillas, alegíndose que la presencia de la luz era de todo punto nece. saria para la formacion de perlas; pero las perlas mas pre. ciosas se forman it menudo en animales ocultos á muclı profundidad debajo de las piedms y de las raices de árboles, a donde nunca llegan los rayos caloriferos del sôl ó la débil luz de la luna; tampoco se comprende que la luz pueda contribuir á la formacion de la concha, y por lo tanto de las perlas. Fil despejo de las orillas solo tiene una importancia indirecta: los animales rapaces pierden sus escondites y el agua esta menos expuesta i corromperse por la mezcla con la hojarasca. Ias primeras perlas encontradas hace siglos en los bosques mas espesos, tenian dos cualidades tarto preciosas como malas; la influencia del sol nunca es enemign, sino solo favorable para una vegetacion baja, y si los relatos de los pescadores dicen que las perlas mas preciosas se en. cuentran en los puntos mas claros y menos poblados de arbustos en los arrojos, debe preguntarse siempre cuàl es la regetacion del fondo.

De la misma importancia que el alimento son las condiciones de la propagacion de los margaritiferos; la mayor parte de los resultados de una cria de perlas dependen de la regularizacion de aquella. Cuanta mas ocasion y seguridad se orrece $i$ los animales para su propagncion $y$ desarrollo, tanta mayor es la esperanza de su aumento, y por lo tanto tambien de una buena cosecha de perlas. Además es un hecho innegable que un mayor múmero de animales en un espacio determinado recoge mas alimento, y que por la ab. sorcion del que es supérfluo, disminuye tambien la cantidad de materia coloranic, enemiga de las perlas, que ya en estado disuclto se introduce en las animales con el agua del arrovo: distribuyéndose entre major número de animales, cacia indi. viduo recibe menos, sin que lá falte por esto ol alimento en general.

Hay dos medios para aumentar y para hacer mas pingüe la cria de conchiferos. En los tiempos antiguos regian severos decretos previnicndo que en los meses de julio y agosto, época de celo de los conchiferos, nadie debia pescar, y menos aun navegar en las aguas en que se criaban las perlas, amenazindose toda colntravencion con multas y penas corpora. les lin nuestros dias nadie recuerda ya astas sảbias reglas, y precisamente en los meses en que el animal necesita la mayor sranquilidad, se le persigue con major cncarnizamiento. Ademas de esta tranquilidad, absolutamente necesaria durante el periodo de la propagacion, el establecimiento de bancos de margaritiferos es un excelente medio para aumentar la cria. I as partes de los arroyos que tienen un fondo puro y sin cieno, con un agua clara, hallándosc asegurados contra las inßuencias exteriores y provistos del número suifciente de animales que corresponda al término medio de la cantidad anual de agua, servirín muy bicn al efecto cuando se confie la cria á gente entendida. Para crear tales bancos de perias son propios sobre todo los animales viejos que ya no las producen, pues toda cria razonable de perlas debe comenzar por la propagacion.

I'ambien respecto à la pesca se han de tener en cuenta ciertas prescripciones, exigidas por las particularidades naturales de los animales. Tanto los cnsinos como la experien. cia demuestran cuan lentamente crecen las perlas; las capas gue al cabo de un año se habian formado de los objetos extranos introducidos en el animal, cran tan delgadas que no podian medirse. Segun las observaciones de los pescado. res, se ha reconocido en conchiferos señalados, que las perlas del tamaio de una cabeza de alfiler alcanzan en unos doce años la dimension de un pequcrio guisante, y que las perlas del tamano regular como las crian los margaritiferos, necesitan unos veinte años. Si jor lo tanto el lento desarrollo de una perla no puede negarse, ¿de qué sirven las frecuentes pescas que sc hacen en los arrojos? I.a paciencia no debe ser una parichia tan lejana de la codicia. Las pescas demasiado repetidas de los siglos pasados son la única causa del mal estado y de la pobreza de las aguas de perlas curopeas.

Asi como un largo intervalo entre las pescas favorece a la perla para alcanzar sus cualidades principales futuras, el brilln y el color, la tranquilidad conveniente contribuis tambien á obtener otra cualidad implortante, es decir, el cles. arrollo de su forma. No cabe duda que el esfuerzo hecho al abrir la concha para buscar perlas puede asimismo producir cambios en la cantidad de secrecion. Un intervalo de seis a sicte años cntre cada pesca es por lo tanto de gran utilidad y de todo punto necesario para la cria de los margaritíferos.

\section{LAS ANODONTAS-ANODONTA}

El otro género principal de las nàyades, el de las anodontas, no puede distinguirse bien de los unios en cuanto al animal. La concha es delgada y frágil; el borde de la abcr. tura es lineal, sin dientes, y por debrjo del lignmento solo se encuentra una lamela longitudinal obtusa

Ias anodontas prefieren las aguas cenagosas y estancadas i las limpias y corrientes, pero algunas especies ó variedacies, se encuentrantambien en grandes rios, raras veces en los pe. qucỉos; eligen los sitios donde se hallan al abrigo de la fuerza del agua, $y$ parece que sobre todo les agradan las desembocaduras de grandes estanques. Lo que mas arriba hemos dicho sobre la dificultad en distinguir las especies de 
unios, se reconoce sobre todo en este género. Rossmaessler quiere deducir el nombre de conchifero dnade para todas las anodontas, mas bien de la prolongacion en forma de pico de la extremidad de la concha, que de la circunstancia de que el animal es alimento favorito de los ánades, pues aun. que puede suponerse que el conchifero guste á los anades, estos dificilmente podrian sacarle con su blando pico de la concha. No soy yo del mismo parecer. Mis investigaciones sobre el desarrollo de la anodonta cisne se hacian en indivi. duos de un pequeño arroyo cenagoso y poco profundo, donde durante semanas enteras he pescado en competencia con los patos. A menudo observé que una de estas aves habia abierto, a pesar de su pico blando, la concha, de modo que podia apoderarse de la carne, y sobre todo de las brán. quias llenas de enbriones. Ios dos tipos mas importantes de las numerosas anodontas diseminadas por la mayor parte de Europa son la anodonia ggnea y la anodonda cillencis. Aquella es oral ó romboidea, con el borde superior recto, ó por lo regular encorvado hácia arriba, y el inferior redon. dendo y divergente del superior. Se encuentran individuos de $0^{\circ}, 20$ de largo por $0^{\circ}, 11$ de alto. Hl segundo tipo tiene una concha prolongada muy delgada, provista de surcos, y cuyo borde superior é inferior son rectos y bastante parale. los. Ningun naturalista consagrado especialmente a las náya des ha hecho la tentativa de determinar las especies por caractéres anatómicos de las partes blandas del animal; y en efecto parece que hay poca esperanza de conducir esta clasi. ficacion a un fin conveniente.

\section{LOS MITILACEOS-MYTI- LACEA}

La familia de los mitilíceos contiene géneros que, tanto por su estructura y género de vida particulares como por su grande utilidad, merecen toda nuestra atencion. La concha cubierta de una epidermis tiene las valvas iguales. La aber. tura carece de dientes ó los ticne apenas visibles. La depresion del músculo anterior es por lo regulat muy ligera; por detris el manto forma una abertura pequeña para el ano y por debajo un tubo respiratorio corto, franjeado en el borde; los lóbulos bucales son estrechos y plegados. A estos caractéres distintivos se agrega una conformacion muy particular del pié y la existenciu de una glảndula, cuyos órganos están en relacion con el género de vida de estos'animales. El mitilo magallánico (fig. 317) se considera la especie mas grande del género, pues puede alcanzar $0^{2}, 1,3$, despojado de su epidermis.

Examinaremos el pié y la glándula, llamada barba en el mitilo comestible (mytilus edulis, fig. 3 I 8) de nuestros mares. I. concha se reconoce iácilmente por tener las coronillas puntiagudas y situadas en el ángulo agudo anterior de las valvas casi triangulares. El lado largo de la concha es el ventral. A ambos lados de la boca se encuentran los dos tentáculos labiales. El pié tiene la forma de un dedo y ya por su pequeno tamaño se vé que no es propio como óryano de locomocion. Por debajo y por detrás de la base del apéndice digital del pié, llamado lejedor, se encuentra la llamada glándula de liso, cavidad desde la cual, en el centro de la cara inferior del tejedor, se corre un surco longitudinal que por delante, cerca de la punta, remata en un corto $y$ profundo surco trasversal. En este hay una placa en forma de media luna, en cuyo borde anterior cóncavo se ven siete aberturas. Cuando el animal empieza a tejer, acerca primero la citada placa ì la gländula de biso, y al retirarse, la sustancia glutinosa se prolonga en un hilo que penctra en el surco abierto del dedo.
Por medio de la placa de tejer, la extremidad anterior del hilo se oprime contra cualquier cuerpo. El conjunto de todos estos hilos constituye la barba y el biso.

El que haya tenido ocasion de arrancar mitilos de los sitios que habitan, se asombrań de la solider de los hilos de biso, contra los que no pueden nada las corrientes y rompientes mas fuertes. Esto lo prueba el uso que en Bideford en el Devonshire se hace del mitilo. En dicha ciudad, un puente de 24 arcos pasa sobre el rio Toridge en su desembocadura en el Tawo. En este puente la corriente es tan rápida que ningun mortero la resiste. La municipalidad $\mathrm{em}$ plea por eso lanchas para traer mitilos, con los que se llenan los intervalos entre las piedras. El conchifero se asegura en seguida contra la corriente fijandose con fuertes hebras en las piedras. Un decreto declara criminal, y consigna se castigarả con el destierro, al que en ausencia y sir consentimiento de la autoridad municipal, arranque estos conchiffcros. Las hebras de la barba sirven al animal tambien para la lo. comocion. Cuando no le conviene ya el sitio donde habita, se acerca lo mas posible al punto en que están fijados los hilos de biso; despues tiende otros en la direccion en que quiere marchar: cuiando estos se fijan, introduce el pié entre los antiguos, los rompe uno despues de otro, y asi sucesiva. mente hasta que llega al punto que le conviene. Fl mitilo comestible se fija alli donde el flujo y refiujo son fuertes, en la region de ha orilia que temporalmente queda descubierta. En muchos puntos de la costa noruega, se ve en el tiempo del refiujo una negra faja de uno a dos piés de ancho, compuesta de innumerables mitilos que sobresalen de la super. ficie del igua. Pero alli donde la marea alta y baja no produce gran diferencia en el nivel, y tambien por otras causas locales, los mitilos se fijon á mas profundidad, de modo que siemjure quedan cubiertos de agua.

El mitilo prospera mejor en el mar del Norte y en los mares de la Europa septentrional. Pertenece a los conchiferos y animales marinos en general poco numerosos, que desde los mares de un contenido normal de sal penetran en los ma. res interiores mas ó menos saturados. Tambien en el mar Caspio se encuentra con algunos otros conchiferos atrofiados, sin haber podido aclimatarse completamente. Sin embargo, se dice que desde aquel punto la subido a los rios, eman. cipandose de la necesidad de sal marina. Su propagacion en condiciones favorables es sumamente asombrosa. Mejer y Mcevius refieren que en una balsa que desde el $S$ de junio hasta el 14 de octubre estaba en la ensenada de Kiel, todas las partes que se habian hallado por bajo del agua estahan tan espesamente cubiertas de mitilos que se con. taban en un metro cuadrado 30,000 individuos, sin contar los pequeños ocultos entre las hebras de los grandes. En la ensenada de Kiel los animales llegan en + ó 5 años à su tamaño completo; con mas rapidez crecen en los primeros dos años.

En todas partes donde prospera el mitilo se le emplea, ya como cebo, ya en la cocina, y para este último uso se han fundado en muchos puntos crias propias de estos conchiferos. Meyer y Moevius nos han dado noticias exactas sobre tal cria nrreglada de mitilos en la ensenada de Kiel. \& En la superficie de los palos y tablas del puerto, de las lanchas de baños flotantes, barcos $y$ desembarcaderos se fijan los mitilos por debajo del agua, y su cria cubre estos objetos a menudo como espeso césped. Sus residencias artificiales son los palos de conchíferos, árboles que los pescadores de Eller. beck: pueblecillo situado en la orilla opuesta de Kiel, plantan por debajo del agua en los sitios pertenecientes a su casa. Como tales árboles sirven ron preferencia los alisos, porque son mas baratos que las encinas y hayas que, sin embargo, 
se emplean tambien. De estos árboles el pescador saca las mmas mas delgadas, las provec de punta en su parte inferior y las planta a una profundidad de dos à tres brazas. Esta operacion se puede hacer en todas las estaciones, mientras que la cosecha de los conchiferos solo se hace en invierno, porcque entonces los animales tienen mejor gusto y pueden comerse sin peligro. Los airboles de conchiferos forman en cierto modo huertas submarinas que, sin embargo, solo se ren cuando el mar está tranquilo y el agua clara. A menudo hemos hecho sacar árboles de conchiferos para recoger sus habitantes, divirtiéndonos con las observaciones de los pescadores. Estos tienen lanchas de una formia anti. quisima, con el fondo plano y los bordes verticales; reman con una especie de palos, y saben hallar el sitio donde se encuentran sus árboles, por medio de señales en la tierra firme; cuando llegan à estar sobre uno, introducen una pértiga en el fondo, despues ligan una cuerda á un gancho y la arrollan al rededor del átbol para subirle a la superficie. Las ramas estan por lo regulas cubicrtas con abundancia do grandes conchiferos que han fijado sus hebras ya en la made. ra, ya en la concha de sus vecinos, y en medio y encima de sus conchas se liallan los animales mas diferentes.

- En la ensemada de Kiel se colocan todos los años unos 1,000 árboles de conchiferos, y otros tantos se sacan despues de haber estado de 3 i 5 años debajo del agua, pues este tiempo necesita el mitilo para desarrollarse. En el mercado de Kiel se venden todos los años unos 800 barriles de mitilos, conteniendo cada cual unos $\$ 2,000$ individuos. Hay años buenos y malos, tanto respecto á la cantidad como á la ca. lidad.»

El mitilo prospera, sin embargo, en todas las costas del Mediterráneo, donde encuentra una base para su tejido. Kobelt que visitó à Otranto, ciudad célebre desde la antigiicdad por su cria de ostras y otros conchiferos, dice lo siguiente: De los 30,000 habitantes de la ciudad actual, cuando menos dos terceras partes se alimentan de los productos del mar, figurando entre ellos principalmente las das especies de mitilos, la comun azul llamada cesze nere y la barbuda modio. la barhata, que lleva el nombre de cosse pelose. La conat de Taranto se encuentra con los estriche di Tirranto en todos los mercados de la Italia meridional hasta Roma. En la parte anterior del mari ficiolo, segun se llama en el dialecto de Ta. rento, ó mas bien en los cuatro dialectos que hablaba mi pes. cador,una ancha zona de agua de $\delta$ à 10 piés de profundidad rodea la orilla. Aqui se hallan series de estacas it una distan. cia de is hasta 20 piés, reunidas entre sí por cuerdas que sirven a los mitilos para fijarsc. Estas cuerdas se fabrican con una fibra vegetal, segun me dijeron, de una graminea pantanosa que crece cerca de Nápoles; yo dudo, sin embargo, de esta noticia, y creo que el material es el esparto español, Macrocholen tenacissima. Se conservan mucho tiempo y los pescadores les llaman fune dei faglia ó cuerdas de paja.

. Cuando en noviembrc estuve en 'larento, la mayor parte de las crias carecian de animales, pero los pescadores estaban haciendo los preparntivos para una nucva cosecha. Dudo por lo tanto de la noticia de Salis sobre que los mitilos se dejan año y medio en las cuerdas; los individuos que se nc. cesitan para la cria se cogen én alta mar ó se emplean ótros jovenes de los criaderos, que i este efecto se conservan. Las cuerdas se fijan por lo regular de modo que queden al des. cubierto durante el reflujo, que en Tarento es de dos piés. Fn algunos criaderos elévanse temporalmente del todo dejandolas dias enteros fuera del agua.

WConté en el mare piccolo unos 30 grupos de estacas, cada uno de los cuales contaba por término medio 200 : pero no pude adquirir noticias cxactas solure la cantidad y valor de los mitilos que se criaban, pues nadic se habia cuidado aun de averiguarlo. El importe debe ser sin embargo muy considerable, pues se envian cargas enteras de conchas frescas y en conserva á todos los mercados italianos. Sobre todo por Navidad la exportacion es enorme, pues entonces en todas las casas italianas hay gran convitc, en el que ademas de di. ferentes pescados, la anguila (capitone) de Chioggia y el cosae de Tarento, representan un papel principal. Los cozse nere frescos cuestan en Tarento, segun el consumo, de 40 a 50 céntimos el kilógramo.

\section{LAS MODIOLAS - MODIOLA}

Este género difiere muy poco del anterior. El animal no parece distinguirse en nada del mitilo; solo las coronillas de la concha no se hallan en la punta anterior nisma, sino que se inclinan Jateralmente. 'Tambien en este género las espe. cies son bastante numerosas y se encucutran en todos los mares. Interesantes son las que con ayuda de su biso se ro. dean de un tejido ó red. «Esta cubierta extraña, dice Philipi al hablar de la modiola vestida, que como un saco oculta toda la concha, se compone en su interior de un tejido de hilos grises, y por fuera de piedrecitas, fragmentos de concha y otros cuerpos análogos, estando en relacion con la parte posterior, de cuyos hilos parece haberse formado. No he visto un biso, y creo que este se teje provisionalmente con hilos muy delgados, contribuyendo quizás por su parte tambien a la formacion del saco. Tambien algunas otras peçue. nas modiolas parecen provistas solo en su jurentud de la barba, la que pierden despues de liaberse fijado en el interior de moluscos del género ascidia.

\section{LOS LITODOMOS-LITHODOMUS}

A los mitilaceos que con la edad pierden el biso pertene. ce tambieu el género de los litodomos. La concha, casi cilindrica, esta redondeada en ambas exiremidades y cubierta de una epidermis muy fuerte. Todas las especies viven en agu jeros practicados por ellas mismas en pieciras, corales ó tambien en conchillos gruesos. El mas conocido es el litodomo litófago (fig. 319), muy comun en el Mediterráneo, siendo tambien notable el lilodomo de cola (fig. 316). El primero es un alimento muy favorito, pero aunque se encuentra en todas partes en las costas calcáreas, no se le trae nuncr en gran cantidad a los mercados, jorque cuesta mucho tiempo y' tratrajo sacarlos de sus guaridas. Pertenece por lo tanto á los conchileros llamados perforadores, aunque este nombre es muy poco propio en cuanto debe indicar la actividad por medio de la cual el litodomo litófago penetra en la roca. Masabajo veremos qué algunos conchiferos se abren por si mismos ca. vidades en la madera y en la roca; pero el litodomo litórago no estí bien provisto para practicar esta operacion, pues la superficie de la concha, y sobre todo la extremidad y cl borde, son lisos, sin huella alguna de dientecitos que pudieran servir para rascar. Tambien se encuentra en la mayor parte de individuos la epidermis ilcsa, aunque al rozar con la piedra, los puntos mas expuestos a la presion deberian desgas. tarse. Se ha pensado que la corriente de agua producida por las pestañas de las bránquias y el manto era propia para ensanchar la cavidad, segun el proverbio: Gutfa caiat lapjdens; pero el que, como yo, haya sacado muchas docenas de litodomos de la cal mas dum, no podrá creer en tales efectos de la corriente. Para proceder con exactitud no basta observar al litodomo litóngo con los otros conchiferos perforadores; muy al contrario, esto nos hace vacilar mas, porque aquellos conchiferos perforan bajo otras condiciones. Lats mismas du 
ras piedras en que el litodomo litóiago abre sas galerias de tarias pulgadas de largo, se perforan cambien por animales de otras clases, por ciertas esponjas y algunos cipunculóideos, y aunque las citadas esponjas están provistas de un sin núme. ro de cuerpecitos siliceos microscópicos, no puede pensarse en que estos puedan producir tales efectos en la picdra. 'Tanbien los fascolosomas y otros cipuncolóideos carecen de armas para perforar. No queda otro remedio que atribuir la construccion y el ensanchamiento de las galerias de todos estos animales, i la fuerza disolvente de cualquier secrecion de su cucrpo, sin que sepamos hasta ahora cuál es el punto en que se segrega y cuál es la naturaleza quimica de esta sustancia. La objecion de que un ácido que disuelre la roca calcriea debe disolver tambien la concha calcirea del aninal, no debe aceptarse, por lo menos respécto á los titodo. mos, porque las capas calcareas de la concha de estos ani. males están cubiernas de una epidermis gruesa muy insensible contral toda clase de reactivos químicos. En otros conchife. ros (savicaía) la concha parece aségurada de otro modo contm las propias secrecionces.

Una colonia de litodomos litófagos ha adquirido fama uni versal por sus hechos, porque han dado una de lás pruebas mas evidentes de la terria de la elevacion ly depresion de cos. tas y de paises enteros. Fn la clusica ṕlaya de Pozzuoli (Puleoli), cerca de Nipoles, sobresalen de las ruinas da un templo tres colummas á una altura de diez pies sobre el nivel del mar, en las cuales se ve una zorra de seis piés de ancho con agujeros de litodomo litúfago. I a costa, con el templo de Sernpis, se hundió por lo tanto en una época desconocida bajo el nivel del agua, volviendo á clevarse à su altura actual despues que los litodomos hubieron practicado sus galerias

\section{LAS DREICENAS-DREYSSENA}

Fetc género llamado taubien tichogonsin difiere respecto al animal de los initilos por tener solo tres estrechas aberturas ên el manto, una que da salida a la barba, otra que da entrada al agua respiratoria y la zercera para la salida de los excrementos y de la corriente respiratoria en su vuelia, La concha y las valvas afectan una forma triangular y sus coronillas estan situadas eu el angulo agudo del tríngulo. Las valvas son aquilladas. Caracteristica es uma placa por debajo de las coronillas que lleva los músculos de serrar. En. tre las seis especies actualmente vivientes la dreicena polimorfa de Europa llamada por Pallas mitilo polimorfo, ha pro. movido sobre todo la atencion como conchifero viajero. Co. nocemos la ripida propagacion dealgunas yerbas perjudiciales en este siglo y tambien la de algunos insectos; la dreicena en cambio forma un cjemplo único de una propagación tan rá. pida, entre los animales de inferior desarrollo. Debenzos á E. de Martens noticins exactas sobre el modo con uue este conchifero de agua dulce avanza lentamente desde el Este hasta el Oeste. El asunto es tan importante respecto à la geografia de los animales, que no podemos menos que reproducir literalmente su relato, omitiendo sin embargo muchas noticias detalladas

* Kespecto a los rertebrados, dice el citado autor, in dis tincion de las diferentes especies, data generalmente de tan poco tiempo que no pucede decirse aun nada sobre un caso histórico en su area de dispersion. La dreicena polimorfa ofrece una de las pocas excepciones de esta regla, no porque esturiera conocida mas ticmpo por los 1raturalistas, sino por. que en casi toda la Europa es la única esprecie de su género, y porque su forma no puede confundirse con ningun otro género de conchiferos de agua diulce.

DEl conocimiento de las esprecies mas notables de nuestros moluscos alemancs de agua dulce no data, excepto muy po. cas esprecies, sino de la segunda mitad del siglo anterior, con Martini en 1768 , y Chrocter en 1779 , mientras que O. 1. Muller distinguió en 1714 las especies danesas, Lin. neo desde 1746 a 1766 las suecas, Ceoffroy en $176 y$ las de la Fiancia septentrional y Lister casi un siglo antes, en 1678 . las inglesas. In circunstancia de que ninguno de estos autores ha observado el citado conchifero, indica yue éste en. tonces no vivia en las regiones examinadas por ellos, supo. sicion inaceptable en especies pequehas, pero no en este conchifero que actualmente en gran numero se encuentm en Havel, en el lago de Tegel, etc., cerca de la orilla, sobre pie. dras u otros conchiferos. Todos los naturalistas del siglo pa. sado solo lo conocen, despues de Pallas, como conchifero propio de /a Rusia meridional. La fecha mas antigua de una publicacion referente á su area de dispersion es 4 año rS25, en que C. E. de Baer dice que se encuentra en innumerables masas en el Haff Frisch y en el Haff de Curlandia, lo nismo que en los grandes rios á muclias leguas de distancia del inar, fijandose en colonias, en las piedras y sobre todo en otras conchas, por medio del biso.

- En el mismo tiempo se le habia encontrado en el Havel. rerca de Postdam, y en los lagos vecinos. Todos los recuerdos jersonales y noticias impresas ņue respecto á esto he podido encontrar en Berlin, nos conducen de un modo unanime al mismo periodo. Algunos años mas tarde, en ${ } \$_{35}$, llamo la atencion en la isla de los Pavos Reales, cerca de Postdam, donde se fijaba en colonias en los palos y estacas. Desde este tiempo ha quedado establecido en el Havel y en el lago de Tcgel, presentándose últimamente ambien en el Spren, en las inmediaciones de Berlin. La presencia de este conchifero en el Danubio puede demostrarse con seguridad hasta 1824.0

En el Elba ha subido hasta Magdeburgo y Halle. En !a desembocacura del Rhin se le vió por primera vez en $1 \$ 26$; pero ahora se ha extendido å Hueningen y Heidelberg. Dusde Holanda se ha propagadio hasta el norte de Francia y. Paris, y ultimamente ha inmigrado desde el territorio del Sena hasta el del Loire. En Inglaterra, en fin, se lc conoce desde 1 2 4 , primero en los astilleros de Lóndres, ahora habita ya diferentes rios de Inglaterra y Escocia.

Aunque no podamos fiarnos mucho de los datos sobre la primera aparicion de cstos conchíferos en los rios de la buropa central, esta aparicion, verificada casi al mismo tiem. po en los principales territorios fuviales de Aleminia é Inglaterra, es de gran importancia Su viaje es probiblenente involuntario, y se ejecuta por medio de los barcos y balsas en que los conchíferos se han fijado, haciendo con aguellos el camino por los rios y canales navegables, cuyos últimos li ayudan a trasladarse de un rio a otro. Contra esta suprosicion se ha dicho que tambien se encuentra en algunos lagos sin comunicacion navegable con rios, por ejemplo, en Meklemburgo y Pomeranin, y además, sobre todo, en la Turq̨uia Eu. ropea: para Albania esta objecion tience alguna inpportancia, pero la tiene menos para las regiones del Báltico, porque aqui solo dernuestra que cicepcionalmente tambien se pro paga i pequeñas distancias por otros medios. La regla, sim embargo, es, que en el territorio del mar del Norte j: del Bál. tico, solo se encuentra en aguas naregables. Por lo que toca a su trasporte por mar haicia las desembocaduras del Rhin y hácia Inglaterra, parece mas probable que se verificó con madera de construccion dentro del buque, que por fuera de este por el agua del mar. En una colonia grande y humeda en su interior, algunos individuos pueden conservarse, sin duda, varios dias por el agua, y probablemente por inas tiempo que en el agua marina, perniciosa generalmente para los 
animales de agua dulce. La dreicena, empero, no es al ınismo tiempo, segun se pretendia, animal de agua dulec y de mar, por lo menos no mas y hasta inenos que la neritina entre los moluscos. En el Báltico solo vive dentro de los hafis, pero no por fuera, y en el territorio del Oder, en la isla de Wollin, solo le encontré en el lado de la misma que da al hafis, pero no al lado marino; cerca de Swinemunde lo observé aisladamente en la cara interior del terraplen, en sociedad ó en compania de la paludina impura y del lemneo ovato, verda. deros moluscos de agua dulce; pero ya no en el lado exterior del terraplen donde de los otros moluscos de agua dulce solo se encontraba la neritina Ruvial. En la playa abierta del Bältico de Misdroy, el nitilo comestible representaba el mismo [anel que en el haffs y en el Havel representa la drcicena, que es el de cubrir las piedras y los palos.
sParece, por lo tanto, probable que la dreicena ha llegado i Alemania é Inglaterra, no desde el Bítico, pero desde los paises de su costa. El resultado de la areriguacion sobre el origen, es que la drejcena ha llegado desde la Rusia meridiomal por los caminos de agua naturalesy artificiales en menos de un decenio a las provincias del Báltico, y desde alli igual. mente, por caunles interiores, hasta el Havel. Desgraciadamente no se ha podido resolver aun la cuestion de si la dreicena polimorfa debe considerarse tambien en el territorio del mar Negro como una especie inmigrada en tiempos his. tóricos y en su forma actual.

\section{LAS PINAS-PINA}

Por una cualidad muy importante que hasta se ha apro-

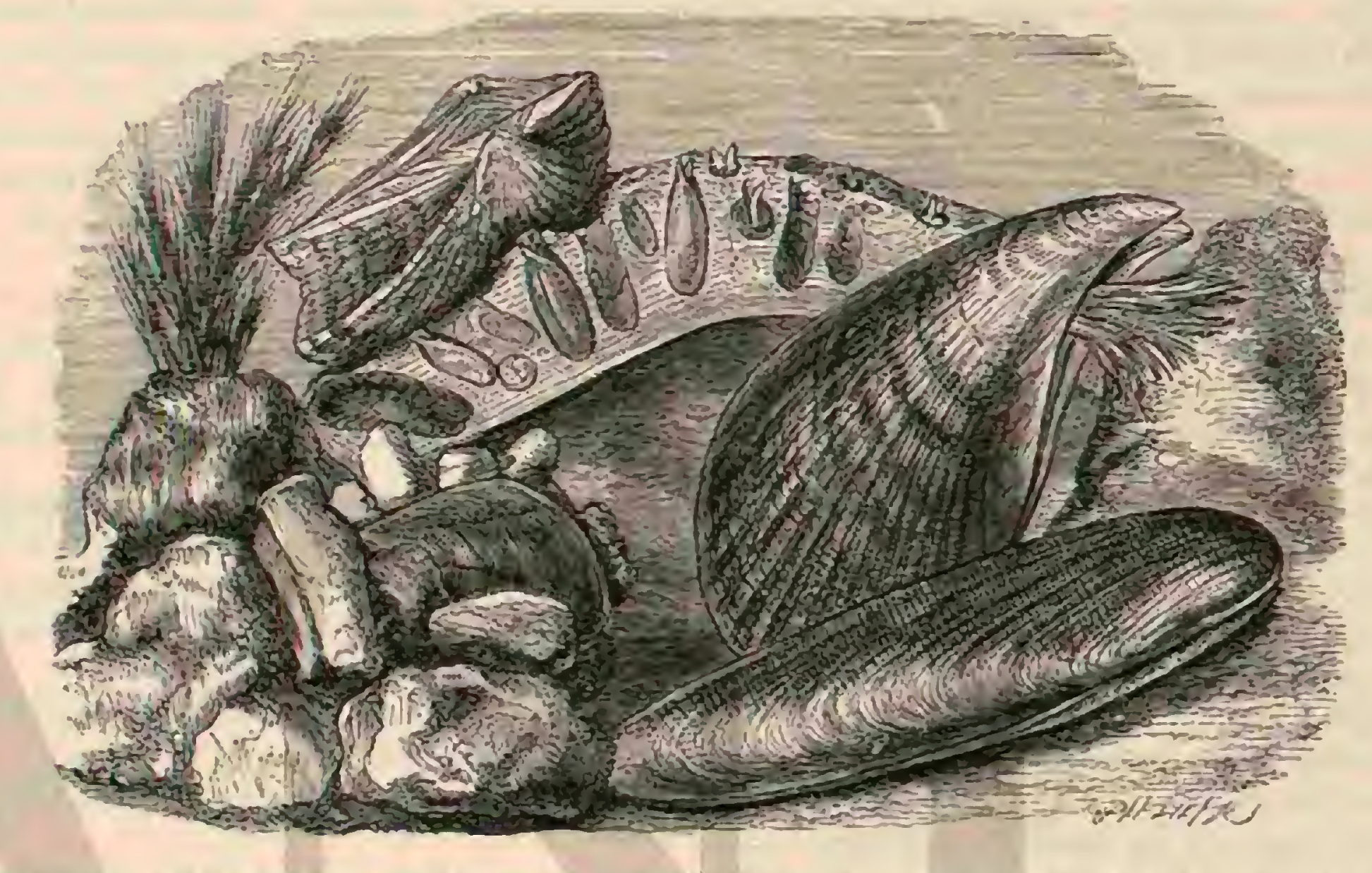

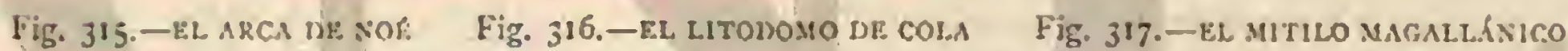
Fig. 3iS. - EL MitII.O COMESTIHLR Fig. 319.-Li. ITOnONO Eitrórsco

vechado para fundar un órden independiente, el de los heteromiarios, sigue i los mitiláceos el género de las pinas: estas tienen los dos músculos de serrar desiguales y situados sobre todo en distancias nuy desiguales del borde. El manto es del todo hendido y carece de un tubo anal. lil primer músculo de serrar se halla inmediatamente por debajo de las co. ronillas, el posterior casi por el centro del animal. La concha de las pinas se compone casi solo de columnitas pirnunidales; es delgada, a menudo cubierta de escamas, entrcabierta en su parte posterior. El ligamento es interno, de modo que li. mita la facultad de la concha de abrirse.

la pina noble (fig. 32r) es la especie que se cita como tipo.

Las pinas viven en los mares cálidos y templados, y llegan en partes a una longitud de dos piés, como la pina escamosa del Mediterrineo. Les gustan las bahias tranquilas con un fondo cenagoso, en el que, a una profundidad de algunos piés, viven sociablemente en grandes masas. Se las persigue ya por su buena carne, ya por el biso, del que en la Italia inferior se hacen toda clase de mimbres y icjidos, pero mas. por curiosidad que porque se hiciese de ellas un articulo de cornercio.

Los antiguos ya han observado q̨ue muy á menudo la pina alberga en la cavidad de su manto un cangrejo redondeado, que llamaban pinnotheres ó finmophylax, el vigilante de la pina. RTa obligacion de estos vigilantes, dicc Ruph re- produciendo la noticia de Plinio, consiste en que deben pe. llizcar la pina cuando existe algun alimento en la concha, $\delta$ cuando hay que temer algun peligro, para que el conchifero contraiga en seguida sus vảlvulas. Plinio anade q̨ue el vigilante recibe por sus servicios una parte de la presa. Con auterioridad hemos hecho mencion de csta fábula. Apenas uecesilamos decir que el papel atribuido al cangrejo en favor del conchifero, no es mas que un cuento bien inventado.

\section{LAS MACTRAS-MACTRA}

CARACTERES. - Lats mactras son moluscos marinos que tienen la concha trasversal inequivalva, triangular, algo abierta por los lados y con los.nates protuberantes. En cada una de sus valvas se advierte un diente cardinal comprimido y doblado, que forma un canal, y cerca de ella una hendidu. in saliente: en la charnela se ven dos dientes comprimidos y entrantes; el ligamento, gue es interior, se inserta en hendidura cardinal.

Por uno de los lados de la concha se ven salir dos tubos. que forman con el manto un pié musculoso y comprimido,

Fastos moluscos viven sumergidos en la arena, á poca distancia de la desembocadura de los rios.

Se puede considerar como tipo de la especic la mactro de fico (fig. 330). 


\section{LAS TELINACEAS - TELLINACEA}

Continuamos ahora algunas de las familias, $\delta$ cuando menos géneros, como representantes de las mismas, cuyo manto acaba en su parte posterior en clos tubos o sifones mas ó menos largos, y cuya concha presenta la escotadura del manto.

Una de las familias de conchiferos mas ricas en especies es la de las tellináceas. El animal tiene el manto dividido en toda su longitud; el pié es comprimido y no produce nunca una barba; las bränquuias afectan la forma de hojas, $y$ las valvas de la concha son bastante igunies.

Las especies pertenecientes al grupo estan diseminadas en todas las regiones de la tierra y viven libremente en la - arena, habitando en el mar ó en el agua dulce.

Entre las especies marinas hay muchas comestibles, sobre todos del género vénus (fig. 324), algunas de ellas notables par la belleza de los colores y por toda clase de excrecencias espinosas: desde hace algunos años estos animales se con. servan vivos en los acuarios, donde se fijan en el cieno. Tam. bien las citéreas (fig. 325) se encuentran en diversos mares. Despues del género vénus, el mas rico en especies es el de las telinas, del que se conocen mas de doscientas especies. Sus conclias son planas y por lo regular de un color muy delicado. Muchas especies de telinas y de donax pueden avanzar saltando, sirviéndose del pié como de una es. pecie de muelle.

Para la observacion y el exámen cientifico se han clegido con preferencia algunas tellináceas pertenecientes al agua dulce, sobre todo del género ciclas, bastante rico en espe. cies, y cuya área de dispersion es muy extensa. Raras veces penetran en el cieno, pues se mueren libremente por medio de las bránquias, y segun se dice pueden suspenderse $y$ reptar como los moluscos acuáticos en la superficie del agua. La especie mas grande es nuestra cyclas ricicola, que. alcanza $v^{m}, 02$ de longitud; las otras, entre ellas la gyclas córnen, apenas mide la mitad. Los huevos de estos animales se desarrollan en la cara interior de las bránquias en una especie de bolsas de cria. Stepanof ha observado últimamente que el origen de estas bolsas presenta gran abalogia con las prominencias que en el género de sapos pipa se forma al. rededor de los huevos colocados en torno de la hembra. Stepanof encontró por lo regular en una brainquia toda una serie de bolsas en diferentes grados del desarrollo.

«En las prineras fases del desarrollo los pequeños ciclas se mueven libremente en las bolsas, nadando en el liqquido contenido en las mismas con auxilio de sus pestañas. Mas tarde, cuando los animales son mayores y mas pesados, llega para ellos un estado de reposo durante el cual se desarrollan el manto, la concha y los órganos internos.

\#Por lo que toca al alimento de los embriones durante su permanencia en las bolsas, se compone de las mismas celdas mucosas de que están rodeados. I.os ciclas se distinguen por este concepto de todos los demis lamelibranquiados que durante la permanencia en las bránquias de la madre conservan todos la císcara de sus huevos, alimentándose de la clara contenida en cllos. $\$$ Sucede por lo tanto lo mismo que con los moluscos de los géneros púrpura, bocina y nerita, en los que algunos hijuelos se alimentan á expensas de los otros huevos.

Los pisidios, géneros propios igualmente del agun dulce, difieren de los ciclas por sus sifones cortos $y$ soldados y por la forma desigual y oblicua de la concha. Ias especies perte. necientes à este grupo son, por lo regular, mucho mas pe. queñas.

\section{LAS SAXICAVAS - SA- XICAVA}

Ia familia de las saxicavas tiene en nuestros mares una serie de representantes entre los que, la saxicuía rugusa, es el mas comun. Todas las saxicavas tienen el manto en su parte anterior tan hendido, que el pequeño pié cónico, provisto de una barba, puede pasar cómodamente. La concha es á menudo, sobre todo en la saxicara rugosa, un poco irre. gular, entreabierta por delante y en el borde central de forma oval prolongada, y cubierta de una epidermis muy ténue. Son por lo regular animales pequeños, de $0^{\prime \prime}, 00 \mathrm{r}$ a $0^{\circ}, 00 \mathrm{r}$ y -medio de largo, que viven en las piedras, en agujeros practicados por ellos mismos, 6 solo en hendiduras 5 entre las raíces de diferentes algas. Perforan lo mismo que las folas solo las piedras blandas, $y$ donde estas faltan, se contentan con pequeños escondites llenos en parte de cieno. Asi por lo inenos me parece á mi, por lo que he visto yo mismo; Gosse, cmpero, dice que en la costa inglesa miles y miles de saxicavas han perforado largos espacios de una piedra calcárea mas dura que la en que viven las folas. Cuando las galerias de estos conchiferos se encuentran una con otra, los animales se perforan tambien entre si; sacados de sus escondites se conservan bastante tiempo vivos en los acuarios.

\section{LOS HIPOPOS-HIPPOPUS}

CARACTERES. - Estos moluscos tienen la concha equival 'a, regular, incquilatera y irasversal, con la lúnula cerrada; su charnela presenta dos dientes comprimidos, desiguales, anteriores y entrantes; el ligamento es marginal y anterior.

Ia única especie que representa á este género es el hipopo mancherdo (fig. 326).

Este inolusco es propio del inar de las Indias.

\section{LAS MIAS-MYA}

Con las mias pasamos a otra familia cuyos caractéres son poco mas ó menos los mismos del género anterior. 'El animal tiene el manto casi del todo cerrado; los palpos labiales son muy pequeños; de las brainquias, la exterior es corta y la interior está soldada con el lado opuesto. La concha, oval, se entreabre en varias extremidades. In valva izquierda tiene por debajo de la coronilla una especie de diente, y la derecha un hoyo parn encajarle.

Entre las pocas especies conocidas, la mia arenaria (fig. $3 \geq 8$ ) es muy comun en todo el Océano septentrional. Vive oculta en la playa arenosa, sobresaliendo en el estado de descanso solo con la extremidad franjeada de los tubos del manto. Tan luego como se la inquieta se retira con la mayor agilidad á su agujero. Las mias sirven de alimento en algunos puntos a las clases pobres de la poblacion, pero mas bien las emplean como cebo.

De una importancia científica son varios géneros fósiles de las mias, por ejemplo, las foladamias, de los que solo se conoce una especie muy rara de las Indias orientales, que sirvio pära la clasificacion de las especies fósiles de la creta $y$ de las formaciones del Jura.

\section{LOS SOLENES - SOLEN}

Los solenes tienen, por su vitalidad, gran semejanza con las mias, á las que además se parecen por estar la concha entreabierta en las partes anterior y posterior, $y$ revestida de 
una fuerte cpidermis parda, à menudo aspera en la region de las coronillas. Fl pie sale de la hendidura interior del manto y sirve para perforar la ligera arena de la playa. Los conchi. feros, que como los mias, tienen la concha mucho mas gruesa que el pié, deben ensanchar penosamente con la concha el agujero practicado por aquel; en los solenes, en cambio, la cuña del pié tiene casi la misma anchura que la concha, por lo cual los animales penetran con gran rapidez en la arena. I os solenes, que en las costas del Mediterráneo sirven de alimento á la gente pobre, bajo los nombres de copa lungra y cafa di Dio, se cogen acercindose á ellos cautelosamente para sacarlus con la pala, ó bien introduciendo en su agujero una barra de hierro delgada, provista de un boton, que des. pues de penetrar en la concha, sirve para extraer el animal.

En las costas europens son comunes tres especies: el solen injirial (fig. 332), el solen ensis y el solen siligna. Fs muy curiosa la especie solen salike (ijg. 3j1). Deshayes dice de un solen africano (solen marginabus), que cuando llega a un terreno pedregoso llena la cavidad del manio de agua, cierra las aberturas de los tubos y retira despues repentinamente el pié, de modo que el agua sale con violencia de los sifones y por su impulso el cuerpo avanza uno ó dos pies de distancia. Esta maniobra se repite hasta que el animal ha llegado á un terreno favorable.

\section{LAS ESCROBICULARIAS -SCROBICULARIA}

CARACTERES. - Fil atributo distintivo de los moluscos comprendidos en este género consiste en las dos largas pro: longaciones que en forma de sifon se proyectan fuera de la concha, constituyendo una especie de tubos; el mayor de cllos sirve para la entrada del agua, y el mas corto para la salida.

Ia especie tipica que representil este género se designa con el nombre de escrobicularia ficonte (fig. $3^{29}$ ): que se le aplicó sin duda por tener esta cualidad, segun dicen los que utilizan como alimento la carne de este molusco.

\section{LAS FOLAS-PHOLAS}

Ins folas nos conducen al grupo de los conchíferos, que à menudo por su forma muy prolongada se ha considerado como un órden independiente, el de las tubicolas. Eil animal de las folas tiene un cuerpo prolongado y el manto casi del todo cerrado; en la parte anterior de cste se halla un agujero circular en el que se encuentra el pié; este es muy fuerte, corto y ancho, rematando en una placa que parece servir de ventosa. I a concha es prolongada y entreabierta por delante y por detras. Ia union de las valvas es muy diferente de la de los conchiferos de estructura natural. Un apéndice interno en forma de cuchara en cada valva, recuerda la parte analoga en las mias. Una hoja calcárea, doblada en cada lado de la region de la abertura, esta perforada de una série de orificios por los cuales penetran algunas partes musculosas que se fijan en dos pedaros de concha sueltos, situados en el dorso. Mu. chas folas, como por ejemplo la fola dactylus (fig. 333), tienen dos de estas placas dorsales, otras solo una. En todas las especies, las conchás, siemprè blancas, están próvistas de series de dientecitos y puntas que comunican á la superficie el aspecto de un raspador tosco. Mucho se ha observado y escrito sobre el modo de perforar de las folas sin obtenerse una ex. plicacion completa. Harece que nuestras verdaderas especies de folas solo perforan en las piedras y maderas blandas. To. mando en consideracion exactamente la musculatura, Ossler ha descrito el medio de que se valen estos animales para prac: ticar los agujeros donde viven, sirviéndoles la concha de lima. "Las folas, dice, tienen dos modos de perforar. Por el primero se fijan con el pié y se levantan casi verticalmente, oprimiendo la parte activa de la concha contra el objero en que se agarran. Despues dan una serie de vueltas sobre su eje, rolviendo cada ver á su posicion vertical. Este modo de perforar se practica casi exclusiramente por los animales jóvenes que penetman verticalmente; pero tan luego como han llegado á dos $\delta$ cuando menos tres lineas de longitud, cambian de direccion y trabajan horizontalmente, impidiéndoles el peso de la concha erigirse verticalmente como antes. En el ensanchamicnto de las galerias, los músculos de serrar son una parte esencial. El animal, fijado sobre su pié, pone en contacio las extremidades anteriores de la concha una con otra. Despues se contraen los músculos, levantan la parte posterior de la concha y oprimen la parte activa de la misma contra el fondo de la cavidad; un momento despues la acti. vidad del músculo posterior de serrar ponc en contacto uno con orro los bordes dorsales de la concha, de modo que las partes fuertes en forma de lima se separan de pronto y rozan rápidamente y con fuerza contra el cuerpo que oprimen. Ia extremidad posterior baja despues, y todo el trabajo empieza de nuevo. En efecto, fácil es reconocer en todos los individuos que los dientes de la parte anterior de la concha de las folas estín desgastados y redondendos por el roce. Su materia es bastante sólida y produce sin duda efectos en sustarcias mas blandas. El naturalista inglés Hancock decia haber encontrado en varios conchiferos perforadores, y tambien en lis folas, en el borde anterior del manto y en el pié, cuerpeciros siliccos microscópicos que sin duda perforaban, al mo. verse aquellas partes del cuerpo, la madera $y$ la piedra. La existencia de estos cuerpecitos, sobre todo en las folas, es sin embargo dudosa. Cierto que encontré en el pié y en el manto de la folas digital del Adriático algunos frngmentos de silex y cuerpecitos cristalinos, pero tan irregulares, tan poco nume. rosos y en una posicion tan indeterminada, q̨ue sin dıda son cuerpos intrusos. 'lambicn otro observador apoya la opinion de que las folas practican sus agujeros por medio de la concha.

«Tuve ocasion de estudiar, dice John Robertson, durante mi estancia en Brighton, la folas digital, conservando cuando menos tres meses 20 ó 30 de estos animales en pedazos de creta sumergidos en agua de mar. La folas practica su agujero rozando la creta con su concha; coge el polvo con el pié y empujălo hảcia afuera por medio del sifon. Parece sin embargo que en las sustancias muy blandas, el disco del pié basta para la excavacion. Mettenheimer obserró una folas cuya extremidad anterior se habia introducido solo a pocns lineas de profundidad en un pedazo de turba marina, pero al cabo de tres dias habia desaparecido en el interior de aquella. Mientras el animal trabajaba, veiase como el espacio libre en el agujero, al lado de la concha, se llenaba poco a poco de fino polvo de turba, que por fin salia de la desem. bocadura de la cavidad. El observador solo pudo atribuir al pié esta operacion. Aungue despues de estas noticias no podemos dudar de la actividad mecánica de las folas al perfo. rar, no queda escluicia la posibilidad de que cualnquier secrecion del conchifero produzcs un efecto disolvente que facilite el trabajo.

Otra particularidad de las folas es la fosforecencia. Panceri ha explicado el procedimiento y la naturaleza de este fenómeno. Cuando los animales sacados de sus agujeros se dejan tranquilamente en una vasija con agua de mar, observindolos en la oscuridad, no se ve fosforescencir alguna; pero si se les toca y mueve, jroducen como unas exhalaciones brillantes que poco á poco fosforecen del todo. Es una 
sustancia mucosa que se separa del animal y se adhiere it todo aquello con que se pone en contácto. la tosforescencia de la materia se pierde tan luego como esta se ha reposado, pero reaparece cuando se repite el movimiento. Los órganos de que se segrega la sustancia mucosa, no muy grandes, estan situados en el borde superior del manto, en la abertura anterior del tubo, y afectan forma de dos fajas paralelas en el sifon respiratorio. Son aglomeraciones de celdas con un contenido grasoso.

Entre las especies mas conocidas merece consignarse la folas calloso (lig. 335.)

\section{LOS TEREDOS-TEREDO}

l.os conchiferos perforadores hasta ahora citados, apenas pueden contarse entre los animales dañinos: pero a las folas sigue una especie que lo es mucho, el teredo, sobre el que reproducimos en primera línea algunas noticias históricas, recogidas por Johston. \&los destrozos que ocasiona este animal vermiforme son bastante grandes, para justificar tanto cl ódio que se le profesa como la severa expresion de Linneo, que le llama calamilas narium (la perdicion de los buques.) Puede introducirse en la madera, destruir los cascos de los

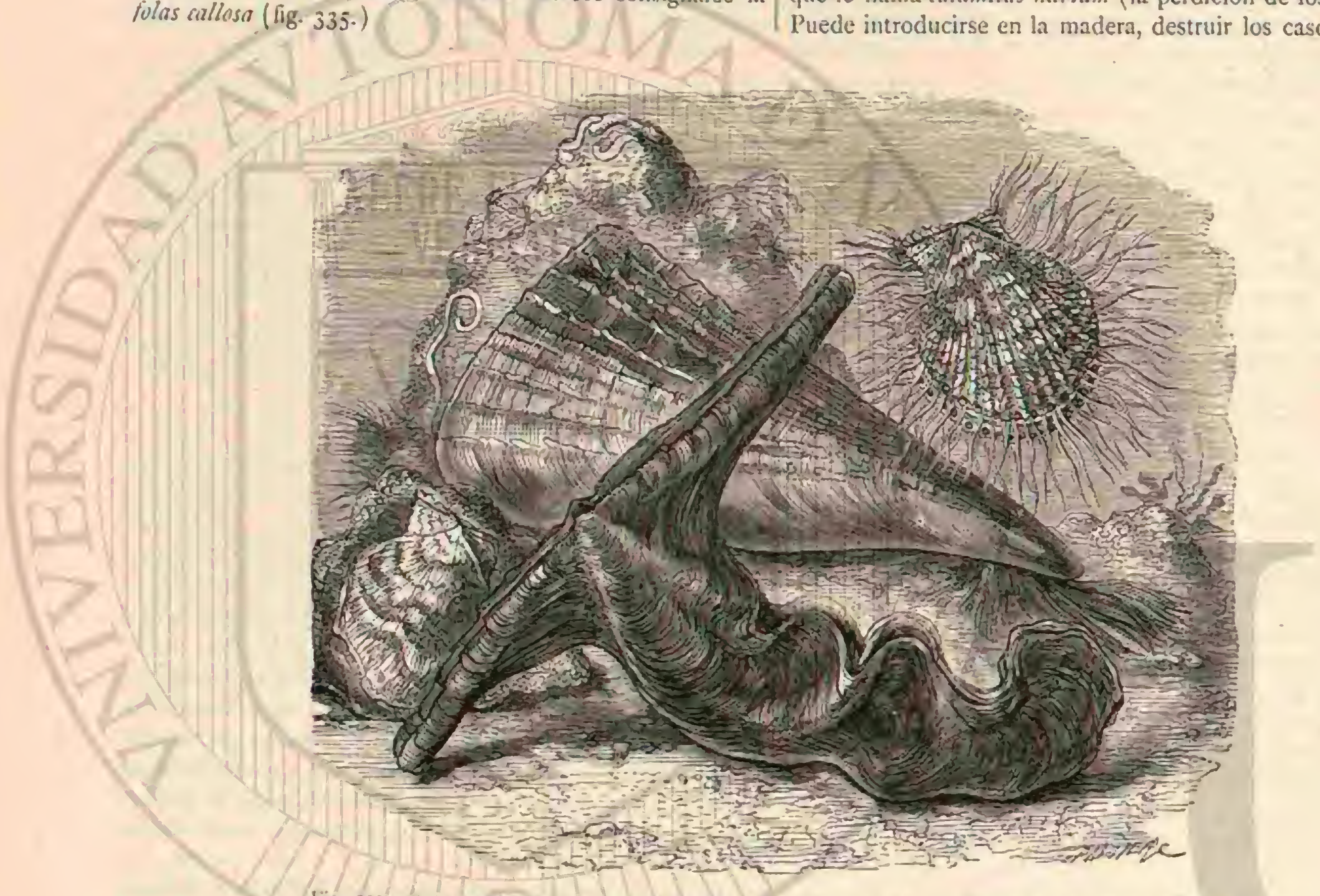

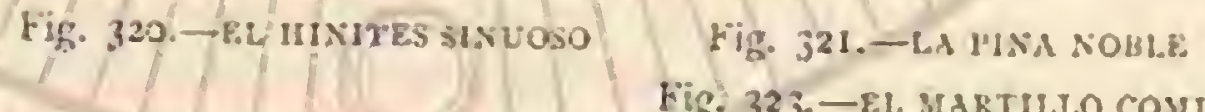

rig. 322.-E. SEINE VIARIANO

buques y toda clase de construcciones marinas; de modo que jronto no pueden resistir el impetu de las olas. Dificil es calcular los perjuicios que el teredo causa de esie modo todos los años; pero deben ser considerables, à juzgrar por las quejas que sobre este animal se elevan en casi todos los mares, y por las muchas y costosas construcciones defensivas contra sus ataques. Un vinjero desconocido dice: a En los mares de la India hay, una pequeña especie de gusanos que penetran en la madera de los buques, perforando la de modo, que por todas partes entra el agua; y aunque no la perforen en seguida, desgástanla de tal modo, que es imposible contener aquella; algunos emplean alquitran, es topa y cal, como capa de los buques, que sin embargo, no solo no bastan para rechazar al gusano, si no que es preciso tambien detencr el buque en su curso. Los portugueses queman sus buques (háblase del ano 1666), hasta que se cubren del todo de una capa de carbon de una pulgada de grueso, pero este procedimiento es peligroso porque a me nudo se incendian. La circunstancia de que el gusano no sucle perforar los buqques portugueses, solo debe atribuirse a la dureza extraordinaria de la madera de construccion em. pleada. En cl Oeste, el teredo despliega la misma actividad. Los primeros navegantes ingleses sufrieron contratiempros a menudo en sus atrevidas empresas por haberse inutilizado sus buques; y mas tarde viéronse en la precision de cubrir el fondo de estos con plomo y cobre. Por lo regular, supónese que el teredo se importó en Europáá mediados del siglo xul desde los mares tropicales, pero consta que algunas especics son jropias de nuestras regiones, de modo que no hay esperanza de verlas destruidas por un invierno riguroso. En los ẵos 1731 y 1732 en los Paises Bajos reinó la mayor cxcitacion, por haber quedado destruida la madera de los diques de Zelandia y Frislandia. Felizmente, el teredo abandonó algunos años despues estos diques; pero temiéndose que el enemigo volviera, los holandeses ofrecieron un gran premio para el que hallase el medio de rechazar el ataque de estos animales. Centemares de ungüentos, barnices y liquidos renenosos se recomendaron al punto, y dificil seria calcular el importe de los perjuicios causados por esta calainidad, que en opinion de Seelleius (que en 1733 publicó una historia natural del teredo), habia sido decretada por Dios para castigar la soberbia de los holandeses. Los autores de aquella época designan el dano, generalmente, como muy considerable, y el coctor lobias Baster cita el teredo como un animal que en arquellos paises ha causado perjuicios por valor de muchos millones. Tambien en Inglaterra ocasionó muchos 
destrozos. El tronco de encina mas sano y duro no pucde re. sistir í estos perniciosos seres, pues en cuatro $\delta$ cinco años lo inutilizan, segun varias veces se ha observado en los asti. lleros de Plymouht. Con buen éxito se la cubierto la parte de la madera que se halla bajo el agua con clavos cortus de cabeza ancha, que en el agua salada pronto cubren toda la superficic con una gruesa caja de orin, impenetrable para los teredos: á consecuencia de esta medida han desaparecido casi en los puertos de Plimouht y Falmouth, donde antes abundaban. Pero en otras regiones ha seguido destruyendo,

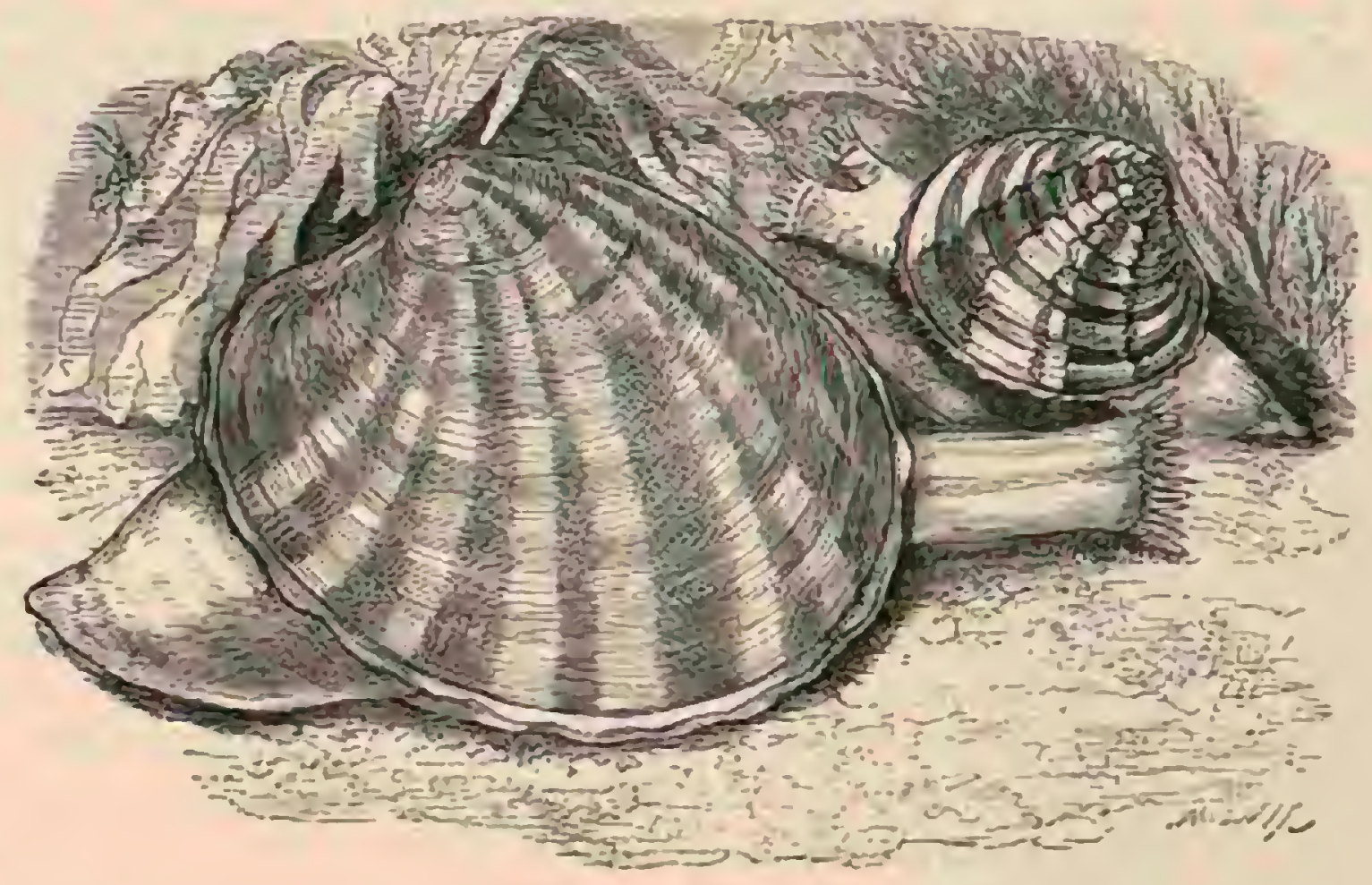

Fig. 324.-I.A VE.กUS עE VมภS

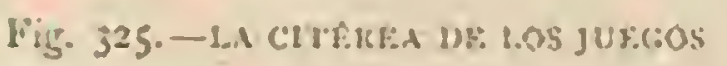

por ejemplo, en las columnas de madera del puente de Port-Patrich, en la costa de Ayrshite, de tal modo, que se cree que este animal, juntamente con un crustriceo tambien dañino (fimnoria ferclirms), ocasionaràn pronto la destruccion completa de todo el material de aquellas columnas. Ningunn clase de madera parece capaz de resistir la fuerza de este

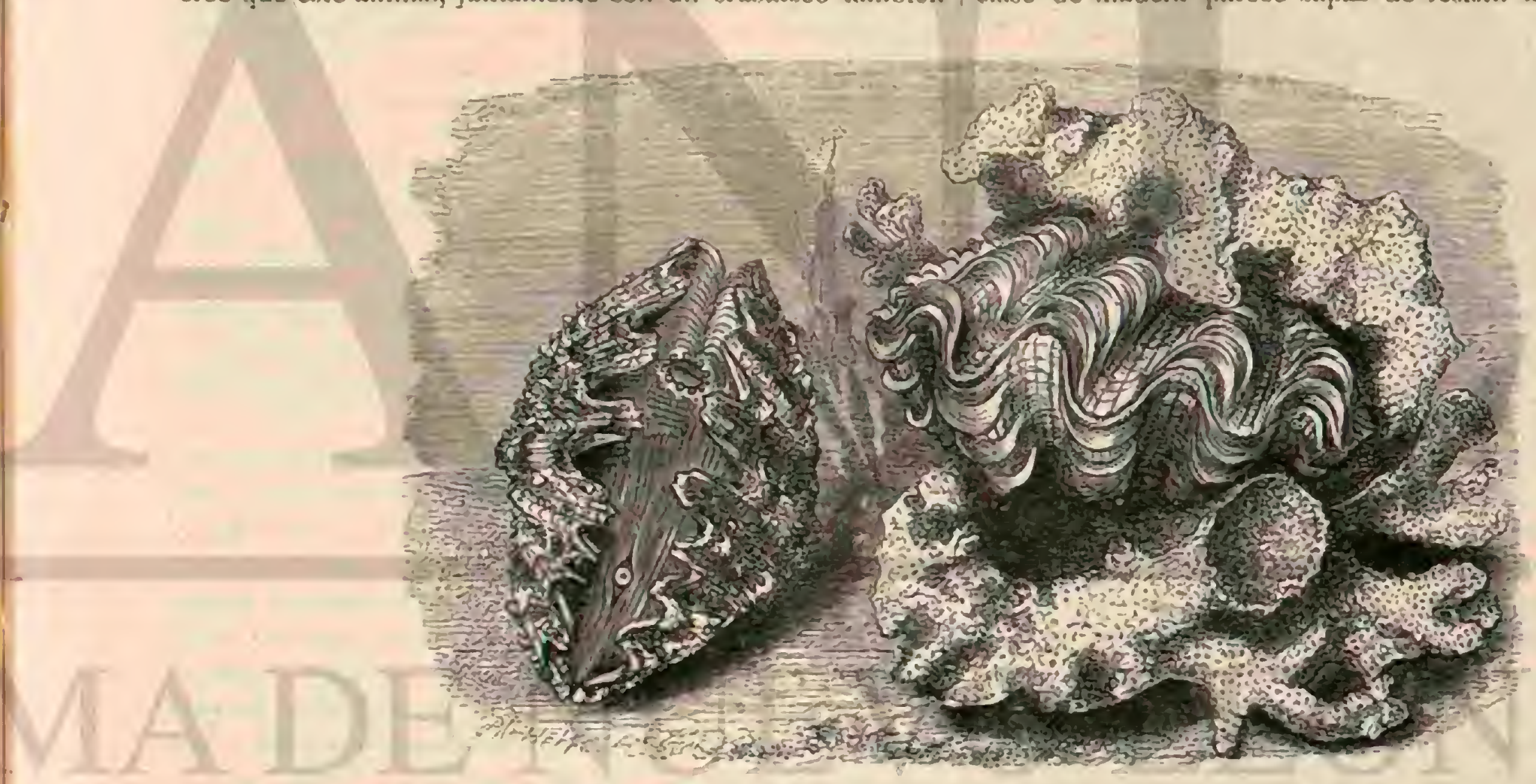

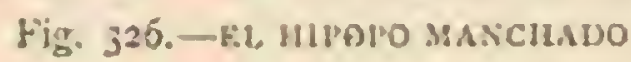

molusco, que en poco tiempo periora el tek indio (tectonsa srandis), y la madera del sisu y del stuce, clasus afines del tet, pero mas duras aun: con mas facilidad perforan las encinas y los cedros, y con major rapidez las maderas blandas, como la del aliso y del pino.

De estas noticias resuita que hace tiempo se ha rechazado la opinion de nue solo habia una especie de teredo propagada poco á poco sobre todo el globo. Hasta ahora se pueden distinguir, cuando menos, hasta ocho $\delta$ diez. especies, reunidas to. das por Linneo bajo el nombre de teredo ratalis (fig. 336). El zoólogo irancés (Quatrefages es el que mejor nos ha instruido sobre las particularidades de algunos teredos de las costas europeas, entre ellos el grande terido fortalis, culpable de la
Fig. 327. -EL TKIDACNA GIGANTESCO

mayor parte de las destrucciones arriba citadas. La concha de este animal, que se encuentra en la extremidad gruesa de la cabeza, está escotada de tal modo, que en rigor solo queda un asiillo ó una concha rudimentaria. La abertura anterior de la concha estí cubierta de tal modo por el minnto, que solo una pequeña verruga que representa el gié, puede salir de su hendidura. La parte del animal situada por detrás de esta cabeza es inuy prolongada hasta los largos sifones, y esta rodenda, con estos, con un tubo calcáreo irregularmente encorvado; alli donde el tubo del manto pasa á los sifones, se observa un fuerte musculo obisrador en forma de anillo, con un músculo trasversal que corresponde sin duda al músculo obturador posterior de los otros dimiarios, mientras que el 
anterior se halla entre las dos pequenas valvas. En este mús culo posterior se encuentran dos placas llamadas paletas, y este es el único punto en que el manto esti soldado innediatamente con el tubo arriba citado. Los órganos internos, so. bre todo el higado, el corazon, las bránquias y los órganos genitales, están situados uno tras otro, $y$ no uno por encima de otro, mientras que los rasgos generales de la estructura son completamente los de los otros dimiarios.

Reproducimos literalmente la descripccion de Quatrefa. ges que mejor ha observado el género de vida de los teredos. "Sabemos, dice este autor, que los citados moluscos perforan las maderas mas duras, y sabemos que sus galerias estän tapizadas de un tubo calcireo-con el que el animal solo estí en relacion por dos puntos correspondientes á las paletas. Nadie desconoce tampoco que los teredos pueden vaciar un pedazo de madera aunque sea del lado sano; sin que se vea por fuera rastro de la destruccion. Por fin es inexacta la opinion de que los teredos solo avamzaban en la direccion de las fibras de la madera : perforan la madern en todas direcciones, $y$ a menudo una misma galeria describen lis curvas mas diferentes, ya siguiendo la fibra, ya cortandola en ángulo recto. Por lo regular la galeria formada por el teredo solo está tapizada de cal á lo largo del cuerpo del animal, mientras que en la extremidad anterior de la madera está descubierta Adamson, obsersador excelente de molus. cos del siglo pasado, encontró que Ta extremidad ciega tenia en algunos casos la misma caja de cal, como el resto de la galeria, y algunos naturalistas que consideraban esto como uria particularidad de los individuos adultos, han fundado sobré esta circunstancia deducciones tara la afinidad sistemática de los teredos; pero Deshayes ya observó galerias que, por una pared divisoria transwersal, estaban cerradas it mayor $\delta$ menor distancia de la extremidad anterior, y yo he observado cosa análoga. Por otra parte, encontré á menudo la extremidad de la gateria de los individuos grandes abierta, mientras que en individuos mas pequeños, e indudable. mente mas jóvenes, esta extremidad estaba cerrada. Creo por lo tanto que la existencialó la falta de esta pared divi. soria es del todo casual.

"La pregunta de que nodo el teredo penetra en la madera, se ha contestado hasta ahora unanimamente considerindose la concha como un instrumento con que el animal abre su morada. Hace algunos años que en Francia é Inglaterra se han sustentado varias teorias, atribujendo la perforacion ả una actividad ya mecánica, ya quimica. Deshayes, célcbre conquiliólogo frances, está prendado de esta liltima opinion. La mejor de sus razones es para nosotros la observacion de que los músculos del teredo no son propios para dar á la concha los movimientos necesarios para practicar galerias tales como el animal las hace. Fil citado naturalista atribuye la perforacion de las galerias a una secrecion propia para disolver la madera. En esta explicacion puede haber algo de exacto, pero no me basta, porque no da cuenta de la regularidad que este trabajo presenta on toda su extension. Cualquiera que sea la clase de madera y la direc. cion de las galerias, el corte es siempre tan marcado cual si la galeria estuviera hecha con un taladro afilado con la mayor precision. Las paredes de la galeria y su extremidad exterior son todas lisas, cualquiera que sea la dureza de las capas de la madera, y se sabe que, por cjemplo, en el abeto esta diferencia es muy grande. La suposicion de que cualquier medio de disolucion pudiera trabajar con tal regularidad, parece muy dificil. Atacaria segun parece mas raipidamente las partes tiernas menos compactas de la madera, de modo qque las mas duras quedarian. Esta objecion debe hacerse tambien contra la suposicion de que la escavacion de las galerias debe atribuirse al ctecto de las corrientes de agua causadas por las pestañas.

En el trabajo de los teredos todo me parece tener el tipo de una actividad mecánica directa. Pero si el animal para esto no emplea la concha, ¿cual es el instrumento de nue sc sirve? La contestacion á esta pregunta me parece dificil. Sin embargo, quiero plantear sobre cste punto una suposicion quizas inexacta: no debe olvidarse que el interior de la gale. ría siemure está lleno de agua, y por lo tanto, tocios los pun. los no protejidos por un tubo calcirco, están sujetos $\dot{a}$ un continuo ablandamiento. Con la actividad mecánica, por débil que sea, basta para absorber esta capa ablandada, y por delgada que esta sea, basta para explicar la excavacion de la galeria, si la actividad de que se trata es continua. Como los repliegues superiores del manto, y sobre todo la capucha de la cabeza, pueden hincharse voluntariamente por la afuencia de la sangre $y$ estan cubiertos de una gruesa epidermis; $y$ como la capucha puede ponerse en movimiento por cuatro fuertes músculos, la considero muy propia para representar el papel de que se trata. Me parece por lo tanto probable, que esta destinada a raspar la madera, despues que esta se ha reblandecido por la accion del agua, y quizás tambien por una stcrecion del animal.

Debemos consignar aqui, que, contra esta suposicion, Harting; zoólogo de Utrecht, ha hecho mas tarde observaciones directas del todo diferentes. Segun él, el teredo se sirve al perforar, cie las dos valvas de su concha como de dos mandibulas ó pimntas de tenaza. Ha descubierto un sin número de dientecitos dispruestos de modo que con cada golpe, la masa de madera se parte en muy pequeños pedacitos cuadrangulares. Los dientecitos se desgastan poco, porque cortan y no mspan, y porque al crecer la concha, cada vez se forman otros nuevos.

4los teredos, continua Quatrefnges, se propagan con extremsa rapider. En Pasajes, cerca de San Sebastian (me refie. ro à un criso que puede dar una idea de este hecho), un barco se hundió, á causa de un accidente: al cabo de cuatro meses se sacó del fondo del mar con la esperanza de poder utilizar la madera; jero en este corto espacio los teredos lo habian perforado de tal modo que, tanto las tablas como las vigas, quedaron inutilizadas.

- Los teredos que se sacan de sus tubos y galcrias y se ponen desnudos en un vaso, continuan viviendo, y yo los he cunservado mas de is dias. Por eso pude ver con comodi. dad algunos rasgos de su actividad vital dificiles de observar en los conchiferos ordinarios à causa de sus conchas. De la respiracion solo hay que decir que como en todos los dimiarios se verifica con dobles tubos del manto. El agua penetra por el sifon inferior mas ancho sale por el tubo anal. Los teredos encerrados en sus tubos calcireos dejans salir a menudo sus sifones, y estos siempre se ilenen de modo que el agua exhalada no se mezcla con la que penetra en las brànquias. Los movimientos que ejecutan los animales cautivos en los vasos, se limitan á lentos ensanchamientos y a con. tracciones un poco mas rápidas, por las que ocasionalmente pueden cambiar de sitio; jero no pueden reptar. Fn sus tu. bos los movimientos deben ser mas limitados aun. Nada en la estructura de sus músculos demuestra (en oposicion a la observacion arriba citada de Harting), que puedan girar sobre su cje, ni yo he observado tal cosa. Al poner un teredo sacado de su tubo en el fondo de un vaso, queda visiblemente contraido. Pronto se despliega, y aun que aumenta tres veces en longitud, su grosor disminuje muy poco. Esse fenómeno, muy extraño á primera vista, se explica por la affuen. cia de agua bajo el manto y por la de la sangre que de los grandes espacios internos penctra il los externos. 
alos teredos ponen huevos; los seros son separados y el numero de los machos muy inferior al de las hembras, sien. do la proporcion de ambos sexos de 1 à 20 . La puesta de los hueros debe verificarse lentamente y durar mucho tiem. po a juzgar por los individuos que tuve en mis vasos. I os. huevos puestos por las hembras se acumulan en el canal branquial, donde se mezclan con los cuerpecitos espermáticos mezclados con el agua respiratoria. La presencia de las larvas en este canal podrá explicarse tambien de otra manera. Los animales tienen al principio la facultad de undar con suma rapidez. Es posible que los huevos penetren en el ca nal con la corriente respiratoria, para pasar en aqquél el pri mer periodo de su vida.

Para estudiar el desarrollo de los teredos, Quatrelages se sirvió de la fecundizacion artificial. Para nosotros, sin cmbargo, basta decir que tambien segun estos estados de desarrollo el teredo es un verdadero conchifero.

En el último estado que pudo observarse el aniunalito, tiene una concha de dos valvas, casi esiérica y de color pardo, de cuya parte central los replicgues del manto pueden alargarse con pié movible. Además el jóven molusco está provis. to en este estado de ojos y orejas. En tal grado de desarrollo salia el tubo superior de la brinquia materna, y vivian en cautividad mas tiempo aun que los individuos adultos.

Las larvas pueden, segun se deduce de la naturaleza de sus órganos de movimiento, avanzar, ya nadando, ya reptando. QCuando nadan, despliegan su aparato de pestañas que se coloca sobre la concha, cubriéndo cuando menos su mitad. Cruzan el agua con la rapidez de un rotifero ó de una hidatina, pero no nadan nunca mucho tiempo, y con inas frecuencia las larvas hacen uso de su pié.»

Mas alli, las larmas no podian observarse en su desarrullo; es bastante jrobable que poco tiempo despues se fijen en la madera y penetrando poco \& poco en clla, pasen por su última metamorfósis. Por lo demás parece que su vida es mas corta. Los pedazos de madera examinados por Quatrefages en octubre estaban por lo regular rellenos de animales. Mas tarde se hacian ya raros $y$ à tines de enero existian apenas algunos individuos. Aseguraron tambien al naturalista que solo en verano se encontraban los gusanos en gran número en la madera y que en invierno casi todos morian. Quatrefages (quiere deducir de esta circunstancia que en los teredos como en inuchos insectos, la propagacion en la especie solo está asegurada por algunos individuos que resisten la intemperie de la mala estacion, y qque tambien estos mueren poco despues de haber puesto los huevos. El teredo tiene un pe. ligroso enemigo en el nereis fucala, que sin embargo no im. pide su propagacion y sus eiectos destructores. Ias larvas de estc anélido rapaz viven juntas con las del teredo, y la forma adulta se encuentra en los tubos de los mismos. Penctra en la piel de los teredos y los devora poco á poco.

\section{LOS GASTROCENÁCEOS -GASTROCH ÆNACEA}

En la familia de los gastrocenáceos se agrupari además algunos géneros que se distinguen por su estructura $\delta$ por la de ciertos tubos particulares. Asi, poi ejemplo, en el género gastrochena el animal tiene un manto grueso, casi cerrado, que se prolonga por detrás en forma de sifoncs. El pie, muy pequeño $y$ puntiagudo, tiene un viso y la concha se compo. ne de dos valvas iguales. Algunas especies, como la gastro. chana modiolina, de la costa inglesa, vive en hendiduras de rocas y construye con pequeñas piedras y fragmentos de roca una especie de nido que envuclve toda la concha y que á su vez esta del zodo cerrado, cxcepto una abertura para los sifones. I a citada especie puede penetrar, segun se dice, en rocas blandas y duras, mientras que otras lo hacen en el interior de conchas y corales donde se rodean de un tubo incompleto.

En el otro género anine, una valva está soldada del todo con un tubo calcírco en forma de man, que se halla libremente en la arena, ó bien fija en corales y rocas. La extremidad anterior tiene a menudo una hendidura y varios tubitos abicrtos, mientras que la yosterior es librc. Estos tubitos se

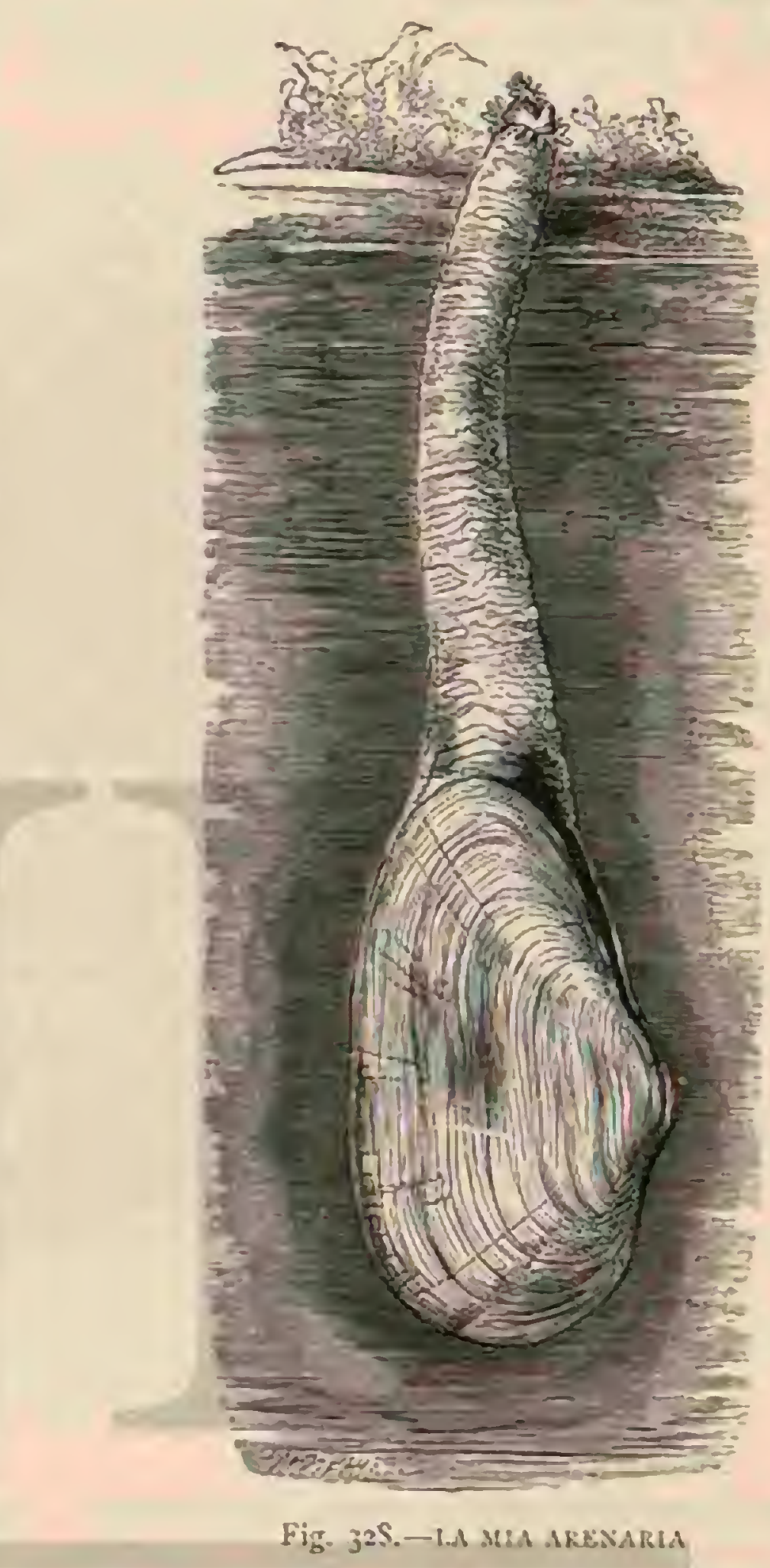

segregan por unos hilos carnosos que sobresalen del manto en número indeierminado. Los animales, dos de cuyas espe. cies habitan en el Mediterranco y lis otras en los mares de la zona cálida, constituyen el transito i los aspergilos, propios de los mares meridionales, hasta el mar Rojo, y que con su concha están verticalmente en la arena. De la existencia de las dos valvas, que si bien encerradas en la concha quedan siempre marcadas, puede deducirse con seguridad que los individuos jóvenes no difieren mucho por su aspecto de los otros conchiferos de estructura normal. Una de las especies mas conocidas de este género, es el aspergilo de mangas (figura 334).

\section{LOS CARDIÁCEOS - CAR- DIACEA}

En las familias y géneros siguientes falta la escotadura del manto: nos limitaremos a la descripcion de una sola.

Los cardiáceos estån representados, entre los conchiferos ahora vivientes, casi solo por el genero de los cárdios, cuya 
concla tienen la forma de corazon y coronillas salientes en. roscadas, desde las cuales se extienden unos surcos en forma de radios hácia el borde (fig. 338). Este animal tiene el manto hendido longitudmalmente hasta mas de la mitad y el pie es muy grande redondo, y encorvado en angulo; dis. tinguiéndose de el cl cardio tuberculoso (fig. 339) por sus tubos prolongados.

Gosse hace la descripcion de una zona de la costa inglesa, abundante en cardios. Examinemos hoy la arena, dice. Una ancha superficie arenosa, por vacia que parezca, es un terreno favorable para el naturalista, sobre todo cuando esta cortada en varios puntos por las rocas. Nos dirigimos it la arena de Goodrington, en la bahia de 'Torquay' (costa meridional de Devonshaire), arena que tiene las condiciones descritas.

- Seguimos nuestro camino por la carretera á lo largo de la costa alegrándonos de la abundancia de flores que guarnecen los bordes del camino. Despues de volver nuestra mirnda hácia las colinas de 'Torquay, llegamos al pueblo de Paingtonc, cuyas casas están tan rodeadas de manzanos, que solo en algun punto sobresalen los techos de paja como islas en un mar de flores rojizas. En el otro lado se extienden espesuras de sauces, cuyas raices se sumergen en agua tran.

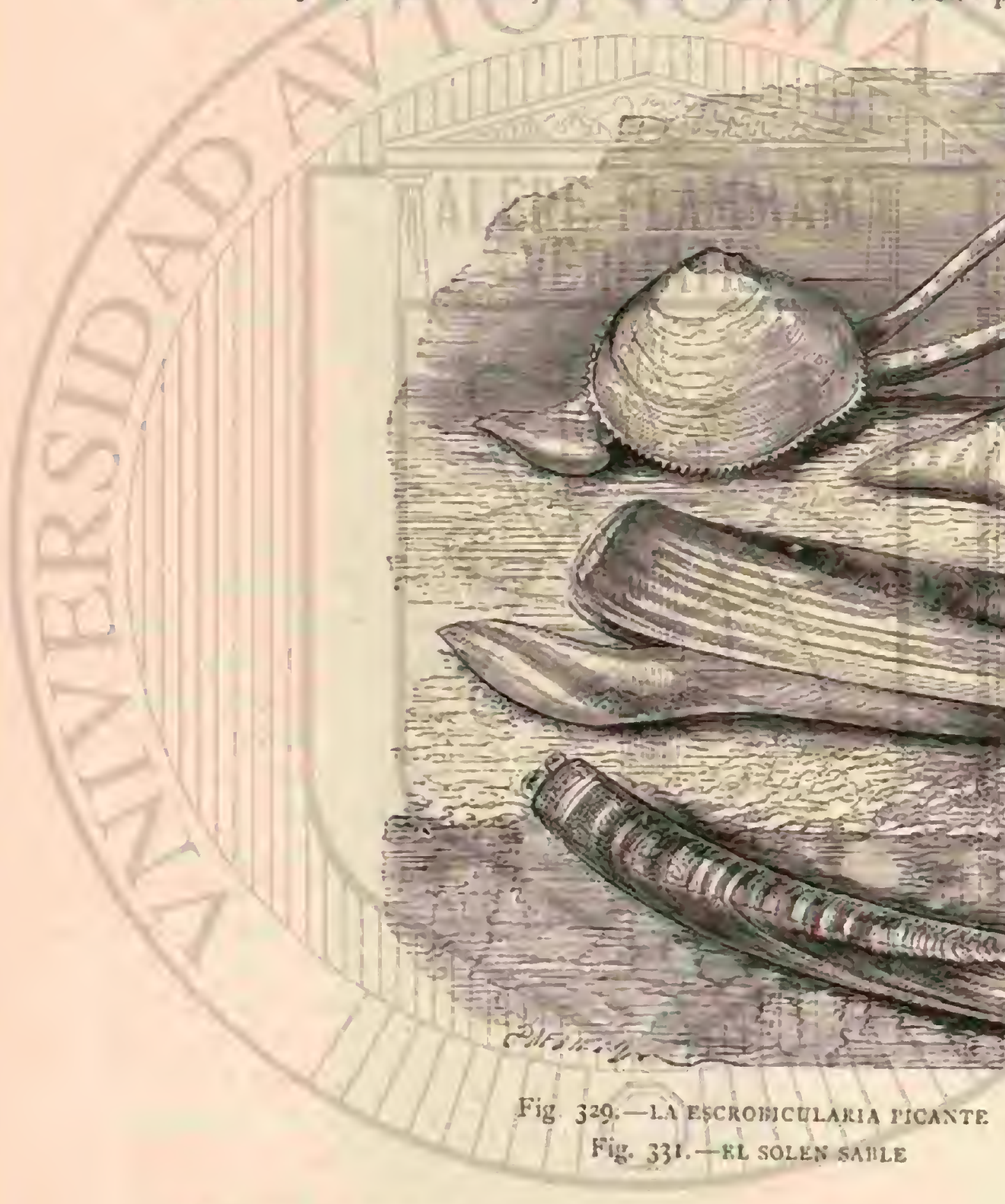

quila; y por fin se abre à nuestra vista toda la extension de la costa y el mar, cuya superficie plateada apenas se riza por un ligero soplo de viento; mas allá, en alta mar, unas líneas of fajas de un azul intenso permiten reconocer que alguna ver. el viento agita las aguils.

* Hemos llegado á la arena de Goodrington. A su izquier. da elévase una roca conocida bajo el nombre de a Cabeca de Roundhamy: al otro lado remos la \& Nari\% de Hopes con sus dos islotes. En la parte opuesta vemos la Cabeza de Berry, y nos encontramos en el borde de la profunda ensenada, poco mas ó menos, en medio de los dos cabos. Inmediatamente por delante de la desembocadura de los verdes sotos çue se extienden hasta el mar, hállase una negra mole de rocias bajas, en medio de las cuales hay charcos de agua estancada, pequeiros y graciosos jardines marinos en los que flotan las hojas verdes de la ulba, que, juntamente con otras plantas marinas, sirven de albergue â miles de séres vivos, vigilantes e inquietos. Es dificil andar, a causa de la desigualdad del suelo, y porque el reflejo del sol hace dificil ver donde debemos poner el pié, mientras que las pequenas olas se agitan de continuo, haciéndonos creer que todo está en movimiento bajo nucsiros piés.

Mas allá, donde el agua es poco profunda, se descubre de

ver. en cuando un objeto que parce una piedm, pero tiene un apéndice de un bonito rojo cscarlata: esperamos el momento en que baja la ola para acercarmos á 61 , y encontramos un bonito individuo del gran cardio espinoso, cuya especic ha hecho célebre todas las costas arenosas que rodean 1 a gran ensenada de lorquay. En efecto, este conchifero ajpe. nas se conoce en otra parte; de inodo que en las obras se le designa ámenudo como cardio de Paingtone. Guisado de un modo conveniente es una verdadera golosina. Al efecto los habitantes de Paingtone lo recogen en cestos $y$ despues de haberlos limpiado algunas horas en agua fria, los frien con una pastia de migas de pan. Asi lo decia un antiguo conocedor de las conchas de estas especies en el siglo pasado. Los animales no han variado desde entonces nada en sus costumbres y su residencia, ni tampoco han perdido nada de su fana; muy al conirario, merecen el favor de los paladares mas refinados, contentándose los pescadores con el mas pre. queño y menos fino cardio comestible (cardium edule), el cual prefiere a la arena, los bancos de cieno en las desembocaduras de los rios, aunque no escasea tampoco en aquella. 1 a última especie, si bien no tan fina como la otra, es mas importante como alinento hunano, por tener un área de dis. persion mas extensa y porque se encuentra en enorme nú- 
mero. Hombres, mujeres y niüos recogen miles de estos conchiferos para comerlos ó venderlos en las ciudades.

\Abundan sim embargo en las costas del N. O. de Escocia, donde constituyen una necesidad vital para la clase pobre, que por lo regular depende de este alimento. En la desembocadura de un rio cerca de Tongue, dice Mac Culloch, el refujo es considurable y los largos bancos de arena ofrecen una abundancia de cardios sin ejemplo. A menudo se emplean de 30 i 40 caballos de los contornos para trasportar cargas enteras de esos conchiferos á muchas leguas de distancia. Sin este alimento, muchos hombres habrian perecido de hambre.
(Tambien las islas Barra y Norduisch tienen abundancia de tales moluscos. $x$

No es ficil, segun Wilson, calcular la acumulacion de tales bancos de conchiferos, pero si diremos que durante muchos años todas las familias de Barra debieron alimentarse de estos moluscos, $y$ se ha calculado que en ese tiem. po hubo veranos en que todos los dias, desde mayo hasta agosto, se recogieron de 100 i 200 cargas de caballo. Ios bancos de Barra son muy antiguos: un autor hace mencion de ellos y dice que en todo el mundo no hay arena mas favorable para los cardios.

«Pero ya es tiempo de decir algo del conchifero, que se

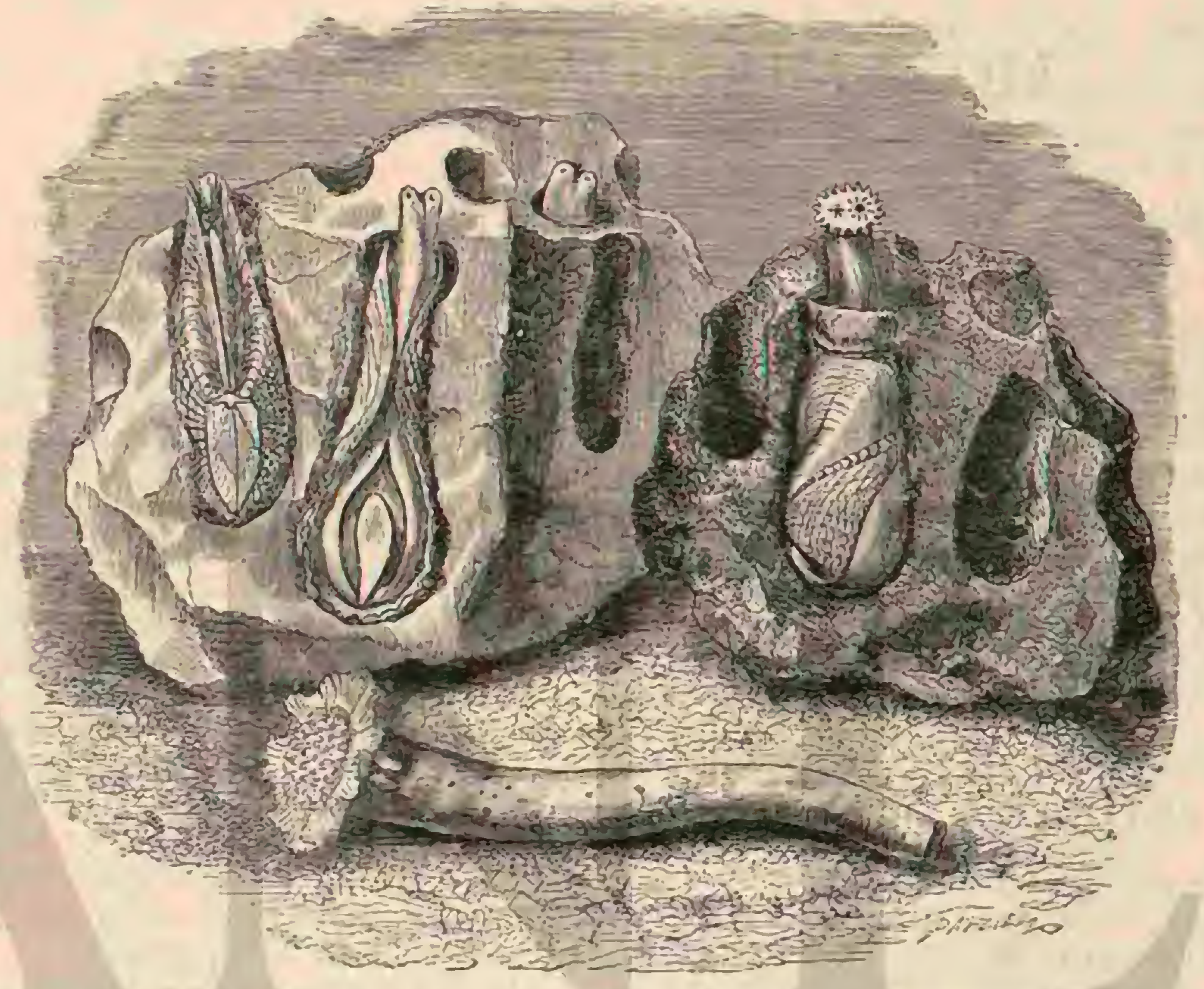

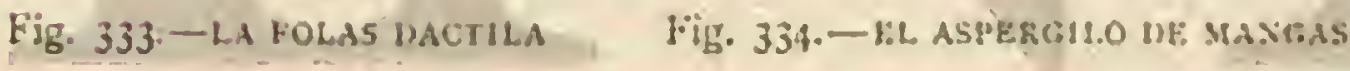

FIR. 335. - I.A FOLAS CALLOSA

halla à nuestros piés. La concha, de dos valvas, sólida, ına. ciza, fuerte y pesada, esta provista de fajas prominentes que en forma de sadios salen de las puntas encorvadas de las valvas y se hallan cubiertas de espinas lisas. Los colores de la concha son agradables, pero no muy vivos; - se componen de tintes de un pardo amarillento ó rojizo, con dos fajas concéntricas. Hácia las coronillas adquieren un color blanco de leche. El animal que habita esta fortaleza es mas bonito de lo que suelen serlo los conchiferos. Las hojas del manto son gruesas y convexas. El color de sus partes anteriores, muy delicado, es un bonito anaranjado, como el de los tubos, mientras que la cara interior es blanca con un viso nacarado. Omitiremos la descripcion demasiado ingenua que el autor inglés hace del pié, pero reproduciremos el relato sobre el modo de emplearle el animal. Alarga el pié todo lo posible, buscarido cualquicr objeto sólido, y aposandose en este franquea dos piés y mas de distancia. En ciertas ocasiones el cardio puede saltar aun mejor, pues mas dẹ uno de estos animales se ha fugado del barco de un solo salto. El pié sirve ambien al animal para penetrar en la arena: al cfecto se alarga, y su aguda extremidad se introduce verticalmente en la arena húmeda. La fuerza muscular cmpleada le basta para penetrar con toda su longitud, y en. corvándose de repente hácia un lado, la punta del pié se agarra en la arena. Por medio de una contraccion longitudinal atrne la concha $y$ el resto del cuerpo, y estos movimientos se repiten hasta que el animal ha llegado a bastante profundidad. El modo de alargar y contraer el pié es muy rápido, y cuando el conchifero tiene toda su fuerza 6 esta muy espantado, desaparece casi al instante en su fortaleza arenosa, con tal rapider que es preciso ser muy ágil para cazarlo si solo se dispone de las dos manos.

El cardio comestible jertenece con otros de su género à los moluscos de gmn resistencia vital, pues soporta grandes cambios de la sustancia salada del mar, y por lo tanto cxtiende su área de dispersion mucho mas allá de los límites mar. cados para los animales mas sensibles a la influencia de un mar mas ó menos salabre. Esto puede decirse sobre todo respecto al Bíltico, á la bahia de Finlandia y a la cie Botnia. It E. de Bar, al hablar de las condiciones vitales de la ostra, dice: \&El cardio comestible, que en el mar del Norte alcanza el tamano de una pequeña manzana, tieric en la costa de Suecia, mas al sur de Stokolmo, el tama. no de una nuez, pero solo á considerables profundidades, mientras que todos los inclividuos arrojados cerca de la orilla son mas pequeños. Cerca de henigsberg solo tienen la 
dimension de arellanas grandes, pero cerca de Rebal no son mas grandes que guisantes ó avellanas pequenas. Tambien el mitilo comestible se encuentra alli, pero tan pequeño, que casi no vale la pena comerlo. A estos conchiferos, originarios de los mares bien salados, se agregan, acomodándose en sentido inverso, animales de agua dulce, sobre todo limneos y paludinas.

Por lo que hace á este cambio, el mar Caspio nos ofre- ce otra prueba de su facultad de adaptarse y tmsformarse. Despues de muchos miles de años, se habrín formado de los conchíferos antes marinos especies de agua dulce, de otra forma, y que se alimentan de un modo diferente, especies nuevas y nuevos géneros á los que ya no podrá aplicarse la tcoría de los adversarios de la doctrina de la trasformacion de que solo son variedades capaces de volver rá. pidamente à su forma primitiva.

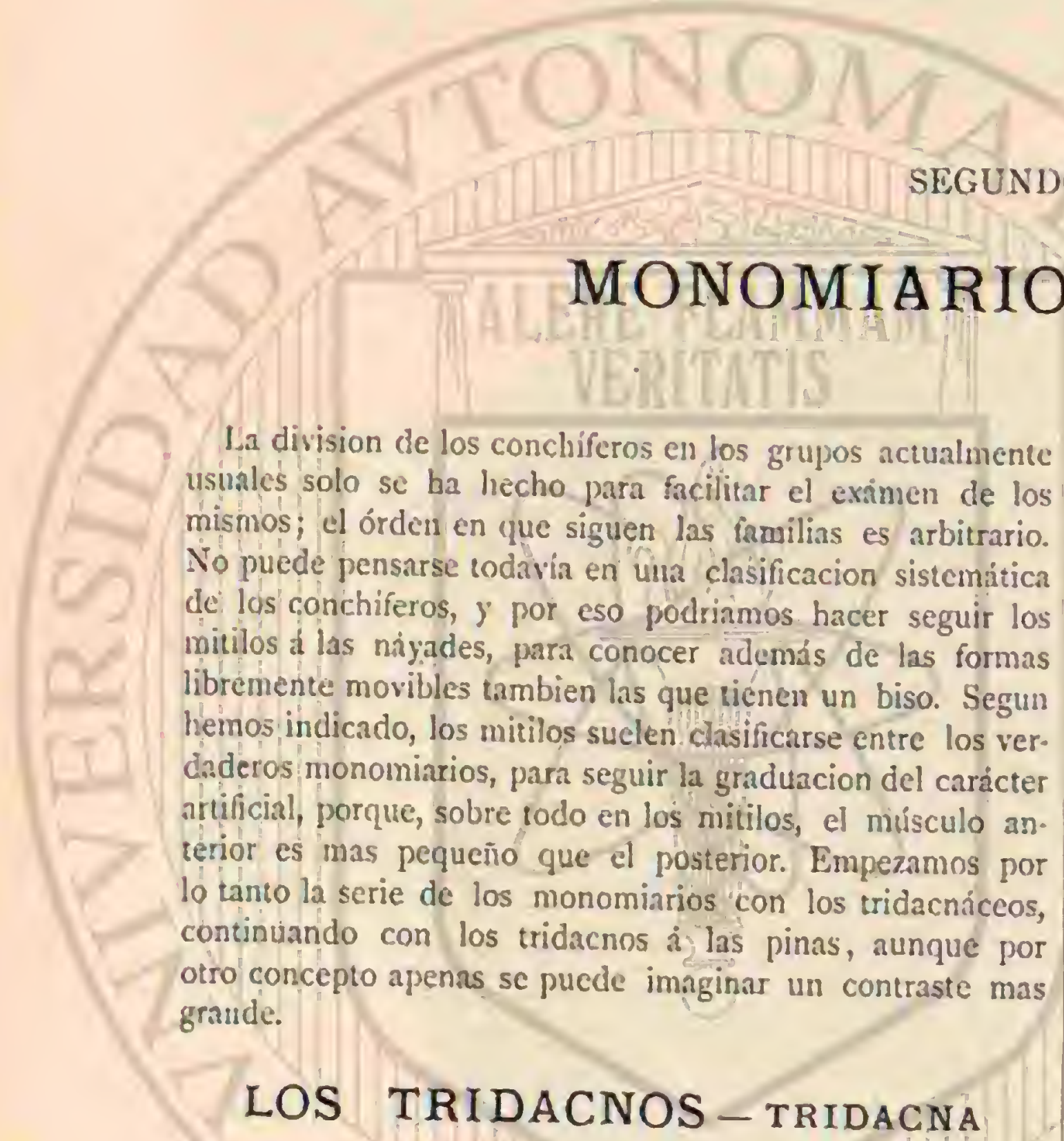

Los tridacnos no son aun verdaderos monomiarios, porque sus músculos solo parecen formar uno por estar muy próximos el uno al otro. El manto se halla del todo cerrado, excepto por tres aberturas. I $I_{a}$ concha es regular, con las valvas iguales. La llamada lúnula, es decir, el espacio cerrado que en la mayor parte de los conchíferos existe inmediata. mente por delante de las coronillas, está abierto de modo que no se necesita otro orificio, como en los conchiferos provistos de barba, para dejar pasar el pié y' el biso. 'Todos los tridacnos pertenecen à los mares chinos, al Océano Indico, al mar Rojo y al mar Austral, y se-distinguen por sus conchas gruesas con listas prominentes, cujas extremidades al cerrarse la concha encajan. El inayor de todos los conchiferos es el tridacno picante que en muchas iglesias se emplea como pila de agua bendita, y que en los grandes museos se encuentra por lo regular aislado en una colunna sólida. No tenemos aun noticias mas exactas que las antiguas procedentes de Rumph.

"Los tridacnos alcanzan una longitud de 3 ấ 5 piés. Las escamas tienen dos reces el espesor de un cuchillo, y estän cubiertas de cieno de tal modo que apenas, se pueden limpiar. El grueso de la concha es por lo regular el de una mano de través y hasta se encuentran tales de mas de medio pié de grueso y de un peso correspondiente. Al romper la concha se ve que se compone de diferentes capas, siendo la última tan afilada que corta como un cuchillo. En las islas Molucas y de los Papues se ha observado que al cerrar la concha corta las cuerdas cual pudiera hacerlo el filo de un hacha, $y$ todo el que quisiera tocar la concha abierta con la mano, perderia ésta si no pusicra antes un objeto entre las valvas para impedir que se cierre. Para sacar la concha del agua, pasa un buzo a su alrededor un nudo corredizo y despues los pescadores la suben is la supernicie. En el barco cortan con un cuchillo las llamadas columnas ó los tendones, y entonces la concha se abre por sí misma y no puede volver a cerrarse. Del mismo modo se salvan tambien todos los animales $y$ hombres cogidos por casualidad entre las valvas. \&.

Tambien el tridacno gigante (fig. $3 \geq i$ ), como otros muchos conchíferos provistos del biso (las pinas y los mitilos) sirven de habitacion segura á crustáccos de caparazon blando.

(4) Tste monstruoso animal, continúa Rumph, lleva consigo siempre un compañero, en cierto modo un vigilante: es una pequenia garnela, que antes hemos descrito bajo el nombre de pinotero. Este animalito pelliaca al conchifero en la carne cuando ve que se puede hacer buena presa; entonces el moluscu cierra en seguida las valvas, y, hasta se cree que este conchifero, que no tiene ojos ni es capaz de defenderse contra los rapaces, no puede vivir si casualmente ese pinotero se pierde dentro de su concha.:

Ademís de muchas cosas extranas, por ejemplo, la de que el tridacno reluce de noche á mucha distancia, el citado holandes da aun algunas noticias sobre el tamaño y la fuerza del tridacno gigante: «En 168 I se encontraron cerca de Célebes dos de estas conchas de las que la una media 8 piés y dos puigadas de circunferencia, la otra 6 piés y cinco pulgadas. La una, en la que un marinn habia introducido una fuerte palanca, encorvó esta al cerrar las valvas: la fuerza del misculo y el peso de las ralvas que es de 3 quintales explican fácilmente este hecho.

Muy minuciosamente describe Rumph la existencia de estos conchiferos gigantescos en las alturas y montañas de Amboina y de las islas Molucas. Es muy instructivo comparar los progresos de nuestra época con los últimos decenios del siglo xvir. Eucontró en las alturas de Amboina tridacnos, carga suficiente "para 406 hombres, y que cxistian en tal número que el citado autor creyó impósible que séres humanos hubiesen podido llevarlos á las montañas. Toma en corrsideracion tambien la opinion entonces muy usual de que las petrificaciones y los animales fosiles eran un fruto natural de las rocas, y criados en las montañas; pero tambien esta teoria la considera como improbable, opinando que solo con el diluvio, en los dias de Noé, aquellos animales pueden haber llegado à las montañas. Ia objecion de que al retirarse las aguas tambien el tridacno gigante hubiera podido bajar al mar, no le parece aceptable, calculando que el des. 
censo del diluvio se ha verificado con una rapidez cinco veces major a la del reflujo ordinario. Además Dios ha querido dejar estas senales del diluvio general, porque habia previsto que mas tarde se presentarian hombres que pondrian en ducha las verdades de la Escritura Sagrada. Aunque el naturalista holandés, por lo demás despreocupado, sostiene una doctrina que actualmente solo se predica ya por los obispos romanos y por el pastor protestante Konak de Berlin, de que la Biblia es un libro intalible tambien respecto it la Historia Natural, tenia ya una idea de la verdad que des. de algunos decenios es del dominio general del mundo ins. truido, es decir una idea de la teoria de evolucion. \&Quizá dice, podria pensarse, que cstos paises estan expuestos á los terremotos, que sin contar el diluvio han formado nuevas moinเañas, clevando con ellas estos conchíferos. Sin embargo, no puede pretenderse respecto a estos paises, à no ser que se supu. siera que todas las islas y montanas en que se encuentran estas conchas se han elevado del mar, lo que no parece aceptable, porque aquellos conchiferos se encuentran en medio de la tierm lirme, en tales montanas y en islas tan grandes que sin duda ya han existido desde el principio de la creacion.

Una segunda especie de tridacno, el tridacno prolongado, muy irecuente en el mar Rojo, se observó hace algunos años muy minuciosamente por Baillent, jóven zoólogo francés. Pertenece á las especies pequenas y llega a una longitud de $0^{m}, 12$ a $0^{\circ}, 20$. Vive escondido en la arena de modo que solo sobresale el borde denticulado de la concha. La-aberlura arriba citada, en el dorso está dirigida por lo tanto hácia abajo, y con el pié $y$ la barba el animal aglomera arena y piedras ó se fija tambien ocasionalmente en una roca, permaneciendo en ella sin duda bastante tiempo. Da la circuns. tancia de que los individuos mas grandes tienen que bus. carse siempre a mayores profundidades. Baillent no puede encontrar palabras para describir el magnifico aspecto que el conchifero, casi siempre abierto, ofrece con los bordes de su manto, cuando en mar calmada se le observa à una pro. fundidad de 12 à 16 piés. El tridacno prolongado, llamado por los àrabes Arbi-sem-Bous es tan comun cerca de Sucz que su concha se emplea para la rábricacion de cal; tambien este animal es un alimiento favorito, y segun se dice, sobre todo los músculos, tienen el gusto de carne de langosta.

las noticias arriba citadas de que el tridacno gigante pue. de cortar una cuerda, parecen dudosas al zoólogo francés, no porque el animal careciera de la-fuerza muscular necesaria, sino porque en tal esfuerzo la concha se romperia. Bajllent ha hecho algunos experimentos notables sobre la fuerza muscular de la especie de Suez. I.os bordes de la concha no pueden cerrarse del todo; el autor pudo por lo tanto fijar en una valva un gancho del que suspendió toda la concha, mientras que en lin otra valva fijaba un vaso que poco a poco se llenaba de agur. Con el peso del vaso y del agua debe contarse, naturalmente, tambien el de la valua inferior $y$ la resistencia a vencer del ligamento, que tambien se vencio, cuando cerca del punto mas alto del peso que se exigia del animal éste se irritaba, y con ayuda de todas sus fuerzas contraia las valvas. Un ejemplar de $0^{m}, 24$ de largo demostró de este modo una fuerza de mas de 7 kilógramos.

\section{LAS CAMAS-CHAMA}

CARACTÉRES. - Las camas tienen la concha irregular, inequivalva y fja; los nates encorrados y desiguales; la charnela no presenta mas que un diente grueso, oblicuo y festo. neado por abajo, el cual se articula en una foseia de la ralra opuesta; hay en este género dos impresiones musculares, distantes $y$ laterales, $y$ el ligamento es exterior y hundido. Las especies que constituyen este género se hallan diseminadas por casi todos los mares de los paises calidos; pero tambien se han visto en el Mediterráneo.

Estos moluscos viven ordinariamente a poca profundidad en el mar: se les encuentra siempre adheridos por la valva inferior $a$ las rocas $y$ i los poliperos, 6 bien agrupados unos sobre otros caprichosamente. Salvo las especies que son es. camosas $\delta$ laminares, rara vez presentan colores brillantes.

Como especie tipo debemos hacer especial mencion de la designada con el nombre de chama lazaro (fig. 340), que se distingue principalmente por el notable desarrollo de sus lá. minas foliácens.

\section{LOS ISOCARDIAS-ISOCARDIA}

CARACTERES. - los isucardias tienen la concha equivalva, cordiforme, con los nates seprarados, divergentes y arrollados en espiral. Existen dos dientes cardinales aplanados, entrantes, de los cuales uno se encorra y hunde debajo del mates; el otro, lateral prolongado, se halla debajo del coselete. El ligamento es exterior y ahorquillado por un lado. El tamaño, forma y situacion de los nates, como tambien el caricter de los dientes cardinales, son tan propios de las conchas de este género, que ha parecido conveniente separarle de las carditas, aun cuando hasta ahora se conocen muy po. cas especies. El animal tiene sifones cortos, y el pié bastante grande y ovalado.

DISTRIBUCION GEOGRAFICA.- las especies de este género, cuyo número es muy reducido, son propias de los mares de Europa, de la India y de la Nucva Holanda. la isocardia globulosa (fig. $33 i$ ) es la especie mas caracteri. zada del género.

\section{LOS MALEACEOS-MA- LLEACEA}

CARACTÉRES. - I a familia de los maleaceos $\delta$ conchas de mearfillo (fig. 323 ) toma su nombre de la forma extmila de la concha. Esta es de partes desigunles, compónese de capas y esta cubierta en su interior de nacar; «l borde presenta una linea recta, se prolonga en la parte anterior, y por lo regular tambien en la posterior, formando una protuberancia en forma de oreja En algunos géneros, por cjemplo en el ma. llens, en el que la concha es muy corta y se prolonga inucho hácia abajo, la comparacion con un martillo esta bien justificada. Fil animal es muy congenérico al de la pina, pero liene efectivamente un solo mísculo casi central para cerrar las valvas. I.os lóbulos del manto están separados en toda su longitud, mas gruesos en el hordey provistos de pequenios tentaculos. El peąucrio pié es vermiforme.

Fl geognosta encuentra en esta familia varios conchiferos muy importantes, de cuya existencia deduce la edad y la afinidad ó igualdad de las respectivas capas y jiedms, mientras que los paleontólogos se instruyen en sus comparacio. nes sobre el predominio de los monomiarios en los periodos mas remotos de la ticrra; mas para el observador de la vida y de las costumbres de los animales, los generos hoy vivientes no ofrecen tampoco un campo fértil como tantos otros conchiferos existentes. Fn cambio, un género, el die las aviculas, tiene gran importancia en in historia de la civilizacion y del comercio. Io que arriba hemos dicho sobre la formacion y la maturaleza de las perlas, fundándonos en las noticias de Hessling, es aplicable esencialmente at las perias 
Inaxinas, aunque el animial y su fisiologin hasta ahora no han sido objeto de un estudio especial y minucioso.

\section{LAS AVICULAS-AVICULA}

CARACTERES. - Todas las especies de avicula tienen en la parte anterior, y à menudo tambien en la posterior del borde, una prolongacion en forma de oreja. El ligamiento carece de dientes 6 tiene en cada valva un diente obtuso. La valva derecha tiene por delante de la oreja anterior una es. cotadura para la barba.

DISTRIBUCION GEOGRAFICA.-Se Conocen Unas 30 especies, que, excepto una que se halla en el Mrediterráneo, son propias todas de los mares calidos. USOS, COSTUMBRES Y REGIMEN. - I LOS COHO- cimientos quic tenemos sobre sü genero de vida, dice Hessling, son menos resultado de un estudio minucioso, que de obserwaciones casuales $\delta$ muy ligeras que además se han conservado de generacion en generacion por las antiguas tradiciones de pescadores \& mavegantes inexpertos. Perteneciendo regularmente a un mismo sitio y a la misma especie, ofrecen un aspecto muy miriado en las profundidades del mar, por la maturaleza del suelo en que habitan y segun los diferentes organismos vegetales y animales que crecen sobre las conchas, y por eso á menudo se les dan nombres diferen. tes. Ora sus conchas están cubiertas completamente de gran. des esponjas en forma de concha (coda de los navegantes), ora de una capa, semcjante por su color al betel (perteneciente tambien á una esponja). Hay bancos en que los animales viven con las conchas del todo descubiertas, mien.
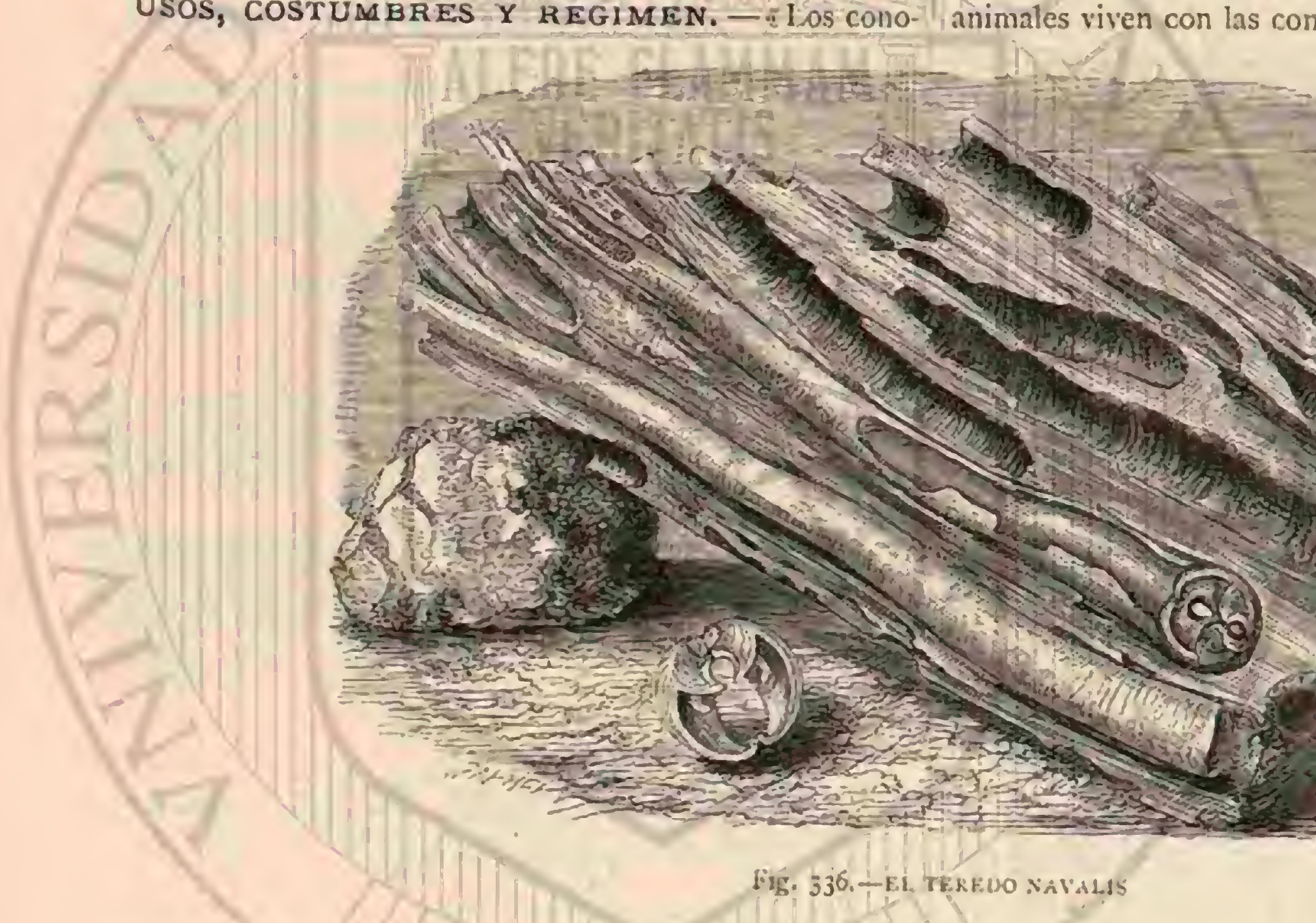
. 
micro de personas que en ia estacion mas farorable se ocu. pan enl la pesca ascenderá á mas de 30,000. Ninguna recibe un salario fijo, pero tiene parte en la ganancia. El jeque del puerto, à quien pertenecen todos los barcos, cobra una pequeña contribucion de uno a dos duros. Los pescadores se alimentan durante la pesca de dátiles, pescado y arroz. Don. de hay muchos pólipos los buzos se ponen un traje blanco, pero por lo regulat van desnudos, excepto una faja en las ca. deras. Cuando van á trabajar se dividen en dos grupos, de los que el uno se queda en los barcos, mientras que el otro se compone solo de buzos. Estos se proveen de un pequerio cesto, saltan al agua $y$ ponen sus piés sobre una piedra en que está fija una cuerda. A una señal dada se deja correr ésta y el buzo baja al fondo. Cuando los conchiferos forman una capa espesa pueden sacar ocho ó diez ả la vez; éntonces sacuden la cuerda y la gente de los barcos la saca tan pronto como es posible. Se ha exagerado mucho el tiempo que quedan bajo el agua, pero por lo regular no excede de 40 segundos. Los ataques de los tiburones no se repiten á menudo, pero en cambio el escualo es muy temido, refiriéndose ejemplos de varios buzos que fueron cortados en dos por esos mónstruos. Para retener la réspiracion se ponen un pedazo de cuero elástico sobre la nariz, que por este inedio queda herméticamenie cerrada. Cada vez que sube á la superficie el bu\%, no entra en el barco, sino que se ngarra a las cuerdas que cuelgan al lado de á bordo hasta que ha aspirado bastante. Por lo regular vuelve al cabo de tres minutos a la jurofundidad. La renta de esta pesca que antes subió hasta 300 millones de libras esterlinas, solo asciende ya á la décima parte. I a segunda region nas célebre de perlas del Asia es la

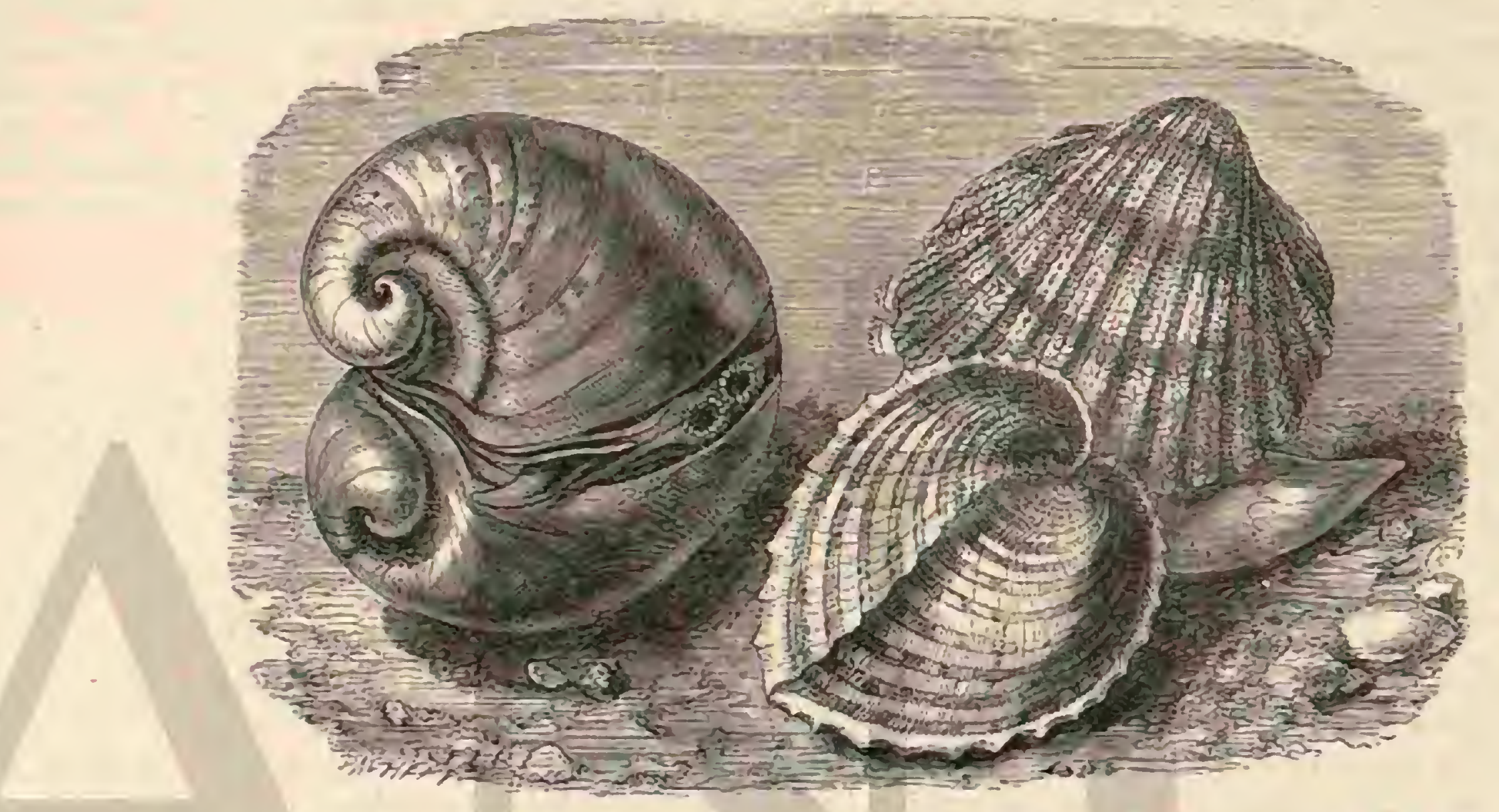

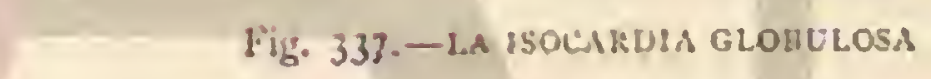

Fig. 33S. - EL CARUIO CORAZOS

fig. 339.-EL CARDIO TUBERCULOSO

costa occidental de Ceylan y las costas del continente opuesto. En la obra de Hessling encontramos la descripcion del oficial inglés Grylls, que para la proteccion de la pesca de perlas tuwo en Aripo, en Ceylan, el mando de una division de tropas, y que dice en su libro que por todas las perhas del mundo no quisicra repetir esta expedicion que le robó varios meses de su vida, pasados al principio casi muriendo de hambre, despues náufrago, y por fin presa de una violenta calentura. Segun este autor, y sacando parte de otros relatos, Hessling da el siguiente bosquejo: \& El sitio elegido por los barcos de perlas es la árida s solitaria costa de Aripo. En la arena exhausta por el calor del sol, solo prosperati arbustos espinosos cuyas hojas cuelgan marchitas de sus ramas. No hay abrigo ni sombra para proteger a los animales de los ra. yos del sol, $y$ de la arena canderte sobresalen los huesos calcinados de los buzos que en su afan de tesoros habian en. contrado la muerte. Lin palacio dórico construido por los ingleses, de grandes piedras arenosas cuadradas, cubierto por iucra del mas bonito estuco de cal de conchas de ostra, y ro. deado de escasos árboles, es el único adorno de esta region la mas uniforme de toda la isla. En este sitio se reunen miles y miles de barcos cuando empieza la estacion de la pesca. Como por encanto se forma desde Condatchy, à lo largo de la playa, una ciudad de chozas habitadas por comerciantes de las mas diferentes regiones. Aventureros y titiriteros se presentan seguidos de hábiles rateros. En todos los puntos no se ve uada sino especulacion con dinero y crédito.
- Los indigenas que gozan fama de ricos hacen conducirse desde el continente en magnificas sillas de mano protegidas por riquisimos parasoles para contemplar este espectáculo pue turba los sentidos. Todos los irages y costumbres indias se presentan, cada casta tiene sus representantes, los sacerdotes y partidarios de todas las sectas acuden, y los titiriteros y bailarinas divierten a la multitud. Durante este perioco todas las mañanas salen unos 200 barcos al mar, tripulados cada uno por dos buzos, dos ayudantes y un soldado con el fusil cargado el cual debe impedir que las perlas se saquen de la concha antes de llegar á la orilla. Cuando toda esta fotilla ha llegado al punto de su destino, empieza el trabajo. Una barca armada queda cerca para su proteccion, y desde la cubierta de esta cmbarcacion, provista de una tienda, puede observarse con comodidad este espectáculo. Los buzos bajan al fonda por medio de piedras de dos á tres quintales de peso ligadas á una cuerda; cada uno está provisto de un cesto en el que recoge tantas conchas como es porible y asi que la pesada piedra se ha sacado, el pescador se agarra con la mano izquierda a las rocas ó plantas marinas. Tan luego como termina su cometido, sube á la superficie y un compañero lo hace entrar enseguida en el barco, mientras que otro sube el cesto con las conchas, sujeto siempre al barco por medio de la cuerda. De este modo alternan los dos buzos hasta las 4 de la tarde, hora en que todos los bascos vuelven con sus cargas á Aripo. Acabada la pesca del dia, el buzo que por mas tiempo se ha mantenido bajo del agua 
recibe un premio. Todos los buzos de aquella region son malayos y educados desde su niñez para su.oficio. El ruido durante el trabajo es tan grande que ahuyenta à los temibles tiburones, y muchas pescas se llevan a cabo sin que se sufra un solo ataque: sin embargo los buzos exigen que durante la pesca los conjuradores de tiburones rezen por ellos en la playa y comparten voluntariamente su ganancia con estos hombres. Aun los buzos católicos del tiempo de los portugueses, no empiezan su trabajo sin fijar antes en su brazo fórmulas de oracion y sentencias de la Sagrada Fscritura.

\$Cuando los barcos tienen su carga á bordo, compiter en rapidez para llegar primero $\$ 1 / 2$ orilla. Alli hay tropas para que madie se quede con las conchns antes de que estén vendidadas en pública subasta o entremadas en los almacenes del gobierno, en los que se colocan las conchas no rendi. das. Cuando los conchiferos se han sacado a tierra se dividen en pequeños montones y se venden en subasta. Esta es úrna divertiday animadisima loteria, porque fácilmente se pagan algunas lihras esterlinas por un gran monton de conchiferós que no contiene ninguna perla, inientras que un pobre soldado paga ro ó 20 céntimos por media docena, hallando una perla tan preciosa que no solamentc puede comprar su licencia, sino pasar toda su vida sin cuidado. En tiempos anteriores el gobierno hizo almacenar odas las conchas y abrirlins por empleados, pero cstos cran tan astuios que á pesar de la vigilancia mas minuciosa, se tragaban perlas. Actualmente las conchas no vendidas se ponen en depósitos de agua, y cuando se han abierto por la descomposicion, las perlas cien y el agua las hace entrar en cinales en que se recogen en gran numero por medio de finas redes de gasa. Pasada la mitad de la estacion de pesca, las conchas. descompucstas por el sol propagan un hedor pestilencial, acompañado por añadidura de calenturas, de vómitos, diar. reas y disenterias. El vienin propagn el hedor a la distancia de muchas idguas, $y$ el aire en el cuartel situado a dos leguas de distancia del almacen apenas puede soportarse, sobre todo de noche. Cuando ya no se encuentran conchas y los buzos se han cansado de la penosa pesca, Aripo quéda abandonado por sus habitantes y solo las tropns han de permanecer alli hasta que la última concha se ha podrido en el almacen.

Asi acaba esta escena lléna de vida. Todos han desaparecido y en la solitaria costa se rompen como siempre con melancólicos golpes las olas del mar; el viento se ha llevado la paja y los trapos de que se habian construido las chozas: la candente arena movediza cubre las pisadas de la multitud que poco antes se oprimia en la playa.

- En la costa npuesta, los bancos de perlas que sc cxtien den en la costa de Tinnevelly al N. E. del cabo Kamory, se han explotado hace muchos siglos. Cuando bajo el domi nio portugués florecia aun la feria de Tuticorin, cincuenta s sesenta mil comerciantes se dirigian á aṇuel siito. Pern los bancos se explotaban demasiado, desapareciendo rápidamente su renta. Sacamos de un articulo del Ausland del año $1 \$ 6_{5}$, las siguientes noticias para completar la historia de la pesca de perlas y la historia natural de la avicula meleagrina. En I \$2z la adninistracion inglesa de la India sacó aun de la renta de la estacion de Tulicorýn 13,000 libras esterlinas; en 1830 unas 10,000 , mientras que durante algunos años despues de este término, el margaritifero citado faltaba del todo en aquellas aguas. Desde 1830 a 1850 se examinaron 14 veces los bancos de conchiferos sin obtener resultado suficiente. El capitan Roberison funcionario en jefe de Tulicoryn buscú la causa principal de este fenómeno en el ensanchamiento del canal de Paumben que habia causado una corriente mas fuerte que impedia a los moluscos fijarse en los bancos. Otro perjuicio para la propagacion del margaritifero encontró el autor en la circunstancia de que los pescadores de schanhs, grandes conchiferos que sirven de bocinas en los templos de los dioses, anclan en aquellos bancos, y con las anclas sacan y matan los margaritiferos. Las conchas muertas influyen perniciosamente en las vivas causando una disminucion continua de las mismas.

Los buzos indigenas, en cambio, buscan la causa en la frecuencia de dos otras especies de conchiferos, de uma modiola, llamada alli sumum, y de una avicula que se fijan entre los margaritiferos y destruyen, en opinion de aquellos buzos, miles de estos. En los años 1860 a 1862 la renta de los bancos de perlas subió á 20,000 libras esterlinas, pero en $16_{3}$, los bancos estaban en tal estado que se desistió de la recoleccion de las conchas. De los 72 bancos examinados, solo z estaban del todo libres de la ya citada especie de modiola; que en otros r I bancos se habia fijado en un núme. ro bastante crecido, mientras que $5 T$ bancos no tenian ningun conchifero. Esta falta inesperada de margaritiferos dió impulso a los experimentos de cria artificial del capitan Philipps que, segun pudo juzgarse, hasta 1865 hicieron espe. rar resuliados del todo satisfactorios; sin embargo; carecemos de noticias recientes.

Los bancos de perlas están situados à unas nueve leguas inglesas de distancia de la costa y se extiencien en una lon. gitud de 70 leguas a una profundidad de 8 á 10 brazas. Es. tan expuestos a fuertes corrientes de mar que a menudo los cubren a yrandes uistancias de arena, destruyendo al mismo tiempo los conchiferos jóvenes. Los animales muertos juntos con aquella especie de modiola, ejercen una influencia perniciosa en la prosperidad de los vivos. En la grande profundidad de los bancos situados en alta mar, no hay remedio contra este mal, y por esto se ha concebico la idea de criar los conchiferos jórenes en bancos artificiales, hasta que se hasa robustecido bastante para arrostrar las infuencins citadas. A tales cxperimentos impulsaron los resultados en apariencia favorables que se habian obtenido en la cria de ostras en las costas francesa é inglesa, resulrados que sin duda podian esperarsc tambien de la cria de las aviculas margarittferas en la costa de Tinnevelly:

* La circunstancia mas esencial, y que pudiera tomarse en consideracion en los experimentos de cria, consiste en cierta diferencia observada entre la ostra comun y el margaritifero: en los sitios donde la primera no se fija, queda sencillamente adherida por el lado convexo de la concha solure el fondo, mientras que el margaritifero se fjja en la roca por medio del disco. Segun las averiguaciones del doctor Celaart, en Ceylau, el animal puede sin cmbargo desprenderse de este biso à su antojo y sin perjuicio, para fijarse en otros puntos, si el sitio ocupado no le conviene ya. Segun los experimentos del mismo doctor, la avicula meleagrina pertenece tambien á los conchiferos de mas resistencia vital; vive aun en agua salo. bre, $y$ en sitios de tan poca profundidad, que todos los dias queda expuesta durante tres horas al sol y á las influencias atmosféricas. Tambien el Capitan Philipis ha reconocido esta resistencia vital, farorable para la cria de conchiferos, procediendo del modo siguiente:

sEl puerto de Tulicoryn esta formado por dos largas islas, entre las cuales y el continente se cxtiende un banco de tres leguas inglesas de largo por una de ancho, á la profundidad de 3 a 7 piés bajo la superficic del mar. Este banco, que está al abrigo de las rompientes, libre de corrientes $y$ sin aftuencia de agua dulce, se ha rodeado de troncos de coral que forman un borde de 3 piés de altura por encima del nivel del Aujo, disponiendose de cste modo una especie de depósito. En él se colocan corales viros, que al cabo de 
algunos años forman un arrecife sólido, el cual puede servir de base para los pequeños conchíferos que deben criarse. Este depósito se divide en tres compartimientos, de los que uno se destina a los conchiferos de mas edad, y los otros dos á la cria. Los conchiferos adultos deben vigilarse atentamente mientras se propigan, y hasta que la progenie empieza à desarrollarse. Entonces se pone en los compartimientos destinados para ella, en los que permanece hasta que es bastante fuerte para poder trasladarse à la alta mar. Esta última medida es necesaria, porque seria imposible construir un sitio espacioso para un numero suficiente de margaritiferos; segun se dice, tambien depende el valor de las perlas de la profundidad y claridad del mar. Este procedimiento, siempre continuado, asegura una abundante produccion, en los bancos de margaritíferos, de animales fuertes, lo cual resulta ya del hecho de que una concha de seis años contiene doce millones (?) de huevos. Como el número de los margaritiferos pescados en 186 I era de 15.874,800 individuos, todos los años puede perecer un numero bastante considerable de los conchíreros pequeños, sin que se perjudiquen por esto los bancos de perlas, mientras que al mismo tiempo queda asegurada la renta de la pesca anual. Segun ya he. mos diclio no tenemos noticias desde el ano i 655 sobre la ejecucion de este magnifico proyecto. $)$

\section{LAS ARCAS - ARCA}

Su concha es trastersal, equivalva en la parte inferior, y desigual en los lados; sus nates están separndos por la faceta del ligamento. La charnela forma linea recta, no tiene costillas en sus extremidades, y está guarnecida de muchos dientes. El ligamento es completamente exterior. El animal de las arcas no presenta sifones que salgan por fuera; su cuerpo está provisto de un pedúnculo deprimiclo que termina por unos hilos tendinosos, con los cuales se rija cl molus. co $\mathrm{cn}$ las rocas. Las muchas especies que representan al género están distribuidas en el Océano Indico, en los mares de Africa, en el Mediterraneo y en el Océano, siendo la mas notable la llamada aria de Nó (fig. 315).

\section{LAS LIMAS-LIME}

Cuando en mayo y junio de 1860 pesujue en la ensenada de Bergen con red, no sabia aun que existiesen conchiferos que fabricaban nidos. Cierto dia cogi una especic de masa de unos $0^{*}, 12$ de diimetro, compuesta de piedrecitas y frag mentos de concha, reunidns y sujetos pur un cios de hilos amarillentos y pardos. « Un nido de conchferos! gritaron mis remeros; $y$ en efecto, al volver el objeto, entrevi por una liendidura bastante estrecha la concha blanca de la lima hions. Snquée el animal de su nido y poniéndólo en una gran vasija de vidrio me entretuve en observar la belleza de su manto y la vivacidad de sus movimientos. Apenas el conchifero se halla libre en el agua, las valvas se abren y cierran con gran violencia y el animal nada en todas direcciones; cuando estí en el nido deja tlotar junto á la abertura el espeso haz de franjas que se halla en el manto, casi del todo hendido, y de este modo no se/ve nada de la concha. Estas imanjas cubiertas de pestanas muy movibles sirven, sin duda, para atraer la presa microscópica y el agua respiratoria. Eitraño es que este conchifero tan viraz habite un nido que segun parece nunca abandona.

Examinemos un poco mas minuciosanente el nido. El animal fija una multitud de objetos por medio de hilos de biso, uno contra el otro. Los nidos que yo vi en Noruega se componian casi exclusivamente de piedrecitas y fragmentos de concha; Iacaze-Duthiers encontró uno en el puerto de Mahon que se componian de madera, piedras, corales, conchas de caracol, etc. Aunque no se ha visto aun el b́rgano de que hace uso al construir su nido, puede arribuirscle, como al mitilo, la facultad de cortar a su antojo los hilos del viso. Despues de reunir las paredes exteriores, el animal tapiza su vivienda por dentro con un rejido mas fino, pare. ciéndose tambien en este concepto al nido de paijaro, mas fino y cómodo, y yoco vistoso por fuera. De este modo forma una buena fortaleza que no devorara ni el pe\% mas rora En estado seco, los hilos de viso que reunen el material se rompen muy fácilmente, por lo cual los nidos aunque frecuentes no son propios para guardarse en las colecciones de objetos naturales. La fig. 34 I representa la lima coman.

\section{LOS PECTENES - PECTENE}

Nuestros lectores conocen sin duda ya el géncro de los pectenes por su concha, que siendo de la especies mas grandes sirve de fuente para guisados finos. (Ragout fin en 60 . quilles), ó bien se emplea como adorno del sombrero y $\mathrm{cl}$ erage de los peregrinos a su vuelta de Palestima. In concha es libre, de forma regular en muchas especies, con ralvas desiguales, y muy cancteristicas las orejas á cada lado de la coronilla, de la cual parten pror lo regular surcos hácin los bordes. El animal tiene los lóbulos del manto completa. mente libres, mas gruesos en el borde, y provistos de varias series de tentáculos carnosos, entre los cuales se hallan numerosos ojos que se distinguen por su brillo de diamante ó de esmeralda, alcanzando en las especies mas grandes cl diámetro de $0^{*}, 001$. Asombrosa es la perfeccion de estos ojos, que, á pesar de su posicion en alto grado extraña, tienen una perfecta estructura úptica. Sin embargo, el conchífero no puede ver con ellos á larga distancia, distinguiendo so. lamente los objetos mas próximos. Cometeriamos por lo tanto una falta si quisiéramos poner en relacion la vista de los pectenes con su excelente facultad de saltar y nadar. Esta facultad se ha observado muchas veces, y los citados movimientos se ejecutan de igual modo que en las limas. Un observador inglés dice que vió saltar alegremente a los hijuelos del Peclen opercularis en un charco de agua abandonada por el reflujo. Sus movimientos eran rảjidos, y de un solo salto franqueaba varias varas de distancia. Es de suponer que tambien los individuos adultos se recrean de un modo análogo, pero sin ser vistos, en la profundidad del mar. El peine ó pectene raniado (fig. 322) es una de las especies mas notables.

\section{LOS ESPÓNDILOS-SPUNDYLUS}

Este género, muy afine del anterior, denuestra que la movilidad de los pectenes no depende de la vista, Los espóndilos, que se fijan con la concha, caracterizanse por sus largas espinas en medio de los surcos, las cuales recogen toda clase de algas y cieno: de modo que solo despues de mucho trabajo la concha adquicre su verdadera belleza. El espóndilo de Lazaro (spundylus graderopus), comun en el Mediterraineo, tiene la valva superior de color de púrpura. De las especies que representan el género, la mas notable, sin disputa, es el espóndilo real (fig. 342).

\section{LOS HINITES-HINNITES}

CARACTERES. - En este género figuran especies bastante parecidas i las ostras, de conchas adherentes, irregulares y muy gruesas, con la valva cóncasa; en la charnela 
hay una foseta para el ligamento. Estos moluscos se encuen. tran en los mares de Europa. Como especie tipo del género se hace mencion del hinites sinuoso (fig. 320).

\section{LAS OSTRAS - OSTREA}

Despues de la avicula meleagrina ningun otro conchifero ticne tanta importancia, ni ocupa tantas fuerzas humanas, ri pone en circulacion tales cantidades como la ostra. Esta especie se halla en todos los mares, pero los datos siguien. tes se refieren a la especie comun (ostrea edulis) de las cos tas europeas. Las valvas de la concha son irregulares y desiguales, y asi como en los pectenes y espóndilos, la una mas

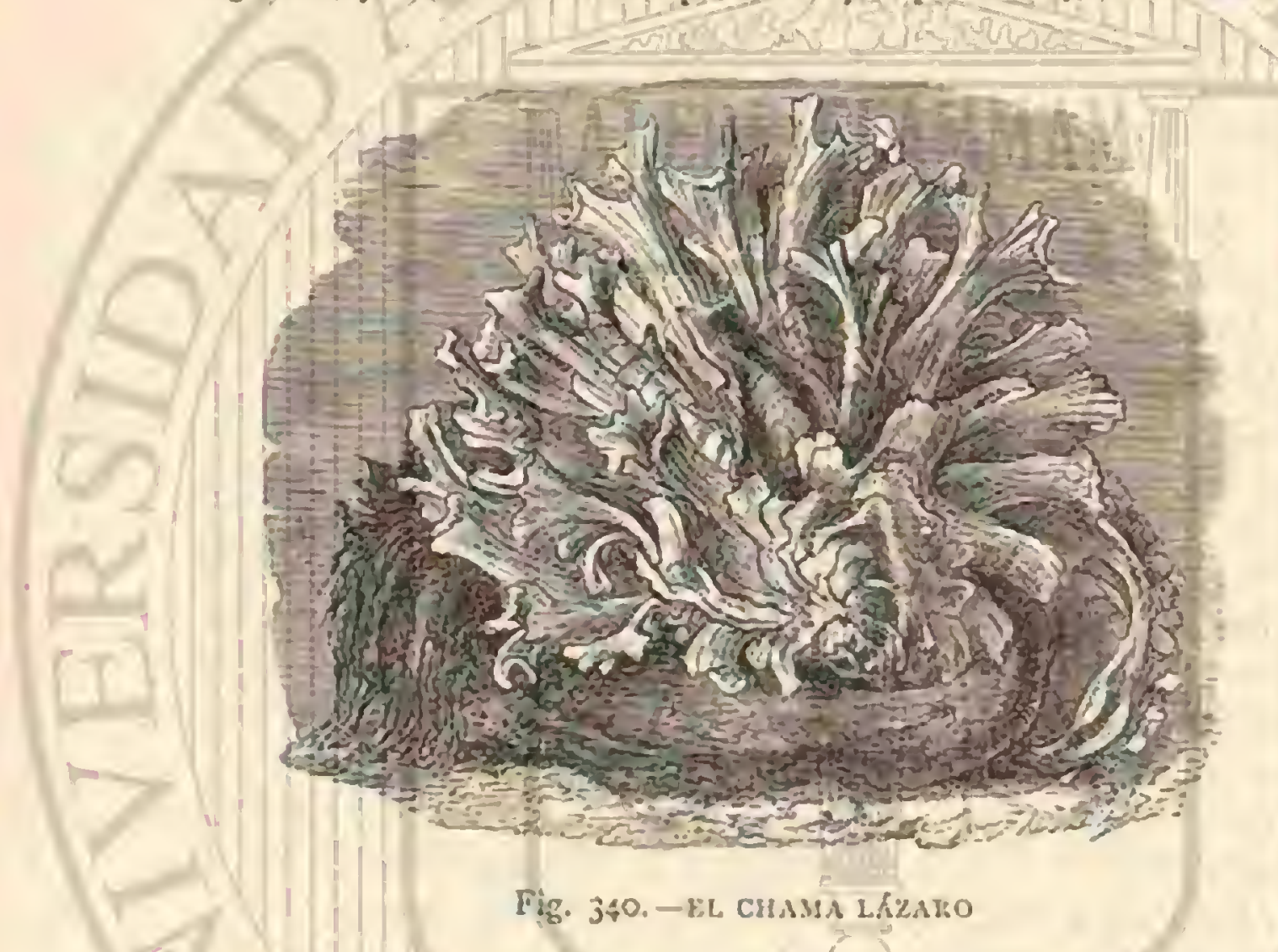

gruesa y profunda que la otra, la cual le sirve de tapa. Ofre. cen notable contraste con oiras conchas lisas, que parecen pulimentadas exteriormente: tambien su interior es muy irregular, hallándose en ellas espacios llenos de agua; y en general toda la sustancia de la concia es mas porosa y penetrante que en/a mayor paste de los conchiferos. Con esta particularidad esti en relacion sin duda la facultad de la ostra de fijarse fácilmente con su valva gruesa et los objetos mas diferentes, por medio de una sustancial seyregada por el animal. Tambien la region de la ibertura ofrece varias particularidades notables; las coronillas, al principio idénticas, llegan a ser muy desiguales con la edad, atrisándose la de la valva superior en su desarrollo. Los dientes no cxisten y el ligamento es interno como en muchos otros conchiferos.

Segun se sabe, para servir las ostras à la mesa, se abren por medio de una hoja de cuchillo introducida entre las valvas á lo largo de la superlicie interior lisa de la tapa, has. ta el nuísculo que la cierra, para cortarle. Tan luego como se ha hecho esto, la valva se abre y no es dificil ya sacar el ligaurento.

Como se ve, el animal de la ostra vive en un recinto cons iruido por el mismo, siendo bastante dificil explicar su estructura Sin cmbargo, como el manto está hundido del todo y solo en el dorso se reunen las dos hojas, sabemos dónde están las partes anterior y posterior, inferior y'su. perior, y descubrimos la boca ocultia al desdoblat la punta anteriur. El manto sensible y contráctil se recoge por lo itegular de modo que por debajo de él sobresalen las hojas branquiales. Una diferencia muy notable entre la ostra y los otros conchiferos consiste en la atrofia completa del pić, que se presenta tan liego como se han fijado los anima. les jóvenes, y cu qque la parte del cuerpo que por arriba sigue al pie no llega á su desarrollo regular. Esto se refiere sobre todo à la glàndula genital. La ostra pertenece con el ciclas y todas las especies de pectenes (excepto el pecten vario de nuestras costas) á los pocos conchiferos hermafroditas. Eil contraste de los sexos, tan marcado por lo regular en el reino animal, es como en muchos moluscos tan poco desarrollado, que las bolsitas productorns de los huevos y de la esperma que componen la glándula forman una masa con fusa, sucediendo á menudo que una misma bolsita glandular es de sexo mixto. Parece, sin embargo, que en muchos individuos un sexo puede ser superior al otro, de modo que hasta puede suprimirle del todo, circunstancia que indica que, en la naturaleza, la separacion de los dos sexos no fué creada, sino que quedó abandonada à la seleccion natural y i la formacion de variedades. El hermafroditismo de la ostra no se presenta nunca, sin embargo, al menos segun las observaciones de Mcevius, de modo que á la ve\% existan en el mismo individuo hucros y esperma, por mancra que una fecundacion independiente no pucde verificarse, sino que la esperma se desarrolla despues de los huevos. En otros individuos; Mavius vió en primavera formarse los productos genitales masculinos sin que se hubiesen desarrollado anies los huevos. II número de los huevos producidos anualmente por-una ostra es considerable, por mas que nos contentemos con uno de los cálculos inferiores. Leuwenhoeck creia que una ostra adulta contenia diez millones de aquellos; otro autor, el célebre napolitano Poli, calcula el número en solo i: 200,000 , progenie suficiente para llenar en estado adulto i2,000 barriles. Pero, aun con este cálculo, estamos muy distantes de las condiciones efectivas. Del relato que el profesor Mocvius de Kiel hizo en I 870 al ministro prusiano de agricultura ycomercio sobre el estado de la produccion y cria de ostras, deducimos que las ostras aduitas producen mas de un millon de hijuelos, pero las de una edad de tres anos mucho menos. Mas importante es aun la circunstancia de que el número de las ostras fecundadas, cuando menos en las costas inglesas y en las de Schleswig, llega á lo mas al jo por $100, y$ á menudo apenas al 10 por 100 del número totaj.

4. Suponiendo, dice Movius, que en un verano solo se propagara el to por 100 de las ostras de un banco en el que existen cien mil y que cada ostra fecuudaca solo produjera mil pequeñuelos, el to por 100 de las ostras madres, produciria, a pesár de eso, diez millones de ostritas. Si todas estas se fijaran en el banco materno 6 cerca de êl, en adelante diez millones de ostras tendrian que repartirse el ali. mento que antes estaba di disposicion de las 100,000 ostras. Cada una de las pequerias absorberin menos alimento que una adulta, pero por su gran número se harian una competencia muy fuerte, tanto entre si como con las adultas, aun en el Grande Océano De aqui resulta que, à causa del alimento, la propagacion de las ostras es bastanic linitada en una distancia determinada del mar. Los pequeños se desarrolian dentro de la cavidad del manto del animal adulto, que solo abandonan despues que su concha se ha formado lo suficiente para poder fijarse en seguida. Segun se dice, pueden propagarse ya despues de algunos meses (?), pero hasta trascurridos algunos años no llegan à su tamano completo, que di. fiere mucho segun lia region y la variedad. No cometeremos probablemenic ningun error \$i consideramos todas las ostras de las costas europeas como una sola especie, así las que vi. ven en las rocas, como las yue habitan en la arena, y tanto las de concha gruesa, como las que la tienen delgada. De la anatomía de los animales no resulta ninguna diferencia particular: las variedades indicadas deben deducirse completamente de los diversos grados del contenido de cal y sal marina, ó en general de las influencias locales.

Debemos ocuparnos ahora dẹ estas condiciones, fijandonos 
ece con el el pecten hermafrolo regular tan poco eros y de masa conta glandiu. n muchos modo que we indica os no fué natural 5 de la ostra un las ob. existin en que una sino que otros in. 5 produc. sarrollado roducidos s que nos wenthorck de aqueel númeen estado estanos ato que el prusiano duccion y ucen mas tres años tancia de nos en las mas al 30 aero total. olo se proen el que produjera es, produ Si ladas 1 , en adeirse el ali.

so ostras. iento que ta compe-

as, aun en alimento, 1 una disesarrollan que sole o lo sufi- pueden lasta tras. $o$, que diicteremos las ostras as que vi a, $y$ tanto da. De la encia parcompletay sal ma. en el área de disjersion de la ostra y en su distribucion geo. gráfica en las costas europyeas. No es posible olvidar del todo cu este punto los bancos y crias artiliciales, aunque solo des pues daremos noticias mas detalladas sobre la cria de ostrns, que últimanente Jlama tanto la atencion. Tomemos por punto de partida el mar Adriático, en el que la ostra vive en todas partes, cuando menos aisladaunente, y en muchos puntos en bancos. En el ingulo extremo, muy obiuso, de la bahía de Mugriar en 'I'rieste, las ostras se fijan en los palos que se hallan en el cieno, mientras que en el cieno muy blando del forido de esta bahia no prosperan. Hace siglos que se crian en los canales y depósitos del arsenal en Venecin, y por lo tanto vemos it este animal prosperar en los lados occidental y oriental del gollo de Venecia bajo condiciones muy diferentes, es decir, en agua salada mezclada de agua dulce, y por otra parte en agua salobre He sacade con la red ostras muy bonitas y grandes en la cuserutua de Sebenico, de un fondo pedregoso y it la profundiclad de unas quince bra. zas; pero no tan cerca del rio Kerke que se pudiern olsservar una mezcla sensible con el agua dulce. La situacion de este pequeño banco demuestra tambien que has corrientes submarinas del flujo son conrenicntes y hasta necesarias, porque traen al indefenso animal su alimento. Mas hácia el sur se encuentran, en territorio italiano, bancos de ostras, célebres ya en la antigïedad, cerca de Brindis y en el golfo de Taren10. No encuentro noticilss sobre su naturaleza, pero despucs de un exnimen del puerto de Brindis y de sus contornos, me parece qque alli falta el fondo pedregoso, y que por lo tanto las ostras deben fijarse en un suclo mas ligero. Desde alli la ostra se extiende por toda la costa oriental y acciden. tal del Mediterránco, aunque sin formar bancos; tambicn ha penetrado en el mar Negrn, fijândose aisladamente en algunos puntos de la costa meridional de Crimea, prueba de su gran facultad de adaptarse al todas las condiciones.

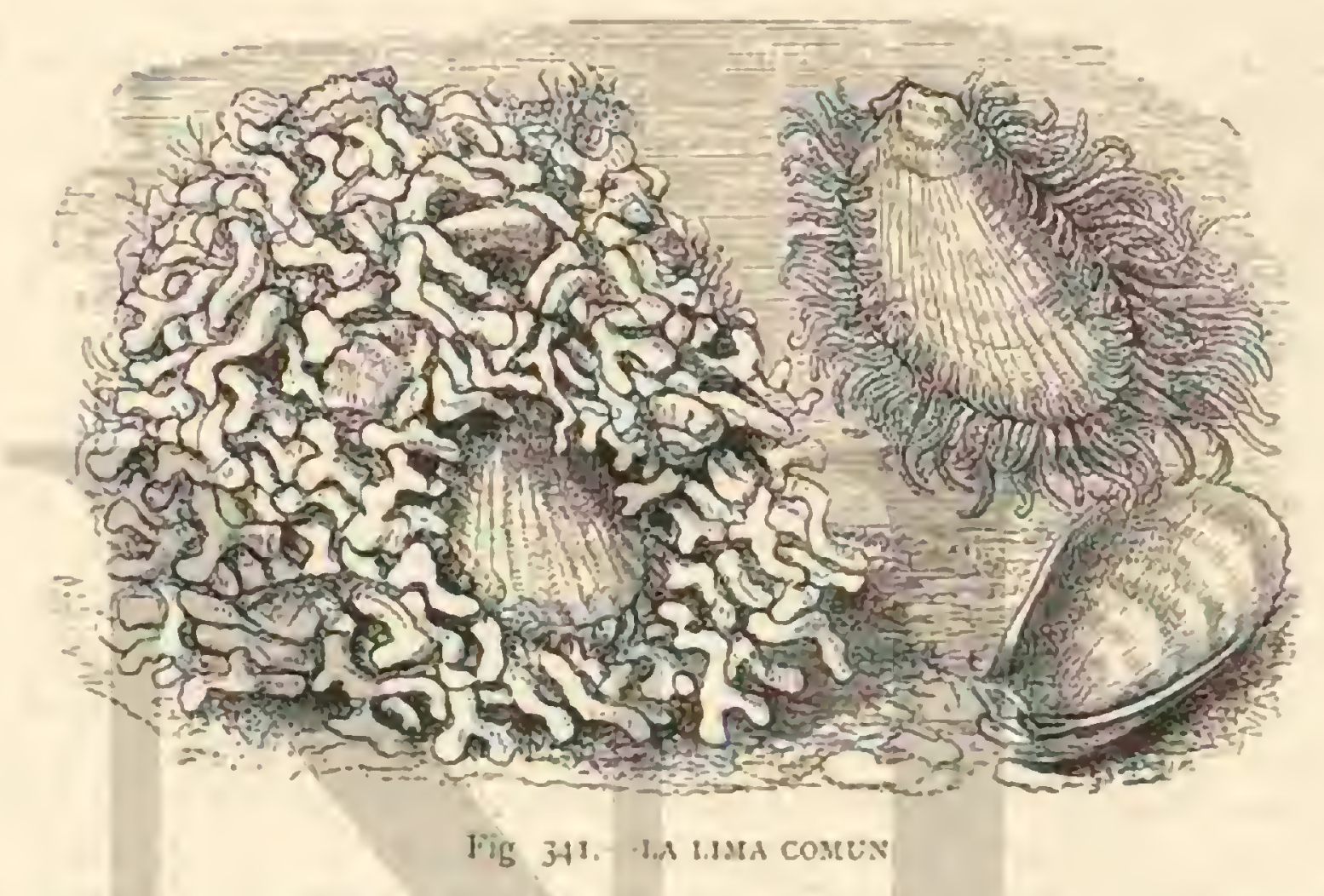

Naturalmente, tambien la parte occidental del Mediterráneo contiene ostras, donde las corrientes y la naturaleza del suelo lo perniten; pero en ninguma parte han formado bancos considembles. $Y$ asi como en la antigüedad se llenaba de ostras el lago de Lucrino, cerca de Tarento, abandonado desde que surgió el Monte Nuevo, en 1538 , lo propio su. cede athora con el lago de Jusaro. Tanto en las costas fran. cesas como en las inglesas del mar del Norte y del Atlántico, se encuentran numerosos bancos de ostras naturales, y en la costa de Noruega este conchifero llega hasta el $65^{\circ}$ norte. En el sur de Noruega se encuentra en muchos puntos en tal mumero, que con pan y manteca se sirve como postre a discrecion. Este agradable descubrimiento gastronómico lo hice cuando, despues de una travesia, las comi por primera vez en la fonda de la villa de Krageroe, situada en la costa meridio. nal de Noruega.

La espresion «ostras de Holstein of de Felensburgo» ha dado lugar á muchas equirocaciones, pues en todo el Báltico no existe actualmente ninguna ostra. Las Ilamadas eostras de Felenshurgo son originarias de la costa occidental, donde cruzan el fondo del mar profundos surcos. Durante el rellujo se descubren grandes distancias del fondo; pero en el fujo solo sobresalen las islas de Pylt, locher, etc. Este territorio se llama los q Wiatten. J Jos bancos de ostras estan situados en las pendientes de los profundos valles del mar de los Watten, en los que las corrientes principales del Alujo y reflujo corren con una rapiciez de cuatro a seis por segundo, es decir, poco mas ó menos con la misma rapider con que el Rhin pasa por delante de Bona. El fondo es bastante sólido, y se compone de arena, de pequenas piedras y de conchas de conchifero. El contenido en sal es de un poco mas del 3 por ciento. En la mayor parte de los bancos, viven al lado de las ostras cicrtos animales de los que, como caracteristicos, solo cito el alejoniums digititum, la scipuliz brequefra y el hechinus miliares. Alli donde se uresentan muchos mitilos y sabelarias, las ostras prosjeran menos, y hasta desaparecen cuando quellas especies predominan. Penr es ann cuando los bancos se cubren de arena y cieno, como por ejemplo un banco situado cerca de la isla de Amrum, que se ha sepultado cada vez mas en la arena.

Fs muy curinsa la circunstancia de que hace poco la ostra se ha fijado voluntariamente en el Limfjort. E. de Baer dice sobre este-hecho: El Limfjort es, segun se sabe, el brazo de mar que en la parte septentrional cruza Jutlandia en toda su anchura, y que hácia el oeste solo estaba separacio del mar del Norte por un estrecho dique natural, abierto en i $\$ 25$ por el canal del $A$ gger. Ya antes, por ejemplo en los años 1 $720 y$ 1760 , el dique se habia abierto pero pronto volvió à cerrarse. Antes de la nueva abertura, el agua del Limfjort, cuando menos en su parte occidental, se consideraba como dulce; el conscjero de Estado Schieht (célebre fisiólogo de Copenlıague, y que turo que examinar el proyecto de fundar bancos de ostras en el Ginyfort), al ocuparse de ello, no dice nada sobre la parte oriental, prero puede suponerse que el agua era ya antes salobrc. Actualmente se han presentado peces ma. rinos y ostras: las viltimas se habian observado por primera re\% en i 5 I en gran ntimero y en estado todavia aciulto; de modo que su immigracion en estado de cria libre debe ha. 
berse verificado ya mucho antes. El profesor Schicht supone que primero se han fijado en la parte occidental, citendién. dose despues hicia el este. Ahora se encuentman casi en to. das partes, cuando el suelo es propio para su progenie. No puede decirse con seguridad cuando emigraron por primera vez; mas todo indica que la inmigracion se ha verificado poco despues de la apertura del canal del Agger. En la costa oc. cidental de Jutlandia se encuentran tambien ostras, pero. segun parece, no en bancos abundantes; en cambio se hallan en la parte oriental de la estrecha peninsula de Eskagen ex. tensos bancos, divididos en tres grupos desde la punta extre. ma de esta peninsuia hasta Hirtsholm. Los uiltimos bancos, regularmente cxplotados, se hallan en la isla de Laesoc; desde donde, segun se dice, se extienden hícia la isla de Anholt. Mas hácia el sur se encuentran tambien ostras, pero mas aisladas, $y$ segun parece de calidad inferior. En los Beltes ya no se encuentran las condiciones necesarias para las ostras, y menos aun en el Báltico.

La causa principal de que las ostras no prosperen ya en el Báltico, consiste sin duda en el exceso de sal. El Báltico, dice Haer, esta en relacion con el Kattegat por medio de tres estrechos de mar, de los que, sobre todo el del centro, el gran Bals, se halla bastante abierto. Como la ostra es heruafrodita, y cada individuo por lo tanto puede propagarse $y$ producir un número muy crecido de huevos, hasta un millon y mas, de los que los embriones dispersos por las olas se fijan y prosperan alli donde encuentran condiciones convenientes, debe existir un obsticulo que no ha permitido se exiendiera hasta el Bático. La parte meridional del Kattegat carece de ostras buenas, mientras que en la parte septentrional dal Bohus-Laen son ya mucho mejores; pero mas grandes y stperiores que en la costa meridional de Noruega, hállanse en la occidental de este pais y de Schleswig, y en general en to. do el mar del Norte. Como en órden inverso el contenido de sal del agua marina disminuye descie el mar del Norte hasta el Kattegat, y mas aun dentro de este último, desde el norte hasta el sur y los confines del Báltico, donde en el golfo de Finlandia y en el de botnia el agua es del todo potable, claro estå que con la disminucion del contenido de sal las ostras se atrofian y desaparecen del todo antes de llegar i los estrechos de comunicacion. Mas al sur de Anholt, hícia los Beltes, la proporcion de sal baja, así como en la costa meridional de Crimea, donde, segun hemos dicho, la concha se atrofia, resultando que el minimum de la proporcion de sal que la ostra necesita para su existencia es de unos ig por 100. La mayor gordura y el mas delicado sabor se adquuieren con un 20 á 30 por mil, y hé aqui porque las ostras mas preferidas se encuentran en sitios donde el contenido de sal marina disminuje por la mezcla con agua dulce. Asi se ob. serva, por ejemplo, en las ostras del Haver, del golfo de Cancal, de la isla de Ré, etc. No queremos decir por esto que en el agua menos salada las ostras mismas se hallen mucho mejor. Las de la costa occidental de Norucga, donde hay tan poca afluencia de agua dulce, se describen como extraordinariamente grandes y prosperan por lo tanto muy bien, mientras que segun parece no han adquirido fama entre los gastrónomos, pues figuran poco en el comercio en gran es. cala. Los romanos de los tiempos posteriores tan amantes de la gastronomia que el desprecio de la misma se consideraba como falta de urbanidad, se hacian llevar las ostras de las mas diferentes regiones del mundo y las criaban en la bahia de Lucrino y en depósitos artificiales. Por muy buenas pasaban las ostras de Bretaña, pero Plinio declaró que las de Circea eran mejores. Otros parecen haber preferido las de otras regiones, y Jurenal asegura que un gastrónomo podia reconocer al primer bocado la procedencia de la ostra Prescin. diendo de las muchas noticias de los antiguos sobre este manjar, solo diremos que Plinio, inteligente en la materia, aseguraba que las ostras de alta mar eran pequenas y malas, considerando como necesario para las buenas la aluencia de agua dulce.

Hemos llegado de la historia natural de la ostma a su uti. lidad y cria, capitulo sobre el cual en los illtimos años se han escrito tratados mus citensos. Fl rey Jacobo de Inglaterra decia al comer ostras que el primero que las habia comido debia ser un hombre valiente. Sin embargo, no es 2si: el hombre se acomodó i comer ostras y otros muchos productos del mar, apenas mas apetitosos, cuando aun no merecia llamarse hombre, cuando se cuidaba muy poco sin duda del aspecto de los comestibles. Los detritus fósiles de Dinamarca demuestran que hace ya miles de años que la ostra constitnia un alinento de importancia entre los habitantes primitivos de las costas europeas. No conozco mejor bosquejo sobre el consumo y la cria de la ostra que el que Bacr ha dado en-su obra arriba citada. \& las tentativas, dice, que últimamente se han hecho en Francia para limpiar los banços de ostras explotados, $\delta$ en otras regiones para procurar mejores criaderos, parecen haber hecho creer a muchos que la cria de óstras es una industria nueva. No es por lo tanto supérfuo advertir que esta cria es muy antigua, y se explotaba greneralmente como la crin artificial de peces que principio hace casi un siglo $y$ se continunba en algunos puntos; pot ejemplo en Baviera, pero en tan pequena escala y de un inudo tan poco visto, que los experimentos modernos en Francil se consideraron mucho tiempo por la ma. yoria del público como cosa nueva; siendo asi que hace quizin un siglo todo naturnlista tecundizaba las ranas artif. cialmente para ubscrinr el desarrollo de estos amimales, y úlimamenté tambieu los peces. Fi autor cree erróneamente que en las ostras la fecundacion artificial no es necesaria, pues segun ya hemos dicho, la esperma y los huevos no se desarrollan en el mismo animal, que por lo tanto, a pesar de ser hermafrodita, no puede fecundarse a si mismo. Sin em. bargo, una fecundacion artificial no es necesaria, ni apenas practicable en gran escala.

\$ la cria dc ostras, continúa Baer, data ya de dos mil años. Plinio dice muj terminantemente que Sergio Crata, hombre que vivió antes de la guerra contra los marsos, es decir un siglo antes de I. C., habia formado depósitos de ostras en grande escala para enriquecerse. Pronto se generalizaron mucho, porque los romanos de los tiempos posteriores eran muy inclinados á las delicias de la mesa y porque las ostras marinas de las costas italianas no son tan exquisitas como las de agua mas dulcificada. Es posible que la cria de ostras sea aun mas antigua, pues ya en las obras de Aristóteles se habla de una traslacion de ostras como de una cosa cono. cida. En tienpo de los emperadores romanos la cria de os. tras era cosa importante y muy discutida en cuanto i economia.

- Desde los tiempos de los romanos la cria de ostras no se ha perdido probablemente nunca, aunque de la Edad Media tenemos pocas noticias respecto a ella, porque las ciencias naturales se descuidaban mucho y solo alguna vez se hablaba de grandes animalés de caza. I.os autores eran en su mayor parte eclesiásticos, que además de escribir sobre la Iglesia, describian tambien las hazañas de los principes 6 de los enemigos invasores; pero al mismo tiempo los frailes eran muy aficionados a aclimatar animales que en la cuaresma pudiesen servir de alimento. Esto se ha demostrado uiltima. mente respecto á los grandes carncoles terrestres y muchos peces, por cjemplo las carpas. Tampoco debe haber cesado la cria y la aclimatacion de las ostras, pues Pontoppidan re. 
fiere que en Dinamarca circulaba la tradicion de que los bancos de ostras de la costa oecidental del Schleswig se ha. bian establecido artificialmenic en 1040. Aunque esta tradicion puede ser infundada, demuestra, sin embargo, que al pueblo era familiar la idea de una cria artificial de ostras. Varios viajeros del siglo pasado dicen que en el Helesponto y en los alrededores de Constantinopla se plantaban ostras, costumbre que sin duda no trae su origen de los turcos, sino que probablemente se ha conservado del tiempo de los bizantinos. Pedro Gylio, autor del siglo xvi que publicó una descripcion minuciosa del Bósforo Tracio, dice tam. bien que alli se plantaban ostras desde tiempo inmemorial.

L Una ley promulgada en 1375 bajo liduardo 111, por la que se prohibió recoger y trasplantar la cria de ostras excepto en majo, demuestra que este ramo de la industria nunca ha cesado del todo en el Occidente. En todo otro tiempo solo podian sacarse las ostras bastante grandes para que un schelin pudiera producir ruido en la concha.

H Al despuntar de nuevo la aficion a las ciencias naturales, observóse que en casi- locias partes donde prosperan las ostras y su pesca, constitujendo un oficio, se dedicaba mas ó menos cuidado tambien à su cria. Lóndres, la capital de In. glaterra, fué pronto un centro principal del consumo de os. tras, de modo que se trataba de tencr sicmpre una gran pro. vision en las cercanias, à cuyo efecto los conchiferos se traian desde mucha distancia para trasplantarlos í la desembocadura del Tánesis, fundandose asi una especie de cria semiartificial, cuyo origen no consta con seguridad, aunque los pescadores de ostras de Kent y de Sussex pretcnden que sus antepasados establecieron estos bancos en 170\%. Esta indus. tria se explota ahora en uny grande escalo. Las ostras se traen desde el sur y desde cl norte álos lados de la desembo. cadurn del 'Timesis y de Medway parn engordarlas por algun riempo en los bancos arrificiales. Johnston refierc q̨ue solo del golfo de Edimburgo todos los años se llevan $1.192,000$ ostras a otros criaderos; muchas mas vienen aun de las islas de Guersey y Jonerscy, donde la cria da mejores resultados. Forbes cree que las ostras consunidas en Lóndres provicnen, en su mayor parte, de estos bancos artificiales. Segun las averiguaciones hechas, la cantidad de ostras enviadas á Lóndres todos los anos asciende \& 130,000 bushels, de las que una cuarta partc se destina al interior y el resto se consunve en l.ondres. \$

Completamos estas noticias con el relato de Mcevius sobre IIhitsable, criadero clásico de ostras en la orilla meridional de la desembocadura del Tramesis. Nos dice que los pescadores de ostras constituyen ahora una especie de gremio con mas de 100 individuos. Wn arrecife de arena de legua y media de largo protege los criaderos de ostras contra el viento de levante. Ios criaderos tienen durante el refujo de 4 á 6 piés de profundidad, de modo que solo en los reflujos extraordinariamente bajos los bancos quedan en seco. El agua era turbia, y su densidad el 7 de mayo de 1868 de I",0024 por I I" Reaumur, que corresponde i un contenido de sal de 3 ' 14 por ciento. Para conservar y mejorar los criaderos de ostras se les provec con frecuencia de conchas de ostras vacias que principalmente vuelven de Londres.

- Los pescadores de Whitstable sacan ostras de los bancos maturales en el mar del Norte, en el canal de la Mancha yen las costas irlandesas, y las depositan en sus criaderos para comunicarles mejor gusto. I as ostras pequeñas del tamanoo de una pulgada ó pulgada y media se buscan regularmente en verano, con preferencia en los bancos naturales del golio del 'ranesis, entre Noergate y Harowich, donde la pesca es libre. La mayor parte las produce la pequeña bahia llamada Balchwater, entre Colchester y Maldon. Ias ostras del mas del Norte y del de Helgoland no adquieren tan buen gus. to y tienen mucho mas valor que las verdaderas ostras del pais. Ia pesca de ostras para el mercado dura por lo regular desde el 3 de agosto hasta el 9 de mayo, y el resto del año los pescadores se ocupan en limpiar los criaderos, interrumpiendo este trabajo solo en el tiempo en que se fijan las os. tras pequeñas. Fsto se hace eu junio ó julio, segun la temperatura del agua.

\#1 comercio de ostras es muy considerable en Whitstable. Los criaderos de este punto no solo sirven para criar y engordar estos conchiferos, sino que tambien son depósitos de ostras de todas las calidades y precios. En Whitstable mismo uma buena ostra del pais valia en i 869 ' ' 25 a I'jo peniques. En los años de 1852 à 1862 el precio del bushel $(r, 400$ a 1,500 ostras) no excedia nunca de dos libras esterlinas; de 1863 a $186_{4}$, el precio subió á 4 libras esterlinas, y en 1 S6S á 1860 se pagaban 8 libras esterlinas.

Menos desconocida cra en Francia, añade Brer, la rria artificial de ostras antes de Coste (que últimanente ha dado mas impulso a la cria de peces y ostras). Bory de S. Vicent pronunció en $8_{45}$ en la Academia de Paris un discurso sobre la necesidad de crear nuevos bancos, asegurando que él mismo habia creado bancos inagotables. Antes un tal Carbonel habia obtenido privilegio por un nuevo y sencillo método de fundar bancos de ostras en la costa francesa, cuyo privilegio vendió, segun se dice, à una sociedad pror 100,000 francos. Los parques de ostras se usaban mucho antes.

los parques de ostras ticnen un doble fin: sirven para engordar los conchiferos, y al mismo tiempo de almacenes. De fama universal gozan hace muchos años los de Ostende, Marenues cerca de Rochefort y los de Cancal en el Norte de Francia. I.as ostras que se crian en Ostende son originarias casi todas de las costas inglesas. Los tres parques de Ostende producen todos los anos unos 15 millones de ostras para el mercado. Los parques de Marennes y de Latermbald, con sus cćlebres ostras, se llaman a Claires: y solo en luna nueva y llena se provecn de agua fresca. Segun las noticias de Claoé en la eRerista de Ambos Mundos, su superficie varia de 250 metros cuadrados á 300 y estan protegiclos contra el mar, por un dique provisto de una compuerta para la regularizacion del nivel del agua. I a cria de las ostras exige el mayor cuidado. Los dueños de criaderos que tienen á su disposicion rarios claires trasladion sus ostras de una á otra para limpiar los mcios; de lo contrario, las ostras se sacan una por una de sus depósitos y se limpian del cieno. Las que en una edad de 12 a 14 meses entran en los claires, al cabo de dos años están ya madirtis para el consumo. Du rante este tiemjohan adquirido en Marennes tambien un color verde que entre los gastrónomos les ha procurado no escasa fama. No se conoce aun con seguridad el origen de este color: pero se suponeque proviene de las plantitas y animalitos microscópicos verdes que constituyen el alimento de las ostras en los claires. No queremos decir con esto que la materia verde 6 el clorofilo de las algas, diatomeas é infusoros se deposite directamente en la ostra si no sale del aljmento asimilado, es decir, de las partes que componen la sangre.

El consumo de ostras que en Paris por ejemplo asciende a 75 millones todos los años, apenas podria causar una dis. minucion sensible en los bancos; si ả pesar de eso en muchos puestos se ha observado la disminucion y hasta desaparicion de los bancos de ostras, este hecho tiene su origen en una serie de causas. Ia osua tiene muchos encmigos naturales de casi todas las clases de animales. Peces, crustaceos y estrellas de mar las persiguen; varios moluscos, sobre todo el Murix tarentinus, Murex erinascus, Purpura lofillsus y 
Vissa reticulata abren agujeros en las conchas para chupar su sustancia. En otros puntos los mitilos se han fijado en tal número en los bancos de ostras, que las últimas por decirlo asi se sofocan; I ultimanente otro animal que los franceses llaman maerle, probablemente un tubulario del género de las abelarias, se ha piesentado como destrucior del precioso conchifero. Pero todos estos enemigos han existido mucho olas yo ya á expensas de la ostra, que sin ellos y sin que las olas, la arena y el cieno hubiesen destruido millones de ostras recien nacidas, hace liempo llenarian todos los mares. I unayor y mas sensible perjuicio lo han suirido los bancos de ostras, sin duda por parte del hombre, i causa de una explotacion mal entendida. La red quese emplea en los sitios donde no se pueden coger las ostras con 4 mano, r que se mareja desde barcos tripulados por cincó ó seis hombres ibre verda deros agujeros y' surcos en los bancos; y el mayor perjuicio consiste entonces en que estos agujeros y surcos se llenan en poco tiempo de cieno, el cual, no solo hace imposible que en adelante los animales se fijen en estos puntos, sino que tambien mata los de los contornos no tocados por la red.

Si fuera posible, pensaba el profesor Coste, salvar solo una parte de los innumerables millones de ostras jóvenes que se devoran en el Océaso, y facilitarles el medio de fjarse, las ostras pronto serian uno de los alimentos mas comunes $y^{\circ}$ baraios. Fin el lago de lucrino se procuró hace ya algunos miles de años que las ostras se fijasen en haces de leña que al efecto se colocaban convenientemente. Ia cria artificial de ostras introducida desde I\$55 en Francia, no es por lo tanto otra cosa sino un perfeccionamiento del método observado antes con los animales jóvenes mas expuestos a los peligros.

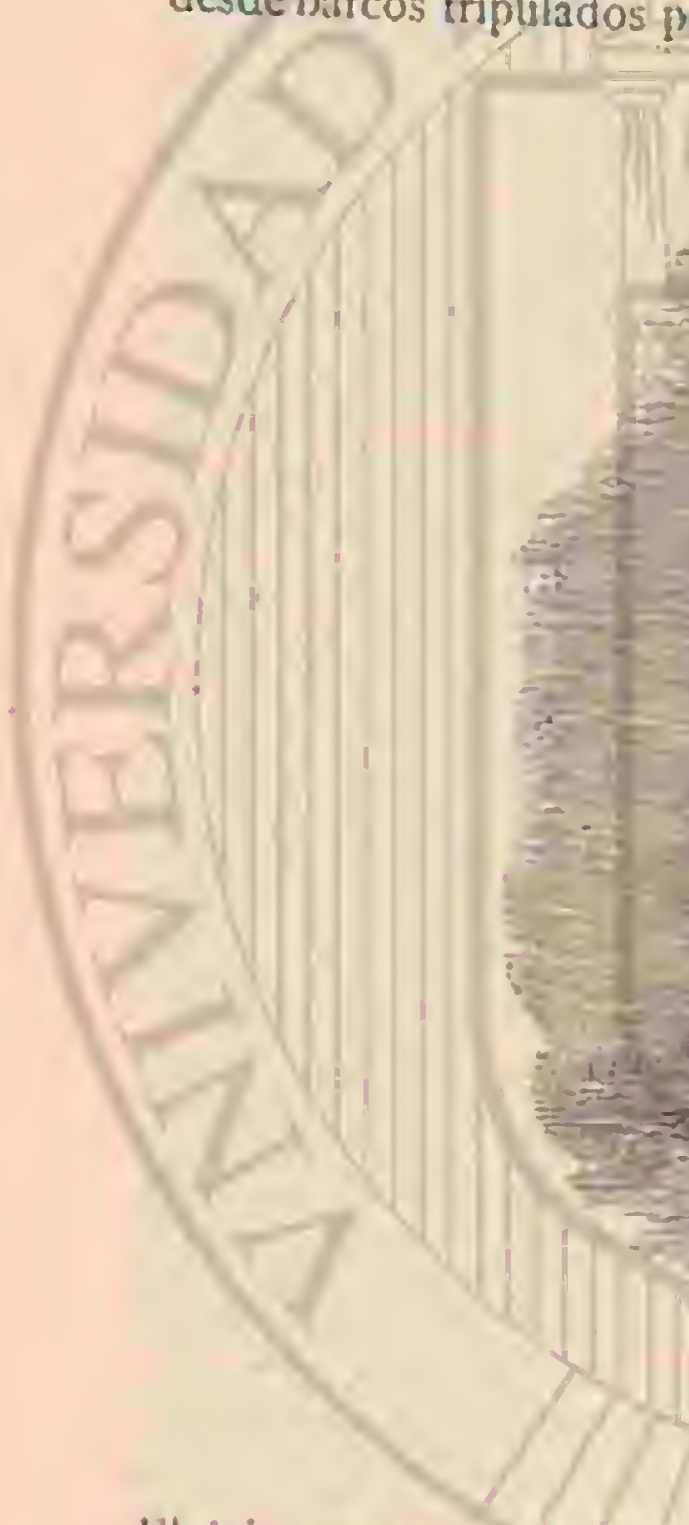

Lil exito en un concepto apenas podih ser dudoso pues los haces de leh̃a pronto se cubrian de ostras júvenes. Pero tambien se reconoció quue los enemigos de los bancos de ostras, sobrc todo el cieno fino amenazaban destruir los colonos de los haces, $y$ además que las ostras jovenes se fijaban en un mimero tan excesivo, que muy probablemente muchos de estos inumembles animalitos perecian por falta de alimento. In una palabra, al cabo de algunos años de costosos experi mentos, resultó que con los haces de leña bajados a la pro fundidad del mar nada podia hacerse en favor de las ostras. Listos experimentos se habian efectuado en ia bahia de Saint briece. Desde entonces se han limitado a los parques de la vigilarse Arcachon que estan en el punto del refujo y pueden de leija perfectamente. Para lit cria de ostras se pronen haces conchas o cubiertas de una capa de conchas, o tambien ladrillos fabricados al efecto. teniendo ques, hasta que se acer de noner tstos objetos en los jar. adultas sc deseme acerque el momento en que las osiras tabjas, se de la cria, pues de lo contrario las ostras jóme culgas, de modo que las El resulten no pueden fijarse en ellas.

Elesulado fué farorable por algunos anos. En is64 se de todo en los parques de Arcachon 35 millones de ostras de todo tamaño que, evaluado el mil en to francos, repre laba que la capital de $1.400,000$ francos. Tambien se calculaba que la renta anual ascenderia a seis millones de ostras y i 24,000 francos. Pero una séric de enemigos animales, sobre todo el murex espinoso, y causas climatéricas diezmaban las ostras, y Mcevius encontró en I 869 en los Parques Impe. riales solo 150,000 ostras madres, $y$ unos seis nillones dc pequenas de unos $0^{\mathrm{m}}, 02$ a $0^{\mathrm{m}}, 03$ de largo.

Nọ sé si esta industria mejora bajo el gobierno de MacMahon; solo me han dicho que las ostras se han abaratado.

Asi como Hueninguen era el centro para la cria de peces de agua dulce, Arcachon debia ser el establecimiento modelo para la produccion de los animales marinos comestibles, y por lo que toca á las ostras, pronto se encontraron muchos empresarios que pidieron al gobierno francés concesiones para la fundacion de parques para la produccion de ostras de cria y de mercado. En Francia toda la zona de la playa que queda descubierta por el reflujo, es decir, la única zona de la costa propia pam los criaderos, es propiedad del Es. tado, y además todas las personas que se ocupan en cualquier género de pesca de mar, se inscriben en el alistamiento de mozos para la marina. El que, por lo tanto, quiera criar ostras en Francia, debe ser primero un hombre de buenos sentimientos patrióticos, $y$ además estar siempre dispuesto á servir en la marina. Se ha demostrado que las crins de ostras emprendidas por alistados y especuladores no daban el resultado apetecido, porquue esta gente no toma un verdadero interés en el asunto, ó bien espera enriquecerse en poco tiempo. Solo los pescadores y habitantes de la costa, que todo 
el año y todas los dias fijan la mayor atencion en las ostras, dedicando su vida à esta industrian, y sin depender de un cambio de gobierno, son propios para criar ostras, como los labitantes de la pequeña isla de Ré. Un cura de la isla es. cribio en I 866 que lo que se habia referido sobre la prosperidad de la cria de ostras en aquel territorio, parecia mas bien una novela $\delta$ un ciento de nodriza que un hecho probable. La verdad era que los experimentos hechos en aque. lla costa no habian salido todos bien, siendo inexacto que los habitantes de la isla de Réles debiesen una prosperidad hasta alli desconocida. "Raros, dice, son los que han logrado un Exito completo en esta industrin, y mas raros aun los que tienen esperanzas fundadas de obtener alguna utilidad en el porvenir, porque los mejores criaderos de ostras rápidamente se acercan i su ruina.

El relato publicado algunos años despues por nuestro ami. go Mœvius está conforne esencialmente con el juicio ante. rior. Desde $18 \sigma_{3}$ la produccion estaba en baja continus, y los criadores razomables de ostras se habian convencido de que la explotacion exagerada de los bancos cra la causa de la des. truccion de la cria de ostras, y de que una cria de millones de ostras jóvenes, desde luego en los parques, era imposible.

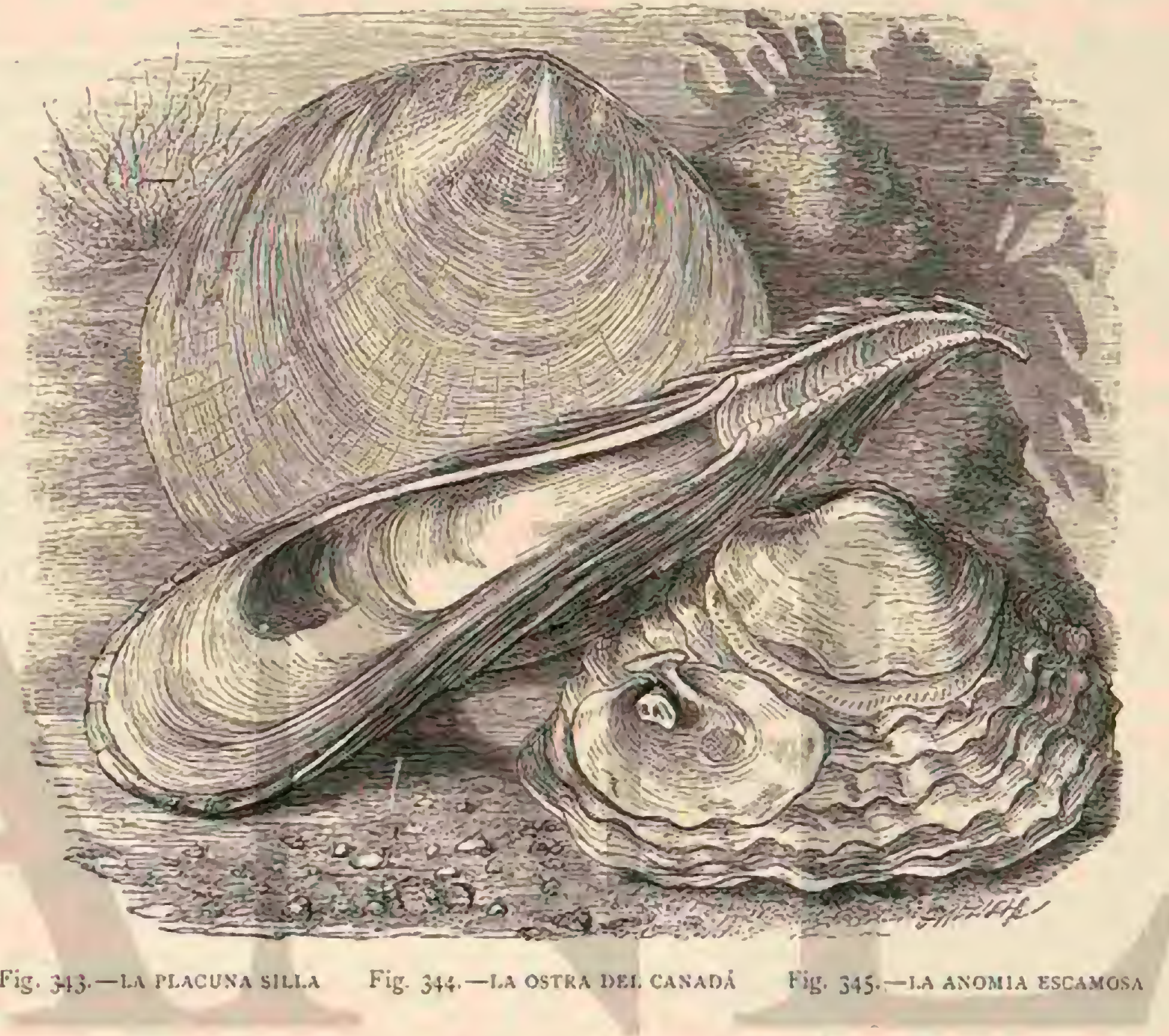

Solo en i $\$_{73}$ hemos recibido noticins sobre el área de dis. persion, el consuno y la cria de la ostra en las costas orientales de la América del Norte, en un relato publicado por la comision de pesca sobre el estado de las pescas marinas en la costa meridional de la Nueva Ingiaterra. Alli se encuentra la ostra de Virginin extendida á alguna distancia de la costa y la ostra del Canadá (fig. 344). Sin embargo, solo en las regiones meridionales de da costa llega aquella à su tamano completo, mientras que en la latitud de Baltimore y de Nueva-York necesita una cria artificial, porqque las ostras se fijan a muy poca profundidad y mueren regularmente en invierno. Por esto se trasladan en gran número á sitios convenientes mas profundos. Esta variedad, sin embargo, es menos apreciada que la que desde el sur se importa en los bancos de ostras naturales y artificiales para engordarla. En ambos casos se trata de lle. var las ostras jóvenes à los puntos donde mas abunde su alimento microscópico en las rocas, $\sigma$ a un fondo compuesto artificialmente de conchas de ostra. Son propias al efecto las mismas localidades situadas mas allí del Océano, como en Europa, las desembocaduras de los rios, los puertos y los estanquees salobres.

Tambien en estos criaderos se reunen pronto otros numerosos animales inferiores, figurando entre ellos algunos enemigos peligrosos de la ostra, como por ejemplo un molusco de $0^{*}, 03$ de largo, llamado por los pescadores el eperforadors (Urosalpino cinerea) y una estrella de mar verde (as. terias arenionla). Los destrozos cque puede causar la última son asombrosos: á un solo propietario de la costa del Connecticut le destruyeron en pocas semanas 2,000 banastas de ostras. Segun cálculo moderado, véndense en el norte del cabo Hatteras todos los años, cuando menos, 30 millones de celemines de ostras, de un valor de mas de 20 millones de pesos fuertes.

\section{LAS PLACUNAS - PLACUNA}

CARACTÉRES. - Este género, afine al anterior, se compone de especies cuya concha es delgada, irregular y muy plana; la charnela presenta en una valva dos dientes cortan. tes g divergentes, y en la otra clos depresiones que sirven para la insercion del ligamento. El carácter mas notable que distingue a estos moluscos consiste sobre todo en su trasparencia.

Las pocas especies que representan el género son todas propians del Octéno Indico.

No solo se utilizan las placunas como alimento: los chinos se sirven de ellas, empleảndolas en vez de vidrios para sus ventanas, gracias à su singular trasparencia. 
De las especies conocidas, citase como la mas notable la fracuna silla (fir:: 343 ).

lin Figipto se ha encontrado una especie fúsil.

\section{LAS ANOMIAS-ANOMIA}

No podemos ocuparnos de las muchas ostras fósiles, y concluimos el capitulo sobre los conchiferos dando á conocer un género y especie congenéricos de la ostra. Es la anomia ephippum, que presenta tanto en la concha como en las par. tes blandas algunas particularidades notables: de la primera, que por lo regular tiene forma de disco, no se puede, sin embargo, indicar una forma determinada, porque la valva inferior, muy delgada, se adapta por su figura completamente al cuerpo extraño que le sirve de base. I a valva superior es mas gruesa y abovedada, pero sepite taribien todas las jurominencias del cuerpo en que el animal descansa en corres. pondencia à esta concha, plana tambien, el animal es muy aptanado.

Cuando se inquieta al animal, los músculos se contraen, por lo cual no solo la concha se cierra, sino que tambien se oprime con fuerza contra la base, cuyo relieve se trasmite á la concha.

I. a anomia no falta en ningun punto de los mares curo. peos, cuando contienen la necesaria cantidad de sal; la region que habita es la misma que la ostra, mas jarece que tambien se encuentra mas arriba de la zona del retlujo.

Entre las especies que se citan, solo haremos mencion de la anomia escamosa (fig. 345).

\section{LOS TUNICADOS-TUNICATA}

Varias reces hemos visitado las pesquerias de las ciudades de la costa italiana y francesa para conocer ciertus animales marinos gue nos sorprenden por su forma y aspecto; y de nuevo invito d mislectores at seguirme en tal paseo. Despues de haber visto lus peces, tiburones, sepias y calamares, llegamos a la serie de cestos llenos de caracoles y conchlieros, que en su generalicad conocemos; pero enmedio encontramos uno lleno de tubérculos parduzcos ó irregulares con arrugas y prominencias, súcios y cubiertos de toda clase de partsitos. Es de todo punto imposible ver por el exterior de estos cuerpos si son formacionès vegetales ó animales; al contacto parecen cuero duro y seco, $;$ no se mueven. Pero al tocar uno nos arroja un fino surticior de agua i la cara, y descubrimos en la superficie, poco apetitosa, un punto un poco mas claro con una fina hendidura en forma de cruz, de la que por medio de una presion podemos sacar aun mas agua. Un hombre del pueblo, que por poco dinero compra una docena de estos tubérculos, abre uno de los mismos con un cuchillo afilado y nos presenta un saco de un amarillo bonito, que con la capa gruesa $y$ tosca solo está en relacion por el punto del que sale el agua y por otro parecido. Nuestro amigo come con el mayor apetito este saco amarillo, dejándonos la capa coriácea para practicar los experimentos cien. ifícos.

Conocemos ahora superficialmente un zunicado y no ne. cesitamos afirmar que aquella capa coriảcea es el manto exterior, mientras que los otros órganos del animal están rodeados de una segunda capa mas fina, que de la primera está suspencidida por medio de dos puntas. El animal que habiaunos cxaminado es una ascidia llamada microcosmus, porque regularmente lleva á cuestas todo un mundo de pa. rissitos vegetales y animales. Al visitar uno de los baños en el puerto de 'Trieste ó de Nápoles, encontrmmos en la cara inferior de la mayor parte de las maderas que se encuentran bajo el agua, además de muchas plantas, otros animales tambien tunicados del grupo de las ascidias, que sin embargo sio cienén lá capa coriácea sino membranosa y trasparente; ptedomina una especic que poco mas 6 menos tiene el aspecto de un intestino. Tambien en ella, cu la ascidia ó falusia intestimal (fig. $3+i$ ), nos convencemos fácilmente que III saco interno mas fino està suspendido de uno exterior mas sólido, con ul que estả reunido nas estrechamente al rededor de dos aberturas que se encuentran al lado de la extremidad anterior.

Los pescadores dalnacios a menudo se han quejado de otro tipo de tunicados. Con frecuencia sacan con stu red en vez de peces, quintales de pequeños animalitos de uno á dos centimetros de largo, que se parecen à un barril abierto por las dos extrenidades, y que la ciencia hace tiempo ha reco. nocido como los congéneres mas afines de las ascidias. Tam. bien su cuerpo está rodeado de un manto sólido que en su commosicion microscópica y química es análogo al de aque. llas. Tenemos que fijarnos sobre todo en la natumleza quimica de este órgano. Hace algunos decenios que la ciencia sistemática consideraba la celulosa como propiedad exclusiva de las plantas, pero se demostró que la celulosa es una sustancia principal del manto de los iunicados, si bien en otra forma que en el reino vegetal.

Podemos examinar ahora mas minuciosamente las dos for. maciones ya indicadas.

\section{UNIVER
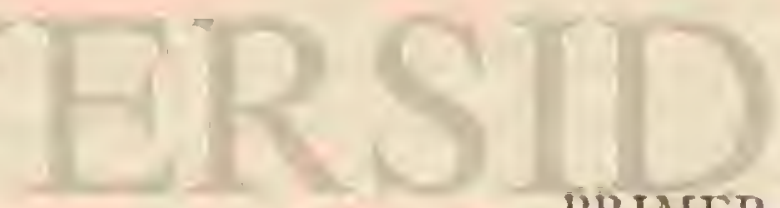 \\ PRIMER ORDEN

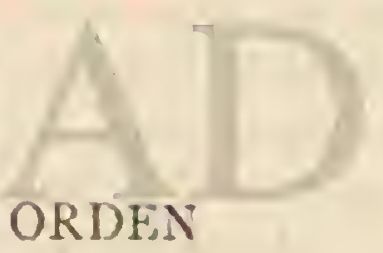

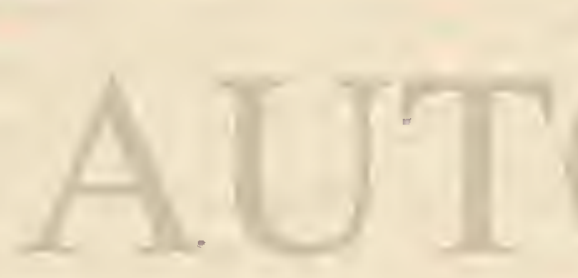
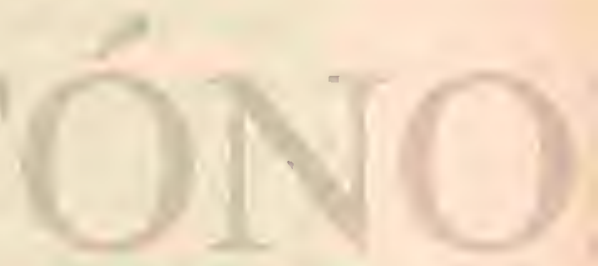

\section{ASCIDIAS - ASCIDI}

Ins ascidias (fig. 3.46) son tunicados que viven poco tiempo libremente como larvas con cola; después se fijan pará siempre en diferentes objetos submarinos. Lo inas conveniente es examinar primero las especies nayores que viven como individuos aislados en todos los mares y en las profun. didades mas diversas: el estudio anatómico superficial nos podrâ servir de guia. Se llaman ascidias sencillas, para distinguirlas de otras especies que afectan la forma de tronco. E: manto exterior muy grueso, debe compararse con una con. cha de dos valvas. Despues que algunos importantes zoúlogos ingleses, como Honcack y Huxley, creian hiaber reconocido por diferentes razones una afinidad intima de las ascidins con los branquiopododos, Lacaze-Dutihers descubrió en la costa africana un genero de ascidias llamado shetrculius, cuyo manto exterior parece exactamente uno de aquellos antiguos esiuches de rapé, y que tambien recuerda el género de branquiópodos thecidun. El cheireulius es respecto à esta concha una forma de tránsito muy conveniente para el zoólogro 
- que comjara en el sentido de Darwin. Una de las aberturas no conduce inmediatamente à la boca, sino á una ancha cavidad branquial en cuyo fondo se halla la boca, en la que el alimento penetra empujado por unas pestanas movibles. Por debajo de la segunda abertum, el intestino se vacia en un corto tubo, por el cual tambien se segregan los productos de la propagacion. Iass ascidias son verdaderos hermafroditas; y su desarrollo embrionario ha adquirido grande importancia por las areriguaciones del zoólogo ruso Kowalebsky, publicadas hace años. El citado autor ha demostrado que en las larvas de las ascidias provistas de una cola de remo, se forma pasajeramente un órgano en las mismas proporciones de una parte del cuerpo del vertebrado, yue hasta ahora se consideró con la propiedad exclusiva y caracteristica de la gran clase à que pertenece tambien el hombre por su estructura y origen. Este órgano es la llamada cuerda dorsal. La ex. plicacion de Kowalebsky constituye un inmenso adelunto, porque es una de aquellas confirmaciones deseadas cuando se sostienen graudes y nuevas hipótesis cientificas como la de Darwin. Sin embargo, en 1874 , el \%oólogo Semper de Wirt\%. burgo ha emitido la suposicion de que los anillados están aun en relaciones mas cercanas con los rertebrados que con las ascidias. Se trata de la existencia de ciertas disposiciones orgetnicas en los riñones de los tiburones que, segun el citado autor, se parecen á los llamados órganos segmentales de los anélidos, ja de la posibilidad de considerar la médula ventral de los anélidos y artrópodos como igual à la médula dorsal de los vertebrados, no solamente por sus funciones, sino tambien analógica y morfológicanente.

Hace ya mas de 50 anos que las ascidias sencillas se han clasificado por Savigny en géneros: el citado naturalista se fijaba, ya en la naturaleza coriacen $\delta$ cartilaginosa de la capa del cuerpo, ya en los apéndices 6 tentáculos que rodean la abertura branquial y la de los excrementos, y que se presentan cuando el animal está en reposo. Al lado de ellos se ven por lo regular varios puntos rojos, designados prematuramente como órganos de la vista. Es verdad que los nervios penetran lo mismo en los tentáculos que en la inmediacion de los citados ojos, pero todos salen de un gánglio situado entre las dos aberturas.

Antes hemos reconocido ya lo numerosas que son ciertas especies; lo mismo sucede con gran numero de otras, y el que se ocupa en recoger animales marinos por medio de la red armstradora, siempre recogerí, si no otra presa, cuando menos ascidias.

Cuando à las ascidias se las tocr ó saca de su elemento, recogen los tubos de la abertura y adquieren una forma que nada tiene de elegante. No sucede asi cuando pueden desplegarse tranquilamente en el acuario. Algunos de los depósitos mas interesantes del acuario de Dliorn de Nipoles son los de las grandes ascidias, sobre todo de la falusia, pirallusia mamillaris, no solamente la boca branquial, sino tambien la abertura anal parecen bonitos cálices de flores. Aun la as. cidia microcosmo, por lo demás tan poco elegante, presenta entonces una estructura tan fina y tan delicados tintes rojos, que-su aspecto recrea la vista. La sensibilidad de los lóbulos del borde es extraordinaria. Cono los animales viven ocul. tos en la arena ó fijos en cualquier cuerpo sólido, se encogen siempre que se les quiere hacer tomar otra posicion. Lo mismo sucede á menudo en un cambio brusco de lux, $\delta$ cuan. do por ejemplo se quita rapidanente la tapa del vaso en que se puso el individuo para la observacion.

Un grupo muy congenérico de las ascidias sencillas es el de las ascidias sociales al que pertenece la darsellina lefrad:formis (fig. 352), propia del mar del Norte y de los mares mas septentrionales. La sociabilidad de la misma no es roluntaria.
Del manto salen apéndices en forma de raices desde los cua. les se levantan retonos, que poco á poco se desarrollan en individuos nuevos sin separarse de sus vecinos ni del animal primitivo.

En un contacto mas intimo se hallan sin embaryo los individuos de los géneros que forman la tercern division, las ascidias compuestas. Los individuos son en este caso muy pequeños, pero se reunen irregularmente ó por determinados sistemas en una masa comun gelatinosa ó cartilaginosa. Los individuos que pertenecen tí un sistema se agrupan al rededor de una abertura comun de excrementos.

A. Giard ha hecho observaciones muy interesantes en la costa oriental yoccidental de Francia sobre el género de vidia, la estructura $y$ la propagacion de las ascidias compues. tas. Sus colonias se encuentran con preferencia en los puntos no expuestos directamente al sol, en la cara inferior de las rocas y piedras, entre algas y yerbas marinas y en conchas vacias. Abundan mas en la rom do la costa é inmediata. mente bajo la superticie del agua: ciertas especies se fijan a mayor profundidad, a 20 ó 30 brazas poco mas ó menos. El aspecto de los troncos depende mucho del sitio y naturaleza de la base. Asi por ejemplo, el amarucio espeso fijado en yerba marina, adquiere segun Giard, la forma de un hon. go con tallo corto, micntras que en una roca solo forma una costra.

Una trasformacion muy particular experimentan, segun el mismo naturalista, estas ascidias durante el invierno. En el didemno de color de cera, que pertenece á las especies llenas de cuerpecitos calcáreos microscópicos, se oscurecian en los primeros dias frios de otono las partes blandas.j crecian extraordinariamente los cuerpos calcireos. Fin el amarucio espeso desaparecian los individuos desde el horde de In colonia.

Ni el olor desagradable propio de la mayor parte de las ascidias, ni su fuerte capa, les pone al abrigo de sus enemigos. Varias limazas las devoran, un pequeno conchifero (crenella) penetra en ellas y ciertos anélidos construyen galerias y tubos en sus colonias, pero sobre todo algunos crustáceos inferiores se fijan en la cavidad branquial sacando su alimento de la corriente de agua que pasa por la brinquia. Estos crustaceos no son por lo tanto verdaderos parásilos, sino comensales (expresion inventada por el conocido naturalista van Beneden, el mayor), que saben sacar su pro. vecho de las provisiones de su anfitrion.

Sin cmbargo, los enemigos de las ascidias no son muy numerosos y la gran resistencia vital y propagacion de es. tos animales compensa con exceso las destrucciones causadas por aquellos. Su tronco cortado casualmente $\delta$ i causa de un experimento, vuelve á crecer. Al cortar la parte superior del cuerpo de un grupo de individuos, el corazon y cl ovario siguen vegetando, todo se reconstruye, lo mismo que el sistema nervioso, sirviendo la masa del ovario como material de formacion. En ciertas especies, como en el ceri. natium concresens, los individuos que se fijan uno al lado de otro se sueldan y el tronco aumenta en tamaño por retoños que salen de los socios reunidos.

Los rutoños son en general el medio de propagacion de la colonia. Pequeñas prominencias y excrecencias en varios puntos del cuerpo de los individuos, indican el principio de la formacion de retonos. Esstos se intercalan ya en el centro del tronco ó se presentan como en los botrilos (fig. 351) en forma de nuevos sistemas en la periferia. Segun las averigua. ciones de Charnier, es errónco el que, cumo antes se creia, to. do un sistema de botrilos, es decir, todos los individuos que se forman alrededor de una abertura comun, lo hacian à lis ver ya como retono colectivo, ya descle el huevo. El indivi- 
duo yue se forma de un husero, no se divide en ocho ó mas individuos, sino que $y$ in en el huevo empiezan a formarse los retoños y entonces se presenia un sistema de animales de igual edad j desarrollo. Todos los individuos que como retoinos han crecido en el tronco, se reproducen tambien sexualmente. Las larvas provistas de la cola de remo, salen al agua libre y cada una funda una nueva colonia, sin llegar segun parece ella misma a formar huevos.

\section{LAS CINTIAS - CYNTHIA}

CARACTERES. - Tiste es otro género, caracterizado del modo siguiente: el ruerpo es sesil, con un caparnaon coriaceo provisto de dos orificios cuadrifidos: el saco braquial esta dividido por pliégues longitucinales y coronado por un circu. lo de tentáculos compuestos $\delta$-scucillos: las mallas del saco branquial carecen de papilas, $y$ el abdómen es lateral.

Conócense varias especies de este género: la mas notable es la cintin momo (fig. 350 ).

Esta ascidia habita en el golfo de Suez.

\section{LAS BOLTENIAS - BOLTENIA}

CARACTERES. - El cuerpo de las boltenias es pedicu. lado por su vertice y con caparazon corícico; el orificio bran. quial dividido en cuatro radios, yel intestival lo mismo. El saco branquial esti plegadolongitudinalmente y coronado de un circulo de tentáculos conpuestos; las mallas del tejido respiratorio carecen de bolsas ó papilas: el abdómen lateral; el higado nulo, y el ovario múltiplc.

Eritre las mrias especies comprendidas en este género, la bollcria reniforme (fig. 348) es una de las mas comunes.

Esta especie es propia de los mares de América.

\section{LOS SINTETIS - SYNTETYS}

CARACTERES. El gTUpo que forman los sintetis ofre ce cierta semejanza con una planta ensanchada. Estos anj. males son algo trasparentes y de un color rerdoso. Eil sincetis de las Jébridas (fig. 349) es la única cspecie conocida de este
género.

\section{LOS PIROSOMOS - PYROSOMA}

A las ascidias compuestas y sedentarias sigue el género de los pirosomos, cuyos especies forman troncos. I.os individuos están reunidos de modo que el cuerpo contun forma un cilindro gelatinoso, huern, cerrado en una extrcmidad y libremente Rotante. Iass aberturas branquial y anal estin opuestas, desembocando las cavidades respiratorias de los individuos hacia atuern, las cloacas en la cavidad del cilindro comun. Segun la naturaleza de la cavidad branquial, y en ge. neral, de la disposicion de los órganos, los pirosomas se parecen, á pesar de su aspecto y género de vida tan diferentes, mas a las ascidias. El nombre de estos animales dice que representan un papel impartante en el grandioso fenómeno de la fosforescencia del mar. Un antiguo observadoringlés refiere el espectáculo que presenció el I I de octubre bajo los 4 " de latitud sur y' a los $15^{\circ}$ de longitud oeste. El buque marchiaba rápidamente y á pesar de eso podia verse durante todà la noche la fosforescencia, y sacarse i cada paso con la red los pirosomas. I.a fosforescencia salia de isumerosals y pequeñas particulas pardas en la sustancia del cuerpo. Al cortar un pirosoma, las particulas pardas se dispersaban en el agua y se presertaban como numerosas chispas. Mas minuciosas son las noticias del navegante Meyen sobre el fenómeno radiante de los pirosomas. La luz es nuy viray de color azul verdoso, muy diferente de la de todos los otros animales radiantes. Cuando se les coge y encierra en un vaso grande con agua no despiden fulgores, pero empiezan en seguida a radiar cuando se les toca. La luz se presenta primero en formalde chispas muy finas, que despues se reunen y cubren tado el tronco. Al tocar un pirosoma en las dos extremidades, las chispas se presentan primero en estas y des. pues en el ceniro. El moviniento del agua produce la fosfo. rescencia; cuando la fuerza vital del tronco estí extinguiéndose se necesitan irradiaciones mas fuertes. En contraste con las noticins de Bennett arriba citadas, Meyen, dice, que cuando se rompe un pedacito del pirosoma, no solamente cesa en este al momento la fosiorescencia, sino tambien en el resto del animal, No ha visto que salieran las particulas fosfores. centes. Sulo Panceri nos ha dado una explicacion satisfactoria de la fosforescencia de los pirosomas. Sabernos ahora que en cada individuo del tronco del pirosoma, brota aquel brillo de dos aglomeraciones de celdas que son los b́rganos radian. tes, y no los ovarios del animal, segun creian los observado. res anteriores. Los puntos radiantes que desde un sitio irritado de la colonia se extienden poco à poco sobre todo el cilinJro, eran, por consiguiente, en un pirosoma de $0^{\circ}, 008$ de largo por $0^{*}, 0,4$ de diâmetro, 6,400, porque cl número de los animales microscópicos se calculaba en 3,200. Sin embargo, Panceri no ha logrado aun completamente areriguar el modo con que el fenómeno radiante se propaga de un individuo al otro y for todo el cuerpo. Probablemente se trata de los nervios que pasan por los músculos, por inedio de los cuales los individuos están reunidos uno con otro.
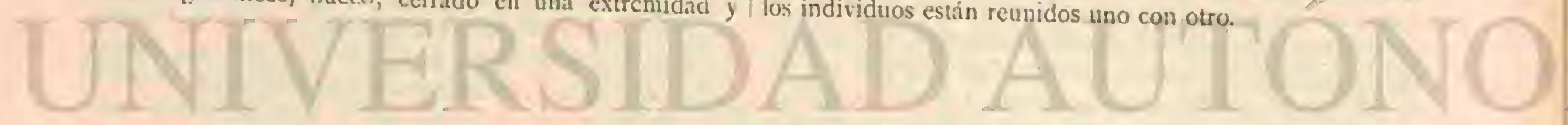

\section{SEGUNDO ORDEN}

El poeta Chamisso, que como naturalista habia acompaiado una expedicion rusa en su vuelta al mundo, publicó en 1819 un tratado sobre las salpas observadas en los mares meridionales, yo pretendio que de estos animales trasparentes pertenecian siempre, dos formas á una especie, que la hija no se parecia siempre a la inadre sino a la abuela, que los indi. viduos de una forma siempre están reunidos en mayor nu-
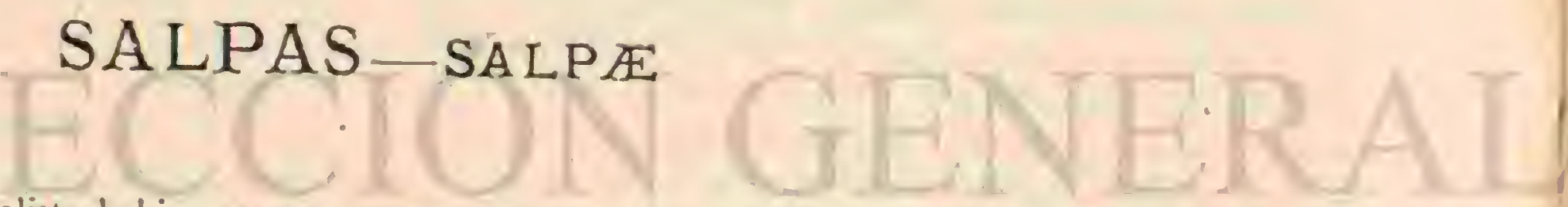

mero en formas de las llamadas cadenas de salpas, mientras que los individuos de la segunda forma vivian aisladamente. Entonces estas noticias se consideraron como iuverosimiles, hasta que unos reinte aìos mas tarde Steenstrup demostró la exactitud de sus opiniones sobre el cambio de las generaciones, $y$ rcunió tambien las salpas en el circulo de los animales sujetos à este modo de propagacion. 
Tambien en las salpas la mayor parte de la masa del cuer. po está formada por el manto. Ya hemos hablado de la igualdad quimica del manto de las salpas con el de las ascidias; pero tambien, por lo demás, nos orientaremos f́ácilmente sobre las partes del cuerpo que se corresponden y sobre su situacion. Tanto los indivicuos en cadena como los aislados, recogen el agua por una abertura anterior en una ancha cavidad, en la que la bránquia está tendida diagonalmente. lan luego como cl agua ha entrado se cierra aquella abertura, el cucrpo se contrae por medio de músculos, el agua sale por otra abcrtura posterior situada un poco al lado y empuja al animal alguna distancia hácin adelante. Fs sorprendente, tanto en las salpas como en las ascidias, cómo el corazon, despues de haberse contraido por algun tiempo en una direccion, de repente se vuclve é invierte toda la circulacion de la sangre. Fi ganglio ccrebral, propio de las ascidias, no falta tampoco en las salpas; se encuentra fácilmente por detrás y hícia arriba de la abertura anterior, y nunca falta en un órgano que se considera como ojo. Por fin notamos en el indi. viduo examinado, unos apéndices en forma de punta que indican que tenemos a uliestra vista un individuo separado de su vecino en la cadena, con el que estaba soldado preci. samente por estos apéndices.

Llegamos al punto mas interesante en la historia natural de las salpas. Hemos descrito un individuo de la cadena. Todos los miembros de tal cadena doble, orgánicamente relacionada, son completamente igmales y desarrollan órganos genitales hermafroditas. Pero de sus huevos no vuelven $a$ salir cadenas, sino individuos aislados que en cada especie se distinguen ya exteriormente de los individuos de cadena, y se demuestran como una nueva generacion de trinsito, por la circunstancia de que nunca se propagan por medio de huevos. Producen, al contrario, retonos internos dispuestos desde un principio como cadenas de salpas y que nacen en esta misma disposicion. Todos los individuos de tal cadena estan igualmente desarrollados, y á menudo se ve cómo por detrás de una cádena ya crecida, se levantan los principios de una $\delta$ de dos nuevas. La cadena de salpas recien nacidas es tan completamente fornada, que todos los individuos em. piezan al mismo tiempo i recoger el agua respiratoria. Al desplegarse sus órganos genitales se cierra el circulo de desarrollo de la especie.

Tambien las salpas encienden, segun Jhonston se expre5a poéticamente, su límpara en la oscuridad; pero nunca tienen la luz tan viva como los pirosomas. Como la capa radiante de la superficie puede quitarse como una sustancia mucosa, el observador inglés creia poder deducir que no existian órganos radiantes particulares, sino que el fenómeno tenia su origen en un proceso de combustion y oxidacion que se extendia sobre toda la superficie, del nismo modo como en muchos cuerpos orgánicos, sobre todo en los peces marinos, el fenómeno radiante no se presenta si no despues de la muerte, al principiar una descomposicion superficial. Sin cm. bargo, hay que averiguar aun mas exactamente este asunto.

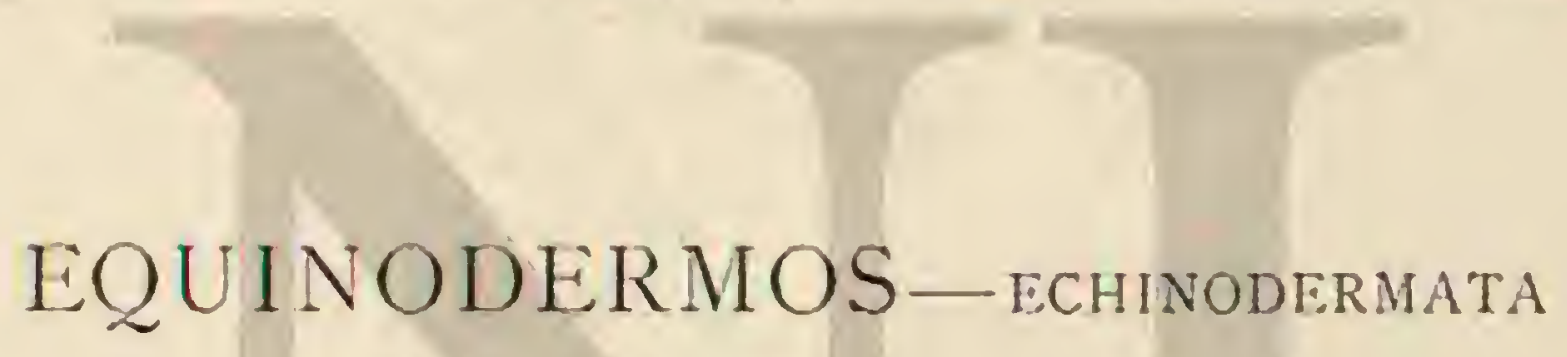

En la mayor parte de las obras zoológicas publicadas des. de 1819 hasta ahora, los animales que no se han comprendido en la clasificacion en vertebrados, artrópodos y moluscos, se agrupan bajo al nombre de radiacios (radiala): debiendo advertirse que Cuvier, crendor de este grupo, y sus partidarios, se veian obligados a comprender en él un simnúmero de de animales que no eran radiados: todos aquellos animales que con raron podian designarse con tal nombre, es decir, aquellos cuyo cuerpo esta dispuesto al rededor de un centro, no forman contraste con cada uno de los otros tres grupos sino cols su conjunto.

Los radiados de Cuvier no son por lo tanto una clase natural, como tampoco lo serian los vertebrados, artrópodos y moluscos reunicios. La zoologia moderna ha rechazado, por lo tanto, casi generalmente, este nombre, o solo conservaidole por la conveniencia sistemática En cambio se ha dado el rango de clase á los equinodermos, aunque de éstos solo se cuentan una 3,000 especies, incluso las fósiles. Fisto podia parecernos extraño, pero debemos hacernos cargo de los muchos vacios que se observan en nuestros conocimientos del mundo fósil, además remos que entre las 3,000 especies de equinadermos se presentan tales diferencias, que alejan los grupos uno de otro, tanto como los moluscos de los caracoles, de los conchíferos, y entre los artrónodos, los aracnóideos de los insectos.

Aunque a continuacion citamos las subdivisiones de los equinodermos como órdenes, lo hacenros considerando que en rigor les perteneceria el rango de clases. L.os zoólogos antiguos carecian, por decirlo asi, del material suficiente jara llenar los vacios en el sistema.

En los paises del interior de los continentes y en las aguas duices no podriamos conocer un equinodermo; pero en cam. bio son ricas en ellos las costas del mar, cuando menos en algunas formas notables. En los espacios arenosos del mar del Norte basta seguir al reflujo para recoger numerosos ejemplares de las estrellas de mar, sobre cuyo nombre los habitantes de la costa de todas las zonas han estado confor. mes. Las prominencias y protuberancjas de la piel les conu. nican un aspecto áspero y espinoso. Los equinodermos mas caracteristicos, sin cmbargo, son los crizos de mar, que raras veces encallan, excepto cuando mueren; jero de los que algunas especieș, cono el echinussaxatilis del Mediterránco, pue. de verse á miles á poca profundidad. Las estrellas y crizos de mar en su posicion natura! tienen la boca hácia arriba. Su piel se distingue por secreciones muy abundantes de materias calizas, ya dispuestas una junto i otra, ó bien reunidas en forma de placas de linea recta en una especie de concha. Esta última, sin embargo, no puede nunca comjararse, con la de los conchiferos y moluscos, pues siempreson verdaderas calcificaciones de la misma piel.

Todos los equinodermos tienen un intestino cerrado, carácter importante que los separa de los otros radiados. Ademds presentan un carácter mas notable, y es la existencia de los piés chupadores, cuyas series irregulares se llaman amiulacra. Para ver la accividad de estos órganos es preciso obscr. var los animales vivos en un vaso de agua: de los surcos que se corren en la cara inferior de los radios parten centenares de cilindros huecos y memibranosos, provistos en su extremidad de un disco chupador: y estos discos sirven tanto jara fijarse cono para moverse. In ereccion y dilatacion de lus piés se efectua cuando en ellos penctra el agua descie dentro. A cada cilindro exterior corresponde una burbujita interna, 
que se halla en relacion con una rama particular de un siste. ma de vasos acuáticos, que al mismo tiempo sirven de órga. mos respiratorios. La pared de los piés chupadores está provista con abundancia de fibms musculosas, cuya construccion permite recogrer el agua y retirarla á la burbujita interna. Sin cmbargo, la estructura del cuerpo y la economia vital de los equinodermos seria incomprensible si no se supiera que la gran cavidad abdominal que contiene los intestinos está lle. na de agua salada que de continuo se renuera. Esta agua se introduce por unos poros microscópicos $\delta$ se absorbe por puntos de la piel que a menudo adquieren la forma de veji. guitas chupadoras. Un erizo de mar pinchado en cualquier sitio del cuerpo, se vacía como un vaso abierto, y no produce poco asombro enconerar, al romperle, un espacio casi vacio; tan reducido es el que ocupan los intestinos rodeados del igua.

En los equinodermos existen ambos sexos, y su desarrollo llevn consigo i menudo las trasformaciones mas particulares.

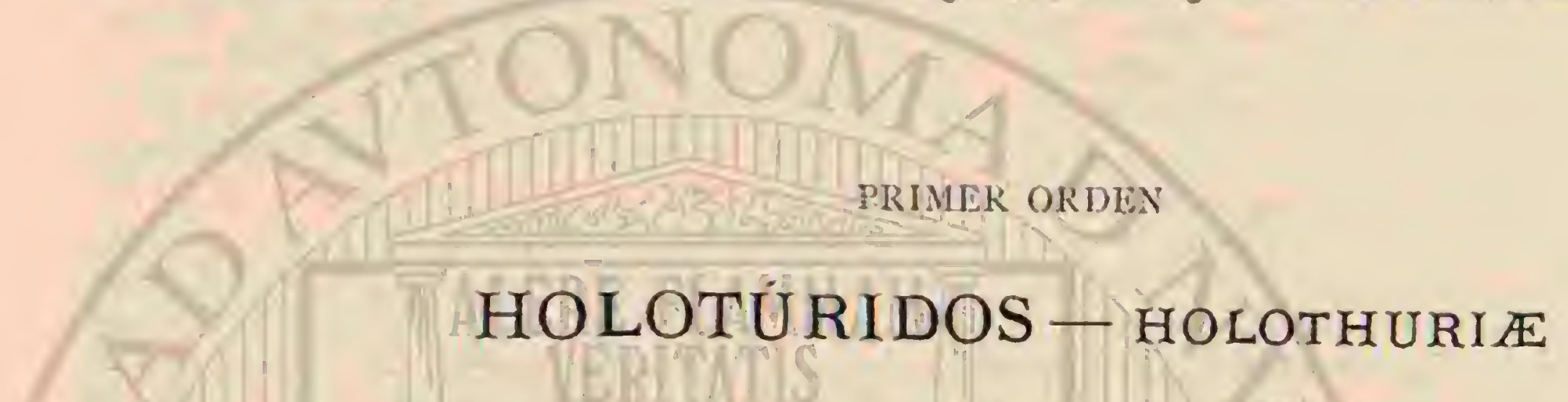

Lás formas mas interesantes de este brden se agrupan en el geinero de las cucumarias. Ta especje cucumaria HJudmanni es una de las formas regulares de holoturido, en cuyo cucruo se corren cinco ambulacras í distancias regulares. Ia misma regularidad presenta la cucumaria doliolumb, de la que podemos ocuparnos un poco mas detenidamente, porque per. tenece à las pocas especies algo vivaces de su grupo; se con. serva muy bien en los acuarios, permitiéndonos observar sus costumbres tranquilas, y en parte muy notables.

I. cucumaria de cinco tentịculos (fig. 35j) es la especie tipica del géncro.

Distinguese de tudos los holotúridos vivos observados hasta ahora por su aficion it trepar. No permanece en el fondo como la holoturia tubulosa y la real, sino que sube á los pe. nascos puntiagudos y grupos de ostras, y con preferencia á los troncos de los corales córneos. Se sirve para ello de los piés chupadores, particularmente largos y delgados; pero cuando ha subido a un sitio que le es conveniente, coloca el cuerpo, si es posible, de modo que se fje sin el aurilio de los pies chupadores. Tan luego como se recobm del espanto de verse cogida, despliega sus tentáculos, al comtrario de la mayor parte de los holotúridos, presentando con elios un adorno muy gracioso, por lo regular del mismo color del cuerpo, que varia en todos los tintes del pardo. Cada tentaculo se compone de un tronco principal, que poco à poco se se adelgara en forma de fina punta, y-que está provisto de una espiral de troncos laterales, que á su vez llevan mmas y ramitas de tercero y cuarto brden. De cste modo la coroma desplegada de tentáculos ofrece un conjunto en extremo gracioso.

Con admiracion, sin embargo, obscrsamos que de los diez tentaculos, solo ocho están desarrollados del modo descrito; mientras que dos se conservan mas pequeños; si se fija la atencion pocos minutos en el animal, nótase tambicn que estos tentriculos desiguales se emplean de un modo diferente. Fn un órden simétrico, aunque no sujeto di una ley rigurosa, los tentaculos se encorvan y penetran hasta la base en la boca, siendo indudable que de este modo los animales recogen su alimerito microscópico, segun se ha observado tambien en otros holoturidos.

Antes hicimos ya mencion del género de las holoturias, que pertenece a las formas en que las ambulacras se acercan de tal modo una a o:ra, que debe desaparecer un lado ventral mas plano, el cual sirve para reptar: pero aunque estas formas se alejan de las ordinarias de los radiados, tienen, sin embargo, de comun con estas, todas las particularidades esen- ciales de la estructura. In el Adriático y Mediterraneo vive la holaturia tubulosa, especie muy comun, mas propia para la obsermacion cuando està viva y para el exámen anatómico, poreque alcaniza 3 la considerable longitud de $0^{\circ, 25}$ y babita tanto en las grandes profundidades como cerca de la costa, en sitios de joco fondo. Hasta puede estar al descubierto algunns horas durante el reflujo, solo con la precaucion de recoger los tentáculos bucales. Ia piel, pardusca, rojiza ó negra, y verdaderamente coriacea, impide que los animales se sequen, y de este modo permanecen como embutidos en la arena $y$ entre las piedras sin dar una señal de vida.

Nilas aves que en la playa buscan su alimento, ni los hom. bres al recoger los frutos del mar, hacen caso de las holoturias al observar los individuos cubiertos de agua: notamos que la boca recoge, por medio de los tenticulos, sin distincion, cieno, piedras, fragmentos de conchiferos, etc., para conducir de este modo tambien sustancias digeribles al largo intestino.

Al coger el animal se contrae convulsivamente y arroja sus propios intestinos; el observador que una vez haya hecho esta experiencia, dejandose ensuciar por el contenido pegnjoso de una holoturia grande, la tratarí otra vez. con precaucion. Por esta cualidad, las holoturias son muy poco propias para tenerlas en museos: cundo estín secas tienen cl aspecto del cuero rugoso, jo conservadas en espiritu de vino parecen salchichones reventados. En todo caso, el que no pueda observarla en esiado libre, se formará una idea mas exacta por los grabados yuue se sacan de ejemplares conservidos.

Entre los holotúridos figuran tambien los solos, psouzs, cuyo cuerpo es sub-cilindrico, su cara inferior plana y blanda, provista de gran número de pjiés tentaculares y la superior convexa y arrugada, de aparicncia coriácea: In especie tipica es el fsolus phantopus (fig. 359); pero criste otra de mas re. ducidas dimensiones el solino breic (fig. 358 ), notable por sus alios ambulacros y por su corona de tentaculos. I.os tiónidos que tambien pertenecen à este mismo género se caracterizan por su cuerpo largo 5 cilindrico, sus piés ientaculares, sus diez tentáculos bucales, su anillo esofágico y sus tubos genitales divididos. Las principales especies de este género son el fionidio hialivo (fig. 356) y el de Drummond (fig. 354) que viven en los mares del Norte.

Con el género de las holoturias, el de los esticopos pertenece a una misma familia. Fi vientre de estas especies es pinno, provisto por lo regular de tres marcadas séries longitudinales de jiés chupadores. Hacemos mencion del genero en este lugar, porque Semper nos ha dado noticias muy pre. 
ciosas sobre el área de dispersion, género de vida y utilidad de varias especies de las islas Filipinas. En la obra Vinjes por el archipielago de las Filitinas dice: Al sacar las especies de esticopos al aire libre se disuelven en pocos minutos, de jando una sustancia nucosa é informe. Por esta circunstancia ofrecen à los habitantes de las islas grandes dificultades en su preparacion para el comercio: el subido precio que se ha fijado para las especies de este género en el tráfico con los chinos, solo es un débil medio para excitar a los indolen. tes malayos á ocuparse en la pesca y penosa preparacion de estos animales, que por lo regular viven á grande profun didad del agua. Para impedir que se disuelvan, las grandes fuenies de hicrro en que se han de hervir, deben.ponerse bajo la superficie del mar. recogiendo con ellas las holoturias sin quue estas abandonen el agua; la primera ebullicion se verifica siempre en el agua marina. Lát especie llamada stihopios naso se distingue además por una grande inmovilidad de la musculatura, que no suele ser propia de los holotúridos. Cuando este animal se irrita, muévese con una violencia semejante à la de un gusano, y sale poco á poco de su propia piel, quedando sin embargo los intestinos ilesos. I.os malayos llaman á estas especies hanginan, es decir, holotíridos

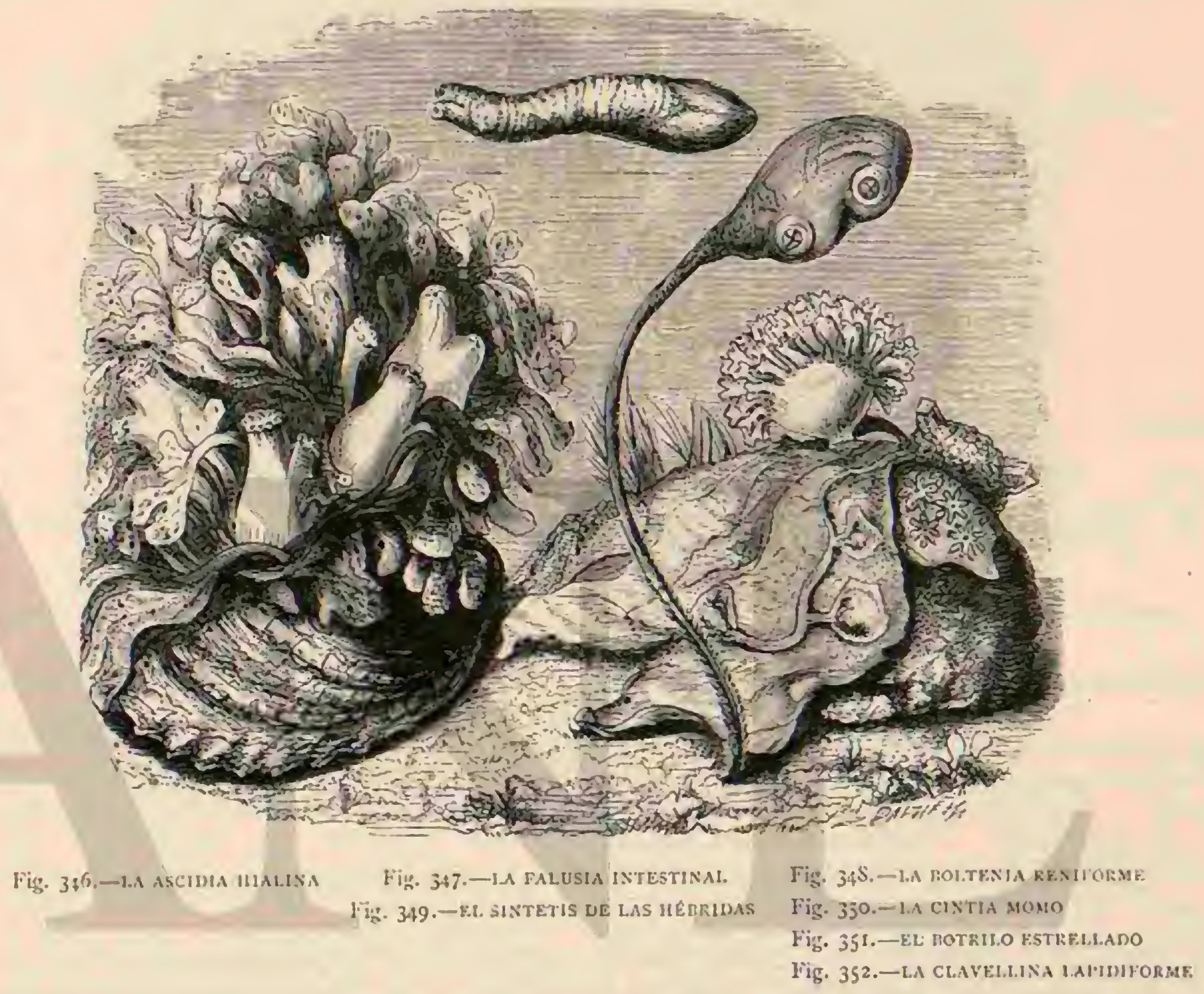

que en el viento se disuelven. Una especie gigantesca alcanza la longitud de casi un metro por 0,20 centimetros de grueso.

Las especies que como alimento constituyen un articulo de comercio pertenecen con preferencin à los géneros de ho lotúridos y esticopos. Semper dice sobre este alimento lo siguiente: "Bajo el nombre de trepang (bicho de mar, balate) los holotúridos preparados de diferentes modos se importan de China y se venden aqui á menudo à precios muy crecidos. Naturalmente, el Exito de la especulacion depende del consumo, pero tambien de la cualidad y del modo de prepa. rar la mercancía. Las especies ordinarias (la looloturia negra, la impaciente y la vagabunda) cuestan por lo regular en Manila, seis ú ocho duros la bámasta, pero a menudo solo tres $\delta$ cuatro, mientras que las especies de esticopos y de bondchia se pagan con frecuencia á cuarenta dollars. El número de las clases que se distinguen en el comercio es bastante grande, y tambien parece que existe gran diferencia en el modo de prepararlas. En las islas de Palao la mayor parte de las especies del género de las holoturias se reunen en grandes fuentes de hierro de cuyos bordes sobresalen en forma de montones. Cubiertas de una doble capa de las grandes hojas del calaclicum sculentum las holoturias se hierven primero, exponiéndose despues a los-vapores de muy reducidas cantidades de agua dulce. Despues se secan y la misma manipulacion se repire dos ó tres veces. Las especies de esticopos deben tratarse con mas cuidado. A la primera ebullicion ya citada con agua narina, sigue una segunda con ngua dulce, y despues se exponen dos ó tres veces a los vapores secindolas alternativamente. Para comerlas se limpia la superficie; arráncase la capa de caliza, y entonces los animales se echan en remojo de 24 a 48 horas en agua dulce. Des pues de lavarlos varias veces y de sacar cuidadosamente los intestinos, la piel dilatada se corta en pedacitos y cómense en sopas bien sazonadas ó con marios platos. Así como los nidos de pajaros comestibles, no tienen gusto propio; forman una masa blanda gelatinosa que los europeos solo comen por la facilidad con que se digiere, mientras que los lujurio. sos chinos les atribuyen cualidades irritantes.

Todos los holotúridos hasta ahora citados pertenecen al sub.órden de los holoturidos pulmonados. El órgano llamado pulmon sirve de recejtáculo al agua que entra y sale con 
bastante regularidad, pero, segun las obsersaciones de Sem- siempre en la parte derecha del pulmon no relacionada con per, de modo que a varias absorciones siguese ripidamente una expulsion del liquido que en pocos segundos forma un grueso surtidor de agua que sale de la cloaca, en la cual se introducen varios parásitos. Los mas notables de estos huéspedes son especies de los géneros de per.fieriasfer y chacelyo. phis, en cujo estómago, Semper reconoció que eran verdaperos parisitos. Tambien encontró Semper en los holotúridos pulmonados, entre ótros séres, dos especies de pinoteros. 4s extraño, dice el autor, gue ambas especies se hallaran en el mismo holotúrido, es decir, en la hololhuria scabri, y los msos intestinales. A causa de estos parísitos los pulmo. nes se atrofian, y hasta varias veces observé que el pulmon infestado por un pinotero se habia hecho rudimentario for. mándose un segundo en otm parte. Los parásitos se hallaban siempre muy cerca de la cloaca, y puede suponerse que cerrando la entrada en la parte derecha del pulmon habian causado el atrofiamiento de esta última, obligando al animal á formar otra nueva. Respecto i la facultad de reproducir las partes del cuerpo perdidas, carecemos de observaciones minuciosas sobre las holoturias. Semper observó que en una

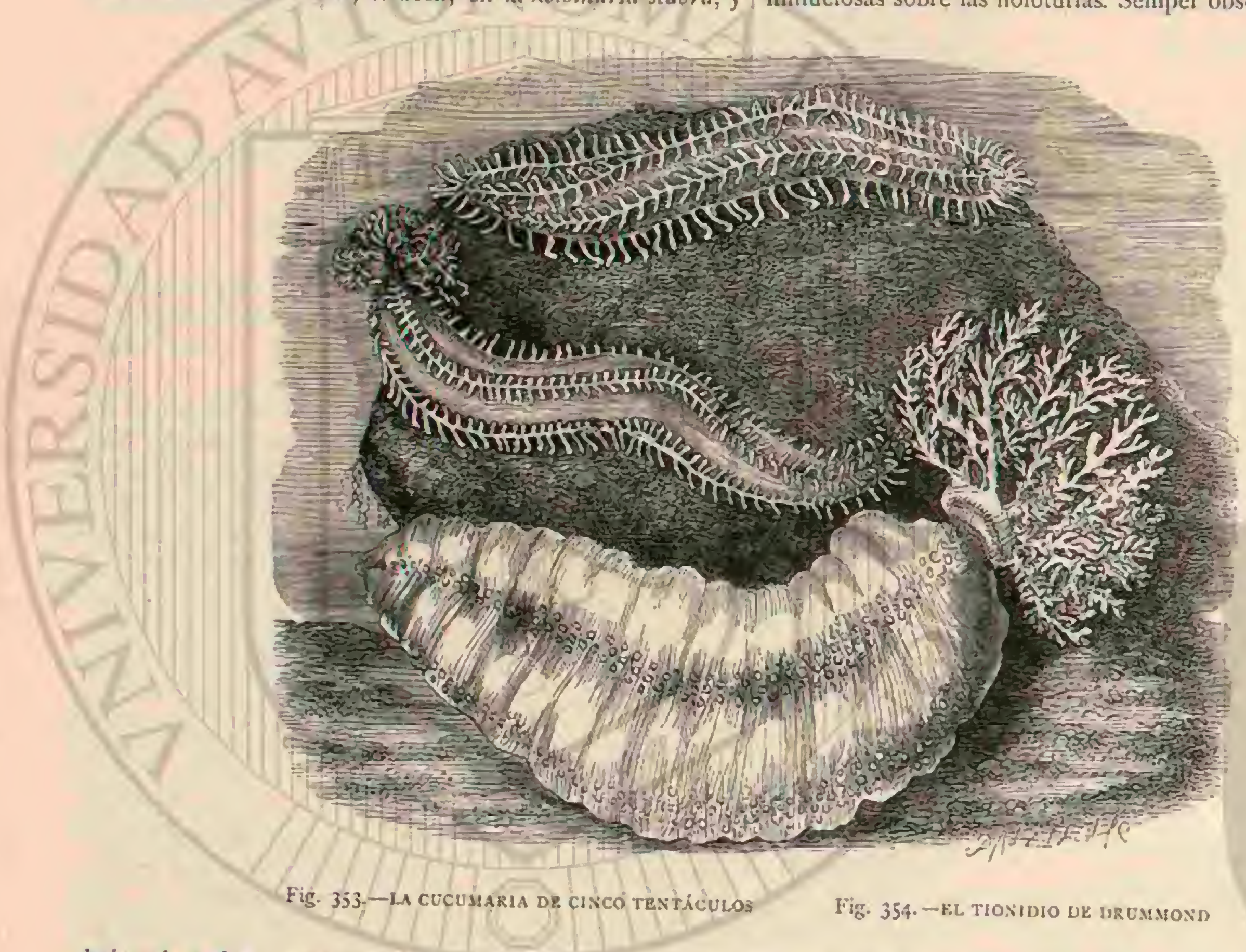

holoturia scabra, que forzosamente se habia desembarazado de su intestino, de los órganos genitales, de los vasos y de la parte irquierda del pulmon, los movimientos respiratorios dela mitad conservada del pulmon pronto volvian á úuncionar y que al cabo de nueve dias los intestinos se habian re producidn.

Un segundo grupo comprende los holoturidos sin pulmones y piés chupadores. Todo su sistema acuático se limita al anillo esofágico con apendices en forma de rejigas, $y$; los tenticulos bucales Se parecen por este concepto á los otros holoturidos jóvenes que en cierto grado del desarrollo se limitan a los tentáculos bucales como órganos del movi. miento, por lo cual podrian considerarse como una de las formas mas antiguas de holotúridos. El género principal es el de las sinaptas, llamado asi por tener como unas anclas calcáreas de dos dientes muy caracteristicas en su piel. El ancla se halla en el tallo en una placa agujercada en la que se sujeta por un boton en su extremidad. Estos úrganos de trepar son bastanie grandes para que puedan verse á la simple vista. De las dos especies curopeas la sinagta inherente habita la costa occidental de Francia; de la segunda, que es digitada, ya hemos hecho mencion antes al hablar del mara. villoso caracol parásito. Sabemos que a causa de la inutilacion voluntaria de los animales madie ha visto tocinvia un

ejemplar ileso, circunstancia propia de todos los holotúridos. Baur dice sobre esto: $\times$ Las sinaptas se dividen por medio de vio!entas contracciones de los músculos en una mayor $\delta$ me. nor parte del cuerpo donde se hallan los tentáculos de la boca. Las partes separadas se mueven aun algun tiempo, pero no les es posible volver a dividirse. La region de la cabeza, en cambio, puede repetir la separacion hasta que por detrás del anillo calcáreo no queda y.a casi nada del tronco. Baur hizo el inieresante descubrimiento de que at todo fragmento con cabeza se le puede privar de la facultad de seguir dividiéndose, separando aquel anillo calcáreo en cualquier sitio por medio de un golpecito, pero no el nervioso, que a pesar de hallarse unido con aquél no influye cn la mutila. cion. En el Meditermineo existe la especic simapta-digifirda (figs. 355 y 357 ) enteramente analoga i la iratherente.

Algunas especjes de sinaptas de los mares meridjonales llegan a tal tamaño que los habitantes las llaman scrpientes marinas. Scmper vió cerca de la isla de Bohol individuos de la sinapta de Besel de mas de dos metros de largo. \&I.OS movimientos son en extremo cachazudos y avanzan por medio de contracciones de su cuerpo, particularmente con ayu. da de los tentáculos bucales. Sus anclas no les sirven de órganos de movimiento, y cuando una vez sc han enganchado con elias, no pueden desenredarse sin perderlas. Aunque las 
anclas son movibles, carecen de músculos que pudician someterlas à la voluntad del animal. Las simaptas solo trepan cuando se las toca rudamente; en una especie nueva de tres piés de largo, en la syropla glalira, aquellos órganos se ocultan de tal modo en la piel que antes de examinarla microscópicamente crei que no tenian anclas.

Tenenios ahora noticias bastante exactas sobre la historia del desarrollo y la trasformacion de los holotúridos. Baur ya examinó del modo mas minucioso la sinapta de Trieste, aunque solo iflimamente se han logrado explicar las primeras fases del desarrollo.

Las larvas microscópicas de los holotúridos y de la mayor parta de los otros equinodermos se cogen principalmente con una fina red de gasa en la superficie del mar.

Baur se apoderó de algunas pasando esta misma red por el fondo habitado por los animales. Al lavar el cieno queedan en aquella.

La larm que no alcanas un milimetro de largo tiene un

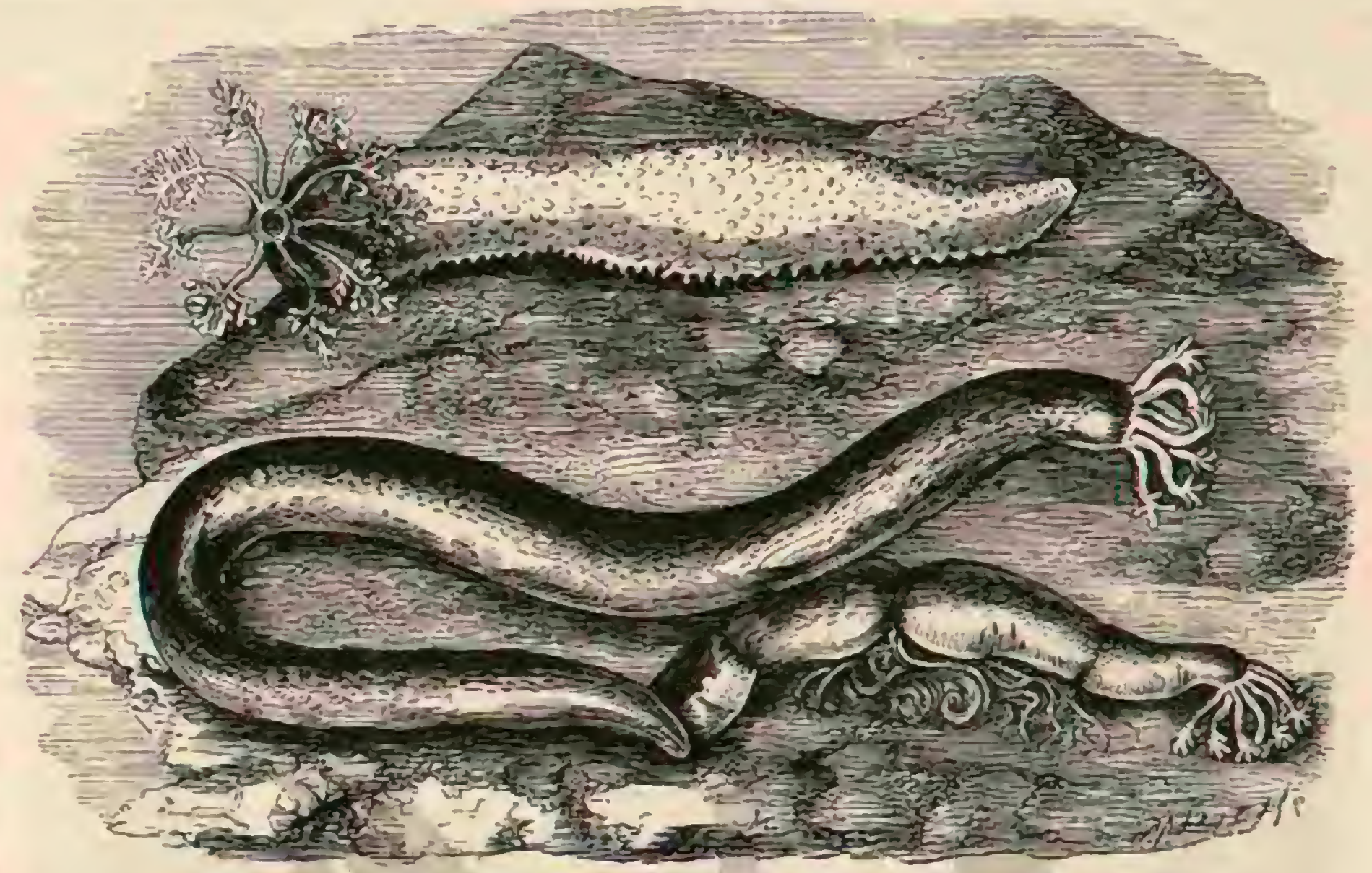

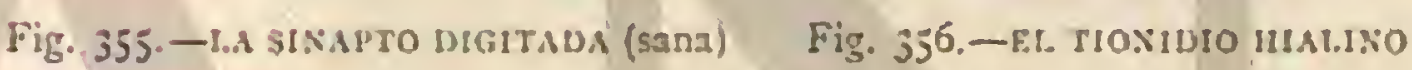

Fig. 357.-LA sisapto digitada (eafermiza)

aspecto del todo diferente del de la de un equinodermo adulto; no es de estructura mdiada sino simétrica, y afecta poco mas ó menos la figura de una lancha del todo plana, con la proa y la popa encorvadas hicia dentro en forma de cubierta y los bordes angulosos. Estos bordes están provistos de un cordon de pestañas por cuya actividad el animalito nada, retorciéndose en espiral con la extremidad anterior, piramidal y dirigida hacia adelante. Mucho tiempo aun des. pues que los animalitos han perdido las pestanas y solo pue. den reptar por el cieno, reconócescles por unas pequeñas rucdas calcareas. Entonces tampoco miden mas de un milimetro, pero crecen bastante ripidamente. El grado del desar. rollo en que probablemente inmigra el caracol parisito queda indicado ya.

Muchos, y quizas todos los holotúridos pequeĩos pasan por un periodo en que su sistema ambulacral se limita exclu. sivamente a los tentáculos branquiales, $\delta$ bien à estos y i varios piés chupadores dispuestos al rededor de la boca. lin tal estado reptan con 12 boca hácia abajo, ocupando la misma posicion ąue los erizos y las estrellas de mar. Cuando se estirar y cuando salen las ambulacras, se colocan de lado. Bajo este punio de vista, exacto para la historia del desarro llo, la sinapta no es una formacion completa sino perteneciente al estado embrional.
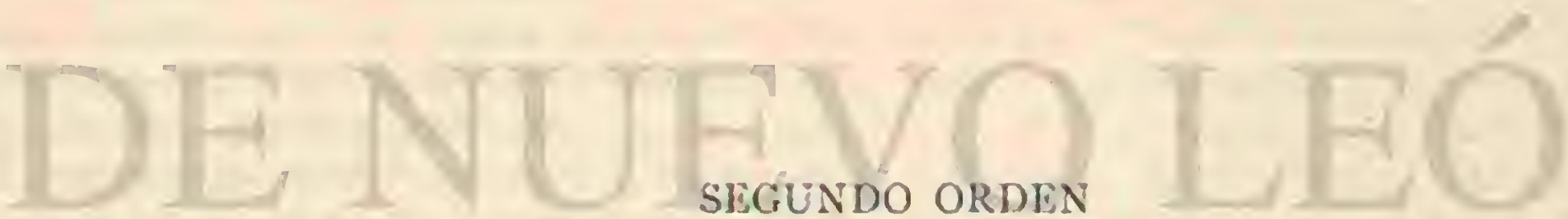

\section{EQUINOIDEOS} ECHINOIDEA

Los equinoideos S erizos del mar (fig. 360) constituyen la division mas rica en formas y especies de los equinodermos. Segun cálculo de Brow, estas uiltimas ascienden al número de 1,650. Entre todas se distinguen como verdaderos erizos de mar las especies del género de los equinos, al cual se refieren principalmente nuestras noticias. I'odas las especies del órden tienen un esqueleto membranoso en forma de concha, compuesto de placas de cuatro, cinco y seis lados: las especies de la familia de los verdaderos erizos de mar tienen en el centro una escotadura dirigida hácia abajo, cubierta de una membrana blanda, excepto en la abertura bucal. En las otras familias la cscotadura de la concha destinada para la abertura bucal cs mucho mas pequeña.

I.os equinos ó verdaderos crizos de mar afectan la forma regular de una manzana ó de un pan; la abertura anal está opuesta à la extremidad bucal, mientras que las series de piés chupadores corrén de un polo al otro. Ias llamadas placas ambulacrales aliernan con otras series, provistas de prominencias perforadas $\delta$ sin perforar; en Estas se halian las espinas, movibles en todas las direcciones; estas últi- 
mas no solo se emplean para la defensa, simo tambien como órganos de movimiento, y hasta pueden servir de brazos para coger y trasportar objetos. Unos órganos muy particulares son los llamados pediculares diseminados en forma de pequerias tenazas entre las espinas de toda la superficie del cuerpo. Estos órganos no son otra cosa sino esjinas modifi. cadas. O. F. Muller los descubrió en el siglo pasado, considerándolos como parásitos de lo eriros de mar. Solo el sabio zoúlogo napolitano Delle Chiaje (1825) los reconoció como partes de los tegumentos membranosos, y últimamente las observaciones de Agrissir nos han explicado el cxtrano uso de los pediculares. Cada cunl recoge los excrementos y los pasa a su inmediato hasta que salen de la concha y cien al agua. Nada mas notable y divertido, dice Agassiz, que observar la habilidad y el órden con que se verifica este tra. bajo. Los excrensentos recorren rápidamente las fajas en que los pediculares son mas espesos, y las tenazas no descansan hasta que toda la superficie del animal queda limpia. Estos pequeños órganos sirven tambien mana alejar a los intrusos. El modo de correr de los equinos no parece confirmar la suposicion de que los pediculares sirven para coger el alimento. Hasta últimamente el zoólogo sueco Sren Lovén no des.

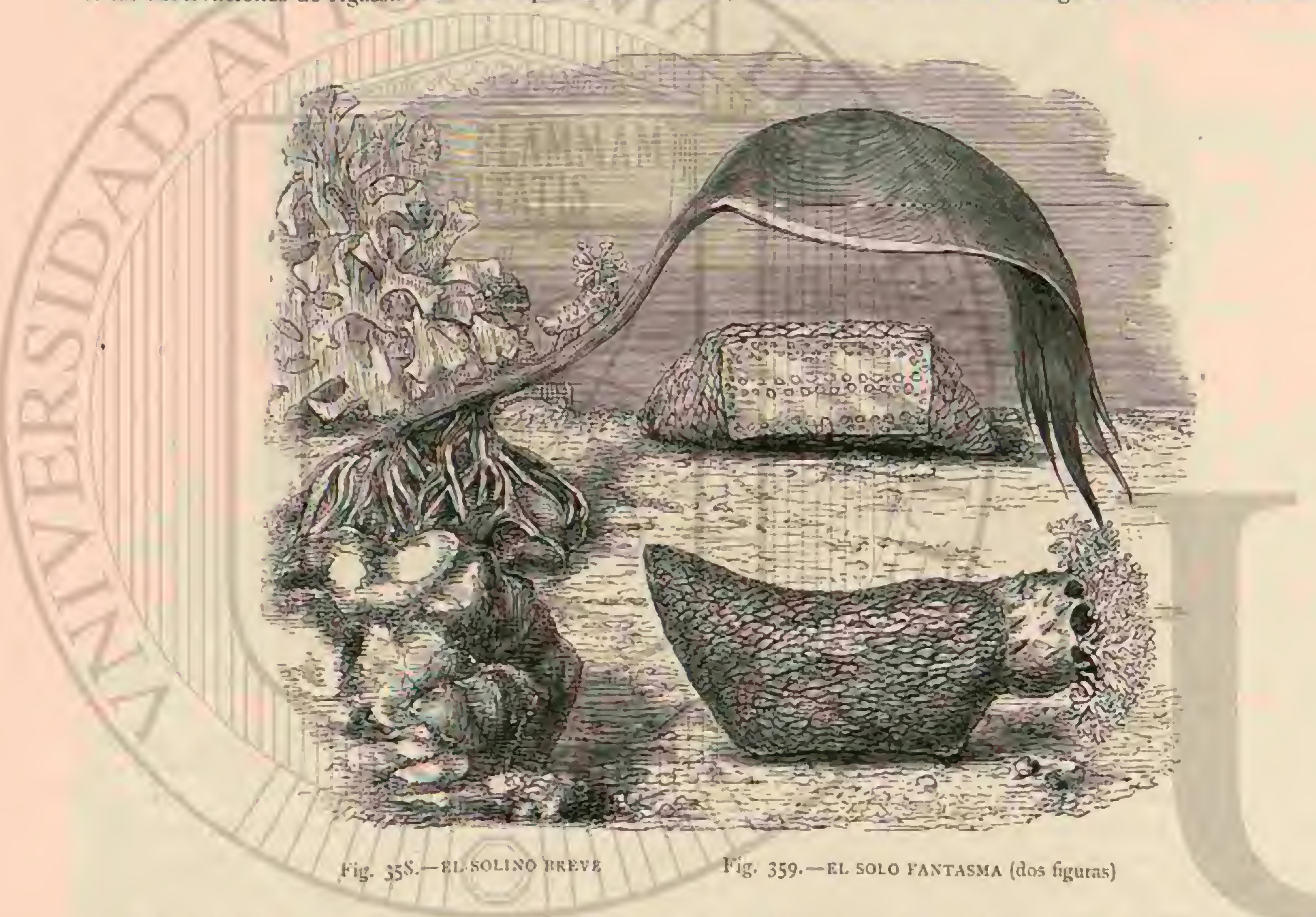

cubrió en todos los equinoideos una nueva especic de órganos microscópicos que llama esfiridios: son cuerpecitos elipsoides, esféricos cerca de la boca y en las placas ambulacrales inferiores. Se parecen por su estructura à las espinas, pero la circunstancia de que están provistos de nervios induce a suponer que son órganos de los scridos. Lovén los consi. dera como una especie de órganos del olfato.

Entre todos los géneros del órden, los equinos son los que están provistos del mas fuerte aparato de trituracion; mas a pesar de su terrible aspecto y de su afilada dentadura, los erizos de mar son regularmente animales nuy inofensivosy perezosos. He obscrvado las costumbres de la especic cihnus saxntilis of (strongylocentrofus liavidirs), comun en todo el Mediterráneo y que tambien à lo largo de la costa de Dal macia vive fornando innumerables bandadas en un fondo pedregoso. En muchos sitios este fondo está del todo cubierto por ellos. La mayor parte de los animales llevan algunos fraginentos de conchas, piedras etc., en el dorso, donde los sujetan con los piés chupadores.

Habiendome llevado un individuo a mi habitacion le retirc la carga del dorso y puisele en una fuente blanca llena de agua de mar. Al cabo de un cuarto de hora se liabia cubierto todo él de algas, poniéndose otra vez el iragmento de concha sobre el dorso. Despues de quitarle la coucha, colo- quéla en su camino, y al encontrarla el crizo de mar fijó en ella los discos de algunos piés colocandolos sobre el borde; despues se sirvió con gran destreza de las espinas y en pocos minutos habia vuelto á fijar la concha en su dorso.

Mi barquero de Lesina que hace anos me acornpañaba en mis excursiones en aquella region podia distinguir desde la barca los machos y las hembras del equino savatilis. Los primeros son un poco mas pequeños, mas oscuros y esféricos; las hembras mas planas de un color violeta rojizo. Hara mi era muy dificil reconocerlos, pero mi ayudante nunca se engañaba; me demostró además que los maclios jamais cubrian su dorso de piedras ó fragmentos de concha, y en efecto, todos los individuos que cogimos sin estos apéndices cran machos, mientras que los que los llevaban cran sin cxccpcion hembras. Como el periodo del celo dura casi todo el año es muy fácil reconocer el sexo en el animal abierto. Lás hembras tienen cinco ovarios en forma de ra. cimo, de un bonito color amarillo, y que ofrecen un alimen. to bastante sabroso. Su consumo regular parece limitarse a las costas francesas del Mediterméneo. En Marsella sólo se llevan todos los años al mercado, segun se dice, cien mil docenas, pagándose por cada una de 20 i 60 céntimos. Este corsumo denuestra que sé comen con predileccion los eri. zos de mar. 
Hasta el verano de IS72, Dorhn no intentó explicar la aficion con que muchos equinos se cubren con diferentes objetos. Observó el erizo de mar de espinas cortas (Toxap. neusles breirispinosus), tambien muy comun en el Mediterráneo, $y$ del cual dice: Raras reces se encontrara en el acuario un ejemplar de estos erizos de mar que no tenga en su lado dorsal un número de conchas de conchifero sujetas por medio de sus piés chupadores. Muchos toxopneustes se ha. llan tan cubiertos de conchas que no se llega à ver al animal mismo; de modo que cuando éste se pone en movimiento créese ver un monton de conchas fiotantes y nadie supondrà of primera vista su existencia.

Despues de repetidas observaciones y experimentos so- bre el modo de alimentacion de este equinoideo, he visto que son peligrosos rapaces. Con preferencia se nutren de esquillas de langosta. Podria creerse que á este gran crustaceo le es fácil librarse del pequeno y perezoso cquinoideo; pero el hecho es que cuando ponia una docena de esquillas en un depósito con otros tantos toxopneustes, éstos devoraban en ocho ó dice dias todas las esquillas. El equinoideo se agarra con sus piés chupadores al cuerpo del crustáceo dando vuclta hasta que le tiene al alcance de la boca, y entonces empieza à devorarle, operacion que por lo regular dura varios dias. A menudo se acercan uno ó dos companeros; y con frecuencia he observado que un toxopneustes puede apoderarse de una esquilla de seis pulgadas de largo

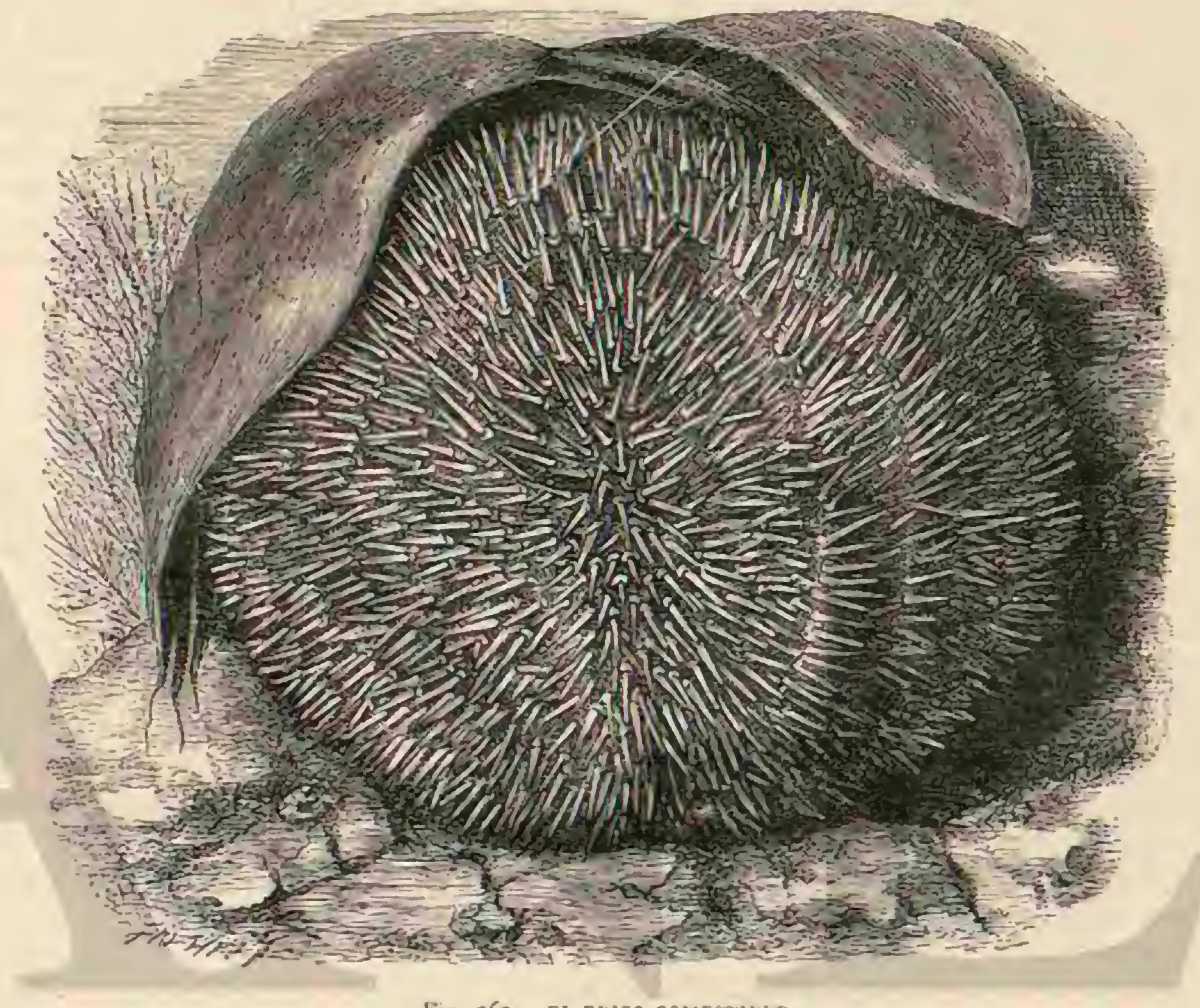

Fig. 360. - E.1. E.M17.0 COMESTHIL.

cogiendo con los piés chupadores la ancha placa de las an. teuns exteriores. El crustàceo hacia grandes esfuer\%os para escaparse, mas por lo regular solo lograba lo contrario. Se comprende que rontra un enemigo tan temible la única sal. racion consiste en la fuga, pero tambien se comprende que por esto el agresor intenta ocultarse, $y$ a csta tendencin atribuyo la extraina inclinacion de los equinos a cubrirse de conchas de conchífero que ticnen un aspecio mucho mas jnofensivo que la coraza espinosa del temible equinodermo.

Debemos confesar que esta cxplicacion de la costumbre de los equinoideos tiene algo de seductor respecto a la es. pecie tan cuidadosamente observada por Dohrn. Pero nin. gun otro observador se ha referido hasta ahora á un equinoi. deo carnivoro, mientras que Agassiz enumera toda una serie de especies que abren agujeros en la roca, costumbre que les obliga a renuaciar a los animales mayores como alimento.

Por lo demàs, apenas hemos empezado a observar el géne. ro de vida de los equinoideos y de sus congéneres de la misma clase, y aun tendremos que conocer una multitud de costumbres inesperadas. Asi por ejemplo existe un erizo de mar que trepa preferentemente por las formaciones arborico- las del mar y sale agarrarse por medio de sus piés chupadores al ramaje mas fino de los pólipos y las algas. Tuvimos ocasion de observar esta especie, el Psammechinus microluher. culatus en el acuario de Dohrn (fig. 361).

Mucho deberiamos hablar aun sobre la locomocion de los equinoideos segun resulta de las noticias de Agassi\% en su gran obra Reitusion of the Echini. Asi, por ejemplo, las especies de arhacin no se sirven en su marcha horizontal de los piés chupadores, sino que corren hábil y rápidamente apoyándose en las espinas como en zancos. La forma de paleta de las espinas alrededor de la boca es resultado sin duda del desgaste por la locomocion. Cuando, sin embargo, los animales quieren trepar ó subir se sirven de sus piés chupadores.

Mas arriba hemos reproducido algunos datos de la tan notable historia del desarrollo de los holotúridos, indicando que rodos los equinodermos, con pocas excepciones, sufren las trasformaciones mas extraordinarias. Con la misma razon con que al hablar de la mariposa se describe su estado de oruga, debe describirse la larva de los equinodermos. Las observaciones mas completas sobre una esfuecie de equinodermo son debidas últimancnte à Mr. Agassiz, refiriéndose 
at Strongylocentrotus Drohachiensis, propio tanto de las costas de la Europa septentrional como de las de la América del Norte. El huevo microscópicose rodea de una capa de celdas lassta llegar á la forma llamada gastrula segun la proposicion de Hackel. Poco á poco la larva se rodea de pestanas. Presenta durante todo su desarrollo casi la simetria mas completa como los animales bilaterales, es decir, los que se dividen en dos partes laternles. De estit larva solo el estómago y el sistema de los vasos de agua se conserva en et equinoideo cuyo cuerpo espinoso se forma alrededor del estómago de la larva, mientras que desaparecen las partés de la misina que no se necesitan para ta nueva estructura. $Y_{2}$ durante este tránsito el animalito cambia del todo su género de vida, y al desaparecer las pestañas se ve obligado á reptar por medio de los piés chupadores y de las espinas. No se conoce el tiempo que necesita para llegar á la edad adulta. Mas importante es la noticia de Agassiz sobre las extrañas metamórfósis a las que las numetosas espectes exuminadas por el están sujetns durante el desarrollo. He demostrado que muchas especies y hasta géneros establecidos por los zoúlogos anteriores no son otra cosa que el estado de jurentud de otras formas conocidas. Esto debe decirse no solamente de los equinoideos verdaderos sino tambien de las otras subdivisiones del órden de que ramos a ocuparnos.

\section{LOS CLIPEASTRIDOS - CLIPEASTRID E}

A los equinoideos tipicos sigue el subórten de clipeasiridos, que derivan su nombre de su forma. Varios géneros como cl de los clipeastros tienen bastante altura, mas tanbien se aseinejan a un escudo. La mayor parte de los géneros, como los equinaracnios, las melitas y otros son aplana. dos y afectan completamente dicha forma. El cuerpo tiene casi siempre la figura de corazon, hasta en las especies en que esta forma se modifica algo à causa de las profundas escotaduras del borde, sin dejar de ser simétrica, las aubu. lacras del dorso forman una graciosa roseta de la que una hoja impar se dirige hácia adulante. Tambien este grupo de equinodermos tiene un aparato masticador. Se distinguen por el grueso y la solidez de la concha cuya pared superior É inferior están reunidas por una multitud de columnitas y paredes divisorias irregulares. Las espinas son cortas, elás. ticas y semejantes á cerdas. Tambien los piés chupadores, en extremo numerosos, son débiles y cortos; como órganos de movimiento solo sirven los de la cara inferior y los del borde. Los aracnoidens (fig. $36_{2}$ ), los encopos (fig. $3 \sigma_{3}$ ) s los equinodiscos (fig. 365 ) deben continuarse tambien en esta familia. Ios clipeastridos pertenecen, excepto algunas pequenas fonmas de tránsito, á los mares cálidos. De su.gé. nero de vida apenas tenemos noticia.

\section{LOS ESPATÁNGIDOS- SPATANGID在}

Este tercer grupo principal, nutique se encuentra en todos los puntos de los mares calidos, pertenece tambien at las zonas templadas $y$ frias. 1 a concha es delgnda y frágil; la parte mas estrecha redondeada es la extremidad anterior; las espinas son cortas, elásticas y parecidas ì cerdas. Asi como en la division anterior, haillase en el dorso una roseta à menudo deprimida, compuesta de vejiguitas respiratorias rodeadas de una faja ondulada, que se llama fasciola. Fosta faja tiene pequerios órganos espinosos con extremidades provistas de pestañas, y parece destinada á limpiar la roseta; pero ademàs estas espinas forman en muchos espatángidos, con la roseta ambulatoria deprimida, un abrigo para los hijuelos. Las aber. turas de los ovarios están situadas de modo que la progenie que nace vira llega en seguida al espacio abrigacio. La cria mas grande encontrada por el naturalista americano media tres milimetros. Los individuos jóvenes tienen gran impor. tancia tambien para la doctrina de la afinidad, porque se pa. recen i los verdaderos equinoideos y ocupan transitoriamen. te un grado característico en la familia de los caliátidos, que hasta ahora tantas dificultades ofreció à la ciencia sistemá. tica. El espatango purpúreo (fig. $3^{66}$ ) es la especie mas co. mun de todas y vive en el Mediterríneo.

La mayor parte de los espatángidos viven á grandes pro. fundidades en un fondo cenagoso, 6 con preferencia arenoso. Medin escondidos, abren surcos llenándose continuamente de arena; pues se alimentan exclusivamente de las sustancias orgínicas y organismos microscópicos contenidios en la arena. Muchos espataingidos penctran del todo en esta, segun Robertson y Giard lo han observado en el amphidesus cordatus, comun en el mar del Norte. Este animal penetra á una prófundidad de 15 \& 20 centimetros en la arena, tapizando su vivienda con una secrecion. El primero de los tubos conduce al centro del dorso y sirve para recibir el agua y el alimento. Este último despues de pasar por el intestino es empujado hácia el segundo tubo. Parece que el animal pue. de hacer salir el agua recogida en el intestino, con violencin por la abertura del canal, pues solo de este modo se explica la fuerte corriente en el tubo posterior por el que la arena gastada vuelve a salir á la superficie. No se sabe cuánto tiempo permanece el anfideto en un mismo punto; tambien es posible que viva siempre en su habitacion obligado á mantenerse del alimento que casualmente llega á ella Casi siempre se encuentran en la morada tapizada de una sustancia mucosa del anfideto algunos pequeños crustáceos, anfipodos del género urotede.

La naturaleza del esqueleto de los equinodermos explica que los restos fósiles de sus antepasados se encuentren en el mayor número. Uno de los eq̧uinoideos mas notables, llamado en otro tiempo asthenosoma por el profesor Grube, pero que solo Wyville observó viro en toda su bellezin, es el astenosoma corí́cco. Los dos zoólogos Thomson $y^{\circ}$ Carpenter encontraron entre Irlanda y las islas de Feroe, à la pro fundidad de 450 braziss, un gran equinoideo de color rojo de escarlata, así como un ejemplar muy grande del equino de Fleming, comun en los nuares septentrionales. Como el mar estaba muy agitado y era dificil sacar la red, los uaturalistas temian queel ininal se rompiera, pero con gran asombrosujo, cayó ileso de la red tomando sobre cubierta la forma de un pan redondo de color rojo. Ia concha era clástica como el cuero y ejecutaba cxtraños movimientos ondulados. Las placas de que se componia estaban sobrepuestas y reunidas por fajas de piel elástica. Thomson le dió el nombre de caleeria.

Pronto se reconoció que un fòsil de la cretn, la equinoturia, cra idéntica á este astenosoma de nuestros mares actuales; Ia exploracion de las profundioades, continuada des. de 1870 , ha demostrado que estos aninales, que se nos han conservado desde el periodo cretáceo, se encuentran en el fondo de diferentes mares. El nombre de eyuinoturia, aplicado al género por Wodward, conocido zoólogo ingles, es. tá elegido en vista de la comparncion de las holoturias, porxque es probable que estas se hayan formado de aqquellas. Las equinoturias a su vez nos hacen remontar a una de las mas antiguas familias de equinoideos, la de los palequinidos, demostrándonos de nuevo que cuanto mas se progresa en la ciencia, tantas mas formas de tränsito se presentan. 


\section{'IERCER OKDEN}

\section{ASTÉRIDOS-ASTERIEE}

Los astéridos ó estrellas de mar tienen tambien la boca dirigida hácia abajo, pero difieren mucho de los equinoideos por la estructura de sus lados dorsal y ventral. En el vientre parten de la boca los surcos con los piés chupadores; el dorso es mas abovedado, y tanto la parte central como los radios del cuerpo tienen tegumentos diferentes, por lo regular un color mas vivo ú oscuro.

Aunque el número de las especies conocidas no excede mucho de 400 , pertenecen, sin enbargo, à causa de ja enor- me multitud de individuos, á los animales mas conocidos de las costas. Los pescadores los persiguen como peligrosos enemigos de los cebos, de los caracoles y bancos de ostras. Esto sucede sobre todo con el sub.órden asterire, ó de los asteridos propiamente dichos: en sus especies los radios se presentan como apéndices inmediatos al disco; son huecos; contienen parte de los intestinos, $y$ cambian la forma, que casi exclusiramentc sc compone de radios hasta ofrecer la de un disco pentagonal. En el dorso del disco, en el ángulo de

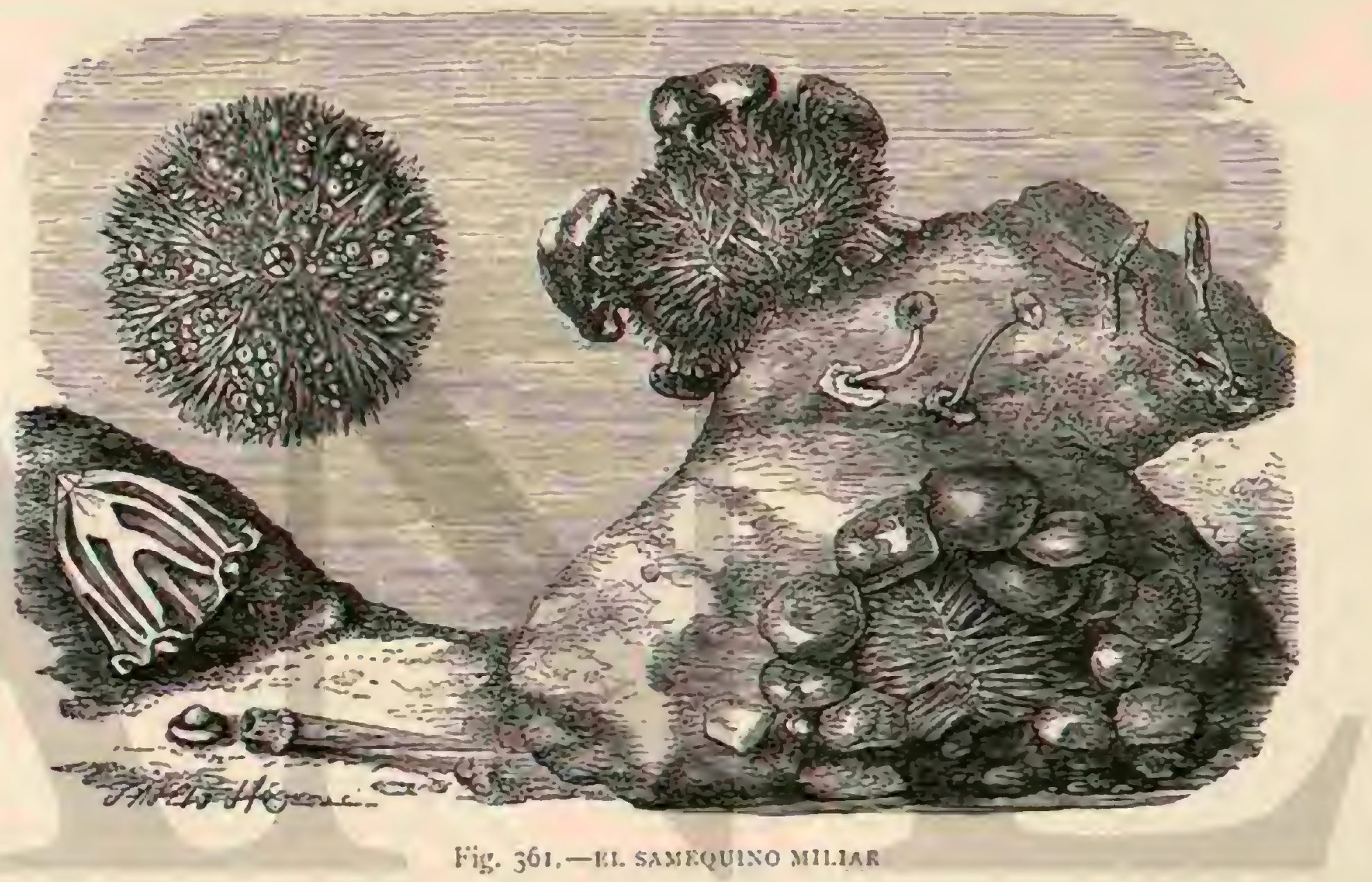

dos radios, hay una placa perforada, llamada placa de madré. poras. Ia mayor parte de los astériclos solo tienen una de estas placas, pero su número puede ascender á cinco. Para la clasificacion sistemática de los géneros debemos fijarnos tambien en la presencia $\delta$ falta de la pequeña abertura anal en el centro del dorso.

La observacion en astéridos viros, por ejemplo del asićracanthion rubiens, especie mas comun del mar del Norte, y' del asteracanthion benuispinum, igualmente comun en el Mediterráneo, ofrecen mucho interés. Colóquese primero al cautivo de espaldas en el agua, y enseguida veremos todos los piés chupadores en movimiento; de manera que muy pronto deja esta prision en extremo incómoda, volviendo todo el cuerpo.

Si le dejamos correr se conduce de un modo muy diferente que el erizo de mar, porque es mucho mas vivaz y repta con mas rapidez. Una asterias aurantiaca de $11 "$, on de diametro franqueó tres pulgadas de distancia en un ininuto. Todo observador notará en seguida que la extremidad de los rádios de un astérido en movimiento se mantiene un poco encorvada hácia arriba. Los piés chupadores de las extremidades levantadas funcionan como palpos, mientras que los otros sirven para la locomocion. En la punta de cada radio hay un ojo, que en los grandes individuos afecta la forma de un puntito rojo. Con el microscopio se ha reconocido que la estructura de este ojo es la de un órgano de la vista.

AIgunas esprecies de astéridos son muy frágiles tambien cuando estản vivas, pero ninguna tan sensible por este concepto coino el asteracanthion temuispinum del Mediterráneo. Este animal, que tiene un diámetro de $0^{\circ}, 122^{\prime \prime} 0^{\prime \prime}, 18$, se reco. noce fácilmente por las prominencias casí espiniformes de la cara superior, pero sobre todo por la circunstancin de que suele tener seis ó siete radios, los cuales se desgastan casi regularmente, pero vuelven á crecer muy pronto. Bastante á menudo se encuentran ejemplares con un solo radio primitivo, y tienen cl aspecto de retoños. En otro lugar, cuando se trate de los ofiuros, encontraremos un ejemplo en que la separacion de los radios, seguida de una formacion de reto. ños, es un procedimiento normal, de modo que es muy pro. bable que lo mismo suceda con los astencintios y otros asté. ridos congenéricos.

Los adjuntos grabados figs. 37 I 375 representan respectivamente al asteracántio rojizo y al asteracintio anaranjado; y la fig. 373 al asterisco verrugoso, que figura tambien en este órden: en él hay que continuar tambien la astrogonia (figura 374), cuyo cuerpo es pentagonal, provisto de placas mayores 
que las del dorso, rodendas de una corona de gránulos, y' cuyo ano es sub central. Las cribelas (fig. $37 \$$ ), los solaster (iig. 376 ) y los jalmipedos (fig. 377), son otros tantos géneros de que dan idca los respectivos grabados.

Los astéridos se alimentan con preferencia de moluscos y conchiferos. Colocan su disco ventral con los piés chupado. res $y$ la boca al rededor de la presa, que pronto se abre por cfecto de la secrecion de un jugo narcótico; una especic de tromja membranosa que sale de la estrella de mar penetra en la concha del molusco y chupa la substancia. los astéridos, $y$ sobre todo la asteria arevicula de las costns norte-ame. ricanas, son por lo tanto los enemigos mas peligrosos de los bancos de ostms. El único medio para exterminarlos consiste en cogerlos con lir red y dejarlos morir en tierra. Cortarlos en pedazos y volver a echaslos al agua, solo seria reproducir. los artificialmente.
Bastante á menudo se encuentran varios astéridos reunidos airededor de una concha, y con frecuencia he visto cómo los pescadores sacaban estrellas de mar que al cazar los ccbos habian mordido el anzuclo. Muchas veces el naturalista hace una pobre pesca en tal ocasion. El único ejemplar del asteronix de Lóven que cogi en mi viaje $\mathfrak{a}$ Noruega, era el que en el Oexfjord me dió un pescador lapon que aun le tenin sujeto en el anzuelo.

Otro de estos pescadores que habia contratado como remero, al oir que recogia las estrellas de mar, tan despreciadas por él, se sintió tan superior à mi, que casi se negó á obede. cerme, y durante todo el viaje se burló de mí.

\section{LOS OFIUROS-OPHIURA}

La mayor parte de los géneros de la segunda division del

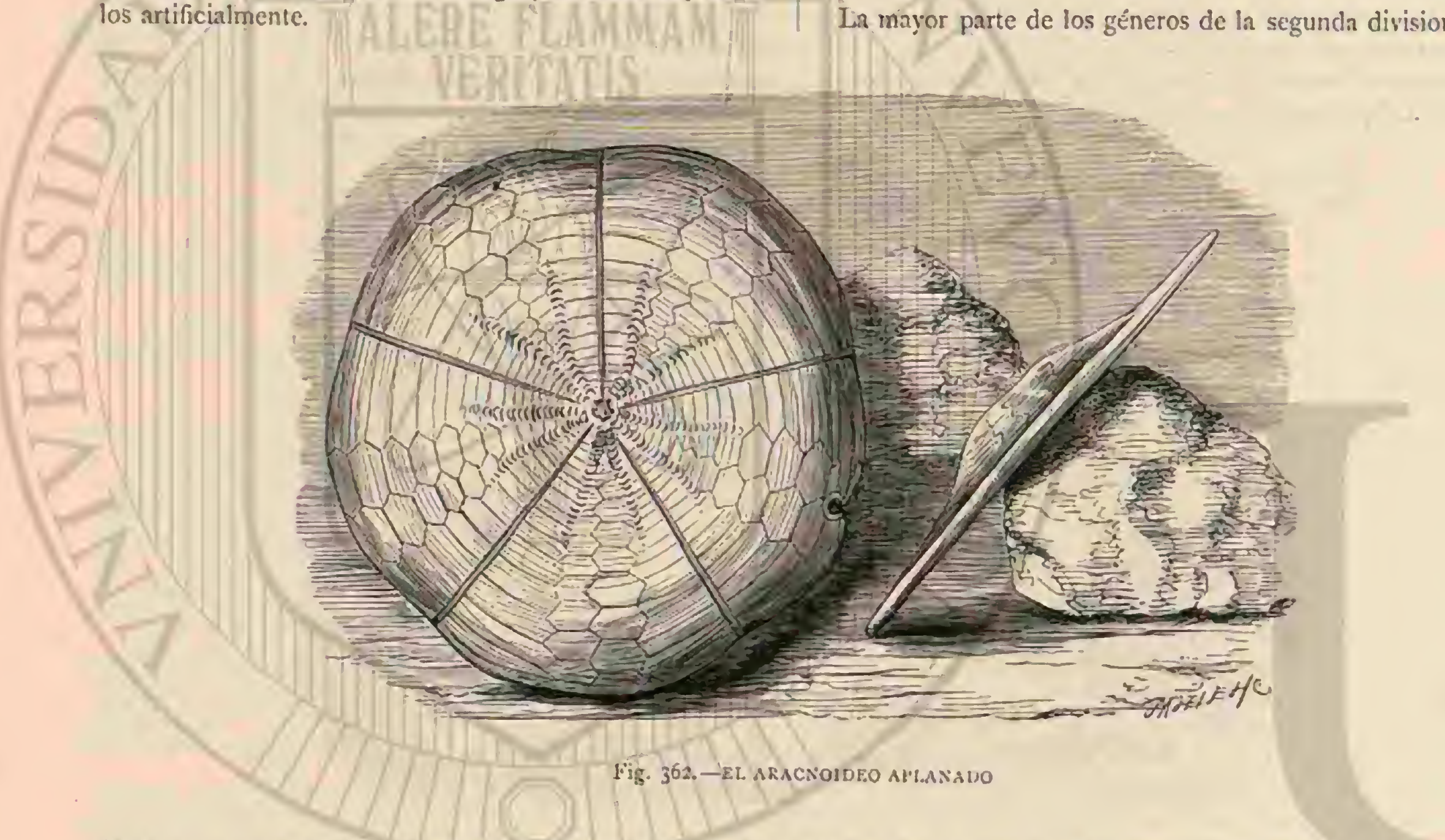

órden se comprende bajo el nombre genérico de oniuros. Es. tos se distinguen por una movilidad extraordinaria de los brazos, que no se presentan como apéndices innediatos de disco, sino que encajan, por decirlo asi, en la cara inferior ciel mismo. Tampoco son huecos, sino llenos de una serie de discos calcareos, que aunque no faltan del todo en los otros astéridos, dejan aun bastante espacio para varios intestinos. I.os ofiuros son tan comunes como las especies de asterias, pero es dificil apoderarse de ellos, pues son astutos y timidos y trepan con extrema agilidad por los troncos de coral, raices, etc. Solo ocasionalmente hacen uso de los piés chu. padores: en cambio se fijan con los brazos, con los que se curoscan al rededor de objetos gruesos y delgados. los brazos se arrancan fácilmente, pero vuelven á crecer muy pronto. El trabajo mas importanie en que se ocupan cs, naturalmenie, el de buscar su alimento; sin entbargo, son mucho menos voraces que las asterias. Ias especies que habitan la profun. didad trepan con preferencia por los corales córnés, de cu. yas partes blandas se alimentan.

El ofiuro blanco (fig. 3 So) es una de las especies mas notables: su disco pentagonal aparece provisto en el origen de los brazos de piezas pectineas con dice y seis articulaciones, halliándose estos revestidos de líminas dorsales triangulares. Tambien el ofiocoma sonrosado (fig. 379) es una especie que debe continuarse junto å los ofiuros: distínguese por sus pie. 2as bucales de forma oval y angulosa, sus brazos armados de tres series de espinas y su coloracion sonrosada oscura.

Entre los ofiuros curopeos hasta ahora conocidos, el mas pequeño es el mas interesante, no por su género de vida, si no por la propagacion por medio de la division, seguida del reemplazo de la mitad separada del cuerpo por otra nueva. Este animalito, el ophinactis virescens, tiene en estado adulto un disco de solo algunos milimetros de diámetro, yes de un color verduaco. Vive cerca de Nápoies y probablemente en todo el Mediterráneo, en la zona de la costa donde repta en increible número entre los espóngilos y algas. Se sabia que tiene seis brazos en vez de cinco, y tambien que estos brazos á menudo son desiguales. Cuando elegi un número de individuos para mi coleccion y encontré que en los menos los seis brazos eran iguales: $y$ que en la major parte una mitad del cuerpo con los tres brazos correspondientes era mas pe queña que la otra, me pareció necesario hacer un exámen minucioso. In algunos centenares de individuos que traje bien conservados, mi jóven amigo el doctor Simruth ha to. grado no solamente darnos una anatomia completa de este ofiuro, sino tambien estudiar el modo como que se divide y vuelve à completarse. De este estudio resulta, que en el ofiactas la division es lenta, pues Sinruth reconoció que el estómago estaba abierto, los nervios y los vasos rotos, las phacas de la dentadura y otms partes duras, separadas. Este 
fenómeno, sin duda, es cfecto de una contraccion nerviosa. La herida se cierra, por lo pronto, uniéndose los bordes de fractura del estómago y los de los tegumentos del cuerpo, cicatrizandose despues y volviendo a formarse la mitad perdida. ¿Cuantas veces esta formacion puede repetirse en el mismo punto? ¿Cómo se verifica la propagacion sexual? ¿lie. nen acaso los pequeñuelos que nacen de los huevos solo cinco brazos segun lo cree Simruth? Estas y otras preguntas aun quedan sin solucion para el zoólogo.

\section{LOS ALECTOS-ALECTO}

Al lado de las numerosas especies con brazos sencillos se encuentran algunas pocas, cuyos brazos se ramifican, ya en la extremidad, ya en la base. Fistas especies forman el género de los alectos. Se ha calculado que en los individuos con los radios mas ramificados, el número de los artejos es de unos ochenta mil. En todas estas especies los brazos y sus ramas tienen la facultad de enroscarse hicia adentro, y probable. mente tambien de atraer el alimento haicia la boca. 'Todos los alectos prefieren las profundidades mayores del mar. De varios ejemplares del alecto verrugoso pescados al extremo norte, sé yo por propia experiencia que se sacaron con ironcos del coral córneo, cogidos casualmente en el anzuclo.

No nos ocuparemos de los fenómenos de desarrollo de las asterias y de los ofiuros, porque son esencialmente los mismos que en los erizos de mar. La figura $3 \delta$ i que representa el asterofiton arborescente dá una idea de las variadas formas que aquellos pueden adoptar: recomendamos tam. bien a los estudiosos los elegantes modelos de cera que rabrica el doctor Ziegler de liriburgo, en Baden, y yue en la mayor parte de las Universidades se emplean frara la explicacion en la enseñanza.

Particular mencion merece el cuidado para la cria del as. térido, bastante raro en el Norte (Asternanthion Midlevi): éste forma con el disco y los brazos una cavidad en la que cuida de los hueros y larvas, que acumulados delante de la boca imponen al animal el mas riguroso ayuno durante todo cl periodo de la reproduccion. Segun me convenci por un cjemplar encontrado en la playa de una de las islas de Feroe, este asteracintio busca, para este periodo, un escondite seguro no expuesto à los golpes de las olas.

\section{CUARTO ORDEN}

\section{CRINOIDEOS - CRINOIDEA}

El plan seguido en esta obra, segun el cual descendemos de las formas superiores á las inferiores, puede justificarse por muchos conceptos; pero, lo repetimos, tiene en general, y sobre todo respecto al mundo de los animales inferiores, el inconveniente de que la descripcion que trata de las relacio. nes naturales de las series de formas, se ha de entorpecer precisamente en este punto.

La vida de los individuos es muy interesante alli donde, con el tamaño, se reune un cierto grado de inteligencia y de energia. La vida del individuo nos conduce, sin embargo, a craminar la de la especie, asi como su manera de formarse; el procedimiento de la creacion, por muchos conceptos cnigmático, de las clases de animales y de sus grupos, nos induce a njiar nuestras miradas necesariamente en el mundo pasado y en los restos de los antecesores de los sércs viros actualer. En esto nos sucede lo mismo que al que quisiera estudiar la historia de los pueblos comenzando por los periodos mas recientes, para terminar poco a poco en la antigiedad. 'Tam. bien la historia de los animales exige este procedimiento en el desarrollo, tanto mas en las regiones donde la vida de los individuos ofrece mucho menos interés que el origen, la trasformacion y la desaparicion de la serie de formas que la zoologia sistematica designa como especies.

A esta observacion nos ha conducido el órden de los crinoideos, bien les comprendamos en su aislamiento ó en su relacion con otras divisiones de la clase de los cquinodermos. lil mundo actual nos presenta solo restos aislados de una division rica en otros tiempos, con la cual ha sucedido lo mismo que con la familia de los nautilos, ó con toda la clase de los branquiópiodos. En una especie propia del mar de las Indias occidentales, el pentacrious caput Mreduse, el verdadero cuerpo se asemeja à un cáliz, segun se le llama tam. bien cientificamente. In cara, dirigida hácia el tallo, esta cubierta de placas y corresponde al dorso de las estrellas ma- rinas; el lado vental esti provisto de una bianda piel elastica, en cuyo centro se encuentra la abertura bucal; cl orificio del intestino se halla situado lateralmente; los surcos corres. pondientes a los ambulacros son marcados. Este cuerpo, con sus brazos ramificados, descansa sobre un tallo mas iargo, inserto en el centro del dorso; se compone de muchas articulaciones muy flexibles, y esta provisto, a intervalos regulares, de ramas dispuestas circularmente. Apenas se han pescado algunas docenas de individuos de este pentacrino, que se conserva en los grandes museos. Lil precio era muy alio aun en 1876: yo pagué al traficante de objetos naturales Damon, en Weymouth, la suma de doscientos veinte marcos por un solo individuo.

Durante largo tiempo el pentacrino de las Indins occidentales, y otrogénero, cl holopus, de que hasta ahora solo se han encontrado dos individuos en la costa americana (en las del Brasil y de Jarbados), parecian ser los únicos representantes aun existentes de los crinoideos pedunculados. No obstante, las cxploraciones hechas en el fondo del mar han hecho cambiar esencialmente nuestras opiniones ambien respecto á este órden. Segun se ha demostrado, en muchos panto del fondo del mar habitan animales semcjantes á los pentacrinos. de modo que ni siquicm se les puede contar yar entre las curiosidades. El conocido zoólogo inglés Govyn Jeffreys cogió con una sola redada, al sur del cabo San Vicente, y à una profundidad de 1,095 brazas, veinte individuos de una especic de pentacrinos (pentacrinus Thomsoni). Iil fondo en que vivian estaba formado por un limo, en el cual se fjaban ligeramente sin arraigarse, segun se reconoció tambien por la extremidad lisamente redondenda del tallo, circunstancia de la que Jefirejs hasta quiso deducir que los animales nadan temporalmente con ayuda de sus brazos.

Mas abundantes son los pentacrimos aun en ciertas partes del mar Austral donde la expedicion de Challenger recogio 
cerca de las islas Meangis, en una sola rez, so individuos, á la profundidad de 500 brazas. He la verdadera existencia de los crinoideos y de su número en el mundo actual, solo podremos formarnos uma idea aproximada cuando el profesor Tohmson haya descrito los tesoros de su interesan te viaje de descubrimientos. No poco, sin embargo, que dari aun oculto, porque muchos géneros como los hyocri. nos se han extraico de una profundidad de $1.375 y^{\circ}$ hasta de $2,3^{2} 5$ bmans.

Otro descubrimiento muy interesante se habia hecho y"a en 1864 por el ilustre naturalista Sars, que tantos méritos tiene adquiridos por sus estudios sobre la zoologia septentrional. Encontró en una profundidad de 300 brazas, cerca de las islas de Sofoden, un crinoideo muy delicado de unos $0^{10}, \mathrm{r}_{4}$ de largo, al que dió el nombre de rizocrino (shizocri. mies) a causa de la abundancia de finas mices por medio de las cuales se fija al tronco. El mismo animal fue pescado por todias las expediciones posteriores que se ocupaban cn la exploracion del Octano Atlántico hasta la costa de la Florida, lo cual ofrece un gran interés para el zoólogo y el paleontólogo, porque se trata de una familia que se creyó ex. tinguida desde la formacion cretácea. Essta fannilia es la

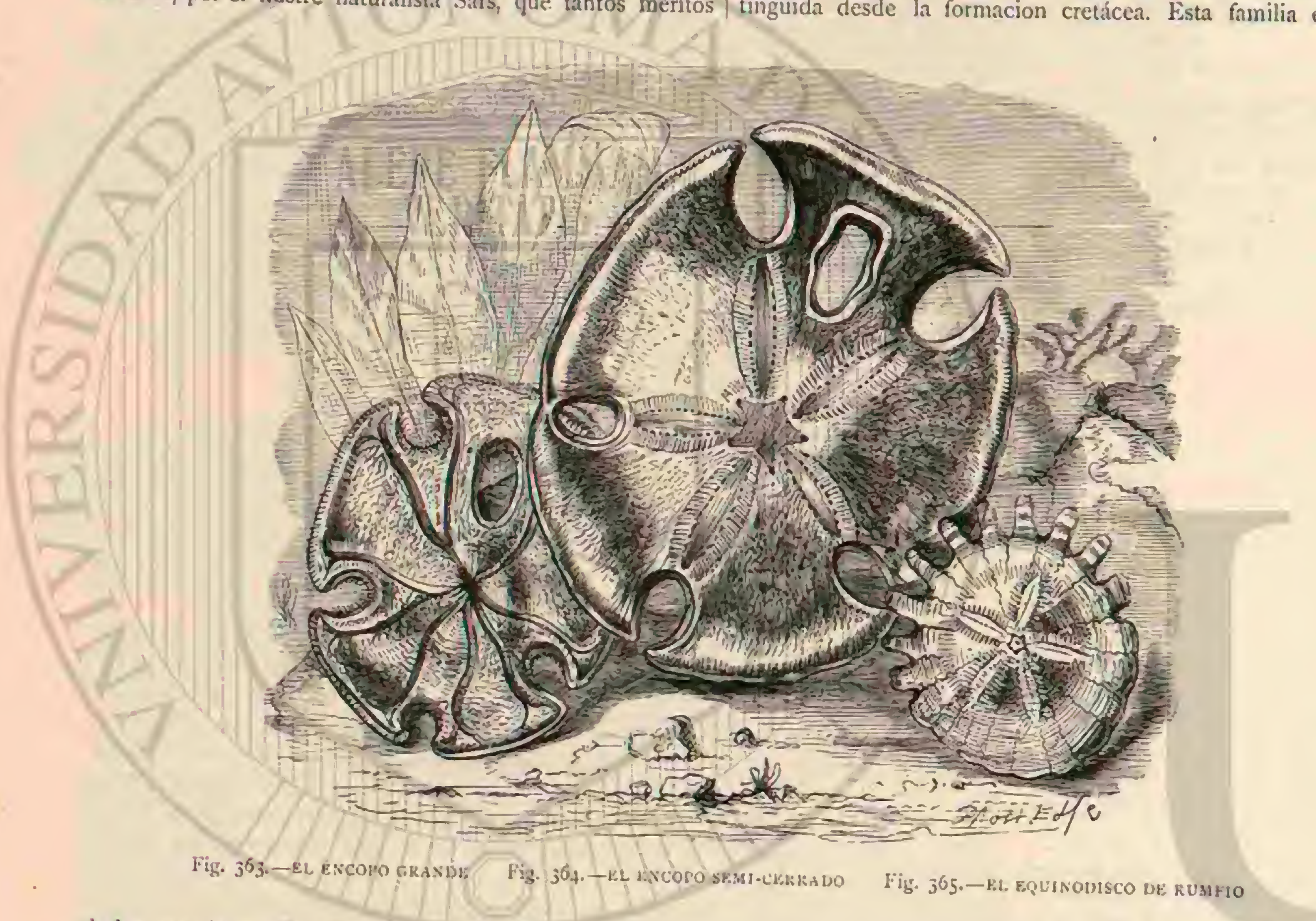

de los apacrinitos. El rizocrino de que tratamos tiene como congénere unas próximo el género bourgucticirisus, y tam. bien éste presenta varios caractéres que indican uma deca. dencia 0 la extincion die la familia. El cuerpo es pequeno, los brazos estrechos y cortos y el tronco sumamente largo, desproporcion que parece depende de una alinuentacion muy desigual. Estos fenómenos se repiten en el rizocrino que puede llamarse bourgueticrino mas atrofiado, hecho que nos oirece una jrueba, digna de tenerse en cuenta, de que los mares de los liempos de la formacion cretácea quedaron cortados, efectuándose no obstante una lenta trasformacion de su fauna animal en nuestros mares actuales.

Hé aqui como estos séres tan poco desarrollados, y su género de vida tan nisterioso, nos permite una ojeada en la historia de la formacion de la tiern, poniendo en relacion lo presente con los periodos pasados ince millones de anos, y representandonos efectivamente la naturaléza de los mares de aquel entonces, y la posicion y el aspecto de la profundidad del mar. l'uede suponerse que la mayor parte de aģuellos animales ņue encontramos rétirados en la profundidad de los Occéanos, son representantes vivos de las épocas verdaderamente primitivas, que prosperaban en otro tiempo como géneros y familias, viviendo nas cerca de la superficic del mar.

\section{LAS COMATULAS - COMATULA}

De los crinoideos que en otros tiempos poblaban en la mayor variedad los mares primitivos, un solo género se ha consermado hasta nosotros, ofreciendo en su desarrollo y inetamorfósis algo de sus condiciones antiguas. Hste género es el de las comatulas, de las que se conocen unas cuarenta especies de lodos los mares. En el Océano Atlántico vive la-comatula rosasa (fig. 382 ) (antedón rosaceus) y en el Mediterrínco la comatula medilerránea. A primera vis. ta el animal parece ser un congénere muy afine de los pentacrinos, pues tanto éstos como aq̧uél tienen un cuerpo en forma de caliz, cuya pared se compone de varios circulos de placas de caliza, con una tapa blanda. La abertura bucal ocura el centro de esta tapa; excéntricamente en la punta de una prominencia en forma de chimenea se encuentra el ano, cinco brazos ahorquillados desçe su origen salen del lado dorsal, de modo que desde la parte bucal se ven ro brazos. Estos se hallan provistos de dos serics de apófisis opues. tas y alternadas, que se llaman pinulas (finmulc) y parecen unas ramas de enredadera provistas de graciosas plumas, porque afectan la forma de bonitos arcos ó espirales. Hasta aqui $y$ aun en otras particularidades la descripcion es casi exactamente la misma del pentacrino; pero alli donde en el 
dorso de este últimn se inserta el tallo, encuéntrase en la comatula un boton rodeado de un circulo de finas ramas elásticas, cada una de las cuales remata en una garra de materia caliza. La observacion en el animal vivo revela al punto para que sirven estos ramos dorsales con sus ganchos.

Antes de que las comatulas, que son de un bonito color rojo, carmesi, pardo, azul 6 amarillo, se hallasen en acuarios, $y$ antes de que los naturalistas ingleses y franceses las observasen vivas, circulaban ideas completamente falsas acerca de su género de vida, creyéndose que se arrastraban por el limo con la boca dirigida hácia abajo, como las estrellas de mar.
Como cerca de Lara, en la costa de Dalmacia, he cogido centenares de individuos del fondo cenagoso, sirviéndome de la red, en puntos donde escasean las algas y las esponjas, tambien yo incurri en este error, creyendo que se alimentaban de las sustancins orgánicas contenidas en el limo. No habia podido reconocer que la red los arrancaba de las plantas ma. rinas à una profundidad de doce as veinte brazas, y ya habia recibido informes de varias partes, cuando por fin yo mismon reconoci en el acuario de Dohrn, en Nápoles, que estos animales eran trepadores perfectos, y que en masa se fijan on los objetos mas diferentes, ofreciendo un aspecto curioso.

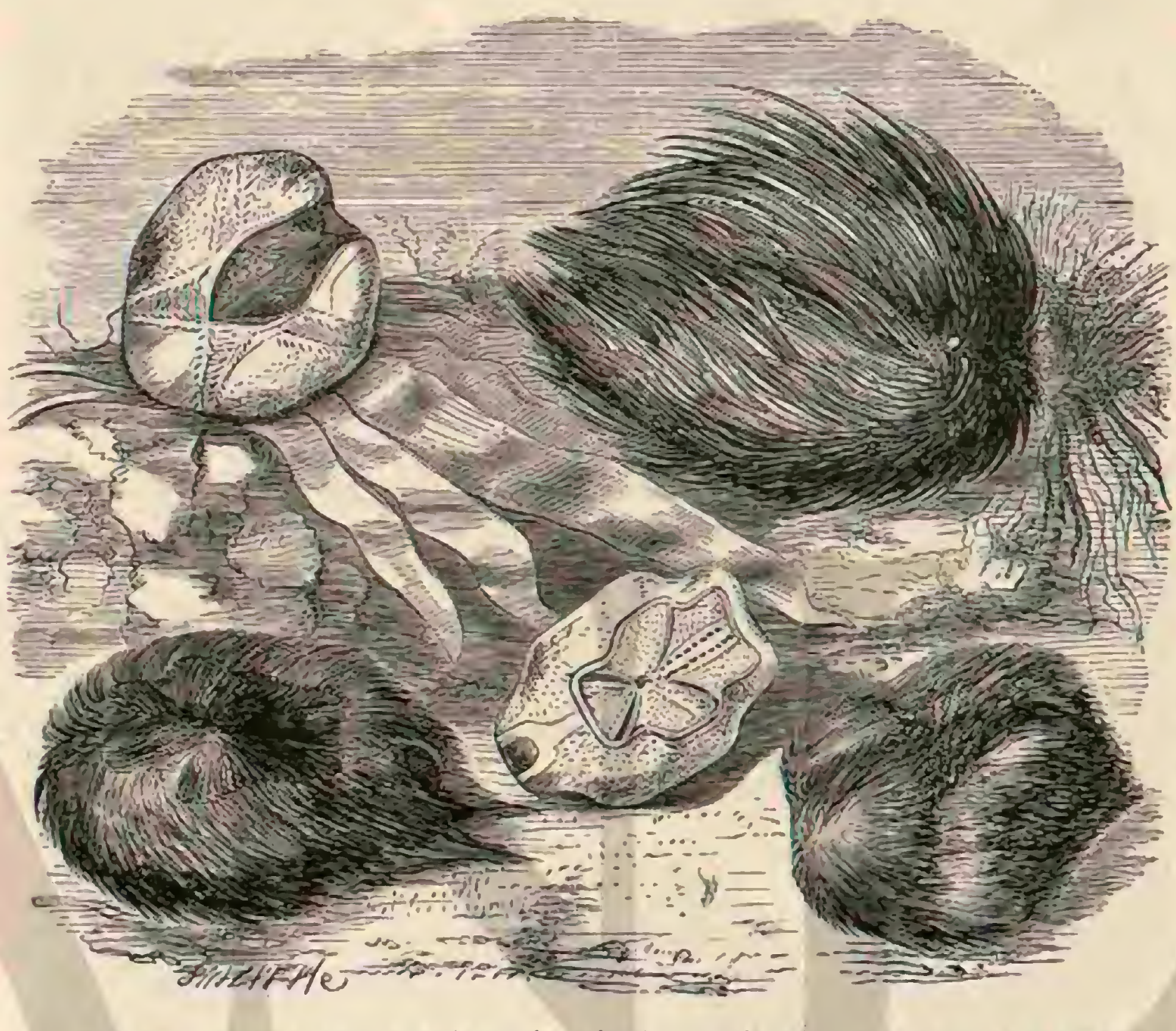

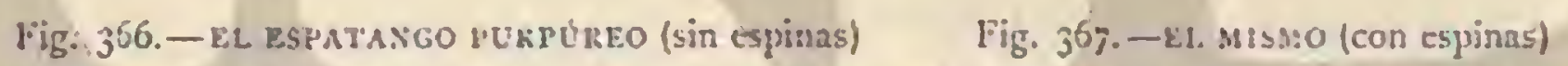

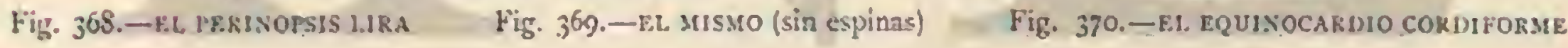

Cunndo se les pone en vasijas donde les falta medio de agarrarse, de modo que i todo su alrededor están cercados de agua, y pueden por lo tanto extender libremente sus bra205, intentan repetidas veces elevin con sus cinco brazos remando con ellos de un modo graciosisimo; pero vuclven á caer, porque no pueden agarrarse en ninguna prominencia ó rama, y permanecen en una posicion cncorvada, que no siéndoles, sin cmbargo, natura], apresura su muerte. Cuando se ponen varios individuos en ura vasija lisa se agarran unos a otros y se rompen los brazos. Se mueven, por lo tanto, solo buscando un objeto en que agarrarse. Esto lo hacen por medio de aquellas ramas dorsales con garras. Se aprovechan, sin embargo, muly poco de la facultad de cambiar de sitio a nado ó trepando, cuando ya han encontrado un punto con. veniente, en el que permanecen con in superficie bucal diri. gida hácia el lado ó hácia arriba, y con los brazos ligeramente encorvados para esperar su alimento.

Para comprender el modo con que la comatula y en general todos los crinoideos se alimentan, se necesita un exámen minucioso de la cara bucal. De la boca salen cinco surcos que se dividen en forma de horquillas dirigiéndose hácia los brazos. Cada brazo tiene, por lo tanto, un surco que se con. timúa hasta la extremidad, y está cubierto de pelitos que pro. ducen una corriente de agua hácia la boca; de modo que basta extender los brazos para empujar los animalitos microscópicos propios para el alimento q̨ue entran en los surcos búcia la boca. Cuanto mas quieta permancce la comatula, con tanta mas seguridad y regularidad verifica la recepcion del alimento. En los sitios en que viren los crinoideos no faltan nunca muchos miles de animalillos y de larvas invisi. bles a la simple vista, y esta vida microscópica se presenta pronto tambicn en los acuarios grandes. Para revisar el ali. mento que reciben, estos animales se aprorechan de la extraordinaria sensibilidad de los brazos, porque los miles de de apótisis plumados ó pinulas que cubren el tallo de los brazos en cos series, son órganos del tacto y de los mas delicados. Cada pinula tiene en la junta algunos pelitos tacti. les: tan luego que un cuerpo extrano al tacto general toca cl brazo ó un animal demasiado grande llega i su alcance, las pinulas se cierran por encima del surco y el brazo se arrolla rechazando naturainsente el intruso.

Iacaze-Duthiers ha dado los informes mas minuciosos sobre la vida de la comatula en sus viviendas naturales. Nos representa al zoólogo coleccionador ' observador, dảndonos a conocer las condiciones vitales de la zona costera con tal claridad, que citaremos sus mismas palabras haciendo tan 
solo algunas abreviaturas necesarias. Nos encontramos en Roscoff, en la costa de la Bretana, en frente de Weymouth, donde la playa arenosa que forma insensible declive, está interrumpida por rocas é islotes de granito, grandes y peque. nos. ¿ntre todas estas rocas y en el Canal aparecen con la marea baja, hermosas y extensas praderas de yerba marina (sostera), y bancos de arena cubiertos de piedra, habitados ambos por numerosas especies de animales. Hay alli toda clase de ascidias sencillas y compuestas, animales de mus. go, sertularios, esponjas, sobre todo calcáreas, estrellas de

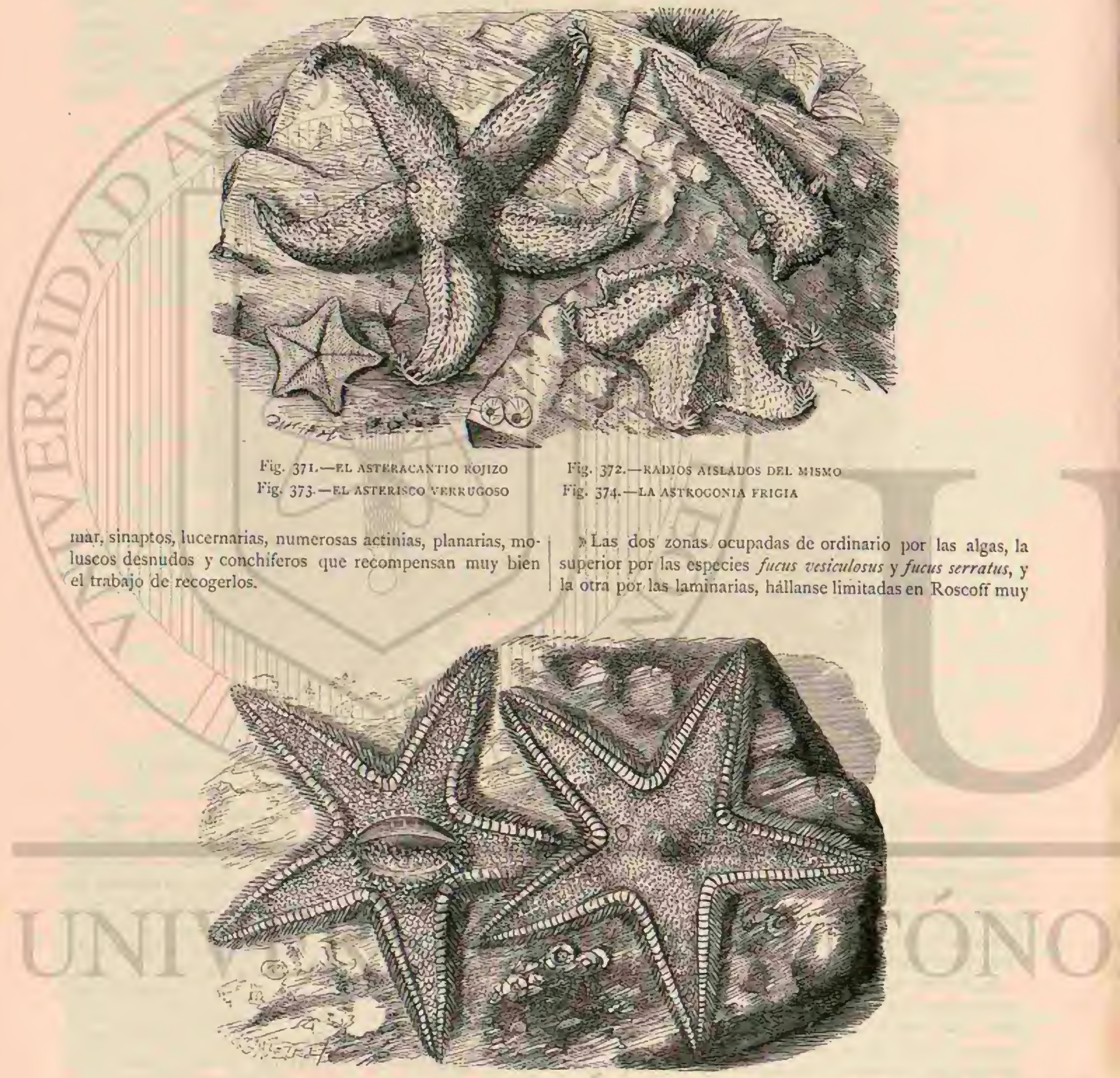

\section{DIR Tris}

marcadamente por la himantalia dorea, alga que se utiliza como abono para los legumbres. Su zona no se descubre del todo sino en la marea mas baja, cuando tambien son accesibles las laminarias. Estas cosas deben verse para poder formarse una iden de las dificultades que se ofrecen cuando se trata de coger esos animiales en medio de las rocas, mientras éstas se hallen bajo el agua, sobre todo si ha de andarse entre las fajas pegajosas y resbaladizas formadas por la himantalia que entre las cavidades de las piedras se enredan en nuestras piernas. Fste trabijo es casi infructuoso, y la recoleccion es en extremo dificil y hasta peligrosa, porque á cada mo. mento se pierde pié. En cambio la zona de las laminarias es mucho mas facil de explorar y de mejores resultados. Lo mas importante para conseguir al fin que apetecemos es la presencia del sargassum, alga que por lo regular se encuentra a mas profundidad en el suelo arenosn, nunque en cicrtas 
circunstancias, de que luego hablaremos, subc i bastante altura.

Fin las horas de la maren mas baja, al retirarse las aguas, ribrense hoyos en el suelo arenoso y en las praderas de algas; en estas cavidades formanse enionces varios charcos y en ellos se fija el sargassum; sube a bastante altura y sirve de albergue á las comatulas jóvenes y viejas. Como los troncos del sargassum tienen muchisimas ramas, estas se enlazan y forman una especie de espesura que constituye el alberguc de la comatula, con preferencia à otros. Tambien los acidios, esponjas, pólipos y animalitos de musgo son en clla tan numerosos que cada tronco de sargasso presenta toda una coleccion. I a comatula se encuentra á reces cri tal multitud que cubre casi del todo las ramas.

Esta manera de apoderarse durante algunos dias del año de la comatula, solo con la mano, se puede practicar en las costas mientras haya una marea muy alta $\delta$ muy baja, y por lo tanto debe exceptuarse el Adriático y el Mediterráneo.

Hemos observado hasta ahora solo la existencia de la co. matula adulta.

Por mucho que se parezca á una flor, no puede simi. larse, sin embargo, á una planta marina, comparacion natural tratandose de los pentacrinos; pero toda comatula pasa en su juventud por el estado de aquellos é indica asi su

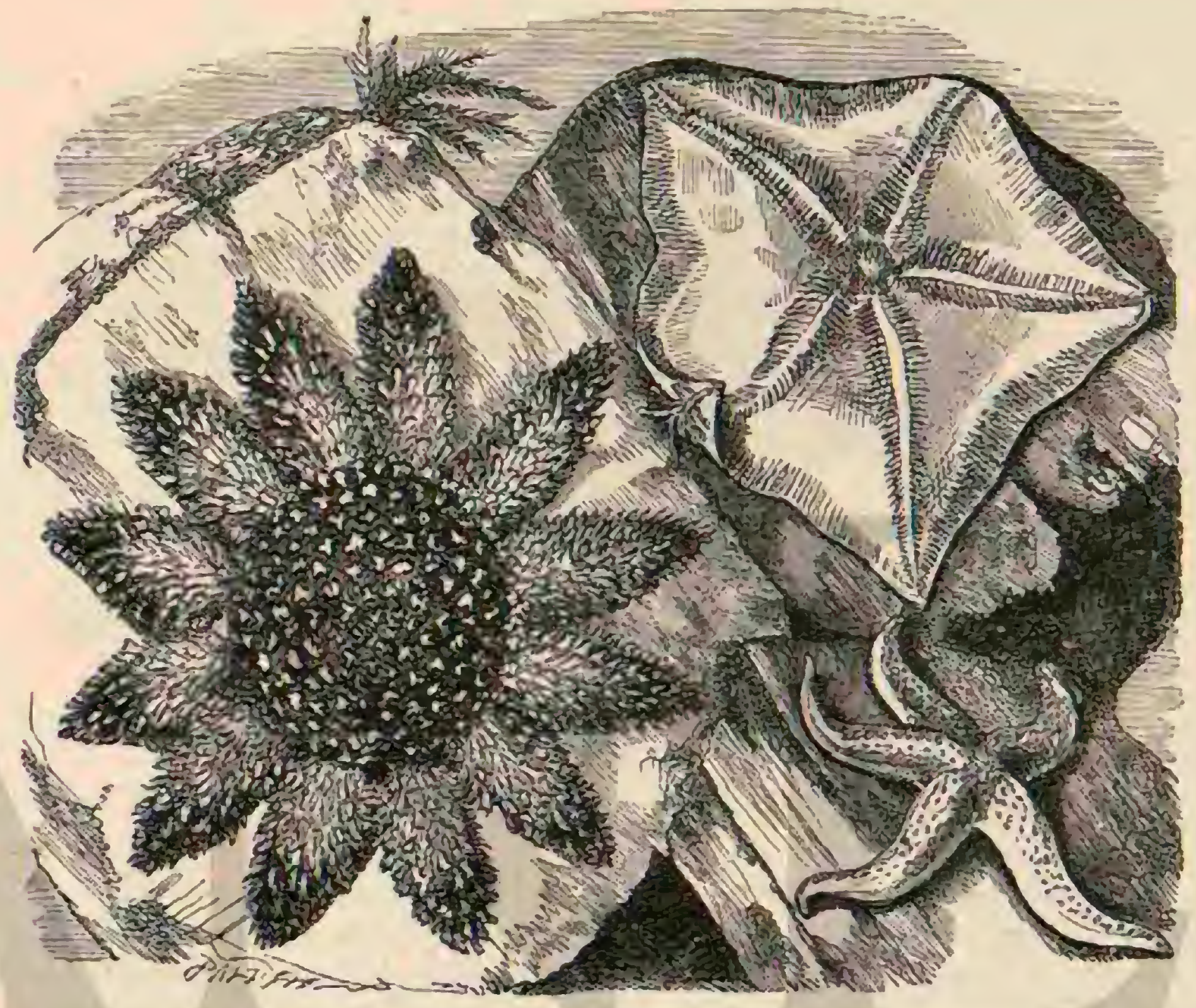

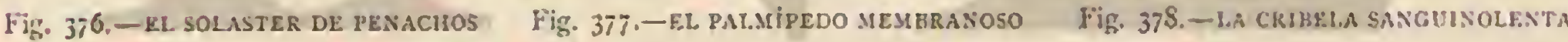

origen de la forma pedunculada. El fin de su desarrollo es andlogo al de sus congeneres de la clase: pero despues de haberse formado el intestino, prolóngase la extremidad pos. teriur y el inimalito se fija con ella en cualquier objeto. Tiene por lo pronto el aspecto de una pequeña maza de tallo corto, tan diminuta, que apenas puede distinguirse á simple visia Este primer periodo, durante el cual no existen los braz.os, pueden compararse con el estado de crisálida de la mariposa, porque in boca, que al principio cxiste en la comatula pequeria, está cubierta entonces de una caja mern. branosa, por debajo de la que el disco bucal del individuo perfecto adquiere su forma definitiva. Poco á poco salen los brazos y continua el creciniento del tallo, que en lo esencial se asemeja al del pentacrino. La comatula pedunculada se parece tan notablemente al pentacrino cuando se halla en tal estado, que la idea de que esa especie deriva su origen de antecesores semejantes á los pentacrinos, parce muy lógica a todo naturalista pensador.

Las comatulas pequenas pedunculadas se encuentron siempre alli donde las adultas existen en gran número; yo las he visto formando grandes masas en el acuario de Dohrn. Entre otros objetos se fijan tambien en los tubos del espirogranfis (sabella moristion).

\section{LOS CELENTERATOS-CELEN- TERATA}

"No todos ticnen la dicha dé ver i Corinto, se decia en la antigüedad para consolar al que por sus modestos recursos debia encerrarse en una esfer de ideas limitadas. Sola. mente los elegidos puecien disfrutar de las delicias de aquellas islas meridionales, que deben su existencia y forma actual á la actividad de los animalitos de coral, manifestada durante miles y miles de años. Nuestros mares curopeos no ofrecen tal riqueeza, mas a pesar de eso, han entusiasmado tal vez á muchos viajeros al ofrecerse á su vista aquellas capri. chosas formaciones, con sus guirnaidas y largas franjas, cuyo cuerpo tiene el aspecto cristalino, de color violeta, rojizo 6 ámarillento. Al pasar nuestra lancha junto á estas formaciones vemos que dilatan y recogen alternativamente el borde de la campanilla 6 del disco para sostenerse por estos movinientos cerca de la superficie. El que haya permanecido largo tiempo en los banos de mar habra trabado conocimien. to mas intimo $y$ harto desagradable con estos animales, que como sirenas excitan por sus colores i tocarlos, lo cual recompensan jroduciendo el escozor mas doloroso: pero los muchos miles de nuestros lectores que no hayn conocido 
tales impresiones en la costa marina, ni visto semejantes cosas, pueden formar idea de ellas, aunque en miniatura, adquiriendo un acuario, que es un bonito adorno, aunque dificil y enojoso de conservar; en él pueden tener las ancmonas marinas, las actinias, que son pólipos lo mismo que los constructores de las rocas de coral, los astéridos, los aca. lefos $y$ otras muchas especies que forman el grupo de los celenteratos.

No conozco ninguna palabra con qque pudiera sustituir el nombre de celenteratos, compuesto de dos palabras griegas, y por lo mismo debo dar una cxplicacion minuciosa para describir la estructura interna de estos animales.

Se da el nombre de celenteritos a los animales cuya cavi- dad correspondiente al intestino de los otros animales no esta cerrada de por sí; sino que se halla en comunicacion con los espacios que corresponden á la cavidad abdominal de los vertebrados, insectos, etc.; pues en el tomado del griego están contenidas las dos palabras «intestino, cavidad abdominal. \%

Ia historia del desarrollo, en la qque tambien se han hecho los mayores progresos desde el ano 1868 , nos ha démostrado que la definicion es exacta. El sistema de cavidades del cuerpo del celenterato, que se compara con la cavidad abdominal, solo se compone, segun demostraremos despues en un pólipo, de los ensanchamentos regulares dispuestos en forma de radios del corto intestino, derivando su origen del

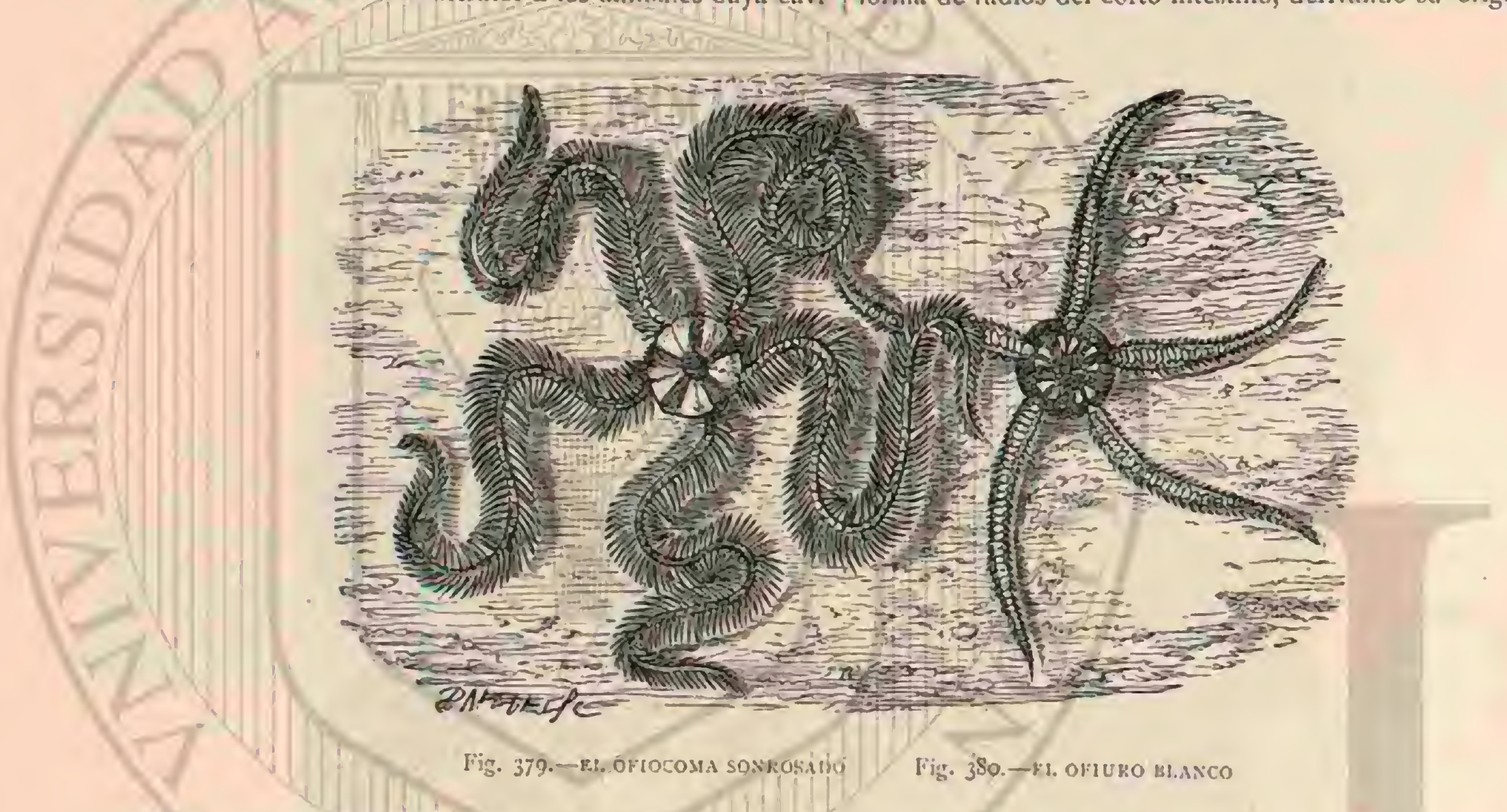

llamado intestino primitivo de la larva. Fil resullado de cste desarrollo embrionario y de larva, es indudablemente uno de aquellos que no vueliéa cocontrarse en todo el resto de la fauna animal, es una especialidad del aparato digestivo, circulatorio y respiratorio que solo vemos indicada cuando mas en los moluscos por la recepcion innedinta del agua en el sistema de circulacion de la sangre. No nos sirren las frases generales al tratar de estas condiciones extranas, y segun hemos dicho ya, deberemos dar una explicacion suficiente, especificando algunos ejemplos. Si en los equinodermos cra de cinco el número fundamental de los radios, en el caso que nos ocupa la division ie la estructura está representada por las cifras cuatro y seis y sus múltiplos: si en los equino. dermos la piel es casi sin excepcion semejante i un esquelcto y coriácea, en las especies de que tratamos la piel coriacea constituye una cxcepcion. Tambien en el caso de que algu. nas ó la mayor parte de las paredes del cuerpo sean duras, o calcíreas, la extremidad anterior, provista de una corona de tentículos ó de varias, consérvase blanda como una for, y las formas libres, mas desarrolladas, seducen a la vista por la delicadeza y la gracia de su conjunto.

En su facultad de desarrollarse en un grado superior re. presentan, a pesar de su notable variedad, el principio de la estabilidad, casi mas aun que los equinodermos. Asi como estos, tampoco ellos har tomado parte con buen exito en las enérgicas tentativas de los poderosos animales en la gran lucha por la existencia y para colonizarse en el continente, ö cuando menos en el agua dulce, ti fin de obtener por el can. bio de residencia el desarrollo de la organizacion. No se po. dria sostener lo contrario por el hecho de que un humilde sér semejante à los pólipos y apenas visible, la hidra, habite como centinela a vanzada, en nuestros fosos y pantanos.

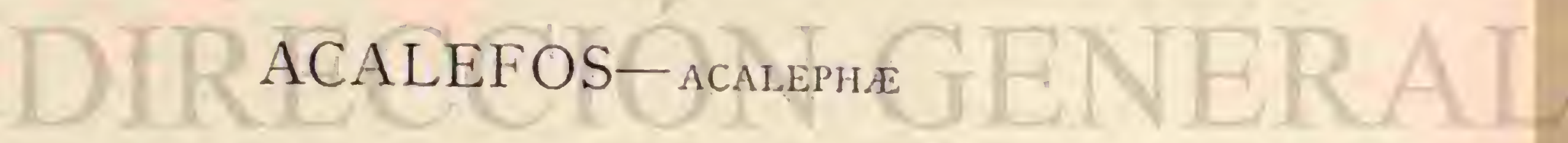

Si pudiéramos atenernos solo á las formas de esta clase, que como individuos de virła aislada alcanzan su completo desarrollo y una propagacion sexual, la caracterizacion general no nos ofreceria dificulandes. Los celenteratos, de una estructura marcadamente radiada, tienen el cuerpo en forma de melon, de paraguas 6 de disco, de una sustancia gelatino. sa 6 cartilaginosa y como trasparente, incolora ó de un tinte muy delicado; todos habitan en alta mar. Su tamano varia desde el de un granito de arena hasta el de unos 35 centimetros de diámetro, ó mas, sin contar las largas hebras agarradizas que se extienden à muchas varas $y$ sirven para coger la presar. No es dificil clasificar todas estos acalefos, que como 
especies nadan libremente; pero á cllas se agrega tal número de géneros, ųue no podemos decir si constituyen individua. lidades 6 colonias, en las que solo las larvas ó generaciones intermedias se parecen à las formas libres; $y$ habria bastante motivo para desesperarse, si se tratara de obligar al mundo vivo a entrar en el antiguo molde de la escuela tradicional.
Tomando, sin embargo, en consideracion los resultados de la nueva zoologia cientifica, tarnbien los acalefos, antes mal conocidos, se clasifican perfectamente en el sistema en una serie continua. Desgraciadamente solo podemos ocuparnos de algunos puntos en estas series, dejando al lector suponer la relacion que entre ellas existe.

\section{PRIMER ORDEN}

\section{TENÓFORAS--CTENOPHORA}

En forma de manzanas trasparentes, de melones $\delta$ de fa. jas, las tenóforas madan $\mathrm{cn}$ alta mar $\delta$ son impelidas por las corrientes $y$ los vientos, hasta cerca de las costas ó a los puertos. Su posicion en el agua es mas ó menos vertical, con la boca dirigida hácia abajo. La cavidad bucal conduce à un estómago tubiforme ó ensanclado, en el que se verifica la digestion; los excrementos vuelven â salir por la boca. La extremidad superior del estómago, si bien puede cerrarse, hállase en comunicacion directa con un espacio en forma de embudo que tiene una abertura opuesta $a$ la boca, $y$ sirve de

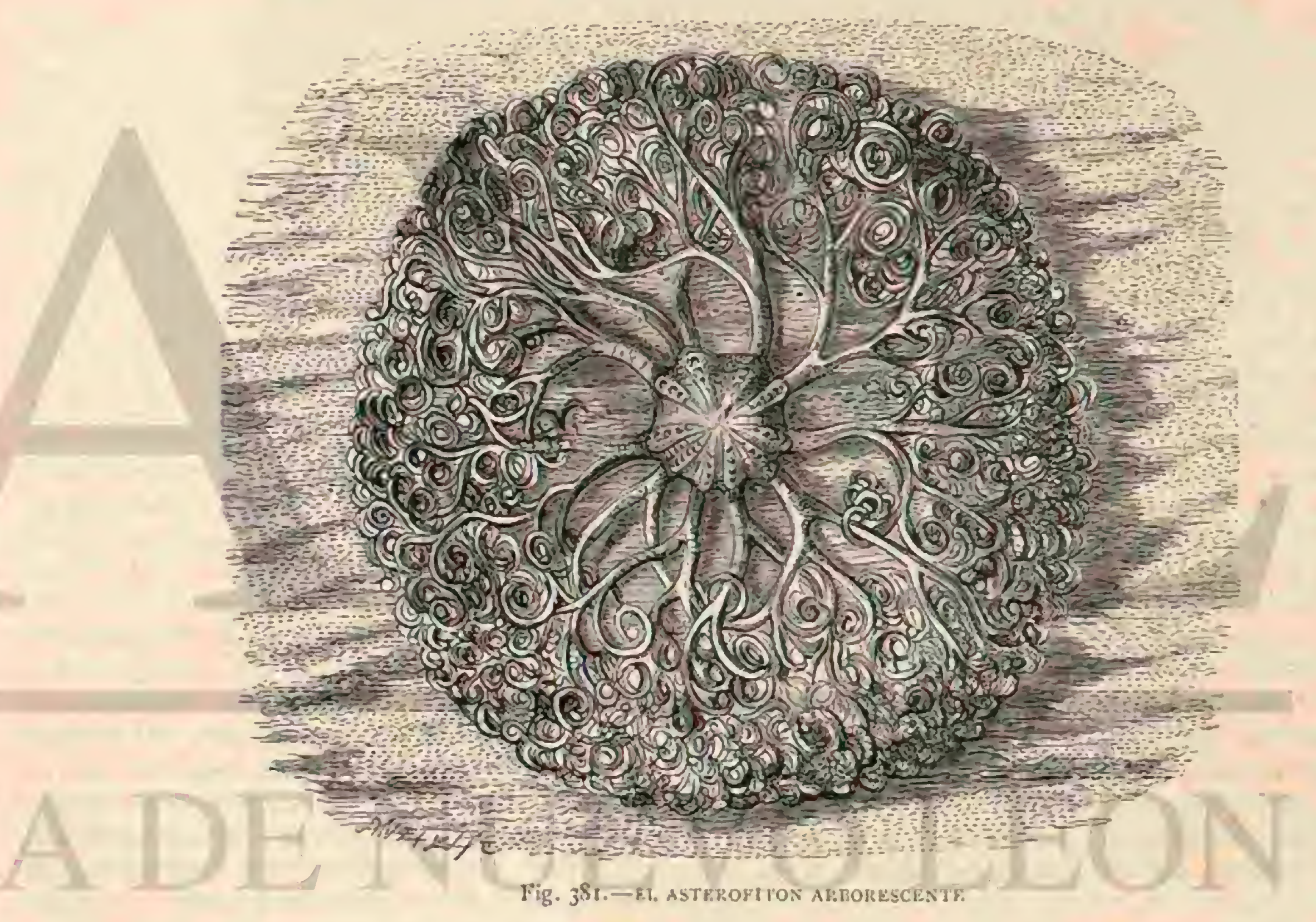

depósito para la sangre y el agua. Iista puede recogerse tambien por la abertura del embudo, aunque parece servir con preferencia para dar salida al liquido del cuerpo despues de su circulacion. Son partes muy notables las costillas que liegan de una extremidad $\{$ otra, $\delta$ solo ocupan cierto trecho. Se componen de cortas serics trastersales de pestanas, y siguen en su direccion los canales que se hallan inmediatamente debajo de ellas. Estas pestañas están soldadas en su base y forman un conjunto que se considera como una serie de plaquitas para nadar $\delta$ renar. Su actividad depende de la voluntad del individuo: de modo que las costillas pueden trabajar aisladas 6 en su conjunto, en cuyo último caso el cuerpo avanza en direccion del polo del embudo. Los otros efectos se limitan á evoluciones del cuerpo que en realidad son a menudo rápidas, ligeras y graciosas, hallándose en re. lacion con las de los otros apéndices exteriores, entre los que deben mencionarse, sobre todo, los de la boca, las partes late. rales erectiles y los bra\%os filiformes. El género guiifpe solo está provisto de estos últimos. En otros géneros sobresalen del cuerpo replicgues membranosos en forma de remos, y de la boca ensanchada con las placas verticales, con cuyo auxilio los movimientos son mas enérgicos y rápidos. Las especies de cucharis, por cjemplo, se empujan cerrando las placas bucales, y cuancio avanzan rápidamente, los brazos están recogidos ó extendicios hácia atrás ả guisa de timon.

A las formas que en otono ó invierno abundan en el Mediterráneo, pertenece el cinfuron de Vinus (cestum exencris) (figura $3 \mathrm{~S} 9$ ). Su cuerpo se prolonga en forma de fajas y 
ofrece, cuando se refeja al sol, un aspecto verdaderamente magnífico. Los hordes de la faja están orlados de pestañas. La forma, de por si elegante, del animal, gana mucho aun con los movimientos viros y graciosos. Cunando se le toca bruscamente suele enroscarse en forma de espiral. Lo mismo que las otras tenóioras, puede sostenerse en un punto por medio de las pestanas, pero tambien cambiar de sitio por movimientos serpentinos.

En el acuario el cinturon de Vénus, y en general todos los acalefos, solo se conservan algunos dias vivos, pues su clc. inento es el mar lióre. Además parece que no encuentran cl alimento suficiente en los acuarios, porque á pesar de su aspecto hetérico sol muy voraces. Las tenoforas se elicuen. tran en todo el año, pero se retiran de la superficie del agua cuando el mar está revuelto ó cuando hace mucho calor. Las formas microscópicas de su juventud se cogen por medio de una fina red. Kowalewsky encontro, sin embargo, mas con. veniente hacer depositar los huevos por individuos cautivos para observar con mas comodidad su desarrollo.

La posicion é importancia de las tenóforas en la economia de la naturaleza son muy inferiores. Alimentándose ellas nismas de pequeños crustáceos, sirven à su vez de alimento à las medusas $y$ anémonas, $y$ divierten la vista del hombre por su fosforescencia en vida y despues de su muerte.

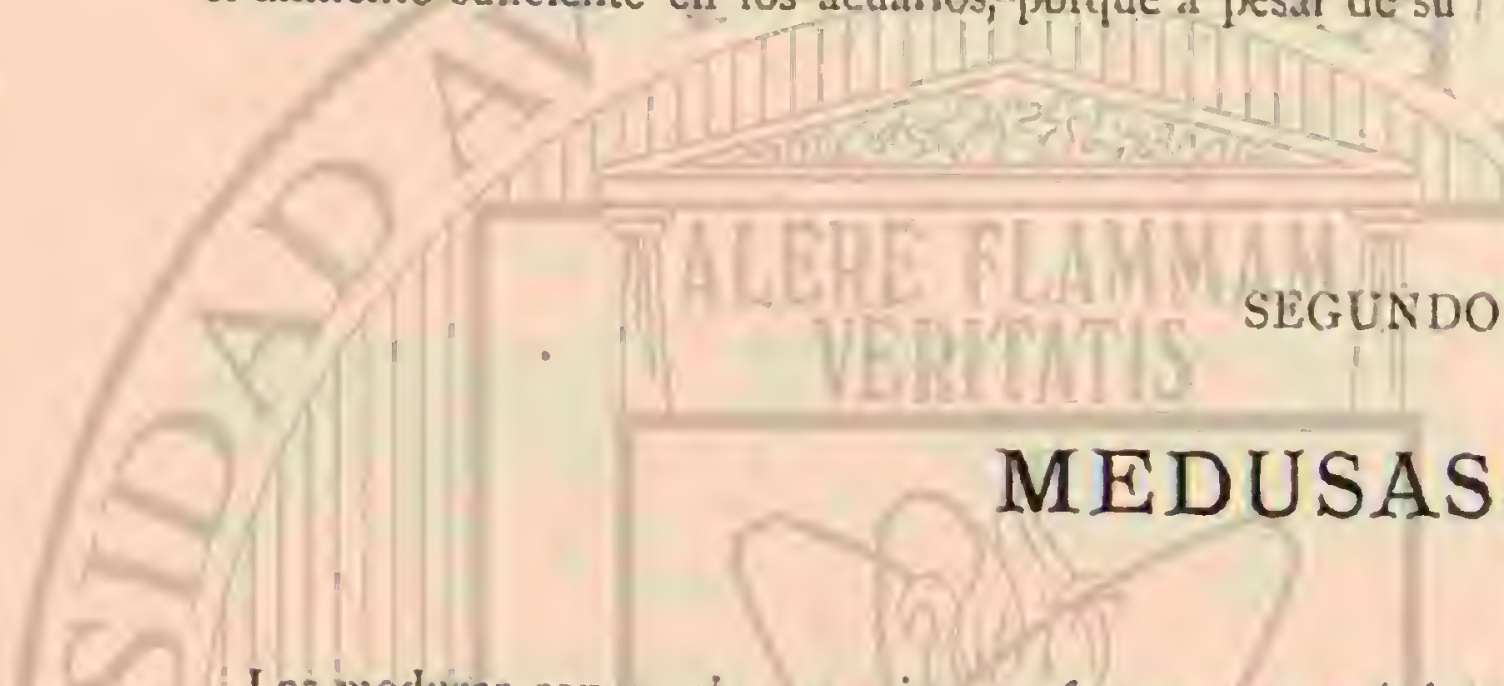

Las medusas son mucho mas ricas en formas caracteristicas y mas notables en colores délicados. Me acuerdo de un magnifico dia en que cerca de la costa noruega vi miles $y$ miles de amarillentas y rojizas cianeas y crisaoras. Tos puer. tos orciodentales del Bailtico se llenan á menudo de verdaderos ejércitos de la medusa azul, y nunque en el Mediterráneo y Adriático no he visto tales agloneraciones, raras veces lie dado un paseo por estos mares sin encontrar muchos, ó cuando menos algunos de los magnificos rizostomos. En los hermosos dias de primavera se les ve casi siempre en las in. mediaciones de la costa, donde una ú otra de las grandes hemisferas azul-rojizss, se encalla $y$ ripidamentc se disuelve. Todos los acalefos tienen un tejido tan abundante en agua, que cuando un individuo de forma de disco y de regu. lar tamano se coloca sobre un papel secante, pronto se eva pora dejando trazados en el papel solo sus cóntorios.

Las grandes medusas son representantes de este grupo de celenteratos, conocidos por todos los habitantes de la costa. La mayor parte del cuerpo forma el discó redondeado hácia arriba, cuyo borde está provisto, por lo regular, de cuatro á ocho y mas puntos colorados en forma de ojos, de una orla ondulada 6 de una membrana natatoria y de hilos extendibles. En el centro de la cara interior del disco se halla la boca, en algunas formas á la extremidad de un tallo y rodea da casi siemprc die algunos brazos ayarradores gruesos. Los órganos genitales estín situados, ya en bolsas particulares al rededor del estómago, ó en sencillos ensanchamientos de los vasos.

Sobre los movimientos de las medusas, Eimer refiere: \$ Hasta ahora en las contracciones del disco de medusa solo se ha pensado en movimientos arbitrarios musculares quue sirven para locomocion, circulacion y respiracion. Esta idea no es del todo vaga, pues segun observaciones que hice en animales vivos é ilesos, las contracciones del disco de la medusa azul sc verifican continuamente de dia, y segun parece tambien de noche, $y$ csta actividad dura aunque el ani mal no se mueva del sitio. Puede interrumpirse, pero solo por poco ticmpo, y entonces el animal sube á for de agua; le gusta permanecer algunos monentos inmóyil. Las coniracciones se siguen con extremn regularidad y solo de ticmpo en tiempo se nota que se hacen mas rápidas 6 mas lentas. No podemos seguir al autor en todos sus experimentos; basta decir que de ellos resulta șue la medusa azul es un poco mas ligera que el agua. Los mas de los acalefos son algo mas pesadus, segun podemos reconocer en algunas otras es. pecies de los mares europeos, como la cianea (figura $3 \delta_{3}$ ), el rizostomo de Cuvier (fig. $3 \delta_{4}$ ), la crisaora brillante (fig. $3 \mathrm{~S} 6$ ) y la aurelia orejuda (fig. 385 ). Apenas podria decirse que alguna especie de las medusas se distingue por su belleza, aunque presentan fenómenos graciosos; el rizostomo de Cu. vier es uno de los séres mas seductores a la vista, asi por su tamaño cono por sus preciosos tintes azules y violáceos.

Para conocer otro grupo de este tipo de animales invito á mis lectores a acompanarme i Lesina, en Jalnacia, donde nos alojamos en el convento de nuestro buen amigo el padre Bonagraziñ. El umbral de la casa está bañado por el mar, y con facilidad cogemos un manojo de plantas acuáticas para llenar con ellas un vaso. Al examinar un fragmento con el microscopio descubrimos un sér delicado y pálido que pe. nosa y lertamente repta con sus largos brazos por la verde superficic. Este animal es un acalefo, afine de un género hace mucho ticmpo conocido (eleutheria ó elnionema), pero incapaz de nadar: es en una palabra la clavatella prolifera. Esta especie tiene seis brazos provistos en la extremidad de verdaderos chupadores y que le sirven para la locomocion. El esófago es muy elástico, y la boca se apodera con facilidad de los pequeños crustáceos que en gran número se hallan en la misma planta. Sobre la base de cada brazo hay una mancla ocular en forma de herradura, en la que encontre una lenteja bien formada, aunque sin poder descubrir nervios que pertenecieran a un verdadero ojo. Un poco mas arriba se encuentm entre cada dos brazos un retoño; todos los de un individuo presentan tan diferentes grados de formacion que fácilmente se puede observar la marcha del desarrollo. En los retoños mas perfectos se re a menudo la disposicion de otro retono nuevo.

Nos extenderiamos demasiado si quisićramos caracterizar, aunque solo fuese por las formas principales, los diferentes generos y familias, sobre todo, respecto a su desarrollo. Sin embargo, debernos llamar la atencion sobre el extraño cam. bio de generaciones entre acalefos adultos como los arriba descritos y séres polipiformes sedentarios. Solo de los huevos de muy pocos acalefos se desarrollan directamente acalefos nuevos, si no larvas polipiformes en las que la generacion de los acalefos se forma por vía de retoños. Lo mismo sucede con la corymorfha mufans. Este acalcfo polipiforme no se 
fija como la major parte de sus congéneres en algas y piedras, simo en la arena fina que cubre el fondo y en la que penetra con la extremidad posterior del tallo. Numerosos apéndices filiformes penetran en el suelo en todas direcciones a manera de raices. I a abertura bucal se halla en la extremidad anterior y está rodeada de una corona de tentaculos; un segundo circulo de estos rodea el ensanchamiento estomacal. Por cncima de este circulo se ven los retorios, que aun cuando penden de sus tallos adriuieren completamente la estructura de las medusas. Mueven vivamente su disco, separanse, y de este modo queda cerrado el circulo del desarrollo, el cambio de la generacion. Otra especie, la tubularia indivisa, nunca produce acalefos libres. En rez de machos, alli donde en la rorymorpha mulans salen racimos de acalefos, prodúcense de cipsulas extrañas que son los órganos genitales masculinos: en la tubularia, el desarrollo de la especie acaba con la forma de pólipo. Sin embargo, las colonias femeninas se parecen mas a la corimorfa, porque las capsulas en que se forman los huevos se desarrollan mu. cho mas que las masculinas, y aunque no se separen recuerdan por su estructura los acalefos.

Una forma mas imperfecta aun es la hydractinia echinata,

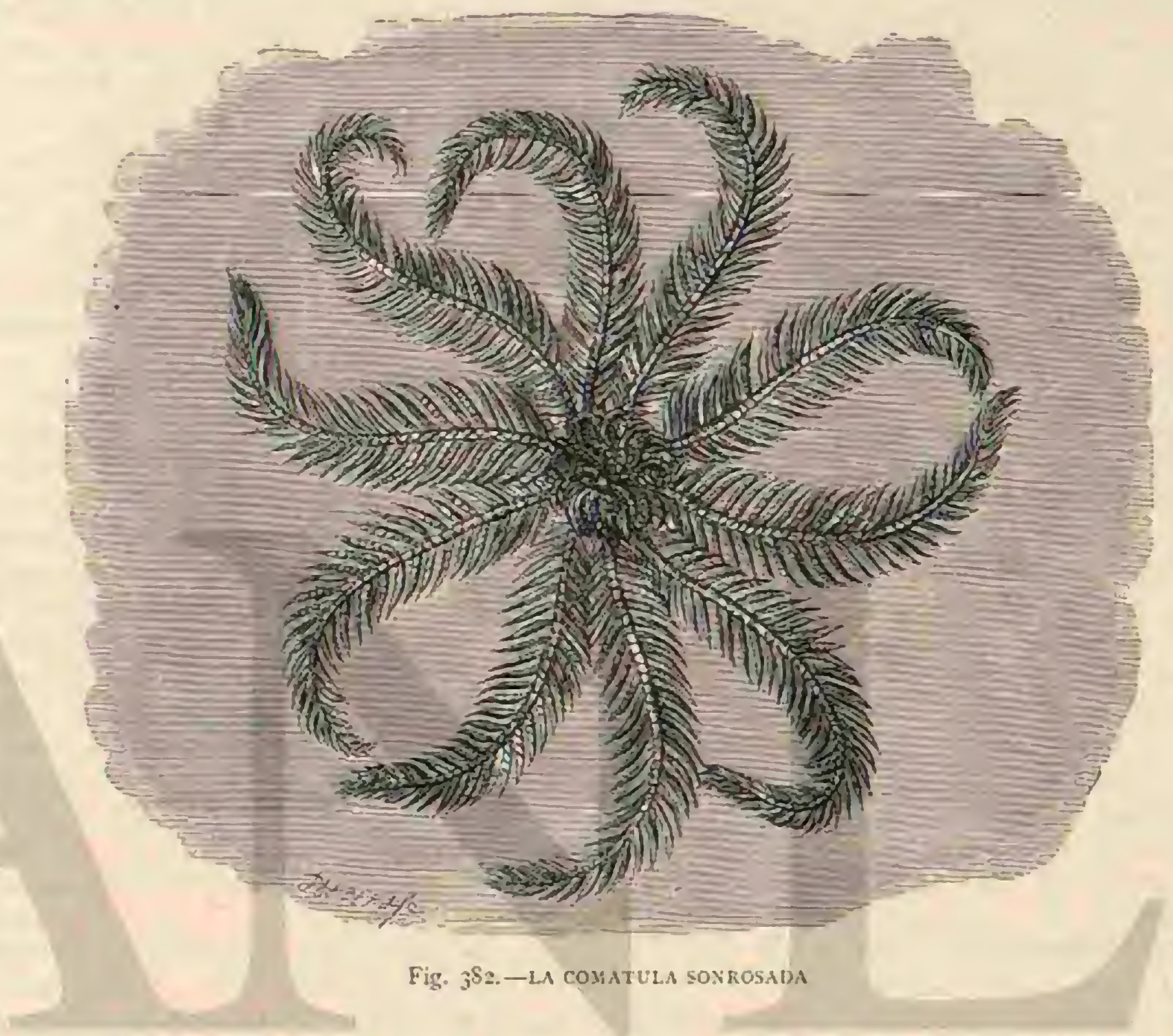

comun en el mar del Norte y en las costas inglesa y noruega. Esta especie se agarra á las conchas habiladas por el cangrejo ermitaño. La parte comun del tronco es uma membrana que se adapta á la superficie del objeto en que aquel se fija, en esta membrana se halla tambien la misma capa quitinosa de que se compone el tubo de cada uno de los pólipos." I canales alimenticios de los mismos se continúan igualmente en la membrana con sus prominencias espinosas, facilitando la vida y el desarrollo. En tal tronco solo se encuentran reunidas dos clases de individuos, no faltando nunca los ali. menticios, provistos de tentículos, boca y cavidad digestiva; sirven para nutrir á sus companeros de colonia que carecen de boca y son solo machos ó hembras. Estas últimas tienen una espesa corona de sencillas cápsulas con huevos. Ia larva con pestañas que nace de estos últimos, se fija.y es la fundadora de una nueva colonia. I.as capsulas no presentan nunca caractéres que pudicran recordar à los acalefos, pero entre éstos, todos los que se desarrollan del modo antes descrito, por medio de grados intermedios polipiformes, se encuentran una vez en el estado de la cápsula que, en la hidractinia espinosa es, sin duda, solo un órgano constante.

En cl extremo limite de estas series tan particulares encontramos el único géncro de celenteratos de agua dulce; el de las hidras. Teniendo una longitud de I á 6 y 8 milimetros, se parecen por su forma casi en un todo al animal de la hidractinia, provisto de la corona de tentáculos. Por lo regular se encontrará en las aguas estancadas cubiertins de plantas la especie hidra verde ó la parda: para esto se deja una reduci. da cantidad de plantas extendidas en una vasija, á fin de examinarlas despues con un anteojo de aumento. Tan luego como se han tranquilizado, los pólipos empiezan á estirarse y i extender sus seis ú ocho tentáculos semejantes il largos hilos. Entonces veremos cómo los animalitos que los tocan que. dan cogidos y cual paralizados; los tentáculos se coniraen y conducen la presa a la boca que se abre con voracidad y es capaz de ensancharse mucho. El microscopio nos enseria las capstalas de ortigas, sobre cuyo efecto daremos algunas noticias al hablar de la anémona marina. Las intimas relaciones de estos animales con los corimorfos que no pueden separarse de los verdaderos acalefos oblign á los naturalistas á clasificar la hidra con los acalefos. La hidra se propaga segularinente por retoños, que salen en el tronco, ý á menudo permanecen unidos à la madre hasta que esta tiene uno ó varios retoños mas. En las paredes del cuerpo se desarrollan periódicamente los huevos bajo prominencias en forma de cápsulas ó verrugas aisladas, ó en su lugnr cantidades de esperma, circunstancia que aumenta aun la afinidad del género con las hidractinias. 
No podemos filosofar sobre el modo de vivir de la hidra como único celenterato de agua dulce. El hecho es que este grupo carece casi del todo de la facultad de adaptarse á la existencia en el agua dulce: pero precisamente por esto merece nuestro particular interés, como le mereció ya el pequeño sér el siglo último, en tan alto grado, que en su observacion se fundó toda una literatura, ocupándose de él los naturalis. tas $y$ amigos de la naturaley, Trembley, Bater, Reaumur, Chaffer, Rófel y otros. Las observaciones de estos autores eran del todo perfectas en su género, si tomamos en consi- deracion la imperfeccion de los microscopios en aquella época.

La particularidad mas notable para aquellos naturalistas antiguos pareció ser la facultad de las hidras de poder dividirse artificialmente, produciendose de los pedazos animales nuevos, brazos, cabezas y colas. Miles de pólipos se cortaron y dividieron de todos los modos posibles, creandose los monstruos y abortos mas grotescos. Trembley logró cortar una hidra en 50 pedazos, creando de cada uno de ellos un pólipo nuevo. Roessel refiere que despedazó un pólipo, obteniendo

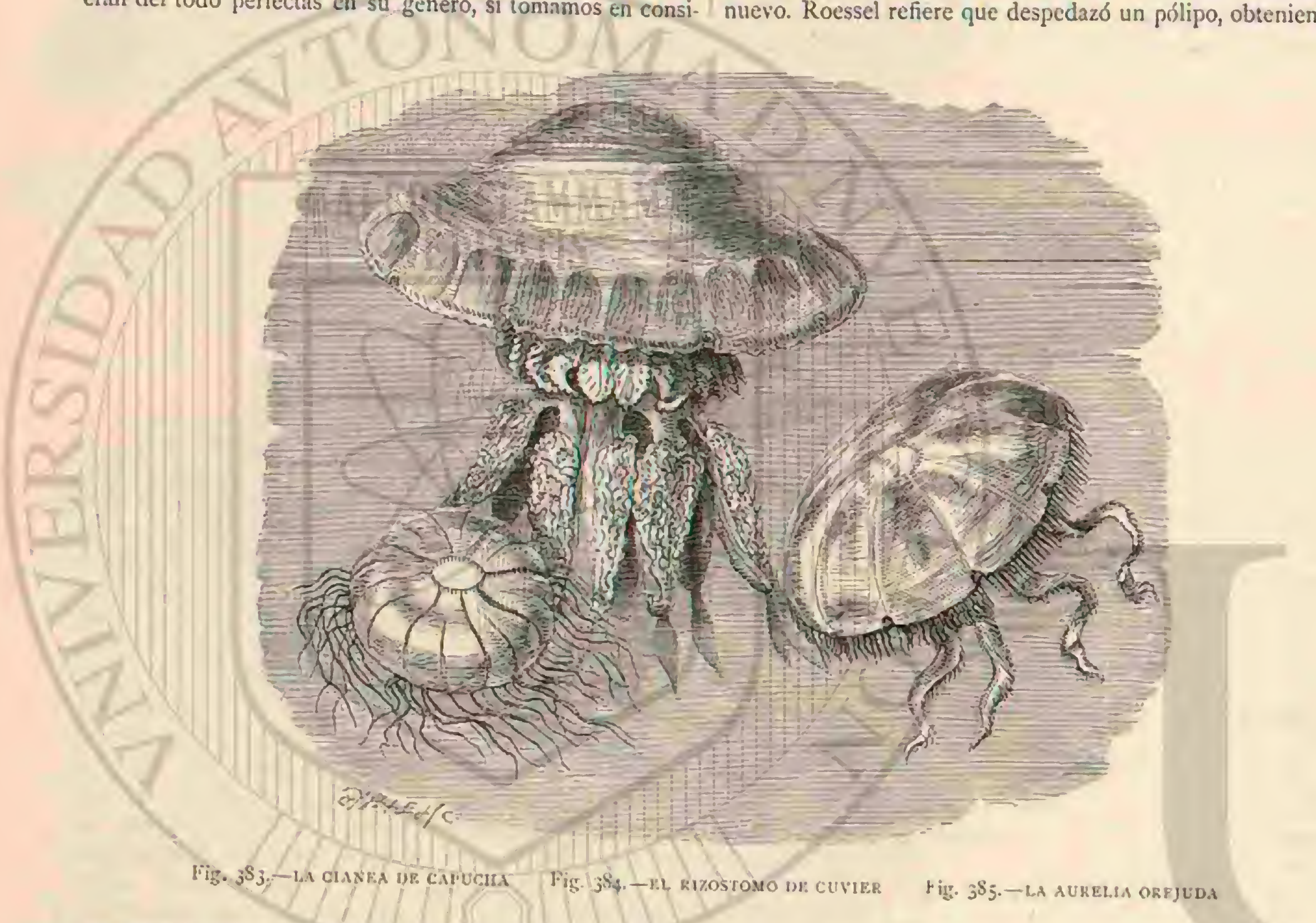

igualmente una cria del todo nueva. Los monstrios artificiales con muchas cabczas y colas se enseñaban á los amigos de las ciencias naturales, $y$ filósofos como Bonnet $y$ Crusius utilizábanse de los experimentos para explicar.por cllos sus teorias sobre la unidad, 6 divisibilidad del alma.

Mayor asombro causó el experimento de invertir el pólipo to mismo que el dedo de un grante, con su interior hácia fuera, experimento que Trembley hizo en 1742 conbuen resultado. Al principio la operacion no turo éxito, porque la hizo en pólipos con el estómago vacio; pero al practicarla en individuos repletos salió perfectamente; el por qué ya lo ve. remos despues. Es de desear que cstos experimentos se renueven en nuestro siglo y por esto mismo reproducimos en este lugar el relato de Trembley.

\&rincipio mi tarea dando de comer al pólijo que quiero invertir, un gusano. Cuando lo ha comido procedo ála operacion. No tengo necesidad de esperar la digestion del gusano: pongo el pólipo con un poco de agua én el hueco de mi mano izquierda; en seguida le oprino con un pequeño pincel en la extremidad posterior, haciendo salir de este modo el gusano por la boca del pólipo, que por consiguiente se abre

bastante. Despues coloco el animal en el borde de mi mano, obligaindole á contracrse siempre mas y á ensanchar de este modo unas y mas el estómago. Tomo luego con la mano de. recha una cerda que sea bastante gruesa y obtusa, cogiéndola del mismo modo que se toma una lanceta para sangrar; la extremidad gruesa la aplico a la posterior y la empmjo hasta dentro del estómago vacío y muy ensanchado. Cuando mas oprimo la cerda, tanto mas se invierte el pólipo. \$ Como sucedia à menudo que el pólipo invertido volvia á tomar su forIna natural, 'Trembley lo ataba como un embutido. Pues, dice Trembley, no es cosa que afecte á un pólipo el verse atravesado. 8

Podria creerse en la exactitud de este hecho, pues Trembley reficre no solamente que muchas de sus victimas se han acostumbrado á digerir con lo que antes era su superficic, sí que tambien formaban retoños exteriormente, reproduciéndose de este modo. Dudamos tanto menos de la exactitud de estos experimentos, cuanto que los contemporáncos de Trembley los afirmaban. Sin embargo, es preciso repetir el exámen para ver si en realidad las dos capas principales de la piel de las hidras pueden cambiar sus funciones. 


\section{SIFONOFOROS - SIPHONOPHORA}

El que crea que es dado á la naturaleza el producir ciertos caprichos, sin duda pensará en los sifonoforos, juguete vivo el mas grotesco que la fantasia pueda imaginar. Bastante dificultad ha ofrecido af los naturalistas explicar el objeto que la naturaleza pudo proponerse al crear estos animales.

Elegimos una de las especies mas complicadas, la phiysophora distichn, que se caracteriza por tener diferentes apéndices $y$ un tubo que por su parte superior empieza con una sejiga constituyendo el eje central. Toda aquella parte del tubo está ocupada por dos series de apéndices natatorios que sirven para la locomocion; debajo de clla se observa un moño de tentáculos muy movibles, entre los cuales hay dos tubos chupadores ó estómagos de los que cada uno independientemente digiere el alimento, conducido por los largos hilos verticales. El producto de la digestion llega al tubo central y desde alli á los diferentes apéndices.

¿Es la fisofora descrita un individuo ó una colonia? Todo podria indicar que es lo primero, sino las dos cosas, pues tiene tres y cuatro $\delta$ mas aberturas bucales independientes, $y$ en general lus estómagos dotados de una actividad aislada. Los observadores antiguos los han llamado sencillamente pólipos, para indicar que aunque no atribuyan a otras partes de la fisofora y otros géneros, el valor de individuos, en todo caso, cuando menos estos estómagos ó tủbos chupadores representan individualidades incompletas. Si agregamos los casos en que la reproduccion se verifica por acalefos que se separan, debemos aceptar la opinion de leuckate que consideró á los sifonoforos como colonias polimorfas, es decir, que las partes de que se componen tienen la importancia de las de un organismo, porque dependen unas de otras. Todas juntas forman en sentido fisiológico un todo, pertenecen a una vida. Pero en todo caso algunos de estos lla. mados órganos son tan independientes, $y$, en el caso de tomar la forma de acalefo, tan desarrollados, que casi ocupan cl rango de individuos. Por lo tanto el sifonoforo puede con. siderarse como una colonia de individuos incompletos diferentes en forma y funciones, pues esta es la significacion de la palabra polimorfa.
En los animales mas desarrollados, dice Brown, los órganos se diferencian siempre mas minuciosa y completamente por la distribucion del trabajo; en este caso lo hacen los diferentes individuos unidos y pertenecientes á una familia de un modo análogo á las condiciones observadas en las hormigas y las abejas. Pero la separacion y el desarrollo han llegado a tal grado y la distribucion del trabajo ha progresado de un modo tan cxclusivo, que estos individuos por lo regular no tienen órganos suficientes para una existencia independiente, aunque a menudo pueden compensar pronto una pérdida ó falta por medio de retoños.

Las consecuencias de esta ingeniosa idea de Vogt y Leuckart corresponden à un sistema mas riguroso y progresivo de género en genero. Sin cmbargo, no debemos prescindir de que, cuando se trata del verdadero conocimiento y de la explicacion del origen de la independencia superior, las formas inferiores han de considerarse como las originarias y que las superiores derivan su origen de antecedentes inferiores semejantes. Sin duda los acalefos polipiformes sin retoños separables eran los antecesores verdaderos de los géneros que producen acalefos de disco libre; y los sifonoforos, que solo se presentan compuestos de sencillos órganos durante el trascurso de períocios enteros del globo, se formaron tales cual hoy los vemos, porque las ventajas en la alimentacion, adaptacion y otras circunstancias les permitieron ascender al rango de individuos mas $\delta$ menos perfectos.

La familia de los fisalidos que pertenece à este órden merece tambien consignarse aqquí. Sus atributos consisten en estar sus especies provistas de numerosos sacos proboscidi. formes, de entre los cuales naceul uno $\delta$ varios tentáculos retråctiles glandulosos, y otros neumóforos fijos $\mathrm{en}$ un disco estomacal sobrepuesto de una vesicula siempre ancha, irregular, prolongada, que presenta una cresta membranosa. La fisalia pelågica (fig. $3_{3} S_{7}$ ) es la q̨ue mas se distingue de todas sus especies.

Otra familia, la de las velellas (fig. 388 ), es tambien notable, caracterizindola muy especialmente un dermato-esqueleto horizontal coronado por una cresta vertical.

\section{PÓLIPOS}

\section{[4}

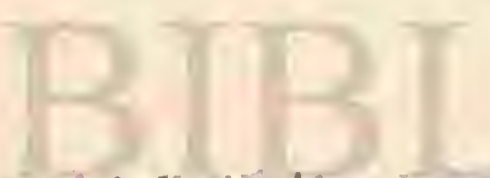

Si los acalefos excitan nuestro interés y si la tortuosa marcha de su desarrollo da que hacer á los naturalistas inas profundios, el ejército de los pólipos, afine por los rasgos principales de la estructura, es mucho mas propio para cxcitar la íntasia y admirar el inmenso poder de los pequeños, en cuanto justifican el lema: Virious unitis, es decir, con fuerzas unidas.

Recreándonos por su gracioso aspecto los acalefos van y vienen por las olas y corrientes. Despues de una corta existencia, que raras veces dura mas de un año, se disuelven en la dispersion general de los átomos, no dejando otro rastro para las miradas humanas que su numerosa cria. Tambien entre los pólipos encontramos géneros cuyas generaciones desaparecen como las de aquellos. Pero tanto mas numcrosos son los otros que en todos los periodos de la formacion del globo han construido monumentos à cuyo lado nada 
valen todas las pirimides erigidas por la mano del hombre. Sus construcciones constituyen una gran parte de los continentes. Alli donde se fijan los animales de coral, estos importantes tipos de la clase de los pólipos, siguese una serie de efectos que dejan atrís en cuanto à la grandiosidad de la construccion y' del trabajo a todo cuanto la vida humana $\delta$ animal es capaz de producir. Pequenisima en sus principios,

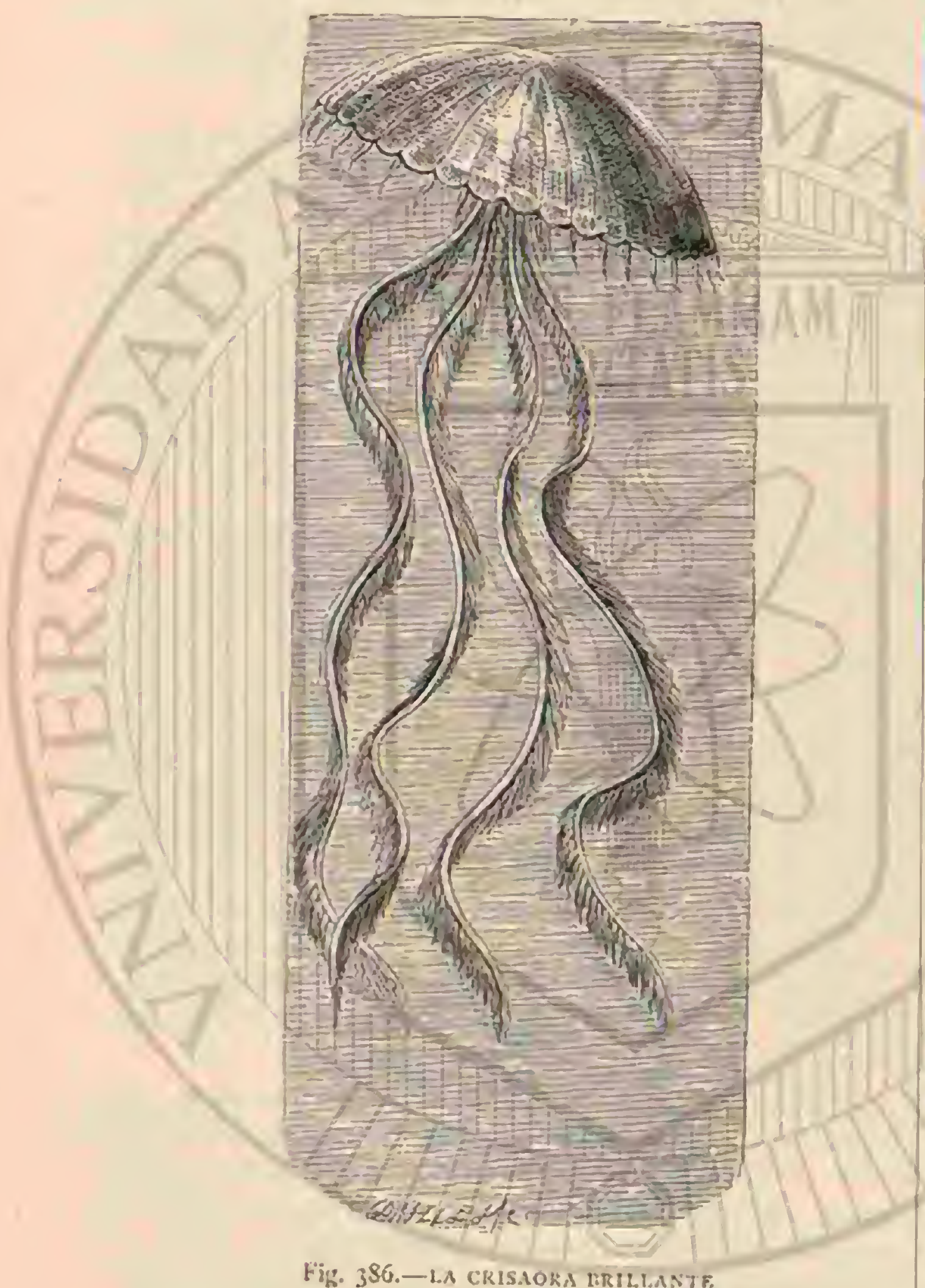

visible solo con el microscopio, la colonia se hace pronto el punto de atraccion de una vida infinitamente variada hasta que el hombre toma posesion del suelo recien creado.

De este modo la vida de los pólipos influye en la de los pueblos, to cual es razon suficiente para someter á estos animales a un minucioso eximen y descripeion.

Casi dos mil años se necesitaron antes de reconocer la afinidad de los verdaderos animales de coral con las grandes anémonas marinas 6 actinias, conocidas ya como animales por Aristóteles y sus contemporáneos. Los griegos y roma. nos, segun nos dice Ovidio, veian en los corales, flores yuue en el momento de sacarse del agua se petrificaban, desde que Perseo depositó en ellas la cabeza de la Gorgona, Medu. sa, cuyo aspecto convertia en piedra a cuantos la miraban. En sus Metamorfósis dice:

Sic et coralium, quo primum contigit suras

Temprore, durescil: mollis fuit herbs sub undis.)

De una descripcion de viaje hecha en 1630 por Moneonni, resulta que hasta el citado año habia cambiado muy yoco la opinion de que los corales eran plantas marinas, o tam. bien árboles de piedra (lithodendra).
Ehrenberg reproduce el respectivo pasaje en su conocido trabajo sobre la naturaleza y los bancos de coral del mar Rojo ( $1 \delta_{32}$ ). "Despues de comer, dice, pescamos los hongos conchiferos y toda clase de arbolillos en el mar Rojo, donde à grandes distancias se encuentran en gran número, porque el mar es alli tan poco profundo, que asi como en un pozo, se puede ver todo lo que hay en el fondo. Tuve el gusto de recorrer yo mismo tuedia legua de camino á lo largo de la playa, divirtiéndome algunas horas en recoger un gran número de estos arbolitos, hongos y conchiferos. Los hongos son duros y están fijos en la arena; y los que pescaba eran rojos y duros, y para blanquearlos se ponen al sol. Cuando estos arbolitos son aun imperfectos 6 no maduros, algunos parecen esos hongos húmedos que crecen en los árboles vicjos; pero oiros, á los piés granujientos de una araña de mar; son blandos y estín llenos de agua, que se puede exprimir como una esponja mojada; entonces tienen toda clase de colores, azul, violeta, gris, pardo, verde y blanco, ofreciendin un aspecto maravilloso.

Eihrenberg cree que el antiguo viajero solo ha observado los corales duros, tomando la noticia sobre el estado blando de los relatós de los árabes. Yo, sin embargo, creo mas bien en una confusion de los corales con verdaderns esponjas de mar, que se encuentran en medio de los corales, y de las que muchas se pueden exprimir exactamente del modo descrito. Aun \& principios del siglo pasado, en 1706 , el conde Marcigli pretendió, con gma asombro de sus contemporaineos, haber areriguado, por observacion, que el coral es una verdadera plania que ticne un jugo lechoso en la cortezay produ. ce flores y frutas. Para dar à conocer esta pretension publicó en $1 ; 25$ la inagnifica obra con grabados en cobre titulada Hishoirt plysique de la Mer. Pero poco antes, en 1723 , el médico y naturalista André de Peyssonel hizo sus averigua. ciones en la costa de Berberia, convenciéndose de que las supuestas flores de coral eran pequeños animalitos de la misma naturaleza de las actinias. Expuso su descubrimiento a los individuos mas notables de la Academia de Paris, pero fue acogido con frialdad, y Reaumur hasta creyó deber callar el nombre de Peyssonel por delicadeza. Este generalizó sus averiguaciones en un viaje á Guadalupe, $y$ despues que sus opiniones se hubieron aceptado en Inglaterm, poco á poco admitiéronse igualmente en su patria.

Sin cmbargo, solo las averiguaciones de Ehrenberg en los arrecifes de conal del mar Rojo nos han dado una base para la clasificacion sistematica de los antozoos ó animales. flores. Todo el que ha visto un pólipo vivo con el cáliz desplegado ó comparado un grabado algo bueno con una flor, comprenderí la exactiud del nombre. Ehrenberg los dis. tinguió de los animalitos de musgo, considerando, sin embargo, ambos grupos como muy congenéricos. Desde entonces hasta hoy nuestros conocimientos sobre ia amatomia y la vida de los pólipos y de los arrecifes de coral han experimentado un aumento continuo. Uno de los progresos mas grandes se veriticó por Darwin, que despues de su célebre vuelta al mundo planteó una nueva teoría de las islas de coral, confirmada en todos los puntos esenciales por el americano Dana en su obra Corals and Coral islands.

Hemos indicado ya la importancia de los pólipos, sobre todo respecto at sus formaciones duras, y naturalnente, se trata ahora del conocimiento de estas, es decir, de las colo. nias de pólipos. Al efecto es necesario conocer la estructura general del cuerpo, para lo cual nos aprovecharemos de los úlitmos irabajos de los excelentes observadores Hacckel y Lacaze-Duthiers. El primcro nos describe el desarrollo de un pequeño pólipo descubierto en el puerto de Tor en la costa árabe, del monoxienia Darivinii. El animal, de tres milimetros 
de largo, presenta una estructura del todo radiada, pues su boca situada en la extremidad superior del cuerpo cilindrico, estả rodeada de ocho tentáculos plumosos. El pólipo se fija por medio de un disco morible opuesto i la boca en su hase, $y$ la superficie arqueada demuestra que no tiene partes duras del esqueleto ó que carece del tronco.

I a monoxenia es el tipo de un pólipo regularmente radiado, de un verdadero animal radioso, como lo son la mayor parte de los pólipos. Hacckel llamó í las partes iguales de un cuerpo de radios, dispuestos en circulo alrededor del eje, antimeras ó piezas opuestas, que tienen en él la misma importancia que los anillos de un anélido $\delta$ de un insecto. La sencillez y mayor compresibilidad de la monoxenia y de sus congéneres se funda en su mayor parte en el desarrollo igual de sus antimeras y en el número limitado de las mismas. En todos estos casos la abertura bucal puede ser del todo circular. Sin embargo, muchos pólipos se extienden trasrersalmente $y$ algunos hasta ticnen la figura de un abanico, formando en la boca una hendidura trasversal. Entonces se observa que ya la primera disposicion de los tentáculos era desigual ó que despues de un principio regular del desarro. 1lo, ciertas antimeras con sus tentáculos, se atrasan 6 avanzan. Esto se reficre con preferencia á los pólipos con tentaculos numerosos que en varios circulos rodean la abertura bucal.

Aunque se hagan algunos diseños se conocen perfecta. mente los pólipos que como la monoxenia no segregan par. tes duras. Los mas de los lectores comprenden en la palabra pólipo ó animal de coral la idea de un tronco ó esqueleto: para explicar la relacion en que este se halla con las partes blandas, comparamos el tronco de pólipos con la concha de caracol y con el esqueleto de los vertebrados. La concha del caracol es una secrecion que aunque rodea el cuerpo, por lo demás plano, solo se halla en una relacion limitada con ćl; es una cubierta que sirve de abrigo al animal ó cuya piel protege. Las partes sólidas de los pólipos empero no son una cubierta en este sentido sino verdaderas partes del animal, partes sensibles y organizadas como los huesos. Nadie considera los huesos de los animales superiores como sencillas secreciones, pues ya se sabe que son partes orgánicas muy sensibles del cuerpo y que contienen venas y nervios. Lo unismo sucede con las partes duras de los corales. Mientras el animal vive, su tronco no es una secrecion muerta, no es una concha á la cual se retira como el caracol; es un error creer que el pólipo habite su tronco ó su celda, pero cn carnbio la parte inferior del pólipo es el estuche en que la supe. rior puede recogerse. En el pólipo vivo el tronco se halla por lo tanto en continua disolucion; el de un individuo adulto guarda con el del jóven la misma proporcion que el esqueleto del buer con el de un becerro.

Sin embargo, en esta comparacion llegamos á un punto en que no puede aplicarse la regla. Con mucha frecuencia al crecer un pólipo hácia arriba su pié calcificado muere sin disolverse. El púlipo está fijo entonces sobre su pasado que le sirve de pedestal; se cria por decirlo asi de símismo y mantienesc sobre los restos de su juventud. Es claro que en los corales una gran parte de la materia que se pierde en el cambio de la de los animales supcriores se consersa, como pasado muerto en relacion inmediata con las partes duras vivas del individuo, $y$ forma con ellas el llamado tronco.
Hasta ahora solo hemos hablado de los animales de coral como individuos completamente aislados; pero en la mayor parte de especies el individuo abandona mas ó menos su individunlidad formándose troncos compuestos que son un resultado de la propagacion por medio de retonos. Todos los pólipos ponen huevos cuando menos en cierto periodo. I.os pequeños séres que nacen de estos huevos vagan poco tiempo libres por el mar y solo entonces se despliega la construccion de que hasta ahora hemos hablado. Enl la mayor parte de especies se ha fundado de este modo el principio de una colonia propagandose a aquellos individuos sedentarios por medio de la division $\delta$ de retonos. Varios grupos de anima. nos han dado ya ejemplos de este tnodo de propagacion. Tambien en los pólipos se presenta alli donde debe salir un retoño un cambio crecido de materias, elévase una fuerte prominencia y el retoño es en todas sus partes una formacion nueva. Conservando cada género y especie sus particularidades en el modo de producir la sangre, saliendo los retonos ya arriba en el cáliz, ya en el centro, ya mas abajo, ora alrededor del tronco, ora en un lado ó alternativamente a derecha é izquierda, por este cambio de la posicion se produce una variedad extrnordinaria de los troncos de pólipos. Mucho mas importante parn el aspecto de los troncos compuestos es, sin embargo, la forma y extension del tronco sencillo, es decir, del esqueleto del incividuo. Combinanse por lo tanto con anguella posicion puramente exterior de los retoños las muchas posibilidades bajo las cuales el tronco se presenta en los individuos aislados. Para producir mayor número aun de formas de los troncos de pólipos debe tomarse en consideracion tanto en la division como al hacer retoños la secrecion de la masa del esqueleto que se deposita dentro de los individuos aislados.

Cuancio nace un tronco compuesto de pólipos, los individuos que en él se encuentran mantiénense por lo regular en una relacion orgánica. Cada cual se comunica con todos sus recinos viviendo todos los individuos de un tronco compucsto segun el principio de un comunismo bien organizado. La comunicacion de animal en animal se verifica regularmente por una sustancia blanda ó calcificada organizada, es decir, que toma parte en el cambio de materia. Esta sustancia intermedia recibe sus canales alimenticios de los individuos inmediatos, y las renas conductoras del jugo vital aseguran al tronco compuesto de pólipos su desarrollo unitario hasta cierto grado, trasformándose en este caso la multiplicidad en una unidad fisiológica. Lo que come cada pólipo redunda indefectiblemente en bien de toda la sociedad, y del trabajo del individuo resultar las construcciones comunes. A estas pertenecen los tallos y troncos, aquellas partes compuestas en que no se encuentra ningun individuo, y cuyo desarrollo no comprenderiamos si no viéramos introducirse tambien en ellos los canales alimenticios. Pero cn todas par. tes se tocan la vida y la muerte cuando menos en los troncos macizos y en la mayor parte de los de forma de árbol. Al extenderse el tronco por medio de retonios $y$ de la division muere por dentro. Los canales alimenticios que se cubren de una nueva sustancia cruzada de nuevas venas sécanse pronto, y sus contornos mas próximos no pueden tomar ya párte en el cambio de materia.

Nos encontramos ahom en estado de presentar los grupos naturales de los pólipos. 


\section{POLIACTINIAS-POLYACTINIA}

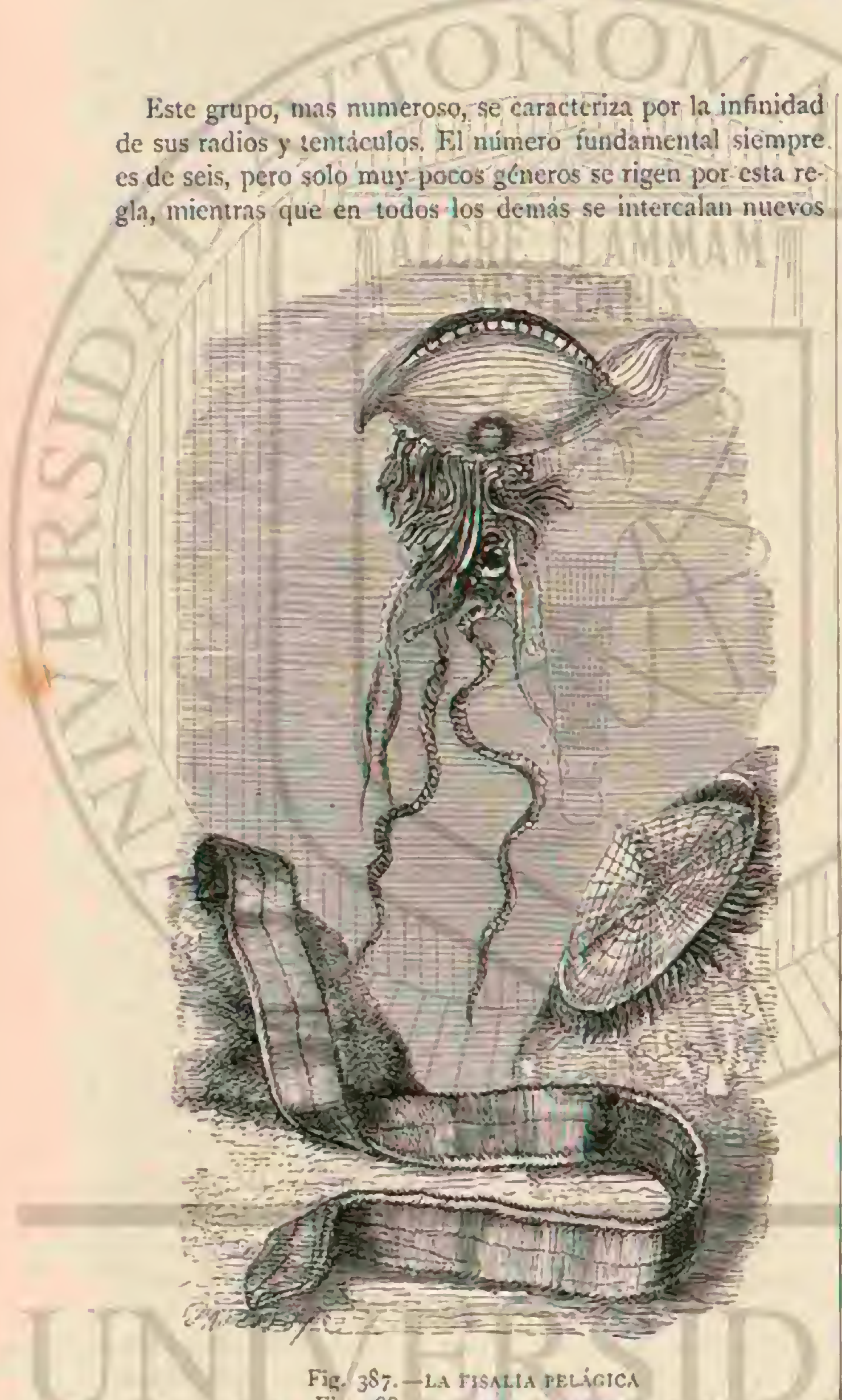

Fig. $3 S$. - in

Fig. 3ST. - FL CESTLM VENERTS

circulos de radios y celdas, por lo cual el órden se ha desig. nado tambien con el nombre de foliciclios.

Creíase antes que estos nucvos circulos se formaban con. secutivamente y con regularidad del número de seis, péro las nuevas averiguaciones de Semper y Lacaze-Duthiers demuestran la inexactitud de aquella llamada, oLey de Milne. Edwards. D

Por lo regular solo el segundo circulo se intercala aun con regularidad; despues se atrasan algunos radios de círcu. los anteriores y otros avanzan en su desarrollo. Lacaze-Duthiers hasta ha demostrado en varios cjemplos que ya en los primeros grados de larva, como en la actinia eywina, el número de seis, que por lo denás determina el desarrollo y toda la disposicion, ya no predomina.
Examinemos ahora algunas familias. En primer término figuran las anémonas marinas $\delta$ actinias, uno de los princi. palés adornos de los acuarios. Diseminadas en todo el mar, representan a su clase, sobre todo en la zona templada. Se distinguen por su tamaño y por su género de vida como individuos y se encuentran con frecuencia en la playa, y generalmentcicn las profundidades: llamando la atencion de todo el mundo por su color vivo, casi siempre magnifico. Ia piel de su cuerpo, sólida y coriácea, hảllase á menudo cubierta de verrugas No segrega particulas calcáreas, por lo que el animal puede contraerse mucho y cambiar de forma. Excepto algunas especies que con su parte posterior se fijan en la arena, construyen ó segregan una celda para su vivienda, las actinias se sirven del disco de su pié para fijarse y cambiar lentamente de sitio.

La belleza cxterior y los vivos tintes, el carácter tranquilo y modesto, propio de las Rores, ocultan la extremada voracidad de las actinias. Devoran grandes pedazos de carne, pero con preferencia chupan la sustancia de los mitilos y ostras. A menucio he visto alimentarlas en el acuario, donde se ob. servan bien, sobre todo las grandes especies con largos tentáculos. Fa actinia permanece inmóvil, semejante à una for, mientras no la excita un alimento en sus alrededores; mas apenas llevn el guardian un pedazo de carne, un pequeño pez. 6 crustáceo, poniéndole al alcince de los tentáculos, estos cogen como por encanto su presa y la introducen en la cavidad estomacal. Digieren completamente la carne $y$ solo arrojan despues la grasa. «Las actinias bien nutridas, dice Moevius, mudan con frecuencia la piel, sin duda porque crecen rápidamente con un alimento abundante. Durante la muda mantiénense contraidas, y cuando despues ruetien a extenderse, la piel mudada rodea la base de su pié como un cinturon nojo y sucio.

Como en todos los pólipos y acalefos, tambien en las actinias la posibilidad de que tan fácilmente se apoderen de animales vivos, solo pucdecxplicarsc por la cxistencia de las cípsulas espinosas microsópicas, varias veces ya citadas. Apenas se hallan en otra especie en un número tan asonibroso como en las actinias, razon por la cual hemos guardado algunas noticias detalladas para este lugar. Una de las formas mas comunes se caracteriza por tener el cuerpo elipsoidal y prolongado, con un corto cuello del que parte un largo hilo hueco que en muchas circunvoluciones llena una gran parte entre la celda y su base, hallandose en relacion inmediata con la pared de aquella. Este hilo se forna en la celda y solo sale cuando todo el órgano se scpara del pólipo y queda agarrado á un objeto extmino. Al comprimir las paredes de la cápsula sale el hilo, cuya superficie es pegajosa ó está provista en la base de pelitos y espinas, de modo quue fácilmente se agarran. Sin duda el contenido del hilo produce el mismo escozor que hace temibles a otros muchos celenteratos. Precisamente esta sustancia, propia del hilo, y que segun parece dificilmente se mezcla con el agun, sale hácia afuera al desplegarse aquel, aumentando naturalmente el efecto al reventarse un sinnúmero de celdas. $A 1$ descargar sale de la cápsula 
espinosa un hilo, y en muchas especies tambien ganchos, como, por ejemplo, en las hidras. Estos, sin embargo, no sirven nunca para herir la presa, que solo debe temer el líquido que se halla en el lado exterior del hilo. Mcevius tocó una gran anthea cereus (figs. $39 \delta$ y 399) con la lengua, y sintió tan fuerte escozor, que solo cesó al cabo de veinticuatro horas. Otra observacion demuestra que unn actinia, por el solo con. tacto, puede ahuyentar á un molusco, Moevius dice: «Habia cado carnéa una actinia mescmbryanthemsum, y mientras con los tentáculos la introducia lentamente en la boca, una rassa reticulata que habia olfateado la carne se acercó; pero en el momento de tocar con su tubo respintorio los tentáculos de la actinia, retiróse. Sin embargo, la carne volvió à excitarla, y acercóse otra vez, mas de nuevo fué ahuyentada. Despues que estos ataques se hubieron repetido varias veces, ofreci al molusco otro pedacito de carne para calmarle. En mi concepto, solamente las capsulas espinosas de la actinia, alarga. das de pronto, pueden explicar el proceder del molusco.

Para no tener que hablar otra vez, al tratar de las esponjas, de los úrganos espinosos, diremos de paso que aquellas, aunque por wuchos conceptos sc parecen à los pólipos, no tienen tales órganos. Lo que ha dado lugar à la suposicion

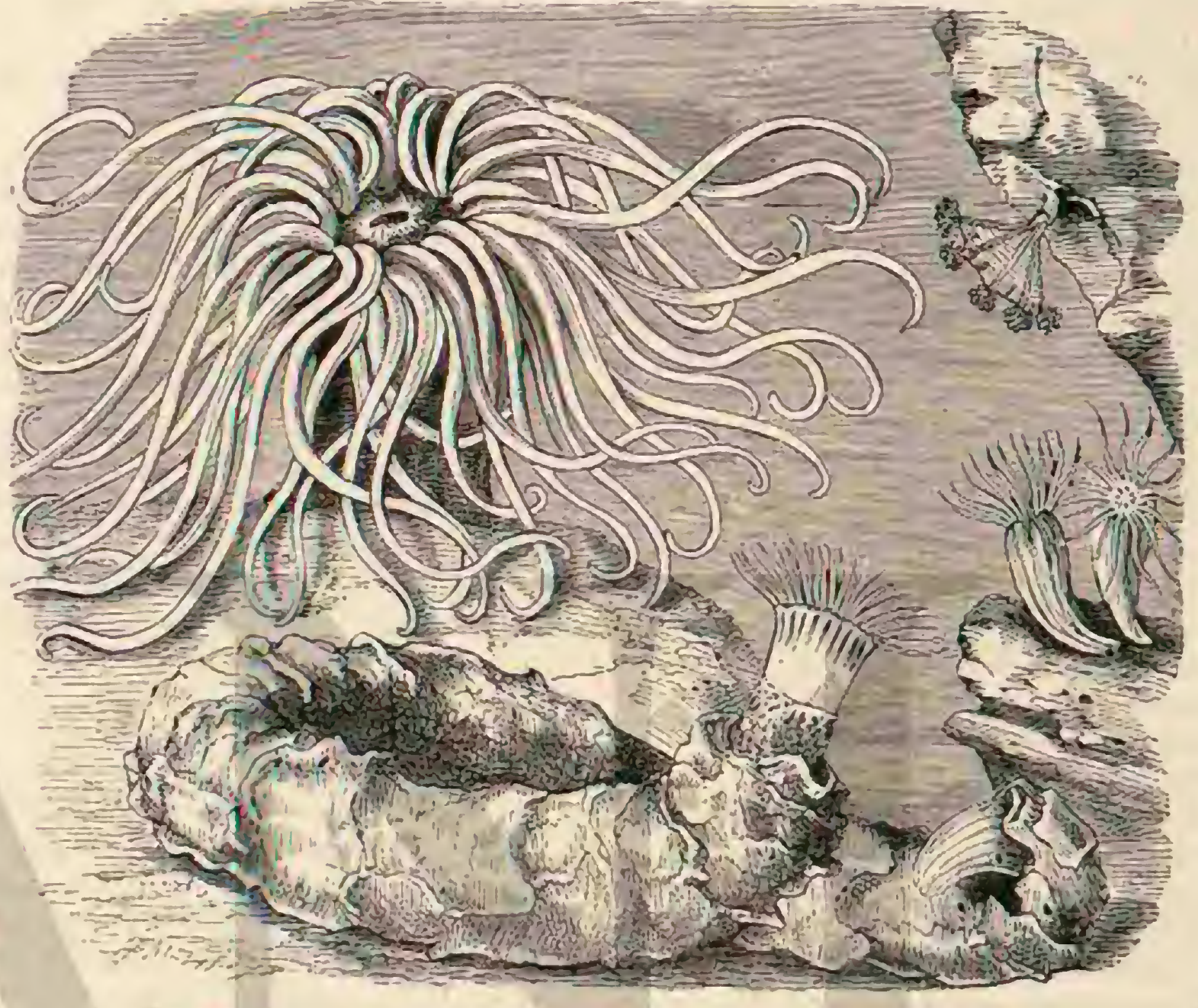

lig. 390, - LA ANTEA TEXTACUIAR Fig. 392, - LA CaLICINARIA ClatForM:
Fig. 391. - LA LUCERTSRIA ORIJA

Iig. 393.-E!. ILANTO J:SCOCl:s de quue muchas esponjas producen escoror, es la circunstancia de que cstán habitadas a menudo por la spongricola fistularis, pólipo microscópico, afine de las actinias y provisto de b́rganos espinosos que fácilmente se extienden sobre toda la esponja.

Mas arriba hemos dicho ya de qué modo el cangrejo er. mitaño alimenta á su amiga é incrailina la activia palliata. Vuelvo a hablar del asunto porque se réfiere a una cosa di. ficil de explicar, por mas que el hecho no sea tan aislado. Las actinias solo se fijan alli donde la corriente del agua les proporciona alimento carnoso; las especies que habitan las zonas expuestas al flujo y reflujo reciben con cada pleamar nuevos séres vivos. Cuanto mas poderosa es la corriente que toca en una costa pedregosa, en la catrada de un puérto ó un muelle, mayor seguridad hay de cnconerar junto $\mathfrak{a}$ otros animales un gran número de actiniss. Es por lo tanto natu. ral que älgunas especies de estas hayan tomado con cl tiempo Ia costumbre de fijarse en los anirales cuya propia necesidad de alimento les obliga á permasecer en el agua corrien. te. Vemos que los cangrejos ermitanos con sus conchas de caracol han sido los mas propios, y asi encontramos, por ejemplo, la gran actinia effarla asociada con preferencia al paguro rayado, uno de los ermitaños mas grandes del Mediterrineo que necesitaba las majores conchas de caracol.
Dos á tres individuos de esta actinia se fijan á menudo en un paguro que es bastante perezoso y no hace ningun caso de su carga. En este caso la anémona marina utiliza para nutrirse, la vida vagabunda de su anfitrion.

El lector podrá formarse idea de la anémona por los grabados adjuntos, figs. 394,395 y 396 ; de la antea tentacular por la fig. 390 y de la actinia équina o purpúrea por la figu. ra $39 \%$.

Como las actinias se conservan fácilmente en gran núme. ro, su modo de propagarse se ha observado de una manera exacta. Pertenecen i los géneros poco numerosos que no forman poliperos ó troncos, y cuya propagacion queda limitada al desarrollo de los huevos. Dalyell, el aficionado observador de animales vivos, conservó una actinia scis anos, criando de ella 276 hijuelos; dos de estos animales vivieron en cautividad cinco años, y à la edad de 10 a 12 meses producian huevos, de los que se obiuro cria al.cabo de doce ó catorce. Vió tambien que las larvas con pestañas infusoriformes per. dicron estas a los ocho dias, despues de lo cual, algunos dias inas tarde, mientras se fijaban salieron los primeros tentacu. los. A menudo las actinias jóvenes pasan todo el periodo de su metamorfósis en la cavidad abdominal de la madre.

Pero tambien en estado libre muchas especies que viven a poca profundidad pueden obscrvarse fácilmente. Gosse nos 
dice cóno y dónde se encuentran las numerosas actinias de las costas inglesas. Mas minuciosas aun son las observaciones de Lacaze-Duthiers sobre algunas especies cuya estructura estudió y sobre cuya área de dispersion y género de vida se instruyó al efecto de redactar la historia de su desarrollo. Nos facilita sobre la actinia equina, tan comun en la costn europen, multitud de detalles que nos representan el género de rida de este aninıl. Encontró esta actinin i lo largo de la costa del canal en todas sus localidades pedregosas en la zona del agua mas baja, es decir, en la que se encuentran ciertas especies de algas (fucus resiculosus y serratus). Para el observador son convenientes sobre todo los individuos que se han fijado en las cavidades de las rocas de las que cuelgan como vejigas claras y trasparentes llenas de agua I os individuos que ofrecen tal aspecto parecen pertenecer à la varic dad que se conservó cinco anos en el acuario de Dalyell. Desde junio à setiembre esiaba llcha de huevos, mientras que la pequeña variedad trasparente, además de los huevos contenia embriones en todos los grados del desarro. lló. En la actinia equina del Mediterráneo, Lacaze-Duthiers no encontró huevos durante toda la estacion favorable, desde abril hasta el otoño. De atras obserraciones que hizo resultó que el periodo de la propagacion de las actinias varía mucho segun el sitio y la especie. Una vez encontró á me. diados del invierno una pequeña sagartia fecundada en la playa arınosa de Dunkerqque.

El zoólogo parisiense describe del modo siguiente la manéa de recoger los embriónes y cómo observaba los pequeños séres. a Los embriones de las diferentes actinins, dice, no pueden propagarse del nismo modo, pues el procedi. micnto con que se logra este fin en especies libres no puede emplearse en las que penctran en la arena ó se retiran a las hendiduras de las rocas. Con la actinin eyuina me servi del siguiente prncedimiento: No léjos dé mi habitacion habia descubierto una de aquellas cavidades pedregosas en que las actinias suclen fijarse. Alli me dirigi provisto de un vaso de vidrio de ancha boca, cristales de reloj y un cuctillo puntiagudo y antado. En la bóveda de la pequeũa gruta elegr los animales que habian quedado más repletos y pendian como pequeñas vejigas trasparentes. Las corté recogiendo el liquido que salia de la herida, y con él los embriones contenidos en la cavidad abdominal. Para qué nada se perdicra raspé con un cristal de reloj la actinia cortada, obteniendu de este modo tambien los mas rerientes grados de desarrollo. Llegado á casa distribui el liquido en pequeños vasos de observacion eligiendo los individuos que queria examinar bajo el microscopio.

Cuando se abre una actinia tecundada. los pequeños que salen tienen una grande inclinacion a hincharse $y$ desple. garse. Esto dura i menudo una y dos horas ó mas, y sin duda el cambio de la residencia excita-su espiritu vital y les hace mas movibles. Por eso es convenicnte observarlos en seguida despues de su nacimiento artificial. Solo poco tiempo despues de practicar el corte en la madre es posible en. contrar las larvas mas jóvenes con seguridad y sin pérdida de tienipo, pues son mas tardias que las demás en su desar. rollo; algun tiempo despues de haber abandonado la nadre caen al fondo de la rasija, apenas se mueven, $y$ entonces es dificil encontrarhas. Tambien las bien desarrolladas y muy vivas limitanse al fin à girar siempre en una misma direccion; de modo que solo se las puede observar de un lado.

. De gran utilidad para el eximen son los masos de cristal con foudo plano y delgado, pues solo con ayuda de estos pueden observarse los embriones un poco mayores. En efec. to, se ve cómo las pequeñas actinias, con sus reinticuatro $\checkmark$ reintiocho tentáculos se tijan tan pronto como han. sa- lido de la madre, dilatándose y desarrollindose despues. Debe aprovecharse este momento, pues mas tarde se cierran a menudo tenazmente, y el anilio bucal se contrae con violencia, de modo que los tentáculos y paredes divisorias se comprimen, no siendo posible distinguir cosa alguna.

la mayor parte de las actinias estån provistas de varios circulos y de tentáculos cilindricos de igual aspecto. De prarticular belleza son las especies que además de los tentáculos de forma regular ticnen por dentro ó por fuera de los tmismos, unos órganos prehensiles y de tacto en figura de hojas lobulosas: estas especies constituyen la sub-familia de las actinins foliformes. Una nueva forma de las mismas (Crambactis) fuć descubierta por Heckel en el mar Rojo, y representada en su magnifica obra: «Corales arabes. $\gg$ De su descripcion re. sulta que el género encontrado en los bancos de coral de Tour se distingue por estar provisto al rededor de la boca de varios círculos de numerosos brazos prehensiles que tienen la forma de delgadas hojas de lechuga. Por debrjo se halla úna corona de muchos brazos bastante gruesos, del todo diferentes de los primeros, de piel recia, sin repliegues y sencillamente fusiformes. Fil verdaciero cuerpo es un disco cilindrico.

Hemos conocido las actinias como individuos nacidos del huevo que es el modo de propagacion mas frecuente; pero algunas especies se inultiplican con la mayor facilidad por pequeños fragmentos que se separan del disco del pié. El zoólogo parisiense Fichart observó este procedimiento en la sagartia pellucida, propia de las costas francesas. Los pedacitos caidos del pié el 23 de agosto se habian desarrollado ya el 7 de setiembre en pequenias actinias de 15 a 16 tentáculos. En muchas especies, por ejemplo en la sagarlia ignea, la reproduccion parece verificarse por medio de las hendiduras que en ellas se forman; pero aun asi, siempre termina por la separacion completa de los individuos.

Ahora bien, nada en la naturaleza existe sin tránsito, de modo, que tambien hay actinias con poliperos, que el zoólo. go, sin embargo, ya no llama actinias, pues las agrupa en una familia bajo el nombre de zonntarias. Su numero no es considerable, pero no es dificil encontrar tambien muchas en nuestras costas. Distinguese el género de los zonntos por estar los individuos reunidos en un tronco ramificado en que el polipero suele formar una costra en figura de raiz y en que los pólipos están reunidos en grupos irregulares mas ó menos grandes. Ambos géneros tienen la particularidad comun de que admiten cuerpos extraños sólidos, conı arena, agujas de esponja, etc., en mayor número en las paredes de su cuerpo, las que adquieren tal solide\%, que al secarse se conserva completamente la forma del pólipo. El hecho es asombroso y solo algunas especies de esponjas apenas pue den compararse con el; sin embargo estamos acostumbrados a considerar como muy pequeña la sensibilidad de las esponjas, mientras que las zoantarias tienen por congéneres mas afines las sensibles actinias.

Las especies mas interesantes entre las palitoas son las que se fijan en ciertas especies de esponjas. Ia mas célebre de estas palitoas es la palythoa fatua, socio eterno de una de las esponjas mas notables (Jijalonema nirabeli), de in que hablaremos en su Jugar. En I 660 solo existian algunos ejem. plares de esta esponja, habitada de sus correspondientes palitoas, en los Museos europeos. Casi al mismo tiempo habia encontrado en el mar Adriático una palitoa muy conge. nérica de la especie japonesa y que se hallaba exclusiva. mente en dos especies muy afines de esponjas, en la aximella ierrucosa y cinamomea. Entre muchos centenares de estas esponjas que yo he examinado, ni un solo ejemplar carecia de sus palitoas. El pólipo se propaga naturalmente en cier- 
tos periodos por huevos, pero las larvas mueren si no en. cuentran su esponja. Pero ¿cómo la encuentran? y ¿en que reconocen su socio sedentario? P'odríamos contestar que por medio del instinto, sin adelantar por eso nada, á no ser que hayamos concretado nuestra idea sobre el particular. Aunque consideremos el instinto como una costumbre heredita. ria, tal explicacion no puede aplicarse a nuestro caso. Las larvas de palitoas solo pueden encontrar y reconocer las axinelas por una especie de sensibilidad parecida a la actividad de nuestros sentidos, pues claro es que desde luego debemos rechazar la suposicion de la casualidad. Las dos axinelas propagan un olor aromaitico muy notable i nuestro olfato, y es de suponer que aunque las larvas de palitoa ca. rezcan de tal sentido en la acepcion admitida al hablar de animales mas desarrollados, deben poseer algo que por su efecto y utilidad pueda compararse con el olfato. Este algo lo debemos buscar en las celdas membranosas de la picl, que no solamente abrigan el cuerpo, sino tambien en los animales inferiores sirve como órgano de la sensibilidad en el sentido mas general $\mathfrak{e}$ indeterminado de la palabra.

Lá palitoa no es un verdadero parásito, pues ni se alimenta de los jugos y partes blandas de la esponja, ni la perjudi. ca robándole su alimento. Exige de ella solo una habitacion en su cuerpo, y come el alimento de que la casualidad le provec. Algunas especies de palitoas (efizonnios) se fijan en las conchas de molusico habitadas por los crusticeos ermitanoos. No se encuentran en las costas europens, pero si á lo largo de las norte-americanas, $y$ últimamente las he recibido de las islas Kerguelas. Cubren poco á poco la concha como una masa compacta de varias líneas de grueso, de la que los pólipos aislados pueden elevarse á otras tantas lineas de altura. La concha del molusco se disuelve del todo bajo esta capa y entonces el polipario forma el único estuche del crus. táceo. El servicio es mutuo: el pólipo provee al crustáceo de un abrigo y el crustáceo sirve â aquél de vehículo proveyén. dole de agua fresca y de alimento nuevo.

$I_{\text {a }}$ f́milia de las antipataceas, con el género antipathe, no corresponde al esqueleto sistemático, porque en ella no se trata de pólipos policiclios, sino de los de un solo círculo. Sin embargo el aúmero de seis es el fundamental y la mayor parte de especies de antipatos tienen seis tentáculos. Forman poliparios compuestos que tienen el aspecto de tiernos arbustos con largas mamas. La altura de un tronco encontrado por Dana cerca de las islas Fichi, era de tres piés de alto por media pulgada de grueso. Toda la forma es fea y tampo. co el color pardusco y los tentáculos pesados de los pequenos pólipos hacen i los animales inturesantes.

Llegramos ahora a las familias de nuestro órden que como individuos segregan un polipario calcáreo. Cuando forman troncos compuestos de los poliparios aislados suélen estar reunidos con una masa sólida (senenquimo). Los troncos se parecen por la forma de su extremidad á una estrella, por lo cual se les ha reunido bajo el nombre de astreáceas. Estas, á las que pertenecen el Theccocyathus olindraceus y el dendrophyllia ramea, se distinguen por su cáliz sólido y liso. Otro grupo de familias, las astreaceas con el esqueleto poroso, presentan una estructura poco mas ligera de sus partes duras que están perforadas de agujeros y galerias microscópicas i menudo visibles tambien a simple vista.

Uno de los representantes mas minuciosamente examina. dos de esta division es el astroides caljeularis, muy comun en muchos puntos del Mediternineo. Ias partes carnosas de este pólipo son de un rojo amarillo, y la extremidad anterior blanda de los individuos puede alargarse a una altura extraordinaria. Estin reunidos solo en la base de los cálices, y se parecen al coral de césped comun: tambien viven en el Medi. terráneo. De este modo el tronco no adquiere gran solider, y puede despedazarse con mas facilidad. El que quierc buscar este coral cerca de Nápoles en su residencia habitual, debe dirigirse al rededor del escarpado cabo de Posilipo, hacia la pequeña isla de Nisita. Ya las grutas del cabo están cubiertas, bajo cl agua, de una abundancia de minerales inferiores, entre ellos tambien nuestro coral. El mayor número, sin embargo, se encuentra en el canal abierto en la roca, cubierto y medio sumergido en el agua, cuya abertura se halla en frente del enbarcadero del Posilipo. Otra residencia favorita es la Gruta Azul de Capri, y otras cuevas que pueden vi. sitarse al dar un paseo en barco al rededor de la deliciosat isla.

Lacaze-Duthiers da bastantes datos acerca de la vida de los astroideos en la costa africana. Sus observaciones sobre el desarrollo de la cria y el origen del pólipo son muy preciosas. Hélas aqui: Encargado del exámen de la vida y desarrollo del coral rojo en Argelia, habia comenzado mis estudios en octubre cerca de Fuente Genois, al oeste de Bona, donde el barco costero que tenia i mi disposicion podia anclar con seguridad. Casi durante un mes examiné el coral rojo, y en cierta ocasion descubri, á un pié de profundidad bajo la superficie del agua, bancos de un. pólipo rojo de na. ranja que cubrian las rocas. Aunque entonces, y mas tarde, en abril y mayo, corté pedaros de este césped de pólipos, nada pude descubrir acerca de su propagacion. Solo en junio, cuando por casualidad uno de los marinos que me acompañaban separó un pedazo de la formacion conocida por ellos bajo el nombre de pólipo, y cuando en esta ocasion algunos animales se rompieron, vi unos cuerpecitos de un color rojo anaranjado que nadaban en el agua. Examiné los pólipos de cerca, y me conrenci de que entonces se cfectuaba la reproduccion.

Esto fué el principio de los estudios de Lacaze-Duthiers sobre los astroideos, estudios que continuó varios años, y de los que resultó que el periodo de la propagacion tiene lugar entre abril y agosto, pero con preferencia en junio.

Sobre las particularidades de la vida de nuestro pólipo en aquella costa, tenemos las siguientes noticias: B Como muchos otros pólipos, suele fijarse bajo las rucas para evitar la luz directa del sol. En el fuerte Genois, en Bona, Lacalle, en el puerto de Argel, se ven a poca profundidad en las pendientes de las rocas, bonitas fajas de un rojo de naranja entre toda clase de aquellos séres que se desarrollan bajo la zona de la playa, y que Quatrefages ha descrito en sus e Recuerdos de un naturalista, $y$ en su $x$ Viaje a Sicilia . Llli donde mejor prospcran, cada vez que retrocede una ola, se descubre una iaja roja. La mejor base para estos pólipos son las piedras duras, tal como se encuentran cerca del puerto fienois y Bona. No sucéde asi cerca de Lacalle, donde la costa se compone de una piedra arenisca muy poco sólida y en la que el mar abre grandes agujeros. Del mismo material se compone la pequeña isla de Maudite, situada en frente de Lacalle. Iacaze. Duthiers no encontró en estos sitios colonias de estos púlipos, y el mismo fenómeno puede observarse en las rocas volcanicas mas sólidas del pequeño puerto de la costr occidental de Capri, en la llamada Piccola marina, donde el impetu de las olas impide el desarrollo de toda vida animal. $\gg$

A pesar de esto, habia en la isla de Maudite aun tantos astroideos, que en el mes de junio todos los dias podia allegarse nuevo material para el exámen, y que Lacaze-1)uthiers podia recoger las larvas con la mano. El modo mas sencillo de reunir las larvas es el de poner troncos entcros en vasos grandes, en los que los pequeños se presentan pronto ý pueden recogerse con una pequeña cucham en la superficie. Oh. 
servando todas las precauciones, como la renovacion diaria del agua, etc., las larvas podian conservarse en la costa africana vivas por espacio de dos meses en verano, á pesar del calor de varios dias. Los pequeños salen del huevo en la cavidad abdominal de la madre, en la que nadan por algun tiempo alegremente, hasta que poco despues salen por la boca para vivir con independencia. Las larvas, que se parecen a pequeños gusanitos longitudinales, tienen la extremidad posterior mas gruesa; en la otra extremidad se nota, poco despues del nacimiento, la boca: Por lo demás, pueden variar mucho de forma, y nadan con gran agilidad por medio de sus pestañas. El trínsito de la larva herviforme al pólipo se verifica como en las actinias. La larva imprime la extremidad gruesa contra un cuerpo duro, y puede contracrse en poco tiempo en forma de un disco. En el polo superior, donde ta boca baja mas al interior, se presentan surcos longitudinales. En la extremidad de los surcos salen los doce tentåculos. No podemos dejar el astroideo de cilliz sin explicar antes la formacion de su polipario, porque lo que se dice de esta especie, con poca diferencia puede aplicarse á todos los otros pólipos que forman troncos.

Podria pensarse que el polipario en todns sus partes se

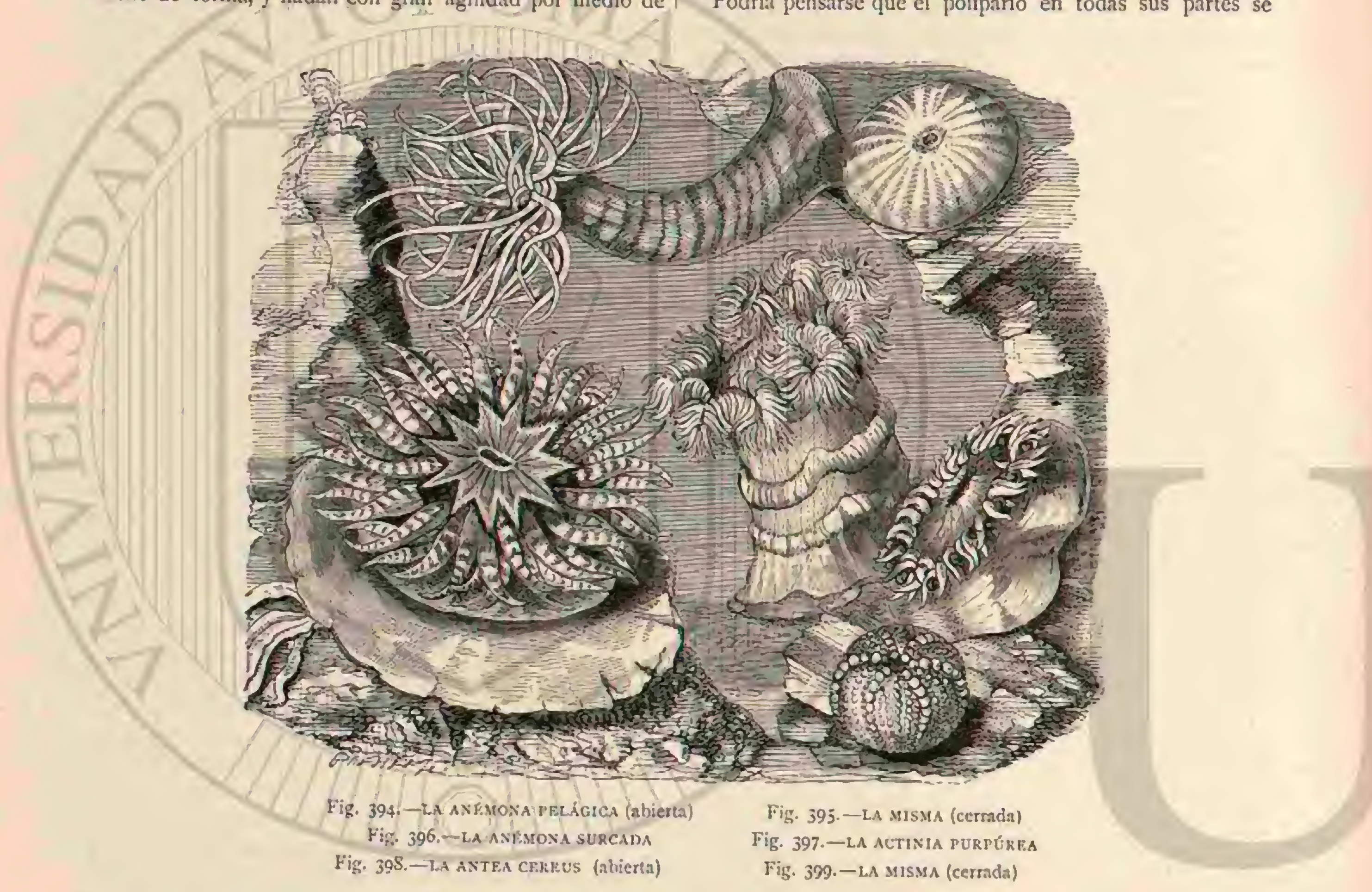

forma al mismo tiempo, como un todo compacto; sin embargo. cometeriamos un error al creerlo asi. I.ns primeros restigios del tronco se presentan como cuerpecitos calcíreos microscópicos, llamados por los franceses con el nombre caracteristico de escleritos. En los estroideos se depositan poco mas ó menos en el período en que empieza el desarrollo de las cámaras y paredes divisorins. Se forman en da capa central del cuerpo. Las partes duras primeras pertenecen por lo tanto à las pa. redes divisorias, $y$ no como podria suponerse á la pared ex. terior. Esta se forma en segunda linea, despues sigue la hoja del pié y por fin la columna. El engordamiento y la calcifi. cacion se verifican siempre por la aglomeracion de cuerpe. citos calcareos que se acercan uno á otro, se tocan y por fin se sueldan en un tronco sólido, pero aun variado.

Además del bonito astroideo vive en el Mediterráneo solo un representante de la division de los perforados ó pólipos con paredes civisorias porosas, es decir, la dendrofilia ramosa ya arriba citada. En el Adriático se sacan á menudo sus ramas, que tienen el grosor de un dedo pulgar, con la red arrastradera, pero en ninguna parte se encuentran en gran número.

Para hallar grandes masas de superforados es preciso di rigirse á los bancos de coral del mar Rojo donde abunda uno de los géneros mas importantes y con mas frecuencia citados, el de las madréporas, bajo cuyo nombre á menudo se comprenden todos los pólipos que forman arrecifes. En los poliparios, los troncos forman, ya grandes lóbulos irregulares, ya afectan la figura de árboles, y los cálices aislados sobre salen por lo regular de la masa comun. En cada tronco se encuentran en la parte superior, puntos en que los cálices apenas se clevan del esqueleto, y al observarlos mas de cerca se notará que estos individuos, ora estan rodeados de las aglomeraciones de la masa comun, ora ocupan un sitio desfavo. rable para recoger el alimento. De modo mejor y mas igual están desarrollados todos los animales que forman las ramas mas delgadas y avanzadas, y en los troncos lobulosos los in. dividuos de las prominencias onduladas.

Ias madréporas ofrecen los ejemplares mas bonitos $y$ grandes parn los museos: las del género porites son mas convenientes para el cxímen microscópico.

El otro grupo de la familia de las astreáceas lo forman las que tienen el esqueleto sólido no poroso.

El que haya tenido ocasion de conocer los pólipos en un musco. debe atenerse para el estudio de cste grupo à las 
grandes especies del género fungia qué casi solo se encuentran como individuos. Son formaciones planas, ya circulares, ya en forma dé lengua ó de torta, que á menudo llegan á un diametro de $0^{\mathrm{m}}, 30$. El tronco se compone de la hoja del pié $y$ de las paredes divisorias verticales, muy numerosas, mientras que la parte que en la mayoría de los géneros suele ser mas desarrollada, la pared principal faita del todo. Designando los fúngidos como individuos, añadiremos que como las actinias solo se propagan por huevos y que cuando excepcionalmente, segun parece, se presenta la formacion de retoños ó la division, este proceso de la reproduccion acaba con la separacion de los retoños. El profesor Semper ha hecho el interesante descubrintiento de que en algunos fúngidos se verifica un cambio de generacion en el que se forman troncos compuestos.
Otra cosa análoga sucede con el flarelo sarinble que pertenece à la familia de los turtrinolidos, cuyo nombre se saca de la forma cónica de los troncos. La mayor parte de las uumerosas especies solo se conocen como individuos; pero Semper nos ha dado á conocer interesantes formaciones de retoños, por los que, cuando menos, periódicamente se forman troncos muy sencillos hasta que los retoños caen. El género flavellum se distingue por ser el animal comprimido, por lo cual la abertura bucal no es circular sino que tiene la forma de una hendidura bastante larga. Semper añade a sus observaciones que, fijándonos solo en los extremos, fäcilmente podemos suponer que de esta sola especie deben hacerse dos iy hasta tres especies. Fl color predominante en todo el animal es un bonito rojo intenso, pero trasparente, y por el disco bucal corren casi siempre dos anchas fajas de

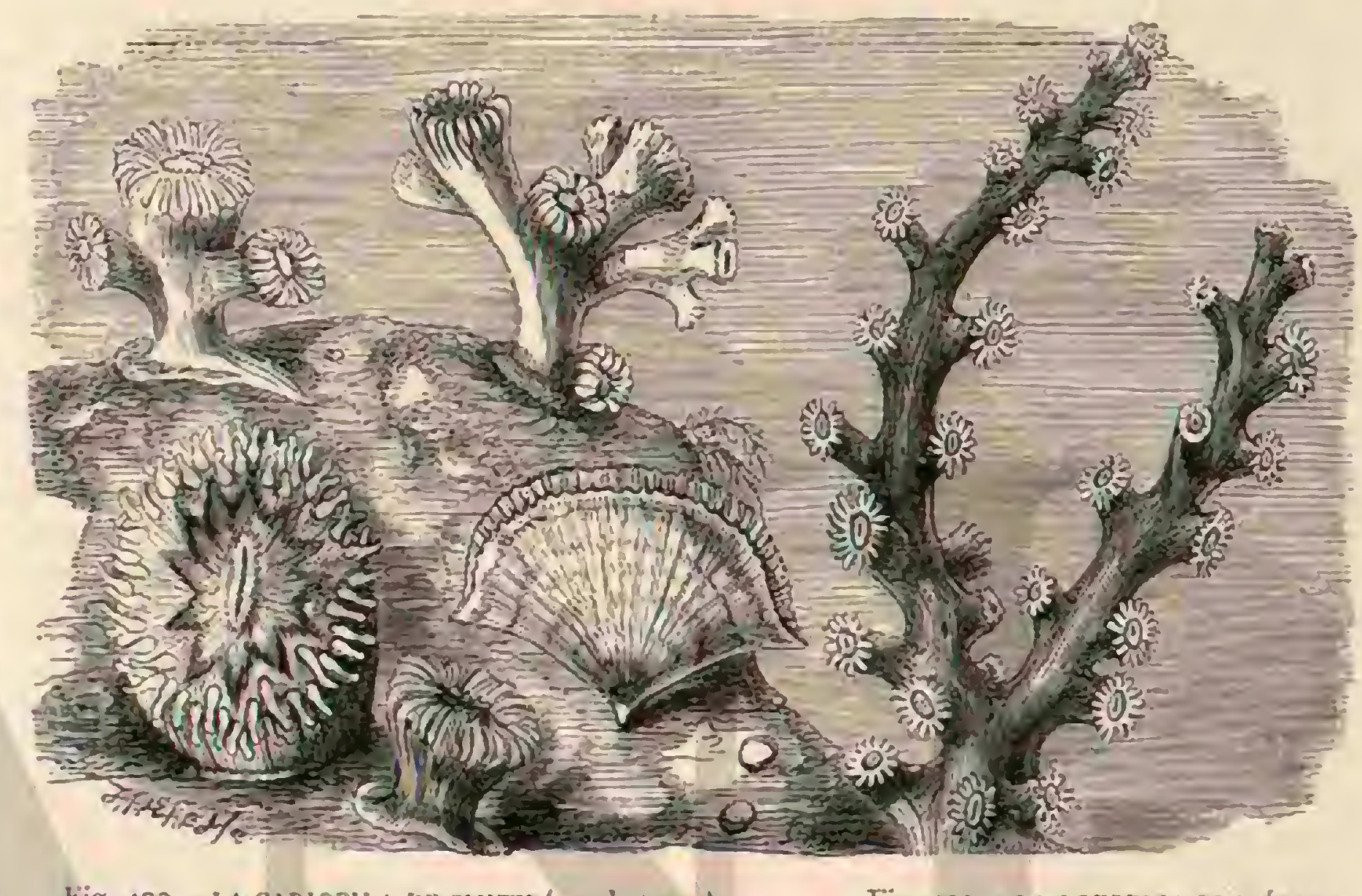

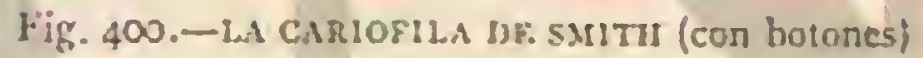

Figg. 401.-LA LOFORLIA BROLIFERA

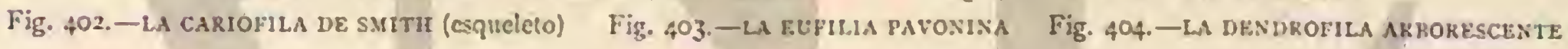

un rojo oscuro, mucho mas marcadas en los ejemplares cla- I se distingue entre otros por la division completa de los cáliros. Por numerosas que sean las especies de los fúngidosy turbinolidos $y$ de algunas otras familias que esencialmente viven como individuos, son muy inferiores en número à las familias que forman troncos compuestos. El ejemplo que mas nos interesa se nos ofrece en la cladocora crespitosa del Mediterránco y dcl Adriático. Los troncos de los individuus son tubos bastante prolongados de $\theta^{\circ}, 05$ i $0^{\circ}$, or. Los retonos salen lateralmente en la extremidad del pié, se encorvan desde luego hácia arriba y crecen al lado de su madre sin reunirse $\delta$ soldarse con ella. El tronco es por lo tanto fragil. La cladocora de césped abunda en muchos sitios en extremo, cubre distancias de mas de 100 metros cúbicos, $y$ se acumula tambien á varios piés de altura. Es por lo tanto el pólipo mas septentrional que al naturalista puede dar una ligera idea de un arrecife. Recuerdo el placer con que en la bahía de Sebenico encontré en mi red arrastradera un banco de cladocoras, de las que eché pesadas cargas" al barco.

Entre los muchos géneros de las astreáceas no porosas, caracteristicas de los mares cálidos, la verdadera astracea es uno de los mas imp̨ortantes, porque él y sus congéneres mas afines representan un papel principal entre los animales constructores de arrecifes. Los cálices son completamente separados uno de otro, rodeado cada uno de una pared, de modo que las paredes se tocan inmediatamente. El género res. Los meandrinos, á los que pertenece la heliastrea heliopora, forman otro género tan numeroso como el anterior, con muchos sub-géneros. En cllos, al dividirse los individuos y al formarse los retoños, solo las partes blandas de los animales se aislan completamente, pero las paredes se reunen de modo yue la superficie estri cubierta de depresiones y frominencias irregularmente circunvueltas, dando á todo el tronco el aspecto de un cerébro. En los ejemplares vivos las depresiones están cubiertas naturalmente de las partes blandas, $y$ en las aberturas bucales se reconocen las dimensiones de cada individuo, de las que en el esquueleto solo se obser. van los limites en dos lados opuestos.

El lector podrá formarse idea aproximada de las variadas familias que comprende este órden por los grabados que res. pectivamente los representan. De las madréfnoras dan idea las figuras $405 \mathrm{y} 406$, de la astrea la 408 y de la fungin las 4 ro a 412. La cariofila (fig. 400) es otra de las especies en qque el polipero afecta la forma de cono, mientras que en la dendro. fila (fig. 404), llamada árhol de cural, el polípero cilindráceo puede alcanzar medio metro de altura. En las lofoelias (figura 401) y las eufilias (fig. 403) se jresenta, respectivamente, el polifero dendroideo y flabeliforme; en los equinóporos (figura 407) el polipero es pétreo. No menos notables por su forma son las lucernarias (fig. 391) caracterizadas por su forma de campana caida: los iliantos (fig. 393) que se reconocen 
por sus delgados tentáculos; $y$ las calicinarias (fig. 392), pequeño corolario de las lucernarias cuyo disco peristoneano en vę de prolongarse para formar ocho brazos tentaculiferos, es redonderdo y simplemente cupuliforme. Por último las sertularias (figs. 413 y 415 ), género de políperos flexibles y no pétreos; las campanularias (fig. +16 ) relacionadas con ellas, pero de las que sin embargo difieren por no tener dentados los troncos ni las ramas, $y$ las plumularias (figs. 414 y 4 I 8 ) en extremo semcjantes i las sertularias; son poliperos que merecen mencionarse aqui.

\section{OCTATINOS - OCTACTINIA}

Ia ségunda gran division de los pólipos comprende aun especies bastante variàdas, pero el aspecto de los incividuos aislados es mas uniforme a causa del número fijo de ocho tentáculos. Estos no son huecos; por lo regular un poco deprimidos y denticulados en los bordes, afectan la forma de graciosas hojas.

\section{LOS ALCIONARIOS - AL- CYONARIA}

Esta familia, qque esencialmente se compone del género alcyonirum; es la mas diseninada; sus especies se liallan con frecuencia en el extremo Norte, y en los mares de los paises cálidos son uno de los productos mas comunes. Los animales se encuentran reunidos en forma de troncos de figura irregular y voluminosa, con gruesos lóbulos, ó ya en forma de un árbol con ramas del diámetro de un dedo ó mas, pero poco numerosas. Los animales aislados suelen sobresalir en forma de blancas flores, de algunos milimetros de longitud, destacándose de la superficie del tronco, rojizo amarillento y manchado, de un brillo particular, y blanda y carnosa al tacto. Con una parte del tronco hâllasc arraigado todo el conjunto, ó se fija solo ligeramente én è suelo, por lo regu. lar à poca profundidad.

$\mathrm{La}$ fig. 419 representa el alcion digitado, uno de los mas notables de esta familia.

Los alcionarios segregan tambien partes de una cubierta 6 escudo, pero estas no se reunen en un tronco sino que se mantienen diseminadas por toda la colonia en forma de cuerpecitos calcáreos, por lo regular microscópicos, dc una forma determinada en las diferentes especies. Los alcionarios vivos y frescos tiersen cierta elasticidad y turgencia; al sacarlos del agua se contraen mucho, incluso todo el tronco compuesto, pero vuelven á dilatarse en el acuario y se conservan sema. nas y meses enteros. Si las partes inferiores se dilatan demasiado, indica esto que los animales no están sanos, aunque, dado este caso, tambien se conservan bastante tiempo. Parece que no tienen enemigos particulares, y de consiguiente, el que quiera comprender la naturaleza por sus fines se vera desde luego algo apurado.

\section{LOS PENATÚLIDOS - PENNATULID死}

CARACTÉRES. - En los alcionarios, cuya formacion individual es muy limitada, vemos, por decirlo asi, el tránsito a la familia de los penatúlidos sujeta i formas determinadas. Ya en muchas especies del género de los alcionios se ob- serva in tendencir á formar tallos: los penatúlidos se caracterizan por la circunstancia de que cada tronco se divide en una parte polipiforme y en otra libre ó tallo, que se fija en el blando fondo del mar.

\section{LOS VERETILOS-VERETILLUM}

CARACTERES.-En las formas mas sencillas que pertenecen al género de los veretilos, representados tambien en el'Mediterráneo, la parte polipifera estí rodeada de pólipos y el tallo es cilindrico. Pocos animales habrá que à su antojo puedan ofrecer un aspecto tan variado como los veretilos. Un tronco que tuve en el acuario algunos meses siempre la vista, ofreció durante dos $\delta$ tres semanas el aspecto de una zanahoria resecada, sin movimiento en el fondo del agua, en un estado en que evidentemente se habian suspendido las mas importantes funciones vitales. No se veia ninguna huella de individuos aislados, no se tocaba alimento alguno, ni efectuábase tampoco el cambio del agua, que es tan importante para la nutricion comun del tronco. Cuando tal es. tado dura algun tiempo, aquel comienza à recoger agua por unos poros invisibles $\delta$ por la piel; la superficie se alisa; algunos individuos se presentan en ella, y á medida que se ele van y salen, el color del conjunto se hace mas vivo y delicado. El tronco se prolonga y ensancha por fin, alcanzando doble ó triple tamano. Sobre el color rojo de los cuerpos y del tronco comun se destacan las blancas coronas de los tentáculos; el pié, dilatado en forma de cebolla, comienza á ser trasparente, y cual-si todos aqueellos séres estuviesen animados de una voluntad comun, se encorva, baja á la arena, y enderćzase cl tronco, que en el periodo de la inaclividad se hallaba horizontalmente en el suelo. Esta facultad de cambiar de posicion y estado es propia no solo de las especies mas afines de los alcionios, sino tambien de la mayor parte de los tipos de la familia.

\section{EL TEROIDO PENÁTULA-PTEROIDES PENNATULA}

CARACTÉRES, - En el cuerpo de estos animales, llamados tambien plumas de mar, pueden distinguirse poco mas. 6 menos las mismas partes que en una pluma. El tronco es bilateral y simétrico, y tanto en la superficie del vientre como en la dorsal se encuentra una region libre de pólipos. Tambien se insertan en estas formas, tan regularmente construidas, los pólipos aislados, en diversas partes laterales de la quilla y en forma de hojas.

Muy notable es el descubrimiento de Koelliker, quien ob. servó que en los troncos de todos los penatúlidos se presentan dos formas distintas; el papel principal le representan 
los individuos sexuales, muy bien provistos de todos los or. ganc/s que necesita un verdadero pólipo; recogen alimento y crádan de la propagacion. I a otra clase de individuos, liamnados rooidios, se comprone de séres atrofiados, que ge. neralmente se reconocen tambien por la estructura de sus cumpañeros referidos, pero distinguiéndose por la falta comlleta de las antenas y de los órganos genitales, asi como por su pequencz. Parecen propios solo para recoger agua en el tronco conuun con sus muchas familias, y para volver à sacarIn, funcion que maturalmente se cjecuta tambien por los in. dividuos perfectos de los alcionarios, y en la mayor parte de los pólipos por éstos solos. Sin embargo, como entre los penatulidos se observa una especie de distribucion del tra. bajo, existe en ellos cieria predisposicion á desarrollarse en un sér colectivo superior. Isa regularidad y la simetria de la mayor parte de los teroidos lo demuestra asi.

Ias formaciones duras de los penatulidos consisten en un eje de materia caliza, á menudo flexible, del todo encerrado en el tronco y puntiagudo.en ambas extremidades, y además en cuerpos calcáreos aislados mas pequeños.

Desgraciadamente no sabemos apenas nada de la historia del desarrollo de los penatulidos. Segun Kolliker, este desarrollo se verifica de modo que el pólipo mas jóven forma por una division longitudinal repetida, de tres á cuatro individuos, por cujo procedimiento puede constituirse un pequeno tronco con dos canales longitudinales en la parte inferior y cuatro en la superior.

Suponicndo repetidas formaciones de retoños laterales; que fícilmente se demuestran en los pólipos de muchos géneros, podria deducirse muy bien un tronco mayor, en el que podemos imaginarnos los pólipos fijos en una ú otra forma. Muchos troncos de penatulidos llevan en la extremidad in. ferior los individuos mas jóvenes, y parece resultar que el desarrollo ulterior de los troncos, es decir, la formacion de nuevos individuos se verifica en el limite de la quilla $y$ del tallo.

En el género teroides las hojas que llevan los pólipos es. tán apoyadas por un número de rayos calcarreos mis fucrtes, que sobresalen del borde como espinas.

\section{LA PENÁTULA FOSFÓRICA-PENNATULA PHOSPHOREA}

El género penátula y otros se distinguen del anterior por la falta de los radios calcáreos. La especie mas conocida es la penátula fosfórica del Mediterráneo y del Atlántico, sobre cuyos fenómenos radiantes debemos noticias muy exactas y curiosas al profesor Panceri de Najpoles. Antes se ignoraba de que parte provenia la fosforescencia de las penátulas, pero todos se inclinaban a creer que se producia en la superficic mucosa, tanto de los pólipos aislados como de todo el tronco. Panceri ha demostrado que solo algunas partes muy determinadas de los pólipos tienen esta facultad, es decir, ocho órganos en forma de fajas, que con sus extremidades superiores, las cuales rodean la abertura bucal en forma de papilas, se extienden hảcia abajo ả lo largn del estómago. Fstản llenos de globulillos granulosos encerrados en celdas; y de otros cuerpecitos de la misma clase que son los que fostorecen. Como las fajas son muy delicadas $y$ de ellas sale la sus. tancia á la menor presion, fricilmente se explica que esta sus. tancia fosforescente se haya encontrado hasta ahorn en partes muy diferentes del tronco.

Para estudiar y obsermar cientificamente el fenómeno de la fosforescencia se necesitan penátulas bastante sanas; conviene que no permanezan demasiado tiempo en un pequeño depósito de agua, para que no se dilaten, ni tampoco deben estar completamente vacias ni contraidas convulsivamente, por el mal tratamiento al cogerlas en la red. Solo en los individuos recien cogidos, y a los que se ha inquietado muy poco, se pueden repetir los experimentos y froducirse las corrientes fosforescentes. La fosforescencia solo se presenta cuando se promueven irritaciones; basta golpear con el dedo la pared del acuario para que se produzcan chispas. Si se coge la penátula con la mano, bien por debajo del agua ó fuern de ella, los puntos y fajas radiantes se hacen mas vivos, y al producirse con regularidad las irritaciones, nos convencemos de que se trata de un órden determinado de los fenómenos radiantes, de corrientes de un curso fijo, que por esto ofrecen el mayor interés fisiológico. Como fenómeno principal, reconocióse la existencia de dos clases de corrientes radiantes, de las que la una depende de los verdaderos pólipos y es visible en la cara posterior de toda la penatula, mientras que la otra depende de los zooidios y se nota en la cara inferior. Ambas corrientes suelen presentarse al mismo tiempo, pero se pueden formar tambien cada una de por sí, sin que se conozca la causa del hecho.

La direccion de las corrientes varia segun cual sea la parte irritada: oprimiendo la extremidad del tallo, la fostorescencia se produce en los radios inferiores; dirigese desde el tallo hácia las extremidades de aquellos y pasa poco a poco á los radios superiores y exteriores. Lo contrario sucede cuando se oprime la punta de las barbas. Irritando el centro del tallo de llas barbas, las corrientes se dirigen al mismo tiempo hácia arriba y abajo, segun el órden local de los radios desde el punto irritado. Tocando al mismo tiempo las dos extremidades del tallo de las barbas, las corrientes se aproximan hasta tocarse. Raras veces salta una por encima de la otra; de modo que el fenómeno se produce entonces por las dos corrientes del primero y segundo punto de irritacion. Por último, cuando se oprime la extremidad de los radios, la corriente fosforescente pasa primero desde la extremidad irritada hácia abajo, al tallo, y ciesde alli á todos los radios en la direccion ordinaria. Tambien se ha reconocido que un corte circular del tallo hasta el eje fijo, impide La continuacion de la corriente. Para dar a conocer todo el hecho es preciso determinar la rapidez de las corrientes radiantes; estas necesitan solo por término medio dos segundos para recorrer toda la extension de la penaitula que mide io centímetros; de modo que emplearian 20 segundos por metro. La rapidez con que se propaga la excitacion nerviosa, es en la rana de 30 metros por segundo, en el hombre de 33 metros, y por consecuencia 600 veces y respectivamente 660 mas grande que la de las corrientes radiantes de la penátula.

Panceri llama muy justamente la atencion sobre la importancia que las penátulas podrian llegar à tener para el estu. dio de la propagacion de la excitacion en el cuerpo animal, si su pesca y su conscrvacion no ofrecieran tantas dificulta. des. Hasta el gran acuario de la Exposicion maritima de Nápoles, que media 13 metros de largo por uno dé ancho y de profundidad, fué reconocido como insuficiente é impropio. Sin embargo, he visto cómo estas penátulas se conservaban muj bien varios meses en la estacion roológica de Dohrn. Si ahora nos ocupamos en averiguar cuáles son los organos que en las penátulas sirren fara propagar y acrecentar la irritacion que produce los efectos radiantes, no podemos contar desde luego con la actividad nerviosa.

Hasta ahora no se han enconirado nervios en las pendtu. las ni en sus congeneres, $y$ probablemente no los ticnen; $\mathrm{el}$ hecho de que la fosforescencia puede propagarse en las mismas partes en direccion opuesta, no permite tampoco suponer la intervencion de aparatos nerviosos, pues de éstos 
sabemos que solo pueden promover la excitacion en un sentido. Preciso es, por lo tanto, imaginarnos una excitacion molecular que se trasmite de celda en celda y que por efecto de la resistencia por vencer, es mucho mas lenta que la que corre por las fibras nerviosas, mediante el moviniento y el sentimiento. La razon de sér del fenómeno radiante de otros muchos cuerpos animales, tanto vivos como muertos, parece explicarse por un procedimiento gradual de combustion de la sustancia grasa; y en las penatulas, mas bien por una oxidacion lenta de los globulillos grasosos contenidos en las fajas radiantes: esto parece lo mas natural.

No terminaremós estos párrafos sin citar, además de la penátula fosforescente; Ia penátula gris (fig. 420 ): esta es bastante grande, se distinguc por sus pinulas desarrollaydas y numerosas y provistas de una infinidad de espiculas de gran tamaño. El color de este zoófito es comunmente agrisado.

Tambien las virgularias constitujen una especie afine ail la anterior. Las caracterizan las alas de los poliperos ó pinulas muy pequeñas 6 inermes y su eje esclerobésico en extrem. desarrollado. Este último caracter las distingue de las pena. tulas. Es notable la virgilaria de alas endebles (fig. 421).

\section{LA UMBELULA DE GROENLANDIA-UMBE- LLULA GROENLANDICA}

De las 150 a 160 especies y variedades de penatúlidos

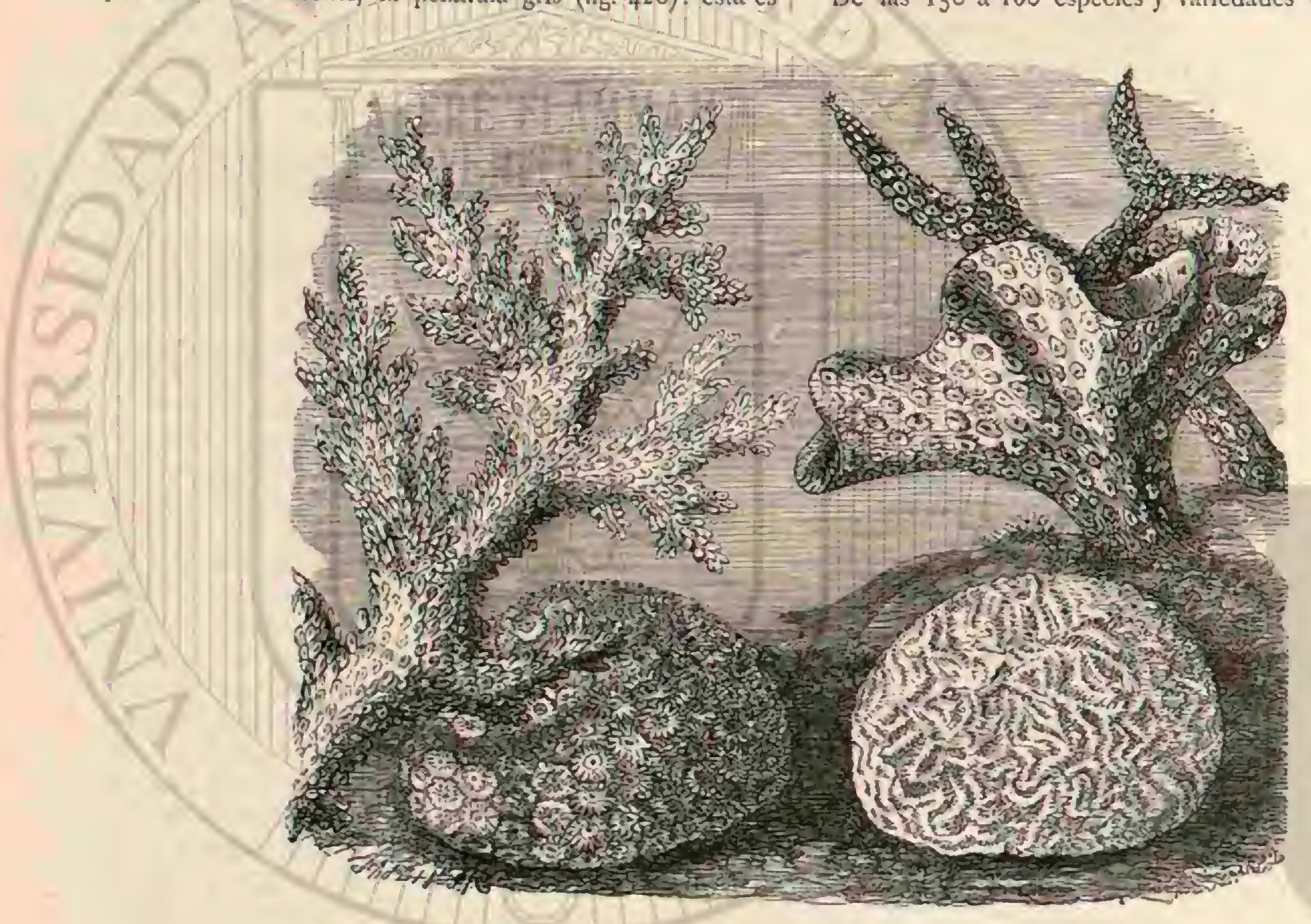

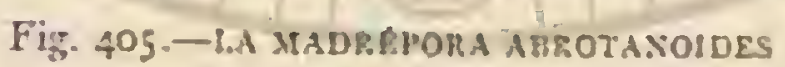

Fig. 4OS. - LA ASTKEA RAULANTR.
Fig. 406. -I.A MADRESORA SPROSA

Fig. 407.-EL. EQU1KótoRO ONDUT.ADO

Fig. 4O9. - - M MLANDKNA CEREBRIFORBE que su monógrafo, el profesor Koelliker, cree poder distinguir, desde mediados del siglo anterior, la umbelula de Groenlandia es la que adquirió mas celebridad, por vivir á grandes profundidades. En el vernno de 1752 , es decir, en un tiempo en que no se sabia niada aun acerca del área de dispersion de los animales en el fondo del mar, la tripula. cion de un buque inglés extrajo à zo leguas alemanas de la costa de Groenlandia, dos ejemplares de esta singular especie, que se hallaban á una profundidad de 1,416 pies. Ios naturalistas Mylius y Ellis, teniendo i la vista los cjemplares conservados en seco, hicieron descripciones y grabados, que si bien defectuosos, eran suficientes para dar a conocer la naturaleza de la umbelula como de un género perténeciente á los penatúlidos. El tronco del pólipo consiste en un largo y delgado tallo en cuya extremidad superior se encuentra un grupo de pólipos. El mas grande de los dos ejemplares groenlandeses tenia una notable longitud, y ambos se per. dieron, poco despues de haber sido descritos, para la ciencia.

Tanto mas interesantes son los descubrimientos hechos últimamente por exploraciones regularizadas en las frofun- didades del mar, segun las cuales consta que varias espe. cies de umbelulas habitan en parajes de mucho fondo en el Atlantico, así como tambien en el mar Austral. En $1 \$_{j}$ Lindahl encontró, acompañando la expedicion de los buques Jngeborg y Gladan, a las órdenes del capitan Von Otter, un ejemplar de este género en la bahia de Baffin a una profun. didad de 400 brazas $(2,400$ piés): esta especie cra la umile. llula miniacen; otra especie encontró el mismo naturalista cul la enirada del Omanakijord en el norte de Groenlandia. Ahora, sin embargo, se observa este notable animal mas hícia el sur, donde penetra con las corrientes frias de la profundidad, o vive en las extensas praderas del fondo del mar. Asi, por cjemplo, tambien se encontró ln umbelula a 25 leguas de la costa de Noruega, en la direccion de Cristian. sund hacia Islandia, con otros animales áricos. Otros dos ejemplares del mismo género fueron cogidos por Thomson, cuando iba con la expedicion del Challengrer, entre Portugal y Madera á la profundidad de 2,120 brazns, y un tercero a casi 1,500 brazas, cerca del pais de los Kierguelos. La umbelula pertenece por lo tanto á los aninales cosmo. 
politas que viren con preferencia en las profundidades y se distinguen por su vasta distribucion geográfica.

\section{LOS GORGÓNIDOS - GOR- GONID压}

Esta familia está por lo regular bien representada en las colecciones de objetos maturales. Se reunen à menudo con los penatúlidos en un solo grupo bajo el nombre de corales de corleza, porque en ambos el eje duro del tronco está cu- bierto de una corteza mas blanda. Ésta se compone de los pólipos y de la sustancia intermedia que los reune; el eje consiste en cuerpecitos calcireos soldados, y tambien en sustancias córneas quee en gran cantidad son segregadas por la parte posterior de los individuos, efectuándose su desarrollo mas tarde y recogiéndose las sustancias alimenticias por me. dio de unos canales que sobresalen de los individuos. Por lo demás, si intentasemos trazar, siguiendo el ejemplo de Darwin, el arbol genealógico de las familias de que se trata, veriamos que ni los penatúlidos parecen descender de los gorgónidos, ni estos de aquellos, indicando unos y otros que

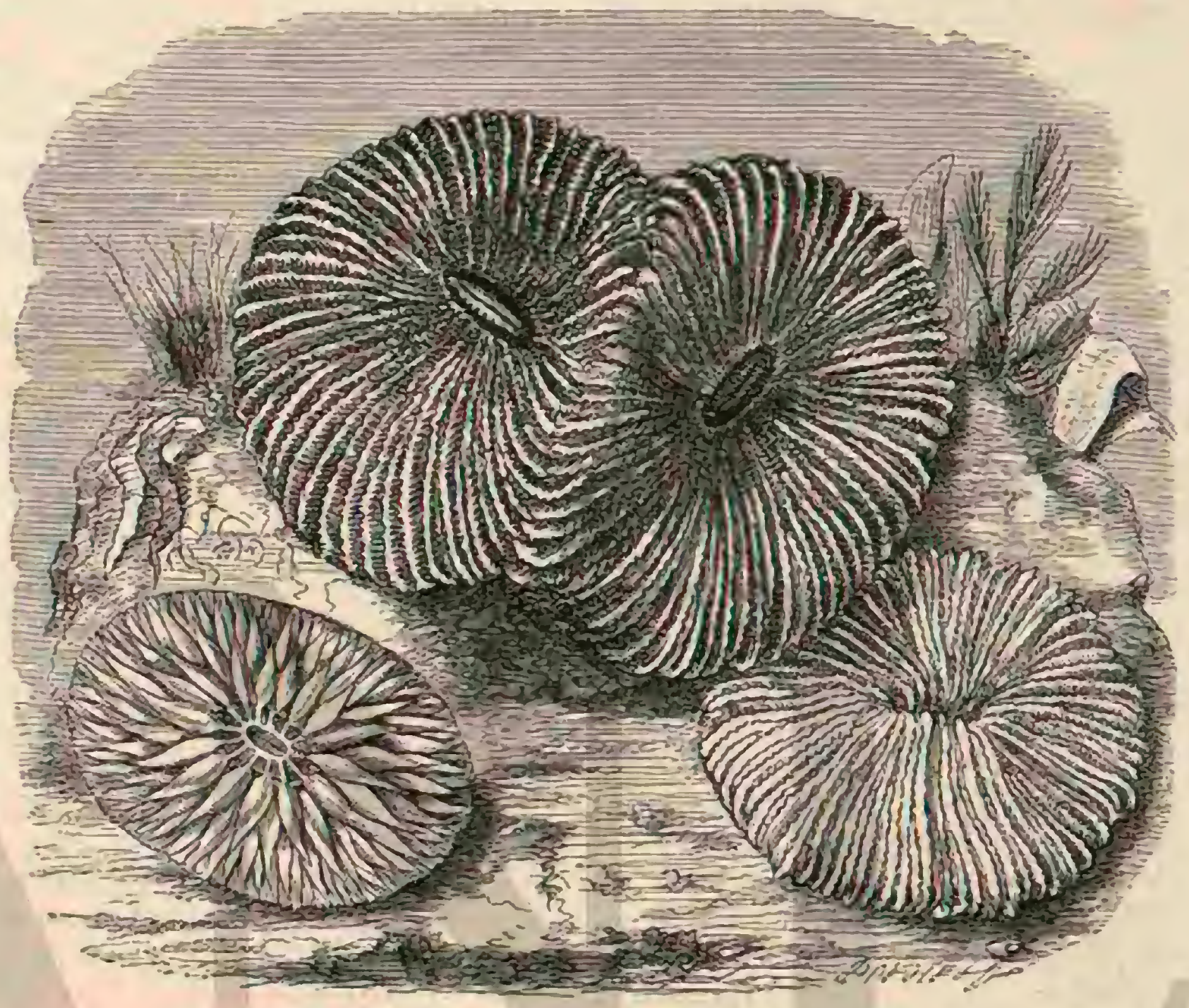

Fig. ;10.-LA FUSGLA APELOTONA1)A

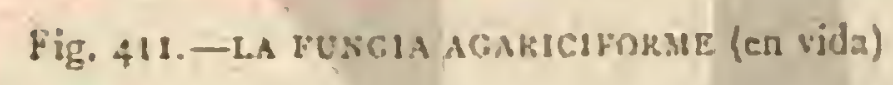

Fig. 412.-2.4 sesss (esqueleto)

los alcionarios son la madre comun. Todos los gorgónidos se arraigan en el fondo del mar, y la ramificacion de su tronco produce las formas mas variadas; árboles irregulares con ramas en todas direcciones; ramificacion en sentido horizontal; ramos sencillos dispuestos en ángulo ó en espiral, abani. cos, redes, etc.

En la mayor parte de los gorgónidos el eje es córneo y flexible, pudiéndose llamarlos corales córneus. A pesar de esta formacion del eje, que se conserva flexibley resulta del endurecimiento y de la consolidacion de la sustancia orgánica, tampoco estos pólipos carecen de la secrecion calcarea. El eje encierra ya algunos cuerpecitos de materia caliza, y la corteza está llena de ellos. Son de gran importancia para la clasificacion sistemática, porque cada-género y especie pro: ducen formas propias.

Una de las especies mas comunes es la gorgónia itálica (fig. 422) que tiene la corteza de color blanquizco, afecta la forma de un arbustito y' mide hasta $11^{\prime \prime}$,oso de diametro. La posicion que este gorgónido y otros ocupan en la economia de la naturaleza no tiene importancia. Del todo inofensivos de por si, no ofrecen ninguna ventaja particular a los otros animales y están bastante exentos de los peligros de la lucha por la existencin. Algunos caracoles parecen buscar los cálices de los pólipos y tambien se encuentran á me- nudo ofiuras trepando aigilmente por su ramaje, sin duda para buscar alimento.

\section{EL CORAL ROJO-CORALLIUM RUBRUM}

En cl género isis, cuyo tronco se compone de fragmentos alternativamente córneos y calcáreos, tenemos el tránsito al importante coral rojo que solo existe en una especie. El tronco 6 el eje de coral se compone de numcrosas y finas capas calcáreas de una estructura microscópica tan determinada que quien la conozca puede reconocer en cada preda. cito fácilmente si es legitimo ó no. El eje fresco, no nlisado artificialmente, ni desgastado por el agua, está cubierto de finos surcos longitudinales en los que termina la capa inferior de los canales del jugo alimenticio antes citados. Lacaze Duthiers ha estudiado con detencion, durante sus repetidas excursiones a la costa septentrional del Africa, la historia natural y la anatomia del coral rojo. Reconoció que los troncos contienen jor lo regular individuos masculinos ó solo femeninos, pero à veces ambos sexos de pólipos mezclados en un tronco, $y$ hasta hermafroditas. A pesar de muchos obstáculos, el naturalista irancés logró estudiar paso ì paso el nacimiento de las larvas, su modo de fijarse y su desarro. llo en el tronco. L.as larras de uno á dos milimetros de 
largo y con pestañas, abandona el huero en la cavidad abdominal, provista de compartimientos de la madre, y tienen la forma prolongada de un gusano.

El coral rojo solo se encuentra en el Mediternineo y en el Adriático; en estas últimas aguas llega hasta mas arriba de Sebenico y se halla con mas frecuencia en algunos puntos dé la costa de Albania, asi como entre las islas Jónicas. En todo este territorio hasta ahora solo los habitantes de la Isla Zlarin cerca de Sebenico le buscan. Sus barcos, bastante sólidos y bien construidos, se dirigen hasta las islas Jónicas y vuelven al cabo de varios meses, por seriembre. Los resultados de la pesca son joco importantes el comparacion con los de la de coral en las costas de Tunez y de Argelia. En este último litoral, en los bancos que a algunas leguas mari: nas de distancia de la orilla se estienden y a una profundidad de $40 y, 100$ brazas, raras veces mas ó menos, la pesca de coral es la mas lucrativa. Se practica principalmente por barcos con tripulacion italiana; los españoles y franceses se dedican menos; $y$ a decir verdad, es un oficio muy pesado. Ias cmbarcaciones varian de 6 it 16 toneladas de capacidad y de 4 á 12 tripulantes, rigiendose por esto tambien el tama. nó y el peso del aparato y de la red que se emplean para sacar los corales del fondo. Fil priniero se compone de dos vigas dispuestas en cruz y fuertemente atadas, debicndo tener los barcos unos tres inctros de longitud; el punto de union de aquellas se asegura con una piedra 6 lo que es mejor, con una barra de hierro. De este aparato penderi de treinta y cuatro á treinta y ocho redes de mallas anchas y $\mathrm{cn}$ figura de bolsas, como las usadas en los buques para limpiar el suelo. Este aparato, fijado en una fuerte cuerda, se baja y sube, segur el tamaño, por medio de un torno colocado en la popa de la embarcacion, $\delta$ que se tiene en la mano. Como los corales no se hallan sino en un fondo pedregoso $y$ escar. pado, y en general están cubiertos de prominencias, debajo de las cuales deben penetrar los brazos de la cruz, sucede diariamente $y$ á todas horas qque el aparato se encalla, oca. sionando continunmente las mayores fatigas para sacarlo, sobre todo porque la pesca se ha de efectuar, sin interripcion en la estacion calurosa.

Los corales pescados varian mucho, conso material, en calidad $y$ valor. Las raices de coral arrancadas de las rocas y perforadas á menudo por anélidos y esponjas, se venden á razon de 5 á 20 francos kilógramo. El precio de la mercancía regular varía entre 45 y 70 francos la misma cantidad; pero si los ejemplares son elegidos, gruesos, y sobre todo de color sonrosado (siel de dingel), se pagan á 400 y hasta $500 \mathrm{y}$ mas francos por kilogramo. Los ejeniplares negros en parte $\delta$ del todo, que se venden á razon de 12 a 15 francos, no derivan su origen de una especie independiente; es que han estado cubiertos mucho tiempo por el cieno, perdiendo su color á causa de una especie de descomposicion, ó de in. fiuencias quimicas desconocidas aun. Ias noticias citadas por Lacaze-Duthiers se completan por una estadistica de la pesca de coral en i $\$ 75$. En este año salieron de los puertos del distrito maritimo de Nápoles 416 barcos, de los que 264 pescaron en las costas italianas; mientras qque los otros se dirigieron á otros bancos de coral del Mediterraineo. Pesca. ron 23,000 kilógramos de prinera calidad, que se vende it I20 francos kilógramo; 20,000 de segunda, á 75 francos el mismo peso, y $67,43^{6}$ i 6 francos, de lo que resulta un total de $4.664,616$ francos. Deduciendo $1.966,800$ por aparejos de los buques, salarios y alimentos, queda una ganancia limpia de 2.697.816 francos, que principalmente fué hecha por los pescadores de coral de Torre del Greco. La fabricacion de adornos y aderezos de coral se efectúa en Paris y Marsella, pero sobre todo en Nápoles, Liorna y Génova.

Además del coral rojo, debemos tambien hacer aqui mencion de otras dos especies: el coral segundo (fig. 423) y el coral noble (fig. 425). La primera es monosa, sub-flabeliforme y solo tiene los pólipos en una cara; su cje es calizo, de color sonrosado y la esclereuquia tiene un tinte rojo escarlata. La segunda difiere por tener las ramas gruesas, redondeadas en la extremidad y en forma de mamilas, aunque sin atenuarse como en el coral segundo. Este se encuentra en las islas Sandwich y el coral noble en el Mediterráneo.

\section{LOS TUBIPORIDOS - TU- BIPORID压}

Nuestra descripcion general de los pólipos termina en la familia de los tubiporidos, compuesta de las poco numerosas y misenos viriadas especies del género tubipora. Los indivi. duos aislados aseméjanse del todo a los otros odactinios, asi por la forma y el número ordinario de sus graciosos tentáculos como por la parte anterior blanda de su cuerpo. Respec. to 1 la formacion de su esqueleto, nótese que se hallan del todo aislados en la creacion actual, pareciéncose a los sirin. goporos y otros cornles extinguidos. Cada individuo segrega un tubo de paredes lisas sin encalcinar las paredes divisorias verticales.

Como los tubos de un órgano se hallan casi paralelamente uno juntoá otro, la secrecion en el tronco se efectúa por medio de paredes trasversales; pero estas no corresponden con las internas, convexas hácia abajo, $y$ por medio de las cuales la parte superior viva del tubo se cierra á intervalos, oprimiéndose contra la parte muerta situada á inas profundidad del tronco. Las paredes trasversales citeriores que dividen el tronco en pisos no son regularmente paralelas ni concéntricas, ni tampoco continuas; pero designan generalmente los grados de desarrollo. Están cruzadas por un gran número de canales alimenticios, de gran importancia para todo el tronco, porque en la superficie nacen los individuos jóvenes; los tubos de lus viejos sepáranse un poco al prolongarse, $y$ en todas partes donde se crea de este modo el espacio para que puedan intercalarse tubos nuevos, éstos salen de las. paredes trasversales que hacen las veces de raices, tan importantes para la propagacion. En los tubiporidos no se observa una division de los individuos ó una formacion de retoños de los tubos mismos.

Ia tubipora purpúrea (fig. 424) es una de las que mas se distingue entre las diversas especies de tubiporidos.
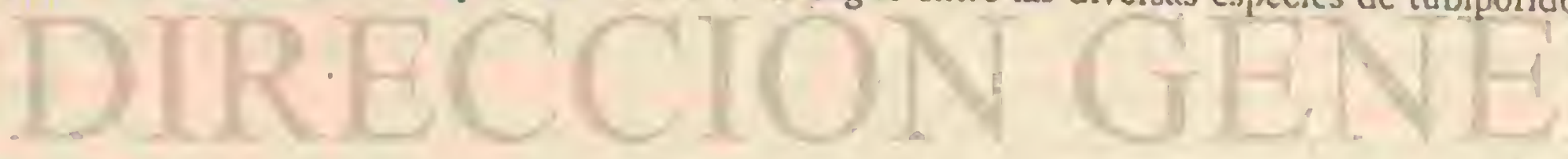


\section{LOS ARRECIFES Y LAS ISLAS DE CORAL}

La estructura y la vida de los pólipos como individuos y colonias 6 troncos que hasta ahora hemos descrito en géne. ros y especies elegidos, ofrecen sin duda un asunto digno de estudio y de gran interés, pero la importancia de la vida de los pólipos es mucho mas general. Muchos miles de generaciones de animales vienen y van, desapareciendo despues de la muerte sin dejar ninguna huella; pero no se reducen á la nada, sino que sus sustancias elementales vuelven à la eterna circulacion de la materia, aunque sin dejar vestigios visibles. Los pólipos, en cambio, cuando menos aquellas numerosas forinas que en su conjunto se designan como corales constructores de arrecifes, erigen monumentos para centenares de miles de años, y la influencia en la vida del cuerpo y en el desarrollo del género humano, es el punto mas importante en que finalmente debe concentrarse la observacion sobre la existencia de los pólipos.

Haeckel ha descrito hace poco, despues de visitar la costå árabe del mar Kojo, los encantos que ofrece á la simple vista un arrecife de coral situado à poca profundidad. "He salido del puerto de Tur, dice, donde vemos los bancos de coral indio con todo el brillo de sus colores. El agua, clara como el cristal junto á la costa, estí casi siempre tan tranquila é inmóvil, que sin dificultad puede reconocerse toda la admi. rable alfombra de coral del fondo, con su variada joblacion de toda clase de animales marinos. Tanto aqui como en la inayor parte del mar Rojo, se corre paralelamente á la costa un largo terraplen de arrecifes de coral, a la distancia de poco mas ó menos un cuarto de hora de la tierra firme. Estos terraplenes 6 barreras contienen el impetu de las olas con su superficie desigual y puntiaguda, que se halla casi á fior de agua; una blanca cresta de espuma señala marcadamente su curso. Aun cuando en la alta mar la tempestad remueve las olas del fondo, aqui en el canal, ó foso cercado por la roca, el agua se mantiene relativamente tranquila, y los pequeños buqques pueden continuar sin obstáculo su viaje á lo largo de la costa. A cierta distancia, hácia la alta mar, el arrecife de coral baja verticalmente; hácia el interior, en cambio, en direccion á. la costa, aplámase poco á poco, y por lo regular la profundidad del camal es tan escasa, que en su fondo se puede contemplar toda la magnificencia de los maravillosos jardines de coral.

No hay pluma ni pincel capaz de describir tal esplen. dor las entusiastas descripciones de Darwin, Ehrenberg, Rausonnet y otros naturalistas que antes habia leido, me hicieron concebir esperanzas que no se defraudaron, pues la pintura no llegaba ui con mucho à la realidad. Una-comparacion de estos paisajes submarinos, tan ricos en formas, y brillantes por sus colores, con las regiones terrestres cubiertas de la mayor abundancia de flores aun no da una idea exacta, pues alli, en la profundidad azul, todo esti en rigor matizado de fiores abigarradas á cual mas graciosas, que no soll otra cosa sino animales de coral viros. La superficie de los grandes bancos de coml de seis a ocho piés de diámetro está alfombrada de miles de encantadoras estrellas de flores; en los àrboles ramificados y en los arbustos se ven capullos sobre capullos; los grandes cálices de vivos tintes que crecen al pić son igualmente corales; y hasta el musgo, de diversos matices, que llena los huecos de los troncos grandes, parece formado, al examinarlo minuciosamente, por millones de diminutos séres de coral. Y todo este conjunto floreciente ostenta un brillo maravilloso en el agua cristalina, bañada por el sol radiante de Arabia.

* Estos admirables jardines de coral, superiores por su csplendor á los encantados jardines de las Hespérides, están poblados además de una variada fauna animal de múltiples especies. Peces de un brillo metálico, de las formas y colo. res mas extraños, retozan en grupos alrededor de los cálices de coral, cual los colibris que en el aire se balancean alrededor de las Rores de las plantas tropicales.

Muchos, variados é interesantes son los animales vertebrados de las clases mas diferentes que se agitan de continuo en los bancos de coral. Graciosos crustáceos trasparentes del grupo de los garnélidos saltan reunidos en gran número;y abigarrados cangrejos trejan entre el ramaje de coral. Tambien rojas estrellas de mar, ofiuros y equinoideos negros agitanse en tropel por las ramas de los arbustos, sin contar los numerosos conchiferos y caracoles; mientras que los gra. ciosos anćlidos, con sus abigarradas brảnquias en forma de plumeros asoman su cabeza por los tubos. Aquil llegra una espesa bandacla de medusas, y con gran sorpresa nuestra reconocemos en la graciosa campanilla un antiguo amigo del Báltico y del mar del Norte, el tenóforo.

"Podria crecrse que en estos encantadores bosques de coral, donde cada sér se trasforma en una flor, reina siempre la paz feliz de los Campos Eliseos; pero si se fija un poco la atencion en este centro de actividad, reconócese pronto que tambien aqui, como en la vida del hombre, continuamente existe la encarnizada lucha por la existencia, lucha que por ser silenciosa y apenas perceptible no es menos desapiadada y terrible. I.a gran mayoria de los séres vivos que aqui se desarrollan en una abundancia extrema se extermina sin cesar para hacer posible la existencia de una minoria preferida. En todas partes reinan el temor y el peligro; y para convencernos de ello basta sumergirnos nosotros mismos en la profundidad. Con rípida resolucion saltamos de bordo, y descendemos á las aguas: una vez dentro de ellas, la luz adquiere un maravilloso brillo verde y azulado, entonces remos de cerca todo el esplendor de los colores del banco de coral; pero pronto reconocemos que el hombre no se pasea impuneniente entre los corales, como podria hacerlo debajo de las palmeras. Las puntas agudas de los corales pedregosos no nos permiten posar nuestro pié en ninguna parte; buscamos al efecto un sitio arenoso descubierto, pero un erizo de mar (dindema), ocuito en la arena, introduce en nuestro pie sus largas espinas provistas de finos ganchos; en extremo frágiles, se rompen en la herida, y solo pueden extraerse cortándolas cuidadosamente. Nos inclinamos para recoger del fondo una actinia verde de esmeralda que parece reposarse entre las valvas de gigantesco conchifero muerto; mas vemos, por fortuna muy a ticmpo, que cl objeto verde no es ninguna actinia, sino el cuerpo del conchifero mismo; si hubiéramos cometido la imprudencia de tocarle, nuestra mano habria quedado aplastada lastimosamente al cerrarse las dos valvas fuertes de la concha. Despues intentamos 
romper una bonita rama violacea de madrépora, mas al punto retiramos la mano, porque un atrevido cangrejo pe. queño (Irafesia), que habita en bandadas entre las ramas, nos pellizca fuertemente con su tijera. Mas dolorosa es aun la experiencia si se trata de coger un coral de fuego (millepora) que se halla al lado. Millones de burbugitas venenosas microscópicas se vacian al contacto mas superficial sobre nuestra piel, y nuestra mano se abrasa cual si hubiera tocado hierro candente. Igual escozor produce una pequeria hidra de aspecto muy inofensivo, pero de la cual evitanos el contacto desagradable, asi como el de uua bandida de medusas que tienen la mala propiedad de producir escozor. Siempre alerta para no ser presa de alğun tiburon que tampoco esca- sean en estas regiones, subimos presurosos á la superficic para volver á bordo.

2. Solo por un estudio minucioso es posible formarse una idea de la superabundancia fabulosa de la vida animal mas diversa que se concentra en estos bancos de coral, luchando por la existencia. Cada troneo es en rigor un pequeño museo zoológico. Colocamos por ejemplo una bonita rama de madréporas, que nuestro buzo acaba de subir, en una gran vasija llena de agua de mar para que los animales de coral des. plieguen tranquilamente sus graciosos cuerpos en forma de Hor. Si al cabo de una hora volvemos á mirar, vemos que no solo el tronco, muy raminicado, cstá cubierto de las flores mas bonitas de coral, sino que centenares de animales gran-

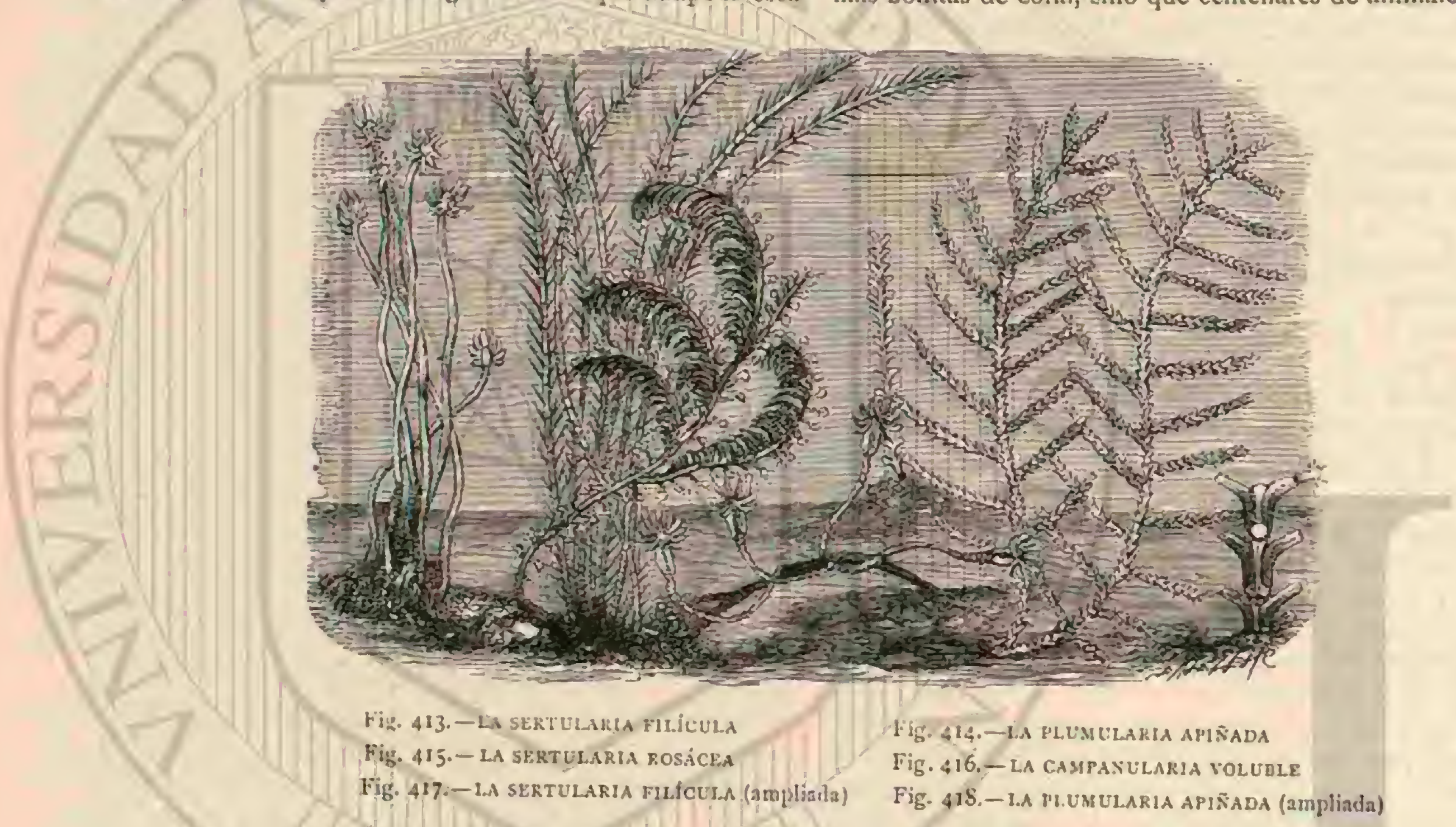

des $y$ miles de nequeños reptan y mainn por el vaso; crustáceos y anélidos, cangrejos y caracoles, conchiferos, estrellas y erizos de mar, medusas y pececillòs, animales todos que antes estaban ocultos en el ramaje del tronco. Y aun cuando saquemos á éste, rompiéndole en pedazos con el martillo encontranos en su interior una multitud de diferentes animalitos sobre todo conchiferos, crustáccos y anćlidos. iY cuainta es la abundancia de séres invisibles que nos descubre el microscopio! ;Qué riquezs en descubrimientos nolables hallarin aun aqui los zoólogos futuros que tengan la suerte de permanecer meses y años enteros en estas costas de corally

Despues de este primer conocimienio superficial de los bancos de coral situados mas al alcance de nosotros los euro. peos, aumenta sin duda el deseo de sondear mas profunda. mente las particularidades de estas formaciones, para observarlas en su extension general. Nos regiremos para esto por los informes de Dana, comprendidos en su obra antes citada, - Los Corales y las islas de coral, de la cual vamos a extractar los capitulos correspondientes, $\delta$ bien traducirlos lite. ralmente, sin volver á nombrar $\$$ cada paso'al ciłado natura. lista.

Todas las especies de coral que forman rocas viven en los mares de la zona calida, donde la temperatura del agua aun durante el invierno no baja de $16^{\circ}$ Reaumur: el mayor calor del verano en el Pacífico es de $24^{\circ}$. Dos líneas septentrional y meridionalmente equidistantes del Ecuador que reunen los sitios de anguella temperaturn igual en invierno, y están muy

onduladas segun las corrientes de agua, encierran la rona de los mares de bancos de coral. Nuestra gcografia de primera enseñanza nos dice ya que al rededor de la zona ecuato. rial se encuentran arrecifes, pero que su distribucion es muy diferente.

Los corales que forman arrecifes, y que ya hemos descrito, fórmanse en su gran majoría entre estos limites. En cl Medi. terráneo escasean los camles, y sin embargo, es nuy favorable para la vida animal. Todas las astreas, casi todos los fúngidos, las madréporas, los porites y la major parte de las es. pecies de todas las demás familias $y^{\circ}$ géneros, constituyen arrecifes. La nuajor varjedad se encuentra naturalmente en el centro de la zoma mas cálida, entre el $15^{\circ}$ y el $18^{\circ}$ de latitud norte, $y$ al sur del Fcuador, donde la temperatura no baja de $18^{\circ}$ y medio Reaumur. A esta region pertenecen las islas de Fridji, cuyas rocas dan un cjemplo de extraordinaria abundancia de corales. Las astreas y meandrinas llegan aqui a su mayor desarrollo. Las madréporas aparecen como arbustos cubiertos de fores, en figura de grandes callices y hojas, extendiendose estas últimas casi a dos metros. Otras muchas especies se encuentran en igual abundancia y extension. Ias islas de Hawaii, en la parte septentrional del Pacifico, entre los $19^{\circ}$ y $20^{\circ}$, se hallan fuera de esta zona mas cálida; sus corales son por eso menos abundantes y no tan ricos en es. pecies. Las madréporas faltan, y solo se ven algunas astreas y fúngidos; mientras que los porites, menos sensibles, y los pociloporos, prosperan alli en grande abundancia. 
Los géneros de coral de las Indias Orientales y del mat Rojo, son csencialmente los unismos que en la parte central del Pacifico, asi como los de la costa de Zanzibar. En las islas de coral orientales del Pacifico, la variedad de los gé. neros y especies es muy considerable, aunque no tanto como en el oeste.

El golfo de Pamamá y los mares vecinos, por la parte septentrional, hasta la punta de la peninsula de California,y meridionalmente hasta Guayaquil, se hallan tambien aun en la zona cálida, pero en la region mas templada. Las especies de pólipos de aquel punto tienen casi todas el caracter de las del Pacifico, y son completamente distintas de las de las In. dias occidentales; las pocas que hay se limitan a un reducido número de géneros, lo cual puede explicarse por la natura. leza y direccion de las corrientes occanicas a lo largo de la costa occidental de América, que hacen retroceder las líneas de la temperatura constante del mar, tanto desde el norte como desde el sur, a mucha distancin hácia el Ecuador, y que tanto por su temperatura baja, como por su direccion, rolviendo hácir el oeste, contienen é impiden la emigracion de especies de la parte central del Pacifico hácia el Panama.

Aunque las rocas de las Indias Occidentales se encuentran dentro de la zona mas cálida, son sin embargo muy pobres en géneros ý especies, en proporcion a las del centro

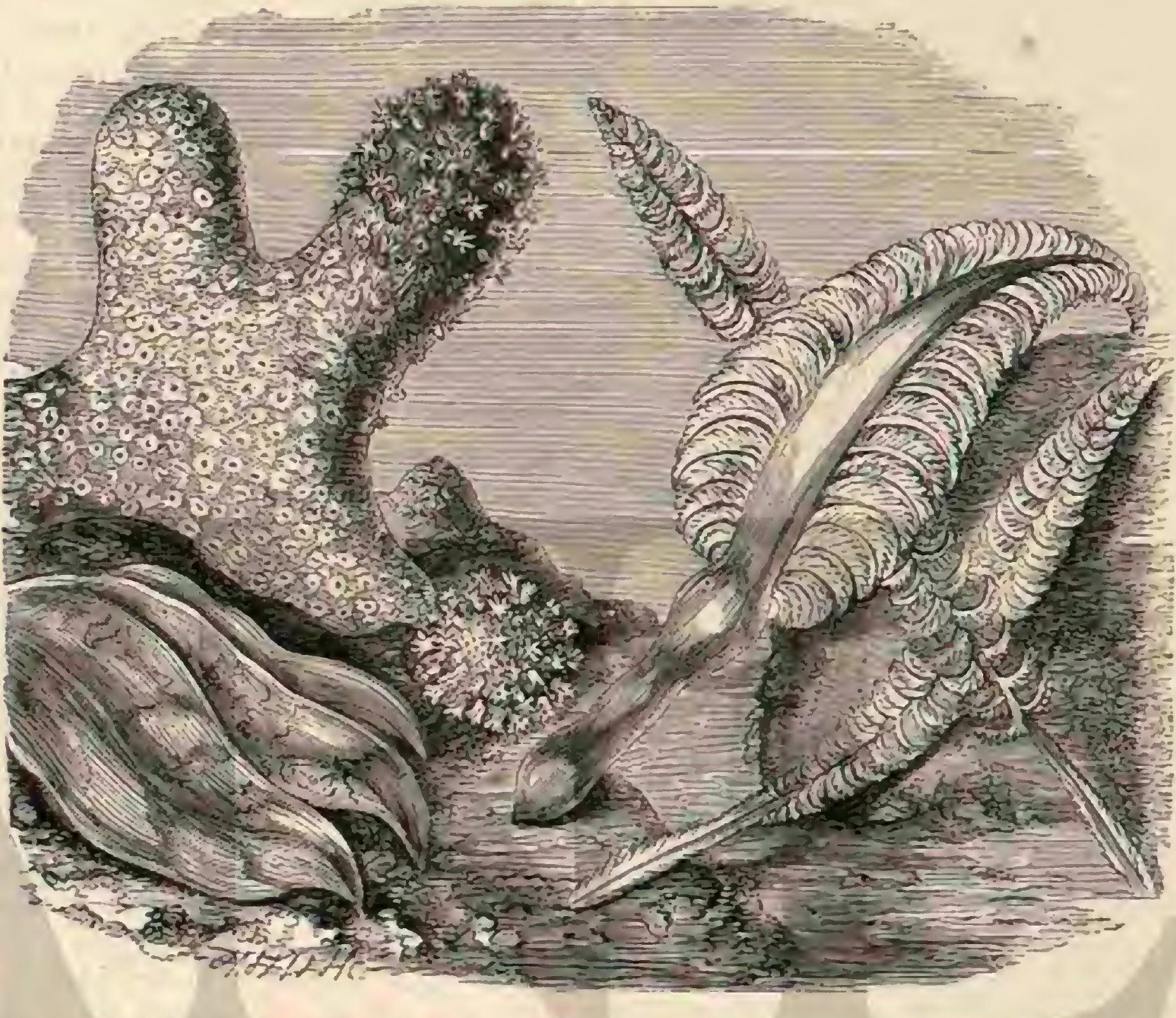

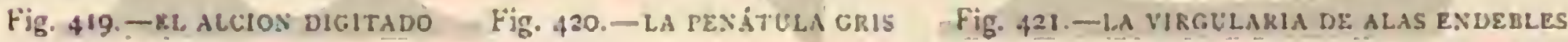

del Pacifico. Encuentranse alli algunas grandes madréporas como por ejemplo la madrepora palmata que se extiende en una superficie de dos metros; y además la madrefora ceri: cornis de forma de árbol que llega á una altura de mas de cuatro metros. Entre los pocos astreos los meandrinos son los mas notables. Atendidas las recientes observaciones del profesor Veryll, parece extraño que ninguna especie de coral de las Indias Occidentales exista en la costa de Panama, y en general se observa que ninguna de las especies citadas se encuentra en el Pacífico 6 en el Occéano Indico. Tambien de la comparacion de las especies de otras clases, resulta que la formacion del Istmo de Panamá produjo un aislamiento, y que desde entonces la transformacion de las especiess se verificó de un modo independiente.

Las islas Bermudas situadas mas hácia el Norte, pero en Ia region del Gulfstream, han recibido sus pocos corales de las Indias Occidentales. Tambien los corales de la costa brasileña al Sur del cabo Koc, se parecen en su gran conjunto á los de las Indias Occidentales, aunque falten los géneros especialmente caracteristicos, como in madrepora, macandrira, oculina y otros.

Cuando Rainoldo Forster y su hijo Jorge, descubricron hace cien anos con Cook lns ishs de coral del mar Austral, opinóse respecto à su origen que los pequeños séres cons. tructores de rocas y de islas subian con sus troncos de in. mensas profundidades, poco a poco, hasta la superficie del agua, y que por lo tanto las mismas especies encontraban sus condiciones vitales en las inas diferentes profundidades. Hemos reconocido con seguridad, por los últimos descubrimientos respecto al fondo del mar, que tainbien los precipicios mas profundos a que pueden llegar aun los aparatos, es decir, profundidades de una legua geograifica, albergan algunas especies de animales de las mas diversas clasc's, y en muchas regiones de los Oć́anos hasta muy numerosas. Pero los séres que habitan en tales profundidades, se han amoldado à las condiciones particulares de aqquellas, al enorme aumento en la presion, al cambio de luz y calor, y á los diversos gases; de modo que no pueden existir mas arriba. El número de los pólipos propios de las profundidades, es en general muy reducido; entre ellos no se halla ninguna es. pecie que á mayor profundidad construya arrecifes, y menos axin se observa que tales construcciones en el transcurso de los siglos lleguen por fin a ser rocas $\delta$ islas visibles.

Ios naturalistas franceses Quoy y' Gaymard que acompañaron la expedicion del almirante d' Urville al mar Austral, supusieron que el limite inferior en que habitan los corales 
se alcinza á las cinco 6 seis brazas ó sea de diez à doce metros, suposicion que fue confirmada por Ehrenberg, segun sus averiguaciones en el mar Rojo. Sin embargo, las mediciones segums en el mar Austral demostraron que aun a una profundidad de 20 brazas se verifica un abundante desarrollo de corales. Darwin observó en los arrecifes de Mauricio, á dicha profundidad, madréporas y astreas, y en compañia de otro naturalista encontró corales vivos linsta este limite en dife. rentes rocis del nar Austral. Tambien las noticias de Ehren. berg se ampliaron, descubriéndose en el mar Rojo depósitos de corales vivos a una profundidad de 25 brazas. Pourtalés, por fin, determina la profundidad en que los corales viven en las rocas de Florida con quince brazas. De este modo to. dos los naturalistas modernos, tambien Dana, que hizo preciosos deścúbrimientos, están conformes en gue los cora. les viros, constructores de arrecifes, solo se encueritran á una profundidad relatimmente reducich y dentro de \%onas de limitada altura. En todas partes donde se sonclea a mas profundidad, arrancando con el ancla ó con la red pedazos del suelo de coral, hállanse restos de éste ó troncos muertos imas ó menos conservados, cubientos de arena. Una de las causas de esta reducida distribucion en la profundidad, es sin duda la temperatura, que influse mucho en tal distribu. cion de todos los séres vivos; sobre todo en el Océano. Sin embargo, no es posible que esta sea la única calsa. Segun ya hemos dicho, un calor de $2 .+$ a 18 gracios comviene para la prosperidad de la mayor parte de los corales que forman arrecifes; y á pesar de esto, la remperatura del agua á cien piés de profundidad en la parte central del Pacifico excede por lo regular de $1 S^{\circ}$ Reamur:

Ocupémonos ahora de las causas locales de que depende el desarrollo de los corales en cuestion. Sobre todo necesitan un agua pura de mar, y prosperan mejor en los anchos canales interiores cntre las rocas, en las grandes lagunas y en el agua poco profunda. Es por lo tanto del todo falso, como en general se pretende, que en los canales y lagunas solo crezcan corales pequeños; esto no se refiere sino a los camales y lagunas estrechos y a las partes de los canales anclios situa dos delante de la desembocadura de las corrientes de agua dulce. No cabe duda que ciertas esprecies necesitan la alta mar; pero al examinar las condicionés especiales ó los pólipos recogidos por fuera, en el lado donde rocan las olas, nos convencemos de que falta número para formar una lista de tales especies. Para hacer deducciones de los numerosos astreas,-meandrinos, pórites y madréporas arrojadas por las olas á la parte cxterior de las rocas, estos géneros tienen sobrados representantes en la pleamar. En las islas de Pomatú se encuentran algunos troncos de pórites de dos á dos y me. dio metros de diámetro.

Algunas especies del mismo género crecen en la parte superior de las rocas, y son varias las que tambien se cricuen. tran à grandes profundidades. Numerosos astreas, meandri. nos y madréporas, habitan en el lado exterior de las rocas expuestas al mas furioso embate de las olas. Aqui se encuen. tran tambien numerosos miléporos y algunos pórites y poci. Inparos. Los montiporos, empero, mas delicados, excepto las especies que se incrustan, habitan en el agua tranquila. Las citadas especies crecen igualmente en aguas poco profundas, por dentro de las rocas, donde no son escasas las astreas, meandrinos y pociloporos aunque exigen un agua pura. Al. gunas especies de madrẹporas, lo mismo que ciertos pórites, no prosperan en el agua sucia; los últimos crecen en algunas partes a varios centimetros sobre el nivel del agua, donde estàn expuestos al sol $y$ a la lluvia. En los pórites que prosperan en el agua turbia de las costas, la influencia de los de. pósitos arrastrados por las olas desde tierra firme es tan grande, que los troncos de coral solo se extienden horizontalmente, mientras las partes superiores quedan destruidas por los depósitos flotantes. Por regla general se observa que los corales no prosperan alli donde los rios ó riachuelos llevan en sus aguas objetos extranos. Por esto encontramos solo pocos pólipos en las costas arenosas ó cenagosas.

En las lagunas que el mar no provee de agua fresca suficiente y que por la fuerte evaporacion llegan á ser demasiado saladas no se encuentrair tampoco corales. Por último, el calor excesiro del agua de las lagunas puede producir la muerte de los pólipos.

Haeckel nos habló ya de la increible abundancia de formas vivas que se fijan encima $y$ dentro de los troncos de co. ral destruyéndoles esencialmente; pero tambien contribuyen por su parte a la construccion de los arrecifes en cuanto segregan partes duras. Cosas análogas refiere L. Agassiz, fundado en sus exploraciones en las rocas de la Florida: un sin númera de esns animales que perforan se fijan en las partes misertas de los troncos, abren por dentro galerias en todas direcciones y destruyen su sólido enlace con el suclo, penetrando tambien hasta la capa interior que contiene los pólipos viros. Estos numerosos animales perforadores pertenecen ¿ muy diferentes clases. Unos de los mas activos son, además del dátil de mar (Vithodomsus), varias savicaras y pedricolas, arcas'y numerosos anélidos, entre los que las sérpulas son los mas grandes y peligrosos, pues perforan regularmente las porriones vivas de los troncos, sobre todo en las madreporas. En la parte inferior libre de un meandrino de unos sesenta y seis centímetros de diaimetro, Agassiz contó 50 ca. vidades del dátil de mar, prescindiendo de centenares de agrujeritos de anélidos; pero todas cstas destrucciones no son nada en comparacion á las causadas por las vioas, de que hablaremos al describir las esponjas. Darwin refiere lo siguiente en su excelente obra sobre la construccion y distribucion de las rocas de coral, al hablar del Keeling-Atoll: a Fu la cara exterior del arrecife debe formarse un gran depósito de materia de coral por la actividad de las olas en los frag. mentos movedizos, pero $\mathrm{en}$ las aguas tranquilas de las lagunas ésto solo puede efectuarse en un grado reducido. Aqui, sin embargo, se observa la actividad de otras inesperadas potencias; grandes bandadas de dos especies de peces llamadas de papagayo, de las que la una habita las olas fuera de la roca, y la otra las lagunas, se alimentan exclusivamente de los troncos de pólipos. Abri varios de estos peces que son muy numerosos y de considerable tamaño, y encontré sus intestinos dilatados por pedacitos de coral y una materia caliza molida. Esta la deben segregar diariamente como excrementos, que llegan à formar un depósito finísimo.

Tambien las holoturias se alimentan de corales vivos, y la particular formacion ósea en el interior de la parte anterior de su cuerpo parece adaptada al cfecto. El número de las especies de holoturias y el de los individuos que vagan por cada uno de estos arrecifes de coral es muy considerable, pues sabemos que se enviar todos los años muchos cargamentos de trefang a la China, esjecie que pertenece al género en cuestion. La multitud de corales que todos los años son devorados por estos séres, y probablemente por otras muchas especiés, que los trasforman en el cieno mas fino, debe ser inmensa. Estos hechos tienen, sin embargo, major importancin bajo otro punto de vista, porque nos demuestran que para el desarrollo de las rocas de coral existen obstículos vivos, y que la ley casi general de ecomer y ser comidos se aplica aun à los troncos de pólipos que forman estos sólidos parapetos, capaces de resistir al empuje del Océano.

Por otro lado, en los corales vivos penetran anélidos y ciertos cirripedos (por ejemplo cremia), sin hacerles dano. 
Se fijan al salir del estado de larva en la superficic del tronco, y quedan encerrados por los pólipos á medida que estos se desarrollan poco á poco, sin desfigurarle ni entorpecer su cre. cimiento. Muchas sérpulas crecen igualmente con el trunco, y su tubo llega entonces á mucha profundidad en la mole de coral, ofreciendo un aspecio magnifico cuando despliegan sus brånquias en medio de los cálices de los pólipos.

Dana ha dedicado en su obra un capitulo especial a las observaciones sobre el crecimiento de los corales, es decir, sobre las condiciones del desarrollo de las especies, no de las rocas, que dependen de otras circunstancias del todo distintas y complicadas. Ya en $1 \$_{30}$, cierto doctor, Allen, hizo experimentos en este sentidio en la costa de Madagascar. En diciembre rompió cierto número de pedazos de coral, plantándolos en un banco profundo, a un metro de la superficie de la marea baja. Llegado el mes de julio, vió que casi alcanzaban á la su. perficie, y que se habian arraigado del todo en el suelo. El aserto de que cn cl golfo de Persia la plaucha de cobre de un buque se cubrió durante veinte meses de una costra de pólipos, de unos $0=, 66$ de grueso, ha sido puesto en duda por Darwin. Segun otro dato, parece que en una ostra de dos años se encontró un fúrigido de $I^{\prime} 25$. kilóstamos de peso; pero desgraciadamente no se sabe si la ostra vivia 6 si el coral habia tenido tiempo de crecer en la concha muerta.

Weiland vió en un pequeira bahia poco profunda, en Haiti, varias ramas de la madrepora cericornis que sobresalian unos $11^{\circ "}, 07$ a $11^{\circ}$, I2 de la superficie. Los pólipos habian muerto en todas las partes expuestas al aire. Lsto fué en julio, y como en invierno el agua de aquella costa tiene de uno i dos metros mas de altura que en verano, queda justificada la suposicion de que el tronco de pólipos crece en los tres meses de invierno de $11^{\prime \prime}, 07$ á $0^{n}, 12$. Otras observaciones seguras de diversos naturalistas dieron por resultado que un tronco del meandrino laberintico habia alcanzado en 20 años $0^{\circ}, 30$ de diámetro por $1^{m}$, 10 de altura. No nos fijaremos en otras varias noticias, limitandonos solo is dar cuenta de las muy interesantes observaciones sobre la incristacion de un buque que en 1792 se hundió en la costa ame. ricana, y cuyo casco se examinó en 1857 . A una profundidad de cuatro brazas, observóse que una madrépora habia alcanzado en los 64 años una aliura de cinco metros, creciendo de consiguiente por térnino medio sobre 1)" oS cada año, mientras que unos troncos muy gruesos que se habian fijado al lado presentaban un desarrollo relativamente mas lento. Todas estas noticias tienen su origen en observaciones ocasionales, y tambien respecto á los otros pólipos, lo mismo que á muchos animales vertcbrados y la mayor parte de los animales superiores, faltan experimentos sistentiticos.

Ocupémonos ahora del tema verdadero de este capitulo.

Los arrecifes y las islas de coral son formaciones de la misma clase, pero que existen bajo condiciones diferentes. Una isla de coral ha sido en todas circunstancias por algun tiempo un arrecife, y lo es todavía en una gran parte. Sin cm. bargo, los nombres significan cosas diferentes. I as islas de coral son arrecifes situados aisladamente en el mar, y que ya solo llegan hasta la superficic del agua ó están cubiertos de vegetacion. Con el nombre de arrecifes de coral, usado en términos generales, se designan principalmente las formaciones de coral á lo largo de las costas de elevadas islas del continente.

Los arrecifes de coral, para empezar con estos, son por lo tanto bancos en el mar, situados a lo largo de las costas de los paises tropicales. En el Pacífico estas moles tienen á menudo la altura de montañas y afectan la forma de islas volcánicas, excepto en la Nueva Caledonia y algunas otras. Las rocas que los rodean están cubiertas por lo reguiar completamente de agua durante la marea alta, pero en la marea baja se ofrecen a la vista como una superficie pedregosa, ancha, plana y desmuda que apenas sobresale á flor de agua, destacandose de un modo singular de las escarpadas pendientes de las islas rodeadas por ellas.

Al acercarse con un buque a un arrecife de coral, durante la alta mares, la prinera señal es una linea de olas furiosas, que se extienden á menudo en un espacio de varias leguas de extension y á gran distancia de la tierra; al observar tales sitios mas de cerca se divisan algunos puntos del arrecife cuando casualmente una ola retrocede, pero un momento despues todo vuelve a quedar cubierto de agua. Es una fortuna para el buque que cruza las regiones desconocidas cubiertas de estos bancos, yue las furiosas olas indiquen continuanente la línea de los arrecifes de coml, pues à menudo reina una calma engatiosa que hace suponer que el agua es profunda, en cuyo caso la embarcacion avanza sin recelo, hasta que pronto sc arrastra sobre masas de coral; y luego chuca ti cortos intervalos y queda encallada algunos momentos despues en la roca. Cuando hay reflujo, las olas se tranquilizan a menudo del todo 6 casi totalnente; pero entonces se ve por lo regular todo el arrecife, y con buena vigilancia, viento fa. vorable y à la clara luz del dia, la navegacion ofrece relativimente pocos peligros.

Muchas de las islas rodeadas de arrecifes de coral tienen parajes formados por el cinturon de rocas, en cl que se abre una entrada. Mientras que en muchas islas solo hay una estrecha faja de bancos de coral, otras están rodeadas en gran parte ó del todo de semejante barrera qque proteje la tierra, como el muelle artificial de un puerto, contra la invasion del mar. Las rocas distan a veces de diez á quince leguas de la tierra y rodean á menudo no solamente una sino varias islas elevadas. En las fornaciones de tal circunferencia, de has mas complicadas hasta las mas sencillas, encuéntranse todos los tránsitos posibles.

El canal interior no es apenas, durnnte la marea baja, bastante profundo para los barcos, pero pueden quedar exhausto á veces tambien del todo. En otros casos solo forma un cs. trecho y laberintico pasaje en el que grandes moles de coral amenazan á los navegantes: y por último podrá tambien pre. sentar grandes espacios de agua libre en las que un buque puede avanzar contra el viento con una profundidad de diez, veinte y cuarenta brazas, aunque debe procederse con precaucion, porque hay varios parajes menos profundos. Varios grupos de corales vivos, desde una extension de pocos piés cuadrados hasta la de varias leguas inglesas cuadradadas, se hallan distribuidos en la ancha superficic dentro de las barreras muy avanzadas. Todas estas variadas formas pueden encontrarse en un solo grupo de islas, es decir, en las de Fidji.

Es natural que los arrecifes arriba descritos no constituyen todo el conjunto de corales, siendo solo las porciones que llegan hasta la superficie del agua. Yor enmedio de cllas, y por fuera de las rocas avanzadas, se encuentran bancos submarinos en relacion con las partes mas elevadas, y todos juntos constittien el fondo de arrecifes de coral cie una isla. Tambien resulta de lo dicho una gran variedad en la extensión de estos. En muchas costas tan solo se encuentran grupos diseminados de corales $\sigma$ algunas formaciones que sobresalen como colinas, ó bien solo puntos que se destacan de los arrecifes de coral. Otras veces, como por cjemplo al Oeste de las dos grandes islas de Fidji, hállase un espacio de poco mas ó menos tres mil leguas inglesas cuadradas, cuyo fondo está cubierto de coral. La roca de Bano Levú solo tiene mas de cien leguas inglesas de longitud. Ia Nue. va Caledonia presenta en toda su costa Occidenta], que 
mide 2'50 leguas inglesas, una roca que aun se continúa en el espacio de 150 mas hácia el Norte. Ia gran roca de Australia forma hasta una linea continua de 1,250 leguas de lon. gitud.

Al examiuar y describir mas minuciosamente las formaciones de coral, deben distinguirse, primero los arrecifes exteriores, construidos por corales que habitan la alta mar, á los cuales pertenecen todas las verdaderas rocas de terraplen y las de cintura, no protegidas por aquellas; segundo, los arrecifes interiores, que se encuentran en agua tranquila, entre un terraplen y la costa de una isla; tercero, canales 6 superficies marinas encerradas por rocas de terraplen que recogen los diferentes depósitos separndos de la costa ó de las rocas; $y$ cuarto, la playa y sus formaciones, es decir, aglomeraciones de arena y de corales en las costas, producidas por las olas y el viento. La descripcion mas minuciosa de estos detalles seria, sin embargo, demasiado larga, y debemos limitarnos por lo tanto al la citada obra de Dana. Sin embargo, intercalaremos aqui lo que este naturalista ha dicho sobre la utilidad de los arrecifes de coral. Todas las costas rodeadas de corales, y sobre todo las de las islas situadas en medio del Océano, tienen grandes ventajias con sus arrecifes de coral; pues los extensos bancosy los canales encerrados por ellos ensanchan de un modo extraordinario su territorio. Sin contar que for-

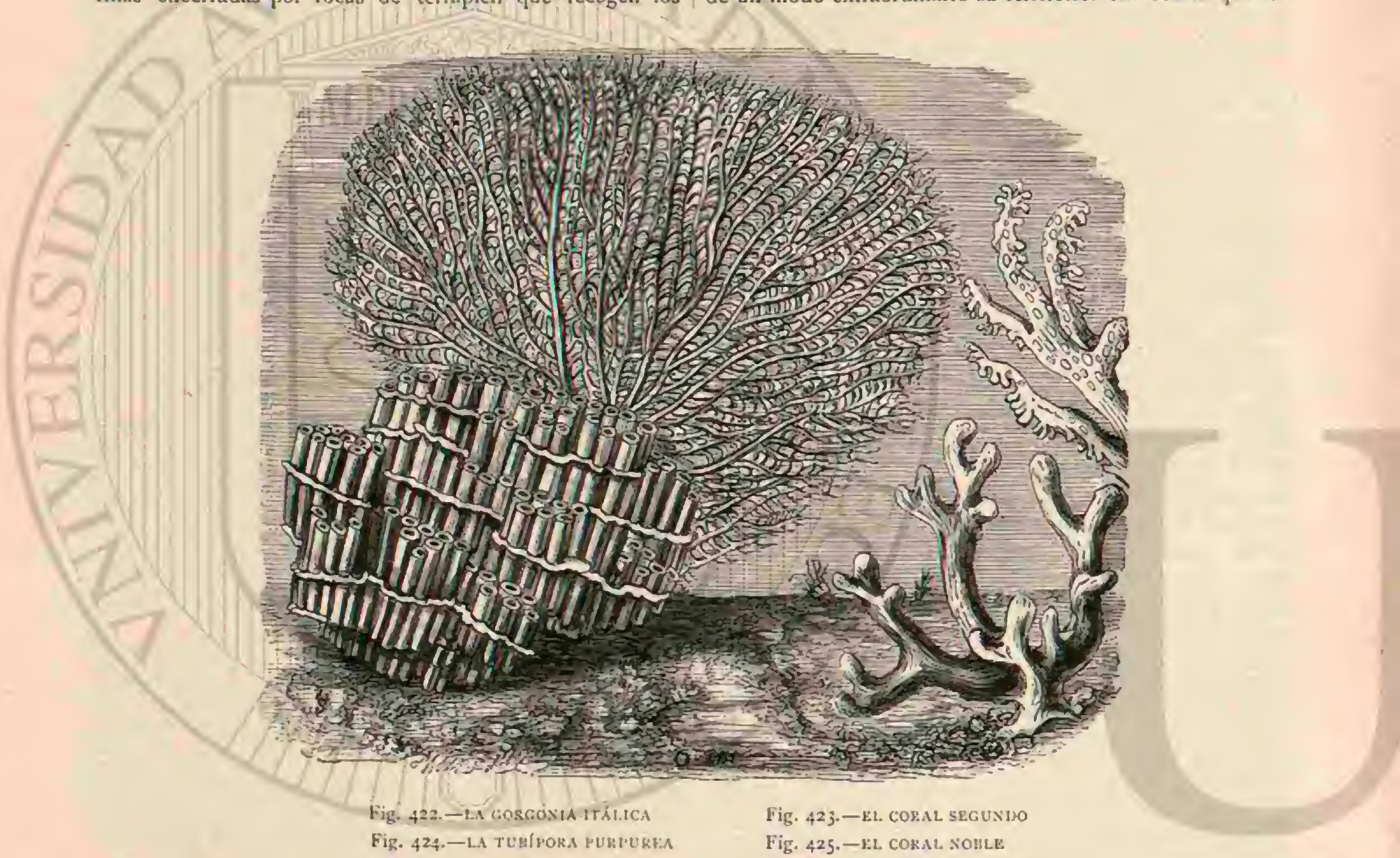

man verdaderas murallas para contener al Océano, sirven al mismo tiempo para recoger la ticra caida con la lluvia de costas montanosas; y obligan a las aguas que bajan de la tierra at depositar el cieno que llevan, conservandole en el territorio. De este modo impiden la destruccion que se opera en todas las costas desprovistas de tales terraplenes, pues el Océano no solamente roba de las costas abiertas, sino que absorbe tambien todo cuanto le llevan los rios. El Delta de Rewa de Viti Leví, formado por los depósitos de un gran rio, cubre una extension de casi sezenta leguas inglesas cuadradas. Ciertamente que esto es un caso extremo en el mar Austral, donde solo pocas islas llegan á tal circunferencin, $y$ por lo tanto escasean tambien los rios tan grandes; pero sera dificil encontrar una isla rodeada de arrecifes de coral quenose haya agrandado en una ú otra parte por efecto de ellos. En estos terrenos aluviales suelen estar situados los pueblos de los indigenas. Algunas llanuras que se extienden alrededor de Tahiti llegan á tener hasta de media legua à tres de ancho, $y$ precisamente en ellas es donde prosperan mejor los bosques de cocoteros y otros árboles.

Los arrecifes ensanchan tambien los puntos de pesca de los indigenas, atrayendo abundantes peces que constituyen el alimento casi exclusivo de aquellos. Las aguas encerradas por los corales son favorables para la mavegacion y facilitan las comunicaciones entre las colomias. Tos indigenas suelen ser tambien por esto muy emprendedores, porque tales circunstancias favorecen la construccion de grandes barcos de vela en los que pueden salir de su propio pais y emprender à menudo viajes a centemares de leguas de distancia. Mientras que las costas puramente pedregosas, como las de Santa Helena, suelen carecer de puertos y estar escasamente pobla. das, las de coral se hallan cubiertas de vegetacion hasta la playa y sus vastas llanuras están pobladas de las mas diversas plantas tropicales. Por las mismas causas se abren puer: tos seguros; muchas islas cuentan una docena, mientras que las costas desprovistas de corales apenas tienen un solo puerto bueno. Hasta para el comercio universal son farorables acyuellas vastas regiones de arrecifes: ademais de las perlas proporcionan el trefang, aquellos holoturidos comestibles de los que miles de quintales se importan todos los años á China, de los arrecifes de coral de las Indias Orientales y de la Australia, y de los de las islas de Fidji.

Vista desde la cubierta de un buque, à cierta distancia, la isla de coral ofrece el aspecto de una seric de puntos oscu- 
ros que se destacan del horizonte; mas examinados éstos de cerca parecen penachos de palmeras, y además se ve como una linea verde, cortada algunas veces, que se corre a lo largo de la superficie del agua. Despues, cuando hemos llegado muy cerca, vemos extenderse á nuestra vista la laguna con su ver. de faja, formando el mas maravilloso conjunto que se pueda imaginar. Por fuera, a lo largo del arrecife de coral, rugen las olas furiosas: dentro de la blanca playa se ven las verdes espesuras y el lago encerrado con sus pequeños islotes. El color del agua de la laguna es á menudo del mismo azul del mar, i una profundidad de ro $i$ is brazas: pero en medio, alli donde el fondo arenoso y los corales suben hasta cerca de la superficic, se obscrvan tintes verdes y amarillos. El verde es delicado y parecido al de una manzana, del todo diferente de los tintes sucios que por lo regular se observan en las aguas poco profundas.

Aunque la faja de plantas rodea á veces toda la laguna, por lo regular está dividida por rocas de diversa extension en islotes nislados. A menudo se encuentran en uno $\delta$ en varios de estos intervalos canales navegables que permiten la entrada en la laguna. 1235 grandes islas de coral suelen formar de este modo una serie de islotes á lo largo de una linea de rocas. Histas islas de laguna se han designado con el nombre de atolones.

Por lo que toca i la construccion de las mismas se parece esencialmente á las de los arrecifes exteriores que rodean las islas elevadas. En ambos casos remos poco à poco clevarse la tierra y pasar la playa blanca á los puntos mas alios cu. biertos de un verde cterno; la laguna cs por lo tanto análoga á los canales rodeados por los arrecifes de coral exteriores.

Aunque solo superficialmente hemos conocido las condiciones exteriores efectivas de los arrecifes de coral y de los atolones, podremos entrar ahora en el exámen de su forma. cion y de las causas que á ista contribuyen.

En su descripcion del mar Rojo, Hacckel ha hablado del esplendor de los jardines de coral. Dana, que con préerencin se refiere á las rocas del mar Austral, dice que las palabras de plantacion de coral y campo de coral son mas convenientes, porque encierran el sentido de una superficie de roca de coral en desarrollo. Lit plantacion de coral tiene el mismo aspecto que un terreno no cultirado cubierto aqul de diferentes arbustos, mientras que alli solo se ven superficies arenosas $E$ incultas, con unas manchitas verdes. Aqui un grupo de arbolitos, alli una alfombra de abigarradas nores. Varios animales crecen diseminados en la superficie, como plantas en la ticra; pero mientras que grandes territorios están cubiertos de ellos, otros no cuentan ninguno. En vez de verde cesped, numerosos fragmentos de corales muertos $y$ de rocas de coral llenan los intermlos entre los arbustos llorecientes, $y$ alli donde los pólipos no crecen reunidos en gran número, se encuentran profundas cavidades entre los ironcos $y$ las rocas pedregosas.

Estos campos de corales vivos se extienden en los paisajes submarinos, en las costas, islas y continentes, pero no á major profundidad de la que exigen sus particularidades, asi como las plantas no se extienden sino hasta donde conviene a su naturaleza. Las larvas viras se fjan en cualquier rincon oculto, en una roca, en troncos de corales nuertos 6 en otra base. Desde alli se eleva el árbol ó cualquier otra forma de la vegetacion coralina. La comparacion con el desarrollo de las plantas puede llevarse aun mas allà. Segun se sabe, los escombros y los desperdicios del bosque, las hojas y los troncos y tambien restos de animales contribuyen a la formacion del suelo, $y$ en los pantanos y hornagueras la aglo. meracion de tales restos se aumenta sin cesar y se forman profundas capas de turba. Muy parecida es la historia del desarrollo de los campos de coral; de continuo se aglomeran grandes y pequeños framentos arenosos de los pólipos que viven en las rocas, de los moluscos y en general restos de organismos, y de este modo se forma y se consolida una ca. pa de ruinas de coral. Estos escombros llenan los intervalos entre los sirios poblados de corales y los puntos vacios, entre los troncos vivos $\delta$ aislados, formando de este modo el dep $\delta$ sito pedregoso hasta que por fin la capa se ha consolidado hasta por debajo del agua. A esta manera de construirse y desarrollarse el coral se adaptan con la major exactitud las condiciones del desarrollo de los pólipos: podria decirse, por el contrario, que el desarrollo de aquel depende del crecimiento particular de los poliperos. Estos mueren por su parte inferior, mientras que crecen por la superior, y solo las partes muertas se cubren de las aglomeraciones de los restos. En el trasporte de esos restos, el trabajo de las corrientes y de las olas toma la parte mas activin. Hemos visto que los pólipos constructores de arrecifes prosperan en medio de las olas, y raras veces bajan á una profundidad major de treinta metros, profundidad donde aun están al alcance del movimiento mas activo del mar. Las grandes rocas arrojadas por las olas en muchas costas a la playa, demuestran la mucha fuerza de aquellas, que impelen tambien grandes fragmentos contra los arrecifes y por encima de los mismos, llenando los canales y las lagunas, ó cubriendo la superficic de los arrecifes. Las rocas de coral muerto que forman la base del ar. recife estan rodeadas de corales viros, que se extienden en el borde, tanto por el desarrollo de los animales, como por los restos que de continuo se depositan.

Pero además de los fragmentos pequeños, las olas mas fuertes arrojan grandes masas sobre el arrecife, y de este modo empieza la elevacion del mismo sobre el nivel, formando aquellos fragmentos la base de una ticrra firme. Mas tarde - los islotes se completan y elévanse sobre el agua á la altura á que llegan las olas, es decir, ì tres metros, cuando la diferencia del fujo y refujo es de uno, y a cinco $\delta$ seis cuando esta diferencia es de dos metros á dos y medio.

De este modo el Océano es el arquitecto al que los animales de coral ofrecen el material para la construccion, y, cuando todo está hecho, disemina en la tierra simientes de lejanas regiones y la cubre de verdura y de flores. I a formacion de los atolones apenas difiere de la de los arrecifes.

Tenemos que hacer mencion aun de algunas causas que modifican la forma y el desarrollo de las construcciones de coral. Por lo general la existencia de puertos en los arrecifes y atolones puede reducirse á la actividad del flujo ó de las corrientes oceánicas locales. Fstos y otros inovimientos del agua arrastran muclios restos de coral, y cl suclo donde esto sucede es verdaderamente perjudicial à la prosperidad de los pólipos. La actividad de las corrientes marinas aumenta á menudo por la de las aguas de la isla, de suerte que con mucha frecuencia los puertos se encuentran en la desembocadura de los valles con sus pequeños riachuelos ó corrientes. I a influencia del agua culce en la vida de los pólipos no es tan grande como regularmente se supone. Mayor qquizás es la infuencia del suclo submarino y de su naturaleza. Alli donde hay hendiduras y grietas que pasan por debajo del nivel con. veniente a los pólijos, es imposibje que se fijen los corales, asi como tampoco alli donde un foncio sólido alterna con arena y cieno. Todas las irregularidades del contorno de los arrecifes y atolones, todas las formaciones de puertos en las islas de coral encuentran de este modo su sencilla explicacion.

El punto mas importante que nos resta explicar se refiere a las causas de la formacion de los arrecifes en figura de dique 6 de atolon de las islas de coral. Esta era la pregunta que 
a primera vista se dirigian los viajeros, los cuales se inclina. ron â veces ì suponer un instinto que enseña da esos séres a dar á las construcciones la forma que opone mayor resisten. cia a la fuerza de las olas. Segun otra teoria, las construccio. nes de coral ocupaban las cimas de los volcanes, cuyo cráter correspondia à la laguma, mientras que las entradas por los arrecifes indicaban los puutos donde el circulo del cráter esta. ba destruido por las irrupciones de la lava. Hace algunos decenios que Danvin ha demostrado la inexactitud de esta supo sicion, que parece muy admisible á primera vista; y en cuanto a la hipótesis de que las cimas de las montañas no volcrinicas eran la base de las colonias de coral, se refuta tambien por las mismas demostraciones de Darwin. Este fue el primero que por un método científico estudió las diferentes clases de construcciones de coral, y comparandolas unas con oiras desarrolló su idea sobre su origen, ateniendose a los liechos. Este metodo rige aun hoy dia, y se confirmó en todos sus puntos esenciales por Dana.

En un mapa grande de las islas Fidji-podremos recordar la situacion de los islotes Gilande, Goro, Ango, Nairai y Nanutu. Observaremos que el arrecife de Goro se oprime estrechamente contra la tierra, sobre cuya costa está basado. El arrecife de la segunda isla es de la nisima naturaleza, pero separase un poco de la costa y forma una especic de dique. En el último de los llamados islotes el dique encierra una gran extension del mar, no siendo la isla otra cosa sino la cumbre de una montana pedregosa rodeada por el mar y por el arrecite de coral como por dos anillos. La suposicion de Darwin nos explica la diferencia en la situacion de los di. ques. Cuando, por ejemplo, la isla de Ango se sumergia len. taimente, la interior desaparecia poco á poco, mientras que el arrecile, que siempre crece hicia arriba, se mantenia a ia superficic. Cuando esta depresion llega a tal graco que solo queda fuera del agua la úlima cima de la nontaña, se forma sin duda un islote como Nanutu. Tambien nos da una idea del grado intermedio de tales depresiones una parte de las islas Fidji, las llamadas isias de la Exploracion. Segun esta suposicion, un arrecife quie rodea en ancho circulo una roca aislada, se debe formar por la depresion lenta de una isla rodeada anteriormente de un arrecife sencillo.

Es un hecho conocido que grandes extensiones de tierra, como la Suecia y Groenlandia, van bajando; pero directamente tambien pucde probarse que los arrecifes con sus islas han sufrido una depresion. La profundidad de los arrecifes debe calcularse muchas veces cuando menos en 300 metros. Como la parte viva de los corales no baja á mas de is ó 20 brazas, la profundidad de 300 metros hasta la que se extien. den los arrecifes solo puede explicarse por una lenta depre. sion del suelo en que se hallan. Naturalmente los arrecifes una vez formados pueden volver á elevarse fuera del nivel del agua, conociéndose algunos arrecifes de roo metros de altura. Reconócese una depresion anterior tan luego como su altura excede de la profundidad regular a que se hallan los corales vivos. La suposicion de que muchas formaciones de arrecifes son la consecuencia de sencillas depresiones parece por lo tanto del todo justificada. A la teoria de Darwin se ha hecho la objecion de que no explicaba la circunstancia de que se formaban canales interiores, mientras qué al contrario debia esperarse que su espacio en la lenta depresion se llenaria del material de los arrecifes. Los canales detras de los diques son una consecuencia de la depresion; y al buscar las causas de este fenómeno se nos ofrecen varias explicaciones, las cuales convienen de tal manera con los hechos observados, que la existencia de los pasajes interiores se ha de reconocer como una particularidad en extremo necesaria de las construccio. nes de coral.
Hemos podido demostrar que el mar toma una parte activa en la construccion de los arreciles; los exteriores, que participan de sus movimientos y recogen su agua pura, crecen mas rápidamente que los interiores donde influyen las corrientes marinas y de agua dulce, con los restos y dejósitos que ilevan consigo. Además, tan pronto como el arrecife en forma de dique se ha separado, cúbrese en ambos bordes de corales vivos y crecientes, mientras que el arrecife en forma de faja solo crece lateralmente. Tambien una gran parte de los restos de los arrecifes exteriores se deposita en ellos nismos, mientras que una considerable porcion del material de los arrecifes interiores contribuye à llenar los anchos canales. En todo caso, esta contribucion por parte de los arrecifes interiores es relativamente mayor que la de los que ticnen forma de dique. La extension de los arrecifes dentro del dique es a menudo 50 veces mas grande que la superficic de este mismo. En tales proporciones del desarrollo el dique puede crecer con una rapidez dos veces mayor que la de los arrecifes interiores. Estos últimos bajan en ciertas circunstancias con mas rapidez que la de su crecimiento, y necesariamente desaparecen por fin. De estas y otras observaciones resulta que un arrecife en forma de dique senala poco masó menos los limites desaparecidos de la tierra rodenda.

Apenas necesitanios decir que la depresion que dió origen al arrecife en forma de dique, mas tarde seria la causa de la formacion de una isla de laguna. Cuando despues de un pe. ríodo de depresion durante el cual el arrecife ó el atolon sc mantenia poco mas ó menos al nivel del agua, se presenta un periodo en que la rapidez de la depresion disminuye $\delta$ cesa del todo, debe formarse una tierra seca y preseniarse la vegetacion, estrechándose entonces mas y mas la laguna; y vice-versa, cuando la depresion se hace mas rápida, cl atolon puede desaparecer poco á poco bajo la superficie del agua. Darwin ha descrito una serie de tales construcciones de coral que están hundiéndose, yo á las cuales llama «arrecifes muertos».

En vista de los hechos citados, dice Dana al terminar su instructivo capitulo sobre la formacion de los arrecifes $y$ ato. lones, es claro que toda isla de coral fuć en otro tiempo una faja de arrecifes al rededor de una elevada isla; de la faja resultó un dique cuando la isla se hundió, y' siguió creciendo cuando la tierra desapareció poco á poco. Por encima de la superficie encerrada se cleva por fin la última cima de la montaña, $y$ algun tiempo despues esta tambien ha desapare cido: solo el dique queda como testigo de la isla hundida. La faja de coral que en otra época, como adorno y parapeto, rodeaba la is!a, mas tarde convirtióse en monumento y único recuerdo de su existencia pasada. El archipiélago de Yoma. tú es un gran cementerio de islas, donde cada atolon indica d sepulcro de una de ellas.

En todo el Océano del Sur se hallan tambien disemindos estos sencillos monumentos, los mas brillantes puntos en ese desicrto de agua.

La existencia de las construcciones de coral depende, segun vemos, de una reunion de condiciones favorables. No se encuentran en la costa occidental de América quicas porque la corriente del mar Polar enfria demasiado toda la region de ln costa. Solo con la isla de Ducie empiera la grande region de coral del Pacifico, que al sur del Ecuador se cx. tiende hasta la costa oriental de la Nueva Holanda, mientras que al norte alcanza su major desarrollo en el archipiélago de las Carolinas. Ricos en arrecifes de coral son los alrededores de las Marianas y Filipinas; mas al O. son no. tables las Maldivas y las Laquediras, los numerosos arrecifes al rededor de Mauricio y Madagascar, y los que se hallan desde la extremidad norte del canal de Mozambique hasta 
el mar Rojo. La costa occidental del Africa no presenta arrecifes notables. En el Nuevo Mundo, por úttimo, el mar de las Antillas, desde Martinica y las Barbadas liasta da punta de Yucatan, la costa de Florida y hasta las Bahamas, son teatro de la silenciosa pero eficaz actividad de los animales de coral.

\section{LAS ESPONJAS-SPONGIA}

El que por primera vez examine una coleccion de esponjas secas 6 conservadas en espiritu de vino no solamente dudará de la naturaleza animal de estos organismos tan diferentes, sino que, juzgando por la impresion mas comun, los clasificará en el reino vegetal. Sin embargo, como las esponjas se hallan en el Museo zoológico, nuestro naturalista quizás pensará que, vivas y observadias en su residencia acos. tumbrada, producen otro efecto $y$ demuestran su caricter animal. Busquemos por lo tanto las esponjas en su vida libre. Solo se hallan en el agua, escaseando mucho en la dulce, en la que no están representadas sino por el género spongilla. En el fondo de muchas aguas, en las columnas de los puentes de madera, encuentranse en verano masas verdosas 6 grises, ramificadas ó redondeadas, del tamaño de un puño $\delta$ de una cabeza, de sustancia blanda y hasta viscosa, que á la simple vista no presentan el mas minimo indicio de la facultad de moverse; sécanse rápidamente por el sol, y aunque conservan en lo esencial su forma, redúcense sin dificultad á polvo. El microscopio demuestra que este polvo se compone en su mayor parte de finas agujas siliceas de dos puntas, pero entonces no sabemos mas que antes. Dirijámonos por lo tanto al mar, donde las esponjas existen en abundancia. Conduciré al lector á algunos puntos del Adriảico y a las islas Jónicas. Cerca de Lesina, ciudad de la isla de igual nombre, está situado en una roca, á orillas del mar, un convento que muchas veces he visitado como huésped. Las rompientes se descubren durante el reflujo, de modo que pueden visitarse para recoger los productos del mar. En ciertos puntos de una extension de ro à 20 metros cundrados están cubiertas de una costra de color blanquizco que fácil mente puede extraerse en pedazos. Está compuesta de cuer. pos de forma irregular que solo demuestran vida cuando en el agua se mezclan con sustancias coloradas. En estas se notan entonces corrientes que salen de las grandes aberturas de los cuerpos-blancos, $y$ que $\sin$ duda deben su origen at cualquier aparato en el interior de estos cuerpos que son esponjas calcáreas. Todas estas esponjas son duras $y$ ásperas al tacto, ó cuando son de una naturaleza mas blanda pre. sentan, por lo menos, una superficie áspera y espinosa. Con un anteojo de poco aumento se reconoce que están llenas de cuerpos espinosos 6 de forma de estrella. Por su aspecto general parecen mas bien plantas q̨ue animales; hasta carecen de los callices y flores que, cuando menos, descubren la vida de los pólipos.

Continuemos sin embargo nuestro viaje y entremos en Argóstoli, en Cefalonia. En el lado de la ciudad, es decir, á la derecha, enirando por detrás del puente, donde la ense. nada se estrecha, $y$ en un pantano salobre, encontramos un espacio de la orilla que desde la superficie del agua hasta pocos piés de profundidad ostenta magnificos colores rojos y azules. Ias formaciones que ofrecen este bonito aspecto extráense fácilmente en pedazos de un tamaño bastante considerable. Tambien en cllas podemos reconocer las corrien tes por un medio empleado en las esponjas calcáreas. En estado seco los pedazos que entonces pierden sus bellos colores presentan una espesa red de agujas siliceas microscópi- cas, que, cuando menos, revelan que estas formaciones son afines de las esponjillas de agua dulce. Pero tambien observamos que para reconocer la verdadera naturaleza de estos organismos no basta el conocimiento de su forma exterior, siempre irregular, y la comparacion con otros séres vivos. Exceptuando algunos naturalistas antiguos, ingleses é italianos, y el profesor Erlangen Esper, los zoólogos se olvidaban casi ifel tuco cie las esponjas, hasta qque en r $85^{6}$ Lieberkuln descubrió mas detalladamente la estructura de nuestra es. ponjilla y algunos años mas tarde la de algunas esponjas marinas. Posteriormente un naturalista inglés, Bowerank, fijó su atencion en la increible variedad de formas de las partes duras, siliceas y calcáreas de las esponjas. Tambien yo me ocupe de este estudio, recunociendo que las esponjas eran de suma importancia para la doctrina de la descenden. cia, porque en ellas se puede observar y estudiarse la tras. formacion de las especies, demostraindose que estas trasformaciones se explican por las partes microscópicas de las esponjas. Desde que Haeckel escribió en $18 ; 2$ su admirable monografia de las esponjas calcíreas, se ha reconocido generalmente que el estudio de estos organismos es en alto grado importante y de gran interés.

De nuestras averiguaciones resultó quue las esponjas son de carácter esencialmente animal; la cuestion era saber si ocu. paban una posicion intermedia entre los verdaderos animales y las plantas, ó si se elevaban á la altura de los celenteratos. Hacckel es de la última opinion, fundándose con preferencia en la historia del desarrollo de las esponjas calcáreas: pero la cuestion es muy dificil y complicada, $y$ no se ha resuelto tampoco por los últimos estudios de F. C. Schulze y Barois.

¿En qué se reconoce, pues, una esponja? se preguntanc con impaciencia. Estudiarcmos las particularidades de su cuerpo en el esçueleto de una esponja de lavar, conocida de todo el mundo. Designamos como esqueleto las partes fibrosas, que se distinguen por una gran elasticidad, y que se han formado del llamado protoplasma. Este se encuentra en estado vivo entre las mallas del esqueleto de la esponja, y cubre la superficie exterior en forma de una red, que á la simple vista parece una membrana negra. El microscopio nos demuestra que entre las mallas gruesas hay siempre otrns mas finas y claras, que sufren una trasformacion continua, aunque lenta. Los hilos del protoplasma pueden ser mas delgados 6 mas gruesos, $y$ la sustancia se halla en un continuo movimiento, conservando la forma de red en toda la superficie de la esponja; de modo que esta recibe el agua por un sinnúmero de pequenisimos poros que de continuo cambian de forma y tamaño. Añadiendo á esta una sustancia colorante se notan las córrientes microscópicas. Por debajo, la superficic variable ofrece un sistema de canales, cuyas paredes están provistas de una capa de celdas con pestañas, que son las que produ. cen aquellas corrientes; las canales, muy finas en la superlicie, se ramifican y ensanchan sucesivamente, y descmbocan por fin en las cavidades que en nuestra esponja ordinária se abren en los agujeros grandes, que á menudo tienen la forma de una chimenea. El agua introducida por los poros es arro. jada con bastanite fuerza por las chimeneas is óculos, consti. 
tuyendo este sistema de vasos del agua, que interviene en la allinentacion, el aparato mas característico para la clase de las esponjas.

Muchas esponjas solo tienen un óculo; todos deben igua. larse a un individuo, y por consiguiente, las esponjas con muchos óculos son troncos compuestos, de lo cual resulta, como es natural, la comparacion con los pólipos. Asi, por cjemplo, la axinella polipoidea del Mediterráneo se parece mucho mas a un polipero que á una esponja. Los óculos presentan una estructurn radiada y se hallan en ligeras depre. siones. Como por lo regular cuentan ocho radios y la esponja viva es de un bonito color pardo amarillo ó amarillo de azu. ire, distinguiéndose por tener un eje mas sólido, la compa. racion con un pólipo de ocho radios parece tanto mas natural.

Sin embargo, no puedo considerar esta analogia como ontogenética en el sentido qque indica Darwin. Fn las esponjas secas, á menudo es difícil, ó imposible, encontrar el número y- la posicion de los óculos; en muchas esponjas éstos no se desarrollan, 6 vuelven á cerrarse, y el agua sale por poros microscópicos. Esta es una de las variantes die los caractéres propios de toda la clase de las esponjas.

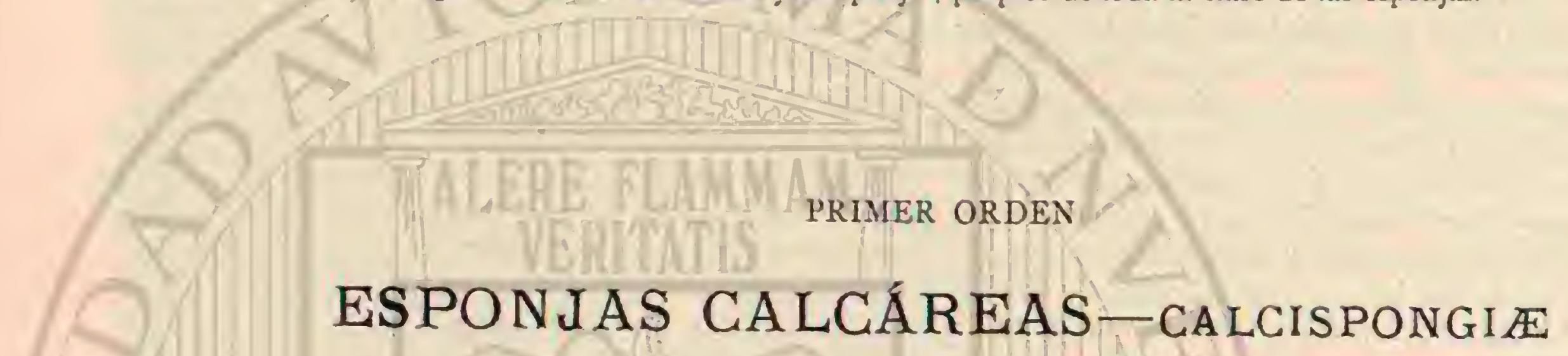

Esta division toma su nombre de la cualidad de que todas las especies segregan formaciones calcáreas unicroscópicas \& que se reconocen a la simple vista, sirviendo el cuerpo como de una especie de esqueleto; tienen la forma de agujas, 6 bien de estrellas de tres y cuatro radios, y lleman la esponja, por lo regular en tal número, que aun estando seca, consérvinse la forma y la circunferencia en la misma, ofreciendo la mayor parte de las esponjas calcáreas cn vida, y despues de muertas, un aspecto semejante al de la creta ó del yeso.

- Entre todas las esponjas las calcireas parecen ser las mas variables. Haeckel, en su historia natural de los calcispóngidos, ha demostrado irrefutablemente que las 1 i i especies conocidas por él en todos los continentes, en rigor no merecen esta catcgoria, pues aunque en ciertos sitios adquieren caractéres particulares, estan reunidas por una infinidad de tránsitos. Las esponjas son el ejemplo mas evidente de la variabilidad de la especie. Sin embargo, Hacckel ha logrado. formar tambien aqui algunas familias naturales en las que se nota un progreso desde lo sencillo hasta lo compuesto. Desgraciadamente solo conocemos el desarsollo de pocas especies. Cuando en el periodo de la madurez, que en nuestras regiones suele llegar en la primavera, se corta una esponja calcárea en pedacitos, salen las larvas y solo se ven con un aumento de 300 á 600 veces con el microscopio. Se componen de dos mitades del cuerpo de un aspecto muy diferente. La una formada de celdas casi cónicas, de las que cada cual tiene un largo liilo morible. Ia semi-esfera inferior que arrastra al nadar presenta grandes celdas redondeadas llenas de granitos. Con esta mitad inferior se fija la larva en un objeto sólido del mar, mientras que la otra, perdiendo los hilos, forma la capa exterior de la pequena costra. Al mismo tiempo se forman en el interior las. partes calcaireas que al. canzan muy rapidamente a la superficie. Solo entonces se forma una cavidad que al alargarse se abre hicia afuera en forma de b́culo. Lin el caso de que esta marcha del desar rollo fuera la general, las esponjas no podrian compararse, segun cree Haeckel, con los celenteratos, y en general con todos los animales en que el canal intestinal $\delta$ parte de mismo se desarrolla de la meinbrana embrionaria remangada. Tambien mis mas recientes observaciones hechas en Najoles indican en las esponjas csta posicion particular.

Hemos visto que la esponja queda formada tan luego como la caridad abdominal se presenta con su b́culo. Fin

rigor, ni siquicra necesita la grande abertura, pues el agua sale por los poros como ha entrado. Esta carencia de una desembocadura da lugar à una formacion, es decir, á una variedad muy frecuente en todas las esponjas y que ha contribuido esencialmente á concluir con las opiniones sistemáticas de la antigua escuela

Podemos ócuparnos ahora de las tres familias principales. Los ascones no pasan del grado de desarrollo otservado en la larva descrita: son cilindros sencillos ramificados, cerrados ¿ abiertos, de paredes delgadas, y á menudo tan clelicados que apenas se distinguen en el agua por un lustre blang̣ui\%. co; pero muy á menudo forman espesas masas del tamaño de una nuer, y hasta de un puino, y entonces naturalmente se reconocen como organismos biancos ó amarillentos. Asi, por ejemplo, la bonita ascetta clathrus se encuentra en abundancia cerca de Nápoles, en las grutas del Posilipo y de la isla Nisita En nuestros mares septentrionales la ascalfis botryoides examinada minuciosamente por Lieberkuhn es muy comun.

Los leucones comprenden las formas en las que las paredes de los canales irregularmente ramificados se vuelven mas gruesas, produciendo formas mas ó menos irregulares como tubérculos y bolas, y tambien botellas y copas. Entre las mas graciosas y grandes se encuenira la leucandrapenicillata de Groenlandia.

Los sicones son las estronjas calcireas mas bonitas y en su fornia mas desarrolladas. La forma principal del individuo es una capa prolongada $\delta$ un cilindro por lo regular pedunculado, cuyas gruesas paredes presentan circulos regulares de escotaduras que salen del grande óculo central. La des. embocadura es ya desnuda como en la leucandra ó provista de una corona de delgadas agujas.

Haechel, cuya monografia arriba citada formará en todos los ticmpos la base de nuestra ciencia, dice lo siguiente so. bre el género de vida de las esponjas calcírtas:

rTodos los calcispóngidos viren en el mar; ninguna for. ma de estos grupos se ha encontrado en el agua duice ó salobre. Lin el Báltico, que tanto escasea de sal, no se conoce hasta ahora ninguna esponja calcárea y parece, por lo tanto, que estos espóngilos solo pueden vivir en agua marina cuyo contenido en sal sea el propio del Océano. En el agua dulce o agua de mar enrarecida mueren muj pronto. Fodos los calcispóngidos hasta ahora conocidos se han recogido ya en 
la costa, ya a poca distancia de la misma, mientras que en lo mas profundo del mar, de donde se han sacado espronjas siliceas muy raras, ni uno solo de aquellos se ha encontrado.

- La mayor parte de los calcispóngidos prefieren la oscuridad y huyen la luz, encontríndose muy pocas especies en los sitios mas 6 menos expuestos á la claridad. Por esto las especies que con preferencin se fijan en las rocas y piedras, se encuentran por lo regular en las grietas $y$ hendiduras de la costa marina, y en la cara inferior de las piedras. Ia mayor parte de las especies viven entre las espesuras de las plantas marinas, y cuanto mas oscuras son éstas, con tanta mayor seguridad se encuentran los calcispóngidos ocultos entre su ramaje. Esta predileccion à la oscuridad es la causa de que muchas esponjas calcáreas se fijen en el interior de las conchas, cáscaras de erizos de mar, tubos de anéli. dos, etc. La gran mayoría de los calcispóngidos esta fija en cl suclo dcl inar, pero hay algunas pocas especies que aum en el estado del todo adulto no están idheridas al suclo; sino que se hallan en completa libertad entre el cieno, de donde las arrastran á veces las olas ó corrientes.

Haeckel cree deber llamar la atencion sobre la poca frecuencia de los calcispóngidos en todos los mares. No puedo conformarme del todo con este aserto, pues aunque son inferiores en nimero a las esponjas siliceas, hay en las costas italianas y francesas del Mediterráneo masas increibles de calcispóngidos. No es, por lo tanto, de suponer qque escaseen o falten en la costa africana opuesta, aunque en las colecciones de Paris no se encuentran ejemplares procedentes de esta última region. Ia mayor parte de los calcispóngidos pertenecen á la zona de la playa hasta una profundidad de dos brazas; desde aqui hasta diez la disminucion es muy notable, $y$ fuera de este limite son muy raros.

Parece que ningun animal se alimenta de las partes blan. das de las esponjas calcireas y solo excepcionalmente se cncuentran parásitos en sus cavidades.

\section{SEGUNDO ORDEN}

\section{HEXACTINÉLIDOS-HEXACTINELLIDE}

La mayor parte de las esponjas designadas con este nombre se distinguen por asemejarse su esqueleto siliceo â un tejido de vidrio. Ya sean las formaciones siliceas aisladas ó solo estén reunidas por medio de ganchos ó apéndices y por el protoplasma pegajoso, ó bien formen tejidos mas artificinles que todos los productos humanos, la forma fundamental es siempre la estrella de eje del cubo. El cubo regular del agrimensor y del nuineralogista se determina por tres ejes iguales que se cruzan en ángulos rectos. Esta forma de cje constituye el carácter distintivo de ese bonito y notable grupo de esponjas. Son los descendientes inmediatos de los ventriculidos tan bien conservados en las capas de creta, sobre todo de Inglaterra. Estos fósiles suelen afectar la forma de copas, con las paredes reticuladas, ó regularmeme perforadas, mientras que en el suclo se fijaban por medio de apén. dices irregulares. En los cjemplares bien conservados las formaciones silicens pueden observarse con el microscopio tan perfectamente como en una esponja viva.

Los hexactimélidos actuales son, pues, descendientes de los ventriculidos; habitan casi exclusivamente las profundidindes del mar, por lo cual solo en los últimos tiempos se conocen en mayor variedad y con bastante igualdad en todas las profundidades oceainicas.

Hace mas de 40 años que el célebre viajero Siebold trajo los primeros hexactinelidos del Japon a Europa, y durante 30 años muchos excelentes naturalistas se han esforzado en vano por explicarse la naturaleza del maravilloso organismo. Hasta el gran Maximiliano Schultze confundió en su descripcion de la hyalonema, este es el nombre de la esponja, la extremidad anterior y posterior. La esponja se compone de un cuerpo macizo redondendo y de un largo mono que se fija en el cieno. Este mono se compone de agujas puntiagudas en ambas extremidades, circunvueltas una alrededor de otra, de modo que muy bien podian parecer un producto artificial, cuando por lo regular se venden en el Japon sin el cuerpo esponjoso $y$ atadins con un hilo como objetos de adorno. Ya hemos hablado de los pólipos inseparables de este moño: la coniusion de los naturalistas respecto á la byalonema es efecto sobre todo de esta particularidad. Las últimas dudas se resolvicron cuando la polithoa se reconoció como compañera constante tambien de otras esponjas.

Willamoes-Suhm, poco antes de su prematura muerte, escribio lo siguiente sobre la pesca de las hyalonemas, que constituyen un artículo comercial bastante importante en el Japon.

«La historia del descubrimiento de la hyalonema es bastante sabida: los japoneses conocieron esta esponja desde la antiguiedad, y cuando el pais se abrió à los europeos, dió principio la discusion sobre la naturaleza de este organismo, discusion que muchos lectores recordarán aun y que solo en 1860 terminó por el minucioso trabajo de Maximiliano Schultze. Cuando la expedicion prusiana á las órdenes del conde de Eulenburgo, y con ella Eduardo Martens, hubo llegado al Japon, este naturalista intentó en vano adquuirir ejemplares frescos, y solo obturo algunos individuos en at. cohol. Desde entonces el profesor Hilgendorf ha adquirido ejemplares frescos de hyalonema y tambien muchos otros animales que los pescadores de Enosima le conservaron en botellas de espiritu. Pero parece que antes de nuestra llegada los pescadores no accedian á llevar inteligentes a la pesca, de modo que hasta ahora no se sabe nada sobre la profundidad en que se cogen las hyalonemas.

- El Challenger pasó la mañana del I 2 de mayo al rededor del cabo, detrás del cual está situada la peņueña isla de Eno. sima, donde los pescadores, sacerdotes y propietarios de los establecimientos de té observan un géncro de vida muy semejante al que se describe en los idilios. Nos encontramos al S. O. á varias leguas de distancin de la isla y nos detenemos cerca de la primera barca de pescadores, cuyo conteni. do, compuesto de hyalonemas recien cogidas, de un cangrcjo gigantesco macrocheirus Kaemffferi, de varios tiburones, y de un macrurus halosantus y beryxt, fuć conducido a bordo. Es- 
tos cran los animales caracteristicos de la localidad. Un pescador que vino á bordo nos dijo que la gente de todos los barcos que estaban en los contornos pescaban los peces de has profundidades $y$ las hyalonenns, los primeros con un sencillo gancho y cebo, y las uiltimas con una larga cuerda provista en toda su longitud de muchos ganchos y de pesas, cuya cuerda arrastraban por el fondo del mar. Durante el dia que pasamos aquui cogieron muchos animales que nos trajeron al buque. Fute una suerte encontrar cstos barcos, pues sin ellos nunca habriamos sabido que nos hallábamos en el paraje donde habitan las hyalonemas. Asi como en las Filipinas, los sencillos aparatos de los indigenas eran mucho mas útiles que los nuestros en general, aunque sirvieron para darnos a conocer la fauna que se encuentra con-las tyalonemas. Ia profundidad que aqui encontramos era de 345 brazas.

Otro paraje muy frecuentado por las hyalonemas, pero de una esperie distinta de la japonesa, es Sctubal, en la costa portuguesa, donde los pescadores de tiburones las cogen a inenudo á una profundidad de 300 á 400 brazas.

Ia mas bonita de todas las esponjas es la cupleciella nspergillum, a causa de la maravillosa y delicada estructura de sus formas siliceas, que ya como largas agujas ó bien estrelitas microscópicas, constituyen la pared de un cilindro hueco ligeramente encorvado de tres ó cuatro centímetros de grueso por treinta a cuarenta de largo.

Tambien la parte superior del mismo está ccrrada por una tapa perforada parecida, que ha dado al animal el nombre de regacera:

La extremidad anterior suéle estar rodeada de circulos de crestas irregulares; la posterior, que esta fija en el cieno, se compone de una espesa capa de finas agujas elásticas. El tubo, del que fäcilmente se extraen las partes blandas, es de un blanco brillante, $y$ puede comprarse hoy dia por 30 ó 40 reales.

La regadera viene de las Filipinas, sobre todo de In isla de Cebú. Willamoes-Suhm dice lo siguiente sobre su área de dispersion y pesca:

(La regadera se pescó hace 70 años castralmente, pero solo un individuo, que en 18 1 llego a manos de Owen. Entonces se hicieron grandes ofertas por otros, y se compró un segundo á un precio muy crecido. Hace ocho ó diez años que eran todavia muy caras, hasta que los pescadores encon- traron cerca de la ciudad de Cebú un sitio donde la euplectela vive en grandes agrupaciones á una profundidad de 100 brazas en el cieno negruzco. Durante nuestra estancia en Cebú el buque se dirigió cierto dia al sitio de la pesca, pero mientras que los pescadores, con sus sencillos aparatos, sacabar gran número de estas esponjas, nosotros necesitibamos una de las grandes redes para arrancar las regaderas yulue sin duda están muy arraigadas en el cieno. Con la euplectela cogimos dos pentacrinos $y$ un gran erizo de mar blando, phormosoma hoplacanlhus, afine del genero asthenosoma de Gresbe, y que se distingue por tener grandes espinas con la punta en forma de maza. El lector recordará qque los hexac. tinélidos se encuentran con frecuencia en el agua profunda, y vermos con interés que aqui, en las Filipinas, la euplectela y en el Japon la hyalonewa, están acompranadas de un buen número de especies que por lo regular hahitan las grandes profundidades.s

Bastante à menudo la regadera está habitada por la aega spungiophila, y casi regularmente por una pareja de garnelas del género pulacmo\%. Estos animales penetran quizảs ya en estado de larra en la regadera, y pronto llegan á ser tan grances, que ya no pueden abandonar la posicion por sí mismos elegida. Esto explica que los habitantes de Cebú y Ma. nila consideren la esponja como una casa hecha por sus inyuilinos. En cierta ocasion hemos conocido otro crustáceo espongicolo, el typton spongicola.

Los hexactinćlidos actuales no son exclusivamente propios sin embargo, de los mares cálidos, sino que se diseminan en nuestra parte del Ecuador hasta las islas de Feroé. Aqui se recogió con la red la bonita holtenia Canpenteri, esponja que tiene la forma de una copa de boca ancha. Las paredes se componen de numerosas formas de agujas grandes y pequeias, y con el copete corto, se fija tambien esta especie en el fondo. Tos congéneres mas próximos de ella son las holte. nias de la costa de Florida.

Deben támbien mencionarse aqui las talasemas, espongiarios ásperos y nudosos en su parte exterior, de enorme ta. maño y de sustancia porosa y algo rigida. El talasema de Neptuno (fig. 426) es sin disputa una de las mas notables especies entre los espongiarios: no parece à primera vista una esponja, y si bien por su forma se asemeja algo a la laalicondria embudo, difiere por sus enormes dimensiones, que llaman la atencion de cuantos le examinan.

\section{UNT/

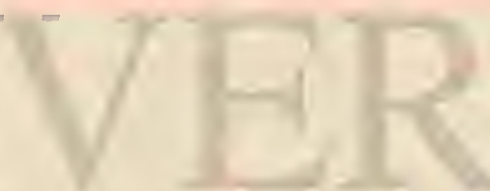 ANCORINÉLIDOS TERCER ORDEN A
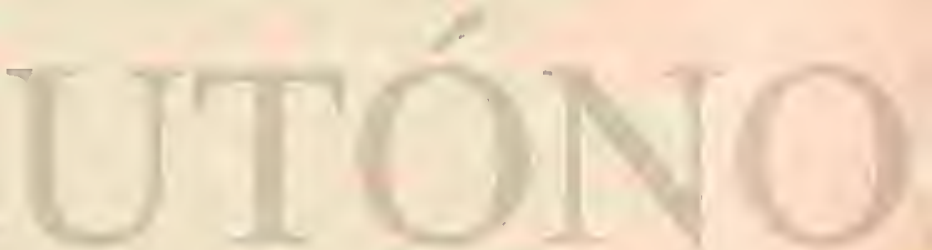 -ANCORINELLID仺}

Las agujas siliceas de este grupo afectan la forma de áncora, en la que por lo regular se distinguen con largo tallo y tres sencillos dientes corvos, a menudo tambien ahorquillado5. Diremos aqui que las formaciones siliceas de todas ias esponjas, incluso las agujas y estrellas de los calcispóngidos, estån cruzadas por un canal que se extiende á todos los ra. dios y ramas, y que en vida del individuo estł lieno de una sustancin orgásica, por medio de la cual crece el cuerpo duro longitudinalmente, mientras que aumenta el grueso por la deposicion de nuevas capas.

Con las áncoras que se presentan en las formas mas varia- das, reúnense regularmente agujas grandes ye pequeñas, ó tam. bien estrellitas, y en algunos géneros, sobre tado en la geodia, unas bolitas siliceas microscópicas de particular estructura. Estas bolas suelen formar una capa exterior á veces de un centimetro de grueso, de la que con frecuencia sobresalen numerosas ancoras. Un ejemplo de esta especie es la geodia gigante, muy comun en el Mediterraneo, cuyos cjemplares de un amarillo azufrado, se encuentran á mentido como cuerpos esféricos de $0^{*}, 25$ a $0^{*}, 55$.

Aunque las puntas de las geodias hieren sensiblemente la mano, su exämen es recomendable, porque en ellas viven 
varios crustáceos, nemertinos y anillados, y entre las puntas se encuentran séres inarinos microscópicos, sobre todo nume. rosos rizópodos vivos.

Una cuestion de gran interes cientifico es la del origen y afinidad de los ancorinélidos. Se conocen numerosos cuerpos siliceos ancoriformes de la llamada arena zerde y de la creta, de los que resulta que nuestros ancorinélidos cuentan gran antigüedad geológica. Sin duda deben reducirse à los litistidos.

\section{CUAR'TO ORDEN}

\section{HALICON DRIADOS - HALICHONDRIAD死}

Podemos designar todo el resto de las esponjas con el nombre comun de lialicondriados; pero es dificil decir á cual de los numerosos grupos pertenecientes a este órden corresponde la categoria superior ó la inferior. Ios halicondriados carnosos, coriaceos, córncos y siliceos existen con tanta des. esperacion de los sistemáticos, como satisfaccion de los par tidarios de la teoria de la descendencia, porque con los otros ordenes constituyen una clase de animales en que es de todo punto imposible determinar las especies, los géneros y familias.

- Las halicondrias propiamente dichas (figs. 427 a 430 ) son espongiarios friables que se caracterizan por no presentar un tejido córnco fibroso y estar provistos de espiculas siliceas. Todas las especies, muy numerosas por cierto, ofrecen gran variedad de formas; son cuerpos muy elàsticos, con la superficie cubierta de numerosos poros.

Las esponjas parecidas á la especie comun y que carecen de agujas siliceas se llaman esponjas córneas, pero la circuns. tancia de que muchas esponjitas que circulan en el comercio, y que pertenecen a este grupo, presentan numerosas agujas siliceas, demuestra cuain artificialcs son estos limites sistemáticos. Por otra parte, en la division de las calineas, que pertenecen á las esponjas siliceas, hay especies cuyo esqueleto córneo, sólido y bastante elástico, solo presenta muy cscasas agujas siliceas, cxistiendo de consiguiente entre las especies córnens y siliceas las mas intimas relaciones de afinidad. Entre las especies córneas, las diferentes clases de las esponjas de lavar, de las de caballo y de las que en las escuelas sirven para limpiar la pizarra, ocupan el primer lugar, á causa de su importancia mercantil. Se pueden agrupar en el género euspongia, pero no ha de pensarse en clasificarlas en verdaderas especies.

Todo el mundo sabe que la esponja de lavar debe tener la cunlidad de no romperse aunque esté del todo seca, de llenarse al momento de agua y de ser muy clástica. La red que empleamos como esponja es por lo tanto el esqueleto que queda despues de sacadas las partes pegajosas y liquidas. Para poder clasificarse en el género de euspongia, la especie debe, ante todo, poderse purgar de estas sustancias. Tales espónji. dos no se encuentran en la zona fria, y-sola aisladamente se hallan en la mitad septentrional de la templada; mientras que en el Mediterráneo y el en Adriático abundan varias clases. En la costa de Dalmacia se encuentra, además de la buena enspongia adriatica, otra mas pequeña del mismo género, que á causa de su epidermis brillante tiene el nombre distintivo de euspongia witens. Al comparar con esta esponja brillante, la de caballo, que con preferencia se recoge en la costa africana, se cree tener à la vista dos especies del todo diferentes; pero en Nápoles he reconocido que en sus costas se encuentran todos los grados, desde la esponja de caballo hasta la euspongin nilens. I'an la primera, la poca solidez de las fibras, el tejido menos espeso, la anchura, cavidades y óculos, son caracteristicos. Además, en las puntas de las fibras suele haber muchos mas cuerpos extraños que en las esponjas finas de lavar, de modo que, á pesar de que se gastan mas pronto, sirven nejor para la piel del caballo que para la del hombre.

De este modo me he convencido tambien de que las demás esponjas de lavar del Mediterráneo solo deben considerarse como especies ó clases locales. La clase mas fina, que se distingue por su blandura y por ser muy comun, la buscada forma de copa, se pesca en la costa de Siria. Mas plana y de un rejido mas espeso es la esponja griega de Zimolica, que como descendiente de ambas clases se ha extendido por todo el Adriatico.

Antes de exponer mis propias observaciones sobre la pesca de esponjas en la costa de Dalmacia, reproduciré una descripcion sobre el modo de practicarla en el mar griego y en la costa de Siria. A medindos de nuestro siglo, Iamiral, in. dividuo de la Sociedad francesa de Aclimatacion se dirigió a los citados centros de pesca con la intencion de recoger alli buenas esponjas sirias vivas, para trasplantarlas a las costas de Provenza.

En su descripcion de viaje y del projecto, que, dicho sea de jaso, no tuvo éxito; dice: $<\mathrm{El}$ barco está tripulado por cuatro pescadores y un ayudante: despues que el buzo ha rezado su oracion, se coloca en la proa, ya desnudo, con una red $\delta$ un saco al rededor del cuello, coge una piedra plana redondeada, sujeta por medio de una cuerda en el barco, y despues de respirar largamente se precipita en la profundidad en busca de su presa. El ayudante, que con el brazo extendido conduce la cuerda que sujeta la piedra y que taubien el buzo oprime en la mano, sigue todos los movimientos del mismo. A una serial dada le sacan à la superficie, donde necesita algunos momentos para recobrar el uso de sus sentidos. Los cuatro pescadores se sumergen alterna. tivamente, de modo que à cada uno le toca el turno una ó dos veces por hora.

y. Esta gente se pone en marcha al salir el sol, aun en ayumas, y no vuelve por lo regular antes de las dos ó las tres de la tarde. Cuando el tiempo es favorable, la profundidad mediana y el sitio bueno, cada buzo puede sacar de cinco á ocho esponjas. Los cuatro se entienden antes sobre la reparticion. El ayudante trabaja a jornal y al barco pertenece la tercera parte de la ganancia.s

En las costas de Dalmacia y de Istria, donde yo mismo presencié la pesca de esponjas, la gente se apodera de ellas sirviéndose de largas horquillas de cuatro dientes, parccidas al tridente de Neptuno. Solo los habitantes de la pequeña isla de Krapano se dedican á este oficio. Cada barco, cuya cubierta tiene un agujero cuadrado, va tripulado por dos 
hombres. El que maneja la horquilla se coloca en el agujero para poder balancear la parte superior del cuerpo, inclinado solbre el agua. El mango de la horquilla tiene de veinte á cuarenta piés de largo. El otro marino se ocupa en remar: mientras impele el barco lentamente sobre un fondo de doce á cuarenta piés, su compañero escudriña el agua con la vista, buscando las esponjas, que se conocen por su piel negra. El tiempo mas favorable es la completa calma, pero cuando el mar estí lijeramente agitado se hace uso del aceite para serenar un espacio de la superficie. $A$ este efecto hay siempre en la proa de la lancha un monton de piedra lisas, $y^{\prime}$ al lado un vaso con aceite: el pescador inmerge algunas de aquellas en el líquido del citado vaso, y las tira una por una formando un cemicirculo. El cfecto es milagroso: la fima capa de aceite que se extiende sobre varias brazas cuadradas, basta para tranquilizar las pequeñas olas, y ya no molestan la vista sus reflejos; pero tambien debe servirse el pescador de la horquilla para encontrar las esponjas en sus escondites. Despues de haber recojido cierto número de esponjas se se pisan y lavan en la orilla hasta que hayan desaparecido la epidermis negra y toda la sustancia contenida entre las fibras. Entonces basta limpiarlas con agua dulce templada para que pueden usarse perfectamente. Los pescadores sirios y griegos tratan sus esponjas finas del mismo modo.

Estas esponjas que tan limpias salen de las manos de los pescadores, se mezclan otra rez en los almacenes de los comerciantes artificialnsente con arena para hacerlas mas pesadas y para conseguir de este modo mayor ganancia.

Otro curioso género en el que figuran especies que ofre. cen un adnirable cjemplo de estructura en su mas alto

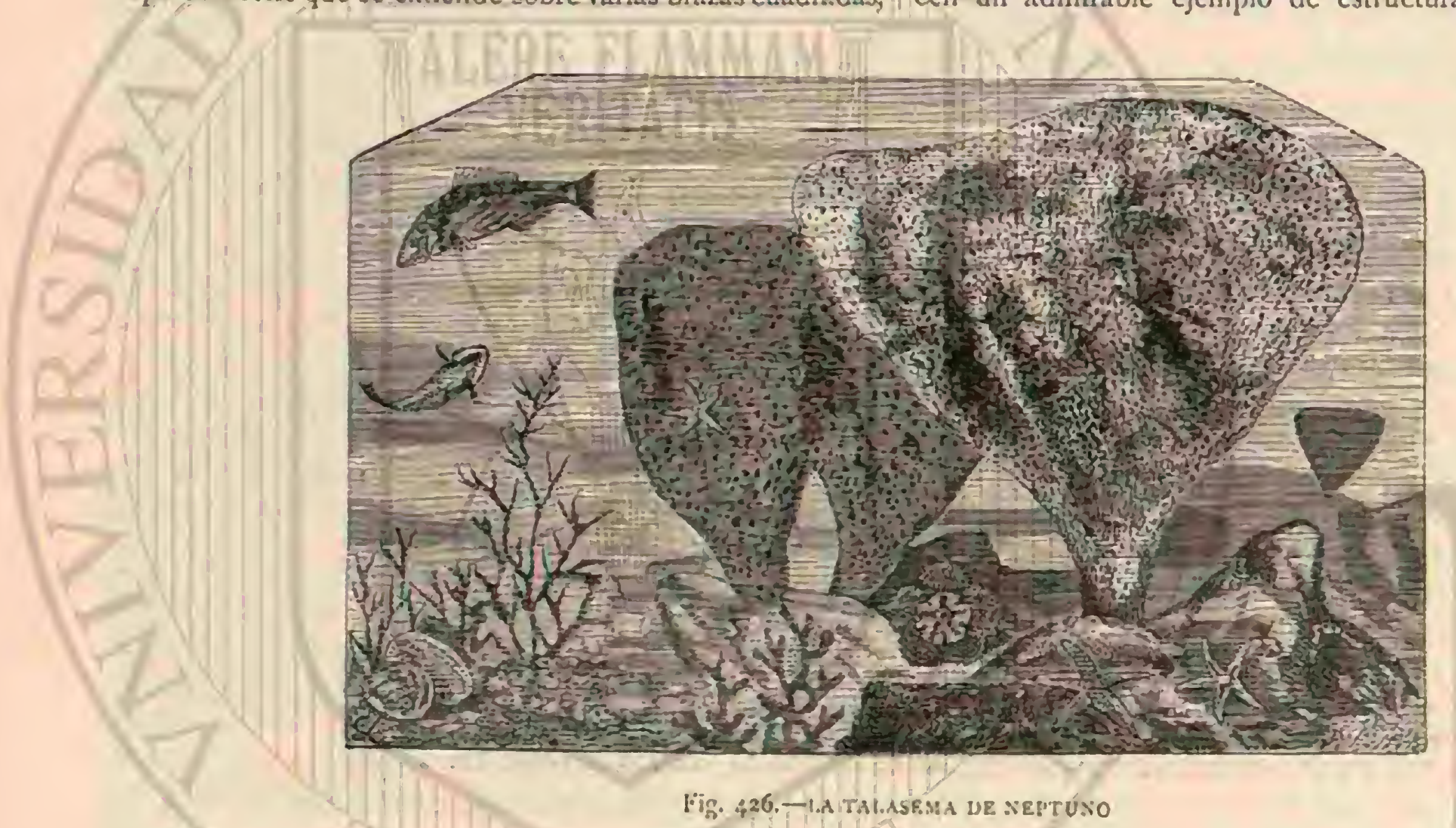

grado de desarrollo es el de los dactilocätix: Ia spongia pumicca, ó sea, el dáctilocálix pumiceo ó pómez (7ig. 432) ofrece como caractéres un armazori compuesto de espiculas confundidas entre si; no tiene la menor elasticidad, siendo por el contrario dura y rigida como una piedra, aunque porosa y ligera como el corcho; pero su atributo mas distintivo con. siste en estar formada enteramente de sicile. Esta esponja se encuentra muy particularmente en los mares de los paises cálidos.

Cuando al principio de mis estudios científicos dirigí mis miradas à la pesca de esponjaś en las aguas adriaticas, llamé la atencion de los pescadores y de las autoridades sobre la circunstancias de que la renta de la pesca podria aumentarse considerablemente por una regularizacion racional de la misma. Sin embargo, la sin razon de los pescadores ha hecho fracasar hasta aliora la aceptacion die mis observaciones. He buscado otro camino para aumentar la produccion en la cria artificial de esponjas. Los experimentos y empresas continuados en los años $\times 86_{3}$ á 1872 han sido favorecidos por el gobierno austriaco; $y$ por la Diputacion de la Bolsa de Trieste. Juagué de la naturaleza de estos organismos inferiores, en general, y de las observaciones hechas por algunos naturalistas, sobre todo por Lieberkuhn, que partiendo una esponja viva en pedazos convenientes y sumergiéndo éstos en sitios abrigados ! de fácil acceso en el mar, se arraigarian y se desarrollarian en nuevas esponjas completas. Este principio se ha contirmado, y despues de muchos errores prácticos, asociado con mi amigo y compañero, el gefe de telégrafos Buccich, en Lesina, tuve el gusto de presentar en la bonita ensenada de Socolizza una cría de 2,000 individuos. Ia condicion principal pam la prosperidad de la cria consiste en que los pedazos partidos no reciban luz directa, aun cuando se sumerjan á una profundidad de 20 ì 30 piés. Por sus hábiles procedimientos el señor Buccich consiguió que por fin solo se perdiera el I por ciento de los retoños artifi. ciales, y tudas las esponjas de nuestra colonia tenian un bonito color negro.

Dé este modo, la empresa en que tomaba interés el mun. do cientifico 5 mercantil, podia parecer tambien-asegurada para el porvenir, mas à pesar de eso ha fracasado. La natu. raleza y los hombres la combaticron: el primer enemigo fué el teredo, anélido que empezó á destruir toda la madera de las plantaciones, y despues los mismos habitantes de las costas y los pescadores de esponjas.

Al principio se burlaban de mi, pero cuando una vez invité à cuatro de ellos á observar por si mismos los resulta. dos, creyeron que se trataba de un hecho sobrenatural. A pesar de esto ninguno de los indigenas de Dalmacia ha hecho la mas minima tentativa para poner por obra una cria de esponjas. Al contrario, destruyeron y robaron nuestras plantaciones hasta que por fin mi fiel compañero Buccich se desanimó. La razon y la utilidad económica de una cria artificial de esponjas, no solo deberia fundarse en que la pérdida momentánea de una renta, puede muy resarcirse. 
con creces en el espacio de $3 \delta 4$ años, sino principalmente en la lenta regularizacion de esa renta con disminucion del trabajo y proteccion del producto natumal. El sistema de explotacion que siguen los pescadores de Thalmacia debe ocasionar poco a poco la ruina del oficio. Hasta ahora esa gente, muy poco instruida, sin comprender tales razones, sigue pescando sin inteligencia ni sistema racional, lo mismo que durante muchos siglos lo han hecho sus padres.

I a propagacion de la esponja de lavar por huevos y larvas se verifica segun mis observaciones en Nảpoles, por Marzo y Abril, y quuizas tambien mas tarde. En los alrededores de los canales se forman numerosos montones de embriones, pero no he podido observiar aun su desarrollo ulterior. E número de descendientes de una esponja de regular tamaño es extrnordinario. Si a pesar de eso los pescadores se quejan del mal resultado de su penoso oficio, y las esponjas se encarecen siempre mas, quedari demostrada la necesidad de imponer un periodo de reda. Ln las primeras semanas de la primavera empiezan los pescadores de esponjas sus expediciones de rapiña, destruyendo ano por año un sin número de millones de futura cria.

\section{LOS CONDROSIOS-CHONDROSIA}

CARACTERES.-La familia de las esponjas gomosas 6 coriácens se caracteriza por muchas particularidades. El tipo quue las representa, el género de los condrosios se fija en forma de reducidas masas irregulares provistas por lo regular de una sola desembocadura. Hay que reconocerles pues como a seres individuales. La superficic que aquellas ofre-

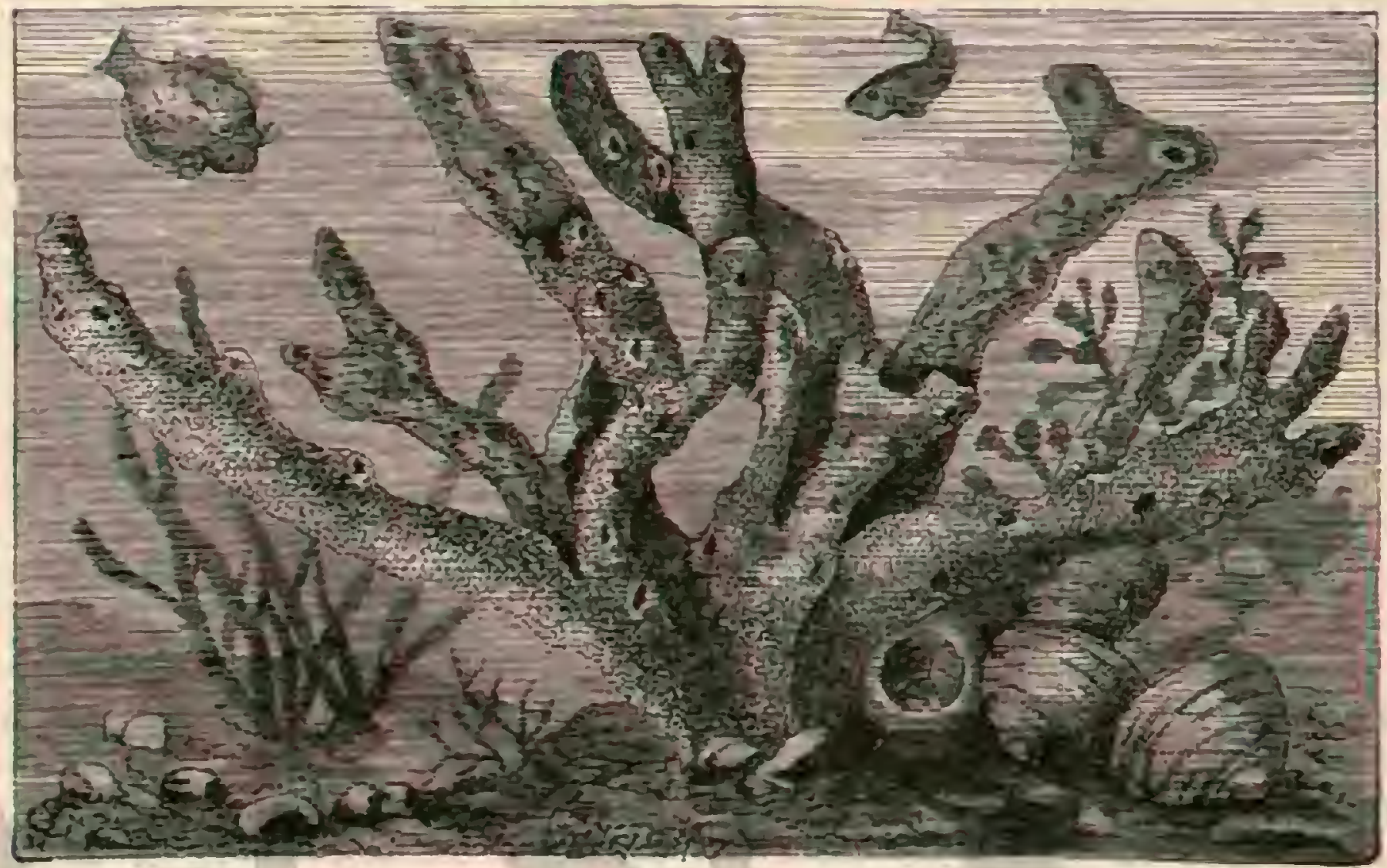

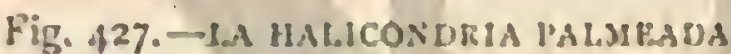

cen es en su parte superior escurridiza y de color oscuro, la inferior que se adhiere al objero que le sirve de base, de co. lor claro. Cuando se las extrae del agua se contraen de un modo extraño, fncultad propia en grado superior de otras esponjas, como por ejemplo de los bonitos limones marinos (lehyra). Por su aspecto los pescadores llaman à los condrocios carmine ó rogmone di marc, es decir, pescado ó riñon de mar. Mientras se mantienen en el agua son bastante duros, pero puestos al aire se secan, formando una masa tan sólida que puede ser comparada à cuero grueso. En este estado se les puede conservar muchos años, y despues de ponerlos en agua fresca adquieren el aspecto de ejemplares recien cogidos. En el agua dulce, en la que muchas esponjas se des. componen trascurridas algunas horas, los condrosios no se trasforman sino al cabo de muchos dias, nunque su actividad vital cesa en el acto.

He podido probar que estos condrosios están en relacion por medio de algunos géneros de consistericia menos com pacta, con el género halisarcia, compuesto de especies de naturaleza del todo blanda, casi mucosa, que puede considerarse como el tronco donde se origina el desarrollo de una rama tan principal del árbol de los espóngilos.

\section{LOS DESMACIDONES-DESMA- CIDON}

Entre las esponjas del actual periodo geológico que segre- gan cueppos fedregosos de us solo eje ocupan el primer lugar. Describiremos, pwes, por lo menos algunas de las formas mas numerosas de estos productos duros; y nos serviremos para ello del género de los desmaridones que, segun parecc, habita todos los mares. Trataremos de demostrar tambien en sus mas pequenos detalles la trasformacion de una de las llamadas especies à la otra, asi como el trinsito á géneros nuevos, segun quicre la ciencia sistemática. Hablamos mas arriba de la imposibilidad de separar los halicondrios verdaderos de los halicondrios pedregosos: entonces se trataba de formaciones pedregosas sencillas en figura de aguja. Estas formas no solo pueden deducirsc teóricimente una de otra, sino que en realidad pasan de individuo a individuo. Hay especies locales en que la mayor parte de los individuos of troncos solo poseen agujas sencillas y lisas. Con frecuencia se reciben troncos de otras localidades al efecto de examinarles, resultancio iguales en un todo a aquellos; pero pre. séntanse, entre las agujas lisas, algunas con prominencias nudosas. Un tercer grupo de los troncos tienc gran número de estas agujas nudosas. El naturalista sistemático que rinde culto a la antigua escuela se complace en extremo al poder consignar una nueva especic que sin embargo no existe; por que para que asi fuera, el circulo de las observaciones y los elementos en que aquellas se fundan han de ensancharse mucho: los caractéres de las especies se pierden en el trascurso del trabajo ó pasan $\{$ muevos supuestos caractéres.

Estos desmacidones que en punto à la trasformacion re- 
presentan un papel tan importante, no pueden absolutamente caracterizarse por su forma exterior ó por su semejanza con tantas otras esponjas. Se les encuentra como costras delgadas 6 gruesas, en forma de arbusto $\delta$ de árbol, y además se les observa como tubos y tubérculos.

Al redactar estas paiginas tenemos a la vista una de las sociedades de esponjas que con tanta frecuencia se encuentran. Ia base forma un tallo de alga ahorquillado, que descansa sobre una piedra. El tronco no ramificado tiene en el lado izquierdo una esponja con muchas ramas, cuya espacic no quiero determinar, pero que ocupa un lugar intermedio entre la clathria morisca, que se encuentra cerca de Argelia, y el género desuracidon. A la derecha, en la rama interior de la alga, he notado que se habin fijado una alga lobulosa cubier. ta del todo por un desinacidino de color marillo sucio.

\section{LAS VIOAS-VIOA}

El género mas nózable por su actividad, y; por lo mismo, mas importante, es el de las vioas. En este concepto es muy superior al de la esponja comun, pues si las vioas no hubieran deșarrollado su actividad desde los tiempos primitivos, las capas de cal y de creta de la costra de la tierra y las costras de los mares actuales, compuestas de estas piedras, tencrian una extension y forma del todo diferentes. Solo los foraminiferos, que conoceremos en el capitula siguiente, $y$ los pólipos, pueden compararse en su actividad constructora con la opuesta ó destructora cie las vioas. Una gran parte de la costa del Mediterráneo y del Adriático está formada de cal, que por su inslinacion a dividirse, da al paisaje de la costa un tipo cáracterisco a menudo tan interesante. In las costas escarpadas de Dalmacia pueden medirse con seguridad algunos miles de leguas de playa cubieria de guijarros grandes $y$ pequeños y de fragmentos de roca, siempre que lo permita la suavidad de las pendientes. Apenas puede leiantarse una de estos millares de piedras sin que se la encuentre mas ó menos perforada, a menudo en tal extremo, que los itstos de la piedra, por otra parte tan sólida, pueden reducirse a pedazos con la mano. Los agujeros, cuya estructura es dificil describir, se comunican entre si. A poca distancia de los Jugares citados se encuentran, ya piedras sueltas, ya la capa exterior de muchas rocas que, bajo la superficie del agua, es. tain tan agujereadas como las piedras descritas; pero esos agu. jeros están obstruidos aun por el destructor, una esponja amarillenta, la wioa celata, tan comun en muchas regiones. Cada agujero en la superficic de las piedras corresponde a un óculo: en estos agujeros la vioa, bien penetra solo superficialmentc, ó bien comienza a fijarse en el estado de alga, pero en ambos casos desarrolla su actividad cxcavando un hoyo, desde el cual avanza destruyendo en todas direcciones.

Tambien muchos conchiferos, por lo regular sedentarios, estan expuestos a la destruccion de las vioas, y esto ha sido siempre asi, segun lo demuestran los conchiferos fósiles. Segun el color, la forma de los agujeros $y$ las figuras de las agujas, pueden distinguirse numerosas formas de vioas, entre las que mencionaremos la irioa Johnstonii, que tambien se en. cuentra en las ostras, y sobre todo en el genero espóndilo, y se caracteriza ficilmente por su magnifico color carmesi. Sin embargo, los conchíferos, mientras viven, nunca son destruidos por las vioas de tal género. La capa de la concha que cubre el manto se encuenira siempre ilesa, y en general la destruccion en los conchiferos no es tan grande como en las piedras. Tal circunstancia está en relacion probablemente con la naturaleza particular de las conchas y con la existencia de una base organica que ofrece major resistencia à la fuerza destruc. tor?.
Esta observacion nos impulsa ì formular una pregunta: ¿cuail es el medio de que se sirven las vioas para perforar los objetos? Por lo pronto esto se atribuiri a las agujas pedrego. sas; pero luego se desistirá de considerarlas como órganos perforadores, teniendo en cuenta que tales instrumentos deberian moverse. Aunque el protoplasma ejecuta movimientos, y en las vioas como en muchas otras esponjas las agujas se colocan a menudo en una direccion determinada, esta fuerza, sin duda, no basta para corroer las rocas por medio de las puntas de las agujas. El modo con que se propaga la esponja demuestra, por el contrario, que se verifica una diso. lucion quimica, pero no sabenos nada de la naturaleza del liquido que ataca a la piedra. La importancia de las vious para la grande circulacion de la materia enferma, se funda en que las yiedras no se disgregan en pequenas particulas, sino que se disuelven como el azucar en un raso de agua, y se mezclan en este estado con el mar. De este se alimentan à su ver. los numerosos conchíferos, segregando del agua recngida y merclada con su sangre las partes compactas de sus conchas, que por fin tambien se disuelven ó se depositan en el fondo del mar, para contribuir à la formacion de nuevas capas terrestres.

\section{LOS ESPÓNGILOS-SPONGILLA}

Mientras que las esponjas han llegado en el mar a una variedad inagotable, en el agua dulce solo se encuentra un género, el de los espóngilos. Su área de dispersion es sin. embargo muy grande, pues sc extiende por el $\Lambda$ sia, Europa y. Arnérica; tambien se ha observado un múmero bastante crecido de especies microscópicas. Ia forma spongilla /luria. filis quie en estos paises se encuentra en las aguas estancadas Y corrientes, carece de color ó es verde; crece como tubérculo, incrustacion 6 rama en el fondo ó cubre las piedras y plantas acuńticas, con preferencia en la madera vieja $\delta$ en determinados sitios de los puentes. Las agujas microscópicas son buzos delgados, unidos en número de 'dos y de tres por las puntas y formando una masa que se endurece: de este modo constituyen una red sólida cuyas agujas fibrosas sobresalen un poco de la supercie de la esponja dindole un aspecto crizado, cuando se la tiene algunos minutos fuera del agua; pues entonces contrae todas sus partes blandas. Fintre los calicondrios marinos los renieros son los que mas se parecen á los cspóngilos. Debe creerse que los últimos descienden de aquellos, tanto mas, cuanto que los renieros son casi los únicos espóngilos que habitan tambien en el agua salobre.

Ya en $1 \$ 56$ Lieberkuhn, a cuya disposicion se lavilaba un abundante número de anjueilos sacadós de Spren, cerca de Berlin, observó minuciosamente la propagacion de los espóngilos por medio de larms libres. A esas larvas las llama espuelas errantes y dice: « Descubri las espuclas errarites por priniera vez, despues de haber dejado espóngilos durante algunas horas en un vaso con agua de rio. Se las reconoce ya á simple vista, pues llegan à alcanzar un tamaño casi de sesenta y seis milimetros de longitud por cinco de diametro. Son regularnente de forma oval, un poco mas puntiagudas en una extremidad, de manera que puede comparárselas à un huevo de gallina. Las formas mas pequenas no llegan ni a la mitad de este tamaio. En la major parte de los ejeu. plares pueden distinguirse sin instrumento alguno un espacio semi-esférico, claro como el agua, en la parte anterior del cuerpo y' un cspacio blanco como la nicve en la parte poste. rior. De la parte anterior se puede hablar: al nadar, la parte ligeramente prismática esta dirigida hảcia adelante, y la que tiene aq̧uella forma mas pronunciada haicia atrás. Ias espue- 
las nadan en las mas diferentes direcciones; temporalmente nadan en la superficic del agua, despues bajan i la profun. didad; se deslizan por cl fondo del vaso y vuelven a elevarse a las capas superiores del liquido; nadan en linea recta y á menudo giran sobre si mismas. Cuando dos individuos se encuentran nadan con frecuencia varios minutos uno al rede. dor del otro y luego vuclven ś scpararse: a menudo permanecen durante algun tiempo inmóviles y despues vuelven à repetir sus movimientos. Al tocarlas, si están paradas, nadan de nuevo.

xil desarrollo de las espuelas errantes se puede observar con mas facilidad del modo siguiente. Un número cualquie. ra de los animalitos se pone en una fuente de cristal llena de agua de lluvia. Pasados dos ó tres dias las larvas cesan de moverse y permanecen en el fondo del agua. Entonces se las distribuye en vasos mas jequeños 6 en platitos de vidrio en los quue se ha echado agua fresca de pozo. Dentro de unn ó mas dias se han adherido ya de tal modo il cristal, que, juntas con este, se les puede sumergirse en el raso ó fuente lleno de agua, sin que se desprendan. Solia renovar el agua cada vez que sacaba las larvas para observarlas, y de este modo se conservaban vivas por lo regular seis semanas, $y$ a veces por mas tiempo. En los espóngilos del Sprea encontré las espuelas desde principios de junio hasta fines de octubre a reces en numero de 100 y mas en un dia.
Lo que Lieberkuhn obscrvó respecto al tránsito de la larra errante al espóngilo sedentario, está conforme en sus rasgos esenciales, con lo que poco despues él mismo, y en los últimos anos tambien otros observadores, han visto en espón. gilos marinos. Tambien en el órden de los halicondrios la propagacion se verifica por medio de larvas errantes que, visibles a menudo a simple vista, se desarrollan en los canales de agua: están encerradas á veces en cámaras de cria, pero siempre, al llegar á la madurez, rompen los canales y se dirigen por una especie de tubo al agua libre. Son casi siempre de forma eliptica, $y^{\prime}$ al penetrar cru el agua libre están ya provistas de pestañas. Estas, en algunns de las especies observadas, desaparecen en la extremidad posterior, donde tambien puecie formarse una corona de pestañas largas. Los desmacidones que llegan a este estado segregan agujas en el interior del cuerpo. Despues la larva se fija en la extremidad superior, las pestanas desaparecen, se forma una cavidad corporal y mas tarde la grande abertura para los escrementos. Mientras solo existe esta abertura sabemos ya que debe considerarse al cuerpo esponjoso como à un individuo; cuando se forma una segunda abertura, puede decirse que se presenta una division del sistema vasal acuatico fundamentalmente importante; la esponja se ha trasformado en un tronco con dos individuos; esto explica cl origen de los troncos con muchos.

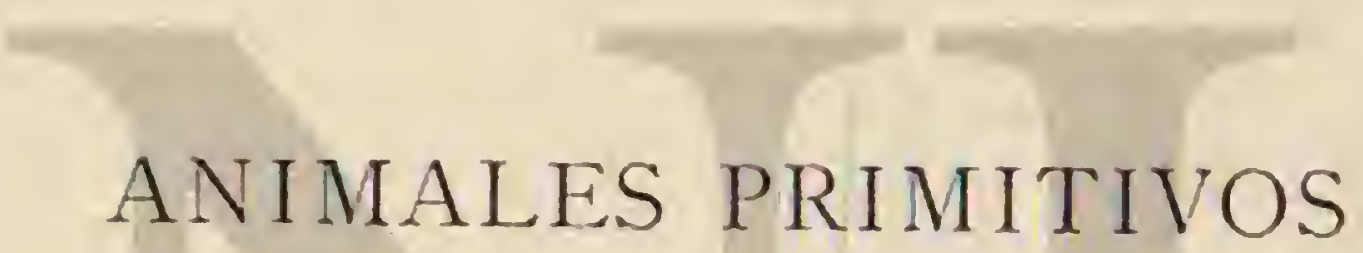

Si en otra ocasion, al intentar determinar limites al grupo de los anélicios, indicábamos las partes defectuosa que hoy se echa de ver en sistemas antiguos muy respetados, po. demos considerar en el grupo de los animales primitivos, grupo adoptado hasta por la mayor parte de los zoólogos, el punto vulnerable de nuestro sistema. El nombre dice mucho, y al propio tiempo nada; mucho, en cuanto nos promete poder dirigir una mirada a los origenes del mundo viviente, á las series mas inferiores de séres sin forma que están trans. formàndose à las formas mas sencillas; nada, en cuanto confunde nuestras ideas acerca del verdadero contenido de la grande division. Las palabras anélidos, moluscos, vertchrados etc., se deducen de la estructura y modo de ser de séres que todos los dias tenemos a la vista $;$ cuyo tipo todo el mundo conoce bajo un animal primitivo: empero no es posible formarnos de ell idea exacta sin una esplicacion muy determinada. Yo, aunque haya visto algunos, no he podido hacer una deduccion ciena sobre las formas y el desarrollo típico de los restantes; el exámen de los denás grupos del reino animal se facilita desde luego por la circunstancia de que para ellos puede indicarse una direccion segura en su formacion y estructura la mayor parte de los animales pri. mitivos, si bien, por lo general, no carecen de forma, se presentan con la disposicion mas diferente y no queda otro remedio que el de contentarse con la indicacion, muy general y raga, de que llamamos animales primitivos ó proiosoos a todos aquellos que se conservan en un grado inferior de la organizacion, y en un desarrollo tan reducido de los tejidos de su cuerpo, cual resulta de la predominacion de la llamada sarcada ó del protoplasma animal.

Para comprender las dificultades con que aqui se tropieza, no hay otro recurso que hacerse presentar por un natu-

ralista, un verdadero protoplasma bajo el microscopio. Un objeto muy á propósito y que se puede adquirir fácilmente en verano son los pélus en los hilos de la tradescantia. Fn estos pelos y cerdas prolongadas, se observa bajo un microscopio de $f$ i 5 reces de aumento, una red de una sustancia liquida, pero espesa, red sujeta à continuas transfórmaciones, cujo movimiento se reduce a deslizarse unos finos granitos contenidos en ellos. Esta movilidad se presenta como una de las cuilidades mas importantes del protoplasma encerrado en las celdas vegetales. Fsta misma sustancia encerrada, tanto en celdas, como circulando libremente, está muy propagada tambien en el reino animal. Pero mientras que en los animales mas desarrollados, el protuphlusma, al primcipio senciIlo, está sujeto á transformaciones, por ejemplo, en el contenido de las fibras musculosas y nerviosas, se conserva en otros, es decir, en los protózoos, en su sencillez primitiva y cn su carencia de formas, dando á todo el organismo el tipo de un carácter mas inferior ó primitivo.

Dadas estas circunstancias, una descripcion general de los protozoos es imposible. Segun la opinion de muchos naturalistas pertenecen a ellos grandes grupos de organismos, cuya naturaleza animal se pone en duda por otros, fundándose en sólidas razones. Llegamos con ellos en general a los limites del mundo vegetal, y mucho se ha averiguado $y$ controvertido acerca la circunstancia de si existen verdaderos limites entre ambos reinos, ó si al contrario, unos séres de naturaleza ambigua ó sencilla hacen insensible el tránsito. No podemos dudar ya de que efectivamente existe tal reino intermedio.

Llegamos además con el estudio de estos protozoos al dificil capitulo de la liamada generacion primitiva y con él casi al limite de la averiguacion efectiva. 


\section{INFUSORIOS}

Mientras estudie en Berlin tuve la suerte de poder ir todos los vicrnes, cuando el tiempo lo prermitia, con ni guerido profesor Ehrenberg ì la caza de infusorios Nuestro equipaje se componia de una pequeria bolsi de lienzo que podia fijarse en un palo largo, cuyo palo se dividia en distintas par. tes y podia llevarse cómodamente en cl bolsillo; además llevábamos numerosas botellitas, largas y delgadas, gue se colocaba en una caja de hoja de lata provista de compartimientós, y por fin un buen anteojo de aumsento. De cste modo nos dirigíamos por cualquier puerta de la ciudad hácia fuera, pero por lo regular llegábamos mas alla de Mabit, en los alrededores del lago de Plotzen, tan estimado por los habitantes de la capital. Nos parábamos entre los charcos y fosos, pucs conociamos ya los sitios favoritos de los diferen. tes animaluchos que los poblaban, y por lo regular el catedratico se procuraba, por medio de los golpes que sacudia con la bolsa die lienzo, la especie deseada, como á representante ncccsaria, colocando el ejemplar en una de las botelli.
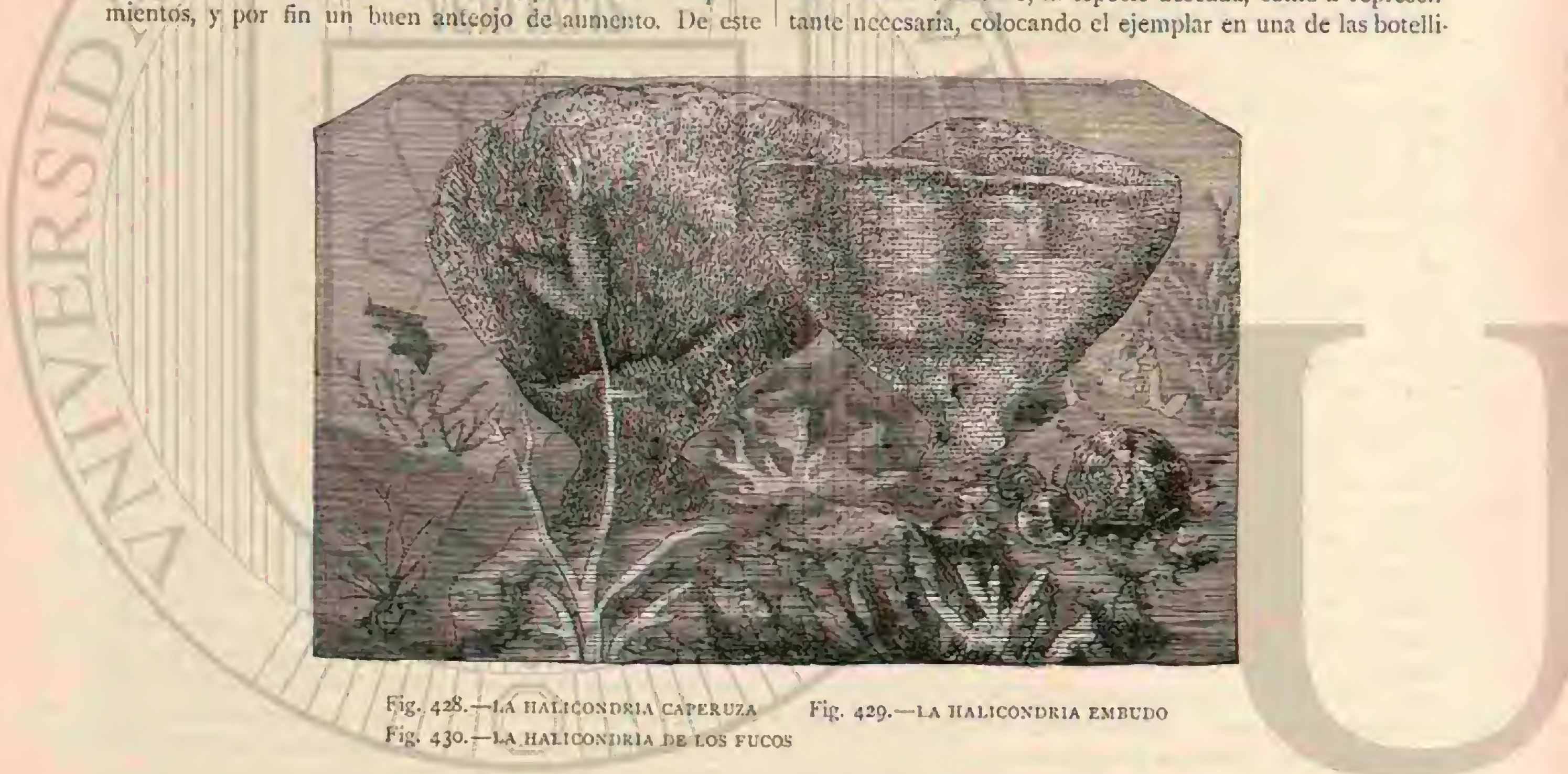

tas. Al dia siguiente, en la clase, los cautivos solian presentarse al aucitorio bajo el-microscopio. Desde aquellos felices tiempos de mi juventud no salgo casi nunca al aire libre sin estar preparado de un modo parecido, con objeto de procu. rarme toda clase de animales microscópicos, que con facilidad se encuentran donde hay agua estancada ó de corriente lenta. Aunque en estos últimos tiempos, sobre todo gracias á las excelentes averiguaciones de Siein, hemos llegado à conseguir in parte nuestros deseos con respecto al conocimiento de los infusorios, queda sin embargo mucho aun que estudiar. Pero aunque todas las proporciones de su estructura y de su desarrollo fueran completamente conocidas, el deseo tan solo de examinarlos y de observar su vivacidad, moveria siempre nuestro interés.

La historia del desarrollo de los infusorios es muy instructiva; empero solo podia dar principio $y$ hacer progresos con el descubrimiento é investigaciones acerca los mismos. Sin embargo, si ąueremos ocuparnos de los infusorios debemos dar, cuando menos, algunas noticias y explicaciones acerca de esta palabra tantas reces mal entendida, $y$ tambien acer. ca de los numcrosos ensayos que respecto a ella se han hecho. En la grande obra de Ehrenberg, mas arriba citada, se encuentra una historia completa de los mismos hasta $1 \$_{5} 8$.
No considcro necesario el añadir palabras à una descripcion hecha ya hace algunos anos.

En 1685 , el célcbre Leeuwenhoeck descubrió los animalitos en una gota de agua pluvial: y dos años mas tarde recibieron su nombre gracias á un segundo descubrimiento. El naturalista esperaba poder reconocer por medio del microscopio la cualidad picante de una simiente y la cubrió de agua. Cuando el agua se hubo evaporado, añadió mas, y grande lué su asombro cuando despues de algun tiempo encoritró el vaso lleno de seres vivos en apariencia, parecidos á los de la gota de agua de lluvia. Este fué el primer resul. tado que se obtuvo de la atenta investigacion hecha con fines cientificos: los organismos cncontrados en ella no se designaron sin embargo sino hasta unos cien años mas tarde por Ledermuller y IVrisberg como infusorios. Despues que Leeurenhock hubo publicado sus observaciones casi se hizo de moda el hacer experimentos con infusiones, gracias al poco trabajo que costaba efectuarlos. Todo el mundo creia poder fijarse con la vista y con un microscopio cualquiera; $y$ de este modo se deducian á veces las cosas mas raras acerca de las infusiones. Publicábanse gran número de libros que pretendian explicar el asunto al público instruido. Griendel de Ack, ingeniero de S. M. Imperial, es el autor de uno de los 
mas notables. Despues de las descripciones de hormigas y moscas que bajo el microscopio aparecen como terribles mónstruos con tenazas, ganchos y escudos, da a conocer tambien un ejemplo de sus experimentos acerca las infusiones. Se trata nada menos que de la procedencia de una rana. \& Por fin, dice, he querido demostrar la maravillosa produccion de una rana, que he observado bajo el microscopio. Cicrto dia cogi una gota de rocio de mayo, poniéndola bajo el anteojo de aumento; entonces observé cono principió a fermentar. Al dia siguiente segui examinándola y encontre ya un cuerpo con una monstruosa cabeza que al dia tercero habia adjuirido la forma de una rana. I a figura 12 la representa muy detalladnmente.

Como Griendel no hace nacer su rana del agua de fuen. te, sino que recoge al efecto el misterioso socio de mayo, en general se recurrió á todos los liquidos posibles, caldo, leche, sangre, saliva, vinagre para hacer con ellos la infusion sobre las mas diferentes sustancias de todos los reinos de la natu. raleza y para solazarse con este fenúmeno.

Generalmente se hacian las siguientes observaciones: el vaso que contenia la infusion era expuesto al aire libre y al cabo de mas ó menos tiempo sicmpre estaba poblado de ni. llones de séres vivos que, sin embargo, por los instrumentos ópticos de entonces solo podian divisarse imperfectamen. te. Mas escasamente se desplegaba la vida de este mundo en pequeño cuando el vaso ustaba ligeramente cubierto, aunque solo fuera con un velo. Solo en mros casos, á menu. do dudosos, los incansables naturalistas aseguraron que se habia desarrollado una vida en la botella cerrada herméticamente, cosa que parecia mas dudosa aun cuando el agua se hervia ó destilaba antes, ó cuando se hervia despues de ponerla en la botella. Además se observaba que en la infu-

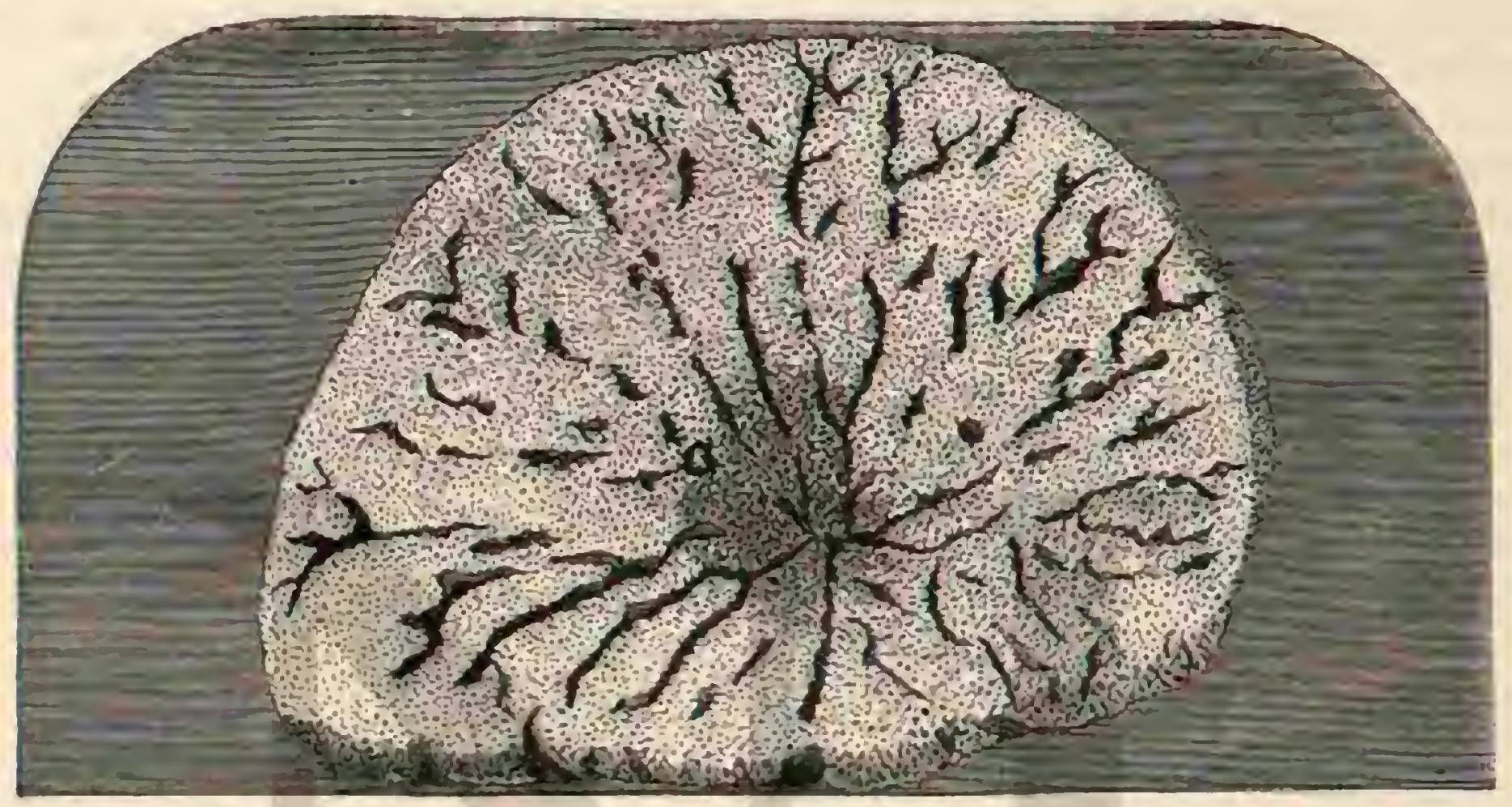

Fig. 431. - LL DACTHLOCALBX JOMME.

sion descubierta, en general en las aguas libres no movidas por el viento, en breve se formaba una ligerisima capa 6 piel çue dió lugar á las mas extranias suposiciones.

¿Dónde se originaban aquellas formas de vida? A csta pregunta nos comestarản algunos naturalistas de an̨uella época, asi como los modemos. Segun ya hemos dicho las opiniones de aquellos eran casi siempre resultado de las observaciones incompletas con instrumentos defectuosos que hacian aparecer los organismos con sus formas diferentes y su naturaleza, como cuerpecitos bastante iguales é indetermimables. Las doctrinas de "Buffon expuestas con tan brillante elocuencia solo se comprenden en relacion con su teoria general acerca el modo de ser de los cuerpos de la naturaleza. Es tanto mas importante conocer algo de esta teoria, en cuanto el período actual de la ciencia se aproxima à ella en algunos de los puntos esenciales. El naturalista estaba convencido de que existia una serie continua de los séres mas perfectos i los mas imperfectos. ¿Un insecto, dice en este sentido, es menos animal que un perro, una ostra es menos animal que un insecto, una ortiga de mar ó un pólipo de agur dulce lo es menos aun que una ostra. Y como la naturaleza pasa por grados insensibles, debemos encontrar séres que son aun menos animales que una ortiga de mar ó un pólipro. Hay séres que no son animales, ni plantas, ni minerales; y vana seria la pretension de clasificarles con uno ú otro grupo. Añadiendo à esto la tésis siguiente: Yo supongo que al observar minuciosamente la natu. raleza se encontrarian séres intermedios, cuerpos organiza. dos que sin tener, por ejemplo, la fuerza de propagarse como los animales y las plantas, demostrarian sin embargo, una especie de vida y movimiento: otros séres que sin ser animales ni plantas podrian contribuir sin embargo, à la composicion de ambos; y, por fin, otros que solo serian la primera reunion de las partes orgánicas mas pequeñas de las formas (molécules organiques).

Esto sentado llegamos a las opiniones del naturalista fran. cés sobre la vida que encontró en las infusiones. Cuando en las infusiones sobre carnes, gelatinas de ternera, simientes vejetales etc., se presentaban de pronto cucrpecitos vivos, Buffon creia que cran las pequeiras particulas vivas de las que la carne y la sustancia rejetal se compone. Y asi, decin tambien, çue el destruir un sér orgánico como se hace por la infusion, no es otra cosa que separar las particulas vivas de que se compone. Ia muerte era para êl una division en un sin número de nuevas vidas que vuelven a entrar en la cir. culacion de otros organismos. El partidario mas caluroso de Buffon, fué Hecdham: los experimentos de ambos, hechos en parte juntamente, tuvieron lugar precisamente à mediados del siglo pasado. Tambien las opiniones de otros sabios naturalistas de aquella época se parecen à las de Buffon. Hrisberg de Goettingen y tambien el zoólogo danés, por otra parte tan circunspecto, O. Fir. Muller entraron en el peligroso campo de las hipótesis, alli donde cesaban las obser. raciones: el uiltimo era de opinion que las plantas y los animales se disolvian en burbugitas microscópicas vivas, diferentes por su materia y estructura de los verdaderos infusorios, y que de estas burgugitas vivas volvia á formarse toda vida superior. 
El importante progreso realizado por Muller en esta materia consiste en que Buffon no habia reconocido la existencia de una verdadern clase animal de los infusorios, mien. tras que Muller distinguka bien los verdaderos animales de las burgugitas primitivas pertenecientes $\dot{a}$ su teoria de la vida orgánica. El baron de Gluchen, conocido por sus trabajos microscópicos, dice á este propósito: «Dificilmente la razon humana inventará una hipótesis mas probable.

Entre los naturalistas antiguos mal avenidos con las concepciones espiritualistas de Buffon, debe citarse, sobre todo, al célebre Spallanzani. En i 68 atacó con razones fundadas en la ciencia el aserto de que de las materias mismas $\mathrm{cm}$. pleadas en la infusion, bien sẹan orgánicas é inorganicas, se desarrollaran sin progenitores los séres vivos. Como adversario decidido de esta generacion primitiva, In llnmada generatio sponfaniea ó ayuivoca: pretendia que los germenes aniniales $y$ regetales se introducian en la infusion por el aire, al que nunca podia cerrarse el paso herméticamente a los yasos; $y$ aunque el desarrollo de los gérmenes uriginarios de las especies ya existentes de infusorios, se farorecia i veces por las sustancias animales y vegetales contenidas en las infusiones, estas sustancias no cran del todo necestrias, segun lo demos. trába la abundante vida que con el tiempo se presentaba tambien en el agua pura.

No intentamos seguir uno por uno los progresos a que el conocimiento de los infusorios dió lugar hasta que Ehrenbers arrojó nueva luz sobre este punto tan 'oscuro y enigmático aun de la Historia natural. Encontré, dice, ya en.1819, la prueba directa, hasta entonces no existente; del gérmen de las simientes aisladas de las setas, por lo cual el origen de estas plantitas de la generncion espoutanea parecia muy vago é in. suficiente, a causa de la multitud de simientes existente, y por lo cual el descubrimiento de Muenchinausen, declarado como inmortal por linnen, de que estas simientes eran infusorios ó pólipos aéreos, se demostraba como inexacto. \$ Para lle. gar con respecto a los infusorios a una seguridad parecida a la que se tenin acerca las formaciones de setas y pelusa, hizo una larga serie de experimentos reasumiendo el resultado de este modo: « Ninguno de los observadores anteriores ha dado realmente á conocer jnmàs como infusiones un solo in. fusorio, porque at la mirada de todos cuantos creian laber averiguado tal cosa se habia escapado del iodo la organizacion de estos cuerpecitos, porque, por lo tanto, nunca observaron con la exactitud que parece necesaria para poder hacer una deduccion tan importante, $y$ porque ademảs en un exámen hecho con el uso de los mejores medios hasta ahora conocidos y en mas de 700 especies, yo mismo nunca he observado un solo caso quue hubiera podido convencerme de que en las infusiones artificiales y naturales se producen organismos de las sustancias infundidas: sí noté en todos los casos mas especialmente observados una propagacion por huevos, division ó retoño. \$ Ehrenberg demostró que los animales que con mas rapidez y frecuencia se observan en las infusiones pertenecen casi siempre ad los que como cosmopolitas se encuentran propagados por todo el globo. Los mas de los infusorios, los mas bonitos y mas grandes, ni siquiera pueden subsistir en el agua pútrida, y por lo tanto no se presentan nunca en las infusiones.

Pero aunque hoy dia nadie piensa ya que se produzcan es. pontaineamente en las infusiones esos séres, á los que, despues de separar muchas noticias extrañas, designamos con el nombre de infusorios, justificado históricamente, pero à pesar de esto muy inexacto, la pregunta principal sobre la posibilidad de la formacion de cuerpos orgínicos sin paternidad, no está decidida aun por una prueba directa é indudable. Dado nues. tro tema actual sobre los verdaderos infusorios, no podemos ocuparnos de los interesantes experimentos de infusion efec. tuados por el quínico Pasteur, ni de las dudas contra su validez general emitidas, por ejemplo, por el botánico Neagli.

Los infusorios iabitan el mar y el agua dulce, y recuerdan por su forma y su género de vida de tal modo á los anélidos microscópicos, que hace años me vi obligado á continuarlos junto á aquellos anélidos. El que estime exacta la teoría de la descendencia no podra menos de hacer descender los turbebelarios de animales parecidos á los infusorios. Por efecto de nuestra fraseologia exagernda, nos hemos acostumbrado it atribuir a los infusorios tal pequeñez, cual si solo bajo un buen anteojo de aumento nos pudiéramos convencer de la existencia dellos individuos citados. lo cierto es que no pocos se ven distintamente bajo un microscopio de 100 á 300 veces de aumento: pero el conocedor divisa muchos otros a simple vista en una botellita expuesta á la luz. No les caracteriza una determinada forma tipica comun; y sin tomar en consideracion ciertos órganos que nunca faltan à los verdaderos infusorios, es muy dificil confundirlos con las larvas ú otros animales inferiores. Sin embargo, debemos fijarnos ante todo en que la gran mayoria de los géneros está provista exteriormente de órganos pelosos movibles, que ya se limitan á un solo lado del cuerpo, ó forman una serie en espiral, bien cubren el cuerpo de un modo mas uniforme $y$ dispuestas en series estrechas. En la mayor parte contribuje además a demostmar el género de infusorios, el descubrimiento de la boca en forma de herradura ó embudo en espiral, de tamaño relativamente proporcionado.

Examinaremos por lo juronto algunos géneros de varios órdenes, en los, que estudiaremos los carnctéres comunes y los particulares. Estos ejemplos bastan para el ligero conocimien. to de la estructura y del género de vida de la generalidad, de la que últimamente el catedrático Stein de Praga ha tratadn del modo mas completo en una obra notable.

\section{PRIMER ORDEN}

\section{ANFITRICOS - ANPHITRICHA}

Stein reune en este órden todos los géneros quue, por la regularidad de su forma plana de concha, solo tienen pestanas en un lado del cuerpo. A este grupo pertenece uno de los génerns mas comunes, el de los estiloniquios ( Stylonychior), cuya especie mas notable es el estiloniquio conchiforme (Sit) lonychos myfilus), que llega à $f_{1}, 025$ de longitud. Es nuy poco exigente en la eleccion de las aguas en que vive, y se multiplica en innumerables masas. Una.grande escotadura, mas estrecha hacia abajo, está orilladia de pestañas, merced á cuyo movimiento conduce el alimento á la verdadera aber. 
tura bucal, que se encuentra en el fondo de esta hendidura; tambien nada el animal con un movimiento continto é uni. forme por medio de estas pestanas, y dos series de estos mismos órganos que sobresalen a derecha e izquierda del borde del cuerpo. Pero asimismo puede andar apoyandose en las puntas de las pestañas mas fuertes y encorvadas, y en unos estilos que se encuentran cerca de la extremidad posterior. En esta se hallan además ires cerdas inmovibles. Provisto de tan numerosos órganos de movimiento, el animalito trepa con extrema agilidad entre las plantas microscópicas, pero absorbiendo casi sin interrupcion su alimento, que se compone de especies pequerias de la propia clase y de algas microscópicas. Un órgano de que nunca carecen es la rejiga, que en intérvalos bastante regulares de diez a doce segundos se contrae, vaciando hicia fuera por una fina abertura su contenido claro como el agua.

Aunque la vejiga contractil ocupe en la mayor parte de las esperies un puesto determinado y despues de cada contraccion vuelva á llenarse, no se le puede atribuir sin embargo una membrana limitante en el sentido estricto de la palabra. Es una cavidad en la parte exterior del cuerpo que se compone de un protoplasma muy espeso. En relacion con esto debe consignarse tambien la circunstancia de que la abertura arriba citada, no parece tampoco ser una abertura regular, que se cierra por la contraccion de sus contornos, sino una hendidura fina, que se abre a cada contraccion del organo y vuelve á cerrarse por medio del protoplasma. En la linea central del cuerpo se observan dos cuerpecitos redondeados que se llaman núcleos. Fistos se han considerado

$$
\text { deados que se llaman núcleos. Histos se har considerndo }
$$

durante nucho tiempo como los órganos genitales de los infusorios, asegurándose haber observado su division en verdaderos huevos ó gérmenes csféricos que se desarrollaban en pequenuelos pestaneados. Segun las observaciones modernas, esta supuesta propagacion se considera sin embargo como dudosa. Los núcleos parecen por el contrario tener la importancia de verdaderos núcleos celurares ú otras trasformaciones parecidas, y representan en la division y en la llamada conjuntacion un papel importante.

Precisamente en los estiloniquios la conjuntacion se ha observado minuciosamente. Dos animales se juntan y se sueldan en parte uno con otro, durante cuyo tiempo se verifica la trasformacion de los núcleos. La opinion anteriormente emitida de que la conjuntacion cra una introduccion al desarrollo de pequenuelos que abandonando el cuerpo materno se trasformaban considerablemente durante su estado erran. te, ha tenido que ceder a una explicacion del todo diterente. Butschli, uno de los obscrvadores mas modernos $y$ habiles de estas trasformaciones, que por cierto han dado lugar a muchos errores, dice: $\mathbb{e}$ Yo he visto penetrar á las supuestas esferas embrionarias en estiloniquios apareados, las he visto propagarse $y$ volver a salir, y he dado ademas la prueba expe. rimental para la naturaleza parasitica de estos embriones, encerrando un animal infestado por cllos con otro no infes. tado bajo el cristal de observacion; entonces he visto como este último animal fué attacado por los supuestos embriones originarios del animal infestado, cuyos embriones penetraron en aquel, propagindose por medio de esferas embrionarias.

\section{PERITRICIOS - PERITRICHA}

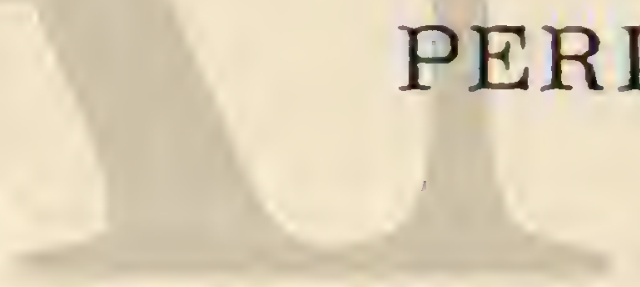

Vamos a comparar ahora á los estiloniquios con un género del órden de los peritricios cujo cuerpo está desnudo, ex. cepto una espiral de pestañas y un círculo de pelitos. El género de las vorticelas es uno de los mas notables y grandes de los infusorios; sus individuos son por lo regular sedentarios y se componen entonces del verdadero cuerpo y de un tallo.

Todas las especies que no forman ironco, sino que se hallan como individuos aislados sobre un tallo que puede contraerse en forma de espiral, se reunen en un género iorticella. En sl existen tambien los tres órganos mas importantes ya observados en los estiloniquios, es decir, el embudo bucal, la vejiga y el cuerpo genital, mientras que el borde prominente en forma de labio, provisto en su interior de largas pestañas, es una particularidad de las vorticelas.

Ademås de la forma en que cada individuo estí aislado sobre un tallo, existe una segunda forma principal, carche. sium, en la que el tallo se ramifica con la formacion de retoño, desarrollandose verdaderos árboles de vorticelas. Apenas conozco un espectáculo microscópico mas gracioso que uno de estos arbustos de fores animadas. Cuando, bien esas flores aisladas, ó las reunidas en una rama comun, se comtraen, ó bien todo el árbol, como tocado por el rajo, se encoge para volver á desplegarse lentamente, la contraccion se verifica

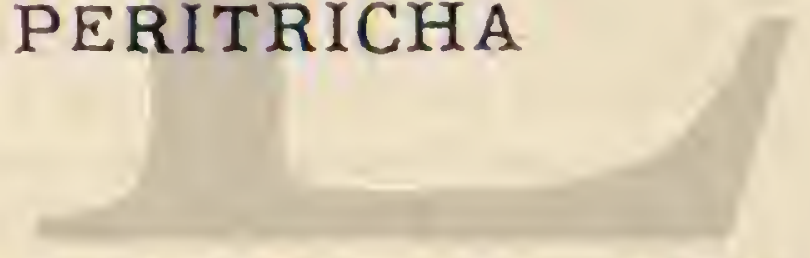

por un ligamento musculoso que pasa por el tallo ó hueco y que falta en otras formas. Estas últimas constituyen el subgenero efistylis al que pertenece la especie epistylis nutans, que ha recibido su nombre especial de la particularidad de inclinarse en el punto de tránsito del tallo al cuerpo, cuando se la asusta ó estorba. El epistilo grande es tambien otra de las especies: se cncuentra sobre la yerba de los estanques y su color es amarillo verdoso. Los caractéres de las vorticelas consisten, además de los ja citados, en su cuerpo desnudo, por lo regular oblicuo en la parte anterior. Aqui se encuentra ya una tapa oblicuamente sobrepuesta, bajo cuyo borde saliente se halla la abertura bucal, $\delta$ bien se encuentra como en los epistilidos un verdadero labio superior $\dot{\varepsilon}$ inferior con pestanas, entre los que cmpieza el embudo bucal que penetra is mucha profundidad en el cuerpo. Sobre la formacion de los arbolitos del epistilo, Stein ha observado lo siguiente: «. L.os animales de un arbolito y las ramas del mismo se propagan por la division longitudiral de los animales ya existentes. Terminada esta division, el tallo de cada individuo es aun muy corto. En su desarrollo: que naturalmente siempre se verifica en el punto donde está reunido con el cuerpo del animal, un indiviciuo toma a menudo la delantera al otro, y el individuo con el tallo mas largo se divide tambien mas pronto que su compañcro de la misma generacion, á conse- 
cuencia de lo cual los animales de un mismo arbolito no guardan todos la misma altura.

\$No siempre todas las ramas de un arbolito acaban en animales, pues algunas de ellas han sido abandonadas por aquellos á quienes deben su origen. Los animalitos separados quedan extendidos, y nadan valiéndose de su corona de pestainas en el agua, para formar mas tarde en otro punto la base de un arbolito nuevo.

- Con mucha frecuencia encontré individuos aislados que acibaban de segregar de su base el rudimento de un tallo; con igual frecuencin enrontré arbolitos que solo llevaban dos ó tres animales.

Las colonias de las vorticelas llamaban antes de mediados del siglo pasado la atencion de los natúnalistas yue se ocu- pabar ya en estudios microscópicos. Se llamaban pólipos de embudo ó falsos, y Rcesel y sus contemporineos sabian que les gustaba fijarse en coleópteros y caracoles acuáticos, presentándose á primera vista como una especic de pelusa. \& A menudo, refiere el citado maturalista, encontré dichos coleópteros en el agua en que busqué polipos de brazos y pólipos falsos. Como, sin embargo, no suponia qque la capa q̨ue los cubria se compusiera de séres vivos, sino que creia ver en ella una especie de pelusa, no hacia caso de ella. Pero como hay muchas especies de pelusa, examiné una vez tambien la de estos coleópteros, $y$ vi bajo el microscopio que la supuesta pelusa se componia de séres vivos, de lo que me convenci con seguridad por las continuas contracciones propias de to. dòs los falsos pólipos.

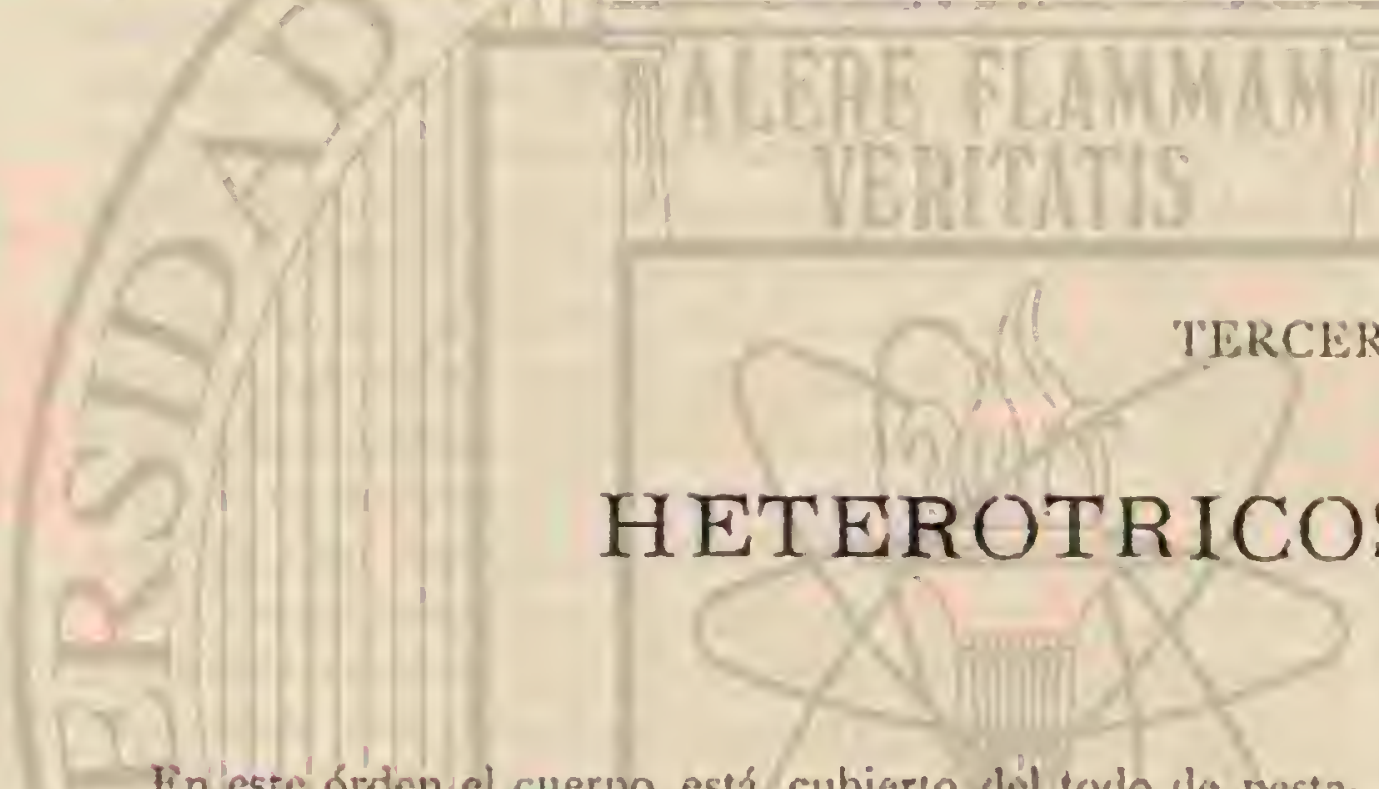

En este órden el cuerpo estŕ cubierto del todo de pesta. nas, dispuestas en series, y una de ellas, mas grande rodea ademas la hendidura bucal.

A este Grden pertenece el género de les estentores (stentor) entre los cuales se distingue el estentor polimorfo. Otra especie muy frecuente, el estentor de Rusel, segun la denominan los natumlistas modernos, se ha descrito muy bien por aquel autor bajo el nombre de tpólipo falso.» issta especie, dice, se encuentra con mas frecuencia en la supesfi: cic exterior de las lentejas de mar, en las que se fija por su parte posterior puntiaguda. Al observar estos animales se echa de ver que cambian casi á cada momento de forma, pero siempre la parte anterior del cuerpo es la mas gruesa y la posterior la mas puntiáguda. Cuanda el pólipo falso abre su parte anterior, donde en rigor se encuentra la cabeza y la boca, esta parte se parece al agujero ancho de una trompa, y tiene, romo ésta, tambien una profunda cavidad, pero en su borde esta provista, como nuestro parpado, de una serie de pestañas cortas y uniformes. Con esta abertura los pólipos falsos en cuestion pueden causar un continuo remolino en el agua, por medio del cual atraen muchos pequeños cuerpos y rechazan los que no les convienen. In sus diferentes movimientos prolongan su cuerpo ó lo alargan del todo, y enton. ces abren siempre la parte anterior. Ora se contraen, ora nadan cambiando de variadas mancras la forma de su cucrpo; cuando estín fijos en una lenteja de mar y se les observa con atencion se notarin las siguientes trasformaciones en su cuerpo: se pueden contraer de tal modo que no se observa casi nada de ellos, pero poco despues vuelven a presentarse en forma de masa; despues abren su parte antcrior, y al sentir un sacudimiento todos los júlipos desaparecen a la vez. Cuando se alejan del sitio en que estaban, nadan poret agua, vuclven à unirse á sus compañeros ó bien se fijan en distinta parte. Fstos individuos libres cambian de forma tambien de diferente modo y parecen ora cortos y gruesos, ora largos y delgados. $\Lambda$ nadar se mueven en linea recta, describen una curva y á veces un circulo.

A los estentores les gusta fijarse con la extremidad posterior, de la que pueden servirse como de una especic de disco

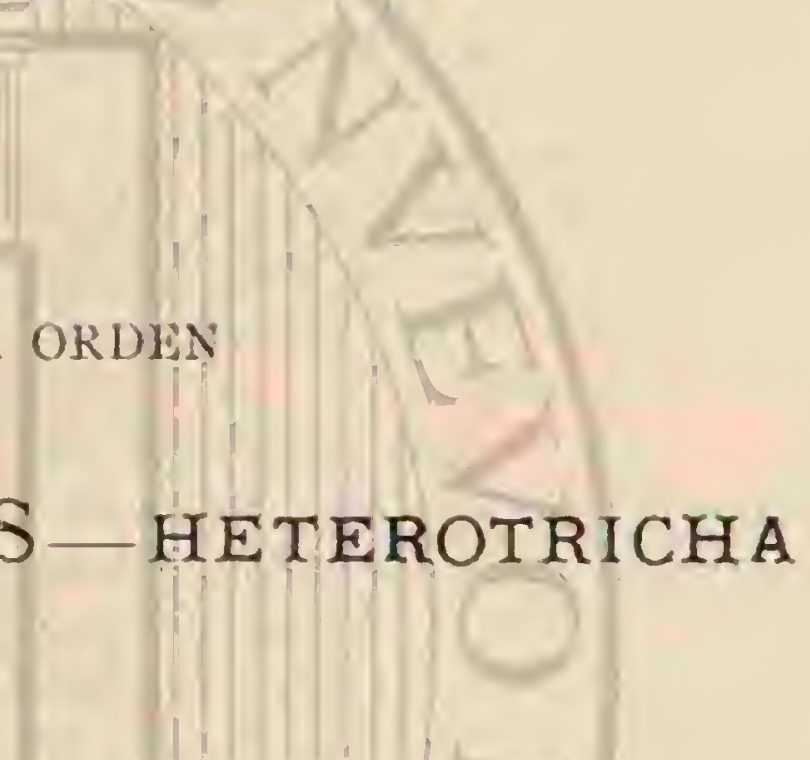

chupacior. Ioś numicrosos cambios de su forma descritos por Rasel se producen por ligamentos nusculosos del protojlasma Aun cuando el cuerpo esté del todo cxtendido, su superficie no es del todo lisa, excepto en su extremidad superior, sino que se observan circulos longitudinales que contienen los ligamentos contrictiles del protoplasma, cuya contraccion produce arrugas en la epidermis. En los surcos se cucucontran tambien las series regulares de pestanas que tienen su raji en las fajas. Fsta estructura explica la rapidè. con que los infusorios pueden cambiar de direccion al nadar: pues solo se necesita un movimiento de la raiz de las pestanas, ejecutado por los ligamentos contráctiles bien hacia adelante 6 hácia atràs, para empujar el cuerpo en una $u$ otra direccion.

Desde 1744 Trembley habia observado en los estentores qृue algunos individuos llevaban una serie lateral de pestains cortas, mientras que otros carccian de ella; habia visto que esto era el principio de una division que consituia el origen de un nucvo individuo. En los ultimos tiempos un naturalista francés, lermontel, ha descrito este suceso que comienza con el levantamiento de una faja lateral denticulada, la que se trasforma en línea pestaneada. Fista línca baja hasta el centro del cuerpo, mas ú menos oblicuamente, des. pues de lo cual se verifica un estrechamiento trasversalmente oblicuo, durante el cual la parte inferior de la linea pestaneada se prolonga en la espiral bucal del nuevo individuo, mientras que la parte anterior desaparece. Pronto el estre. chamicnto es tan profundo que el animal antcrior parece encajar en cl posterior como en un embudn. Aquel ha conscrvado la espiral pestaineada, la rejiga contráctil, la boca y el esófago y la mitad superior del núdeo. Excepto la otra mitnd de este, el animal superior tiene todos estos órganos recien formados.

\section{LOS ESPIROSTOMOS-SPIROS- TOMUM}

Este género pertenece al mismo órden: recibe su nombre de la serie de pestañas que en espiral pasa por su cuerpo y 
cuya extremidad superior se interna en el emberdo bucal. Al lado de las pestañas corren unas fajas musculares de las que cada una pertencece à una pestana cuyos movimientos y posicion regulariza. Una especic, el espirostomo ambiguo. se distingue por varias particularidades. Alcanza la longitud de una linea a linea y media, de modo que es un verdadero gigante entre sus compaieros de la misma clase y puede confundirse fácilmente con un turbelario. La vejiga contráctil se prolonga en forma de vaso y se extiende desde la extremidad posterior hasta casi la anterior. Ias fajas de la capa epidérmica que debe compararse con los músculos, corren con gran regularidad en forma de espiral, y cuando lodas à la vez se contraen, cosa que sucede á menudo, el cuerpo se vuelve mas corto en forma de una circunvolucion espiralada. Esta paricularidad no es propia cxclusivamente de los espirostomos, pero puede observarse mas claramente en ellos. El animal es bastante comun, pero nunca se encuentra reunido en tales sociedades como las vorticelas

\section{HOLOTRICOS-HOLOTRICHA}

Ln este cuarto órden están reunidos todos los géneros cuyo cuerpo esti cubierto por completo de pestañas. No intentaremos, sin embargo, hacer una descripcion detallada de los géneros y especies, que nos ofrecerian una multitud de diferencias exteriores, aun que guarden conformidad con los otros representantes de su estructura Sobre esta base tmataremos solo de completar el cuadro de la vida de los in. iusorios.

Al considerar los otros protozoos resulia que los infuso. rios son muy superiores a aquellos, respecto a los b́rganos de movimiento. El progreso en los infusorios consiste en la formacion rayada del protoplasma, y en general del contraste de una capa epidérmica mas sólida, ya solo elástica ó in. dependientemente contractil del protoplasma interior mas blando. Este es el punto de que tendremos que hablar mas minuciosamente, porque precisamente este protoplasma que llena el interior de los infusorios demuestre su intima afinidad con los proto\%oos, y porquue en general tocio el organismo del cuerpo del infusorio sol o puede explicarse despues de haber conocido el protoplasma como ógano alimenticia.

Es fảcil observar los infusorios bajo el microscopio cuando comen, y tan solo es preciso sujetarles baju el cristal de modo que no puedan alejarse del ceniro, dándoles, sin embargo, el espacio suficiente para mover sus pestañas La corriente originada por las pestañas de la headidura bucal se dirige en linea recta ó espiralada hácia la boca, en la que se acumula una considerable masa de alimento, que despues se empuja por el esófago hácin el interior del cuerjo. Muchos infusorios, por ejemplo, los generos dilodon, Bursaria devoran rambien algas y confervas mas lígas que su propio cuerpo, y con las que nadan en el agua cual si fotara sobre una viga.

Is cierto que todos los infusorios que se alimentan de sustancias sólidas tienen una boca s un esbágo, pero tambien consta que no tienen vestigio de intestino. Al contrario, su interior esti. lleno de sarcoda, gue no se sspara distintamente de la sarcoda epidérmica; á esta sustancia liegan los alinentos que se digieren por ella, excepio los restos que se sacian por una abertura determinada. A pesar de esas observaciones, sacadas de la vida diaria, nos extrañara çue haya animales que detrás del esófago ni tienen estómago ni intestino, sino un espacio digestivo lleno de una sustancia perteneciente al mismo animal. No nos ocupartmos en buscar la solucion fisiológico fisica de estc hecho, pres solo tenemos que compa. rarle con otro parecido mencionado ya al describir los turbelarios. Para cl que quicra hacerse cargo de ello, la afinidad de los infusorios con aquellos anclidos es tanto mas clara, en cuanto tambien la forma exterior del cuerpo de muchos infusorios del todo pestañeados, las pestañas mismas, $y$ por fin la existencia de ciertos órganos en forma de barritas en ambos organismos nos dan los indicios mas evidentes.

La masa digestiva del protoplasma nos parecerá, sin cm. bargo, menos extraordinaria, despues de que mas adelante hayamos conocido clases enteras de séres que de un modo mas sencillo aun que los infusorios, recogen y digiercn su alimento por medio del protoplasma.

Mas arriba ya hemos hecho mencion de la generacion. Bronn recopila las noticias respecto á ella del modo siguiente: La division y formacion de retonos, quizas tambien la formacion de gérmenes interiores reunidos, en relacion con la brevedad del tiempo despues del cual un pequeñuelo a su ver. está en condiciones para propagarse: tenderia a conducir à un resultado enorme por el múmero, si el cansancio del in. dividuo que se propaga no la pusiese un limite. La propaga. cion efectivamente observada debe distinguirse muy bien de la calculada segun algunos casos. Asi, por cjemplo, la division de una vorticela solo exige de tres cuartos de hora á una hora; y como cada parte separada puede dividirse en cl mismo tiempo otra ver, resultarian dentro de diez, horas mil individuos, y dentro de veinte looras un millon; pero en realidad se presentan entre las divisiones intervalos siempre mas gran. des, y por fin cesa la division del todo; de manera que la formacion de solo ocho divisiones se ha observado dentro de unas tres horas; la de sesenta y cuatro individuos dentro de seis, y la de doscientos dentro de veinticuatro horas. Asi, por ejemplo, la especie paramacium aurelia, del órden de los 1.0. lotricos, necesita cuando menos dos horas: pero à menudo inu. cho mas para una division longitudinal, y puede aumentarse en veinticuatro horas el número de ocho, que cn una semana daria el resultado de dos millones de individuos. L.os estilo. niquios dan en veinticuatro horas, por medio de la division trasversal, tres individuos, que despues de una madurey de veinticuatro horas, pueden dar, dentro de otras veinricuatro horas, doce individuos, de modo que tambien aqqui, dentro de veinte dias, puede suponerse una multiplicacion posible liasta un millon.

Un numero bastante crecido de infusorios tiene la facultad 
can, para esperar en el cieno enjuto una nueva vida, ó para volar con el polvo por encina de las montañas ó de los valles. 'lienen, segun sabemos, esta resistencia vital, comun en muchos otros organisınos inferiores y en sus gérmenes, circunstancia que explica el fénúmeno, considerado antes como milagroso, de que despues de una lluvia a que sucedia una larga sequia, los pequeños estanques que acaban de formarse presentaran una rica adundancia de séres vivos.

Antes de separarnos de los infusorios harenos una pre. gunta peligrosa y dificil. ¿Qué hay de la vida del alma en los infusorios? El hecho de que el fisiólogo Eugelmann, bencmérito tambien por sus trabajos en el terreno de la ciencia de los infusorios, ha intentado atribuir estos una facultad muy desarrollada del alma, nos obliga á esta pregunia. El ci. tado naturalista observaba la division de retoños de vortice. las f. el mocio con que estos retonos busciban 6 cucontmbari los individuos sédentarios de los arbolitos para aparearse con ellos. All principio, dice, los retoños ragaban por el agua con una rapidez, bastante constante (unos $0^{\circ}, 006$ i $0^{\prime \prime}$ ool por segundo) y siempre girando sobre su cje longitudinal, avanzando por lo regular en línea bastante recta. Esto duraba de cinco à diez ninutos ó más, mientras no sucediera algo dé particular: despues se cambiaba de repentela escena. 11 lle. gar casualmente cerca de una vorticela sedentaria, el retoño, cambiaba de direccion, se acercaba da la vorticela, jasando por encina de ella y examinandola en todas sus partes. Despues queleste juego habia durado algunos minutos, siendo repetido en diferentes individos sedentarios, el retoño se tijaba por lo regular en la extremidad superior, cerca del tallo. Al cabo de pocos minutos, el apareamiento cstaba ya verifi. cándose visiblemente.

3Otra vez obscrvé un espectáculo mas notable aun en el concepto lisiológico, y especialnente psico-fisiológico. Un retoño libre se cruzó en el camino de una vorticcla grande que con extrema rapides, nadala por las goias, y que de la manera acostumbrada habia abandonado su tallo. Ln el momento del cncuentro (pues los animales no se tocaban) el retono cambiỏ de repente de díreccion y siguió á la vorricela con grande rapidez. Entonces tuvo lugar una verdadera caza, que duró unos cinco segundos. Durante este tiempo el retolio se mantenia apenas la décimaquinta parte de un milimetro de. tràs de la vorticela, pero no la alcanzó, sino que la perdió de vista al liacer aquella una evolucion lateral repentina. El retoño continuó despues su propio camino con menos rapidez. Estos detalles son noiables porque demuestran una percepcion fina y rápida, una decision de la voluntad enérgica y. segura, y una inervacion ( 1 ) notora libre.

Iil fisiólogo de Utrecht se inclina por lo tanto a encontrat en las vorticclas una facultad intelectual muy desarrollada, atribuyendoles no solamente la sensacion, sino tambien la percepcion, la voluntad independiente y la ejecucion sápiàa de la roluntad fijada en un objeto determinado. Seria fácil observar tambien en orros infusorios acciones y hechos parecidos. En cuanto i la vorticela, ine parece que existe una explicacion mucho mas sencilla para la caza descrita por Fingelmann: el animal que nada delante produce un remolino que, arrebatando al segundo animal, le impele á seguirle. Mas dificil es el otro caso, que, sin embargo, no débe con. sidcrarse por sí solo, sino en cuanto concierne en términos generales á la sensacion $y$ a la facultad de percepcion de los animales que carecen de nervios.

Hemos conocido en esta obra tantos cjemplos de la facul. tad intelectual de los animales superiores, que ha llegado ya

(1) La infucacia sobre los órganos de movimienio que en los anima. les desarrollados se cjerce por los nervios sobre los músculos. el caso de buscar una explicacion sobre los ferómenos co:respondientes en cl mundo de los animales desarrollados. En los pólipos ya se ha buscado en vano un sistema nervioso, $y$ mas sencilla es, segun hemos visto y veremos aun, la estructura de los protozoos. Si hablamos del libre albedrio y de la voluntad de una hormiga, de un cefalópodo ó de un cangrejo, comparando sus acciones dirigidas a un fin determinado con las de un perro, de un mono y hasta de un hombre, lo hace. mos con toda razon, porque todos aqquellos vertubrados po. seen un sistema nervioso que en sus partes aisladas sostiene la comparacion con el aparato nervioso y de los sentidos de los animales vertebrados $y$ del hombre, $y$ de cuyo sistema esperamos, por lo tanto, tambien manifestaciones parecidas. Sin entrar aqui en una disquision sobre la naturaleza y el sér del alma, creemos no encontrar oposicion alguna al designar cl sistema nervioso cono el órgano del alma. Allí, pues, donde encontramos netrios podemos deducir facultades intelectuales dependientes de la actividad de los nervios: precisamente por esto la vida animal presenia tan extraordinaria riqueza en sus manifestaciones.

¿Pero qué decir del alma de los animales que no tienen sistema nervioso? Aqui se nos presenta la misma dificultad que en la preginta sobre el periodo desde el cual el animal jóven que se desarrolla, 6 el foto animal, tienen un alma; $y$ resulta que no puede trazarse ningun linite entre las mani. festaciones vitales en general y los fenómenos intelectuales, por lo que nada hemos logrado con la explicacion hace poco satisfactoria ácerca del alma y: su órgano. La comparacion con la revelacioni del alma en el animal que ya está desarrollíndose y en el feto humano, nos indica sin embargo que con mas razon la pregunta tendria que hacerse en un sentido inverso. ¿Dónde émpiezan en el mundo organico las manifestaciones que debén designarse como intelectuales? En estos últimos tiempos se ha vuclto á poner sobre el tapete la anti. gua hipótesis de que las mas pequeñas partes de la materia, los dtomos, tenian alma, sensacion y voluntad. Esto nos da una idea salisfactoria de lo que buscamos. I a respuesta a nuestra pregunta se encontraria si tuviésemos un medio para distinguir los movimientos voluntarios del protoplasma de los organismos inferiores de nuestros protozoos, de los involuntarios. Llamamos involuntaria á la corriente del protoplasma en las celdas vegretales, porque suponemos que solo es una manifestacion de procesos quimicos y fisicos en el interior de la celda y la contestacion á irritaciones exteriores anailogas, sin vestigio alguno de lo que segun nuestras expericucias lla. mamos sensacion, idea y conocimiento.

Tales movimientos se encuentran sin duda tambien en todos los grupos de los protor.0os, segun lo demuestra el ejemplo de la gromia, de que mas adelante hablaremos. Estos morimientos se realizan sin embargo en su totalidad en determinadas acciones, por ejeinplo, en la recepcion del alimento, para las que, segun las experiencias, en los animales mas desarrollados suponemos sensacion y voluntad. Otvida. mos demasiado fácilmente que aqucllas sensaciones, sentimientos de alegria y de enojo, son resultados de la circunstancia de que las impresiones que las originan se producen desde el exterior a un órgano particular, al centro del sistema nervioso, donde en cierto modo se renuevan y se trasforman de una manera hasta ahora misteriosa en sensacion. Pucdo suponer que el protoplasma de la gromia tiene gusto; pero no me adclanto mas cn esta suposicion, y no puedo oponerme cuando un amigo de la animalidad de las plantas da a la recepcion del alimento el caricter de una accion re. unida con un sentimiento agradable. Vemos sin embargo que en el reino de los proteos, al que sigue el de los iniuso. rios, la irritabilidad del protoplasma $y$ la facultad de con- 
testar á diferentes irritaciones se efectúa de distinto modo. No es esta ocasion oportuna para establecer y fijar diferencias. Jos infusorios nos presentan la division en la sustancia corporal, del todo uniforme aun para la vista en las clases inferiores de los proteos, tan desarrollada, que las fajas de protoplasma motoras nada tienen que ver ya con la masa digestiva. Poseen verdaderos órganos de movimiento y en ellos la irritabilidad ha aumentado de tal modo que propagan la irritacion casi con la misuna rapide\% que en los animales provistos de nervios. La contraccion de un arbolito de vorticelas inuy ramificado se verifica á nuestra vista con la rapidez del rajo. Y sin embargo, la irritacion que en un instante se ha cjercido en un animal de la colonia, debe comunicarse por el tronco á todas las ramas, hasta à los animalitos que en sus puntas se hallan, antes de que la extraccion pueda verificarse.

¿Tienen las vorticelas en esta ocasion una sensacion, una especie de conocimiento? Nada afirmaremos ni negaremos en absoluto. Tienen que experimentar algo parecido á la sen. sacion, y algo análogo al conocimiento debe desarrollarse en ellas despues del choque. Pero la composicion del cuerpo, la division del trabajo no se ha desarrollado aun en ellas de tal modo que la sensacion del golpe y tacto puedan separarse de una llamada sensacion muscular que no llega completamente al conocimiento de los animales. Lina cosa parecida sucede en el sentido del gusto: por parte de los procesos que se verifican al recoger el alimento, podrá reducirse quizas en su tiempo á las lejes de la afinidad quimica. Tampoco el infusorio puede pasar de tal sensacion general, oscura y apenas perceptible; pero podemos suponer que los infusorios tienen, en un ejercicio particular de ciertos puntos de la capa epidérmica, ocasion para formar aparatos nerviosos sensibilisimos. $\mathrm{Y}$ esto sentado, entramos en el terreno de los séres, en los que segun opinion vulgar existe un alma. Compren. demos ahora por lo menos lo que esto quiere decir: el alma se desarrolla en la vida del individuo del mismo modo que du. rante el desarrollo histórico del mundo vivo en general se ha formado poco á poco de lo infinitamente pequeño.

\section{QUINTO ORDEN}

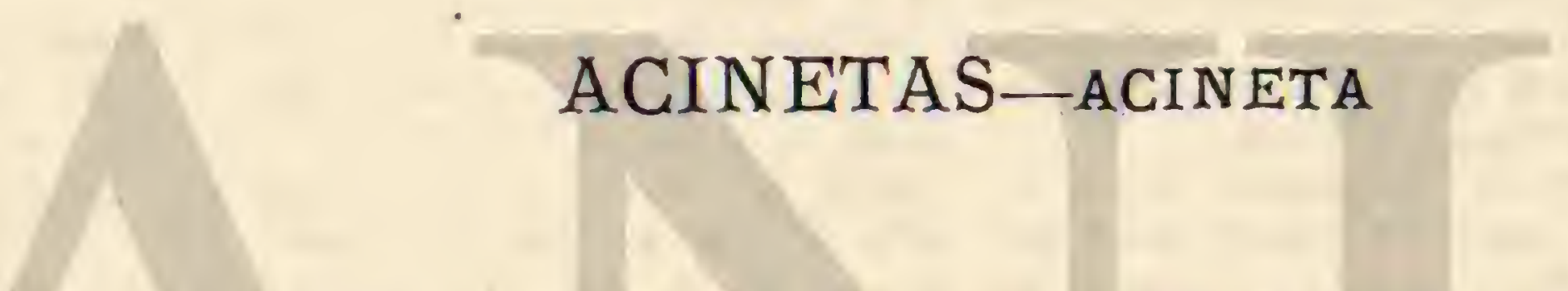

Los intervalos que se echan de ver en la serie de que venimos ocupándonos, se explican tambicu porque à menudo tenemos que clasificar sistemáticamente géneros ó grupos mayores como \&apéndices de clases por lo demás bien limitadas. Esto quiere decir que las razones que se sacan del désarrollo 5 anatomia $n o$ bastan para dar como seguro un origen comun, aun que éste sea mas ó menos probable. En esta situacion nos encontramos respecto á los infusorios con el orden de las acinetas. Estos séres microscópicos estån fijos por medio de un tallo y eligen como residencia á menudo otros animales acuáticos, tanto de nar como de agua dulce. El cuerpo prolongado en forma de maza ó redondeado, deprimido á menudo en su parte anterior, contiene un espeso protoplasma con un núcleo considerable y con un punto ó varios que afectan la formacion de vejiga y pueden compararse con las vejigas contráctiles de los infusorios. Tambien a causa del nícleo la afinidad con los infusorios podia suponerse como probable, aun que la semejanza en el animal desarrollado no pasa mas allá y es por lo demás bastante escasa.

Las acinetas, solo durante un corto periodo de vida libre en su jurentud, poseen pestanas que desaparecen tan luego como los animales se han fijado, y entonces se desarrollan en estos unos finos apéndices, muy particulares, del protoplasma, por medio de los cuales y faltando la boca se verifica la recepcion del alimento. Estos apéndices se encuentran en forma de radios extensibles y retráctiles en la parte anterior del cuerpo, terminando en un botoncito que al igual de un disco chupador se fija en la presa y conduce el liquido ab. sorbido hácia el interior de la acineta.

En una acineta encontrada cerca de Heligoland, R. Hertwig observó, además de los órganos chupadores descritos, unos hilos particulares con la extremidad puntiaguda. 4 Al llegar, dice, un infusorio al alcance de los hilos, éstos se encorvan para agarrar su victima, la que á su contacto se paraliza $y^{\circ}$ muere poco á poco. Por medio de la contraccion de los hilos el cuerpo muerto es aproximado á la podófria, poniéndose en contacto con los iubos chupadores que son mas cortos. Esta se hincha con sus extremidades, fijándolas en la superficie del cuerpo de la presa. Su movimiento de extension y de retraccion aleja y acerca el infusorio muerto hasta que Este comienza á disminuir. Entonces se ha establecido una corriente desde el cuerpo del mismo hácia el interior de la podófria. Al alargar el tubo chupador los granitos del protoplasma del infusorio entran en aquel, que por medio de la retraccion los introduce en el organismo absorbente.

Hertwig logró tambien observar exactamente el modo de propagarse de la acineta de Heligoland. Fórmanse en la extremidad exterior, entre los tentáculos y los tubos chupado. res, unas prominencias en cada una de las cuales jenctra una escrecencia del núcleo. Estas escrecencias se convierten en retoños, cucrpos conchiformes planos, quue por fin se separan, moviéndose perezosâmente por medio de las pestañas.

Por lo regular no se alejan mucho del animal materno si desde luego no se fijan al lado del mismo, cubriendo à me. nudo a gran distancia los tubularios, en los que estas acinetas se encuentran con mas frecuencia. He tenido ocasion de observar al mismo animal en Nápoles.

Tambien estos animales estain expuestos à la persecucion de numerosos enemigos. I a podúfria de Heligoland es perseguida por pequetios crustáceos, sobre todo por los anfipodos, y entre estos con preferencia por la voraz caprela. Además un infusorio hipotriquido q̨ue rápidamente se propaga, pene tra en el punto que separa el tallo del cuerpo y en que, por lo tanto, esta preservado de la accion de los tentáculos, al interior de la podofria y la destruye. 


\section{RIZÓPODOS-RHIZOPODA}

Nos hallamos, impulsados por nuestro desco de observar a los animales marinos de las clases inferiores, en cualquier punto del litoral del Mediterráneo, $y$ hace algunos dias que tenemos en nuestra habitacion un pequeño grupo de plantas con arena y cieno, sacadas de una roca poblada de algas y puestas en un gran vaso de cristal llemo de agua. Todos los animales grancles, visibles desde luego a-simple vista, sacados con cl cuidado posible por medio de una fina te. naza, se ban extraido del agua, porque nuestras intenciònes se dirigen con preferencia á la observacion de otros fenó. menos, Examinando las paredes del vaso pour medio del anteojo de aúmento nos hemos fijado en uno viótro punto en uń granito parduzco, ý hasta observamos á los individuos mas grandes que estan rodendos de una aurcola de hilos ligeros. Hemos colocado con precaucion uno de estos cuer. pos bajo cl microscópío. la red de hilos ha desaparecido por lo pronto, pues está recogida en la ciscara oval, bas. tante clástica; pero con alguna paciencia vemos como vuelve á presentarse. Estc animal es la gromia oijforme. De Ia siguiente descripcion hecha por Max Schuleze, uno de los conocedores mas excelentes de los rizbpodos, resaltara claramente el caricter de estos séres particulares.

* Despues de álgun tiempo de tranquilidad completa salen de la sencilla y graude abertura de la cáscara unos hilos fonos de una sustancia incolora y trasparente, compuesta de unos granos en citremo finos. Los hilos que salen primero buscan por medio del tacto un cuerpo sólido (aqui la pared del vaso) en el que se extienden longitudinamentc. Los primeros hilos son muj firos, pero pronto se presentan hilos mas anchos, los que al extenderse se ramifican, y haciéndose cada vez mas finos llegan a una longitud seis ú ocho veces mas grande que el cuerpo del animal. Cuando de este modo todos los hilos han salido de la abertura de la cáscara, cesan poco i poco de extenderse longitudinalmente; en cambio las ramificaciones son casi siempre mas numerosas, formàndose una multitud de puentes que moviéndose de continuo, representan poco ì poco una red de malla que á cada instante cambia de aspecto. Debo consignar aqui que cuando el animal está en un sitio cómodo y tiene ticmpo necesario, rodea poco a poco toda la superficie exterior de la ciscara de una delgada caja de la sustancia móvil.

¿Alli donde en la jeriferia de la red del protoplasma, tal es el nombre que damos al débil tejido, se encuentran vírios hilos, formánse i menudo de la sustancia que de conti. nuo segrega, anchas placas, de las que en nucvas direcciones vuelven a salir otros hilos, $\lambda$ l observarlos mas minuciosamente se reconocen en ellos granitos movibles que salen del interior de la cáscara, avanzan bastante räpidamente.a lo largo de los hilos hácia la periferia, y al llegar á la citre midad de los mismos, ruelven en direccion al cuerpo. Pero como al nismo tiempo nuevas masas de globulitos siguén siempre a cada hilo, preséntase una corriente ascendente y otra descendenic lin los hilos anchos que contienen numerosos, globulitos, ambas corricntes se dejan reconocer siem. pre al misino tiempo, mientras que en los hilos finos, cuyo diametro es a menudo menor que el de los globuliıs, estos no son tan numerosos. No se presentan aqui tampoco en el interior del hilo, sino que corren à lo largo de la superfi. cie. Cuando uno de estos globulitos llega siguiendo su camino a un punto donde el hilo se divide, se para a menu. do algun ticmpo hasta que toma uno ú otro camino. Alli donde existe un puente entre dos hilos, los globulitos pasan tambien de uno á otro, sucediendo, á menudo, que una corriente centripeta choca con una centrífuga y la obliga at retroceder. Tambien en el interior de un nido ancho se obser. va á veces como se para un globulito, racila, $y$ por fin retrocede.

Los hilos se componen de una sustancin granuloka, siendo los granitos en/extremo finos: no existe diferencia entre ha piel y la sustancia. Ell inovimiento de los globulitos que suben y bajan con regularidad, solo puede explicarse como pro. ducido por el ascenso y descenso de la sustancia contráctil que sale del interior de la cáscara, y sigue en una mitad del hilo una direccion centrifuga y en la otra una direccion cen. tripeta, llevando naturalmente consigolos globulitos mas grandes, por lo que venimos en conocimiento de la existencia de tal movimiento.

Cuando lós hilos cil su camino se emcuentran con un cuerpo que les parece necesario, como por ejemplo el alimento, se oprimen contra él y' se extienden en su superficie, reuniéndose a los hilos vecinos y formando de este modo una capa mas ó menos compacta al rededor del cuerpo citado. En esta capa, lo mismo que en los hilos, cesa la corriente de los globulitos. L.os hilos se encorvan, se contraen y se reunen en una red espesa ó en anchas placas, hasta que la presa se ha acercadó à la abertura de la cáscara, y por fin entm en la misma. Muy parecidos fenómenos se observan tambien cuando los hilos se recogen por una ú otra causa. Las corrientes regulares de los granitos se paralizan, los hilos se en. corvan, sueltan la pared del vaso, se reunen y llegan por fin, en forma de una sustancia orgánica descompuesta, a la abertura de la cáscara, en la que entran lentamente.

La descripcion de los hilos parecidos á un tejido de raices que han dado á toda la clase el nombre de rirópodos, debe admitirse como veridica en todos sus detalles. Deducimos de ella que en estós animales, la misma sustancia citada es la que les procura el movimiento, la alimentacion y la sensacion. Ios hilos al ponerse en contacto con un cucrpo exitano se contraen y se extienden como tentáculos No es posible formarse una idea concreta de la sensacion, porque al simpli. ficarse la organizacion, desaparecen los limites que determinan la sensacion, aunque sea en extremo débil, es decir, pura irritabilidad. En el interior de la cascara de nuestra gromia solo existe una sustancia contráctil, en la que suelen presentarse vejigas variables: regularmente se encuentran en la parte posterior de la caiscara algunos núcleos esféricos que sin dudi estan en relacion con la propagacion.

El que no tenga ocasion de ver el juego maravilloso de la red de la gromia, hảgase enseñar por persona príctica en el manejo del microscopio un sér congenérico del agua dul. ce, la arsella. En el estado desarrollado está rodeada de una cascara parda no trasparente; el lado dorsal es convexo y el ventral deprimido, provisto en su centro de una abertura circular. El animal semeja un gracioso estuche. Por la abertura sale parte de la sustancia blanda en forma de cortos apéndi. ces variables. Esta sustancia blanda tiene el valor de una 
celda, porque contiene siempre un núcleo con globulitos, mientras que la cáscara representa la membrana de la celda. Los ejemplares jóvenes son trasparentes, de modo que se pueden observar bien los cuerpos movibles del protoplasma. Entonces se ve tambien que el estuche pasa imperceptiblemente de una base uniforme á un estado en que parece componerse solo de granitos $\sigma$ facetas pardas.

El mismo frsiólogo á quien mas arriba hemos oido deducir de ciertos hechos observados una vida intelectual muy desarrollada en los infusorios, se inclina tambien á atribuir a las arcelas una voluntad y actividad determinada. Engelmann observó que en las arcelas se presentaban bajo el microscopio burbugitas de aire en el protoplasma, por medio de las que los animales se mantenian en la superficie del agua, mientras que otros animales, abandonándoias, descendian hasta el fondo. Deduce de esto el fisiólogo citado la voluntad $y^{\prime}$ facultades intelectuales del protoplasma. Tambien en este caso somos de otro parecer. No puede negarse que en el cuerpo de las arcelas se forman burbujas de gas, de las que dependen ciertas posiciones del cucrpo; pero la circunstancia, observada tambien por Egelmann, de que, no solamente en la cautividad, bajo el microscopio, se verifica este suceso, sino tambien en libertad, hubiera debido contribuir a darnos una explicacion menos inaginaria. Hemos de ponernos ante todo en relacion con las vejigas contráctiles de los infusorios que, segun se ha demostrado, dependen del oxigeno. Tambien las burgujas de gas de las arcelas proceden sin duda de procesos químicos y no debemos soñar en una actividad del alma voluntaria 6 involuntaria.

De las arcelas ì los amobeos desnudos solo media un paso, por el que dejamos a un lado los rizópodos de concha. Al examinar con un buen microscopio el cieno de aguas estancadas ó el depósito de las infusiones, la vista se fija á menudo en pequeñas particulas mucosas, fijas, que en su conjunto se parecen á la sustancia blanda de las arcelas. La capa exterior es una sustancia trasparente y uniforme; $\mathrm{cn} \mathrm{cl}$ interior se encuentran además del núcleo muchos granitos mas finos. Ia particula deja salir en uno ó en otro punto un apéndice del líquido, con el que se reune despues el resto de la sustancia del cuerpo. De este modo vacila la sustancia liquida hácia una ú otra direccion, alimentandose de séres or. gánicos mas pequeños que se digieren por el protoplasma.

$A$ las gromias ó rizópodos provistos dé una cáscara sencilla, llamados monotalamios, siguen en gran número los politalamios.

Su cáscara ó concha compuesta por lo regular de cal, y en algunos géneros tambien de sustancia de guijarro, se compone de varias ó numerosas cámaras que, por lo regular, so. lo estan indicadas exteriormente. En algunas familias las camaras se hallan unas á continuacion de otras en línea recta, en otras forman un conglomerado irregular, pero en la mayor parte parecen graciosas conchas de caracol. Así, por ejemplo, la gutulina comun, especie fósil, forma con pocas cámaras una circunvolucion parecida á un helice, Una aber. tura que da salida á los apéndices, soló es visible en la ultima camara: pero en el interior las cimaras están reunidas por aberturas parecidas.

De la disposicion espiralada resultan unas formas muy graciosas, á modo de los nautílidos y amonites, como la presenta, por cjemplo, la dentridina, igualmente fósil. Tambien este género pertenece al grupo con una abertura en la útima cámara. Numerosos son los géneros en que las paredes de todas las cámaras están perforadas por finos agujeros, de los que salen los apéndices variables y de cuya cualidad el grupo recibe el nombre de foraminiferos.

Disolviendo la cimara calcirea cuidadosamente en un acido muy enrarecido, se logra á veces conservar ilesa la sustancia blanda. El protoplasma llena todas las cámaras, y los apéndices y finos hilos se extienden entonces de una á otra, notåndose tambien un núcleo muy marcado.

De estos politalamios se han descrito I,600 a 1, Soo especies fósiles y vivas, pero este número debe reducirse mucho, porque se sabe ya que las mas de las supuestas especies son variedades. En su tamaño estos séres varian desde el dismetro de $0^{\text {m}}, 010$ al de una moneda de á duro. Estas grandes formas pertenecen sin embargo todas à la familia fósil de los numulites.

Max Schultze dice hablando de los sitios en que se encuentran los monotalamios y politalamios vivos: \& La multitud asombrosa de conchas de rizópodos en la arena de mu. chas costas maritimas, ha encontrido ya nins de un admirador. Yanos Plancio contó, en 1739 , con ayuda de un anteojo de poco aumento seis mil de estas conchas en una onza de arena de Rimini, a orillas del Adriático, y d'Orbingny indicó cl número de las mismas en una cantidad grande de arena

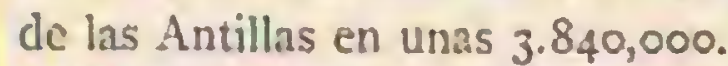

De una arena muy rica en conchas pequeñas, recogida en Molo-dei-Gaeta, separé por medio de un fino arnero todos los granitos que median unas de la décima parte de una línea, $y$ al examinarlos con el microscopio, vi que el resto se componia de una mitad de conchas de rizópodos bien con. servadas, y de otra de fraginentos de sustancias minerales y orgánicas, proporcion que, segun las noticias d'Orbingny, es dificil encontrar tan favorablemente. En un centigramo de esta fina arena conté 500 conchas de rizópodo, de lo que resultarian para la on\%a de 30 gramos $1.500,000$. Hil número indicado por d'Orbingny es por lo tanto muy exagerado.

$₫$ Despues de haber reconocido in abundancia de conchas de politalamios en la arena de la costa, nada tiene de extraño que vayamos en busca de individuos vivos en el fondo del mar, á poca distancia de aquella. Cerca de Ancona, donde en el puerto, lo mismo que à lo largo de la costa septentrional, existe una arena muy abundante en tales conchas, las he recogido en muchos sitios, hasta en la profundidad de 20 piés escasos y en cantidades de esta arena, conservindolas bastante tiempo en pequenas botellitas. Sin embargo, nunca salia del depósito un animal vivo, aproximáncose á. la pared de vidrio, y el exámen de la arena demostraba qque-solo pocas de Jas conchas, existentes en gran número, contenian aun restos de una sustancia organica. Pero en una pequeña isla pedregosa y cubicrta de algas, situada al sur del puerto, pesqué á poca profundidad de la superficie del agua, y hasta en sitios que acaso se quedaban secos en la marea haja: separando del cieno las partes animales y vegetales mas ligeras, vi al cabo de algunas horas numerosos rizópodios que reptaban por las paredes del cristal, y el examen del depósito presentaba casi todos los politalamios vivos y lienos de una sustancia orgánica. Experiencias parecidas lice tambien cerca de "Venecia. El eximen de la arena del Lido, aun cuando la habia recogido á alguna distancia de la costa, no me proporciónó nunca individuos vivos, mientras que el cieno de las lagunas mezclado de algas, despues de estar limpio de restos orgánicos que fảcilmente se descomponen, me facilitó numerosos rotalios, miliólidos y gromias vivos. Los rizópodos del mar parecen, por lo tanto, fjar su residencia con predileccion en los sitios doncie una rica vegetacion les preserva del im. petu de las olas, ofreciendo a sus tiernos órganos un apoyo seguro para fijarse. Aquí encuentran al mismo tiempo un alimento abundante en los diátomos é infusorios que siempre 
se hallan en las grandes y pequeñas plantas marinas. Ia residencia favorita de muchos politalamios son esponjas de toda clase, que les ofrecen con mayor abundancia el alimento y un abrigo mas seguro.

Erhenberg ha examinado hace ya varios decenios muchos centenares de muestras de cieno recogidas por él en todos los mares, entre otras algunas extraidas de una profundidad de 10 a 12,000 piés, a la qque se llegaba al sondear las lineas de los telégrafos submarinos. Casi siempre las conchas de politalamios constituyen uma gran parte de este cieno. El gran naturalista de Berlin encontró á menudo en tales con. chas, recogidas con la sonda, restos de una sustancia animal blanda, y creyó poder deducir de esta circunstancia que los animales viven efectivamente en la profundidnd, y: contribu: buyen, por su asombrosa propagacion en los mismos lugares, á llenar poco à pocó los valles submarinos.

Las cuidadosas averiguaciones sobre las profindidades y la naturaleza de su fondo, han confirmado la parte extranrdi. nario đ̧ue las conchas de politalamios tienen en la formacion del cieno del seno del mar, desde las zonas árticas hasta las antárticas. Además de otros géneros menos numerosos, se deben tomar en consideracion, sobre todo, los globigerinos y orbulinos, compuestos los primeros de esferas de tamaño variable, y los últimos de una gran esfera regular. Los restos de su concha se encuentran en miles de leguas cuadradas en el fondo del mar, y en tales masas, que constituyen una parte principal caracteristica del cieno; de modo que puede ha. blarse con propiedad del «fondo ó cieno de globigerinos.

Los naturalistas de la expedicion del Challenger han fijado su particular atencion en este asurto importantisimo é interesante, y debemós especialmente á los esfuerzos de los señores Murray y W. Thomson las noticias referidas por el ultimo, en otono do 18,6 , á la reunion de los naturalistas ingleses. Tomanos del relato de Thomson lo siguiente:

"La profundidad media del Océano es de un poco mas de 2,000 brazas, probablemente de unas 2,500 brazas. Una gran parte de mar es menos profunda y parece que una pro: fundidad de 2,000 brazas es la mas frecuente. Alli donde alcanza à 2,500 ó 3,000 urazas deben suponerse probablemente valles submarinos, excę̧to en $/ a$ parte septentrional del $\mathrm{Pa}$ cífico, donde se encuentran inmensos espacios de agua de una profundidad á menudo de mas de 3,000 brazas. Una gran parte del norte del Atlantico tiene una profundidad de unas 2,000 brazas: pero descie el sur de Groenlandia, al que pertenecen los diferentes grupos de islas, hasta 'Tristan de de Acuña, se extiende una profundidad media. En el sur del Atlántico esta profundidad media, el llamado banco de Dolphin, asi denominado en honor del buque americano que por primera vez le sondeó, tiene $\delta$ cada lado una profundidad de mas de 3,000 brazas, y estas profundidades son marcadamente paralelas à los ejes de la América del Sur y del Africa; este fondo, caracterizado por su gran profundidad con los rasgos mas generales, está cubierto de ciertos depósiios. Todo el fondo del mar recibe poco à poco ciertas aglomeraciones $y$ éstas se aumentan en formaciones que debe considerarse como las capas pedregosas del porvenir. Ia geologia nos ha enseñado que la superficie sólida de ki Tier. ra, excepto ciertas piedras volcánicas, se compone de capas depositadas en tiempos remotos en el fondo del mar. Sabe. mos que las partes de que se componen estas capas se han originado hasta cierto grado por la lenta destruccion de la tierra, y consideramos el Océano como el gran conservador y restaurador del material que en el porvenir formará islas y continentes, cuando el fondo del mar se habrá elevado sobre la superficie del mismo. Toda la superficie submarina recibe tales depósitos, y uno de los principales propósitos de la ex. pedicion del Challenger era la de averiguar de qué se componen aquellos depúsitos, cuáles son las condiciones en qque se verifican y cuál es la proporcion de estos depósitos nuevos á los antiguos y sólidos. Tomando en consideracion los citados fenómenos, conocidos por todo el mundo, no nos asombramos al encontrar que los gusanos terrestres se propagaban a la distancia de muchos centenares de millas inglesas por el mar. Encontramos por lo tanto capas fangosas y varios depósitos, que se diferenciaban segun el material de su origen y que contenian los restos de animales que viven en los puntos donde los depósitos habian bajado al fondo. En una palabra, hallamos hasta cierta distancia en la tierra esas deposiciones, en su mayor partc compuestas de aquel material.

*. Hace ya muclios años, antes de que se sondeara el mar parm la colocacion del telégrafo submarino, se sabia ya que una gran parte del fondo de la region septentrional del Atlantico se componia de un depósito que hoy dia conocemos bajo el nombre devicno de globigerinos. Se forma de las conchas de pequeños foraminiferos pertenecientes con preferencia al genero de los globigerinos. En estado seco el cieno tenia poco mas ó menos el aspecto de sagú fino y las pequeñas conchas demóstraban que el depósito estaba casi exclusivamente compuesto de ellas.

r. ¿Dónde viven estos séres? ¿Viven en el fondo del mar ó eu la superficie, desde la que despues de la muerte, las conchas bajan á la profundidad? Hasta los últimos tiempos pocos de estos sétes se habian encontrado vivos en la superficie, y la opinion general era la de que vivian en el fondo, donde se econtraban sus conchas. Uno de mis compa. neeros de viage, Mlurray, fijaba su atencion particularmente en la naturaleza del material sacado del fondo del mar, en su composicion y en la averiguacion de sus origenes. Llegó á obtener el resultado de convencerse de que los globigeri. nos viven cerca de la superficie del mar $y$ de que toda la masa de conchas que compone el fondo ha descendido de la superficie. Las conchas del fondo son pequeños globulitos aglomerados de superficic aspera y perforados por aguje. ros nicroscópicos. Los globigerinos cogidos en la superficie tienen la misma forma que la concha, pero esta no es blanca y opaca, sino trasparente é incolora. Prarece que estos foraminiferos tienen el mismo peso que el agun á causa de las gotitas de aceite que contienen. Nadan en numero de muchos miles en la superficie, mientras que los individuos muertos caen al fondo, donde nunca se encuentra uno de estos animales vivo. No cabe duda, por lo tanto, ņue el cieno de globigerinos es tan solo una aglomeracion de conchas, conchas pertenecientes à séres que vivieron en la superlicié ó à poca profundidad. Si esto es asi deberia esperarse que los depósitos originarios de ellos se extendiesen à la misma distancin en que se encuentran los animales, pero no sucede asi, y este es uno de los hechos tnas notables averigua. dos por la expedicion del Challenger. $A$ una profundidad de 2,000 brazas las conchas son corroidas y amarillentas, no blancas y trasparentes como las de mayor profundidad; a una profundidad de 2,500 brazas no se encuentran ya conchas sino que el suelo se compone de un cieno rojo uniforme que no contiene cal carbónica. Ahora bien, como una parte muy grande del Océano es de una profundidac de mas de 2,000 brazas, probablemente la mayor parte del fondo del mar está cubierta de cieno rojo y no de aquellas formaciones de cal. ¿ Pero cómo es posible que los depósitus de cal hayan cedicio a cierta profundidad su puesto al cieno rojo? Sin duda cl depósito de cal no ha podido verificarse, porque la cal carbónica de las conchas de globigerinos se ha disuelto de uno ú otro modo hạsta ahora inexplicable. 
El cieno rojo se compone de barro y de hierro. Estos cuerpos se encuentran en esta composicion particular, en cantidad muy poco considerable en las conchas. Pero lleyamos á averiguaciones quimicas que nos desvian demasiado de nuestro tema y en las que podemos engolfarnos tanto menos, en cuanto falta mucho aun que investigar hasta que se hayan explicado las causas de este fenómeno.

Los hechos demostrados respecto á los foraminiferos por los naturalistas ingleses, en rigor solo son una afirmacion $y$ una ampliacion de los descubrimientos ya citados de Ehrenberg que reconoció la grande uniformidad de muchos de los foraminiferos actuales, que son los que han dado el matcrial para los depósitos de cretn, y habló de «animalitos de creta vivos. Esto, que era entonces en rigor una paradoja, una idea revolucionaria, lo hemos adnitido ya, i causa del descubrimiento de los pentacrinitos y esponjas vidriosas y vivas. Hemos visto que los politalamios han contribuido mas a la construccion de la costra de la tierm, que todas las otras plantas y animales juntos. Al decir csto no hemos olvidado los poderosos depósitos de carbon, los arrecifes 6 islas de coral y los depósitos de huevos en la costa de Siberia; pues desde las cales silúricas hasta la creta han tomado parte en la fabricacion del material para el armazon de la tierra: tan considerable ó mas considerable aun suele ser, segun Bronn, su abundancia en las piedras terciarias inferio. res, en las que en los alrededores de Paris se ha distinguido una cal de numulites, en la Francia occidental una cal de al. veolinos y por fin en una zona larga y ancha que desde am. bas costas del Mediterraneo se extiende hasta el Himalaya: la cal de numulites; estas cales se componen de las conchas de los citados géneros de rizópodos y sobre todo de la uiltima i una profundidad de muchos centenares de piés.

\section{EL EOZOON-EOZOON}

Tenemos aun que hacer mencion de un cuerpo, accrca de cuya maturaleza, desde su descubrimiento, verificado hace unos diez anos, los observadores no han podido ponerse de acuerdo. Hablamos del eozoon $\delta$ animal de la aurora, segun su descubridor Dawson lo ha llamado, en la seguridad de que era un animal ó cuando menos un sér orgánico. El nombre debia significar q̨ue era el mas antiguo de los séres orgánicos conocidos y que segun el estado de nuestros conocimientos con el principiaba, por decirlo asi, la aurora de la creacion orgánica. Las picdras silúricas, division de la grande formacion de grauriacha se consideraban como las capas mas antignas que contenian petrificaciones. En esta formacion existen los restos de una fauna animal que si efectivamente representaban los primitivos clementos de la vida, destruiria las idcas é hipótesis de Darwin. esi mi teoria es exacıı, dice Darwin, sin duda antes del depósito de las capas silúricas mas antiguas debian haber pasado ya épocas tanto 6 mas largas que las subsiguientes, y toda la superficie de la tierra debia haber sido habitada durante estas épocas del todo desconocidas. Los geólogos ya habian afirmado que las piedras inferiores á las capas silúricas eran en su principio, 10 mismo que las formaciones que contienen petrificaciones, depósitos neptúnicos, adquiriendo solo mas tarde, bajo la influencia del fuego, su naturaleza ac. tual: tambien podia suponerse que en la época de su primera formacion, la tierra tenia ya una poblacion orgánica, pero apenas se pensaba en la posibilidad de descubrir los restigios primitiros, y este descubrimiento parecia hecho de un modo algo cxtraño.

Debemos à la comișion geológica del Canadá este descu. brimiento que se refiere á la capa de poco menos 20,000 piés de grueso, situada a mucha profundidad por bajo de las mas antiguas piedras silúricas, y que se llama la formacion lauréntica inferior. La masa colosal tiene en diferentes puntos un aspecto diferente, aunque sin duda del mismo origen. Pero las infuencias quimicas y mecánicas han producido muchas variaciones. Dawson crevó reconocer el origen de la piedra en un ser organico quue formaba conchas, $y \mathrm{el}$ pro. fesor Carpentier confirmó por averiguaciones mas minuciosas que el descubrimiento nos habia proporcionado una forma colosal de los rizópodos. Convencióse por cjemplares pulimentados de que la formacion en grandes masas consistia en un animal ó mas bien protística, y que el sistema cóncavo irregular mas tarde llenado, correspondia a las cámaras de los foraminiferos que viven en nuestros mares. Unas formas del eozoon del todo parecidas à las americanas se han encontrado en las capas correspondientes de Bohemia y de Baviera.

Podemos poner aun en tela de juicio que la exjstencin del eozoon arroje luz sobre el conocimiento de la maturaleza de los organismos primitivos. Presenta un tamaño que mas tarde no ha vuelto a encontrarse en este grupo, una variacion de la forma $y$ una irregularidad que no sin razon deben confrrmar a los partidarios de la doctrina de la descendencia en la hipótesis de que en ellas se halla el germen para la division en variedades y especies. Por fin el cozoon supone una fauna contemporanca parecida a ćl, y dirige nuestras mirndas á formas mas inferiores y sencillas, que se han conservado hasta nuestros dias.

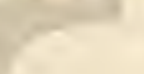

Una segunda grande division de los rizópodos se opone bajo el nombre de radiolarios á los politalamios y á sus con. géneres mas próximos. La sustancia blanda interior de aque. llos se compone de una cápsula encerrada por una membrana sólida y que contiene protoplasma, burgujitas, gotas de grasa y núcleos; tambien la capa del cuerpo que aparece al exterior de la cápsula conticne en mayor ó nuenor núnero cel. das amarillentas, por medio y encima de las cuales se extiende el protoplasma para cubrir la verdadera superficie con sus apéndices variables. El protoplasma que se emcuentra por fuera de la cápsula está en relacion con el interior por medio de finisimos poros de la menibrana capsular. Solo pocos géneros de estos radiolarios caracterizados por su cápsula central carecen de partes duras; todos los demás segregan partes pedregosas en forma de agujas y estrellas aisladas, $\delta$ de es. queletos que asombra por su variedad y por la gracia de sus formaciones. Poseemos una voluminosa obra en fólio de Haeckel, en la que solo están descritos los radiolarios que el citado autor recogió y observó durante algunos meses en el puerto y en el estrecho de Mesina: Pertenecen al gran número de séres delicados y trasparentes que nadan libremente, permanecen en buen tiempo at millares en la superíciey cuya presencia depende mucho de las corrientes y vientos.-

Tambien los mares de la época primitiva posterior estaban poblados de radiolarios. Numerosas formas de sus conchas se encuentran al lado de los politalamios y al lado de la creta siciliana; Ehrenberg ha demostrado la cxistencia en grandes masas de sus restos en un depósito de mas de mil piés de espesor de la isla de Barbados.

Acerca la presencia de los radiolarios en otros puntos de los mares actuales, solo teniamos noticias aisladas. Ia expedicion del Challenger ha arrojado nueva luz sobre este particular. A continuacion de su relato sobre los foraminiferos Wyille Thomson dice: 8 los radiolarios difieren un tanto por su residencia de los foraminiferos. Cuando la red, à una profundidad de 1,000 brazas, pasa por el mar, el número de 
los radiolarios aumenta, y los individuos de las especies que tambien viven en la superficic son mas grandes. Muchas formas que faltan del codo en la superficie no comienzan a presentarse sino \& la profundidad citada. Suponemos por lo tanto, y sin duda con razon, que los radiolarios viven à todas profundidades, aun en las que alcanzan à cinco millas inglesas. Se comprende que los séres que viven de este modo contribuyen consicienblemente á la formacion de capas en el fondo del mar. Encontramos un depósito que Murmy desig. nó como cieno de radiolarios, porque se componia casi exclusivamente de los restos de éstos. Las conchas de los foraminiferos parecen disolverse del todo antes de-llegar a las mayores profundidades; cl cieno rojo cualquiera que sea su origen se deposita del modo regular; las cónchas de los sa. diolarios que viven á todas yrorundidades son tan numerosas que cubren todas las sustancins que componen el suelo. Pero esta capa de rádiolarios solo se encuentra en las extremas profundidadés del Océano y no forma por lo tanto depósitos contíumos.

\section{LOS RADIOLARIOS DE AGUA DULCE}

Hay en el agua dulce bastantes organismos microscópicos desnudos ó provistos de una concha, ya pedregosa, ya clás tica, quic recuerdan por su aş̧ecto a los radiolarios; de modo que algunos naturalistas los han llamado radiolarios de agun dulce. Sin cinbargo, à todos los séres denominados con estc nombre les falta la cápsula interior caracteristica de los radiolarios verdaderos. Como cjemplo clegimos ia clatrulina elegante. La sustancia blanda, con núcleo y apéndices mriables, construje como concha una esfera agujereada que por me. dio de un tallo se fija en cuallquier parte. Greef, al que debe. mos una descripción cxacta de estas fórmas y otms genéricas. llama la atencion sobre la circunstancia de que con mucha frecuencia in clatrulina fijada al principjo en un objeto extra. no, lleva uno 6 varios compañeros de la misma especie, y no cree que esto sea casual.

Conócesc una doble propagacion de las clatrulinas. En el primer caso se divide la sustancia blanda en el interior de la esfera agureada en dos mirades. I a una queda en posesion de la concha, la otra sale por uno de los agujeros y se trasiorma dentro de una hora, por la secrecion de la concha y tallo, en una clatrulina perfecta. Precisamente en esta clase de propa gacion sucederit con frecuencia que la mitad inmigrante su fije en la mitad materna.

Fn el otro caso la sustancia blanda da el maicrial a un imajor número, es decir, á ocho ú diez retonos que dentro de la esfera agujereada se rodean de una cubierta dura, la que abandonan para salir de la concha. Fintonces estản jrovistos de órganos pestaicados, pero el estado crrante no dura mucho tiempo.

\section{LOS NOCTILUCOS-NOCTILUCA}

A continuacion inmediata de los rizúpodos, ó cuando me. nos muy cerca de ellos, se clasifica ahora comunmente un animalito que entre los muchos habitantes radiantes del mar ha recibido especialmente el nombre de noctiluco. Es un rizópodo, pero vuclto hacia dentro, es decir, un animal en que los apendices variables se muifican en el interior del cuerpo, exteriormente liso y que afecta la forma de un riūon. De una escotadura del cuerpo sale un órgano móvil en forma de lá. tigo que sirve al animal de remo. En este punto se halla tambien una abertura por medio de la cual recoge el alimento que pasa al interior de la red variable del protoplasma; en otro lugar he llamado la atencion sobre la uniformidad variable de esta red con el aparato alimenticio de uno de los in. fusorios verdaderos mas notables (trashelius oarum). Por de. tsàs de la abertura se encuentra una gran aglomeracion de protoplasmas, desde la cual los apéndices muy ramificados se extienden por el espacio interior de ias celdas, para fijarse con las ramitas, siempre mas finas, en la pared del cuerpo. Esta red es la que recibe el alimento. Los noctilucos despiden de nóche una luz fosforescente.

\section{LOS MIXOMICETES-MYXOMY- CETES}

Los verdaderos rizópodos, de que arriba lablamos, como en otro tiempo las esponjas, no se consideran ya, por una seric de naturalistns muy reputados, como animales verdaderos. La irritabilidad del protoplasma no les basta para atribuir alma a estos séres; por su actividad, los rirópodos se elevan sobre la irritabilidad mecánica de las mimosns. En los mixomicetes, cuya naturaleza, con preferencia vegetal, hasta hace poco se ha discutido, encontramos estados del protoplasma, en los que se repiten todos nquellos fenómenos de los apéndices variables de los rizópodos.

A tales séres en los que desaparecen los caractéres, haciéndose por ló tanto dudosos, nos conduce tanto una pre. tension cxagerada sobre los lacehos que han dado origen á la doctrina de la descendencia, cuanto la observacion directa, del todo independiente de las opiniones. Ln todos los rizópo. dos que siguen a los radiolarios! politalamios se forma un orgabismo, en extremo sencillo, por la circunstancia de que en el protoplasma hay burbujitas y nicleos independientes. Is, sin embargo, preciso, por paradóịco que parezca, que hayan existido organismos sin brganos, y los hay, en efecto, en gran número. Para estos organismos sin órganos que en su estado del todo desarrollado figuran con cuerpo de protoplasma, li. bremente movible, como desnudos, homogéneos y sin estruc. tura, su monografista Haeckel, ha propuesto el nombre de moneros. A pesar de su sencillez, se diferencian, sin embargo, por su aspecto, distribucion de la ramificacion de las patas falsas, y por el desarrollo de su genero de vida, pudiendo distinguirse nada menos que siete géneros, aunque casi todos solo con una especie. Hemos tomado una al acaso, el Protn. mixa anaranjado (Protonyata alerantiaia), descubierto por Haeckel en la costa de Iancarote (Canarias), y que vienc as ser un cuerpo sin forma determinada, de la especie mas sen. cilla, del cual irradian rudimentos de patas que se confun. den unas con otras.

No podemos detenernos en el estudio de las manifestacio. nes de vida de estos séres sin exponernos al justificado reproche de traspasar los limites de la vida animal; pero era preciso llegar à este punto al través del laberinto de los organismos animales inferiores. Fi Protomy:xa aurantiaca, cuya figura representa, en microscópico tamaũo, un sol, puede decirse que alumbra la senda recorrida por todo el nuundo organizado; en el vemos un simbolo de la mayor sencillez, unida á la posibilidad de adaptar todas las formas, desarrollos y
perfecciones imaginables. 


\section{ÍNDICE ALFABÉTICO}

DF, LAS CLASES, FAMUIAS, TRIBUS, GF́NFROS Y ESPECIES CONTENIDOS EN EL TOMO SÉTIMO

Acalefos 256

Acantocéfalos 100

Acantocercos 56

Acantonix 20

Acantonix pintado $2 \mathrm{I}$

Acatinelas 154

Aceras 102

Acinetas 299

Acorazados 34

Acteres $6 \hat{j}$

Actinias 265

Afroditeos 68

Agatinos 148

Aibiones 82

Albuneas 30

Albunea asiática idem

Alcionarios 270

Alcion digitado idem

Alcionelas 119

Alectis 251

Alfeos $4 \mathrm{~T}$

Alfeo de pico corto idem

Amficora 74

Amfipepleas 152

Amfistomos i I I

Ampularias 757

Ancilas 172

Ancilos 152

Ancilo lacustre idem

Ancorinélidos 286

Anculas 196

Anélidos 66

Idem anillados 67

Idem estrellados 90

Idem redondos 91

Anémonas 265

infipodos 46

infitricos 294

Anguilulas 93

Animales primitivos 291

Anodontas 213

Anomias 238

Anomia escamosa idcm

Anomuros 29

Anoplia $\mathrm{IO}_{3}$

Antes ccreus 265

Idem tentacular idem

Anthocotyle merlucii Ios

Aplisias 194

Aplisia esquiladora 195

Apocrinitos 252

Aporais 184

Apos 54

Apo cancriforme idem

Aracnoideos 248

Arcas $23 \mathrm{I}$

Arca de Noe idem

Arcturos 50

Arcturo de Baftin idem

Arenicolas 70

Arenicola de los pescadores idem

Árgonauta 130

Argulo hojoso 6:

Arpas I7 72
Arsella 300

Ascarinos 94

Ascidias 238

Ascones 28.4

Aselinos 50

Aselus idem

Aspergilo de mangas 223

Aspidogaster rog

Asteracantios 249

Asterias 250

Asteridos 249

Asteriscos idem

Astreaceas 267

Astrogonias idem

Astroideos idem

Atlantas 189

Aucorelas 63

Aulacostomos $\mathrm{S}_{2}$

Aurelia orejuda 258

Auriculaceos 150

Autolitos 76

Ariculas 228

Avicula melengrina idem

Axios 37

Balanidos 64

Boltenins 240

Boltenia reniforme idem

Bopirinos 50

Bopiro de los cangrejos idem

Botrilos 239

Botriocefálidos 115

Botriocéfalos idem

Branquiopodos 51

Braquiopodos $\mathrm{S}_{3}$

Braquipos 52

Braquipo salino idem

Briozoidos II 5

Bucinidos 173

Bucino ondulado idem

Idem papiráceo idem

Buláceos 192

Bula ampulosa idem

Idem cilindrácea idem

Idem lignaria idem

Bulinos 147

Bythotrephes 56

Cabrajos 39

Cabrajo Norte americano 40

Cafiras 26

Cafira de Roux idem

Calamares 133

Calanidos $60^{\circ}$

Calapos $2 \hat{3}$

Calcispóngidos 284

Calianasas 37

Calianasa subterránea idem

Calicinarias 270

Caligos 62

Calinos $6_{3}$

Caliptreas 164

Camarones 42

Camas 227
Cama lázaro 227

Campanularias 270

Camposcias in

Camposcia embotada idem

Cangrejos 9

Idem arquendos 13

Idem cuadrangulares to

Idem ermitaños 30

Idem propiamente dichos i6

Idem redondos 23

Idcm triangulares 18

Cangrejo Ruvial 37

Cangrejo de las piedras 39

Idem marino idem

Idem paguro 16

Idem rana 29

Idem vergonzoso 23

Cantáridas 163

Cantocampos 57

Caprelas 49

Capucha húngara 164

Capulidos 163

Caracoles 138

Caracol de las viñas 139

Caracoles enanos 750

Carbaseas 1 ro

Carcinos 15

Cardiaceos 223

Cardios idem

Caridinos 40

Caridinos propiamente dichos $\$ 2$

Carinarias 190

Carinaria vidriosa idem

Cariofila 269

Cariofilos 116

Carpilios 16

Carpilio manchado idem

Cassis ${ }_{1} 8_{3}$

Cauris is ${ }_{2}$

Cecropos $6_{3}$

Cefálóforos 142

Cefalóforos de lengua estrecha I 70

Cefalópodos 122

Celenteratos 255

Celeporas 12 I

Cenuros 115

Cerapos 48

Cerapo tubular idem

Ceritios 167

Cestoidos I II

Cetoquilo Austral 60

Cianos 49

Ciamo oval idem

Cianea 258

Ciclatela anelidocolo 108

Ciclopidos 60

Ciclostomidos 157

Ciclostoma elegante idem

Cidipes 257

Cimbuliaiceos $20 \mathrm{r}$

Cimbulio de Peron 202

Cimotordos 50

Cimotea estro idem

Cintias 240 
Cintia Momo 240

Cinturon de Vénus 257

Cipreos iso

Cipridos idem

Cipreo moneda $\mathrm{IS}_{2}$

Cipridinas 57

Cipris idem

Cirratulos 69

Cirratulo Medusa idem

Cirripidos $6_{3}$

Cirroteutis 134

Citeres 57

Cladoceros 55

Clausilias 148

Clavatela prolifera 258

Clavelina lepadiforme 239

Cleodoros 201

Clepsineos 82

Clepsinos $8_{3}$

Clicnos In 4

Climenidos 70

Clioideas 202

Clipeastridos 248

Colombelas y 7

Colombela brillante $x>2$

Comátulas 252

Conchas de nartillo 227

Conchiferos:20

Concolepas i74

Concolepa peruano idem

Condracantos 63

Condrosios 289

Conoideos 179

Cono almirante idem

Idem cedonulli idem

Iden mosaico idem

Copepodos 60

Coral noble 274

Coral rojo 273

Idem segundo 274

Coriicidos 60

Corimorfa 258

Corinos 20

Corino espinoso idem

Coriste 16

Idem dentado idem

Corofidos 47

Corofido de cuernos largos idem

Crangones 40

Cranidos 86

Crescis 201

Cribelas 250

Crinoidcos $25 \mathrm{r}$

Criocarcinos 20

Criocarcino cornudo idem

Criptopodios 22

Criptopodio abovedado idem

Crisaora brillante 258

Cristatelas 118

Crustáceos 5

Cuculano elegante ni

Cucumaria de cinco tentáculos 242

Cupularias 121

Dactilocalix 288

Dactilóceros 48

Dactilócero de Niza idem

Dactilocotilos 108

Dafnia 56

Decápodos 8

Decaipodos 130

Delfinulas i 86

Delfinula delfin idem
Dendrocalos 105

Dendrofila 269

Dendronotos 197

1)endronoto arborescente idem.

Dentolios 203

Desmacidones $2 S_{9}$

Diacoris II

Dibranquiados 125

Dimiarios 207

Dimifilos 104

Diplozodon paradójico 108

- Diporpa idem

Distomos ron

Docleas 10

Docléa ovejajiden

Docmio trigonocefalo 96

Dolabélas' 195

Dolabela callosa idem

Dólios 182

Dorididos Ige

Doris idem

Doripas 25

Doripa lanosa idem

Dotos 196

Doto coronado idem

Dreicenas 210

Dromias 27

Dromia vulgar 28

Eburnas 174

Eburna areolada idem

Eledone 129

Idem de almizcle idem

Elicidos 1.44

Elisias 198

Elisia esprenelia idem

Einarginulas is?

Emarginula reticulada jdem

Encopos 248

Enoplos 92

Enoploteutis I 34

Entomostráceos 59

Eolididos I 9 ?

Folidos idem

Eozoon 303

Epistilos 295

Epistilo grande idem

Equinococa II 5

Equinodermos 241

Equinodiscos $24 \mathrm{~S}$

Equinoideos 245

Equinos idem

Equinóporos 269

Equinorincos 100

Erictos 45

Eirmeláceos is

Ermitaño Bernardo $3 \mathrm{I}$

Erizos de mar 245

Escalarias 170

Fiscalaria preciosa idem

Escaras 121

Fiscilaros $3^{6}$

Escrobicularias 219

Escrobicularia picante idem

Esferomas 50

Espatangidos 248

Espatango purpureo idem

Espirostomos 296

Espirulas 134

Espondilos 231

Espongilos 290

Esponjas $28_{3}$

Idem calcaireas 28 .
Esquizópodos 44

Esquizostomos 105

Estomatópodos 43

Estenorincos is

Estenorinco falángeo idem

Estenostomos 104

Estentores 206

Estiloniquios 294

Estiloniquio conchiforme idem

Estomatelas 187

Estomatela imbricada idem

listrombos i $\delta_{\text {q }}$

Estrongilidos 96

Etras 23

Litra deprimido idem

Eufilias 260

Eulimenes 54

Eulimene diáfano 55

Eunices 60

Lunice gigantesco idem

Eurinomos 21

Furinomo rugoso idem

Falusias 239

Falusia intestinal idem

Fascolosomas go

Filactolematos ix

filodinios 89

Filaridos 96

Filinos 194

Filino de ojos idem

Filiroes 191

rilodoceos 69

Filodoce laminoso idem

lilopodos 5 I

Fisalia pelágica $26 \mathrm{I}$

Fisas 157

Fisofora distica 261

Fisurelas 164

Fisurela grande idem

lilarelos 269

Filoscularias $\$ 9$

Filustras 119

Folas 2 r 9

Forus $86_{3}$

Fredericilas irg

Fronima sedentaria 48

Fungia 260

\section{Galateas 33}

Gaicnas 26

Galcra 43

Gamarinos 47

Gastrocenáceos 223

Gecarcinos 10

Gelasimos II

Geodia gigante 286

Geoplana subterránea 107

Gimnobranquios 196

Ginnolematos I I 9

Glaucos 198

Glicereos jo

Globigerinos 302

Gonodactilos 46

- Gonodactilo gotoso idem

Gonoplax is

Idem angular 12

Gordiáceos 99

Gordios idem

Gorgonia itálica 273

Gorgonidos idem

Grapsos 12

Grapso pintado I 3 
Gronia oviforme 300

Halicondriados $2 \delta 7$

Halicondrias idem

Haliotis 187

Haliotis tuberculada idem

Halisarca 289

Halopos 251

Harpactidos 60

Helicosyrinx parásita 199

Helix 140

Hemopis 82

Hemopis sanguijuela idem

Herpilobios 63

Heteropodos 189

Heterotricos 296

Hexactinélidos $2 S_{5}$

Hialenceas 201

Hialeas idem

Hialonema 285

Hidatinidos 88

Hinites 231

Hinites sinuoso 232

Hiperidos $4 S$

Hipopos 2 is

Hipopo manchado idem

Hirudineos io

Holotricos 297

Holotúridos 242

Homolos 29

Husos 178

Huso antiguo idem

Hydractinia echinata 259

Ibacos 37

Ibaco moteado idem

Idolea 50

Ifis 24

Ifis de sicte espinas 25

lliantos 269

Inacos 18

Infusorios 292

Ione 50

Ione torácico idem

Isopodos 49

Isopodos nadadores 50

Isocardias 227

Isocardia globulosa idem

Ixas 25

Ixa cilindrico idem

Jaculina $\sigma_{\hat{3}}$

Jantinas 160

Jantos 17

Janto Rorido idem

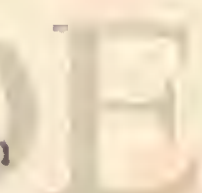

Iacunas 162

Lambros 2 :

Lamelarias 168

Lamelibranquios 205

Lamproglenas $6_{3}$

Langostas 34

Iangosta comun idem

Idem fiuvial ra

Lemodipodos 49

Lepthodora hyalina 56

Lernantropos 62

Limnadia 54

Lepadidos 63

Lepas 64

Leprolins 118

Leptodera yj

Lerneas $6 j$
Lernentomas $6_{\hat{j}}$

Lerneocéridos idem

Lerneoceros idem

Lerneodiscos idem

Lerneonémidos 62

Lerncopodos $6_{3}$

Leucifer 44

Leucones 284

I.eucosias 23

Ligia oceanica 49

Limacinas 202

l.imas $23 \mathrm{I}$

Lima comun idem

limazas 149

Limnertceas I 5 I

limneas idem

Limulos 58

Limulo polifemo 59

Linceos 56

Lingulidos $\mathrm{S}_{7}$

Lisa is

I isianasas 47

Lismata de cola sedosa 41

Litiopas 16 ;

Litodidos 29

Litodomos 215

Litorinas 160

Litorina litoral 162

Lofoelins $26 \mathrm{~g}$

Lofofos $1: 9$

Loligonsis 134

Lombricinos 77

Lombriz terrestre idem

L.ombriz de los perros 95

Loxoxomas 110

I.ucernarias 260

Lumulites 121

Lupas 27

Macruros 34

Mactras 217

Mactra de pico idem

Magilos 175

Magilo antiguo idem

Malacobdelas $8_{3}$

Maleaceos 227

Marginelas 170

Menndrinos 260

Medusas 258

Melanias 560

Membraniporas I 19

Mermis 100

Mesostomos 105

Mera esquinado is

Mlias 218

Mia arenaria idem

Micipas 14

Microstomeos 104

Mictiris is

Mictiris longicarpa idem

Miras 23

Nira fugaz idem

Mitiláceos 214

Mitilo comestible idem

Mitras 170

Mitra episcopal idem

Mixomicetes 304

Modiolas 215

Moluscos 121

Monomiarios 226

Monostomos il I

Monotalamios $30 \mathrm{r}$

Murex 175
Mysis 44

Naidinos 78

Nasas 174

Nasa reticulada idem

Naticas 165

Nauplios 59

Nautilos 136

Nautilo Pompilio idem

Navicelas I 86

Nàyades 207

Nefelio 82

Nefrops de Noruega 40

Nemertes 103

Nemertidos idem

Nemertineos 102

Nereidos 69

Nereis engañoso idem

Neritidos 185

Neritinas 186

Nelumodermones 202

Neurobranquiados 157

Nicotoes 63

Noctilucos 304

Noteidos 87

Notomata 89

Notodelfos 6r

Nursias 25

Ocipodos 13

Octatinos 270

Octópodos 125

Ofiocoma sonrosado 250

Ofiuros idem

Ofiuro blanco idem

Olivas 172

Oliva pórfido idem

Olulana tricuspide 97

Ommatostrefes I 34

Onicoteutes idem

Oniscodeos 49

Onisco de los muros idem

Opistobranquios I9I

Orquestia de la costa 47

Ortoceras $1_{3} 8$

Ustracodeos 57

Ostras 232

Ostra comun idem

Otion 64

Ovulos 182

Oxiuridos 96

Pagurinos 30

Paguro de Prideaux 31

Palitoss 266

Palmipedos 250

Paludicelas is 8

Paludinas 559

Pandalos 42

Paramicipas 14

Paramicipa filira idem

Parásitos $6 \mathrm{I}$

Parmóforos 165

Parmóforo austral idem

Parténopes 2I

Parténope hórrido idem

Patelas 187

Pecilopodos 58

Pectenes 6 peines 231

Peine variado idem

Peldogaster $6_{4}$

Pelodera 93

Peltidios $60^{\circ}$ 
309

Penátula fosfórica 2$\rceil 1$

Idem gris $27^{2}$

Penatúlidos $27^{\circ}$

Penclas 63

Peneos 42

Penen caramote iden

Pentacrinos 251

Peritricos 295

Pileopsis 164

Idem húngaro 165

Pinas 217

Pina noble idem

Pinoteros 13

Pinotero guisante idem

Pirimelas 17

Pirosonjos 240

Pirulos 179

Pisa Is

Placunas 237

Placuma silla $23^{8}$

Planarias 105

Planaridos 101

Planárias idem

Planorbis 15:

Idem cóneo idem

Pleurobranquios 195

Pleurotomas 199

Pluraas de mar 270

Plumatelas ing

Plumularias 270

Podoftalinos 2 ;

Idem vijia idem

Polia crusigeral103

Poliactinisis 264

Polibios 27

Polibio de Henslow idem

Policcras $\$ 96$

Policera ocelada idem

Pólipos 281

Polistomos 100

Polistomo integérrimo id̉em

Politalamios 301

Polycelis 106

Pomatias 157

Pontobdelas 83

Pontolitna\%: 199

Pontolimara de cabeza ancha idem

Pontonias 42

Porcelanat 3.3

Porcelio de las bodegas 49

Portuno linnoso idem
Potelidon

Poxiquilon

Pranizas $\mathrm{g}_{3}$

Prastomosi

Priápulon pos

Protozogh luiados 1 s

Psolus phinisi

Pulmonarlutopus 242

Pulpo de bis 1.70

Pulpo villis inzos largos i28

Pupas r likar 125

Pupa verit

Púrpurn! the idem

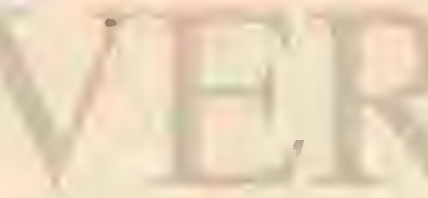

Quetogastel
Quetoptert 78

Quetoptivinge 78
Quetoptoting 70

iNDIC:

Quetopodos 68

Quitones 189

Quitonidos 188

Rabdocelos 10 ;

Radiolarios 303

Radiolarios de agua dulce $3^{\circ} 4$

Ranelas is?

Remipes $3^{\circ}$

Remipes oval idem

Rinconélidos 86

Ripidoglosados $\mathrm{IS}_{5}$

Risoas 160

Rizocrinos 252

Rizópodos 300

Rizoquilos 175

Rizostomo de Cuvier 258

Rosias 130

Rostelarias $1 \$ 5$

Rostelaria Haso idem

Rotiferos $\mathrm{S}_{7}$

Rotifero amarillo idem

Sabelas 74

Salpas 240

Sanguijuelas medicinales is

Saxicavas 2 i $S$

Sebenarias 121

Sepia comun $13 \mathrm{I}$

Sepiolas 130

Serpuláceas 73

Serpulas iden

Serpula de anillos plegados 74

Serularias 270

Sicones $2 S_{4}$

Sida 56

Sifonoforos 261

Silicuarias 167

Silicuaria anguiliforme idem

Silis 69

Silis manchado idem

Sinaptos 199

singamo traqueal 97

Sintetis 240

Sintetis de las Hébridas idem

Sipúnculos 91

Solarios 163

Solario perspectiva idem

Solaster 250

Solenes 218

Solino breve 242

Sucineos 148

Talamitas 13

Talasema de Neptuno a $\$ 6$

Talasemos 9 T

Talitro langosta 47

Taumops trasparente 48

Tecidio $\$_{4}$

Telescopios $16_{3}$

T'elescopio imperial idem

Telsusas $\mathrm{r} 4$

Teliniceas 218

Tenias It 4

Teniadeos idem

Tenioglosos 159

Tenobranquiados idem

Tenoforas 257

Terebelíceos it
Tercbela conchilega 72

Terebela tommalina idem

Terebras 174

Terebra manchada idem

Terebrátulas $S_{5}$

Terebratúlidos 84

l'eredos 220

Teroccros 185

T'eroido penátula 270

Teropodos $20 \mathrm{I}$

Terotráqueos ino

T'estacelas 150

Tetis ins

Tetis fimbria iden

Tetrabranquiados $8^{6}$

Tetrafilidos 116

'letrastema ro3

lias 24

Tia pulimentado idem

Ticdcmannia 201

Tionido de Drummond 242

Tioniciio hialino idem

Tiptones 42

Torrea vitrea ;o

Traqueliastes 63

Tremitodos 107

Triconocéfalo 90

Tricotraquélidos 97

Tridacnos 226

Tridacno gigante idem

Idem prolongado 227

Trilobites 57

Triquina espiral 97

Tristomum 107

Tritonios i $\mathrm{S}_{2}$

'Irocos I $8 \%$ '

Tubicularias $S_{9}$

Tubicolas $7 \mathrm{I}$

Tubiticinos $; 8$

Tubipora purpurea 274

Tubipóridos idem

Tubuliporas I 9

Tunicados 238

Turbelarios 102

Tubinolidos 269

Turbinos 186

Turbos idem

Turritelas 167

Umbelula de Groenlandia 272

Unios 207

Urolábeos 92

Valvados 160

Velellas $26 \mathrm{I}$

Venus $28 \delta$

Veretilos 270

Vermetos 165

Vioas 200

Virgilaria de alas endebles 272

Vitrinos ias

Volutacens i 70

Volutas idem

Vortex 105

Vorticelas 295

Zoantos 266

Zocimo puntuado $1 ?$

Zocimo rugoso idem 